$-1525 \times$.

$=-$

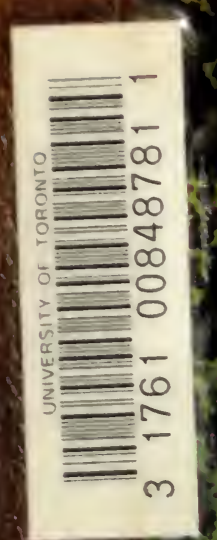

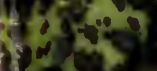

s.

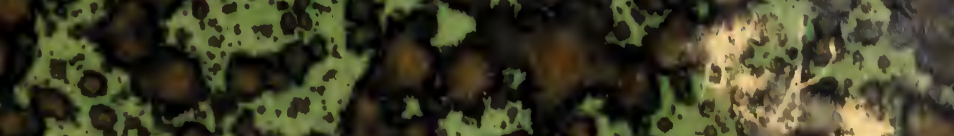

1.0.

siv

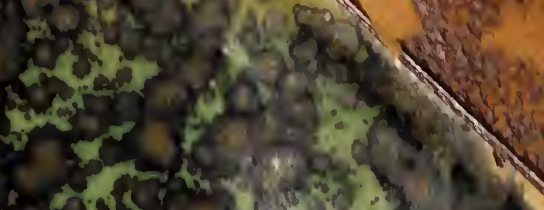

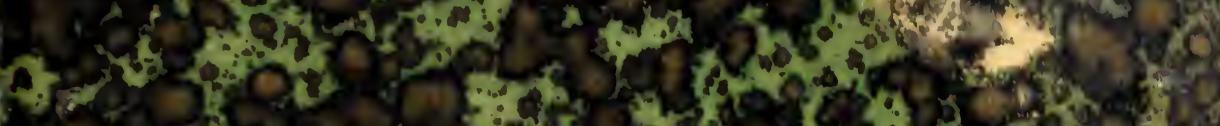

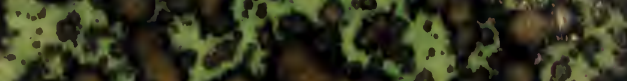

40

$x^{3}$

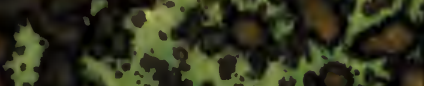

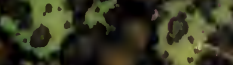

20

(1)

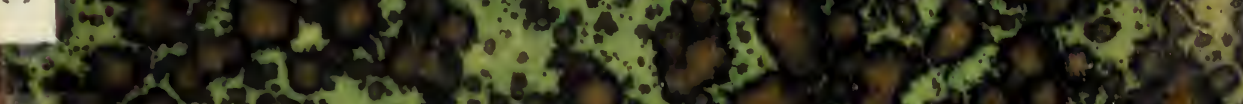

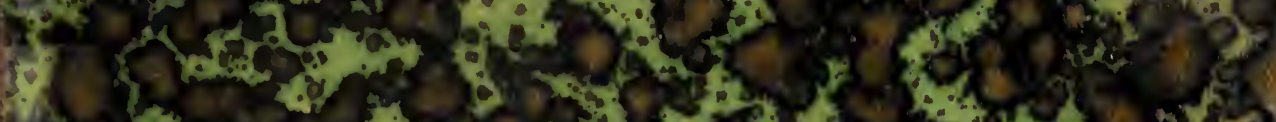
3) 4 ( to 20 .

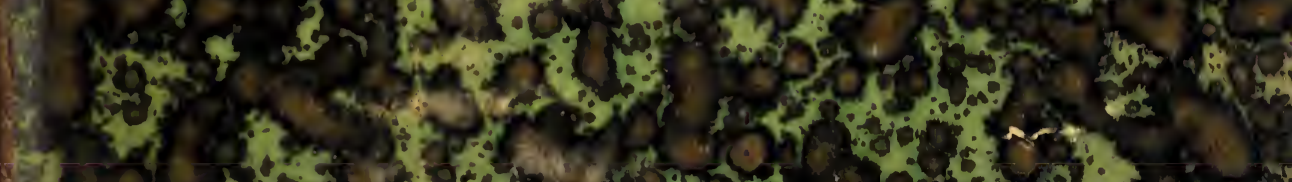

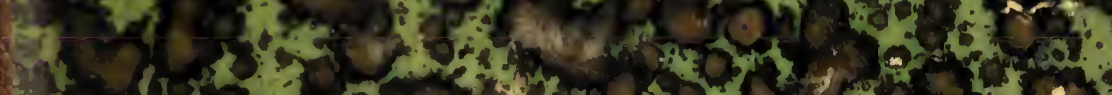

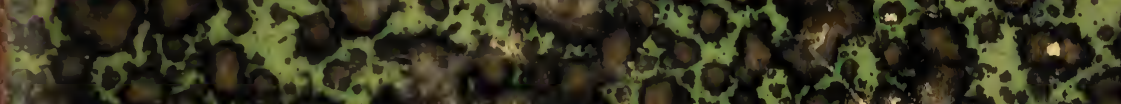
6050 .

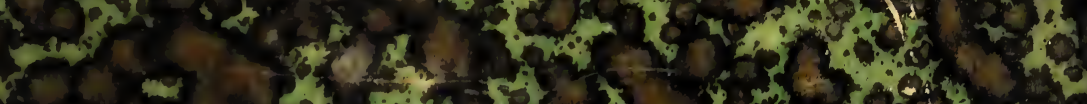

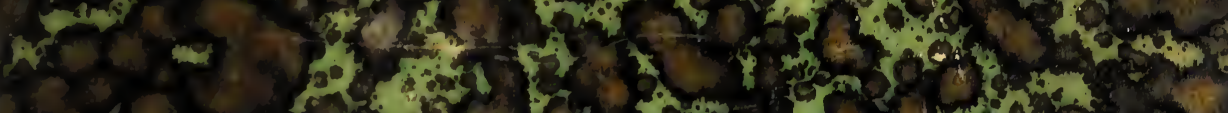

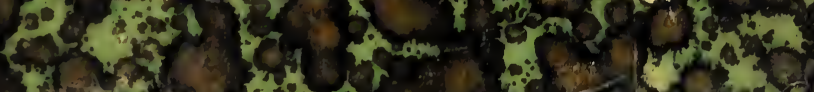

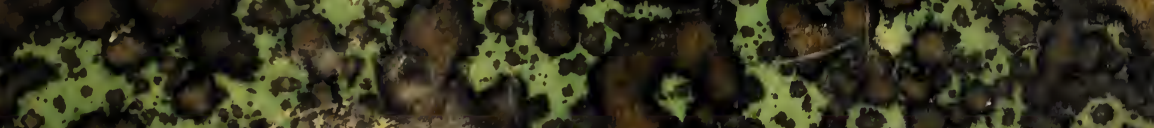

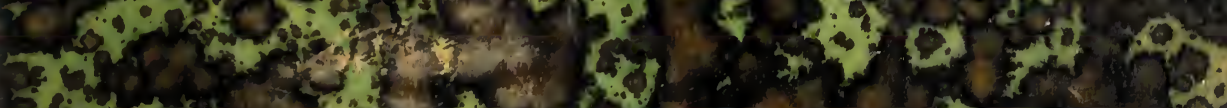
the

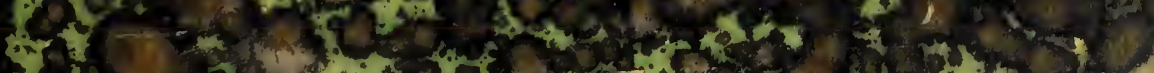
$350.5 \%$.

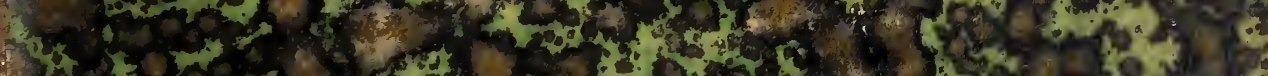

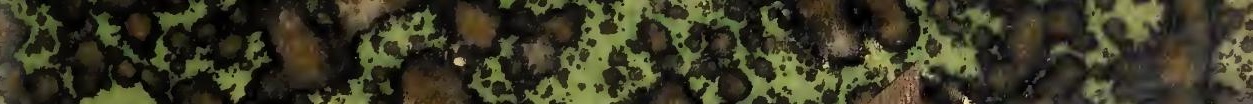

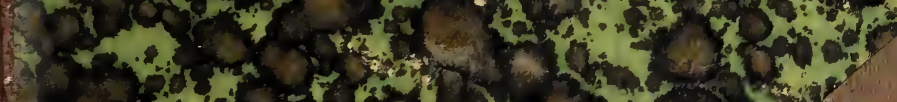

How

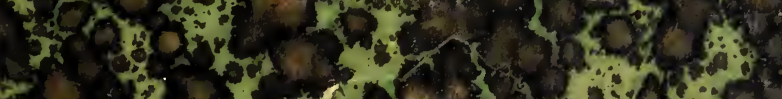

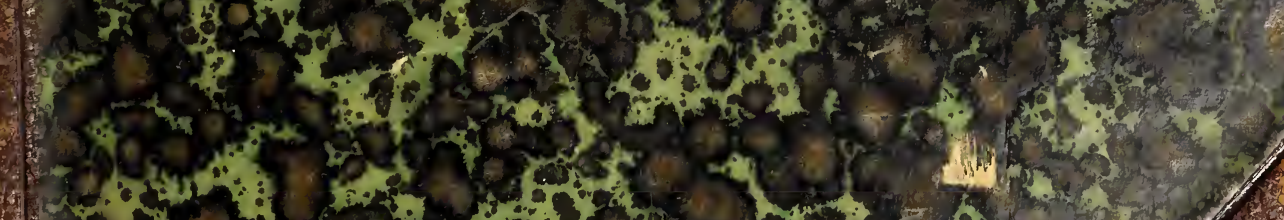

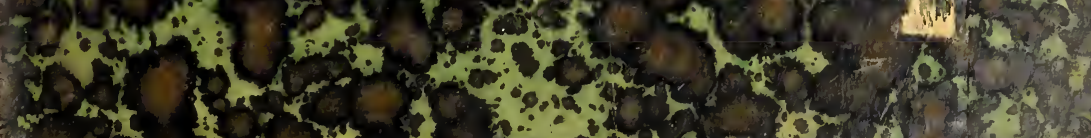

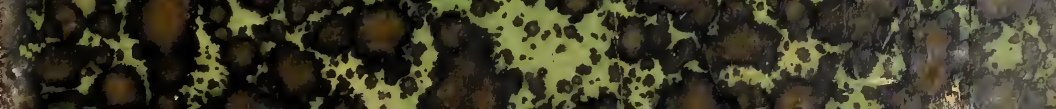






\section{VORTRÄGE ÜBER}

\section{BOTANISCHE}

\section{STAMMESGESCHICHTE}

GEHALTEN AN DER REICHSUNIVERSITÄT

ZU LEIDEN

EIN LEHRBUCH

DER PFLANZENSYSTEMATIK

VON

J. P. LOTSY

ERSTER BAND:

ALGEN UND PILZE.

Motto: The most difficult as well as the most fascinating problem in connection with any group is its phylogeny. The data upon which we base opinions concerning phylogeny are never sufficient but such opinions usually stimulate research and are necessary to progress

JENA

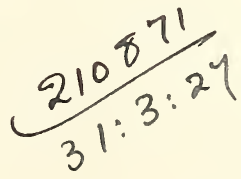

VERLAG VON GUSTAV FISCHER 1907. 
Alle Rechte vorbehalten.

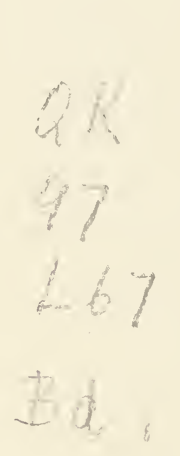

Germany

.

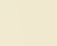
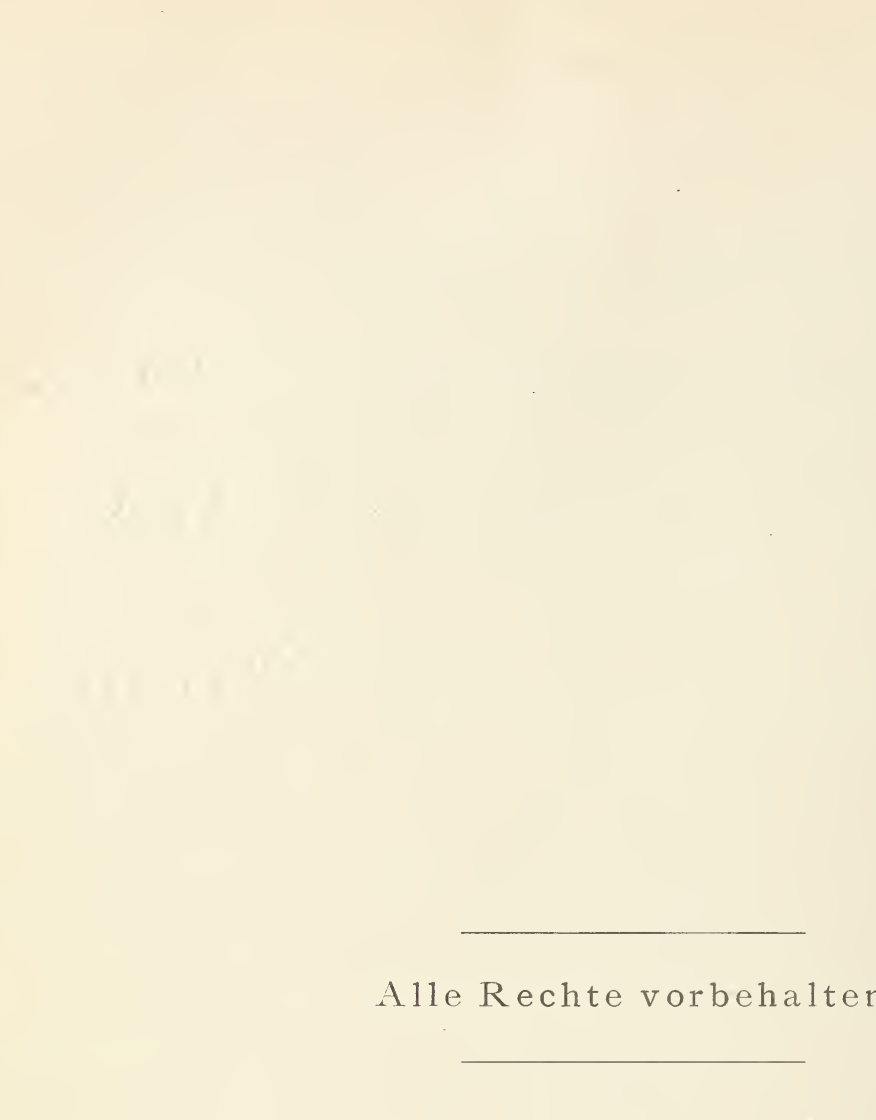

\title{
(n)
}

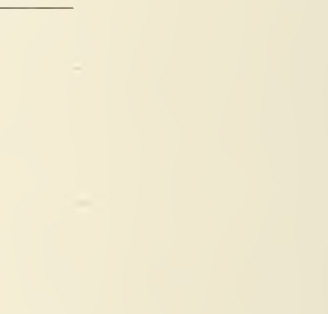

y




\section{Vorwort.}

Dieses Buch bildet den Anfang eines Versuches, die Systematik der Gewächse für Studenten in solcher Form zu bieten, daß sie zu selbständigem Nachdenken und Untersuchungen über die Verwandtschaft der Organismen gebracht werden.

Es enthält die vom Verf. an den Reichsuniversitäten in Leiden und zum Teil in Utrecht gehaltenen Vorlesungen. Der Autor gehört nicht zu denen, welche meinen, für die Veröffentlichung von "Vorlesungen“ um Entschuldigung bitten zu müssen; seiner Ansicht nach steckt gerade in "Vorlesungen" eine Menge nicht gerade angenehmer Literaturarbeit, welche bei dem beschränkten Hörerkreise einer Universität keinen entsprechenden Nutzen abwirft, welche aber durch Veröffentlichung der "Vorlesungen" vielen anderen Arbeit ersparen kann.

Dem vorliegenden Bande, die Algen und Pilze behandelnd, werden zwei weitere Bände, deren einer die Archegoniaten, und deren anderer die Phanerogamen behandeln wird, möglichst bald folgen.

Der Plan zu diesem Werke wurde gefaßt und die Ausführung angefangen nach der Lektüre einer Vorlesung von Hugo de VRIES, in welcher eine höhere Pflanze als ein Doppelwesen betrachtet wurde. Dies führte Verf. dazu, ganz theoretisch nachzuspüren, in welcher Weise die Rückkehr zum ursprünglichen Zustande des Einzelwesens stattfand, und brachte ihn zum Aufstellen seiner Begriffe der $\mathrm{x}$ - und der $2 \mathrm{x}$ Generation.

Im vorliegenden Bande wird man überall das Bestreben finden, festzustellen, was $\mathrm{x}$ - und was $2 \mathrm{x}$-Generation ist. Als sich meine Literaturstudien ausdehnten, fand ich, daß zumal Dangeard und Maire bereits ähnliche Auffassungen verkündet hatten, so daß derselbe Gedanke wieder einmal in verschiedenen Köpfen entstanden ist.

Das ist übrigens selbstverständlich, und erwähne ich dies hier nur, um nicht den Eindruck zu erwecken, als wollte ich mir irgend eine Priorität in dieser Angelegenheit zusprechen.

Als ich den Plan dieses Buches bereits in großen Zügen ausgearbeitet hatte, und schon ein Teil der Algen geschrieben war, erschien OLtmains schönes Algenbuch, das meine Arbeit wesentlich erleichtert hat, und dem ich vieles entnommen habe. Dem Leser, der sich näher über die Algen unterrichten möchte, sei dieses Buch aufs angelegentlichste empfohlen. Möge ihm bald ein ähnliches über die Pilze folgen! 
Vorliegender Band soll mit einem anderen Maßstab als der OLTMannssche gemessen werden, letzterer ist das Resultat jahrzehntelanger Arbeit eines Spezialforschers, dieser nur eine schnelle Durcharbeitung: der vorliegenden Literatur, welche in den derzeitigen Stand der Wissenschaft einführen und zu weiteren Forschungen reizen soll.

Dementsprechend ist der Spekulation ein großer, aber, wie der Autor hofft, nicht ein zu großer Platz eingeräumt.

Sollte das Buch der Pflanzensystematik neue Freunde erwerben, oder jüngeren Forschern einen besseren Einblick in die brennenden Fragen der Systematik geben, oder auch nur diesem oder jenem Arbeit ersparen und dadurch mehr Zeit zu neuer Forschung geben, so wäre der Autor für seine Mühe belohnt.

Daß bei dem großen Umfang der Aufgabe sich hier und dort Ungenauigkeiten finden werden, ist wohl zweifellos, für Vorschläge zur Verbesserung wäre der Autor seinen Fachgenossen dankbar. Die Figuren sind Reproduktionen von farbigen Wandtafeln, zum Teil vom Verfasser, zum weitaus größten Teilè aber von Fräulein C. Ritsema gezeichnet und vom Verf. bei seinen Vorlesungen benutzt; sie sind also sämtlich etwas schematisch. S Schließlich möchte ich nicht verfehlen, Herrn BuRGEFF in Jena für das Lesen der Korrekturen und Herrn Dr. Jongmans in Leiden für die Herstellung des Registers meinen besten Dank anszusprechen.

Kleine Ehre im Juni 1906.

A lm en

J. P. Lotsy. 


\section{Erste Vorlesung.}

Meine Damen und Herren! Als Sie sich hierher begaben, um Vo1lesungen über Systematische Botanik zu hören, konnten Sie erwarten, in erster Linie eine Definition des Begriffes „Pflanze“ zu vernehmen, da ohne eine solche Ihnen Betrachtungen über das Pflanzenreich mit Recht ganz vag vorkommen müssen.

Dennoch ist es in der Tat äußerst schwer, eine Definition dieses Begriffes zu geben. Sogar einen allgemeineren Begriff, den Begriff „Lebewesen, zu definieren, ist gar nicht leicht, und erst vor einigen Jahren gelang es Herbert Spencer, diesen Begriff dahin zu begrenzen, daß man unter Leben das Vermögen, die inneren Bedingungen stets den äußeren zu adjustieren, zu verstehen habe.

Eine sorgfältige Vergleichung der Eigenschaften von lebenden Wesen und leblosen Gegenständen wird Sie lehren, wie richtig Spencers Definition ist.

Ich brauche nun wohl kaum zu betonen, daß eine Pflanze ein Lebewesen ist; eine der Haupteigenschaften der Lebewesen, das Vermögen zur Vermehrung, besitzt sie in ausgiebigem Maße, und sie wird also bereits dadurch als lebendig charakterisiert. Die Schwierigkeit, welcher wir begegnen, liegt also nicht in der Abtrennung der Lebewesen von der leblosen Welt, sondern in der Sonderung der Lebewesen in Pflanzen und Tiere.

Seit uralten Zeiten hat man die Lebewesen in Pflanzen und Tiere eingeteilt, und dieser erste systematische Versuch enthielt bereits den ersten systematischen Fehler. Denn diese erste systematische Einteilung ist, wie Sie alsbald sehen werden, falsch; es gibt zwischen Pflanzen und Tieren keine scharfe Grenze.

Ich sehe, in Gedanken, bereits einige von Ihnen ungläubig schmunzeln, denn schwerlich können Sie sich eine Verwechselung eines Baumes mit einem Pferde vorstellen, und an zwei recht charakteristische Verschiedenheiten zwischen beiden denkend, neigen Sie vielleicht der Meinung zu, daß die Unbeweglichkeit des einen und die Beweglichkeit des anderen ein Maß für Tier- oder Pflanzennatur bilden könne. 
In der Tat bewegen die Pflanzen, welche Sie gewohnt sind zu betrachten, sich nicht von der Stelle, während die Tiere, welche wir tagtäglich um uns herum sehen, dies wohl tun. Ich brauche aber nur das Bild von Tieren wie Actinien und Austern heraufzurufen, um Sie daran zu erinnern, daß auch im Tierreiche Formen vorkommen, welche dermaßen ihrem Heim ergeben sind, daß sie mit Recht festgewurzelt heißen dürfen.

Auf der anderen Seite zeigt uns ein Blick in die mikroskopische Pflanzenwelt, daß da hochgradig bewegliche Wesen vorkommen, und daß viele dieser in kurzer Zeit eine beträchtliche Strecke zurücklegen können.

Eine andere auf der Hand liegende Differenz, aus der Erfahrung herangezogen, daß wir zwar viele grüne Pflanzen, aber keine grünell Tiere im täglichen Leben kennen, hat zu der Meinung geführt, daß Pflanzen sich als chlorophyllhaltige, Tiere sich als chlorophyllose Organismen definieren lassen; dadurch scheidet man aber die ganze Gruppe der Pilze aus dem Pflanzenreich aus, eine Verbannung, welche Sie wohl nicht befürworten möchten, während überdies, noch ganz abgesehen von der Verwandtschaft zwischen dem Chlorophyll und dem Farbstoff der roten Blutkörperchen, bei gewissen Tieren ein grüner Farbstoff gefunden wird.

Als man tiefer in das Wesen der Pflanzen und Tiere eindrang, versuchte man in der allgemeinen Verbreitung der Cellulose im Pflanzenreich und der vermuteten völligen Abwesenheit dieser Substanz im Tierreich ein Mittel zur Unterscheidung zwischen beiden Reichen zu finden. Aber auch dies mißlang, indem gewisse Pflanzen keine Cellulose, gewisse Tiere aber, die Tunicaten, in ihrem Mantel Cellulose abscheiden.

Ein letzter Versuch wurde gemacht, indem man Tiere definierte als Lebewesen, welche feste Substanz zu ihrer Ernährung aufnehmen können, Pflanzen als solche, welche nicht dazu im stande sind.

Auch dieser Versuch litt Schiffbruch, als es sich herausstellte, daß viele Tiere, z. B. Bandwürmer, keine feste Nahrung aufnehmen können, während gewisse Organismen, welche man gewöhnlich zu den Pflanzen stellt, die Myxomyceten, wohl dazu im stande sind.

Während schließlich das Auffinden gewisser niedriger Lebewesen diese Unterscheidung ganz über den Haufen warf; gibt es doch Organismen, welche, je nach Umständen, Chlorophyll besitzen und dann ihre eigene Nahrung bereiten, farblos sind und dann, wiederum nach Umständen, vorbereitete Nahrung in flüssigem oder festem Zustande zu sich nehmen.

Also bei einem Individuum ausgesprochen „tierische“ und „pflanzliche“ Ernährung. Mit der Entdeckung solcher Wesen wurde dem Suchen nach einem durchgehenden Unterschied zwischen Pflanzen- und Tierreich auf immer ein Ende gemacht.

In der Tat gelangen wir bei der Suche nach immer niedrigeren Lebewesen zuletzt zur Gruppe der Flagellaten, deren Repräsentanten sowohl tierische wie pflanzliche Eigenschaften besitzen, und es liegt auf der Hand, die Mitglieder dieser Gesellschaft als die gemeinsamen Ahnen von Tieren und Pflanzen zu betrachten.

Als solche genügen sie auch einer Anforderung, welche wir an die ersten Lebewesen auf der Erde stellen müssen, nämlich das Vermögen zu besitzen, im Wasser zu leben; denn wie wenig wir auch von dem ersten Auftreten des Lebens auf der Erde wissen, so weisen doch ver- 
schiedene und zahlreiche Umstände darauf hin, daß das Leben im Wasser entstand.

Durch eine einfache Ueberlegung können wir eine Grundeigenschaft der ersten Lebewesen feststellen: sie müssen im stande gewesen sein, aus anorganischen Substanzen ihre Nahrung zu bereiten, denn selbstverständlich komnten die ersten Lebewesen nicht die Körper ron anderen Lebewesen als Nahrung benutzen.

Nachdem man zu dieser Ueberzengung gekommen war, hat man lange Zeit gemeint, damit eine andere Eigenschaft der er'sten Lebewesen feststellen zu können. Unter den rezenten Lebewesen, welche man damals kannte, waren nur die gefärbten, und zwar vorwiegend die grünen, im stande, ihre Nahrung aus anorganischen Substanzen zu bereiten, und so meinte man schließen zu dürfen, daß auch die ersten Lebewesen gefärbt gewesen seien. Als aber farblose Pflanzen, niedrige Bakterien, wie z. B. Nitromonas, entdeckt wurden, welche ebenfalls aus anorganischer Substanz ihre Nahrung bereiten konnten, war nichts mehr dariiber auszusagen, ob die ersten Lebewesen gefärbt gewesen sind oder nicht.

Wir haben oben absichtlich immer geredet von der Bereitung der Nahrung aus anorganischen Substanzen und nicht von Ernährung mittels anorganischer Substanz, denn letzterer Ausdruck ist nicht ganz richtig, wie aus folgendem hervorgehen wird.

Stellt man einer grünen Pflanze in der Form geeigneter anorganischer Salze die Elemente C, H, O, N, S, P und Fe nebst Sonnenlicht und Wärme zur Verfügung, so kommt sie damit vollkommen aus, während ein höheres Tier oder eine höhere farblose Pflanze, etwa ein Hutpilz, bei gleicher Diät den Hungertod stirbt.

Die grüne Pflanze besitzt nämlich in ihren Chlorophyllkörnern kleine, aber ausgezeichnet ausgerüstete chemische Laboratorien, welche aus der Kohlensäure der Luft und aus dem von den Wurzeln herbeigeschafften Wasser Stärke bilden können und letzteres in Verbindung mit Nitraten in Eiweißsubstanzen umzubilden verstehen.

Darum hört man öfters, die grüne Pflanze lebe von anorganischer, das Tier von organischer Nahrung.

Dies trifft aber nicht zu: beide, Tier und Pflanze, leben von organischer Nahrung, aber die grüne Pflanze kann diese Nahrung synthetisch im Licht - photosynthetisch also - selbst bereiten, während das Tier von anderen Lebewesen, seien sie nun lebendig oder tot, die nötige Nahrung entnehmen muß.

Niemand wird sagen wollen, daß ein Chemiker, der synthetisch bereiteten Zucker ißt, von anorganischer Substanz lebt; die grüne Pflanze tut dies auch nicht, der einzige Unterschied zwischen ihr und dem Chemiker ist, daß dieser zur Synthese in sein Laboratorium gehen muß, während jene zahlreiche chemische Laboratorien in der Form von Chlorophyllkörnern bei sich führt.

Wir bemerkten bereits, daß wir jetzt auch farblose Pflänzchen kennen, welche ihre eigene Nahrung bereiten, und daß also die ersten Lebewesen recht gut farblos gewesen sein können.

Wir müssen also unter den jetzt lebenden Organismen die einfachsten als die den Urlebewesen am nächsten stehenden betrachten, also jene Gruppe, welche den Namen: Protomastigina trägt.

Diese Protomastigina bestehen aus einem einfachen Protoplasmaklümpchen mit einem Zellkern. Wie sehr verschieden nun auch die 
verschiedenen Pflanzen und Tiere sind, so stimmen sie doch alle darin überein, daß in ihrem Lebenscyklus ein Stadium vorkommt, auf welchem sie aus einem ähnlichen, einfachen, kernhaltigen Protoplasmaklümpchen bestehen.

Es ist eben das Leben an ein solches Klümpchen gebunden.

Protoplasma ist eine zäh-schleimige Flüssigkeit, welche eine Schaumstruktur besitzt und aus eiweißartigen Substanzen besteht; es ist der Träger des Lebens.

Ohne Protoplasma kein Leben, ist ein Satz, den wir ruhig vertreten können; wir können wohl hinzufügen: ohne Kern ${ }^{1}$ ) kein vollkommenes Leben, denn bei Beseitigung des Kernes hören gewisse Lebensfunktionen auf.

Der Kern ist ein rundes Körperchen, das sich im Plasma befindet und außer gewissen Eiweißsubstanzen, Nukleinen, einen hohen Gehalt an gewissen anorganischen Substanzen, z. B. Phosphor, aufweist. Wo Kern und Protoplasma eigentlich erst zusammen ein Ganzes bilden, und da dieses Ganze das Vermögen hat, Energie zu entwickeln (selbstverständlich aus äußeren Energiequellen entliehen), hat SACHS vorgeschlagen, diese Kombination mit dem Namen: Energide zu belegen.

Die allereinfachsten Organismen, wie z. B. jene Protomastigina, bestehen nun aus einer einzigen Energide. Diese kann sich mittels Teilung in zwei Energiden spalten, diese wiederum u. s. w. Während nun bei diesen einfachsten Organismen die Tochterenergiden sofort nach ihrer Bildung auseinandergehen und jede für sich ihren Weg verfolgt, findet eine solche Trennung bei den höheren Lebewesen nicht statt. Auch sie bestehen, wir erwähnten dies ja bereits, in einem gewissen Moment ihres. Daseins aus einer einzigen Energide; auch bei ihnen teilt sich diese Energide, aber die jungen Energiden trennen sich nicht; sie bleiben zusammen und bilden eine Kolonie. Je mehr Teilungen stattfinden und je öfter sich diese wiederholen, desto größer wird selbstverständlich der Energidenkomplex, der Körper des betreffenden Lebewesens.

Während sowohl bei den niedrigsten wie bei den höchsten Lebewesen die Energiden mikroskopisch klein sind, sind die höheren Lebewesen für das unbewaffnete Auge sichtbar, die niedrigsten nicht. Dies kommt nun daher, daß die höheren Lebewesen aus zahllosen Energiden bestehen, die niedrigen aus einigen wenigen oder gar nur aus einer einzigen. Die Energiden aber, welche z. B. einen Elefanten zusammenstellen, sind jede für sich nicht größer als die Energide, welche ganz. allein eine Protomastigine darstellt.

"Größe" hängt also der Hauptsache nach von der Zahl der den Körper zusammenstellenden Energiden ab.

Selbstverständlich muß bei den Wesen, welche nur aus einer einzigen Energide bestehen, diese Energide im stande sein, sämtliche Lebensfunktionen auszuüben; erst bei den höheren Lebewesen findet zwischen den verschiedenen Energiden eine Arbeitsteilung statt, und verlieren gewisse Energiden das Vermögen, gewisse Funktionen auszuüben, während sie sich im Gegenteil in der Ausübung anderer Funktionen auszubilden. verstehen.

Ebenso ist in der primitiven menschlichen Gesellschaft jedermann im stande - in primitiver Weise - das Land zu bearbeiten, ein Haus

1) Damit soll nicht gesagt werden, daß ein morphologisch ausgebildeter Kern unumgänglich notwendig ist; schon die Anwesenheit von durch das Plasma verbreiteten Nukleinen. scheint bisweilen zu genügen. 
zu bauen, als Arzt zu fungieren. während in unserer gebildeten Gemeinschaft ein Arzt keine Hänser zu bauen versteht, ein Maurer kein Land bearbeiten und ein Bauer die Heilkunst nicht ausüben kann; aber jeder kennt seinen eigenen Beruf, weit besser als der Wilde, der in allem ein wenig bewandert war. Ebenso wie in dem Staat die Vervollkommmung durch Spezialisierung des einzelnen stattfindet, so findet auch im Pflanzen- und Tierkörper Terrollkommnung' mittels Spezialisierung der einzelnen Energiden statt.

Beim mono-energiden Wesen muß die Energide Nahrung verzehren, Licht wahrnehmen, ITärme perzipieren, während in unserem Körper die Energiden des Magenepithels weder Wärme noch Licht perzipieren, aber ausgezeichnet verdauen, die Energiden der Retina des Auges sehr begierig Licht wahmehmen, aber nicht den g'eringsten Wert auf die Darreichung eines Tellers Suppe legen; die Energiden der Hautpapillen verspüren leicht Temperaturdifferenzen, können aber keinen Unterschied zwischen Licht und Finsternis wahrnehmen.

So ist die ganze Vervollkommumng, die ganze Entwickelung des Pflanzenreiches die Folge des Zusammenbleibens der ursprünglich sich sofort trennenden Energiden und des Umstandes, daß unter diesen Energiden eine Arbeitsteilung stattfindet. Dadurch sind jene zahllosen Pflanzenformen, welche wir um uns herum sehen, entstanden, und es ist die Aufgabe der Systematik, zu verfolgen, wie sich diese niedrigen Organismen zu höheren entwickelt haben, wie diese letzteren aus den ersteren entstanden sind, also den Grad der Verwandtschaft festzustellen, oder mit anderen Worten die Systematik als Stammesgeschichte zu betreiben.

Es bringt uns dies zu unserer eigentlichen Aufgabe. Beim Aufstellen des Stammbaumes werden wir die niedrigsten Organismen unten, die höheren stets höher einsetzen.

Ich will jetzt versuchen, zunächst einen ganz kurzen Stammbaum des ganzen Pflanzenreiches zu entwerfen.

\section{(Stammbaum siehe p. 6.)?}

Die Protomastigina, welche wir als die nächsten Verwandten der ersten Lebewesen betrachten, sind farblose, mittels Cilien umherschwimmende Organismen ohne Zellwand. Ihr Körper ist öfters im stande, amöboide Bewegungen zu machen. Nachkommen von diesen haben die Eigenschaft erhalten, verschiedene Farbstoffe zu bilden in 4 verschiedenen Farben: grün, gelbbraun, rot und blaugrün. Diese Organismen bilden die große Gruppe der Flagellaten. Von diesen haben die Euglenoidina es nicht weiter bringen können. Aus einer anderen Flagellatengruppe, der der Polyblepharideen [Pyramidomonas], ist durch Kolonienbildung und Spezialisierung der Energiden ein großer Teil der sogenannten grünen Algen hervorgegangen, und zwar die Isokonten, von welchen sich dann später die kleine Gruppe der Akonten abgezweigt hat. Von einer anderen Gruppe der Grünalgen, von den Stepkanolionten, kennen wir keine Flagellaten-Ahnen, sie sind also direkt von den Protomastiginen abzuleiten, während der übrig bleibende Teil der Grünalgen. die Gruppe der Heterokonten, in den Chloromonaden wurzelt.

Aus den Isokonten sind weiter die Charophyten und Archegoniaten und aus diesen schließlich die höheren Pflanzen. die Spermaphyta, hervorgegangen, so daß der Hauptstamm der Pflanzen folgenden Verlauf 


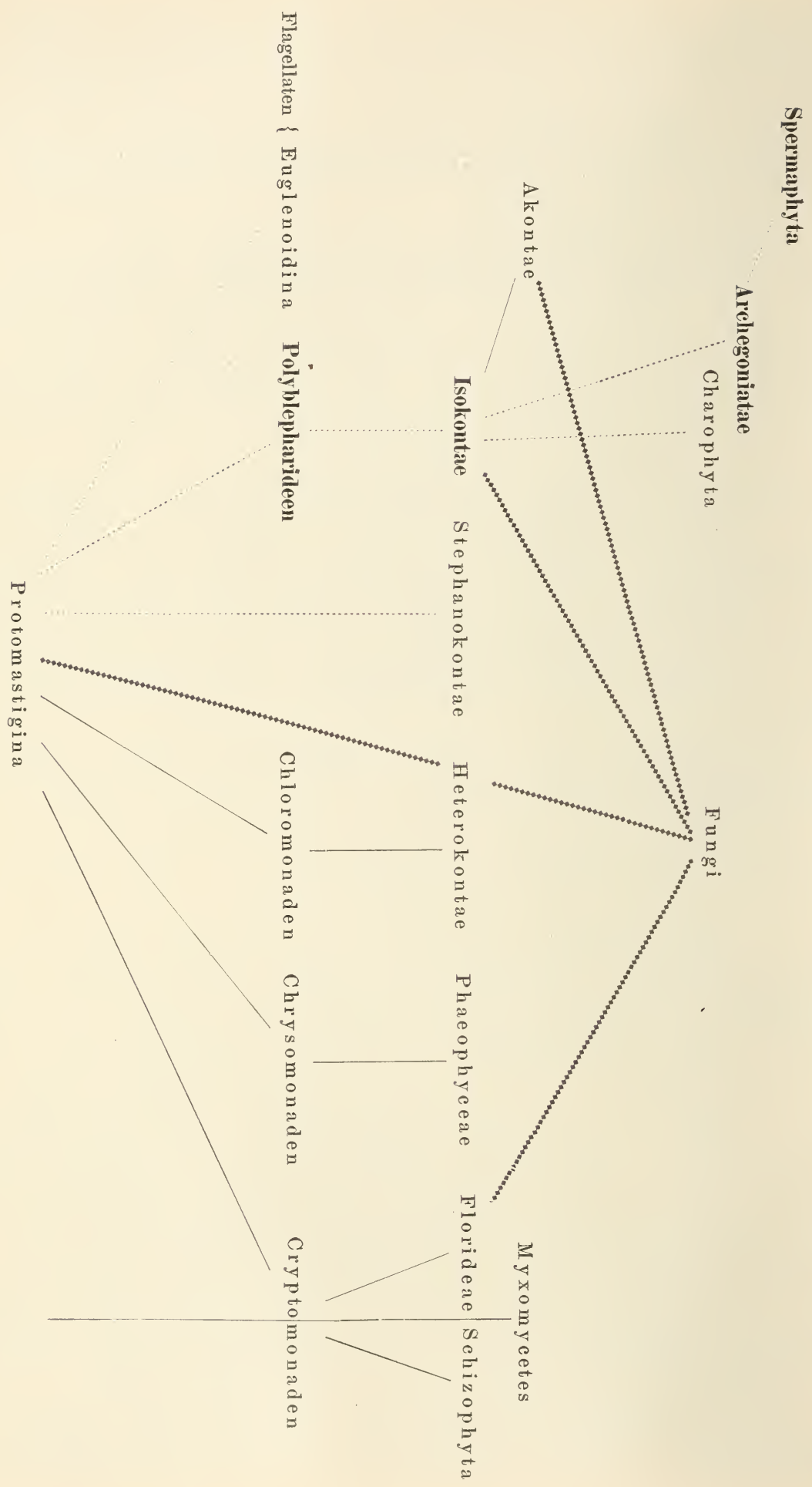


hat: Protomastigina - Polyblepharideae - Isokontae - Archegoniatae - Spermaphyta.

Aus der gelbbramen Flagellatengruppe der Chrysomonaden sind die Phïophyceen hervorgegangen, deren niedrigere Repräsentanten von den Peridineen und Diatomeen gebildet werden und welche in Fucus ihren Höhepunkt 'erreichen.

Die Flagellatengruppe der Cryptomonaden enthält verschieden gefärbte Organismen, aus den roten sind die Florideen, aus den blaugrünen die Schirophyten abzuleiten, aber hier ist der Anschluß noch recht problematisch.

Alle bis jetzt genannten Pflanzengruppen können mittels Photosynthese ihre eigene Nahrung bereiten; es bleiben noch 2 große Gruppen des Pflanzenreichs, welche nicht dazu im stande sind, zu betrachten: die Fungi einerseits und die Baliterien und Myxobaliterien andererseits; letztere beiden bilden mit den Blaualgen die Gruppe der Schizophyten, deren blaugrüne Repräsentanten den Namen Schirophyceen oder Cyanophyceen tragen; die erstere, die der Fungi, ist eine recht heterogene Gruppe verschiedener Abstammung - polyphyletischen Ursprungs welche in Alionten, Isokonten, Protomastiginen und Florideen wurzelt. Der Tollständigkeit wegen sei noch der Gruppe der Myxomyceten g'edacht, welche meiner Anschauung nach eigentlich tierischer Natur ist und von Amöben abgeleitet werden muß.

Selbstverständlich können Sie die Tragkraft dieser Auseinandersetzung jetzt noch nicht ermessen; die detailliertere Behandlung, zu welcher wir jetzt übergehen, wird uns die ganze übrige Zeit, welche für diese Vorträge zur Verfügung steht, beschäftigen, und wenn Sie am Ende derselben diesen Stammbaum in seinen großen Zügen werden verstanden haben, rechne ich mich für meine Mühe reichlich belohnt.

Beschäftigen wir uns zunächst mit der Gruppe der Isokonten. Diese Gruppe der Grünalgen kann von dem Flagellatengenus Pyramidomonas abgeleitet werden.

\section{Isokonten.}

Sämtliche Isokonten, wie verschieden die dazu gehörigen Formen auch sein mögen, haben ein gemeinsames Merkmal. Sie bestehen an irgend einem Momente ihres Daseins aus einer einzelnen Energide, welche 2 (selten 4) gleichlange Cilien trägt. Bei den niedrigsten Arten des Genus Chlamydomonas besitzt diese Energide noch eine Zellwand während eines Teiles ihres Daseins; bei allen übrigen Isokonten ist sie dauernd nackt. Der Körper besteht selbstverständlich aus einer kernhaltigen Protoplasmamasse (Fig. 1). Ein bestimmter,

Fig. 1. Isokontenschwärmer. C.V. kontraktile Vakuolen. S. Stigma oder Augenfleck. K. Kern oder Nucleus. Chr. Chromatophor. $P$. Pyrenoid.

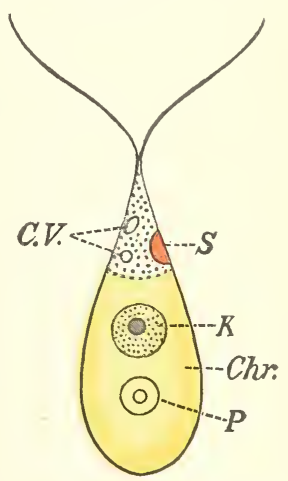

öfters kappenförmiger Teil des Plasmas zeigt eine dichtere Struktur als der' übrige und ist grün gefärbt; diesen Teil nennen wir das Chromatophor. An einer Stelle des Chromatophors befindet sich ein rundes, dunkler gefärbtes Körperchen, von einer helleren Zone umgeben, dieses nennen 
wir das Pyrenoid. Das Pyrenoid ist ein wichtiges Organ der Pflanze. Schmiтz (1884), welcher es zuerst beschrieb, meinte, daß der Körper des Pyrenoids zu Stärke umgebildet werden könnte, aber daß diese Stärke auch in anderen Teilen des Chromatophors entstehen könnte. Meyer (1883) hält die Pyrenoide für Proteidkristalloiden und Schimper (1883, 1885) glaubt mit MEYER, daß sie kristalloider Natur sind, aber glaubt dennoch, daß sie in irgend einer Verbindung mit der Stärkebildung stehen.

Bei Hydrodictyon versuchte KLEBs (1891) einen Unterschied zwischen Pyrenoiden-Stärke und Stroma-Stärke nachzuweisen, aber TimBERLAKE (1901) meint, daß auch die Stroma-Stärke von den Pyrenoiden herrührt, und daß das Pyrenoid ein Stärkebildner par excellence ist, welcher seine eiweißartig’e Substanz zu Stärkekörnern umbildet (vergl. Fig. 23, p. 43).

Das Pyrenoid ist also ein sehr wichtiges Organ. Das erste Produkt der Photosynthese, welches bei der Umsetzung der Kohlensäure gebildet wird, ist noch gänzlich unbekannt, offenbar aber geht es mit dem Körper des Pyrenoids irgend eine Verbindung ein, wodurch dieses in Stärke umgesetzt wird.

Vorn ist die begeißelte Energide, die Schwärmspore, zugespitzt und trägt auf dieser Spitze 2 gleichlange Cilien, mit deren Hilfe sie sich durch das Wasser hin fortbewegt. Dabei werden diese Cilien schnell rückwärts geschlagen und langsam unter geringerem Ausschlag wieder nach vorn gebracht, wodurch sich also die Schwärmspore, mit dem spitzen farblosen Ende nach vorn gerichtet, vorwärts bewegt.

Im farblosen Teil der Schwärmspore finden sich weiter 2 kontraktile Vakuolen, das sind 2 Bläschen, welche sich rhythmisch zusammenziehen und entspannen; ihre Funktion ist noch nicht recht klar.

Schließlich liegt an der Grenze des farblosen und des gefärbten Plasmas, oder wohl auch auf dem Chromatophor, ein rot gefärbter Fleck, der sogenannte Augenfleck oder das Stigma, welcher dem Schwärmer erlaubt, verschiedene Lichtintensitäten zu perzipieren.

Wie wir bereits sahen, macht jeder Isokont ein Schwärmsporenstadium durch, und es liegt also auf der Hand, Organismen, welche zeitlebens aus einem solchen Schwärmer bestehen, als die vermutlichen Ahnen der Isokonten zu betrachten. Unter den Flagellaten gibt es nun, in der Gruppe der Polyblepharideen, das Genus

\section{Pyramidlomonas,}

welches zeitlebens auf dieser niedrigen Stufe verharrt, und dies ist der Grund, daß wir Pyramidomonas als einen Organismus betrachten, welcher den vermutlichen Ahnen der Isokonten näher steht als irgend ein anderer Organismus. Pyramidomonas (Fig. 2) besitzt keine eigentliche Zellwand, ein Cellulosereaktion ist nicht zu erzielen; der Körper ist einfach von einer etwas starren protoplasmatischen Hautschicht umgeben. Der Körper hat die Form eines Kegels, dessen Spitze etwas abgerundet ist, während sich an der Basis 4 breite Rippen erkennen lassen. Das Chromatophor ist tief becherförmig, nach vorne hin vierlappig, welche Lappen in die Rippen hineinragen; ein Kern, ein Pyrenoid, ein Stigma und 2 kontraktile Vakuolen sind vorhanden.

Der Organismus schwimmt mittels 4 Cilien. Die Fortpflanzung findet in höchst einfacher Weise durch Längsteilung statt. Dabei teilen sich zunächst Chromatophor und Pyrenoid; der Nucleus soll sich erst nachträglich teilen. Die Teilung fängt am hinteren, spitzen Ende an 
und schreitet von dort allmählich vorwärts. Durch diesen Teilung'smodus wïrden die Tochterindividuen statt $t$ nur 2 Cilien erhalten, wemn nicht kurz vor vollendeter Teilumg jede Hälfte 2 neue Cilien hervorbrächte. Ton den 4 Cilien eines Pyramidomonas sind also immer 2 älter als die beiden übrigen. Tährend der Teilung wird die Beweg'ung des Pflänzchens nicht unterbrochen.

Unter gewissen, wohl meistens ungünstigen Lebensbedingungen rundet sich Pyramidomonas ab und umgibt sich mit einer schützenden festen Membran; verbessern sich die Beding'ung'en, so zerbricht el diese und schlüpft heraus.

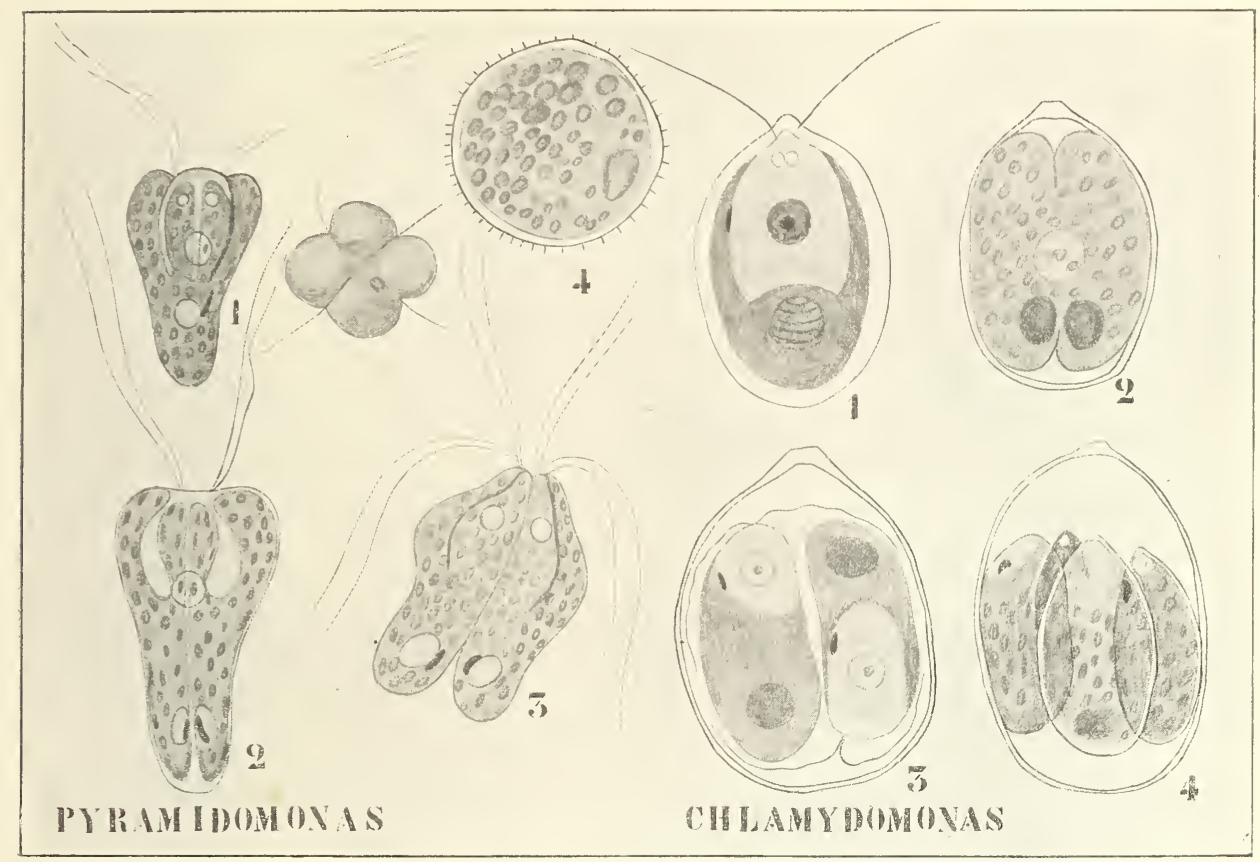

Fig. 2. I. Pyramidomonas tetrarhynchus (nach DiLL). 1 Ein Individuum: links von der Seite, rechts von oben betrachtet. 2 und 3 Teilungsstadien, 2 vor, 3 nach der Regeneration der Cilien. 4 Ein encystiertes Individuum. - II. Chlamydomonas (nach Gokoschankiv). 1 Gefärbtes Individuum, becherförmiges, unten verdicktes Chromatophor, Pyrenoid, Kern, Stigma, kontraktile Vakuolen, Cilien und Cellulosewand zeigend. 2, 3 und 4 Teilungsstadien eines zur Ruhe gekommenen Individuums.

Pyramidomonas ist also ein äußerst einfaches Wesen; mono-energid, frei schwimmend, sich durch einfache Längsteilung vermehrend und jeder anderen Fortpflanzungsweise entbehrend, im stande, unter ungünstigen Bedingungen das Leben durch Einkapselung zu retten, besitzt es nur die unentbehrlichsten Existenzmittel, ein Dasein, welches ïberdies durch die Abwesenheit einer schützenden Nembran während des regetativen Lebens stündlich gefährdet ist.

In dieser Hinsicht ist das niedrigste Isokontengenus

\section{Chlamydomonas}

weit besser ausgerüstet. Betrachten wir dieses höchst interessante Geschlecht etwas näher: der Bau der Energide ist der Hauptsache nach 
dem von Pyramidomonas gleich; Chromatophor, Pyrenoid, Nucleus, Stigma und kontraktile Vakuolen sind vorhanden, überdies aber besitzt Chlamydomonas eine schützende Cellulosemembran, die Zelle ist entstanden!

Während sich Pyramidomonas noch während des Herumschwimmens teilt, tritt Chlamydomonas zur Ausführung dieses interessanten Vorganges zunächst in einen Ruhezustand ein, indem er die Cilien verliert und unbeweglich wird. Dann teilt sich der Inhalt, die Energide, durch ein oder zwei Längsteilungen in 2 oder 4 Tochterenergiden, welche, nachdem sie je 2 Cilien und eine feste Cellulosemembran gebildet haben, aus der Hülle des Mutterindividuums ausschlüpfen.

Während man also bei Pyramidomonas eigentlich nicht von Mutter und Kindern reden kann, da nach der Teilung nichts übrig bleibt, haben wir hier in dem Zurückbleiben der Hülle des alten Individuums eine erste Andeutung einer Mutter. Das ist aber nicht der einzige, sogar nicht der wichtigste Unterschied zwischen Chlamydomonas und Pyramidomonas; während es bei letzterem nur eine Fortpflanzungsweise gibt, die vegetative T'eilung, hat Chlamydomonas überdies einen Vermehrungsmodus aufzuweisen, welchen wir mit dem Namen: geschlechtliche Fortpflanzung belegen. Im Gegensatz dazu nennen wir dann die vegetative Teilung die ungeschlechtliche Fortpflanzung.

Während sich also Pyramidomonas nur ungeschlechtlich zu vermehren vermag, kann Chlamydomonas sich sowohl ungeschlechtlich wie geschlechtlich fortpflanzen, und damit tritt er aus der Gruppe der Flagellaten heraus, denn bei der ganzen Flagellatengruppe ist keine geschlechtliche Fortpflanzung vorhanden.

Während sich bei der ungeschlechtlichen Fortpflanzung das Mutterindividuum in 2-4 Tochterindividuen teilt, spaltet sich als Vorbereitung zur geschlechtlichen Fortpflanzung das Mutterindividuum in 8-32 Stücke, welche sich von den ungeschlechtlich erzeugten Individuen jedoch nur durch ihre geringere Größe unterscheiden.

Während nun ein ungeschlechtlich entstandenes Individuum ohne weiteres seine Entwickelung fortsetzen kann, können sich diese geschlehtlichen Fortpflanzungszellen oder Gameten nicht unabhängig entwickeln; isoliert man eine solche Gamete, so geht sie zu Grunde.

Nur wenn 2 Gameten zusammenkommen, ist Entwickelung möglich (Fig. 3).

Man sieht, daß die Gameten (Fig. 34 ) sich zunächst, ohne irgend welche Notiz voneinander zu nehmen, durch die Flüssigkeit bewegen. Kommen aber 2 Gameten, von verschiedenen Individuen erzeugt ${ }^{1}$ ), nahe zu einander, so nimmt die Schnelligkeit der Bewegung ab; sie drehen umeinander herum, werfen ihre Cellulosemembran ab und verwirren sich mit den Cilien. Alsbald verschmelzen die Plasmakörper zu einer Masse, diese rundet sich ab, die Cilien werden abgeworfen, und das Ganze umgibt sich mit einer festen Membran. Dieses Verschmelzungsprodukt von 2 Gameten wird Zygote genannt.

Die Zygote bildet alsbald einen roten Farbstoff aus, welcher die grüne Farbe völlig verdeckt, während die Membran dicker wird und feinere Skulpturen angelegt werden. Nach einer längeren oder kürzeren Ruheperiode fängt die Zygote an zu keimen. Diese Keimung äußert

1) oder auch wenn sie vom selben Individuum erzeugt wurden? Weder GonoscHANKIN noch DILL lassen sich darüber aus. 
sich dahin, daß die Membran sich stark dehnt und der Inhalt der Zygote sich in t-s Stücke teilt, deren jedes sich mit einer Membran umgibt und, indem es die inzwischen verschleimte Zygotenwand durchbricht, wegschwimmt. Diese jungen Chlamydomonaspflänzchen sind in keiner Weise von den auf ungeschlechtlichem Wege entstandenen zu unterscheiden.

Dennoch gibt es zwischen beiden einen wichtigen Unterschied, denn während die ungeschlechtlich erzeugten Pflänzchen bloß eine Mutter haben, besitzen die geschlechtlich erzeugten, wenigstens wenn die Gameten verschiedenen Individuen entstammen, einen Vater und eine Mutter.

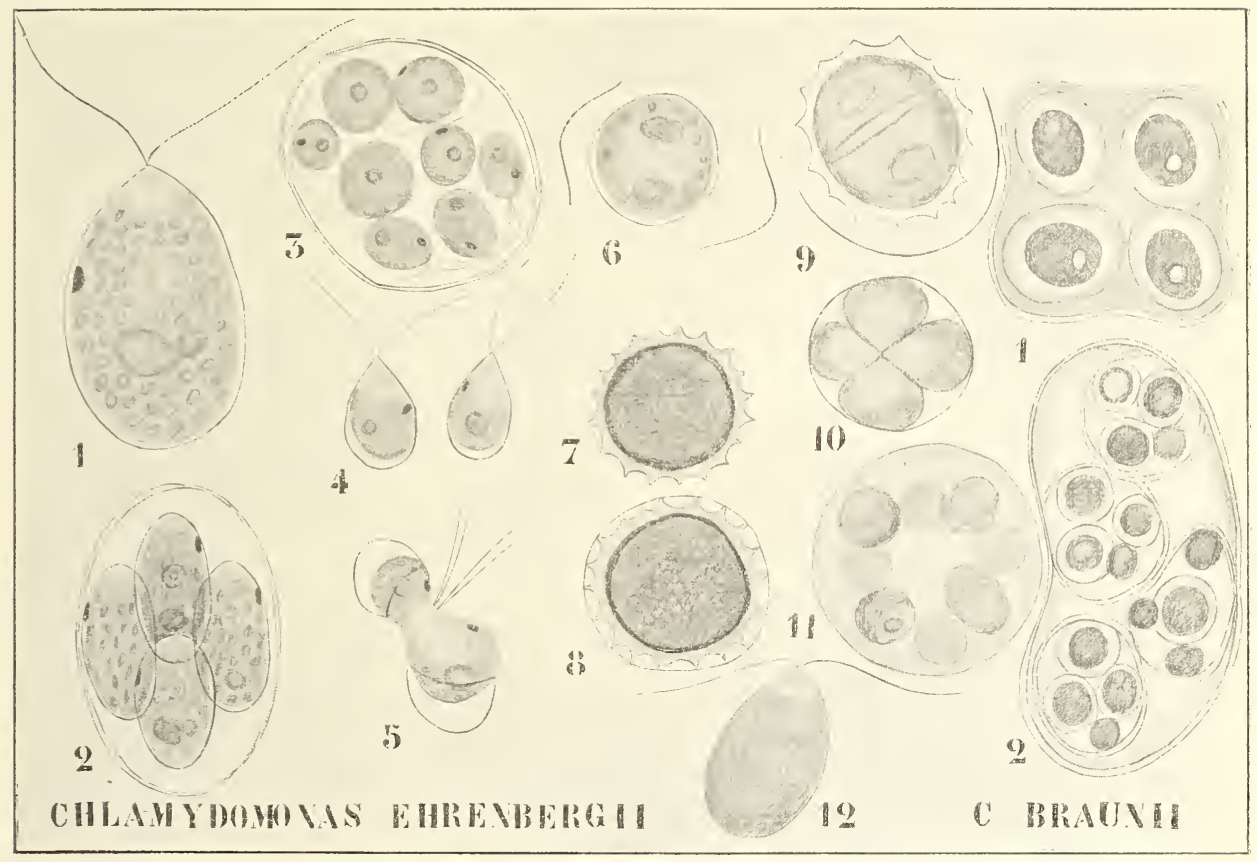

Fig. 3. I. Chlamydomonas Ehrenbergii (nach GoroschankIN). 1 Vegetatives Stadium. 2 und 3 Gametenbildung. 4 Gameten. 5 Kopulation der Gameten. 6 Junge Zygote zwischen den abgestreiften Membranen der Gameten. 7 und 8 Ausbildung der Zygotenmembran und des roten Oeles. 9, 10, 11 Keimung der Zygote. 12 Aus der Zygote entstandenes Individuum. - II. Chlamydomonas Braunii (nach Goroschankin). 1, 2 Palmellastadien.

Erstere können also nur die Eigenschaften der Mutter ererben, letztere solche vom Vater und von der Mutter erhalten.

In der Zygote werden also die Eigenschaften des Vaters mit denen der Mutter gemischt, das steht fest. Es fragt sich nun, ob dabei ein Mittelding zwischen Vater und Mutter entsteht, ob also die individuellen Verschiedenheiten zwischen beiden ausgeglichen werden, die Art also konstant gehalten wird, oder ob durch diese Mischung neue Eigenschaften entstehen können.

Da die Verschiedenheiten zwischen zwei Individuen einer Rasse zu gering sind, um sie bei den Kindern auseinanderhalten zu können, hat 
man zur Lösung dieser Frag'e die Erzeugung von Kindern zwischen zwei leicht zu unterscheidenden Varietäten oder Arten veranlaßt: solche Kinder nennt man Bastarde oder Hybriden.

Man hat nun gefunden, daß bei gewissen Hybriden der Bastard ein Zwischending zwischen Vater und Mutter ist, daß da also durch die Mischung der Eigenschaften der Eltern zu einer Nivellierung der beiderseitigen Differenzen geschritten wird, was also, falls sich dies ohne weiteres auf die legitime Vereinigung zweier Individuen der gleichen Rasse übertragen ließe, zur Konstanz beitragen würde.

Bei anderen Bastarden aber zeigen die Nachkommen in gewisser Hinsicht ganz den Charakter des Vaters, in anderer ganz den der Mutter.

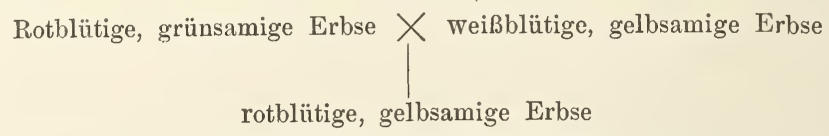

Kreuzt man z. B. eine rotblütige, grünsamige Erbse mit einer weißblütigen und gelbsamigen, so hat der Bastard die roten Blüten des einen Elters und die gelben Samen des anderen.

In der Blütenfarbe gleicht er also z. B. dem Vater, in der Samenfarbe der Mutter.

Es dominiert also nicht einfach im Bastard der eine oder der andere Elter, sondern die Eigenschaften der Eltern bekämpfen sich in der Zygote, und in diesem Kampf siegt das eine Mal eine väterliche Eigenschaft, das andere Mal eine mütterliche.

In wieder anderen Fällen kann der Bastard in allen Eigenschaften entweder dem Vater oder der Mutter gleichen, während in gewissen Fällen Eigenschaften auftreten können, welche weder vom Vater noch von der Mutter gezeigt wurden; in jenen Fällen tritt aber meistens keine ganz neue Eigenschaft auf, sondern es gelangt irgend eine latente Eigenschaft der Eltern zur Entwickelung.

Das einzige, was sich also von der geschlechtlichen Fortpflanzung sagen läßt, ist, daß dabei eine Mischung der einzeln en Eigenschaften der Eltern stattfindet, welche wenigstens unter Umständen zu einer besseren Eigenschaftenkombination führen kann, eine Kombinationsbesserung, welche also dem betreffenden Individuum einen Vorzug im Kampf ums Dasein verleiht.

Gesetzt den Fall, es hätte z. B. ein Vater-Chlamydomonas eine dicke schleimige Membran, welche ihn gegen Schneckenfraß schützte; er kann aber nur schlecht Kälte vertragen; seine Gameten paaren sich mit denen einer Mutter-Chlamydomonas mit dünner Membran, aber großer Kälteresistenz, so könnte das Kind die Schleimmembran des Vaters und die Kälteresistenz der Mutter erben, und diese neue Eigenschaftenkombination wäre offenbar eine nützliche.

Die Verschmelzung von verschiedenen Individuen entstammenden Gameten kann also einen rechı nützlichen Effekt haben, aber wir kennen auch Fälle, wo Gameten, von einem einzigen Individuum erzeugt, miteinander kopulieren. Dadurch kann keine neue Eigenschaftskombination entstehen, überdies kann überhaupt das nützliche Resultat nie ein Erklärungsgrund für die Ursache irgend eines Vorganges sein, und bleibt also die Ursache der Gametenkopulation noch zu erforschen.

Man hat nun verschiedentlich versucht, dieses Auftreten zu erklären. VAn ReEs und DangeARD suchen die Erklärung in einem Hungerzustand der Gameten, welcher sie dazu führt, eine andere Gamete zu fressen; 
diese hat aber die gleiche Neigung, und so fressen sie sich gegenseitig, d. h. rerschmelzen miteinander. Tie phantastisch dies nun auch auf den ersten Blick scheinen mag, so haben doch Kuess' Untersuchungen gezeigt. daß vieles für diese Auffassung spricht.

Ǩ EBs zeigte nämlich. daß, solange man Chlamydomonas in einer 0,t-proz. Kropschen Lösung kultiviert, die Pflanze sich nur ungeschlechtlich fortpflanzt: bringt man sie aber in destilliertes Wasser, so werden sofort Gameten gebildet, welche kopulieren und eine Zygote bilden. Isoliert man eine Gamete in einem Gläschen mit destilliertem Wasser, so geht diese zu Grunde; gibt man dieser Einsamen aber neue Nährlösung, so kann sie sich ohne Kopulation zu einer neuen Pflanze entwickeln.

Die Stillung des Hung'ers, ob diese num durch Kopulation mit einer anderen Gamete oder durch die Erhaltung neuer Nährlösung geschieht, ist also die Ursache der Entwickelungsmöglichkeit der Gameten, und so kann „Hunger" die erste Veranlassung zum Auftreten einer geschlechtlichen Fortpflanzung gewesen sein.

Nachdem die Plasmakörper der Gameten miteinander verschmolzen sind. fängt eine andere Verschmelzung an, und zwar eine höchst wichtige: die Kerne der beiden Gameten verschmelzen und bilden den Zygotenkern.

Wie rerschieden nun auch bei den verschiedenen Pflanzen- und Tierklassen die Fortpflanzungszellen sind und welche Mittel auch zum Zusammenbringen dieser Zellen führen mögen, der Zweck ist immer derselbe: die Terschmelzung eines Kernes des Vaters und eines der Mutter. Wo 2 gleiche Gameten, wie bei Chlamydomonas, miteinander verschmelzen, besitzt die eine einen Vater-, die andere einen Mutterkern, aber auch wenn, wie bei den Säugetieren, eine Eizelle mit einem Spermatozoon verschmilzt, verschmelzen miteinander ein Vater- und ein Mutterkern. Das Spermatozoon besteht, mit Ausnahme des Schwanzes, fast ganz aus einem vom Vater herrührenden Kern, und nicht der Schwanz, sondern nur der Kern tritt in die Eizelle ein und verschmilzt dort mit dem Kern der Eizelle, welcher also von der Mutter herrührt.

Da nun das Wesentliche der geschlechtlichen Fortpflanzung in der Vermischung der väterlichen und mütterlichen Eigenschaften besteht, liegt es auf der Hand, die Kerne für die Träger jener Eigenschaften zu halten.

Der Beweis wurde von Boveri und LoEB erbracht.

Es ist zur Entwickelung eines Seeigeleies dessen Verschmelzung mit einem Spermatozoon nicht unumgänglich notwendig. Dazu genügte bereits, eine Veränderung im osmotischen Druck zu veranlassen. Ein in dieser Weise parthenogenetisch ${ }^{1}$ ) entstandenes Wesen kann selbstverständlich nur mütterliche Eigenschaften besitzen. BoverI kam nun auf den Gedanken, den Eikern zu entfernen und durch den Spermatozoenkern $\mathrm{zu}$ ersetzen und zu versuchen, ob er nun das Ei mit dem männlichen Kern sich parthenogenetisch entwickeln lassen könne. Falls dies gelänge, würde ein Tier mit nur väterlichen Eigenschaften entstehen müssen. Um nun den Einfluß der Operation besser verfolgen zu können, wollte er den Eikern nicht durch einen Spermakern der gleichen Seeigelart, sondern durch einen einer anderen ersetzen. Er wollte also sozusagen ein kernloses Ei hybridisieren und sehen, ob nun diese Hybride eine wirkliche Hybride sein würde, oder ob sie nur väterliche Eigenschaften besäße.

1) d. h. also ohne Befruchtung. 
Dieser schwierige Versuch gelang vollkommen, und es war also bewiesen, daß durch Entfernung des Einucleus Tiere mit rein väterlichen Eigenschaften geboren werden können, daß es also der Nucleus ist, welcher bestimmt, was aus dem Plasma gemacht werden wird, daß das Plasma nur Baumaterial, der Kern der Baumeister ist.

Daraus folgt also daß der Kern der Träger der erblichen Eigenschaften ist, und daher rührt es, daß bei dem Vorgang, bei welchem die Eigenschaften zweier Individuen gemischt werden, bei der geschlechtlichen Vermischung oder Befruchtung, immer zwei Kerne miteinander verschmelzen.

Kehren wir jetzt zur Chlamydomonas zurück. Ihre Fortpflanzung ist, wie wir sahen, geschlechtlich und ungeschlechtlich; während des vegetativen Lebens schwimmen die Individuen frei herum. Bisweilen aber treten bei allen Chlamydomonasarten Ruhezustände auf: die Individuen verlieren ihre Cilien, umgeben sich mit dicken Schleimhüllen und teilen sich in diesem Zustand; so entstehen eingeschachtelte Individuengenerationen, von welchen jedes Individuum sich wieder mit einer Schleimhülle umgibt.

So rührt auf Fig. 3, in der unteren rechten Figur, die äußere Membran von der Großmutter her, die Membranen, welche die Vierergruppen umgeben, gehörten den Müttern, während die Individuen selber die Kinder sind. Hier sind also drei Generationen vorhanden, von denen zwei nur durch ihre Membranen repräsentiert sind.

Solche Ruhezustände hat man, ihrer Aehnlichkeit mit dem Isokontengenus Palmella wegen: Palmellastadien genannt. Sie finden sich gelegentlich bei Algen der verschiedensten Verwandtschaftskreise.

Trotzdem nun bei allen Chlamydomonasarten, die geschlechtliche Fortpflanzung mittels Gametenkopulation stattfindet, so gibt es doch wichtige Unterschiede in der Weise des Zusammentrittes der Gameten, Unterschiede gerade deswegen so wichtig, weil solche Kopulationsverschiedenheiten bei den höheren Gruppen immer mit Familienverschiedenheiten gepaart sind und also dort verwendet werden zur Trennung und Charakterisierung große1 Gruppen.

In dieser Hinsicht besitzt also Chlamydomonas eine ganze Reihe potentieller Möglichkeiten, welche bei ihren Nachkommen realisiert wurden.

Bei den primitivsten Formen, wie $C$. longistigma, finden wir Isogameten, d. h. Gameten gleicher Größe, welche mit einer Cellulosemembran bekleidet sind. Nachdem sie ihre Cilien eingehakt haben, schlüpfen sie aus ihren Membranen aus und fangen sofort an miteinander zu verschmelzen.

Es gibt hier also keinen morphologischen Unterschied zwischen männlichen und weiblichen Gameten; bei $C$. Braunii hingegen finden wir größere weibliche und kleinere männliche Gameten, also bereits eine Andeutung der Eier und Spermatozoen der höheren Gewächse. Solche Gameten nennt man im Gegensatz zu den Isogameten: Heterogameten.

Bei B. Braunii entstehen diese Makro- und Mikrogameten stets in verschiedenen Individuen, so daß wir hier von männlichen und weiblichen Pflanzen reden können.

Wenn nun eine Mikrogamete in die Nähe einer Makrogamete gelangt, verwickeln sich alsbald deren Cilien, aber die Gameten werfen ihre Membranen nicht ab, nur an den Stellen, wo sie einander berühren, werden diese gelöst, es entsteht also in beiden Membranen ein Loch, 
durch welches der Inhalt der Mikrogamete in die Makrogamete tritt, dort verschmelzen die beiden Kerme, die Zygote zieht sich zusammen, rumdet sich ab und bildet eine Membran, welche also innerhalb der Thand der Makrogamete lieg't.

Wrir haben hier demnach eine Kopulation, welche in gewisser Hinsicht der ron Spirogyra ähnlich sieht.

Bei wieder einer anderen Chlamydomonasart, bei der $C$. Steinii sind die Gameten rom Anfang an nackt, sie entbehren einer Cellulosemembran. Diese nackten Gameten verschmelzen miteinander zu einer, anfang's

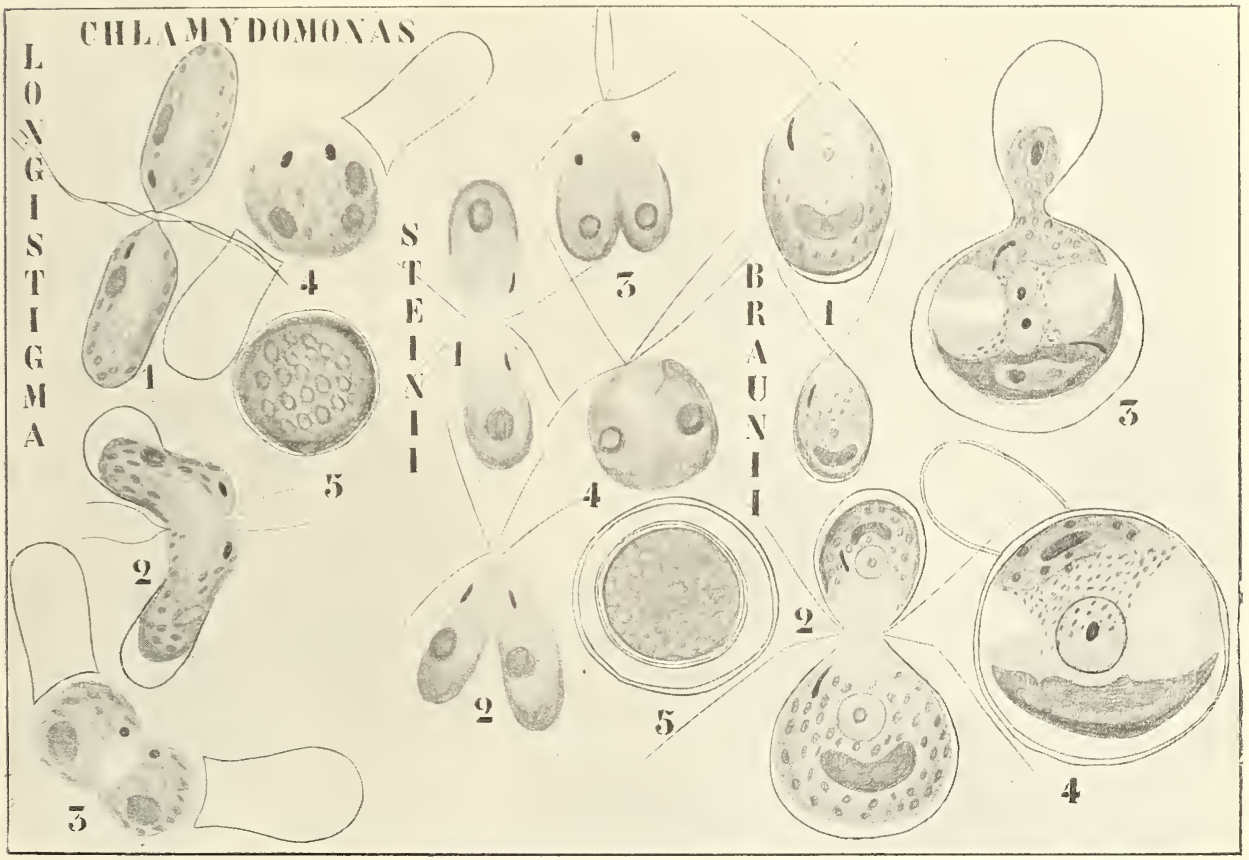

Fig. 4. Nach Will und Goroschankin. I. Ch la m ydomonas longistigma Dill. 1 Begegnung der Gameten. 2 Die Gameten fangen an auszuschlüpfen und zu verschmelzen. 3, 4 Kopulation der Energiden, die Membranen liegen dicht bei der Zygote. 5 Die Zygote hat Membran und roten Farbstoff gebildet. - II. Chl. Steinii. 1, 2, 3, 4 Verschiedene Kopulationsstadien nackter Gameten. 5 Die mit einer Doppelmembran umgebene Zygote. III. Chl. Bra unii. 1 Die Heterogamie zeigend, die große Gamete ist die weibliche. 2 Kopulation der Gameten und Verwachsung ihrer Membranen an der Spitze, wodurch ein Kopulationskanal gebildet wird. 3, 4 Der Inhalt der männlichen Gamete tritt in die weibliche über, Verschmelzung der Kerne.

noch beweglichen Zygote, welche aber alsbald zur Ruhe kommt, sich abrundet und sich mit einer Membran umgibt.

Hier tritt nun jene Form der Isogametenkopulation auf, welche in der ganzen Isokontenreihe herrscht; die Gameten der Isokonten sind nämlich immer nackt.

Wenn wir uns jetzt zurechtlegen wollen, wie aus einer Stammform, wie Chlamydomonas, die höheren Isokonten entstanden sind, so können wir uns á priori drei Möglichkeiten denken:

Die Zelle kann ihre Beweglichkeit beibehalten, aber, indem sich die Tochterzellen nicht voneinander trennen, Kolonien bilden; da jedes der 
die Kolonie zusammensetzenden Individuen Cilien besitzt, würde durch das Zusammenwirken dieser Cilien auch die Kolonie beweglich sein.

Eine zweite Möglichkeit ist dadurch gegeben, daß zwar die Tochterzellen miteinander in Verbindung bleiben könnten, ihre Beweglichkeit aber verlieren. Fände dabei die Teilung nur in einer Raumrichtung statt, so entständen Zellenfäden; fände sie in zwei Richtungen des Raumes statt, so entständen Platten; in drei: Körper. Durch Verzweigung der Fäden könnten dann Büschel entstehen.

Eine dritte Möglichkeit ist folgende: Die unbeweglich gewordene Zelle wächst zu einer Röhre heran, innerhalb dieser Röhre vermehren

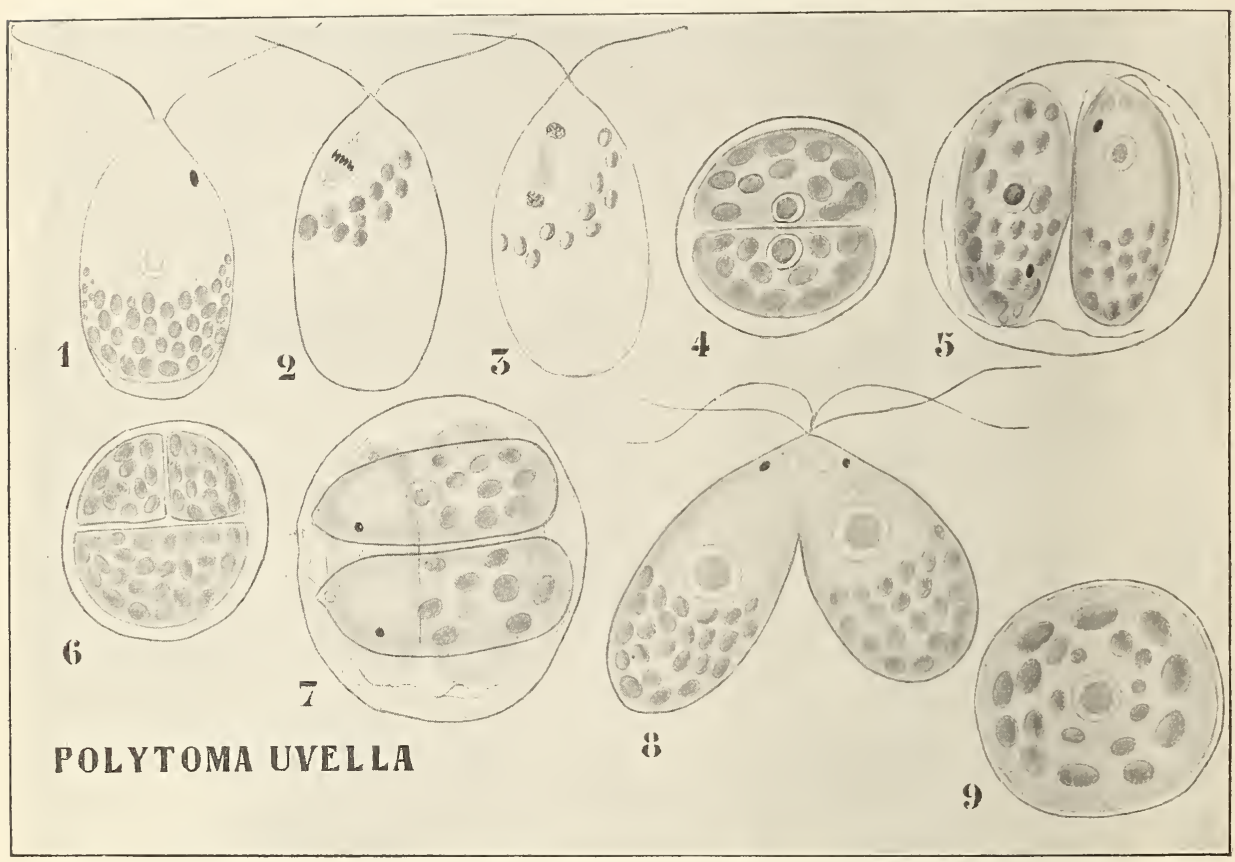

Fig. 5. (2 3 nach DANGEARD, die übrigen nach FrANCÉ.) Polytoma uvella. 1 Vegetatives Exemplar, mit Nucleus, Stärke, 2 kontraktilen Vakuolen und Stigma. 2, 3 Kernteilung. 4 Die Teilung der Energide nachdem die Zelle zur Ruhe gekommen ist. 5 Die zwei jungen Individuen. 6, 7 Derselbe Vorgang, wenn, statt 2, 4 junge Individuen entstehen. 8 Gametenkopulation. 9 Zygote.

sich die Energiden, wodurch also die Plasmamasse vielkernig wird. Durch Verzweigung, Verflechtung u. s. w. solcher Röhren könnten dann kompliziertere Gebilde entstehen.

Diese drei Möglichkeiten sind nun in der Tat bei den höhern Isokonten realisiert, und auf diese Prinzipien haben Blackman und Tansley (1900-1902) ihr System der grünen Algen aufgebaut, welchem wir uns mit geringen Abänderungen anschließen.

Die Gruppe, welche aus beweglichen Kolonien oder sogenannten Cönobien besteht, ist die der Volvocineae, die Gruppe, deren Repräsentanten aus multicellulären, aber monoenergiden Fäden, Platten und Körpern besteht, ist die der Ulotrichales; diejenige, welche aus langen, öfters röhrenförmigen, von vielen Energiden bewohnten Energiden besteht, ist die Gruppe der Siphonales. 
Folgende Uebersicht mag den erörterten Zusammenhang ilhustrieren:

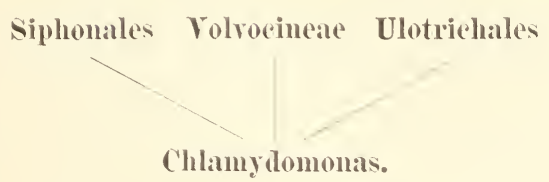

Hierbei ist ein Punkt noch nicht berücksichtigt, nämlich die Anpassung an organische Nahrung und der dadurch herbeigeführte Chlorophyllverlust. TTir haben bereits früher bemerkt, daß dadurch die polyphyletische Gruppe der Pilze entstanden ist. Dieses Anftreten farbloser Formen fängt schon recht früh im Stammbaum an. Wir kemnen bereits ein Pflanzengenus, welches man ruhig als einen farblosen Chlamydomonas betrachten kann. es ist das Genus Polytoma. Umstehende Fig. 5 wird besser als eine lange Beschreibıng die große Uebereinstimmung mit Chlamydomonas zeigen.

ITie wir sehen, ist Polytoma urella ein Chlamydomonas, welchem Chromatophor und Pyrenoid fehlt. Der Organismus kommt häufig in faulenden Flüssigkeiten ror, ich erhielt ihm in Leiden aus Wasser, in welchem Heu faulte. Die Stärke wird nicht durch Photosynthese gebildet, sondern ist eine, aus organischer Nahrung gebildete Reservesubstanz. Es ist Polytoma also ein "Pilz“, der direkt von Chlamydomonas abzuleiten ist.

Gehen wir jetzt zur Betrachtung derjenigen Gruppe über, welche aus beweglichen Zellenkörpern besteht, zu der der Tolvocineen. 


\section{Zweite Vorlesung.}

\section{Die Volvocineae.}

Der erste Schritt, welchen eine Form wie Chlamydomonas auf dem Weg zur höheren Entwickelung machen könnte, wäre das Zusammenbleiben der Tochterindividuen, wodurch eine Kolonie entstehen würde.

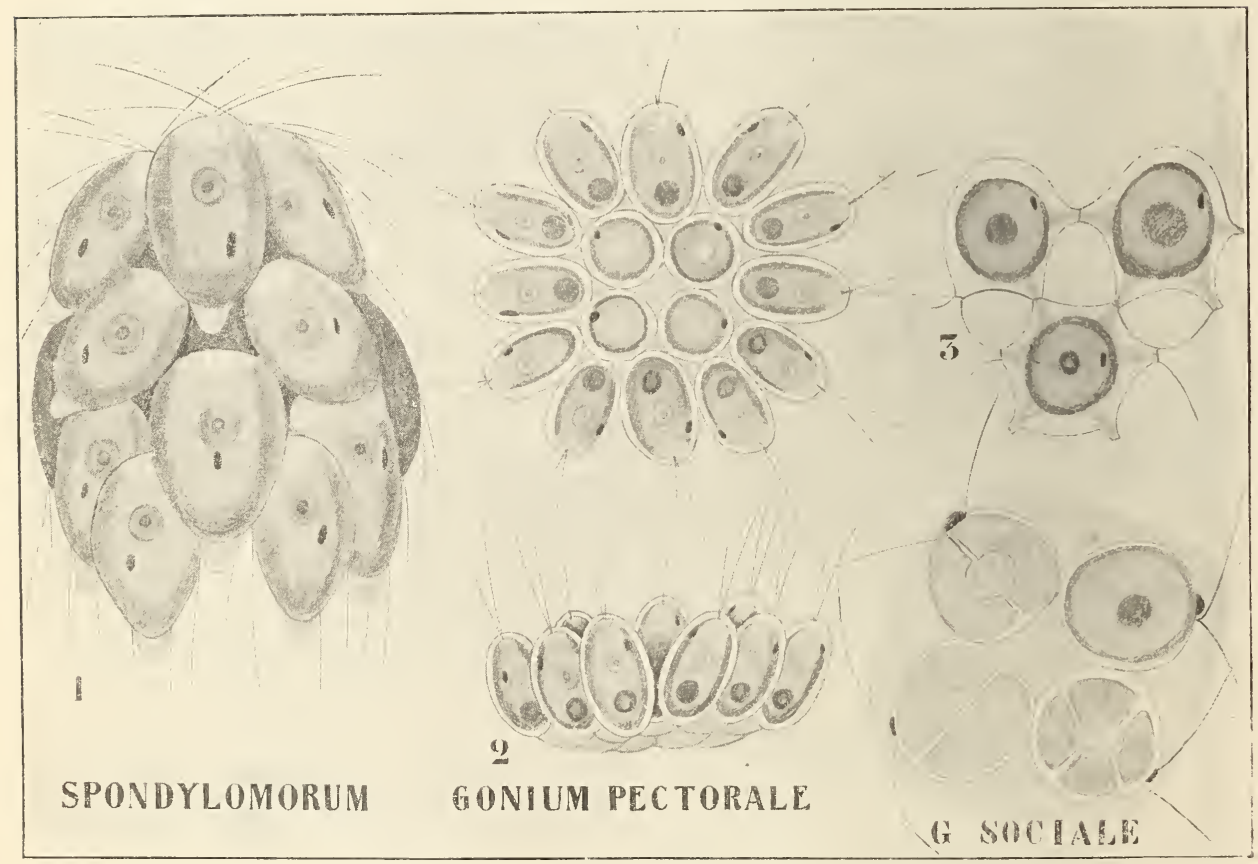

Fig. 6. I. Spondylomorum quaternarium nach Stein. 1 Habitusbild. - II. Gonium pectorale MüLlER, nach STEIN, 2 Eine Kolonie von oben und von der Seite betrachtet. 3 Die Plasmaverbindungen zwischen den Zellen zeigend. - III. Go n i um so ciale (DUJ.) Warm. Eine Kolonie mit ihren Zellen in verschiedenen Teilungsstadien nach CoHN.

In einer solchen Kolonie würde anfänglich der Zusammenhang noch so gering sein, daß die Zellen durch einfachen Druck noch auseinandergehen würden.

Auf dieser Stufe steht das Genus Spondylomorum, welches 
Genus nur eine Art: Spondylomorum quaternarinm enthält, welche im Plankton des Süßwassers in Europa und Asien gefunden wird.

Die Kolonien bestehen aus 16 Inaividuen, welche in 4 alternierenden Kränzen, ein jeder aus 4 Individnen bestehend, um die Länosachse geordnet sind (Fig. 7). Der Bau der einzelnen Individuen ist in allen wesentlichen Teilen wie der von Chlamydomonas, nur besitzen sie, statt 2, 4 Cilien, in welcher Hinsicht sie an Pyramidomonas erinnern. Bei der ungeschlechtlichen Fortpflanzung entsteht in jeder Zelle durch succedane Teilung der Energide ein aus 16 Zellen bestehendes Koloniechen, welches die verschleimende Membran der Nutterzelle durchbricht und fortschwimmt. Eine geschlechtliche Fortpflanzung komnte noch nicht nachgewiesen werden. Die charakteristische Eigenschaft dieser Pflanze ist der ganz geringe Terband zwischen den einzelnen Individuen. Weit vollkommener ist diese beim Genus

\section{Goniunt.}

Die Zellen, welche hier in einer Ebene liegen, verursachen die tafelförmige Gestalt der Kolonien. Die Cilien sind sämtlich nach einer Seite hin gerichtet. Der Bau der einzelnen Zellen ist wesentlich der eines Chlamydomonas. Es gibt 2 Arten, welche beide im Süßwasser Europas vorkommen. Die häufigere von beiden ist jedenfalls das 16-zellig*e Gonium pectorale, welches auch um Leiden häufig ist, während ich das t-zellige Gonium sociale nie gesehen habe. Der bessere Verband zwischen den einzelnen Zellen wird bei Gonium sociale durch eine Gallerthülle, bei $G$. pectorale außerdem noch durch Plasmaverbindungen zwischen den einzelnen Zellen hergestellt.

Bei der ungeschlechtlichen Fortpflanzung teilt sich die Energide der einzelnen Zellen successive

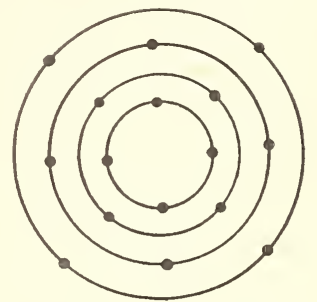

Fig. 7. Schema der Zellanordnung bei Spondylomorum. in so viele Stücke, als die Kolonie, welcher sie angehört, Individuen zählt. Diese treten zu einer Niniaturkolonie zusammen, durchbrechen die verschleimende Membran und schwimmen fort.

Gameten sind noch nicht bekannt, aber das Vorkommen roter, dickwandiger runder Zellen, welche offenbar zu Gonium gehören und sich nur als Zygoten deuten lassen, macht ihr Vorhandensein im höchsten Grade wahrscheinlich.

Weit besser ist in dieser Hinsicht das Genus

\section{Stephanosphaera}

bekannt, dessen einzig'e Art, Stephanosphaera pluvialis CoHs, einige wenige Nale in Regenwasserpfützen gefunden wurde.

Die Kolonien sind aus 8 oder weniger Individuen zusammengesetzt, welche sich um den Aequator einer Schleimkugel herum angeordnet finden. Die Individuen bilden Protoplasmafortsätze, welche jedoch nicht zu einer Verbindung der Individuen, wie bei Gonium, führen.

Bei der ungeschlechtlichen Fortpflanzung bildet sich durch Teilung der Energide eine junge Kolonie in jedem Individuum; bisweilen nehmen aber ein oder mehrere Individuen an der ungeschlechtlichen Fortpflanzung nicht teil. Die jungen Kolonien bestehen aus 2-8 Individuen, durchbrechen die verschleimende Membran der Mutter und schwimmen davon. 
Bei der geschlechtlichen Fortpflanzung zeigt sich ein ganz anderes Bild. Jedes Individuum bildet 4-32 spindelförmige Gameten, deren jede 2 Cilien besitzt und welche öfters bereits innerhalb der Schleimumhüllung der Mutterkolonie kopulieren. Aus der Kopulation entsteht eine runde, rot gefärbte Zygote. Bei der Keimung dieser Zygote entstehen 2-8 Schwärmer, welche Cilien bilden und ausschlüpfen; sie haben die Gestalt eines Individuums einer vegetativen StephanosphaeraKolonie. Diese Schwärmer bilden alsbald eine Schleimhülle und teilen sich, indem sie ein 8-zelliges Täfelchen bilden; durch Auseinanderweichen dieser Zellen entsteht dann der äquatoriale Individuenkranz der Stephanosphaerakolonie.

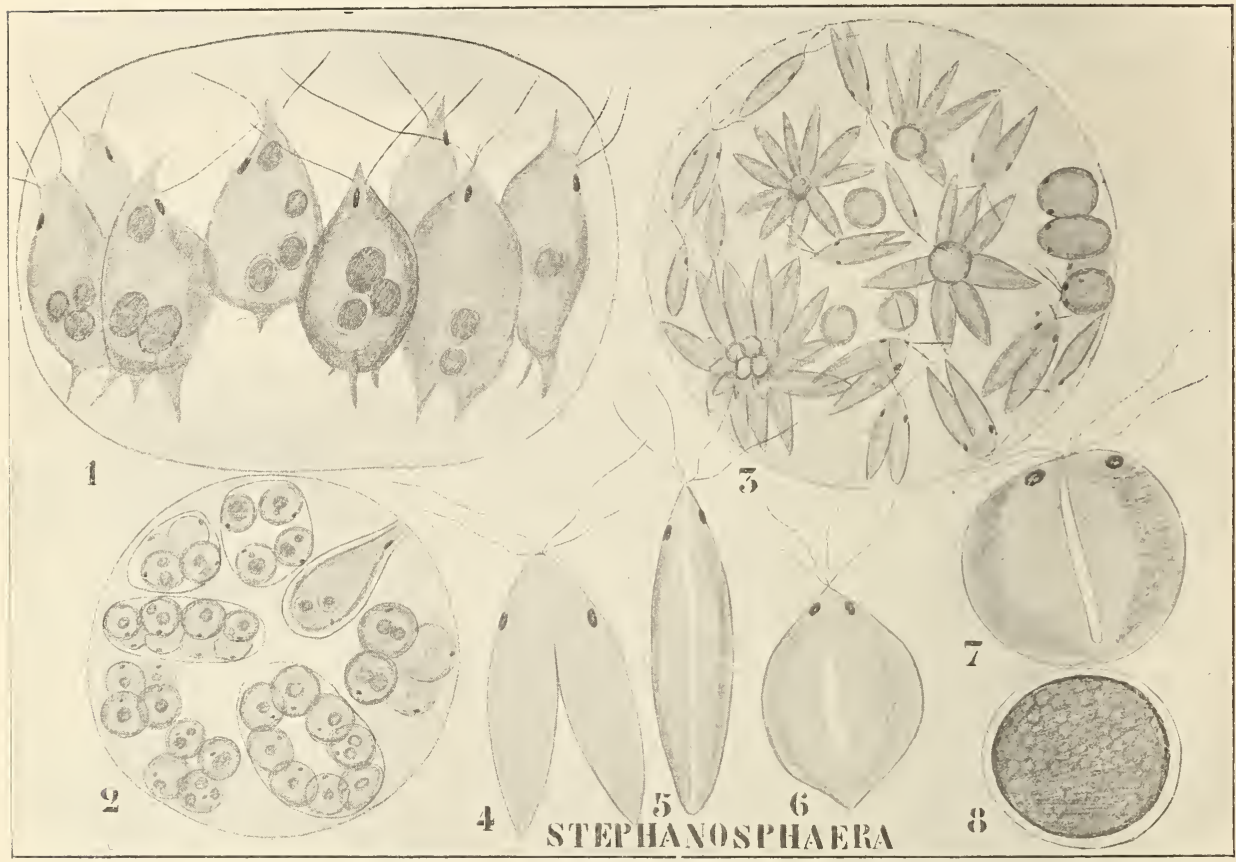

Fig. 8. Stephanosphaera pluvialis CoHn (nach Hienonymos). 1 Vegetative Kolonie, deren Zellen nur wenige Protoplasmafortsätze haben. 2 Eine sich ungeschlechtlich fortpflanzende Kolonie; ein Individuum blieb vegetativ. 3 Gametenbildung in einer geschlechtlichen Kolonie; einige Gameten kopulieren bereits. 4-8 Zygotenbildung aus kopulierenden Isogameten.

Bei Gonium und Stephanosphaera liegen die die Kolonie zusammenstellenden Individuen in einer Ebene; bei den höher entwickelten ist dies nicht mehr der Fall; die Individuen streben offenbar die Anordnung; auf einer Kugeloberfläche an. Während bei den niedrigsten der hierhergehörigen Formen noch Paarung von Isogameten stattfindet, begegnen wir bei den böheren bereits einer Eibefruchtung durch Spermatozoiden, wie z. B. bei

\section{Eudorina.}

Auch Eudorina ist nur durch eine Art repräsentiert, welche aber weitverbreitet ist; sie wurde bis jetzt im Süßwasser Europas, Asiens, Neu- 
Seelands und Nordamerikas gefunden und trägt den Namen Eudorina elegans.

Die Kolonien bestehen aus 32, 16 oder \& Zellen, welche auf einer Kngelobertläche gleichmäßig rerteilt sind. Ein jedes Individum besitzt 2 Cilien.

Die ungeschlechtliche Fortpllanzung findet in folgender Weise statt: Der Inhalt eines jeden Individum teilt sich zunächst einmal und damn durch eine die erste rechtwinklig kreuzende Wand in 4 Stücke (Fig. 10 a). Jetzt tritt in jedem Quadranten eine Antikline auf (Fig. 10b). Es ist dies aber nur schematisch richtig, denn in der Tat haben sich vor der Bildumg der Antiklinen die beiden ersten Scheidewände stumpfwinklig abgebogen (Fig. 10c), und setzen sich die Antiklinen an den so entstandenen

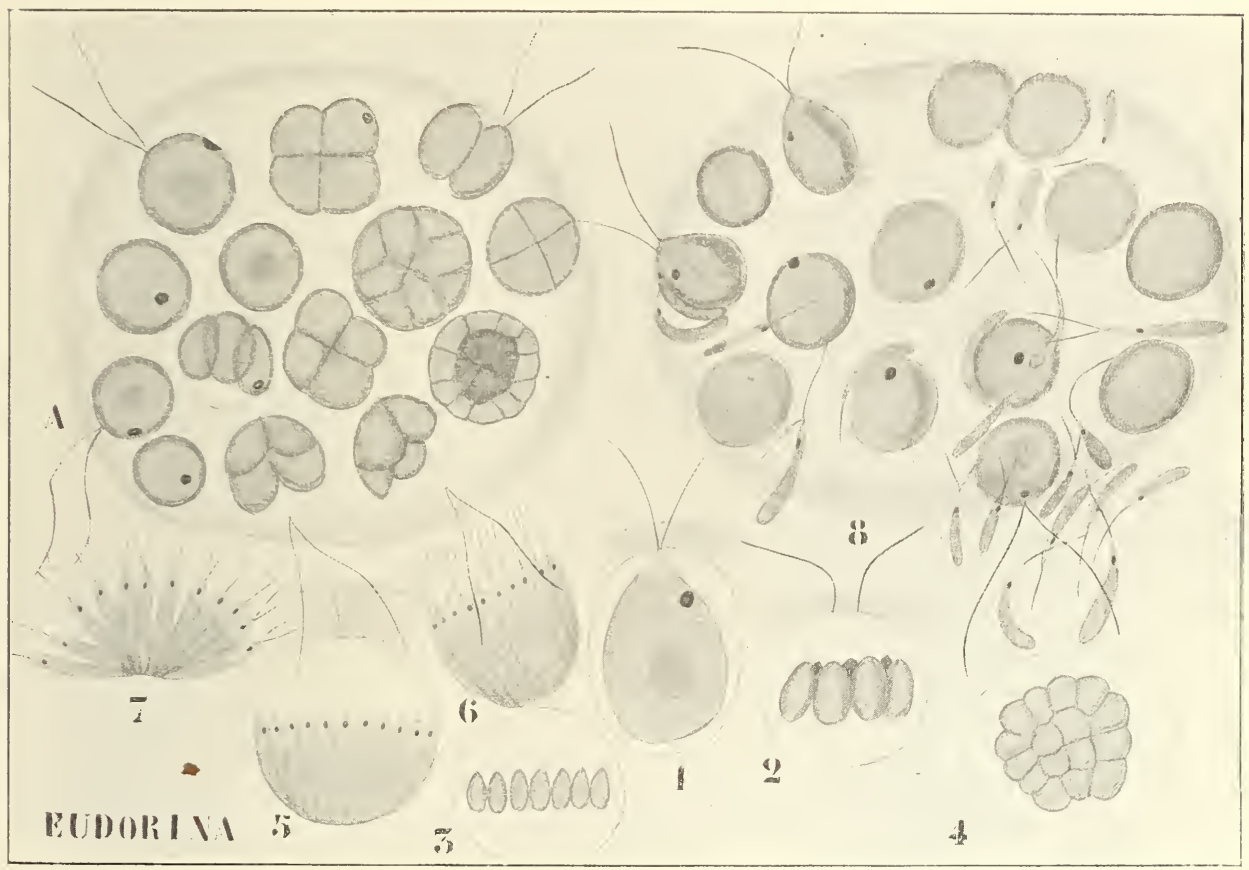

Fig 9. Eudorina elegans nach GoEbEL. A Eine sich ungeschlechtlich fortpflanzende Kolonie; die Gallerthülle ist gequollen. 1 Ein Individuum einer $\delta$ Kolonie. 2-6 Bildung der Spermatozoidentäfelchen. 7 Ein sich in die einzelnen Spermatozoiden spaltendes Spermatozoidentäfelchen. 8 Weibliche Kolonie, welche bereits einen großen Teil ihrer Individuen zu Eiern abgerundet hat und in welche Spermatozoen schon eingedrungen sind.

Ecken an; in dieser Weise bildet sich ein zentrales Kreuz, aus 4 Zellen bestehend (man vergl. auch A der Fig. 9). Jetzt tritt in jeder Zelle eine Perikline auf, wodurch die Länge der Kreuzzellen reduziert wird und ein peripherischer Zellenrand gebildet wird (vergl. Fig. 9 A). Die 4 zentral gelegenen Zellen stellen jetzt ihre Teilungen endgiiltig ein. Die Randzellen fangen aber jetzt an, sich in einer, dem Täfelchem parallelen Richtung zu teilen und bilden so einei hervorstehenden Ringwall; dadurch nimmt das Täfelchen zunächst die Form eines niedrigen Cylinders an. Indem der Ring höher und höher wird, neigen sich die oberen Enden zueinander hin, schließen zuletzt zusammen, und eine Hohlkugel 
ist entstanden. Nachdem die Individuen Cilien gebildet haben, fängt die Kolonie sich zu bewegen an, kommt durch die Auflösung der Gallerthülle der Mutterkolonie frei und kann bereits am Abend ihres Geburtstages neue Tochterkolonien bilden.

Die jungen Kolonien haben also zwei Pole: einen, an welchem die 4 Kreuzzellen liegen, und einen, an welchem die Ränder des napfförmigen Scheibchens zusammengekommen sind.

Die Geschlechtsorgane sind diöcisch verteilt; männliche und weibliche Kolonien werden gebildet.

Die Bildung der Eier in den weiblichen Kolonien geht in überaus einfacher Weise vor sich. Die Individuen werden etwas größer, runden sich $a b$, entfernen sich durch Verschleimung ihrer Membranen etwas voneinander, und die Eizelle ist fertig.

In den Zellen der männlichen Kolonien finden behufs Bildung der Spermatozoen zunächst Teilungen statt, wie jene, welche die Ausbildung ungeschlechtlicher Kolonien einleiten. Weiter als zur Bildung der Zellplatte kommt es aber nicht. Die Zellen der Zellplatte strecken sich jetzt in einer Richtung senkrecht zu derselben und bilden 2 Cilien und einen Augenfleck, während ihre Farbe von Grün zu Orange wechselt.

Das so gebildete, aus 64 spermatozoiden bestehende Bündel fängt bereits innerhalb der Mutterzelle an, sich zu bewegen, durchbricht als-

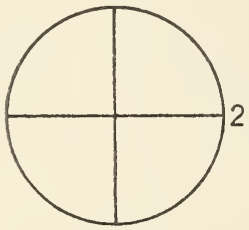

a

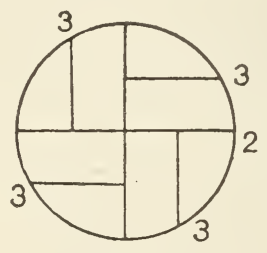

b

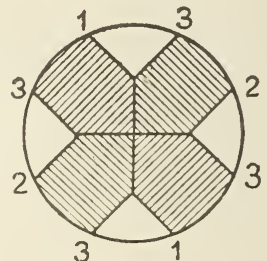

C

Fig. 10 .

bald deren Membran und schwimmt davon. In der Nähe einer weiblichen Kolonie angelangt, werden sie offenbar von dieser angezogen, und das ganze Bündel verwirrt seine Cilien alsbald mit denen der weiblichen Kolonie. Jetzt fällt das Bündel in seine einzelnen Spermatozoen auseinander, welche sich in den Schleim der weiblichen Kolonie hineinbohren und jede für sich mit einem Ei verschmelzen.

Die entstandenen Zygoten umgeben sich mit 2 Membranen und bilden den üblichen roten Farbstoff.

Die Keimung der Zygote ist nicht bekannt, weder GoRoschankin noch Goebel haben sie gesehen; Wille gibt aber an, es soll, ganz ähnlich wie bei der ungeschlechtlichen Fortpflanzung in der Zygote, eine neue Kolonie gebildet werden. Ob dies auf GoebeLs (1. c. p. 43) ausgesprochene Vermutung, daß dem so sei, zurückzuführen ist, weiß ich nicht.

Die am höchsten entwickelte Volvocince ist zweifellos

\section{Volvox,}

von welchem Genus 2 europäische und eine ostindische Art bekannt sind. Wir wählen als Beispiel: 


\section{Volvox minor STEIx.}

$=$ Volvox aurens EhrbG. Bei Volvox minor haben wir mit kugeligen Kiolonien zu tum, welche einen Durchmesser von 170-850 $\mu$ erreichen, je nach Geschlecht und äußeren Bedingungen.

Auch die Anzahl der Individuen, welche eine Kolonie zusammensetzen, schwankt sehr. In regetativen Kolonien fand KLEIN (1889) 200 bis 3000 Zellen, in den männlichen zwischen 210 und 4400, während $V$. globator in den ungeschlechtlichen Kolonien zwischen 1500 und $16 \pm 00$, in den geschlechtlichen zwischen 10000 und 22000 Zellen enthält.

Die Zellen sind in einer einzig*en Schicht an der Oberfläche einer Kugel angeordnet; der große Innemraum ist mit Schleim erfüllt. Jede Zelle

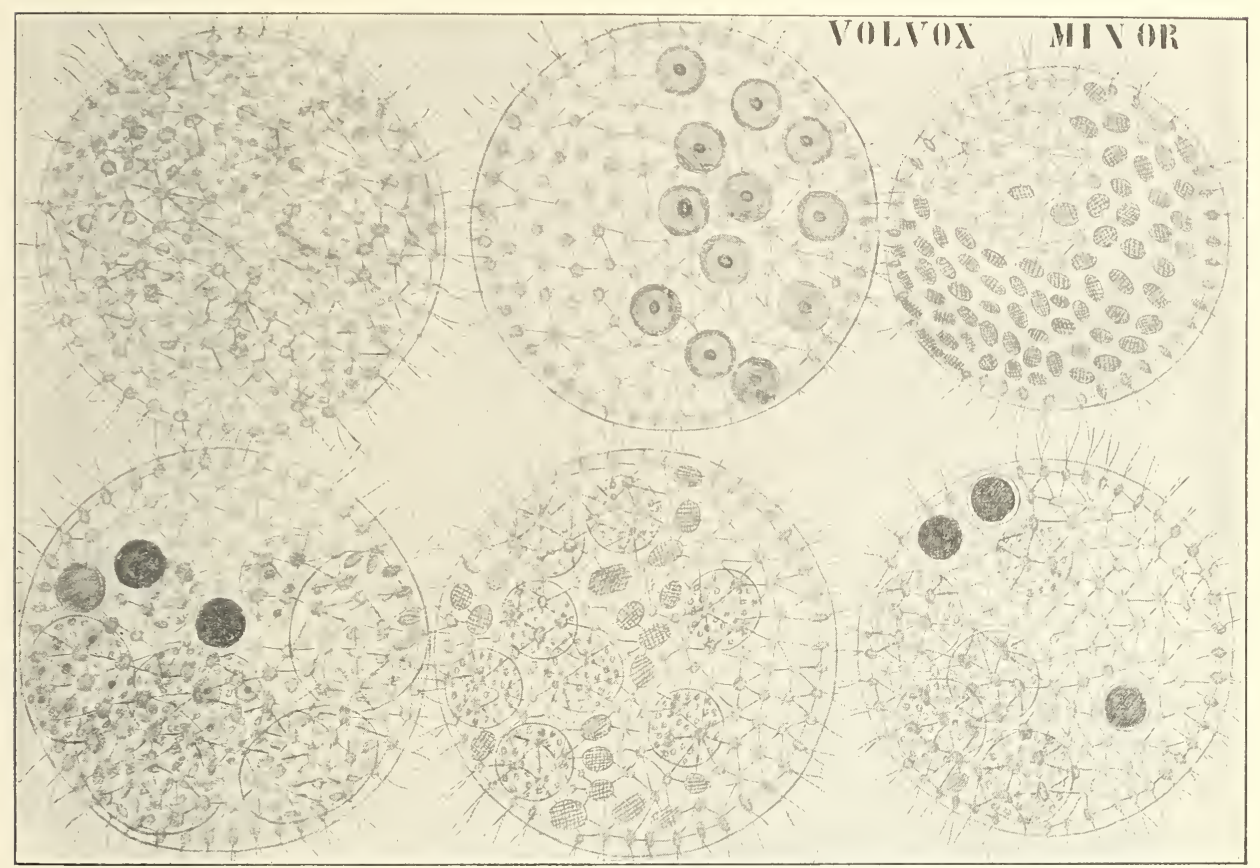

Fig. 11. Volvox minor nach KLEIN (schematisch). Von links nach rechts: Obere Reihe: $1 \mathrm{Sehr}$ große ungeschlechtliche Kolonie mit 6 Tochterkolonien; in den Tochterkolonien Parthenogonidien. \& Besonders große weibliche Kolonie mit besonders zahlreichen reifen Eiern. $3 \mathrm{Sehr}$ große männliche Kolonie (E Sphaerosira volvox EHRENBG). Untere Reihe: 4 Kolonie mit Zygoten, weiblichen Tochterkolonien, männlichen Tochterkolonien und Tochterkolonien, deren Qualität noch unbestimmbar. 5 Vorwiegend vegetative Kolonie, in der sich nachträglich Spermatozoidenbündel entwickelt haben, häufig im September und Oktober. 6 Monöcisch proterogyne Kolonie mit jungen Spermatozoidenbüscheln und vegetativen Tochterkolonien.

hat 2 Cilien; der Protoplast der vegetativen Zellen ist. von oben betrachtet, fast kreisrund.

Der Chromatophor ist fast eine Hohlkugel, erreicht aber nicht ganz den oberen cilientragenden Teil der Energide, welcher also farblos ist. In dieser Partie finden wir die üblichen zwei kontraktilen Vakuolen und ein Stigma. Ein oder mehrere Pyrenoide sind vorhanden. Nach 
KLEIs nimmt der Chromatophor bei der Reifung der Eier an Größe ab. - Die Protoplasten sind untereinander durch feine Protoplasmafäden verbunden, welche sich mittels verdünnter Jodlösung leicht sichtbar machen lassen. Die Zahl der Plasmodesmen wechselt zwischen 1-3, und die Eier bilden mehrere Plasmaverbindungen zwischen sich und den anliegenden Zellen aus.

Bei Volvox globator ist der Umriß der Protoplasten unregelmäßig, indem dicke Pseudopodien auftreten, in welche auch die Chromatophoren Ausläufer hineinsenden; dieses letztere geschieht jedoch nur bei jüngeren Zellen, bei älteren ziehen sich die Chromatophorenfortsätze wieder ein; der Chromatophor wird dann rund mit scharfer Kontur.

Die Zellwand der einzelnen Individuen ist stark schleimig verdickt,

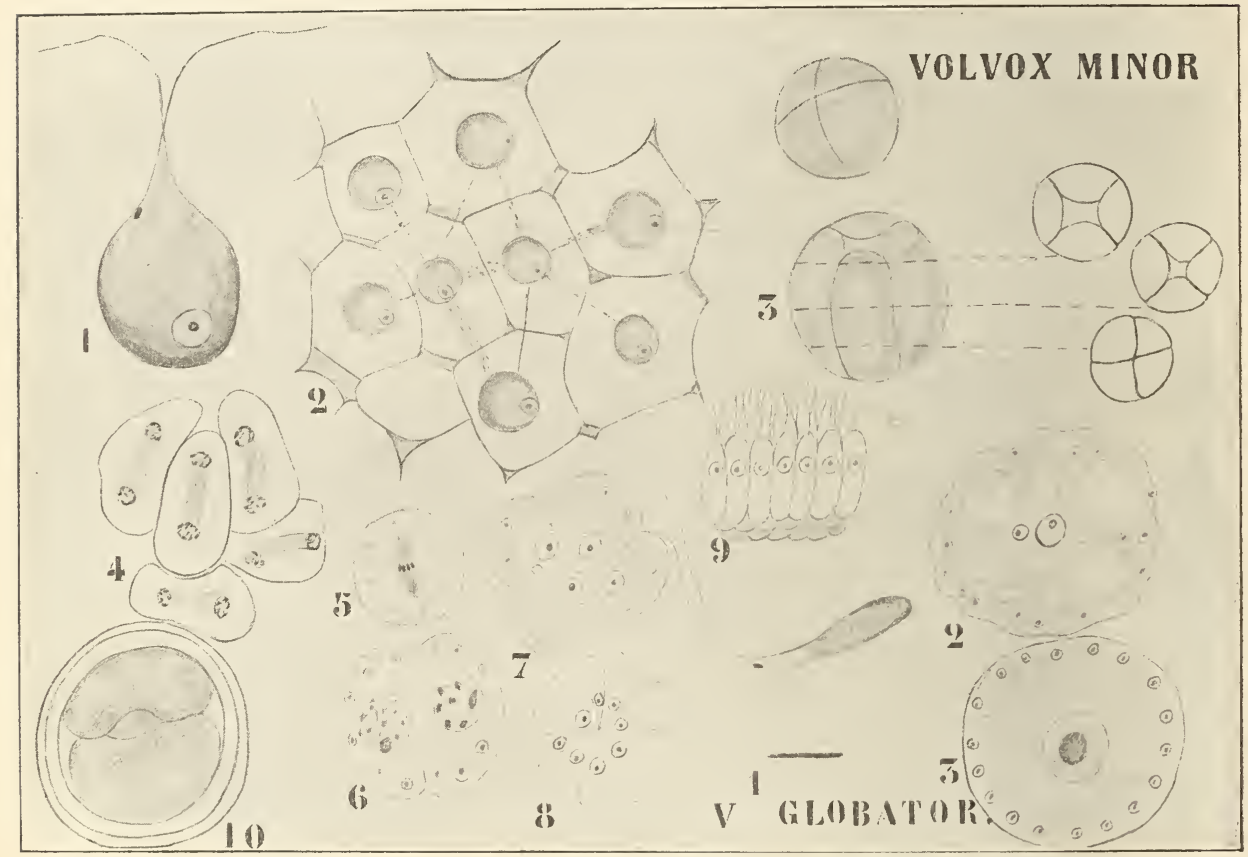

Fig. 12. I. Volvox minor nach OvErTon. 1 Einzelne Zelle. 2 Oberflächenpartie einer Kolonie, gefärbt; Felderung sehr deutlich, Knotenpunkte kollenchymartig verdickt. 3 Teilungen bei der Bildung von Tochterkolonien. 4 Die simultane Teilung der Kerne in einer jungen Kolonie. 5-9 Bildung der Spermatozoidentäfelchen. 10 Keimung der Zygote (nach KIRCHNER). - II. Volvox globator. 1 Gefärbtes und ungefärbtes Spermatozoid; enthält einen langgestreckten Nucleus, ein Pyrenoid und einen Chromatophor nebst Stigma und kontraktilen Vakuolen. 2-3 Befruchtung.

die Grenze zwischen den Individuen läßt sich jedoch gut nachweisen, indem sich an der Stelle, wo zwei Individuen aneinander geraten, eine Mittellamelle aus festerer Substanz herausbildet. Die Grenze nach dem Protoplasten hin ist ohne spezielle Behandlung unsichtbar, indem die Hülle den Protoplasten eng umschließt.

Auch an der dem Innenraum angrenzenden Seite der Zelle ist eine Schleimmembran vorhanden, welche an jungen Volvox globatorKolonien leicht $\mathrm{zu}$ sehen ist. 
Trir sahen bereits, daß die Plasmakörper der Volvox-Kolonien in erhöhtem Laße nit den Fortptlanzungszellen in Terbindung treten; da liegt es auf der Hand, an eime Nahrungszufuhr zu den Fortpflanzungszellen zu denken, und diese Auffassung ist wahrscheinlich richtig. Aber in einer anderen Hinsicht noch haben die Plasmaverbindungen große Bedeutung.

Eine Volvox-Kolonie bewegt sich, als wäre sie ein einziges Individuum, sie schwimmt vorwärts und rückwärts, hält still, wenn dies nötig ist, d. h. sie hält ror einem Hindernis ein, ja weiß ein solches recht gewandt zu umgehen.

Dies wäre nun offenbar ummöglich, wenn die Cilien eines jeden Individuums sich willkürlich bewegten, auch wenn sie sämtlich in der gleichen Richtung ausschlügen. Im ersteren Falle würden ganz unregelmäßige Bewegungen resultieren, im letzteren würde eine einfache Drehung der Kug.el um die Achse stattfinden.

Es muß also zwischen den einzelnen Individuen eine ,Verständigung“" über die auszü̈benden Cilienbewegungen stattfinden, und man sieht in der Tat, daß bei einer sich geradlinig fortbewegenden Volvox-Kugel die linksseitigen Cilien nach links, die rechtsseitigen nach rechts ausschlag'en.

Sämtliche Indiriduen der Kolonie werden also von einem gemeinsamen Willen regiert, ein Wille, der diffus an das Plasma gebunden sein muß und der nur deswegen alle Individuen umfassen kann, weil sie mittels Plasmaverbindungen miteinander in Verbindung sind. Dieser Terband zwischen den Individuen kommt weiter noch in der Kernteilung zum Ausdruck, indem in jungen Kolonien die Kernteilung in den einzelnen Individuen simultan stattfindet.

Die Fortpfianzung findet wiederum ungeschlechtlich und geschlechtlich statt. Betrachten wir zunächst die erstere. Bei den bis jetzt besprochenen Volvocineen war jedes Individuum einer Kolonie im stande, sich ungeschlechtlich fortzupflanzen, nicht so bei Volvox; bei dieser sind nur bestimmte cilienlose Individuen dazu im stande, welche man mit dem Namen „Parthenogonidien" bezeichnet. Bei Volvox globator enthält jede Kolonie gewöhnlich 8 Parthenogonidien, bei Volvox minor wechselt die Zahl zwischen 1 und 14. Die Parthenogonidien sind nicht gleichmäßig über die ganze Kolonie verteilt, sondern befinden sich nur auf der hinteren Hälfte, d. h. derjenigen Hälfte, welche bei der gewöhnlichen Bewegung nach hinten gerichtet ist. Oefters befindet sich an dem vorderen Pole eine Oeffinung in der Kolonie.

Die Parthenogonidien sind größer als die anderen Individuen der Kolonien, sie sind bereits bei sehr jungen Kolonien sichtbar und cilienlos, entwickeln sich aber nicht weiter, bevor diese sich aus der Mutterkolonie befreit haben.

Um sich zu einer jungen Kolonie zu entwickeln, teilt sich die Parthenogonidie zunächst in 2 und dann durch eine zur ersteren senkrechte Wand in 4 Zellen. Ueber die weitere Entwickelung sind die verschiedenen Autoren uneinig; einige meinen, daß sich so wie bei Eudorina zunächst eine Zellplatte bildet, welche sich später napfförmig vertieft und durch Verwachsen der Ränder die Hohlkugel bildet, während andere meinen, daß die Hohlkugel vom Anfang an vorbereitet wird durch Teilungen und Konkavwerden der Individuen. Die Sache erheischt erneute Untersuchung.

$\mathrm{Ob}$ die Parthenogonidien als ungeschlechtliche Individuen zu betrachten sind oder so, wie BüTschli will, als parthenogenetische Eier, 
scheint mir schwer zu entscheiden. Für beide Anschauungen läßt sich manches vorbringen.

Die aus den Parthenogonidien auf jeden Fall ungeschlechtlich entstandenen jungen Kolonien schlüpfen aus der Mutterzelle heraus und begeben sich in den inneren schleimerfüllten Raum, wo sie sich hin und her bewegen. Sehr dicht kann der Schleim also nicht sein. Kurz vor der Geburt stellt die Mutterkolonie ihre Bewegung ein, und auch die Tochterkolonien kommen zur Ruhe. Alsbald sieht man, wie eine der letzteren sich wieder zu bewegen anfängt und sich an die Wand der Mutterkolonie andrückt. An der berührten Stelle weicht letztere höckerartig aus, und die Tochterkolonie schiebt sich durch, wobei sie selbstverständlich ein Loch macht. Nahe an der ersten Stelle drängt sich alsbald eine andere Tochterkolonie heraus, und dies wiederholt sich, bis sämtliche Tochterkolonien ausgeschlüpft sind. Meistens tritt also jede Tochterkolonie durch ein eigens gemachtes Loch heraus, nur selten entschlüpft eine durch das von einem ihrer Vorgängerinnen gemachtes, und die Folge dieses Vorgehens ist eine Zerfetzung der Mutterkolonie, welche dann auch alsbald zu Grunde geht.

Wir haben bereits früher gesehen, daß bei Volvox-Kolonien öfters ein Loch am vorderen Pol vorhanden ist; diese wie zum Gebären vorbereitete Oeffnung wird aber nur in seltenen Fällen zu diesem Zweck benutzt, und zwar bei kleinen Mutterkolonien (400-500 $\mu$ ), mit sehr

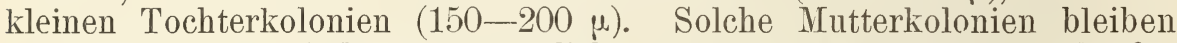
auch während des Gebärens beweglich, und die Tochterkolonien schlüpfen nacheinander durch das Polloch heraus. Die Mutterkolonie wird also nicht beschädigt und sie schwimmt denn auch noch lange lebhaft umher. Die für alte Volvox-Kolonien charakteristische Drehung um die Achse herum während der Vorwärtsbewegung zeigt sich bereits an den eben geborenen Tochterkolonien.

Bei der geschlechtlichen Fortpflanzung bilden die offenbar durch Cilienlosigkeit etc. vorgebildeten Eier sich zunächst aus. Sie nehmen an Größe zu und werden dunkelgrün, wodurch sie leicht von jungen Parthenogonidien zu unterscheiden sind. Die Farbe der Zygoten ist, in Wasser betrachtet, schmutzig-rotbraun, in Glycerin schön orangeret.

Die Spermatozoidentäfelchen von Volvox werden in ähnlicher Weise wie bei Eudorina gebildet; bei $V$. minor enthält jedes Täfelchen in der Regel 32 Spermatozoen, aber 8 und 16 kommen auch vor, während V. globator 32-256 Spermatozoen pro Täfelchen aufweist.

Diese Spermatozoidentäfelchen bohren sich durch die Wand der weiblichen Kolonien hindurch, spalten sich in deren Innenraum in die einzelnen Spermatozoen, und letztere treten also von der Innenseite in die Eier hinein.

Die Spermatozoen von Volvox minor enthalten einen runden Kern, 2 kontraktile Vakuolen, 2 Cilien, ein Stigma, einen gelborangen Farbstoff und einen Chromatophor mit Pyrenoid. Bei Volvox globator hingegen ist der Kern langgestreckt, ein insoweit interessanter Umstand, als darin bereits die charakteristische Kernform der Spermatozoen der Farne und sonstiger höheren Organismen auftritt.

Das Ei enthält eine größere Zahl Pyrenoide, einen großen Kern und ist stark vakuolisiert.

Bei der Kopulation tritt der Kern des Spermatozoons in das Ei 
hinein und rerschmilzt mit dem Eikern; was mit dem Chromatophor des Spermatozoons geschieht, weiß man nicht.

Und doch ist dies eine Frage von hohem Interesse, über welche wir auch im alloemeinen noch fast gar nichts wissen.

Soweit bis jetzt bekannt, werden Chromatophoren, d. h. alle deutlich begrenzten, gefärbten Plasmapartien, oder solche Partien, welche weniostens unter giünstigen Beding'ung*en Farbstoff bilden können (Leukoplasten), nie gebildet, sondern entstehen, wie Schmitz und zumal Schmper zeigten, immer durch Teilung bereits rorhandener Chromatophoren.

Bei allen Photosynthetikern ${ }^{1}$ ) im Pflanzenreich konnte ScHIMPER Chromatophoren (öfter's als Leukoplasten) in der Eizelle nachweisen, und da die junge Pflanze durch wiederholte Teilung aus dieser Eizelle sich bildet, und mit jeder Zellteilung eine Teilung oder wenigstens Verteilung der Chromatophoren über die Tochterzellen gepaart ist, ist es klar, daß z. B. die Anwesenheit von Chlorophyllkörnern - grünen Chromatophoren - in den Blättern auf die Leukoplasten der Eizelle zurückzuführen ist.

Ganz anders in den o Fortpflanzungszellen. In den Spermatozoen der Gefäßkrsptogamen, in den generativen Zellen der Pollenkörner höherer Pflanzen hat man keine Chromatophoren nachweisen können; bei der Kopulation ron Spirogyrazellen geht nach CHmielevsir der Chromatophor der männlichen Zelle zu Grunde.

Beim geg*enwärtigen Stande der Frage müssen wir also annehmen, daß die Chromatophoren nur in der weiblichen Linie vererbt werden, daß alle Chlorophyllkörner eines Baumes Derivate der Chromatophoren der Eizelle sind, und daß sie nicht zum Teil vom Vater herrühren.

Die Frage wäre einer experimentellen Bearbeitung sehr wert; zunächst sollte einmal festgestellt werden, was aus den Chromatophoren bei der Kopulation einfacher Isogameten wird, und dann sollte man versuchen, bei höheren Pflanzen Hybride zwischen Formen mit verschieden gestalteten Chromatophoren zu erzielen; geeignete Versuchspflanzen dürften aber nicht leicht aufzufinden sein.

Aus der Zygote von Tolvox schlüpft nach Krrchner der Inhalt, von der inneren Zygotenmembran umgeben, aus, indem diese Schicht stark aufquillt. Jetzt bildet der Inhalt eine neue zarte Membran und bildet sich dann, genau wie in den Parthenogonidien, zu einer neuen Volvox-Kugel aus.

Es scheint dies sehr von der Keimung der Zygoten, bei Stephanosphaera z. B.. abzuweichen, aber OLtwanns gibt eine scharfsinnige Deutung des Vorganges. Wir sahen, daß bei der Keimung von Stephanosphaera aus der Zygote 2-8 Schwärmer entstehen; bei Pandorina, einer anderen, nicht von uns behandelten Volvocinee, entsteht aus der Zygote nur ein (selten 2-3) Schwärmer, und nun meint Ortmanns, daß die ausschlüpfende Plasmamasse von Volvox mit einem einzigen Schwärmer zu vergleichen sei. Dabei stützt er sich auf die Beobachtung KIRCHNERs, daß vor der Teilung sich farbloses Plasma an einem Ende des Zygoteninhaltes ansammelt, ein Vorgang, der sich wohl nur als das Rudiment der Ausbildung eines Vorderendes einer Schwärmspore verstehen läßt.

Es bleibt noch die Verteilung der Geschlechter bei Volvox minor zu besprechen. Trotz des Vorkommens sehr einfacher Fälle ist diese doch im allgemeinen recht kompliziert. Zu den einfachen Fällen gehören : rein ungeschlechtliche, rein weibliche und rein männliche Kolonien :

1) Pflanzen, welche ihre Nahrung mittels Protosynthese bereiten. 
zu den komplizierten: monöcisch proterogyne Kolonien, welche überdies noch auf ungeschlechtlichem Wege Tochterkolonien bilden, vorwiegend vegetative Kolonien, welche später noch Spermatozoenbündel ausbilden, und weibliche Kolonien, welche sowohl weiblichen wie männlichen Kolonien das Dasein schenken.

Noch viel mehr Kombinationen kommen vor, sie hängen zum Teil von noch im einzelnen unbekannten Umständen ab. Wer sich für diese Fragen interessiert, lese KuEINs interessante Aufsätze in den Berichten und in Pringsheims Jahrbüchern.

Bevor wir Volvox verlassen, sei es mir gestattet, hier einige Betrachtungen allgemeiner Natur einzuschalten.

Wir haben früher gesehen, daß der Zellkern der Träger der erblichen Eigenschaften des Organismus ist. Alle Kerne entstehen aus dem Zygotenkern, und da schließlich von den somatischen Zellen wieder Fortpflanzungszellen gebildet werden, muß der Organismus, trotz dieser zwischenliegenden zahllosen Kernteilungen, die von den Eltern erhaltene Vererbungssubstanz den Fortpflanzungszellen wieder abliefern.

Dazu ist es unbedingt erforderlich, daß bei jeder Zellteilung, bei jeder Kernteilung also dafür gesorgt ist, daß die Tochterkerne dem Mutterkern völlig gleich sind. Besitzt der Mutterkern die Eigenschaften A, B, C, D etc., so müssen auch die Tochterkerne diese Eigenschaften besitzen. Gesetzt den Fall, es seien diese Eigenschaften jede für sich im Kern an bestimmte Träger gebunden, so muß nicht nur der Kern als solcher dividiert werden, sondern ein jeder dieser Träger muß bei jeder Kernteilung genau halbiert werden.

Kennen wir nun diese hypothetischen Träger erblicher Eigenschaften? Bestimmt bejahend dürfen wir diese Frage nicht beantworten, aber wenn wir im Kern eine Substanz nachweisen können, über deren vollkommen gleichmäßige Verteilung über die Tochterkerne mit größter Sorgfalt gewacht wird, dürfen wir darin wohl einen Hinweis erblicken, daß diese Substanz die Trägerin der erblichen Eigenschaften sei, und wenn nun noch andere Umstände hinzukommen, z. B. ein eigentümliches Betragen dieser Substanz bei der Fortptlanzung, so wird es uns in hohem Grade wahrscheinlich, daß wir die Träger der erblichen Eigenschaften vor uns sehen.

Eine solche Substanz kennen wir nun in der Tat im Kern, sie wird mit dem Namen Chrom at in angedeutet. Verfolgen wir also die Schicksale dieses Chromatins, d. h. also, sehen wir uns die Kernteilung etwas genauer an.

Bei geeigneter Doppelfärbung eines Kernes erhalten wir verschiedene Bilder je nach der Phase, in welcher sich der Kern befindet.

Der ruhende Kern einer höheren Pflanze z. B. ist ein runder Körper, innerhalb welches sich eine blau gefärbte, viel kleinere Kugel, der sogenannte Nucleolus befindet. Dieser Nucleolus ist eine mit Reservesubstanz erfüllte Vakuole. Im eigentlichen Kernkörper erblicken wir unregelmäßig verzweigte, rot gefärbte Stücke, welche zusammen das sogenannte Chromatin bilden. Bei genauerer Betrachtung zeigen sich die Grenzen der einzelnen Stücke oder Chromosomen (Fig. 13, 1).

Fängt der Kern an sich zu teilen, so wird dieser Vorgang dadurch eingeleitet, daß die Chromosomen zusammen einen Faden bilden (Fig. 13, 2), den sogenannten Kernfaden. Dieser Kernfaden kommt dadurch zu stande, daß die Chromosomen unter Einziehung ihrer Ausstülpungen sich Kopf an Schwanz legen. Dieser Kernfaden zerbricht später wieder in eine Anzahl von Stücken (Fig. 13,3), und es ist eine höchst eigentümliche Er- 
scheinung, daß die Zahl der Stücke immer genau dieselbe ist, und zwar der Anzahl der Chromosomen, aus welchen er gebildet wurde, gleich ist. Mit anderen Wrorten: die Chromosomen haben während des Stadiums des Kernfadens ihre Individualität nicht verloren. Daß sie sich während dieser Periode nicht unterscheiden lassen, liegt einfach daran, daß sie so g'enau aneinander paßten. daß die Grenze zwischen je zwei Chromosomen unsichtbar war.

Sobald nun der Kernfaden wieder in seine Chromosomen auseinandergefallen ist. ordnen sich diese alsbald zu einem Ring um den Aequator des Nucleus herum (Fig. 13, 3). Bis jetzt ist der Nucleus intakt geblieben, aber nun fängt die Auflösung der Membran an, und Plasmafäden treten durch Oeffnungen an den Polen in den Kern hinein und

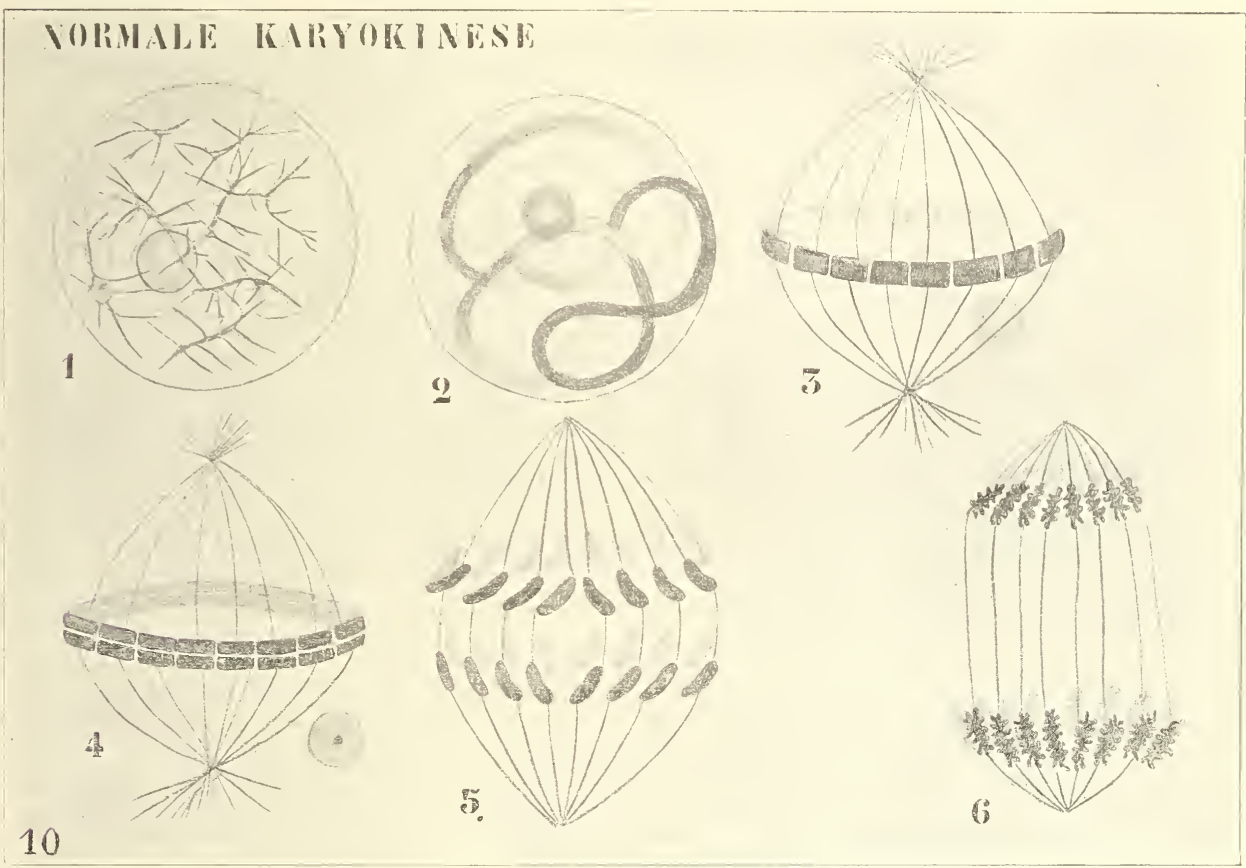

Fig. 13. Schema der Kernteilung.

legen sich an die Chromosomen an. Dann spaltet sich jedes Chromosom durch einen Längsschnitt (Fig. 13, 4) in zwei gleiche Hälften; es findet also eine gleichwertige Teilung (Aequationsteilung) statt. Die so gebildeten halben Chromosomen bewegen sich unter Verkürzung dieser Plasmastrahlen oder achromatischen Strahlen nach den Polen hin (Fig. 13, 5). Dort angelangt, sieht man, daß sie schon wieder anfangen Ausstülpungen zu treiben (Fig. 13, 6), alsbald wird nun um jede Chromosomenmasse herum eine Membran gebildet, und die jungen Nuclei sind fertig; die Chromosomen bilden längere Ausläufer, und wir erhalten dasselbe Chromatinbild, von welchem wir bei Betrachtung des ruhenden Kernes ausgingen.

Wie man sieht, hat jeder der Tochterkerne g'enau die Läng’shälfte eines jeglichen Chromosoms erhalten. 
Wird ein Chromosom sehr stark vergrößert, so sehen wir, daß es aus Scheibchen intensiv gefärbter Substanz besteht, welche dicht nebeneinander liegen, etwa in der Weise wie Gulden in einer Rolle (Fig. 14).

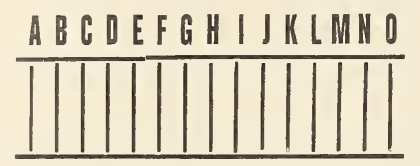

Fig. 14 .

Nimmt man nun an, daß ein jedes dieser Scheibchen den Träger einer bestimmten Eigenschaft darstellt, so sehen wir, daß durch die Längsteilung des Chromosoms Sorge dafür getragen wird, daß in jedem Tochterkern wenigstens ein Träger von jeder Eigenschaft, welche der Mutterkern besaß, vorhanden ist.

Wir sehen also, daß bei der Kernteilung dafür gesorgt wird, daß jeder Tochterkern dem Mutterkern völlig gleich ist.

Kehren wir zu Volvox zurück, so sehen wir, daß wir in jenem Genus das höchste der Volvocineen erreicht haben, und man könnte sagen, daß Volvox das Ideal ist, welches durch ein Zusammenbleiben von beweglichen Teilprodukten zu erreichen ist. Ob man ein solches Wesen als Kolonie oder als höhere Einheit auffassen will, ist Geschmacksache, womit zu gleicher Zeit gesagt ist, daß eine scharfe Linie zwischen einer Kolonie und einem vielzelligen Lebewesen sich nicht ziehen läßt. Auf jeden Fall aber steht Volvox noch auf einer verhältnismäßig niedrigen Entwickelungsstufe, indem eine, auch nur einigermaßen bedeutende Arbeitsteilung zwischen den Zellen nicht aufgetreten ist.

Sehen wir nun zunächst, was auf dem Wege der von vielen Energiden bewohnten Zellschläuche erreicht wurde, wenden wir uns also zu der Gruppe der Siphonales. 


\section{Dritte Vorlesung.}

\section{Die Siphonales.}

Die Ableitung dieser Gruppe mag durch folgendes Schema angedentet werden:

Siphonales

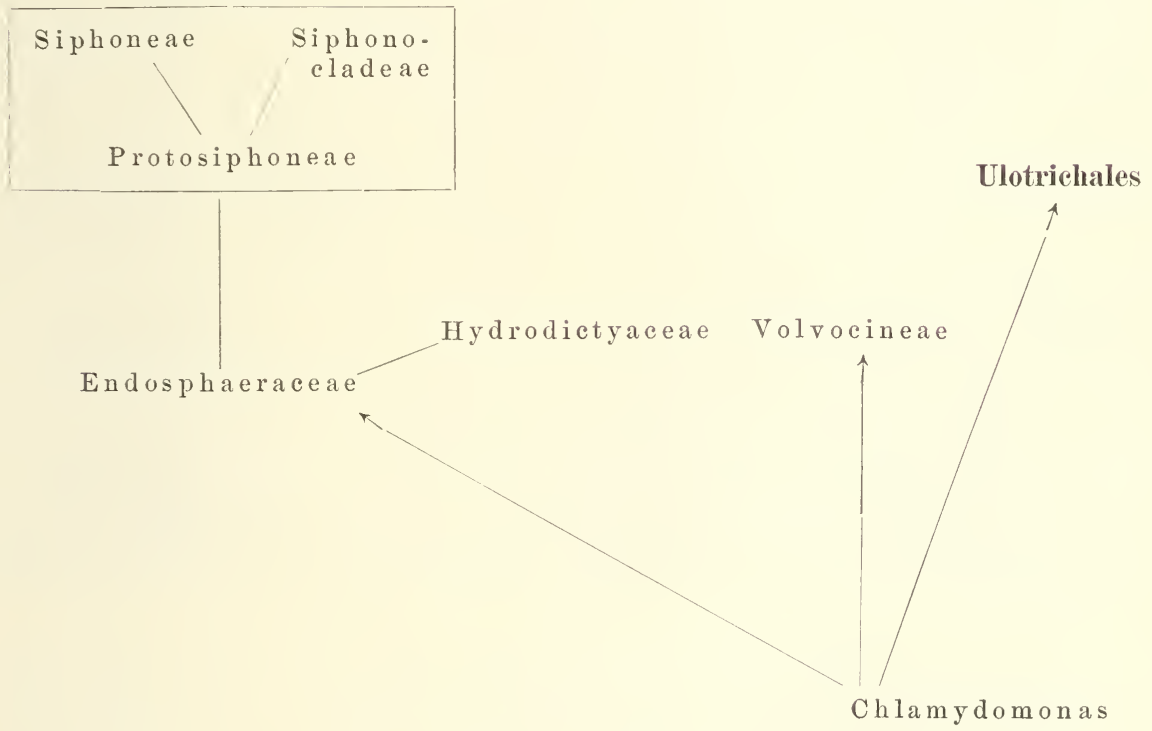

Die Entstehung der Siphonales wird sozusagen vorgeahnt durch einen ausgesprochenen Widersinn zur Zellteilung. Die niedrigsten Formen der Gruppe der Endosphaeraceae, von welchen ich die Siphonales ableiten möchte, sind strikt einzellig, nicht homocellulär, sondern bestehen nur aus einer einzigen Zelle, aber auch bei jenen Formen, welche Kolonien bilden, ist die Abwesenheit von Zellteilungen nicht weniger auffallend; die Individuen, welche die Kolonie zusammensetzen, sind nicht durch Zellteilung, sondern durch Teilung der Energide gebildet, in der ganzen Gruppe wird mit verschwindend wenigen Ausnahmen die Zellwand nicht geteilt.

Zur Einführung in diese Gruppe ist eine nähere Betrachtung der Familie der 


\section{Endosphaeraceae}

am Platze. Wie der Name bereits andeutet, sind dies kugelige Wesen, welche in einem anderen Organismus wohnen, und zwar in höheren Pflanzen. Als erstes Beispiel sei

\section{Chlorochytrium Lemnae}

gewählt. In den Intercellularräumen von Lemna trisulca findet• man öfters elliptische Zellen mit dunkelgrün gefärbtem Inhalt, welche ein Entwickelungsstadium unserer Alge darstellen.

Sie befinden sich stets in der subepidermalen Zellenschicht und sind von ziemlich wechselnder Form. Auf der Epidermis wird über unserer

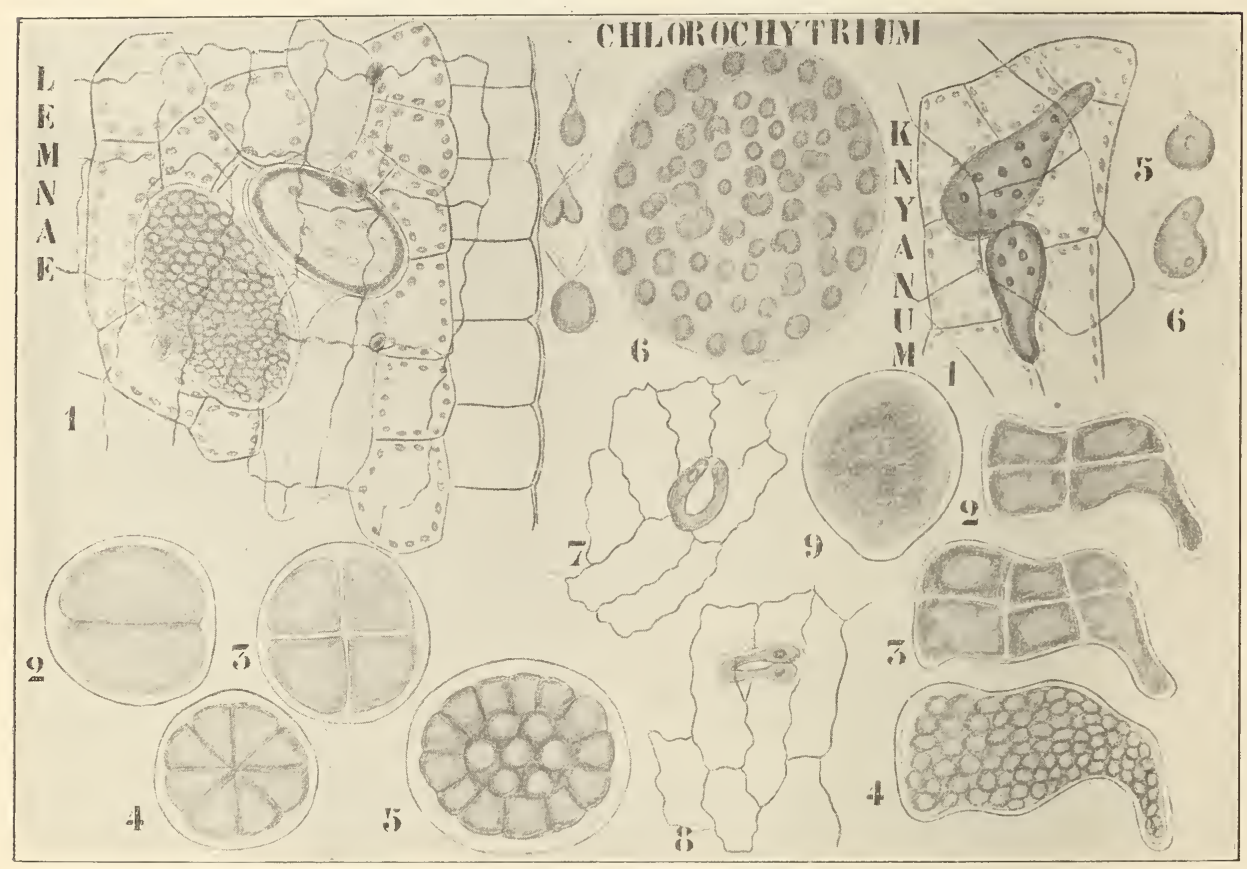

Fig. 15. I. Chlorochytrium Lemnae (nach KLEBS). 1 Derbwandige Zelle in Lemna trisulca; die Zellen liegen im Chorophyllgewebe; zwei Zellen sind leer, von den beiden vollen hat eine schon Gameten gebildet; der Cellulosepfropf über jeder Zelle sehr deutlich. 25 Teilungen zur Bildung der Gameten. 6 Die Gameten, aus dem ausgeschlüpften Endospor ausschwärmend, nebst Kopulation derselben. 7 Die Zygote auf der Epidermis einer Lemna. 8 Keimung und Eindringen einer Zygote. 9 Vegetative Zelle. - II. Chlorochytrium Kny an um (nach KLeBs). 1 Zellen in Lemna minor. 2-6 Zoosporenbildung.

Alge stets ein Cellulosepfropf gefunden, welcher den Rest der Zygotemembran darstellt, aus deren Keimung unser Pflänzchen hervorging. Junge Individuen haben eine verhältnismäßig dünne Zellwand, diese verdickt sich allmählich, und im Innern entstehen durch wiederholte Teilung eine Anzahl von nackten Zellen, deren Gametennatur aus ihrem nachträglichen Verhalten hervorgeht. Es hat sich also das ganze Pflänzchen in ein Gametangium verwandelt. Die innere Schicht der Gametangiumwand verschleimt dann, und die Gameten treten, noch vou dieser Schleimblase umhüllt, heraus. Jetzt wird es klar, daß jede 
Gamete உ Cilien besitzt. und sehen wir. da Kopulation öfters noch imnerhalb der Schleimblase stattfindet, daß Schwestergameten miteinander kopulieren kömnen. Die Schleimblase reißt alsbald ein. und die Gameten, eventuell bereits zu Zygoten rereinigt. treten heraus.

Die Zyoten, welche, ihrer Entstehung entsprechend, 4 Cilien bebesitzen, zeichnen sich nun rou den meisten Zygoten dadurch aus, daß sie diese nicht so bald abwerfen, sondern im Gegenteil längere Zeit herumschwärmen und ein Lemnapflänzchen zu erreichen suchen. Gelingt ihnen das nicht, so gehen sie alsbald zu Grunde, sonst befestigen sie sich auf der Epidermis. und zwar immer an der Grenze zwischen zwei Epidermiszellen (Fig. 15, 7). Hier drücken sie sich mit ihrem cilientragenden Ende an die Epidermis an und rotieren wie ein Kreisel herum, bald schmeller, bald langsamer, ein Spiel, welches 2-3 Stunden, ja sogar noch länger anhalten kamn. Sind sie zur Ruhe gekommen, so zeigt sich, daß die Zygote eine Membran gebildet hat, sie verbleibt in diesem Ruhestand wenigstens 24 Stunden. Meistens dringt sie erst unter Bildung eines Keimschlauches (Fig. 15, 8) am 2. oder 3. Tag zwischen zwei Epidermiszellen hindurch in die Lemma ein. Der Keimschlauch schwillt im Innern der Lemna auf. und in diese Aufschwellung tritt die Energide der Zygote ein, indem die Zygotenwand durch Apposition ron Cellulose verdickt wird und zu dem bereits besprochenen Celluloseknöpfchen anschwillt. Das eingetretene Chlorochytrium fängt jetzt zu wachsen an und bildet alsbald die elliptische Zelle, welche Ausgang'spunkt unserer Betrachtungen war.

Die beim Herannahen des Winters gebildeten Individuen sind öfters etwas runder (Fig. 15̌, 9) und dickwandiger, entstehen aber in ähnlicher Teise und wandeln sich im Frühjahr ebenfalls zu Gametangien um.

Ob Chlorochytrium einkernig ist oder nicht, finde ich nirgends angegeben; wabrscheinlich ist dies wohl; auch FrEminan erwähnt das bei seiner überdies noch etwas fraglichen "midsummerstage" von Chl. inclusum KJELL.. nicht, trotzdem er die Anwesenheit mehrerer Pyrenoiden feststellt.

Chlorochytrium Lemnae ist demnach ein strikt einzelliges, höchst wahrscheinlich monoenergides Wesen (wie aus der wiederholten Zweiteilung bei der Gametenbildung gefolgert werden darf), welches sich ohne weiteres in ein Gametangium umbildet, und dessen Zygoten wieder zu jungen Chl. Lemnae keimen. Eine ungeschlechtliche Fortpflanzung ist bei dieser Art nicht bekannt geworden.

Ganz anders bei Chlorochytrium Knyanum. Auch diese Art ist strikt einzellig, gewöhnlich aber etwas mehr in die Länge gestreckt als ihre Verwandte, und es ist kein Cellulosepfropf über ihren Zellen vorhanden. Sie bewohnt hauptsächlich Lemna minor und gibba ${ }^{1}$ ) und fällt durch das häufige Vorkommen einer siphoneenartigen Verlängerung ihrer Zellen (Fig. 15, II 2-4) auf. Während sich nun Chl. Lemnae zu einem Gametangium umbildet, tut dies Chl. Knyanum zu einem Zoosporangium, und so wie bei Chl. Lemnae werden gegen den Winter dickwandigere Zellen gebildet.

Der Umstand, daß Chl. Lemnae nur Gametangien bildet, Chl. Knyanum nur Zoosporangien, führte zu der Vermutung, daß beide Entwickelungsstadien einer und derselben Art seien, aber es gelang KLEBs nicht, diesen Zusammenhang experimentell nachzuweisen; wir sahen ja bereits. daß die Fortpflanzungszellen immer wieder zu Individuen heranwachsen, denen, aus welchen sie entstanden ähnlich.

1) Aber auch Ceratophyllum demersum und Elodea canadensis. 
Während also das Genus Chlorochytrium strikt einzellig ist, finden wir bei einem anderen Genus der Endosphaeraceae bereits den allerersten Anfang einer Cönobienbildung, und zwar bei dem Genus, von welchem die Familie ihren Namen entliehen hat, bei

\section{Endlosphaera.}

Endosphaera biennis lebt im Gewebe von überwinterten abgestorbenen Potamogetonblättchen und wurde von KLEBs bei Straßburg gefunden.

Im Frühjahr findet man in solchen Blättern große, chlorophyllhaltige, dickwandige Zellen, meistens mehr oder weniger kugelförmig (Fig. 16, 1), bisweilen aber auch von dreieckiger oder auch unregelmäßiger Gestalt.

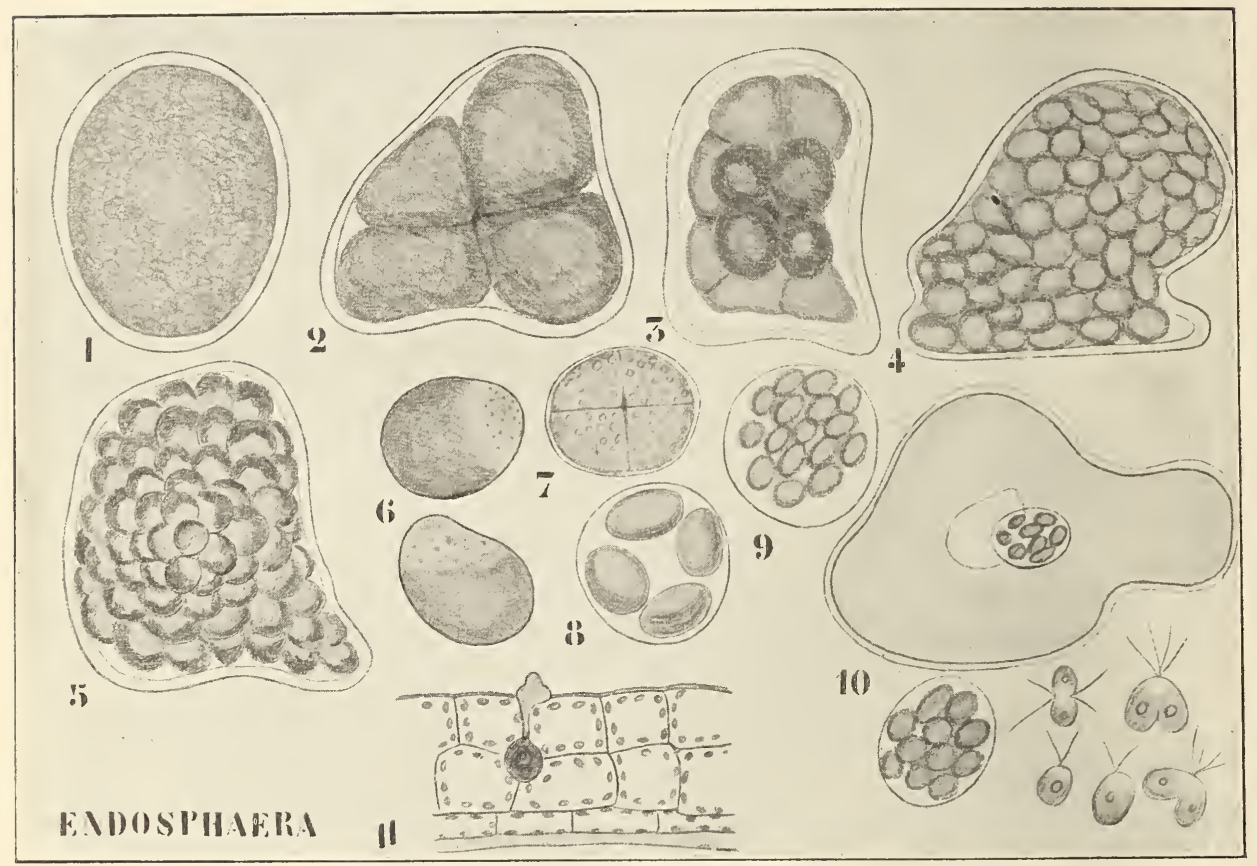

Fig. 16. Endosphaera nach KLeBs, 1 Vegetative Zelle. 2-4 Bildung der Zoosporen in der zum Sporangium verwandelten Zelle. 5 Die Zoosporen haben sich mit einer Membran umgeben und ein intrazelluläres Coenobium gebildet. 6-9 Umbildung einer Cönobienzelle in ein Gametangium. 10 Die ausgeschlüpfte innere Sporangienhaut noch ein Gametangium umschließend, welches ebenfalls bald durch den Riß austreten wird. 10 Kopulation der Gameten. 11 Keimende Zygote auf einem Potamogetonblatt.

Bringt man solche Blätter in frisches Wasser, so bildet sich die Endosphaera direkt zu einem Zoosporangium um (Fig. 16, 4), die Zoosporen, welche durch wiederholte Zweiteilung entstehen, erreichen aber nie ein eigentliches Schwärmstadium, sondern umgeben sich noch, bevor sie Cilien gebildet haben, bereits innerhalb der Mutterzelle mit einer Membran und zeigen dann die Anwesenheit eines scharf begrenzten Chromatophors.

Strikt einzellig ist dieses Wesen demnach eigentlich nicht, aber die Vielzelligkeit entsteht nicht durch Zellteilung, sondern durch Bildung eines Coenobiums innerhalb der Mutterzelle. Allmählich sieht man nun 
die grüne Farbe der cönobienzellen an Intensität zunehmen, und es zeigt sich. wie jede membranumgebene Zoospore sich schließlich zu einem Gametangium umbildet (Fig. 16, 6-9). Inzwischen ist die Innenwand des ursprünglichen Individuums, des Zoosporangiums also, verschleimt und tritt. die Gametangien umschließend, durch einen Riß aus dem Zoosporangium heraus.

In dieser Schleimwand entsteht alsbald ebenfalls ein Riß (Fig. 16, 10), und es kommen die Gametangien heraus oder aber auch bereits die Gameten, wenn sich, wie öfters der Fall, die Wände der Gametangien schon innerhalb der Blase durch T'erschleimung gelöst haben.

Die Gameten kopulieren jetzt in der üblichen Weise, die Zygoten kommen aber nicht sofort zur Ruhe, sondern schwimmen mit ihren 4 Cilien noch stundenlang umher. Finden sie während dieser Zeit keine lebenden Potamogetonblätter. so gehen sie zu Grunde; gelingt es aber, so heften sie sich an deren Epidermis zwischen zwei Zellen an und dringen in ähnlicher Weise in das Blatt ein, wie dies bereits für Chlorochytrimm (Fig. 15) beschrieben wurde; auch hier deutet also ein Cellulosepfropf die Eintrittsstelle der Endosphaera an.

Die eingedrungene junge Zelle wächst, indem sie Stärke und ein farbloses Oel anhäuft, und unter Membranverdickung zu dem beschriebenen Endosphaera-Individuum heran, fällt mit dem absterbenden Potamogeton lucens-Blatte auf den Boden des Gewässers und bildet sich im Frühjahr wieder in ein Zoosporangium um.

ITir begegnen also bei Endosphaera der ersten Andeutung einer Cönobienbildung, wie wir sie später bei den Hydrodictyaceen werden kennen lernen, eine Cönobienbildung, welche aber bislang nur noch ein recht ephemeres Dasein führt, indem die konstituierenden Zellen sich alsbald in Gametangien umbilden.

Während wir bei Chlorochytrium und Endosphaera höchstens bei Chl. Knyanum einer Andeutung einer Schlauchbildung begegneten, tritt dieses Charakteristikum der Siphonales bei einem anderen Genus der Endosphäraceen bereits in beträchtlicher Ausbildung zu Tage, und zwar bei

\section{Phyllobium.}

In der Umgebung Straßburgs fand KLEBS an den sumpfigen Ufern des Kleinen Rheins diesen Organismus in großer Menge, hauptsächlich in den Blättern von Lysimachia Nummularia, später wurde er ebenso reichlich von Woronin bei Wiesbaden gesammelt. Außer in dieser Pflanze kommt unsere Alge in Ajuga reptans, Chlora serotina und Erythraea centaurea vor.

Ein von unserer Alge infiziertes Lysimachia nummularia-Blatt fällt durch die Anwesenheit kleiner knotenartiger Verdickungen der Blattlamina auf, welche regelmäßig reihenartig angeordnet sind; es rührt dies daher, daß sie den Blattnerven folgen.

Bei näherer Untersuchung stellt es sich heraus, daß diese Verdickungen ihre Entstehung großen, dunkelgrünen, dickwandigen, in dem Gefäßbündel vorhandenen Zellen verdanken, welche dort aber außer einem Auseinanderdrängen der Gefäße keine weiteren Veränderungen verursachen (Fig. 17, 6).

Diese Zellen besitzen zumal später eine sehr stark verdickte, geschichtete Wand, und es stellt sich heraus, daß sie lange, röhrenförmige Ausläufer besitzen, welche farblos sind, zwischen den Zellen des Gefäßbündels verlaufen und entweder verzweigt oder unverzweigt sind. Be- 
trachtet man eine solche Zelle während ihrer vollen vegetativen Entwickelung, so findet man sie intensiv grün gefärbt und beobachtet in ihr meistens einige runde, orangefarbene Oeltropfen, welche durch Blaufärbung mit $\mathrm{H}_{2} \mathrm{SO}_{4}$ ihre Carotinnatur verraten.

Neben diesen großen Zellen trifft man in den Blättern meist kleinere Ruhestadien an, welche keinen eigentlichen Schlauch oder höchstens eimen recht kurzen (Fig. 17, 8) besitzen, und meistens allein oder zu zweien (Fig. 17, 10) unter einer Spaltöffnung der Blattunterseite liegen.

Wir kommen später auf diese kleineren Ruhestadien zurück; wegen des Vorkommens dieser zwei Zellenarten nannte KuEBs seinen Organismus: Phyllobium dimorphum.

Bringt man nun eingetrocknete Lysimachia-Blätter in frisches Wasser, so bildet sich jede Ruhezelle zu einem Gametangium um, welches mit

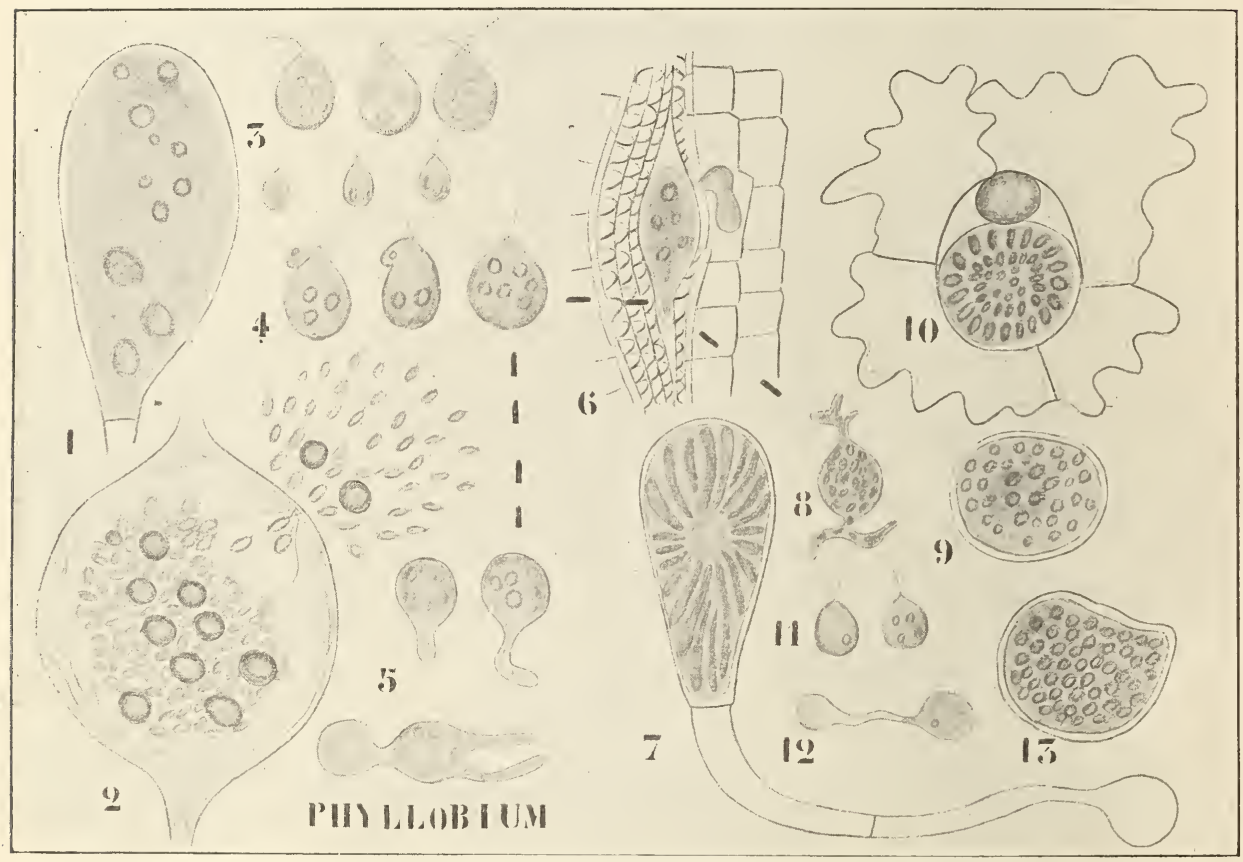

Fig. 17. Phyllobium dimorphum (nach KLEBs). 1 Oberer Teil einer vegetativen Zelle, die ihr Plasma bereits zurückgezogen hat. 2 Gametangium mit austretenden Gameten. 3 und 4 Kopulation zwischen Makro- und Mikrogameten. 5 Auf dem Objektträger gekeimte Zygoten. 6 In ein Gefäßbündel eingedrungene Pflanze. 7 Bildung einer Ruhezelle (Gametangium). 8 Kleine Zelle, aus der Keimung einer Zygote entstanden, aus der Atemhöhle des Blattes. 9 und 10 Kleine Ruhezellen, in der Umbildung zu Zoosporangien begriffen. 11 Zoosporen. 12 Keimung einer Zoospore auf dem Objektträger. 13 Auf dem Objektträger aus einer Zoospore gebildete Ruhezelle.

einem Riß sich öffnet (Fig. 17, 2) und die Gameten austreten läßt. Betrachtet man nun mehrere Gametangien, so zeigt es sich, daß einige Makro-, andere Mikrogameten liefern. Gleichartige Gameten kopulieren nicht miteinander, die Kopulation findet ausschließlich zwischen Nakround Mikrogameten statt, und sie ist so vollkommen, daß sogar die Cilien der kleinen Gamete gänzlich mit dem Leibe der großen verschmelzen, so daß die Zygote statt 4 nur 2 Cilien aufweist.

Läßt man nun die Zygoten auf einem Objektträger keimen, so bilden 
sie einen Keimschlauch (Fig. 17, 5), der sich alsbald verzweigt, und in welchen die ganze Energide eintritt, so daß die ursprüngliche Zygotenmembran nur mehr einen leeren Raum umschließt.

Tollständig entwickeln sich die Pflänzchen aber nur, wenn sie in lebendigee Lysimachia-Blätter eindringen können.

Der Keimschlauch sucht damn auf dem kürzesten Wrege die Gefäßbündel zu erreichen, tritt in eines derselben hinein und wächst zwischen den Spiralzellen weiter (Fig. 17, 6). Die Plasmamasse tritt in das anschwellende Ende des Keimschlauches ein, und die junge Pflanze ist an ihren Bestimmungsort gelangt.

Sie kamn nun entweder fast elliptisch bleiben oder zu langen, grünen, verzweigten oder unverzweigten Schläuchen heranwachsen. Beim Uebergang in den Ruhezustand schwillt ein Teil der Pflanze an; das Plasma zieht sich aus dem Schlauche zurück, trennt sich mit einer IVand von dem jetzt leeren Schlauche ab (Fig. 17, 7), und die Ruhezelle ist fertig. Es treten jetzt im Plasma breite, stäbchenförmige, mehr oder weniger gebogene, dunkelgrüne Partien auf; Oel und Stärke wird gebildet, und schließlich bildet sich die Ruhezelle zu einem Gametangium um, aus welchem wiederum Makro- und Mikrogameten entstehen.

Wir sehen also, daß die Ruhezelle einfach zum Gametangium wird, und daß die Zyoten zu mehr oder weniger verzweigten Schläuchen auskeimen, welche ganz einfach dadurch Ruhezellen bilden, daß sie das Plasma an einer angeschwollenen Stelle des Schlauches konzentrieren und durch eine Membran vom leeren Teile aborenzen.

Unter anderen Bedingungen aber entstehen aus den Zygoten nicht solche lange Schläuche mit Ruhezellen, sondern nach einer geringen Verzweigung (Fig. 17, 8), oder auch ohne eine solche die kleinen Ruhezellen, von welchen bereits oben die Rede war, und welche nicht in den Gefäßbündeln, sondern einzeln oder zu zweien dicht unter den Spaltöffnungen liegen.

Diese kleinen Ruhezellen verwandeln sich später zu Zoosporangien, welche 2-ciliëge Zoosporen bilden, die ausschlüpfen und, auf dem Objektträger kultiviert, alsbald in den Ruhestand eintreten (Fig. 17, 11-13).

Die kleinen Ruhezellen bilden also eine schlauchlose ungeschlechtliche Generation neben der öfters stark schlauchförmig verzweigten geschlechtlichen. Ein obligater Generationswechsel liegt hier aber offenbar nicht vor, es hängt von äußeren Umständen ab, ob eine Zygote die geschlechtliche oder ungeschlechtliche Generation bilden wird. Es ist noch nicht gelungen, aus den Zoosporen wieder geschlechtliche Individuen großzuziehen, aber man darf wohl annehmen, daß auch dies in der Natur vorkommt.

Blicken wir nun auf die Gruppe der Endosphaeraceen zurück, so begegneten wir in Chlorochytrium rein einzelligen Individuen, bei Endosphaera konstatierten wir eine Neigung zur Cönobienbildung und bei Phyllobium eine solche zur Bildung langer Schläuche.

Diese beiden Neigungen der Endosphaeraceen nun haben sich bei ihren Nachkommen weiter ausgebildet, indem einerseits aus ihnen die cönobienbildenden Hydrodictyaceae, andererseits die schlauchbildenden Siphonales hervorgingen.

Die Hydrodictyaceen entwickelten sich dadurch, daß das ephemere. nicht wachstumsfähige Coenobium von Endosphaera langlebig wurde und die Fähigkeit des Wachsens erwarb, die Siphonales, indem der langschläuchige polyenergide Zustand sich mehr und mehr herausbildete.

Bevor wir aber diese Sachen weiter verfolgen, sei es gestattet, 
darauf hinzuweisen, daß in der Gruppe der Endosphaeraceae bereits "Arbeitsunfähigkeit" und damit verknüpfter Parasitismus auftrat.

Es wäre verführerisch, an Formen wie Chlorochytrium und Endosphaera die Synchytriaceae, an letztere zumal Synchytrium anzuschließen ; das ist aber, weil die Zoosporen dieser Formen nur eine Cilie besitzen, wohl kaum möglich. Ebensowenig kann man mit gutem Rechte ein Geschlecht wie Pseudolpidium davon ableiten, welches zwar 2 Cilien besitzt, da die Insertion der Cilien dort ganz anders ist, nämlich eine seitlich, eine an der Spitze; wir kommen auf diese Formen später zurück, aber zweifellos ist von einer Form, wie Phyllobium, das von Lagerherm beschriebene Rhodochytrium abzuleiten.

Spilanthes Lundii D.C. oder eine nahe verwandte Species, eine Composite, erkrankt in Ecuador öfters durch diesen Parasiten, welche

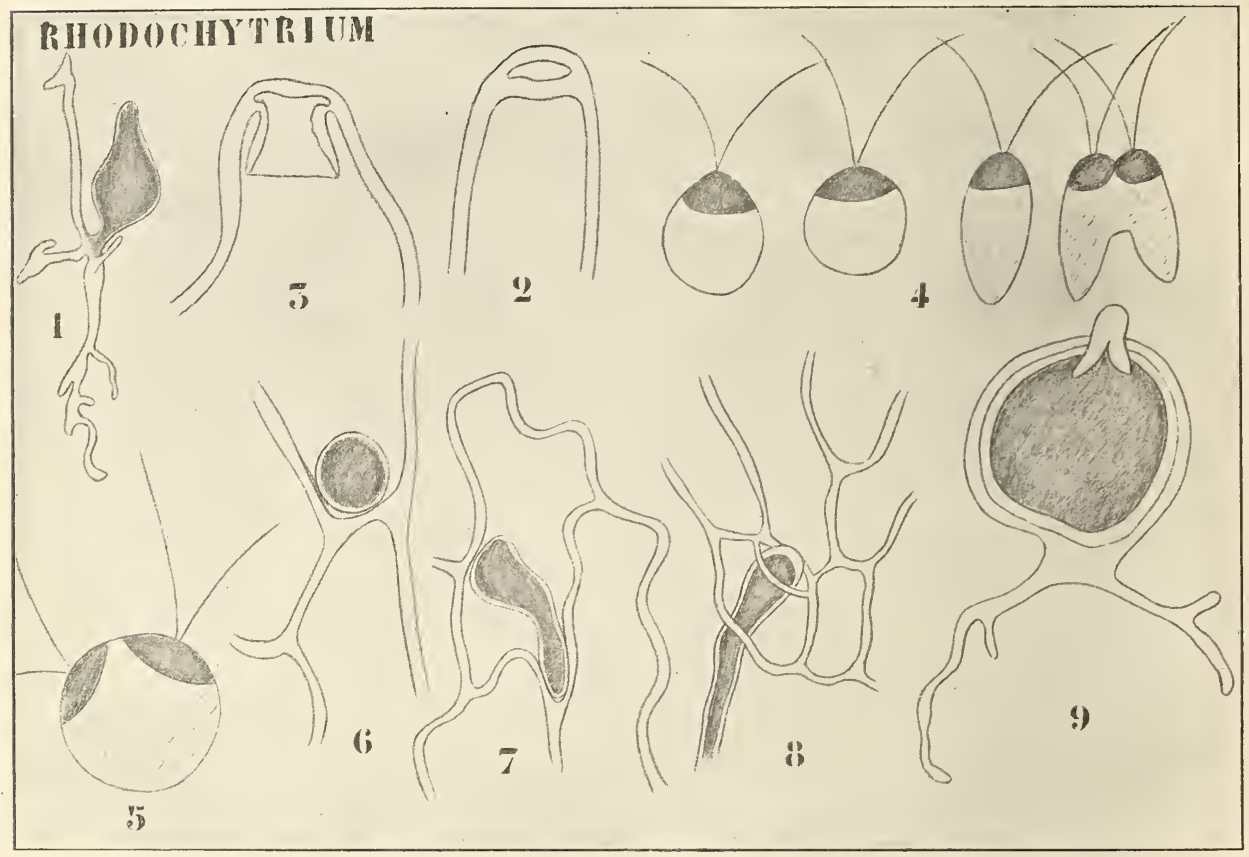

Fig. 18. Rhodochytrium Spilanthidis LAGERH. 1 Gametangium mit Rhizoiden. 2 Spaltung der Wand zur Oeffnung des Gametangiums. 3 Bildung der Manschette. 4 Gameten und deren Kopulation. 5 Vierciliëge Zygote. 6-8 Keimung der Zygote auf der Epidermis des Spilanthes. 9 Dauergametangium.

Krankheit zuerst im November 1899 von LAGERHEIm in der Nähe Quitos bemerkt wurde. So ein krankes Spilanthes-Exemplar zeigt bereits, mit bloßen Augen betrachtet, eine große Menge von kleinen blutroten Punkten, welche in den Stengelteilen und den Blättern sitzen; es sind die Gametangien des Parasiten.

Mit schwacher Vergrößerung erkennt man, daß die meisten und größten Sporangien immer an den Blattnerven sitzen und an dünnen Querschnitten bei genügender Vergrößerung, daß jedes Gametangium mit seiner Basis einem Gefäßbündel ansitzt.

Die Gametangien stehen offenbar noch auf einer niedrigen Differenzierungsstufe, da die von ihnen produzierten Gameten auch ohne 
Kopulation sich zu entwickeln rermögen. Die Gameten haben 2 Cilien, die Zrgoten $t$ und sind bloß an dem den Cilien zugekehrten Teile rot gefürbt. Es sei hier gleich bemerkt, daß der rote Farbstoff Carotin ist, welches wir ja schon neben dem Chlorophyll bei Phyllobium antrafen; es läßt sich also Rhodochytrium als ein in Bezug auf die grüne Farbe farblos gewordenes Phyllobium betrachten, während das Carotin geblieben ist. Carotin kommt übrigens bei vielen Pilzen vor, man verol. z. B. Wents Arbeit über Monilia und das Carotin bei Pilobolus.

Die Zygoten heften sich auf einem Blatt- oder Stengelstïcke von Spitanthes an. und zwar immer auf der Grenze zweier Epidermiszellen, wo sie sich mit einer Membran umgeben. Hier wird ein Keimschlauch getrieben, welcher zwischen zwei Epidermiszellen hindurch in das Innere der Pflanze eintritt, in der gleichen Weise, wie Chlorochytrium in die Lemna-Pflanze eindringt. Ebenso wie bei Chlorochytrium bleibt die Zyotenmembran als Cellulosepfropf über der Eintrittsstelle sitzen. Der Keimschlauch wächst nun wie bei Phyllobium auf ein Gefäßbündel zu und verlängert sich so lange, bis er dieses mit seiner Spitze erreicht. Die Spitze wächst jetzt zu zahlreichen dünnen Schläuchen aus, welche sich stark und unregelmäßig verästeln, das Gefäßbündel auf einer weiten Strecke dicht umspinnen und den Verzweigungen desselben genau folgen. Diese Verästelungen (Fig. 18, 1) belegt LAGERHEIM mit dem Namen Rhizoiden.

Der schlauchförmige Teil der Alge, d. h. also der Keimschlauch, der von der Eintrittsstelle bis zum Gefäßbündel reicht, bildet sich jetzt zum Gametangium durch einfaches Aufschwellen aus; ob das Gametangium dabei von den Rhizoiden mittels einer Querwand abgetrennt wird, konnte nicht ermittelt werden, ist aber höchst wahrscheinlich.

Im Gametangium entstehen die Gameten wohl durch wiederholte Zweiteilung, wie aus vorzeitig geöffneten Gametangien geschlossen werden kann, und das spricht wohl dafür, daß das Gametangium zunächst einkernig sei; es bedarf dies aber erneuter Untersuchung:

Die Gametangien öffnen sich an der Spitze mittels einer Oeffnung, welche zur Bildung eines eigentümlichen, einer Manschette ähnlichen inneren Kragens führt, der durch das Spalten der Membran an dem Gametangiumscheitel zu stande kommt. Dauergametangien entstehen in fast genau derselben Weise wie die gewöhnlichen und unterscheiden sich von diesen nur durch eine stärker verdickte Membran.

Es ist also Rhodochytrium offenbar ein von einer der Endosphaeraceen abzuleitender Pilz, als dessen nächster jetzt lebender Verwandter Phyllobium anzusehen ist.

Sehen wir jetzt, wie sich die Endosphaeraceae in autotropher Richtung weiter entwickelt haben, und betrachten wir dazu zunächst die Gruppe der

\section{Hydrodictyaceae,}

welche Familie aus 2 Genera besteht: Pediastrum und Hydrodictyon ${ }^{1}$ ), welche beide kosmopolitische Süßwasserbewohner sind.

\section{Pediastium}

ist eine grüne, mikroskopische Alge, welche aus recht zierlichen, vielzelligen, runden Scheibchen besteht und an der Oberfläche von Gräben, Kanälen, Pfützen und Seen treibt.

1) Oltmanns rechnet hierzu noch Euastropsis LAGERH., eine mir unbekannte Form. 
Bei der ungeschlechtlishen Fortpflanzung kann jede Zelle zum Sporangium werden, ohne ihre Gestalt zu ändern. Es heißt in der Literatur, daß sich der Inhalt eines Sporangiums mittels successiver Zweiteilung in Zoosporen zerlege. Es bedarf dieser Vorgang wohl erneuter Untersuchung, da die alsbald zu erwähnende Vielkernigkeit von Pediastrum nicht für diese Auffassung spricht; wahrscheinlich scheint es mir, daß die Zoosporen hier durch Spalten des Plasmas, so wie bei Hydrodictyon, gebildet werden.

Die ausgebildeten Zoosporen schlüpfen zwar aus dem Sporangium aus, bleiben aber von der verschleimenden Innenschicht der Sporangiumwand umschlossen. Sie besitzen 2 Cilien, mittels welcher sie einige Zeit innerhalb der Schleimblase herumschwimmen, alsbald aber zur Ruhe

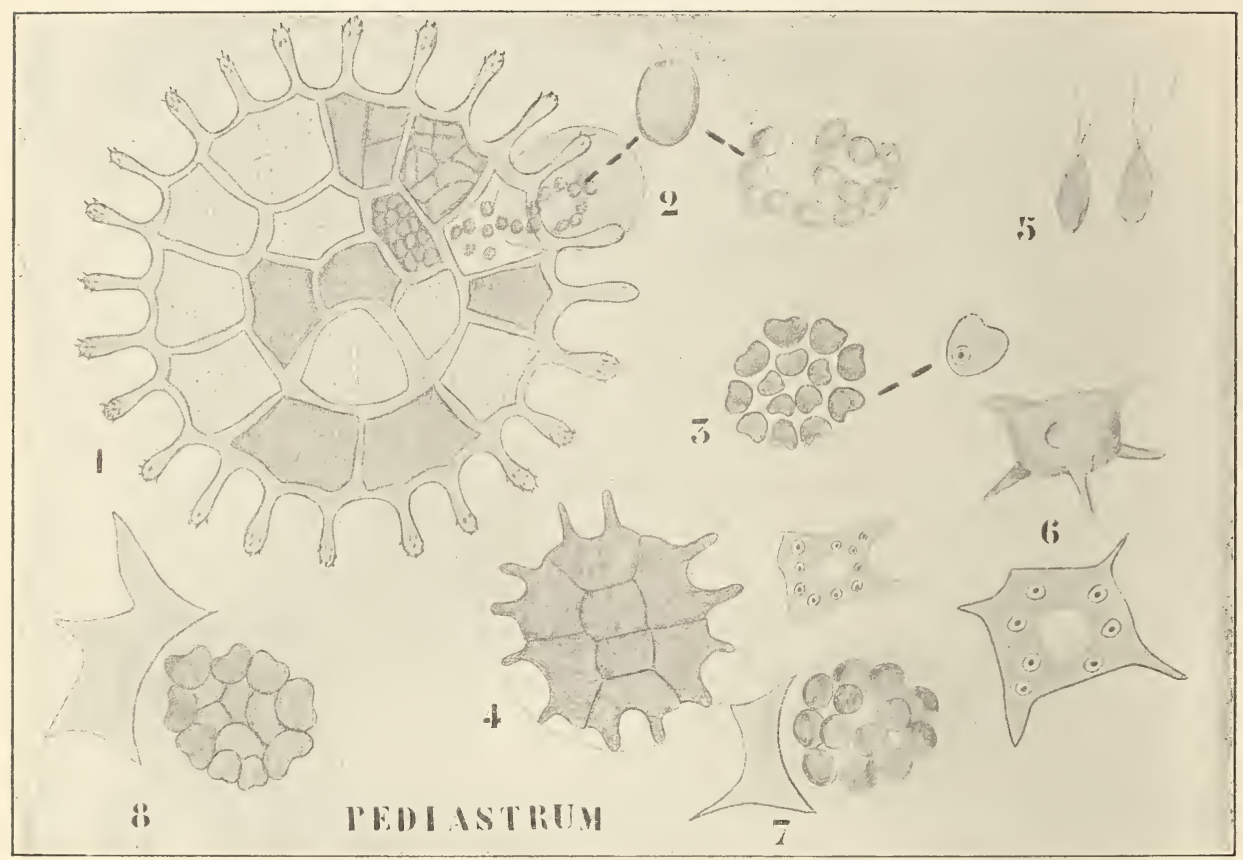

Fig. 19. Pediastrum. 1 P. Boryanum (TurP) Menegh. nach A. Braun. 2 Die Schwärmer legen sich zu einer neuen Kolonie aneinander. 3 Eine junge Kolonie, deren Zellen noch monoenergid sind. 4 Kolonie mit polyenergiden Zellen. 5 Gameten. 6 Polyeder. 7, 8 Bildung der jungen Kolonie innerhalb des Polyeders. (2-8 schematisiert nach BRAUN und ASKENASY.)

kommen, nachdem sie sich in der Form einer Zellenscheibe angeordnet haben. Jede Zoospore umgibt sich nun mit einer Membran, und es wird alsbald die abweichende Form der Randzellen angedeutet (Fig. 19, 3). Jede Zelle fängt nun zu wachsen an (Fig. 19,4), und es zeigt sich, daß inzwischen die Energiden sich vermehrt haben, so daß die Zellen jetzt vielkernig sind.

Die Randzellen dokumentieren sich mehr und mehr als solche, indem sie die für jede Art charakteristischen, oft recht schönen Hörner oder Zacken ausbilden, welche die Zierlichkeit der Scheibchen noch erhöhen.

Dieses verschiedene Verhalten der Randzellen und der zentral gelegenen Zellen des Coenobiums beruht wohl nicht auf einer speziellen 
Eigenschaft der Raudzellen, sondern auf dem Umstand, daß die zentralen Zellen durch die sie umringenden Randzellen an der Ausbildung der Hörner gehindert werden.

Trir sehen hier zum ersten Male ein Beispiel des Einflusses, welchen verschiedene Zellen einer Kolonie aufeinander anch in morphogenetischer Hinsicht ausüben.

Es braucht wohl nicht betont zu werden, daß die Pctiastrum-Kolonie dem Coenobium von Endosphaera völlig homolog ist, nur hat das Coenobinm die Fähigkeit zum Nachstum erhalten und ist damit vom ephemeren in den langlebigen Zustand übergegangen; die Zellen eines Pediastrum-Scheibchens entstehen also nicht durch Zellteilung, und alle Zellen einer Scheibe sind Geschwister.

TTir haben gesehen, wie die Zoosporen entstehen; unter anderen Umständen kann sich jede Zelle, ebenfalls ohne die Form zu änderı, zu einem Gametangium umbilden. Da in einer Zelle mehr Gameten als Zoosporen gebildet werden, sind erstere kleiner (Fig. 19, 5) als die letzteren. und sie sind auch dadurch von den Zoosporen verschieden, daß sie ganz aus der Mutterzelle herausschlüpfen und frei im Wasser herumschwimmen.

Sie kopulieren miteinander und bilden runde Zygoten, welche sich mit einer dicken Membran umgeben und ziemlich beträchtlich wachsen.

Askexasy nun fand neben diesen r/ygoten stachelige Körper (Fig. 19, 6), sogenamnte Polyeder, von welchen er nach Analogie mit Hydrodictyon wohl mit Recht vermutet, daß sie aus in den Zygoten gebildeten Schwärmern (man vergleiche das bei Hydrodictyon Gesagte) entstanden sind.

Der Name Polyeder für diese zackig'en Zellen rührt daher, daß man diese Gebilde früher für unabhängige Algenarten gehalten hat, welche man zu einem besonderen Genus: Polyedrium, vereinigte.

Diese Polyeder wachsen, werden vielkernig und bilden, wie die vegetativen Zellen von Pediastrum, Zoosporen, welche sich innerhalb der ausschlüpfenden und verschleimenden Innenmembran (Fig. 19, 7, 8) zu einer Zellenscheibe anordnen, genau so, wie das bei den in vegetativen Zellen gebildeten Zoosporen geschah, und so Pediastrum-Cönobien bilden, welche von den auf ungeschlechtlichem Wege entstandenen nicht zu unterscheiden sind.

Betrachten wir jetzt

\section{Hydrodictyon}

etwas näher. Diese Alge tritt öfters in großer Menge in Süßwasser auf, in anderen Jahren ist sie kaum zu erhalten. Im Jahre 1904 war sie im kleinen Teiche im Leidener Botanischen Garten sehr schön entwickelt. Sie hat die Form eines allseitig geschlossenen, mehr oder weniger cylindrischen Netzes, mit ungefäh sechseckigen Maschen. Jede Masche wird von ebensovielen Zellen begrenzt, wie die Masche Seiten hat, so daß also jede Maschenseite von einer einzigen Zelle eingenommen wird.

Die Entwickelung lehrt, daß die Zellen zu netzförmigen Kolonien vereinigte Individuen sind, und daß, so wie bei Pediastrum, sämtliche Individuen, welche die Kolonie zusammensetzen, Geschwister sind.

Betrachtet man die Zellen näher, so zeigt sich, daß diese eine große zentrale Vakuole besitzen und einen wandständigen Protoplasmasack.

In diesem Plasmasack kann man 3 Zonen unterscheiden: Hautschicht, Körnerplasma und Vakuolenwand (vergl. Fig. 21). 
Im Körnerplasma treffen wir an der Außenseite zunächst den netzartig durchbrochenen Chromatophor an, welcher die ganze Plasmamasse umgibt, und in welchem sich eine Anzahl von Pyrenoiden befindet, welche nach innen zu etwas hervorragen. Mehr nach innen zu liegen

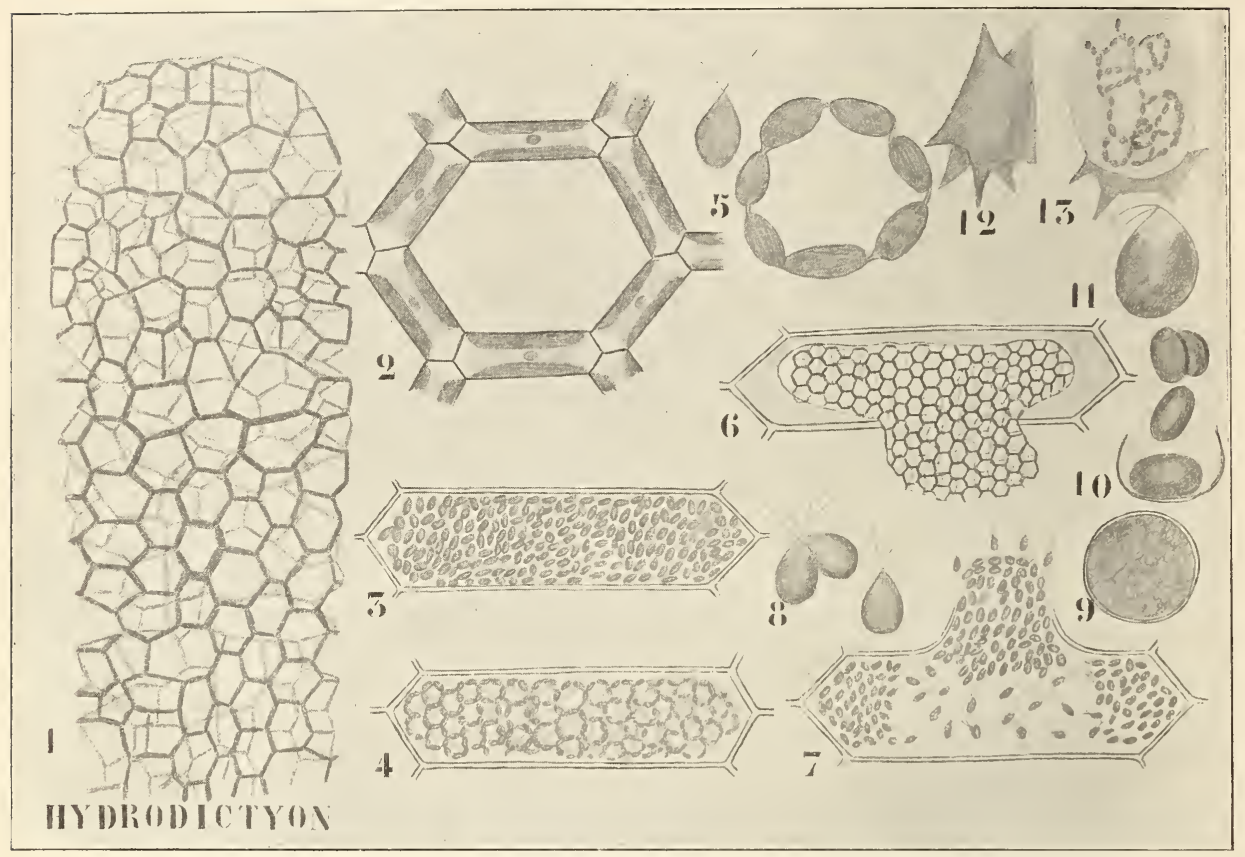

Fig. 20. Hydrodictyon nach Klebs, Warming und Artari. 1 Netz. 2 Eine der Maschen stärker vergrößert. 3 Bildung der Fortbildungsenergiden. 4 Zoosporangium mit einem jungen Netze. 5 Einzelne Zoospore und einige zur Bildung einer Masche zusammentretende Zoosporen. 6 Austreten eines auf ungeschlechtlichem Wege entstandenen Netzes. 7 Gamctangium mit Gameten. 8 Kopulation von Gameten. 9 Zygote. 10 Keimende Gamete, welche 4 Schwärmer bildet. 11 Zygotenschwärmer. 12 Polyeder. 13 Netzbildung in einem Polyeder.

die zahlreichen Kerne, denn die Zellen von Hydrodictyon sind polyenergid. Mit dem Chromatophor von Hydrodictyon ist es aber eine eigene Sache. Timberlake (1901) zeigte bereits, daß er, nachdem der Farbstoff mit Alkohol ausgezogen wurde, vom übrigen Plasma nicht

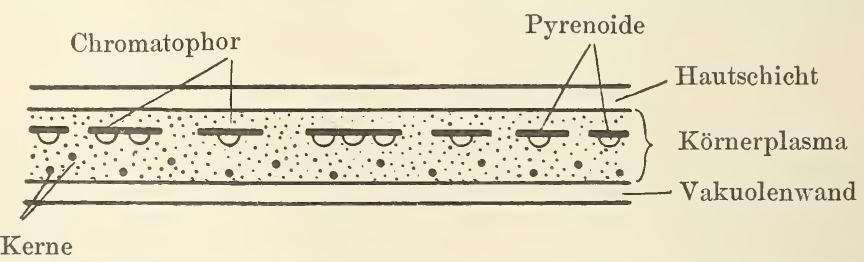

Fig. 21. Schematischer Längsschnitt durch einen Teil des wandständigen Plasmas von Hydrodictyon.

zu unterscheiden ist, und also den Namen Chromatophor nicht verdient. Nach ihm gibt es bei Hydrodictyon überhaupt keinen Chromatophor, sondern nur eine partielle Grünfärbung des Plasmas. 
Auch KLebs legt, trotzdem er den Namen Chromatophor verwendet, den Nachdruck auf die großen Differenzen zwischen dem Chromatophor ron Hydrodictyon und denen anderer Gewächse, indem er sagt. 1. c. Sp. 792 :

„Ohne Zweifel steht aber Hydrodictyon noch auf einer niederen Stufe in der Ausbildung seines Chromatophors, was schon Schrmper für andere niedere Algen hervorgehoben hat. Nicht allein daß sich statt einzelner Chlorophyllkörper hier nur eine einzige zusammenhängende Schicht findet, es kommt noch hinzu, daß dieselbe in ihrem ganzen Verhalten den Eindruck eines noch wenig differenzierten Plasmabestandteiles macht. Sie besitzt keine selbständige Fähigkeit der Termehrung, sonderu wird erst bei der Fortpflanzung passiv mit geteilt. Sie ist, abgesehen

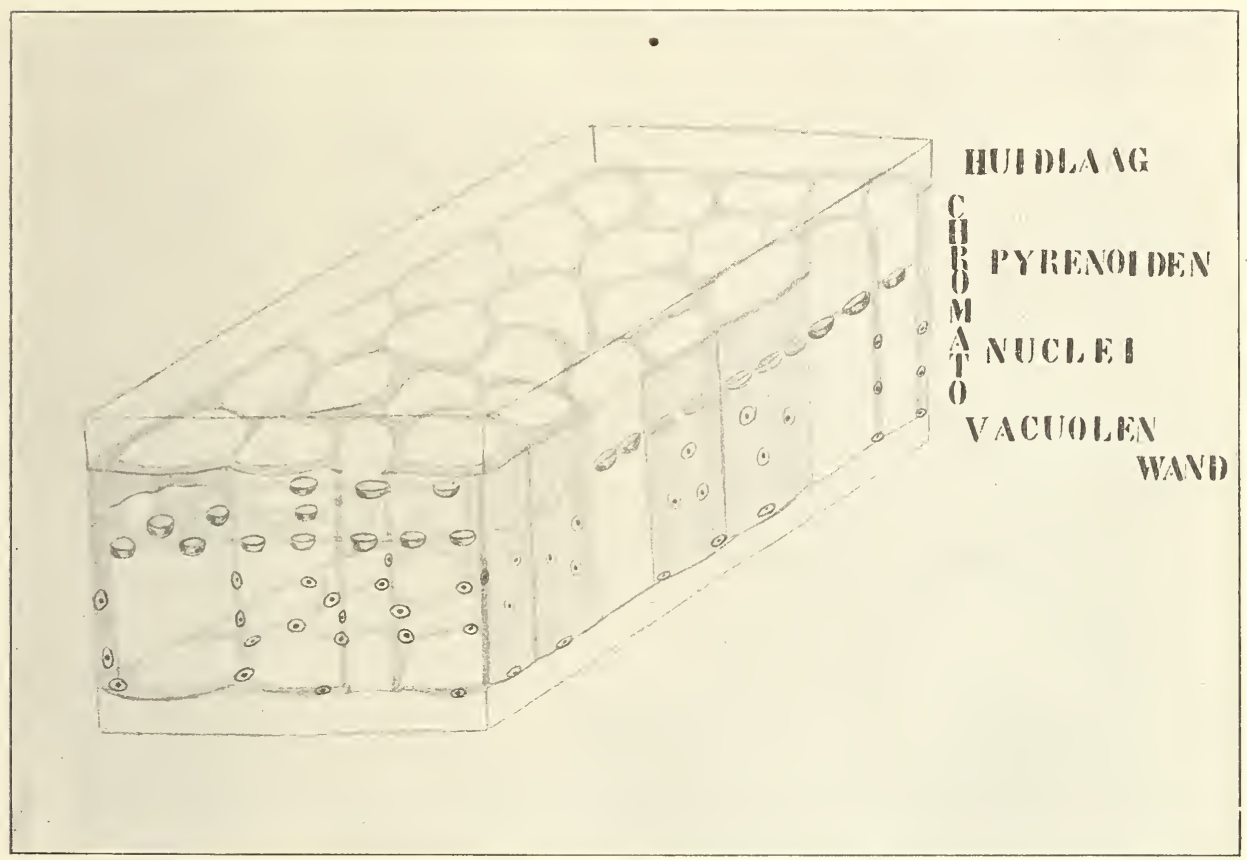

Fig. 22. Schematische Darstellung der möglichen Ausbildung des Chromatophors. Huidlaag $=$ Hautschicht.

von ihrer eigenen Ernährungsfunktion, dem Stoffwechsel wie alle anderen Plasmabestandteile unterworfen; ja, in der Art ihrer Ausbildung prägt sich der augenblickliche Ernährungszustand der ganzen Zelle am deutlichsten aus."

KLEBS zeigt dann weiter, welche Veränderungen auftreten. In hungernden Zellen ist der Chromatophor sehr stark durchbrochen, so daß er nur noch aus Maschen mit sehr schmalen Wänden besteht, bei guter Ernährung werden die Maschen stets enger, und bei sehr guter Ernährung werden sogar Ausläufer in der Gestalt unregelmäßiger Röhren gebildet, welche das Körnerplasma quer durchsetzen und auf der Grenze der Vakuolenwand miteinander durch grün gefärbte Plasmapartien in Verbindung treten. In dieser Weise entsteht eine Art Doppelchromatophor, wovon Fig. 22 eine schematische Darstellung gibt, zwischen welchen 
die mehr oder weniger cylindrischen Röhren ausgespannt sind. Bei dieser Maximalausbildung der Grünfärbung werden die Kerne in den Chromatophor aufgenommen; sie befinden sich sowohl in der Unterschicht, wie in den cylinderförmigen Verbindungsplatten. Zu gleicher Zeit sinken die Pyrenoide herunter, sie werden durch zwischen ihnen ausgespannte farblose, dichtere Plasmapartien verbunden und mittels ähnlicher Plasmastränge an die äußere Chromatophorenschicht angehängt, so daß im Chromatophor ein farbloses Plasmanetz eingehängt ist, dessen Knoten die Pyrenoide enthalten.

Den plattenförmigen Chromatophor der jungen Zellen, durch dessen Verzweigungen nach ARTARI der kompliziertere Chromatophor der älteren Zellen entstehen soll, hat KLEBs nie gesehen.

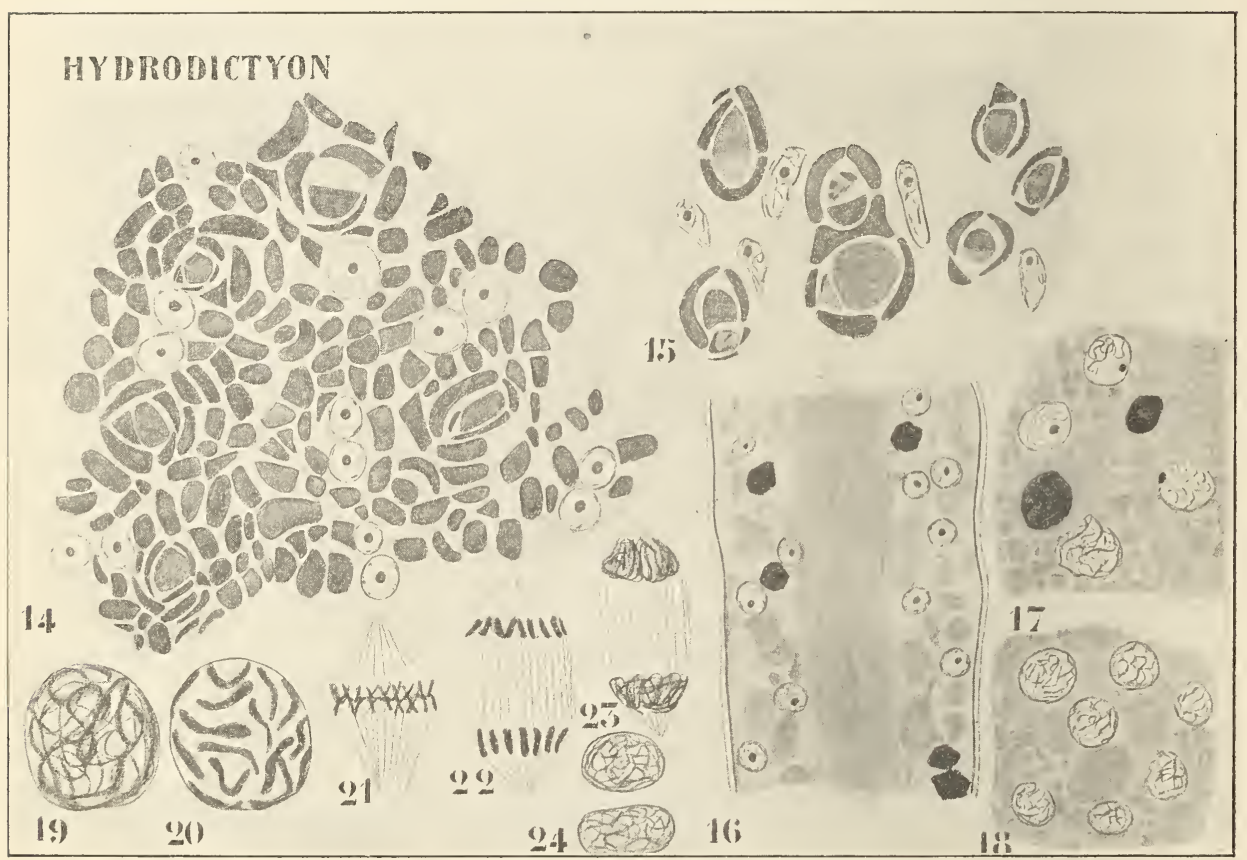

Fig. 23. Hydrodictyon (nach TImberLAkE). 14 Ein Flächenschnitt einer Zelle, welche schnell Stärke bildet. $15 \mathrm{Jd}$. einer Zelle, wo die Stärke ungefähr ebenso schnell gelöst wie gebildet wird. 16 Längsschnitt einer Zelle, zentrale Vakuole, Vakuolen im wandständigen Plasma und stärkefreie Pyrenoide zeigend. 17 Flächenschnitt einer ähnlichen Zelle. 18 Die Pyrenoide sind gelöst. 19-24 Kernteilung.

Die ganze Darstellung spricht meines Erachtens sehr für TrmBERLAKEs Auffassung, daß wir es hier nicht mit einem Chromatophor in der gewöhnlichen Bedeutung dieses Wortes zu tun haben, sondern daß, je nach dem Ernährungszustand, das Plasma sich partiell mehr oder weniger grün färbt.

In Bezug auf die Pyrenoide sahen wir bereits früher, daß diese nach neueren Untersuchungen Timberlakes die Stärke bilden, indem sie ihre Substanz an der Peripherie fortwährend in Stärke umbilden, diese umgebildeten Stücke abschneiden und wegschieben (p. 8).

Wird die Stärke nun sehr energisch gebildet und nicht entsprechend 
schmell gelöst, so häuft sie sich (Fig. 23, 14) an, und scheint es, als seien zweierlei Arten von Stärke vorhanden, nämlich mit und ohne Terbindung mit Pyrenoiden. Es hat dies zu der Auffassung geführt, daß bei Hydrodictyon Pyrenoidstärke und Stromastärke anwesend seien. Der Umstand aber. daß man die Stärkekörner immer so arrangiert findet, daß jedes Stärkekorn sich doch in einer gerrissen Relation zu irgend einem Pyrenoid befindet (Fig. 23, 14), führte Trmberlake zu der Auffassung, es sei auch die sogenannte Stromastärke von Pyrenoiden gebildet und nur durch Zwischenschiebung von später abgetrennten Stärkekörnern von ihrem Bildner entfernt worden.

Ob dies aber in allen Fällen zutrifft, ist wenigstens fraglich. Die großen Entfernungen, welche man z. B. in den gelappten CladophoraChromatophoren zwischen Stromastärkekörnern und den diesen am nächsten liegenden Prrenoiden antrifft, mahnen da doch zur Vorsicht ${ }^{1}$ ).

ITird die Stärke ungefähr ebenso schnell gelöst, wie sie gebildet wird, so kommt es bei Hydrodictyon überhaupt nicht zur Bildung von Stromastärke (Fig. 23, 15), und diese Beobachtung spricht nun gewiß wieder sehr für TImBERLAKEs Auffassung; Untersuchungen an lebendem Material bleiben aber noch wünschenswert zur definitiven Entscheidung.

Wir sahen bereits früher, daß die Hydrodictyon-Zelle voll einer Anzahl von Energiden bewolnt wird und demnach vielkernig ist.

Bei der Fortpflanzung werden in jeder Zelle eine Anzahl von Zoosporen resp. Gameten gebildet.

Beide Torgänge werden in der gleichen Weise eingeleitet, es vermehrt sich sowohl das Plasma wie die Zahl der Kerne, letzteres mittels normaler Karyokinese (Fig. 23, 19-24). Nit anderen Worten, es vermehren sich die Energiden. Alsbald verschwinden durch Auflösung die Pyrenoide (Fig. 23, 18). Diese Pyrenoidenauflösung findet überhaupt nur auf diesem Stadium des Lebens unserer Pflanze statt, und dies legt die Vermutung nahe, es enthalten die Pyrenoide gewisse bei der Fortpflanzung verwendete Substanzen.

Nach den letzten Untersuchungen TrmberLakes treten nun im Plasma Spalten auf, welche ohne jegliche Rücksicht auf die Kerne das Plasma zunächst in vielkernige Stücke zerlegen (Fig. 24, 26); diese Spalten nehmen sowohl in der äußeren wie in der inneren Hautschicht (Vakuolenwand) ihren Ursprung (Fig. 24, 27). Diese Spaltenbildung hält so lange an, bis der ganze Plasmaschlauch in einkernige Stücke zerteilt ist.

Zunächst schließen diese Plasmastücke ganz genau aneinander, so daß die Schlauchnatur des protoplasmatischen Wandbelages gewahrt bleibt und dieser Schlauch durch den osmotischen Druck der Vakuole gespannt und also wandständig bleibt, jetzt aber ziehen sich die einzelnen Energiden etwas zusammen (Fig. 24, 28), der Druck wird dadurch selbstverständlich aufgehoben, der Schlauch kollabiert, und die einzelnen Plasmastücke liegen jetzt im Innern der Zelle (Fig. 20, 3). Sie haben inzwischen 2 kontraktile Vakuolen und 2 Cilien gebildet (Fig. 24, 32) und verteilen sich unregelmäßig in der Zellenflüssigkeit.

Dieser Vorgang findet genau in derselben Weise statt, ob nun schließlich Gameten oder Zoosporen gebildet werden; die einzige Differenz liegt darin, daß die Zoosporen größer als die Gameten sind.

1) TrmberLAkes Starch Formation in Cladophora, Science, N. S. Tol. 15 p. 457, habe ich nicht gesehen. 
Verfolgen wir zunächst das Schicksal der Zoosporen. Die zum Zoosporangium gewordene Zelle öffnet sich nicht (Fig. 20, 3), die Zoosporen können also nicht herausschwimmen. Sogar innerhalb der Zelle ist ihr Schwimmvermögen offenbar nicht groß, sie wackeln nur etwas hin und her und arrangieren sich meistens innerhalb einer Stunde $\mathrm{zu}$ einem Miniaturnetzchen innerhalb des Zoosporangiums (Fig. 20, 4). Jetzt verschwinden die Cilien, vermutlich indem sie eingezogen werden und umgibt sich jede Zoospore mit einer Cellulosemembran. wodurch die ganze jetzt noch einkernige und pyrenoidenlose Zelle gebildet wird. Das Pyrenoid tritt aber sehr bald auf (Fig. 24, 32). Das junge Netz tritt durch Verschleimung der Sporangiumwand alsbald heraus (Fig. 20,6), die einzelnen Zellen desselben strecken sich, die Kerne vermehren sich

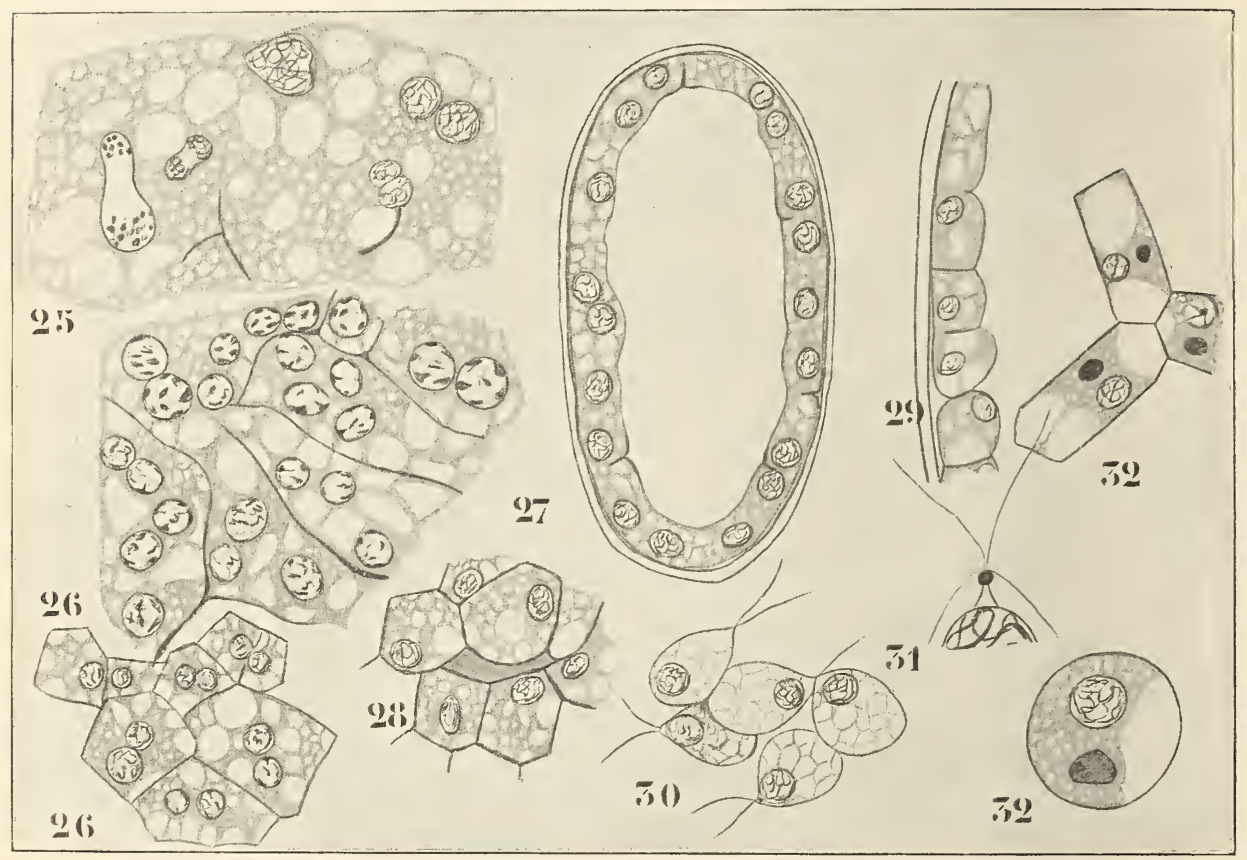

Fig. 24. Hydrodictyon (nach Timberlake). 25 Auftreten der ersten Plasmaspalten bei der Bildung der Fortpflanzungszellen. 26 Weiterspaltung. 27 Die Spalten gehen sowohl von der inneren wie von der äußeren Hautschicht aus. 28 Einkernige Stïcke in der Flächenansicht, die Stücke fangen, wie die breite Spalte in der Mitte zeigt, an, sich zu kontrahieren. 29 Die Bildung der einkernigen Stücke im Längsschnitt. 30 Die Fortpflanzungszellen fangen an Cilien zu bilden. 31 Spitze eines Schwärmers. 32 (unten) Eine Zoospore, welche eben eine Zellwand gebildet hat; das Pyrenoid hat sich wieder de novo gebildet. 32 (oben) Junge monoenergide Individuen eines jungen Zellnetzes, jedes mit einem Pyrenoid.

und die junge Kolonie ist geboren. Zellteilung findet also bei Hydrodictyon nicht statt, das Netz ist eine Kolonie, die dasselbe zusammensetzenden Individuen sind die ausgewachsenen Geschwisterzoosporen, welche sich netzförmig arrangiert haben.

Wenn dagegen die Hydrodiciyon-Zelle sich in ein Gametangium umbildet, der Inhalt also in Gameten zerlegt wird, so öffnet sie sich (Fig. 20, 7) und die Gameten schwimmen heraus. Diese Gameten können 
jetzt sowohl paarweise kopulieren (Fig. 20, s) als sich parthenogenetisch entwickeln.

Beide umgeben sich mit einer Membran (Fig. 20,9); das weitere Schicksal der Parthenosporen ist unbekannt, die Zygoten aber nehmen bedeutend an Größe zu und bilden nach längerer Ruhezeit $2-4^{1}$ ) sehr große Schwärmer (Fig. 20. 10, 11), welche aus der Zvoote heraustreten, sich mit einer Doppelmembran umgeben und zu großen polygonalen unbeweglichen Körpern, den sogenannten Polyedern (Fig. 20, 12), heranwachsen.

In diesen Polyedern vermehren sich alsbald die Kerne, es werden damn in genau derselben Weise wie in den vegetativen Zellen Zoosporen gebildet und diese arrangieren sich auch hier zu einem, durch Verschleimung der Innenwand heraustretenden Netz (Fig. 20, 13, ); die Außenwand ist inzwischen gesprengt worden. Es sind diese Netze aber unregelmäßiger als die, welche in den vegetativen Zellen gebildet werden, und daran kann man sehen, ob man mit einem jungen Zoosporangiumoder mit einem jungen Polyedernetz zu tum hat.

TVir sahen bereits oben, daß die Gameten auch ohne Kopulation eine Membran bilden können und sich also wenigstens so weit entwickeln können; das machte es interessant zu erörtern, unter welchen Umständen Hydrodictyon Zoosporen, unter welchen es Gameten bildet.

In seinem Flora-Artikel von 1890 konnte nun KLEBS nachweisen, daß äußere Umstände bestimmen, ob die Alge Zoosporen oder Gameten bilden wird.

Mit anderen Worten, jede Zelle eines Hydrodictyon ist im stande. sowohl Zoosporen wie Gameten zu bilden, und es hängt nur von äußeren Umständen ab, ob erstere oder letztere gebildet werden.

Ich will aus der Fülle der KLEBsschen Versuche nur einige wenige herausgreifen.

Man kann gesunde erwachsene Hydrodictyon-Netze zu jeder Zeit zur Zoosporenbildung zwingen, indem man sie einige Zeit in 0,5-1-proz. Nährlösung ( $\mathrm{MgSO}_{4} 1$ Teil, Kaliumphosphat 1 Teil, $\mathrm{KNO}_{3} 1$ Teil, $\mathrm{Ca}\left[\mathrm{NO}_{3}\right]_{2} 4$ Teile) kultiviert und dann in frisches Wasser bringt, wobei man aber für gute Beleuchtung zu sorgen hat.

Ja sogar ein Netz, welches bereits die Gametenbildung angefangen hat, kann man in ein Zoosporen bildendes verwandeln durch Kultur in der oben besprochenen Weise und nachträgliche Einsetzung in reines Wasser.

Gesunde Netze kann man dagegen zur Produktion von Gameten zwingen durch Kultur in einer 7-10-proz. Rohrzuckerlösung. Bei dieser Kultur ist Licht nicht nötig, direktes Sonnenlicht sogar schädlich.

Am sichersten erhält man Gameten, sogar in Netzen, welche bereits angefangen hatten, Zoosporen zu bilden, wenn man die "Zuckerkulturen" bei einer Temperatur von $10-12^{\circ} \mathrm{C}$ vor ein mäßig helles, nie geöffnetes Fenster setzt in solcher Weise, daß sie nie von einem direkten sonnenstrahl getroffen werden. Bringt man eine solche Kultur 10-14 Tage nach Anfang des Versuches in einen Thermostaten von 26-28 ${ }^{\circ} \mathrm{C}$, so elfolgt innerhalb weniger Tage, sogar öfters bereits innerhalb 24 Stunden reichliche Gametenbildung.

Wir können also im allgemeinen sagen, daß Zoosporen gebildet werden, wenn der Ernährungszustand reichlich und günstig ist, daß Gameten gebildet werden, wenn zwar die Nahrungszufuhr reichlich ist,

1) Ausnahmsweise scheinen auch 5 gebildet zu werden. 
die Umstände für den Verbrauch derselben aber ungünstig sind, so daß eine gewisse Quantität organischer Nahrung angehäuft wird.

Es zeigen KueBs' Versuche, daß die Zoosporen bildenden Hydrodictyon-Netze mit den gametenbildenden nicht im Verhältnis eines Generationswechsels stehen, aber daß es ausschließlich von äußeren Umständen abhängt, ob eine Hyárodictyon-Zelle Zoosporen oder Gameten bilden wird.

Damit ist aber die Möglichkeit eines Generationswechsels bei Hyclrodictyon noch keineswegs ausgeschlossen.

Wir erinnern uns, daß die Zygote 4 große Schwärmer bildet, welche zu Polyedern auswachsen, und daß in diesen mittels Zoosporen wieder Netze gebildet werden.

Es wäre nun recht gut möglich, daß diese Zygote die Zelle ist, in welcher die ungeschlechtliche Generation gebildet wird, daß die Zygote also, wie ich es ausdrücke, zum Gonotokonten ${ }^{1}$ ) wird.

Gerade die Bildung von 4 großen Schwärmern in der Zygote führt mich zu dieser Auffassung.

Die Sache liegt nämlich so: Wir haben früher gesehen, daß in den Kernen der Pflanzenzellen eine bestimmte Chromosomenzahl vorhanden ist. Nehmen wir an, es besitzen sowohl eine Hydrodictyon-Zoospore wie eine Hydrodictyon-Gamete x Chromosomen im Kern, so wird das aus einer Zoospore oder aus einer Parthenospore hervorgegangene Individuum gleichfalls x Chromosomen in den Kernen enthalten.

Wenn aber 2 Gameten miteinander kopulieren, verschmelzen, wie wir sahen, auch deren Kerne, es muß also der Zygotenkern 2 x Chromosomen enthalten, und wenn die Zygote sich durch Aequationsteilungen zu einer Pflanze entwickelt, müssen sämtliche Zellen dieser Pflanze Kerne mit 2x Chromosomen führen.

Falls diese Pflanze nun wieder durch Aequationsteilung Gameten bildete, würden die aus diesen entstehenden Zygoten 2x Chromosomen besitzen, die der nächsten Generation $8 \mathrm{x}$, die der folgenden $16 \mathrm{x}$ u. s. w. Es ist klar, daß dies alsbald zu der Absurdität führen würde, daß ein Organismus nur aus Chromosomen bestände, und es muß also in irgend einem Moment nach der Bildung des Zygotenkernes eine Reduktion der Chromosomenzahl stattfinden.

Es ist nun prinzipiell gleichgültig, ob diese Reduktion sofort nach der Bildung der Zygoten stattfindet, in welchem Falle die 7ygote selber zum Gonotokonten wird, oder aber ob sie erst viel später eintritt, nachdem die Zygote durch Teilung eine Generation mit 2x Chromosomen in den Zellkernen (kurz: 2x-Generation) gebildet hat. In letzterem Falle wird nicht die Zygote zum Gonotokonten, sondern wird eine oder mehrere der der 2x-Generation angehörigen Zellen zum Gonotokonten.

Einen klaren Fall des letzteren Verhaltens bieten die Farne uns dar. Die Gameten der Farne sind in Eier und Spermatozoen spezialisiert; aus der Zygote (dem befruchteten Ei) bildet sich die Farnpflanze, die $2 \mathrm{x}$-Generation. In ihren Sporangien bilden die Farnpflanzen „Sporenmutterzellen“, welche so wie die Zygote von Hydrodictyon vier Sporen bilden. Es sind also bei den Farnen die Sporenmutterzellen die Gonotokonten.

Daß ein Farn die Kopulation viel besser ausnutzt als ein Hydrodictyon, steht also außer Frage, während letztere pro Zygote nur 4 Nach-

1) Nachkommenbildner. 
kommen bilden kann, bildet der Farn pro Zyoote Tausende und abermals Tausende ron Nachkommen.

Die Reduktion der Chromosomenzahl findet immer statt bis zur Zahl der Gameten, welche zusammengetreten sind, also bis zur Hälfte.

Es enthält der Gonotokont demnach immer 2x Chromosomen, die aus ihm herrorgehenden Fortptlanzungszellen, welche man im allgemeinen mit dem Namen Gonen bezeichnen kann, x Chromosomen.

Die 4 aus einer Farnsporenmutterzelle hervorgehenden Sporen enthalten demnach $\mathrm{x}$ Chromosomen; diese Sporen keimen zu Prothallien, deren Zellen $x$ Chromosomen besitzen, diese bilden Gameten mit ebenfalls $\mathrm{x}$ Chromosomen, und die von diesen g'ebildeten Zygoten keimen zu Farmptlanzen mit Zellen mit 2x Chromosomen.

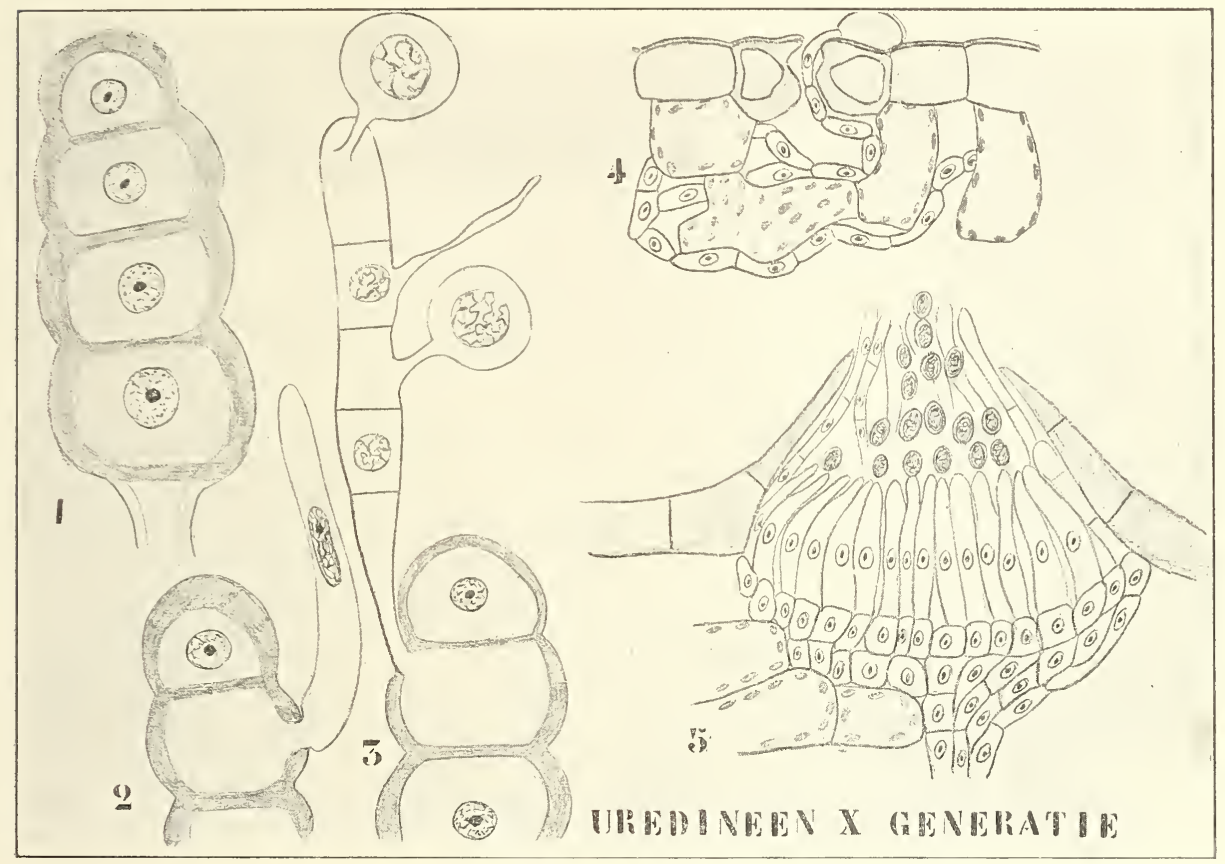

Fig. 25. Uredineen (nach BlackmaN). Schematisiert. 1 Reife Teleutospore. 2 Anfang der Bildung eines Promyceliums. 3 Promycelium mit 2 Sporidien. 4 Keimende Sporidie und Bildung des uninukleären Mycels, z. B. in einem Berberitzenblatt. 5 Spermogonium.

Das Prothallium der Farne ist demnach eine $\mathrm{x}$-Generation, die Farnpflanze eine $2 x$ Generation, und es findet ein fortwährender Generationswechsel zwischen beiden statt.

Eine Betrachtung des Tier- und Pflanzenreiches zeigt nun, daß in bei weitem den meisten Fällen in den Gonotokonten 4 Gonen gebildet werden und in allen Fällen zwei oder ein Mehrfaches dieser Zahl.

Es ist gerade dieser Umstand, der mich dazu veranlaßt, anzunehmen, daß die 2-4 Schwärmer, welche in der Hydrodictyon-Zygote gebildet werden, Gonen sind, daß also die Zygote bei Hydrodictyon sofort zum

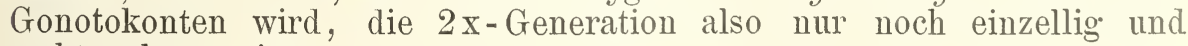
recht ephemer ist. 
Es bleibt nun noch zu erörtern, weshalb im Gonotokonten wenigstens 2 Gonen gebildet werden müssen, wenn auch eine nachträglich zu Grunde gehen kann.

Sehen wir zu, wie dieser eigenartige Rhythmus, die Zusammenkunft der elterlichen Kerne (Gametenkerne), ihr Zusammenbleiben und ihre Trennung stattfindet.

Wir können dabei verschiedene Fälle unterscheiden. Bei den Uredineen, einer Pilzfamilie, enthalten sämtliche Zellen der $2 \mathrm{x}$ Generation während ihres ganzen Daseins 2 Kerne, erst im allerletzten Moment ihrer Existenz wird ein Organ gebildet: die Teleutospore, in welchem diese Kerne miteinander verschmelzen, eine Vereinigung, welche nur sehr kurz anhält, denn sie trennen sich alsbald wieder; die von ihr

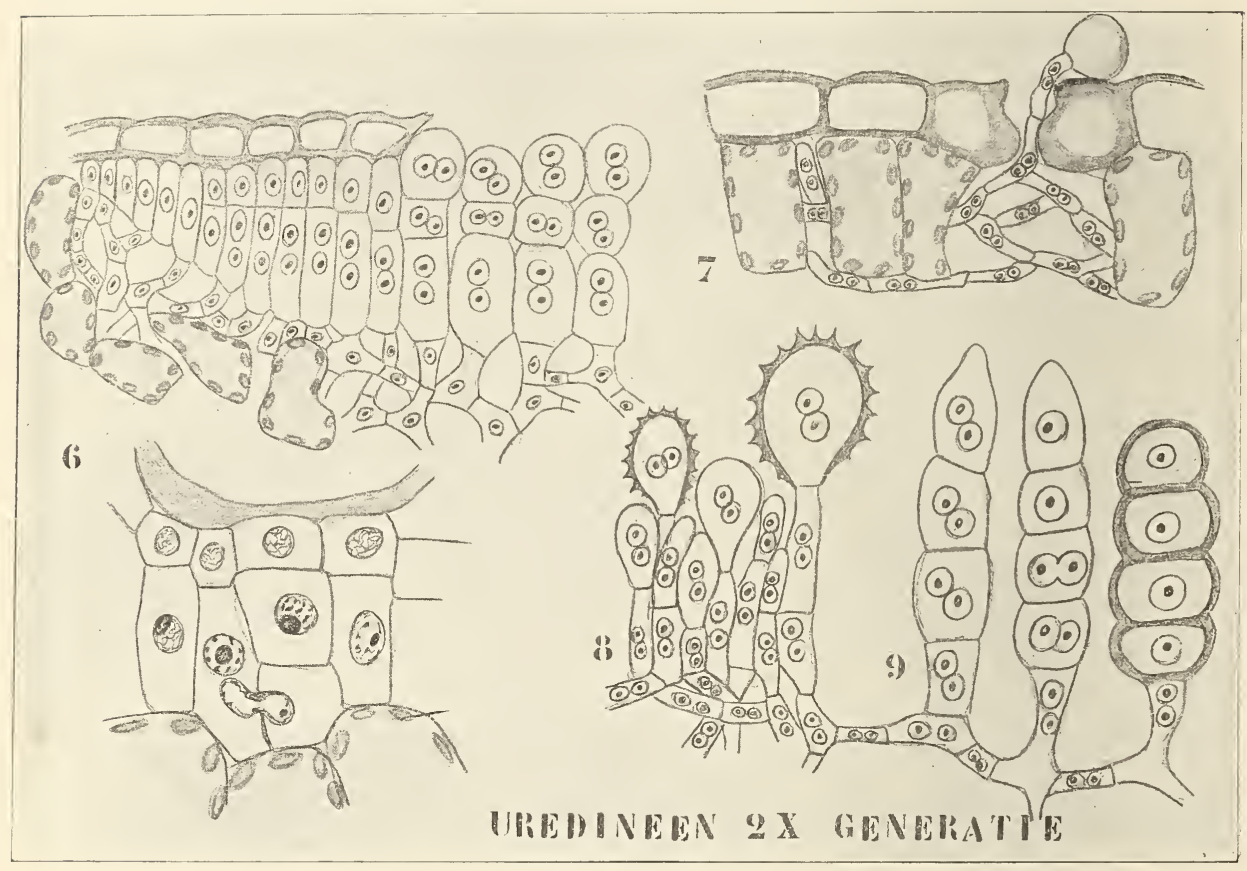

Fig. 26. Uredineen (nach BLACкMaN). Schematisiert. 6 Peripherischer Teil eines jungen Aecidiums, z. B. auf der Berberitze. In der oberen Figur sind einige der fertilen Zellen bereits binukleär; in der unteren sieht man, wie die fertilen Zellen durch seitliche Kopulation binukleär werden. 7 Keimung einer Aecidiospore, z. B. auf einem Grasblatt und Bildung des binukleären Mycels. 8 Uredospore. 9 Junge (noch binukleäre) und alte uninukleäre Teleutosporen.

gebildeten Zellen, die Sporidien, enthalten nur einen Kern, sie keimen zu Mycelien, welche die $\mathrm{x}$-Generation darstellen, die Teleutospore ${ }^{1}$ ) ist also zum Gonotokonten geworden (Fig. 25 u. 26).

Ein anderes Beispiel liefert Cyclops. Im Ei ist natürlich der Eikern vorhanden; aurch das eindringende Spermatozoon kommt der Spermakern hinzu und wird das Ei zweikernig. Dieser zweikernige Zustand

1) Die eigentliche Reduktion findet wohl bei der Teilung des Promycelnucleus statt, da dieser Nucleus aber der in den Keinschlauch eingetretene Teleutosporennucleus ist, darf man sagen, es sei die Teleutospore zum Gonotokonten geworden. 
bleibt auch während der jetzt folgenden, zum Aufbau des Körpers führenden Zellteilungen fortbestehen, und zwar wenigstens bis zur Bildnmg der Keimblätter. so daß wenigtens im ersten Lebensstadimm Cyclops in jeder Zelle seines Körpers einen väterlichen und einen mütterlichen Kel’n enthält, welche sich auch selbständig; aber in gleichem Rhythmus teilen. Wir sagen dann, dem Torgang René Marres folgend, daß jede Zelle ein Synkaryon enthält.

Bei weitaus den meisten Oroanismen ist dies nicht der Fall. Bei fast allen Organismen verschmelzen der väterliche und der miitterliche Kern direkt nach der Befruchtung; und ist also auch die $2 x$-Generation einkernig.

Daß sich väterliche und miitterliche Elemente dennoch trennen kömnen, hat seinen Grund in dem Beibehalten der Individualität der einzelnen Chromosomen bei der Kernverschmelzung, Diese Verschmelzung ist also unvollkommen, auch im Zygotenkern bleiben väterliche und mütterliche Chromosomen getrennt, der Unterschied zwischen einer Zelle mit 2x-Kernen und einer solchen mit einem

$2 x$-Kern ist also nur ein gradueller.

Terfolg'en wir nun das Schicksal der Chromosomen in dem häufigsten Falle, in dem, bei welchem in der Zygote sich ein 2x-Kern bildet. Die Chromosomen reihen sich in dem $2 x$-Kern nur aneinander.

Der Chromatinfaden, welchen wir bereits im Kern beobachteten, besteht also zur einen Hälfte aus väterlichen, zur anderen aus mütterlichen Chromosomen. Greifen wir einen sehr einfachen Fall heraus: nehmen wir an, daß wir mit einem hypothetischen Wesen zu tun haben, das nur ein einziges Chromosom in seinen Gameten enthält, so wird der Kernfaden der Zygoten aus einem väterlichen und einem mütterlichen Chromosom bestehen.

Die durch Teilung des Zygotenkernes entstehenden Kerne der 2xGeneration werden dann in dieser Weise gebildet werden:
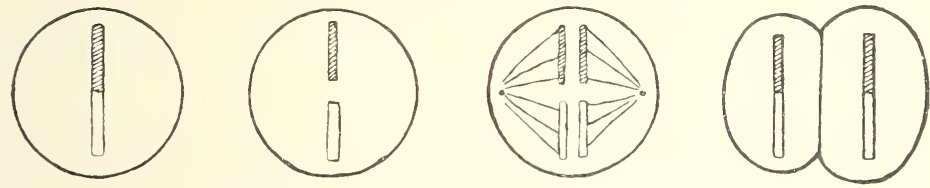

Fig. 28.

Wie man sieht, eine vollkommen normale Karyokinese, bei welcher die Tochterkerne, gerade wie der Zygotenkern, ein väterliches und ein mütterliches Chromosom enthalten.

Wie gelangen wir nun aber zum Stadium der 2 x-Generation zurück, oder mit anderen Worten, wie werden Fortpflanzungszellen mit nur einem Chromosom gebildet? Wir sahen bereits wo dies stattfindet, nämlich in den Gonotokonten.

Der Gonotokont enthält nun ein väterliches und ein mütterliches Chromosom und stimmt in dieser Hinsicht mit den übrigen Zellen der $2 \mathrm{x}$-Generation überein, weicht aber darin von diesen ab, daß hier eine Ausnahme von der Regel eintritt, daß der Kernfaden in ebensoviel Stücke auseinanderfällt, wie er zu seinem Aufbau gebraucht hat. Denn während der Kernfaden des Gonotokonten aus 2x Chromosomen gebildet wurde, fällt er nur in $\mathrm{x}$ Stücke auseinander. 
Die numerische Reduktion der Chromosomen findet also ganz plötzlich während der Ruheperiơle des Gonotokonten statt.

Wie geschieht dies? Sind die Chromosomen, in welche jetzt der Kernfaden auseinanderfällt, wohl denen äquivalent, aus welchen er aufgebaut wurde?

Es fällt öfters auf, daß die Chromosomen, zu welchen der Kernfaden zerbricht, viel dicker sind als diejenigen, welche zu seinem Aufbau gedient haben, und so liegt es nahe, zu vermuten, daß wir es hier nur mit einer scheinbaren Reduktion der Chromosomenzahl zu tun haben, und daß die Täuschung dadurch verursacht wird, daß sich die Chromosomen seitlich der Länge nach aneinander legen. Dies ist in der Tat der Fall: die fraglichen Chromosomen bestehen faktisch aus 2 ursprünglichen Chromosomen, sind bivalent.

Fig. 29.

Fig. 30 .
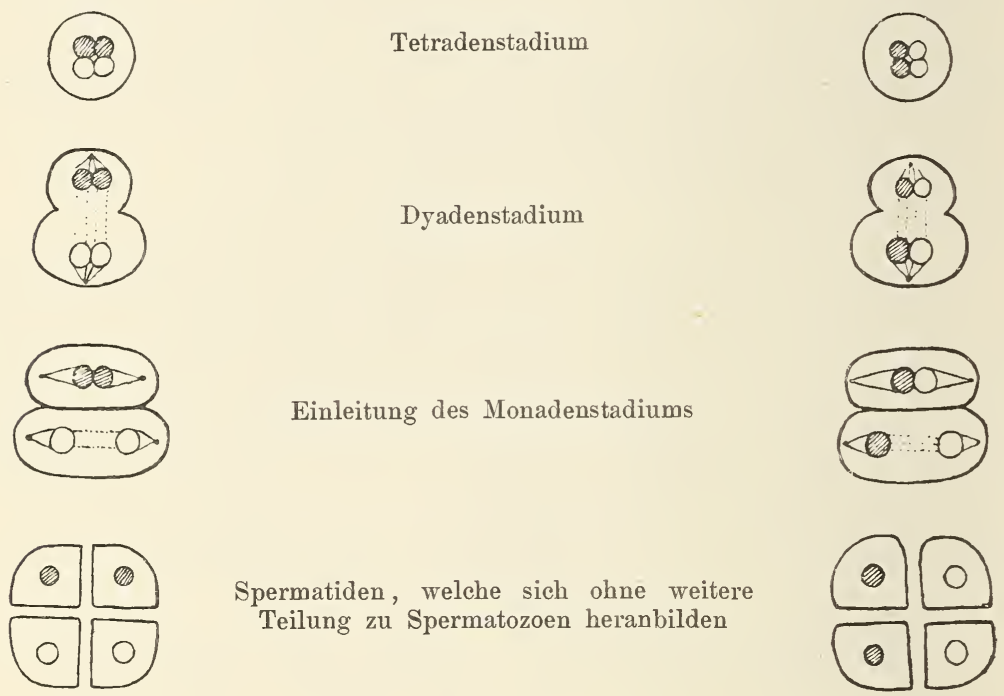

Fig. 29 und 30. Schematische Darstellung der Spermatozoenbildung eines höheren Tieres. Die väterlichen Chromosomen weiß, die mütterlichen schraffiert. In Fig. 29 wird angenommen, daß bereits im Dyadenstadium väterliche und mütterliche Chromosomen getrennt werden; in Fig. 30 wird die Trennung bis zur nächsten Teilung hinausgeschoben; das Resultat ist in beiden hypothetisch möglichen Fällen dasselbe.

Im Gonotokonten begegnen wir also zu Anfang der Ruheperiode univalenten, am Ende derselben bivalenten Chromosomen.

Wir wollen den Fall für die Spermatozoenbildung eines höheren Tieres einmal verfolgen. Wir sehen dann im Gonotokonten zunächst ein univalentes, später ein bivalentes Stadium. Hiernach wird das bivalente Chromosom, so gut wie bei der normalen Karyokinese, der Länge nach gespalten.

Die Spaltung ist nur deutlich sichtbar, wenn man das Chromosom von der Endfläche betrachtet; man sieht dann das sogenannte Tetradenstadium. Die Spaltungsprodukte werden bei der jetzt stattfindenden Zellteilung auseinandergezogen, so daß jede Zelle wieder ein bivalentes Chromosom 'ienthält (das Dyadenstadium der Fig. 30). Bis jetzt sind 
also das väterliche und das mütterliche Chromosom zusammengeblieben, bei der jetzt ummittelbar folgenden Zellteilumg findet die Tremnumg statt, indem diese Zellteilung in einer Ebene senkrecht zu der vorangehenden stattfindet. In dieser Weise entstehen $t$ Zellen, deren jede nur ein Chromosom enthält, und zwar entweder ein väterliches oder ein mütterliches.

In Fig. 29 findet die 'Trennung' von väterlichen und mütterlichen Chromosomen bereits im Dyadenstadium statt, aber beide Zellen enthalten noch 2 Chromosomen.

Unterblieb aber die eine Längsspaltung, welche zur Bildung des Tetradenstadiums geführt hat, so komnte bereits im Dyadenstadium eine vollkommene Trennung, eine Reduktion zum x-Stadium stattfinden; woraus also folgt, daß wenigstens 2 Gonen gebildet werden müssen, wenn auch eine später zu Grunde gehen kann.

Kehren wir jetzt zu den Hydrodictyeen zurück, so sehen wir, daß Pediastrum und Hydrodictyon das Vermögen der Zellteilung gänzlich abgeht, und daß ebenso das Vermögen zur Bildung langer Schläuche, wie es die höheren Endosphaeraceen besitzen, fehlt.

Es sind also die Hydrodictyeae als ein Seitenzweig der Endosphaeraceae zu betrachten, welche das bei diesen in initio vorhandene Vermögen zur Bildung von Cönobien weiter ausgebildet haben, sie sind also einer Form wie Endosphaera direkt anzuschließen.

Das ebenfalls bei den Endosphaeraceen in Potenz vorhandene Vermögen zur Schlauchbildung (am höchsten bei Phyllobium vorhanden) hat sich nun ebenfalls weiter entwickelt und zur Bildung der

\section{Siphonales}

geführt, von welcher großen Gruppe, die Familie der

\section{Protosiphoneae}

die einfachste ist, deren Betrachtung wir also mit

\section{Protosiphon botryoides (KG.) KLEBS}

anfangen wollen. Dieser Organismus ist offenbar mit Phyllobium nahe verwandt. Die Lebensgeschichte dieser Alge wurde, erst 1896 von KLEBs klargelegt. Bis zu jenem Moment wurde diese Alge mit Botrydium granulatum, einem ganz anderen Organismus als zur Lebensgeschichte des letzteren gehörend, betrachtet. Sowohl der Artikel von Rostafinski und Woronin über Botrydium granulatum in der Bot. Zeitung von 1877, wie die in Engler und Prantu gegebene Darstellung ist demnach unrichtig. Dennoch sind Botrydium und Protosiphon trotz äußerlicher Aehnlichkeit leicht auseinanderzuhalten, da Protosiphon einen einzigen, recht wenig differenzierten, netzartig durchbrochenen Chromatophor in der Weise von Hydrodictyon besitzt, während Botrydium zahlreiche wohldifferenzierte kleine Chromatophoren aufweist.

Wie wir bereits bemerkten, ist der Chromatophor dem von Hydrodictyon recht ähnlich, d. h. also, daß ein eigentlicher Chromatophor fehlt, aber daß ein größerer oder kleinerer Teil des Plasmas, je nach Umständen, grün ist. Es ist eine große zentrale Vakuole vorhanden, und ebenfalls wie bei Hydrodictyon finden wir melırere Pyrenoide und zahlreiche Kerne in jeder Zelle. 
Während sowohl den Endosphaeraceen wie den Hydrodictyeae jedes Zellteilungsvermögen völlig abgeht, ist Protosiphon dazu wohl im stande, unter natürlichen Bedingungen aber nicht in der Form gewöhnlicher Zellteilung, sondern mittels Knospenbildung.

Es wird nämlich an dem dicken grünen Teil des Pflänzchens (Fig. 31, 2) eine seitliche Ausstülpung gebildet, welche größer und größer wird, eine Art von Seitenzweiglein bildet (Fig. 31, 3) und schließlich vom Mutterindividuum ganz getrennt wird (Fig. 31, 4).

Wenn nun dies wohl kaum als normale Zellteilung betrachtet werden kann, so zeigen doch junge in Nährlösung gebrachte Zellen, daß die Fähigkeit dazu besteht, aber unter den Umständen, welche in der Natur vorkommen, nicht realisiert wird.

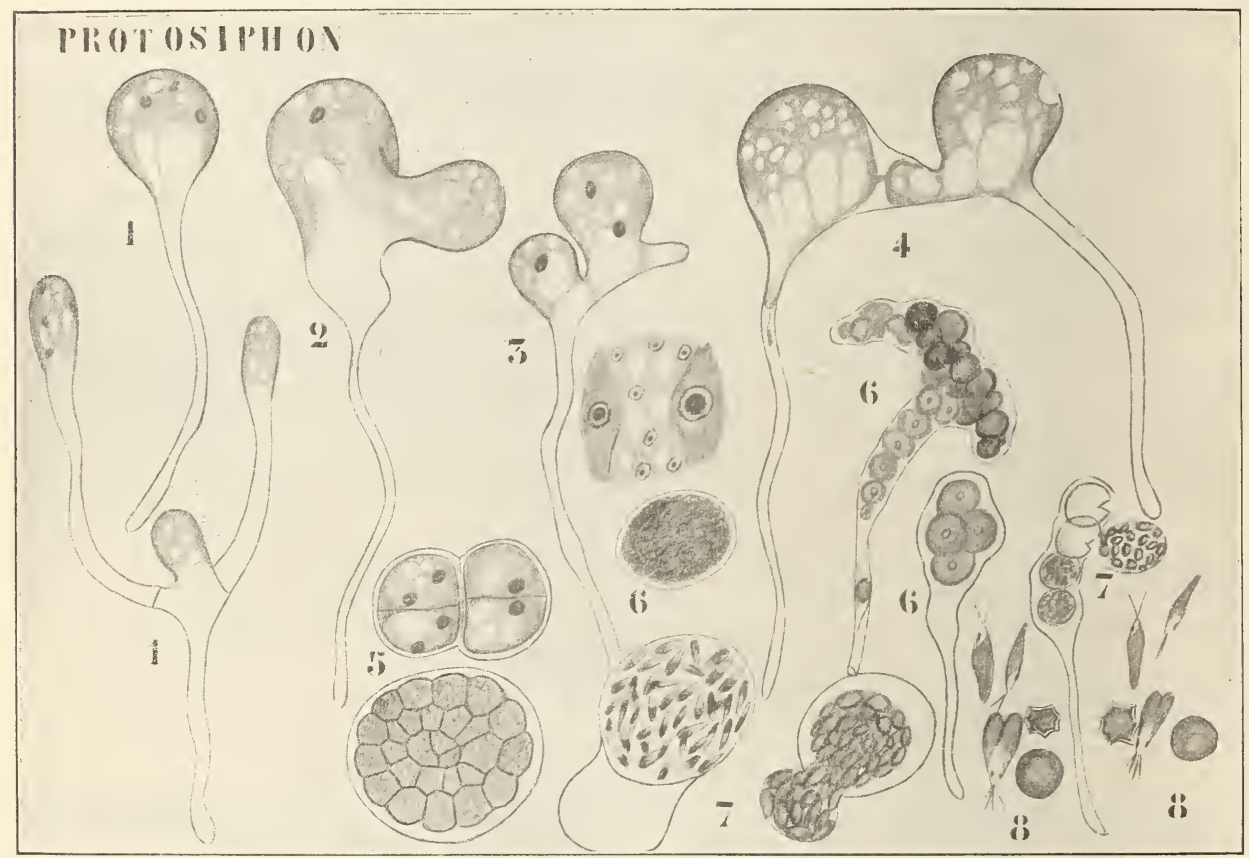

Fig. 31. Protosiphon botryoides (nach KLeBs und Rostafinski und Woronin). 1 Vegetatives Pflänzchen (oben unverzweigt, unten verzweigt). 2-4 Vermehrung durch Knospenbildung. 5 Normale Teilung eines Individuums in Nährlösung kultiviert. 6 Cystenbildung. 7 Bildung der Schwärmer in den Cysten. 8 Kopulation, Zygoten (eckig) und Parthenosporen (rund).

Die Form der Protosiphon-Zellen ist sehr verschieden, am Anfang kugelförmig, bilden sie alsbald ein schlauchförmiges Rhizoid und gleichen im erwachsenen Zustand (Fig. 31, 1) sehr einem Botrydium-Pflänzchen, von welchem sie aber auch äußerlich durch das unverzweigte Rhizoid zu unterscheiden sind.

In der Natur wachsen sie auf feuchtem Boden, und zwar meistens mit Botryaium zusammen, lassen sich aber auch in Nährböden kultivieren.

Wenn in irgend einer Weise das Wachstum stark gehemmt wird, z. B. durch Austrocknen, durch eine wasserentziehende Salzlösung, durch 
starke Insolation, zieht sich das Plasma zu Ballen zusammen (Fig. 31, 6), welche alsbald eine Membran bilden und so zu Cysten werden. Diese Crsten färben sich in hellem Sonnenlicht rot und können das Eintrocknen vertragen. Der rote Farbstoff färbt sich mit $\mathrm{H}_{2} \mathrm{SO}_{4}$ schön blau und ist also wohl Carotin oder wenigstens mit dieser Substanz nahe verwandt.

Sowohl jede vegetative Zelle wie jede Cyste besitzt das Vermögen, Schwärmer zu bilden. sie tun dies beim Uebergang von trockner oder feuchter Luft in flüssiges Wrasser, oder unter dem Einfluß der Finsternis, weun sie vorher in Nährlösungen kultiviert wurden.

Die Schwärmer sind klein, lichtempfindlich, im Besitze zweier Cilien, eines Augenfleckes und zweier kontraktilen Vakuolen und grün oder rot je nach der Farbe der sie bildenden Zellen.

WTas für Dinge diese Schwärmer eigentlich sind, ob Zoosporen oder Gameten, läßt sich schwer bestimmen, da sie sowohl mit als ohne Kopulation sich entwickeln können.

Im Wasser, im Licht und bei einer Temperatur von $1-24^{\circ} \mathrm{C}$ kopulieren sie und bilden sternförmige Zygoten, welche eine Ruheperiode durchmachen.

In Nährlösung im Dunklen oder in allen Fällen bei Temperaturen von 25-27 $\mathrm{C}$ kopulieren sie nicht, gelangen alsbald zur Ruhe, und bilden runde glatte Zellen (Parthenosporen), welche sofort zu jungen Pflänzchen auskeimen.

Es sind also die Schwärmer undifferenzierte Dinge, welche sich je nach Umständen als Gameten oder als Zoosporen betragen.

Der Umstand, daß hier aus der Zygote nur ein Keimling entsteht, konnte den Eindruck erwecken, als wäre denn doch hier ein Funktionieren derselben als Gonotokont ausgeschlossen. Mit Unrecht jedoch, es läßt sich sogar aus der Zahl der Keimlinge kein Schluß über die in der Zygote gebildeten Gonen ziehen. Leider ist in diesem Falle, wie in fast allen ähnlichen noch gar nichts bekannt, es sei hier ein Studium des Kernverhaltens in solchen Fällen aufs angelegenlichste empfohlen, aber wir wissen durch KLEBAHNs Untersuchungen, daß trotzdem bei der Keimung von Closterium nur 2 Gonen (Closterium-Individuen) ans Tageslicht treten, in der Tat deren 4 gebildet werden. Zwei derselben bleiben jedoch gänzlich rudimentär, ihr Vorhandensein äußert sich nur in der Anwesenheit von 2 weiteren Kernen, welche alsbald desorganisieren.

Resumierend darf man also Protosiphon als den niedrigsten Repräsentanten der Siphonales betrachten, er bildet den Typ der Familie der Protosiphoneae.

Die übrigen Siphonales kann man dem Beispiel von BLackman, und TANster folgend, in zwei Gruppen einteilen, in Siphoneae und Siphonocladeae.

Zu den Siphoneae gehören, mit Ausnahme des Seitenzweiges der Vaucheriaceae, nur Meeresalgen, sie sind dadurch charakterisiert, daß in ihrem schlauchförmigen Thallus keine Querwände auftreten, außer wenn Zoosporangien oder Gametangien vom vegetativen Teil des Thallus getrennt werden müssen, die Siphonocladeae dagegen besitzen auch im vegetativen Thallus Querwände, wodurch dieser sogar in zellenähnliche Abteilungen zerlegt werden kann, welche jedoch immer mehrkernig sind.

Die Anordnung der Familien, welche ich mit Ihnen aus diesen beiden Gruppen behandeln möchte, scheint mir am natürlichsten in folgender Weise zu geschehen, ich gebe dabei die zur Besprechung kommenden Genera an. 


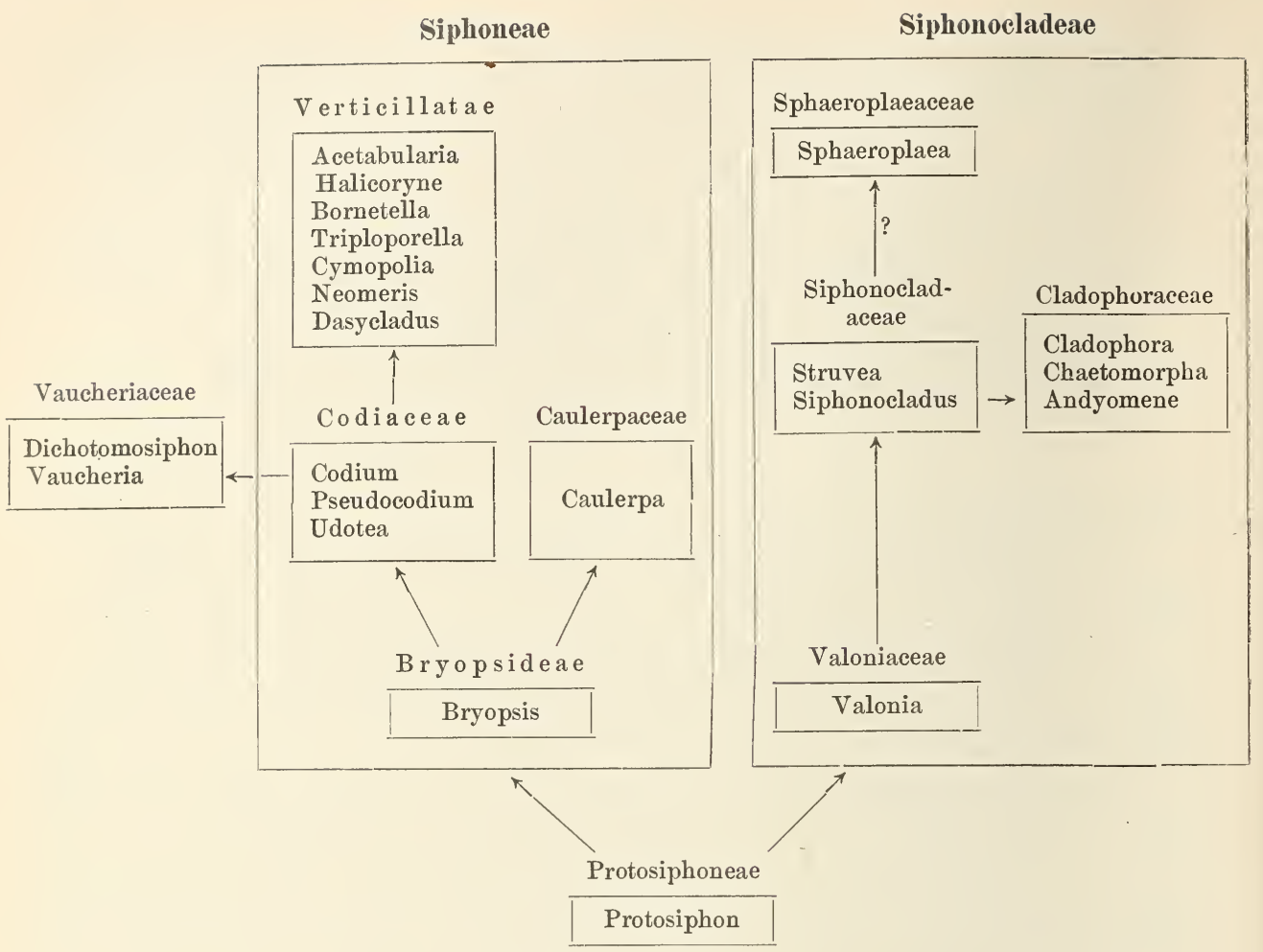

Fangen wir also mit der Betrachtung der Familie der

\section{Bryopsideae}

an. Sie umfaßt nur ein einziges Genus:

\section{Bryopsis.}

Bryopsis besteht aus einer einzigen Zelle, welche in einen befestigenden Teil, das Rhizoid, und einen die Nahrung bereitenden Teil, den Assimilator, differenziert ist.

Der Assimilator ist verzweigt und zwar so, daß die zweireihig gestellten Seitenzweiglein in einer Ebene liegen, wodurch das Ganze den Eindruck eines gefiederten Blattes macht. Radiäre Verzweiguug findet aber bisweilen auch statt.

Die Seitenzweiglein können sich unter Umständen wieder verzweigen, wodurch ein doppelt gefiederter Assimilator entsteht. Diejenigen Zweige, welche selber Zweige bilden, haben ein unbegrenztes Längenwachstum, sind also Längstriebe, diejenigen, welche nicht dazu im stande sind, die Kurztriebe, werden öfters Blätter genannt.

Daß die Zelle vielkernig ist, bedarf nur der Erwähnung, besonders betont aber muß werden, daß nicht ein großer Chromatophor vorhanden ist, sondern zahlreiche kleine. Jeder derselben besitzt ein Pyrenoid, das Produkt der Photosynthese ist Stärke.

Das Plasma ist wandständig, die zentrale Vakuole also sehr groß. 
In den älteren Thallusteilen können bisweilen, wie bei Caulerpa, freiendende Cellulosebalken gebildet werden.

Die Fortpflanzung geschieht mittels Gameten, und zwar durch kleinere männliche und größere weibliche, welche auf verschiedenen Individuen gebildet werden. Die männlichen haben einen sehr kleinen gelblichen Chromatophor, aber kein Stigma, die weiblichen einen grünen Chromatophor, beide natürlich zwei Cilien. Sie werden in Kurztrieben gebildet, welche sich mittels einer Wand vom Längstrieb abtrennen und ohne bedeutende Formveränderung zu Gametangien werden.

Die Kopulation wurde 1880 von BERTHOLD beobachtet, aber nicht publiziert, 1896 nahm OLtuanss sie wahr und publizierte Bertholds und seine Beobachtung in seinem schönen Algenwerke.

1

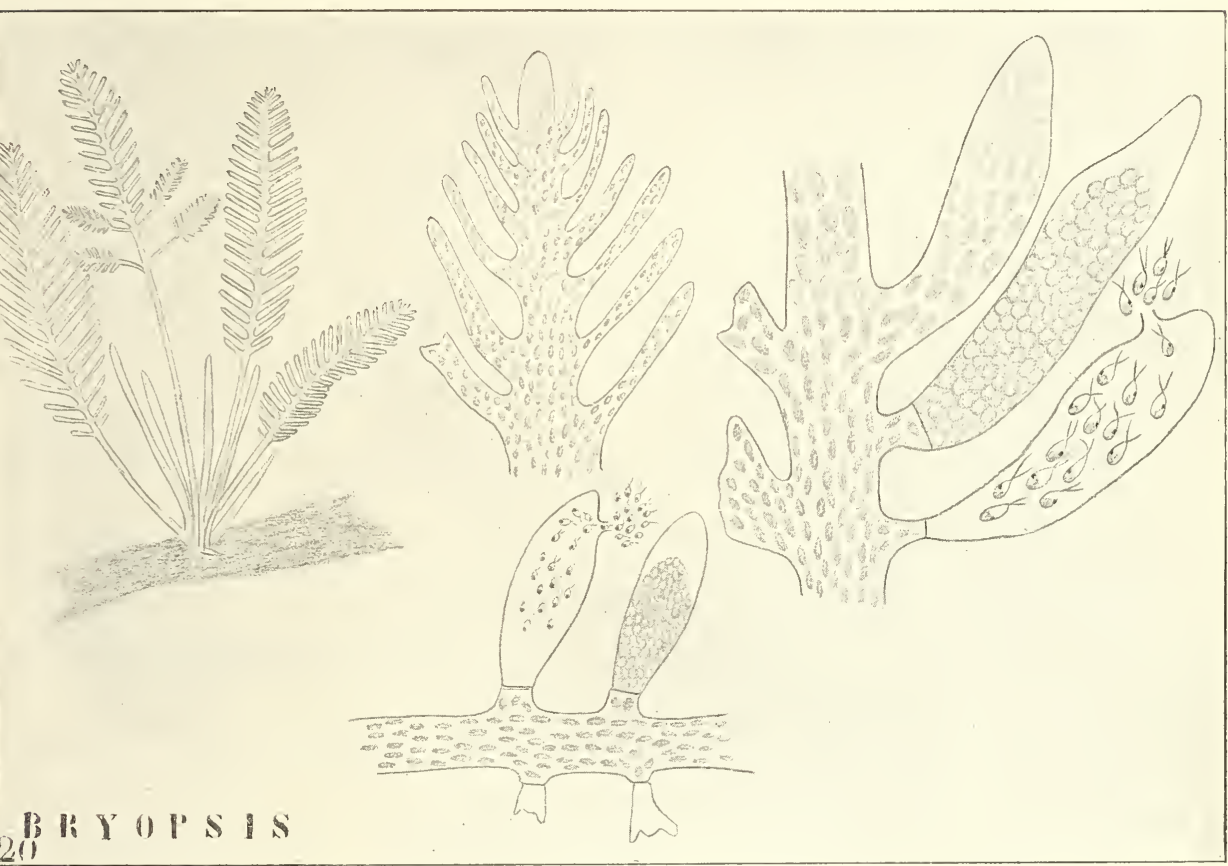

4

Fig. 32. Bryopsis. 1 Habitus, nur die Assimilatoren sind sichtbar; die Rhizoide sind ins Substrat versenkt. 2 Assimilator stark vergrößert, die Einzelligkeit zeigend. 3, 4 Bildung der Gametangien, selbige mittels einer Querwand vom übrigen Teil des Thallus getrennt; 3 weibliche, 4 männliche Pflanze.

Die Kopulation bietet nichts Besonderes, in der gewöhnlichen Weise wird eine runde Zygote gebildet. Die Zygoten keimen sehr bald zu neuen Bryopsis-Pflänzchen aus.

Ungeschlechtliche Vermehrung kann dadurch stattfinden, daß Kurztriebe abbrechen und zu neuen Individuen auswachsen. Darüber berichtet WRIGHT, der sie zu Taucheria-ähnlichen, in seinen Kulturen jedoch absterbenden Schläuchen auswachsen sah, nach NoLL können sie sich aber zu neuen Individuen entwickeln. 
Wir sahen bereits, daß sich bei einer Bryopsis, trotz ihrer „Einzelligkeit", ein deutlicher Unterschied zwischen dem normaliter aufgerichteten und dem normaliter abwärts gerichteten Teile bemerkbar macht.

Einen solchen Unterschied nennt man einen Unterschied zwischen Basis und Spitze, und man sagt, daß die Pflanze die Erscheinungen der Polarität zeigt, was also nur besagt, daß es einen Unterschied zwischen den beiden Polen gibt.

Bei Bryopsis bildet die Spitze der Coenocyte normaliter grüne Stengel und Blätter, die Basis Rhizoide.

Könnte man dieses Verhalten umkehren und die Basis zwingen, Assimilatoren, die Spitze, Rhizoide zu bilden, so würde man sagen, daß es gelungen war, die Polarität umzukehren.

NoLL gelang dies nun in der 'Tat, und solche Versuche sind zumal deswegen wichtig, weil sie zeigen, daß es nicht ein mystisches Etwas ist, das die Polarität verursacht und also die Form bestimmt, sondern im Gegenteil beweisen, daß die Form einer Pflanze von äußeren Faktoren, von der Einwirkung der Außenwelt bedingt wird.

Noll kehrte die Polarität dadurch um, daß er isolierte Bryopsispflänzchen mit der Spitze in Sand einpflanzte, so daß die Rhizoide über den Sand herausragten und von Wasser umspült waren. War die Wachstumsintensität sehr stark, so krümmte sich der gefiederte grüne Stammteil einfach um und blieb Stamm. War das Wachstum nicht so stark, so wuchs die Spitze des Stengels einfach zu einem Rhizoid aus, während dagegen bei einer Anzahl invers gestellter Pflänzchen ein Rhizoid gerade nach oben wuchs und sich zu einem Assimilator umbildete.

Noll betrachtete als Ursache dieser Umkehrung die inverse Stellung in Bezug auf die Schwerkraft.

Schon früher aber hatte BERTHOLD (1882) gezeigt, daß eine ähnliche Erscheinung auftritt bei schwacher Lichtintensität.

Da also zwei Ursachen für dieselbe Erscheinung bekannt waren, versuchte Winter (1890) herauszufinden, was die wirkliche Ursache sei.

Nach Nolus Versuchen war es nicht möglich, zu entscheiden, ob die inverse Stellung, der Kontakt mit den Sandkörnern oder der Mangel an Licht der Reiz war, der die Spitze veranlaßte, zu einem Rhizoid auszuwachsen.

Es zeigte WiNkLer nun zunächst, daß auch normal gestellte Individuen ihre Spitzen in Rhizoide verwandelten, wenn sie nur mittels Staniolhülsen verdunkelt wurden.

Bei diesen Versuchen waren die Pflänzchen nicht eingepflanzt, sondern allseitig von Wasser umgeben, nur die Assimilatoren waren verdunkelt, die Rhizoide hingen aus der Hülse frei herunter, waren also belichtet. Es zeigte sich nun, daß die Chloroplasten der Dunkelheit entflohen und sich in die farblosen Rhizoide hineinbegaben, wonach diese sich heraufkrümmten und zu Assimilatoren auswuchsen.

Hing er dagegen seine Pflänzchen invers auf und verdunkelte er die Rhizoide, was also für diese normal war, während die Stämmchen unverdunkelt ins Wasser herunterhingen, so blieben eben Rhizoide Rhizoide und Stämmchen Stämmchen.

Die Ursache der von NoLL beobachteten Umkehrung der Polarität kann also nicht die inverse Lage in Bezug auf die Schwerkraft sein. Hingegen scheint die Schwerkraft wohl Einfluß auf die Verzweigung zu haben, denn WinkLer bemerkte, daß die aufstrebende Spitze nie Zweige bildet, bevor sie die aufrechte Lage erreicht hatte. 
Es ist also sehr gut möglich, daß eine Bryopsis sich nur dann normal verzweigen kann, wenn ihre Spitze rom Nittelpunkt der Erde hinweg wächst.

Ebensowenig kann Kontakt für die Veränderung verantwortlich g'emacht werden, denn nur durch Terdunklung, ohne Kontakt, kann, wie wir sahen, ein Assimilator in ein Rhizoid verwandelt werden.

Der umgekehrte Tersuch wurde jedoch nicht unternommen, es wurde nicht untersucht, ob vielleicht im Lichte Kontaktreiz die Assimilatoren veranlassen könnte, zu Rhizoiden auszuwachsen.

Demnoch gibt es verschiedene Erfahrungen an anderen Algen, welche auf eine solche Möglichkeit hinweisen. So konstatiert Borge (1894), daß rerschiedene Algen: Spirogyra, Mougeotia, Keimpflänzchen von Taucheria, nur durch Kontaktreiz zu Rhizoidbildung veranlaßt werden können. Und nach BRAND (1899) bildet Cladophora profunda nur apikale Rhizoide durch Kontakt mit Steinkohlenschlacken, mit welchen Dampfer. ihre Fundorte oft reichlich versorgen.

Auf Grund der oben erwähnten und weiterer Versuche gelangt Tinkler zu dem Schluß, daß die Umkehrung der Polarität nicht von der Schwerkraft, sondern von der Lichtintensität verursacht wird.

Durch Regulierung der Lichtintensität kann man also auf die Qualität des Tegetationspunktes von Bryopsis Einfluß ausüben.

Tird eine wachsende Stammspitze oder ein Rhizoid unseres Pflänzchens intensiv beleuchtet, so wächst es zu einem negativ geotropischen Assimilator aus, ist die Lichtintensität gering, zu einem positiv geotropischen Rhizoid.

Aus einem im selben Jahre von NolL (1900) publizierten Artikel geht aber hervor, daß auch er das Licht für die Ursache der beobachteten Erscheinumgen hielt und daß nur ein Druckfehler in seiner Veröffentlichung zu der Auffassung führte, er hielte die Schwerkraft für den bedingenden Faktor.

Bryopsis läßt sich also leicht von äußeren Faktoren beeinflussen, und es war also interessant, zu versuchen, wie sie sich bei Regeneration verhielt. Auch dies untersuchte WINkLER. Er wurde dabei von folgenden Ueberlegung'en geführt:

Bei normaler Regeneration wird das verloren gegangene Stück oder Organ von einem ihm ähnlichen ersetzt, d. h. wenn eine Wurzel verloren geht, entsteht eine neue Wurzelspitze und nicht z. B. eine Blütenknospe. Verliert ein Salamander sein rechtes Hinterbein, so wird ein rechtes Hinterbein und nicht eine Hand regeneriert u. s. w. Durch LoEBs (1891/92) interessante Versuche wissen wir aber, daß es Ausnahmen von dieser Regel gibt, und daß bisweilen mehr oder weniger von äußeren Bedingungen abhängig ein vom verloren gegangenen verschiedenes Organ gebildet werden kann.

Loeb nannte diese Erscheinung Heteromorphose. So konnte er z. B. bei Tubularia mesembryanthemum, einem Hydroidpolypen, Individuen mit zwei Köpfchen entstehen lassen dadurch, daß er ein nicht zu kleines Stück aus dem Stamm herausschnitt und beide Seiten von Wasser umspülen ließ.

Sowohl am apikalen wie am basalen Schnitt wird damn ein Polrp gebildet. Seit dieser Veröffentlichung hat man noch eine ganze Reihe von Tieren auf diese Erscheinung der Heteromorphose hin untersucht.

Nur bei Planarien und Hummern wurde sie konstatiert. Bei letzteren gelang es HerBst (1896), statt abgeschnittener Angen die Bildung ron Antennen zu veranlassen. 
Es sind also nur wenige Fälle von Heteromorphosen bekannt, und es ist darum interessant zu erfahren, daß auch Bryopsis diese Erscheinung zeigt, und zwar neben normaler Regeneration.

Letztere ist leicht zu beobachten: Schneidet man von einem Bryopsispflänzchen den gefiederten Teil des Assimilators ab, und pflanzt man es normal ein, so regeneriert sich der Assimilator alsbald. Dies geschieht auch, wenn man das frei aufgehängte Pflänzchen in inverse Lage bringt.

Ebenso leicht ist es, die Regeneration des Rhizoidenteiles zu beobachten, wenn man letzteren abschneidet und dann das Pflänzchen mit dem Stummel in Sand einpflanzt oder bei inverser Lage diesen Teil verdunkelt.

Jetzt wurde aber folgender Versuch vorgenommen: Wieder wurde der Rhizoidenbüschel abgeschnitten, jetzt aber das Pflänzchen umgekehrt und mit dem gefiederten Teil des Assimilators in Sand eingepflanzt, der Stummel aber der Einwirkung des Lichtes ausgesetzt.

Die Mehrzahl der Pflänzchen regenerierte nun nicht, sondern krümmte den Assimilator aufwärts. 6 von 30 Versuchspflanzen aber bildeten ihre Kurztriebe (Blättchen) zu Rhizoiden um, und bei einer dieser 6 fand Heteromorphose statt; es wurde am basalen Ende des Assimilators ein gefiederter Assimilator gebildet.

Ein ähnlicher Versuch, wobei der Blattteil nicht in Sand eingepflanzt, sondern eingegipst wurde, um jedem Wachstum vorzubeugen, wurde gemacht mit dem Ergebnis, daß bei 17 von 30 Versuchspflanzen Heteromorphose stattfand, die übrigen 13 gingen zu Grunde.

Leicht gelingt folgender Versuch. Schneidet man das gefiederte Blatt weg, und pflanzt man die Pflänzchen jetzt invers ein, also mit der Schnittfläche in Sand, so bilden die Pflänzchen Rhizoide. Von 30 Versuchspflanzen zeigten 24 diese Heteromorphose.

Ein Stammstück einer Bryopsis bildet also, ob nun der basale oder apikale Teil entfernt wird, im Licht einen Assimilator, im Dunklen Rhizoide.

Was wird nun geschehen, wenn sowohl die Rhizoide wie der gefiederte Teil des Assimilators abgeschnitten werden und das übrig bleibende gerade Stammstückchen allseitig beleuchtet wird?

WinkLer verwendete zu diesem Versuch 20 solcher Stückchen; um jede Einwirkung der Schwerkraft auszuschließen, wurden diese in ein Glasgefäß der fortwährenden Strudelung eines ziemlich kräftigen Wasserstromes ausgesetzt, so daß sie fortwährend rotierten, also in dem einen Augenblick der eine, im anderen der andere Pol nach unten gerichtet war.

Der Versuch wurde nach 14 Tagen beendet; ein Teil war abgestorben, ein Teil hatte nur an einem Pol einen Assimilator regeneriert, bei 12 Pflänzchen aber fand Regeneration beider Pole statt, und zwar wurde an beiden Seiten ein Assimilator gebildet.

Damit gelangen wir wieder zur Frage der Polarität.

Eine normale Bryopsis ist polar entwickelt, d. h. an dem einen Pol wird etwas anderes gebildet als am anderen; aus den Versuchen geht aber hervor, daß wir es hier nicht mit einer Eigenschaft der Art zu tun haben, daß die Polarität der Bryopsis nicht etwas Inhärentes, unter allen Umständen Auftretendes ist, sondern daß sie von äußeren Bedingungen abhängt.

Die Polarität, der Unterschied im Verhalten der beide Pole, wird 
einfach dadurch verursacht, daß der eine Pol anderen Einflüssen ausgesetzt ist. als der andere; werden beide Pole den gleichen Einflüssen ausgesetzt, so bilden sie homologe Organe, wie aus dem Versuch mit den aufgestrudelten Bryopsis-Stückchen hervorgeht.

Man darf also bei Bryopsis nicht von einer erblichen Polarität reden.

Kehren wir jetzt zur Stelle ron Bryopsis im System zurück, so haben wir es offenbar mit einer noch recht einfachen Siphonale zu tun, bei welcher erst eine geringe Differenzierung eingetreten ist und bei welcher zumal von Gewebebildung noch keine Rede ist. Bei der Familie der

\section{Codiaceen}

wird dies anders. Die Thallome bestehen hier aus fadenförmigen Röhren, welche mehr oder weniger verwebt sind und dadurch öfters den Eindruck einer mehrzelligen Pflanze machen. Es kann in den bisweilen ziemlich massiven Körpern eine Differenzierung in "Gewebe" entstehen, dadurch, daß im zentralen Teile die Fäden in der Richtung der Längsachse verlaufen, während sie sich an der Peripherie nach auswärts biegen und eine Art Rinde bilden.

Der Thallus ist am Substrat mittels Rhizoiden angeheftet und die Oberfläche öfters in sehr hohem Grade mit Kalk inkrustiert. Die Chromatophoren sind zahlreich, scheibenförmig, rund oder elliptisch, bisweilen mit, in anderen Fällen ohne Pyrenoide.

Alle Repräsentanten der Codiaceen sind Bewohner des Meeres und wohl vorwiegend der heißeren Gegenden; bereits im Mittelmeer gibt es mehrere A.rten. Wir müssen aber unsere Betrachtungen auf einige wenige Formen beschränken.

Die einfachste Codiacee ist wohl die von Ernst in Neapel entdeckte

Udotea minima ERNST.

In einfachster Form besteht sie aus aufstrebenden, dichotom verzweigten grünen Fäden von $1-3 \mathrm{~cm}$ Länge und $50-90 \mu$ Dicke, welchen farblose rhizomartige Rhizoide entspringen (Fig. 33, 1).

Diese Fäden erinnern hochgradig an die einer Vaucheria. Oefters begegnet man Einschnürung und findet, daß an diesen Stellen die Schlauchmembran ringförmig verdickt ist. Die Schläuche sind polyenergid und enthalten zahllose kleine Chloroplasten. Da diese Struktur allen Codiaceen zukommt, werden wir dies weiterhin nicht mehr erwähnen.

Bei höher entwickelten Individuen unserer Art schlingen sich mehrere grüne Fäden umeinander: es entsteht dadurch ein Stielchen von $1-1 \frac{1}{2} \mathrm{~cm}$ Länge. Jetzt breiten sich die bis dahin zu einem Tau vereinigten Fäden in einer Fläche aus, es entsteht also an der Spitze des Stielchens ein fächerartiger flacher Blattteil, aus parallelen Fäden bestehend (Fig. 33, 2).

Bei noch größeren Exemplaren können an diesen „Fächerfäden ${ }^{6}$ Seitenzweiglein entstehen, welche diese Fäden mehr oder weniger zusammenhalten; von einer eigentlichen Gewebebildung kann aber noch nicht die Rede sein.

Diese tritt erst bei Udotea Desfontainei auf. Bei dieser Art gibt es kein fadenförmiges Stadium; vom Anfang an besteht die Pflanze aus fächerförmigem gestielten Thallomen (Fig. 33, II 1).

Dennoch kann unter bestimmten Bedingungen eine Bildung auftreten, welche an das fadenförmige Stadium der U. minima erinuert. 
Es geschieht dies, wenn man Stücke vom Fächerteil abschneidet; aus der Schnittfläche wachsen dann dichotom verzweigte freie Fäden hervor (Fig. 33, II 2), denen des unvollkommenen Stadiums von U. minima ähnlich.

Während am Rande der „Blattscheibe“ von U. Desfontainei die Fäden, wie bei U. minima, nur nebeneinander liegen oder höchstens von einzelnen Seitenzweiglein beisammengehalten werden (Fig. 34, 1), ist der Verband in den älteren Teilen ein viel festerer.

Dort treten an beiden Seiten des Fächers Seitenzweiglein auf, welche sich sehr stark verzweigen und dicht aneinander schmiegen (Fig. 34, 3), so daß schließlich an den beiden Flächen des Fächers eine hochgradig an die Epidermis höherer Pflanzen erinnernde Rinde gebildet wird.

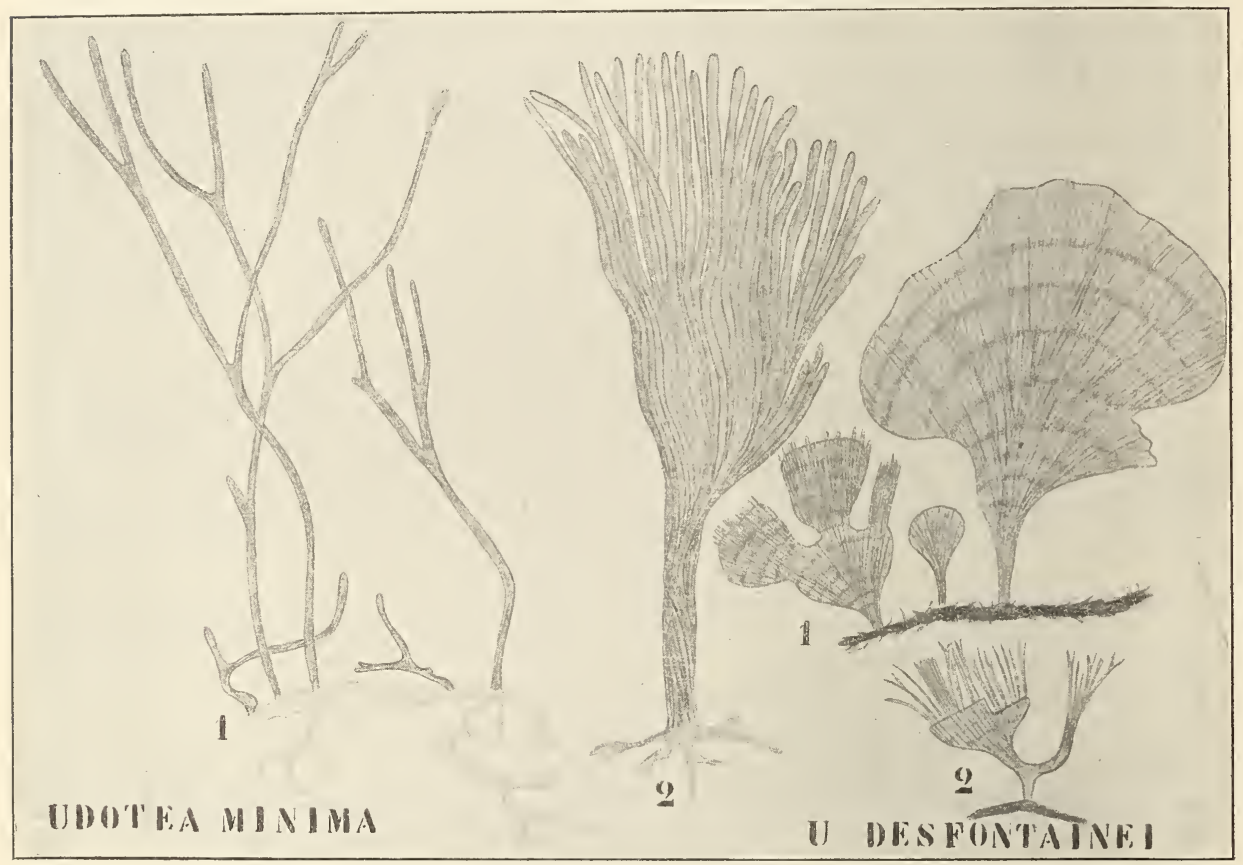

Fig. 33. I. Udotea minima ERNst (nach ERNst). 1 Einfache (ursprüngliche) Thallusform. 2 Junger gestielter Thallus, mit kleiner, am Rande wieder in die freien Fäden auslaufender Fahne. - II. Udotea Desfontainei (nach ERNST). 1 Habitusbild. 2 Regeneration einer verstümmelten Pflanze mit 2 Stielen. Aus der Schnittfläche entspringen freie, dichotom verzweigte Schläuche. Alles schematisiert.

Zwischen beiden Rindenschichten findet sich dann eine einzelne Schicht paralleler Hyphen.

Eine ähnliche Gewebebildung treffen wir bei Codium an, sie ist dort aber noch komplizierter. Schon bei Pseudocodium besteht der Kern der Pflanze aus cylindrischen, abgesehen von den Verzweigungen, parallelen Schläuchen, die peripher gelegenen aber bilden kurze, gestielte, cylindrische Zweiglein (Fig. 34, II 1), welche so dicht gedrängt stehen, daß sie polygonal werden und, von oben betrachtet, an die Facetten eines Fliegenauges erinnern. 
Diese, eine Rinde bildenden Zweiglein werden Palisadenschläuche genamnt und schließen zu einer festen Hautschicht zusammen.

Bei Codium ist der Aufbau des Thallus dem von Pseudocodium ähnlich, aber dadurch kompliziert, daß die Palisadenschlänche an ihrer Basis wieder zu cylindrischen Schläuchen, sogenannten Verankerungsschläuchen. auswachsen (Fig. 34, III 2-4), welche wieder in den Thallus hineinwachsen und so die viel lockerer gestellten Palisadenschläuche befestigen. Ueberdies schließen sich hier die Palisadenschläuche durch Bildung einer ringförmigen Querwand bis auf einen feinen Kanal von den Hauptschläuchen ab.

Die Palisadenschläuche stehen hier sehr locker und bilden an ihrer Spitze öfters lange Haare, welche jedoch nur ein ephemeres Dasein fiihren, da sie bald abfallen.

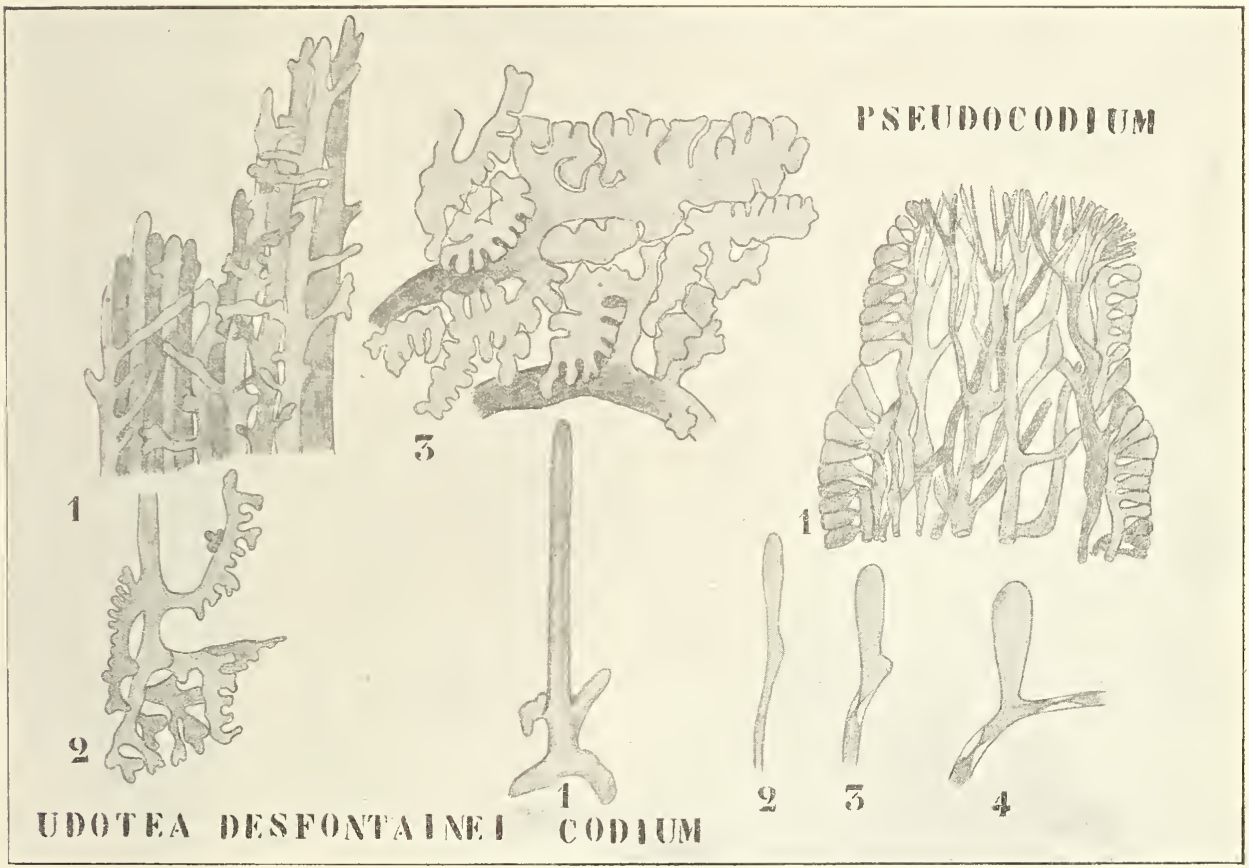

Fig. 34. I. Udotea Desfontainei (nach Gruber in Oltmanrs). 1 Stück vom Sproßrande, Längsfäden mit jungen Seitenzweigen. 2 Gelapptes Ende eines Seitenzweiges freipräpariert. 3 Die Seitenzweige aneinander geschmiegt. - II. P s e u d o c od i u m. 1 Längsschnitt durch den Scheitel, nach Oltmanns. - III. Codium (nach Berthold und Oltmands). 1 Keimling. 2, 3, 4 Bildung der Verankerungsfäden der Palisadenschläuche.

Selbstverständlich fällt die Aufgabe der Photosynthese hauptsächlich diesen Palisadenschläuchen zu; damit in Beziehung steht die Bildung der Fortpflanzungsorgane, der Gametangien an ihnen (Fig. 35, 2).

Die Gametangien entstehen als seitliche Ausstülpungen der Palisadenschläuche, von welchen sie sich mittels einer Wand abschneiden. Diese Wand wird nach BERTHOLD als ein dicker Ring angelegt, aber später wird noch eine Lamelle quer über diesen Ring gelagert.

Leicht ist es, zwei Arten von Gametangien zu unterscheiden: dunkelgrün, fast schwarz gefärbte und gelbliche. Die ersteren sind Makro-, 
die zweiten Mikrogametangien. Sie kommen in der Regel auf verschiedenen Individuen vor, so daß man männliche und weibliche Pflanzen unterscheiden kann; ausnahmsweise gibt es aber auch hermaphrodite Individuen.

In beiden werden Gameten mit 2 Cilien gebildet; während die weiblichen (Fig. 35, 9) zahlreiche dunkelgrüne Chloroplasten besitzen, enthalten die männlichen meistens nur einen (höchstens 3) verfärbten gelblichen Chromatophor. Der Kern liegt im vorderen farblosen Teile. Die normal verlaufende Kopulation (Fig. 35, 11) wurde 1896 von OLtmanns beobachtet. Die Zygoten keimen direkt zu neuen Codium-Individuen aus, welche zunächst aus einem unverzweigten Faden bestehen.

WENT hat angegeben, daß die Makrogameten auch ohne Kopulation keimen können; falls dies richtig ist, würde hier ein Fall von Partheno-

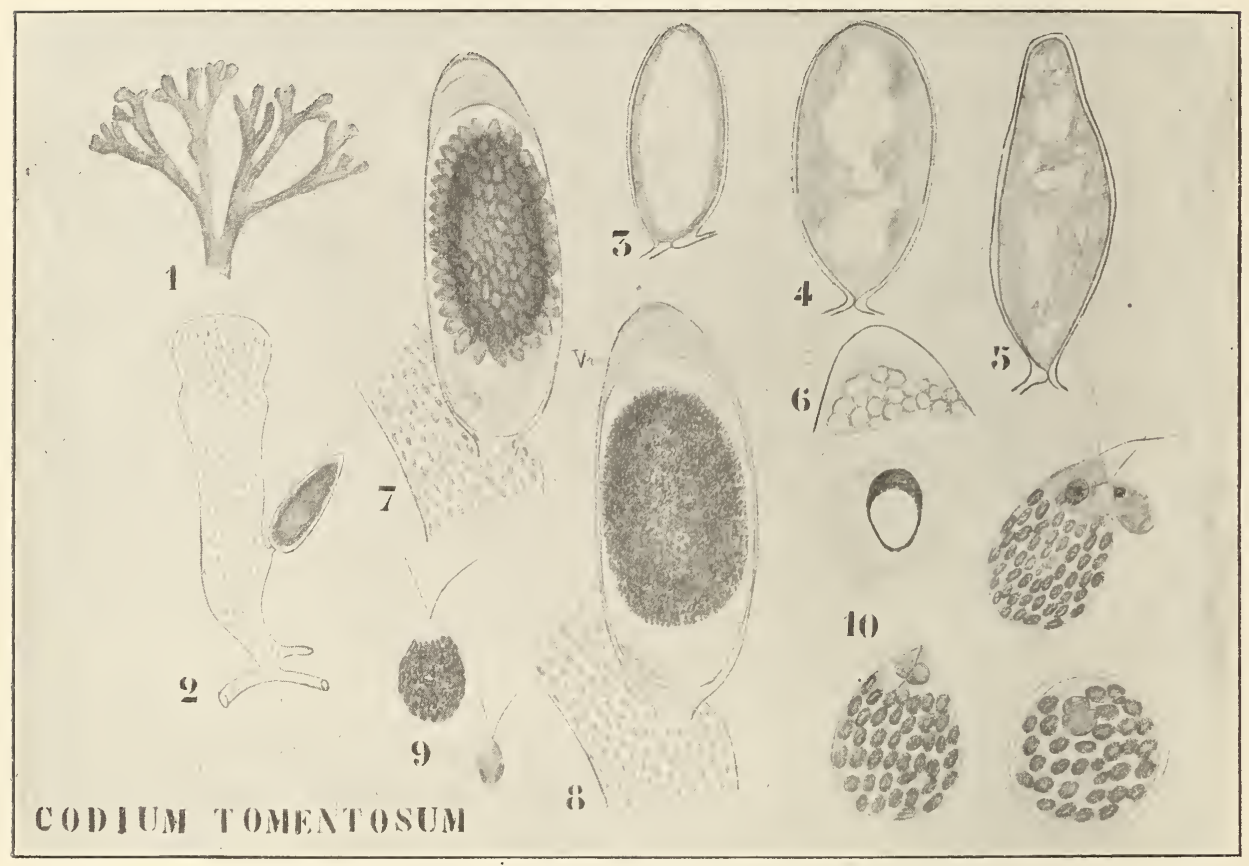

Fig. 35. Codium tomentosum. 1 Habitusbild der Spitze eines Hauptzweiges. 2 Palisadenschlauch mit Gametangium. 3-6 Vakuolenbildung im Gametangium (nach WENT). 7 Makrogametangium (nach T'HURET). 8 Mikrogametangium (nach THURET). 9 Makro- und Mikrogameten (nach WENT). 10 Vakuole in der Gamete (nach WENT). 11 Kopulation nach OLtmanns.

genese vorliegen, möglicherweise aber waren Mikrogameten im Meerwasser vorhanden.

Ungeschlechtliche Fortpflanzung scheint nicht vorzukommen, bei Udotea ist die Fortpflanzung noch gänzlich unbekannt.

Bevor wir die Codiaceen verlassen, seien hier noch einige Betrachtungen allgemeiner Art eingefügt.

Schon wiederholt haben wir das Wort Vakuole genannt und gesehen, daß man darunter eine mit Zellsaft erfüllte Höhle im Plasma versteht. Diese Höhlung liegt nicht direkt im Körnerplasma, sondern 
ist ron einer hyalinen Plasmaschicht umgeben. welche rollständig der Hantschicht des Plasmas gleicht.

A priori gibt es num zwei Möglichkeiten, entweder ist die Takuole nur eine Höhle, ein Loch, und die hyaline Schicht gehört dem Plasma an, oder aber die Vakuole ist eine Blase und die hyaline Schicht zu ihı gehörig, nämlich als Blasenwand.

Im ersteren Falle ist die Takuole eigentlich ein negativer Begriff, ein Loch, im letzteren Fall aber etwas Positives, und ebensogut ein Organ der Zelle, als Kern und Chromatophor.

Letztere Theorie wurde zuerst von DE VRIEs ausgesprochen, der, um seine Auffassung zu betonen, diesem Organ einen bestimmten Namen: Ton op last beilegte.

Da der Tonoplast durchaus nicht immer leicht zu beobachten ist, versuchte DE TRIES (1885) zunächst, eine Methode zu erfinden, um nachzuweisen, daß überall, wo Vakuolen vorkommen, Tonoplasten vorhanden sind.

Dabei beuntzte DE TrIEs in ingeniöser Weise verschiodene Eigenschaften des Protoplasmas. Er zeigte zunächst, daß beim langsamen Absterben der Zelle das Plasma viel früher abstirbt als der Tonoplast.

Bringt man nun eine solche Zelle, deren Plasma abgestorben ist, aber deren Tonoplasten noch leben, in eine plasmolysierende Lösung, d. h. in eine Lösung, welche die Tomoplasten kontrahiert, so fallen letztere als kugelförmige hohle Körper verhältnismäßig leicht auf. Zu diesem Zwecke wirkt eine 10-proz. Kalisalpeterlösung vorzüglich.

DE VRIEs fand nun weiter, daß die 10-proz. Salpeterlösung an sich schon genügte, um das Plasma zu töten, so daß es nicht nötig war, die Zellen erst zum Absterben zu bringen, daß man im Gegenteil das Reagens direkt auf die lebende Zelle einwirken lassen kann.

Es ist nun bekannt, daß tote Plasmateile Anilinfarbstoffe speichern, sich also färben, lebende dagegen nicht, also farblos bleiben. Indem DE VRIEs nun seine 10-proz. Kalisalpeterlösung mit Eosin rot färbte und dieses Reagens auf die lebende Zelle einwirken ließ, tötete er nicht nur das Körnerplasma, sondern färbte es gleichzeitig rot und erzielte also Präparate, in welchen die zu einer Kugel kontrahierten farblosen Tonoplasten im umgebenden rot gefärbten Körnerplasma leicht auffielen.

Während dieser Behandlung kann sich selbstverständlich auch die Hautschicht des Plasmas kontrahieren, öfters aber stirbt diese bereits bei der ersten Berührung mit dem Reagens ab, kontrahiert sich also nicht; in diesem Falle erhält man die elegantesten Präparate, aber auch wenn sich die Hautschicht kontrahiert, bleibt das Resultat recht instruktiv.

DE VRIEs hat also klar nachgewiesen, daß, wo sich eine Vakuole befindet, diese immer von einer hyalinen Plasmaschicht umgeben ist.

Anders steht es mit der Frage, ob diese Schicht der Vakuole angehört, ob sie also ein dilatierter Tonoplast ist, oder ob sie nur eine innere Hautschicht des Plasmas ist.

DE VRIEs zeigte weiter, daß bereits in sehr jungen Organen, im Vegetationspunkt z. B., die vorhandenen Vakuolen von einer hyalinen Plasmaschicht umgeben sind.

Bei sehr kleinen Vakuolen ist es num nicht mehr möglich, zu sehen. ob der Tonoplast ein hohles, blasenförmiges Organ oder ein solides Körperchen ist. 
DE VRIEs neigt zur letzteren Auffassung hin und meint, daß bereits, bevor die Höhlung, die Vakuole, da ist, ein solider Körper vorhanden ist, der Tonoplast, der den Zellsaft in ähnlicher Weise bildet, wie die Leukoplasten die Stärke bilden.

Da es aber kein Mittel gibt, solche Tonoplasten von Leukoplasten zu unterscheiden, konnte er seine Meinung nicht definitiv erweisen.

Die Auffassung, es sei die Vakuolen-Flüssigkeit das Exkret eines Tonoplasten, führt zu wichtigen Konsequenzen.

Während man früher meinte, es könne ein jedes Teilchen des Plasmas Stärke bilden, stellte es sich später heraus, daß nur bestimmte differenzierte Teile desselben, die Chloro- resp. Leukoplasten dazu im stande sind, erstere aus $\mathrm{CO}_{2}$ und $\mathrm{H}_{2} \mathrm{O}$, letztere aus Zucker. Weiter stellte es sich heraus, daß diese Organe sich nie neu bilden, sondern ausschließlich durch Teilung bereits vorhandener entstehen.

Ebenso meinte man, es könne der Zellsaft überall im Plasma entstehen, es könnten also überall neue Vakuolen gebildet werden.

Falls DE VRIES' Auffassung aber richtig ist, daß der Zellsaft ein Exkret des Tonoplasten sei, so liegt es auf der Hand, zu vermuten, es können sich die Vakuolen ebensowenig wie die Chromatophoren de novo bilden, sondern nur durch Teilung bereits vorhandener Tonoplasten entstehen.

Diese Frage ist nun deshalb von höchster Wichtigkeit, weil sie mit DE VRIEs' Theorie der panmeristischen Zellteilung in Zusammenhang steht. Unter „panmeristisch" versteht DE VRIES eine Zellteilung, bei welcher ein jedes Organ der Zelle sich nur durch Teilung vermehrt, die Organe, welche zusammen das Plasma zusammensetzen, sich also nicht de- novo bilden können. Dieser Auffassung steht die neogenetische gegenüber, nach welcher eine Neubildung von Organen stattfindet.

Für gewisse Organe der Zelle, z. B. für Kerne und, wenn auch nicht so überzeugend ${ }^{1}$ ), für Chromatophoren, ist die ausschließliche Entstehung durch Teilung bereits vorhandener erwiesen.

Dieser Beweis fehlte noch für die Tonoplasten, WENT (1888) hat aber in einer ausführlichen und wichtigen Untersuchung den Beweis zu erbringen gesucht, daß auch diese sich nie de novo bilden.

In dieser Arbeit gelangt er zu folgenden Resultaten:

1) Alle lebenden Pflanzenzellen enthalten Vakuolen, welche von einer ihnen gehörenden Wand (Tonoplast) umgeben sind.

2) In allen jungen Zellen findet Teilung und Verschmelzung von Vakuolen statt.

3) Alle in einer Pflanze vorhandenen normalen Vakuolen entstammen den in der Eizelle vorhandenen Vakuolen, aus welchen sie durch Teilung hervorgehen.

4) Die Tonoplasten sind Organe, den Kernen und Chromatophoren gleichwertig.

5) Normale Vakuolen entstehen nie durch Protoplasmadifferenzierung; die sogenannte Neubildung von Vakuolen, welche man beobachtet bei der Einwirkung von Wasser auf Plasma, besteht in der Vergrößerung bereits vorhandener Vakuolen oder ist, gerade wie das Blasigwerden von Kernen und Chromatophoren, keine echte Vakuolenbildung, sondern ein Entstehen pathologischer Vakuolen.

1) Man denke an die "Chromatophoren" von Hydrodictyon etc. 
DE VRIEs meint num, indem er sich auf diese Untersuchungen stützt, daß damit in der Tat bewiesen sei, daß die Tonoplasten sich nie de novo bilden.

Um num die alte Meinung, als sei das Protoplasma nur ein Flüssigkeitengemisch, deren Differenzierung man öfters auf einfache physische Gesetze zurückführen kann, zu entkräften, behandelt DE VRIEs in seiner Intercellularen Pangenesis das Verhalten zwischen Hautschicht und Körnerplasma.

Der alten Theorie nach würde sich die Anwesenheit einer Hautschicht erklären lassen aus dem allgemeinen Gesetz, daß Flüssigkeiten an ihrer Peripherie dichter sind als im Innern.

Es fragt sich aber dann in erster Linie, ob die Hautschicht überhaupt aus Körnerplasma gebildet werden kamn, oder ob beide Teile autonome Bildungen sind.

DE VRIEs meint, daß manches für die Autonomie der Hautschicht spricht, trotzdem er den exakten Beweis dafür nicht zu liefern vermag.

Acceptieren wir die Resultate dieser Untersuchumgen, so stellt es sich heraus, dals die Zelle außer dem Kern noch eine ganze Reihe von Organen besitzt, welche sich selbständig teilen können und selbständig zu wachsen vermögen, aber nicht im stande sind, sich de novo zu bilden. Das Plasma ist also keine einfache Emulsion verschiedener Flüssigkeiten, sondern besteht aus einer Anzahl bestimmter, wohldifferenzierter Organe.

Nun finden wir außer den bereits besprochenen Elementen im Körnerplasma eine Anzahl sehr kleiner Partikelchen oder Körnerchen, und es liegt die Frage nahe, ob diese Partikelciren nicht ebenfalls Organe der Zelle sind. Diese Frage wurde von Altmann bejaht und ihnen der Name „Granulae" beigelegt.

So kam man nach und nach, von dem berühmten Satz

omne vivum ex vivo ausgehend, zu einem

omnis cellula e cellula,

omnis nucleus e nucleo,

jedes Chromatophor aus einem Chromatophor,

jeder Tonoplast aus einem Tonoplast,

und schließlich jede Granula aus einer Granula.

Diese Auffassung, nach welcher das Plasma also in letzter Instanz aus einer Anzahl sehr kleiner Teilchen bestehen würde, deren jedes für sich im stande sei, zu wachsen und sich zu vermehren, hat eime große theoretische Bedeutung.

Denn wenn man sieht, daß jede neue Untersuchung wieder kleinere unabhängige Teilchen im Plasma ans Licht bringt, so ist man wohl berechtigt, anzunehmen, daß es noch kleinere unabhängige Einheiten gibt, welche wir nicht sehen können.

Was ist nun die Bedeutung dieser Auffassung? Wir acceptieren ganz allgemein, daß die Eigenschaften der verschiedenen Lebewesen von den Eigenschaften ihres Plasmas abhängen.

Soll man nun annehmen, es sei die Zahl der Protoplasmaarten unendlich groß, oder ebenso groß wie die Zahl der Pflanzen und Tierarten? Oder aber ist auch eine einfachere Auffassung möglich?

Gewiß, man kann sich die zahllosen und komplizierten Eigenschaften der Lebewesen als die Folge verschiedener Kombinationen einer viel geringeren Zahl von elementären Eigenschaften denken.

So wie man mit 26 Buchstaben eine unendliche Zahl von Büchern mit sehr verschiedenem Inhalt drucken kann, so kann man sich denken, 
daß die sehr verschiedenen Eigenschaften eines Löwen und einer Pflanze z. B. auf verschiedenen Kombinationen elementärer Eigenschaften beruhen.

Nimmt man nun für diese elementären Eigenschaften materielle Träger an, so kann man sich das Protoplasma aus einer Anzahl solcher elementären Eigenschaftsträger oder, wie DE VRIES sie nennt, aus Pangenen aufgebaut denken.

Diese Pangene sind demnach unsichtbare Organe des Plasmas, ein jedes aus einer großen Zahl von Molekeln bestehend, und sogar von den kompliziertesten chemischen Substanzen durch 3 Eigenschaften verschieden, Eigenschaften, welche nur lebender Substanz zukommen:

Sie ernähren sich, wachsen und vermehren sich durch Teilung.

Man muß sich dieser Auffassung nach, das Plasma vorstellen als eine Ansammlung zahlloser Pangene, in einer Lösung rein chemischer Substanzen, wie Albumine, Glukosen, anorganischer Salze u. s. w. suspendiert.

Da der Kern der Träger aller erblichen Eigenschaften des Organismus ist, muß er alle Pangenarten, welche das Individuum zur Kombination seiner Eigenschaften braucht, enthalten.

Es braucht aber das Plasma der verschiedenen Zellen nicht sämtliche Pangenarten zu enthalten. Sie brauchen nur jene Pangene. welche zur Ausübung der Funktionen einer jeden Zellenart nötig sind.

So braucht die photosynthesierende Zelle in ihrem Plasma die Pangene, welche zur Bildung von Chromatophoren nötig sind.

Dazu teilt sich nun nach DE VRIEs' Meinung das im Nucleus vorhandene Chromatophorenpangen in 2 Hälften. Die eine Hälfte verbleibt im Nucleus und regeneriert sich wieder, denn der "Pangenensatz", welcher in jedem Nucleus, wie gesagt, vorhanden ist, muß komplett bleiben, die andere tritt aus dem Nucleus heraus teilt sich wiederholt im Plasma der Zelle und bildet so die Chromatophoren.

Bei einer der Chromatophoren entbehrenden Zellenart ist die Anwesenheit von Chromatophorenpangenen im Plasma überflüssig, das betreffende Pangen tritt also nicht aus dem Nucleus heraus.

Der Kern ist also dem Schriftkasten eines Setzers vergleichbar, das Plasma dem Satz.

Muß in einer Druckerei das Wort "leer" gesetzt werden, so nimmt der Setzer aus seinem Schriftkasten ein l, zwei e und ein $r$ und beläßt alle übrigen Buchstaben im Kasten.

Um nun ein vollkommenes Analogon zu Kern und Plasma zu haben, muß man aber annehmen, daß sich die Buchstaben sowohl im Schriftkasten wie im Satz vermehren können.

Es würde dann in einer Druckerei die Anwesenheit von 26 Buchstaben genügen.

Der Setzer würde dann nicht ein ganzes 1 herausnehmen, sondern es in zwei Stücke zerbrechen, ebenso mit dem e und mit dem r. Nicht nur, daß diese Buchstaben sich sowohl im Kasten wie im Satz regenerieren würden, sondern das e würde im gedachten Falle sich sogar zu zwei e vermehren, und es würde also das Wort „leer" mit einem halben $\mathrm{l}$, einem halben e und einem halben $\mathrm{r}$ gesetzt, und die 26 Buchstaben im Kasten blieben durch ihr Regenerationsvermögen trotzdem intakt.

Man sieht, daß diese Thecrie der Pangenesis, von Darwin aufgestellt und von DE VRIES modifiziert und ausgearbeitet, eine schöne Analyse der Eigenschaften der Lebewesen ermöglicht. 
Durch DARwrx aus philosophischen Gründen abgeleitet, erhielt sie eine wichtige Stütze durch die Konstatiernng der Anwesenheit einer Anzahl winziger, unabhängiger, teilungsfähiger Organe im Plasma, denen sämtlich die Eigenschaft der "Neubildumg"* abging.

Fiir den Nucleus gelten diese Eigenschaften unbedingt, und dies ist zweifellos von großer Wichtigkeit, da wenigstens alle höheren Zellen einen Nucleus entlialten.

Im Falle der Chromatophoren bin ich voll der absoluten Unmöglichkeit einer Neubildung persönlich noch nicht so ganz überzeugt, jedenfalls aber sind sie als Argument für die Theorie, dem Kern gegenüber, ihrer Beschränkung auf bestimmte Zellarten halber, weniger wertvoll. Sie fehlen z. B. den meisten tierischen Zellen.

Schreiten wir jetzt zur Würdigung der Vakuolen in dieser Hinsicht. Sie besitzen als Argument einen viel geringeren Wert, denn Zweifel an der Richtigkeit ron DE VRIEs' und Wents Resultaten sind keinesweg's ausgeschlossen.

Schon bald nach dem Erscheinen von WENTs Arbeit wurde von verschiedenen Seiten bemerkt, daß vieles bei den Algen gegen die vertretene Auffassung spreche. Es liatte aber noch niemand die Algen mit spezieller Rücksicht auf diese Frage untersucht, und dies veranlaßte WENт (1890), diese Klasse zu untersuchen.

Es gelang ihm vollkommen, nachzuweisen, daß man öfters fälschlich durch schlechte optische Hilfsmittel and durch fehlerhafte Konservierungsund Präparationsmethoden auf Verschwinden und Wiederauftreten von Takuolen geschlossen hatte.

Er meint aus seinen Untersuchungen den Schluß ziehen zu dürfen, daß auch bei den Algen die Vakuolen sich ausschließlich durch Teilung vermehren.

Er zeigt z. B., daß bei Codium eine jede Gamete eine Vakuole enthält, und daß diese Vakuolen durch Abschnürung aus der großen zentralen Vakuole des Gametangiums entstehen.

Den Beweis versucht er in folgender Weise zu erbringen:

Im jungen Gametangium findet sich eine sehr große zentrale Vakuole, von einer ihr eigenen Wand umgeben.

Die Quantität des Plasmas nimmt nach und nach zu, die wandständige Plasmaschicht wird also dicker und fängt nun an Ausstülpungen zu bilden, welche in die Vakuole hineindringen und diese in verschiedene kleinere zerteilen. Die Chromatophoren verteilen sich inzwischen unregelmäßig und werden immer dunkler, so daß man schließlich die Vakuolen bloß hindurchschimmern sieht. Diese sind inzwischen kleiner und kleiner geworden, nur an der Basis des Gametangiums bleibt eine viel größere Vakuole zurück, welche sehr klar zu sehen ist, da sich hier der Plasmaschlauch von der Basis des Gametangiums zurückzieht. $\mathrm{Ob}$ aber diese Vakuole sich noch bis zu einer gewissen Höhe in die grüne Masse hinein fortsetzt, konnte WENT nicht entscheiden.

Jetzt fängt das Plasma an sich in eine Anzahl von Stücken, die späteren Gameten, zu spalten, deren jedes eine Vakuole enthält. Die große Vakuole an der Basis und vielleicht auch im Zentrum nimmt nach WENT an deren Bildung keinen Anteil.

WENT nimmt num an, daß die Vakuolen der Gameten aus dem oberen Téil der ursprünglichen zentralen Vakuole des Gametangiums hervorgegangen sind durch wiederholte Teilung, und daß die große Vakuole an der Basis ein größerer Rest dieser zentralen Vakuole sei. 
Man sieht, daß die damalige unvollkommene Technik schuld daran ist, daß dieser Schluß keineswegs zwingend genannt werden kann, denn es konnte z. B. WeNT nicht bestimmen, wie weit sich dieser größere Rest in die Gametenmasse hinein erstreckt.

Ich persönlich halte es nach unseren neueren Erfahrungen an Hydrodictyon für sehr unwahrscheinlich, daß die Vakuolen der Codiumgameten durch Teilung aus der großen zentralen Vakuole hervorgehen.

Diesen Standpunkt vertrat KLEBS bereits bald nach der Publikation von Wents Artikel; in seiner Kritik weist er darauf hin, daß die zentrale Vakuole von Hydrodictyon intakt bleibt bis zur Reife der Zoosporen.

Es wendet sich aber die Kritik von KLEBS auch noch gegen einen anderen Punkt von Wents Arbeit.

Went hatte in seiner Arbeit gesagt, daß von jetzt an ein jeder, der die Auffassungen von ihm und DE VRIES nicht acceptierte, den Beweis zu erbringen hätte, daß normale Vakuolen im Plasma entstehen können an einer Stelle, wo solche vorher nicht vorhanden waren.

Went gibt aber zu, daß infolge verschiedener Einflüsse, z. B. von Wasser, Vakuolen gebildet werden können an Stellen, wo sich solche vorher nicht befanden, erklärt solche Vakuolen aber für pathologische statt für normale und meint, solche pathologische Vakuolen seien den normalen keineswegs gleichwertig.

KLEBS bemerkt nun, daß es sich also in erster Linie darum handelt, festzustellen, wo die Grenze zwischen normalen und pathologischen Vakuolen liegt, und WENT gibt in seiner Arbeit selber zu, daß dies keineswegs leicht sei, daß es im Gegenteil beim Desorganisieren ron Meeresalgenzellen mittels Aq. dest. sehr schwer sei, zwischen normalen und pathologischen Vakuolen zu unterscheiden.

Wenn also Wents Arbeit die Frage nicht erledigen konnte, so hat sie, neben vielen sonstigen wichtigen Ergebnissen, durch die scharfe Fragestellung wesentlich zur Klärung der Sache beigetragen, wenn auch meiner Ansicht nach die Sache seitdem nicht zu Gunsten der DE VRIEsWentschen Auffassung entschieden ist.

Denn Pfeffer (1890) hat, glaube ich, einwandsfrei die Neubildung von Vakuolen im Myxomyceten-Plasmodium erwiesen, und wenn auch eine Schwalbe keinen Sommer macht, so hat doch zur Entscheidung ähnlicher Fragen ein positives Resultat ein gewaltiges Uebergewicht gegenüber vielen negativen.

Pfeffer benutzte bei seiner Untersuchung Plasmodien des Myxomyceten Chondrioderma difforme und brachte sie in eine gesättigte Lösung. irgend einer nicht leicht löslichen Substanz, welcher Lösung feste Partikelchen dieser Substanz zugefügt wurden. Es stellte sich heraus, daß eine Asparaginlösung recht zweckmäßig war. Die Asparaginkristallchen befanden sich alsbald im Plasma, und zwar im Körnerplasma ohne daß auch nur die Spur einer Vakuole vorhanden war.

Bringt man nun solche mit Asparaginkristallchen gespickten Plasmodien in frisches Wasser, so bilden sich um die sich langsam lösenden Kristallchen herum Vakuolen.

Die Vakuolen können also durch Neubildung entstehen.

Diese künstlich, ohne Hilfe eines Tonoplasten gebildeten Vakuolen sind von normalen nicht zu unterscheiden. Ja PFEFFer konnte sogar deren Teilung und Verschmelzung nebst schwacher Pulsierung beobachten.

Beide Vakuolen, künstliche und die schon vorher vorhandenen, be- 
sitzen eine Trand. nehmen feste Partikelchen auf, stoßen diese auch aus, mit einem Worte, sie sind identisch und normale Vakuolen.

Die Takuolenwand ist demnach kein Organ suigeneris. sondern gehört dem umgebenden Plasma an, die Takuole ist eben nur ein Loch.

Aus diesen Beobachtungen folgt direkt, daß sich die Takuolenwand aus dem Körnerplasma zu bilden vermag; und Gleiches wies Pferfer für die Hautschicht der Plasmodien nach.

Innere und äußere Hautschichten sind demnach keine autonomen Oroane.

Zwar wurde noch nicht nachgewiesen, daß die Verhältnisse bei höheren Pflanzen ebenso liegen, es ist dies aber meiner Ansicht nach sehr wahrscheinlich.

PFefFer faßt das Resultat, wie folgt, zusammen:

"Nach allen Erfahrungen sind aber die Innenmassen des Cytoplasmas jederzeit befähigt, an der Grenze und im Grenzdienst die Formation und die Funktion der Plasmahaut zu übernehmen, und diese ist demgemäß nicht. wie DE VRIES und seine Schüler ohne zureichenden Grund annahmen, ein Organ, das analog wie der Zellkern, immer nur von seinesgleichen abstammt."

Von den Altmansschen Granulis weiß man schon lange, daß sie wenigstens zum Teil aus Nahrungspartikelchen bestehen.

Demnach sind also keinesweg's so viele "Organe" im Plasma vorhanden, wie DE VRIEs und seine Schüler annahmen.

In normalen, überall vorhandenen Zellen, d, h. also in Zellen ohne Chromatophoren gibt es nur ein unabhängiges Organ: den Zellkern.

Die panmeristische Hypothese der Zellteilung ist also bei weitem nicht bewiesen, es wurde im Gegenteil die Möglichkeit der Neogenese von Vakuolen experimentell nachgewiesen.

Damit entfällt den Pangenen die morphologische Stütze, und bleiben sie, wie zu Zeiten DARwins, eine rein philosophische Spekulation, welche aber als Arbeitshypothese zu glänzenden Untersuchungen und Resultaten geführt hat.

Kehren wir nach diesen Abschweifungen zu den Siphonales zurück.

Bei den Codiaceen fanden wir eine höhere Entwickelungsstufe als bei den Bryopsiden, indem die Fäden zu Geweben verflochten wurden, bei den

\section{Caulerpaceen}

dagegen, begegnen wir wieder einer Einzelzelle, aber mit so hoher Differenzierung, wie sie sonst nur bei höheren Gewächsen auftritt.

Es gibt in dieser Familie nur ein Genus, nämlich

\section{Caulerpa,}

welches aber aus einer sehr großen Zahl von Arten besteht. Frau WeBER vaN Bosse (1898) zählt in ihrer Monographie nicht weniger als 54 lebende und 4 fossile Arten nebst zahllosen Varietäten auf.

Wie verschieden nun auch das äußere der verschiedenen CaulerpaArten sein mag, so sind sie doch dadurch leicht ron alien sonstigen Algen zu unterscheiden, daß sie trotz ihrer öfters beträchtlichen Größe nie Querwände, sondern zahllose nach imnen gerichtete Cellulosebalken besitzen. 
Es ist nicht möglich, die Caulerpa-Arten phylogenetisch zu behandeln, da die Caulerpen zweifellos sehr alte Formen sind, von welchen die jetzt lebenden nur einen Rest verschwundener Entwickelungsreihen darstellen.

Ueberdies erlaubt ihre Verbreitung über fast alle Meere keinerlei Schlüsse aus geographischen Gründen, und schließlich fehlt uns durch den gänzlichen Mangel an Fortpflanzungsorganen einer der wichtigsten Anhaltspunkte.

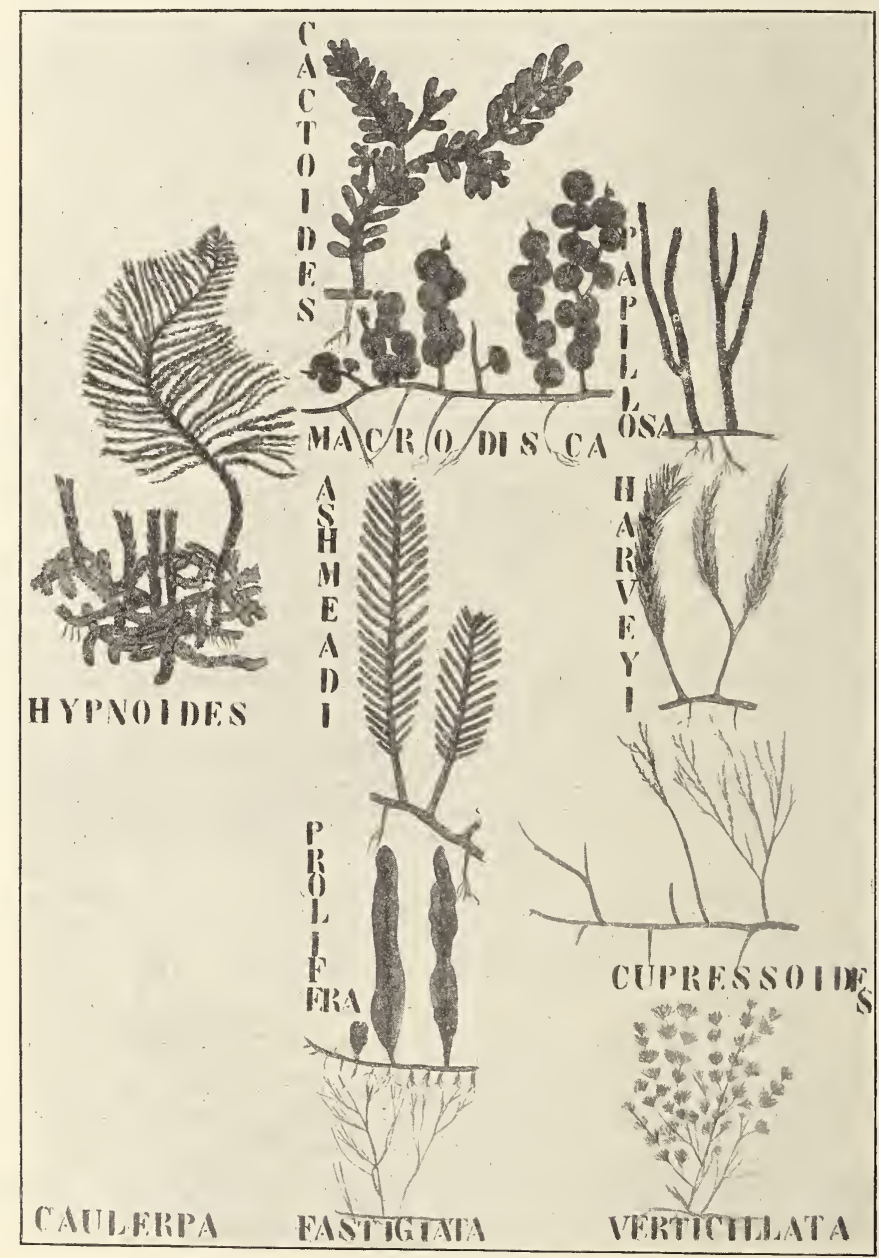

Fig. 36. Caulerpa-Arten nach REINKE.

Wir können sie also nur, dem Beispiel Reinkes folgend, nach der geringeren oder größeren Differenzierung ihrer Thallome anordnen, um so einen Ueberblick zu gewinnen.

Wir unterscheiden bei den Caulerpen aufrechte, grüne, der Photosynthese dienende Organe, welchen Reinke den Namen Assimilator zugelegt hat, und ein meistens im Schlamm kriechendes, mehr oder weniger cylindrisches, oft braunes oder farbloses Organ, das sogenannte Rhizom, 
nebst den daraus hervorsprossenden Rhizoiden, welche öfters fälschlich Wurzeln gemannt werden.

Als einfachste Form kann sicher Caulerpa fastigiata gelten, welche wir also als die Grundform der Caulerpen betrachten wollen.

Ton ihr geht ReInke bei der Aufstellung seines Systems aus. Sie wurde im Großen Ozean auf den Freundschaftsinseln, im Atlantischen an der Küste Westindiens und in Brasilien gesammelt, hat also eine überaus weite Verbreitung in tropischen Gebieten.

Es ist ein rasenbildendes Pflänzchen, mit horizontalem, fadenförmigem Rhizom, mit dünnen farblosen Wurzeln und unregelmäßig verzweigten, fadenförmigen Assimilatoren, denen einer Vaucheria sehr ähnlich. Zwischen Haupt- und Nebenzweigen gibt es keinen morphologischen Unterschied. Daß wir es mit einer echten Canlerpa zu tun haben, geht aus dem Vorhandensein der typischen Cellulosebalken unzweideutig hervor.

Ungefähr auf gleicher Stufe wie diese Gruppe steht jene, zu welcher C. verticillata gehört. Sie findet sich auf den Freundschaftsinseln und an den Küsten Ostindiens. Hier begegnen wir einer Differenzierung in kurze, wirtelige Seitenzweige und lange, diese tragende Hauptzweige.

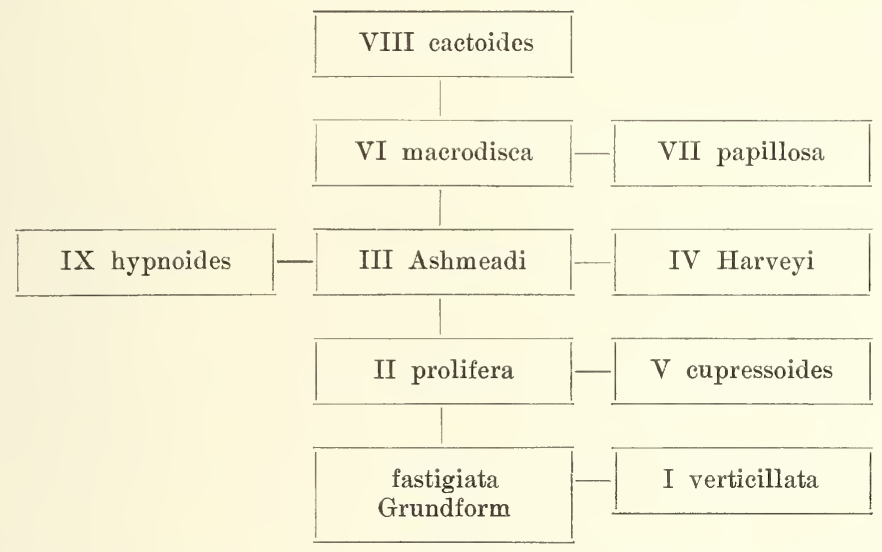

Von der Grundform kann die Prolifera-Gruppe abgeleitet werden, durch Abplattung der Assimilatoren. C. prolifera selber ist die höchstentwickelte Form dieser Gruppe, die niedrigsten ähneln der fastigiata weit mehr, deren Assimilatoren sind nur wenig flach, und sogar prolifera kann, wie wir später sehen werden, unter bestimmten Umständen schmale, fast cylindrische Assimilatoren bilden, welche denen der fastigiata ähneln.

Prolifera wird im Mittelmeer, an den Küsten von Florida und Westund Ostindien angetroffen. Sie ist also ebenfalls eine weitverbreitete Species. C. Ashmeadi kann als eine proliferc mit stark eingeschnittenen Assimilatoren betrachtet werden, dies wird durch die Existenz von Uebergangsformen mit nur wenig eingeschnittenen Assimilatoren plausibel. Sie ist nur von den Küsten Floridas bekannt. Von ihr kann man Harveyei durch eine noch feinere Verteilung der Assimilatoren ableiten, welche aber nicht 2-, sondern 5-zeilig inseriert sind. In dieser Hinsicht gibt es aber ebenfalls Uebergangsformen: so die C. alternifolia mit 2-zeilig alternierenden, die C. trifaria mit 3-zeiligen Zweigen von Neu-Holland. Ueberdies kommen am gleichen Exemplar 2- und mehrreihige Assimilatoren bisweilen vor. 
Leichter läßt sich $C$. hypnoides als eine doppelt gefiederte $C$. Ashmeadi betrachten. Die in Neu-Holland, Neu-Seeland und Tasmania vorkommende Art weicht aber von allen sonstigen durch die stacheligen Anhängsel ihrer Rhizome ab.

Auf den ersten Blick erscheint es sehr schwer, eine Form wie $C$. macrodisca von C. Ashmeadi abzuleiten. sind doch die Seitenzweige der Assimilatoren in große schüsselförmige Blasen verwandelt. Durch die Existenz von Zwischenformen mit nur wenig angeschwollenen Seitenzweigen, wie solche in der $C$. racemosa vorliegen, geht dies aber leichter. Die C. macrodisca kommt auf Celebes und in dem Anambas-Archipel vor. C. papillosa ist einfach eine macrodisca mit sehr dichtgedrängten blasigen Seitenzweigen; sie stammt aus Neu-Holland.

Ein ganz anderer Typus, dessen Anschluß zur Zeit unmöglich ist, ist die ebenfalls neuholländische $C$. cactoides. Sie entfernt sich von allen sonstigen Formen durch die Artikulation des Hauptstammes des Assimilators.

Man sieht, daß die Verwandtschaft aller Species höchst problematisch ist, die hier gegebene Anordnung kann nur als eine Erleichterung zur Uebersicht der großen Zahl der Species betrachtet werden.

Daß wir so wenig über die Verwandtschaft innerhalb dieser Gruppe sagen können, liegt wohl hauptsächlich an der anscheinenden Abwesenheit von Fortpflanzungsorganen.

Bedenkt man, wie viele Caulerpen sich in den Herbarien befinden, und wie viel Mühe die vorzügliche Kennerin der Gruppe, Frau WEBER VAN Bosse, auf ihrer einjährigen, ununterbrochenen Untersuchungsreise im Indischen Archipel es sich kosten ließ, um Fortpflanzungsorgane aufzufinden, so darf man wohl fast glauben, daß diese wirklich fehlen.

Selbstverständlich fehlt ihnen nicht das Vermehrungsvermögen, abel dies geschieht auf vegetativem Wege, indem abgebrochene Stücke sich wieder bewurzeln und weiterwachsen, also durch Fragmentierung.

Betrachten wir jetzt die einzelnen Organe etwas näher:

\section{Das Rhizom.}

Das Rhizom wächst horizontal entweder im Boden oder über demselben kriechend. Es verzweigt sich also vorwiegend in einer horizontalen Ebene. Das Wachstum findet ausschließlich an dem konisch zugespitzten Ende statt und ist, prinzipiell wenigstens, unbegrenzt.

Der Querschnitt ist ein Kreis, der Bau also radiär, aber trotzdem verhält es sich wie ein dorsiventrales Organ, indem es an der Oberseite Assimilatoren, an der Unterseite aber Wurzeln bildet.

Verzweigung findet durch Bildung seitlicher Auswüchse auf größere oder geringere Entfernung von der Spitze statt.

KLемm zeigte, daß Rhizome als Adventivbildungen an Assimilatoren gebildet werden können, und nach Beobachtungen der Frau WEBER vaN Bosse im Freien können die Spitzen der Assimilatoren, wenn sie aus irgend einer Ursache mit dem Boden in Berührung kommen, zu Rhizomen auswachsen.

Während die Rhizome meist nackt sind, sind sie bei Gruppe IX mit kleinen Blättern bedeckt, welche entweder mit den „Blättern“ der Assimilatoren übereinstimmen oder farblose „Blattschuppen" sind, wie bei C. hypnoides. 


\section{Die Wurzeln.}

Die Thurzeln sind wie die Rhizome radiär gebaut nnd verlängerm sich ebenfalls durch Spitzenwachstum; während aber das Wachstum der Rhizome unbegrenzt ist, ist das der ITurzeln begrenzt.

Wir können zwischen gewöhnlichen und Haarwurzeln unterscheiden, erstere finden sich bei allen Caulerpen, letztere nur bei gewissen Arten.

Normale Trurzeln entstehen auf einige Entfernung des Vegetationspunktes an der Unterseite der Rhizome. Auch können Adrentivwurzeln aus der Basis der Assimilatoren gebildet werden. Die Wurzeln bilden Seitenwurzeln. welche vielfach in ähnlicher Weise wie die Haarwurzeln der Phanerogamen mit Sandkörnern verwachsen.

Die Haarwurzeln umgeben das ganze Rhizom als ein dichter Filz,

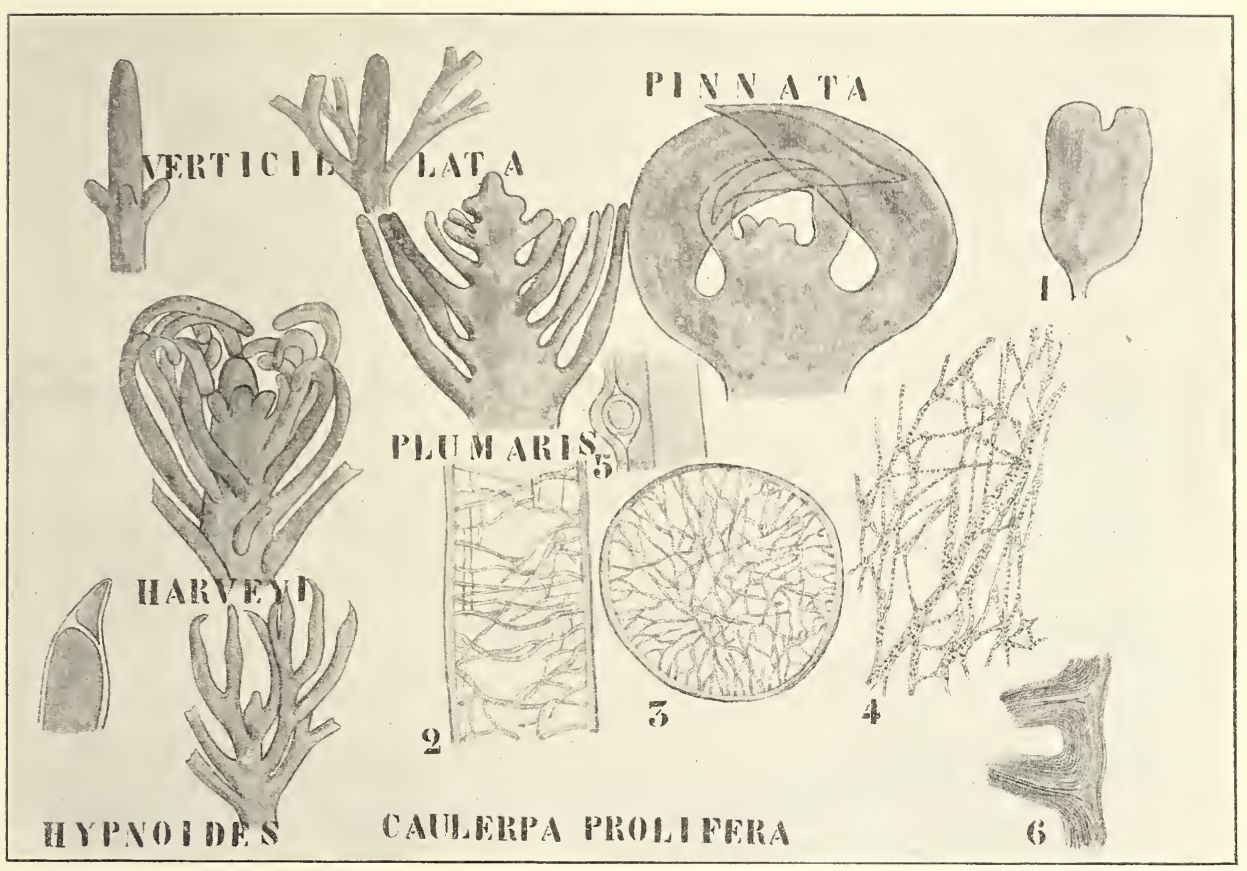

Fig. 37. I. Vegetationspunkte von verschiedenen, mit Namen bezeichneten CaulerpaArten (nach Reinke). - II. Caule rpa prolifera (nach DIPPEL, JANsE und StRASBURGER). 1 Schutz des Vegetationspunktes. 2 und 3 Längs- und Querbälkchen. 4 Plasmastränge. 5 Einschließung eines Balken durch Auflagerung einer Schicht auf die Zellwand. 6 Verdickungsschicht auf Längswand und Querbalken.

als Beispiel darf C. Lycopodium genannt werden; bei C. hypnoides können die Spitzen der Rhizomschuppen zu Haarwurzeln auswachsen.

Die Assimilatoren.

Während Rhizome und Wurzeln der Caulerpen im ganzen recht einförmige Gebilde sind, sind, wie wir bereits sahen, die Assimilatoren recht mannigfach gestaltet.

Die Assimilatoren wachsen so wie die Rhizome an der Spitze (bei einigen vielleicht daneben interkalares Wachstum); während aber das Rhizom unbegrenzt wächst, wachsen die Assimilatoren nicht unbegrenzt. 
Veg etationspunkte.

Bei C. fastigiata wächst der Vegetationspunkt nach Art einer Vaucheria, und welden die Seitenzweige in unregelmäßiger Entfernung von der Spitze angelegt.

Bei $C$. verticillata hingegen entstehen in regelmäßiger Entfernung wirtelige Ausstülpungen, wodurch eine äußerliche Differenzierung in Knoten und Internodien entsteht. Hier wird der Vegetationspunkt durch die schneller wachsenden Seitenzweige geschützt.

Bei $C$. prolifera werden keine Seitenzweige an den Assimilatoren gebildet, sie wachsen nur in die Länge.

Dennoch wird dabei ein Schutz des Vegetationspunktes geschaffen, indem, wenigstens in der Jugend, die lateralen Partien schneller wachsen als die mediane, so daß der Vegetationspunkt in eine Einburhtung zu liegen kommt.

\section{Die Anpassung bei Caulerpa.}

REINkE schließt aus dem großen Formenreichtum der Caulerpen, sowie aus den sehr gleichmäßigen Lebensbedingungen, daß die Formenbildung auf äußeren Ursachen beruht. Ob die Lebensbedingungen wirklich so einförmig sind, wie REINkE vermutet, ob nicht Lichtverschiedenheiten, Wellenschlag, Temperatur etc. dennoch als wichtige formbildende Faktoren gewirkt haben können, mag dahingestellt bleiben; zuzugeben ist, daß die spezifische Struktur ein Hauptfaktor ist. Ob der Formenreichtum aber, wie REINkE meint, alle Umstände in Betracht gezogen, so ungewöhnlich groß ist, ist zweifelhaft. Bei der ausschließlich negativen Vermehrung bleiben eben viele neue Formen erhalten, welche sonst nicht erblich sind und also bald wieder verschwinden.

Betrachten wir nach dieser Uebersicht die einzige europäische Art:

\section{Caulerpa prolifera}

etwas näher und lernen wir daran zunächst einmal die Cellulosebalken kennen.

Im Rhizom verlaufen sie ungefähr radiär (Fig. 37, 3), sind aber nach dem Zentrum zu durch Anastomosen reichlich miteinander verbunden.

In den flachen Assimilatoren sind sie senkrecht auf den flachen Seiten orientiert und reichen von der einen Fläche zur anderen; es sind dies die Querbalken, welche hier und da von Längsbalken gestützt werden.

Die dicke Zellwand ist an der Außenseite mit einer Cuticula bekleidet, welche über den Befestigungsstellen der Querbalken etwas eingewölbt ist (Fig. 37, 6). Die Membran selber ist deutlich geschichtet, und diese Schichten setzen sich über die Querbalken fort (Fig. 37, 6). Wie dies geschieht ist leicht verständlich, wenn man weiß, daß die Balken im Vegetationspunkt noch sehr dünn sind, und daß die Celluloseschichten durch Apposition aufgelagert werden. Noll konnte den Nachweis dadurch erbringen, daß er Pflanzen lebendig mit Berlinerblau färbte und so die neu angelegten Schichten als farblose Auflagerungen konstatieren konnte.

Interessant ist die Fig. 37, 5, welche zeigt, daß Längsbalken in dieser Weise ganz in die Wand aufgenommen werden können. Der Balken in unserer Figur lag zuerst in einiger Entfernung von der Wand, es wurde auf letzterer eine neue Schicht aufgelagert, welche den Balken 
in Terbindung mit der Wand brachte, und die jüngste Schicht schloß ihn schließlich ein.

Die Balken entstehen in den Tegetationspunkten, und zwar ausschließlich dort, aus dem angehäuften Plasma. welches sich teilweise zu dünnen Strängen differenziert.

Nach Janse können sie ohne irgend welche Verbindung mit der Wrand frei in der Mitte eines Plasmastranges entstehen und sich erst später an die Seitenflächen anheften.

In den Vegetationspunkten lieg'en die jung'en Balken sehr gedrängt, durch interkalares Wachstum entfernen sie sich voneinander, bis die Entfernung konstant bleibt, indem das interkalare Wachstum erlischt.

Wir haben bis jetzt von Cellulosebalken geredet, die Substanz dieser Gebilde ist aber gewiß keine echte Cellulose, sondern wahrscheinlich ein verwandtes Kohlehydrat, dessen chemische Natur aber noch unbekannt ist.

Die Funktion der Balken ist noch nicht vollständig aufgeklärt.

Eine Funktion ist aber durch einen hübschen Versuch Janses bekannt geworden. Bis auf ihn wurde ziemlich allgemein angenommen, daß diesen Balken die Auseinanderhaltung der Zellwände zukäme, und daß ohne sie die Zelle kollabieren würde. JANse bemerkt aber mit Recht, daß der vorhandene Turgor die Gefahr des Kollabierens ausschließt, daß im Gegenteil eher durch den Turgor die Bandform in eine cylindrische verwandelt werden würde.

Um zu zeigen, daß dies in der Tat der Fall sein würde, schnitt er die Querbalken über eine Distanz von etwa $1 \mathrm{~cm}$ durch. Die operierten Pflanzen wurden in ein Aquarium gestellt, wo die Wunde in 24 Stunden heilte. Es stellte sich nun heraus, daß an der Stelle, wo die Querbalken durchschnitten waren, der Thallus sich infolge des Turgors aufblies.

Die Balken verhindern hier also die Aufblähung der Thallus und erlauben der Bandform zu persistieren.

Selbstverständlich aber kann dies nicht ihre ausschließliche Funktion sein, denn bei cylinderförmigen oder kugelförmigen Organen wären sie in dem Falle überflüssig.

Noll zeigte nun, daß Salzlösungen leicht und schnell durch die Balken in die Zelle eindringen, viel schneller als durch das Plasma, und meint, daß sie also die Aufnahme von Nährsalzen erleichtern.

Auch dies mag eine ihrer Funktionen sein, mit REINkE betrachte ich aber als ihre Hauptfunktion die Stützung des Protoplasmas.

Letzteres ist zwar in erster Linie wandständig, überzieht aber auch alle Balken, und überdies sind noch zahlreiche Plasmastränge zwischen denselben ausgespannt. Die Hauptfunktion der Cellulosebalken ist also die eines Gerüstes für die große Plasmamasse der Riesenzelle.

Fragen wir uns zum Schluß, mit welchen Formen Caulerpa am nächsten verwandt ist, so liegt es auf der Hand, in erster Linie an Bryopsis zu denken, welche gleichfalls eine große Zelldifferenzierung aufweist. Eine Form wie C. Ashmeadi z. B. ähnelt gewiß einer Bryopsis. Diese Vermutung wird noch dadurch erhöht, daß in alten Stammstücken von Bryopsis ebensolche Cellusosebalken, wie bei Caulerpa, gefunden werden.

Es soll aber nicht verschwiegen werden, daß Dixon vor kurzem bei Codium in den Fadenspitzen Gebilde antraf, welche ebenfalls an solche Balken denken lassen.

Solange wir über die Fortpflanzungsorgane von Caulerpa nichts 
wissen, ist es nicht möglich, etwas Sicheres über ihre Verwandtschaft zu sagen.

Am wahrscheinlichsten scheint mir die WrLlesche Auffassung, welche Codiaceen und Caulerpaceen als ebenbürtige Seitenzweige der Bryopsideen betrachtet.

Alle bis jetzt betrachteten Siphonales waren isogam oder in geringem Grade heterogam. Eier und Spermatozoen kommen nicht vor.

Solches ist dagegen der Fall bei einer anderen Algengruppe, welche wir hier unterbringen müssen, aber welche wegen vieler Abweichungen vom Typus der Siphonalen nicht als eine direkte Fortsetzung, sondern als ein Seitenzweig dieses Stammes betrachtet werden muß, es ist dies die Familie der

\section{Vaucheriaceen.}

Sie verhält sich aber in so vielen Punkten anders als die übrigeı Familien der Siphonales, daß es sich nicht entscheiden läßt, aus welcher Familie sie entstanden ist.

In erster Linie weicht sie von den übrigen Siphoneen dadurch ab. daß sie oogam ist. Viel wichtiger scheint freilich auf den ersten Blick der abweichende Bau der Zoosporen zu sein.

Wir sahen früher, daß alle Isokonten durch den Besitz von Zoosporen mit zwei gleichlangen Cilien gekennzeichnet sind. Bei den Vaucheriaceen aber besitzt die normale Zoospore eine große Zahl von Cilien, ja ist damit anscheinend gleichmäßig bekleidet.

Bei näherer Betrachtung zeigt sich aber, daß diese anscheinend so abweichend gebaute Zoospore sich in der Tat sehr leicht auf den üblichen Isokontentypus zurückführen läßt.

Sie darf nur nicht als eine einfache, sondern muß als eine zusammengesetzte Zoospore betrachtet werden. Schon ihre außergewöhnliche Größe führt zu dieser Vermutung, welche durch ein Studium der Cilieninsertion bestätigt wird. Es zeigt sich nämlich, daß die Peripherie der Zoospore von einer Anzahl von Cilien eingenommen wird, und daß sich unter jedem Cilienpaar ein Kern befindet.

Sie werden sich noch erinnern, daß die Gameten von Codium, bevor sie sich frei machen, an der Oberfläche eines, vom wandständigen Plasma gebildeten Ellipsoids liegen. In der Mitte dieser Plasmamenge befindet sich die zentrale Vakuole.

Auch im Innern der Vancheria-Zoospore wird eine große Vakuole angetroffen. Denken wir uns nun, daß im Codium-Gametangium die Gametenbildung nicht zu Ende geführt, sondern vor der Trennung derselben unterbrochen würde, daß sich aber die Cilien der Gametenprimordien wohl ausbildeten, so würde eine zusammengesetzte Gamete entstehen. Mutatis mutandis läßt sich dies auf Vaucheria übertragen, deren Zoospore ist ja eben eine zusammengesetzte Zoospore.

\section{Die Vaucheriaceae}

sind demnach Isokonten, und zwar Siphonales mit zusammengesetzten Zoosporen und Oogamie. Betrachten wir sie etwas näher. Sie umfassen zwei Genera, das große Vaucheric-Geschlecht und das monotypische Dichotomosiphon, vor kurzem von ERNst beschrieben. Hauptunterschied zwischen Vaucheria und letzterem Genus ist die Abwesenheit echter 
Dichotomie und Stärke bei ersterem, die Anwesenheit beider bei letzterem. Betrachten wir also zunächst das Genus

\section{Vaucheria.}

Die letzte şstematische Bearbeitung rührt von Goetz her. Wir wollen ihr folgen und betrachten zunächst die

\section{vegetativen Organe.}

Die Taucherien sind lange, schlauchförmige Siphonales, also auch polvenergid. Die zahlreichen Chromatophoren sind klein, mehr oder weniger spindelförmig und enthalten keine Pyrenoide. Querwände werden nur bei Bildung von Fortpflanzungsorganen, sowie nach Ver-

\section{VAIIOHERIA I (ONGROSIRA)}
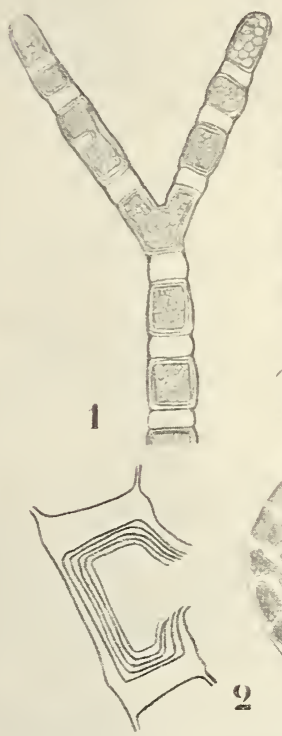

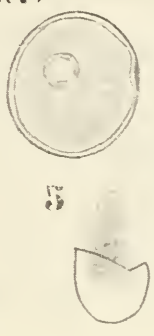

$\overline{3}$

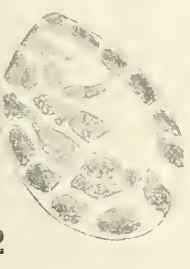

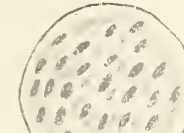

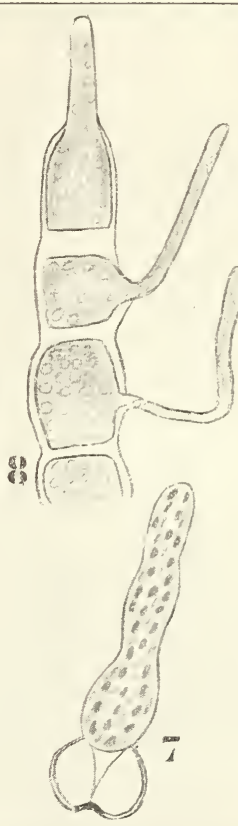

Fig. 38. Vaucheria geminata nach StaHI. 1 Faden mit Cysten. 2 Cyste, aus welcher der zu amöboiden Schwärmern umgebildete Inhalt ausgeschlüpft ist. 3 Ámöboide Schwärmer. 4 Dieselben beim Keimen. 5 oben, Eingekapselter und farblos gewordener amöboider Schwärmer. 5 unten, Ausschlüpfen des Schwärmers aus einem ähnlichen Zustand. 6 Eingekapselter amöboider Schwärmer beim Ausschlüpfen, 7 Keimende, 8 vegetativ keimende Cysten.

wundung gebildet.: Der Schlauch wächst an der Spitze, Seitenzweige werden stets in einiger Entfernung von der Spitze und an beliebigen sonstigen Punkten der Zelle gebildet; echte Dichotomie wurde nie gefunden.

Die Vaucherien besitzen farblose oder schwach gefärbte, meistens krallenartige Rhizoide an der Basis der Zelle, mittels welcher sie sich am Substrat anheften. Nach Borzi entwickeln sie sich durch Kontaktreiz und nur an jungen Pflanzen.

Die Fortpflanzungsweise ist ziemlich mannigfach. In erster Linie 
kann sich ein jedes Stück des Thallus zu einem neuen Individuum regenerieren, ja sogar die aus angeschnittenen Fäden austretende Plasmamassen, welche, wie alle Flüssigkeiten, infolge der Oberflächenspannung alsbald Kugelform annehmen, können sich mit einer Cellulosemembran umgeben und zu neuen Individuen auswachsen.

Weiter gibt es eine Art von

\section{Cystenbildung.}

Unter bestimmten, ungünstigen Umständen, z. B. auf gebaggertem, austrocknendem Schlamm, zieht Vaucheria geminata ihr Plasma zu gesonderten Plasmaklumpen zusammen, welche sich mit einer Membran umgeben.

Bisweilen ist die Trennung zwischen zwei Plasmaklumpen unvollständig, sie bleiben denn mittels einer Plasmabrücke verbunden (Fig. 38, 1 links) und encystieren sich zusammen.

Da man diesen Zustand früher nicht als zu Taucheria gehörig erkannt hatte, wurde er als ein gesondertes Genus unter dem Namen Gongrosira beschrieben und noch jetzt als Gongrosira-Zustand angedeutet. Stahl brachte die Sache zur Klarheit.

Gelangt die Alge in diesem Gongrosirc-Zustand wieder ins Wasser, so keimen die Cysten, indem sie die Membran des Fadens durchbohren. direkt zu neuen Vaucherien aus (Fig. 38, 8), oder aber der Inhalt schwillt, zerbricht dabei die Membran und tritt, von der inneren verschleimten Wandschicht umgeben, aus.

Diese dünnwandige Zelle kann nun wieder direkt auskeimen, meistens aber zerfällt ihr Inhalt in eine Anzahl von nackten Plasmastücken, welche durch ein Loch in der Membran austreten und auf festem Substrat sich amöboid bewegen (Fig. 38, 3).

Diese amöboiden Schwärmer können, nachdem sie eine Membran gebildet haben, direkt auskeimen (Fig. 38, 4) oder sich wieder einkapseln unter Bildung einer dickeren Membran (Fig. 38, 5). In letzterem Falle bilden sie viel Oel und werden fast völlig farblos. Bei der Keimung schlüpft der inzwischen grün gewordene Inhalt wieder als Schwärmer aus und keimt $\mathrm{zu}$ einer Vaucheria aus, oder aber sie keimen vegetativ (Fig. 38, 6, 7).

Trotz Stahls vorzüglichen Beobachtungen scheint mir die Möglichkeit nicht ausgeschlossen, daß die Amöboidenstadien Parasiten sind. Der Entwickelungsgang würde dann wesentlich einfacher und weniger $a b$ weichend sein. Zwar gibt es, wie OLtmanns bemerkt, amöboide Schwärmer bei den Conferven, aber die hier erwähnten Schwärmer weichen so sehr von gewöhnlichen Vaucheria-Schwärmern ab, daß sie höchst sonderbar sind.

\section{Die ungeschlechtliche Fortpflanzung.}

Bei den Vaucherien sind 2 Arten ungeschlechtlicher Sporen bekannt: Zoosporen und Aplanosporen. Zwischen beiden gibt es, wie weiter unten ausgeführt werden soll, Uebergänge.

Es ist nicht gelungen, bei allen Arten ungeschlechtliche Sporen nachzuweisen; solche scheinen den $V$. terrestris, $V$. aversa und $V$. de Baryana abzugehen.

Die Zoosporen entstehen an den Spitzen der Fäden sowohl an Haupt- wie an Seitenzweigen. Dabei schwillt die Spitze meistens zunächst etwas auf und ist durch ihre dunkelgrüne, fast schwarze Farbe 
leicht aufzufinden. Die dunkle Färbung wird durch die Masse der hier angesammelten Chromatophoren verursacht, welche mit dem zuströmenden Plasma hierher gebracht wurden.

Alsbald sieht man den Inhalt des jungen Zoosporangiums sich etwas zurückziehen, wodurch eine farblose Zone zwischen dem schwärzlichen Teil und dem grünen Plasma entsteht; nach einigen Zuckungen wird hier die das Zoosporangium abtrennende Membran gebildet.

Die Spitze des Zoosporangiums öffnet sich alsbald, und die Zoospore schlüpft aus. Deren Bau wurde schon oben besprochen.

Bei $\Gamma$. ornithocephala beschreibt ITALz und bei $T$. polysperma Goetz etwas anders gestaltete Zoosporen.

Diese sind nämlich nicht über ihre ganze Oberfläche mit Cilien bekleidet, sondern nur am vorderen kleineren Teile. Dieser Fall ist nicht ohne Wichtigkeit, indem darin vielleicht ein Uebergang zu den Aplanosporen rorlieg't.

Zu einer solchen Auffassung gelangt man leicht durch die Beobachtung, daß die Schwärmperiode dieser Zoosporen viel kürzer ist als die der normalen. Schwimmen letztere doch etwa 1/2 Stunde herum, bevor sie sich zur Ruhe setzen, erstere nur $1 / 2-1 \frac{1}{2}$ Minute, wenigstens bei $T$. ornithocephala.

Bei Vaucheria piloboloides beschreibt ERNst gänzlich unbewegliche Zoosporen ohme Cilien, welche sich bereits innerhalb des Zoosporangiums mit einer Membran umgeben. Sie schlüpfen durch einen Riß in der Sporangiumspitze aus.

Ernst hält dies für eine Folge der Zunahme des osmotischen Druckes innerhalb der Zoospore; dadurch dehnt sie sich und drückt sich selber heraus. Aus der Ausdehnung der Spore nach dem Ausschlüpfen geht in der Tat hervor; daß sie unter Druck gestanden hat.

Dennoch wirkt vielleicht ein anderer Umstand mit. Bei einer in einem hiesigen Süßwasserkanal an der Ryı en Schiekade von mir gefundenen Form (ERnsts Species ist marin) bemerkte Fräulein stud. J. Hingst, daß beim Ausstoßen der Spore die das Sporangium vom Faden trennende Membran plötzlich in das Sporangium hineingewölbt und infolgedessen die Spore sozusagen hinausgeschleudert wurde. Das scheint also auf einen osmotischen Ueberdruck im Vaucheria-Faden hinzuweisen.

Sowohl bei ERnsts mariner, wie bei unserer Süßwasserform keimen die Sporen alsbald, nachdem sie ausgestoßen sind.

Bei unserer Form passiert es aber, daß das Sporangium, ohne Zoosporen zu bilden, vegetativ auskeimt. Gleiches beschreibt Ernst für seine Form, und dies scheint mir nicht unwichtig für die Erklärung der sogenannten Brutknospen des Dichotomosiphon, sowie zur Feststellung der Tatsache, daß Sporangien auch in Wasser zu ,Konidien“ werden können.

Bei noch anderen Vaucherien, z. B. bei T. uncinata, kommen ebelfalls Aplanosporen vor, welche aber entweder gar nicht ausgestoßen werden und dann nach einiger Zeit innerhalb des Zoosporangiums auskeimen, oder aber erst durch Degeneration der Sporangiumwand frei werden. In beiden Fällen keimen sie erst nach längerer Ruhepause.

Von allen theoretisch möglichen Fällen der Zoosporenbildung kommt also nur eine, die vollständige Bildung einzelner Zoosporen, bei den Vaucherien nicht vor. Sie bleiben auf einem früheren Entwickelnngsstadium stehen und schlüpfen als zusammengesetzte Zoosporen aus. 
Geht die Reduktion nicht weiter, so sind sie vollständig mit Cilien bedeckt, aber alle weiteren Reduktionen, mit nur teilweiser Ausbildung der Cilien anfangend, bis zur Keimung des Zoosporangiums selber, wurden nachgewiesen.

KLEBS arbeitete die Bedingungen, unter welchen Zoosporenbildung: erzielt werden kann, aus und gibt folgende einfachen Vorschriften, unter deren Befolgung man sich zu jeder Zeit Zoosporen verschaffen kann:

1) Man übergießt die während einiger Tage feucht (nicht in Wasser) und hell kultivierten Algen mit frischem Wasser.

2) Die hell, in 0,2-0,5 KNopscher Lösung kultivierten Algen werden in frisches Wasser gebracht.

3) Wasserkulturen in 0,1-0,2-proz. Nährlösung werden ins Dunkle gestellt.

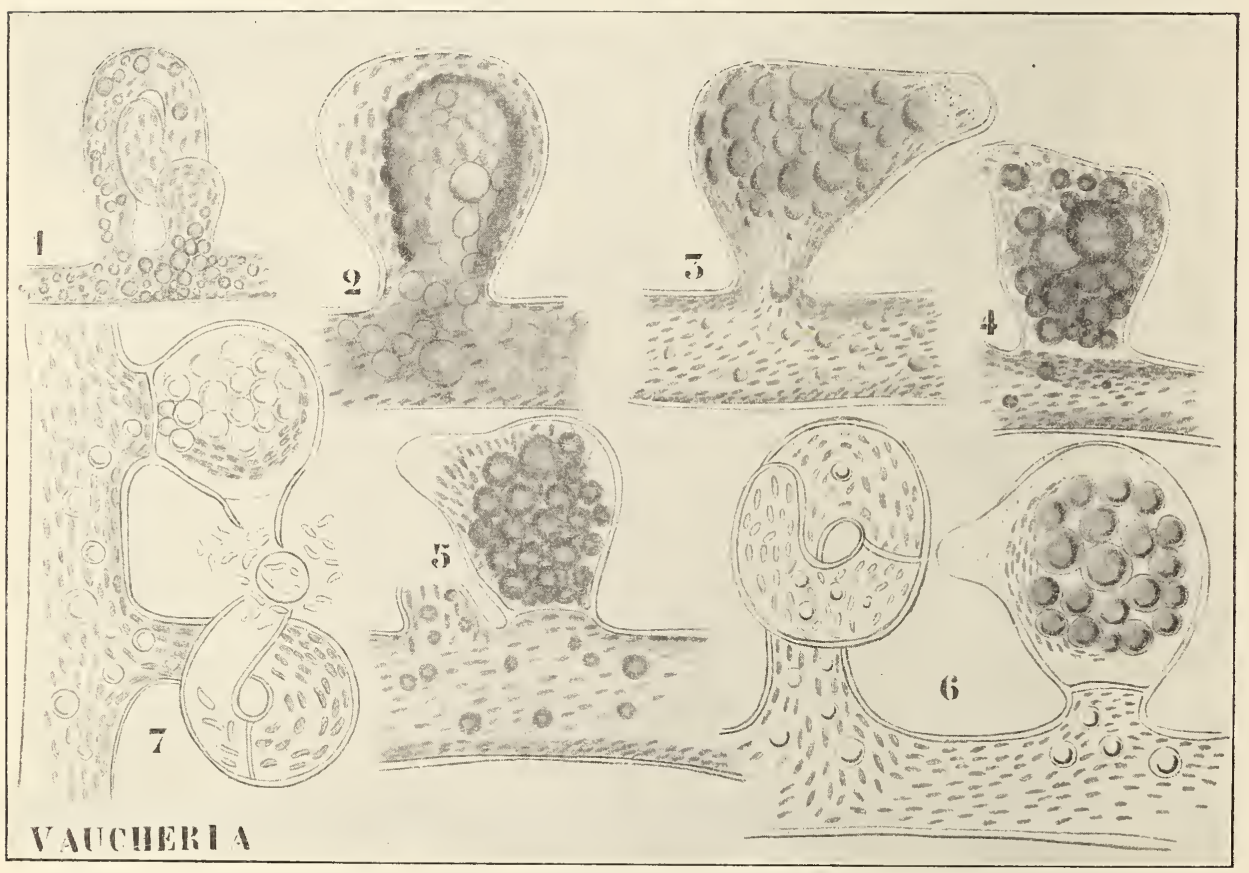

Fig. 39. Vaucheria sessilis nach SAchs und OLtmanns. 1 Junge Geschlechtsorgane. 2-5 Entwickelung des Oogoniums. 6-7 Reifung der Spermatozoen und des Eies.

Um besonders lebhafte Zoosporenbildung zu erzielen, kombiniert man Methode 1 oder 2 mit Methode 3.

Zur Bildung echter Aplanosporen kultiviere man Vaucheria geminata (VAUch.) D.C., V. racemosa (VAUCH.) D.C. oder V. uncinata KUETZ am besten auf feuchter Erde in relativ trockener Luft oder in 4-6-proz. Rohrzuckerlösung.

\section{Geschlechtliche Fortpflanzung.}

Diese wurde bei allen Vaucherien nachgewiesen, und zwar werden Antheridien und Archegonien meistens auf demselben Faden gebildet.

Schreitet die Pflanze zur Antheridienbildung, so entsteht zunächst 
ein kurzer Seitenzweig, der sich mehr oder weniger krümmt (Fig. 39, 1). Oefters geht die Krümmung viel weiter als auf unserer Figur, so daß eine Art Korkzieher entsteht; auf jeden Fall wird alsbald eine Querwand gebildet, wodurch das eigentliche Antheridium abgetrennt wird. In diesem Antheridium bilden sich zahlreiche farblose Spermatozoen mit 2 Cilien, ron welchen die eine nach Art der Phaeophyceen-Schwärmer nach ror'ne, die andere nach hinten gerichtet ist. Durch Verschleimung der Antheridienspitze gelangen sie ins Freie.

Gegeniiber dem Antheridium bildet sich das Oogon als eine knospenähnliche Ausstülpung des Fadens aus. Alsbald wird auch dieses durch eine Membran abgetrennt. und der inzwischen sehr ölreich gewordene Inhalt (Fig. 39, 느-4) differenziert sich jetzt in eine farblose Spitze, den sogenannten Schnabel, und in einen grünen Teil.

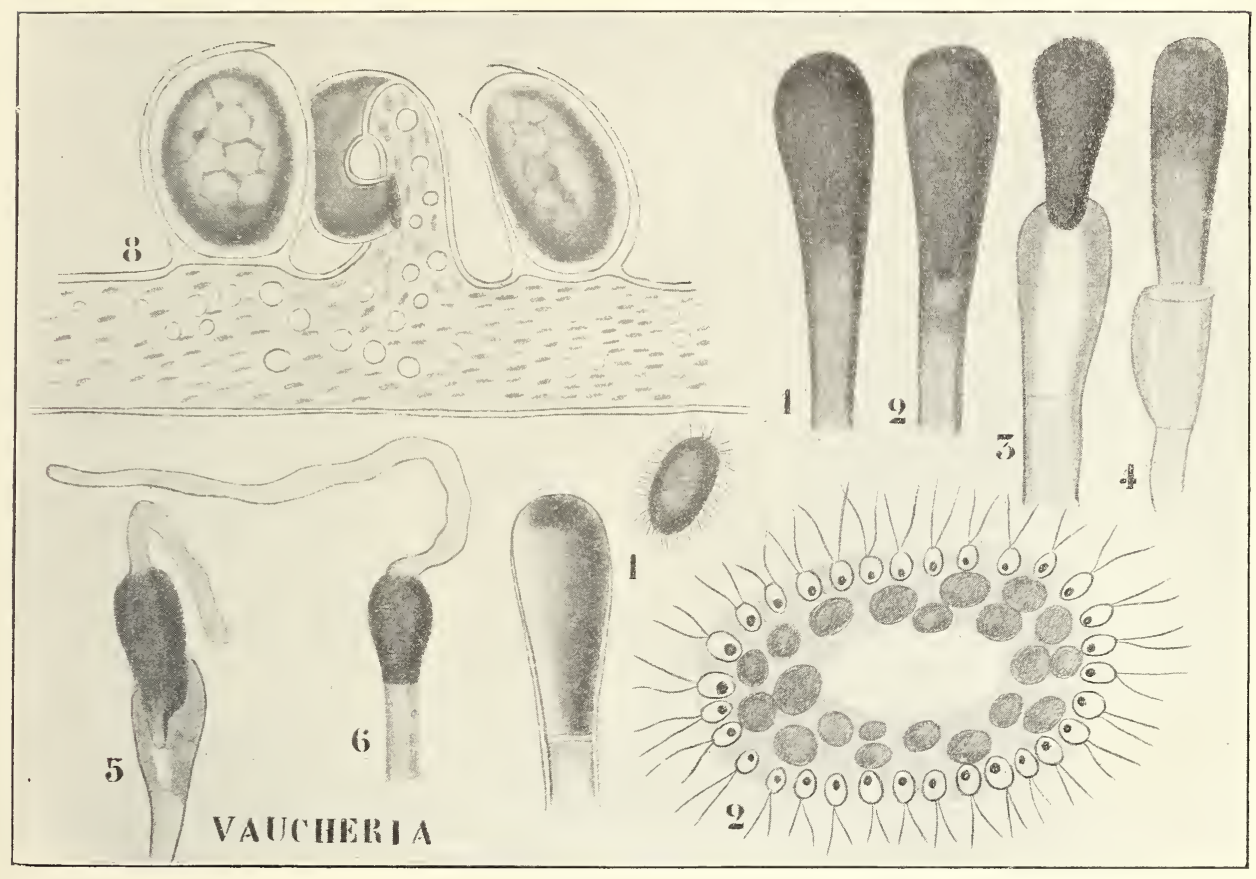

Fig. 40. 8 Reife Zygoten. 9 1-5 Vaucheria piloboloides nach ERNst, Entwickelung der Aplanospore. 6 Vegetativ keimendes Sporangium. $1-2$ Zoospore einer normalen $\mathrm{V}$ a $\mathrm{c}$ h e ri a nach STRAsBuRGER.

Bei der Reife öffnet sich das Oogon an der Spitze, der größte Teil des farb- und kernlosen Plasmas wird ausgestoßen, der Rest rundet sich za einem kugelförmigen Ei ab. Spermatozoen dringen jetzt durch den Oogonhals in dasselbe ein, eines von diesen verschmilzt mit dem Ei, und die so gebildete Zygote umgibt sich mit einer dicken Membran. Bei der Reife fällt das Oogon mit der Zygote ab.

Die Keimung findet erst nach einer Ruheperiode statt, dabei wird die dicke. Zygotenmembran vom Keimschlauch durchbrochen und die Zygote wächst direkt zu einer neuen Taucheria aus.

So weit läßt sich die Sache ohne Schwierigkeit an jeder Taucheria verfolgen, wir lernen damit aber nichts über das Verhalten der Kerne 
und über die wirkliche Natur des Eies. Dennoch liegt die Frage auf der Hand, ob auch hier das Ei, wie üblich, einkernig ist, und wenn sich dies in der Tat herausstellen sollte, ob dann dieser Kern durch Verschmelzung verschiedener entstanden sei, oder aber ob ein Kern vor den anderen zur Fortpflanzung auserkoren wurde. Erst 1895 wurde dieser Punkt von Oltmanns entschieden.

\section{Die Cytologie der Oogonien.}

Schon bei der ersten Bildung der Oogonien treten zahlreiche Kerne in die Ausstülpung hinein (Fig. 41, 1-2) und mit diesen zahlreiche Chlorophyllkörner.

Mehr und mehr Kerne treten aus dem Faden in das junge Geschlechtsorgan ein, und es zeigt sich, wie die Kernzahl hier relativ viel höher

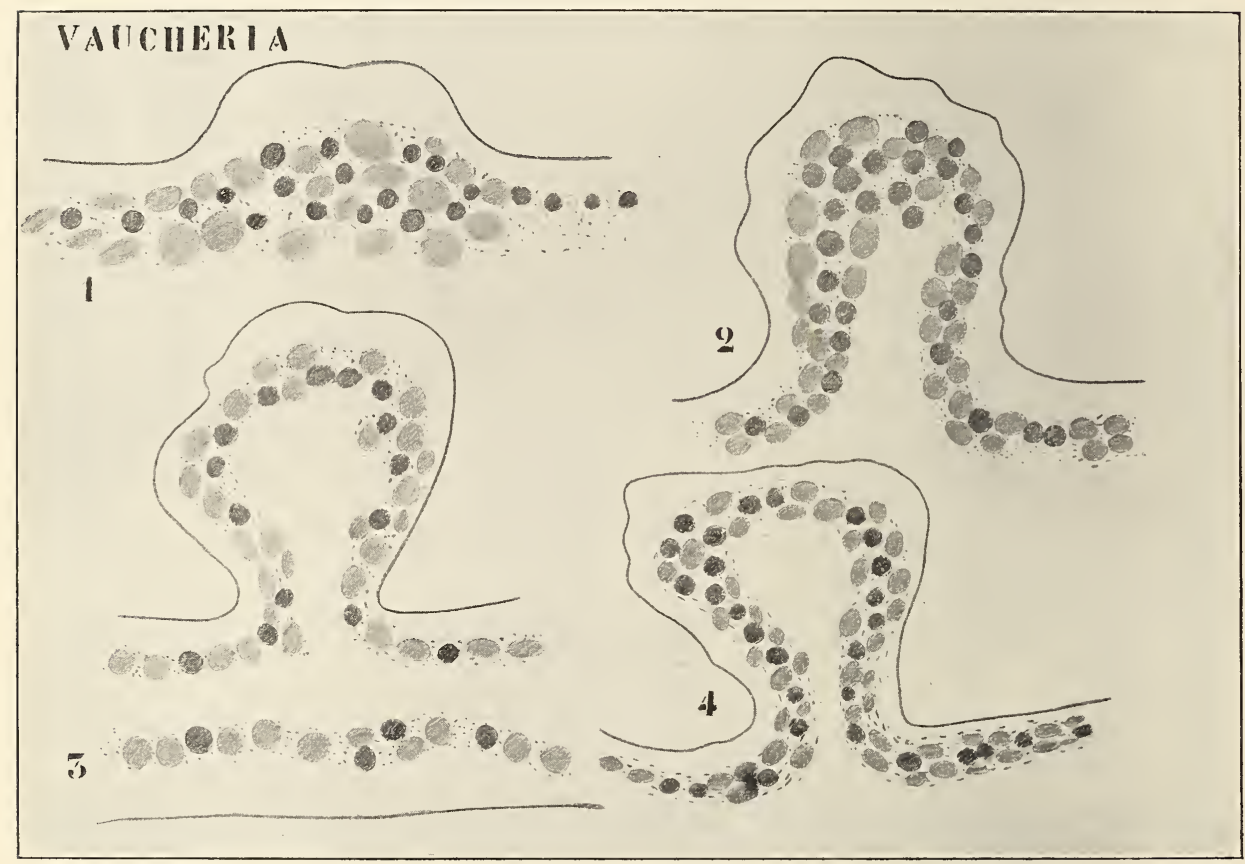

Fig. 41. Cytologie der Vaucheria-Oogonien, junge Stadien, nach Oltmanns.

ist, als in den vegetativen Teilen. Dies mag wenigstens zum Teil auf Kernteilung beruhen.

In Fig. 41, 1 gibt es noch eine kernfreie Plasmamasse an der Spitze des Oogoniuminhalts, alsbald aber dringen die Kerne weiter vor (Fig. 41, 2) und verteilen sich nun gleichmäßig um die zentrale Vakuole herum (Fig. 41, 3). Die Vakuole ist gänzlich mit den nicht abgebildeten Oeltropfen erfüllt. Jetzt liegen die Kerne an der Innenseite, die Chromatophoren an der Außenseite des Plasmas, aber bald dringen sie weiter vor und kommen zwischen die Chromatophoren zu liegen (Fig. 41, 4, Fig. 42, 5).

Zunächst zeigt sich, indem der Plasmabelag meistens dünner wird, die erste Andeutung der Schnabelbildung (Fig. 42, 5, 6) dadurch, daß eine chloroplasten- und bald kernfreie Plasmamasse an der Spitze des 
Oogons erscheint. Es zeigen sich in der Nähe des Schnabels Figuren, welche auf eine Karyokinese hindeuten (Fig. 42, 5). In 2-3 Stunden nimmt das Plasma an Quantität zu, der Schnabel wird deutlicher und gänzlich chlorophyllfrei (Fig. 42, 8). Alle Kerne, bis auf einen, ziehen sich allmählich aus dem Oogon zurück und treten wieder in den Faden ein. Dieser eine Kern liegt in der Nähe des Schnabels (Fig. 42, 7), und bald ist nur ein Kern noch im Oogon vorhanden (Fig. 42, 8). Inzwischen hat sich die zentrale Takuole in eine Anzahl kleinerer geteilt, und tritt auch ein Teil der Chromatophoren wieder in den Faden zurück. Das Oogon kontrahiert sich, und die das Oogon rom Faden trennende Wand wird gebildet (Fig. 42, 9).

Es fällt jetzt auf, daß die Membran an der Spitze des Oogons (Fig. 42, 9) viel dünner ist als an den anderen Stellen, und daß der

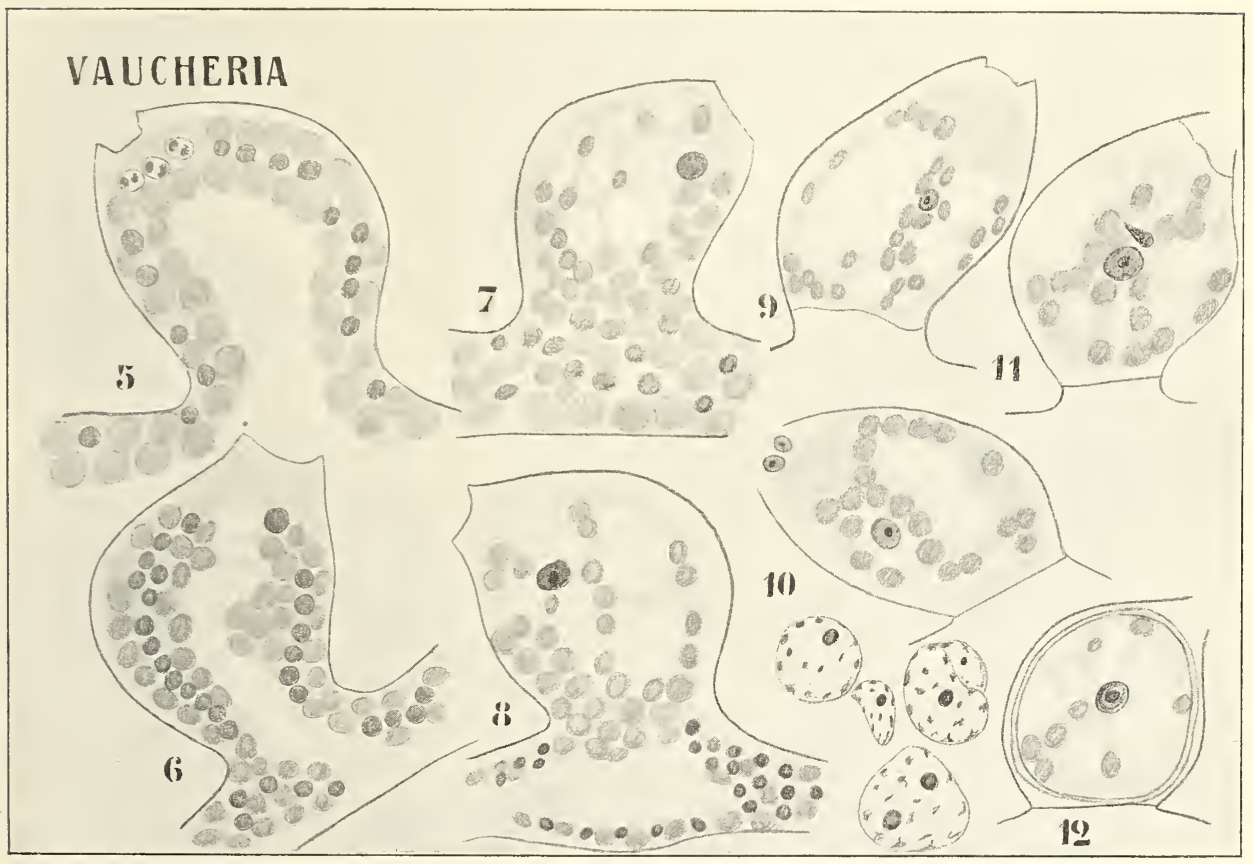

Fig. 42. Cytologie der Vaucheria-Oogonien, weitere Stadien, nach OLtmanns.

Schnabelteil recht plasmareich geworden ist. Das Oogon öffnet sich jetzt und stößt einen Teil des kernlosen Schnabelplasmas aus, von dem aber ein nicht unbeträchtlicher Teil zurückbleibt (Fig. 42, 9-10). Jetzt dringen Spermatozoen in den Hals ein (Fig. 42, 10), und bald gelingt es einem, in das Ei vorzudringen, in welchem es sich sofort zu dem Eikern hinbewegt (Fig. 42, 11), um mit ihm zu verschmelzen (Fig. 42, 12). Die Zygote umgibt sich darauf mit einer Membran, womit die Befruchtung vorüber ist. Es mag aber noch etwas über die zur Entwickelung nötige Zeit hinzugefügt werden. Untersucht man morgens 8 Uhr gut wachsende junge Kulturen, so findet man die Antheridienentwickelung bereits weit fortgeschritten, sie fängt nämlich schon am Abend vorher an, während die Bildung der Oogonien erst während der Nacht oder in den frühen Morgenstunden einsetzt. 
Mittags zwischen 3 und 6 Uhr wird der Schnabel des Oogons sichtbar, und abends zwischen 8 und 11 Uhr wird das Antheridium durch eine Querwand abgegrenzt.

Die Kerne des Oogons fangen gegen Mitternacht an in den Faden zurückzutreten, und zwischen 1 und $2 \mathrm{Uhr}$ wird die trennende Wand gebildet. Zwischen 2 und 4 Uhr nachts öffnen sich die Oogonien, so daß vorwiegend um 3 Uhr herum die Befruchtung stattfindet; die Verschmelzung von Ei und Spermakern aber findet erst zwischen 8 und 10 Uhr morgens statt. Obige Zeiten sind approximativ richtig für Juni und Juli, im Oktober verläuft der Prozeß etwas schneller.

So weit die Ausführungen Oltmanns; vor kurzem beschrieb Davis den Vorgang etwas anders. Während Outmanns bei Vaucheria sessilis, aversc u. s. W. fand, daß das Ei dadurch einkernig wird, daß alle Kerne

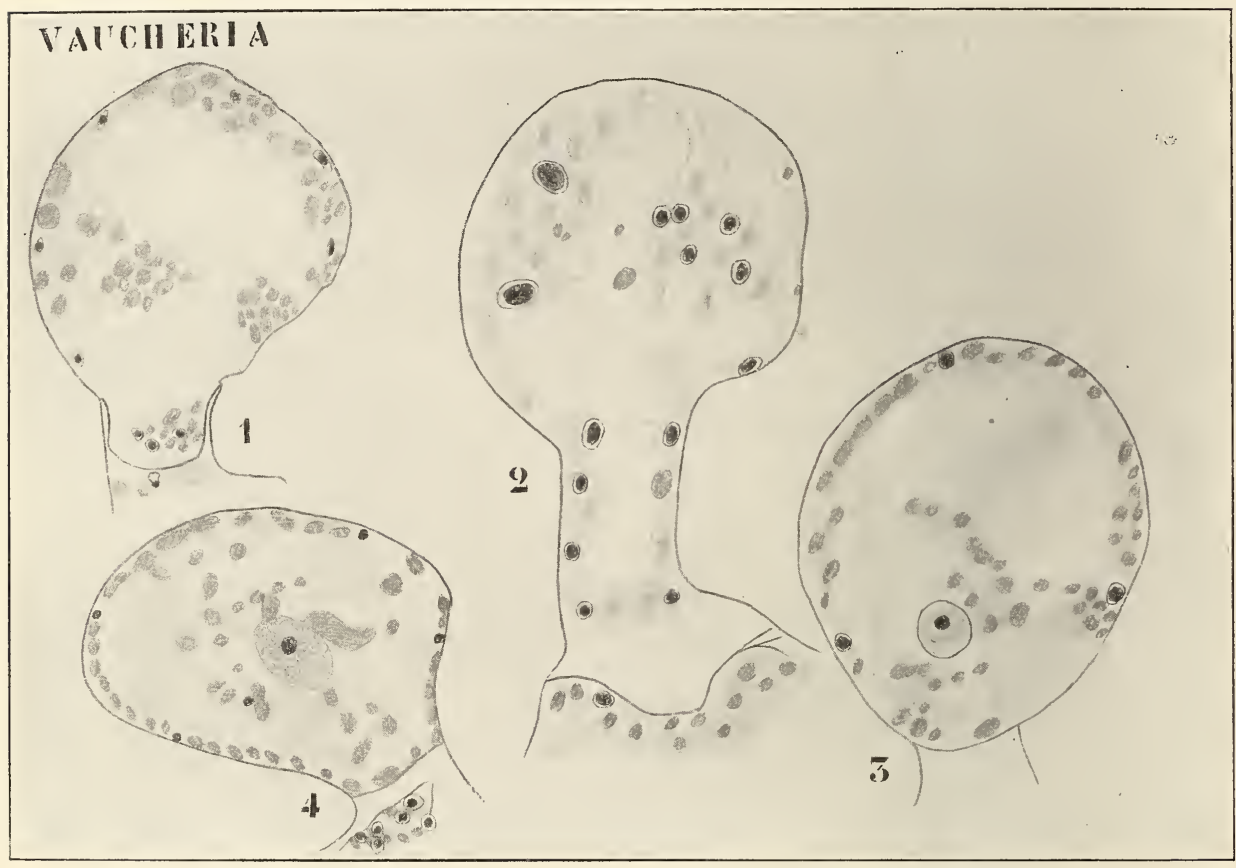

Fig. 43. Vaucheria geminata racemosa (nach DAvIs). 1 Oogonium bcreits mit einer Membran gegen den Faden abgetrennt und dennoch vielkernig. 2 Aelteres Stadium, viele Nuclei bereits degenerierend. 3 Der Einucleus in der Mitte, degenerierende Nuclei an der Peripherie. 4 Der Einucleus in seiner definitiven Größe.

bis auf einen das Oogonium verlassen, beobachtete DAvis bei Vaucheria geminata racemosa das Einkernigwerden infolge eines Degenerationsprozesses, der die überzähligen Kerne befällt.

Der Vorgang wird wohl zur Genüge durch oben stehende Figuren illustriert. Fig. 43, 1 und 2 zeigen deutlich, daß das Oogon bereits mittels einer Querwand vom Tragfaden abgetrennt ist, während es noch vielkernig ist. $\mathrm{Ob}$ hier nun Verschiedenheiten bei verschiedenen Species vorliegen, oder ob einer von beiden Forschern sich getäuscht hat, muß vorläufig dahingestellt bleiben. Analoge Erscheinungen bei der Eibildung der Oomycetes könnten dazu verführen, die Davissche Darlegung für 
die wahrscheinlichere der beiden zu halten, doch läßt sich ja a priori gar nichts g'egen Oltuanss' Darstellung einwenden, und nach den Figuren zu urteilen, sind die OLtuannsschen Präparate den Davisschen weit überlegen, was einen unwillkürlich dazu bringt, die OLtwanssschen Resultate für die richtigeren zu halten; da bleibt wohl nichts ïbrig, als ruhig abwarten.

Wenden wir uns jetzt der Cytologie der Antheridien zu, welche ebenfalls ron OLtuans untersucht wurde.

WVir haben bereits früher gesehen, daß das junge Antheridium im Anfang den gleichen Bau zeigtt wie ein vegetatives Seitenzweiglein (Fig. 44).

In dem jungen Antheridium liegt, wie bei diesem, vielkerniges Protoplasma mit Chloroplasten, aber in der Spitze ist nur Körnerplasma vorhanden (Fig. 44, 1).

Auch hier gibt es bisweilen Bilder, welche auf Karyokinese hin-

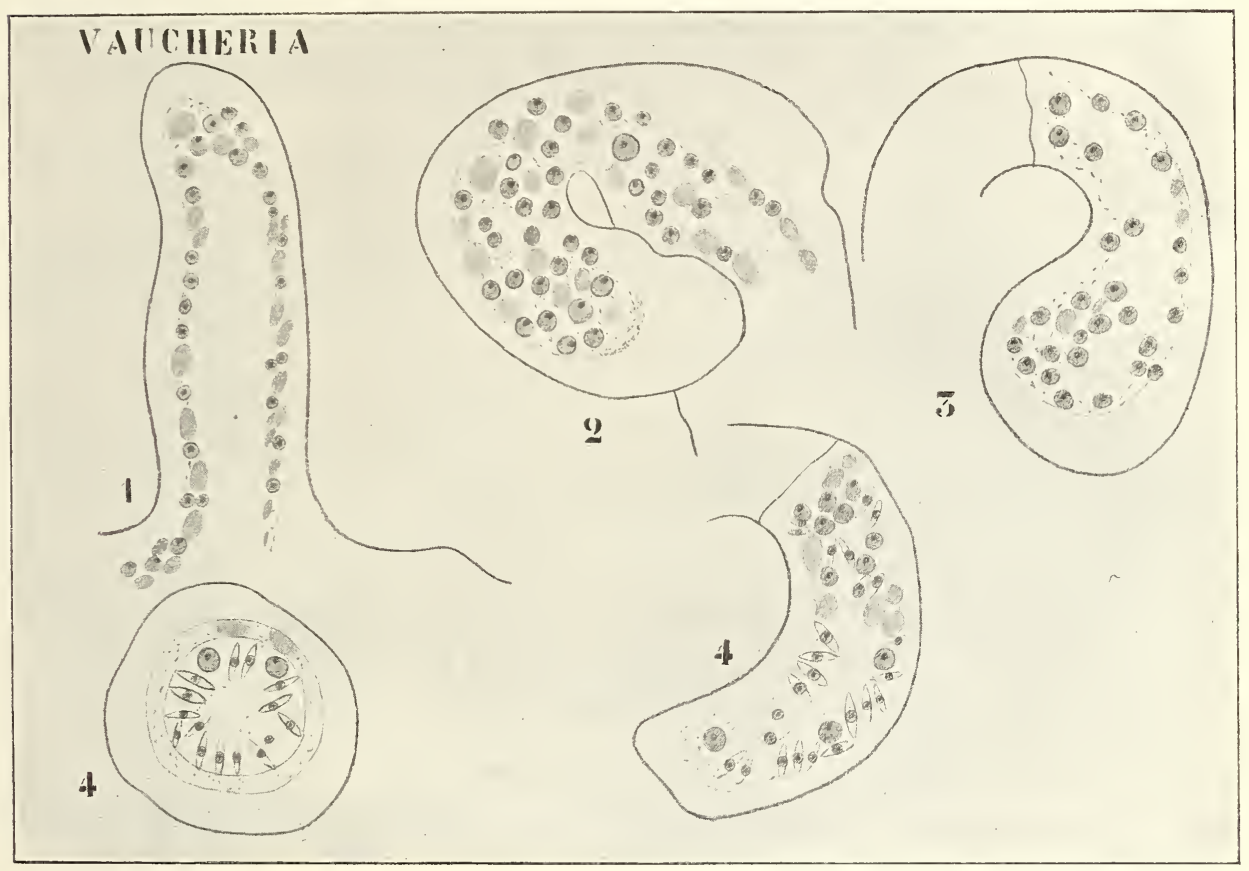

Fig. 44. Vaucheria-Antheridien (nach Olmmanns).

deuten. Alsbald nimmt die Qantität des Plasmas zu und biegt sich die Spitze nach dem Faden hin (Fig. 44, 2), das Plasma ist inzwischen stark vakuolisiert; jetzt wird eine Querwand gebildet (Fig. 44, 3), die das eigentliche Antheridium abtrennt, und die kleinen Vakuolen verschmelzen wieder zu größeren (Fig. 44, 4). Die Kerne arrangieren sich an der inneren Seite des Plasmaschlauches, nehmen spindelförmige Gestalt an (Fig. 44, 3 und 4) und stellen sich mehr oder weniger radiär ein, ja dringen sogar in den Vakuolenraum ein. Dieses für Kerne ungewöhnliche Verhalten rührt daher, daß diese scheinbaren Kerne keine eig'entlichen Kerne, sondern ganze Spermatozoen sind, deren dümne Plasmaschicht und Cilien während der Präparation unkenntlich wurden. Chloroplasten enthalten sie anscheinend nicht. 
Das Antheridium öffnet sich jetzt alsbald an der Spitze und die Spermatozoen schwimmen fort.

Nachdem nun in der beschriebenen Weise (p. 84) die Zygoten gebildet sind, machen sie eine längere Ruheperiode durch. Schließlich fallen sie, noch von der Oogoniumwand umschlossen, ab: es löst sich also das Oogon vom Tragfaden ab. Erst später kommen sie durch Zerbröckelung oder Verschleimung, letzteres nur bei $V$. terrestris LyngB., der Oogonwand frei.

Die Zygoten keimen erst etwa nach 4 Wochen nach der Loslösung zu neuen Individuen aus.

Pringsheim meinte früher, daß bei Vaucheria ein Generationswechsel sich vorfände, indem die Zygoten zu ungeschlechtlichen, die Zoosporen $\mathrm{zu}$ geschlechtlichen Individuen auskeimten. Dem ist nicht so. KLEBS hat unwiderleglich gezeigt, daß es nur von äußeren Bedingungen abhängt, ob Oogonien und Antheridien oder Zoosporen gebildet werden, ja es bedingen sogar die äußeren Umstände, ob männliche oder weibliche oder Geschlechtsorgane gebildet werden.

Während z. B. meistens nur ein Antheridium bei einem Oogon gebildet wird, gelang es KLEBS durch Luftverdünnung, bis 8 Antheridien pro Oogon entstehen zu lassen.

Beim Beginn unserer Betrachtung der Vaucheriaceen bemerkten wir, daß außer Vaucheria noch ein zweites Genus besteht, welches sich durch seine dichotome Verzweigung von ersterem unterscheidet; nach dieser Eigenschaft wurde es von ERNst

\section{Dichotomosiphon}

genannt. Von diesem Genus ist nur eine Art: D. tuberosus (A. BR.) ERnst bekannt. Es wurde diese Alge zuerst 1848 von Alexander Braun bei Onnens (près Grandson, Cant. de Vaud à la poissine) in sterilem Zustande angetroffen und später, ebenfalls steril, an drei verschiedenen Orten in Nordamerika aufgefunden. Sie wurde von A. Braun mit dem Namen Vaucheria tuberosa belegt. Im Jahre 1901 sammelte ERnst bei Genève, in einem Graben des Moores Grevin am Fuße des Mont Salève, Nitella tenuissina, welche er später in Zürich in ein Aquarium stellte. Aus dem miteingeführten Schlamm entwickelte sich nun nicht nur die Dichotomosiphon (Fig. 45), sondern fruktifizierte auch.

Unsere Alge unterscheidet sich von allen Vaucheria-Arten durch ihre dichotome Verzweigung, überdies sind die Fäden in regelmäßigen Abständen eingeschnürt. An diesen Einschnürungsstellen ist die Membran verdickt und meistens rotbraun gefärbt. Der protoplasmatische Inhalt besteht der Hauptsache nach, wie bei Vaucheria, auch hier aus zahlreichen Kernen und Chromoplasten, aber als Reservesubstanz wird kein Oel, sondern Stärke angetroffen.

Die ringförmigen Membranverdickungen, die Anwesenheit von Stärke statt eines fetten Oeles brachten ERnst dazu, der Pflanze in der Nähe der Codiaceae einen Platz anzuweisen. Unmöglich ist dies ja nicht, aber solange wir keine Codiacee mit oogamer Befruchtung kennen, ziehe ich es vor, sie mit Oltmanns als eine Vaucheriacee zu betrachten, trotzdem zugegeben werden muß, daß unsere Unkenntnis einer Zoosporenbildung bei dieser Pflanze auch diese Einreihung recht unsicher macht.

Oogonien und Antheridien bilden sich an der Spitze der Gabelzweiglein letzter Ordnung, und zwar immer mehr Antheridien als Oogonien. 
Die Oogonien entstehen als Anschwellungen der Zweigspitzen, vieles Plasma tritt in sie hinein, ein farbloser Schnabel wird gebildet und der ganze Inhalt ballt sich zu einem Ei zusammen, ein Ausstoßen farblosen Plasmas, wie bei Taucheria, findet nicht statt.

Die Antheridien werden in ähnlicher Weise wie bei Tracheria gebildet, und auch die Spermatozoen erimnern sehr an die der Tancherien. Die Oogoniummembran verschleimt an der Spitze, und durch die so gebildete Oeffnung (Fig. 45, 5) treten die Spermatozoen ein. Die Zygote umgibt sich mit einer dicken Membran. Thre Keimung wurde noch nicht beobachtet, auch von der Cytologie dieser Alge ist noch nichts bekannt.

Die ungeschlechtliche Fortpflanzung ist auf die Bildung von Brutknöllchen an den Enden rhizoidenähnlicher Ausläufer beschränkt

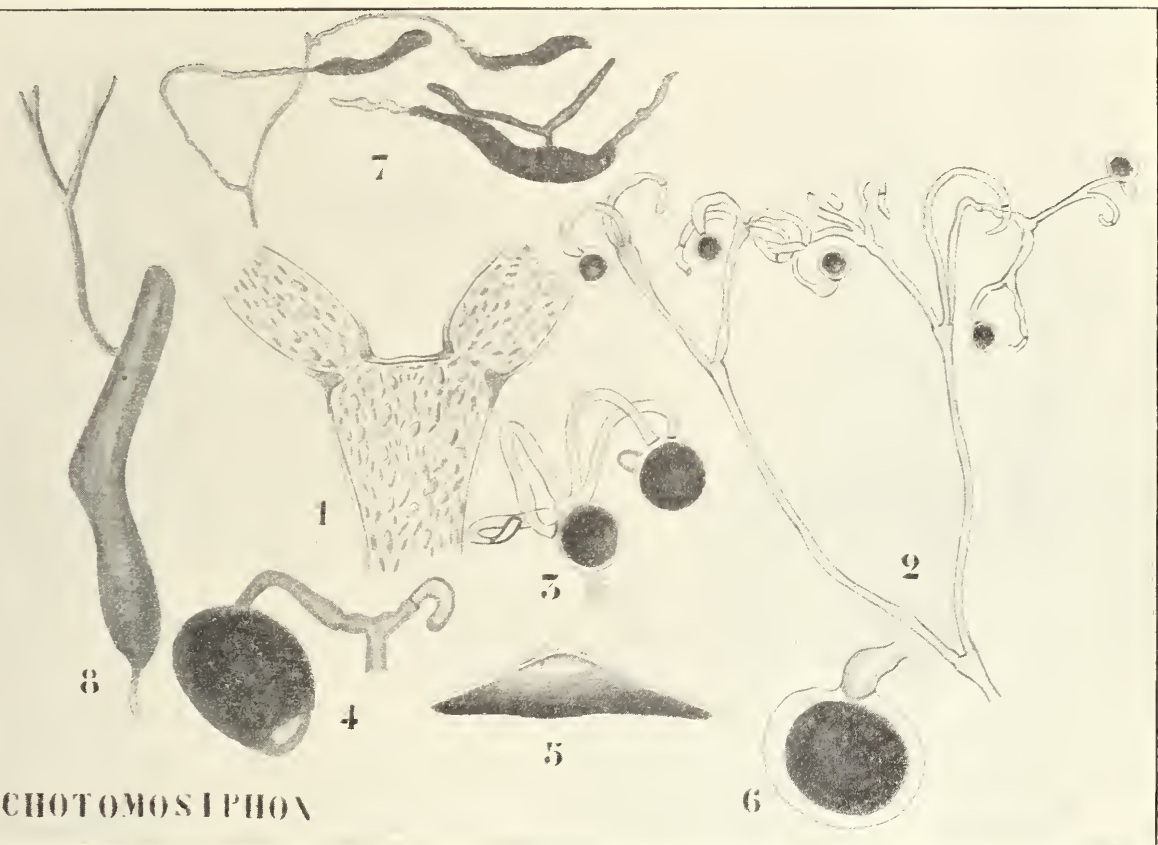

Fig. 45. Dichotomosiphon tuberosus nach ERnst. 1 Gabelungsstelle mit der Einschnürungsstelle der Aeste und den rotbraun gefärbten, ringförmigen Membranverdickungen. 2 Teil einer fertilen Pflanze nach der Befruchtung. Die sämtlichen Antheridien sind entleert, ihre Membran aber noch vollständig erhalten. In den Oogonien haben sich die Zygoten gebildet. 3 Doppelte dichotomische Verzweigung; von den 4 Aestchen bildeten 2 Oogonien und 2 Antheridien. Die antheridientragenden Aeste krümmen sich während ihrer Entwickelung immer so, daß ihre Spitzen in die Nähe der Oogonien zu liegen kommen. 4 Soeben befruchtetes Oogon, der Empfängnisfleck noch sichtbar. 5 Spitze des Oogons unmittelbar nach der Befruchtung, eine Ausstoßung von Plasma wie bei Vaucheria findet nicht statt. 6 Reife Zygote im Oogon. 7, 8 Bildung der Brutknöllchen und Keimung derselben.

(Fig. 45, 7). Sie dürfen wohl als zu Conidien reduzierte Sporangien betrachtet werden, wie wir solche ja schon bei Vaucheria kennen lernten. Sie keimén später mit seitlichem Keimschlauch zu DichotomosiphonPflänzchen aus.

Von der Gruppe der Siphoneae bleibt nun noch eine, die der 


\section{Verticillatae oder Dasycladaceae,}

zu behandeln. Ueber deren Stellung im System läßt sich streiten. Mit Blackman und Tansley stelle ich sie in die Gruppe der Siphoneae, Oltmanns aber in die der Siphonocladeae; für beide Anschauungen läßt sich, wie so oft in systematischen Fragen, manches sagen, eine sichere Entscheidung aber nicht herbeiführen.

Die Gruppe der Terticillatae, d. h. also der Siphoneen mit wirteligem Verzweigungsmodus, läßt sich in Untergruppen einteilen, und zwar unterscheide ich, dem Beispiel Oltmanns' folgend, deren 4:

1) Dasycladeae: Gametangien an den Spitzen der Seitenachsen 1. Ordnung. Dasycladus, Neomeris, Cymopolia.

2) Triploporelleae: Die primären Seitenachsen werden selber zu Gametangien. Triploporella etc.

3) B o r n e t e 11 e a e : Gametangien seitlich an den primären Seitenachsen. Bornetella etc.

4) A cetabularieae: Sporangien stark verlängert, meistens ziemlich fest zu Schirmen vereinigt. Halicoryne, Acetabularia etc.

Als einfachster Repräsentant der ganzen Gruppe mag

\section{Dasycladus}

betrachtet werden. Dieses Genus ist monotypisch, die einzige Art kommt im Mittelmeer, auf den Canarischen Inseln etc. vor.

Sie wächst gesellig auf Steinen und sonstigem Substrat. Die Pflänzchen sind $\pm 5 \mathrm{~cm}$ hoch, bestehen aus einer unverzweigten Hauptachse, welche mit dicht gedrängten Wirteln von Seitenachsen besetzt ist. Diese Seitenachsen verzweigen sich ebenfalls, auch die Seitenachsen 2. Ordnung sind wirtelig gestellt. Sie greifen ineinander und so resultiert ein einem grün gefärbten Schwämmchen nicht unähnliches Gebilde (Fig. 46).

Der unterste Teil des Hauptstammes trägt keine Seitenzweige, so daß ein ganz kurzes Stielchen entsteht, welches in die das Pflänzchen befestigenden Rhizoide ausläuft.

Die Hauptachse wird von einem ununterbrochenen Schlauch gebildet, Querwände treten in demselben nicht auf, aber es sind die Seitenzweige durch Querwände von der Hauptachse getrennt.

Die Seitenachsen verzweigen sich meistens 2-3mal, bei jeder Verzweigung werden die gebildeten Seitenästchen kleiner, so daß die peripher gelegenen Wirtel aus den kürzesten Gliedern bestehen.

Die Membran der Hauptachse ist stark verdickt, außerdem noch an der Außenseite von einer dicken Kalkkruste bedeckt. Auf einem Querschnitt (Fig. 46, 6) hat es den Anschein, als bestände die Wand aus einer Anzahl getrennter, sehr dicker Stückchen, das rührt daher, daß die Wand an den Ansatzstellen der Seitenachsen nicht verdickt ist; zweifellos erlaubt dies die Ab- und Zufuhr von Nahrungssubstanzen.

Schickt unsere Pflanze sich zur Fruktifikation an, so schwellen die Spitzen der primären Seitenachsen kugelig an, trennen sich durch eine Wand ab und werden so zu Gametangien.

Diese Fruktifikation beschränkt sich auf die obere Hälfte oder auf die oberen zwei Drittel, der untere Teil der Pflanze bleibt steril. In 
den Gametangien bilden sich eigentümlich quadratische Gameten mit ? gleichlangen Cilien. Da alle Gametangien sich gleichzeitig öffnen, treten die Gameten in der Gestalt eines grünen Nebels aus, und da fast alle Chromatophoren und fast alles Plasma in die Gametangien eingetreten war, erblassen die Pflänzchen plötzlich und gehen alsbald zu Grunde.

Zur Kopulation sind von verschiedenen Individuen herstammende Gameten notwendig.

Die Gameten enthalten mehrere Chromatophoren und einen großen basalen Augenfleck. Die Zygoten keimen sofort zu neuen Pflänzchen aus. Zur gleichen Familie gehören noch zwei Genera, welche hier ebenfalls im Anschluß an OLtuarns behandelt werden mögen.

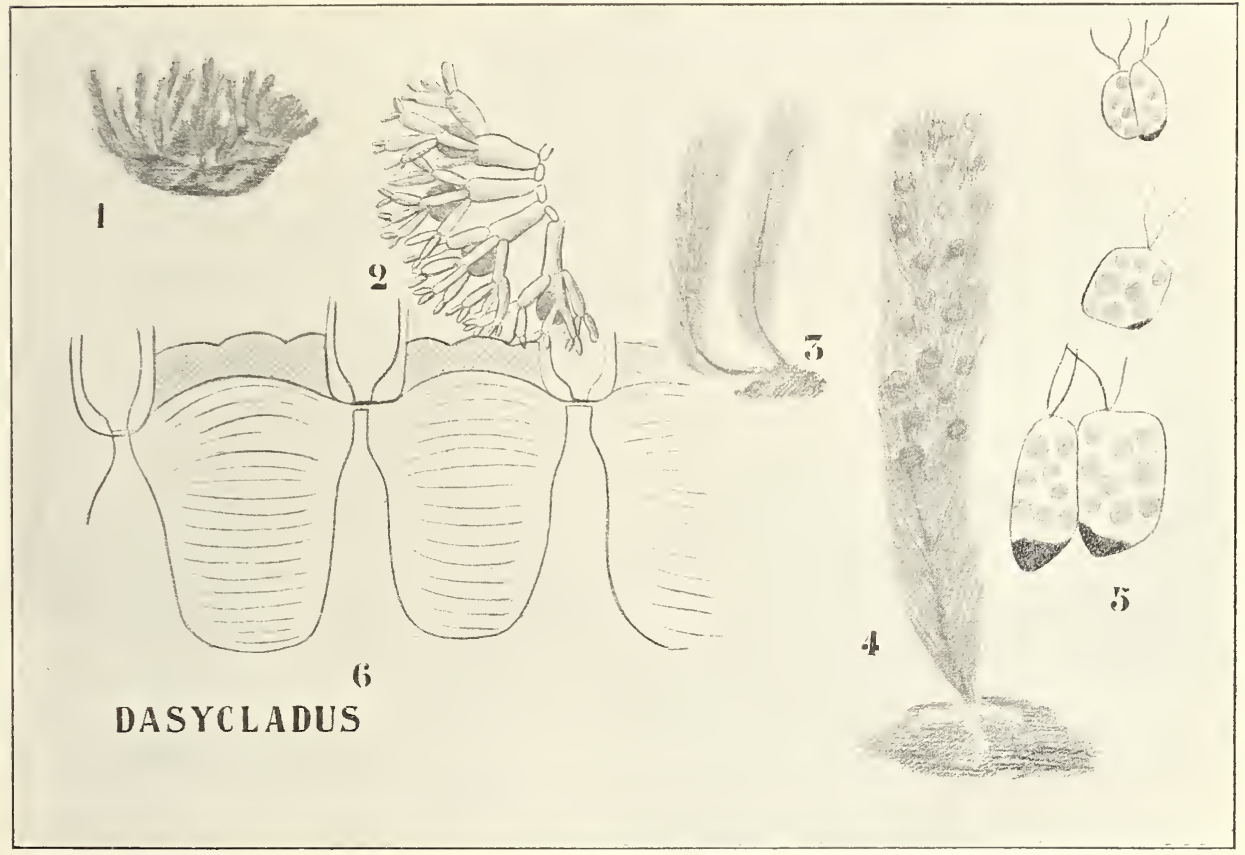

Fig. 46. Dasycladus claviformis. 1 Habitusbild einer Ansiedelung. 2 Querschnitt eines Stückes eines fertilen Zweigwirtels mit Gametangien. 3, 4 Habitusbild steriler und fertiler Pflänzchen. 5 Gametenkopulation. 6 Querschnitt durch die Wand der Hauptachse. Alles nach OltmanNs, nur 4 nach NäGELI.

\section{Neomeris}

zeigt große Uebereinstimmung mit Dasycladus. Auch hier findet sich ein zentraler Hauptstamm mit wirteligen Seitenachsen, welche terminal Gametangien tragen.

Während die jüngeren Seitenachsen sich von denen von Dasycladus nur durch die Anwesenheit einiger langer Haare auf der Spitze unterscheiden, zeigen die oberen eine Abweichung vom Terhalten der Dasycladus-Zweige, welche von überwiegendem Einfluß auf den Habitus der Pflänzchen ist.

Die Seitenzweige 2. Ordnung schwellen nämlich an den älteren 
Teilen der Pflanze derart apikal an, daß sie blasenförmig werden. Die Blasen benachbarter Zweige platten sich gegenseitig ab, und so wird ein zusammenhängender Mantel um das ganze Pflänzchen herum gebildet, welcher aus einer Anzahl grüner Facetten besteht; denn seine periphere, der Photosynthese sehr günstige Lage veranlaßt das Eintreten vieler Chromatophoren (Fig. 47, 1).

Bilden sich nun an der Spitze der Seitenzweige 1. Ordnung die Gametangien aus, so sind sie vom Mantel bereits ausgiebig geschützt.

Dennoch genügte dieser Schutz offenbar nicht, denn die Pflanze scheidet erstens noch eine dicke Kalkschicht um jedes einzelne Gametangium aus (Fig. 47, 2), weiter noch einen um die Zweige, welche die Gametangien tragen, und schließlich verkalken die nach innen gekehrten

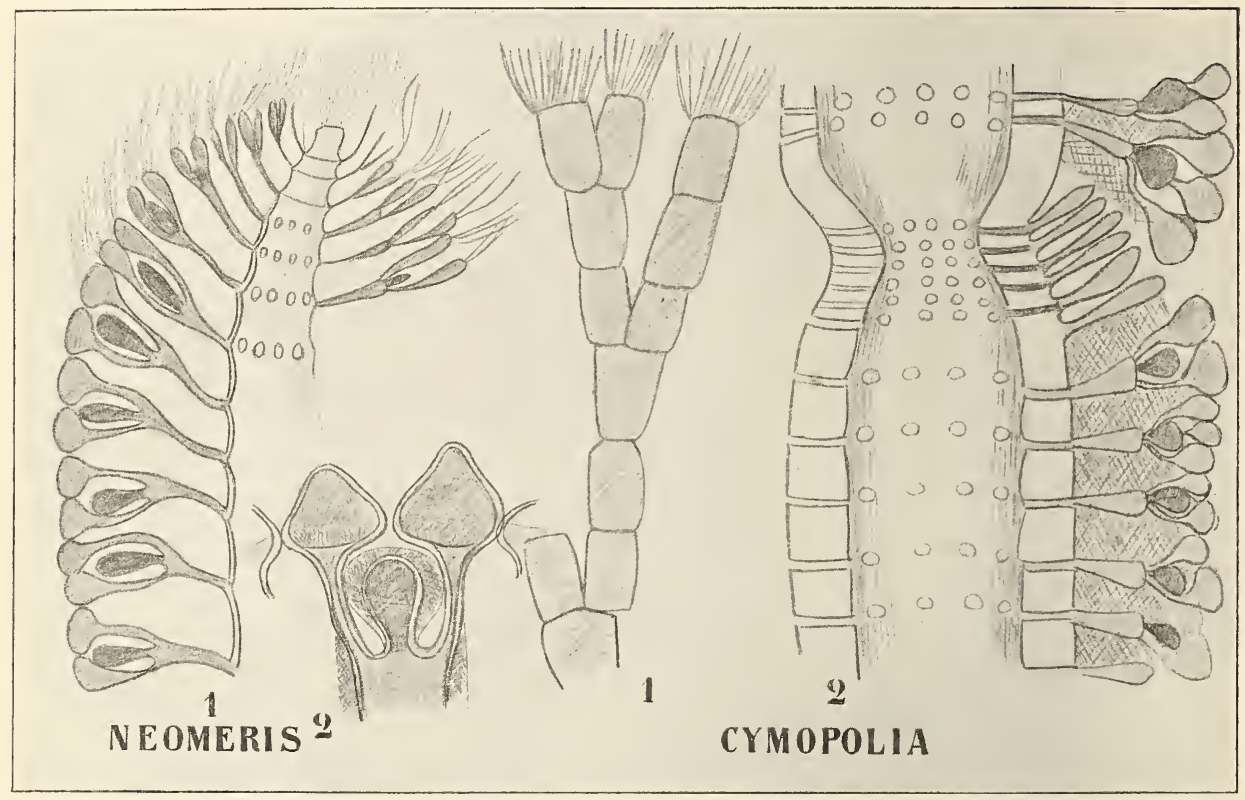

Fig. 47. I. Neomeris. 1 Oberes Ende der Pflanze nach Cramer. 2 Partiell verkalkter Wirtelast nach Church. - II. Cymopolia. 1 Habitusbild nach OLtmanns. 2 Längsschnitt eines Gliedes nach SoLMs.

Seiten der blasenförmigen Spitzen der Zweige 2. Ordnung, so daß die ganze Pflanze von einem Kalkmantel umgeben ist.

Die Außenseite der Blasen ist aber nicht verkalkt, die Photosynthese wird also durch diesen Verkalkungsvorgang nicht gehindert. Die Verkalkung findet bei verschiedenen Neomeris-Arten in verschiedener Ausgiebigkeit statt, darauf einzugehen, ist hier nicht der Ort.

Wir redeten bis jetzt auch hier von Gametangien, trotzdem der Ausdruck nicht ohne weiteres benutzt werden darf, denn in diesen Organen werden wenigstens nicht direkt Gameten gebildet.

Der ganze Inhalt des Gametangiums umgibt sich nämlich mit einer Membran, wird also zu einer Cyste.

Diese Cysten sind dadurch ausgezeichnet, daß sie an dem einen Ende einen Deckel besitzen. Aehnlich gedeckelte Cysten kennen wir 
nun bei einem anderen Siphoneengenus, und zwar bei Acetabularia, und wissen, daß dort diese Cysten Gameten erzeugen, so daß wir allen Grund haben, anzunehmen, daß es sich bei Neomeris ebenso verhält.

Es ist diese Crstenbildung wohl korrelativ mit der starken Terkalkung dieser Algen entstanden als ein Ruhezustand, den der Gametangiuminhalt durchmacht, und jetzt als eine Anpassung zu betrachten. Gesetzt den Fall, es öffneten sich die Gametangien normalerweise und entließen die Gameten, so würden letztere sich nur in den von dem die ganze Alge umgebenden Kalkmantel begrenzten Raum bewegen können, nicht aber ins Freie treten. Eine Kopulation von Gameten, welche von verschiedenen Individuen herrührten, wäre dann unmöglich.

Jetzt aber gelangen die Cysten, da die ganze Pflanze alsbald nach deren Bildung abstirbt und zerbröckelt, ins Freie, und so können die in denselben sich bildenden Gameten frei ins Meer hinausschwimmen.

Das Genus

\section{Cymopolia}

sieht auf den ersten Blick einer Neomeris recht unähnlich, und man empfindet kaum Neigung; sie als nahe verwandt zu betrachten.

Während Neomeris unverzweigt und ungegliedert ist, ist Cymopolia verzweigt und gegliedert. Die Verzweigung ist natürlich ein Unterschied gegen Neomeris, aber die Gliederung und die allgemeine Struktur sind nur gering'e Modifikationen des Neomeris-Typus.

Beide lassen sich zurückführen auf periodische Einschnürung der Hauptachse und auf den Umstand, daß nicht wie bei Neomeris nur fertile, sondern überdies auch noch sterile Zweigwirtel vorkommen.

Vergleicht man eine fertile Partie einer Cymopolia mit Neomeris, so ist die Uebereinstimmung so auffallend, daß man beide als Stücke nahe verwandter Arten betrachten könnte.

Der einzige Unterschied liegt eigentlich in der Verkalkung. Bei Cymopolia bildet sich an der Außenseite zwischen den Zweigen eine zusammenhängende, sehr dicke Kalkschicht, welche sämtliche Organe umschließt, und zwar derart, daß die Gametangien völlig vom Kalk eingeschlossen sind.

Die Gliederung resultiert von der periodischen Produktion sehr kurzer steriler Seitenzweige, und zwar unter Einschnürung der Hauptachse; diese sterilen Seitenzweige bilden apikal Haare, welche einen bedeutenden Anteil an der Photosynthese nehmen.

Sobald aber die Hauptachse sich wieder verlängert, und so wieder ein fertiler Teil gebildet ist, werden die sterilen Zweige zwischen zwei fertilen Stücken eingeschlossen, und die Haare sozusagen abgekniffen.

Um die sterilen Zweige herum bildet sich kein Kalkmantel aus, dadurch ist die Pflanze gelenkig und läuft weniger Gefahr, vom Wellenschlag abgebrochen zu werden, als wenn sie aus einem Stücke gebildet wäre.

In den Gametangien von Cymopolia nun wird keine Cyste gebildet, und das könnte zu der Vermutung führen, daß hier normale, direkt Gameten bildende Gametangien vorlägen.

Es hat aber Soums bei einem Exemplar von St. Domingo beobachtet, daß die Cymopolia-Gametangien direkt keimen kömnen. Ob dies num der übliche Vorgang bei Cymopolia ist - in welchem Falle wir mit Geschlechtsverlust, mit Apogamie, zu tun hätten - oder ob es nur ein Sichbehelfen dieses einen Exemplares war, während normalerweise Gameten gebildet werden, muß bis auf weiteres dahingestellt bleiben. 
Während also bei den Dasycladeen die Gametangien an den Enden der primären Seitenzweige gebildet werden, lernen wir in den

\section{Triploporelleae}

Formen kennen, deren primäre Seitenzweige selber zu Gametangien werden. Das hierhergehörige Genus Triploporella ist nur fossil bekannt, und zwar sind nur die Gametangien erhalten geblieben.

Die Hauptachse war unverzweigt und trug zahlreiche wirtelig gestellte primäre Seitenzweige, welche unter Aufschwellung zu Gametangien wurden und durch gegenseitigen Druck unterdessen mehr oder weniger polygonal sich ausbildeten. In diesen Gametangien bildeten sich zahlreiche Cysten, über deren Keimung wir natürlich nichts wissen.

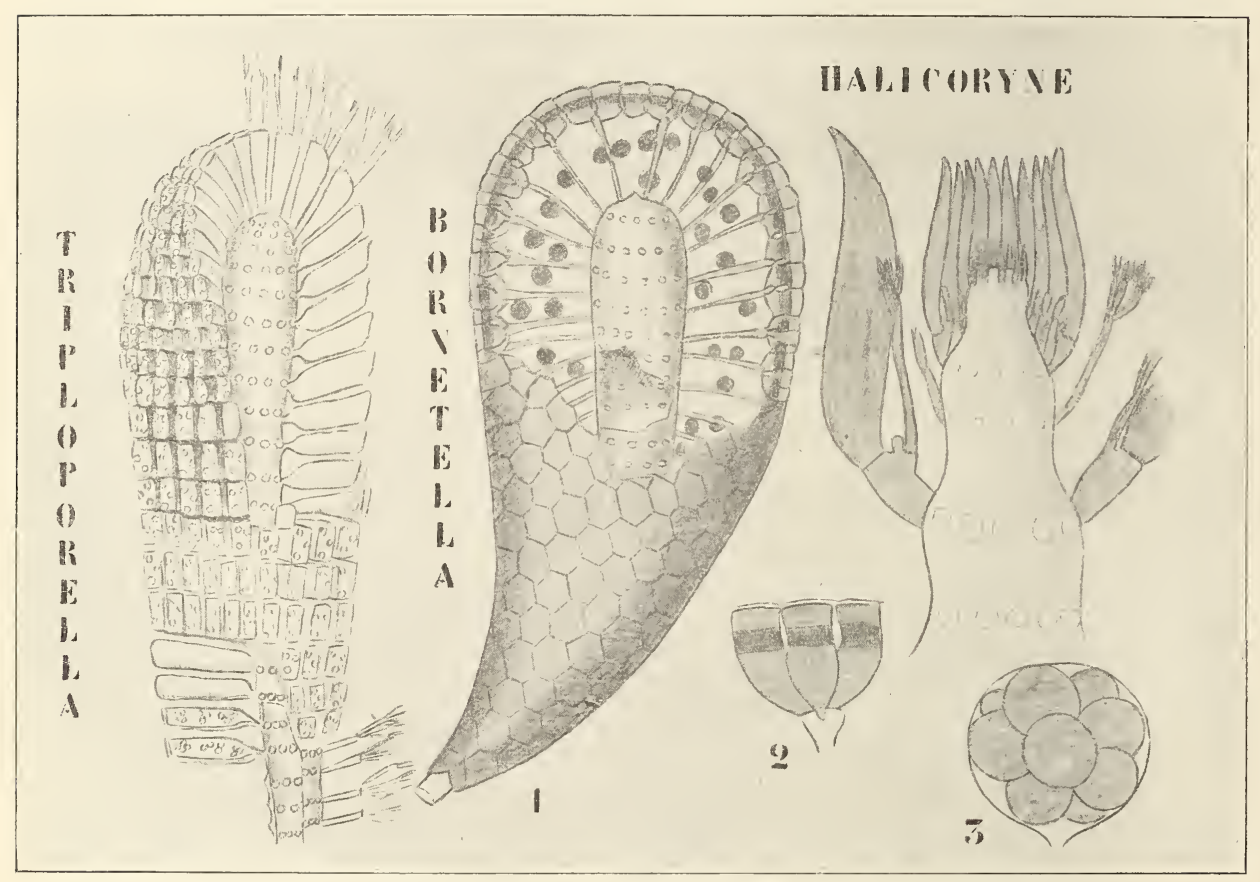

Fig. 48. I. Triploporella (Rekonstruktion nach Stennmann). - II. Bornetella (nach Solms und CRAMER). 1 Die ganze Pflanze. 2 Einzelne Elemente der Facettenrinde, die Kalkringe zeigend. 3 Gametangien mit Cysten. - II. Halicoryne (nach Cramer).

An der Spitze eines jeden Gametangiums befinden sich 3 Narben, und in Verbindung mit in der Nähe dieser Fossilien gefundenen Zweiglein ist es wahrscheinlich, daß dies die Anheftungsstellen der die Photosynthese besorgenden Zweige gewesen sind, während überdies wahrscheinlich unter dem Komplex von fertilen Zweigen noch sterile gesessen haben.

Bei der dritten Gruppe, der der

\section{Bornetelleae,}

begegnen wir einem Aufbau, der sehr an den von Neomeris erinnert, nur sind hier die Seitenzweige 2. Ordnung sofort nach ihrem Entstehen 
blasenförmig angeschwollen, so daß eine allseitig geschlossene Rinde entsteht. welche durch die gegenseitige Abplattung der Elemente, von oben betrachtet, facettiert erscheint und deswegen Facettenrinde genannt wird.

Auch hier findet sich ein Kalkmantel, der aber auf ganz andere Treise als bei Neomeris oder bei Cymopolia entsteht. Er wird hier von schmalen Kalkringen gebildet, von denen sich in jedem blasigen Seitenzweiglein 2. Ordnumg einer ausbildet, und zwar werden sie in allen auf gleicher Höhe angelegt, so daß ein ununterbrochener, aus Ringen zusammengesetzter Kalkmantel resultiert.

Die Kalkringe sind also lokale Verdickungen der Seitenwände der Zweige 2. Ordnung, und bleibt auch hier die nach außen gekehrte Trand, mit Rücksicht auf die Photosynthese, unverkalkt.

Die Gametangien werden bei Bornetella seitlich an den Zweigen 1. Ordnung gebildet. In ihnen bildet sich eine Anzahl runder, gedeckelter Cysten, welche wohl wie jene von Acetabularia Gameten bilden.

Bornetella ist ein tropisches Algengenus, Exemplare wurden z. B. von Frau Weber van Bosse auf Flores und Celebes gesammelt.

Als letzte Gruppe der Verticillaten soll hier die Familie der

\section{Acetabularieae}

behandelt werden. Es sind Algen mit stark verlängerten, meistens zu Schirmen verwachsenen Gametangien.

Während bei den Dasycladeen und Bornetelleen alle Seitenzweige fertil waren, oder, wie bei Cymopolia, abwechselnd fertile und sterile Wirtel gebildet werden, treten in der Gruppe der Acetabuiarieae die sterilen Zweige mehr in den Vordergrund.

Während beim einfachsten Genus dieser Familie, bei Halicoryne (Fig. 48, II), noch in regelmäßiger Abwechslung fertile Wirtel gebildet werden, entsteht bei Acetabularia z. B. nur ein einziger fertiler Wirtel.

Bei Halicoryne besteht der sterile Wirtel aus 8 Gliedern. Der primäre Zweig ist lang und dünn-cylinderförmig, die sekundären und tertiären Zweig'e werden stets kürzer, so daß die sterilen Zweige pinselförmig sind.

Die fertilen Wirtel bestehen aus 16 Gliedern. Das Gametangium ist apikal, während das untere sterile Glied an seinem oberen Ende einen pinselförmigen, den sterilen Zweigen düchaus ähnlichen Seitenzweig trägt, zwischen demselben und dem Gametangium aber ein recht kleines, reduziertes Höckerchen angelegt wird.

Wir werden am Ende unserer Betrachtungen dieser Gruppe sehen, daß das Gametangium als seitlich angelegt betrachtet werden muß, und daß es den in Wirklichkeit apikalen Pinselzweig zur Seite geschoben hat.

Die sehr langen Gametangien liegen dicht aneinander, sind aber frei, nicht seitlich verwachsen.

Dagegen sind im Genus Acetabularia die Gametangien ganz oder teilweise seitlich verwachsen. Der Uebergang zwischen beiden Geschlechtern ist fast unmerklich, Acetabularia cremulata weicht von Halicoryne eigentlich nur dadurch ab, daß die Gametangien der ersteren in ihren unteren Teilen seitlich miteinander verwachsen sind.

Eine andere Differenz liegt darin, daß bei Halicoryme das sterile Glied der fertilen Zweige nur an seiner Oberseite einen sterilen Pinselzweig' trägt, und so eine sogenannte Corona superior entsteht, während 
Acetabularia überdies noch an der Unterseite sterile Zweiglein trägt, so daß hier sowohl eine Corona superior wie eine Corona inferior vorhanden ist.

Während also auch bei den niederen Acetabularien noch abwechselnd sterile und fertile Wirtel gebildet werden, liegt der Fall bei der klassischen Acetabularia, bei Acetabularia mediterranea, wesentlich anders.

Dort werden längere Zeit nur sterile Zweige gebildet, und erst wenn die Pflanze durch die Photosynthese dieser Zweige eine genügende Quantität Reservenahrung angesammelt hat, schreitet sie zur Bildung eines einzigen Wirtels seitlich verwachsender Gametangien.

Da vorher oder zu gleicher Zeit die sterilen Zweige abgefallen sind, erhalten wir ein Pflänzchen, das einem aufgespannten Regenschirm nicht

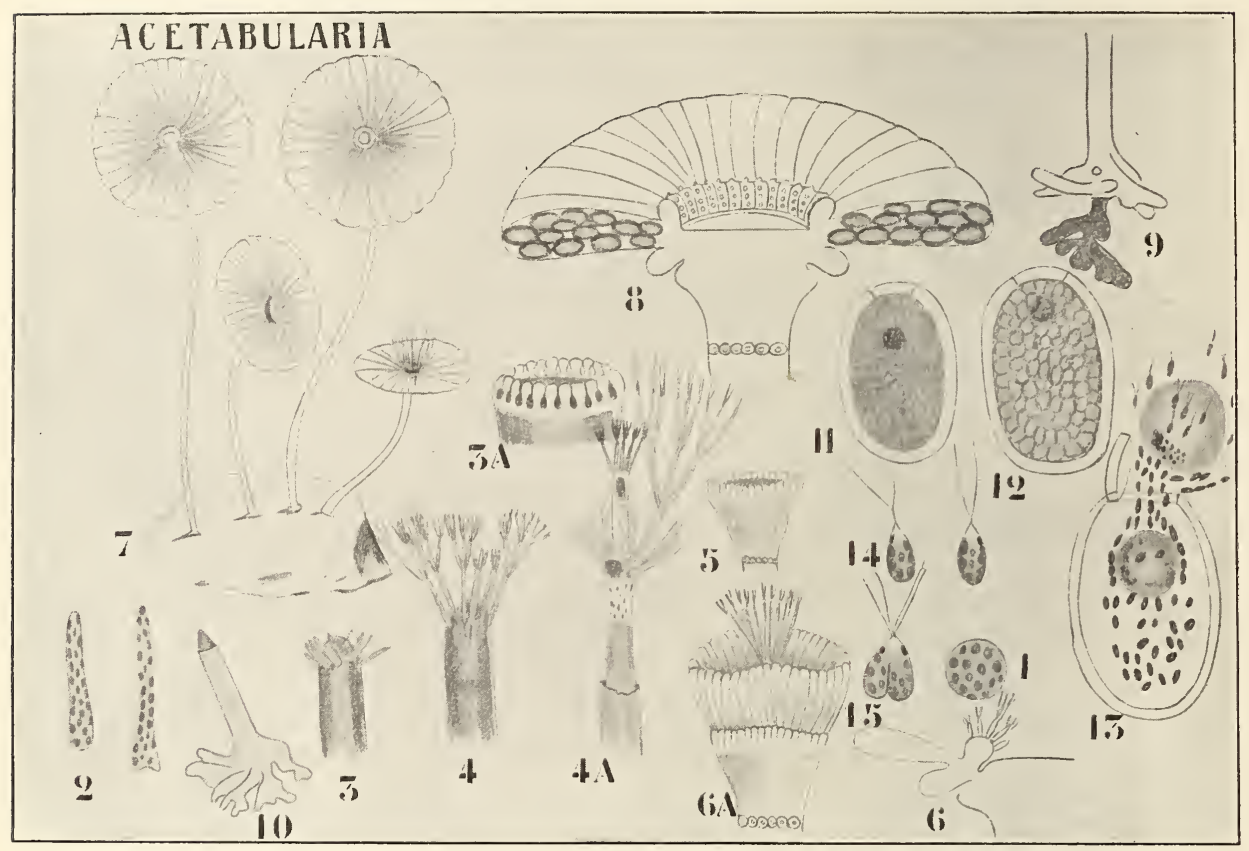

Fig. 49. A cetabularia mediterranea (nach Woronin, DE BARY, Strasburger und v. Wettstein). 1 Zygote. 2 Keimpflänzchen. 3 und 4 Bildung steriler Zweige an Keimpflänzchen; 4 A an einem Erneuerungssproß. 3 A, 5, 6 Anlage der Gametangien. 6 A Bildung der Coronae superior und inferior. 7 Habitusbild der fruktifizierenden Pflanze. 8 Längsschnitt eines Gametangienstandes, die Cysten zeigend. 9 Ausbildung der basalen Ueberwinterungsblase. 10 Ausbildung eines Erneuerungssprosses. 11 Cyste, den Deckel zeigend. 12-13 Keimende Cysten, letztere die Gameten entlassend. 14 Gameten. 15 Gametenkopulation.

unähnlich ist (Fig. 49, 7), und das auf den ersten Blick eine recht isolierte Stellung einzunehmen scheint.

Am leichtesten verschaffen wir uns eine Einsicht in die Entwickelung unserer Pflanze, wenn wir von den in den Gametangien gebildeten Cysten ausgehen. Deren bildet jedes Gametangium etwa 100 aus, so daß große Exemplare bis 10000 Cysten liefern können.

Diese Cysten sind vielkernig und gelangen durch Verwesung der Schirme ins Freie. Im Mittelmeer werden diese Cysten im Juni gebildet 
und gelangen im Juli und August ins Freie. Sie keimen erst im Februar oder Järz des nächsten Jahres, indem sie eine große Anzahl von 2-ciligen Gameten bilden. während die große zentrale Takuole, in der Gestalt einer oder zweier Blasen, bestehen bleibt (Fig. 49, 13). Nun wird wohl infolge ron Wasseraufnahme und dadurch verursachter Druckzumahme der rorgebildete Deckel (vergl. die beiden Striche in der Cystenwand der Fig. 49, 11 und 12) aufgeklappt (Fig. 49, 13).

Gameten, aus der gleichen Cyste gebürtig, kopulieren nicht, wohl aber Gameten verschiedener Cysten. Die Gameten sind Isogameten, und die gebildeten Zygoten (Fig. 49, 1) können sofort auskeimen.

Das Keimpflänzchen (Fig. 49, 2) ist zunächst gänzlich unverzweigt, alsbald aber bildet es an der Basis rhizoidenartige Ausstülpungen, mittels welcher es sich am Substrat befestigt. Dann wird ein Wirtel steriler Zweige angeleg't (Fig. 49, 3) und zu der Ausbildung derselben gewöhnlich die Vegetationsperiode des ersten Jahres verwendet. Inzwischen hat sich der untere Teil des Keimlings stark verkalkt, und am Ende der ersten Vegetationsperiode stirbt nun das Pflänzchen bis auf diesen verkalkten Teil ab. An der Unterseite dieses verkalkten Teiles hat sich in irg'end einem Risse des Gesteins, zwischen den Rhizoiden ein sackartiges Organ, die sogenannte Basalblase (Fig. 49, 9) gebildet, und in diese Blase hat sich das Plasma des Keimling's zurückgezogen und sich mittels einer Scheidewand vom leeren Teil des verkalkten unteren Stückes abgetrennt. Nächstes Jahr bildet sich imnerhalb der alten Umhüllung eine neue IVand, und durch Streckung bildet sich nun ein Erneuerungssproß, ein neues Acetabularia-Pflänzchen also, welches alsbald mit seiner Spitze aus dem vom vorjährigen Pflänzchen übrig gebliebenen verkalkten Basalstück hervorragt (Fig. 49, 10). Dieses bildet nun meistens eine Anzahl steriler Zweigwirtel (Fig. 49, 4, 4A), welche öfters rötlich gefärbt sind. Schließlich aber bildet sich an der Spitze ein Wirtel seitlich verwachsender fertiler Zweige (Fig. 49, 3 A, 5, 6 A), während zu gleicher Zeit die sterilen Zweige abfallen, und ihr früheres Vorhandensein nur durch die Anwesenheit von Narben (Fig. 49, 5, 6 A) unter den jungen fertilen Hütchen verraten wird.

Auch bei Acetabularia bildet sich am sterilen Gliede der fertilen Zweige eine Corona superior und inferior aus (Fig. 49, 6). Die Corona inferior ist $\mathrm{zu}$ einem Höcker reduziert, und nur die Corona superior trägt sterile Zweiglein, welche als Schopf die jungen Fruchtschirme krönen (Fig. 49, 6 A, 7 rechts) aber auch alsbald abfallen (Fig. 49, 8). Auch hier verraten die Narben (Fig. 49, 8) ihre frühere Anwesenheit. Da die Gametangien völlig seitlich verschmelzen, ist im Schirm nur ein Hohlraum vorhanden, auch die Höcker der Coronae verschmelzen seitlich, so daß an den reifen Fruchtständen die Coronae nur durch einen oberen und unteren Ringwall repräsentiert sind. Von diesen ist die obere durch die Narben der abgefallenen sterilen Zweiglein raul, die untere aber glatt (Fig. 49, 7, 8).

Es fragt sich jetzt, von welcher Gruppe die Familie der Acetabularieae abzuleiten ist, und da ist vermutlich die Solmssche Auffassung, nach welcher sie von Formen wie Bornetella abgeleitet werden müssen, richtig.

Wir müssen dann die fertilen Zweige mit ihren apikalen Gametangien betrachten als Zweige, deren Gametangien ursprünglich seitlich standen, sich aber aufgerichtet und dadurch die eigentliche Spitze des Zweiges zur Seite gedrückt haben, die Corona superior besteht also aus den eigentlichen Spitzen der fertilen Zweige. Dafür sprechen auch 
die Resultate Howes (zitiert nach OLtmanns), welche zeigen, daß erst die Corona superior gebildet wird und später seitlich die Gametangien angelegt werden, wie das die Stellung dieser Organe in Fig. 49, 6 noch andeutet.

Damit sind wir also am Ende unserer Gruppe der Siphoneae angelangt und wenden uns jetzt der der

\section{Siphonocladeae}

Zu.

Diese Gruppe besteht aus einer progressiven Reihe, bei welcher das einzellige polyenergide Prinzip nach und nach aufgegeben wird, indem der Thallus in kleinere und kleinere Abschnitte geteilt wird, welche eine je länger je kleinere Zahl von Kernen enthalten.

Bei den niedrigeren Formen ist die Keimpflanze noch einzellig, und werden erst später Querwände gebildet, die Ontogonie ist hier also eine Wiederholung der Phylogenie; bei den höheren Formen dagegen ist dies nicht mehr der Fall, die Septierung tritt schon in zartester Jngend auf. Bei den allerhöchsten Formen können die Abschnitte so klein werden, daß sie sogar nur 2 Kerne enthalten; dem Augenschein nach ist ein solcher Organismus vielzellig und monoenergid, erst die Cytologie lehrt den wahren Sachverhalt und damit die Verwandtschaft kennen.

Die einfachste Familie ist die der

\section{Valoniaceae,}

welche nur ein Geschlecht: Valonia enthält.

Valonia ist eine Alge, welche in der Jugend einzellig ist, aber selbstverständlich von vielen Energiden bewohnt wird.

Die Zelle ist sehr groß, blasig, öfters $1-2 \mathrm{~cm}$ hoch und fast ebenso breit; in der Mitte findet sich eine riesige Vakuole, während im wandständigen Plasma zahllose Kerne und scheibenförmige Chromatophoren vorhanden sind.

FAIrchild (1894) hat nachgewiesen, daß diese Kerne sich nur zum Teil karyokinetisch teilen, zum Teil aber sich durch Fragmentierung vermehren.

Der Inhalt der Vakuole besteht aus einer wässerigen Lösung anorganischer Salze. Da der in der Zelle herrschende Turgor durch die wasseranziehende Kraft dieser Lösung verursacht wird, muß diese größer sein als die des Meerwassers.

Trotzdem zeigte Arthur Meyer (1891) durch chemische Analyse dieses Zellsaftes, daß sie nur $2 / 3$ des Salpeterwertes des Meerwassers besaß.

Falls dies richtig wäre, könnte die Alge selbstverständlich nicht existieren, es muß also irgend eine wasseranziehende Substanz der Analyse entgangen, oder irgend ein Versuchsfehler vorhanden sein. Letzteres scheint nun nicht ausgeschlossen zu sein. Es wurde nämlich folgende Methode benutzt. Die auf einem Stein gedrängt wachsenden Valonien wurden schnell in destilliertem Wasser abgespült, dann angeschnitten und umgekehrt auf ein Glasgefäß gesetzt, in welches der Zellsaft heruntertropfte. MExer gibt selber zu, daß dabei Aq. dest. mit dem Zellsaft gemischt wurde. Nun schließt die schwammige Natur eines solchen Valonienpolsters meiner Ansicht nach nicht aus, daß ent- 
weder nicht unbedeutende Mengen Aq. dest. festgehalten wurden und mit heruntertropften oder aber proportionell zu viel Zellsaft zurückbehalten wurde. Die Frage bedarf sicher näherer Untersuchung.

Man kann aus Neapel bezogene Valonien recht gut weiter kultivieren, ich habe in Leiden Kulturen, welche mehr als ein Jahr alt sind. Für den, der ähnliche Kulturen machen will, sei hier die Zusammensetzung des Neapler Meerwassers angegeben:

$\begin{array}{llrl} & 100 \text { Teile enthalten: } \\ 2,942 & \mathrm{NaCl} & 0,136 & \mathrm{CaSO}_{4} \\ 0,05 & \mathrm{KCl} & 0,248 & \mathrm{MgSO}_{4} \\ 0,322 & \mathrm{MgCl} & 0,011 & \mathrm{CaCO}_{3} \\ 0,056 & \mathrm{NaBr} & 0,0003 & \text { Eisenoxyd. }\end{array}$

Es hat nun NolL nachgewiesen, daß man gut tut, dergleichem Wasser noch einige Tropfen einer vollständigen Nährlösung zuzufügen, da selbstverständlich in einem Aquarium viel weniger Wasser mit der Alge in Berührung kommt, als im bewegten Meere, wo große Wassermengen an jedem Individuum vorbeiziehen.

Selbstverständlich reizten so große Zellen, wie die der Valonia, zur Untersuchung der Regenerationsmöglichkeit des Protoplasten.

KLEm (1894) fand, daß beim Durchschneiden der Valonia-Zelle die Ränder des durchschnittenen Protoplasten sich umbiegen, die Wunde dadurch geschlossen, der Turgor dann wieder hergestellt und eine neue Cellulosemembran gebildet wurde.

Nach unseren jetzigen Anschauungen läßt sich das Plasma am besten betrachten als eine Emulsion verschieden schwerer Flüssigkeiten. Offenbar ist das aber nicht ohne weiteres richtig, denn keine Emulsion, welche wir kennen, kann sich so verhalten. Wir haben es hier wieder mit einer der vielen unerklärten Eigenschaften der lebendigen Substanz zul tun.

In der großen, jungen Valonia-Zelle entstehen alsbald in größerer Zahl uhrglasförmige Wände, deren Ränder sich an die Außenwand anheften und die Randzellen bilden.

Der Bildung dieser uhrglasförmigen Wände ging eine Ansammlung von Plasma und Kernen an den entsprechenden Stellen voran.

Diese Randzellen können entweder als solche bestehen bleiben oder aber zu Zweigen oder zu Rhizoiden auswachsen.

Am mittleren Teile der Mutterzelle bleiben sie in der Regel unentwickelt, sie bilden dort öfters eine Art Panzer an der Peripherie der großen Zelle, die der Spitze am nächsten stehenden wachsen meistens zu gleichwertigen Zweigen aus, während die der Basis benachbarten zu Rhizoiden, welche die Pflanze am Substrat befestigen, auswachsen. Den hier beschriebenen Zustand (Fig. 50, 1) darf man als den typischen betrachten, vielfach kommen aber Modifikationen vor, welche großen Einfluß auf den Habitus der Pflanze ausüben.

So können z. B. vorwiegend im mittleren oder im unteren Teile der Zelle Randzellen gebildet werden, und diese kömnen zu Zellen auswachsen, welche erst eine kleine Strecke horizontal kiiechen, sich dann aber, unter Zunahme ihres Durchmessers, aufwärts wenden. So entstehen zahllose mittels kurzer Ausläufer verbundene, dichtgedrängte palisadenähnliche Zellen (Fig. 50, 2), welche bei oberflächlicher Betrachtung den Eindruck einer größeren Menge dichtgedrängt stehender, aber isolierter Zellen erwecken. 
Andere Talonia-Arten, wie $T$. ovalis und $T$. ventricosa AG., müssen im Vergleich mit $V$. utricularis entweder als primitive oder als reduzierte Formen betrachtet werden, sie verzweigen sich nämlich nicht und bleiben also lebenslänglich eine große Blase.

Die Valonien pflanzen sich mittels Zoosporen, welche bei gewissen, Arten 4, bei anderen wieder 2 Cilien tragen, fort. Sie keimen sofort zu neuen Pflänzchen aus. Eine geschlechtliche Fortpflanzung ist noch nicht bekannt geworden.

KUCKUCK (1903) wies nach, daß sich bei der Schwärmsporenbildung an der Spitze der Zelle viel Plasma und viele Chromatophoren ansammeln.

Infolgedessen wird die Zelle so schwarz, wie die Spitze eines zoosporenbildenden Vaucheria-Fadens.

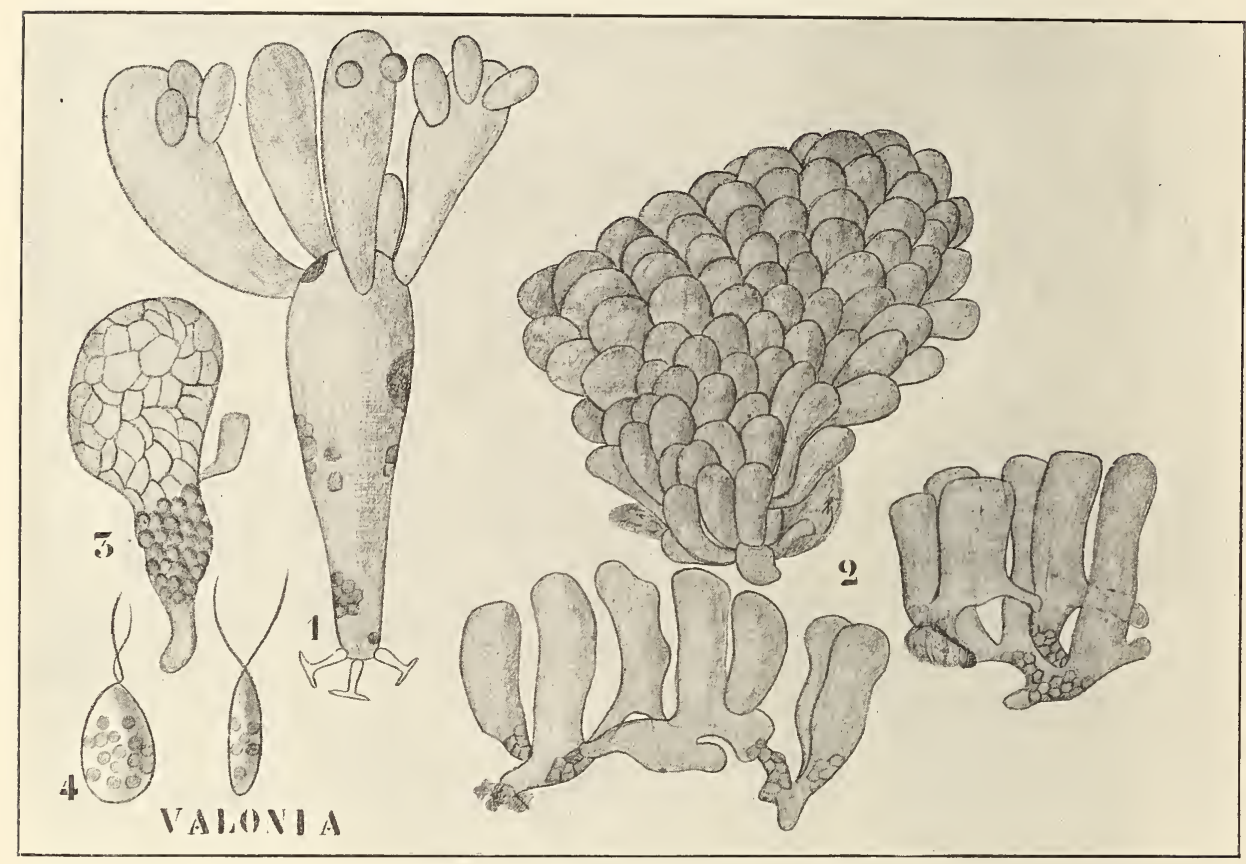

Fig. 50. Valonia utricularis (Rотн) Ag. 1 Ganze Pflanze (nach Schмiтz) die schlauchförmige Stammzelle trägt an der Spitze 5 entwickelte Astzellen und 2 Randzellen, die noch nicht zu Astzellen ausgewachsen sind, in der unteren Hälfte der Stammzelle finden sich kleine Randzellen in größerer Anzahl, an der Basis sind 3 Randzellen zu Rhizoiden ausgewachsen. 2 Polster und verzweigte Zellen mit Randzellen (nach OLtwanns). 3 Zelle, welche Schwärmsporen bildet. 4 Schwärmer (beide nach FAMINTziN).

Nur diese accumulierte Plasmamasse zerfällt in Zoosporen, welche durch kleine Löcher in der Membran der Zelle ausschlüpfen. Später werden diese Oeffnungen wieder geschlossen, und das übrig bleibende Plasma kann noch wiederholt in gleicher Weise Zoosporen bilden.

Betrachten wir jetzt die nächste Familie, die der

\section{Siphonocladaceae.}

Das einfachste Genus dieser Familie ist 


\section{Siphonocladus.}

Als Beispiel nehmen wir die sehr einfach gebaute Siphonocladus pusillus, eine Bewohnerin der griechischen Meere.

In der Jugend besteht unsere Alge aus einem unverzweigtem Schlauche von etwa $1 \mathrm{~mm}$ Dicke und 2-3 cm Länge, welcher mittels eines reichlich rerzweigten Rhizoidensystemes am Substrat befestigt ist.

In diesen Rhizoiden sind Querwände vorhanden. Erst viel später teilt sich die Zelle mittels quer- und schiefstehender Wände in eine Anzahl ron Abschnitten (Fig. 51).

Einige dieser Wände sind uhrglasförmig, wie die von Valonia, und Siphonocladus kann denn auch als ein Nachkomme valoniaähnlicher

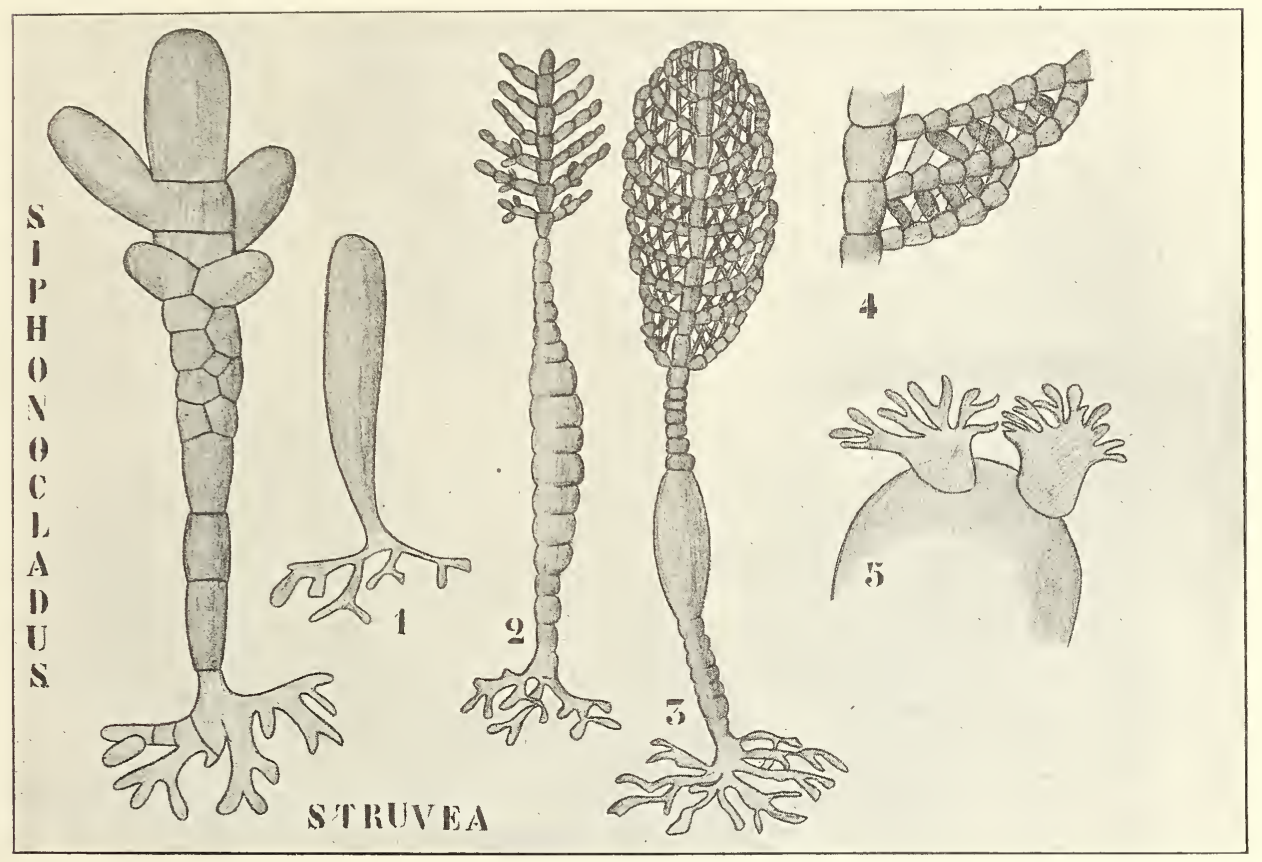

Fig. 51. I. Siphonocladus pusillus (nach Schmitz), II. Struvea (nach MURRAY und Boodle). 1 Stiel, noch einzellig. 2, 3 Verzweigung und Spreitenbildung. 4 Stück einer Spreite, stärker vergrößert. 5 Hafter.

Ahnen betrachtet werden, bei welchem die Wandbildung stärker ausgeprägt ist.

Bei der Bildung dieser Querwände bleibt stets ein endständiges Stück, von der Form einer Scheitelzelle, ungeteilt.

Bei Siphonocladus pusillus wachsen die meisten der so gebildeten Zellen zu kurzen Seitenzweigen aus, bei anderen Arten aber kömmen sie zu wiederholt verzweigten und miteinander verwebten Seitenzweigen auswachsen, so daß schließlich ein an g'ewisse Cladophora-trten erimnernder' Ballen entsteht.

Fast alle Zellen von Siphonocladus pusilhus können Zoosporen bilden. welche direkt zu neuen Pflänzchen auskeimen. 
Von Siphonocladus aus gelangt man leicht zu Struvea.

Struvea ist ein seltenes Algengenus, dessen Arten in tropischen Meeren wachsen. Auch sie ist in der Jugend, so wie Siphonocladus, einzellig und mit Querwände besitzenden Rhizoiden am Substrat befestigt (Fig. 51, 1).

An der Basis der Zelle entstehen alsbald ringförmige Einschnürungen (Fig. 51, 2), welche jedoch nicht zu Septenbildung führen. Erst später wird der Thallus vielzellig, indem nahe der Spitze des Schlauches eine

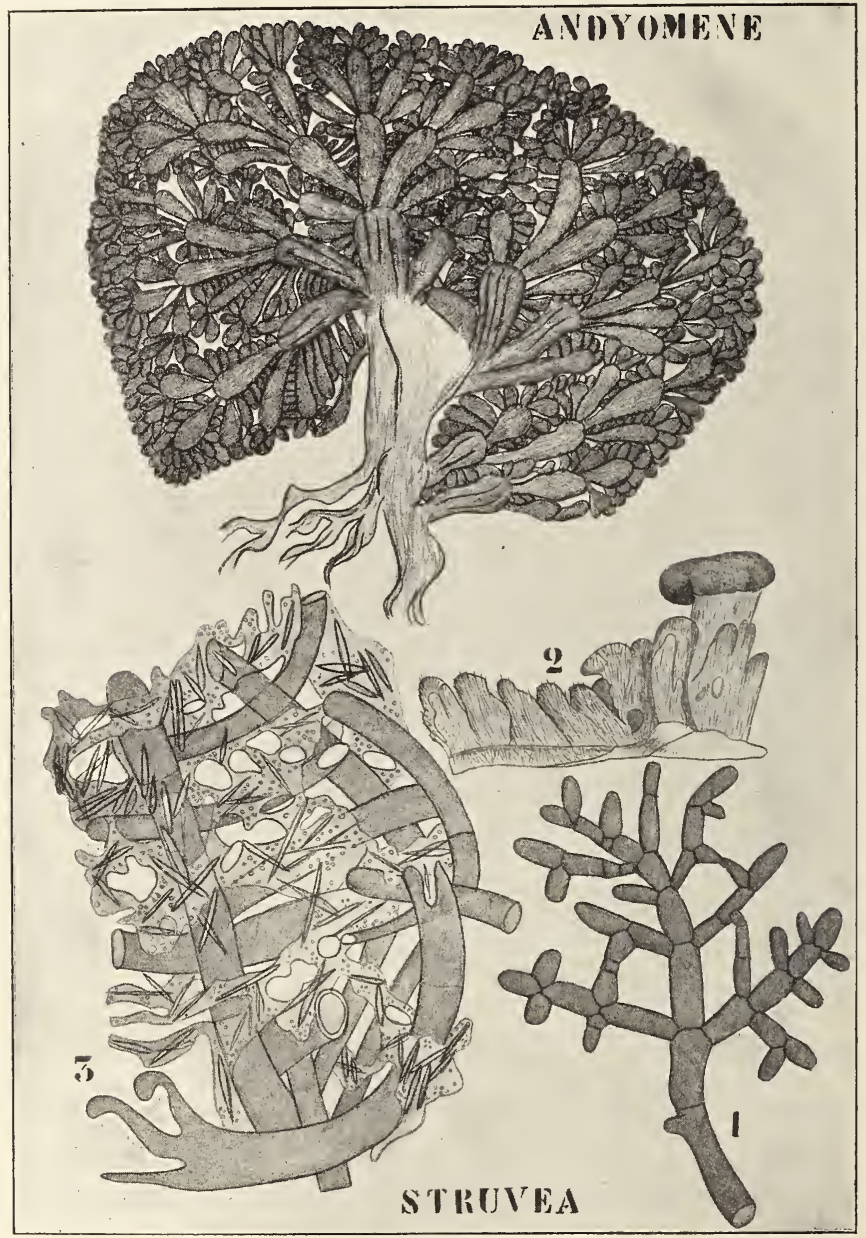

Fig. 52. I. Andyomene flabellata (nach Oltmanss). II. Struvea delicatula (nach WEBER VAN Bosse). 1 Ein Zweig der Struvea, welcher aus der Spongie herausgewachsen ist. 2 Habitus der Spongie mit der Struvea in Symbiose; rechts besteht die Spitze des Symbionten ausschließlich aus Fäden der Struvea. 3 Querschnitt, die Algenzellen sind die Stiele der Struvea, die Nadeln gehören der Spongie an.

Anzahl unter sich paralleler und zur Längsachse des Schlauches senkrecht orientierter Querwände gebildet werden. Dadurch wird der Stiel artikuliert. Auch hier bleibt die Spitze querwandfrei, es wird also ebenso 
wie bei Siphonocladus eine Scheitelzelle g'ebildet. Während diese aber dort nicht funktionierte, ist es hier der Fall, sie sorgt für das weitere Längenwachstum.

Die Stielartikulationen bilden im oberen Teile des Schlauches ebenfalls gegliederte Seitenzweige, wodurch eine gefiederte "Blattspreite" entsteht (Fig. 51, 2, 3).

Die "Blättchen" verzweigen sich nochmals, und zwar in derselben Ebene, das "Blatt" wird also doppelt gefiedert.

Jetzt biegen sich die Spitzen der Seitenzweige 1. Ordnung bogenförmig zu den nächsthöheren hin, wodurch die Seitenzweiglein 2. Ordnung kreuzweise übereinander greifen (Fig. 51, 4).

Schließlich bilden sich an den Kontaktstellen ein oder zwei kurze Seitenzweiglein mit rhizoidenähnlichen Ausläufern, welche um den Zweig, welchen sie berühren, herumwachsen und so dem Ganzen Halt verleihen (Fig. 51, 5).

Die Fortpflanzung von Struvea ist noch völlig unbekannt.

Struvea ist weiter besonders interessant, weil sie unter ihren Arten, eine zählt, welche mit einem Tiere in Symbiose lebt, wie Frau WEBER VAN Bosse (1890) nachwies.

Es handelt sich hier um die Symbiose von Struvea delicatula mit der Spongie Halichondria.

In freiem Zustande zeigt diese Struvea einen der oben beschriebenen Art entsprechenden Bau, die Seitenzweiglein sind verankert, und da das Pflänzchen gesellig wächst, und an jeder Stelle, wo sich die Seitenzweiglein berühren, Hafter sich bilden, können sich benachbarte Individuen vereinigen und ziemlich große, gitterartig durchbrochene Massen bilden.

Bei den mit der Spongie in Symbiose getretenen Exemplaren aber ändert sich der Habitus gänzlich. Die schönen Spreiten werden nicht gebildet, es entstehen dickwandige, unregelmäßig verzweigte Schläuche, welche man nie für eine Struvea halten würde.

Diese Röhren waren denn auch schon lange bekannt, bevor Frau WEBER van Bosse ihre eigentliche Natur erkannte, und als gesondertes Genus unter dem Namen Spongocladia vaucheriaeformis beschrieben worden. Es ist also recht gut möglich, daß sämtliche bis jetzt beschriebene Spongocladia-Arten nur durch Symbiose umgebildete StruveaArten sind.

Von den Siphonocladaceen ausgehend, findet man leicht Uebergänge zu der Gruppe der

\section{Cladophoraceae.}

Stellen wir uns vor, daß bei einem Siphonocladus, die Seitenzweige sämtlich in einer Ebene gebildet wurden und so eng aneinander schlossen, daß sie miteinander verklebten, so würden wir die zierlichen, blattähnlichen Thallome die Andyomene flabellata erhalten (Fig. 52).

Die Verzweigungen höherer Ordnung werden jedesmal etwas kleiner. bis schließlich am Rande nur sehr kurze Zellen gebildet werden.

Diese letzten Verzweigungen bilden die Zoosporen, welche durch ein Wandloch ausschlüpfen.

Von den übrigen Cladophoraceen ist Chaetomorpha gewiß die einfachste.

\section{Chactomorpha}

ist ein unverzweigter Isokont mit Querwänden, welche den Faden in 
polyenergide Abschnitte verteilen. Die basale Zelle ist zu einem Rhizoid, welches die Pflanze am Substrat befestigt, ausgewachsen.

Alle Zellen mit Ausnahme der basalen können sich teilen. In jeder Zelle findet sich ein einziger netzförmig durchbrochener Chromatophor mit zahlreichen Pyrenoiden, welcher sich aber in kleinere Stücke zerteilen kann. Nähere Untersuchung wäre hier erwünscht, um zu bestimmen, ob man es hier mit einem echten Chromatophor oder nur mit einer partiellen Färbung des Plasmas, deren Ausgiebigkeit wie bei Hydrodictyon vom Ernährungszustande der Zelle abhängt, zu tun hat.

Bei der Fortpflanzung kann jede Zelle sich entweder zu einem Zoosporangien oder zu einem Gametangium ausbilden. Die Zoosporen haben 4, die Gameten 2 Cilien, es sind normalerweise kopulierende Isogameten. Die Zygote keimt sofort.

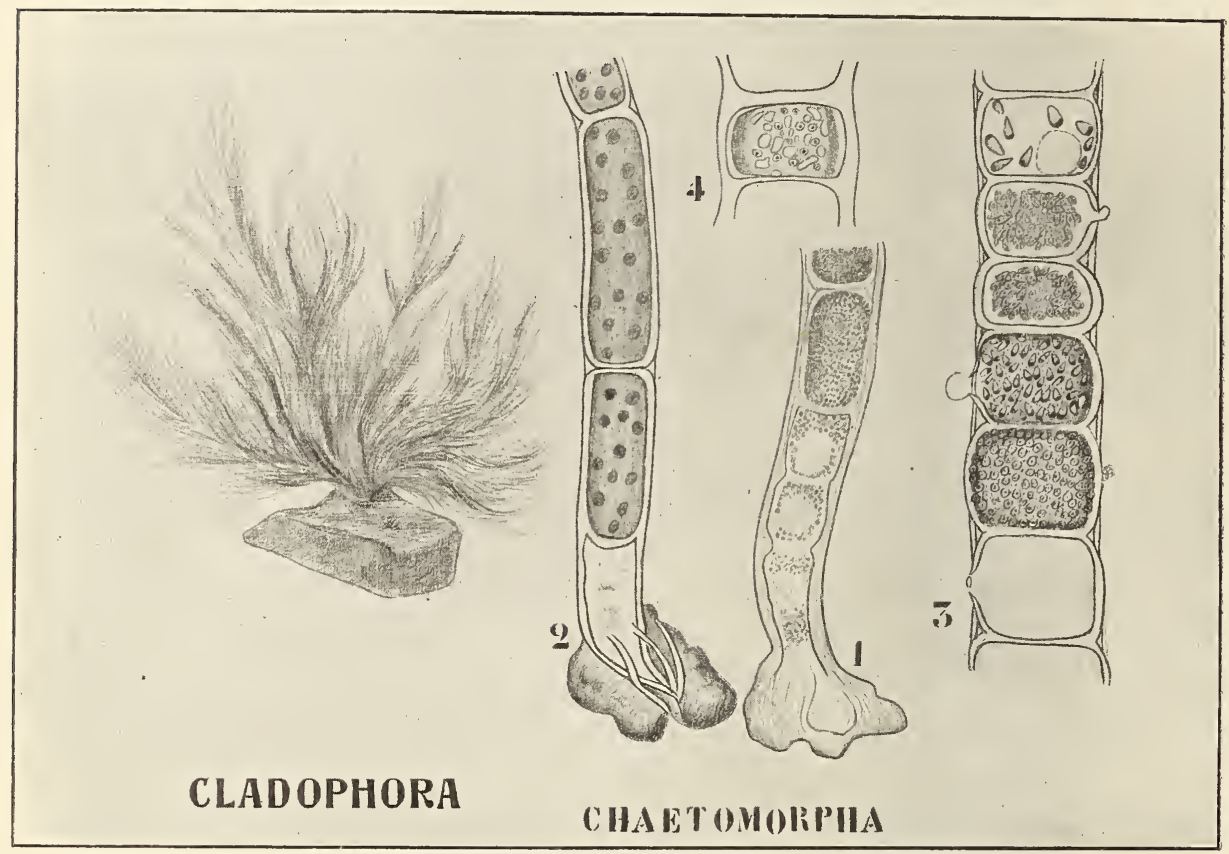

Fig. 53. I. Clad ophora spec. Habitusbild; II. Cha etomorpha (nach RosEnvingE und ThuneT). 1, 2 Basalteile mit Rhizoiden. 3 Zoosporenbildung. 4 Netzförmiger Chromatophor von Urospora.

Von Chaetomorpha unterscheidet sich

\section{Cladophora}

durch die reichliche Verzweigung und durch die, wenigstens bei den höchstentwickelten Arten vorhandene, Scheitelzelle.

Bei Chaetomorpha konnte sich, wie wir sahen, ein jeder Abschnitt teilen, bei den niedrigeren Cladophora-Arten ebenfalls, aber nach und nach erlischt das Teilungsvermögen der Abschnitte, und wird diese Aufgabe der Scheitelzelle überwiesen.

Die Verzweigung kommt zu stande, indem am apikalen Ende der 
Zellen eine Ausstülpung entsteht, welche später von einer Querwand abgeschnitten wird.

In jeder Zelle findet sich stets mehr als ein Kern (STrasburger, Berthold), es sind entweder viele Chromatophoren, je mit einem Pyrenoid, rorhanden. oder aber es findet sich nur ein gitterartig durchbrochenes Chromatophor mit vielen Pyrenoiden.

Die Zellteilung findet durch Bildung eines Celluloseringes an der Zellwand statt, deren Oeffinung kleiner und kleiner wird, wodurch der Protoplast durchgeschnürt wird. Bei dieser Methode der Zellteilung spielen die Kerne keine Rolle. Der Vorgang ist dem von Codium vollkommen analog. nur ist der Ring dort dicker.

Kleine Cladophora-Arten sind mittels einer scheibenförmigen, gelappten Terbreiterung der Basalzelle am Substrat befestigt, größere Arten

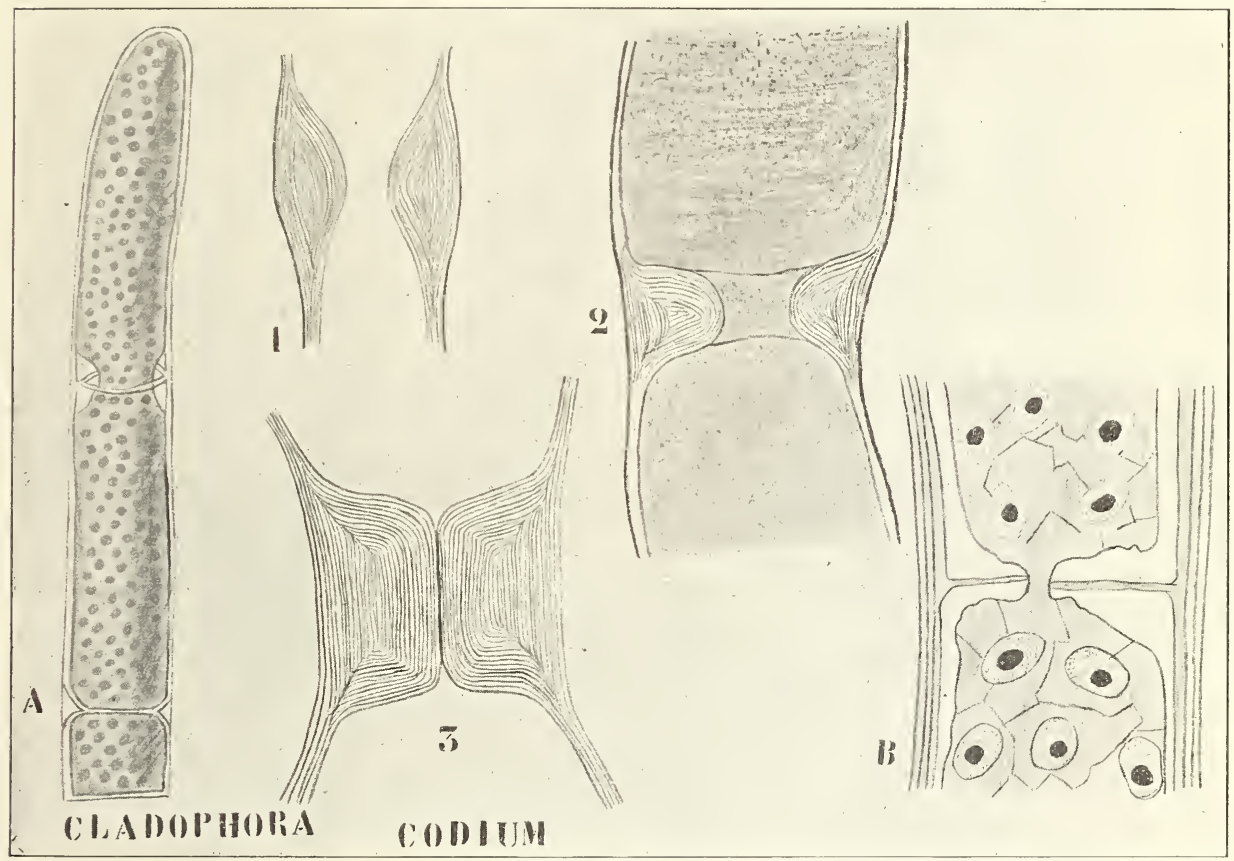

Fig. 54. Zellteilung von Cladophora (A, B) und Codium. (1, 2, 3) nach ThureT, BERTHOLD und STRASBURGER.

bilden außerdem an den basalen Enden höher gelegener Zellen, sowohl der Hauptachse wie der Seitenzweige, Rhizoide zur besseren Befestigung. Zur Ueberwindung ungünstiger Perioden bilden viele CladophoraArten eine Art von Rhizomen.

Wenn die Rhizoide das Substrat berühren, bilden sie nämlich öfters vielzellige flache Zellkörper, welche Reservesubstanzen ansammeln und am Leben bleiben, auch wenn der ganze übrige Teil der Alge abstirbt (Fig. 55, 4). In diesem Zustande überwintern viele CladophoraArten.

Im Frühjahr keimen dann die Zellen solcher Rhizome zu neuen Individuen aus (Fig. 55, 5). 
Andere Cladophora-Arten überwintern, indem sich die Fäden in den Thallus anderer Algen einbohren, also parasitisch werden. Oefters findet man in größeren Meeresalgen, z. B. in Polyides rotundus, solche Fäden.

Ueberdies können die Zweige bei Cladophora in mancherlei Weise als Ueberwinterungsorgane dienen. Entweder füllen sich dann alle Zellen eines Seitenzweiges, oder nur einige wenige mit Reservesubstanzen, und verdicken ihre Wand. Auch wenn der Rest des Thallus abstirbt, bleiben diese, Akineten genannten Zellen, am Leben.

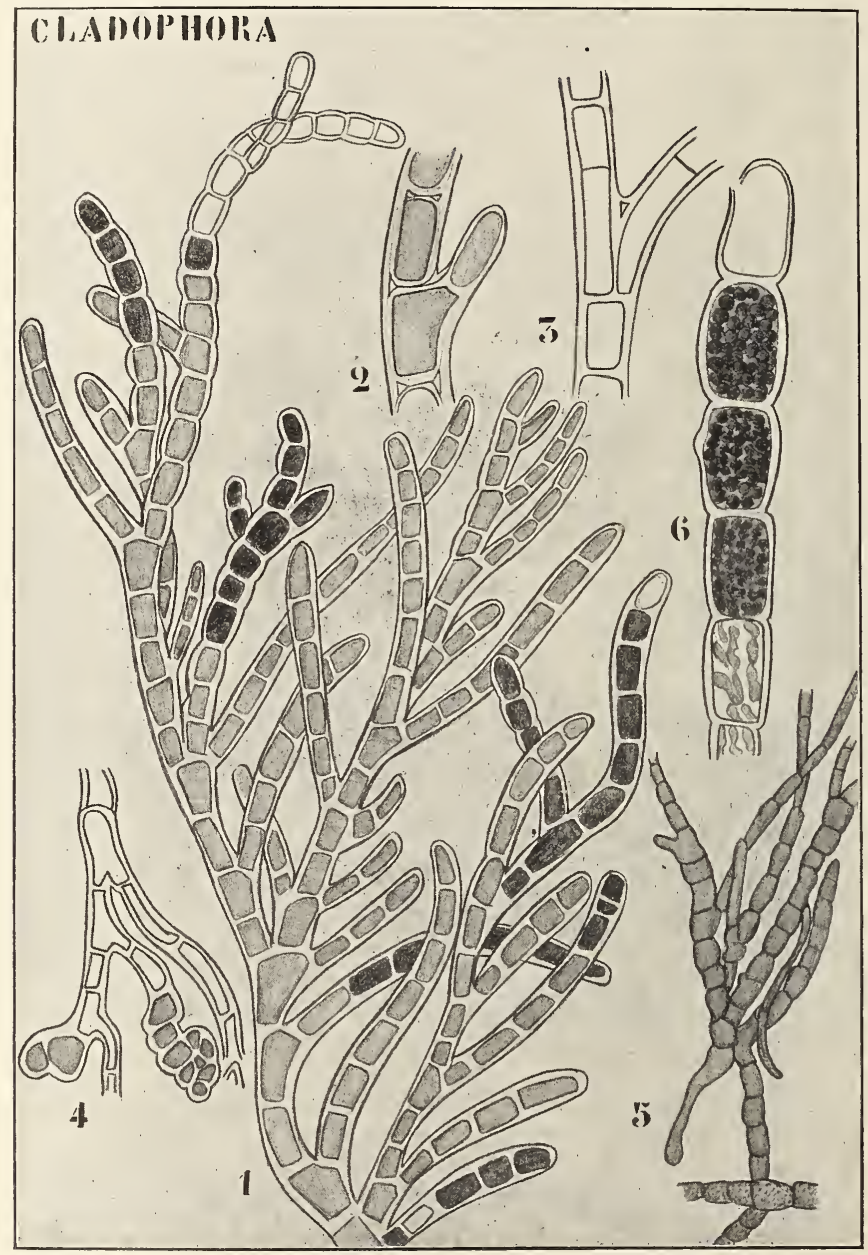

Fig. 555. $1 \mathrm{Cladophora} \mathrm{mit} \mathrm{Zoosporangien} \mathrm{(nach} \mathrm{OLtmanns).} 2$ Junger Seitenzweig von $=$ Cl. hamosa (nach Rosenvinge). 3 Aelterer Seitenzweig von derselben mit dem Muttersproß verwachsen (nach Nordhausen). 4 A crosiphonia vernalis, Rhizoide mit Reservestoffe führenden Rhizomen (nach KJELLmaN). 5 Cl. glomerata, keimendes Rhizom (nach Oltmanns). 6 Zoosporangien von Cladophora (nach Oltmanns).

Solche Akineten können entweder direkt zu jungen CladophoraPflanzen auswachsen oder aber Schwärmsporen bilden.

Schwärmsporen vom gewöhnlichen Typus, nur mit 4 statt mit 2 Cilien 
ausgestattet, werden bei Cladophora mit Torliebe in den 3 oder 4 Endzellen der Zweig*e g'ebildet; sie gelang*en durch eine laterale Oeffumng' ins Freie.

Bei nur recht wenigen Cladophora-Arten wurden bis jetzt Gameten nachgewiesen, sie entstehen in gleicher Weise wie die Zoosporen, haben aber statt 4 nur 2 Cilien; die Zygote keimt sofort.

So sind wir denn bei der letzten Gruppe der Siphonales angelangt, bei den

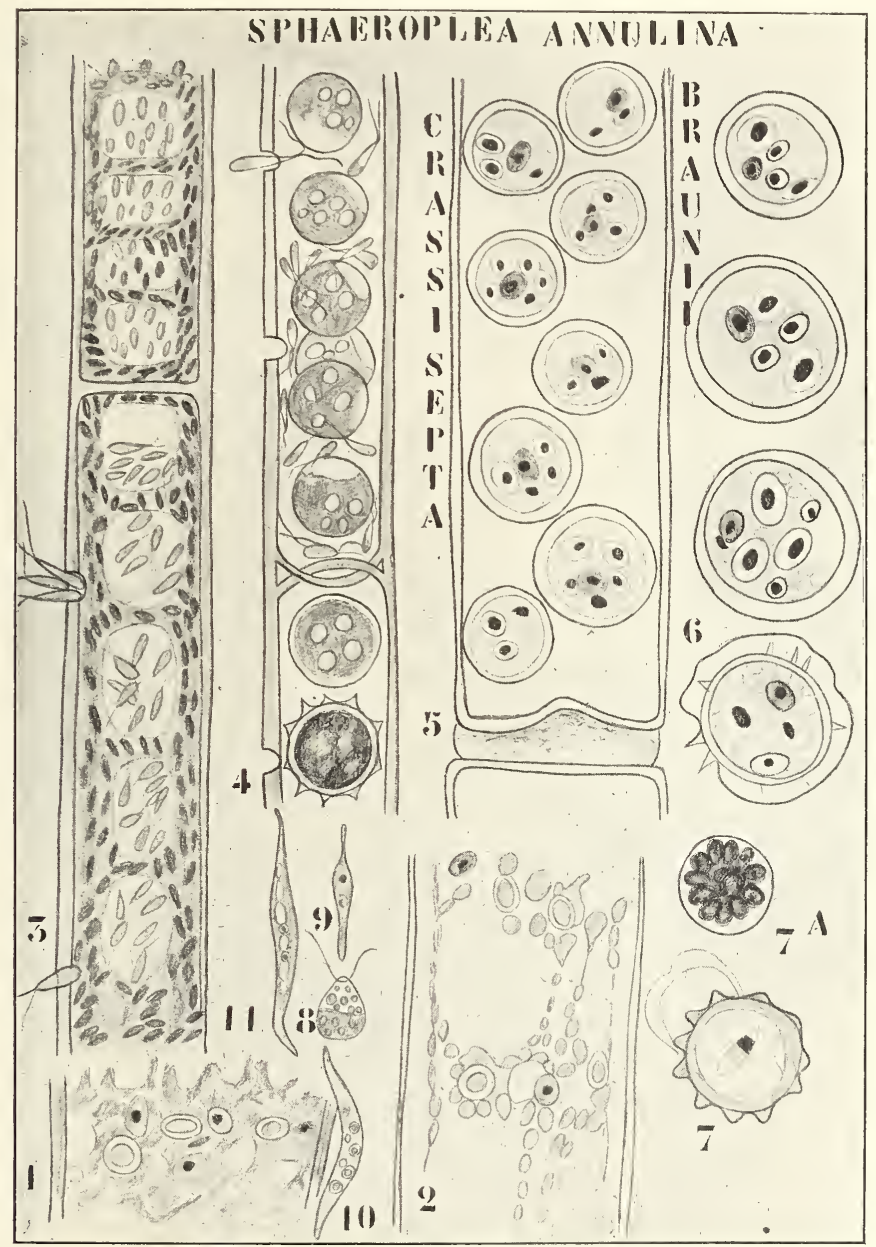

Fig. 56. Sp ha e r o p la e a (nach Bradn, Klebahn und Heinricher). 1, 2 Chromatophor mit Kernen und Pyrenoiden. $3 \delta$ Faden mit Spermatozoiden. $4 q$ Faden mit Eiern und einer Zygote; Spermatozoen dringen ein. $5 \mathrm{Sph}$. crassisepta mit einkernigen Eiern, mit Spermakern und Pyrenoiden. $6 \mathrm{Sph}$. Braunii mit vielkernigen Eiern und Pyrenoiden. 7, 7 A Keimende Zygoten. 8 Zoospore aus der Zygote entstanden. 9 Keimlinge.

\section{Sphaeroplaeaceae,}

deren Einsetzung an diese Stelle freilich von zweifelhafter Richtigkeit ist. Die Familie enthält nur ein Geschlecht und eime Art: 


\section{Sphaeroplaea annulina.}

Sie zerfällt aber nach KLeBAHN in 2 Varietäten: Sph. Braunii und Sph. crassisepta.

Bis jetzt wurde Sphaeroplaea nur in Europa gefunden, der locus classicus ist der Auersperg-Brunnen in Graz; im Jahre 1905 trat sie in wenigen Exemplaren im Victoriahause des Leidener botanischen Gartens auf, ich konnte aber bloß sterile Exemplare finden.

Die Alge ist unverzweigt, besteht aus langen Zellen und hat, da sie frei schwimmt, keine Rhizoide.

Die Chloroplasten sind in eigenartigen, ringförmigen Zonen lokalisiert, welche aber durch ebenfalls Chloroplasten enthaltende Plasmastränge verbunden sind (Fig. 56, 2). Zwischen den Chloroplasten, in den ringförmigen Zonen also, liegen die Pyrenoide. Da dies für Pyrenoide ungewöhnlich, betrachtet man vielleicht besser den ganzen grün gefärbten Teil als ein Chromatophor.

Ungeschlechtliche Fortpflanzung wurde nie beobachtet.

Die geschlechtliche Fortpflanzung findet mittels Eier und Spermatozoen statt, die Oogonien und Antheridien sind gewöhnliche Fadenzellen, welche wohl ihren Inhalt, nicht aber ihre Form ändern.

In den Antheridien entstehen durch wiederholte Teilung der Kerne bis zu 300 Spermatozoen. Sie besitzen 2 Cilien, sind braungelb gefärbt und schlüpfen durch kleine Löcher, welche sich in der Zellwand bilden, heraus.

In den Oogonien entstehen die Eier in viel geringerer Zahl; bei der var. crassisepta sind die Eier einkernig, bei der var. Braunii mehrkernig, im letzteren Falle funktioniert aber doch nur einer derselben als Eikern, die übrigen gehen zu Grunde.

Am Ei befindet sich ein farbloser Empfängnisfleck. Die Spermatozoen dringen durch kleine Oeffnungen in den Oogonien zu den Eiern vor; ein Spermatozoon verschmilzt mit jedem Ei. Der Spermnucleus tritt hinein und verschmilzt mit dem einzigen oder mit dem funktionierenden Eikern. Die Zygote umgibt sich mit einer derben Membran, der Inhalt färbt sich zunächst braun, später rot.

Bei der Keimung bildet die Zygote normaliter 4, unter Uniständen aber auch mehr Schwärmer, welche ein eigentümliches rotes Querband besitzen und zu neuen Sphaeroplaeen auskeimen. Auch hier wurde also die Zygote zum Gonotokonten.

Werfen wir jetzt, nachdem wir den ganzen Stamm der Siphonales behandelt haben, nochmals einen Blick zurück.

Wir haben gesehen, daß die ersten Organismen monoenergid waren und frei umherschwammen.

Von diesen hat sich der Stamm der Volvocinecie durch Zusammenbleiben der Tochterindividuen unter Beibehaltung der Beweglichkeit mittels Cilien entwickelt, es entstanden so freibewegliche Kolonien. Auf diesem Wege zur Weiterentwickelung wurde aber nur ein succès d'estime erreicht, eine höhere Form als Volvox entstand nicht.

Die Natur schlug aber zu gleicher Zeit einen anderen Weg ein und versuchte, was durch den Verlust der Beweglichkeit zu erreichen war: dieser Versuch führte zu nichts Besserem als zu Hydrodictyon.

Da wurde noch ein anderer Weg eingeschlagen, nicht Vermehrung der Zellen, sondern Vergrößerung der Zelle und Vermehrung der Ener- 
giden wurde versucht, auch wurde diese Riesenzelle möglichst differenziert, das Ergebnis war Caulerpa oder bei Terwebung von verschiedenen Röhren: Codium.

Die weitere Ausbildung der bereits bei Codium andentungsweise vorhandenen Heterogamie führte zu Formen, wie Taucheria, mit ausgebildeten Oogonien und Antheridien.

Eine Terbesserung der Einzelligkeit der polyenergiden Organismen war die Zerteilung der Riesenzellen mittels Septen in eine größere Zahl von Abschnitten. Dadurch wurde die Verwundungsgefahr sehr herabgesetzt, unter Beibehaltung der Isogamie wurde hierdurch Cladophora, unter Ausbildung der Heterogamie Sphaeroplaea erreicht.

Unter Beibehaltung der unabhängigen Lebensweise war auch hiermit offenbar nichts weiter zu erreichen, es stand aber noch die Möglichkeit, zu einer abhängigen Lebensweise überzugehen, offen.

Auch dieser Weg wurde eingeschlagen, saprophytische und parasitische Fungi entstanden.

Sehen wir also zunächst, wie unsere Organismen diese Gelegenheit ausgenutzt haben. 


\section{Vierte Vorlesung.}

\section{Die niederen Fungi.}

Schon früh war eine Neigung zur Aufgabe der Eigenernährung vorhanden, wir sahen schon, daß bei den freischwimmenden monoenergiden einzelligen Formen ein solcher Faulenzer sich vorfand: Polytoma, welcher seine Chromatophoren verlor und seine Nahrung faulenden Substanzen entnahm. Das ist aber nur eine einzige Ausnahme im ganzen Stamm der Volvocineen.

Viel verbreiteter wurde diese Lebensweise unter der Gruppe der Siphonales. Schon unter den ersten noch rein einzelligen Formen entstand die Neigung zum Parasitismus, und daraus entstand ein Teil jener Gruppe von Pilzen, welche wir unter dem Namen der Archimyceten kennen.

Betrachten wir also die Gruppe etwas näher. Sie läuft der Gruppe der Endosphaeraceen parallel, und wir werden sehen, daß, während die niedrigsten Formen einzellig sind. es andere gibt, bei welchen ebenso wie bei Endosphaera ein ephemerer Coenobiumzustand auftritt, indem die gebildeten Tochterzellen, noch bevor sie Cilien gebildet haben, sich mit einer Membran umgeben und zu Zoosporangien werden; das ist der Fall bei Synchytrium.

Eigentlich aber darf dieser Organismus nicht als ein Seitenzweig der isokonten Siphonalen betrachtet werden, da die Schwärmsporen des Synchytrium nicht 2 gleichlange sondern nur eine einzige Cilie besitzen. Deswegen sollten eigentlich von den hier zu behandelnden Archimyceten die Genera Olpidiopsis, Synchytrium, Rhinidium, Polyphagus und Hyphochytrium ausgeschlossen werden, denn bei allen besitzen die Schwärmer nur eine Cilie.

Ich glaube in der Tat nicht, daß diese Formen von Isokonten abstammen, wage es aber nicht, sie abzutrennen, da ich mit Rücksicht auf den Umstand, daß manche Angaben über die Zahl der Cilien in dieser Gruppe älteren Beobachtungen entstammen, von deren Richtigkeit ich nicht überall sicher bin.

Ich wäre sehr geneigt, anzunehmen, daß es unter den großen Gruppen der Archimyceten-Siphonomyceten zwei Reihen gibt, eine eincielige mit den Generis: Olpidiopsis, Synchytrium, Rhizidium, Polyphagus, Hyphochytrium, Monoblepharis und Pythium, und eine andere mit den Geschlechten: Pseudolpidium, Lagenidium, Myrioblepharis und allen übrigen. Erstere wäre dann wohl von viel niedrigeren Organismen, letztere von den Isokonten abzuleiten. Die ganze Sache ist aber sehr mißlich, wer 
weiß, ob nicht die parasitische Lebensweise zum Verlust einer Cilie geführt hat. Ueberhaupt treten bei den Pilzen allerhand Umstände auf, welche die phylogenetische Behandlung erschweren; denn während bei den grünen Organismen nur diese selbst sich fortbilden konnten, können die Vertreter der Pilzreihe nicht nur durch Weiterentwickelung von Pilzen sich ausgebildet haben. sonder'n es können der Reihe der Pilze auf jeder Entwickelungsstufe von auswärts, aus den Algen neue Mitglieder zug'eführt worden sein.

Die Einteilung; welche ich Thnen also z. B. von der Gruppe der Siphonomyceten geben werde, ist als eine provisorische $\mathrm{zu}$ betrachten, neues Licht wird nur durch neue Untersuchungen entzündet werden können.

Bei der Einteilung dieser Gruppe werde ich auf einen Faktor großes Gewicht legen, mit welchem wir bis jetzt nicht zu rechnen hatten, ich meine die durch den Uebergang von Wasser- zum Landleben herbeigeführten Veränderungen. Das wichtigste Resultat dieser Veränderung in der Lebensweise war die zumal von BREFELD nachgewiesene Umbildung von Zoosporangien zu Konidien.

Gehen wir jetzt zur Betrachtung der niedrigsten Pilze, der Archimyceten, über. Eine erste Einteilung ist leicht zu machen, bei einem Teile der Repräsentanten nämlich besitzt die junge Pflanze in den ersten Lebensstunden keine Zellwand, ist also nur eine nackte Energide, bei den übrigen ist die Energide vom Anfang an mit einer Zellwand umgeben.

Die erste Gruppe wird Myxochytridiaceae, die zweite Mycochytridiaceae genannt. Die weitere Einteilung wird aus der Behandlung der Repräsentanten hervorgehen.

\section{Myxochytridiaceae.}

Fangen wir die Betrachtung dieser Gruppe mit der Familie der

\section{Monolpidiaceae}

an, und zwar mit einem sehr einfachen Repräsentanten, mit

\section{Pseudolpidium Saprolegniae.}

In den Zoosporangien oder in den Hyphen des SiphonomycetenGenus Saprolegnia waren seit längerer Zeit zwei Arten von kugeligen Körpern bekannt, und zwar glatte und stachelige.

Anfänglich wurden sie für Fortpflanzungsorgane der Saprolegnia gehalten, und daß diese Auffassung nicht von Anfängern herrührte, beweist wohl der Umstand, daß sie von Männern wie NäGELI (1846) und Pringsheim (1858-1860) verkündigt wurde.

Im Jahre 1855 entdeckte aber Alexander Braun ihre wahre Natur, indem er die Meinung aufstellte, daß sie nicht zum Entwickelungsgang der Saprolegnia gehörten, sondern einen in derselben lebenden Parasiten darstellten. Dieser Meinung war auch ConNu, der 1872 eine detailliertere Beschreibung dieses Organismus gab und seine parasitische Natur zu beweisen suchte. Der strikte Beweis wurde aber erst 1880 von Alfred Fischer erbracht.

Bei seinen Untersuchungen ging er von den in den glatten Sporangien gebildeten Schwärmern aus (Fig. 57, 1). Diese besitzen 2 Cilien, mittelst welcher sie im Wasser herumschwimmen. Gelangt num ein 
solcher Schwärmer in die Nähe eines Saprolegnia-Fadens, so schwimmt er auf diesen $\mathrm{zu}$, heftet sich an demselben an, bildet eine Membran und bald darauf einen kurzen Keimschlauch, der die Wand der Saprolegnia durchbohrt. Der Keimschlauch öffnet sich an seiner Spitze, und der ganze Inhalt des eingekapselten Schwärmers tritt in den Faden ein. Die nackte Energide fängt nun an das Plasma der Saprolegnia zu verdauen und wächst stark an, während der Saprolegnia-Faden immer ärmer an Plasma wird und schließlich abstirbt. Der Parasit weist während dieses Stadiums starke amöboide Bewegungen auf, rundet sich aber alsbald $a b$ und umgibt sich schließlich mit einer Membran, welche wenigstens in einem Teil der Fälle nicht glatt, sondern stachelig ist. Nach einiger Zeit teilt sich der Inhalt dieser Stachelkugel in eine größere

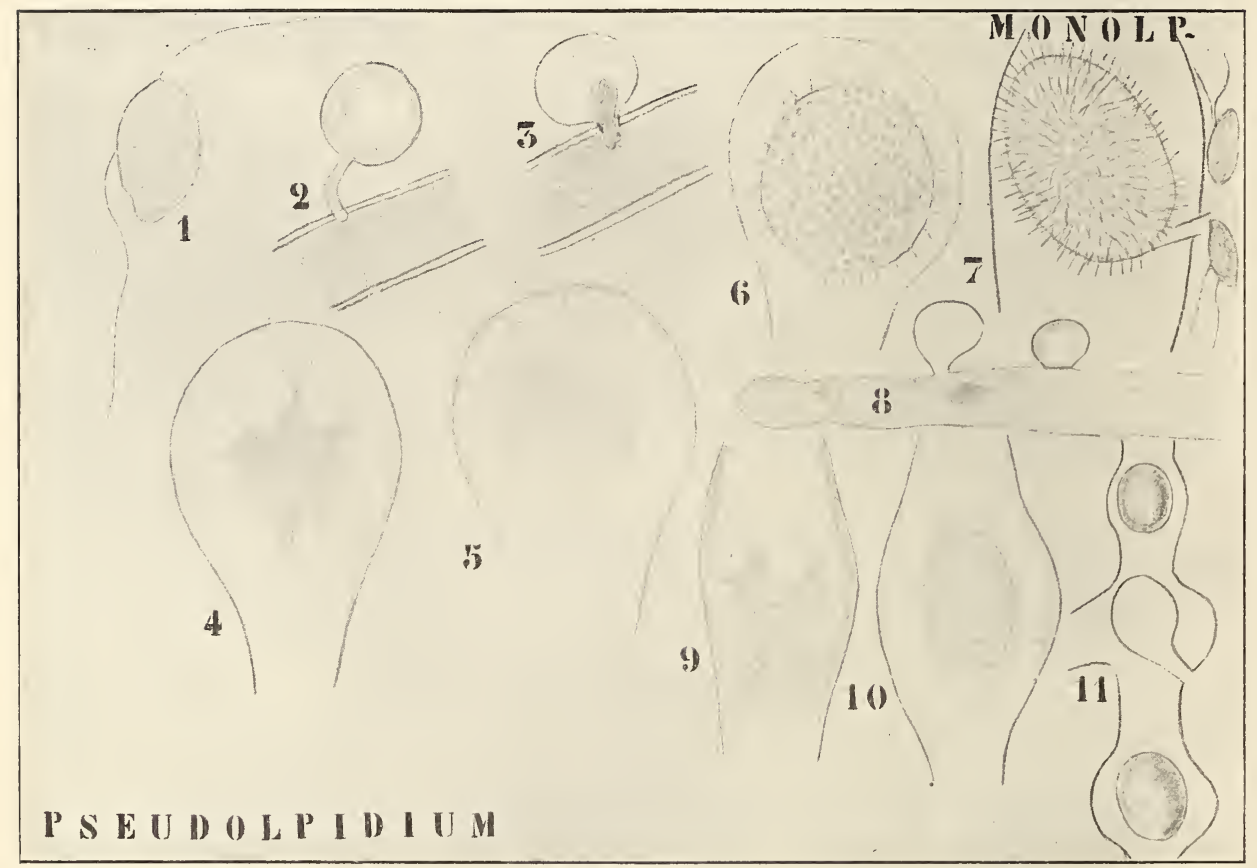

Fig. 57. Pseudolpidium S aprolegniae (nach A. Frscher). 1 Schwärmer aus einem glatten Sporangium. 2 Keimend auf einer Saprolegnia. 3, 8 Der Inhalt des Schwärmers tritt in den Saprolegniafaden ein. 4, 5 Der amöboide Zustand des Parasiten im Innern der Saprolegnia. 6 Bildung des stacheligen Sporangiums. 7 Die Stachelkugel läßt die Schwärmer austreten. 9 Amöboider Zustand eines solchen Schwärmers in der Saprolegnia. 10, 11 Bildung der glatten Sporangien.

Zahl von Schwärmern; die Kugel bildet einen Schlauch, welcher die Außenwand des Fadens durchbohrt, ins umliegende Wasser eintritt, dort sich öffnet und die Schwärmer austreten läßt. Diese Schwärmer sind in keiner Hinsicht von den in den glatten Kugeln gebildeten verschieden. Auch diese Schwärmer dringen wiederum in ähnlicher Weise, wie die schon beschriebenen, in Saprolegnia-Fäden ein, fressen wieder unter amöboider Bewegung das Saprolegnia-Plasma, runden sich ab, umgeben sich mit einer Membran und werden zu glatten Sporangien, welche wieder Schwärmer bilden und wieder den gleichen Entwickelungsgang anfangen. 
Der Organismus bildet also zwei Arten von Sporangien, glatte und stachelige, das ist aber anch der einzige Unterschied zwischen beiden. Die Fortptlanzumg ist demnach eine rein ungeschlechtliche, von eimem Generationswechsel kann keine Rede sein. Der Parasit durchläuft in 6-S Tagen seinen ganzen Entwickelungsomang:

Während also beim Genus Pseudolpidium keine geschlechtliche Fortptlanzung rorhanden ist, finden wir sie bei einem anderen Genus der Monolpidiaceae. und zwar bei der 1884 von ZopF beschriebenen

\section{Olpidiopsis Schenkiana.}

Dieser Parasit auf Spirogyra bildet ebenfalls, wie Pseudolpidium, Schwärmersporen, welche aber nur eine Cilie besitzen. Sie heften sich

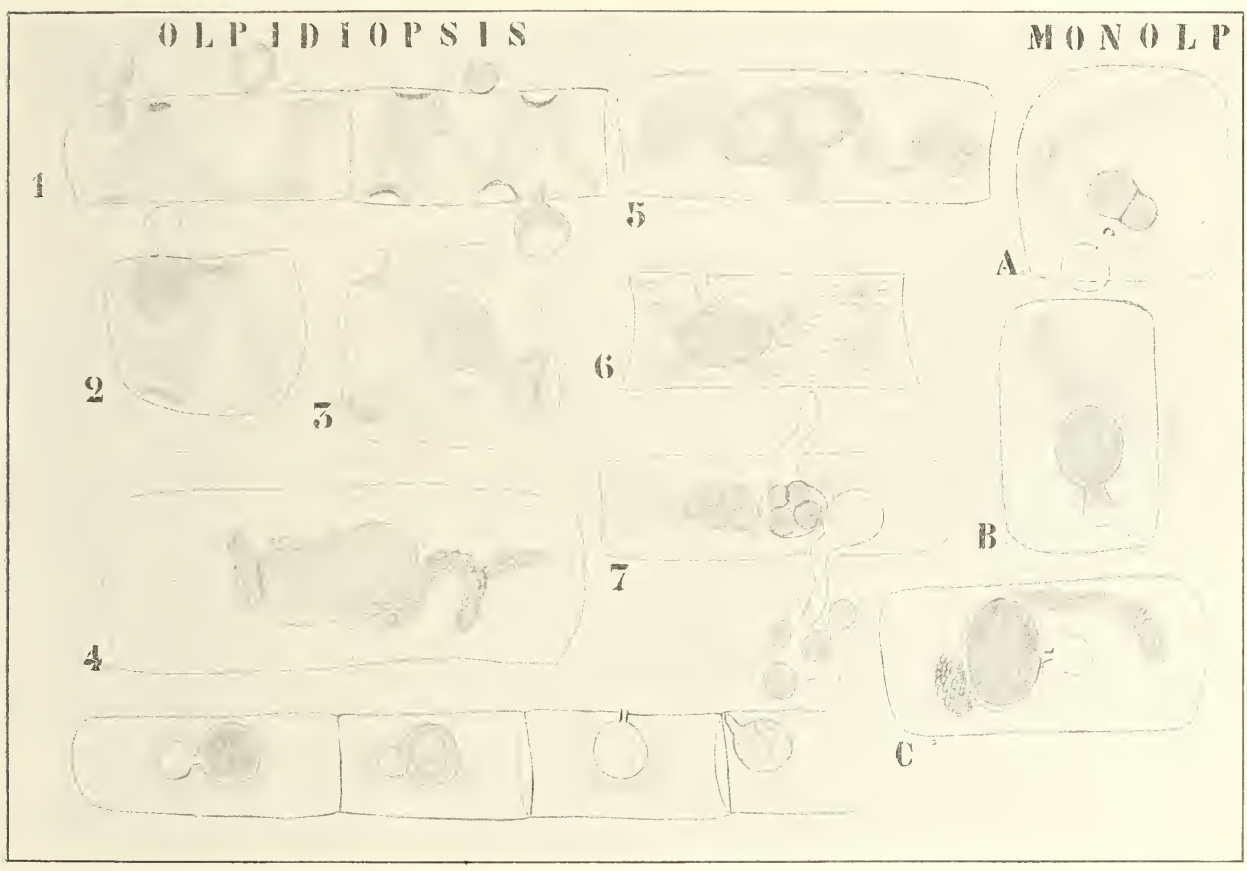

Fig. 58. Olpidiopsis Schenkiana (nach ZopF). 1 Keimung der Zoosporen auf einem Spirogyrafaden. 2 Eintritt des Parasiten. 3 Vegetativer Zustand. 4 Der Parasit zum Sporangium geworden. 5, 6, 7 Schlauchbildung und Entlassung der Zoosporen. A, B, C Kopulation.

an Spirogyra-Fäden an, bilden einen Keimschlauch, welcher die Wand durchbohrt, und lassen den Inhalt als nackte Energide in die SpirogyraZelle eintreten. Auch hier wird das Plasma vom Parasiten verzehrt, der Parasit wird zunächst kugelig, nimmt aber alsbald eiförmige Gestalt an, umgibt sich mit einer Membran und wird so zum Sporangium.

Das Sporangium bildet alsbald einen Schlauch, der die Tand der Spirogyra-Zelle durchbohrt und die inzwischen wohl durch wiederholte Zweiteilung entstandenen Zoosporen austreten läßt; die austretenden Zoosporen infizieren neue Spirogyra-Fäden, und es fängt die Entwickelung. von neuem an. Zahllose solcher Generationen folgen im Sommer auf- 
einander, denn zum Durchlaufen dieses Entwickelungsganges braucht das Pflänzchen nur etwa 48 Stunden.

Im Herbst aber, oder in Kulturen bisweilen bereits nach 2-3 Wochen, treten geschlechtliche Individuen auf.

Die aus der eingekapselten Schwärmspore ${ }^{1}$ ) entschlüpfte Energide umgibt sich alsbald mit einer Nembran und teilt sich in zwei Zellen (Fig. 58, A), eine dieser beiden vergrößert sich, und es tritt der Inhalt der kleineren Zelle in die größere über, wir haben es hier also mit einem Oogon und mit einem Antheridium zu tun. Leider ist die Keimung der Zygote nicht bekannt.

Im gleichen Spirogyra-Faden können ungeschlechtliche und geschlechtliche Individuen des Parasiten vorkommen.

Zur Familie der Monolpidiaceae gehört noch eine Anzahl anderer Genera, welche aber alle in der Hinsicht übereinstimmen, daß die Pflanze während der ganzen Dauer ihres vegetativen Lebens nackt ist, sich kurz vor der Fruktifikation mit einer Membran umgibt und so in toto zum Sporangium wird, daher der Name Mo nolpidiaceae.

Anders bei der Familie der

\section{Merolpidiaceae,}

bei welcher aber ebenfalls die Pflanze während des vegetativen Lebens nackt ist. Auch hier umgibt sie sich kurz vor der Fruktifikation mit einer Membran, der Inhalt aber, die Pflanze selber also, verwandelt sich nicht zu einem Zoosporangium, sondern bildet deren mehrere, daher der Name M e rolpidiaceae.

Ein Beispiel wird Ihnen das klar machen. Wählen wir dazu das 1868 von Woronin untersuchte

\section{Synchytrium Mercurialis FckL.}

Dieser Pilz wurde von Woronin sowohl bei St. Petersburg, wie bei Langen-Schwalbach auf Mercurialis perennis angetroffen. Er lebt parasitisch auf Mercurialis perennis und bildet auf der unteren Seite der Blätter dieser Pflanze oder auch wohl auf beiden Seiten kleine Warzen. Macht man einen Längsschnitt durch ein solches Höckerchen, so stellt es sich heraus, daß es von einer stark vergrößerten Epidermiszelle gebildet wird, welche von einer, von den umgebenden Epidermiszellen ausgehenden Wucherung wie von einem Ringwall umgeben ișt (Fig. 59, 1).

Im Innern einer solchen hypertrophierten Epidermiszelle befindet sich eine große, länglich-ovale Spore, welche in reifem Zustande von einer dicken braunen Wand bekleidet ist. Während des Winters faulen die auf den Boden gefallenen Mercurialis-Blätter und die Sporen werden infolgedessen frei. Im Frühjahr keimen sie in der faulenden Laubmasse und können dann, in unten zu beschreibender Weise, die jungen Mercurialis-Sprossen in dem Moment, wo sie sich durch diese Laubmasse hindurcharbeiten, infizieren.

Am besten kann man die Keimung dieser großen Sporen verfolgen, wenn man im Herbst eine Anzahl infizierter Mercurialis-Blätter mit nach Hause nimmt und in einem mit Wasser gefüllten Glasgefäß aufbewahrt.

1) Ganz sicher ist der genetische Zusammenhang noch nicht, da der strikte Beweis, daß die Geschlechtspflanzen aus den Schwärmern entstehen, nicht erbracht wurde. 
Man sollte das Masser jede 2-3 Tage wechseln und die verfaulten Blattpartikelchen mitausschütten; so fault dann schließlich die ganze Blattmasse weg und es bleiben die Sporen auf dem Boden des Gefässes zuriick.

Im Frühjahr beginnt die Keimung. Es zeigt sich nun, daß die Spore von 2 Wänden, einem Exospor und einem Endospor, umgeben ist. Durch einen Riß im Exospor quillt alsbald das Endospor heraus (Fig. 59, 2), diese Ausstülpung vergrößert sich so lange, bis der ganze Inhalt der Spore darin übergetreten ist (Fig. 59, 3). Das leere Exosporium bleibt noch lange mit diesem Endosporsack in Verbindung.

Im Plasma treten nun Teilungen mit Zellwandbildungen gepaart auf, wodurch ein vielzelliger Körper entsteht (Fig. 59, 4). Dieser Zell-

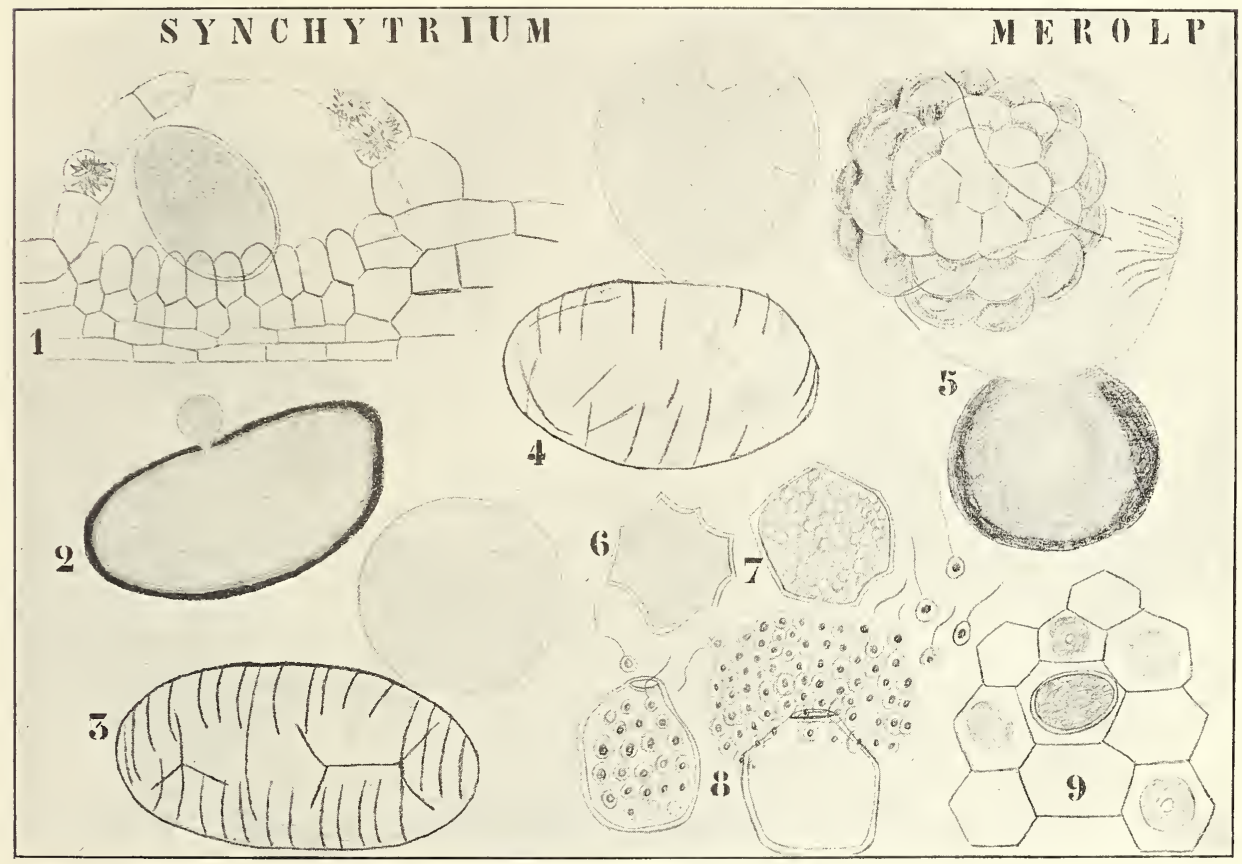

Fig. 59. Synchytrium M ercurialis FCKL. (nach Woronin). 1 Längsschnitt einer Warze. 2, 3 Keimung der Dauerspore. 4 Bildung der Sporangien in der Keimblase. 5 Austritt der Sporangien. 6-8 Sporangien zoosporenbildend. 9 Die Parasiten im Vegetationszustande in den Epidermiszellen der Mercurialis.

komplex fängt alsbald zu schwellen an, zerreißt das Endospor und tritt in Form einer Maulbeere heraus (Fig. 59, 5). Sodann fällt er in seine einzelnen Zellen auseinander, und es bildet sich in jeder Zelle eine Anzahl von Zoosporen aus (Fig. 59, 6-8). Der Zellkomplex bestand also aus Zoosporangien. Die Zoosporen besitzen nur 1 Cilie, sie dringen in der Natur in die jungen Mercurialis-Sprosse ein. Hier sieht man sie als nackte Energiden in den Epidermiszellen liegen; sie müssen wohl ihre Nahrung aus in die betreffenden Epidermiszellen eintretenden Substanzen entnelimen, denn die infizierte Zelle geht nicht nur nicht zu Grunde, sondern wird sogar zu übermäßigem Wachstum gereizt, ein Reiz, der sich sogar in den benachbarten Epidermiszellen zeigt, so daß 
eine kleine Galle gebildet wird. Der Parasit umgibt sich jetzt mit einer Membran und wird zur Spore, von welcher wir bei unseren Betrachtungen ausgingen.

Die Fortpflanzung ist demnach rein ungeschlechtlich, eine geschlechtliche scheint der ganzen Familie der Merolpidiaceae, auch wohl Synchytriaceae genannt, zu fehlen.

Ueber die Cytologie liegen Mitteilungen von Dangeard (1893), Rosén (1893), Stevens (1903), Loewenthal (1904) und Harper (1899) vor.

Letzterer bringt die meisten Angaben, aus welchen folgendes entnommen werden mag:

Synchytrium decipiens ist ein Parasit auf Glycine comosa, wo sie

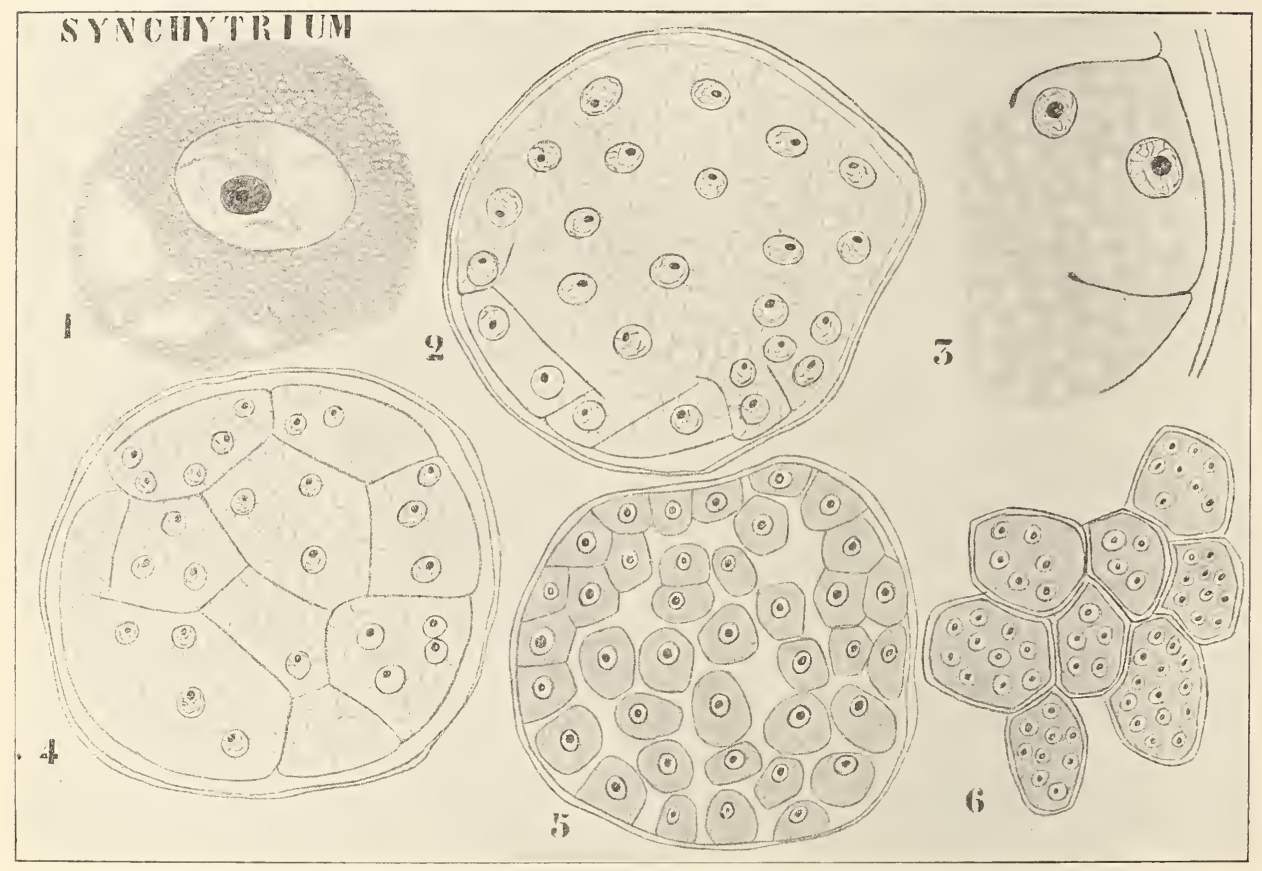

Fig. 60. Synchytrium decipiens (nach HARPER). 1 Fast erwachsene Zelle. 2 Vielkerniger Zustand, in welchem die progressive Spaltung, von der Peripherie ausgehend, angefangen hat. 3 Stück der Peripherie beim Anfang der Spaltung. 4 Schnitt, die Oberfläche der Zelle bei Anfang der Spaltung zeigend. 5 Die Zelle beim Ende der Spaltung die uninucleären Sporangien zeigend. 6 Anfang der Bildung der Schwärmer.

die Epidermiszellen in ähnlicher Weise wie S. Mercurialis zur Hypertrophie veranlaßt.

Der Parasit besitzt bis zum erwachsenen Zustand einen Kern.

Bald tritt er in den Sporenzustand ein, und die Sporangien werden durch progressive Spaltung des Inhaltes gebildet. Die jungen Sporangien, die Zellen des Maulbeerstadiums, sind zunächst einkernig, alsbald fängt aber die Keimung an, welche sich durch das Mehrkernigwerden der Sporangien äußert, es werden dann die Membranen um sie herum gebildet, und es treten nach dem Austritt dieser Sporangien die uninukleären Zoosporen heraus. 
Der gamze Torgang ist also, wie schon auf p. 38 bemerkt, vollkommen dem Terhalten von Endosphaera analog.

Nun ist ein anderes Synchytrim bekannt, nämlich S. Taraxaci, bei welchem dieser Coenobiumzustand nicht auftritt. Die kleinen Sporangien, welche bei $S$. mercurialis im Maulbeerzustand aus der Dauerzelle austreten, werden nicht gebildet, sondern die Dauerspore bildet direkt Zoosporen. Dort wird die Entwickelung abgekürzt, indem keine Spaltung bis zu einkernigen Stücken stattfindet, sondern die vielkernigen Stücke zerfallen, nachdem sie ihre Nuclei vermehrt haben, in Schwärmsporen. Die Bildung der Sporangien wird also ïbersprungen.

Wir kommen hierauf bei der Besprechung der Sporenbildung der Mucorineen zurïck.

Gehen wir jetzt zur Besprechung der Gruppe der

\section{Mycochytridiaceae}

über, welche übrigens wohl kaum eine natürliche ist, und betrachten wir zunächst die Familie der Holochytridiacecı, von welcher wir als Beispiel

\section{Lagenidium Rabenhorstii ZopF}

wählen. Dieser 1884 durch ZopF bekannt gewordener Organismus lebt in Spirogyra-Fäden und ist so häufig, daß man ihn fast stets erhalten kann. Die Schwärmer besitzen 2 Cilien und heften sich an die Spirogyren an. Hier bilden sie einen Keimschlauch, welcher die Wand der Spirogyra-Zelle durchbohrt, und dessen eingedrungene Spitze kugelig anschwillt, alsbald aber zu einem langen Keimschlauch auswächst.

Von der Cytologie ist leider nichts bekannt, wahrscheinlich aber ist dieser Keimschlauch polyenergid. Falls dies sich in der Tat als richtig herausstellen sollte, gehörte dieser Organismus nicht hierher, sondern zu den Siphonomyceten.

Bald treten in dem Keimschlauch Querwände auf und verzweigt sich das Mycelium dermaßen, daß es die ganze Spirogyrc-Zelle ausfüllt. Auch diese Zweige trennen sich durch Querwände ab, so daß schließlich der Organismus ein homocelluläres Aussehen hat.

Jede Zelle dieses Mycels kann zum Zoosporangium werden. Dazu bildet sie einen Schlauch, welcher die Spirogyra-Wand durchbohrt, und dessen ausgetretene Spitze kugelig anschwillt. Das Plasma der Zelle tritt gänzlich in diese Anschwellung ein, teilt sich dort in eine Anzahl von Schwärmern, die Wand der Anschwellung verschleimt, und die 2-ciliëgen Zoosporen treten aus.

Das vegetative Leben unseres Parasiten ist in 24-76 Stunden zu Ende, dann fängt die Fruktifikation an, welche ebenfalls nur wenige Stunden in Anspruch nimmt, so daß ein 5-tägiges Lagenidium schon recht alt ist.

Etwa im Monat Juni hört die ungeschlechtliche Vermehrungsweise nach und nach auf und wird von der geschlechtlichen abgelöst. Meistens ist dazu die Anwesenheit zweier Individuen in einer Spirogyra-Zelle erforderlich. Diese legen sich nach der Weise zweier kopulierenden Spirogyra-Fäden aneinander (Fig. 61, E), und die Plasmakörper der Zellen des männlichen Fadens treten in die des weiblichen über, wo das ơ und + Plasma sich zu einer Zygote vereinigt.

Wie schnell dieser Vorgang verläuft, geht aus den Figuren A-D hervor. Die hier miteinander kopulierenden Zellen sind die Endzellen 
der betreffenden Fäden, ein Ausnahmefall, welche aber der Beobachtung recht günstig ist. Der ganze Vorgang war in 6 Stunden beendet.

Wenn nur ein Individuum in einer Spirogyra-Zelle vorhanden ist, weiß es sich dadurch zu helfen, daß die Kopulation zwischen 2 Zweigen stattfindet (Fig. 61, F).

Cytologie und Keimung der Zygoten sind vollkommen unbekannt, eine Untersuchung also sehr anzuraten.

$\mathrm{Zu}$ dieser Familie gehören noch einige andere Arten, denen allen dieses gemeinsam ist, daß sich jede Zelle zu einem Sporangium umbilden kann, und daß Fruktifikation nur einmal stattfinden kann, weil nach derselben nur die Zellwände zurückbleiben.

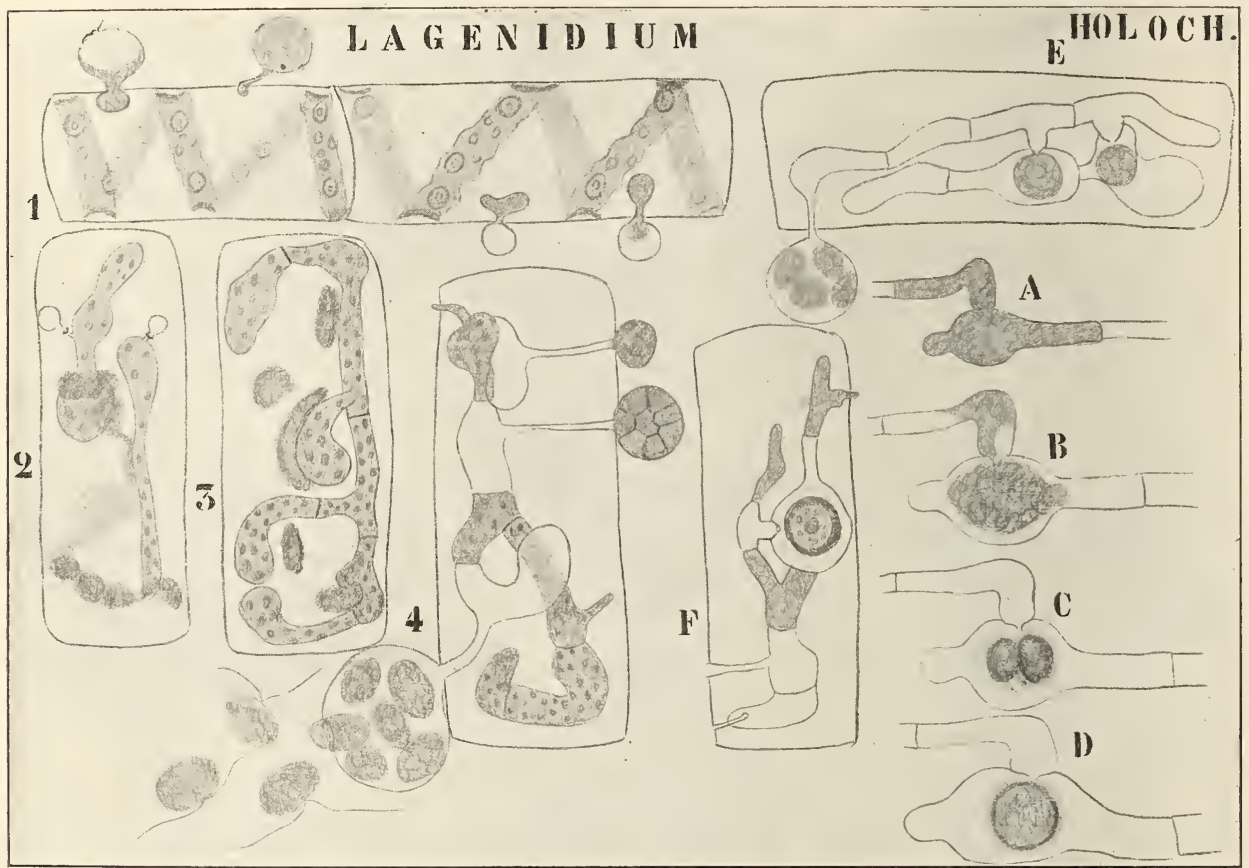

Fig. 61. Lagenidium Rabenhorstii (nach Zopf). 1 Eben in die Spirogyra eindringende Keimpflänzchen. 2 Zwei zu einem langen Keimschlauch ausgewachsene Pflänzchen. 3 Der Keimschlauch in Zellen zerlegt. 4 Bildung der Zoosporangien und Austritt der Zoosporen. A Anfang der Kopulation, zwischen zwei Individuen. B-E Bildung der Zygoten. E Neben Zygoten ist ein Zoosporangium vorhanden. F Kopulation zwischen zwei Zweigen eines Individuums.

Dies ist bei der Familie der

\section{Sporochytriaceae}

nicht der Fall. Zwar fruktifizieren auch hier die Individuen nur einmal, aber nach der Fruktifikation bleibt ein Rest übrig, ein sehr zartes Mycelium, welches aber ebenfalls bald zu Grunde geht.

Die Entwickelung dieser Organismen ist sehr einfach, aber in ihren Details noch recht wenig bekannt, cytologisch weiß man so gut wie gar nichts. 


\section{Rhizidium bulligerum ZopF}

macht eine sehr einfache Entwickelung durch. Auch sie lebt parasitisch auf Spirogyra, befällt aber meistens nur im Absterben begriffene oder im Noment der Kopulation geschwächte Zellen. Die einciliëge Schwärmspore heftet sich an die Trand der Spirogyra-Zelle an, durchbohrt diese mittels eines kurzen Keimschlauches, welcher, kaum eingedrungen, kugelig' anschwillt. Die Trand der Schwärmspore geht nicht zu Grunde, sondern verdickt sich zu einem Cellulosepfropf, daher der Name bulligerum. Die kugelige Anschwellung bildet nun einen Keimschlauch, der hart an seiner Ursprungsstelle sich stark verzweigt und ein sehr zartes Mycelium

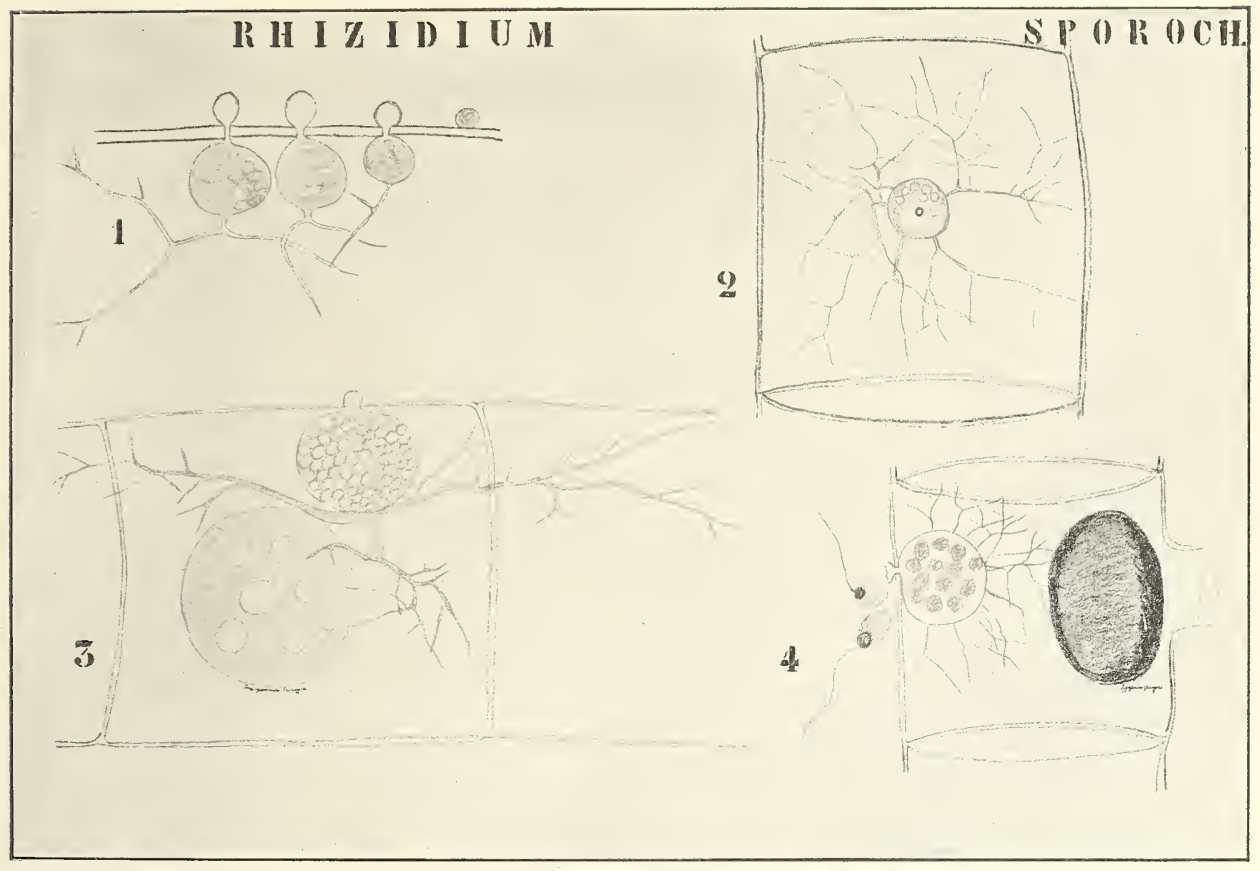

Fig. 62. Rhizidium bulligerum (nach ZoPF). 1 Eintritt der Schwärmsporen, Anfang der Mycelbildung. 2 Individuum, von oben betrachtet. 3 Schwärmsporenbildendes Individunm, von der Seite gesehen. 4 Austritt der Schwärmer. Die große Spore in der Zelle ist eine Spirogyrazygote.

bildet, das entweder auf die infizierte Spirogyra-Zelle beschränkt bleibt, oder aber auch in benachbarte Zellen vordringt.

Der Inhalt des kugeligen Körpers teilt sich nun zu Schwärmeru. welche durch den verschleimenden Cellulosepfropf das Sporangium verlassen. Damit ist die Sache beendet, das zurückbleibende Mycel stirbt ab. Die Fortpflanzung ist also hier rein ungeschlechtlich. Bei dem zur gleichen Familie gerechneten

\section{Polyphagus Fuglenae Now.}

aber wurde von Nowakowski (1876) eine geschlechtliche Fortpflanzung beschrieben. Der Organismus findet sich an der Oberfläche ron Teichen. wo er auf dem Flagellaten Euglena parasitiert. Er unterscheidet sich 
von allen anderen Arten dadurch, daß er nicht auf einem Individuum parasitiert, sondern mehrere zu gleicher Zeit aussaugt.

Die Schwärmspore keimt an der Wasseroberfläche in der Mitte von Euglena-Ansammlungen, deren Individuen eben anfangen sich zu encystieren. In diese jungen Cysten dringt das feine Mycelium der keimenden Schwärmspore ein und saugt sie aus. Je mehr Nahrung sie zı sich nimmt, je mehr Euglenen die Myceliumzweige zu erreichen wissen, um so mehr nimmt die Schwärmspore an Umfang zu. Schließlich wächst die, selbstverständlich schon lange mit einer Membran bekleidete, Schwärmspore zu einem langen Sporangium aus, in welchem einciliëge Zoosporen gebildet werden, welche durch ein Loch an der Spitze des Sporangiums austreten. Dann fängt die Entwickelung von neuem an.

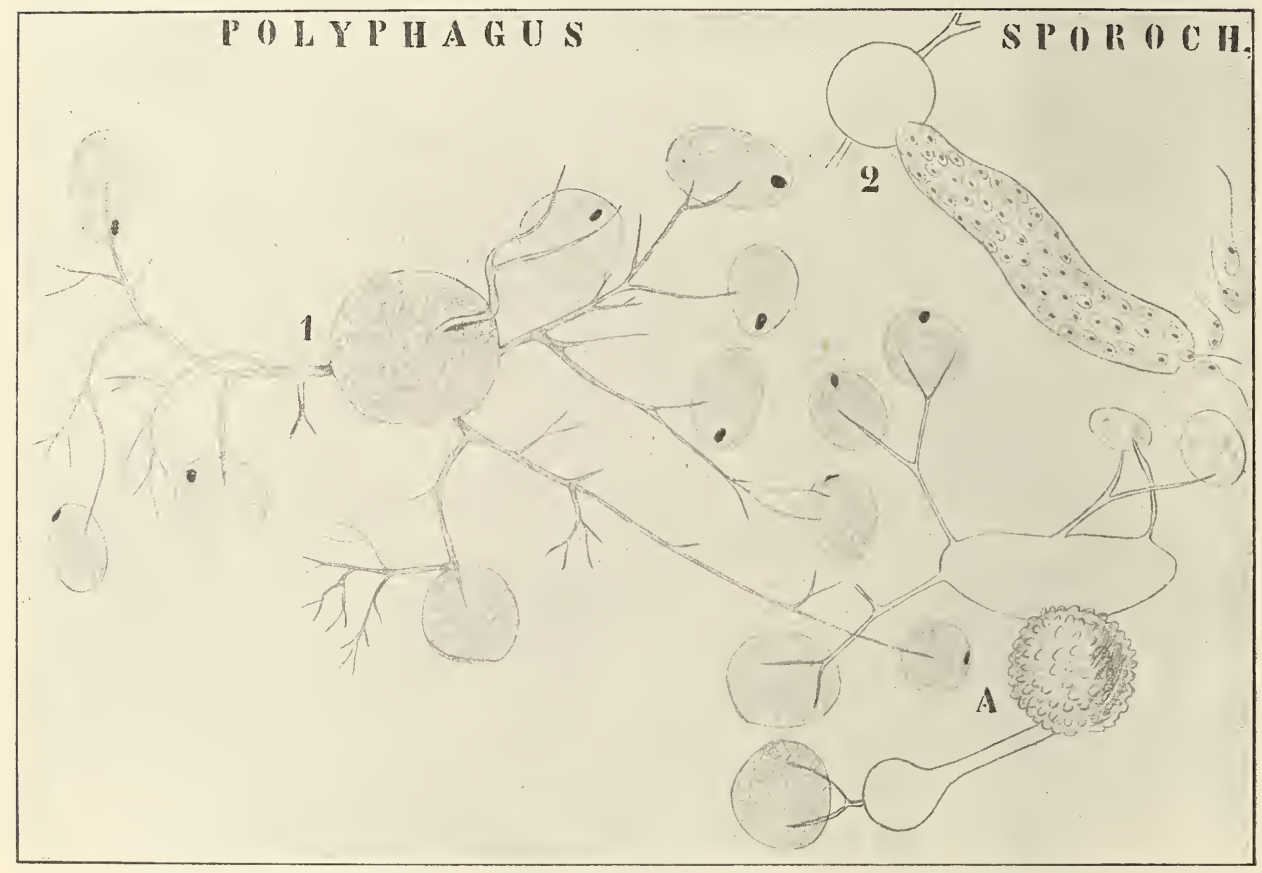

Fig. 63. Polyphagus Euglenae (nach Nowakowski). 1 Individuum, das mehrere Euglenen befallen hat. 2 Bildung des Zoosporangiums und Austritt der Schwärmer. A Kopulation zwischen zwei kleinen Individuen.

Bisweilen tritt aber geschlechtliche Fortpflanzung auf, zwei meistens kleine Individuen bilden Seitenzweige, welche miteinander kopulieren (Fig. 63, A), der Inhalt des einen tritt in den anderen ïber, und es resultiert eine warzige Zygote.

Die Keimung der Zygote ist ebensowenig, wie die Cytologie bekannt. Auch hier tritt nur einmalige Fruktifikation auf, das zarte zurückbleibende Mycel stirbt alsbald ab.

Wohl näher mit Rhiridium als mit Polyphagus verwandt ist das mir nur aus einem, Referat von Magnus bekannte Zygorhiridium Willei, welches $1904^{\circ}$ von Loewenthal beschrieben wurde. Ich gebe 
hier wieder. Was MAgrus in seinem Referat davon sagt. Es ist eine Chytridiacee, welche auf Cylindrocystis Brebissonii bei Christiania gefunden wurde.

Der einzellige Parasit sitzt außen der Wirtszelle auf und sendet in dieselbe nur eine Blase und davon ausgehende sehr feine, kurze Hyphen.

Der außerhalb der Wirtszelle gelegene größte Teil des Parasiten entwickelt sich oft zum Zoosporangium, wobei der gesamte Inhalt in viele - bis zu 40 -- Zoosporen zerfällt; ein solches Zoosporangium öffnet sich durch Abwerfung eines Deckels; die Zoospore trägt an ihrem spitz zulaufenden Hinterende eine Geißel, setzt sich aber seitlich an der ITirtszelle fest.

Im anderen Falle sendet der aufsitzende Parasit außerhalb der Wirtszelle einen, seltener zwei schlauchförmige Fortsätze aus, die zu anderen, gewöhnlich größeren. Parasiten hinwachsen und mit ihnen kopulieren.

Ersteres sind die befruchtenden männlichen, letzteres die befruchteten weiblichen Geschlechtszellen der Parasiten. Aus der Kopulation geht die Zygote hervor, die eine etwa $1 \mu$ dicke durchsichtige, ungefärbte, glatte Membran hat.

Auch hier ist aber leider die Keimung der Zygote sowie die Cytologie unbekannt.

Während bei allen diesen Formen das Mycel noch recht schwach ist, wird in der Familie der

\section{Hyphochytridiaceae}

ein kräftiges Mycel gebildet. Als Beispielt gelte:

\section{Hyphochytrium infestans ZopF,}

welches parasitisch auf höheren Pilzen aus der Gruppe der Ascomyceten lebt. Es wurde von ZopF auf einer Helotium-ähnlichen Periracee auf Pappeln bei Berlin im Februar 1879 entdeckt.

Wir haben es hier also mit einem landbewohnenden Pilz zu tun, welcher sich aber das zu seiner Entwickelung nötige Wasser durch Zersetzen des Wirtes verschafft. Die Entwickelung ist noch recht unvollständig bekannt.

Der erwachsene Pilz besteht aus einem kräftigen homocellulären, spärlich verzweigten Mycel, welches den ganzen Periza-Körper durchsetzt und in der Ascusschicht besonders üppig gedeiht. Es verhindert die Reifung der Asci. Sowohl intracellulär wie apikal bildet es durch Anschwellung der Zellen Sporangien, deren Inhalt in einciliëge Schwärmer zerfällt (Fig. 64).

Vielleicht gehört der Organismus gar nicht hierher, und ist mit Pythium unter den Siphonomyceten einzureihen, bei welchem Falle es sich als polyenergid herausstellen dürfte.

Wir kommen jetzt zu der Besprechung derjenigen Pilze, welche zweifellos von Siphonophyceen abzuleiten sind, zu der Gruppe der

\section{Siphonomyceten.}

Es ist dies eine außergewöhnlich formenreiche Gruppe, deren Vertreter jedoch dieses gemeinsam haben, daß die meistens schlauchförmige. öfters vielfach verzweigte Zelle, welche ihr Thallus bildet, polyenergid ist. 
Bei der Einteilung dieser Gruppe, welche, nebenbei bemerkt, sehr schwierig ist, müssen wir uns zunächst fragen, von welchen Formen die Siphonomyceten abstammen dürften; etwas Näheres, als schon bemerkt wurde, läßt sich aber gar nicht aussagen, wir müssen damit zufrieden sein, daß sie grünen Algen, und zwar Siphonophyceen, entstammen.

Daher sind diejenigen Siphonomyceten, welche die größte Algenähnlichkeit haben, an den Anfang der Reihe zu stellen, wenn damit auch keineswegs gesagt werden soll, daß sie wirklich als niedrigste Siphonomyceten, als Prototypen der Gruppe zu betrachten sind. Gerade die Gruppe, welche am meisten an Siphonophyceen erinnert, ist, da sie oogam ist, gewiß nicht primitiv. Es ist die Gruppe der

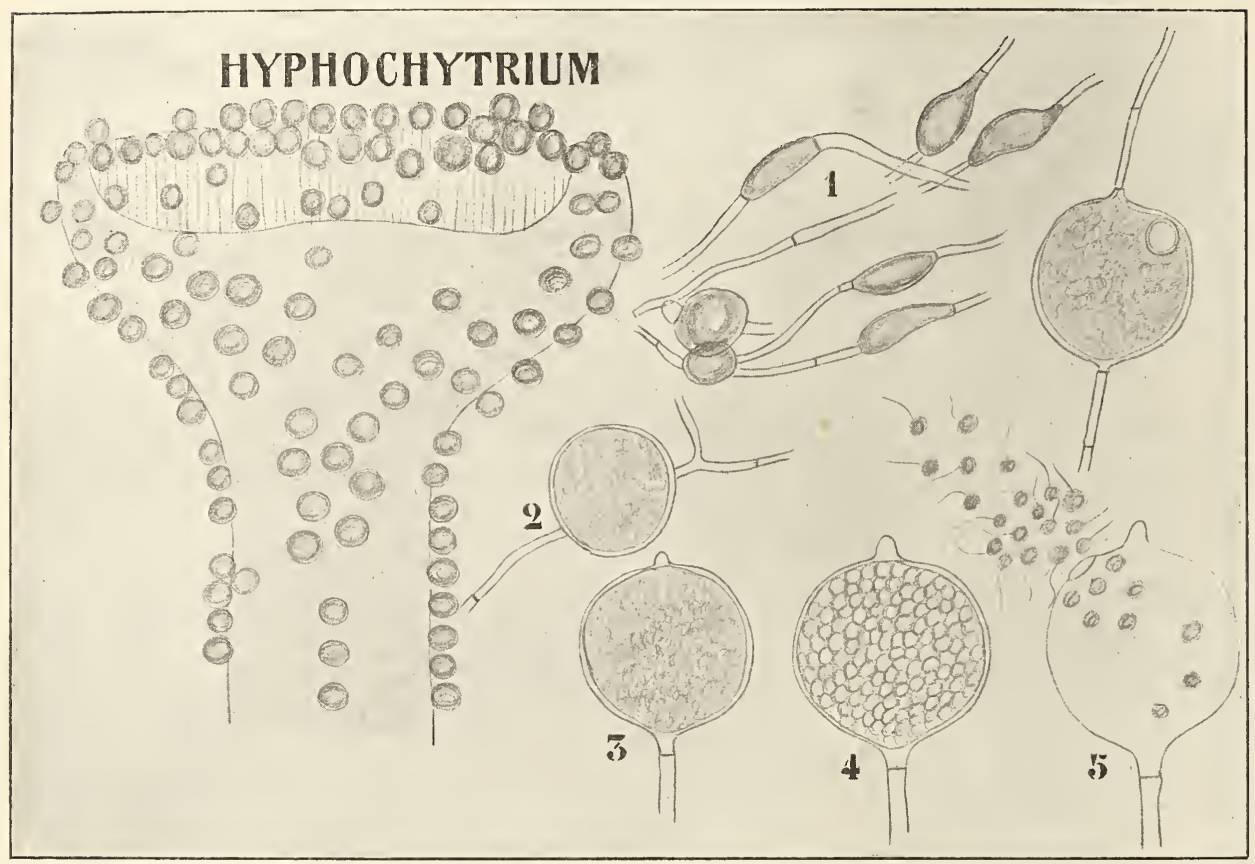

Fig. 64. Hyphochytrium infestans nach Zopf. Links die vom H. befallene Pezizacee. 1-5 Entwickelung des Sporangiums und der Zoosporen.

\section{Monoblepharideae.}

Die Angehörigen dieser Familie sind Wasserbewohner, sie leben in Teichen und Gräben, auf faulenden Zweigen, sind aber nur selten gefunden worden.

Wir kennen bis jetzt mit Sicherheit nur ein Genus:

\section{Ironoblepharis,}

welches nur einige wenige Arten umfaßt. Die erste Mitteilung über dieses Genus rührt von Connu (1871) her. Im nächsten Jahre bildet er in seiner Monographie der Saprolegnieen 2 Arten ab: M. sphaerica und M. polymorpha und beschreibt diese ausführlich. 1878 beschrieb Reinsch unter dem Namen Saprolegnia siliquaeformis einen Pilz, welcher von Cornu zu Monoblepharis gezogen, von Fischer (Rabenhorst, 
Kryptogamenflora) und ron Thaxter (Bot. Gaz. XX, 1895, p. 437) wieder aus diesem Genus ausgewiesen und Gonapodya zugewiesen wurde. Bis zum Jahre 1895 wurden dann keine Monoblepharideen mehr gefunden, als THaxter in Amerika wieder einige Arten entdeckte.

Ich will hier

\section{Monoblepharis insignis THAXTER}

mit Thnen besprechen, welche dasselbe Vorkommen wie die Cornuschen Arten zeigt, nämlich auf abgestorbenen, in Wasser liegenden Baumzweigen. Sie wurde bei Weston und Metford in Massachusetts entdeckt.

Der Pilz besteht aus festen, geraden Fäden, welche sich nur selten

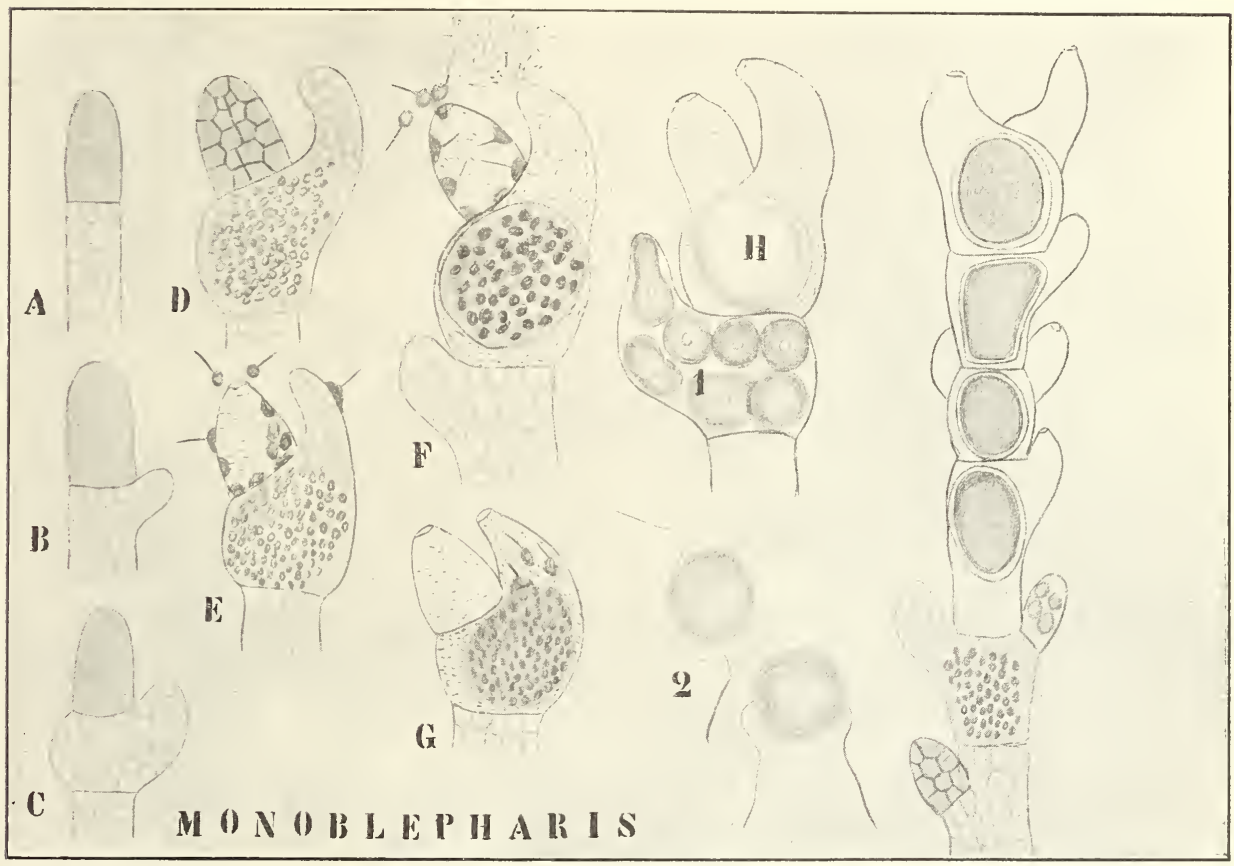

Fig. 65. Monoble pharis insignis nach THAxter. A-C Bildung des Antheridiums und des Oogons. D Anfang der Spermatozoen- und der Eibildung. E Ausschlüpfen der Spermatozoen, eins bewegt sich amöboid auf das Oogon. F Eibildung. G Die Spermatozoen im Oogon. H Zygote; die mit 1 bezeichnete Zelle ist nach THAXTER ein Zoosporangium, mag aber nach WoronIN vielleicht ein von einem Parasiten befallenes Oogon sein. 2 Zoosporen nach THAXTeR, vielleicht aber nur Parasiten. - Rechts ein Faden mit vielen Zygoten in successiv gebildeten Oogonen.

verzweigen und sugar im sterilen Zustande leicht von anderen Siphonomyceten durch die alveoläre Struktur ihres Plasmas zu unterscheiden sind.

Wenn die Pflanze sich zur Fortpflanzung anschickt, bildet sie in der Nähe der Spitze eine Querwand, wodurch eine wahrscheinlich rielkernige Scheitelzelle gebildet (Fig. 65, A) wird. Diese wird später zum Antheridium. Alsbald bildet der Faden direkt unter dem Antheridium eine Ausstülpung, und es entsteht etwas weiter nach unten eine zweite Querwand, wodurch eine zweite Zelle abgetrennt wird. welche zum Oogonium wird. 
Verfolgen wir zunächst die weitere Entwickelung des Antheridiums. Sein Plasma zelfällt in eine Anzahl nackter Energiden: die Spermatozoiden. Jeder derselben bildet eine einzige Cilie und die Spermatozoen schlüpfen heraus.

Sogar wenn sie noch in dem Antheridium geschlossen sind, zeigen diese Spermatozoiden die auffällige Eigenschaft, sich amöboid bewegen zu können. Sie schwimmen nicht auf die Oeffnung des Antheridiums zu, wie andere Spermatozoen, sondern kriechen an der Innenseite des Antheridiums empor, bis sie die Oeffnung erreicht haben. Dann erst verwenden sie ihre Cilie und schwimmen fort.

Es bleibt nach dem Ausschwärmen der Spermatozoen etwas Plasma im Antheridium zurück, was aber keine Bedeutung haben dürfte.

Während sich im Antheridium die Spermatozoen entwickelten, sind auch im Oogon Veränderungen aufgetreten: Diese zeigen sich zunächst in der Bildung von Oeltropfen und in dem Auswachsen der Ausstülpung zu einem Halsteile (Fig. 65, D), welcher letztere sich etwas nach dem Antheridium hinkrümmt. Die Oeltropfen sammeln sich zu einer kugeligen Masse im Oogonbauch an, auch das Plasma strömt, mit Ausnahme eines dünnflüssigen Restes, dort hin. So wird das auffallend fettreiche Ei gebildet.

Es öffnet sich dann das Oogon an der Spitze, und der dünnflüssige Plasmarest wird mit bedeutender Kraft ausgestoßen.

Schon bevor sich das Oogon geöffnet hat, sieht man öfters Spermatozoen auf dessen Außenseite herumkriechen. Diese dringen nun in das Oogon ein, und es verschmilzt wohl ein einziges mit dem Ei, wodurch die Zygote gebildet ist.

Ein Faden kann nacheinander eine ganze Reihe von Antheridien und Oogonen bilden, oder aber er kann nach kürzerer oder längerer Zeit zur Bildung von Organen schreiten, welche nach THAXTER Zoosporen bilden. Die Anlage dieser Zoosporangien erfolgt genau wie die der Oogonien. In diesen Organen werden aber keine Eier, sondern sehr große zweiciliëge Schwärmer gebildet, welche THaxter für Zoosporen hält.

Es würden dann die Spermatozoen eine, die Zoosporen aber zwei Cilien haben, dieser Umstand brachte Woronss dazu, zu fragen, ob die vermeintlichen Zoosporen nicht Parasiten sein könnten.

In der Bildung seiner Oogonien und Antheridien zeigt Monoblepharis insignis offenbar Anklänge an Vaucheria. Falls die fraglichen Organe aber Zoosporen sind, ist sie dadurch von Vaucheria recht verschieden.

Zoosporen mit vielen Cilien, so wie die der Vaucheria, waren bis 1895 bei Siphonomyceten gänzlich unbekannt.

In diesem Jahre wurden sie von THaxter bei einem gleichfalls im Wasser lebenden Pilze, dem Genus Myrioblepharis angehörig, entdeckt. Leider ist von diesem Genus die geschlechtliche Fortpflanzung gänzlich unbekannt. Der Umstand aber, daß er mit Myrioblepharis insignis zusammen vorkommt, regt die Frage an, ob er nicht zu dem Entwickelungskreise von Monoblepharis insignis gehören könnte. In dem Falle konnte aber der Namen Monoblepharis insignis nicht bestehen bleiben, da wir später sehen werden, daß Monoblepharis nach Woronis einciliëge Zoosporen besitzt.

\section{Myrioblepharis paradoxa}

wurde von THAxтеR mit Monoblepharis insignis zusammenwachsend entdeckt. 
Sie zeigt denselben Habitus wie Monoblepharis, pflanzt sich aber nur ung.eschlechtlich fort (Fig. 66).

Dazu schwellen die Spitzen der Fäden stark au, trennen sich mittels einer Querwand rom Rest des Fadens und werden zu Zoosporangien. Die Takuolen im Zoosporangium werden bedeutend kleiner, und die dadurch rerdichtete Plasmamasse wird, ohne daß weitere Veränderungen stattgefunden haben, in toto ausgestoßen. Aber nicht ganz, sie bleibt auf der geöffneten Spitze des Zoosporangiums liegen, wo sie durch eine sie nmgebende Schleimmasse festgehalten wird.

Inzwischen bildet sich innerhalb des leeren Sporangiums durch Hervorstülpung der basalen TTand ein zweites (Fig. 66, 3). Dieses zweite Zoosporangium zerreißt, wenu es die nackte Plasmamasse, welche

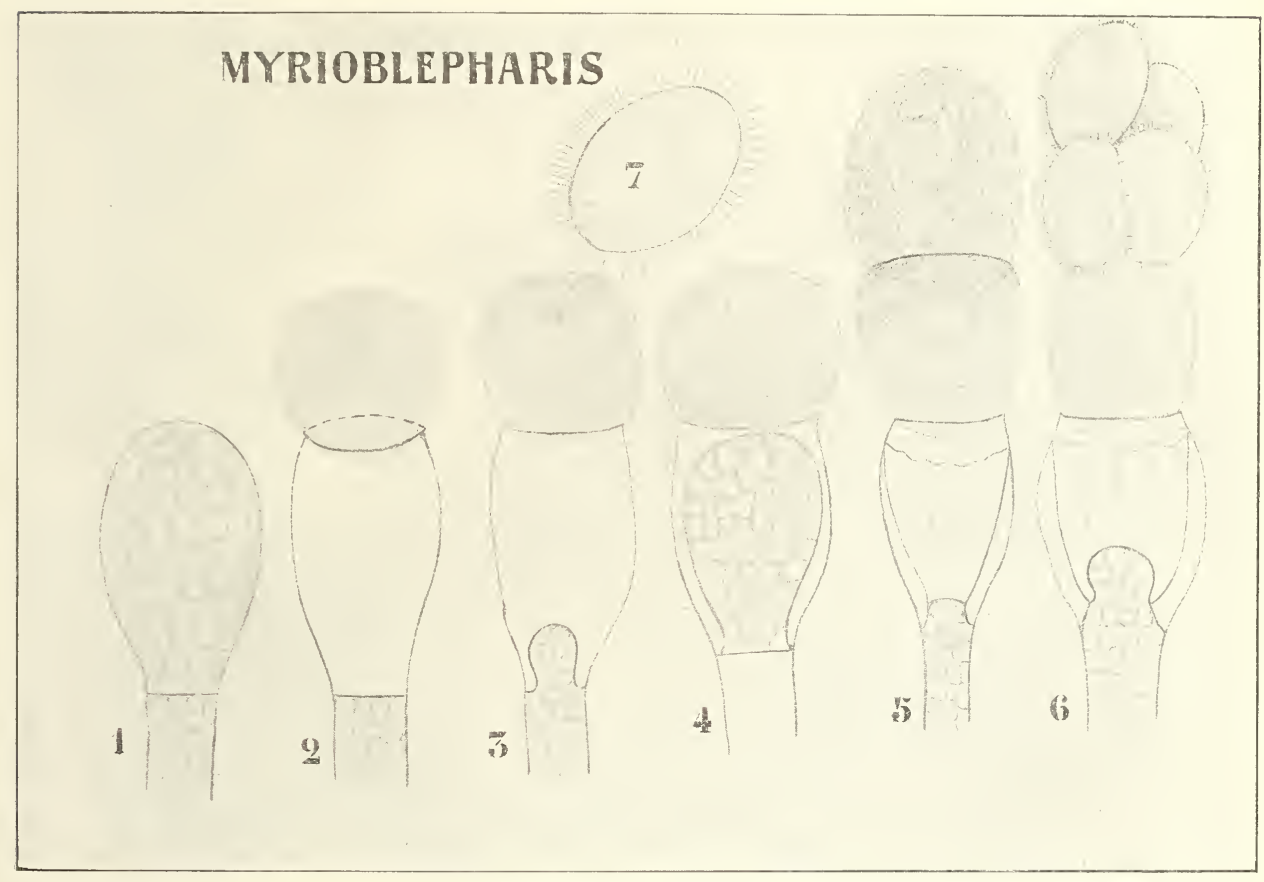

Fig. 66. Myrioblepharis paradoxa (nach THAxTER). 1-6 Bildung des Zoosporangiums und der Zoosporen.

vom ersten ausgestoßen wurde, berührt, und läßt seinen Inhalt gleichfalls austreten. Beide Plasmamassen bleiben nun an der Spitze des ersten Zoosporangiums kleben. Inzwischen fängt die Bildung des dritten Sporangiums an; bevor es aber ausgewachsen ist, teilt sich die aus dem ersten Zoosporangium ausgetretene Plasmamasse in 4 vielciliëge Zoosporen. welche fortschwimmen.

Im Jahre 1900 fand LAgERHerm eine Nethode, wodurch sich Monoblepharideen immer leicht beschaffen lassen. NLan nimmt dümne Zweig'e verschiedener Bäume, die von Flechten oder Pyrenomyceten befallen sind und den Winter über im Wasser gelegen haben, im feuchten Zustande mit nach Hause. Legt man num einige (nicht zu viele) in eine Schale mit reinem Leitungswasser, so treten fast ohne Ausnahme Mono- 
blepharideen an denselben auf. Vorzugsweise zeigen sich dieselben an Stellen, wo die Rinde abgefallen ist, an den Flechten und an den alten Perithecien der Pyrenomyceten. Am besten entwickeln sich die Monoblepharideen, wenn das Wasser sich klar hält und also nicht gewechselt zu werden braucht, was man dadurch erreicht, daß man nur einige wenige Zweigstücke in jede Kulturschale legt. Die Zweigstücke müssen nahe der Wasserfläche liegen, weil die Monoblepharideen sich sonst nicht oder nur kümmerlich entwickeln. Durch Auflegen eines Glasdeckels hält man die Kulturen staubfrei.

Die Vegetationszeit der Monoblepharideen scheint in das Frühjahr und den Herbst zu fallen. Die im Frühjahr gebildeten Oosporen keimen im Herbst und entwickeln dann an den Zweigen, die im Sommer im

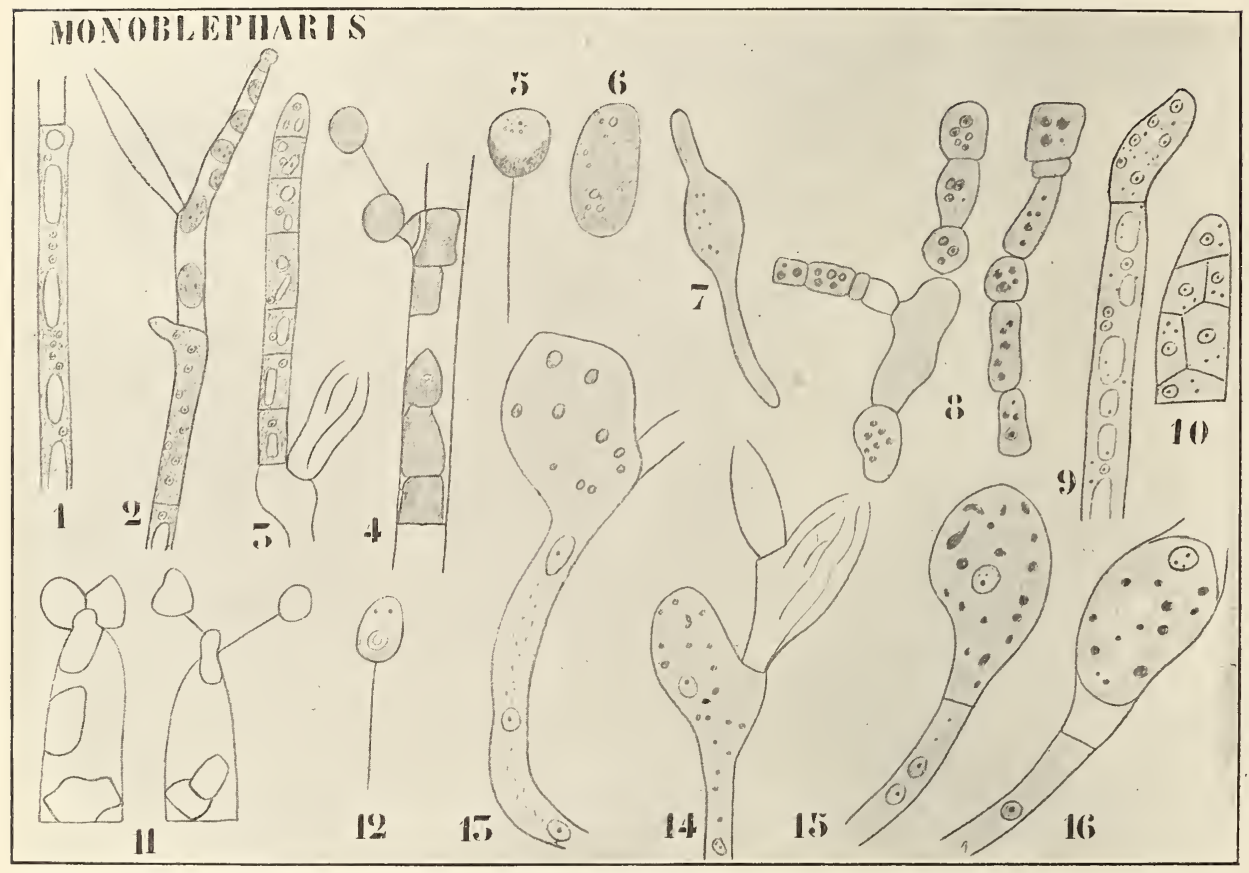

Fig. 67. Mo noblepharis (nach LAGERHeIm). 1 Vielkernige vegetative Hyphe. 2, 3 Zoosporenbildung. 3 Die einkernigen Stücke werden zu Zoosporen. 4 Ausschlüpfen der Zoosporen. 5 Zoospore, bei der Bewegung wird die Cilie nachgeschleppt. 6, 7 Keimung einer Zoospore. 8 Gemmenbildung. 9 Anlage eines Antheridiums, das Anth. ist vielkernig. 10 Anfang der Spermatozoenbildung. 11 Ausschlüpfen der Spermatozoen. 12 Spermatozoon. 13 Anfang der Oogonienbildung, ein großer Kern tritt in die Oogonanlage ein. 14 Der Kern im jungen Oogon. 15 Das Oogon hat sich mittels einer Querwand vom Faden getrennt. 16 Oeffnung des Oogons, das Ei bewegt sich auf die Oeffnung zu.

Wasser gelegen haben, eine neue Vegetation, deren Oosporen überwintern, um im Frühjahr sich weiter zu entwickeln. Im Sommer scheinen sie durch Algen unterdrückt zu werden. Die von LAGERHeim beobachteten $M$. brachyandra und $M$. polymorpha zeigen sich als kleine, bis ungefähr 5 mm hohe, dichte Büschel oder Rasen, die im vegetativen Zustand weiß, im fruktifizierenden bräunlich sind.

Lagerhem wies nach, daß die Monoblepharideen in der Tat poly- 
energid sind, die Kerne zeigen eine große Aehnlichkeit mit denen der Saprolegniaceen.

Die Zoosporangien bilden sich an den Hyphenspitzen, sie enthalten viele Kerne; die Zoosporen werden in derselben Weise wie bei den Saprolegniaceae gebildet, sie haben einen Kern und eine Cilie.

Bei einer von LAGERHeIm beschriebenen neuen Art, bei $M$. brachyandra, tritt Gemmenbildung auf. Teile der Hauptachse und der Zweige zergliedern sich in kürzere oder längere Zellen; diese runden sich $a b$ und bleiben rosenkranzähnlich aneinander hängen. Ihre Membran verdickt sich und wird bräunlich, im Zellinhalt treten Fettröpfchen auf. die sich im Zentrum ansammeln. Die Keimung wurde nicht beobachtet.

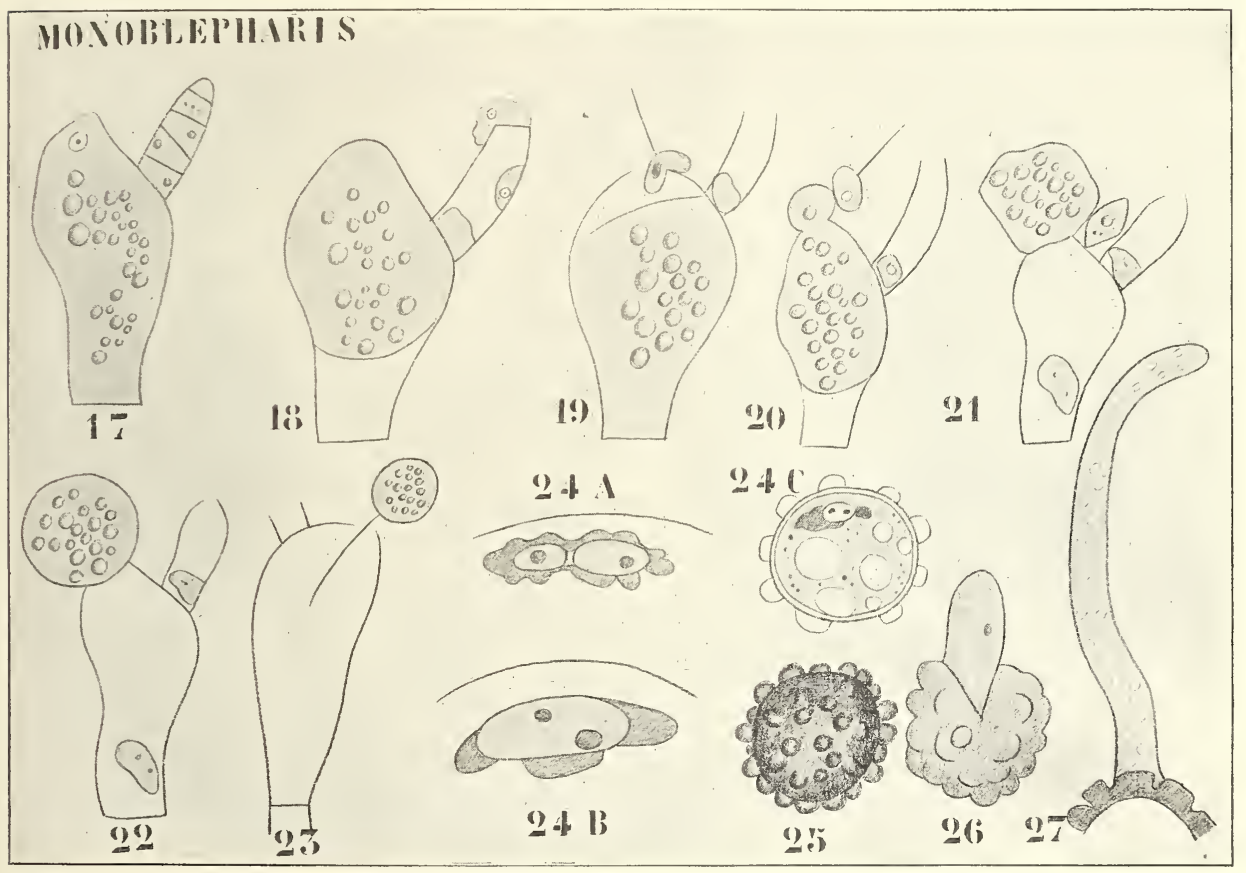

Fig. 68. Monoblepharis (nach LAGERHeIM). 17 Antheridium und Oogon noch ungeöffnet. 18 Ein Spermatozoon kriecht heraus. 19 Ein Spermatozoon dringt in das Oogon ein. 20 Kopulation. 21 Die Zygote kriecht aus dem Oogon heraus. 22, 23 Eingekapselte Zygoten. 24 A, B, C Verschmelzung von Ei und Spermakern. 25 Reife Zygote. 26, 27 Keimende Zygoten.

In den Antheridien sind so viele Zellkerne vorhanden wie später Spermatozoiden. Die Oogonien sind einkernig, indem nur ein Kern in das junge Oogon eintritt.

Bei M. polymorpha und M. brachyandra wird nach den Beobachtumgen Lagerheims die Zygote amöboid beweglich und kriecht aus dem Oogon heraus. Bei M. brachyandra bleibt sie an der Spitze des Oogons kleben. bei $M$. polymorpha tritt sie ganz heraus. Es können die amöboiden Bewegungén noch lange, sicher mehr als eine Stunde anhalten. Nachdem sie aufgehört haben, wird die Zygote von einer allmählich dicker werdenden Membran umgeben. 
Nicht befruchtete Eier umgeben sich innerhalb des Oogons mit einer Membran.

In der jungen Zygote bleiben die elterlichen Kerne zunächst nebeneinander liegen, erst bei der Ausbildung der Oosporenwarzen verschmelzen sie. Die Zygote wächst nach der Ruhe zu einer neuen Monoblepharis aus.

Ich habe dem LAGERHermschen Artikel nur die Cytologie entnommen, da ich Thnen die Morphologie an der Hand der schönen Abbildungen WORONINS schildern möchte.

Dieser verdienstvolle Forscher hat leider seine MonoblepharideenArbeit nicht mehr veröffentlichen können, nur die Tafeln und ein Teil des Textes waren fertig und wurden seinem Wunsche gemäß nach seinem Ableben von Tranzschel veröffentlicht.

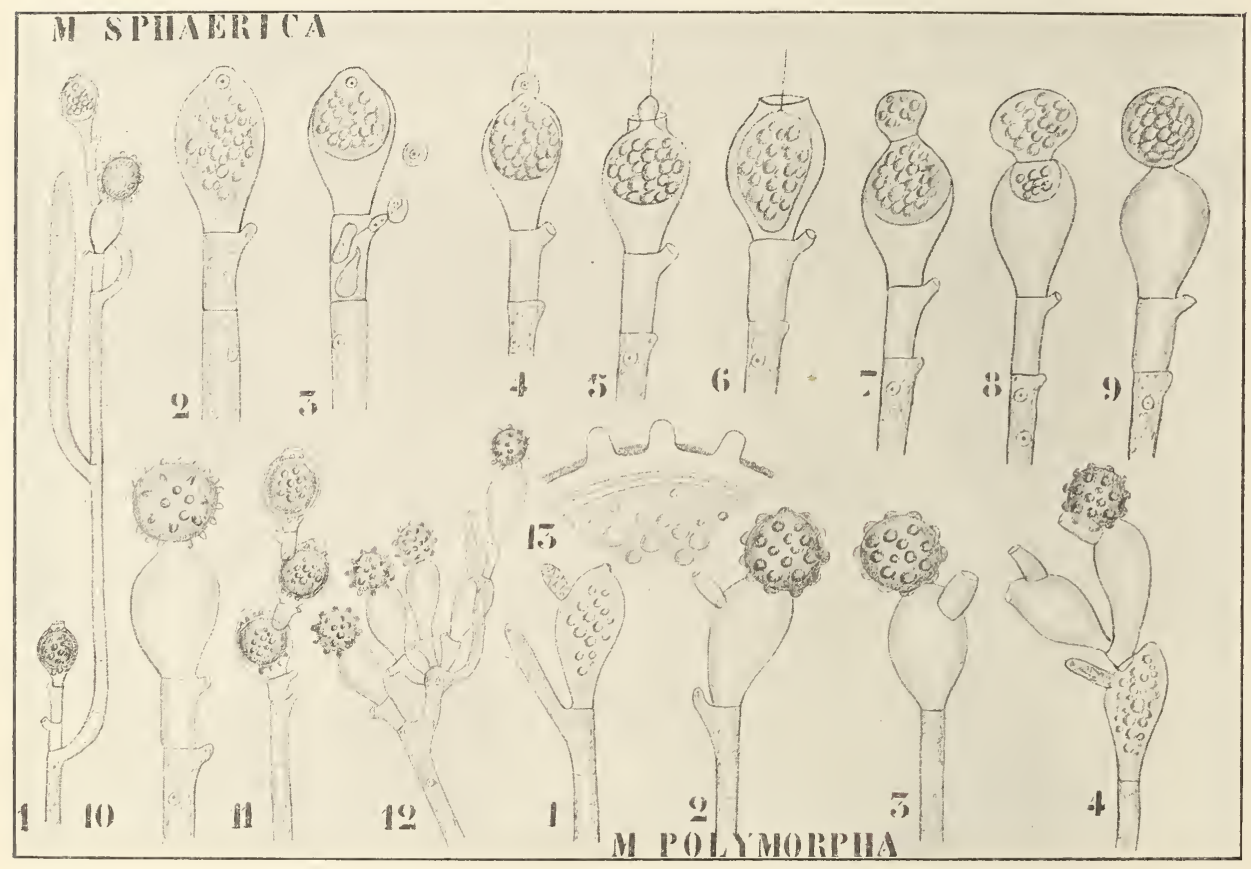

Fig. 69. I. Monoblepharis sphaerica (nach Woronin). 1 Faden mit einem Zoosporangium, Oogonien und Antheridien. 2 Oogon und Antheridium noch geschlossen. 3 Oeffnung des Antheridiums. 4 Das Spermatozoon sitzt der Papille des noch immer ungeöffneten Oogons auf, welche es, um einzudringen, auflöst. 5, 6 Kopulation eines Spermatozoons mit dem Ei, das Ei dadurch scheinbar cilie-tragend. 7-10 Ausschlüpfen und Einkapseln der Zygote. 11 Faden mit 3 Oogonien. 12 Büschelig verzweigter Faden. 13 Querschnitt der Oogonwand. - II. M. polymorpha (nach WoronIN). 1-4 Oogonien und Antheridien tragende Fäden. Das Antheridium epigyn, während es bei M. sphaerica hypogyn ist.

Monoblepharis sphaerica unterscheidet sich von den übrigen Monoblepharis-Arten durch ihr terminales Oogon und hypogynes Antheridium. Die Zygoten können sowohl innerhalb als außerhalb des Oogons ihre Membran bilden. Die Membran ist braun und warzig. Das Ei tritt an die Spitze des Oogons heran, verschmilzt dort mit einem Spermatozoid, und es sieht dann aus, als besitze das Ei eine Cilie. Woronin machte die hübsche Beobachtung, daß hier das Oogon geschlossen bleibt, bis 
ein Spermatozoon angelangt ist; dieses umhüllt kappenförmig die Oogonpapille (Fig. 69, 4) und löst diese auf. Auch bei $M$. sphaeriea können die Zrooten sich schon innerhalb des Oogons mit einer Membran umgeben, es sind dies aber keine parthenogenetisch entstandenen, sondern echte Zygoten; bisweilen fand Trorovin Oogone, welche geschlossen blieben, in welchen dann aber auch das Ei abstarb. Ob die Parthenosporen LAGERHEIMs nicht doch auch nur im Oogon verbliebene Zygoten ron anderen Monoblepharis-Arten waren, muß dahingestellt bleiben.

Außer M. sphaerica Cornu fand Woronin noch $M$. polymorpha Corve und 1 . polymorpha var. macrandra LAgERHEIM, welche er zur Artswürde erhebt, und die also Monoblepharis macrandra (LagerH.) Toronis heißt. Br Monoblepharis polymorpha ist das Antheridium

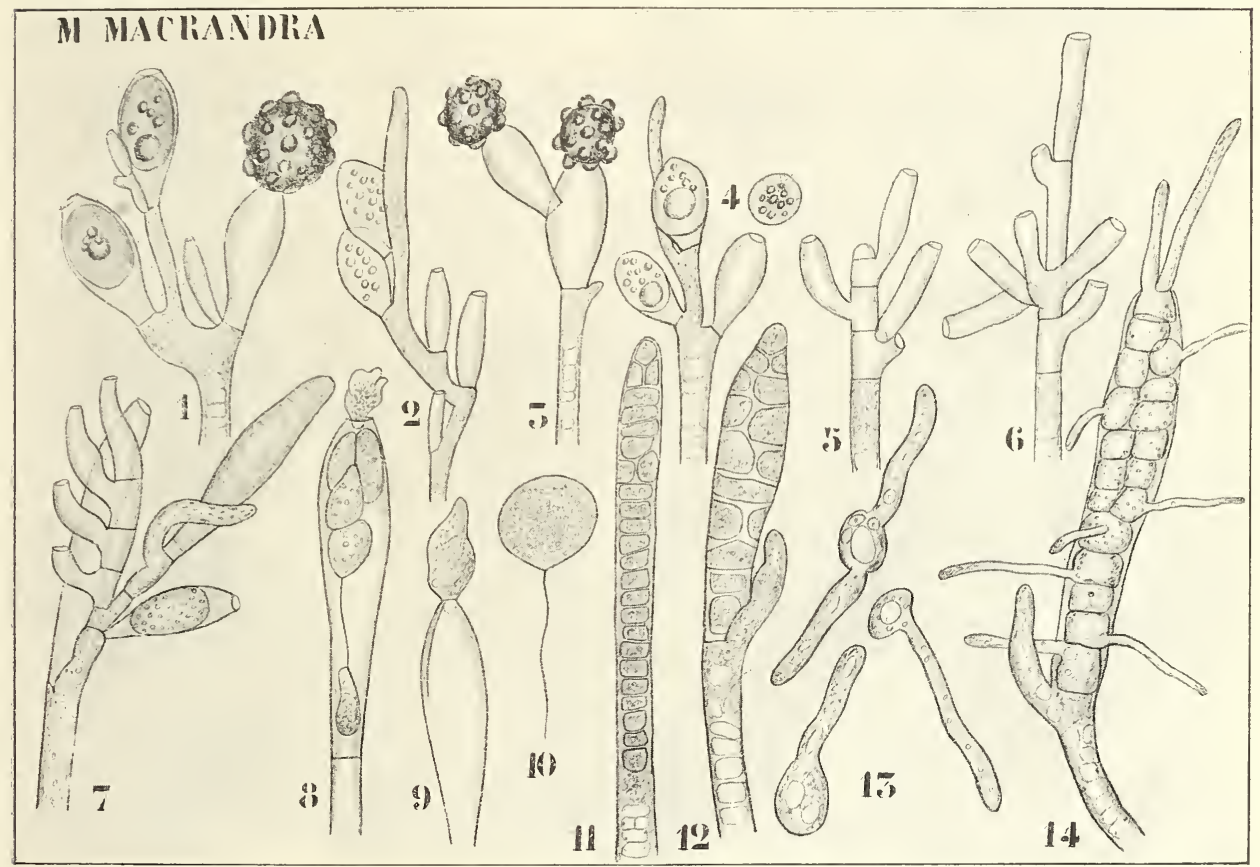

Fig. 70. Monoblepharis macrandra (nach Wononis). 1, 2 Hermaphrodite Fäden. 3, 4 Weibliche Fäden. 5, 6 Männliche Fäden. 7 Hermaphroditer Faden, der zwei Zoosporangien trägt. 8-10 Zoosporangien und Zoosporen. 11 Sporangium mit einer Reihe von Zoosporen. 12 Sporangium mit zwei Reihen von Zoosporen. 13 Ausgeschlüpfte Zoosporen keimend. 14 Zoosporen innerhalb des Sporangiums keimend.

stets epigyn und sitzt dem oberen Teile des Oogoniums auf. ITORONIN hat nie einen Fall gesehen, wo das Antheridium hypogyn g'ewesen wäre. Nie beobachtete er bei $M$. polymorpha Oosporen innerhalb des Oogoniums. die reife Oospore ist immer eine äußere. Die Warzen der reifen Oosporen sind farblos oder schwach gelblich gefärbt, etwa wie die von $M$. sphaerica. während die von $M$. macrandra braun sind.

LAgERHeIms $M$. brachyandra $\beta$ longicollis ist nach Woronins Ansicht ein Bastard zwischen $M$. polymorpha und $M$. sphacrica.

Bei M. macrandra kommen hermaphrodite. männliche und weibliche 
Fäden vor. Auch können Zoosporangien, Oogonien und Antheridien auf dem gleichen Faden gebildet werden.

Die Zoosporangien können bisweilen recht lang werden und die Zoosporen in einer oder 2 Reihen angeordnet zeigen. Die Zoosporen können austreten und dann auskeimen, oder auch innerhalb des Zoosporangiums keimen. Der Keimschlauch durchbohrt dann die Zoosporangiumwand.

Die Gruppe der Monoblepharideen weicht von allen anderen Siphonomyceten durch die Bildung von Spermatozoen ab; bei allen übrigen Siphonomyceten tritt an der Stelle der freien Gametenbildung eine Kopulation der Gametangien ein. Diese Kopulation kann entweder zwischen gleichgestalteten Gametangien stattfinden oder zwischen ungleichgestalteten.

Wir teilen die Siphonomyceten also in folgender Weise in drei große Gruppen ein :

\section{Siphonomyceten.}

A. Befruchtung mittels Spermatozoen und Eier: Monoblepharideen.

B. Kopulation von gleich gestellten Gametangien: Zygomycetes.

C. Kopulation von ungleich gestellten Gametangien: Oomycetes.

Betrachten wir zunächst die Gruppe der

\section{Zygomycetes}

und fangen wir mit der Betrachtung der geschlechtlichen Fortpflanzung an. Als Beispiel nehmen wir

\section{Sporodinia grandis,}

wobei wir bemerken, daß die geschlechtliche Fortpflanzung der übrigen Zygomyceten in der Hauptsache der von Sporodinia gleich ist. Sporodini grandis ist ein Pilz, der auf höheren Pilzen, wie Boletus und Agaricus, parasitiert.

Die Kopulation findet zwischen aufrechten Zweigen des Mycels statt.

Wenn ein weiblicher Zweig in die Nähe eines männlichen kommt, bilden beide Ausstülpungen, welche aufeinander zu wachsen und sich aneinander legen, indem sie stark anschwellen. Erst nachdem Berührung stattgefunden hat, werden die Gametangien durch Bildung einer Querwand geschaffen (Fig. 71, D). Jedes dieser Gametangien ist polyenergid. Diese Energiden trennen sich aber nicht voneinander, es werden die Gameten nicht sichtbar, aber man muß sie meines Erachtens ebensogut als Gameten betrachten, wie die Gameten in einem Bryopsis-Gametangium. Die Trennungswände zwischen den Gametangien werden jetzt aufgelöst, wodurch sich die $\delta$ und $q$ Gameten vermischen können. In diesem Stadium verdickt sich die Zygogametangienwand zum Exosporium. Darin finden wir noch stets ein große Anzahl von Kernen, von denen sich nach und nach eine gewisse Anzahl an der Peripherie anhäuft. Inzwischen hat sich der Inhalt mit einer Membran umgeben, ist also zur "Zygote" geworden, welche alsbald eine zweite Membran bildet, so daß die Zygote von zwei Membranen umgeben ist, und überdies noch von der verdickten Zygogametangienwand geschützt wird (Fig. 71, I). Selbstverständlich haben wir es hier nicht mit einer einfachen, sondern mit einer zusammengesetzten "Zygote“ zu tun, denn die schon von Gruber (1901), welchem wir diese Resultate verdanken, ausgesprochene Vermutung, daß. 
die of und $q$ Kerme in dem Zyoogametangium miteinander kopulieren, wurde neuerdings von DANGEARD (1906) bestätigt. Wir haben es hier also offenbar mit einer Kopulation virtueller Isogameten zu tun. Die peripheren Kerne sind wohl ausgestoßene, überzählig'e Kerne, welche nicht zur Kopulation kamen.

Die Kopulation der Gametangien ist offenbar eine sehr nützliche und für landbewohnende Pilze unumgänglich notwendige Vermehrungsweise. Nützlich, weil dadurch keine Gameten verloren gehen, notwendig, weil zur Kopulation ausgetretener Gameten flüssiges Wasser eine conditio sine qua non ist.

Das kopulierende Gametangium ist also als eine Entwickelungshemmung zu betrachten, es öffnet sich nicht und bildet seine Gameten

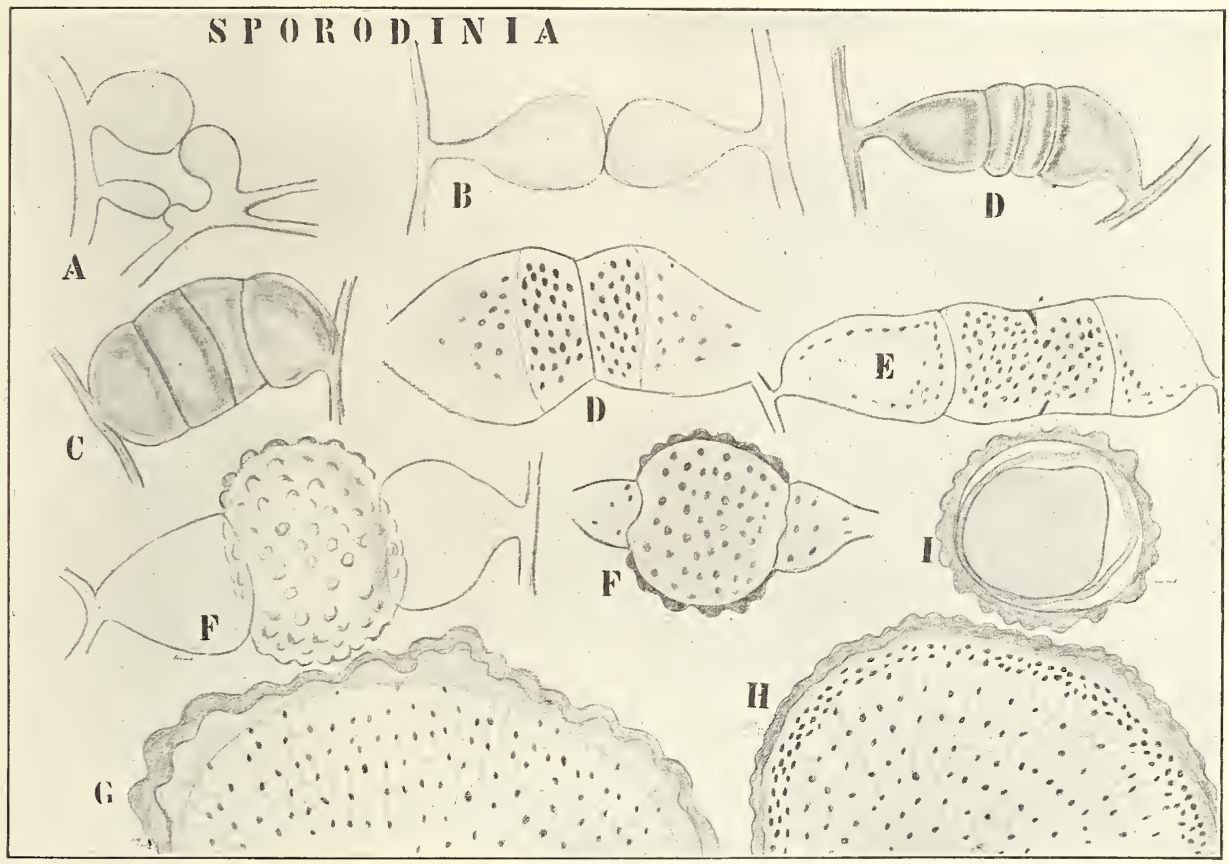

Fig. 71. Sporodinia grandis (nach GRUBER). A, B Seitenzweige des Mycels, sich zur Kopulation anschickend. C, D Die Gametangien sind gebildet, sie enthalten viele Kerne. E Fusion der Gametangien. F Die Zygogametangienwand hat sich verdickt. G Die Kerne im Zygogametangium gleichmäßig verteilt. H Periphere Anhäufung eines Teiles der Kerne. I Bildung der Zygote.

nicht vollständig aus, ebenso ist die Konidie, wie wir alsbald sehen werden, als ein reduziertes Zoosporangium anzusehen.

Als die Pilze zu Landbewohnern wurden und sich von der Anwesenheit flüssigen Wassers unabhängig machten, gab es a priori zwei Möglichkeiten, um diesen Zweck zu erreichen. Es konnten entweder die Zoosporen sich noch innerhalb des Sporangiums mit einer Membran umgeben und dann frei werden und keimen, oder aber es konnten die Gameten sich nicht mehr differenzieren und in dem Sporangium beschlossen bleiben. Im letzteren Falle müßte dann das Sporangium selber auskeimen. 
Beide Möglichkeiten sind in der Tat realisiert worden. Im ersteren Falle wurde das Zoosporangium zum Sporangium, im zweiten zur Konidie. Wir können also das Sporangium als eine Zwischenstufe zwischen Zoosporangium und Conidie betrachten.

Wir können demnach die Zygomycetes einteilen in:

\section{A. Sporangiophorae . Mucorineae \\ B. Conidiophorae . . Entomophtoreae.}

Da aber, wie wir sahen, Sporangien den Uebergang von Zoosporangien zu Conidien bilden, kann man nicht erwarten, daß diese Einteilung eine scharfe sein wird. Das ist denn auch in der Tat nicht der Fall. Es gibt z. B. in der Gruppe der Mucorineen einige

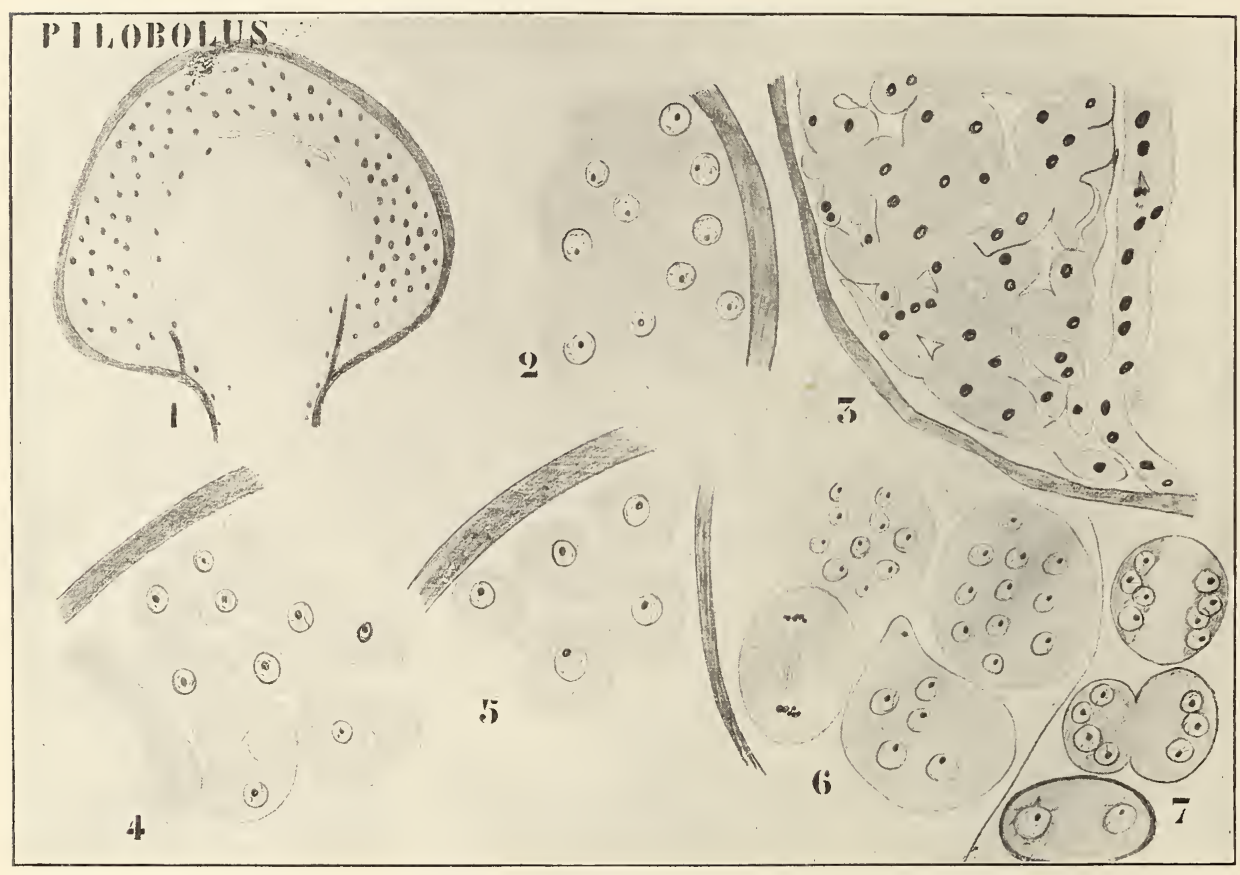

Fig. 72. Bildung der Sporen im Sporangium von Pilobolus (nach HARPER). 1 Das polyenergide Sporangium. 2 Ein Teil desselben vergrößert. 3-5 Spaltung bis zur Bildung einkerniger Stücke. 6 Vielkernigwerden dieser Stücke. 7 Teilung bis zur Bildung 2-kerniger Sporen.

Formen mit Konidien; die Einteilung besagt nur, daß bei den Mucorineen die Sporangien, bei den Entomophtoreen die Konidien überwiegen.

Es darf aber das Sporangium der Mucorineen nicht ohne weiteres als ein einfaches Zoosporangium betrachtet werden. Es ist vielmehr mit einer Dauerspore von Synchytrium zu vergleichen. Wir sahen, daß es bei Synchytrium Arten gibt, welche den Inhalt ihrer Dauersporen in einer Anzahl von membranumhüllten Sporen zerlegt, welche dann später zu Zoosporangien werden. Bei anderen Arten aber, bei S. Taraxaci z. B., findet eine Abkürzung des Prozesses statt, indem die Zerklüftung. des Protoplasmas der Dauerspore nicht bis zur Bildung von einkernigen Sporen fortschreitet, sondern früher aufhört, wenn die Stücke noch 
mehrkernig sind. Diese vielkernigen Stücke werden nun nach Vermehrumg ihrer Kerne zu Zoosporangien. Das einkernige Stadium ist also übersprungen worden.

HArper (1899) zeiot nun, daß wir es bei Pilobolus mit einem Fall zu tun haben, welcher dem von Synchytrium decipiens zu vergleichen ist.

Bei Pilobolus werden also durch Spaltung des Plasmas einkernige Stiicke gebildet, die Protosporen Harpers (Fig. 72, 5). Diese umgeben sich aber nicht mit einer Membran, sondern vermehren sofort ihre Kerne, sind also mit den Zoosporangien von Synchytrium decipiens vergleichbar, nur sind sie nackt. Diese bilden aber keine Zoosporen, sondern werden durch Teilung' zu unbeweglichen Sporen, welche sich mit einer Membran umgeben. Diese Teilung' wird aber nicht ganz durchgeführt,

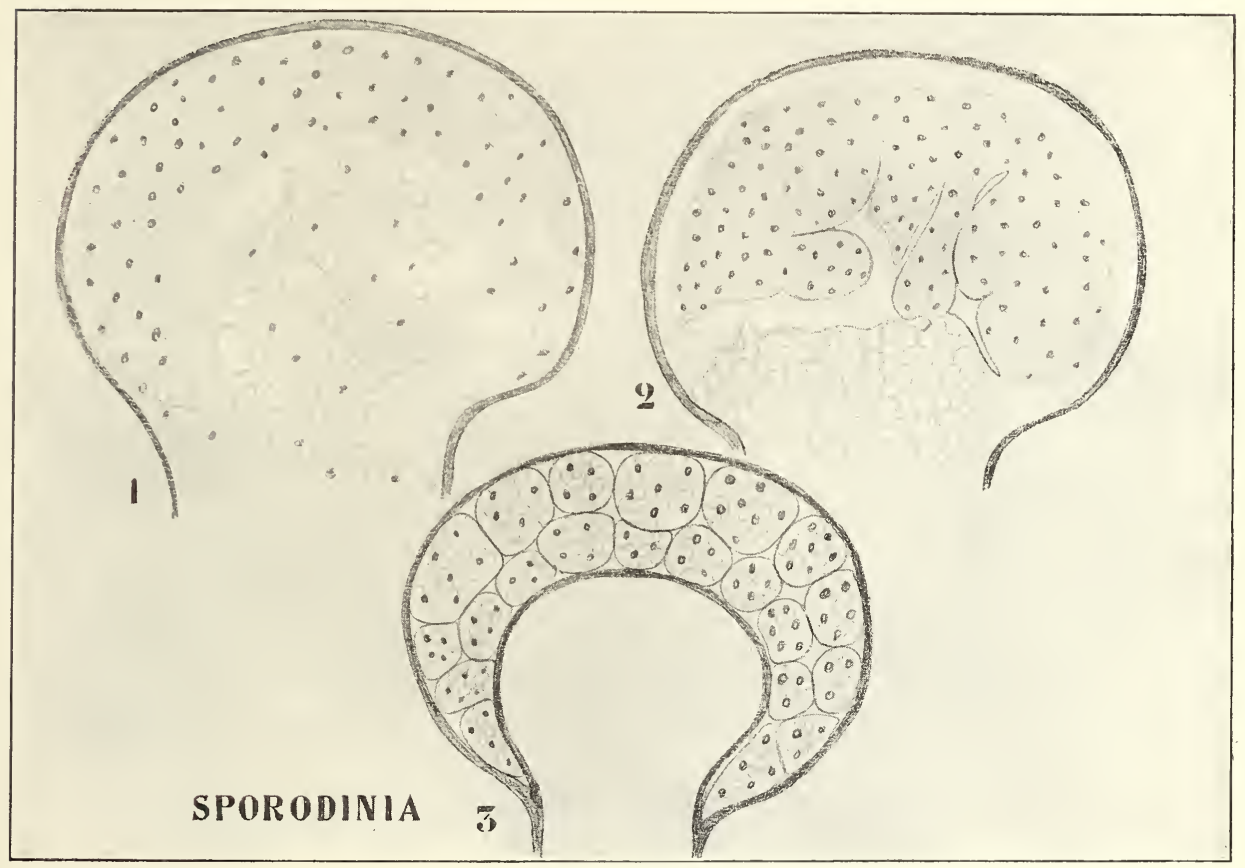

Fig. 73. Sporodinia grandis (nach HARPER). 1 Sporangium. 2 Spaltung. 3 Bildung der vielkernigen Stücke.

sondern hört auf, als die Stücke noch 2-kernig sind, die Spore von Pilobolus besitzt demnach 2 Kerne.

Bei Sporodinia dagegen haben wir einen Fall, der mit Synchytrium Taraxaci vergleichbar ist, aber eine noch weitere Reduktion zeigt. Die erste Spaltung führt nämlich nicht zur Bildung einkerniger Protosporen, sondern hört schon auf, wenn die Stücke noch mehrkernig sind. Diese teilen sich nun nicht wie bei Synchytrium Taraxaci nach Vermehrung ihrer Kerne in Zoosporen, sondern umgeben sich mit einer Membran und keimen sofort.

Bevor wir nun zur näheren Betrachtung der Mucorineen schreiten. müssen wir erwähnen, daß das Sporangium dieser Lebewesen entweder mittels einer flachen Wand vom übrigen Teil der Zelle getremnt werden 
kann, oder aber mittels einer sich in das Sporangium hervorwölbenden Wand. Im ersteren Falle sagen wir, daß keine, im letzteren dagegen, das eine Columella vorhanden ist.

Die folgende Einteilung ist nun wohl ohne weiteres klar:
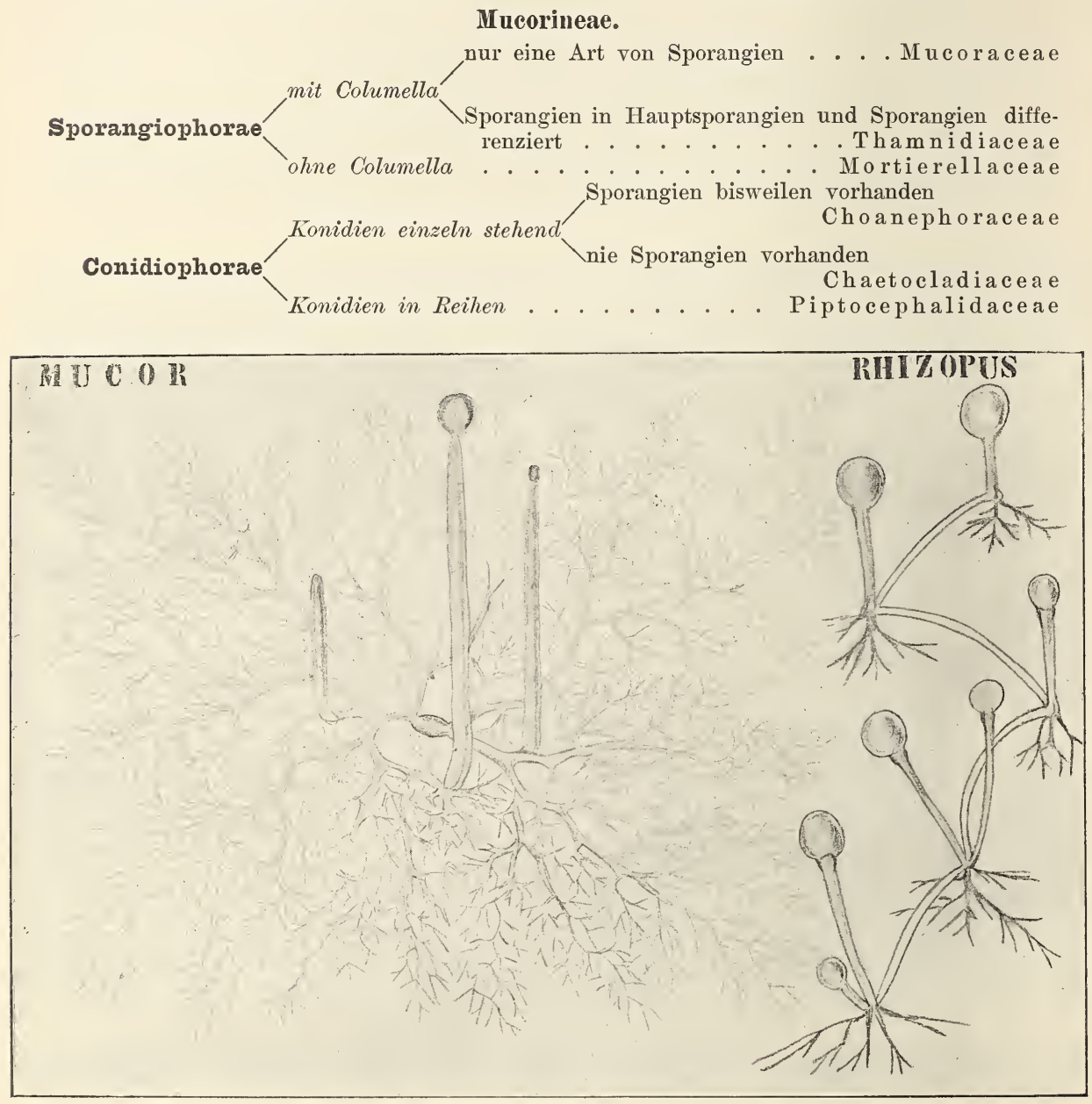

Fig. 74. Differenzierung zweier Mucoraceae-Mycelien (nach KNY und BREFELD).

Betrachten wir zunächst die Familie der

\section{Mucoraceae}

etwas näher. Sie umfaßt viele Genera und Arten, welche meistens saprophytisch leben, von welchen einige aber pathogen für Tiere, andere für Pflanzen sind. So kommen Mucor-Arten vor, welche Krankheiten bei Vögeln und Säugetieren verursachen, dagegen sind die Chaetocladiaceae und Piptocephalidaceae Parasiten auf Mucor.

Im allgemeinen trifft man bei den Mucorineen zweierlei Arten von Mycelien an, oder richțiger, das Mycelium ist in ein Ernährungsmycel, 
welches dem Substrat die nötige Nahrung entzieht, und in ein Luftmrcel. welches rorwiegend der Fortpflanzung dient und also wohl besser als Fortpflanzung'smycel zu deuten ist. differenziert.

Während bei der überwiegend größeren Zahl der Mucoraceen das Ernährungsmycelium aus einem schön verzweigten Schlauch besteht und keine weitere Differenzierung aufweist, begegnen wir bei Rhi sehr nützlichen Differenzierung, welche diesen Pilz in stand setzt, nach Erschöpfung des Substrats neue Nahrungsquellen aufzusuchen. Das eigentliche Ernährungsmycel ist dem von Mucor ähnlich, es kann aber lange, dicke Seitenzweige bilden, welche sich über das Substrat erheben, sich aber in der Weise von Ausläufern vieler Phanerogamen alsbald wieder nach dem Substrat zuwenden und an der Berührungsstelle ein

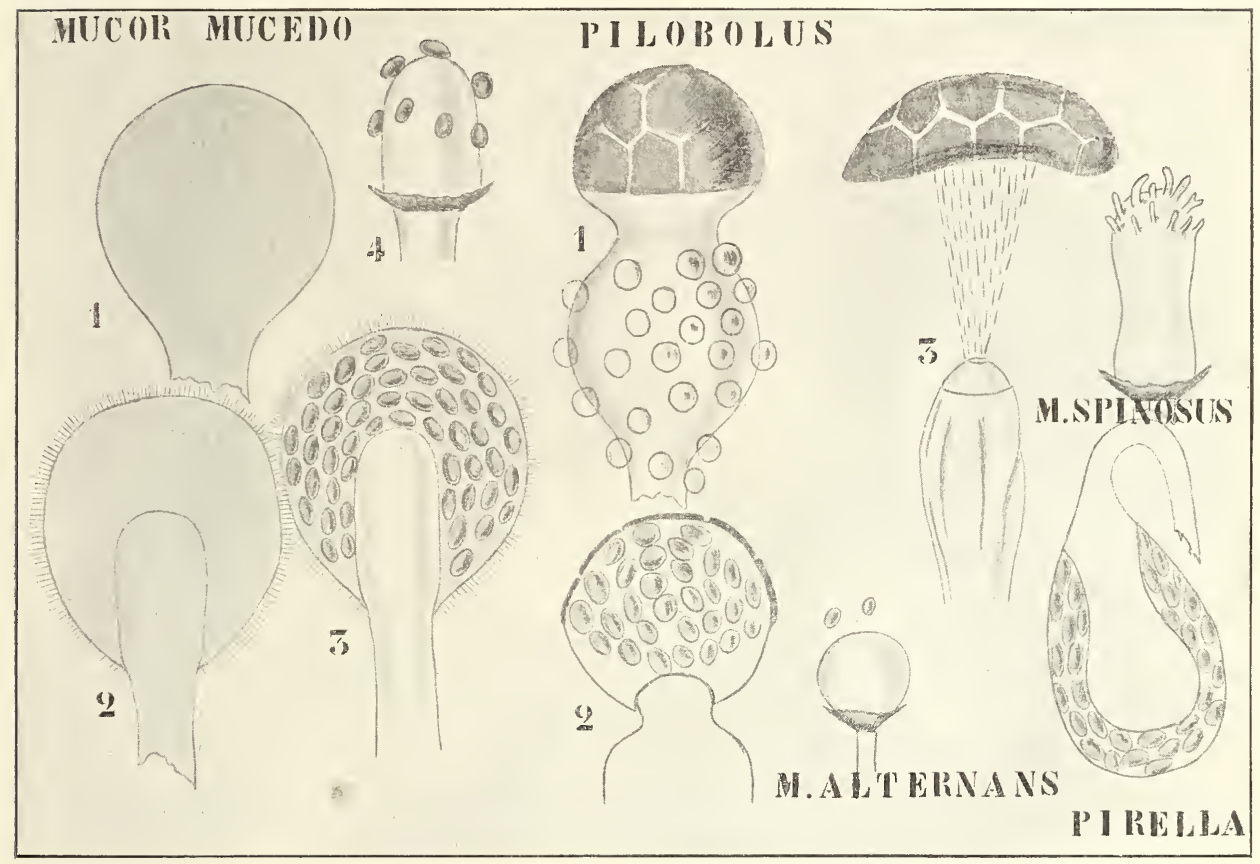

Fig. 75. I. 1-4 Mucor mucedo (nach BREFEt,D). - II. 1-3 Pilobolus cristallinus. - III. Mucor alternans, kugelige Columella mit Basalkragen und Sporen (nach Gayon und Dubourg). - IV. Mucor spinosus (nach Zopf). - V. Pirella circinans mit klöppelförmiger Columella (nach BAINIER).

neues Ernährungsmycel bilden. In dieser Weise läuft das Mycel fort, eine Eigenschaft, die in Kulturen unangenehm sein kann. An den Berührungsstellen wird aus dem Ernährungsmycel meistens wieder ein Fortpflanzungsmycel gebildet (Fig. 74).

Sehen wir jetzt einmal, wie die Fortpflanzung geschieht, und betrachten wir zunächst die ungeschlechtliche.

Das Mycel besteht, wie bei allen Siphonomyceten, aus einer einzigen reichlich verzweigten Zelle; wenn der Pilz sich zur Fortpflanzung anschickt, erhebt sich von demselben das Fortptlanzungsmycelium. In dem Ernährungsmycelium entstehen jetzt um das Fortpflanzungsmycel herum Querwände, und die zwischen dem Fortptlanzungsmreel und diesen 
Querwänden vorhandenen Energiden begeben sich in das Fortpflanzungsmycel. Im einfachsten Falle, z. B. bei Mucor mucedo, besteht das Fortpflanzungsmycel aus einem aufrechten, dicken, unverzweigten, cylindrischen Schlauch, welcher alsbald an der Spitze stark anschwillt und, nachdem der größere Teil des Plasmas in diese Anschwellung eingetreten ist, selbige mittels einer Querwand vom Sporangienträger trennt (Fig. 74 u. 75).

Diese Querwand hat bei den Mucoraceae eine sehr eigentümliche Form, sie ragt weit in das Sporangium hinein und bildet so die Columella. Diese Columella kann kugelig sein (M. alternans), cylindrisch (M. mucedo), ja sogar klöppelförmig (Pirella), sie kann glatt sein, wie in den soeben erwähnten Fällen, oder aber stachelı, wie bei M. spinosus (vergl. Fig. 75).

In dem Sporangium haben sich in der bereits beschriebenen Weise inzwischen die Sporen gebildet, alles Plasma ist dabei verbraucht worden, die Substanz, welche sich zwischen den Sporen befindet, die sogenannte Zwischensubstanz, ist kein Plasma, sondern vermutlich ein Verschleimungsprodukt der Sporenmembran.

Beim Genus Mucor ist die Sporangienwand sehr dünn und mit zahllosen Kalkoxalatnadeln besetzt (Fig. 75, 2,3), sie ist im höchsten Grade hygroskopisch, eine Eigenschaft, welche auch der Zwischensubstanz zukommt. Eine recht geringe Zunahme der Luftfeuchtigkeit verursacht einen Riß, die Zwischensubstanz saugt dann gierig Feuchtigkeit auf, quillt dadurch stark auf und schleudert die Sporen fort. Infolge dieser Eigenschaft ist es unmöglich, ein reifes Mucorsporangium in einem Tropfen Wasser unter dem Mikroskop zu betrachten, Sporangienwand und Sporen werden bei der Berührung mit dem Wasser sofort weggeschleudert, so daß nur die Columella, und der untere, nicht hygroskopische Teil der Sporangienwand, der sogenannte Kragen übrig bleiben. Nebenbei bemerkt, ist die Form dieses Kragenrestes für die Systematik der Arten wichtig.

Nicht bei allen Mucoraceen aber ist die Sporangienwand so zerbrechlich, bei einem sehr schönen Pilze, der auf Pferdemist vorkommt, ist dies nicht der Fall. Dieser Pilz heißt Pilobolus cristallinus und verdankt seinen Speciesnamen dem Umstande, daß die Sporangienträger eine große Menge Wassertropfen ausscheiden, welche demselben ein kristallinisches Aussehen verleihen (Fig. 75, II 1). Dadurch und durch die helle, weiße Farbe der Sporangienträger hat mit Pilobolus besetzter Pferdemist ein bereiftes Aussehen. In Java ist der Pilz bisweilen so häufig, daß Wege, wo viele Pferde passieren, aussehen, als wären sie von Reif bedeckt.

Bei Pilobolus nun ist die Wand des Sporangiums, wenigstens am oberen Teile, sehr dick und stark mit einer kohlschwarzen Substanz inkrustiert. Da die Inkrustierung von verschiedenen Zentren ausgeht, und zwischen den so inkrustierten Stücken schmale Streifen nicht inkrustiert werden und weiß bleiben, hat die Sporangienwand ein gefeldertes Aussehen.

Unterhalb des Sporangiums finden wir dann auf dem oberen angeschwollenen Teil des Sporangienträgers die schon erwähnten Wassertropfen, welche durch den hohen osmotischen Druck, welcher im Innern herrscht, herausgepreßt wurden. Auf einem Längsschnitt durch das Sporangium und den oberen Teil des Sporangienträgers (Fig. 75, II 2) sehen wir, daß die Wand der unteren Hälfte des Sporangiums nicht inkrustiert und recht dünn ist, und daß die Columella nur eine kleine Strecke in das Sporangium hineinragt. 
Einige Zeit nach dem Heramreifen der Sporen spaltet sich die obere Hälfte der Columella in zwei Lamellen, so daß das Sporangium nur lose mit der Columella verklebt ist. Indem der Druck im Sporangienträger stets zunimmt, reißt die Columella schließlich an der Spitze, das Wasser wird herausgespritzt und schleudert das ganze Sporangium, dessen untere Hälfte kollabiert, fort (Fig. 75, II 3). Das Sporangium hat dann das Aussehen eines einseitig eingedrückten Gummiballes. Zu gleicher Zeit kollabiert der Sporangienträger und fallen die ausgeschiedenen TVassertropfen ab.

Das Sporangium kann so auf viele Centimeter Entfermung weggeschleudert werden, die Sporangienwand trocknet ein, zerstäubt und die Sporen werden frei.

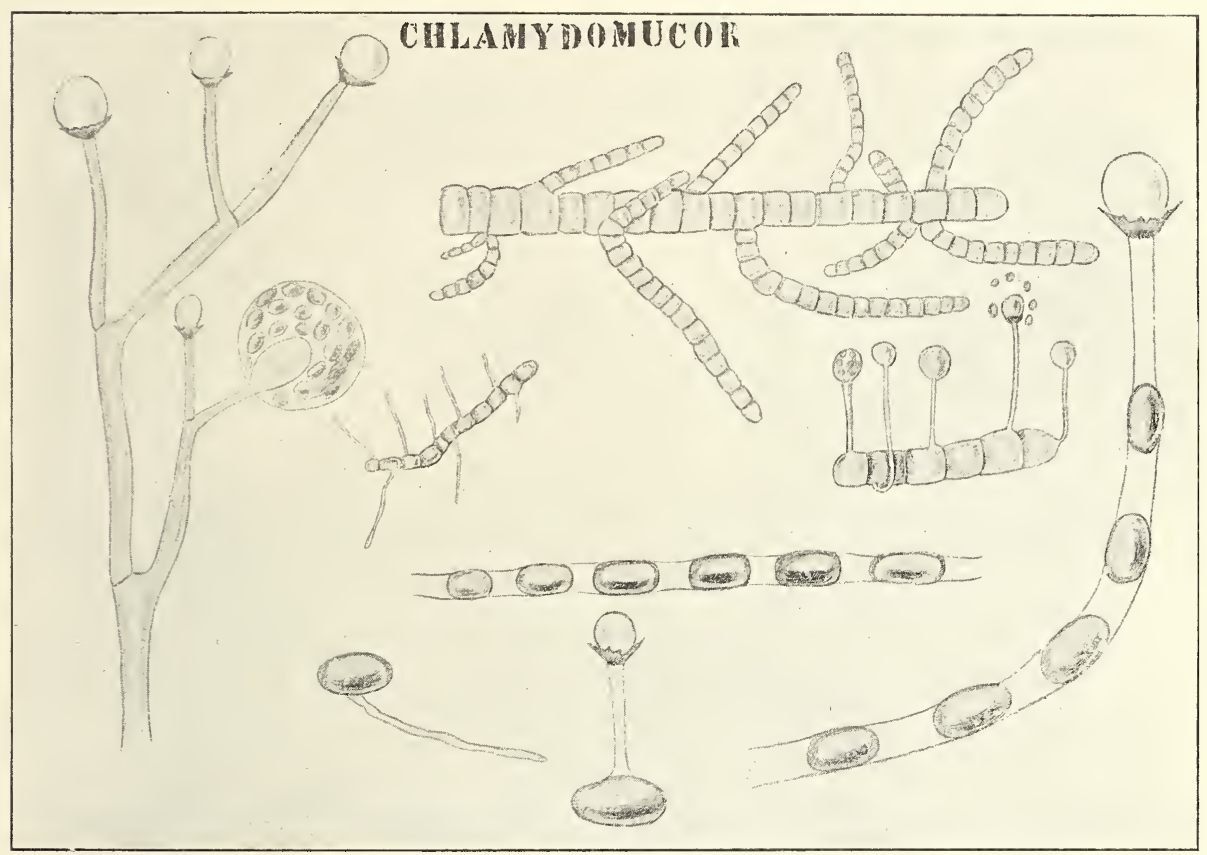

Fig. 76. Chlamydomucor racemosus (nach BREFetD). Links: Sporangienträger. Rechts oben: Faden in Gemmenbildung. Darunter keimende Gemmen, und zwar links vegetativ, rechts fruktifikativ keimend. Die übrigen Figuren zeigen die Bildung und Keimung der Chlamydosporen.

Man kann sich die weggeschleuderten Sporangien leicht verschaffen, indem man etwas oberhalb einer Pilobolus-Kultur Deckgläschen oder Objektträger befestigt.

Bei den Mucoraceen werden wir zum ersten Male die Bekanntschaft von bei den höheren Pilzen sehr häufigen ungeschlechtlichen Fortpflanzungszellen machen, welche Gemmen, Oidien und Chlamydosporen genannt werden.

Lernen wir sie an Chlamydomucor racemosus kemnen (Fig. 76).

Unter normalen Bedingungen bildet er, wie Mucor mucedo, Sporangien, welche hier aber an verzweigten Sporangienträgerm entstehen. Kultiviert man ihn aber unter Wasser, so treten in dem ursprünglich 
einzelligen Mycel Querwände auf, wodurch der Schlauch vielzellig wird. Solche Zellen nennt man Gemmae oder Oidien. Bringt man diese in eine gute Nährlösung, so keimen sie vegetativ zu neuen Mycelien aus, legt man sie aber a uf einen Nährboden, so keimen sie fruktifikativ, d. h. sie bilden kein Mycel, sondern kurze Sporangienträger, deren jeder an der Spitze ein Sporangium bildet.

Unter sonstigen ungünstigen Lebensbedingungen kann das Plasma sich sowohl im Ernährungsmycel, wie in den Sporangienträgern zu Klumpen zusammenballen, deren jeder sich dann nachträglich mit einer derben Membran umgibt, wodurch er zur Chlamydospore wird. Dieses passiert zumal in den Sporangienträgern, welche ihre Sporen bereits ausgeschleudert haben; die Plasmareste des Sporangiumträgers werden in dieser Weise noch nützlich verwendet.

In Nährlösung keimen diese Chlamydosporen negativ, auf Nährboden fruktifikativ.

Die oben beschriebenen Gemmen können sich aber auch noch anders verhalten; bringt man in Gemmen geteilte Fäden in eine zuckerhaltige Nährlösung, so trennen sich die Gemmen von einander und vermehren sich sproßpilzartig, d. h. wie die Saccharomyceten mittels Knospenbildung. Gerade so wie die Saccharomyceten können sie dann die Nährlösung vergären unter Alkohol und $\mathrm{CO}_{2}$-Bildung. Dies hat sogar zu der Meinung Veranlassung gegeben, daß die Saccharomyceten nur Entwickelungsstadien von Mucoraceen seien, eine Meinung, welche jedoch nicht stichhaltig ist.

Wir haben bereits gesehen, wie im Prinzip die geschlechtliche Fortpflanzung stattfindet; es wurde dies an dem Beispiel von Sporodinia grandis illustriert.

Dort findet die Kopulation zwischen zwei Zweigen des Luftmycels statt, bei Mucor und den meisten anderen Formen dagegen zwischen Zweigen des Ernährungssystems, und zwar meistens zwischen Mycelien verschiedener Individuen.

Bis vor kurzem war es schwer, Zygosporen von Mucor zu erhalten, man war dabei auf den Zufall angewiesen. Die schönen Untersuchungen von Blakeslee (1904) haben gelehrt, daß der Grund darin liegt, daß die meisten Mucorineae nur dann Zygosporen bilden, wenn männliche und weibliche, oder wie er sich vorsichtig ausdrückt, wenn + und - Pflanzen zusammenkommen. E1 teilt demnach die Nucorineae in zwei Gruppen ein :

1) homothallische (z. B. Sporodinia), welche Zygosporen auf den Zweigen desselben Thallus bilden, bei welchen also durch Aussaat einer einzigen Spore Zygosporen erhalten werden können, und

2) heterothallische (Rhizopus, Mucor, Phycomyces), bei welchen die gleichzeitige Anwesenheit eines ơ und eines $q$ Individuums zum Erhalten von Zygosporen erforderlich ist.

Ist man einmal im Besitz von o und $q$ Pflanzen, so ist es sehr leicht, Zygosporen zu erhalten. Man säe dann nur eine Sporangienspore der $\delta$ und eine der $q$ Pflanze auf einem Nährboden in einiger Entfernung von einander aus. Die Mycelien wachsen nun im Kreise um die Sporen herum und berühren einander alsbald in einer Linie, welche etwa in der Mitte zwischen den beiden Sporen liegt, dort bilden sich nun sofort zahlreiche Zygosporen, so daß ein schwarzer Strich senkrecht auf der Verbindung'slinie zwischen beiden Sporen gebildet wird ${ }^{1}$ ).

1) Vor kurzem (Ann. mycologici 1906 S. 1-28) hat BLAKESLEE nachgewiesen, daß alle Sporen eines Sporangiums entweder $\delta$ oder $q$ sind, daß dagegen in einem Sporangium von Phycomyces nitens nicht nur $\widehat{\sigma}$ und $\mathcal{+}$, sondern auch sogar homothallische, man könnte sagen he rmaphrodite Sporen vorkommen. 
Das Exosporium kann sehr verschiedene Struktur besitzen, meistens ist es warzig oder stachelig, bisweilen, z. B. bei Phycomyces, mit hübschen geweihähnlichen Auswüchsen versehen.

Falls die Wand des Zygogametangiums nicht verdickt ist, wird öfter's eine schützende Hülle von Auswüchsen der Tragzellen gebildet (siehe Fig. 77, Absidia).

Trotzdem im allgemeinen die beiden kopulierenden Gametangien bei den Zygomyceten gleichförmig sind, finden wir dennoch bei Mucor heterogamus schon eine Annäherung an eine Differenzierung in Oogonien und Antheridien, indem das weibliche Gametangium viel größer als das männliche ist.

Parthenogenese, d. h. Ausbildung einer „Zygospore“ ohne Befruch-

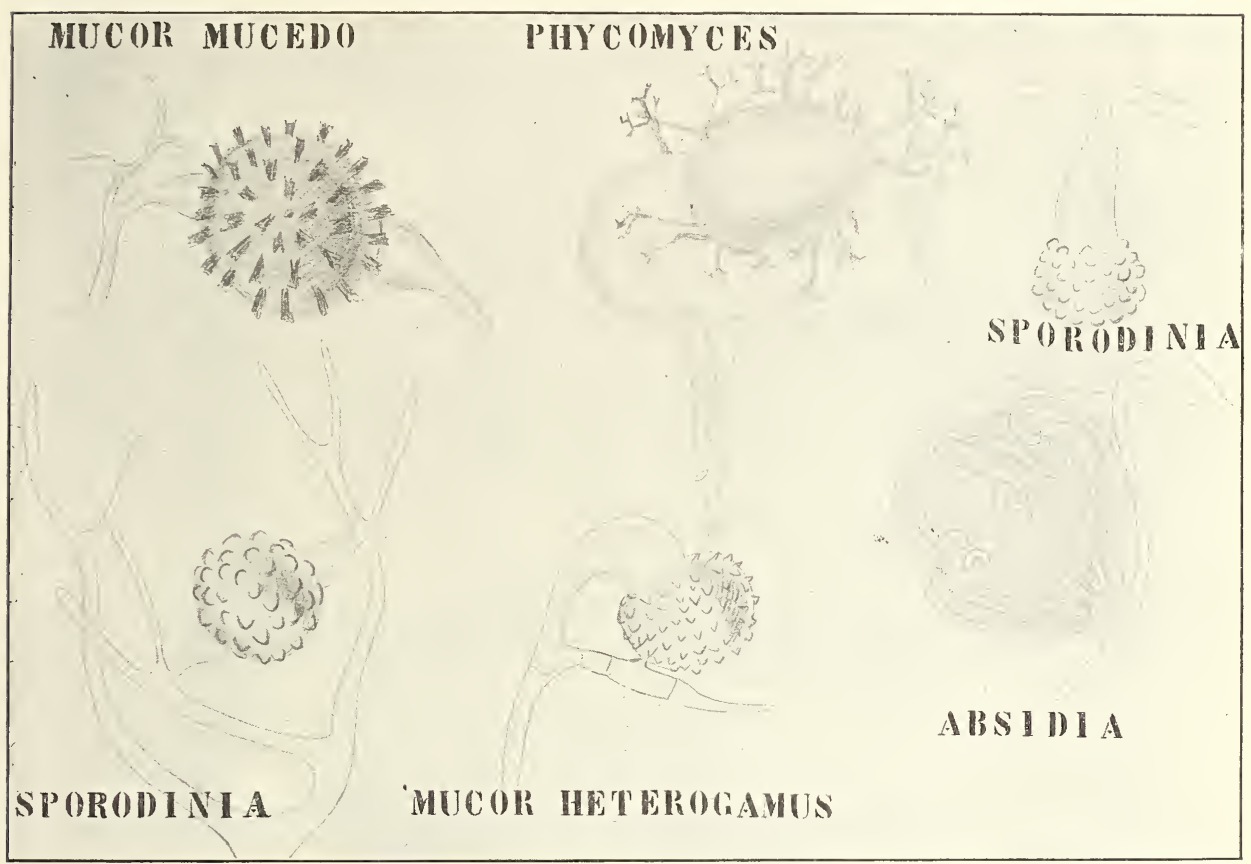

Fig. 77. Verschiedene Zygosporenformen bei den Mucorineen.

tung, also Entwickelung des weiblichen Gametangiums ohne Kopulation, kommt z. B. bei Sporodinia grandis vor.

Dieser Pilz bildete den Gegenstand einer ausführlichen Untersuchung: durch KLEBs (1898), welcher versuchte, festzustellen, welche Bedingungen für die Ausbildung der Fortpflanzungsorgane erforderlich sind. Dieser Studie sei folgendes entnommen:

\section{Sporodinia grandis.}

Sowohl aus der ungeschlechtlichen Spore wie aus der Zygote entwickelt sich ein vegetatives Mycel. Kultiviert man dieses unter Masser. so bleibt es steril, wächst so lange, als Nahrung vorhanden ist und geht schließlich durch Erschöpfung zu Grunde.

Sobald die Bedingungen die Bildung eines Luftmycels erlauben. 
fängt auch unter normalen Umständen die Bildung von Fortpflanzungsorganen an diesem Luftmycel an.

Es gelingt aber auch, ein steriles Luftmycel $\mathrm{zu}$ erhalten und $\mathrm{zu}$ behaiten, wenn man den Pilz kultiviert:

1) auf stark saurem Substrat in feuchter Luft bei $23-25^{\circ} \mathrm{C}$,

2) auf jeglichem Substrat in feuchter Luft bei $28-30^{\circ} \mathrm{C}$,

3) auf jeglichem Substrat bei Zimmertemperatur bei einem Luftdruck, der auf 20-30 mm Quecksilberdruck herabgesetzt ist.

Unter normalen Bedingungen aber kann jede Lufthyphe entweder zum Sporangienträger oder zum Gametangienträger werden.

Sporangienträger erhält man bei guter Ernährung und nicht mit Wasserdampf gesättigter Atmosphäre. Ein relativer Feuchtigkeitsgehalt von 70-80 Proz. ist als optimal für die Sporangienbildung zu betrachten, bei 40 Proz. können keine Sporangien mehr gebildet werden.

Als direkte Ursache der Sporangienbildung ist die Transpiration zu betrachten, denn bei relativ feuchter Luft löst jeder Umstand, der Transpiration verursacht, z. B. Hineinbringen von Chlorcalcium oder $\mathrm{H}_{2} \mathrm{SO}_{4}$, starke Bewegung der Luft, die Sporangienbildung aus.

"Zygoten" werden nur in wasserdampfgesättigter oder fast gesättigter Luft gebildet, falls wenigstens nicht zu viel Nahrung vorhanden ist, und in dieser Nahrung bestimmte Substanzen, besonders Kohlehydrate, vorhanden sind.

Falcks (1902) Einwendungen gegen Klebs'Resultate sind nicht stichhaltig, man vergleiche dazu KLE Bs' (1902) Bemerkungen über diese Arbeit.

Während die Mucoraceae Sporangienträger mit nur einer Art von Sporangien bilden, bilden die Vertreter der Familie der

\section{Thamnidiaceae}

deren zweierlei: Sporangien und Sporangiolen.

Als Beispiel wählen wir:

\section{Thamnidium elegans.}

Dieses Pilzchen wächst auf Pferde- und Hundemist und auf allerlei stärkehaltigem Substrat, z. B. auf gekochten Kartoffeln. Das Ernährungsmycel breitet sich im Substrat aus, das Fortpflanzungsmycel erhebt sich in die Luft.

Die Sporangienträger tragen an der Spitze ein normales großes Sporangium, das ebenso, wie die Sporangien von Mucor, eine Columella und eine stark hygroskopische, mit Kalkoxalatnadeln besetzte Membran besitzt. Bei Erhöhung der Luftfeuchtigkeit wird es zersprengt und werden die Sporen ausgestreut.

Etwas unterhalb des terminalen Sporangiums verzweigt sich der Sporangienträger und bildet eine Anzahl viel kleinerer Sporangien: die sogenannten Sporangiolen. Diese unterscheiden sich überdies von den Sporangien durch die Abwesenheit einer Columella und durch die festere Struktur ihrer Membran, welche durch Erhöhung der Luftfeuchtigkeit nicht zersprengt wird. Die Sporangiolen streuen demnach ihre Sporen nicht aus, sondern fallen als solche ab.

Der Pilz zeigt sowohl in der Entwickelung seiner Sporangien wie in der seiner Sporangiolen große Variabilität, welche in hohem Grade von der Quantität und der Qualität der vorhandenen Nahrung abzuhängen scheint. 
. Man kann Sporangienträger erhalten, welche gar keine Sporangien, sondern nur Sporangiolen bilden. Die Reduktion kann so weit gehen, daß an einem zweimal dichotom rerzweigten Träger nur 4 Sporangiolen gebildet werden, meistens aber ist der Sporangienträger normal entwickelt, nur fehlt eben das terminale Sporangium. Unter anderen Bedingungen bleibt die Bildung der Sporangiolen gänzlich aus, der Sporangienträger verzweigt sich nicht und ist von einer Mucor-Fruktifikation nicht zu unterscheiden. Unter günstigen Bedingungen wird die normale Fruktifikation gebildet, und sehr üppige Exemplare kömnen sogar auf den Verzweigungen noch Sporangien bilden. Die Figuren illustrieren dies wohl zur Genüge.

Während die Sporangien immer eine große Anzahl von Sporen enthalten, ist die Zahl derselben in den Sporangiolen gering. Meistens

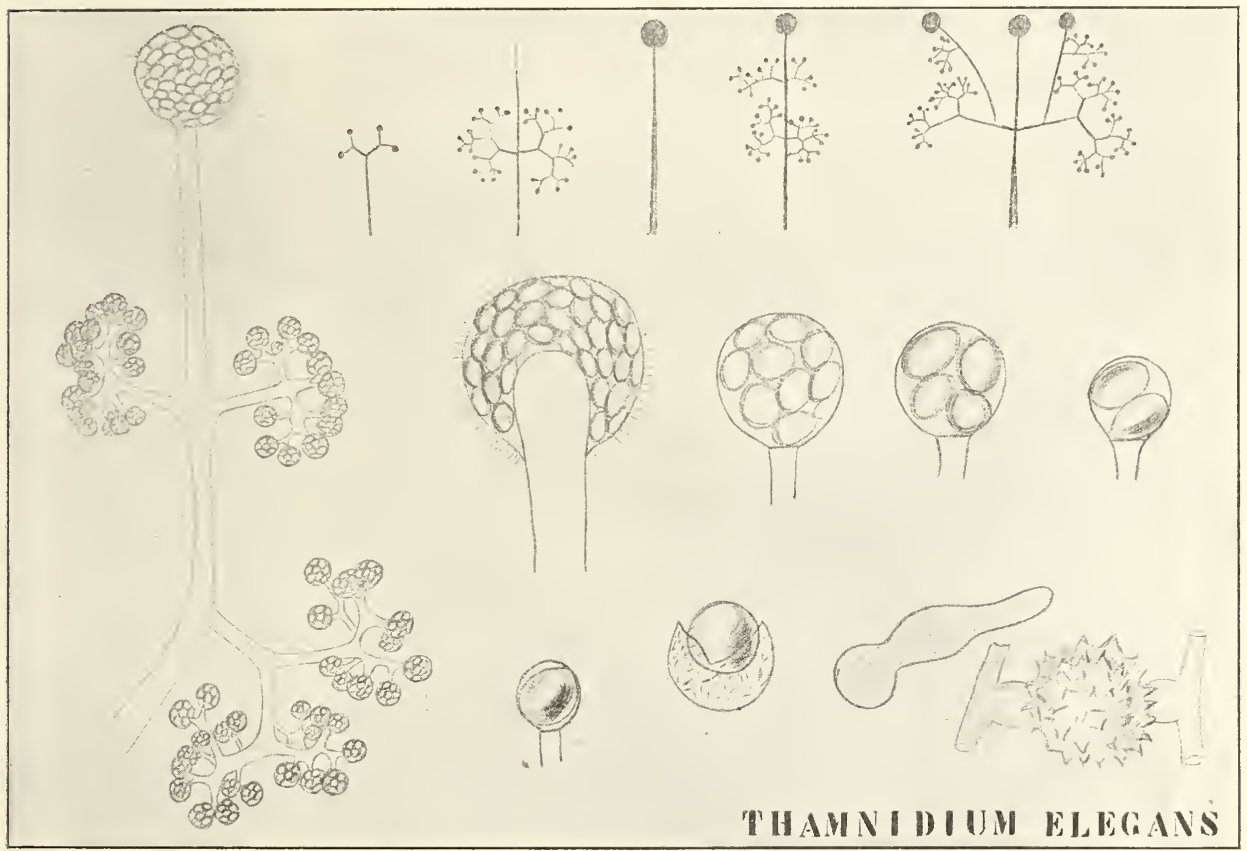

Fig. 78. Thamnidium elegans (nach BREFELD und BAINIER). Links: normaler Sporangienträger mit Sporangium und Sporangiolen. Rechts, obere Reihe: verschiedene Modifikationen der normalen Fruktifikationen. Mittlere Reihe: Sporangium, die Columella zeigend, 3 Sporangiolen mit verschiedener Sporenzahl. Untere Reihe, von links nach rechts: einsporige Sporangiole, Austreten der Spore, Keimung der Spore, Zygogametangium.

sind 4 Sporen vorhanden, dennoch sind auf der einen Seite Sporangiolen mit 10 Sporen nicht selten, während auf der anderen Seite die Zahl bis auf 1 herabgesetzt werden kann.

Da nun im letzteren Falle die Spore die Sporangiole vollständig ausfüllt, würde es schwer sein, zu entscheiden, ob wir es hier mit einer Sporangiole oder mit einer Konidie zu tum haben. wenn sich nicht ror der Keimung die Sporangienwand spaltete und die Spore herausließe.

Die Zygosporenbildung ist normal.

Gehen wir jetzt zur Betrachtung der letzten Gruppe der Sporangio- 
phoren über, zu derjenigen Gruppe, bei welcher gar keine Columella gebildet wird, zur Familie der

\section{Mortierellaceae.}

Als Beispiel wählen wir:

\section{Mortierella Rostafinskii,}

einen Pilz, der auf Pferdemist vorkommt. Er bildet unverzweigte Sporangienträger wie ein Mucor, aber das Sporangium besitzt keine Columella.

Das Mycel, welches die Sporangienträger bildet, ist sehr vergänglich, mit Ausnahme von Hyphenbüscheln an der Basis der Sporangienträger,

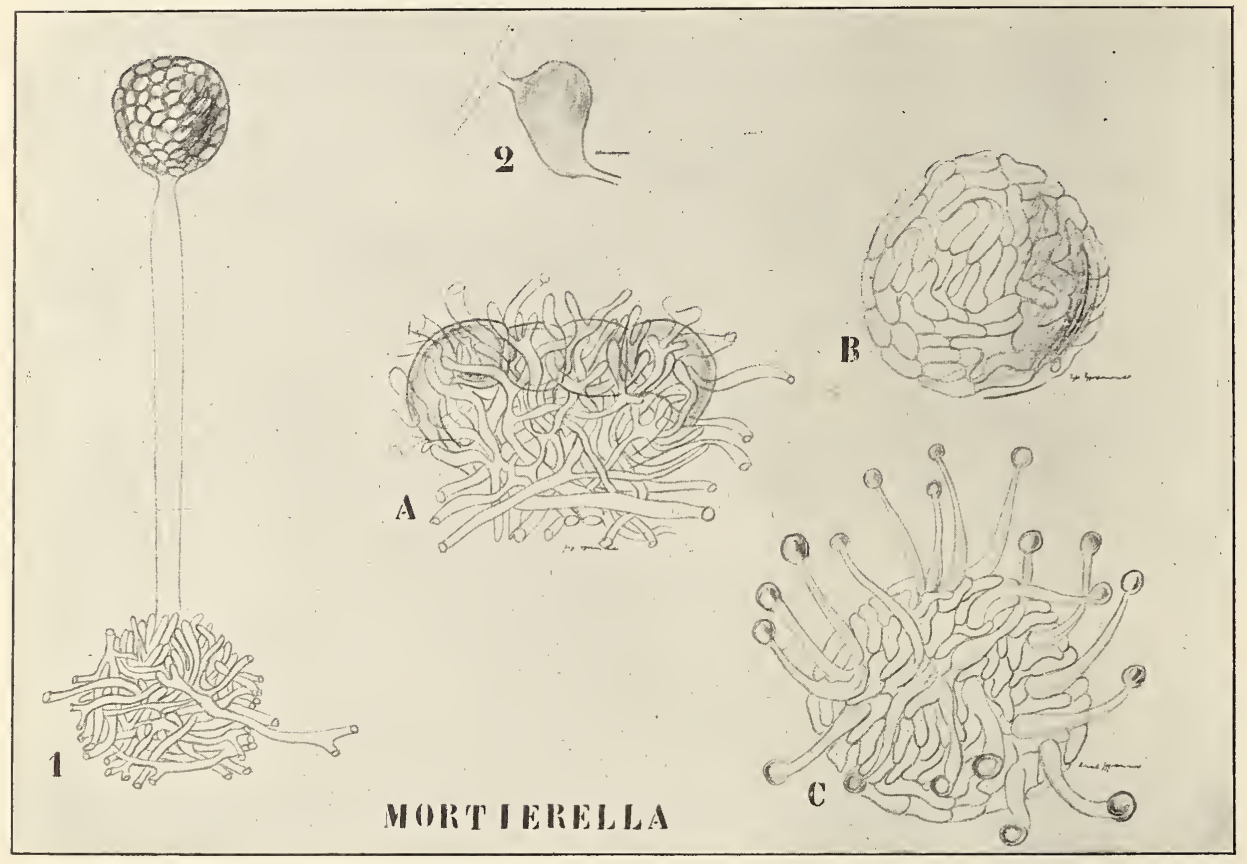

Fig. 79. Mortierella Rostafinskii (nach BREFELD). 1 Sporangienträger mit basaler Umhüllung. 2 Gemme. A Bildung der Zygosporenfrucht. B Fertige Zygosporenfrucht. C Fruktifikative Keimung der Zellen der Umhüllungshyphen der Zygosporenfrucht.

welche um den Fuß herum eine Art Umhüllung bilden. Lange nachdem das Ernährungsmycel verschwunden ist, ja Wochen und Monate später, stehen die Sporangienträger noch aufrecht, durch die Umhüllungshyphen mit dem Substrat verbunden.

Die Zygospore wird in der üblichen Weise durch Kopulation von Gametangien gebildet, wird aber gänzlich von einem Hyphenmantel umhüllt (Fig. 79, A). Diese Umhüllung wird nachträglich so dicht, daß zwischen den Hyphen keine Zwischenräume übrig bleiben und das Ganze den Eindruck einer Frucht macht (Fig. 79, B).

Wir erhalten also eine pseudoparenchymatische Frucht, in welcher die große kugelige Zygospore beschlossen bleibt.

Höchst auffallend ist nun die Tatsache, daß diese Zygospore nicht 
zum Keimen zu bringen ist, auch nicht, wenn man sie aus ihrer Umhüllumg befreit.

Dennoch dient die Sporenfrucht der Fortpflanzung, indem sie die Pflanze in den Stand setzt, ungünstige Lebensumstände zu überleben, denn die Zellen der Umhüllungshyphen können Sporangienträger bilden. Infolgedessen ist eine "keimende" Sporenfrucht von vielen Sporangienträgern bedeckt.

Es scheint demnach, daß die Zygosporen der Mortierella ihre Keimkraft verloren haben, selbstverständlich ist es aber ebenfalls möglich, daß sie nur unter bestimmten, bis jetzt unbekannten Bedingungen zu keimen vermögen.

Mortierella ist durch BREFELDs Untersuchungen bekannt, durch

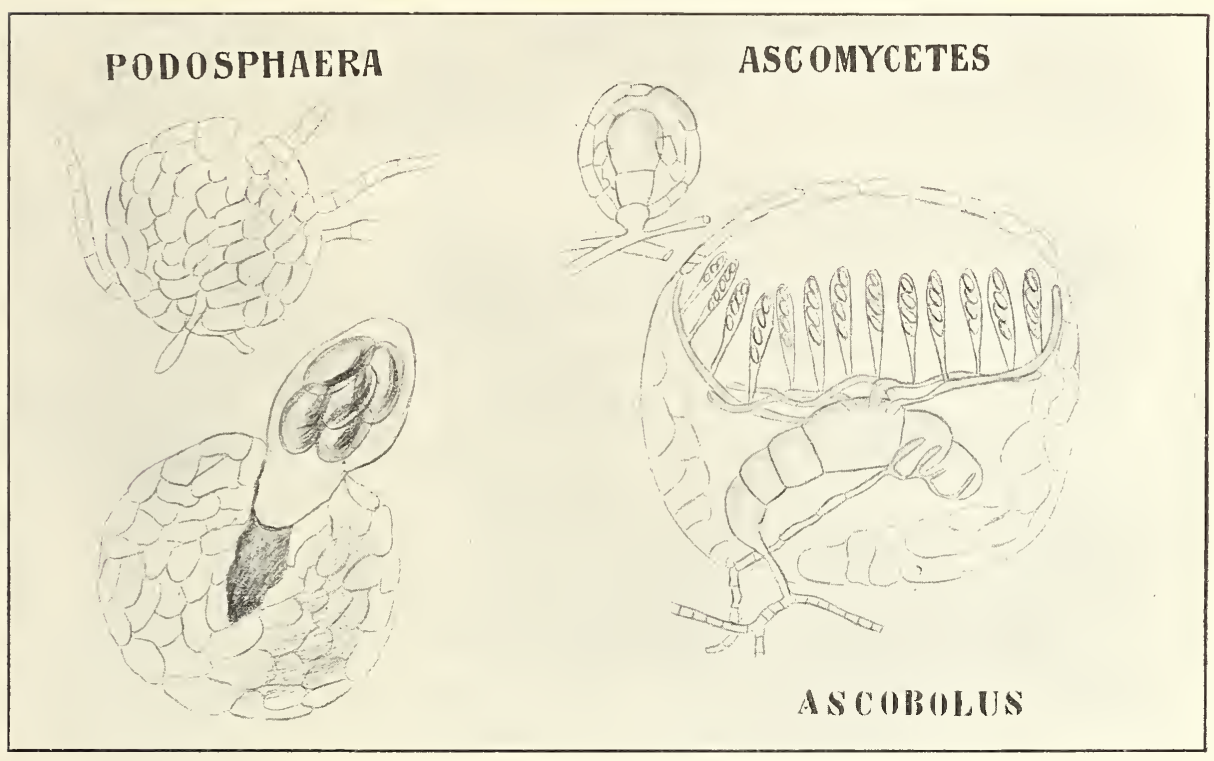

Fig. 80 .

seine an sie geknüpften Spekulationen berühmt geworden. BREFELD will nämlich von ihr eine höhere Pilzgruppe, die der Ascomyceten, ableiten.

Dazu vergleicht er sie mit Formen, wie Podosphaera (Fig. 80), welche in einer Hyphenumhüllung einen einzigen Ascus, d. h. einen Schlauch mit Sporen besitzen. Er meint nun, daß eine derartige Form leicht aus einer Form, wie Mortierella, entstehen könnte durch Verkürzung des Sporangienstiels, wodurch dann nicht die Basis des Sporangienstiels, sondern das Sporangium selbst von einer Hyphenhülle umgeben wäre. Er betrachtet also die Asci, die Sporenschläuche der Ascomyceten, als die Homologa der Sporangien der Siphonomyceten, als Sporangien, deren Sporenzahl konstant geworden ist.

Offenbar beruht diese Meinung aber auf einer äußerlichen Aehnlichkeit zwischen dem unteren Teil des Sporangienträgers von Mortierella. und der Sporenfrucht von Podosphaera. Ueberdies kann bei Mortierclla die Hyphenumhüllung vollständig fehlen, und sind Ascomyceten wie Podosphaera mit nur einem Ascus in der Ascusfrucht recht selten. Num 
kommt noch hinzu, daß, wenn man z. B. die jungen Stadien der A scusfrucht eines anderen Ascomyceten, von Ascobohus z. B. (Fig. 80), mit den jungen Stadien der Zygos por enfrucht von Mortierella vergleicht, eine viel größere Aehnlichkeit bemerkbar wird. In der Tat ist denn auch zweifellos die Ascusfrucht mit der "Sporenfrucht" von Mortierella und nicht mit dem Sporangium von Mortierella homolog. Es sind dies aber Fragen, auf welche wir später zurückkommen, mir lag nur daran, zu zeigen, daß BRefelds Vergleich von Mortierella mit Podosphaera ganz willkürlich ist.

Gehen wir jetzt zur Behandlung der Conidiophoreen über, und betrachten wir zunächst das zur Familie der Choanephoraceen gehörende Genus

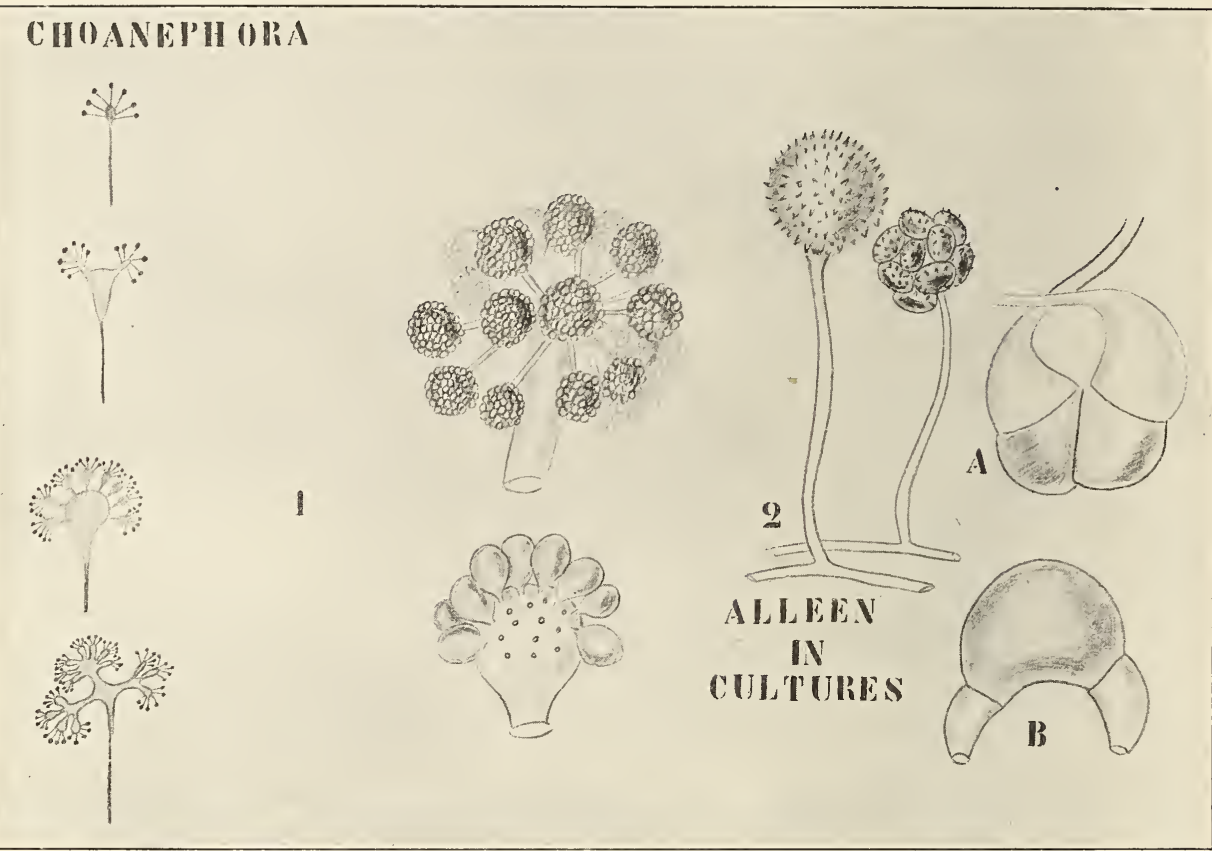

Fig. 81. Choanephora infundibulifera (nach Cunningham). Links: verschiedene Formen der Konidienträger. Rechts : gut ausgebildeter Konidienträger, darunter ein Köpfchen, von welchem schon einige Konidien abgefallen sind. 2 In Kulturen gebildete Sporangien. A Kopulierende Gametangien. B Zygogametangium.

welches nur eine Art:

\section{Choanephora,}

\section{Choanephora infundibulifera (Currey) Saccardo}

enthält. Diese wurde von Cunningham in Ostindien auf Blumen verschiedener Hibiscus-Arten entdeckt. Sie bildet auf diesen Fruktifikationsorgane (Fig. 81, 1), welche an den Enden schirmartiger Verzweigungen Köpfchen von Konidien tragen.

Diese Konidienträger können je nach dem Ernährungszustande mehr oder weniger verzweigt sein. Verschiedene Modifikationen sind auf der 
Fig'ur abgebildet. Die Konidien können ohne weiteres zu neuen Mycelien auskeimen.

Könnte man von diesem Pilze keine anderen Fruktifikationsorgane, so würde es äußerst schwer sein, seine systematische Stellung zu bestimmen.

Als Cunningham aber diese Form kultivierte, stellte es sich heraus, daß sie unter bestimmten Bedingungen Sporangien zu bilden vermag, welche mit Mortierella die Abwesenheit einer Columella gemein haben, und wurde damit also ihre Zugehörigkeit zu den Mucorineen entdeckt. In der Natur kommen Sporangien nie vor, ohne Kultur wäre also die systematische Stellung dieses Pilzes rätselhaft geblieben. Zygosporen werden in normaler Weise, aber selten, gebildet.

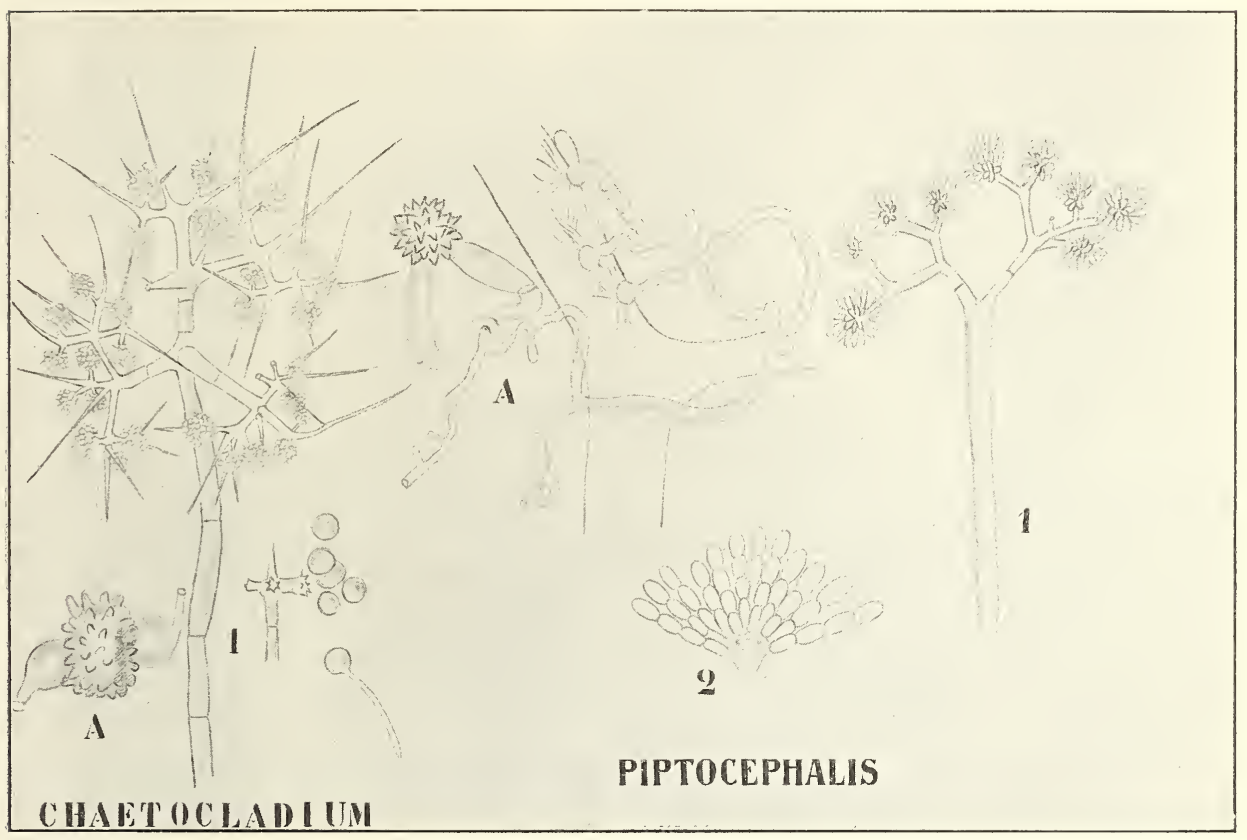

Fig. 82. I. Chaetocladium Brefeldii (nach BREFELD). 1 Konidienträger, rechts ein morgensternartiges Astende eines Konidienträgers, die Sterigmen zeigend, darunter eine keimende Konidie. A Reife Zygospore mit Suspensoren. - II. Piptocephalis Freseniana (nach BREFeld und SACHS). 1 Ein gabeliger Konidienträger. 2 Ein abgefallenes Köpfehen mit Konidienketten. A Ein Mucorschlauch, in welchen die Haustorien der Piptocephalis eingedrungen sind, das Mycel des letzteren hat eine Zygospore gebildet.

Die Konidienträger sind wohl den Sporangiolen von Thamnidium homolog, wir haben denn hier in Vergleich zu Thamnidium einen höheren Differenzierungszustand, da Sporangien und Sporangiolen auf verschiedenen Trägern gebildet werden.

Während also bei den Choanephoraccen, sei es auch nur in der Kultur, noch Sporangien gebildet werden, kommen solche bei den übrigen Conidiophoreen nie zur Entwickelung. Es sind dies Parasiten, welche das Vermögen der Sporangiumbildung vollständig verloren haben. Zrrei der hierher gehörigen Genera: Chactocladium und Piptocephalis. leben parasitisch auf Mucor-Arten, deren Zellen sie mittels Haustorien aus- 
saugen. Beide bilden Zygosporen und zeigen dadurch, sowie durch die Einzelligkeit ihrer Thallome ihre Zugehörigkeit zu den Zygomyceten.

Bei Chaetocladium stehen die Konidien einzeln, bei Piptocephalis in Reihen.

Die Konidien der Chaetocladiaceen lassen sich ohne besondere Schwierigkeiten von den Sporangiolen der Thamnidieen ableiten. Bei den in Reihen gebildeten Konidien von Piptocephalis stoßen wir auf viel größere Schwierigkeiten, denn es ist mir wenigstens kein Fall eines polyenergiden Organismus bekannt, welcher seine Sporangien in Reihen bildet, wohl aber bildet Albugo in ähnlicher Weise "Konidien", welche noch mit Zoosporen keimen. v. TAvel umgeht diese Schwierigkeit, indem er annimmt, es seien die ganzen Ketten als Sporangien zu betrachten, indem er sagt: "zur Reifezeit werden die Konidien von Piptocephalis durch Querwände durchsetzt".

Ich glaube aber, daß es keineswegs feststeht, daß die Konidien von Piptocephalis von Sporangien abzuleiten sind. Damit wird aber BREFELDS Meinung, daß die Konidien im allgemeinen von Sporangien abzuleiten sind, keinesweg's abgewiesen, wir werden später bei der Besprechung der Peronospora-Arten die schönsten Beweise für BrefeLDs Auffassung in diesem Punkte kennen lernen.

Gehen wir jetzt zur Besprechung der letzten Gruppe der Zygomyceten, zu der der

\section{Entomophthoraceen}

über und besprechen wir als Beispiele einige Empusa-Arten, und zwar zunächst die von BREFELD (1873) sehr genau untersuchte Empusa muscae.

Von Monat Juni an bis tief in den Winter hinein kann man öfters auf den Fensterscheiben angeklebte tote Fliegen antreffen, welche von einer weißen mehligen Masse umgeben sind.

Diese mehlige Masse besteht nur aus den Sporen des Pilzes. Wir haben es hier nun nicht mit einem Verschimmeln einer toten Fliege zu tun, sondern sehen das Resultat einer Fliegenkrankheit, der Pilz hat die lebende Fliege infiziert, getötet und fruktifiziert jetzt.

Nach BREFELD soll die Entwickelung in folgender Weise stattfinden. Eine Empusa-Spore, welche auf eine Fliege gelangt, bleibt leicht zwischen den Haaren, welche den Fliegenkörper bedecken, kleben. Sie bildet dann einen kurzen Keimschlauch, welcher die Chitinhaut durchbohrt und in den Fettkörper der Fliege eindringt; dort schwillt er kugelig an und fängt nun in der Weise der Hefezellen zu sprossen an. Diese Sprossen fallen alsbald auseinander und sind nach BREFELD als Gemmen zu betrachten. Sie gelangen in die Blutbahn und werden in dieser Weise durch den ganzen Fliegenkörper verbreitet, der Hauptsitz ihrer Entwickelung bleibt aber nach wie vor der Fettkörper der Fliege.

Nach 2-3 Tagen ist die Fliege von dem Pilze vollständig ausgesogen, ihr ganzer Körper von den Gemmen erfüllt. In ihren letzten Stunden heftet sie sich gewöhnlich an eine Fensterscheibe an und verendet alsbald.

Die ganze Fliege ist nun sozusagen von den Gemmen ausgestopft. Diese Gemmen fangen nun zu keimen an und bilden mehr oder weniger verzweigte Mycelfäden, welche die Fliegenhaut dúrchbohren und deren Spitzen also ins Freie gelangen und sich durch Bildung einer Querwand zu Konidienträgern verwandeln. 

bildet.

An der Spitze eines jeden Konidienträgers wird eine Konidie ge-

THAxter betrachtet diese Konidien als Sporangien, wobei er sich hauptsächlich auf $E$. sepulchralis beruft, bei welcher innerhalb der "Konidie" eine Spore sichtbar sein soll.

Trahrscheinlich stecken nun in obiger Darstellung zwei Fehler, erstens sind die in Fig. 83, 3 und 4 gezeichneten Gemmen wahrscheinlich nur Fettzellen der Fliege, und werden die wirklichen Gemmen, welche später zu Konidienträgern auswachsen, durch Septierung eines ursprünglich unicellulären Mycels, welches bis jetzt übersehen wurde, gebildet. Zweitens ist die "Spore" innerhalb der Empusa sepulchralis"Konidie" (Fig. 83, II 1) vermutlich nur der kontrahierte Konidieninhalt. IIan vergleiche darüber das unten bei Empusa sciarae Gesagte.

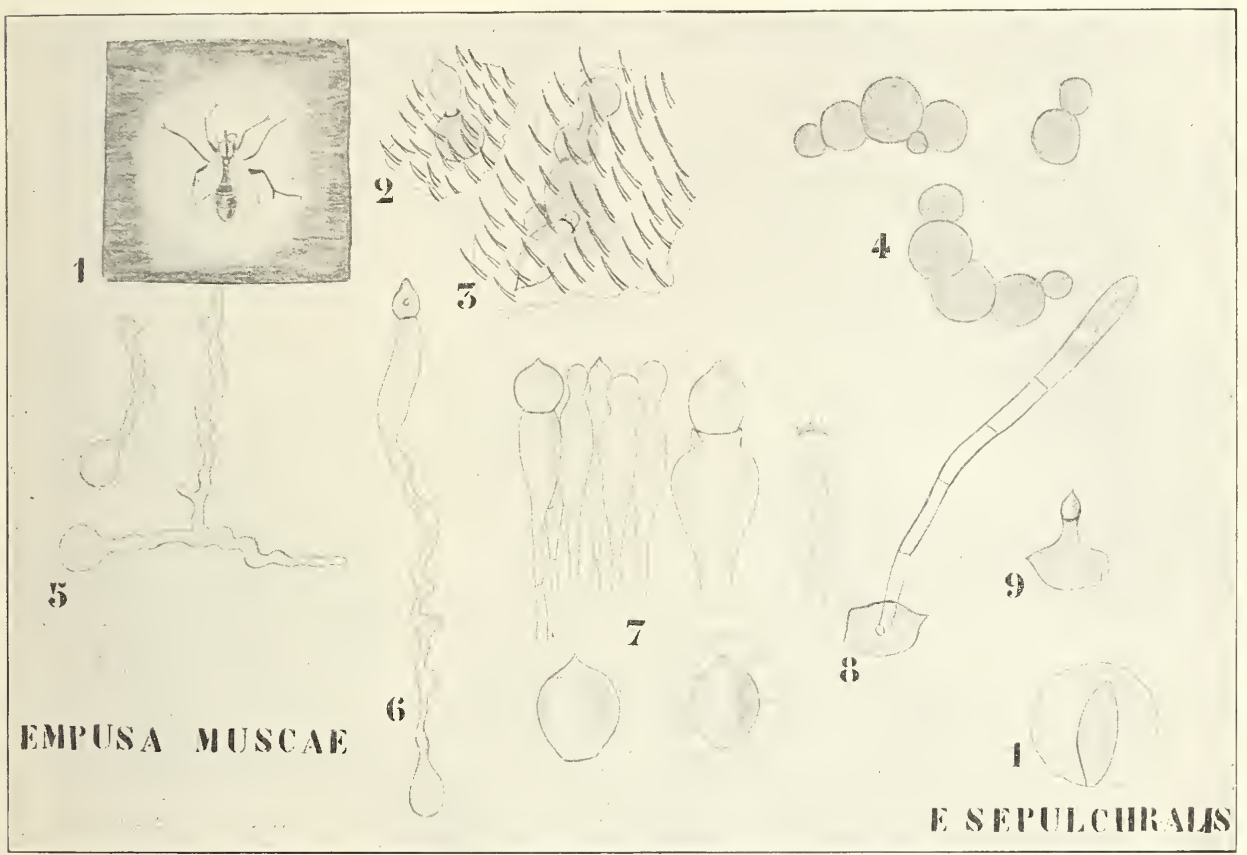

Fig. 83. I. Empusa muscae (nach BREFELD). 1 Tote Fliege an einer Fensterscheibe, von Konidienstaub umgeben. 2 Eindringen der Spore. 3 „Hefeähnliche Sprossung“. 4 „Die hefeähnlichen Vermehrungszellen“. 5 Auskeimende Gemmen. 6 Bildung der Konidienträger. 7 Konidienträger und ausgeschleuderte Sporen. 8 Vegetative Keimung einer Konidie. 9 Fruktifikative Keimung einer Konidie. - II. 1 Rechts unten eine Spore von Empusa sepulchralis.

Interessant ist die Weise, in welcher die Konidien verbreitet werden. es geschieht dies mittels einer Ausschleuderung, welche der bei Pilobolus analog ist. Der Konidienträger nimmt mittels Endosmose Wasser auf, wodurch ein starker Ueberdruck im Innern entsteht, der sich durch ein bauchiges Anschwellen des Konidienträgers äußert (Fig. 83, 7). Offenbar übt aber die Konidie einen noch stärkeren wasseranziehenden Einfluß aus, denn die Trennungsmembran, welche ursprünglich flach war, ragt jetzt halbkugelig in den Konidienträger vor, so daß die Konidie ungefähr 
wie ein Kork in einem Flaschenhals sitzt. Dies kann offenbar nur dann zu stande kommen, wenn der Druck in der Konidie höher als der im Konidienträger ist. Schließlich wird die Zwischensubstanz zwischen der Konidienmembran und der Spitze des Konidienträgers gelöst, und die Konidie wird, wenn der Druck in dem Konidienträger zu groß geworden ist, wie der Pfropfen aus einer Champagnerflasche herausgeschleudert.

Dabei zerreißt meistens die Membran des Sporangienträgers und wird das in ihm vorhandene Plasma mitherausgeschleudert, welches dann um die Konidie herum eine Art Mantel bildet (Fig. 83, 7 rechts unten) und beim Ankleben der Spore Dienste leistet. Der Sporangienträger selber kollabiert dann selbstverständlich.

Die Konidien können so mehrere Centimeter weit fortgeschleudert werden, hat der Schuß getroffen, d. h. hat die Konidie eine Fliege erreicht, so fängt die Entwickelung des Pilzes von neuem an, fällt sie aber ins Wasser, dann keimt sie zu einem Keimschlauch aus, welcher auf der Suche nach einem Fliegenkörper sich möglichst stark verlängert, indem er das Plasma stets an der Spitze ansammelt, und nach hinten mit einer Membran vom leeren Schlauchstück trennt. Der Faden besteht dann schließlich aus einer Anzahl von Zellen, welche mit Ausnahme der terminalen aber leer sind (Fig. 83, 8). Erreicht er auf diese Weise keinen Fliegenkörper, so geht er aus Erschöpfung zu Grunde.

Fällt die abgeschleuderte Konidie aber auf irgend ein festes Substrat, so genügt einige Feuchtigkeit, um sie dazu zu veranlassen, einen zweiten Schuß abzufeuern. Dann keimt sie fruktifikativ (Fig. 83, 9), d. h. sie bildet einen ganz kurzen Konidienträger, der an der Spitze eine kleine Konidie bildet. Gelingt auch dies nicht, so kann die sekundäre Konidie eine tertiäre bilden u. s. w., bis das Vermögen dazu durch die zunehmende Kleinheit der Konidien erschöpft ist.

Bei dieser Empusa-Art sind keine geschlechtlichen Fortpflanzungsorgane bekannt, wohl aber bei der von THAxter (1888) beschriebenen

\section{Empusa sepulchralis Thaxter.}

Es lebt diese Art auf Mücken, auf Tipula-Arten in North Carolina, aber ausschließlich an feuchten Oertlichkeiten. Sie wird hauptsächlich auf solchen Mücken angetroffen, welche an der Unterseite von Holzbrücken oder Baumstämmen über Bächen sitzen.

Wenn viele infizierte Mücken von einer dunkeln Brücke herunterhängen, bieten diese mit dem weißen Pilzkleid bedeckten Langbeine einen so schauerlichen Anblick, daß Thaxter als Speciesnamen den Ausdruck sepulchralis wählte.

Der Körper der Tipula wird von Gemmen ausgefüllt. Diese keimen und bilden Konidienträger, welche aber nicht wie die von $E$. muscae unverzweigt sind, sondern sich am oberen Ende verzweigen und also mehrere Konidien liefern; die Konidien sollen nach THaxter ihre Sporangiennatur noch dadurch zeigen, daß innerhalb der "Konidie" eine Spore vorhanden ist (Fig. 84, 3), OLIVE meint aber, daß diese „Spore“ nur durch die Kontraktion des Konidieninhalts vorgetäuscht wird.

Die Zygosporen werden in dem Fliegenkörper gebildet, die bei der Keimung zweier Gemmen hervorsprossenden Zweige kopulieren in der Weise zweier Spirogyra-Zellen (Fig. 84, A). An dem weiblichen Kopulationszweige entsteht aber eine seitliche Ausstülpung, die alsbald an Größe zunimmt und in welche das Plasma der kopulierenden Zellen 
ganz eintritt. Diese Ausstiilpung wird zur Zygospore (Fig. 84, A-D) und bricht schließlich ab (Fig. 84, E).

Außer den bereits beschriebenen Organen treffen wir bei dieser Empısa noch eigentümliche, sehr dicke, an der Spitze mit kurzen Ausstülpungen versehene Hyphen an, welche wie die Konidienträger aus dem Körper der Mücke hervorbrechen. Sie tragen den Namen Cystiden und sind zweifellos modifizierte Konidienträger. Ihre Funktion ist unbekamnt.

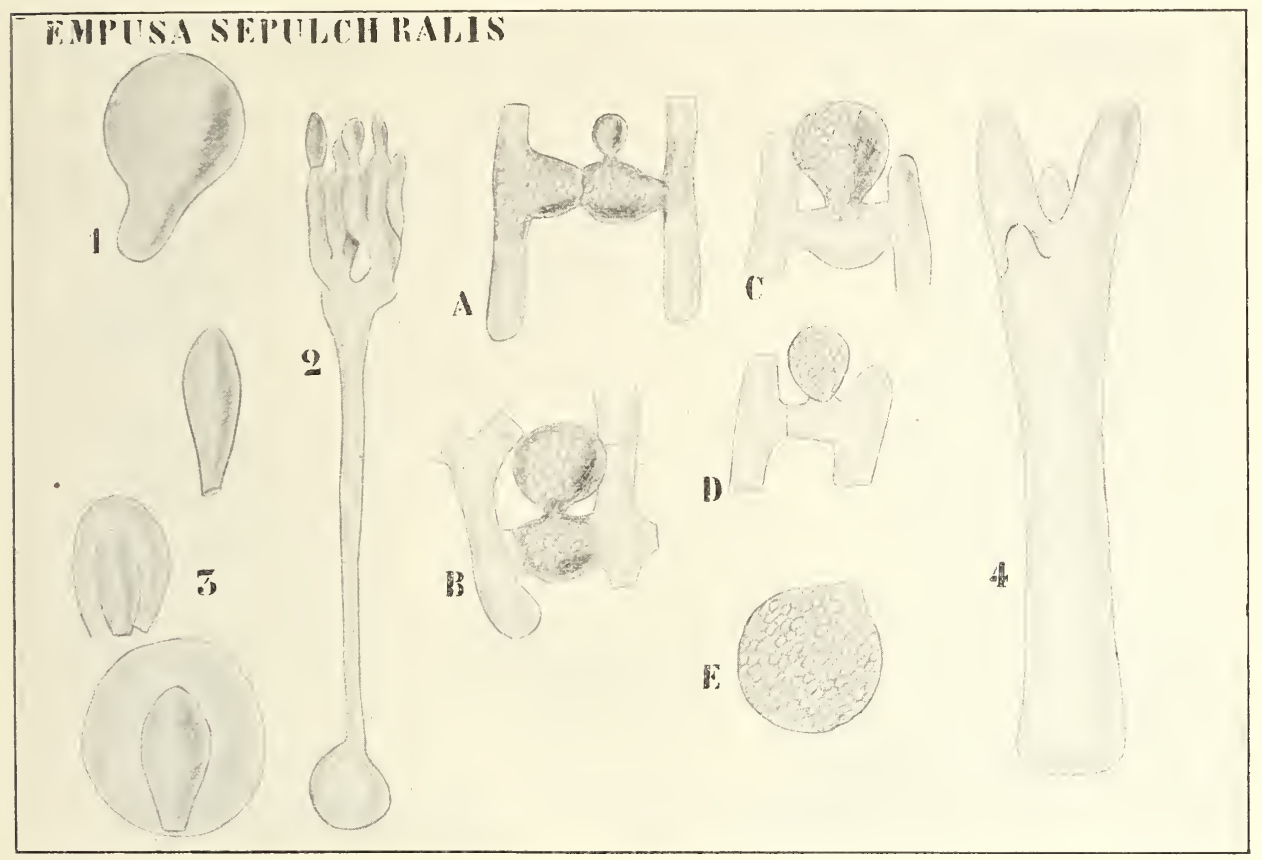

Fig. 84. Empusa sepulchralis (Thaxter). 1 Gemme. 2 Ausgekeimte Gemme mit Konidienträger. 3 Konidien. A-D Bildung der Zygospore. 4 Cystide.

Vor kurzem hat OLIve (1906) Empusa von neuem bearbeitet und zumal einer von ihm entdeckten Art, der

\section{Empusa sciarae Olive}

seine Aufmerksamkeit zugewendet. Diese wurde in Amerika auf einer kleinen Mistfliege auf einer Sciara spec. gefunden. Wenn man die Gefäße, in welchen diese Fliegen gehalten werden, feucht hält, gelingt es leicht, die Larven zu infizieren. Diese bilden ein vorzügliches Material für die Untersuchung des vegetativen Lebens des Parasiten.

Aus OLIves Untersuchungen geht hervor, daß das Mycelium im jungen Zustande polyenergid und unicellulär ist (Fig. 85, 1), und erst später Querwände bildet, wodurch es schließlich in Gemmen zerteilt wird. Diese Gemmen fallen aber hier nicht immer auseinander, sondern keimen in situ, runden sich aber vorher doch etwas ab, wodurch der Zusammenhang gelockert wird, und die Gemmen schließlich doch freikommen können.

Bei anderen Arten aber, z. B. bei $E$. aphidis, bleiben die Hyphen bis zur Fruktifikation unicellulär, dort kann also von einem Auseinander- 
fallen in Gemmen keine Rede sein, die regetativen Hyphen wachsen dort direkt zu Konidiophoren aus. Bei E. sciarae wachsen einige Hyphen zu Rhizoiden aus, mittels welcher das tote Insekt am Substrat befestigt wird.

Der Keimschlauch der Gemme entwickelt sich bei E. sciarae alsbald zu einem verzweigten Konidienträger. Die Konidien von E. sciarae sind uninukleär und müssen bei der Keimung also erst ihre Kernzahl vermehren; leider gelang es OLIve nicht, diesen Vorgang zu beobachten, da es nicht gelang, ein vegetatives Mycel zu kultivieren, sondern nur Stadien erhalten wurden, wie die in Fig. 83, 8 und 9 von Empusa muscae abgebildeten.

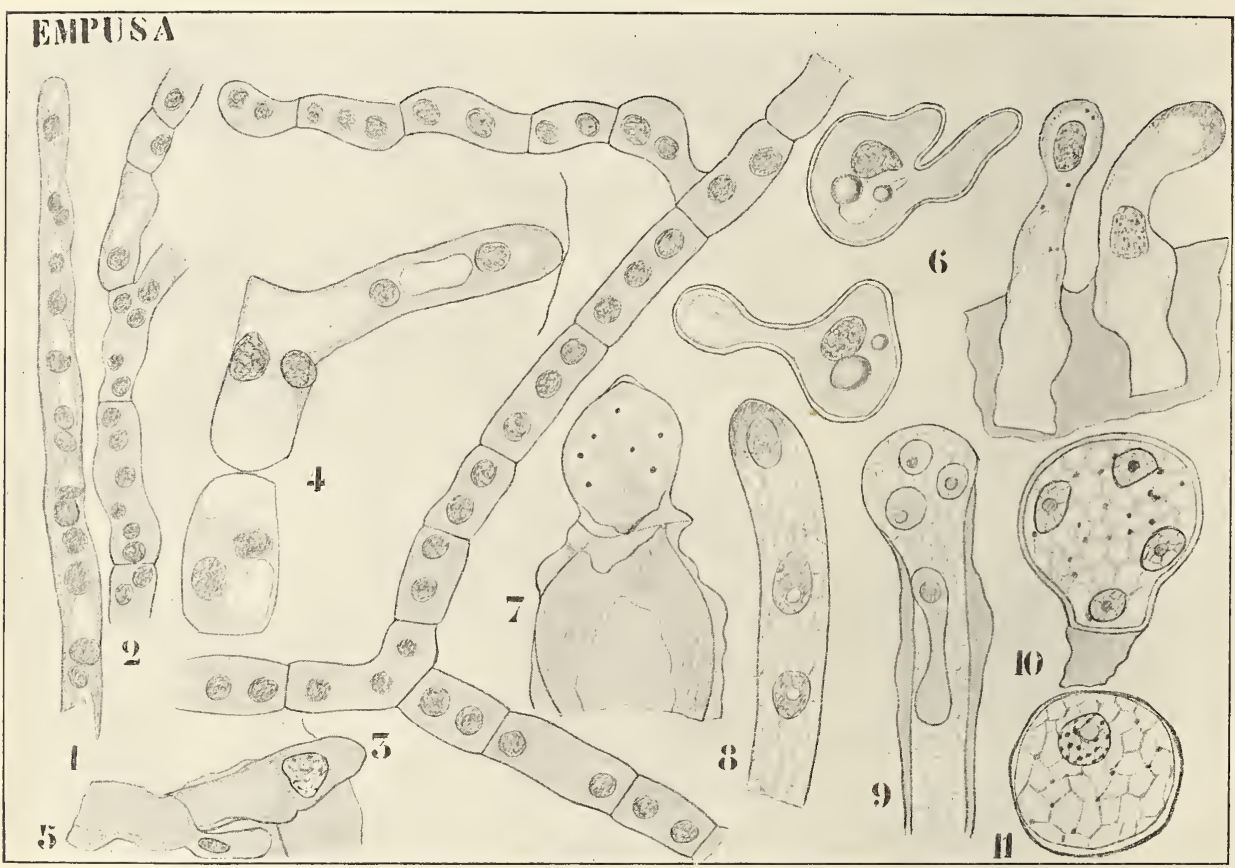

Fig. 85. Empusa sciarae (nach OLrve). 1 Jüngstes Stadium des Mycels im Fliegenkörper. 2, $3 \mathrm{Zu}$ der Bildung von Gemmen führende Querwandbildung. 4 Keimung einer Gemmc. 5 Verzweigung des jungen Konidienträgers. 6 Konidienbildung, Konidien einkernig. 7 Vielkerniges Konidium von Empusa muscae. 8, 9, 10, 11 E. culicis, Bildung von Dauersporen. 11 ist ein dünner Schnitt, in welchem nur ein Nucleus liegt, die anderen Nuclei waren in den anderen Schnitten.

Während die Konidien von E. sciarce uninukleär sind, sind die von E. muscae multinukleär. Cavara war der erste, der darauf aufmerksam machte, daß bei einem Vertreter des verwandten Genus Entomophthora die Konidien einkernig sind, während sie bei E. muscae vielkernig sind. Wie schon bemerkt, fand aber OLIve beim Genus Empusa Arten mit vielkernigen Konidien. Von den 6 von ihm untersuchten Arten haben 4 einkernige Konidien (E. sciarae, E. americana, E. aphidis und eine unbestimmte Art), die von E. culicis haben normaliter binukleäre, selten trinukleäre Konidien, während die von E. muscae mehrere bis 18 Nuclei besitzen. 
Bei allen ist der Konidiophor ursprünglich mehrkernig, bei E. culicis nur 2-3-kernig. Wird nun nur eine Konidie gebildet an der Spitze des unverzweigten Konidienträgers, so ist diese Konidie mehrkernig (E.culicis, $E$. muscae); werden aber mehrere gebildet, so werden die Konidien einkernig (die übrigen untersuchten Arten).

Bei E. culicis kömnen an den Spitzen von großen Hyphen Dauersporen gebildet werden. Solche Hyphen sind 4-5-kernig, alle Kerne treten in die Dauerspore ein. Ob dies Azygosporen sind, muß vorläufig dahingestellt werden. Die von Vurluemin in den Azygosporen von Entomophthora glocospora nachgewiesenen Kernverschmelzungen konnte Olive nicht bestätigen.

Wir können jetzt die Gruppe der Zygomyceten verlassen und uns der Behandlung der

\section{Oomyceten}

zuwenden. Diese Gruppe unterscheidet sich von den Zygomyceten durch die Ungleichheit der kopulierenden Gametangien, mit anderen Worten: die Gametangien sind in Oogonien und Antheridien differenziert.

Wir können bei den Oomyceten zwei Gruppen unterscheiden, und zwar eine, bei welcher echte Befruchtung herrscht, und eine, bei welcher diese fast vollkommen durch Parthenogenese abgelöst ist; die erste Gruppe ist die der Peronosporeae, die letzte die der Saprolegnieae. Ueberdies unterscheiden diese Gruppen sich noch darin, daß die Peronosporeae meistens Parasiten auf Landpflanzen, die Saprolegniaceae dagegen Wasserbewohner sind.

$\mathrm{Zu}$ den Peronosporeae gehören 3 Familien: die Albuginaceae, die Peronosporaceae und die Pythiaceae.

Betrachten wir zunächst die Familie der Albuginaceae und wählen wir als Beispiel das Genus

\section{Albugo,}

welches vielleicht besser unter dem Namen Cystopus bekannt ist. Fangen wir mit

\section{Albugo (Cystopus) candida}

an. Auf dem gewöhnlichen Hirtentäschel (Capsella bursa pastoris) findet man zumal im Herbst sehr häufig einen Pilz, der große, dicke, weiße Anschwellungen auf den Stengelteilen verursacht und zumal die Infloreszenz stark deformiert.

Der Pilz ist so häufig, daß es z. B. um Leiden unmöglich ist, Capsella-Kulturen vor diesem Pilz zu schützen.

Machen wir einen Schnitt durch einen infizierten Teil, so finden wir, daß die Schwielen aus dicht aneinander gepreßten Konidienträgern bestehen, welche also in ihrer Gesamtheit als ein Hymenium bezeichnet werden können. Diese Konidien fallen ab, und ihr Inhalt zerfällt, wenn die Konidien mit Wasser in Berührung kommen, in eine Anzahl von Zoosporen. Dies geschieht z. B., wenn Regen die Pflanzen benetzt. und wenn nun solche mit Zoosporen versehene Regentropfen auf andere Capsella-Pflänzchen fallen, so gelangen die Zoosporen alsbald in die Nähe einer Spaltöffnung, in welche ihr Keimschlauch eindringt (Fig. 86. 6). Versuche haben aber gelehrt, daß die Keimschläuche auch die Epidermis durchbohren können, so zeigt z. B. Fig. 86, 7 einen Keimschlauch, der 
die Epidermis einer Kartoffelknolle durchbohrt. Einmal eingedrungen, breiten die Hyphen sich am liebsten zwischen der Epidermis und der subepidermalen Zellenschicht aus (Fig. 86, 8) und senden von dort Haustorien in die letztere ein.

An diesen Hyphen entwickeln sich die Konidienträger, welche die Konidien in Reihen abschnüren. Jede derselben besitzt, wie ZaLewski (1883) nachwies, 4-8 Nuclei, welche sich nicht mehr teilen, sondern sich nur derartig über die Zoosporen verteilen, daß jede derselben einen Kern erhält.

Im Innern des Stengels werden die Oogonien und Antheridien gebildet, am leichtesten kann man diese auffinden durch Untersuchung derjenigen infizierten Stellen, welche beim Umknicken leicht abbrechen. Die Bildung der Oogonien verursacht nämlich hier eine Sprödigkeit des Stengels.

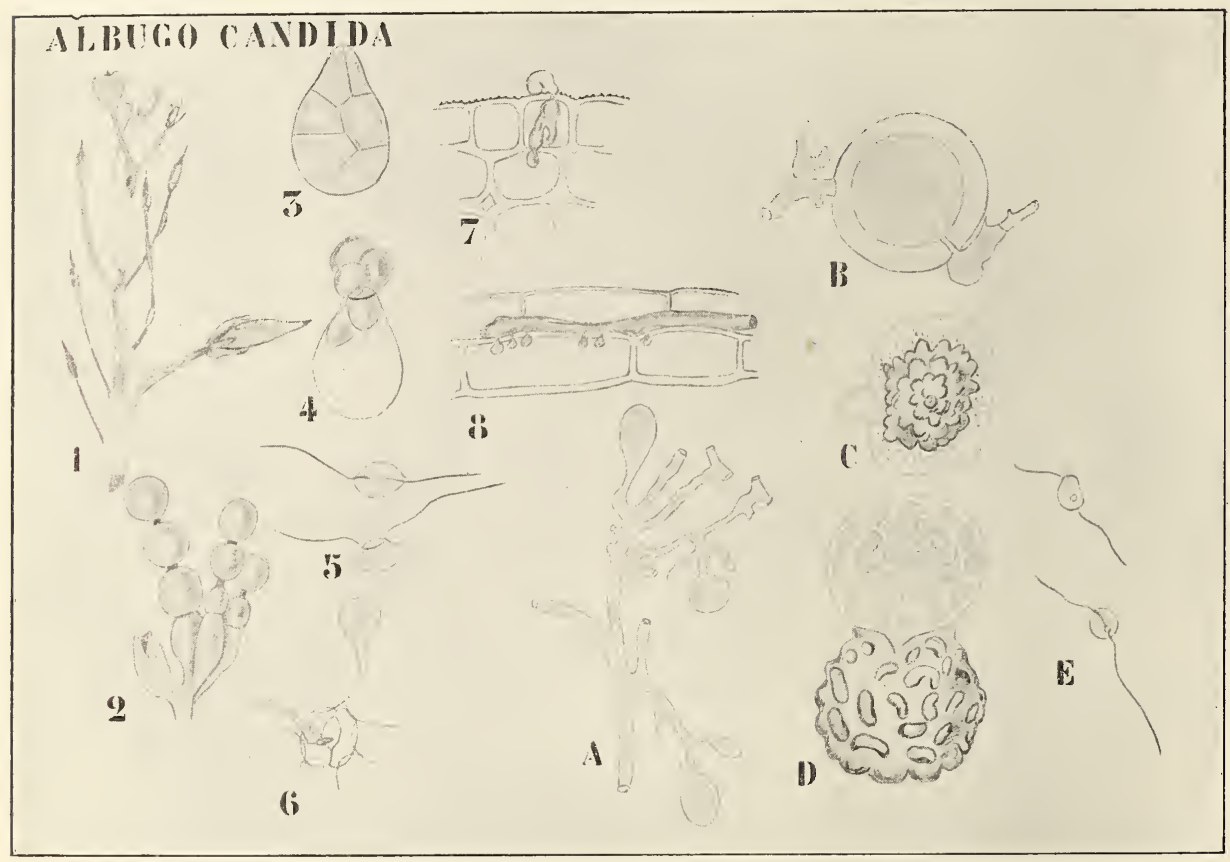

Fig. 86. Albugo candida (hauptsächlich nach DE BARY). 1 Infizierte Infloreszenz mit den vom Pilze verursachten Anschwellungen. 2 Konidien. 3-4 Keimung der Konidien. 5 Schwärmer. 6 Keimung der Schwärmer, Eindringen in eine Spaltöffnung. 7 Ein keimender Schwärmer, welcher die Haut einer Kartoffelknolle durchbohrt. 8 Haustorienbildung. A Junge Stadien der Bildung der Oogonien und Antheridien. B Kopulation eines Oogons mit einem Antheridium. C Ausbildung der Zygospore. D Keimende Zygospore. E Schwärmer der Zygospore entschlüpft.

Die Oogonien entstehen als - meistens terminale - Anschwellungen der Hyphen. Alsbald legt sich ein Antheridium an das Oogon an, in welch letzterem sich ein großes Ei, von einer Zone Periplasma umgeben, ausbildet.

Das Antheridium bildet nun einen Befruchtungsschlauch, der bis ans Ei durchdringt. Nach stattgefundener Befruchtung umgibt sich die Zygote mit einer dicken, warzigen Haut, dem Exosporium, und gelangt nach eingetretener Fäulnis der Capsella ins Freie. 
Bei der Keimung verwandelt sich der Inhalt in eine Anzahl von Zoosporen, welche genau so wie die in den Konidien gebildeten Zoosporen neue Capsellen infizieren. Bis vor kunzem war wenig mehr von der Entwickelung der Albugo-Arten bekannt, und in den Lehrbüchern findet man auch jetzt noch wenig mehr. Die Zahl ihrer Arten ist nicht groß, aber neuere Untersuchungen haben dargetan, daß diese eine sehr interessante Serie bilden, welche uns lehrt, wie, trotzdem Oogonien und Antheridien vorhanden sind, von einer Kopulation von Isogamenten bis zur Heterogamie geschritten werden kann.

Sehen wir also, wie das Ei der Albugo candida z. B. phylogenetisch entstanden ist. Die Aufschlüsse darüber verdanken wir ausschließlich der Cytologie und die Serie wurde durch die Untersuchungen von WaGer

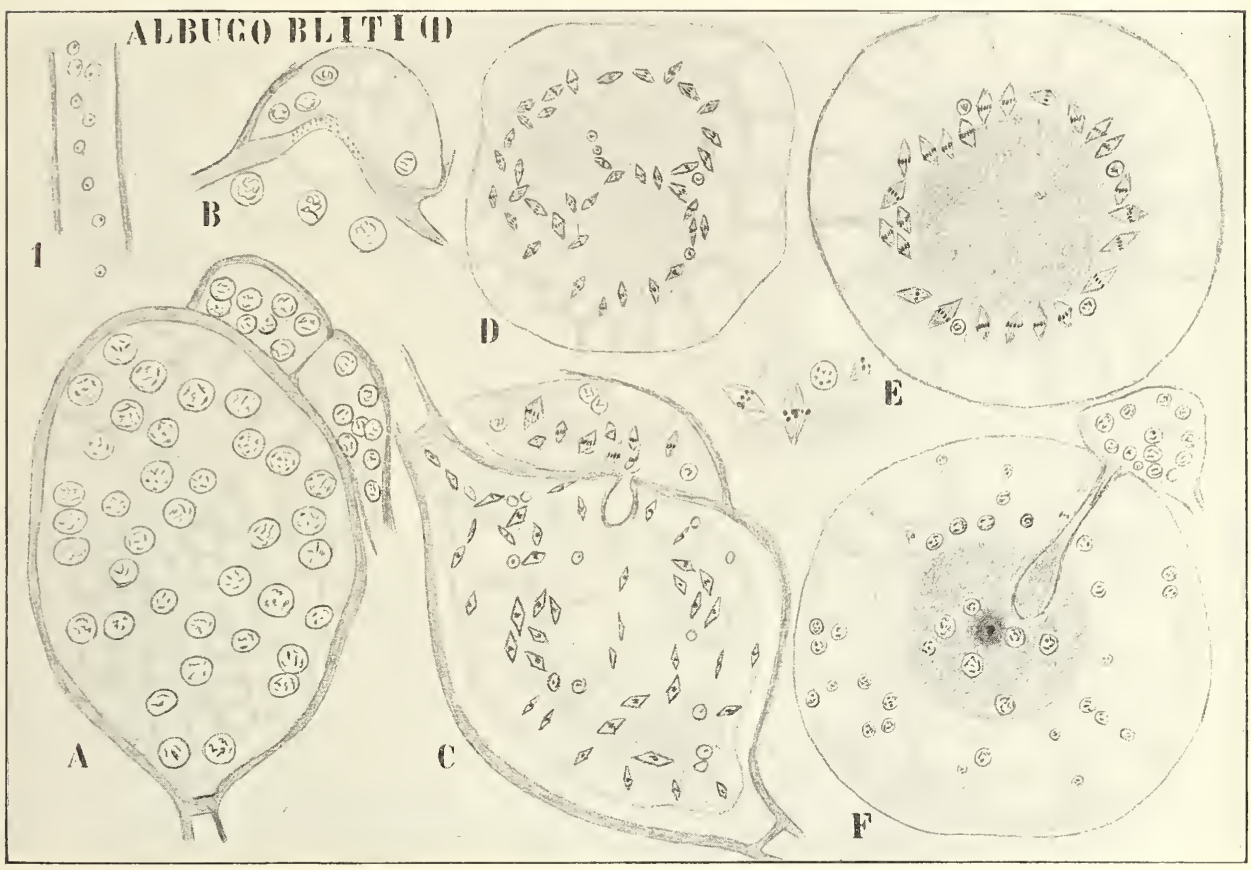

Fig. 87. Albugo Bliti (nach Stevers). 1 Vegetative Hyphe. A Oogon und Antheridium. Die Kerne im Oogon regelmäßig verteilt. B Kopulation zwisehen Oogon und Antheridium, die Kopulationspapille des Oogons ragt in das Antheridium vor. C Kernteilung im Oogon und im Antheridium, das Antheridium bildet eben den Befruchtungsschlauch. D Die Kerne im Oogon fangen an sich umzuordnen. E Die Kerne liegen auf der Grenze von Eiplasma und Periplasma, bei der Teilung treten die Tochterkerne zum Teil in das Ei, zum Teil in das Periplasma. F Befruchtungsschlauch, bis zum Ei vorgedrungen, Bildung des Cönocentrums.

(1896), Stevens (1899), Davis (1900), Stevens (1901) und Ruhland (1904) klargelegt.

Fangen wir unsere Betrachtungen mit

\section{Albugo Bliti}

an. Dieser Pilz findet sich auf Amaranthus-Blüten. Die Hyphen enthalten, wie alle Siphonomyceten, eine Anzahl von Energiden, sind demnach multinukleär. 
Bei der Bildung der Oogonien und Antheridien tritt eine große Anzahl von Energiden in diese ein, so daß auch diese vielkernig sind. Das Antheridium legt sich nun an das Oogon an (Fig. 87, A) und es zeigt sich alsbald die eigentümliche Tatsache, daß es das Oogonium ist, welches eine Kopulationspapille erzeugt, die in das Antheridium vorragt (Fig. 87, B). Die Wand der Papille wird offenbar durch ein Enzym erweicht, wodurch ihre Struktur körnig wird (Fig. 87, B), und durch diese erweichte Stelle tritt dann später der vom Antheridium gebildete Befruchtungsschlauch ein (Fig. 87, C, F).

Die vom Oogonium gebildete Kopulationspapille ist wohl als ein Rudiment einer Oeffnungspapille zu betrachten, als eine Erinnerung an die Zeiten, wo das Gametangium bei den Ahnen die Gameten entließ.

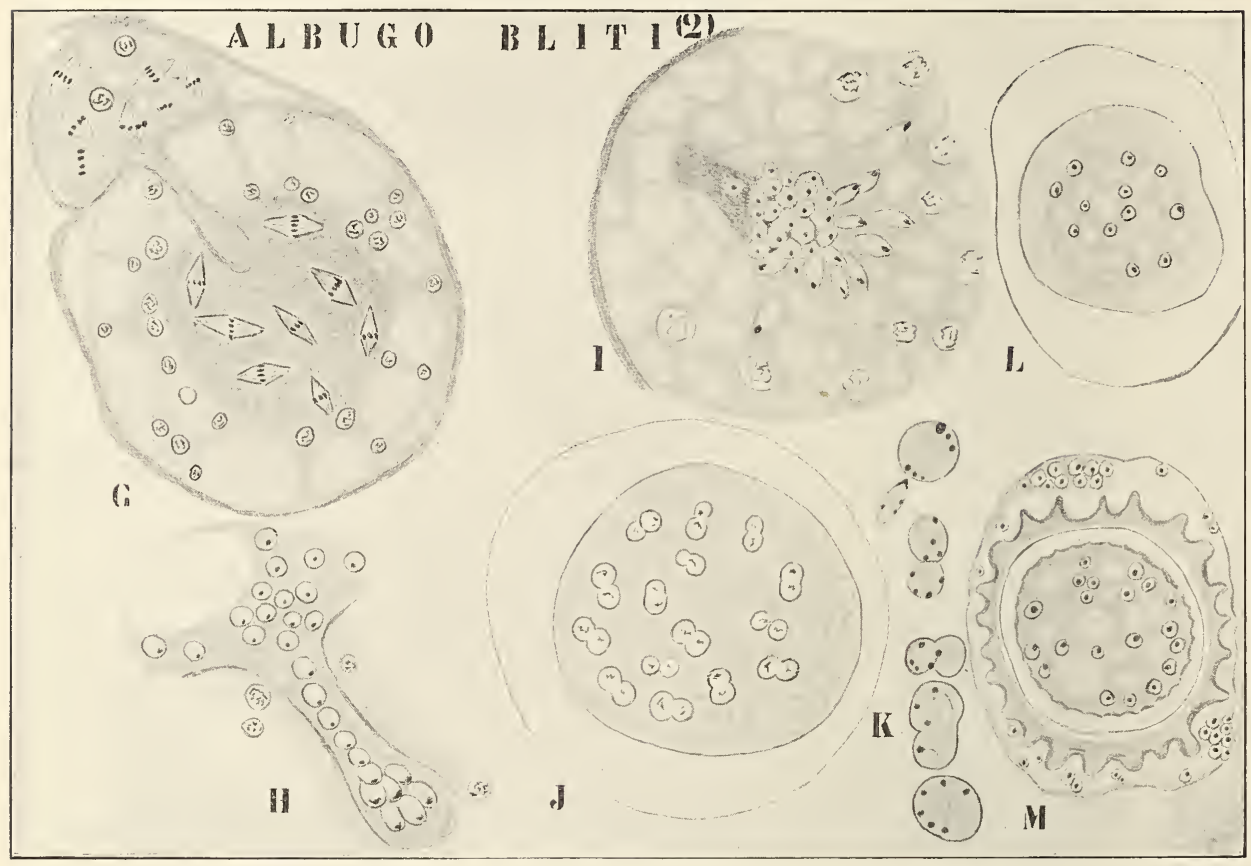

Fig. 88. Albugo Bliti (nach Stevens). G simultane Kernteilung im Ei und im Antheridium. H Eintritt der Antheridienkerne in den Befruchtungsschlauch. I Oeffnung des Befruchtungsschlauches, Eintritt der Spermakerne in das Ei. J, K Kopulation der Gametenkerne. L Zygote mit Kopulationskernen. M Die fertige Zygote noch von Periplasmakernen ungeben.

Alsbald teilen sich nun die Kerne im Antheridium und im Oogon simultan, wodurch ihre Anzahl verdoppelt wird (Fig. 87, C).

Während die Kerne ursprünglich regelmäßig in den Gametangien verteilt waren (Fig. 87, A), fängt jetzt eine Umordnung an, die dahin zielt, eine zentrale Plasmamasse kernfrei zu machen. Die erste Andeutung dieser Umordnung sehen wir in Fig. 87, D, das Resultat in Fig. 87, E.

Diese zentrale Plasmamasse wird nachher zum Ei. Auf dem Stadium der Fig. 87, E liegen also im Periplasma hart an der Grenze der kernfreien zentralen Masse die Kerne auf einer Kugeloberfläche. 
Diese Umänderungen haben stattgefunden, während sich die Kerne in der Metaphase befanden. Die Kernteilung wird jetzt vollendet, es bevegen sich die Chromosomen auf die Pole zu und arrangieren sich dort zu den Tochterkernen. Bei denjenigen Kernspindeln nun, welche ganz im Periplasma lagen, ist das Resultat, daß die beiden Tochterkerne in das Periplasma zu liegen kommen. Einige Spindeln aber hatten sich so arrangiert, daß der eine Pol im Periplasma, der andere im zentralen Plasma liegt, von den aus ihnen gebildeten Tochterkernen kommt demnach der eine ins Periplasma, der andere ins zentrale Plasma zu liegen.

Es treten in dieser. Weise mehr und mehr Kerne in die zentrale Plasmamasse, in das Ei ein. Auf diesem Stadium wird in der Mitte des Eies eine bestimmte, sich etwas anders färbende Plasmaportion sichtbar, das sogenannte Coenocentrum (Fig. 87, F), und dringt der Befruchtung'sschlauch bis in das Ei vor.

Dann findet sowohl im Oogon, wie im Antheridium eine zweite Kernteilung statt, an welcher die im Periplasma liegenden Kerne nicht teilnehmen; diese beteiligen sich auch nicht an der Befruchtung und gehen schließlich zu Grunde. Durch diese Teilung wird also die Anzahl der Kerne sowohl im Antheridium wie im Ei verdoppelt (Fig. 88, G).

Die Antheridienkerne treten nun in den Befruchtungsschlauch ein (Fig. 88, H), dieser öffnet sich alsbald an der Spitze (Fig. 88, I) und läßt die Spermakerne in das Ei übertreten, wo nun je ein Spermakern mit einem Eiker'n verschmilzt.

Später werden um das Ei herum zwei Sporenhäute gebildet (Fig. 88, M), und die Zygospore überwintert in diesem vielkernigen Zustande. Die Periplasmakerne gehen zu Grunde.

Wir haben bis jetzt bei Albugo Bliti immer von einem Ei geredet. Ist das nun richtig? Gewiß nicht, denn ein Ei ist eine weibliche Plasmamasse mit einem einzigen Kern, während hier eine große Anzahl von Kernen im „Ei“" vorhanden ist.

Was wir hier ein Ei genannt haben, ist in der Tat eine Anzah] miteinander verklebter weiblicher Gameten, deren Grenzen nicht sichtbar sind, es ist also viel besser, hier den von DAvis eingeführten Begriff: Cönogamete zu verwenden.

Bei Albugo Bliti kopulieren also miteinander zwei Gametangien, welche trotz ihrer Größendifferenz, Isogameten miteinander kopulieren lassen.

Die Gametangien sind hier also in Oogonien und Antheridien differenziert, der Inhalt aber besteht noch aus Isogameten.

Daß diese Gameten miteinander zu einer Cönogamete verklebt sind, und daß schließlich eine Cönozygote gebildet wird, tut der Isogametennatur keinen Abbruch, ebensowenig wie die Schwärmsporennatur der Cönozoospore von Vaucheria durch die Verklebung der Zoosporen zu der bekannten Riesenzoospore aufgehoben wird.

Im Oogon von Albugo Bliti findet sich also eine Cönogamete, in dem der $A$. candida dagegen findet sich, wie WAGER nachwies, ein echtes Ei, d. h. eine einkernige Plasmamasse. Wie kann sich nun dieses einkernige Ei aus einer Cönogamete gebildet haben?

Das zeigen uns andere Albugo-Arten. Sehen wir also zunächst, wie die Befruchtung bei

\section{Albugo Tragopogonis}

geschieht. Auch hier wird, wie STEvENs (1901) nachwies. zumächst im Oogon eine kernfreie Plasmamasse gebildet. 
Während aber bei A. Bliti auf diesem Stadium noch keine Spur eines Cönocentrums vorhanden ist, zeigt dieses sich hier bereits als ein Fleck im Zentrum der zentralen Plasmamasse. Auch hier treten in derselben Weise wie bei A. Bliti wieder einige Kerne in die Zentralplasmamasse ein, und auch hier findet eine zweite Kernteilung simultan im Oogon und im Antheridium statt (Fig. 89, G).

Es zeigt sich hier aber die bemerkenswerte Tatsache, daß von den Kernen in der Cönogamete sich einer an das Cönocentrum anschmiegt, und daß nur dieser, indem er sich stark vergrößert, am Leben bleibt, während die übrigen degenerieren (Fig. 89, H). So wird also ein echtes Ei gebildet, insoweit als die Plasmamasse einkernig ist, die Plasmamasse selber ist aber aus den Körpern vieler Gameten aufgebaut worden.

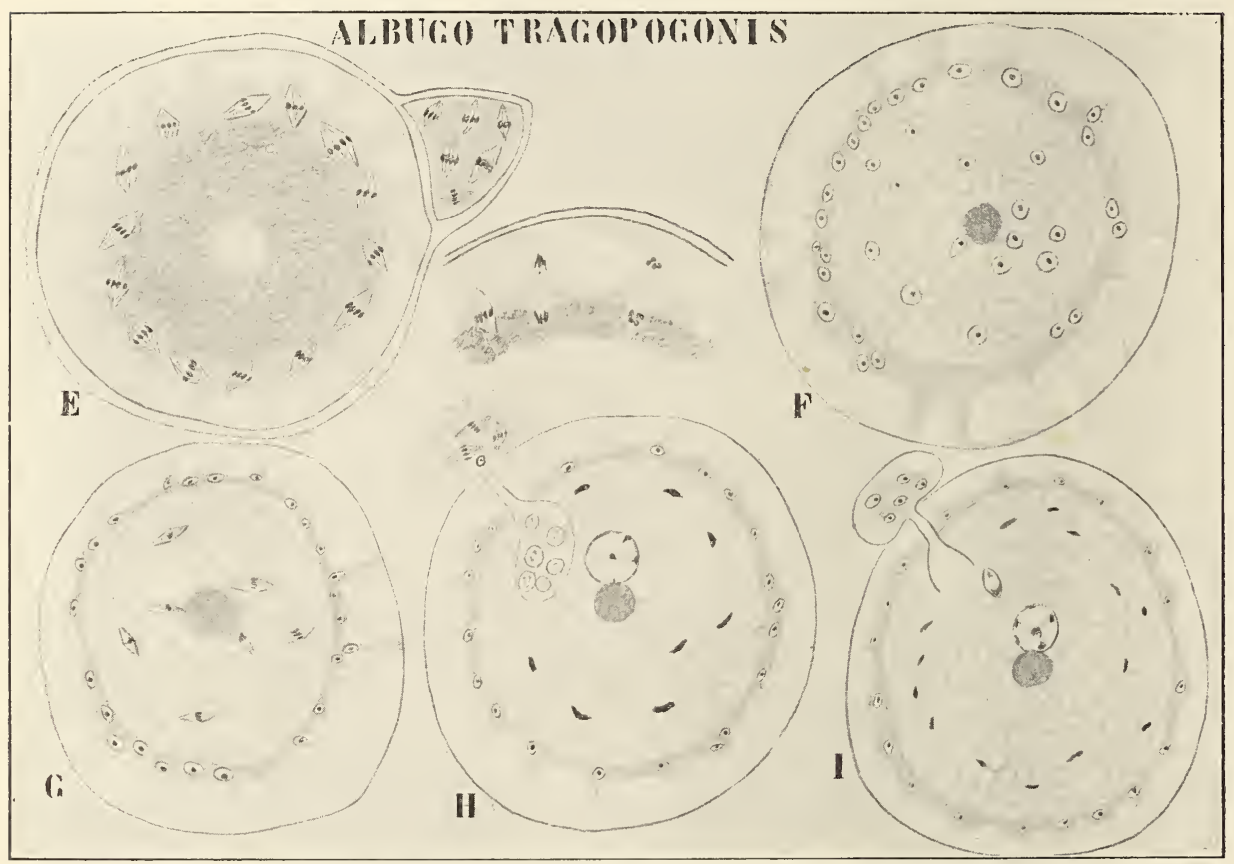

Fig. 89. Albugo Tragopogonis (nach Stevens). E Links: kernfreie zentrale Plasmamasse im Oogon, rechts: die Kernspindeln auf der Grenze der zentralen Plasmamasse und des Periplasmas. F Vielkernige Cönogamete mit Cönocentrum, ein Kern in Berührung mit dem Cönocentrum. G Kernteilung in der Cönogamete. H Derjenige Gametenkern, welcher mit dem Cönocentrum in Berührung geblieben ist, hat sich vergrößert, die anderen sind degeneriert. I Die Spermakerne werden in das Ei eingeführt.

Man kann aber sagen, daß durch Degeneration der Kerne mit Ausnahme eines einzelnen die Cönogamete zum Ei geworden ist. Die Kerne aus dem Antheridium treten, gerade so wie bei A. Bliti, in das Ei ein, da aber nur einer derselben einem weiblichen Kern begegnet und also nur einer kopulieren kann, gehen die übrigen zu Grunde. Die Zygote enthält also nur einen Kern, welcher alsbald das Cönocentrum anscheinend verzehrt (Fig. 90, K).

Dann werden die Zygosporenhüllen gebildet, und der Zygotenkern 
teilt sich wiederholt, so daß die überwinternde Zygospore eine Anzahl von Kernen enthält.

Anscheinend ist diese Zyoospore also von der Zygospore der A. Bliti nicht verschieden, aber während die Winterspore von A. Bliti in der Tat eine ganze Anzahl von Schwesterzygoten enthält, enthält hier die Winterspore eine Anzahl von Tochterkernen des einzigen Zygotenkernes, es hat eben die Zygote angefangen zu keimen.

Bei A. Tragopogonis ist also die Zygote durch Degeneration der überschüssigen Gametenkerne zum Ei geworden.

Das gleiche Resultat kann nun noch auf anderem Wege erreicht werden und wird in der Tat auf besonderem Wege erreicht bei

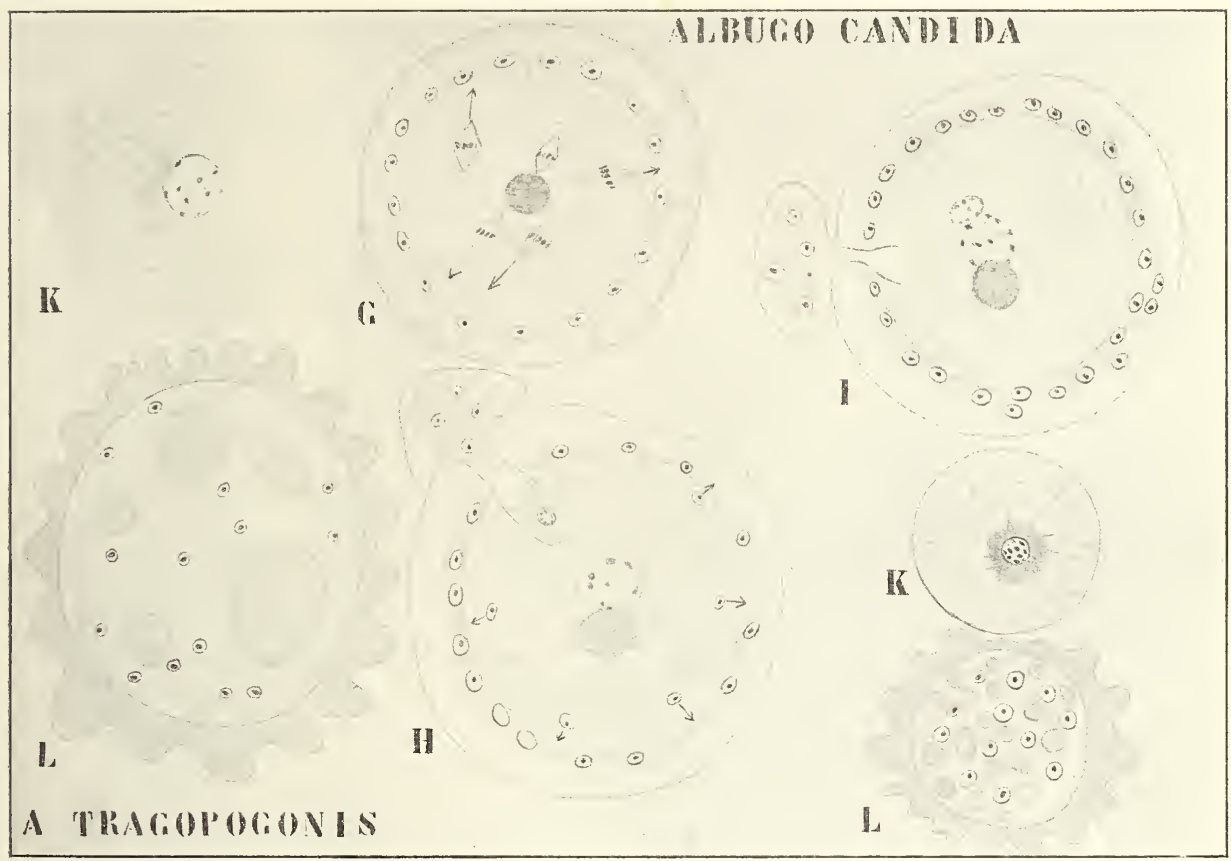

Fig. 90. I. Albugo Tragopogonis (nach STevens). K Zygote mit Kern und geringem Rest des Cönocentrums. L Vielkernige überwinternde Zygospore. - II. A 1 bu g o can'dida (nach Stevens, Doris und WAger). G Die überzähligen Kerne im Begriff, aus dem Ei auszuwandern. H Eikern in Verbindung mit Cönocentrum. I Kopulation von Ei und Spermakern. K Einkernige, L vielkernige Zygote.

\section{Albugo candida.}

Auch bei dieser Art wird in der üblichen Weise eine kernfreie zentrale Plasmamasse im Oogon gebildet. Auch hier tritt in diese Masse wieder eine Anzahl von Kernen ein. Während aber bei A. Tragopogonis die Cönogamete durch Degeneration der überschüssigen Kerne einkernig wird, wird hier das gleiche Resultat dadurch erreicht, daß die überflüssigen Kerne das Ei wieder verlassen, sie wandern wieder aus und kommen in das Periplasma zu liegen (Fig. 90, G. die Pfeile greben die Bewegungsrichtung an).

Auch tritt hier nicht mehr eine ganze Anzahl ron Spermakermen in 
das Ei ein, um dort mit Ausnahme eines auserwählten zu Grunde zu gehen, sondern es bleiben sämtliche Spermakerne mit Ausnahme eines einzigen heraustretenden im Antheridium liegen.

Die übrige Entwickelung findet wie bei A. Tragopogonis statt.

A priori ist nun noch eine dritte Möglichkeit zur Eibildung gegeben. Es könnte sich nämlich überhaupt nur ein einziger Kern in die zentrale kernfreie Plasmamasse hineinbegeben, dieser Fall ist nach RuHLAnd bei Albugo Lepigoni realisiert.

Wir sehen also, wie uns bei den Albugo-Arten eine sehr schöne phylogenetische Serie bewahrt geblieben ist.

Gehen wir jetzt zur Behandlung der zweiten Familie der Peronosporeae, zu der der

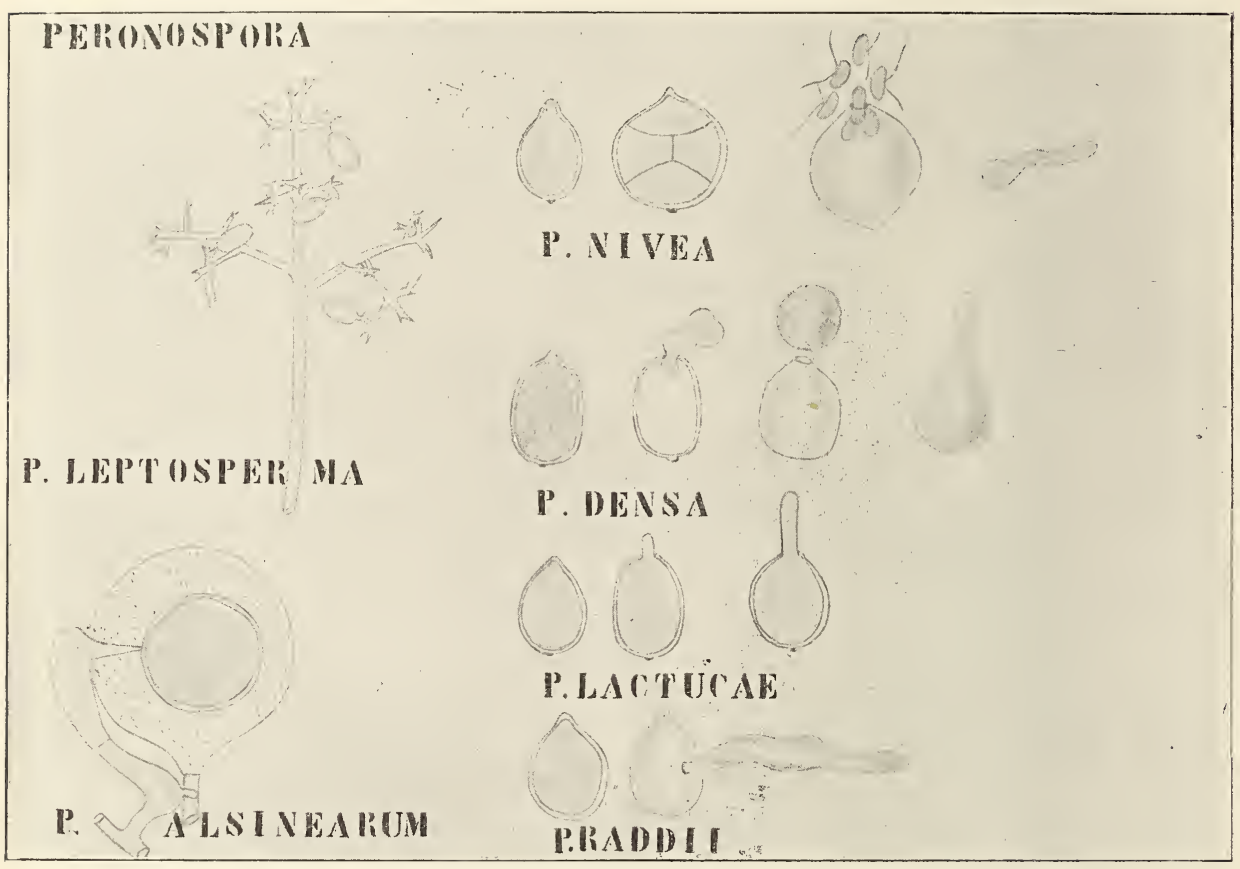

Fig. 91. Peronospora leptosperma (nach DE BARY). Konidienträger. P. Alsinearum (nach DE BARY). Oogon und Antheridium. - Die übrigen Arten nach BREFELD: Keimungsweisen der Konidien.

\section{Peronosporaceae}

über. Es sind dies Parasiten, deren Hyphen sowohl intercellulär, wie intracellulär leben, und welche öfters große, fingerförmig verzweigte Haustorien in die Zellen der Wirtspflanze hineinsenden, welche so groß sein können, daß sie die infizierte Zelle fast ganz ausfüllen.

Wählen wir als Beispiel das Genus

\section{Peronospora.}

Die Konidienträger sind meistens wie bei $P$. leptosperma reichlich verzweigt und gelangen durch die Stomata ins Freie. Die Konidien fallen $a b$ und zeigen durch ihre Keimungsweise, daß sie bloß meta- 
morphosierte Zoosporangien sind. So finden wir z. B. bei Peronospora nivea, einer Art, welche auf Petroselimum, Daucus, Aegopodinm vorkommt, Konidien, deren Inhalt in Zoosporen auseinanderfällt, welche aus der Konidie ausschwärmen. Die Konidie ist hier also bloß ein sich in toto loslösendes Sporangium.

Bei P. densa, welche auf Alectorolophus, Euphrasia, Odontites und Pedicularis vorkommt, tritt der ganze Inhalt der Konidie durch eine apikale Oeffnung heraus, umgibt sich darauf mit einer Membran und keimt. Trotzdem hier also keine Schwärmsporen mehr gebildet werden, deutet doch dieses Austreten des Plasmas auf eine recente Reduktion der Zoosporenbildung, also darauf hin, daß die Konidie noch vor nicht sehr langer Zeit ein Sporangium war.

\section{PERONOSPORA PARASITICA}
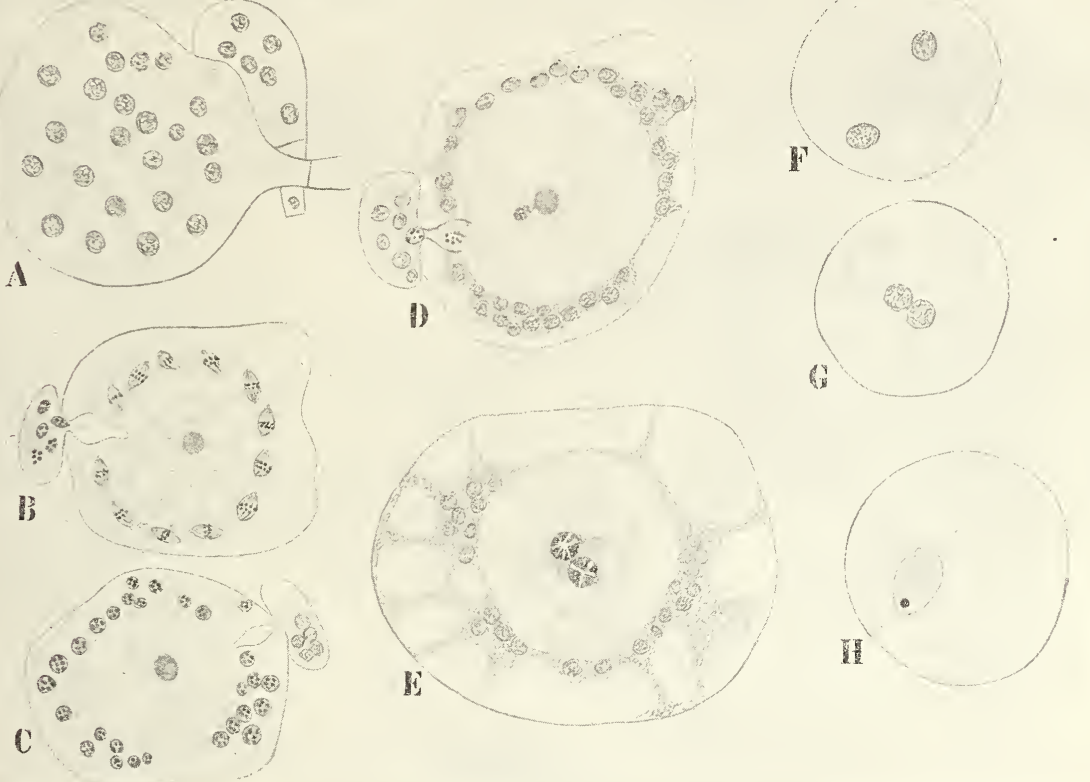

Fig. 92. Peronospora parasitica (nach WAGER). A Die Kerne gleichmäßig im Oogon verteilt. B Simultane Kernteilung im Oogon und im Antheridium, die Kerne geben eine zentrale Plasmamasse frei. C Im Ei nur ein Cönocentrum. D Einer der Kerne ist, vom Cönocentrum angezogen, wieder in das Ei getreten. E Ei und Spermakern dem Cönocentrum angepreßt. F Ei und Spermakern entfernen sich voneinander. G Erneute Annäherung. H Kopuliert.

Bei $P$. Lactucae, welche auf Salat vorkommt, keimt die Konidie direkt, aber der Keimschlauch tritt noch immer durch das apikale Ende der Konidie heraus, an derjenigen Stelle also, wo sich früher das Zoosporangium öftnete. Es scheint fast, als erinnerte sich die Konidie ihrer Abstammung von einem Zoosporangium. Erst bei P. Raddii, einer Art. welche auf den Köpfchen von Anthemis, Chrysanthemum leucanthemum. Matricaria etc. schmarotzt, ist diese Erimmerumg völlig erloschen; der Keimschlauch tritt an irgend einer beliebigen Stelle der Konidie hervor.

Die Oogonien und Antheridien entstehen im großen und ganzen wie 
bei Albugo. Auch hier wird nur ein Ei im Oogon gebildet und bleibt etwas Periplasma unverwendet zurück.

Bis vor kurzem war von der Cytologie noch nichts bekannt. Neuerdings aber wurde sie von Wager (1889), BerLese (1898), Wager (1900) und Ruhland (1904) näher untersucht. Wir wollen hier in aller Kürze die von Wager an Peronospora parasitica gewonnenen Resultate mitteilen (Fig. 92).

Oogonium und Antheridium enthalten eine große Anzahl von Kernen, welche sich alsbald in beiden Organen simultan einmal teilen. Im Oogon wird in der schon bei Albugo beschriebenen Weise das zentrale Plasma kernfrei, es bildet sich darin alsbald ein Cönocentrum. Die Kernteilung ist inzwischen beendet, es liegen die Tochterkerne in einer Hohlkugel um die zentrale Plasmamasse herum (Fig. 92, C). Eine von diesen wird vom Cönocentrum angezogen und tritt wieder in das Ei ein.

Wir erhalten somit folgende Serie der Eibildung aus einer Cönogamete:

bei Albugo Bliti eine vielkernige Cönogamete,

Tragopogonis ein Ei, welches durch Degeneration der überschüssigen Kerne entstand,

candida ein Ei, welches durch Herauswandern der über-

zähligen Kerne sich bildete,
"Peronospora parasitica ein Ei, welches dadurch entsteht, daß nur ein Kern in die zentrale Plasmamasse hineintritt.

Die im Periplasma liegenden Kerne gehen auch bei Peronospora schließlich zu Grunde. In Einklang mit dem Eintritt eines einzigen Kernes in das Ei tritt nur ein Kern aus dem Antheridium heraus; die übrigen gehen zu Grunde. Eikern und Spermakern schmiegen sich nun dem Cönocentrum an, welches letzteres alsbald verschwindet. Alsbald aber entfernen sich Ei- und Spermakern wieder voneinander, um schließlich doch nach erneuter Annäherung zu verschmelzen.

Die Zygote überwintert hier im einkernigen Stadium, um aber doch im Frühjahr mittels Zoosporen zu keimen.

Wenden wir uns jetzt der letzten Familie der Peronosporeae, der der

\section{Pythiaceae}

zu, von welcher wir das Genus Pythium behandeln wollen. Während die meisten Pythium-Arten im Wasser leben, wo sie auf faulenden Pflanzenteilen und Insekten vorkommen, gehört die bestbekannte Art

\section{Pythium de Baryanum}

$\mathrm{zu}$ denjenigen Arten, welche parasitisch auf Landphanerogamen leben. Sie schmarotzt auf einer ganzen Reihe von Phanerogamen, besonders gern auf Lepidium sativum und auf Gurken und Melonen. Am leichtesten erhält man sie durch das Aussäen von Gurken oder Kresse in einem Boden, welcher einer feuchten Stelle eines Gartens entnommen ist. Man soll dann die Sämlinge etwas übermäßig feucht halten.

Das erste Zeichen der Krankheit ist das Umfallen der Sämlinge, welches durch das Eindringen des Parasiten in das Hypokotyl verursacht wird.

Es wird dieses hart am Boden ausgezogen, wodurch seine Turgeszenz verloren geht. Der Pilz dringt durch eine Spaltöffnung ein und 
wächst quer durch die Zellwände hindurch in das Hypokotyl hinein (Fig. 93).

Hier bildet er sodann Zoosporangien, welche durch Anschwellung von interkalaren oder terminalen Zellen entstehen. Ihre Keimung ist recht eigentümlich. Zunächst entsteht ein Keimschlauch, als wäre das Zoosporangium eine Konidie, dieser schwillt aber an der Spitze zu einer kugeligen Blase an, in welche das Plasma des Sporangiums hineintritt. Dort zerfällt es in eine Anzahl ron Zoosporen (mit je ein oder je zwei (ilien?), welche ausschwärmen und zu neuen Mycelien auskeimen.

Man kann aber auch die Zoosporangien in der Art von Konidien direkt zu neuen Mycelien auskeimen lassen. Dazu braucht man nur alte Zoosporangien auszusäen.

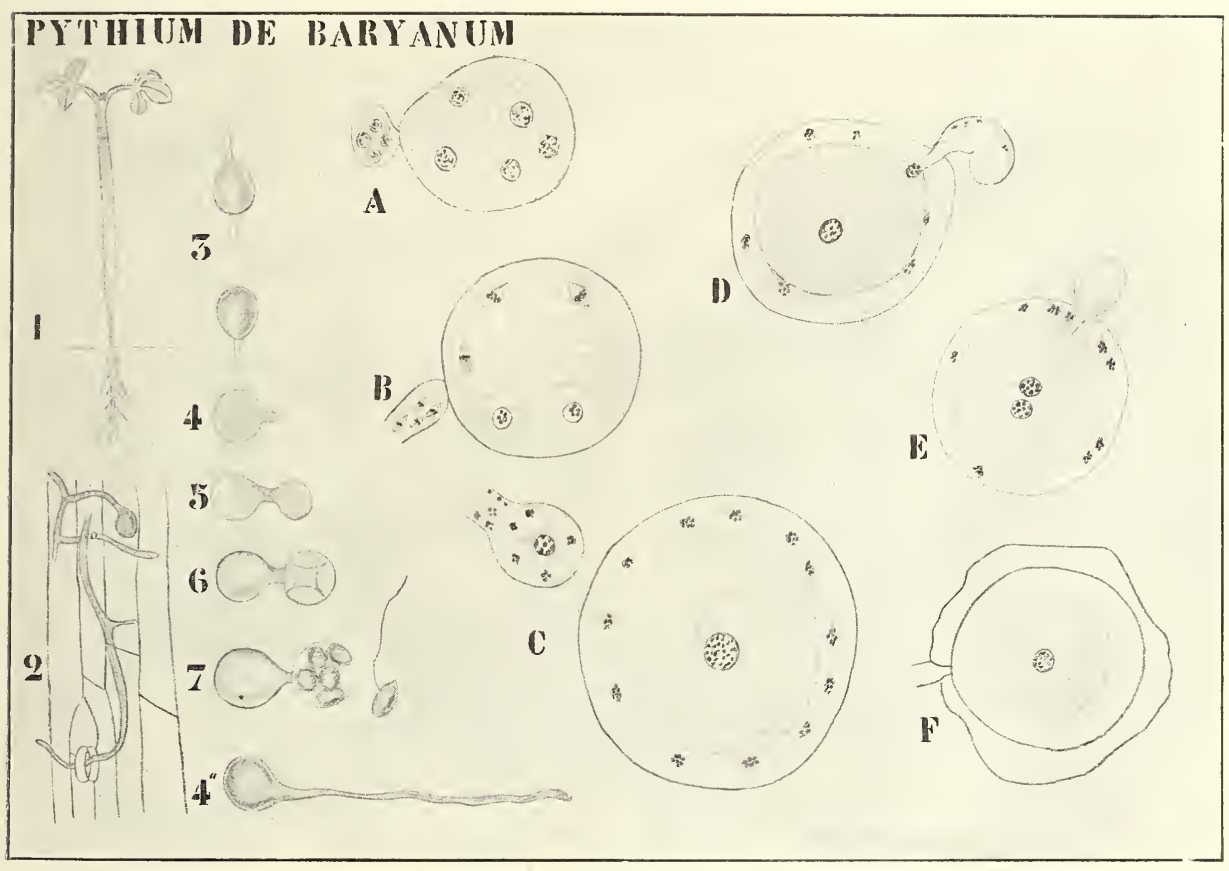

Fig. 93. Pythium de Baryanum (nach MrYAke). 1 Infizierte Kressenpfanze. 2 Eindringender Parasit. 3 Zoosporangienbildung. 4-7 Zoosporenbildung. $4^{\prime \prime}$ Ein in der Art einer Konidie keimendes Zoosporangium. A Oogon und Antheridium, die Kerne im Oogon gleichmäßig verteilt. B Kernteilung im Oogon und im Antheridium. C Einkerniges Ei, im Antheridium alle Kerne bis auf einen degeneriert. D Eintritt des Spermakerns. E, F. Kopulation von Ei- und Spermakern.

Die Cytologie von Pythium ist erst seit 1901 bekannt, in welchem Jahre Trow (1901) und Mryake (1901) beide in der gleichen Zeitschrift ihre Resultate veröffentlichten. Der Hauptsache nach stimmen diese überein.

Bei Pythium de Baryanum, dessen Cytologie wir hier nach Mrrake behandeln wollen, sind Oogonien und Antheridien mehrkernig, besitzen aber viel weniger Kerne, als die gleichnamigen Organe bei Albugo oder Peronospora. Im Antheridium sind mehr als 4 Kerne rorhanden. Auch hier findet im Oogon und im Antheridium simultan eine Kern- 
teilung statt, und auch hier wird eine zentrale Plasmamasse im Oogon kernfrei. So wie bei Peronospora tritt später ein einziger Kern wieder in diese zentrale Plasmamasse ein, wodurch sie zum Ei wird. Die Kerne im Protoplasma degenerieren auch hier.

Das Antheridium verhält sich aber etwas anders als bei Albugo oder Peronospora. Es degenerieren nämlich noch innerhalb des ungeöffneten Antheridiums alle Kerne bis auf einen, dieser tritt in das Ei iiber, kopuliert mit dem Eikern und die Zygote überwintert im einkernigen Stadium, wie die von Peronospora. Ein Cönocentrum wurde nicht gefunden.

Stellen wir hier nun die an Albugo, Peronospora und Pythium gewonnenen Resultate zusammen, so erhalten wir folgende Reihe:

Albugo Bliti

Albugo Tragopogon is

Albugo candida

Peronospora parasitica
Wie oben.

Sämtliche Antheridienkerne funktionieren

Sämtliche Antheridienkerne treten in das Oogon über,

Trotzdem das Antheridium viele Kerne enthält und sich öfnet, tritt nur ein Spermakern heraus, die übrigen degenerieren später im Antheridium.

Schon im ungeöffneten Antheridium degenerieren alle

Kerne bis auf einen. und kopulieren mit den in gleicher Zahl vorhandenen Kernen in der Cönogamete.

degenerieren da aber bis auf einen, welcher mit dem Eikern kopuliert. Das Ei ist aus der Cönogamete durch Degeneration von allen Kernen bis auf einen entstanden.

Der ausgetretene Spermakern kopuliert mit dem Eikern. Das Ei ist aus der Cönogamete durch Herauswandern aller Kerne bis auf einen entstanden.

Der ausgetretene Spermakern kopuliert mit dem Eikern. Das Ei ist aus der zentralen Plasmamasse entstanden durch Einwandern eines einzigen Kernes.

Wie oben.
Pythium de Baryanum

Wenden wir uns jetzt derjenigen Familie zu, bei welcher Parthenogenese in ausgiebigstem Maße an Stelle der Befruchtung getreten ist, der Familie der

\section{Saprolegniaceae.}

Diese Organismen sind leicht zu erhalten. Man braucht nur eine tote Fliege oder ein sonstiges Insekt ins Wasser zu legen, welches ein wenig Schlamm aus einem Teiche oder Graben enthält. Man sieht dann diese Fliege bald von einer Corona paralleler, weißer Pilzhyphen umgeben. Im vegetativen Stadium sind diese Fäden sehr straff, daher die parallele Lagerung; fängt aber die Fruktifikation an, dann werden sie mehr oder weniger schlaff und verwirren sich dadurch einigermaßen, wodurch die hübsche Regelmäßigkeit der Corona gestört wird.

Gesetzt den Fall, wir haben in obiger Weise eine

\section{Achlya}

erhalten, so geschieht die Fortpflanzunguetwa in folgender-Weise (Fig. 94). 
Eine im Wasser herumschwimmende Zoospore hat eine tote Fliege gefunden und sich auf dieser angesiedelt. Hier keimt sie zu einem bäumchenähnlich verzweigten, aufrechten Pflänzchen (Fig. 94, 0 unten), welches von seinen Zweigen Ernährungshyphen nach der Fliege sendet. etwa in der Weise, wie gewisse tropische Ficus-Arten Luftwurzeln bilden.

Diese dringen in den Fliegenkörper ein und bilden schließlich Hyphen, welche aus der Fliege heraustreten und um diese herum die schon erwähnte Corona bilden.

Nach einiger Zeit schwellen die Spitzen dieser Hyphen etwas an. tremnen sich mittels einer Querwand vom übrigen Teile der Zelle ab und werden zu Zoosporangien. Ihr Inhalt zerfällt in eine Anzahl von Schwärmsporen, welche nach einer gelegentlichen Beobachtung Hum-

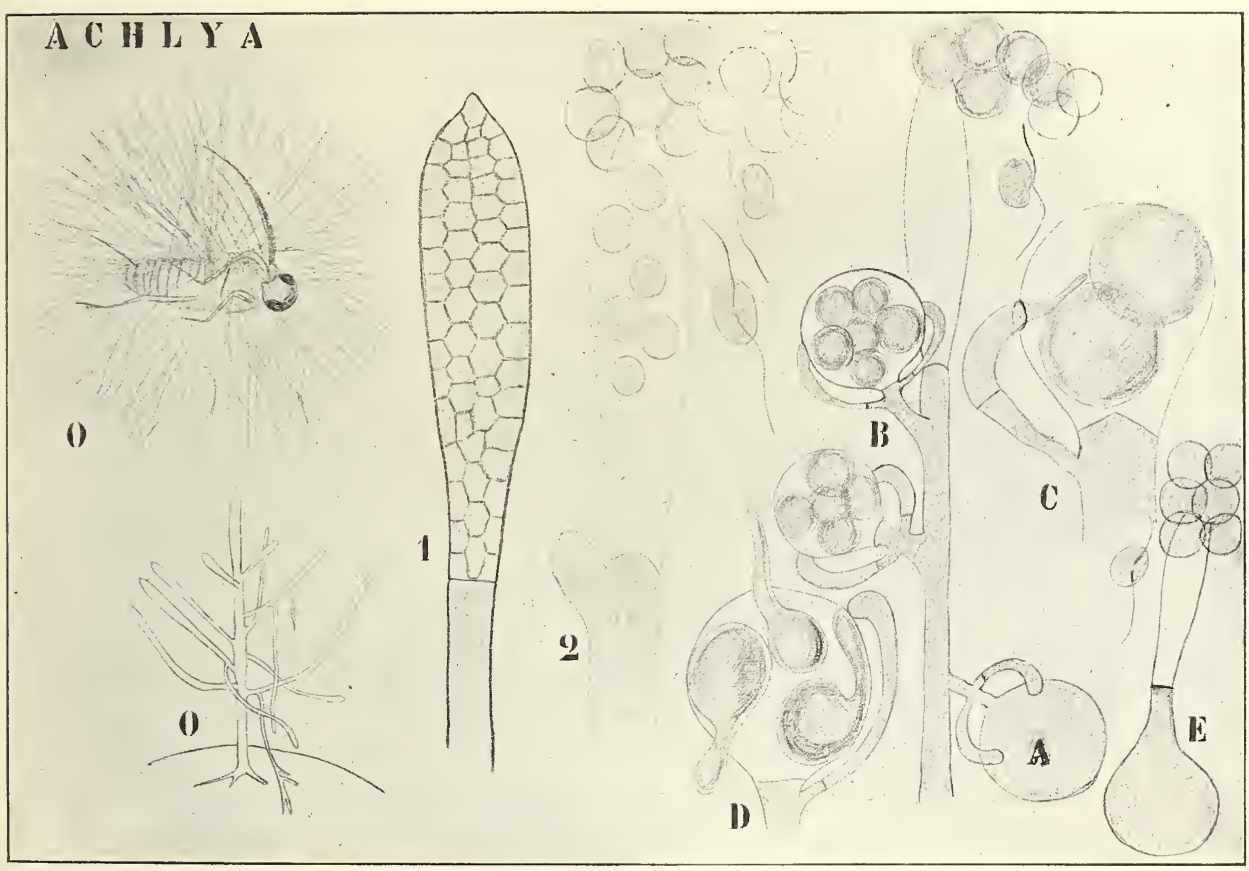

Fig. 94. A chlya (nach DE BARY). 0 Unten: junges Pflänzchen auf einer Fliegenhaut, oben: Kultur mit dem Beginn der Fruktifikation. 1 Beginn der Schwärmsporenbildung. 2 Austreten der biplanetischen Schwärmer. Rechts A-C Achlya racemosa HrLDEBR. A Junges Oogon. B Reifes Oogon. C Eindringen des Befruchtungsschlauches. D, E Keimung der Zygoten resp. Parthenosporen von Achlya polyandra. I) vegetative, E fruktifikative Keimung.

PHREys 2 Cilien besitzen, deren Cilien aber in der Regeel nicht sichtbar sind. Sie schwärmen nach der sich öffnenden Spitze des Sporangiums hin, treten aber nicht ganz heraus, sondern bleiben auf der Spitze kleben und umgeben sich dort mit einer Membran (Fig. 94, 2). Nach einigen Stunden jedoch schlüpfen sie aus dieser Membran heraus. schwimmen fort und zeigen jetzt deutlich ihre beiden Cilien. Es kommen also bei diesen Zoosporen zwei Schwärmstadien vor, man nennt sie deshalb biplanetisch. Sobald sie ein günstiges Substrat erreicht haben. umgeben sie sich nochmals mit einer Membran und keimen zu einem neuen Achlya-Pflänzchen aus. 
Nach einiger Zeit fangen die Hyphen, welche zuvor Zoosporangien gebildet haben, an Oogonien und Antheridien zu entwickeln. Die Oogonien entstehen durch terminale Anschwellung kurzer Seitentriebe, während die Antheridien als laterale Ausstülpungen des Oogoniumstieles entstehen, und zwar werden öfters unter jedem Oogon 2 Antheridien gebildet. Oogon und Antheridien trennen sich mittels einer Querwand vom übrigen Teile ab. Im Oogon wird eine Anzahl von Eiern gebildet, und die Antheridien bilden einen Keimschlauch, welcher bis zu den Eiern vordringt, sich aber bei den meisten Arten nicht öffnet.

Bei solchen Arten entwickeln sich also die Eier parthenogenetisch, und bis vor kurzem meinte man, daß bei Achlya nie Befruchtung stattfände. Vor kurzem (1904) hat aber Trow bewiesen, daß es auch Achlyen gibt, bei welchen echte Befruchtung vorkommt.

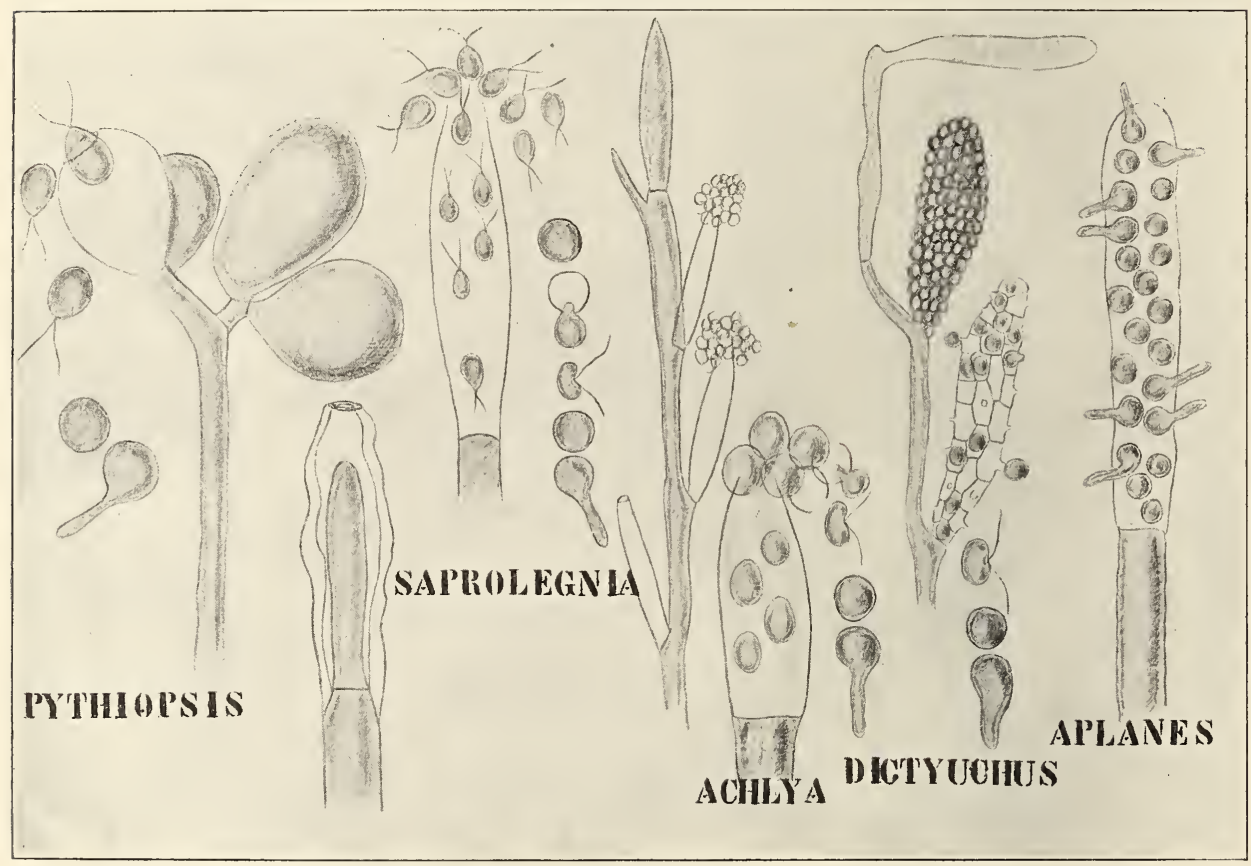

Fig. 95. Ungeschlechtliche Fortpflanzung bei den Saprolegniaceae. Figurenerklärung im Text.

Die ungeschlechtliche Fortpflanzung ist bei den verschiedenen Saprolegniaceen-Geschlechtern ziemlich verschieden.

Beim Genus Pythiopsis entstehen die großen Sporangien terminal an kurzen Seitenzweigen, die Zoosporen haben 2 Cilien, treten aus dem Sporangium heraus, runden sich ab und keimen direkt zu neuen Pflänzchen aus, sie sind also monoplanetisch.

Bei Saprolegnia stehen die Sporangien terminal an den Haupthyphen, nachfolgende wachsen durch die früheren hindurch in der Weise, wie das früher für Myrioblepharis angegeben wurde. Die zweiciliëgen Zoosporen verlassen das Sporangium direkt, runden sich aber sodann ab, kapseln sich ein und schlüpfen später wieder aus, um nach nochmaliger Abrundung zu neuen Individuen auszukeimen. Sie sind also diplanetisch. 
Während sie im Moment des Ausschlüpfens aus dem Zoosporangium birnförmig sind und die Cilien terminal tragen, sind sie im zweiten Schwärmstadium bohnenförmig und tragen die Cilien lateral.

Bei Achlya entstehen die Zoosporangien in derselben Weise wie bei Saprolegnia, die nachkommenden Sporangien wachsen aber nicht durch die älteren hindurch, sondern an diesen vorbei. Die Sporangienstände bilden also ein Sympodium. Trotzdem die Cilien der noch in Zoosporangien beschlossenen Zoosporen erst bei einer Art bekannt wurden, darf man wohl annehmen, daß sie denen von Saprolegnia gleich sind. Sie sind ebenfalls diplanetisch. schwärmen aber nicht ganz aus dem Zoosporangium heraus, sondern bleiben an der Austrittsöffnung stehen, wo sie sich einkapseln. Die aus diesen Membranen ausschlüpfenden

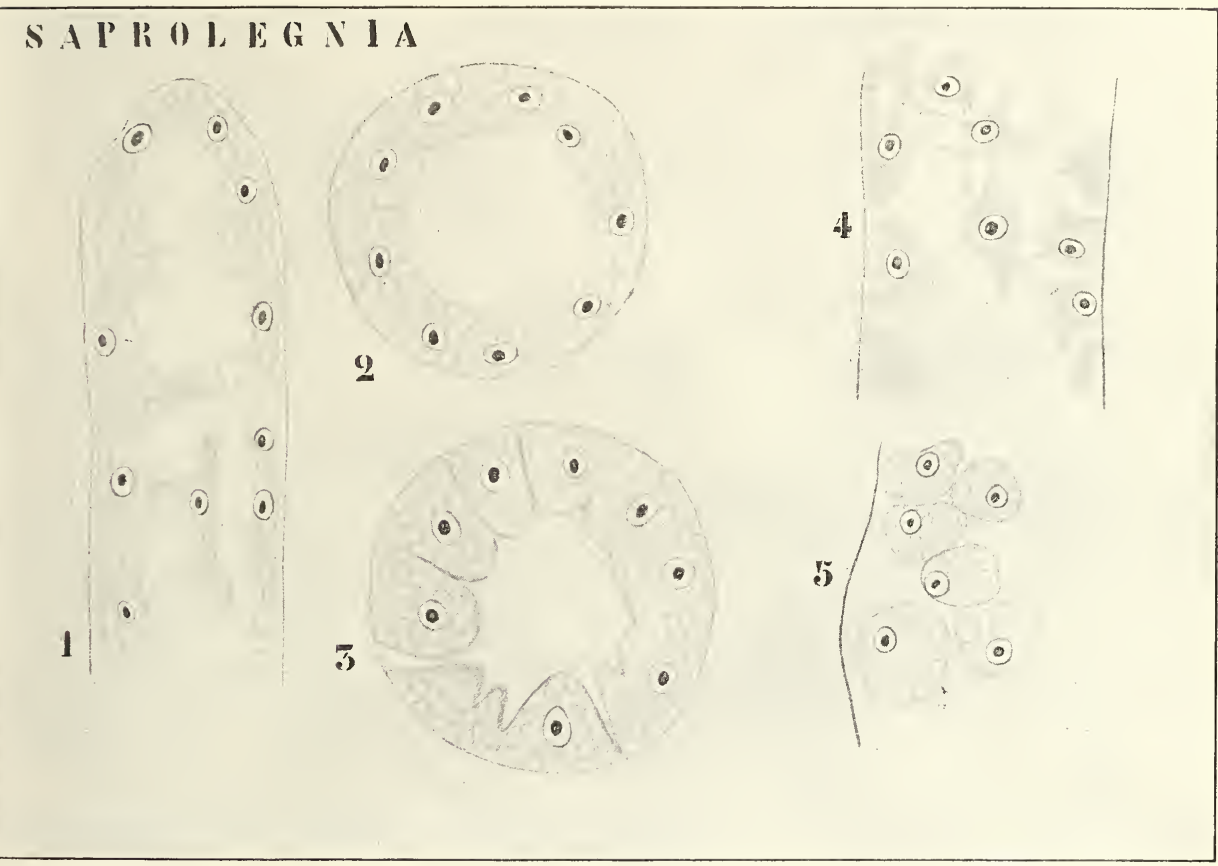

Fig. 96. Zoosporenbildung bei Saprolegnia (nach DAvIS). 1 Spitze des Sporangiums, die Bildung der zentralen Vakuole zeigend. 2 Querschnitt eines Zoosporangiums mit ausgebildeter zentraler Vakuole. 3 Anfang der Spaltung. 4 Zusammenziehen der Energiden. 5 Abrundung der Energiden.

Schwärmer sind denen von Saprolegnia gleich und keimen in derselben Weise.

Bei Dictyuchus ersparen sich die Zoosporen die Mühe, ganz auszuschwärmen, sie umgeben sich an Ort und Stelle mit einer Membran, so daß das Zoosporangium gekammert wird. Jede Zoospore schwärmt nun später durch eine laterale Oeffnung aus seinem Känmerchen aus (vergl. Fig. 95); sie haben Bolmenform, besitzen 2 laterale Cilien und keimen nach stattgefundener Abrundung zu neuen Pflänzchen aus.

Am trägsten ist das Genus Aplanes, bei welchem das Schwärmen ganz aufgegeben wurde, und dessen Energiden nach stattgefundener Einkapselung, die Sporangienwand durchbohrend. zu neuen Ptlänzchen keimen 
wollen, denn selbstverständlich kommen sie wegen Nahrungsmangels nicht über die ersten Entwickelungsstadien hinaus, und ist es offenbar unmöglich, in dieser Weise neue Insekten zu infizieren. Aplanes bildet denn auch nur selten diese ganz nutzlosen Sporangien, aber um so mehr Eier. Wir dürfen sie denn auch als eine Form betrachten, welche im Begriffe steht, ihre ungeschlechtliche Fortpflanzung ganz aufzugeben, und welche für ihre Vermehrung bald ausschließlich auf ihre Eier angewiesen sein wird.

Die Weise, in welcher die Zoosporen gebildet werden, ist recht einfach.

Im Zoosporangium findet keine Kernteilung statt, die Bildung der Zoosporen beruht einfach auf einer Individualisierung der Energiden,

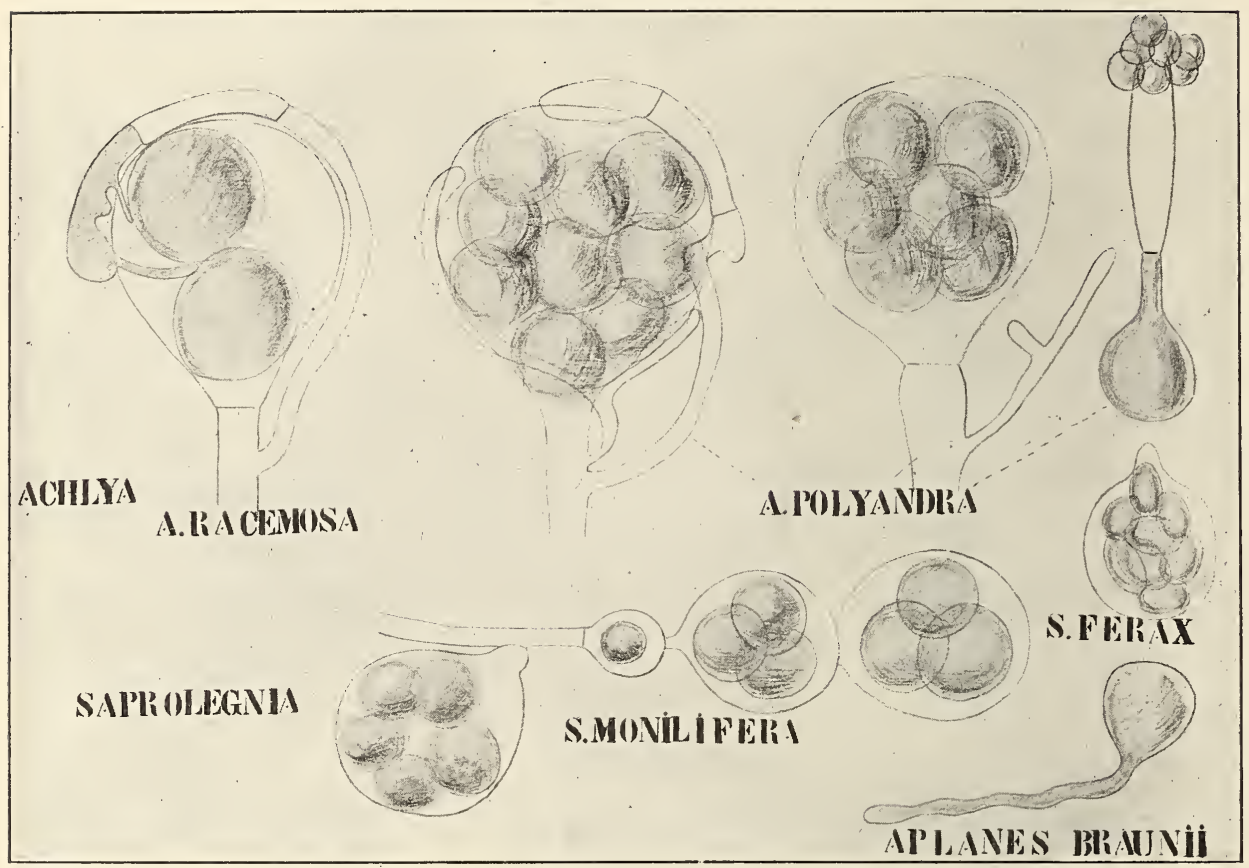

Fig. 97. Figurenerklärung im Text.

was durch Spaltung des Protoplasmas und durch Zusammenziehen der Spaltungsprodukte erreicht wird. Jede Zoospore besitzt demnach einen Kern (vergl. Fig. 96).

Was nun die geschlechtliche Fortpflanzung betrifft, so haben wir gesehen, daß sowohl echte Befruchtung wie Parthenogenese vorkommt. Der Uebergang findet recht allmählich statt. Während Trow bei Achlya de Baryana nachwies, daß der Befruchtungsschlauch bis zum einkernigen Ei vordringt, sich dort öffnet und einen Spermnucleus austreten läßt, welcher mit dem Einucleus kopuliert, finden wir andere Formen, welche sogar keine Antheridien mehr ausbilden.

Dazwischen aber liegen viele Uebergänge.

Bei Achlya racemosa z. B. werden noch ebensoviele Befruchtungsschläuche vom Antheridium in das Oogon geschickt, wie Eier vorhanden 
sind, sie öffnen sich aber nicht. Achlya polyandra dagegen bildet nie Befruchtungsschläuche, ja es kann sogar vorkommen, daß die Antheridien sich nicht mehr an das Oogon anpressen, sondern ganz rudimentär bleiben. Bei Saprolegnia monilifera werden sogar nie Antheridien gebildet.

Die Keimung der Oosporen ist ziemlich verschieden: Achlya polyandra. bildet z. B. einen Keimschlauch, der seine Spitze sogleich in ein Zoosporangium verwandelt; Saprolegnia ferax läßt die Zoosporen direkt in der Oospore entstehen und aus dieser ausschlüpfen, während die Oospore von Aplanes Braunii direkt vegetativ zu einer neuen Pflanze auskeimt.

Ueber die Befruchtung der Saprolegniaceen ist viel gestritten worden,

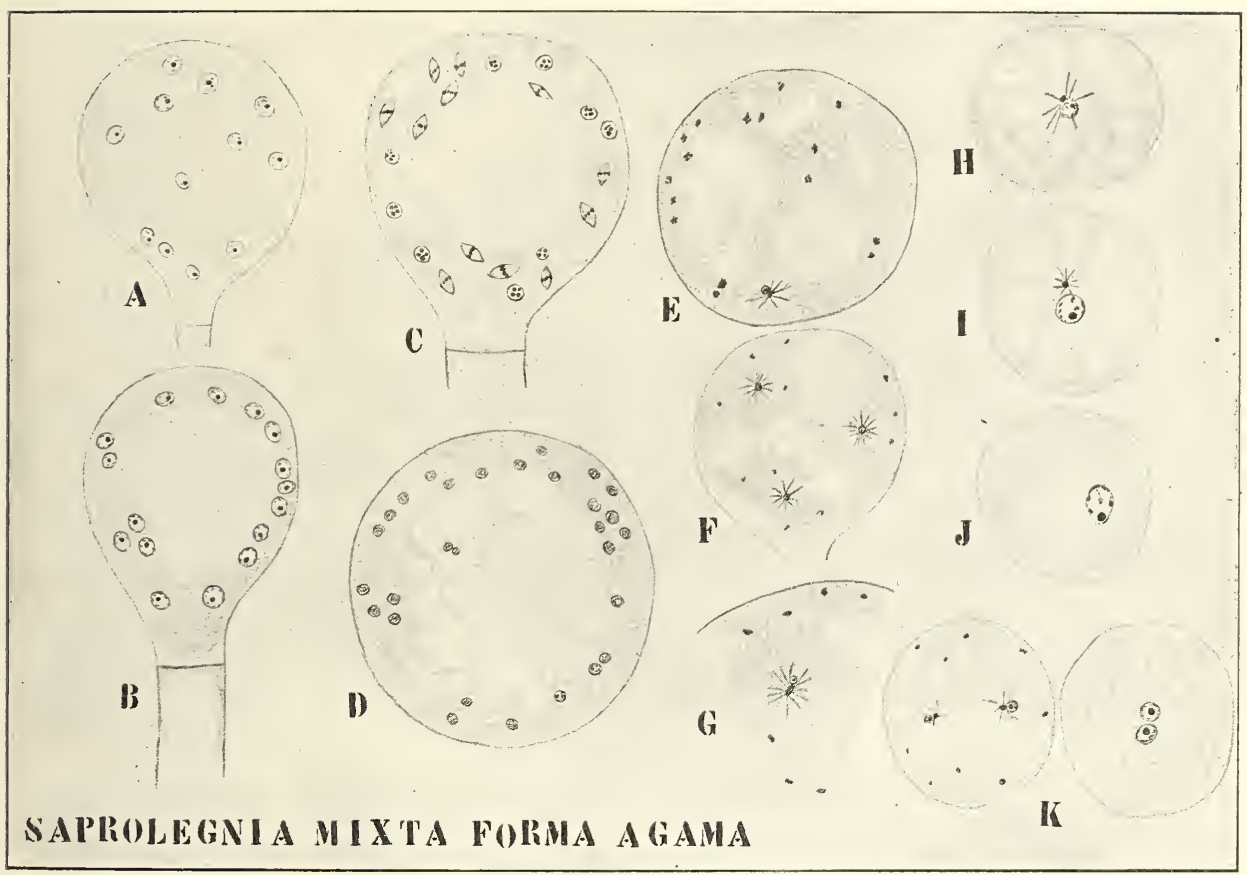

Fig. 98. Saprolegnia mixta forma agama (nach DAvis). A, B Junge Oogonien. C. Kernteilung im Oogon. D Oogon nach der Kernteilung. E Die Kerne mit Ausnahme derjenigen, welche mit einem Ovocentrum in Kontakt sind, gehen zu Grunde. F, G Ausbildung der Eier um die Ovocentren herum. H, I, J Weitere Ausbildung des einkernigen Eies und Verschwinden des Ovocentrums. K zweikernige Eier, dadurch entstanden, daß 2 Orocentren in ein Ei gelangten.

man wollte im allgemeinen die Existenz einer echten Befruchtung bei den Saprolegniaceen überhaupt nicht zugeben. Dieser Standpunkt ist aber durch Trows Untersuchungen an Achlya de Baryana unhaltbar geworden. Bei Saprolegnia aber ist bis heute keine echte Befruchtung' bekannt geworden, zwar hat Trow in Saprolegnia-Eiern 2 Kerne nachgewiesen und daraus auf das Stattfinden einer Befruchtung geschlossen. aber DAvis (1903) hat gezeigt, daß sich die Zweikernigkeit ron Saprolegnia-Eiern auch noch in anderer Weise, und zwar ohne Befruchtung deuten läßt. 
Zu seiner Untersuchung wählte er eine Reinkultur von Saprolegnia mixta forma agama, von welcher er bestimmt wußte, daß sich darin keine Antheridien befanden. Eventuell darin vorkommende 2-kernige Eier konnten, also nicht durch Eindringen eines Spermakernes entstanden sein.

Das junge Oogon ist vielkernig und enthält eine dichte Plasmamasse. Alsdann wird eine große zentrale Vakuole gebildet, infolgedessen die Kerne in den protoplasmatischen Wandbelag zu liegen kommen. Hier teilen sie sich, wodurch ihre Zahl verdoppelt wird. Bald tritt eine Anzahl strahliger Cönocentren auf, welche hier, da sie mit der Eibildung zu tun haben, Ovocentren genannt werden. Alle Kerne, mit Ausnahme derjenigen, welche mit einem Ovocentrum in Berührung sind, degenerieren. Um die $\mathrm{Ov}$ ocentren herum rundet sich das Plasma zur Eibildung ab, infolgedessen werden in der Regel ebensoviele einkernige Eier gebildet, wie Ovocentren vorhanden sind. Der Eikern vergrößert sich bedeutend, und das Ovocentrum verschwindet schließlich. Bisweilen aber bildet sich um 2 Ovocentren herum ein einziges Ei, ein solches Ei ist dann selbstverständlich zweikernig (vergl. Fig. 98).

Es können also bei Saprolegnia zweikernige Eier ohne Befruchtung entstehen, bei Achlya de Baryana ist echte Befruchtung aber nachgewiesen, so daß spätere Untersuchungen zu entscheiden haben werden, ob es noch andere Achlya-Arten und ob es auch vielleicht SaprolegniaArten gibt, bei welchen echte Befruchtung stattfindet.

Die Saprolegnia-Frage konnte hier wegen Platzmangels nicht erschöpfend behandelt werden, manche verdienstvollen Forscher wurden gar nicht genannt, die Quintessenz glaube ich aber wiedergegeben zu haben. Nur sei noch bemerkt, daß Trow im Oogon eine Reduktionsteilung nachgewiesen zu haben glaubt. Falls dies richtig wäre, würde die Achlya-Pflanze eine $2 \mathrm{x}$-Generation sein. Wahrscheinlich erscheint das nicht, Näheres ist auch wohl hier abzuwarten.

Wir wollen die Saprolegniaceen nicht verlassen, ohne einen Blick auf die Bedingungen geworfen zu haben, welche Einfluß auf ihre Fortpflanzung ausüben. Diese Fragen sind von KuEBS (1899) eingehend untersucht worden.

Die hübsche Art, in welcher es KLEBS gelang, Reinkulturen von Saprolegnien zu erhalten, beruht auf der Eigenschaft des Mycels, durch starkes Wachstum an aus anklebenden Keimen sich entwickelnden Bakterienkolonien vorbeizuwachsen. Eine Rohkultur wird dadurch erhalten, daß man in die Nähe einer infizierten Fliege eine gekochte Fliege bringt, welche man, nachdem der Pilz sich darauf angesiedelt hat, in frisches Wasser legt. In die Nähe derselben bringt man dann gekochte Fliegenbeine. Ein solches Fliegenbein wird nun 24 Stunden später auf Fleischextraktgelatine gelegt, wo die Saprolegnia viel schneller wächst als die miteingeführten Bakterien. Dadurch wird in etwa 2 Tagen die Peripherie des sich zentrifugal ausdehnenden Mycels fast ganz bakterienfrei. Ein Stückchen Gelatine, das einige wenige Saprolegniaspitzen enthält, wird nun an der Peripherie des Mycels ausgeschnitten und auf neuen Nährboden gelegt. Von der so erhaltenen Kultur wird in ähnlicher Weise neues Impfmaterial gewonnen und die Ueberimpfung so lange wiederholt, bis vollständig bakterienfreie Kulturen erhalten worden sind. Ein Mycel einer solchen Reinkultur wurde nun in sterilem Wasser weiterkultiviert, dort entwickelte es zunächst Zoosporen, zerfiel aber alsbald in Gemmen. 
Jetzt impfte KLeBs mit einer einzigen der so erhaltenen Gemmen eine neue Gelatineplatte und war nun ganz sicher, eine Reinkultur einer einzigen Saprolegnia-Art zu besitzen. Diese Art war:

Saprolegnia mixta DE BARY.

Auf Gelatine kultiviert, bleibt das Mycel steril; bringt man es aus der Gelatine in reines Tasser, so schreitet es ausnahmslos zur Bildung von Zoosporen.

Verschiedene Versuche belehrten KLeBs, daß die Zoosporenbildung die direkte Folge einer plötzlichen Nahrungsentziehung war.

Aus seinen vielen Versuchen kounte KLEBs weiter beweisen, daß das vegetative Wachstum und die Bildung von Fortpflanzungsorganen von verschiedenen äußeren Bedingungen abhängen, daß jeder Vorgang sein eigenes Optimum besitzt, und zwar so, daß im allgemeinen gute Nahrung das Wachstum, Ernährungsstörungen die Fortpflanzung förderu. Daher gelang es ihm, die Fortpflanzung während Hunderten von Generationen absolut zu unterdrücken. Unter den optimalen Bedingungen für vegetatives Wachstum konnte er eine Saprolegnia 6 Jahre lang ununterbrochen wachsen lassen, ohne Bildung eines einzigen Fortpflanzungsorgans, und konnte dennoch an jedem beliebigen Tage dieses langen Zeitraumes durch Aenderung der äußeren Umstände Stückchen des betreffenden Pilzes zwingen, Fortpflanzungsorgane zu bilden.

KLEBS' Untersuchungen geben nun auch eine Erklärung für das normale Verhalten der Saprolegnien in der Natur. Eine Saprolegnia, welche sich aus einer auf einer Fliege gelandeten Zoospore entwickelt, bildet zunächst ein Mycel innerhalb der Fliege, nachher wachsen Myceliumzweige nach auswärts und bilden Zoosporangien, während erst nach Verlauf dieses Prozesses Gametangien gebildet werden, und schließlich der Rest des Plasmas sich zu Gemmen zusammenballt.

In diesem Cyklus würde man nun leicht eine unveränderliche Ontogenese erblicken, was jedoch gänzlich unrichtig ist; man hat es im Gegenteil in der Hand, die Reihenfolge nach Belieben zu ändern.

KLEBs zeigte, daß man folgendes erzielen kann:

1) Ununterbrochenes lebhaftes Wachstum: in allen guten Nährlösungen, solange frische, unveränderte Nahrung anwesend ist.

2) Gänzliche und vollständige Umbildung des Mycels in Zoos porangien: indem man das gut genährte Mycelium in reines Wasser bringt.

3) Wachstum nebst Zoosporenbildung: durch Kultur des Myceliums in Agaralbumin, welches sich in strömendem Wasser befindet.

4) Zunächst Wachstum, dann lebhafte Gametangienbildung: in Lösungen von Leucin (0,1-proz.) oder Hämoglobin $(0,05$ bis 0,1-proz.).

5) Wachstum, nachher Sporangienbildung und schließlich Gametangienbildung: entweder bei Kultur auf toten Insekten, oder indem man auf Gelatine-Fleischextrakt kultiviertes Mycelium in Wasser bringt.

6) Wachstum und gleichzeitige Zoosporangien- und Gametangienbildung: in Wasser mit ein wenig Fibrin oder Syntonin.

7) Wachstum, dann Gametangien und schließlich Zoosporangien (die Umkehrung des normalen Naturvorganges also): indem man das kräftig genährte Mycelium in 0.01-proz. Hämoglobin bringt. 
Daraus läßt sich also leicht erklären, weshalb in der Natur die Saprolegnia erst Mycelien bildet, dann Zoosporen und zuletzt Gametangien.

Die auf der Fliege gelandete Zoospore findet in derselben Nahrung, in welcher sich das Mycelium vegetativ entwickelt; zu gleicher Zeit diffundiert Nahrung in das umgebende Wasser, so daß sich auch dort Nycelium bilden kann; die Diffusion findet konzentrisch statt, wodurch die kreisförmige Ausbildung des Mycels um die Fliege herum bedingt wird. Schließlich wird die Lösung in einiger Entfernung von der Fliege zu dünn, die Myceliumspitzen kommen in reines Wasser, und dieser Reiz löst die Zoosporangienbildung aus. Man hat es in der Tat, wie KLEBS zeigte, in seiner Gewalt, lange oder kurze Myceliumfäden um die Fliege herum zu züchten, indem man das Wasser sehr ruhig hält (breiter

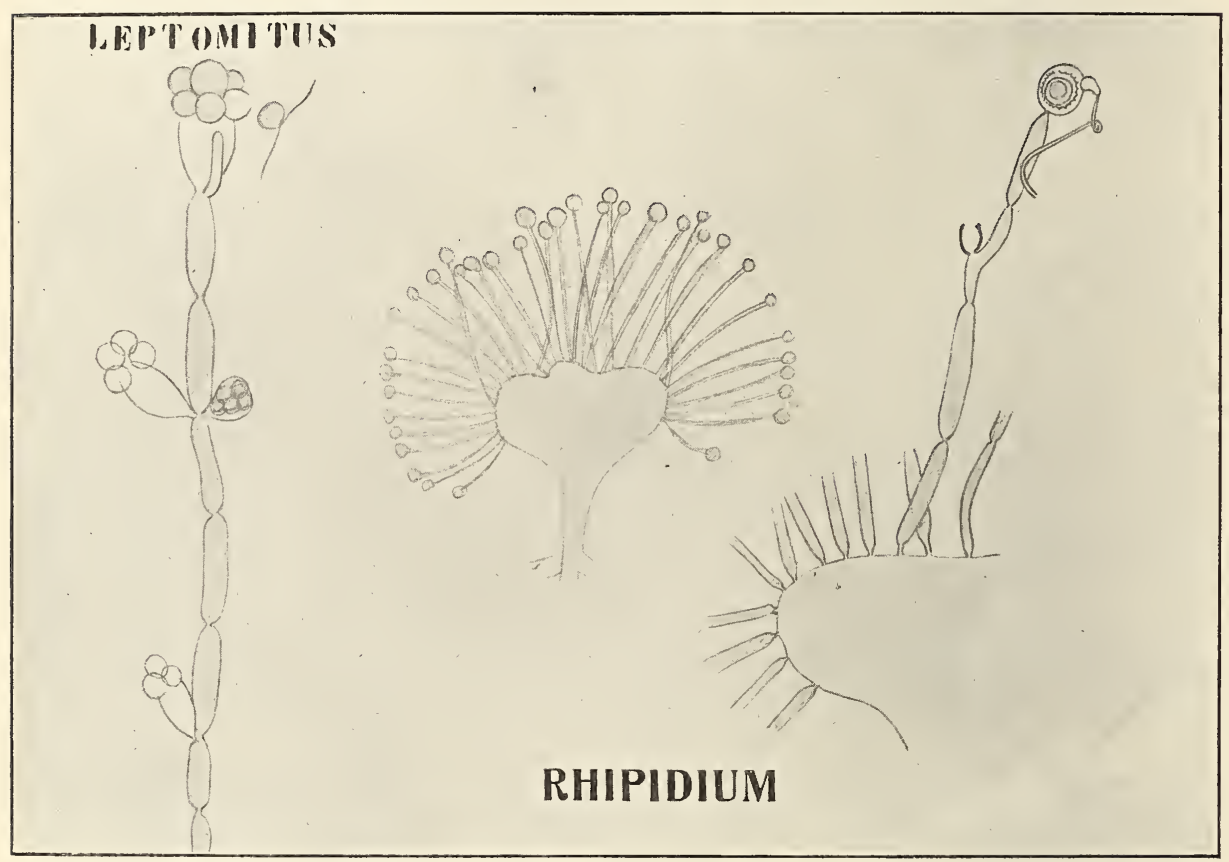

Fig. 99. Apodachlya pyrifera (nach ZopF), Leptomitus und Rhipidium interruptum (nach CoRNu). Fin ganzes Pflänzchen und ein Stück des Scheitels mit Nebenästen, deren einer ein Zoosporangium und ein Oogon mit Antheridium trägt.

Diffusionsstrom) oder in Bewegung setzt (schmaler Diffusionsstrom). Tritt schließlich Erschöpfung der Nahrung ein, so werden Gametangien gebildet.

Von der Gruppe der Siphonomyceten bleibt nun nur noch eine Familie, die der

\section{Leptomitaceae}

zu besprechen übrig. Sie umfaßt einige wenige, nur unvollständig bekannte Genera und weicht von den Saprolegniaceen eigentlich nur dadurch ab, daß ihr Thallus nicht aus einer glatten Röhre besteht, sondern daß die Röhre in regelmäßigen Entfernungen eingeschnürt ist (vergl. Fig. 99). 
Es sind ebenfalls Wasserbewohner, deren Entwickelung aber noch so wenig bekannt ist, daß ich von einer näheren Besprechung der Gruppe Abstand nehme und auf das von Fischer in Rabenhorsts Kryptogamenflora darüber Gesagte verweise.

Wir haben jetzt alle Pflanzengruppen der Isolionten besprochen, welche sich durch Energidenvermehrung ohne Zellteilung, d. h. also unter Beibehaltung der Einzelligkeit, entwickelt haben, und wir haben gesehen. daß auf diesem Wege ein großer Formenreichtum entstanden ist.

Zu großer Höhe hat es aber keine dieser Pflanzenformen gebracht, keine von ihnen kann als Ahne der höheren Pflanzen betrachtet werden.

Es wurde aber gleichzeitig mit dieser Entwickelungsrichtung eine andere eingeschlagen, und zwar von niedrigen Organismen, auf der Entwickelungshöhe eines Chlamydomonas.

Diese versuchten, durch Zellvermehrung zu höherer Ausbildung zu gelangen, behielten aber die Einkernigkeit bei, d. h. also, jede ihrer Zellen wird von nur einer Energide bewohnt.

Während wir also die soeben abgetane Gruppe mit dem Namen der unicellulären polyenergiden Isokonten andeuten können, müssen wir uns jetzt mit einer Gruppe beschäftigen, welche man die der multicellulären monoenergiden Isokonten nennen kann. 


\section{Fünfte Vorlesung.}

\section{Multicelluläre monoenergide Isokonten.}

Auch diese Gruppe kann von Chlamydomonas abgeleitet werden, und zwar mittels des Genus Chlorangium, welches ja nur ein festsitzender Chlamydomonas ist. Es sind von diesem Genus 2 Arten bekannt, von denen die eine das Süßwasser, die andere das Meer bewohnt. Die Süßwasser-Art heißt

Chlorangium stentorinum (EHRB.) STEIN

und findet sich in Europa auf Cyclops-Arten angewachsen. Die Pflanze ist in der Jugend einzellig und mittels eines Gallertstielchens an den Cyclopskörper angeheftet. Die Chromatophoren, in der Zweizahl, selten in der Einzahl vorhanden, sind bandförmig, und an der Basis der Zelle finden sich zwei kontraktile Vakuolen (vergl. Fig. 100).

Da wir gewohnt sind, wie bei Chlamydomonas, kontraktile Vakuolen am Vorderende der Zellen zu finden, ist diese Anordnung auffallend. Die Erklärung ist aber recht einfach. Chlorangium kann sich seines Schleimstieles entledigen, 2 Cilien bilden und fortschwimmen. Er ist dann eine Schwärmspore geworden. Später aber heftet er sich mit seinem Vorderende an einen Cyclops an; dieses Vorderende wird damit zur Basis; daher die sonderbare Lagerung der kontraktilen Vakuolen. Während des freischwimmenden Stadiums gleicht Chlorangium einem Chlamydomonas so sehr, daß man ihn ohne Kenntnis seiner Entwickelungsgeschichte sicher als einen solchen betrachten würde. Während des Schwärmstadiums bildet sich am Vorderende ein Augenfleck aus.

Einige Zeit nach dem Anheften teilen sich die Individuen, d. h. ihre Energiden, die Zellwand bleibt ungeteilt, und es gleitet nun die eine Tochterenergide an der anderen entlang, bis sie ungefähr in eine gerade Linie übereinander zu liegen kommen (Fig. 100, 3). Jede derselben bildet dann wieder eine Membran und ein Schleimstielchen, welches sich an irgend einer Stelle der Mutterwand anheftet, diese wird gesprengt, und es entsteht so eine Kolonie von meistens 4 Individuen (Fig. 100, 6), welche alle dem Reste des Mutterindividuums ansitzen. Dieser Prozeß kann sich nun bei den Tochterindividuen wiederholen, wodurch komplizierte Kolonien gebildet werden können (Fig. 100, 7). Den Unbilden des Lebens können diese Organismen durch sogenannte Akinetenbildung widerstehen, d. h. dadurch, daß die Individuen sich abrunden und eine dicke Membran bilden (Fig. 100, 8). 
Jede Zelle ist im stande, eine große Anzahl von Schwärmern zu bilden. welche wohl, obgleich ihre Kopulation noch nicht gesehen wurde, als Gameten zu betrachten sind.

Wir sehen also, daß hier Kolonien unbeweglicher Zellen gebildet werden, echte Zellteilung, d. h. eine Teilung, an welcher sich auch die Zellwand beteiligt, findet aber nicht statt.

Die hier beginnende Entstehung von Kolonien unbeweglicher Individuen kann nun in drei Richtungen ausgebildet werden, und zwar:

1) durch Entstehung von Kolonien unbestimmter Gestalt (Protococcaceae, Pleurococcaceae),

2) durch Entstehung von Zellenplatten, wie die der Ulvaceae (Ulvales),

3) durch Bildung von Zellenfäden (Ulotrichales).

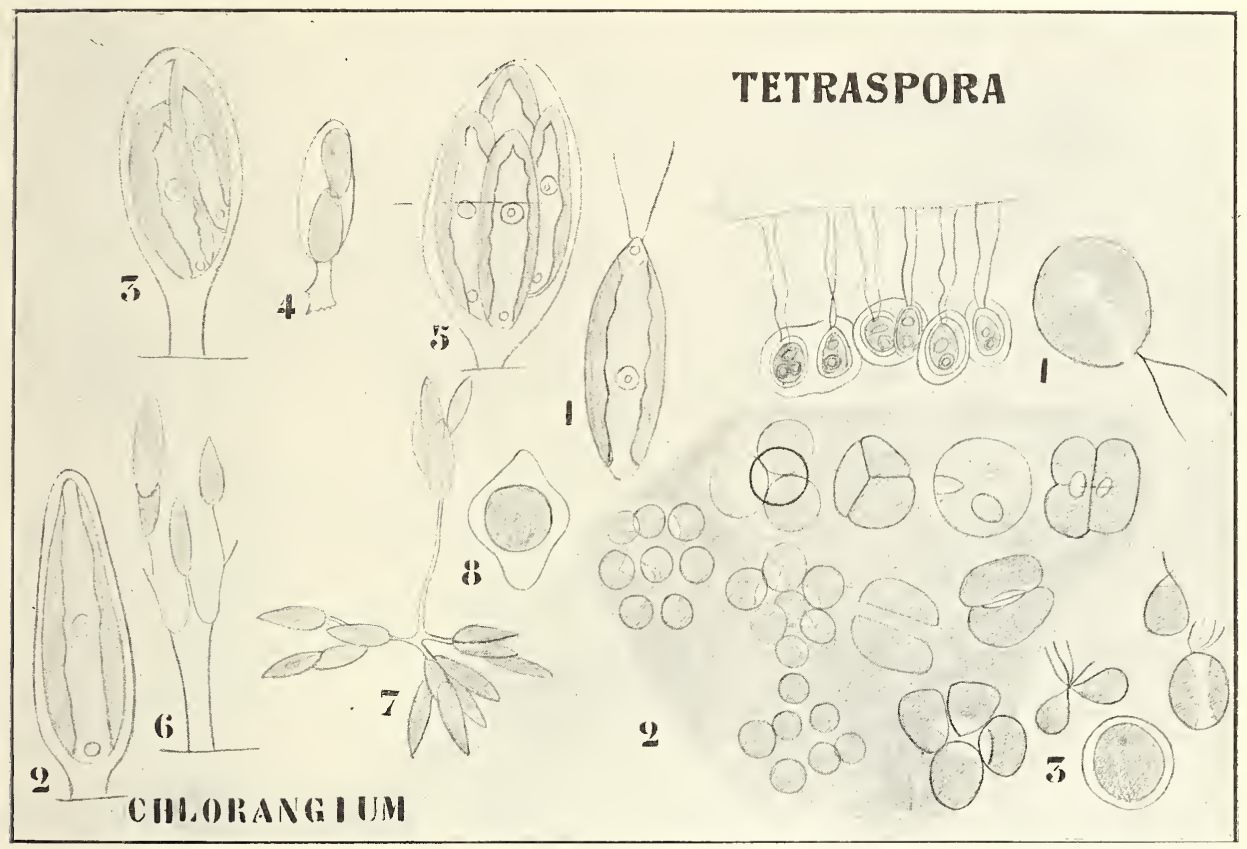

Fig. 100. Chlorangium stentorinum (nach Cienkowsky). 1 Schwärmspore. 2 Einzelliges Individuum mit Gallertstielchen. $3-5$ Teilungsstadien. $6-7$ Mehrzellige Kolonien. 8 Ruhende Akinete. Die übrigen Figuren gehören zu Tetras pora (siehe dort).

Gruppe 1 und 2 sind auf verhältnismäßig niedriger Entwickelungsstufe stehen geblieben, ebenso Gruppe 3, sie hat aber durch Ausbildung der '2x-Generation zum Entstehen der höheren Pflauzen Veranlassung' gegeben.

Die Pleurococcaceae sind in gewisser Hinsicht als degenerierte Protococcaceae zu betrachten, indem bei ihnen keine beweglichen Schwärmsporen mehr vorkommen, sondern deren Inhalt sich in unbewegliche Portionen teilt; echte Zellteilung wird also auch hier nicht gefunden. Uebrigens bilden Pleurococcaceae und Protococcaceae eine noch wohl recht heterogene Gruppe, welcher nähere Untersuchung. zumal an Reinkulturen, recht not tut.

Zwischen Chlorangium, den Protococcaceen, den Pleurococcaceen 
und Formen wie Chlorochytrium (Endosphaeraceae) und Pediastrum (Hydrodictyaceae) bestehen zweifellos mancherlei Beziehungen. Die Wertschätzung derselben als Anfangsglieder der multicellulären monoenergiden Isokontenreihe ist also keineswegs als Tatsache, sondern nur als Iöglichkeit zu betrachten.

An Chlorangium schließt man also wohl am besten die

\section{Protococcaceae}

an, von welcher Familie ich

\section{Cystococcus humicola}

mit Ihnen besprechen möchte. Diese Alge wird unter anderem auf Bäumen angetroffen, auf welchen sie grüne Ueberzüge bildet. Sie ist

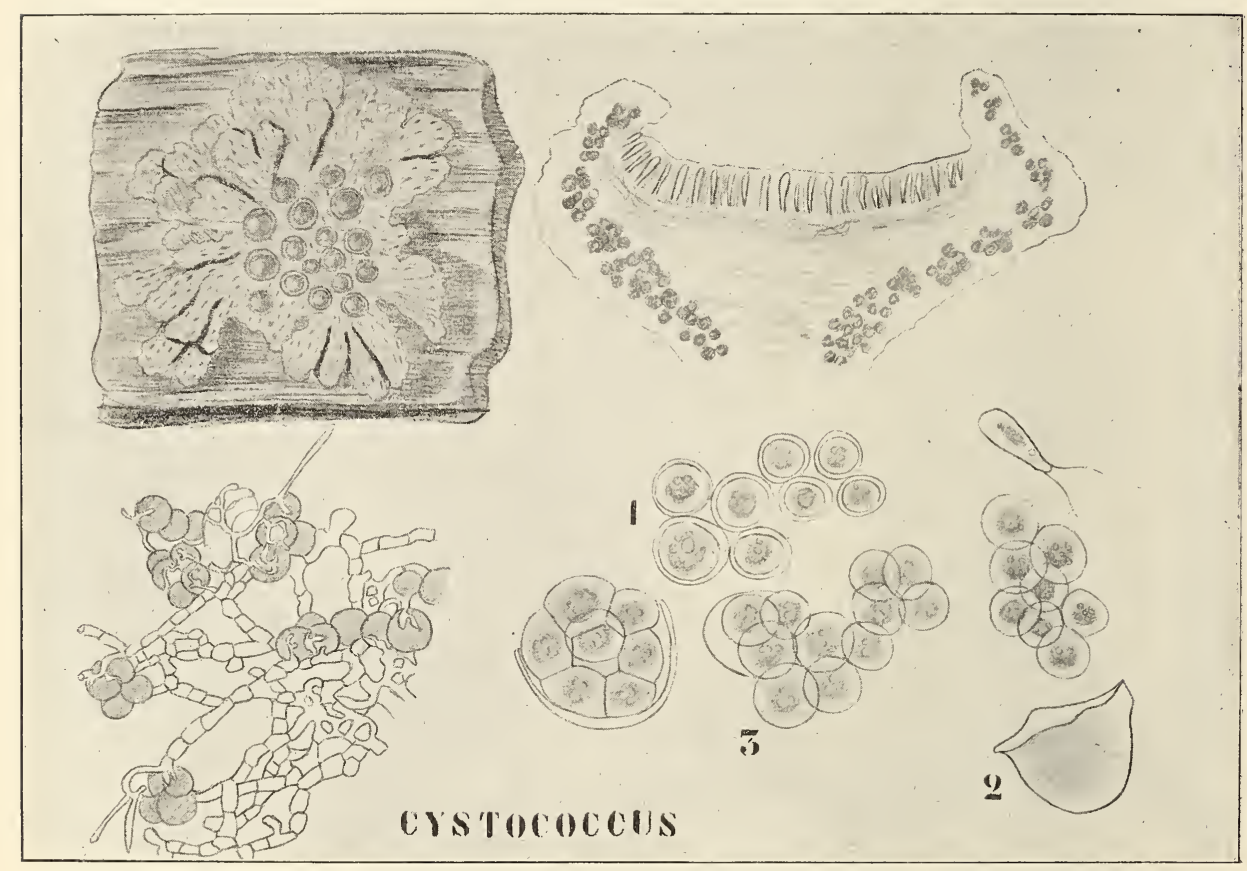

Fig. 101. Links oben: die Flechte Phys cia parietina, Habitusbild. Rechts daneben : Querschnitt durch die Frucht, die Asci (Sporensäcke des Pilzes) und die Algen zeigend. Links unten: Algenzellen, von den Pilzfäden umsponnen. Rechts: Fortpflanzungsstadien der Alge aus den Kulturen BeIJERINCKs.

dort aber keineswegs häufig, die meisten grünen Anflüge an Baumstämmen bestehen aus Pleurococcus-Arten, und es würde recht schwer halten, sich Cystococcus aus solchen Anflügen zu verschaffen. Glücklicherweise gibt es einen anderen Weg, der leicht zum Ziel führt.

Es ist Ihnen bekannt, daß die Pflanzen, welche unter dem Namen "Lichenen" bekannt sind, keine Einzelwesen, sondern Vereinigungen zweier Lebewesen sind, deren eines stets eine Alge, deren anderes immer ein Pilz ist, oder wie man sagt, eine Flechte ist das Resultat einer Symbiose zwischen einem Pilz und einer Alge. In sehr vielen Fallen nun ist der Algenkomponent unser Cystococcus humicola. 
BeiJerixck (1890) gelang es als erstem, Cystococcus in Reinkulturen aus dem Flechtenthallus zu gewinnen.

Dazı machte er dünne Schnitte durch einen Physcia-Thallus, spülte sie zwecks Entfernung anhängender Bakterien mit destilliertem Wasser ab und legte sie auf ein Gelatinepräparat, welches nur recht wenig Nahrung enthielt, um die Entwickelung der Bakterien und des Pilzes möglichst zu beschränken. Ein solches Substrat erhält man z. B. durch Auflösung ron 10 Proz. Gelatine in Grabenwasser.

Alle Schnitte, welche trotzdem Schimmel- oder Bakterienentwickelung. zeigten, wurden rom Substrat abgehoben und weggeworfen, während die übrigen auf einen guten Nährboden (10 Proz. Gelatine in Malzextrakt) gebracht wurden. Dort wurden sie mittels sterilisierter Nadeln zerzupft, auf der Oberfläche des Substrates zerrieben und verteilt. Nach wenigen Tagen zeigten sich überall kleine grüne Kolonien der Alge, welche in Reagenzröhrchen übergeimpft wurden.

Die so kultivierte Alge besitzt einen Chromatophor, einen Kern, ein Pyrenoid und eine Vakuole, welche meistens aber schwer zu erkennen sind, so daß man nur grüne Kugeln sieht. Die Vermehrung findet durch Teilung des Inhalts in unbewegliche Stücke statt. Diese sprengen die Hülle der MLutterzelle, runden sich ab und umgeben sich mit einer Membran. Das ist die normale Vermehıungsweise unserer Alge in Nährlösungen. Sonderbarerweise bildet die Alge auf festerem Substrat Schwärmer, und zwar am leichtesten auf Gelatine mit wenig organischer Nahrung. Es sind dies normale Isokontenschwärmer mit 2 Cilien am farblosen Vorderende.

Da keine Kopulation beobachtet wurde, sind dies wohl Zoosporen, und ist also die Vermehrung in der Nährlösung wohl als eine gehemmte Zoosporenbildung zu betrachten. Diese Reduktion der Zoosporen zu unbeweglichen Plasmastücken ist nun bei den

\section{Pleurococcaceae}

normal geworden. Ich will von dieser Familie zunächst eine recht einfache Form:

\section{Chlorella vulgaris BeIJERINCK}

mit Ihnen besprechen. Es ist dies eine der häufigsten Algen, welche fast in jeder Probe Grabenschlamm und an jeder Wasserpflanze angetroffen wird. Auch tritt sie oft in Wasserflaschen im Laboratorium auf, falls darin einige organische Substanz vorhanden ist. Auch diese Art kann man, wie BEIJERINCK nachwies, auf Gelatine oder Agar kultivieren.

So wie Cystococcus häufig mit Pilzen symbiotisch vorkommt, trifft man Chlorella öfters mit Tieren symbiotisch an. Es ist nämlich diese Pflanze diejenige, welche die sogenannten Zoochlorellen bildet, welchen Hydra viridis und Stentor ihre grüne Farbe verdanken. Auch lebt sie, wie Frau Weber van Bosse nachwies, bisweilen symbiotisch mit Noctihuca.

Interessant ist es nun, daß die symbiotische Chlorella nicht in den Vakuolen, sondern im Plasma der Tiere vorkommt. Dadurch ist ein farbloser Stentor, welcher mit Chlorella ernährt wird, von einem mit roochlorellen leicht zu unterscheiden, bei ersterem liegen die Algenzellen in den Vakuolen, bei letzterem im Plasma selber. wo sie also dieselbe Lagerung zeigen wie die Chlorophyllkörner bei den höheren Pflanzen. 
Daher hat man wohl sogar noch vor kurzem behauptet, daß die Chlorophyllkörner phylogenetisch als eingedrungene Algen zu betrachten sind. Trotzdem diese Behauptung keineswegs als unmöglich bezeichnet werden darf, muß man aber wohl im Auge behalten, daß ein Chlorophyllkorn nicht einer ganzen Algenzelle, sondern nur deren Chromatophor homolog ist, so daß nach dieser Hypothese die eingedrungene Alge sowohl ihr Plasma wie ihren Kern verloren haben müßte! Zwar hat BeiJerinck im Hypokotyl des roten Klees teilweise farblose Chlorophyllkörner angetroffen, da aber, wie wir wissen, Chloroplasten zu farblosen Leukoplasten werden können, liegt kein Grund vor, diese farblosen Teile als Homologa des Algenplasmas zu betrachten.

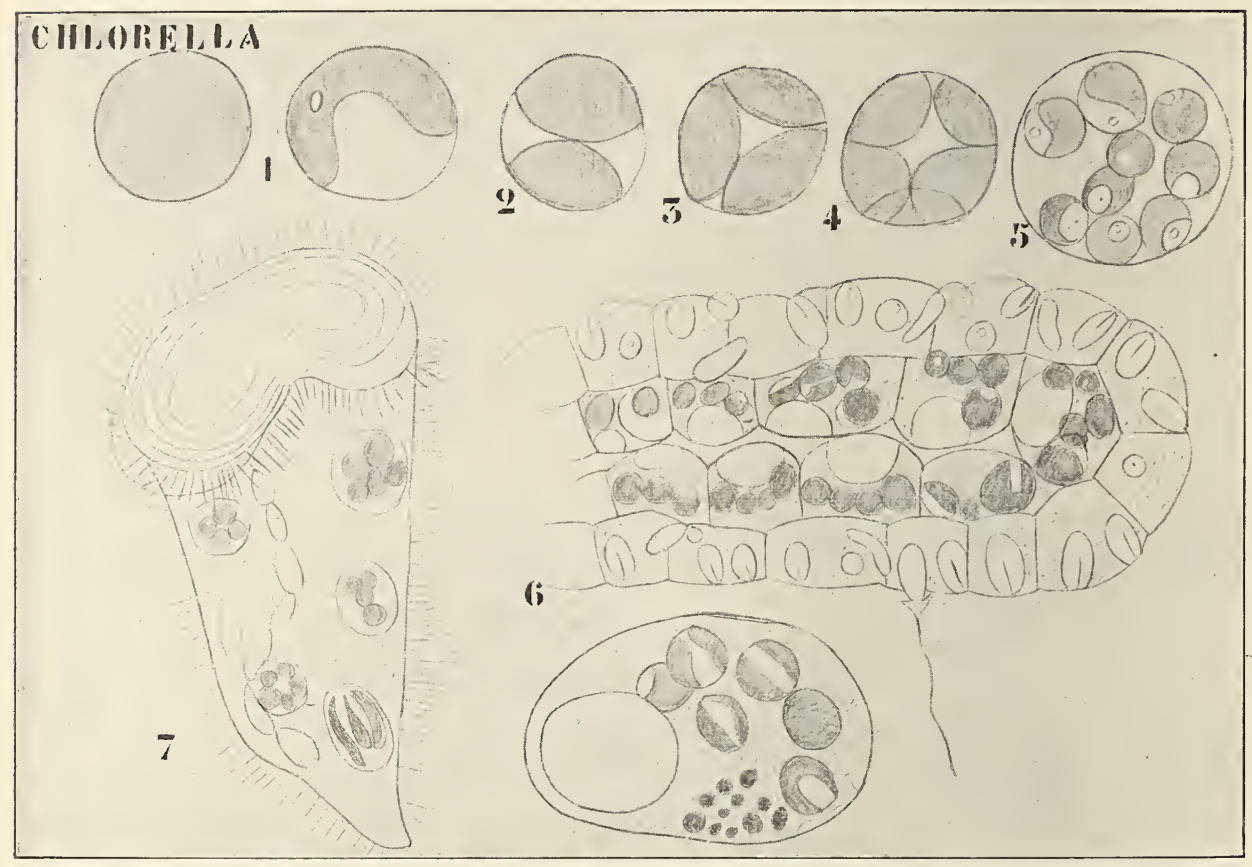

Fig. 102. Chlorella vulgaris (nach BeiJerinck). 1 Apikale und laterale Ansicht einer Zelle. 2-5 Teilung des Inhaltes behufs ungeschlechtlicher Vermehrung. 6 Längsschnitt eines $\mathrm{H}$ ydra-Tentakels mit Zoochlorellen im Plasma der Entodermzellen, unten eine solche Zelle vergrößert; die schwarzen Pünktchen stellen reduzierte Chlor ell a-Zellen dar, sie sind in der Natur rot. 7 Mit Chlorella ernährter Stentor, die Algen liegen in den Vakuolen, in 4 Vakuolen nur Chlorella, in der fünften (rechts unten) Scenedesmus.

Daß aber die Zoochlorellen sicher eingedrungene Algen sind, konnte BEIJERINCK nach Ueberwindung vieler Schwierigkeiten durch Kultur von Zoochlorellen aus Hydra auf Gelatine beweisen.

Die Chlorellen besitzen ein gleichförmiges Chromatophor und einen Kern. Bei der Teilung des Inhaltes teilen sich zunächst das Chromatophor und der Kern in 2, 4, 8, 16 Stïcke, schließlich auch das Plasma; diese Teilstücke umgeben sich mit einer Membran und gelangen durch Zersprengung der Membran der Mutterzelle ins Freie. Sie sind also als Zoosporen, welche keine Cilien mehr ausbilden, zu betrachten. Schwärmer werden nie gebildet. 
Wie man sieht, tritt weder bei Cystococcus noch bei Chlorella echte Zellteilung auf, sie sind rein einzellig, stehen also in dieser Hinsicht auf der gleichen Entwickelungsstufe mit Chlorangimm.

Tährend nun bei Chlorella die aus den Aplanosporen (d. h. reduzierten Zoosporen) gebildeten Zellen sich sofort voneinander loslösen, finden wir bei

\section{Scenedesmuts}

bereits eine Bildung von selbstverständlich unbeweglichen, zusammenhängenden Kolonien.

Bei einem normalen Scenedesmus sind 4-8 Individuen zu einer

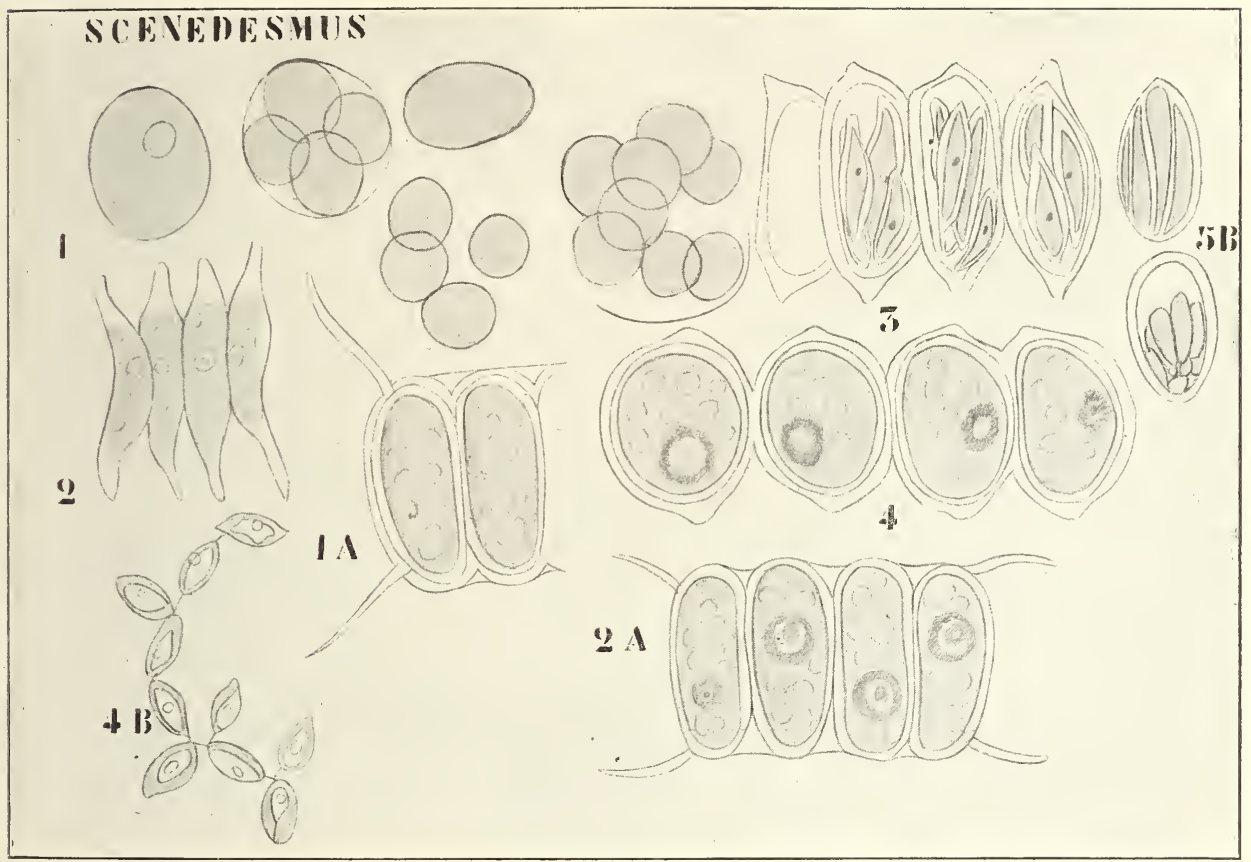

Fig. 103. 1-4 Scenedesmus acutus. 1 Kugelige Zellen (nach BeIJERINCK). 2, 3, 4 Normale Kolonien (nach SENN), in 3 Aplanosporen bildend. 1 A, 2 A S. caudatus (nach Senv). 4 B, 5 B Dactylococcus (nach Artari), bei 5 B Aplanosporen bildend.

fadenförmigen Kolonie vereinigt, die beiden Zellen zeigen öfters schwanzähnliche Anhängsel, z. B. S. caudatus.

Die Vermehrung geschieht durch Aplanosporenbildung, diese treten nach Zersprengung der Muttermembran als kleine Kolonie heraus.

Unter bestimmten Umständen, z. B. bei der Kultur auf Gelatine in Gegenwart vieler organischer Nahrung, kann man Scenedesmus dazu zwingen, runde chlorellaähnliche Zellen zu bilden (Fig. 103, 1). Unter wieder anderen Umständen bildet sie dactylococcusähnliche Kolonien dadurch, daß die Individuen aneinander vorbeischieben. Scenedesmus ist also offenbar ein sehr plastischer, Biaiometamorphose ${ }^{1}$ ) sehr zugäng'-

1) d. h. Formveränderung durch äußere Bedingungen.

I.otsy, Botanische Stammesgeschichte. I. 
licher Organismus. Man hat diese Vielförmigkeit mit dem Namen Pleomorphismus und Polymorphismus angedeutet, was ja im Grunde ganz richtig ist. Dennoch hat man diejenigen, welche von Polymorphismus bei diesen und ähnlichen Algen redeten, z. B. in jüngerer Zeit CHODAT, sehr scharf angegriffen. Daran ist aber eigentlich nur der Umstand schuld, daß man früher das Wort Polymorphismus mißbraucht hat, indem man, auf Rohkulturen sich stützend, verschiedene Arten als verschiedene Entwickelungszustände einer einzigen betrachtete und dieses Verhalten fälschlich als Polymorphismus bezeichnete.

Es ist also wohl besser, dieses Wort ganz fallen zu lassen und von Biaiometamorphosen zu reden. Mit dieser Verteidigung der modernen ..Polymorphisten“ soll selbstverständlich nicht gesagt werden, daß diese nun nie einen Fehler gemacht haben, daß alles, was sie mit Polymorphismus bezeichnet haben, wirklich Biaiometamorphose ist, aber gewiß wollten sie nicht den alten Polymorphisten das Wort reden. Bei Untersuchungen über diese Algen-Biaiometamorphosen ist selbstverständlich eine erste Bedingung die absolute Sicherheit, daß man Reinkulturen vor sich hat, und diese ist nur dann zu gewinnen, wenn man von einer einzigen Zelle ausgeht. Gegen dieses Grundprinzip ist wohl auch von den Modernen gesïndigt worden. Erneute Untersuchungen sind daher sehr erwünscht.

Recht interessante Tatsachen bei Scenedesmus sind:

1) die Unfähigkeit dieser grünen Alge, bei Abwesenheit organischer Substanz zu wachsen,

2) das Ausscheiden eines die Gelatine verflüssigenden Fermentes,

3) das Farbloswerden bei Kultur im Finstern und die dann angenommene saprophytische Lebensweise.

Bevor wir nun die Familie der Pleurococcaceae verlassen, will ich noch eine der kompliziertesten Genera dieser Familie, Coelastrum, mit Thnen besprechen und wähle dazu

Coelastrum reticulatum (Dangaard) Senn,

eine ursprünglich tropische Art, welche in Ecuador, Paragua, Sumatra, Ostindien und Abessinien gefunden wurde. Sie wurde nach Europa, wahrscheinlich mit tropischen Wasserpflanzen eingeschleppt und z. B. in den botanischen Gärten in Caen und Genf in Warmwasserbassins angetroffen. Bei Basel fand Senn (1899) sie in einem zementierten Bassin auf einem Landgute in der Nähe von Warmhäusern, so daß sie auch dahin wohl in ähnlicher Weise gelangt ist.

Die Zellen enthalten ein hohles kugelförmiges Chromatophor, welches an einer Stelle ein kreisrundes Loch besitzt. Diesem Loche gegenüber liegt im Chromatophor das Pyrenoid, während der Kern sich in der Nähe der Oeffnung befindet. Die Membran der Zelle ist recht dünn und wird von einer Schleimschicht umgeben, welche bei den einzelligen Individuen eine gleichmäßig dicke Schicht um die Zelle herum bildet. Die Zelle kann in einen Ruhezustand eintreten, sie füllt sich dann mit einem gelben Oel (Fig. 104, 2). Solche Zellen werden später bei Anwesenheit genügender Nahrung und Sauerstoffes wieder grün. Die Fortpfianzung findet mittels Teilung des Inhaltes statt. Nachdem die Teilstücke eine Membran gebildet haben, treten die neuen Schleimschichten durch Fortsätze miteinander in Verbindung. So entstehen Kolonien von 2-16 Zellen, welche die Muttermembran abstreifen und so frei werden. Da jede dieser Tochterzellen in gleicher Weise eine neue Ko- 
lonie gebären kann und diese öfters mit den leeren Schleimschichten der Mü̈tter in Verbindung bleiben, können Ansammlungen entstehen, welche aus verschiedenen Generationen zusammengesetzt sind (Fig. 104, 7).

Treten die Tochterzellen nicht durch Schleimfortsätze in Verbindung, so gehen sie bei der Abstreifung der Nuttermembran auseinander, und es entstehen isolierte Zellen.

Mit Coelastrum ist etwa das Höchste erreicht, was auf diesem Wege zu erreichen war.

Sehen wir jetzt, was auf dem Wege der Zellplattenbildung erreicht worden ist. Als eine der niedrigsten Formen dieser Gruppe ist

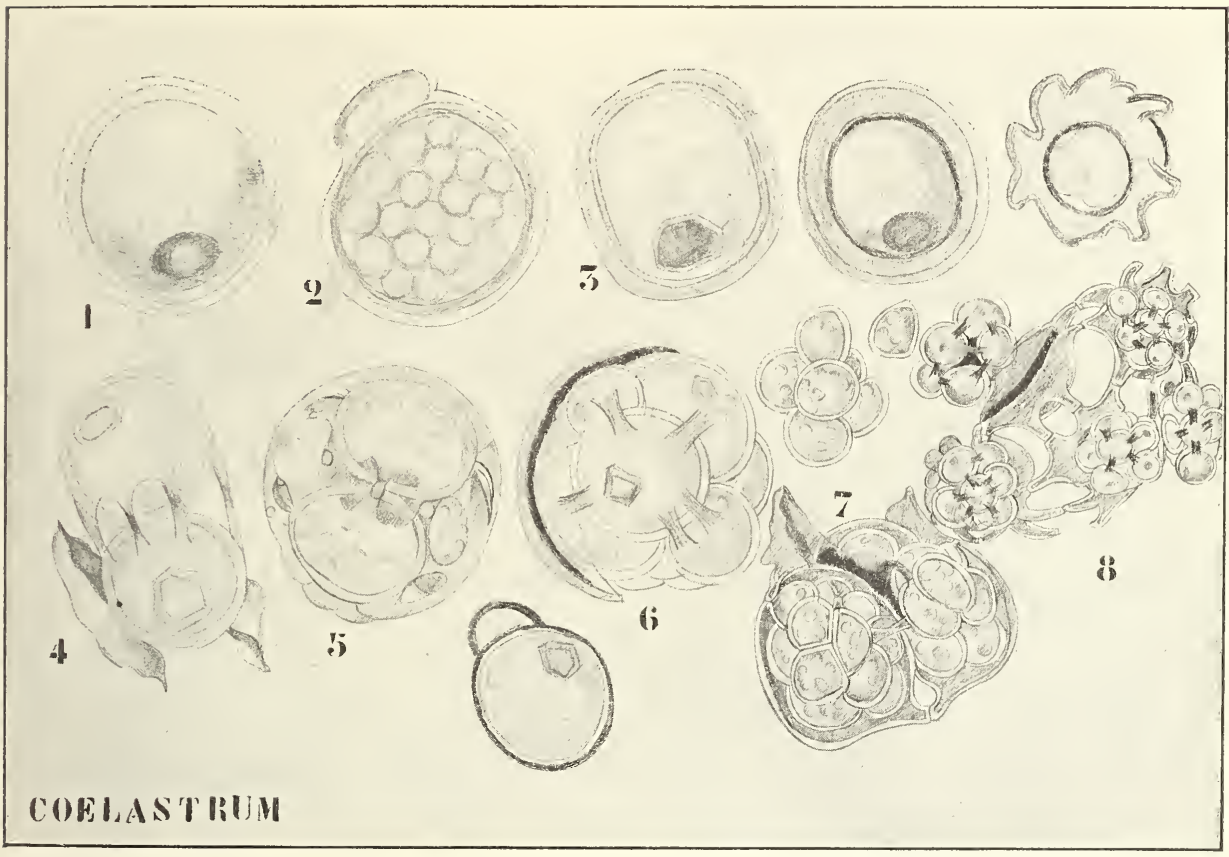

Fig. 104. Coelastrum reticulatum (nach SENN). 1 Ein normales Individuum. 2 Ein solches im Ruhezustand. 3 Einzellige Individuen mit regelmäßiger und unregelmäßiger Schleimschicht. 4 Individuen, durch Zweiteilung des Inhalts entstanden, die Muttermembran abgestreift, die Tochterindividuen durch Schleimarme miteinander verbunden. 5, 6, 7 Bildung komplizierterer Kolonien.

\section{Tetraspora}

zu betrachten. Tetraspora lubrica bildet hohle Schleimröhren, welche eine entfernte Aehnlichkeit mit Enteromorpha aufweisen, und wird auf dem Boden des Süßwassers in Europa, z. B. in Gräben um Leiden herum, angetroffen.

Später lösen sich diese Schleimröhren vom Substrat ab und liegen an der Oberfläche des Wassers, wo sie unregelmäßige Schleimmassen bilden. Diesen leichtbeweglichen Schleimmassen sind die TetrasporaZellen in éiner Schicht eingestreut, bei älteren Exemplaren können jedoch mehrere Schichten vorkommen. Die Zellen besitzen sogenannte Psendocilien, Plasmastränge, welche bis an die Oberfläche der Schleimschicht 
heranreichen. Sie vermehren sich durch Teilung, und da die zweite Teilung senkrecht zur ersten stattfindet, liegen meistens 4 Zellen in einer Gruppe zusammen. Dadurch entsteht wohl eine Vergrößerung der Kolonie, aber keine Verbreitung, diese kann dadurch erreicht werden, daß einzelne Zellen sich aus dem Verbande loslösen, indem sie Cilien bekommen und davonschwimmen; diese Cilienbildung geschieht unabhängig von den vorhandenen Pseudocilien.

Eine solche davonschwimmende Zelle braucht sich aber keineswegs direkt zu einer neuen Tetraspora zu entwickeln, sondern kann zunächst eine Anzahl von unbeweglichen runden Zellen bilden, ihrer Aehnlichkeit mit Palmella wegen, Palmellastadien genannt. Diese palmellaähnlichen

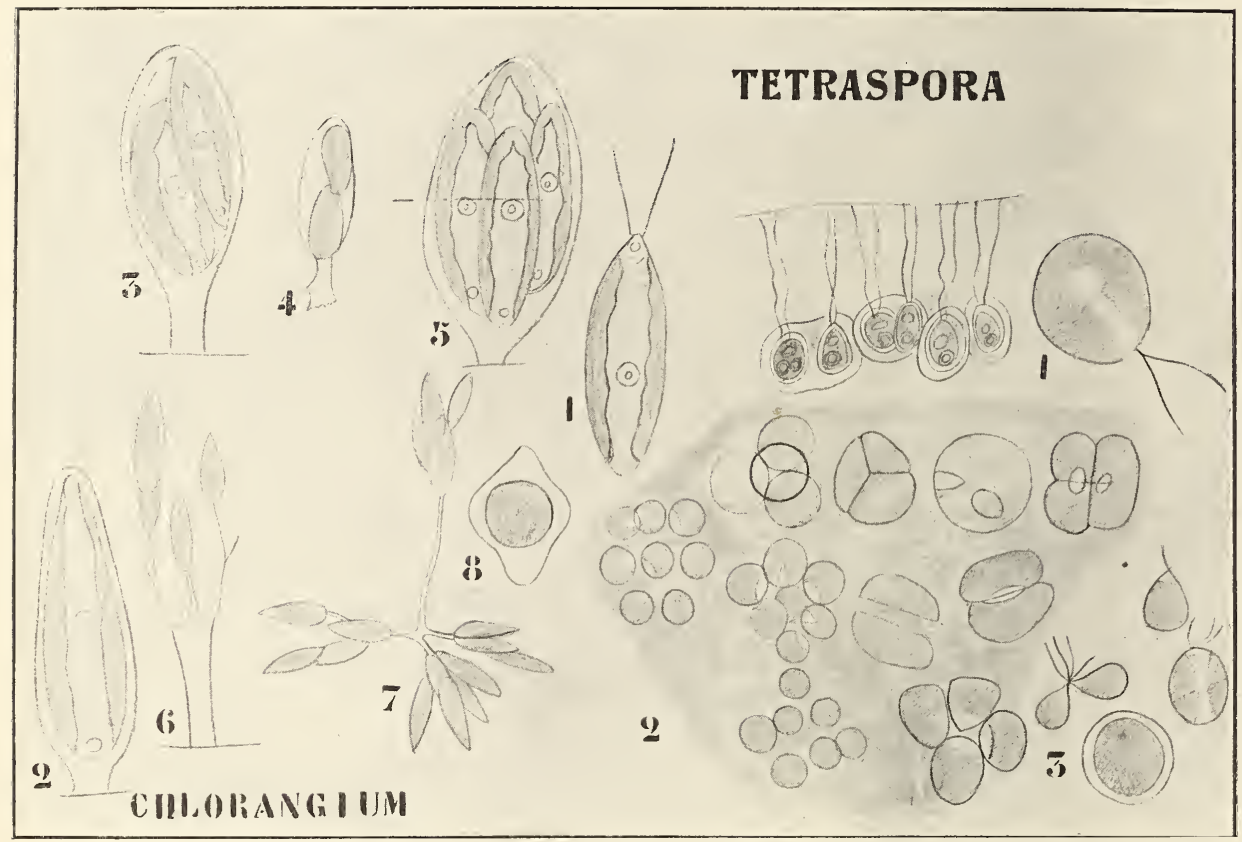

Fig. 105. I. Chlorangium (siehe p. 173). - II. Tetraspora (nach Reinke und СHоDAт). 1 Rechts: schwärmendes Individuum, links: ein Querschnitt des Thallus mit Pseudocilien. 2 Flächenansicht des Thallus mit sich teilenden Zellen. 3 Kopulierende Gameten.

Individuen bilden eine dicke Membran aus; ihre Weiterentwickelung ist nicht bekannt.

Außer dieser Fortpflanzungsweise gibt es noch die geschlechtliche mittels Isogameten, von denen 8 in jeder Zelle entstehen. Die von ihnen gebildeten Zygoten keimen direkt.

Auf einer bedeutend höheren Entwicklungsstufe steht das Genus

\section{Monostroma,}

welches, in frühester Jugend aus einer Hohlkugel bestehend, alsbald zu einer hohlen Röhre auswächst. Diese Röhre reißt dann später einseitig ein, breitet sich aus, und so entsteht ein flacher Thallus, welcher durch Teilung seiner Zellen stets breiter wird (Fig. 106). Die Alge wird sowohl 
in süßem wie in Brackwasser angetroften. Die Zellen sind im stande. Rhizoiden zu bilden, mittels welcher sich die Alge am Substrat anheftet.

In den Zellen können sich Zoosporen mit 4, oder Gameten mit ״ Cilien bilden. Die Zygote keimt direkt zu einer neuen Monostroma aus. Als höchste Stufe in dieser Entwickelung'sreihe mag'

\section{Ulva}

gelten, welche sich von Monostroma direkt durch den zweischichtigen Thallus unterscheidet (Fig. 107).

Ulva ist ein marines Algengenus, welches in der Jugend aus einem kurzen Zellfaden besteht, der sich alsbald durch Längsteilungen der einzelnen Zellen zu einem flachen Thallus ausbreitet.
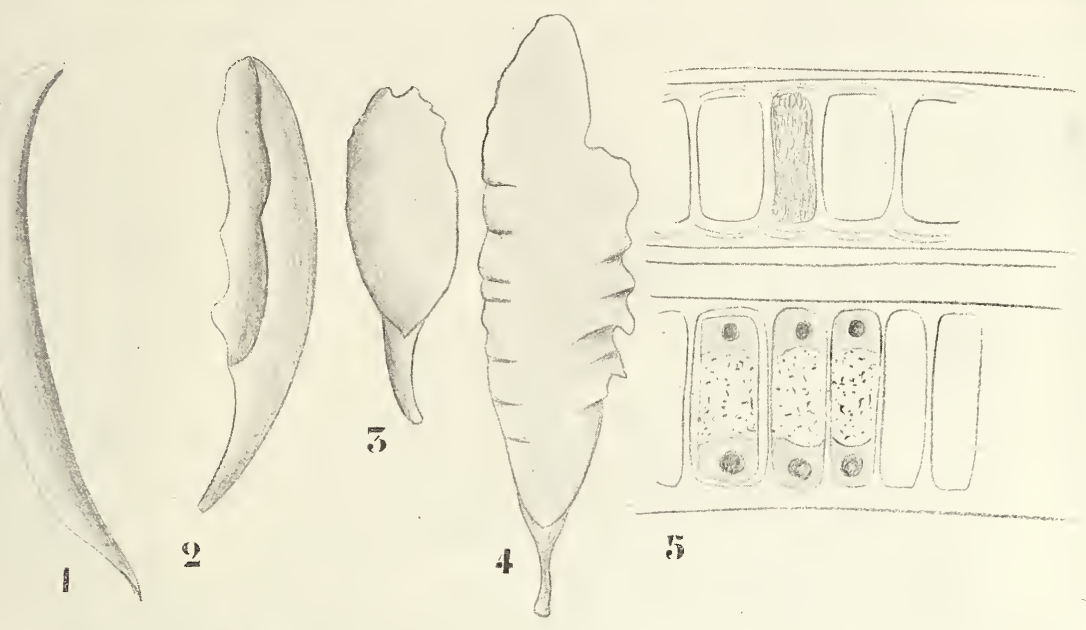

MONOSTROMA

\section{MONOSTROMA}

Fig. 106. Monostroma fuscum (nach Rosenvinge). 1 Allseitig geschlossenes rohrförmiges Stadium. 2-4 Einseitiges Einreißen der Röhre und plattenförmige Ausbreitung des Pflänzchens. 5 Querschnitte durch den Thallus, der obere Stärkekörner, der untere die Chromatophoren zeigend.

Auch Ulva ist mittels Rhizoiden am Substrat befestigt. Diese Rhizoiden wachsen eigentümlicherweise nicht an der Außenseite des Thallus entlang, sondern zwischen den beiden Zellschichten hindurch.

Die Alge bildet Zoosporen und Gameten, und zwar meistens am Rande des Thallus; da die entleerten Zellen farblos sind. wird so der Thallus öfters in recht zierlicher Weise weiß umrandet.

Da hier die am höchsten stehende, uns bekannte plattenförmige Isokonte vorliegt, sehen Sie, daß auch auf diesem Nege nur weniges elreicht wurde. Zur höchsten Entwickelung gelangte diejenige Gruppe. welche den Kellfaden als Ausgangspunkt benutzte. 

Genus

Die allereinfachste Fadenalge, welche bekannt wurde, gehört zum

\section{Radiofilum,}

welches 1894 von Schmide in Torfstichen bei Virnheim in Westfalen entdeckt wurde. Das Pflänzchen besteht aus einer einfachen Reihe von Zellen, welche von einer dichten Schleimhülle umgeben ist. Der Faden wächst durch Querteilung der Zellen. Die Fortpflanzung geschieht in einfachster Weise, nämlich dadurch, daß eine Zelle 2 Cilien bildet, sich aus dem Verbande loslöst und als Schwärmspore davonschwimmt.

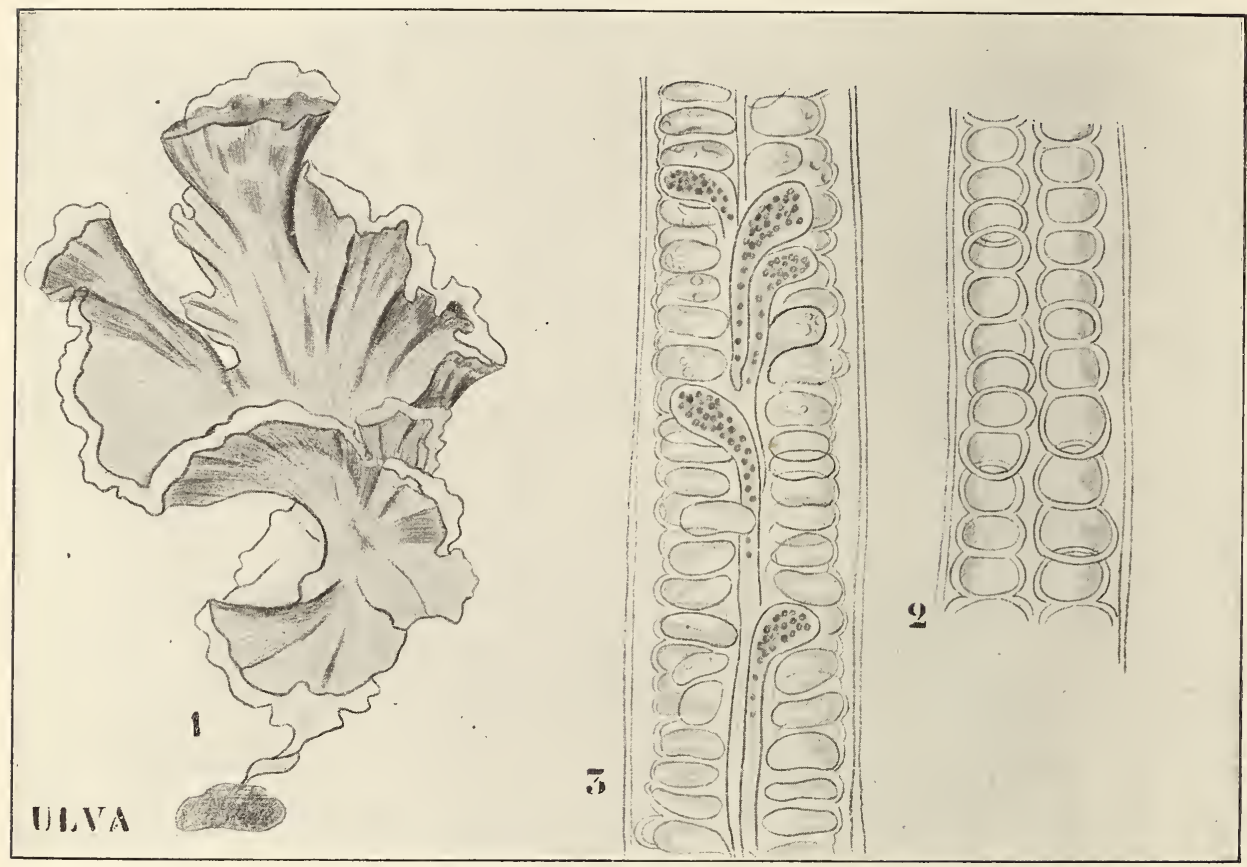

Fig. 107. Ul va lactuca (nach THURET). 1 Habitusbild. 2 Längsschnitt durch den Thallus. 3 Längsschnitt an einer Stelle, wo die Zellen zu Rhizoiden auswachsen.

Auf bedeutend höherer Entwickelungsstufe steht das Genus

\section{Ulothrix.}

Es findet sich in Süßwasser, und zwar meistens in strömendem, in der Brandungszone der Küste und an feuchten Felsen u. s. w., alles Stellen, wo viel Sauerstoff vorhanden ist. In der Tat ist denn auch Ulothrix eine sauerstoffbedürftige Alge.

Als Beispiel mag die vielfach untersuchte Ulothrix «onata dienen. Sie besteht aus einem einfachen Zellfaden, der mittels einer farblosen Basalzelle am Substrat befestigt ist, und unterscheidet sich leicht von allen anderen Fadenalgen durch die auffallende Breite der Zellen im Vergleich zu deren Länge. Neistens sind diese breiter als lang, höchstens isodiametrisch.

Das Chromatophor ist bandförmig und in der Zelle wie ein Gürtel 
gelagert. Alle Zellen sind teilungsfähig und nehmen am Längenwachstum des Fadens teil. Die Fortpflanzung ist ziemlich kompliziert.

Erstens können Makrozoosporen gebildet werden, welche in der Einzahl oder in wenigen Exemplaren in jeder Zelle entstehen können; die gebildete Zahl hängt von der Quantität der Nahrung ab.

Diese Zoosporen werden aus dem Teile des Plasmas, welcher sich zwischen der Hautschicht und der Takuolenwand befindet, gebildet, diese bleiben also bestehen. Die Makrozoosporen treten aus einer sich in der Zellenwand bildenden Oeffnung heraus und sind anfänglich noch von der Hautschicht wie von einer Blase umgeben (Fig. 108, 2).

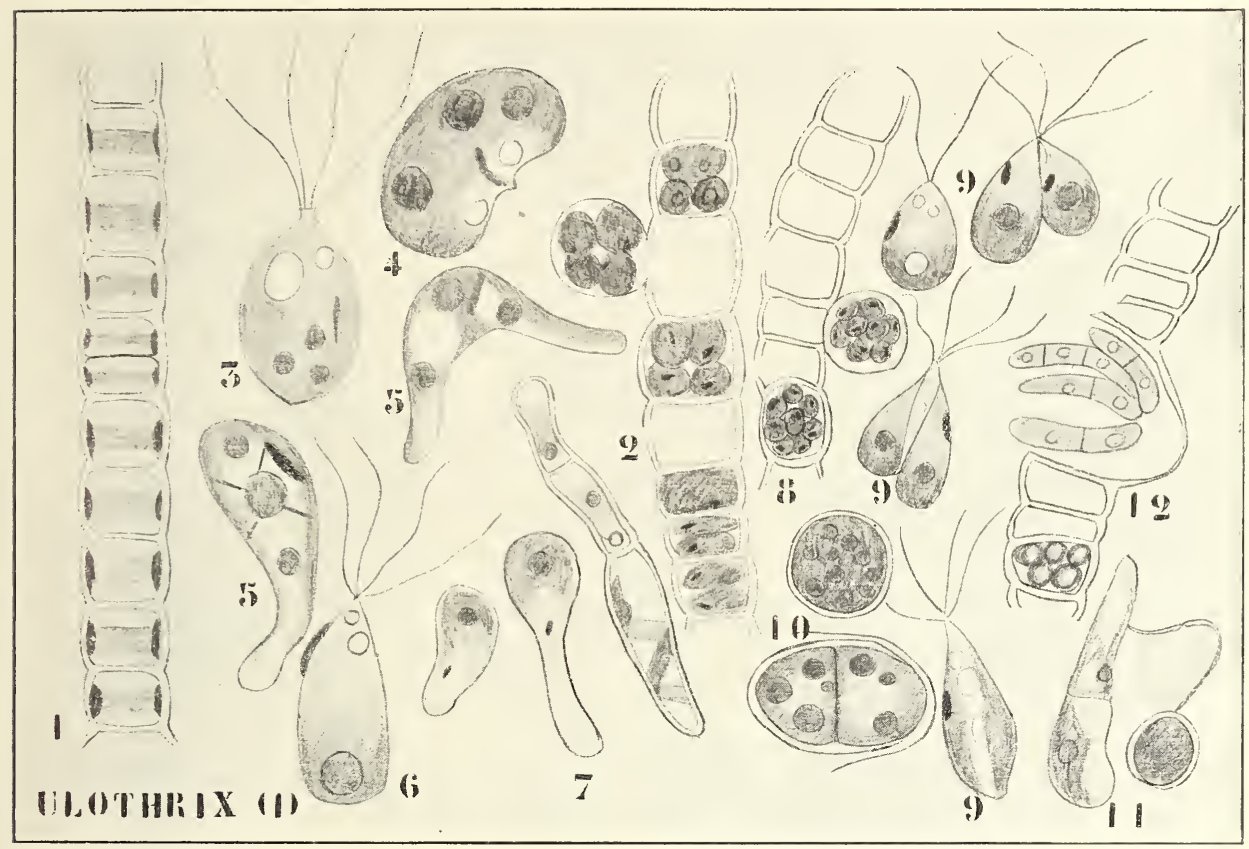

Fig. 108. Ulothrix zonata (nach KLEBS). 1 Vegetativer Faden, die gürtelförmigen Chromatophoren zeigend. 2 Zoosporenbildung. 3 Makrozoospore. 4, 5 Keimungsweise derselbell. 6 Mikrozoospore. 7 Keimung derselben. 8 Gametenbildung. 9 Kopulation. 10, 11 Parthenospore und Keimung derselben. 12 Faden mit gekeimten Zoosporen und ungekeimten Parthenosporen.

Nach ihrer Befreiung schwimmen sie fort; sie besitzen 4 Cilien, ein Chromatophor und einen deutlichen Augenfleck (Fig. 108, 3). Sie sind im stande, 24 Stunden lang herumzuschwärmen, legen sich dann seitlich am Substrat an (Fig. 108, 4) und bilden, nachdem sie sich mit einer Membran umgeben haben, an der einen Seite ein Rhizoid, während die andere zu einem Faden auswächst (Fig. 108, 5).

Neben Makrozoosporen können Mikrozoosporen gebildet werden, sie entstehen genau so wie die ersten, werden aber in größerer Zahl in einer Zelle gebildet. Auch sie besitzen 4 Cilien, unterscheiden sich aber leicht von den Makrozoosporen durch ihren ïber die Oberfläche des Körpers hervorragenden Augenfleck und dadurch, daß sie sich mit dem Vorderende am Substrat anheften. Sie sind weit mehr lichtempfindlich 
als die Makrozoosporen. Auch sie wachsen sofort zu einem neuen Faden aus. Die geschlechtliche Fortpflanzung findet mittels Gameten statt, sie entstehen in ähnlicher Weise wie die Zoosporen, besitzen aber nur je zwei Cilien. Gameten, von verschiedenen Fäden herrührend, kopulieren leicht miteinander, die Zygote schwimmt noch einige Zeit mit den vier Cilien herum, unterscheidet sich aber leicht von einer Zoospore durch die Anwesenheit von 2 Chromatophoren und 2 Augenflecken.

Auch ohne Kopulation können sich die Gameten entwickeln, man nennt sie dann Parthenosporen. Künstlich kann man die Gameten durch Einbringen in eine 0,5-proz. Nährlösung zur Parthenogenese zwingen. Dadurch wird die Neigung zur Kopulation aufgehoben.

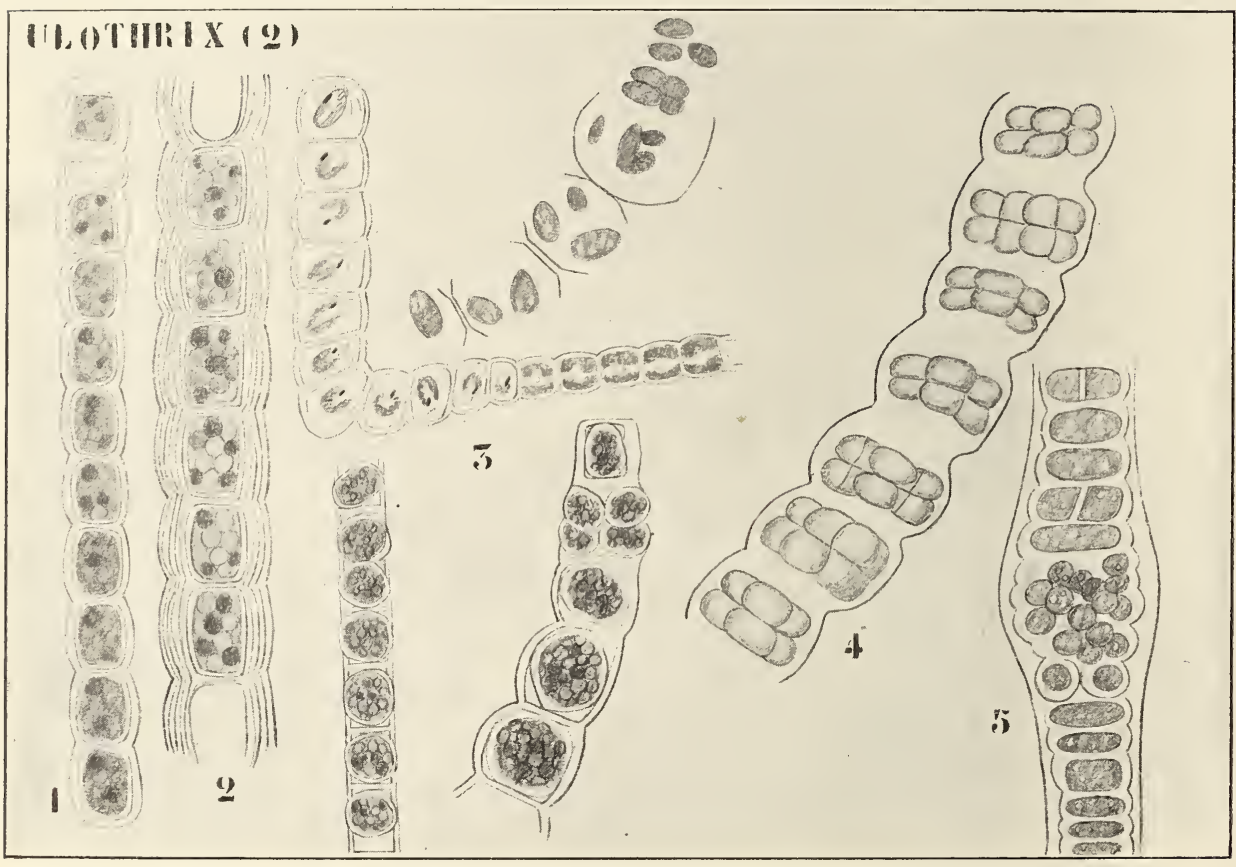

Fig. 109. Ulothrix (nach GAY und Cienkowski). 1 Akinetenbildung. 2 Hypnocystenbildung. 3 oben: Zoosporen in Zellen mit verschleimenden Membranen, unten: 2 Fäden mit Hypnosporen. 4 Schizomerisstadium. 5 Palmellastadium.

Nach Klebs teilt sich der Protoplast der Zygote bei der Keimung in 4, der der Parthenospore in 2 Stücke, die erste Kernteilung ist hier also wohl eine Aequationsteilung, die zweite eine Reduktionsteilung. Diese Teilstücke schwärmen nicht aus, sondern wachsen jedes für sich zu neuen Fäden aus. Die Sache bedarf aber noch erneuter Untersuchung, da DODEL angibt, daß sich 2-14 Zoosporen in der Zygote bilden können, ihren Austritt konnte er aber nicht beobachten.

Unter dem Einfluß besonderer Umstände können bei Ulothrix sehr verschiedene Zustände und Modifikationen der normalen Fortpflanzungsweise auftreten.

Akineten, d. h. vegetative Zellen, welche in einen Ruhezustand eintreten, können gebildet werden : 
1) durch Verschleimung der Querwände, unter Beibehaltung der normalen Form (Fig. 109, 1); nach dem Auseinanderfallen des Fadens in seine einzelnen Zellen keimen diese Akineten sofort zu neuen Fäden:

2) in ähnlicher Weise, aber unter Verdickung der Membranen und Ansammlung von Reservesubstanzen. Sie keimen entweder direkt oder nach Beendigung einer Ruheperiode und werden häufig Hypnocysten genannt (Fig. 109, 2).

Der Akinetenbildung, d. h. der Metamorphose der ganzen Zelle gegenüber, stehen sehr verschiedene Aplanosporenbildungen, d. h. unbewegliche Modifikationen von Zoosporen. Dabei begegnen wir allen denkbaren Uebergängen von normalen Zoosporen zu Aplanosporen. - In einigen Fällen werden zwar die Zoosporen vollständig ausgebildet, es entsteht aber keine Ausfuhröffnung im Zoosporangium, so daß die Zoosporen versuchen, sich durch die verschleimende Membran hindurchzuarbeiten. Das gelingt ihnen jedoch öfters nicht, sie keimen dann in der Schleimmasse (Fig. 109, 3 oben). In anderen Fällen verschleimt die Membran des Sporangiums nicht, die Zoosporen zeigen dann einige amöboide Bewegungen, umgeben sich darauf mit einer Membran und können, da sie Reservesubstanzen angesammelt haben, schlechte Zeiten überleben, man nennt sie Hypnosporen (Fig. 109, 3 unten). Selbstverständlich können eine oder mehrere Hypnosporen in einer Zelle entstehen. Weiter sind noch sogenannte Schizomerisstadien bekannt (Fig. 109, 4). Sie beruhen auf Aplanosporenbildung, diese Aplanosporen gelangen durch Verschleimung. der Membran des Sporangiums ins Freie, wo sie dann später wieder Zoosporen bilden können. Schließlich können noch Palmellastadien (Fig. 109, 5) gebildet werden, welche wohl nur dickwandige Modifikationen von Schizomerisstadien sind, wie Ortuanns, dessen Darstellung übrigens hier gefolgt wurde, mit Recht bemerkt.

Genus

Während nun Ulothrix isogame Befruchtung besitzt, zeigt das

\section{Cylindrocapsa}

oogame Befruchtung. Es gibt von diesem Genus 4 Arten, von denen C. involuta am besten bekannt ist. Die Alge ist aber recht selten, sie wurde von Reinsch in Franken entdeckt und von Cienkowski (1876) in beschatteten Teichen in der Nähe von Jareslow (Nord-Rußland) wiedergefunden und genauer untersucht.

Die Alge ist in der Jugend angeheftet, löst sich aber alsbald ab und flutet dann an der Oberfläche des Wassers; die Fäden sind unverzweigt.

Am Anfang ähnelt sie einer Conferva (Fig. 110, 1, 2), sie besteht aus ziemlich langen Zellen mit verhältnismäßig dünner Wand. Alsbald aber ändert sich dies, wir sehen Einschnürungen zwischen den Zellen auftreten (Fig. 110, 3), die IVände fangen an zu verschleimen, und durch Teilungen werden die Zellen kürzer und runder.

Zoosporen wurden mit Sicherheit noch nicht nachgewiesen, wohl aber Gameten, welche zu Eiern und Spermatozoen differenziert sind. Beide bilden sich in demselben Faden (Fig. 110, 4), die Eier, indem einige Zellen sich stark vergrößern, ihre Wand verschleimen lassen und den grün bleibenden Inhalt zu einem Ei zusammenballen, die Spermatozoen durch wiederholte Teilungen in den Kellen. Dadurch entstehen zunächst Spermatozoenmutterzellen, welche je ¿ Spermatozoen mit 2 Cilien bilden. Sie sind so wie die Spermatozoenmutterzellen rotbram 
gefärbt. Die Spermatozoen schwimmen in das sich inzwischen öffnende Oogon ein, wo eines mit dem Ei verschmilzt; die so gebildete Zygote umgibt sich mit einer dicken Membran und accumuliert ein rot gefärbtes Oel.

Schließlich ist der ganze Faden mit Ausnahme der Oogonien zur Spermatozoenbildung verbraucht, so daß er nur aus Reihen von leeren Zellen besteht, hie und da von einer Zygote unterbrochen. Parthenogenese scheint vorzukommen, auch werden Akineten und palmellaähnliche Stadien angetroffen.

Die folgenden Familien der Ulotrichales unterscheiden sich von den bereits besprochenen durch den Besitz langer, farbloser, spitzer Zellen,

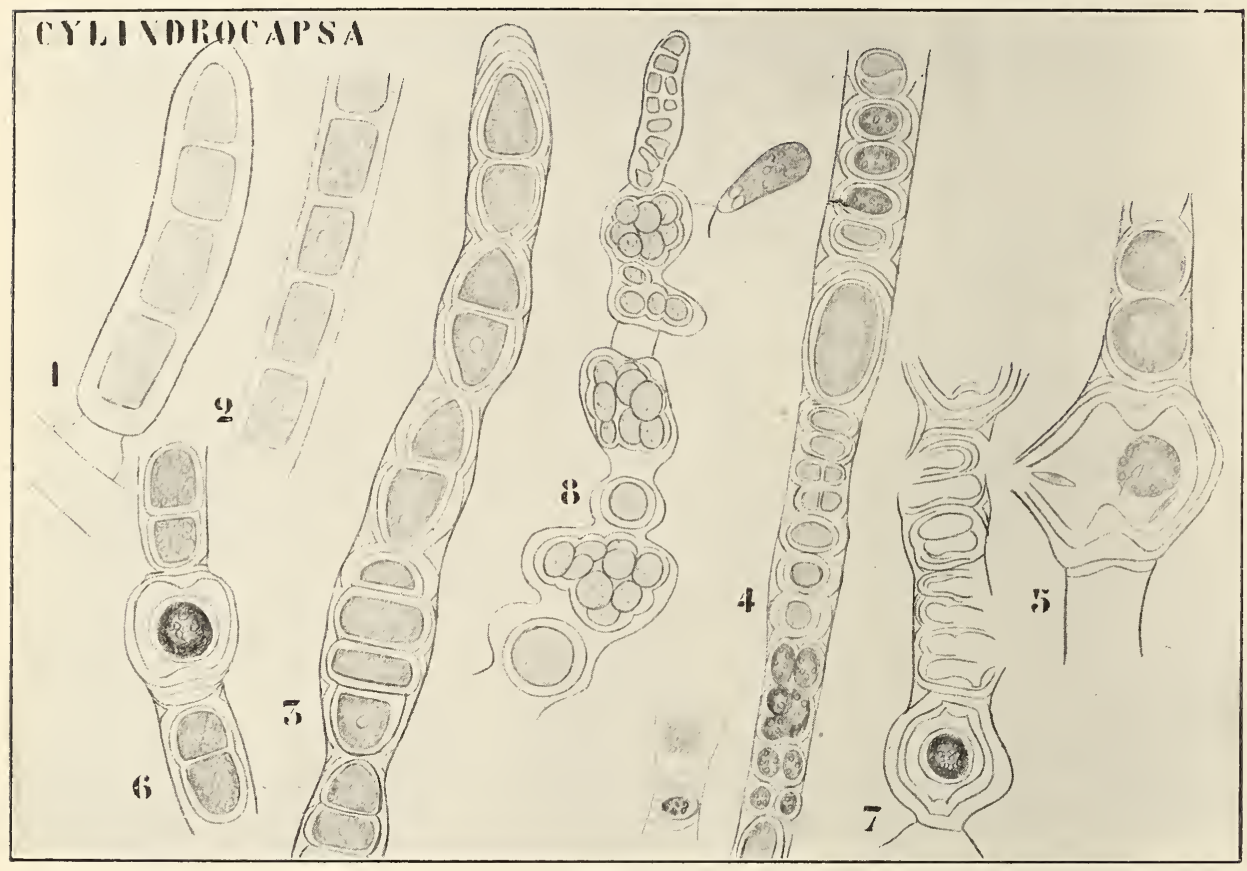

Fig. 110. Cylindrocapsa involuta (nach CIENKowskI). 1 Junger angehefteter Faden. 2 Teil eines jungen, bereits flutenden Fadens. 3 Aelterer vegetativer Faden. 4 Faden mit einem jungen Oogon und Spermatozoenmutterzellen (die dunkeln Zellen), oben ein stärker vergrößertes Spermatozoid. 5 Oogon mit Ei und eingetretenen Spermatozoen. 6 Faden mit Zygote. 7 Faden, nur aus einem zygotenhaltigen Oogon und im übrigen aus leeren Zellen bestehend. 8 Palmellastadium.

sogenannter Haare. Von diesen ist eine, die der Chaetophoraceen, isogam, die zweite, die der Coleochaetaceen, oogam.

Die Familie der Chaetophoraceae ist eine recht vielförmige und enthält mehrere Genera. Die Form variiert von reich verzweigten Zellfäden bis zu Zellscheiben, während mancherlei Uebergänge zwischen beiden Formen vorkommen.

Als Beispiel der ersteren möchte ich

\section{Draparnaldia}

mit Ihnen besprechen. Draparnaldia ist eine Alge, welche zumal in 
schwach strömendem Wasser, in sandigen Gegenden, aber auch in der Umgebung Leidens rorkommt. Sie bildet gerade Fäden, welche in gewissen Entfermungen reich verzweigte verhältnismäßig kurze Seitenzweige tragen. Die Alge ist demmach in Lang- und Kurztriebe differenziert.

Die Langtriebe haben kurze, helle, öfters fast weiße Zellen, was durch die schmale Bandform der Chromatophoren verursacht wird. Die Kurztriebe haben in jeder Zelle ein viel dunkler grünes und breiteres Chromatophor. In Verbindung damit wird die Photosynthese hauptsächlich von den Kurztrieben besorgt. Wir haben hier also eine Differenzierung in den Funktionen der Zellen, welche an die verschiedene Rolle. welche Stengel und Blatt bei den höheren Pflanzen zu erfüllen haben.
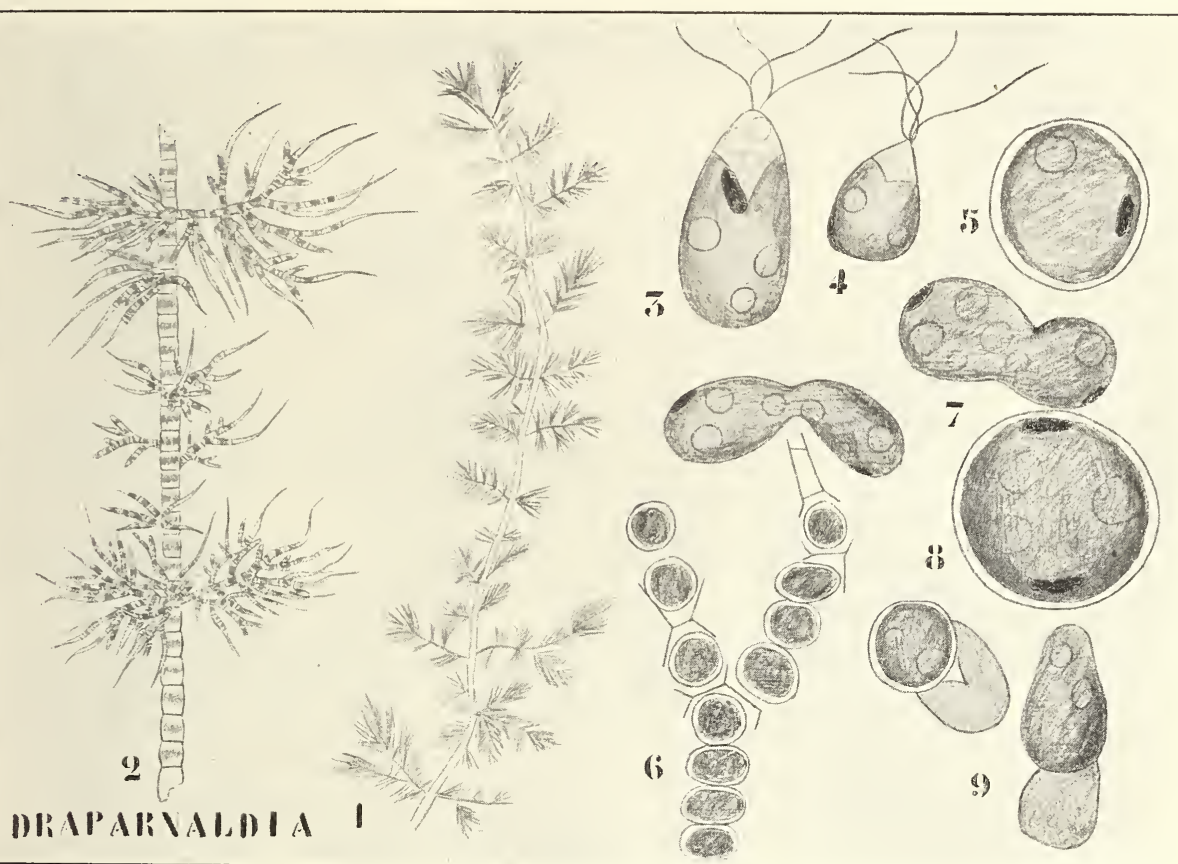

Fig. 111. Draparnaldia (nach Oltmanns und KLeBs). 1 Habitusbild eines Längstriebes. 2 Ein Stück eines Längstriebes, stärker vergrößert. 3 Zoospore. 4 Mikrozoospore. 5 Zur Ruhe gekommene Zoospore. 6 Ein Fadenstück mit Dauerzellell. 7 Kopulierende Mikrozoosporen. 8 Zygote. 9 Dauersporen keimend.

erinnert. Das Pflänzchen ist mit Rhizoiden am Substrat befestigt; fast alle Seitenzweige enden in Haaren. Wachstum findet hauptsächlich durch Teilumg gewisser Zellen an der Basis der Seitenzweige statt, ist also interkalar. Die ganzen Pflänzchen, welche eine ziemlich ansehnliche Länge erreichen, sind in eine Schleimmasse eingehüllt, welche durch Terquellen der Zellwände gebildet wurde. Sie fühlen sich deswegen schleimig an. was die makroskopische Erkennung der Alge erleichtert.

Jede Zelle der Seitenzweige, mit Ausmahme der Haarzellen, kamn Zoosporen bilden. Es entstehen in diesen Zoosporangien eine, 2 oder 4 Koosporen, die 4 Cilien, mehrere kontraktile Vakuolen und einen Augenfleck besitzen. Nach einigem Herumschwimmen lommen sie zu 
Ruhe und keimen direkt zu neuen Draparnaldien aus. Findet die Zoosporenbildung lebhaft statt, so werden die Seitenzweige gänzlich erschöpft; es bleiben dann nur die großen Zellen der Hauptzweige übrig. Kultiviert man nun diese Hauptzweige in verdünnter Rohrzuckerlösung am Lichte weiter, so ermöglicht ihnen dies die Bildung neuer Seitenzweige.

Am sichersten erhält man Zoosporen, wenn man die Alge aus strömendem in ruhiges Wasser überträgt; es läßt sich die Zoosporenbildung zu einem Maximum steigern, wenn man das im Dunkeln bei Zimmertemperatur ausführt. Außer gewöhnlichen Zoosporen bildet Draparnaldia Mikrozoosporen, sie sind kleiner als die ersteren und besitzen 4 Cilien, welche länger als der Körper sind. Ein anderes Unterscheidungsmerkmal bietet die Lage des Stigmas, bei den gewöhnlichen Zoosporen liegt dies im oberen Drittel des Körpers, bei den Nikrozoosporen in der unteren Hälfte, überdies springt es hier stark vor.

Die Mikrozoosporen sind viel lichtempfindlicher als die gewöhnlichen Zoosporen, während die gewöhnlichen sich zu einem breiten grünen Rande an der Lichtseite des Kulturgefäßes ansammeln, häufen sich die Nikrozoosporen am Punkte intensivster Beleuchtung zu einer kleinen grünen Wolke an. Durch diese Eigenschaft kann man die Mikrozoosporen schon makroskopisch von den gewöhnlichen unterscheiden. Die gewöhnlichen Zoosporen keimen direkt zu neuen Pflänzchen aus, die Mikrozoosporen bilden Dauerzellen, welche durch Kopulation oder ohne solche entstehen können.

Diese bis jetzt als Mikrozoosporen bezeichneten Gebilde können sich also unter Umständen als Gameten verhalten, unter anderen als Zoosporen. Man betrachtet sie demnach wohl am besten als Gameten mit geringer geschlechtlicher Neigung.

Die Kopulation dieser Gameten findet nie frei im Wasser, sondern ausschließlich im Schleim der Alge statt, und erst nachdem die amöboid gewordenen Gameten ihre Cilien abgeworfen haben. Bei der Keimung. schlüpft der ganze Inhalt der Zygote aus, umgibt sich mit einer neuen Membran und keimt zu einem neuen Pflänzchen aus. KLeBs meint, daß die Parthenosporen sich genau so betragen; absolute Gewißheit über diesen Punkt konnte er sich aber nicht verschaffen, da die Parthenosporen sehr schwer von den Zygoten zu unterscheiden sind. In der Natur kommt es vor, daß in jeder Zelle nur eine Mikrozoospore gebildet wird, welche ohne auszuschlüpfen zur Parthenospore wird (Fig. 111, 6).

Wir haben in Draparnaldia eine fadenförmige Chatophoree kennen gelernt, betrachten wir jetzt als Beispiel einer scheibenförmigen, die

\section{Pringsheimia scutata,}

eine im Meere epiphytisch auf anderen Algen, besonders gerne auf Polysiphonia, wachsende Alge. Wenn wir daran denken, daß wir als Kriterium der Chaetophoraceen die Anwesenheit von Haaren hervorhoben, so fällt uns sofort die Abwesenheit derselben bei unserer Pflanze auf. Es hat aber KLEBS nachgewiesen, daß die Intensität der Haarbildung bei den Chatophoraceen von den herrschenden Bedingungen abhängt, und daß man z. B. bei Stigeoclonium die Haarbildung vollständig unterdrücken kann. Oltmanss betrachtet denn auch Pringsheimia als eine Chatophoracee, welche die Fähigkeit der Haarbildung. verloren hat. Pringshermia bildet einschichtige, am Rande wachsende Zellscheibchen, welche, wie gesagt, epiphytisch leben. 
Die Zoosporen werden hauptsächlich in den zentral gelegenen Zellen gebildet, sie besitzen 4 Cilien. Daneben werden kopulierende zweicilige Isogameten gebildet.

Ton den Chatophoraccen lassen sich nun zwei Familien ableiten, die eine. die der Coleochaetaceae, ist als eine scheibenförmige Chaetophoraceen-Gruppe zu betrachten, welche Oogamie erwarb, die andere, die der Chroolepideen, verdankt ihre Entstehung dem Uebergang vom Wasser- zum Landleben.

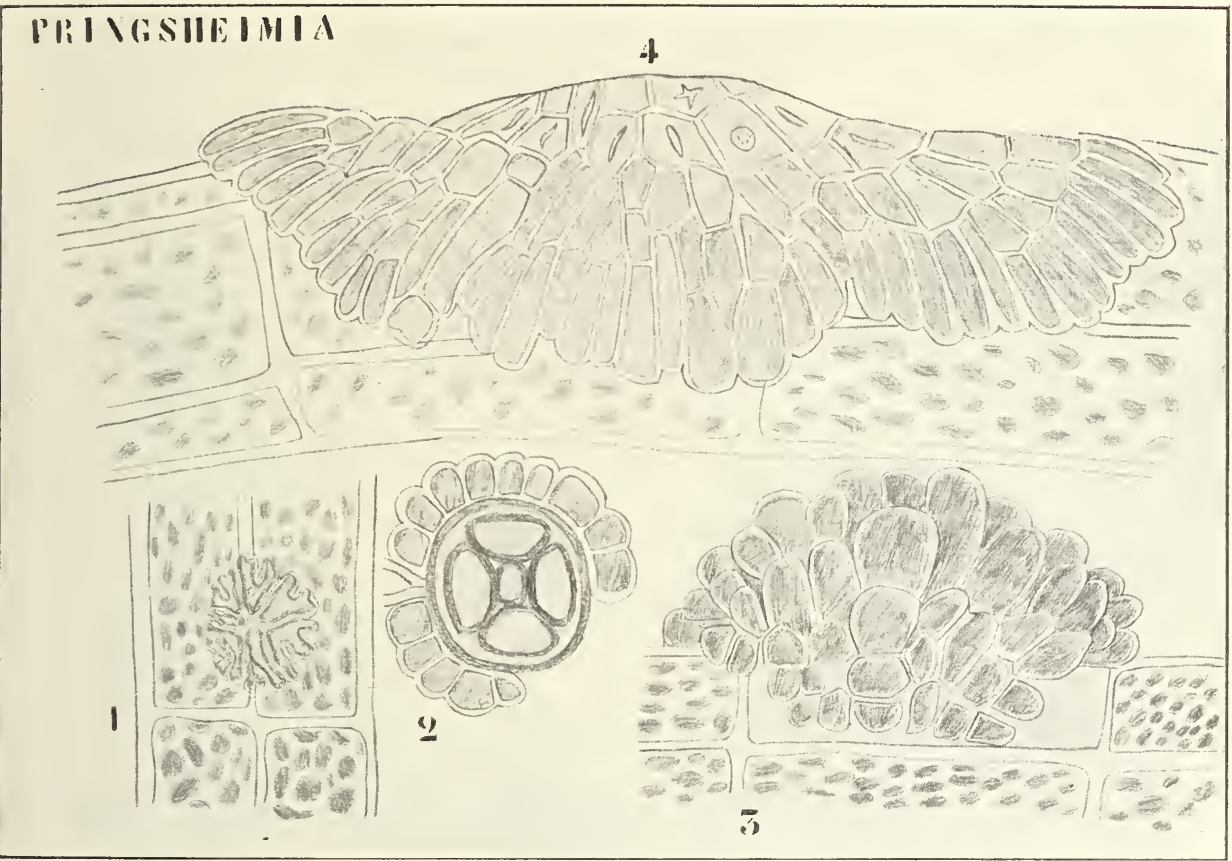

Fig. 112. Pringsheimia scutata (nach ReInke). 1 Junge Scheibe auf Polysiphonia. 2 Querschnitt einer solchen. 3 Scheibe, Zoosporen bildend. 4 Aeltere Scheibe, aus deren zentralen Zellen die Schwärmer entschlüpft sind.

Betrachten wir zunächst die Familie der

\section{Chroolepideae.}

Es sind dies Algen, welche auf Baumstämmen, Steinen und in den Tropen auch vielfach auf Blättern höherer Pflanzen vorkommen, also an der Luft lebende Algen. Auch in dieser Familie kommen fadenund scheibenförmige Algen vor, welche durch ihre Farbe auffallen. Sie sind nämlich nicht grün, sondern gelbrot, durch die Anwesenheit eines gefärbten Oeles, welches wohl infolge starker Belichtung sich gebildet hat. Die Chloroplasten sind vorhanden und rein grün, aber vom gelben Oel verdeckt, das, da es durch $\mathrm{H}_{2} \mathrm{SO}_{4}$ blan gefärbt wird, wohl Carotin enthält. Eine europäische, fadenförmige Chroolepidec, dem Genus Chroolepus angehörig, tränkt die von ihm bewohnten Felsen mit einem Teilchenduft, weshalb Stücke derselben, z. B. im Har'z, unter dem Namen Teilchen- 
stein verkauft werden. Wir wollen uns jedoch, um nicht zu ausführlich zu werden, auf die Besprechung eines scheibenförmigen Genus, auf

\section{Cephaleuros}

beschränken. Diese Algen bestehen aus Zellscheibchen, welche bei gewissen Arten epiphyll leben, bei anderen aber sogar in das Blatt eindringen und parasitisch werden.

Jede Zelle eines solchen Scheibchens kann zu einem Organ anschwellen, welches von OLtmanns als Gametangium gedeutet wird, und dessen Gametangiumnatur bei anderen Genera, z. B. für die hier abgebildeten Trentepohlia-Arten, von Wille bewiesen wurde, indem er die Kopulation der in demselben gebildeten Gameten nachwies. Außer diesen

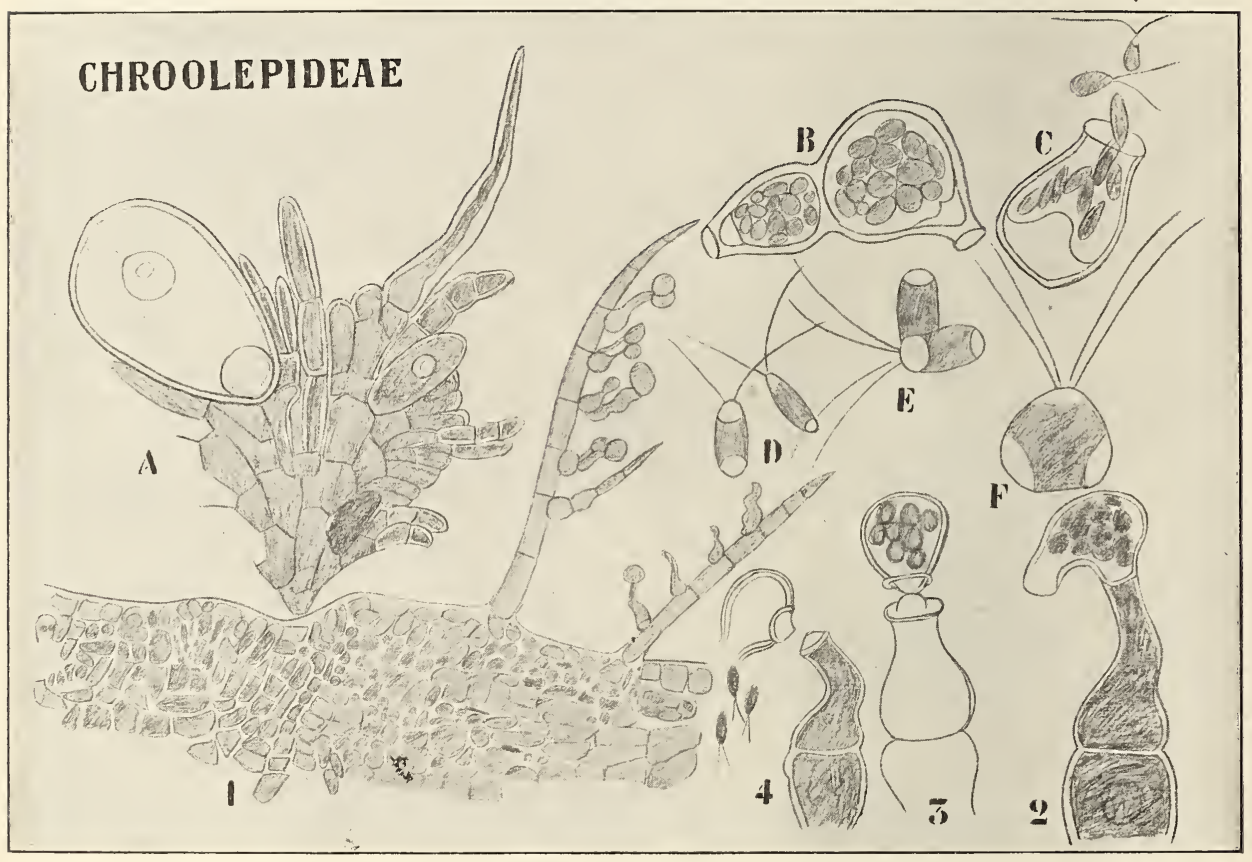

Fig. 113. Chroolepideae (nach KARsten und WILle). A Cephaleuros la evis mit einem jungen (rechts) und einem entleerten Gametangium. B, C Chroolepus umbrina, Gametangien. D, E Kopulation der Gameten bei Trentepohlia Bleischii. 2-4 Sporangien und Zoosporen von Cephaleuros mycoidea.

Gametangien werden Sporangien gebildet. Sie entstehen an Zweigen, welche senkrecht vom Scheibchen sich erheben. Bei vielen Arten bilden sie einen Fortsatz, der Karsten veranlaßte, sie als Hakensporangien zu deuten. An der Anheftungsstelle des Sporangiums reißt die Membran leicht ab (Fig. 113, 3), und es mag der Fortsatz, der bei gewissen Arten gefunden wird, einen Vorteil haben, indem über das Blatt kriechende Insekten diese Sporangien verbreiten. Wir haben es hier durch die Loslösung der Sporangien also mit einem Fall zu tun, wo bei einer Alge das Sporangium zur Konidie wurde, wohl auch hier infolge des Landlebens. In diesen Konidien sind aber die Zoosporen schon vorgebildet, 
diese treten. Wenn die vom Winde oder durch Insekten verbreiteten Sporangien mit ITasser in Berührung kommen, sofort heraus und keimen zu neuren Pflänzchen.

Wir haben es hier also mit hochgradig an das Landleben angepaßten Organismen zu tun. welche aber, da ihre Fortpflanzung isogam geblieben ist, auf einer niedrigeren Entwickelungsstufe als die Coleochaetaceae stehen, welche letzteren demn auch als die höchsten Isokonten betrachtet werden müssen. Als Beispiel dieser Gruppe wähle ich das Genus

\section{Coleochate.}

Es sind dies Algen, welche sowohl auf totem Substrat wie auf anderen Pflamzen, aber stets unter Wasser leben; man trifft sie z. B. nicht selten an der Unterseite von Nymphaea-Blättern an.

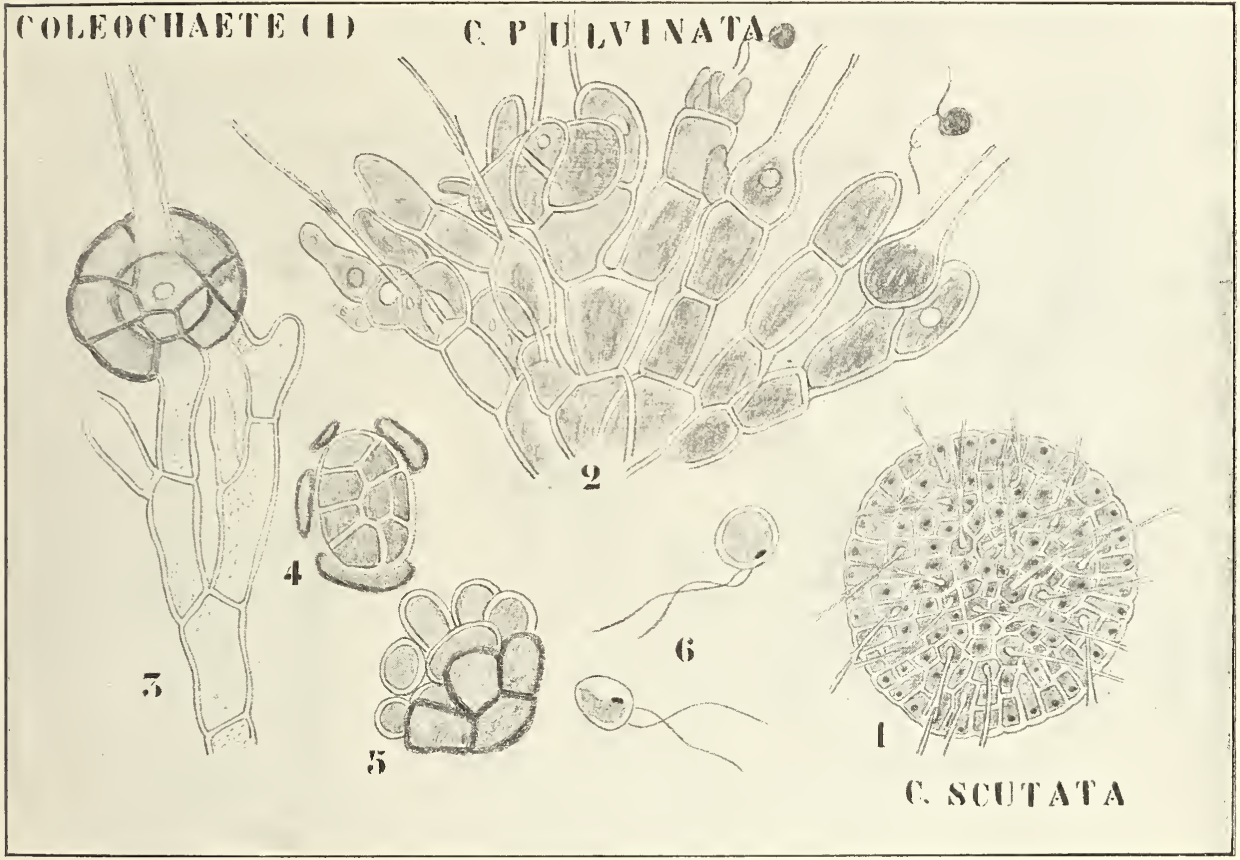

Fig. 114. Coleochaete (nach Pringsherm). 1 C. scutata steril. 2 C. pul vinata A. BR. mit Oogonien und Antheridien. 3 Reifes berindetes Oogon. 4, 5 Keimung der Zygoten. 6 In den keimenden Zygoten gebildete Schwärmer.

Die verschiedenen Coleochaete-Arten zeigen ziemlich verschiedene Form; so besteht $C$. pulvinata aus einer Scheibe, von welcher sich zahlreiche verzweigte Fäden erheben, welche durch Schleim zu einem ziemlich regelmäßigen Polster verbunden sind. Bei anderen Formen aber. z. B. bei $C$. scutata, fehlen diese aufrechten Zweige; solche Formen sind demnach zu einer Basalscheibe reduziert. Fast jede Zelle trägt ein Haar, ein sogenanntes Scheidenhaar, das dadurch entstelit, daß die inmere Nembranschicht sich beim Wachstum des Haares hervorwölbt und die äußere zerreißt, wodurch letztere die Basis des nenen Stückes scheidenförmig umgibt (Fig. 114, 2). 
Die ungeschlechtliche Fortpflanzung findet mittels Zoosporen statt; sie entstehen bei C. pulvinata meistens an den terminalen Zellen der aufrechten Zweige, in jeder Zelle wird bloß eine Zoospore gebildet, welche 2 Cilien und ein Stigma besitzt. Während des Sommers pflanzt sich nun Coleochaete fast ausschließlich durch Zoosporen fort. Gegen den Herbst wird diese Fortpflanzung von der geschlechtlichen abgelöst.

Es bilden sich dann an den Enden der Zweige kurze Seitenzweiglein, deren jedes ein Antheridium repräsentiert. Bei C. pulvinata enthalten die Antheridien kein Chromatophor, sind also die Spermatozoen farblos, wohl aber bei $C$. scutata, sie bilden denn auch grüne Spermatozoen.

Die Oogonien entstehen als Anschwellungen von terminalen Zellen, in ihnen bildet sich ein Ei aus, das nach der Befruchtung zur Zygote

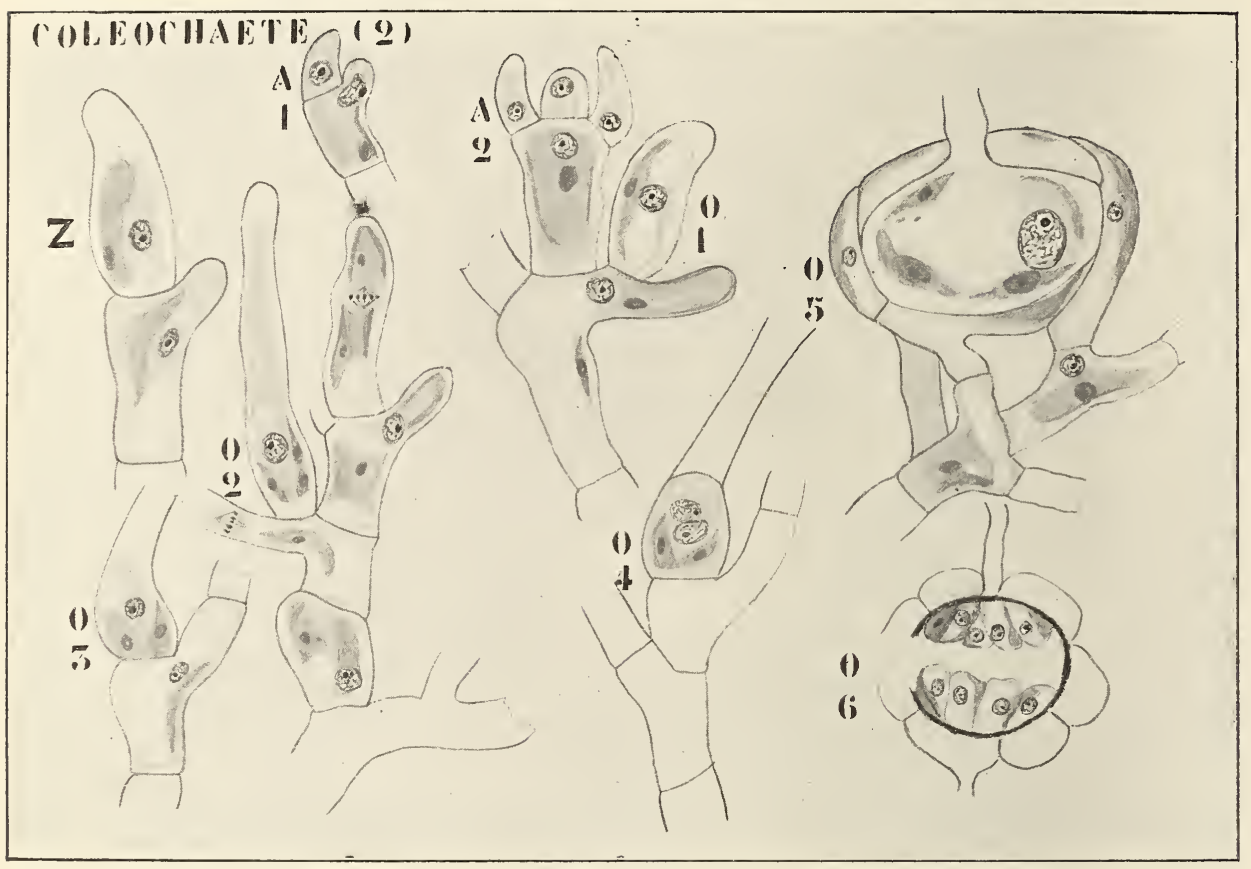

Fig. 115. Coleochaete pulvinata (nach Outmanss). $Z$ bezeichnet die Zoosporangien, $A$ die Antheridien, $O$ die Oogonien. Die dazu gestellten Zahlen bezeichnen die verschiedenen Entwickelungsstadien. $O_{6}$ ist eine keimende Zygote.

wird. Die Zygote bleibt nun im Oogon liegen, und dieses wird ron benachbarten Zweigen umrindet. Bei der Keimung teilt sich die Zygote in eine Anzahl von Zellen, welche je eine Zoospore bilden.

Betrachten wir jetzt diese Vorgänge an der Hand der Cytologie nach Oltmanss' Untersuchungen an C. pulvinata etwas näher.

Ueber die Zoosporen ist nichts Näheres zu bemerken, und für die Antheridien genügt ebenfalls das schon Gesagte, woraus hervorgeht, daß im Antheridium nur ein Kern und kein Chromatophor vorhanden, das Spermatozoon also farblos ist. In jedem Antheridium wird ein einziges 2-ciliges Spermatozoon von Zoosporenform gebildet.

Die Oogonien entstehen durch Anschwellen und gleichzeitige Verlängerung der Endzellen der Fäden, wodurch eine bauchige Zelle mit 
einem langen Hals entsteht $\left(\mathrm{O}_{2}\right)$, welche ein einziges großes Chromatophor enthält. Der Hals öffnet sich $\left(O_{3}\right)$, und der Inhalt ballt sich zu einem Ei zusammen. Ein Spermatozoon dringt alsbald ein, sein Kern legt sich dem Eikern an $\left(\mathrm{O}_{4}\right)$, verschmilzt mit demselben, und die Zygote wird gebildet. Die Zygote wächst num bedeutend, und das Oogon wird von herumwachsenden Seitenzweigen berindet $\left(O_{5}\right)$, wir können also von einer Zygotenfrucht reden.

Inzwischen hat sich der Chromatophor in 8 Stücke geteilt, und es bildet sich um die Zygote herum eine dicke braune Schicht, welche zum Teil aus der Oogoniumwand, zum Teil aus den inneren Wänden der Berindungszellen gebildet wird.

In diesem Zustande überwintert die Frucht. Bei der Keimung wird zunächst eine Querwand gebildet, wodurch die Zygote in 2 Zellen geteilt wird, in jeder Hälfte entstehen durch weitere Teilung 8-16 Zellen $\left(\mathrm{O}_{6}\right)$.

Darüber sagt OLtuanss wörtlich: ,bald bildet sich nach vorautgegangener Kernteilung eine Wand, welche auf der Längsachse des einstigen Oogoniums senkrecht steht. Sie ist Querwand zu nennen. Nunmehr folgen Längswände, welche Oktanten bilden, und letztere zerfallen wieder durch einige Teilungen, bis 8-16 Zellen in jeder Kugelhälfte herausgeschnitten sind. Da keine Querteilungen mehr einsetzen, berühren alle entstandenen keilförmigen Zellen mit einer schmalen Fläche die erste (Quer-)Wand. Sind sie fertig gebildet, dann reißt die Zrgote in der Region, welche etwa der Querwand entspricht, auf, und alsbald tritt aus jeder der geschilderten Zellen ein Schwärmer hervor."

Da liegt es nun auf der Hand, zu meinen, es sei der hier gebildete Zellenkomplex ganz oder zum Teil eine $2 \mathrm{x}$-Generation.

Untersuchungen von ALLEN (1905) an Coleochaete scutata sind aber dieser Auffassung nicht günstig. Trotzdem er die Zahl der Chromosomen in den Zellen, welche sich bei der Keimung der Zygote bilden, nicht mit der der vegetativen Zellen hat vergleichen können und Sicheres also nicht vorliegt, scheint doch schon die erste Teilung des Zygotenkernes heterotypisch zu sein, die folgende homöotypisch. Das hieße also, die erste Teilung wäre eine Trennungsteilung, die übrigen Aequationsteilungen.

Aber sogar wenn das sich als unbedingt richtig herausstellen würde, so wäre damit keineswegs gesagt, daß alle Coleochaete-Arten sich genau so verhielten. C. pulvinata steht durch die farblosen Spermatozoen entschieden auf einer höheren Entwickelungsstufe als $C$. scutata, und die eigentümliche Zweiteilung der Zygote, welche Otwmanns beschreibt, gefolgt von der unabhängigen Weiterentwickelung der beiden Hälften, legt die Vermutung nahe, daß hier wenigstens die erste Teilung eine homöotypische sein wird, und daß also C. pulvinata eine wenigstens zweizellige $2 \mathrm{x}$-Generation ausbildet.

Wie dem auch sei, und nähere Untersuchungen sind entschieden abzuwarten, so steht e ins fest: daß die höheren Pflanzen durch eine derartige Ausbildung einer 2 x-Generation entstanden sind, und deswegen ist es vorläufig mit aller Reserve wohl am besten, die höheren Pflanzen an Coleochaete anzuschließen.

Wir sehen aber auch hier wieder, wie schwer es ist, einigermaßen die Phylogenese des Pflanzenreiches im Detail zu verfolgen.

Wir liaben also die Reihe der Isokonten, weiche doch wohl jedenfalls als die Ahnen der höheren Gewächse zu betrachten sind, abgehandelt. 
Wir haben gesehen, wie sie alle Entwickelungsmöglichkeiten einer $\mathrm{x}$-Generation versucht haben. Sie haben versucht, weiterzukommen durch Bildung beweglicher Cönobien (Volvocales), durch Bildung polyenergider Zellschläuche (Siphonales), durch Bildung unbeweglicher Cönobien (Pleurococcaceae und Protococcaceae), durch Bildung von Zellenplatten (Ulvales), durch Bildung von Zellenfädeu (Ulotrichales), alles vergebens, das Prinzip war offenbar falsch, auf dem Wege der x-Generation ließ sich anscheinend das Höchste nicht erreichen, erst nachdem dieser Plan aufgegeben wurde, nachdem Weiterentwickelung auf dem Wege der $2 \mathrm{x}$-Generation versucht wurde, nachdem also durch bleibende Vereinigung zweier Wesen ein Doppelwesen, eine $2 \mathrm{x}$-Generation herausgebildet wurde, konnten die höheren Pflanzen entstehen.

Bevor wir aber diese höheren Pflanzen besprechen, müssen wir noch die nicht-isokonten Gruppen der niedrigeren Gewächse durchnehmen.

\section{Akontae.}

In erster Linie müssen wir uns mit einer kleinen Gruppe beschäftigen, welche wahrscheinlich durch Verlust der Cilien aus der Gruppe der Isokonten entstanden ist: die Gruppe der Akontae, so genannt, weil die Fortpflanzungszellen, die Gameten, keine Cilien besitzen. Eine Andeutung eines solchen Verlustes sahen wir schon bei den Gameten von Draparnaldia, welche zwar Cilien ausbilden, sie aber vor der Kopulation verlieren; daß sie trotzdem kopulieren können, verdanken sie ihrer amöboiden Bewegungsfähigkeit. Bei den Akontae aber ist ein anderer Weg eingeschlagen worden, bei ihnen findet die Kopulation der Gameten nicht im Freien statt, sondern es kopulieren die Gametangien miteinander in der Weise der Gametangien der Mucorineen.

Deshalb werden diese Akonten, zu welchen ich nicht, wie OLTmanns, die Diatomeen und Desmidiaceen rechne, öfters mit dem Namen Conjugaten angedeutet. Ich bringe zu ihnen zwei Familien, welche aber keineswegs scharf voneinander getrennt sind: die Mesotaeniaceae und die Zygnemaceae. Von diesen ist die erstere die einfachste, betrachten wir also zunächst die Familie der

\section{Mesotaeniaceae,}

und zwar zunächst das einfachste Genus derselben.

\section{Mesotaenium.}

Die Pflanzen dieses Genus bestehen aus einer einzigen kurz-zylindrischen Zelle mit abgerundeten Endflächen. Sie pflanzen sich ungeschlechtlich mittels einfacher Querteilung fort. Dabei passiert es aber öfters, daß die äußere Schicht der Zellwand nicht durchschnitten wird, sondern sich von der inneren abhebt (Fig. 116, 2); so entsteht ein Säckchen, in welchem die Tochterindividuen liegen. Da sich dieser Vorgang wiederholen kann, und die Zellen jede für sich eine ziemlich dicke Schleimumhüllung bilden, entstehen so Kolonien, welche recht gut gegen Eintrocknung geschützt sind. Das hat seine Vorteile; denn unsere Pflanzen leben zwar an feuchten Orten, aber doch auf dem Lande.

Das Chromatophor ist bei einigen Arten plattenförmig, bei anderen sternförmig. Bei der Kopulation legen sich die Individuen aneinander, bilden kurze Ausstülpungen, welche einander alsbald berühren und 
durch Auflösung der trennenden Wandstücke einen Kopulationskanal bilden. Am besten ist die Kopulation beim Genus

\section{Cylindroeystis}

bekannt. Bei den Vertretern dieses Genus wird der Kopulationskanal so stark durch Ausdehmung der Wand erweitert, daß die beiden kopulierenden Individuen zusammen ungefähr ein Viereck bilden (Fig. 116. 5-6). Damit ist die Zygote hergestellt, sie bildet normalerweise keine eigene WTand; zwar scheint dies bisweilen der Fall zu sein (Fig. 116, 7 links), das beruht aber auf einer Täuschung, indem die innere Wandschicht der kopulierten Individuen sich von der äußeren getrennt hat.

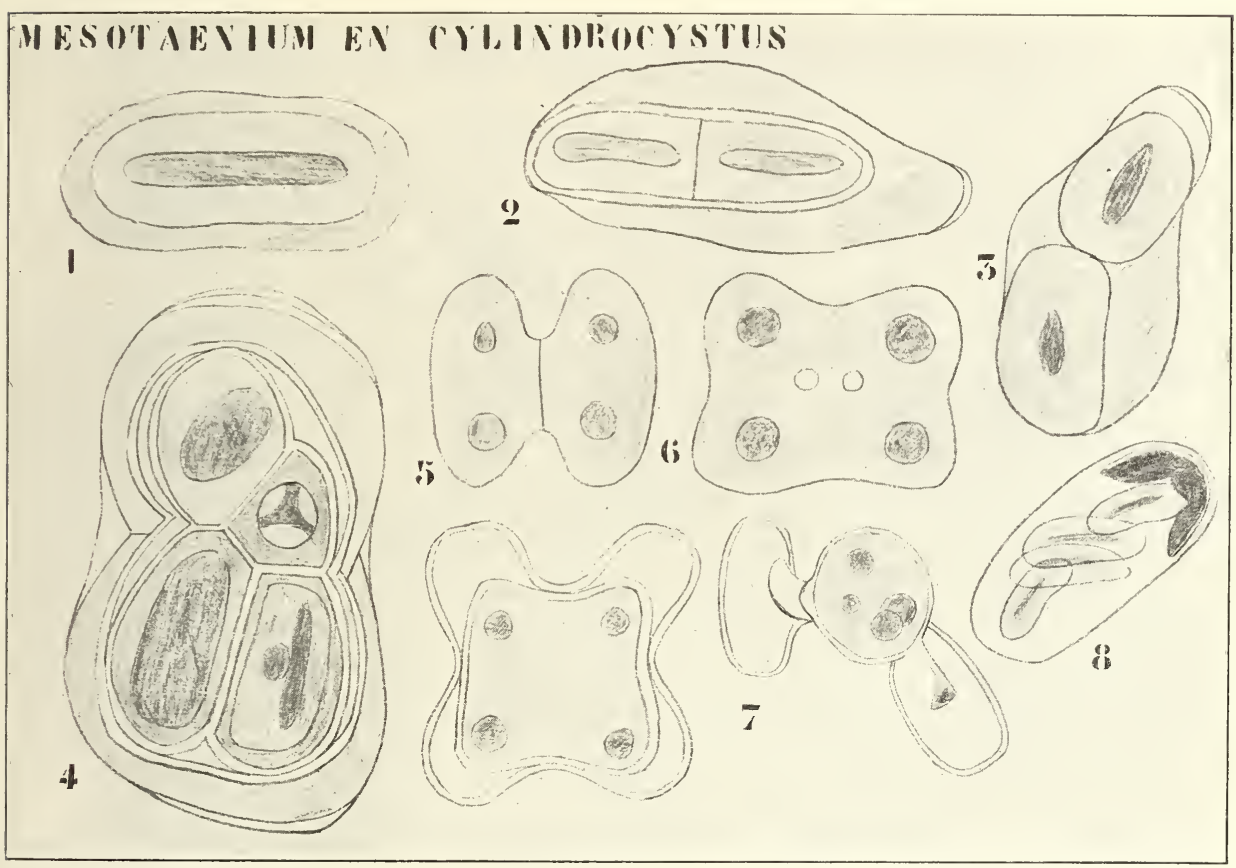

Fig. 116. Mesotaenium und Cylindrocystis (nach DE BARY). 1 Eine vegetative Zelle eines Mesotaenium. 2, 3 M. chlamydosporum in Teilung. 4 Eingeschachtelte Individuen von M. Braunii. 8 Keimung der Zygote von M. chlamydosporum. 5-7 Kopulation von Cylindrocystis Brebissonii.

Unter Umständen kann aber die junge nackte Zygote aus den vereinigten Wänden der kopulierten Individuen herausschlüpfen und sich nachträglich mit eigener Wand umgeben (Fig. 116, 7 rechts).

Am interessantesten ist die Keimung der Zygoten, indem bei Mesotaenium in jeder Zygote 4 junge Individuen gebildet werden, offenbar ist also hier die Zygote Gonotokont geworden.

Die Gruppe der

\section{Zyginemaceate}

läßt sich von den Mesotacniaceae leicht ableiten. MIan kamn sie als MLesotaeniaceae betrachten, deren Individuen nach der Teilung zusammen- 
hängend bleiben. Zwar kommen bei Spirogyra ganz anders geformte Chromatophoren vor als bei Mesotaenium und Cylindrocystis, aber das Mesotaenium-Genus Spirotaenia hat, wie schon der Namen andeutet, ganz ähnliche Chromatophoren wie Spirogyra. Ueberdies können auch bei den Zygnemaceen die Individuen sich voneinander loslösen. Das geschieht in folgender Weise:

Die Zygnemaceae bilden einfache, unverzweigte Fäden aneinander gereihter Individuen. Nacht man z. B. bei Mougeotia einen Längsschnitt an der Grenze zweier Individuen (Fig. 117, II), so sieht man eine dünne Schicht, die Cuticula, welche die Zellen überzieht; in der Tat sitzen denn auch die verschiedenen Individuen eines Fadens in einer langen Cuticularröhre, welche selber wieder von einer Schleimschicht

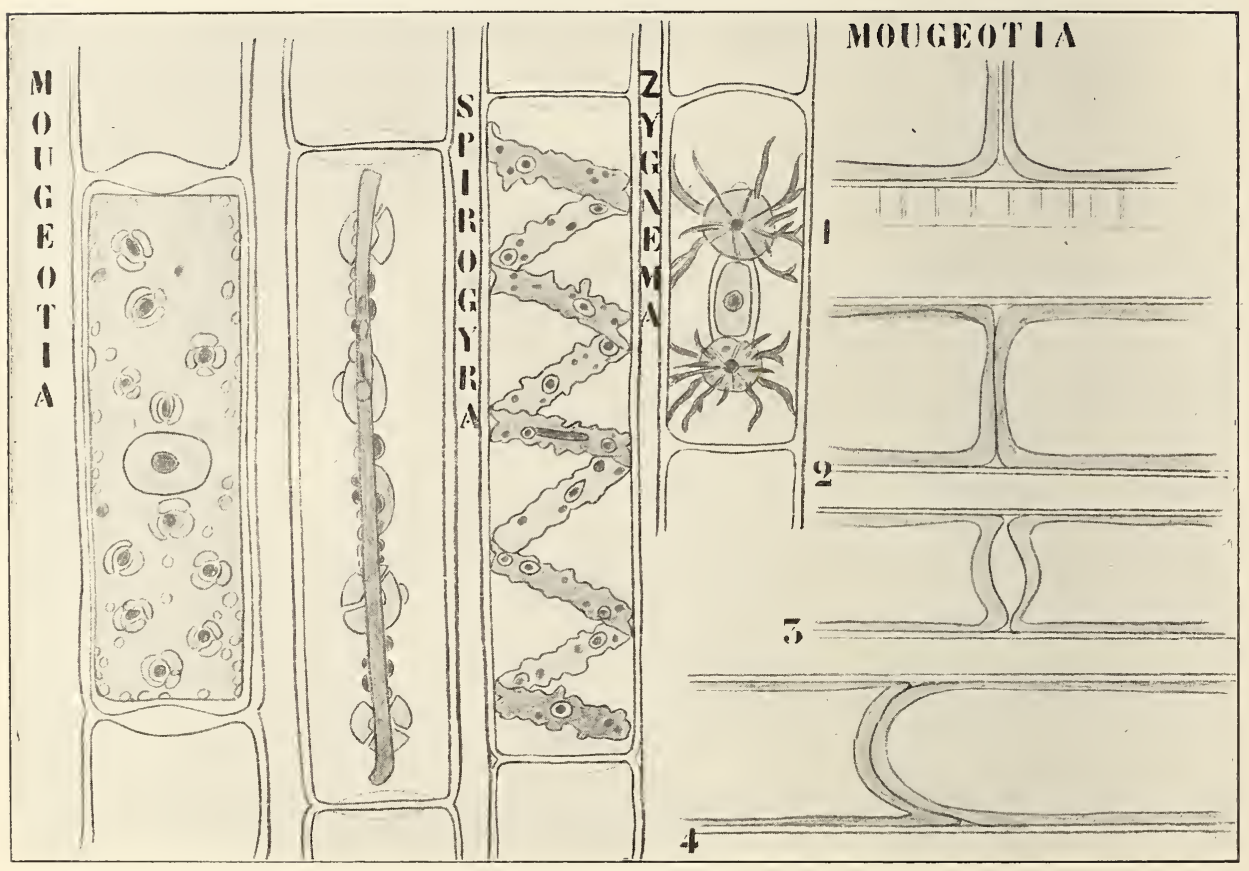

Fig. 117. I. Z y gn e m a c e e n - Chromatophoren (nach PALLA). M o u g e oti a (links von der Fläche, rechts von der Seite betrachtet), Spirogyra und Zygnema. - II. Zerbrechen des Fadens bei Mougeotia. 1-4 nach BenEcke.

umgeben ist. Das Loslösen der Individuen geschieht nun zumal dann, wenn eine der Zellen abgestorben ist und der Vorgang beruht auf einer Turgorzunahme der angrenzenden lebenden Zelle. Man kann den Vorgang bei Mougeotia besonders schön beobachten. Die Zellen grenzen hier mit gewöhnlichen flachen Wänden aneinander (Fig. 117, II 2). Da in der toten Zelle der Druck aufgehoben ist, wölbt sich die Grenzwand derselben nach innen vor, das geschieht aber auch zunächst bei der angrenzenden lebenden Zelle (Fig. 117, II 3), in ihr nimmt aber der Druck so sehr zu, daß sie sich nach außen zu vorwölbt und dadurch die tote Zelle wegzuschieben versucht (Fig. 117, II 4). Da diese aber zu genau in die Cuticularröhre paßt und ein Hinausschieben dadurch ausgeschlossen 
ist. zerreißt die Cuticula zwischen den beiden, und der Faden bricht plötzlich ab.

Die Zelle der Zygnemaceae ist durch den eigentümlichen Chromatophoren leicht kenntlich. Sie ist plattenförmig, sternförmig oder spiralförmig gewunden.

In jeder Zelle ist selbstverständlich nur ein Kern vorhanden, der öfters in einer Plasmaansammlung, welche man Kernsäckchen nennt, aufgehängt ist. Bei Zygnema liegt der Kern zwischen den beiden sternförmigen Chromatophoren. Die Chromatophoren besitzen mit wenigen Ausnahmen Pyrenoiden, das Produkt der Photosynthese ist stets Stärke. Dem Chromatophoren angeschmiegt fand PALLA kleine sich mit Eosin etwa wie der Kern färbende Körperchen, welche er Karyoiden nennt (die

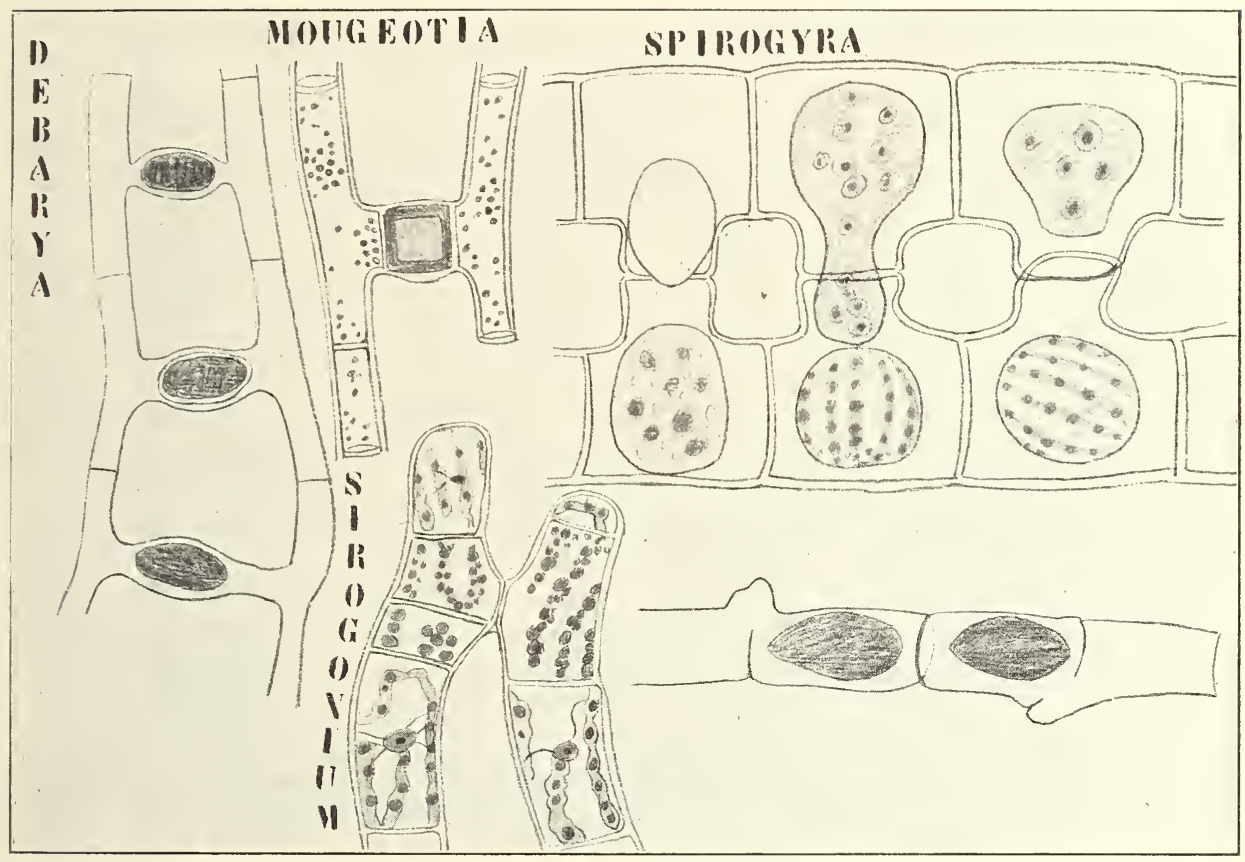

Fig. 118. Kopulation bei den Zygnemaceen (nach WITTrock und DE BARY).

kleinen halbkreisförmigen Figuren der rechten Figur von Mougeotia), ihre Funktion ist vollkommen unbekannt, Pallas Vermutung, daß es sich hier um kleine Kerne handelt, vermag ich mich nicht anzuschließen.

Die Zygnemaceen sind stets von einer Schleimschicht umgeben, welche, wie man nach geeigneter Färbung sehen kann, aus Stäbchen besteht.

Die Zellteilung findet simultan mit der Kernteilung statt, zwischen die jungen Tochterkerne schiebt sich ein Cellulosering ein, welcher etwa in der Weise einer Irisblende ihre Oeffnung verkleinerud zur Querwand wird.

Die Spirogyren können sich bewegen, es geht dies z. B. daraus hervor, daß verwirrte Fäden sich wieder zu entwirren verstehen. Tie dies aber geschieht, ist noch unklar. Eine ungeschlechtliche Fortptlanzung besteht, mit Ausnahme der normalen 'Teilung', nicht. 
Dagegen findet sich bei allen eine geschlechtliche Fortpflanzung mittels Kopulation. Kopulierende Spirogyren sind leicht mikroskopisch an der Lagerung der Fäden zu erkennen. Während bei nicht kopulierenden Spirogyra-Massen die Fäden so ziemlich parallel liegen, hat eine kopulierende Masse das Aussehen eines verwirrten Netzes. Wie gesagt kopulieren alle Zygnemaceen, aber die Details dieses Vorgangs sind bei den verschiedenen Vertretern ziemlich verschieden.

Dem einfachsten Fall begegnen wir bei Debarya (Fig. 118).

Zwei Fäden legen sich einander parallel, und die einander gegenüber liegenden Zellen bilden Kopulationsfortsätze, welche zu Kopulationskanälen verschmelzen. Bemerkenswert ist hier, wie in allen ähnlichen Fällen, das genaue Zusammenstoßen der Kopulationsfortsätze; dabei mag wohl Chemotaxis im Spiele sein.

Die Energiden der kopulierten Zellen werden nun zu cilienlosen Gameten, bewegen sich aufeinander zu (das Genauere ist noch unbekannt), begegnen sich in der Mitte des Kopulationskanals und verschmelzen dort zu einer sich mit einer dicken Wand umhüllenden Zygote. Mougeotia stimmt in der Weise der Zygotenbildung genau mit Debarya überein, nur tritt bei ihr diese Komplikation auf, daß die Kopulationsfortsätze hart an der Zygote je mittels einer Querwand verschlossen werden, so daß die Zygote von einer Zelle umschlossen ist. Die Bildung dieser Querwände wird dadurch ermöglicht, daß in den kopulierten Zellen nach dem Herausschlüpfen der Gameten noch etwas Plasma zurückbleibt.

Bei Debarya und Mougeotia verhalten sich also die Gameten vollkommen gleich, wir haben mit Isogametenkopulation zu tun.

Bei Spirogyra dagegen verhalten sich die Gameten ungleich, dem Betragen nach sind sie heterogam, trotzdem sie der Form nach Isogameten sind. Es tritt nämlich die eine Gamete ganz in das Gametangium der anderen ein, ja es treten in der Regel sämtliche Gameten des einen Fadens in die des anderen über, so daß wir hier von männlichen und weiblichen Fäden reden können. Ja es kann sogar vorkommen, daß ơ und क Fäden schon äußerlich zu unterscheiden sind. Bei Spirogyra inflata z. B. sind die weiblichen Zellen vergrößert und angeschwollen und Gruber bemerkte, daß die ơ Fäden von Spirogyra crassa meistens zahlreichere und kleinere Zellen besitzen als die weiblichen. Infolgedessen ist es stets einer Anzahl männlicher Zellen unmöglich, mit weiblichen zu kopulieren. Gewöhnlich liegen die steril bleibenden Zellen unregelmäßig zwischen den fertilen, aber es kommt auch vor, daß regelmäßig eine sterile mit einer fertilen abwechselt. Das bildet gewissermaßen einen Uebergang zu Sirogonium. Hier fruktifizieren nicht alle, sondern nur gewisse Zellen eines jeden Fadens, welche sich vor der eigentlichen Kopulation teilen.

Bei der Kopulation biegen die Fäden aufeinander zu, und es kopulieren die Zellen, welche sich dabei berühren; eine solche Kopulation nennt man knieförmig. Im weiblichen Faden teilt sich nun die kopulierende Zelle einmal, das eine Teilstïck wird die $q$ Gamete bilden, das andere bleibt steril. Im männlichen Faden aber teilt sich die kopulierende Zelle zweimal, so daß das männliche Gametangium zwischen 2 sterile Zellen zu liegen kommt, von diesen beiden ist die eine größer als die andere. Die männliche Gamete begibt sich nun in das weibliche Gametangium und verschmilzt dort mit der $q$ Gamete zu einer Zygote. Die Cytologie dieser Vorgänge ist unbekannt, der Umstand aber, daß 
die Teilungen in der weiblichen und in der männlichen Zelle verschieden verlaufen, macht nicht geneigt, hier an eine große Bedeutung zu denken. Tiele Zygnemaceen, bei welchen sonst normale Kopulation zwischen zwei Fäden stattfindet, wissen sich bei Abwesenheit eines zweiten Fadens durch seitliche Kopulation benachbarter Zellen zu helfen (vergl. die Fig. 118 rou Spirogyra, rechts unten). Benachbarte Zellen bilden dann nahe der Trennungswand sich zueinander hinneigende kurze Kopulationsschläuche. Nach Auflösung der Trennungswand entsteht dann ein kleiner gebogener Kopulationskanal, durch welchen der Inhalt der einen Zelle in die andere überschlüpft. In dieser Darstellung darf man, da die Struktur der Chromatophoren außer Acht gelassen wurde, durchaus keine phylogenetische Reihe erblicken.

Die Cytologie der Befruchtung bedarf noch sehr der näheren Untersuchung, da die von verschiedenen Forschern erhaltenen Resultate einander noch vielfach widersprechen.

Erstens schon in Bezug auf die Chromatophoren. Nach Overton sollen sich bei Spirogyra die Chlorophyllbänder mit den Enden aneinander legen, während CHurelewsixy angibt, daß das ¿ Chlorophyllband zu Grunde geht. Letzteres scheint das wahrscheinlichste, schön wäre es, wenn man Hybriden zwischen Arten mit verschieden geformten Chloroplasten erzeugen könnte. Auch in Bezug auf die Kerne steht es nicht besser. Nach Overton verschmelzen beide Kerne ohne weiteres zu einem Zygotenkern, nach CHмielewsky aber teilt sich der Zygotenkern später in 4, von diesen sollen 2 zu Grunde gehen und 2 von neuem miteinander verschmelzen. Aus theoretischen Gründen wäre es wahrscheinlicher, wenn $3 \mathrm{zu}$ Grunde gingen und nur einer übrig bliebe.

Bei der Keimung entsteht nämlich nur ein Keimpflänzchen und es wäre dann dieses Verhalten des Zygotenkernes dem des Zygotenkernes der Mesotaeniaceen, wo 4 Keimlinge gebildet werden, analog, der einzige Unterschied würde der sein, daß von den 4 Keimlingen 3 zu Grunde gingen. Der Keim teilt sich alsbald, die eine Zelle wird zum Rhizoid, womit Spirogyra in der Jugend am Substrat befestigt ist, die andere bildet durch weitere Teilungen den Spirogyra-Faden.

Während bei Spirogyra und den anderen behandelten Formen die Zygotenmembran vom Keimling zerrissen wird, öffnet sich bei Craterospermum die Zygote mittels eines Deckels. Das weitere Verhalten ist sehr eigentümlich. Zunächst bildet sich ein langer einzelliger Keimschlauch mit 4 Chromatophoren und 4 Kernen. Dann werden 4 Querwände gebildet in solcher Weise, daß jedes Chromatophor quergeteilt wird; zu gleicher Zeit werden auch die den Chromatophoren anliegenden Zellkerne geteilt. In dieser Weise entstehen 3 Zellen mit 2 Kernen und an jedem Ende dieser Reihe je eine Zelle mit einem Kern. Da diese zweikernigen Zellen sich nun später immer so teilen, daß von den Tochterzellen immer die eine zweikernig, die andere einkernig ist, bleiben stets 3 zweikernige Zellen bestehen, wie groß auch die Gesamtzahl der Zellen werden mag (Berthold).

Wir sahen bereits, daß bei vielen Zygnemaceen seitliche Kopulation benachbarter Zellen vorkommt, und dieser Umstand veranlaßt mich, hier ein Pilzgenus anzuschließen, das ähnliche Kopulation zeigt. Ich gebe aber sofort zu, daß dieser Anschluß recht problematischer Natur ist. Wo doch die Zygnemaceen eine Gruppe bilden, welche offenbar die Termehrung durch Zoosporen verloren hat, wo überdies ein Landbewohner mit einem Wasserbewohmer verglichen wird, da sind die Tergleichs- 
punkte so wenig zahlreich, daß der Wert einer daraus gezogenen Schlußfolgerung sehr gering ist.

Der Umstand aber, daß Basidiobolus, der betreffende Pilz, von Anfang an multicellulär ist und jede seiner Zellen nur von einer Energide bewohnt wird, scheint mir in Verbindung mit der in mancher Hinsicht an die Zygnemaceen erinnernden Zygotenbildung zu zeigen, daß der Platz, welchen ich ihm hier anweise, besser ist als einige andere, an welche er möglicherweise noch gestellt werden könnte.

Die Familie der

\section{Basidioboleae}

enthält nur ein Genus: Basidiobohs, mit der Art:

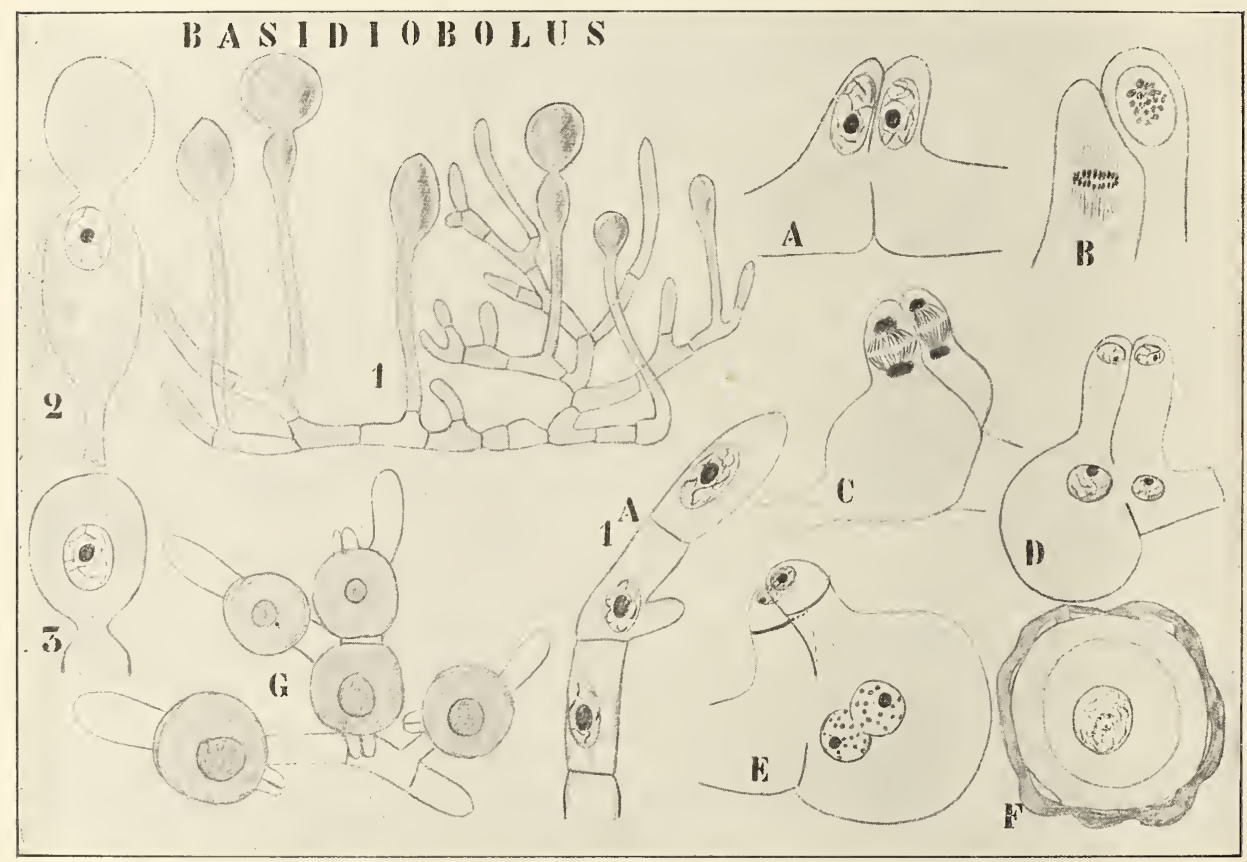

Fig. 119. Basidiobolus ranarum (nach EmDAy und FAIRchild). 1 Konidienbildende Pflanze. $1 \mathrm{~A}$ Vegetativer Faden. 2, 3 Uebertritt des Kernes aus der Zelle in die Konidie. A-G Zygotenbildung.

Basidiobolus ranarum EidaM.

Von Eidam (1886) entdeckt, wurde sie von Chmielewsky (1890), Fairchild (1897), Raciborski $(1896,1899)$ und Woycicki (1904) näher untersucht.

Der Pilz findet sich auf Exkrementen von Fröschen und bildet ein homocelluläres Iycel, welches in jeder Zelle einen Kern enthält. Bei der ungeschlechtlichen Fortpflanzung bildet jede Zelle einen aufrechten Schlauch, einen Konidienträger, der an der Spitze etwas angeschwollen ist und alsbald eine große kugelige Konidie bildet. Diese wird abgeworfen und keimt zu einem neuen Mycel aus.

Bei der geschlechtlichen Fortpflanzung bilden zwei nebeneinander 
liegende Zellen nahe der Scheidewand je eine kleine Ausstülpung, welche sich aneinander pressen. Der Kern jeder Zelle tritt in diese Ausstülpungen ein. Auf diesem Stadium bildet sich ein Loch in der Scheidewand der beiden Zellen. Beide Kerne teilen sich nun; der eine Tochterker'n bleibt in der Spitze der Ausstülpung liegen, und es bildet sich bald unter ihm eine Querwand, wonach er zu Grunde geht. Die beiden anderen Tochterkerne treten in ihre respektiven Zellen zurück, eine von diesen ist inzwischen angeschwollen und es tritt der Kern aus der nicht angeschwollenen Zelle in die angeschwollene über. Dort verschmilzt er mit dem anderen Kern, wodurch die Zygote, welche sich später mit dicker Membran umgibt, nach FaIrchilds Meinung gebildet ist. So einfach liegt die Sache aber mach Woycrckrs Untersuchungen nicht; nach ihm soll sich zwischen die Stadien der Fig. $119 \mathrm{E}$ und F noch ein anderes einschieben. Die beiden Kerne der Fig. 119 E sollen nicht direkt miteinander verschmelzen, sondern sich erst einmal teilen, wodurch 4 Kerne entstehen, von diesen sollen 2 zu Grunde gehen und 2 miteinander zum eigentlichen Zygotenkern verschmelzen. Ob freilich die Reihenfolge, in welche Worcick seine Schnitte gestellt hat, richtig ist, muß dahingestellt bleiben. Vielleicht hat er Teilungen, welche nach der Kopulation stattfanden, als präkonjugale aufgefaßt. Nähere Untersuchung wäre, zumal da die Keimung der Zygote noch nicht bekannt ist, sehr erwünscht.

Wir haben früher bei Lagenidium und ähnlichen Pilzen gesehen, daß die ungeschlechtliche Fortpflanzung gegen den Winter hin öfters von der geschlechtlichen abgelöst wird. Das hat für die Pflanze eine nützliche Seite, weil die Zygoten mit ihren dicken Membranen viel besser den Unbilden des Winters widerstehen können als die ungeschlechtlichen Zoosporen.

Wenn wir nun sagen, es ist die Zygotenbildung zur Winterszeit eine nützliche Anpassung, so ist das nur das Konstatieren einer Tatsache, keineswegs eine Erklärung. Eine Erklärung für die Zygotenbildung erhalten wir nur dann, wenn wir die Bedingungen der Zygotenbildung bestimmen können. Das hat nun für Basidiobolus Racrborski getan und überdies den Einfluß äußerer Umstände auf die Entwickelung der vegetativen Organe dieses Pilzes studiert. Aus seiner interessanten Arbeit sei folgendes hervorgehoben. Die Ursache der Zygotenbildung ist bei Basidiobolus Nahrung'smangel, und da nun bei vielen Pilzen im Herbst Nahrungsmangel eintritt, haben wir hier die Erklärung für die Häufigkeit der Zygotenbildung kurz vor dem WVinter. Der Nutzen dieser Bildungen als Ueberwinterungsorgane ist demnach ein Zufall, der mit der Ursache nichts zu tun hat. Auch wenn auf die nahrungsarme Herbstzeit eine sehr günstige Zeit folgte, würden die Zygoten gebildet werden.

Sehr auffallend ist der Einfluß äußerer Beding'ungen auf die Form der vegetativen Stadien unseres Pilzes. Kultiviert man einen Basidiobolus in einer Peptonlösung, so bildet er lange Fäden mit senkrecht zur Längsachse gerichteten Querwänden, wie sie auf der Fig. 119 abgebildet sind, ganz normale Pilzhyphen also. Kultiviert man ihn aber in 6-proz. NaCl oder in 20-proz. Glukoselösung, so erhalten wir kurze gedrungene Zellen, welche nur in losem Zusammenhang miteinander sind, und in welchen die Wände meistens schief, ja sogar longitudinal gebildet werden. Kultiviert man unseren Pilz in einer Nährlösung, welche 1 Proz. Ammoniumsulfat oder 1 Proz. Chlorammonium enthält, so bilden 
sich ähnliche lockere Zellenkomplexe, aber es sind die Zellen überdies je mit dicken geschichteten Membranen umgeben und es lösen diese Zellen schließlich den Verband ganz auf, so daß Palmella-ähnliche Zustände entstehen. Sogar noch tiefere Umbildungen können durch Modifikation der äußeren Bedingumgen erhalten werden. Bringt man z. B. Basidiobolus aus einer Peptonlösung, in welcher er normale multicelluläre monoenergide Hyphen gebildet hat, in eine 10-proz. Glyzerinlösung, welche 1 Proz. Pepton und 1 Proz. Glukose enthält und erhöht man die Temperatur bis $\mathrm{zu} 30^{\circ} \mathrm{C}$, so entstehen polyenergide Zellen, welche man also, wenn man ihre Abstammung nicht kennte, zu den Siphonomyceten stellen würde. Daraus ersehen wir also, daß die Grenze zwischen den monoenergiden und polyenergiden Gewächsen keine scharfe ist, und es ist uns damit ein Fingerzeig gegeben, wie die polyenergiden aus den monoenergiden entstanden sein können.

Damit sind wir am Ende unserer Besprechung der Akonten, welche wir als einen Seitenzweig der Isokonten betrachten, angelangt und müssen uns nun einer Gruppe zuwenden, die sich nicht von den Isokonten ableiten läßt, sondern diesen parallel verläuft, die Gruppe der Stephanokonten. 


\section{Sechste Vorlesung.}

\section{Stephanokonten.}

Konnten wir die Isokonten verhältnismäßig leicht mittels Chlamydomonas und Pyramidomonas an die Flagellaten anschließen, so stoßen wir bei den Stephanokonten auf größere Schwierigkeiten, denn es sind die Stephanokonten gekennzeichnet durch den Besitz von Schwärmsporen, welche einen Kranz von Cilien um den Scheitel herum besitzen.

Flagellaten mit solchen Ciliensträngen kennen wir nicht, deshalb liegt der Ursprung der Stephanokontenreihe im Finstern.

Ich möchte nun 2 Algenfamilien zu dieser Gruppe bringen: die Derbesiaceae und die Oedogoniaceae, erstere ist polyenergid monocellulär, letztere multicellulär monoenergid. Falls dies richtig, haben wir hier also ähnliche Entwickelungsreihen wie bei den Isokonten.

Wir müssen dann annehmen, daß es früher Organismen auf der Entwickelungsstufe einer Pyramidomonas, aber mit einem Cilienkranze gegeben hat und daß diese sich in zwei Richtungen entwickelt haben, die eine unter Beibehaltung der Einzelligkeit bei Vermehrung der Energiden, die andere durch simultane Energiden- und Zellteilung. Von diesen beiden Reihen würden dann fast alle Vertreter ausgestorben sein, es ständen dann die Derbesiaceae und die Oedogoniaceae als letzte Reste einer verschollenen großen Stephanokontengruppe da.

Betrachten wir nun zunächst die

\section{Derbesiaceae}

mit dem einzigen Genus:

\section{Derbesia.}

Von diesem Genus gibt es z. B. bei Neapel einen Vertreter. Da dieser dort z. B. ein ständiger Bewohner der. Aquarien sein soll, ist es gewiß auffallend, daß wir noch so wenig von diesem Pflänzchen wissen. Es lassen sich an ihm ein kriechendes Rhizom und aufrechte, wenig verzweigte schlauchförmige Assimilatoren unterscheiden. An der Basis der Zweige entstehen dicht beieinander zwei Querwände, so daß der übrigens einzellige Thallus dort von kleinen Zellchen unterbrochen ist, diese Zellchen können sich nun ein wenig vergrößern und dabei entsteht ein Querriß, der nach Oltuanns entfernt an den bei Oedogoninm erinnert. und der für mich neben der Struktur der Schwärmer Grund war. die Alge in die Gruppe der Stephanokonten zu stellen. Diese Stelle ist 
aber, ich gebe das ger'n zu, recht zweifelhaft, denn die Zoosporen besitzen zwar einen Cilienkranz, weichen aber in ihrer Cytologie, falls die Beobachtungen BerTHolds richtig sind, bedeutend von allen bekannten ähnlichen Bildungen ab, ja es ist sogar nicht bekannt, ob wir hier mit Zoosporen oder Gameten zu tun haben. Die reifen "Zoosporen“ besitzen einen Kern und sind stark abgeplattet, das tut selbstverständlich ihrer eventuellen Stephanokontennatur keinen Abbruch, auch nicht der Umstand, das im „Zoosporangium" mehr Kerne anwesend sind als Zoosporen gebildet werden. Aber falls die BERTHOLDsche Angabe richtig ist, daß der Kern der "Zoosporen“ das Verschmelzungsprodukt mehrerer Kerne ist, haben wir hier mit einem ganz einzig dastehenden Falle zu tun. Erneute Untersuchung ist demnach im höchsten Grade erwünscht.

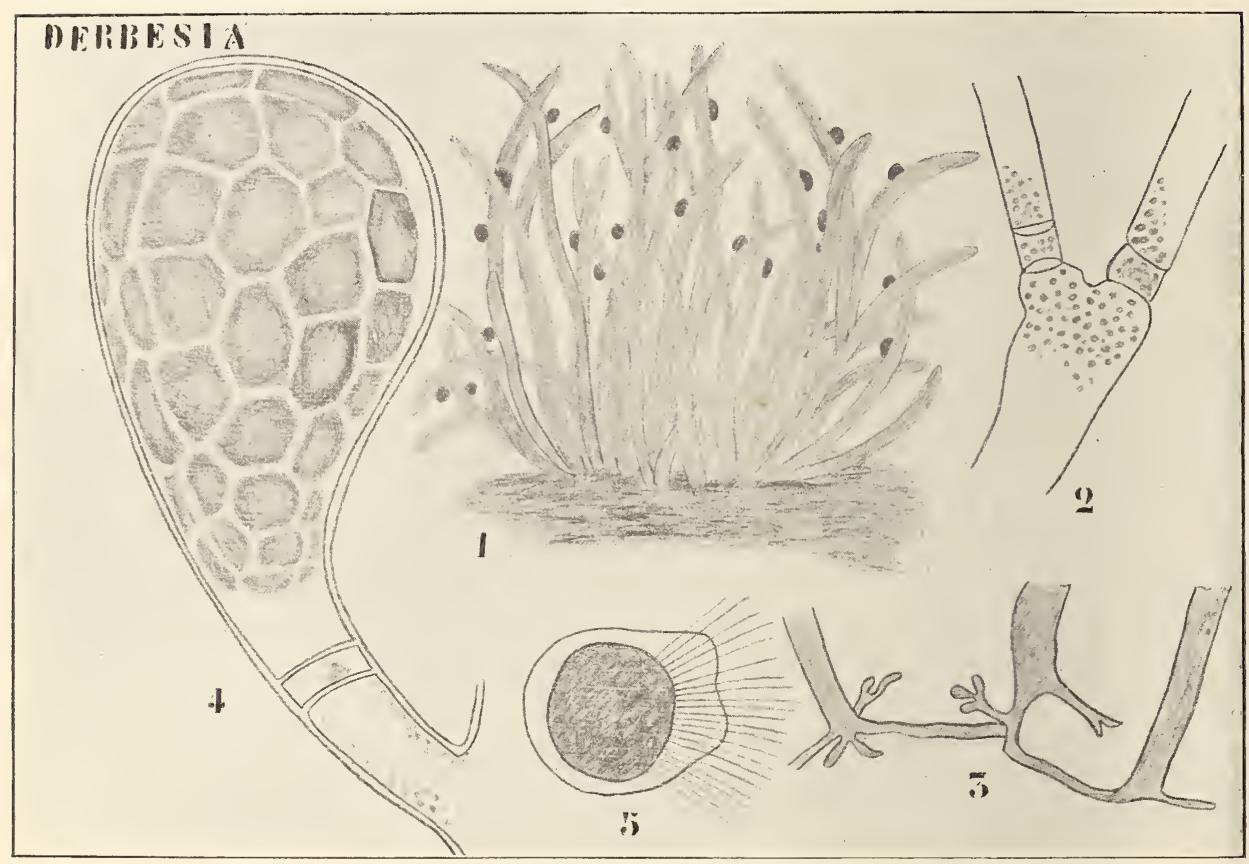

Fig. 120. 1 Derbesia Lamourouxii, Habitusbild (nach OLtmanns). 2 Bildung kleiner Zellen an der Basis der Aeste von D. marina (nach KJELMANN). 3 Rhizom von D. Lamourouxii (nach Grober). 4 Zoosporangium von D. marina (nach KUCKUCK). 5 Zoospore (nach SoLIER).

Die andere Stephanokontenfamilie und die einzige, welche also mit Sicherheit hierher gehört, ist die Familie der

\section{Oedogoniaceae.}

Sie ist oogam und steht also auf höherer Entwickelungsstufe. Betrachten wir davon das Genus

\section{Oedogonium.}

Der Oedogonium-Thallus besteht aus einem einfachen, mittels eines Rhizoides angehefteten Zellfaden. Charakteristisch für alle Oedogoniaceen 
ist die Weise, in welcher die Zelle sich teilt. Dies geschieht nämlich vermittelst interkalaren Wachstums. Folgende Beschreibung dieses Vorganges ist wörtlich der schönen Arbeit KRAskovits' entnommen:

„Unter interkalarem Wachstum versteht man in vorliegendem Falle ein auf eine bestimmte Zellwandregion lokalisiertes Längenwachstum, wodurch die Zelle gleichsam ruckweise schnell an Länge gewinnt. Pringshem hat die dabei mitwirkenden und ausgebildeten Teile der Zelle mit besonderen Namen belegt, die ich im folgenden beibehalten habe."

.Betrachtet man einen Zellfaden von Oedogonium, der deutliche Polarität aufweist - ,oben' und, unten' sind stets auf die Lage zur Befestigung'sstelle (Rhizoid) bezogen —, so sieht man in einzelnen Zellen, symmetrisch zu beiden Seiten in der oberen Region einen stark lichtbrechenden ,Körper ${ }^{6}$ der Zellwand anliegen (Fig. 121, 1). Es ist dies der optische Durchschnitt eines an der Innenfläche der Membran ringförmig verlaufendell Wulstes (Fig. 121, 2). Pringshem namnte diese Bildung ,Ring.6 oder ,Zellstoffring". Nebenbei finden sich in der Literatur noch die Bezeichnungen ,Zellhautring" und ,Cellulosering.6, Namen, welche auf Grund der chemischen Reaktion dieses Gebildes derart gewählt wurden."

„Dieser Ring bezeichnet die Stelle, an der das interkalare Wachstum vor sich geht. Nach einiger Zeit nach dem Auftreten des Ringes reißt die umgebende Membran ringförmig (der Riß steht also senkrecht auf der Längsachse der Zelle) ${ }^{1}$ ) auf, es treten die Rißstücke der Zellwand auseinander und dazwischen schiebt sich ein neuer, durch Ausdehnung des Ringes entstandener Membrancylinder ein (Fig. 121, 3). Dadurch hat die Zelle in kurzer Zeit eine bedeutende Zunahme an Länge erfahren. Das Auftreten einer Querwand läßt die Zweiteilung vollendet erscheinen."

Auf diese Querwand kommen wir später zurück, sie hat mit dem interkalaren Längenwachstum direkt nichts zu tun.

„Da der Ring im oberen Teile der Zelle angelegt wird, zerfällt die umhüllende Membran beim Aufreißen in zwei ungleiche Teile, einen kürzeren oberen, die ,Kappe', und einen längeren unteren, die ,Scheide6. Scheide und Kappe sind stets scharf gekennzeichnet, indem die Außenfläche der neuen, dem Ring entstammenden Membran um die Rißfläche der Kappe oder Scheide von der Außenfläche nach innen verschoben erscheint. Im optischen Durchschnitt erscheint dort eine stufenartig. verlaufende Begrenzungslinie (Fig. 121,4), welche dadurch zu stande kommt, daß bei jeder weiteren Ringbildung dieser etwas unterhalb der letzten Kappe oder Scheide angelegt wird. Die Querwand wird immer etwas über der Mündung der Scheide angelegt; es resultieren sonach 2 Zellen, eine ,Kappenzelle" und eine ,Scheidenzelle" (Fig. 122).

„Die Deutungen, welcher die Botaniker über den Wachstumsprozeß. das Auftreten und die Entwickelung des Ringes gegeben haben, sind verschieden; es lassen sich 2 Gruppen unterscheiden. Die einen, Pringsheim, Hofmeister, Strasburger und Hirn, faßten den Ring als eine lokale, nur auf jene Stelle beschränkte Bildung auf; die anderen, DE BARy, teilweise auch v. MoHL, besonders aber Dippes, gaben ilirer

1) Bei Kraskovits steht: „.. . reißt die umgebende Membran in der zur Zellenlängsachse normalen Symmetrieebene des Ringes auf ..." 
Meinung dahin Ausdruck, daß die Ringbildung mehr oder minder mit der Ausbildung einer neuen Membranschicht im Inneren der Zelle zusammenhinge."

„Nach ersterer Auffassung wäre stets nur der Ring und sein Produkt, der interkalare Membrancylinder (samt Querwand), eine neue Bildung, während der übrige Teil der entstandenen Tochterzellen nur von den Resten der primären Membran umkleidet wäre. Auch bei fortgesetzter Teilung müßte dieses Verhältnis weiterbestehen. Es würde stets bei einer Teilung die ,obere Zelle ${ }^{6}$ zum Teil mit der von der letzten Teilung herrührenden älteren Membran (Kappe) und dem gestreckten Ringe mit Scheidewand als neuen Bildungen begrenzt sein. Die untere bliebe gleichfalls immer von einer alten Membran (Scheide) und von der neuen, nach oben abschließenden Quermembran eingeschlossen."

„Nach der zweiten Darstellung bildete sich an der Innenfläche der Membran eine neue Schicht aus, von der eine Einfaltung den Ring darstellte. In diesem Falle würden beide Zellen stets von einer neuen Hülle umgrenzt sein."

Nach sorgfältiger Untersuchung entschied sich nun Kraskovits für letztere Auffassung, in den Details aber fand er manches Neue.

Sehen wir also, wie nach Kraskovits' Untersuchung sich die Sache gestaltet.

Daß die Neubildung sich nicht auf die ringförmige Verdickung beschränkt, konnte KRaskovits deutlich an einer abnormen Scheitelzelle sehen, welche offenbar eine durch Kultur verursachte Wachstumshemmung vorstellte (Fig. 121, 5) ; da zeigten sich nicht bloß Ringe, sondern kapuzenförmige neue Membranstücke an der Innenseite der alten Membran dieser letzteren aufgelagert. Noch deutlicher wurde die Existenz einer neuen inneren Membranschicht nachgewiesen, als es gelang, durch vorsichtigen Druck die Kappen von einer Zelle loszulösen (Fig. 121, 6). Wäre nur ein Ring gebildet worden, so hätte nach der Loslösung der Kappen die Zelle naçh oben offen sein müssen, sie war aber vollkommen geschlossen.

Es konnte nun Kraskovits nachweisen, daß die Ringbildung dadurch eingeleitet wird, daß ein nach außen keilförmig zugespitzter ringförmiger Teil der alten Membran verschleimt; sobald die Verschleimung dieses Wandteiles stattgefunden hat, wird eine neue Zellwandschicht von der Zelle ausgeschieden, die ganze Zelle also an der Innenseite von einer neuen Wandschicht bekleidet. Diese Wandschicht ist an der Stelle, wo sie den Verschleimungsring berührt, dicker als an anderen Stellen.

Der optische Längsschnitt zeigt in einem solchen Stadium den Verschleimungsring als ein halb in der alten Wand steckendes birnförmiges Stück. Der keilförmige Teil dieser Birne steckt in der alten Wand, der halbkugelige Teil ragt in das Zelllumen hinein. Ueber das halbkugelige Stück ist die neue Membranschicht hervorgewölbt (Fig. 121 rechts unten).

Durch diese ringförmige Verschleimung ist die alte Zellwand an einer ebenfalls ringförmigen Zone recht dünn geworden; infolgedessen dringt nun Wasser ein, wodurch der Schleim mehr und mehr quillt. Schließlich wird die alte Wand an dieser Stelle zerrissen und es kann sich der vorgewölbte, wie gesagt dickere Teil der neuen Innenschicht strecken. Die Streckung beruht nun nach Kraskovits in der Hauptsache eben auf der Quellung dieses Schleimes; daß dadurch nicht die Auswölbung der Innenschicht zerreißt oder beträchtlich mehr ausgewölbt wird, be- 
l'uht auf dem Gegendruck, der durch den osmotischen Druck im Innern der Zelle ausgeübt wird. Es resultieren also zwei Kräfte, welche der Zellwand parallel verlaufen, daher die Streckung.

Die Querwand wird ganz unabhängig von diesem interkalaren Wachstum g'ebildet, hängt aber von der Kernteilung ab, von welcher wieder das interkalare Wachstum unabhängig ist. Die Querwand wird nach Pringsheim und Strasburger simultan mit der Karyokinese gebildet und ist anfangs mit der Zellwand nicht verbunden, schwimmt also in der Form einer Scheibe frei in der Zelle, ist also frei beweglich. Schon vor dem Aufreißen des Ringes liegt also ein Kern zu jeder Seite der neuen Querwand (vergl. Fig. 123, 4-6).

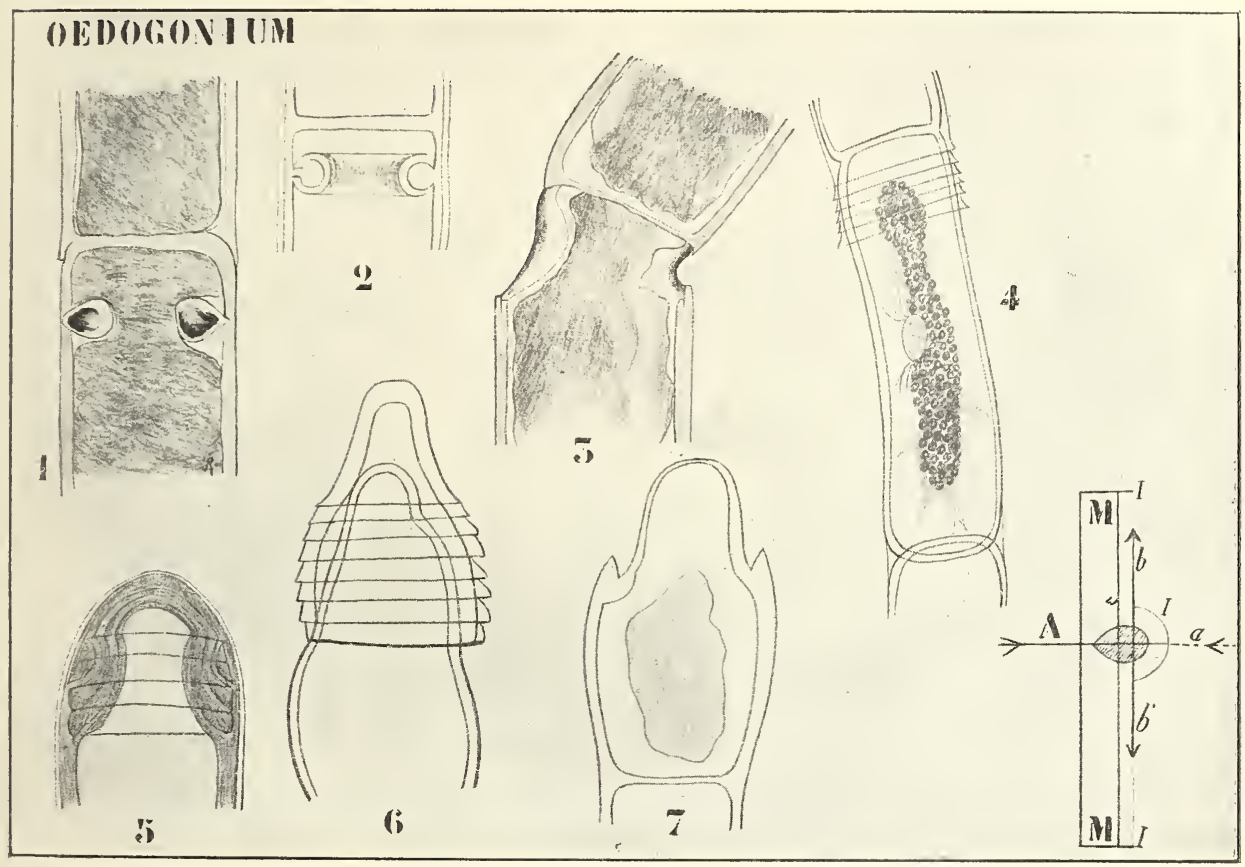

Fig. 121. 1 Oed. Crispum. Kappenzelle mit junger Ringanlage, behandelt mit Thioninzuckerlösung. 2 Ringbildung bei Oedogonium tumidulum. 3 Oed. erispum, ältere Ringanlage als bei 1 bei gleicher Behandlung. 4 Zoosporenbildung bei $\mathrm{O}$. g e melliporum nach Pringsheim. 5 Oed. Vaucherii. Mißbildung (Hemmungserscheinung) an einer Scheitelzelle. Vesuvinfärbung. Die Figur zeigt deutlich, daß die Neubildung nicht auf den Ring beschränkt ist. 6 Oed. Vauch erii. Kappenzelle nach Behandlung mit Cuprox. zerquetscht. Die Kappen sind alle abgehoben. 7 Id. nach Entfernung von 10 Kappen. 8 Schema der Ringbildung. Der Schwellkörper ist schraffiert dargestellt. M. Zellmembran. $I=$ junge Innenschicht. A Kraft von außen. $a$ Gegendruck von innen. $b b^{\prime}$ sind die öffnenden Kräfte, welche die Reste von A sind, 2 nach Strasburger, 4 nach Pringshem, alle übrigen nach KRASKOvits.

Die lose Querwand rückt sodann nach der Mündungsstelle der Scheide hinauf, um sich nach dem Aufreißen des Ring'es und vollendeter Streckung desselben mit dem Membrancylinder dortselbst zu verbinden. Diese Verbindung erfolgt stets etwas über der Scheidenmündung, womit Raum für die nächste Ringanlage in der Scheidenzelle gegeben ist. Die Querscheidewand ist im Momente der Verbindung mit der Wand der 
Zelle einschichtig und bleibt dies, bis in eimer benachbarten Zelle eine neue Teilung stattfindet.

Die hier nach Kraskovits reproduzierte schematische Darstellung wird die Zellteilung von Oedogonium nun wohl klar machen.

Man sieht daraus, daß die Teilungsvorgänge in der Scheidenzelle genau so wie die in der Kappenzelle verlaufen.

An der soeben beschriebenen Kappenbildung sind nun die Oedogoniaceen leicht kenntlich.

Immer wird man in einem Oedogonium-Faden einzelne Zellen finden, welche an ihrem oberen Ende eine Anzahl solcher Kappen tragen; die Scheiden sind viel weniger resistent und gehen bald zu Grunde. Daß
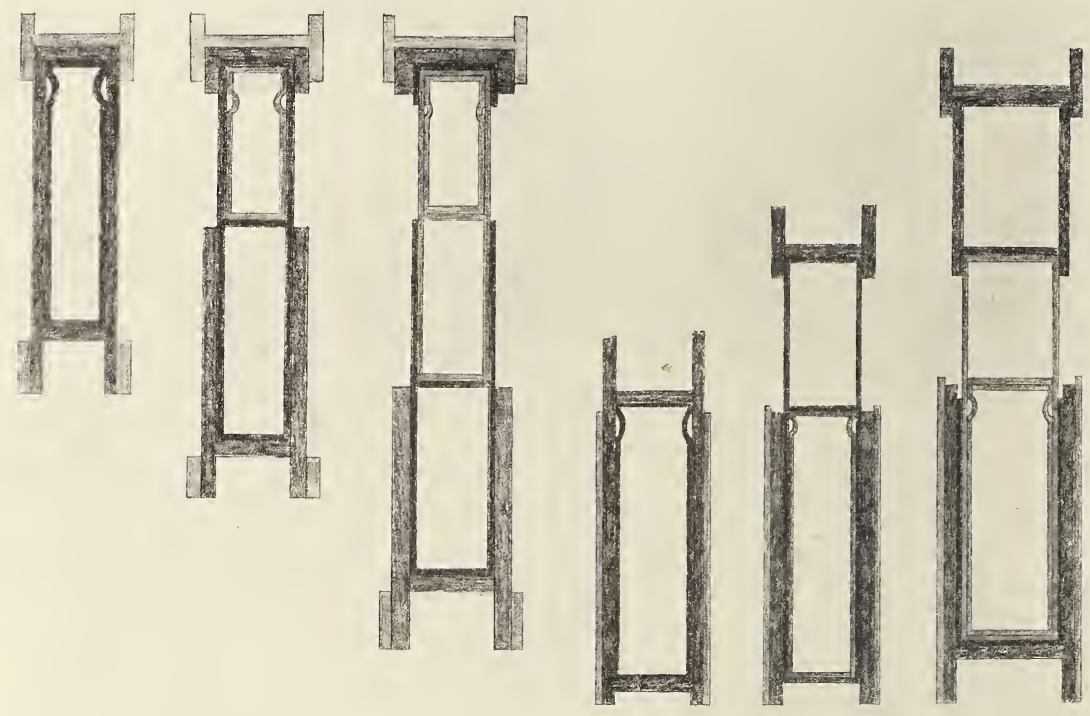

I

II

III

$\mathrm{I}^{\prime}$

$\mathrm{II}^{\prime}$

III' $^{\prime}$

Fig. 122. Schema der Zellteilung (nach Kraskovits). Die 3 linken Figuren beziehen sich auf die Teilung der Kappenzelle, die 3 rechten auf die der Scheidenzelle. Es soll. um Mißverständnis zu vermeiden, hervorgehoben werden, daß das nach vollzogener Teilung bis zur nächsten Ringbildung andauernde Stadium nicht abgebildet ist. Es ist nach erfolgter Streckung eines Ringes sofort die Anlage des nächsten eingezeichnet. Andernfalls müssen noch zwei Figuren zwischen I und II, II und III dazu gezeichnet gedacht werden. Die Querwand bleibt bis zur Teilung einer Nachbarzelle einschichtig.

man an einzelnen Zellen öfters eine ganze Reihe von Kappen antrifft, rührt daher, daß nur wenige Zellen eines Oedogonium-Fadens teilungsfähig sind.

Wir sahen bereits, daß der Oedogonium-Faden wenigstens in der Jugend mittels einer Haftscheibe (Rhizoid) am Substrat befestigt ist.

Die Zellen besitzen einen großen Zellkern und ein großes, stark gelapptes Chromatophor von der Form eines Hohlcylinders, welches dem cylindrischen Teile der Zellwand angeschmiegt liegt. Das Chromatophor enthält eine Anzahl von Pyrenoiden und Stärkekörnern, welche je 
nach den Umständen auf die nächste Umgebung der Pyrenoide beschränkt oder über das ganze Chromatophor zerstreut sind.

Jede Zelle eines Oedogonium-Fadens kann sich ohne Formveränderıng zu einem Zoosporangium umbilden, das eine einzige Zoospore bildet. Die Zoospore hat ein farbloses Vorderende, welches da, wo es am grünen Teile angrenzt, von einem Cilienkranz umgeben ist. Das farblose Vorderende liegt im Zoosporangium ḋer Längswand angedrückt. Das Zoosporangium öffnet sich mittels eines ringförmigen Querrisses. und die Zoospore tritt anfangs noch von einer Schleimmasse umhüllt heraus (vergl. Fig. 123).

Die Zoosporen keimen direkt zu neuen Pflänzchen.

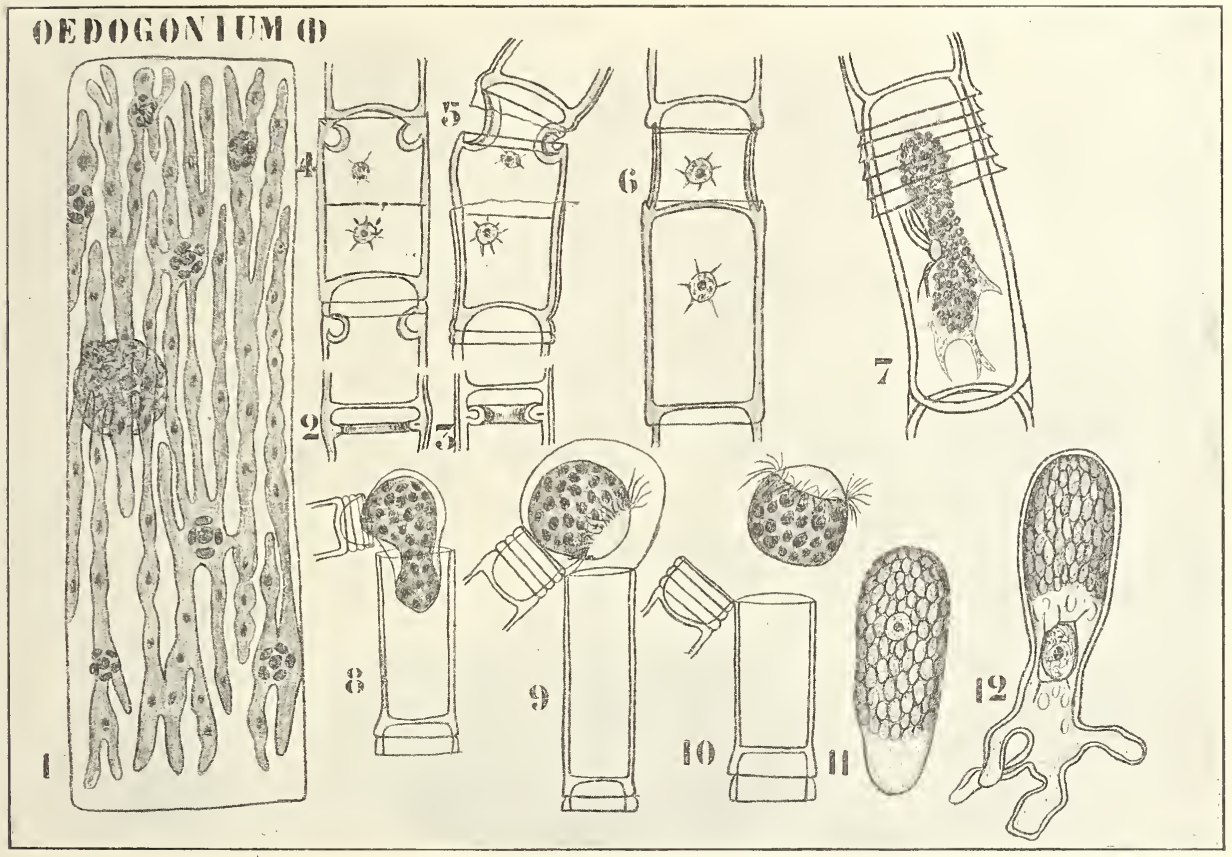

Fig. 123. 1 Oedogonium-Zelle (nach Schмidt). 2, 3 Bildung des Zellringes. 4, 5, 6 Bildung der Querwand. 2-6 nach HIRN, für genauere Zeichnungen des interkalaren Wachstums siehe oben. 7 Zoosporenbildung (nach Pringshein). 8, 9, 10 Ausschlüpfen der Zoospore aus dem Zoosporangium nach HIRN. 11, 12 Keimlinge.

Die geschlechtliche Fortpflanzung ist, wie bereits bemerkt, oogam. Antheridien und Oogonien können auf dem gleichen oder auf verschiedenen Fäden gebildet werden. Bei der Bildung der Antheridien entstehen flache scheibenförmige Zellen Fig. 124, 13), welche je 2 hellgrïne oder gelbliche Spermatozoen (Fig. 124, $\overline{13}$ ) $\overline{\bar{b}}$ ilden.

Das ist also eine ganz gewöhnliche Geschichte, sie ist aber bei den Oedogonien Ausnahme, insoweit es sich um die Entstehung der Antheridien handelt. Bei weit den meisten Oedogonien-Arten nämlich entstehen die Antheridien auf zu diesem Zweck ausgebildeten stark reduzierten Fäden, welche sich an die weiblichen Fäden anheften und Zwergmännchen heißen. 
Wie entstehen nun diese Zwergmännchen? Bei Oedogonium diplandrum ist die Sache recht einfach, dort schlüpft der Inhalt des Antheridiums aus, bevor die spermatozoenbildende Zweiteilung ausgeführt wird; es schlüpft also eine Spermatozoenmutterzelle, welche Cilien gebildet hat, aus. Diese wird von Oltmanns mit dem Namen Androspore bezeichnet. Die gelblichen Androsporen schwimmen nun auf die weiblichen Fäden zu, setzen sich in der Nähe der Oogonien fest, umgeben sich mit einer Membran und sind so zu Zwergmännchen geworden. Später teilt sich der Inhalt in zwei Spermatozoen, welche durch deckelförmiges Abreißen der Spitze des Zwergmännchens frei werden und herausschlüpfen.

Wir haben hier also nur mit einer Unterbrechung der normalen Spermatozoidenentwickelung zu tun, indem der Inhalt des Antheridiums

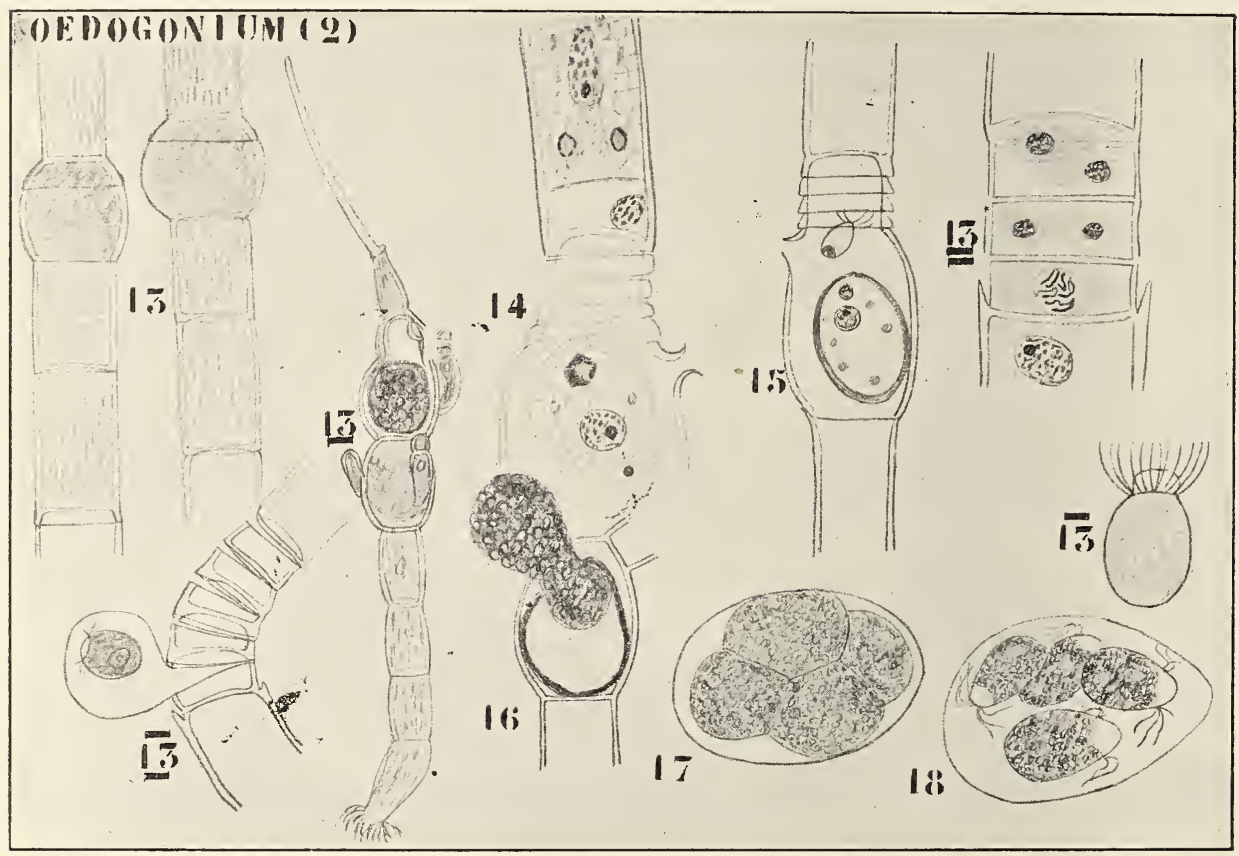

Fig. 124. O edogonium (nach Pringsheim, Hirn, Klebahn). 13 Oogoniumbildung. 13 Oed. Boscii, Fadenstücke mit Antheridien. $\overline{13}$ Spermatozoid. 14 Oeffnung des Oogons, die Schleimpapille ragt heraus. 15 Oogon mit Zygote und zu spät in das Oogon eingedrungenes Spermatozoon. 16-18 Schwärmerbildung in der Zygote von Oed.spec. nach Juryani. 13 o ed. Bra u n i i, Fadenstück mit ausschlüpfender Androspore. 13 Oedog. ciliatum, ganzes Pflänzchen mit 2 Oogonen und $3 \mathrm{Zwergmännchen.}$

herausschlüpft und erst, nachdem er bei den weiblichen Geschlechtsorganen angelangt ist, die Spermatozoen bildet.

Bei den übrigen Oedogonien entstehen die Androsporen auf den nämlichen Individuen, welche die Oogonien bilden. Im Gegensatz zu denen von $O$. diplandrum sind sie meistens grün und öfter auch größer. Die aus ihnen gebildeten Zwergmännchen sind mehrzellig. Wir haben es hier wohl mit einer früheren Unterbrechung der Spermatozoiden- 
entwickelung zu tum, die Androsporen sind hier wohl Antheridiummutterzellen und keine Spermatozoidmutterzellen.

Dieser OLtuannsschen Auffassung der Sache wird wohl ein jeder beipflichten können.

Ton der Cytologie wissen wir verhältnismäßig wenig. Nach einigen Teilungen einer vegetativen Zelle entsteht eine Oogoniummutterzelle, welche sich in ein Oogon und in eine Stielzelle teilt. In der Zelle, welche zum Oogon werden soll, wird in gewöhnlicher Weise ein Ring gebildet, welcher sich in oben beschriebener Weise streckt. Das neue ILembranstück wird aber nicht cylinderförmig wie bei einer vegetativen Zelle, sondern dehnt sich seitlich aus, so daß ein mehr oder weniger kugeliges Oogon entsteht. Kernteilung findet nicht statt. In dem neuen Membranstück entsteht ein Loch, der Inhalt bildet sich zum Ei um, eine dabei öfters abgetrennte Plasmamasse ist kernlos. Der Lochbildung geht eine papillenartige Auftreibung voraus, die oben gezeichnete Schleimpapille; sie öffnet sich an der Spitze. Ein Spermatozoon dringt hinein, Spermakern und Eikern verschmelzen; die Zygote verdickt ihre Membran und der Inhalt wird mennigrot.

Der noch rote Inhalt schlüpft von einer dünnen Membran umgeben aus der Zygote aus, teilt sich in 4 Schwärmer, welche, zunächst noch rot, alsbald grün werden und jeder zu einem neuen Oedogonium-Pflänzchen auswachsen.

Meiner Auffassung nach ist die Zygote Gonotokont geworden.

Damit sind wir dann am Ende unserer zweiten Entwickelungsreihe, der Stephanokonten-Reihe, angelangt, und müssen uns jetzt den Heterokonten zuwenden. 


\section{Siebente Vorlesung.}

\section{Heterokonten.}

Während wir über die Ahnen der Stephanokonten absolut nichts aussagen konnten, sind wir bei den Heterokonten insoweit glücklicher, als wir wohl Chloramoeba als das Prototyp der Heterokonten betrachten dürfen. Von ihr möchte ich nämlich die Confervales ableiten, die einzige Gruppe, welche meiner Ansicht nach zu den Heterokonten gehört. OLTManns stellt noch die Botrydiaceae und Chlorotheciaceae hierhin, es will mir diese Einreihung nicht gut einleuchten, ich füge aber gleich hinzu, daß ich gar nicht weiß, wo sie untergebracht werden sollen.

Die Heterokonten in dieser von Bohlin u. A. herrührenden Fassung sind charakterisiert durch den Besitz einer langen und einer sehr kurzen Cilie an den Schwärmsporen, sowie durch gelbgrün gefärbte kleine Chromatophoren, welche mit Salzsäure behandelt sich bläulich verfärben. Das weist auf einen außerordentlich hohen Gehalt an Xantophyll hin. Das merkwürdigste an den Confervales ist aber die Zellwand, welche in näher zu beschreibender Weise aus 2 Stücken besteht. Fangen wir also unsere Betrachtung mit den Chloromonaden an, und zwar mit der einfachsten Form, mit dem nackten

\section{Chloramoeba.}

Es ist dies ein, wie gesagt, nacktes Lebewesen mit zwei ungleich langen Cilien, das sich amöboid bewegen kann, aber nur selten längere Pseudopodien bildet. Es enthält einen Zellkern, eine kontraktile und mehrere gewöhnliche Vakuolen. 2-6 Chromatophoren von gelbgrüner Farbe, welche Oel produzieren, sind vorhanden. Unter bestimmten Umständen wird Chloramoeba farblos und lebt dann saprophytisch, dieser Zustand läßt sich z. B. durch Kultur in 2-4-proz. Dextrose- oder Lävuloselösung hervorrufen. Dabei entfärben sich aber wohl nur die Chromatophoren, ohne zu verschwinden, denn man kann sie bei Kultur im Hellen wieder grün werden lassen. Die Fortpflanzungsweise der Chloramoeba ist noch unbekannt, aller Wahrscheinlichkeit nach findet Zweiteilung statt. In ungünstigen Lebensbedingungen kann unser Flagellat sich encystieren.

Von dieser Form wird

\section{Chlorosaceus}

abgeleitet. Dieser Organismus bildet hohlkugelige, nur mit Wasser gefüllte Schleimkolonien. Er bildet insoweit einen Uebergang von Chloramoeba zu den heterokonten Algen, als die Individuen anfangen, eine Zellwand zu bilden. An der der Peripherie der Kolonie benachbarten Seite der Energiden, an der Außenseite also, besitzen diese eine 
zwar düimne, aber dennoch deutlich sichtbare Zellwand, nach innen zu wird diese aber mehr und mehr undentlich und geht in den Kolonieschleim über. Der Organismus pflanzt sich mittels Längsteilung fort,

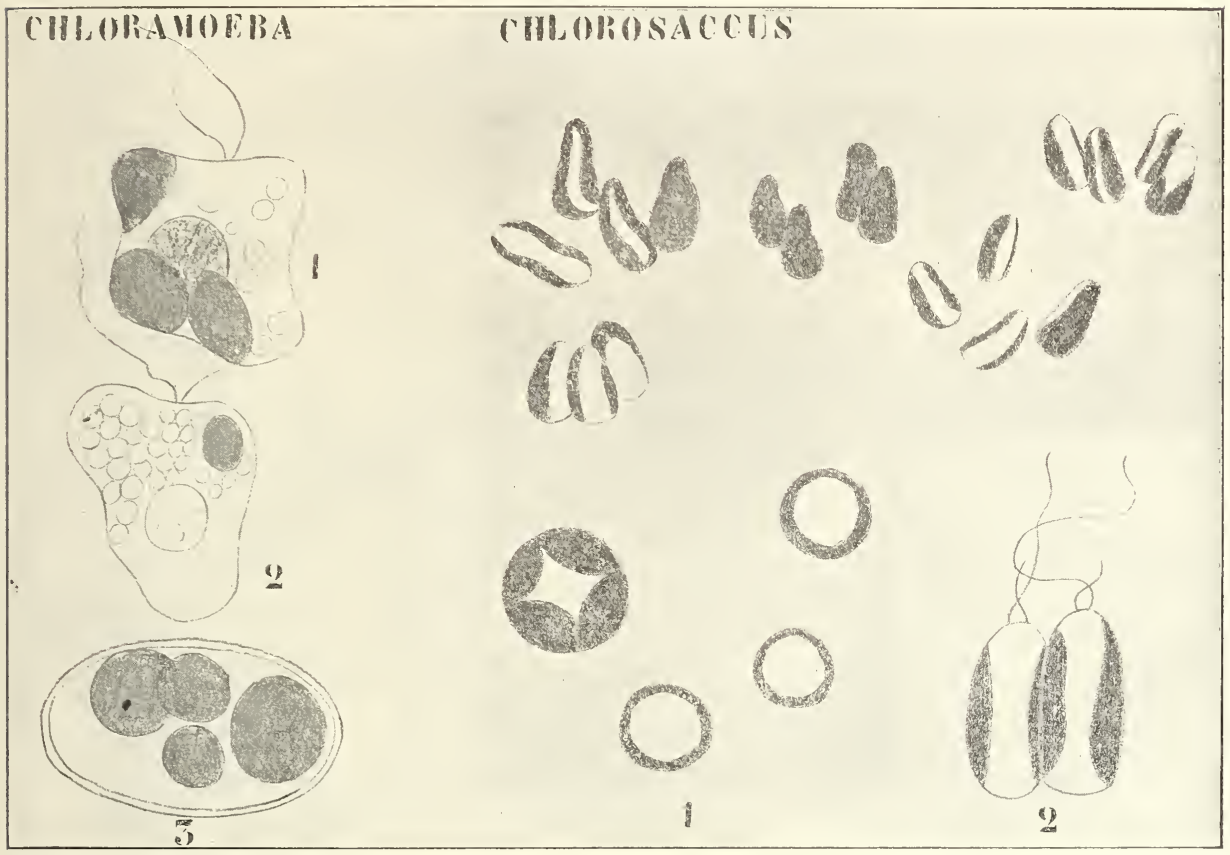

Fig. 125. I. Chloramoeba heteromorpha (nach BoHLIN). 1 Normales Exemplar mit 3 Chromatophoren und einem Kern. 2 Farbloses Exemplar, der dunkle Fleck rechts oben ist der Kern. 3 Encystiertes Exemplar. - II. Ch lo rosace us fl uidus (nach LUTHER). 1 Gallertkolonie. 2 Schwärmer.

und da zwei Längsteilungen jedesmal kurz aufeinander folgen, werden ViererGruppen gebildet. Jede Energide kann nun zwei ungleich lange Cilien bilden und davonschwimmen, sie besitzt 2 Chromatophoren, eine kontraktile Vakuole und einen Kern. Oelhaltige Ruhezellen können gebildet

werden. Von Chlorosaccus können wir dann die

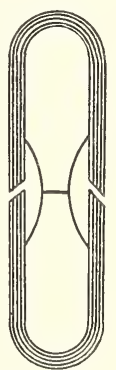

3

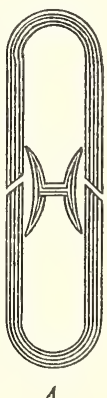

4

Schematische Darstellung der Teilung einer Confervazelle.

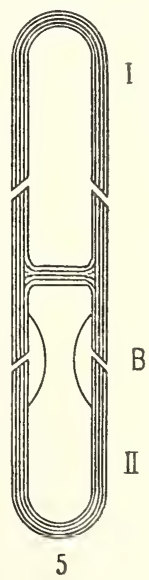

\section{Confervales}

ableiten. Bei dieser Gruppe ist gar keine geschlechtliche Fortpflanzung. bekannt, ein Umstand, der die systematische Anordnung sehr erschwert. Auch in anderer Hinsicht ist sie so unvollständig bekamnt, daß noch bedeutende Ungewißheit herrscht. 
Bei den in dieser Hinsicht gut untersuchten Confervales besteht die Zellwand nicht aus einem, sondern aus 2 Stücken, von welchen das eine auf das andere paßt.

Nehmen wir als Beispiel eine Fadenform mit monoenergiden Zellen, so sehen wir, daß die beiden Membranstücke etwa aufeinander passen wie der Deckel auf eine Dose (vergl. vorstehende Figur). Bei der Zellteilung wird nun zunächst diesem Gürtel gegenüber ein loses cylindrisches Wandstück in der Zelle gebildet (Fig. B), alsbald entsteht in mittlerer Höhe dieses neuen Stückes eine Querwand, wodurch ein auf dem optischen Längsschnitt H-förmiges Stück resultiert (Fig. 3). Dieses H-Stück — wie wir es nennen wollen - verdickt sich nun durch Auflagerung neuer Lamellen und es weichen jetzt die Zellwandhälften auseinander, während die Arme

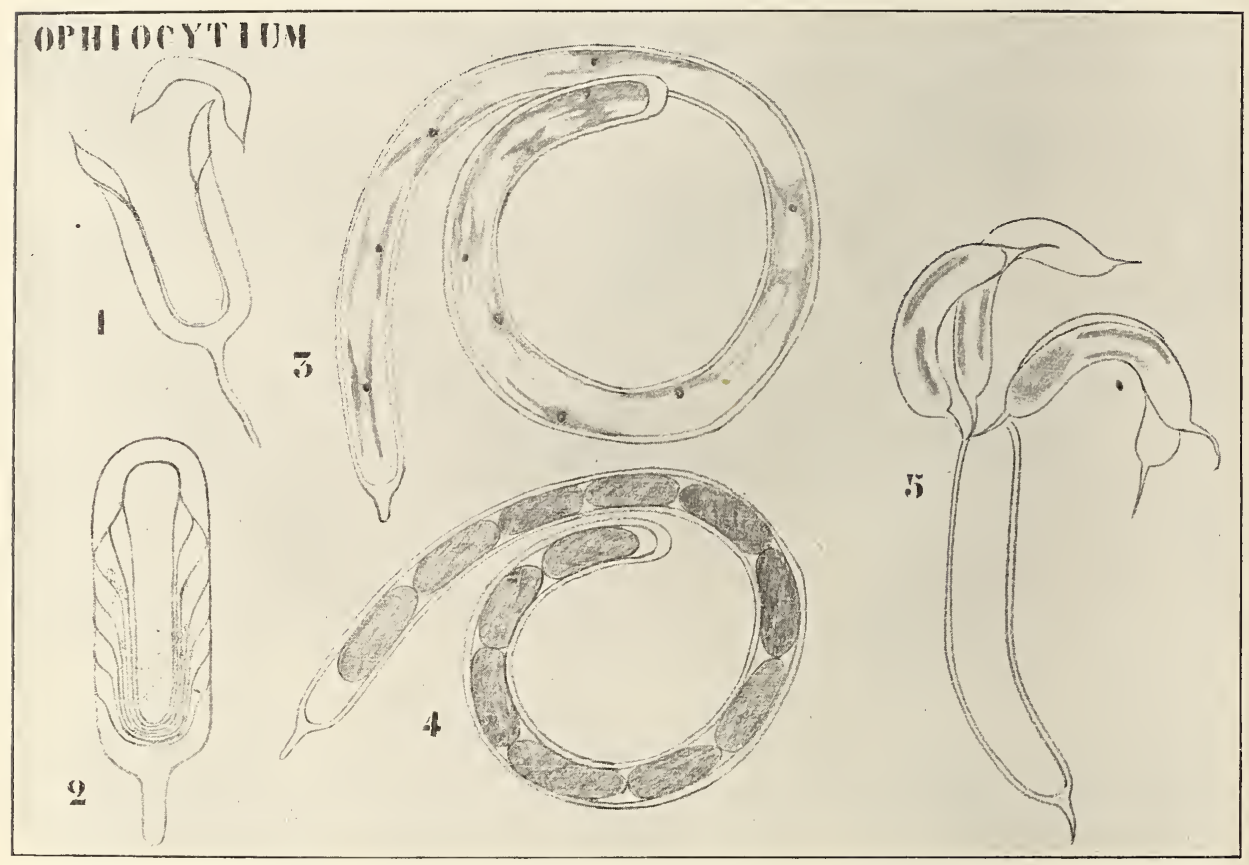

Fig. 126. Ophiocytium (nach BoHLIN). Figurenerklärung im Text.

des H-Stückes sich verlängern und mehr und mehr in die entstehende Oeffnung zwischen den Zellwandhälften hineingetrieben werden; so ist also schließlich die Zelle durch Einschiebung dieses interkalaren Stückes verlängert und zu gleicher Zeit geteilt (Fig. 4, 5). Neue Zellteilungen setzen immer in gleicher Weise dem Gürtel einer Zelle gegenüber ein.

Wie man sieht, entsteht durch das Einschieben des H-Stückes eine dicke Querwand zwischen zwei benachbarten Zellen, die Zellen selber sind aber durch den sich auf halber Höhe befindlichen Gürtel recht zerbrechlich (Fig. 127, 1, 2, 3). Bei der Schwärmsporenbildung brechen denn auch die Zellen in den Gürtellinien entzwei, und der Faden zerfällt in eine Anzahl von H-förmigen Stücken (Fig. 127, 7).

Die fadenförmigen Conferven kann man sich natürlich leicht aus einzelligen Formen durch Teilung der Zellen entstanden denken.

Wir haben nun früher bei den Isokonten gesehen, daß eine höhere 
Entwickelungsstufe sowohl durch Zellteilung wie durch Energidenteilung erreicht werden kann, auf ersterem Wege entstehen multicelluläre monoenergide Organismen, auf letzterem unicelluläre polyenergide. Beide Entwickelungsrichtungen finden wir nun auch bei den Heterokonten, auf ersterem Wege entstanden die Confervas, auf letzterem Wege z. B. Ophiocytium (Fig. 126). Daß Ophiocytium keine siphonale Alge, sondern ein Heterokont ist, geht nicht aus der Struktur ihrer Schwärmer hervor, demn sie bildet überhaupt keine, sondern aus ihrer Membranstruktur.

Ein junges Ophiocytium besteht so aus einer einzigen Zelle mit einer sich aus zwei Hälften zusammensetzenden Membran. Es ist mittels eines Stielchens befestigt. Beim Wachstum der Zelle - Teilung findet nicht statt - wird ein fingerhutförmiges Membranstück im Inneren der

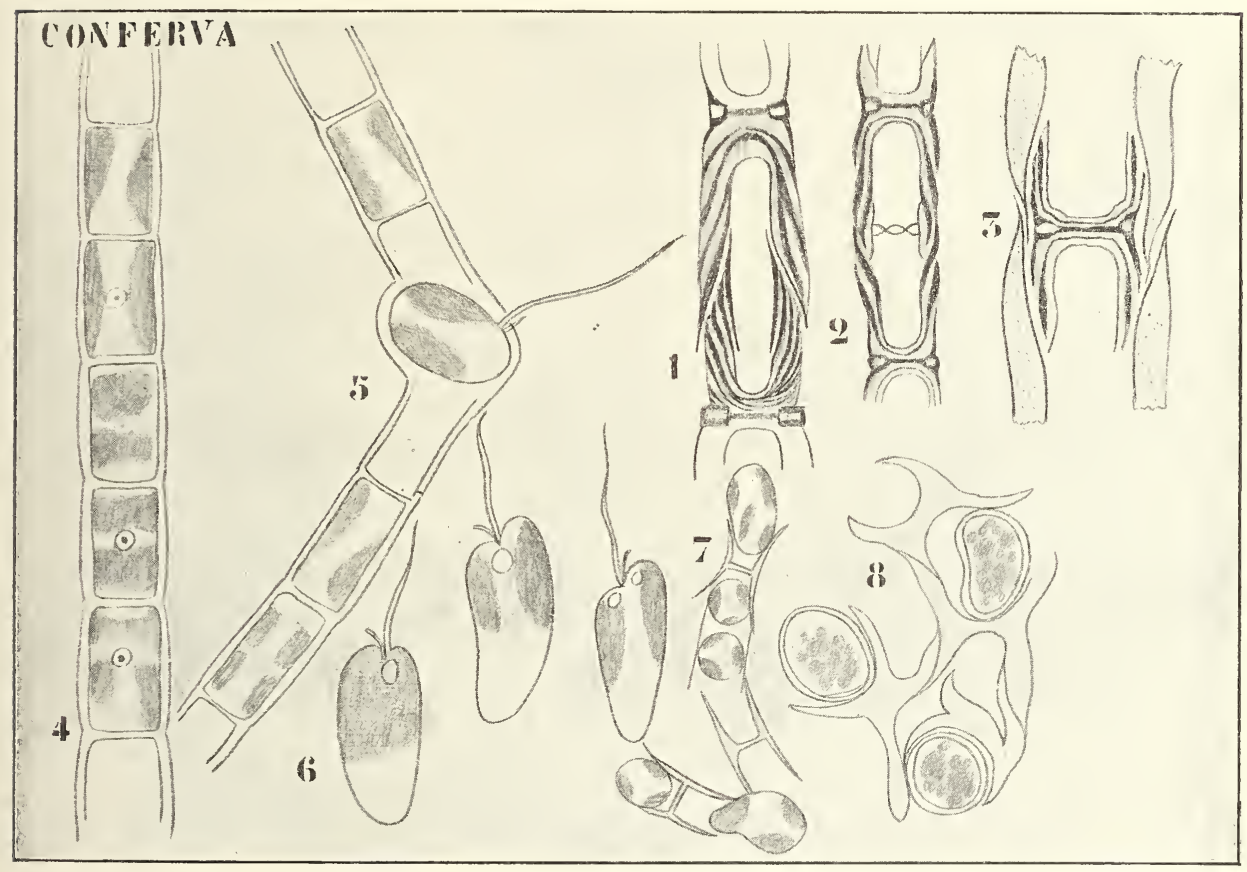

Fig. 127. Conferva bombycina. 1, 2, 3 Zellteilung (nach GAY). 4 C. minor, Stück eines Fadens (nach KLEBS). 5 Ein Fadenstück derselben Alge, in Zoosporenbildung begriffen (nach KLEBs). 6 Schwärmsporen. 7 Aplanosporenbildung (nach OLtmanns). 8 Dauer-Aplanosporen von C. bo m b y in a (nach GAY).

Zelle gebildet. Es liegt dies der Wand dicht an, und die Mündung des Fingerhutes liegt auf gleicher Höhe mit dem Gürtel der Zelle. Die Ränder dieser Mündung verdickten sich stark, die Membranhälften schieben sich auseinander und der verdickte Ringteil wird in die dadurch erweiterte Gürtelspalte eingeschoben (Fig. 126, 1). Nene ebenso gebildete Fingerhüte werden fortwährend eingeschoben (Fig. 126, 2) und so entsteht schließlich ein polyenergider, langer, öfters gewundener Zellschlauch (Fig. 126, 3).

Wir haben also innerhalb der Heterolionten-Gruppe zwei Entwickelungsreihen: eine polyenergide und eine monoenergide.

Von beiden sei ein Beispiel besprochen. 


\section{Ophiocytium}

gehört, wie wir schon sahen, der polyenergiden Reihe an. Das Wachstum wurde bereits beschrieben. Die Chromatophoren sind zahlreich, plattenförmig, öfters rotgefleckt. Zur Fortpflanzung bildet das Pflänzchen eine Anzahl von Aplanosporen (Fig. 126, 4), welche durch die sich deckelig öffnende Spitze herausgeschoben werden und öfters schon keimen, wenn sie noch teilweise in der Oeffnung stecken (Fig. 126, 5). Eine geschlechtliche Fortpflanzung ist unbekannt.

\section{Conferva.}

Die Membranstruktur wurde schon beschrieben, Abbildungen derselben, die genauer als obenstehende schematische Zeichnungen sind, finden sich auf der Fig. 127.

Die Fäden der Conferven schwimmen als gelbliche Massen an der Oberfläche von Gräben und Teichen und bilden dort öfters dichte "Watten". In jeder Zelle können 1-2 Zoosporen mit 2 ungleichen Cilien gebildet werden, sie sind überdies stark amöboid beweglich. Sie keimen zu neuen Fäden, welche in der Jugend angeheftet sind, alsbald sich aber loslösen. Auch Aplanosporenbildung kommt vor.

Merkwürdig ist das anscheinend völlige Fehlen einer geschlechtlichen Fortpflanzung. Das macht diese Algen so langweilig und verursacht beim Botanisieren öfters den Ausruf der Studenten: nur eine Conferva. Nun findet man aber bei Conferva öfters Zellen mit 2 Kernen und 4 statt 2 Chromatophoren, wenn auch der Faden sonst einkernige Zellen mit 2 Chromatophoren besitzt. Auch ist ein Genus: Binuclearia bekannt, das konstant 2 Kerne pro Zelle hat. Wäre es nun nicht möglich, daß wir hier mit einer Form einer $2 \mathrm{x}$-Generation $\mathrm{zu}$ tun haben, der $2 \mathrm{x}$-Generation der Basidiomyceten vergleichbar? Binuclearia könnte recht gut eine solche $2 \mathrm{x}$-Generation einer Conferva sein, und Conferven mit binukleären Zellen neben uninukleären könnten erstere durch seitliche Kopulation zweier Zellen gebildet haben. Selbstverständlich ist dies reine Phantasie, vielleicht aber doch einer Prüfung wert.

Es bleiben nun noch 2 Gruppen grüner algenähnlicher Organismen zu besprechen übrig: die Desmidiaceae und die Characeae. Ich weiß absolut nicht, wo sie hinzustellen sind. Die Desmidiaceen gleichen den Mesotaeniaceen und Zygnemaceen durch die Gestalt ihrer Chromatophoren, wenn auch nur oberflächlich, den Heterokonten auch nur entfernt durch ihre Membranstruktur, und die Aehnlichkeiten in der Kopulation zwischen Desmidiaceen und Diatomeen, auf welche Oltmanns, um eine Verwandtschaft wahrscheinlich zu machen, Gewicht legt, kann ich mir ganz gut unabhängig voneinander entstanden denken. Summa summarum ich wußte nicht, welchen Platz im System man den Desmidiaceen zuweisen soll.

Mit den Characeen steht es noch schlimmer; darin bin ich mit OLtmanns völlig einig, daß sie ganz isoliert dastehen, sie zeigen weder mit den Algen noch mit den Moosen direkte Beziehungen, vielleicht noch etwas mehr mit den letzteren wie mit den ersteren.

Unter diesen Umständen scheint es mir am besten, von diesen beiden Gruppen die Desmidiaceen hier am Ende der grünen Algen zu behandeln, die Characeen aber, um ihre geringe Verwandtschaft mit den Algen recht zu betonen, an das Ende dieses Bandes zu stellen. Ihnen gehen dann die Basidiomyceten voran, und da die Moose erst im zweiten Bande behandelt werden, so ist wohl ihre isolierte Stelle gehörig betont. 


\section{Achte Vorlesung.}

\section{Desmidiaceae.}

Konnte ich Oltwanns in seinen Verwandtschaftsauffassungen zwischen Desmidiaceen und Diatomeen nicht beipflichten, so scheint mir seine Darstellung dieser Gruppe selber so gut geeignet, den Studenten eine Einsicht in dieselbe zu gewähren, daß ich ihm der Hauptsache nach hier folgen werde.

Es sind die Desmidiaceen ausschließlich Bewohner des süßen Wassers, im Meere fehlen sie. Sie bevorzugen Moorboden mit sandigem Untergrund und sind bestimmt kalkfeindlich. Einer der schönsten Fundorte von Desmidiaceen in den Niederlanden bilden die Isoetes-Seen in der Nähe des Dorfes Weert in Limburg, wo der Niederländische Botanische Verein eine Untersuchungsstation besitzt.

Bei weitem die meisten Desmidiaceen sind rein einzellig, es kommen aber homocelluläre Fadenformen vor, zumal in den Tropen, aber auch in unseren Breiten. Die Form der Zelle ist, wohl in Uebereinstimmung: mit dem Umstand, daß ihrer Entwickelung von keiner Seite Widerstand geboten wird, bei den verschiedenen Generen sehr verschieden und da die Formen für die Genera charakteristisch sind, ist es leicht, das Genus, zu welchem irgend eine Desmidiacee gehört, zu bestimmen; dagegen ist die Artbestimmung durch die große Variabilität recht schwer.

Mit Penium anfangend, kann man unter Oltmanns' Führung leicht eine Uebersicht über die verschiedenen Formen gewinnen. Penium bildet stark verlängerte ovale Stäbchen; diese Form wird von Closterium so ziemlich beibehalten, nur krümmt sich die Zelle, spitzt sich an den Enden zu und schwillt in der Mitte etwas an. Auch kann man leicht von Penium zu Pleurotaenium gelangen unter der Annahme, daß sich ein Penium-ähnlicher Ahne in der Mitte etwas eingeschnürt hat. Vou Pleurotaenium läßt sich Cosmarium ableiten, bei dem die Einschnürung: sehr stark geworden ist und welches an den Enden stark abgeflacht ist. Ueberdies ist die ganze Zelle bei Cosmarium stark von der Rückenseite nach der Bauchseite hin zusammengedrückt. Daher macht ein Cosmarium je nach der Seite, welche dem Beschauer zugekehrt ist, einen ganz verschiedenen Eindruck (vergl. die 3 Ansichten ein und desselben Individuums, welche in Fig. 128 abgebildet sind). Aus demselben Grunde ist es beim Determinieren unerläßlich, die Zellen zu rotieren, bis man alle Seiten gesehen hat.

Noch stärker als Cosmarium ist Euastrum abgeflaclit, es unterscheidet sich überdies noch durch andere Eigentümlichkeiten. Während 
nämlich bei den bis jetzt besprochenen Formen der Rand der Zelle nicht eingeschnitten ist, ist er bei Euastrum mit tiefen Einkerbungen versehen, wodurch dieser Organismus zu den schönsten „Kunstformen der Natur" gehört.

Bei den fadenförmigen Generen hat jede Zelle meistens die Gestalt eines Penium, eines Pleurotaenium oder eines Cosmarium.

Nach der Zellform sind in erster Linie die Chromatophoren auffallend. Bei allen Generen, mit Ausnahme von Pleurotaenium, sind die Chromatophoren plattenförmig. Bei Pleurotaenium dagegen sind eine Anzahl von wandständigen schmalen, bandförmigen Chromatophoren vorhanden. Diese plattenförmigen Chromatophoren strahlen meistens von einem stabförmigen Mittelteil wie Schaufeln von einer Achse aus und

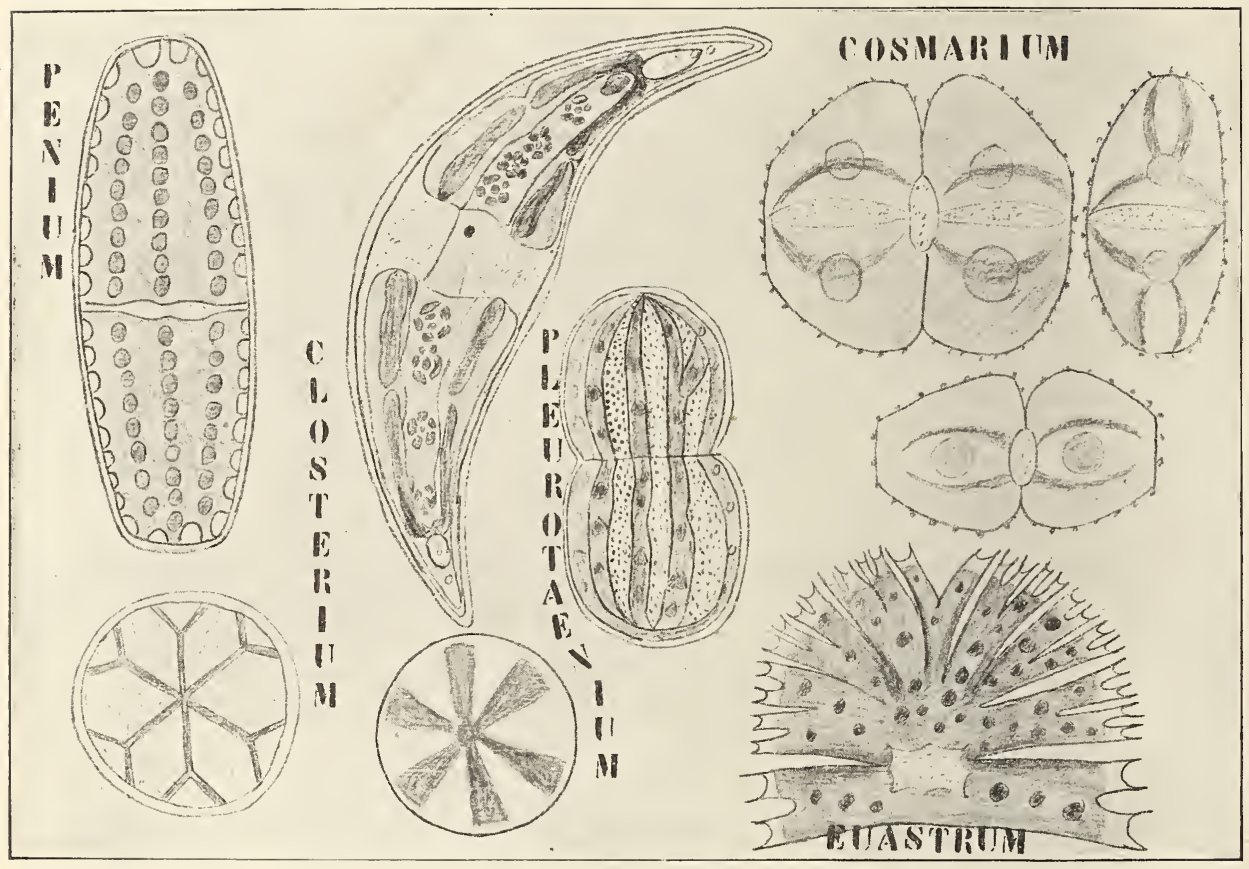

Fig. 128. Verschiedene Desmidiaceen (nach DE BARY, NäGELI und PALLA).

können sich überdies noch verzweigen (vergl. die untere linke Ecke der Fig. 128).

Es sind meistens zwei solcher Chromatophorensysteme vorhanden, oder wenn man die Schaufeln als breite Rippen des Chromatophors betrachtet, kann man sagen, es gibt meistens 2 Chromatophoren in jeder Zelle. Dadurch erhält die Zelle einen öfters schon durch die Einschnürung angedeuteten symmetrischen Bau. Zwischen den Chromatophorensystemen bleibt öfters ein ziemlich breiter farbloser Streifen übrig, in welchem der Kern liegt (vergl. Fig. 129 Closterium).

Die Desmidiaceen-Zelle enthält eine große zentrale Vakuole, wodurch das Plasma wandständig wird; überdies ist das Plasma selber vakuolisiert und es fällt z. B. bei Closterium an jedem Ende der Zelle eine größere Vakuole besonders auf. In diesen Vakuolen findet man nun 
öfters (bei Closterium immer) stäbchenförmige Gipskriställchen, welche sich in molekularer Bewegung' befinden und überdies noch von um die Takuole herum verlaufenden Plasmaströmungen in Bewegung gesetzt werden.

Diese Gipskriställchen scheinen durch ihren Druck auf das Plasma der Desmidiacee einen Eindruck zu geben von der Stellung, welche ihr Körper in einem bestimmten Moment in Bezug auf die Schwerkraftsrichtung einnimmt.

Die Wand der Zellen besteht aus zwei Schichten, einer inneren und einer äußeren, welche aber ganz dicht aneinander geschmiegt liegen.

Betrachtet man nun eine Desmidiacee mit einer starken Vergrößerung: von der flachen Seite, so sieht man auf der Wand größere und kleinere Pünktchen. Außer diesen kann die Wand allerlei Warzen, Stacheln, in einem Worte allerlei Emergenzen aufweisen.

Diese Pünktchen werden besonders deutlich, wenn man verschiedene Reagentien verwendet und Querschnitte auflegt, wie dies zumal LüTKEMÜLLER gemacht hat. Es stellt sich dann heraus, daß die kleinen Pünktchen die Endflächen kleiner Stäbchen sind, welche sich nur in der äußeren Membran befinden (vergl. Fig. 129 Tetmemorus), sie werden denn auch Stäbchen genannt. Die größeren Punkte dagegen sind Kanäle, welche quer durch beide Membranen hindurch verlaufen.

Die Verteilung dieser Poren über die Oberfläche der DesmidiaceenWrand ist bei verschiedenen Formen recht verschieden. Sie können ziemlich gleichmäßig über die ganze Wand verbreitet sein oder aber in bestimmten Zonen fehlen und an anderen Stellen, zumal an den Polen, besonders gut entwickelt sein.

Es sind diese Poren die Ausmündungsöftnungen der oben erwähnten Kanäle, welche Schleimkanäle darstellen. Diese Schleimkanäle zeigen öfters einen sehr komplizierten Bau: man unterscheidet zwischen dem Pcrenkanal und dem Porenmantel. Letzterer wird gebildet von dem dem Porenkanal direkt benachbarten Membranstück, welches sich öfters anders färbt (vergl. Fig. 129 Tetmemorus und Cosmarium). Die Schleimmassen, welche sich an der Innen- oder Außenseite der Porenkanäle anhäufen, bezeichnet man mit dem Namen Porenknoten, oder wenn sie, wie bei Xanthidium, eine nelkenähnliche Gestalt haben: Porennelken.

Die Verteilung dieser Porenkanäle über die Oberfläche des Körpers ist maßgebend für die Weise, in welcher der Schleim abgeschieden wird. Wenn die Porenkanäle regelmäßig verteilt sind, aber ziemlich große Zwischenräume aufweisen, bildet der Schleim eine bald zerfließende, gleich dicke Schicht um die ganze Zelle herum (Tetmemorus). In den Fällen, wo ein echter, mehr oder weniger Struktur aufweisender Schleimmantel um die ganze Zelle herum gebildet wird, stehen die Schleimkanäle ebenfalls regelmäßig verteilt, aber einander dichter genähert (Cosmarium), und wird die Schleimumhüllung sehr dick. während dennoch die Schleimprismen deutlich bleiben, so haben wir mit der Nelkenstruktur von Xanthidium zu tun.

Besonders große oder zahlreiche Poren an den Polen finden sich bei Euastrum und Closterium, welche in kurzer Zeit bedeutende Schleimstränge an diesen Stellen ausscheiden können, übrigens aber nur von einer dünnen Schleimschicht umgeben sind. Die langen Schleimsträng’e an den Polen der Closteriums und Euastmums sind bei einfach im Tasser liegenden Individuen nicht sichtbar, Zusatz von Tusche läßt sie sofort hervortreten, da die feinen Tuscheteilchen natürlich nicht in den ron 
ihnen eingenommenen Raum vordringen können. Die Schroederschen Figuren zeigen dies recht schön (Fig. 129).

Viele Desmidiaceen zeigen Eigenbewegung. Wie geschieht diese? Vorausgesetzt sei, daß die Desmidiaceen-Zelle sich nicht frei im Wasser bewegen kann, sondern ein festes Substrat als Ansatzpunkt braucht. Sie kann sich dann zwar oberhalb eines solchen Gegenstandes erheben; das ist aber nur scheinbar eine freie Bewegung, denn es geschieht durch Ausscheidung eines Schleimstranges wie der von Euastrum. Durch abwechselnde Ausscheidung solcher Schleimstränge an den Polen (vergl. Fig. 129 Closterium) kann sich dieses Lebewesen vor- und rückwärts bewegen.

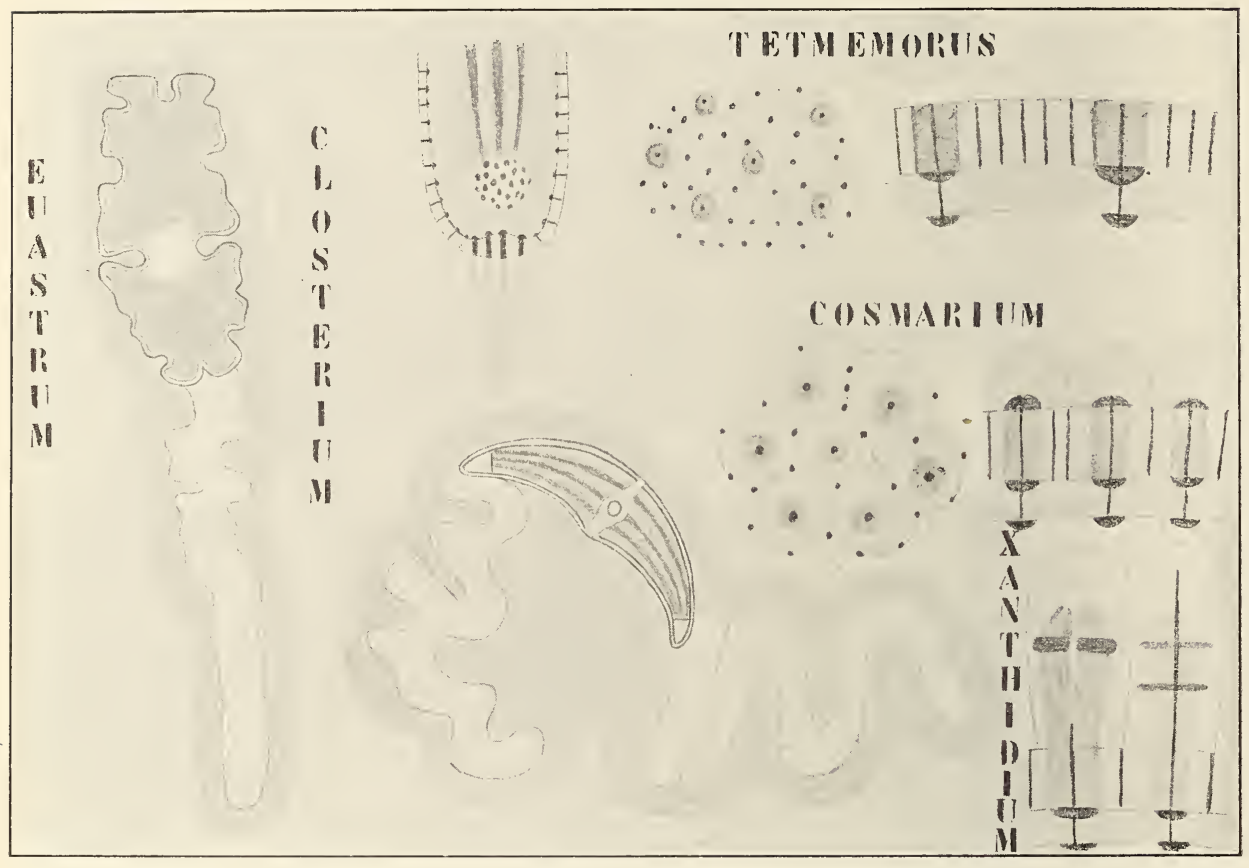

Fig. 129. Schleimbildung bei De smidiace en (nach HAUPTFLEISCH, KLEBS, ScHroEDER und LÜtкemülLER). Eu astrum. Polärer Schleimstrang sichtbar gemacht mittels Tusche. Closterium. Oben die polär bedeutend entwickelten Schleimkanäle, unten ein Exemplar in Tusche mit Schleimsträngen an beiden Polen. Wandstruktur und Schleimbildungen bei Tetmemorus, Cosmarium und Xanthidium.

Offenbar spielt also die Schleimbildung bei der Bewegung der Desmidiaceen eine bedeutende Rolle, aber dadurch werden nicht alle Bewegungen erklärt, z. B. nicht die hin- und herschlagende Bewegung bei Closterium oder gar das bekannte Purzelbaumschlagen desselben. Worauf dies beruht, ist noch unklar.

HAUPTFLeisCH und LütKemüLler haben gezeigt, daß die Zellwand der Desmiaiaceen aus zwei Hälften besteht, ungefähr in der Weise der Conferva-Zellen. Die Ränder dieser beiden Hälften sind so wie bei Conferva schräg abgeschnitten, so daß die eine auf der anderen etwa wie ein Deckel aufsitzt. 
Die Zellteilung steht natürlich in direkter Verbindung mit dieser TVandstruktur, und kann sehr kompliziert werden. Einer der kompliziertesten Fälle ist der von Penium, welcher hier besprochen werden mag. Die jung'e Penium-Zelle besteht aus den beiden Hälften $1 \mathrm{~A}$ und $1 \mathrm{~B}$, die Querlinie gibt die Grenze zwischen beiden Hälften, den sogenannten Gürtel, an. Diesem Gürtel gegenüber wird, entfernt an Oedogonium erimnernd, ein Cellulosering gebildet; durch Streckung desselbèn wird interkalar ein breites Gürtelstück eingeschaltet, sobald die Zelle sich zu teilen anfängt. Etwa in halber Höhe dieses Gürtelstückes setzt sich die Querwand an. Wir kriegen damn das mit $1 \mathrm{~A}, 2 \mathrm{~A}, 2 \mathrm{~B}, 1 \mathrm{~B}$ bezeichnete Stadium.

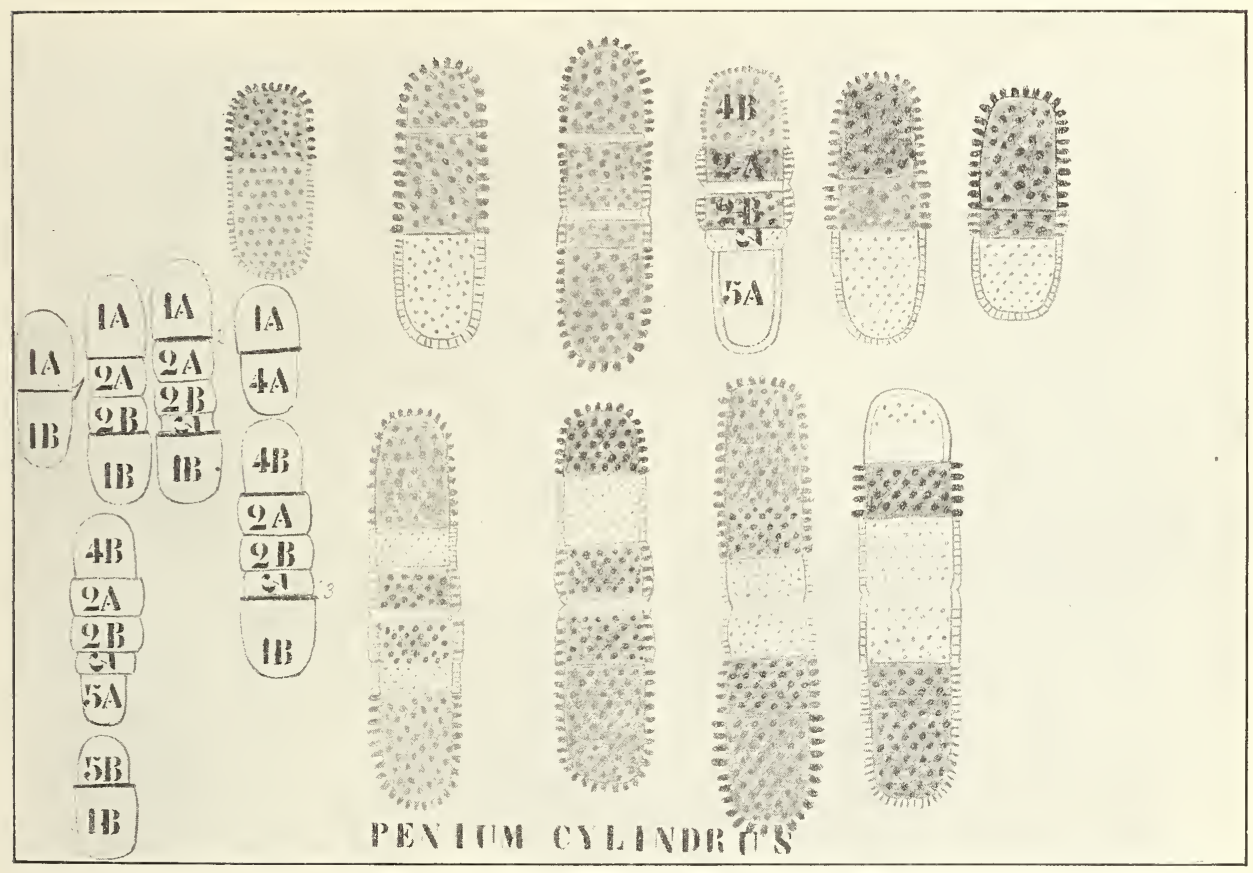

Fig. 130. Zellteilungen bei Penium (nach LÜtKenüLLeR).

In einfachen Fällen, z. B. bei gewissen Closterium-Arten, spaltet sich nun diese Querwand, womit die Teilung vollendet ist. Die neuen Stücke $2 \mathrm{~A}$ und $2 \mathrm{~B}$ werden dann einfach zu der Größe und Form der Stücke $1 \mathrm{~A}$ und $1 \mathrm{~B}$ auswachsen und deren Struktur annehmen, womit die Sache beendet ist. Bei unserem Penium aber nicht; es bildet sich lier zunächst in der Zelle $2 \mathrm{~B}$ ein neuer Gürtel, welcher dadurch bezeichnet werden mag, daß die beiden Hälften dieser Zelle mit $2 \mathrm{~B}$ resp. 3 angedeutet werden. Dann wird zwischen $1 \mathrm{~A}$ und $2 \mathrm{~A}$ ein neues Gürtelstück gebildet, in welchem in normaler Weise die Querwand entsteht. diese Querwand spaltet sich und das Penium ist num in zwei ungleiche Individuen zerteilt, das eine aus den Membranstïcken $[1 \mathrm{~A}$ und $4 \mathrm{~A}]$, das andere aus den Membranstücken [4B, 2A, 2 B, 3 und 1 B] besteliend. Verfolgen wir die weiteren Schicksale dieses letzteren Individuums.

Es bildet dies in normaler Weise auf der Grenze ron 3 und $1 \mathrm{~B}$ 
ein Gürtelstück, welchem sich auf halber Höhe eine neue Querwand ansetzt. Letztere spaltet sich, wodurch die Individuen $[5 \mathrm{~B}, 1 \mathrm{~B}]$ und $[4 \mathrm{~B}, 2 \mathrm{~A}, 2 \mathrm{~B}, 3,5 \mathrm{~A}]$ entstehen.

Ein Individuum wie letzteres sieht aber in Wirklichkeit ganz anders aus, da die Membranstücke verschiedenen Alters andere Skulpturen und durch Einlagerung von Eisenteilen andere Farben besitzen. In der Tat sieht es so aus, wie das mit entsprechenden Buchstaben bezeichnete Individuum der oberen Reihe. Wir sehen also, daß die Gürtelbildung und die Teilung bei Penium voneinander unabhängig sind, und da nun Gürtel an jeder Stelle gebildet werden können und der Wechsel zwischen Teilung und Gürtelbandbildung ohne bestimmte Regel erfolgt und desto mehr Kombinationen möglich sind, je mehr Segmente eine

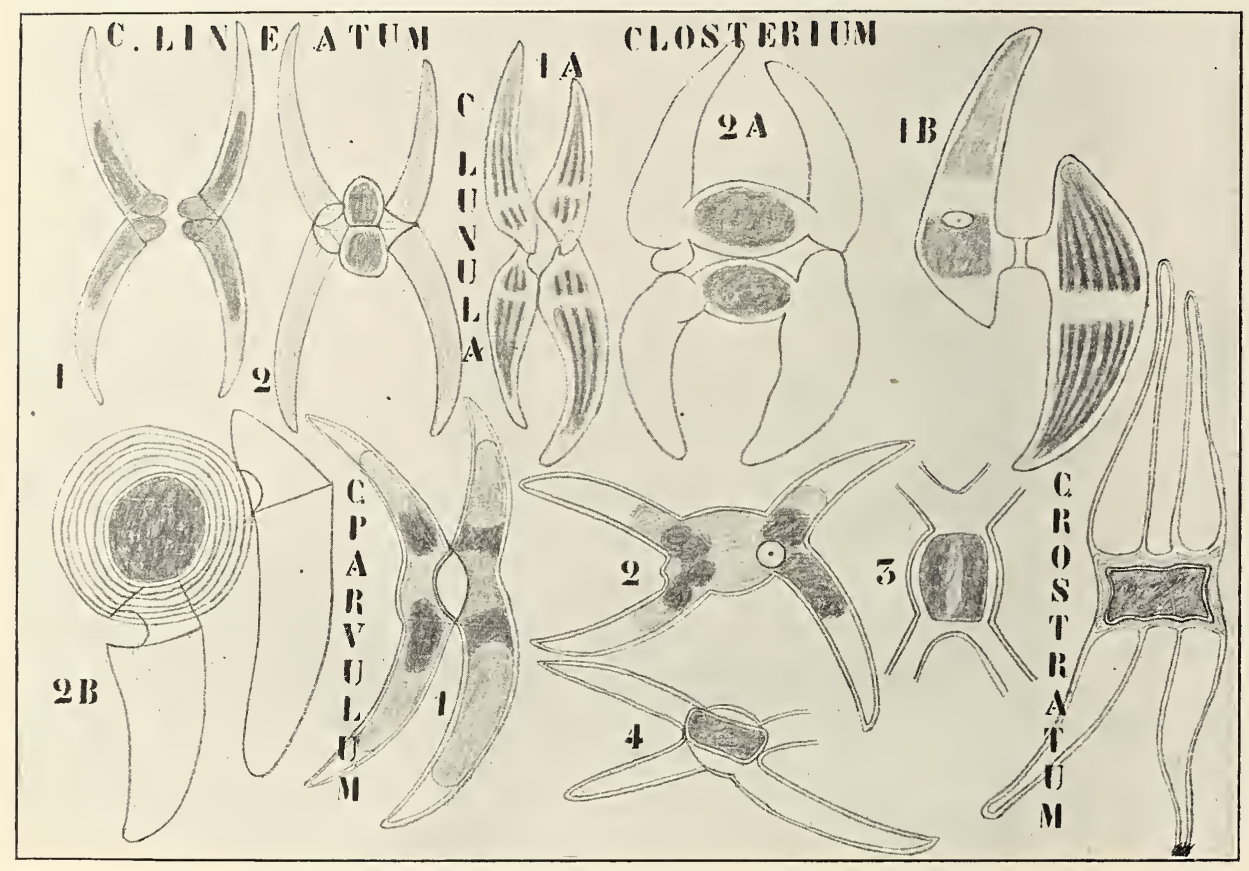

Fig. 131. Kopulationsarten bei Closterium (nach DE BARY, RALFS und MorREN), nach OLTMANNs zusammengestellt.

Zelle bereits besitzt, so gelangen nicht selten Individuen von ganz paradoxem Aussehen zur Beobachtung, an denen Segmente sehr verschiedenen Alters unmittelbar übereinander liegen und die ältesten Zellabschnitte bald an den Enden, bald in der Mitte sich finden. Einige Fälle sind hier abgebildet, für Näheres sei auf LÜTK EMÜLLER verwiesen.

Die geschlechtliche Fortpflanzung geschieht bei allen Desmidiaceen mittels Kopulation. Da alle Modifikationen dieses Vorganges bei Closterium sich finden, wollen wir unsere Betrachtung auf dieses Genus beschränken.

Bei Closterium lineatum legen sich die Individuen aneinander und brechen an dem Gürtel entzwei. Inzwischen hat sich das Plasma in jeder Zelle in zwei Stücke geteilt, deren je eines mit einem entsprechenden 
Stïcke der anderen Zelle verschmilzt, so daß zwei miteinander verklebende Zygoten, die sogenamnte Doppelspore (Fig. 131, 2) entstehen.

Nach OLTuAnss' Auffassung werden also in jeder Zelle zwei Gameten gebildet, welche durch paarweise Verschmelzung 2 Zygoten liefern.

Solange wir aber nicht wissen. ob bei dieser vermuteten Gametenbildung sich auch der Kern geteilt hat, scheint mir diese Auffassung wenig sicher, wenn auch nicht unwahrscheinlich.

Bei Closterium Irmula liegen bei der Paarung meistens 4 Individuen beieinander. Es sind dies stets junge Individuen, deren eine Zellhälfte noch nicht ganz ausgewachsen ist; zwischen diesen jungen Zellhälften entsteht nun ein Kopulationskanal, in welchem die Zygote gebildet wird. Trotzdem hier also in jedem Individuum nur eine Gamete

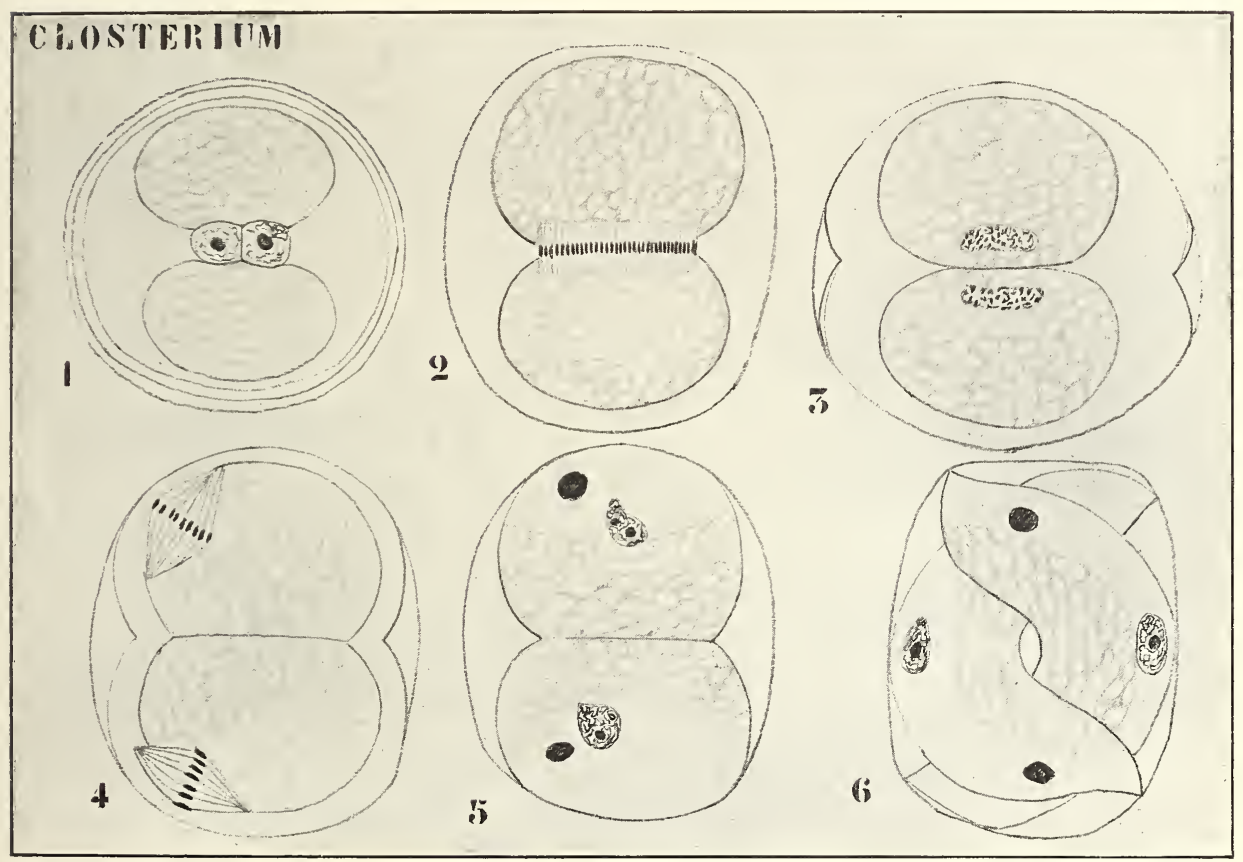

Fig. 132. Keimung der Zygote von Closterium (nach KLeBAHN).

gebildet wird, entstehen durch die Proximität zweier Paare dennoch Doppelsporen. Notwendig ist dies aber keineswegs, wie die Fig. $1 \mathrm{~B}$ und $2 \mathrm{~B}$ zeigen, wo nur 2 Individuen sich gepaart haben. Der Kopulationskanal verschleimt alsbald, wodurch die Zygote in eine Schleimumhüllung zu liegen kommt.

Bei den meisten Closterium-Arten kopulieren aber erwachsene Individuen. Als Beispiel möge $C$. parvulum dienen.

Die Individuen legen sich aneinander und bilden Ausstülpungen, welche nach stattgefundener Berührung die trennende Wandschicht auflösen, wodurch ein Kopulationskanal gebildet wird. Dieser erweitert sich mehr und mehr, während die Individuen sich öffnen; der Inhalt tritt nun in den Kopulationskanal ein und bildet dort die Zygote, welche sich später mit einer Membran umgibt. 
Bei C. rostratum entstehen überdies Querwände, welche den Kopulationskanal gänzlich von den leeren Zellen abschließen und so noch eine besondere Hülle um die Zygote bilden.

Die Keimung der Closterien ist von KLEBAHN beschrieben worden.

Die Zygoten werden von April bis Juni gebildet und zeigen zunächst 4 grüne Chromatophoren; später sind nur 2 gelbe Ballen vorhanden, deren Entstehung aus den Chromatophoren noch nicht klar ist. In diesem Zustande befindet sich die Zygote noch im nächsten Frühjahr, während die zwei Kerne noch gesondert, wenn auch aneinander gepreßt liegen (Fig. 132, 1). Alsbald verschmelzen sie nun, und es schlüpft der ganze Zygoteninhalt, nur von der inneren Schicht der Zygote umgeben, heraus. Jetzt teilt sich der Kern (Fig. 132, 2) und es entfernen sich die Tochterkerne voneinander (Fig. 132, 3, 4). Sofort aber teilen sie sich wieder (Fig. 132, 4) und es degeneriert von jedem Tochterkernpaare der eine Kern (Fig. 132, 5), während die beiden anderen die Kerne der beiden sich jetzt ausbildenden Keimpflänzchen bilden.

Cosmarium verhält sich genau so, auch es bildet 2 Keimpflänzchen pro Zygote und das gilt für alle daraufhin untersuchten Desmidiaceen.

Wie soll man das nun erklären? Wir erinnern uns, daß bei den Mesotaeniaceen 4 Keimpflänzchen pro Zygote gebildet werden, es sind also hier die degenerierenden Kerne wohl Kerne degenerierter Keimpflänzchen.

In beiden Fällen ist meiner Anschauung nach die Zygote zum Gonotokont geworden. Die Zelle der Desmidiaceen ist also eine $\mathrm{x}$-Generation und falls dies richtig, ist auch dem Umstand, daß die meisten Desmidiaceen eine Gamete pro Zelle, Closterium lineatum deren aber vielleicht zwei bildet, kein Gewicht beizulegen.

Hiermit haben wir also die Gruppe der grünen Algen mit den sich daran direkt anschließenden Pilzen behandelt. Ich habe versucht, Ihnen von dieser Gruppe eine ziemlich eingehende Uebersicht zu geben, da sie als die direkten Ahnen der höheren Gewächse zu betrachten ist.

Ueber die anderen Algengruppen werde ich mich, da sie nur Seitenzweige oder kurze Parallellinien des Stammbaumes der höheren Gewächse bilden, kürzer fassen können.

Wenden wir uns also zunächst der Gruppe der braunen Algen zu. 


\section{Neunte Vorlesung.}

\section{Die Phaeophyten-Reihe.}

So wie die grünen Algen sich mittels der grünen Flagellaten von den Protomastiginen ableiten lassen, so lassen sich die Phaeophyten von derselben Urgruppe durch Vermittelung der

\section{Chrysomonaden}

herleiten. Es ist dies eine recht formenreiche Gruppe, deren Vertretern aber dieses gemeinsam ist, daß sie ein oder mehrere goldgelbe bis braune Chromatophoren besitzen und daß sie monoenergid sind.

Die in Mehrzahl verhandenen kontraktilen Vakuolen liegen meistens am Vorderende; bei einigen Arten finden sich auch große Nahrungsvakuolen, welche, wenn nötig, im stande sind, feste Nahrung aufzunehmen; in dieser Hinsicht kann man von tierischer Ernährungsweise reden.

Das Produkt der Photosynthese ist Leukosin, eine in Form von Tropfen vorhandene Substanz, deren chemische Natur noch schlecht bekannt ist. Daneben findet sich nach Hans Meyer noch ein fettes Oel.

Die Repräsentanten unserer Familie sind entweder nackt oder besitzen eine Zellwand. Im letzteren Falle kann die Zellwand oben offen sein und einen Kragen um den oberen Teil der Energide bilden (man vergl. die Fig. 136 III von Dinobryon), in welchem Falle die Membran Cellulosereaktion gibt. In anderen Fällen ist die Membran verkieselt.

Mit Senn unterscheiden wir drei Gruppen:

1) mit einer Cilie . . . . . . Chromulinaceae

2) mit zwei ungefähr gleichen Cilien . . Hymenomonadaceae

3) mit zwei ungleichen Cilien... . Ochromonadaceae

Die einfachste

\section{Chromulinacee}

ist wohl Chrysamoeba ; ein Organismus, der sich in Süßwasserplankton befindet und dessen einfacher Bau eine Abbildung wohl unnötig macht. Chrysamoeba besteht aus einer nackten ovalen Energide mit einer langen Cilie am schmalsten Ende, 2 braunen Chromatophoren und führt keinen Augenfleck. Unter Umständen vermag es ziemlich lange Pseudopodien zu bilden, welche zweifellos durch Vermehrung der Oberfläche das Schwebevermögen vermehren; die Cilie bleibt als Bewegungsorgan beibehalten. Im Körper finden sich weiter 2-3 kontraktile Takuolen, 1 große un- 
bewegliche Vakuole und Leukosine. Die Bewegung ist äußerst träge. Die Fortpflanzung findet mittels Zweiteilung statt; in ungünstigen Umständen encystiert sich das Wesen. Aus einer solchen Cyste schlüpfen später 2 Individuen aus, welche während dieser Ruheperiode durch Teilung aus dem alten hervorgingen.

An Chrysamoeba können wir nun

\section{Chromulina}

anschließen, ein ebenfalls mit einer Cilie versehenes Lebewesen, mit 1-2 Chromatophoren, das aber meistens einen Augenfleck besitzt. In amöboider Beweglichkeit ist sie, mit Chrysamoeba verglichen, schon sehr

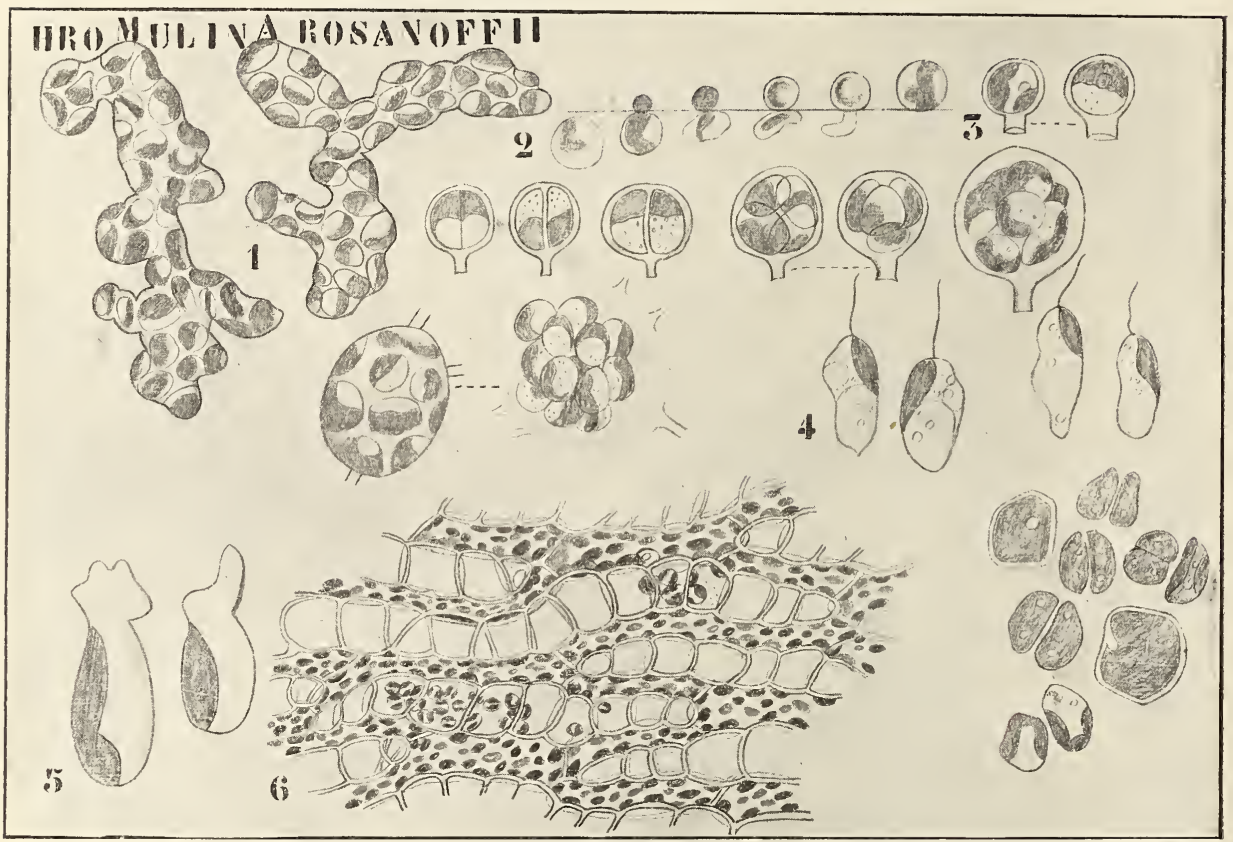

Fig. 133. Chromulina Rosanoffi (nach WoronIN). 1 Encystierte Individuen an der Oberfläche des Wassers. 2 Ein Individuum sich aus dem Wasser erhebend. 3 Schwärmerbildung und Ausschlüpfen derselben durch die verschleimende Membran. 4 Schwärmer. 5 Amöboid bewegliche Stadien aus einem Sphagnumblatt. 6 Die Chromulinen im Sphagnumblatt, nachdem sie sich mit einer Membran umgeben haben; rechts sich teilend.

zurückgegangen, da nur noch der hintere Teil des Körpers diese Eigenschaft in geringem Grade besitzt. Als Beispiel wählen wir die

\section{Chromulina Rosanoffi,}

welche voll Woronin (1880) unter dem Namen Chromophyton Rosanoffi beschrieben wurde. Sie wurde von ihm in Finland im Herbst in Moorteichen angetroffen. An hellen, sonnigen Tagen ist dort die Oberfläche des Wassers mit einem gelben Pulver bedeckt, welches bei Regen verschwindet, alsbald aber wieder erscheint. Dieser Staub besteht aus encystierten Individuen, welche mittels Schleim zu verschieden großen Klumpen verbunden sind (Fig. 133, 1) und auf dem Wasser schwimmen. 
Das ist hier buchstäblich wahr, denn die Organismen liegen der obersten Wasserschicht auf. Wie gelangen sie nun dorthin, wie können so zarte Organismen die Oberflächenschicht, deren Kohäsion so groß ist, durchdringen? Anderen kleinen Organismen ist diese Oberflächenschicht ein unüberwindbares Hindernis. Die Perforation derselben geschieht in folgender Weise: Die Schwärmer der Chromulina stoßen an der Oberflächenschicht an, gelangen dort zur Ruhe (Fig. 133, 2) und wachsen nun sozusagen durch die Oberflächenschicht hindurch, so wie ein Chytridiaceen-Schwärmer durch die Wand einer Spirogyra-Zelle hindurchwächst. Die Membran ist sehr plastisch und besteht vermutlich aus ein chitinähnlichen Substanz; sie bildet einen kleinen Knopf, der die Oberflächenschicht durchbohrt, dieser schwillt mehr und mehr an, und es tritt die ganze Energide in diese Blase über, welche mittels eines kurzen Stielchens in der Oberflächenschicht verankert bleibt. So liegen demn die Ruhezellen buchstäblich auf dem Wasser.

Da ihre Wand schwer zu benetzen ist, machen sie den Eindruck von Staub, sobald es aber regnet, werden sie durch das Anschlagen der Reg'entropfen benetzt und sinken herunter, daher ihr fast unheimlich schnelles Verschwinden bei Regen. Das Auftauchen und Heruntersinken läßt sich im Laboratorium recht einfach mittels einer Gießkanne an einer Kultur in einer Glasschale demonstrieren.

Nachdem die Cysten benetzt sind, teilt sich ihr Inhalt (Fig. 133, 3) in eine Anzahl von Schwärmern, welche ausschlüpfen und davonschwimmen; das Ausschlüpfen wird durch Verschleimung der Cystenmembran ermöglicht; der gleiche Entwickelungsgang fängt dann von neuem an.

Diese beweglichen Chromulinen dringen nun gegen den Winter gern in die Wasserzellen von Sphagnum-Blättern, welche sich in den Teichen befinden, ein, bewegen sich dort, nachdem sie die Cilien abgeworfen haben, amöboid (Fig. 133, 5) und umgeben sich mit einer Membran (Fig. 133, 6).

Im Sphagnum-Blatte vermehren sie sich nun durch Teilung (Fig. 133, 6 rechts), wobei sich die ganze Zelle, auch die Zellwand, teilt. So werden schließlich die Wasserzellen des Sphagnum-Blattes mit diesen Dauerzellen ausgefüllt. Schließlich bildet jede derselben eine Anzahl Schwärmer.

Wir haben hier also Cysten auf der Oberfläche des Wassers und sich teilende Dauerzellen im Inneren der Sphagnum-Zellen. Beide bilden schließlich Schwärmer.

Bei einer anderen Chromulina-Art, bei

\section{C. mucicola,}

sind die Zellen von einer gemeinsamen Schleimschicht umhüllt, in welcher sie sich langsam hin und her bewegen. Solche Schleimmassen sind mit einem Ende an Wasserpflanzen befestigt und können im Wasser flutend mehrere Centimeter lang werden. Dadurch wird ein Uebergang zum höchsten Chromulinaceen-Genus, zu

\section{Hydruins}

gebildet. Es ist dies ein Bewohner kalter Gebirgsbäche, welcher stellenweise, z. B. in der Isar bei München, häufig ist, offenbar aber auch wieder verschwinden kann, er soll z. B. bei Schierke im Harz vorkommen, Anfang der 90er Jahre habe ich ihn dort aber nie finden können. Er bildet schön verzweigte, öfters fußlange Schleimsträng’e, in welchen die gelbbraunen Individuen eingebettet sind. 
In der Jugend ist ein solcher Schleimstrang unverzweigt und enthält nur eine einzige Energide, deren Chromatophor nach oben gerichtet ist (Fig. 134, 1). Diese Energide teilt sich der Länge nach (Fig. 134, 3), da aber eine der beiden Tochterzellen hinuntergeschoben wird (Fig. 134, 2) und dies immer geschieht, bleibt auch später (Fig. 134, 4, 5) stets eine Energide an der Spitze des Schleimstranges liegen und fungiert als Scheitelzelle. Die hinuntergeschobenen Energiden teilen sich ebenfalls der Länge nach, es wächst dadurch der Faden in die Breite.

Die Verzweigung kommt durch Hervorwölbung der Schleimschicht über einer x-beliebigen Energide zu stande. Eine solche Energide fängt dann nämlich als Scheitelzelle eines Seitenzweiges zu fungieren an (Fig. 134, 5).

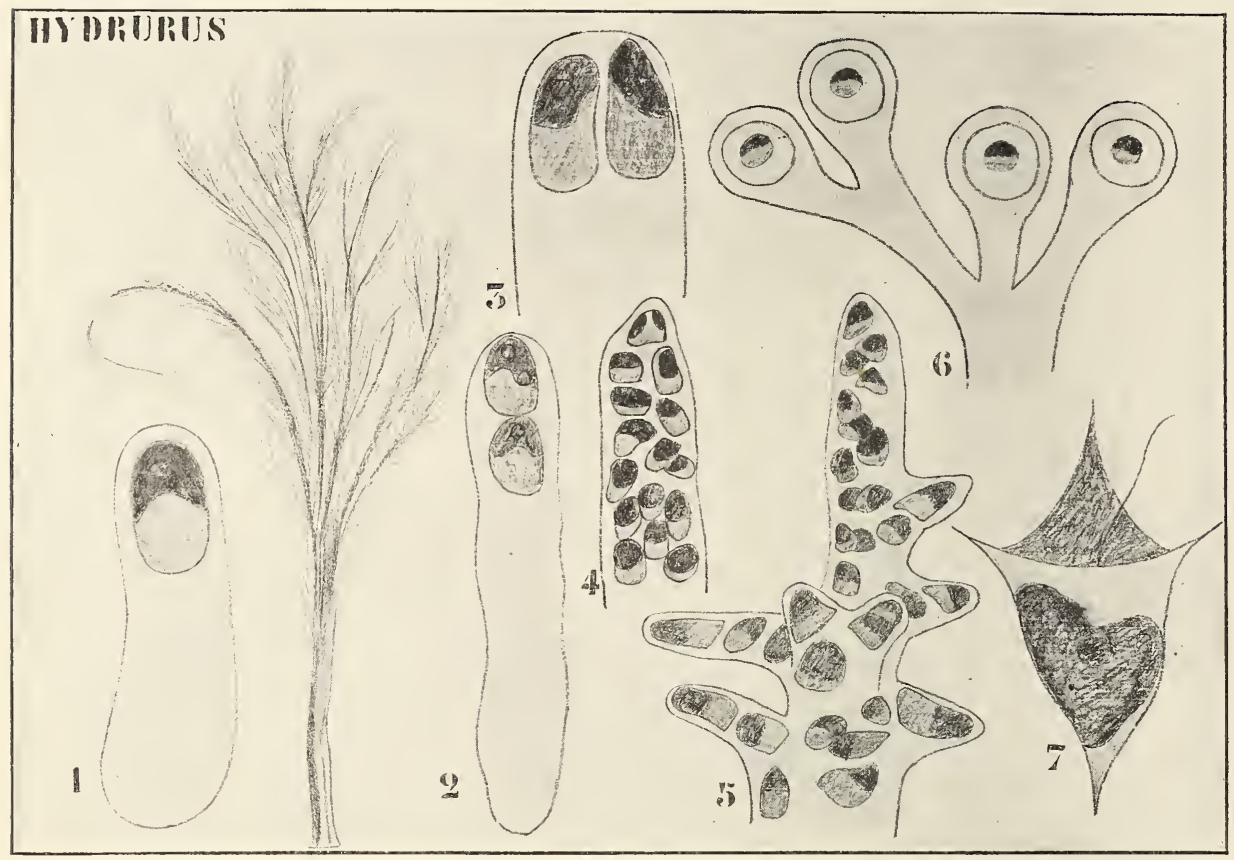

Fig. 134. Hydrurus (nach Rostafinski, Berthold und KleBs). 1-4 Keimpflanzen. 5 Verzweigung. 6 Dauerzellen. 7 Schwärmer. Die große Figur neben 1 ist ein Habitusbild einer erwachsenen Kolonie.

Bei der ungeschlechtlichen Fortpflanzung werden die Schwärmer in der Zweizahl von den Energiden gebildet, sie besitzen eine Cilie, schlüpfen rund heraus, nehmen aber alsbald die Form eines Tetraeders an (Fig. 134, 7). Nach einigem Herumschwimmen setzen sie sich fest, bilden eine Schleimhülle und kriechen in derselben hinauf, wodurch das junge Stadium, von welchem wir ausgingen (Fig. 134, 1), gebildet ist.

Hydrurus kann Wärme nicht vertragen, und überlebt den Sommer mittels Dauerzellen. Die Bildung von Dauerzellen fängt damit an, daß gewisse Energiden der Kolonie lange Schleimröhren bilden, wodurch sie aus der Kolonie hinausgeschoben werden (Fig. 134, 6). Später bilden sie innerhalb dieser Schleimröhren eine eigene Schleimmembran und schließlich noch eine Kieselmembran. 
Die bekannten Coccolithophoren, deren Kalkschalen auf den Meeresböden Ablagerungen bilden und in manchen so gebildeten Gesteinen fossil nachgewiesen sind, gehören wohl zum Teil hierher, d. h. die einciligen Formen, die zweiciligen werden wohl besser zu den Hymenomonaden gebracht. Sie sind von Lohmans (1902) untersucht worden; auf seine Arbeit sei hier verwiesen.

In der Gruppe der Chromulinaceae haben wir nun bei Hydrurus unbewegliche Kolonien kennen gelernt, es gibt aber auch bewegliche Kolonien, welche man die Tolvocineae unter den Chromulinaceen nennen könnte. Hierher gehört z. B. Chrysosphaerella.

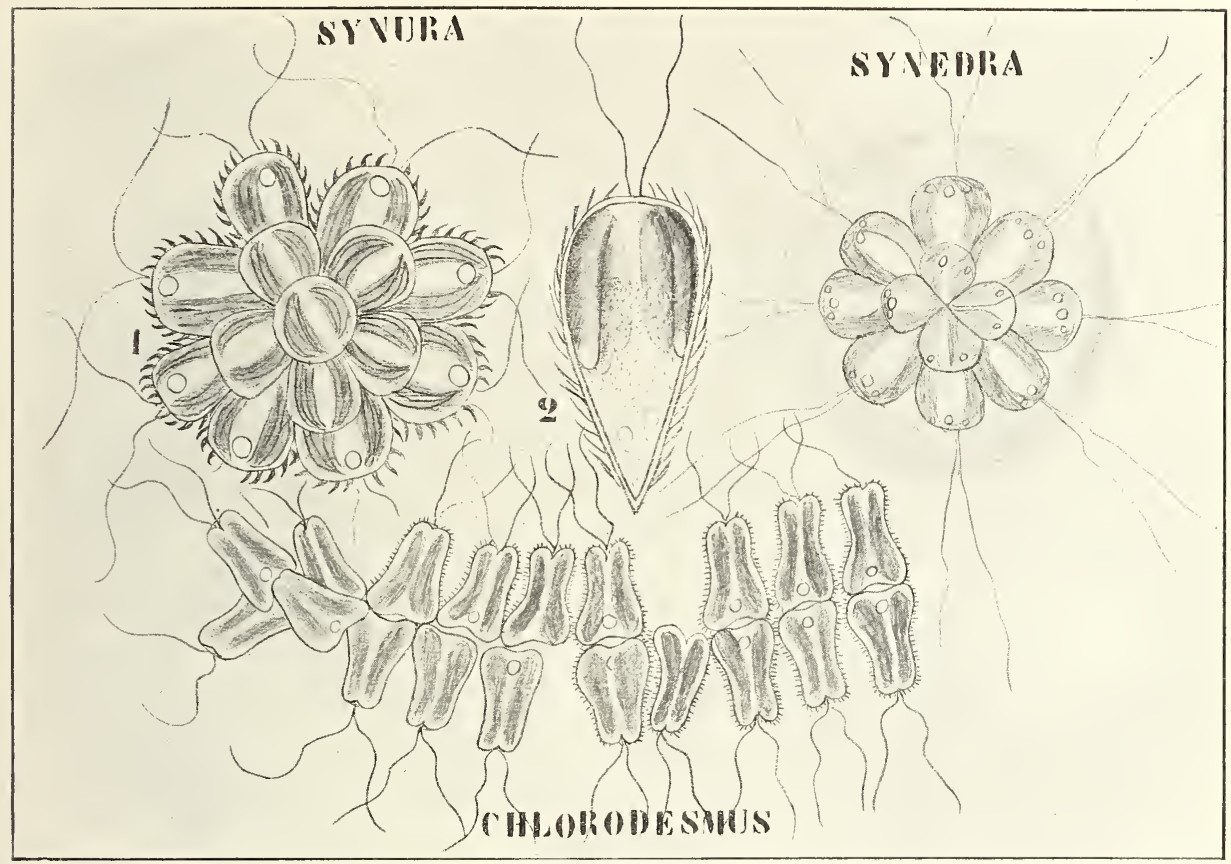

Fig. 135. Volvocinoide Hymenomonaden.

Die zweite Gruppe der Chrysomonadinen, die der

\section{Hymenomonaden,}

ist durch den Besitz zweier gleich langer Cilien charakterisiert. Als einfachste Form sei

\section{Wysotzkia}

besprochen. $W$. biciliata ist eine nackte Energide von langgestreckter Form, welche am Vorderende 2 gleichlange Cilien besitzt und 2 Chromatophoren enthält. Sie kann ihre Form ziemlich bedentend ändern, ja sogar amöboid werden. Außer der gewöhnlichen Er'nähı'ung mittels Photosynthese findet auch Aufnahme fester Nahrung statt. Die Teilung erfolgt erst, nachdem der Organismus zur Ruhe gekommen ist.

Hymenomonas, ein ebenfalls nur aus einer nackten Energide bestehendes Lebewesen mit 2 Cilien, unterscheidet sich von Wysotsikia 
durch viel geringere amöboide Beweglichkeit und durch den Verlust des Vermögens, feste Nahrung aufzunehmen. Auch in dieser Gruppe hat sich eine volvocinoide Reihe entwickelt, welche zu der Entstehung von Formen wie Chlorodesmus, Symura, Synedra etc.(Fig. 135) Veranlassung gab.

Da erinnert Chlorodesmus durch ihre Plattenform an Gonium, Synura durch ihre Maulbeerform an Pandorina, während die hohlkugelige Synedra an Volvox erinnert, durch die Abwesenheit von Plasmaverbindungen aber entschieden in dieser Reihe einen niedrigeren Platz einnimmt als Volvox in der ihrigen. Auch unterscheiden sie sich von den Volvocineen durch das Teilungsvermögen der Kolonie als Ganzes und durch das gänzliche Fehlen einer geschlechtlichen Fortpflanzung.

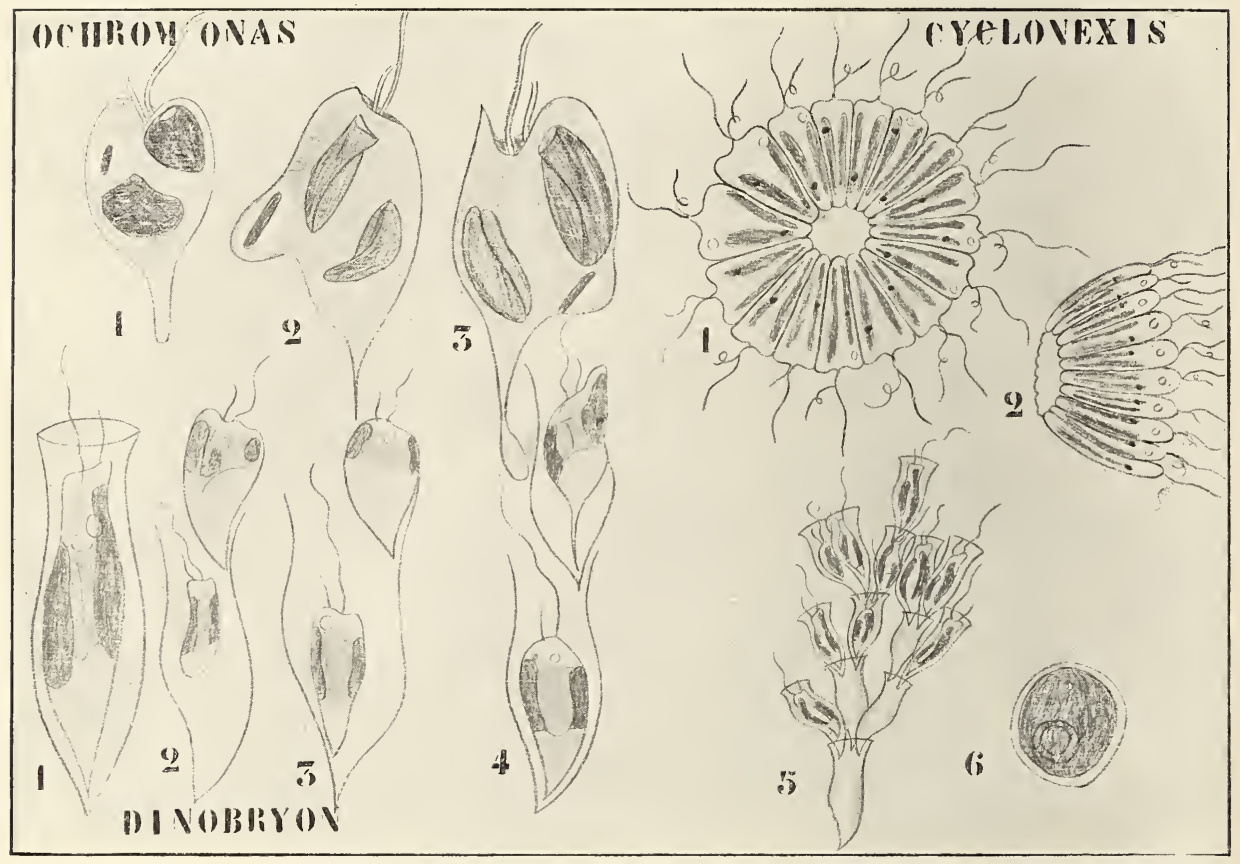

Fig. 136. Ochromonaden. I. Ochromonas (nach Senr). 1 Die Nahrungsvakuole eingezogen, 2 ausgestülpt, 3 wieder eingezogen. - II. Cyclon exis (nach SENN). 1 von oben, 2 von der Seite betrachtet. - III. Dinobryon (nach KuEBS und SENN). 1 Einzelnes Individuum. 3-4 Kolonienbildung. 5 Kolonie. 6 Dauerzelle.

Trotzdem diese Formen Süßwasserbewohner und daher ziemlich leicht zu erhalten sind, ist ihre Entwickelungsgeschichte nur noch sehr unvollständig bekannt.

Die Gruppe der

\section{Ochromonaden}

unterscheidet sich von voriger durch den Besitz zweier ungleich langer Cilien.

\section{Ochromonas mutabilis}

ist wieder ein recht einfacher, ganz nackter Organismus mit 1-2 Chromatophoren, einer kontraktilen Vakuole und meistens einem Stigma. 
Das Ding ist verhältnismäßig stark amöboid und kann mittels einer ausstülpbaren Nahrungsvakuole feste Nahrung aufnehmen (Fig. 136).

Auch diese Gruppe ist alsbald zur Kolonienbildung geschritten, und zwar zunächst zur Bildung beweglicher Kolonien, welche stark an Gonium erinnern, aber aus rein nackten Energiden bestehen. So entstand das Genus Cyclonexis, welches in Moortümpeln angetroffen wird; es hat das Termögen der Ochromonas, feste Nahrung aufzumehmen, vollständig' verloren.

Ein anderer Teil der Ochromonaden hat eine Zellwand gebildet und ist zur Bildung unbeweglicher Kolonien geschritten. Die Zellwand ist recht eigentümlich, sie ist am oberen Ende offen und bildet dort einen Kragen. So z. B. bei Dinobryon. Durch Längsteilung vermehrt es sich. die Tochterenergiden schlüpfen aber nicht ganz aus der Membran heraus, sondern setzen sich an der Innenseite des Kragens an und bilden dann selbst eine einseitig offene, kragenförmig abstehende Membran. Da dieser Vorgang sich ziemlich oft wiederholen kann, entstehen baumartig verzweigte Kolonien (Fig. 136, 5).

Wir sehen also, daß die Gruppe der Chrysomonaden manche Entwickelungsmöglichkeit potentiell enthält und dieser Umstand bestimmt uns anzunehmen, daß die Reihe der Phaeopliyten aus ihr hervorgegangen ist, ebenso wie die Isokonten aus den grünen Flagellaten hervorgingen. Zwischen Isokonten und Phaeophyten besteht also nur ein sehr entfernter Verwandtschaftsgrad, es sind eben Parallelreihen.

Wie aber die Phaeophyten aus den Chrysomonaden hervorgegangen sind ist noch sehr fraglich. Gerade die große Gruppe der Tange (Fucaceen etc.) läßt sich noch sehr schwer ableiten, da die Cilien ihrer Schwärmer lateral inseriert sind, eine Stellung, welche bei den Chrysomonaden nicht vorkommt. Zwar kennen wir niedrige Formen, wie Phaeococcus und Phaeothamnion mit lateral inserierten Cilien, aber es sind diese sich auch geschlechtlich fortpflanzenden Organismen keine Flagellaten mehr, sondern niedrige Mitglieder der Phaeophyten-Reihe, deren Anschluß wir eben suchen.

Wir werden noch weit mehr von diesen niedriger stehenden Organismen wissen müssen, bevor wir einen guten Anschluß werden finden können. Vorläufig müssen wir uns mit der Annahme abfinden, daß die Chrysomonaden Formen sind, welche durch den Besitz gelbbrauner Chromatophoren mit den Ahnen der braunen Algen nahe verwandt sind.

Diese braunen Algen nun sind im allgemeinen festsitzende Organismen; nur 2 Gruppen: die Peridinales und viele Diatomeen schwimmen oder schweben, unter letzteren kommen aber auch angewachsene Formen vor.

Die Peridinales besitzen Cilien, die Diatomeen nicht, aus diesen und anderen Gründen halte ich die Peridinales für die niedrigere der beiden Gruppen und möchte diese also zunächst mit Thmen besprechen. 


\section{Zehnte Vorlesung.}

\section{Die Peridinales.}

In dieser Gruppe lassen sich zwei Familien unterscheiden: die Gymnodiaceae und die Peridinaceae, während vielfach auch die Prorocentreae dieser Gruppe zugezählt werden. Letztere möchte ich aber als eine gesonderte Gruppe betrachten, von welcher sich vielleicht die Diatomeen ableiten lassen, darüber später Näheres.

Fangen wir unsere Betrachtung mit der einfachsten Familie, mit der der

\section{Gymmodinaceae}

an.
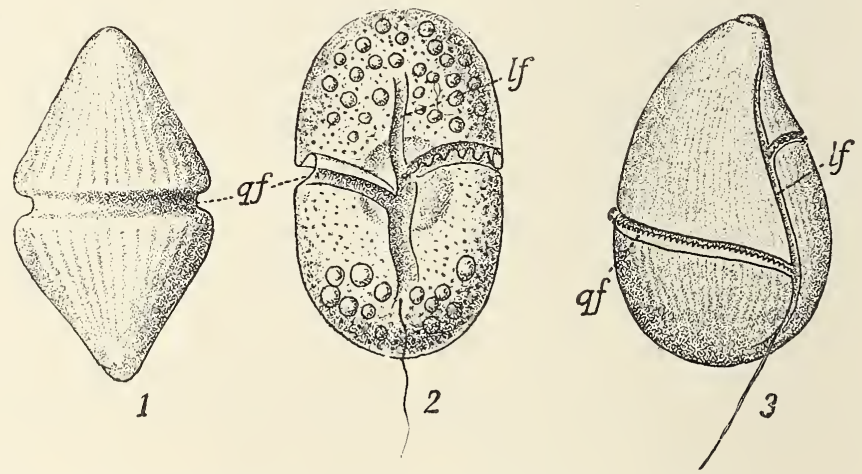

Fig. 137. 1, 2 Gymnodium rhomboides ScHütt. \& Gymn. spiral e BeRGH. (alle nach ScHÜтT). $q \dot{f}$ Querfurche. $l f$ Längsfurche.

Die einfachsten Formen sind nackt, andere besitzen eine einfache strukturlose Cellulosemembran, während wieder andere Schleimbildung zeigen. Einige besitzen Chromatophoren, andere sind farblos. Das Eigentümliche dieser Organismen ist der Besitz einer um den Aequator des Körpers herumlaufenden Querfurche. An der einen Seite des Körpers treffen wir überdies eine Längsfurche an, welche die Querfurche senkrecht schneidet und länger oder kürzer sein kann. Am Schneidepunkt der beiden entspringen 2 Cilien, deren eine sich nach außen und hinten streckt, deren andere sich dagegen in die Querfurche hineinlegt (Fig. 137, 2). 
Die nach hinten gerichtete Cilie schlägt das Wasser wie eine Peitsche, während die in einer Querfurche liegende sehr schnelle undulierende Bewegungen macht, so wie die, welche zu standie kommen, wenn Kinder versuchen, mit einem Tau die Bewegungen einer Schlange nachzuahmen.

Variationen dieses Aufbaues kommen z. B. dadurch zu stande, daß die Querfurche nicht kreisförmig, sondern spiralförmig verläuft, wodurch sie an zwei ziemlich entfernten Orten in die Längsfurche ausmündet.

Zur leichteren Beschreibung eines solchen Organismus nennen wir die Seite, an welcher sich die Längsfurche befindet, die Bauchseite, die dieser gegenüberliegende die Rückenseite, den Pol, nach welchem die freie Cilie gerichtet ist, den antipikalen, den diesem gegenüberliegenden den apikalen.

\section{Die Peridlinaceae}

zeigen nun die gleiche eigentümliche Quer- und Längsfurche wie die Gymnodiniaceen und ihr Bau stimmt also in hohem Grade mit dem Bau dieser überein. Sie sind aber durch den Besitz einer aus einer Anzahl von Stücken bestehenden Panzermembran von den Gymnodiniaceen verschieden.

Dies mag, dem Beispiele Oltmanns' folgend, an

\section{Goniodoma}

demonstriert werden (vergl. Fig. 138).

Wir können nun eine ober- und eine unterhalb der Querfurche gelegene Panzerhälfte unterscheiden, welche hier Ober- und Unterschale genannt werden sollen. Diese beiden Schalen berühren sich aber nicht in der Querfurche, sondern stoßen dort beide an ein besonderes Panzerstück an, das die Querfurche bekleidet und Gürtelpanzer genannt wird. Auch die Längsfurche ist gepanzert mit einem Stück, welches Schloßpanzer heißt.

Bei Loslösung dieser verschiedenen Stücke erhalten wir also folgende vier: 1) Oberschale, 2) Unterschale, 3) Schloßpanzer, 4) Gürtelpanzer. Am Schloßpanzer kann man nun wieder ein ober- und unterhalb des Gürtelpanzers gelegenes Stück unterscheiden. Bei Goniodoma besteht das obere Stück des Schloßpanzers aus 2 Platten, das untere aus einer. Sie sind hier besonders leicht zu sehen, da die Längsfurche hier außerordentlich breit ist, bei sehr schmaler Längsfurche sind sie oft sehr schwer nachzuweisen. Das unterhalb der Querfurche gelegene Stück des Schloßpanzers besteht nur aus einer mit einem Loch versehenen Platte, durch welches Loch die Cilien herausragen, und deshalb Cilienspalte heißt.

An der Oberschale unterscheidet man zunächst ein Stïck, welches den Pol bedeckt, den sogenannten Deckel. Dieser besteht bei Goniodoma aus 3 Platten, welche in der Mitte nicht aneinander stoßen, sondern eine Oeffnung übrig lassen, den Apikalporus.

Zwischen Deckel und Gürtel liegen 5 andere Platten, die Prääquatorialplatten, welche zusammen das sogenannte Zwischenband bildeı.

Die Unterschale besteht ebenfalls aus einem aus 3 Stücken zusammengesetzten Deckel, welcher aber keineu Porus besitzt und aus einem Zwischenband besteht. Alle anderen Peridinaceae. wie sehr ihre For'm auch auf den ersten Blick von Goniodoma abzuweichen scheint. lassen sich auf dessen Bauplan zurückführen. Dabei findet aber sowohl 
Vermehrung wie Verminderung der Plattenzahl in den einzelnen Stücken statt. Es sei dies, ebenfalls nach Oltmanns' Beispiel, an Ceratium macroceras demonstriert (Fig. 139).

Der Gürtel ist hier leicht zu erkennen, der Schloßpanzer besteht nur aus einer Platte, der Schloßplatte. Betrachtet man den Organismus von der Rückenseite (untere Figur links), so sieht man leicht die prä- und postäquatorialen Zwischenbänder, deren jedes hier nur aus 3 Platten besteht. Die prääquatorialen Platten zeigen nichts besonderes, von den postäquatorialen sind aber $2 \mathrm{zu}$ ziemlich langen Hörnern ausgezogen. An der linken Figur ist daran nur eins (rechts) gut sichtbar, das linke ist von dem dritten und größten Horn, worüber gleich, fast

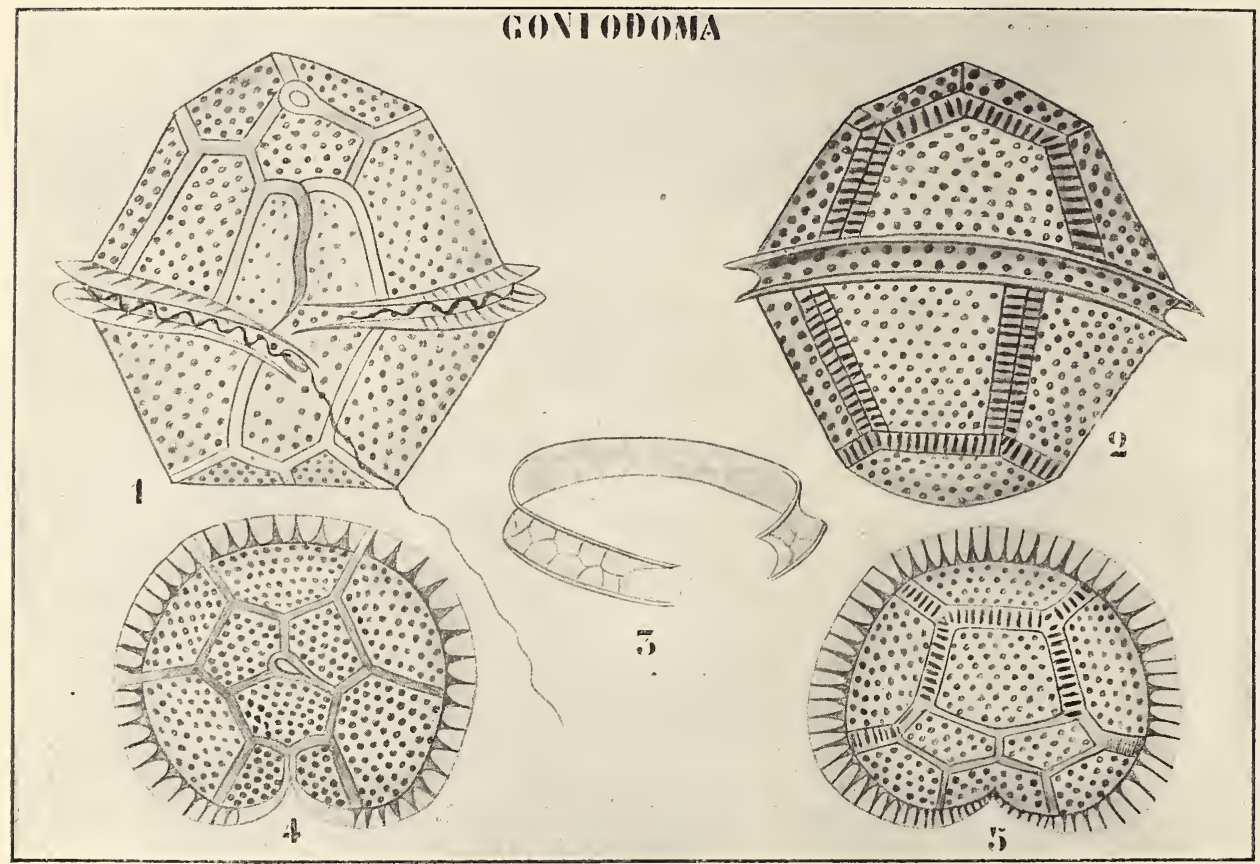

Fig. 138. Goniodoma acuminatum (nach STEIN und ScHüTT). 1 Bauchseite. 2 Rückenseitc. 3 Gürtel. 4 apikale Seite. 5 antapikale Seite.

ganz verborgen. In der rechten Figur sind aber beide Hörner, die seitlichen, gleich gut sichtbar.

Der apikale Deckel besteht aus 4 Platten, den sogenannten Endplatten, der antapikale aus einer einzelnen Platte. Beide Deckel sind lang ausgezogen, der apikale bildet das Vorderhorn, der antapikale das Hinterhorn, welches letztere in der Mitte zwischen den beiden soeben beschriebenen Hörnern steht. Das Vorderhorn zeigt einen großen Apikalporus.

Ceratium tripos biegt das Hinterhorn nach außen um (das rechte Horn der Fig. Tripos), während von den beiden Zwischenbandhörnern nur eines entwickelt und ebenfalls umgebogen ist, gerade wie bei $C$. macroceras. C. tripos hat also nur 3 Hörner, C. macroceras 4, das Horn der linken Postäquatorialplatte fehlt bei $C$. tripos. 
Bei vielen Peridinaceae bilden die Aequatorialplatten Flügel, wodurch die Cilie in der Querfurche besser geschützt wird, das sieht man schon bei Goniodoma, die Flügelentwickelıng kann aber viel ausgeprägter sein.

Eine Untergruppe der Peridinaceae, die der Dinophysen, leistet Außerordentliches auf dem Gebiete der Flügelbildung, es ist dies aber nicht der einzige Unterschied, der ganze Bauplan weicht von dem der Euperidineen ab.

Zunächst fällt es auf, daß die Querfurche nicht äquatorial verläuft, sondern dem apikalen $\mathrm{Pol}$ sehr genähert ist, dadurch ist die apikale "Hälfte" viel kleiner als die antapikale, das Ganze zeigt infolgedessen eine gewisse Aehnlichkeit mit einer Kanne (Fig. 140, 1).

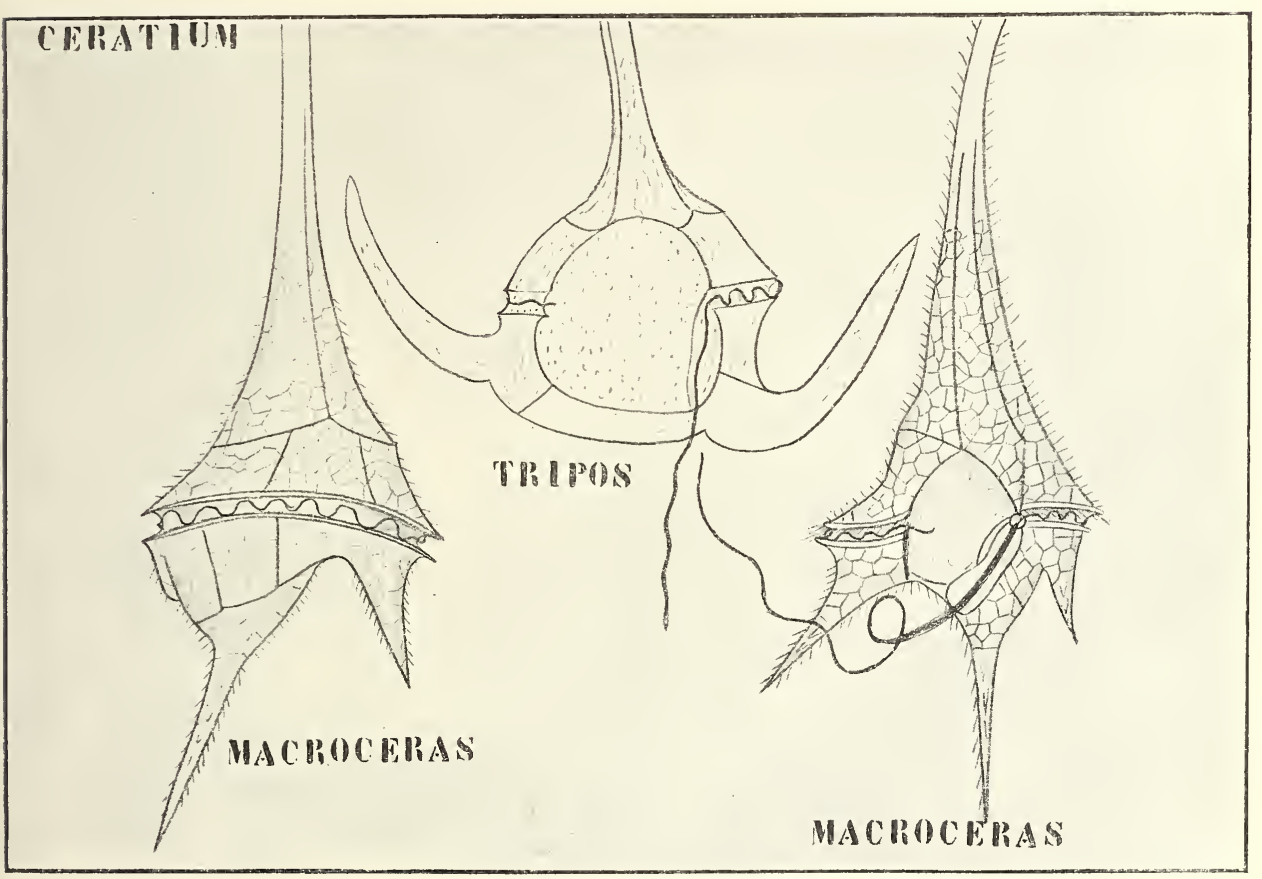

Fig. 139. Ceratium macroceras (nach Stein). C. tripos (nach SchÜтT).

Die Panzerung ist einfacher wie bei den Euperidineen. Die Zellen sind meistens seitlich abgeplattet. Die Oberschale, der Gürtel und die Unterschale besitzen eine Längsnaht, welche um den ganzen Körper herum von der Rücken- nach der Bauchseite hinläuft; der Organismus besteht also aus einer linken und aus einer rechten Hälfte. Da nun jedes Panzerstück hier nur aus einer Platte besteht, haben wir im ganzen 6 Platten, je eine linke und rechte Oberschalen-. Gürtel-- und Unterschalenplatte.

Wie schon bemerkt, ist die Flügelbildung besonders ausgeprägt. zunächst sind Ober- und Unterschale um die Querfurche herum geflügelt (vergl. Phalacroma); bei Omithoceros sind diese Flügel ganz außerordentlich groß und öfters kelchähnlich heranfgebogen, wodurch recht zierliche Formen entstehen.

Ueberdies finden sich Flügel an der Längsfurche entlang; ron diesen 
ist der rechte Flügel immer am kleinsten und besitzt keine Stützadern, während der linke bisweilen (z. B. bei Ornithoceros) besonders groß werden kann und durch ein Adersystem gefestigt ist.

Der rechte Flügel wird von der rechten Hälfte der Unterschale gebildet, von dem linken Flügel aber bildet die linke Schale den oberen Teil, die rechte Schale den unteren. Die Flügel um die Querfurche herum dienen als Schwebeorgane (Fallschirm), die um die Längsfurche herum als Steuer. Die Hörner der Ceratien sind ebenfalls als Schwebevorrichtungen $\mathrm{zu}$ betrachten und verlängern sich, wenn die Dichte des Wassers abnimmt. Diese Anpassung gehört wohl in das Gebiet der Biaiometamorphosen.

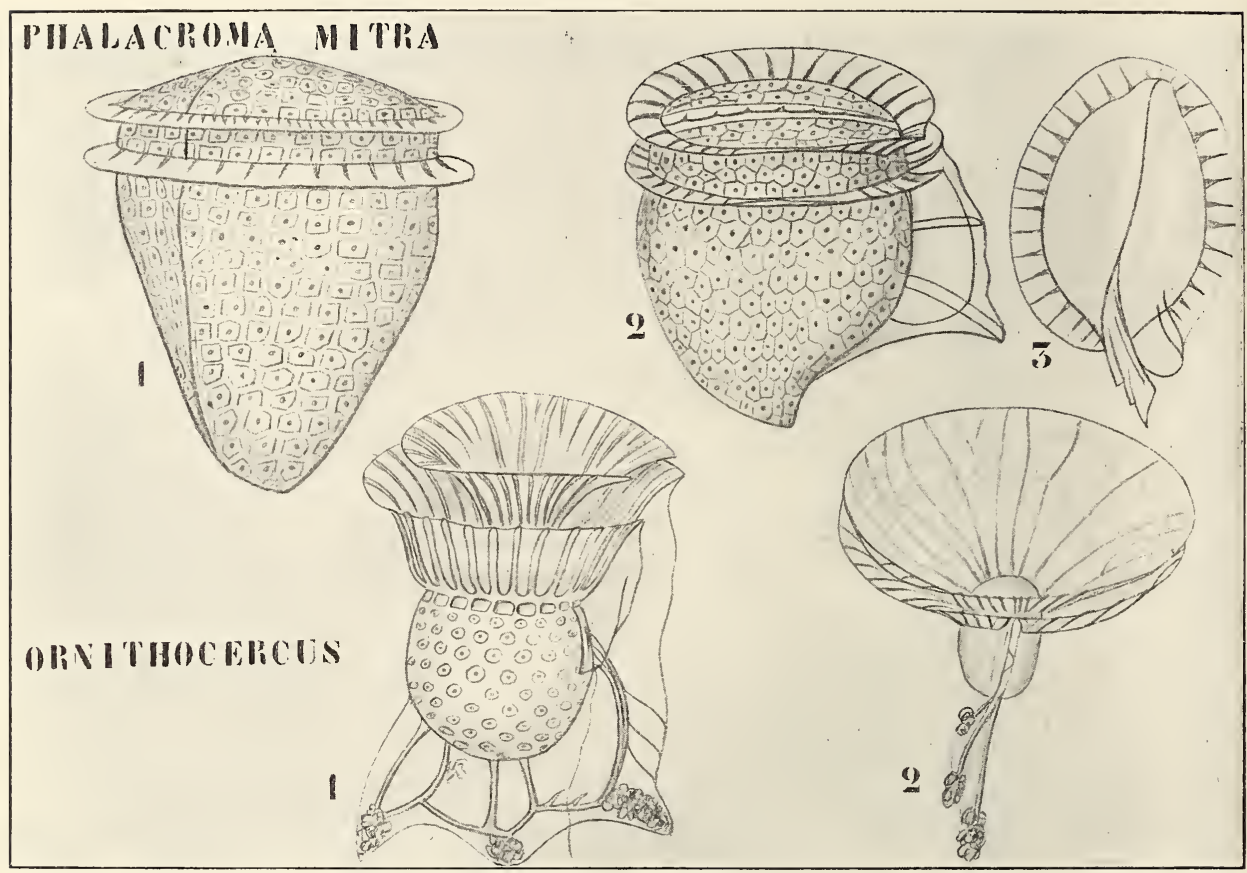

Fig. 140. Dinophysen (nach SchÜтT). Phalacroma mitra und Ornithoceros. näher.

Betrachten wir jetzt die Membranstruktur dieser Organismen etwas

Es zeigt sich bei genauerer Beobachtung, daß die Panzerstücke nicht flach aneinander liegen, sondern daß die einen stets etwas über die anderen hingreifen. Die untergreifenden Platten sind mit Falzrändern versehen, welche unter den dickeren Rand der übergreifenden Platten geschoben sind.

Diese Falzränder zeigen nun öfters Rippen, welche in Vertiefungen des Randes der übergreifenden Platte passen und so die Befestigung. verstärken. Oefters sind die Ränder der einander berührenden Platten in besonderer Weise skulptiert wie die mehr zentral gelegenen Teile, man redet dann von Interkalarstreifen. Die Membran der Peridinaceae besteht zunächst, nach SсHÜтT, aus einer dünnen strukturlosen Schicht, welche aber von Anfang an von zahlreichen kleinen Löchern durch- 
bohrt ist. An jenen Stellen ist nämlich vom Peridinaceae-Körper keine Trand gebildet worden. Alle Verdickungen der Membran, wie Rippen, Stacheln. Flügel, werden dieser Wand von außen aufgesetzt, was eben durch die offenen Poren ermöglicht wird. Durch diese tritt nämlich Plasma heraus, welches das ganze Individuum umgibt und die Verzierungen anbringt. An lebenden Omithoceros-Exemplaren konnte ScHÜтT dieses extracelluläre Plasma schön beobachten.

Bei vielen Peridinacene kann man übrigens Pseudopodien aus den Poren hervortreten sehen, besonders dicke aus dem Apikalporus, letztere dienen zur zeitweiligen Befestigung der Individuen an irgend einem festen Substrat.

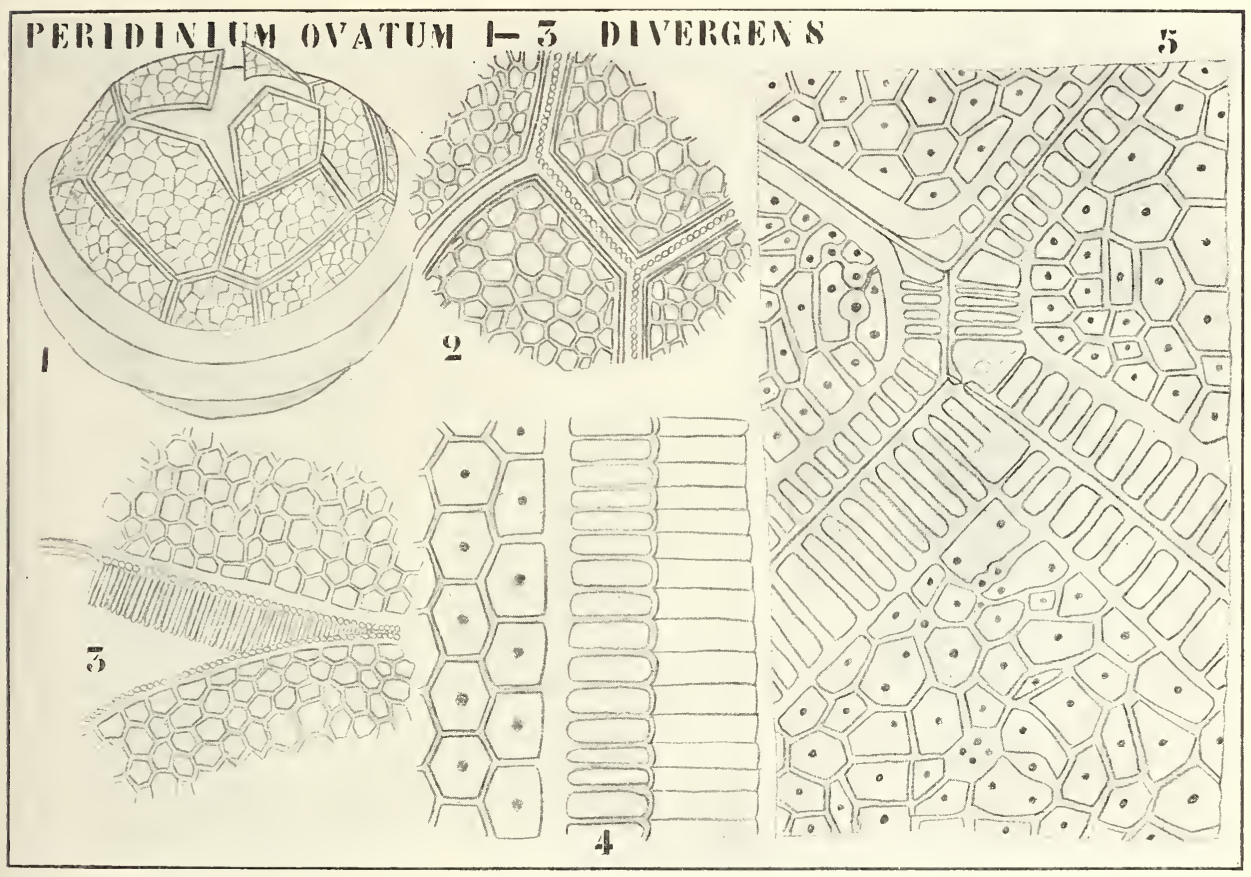

Fig. 141. Plattenbefestigung und Struktur (nach ScHÜTT). 1 Durch Druck gespaltener Panzer. 2 Interkalarstreifen. 3 Falzrand. 4 Idem mit besonders deutlichem Interkalarstreifen. 5 Poren. 1-3 Peridinium ovatum. 4, 5 P. divergens.

Was nun die Struktur der Energide anbetrifft, so besitzen diese zunächst einen besonders großen Kern. Im Plasma finden sich weiter normale Vakuolen und Organe, welche Schüтt Pusulen nennt. Diese Pusulen sind von einer viel dickeren Hautschicht umgeben als die normalen Vakuolen, und die größte derselben, von SchüTT die Sackpusule genannt, mündet mit einem Ausführgange in die Geißelspalte aus.

Die sogenannte Sammelpusule ist meistens kleiner und mündet ebenfalls mit eigenem Kanal in die Geißelspalte aus. Sie wird von einer Anzahl von. kleinen Pusulen umgeben, deren jede mit eigenem feinen Kanälchen mit ihr in Verbindung steht. Diese Pusulen sind wohl den kontraktilen Vakuolen der Isokonten homolog; man kamn sie aber schwerlich so nemmen, da sie sich nicht zusammenziehen. 
Chromatophoren gibt es wohl überall, auch bei den farblosen Formen, wo sie in der Form von Leukoplasten vorhanden sind. Sie sind meistens gelb oder braun, selten grün, auch kommen fast rote vor. Dieses Rot ist aber nur eine besondere Nüance von Braun und etwas ganz anderes als das Rot der Florideen.

Der braune Farbstoff ist nicht mit dem der Diatomeen identisch. Die Chromatophoren liegen peripher, sind verhältnismäßig "klein und immer in der Mehrzahl vorhanden. Stärke scheint nur selten vorzukommen und nur in den Leukoplasten, nicht in den gefärbten Chromatophoren. Das erste sichtbare Produkt der Photosynthese ist wohl Oel. Die Zellteilung kann man am bequemsten bei den Dinophysen wahrnehmen.

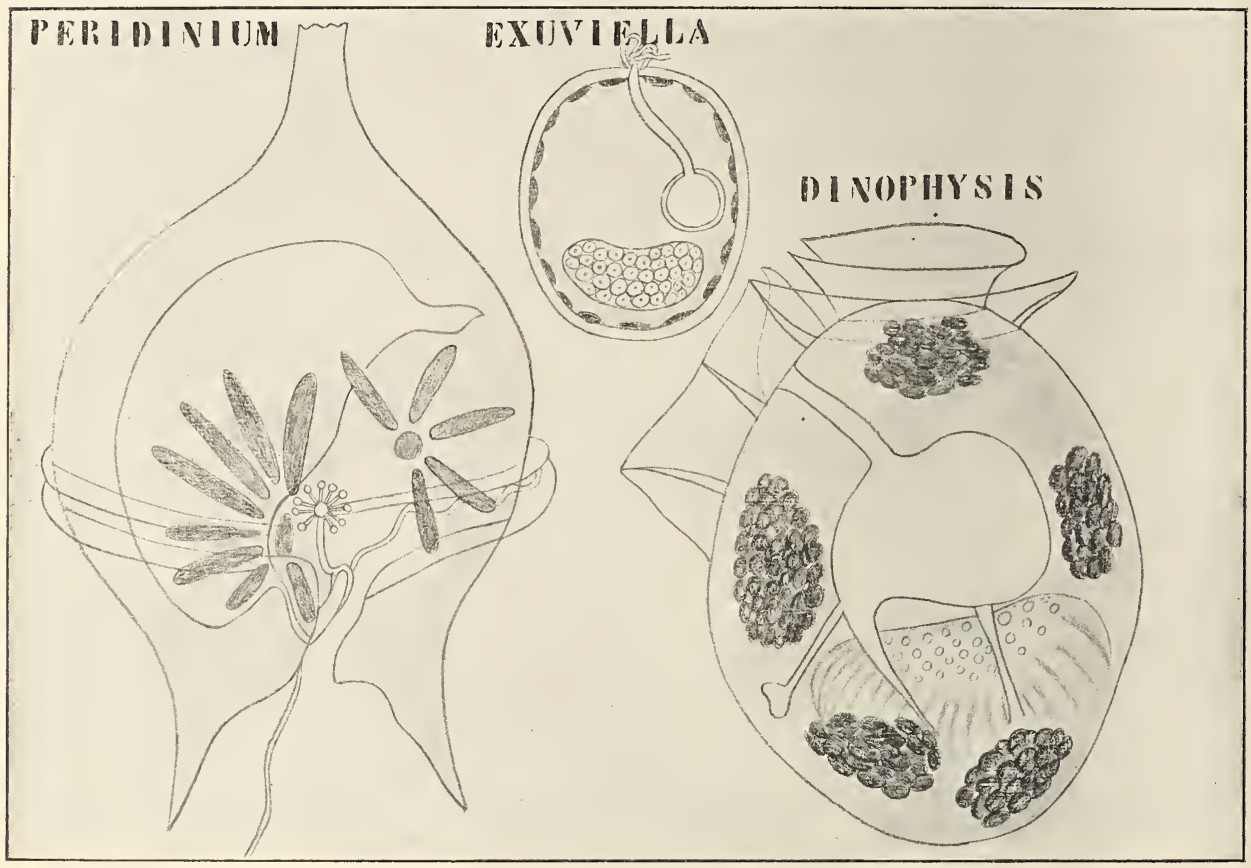

Fig. 142. Energidenstruktur der Peridineen (nach SCHÜTT). I. Peridinium. Die große Vakuole mit Ausführgang ist die Sackpusule, die kleinere, ebenfalls mit Ausführgang und von einer Reihe in sie mündender Vakuolen versehen, die Sammelpusule. Der Kern ist hier nicht sichtbar, die Chromatophoren strahlig um zwei Zentren. - II. Exu viella. Die Chromatophoren wandständig: unten der Kern, oben die Sackpusule mit Ausführgang. - III. Dinophys is. Unten der Kern, daneben die Sackpusule, 5 Anhäufungen von Chromatophoren.

Wir sahen bereits, daß diese mittels einer Sagittalnaht in eine linke und eine rechte Hälfte geteilt sind. An der Sagittalnaht teilt sich nun bei der Zellteilung zunächst die Energide, wodurch zwei Plasmaballen entstehen (Fig. 143, 1); sobald diese gebildet sind, wird die Schale an der Sagittalnaht zersprengt. Inzwischen aber haben die Plasmaballen an ihren nackten Hälften eine junge Membran gebildet, welche nun so weit ausgedehnt wird, bis sie dieselbe Form wie die alte Hälfte angenommen hat, erst dann wird die für die Art charakteristische Skulptur auf dem neuen Wandstück angelegt. Wir können diese Teilung 
also als eine Spaltung mit Reg'eneration der dadurch verloren gegangenen Körperhälfte bezeichnen.

Bei den Ceratien reißen die Zellhälften in einer zur Längsachse schrägen Richtung auseinander. In jeder Hälfte hat sich zuvor eine neue Wand gebildet, welche nachträglich die Struktur des fehlenden Stückes annimmt. Die Zellteilung der Peridinaceae bedarf aber im Detail noch sehr ermeuter Untersuchung.

Bei dieser Zellteilung' können die aneinander vorüberschiebenden Zellhälften zusammenhängen bleiben und da sich das wiederholen kann, können, z. B. bei Ceratium, ziemlich lange kettenförmige Kolonien entstehen. Radförmige Kolonien von Dinophysis aggregata, welche ich in dem Siboga-Material antraf, sind wohl in ähnlicher Weise entstanden.

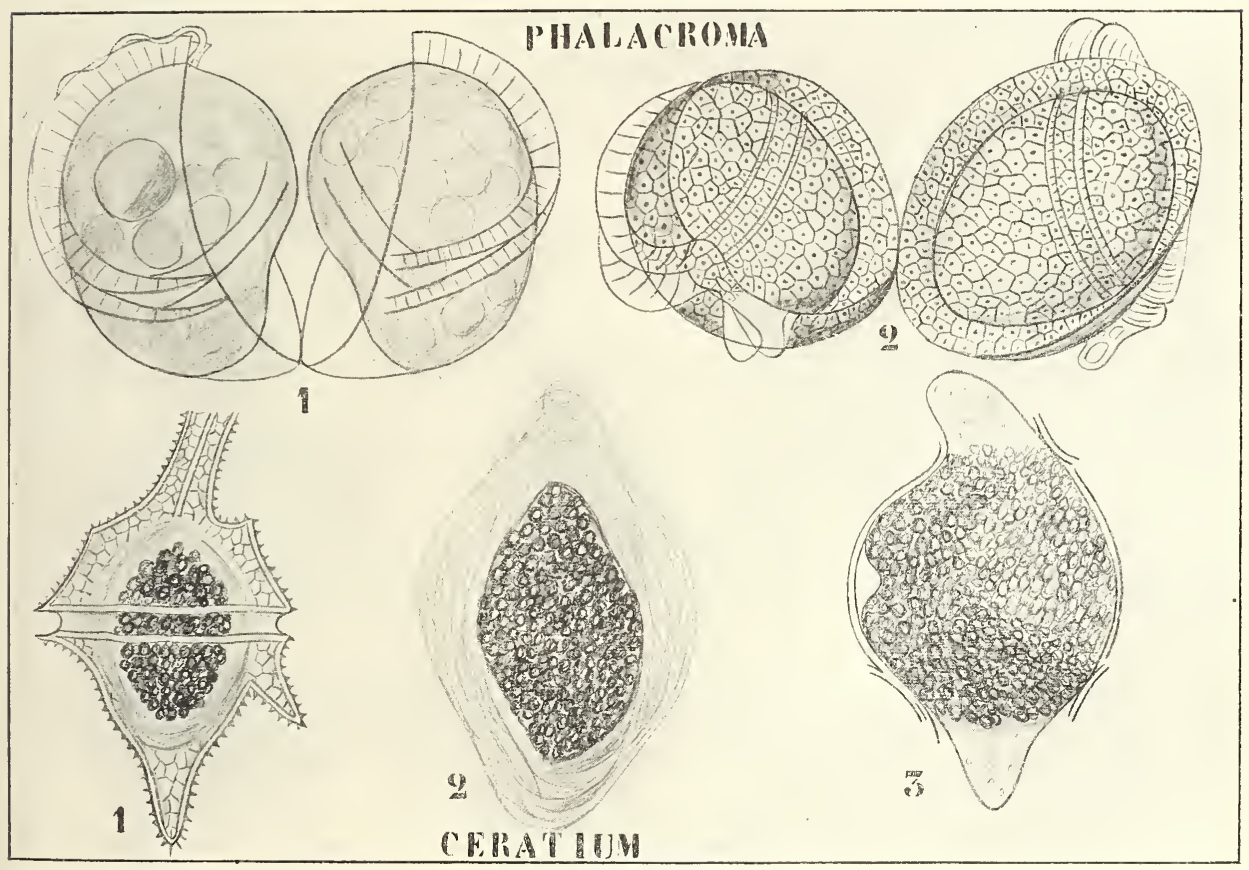

Fig. 143. Zellteilung bei Phalacroma (nach ScHÜтT). Dauerzellenbildung bei Ceratium (nach Schilling).

Außer dieser vegetativen Vermehrung kommt eine ungeschlechtliche mittels Schwärmsporenbildung vor.

Es entstehen diese Schwärmer durch Teilung der Energide, welche entweder schon innerhalb des Panzers stattfindet oder erst nachdem der Inhalt, von einer jungen Membran umgeben, aus dem Panzer herausgetreten ist (vergl. Fig. 144).

Geschlechtliche Fortpflanzung ist erst kürzlich (1904) von ZEDERBAUER bei Ceratium hirundinella beschrieben worden. Nach ihm lassen 2 Individuen ihren Inhalt schlauchförmig hervortreten (Fig. 144, 1), legen sich so aneinander, daß das eine Individum den apikalen, das andere den antapikalen Pol nach oben gerichtet hat und lassen ihre Plasmamassen zu einer Zygote verschmelzen. Die Keimung derselben ist noch nicht bekannt. 
Ruhezustände sind z. B. bei Ceratium bekannt; der Inhalt umgibt sich mit einer dicken Membran, zersprengt den Panzer und keimt schließlich zu einem neuen Individuum aus.

Es bleibt nun noch eine kleine Familie, deren Anschluß nach unten leider nicht bekannt ist, zu besprechen übrig, die Familie der

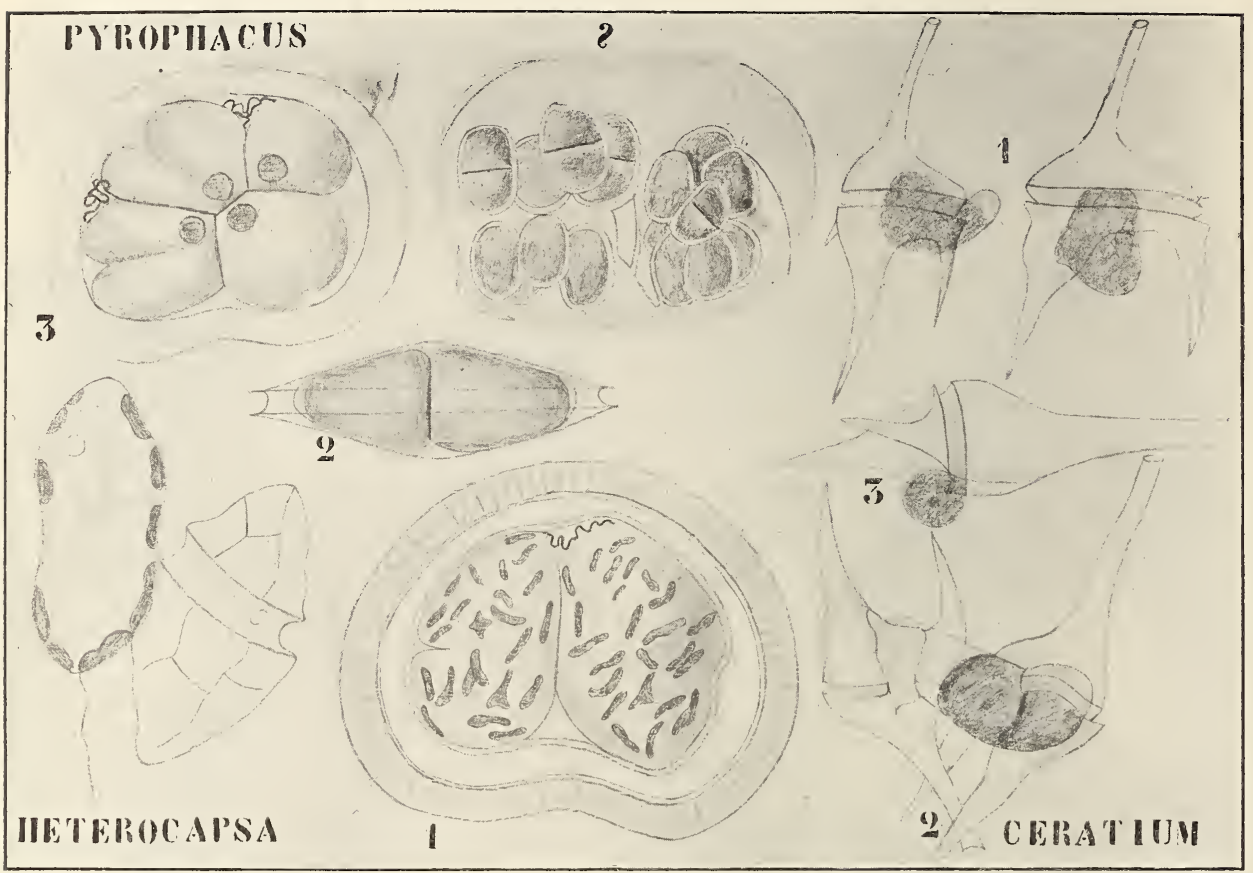

Fig. 144. Schwärmsporenbildung und geschlechtliche Fortpflanzung bei Pcridineen (nach SchüтT und ZenerbaukR). I. 1, 2, 3 Schwärmsporenbildung bei Pyrophacus. II. ? bei einer unbekannten Peridinee. - III. Heterocapsa. Bildung eines einzigen Schwärmers. - IV. Ceratium. Kopulation. 1 Zwei Individuen mit Kopulationsschläuchen. 2 Kopulation. 3 Zygote.

\section{Prorocentreae.}

Es sind dies marine Ubiquisten. Sie sind rein einzellig, länglich, oval oder mehr rundlich und in einer Richtung abgeplattet. Die Membran

Fig. 145 .
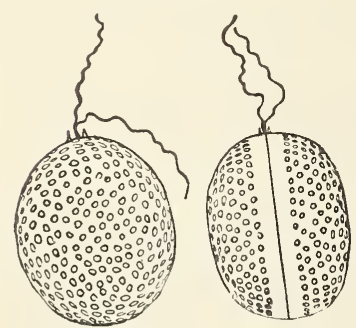

Fig. 145 . (nach SCHÜTT)

Fig. 146. Prorocentrum micans EHrb. (nach SсHӥтT).
Fig. 146.

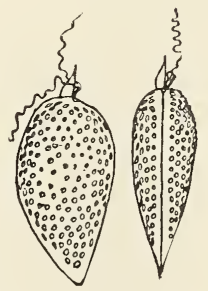

Exuviella marina CIENk. besteht aus 2 Schalen, welche fest zusammenschließen und welche mit zugespitzten Rändern übereinandergreifen, die eine ist aber nicht, wie bei den Diatomeen, größer als die andere. Die Schalen sind mit feinen Poren bedeckt, nur an der Naht entlang befindet sich eine porenfreie Zone, durch welche eine Art Gürtel gebildet wird. Die Schalen bestehen aus Cellulose und sind nicht verkieselt. In der unteren Schale 
befindet sich an einer Stelle eine Spalte, aus welcher die 2 ungefähr gleichlang'en Cilien hervorrag'en. Daneben findet sich öfters ein stachelförmiger Auswuchs der Membran. Braune Chromatophoren und Pusulen sind vorhanden. Außer der Zweiteilung ist keine Fortpflanzungsweise bekannt. Die Chromatophoren sind zahlreich oder es gibt deren nur zwei große plattenförmige.

Ich möchte annehmen, daß diese Gruppe der gemeinsame Ahne von Dinophysen und Diatomeen ist. Die Dinophysen sind sehr leicht abzuleiten, und um aus einer Prorocentree eine Diatomee zu erhalten, ist nur Größerwerden der einen Schale, Verkieselung und Cilienverlust nötig. Das sind nun keine Differenzen, welche eine Ableitung unmöglich machen, und so scheint es mir "faute de mieux" am besten, die Diatomeen hier anzuschließen. 


\section{Elfte Vorlesung.}

\section{Die Diatomeen.}

Wir unterscheiden bei den Diatomeen:

1) unbewegliche Planktondiatomeen,

2) bewegliche Schlammdiatomeen,

3) auf Wasserpflanzen befestigte Diatomeen,

4) zu Kolonien vereinigte angewachsene Diatomeen.

Es finden sich Diatomeen sowohl in Süß- wie in Salzwasser, ja eine und dieselbe Art kann in beiden Elementen vorkommen. Auch auf feuchten Stellen auf dem Boden, an Felsen, an Baumstämmen, ja sogar im Staub der Luft werden Diatomeen angetroffen. Da ihre Membranen im höchsten Grade verkieselt sind, sind sie fossil erhalten und ihr Vorkommen in der Steinkohle ist einer der besten Beweise dafür, daß diese Substanz in Sümpfen gebildet wurde. Aber erst in späteren Erdperioden traten die Diatomeen so massenhaft auf, daß ihre als Kieselgur bekannten und in der Dynamitfabrikation verwendeten Skelette große Ablagerungen lieferten. Solche Diatomeen-Erde kommt z. B. in Holland bei der "Renkumsche beek" vor. Für die Konstanz mancher Arten liefern solche fossile Diatomeen den besten Beweis, gibt es doch welche darunter, die jetzt noch leben. In lebendem Zustande bilden sie die Nahrung von vielen Tieren, z. B. von Austern, welche, wie ich nachweisen konnte, recht gut zwischen Diatomeen und fein zerhackten Cyklopsindividuen unterscheiden können und letztere ausstoßen, während sie erstere gierig aufnehmen und, wie mir Zählungen bewiesen, verdauen.

Fangen wir die Betrachtung der Diatomeen mit den unbeweglichen

\section{Planktondiatomeen}

an. Thre Membran ist stark verkieselt und besteht im einfachsten Falle aus zwei Schalen, welche wie die Hälften einer Pillenschachtel übereinander schließen. Dennoch gibt man den Teilen dieser zwei Hälften noch besondere Namen. Man stellt sich dabei vor, daß jede Hälfte gefertigt wurde wie die Hälften einer Pillendose, also aus einem kreisrunden Stücke, und aus einem diesem als Rand aufgesetzten und dann kreisförmig gebogenen Viereck. Diese kreisrunden Stücke nennt man die Schalen oder Valvae, die Randstücke die Pleurae oder Gürtel. Der kleinere Gürtel ist nicht fest mit dem größeren verbunden, sondern kann in diesem hin- und hergeschoben werden.

Die Schale oder Valva kann, wie das kreisförmige Stück der Pillendosenhälfte, ganz flach sein, ist aber meistens etwas gebogen (vergl. die. 
Figur von Antelminellia), ist diese Biegung stark, so daß auch an der Schale wieder ein Rand entsteht, so redet man von Schalendeckel und Schalenmantel. In der Figur von Triceratium ist die ganze Seitenfläche mit Ausnahme des ziemlich schmalen Gürtels aus den zwei Schalenmänteln zusammengesetzt. Zwischen Schale (resp. Schalenmantel) und Gürtel können nun noch eine Anzahl von accessorischen Platten eingeschaltet werden, welche fest mit beiden verbunden sind. Solche Stücke nennt man Zwischenbänder oder Copulae. Die Copulae können Ringe aus einem Stïck sein (vergl. die Figur von Rhabdonema) oder aber aus verschiedenen kleineren Stücken zusammengesetzt sein. In ersterem Falle redet man von einem Ringpanzer, in letzterem von einem Schuppenpanzer (vergl. die Figur von Eupodiscus).

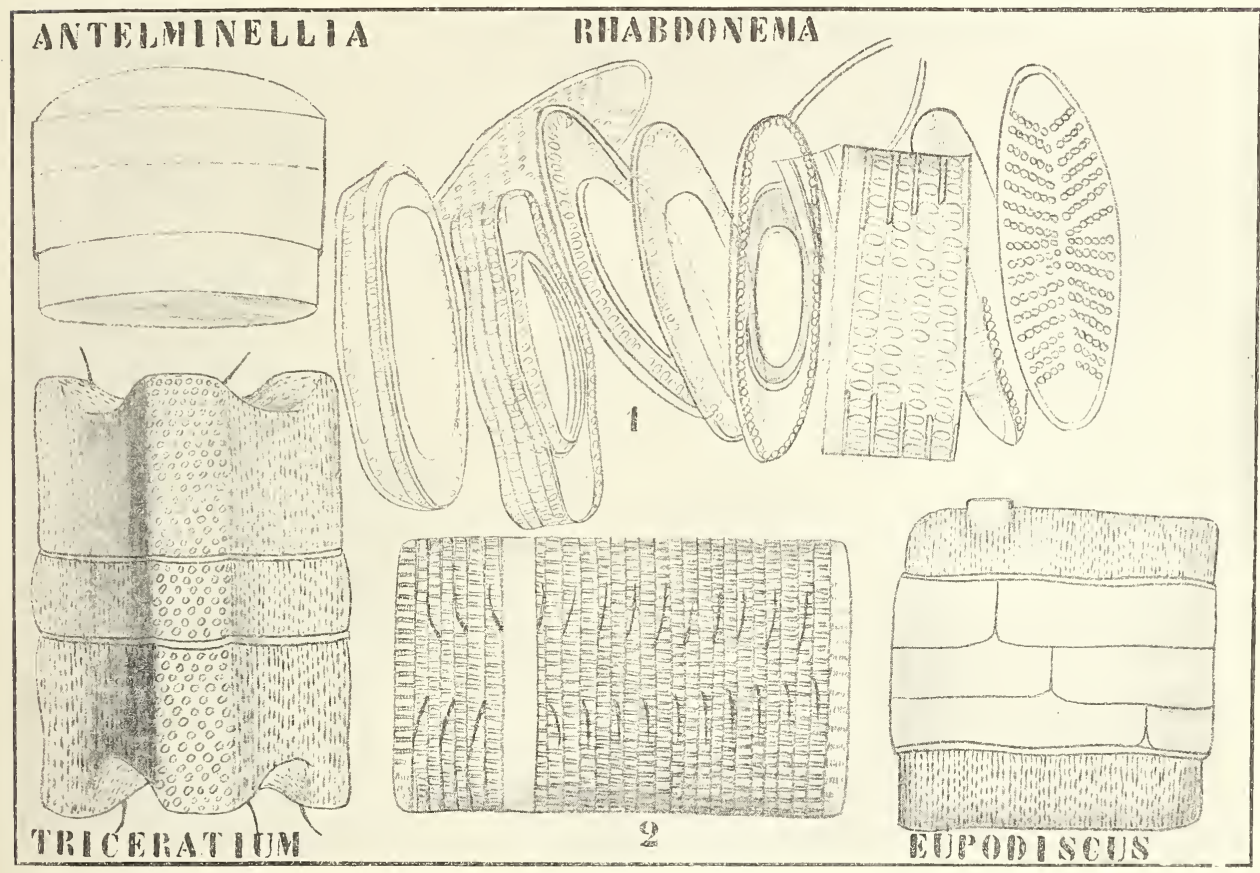

Fig. 147. Schalenstrukturen von Diatomeen (nach ScHÜтt, SмIтH und WiLLE).

Im einfachsten Falle haben wir nur einen Zwischenring, in komplizierten Fällen deren viele (Rhabdonema). Oefters wachsen von den Zwischenbändern Querwände in das Innere der Zelle hinein, sie bilden aber nie vollständige Lamellen, sondern haben stets ein großes Loch im Zentrum, so wie die alten Scheibenblenden der Mikroskope (vergl. die Figur von Rhabdonema). Dadurch wird die Zelle, zumal da noch Septen vom Schalenmantel und von dem Schalendeckel ausgehen können, gekammert, und die Struktur kann sehr kompliziert werden. Anch die

\section{Membranstionktur}

kann recht kompliziert sein. Nur recht wenige Diatomeen besitzen eine glatte Zellwand, die große Mehrzahl ist schön skulpturiert mittels Punkten, Streifen, Netzwerk etc. Alle diese Verzierungen werden der 
ursprünglich glatten Membran entweder an der Innen- oder Außenseite aufgesetzt. Einen einfachen Fall der letzteren Art finden wir bei

\section{Fupodiscus argus.}

Es ist dies eine fast kreisrunde scheibenförmige Plankton-Diatomee, deren Schalen, von oben betrachtet, große Oeffnungen zu besitzen scheinen.

Die Grundmembran ist ziemlich dick und besitzt nur kleine, schief nach oben gerichtete Porenkanäle (vergl. Fig. 148, I). Gewisse Stücke der Grundmembran sind aber nach außen sehr stark verdickt, wodurch ein Balkensystem entsteht, bei welchem die Balken durch große teetassenähnliche Zwischenräume voneinander getrennt sind. Die Ẉand

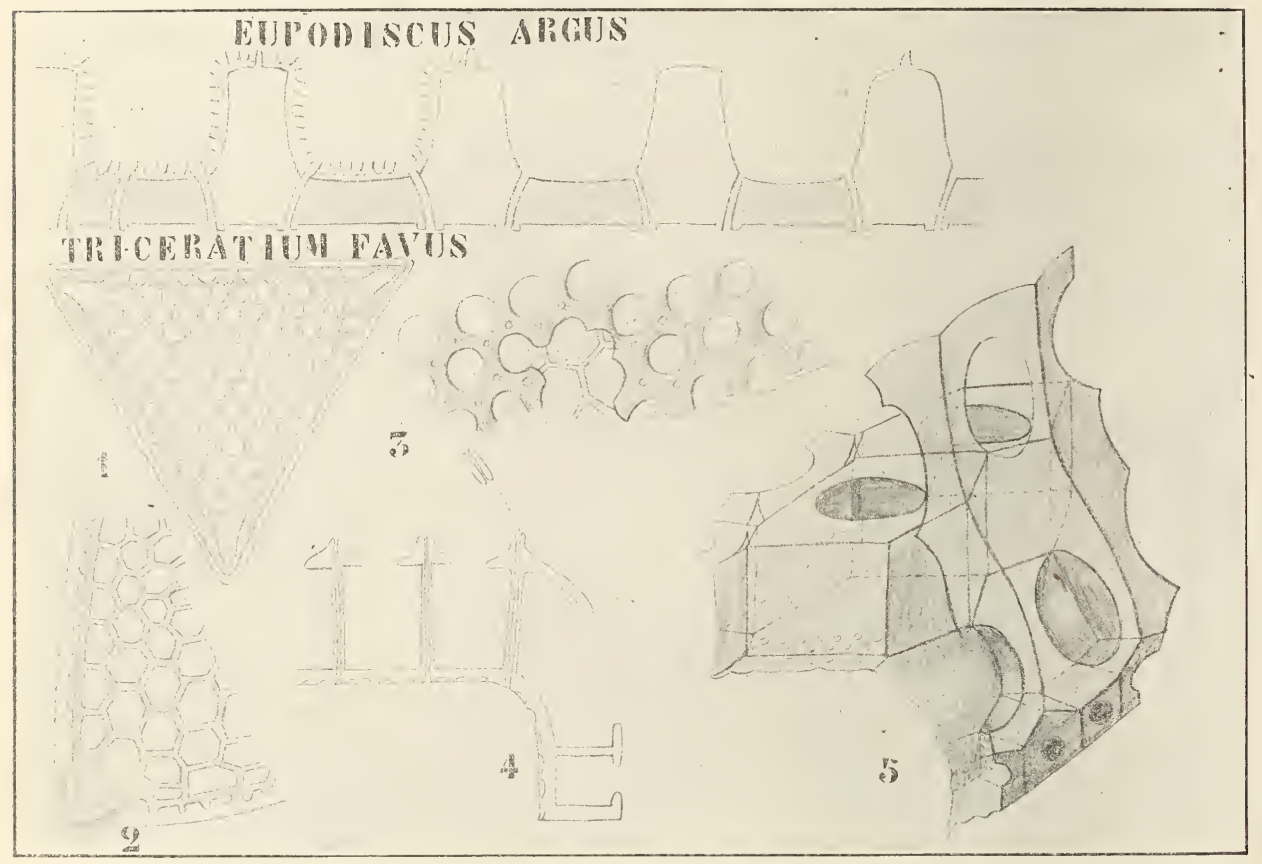

Fig. 148. Schalenstrukturen von Diatomeen (nach MüLLER). I. Eupodiscus argus. - II. Triceratium favus.

dieser Teetassen ist auf der Innenseite mit Stacheln bedeckt. Bei Einstellung des Mikroskopes auf die Ebene, in welcher sich die Außenseiten der Balken befinden, wird so der Eindruck großer, runder Löcher erweckt.

Viel komplizierter ist die Schalenstruktur einer anderen PlanktonDiatomee, der dreieckigen Triceratium favus. Der Grundmembran sind hier Balken aufgesetzt, welche sechseckige Kammern bilden, die aber nicht mit einer sechseckigen Oeffnung nach außen münden, sondern mit einer runden. Es rührt dies daher, daß sie mit einer dünnen, durch runde Oeffnungen perforierten Membran bedeckt sind. Je nach der Einstellung sieht man also Sechsecke (Fig. 148, II 1) oder Kreise (Fig. 148, II 3). Diese runden Oeffnungen sind kleiner als die Sechsecke, so daß jedes Kämmerlein scheinbar einen nach innen umgebogenen Rand besitzt 
(Fig. 14s, II j). Wo зे Kämmerlein aneinander schließen, finden wir auf der Außenmembran eimen kleinen Stachel, welcher von einem Kanal durchbohrt ist (Fig. 148, II 4). Die Struktur der Schale ist nun noch durch Flügelbildung am Rande der Schale kompliziert, dieser Flügel ist in Felderchen eingeteilt, deren jedes im Zentrum eine kreisrunde Oeffnung besitzt (Fig. 148, II 5). Ueberdies ist noch die Grundmembran getïpfelt.

In allen diesen Fällen haben wir mit ausspringenden Verdickungen, d. h. der Grundmembran von außen aufgesetzten Balken zu tun, in anderen Fällen aber kennen wir einspringende Verdickungen, Erhebungen der Innenseite der Membran, worüber ich gleich reden werde. Die bis jetzt betrachteten Formen waren unbewegliche Plankton-Diatomeen, sehen

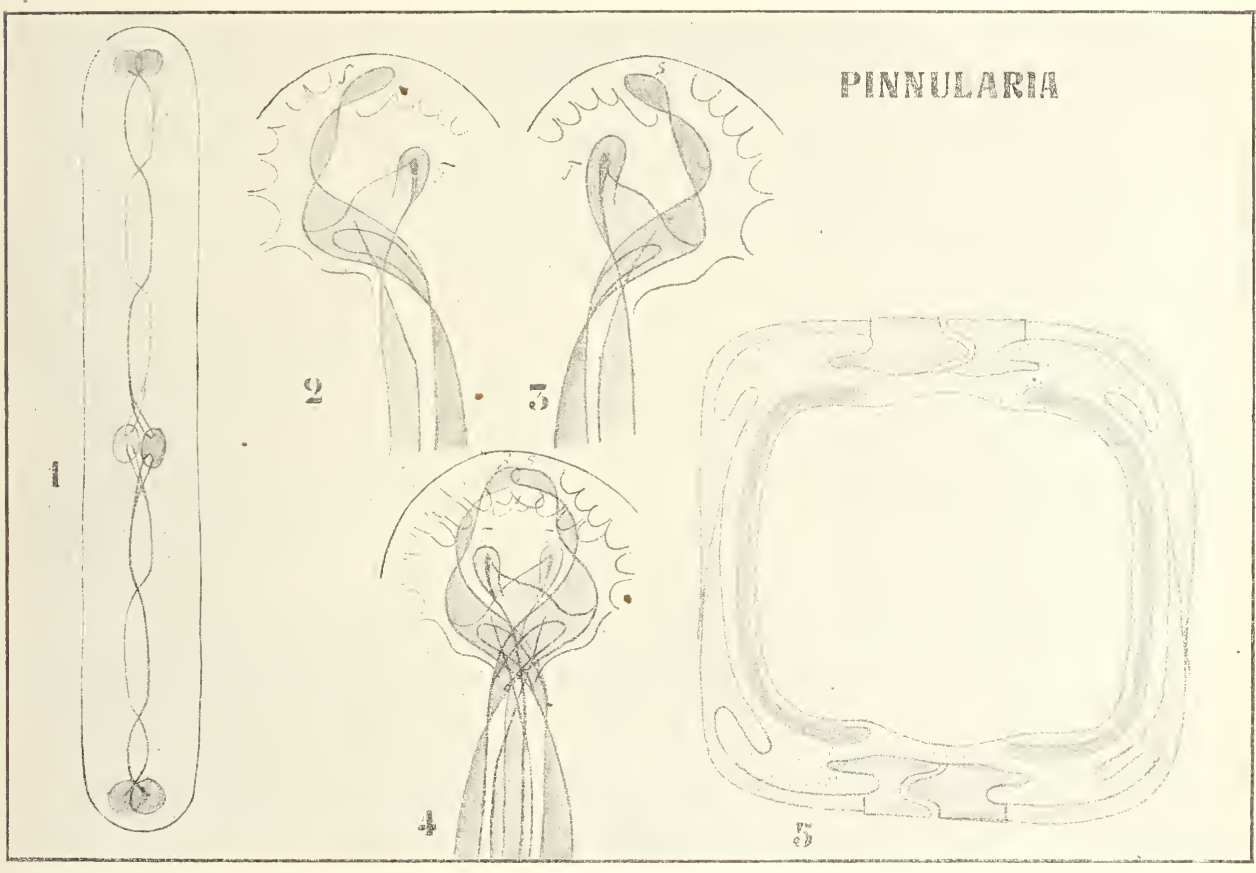

Fig. 149. Pinnularia (nach O. MüLlen und LAdTERBorN). (Fig. 5 aber korrigiert nach Flögel.) 1 Die Raphen der Ober- und Unterseite; die Durchsichtigkeit der Schalen bewirkt, daß beide zu gleicher Zeit sichtbar sind. 2 Endknoten von Ober- und Unterseite nebeneinandergelegt, Polspalte und Trichterkörper zeigend. 4 Endknoten in normaler Lage. 5 Quersehnitt dureh die Zelle.

wir uns jetzt einmal eine typisch bewegliche Schlammform an. Auch bei diesen treffen wir die Schachtelstruktur an, im übrigen aber weichen sie im Bau beträchtlich von den Plankton-Diatomeen ab. Nährend letztere radiär symmetrisch sind, sind erstere bilateral symmetrisch. Jene werden deswegen auch wohl Centricae, diese Pennatae genannt. Als typisches Beispiel einer Pennate mag.

\section{Pinnularia viridis}

gelten. Bei Betrachtung einer Pimmlaria fïllt uns zunächst auf beiden Schalenhälften, sowohl auf der Epitheca wie auf der Hrpotheca, eine 
etwas geschlängelte Linie, die Raphe auf. Die Achse, in welcher die Raphe liegt, nennen wir die mediane oder apikale Achse, die kurze senkrecht zu ihr gestellte Achse die transversale oder die transapikale Achse.

Betrachten wir die Schale etwas näher, so sehen wir eine ganze Anzahl paralleler Querbänder von der Peripherie nach der Raphe verlaufen, letztere aber nicht erreichen. Diese Querbänder sind fingerförmig umgebogene Bälkchen, welche auf dem Querschnitt recht gut zu sehen sind (Fig. 149, 5).

Betrachten wir jetzt die Raphe etwas genauer. In erster Linie fallen auf jeder Schale 3 dicke Knoten im Verlauf der Raphe auf, ein sogenannter Mittelknoten und 2 Endknoten. Der Mittelknoten ist ein verdickter solider Knopf, welcher an der Innenseite der Membran befestigt ist. Die Befestigungsstelle nennen wir die Basis des Mittelknotens, das freie in das Innere der Zelle hineinragende Ende die Spitze.

Die Endknoten sind dagegen große Höhlungen in den Polen der Schalen, sie liegen also ganz in der Schalensubstanz. Sie stehen mittels der Raphe miteinander in Verbindung. Diese Raphe stellt einen scharf geknickten Spalt dar (Querschnitt derselben Fig. 5, oben und unten in der Mittellinie), welche nach LaUterborn die Membran quer durchschneidet, nach FLöGEL aber aufhört, bevor sie die Innenfläche erreicht, so daß der Spalt nach innen zu durch eine feine Membran vom Plasmakörper getrennt ist. Diese Auffassung wird von MüLLER geteilt und scheint auch am besten zu der später zu beschreibenden Funktion der Raphe zu passen. Wir können nun zur leichteren Orientierung das Außenbein des geknickten Raphenspaltes die äußere Spalte, das Innenbein die innere Spalte nennen.

Die Endknoten sind, wie bereits bemerkt, Höhlungen in der Schalensubstanz. In jeder dieser Höhlen befindet sich eine Platte, welche wie das Schraubenblatt einer Dampferschraube gewunden ist, und an ihrer Spitze ein Loch besitzt. Diese durchlöcherte Schraubenplatte wird Trichterkörper genannt, sie ist in der Fig. 149 mit $T$ bezeichnet. An der Außenseite des Endknotens ist die Membran ganz von einer schraubenförmig gewundenen Spalte, der sogenannten Polspalte (siehe Fig. 149 und 150), durchbohrt. Die untere Spalte der Raphe mündet nun so in den Endknoten aus, daß ihre Oeffnung genau der Schraubenplatte gegenüberliegt, die Polspalte ist die Fortsetzung der oberen Spalte der Raphe. Aeußere und innere Spalte der Raphe verändern sich nahe dem Mittelknoten in zwei runde allseitig geschlossene Kanäle, welche sich alsbald $\mathrm{zu}$ einem einzigen Kanal vereinigen, welcher in einer Ringfurche, die sich in dem freien Ende des Zentralknotens befindet, ausmündet (vergl. Fig. 150).

Betrachten wir also die Sache noch einmal von dieser Oeffnung: in der Ringfurche des Zentralknotens ausgehend. Wir kommen dann zunächst in einen Kanal, der sich in zwei Arme spaltet. Der obere Arm mündet in die obere Spalte der Raphe, welche in der Polspalte endet. Diese obere Spalte ist nach oben und unten zu offen, nach oben steht sie mit der Außenwelt in Verbindung, nach unten mit der Innenspalte, und da sie länger ist wie diese, steht dieses längere Stück als Polspalte mit dem Endknoten in Verbindung. Der untere Arm mündet in die untere Spalte der Raphe. Diese steht nach oben mit der äußeren Spalte in Verbindung, ist nach unten zu geschlossen und mündet an ihrem Ende in den Endknoten der Trichterplatte gegenüber aus. Schematisch mag dies so dargestellt werden, wie Fig. 150 angibt. 
Dieser ganze Apparat dient nun der Fortbewegung der Pinnularia. Er funktioniert in folgender WVeise: Plasma tritt in den Kanal des Zentralknotens ein, tritt durch den unteren Seitenarm desselben in die untere Raphespalte ein und durch diese in den Endknoten; dort wird es gegen die Schraubenplatte gespritzt, läuft an dieser hinauf, bis es die Trichterspalte erreicht hat, tritt durch diese hindurch und läuft an der Innenwand des Endknotens hinauf, bis es in die Polspalte gelangt, von wo es nun als feines Plasmamembränchen halb aus dieser Spalte nach außen hervorragend durch den Kanal, in welchen diese obere Raphespalte ausläuft, via Zentralknoten wieder in die Zelle zurücktritt.

Da nun in der unteren Schale die Raphe in gegenseitiger Richtung gekrümmt ist und da die beiden Hälften einer jeden Schale symmetrisch gebaut sind, bilden die Raphenspalten zusammen ein kompliziertes Schraubensystem, welches die hervorragenden Plasmamembränchen zwingen, eine Schraubenbewegung auszuführen. Da nun zwischen dem Plasmamembränchen und dem Wasser genügend Reibung stattfindet, um Fortbewegung zu erlauben, kann unsere Pinmularia sich schwebend im Wasser bewegen, noch besser aber über Schlamm, wo die Reibung größer ist. In unserer Figur 149 sind obere und untere Raphenspalte neben- statt übereinander gezeichnet, was den Schein erweckt, als ständen sie nicht miteinander in Verbindung.

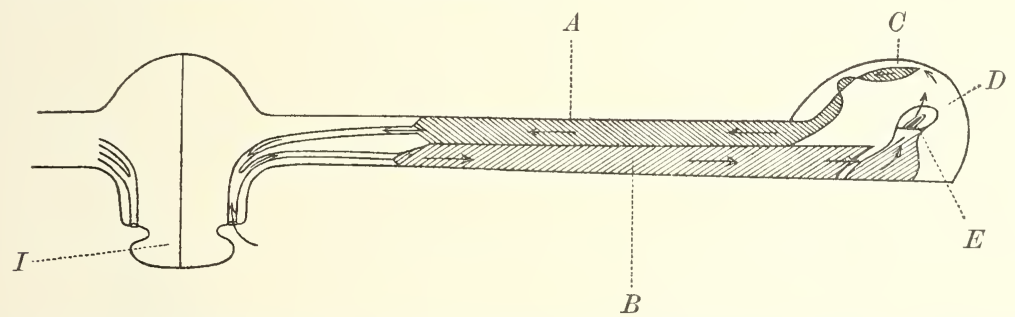

Fig. 150. Schematische Darstellung der Raphe ete. bei Pinnularia. I Mittelknoten, die Linie in der Mitte gibt nur die Mitte der Schale an. $A$ Obere Spalte. $B$ Innenspalte. $C$ Polspalte. $D$ Endknoten. $E$ Trichterkörper.

Früher hat man ganz verschiedene Ursachen für die Fortbewegung. der Diatomeen gesucht und auch jetzt sind die Akten noch wohl kaum als geschlossen zu betrachten. Nan hat gemeint, daß abwechselnde End- und Exosmose die Bewegung verursache, man hat den Schleim, welcher, wie 2, 3 und 4,5 der untenstehenden Figur zeigen, in sehr verschiedener Quantität von der Zelle ausgeschieden wird, für die Bewegung verantwortlich gemacht, aber die MüLLERsche Auffassung der Plasmabewegung ist wohl die wahrscheinlichere und erhält auch durch die Fortbewegung feiner Tuscheteilchen neue Stütze.

Ist kein Schleim vorhanden, so laufen die Tuscheteilchen hart an der Raphe entlang (Fig. 151, 6, 7 rechts); ist Schleim vorhanden, so befinden sie sich in einiger Entfernung von derselben. Dies wird durch die Dünnflüssigkeit des Schleimes möglich gemacht, welcher selber rom Plasmasaum in Bewegung gesetzt wird. Einige Pennaten haben nu auf einer Schale eine Raphe, bei anderen ist sie ganz verschwunden, solche Formen sind unbeweglich geworden, so z. B. die

\section{Angewachsenen Diatomeen,}

welche ja meistens zu dieser reduzierten I'ennaten-Gruppe gehören. Ganz einfache hierher gehörige Formen sind die in der Weise von 
Schildläusen, Algen oder anderen Wasserpflanzen aufsitzenden CocconeisArten. Sie sind nur mit einer ganz dünnen Gallertschicht am Substrat befestigt. Andere dagegen bilden längere oder kürzere Schleimstielchen, welche sich sogar wie bei Licmophora bäumchenartig verzweigen können.

Obenstehendes ist ja nur ein Griff in den Formenreichtum der Diatomeen-Gruppe, wir redeten z. B. gar nicht von kettenförmigen Plankton-Diatomeen, von verschiedenen Arten von Schwebevorrichtungen und von mancherlei anderen Sachen. Ich verweise dafür auf ScнÜтт in Engler und Prantl, auf Oltmanns und auf die Spezialliteratur.

Wir müssen aber, bevor wir von den Diatomeen Abschied nehmen, erst noch den Bau der Energiden und die Fortpflanzung kennen lernen.

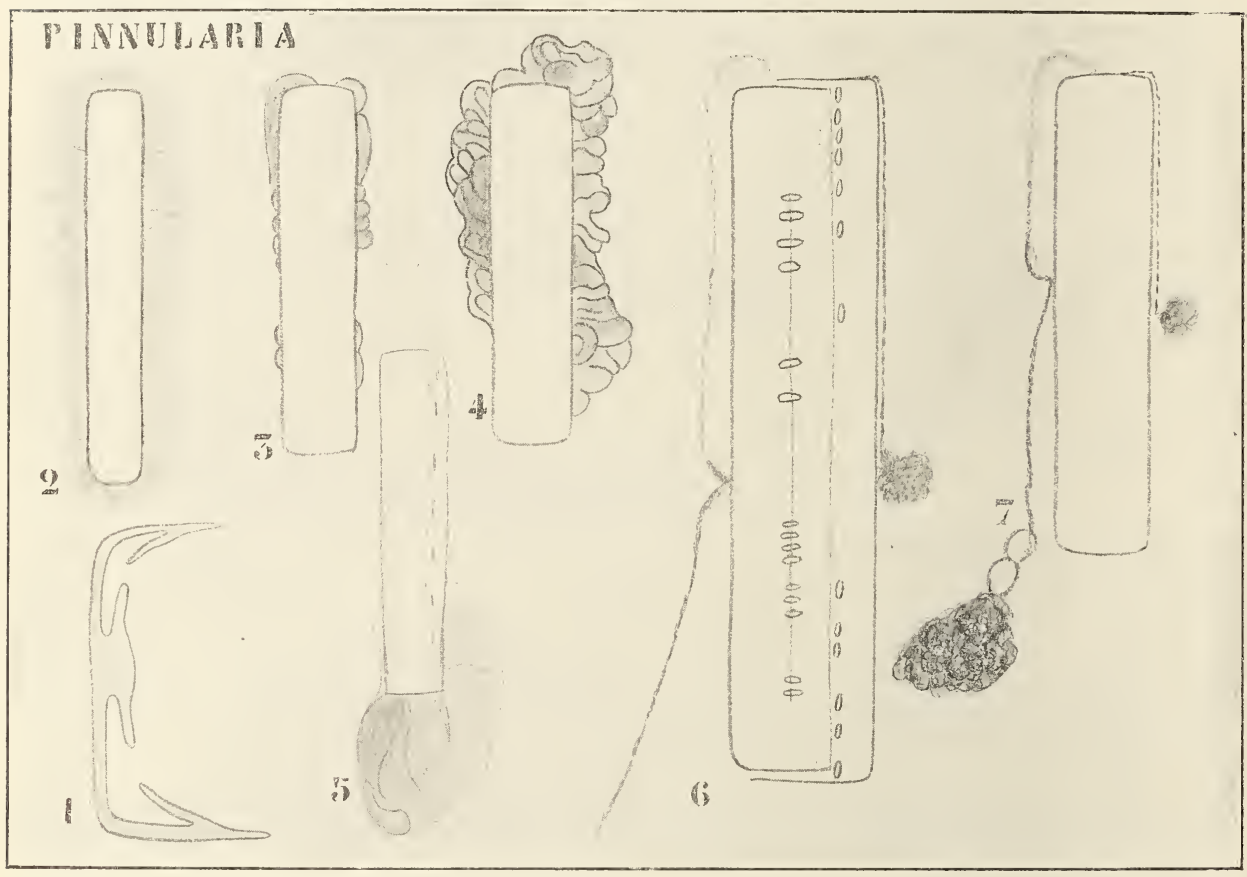

Fig. 151. Pinnularia (nach O. MüLreR). Schleimabsonderung und Fortbewegung von Tuscheteilchen durch den aus der Raphe austretenden Plasmasaum.

Das Plasma ist wandständig und es liegen darin die Chromatophoren. Bei einigen Arten sind dies kleine, mehr oder weniger linsenförmige Plättchen, bei anderen große, bisweilen recht absonderlich gestaltete Platten. Die Farbe ist braun oder gelb, meistens ein eigentümliches Dunkelbraun, welches man Diatomeenbraun nennt. Weiter ist eine Diatomee mit blaugefärbten Plasmaenden von MoLisch (1903) beschrieben worden, die blaue Farbe mag wohl vom Zellsaft, der in kleinen Vakuolen verteilt ist, herrühren. Diese blaue Navicula ostrearia kommt zumal in Austernbassins vor, wo sie das Wasser blau färben kann.

Das erste sichtbare Produkt der Photosynthese ist ein fettes Oel, es gibt aber auch saprophytische Diatomeen, welche sogar ihre Chromatophoren vollständig eingebüßt haben. Recht bemerkenswert ist die Beobachtung Karstens, daß man die Diatomeen durch geeignete Kultur 
zur Reduktion ihrer Chromatophoren und unter anderen Bedingungen wieder zur Regeneration derselben bringen kann.

Im Zentrum der Zelle befindet sich fast stets ein Plasmasäckchen, in welchem der Kern aufgehängt ist, ungefähr in der Weise wie bei Spirogyra.

Der Nucleus ist rund oder nierenförmig und normal gebaut.

GRAM hat bei Rhinosolenia mehrere Kerne in einer Zelle gefunden,

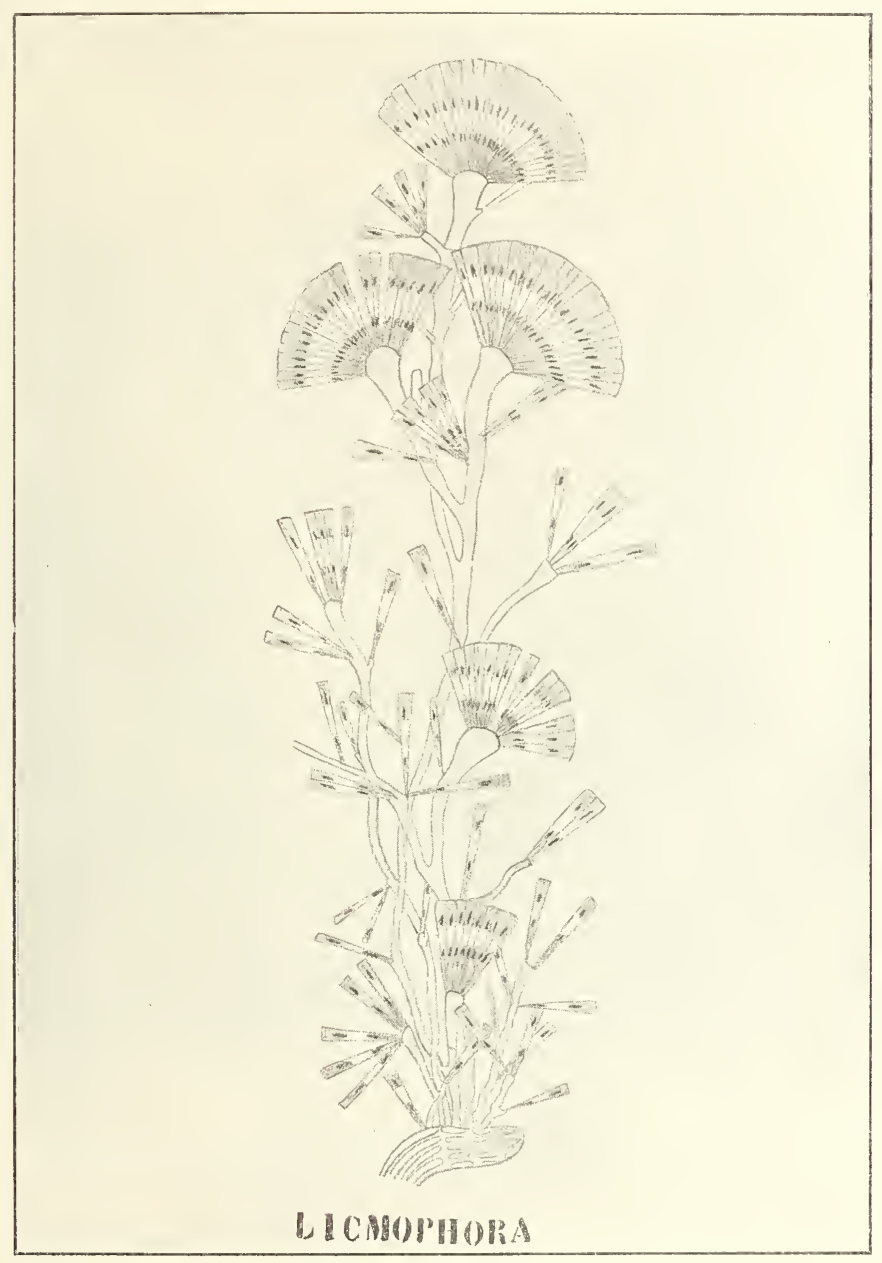

Fig. 152. Li emophora (nach Sмmин).

ich fand dasselbe bei einigen Plankton-Diatomeen der Siboga-Expedition; es steht dies wahrscheinlich mit der später zu besprechenden Bildung der Mikrosporen in Verbindung. Lauterbors wies die Anwesenheit von Centrosomen nach. Die

$$
\text { Teilung: }
$$

ist durch die Untersuchungen LnUtenborss an Surivella genaner bekannt geworden. 
Surirella calcarata besitzt wandständiges Plasma, das fingerförmige Ausstülpungen in die zentrale Vakuole hineinsendet, und ein großes, flaches, fast $\mathrm{H}$-förmiges Chromatophor. Der Kern ist in einem Plasmasack im Zentrum der Zelle aufgehängt. Das erste Zeichen beginnender Zellteilung ist die Wanderung vom Kernsäckchen nebst Kern in den breiten Pol der Zelle. Dann bildet sich aus dem Centrosom die achromatische Spindel, welche in den Kern eindringt und die Chromosomen nach den Polen hinzieht. Inzwischen entsteht die Teilungswand, zunächst als ein protoplasmatisches Häutchen, welches am schmalen Pole der Zelle anfangend sich nach dem breiten Ende hin fortschiebt und das Chromatophor in der Querbrücke durchschneidet.

In der Plasmalamelle entstehen nun die beiden neuen Hypotheca,

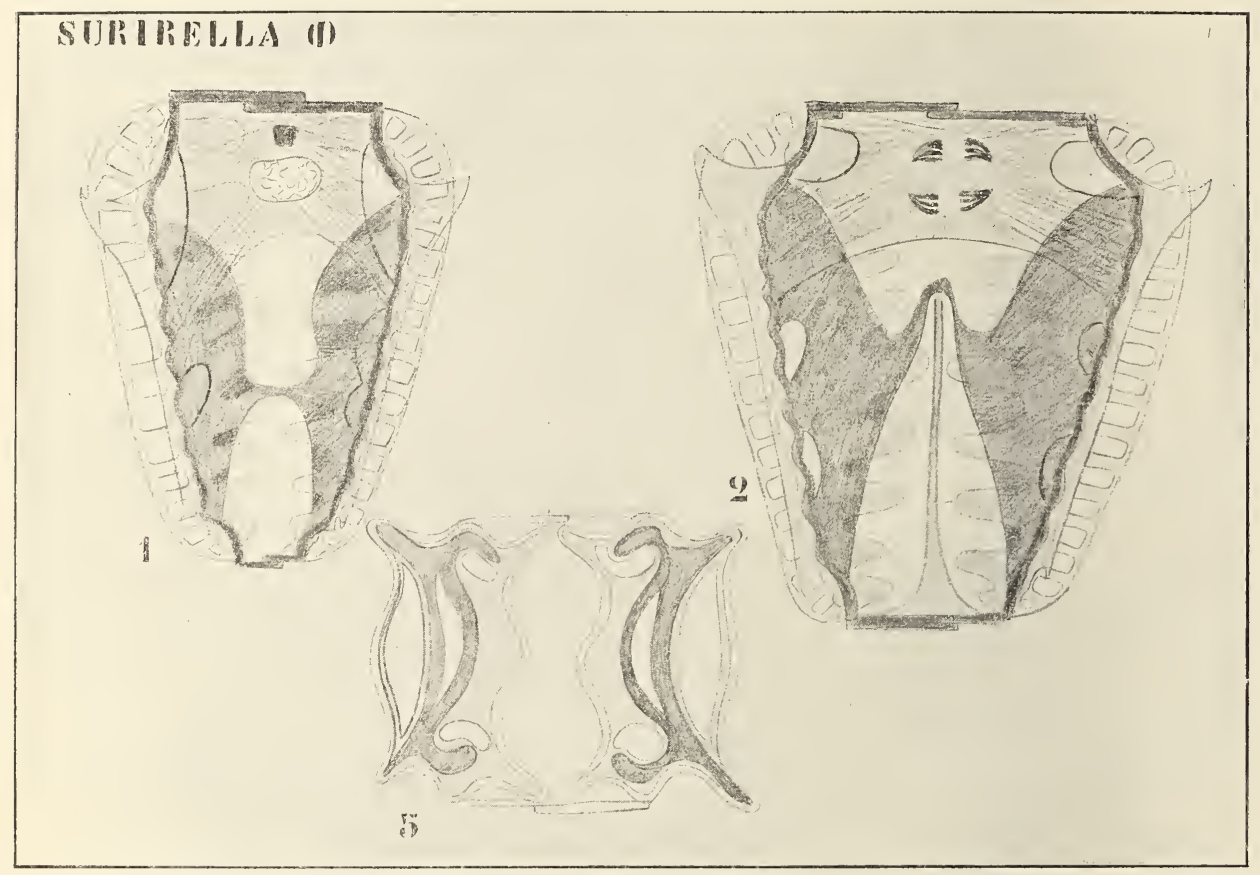

Fig. 153. Teilung von Surirella (nach LAUTERBORN). 1 Der Kern ist an den einen Pol der Zelle gelagert. 2 Der Kern in Teilung, die junge Wand im Begriffe, das Chromatophor zu durchschneiden. Für 3 und 4 siehe Fig. 154. 5 Die Teilung vollendet.

als dünne, flache, richtige Membränchen, welche nachträglich gehörig skulpturiert werden. Die jungen Kerne begeben sich wieder in die Witte der Tochterzellen, die Chromatophoren regenerieren sich und die Gürtel werden, allerdings erst viel später, gebildet. Aus dem Gesagten geht hervor, daß bei den Diatomeen die Hypotheca stets jünger als die Epitheca ist. Die alten Membranen bleiben bis zur völligen Ausbildung der Hypotheca, trotzdem sie auseinander geschoben werden, zusammenhängen, was vermutlich durch Schleim bewirkt wird. Erst nachdem die Hypothecae ganz fertig sind, trennen sich die Tochterindividuen. Die 
Geschlechtliche Fortpflanzung

der Diatomeen findet mittels Auxosporenbildung statt; die Kenntnis dieses Vorganges verdanken wir hauptsächlich KLebahn und Karsten. Recht auffallend bei diesem Vorgang ist die Anwesenheit eines „Kleinkernes" auch bei Formen, welche nicht sexuell sind. Dafür hat OLTMaxrs meiner Meinung nach eine recht hübsche Erklärung gefunden, die hier folgen soll.

Als Typus betrachtet Oltmanns den Vorgang bei

Rhopalodia gibba,

einer Pennate, welche von Klebahn genau untersucht wurde. Die Kopu-

\section{STIRIREILA (2)}
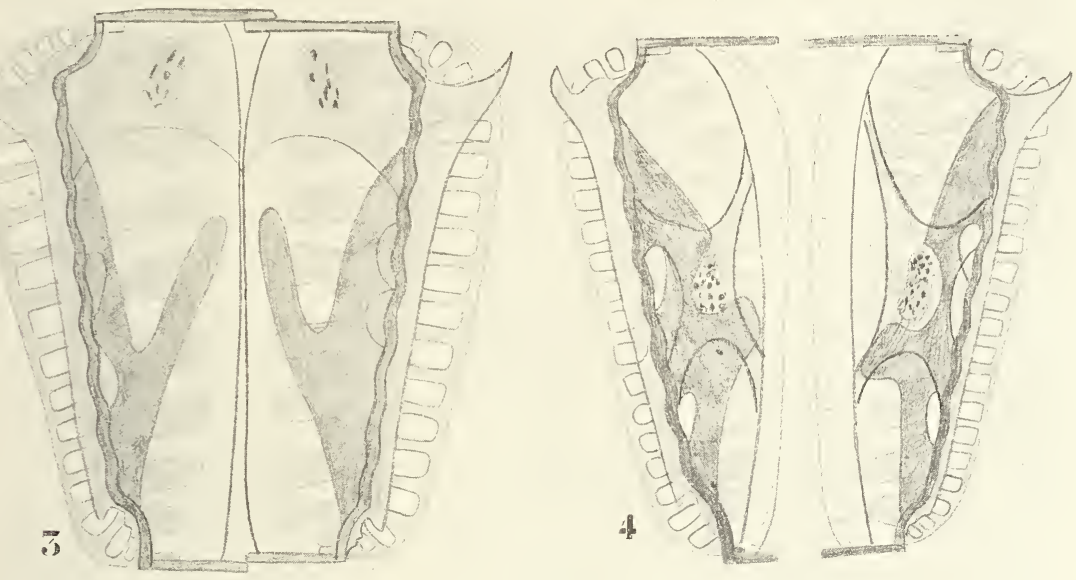

Fig. 154. Surirella." Teilung (nach LAUTERBorN). 3 Abspaltung der jungen Plasmaschicht. 4 Anfang der Bildung der neuen Schalenhälften.

lation fängt damit an, daß sich 2 Individuen mit den Gürtelseiten aneinander legen und sich mittels Schleimausscheidung an den Polen aneinander befestigen (Fig. 155, 1).

Die beiden miteinander kopulierenden Zellen sind öfters sehr rerschieden groß. Jede derselben enthält einen Kern, Chromatophoren und Pyrenoide. In jeder Zelle wird nun Schleim gebildet, wodurch die Schalen sich öffnen und das Plasma kontrahiert wird (Fig. 155, 2): die Plasmamassen legen sich nun aneinander, ohne jedoch zu verschmelzen. In jeder Energide findet nun zweimalige Kernteilung statt, wodurch 4 Kerne gebildet werden, zwei derselben werden aber zu sogenamnten Kleinkernen reduziert (Fig. 155, 3, 4). Danach teilen sich die Plasmamassen in 2 Stücke (Fig. 155, 5). Faktisch bilden sich also in jeder Zelle 
4 Gameten, von denen aber nur zwei zur Entwickelung gelangen, die Anwesenheit der beiden anderen wird nur dadurch verraten, daß jede Gamete den Kern in reduzierter Form als Kleinkern enthält.

Die Gameten verschmelzen nun miteinander (Fig. 155, 6, 7), so daß 2 Zygoten gebildet werden, die Gametenkerne verschmelzen dabei zu den Zygotenkernen, die- Kleinkerne gehen zu Grunde.

Jede Zygote wächst nun alsbald zu einer sogenannten Auxospore aus, welche hier langcylindrisch ist (Fig. 155, 8), es liegen also 2 Auxosporen nebeneinander, und sind von gemeinsamer Schleimhülle umgeben. Die Schalen der kopulierenden Individuen sind inzwischen abgeworfen, bleiben aber öfters an der Auxospore kleben (Fig 155, 8). Jede Auxospore bildet ihre eigene Membran, das sogenannte Perizonium. Das

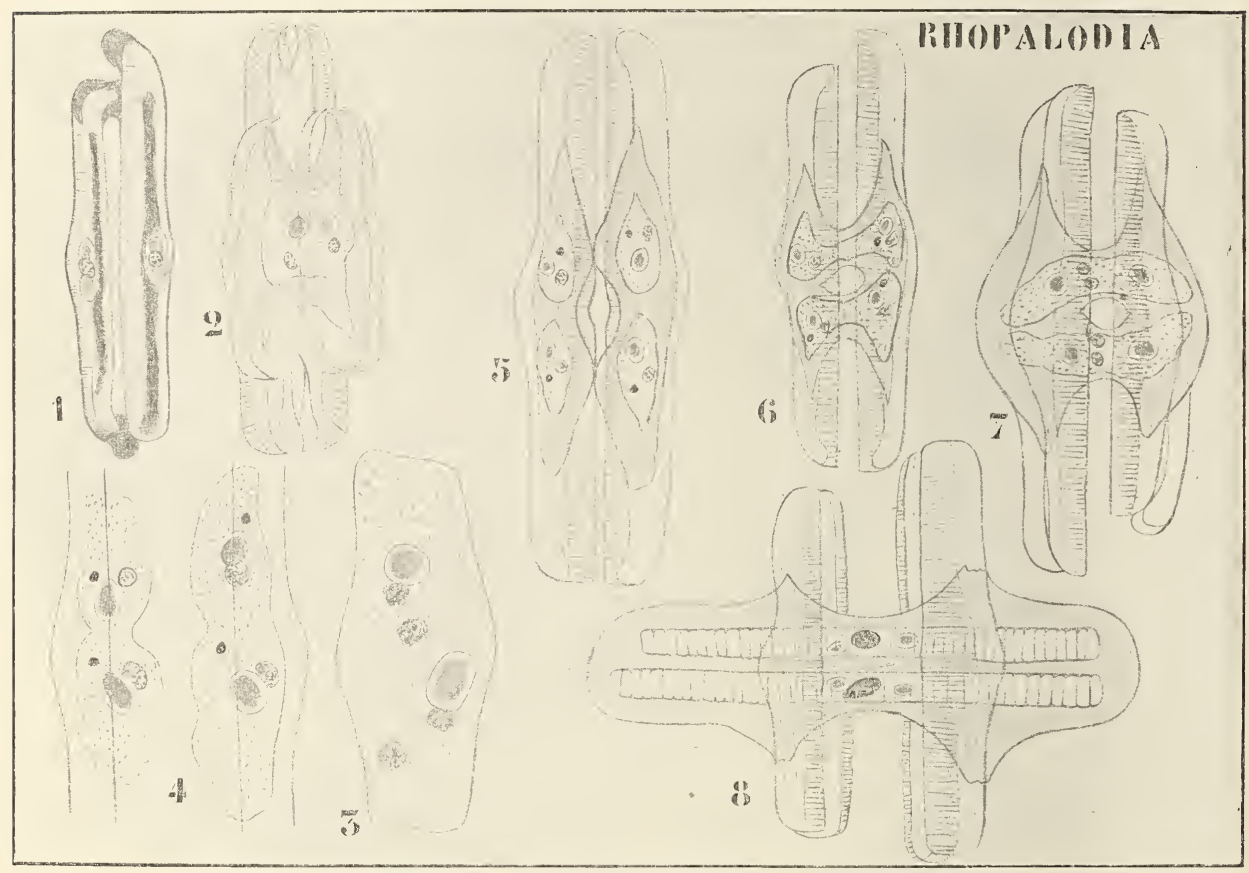

Fig. 155. Kopulation bei Rhopalodia gibba (nach KLEBAHN).

Plasma kontrahiert sich schließlich innerhalb dieses Perizons und bildet die Schalen der jungen Diatomee.

Falls dies richtig wäre, müßte also die Diatomee eine $2 \mathrm{x}$-Generation sein. Da es aber bekannt ist, daß die Auxosporen sich in vielen Fällen teilen können, ist es sehr wohl möglich, daß auch in Auxosporen, welche sich anscheinend nicht teilen, eine Reduktionskernteilung stattfindet.

In diesem Falle wäre der Diatomeen-Körper eine x-Generation. A priori ist nun beides gleich gut möglich. Ist der Diatomeen-Körper eine $\mathrm{x}$-Generation, so findet bei der Gametenbildung keine Reduktionsteilung statt, sondern diese muß in der Zygote stattfinden, ist er aber eine $2 \mathrm{x}$-Generation, so muß die Reduktion bei der Gametenbildung stattfinden und die Vierzahl der Gameten läßt in der Tat daran denken. Eine genaue Untersuchung dieses Punktes wäre sehr erwünscht; aus dem 
soeben Torgetragenen würde man zu der Auffassung hinneigen, daß der Diatomeen-Körper eine 2 x-Generation sei, was der Gruppe eine höhere Stelle im System verschaffen sollte, als ihr hier eingeräumt worden ist. Dagegen zeigen die neuen Untersuchungeu KARstens an Plankton-Diatomeen mit Mikrosporen wieder so sehr an normale Gametenbildung erinnernde Vorgäng'e, daß man den Diatomeen-Körper für eine $\mathrm{x}$-Generation halten muß: wie gesagt, neue Untersuchungen sind abzuwarten.

Bei Surirella ist eine noch stärkere Reduktion bei der Gametenbildung aufgetreten als bei Rhopalodia. Dort werden scheinbar gar keine Gameten mehr gebildet. Es schlüpft die Energide eines jeden Individuums aus ihrer Schale heraus, und beide verschmelzen miteinander.

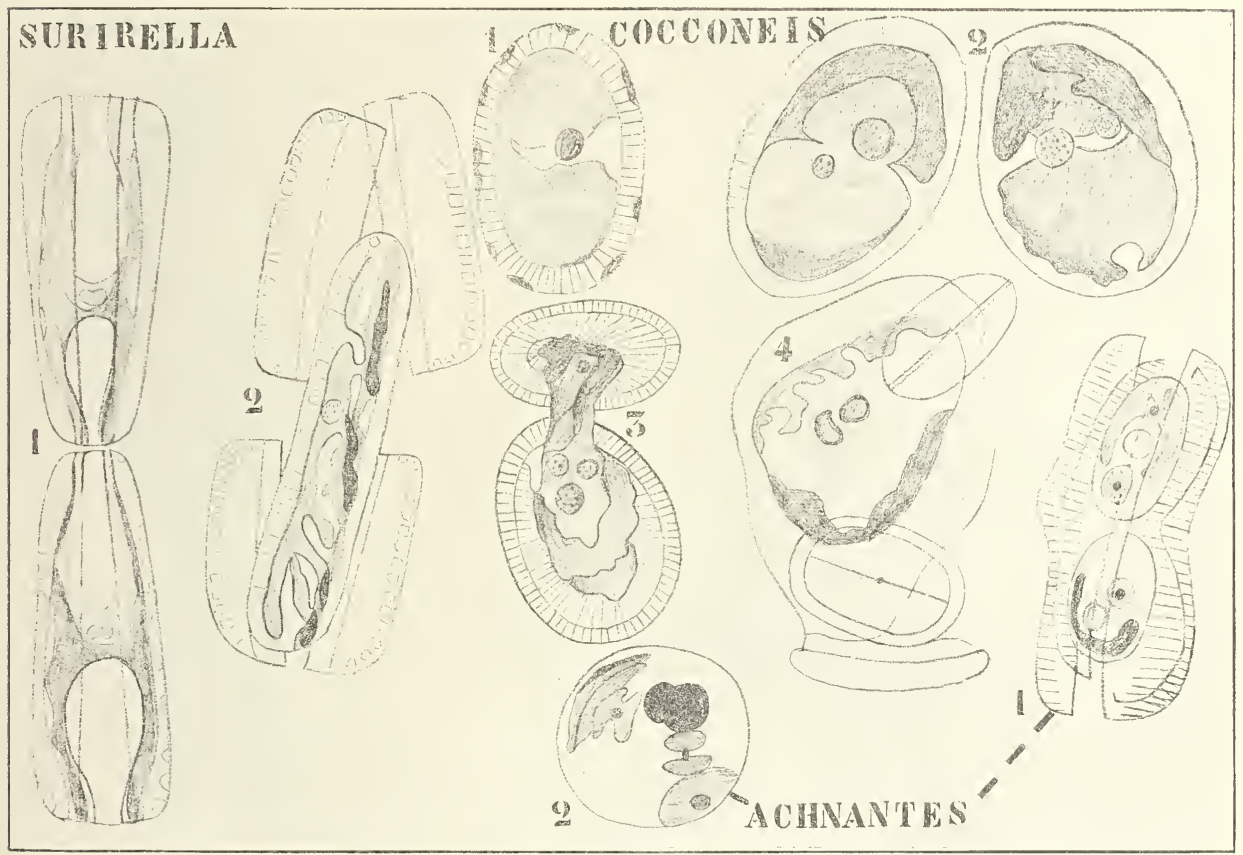
KARSTEN).

Fig. 156. Auxosporenbildung bei mit Namen bezeichneten Diatome en-Genera (nach

Dennoch werden hier zweifellos in rudimento Gameten gebildet. denn auch hier entstehen in jeder Zelle 4 Kerne, von denen aber drei zu. Grunde gehen.

Bei Cocconeis, der Schildlans-Diatomee, verläuft der Vorgang in wieder etwas anderer Weise. Der Kern teilt sich nämlich nur einmal. es werden also nicht 4, sondern 2 Gameten gebildet, und diese nicht einmal vollständig, da wieder der Kern des einen degeneriert. So entsteht also in jeder Zelle eine Gamete. Nun sind die Cocconeis-Arten aber angewachsen; um nun die Kopulation zu ermöglichen. wird zwischen zwei benachbarten Individuen ein Schleimkanal gebildet (Fig. 156, 3). wodurch die Gamete des einen Individums in das andere übertritt und mit der 
dortigen Gamete verschmilzt. Wir haben hier also einen Vorgang, der in gewisser Beziehung an die Kopulation bei Spirogyra erinnert.

Bei Achnanthes findet Kopulation zwischen Schwestergameten statt, in der Zelle werden 2 Gameten (je mit einem normalen und einem Kleinkern) gebildet, welche zusammen zur Zygote verschmelzen (Fig. 156, 1, 2).

Bei Synedra affinis teilt sich der Inhalt der Zelle in 2 Gameten, mit je nur einem Kern. Jede derselben entwickelt sich ohne Kopulation zu einer Auxospore, welche hier also parthenogenetisch entsteht. Zwar kann nachher in der Auxospore der Kern sich, nach Karsten, unter Umständen teilen, da diese Teilstiicken dann aber sofort wieder miteinander verschmelzen, ist dies wohl bedeutungslos.

Auch bei Rhabdonema arcuatum werden 2 Gameten gebildet, dereu

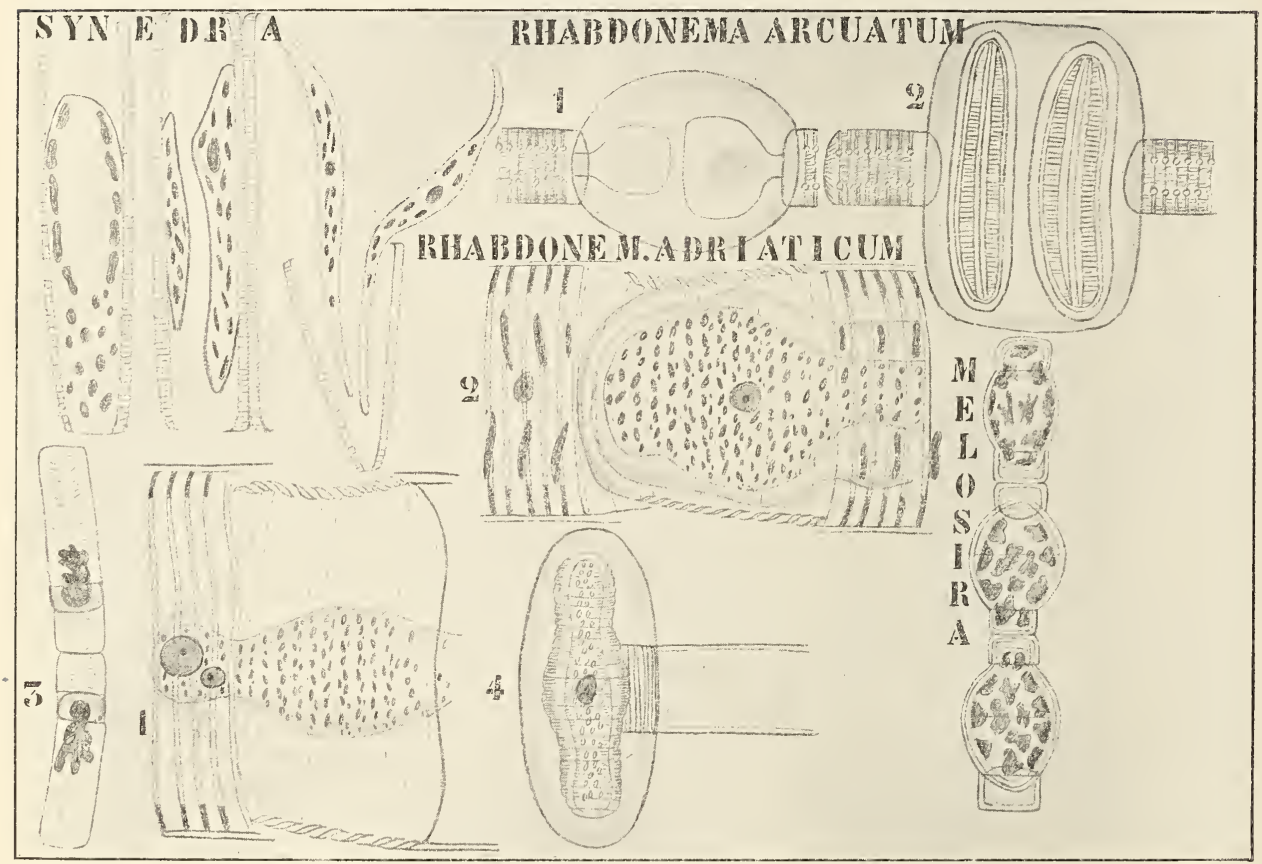

Fig. 157. I. Synedra. - II. Rhabdonema. - III. Melosira.

jede parthenogenetisch eine Auxospore bildet. Bei Rhabdonema adriaticum tritt in soweit Reduktion ein, als die Bildung der beiden Gameten nur durch eine Kernteilung angedeutet ist (Fig. 157, II 1 unten links). Der eine Kern wird nun ausgestoßen (Fig. 157, I[ 2), und die Gamete entwickelt sich parthenogenetisch zur Auxospore (Fig. 157, 3, 4).

Bei Melosira findet sogar keine Kernteilung mehr statt, die ganze Energide tritt aus den Schalen heraus und wird zur Auxospore. Diese Weise von Auxosporenbildung tritt bei vielen Plankton-Diatomeen auf.

Die größte beobachtete Gametenzahl war also vier (bei Rhopalodia), wovon sogar noch zwei reduziert waren. Das gilt aber seit kurzem nicht mehr.

Bei gewissen Plankton-Diatomeen waren von Murray, Gran, Bergen 
und v. BREEMEn sogenannte Mikrosporen nachgewiesen worden, deren Funktion aber völlig unklar war.

Eine recht wahrscheinliche Erklärung dieser Gebilde verdanken wir Karsten (1904). An einer antarktischen Plankton-Diatomee, an Corethron Taldivae, konnte er nachweisen, daß durch successive Zweiteilungen der Kerne (Fig. 158, 1-6) 128 Mikrosporen pro Zelle gebildet werden.

Da das Material in Alkohol konserviert war, konnte natürlich manches nicht nachgewiesen werden, z. B. nicht, ob diese Mikrosporen Cilien besitzen oder nicht. Da sie aber wahrscheinlich Gameten sind, welche nach Austritt aus der Zelle auf offenem Meere kopulieren, scheint mir das eventuelle Vorhandensein von Cilien nicht so unwahrscheinlich wie Karsten, der meint, daß es sich herausstellen wird, daß sie unbeweglich sind. Hoffentlich hat er Unrecht, denn es könnte uns

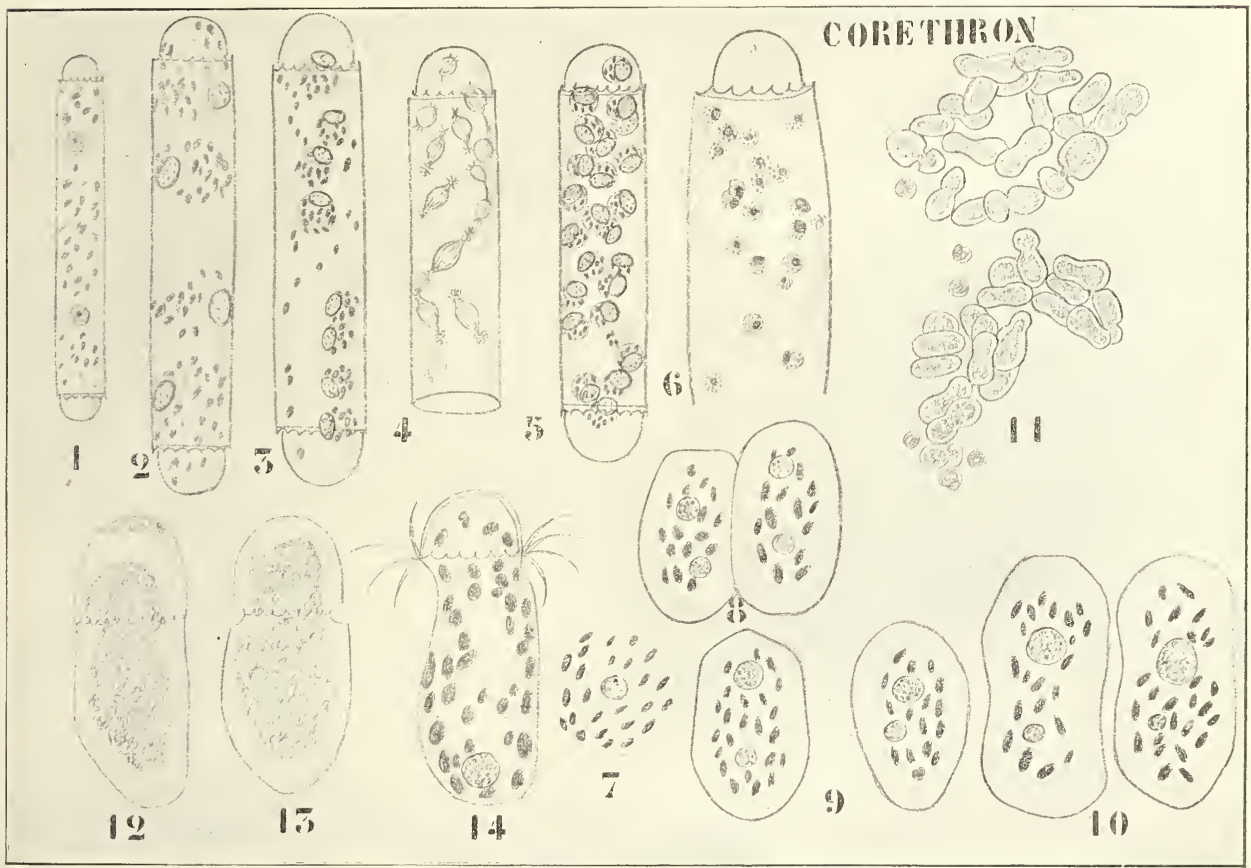

Fig. 158. Mikrosporenbildung und Kopulation bei Corethron Valdiviae (nach Karsten). Figurenerklärung im Text.

die Insertion der Cilien vielleicht über die systematische Verwandtschaft der Diatomeen belehren.

Auch folgendes ist - wie könnte es anders sein bei Alkoholmaterial - zum großen Teile auf Vermutungen basiert, aber so plausibel. daß es mich sehr wundern würde, wenn spätere Untersucher an lebendem Material Karstens Resultate nicht bestätigen würden.

Nach ihm kopulieren je 2 Gameten zu einer Zygote (Fig. 158, 7). In dieser Zygote werden bei der Keimung 4 Kerne gebildet, es entstehen aber nur 2 Keimpflänzchen ursprïnglich mit zwei gleich großen Kermen, dann mit einem Groß- und Kleinkern (Fig. 15s. 10), und schließlich nur mit einem Kern, indem der Kleinkern ganz schwindet. 
Da haben wir also einen Fall wie bei den Desmidiaceen, meiner Anschauung nach ist die Zygote Gonotokont geworden, und die Individuen der Corethron sind $\mathrm{x}$-Generationen.

Daneben kommen parthenogenetische Auxosporen bei Corethron vor, welche durch Ausschlüpfen der ganzen Energide entstehen. Dies dürfte also ein Notbehelf sein. Es ist nicht unwahrscheinlich, daß bei vielen Plankton-Diatomeen Mikrosporen gefunden werden.

Ruhestadien sind z. B. bei Chaetoceras bekannt. Gegen das Ende der Vegetationszeit kontrahiert sich das Plasma der Zellen, umgiebt sich mit einer dicken Kieselmembran und erlaubt ihnen so, ungünstige Umstände zu überleben. Die Keimung solcher Ruhestadien ist unbekannt.

Viele Diatomeen können das Austrocknen ausgezeichnet vertragen. Es zieht sich dabei das Plasma in einer Ecke der Schale zusammen, in diesem Zustande können Diatomeen im Staube der Luft verbreitet werden. Nachdem wir also die niedrigeren Gruppen besprochen haben, wollen wir zur Betrachtung der eigentlichen Braunalgen, zur Gruppe der Phaeophyceen übergehen. 


\section{Zwölfte Vorlesung.}

\section{Phaeophyceae.}

Diese große Gruppe läßt sich nach der Fortpflanzungsweise in 3 kleinere einteilen, nämlich:

A. Zoosporen, daneben Gameten, welche sich wenigstens einige Zeit mittels Cilien bewegen. . .

B. Ungeschlechtliche Fortpflanzung mittels Aplanosporen, geschlechtlich nicht oder unvollständig

bekannt . . . . . . . . . Alinetosporeae

C. Ungeschlechtliche Fortpflanzung mittels Tetra-

sporen oder fehlend, geschlechtliche oogam . Cyclosporeae

Wenden wir uns zunächst der Gruppe der

Phaeosporeae

\section{Phaeosporeae}

zu. Hier können wir mit Outmanss 4 Gruppen unterscheiden:

A. Thallus aus verzweigten Fäden bestehend oder Körper, welche man als aus Fäden bestehend betrachten kann. Längenwachstum meistens interkalar, sehr selten mittels Scheitelzelle
a.) Isogam .
ß) Heterogam

\section{Ectocarpaceate \\ Cutleriacene}

B. Stark und regelmäßig verzweigte Algen, mit auffallend großen Scheitelzellen. Isogam . . .

C. Lederartige Tange, mit stark differenziertem Gewebe. Wachstum interkalar. Zoosporangien von Paraphysen umgeben. Gameten unbekannt.

Sphacelariaceae

Laminariaceae

\section{Eetocarpaceac.}

Ich beabsichtige keineswegs, hier eine auch nur einigermaßen vollständige Uebersicht über diese Gruppe zu geben, sondern beschränke mich auf jene Formen, welche an unserer Küste vorkommen oder welche zum Verständnis der Gruppe notwendig sind. Mit einigen kleinen $A b$ weichungen schließe ich mich dabei an OLtunanss' Auffassung an, welche sich wieder zumal auf Untersuchungen von Resnke, Kuckuck und KJELLMAN stützt.

Ein gutes System läßt sich noch kaum geben, dazu ist zumal die Kenntnis der Keimpflänzchen noch zu gering. Folgende Uebersicht. der' Oltmannsschen Behandlung entlehnt, mag das Verständnis erleichtern. 


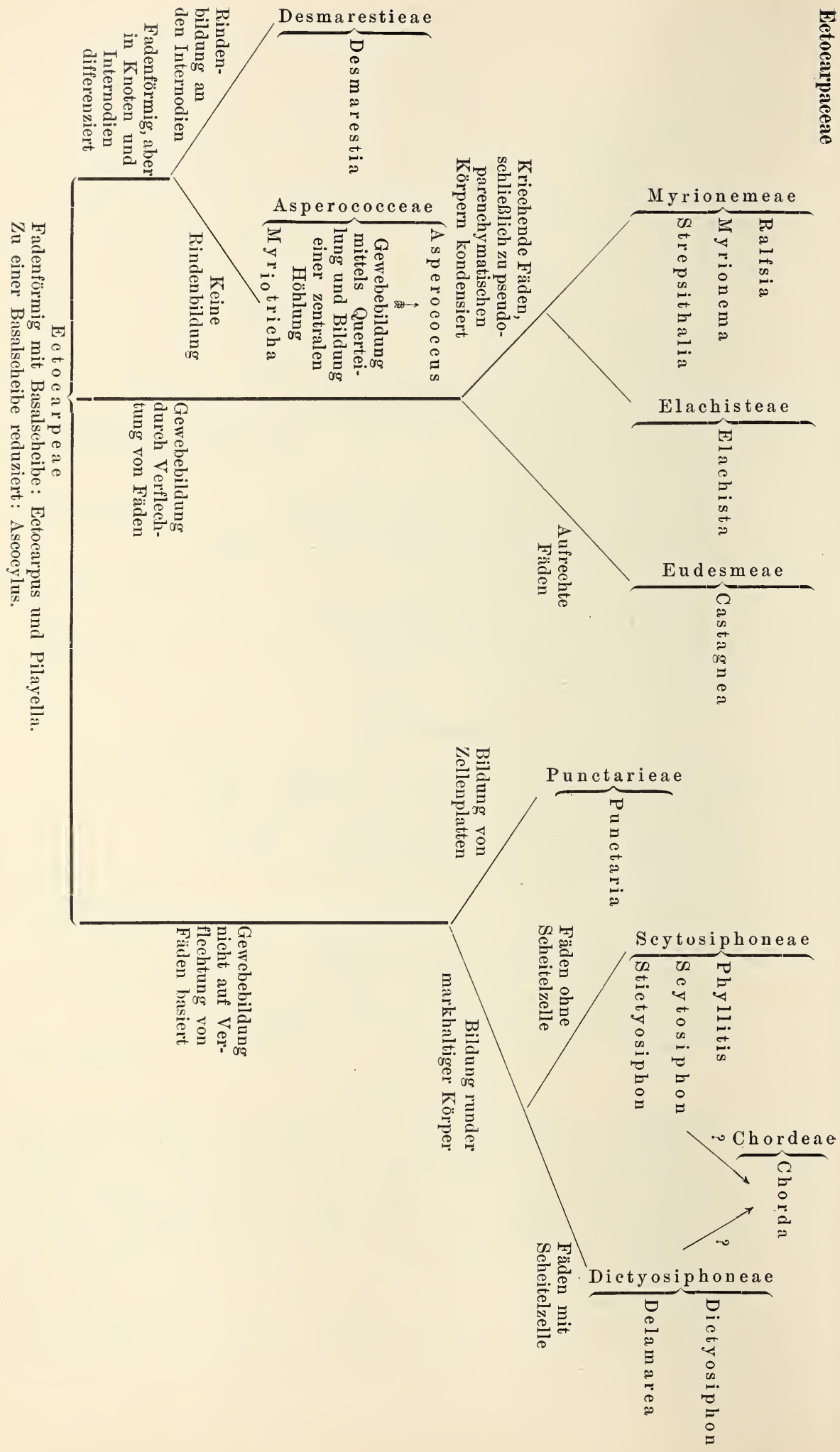


Als einfachste Gruppe ist die der Ectocarpeae zu betrachten. Sie besteht aus verzweigten Fäden und aus reduzierten scheibenförmigen Epiphyten. Die übrigen Gruppen werden, wie umstehendes Schema angibt, von dieser Gruppe abgeleitet.

Betrachten wir also zunächst die Gruppe der

\section{Ectocarpeae.}

Ihre Vertreter sind mit einer einzigen Ausnahme marin. Es liegt nicht in meiner Absicht, die ganze Gruppe mit Ihnen zu behandeln, ich beschränke mich auf zwei Genera: Ectocarpus und Ascocychus.

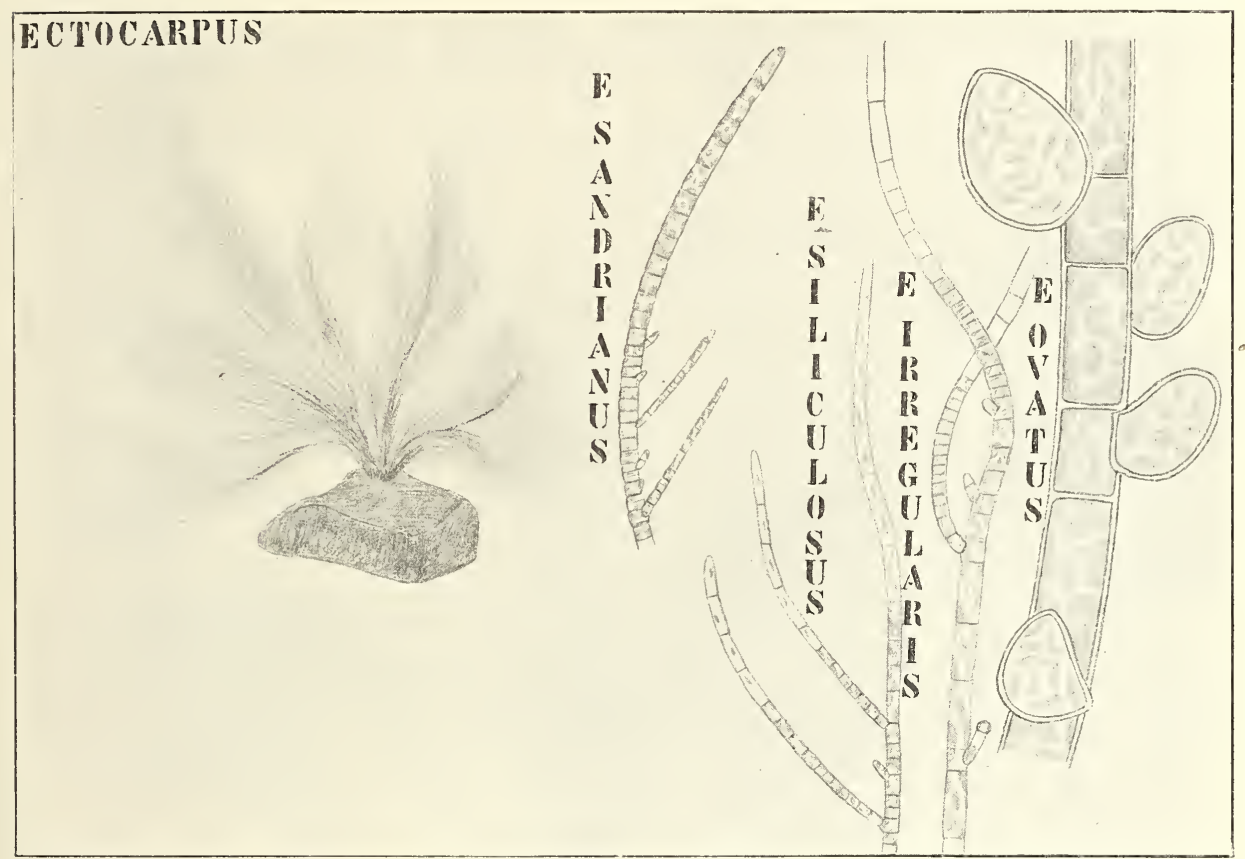

Fig. 159. I. Ectocarpus spec. Habitusbild. - II. E. sanderianus. - III. E. siliculosus. - IV. E. irregularis. Zuwachszonen (nach KuckUCK). - V. E. ovatus. Unilokuläre Sporangien (nach KUCKUCK).

\section{Eetocarpus}

kommt wohl in allen Meeren vor, weit mehr aber in nördlichen als in südlichen. Das Genus umfaßt 30-40 schwer zu unterscheidende, d. h. stark variierende Arten. Die Pflänzchen erinnern sehr an Cladophoren (Fig. 159, I), sind aber nicht grïn, sondern gelbbraun. Sie bilden aus kriechenden Zweigen ein Scheibchen, das loser oder fester zusammengesetzt ist, und an die Scheiben der Chactophoraceen erinnert. Daraus erheben sich aufrechte meistens stark verzweigte Zellfäden. Die Zellen sind monoenergid, das Plasma stark vakuolisiert und ein oder mehrere Chromatophoren sind vorhanden. Die Fäden enden in einer spitzen Zelle oder in einem farblosen Haare, hierin erimnern sie ebenfalls an die Chactophoraceen. 
Das Wachstum findet bei verschiedenen Arten in verschiedener Weise statt. Bei niedrigen Formen, z. B. bei E. sanderianus, findet es durch willkürliche Teilung der Zellen statt, ohne daß man von einer Scheitelzelle oder von einer bestimmten interkalar gelegenen Wachstumszone reden kann. Bis an die Spitze der Fäden sind die Zellen regelmäßig mit Chromatophoren versehen.

Bei anderen, z. B. bei E. siliculosus, findet das Wachstum in ähnlicher Weise statt, aber die der Spitze des Fadens benachbarten Zellen wachsen bedeutend in der Länge, ohne ihre Chromatophoren zu vermehren. Dadurch entstehen hellgefärbte haarähnliche Spitzen.

Bei wieder anderen, z. B. bei E. irregularis, finden wir ein typisches trichothallisches Wachstum, d. h. wir beobachten in jedem Zweige eine interkalar gelegene Wachstumszone, welche nach unten hin normale Thalluszellen, nach oben aber mehr oder weniger farblose Haare bildet. Schließlich fand Kuckuck bei einer Höhlenbewohnerin von Helgoland, bei Ectocarpus lucifugus, Scheitelzellenwachstum nebst sparsamen interkalaren Teilungen. Die kriechenden Zweige dagegen wachsen bei allen Ectocarpen mittels einer Scheitelzelle.

Die Fortpflanzung findet mittels Sporangien und Gametangien statt. Sporangien und Gametangien finden sich bei Ectocarpus auf den gleichen Individuen und zwar werden stets zuerst Sporangien gebildet und dann Gametangien. Anscheinend werden Gametangien gebildet, wenn die Lichtintensität zunimmt, also im Winter meistens Zoosporangia, im Frühjahr die Gametangien. Da also die Zoosporangien sozusagen von den Gametangien abgelöst werden, gibt es selbstverständlich eine Zeit, in welcher erstere noch nicht verschwunden, letztere aber schon erschienen sind, dann findet man beide auf ein und demselben Exemplar.

Das Zoosporangium von Ectocarpus, ein junger umgebildeter Seitenzweig (vergl. Fig. 159 E. ovatus), ist einzellig. Je nachdem die Thalluszellen ein oder mehrere Chromatophoren enthalten, enthält auch das junge Sporangium deren ein oder mehrere. Aber in beiden Fällen findet nebst Kernteilung auch Chromatophorenteilung statt, so daß sogar, wenn die vegetative Zelle nur ein Chromatophor enthält, das ältere Sporangium deren viele aufweist (vergl. Fig. 160 E. lucifugus).

Nach einiger Zeit findet man an jedem Chromatophor einen braunroten Fleck (vergl. Fig. 160 E. lucifugus), das spätere Stigma. Dann werden ebenso viele Schwärmsporen gebildet, als Kerne vorhanden sind, welche durch die verschleimende oder aufreißende Spitze des Sporangiums heraustreten. Die Zoosporen besitzen zwei seitlich inserierte Cilien, deren eine nach vorne, deren andere nach hinten gerichtet ist. Sie heften sich mit der vorderen und längsten Cilie an irgend einem Substrat an (vergl. Fig. 160). Alsbald schwillt die Spitze der Cilie zu einem kleinen Scheibchen an und der Zoosporenkörper wird dem Substrat genähert, indem die Cilie eingezogen wird, d. h. mit dem Körper verschmilzt; später verschmilzt auch die hintere Cilie mit dem Zoosporenkörper, dieser umgibt sich mit einer Membran und keimt zu einem neuen Pflänzchen aus.

Gametangien oder, wie man sie noch allgemein nennt: plurilokuläre Sporangien, entstehen ebenfalls als kurze Seitenzweige, aber es werden darin zahlreiche Querwände gebildet, wodurch die Zweiganlage in eine Anzahl von scheibenförmigen Zellen geteilt wird. Jede dieser scheibenförmigen Zellen wird nun durch Längswände in eine Anzahl von 
Kammern geteilt. Jede der so gebildeten kleinen Zellen enthält einen Ker'n und ein oder mehrere Chromatophoren. Da in jeder Zelle nur eine Gamete gebildet wird, besitzt auch diese ein oder mehrere Chromatophoren.

Um die Gameten herauszulassen werden die Wände des Gametangiums von der Spitze anfangend bis zur Basis fortschreitend nach und nach gelöst, die Gameten verlassen das zusammengesetzte Gametangium also durch eine Oeffnung in der Spitze (vergl. Fig. 160 E. siliculosus). Bei Ectocarpus Reinboldii aber entläßt jede Zelle ihre Gamete durch eine eigene seitliche Oeffnung (vergl. Fig. 160).

Die Gameten von Ectocarpus siliculosus kopulieren leicht zusammen, wenn man nur Gameten, die von verschiedenen Exemplaren herrühren,

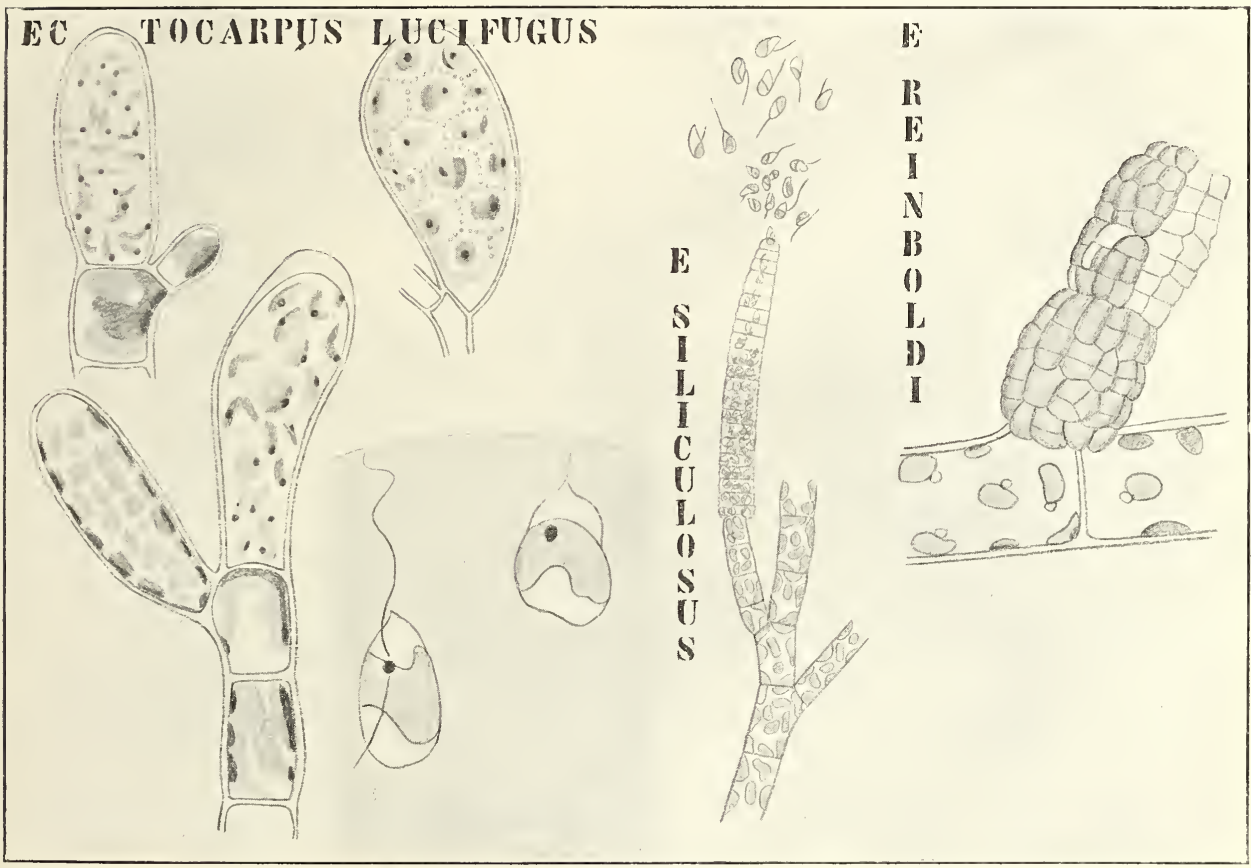

Fig. 160. Sporangien, Zoosporen, Gametangien und Gameten bei Ectocarpus (nach THuRet und KUCKUCK).

beieinander bringt. Dies wurde von BERTHOLD nachgewiesen und von Oltmanns bestätigt.

Man isoliert dazu einige Exemplare in gesonderten Glasgefäßen und wartet das Austreten der Gameten, welches in Neapel im März und April zwischen 9 und 10 Uhr morgens stattfindet, ab. Bringt man nun Gameten verschiedener Exemplare in einen Hängetropfen, so sieht man alsbald einige derselben sich an der Lichtseite des Tropfens festsetzen (vergl. Fig. 161).

Es sind dies die weiblichen Gameten. Zahreiche mämnliche sammeln sich nun um diese herum an, sie sind ebenso groß wie die weiblichen und berühren diese mit der Spitze ihrer vorderen Cilie (vergl. Fig. 161). heften sich mit dieser an sie an, und pendehn hin und her. Alsbald 
fängt einer der männlichen Gameten an, seine Cilie einzuziehen, nähert sich dadurch dem weiblichen und verursacht damit das sofortige Fortschwimmen der übrigen männlichen Gameten. Dieser eine nähert sich dem weiblichen mehr und mehr und verschmilzt mit ihm zur Zygote. Die Kerne verschmelzen dabei miteinander, die Chromatophoren nicht. Falls letzteres richtig ist, muß entweder die Hälfte der Chromatophoren zu Grunde gehen oder aber die erste Teilung der Zygote für deren

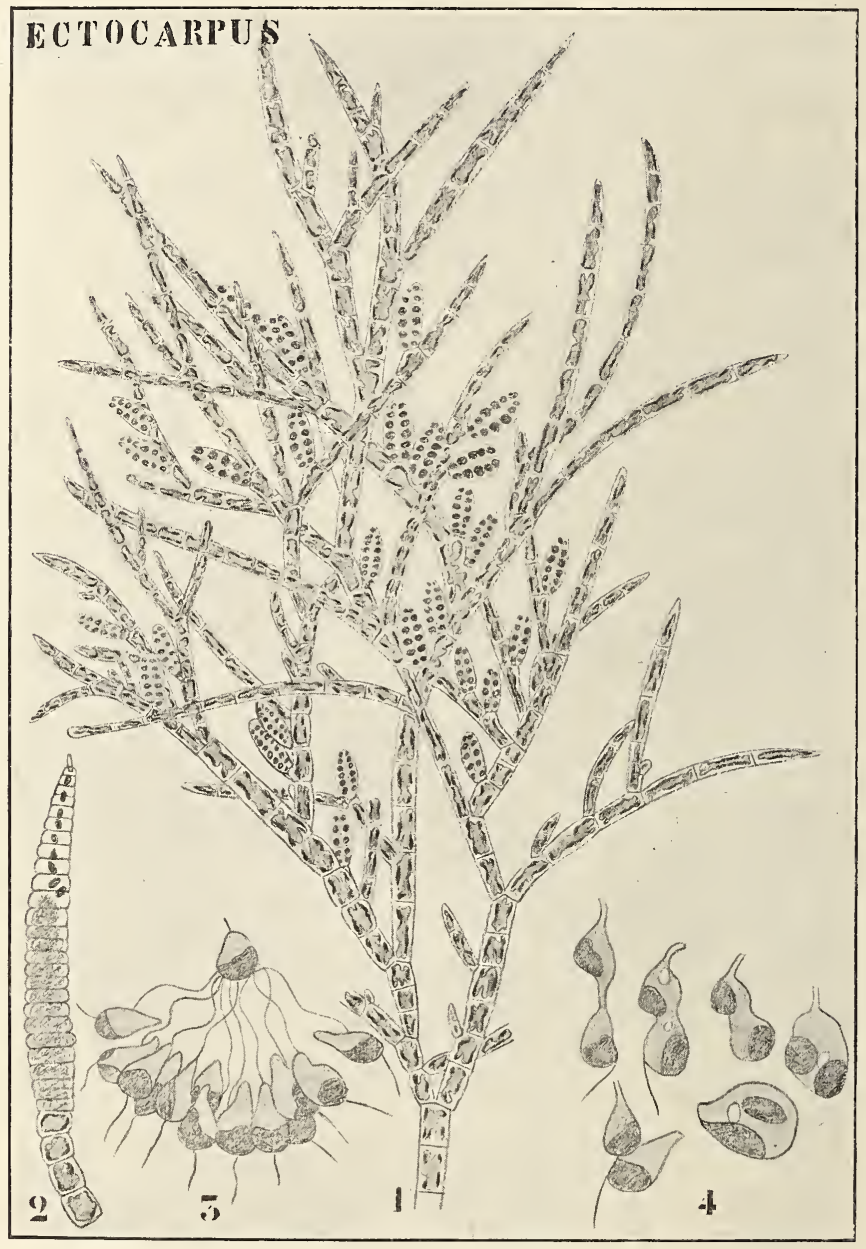

Fig. 161. Ectocarpus spec. 1 Habitus eines Zweiges mit Gametangien. 2 Gametangium. 3-4 Kopulation der Gameten (nach BERTHOLD).

Verteilung sorgen, sonst würde das aus der Zygote entstandene Exemplar einer Art mit einem Chromatophor pro Zelle, deren zwei haben. Ueber die Cytologie der Keimung ist leider nichts bekannt.

Wir haben hier, also morphologisch gesprochen, mit einer Kopulation von Isogameten zu tun, physiologisch gesprochen aber mit einer von Eiern und Spermatozoen. Bei Ectocarpus (Giffordia) secundus (Fig. 162) sehen wir auch schon eine morphologische Differenzierung in den Gameten, 
ja sogar schon in den Gametangien auftreten. Auf dem gleichen Exemplare werden dort nämlich zwei Arten von Gametangien gebildet: dunkelbraune mit relativ großen Kammern und hellgelbe mit sehr kleinen Kammern, von welchen erstere Makio-, letztere Mikrogameten liefern.

Oltmanss macht darauf aufmerksam, daß die Möglichkeit nicht ausgeschlossen ist, daß bei Ectocarpus neben Gametangien auch plurilokuläre Sporangien vorkommen, welche neutrale Schwärmer liefern, die nie kopulieren. Er meint, daß es sich herausstellen wird, daß diese Schwärmer nicht parthenogenetisch sich entwickelnde Gameten, sondern Zoosporen sind, wir würden dann bei Ectocarpus etwas ähnliches, wie die Makro- und Mikrosporen von Ulothrix haben. Gewisse Ectocarpi bilden statt Zoosporen Aplanosporen.

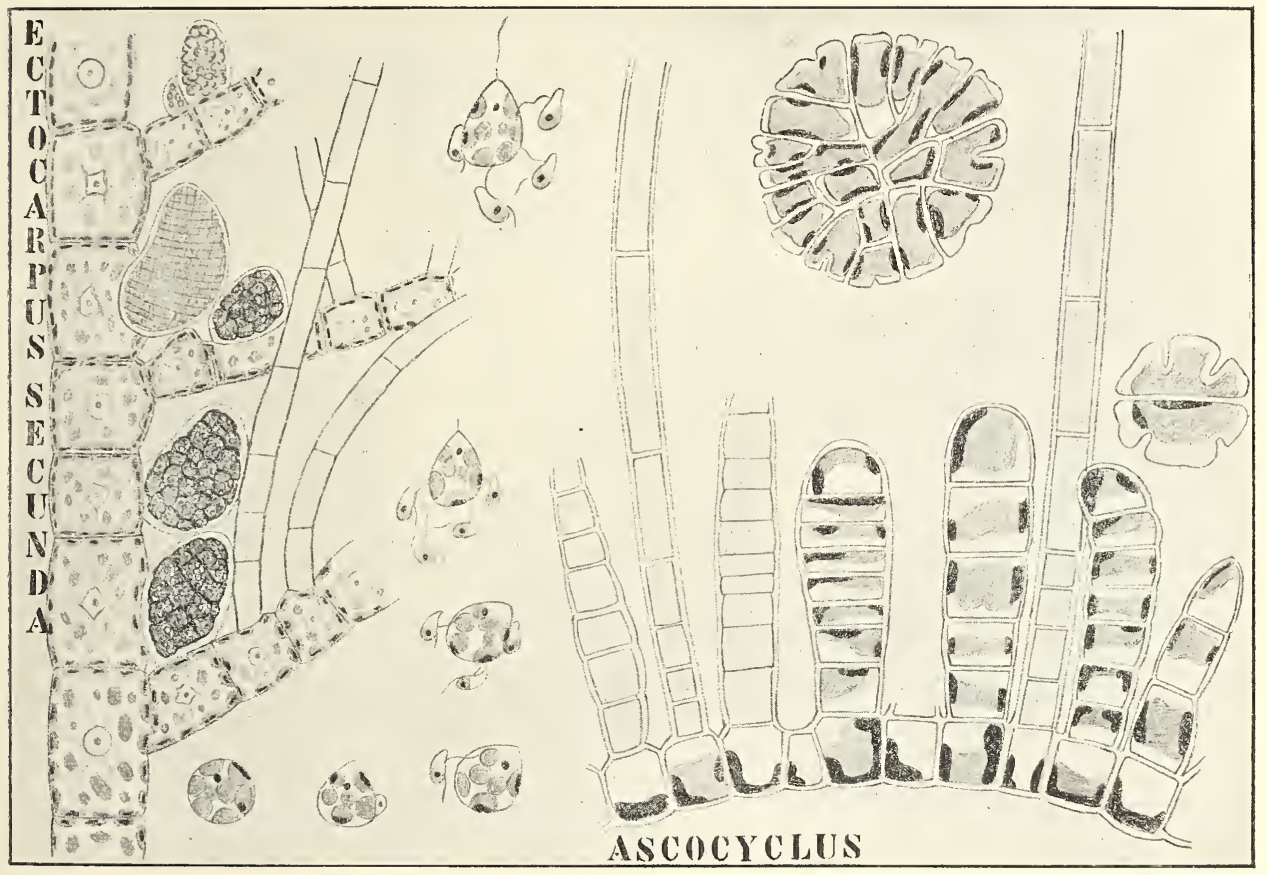

Fig. 162. I. Ectocarpus secundus (nach Bornet und SAuvageau). Makro- und Mikrogametangien, Makro- und Mikrogameten. - II. A s co cy cl us s e c u n d us (nach REINKE). Oben: Zwei Scheiben verschiedenen Alters, von oben gesehen. Unten: Querschnitt durch eine Scheibe mit Gametangien und Haaren.

Wir machten schon früher auf den Parallelismus aufmerksam, der in gewissem Sinne zwischen den Ectocarpcen und Chactophoraceen besteht. Das zeigt sich auch darin, daß auch bei den Ectocarpeen zu einer Scheibe reduzierte Formen vorkommen, welche an Coleochaete scutata erinnern. Ein Beispiel davon liefert das Genus Ascocychs, welches an den Küsten des Atlantischen Ozeans, z. B. auf Helgoland, und im Mittelmeer rorkommt.

Die vermutlichen Gameten, welche bei Ascocychus in ziemlich einfachen Gametangien (vergl. Fig. 162) gebildet werden, flachen sich sofort nach ihrer Anheftung ab und bilden Ausstülpungen, welche sich 
schließlich zu scheibenförmigen Thallomen entwickeln. An der Unterseite dieser Scheibchen bilden sich dann Gametangien und Haare.

Die normalen Ectocarpeae sind also reichlich verzweigte braune Algen, bei welchen man aber nicht zwischen Internodien und Knoten unterscheiden kann. Das kann man wohl bei den Familien der Desmarestieen und Asperococcaceen, welche ich hier zusammen behandle, ohne damit sagen zu wollen, daß zwischen ihnen eine nahe genetische Verwandtschaft besteht.

Betrachten wir zunächst von der Familie der Desmarestieae das Genus

\section{Desmarestia.}

Eine der Arten, Desmarestia aculeata, kommt z. B. bei Helgoland vor und ist an gewissen Stellen der Ostküste von Amerika in solchen

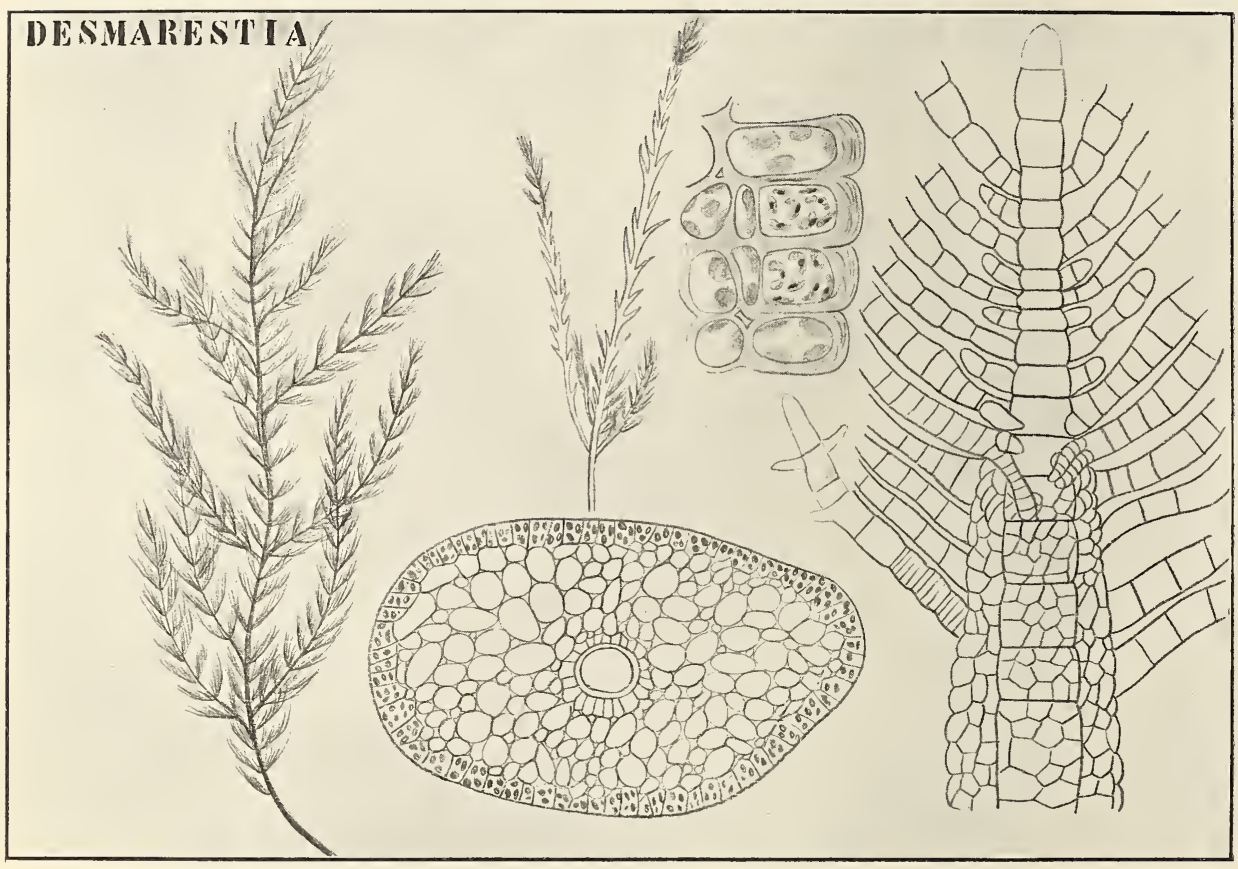

Fig. 163. Desmarestia aculeata (nach Reinke und OLtmanns). Links: ein Exemplar im Frühjahr; rechts: ein Stück der wachsenden Region. In der Mitte unten: Querschnitt, die Rinde zeigend, oben links: Exemplar im Herbst, rechts: unilokuläre Sporangien.

Mengen vorhanden, daß sie zur Düngung benutzt wird. Gut entwickelte Exemplare können eine Länge von 2 Metern erreichen.

In erwachsenem Zustande kann man Lang- und Kurztriebe unterscheiden, beide stehen in zweizeiliger Anordnung an der Hauptachse und tragen Bündel brauner Fäden. Jedes dieser Büschel besteht aus einem Hauptfaden mit zweizeilig gestellten unverzweigten Seitenfäden (vergl. die rechte Figur), welche opponiert stehen, und zwar bildet jede Zelle des Hauptfadens 2 Seitenfäden an ihrem oberen Ende. Der obere Teil einer jeden Zelle des Hauptfadens fungiert also als Knoten, der untere als Internodium. Die Seitenfäden bilden alsbald an ihren 
basalen Zellen Fäden, welche an dem Hauptfaden entlang herunterwachsen und so die aus mehreren Schichten zusammengesetzte Rinde bilden. Die äußeren Schichten dieser Rinde enthalten normale Chromatophoren und beteiligen sich lebhaft an der Photosynthese, die inneren werden farblos. Von den Seitenfäden geht eine Anzahl bald zu Grunde und wird abgeworfen, das zurückbleibende Stümpfchen wird von der wachsenden Rinde überwallt, andere aber bleiben bestehen, indem sie einen interkalaren Vegetationspunkt bilden, der sie wenigstens so viel herausschiebt als die Rinde an Dicke zunimmt (z. B. der Faden links unten an der rechten Figur). Diese Fäden liefern die späteren Kurztriebe; einige wenige auch Längstriebe.

Mittels einer interkalaren Zone im Hauptfaden können nachträglich Seitenfäden eingeschoben werden.

Die Pflanzen sind in der Regel mehrjährig. Im Sommer werden die Fadenbüschel abgeworfen und es zeigen sich die Kurztriebe als Dornen (vergl. Fig. 163). Im Januar werden die Fadenbüschel neu gebildet. bekannt.

Bis jetzt sind nur unilokuläre Sporangien als Fortpflanzungsorgane

Die zweite Gruppe der Braunalgen, welche eine Differenzierung in Knoten und Internodien aufweist, aber nichts der Rinde von Desmarestia Vergleichbares bildet, ist die der

\section{Asperococceae.}

Als einfachste Form derselben betrachte ich mit Kuckuck Myriotricha, und ich folge überhaupt der Darstellung in seiner 1899er Arbeit.

\section{Myriotricha repens (HAUCK) KARs.}

ist eine bei Rovigno im adriatischen Meere häufige Alge, und wurde dort von Kuckuck näher untersucht.

Die keimende Spore bildet auf dem Thallus von Scytosiphon adriaticus zunächst einen kriechenden wenig verzweigten Faden (Fig. 164, 1), welcher zwischen den Rindenzellen der Scytosiphon hindurchwächst, wobei er genau den Grenzen der Zellen folgt. Dieser kriechende Faden wächst mittels einer Scheitelzelle. Von ihr aus streben Zweige vertikal aufwärts. Sie entstehen als Ausstülpungen einer Zelle des kriechenden Fadens, welche sich alsbald mit einer Querwand von der Initialzelle trennen. Dann teilt sich jede mittels einer neuen Querwand in eine obere und eine untere Zelle. Die untere wächst nun viel schneller als die obere, so daß eine chromatophorenreiche kleine obere Zelle von einer langen glashellen, viel weniger gefärbten unteren Zelle getragen wird. Die untere Zelle teilt sich nicht mehr, die obere macht schnell einige Teilungen durch und bildet zu gleicher Zeit ein farbloses Haar. Die unteren Zellen werden nun recht breit, während die Haarzellen schmal bleiben (Fig. 164, 7, 8, 9). Später verlieren die weiter nach unten liegenden Zellen ihr Teilungsvermögen und das IVachstum wird auf das obere Drittel des Fadens beschränkt, auch werden einzelne Längswände gebildet (Fig. 164, 4). Die Fäden verzweigen sich nicht, die scheinbaren Seitenfäden sind Haare.

Die Fortpflanzung findet mittels unilokulärer und plurilokulärer Sporangien statt, welche meistens auf verschiedenen. bisweilen aber auch auf denselben Fäden vorkommen. Die Sporangien entstehen an 
kurzen Zellen, welche auf gewisse Entfernungen voneinander im Faden gebildet werden, so entsteht eine scharfe Differenzierung in kurzzellige fertile Knoten und langzellige sterile Internodien (Fig. 164, 3, 4, 5, 6). Die plurilokulären Sporangien, vermutlich Gametangien, bestehen aus 6-8 reihenförmig angeordneten Zellen. Plurilokuläre Sporangien sind auf die aufrechten Fäden beschränkt, unilokuläre kommen auch wohl an den kriechenden vor (Fig. 164, 2).

Eine andere Art:

\section{Myriotricha protasperococcus BeRTHOLD}

war nur recht unvollständig bekannt, als KuckUcK sie bei Rovigno neu entdeckte und näher untersuchte.

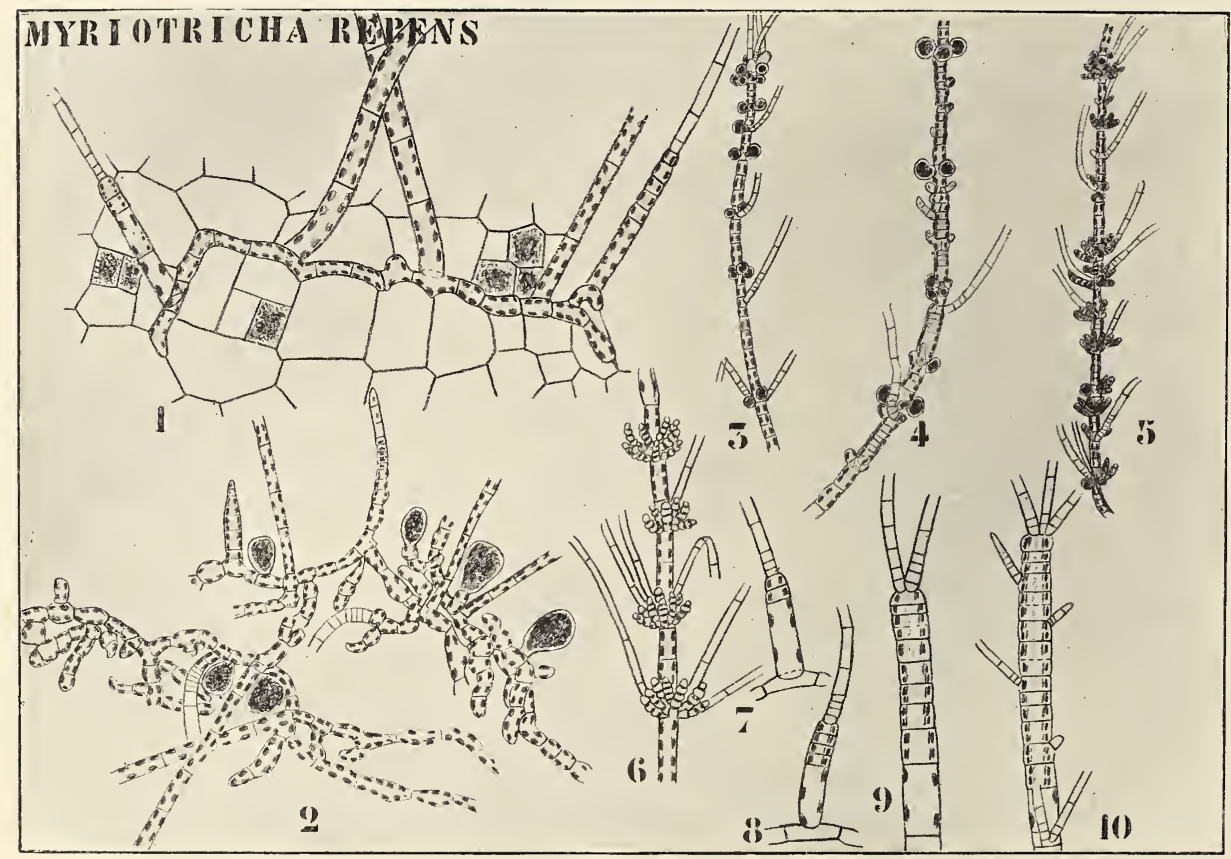

Fig. 164. Myriotricha repens (nach KUCKUCK). Figurenerklärung im Text.

Die ersten Stadien entsprechen genau denen von $M$. repens (Fig. 165, 1, 2), die Längswände treten aber viel ausgiebiger auf, so daß statt eines Fadens ein körperliches Gebilde entsteht (Fig. 165, 6, 12). Auch hier bleiben die Pflänzchen unverzweigt, und auch hier erhalten wir eine Differenzierung in fertile Knoten und sterile Internodien (Fig. 165, 10). Junge fertile Knoten können aber in den Internodien gebildet werden, werden also zwischen den alten eingeschoben.

Betrachten wir zunächst die Entstehung der plurilokulären Sporangien. In den Knoten, welche öfters nur aus einer Zelle bestehen, aber auch 2-4 Zellen hoch sein können, treten zunächst zwei Längswände auf, welche die Knotenzelle in Quadranten zerlegen (Fig. 165, 4), darnach werden antikline Wände gebildet (Fig. 165, 5) und alsbald entsteht durch Bildung von tangentialen Wänden eine zentrale Gewebs- 
masse von einem Mantel kleiner flacher Zellen umgeben (Fig. 164, 8). Diese M[antelzellen können öfters noch durch horizontale Wände zerteilt werden. Oefters stellt dieser Mantel schon den plurilokulären Sporangiensorus dar (Fig. 165, 7, 9). Bei kräftiger fruktifizierenden Exemplaren aber bildet der plurilokuläre Sporangiensorus mehrerere Schichten um die zentrale Partie herum (ein Anfang in Fig. 165, 9), und in extremen Fällen können die plurilokulären Sporangien stark hervorragen (Fig. 165, 13).

Die unilokulären Sporangien entstehen in ähnlicher Weise aus dem Mantel der vielzellig g'ewordenen Knotenzelle, sie bilden öfters eine Stielzelle (Fig. 165, 6, 12, 14). Die Pflanzen mit unilokulären Sporangien zerlegen später auch ihre Internodienzellen vielfach in ähnlicher

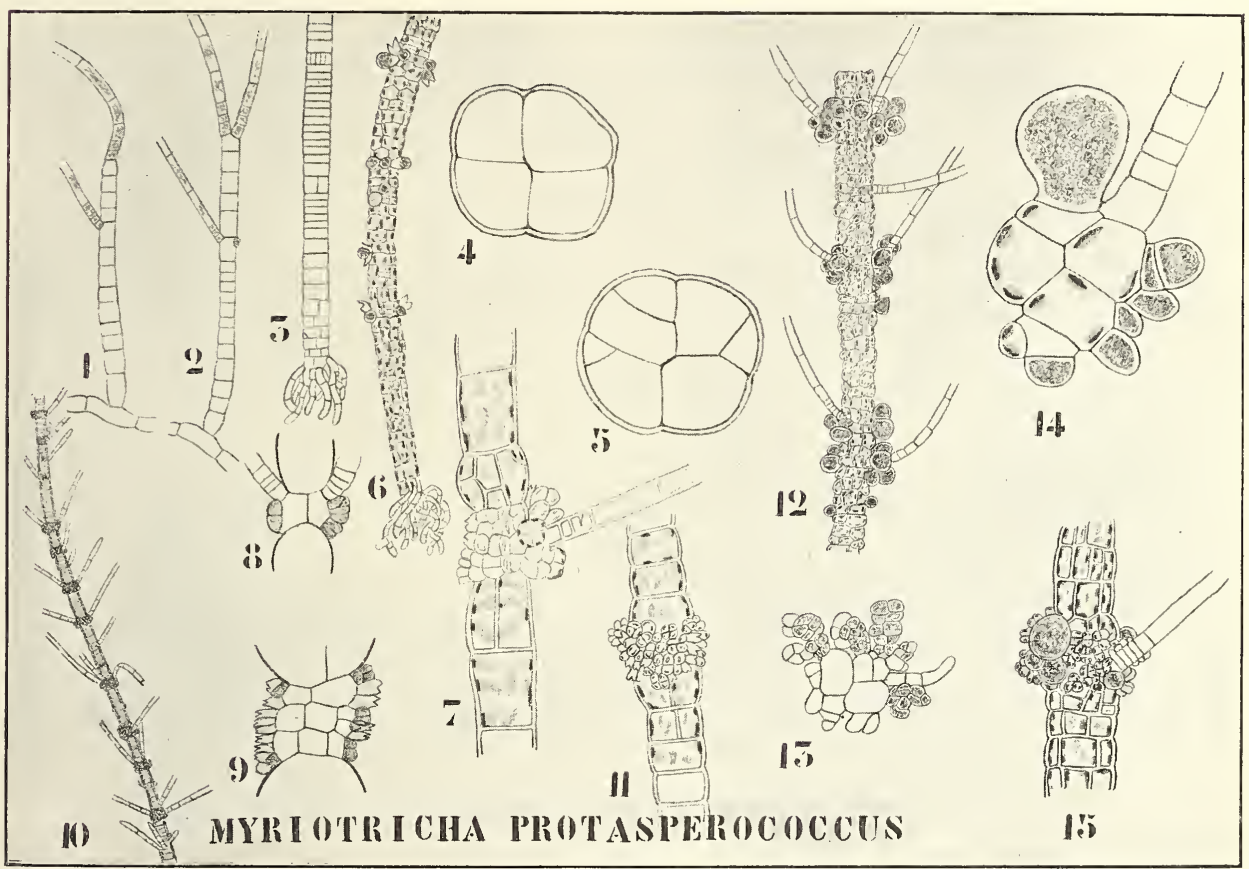
im Text.

Fig. 165. Myriotricha protasperococeus (nach KUCKUCK). Figurenerklärung

Weise wie die Knotenzellen in einen zentralen Gewebeteil und in einen Mantel.

Zoosporen und Gameten sind nicht bekannt, wahrscheinlich sind die unilokulären Sporangien Zoosporangien, die plurilokulären Gametangia.

An Myriotricha protasperococcus läßt sich sofort das Genus

\section{Asperococeris}

anschließen und zwar mittels des ebenfalls von Kuckuck untersuchten

Asperococcus scaber.

Auch diese Art kommt bei Rovigno vor. Kucruck nahm sie mit nach Helgoland und kultivierte sie dort weiter. 
Während bei Myriotricha die aufrechten Fäden an kriechenden gebildet werden, entstehen sie hier auf einer basalen Scheibe; das ist aber keineswegs bei allen Asperococcen der Fall, bei A. bullosus z. B. entsteht der Körper der Alge so wie bei Myriotricha auf einem kriechenden Faden.

Die erste Entwickelung entspricht der von Myriotricha (Fig. 166, 4-6), alsbald aber tritt in allen Zellen des Körpers Gewebebildung auf (Fig. 166, 7), wodurch das Fadenstadium auf immer verlassen wird. So entsteht ein zentraler Gewebskörper, der aus 4 Zellreihen gebildet ist und eine kleinzellige Rinde (Fig. 166, 7, 3). Die Sporangien entstehen als Ausstülpungen der Rindenzellen, von welchen sie durch eine Querwand getrennt sind, sie besitzen also eine Stielzelle. Unilokuläre und plurilokuläre entstehen in ähnlicher Weise (Fig. 166, 9, 10), nur

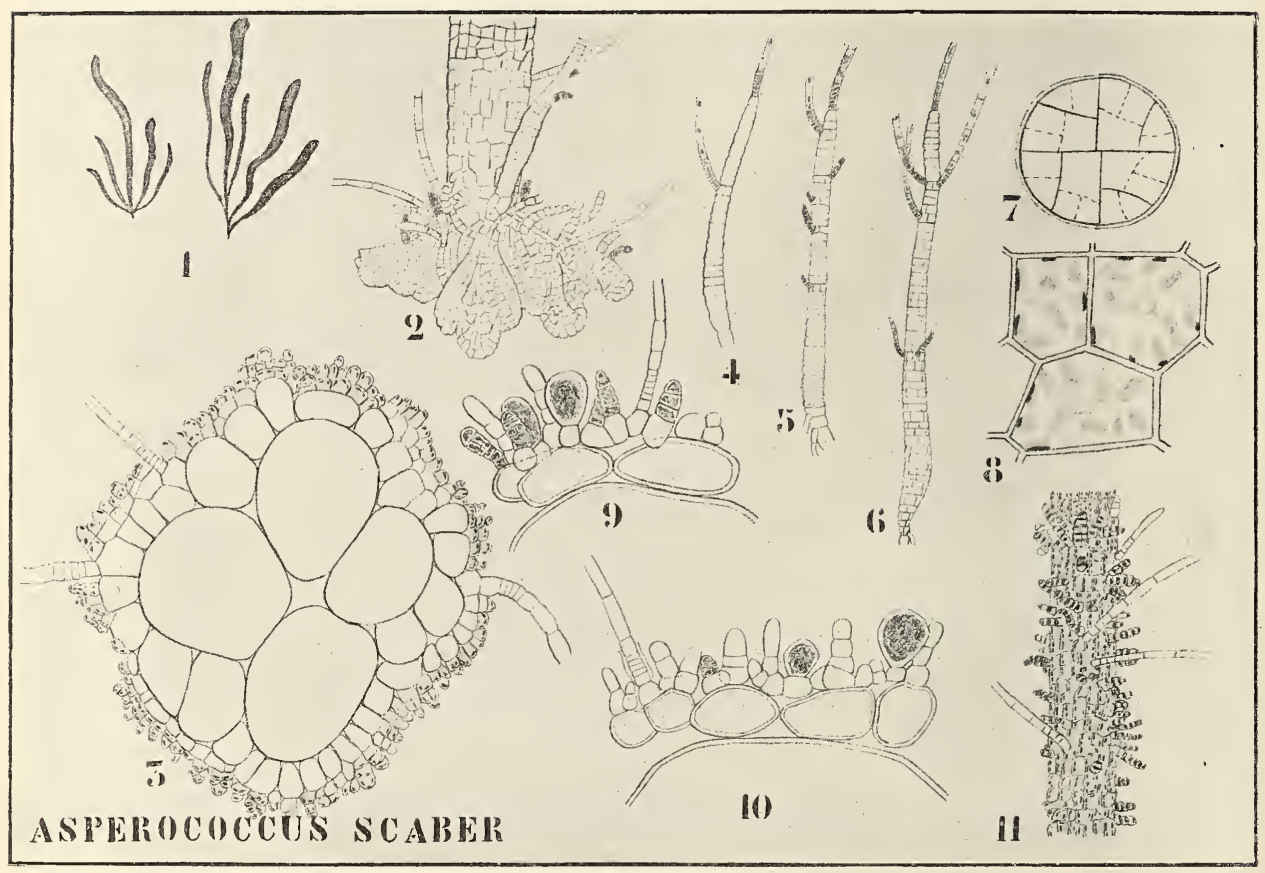

Fig. 166. Asperococeus scaber (nach Kuckuck). 1 Habitusbild. 2 Basalscheibe. 4-6 Junge Individuen. 7, 3 Gewebebildung in den Zellen. 8 Rindenzellen von der Fläche gesehen. 9, 10 uni- und plurilokuläre Sporangien. 11 Fruktifizierendes Exemplar.

werden die plurilokulären selbstverständlich mehrzellig. Auch hier sind vermutlich die unilokulären: Zoosporangien, die plurilokulären: Gametangien. Auch auf der basalen Scheibe werden bisweilen plurilokuläre Sporangien gebildet.

Asperococcus bullosus, eine Mittelmeerform, die viel größer ist als A. scaber, bildet ihren Gewebskörper genau in derselben Weise wie A. scaber.

Da aber die zentralen Zellen auseinander weichen und viele in der Rinde radiäre Wände auftreten, entsteht ein sackförmiger Thallus von ansehnlicher Größe (bis zu $20 \mathrm{~cm}$ ) (Fig. 167), während A. scaber höchstens $2 \mathrm{~cm}$ hoch wird. 
Die aus den unilokulären Sporangien entschlüpfenden Schwärmer keimen ohne Kopulation, sind also wohl Zoosporen. Sie bilden kriechende Fäden, an welchen später, wie gesagt, die Asperococcus-Körper entstehen. Während bei A. scaber auch noch plurilokuläre Sporangien gefunden werden, sind diese bei $A$. bullosus, bis jetzt wenigstens, noch nicht g'efunden worden.

Gehen wir jetzt zur Betrachtung jener Gruppe über, deren Gewebebildung auf einem Verflechten von Fäden beruht. Die einfachsten Vertreter dieser Gruppe sind die

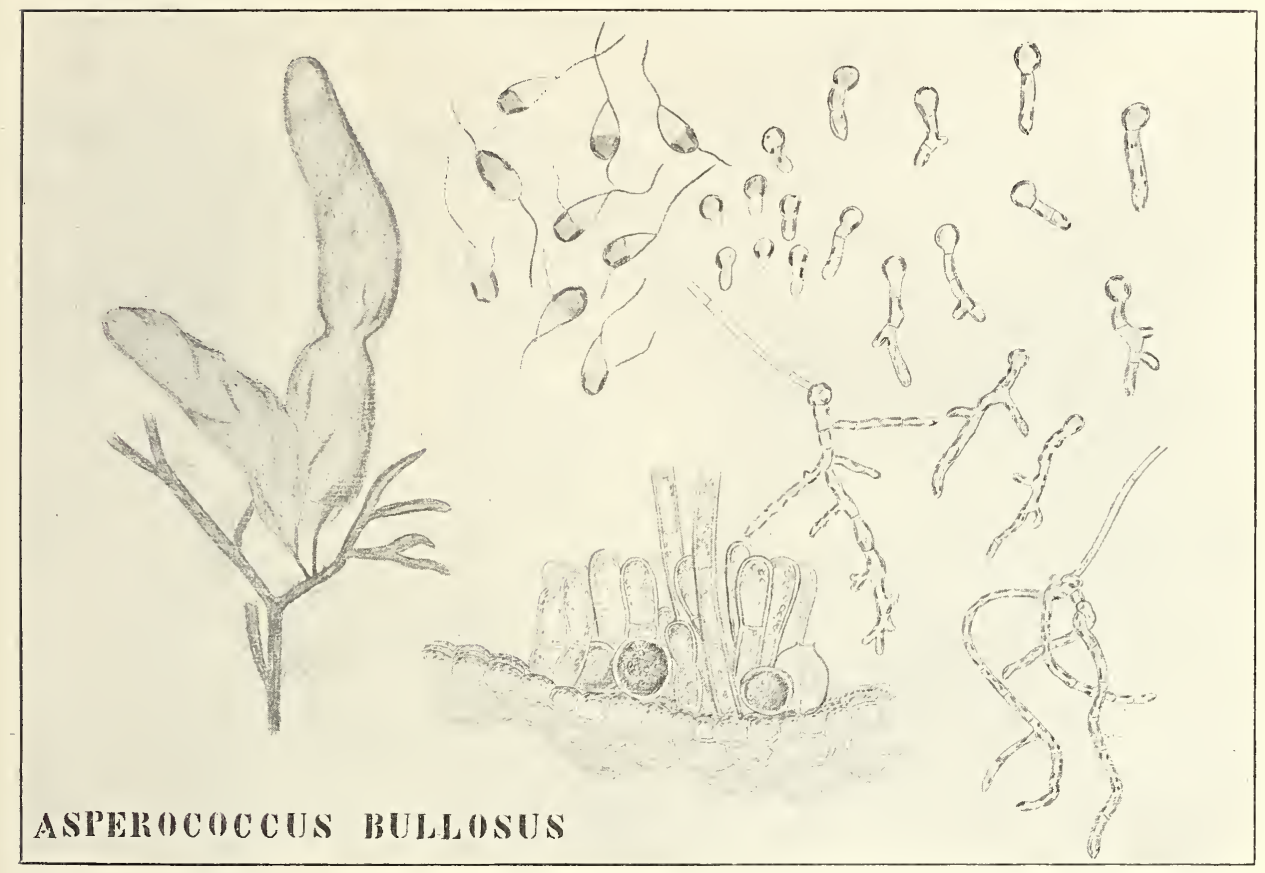

Fig. 167. Asperococeus bullosus (nach Bornet und Thuret). Links: 2 Exemplare auf einer Floridee. Zoosporen, Keimpflänzchen und Zoosporangia.

\section{Myrionemeae}

eine Familie, in welcher kriechende Fäden schließlich einen pseudoparenchymatischen Körper bilden. Als einfachste Form gilt hier

\section{Strepsithalia,}

ein auf anderen Algen kriechendes Pflänzchen. Die reich verzweigten kriechenden Fäden bilden später aufrechte Zweige. welche an der Basis fruktifizieren. Bei jungen Pflanzen sind diese Bündel aufrechter Zweige deutlich voneinander getrennt, bei älteren aber stehen sie so gedrängt. daß sie Polster bilden, welche an Chactophora erinnern, zumal weil zwischen den aufrechten Zweigen reichlich Schleim abgeschieden wird. Die unilokulären Sporangien sitzen an der Basis der aufrechten Fäden (Fig. 168, 1), die plurilokulären sind (Fig. 168. ㄴ) mmgebildete Spitzen kurzer aufrecliter Fäden. 
Von Strepsithalia läßt sich nun leicht

\section{Myrionema}

ableiten. Bei diesem Genus sind die kriechenden Fäden zu einer Basalscheibe vereinigt, welche also aus einem Pseudoparenchym besteht, in ihr ist aber der Verlauf der einzelnen Fäden noch deutlich zu sehen, etwa so wie bei Coleochaete soluta. Aus dieser Scheibe erheben sich aufrechte Fäden, welche an ihrer Basis die unilokulären Sporangien tragen, so wie Strepsithalia dies tut. Die plurilokulären Sporangien sind wie bei Strepsithalia umgebildete Spitzen kurzer aufrechter Fäden.

Wir sahen früher bei den Coleochaeten, daß die scheibenförmigen Arten als reduzierte Polsterarten zu betrachten sind. Was wir dort als

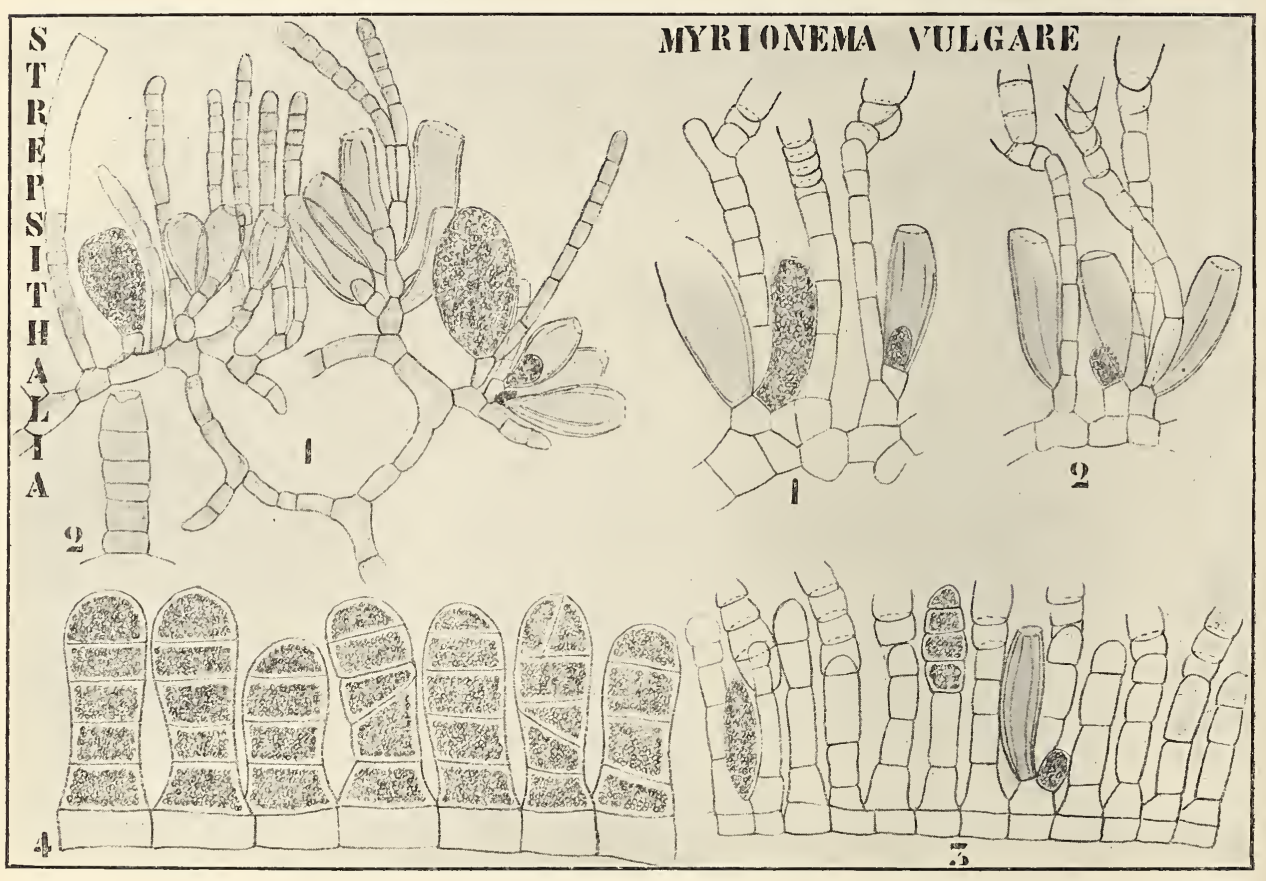

Fig. 168. I. Strepsithalia Liagorae (nach Sadvagead). 1 Pflanze mit unilokulären Sporangien. 2 Plurilokuläres Sporangium. - II. M y rionema vulgare (nach SAUvagead). 1, 2 normale Individuen, 3, 4 rückgebildete.

phylogenetisch geschehen betrachteten, läßt sich hier an einer und derselben Art, ja sogar an einem und demselben Exemplar beobachten. Sowohl die Assimilatoren, d. h. die aufrechten Fäden, wie die Haare können reduziert werden und dies kann soweit gehen, bis nur die Basalscheibe übrig bleibt. Fig. 168, II $?$ ist ein reduziertes Exemplar, welches noch Haare bildet, Fig. 168, II 4 ein Exemplar, welches sogar die Haare verloren hat und nur noch plurilokuläre Sporangien trägt.

Das nächste Genus :

\section{Ralfsia}

ist als eine höher stehende Myrionema zu betrachten. Diese Pflanzen 
bilden auf Steinen, z. B. der Meeresdeiche, verhältnismäßig große dicke Krusten voll dunkelbrauner bis schwarzer Farbe (Fig. 169, 1).

Hier haben wir mit kompakten pseudoparenchymatischen Scheiben zu tun, welche in der Weise von Coleochaete scutata Randwachstum zeigen. Nur am Rande sind sie einschichtig, nach dem Zentrum zu mehrschichtig, da vertikale dichtgedrängte aufrechte Fäden entstehen (Fig. 169, 2), welche, da sie nur kurz bleiben, die Scheibenform des Ganzen nicht stören. Das Ganze ist von einer Cuticula bedeckt, welche jedoch später abgeworfen wird. Dann wachsen die Zellenreihen zu plurilokulären Sporangien aus (Fig. 169,3) oder zu ziemlich langen, lockeren Assimilatoren, welche an ihrer Basis die unilokulären Sporangien tragen

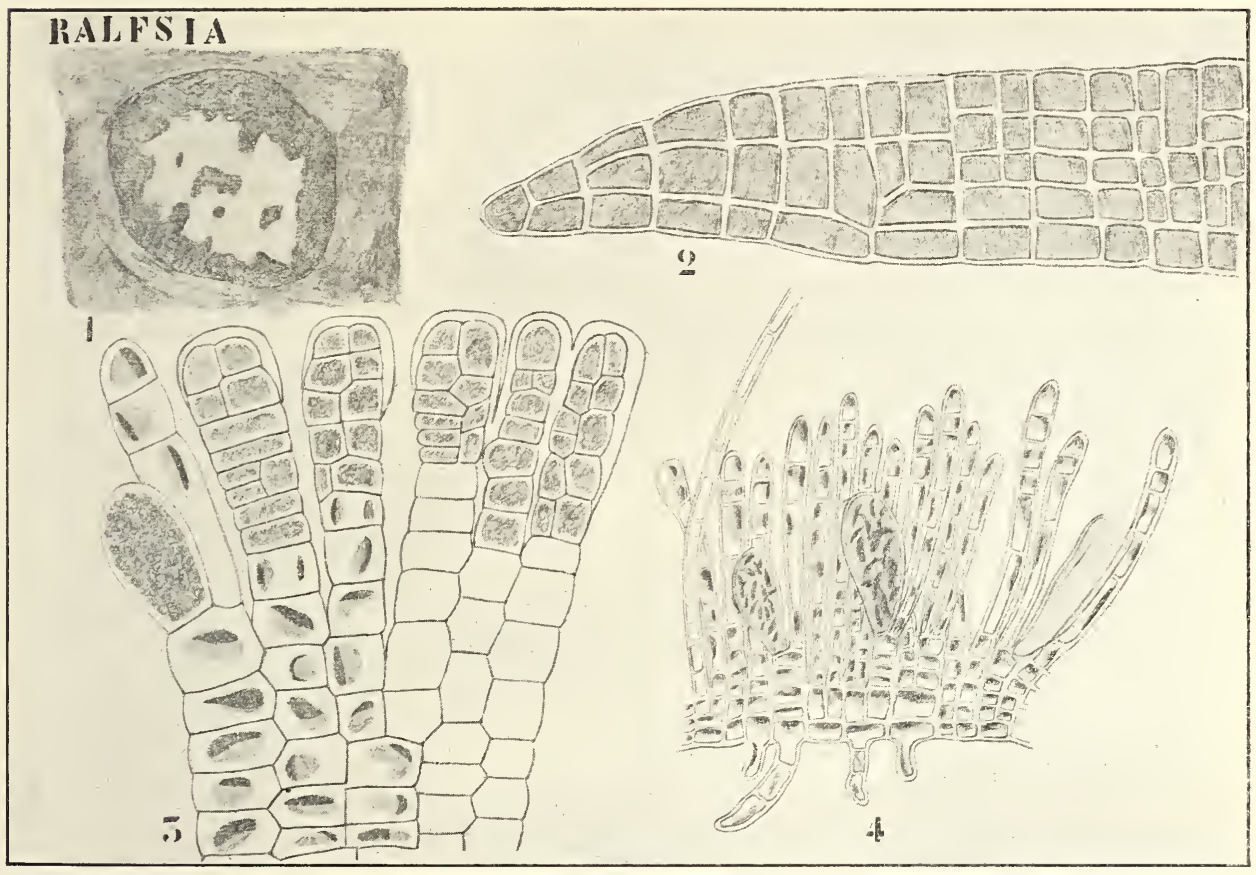

Fig. 169. Ralfsia (nach KUCKUCK). 1 Habitusbild eines fruktifizierenden Exemplars. 2 Querschnitt durch den Thallusrand. 3 Unilokuläres und plurilokuläre Sporangien. 4 Unilokuläre Sporangien.

(Fig. 169, 4). Bei der ganzen Gruppe der Myrionemaceen sind die Haare farblos. Darin sind sie von der Gruppe der

\section{Elachisteae}

verschieden. Diese besitzen gefärbte Haare. Als Beispiel derselben werde ich

\section{Elachistea}

mit Ihnen behandeln. Es sind dies polsterförmige Algen, welche auf größeren Tangen wie Fucus, Himanthalia, Cystoseira etc. Wachsell. Die vertikalen Fäden stehen hier so dicht gedrängt, daß sie ein Parenchỵm 
bilden, welches im Innern fast farblos, an der Peripherie braun ist (Fig. 170, 4).

Diese vertikalen Fäden werden A ssimilatoren oder gerade bei Elachistea öfters Paraphysen genannt. Die langen braunen Haare ragen weit über die Assimilatoren hervor (Fig. 170,4) und erteilen dem Pflänzchen das stachelige Aeußere (Fig. 170, 1). Sie nehmen in hohem Grade an der Photosynthese teil.

An der Basis der Assimilatoren bilden sich unilokuläre und plurilokuläre Sporangien, letztere sind vermutlich Gametangien, zwar wurde die Kopulation der in ihnen gebildeten Schwärmer von BorNET und ThUret nicht beobachtet, aber zu jener Zeit (1847) wurde darauf noch kaum geachtet.

Die Schwärmer keimen in den Haargrübchen der Cystoseiren, so

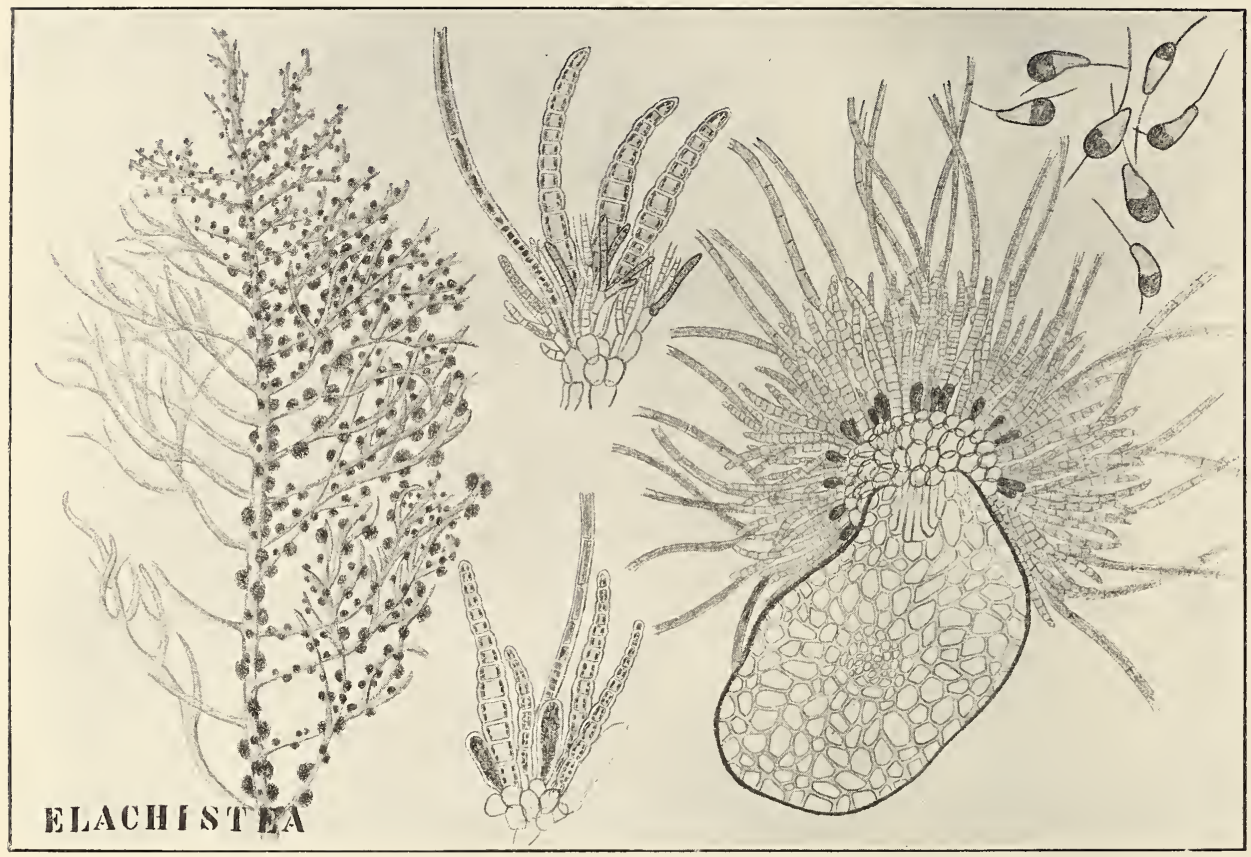

Fig. 170. Elachistea pulvinata (nach THuRET). 1 Eine Cystoseira, deren rechts gelegene Zweige zumal von der Elachistea bedeckt sind. 2, 3 Plurilokuläre Sporangien. 4 Querschnitt der Cystoseira mit Polstern der Elachistea mit unilokulären Sporangien in einer Haargrube befestigt. 5 Schwärmer.

daß die Elachistea stets mit einem Füßchen (Fig. 170, 4) in einer solchen Grube befestigt ist.

Von der Gruppe, welche durch Verflechtung von Fäden ihre Thallome bildet, bleibt nun noch die Familie der

\section{Eudesmeae}

zu besprechen übrig. Von dieser Familie möchte ich das Genus

\section{Castagnea}

mit Ihnen behandeln. 


\section{Castagnea virescens,}

eine z. B. auf Helgoland häufige Alge, bildet eigentümliche braungrüne schleimige verzweigte Stränge von 10-20 cm Länge und einigen Millimetern Dicke. Man kann den Thallus zerquetschen und dann leicht beobachten, daß er nur aus verflochtenen einreihigen Zellfäden besteht.

Die Keimpflänzchen sehen wie ein Ectocarpus aus. Aus einem kriechenden Faden erhebt sich ein aufrechter mit interkalarem Vegetationspunkt welcher alsbald Seitenzweige bildet, die ebenfalls interkalare Vegetationspunkte besitzen (Fig. 171, 2).

Diese Seitenzweige wachsen steil aufwärts und schlingen sich dabei um die Hauptachse herum, etwa so, wie ein Kabeltau gedreht wird. Die

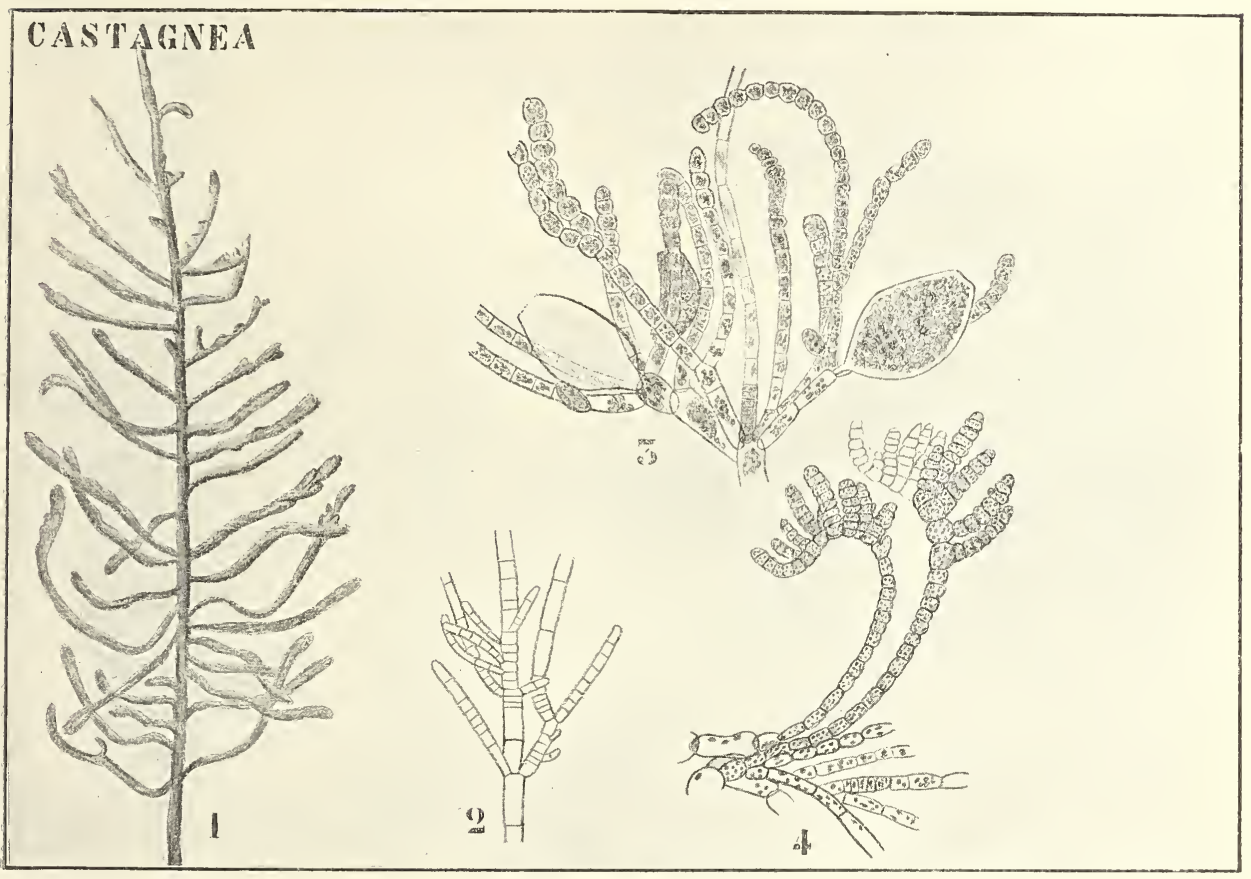

Fig. 171. Castagnea virescens (nach KüTzing, Reinke und Thuret). 1 HabitusbiĪd. 2 Spitze eines Keimlings. 3 Seitenzweige zweiter Ordnung mit unilokulären Sporangien, 4 id. mit plurilokulären.

Verbindung zwischen diesen Seitenzweigen wäre aber so noch zu schwach. Bald bilden sie Seitenzweige 2. Ordnung, welche sich stark verzweigen und rechteckig auf der Hauptachse stehen. Sie bilden viel Schleim, daher die schlüpferige Beschaffenheit der Alge. Diese Seitenzweige 2. Ordnung enthalten viele Chromatophoren und fungieren als Assimilatoren, sie bilden auch farblose Haare mit basalem Tegetationspunkt (Fig. 171, 3). Die unilokulären Sporangien entstehen an der Basis der Assimilatoren, da sie aber diese später beiseite drängen. sieht es öfters so aus, als ständen sie terminal (Fig. 171. 3). Die plurilokulären Sporangien entstehen als Seitenzweige 3. Ordnung mahe der 
Spitze der Assimilatoren (Fig. 171, 4), deren Endzelle sich schließlich auch zu einem Sporangium umbildet.

Castagnea läßt sich also betrachten als ein Ectocarpus vom Typus des irregularis, dessen Zweige 1. Ordnung sich um die Hauptachse herumgewunden haben, und bei welchem eine Arbeitsteilung, die zur Ausbildung von Zweigen 2. Ordnung zu Assimilatoren führte, auftrat. Diese von Reinke, Kuelmann, Schmitz und Oltmanns vertretene Ansicht ist recht plausibel.

Wir müssen uns nun noch mit jener gewebebildenden Gruppe der Ectocarpaceen beschäftigen, bei welcher die Gewebebildung nicht auf einer Verflechtung von Zellfäden basiert ist. Die erste Gruppe derselben, die Punctarieae, von welcher ich

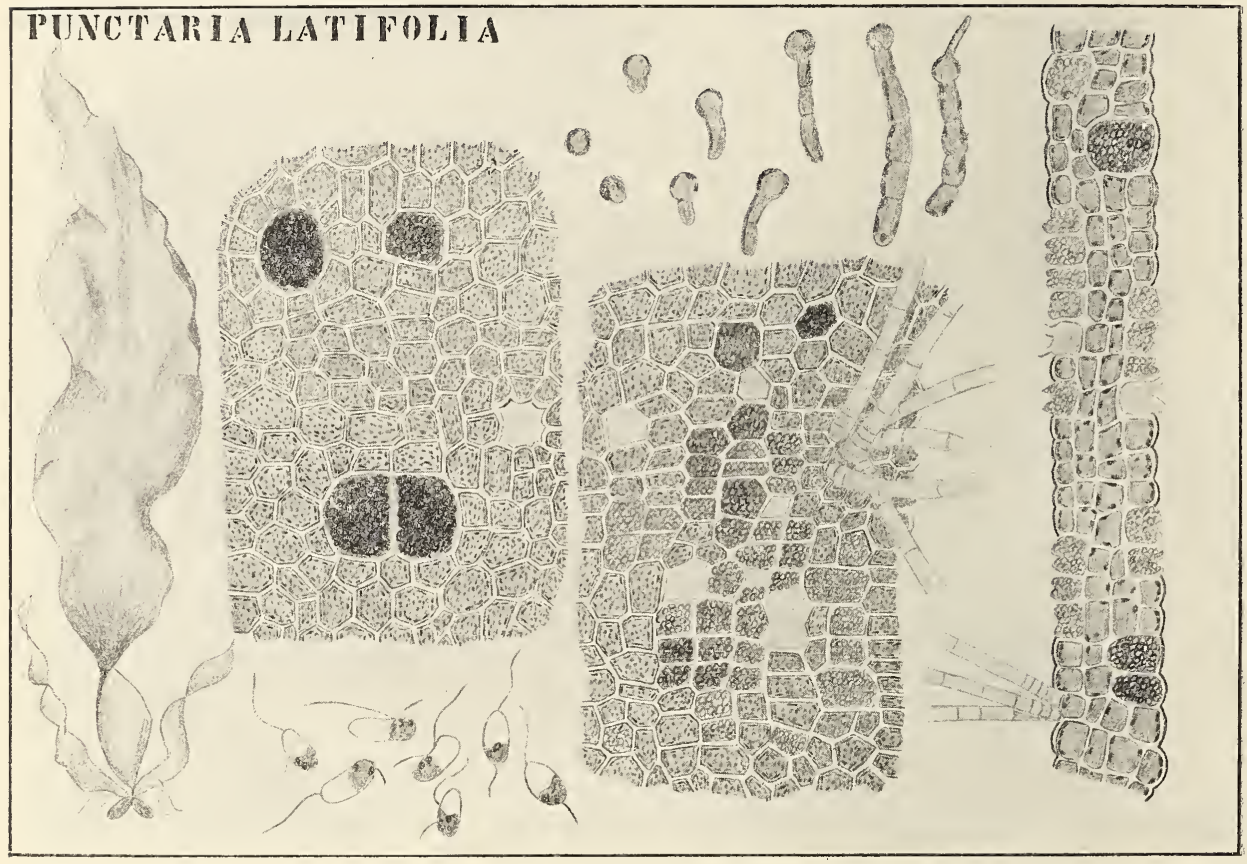

Fig. 172. Punctaria latifolia (nach THURET). 1 Habitusbild. 2 Thallus mit unilokulären Sporangien von oben betrachtet. 3 Idem mit plurilokulären Sporangien und Haarbüscheln. 4 Querschnitt eines Thallus mit unilokulären und plurilokulären Sporangien. 5 Schwärmer. 6 Keimpflänzchen.

\section{Punctaria}

besprechen möchte, bildet ein Gegenstück zu den Ulvaceae, d. h. sie bildet Zellplatten, welche einer Ulva so sehr gleichen, daß man Punctaria fast als eine braune Ulva betrachten kann, deren Thallus aber nicht aus zwei, sondern aus vier Zellschichten besteht.

So wie bei Ulva wird zunächst ein Zellfaden gebildet, welcher dann zu einer Zellplatte wird, die zunächst aus zwei, später aus vier Schichten besteht. Solange sie noch aus zwei Schichten besteht, werden die unilokulären Sporangien gebildet, so daß diese in dem erwachsenen Thallus eingesenkt sind. Erst nachdem der Thallus vierschichtig ist, werden die 
plurilokulären Sporangien angelegt. In noch einer Hinsicht ist Punctaria von Ulva verschieden; sie kann nämlich Haarbüschel bilden. P. plantaginea findet sich im Atlantischen Ozean, in der Nordsee etc., P. latifolia im Mittelmeer.

Schwärmer sahen Thuret und Bornet sowohl in den uni- wie in den plurilokulären Sporangien entstehen, erstere waren wohl Zoosporen, letztere Gameten.

Es bleibt diejenige gewebebildende Gruppe der Ectocarpaceae zu betrachten, welche runde mit Mark versehene Körper bildet. In der Jugend sind sie einreihig fadenförmig oder wenigstens phylogenetisch von solchen Formen abzuleiten. Wir unterscheiden nun dabei zwei Gruppen, bei der einen wächst der Faden interkalar in die Länge bei der anderen mittels Scheitelzellen.

Betrachten wir zunächst die erstere, die der

\section{Scytosiphoneae,}

und sehen wir zunächst, wie Stictyosiphon, ein Pflänzchen aus der Adria und aus dem Baltischen Meere, gebaut ist. Der Thallus ist fadenförmig und mäßig verzweigt. Keimpflänzchen und junge Seitenzweige erinnern in ihrem Aufbau in hohem Grade an Myriotricha. Zunächst nur aus einer Zellenreihe bestehend, welche an der Spitze einige mittels interkalarer Vegetationspunkte wachsende Haare trägt, treten alsbald Längswände auf, welche in jeder Zelle Quadranten bilden, wodurch also ein aus 4 Längsreihen gebildeter Faden entsteht. Dann entstehen perikline und antikline Teilungen, wodurch eine Rinde gebildet wird und 4 zentrale Zellenreihen übrig bleiben (Fig. 173, 2). Diese zentralen Zellenreihen teilen sich nicht mehr, so daß das Mark lebenslang aus 4 Zellenreihen besteht. Hingegen teilt sich die Rinde durch radiäre Wände, bleibt aber einschichtig bis die plurilokulären Sporangien entstehen. An ihren Bildungsstellen nämlich wird die Rinde mehrschichtig (Fig. 173, 3); die Sporangien erheben sich aber kaum über die Oberfläche. Diese plurilokulären Sporangien sind unregelmäßig über den Thallus zerstreut.

Stictyosiphon ist also Myriotricha protasperococcus vergleichbar, nur ist es über seine ganze Oberfläche fertil geworden, so daß die Differenzierung in Knoten und Internodien fortfällt. $\mathrm{Ob}$ aber eine genetische Verbindung zwischen beiden besteht, muß dahing'estellt bleiben. Unilokuläre Sporangien sind unbekannt, Längenwachstum findet interkalar statt.

Prinzipiell gleichen Aufbau besitzt die unverzweigte

\section{Scytosiphon lomentarius,}

eine Art, welche z. B. bei ,den Helder ${ }^{6}$ vorkommt. Im erwachsenen Zustande ändert sich aber ihr Aussehen nicht unbedeutend, indem die Markfäden auseinander weichen, wodurch eine zentrale Höhlung entsteht. Um dies zu ermöglichen, muß Dickenwachstum stattfinden, was durch radiäre Teilungen der Rindenzellen ermöglicht wird. Da dieses Wachstum der Rinde aber an gewissen Stellen in recht geringem Grade stattfindet, entstehen dort Einschnürungen (Fig. 174, 1).

Die plurilokulären Sporangien werden von den Rindenzellen gebildet, welche dann sich mittels tangentialer Wände teilen; sie erheben sich durch Streckung über die Oberfläche. Diese vermutlichen Gametangien stehen zunächst in kleinen Sori beieinander, fließen aber alsbald mit 
benachbarten Sori zusammen, indem die dazwischen gelegenen Rindenzellen fertil werden.

\section{Phyllitis,}

eine auch an unserer Küste, z. B. bei „den Helder" vorkommende Pflanze, ist eigentlich nur ein breites, stark abgeplattetes Scytosiphon. Auch hier finden wir eine Rinde und farblose zentrale Zellenreihen vor,

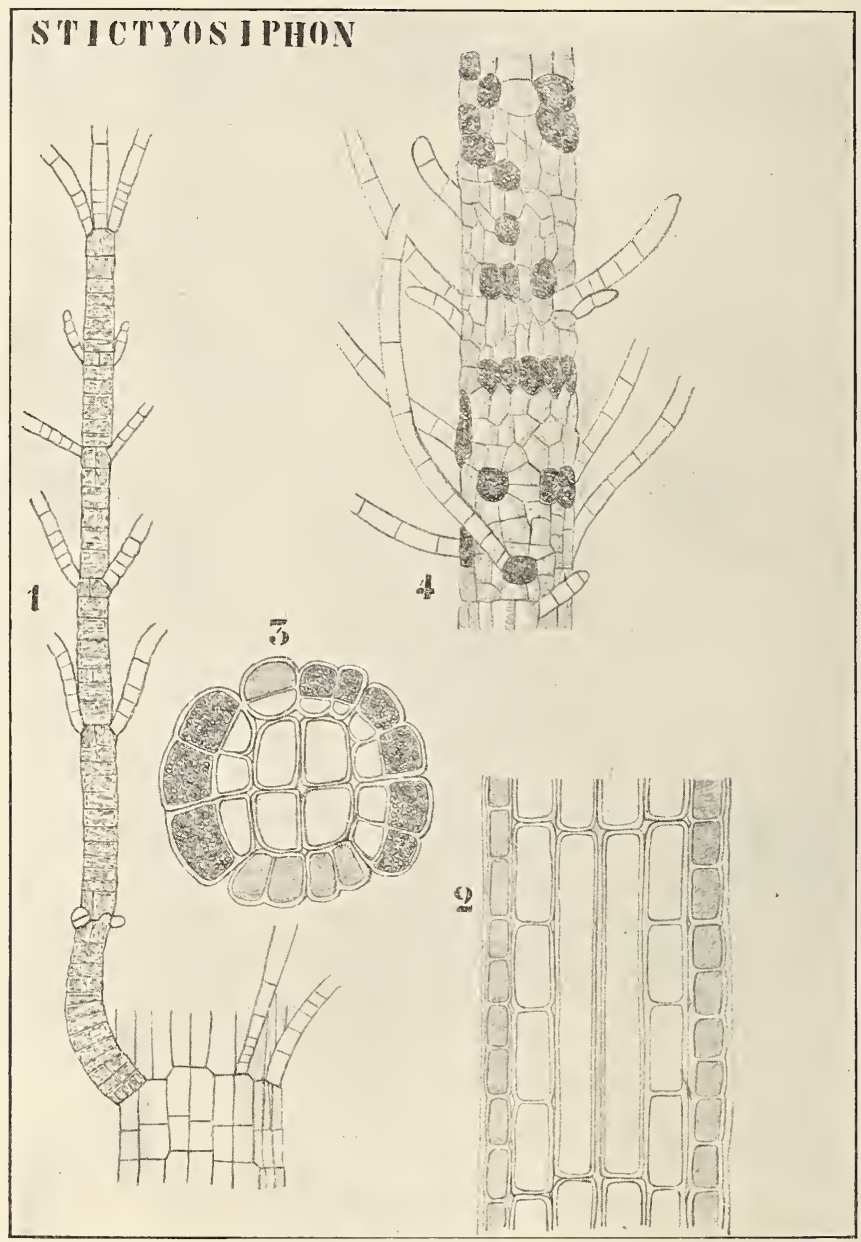

Fig. 173. Stictyosiphon tartilisis (nach REINkE). 1 Junger Zweig. 2 Längsschnitt, 3 Querschnitt ein Sprosses, ersterer steril, der zweite fruktifizierend. 4 Fruktifizierender Sproß von außen betrachtet.

welche aber nur stellenweise auseinander weichen, so daß der Thallus nur hier und da blasig aufgetrieben, sonst aber flach ist.

Von Fortpflanzungsorganen sind nur plurilokuläre Sporangien bekannt, sie werden in den Rindenzellen gebildet und stehen in großen Sori zusammen. Sobald die vermutlichen Gameten ausschwärmen, bilden sich auf dem Thallus große unregelmäßige weiße Flecke. Das 
rührt einfach daher, daß die photosynthierenden Rindenzellen sich an jenen Stellen ganz in Gameten aufgelöst haben. Schwärmen diese nun aus, dann bleiben an jenen Stellen nur die Zellwände der Rindenzellen übrig, durch welche das farblose Zentralgewebe hindurchschimmert (Fig. 175, 3).

Der Bau der Gruppe der

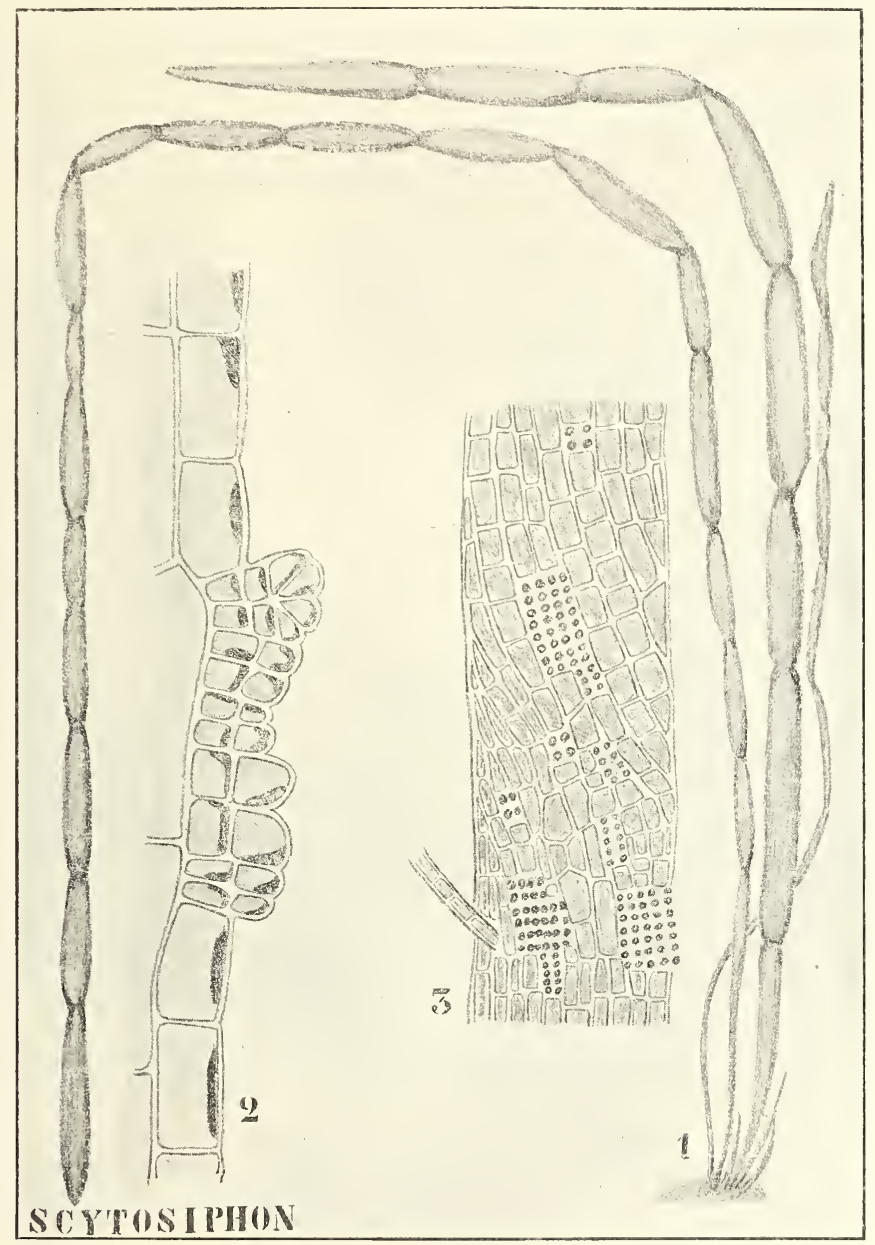

Fig. 174. 1 Seytosiphon lomentarius (nach Ottmanns). 2 Se. pygmaeus (nach REINKE). Längsschnitt durch die Rinde an einer Stelle, wo sich plurilokuläre Sporangien befinden. 3 Plurilokuläre Sporangien von außen betrachtet.

\section{Dictyosiphoneace}

stimmt der Hauptsache nach mit dem der Scytosiphoneae überein; uur wachsen die Keimlinge im fadenförmigen Stadium mit einer Scheitelzelle. Nachdem aber Gewebebildung aufgetreten ist, findet auch hier interkalares Wachstum statt. Die Gruppe braucht hier nicht näher besprochen zu werden, ich verweise also auf Otwuinns, wobei ich nur noch be- 
merke, daß die Rindenzellen öfters zu kurzen Zellfäden, zu Assimilatoren, auswachsen. kannten

Die letzte Gruppe der Ectocarpaceen wird von den allgemein be-

\section{Chorda-}

Arten gebildet, von welchen Chorda filium auch an unserer Küste vorkommt. Wer kennt nicht jene öfters mehrere Meter langen, schlaffen, unverzweigten, peitschenförmigen Algen von der Dicke eines Gänsekiels, welche mit einem Haftscheibchen an Steinchen befestigt, sozusagen auf Strom verankert liegen, und welche, in ihrem unteren Teile öfters gedreht, uns stets wieder über die Widerstandsfähigkeit des unglaublich dünnen Stielchens, mit welchem sie befestigt sind, staunen lassen?

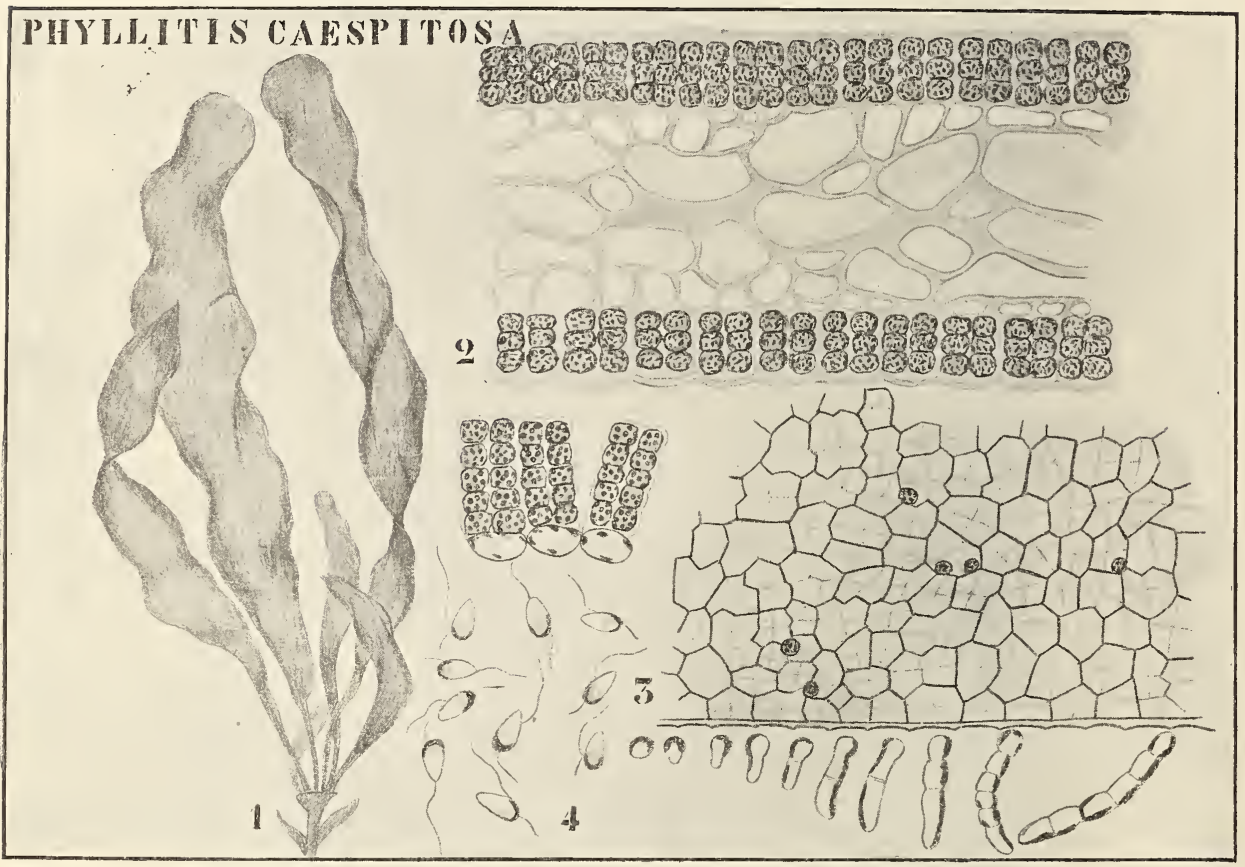

Fig. 175. Phyllitis caespitosa (nach THURET). 1 Habitusbild. 2 Querschnitt durch einen jungen, eben fruktifizierenden Thallus. 3 Thallus, von oben betrachtet, nach dem Austritt der Schwärmer. 4 Plurilokuläre reife Sporangien, Schwärmer und Keimlinge.

Ein Längsschnitt durch den Thallus zeigt von außen nach innen eine palisadenähnliche Rinde (Fig. 176, 4), lange und breite Zellen und ganz innen lange dünne Zellfäden, welche von hyphenartigen Auswüchsen der breiteren Zellen festgehalten werden, und so verhindert werden, sich in der schleimgefüllten Zentralhöhle zu verirren. Diese hyphenähnlichen Fäden, welche die zentralen Fäden festhalten, dringen nun in gewissen Entfernungen in die zentrale Höhle ein und bilden dort, indem sie sich miteinander verweben, Diaphragmen.

Die Alge fruktifiziert fast über die ganze Länge des Thallus, nur nicht am unteren Ende. Die Sporangien entstehen aus der ursprünglich 
einschichtigen Rinde. Diese Rindenzellen teilen sich durch Tangentialwände in nach außen gelegene, keulenförmige, gestreckte Assimilatorzellen und nach innen gelegene flache Basalzellen. Die basalen Zellen wachsen später seitlich aus, wodurch die Assimilatorzellen voneinander entfernt werden (Fig. 176, 3 links). An den lateralen Enden dieser Basalzellen entstehen nun als Ausstülpungen die unilokulären Sporangien (Fig. 176, 5).

Wie entsteht nun die soeben beschriebene komplizierte Thallusstruktur? Aus der Zoospore entsteht zunächst ein kriechender Faden, von welchem sich alsbald vertikale einreihige Zellfäden erheben (Fig. 176, 1). In allen Zellen dieser Vertikalfäden entstehen nun alsbald Quadranten, später folgen tangentiale Wände, wodurch zentrale und periphere Zellen gebildet werden. Wahrscheinlich bilden die zentralen Zellen durch weitere

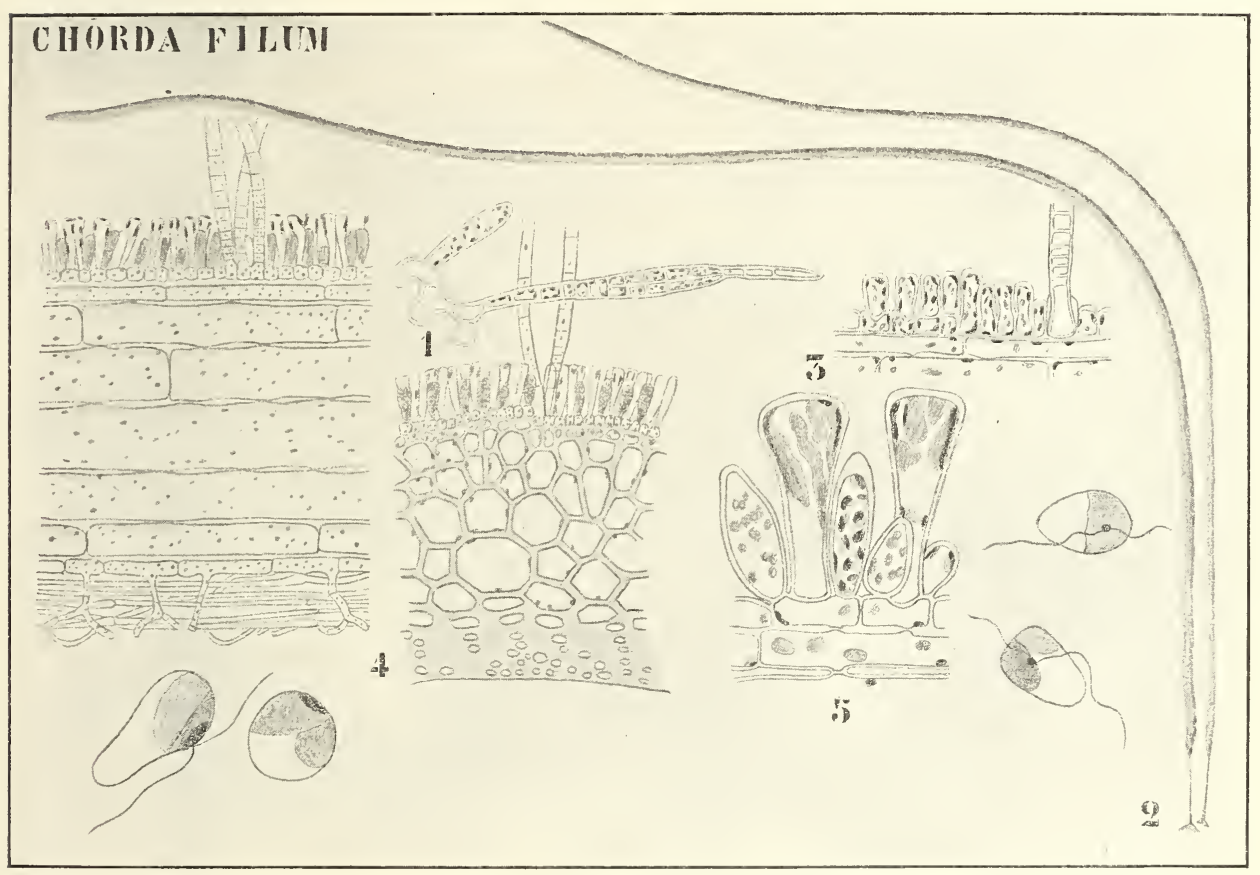

Fig. 176. Chorda filium (nach Reinke). 1 Keimling. 2 Habitusbild (Orig.). 3 Längsschnitt durch die Rinde eines jungen Thallus. 4 Längs- und Querschnitt durch einen erwachsenen Thallus. 5 Unilokuläre Sporangien.

Teilungen und durch Auseinanderweichen die dünnen Fäden und die zentrale Höhlung, während die breiten langen Zellen und die Rinde aus den peripheren Zellen entstehen.

Haare können überall gebildet werden. Die junge Pflanze wächst ohne bestimmte Scheitelzelle. Ob man nun eine Chorda von einer Delamarea (Dictyosiphoneae), welche das Scheitelwachstum verloren hat, ableiten muß oder aber von einer Form wie Scytosiphon, ist fraglich, letzteres scheint mir am wahrscheinlichsten.

Damit dürfte also die große Familie der Ectocarpaceae genügend besprochen sein; wenden wir uns also zunächst den 


\section{Cutleriaceen}

zu, und betrachten wir das Genus

\section{Cutleria.}

Bei Cutleria multifida sind die geschlechtlichen und die ungeschlechtlichen Individuen recht verschieden; der Gametophyt hat hier die Form eines abgeflachten aufrechten, vielfach zerschlitzten Thallus. Diese Form ist stets unter dem Namen Cutleria multifida bekannt gewesen. Hingegen hat der Sporophyt die Form flacher, über das Substrat kriechender Krusten von einigen Centimetern bis zu Handgröße. Dieser war früher, als man den Zusammenhang mit Cutleria noch nicht kannte, als ein gesondertes Genus, als Aglao\%onia, bekannt.

Auf dem Gametophyt finden wir Gametangien in der Gestalt von plurilokulären Sporangien, auf dem Sporophyt Zoosporangien in der Gestalt von unilokulären Sporangien.

Wir haben also bei Cutleria einen Gametophyten und einen Sporophyten, stellen diese nun die $\mathrm{x}$ - und $2 \mathrm{x}$-Generation dar?

Auf den ersten Blick würde man gewiß geneigt sein, solches anzunehmen, und eine Beobachtung würde diese Meinung noch verstärken. Man fand nämlich, daß aus den kopulierten Gameten des Gametophyten (Cutleria-Stadium) der Sporophyt (Aglaozonia-Stadium) entstand, und daß die vom Aglao\%onia-Stadium gebildeten Zoosporen den Gametophyten lieferten.

Dennoch haben wir hier aller Wahrscheinlichkeit nach nicht mit einer $\mathrm{x}$ - und einer $2 \mathrm{x}$-Generation $\mathrm{zu}$ tun, sondern es gehören beide der $\mathrm{x}$-Generation an; wir haben also mit getrennten Teilen der gleichen Generation zu tun. Es ist das Aglaozonia-Stadium der bei den Phaeophyceen so häufigen Basalscheibe vergleichbar. Verglichen mit Myriotricha repens z. B., hätten wir hier einen Fall, wo die kriechenden Zweige mit Zoosporangien sich von den aufrechten mit Gametangien getrennt hätten.

Dafür spricht in erster Linie eine Beobachtung von SAuvagEau. Aus der Zygote entwickelt sich immer zunächst ein aufrechter Faden, das sogenannte Säulchen. An der Basis dieses Säulchens wird dann später die Aglao\%onia-Kruste gebildet; das Säulchen bleibt aber noch lange bestehen. Nun zeigte SAuvageau, daß an diesem Säulchen Cutleria-Sprosse entstehen können, und es liegt also auf der Hand, das Säulchen für eine rudimentäre Cutleria zu halten. Ist dies richtig, dann ist es leicht einzusehen, wie eine Trennung zwischen dem kriechenden und dem aufrechten Teile der Pflanze entstehen konnte.

Gesetzt den Fall, die ursprünglichen Cutleria-Pflanzen beständen aus einem aufrechten, die Gameten produzierenden Teil (unser CutleriaStadium) und einer kriechenden Basalscheibe (unsere Aglao\%onia), welche die Sporangien bildete, etwa wie dies bisweilen bei Myriotricha geschieht. Falls nun die Entwickelung des aufrechten Teiles von anderen Bedingungen abhängt als die des, kriechenden Teiles, so würde, falls erstere ihr Optimum erreichten, das Cutleria-Stadium, falls letztere ihr Optimum erreichten, das Aglaozonia-Stadium entstehen.

Für diese Auffassung spricht erstens, daß die Entwickelungszeiten beider Stadien verschieden sind. Im Sommer trifft man im Mittelmeer Aglaoronia, im Winter Cutleria an; in England gerade umgekehrt, dort ist Aglao:onia die Winterform; d. h. also, in beiden Gebieten wird das 
Aglao:onia-Stadium gebildet, wenn die Lebensbedingungen ungünstig werden.

Auch spricht dafür der Umstand, daß im Norden das CutleriaStadium ïberhaupt stark zurücktritt. Nur sehr selten kann man bei Helgoland eine Cutleria finden, dagegen ist Aglao\%onia dort immer vorhanden, und das gleiche gilt für die schottischen und skandinavischen Küsten.

Im Süden dagegen ist das Umgekehrte der Fall; bei Neapel z. B. ist Aglaozonia unbekannt, es wird nur Cutleria gebildet.

Offenbar bedingen also südliche Verhältnisse die Bildung des Cutleria-Stadiums, nördliche die des Aglao\%onia-Stadiums.

Nun treffen wir aber offenbar auf eine andere Frage: Wie kann die

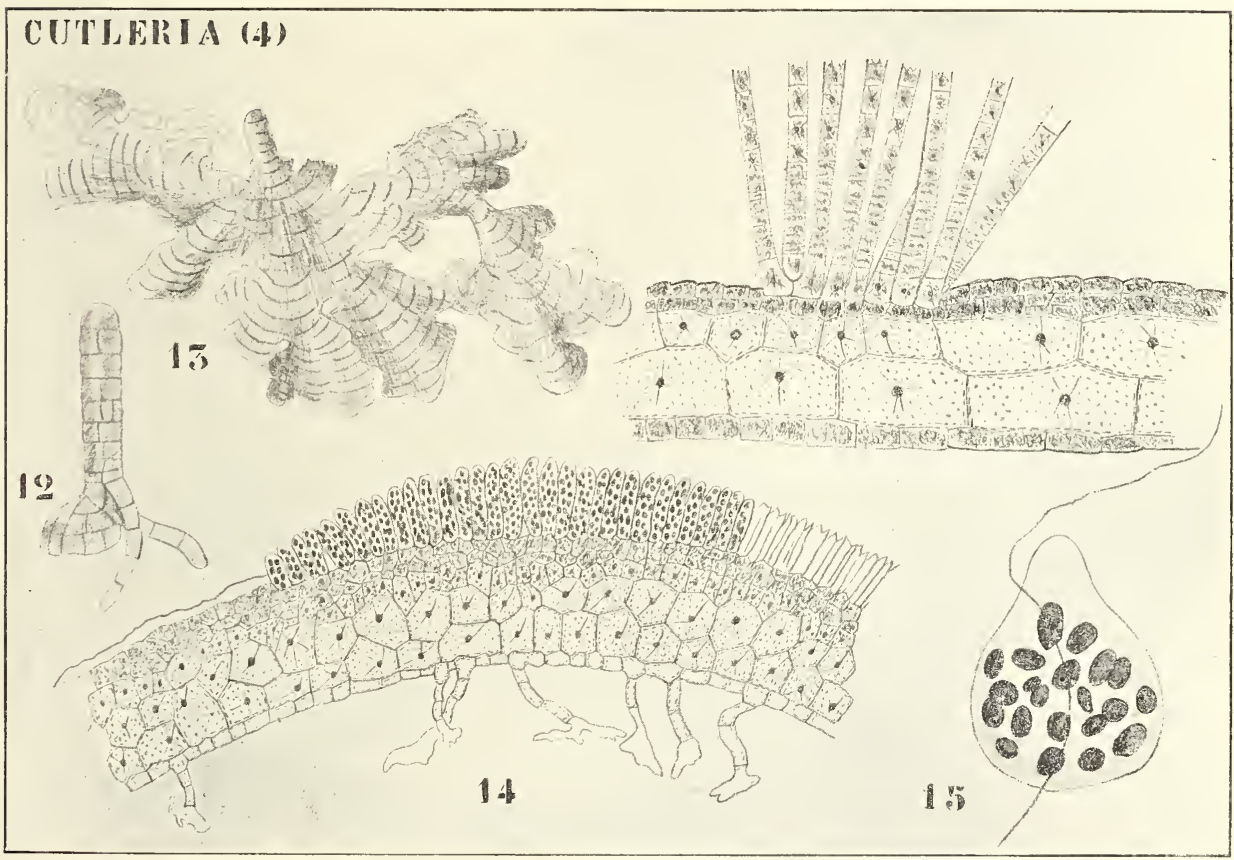

Fig. 177. Cutleria (nach Falkenberg, Kuckuck und Sauvagead). 12 Keimling einer Zygote. $13 \mathrm{Aglaozonia-Stadium,} \mathrm{rechts} \mathrm{Querschnitt} \mathrm{durch} \mathrm{einen} \mathrm{sterilen} \mathrm{Thallus}$ mit Haarbüscheln. 14 Querschnitt durch einen Thallus, welcher an seiner Oberseite unilokuläre Sporangien gebildet hat. 15 Zoospore.

Cutleria sich bei Neapel, die Aglaoronia sich bei Helgoland fortpflanzen, wenn an der einen Stelle das Aglaoronia-Stadium, an der andern das Cutleria-Stadium fehlt oder wenigstens sehr selten ist.

Die Antwort ist einfach und eine neue Stütze für obige Auffassung: aus den Cutleria-Gameten können sich nachg'ewiesenermaßen direkt neue Cutlerien bilden, und es liegt auf der Hand, anzunehmen, daß im hohen Norden aus den Zoosporen der Aglaozonien direkt neue Aglaoroinien entstehen können. Das ist bei Helgoland, wie Kuckuck nachwies, schon fast der Fall. Aus Aglaozonia-Sporen entsteht in der Regel ein kleines Cutleria-Pflänzchen, welches alsbald an seiner Basis Aqlao:onia bildet und dann abstirbt, während die Aglao:onia bestehen bleibt. 
Schließlich, und das ist wohl als Schlußstein zu betrachten, gelang es KucKuck, unter günstigen Bedingungen bei diesen Pflänzchen den Cutleria-Teil vor dem Absterben Gameten produzieren zu lassen.

Wir dürfen also wohl folgende Schlüsse ziehen: P otential ist Cutleria eine Pflanze, welche aus einer basalen sporangienbildenden Scheibe und aus aufrechten, Gameten bildenden Zweigen besteht. Da die Scheibe ein anderes Entwickelungsoptimum besitzt als die aufrechten Zweige, entwickeln sich in der Regel entweder nur die einen oder die anderen. Dadurch erhalten wir eine Trennung in ein Cutleria- und in ein Aglaozonia-Stadium, eine Trennung in einen Sporophyten

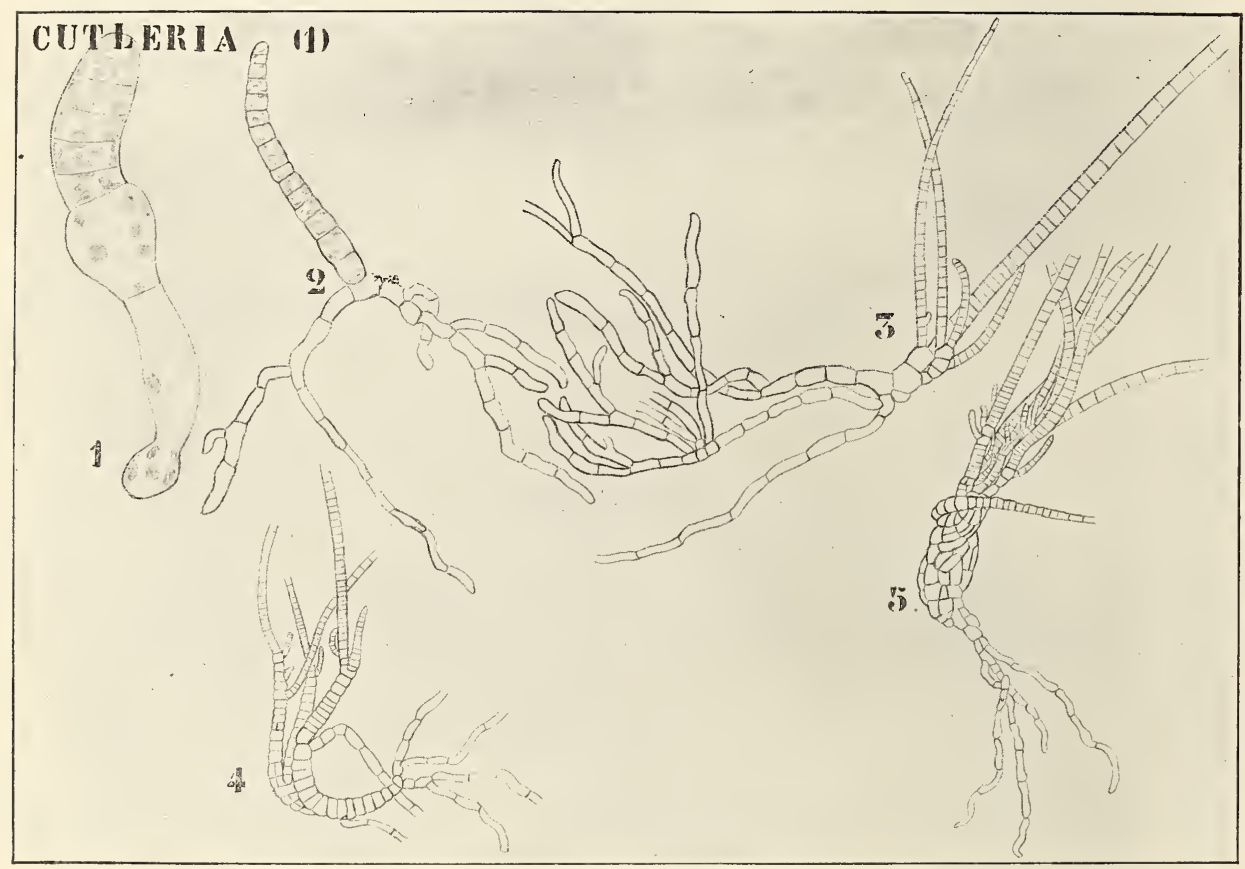

Fig. 178. Junge Stadien von Cutleria (nach Kuckuck und Sadvagead).

und einen Gametophyten, welche aber beide der xGeneration angehören.

Betrachten wir jetzt unsere Pflanze näher und fangen wir mit dem

\section{Aglaozonia-Stadium}

an. Die kopulierten Gameten der Cutleria bilden bei der Keimung einen aufrechten Faden, der mit einigen Rhizoiden am Substrat befestigt ist.

Dieser Faden besteht ursprünglich aus einer einzigen Zellreihe, wird aber alsbald mehrreihig, wodurch er eine festere Beschaffenheit erhält und Säulchen genannt wird (Fig. 177, 12). An der Basis fangen alsbald einige. Zellen sich schneller zu teilen an und wachsen $\mathrm{zu}$ einem kleinen Scheibchen aus (Fig. 177, 12).

Diese Scheibchen besitzen Randwachstum, etwa wie Ralfsia, und 
wachsen so zu großen gelappten Scheiben aus, welche man als Aglaozonia beschrieben hat (Fig. 177, 13).

Die Scheibe ist mit Rhizoiden am Substrat befestigt (Fig. 177, 14) und bildet an der Oberseite Haarbüschel (Fig. 177, 13 rechts), diese Haarbüschel sind, da sie aus Epidermiszellen hervorgingen, etwas in den Thallus eingesunken.

Die Oberflächenzellen, welche man recht gut Rindenzellen nennen kann, wachsen an der oberen Seite zu unilokulären Sporangien aus (Fig. 177, 14). Die Zoosporen sind sehr groß (Fig. 177, 15), besitzen zwei lateral inserierte Cilien, von denen die vordere länger als die hintere ist, eine große Zahl von Chromatophoren und eimen roten Augenfleck.

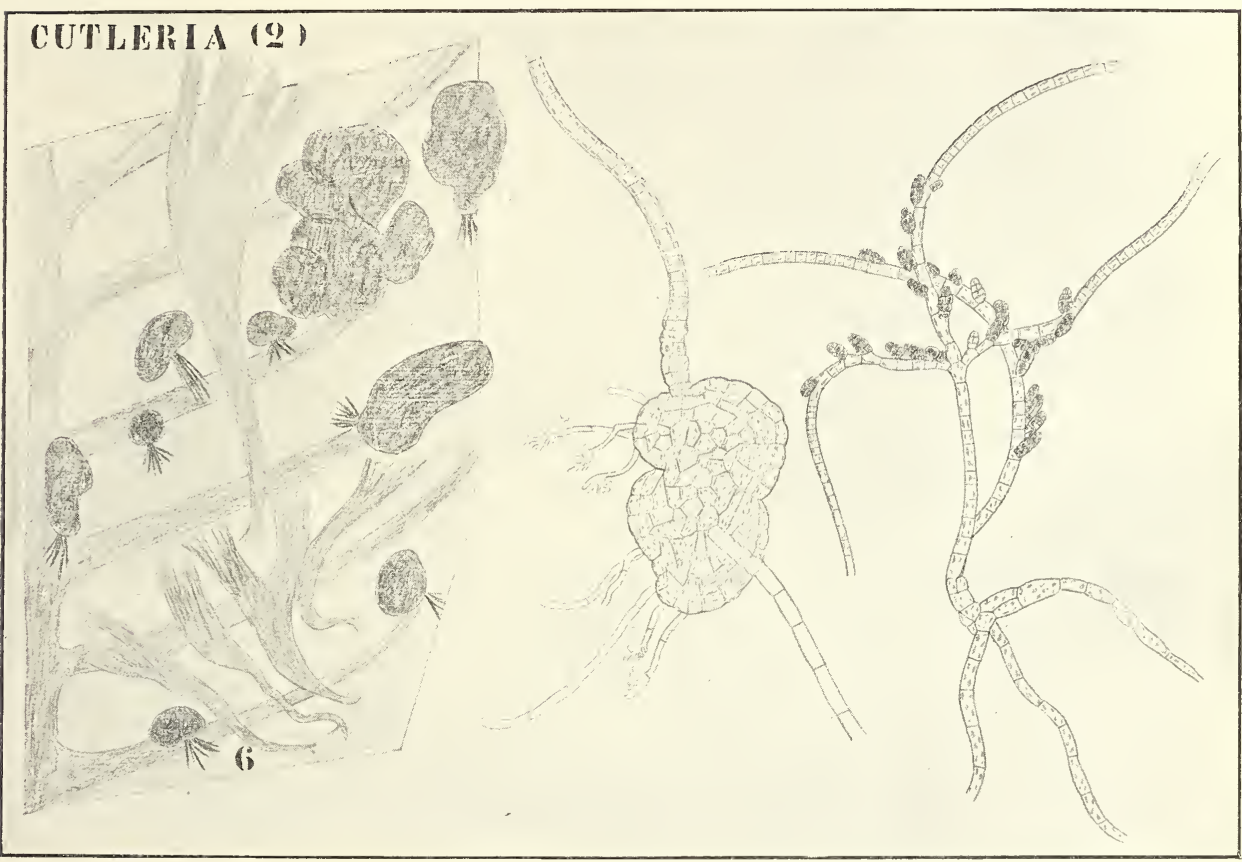

Fig. 179. Cutleria (nach KUCKUCK). 6 Aus Aglaozonia-Sporen bei Helgoland kultivierte Exemplare auf einer Delesseria, links ziemlich weit ausgebildete CutleriaStadien, daneben Aglaozonia-Stadien. In der Mitte ein Keimling, der sehr bald zur Bildung der Aglaozonia schritt, rechts eine Cutleria, welche in frühester Jugend schon Gametangien bildete.

Die Zoosporen können nun sofort zu Cutlerien auswachsen. sie bilden dann zunächst einen einfachen Faden, welcher mittels eines Rhizoids angeheftet ist (Fig. 178, 1, 2).

Im aufrechten Faden entsteht nun ein basaler interkalarer Tegetationspunkt, welcher Seitenzweig'e bildet, die sich wieder verzweigen können (Fig. 178, 3, 4). Schließlich bilden diese Zweige in ihrem unteren Teile ein pseudoparenchymatisches Gewebe (Fig. 178, 5), welches sich mehr und mehr vergrößert, während die Spitzen frei bleiben. So entsteht ein junger Cutleria-Thallus (die aufrechten Exemplare der Fig. 179, 6). Später bildet sich darin durch verschiedene Teilungen 
und Differenzierungen ein zentraler Teil und eine Rinde aus (Fig. 178, 7, 8). Bisweilen aber geht die Cutleria schon auf einem recht jungen Stadium zur Bildung einer Aglaozonia-Scheibe an der Basis über (Fig. 179, 7 in der Mitte), in welchem Falle also fast direkt aus den Aglaononien-Sporen wieder Aglaozonien gebildet werden. In wieder anderen Fällen schreitet das junge Cutleria-Pflänzchen (Fig. 179, 8 rechts) schon im Fadenstadium zur Bildung von Gametangien.

Die Gametangien der Cutleria sind plurilokulär, sie bilden sich in normalen Fällen an älteren Thallomen an der Basis der Haarbüschel, welche an der Oberfläche der Sprosse gebildet werden.

Die Gametangien sind in Makro- und Mikrogametangien differenziert, bei ersteren sind die Kompartimente groß, bei letzteren klein, was, da

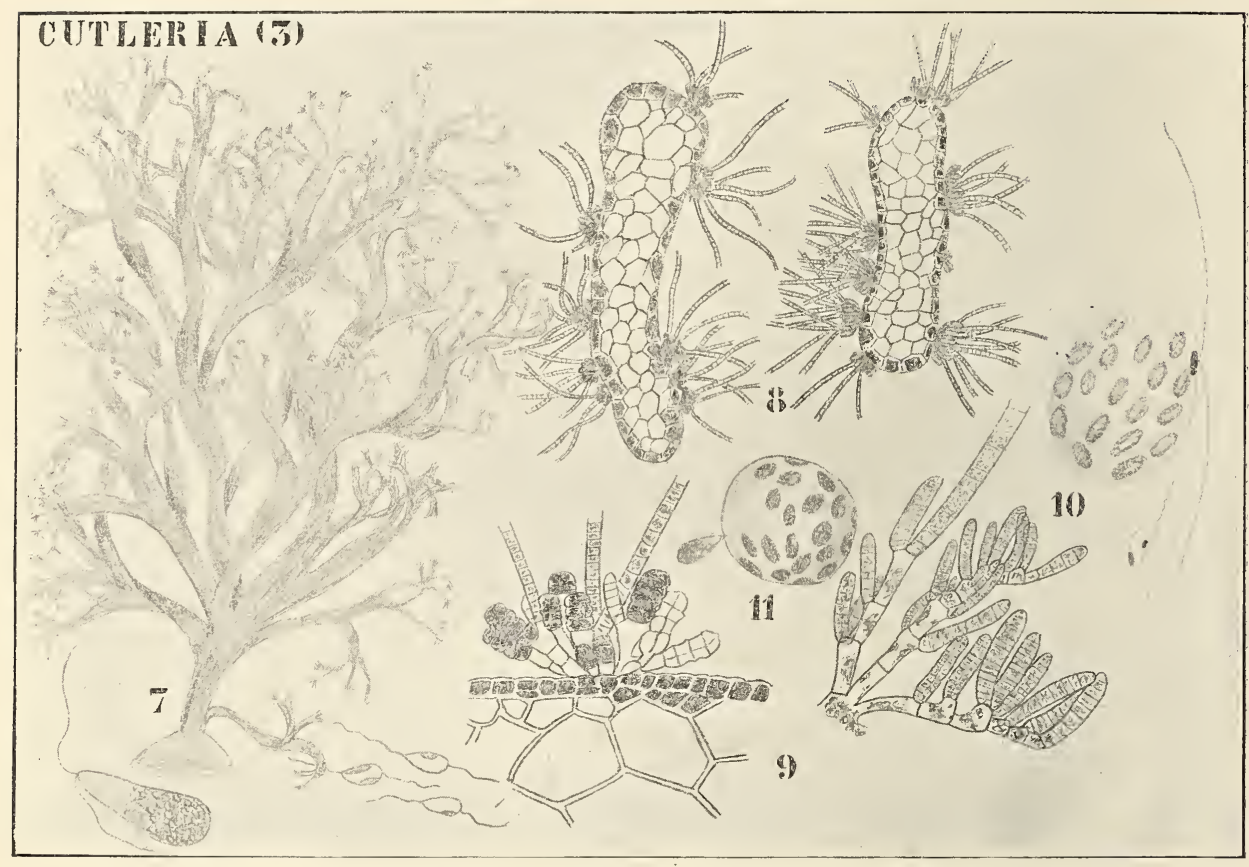

Fig. 180. Cutleria (nach ThURET). 7 Habitus. 8 Querschnitte des Thallus mit Gametangien, links Makro- rechts Mikrogametangien. 9 Idem, Stücke stärker vergrößert. 10 Oben eine Makro-, unten eine Mikrogamete. 11 Ei mit einem Spermatozoon kopulierend.

in jedem Kompartiment eine Gamete entsteht, einen bedeutenden Unterschied in der Größe dieser beiden Gametenarten bedingt (Fig. 180, 10). Ueberdies sind die Makrogameten mit zahllosen dunkelbraunen Chromatophoren versehen, während die Mikrogameten nur ein einziges, kleines, gelbes Chromatophor besitzen. Hieraus folgt, daß man sehr geneigt ist, hier von Eiern und Spermatozoen zu reden, und mit Recht, denn die Befruchtung findet erst statt, wenn die Makrogamete die Cilien eingezogen und sich abgerundet hat (Fig. 180, 10). Wir sehen hier also aus einer Makrogamete sich ein Ei bilden. Die Eier können sich auch parthenogenetisch entwickeln; die Keimprodukte der Parthenosporen und der Eier sind nicht verschieden. Normalerweise entwickelt sich daraus, wie schon bemerkt, eine Aglaononia, an welcher das Säulchen 
noch lange erhalten bleibt. Bisweilen aber können sie direkt zu Cutleria-Thalli auskeimen.

Der Anschluß der Cutleriaceen ist wohl bei den Ectocarpaceen durch Vermittelung von Formen wie Ectocarpus secundus zu suchen; eine früh fruktifizierende Cutleria wie die der Fig. 179, 8 rechts ähnelt einem Ectocarpus sehr.

Die dritte Familie der Phaeosporeen, die durch die großen Scheitelzellen ausgezeichnete Familie der Sphacelariaceen, ist wohl von den Ectocarpaceen abzuleiten. Da sie zum Verständnis des Stammbaumes der Pflanzen nicht unbedingt nötig ist, möchte ich sie hier nicht behandeln, sondern verweise auf die Darstellung bei OLtmanns.

Wir schreiten also sofort zu der Besprechung der letzten Gruppe der Phaeosporeen, zu der der

\section{Laminariaceen,}

jener Gruppe der borealen Riesentange, zu welcher auch die mehr als $200 \mathrm{~m}$ lange Macrocystis gehört. Ich muß mich dabei aber auf die Besprechung des einzigen an unserer Küste vorkommenden Genus

\section{Laminaria}

beschränken, wovon ich nur das Nötigste mitteilen werde. Ich möchte aber, zur näheren Bekanntschaft mit dieser sehr interessanten Gruppe, die Lektüre des betreffenden Oltmannsschen Kapitels sehr empfehlen.

Alle Laminarien sind eigentlich arktische oder antarktische Pflanzen, nur Ausläufer ihres Verbreitungsbezirkes ragen in die gemäßigte Zone hinein und wir müssen also schon dankbar sein, daß es an unserer Küste je einen Vertreter der beiden Hauptgruppen der Laminarien, der Saccharina- und der Digitata-Gruppe gibt.

Die Keimpflänzchen beider Gruppen stimmen in der Form überein. Aus einer aus vielen Hyphen gebildeten Keimscheibe strebt ein rundes Stielchen aufwärts, welches in einem laubähnlichen Thallus endet.

Die Laminarien der Saccharina-Gruppe behalten lebenslang diese Form (vergl. untenstehende Fig. 181), nur ändern sie ihre Befestigungsweise. Es bilden sich nämlich am Stielchen etwas oberhalb der Haftscheibe zahlreiche dichotom verzweigte wurzelähnliche Organe, die sogenannten Klauen, welche die Befestigung übernehmen und durch ihr Längenwachstum sogar die ursprüngliche Befestigung zerreißen. Auch in der Digitata-Gruppe kommt dieser Wechsel in der Befestigungsweise zu stande.

Die Laminarien der Digitata-Gruppe haben aber ein ganz anderes Laub, es ist viel breiter und alsbald fächerförmig zerschlitzt (vergl. Fig. 181). An der Grenze von Stiel und Laub liegt bei allen Laminarien eine interkalare Zuwachszone, welche den jährlichen Laubwechsel besorgt. Dieser findet bei uns im Februar und März statt.

Bei Laminaria saccharina entsteht hart unter dem Laube eine scheibenförmige Verbreiterung, welche zeigt, daß die Zuwachszone genau auf der Grenze zwischen Laub und Stiel gelegen ist. Diese scheibenförmige Verbreiterung bildet nun ein neues Laub aus, welches das alte emporhebt (vergl. Fig. 181). Das alte Blatt wird bald durch die Wellen zerrissen und bricht ab.

Bei Laminaria Cloustoni findet der Laubwechsel genau in derselben Weise statt, nur mit dem Unterschied, daß auch beim jungen Laub der 
Rand bald zerschlitzt wird und die so gebildeten Blattschleifen selbständig weiter wachsen. Auch hier wird das alte Laub emporgehoben (vergl. Fig. 181) und fällt alsbald ab.

Die Fruktifikation findet im Herbst oder am Anfang des Winters statt, und das Laub, welches fruktifiziert hat, wird nächstes Frühjahr abgeworfen.

Der anatomische Bau der Laminarien, auf welchen hier nicht näher eingegangen werden kann, hat, bevor das Dickenwachstum, welches sich

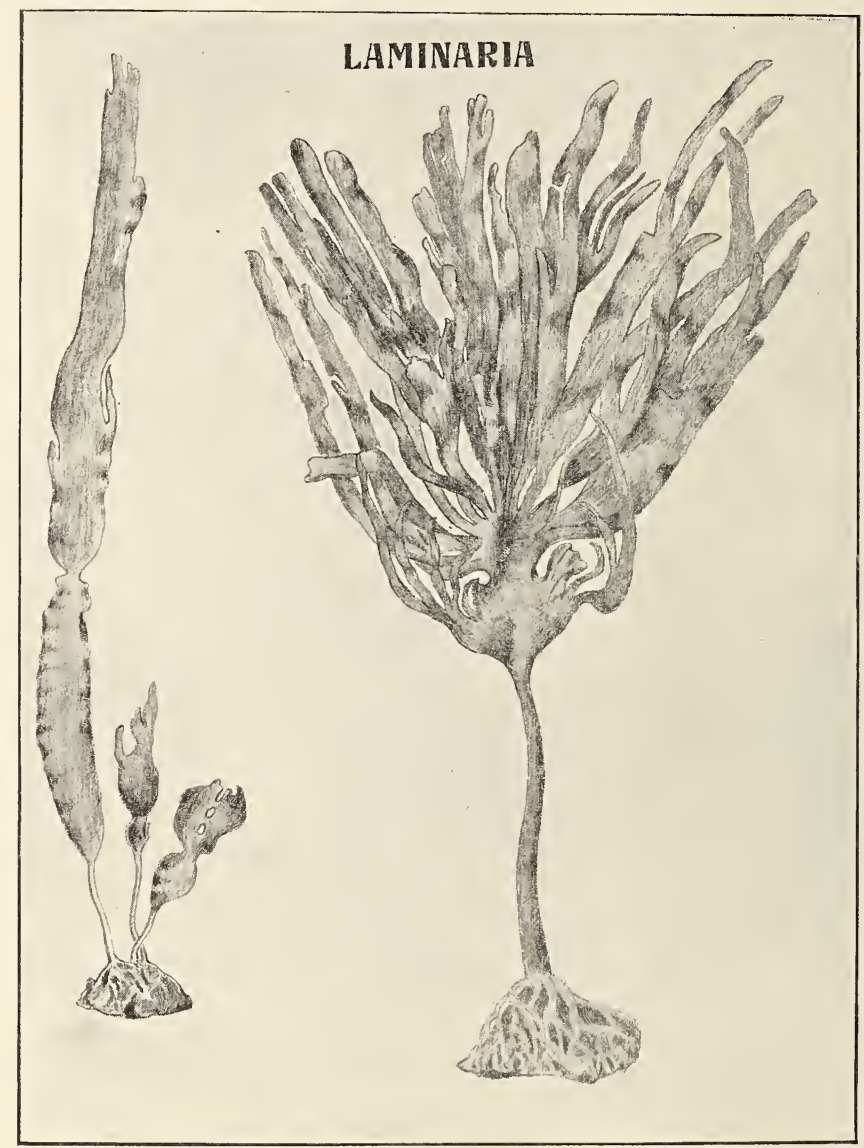

Fig. 181. Habitusbilder von Lamina ria (nach OLtmanns). Links L. saccharina, rechts L. Clonstoni, beide im Laubwechsel.

hier findet, eingesetzt hat, große Aehnlichkeit mit der einer Chorda, und es lassen sich denn auch die Laminarien von Chorda ableiten unter der Annahme, daß sich der größte Teil des runden Chorda-Thallus laubartig abgeflacht hat.

Die Sporangien und Paraphysen (Assimilationszellen) entstehen genau wie bei Chorda, nur bilden die Paraphysen hier an den Spitzen eine dicke Schleimmembran, welche die Sporangien sehr schützt. Die Sporangien bilden große Soren, welche fast das ganze Laub bedecken können. Nur unilokuläre Sporangien sind bekannt, Thuret sah die normal ge- 
bauten Schwärmer direkt keimen. Nur wenige Botaniker sahen überhaupt diese Schwärmer, vor 2 Jahren sah sie Frl. Hingst in meinem Laboratorium an von „den Helder" mitgebrachtem Material.

Wir können jetzt von der Gruppe der Phaeosporeen Abschied nehmen und sollten uns der Besprechung der Akinetosporeen zuwenden. Da aber auch diese Familie zum Verständnis des Stammbaumes der Gewächse kaum nötig ist, verweise ich auch hier auf die Darstellung bei OLTmanns. Es gibt davon zwei noch unvollständig bekannte Familien, die

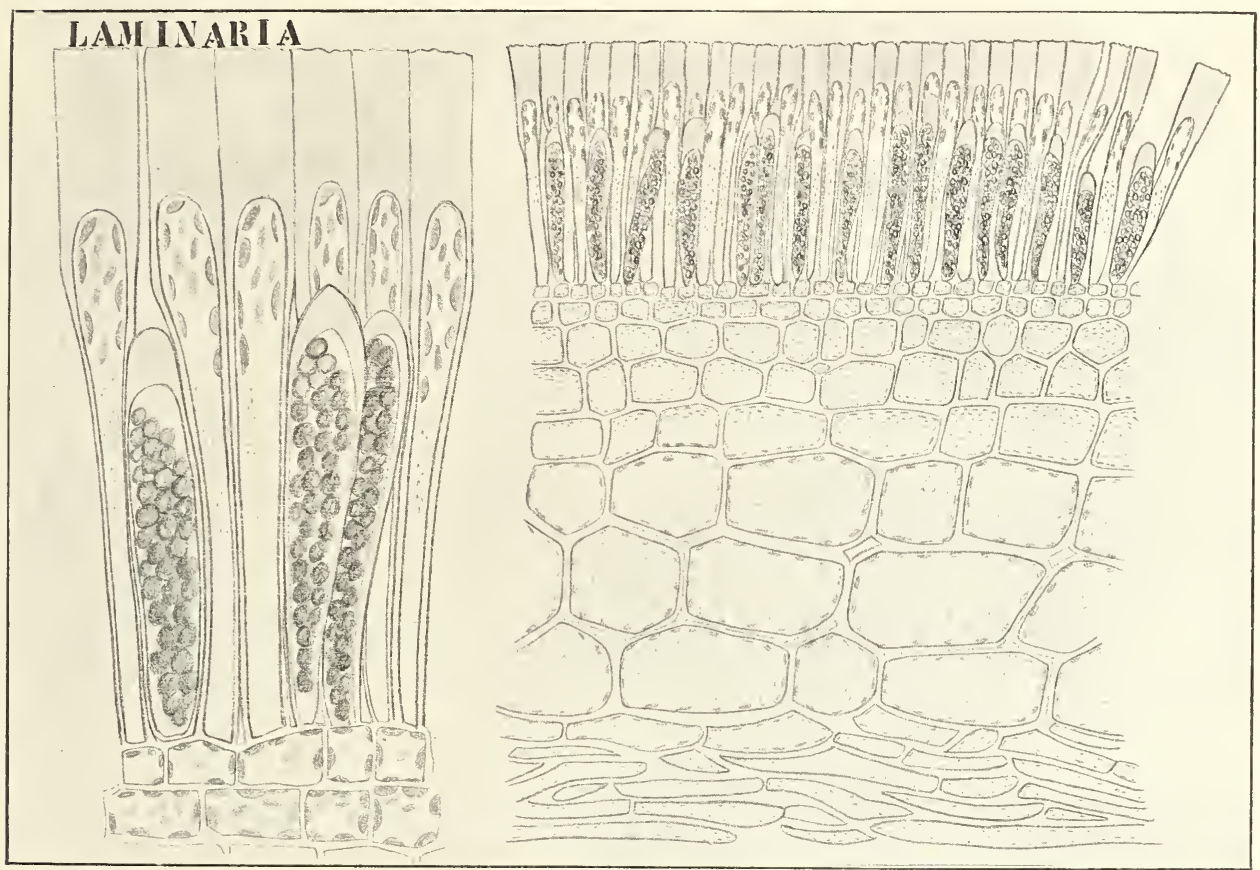

Fig. 182. Laminaria saccharina, fruktifizierend (nach KuCKUCK). Rechts ein Längsschnitt mit Rinde und Mark, links ein Stück der Peripherie, stärker vergrößert.

Tilopterideen und die Choristocarpeen, deren Anschluß durch folgendes Schema dargestellt werden mag:

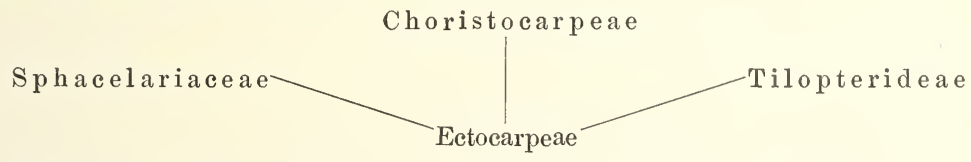

Auch sie sind zum Verständnis des Stammbaumes entbehrlich, wenden wir uns also lieber der letzten Gruppe der braunen Algen zu. der der

\section{Cyclosporeae.}

Diese läßt sich scharf in zwei Familien zerlegen, nämlich in:

1) Dictyotace a e: mit ungeschlechtlichen Tetrasporen und daneben an der Oberfläche des Thallus gelegenen Sexualorganen; 
2) Fucaceen: ohne ungeschlechtliche Fortpflanzungsorgane, mit in Gruben des Thallus versenkten Sexualorganen.

Betrachten wir also zunächst die Familie der

\section{Dictyotaceen,}

von welcher ich zwei Genera: Dictyota und Padina besprechen möchte. In der Jugend ist Padina ein cylindrisches Pflänzchen mit einem mehr oder weniger scheibenförmigen Basalstück (Fig. 183, 1). Es wächst mittels einer Scheitelzelle (Fig. 184, 7, 8), nach und nach nimmt die Spitze an Breite zu, wodurch sie fächerförmig wird (Fig. 184, 9, 10).

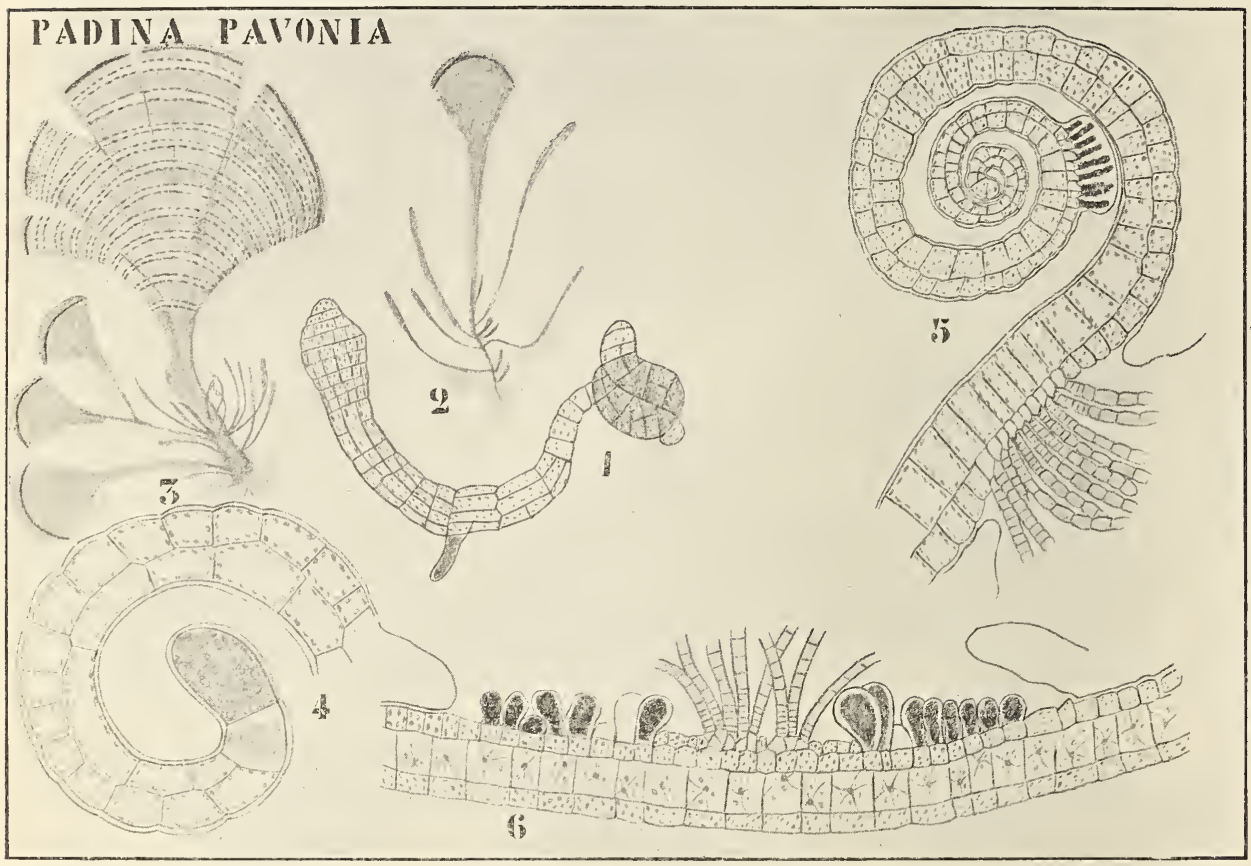

Fig. 183. Padina. 1 Junges Pflänzchen (nach REINKE, die übrigen nach GRUBER). 2 Junges Pflänzchen. 3 Halberwachsene Pflanze. 4 Schnitt durch den gerollten Rand. 5 Id. 6 Sporangien.

Die Scheitelzelle verliert nun ihr Teilungsvermögen, dagegen wird dieses von den aus den Segmenten hervorgegangenen Randzellen erworben (Fig. 184, 11). So entsteht eine teilungsfähige Randzone (Fig. 184, 12).

Der Rand biegt sich nun nach der flachen Seite des Thallus hin um (Fig. 184, 13), und zwar so sehr, daß auf dem Längsschnitt eine Spirale resultiert (Fig. 183, 5). In den von den randständigen Scheitelzellen - wenn ich mich so ausdrücken darf - gebildeten Segmenten tritt nun alsbald eine Längsteilung auf (Fig. 183, 4), wodurch der Thallus zweischichtig wird. Die äußere Schicht wird alsbald viel kleinzelliger als die innere (Fig. 183, 5). Diese kleinzellige Schicht bildet Haare und Fortpflanzungsorgane, wenigstens unter normalen Bedingungen. BITTER 
wies aber nach, daß unter bestimmten Umständen auch Fortpflanzungsorgane vou der imneren Schicht gebildet werden können.

Später teilt sich die innere Schicht noch einmal, so daß im erwachsenen Zustande der Thallus dreischichtig ist, nämlich aus einer Mittelschicht und zwei Rindenschichten besteht (Fig. 183, 6), ja die Mittelschicht kann schließlich noch mehrschichtig werden.

Die Form des Thallus verändert sich während der Entwickelung bedeutend, zunächst cylindrisch, wird er dann fächerförmig, um schließlich durch die herrschenden Spannungen mehr oder weniger trompetenförmige Gestalt anzunehmen.

Unter den Fortpflanzungsorganen lassen sich drei Arten leicht unterscheiden: Tetrasporangien, Oogonien und Antheridien. Zur Bildung der

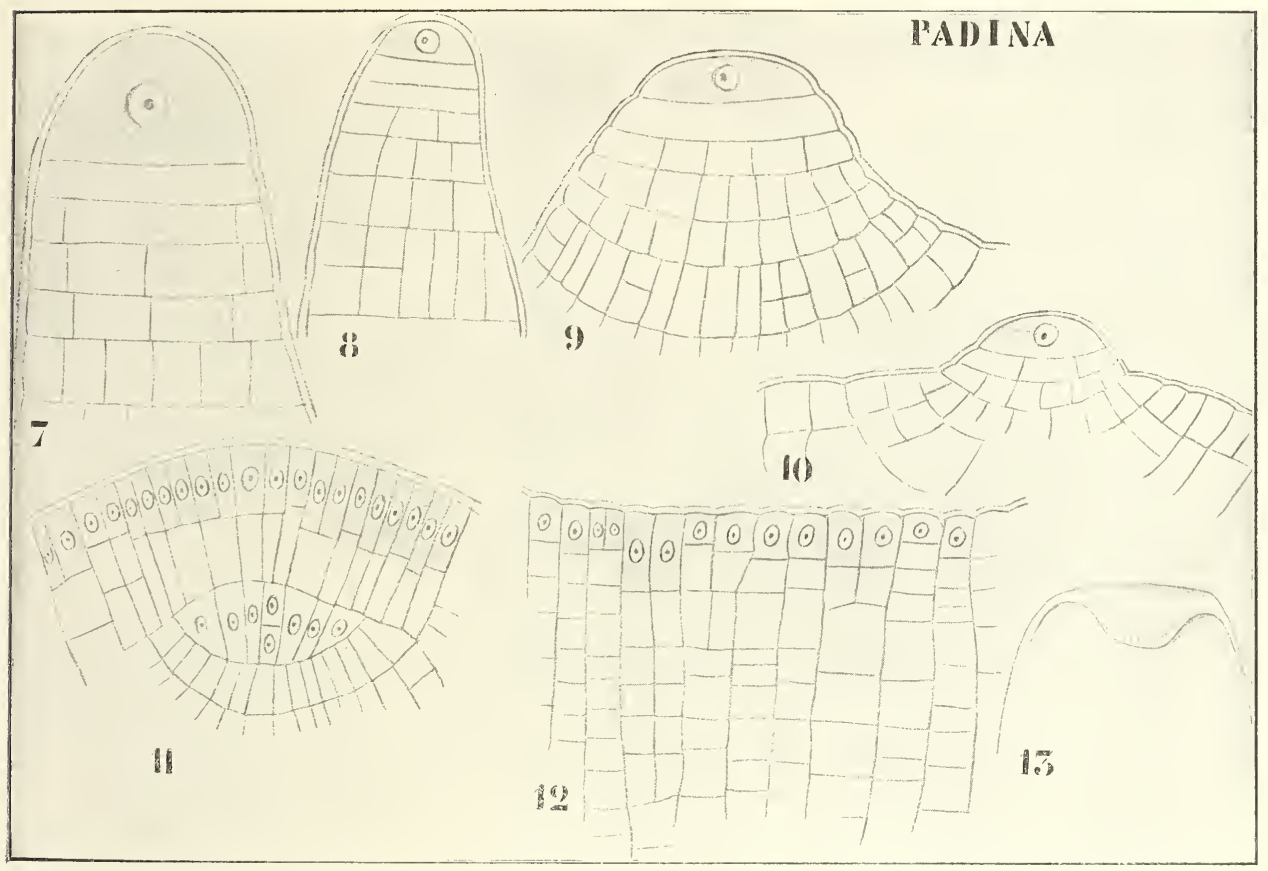

Fig. 184. Padina, junge Stadien (nach ReINke).

Tetrasporangien stülpen sich die Rindenzellen hervor, wobei sie die Cuticula aufheben und schließlich zerreißen (Fig. 183, 6). Dann entsteht eine Querwand, wodurch die 'Tetrasporangium-Anlage in das eigentliche Tetrasporangium und den Stiel zerlegt wird (Fig. 185, 14, 15).

In jedem Tetrasporangium entstehen nun 4 nackte unbewegliche Sporen, die Tetrasporen, welche ohne weiteres zu neuen Individuen auswachsen können.

Exemplare mit Tetrasporen produzieren keine Oogonien oder Antheridien. Diese entstehen auf anderen Exemplaren, welche jedoch äußerlich nicht von den Tetrasporen-Exemplaren zu unterscheiden sind. und zwar Oogonien und Antheridien auf dem gleichen Exemplar, so daß Padina einhäusig ist.

Die Haare sind auf dem Thallus in konzentrische Randzonen ge- 
stellt, die Tetrasporangien werden seitlich von diesen Haarreihen gebildet und wenn nun die Haare später abfallen, kann man die Tetrasporangienreihen als braune konzentrische Doppelstreifen auf dem Thallus sehen (Fig. 183, 3).

Ebenfalls an den Haarreihen entlang, also ebenfalls als Doppelstreifen, aber, wie gesagt, auf anderen Pflanzen, entstehen die Oogonia (Fig. 186, 21).

Die Antheridien dagegen entstehen in schmalen radiären Reihen, welche, wie Oltmanns treffend bemerkt, wie Markstrahlen quer durch die Oogonienreihen hindurchwachsen.

Oogonien sowie Antheridien sind umgebildete Rindenzellen (Fig. 186, 23), die Oogonien haben eine Stielzelle, die Antheridien nicht. In jedem

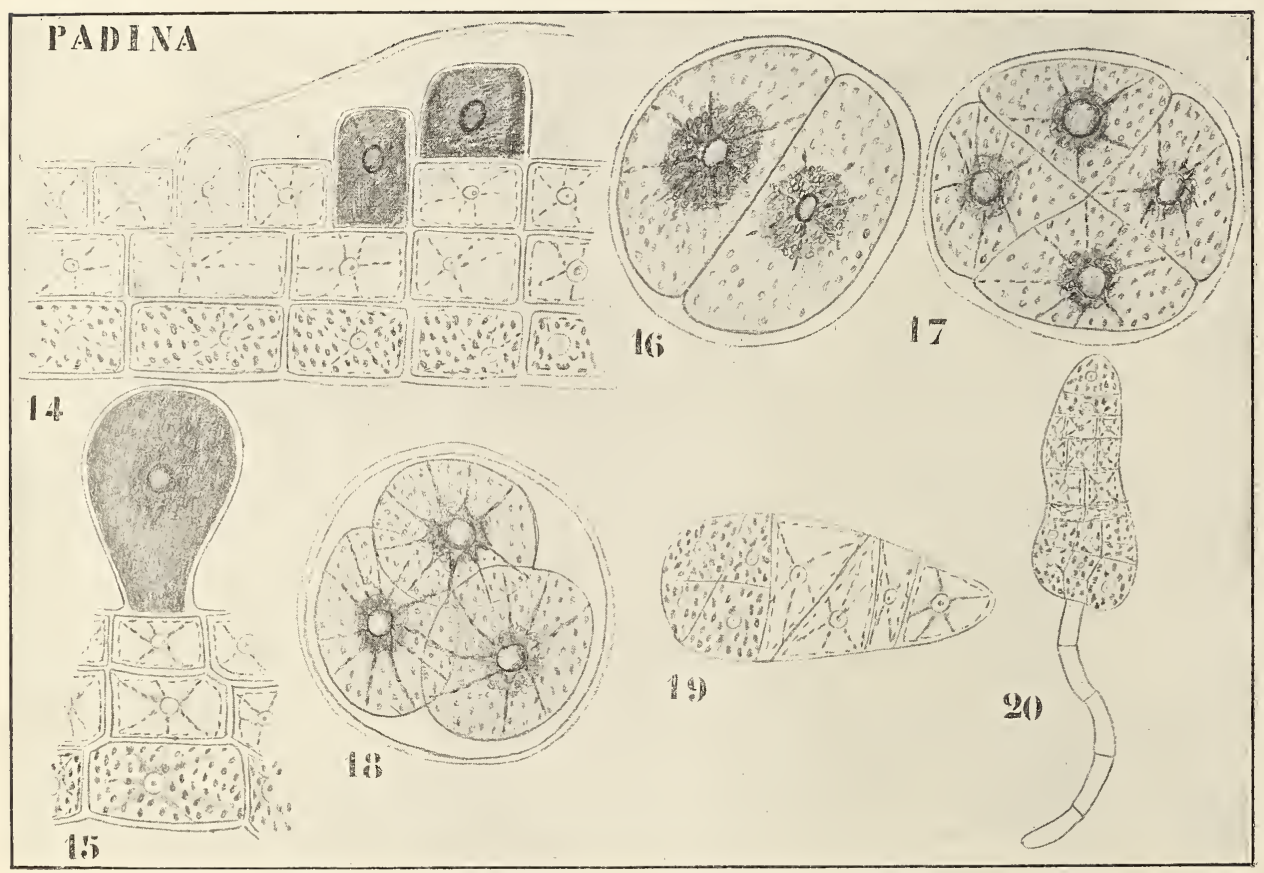
REINKE).

Fig. 185. Padina. Tetrasporangien, Tetrasporenbildung und Keimung derselben (nach

Oogon entsteht ein nacktes kugeliges unbewegliches Ei, in jedem Antheridium, das in viele kleine Zellen zerlegt wird, eine Anzahl vermutlich beweglicher Spermatozoen.

Wir wissen nicht, ob bei Padina Befruchtung unumgänglich nötig ist, oder ob sich die Eier auch parthenogenetisch entwickeln können.

Was nun die Bedeutung dieser Verhältnisse betrifft, so können wir aus Analogie mit Dictyota wohl annehmen, daß die Tetrasporen-Individuen der Padina eine $2 \mathrm{x}$-Generation, die Geschlechtsindividuen eine $\mathrm{x}$-Generation darstellen. Die $\mathrm{x}$-Generation ist demnach bei Padina von der $2 \mathrm{x}$-Generation nicht zu unterscheiden. Trotzdem auch bei 


\section{Dictyota}

keine äußerlich wahrnehmbaren Verschiedenheiten zwischen der $\mathrm{x}$ - und der $2 \mathrm{x}$-Generation bestehen, haben wir da sogar mit 3 Arten von Individuen zu tun. Das rührt daher, daß die x-Generation zweihäusig geworden ist, und wir also neben Tetrasporen-Individuen männliche und weibliche Individuen vorfinden.

Dictyota ist so wie Padina (Fig. 184, 8, 9) in der Jugend cylindrisch, ändert ihre Form aber alsbald in die bekannten bandförmigen dichotom verziweigten Thallomen (Fig. 187, 1).

Schon während des cylinderförmigen Stadiums bilden die Segmente in normaler Weise eine Rinde und einen zentralen Zellfaden. Auch im

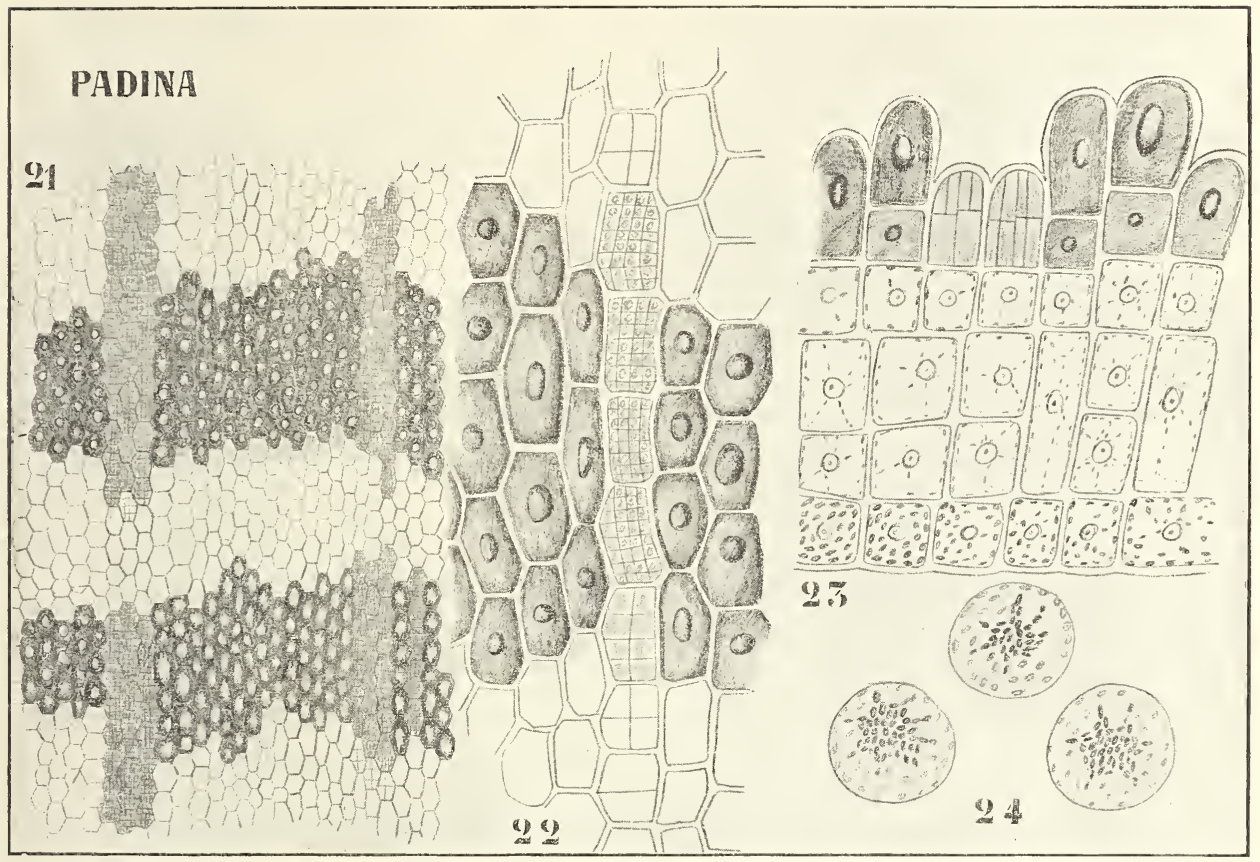

Fig. 186. Padina (nach REINKE). 21 Exemplar mit Oogonien (die breiten horizontalen Streifen) und Antheridien (die schmalen vertikalen Streifen). 22 Ein Stück, stärker vergrößert. 23 Quersehnitt, die Bildung von Oogonien und Antheridien (die zwei mittleren Zellen) zeigend. 24 Eier.

erwachsenen bandförmigen Zustande ist der Thallus dreischichtig. Die Scheitelzelle bleibt hier aber bestehen (Fig. 188 A) und die Verzweigung findet mittels echter Dichotomie statt (Fig. 188, B, C).

Die Tetrasporangien und die Tetrasporen werden wie bei Padina gebildet.

Bei der Bildung der Oogonien stülpen sich eine Anzahl dicht nebeneinander gelegener Zellen hervor, so daß nach Bildung der üblichen Stielzelle und nach bedeutendem Wachstum des jungen Oogons ein dichter Oogoniumsorus entsteht (vergl. Fig. 188), welcher ïber die Oberfläche des Thallus hervorragt. In jedem Oogon entsteht dann ein 
einziges unbewegliches nacktes Ei, welches durch Verschleimung der Oogoniumwand frei wird.

Auch die Antheridien entstehen in Sori (Fig. 188, 5). Auch hier teilt sich die Anlage in ein eigentliches Antheridium und eine Stielzelle, ersteres wird durch zahlreiche Wände in kleine Zellchen zerlegt, deren jedes ein sehr kleines fast farbloses Chromatophor enthält. Diese Spermatozoen wurden früher für unbeweglich gehalten; Wrlulams entdeckte ihre Beweglichkeit (Fig. 188, 6), aber die Spermatozoen sind so klein, daß er noch nicht mit Sicherheit entscheiden konnte, ob ein oder zwei Cilien vorhanden sind, letzteres ist wohl das wahrscheinlichere.

Williams erbrachte den Nachweis, daß im Oogon die ganze Energide ohne Kernteilung zum Ei umgebildet wird und daß die Thalluszellen der Geschlechtspflanzen 16 Chromosomen in den Kernen enthalten.

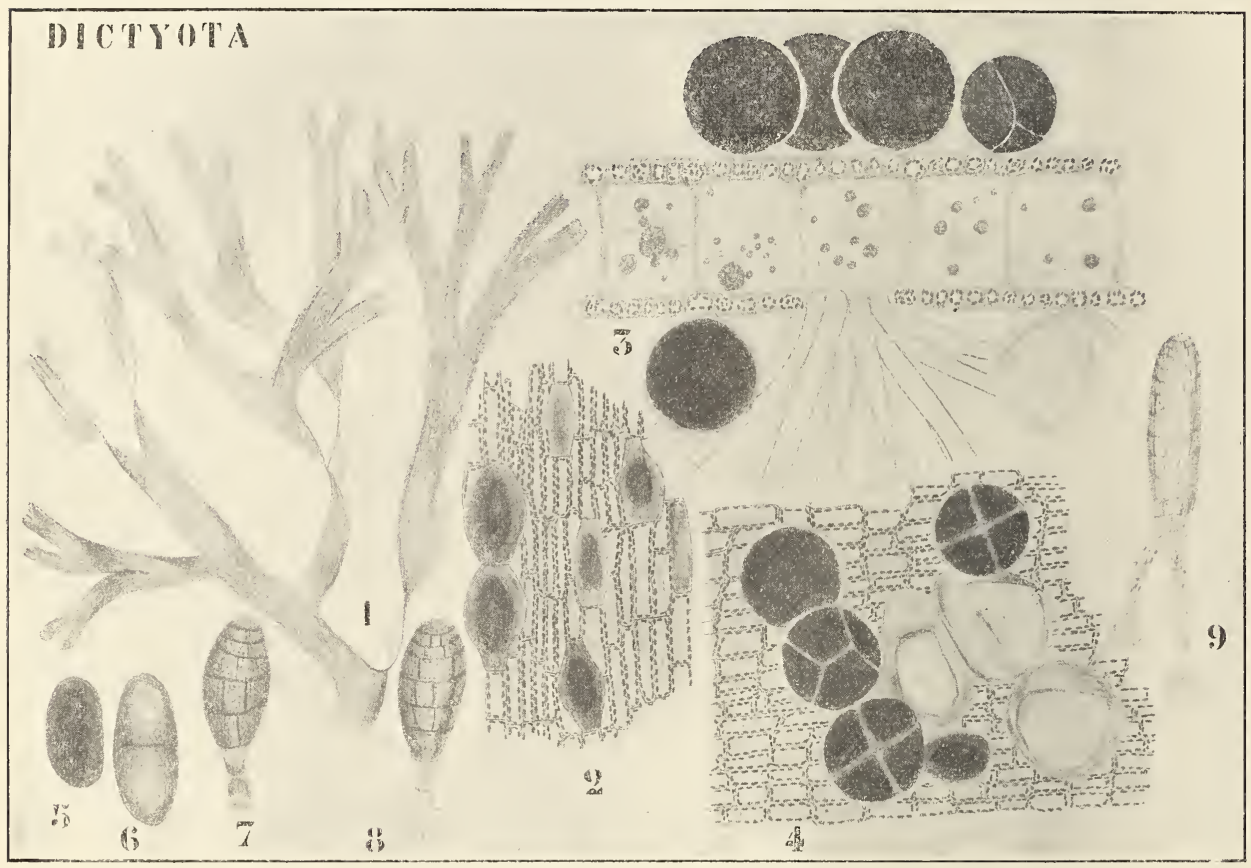

Fig. 187. Dictyota dichotoma, Tetrasporenpflanze (nach THuRET). 1 Teil eines erwachsenen Individuums. 2 Junge Tetrasporangien, von ohen gesehen. 3 Querschnitt durch einen Thallus mit Tetrasporangien und Haarbüscheln. 4 Reife und entleerte Tetrasporangien. 5-9 Aus den Tetrasporen hervorgegangene Keimlinge.

Auch der Kern des Eies besitzt 16 Chromosomen. Letzteres ließ sich feststellen bei der Bildung der Eier sowie bei der Keimung von parthenogenetischen Eiern, deren erste Kernteilung ebenfalls 16 Chromosomen aufweist.

Die normale Entwickelung findet aber mittels Befruchtung statt. Die Zahl der Spermatozoen, welche eine einzige Pflanze zu bilden vermag, ist erstaunlich, sie wird von WiLliams auf 500 Millionen geschätzt. Auch die männlichen Pflanzen enthalten 16 Chromosomen, sowohl in den Kernen der Thalluszellen, wie in den Spermakernen. 
Die Eier besitzen nur kurze Zeit die Anziehungskraft für die Spermatozoen, welche wir bei Fucus so leicht beobachten können. Nach dem Eindringen des Spermatozoons fängt die Zygote sich zu teilen an, und die auftretenden Kernfiguren zeigen, wie zu erwarten war, 32 Chromosomen, es ist also eine 2x-Generation gebildet worden.

Diese $2 x$-Generation bildet nun später die Tetrasporen, und wie schon Motтier nachwies, ist die Tetrasporenmutterzelle, d. h. also die Energide des Tetrasporangiums der Gonotokont, und zwar bringt die erste Teilung die Reduktion der Chromosomen. Die Tetrasporen besitzen demnach nur 16 Chromosomen.

Hier haben wir also für das erste Mal eine richtige 2x-Gemeration, welche jedoch, wie gesagt, äußerlich von der zugehörigen x-Generation nicht zu unterscheiden ist.

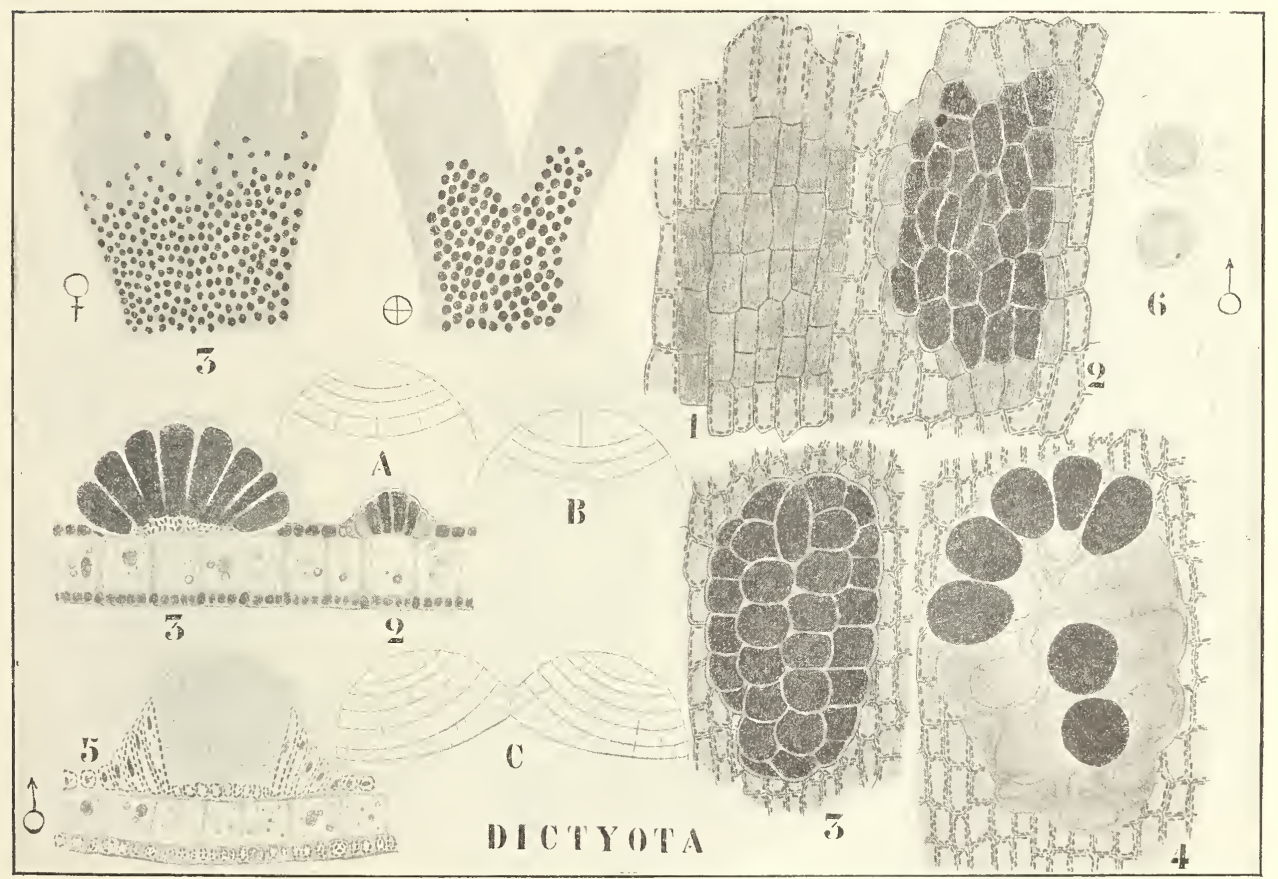

Fig. 188. Diety ot a (nach ThuRer und WiLlinds). 3 Weibliches, daneben TetrasporenExemplar, von oben betrachtet. 1-4 Bildung von Oogoniensori, von oben betrachtet und im Querschnitt. 5 Antheridienbildung. 6 Spermatozoen. A Scheitelzelle. B, C Dichotomie.

In unserer Fig. 189 stellt 1 einen ruhenden, vegetativen Ker'u einer 'Tetrasporenpflanze dar, 2 einen solchen in Teilung', sie enthält 32 Chromosomen. Der Kernfaden des Tetrasporangiums besteht also aus 32 aneinander gereihten Chromosomen. Bei der ersten Teilung des Tetrasporangiumkerns stellt es sich aber heraus, das nur 16 Chromosomen vorhanden sind (Fig. 189, 3), es hat also eine Trennungsteilung stattgefunden. Die gleiche Zahl finden wir in den Tetrasporen und sie bleibt auch bei deren Keimung (Fig. 189, 4) bestehen, so daß die hieraus hervorgehenden mämmlichen und weiblichen Pthanzen in ihren sämtlichen Zellen 16 Chromosomen besitzen. Für die Antheridien zeigt dies 
Fig. 189, 6, während Fig. 189, 7 die Kernteilung darstellt, welche das Oogon von der Stielzelle trennt. Fig. 189, 8 läßt die Befruchtung sehen und Fig. 189, 9 die erste Teilung der Zygote, aus welcher wir ersehen, daß wieder 32 Chromosomen vorhanden sind, eine Zahl, welche im Thallus der sich hieraus entwickelnden Tetrasporenpflanzen beibehalten wird. Wo die Dictyotaceen nach unten anzuschließen sind, weiß ich nicht, und könnte noch nicht einmal eine plausible Hypothese aufstellen. Sie können sich meines Erachtens aus fast jeder niedrigen Form entwickelt haben.

Wir kommen jetzt zur Behandlung der letzten Gruppe der Braunalgen, zu der der

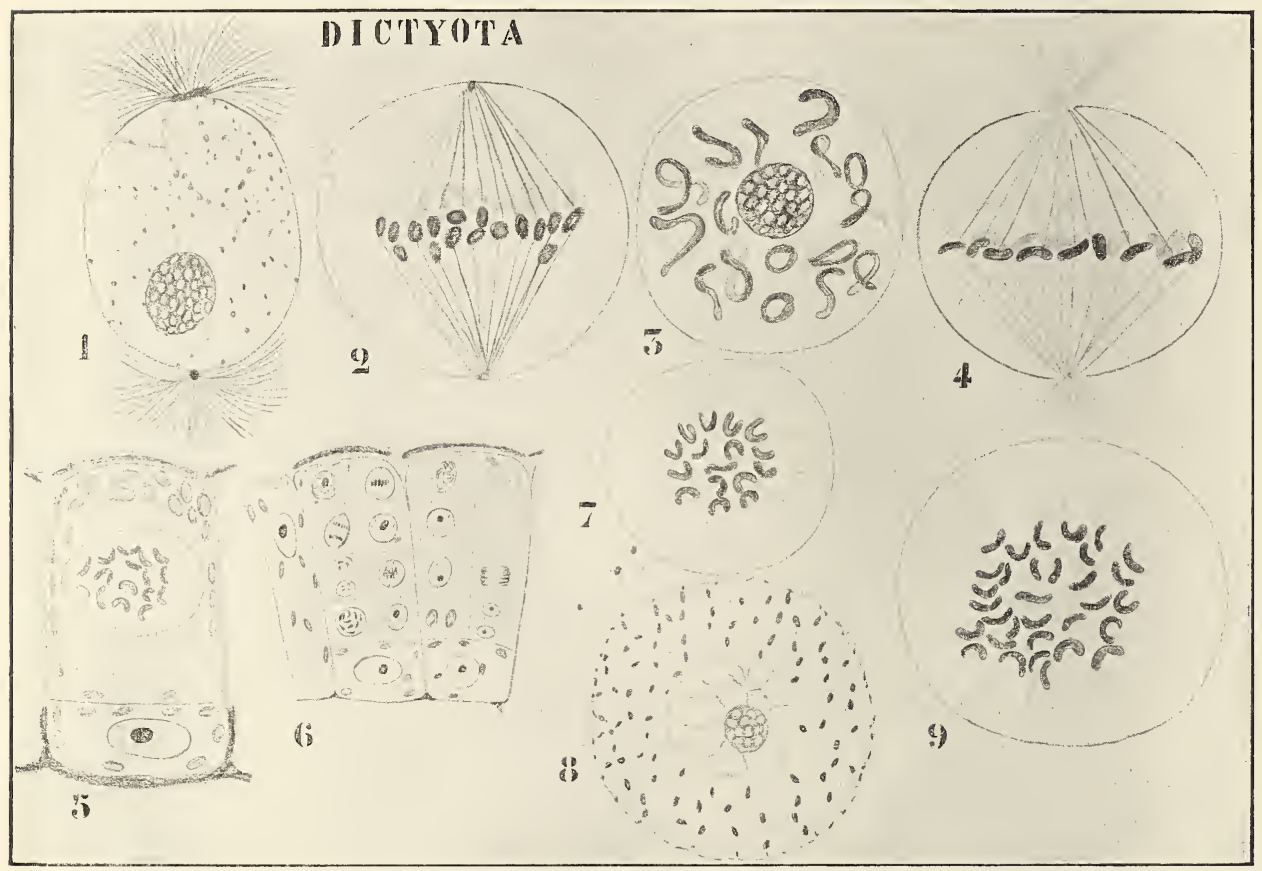

Fig. 189. Dictyota-Kernteilungen (nach WiLliaMs), etwas schematisiert.

\section{Fucaceen,}

mit deren Anschluß nach unten es nicht besser steht. Mit Recht sagt OLtunans: „streng genommen, weiß man nicht viel mehr, als daß sie das Endglied" der Phaeophyceen-Reihe ausmachen, und das ist herzhaft wenig".

Ich muß für manche Frage auf Oltmanns' Bearbeitung der Gruppe hinweisen, ich kann hier nur Fincus und Himanthatia und von diesen in der Hauptsache nur die Fortpflanzung mit Thnen behandeln. Es sind dies die borealen Genera; in südlicheren Gegenden sind die Fucaceen durch Cystoseira, Sargassum. und andere Genera vertreten.

Das Genus Fucus ist an unserer Küste ziemlich stark vertreten. Ihnen sind ja allen diese Tange, welche an der Grenze der Gezeiten oder wenigstens nur wenig unterhalb der Linie des tiefsten Wasser- 
standes an unseren Meeresdeichen und Pfählen vorkommen, bekannt. Es ist eine der wenigen Meeresalgen, welche beträchtliche Quantitäten Süßwasser vertragen könmen, daher finden wir an den "Pieren" bei Katwyk, welche täglich vom ausströmenden Rheinwasser überflutet werden, voll Meeresalgen nur Fucus, Enteromorpha, Porphyra und UlothrixArtel. Schön entwickelt sind sie aber dort nicht, der beste Fundort ist "den Helder".

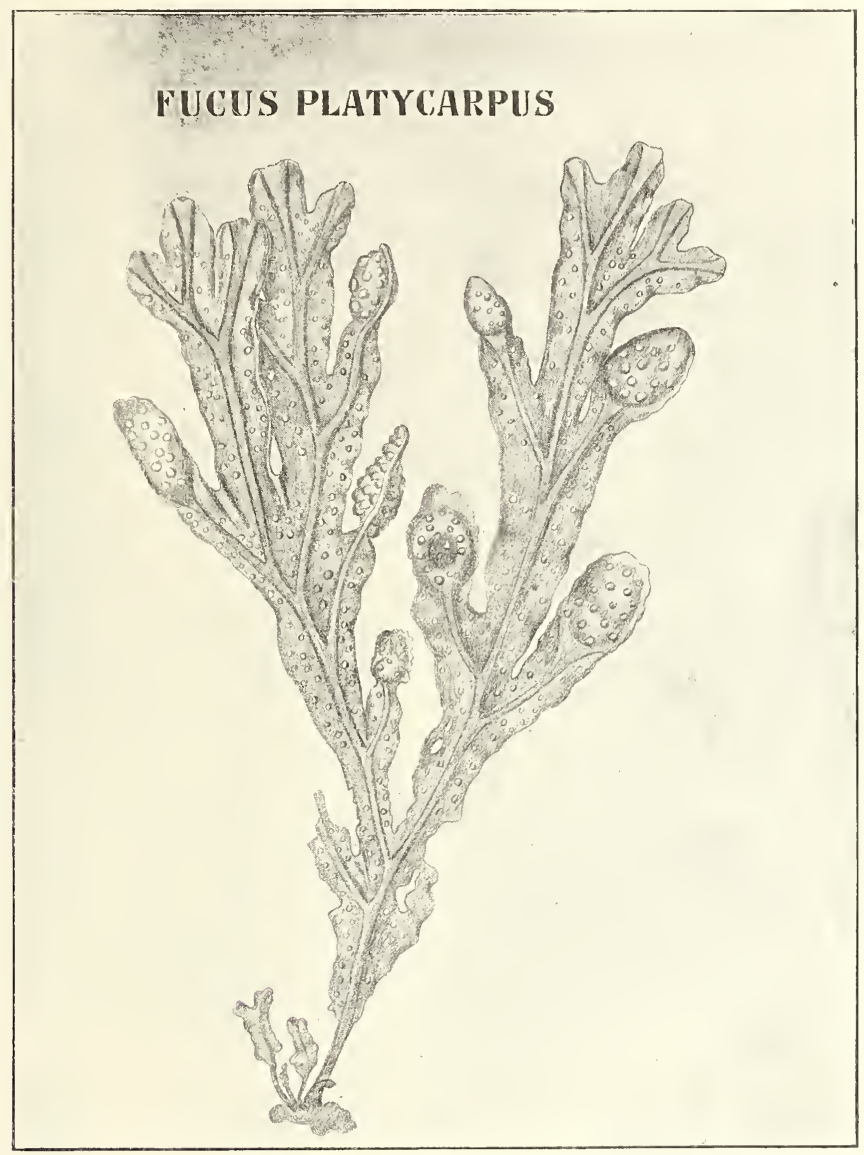

Fig. 190. Fucus platycarpus (nach ThureT).

Himanthalia wächst in tieferem Wasser, sie wird bei Sturmwetter an unserer ganzen Küste angespült; ob diese Pflanzen in goeringer Entfernung von unserer Küste wachsen oder von England herüberkommen, ist nicht bekannt.

Betrachten wir zunächst das Genus

\section{Fucus.}

Es sind dessen Vertreter feste, g'roße. bramorün gefärbte Pflanzen (siehe Fig. 190) auf deren Bau wir später zurückkommen. Ungeschlechtliche Fortpflanzung findet nicht statt. Geschlechtliche Fortptlanzung mittels 
Eier und Spermatozoen. Was die Verteilung der Geschlechter betrifft, können wir bei Fucus zwei verschiedene Gruppen unterscheiden: hermaphrodite Arten, in dieser Hinsicht an Padina erinnernd, und eingeschlechtige wie bei Dictyota. Von den an unserer Küste vorkommenden Arten ist Fucus platycarpus hermaphrodit, F. vesiculosus und F. serratus zweihäusig. Ascophyllum, ein verwandtes Genus, ist ebenfalls zweihäusig, und nun fand Williams eine Pflanze, welche zwar Ascophyllum ähnlich war, aber hermaphrodit war. Dies brachte ihn auf den Gedanken, ob da vielleicht ein Bastard zwischen Fucus vesiculosus und Ascophyllum vorlag und in der Tat konnte er durch die Befruchtung von Fucus vesiculosus-Eiern mit Ascophyllum-Spermatozoen im November 1898 Bastarde erzielen, welche im Februar 1899 noch gut wuchsen. Da er aber, soweit ich weiß, später nie etwas darüber publiziert hat, fürchte ich, daß sie zu Grunde gegangen sind.

Hybriden zwischen Fucus vesiculosus +9 und $F$. serratus $\delta$ waren früher schon von THURET gemacht.

Gewöhnlich werden die Eier und Spermatozoen während der Ebbe halb ausgestoßen, um während der Flut ganz auszutreten. Oltuanns, der beste Kenner der Fuci und mit Thuret u. a. der Grundleger unserer Kenntnis dieser Gruppe, beobachtete aber, daß im Baltischen Meere, wo fast keine Ebbe oder Flut herrscht, die Geschlechtsprodukte periodisch unter Wasser ausgestoßen werden.

Das Verhalten an unserer Küste gibt uns nun ein Mittel an die Hand, um auch an weit im Inlande gelegenen Stellen die Befruchtung, wenigstens die äußerlichen Vorgänge dabei, zu demonstrieren. Dazu sammelt man an der Meeresküste bei Ebbezeit männliche und weibliche Exemplare von Fucus serratus, welche man gesondert hält. Um dies tun zu können, muß man sie erst zu unterscheiden wissen. Das ist nun ganz leicht. Schneidet man nämlich von dem fruktifizierenden Teile mit einem Taschenmesser ein Scheibchen ab und hält dann den so behandelten Teil gegen das Licht, so zeigen die weiblichen Pflänzchen die mit Eiern gefüllten Oogone als dunkle Punkte auf hellgelbem Grunde, während die männlichen nur eine diffus rotgelbe Farbe zeigen, in der weiter nichts zu unterscheiden ist. Die Pflanzen werden nun lose, gesondert verpackt und abgeschickt. Am nächsten Tage wird man auf den männlichen Pflänzchen orangefarbige Tröpfchen sehen, welche aus ausgetretenen Antheridien bestehen. Man schneidet nun solche Spitzen ab und wäscht sie in einem Meereswasser (künstliches genügt) enthaltenden Becherglase aus, bis die Flüssigkeit durch die Millionen aus den sofort platzenden Antheridien ausgetretenen Spermatozoen dunkelorangefarbig ist. In gleicher Weise werden die Spitzen der weiblichen Pflanzen abgewaschen; in dem betreffenden Becherglase bildet sich alsbald ein brauner Bodensatz, welcher aus den Eiern besteht. Mischt man nun einen Tropfen dieses Bodensatzes mit einem Tropfen Spermatozoenwasser auf dem Objektträger und betrachtet man diese Mischung unter dem Mikroskop, so ist die Befruchtung leicht wahrzunehmen. Man sieht, wie die Spermatozoen von den Eiern angezogen werden, sich an deren Oberfläche ansammeln, und zwar öfters in so großer Quantität, daß sie die viel größeren Eier in Rotation versetzen.

Beobachtet man ein solches Ei während einiger Zeit, so sieht man, daß es seine Anziehungskraft für die Spermatozoen verliert, was sich dadurch äußert, daß diese plötzlich das Ei verlassen. Ein solches Ei 
ist befruchtet, d. h. ein Spermatozoon ist in dasselbe eingedrungen. Es geschieht dies, wie Farmer und Williams zeigten, imnerhalb 10 Minuten nach der Ankunft der Spermatozoen und schon nach 10 Minuten sind Spermnucleus und Eikern zusammen verschmolzen. Das ganze Spermatozoon tritt in das Ei ein, also auch sein Chromatophor. Ob letzteres bestehen bleibt, oder zu Grunde geht, ist bei der großen Zahl von Chromatophoren im Ei nicht zu bestimmen. Mit Strasburger nehmen wir an, daß nur der Spermatozoenkern seine Reise nach dem Eikern hin fortsetzt, und daß der Rest des Spermatozoons bald nach seinem Eindringen zurückbleibt.

Nach der Befruchtung wird alsbald eine Membran gebildet und schon am nächsten Morgen kann man die Keimung der Zygote be-

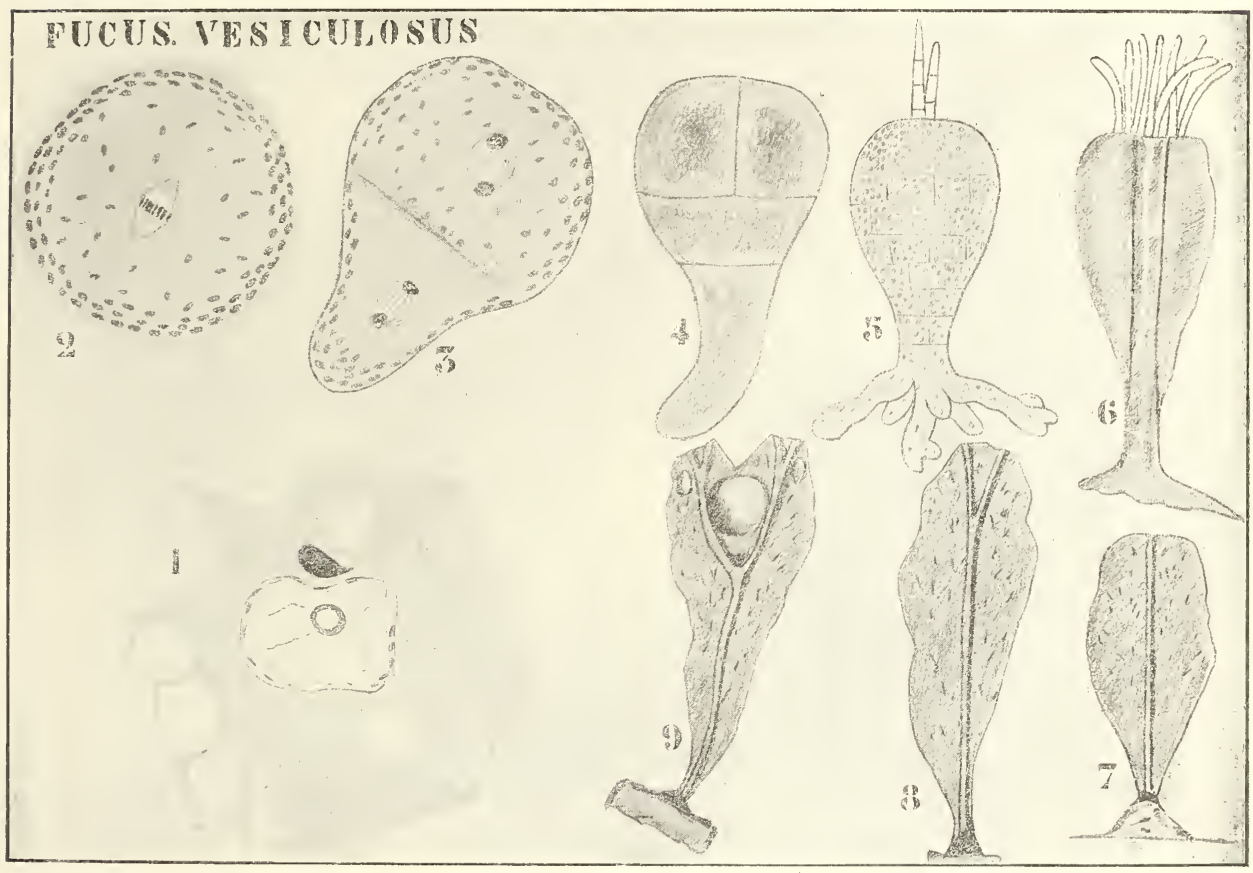

Fig. 191. Fucus. Befruchtung und Keimung. 1 Der Spermakern dicht an dem Eikern. 2 Erste Teilung des Kernes in der Zygote. 3 Erste Wandbildung in der Zygote. 4-9 Junge Fucus-Pflänzchen.

obachten. Sehr viel länger läßt sich in der Regel in einem Laboratorium im Inlande der Keimling nicht am Leben halten; folgendes ist OLtmanns und FARMer entliehen. Alsbald nach der Befruchtung teilt sich der Zygotenkern; da die Kernspindel sich parallel zu den einfallenden Lichtstrahlen stellt, steht die erste Wand senkrecht zu den einfallenden Lichtstrahlen. Die vom Lichte abgekehrte Seite wird nun zu Rhizoid, die demselben zugewendete Seite zur Spitze.

Dann werden weitere Wände gebildet, wodurch das Ganze vielzellig wird, die Wurzelhaare nehmen an Anzahl zu und die ganze Pflanze wird keulenförmig. Bis auf dieses Stadium ist der Querschnitt ein Kreis, alsbald aber wird der Thallus abgeplattet, ein Nittelnerv gebildet 
und es tritt Dichotomie ein, welche jedoch später durch seitliche Verschiebungen gestört wird, so erhalten wir dann die erwachsene FucusPflanze.

Bei Fucus vesiculosus und anderen Arten entstehen schließlich durch Auseinanderweichen der Gewebselemente zu beiden Seiten des Mittelnerven Schwimmblasen. An der Basis der Fucus-Pflanze stirbt

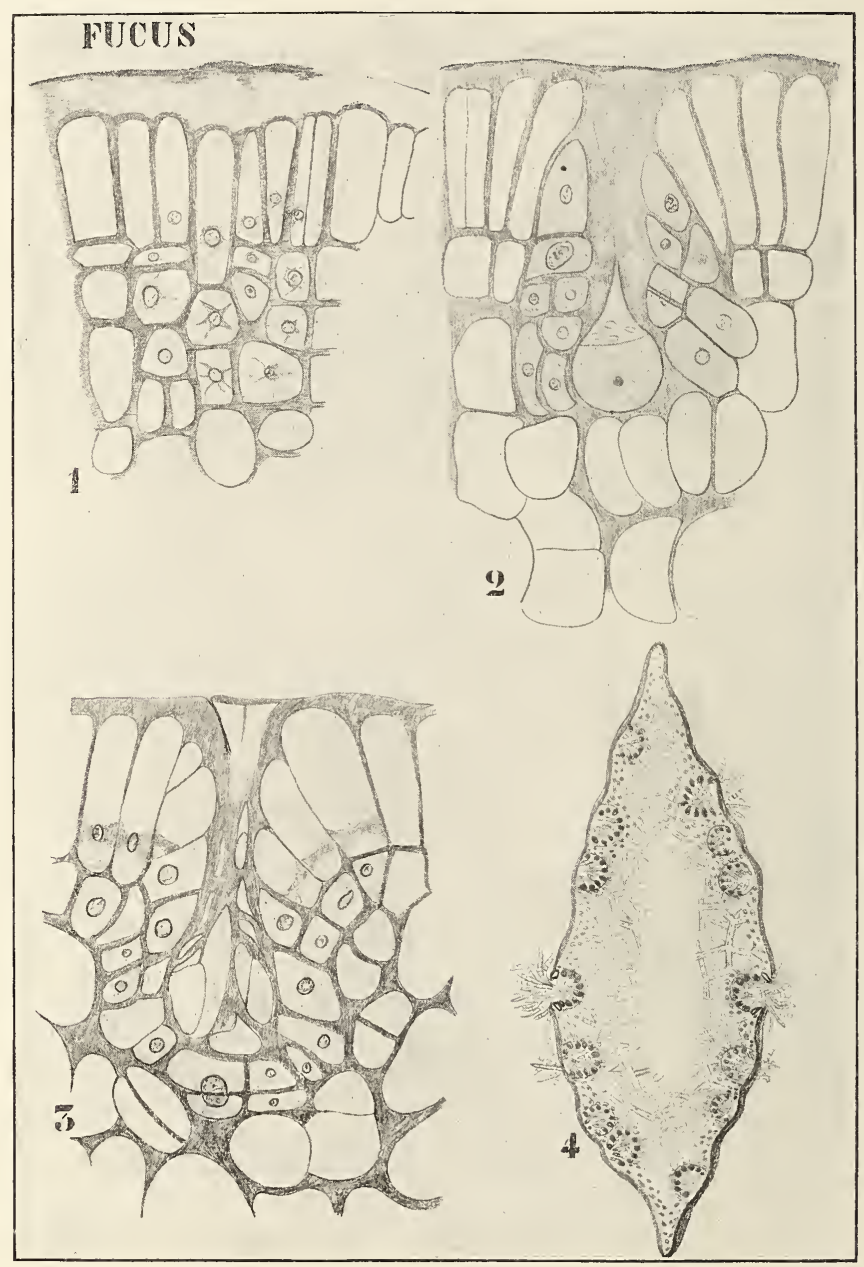

Fig. 192. Entwickelung der Haargrübchen bei Fucus (nach Bower).

später das Gewebe bis auf den Mittelnerv ab, dieser wird durch Dickenwachstum verstärkt und durch Verwebung von Rhizoiden wird eine Haftscheibe gebildet.

Damit sind die äußerlich wahrnehmbaren Formveränderungen der Fucus-Pflanze geschildert. Für den anatomischen Aufbau verweise ich auf Oltmanns; es genügt hier zu erwähnen, daß schließlich ein im wesentlichen an Laminaria erinnernder Bau zu stande kommt, welcher 
hier jedoch aus Teilungen einer zunächst drei- später aber vierseitigen Scheitelzelle hervorgeht.

Es finden sich über das ganze Laub einer Fucus-Pflanze zerstreut sogenannte Haargrübchen, deren Entwickelung von BowER untersucht wurde.

Es sind dies krugförmige Vertiefungen im Laube, welche mit einem schmalen Hals nach außen münden. An der Basis entwickeln sich mit eigenem basalen Vegetationspunkt versehene Haare, welche als pinselförmige Büschel aus der Mündung hervorragen.

Diese Haargruben entstehen nach Bower dadurch, daß eine Zelle der Außenrinde in der Entwickelung zurückbleibt (Fig. 192, 1), die umliegenden Zellen dagegen teilen sich lebhaft, wodurch die Initialzelle in eine Grube versenkt wird (Fig. 192, 2) und alsbald degeneriert (Fig. 192, 3). Durch Teilungen der Nachbarzellen, sowie auch durch die der Zelle, welche die Initiale trägt, wird die Wand der Haargrube weiter ausgebildet.

Diese Entwickelungsweise wurde yon späteren Untersuchern bestätigt, nur fand OLtmanns bei Ascophyllum, daß die Initialzelle nicht degeneriert.

In seinem Buche aber sagt er: „Trotz der erwähnten Abweichungen stimmt doch, das mag nochmals betont werden, die Konzeptakelentwickelung überall bei den Fucaceen darin überein, daß die Nachbarzellen der Initiale die Hauptarbeit leisten, daneben auch die ,Basalzelle6 derselben; die Initiale selber verhält sich etwas verschieden, sie geht entweder zu Grunde oder wächst zu einem Haar aus u. s. w.; überall aber kommt ihr zweifellos irgend eine nennenswerte Funktion nicht zu."

Dieser Auffassung ist vor kurzem Miss Srmons (1906) auf Grund sehr schöner Präparate von Sargassum entgegen getreten.

Sie zeigte im Gegenteil, daß die Initiale bei Sargassum nicht nur nicht degeneriert, sondern eine aktive Zelle ist, welche das ganze Haargrübchen bildet. Die Initialzelle ist, wie Bower richtig bemerkte, eine Rindenzelle, aber bedeutend größer als die umgebenden (Fig. 193, 1). Die Form ist die einer mehr oder weniger weitbauchigen Flasche. Alsbald teilt sich der Kern (Fig. 193,33 A, 2) und es wird eine gebogene Zellwand gebildet (der Columella der Mucorineen vergleichbar, wenn man sich den Bauch der Initialzelle als Sporangium denkt), welche zwei sehr verschieden geformte Zellen bildet. Die obere Zelle, die Zungenzelle von Miss Simons, ist cylindrisch, während die untere konisch oder keilförmig ist. Die untere Zelle teilt sich nun durch eine Längswand (Fig. 193, 3 B), wodurch die Haargrübchenanlage dreizellig wird. Diese beiden unteren Zellen teilen sich nun durch Längswände in solcher Weise, daß auf einem medianen Längsschnitt 5 Zellen zu sehen sind. Vier von diesen sind vor kurzem gebildete junge Zellen, die fünfte ist die Zungenzelle, sie fällt auf diesem und auf manchem älteren Stadium noch recht auf. Der Mund der Haargrube ist von einem Randring. epidermalen Gewebes von 1-2 Zellen Tiefe umgeben. Diese Kleinigkeit ausgenommen ist also jeder Teil der Haargrube das Produkt der Initialzelle.

Die Zungenzelle degeneriert später oder kann zu einem Haar auswachsen. Wahrscheinlich hat Bower die Initialzelle und das zweizellige Stadium der Haargrube gesehen (Fig. 192, 1 nach Bower), aber da er die Teilung der Initialzelle nicht fand. bei späteren Stadien die Zungenzelle für die Initialzelle gehalten. So wurde die Degeneration 
der Zungenzelle tür Degenerieren der Initialzelle gehalten, und die Teilung der unteren Zelle nur als eine Teilung einer $\mathrm{x}$-beliebigen Kortikalzelle betrachtet. Die Wandzellen der Haargrube bilden später die Haare.

In solchen Haargruben können nun unter Umständen Geschlechtsorgane gebildet werden. In der Regel geschieht das aber in den Haargruben überaus ähnlichen Vertiefungen, welche auf den fertilen Teil des Laubes beschränkt sind und Konzeptakeln genannt werden. Die Homologie dieser Organe mit den Haargruben wurde zuerst von Bower entwickelungsgeschichtlich nachgewiesen und nun auch von Miss Simons bei Sargassum bestätigt. Ob nun phylogenetisch die Konzeptakeln zuerst da waren und durch Sterilwerden Haargruben wurden, oder ob umgekehrt

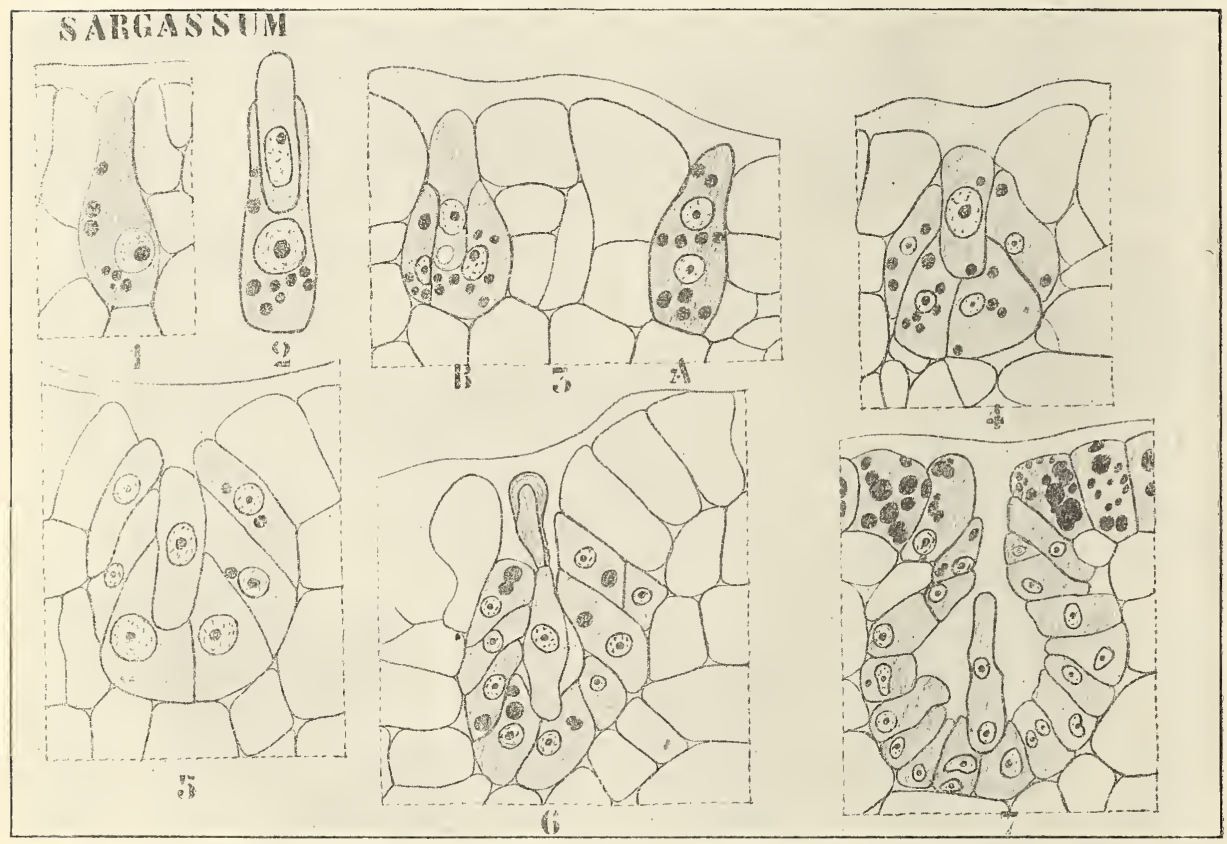

Fig. 193. Entwickelung der Haargrübchen bei Sargassum (nach Miss Simons). 1 Initialzelle. 2 Zweizelliges Stadium, die Zungenzelle und die untere Zelle zeigend. 3 B Dreizelliges Stadium. 3 A Stadium zwischen 1 und 2, zwei Kerne in der Initiale zeigend. $4-7$ Weitere Entwickelungsstadien.

zunächst Haargruben gebildet wurden, welche später fertil wurden, ist nicht so leicht zu entscheiden. Manches spricht aber, wie Miss Srmons bemerkt, für Bowers Auffassung, daß die Haargruben steril gewordene Conceptacula sind.

Das Beschränktsein von Konzeptakeln auf speziellen Fruchtzweigen, das Vorkommen der Haargruben auf vegetativen und fertilen Zweigen, die gelegentliche Entwickelung von Sexualorganen in den Haargruben, legt die Neinung nahe, daß der Thallus der Fucaceae ursprünglich über seine ganze Oberfläche fruktifizierte, erst später Fruchtzweige entwickelte und nun die Konzeptakeln seines vegetativ gewordenen Teiles in sterile Haargruben verwandelte. 
Betrachten wir jetzt die Fruktifikation. Bei Sarcophycus (syn. Durvillea), einem nicht europäischem Fucaceen-Genus von Laminariaähnlichem Habitus entspringen der Konzeptakelwand verzweigte Haare, welche seitlich die Oogonien tragen (Fig. 195, 1).

Bei allen anderen Fucaceen aber entstehen die Oogonien jedes für sich als Ausstülpungen der Zellen der Konzeptakelwand. Sie bilden eine Stielzelle (Fig. 195, 2). Bei Fucus bilden sich in jedem Oogon 8 Eier, dazu hat sich der Oogonnucleus also 3mal geteilt (Fig. 195, 3). Bei Ascophyllum werden nur 4 Eier gebildet, bei Pelvetic zwei, bei den meisten Genera, z. B. bei Himanthalia, aber nur eins.

In allen diesen Fällen aber werden, wie Oltmanns zeigte, 8 Eier angelegt, d. h. der Kern teilt sich in 8 Kerne, von diesen gehen aber

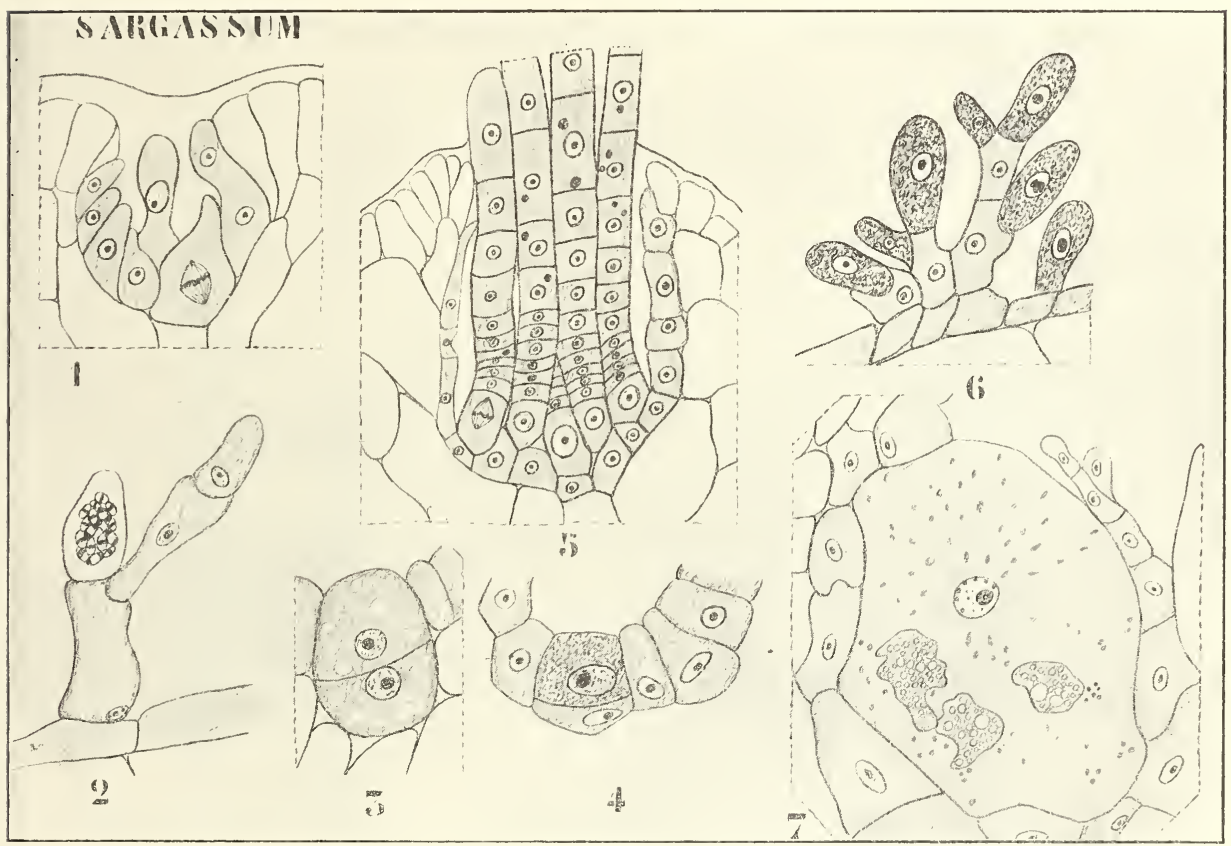

Fig. 194. Entwickelung der Geschlechtsorgane bei Sargassum (nach Miss Simoxs). 1 Junges Konzeptakel. 2, 6 Antheridienstände. 5 Haargrube, die basalen Vegetationspunkte der Haare zeigend. 3, 4, 7 Oogonienbildung.

nachträglich bei Arten wie Himanthalia 7 zu Grunde und es entwickelt sich nur einer zu einem Ei. Ja Miss Simons hat vor kurzem nachgewiesen, daß die Reduktion noch weiter gehen kamm. In der Regel findet bei Sargassum filipendula gar keine Kernteilung statt, und es wird der Oogoninhalt sofort zum Ei, nur in äußerst seltenen Fällen weist auch dort noch eine Kernteilung im Oogon auf die Abstammung von Ahnen mit mehreren Eiern in dem Oogon hin.

Bei der Bildung der Eier im Fucus-Oogon sieht man zwischen den bramen jungen Eiern (Fig. 195, 2, 4), solange sie noch polygonal sind, farblose Streifen. Das sind, wie Farmer und Wiluiams nachwiesen, und Oltmanns bestätigte, dümne Wände, woraus folgt, daß die FucusOogonien eigentlich plurilokuläre Gametangien sind. 
Die Wand der Oogonien besteht aus drei verschiedenen Schichten, von außen nach innen: Exo-, Meso- und Endochiton. Das "Exochiton ist durch einen ziemlich großen schleimerfüllten Raum vom Mesochiton geschieden. Mesochiton und Endochiton liegen dagegen dicht aneinander.

Vermutlich infolge Quellung dieses Schleimes, zerreißt beim Oeffnen

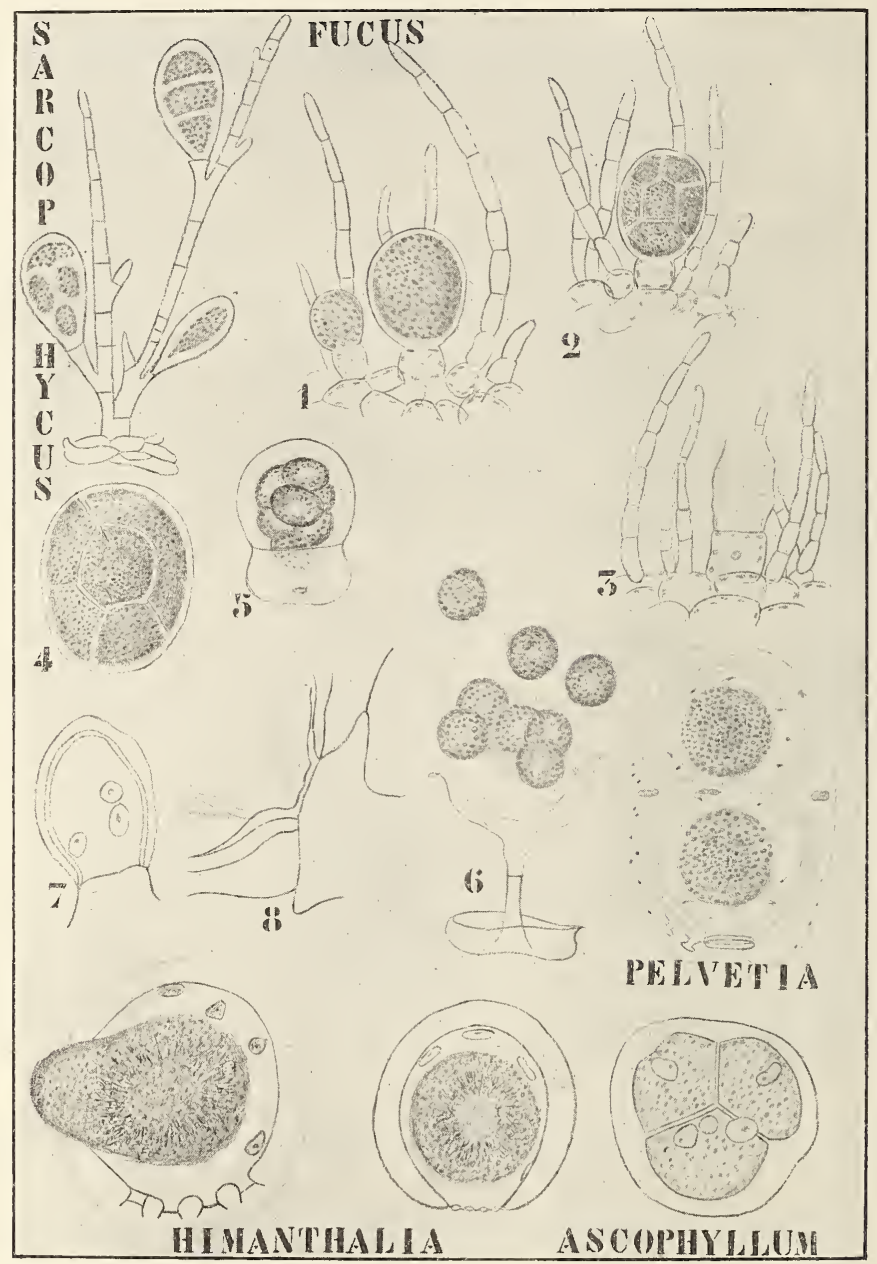

Fig. 195. Weibliche Geschlechtsorgane der Fucaceen (nach Thuret, OLtmanns, Murray und Farmer). I. Sa reoph ycus. Verzweigte Fäden mit Oogonien. - II. Fucus. 1 Oogonium mit ungeteiltem Inhalt. 2 Inhalt in 8 Stücke geteilt. 3 Das Oogon ausgeschlüpft. 4 Das ausgeschlüpfte Oogon. 5, 6 Austritt der Eier. 7 Längsschnitt durch ein junges Oogon, Endochiton, Mesochiton und Exochiton zeigend. 8 Idem, die Basis stärker vergrößert. - III. Pel v e tia. Oogon mit eindringenden Spermatozoen. - IV. Himanthalia. Links austretendes Ei, rechts jüngeres Stadium, beide die degenerierten Eier zeigend. V. Ascophy $11 \mathrm{um}$. Oogon mit 3 ausgebildeten und 5 reduzicrten Eiern.

der Oogonien zunächst das Exochiton. Später schlüpft das ganze Oogon aus dem Exochiton heraus, während letzteres an der Stielzelle befestigt 
bleibt. Das die Eier umschließende Oogon (Fig. 195, 4) liegt dann im Meerwasser, es reißt nun das Mesochiton entzwei und läßt das Endochiton hervortreten (Fig. 195, 5). Schließlich zerreißt auch dieses und es treten die Eier heraus (Fig. 195, 6).

Bei Pelvetia bleibt das Exochiton ebenfalls im Konzeptakel zurück, aber Endochiton und Mesochiton zerreißen nicht, sondern verschleimen

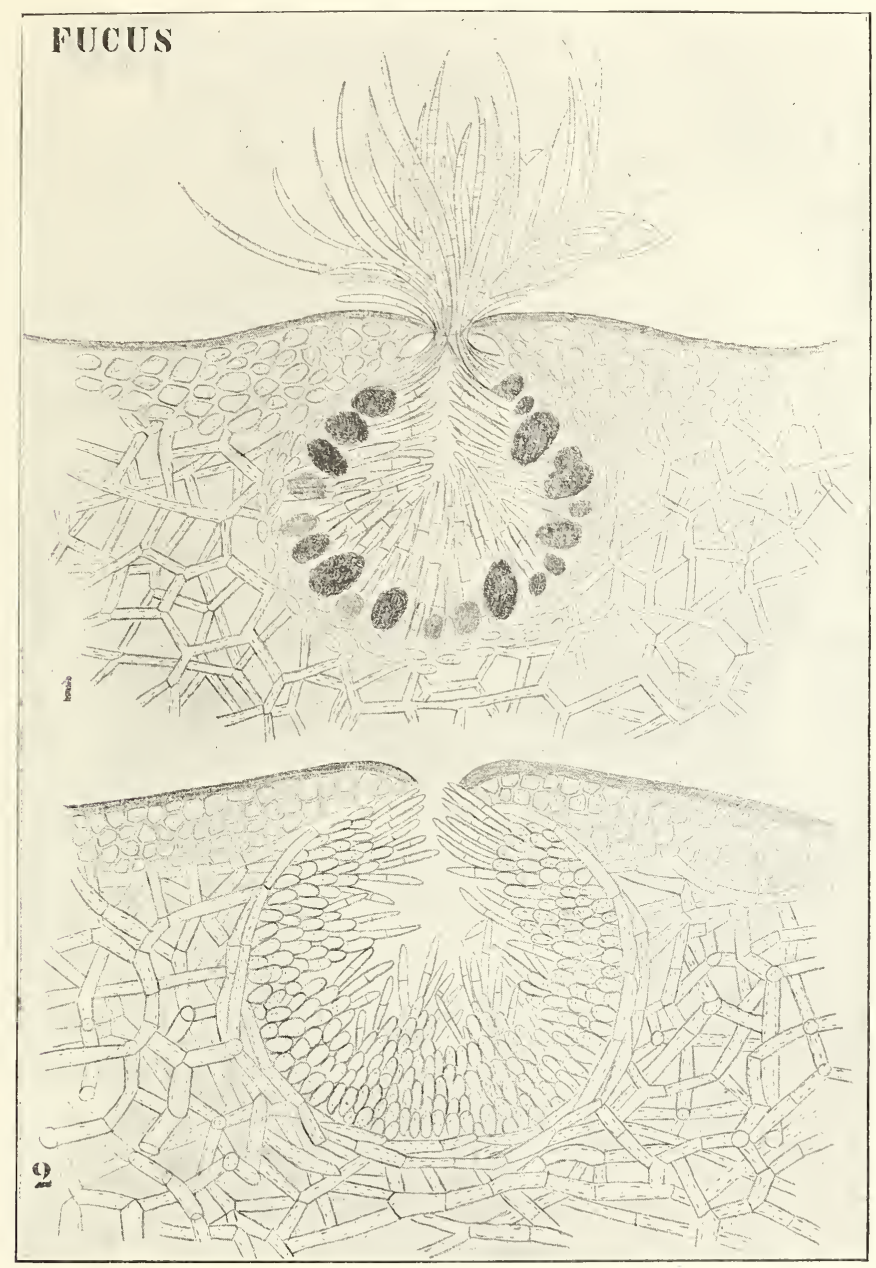

Fig. 196. Fucus. Oben weibliches, unten männliches Konzeptakel, schematisiert.

nur, und zwar in solchem Maße, daß die Spermatozoen durch die Membranen hindurch eindringen können, so daß die Eier hier im Oogon befruchtet werden.

Die Antheridien entstehen ebenfalls in Konzeptakeln, und zwar bei den eingeschlechtigen Arten in getrennten.

Es sind die Antheridien die Initialen kurzer Seitenzweige an reich verzweigten Haaren. 
In jedem Antheridium entstehen durch Teilung des ursprünglichen Kernes deren 64 und schließlich 64 Spermatozoiden. Das Spermatozoid enthält einen Kern, einen Augenfleck, ein oder zwei kleine Chromatophoren und zwei ungleich lange Cilien.

Was ist nun die Fucus-Pflanze, eine $\mathrm{x}$-Generation oder eine $2 \mathrm{x}$ Generation?

Nach Farmer und Williams, deren Resultate von Strasburger bestätigt werden, ist sie eine $2 \mathrm{x}$-Generation und die Reduktion soll bei der ersten Teilung im Oogon und im Antheridium stattfinden. Ich bin aber durch ihre Zeichnungen nicht überzeugt worden, StRASBURGER hat überhaupt nur einmal diese heterotypische Teilung gesehen und seine Figur zeigt wenig. Das Objekt ist offenbar ein sehr schwieriges. Sollte

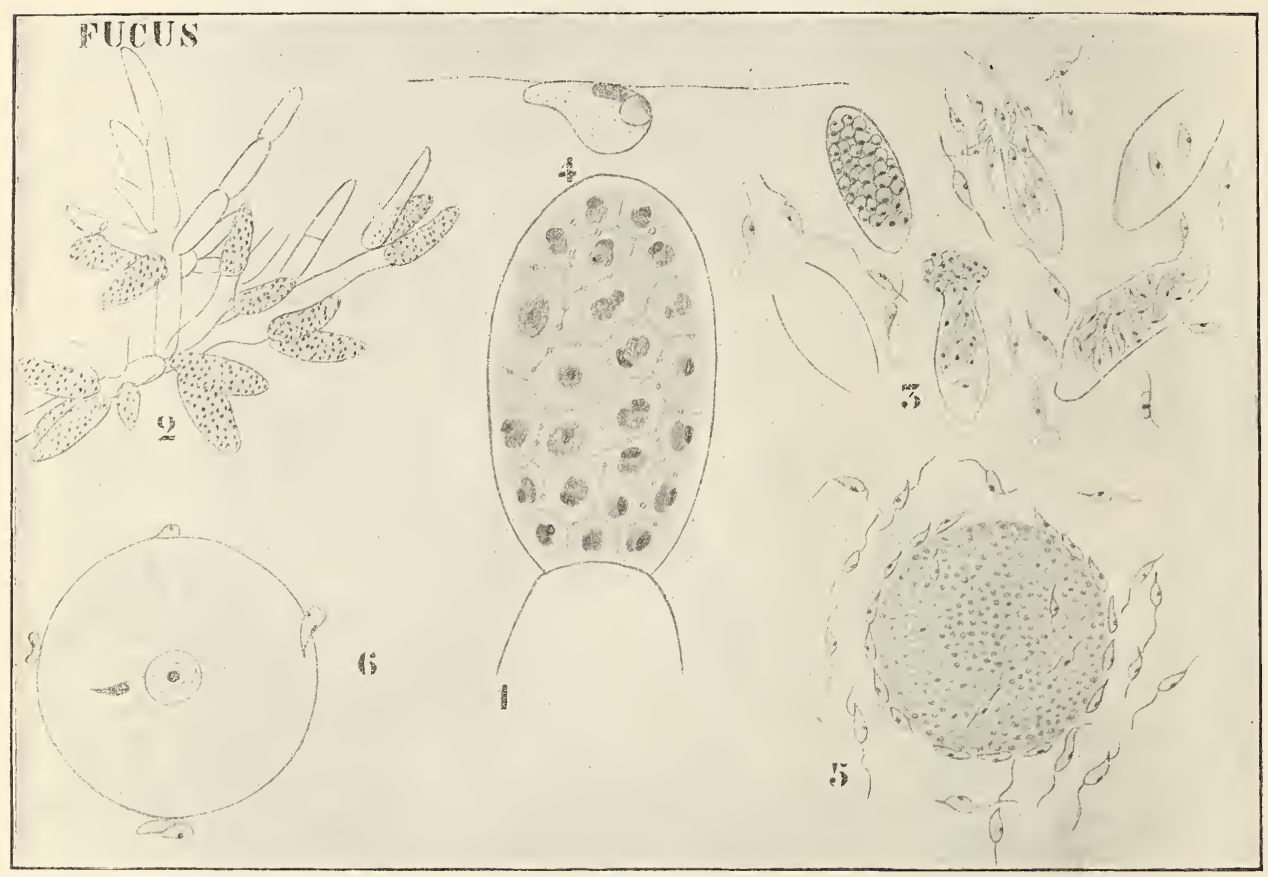

Fig. 197. Fucus, Antheridien, Spermatozoen und Eibefruchtung (nach THUreT, GUIGNARD und FARMer). 1 Antheridium, in welchem eben die Spermatozoen gebildet werden. 2 Antheridienstand. 3 Antheridien, die Spermatozoen entlassend. 4 Spermatozoen. 5 Ei von Spermatozoen umgeben. 6 Eindringen der Spermatozoen in das Ei.

es sich bei hoffentlich bald vorzunehmender Nachuntersuchung herausstellen, daß Fucus in der Tat eine $2 \mathrm{x}$-Generation ist, so würde er eine ganz isolierte Stelle einnehmen, und nur den höheren Tieren vergleichbar sein, denn im Pflanzenreiche werden die Geschlechtsorgane überall auf einer x-Generation, welche allerdings rudimentär sein kann, gebildet, und auch mit den höheren Tieren wäre der Fall nicht homolog, denn dort geschieht die Bildung der Geschlechtsenergiden noch immer durch eine Vierteilung.

Wäre Fucus eine $2 \mathrm{x}$-Generation, so könnten die Oogonien und Antheridien nicht den Oogonien und Antheridien einer Padina oder Dictyota 
homolog sein, denn diese werden auf der $x$-Generation gebildet. Diese Ueberlegungen bestimmen mich persönlich, bis die FArmer-StrasBURGERsche Ansicht besser begründet ist, die Fucus-Pflanze für eine $\mathrm{x}$-Generation zu halten.

Bei

\section{Himanthalia}

haben wir es mit einer Form zu tun, welche während des ganzen Lebens

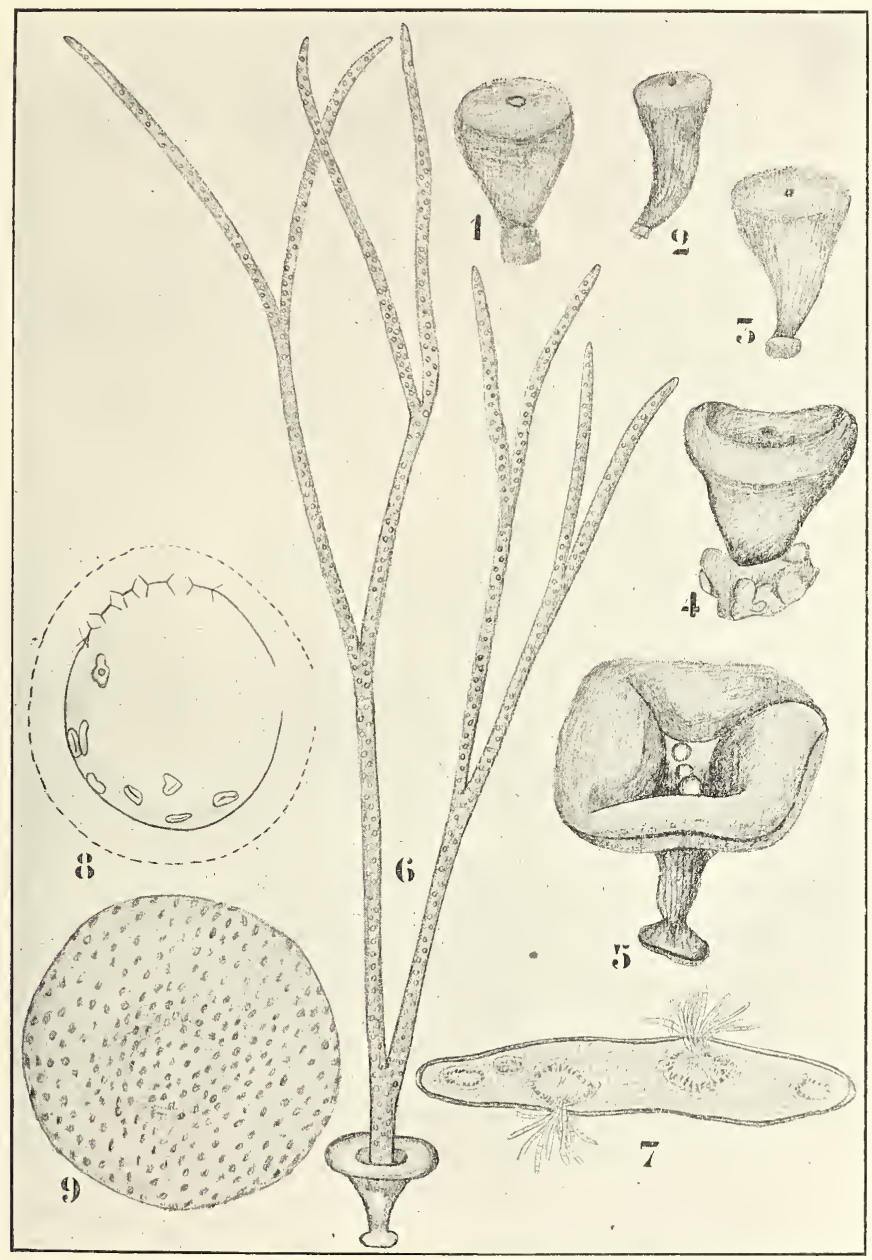

Fig. 198. Himanthalia lorea (nach Oltmanns, THURet und HAdCk). $1-5$ vegetative Pflanzen. 6 Fruktifizierende Pflanze. 7 Querschnitt durch den fertilen Teil, die Konzeptakeln zeigend. 8 Oogon, aus welchem das Ei ausgetreten ist und 7 Kerne zurïckgeblieben sind. 9 Das ausgetretene Ei.

mit einer dreizelligen Scheitelzelle wächst. Der vegetative Teil ist ursprünglich wie bei Fucus cylindrisch, flacht sich aber nicht wie bei diesem später laubartig ab, sondern bildet ein gestieltes Schüsselchen (Fig. 197, 5). Aus der Mitte dieses Schüsselchens entwickelt sich dam 
später ein riesiges, fertiles, dichotom verzweigtes Stück, das mit Konzeptakeln bedeckt ist. Da das fertile Stück leicht an der Basis abreißt, findet man die angespülten Exemplare meistens ohne vegetative Teile.

Die Spermatozoenbildung zeigt nichts Besonderes. Im Oogon werden durch 3mal wiederholte Kernteilung 8 Kerne gebildet, also 8 Gameten angelegt, von welchen sich nur eine zum Ei entwickelt. Die 7 überzähligen Kerne lassen sich bei Himanthalia besonders leicht demonstrieren. Es bleiben nun noch 2 Gruppen von "Algen" zu besprechen: die Rhodophyceen und die Schinophyceen.

Ihr Ursprung ist noch recht dunkel; die Rodophyceen sind rot, die Schirophyceen blaugrün. In der Gruppe der Cryptomonadinen kennen wir rote und blaugrüne Flagellaten, aus welchen also vielleicht diese Gruppen sich entwickelt haben. Rhodomonas baltica ist eine 2-ciliege Flagellate aus dem Baltischen Meere, mit einem großen roten Chromatophor und einem Zellkern, und könnte den Ahnen der Rhodphyceen nahe stehen. Aber dies ist schon recht problematisch. Noch gewagter scheint mir die Ableitung der Schinophyceen von blaugrünen Cryptomonaden; denn in Bezug auf den Kern zumal bieten die Schirophyceen so eigentümliche Verhältnisse, daß ihr Ursprung recht unklar ist.

Wenden wir uns, diese Unkenntnis bedauernd, zunächst der Gruppe der Rhodophyceen zu. 


\section{Dreizehnte Vorlesung.}

\section{Rhodophyceae.}

Diese Gruppe kann sofort in zwei Untergruppen zerlegt werden, in die der Bangiaceen und in die der Florideen. Während wir bei Bangi-

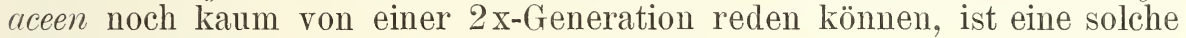
bei den Florideen schon deutlich vorhanden.

Zur Gruppe der Bangiaceen gehört u. a. das Genus

\section{Porphyira,}

welches ich mit Ihnen besprechen möchte. Es ist dieses Geschlecht an unseren Seewehrungen überall anzutreffen.

Es sind Pflanzen von Ulva-ähnlichem Habitus, welche so wie diese mittels Rhizoiden am Substrat befestigt sind. Der Thallus ist bei einigen Arten so wie bei Monostroma einschichtig bei anderen, so wie bei Ulva zweischichtig. Die Entwickelung stimmt aber in beiden Fällen mehr mit Ulva als mit Monostroma überein, da der Thallus ursprünglich aus einem einreihigen Zellfaden besteht, welcher sich durch laterale Teilungen zu einer Zellenplatte entwickelt. Im Gegensatz zu den Florideen stehen die Zellen hier nicht mittels einer großen Oeffnung in der Zellwand miteinander in Verbindung. Jede Zelle enthält einen Kern und ein großes, gelapptes, plattenförmiges, pyrenoidführendes Chromatophor, dessen Arme in gewissem Sinne zu groß für die Zelle sind, so daß sie umgebogen werden, und an den Wänden der Zelle hinauflaufen.

Die Fortpflanzung ist durch BerTholds Untersuchungen (1882) gut bekannt geworden. Betrachten wir zunächst die ungeschlechtliche Fortpflanzung. Behufs dieser teilen sich die Energiden der vegetativen Zellen 1- bis $2 \mathrm{mal}$, so daß in jeder Zelle 2 oder 4 Sporen entstehen. Daher bleibt der Thallus einschichtig, da die eine oder zwei einander kreuzenden Teilungsspalten senkrecht zur Oberfläche des Thallus stehen. Durch eine Oeffnung in der Zellwand schlüpfen diese Sporen heraus und können sich 48 Stunden lang amöboid bewegen, bevor sie zu neuen Pflänzchen auswachsen.

Geschlechtliche Fortpflanzung.

Am einfachsten liegen die Verhältnisse bei Porphyyra lencosticta. Bei dieser Art kann ein Individuum sowohl ungeschlechtliche Sporeu wie männliche und weibliche Geschlechtsorgane produzieren. Bei den meisten Porphyras gibt es aber 3 Arten von Individuen: ungeschlechtliche, männliche und weibliche. 
Die weiblichen Geschlechtsorgane sind Oogonien, sie entstehen einfach durch Vergrößerung einer Thalluszelle, welche dabei kaum über die Oberfläche des Thallus hervorragt (Fig. 199, 3).

Die Antheridien sind Thalluszellen, in welchen durch wiederholte Teilung bis 64 nackte unbewegliche Energiden, die sogenannten Spermatien, entstehen.

Zur Befruchtung heften die passiv dorthin gelangten Spermatien sich an den Oogonien an und umgeben sich mit einer Membran. Alsbald wird nun sowohl die Oogonien- wie die Spermatienwand durchbohrt und es tritt der Spermatieninhalt in das Oogon über (Fig. 199, 3). Dann verschmilzt der Spermatienkern mit dem Eikern und es entsteht die Zygote.

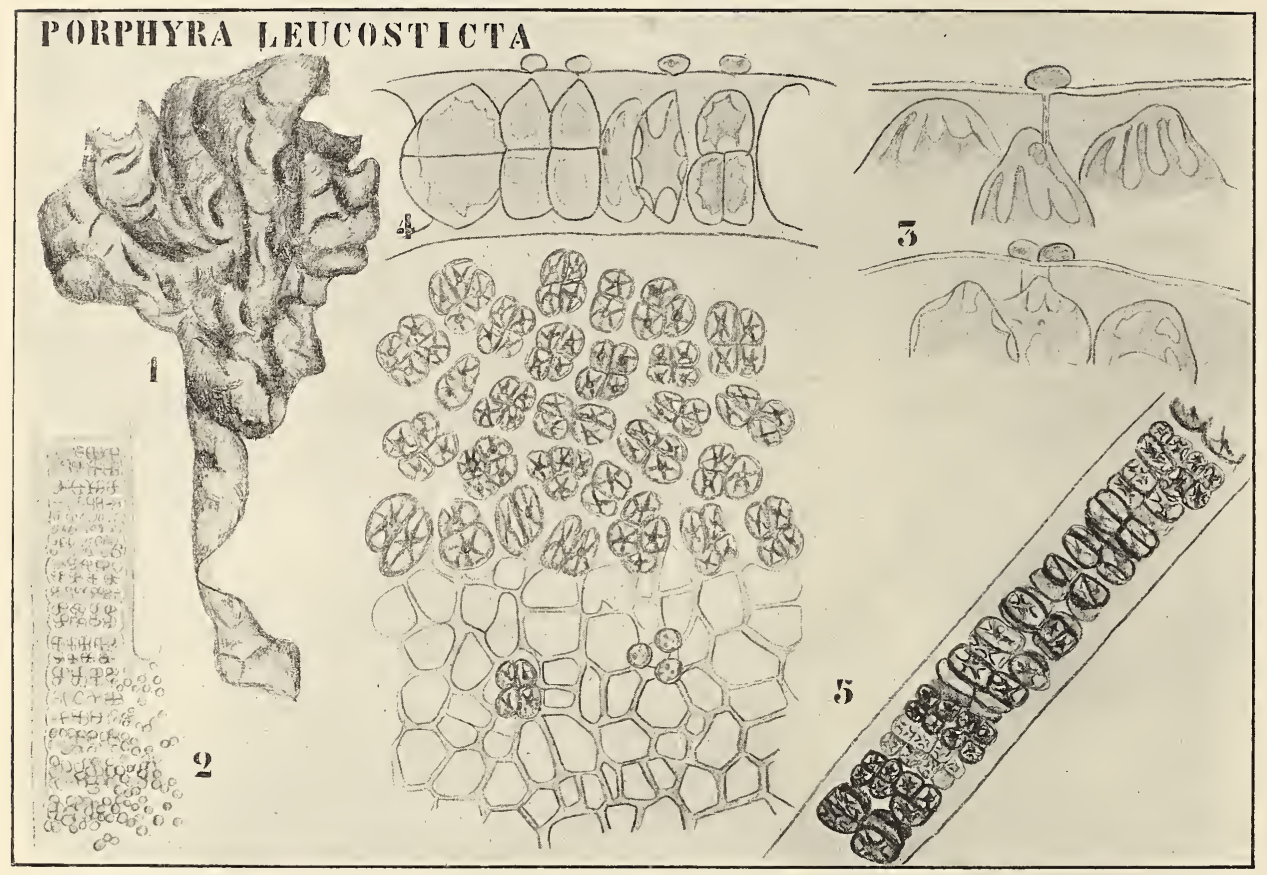

Fig. 199. Porphyra leucosticta (nach Berthold). 1 Habitusbild (Orig.). 2 Spermatienbildung. 3 Kopulation. 4 Bildung der Carposporen. 5 P. laciniata. Austritt der Carposporen, rechts unten Carposporen, von oben betrachtet und im Querschnitt.

Die Zygote teilt sich nun meistens in 8 , selten in weniger Zellen (Fig. 199, 5), wodurch der Thallus mehrschichtig wird.

Meiner Auffassung nach ist also die 2x-Generation höchstens zweizellig, vielleicht auch wird die Zygote sofort Gonotokont wie bei der Coleochaete von Allen.

Aus jeder dieser 8 Zellen schlüpft die Energide, welche wir Carpospore nennen, als amöboid bewegliches Körperchen aus, welches wahrscheinlich direkt zu einer neuen Porphyra keimt.

Ein Thallus mit Carposporen läßt sich also stets von einem mit ungeschlechtlichen unterscheiden, da ein carposporentragender Thallus mehrschichtig, ein ungeschlechtliche Sporen tragender immer einschichtig ist.

Trotzdem die ungeschlechtlichen Sporen meistens zu 4 in einer Zelle 
gebildet werden und Tetrasporen heißen, darf man sie nicht mit den Tetrasporen der Dictyotaceen vergleichen; dagegen spricht schon ihr Vorkommen auf den gleichen Individuen mit den Sexualorganen.

Während wir bei den Dictyotaceen eine gut entwickelte $2 \mathrm{x}$-Generation haben, die Tetrasporenpflanzen, ist hier auch die Tetrasporenpflanze vermutlich eine $\mathrm{x}$-Generation und ist die $2 \mathrm{x}$-Generation recht klein, vielleicht auf die Zygote beschränkt, vielleicht aus einigen wenigen, sämtlich fertilen Zellen bestehend.

Bei Porphyra laciniata ragen die Oogonien meistens bedeutend weiter über die Oberfläche des Thallus, und zwar an beiden Seiten hervor (Fig. 200, 1), und es bildet sich an der Zygote eine bedeutend

\section{P()RPIYYRA IAACINIATA}

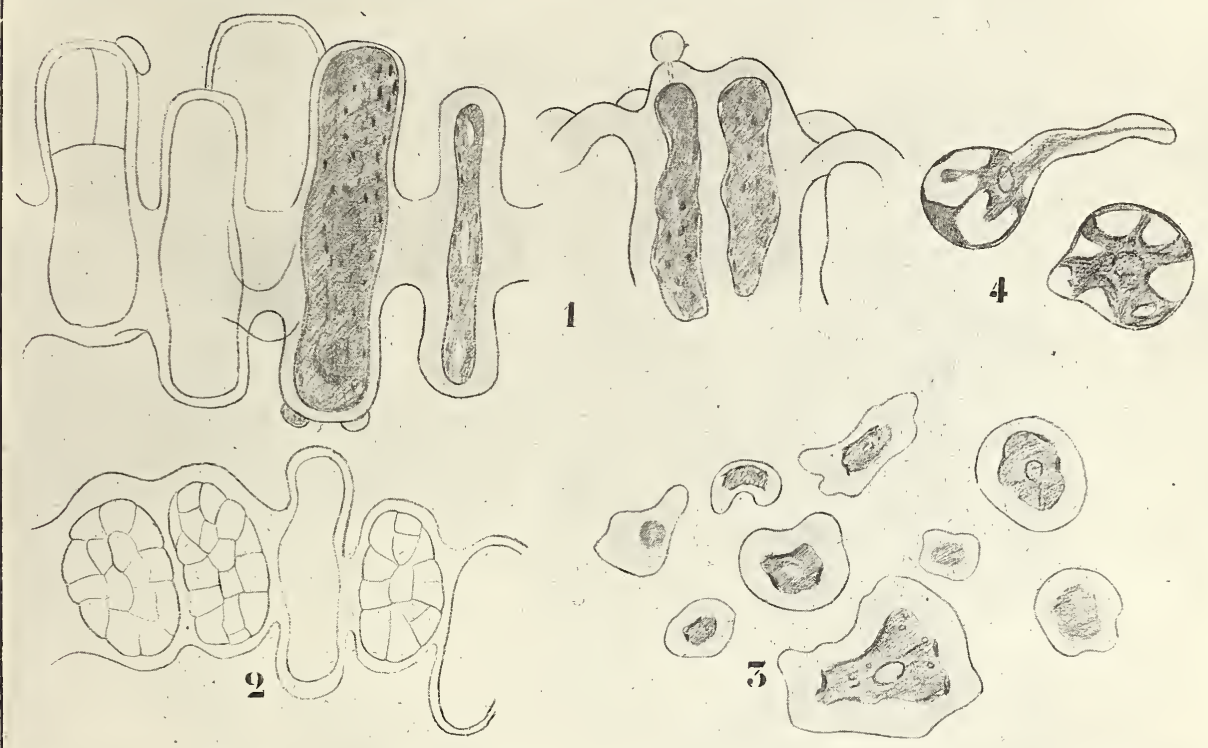

Fig. 200. Porphyra laciniata (nach Berthold). 1 Oogonien, zum Teil mit Spermatien kopulierend. 2 Die Zygote, in viele Zellen geteilt. 3 Ausgeschlüpfte, amöboid bewegliche Carposporen. 4 Keimende Carposporen.

größere Carposporenzahl. Ob dies eine größere Ausbildung der 2xGeneration bedeutet oder ob hier die Zygote sofort zum Gonotokonten geworden ist, werden cytologische Untersuchungen zeigen müssen.

Wenden wir uns jetzt der großen Gruppe der

\section{Florideen}

zu. Diese Gruppe ist trotz des großen Formenreichtums eine natürliche, da die geschlechtliche Fortpflanzung bei allen ihren Tertretern auf dem gleichen Prinzip beruht.

Ich will Sie mit dem vegetativen Aufban, wie interessant dieser anch sei, nicht beschäftigen, doch verweise ich dazu anf Outwanss' unentbehrliches Buch, und beschränke mich auf eine Uebersicht der Fortptlanzungsverhältnisse, deren Aufklärung wir ebenfalls Ottusnss verdanken. 
Die Fortpflanzungsorgane der Florideen sind: ungeschlechtliche Tetrasporangien, weibliche und männliche Geschlechtsorgane.

Ob hier die Tetrasporen als Gonotokonten zu betrachten sind, muß

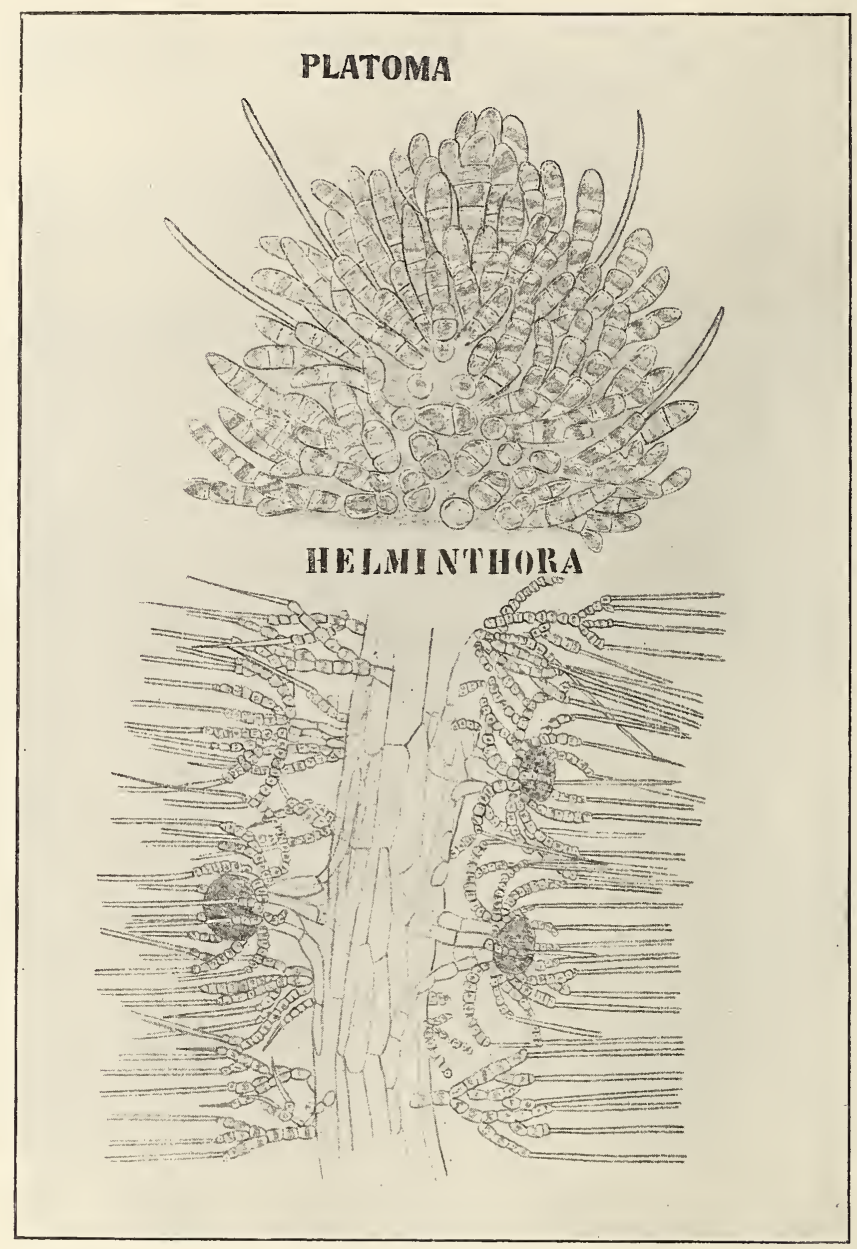

Fig]Fig. 201. I. Thallusspitze von Platoma. - II. Längsschnitt durch den Thallus von Helminthora.

einstweilen dahingestellt bleiben ${ }^{1}$ ). Dafür spricht die fast konstante Vierzahl und das vielfache Vorkommen derselben auf getrennten Individuen;

1) Soeben erscheint in der Bot. Gazette (Juni 1906) eine vorläufige Mitteilung YAMANoUchIs, aus welcher hervorgeht, daß bei Polysiphonia violacea die Reduktionsteilung in der Tetrasporenmutterzelle stattfindet. Es enthalten in Einklang damit die Tetrasporenpflanzen 40 Chromosomen in den Kernen der vegetativen Zellen, die keimenden Tetrasporen und die Geschlechtspflanzen 20. Da bilden also die Tetrasporenpflanzen zweifellos die $2 x-G e n e r a t i o n$, die Geschlechtspflanzen die x-Generation, die auf den Geschlechtspflanzen gebildeten sporogenen Zellen gehören aber bereits der $2 \mathrm{x}$-Generation an, so daß hier im Leben der $2 \mathrm{x}$ Generation zwei Phasen zu unterscheiden sind, eine parasitische und eine frei lebende. Folgende Darstellung wird dadurch nicht berührt, wenn man nur im Auge behalten will, daß, wo ich von der $2 x$-Generation rede, die anfängliche parasitische Phase gemeint ist, und ich es in der Mitte lasse und auch jetzt noch lassen muß, bei welchen Formen dies die einzige Phase dieser Generation ist, bei welchen sie noch von einer frei lebenden gefolgt wird. 
dagegen der Umstand, daß bei Batrachospermum den Tetrasporen wohl homologe Organe, die Monosporen auf den gleichen Individuen - wenn auch auf den Jugendstadien - vorkommen wie die Geschlechtsorgane,

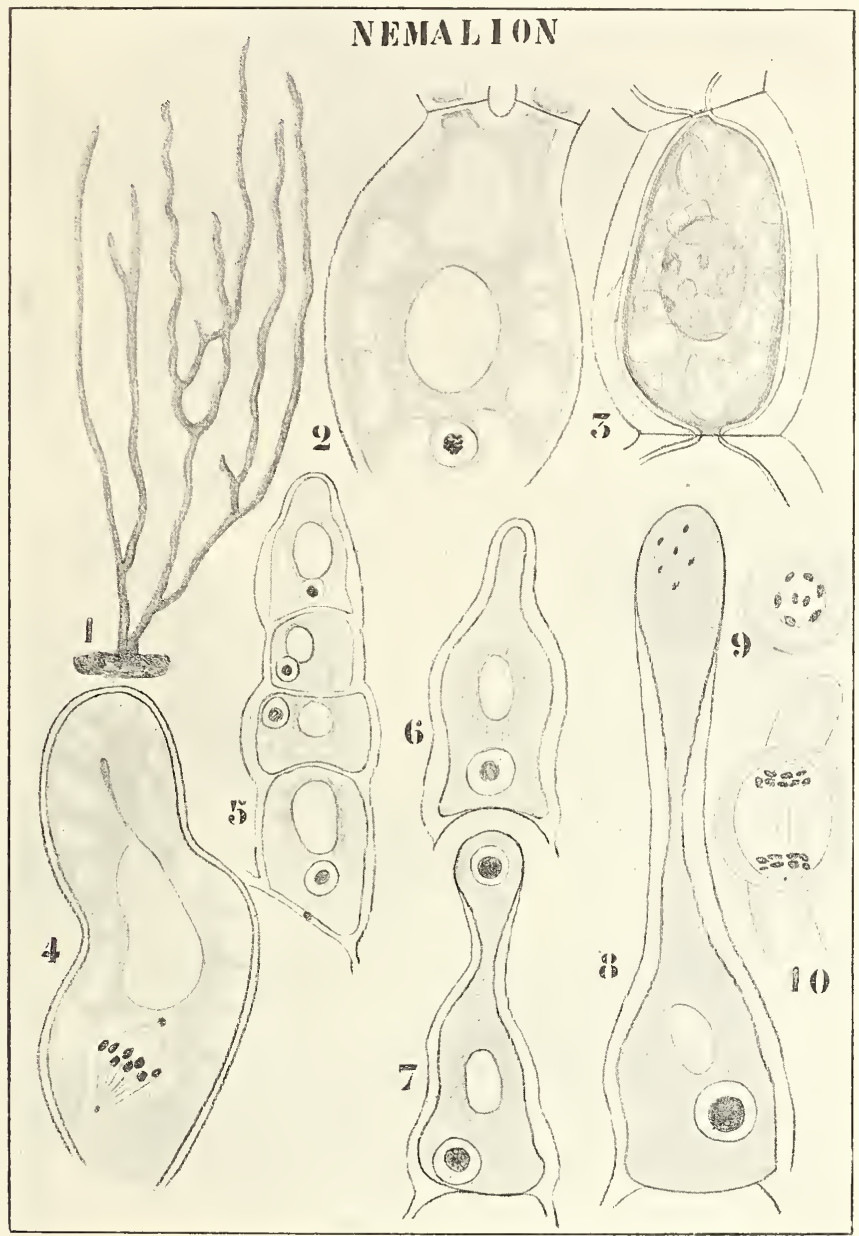

Fig. 202. Nemalion multifidum. 1 Habitusbild (nach Oltmanss, die übrigen nach WOLFE). 2, 3 Struktur des Chromatophors. 4 Kern- und Chromatophorteilung. 5 Weiblicher Zweig. 6 Anfang der Trichogynbildung. 7 Trichogyne gebildet, Kern geteilt. 8 Der neue Kern degeneriert, Oogonkern unten. 9 Spermatienmutterzelle. 10 Spermatienmutterzelle an der Trichogynespitze mit Kernteilung.

und die Bemerkung Bornets, daß man beim Durchmustern größerer Quantitäten von Florideen öfters einige findet, welche neben Geschlechtsorganen Tetrasporen besitzen.

Falls die Untersuchungen Wolfes richtig sind, kann Temation wenigstens ohne Hilfe von Tetrasporen die Reduktion ausführen. aber da Nemalion überhaupt keine Tetrasporen bildet, spricht dies weder füı noch gegen die Gonotokontennatur der Tetrasporangien.

Fangen wir also unsere Betrachtungen mit der einzigen Floridec. deren Entwickelungsgang auch cytologisch vollständig bekamnt ist, mit 
Nemalion multifidum AG.

an, einer Art, welche sowohl an den europäischen wie an den amerikanischen Küsten des Atlantischen Ozeans häufig ist.

Es ist eine verzweigte, cylindrische, weiche, schleimige Alge, welche durch diese Eigenschaften an die Mesogloeaceen unter den Braunalgen erinnert (Fig. 202, 1). Sie besteht aus einem zentralen Strang von Zellenfäden, deren jeder mittels einer Scheitelzelle wächst ${ }^{1}$ ) und seitlich Kurztriebe bildet, welche als Assimilatoren fungieren. Das Ganze gleicht sehr der Struktur einer Helminthora, weshalb ich diese hier (Fig. 201) abbilde.

Am Ende solcher Kurztriebe entstehen die Antheridien und die weiblichen Geschlechtsorgane auf denselben Individuen. Die Antheridien, welche kurzgedrängte Köpfchen bilden, entwickeln wie diejenigen der Bangiaceen (Porphyra z. B.) unbewegliche Spermatien.

Das Oogon ist die Scheitelzelle eines Zweiges (Fig. 202, 5), sie bildet einen sehr langen haarähnlichen Hals (Fig. 202, 8), die sogenannte Trichogyne. Diese Trichogyne kopuliert mit einem Spermatium, und es bildet das Oogon nach der Befruchtung kurze wenigzellige Zweiglein, von welchen die den Spitzen derselben benachbarten Zellen je eine nackte amöboid bewegliche Carpospore bilden.

Betrachten wir jetzt diese Vorgänge an der Hand der Wolfeschen Untersuchung etwas näher.

Die Nemalion-Zelle besitzt ein Chromatophor, welches aus einem hohlen, ellipsoidischen, zentralen Teil und aus davon allseitig ausstrahlenden Ausstülpungen besteht. Diese Ausstrahlungen werden in der Nähe der Zellwände zu flachen Platten und bilden schließlich eine dünne Schicht, welche der Zellwand flach anliegt und an zahlreichen Stellen durchlöchert ist (Fig. 202, 2, 3).

Diesen zentralen ellipsoidischen Teil des Chromatophors hat man früher für ein Pyrenoid gehalten, vielleicht ist das sogenannte Pyrenoid von Porphyra nichts anderes. Der Kern besitzt einen "Nucleolus", der offenbar das gesamte Chromatin enthält. Mittels großer Poren, die allen Rhodophyceen mit Ausnahme der Bangiaceen eigen sind, besteht sehr ausgeprägte Kontinuität des Plasmas.

Wenn eine Scheitelzelle sich in ein Oogon zu verwandeln anfängt, bildet sie zunächst eine Ausstülpung, die junge Trichogyne (Fig. 202, 6). Dann teilt sich der Nucleus, und der eine Tochterkern begibt sich in die Spitze der Trichogyne (Fig. 202, 7), der andere bleibt an der Basis liegen. Der obere Nucleus degeneriert alsbald, das befruchtungsfähige Oogon enthält also nur einen Nucleus, den Einucleus, und die Zellwand ist an der Trichogynespitze recht dünn geworden.

Sehen wir jetzt einmal zu, wie die Spermatien gebildet werden. Die Spermatiummutterzellen oder Spermatangien oder Antheridien sind gewöhnlichen vegetativen Zellen homolog, aber farblos. Bei der Zellteilung, welche zu der Bildung der Spermatangien führt, erhält der Kern derselben, genau so wie die vegetativen Zelien, 8 Chromosomen. Trotz der Farblosigkeit des Spermatangiums ist ein Chromatophor vorhanden, welcher aber alsbald degeneriert. Der ganze Inhalt des Spermatangiums tritt nun, von der inneren Wandschicht umgeben, heraus. Der Nucleus enthält dann eine große Anzahl von Granula, welche nach WoLfE als Nahrungspartikelchen betrachtet werden müssen. Diese Granula sind meistens wieder verschwunden, wenn der Inhalt des Spermatangiums die Trichogyne erreicht. Dieser Inhalt, der Androspore gewisser Oedogonium-

1) so wie Platoma, vergl. Fig. 201. 
Arten vergleichbar, gewöhnlich Spermatium genannt, teilt, nachdem er mit der Trichogyne verklebt ist, seinen Kern, so daß eigentlich erst jetzt zwei unbewegliche Spermatozoen gebildet werden. Der Name Spermatium für das Ganze ist also eigentlich nicht richtig. Bei dieser Teilung stellt es sich heraus, daß die Zahl der Chromosomen ebenso wie in den vegetativen Zellen 8 beträgt.

Die Befruchtung und die Folgen derselben.

Beide männlichen Kerne treten in die Trichogyne hinein. Einer derselben degeneriert, der andere verschmilzt mit dem Eikern (Fig. 203, 1--4).

Darauf teilt sich der Zygotenkern (Fig. 203, 5) und es wird alsbald eine Querwand gebildet, welche eine basale Zelle abschneidet. Diese Zelle

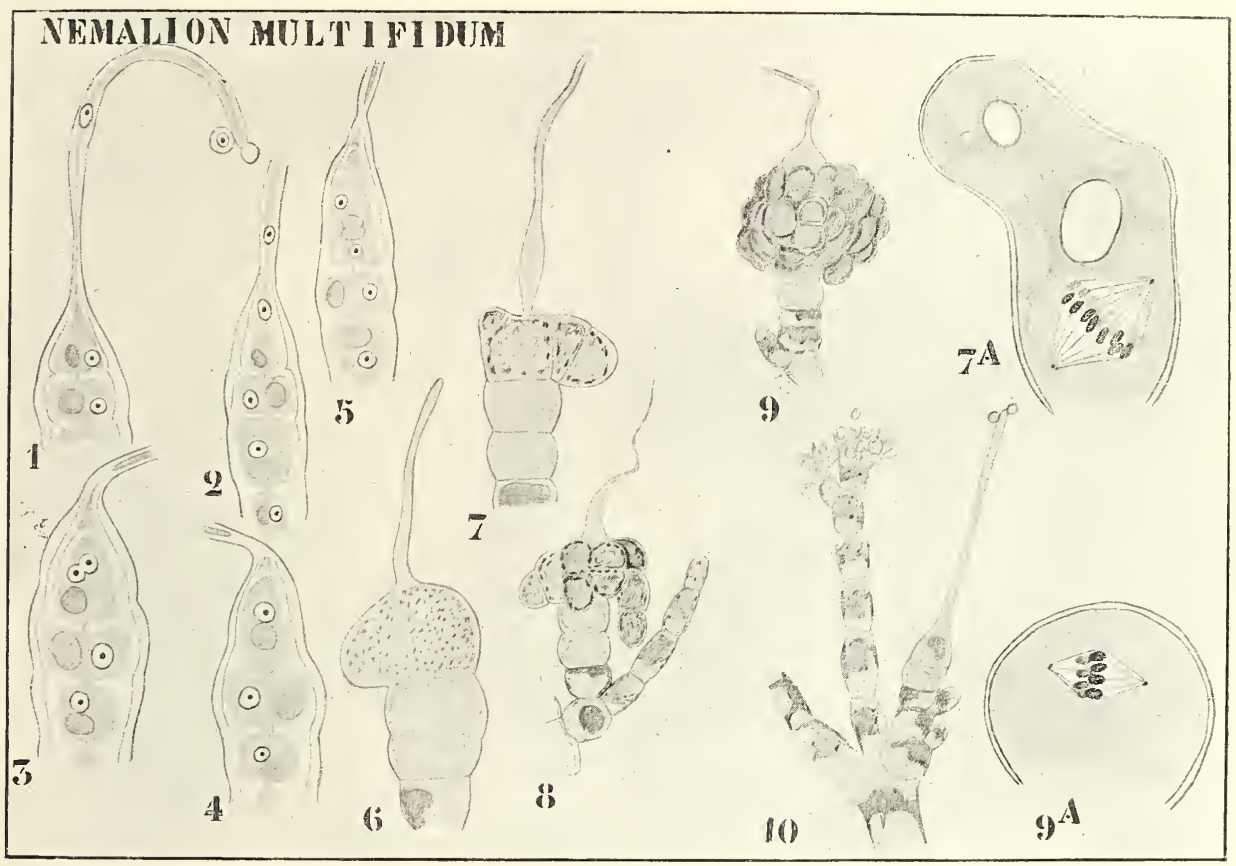

Fig. 203. Nemalion multifidum (nach WrLle und Wolfe). 1-4 Eintritt des Spermnucleus und Verschmelzung desselben mit dem Eikern. 5 Erste Teilung in der Zygote. 6-9 Bildung der sporogenen Fäden. 10 Ein Zweig mit einem AntheridiumKöpfchen und einem Oogon. $7 \mathrm{~A}$ Kernteilung in einer der basalen Zellen der sporogenen Fäden, $9 \mathrm{~A}$ in einer der Endzellen.

teilt sich meistens nicht weiter und wird zur Stielzelle. Der Umstand aber, daß sie sich auch durch eine Längswand nachträglich teilen kann, führt zur Vermutung, daß zwischen ihr und der oberen Zelle kein prinzipieller Unterschied besteht, denn mit solchen Längswänden fängt die Bildung der sporogenen Fäden an letzterer an.

Normalerweise bildet also nur die obere Zelle eine Anzahl kurzer Fäden, die sogenannten sporogenen Fäden (Fig. 203, 6-8), welche durch Querwände in eine Anzahl von Zellen zerlegt werden. Die der Spitze eines jeden Fadens benachbarten Zellen verwandeln nun ihren Inhalt in je eine Carpospore, welche ausschlüpft. Ob sämtliche Zellen der sporogenen Fäden dazu im stande sind, ist noch unklar. 
Wie steht es nun hier mit der $\mathrm{x}$ - und der $2 \mathrm{x}$-Generation? Die ganze Pflanze ist, wie wir sahen, eine $\mathrm{x}$-Generation, die allerersten Teilungsstadien der Zygote hat WOLFE nicht beobachtet, aber wohl einige spätere (Fig. 203, 7A) aus welchen hervorgeht, daß die sporogenen Fäden der $2 \mathrm{x}$-Generation angehören und 16 Chromosomen besitzen. In den Endzellen der sporogenen Fäden besitzen die Kerne aber nur 8 Chromosomen (Fig. 203, 9 A). Folglich ist hier ein Gonotokont aufgetreten, wie das aber genau geschieht ist bis jetzt nicht zu sagen.

Nemalion war eine für die Forschung gut geeignete Alge, sie zuerst hat uns durch Willes Untersuchungen von 1894 über die Befruchtung bei den Florideen Aufschluß gegeben.

Vordem meinte man, daß die Trichogyne der Florideen durch

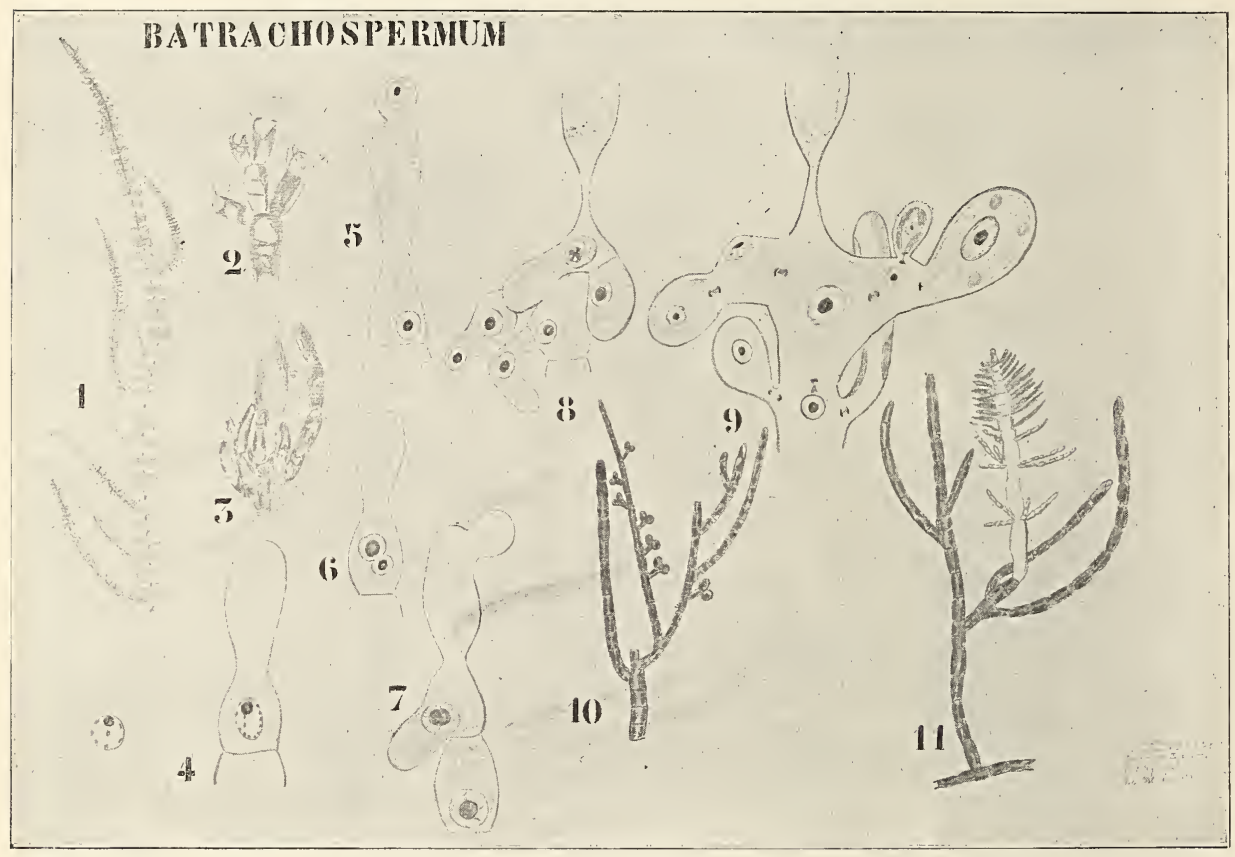

Fig. 204. Batrachospermum (nach Wettstein, Schmidel und Sirodot). 1 Habitusbild eines Zweiges des erwachsenen Stadiums. 2 Antheridienköpfchen. 3 Oogon. 4-9 Befruchtung und Bildung der Carposporen. 10 Jugendstadium mit Monosporen. 11 Batrachospermum-Zweig auf einem Chantransia-Stadium.

Querwände in eine Anzahl von Zellen geteilt wäre, und daß die befruchtende, rätselhafte Wirkung, vom Spermatium ausgeübt, durch geschlossene Zellwände hindurch dringe. $\mathrm{Zu}$ meiner Studentenzeit herrschte diese Auffassung noch allgemein. Jetzt wissen wir aber, daß wir mit einer normalen Befruchtung, mit der Vereinigung zweier Kerne zu tun haben und daß die Folge davon das Entstehen einer $2 \mathrm{x}$-Generation ist, welche später wieder Sporen mit $\mathrm{x}$ Chromosomen liefert.

Die $2 \mathrm{x}$-Generation wird hier von der x-Generation mittels Plasmaverbindungen zwischen der hypogynen Zelle der $2 \mathrm{x}$-Generation und den darunter gelegenen Zellen der x-Generation ernährt, bildet aber auch wohl selber noch photosynthetisch Nahrung.

Zum Verständnis beschreibender Florideen-Werke mag hier erwähnt 
werden, daß man Oogonium samt Trichogyne meistens Carpogon nennt, die befruchtete Eizelle mitsamt den sich daraus entwickelnden sporogenen Fäden mit dem Namen Cystocarp bezeichnet. Die sporogenen Fäden heißen auch wohl Gonimoblasten.

Batrachospermum hat viel Aehnlichkeit mit Nemalion; aber wir kriegen dort eine Komplikation durch die Bildung ungeschlechtlicher Sporen neben den geschlechtlich entstandenen.

Die Batrachospermum-Pflänzchen, welche im Süßwasser vorkommen, sind entweder rot oder fast grün gefärbt. Ihr Bau weicht von dem der Nemalion-Pflänzchen ab, indem der Zentralstrang nicht aus mehreren, sondern nur aus einer Zellreihe gebildet ist, und also dem Längssproß einer Draparnaldia vergleichbar ist. So wie bei Drapannaldia trägt auch hier der Längssproß die mit der Photosynthese betrauten Kurztriebe, welche in dichten Wirbeln stehen und später den Längssproß berinden. An den Spitzen dieser Assimilatoren entstehen ungefähr in derselben Weise wie bei Nemalion Oogonia und Antheridia.

Auch hier schlüpft der Inhalt des Antheridiums heraus und teilt sich später nach DAVIs in zwei unbewegliche Spermatozoen. Beide Spermakerne scheinen wenigstens bisweilen in die Trichogyne eindringen zu können, aber es verschmilzt deren nur einer mit dem Eikern. Auch hier entstehen aus der Zygote sporogene, sich verzweigende Fäden, deren Spitzen Carposporen bilden. Ob dabei Chromosomenreduktion stattfindet, ist unbekannt.

Während bei Nemalion die Carposporen gleicher Art direkt zu neuen Pflänzchen auswachsen, ist das hier nicht der Fall. Aus der Carpospore entwickelt sich ein ganz anders gestaltetes, aus einreihigen verzweigten Zellfäden bestehendes stahlblaues bis schwarzgrünes Pflänzchen, welches so sehr von Batrachospermum in seinem Vorkommen abweicht, daß man es als ein anderes Genus: als Chantransia beschrieben hat (Fig. 204, 10).

Dieses Chantransia-Stadium nun entwickelt an kurzen Seitenzweigen, aus der anschwellenden Endzelle, je eine nackte ungeschlechtliche Monospore, welche zu einem neuen Chantransia-Stadium auskeimt.

Batrachospermum kommt dauernd in zwei verschiedenen Formen vor, in einer Chantransia-Form und in einer Batrachospermum-Form. Welche von beiden auftritt, hängt, wie zumal Sirodot nachwies, von äußeren Bedingungen ab und zwar hauptsächlich von der Lichtintensität. Ist diese gering, so entwickelt sich die Chantransia-Form, ist sie stark, die Batrachospermum-Form. Daraus folgt, daß von der Pflanze, wenn sie in dunklen Gewässern wächst, Jahre und Jahre lang nur die Chantransia-Form auftreten kann, welche sich stets mittels ihrer Monosporen erneuert. Nimmt die Lichtintensität zu, so entstehen aus den Monosporen nur wenige Chantransia-ähnliche Zellen, welche alsbald Batrachospermum-Zweige bilden. Auch ältere Chantransia-Stadien können bei Zunahme der Lichtintensität Batrachospermum-Sprosse bilden (Fig. 204, 11).

Wir haben hier also einen dem Aglaoronia- und dem CutleriaZustande von Cutleric analogen Fall, nur daß es dort hauptsächlich ron der Temperatur, hier von der Lichtintensität abhängt. welche der beiden möglichen Formen sich entwickeln wird. Auch bei den Moosen treffen wir einen analogen Fall an, dort bildet das Protonema erst bei gewisser Lichtintensität Moosknospen, bei geringerer Lichtintensität wächst es unbestimmte Zeit als Protonema weiter.

Der Namen Chantransia für die Schattenfor'm des Batrachospermmm 
ist unglücklich gewählt. Während wir nun dank SrRodots Untersuchungen die Süßwasser-Chantransien als Biaiometamorphosen von Batrachospermum betrachten dürfen, ist dies mit den Meeres-Chantransien keineswegs der Fall. Diese bilden ein selbständiges Genus, welches neben ungeschlechtlichen Sporen Sexualorgane bildet und mit Batrachospermum nichts zu tun hat.

Während bei den bis jetzt betrachteten Nemalionales die sporogenen Fäden sehr kurz sind, ist dies bei Dermonema nicht der Fall. Da entwickeln sich diese viel kräftiger, so daß wir hier mit einer viel bedeutenderen Entwickelung der 2 x-Generation zu tun haben. Die Zygote bildet nämlich lange sporogene Fäden, welche parallel der Oberfläche im Gewebe der x-Generation verlaufen. Diese sporogenen Fäden bilden

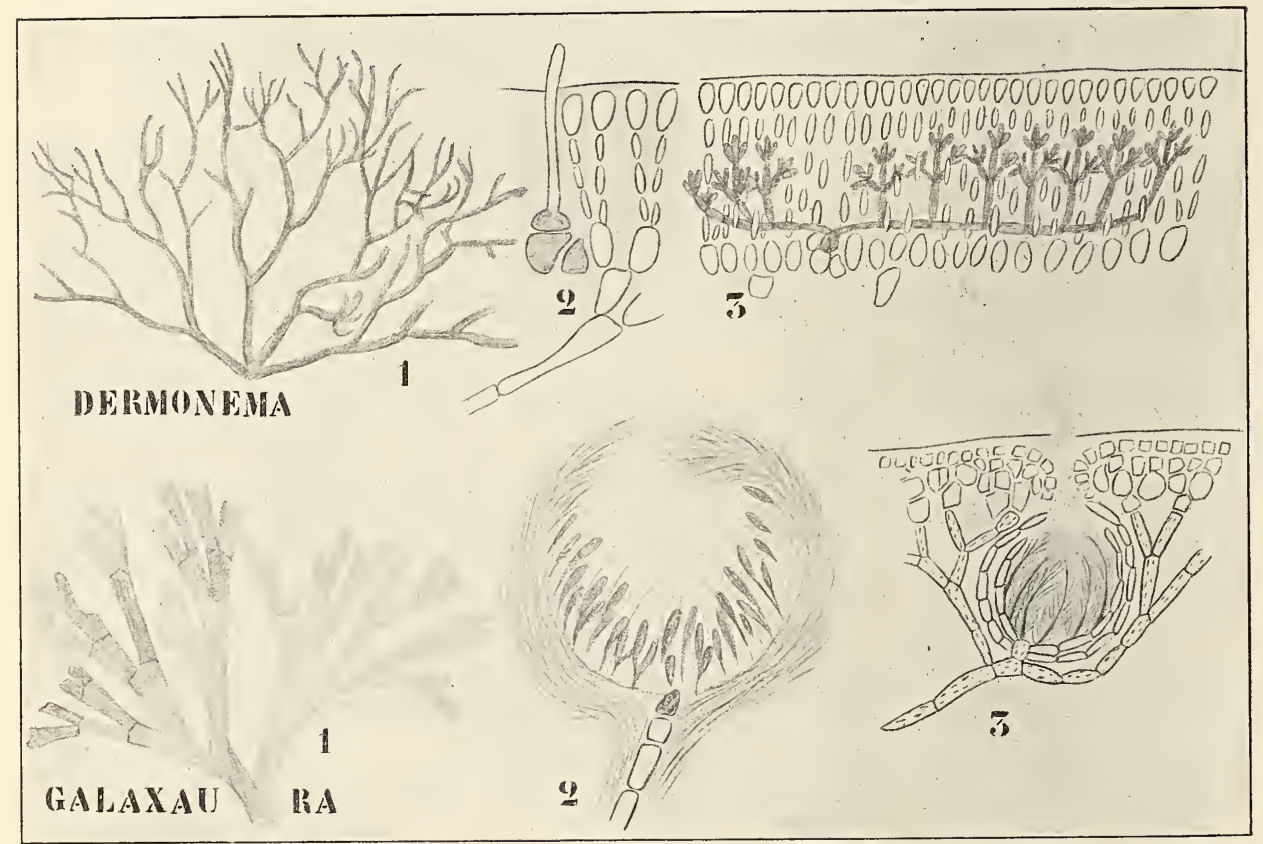

Fig. 205. I. De rmo ne ma di chotoma GRÈv. 1 Habitusbild (Original). 2, 3 De rmonema (nach Schmitz). 2 Unbefruchtetes Oogon. 3 Sporogene Fäden. II. Galaxaura marginata LiNk. 1 Habitusbild (Original). 2, 3 Sporogene Fäden (nach Schмitz).

Seitenzweige, welche fast rechteckig auf denselben stehen, sich verzweigen, und deren Spitzen die Carposporen liefern (Fig. 205, 3).

Es wird also hier die $2 \mathrm{x}$-Generation von der x-Generation geschützt. Noch schöner geschieht dies bei der Gruppe der Chaetangiaceen und in dieser am schönsten bei Galaxaura. Schon vor der Befruchtung bilden sich dort unter den Oogonien Fäden, welche aufwärts wachsen und um die inzwischen befruchteten Oogonien herum eine Umhüllung bilden, welche nach außen ausmündet und sehr an die Perithecien gewisser Ascomyceten erinnert (Fig. 205, 2, 3).

Die sporogenen Fäden, die $2 \mathrm{x}$-Generation also, kriechen über die Wand dieses "Peritheciums", bilden fiederförmig verzweigte Aeste, welche in die Höhlung hineinwachsen und die Carposporen tragen. 
Bei den Nemalionales steht, wie wir sahen, die $2 \mathrm{x}$-Generation nur mittels ihrer hypogynen Zelle mit der x-Generation in Verbindung.

Bei der Gruppe der

\section{Cryptomeniales}

hingegen wird die $2 \mathrm{x}$-Generation mehr parasitisch; sie versucht ihre sporogenen Fäden mit bestimmten Zellen der x-Generation in Verbindung.

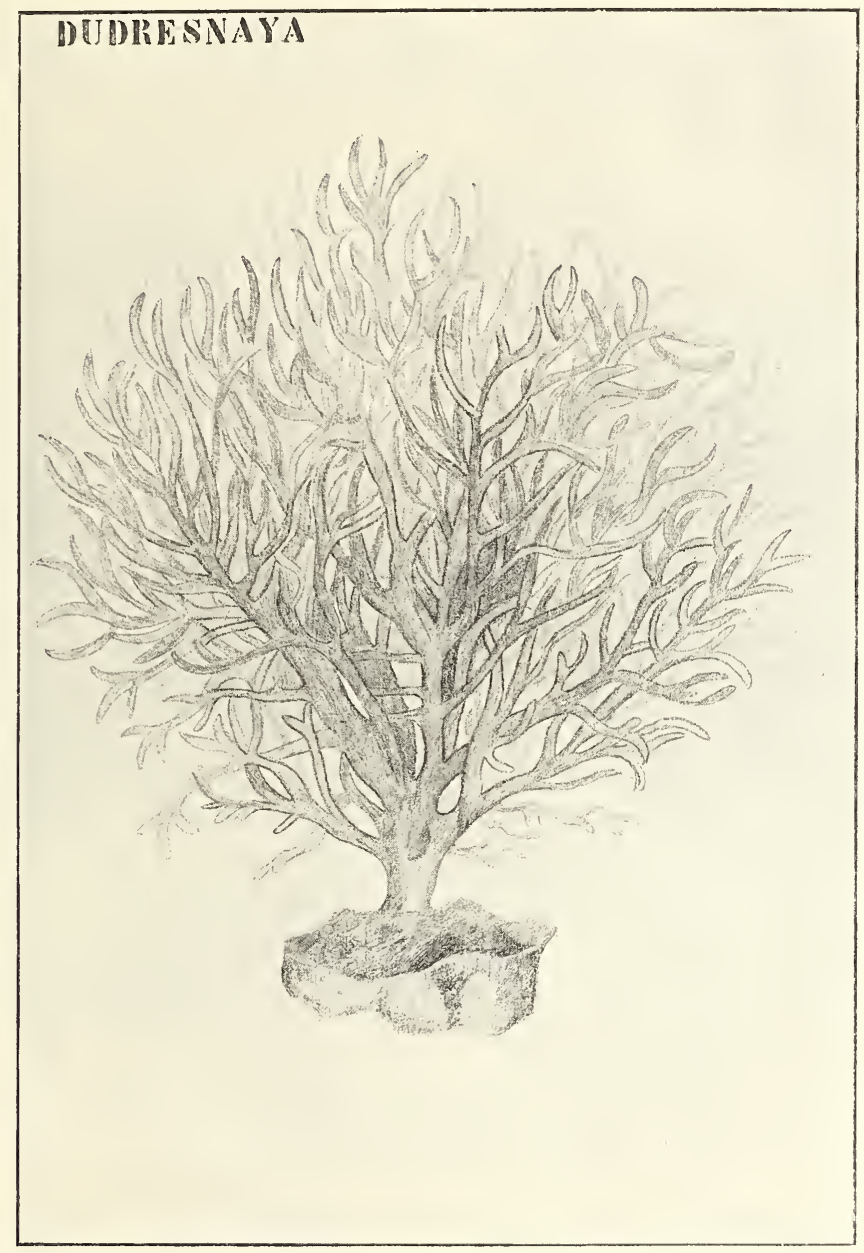

Fig. 206. Dudresnaya (nach Berthold).

zu bringen, um diesen Nahrung zu entnehmen. Diese Zellen der x-Generation heißen Auxiliarzellen.

Als Beispiel sei

\section{Dudresnaya}

behandelt. Dudresnaya ist eine u. a. im Mittelmeer rorkommende riel kräftigere Pflanze als Batrachospermum, der Habitus mag aus obenstehender Abbildung hervorgehen. 
Wir sahen schon bei Batrachospermum, daß dort der Längstrieb von Ausläufern der Kurztriebe berindet wird. Dasselbe gilt für Dudresnaya (Fig. 207, 6). Auch hier werden die Fortpflanzungsorgane auf den Kurztrieben gebildet. Der Seitenzweig, welcher das Oogon trägt, ist zunächst unverzweigt (Fig. 207, 1), alsbald bildet er aber Seitenzweiglein, welche dem Ganzen ein mehr oder weniger gefiedertes Aussehen verleihen (Fig. 207, 2). Die Endzelle des Hauptseitenzweiges bildet sich nun in üblicher Weise in Trichogyne und dann in ein Oogon um.

Die Trichogyne kann sehr lang werden und zeigt öfters einige Spiralwindungen (Fig. 207, 3). Nachdem Befruchtung stattgefunden hat, entwickelt sich aus der Zygote die $2 x$-Generation, welche hier aus langen sporogenen Fäden besteht. Diese sporogenen Fäden fusionieren nun

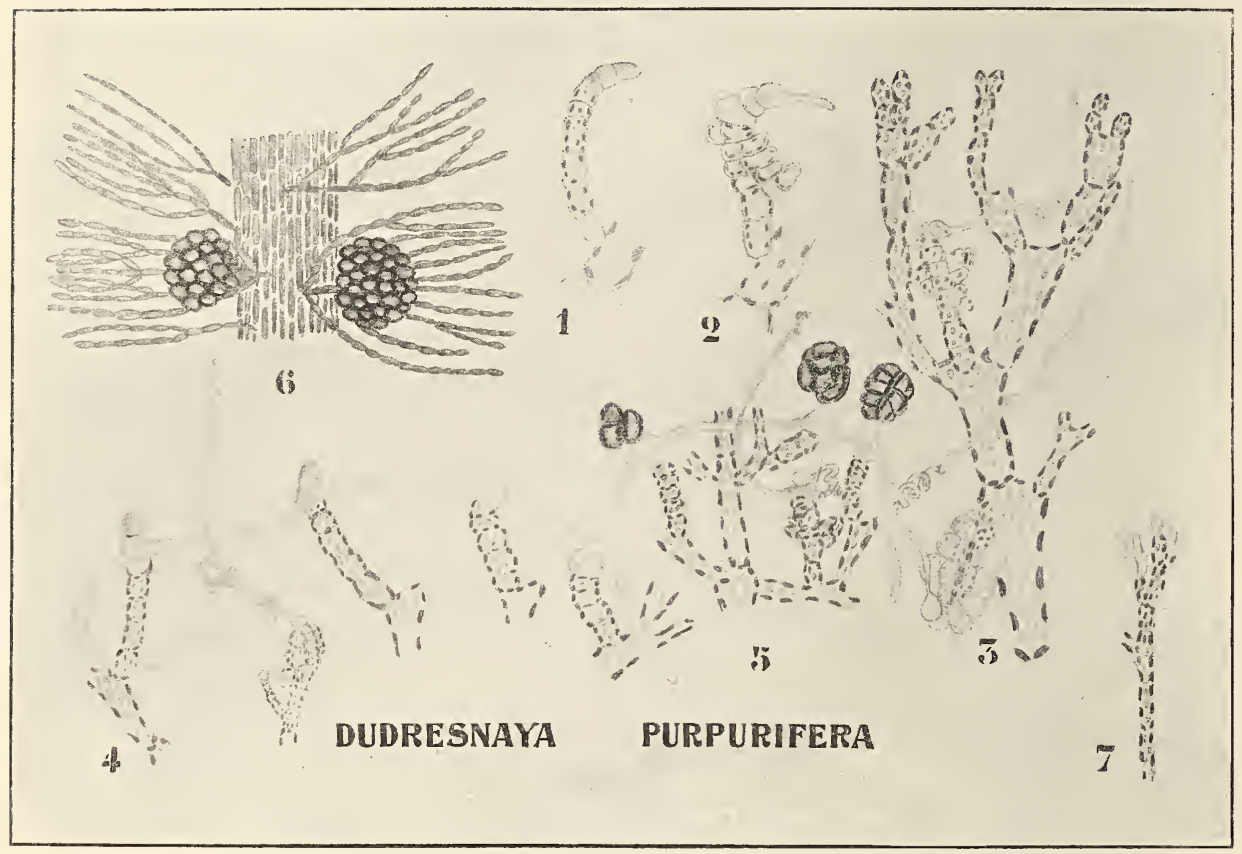

Fig. 207. Dudresnaya (nach Thuret). 1 Junger Oogonzweig. 2 Aelteres Stadium. 3 Erwachsene Oogonen mit langen Trichogynen. 4 Die sporogenen Fäden mit den Auxiliarzellen verbunden. 5 Ausbildung der Carposporen. 6 Stück eines Exemplars mit reifen Carposporen. 7 Antheridienköpfchen.

alsbald mit Zellen des Tragzweiges des Oogons und zwar am liebsten mit den Endzellen der Seitenzweiglein (Fig. 208, 7, links), können es aber auch mit anderen Zellen tun. Die Fusion einer Zelle der sporogenen Fäden - denn diese teilen sich alsbald durch Querwände - kann auch mit mehreren Zellen der Seitenzweiglein stattfinden.

In Fig. 208, 7 hat die linke sporogene Zelle mit 2 Auxiliarzellen - so werden diese fusionierenden Zellen der x-Generation genannt - fusioniert, die rechte sogar mit fünf, deren eine einem anderen Faden angehört. Auch nach der Fusionierung bleiben die Kerne an ihrem Platz, der Kern der Auxiliarzelle in der Auxiliarzelle, der Kern der sporogenen Fadenzelle in dieser, eine Verschmelzung beider Kerne findet nie statt, 
die $2 \mathrm{x}$-Generation behält ihre Individualität, sie parasitiert nur auf der $\mathrm{x}$-Generation.

Sobald sie stark genug ist, verlängert sich ihr sporogener Faden und wächst auf benachbarte Zweige, deren geschwollene Endzellen direkt als Auxiliarzellen kenntlich sind, zu (Fig. 207, 4, und Fig. 208, 7). Offenbar werden die Spitzen der sporogenen Fäden chemotaktisch von diesen Auxiliarzellen angezogen. Nachdem Fusion stattgefunden hat, stellt sich der Kern der sporogenen Zelle genau der Fusionsstelle gegenüber (Fig. 208, 7), tritt aber nicht in die Auxiliarzelle hinein, im Gegenteil schmiegt sie sich der distalen Wand der sporogenen Zelle an, während der Kern der Auxiliarzelle sich ebenfalls möglichst weit vom Fusionskanal entfernt. Offenbar üben beide Kerne vielmehr einen ab-

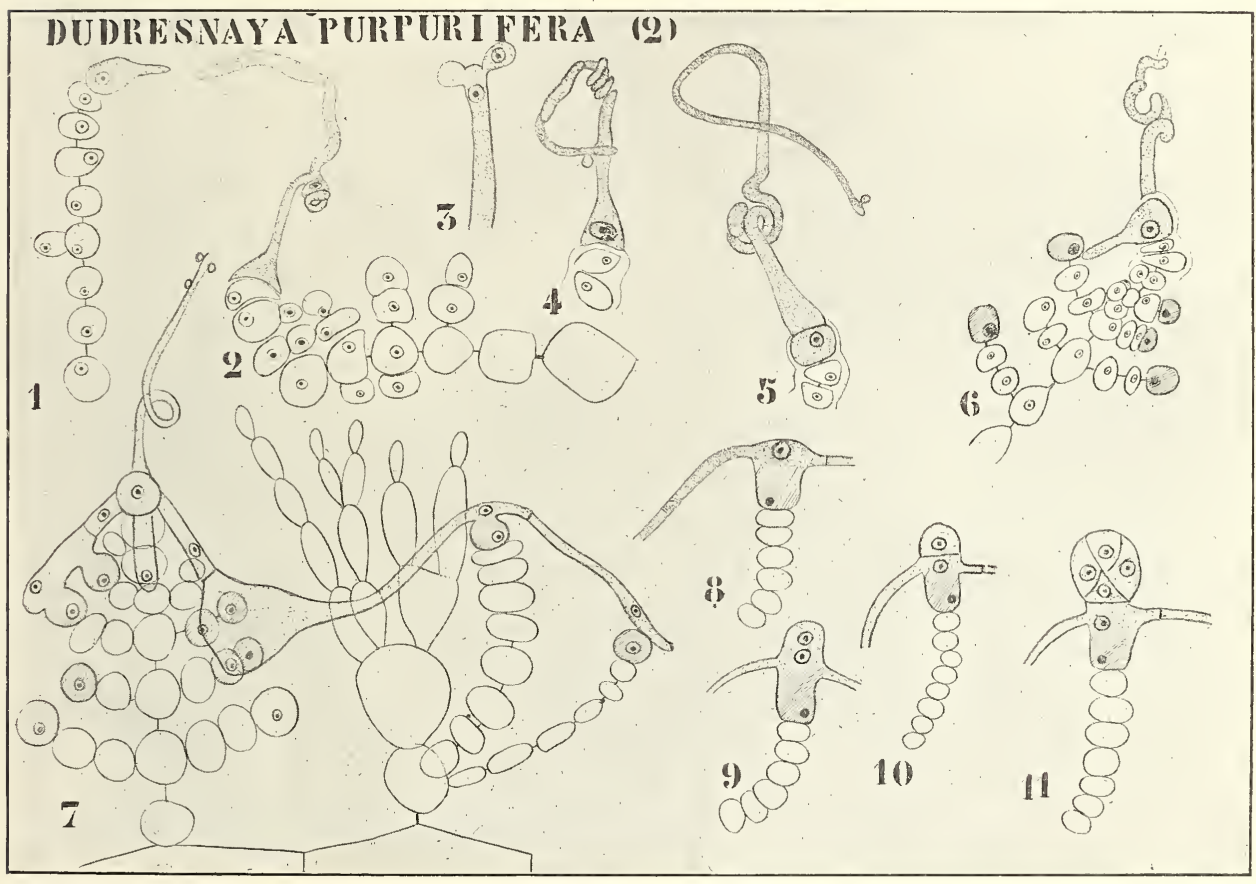

Fig. 208. Dudresnaya. Befruchtung und Fusionierung der sporogenen Fäden mit den Auxiliarzellen. (Schematisch nach OLtmanss.) Die Geschlechtsorgane und deren Derivate punktiert, die Auxiliarzellen schraffiert, die vegetativen Zellen weiß.

stoßenden wie einen anziehenden Einfluß aufeinander aus (Fig. 208, 8). Alsbald erhebt sich der der sporogenen Zelle angehörige Membranteil der Fusionszelle buckelartig (Fig. 208, 9), und der 2x-Kern begiebt sich sofort in diese Ausstülpung, froh der Gegenwart des x-Kernes zu entrinnen, und teilt sich. Zwischen den beiden Tochterkernen wird eine Quer'wand gebildet. Hierdurch entsteht also (Fig. 208, 10) eine obere, der $2 x$-Generation gehörige Zelle, die sogenannte Zentralzelle, und eine untere Fusionszelle, die in ihrem oberen Teil einen $2 x$-Kern, in ihrem unteren einen x-Kern enthält, die Fußzelle.

Die Zentralzelle teilt sich nun in eine Anzahl von Zellen, welche die Carposporen bilden (Fig. 208, 11). 
Entweder diese Zentralzelle oder Produkte derselben müssen als Gonotokont fungieren, oder es wäre auch möglich, daß gar keine Reduktion hier vorkäme, sondern daß die Carposporen zu Tetrasporenpflanzen auswüchsen, welche dann die frei lebende Phase der 2x-Generation darstellten und deren Tetrasporenmutterzellen dann Gonotokonten wären. Diese Verhältnisse bedürfen eingehender Untersuchung.

Eine der von der Zentralzelle gebildeten Zellen bleibt steril und wird Stielzelle genannt.

Der obere Teil der Fusionszelle wächst wieder zu einem sporogenen Faden aus, der $2 \mathrm{x}$-Kern tritt in diesen hinein und nachdem dieser sporogene Faden eine neue Auxiliarzelle erreicht hat, fängt derselbe Vorgang von neuem an.

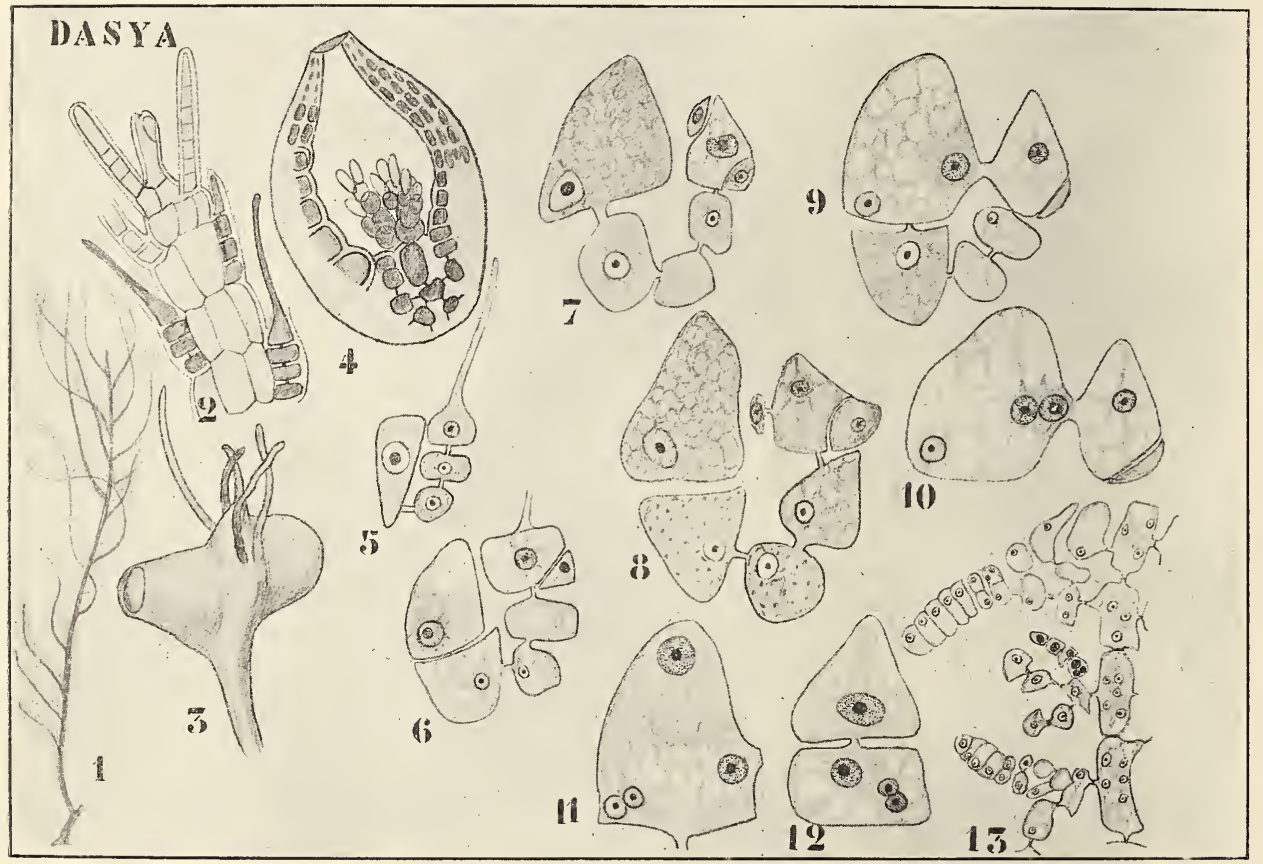

Fig. 209. Das ya elegans (nach Falkenberg und Oltmanns). 1 Habitusbild. 2 Fertiles Stück mit 3 Carpogonästen, d. h. also Aesten, welche Oogonien tragen. 3 Fruchtast. 4 Längsschnitt einer Frucht. 5 Carpogonast mit Tragzelle. 6 Die Tragzelle hat sich in eine Auxiliarzelle und eine Basalzelle geteilt, das Oogon hat ein kleines steriles Zellchen abgeschnitten. 7 Bildung eines rudimentären sporogenen Fadens. 8 Die sporogene Zelle wächst auf die Auxiliarzelle zu. 9 Der Kern der sporogenen Zelle ist in die Auxiliarzelle übergetreten. 10 Der $2 \mathrm{x}$-Kern hat sich geteilt. 11 Die Tochterkerne gehen auseinander. 12 Bildung der Zentralzelle. 13 Die Zentralzelle hat eine Reihe von Carposporenzellen gebildet. Ueberall der weibliche Kern und seine Derivate punktiert, die Auxiliarkerne schraffiert.

Wir verdanken unsere Kenntnis dieser Vorgänge den schönen Untersuchungen von Oltmanss, vor ihm meinte man, infolge von Schmitz's Untersuchungen, daß die Auxiliarzellen Oogonien ohne Trichogyne und die sporogenen Fäden Befruchtungsschläuche seien.

Wie wir sahen, parasitiert bei Dudresnaya die $2 \mathrm{x}$-Generation wenigstens anfänglich hochgradig auf der x-Generation. 
Sowohl bei den Nemalionalen wie bei den Cryptomenialen hatten wir mit langen sporogenen Fäden zu tun, welche die Carposporen entwickeln, in letzterem Falle, nachdem sie in beträchtlicher Entfernung gelegene Auxiliarzellen aufgesucht hatten.

Bei der Gruppe der

\section{Ceramiales}

stehen Oogonien und Auxiliarzellen dicht nebeneinander. In Verbindung damit sind die sporogenen Fäden entweder sehr kurz oder es besteht die junge $2 x$-Generation aus einer einzigen Zelle, welche in die Auxiliarzelle himeintritt und sich dort weiter entwickelt.

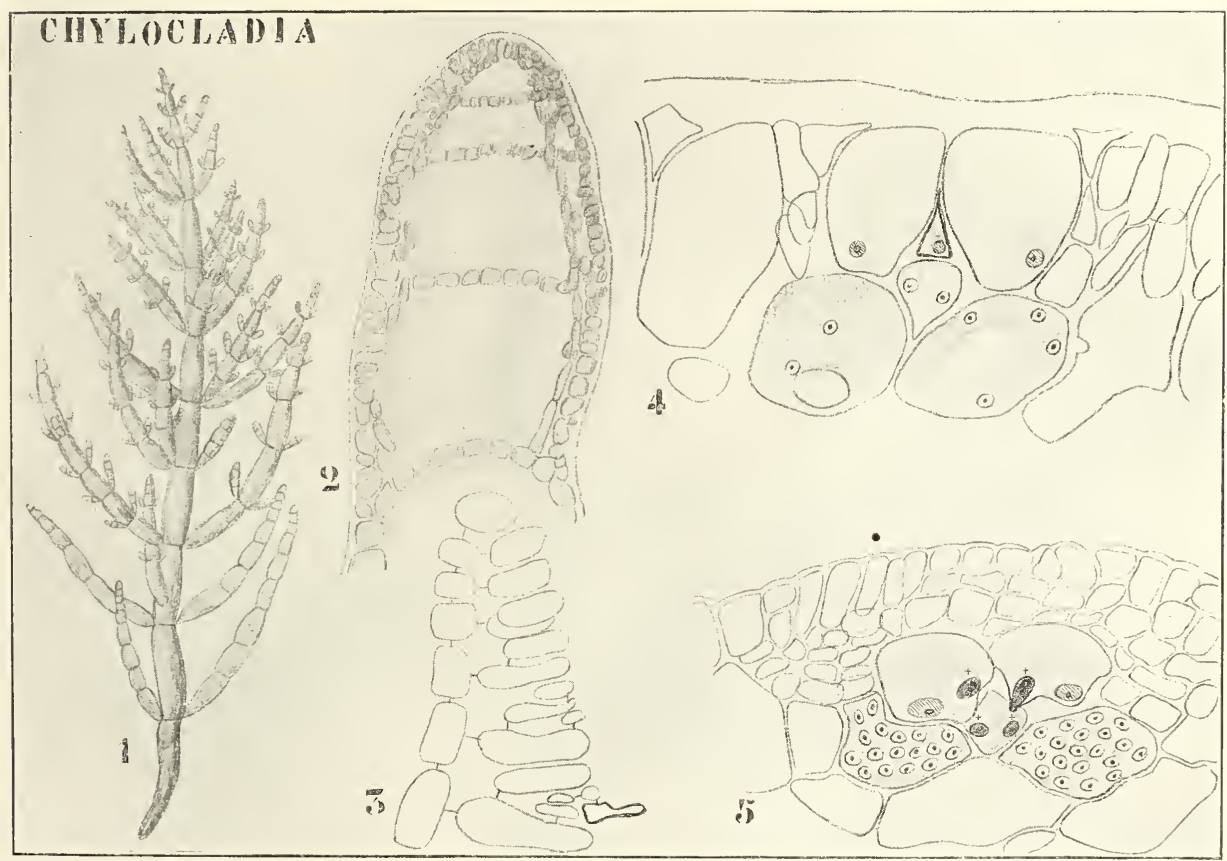

Fig. 210. Chylocladia (nach Engler u. Prantu und Hassenkamp). 1 Habitusbild. 2 Längsschnitt. 3 Längsschnitt, ein Carpogonästchen zeigend. 4 Querschnitt, das Oogon und die beiden Auxiliarzellen zeigend. 5 Uebertritt von 2 Kernen aus der Zygote in die Auxiliarzellen. Die Kerne der Auxiliarzellen schraffiert, der Zygotenkern und dessen Derivate mit einem + bezeichnet.

Als Beispiel sei Dasya elegans, ebenfalls an der Hand von OLTmanns' Untersuchungen, behandelt. Dasya elegans ist eine hübsch verzweigte Alge, welche sowohl an den europäischen wie an den amerikanischen Küsten vorkommt.

Die Carpogonäste, d. h. die Zweiglein, welche die Oogonien tragen, sind sehr kurz und bestehen meistens ans zwei bis drei sterilen Zellen, welche das Oogon an der Spitze tragen. Später werden die befiuchteten Oogonien von einer Anzahl steriler Zellen hïllenartig umschlossen (Fig. 209, 2--4). Von allem unwesentlichen Beiwerk abgesehen, geschieht die Bildung der Carposporen in folgender ITeise. Es stellt sich 
heraus, daß der Carpogonast an einer im Innern des Thallus sich befindenden Zelle befestigt ist, an der sogenannten Tragzelle (Fig. 209, 5). Diese Tragzelle ist die Auxiliarmutterzelle. Sie teilt sich nämlich mittels einer Horizontalwand in eine Auxiliarzelle und in eine Basalzelle (Fig. 209, 6).

Inzwischen ist das Oogon, welches schon vor der Befruchtung ein kleines steriles Zellchen abgeschnitten hat (Fig. 209, 6), befruchtet worden und bildet einen rudimentären sporogenen Faden, welcher hier sporogene Zelle genannt wird (Fig. 209, 7). Diese wächst auf die Auxiliarzelle zu und deponiert ihren Nucleus in der Auxiliarzelle (Fig. 209, 8, 9). Dort bleibt er in ehrfurchtsvoller Entfernung von dem Auxiliarnucleus liegen und teilt sich alsbald (Fig. 209, 10). Während der eine Tochter-

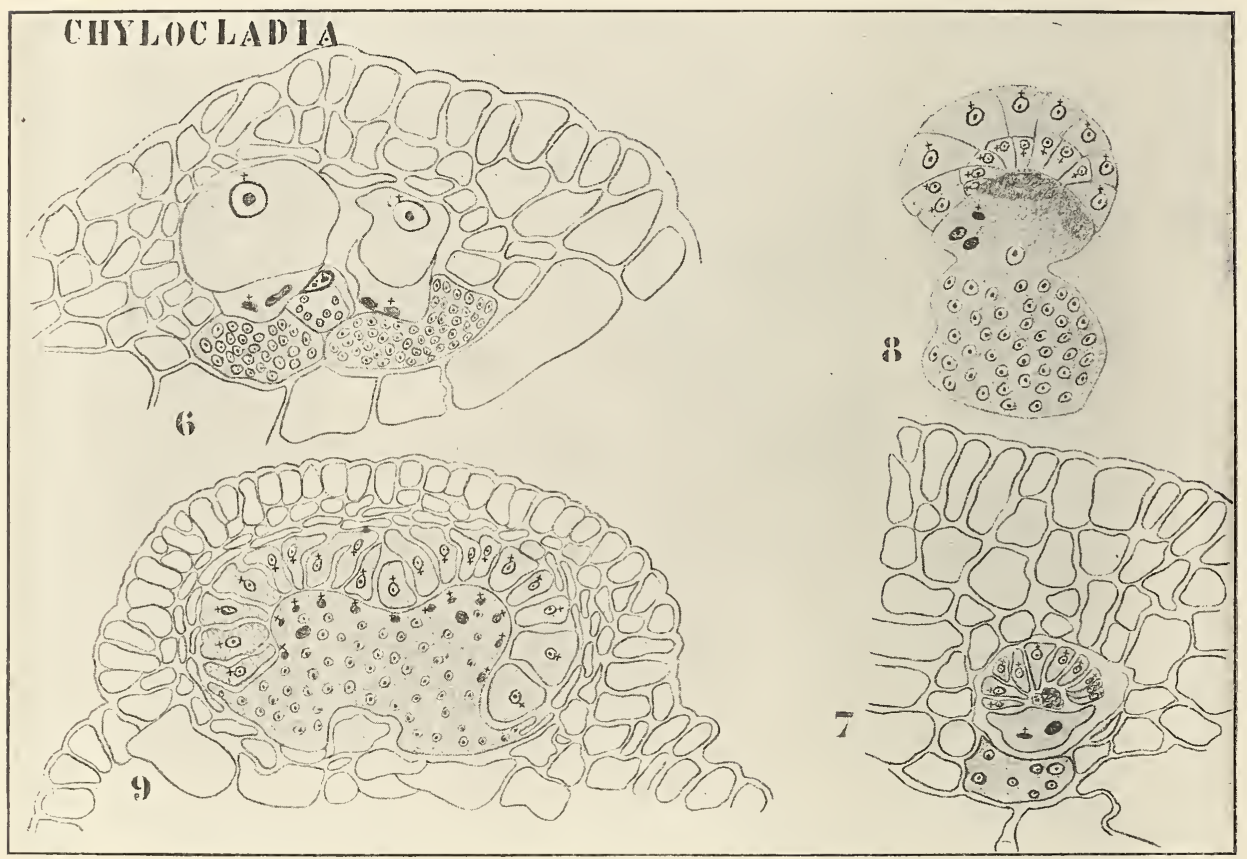

Fig. 211. Chylocladia (nach Hassenkamp). 6 Die Auxiliarzelle in Zentralzelle und Fußzelle geteilt. $7-9$ Weitere Entwickelung (vergl. den Text).

kern an der Stelle, wo der $2 x$-Nucleus deponiert wurde, liegen bleibt, begibt sich der andere nach der Spitze der Auxiliarzelle hin, wo er sich alsbald bedeutend vergrößert (Fig. 209, 11). Inzwischen hat sich auch der Kern der Auxiliarzelle geteilt, und die Auxiliarzelle teilt sich nun selber in eine obere Zentralzelle und eine untere Fußzelle (Fig. 209, 12). Die Zentralzelle enthält einen 2x-Kern; die Fußzelle enthält den Schwesterkern desselben und die Tochterkerne des Auxiliarzellenkernes, also einen $2 \mathrm{x}$-Kern und zwei x-Kerne. Letztere Zelle bleibt ungeteilt, während die Zentralzelle einer Anzahl reihenförmig angeordneter Zellen das Dasein gibt, deren Inhalt je eine Carpospore liefert (Fig. 209, 13).

Bei den Gigartinales haben wir prinzipiell dasselbe, auch dort werden 
die Carposporen bildenden Zellen an der Auxiliarzelle, in welche erst ungefähr so wie bei Dasya ein $2 x$-Kern deponiert wurde, gebildet. Sie stehen dort aber in viel längeren Reihen als bei Dasya.

Abweichende Fälle finden wir bei den Rhodymeniales; der am meisten abweichende Fall sei hier an der Hand der Untersuchungen Hassenkayps besprochen. Er betrifft Chylocladia lialiformis. Der anatomische Bau dieser Pflanze interessiert uns augenblicklich nur insoweit, als Läng'sfäden vorhanden sind, welche an Tragzellen kleine fertile Zweiglein bilden, die ungefähr wieder wie die von Dasya gebaut sind.

Das ist leicht auf einem Längsschnitt zu sehen (Fig. 210, 2, 3). Auf dem Querschnitt (Fig. 210,4) fallen zwei große Auxiliarzellen, an beiden

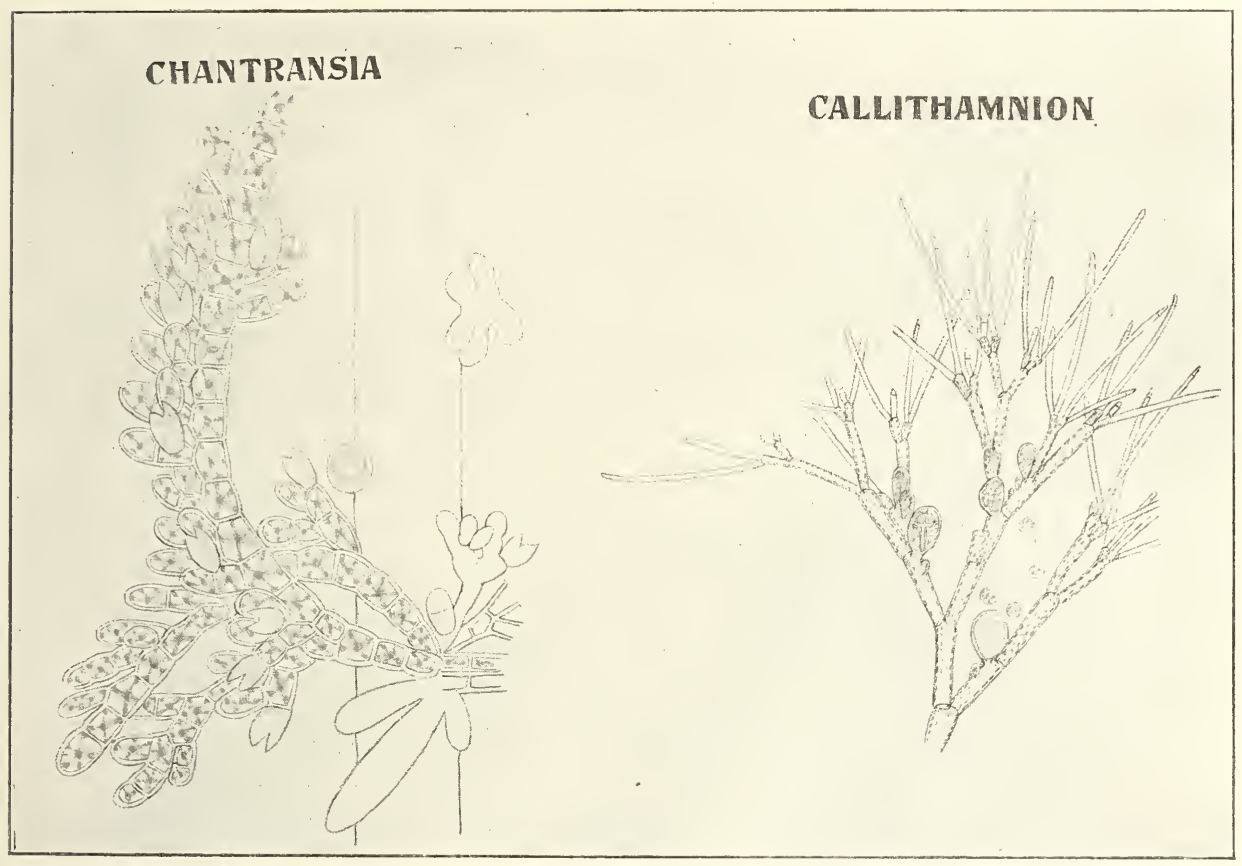

Fig. 212. Chantransia secundata mit Monosporen (nach Ortmanns). Calli thamnion corymbosum mit Tetrasporen (nach THuReT).

Seiten des fertilen Zweiges eine, auf. Jede dieser Auxiliarzellen ist entstanden durch Vergrößerung einer Oberflächenzelle, welche sich durch eine Tangentialwand in eine Auxiliarzelle und in eine Basalzelle teilte, sobald die Befruchtung stattgefunden hatte. Die Basalzellen fallen alsbald durch die große Zahl der in ihnen vorhandenen Kerne auf (Fig. 210, 5). Auch benachbarte Zellen sind polyenergid. Das ist übrigens bei den Florideen nichts Außergewöhnliches; zwar sind es monoenergide multicelluläre Gewächse, welche aber öfters einige polyenergide Zellen besitzen. ein Zeichen, daß es in der Natur keine scharfen Grenzen gibt. Die Auxiliarzellen selber aber sind strikt monoenergid. albesitzen also nur einen Kern.

Nach der Befruchtung bildet der Zygotenkern durch zweimalige 
Teilung 4 Kerne (falls, wie ausnahmsweise vorkommt, nur eine Auxiliarzelle vorhanden ist, werden nur 2 Kerne gebildet). Dann fusioniert das Oogon mit beiden Auxiliarzellen (Fig. 210,5) und läßt in jede einen 2 x-Kern übertreten. Dieser $2 \mathrm{x}$-Kern teilt sich, der eine Tochterkern begibt sich in die Spitze der Auxiliarzelle, und diese teilt sich in eine Zentralzelle mit einem $2 \mathrm{x}$-Kern und eine Fußzelle mit einem $2 \mathrm{x}$ - und einem x-Kern. Die Zentralzelle teilt sich nun wiederholt so, daß auf dem Querschnitt fächerförmig arrangierte Zellen entstehen. Jede derselben schneidet eine Stielzelle ab (Fig. 211, 7, 8), im übrig bleibenden Stück nimmt der Kern an Größe zu, es sammeln sich Reservesubstanzen an, und die Energide tritt schließlich als Carpospore aus demselben heraus. Um die für die große Zahl der Carposporen nötige Nahrung zu

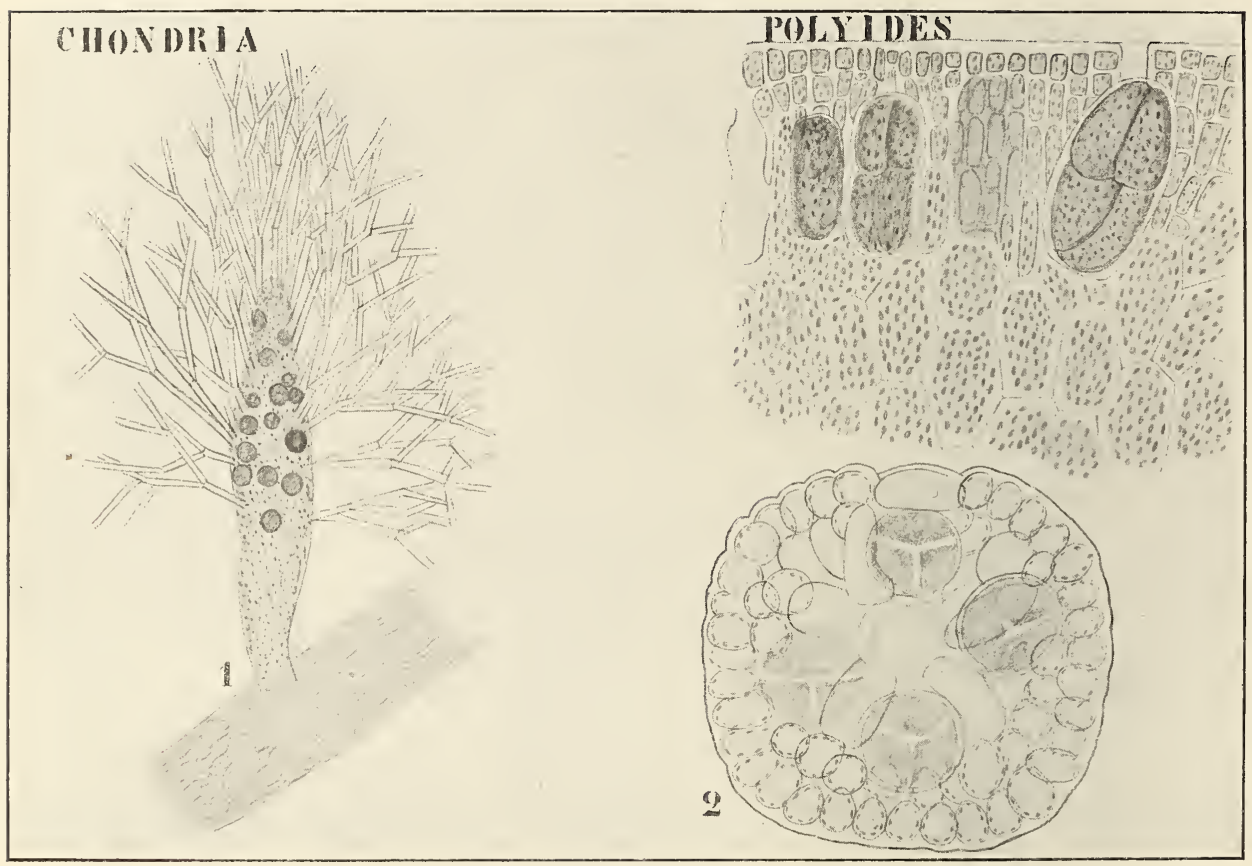

Fig. 213. Verschiedene Tetrasporangien (nach THURET). I. Chondria. 1 Stichidium. 2 Querschnitt eines solchen. - II. Polyides. Querschnitt.

erhalten, sind in erster Linie die Fußzellen mit den Basalzellen verschmolzen (Fig. 211, 8), und diese letzteren haben zahllose Anastomosen mit benachbarten vegetativen Zellen gebildet. Schließlich verschmelzen sie auch noch mit den Stielzellen, und es entsteht so eine riesige Fusionszelle (Fig. 211, 9), welche die Carposporen oder richtiger die Carposporen bildenden Zellen trägt, und sie ernährt.

Wir haben also bei den Florideen eine sich aus der Zygote entwickelnde $2 x-G e n e r a t i o n, w e l c h e$ in besonderen Zellen je eine Carpospore bildet ${ }^{1}$ ).

1) In diesen besonderen Zellen kann vielleicht eine Reduktionsteilung stattfinden, wie bei Nemation wahrscheinlich ist, in welchem Falle die Carposporen zu neuen Geschlechtspflanzen auswachsen, oder es findet keine solche statt, in welchem Falle aus den Carposporen Tetrasporenpflanzen sich entwickeln. Letzteres wurde, wie bemerkt, bei Polysiphonia nachgewiesen. 
Bei den Nemalionales besteht die $2 x$-Generation aus einer Anzahl kurzer, zu einem Bündel vereinigter sporogener Fäden, welche direkt aus der Zygote entstehen. Bei Dermonema, Galaxaura etc. entwickeln diese sporogenen Fäden sich schon zu langen Sprossen, welche nur an der Spitze Carposporenzellen bilden.

Bei den Cryptomeniales fängt die $2 \mathrm{x}$-Generation an mehr parasitisch zu werden, und zwar auf den Auxiliarzellen, also in ausgiebigerer Weise als die Mooskapsel (2x-Generation) auf der Moospflanze, da hier für jeden 2 x-Kern eine Auxiliarzelle, wie Ortmanns sich ausdrückt, Ammendienst verrichten muß. In dieser Gruppe haben sich die sporogenen Fäden behufs Deponierung der 2 x-Kerne in der Nähe der Auxiliarzellen sehr entwickelt.

\section{CHONDRIA}
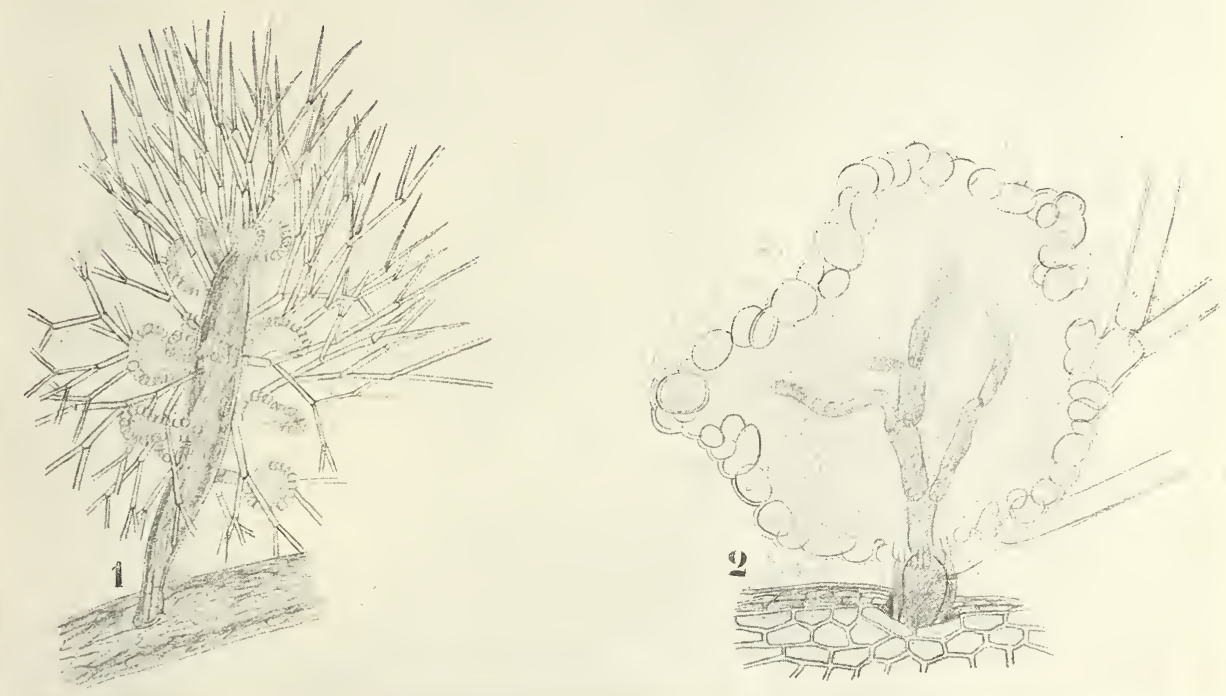

Fig. 214. Antheridienstände von Chondria (nach THURET).

In der Gruppe der Ceramieen dagegen sind die sporogenen Fäden sehr kurz. Die Auxiliarzelle tut nun nicht allein Ammendienst für den $2 x$-Kern, sondern die ganze $2 x$-Energide schlüpft in die Auxiliarzelle herüber, wo sie als Endoparasit lebt.

Bei Chylocladia kommt nun noch eine komplizierte Terschmelzung der Auxiliarzelle mit anderen Zellen hinzu, wodurch der hier ebenfalls in die Auxiliarzelle eingedrumgenen 2 x-Energide möglichst viel Nahrung zugeführt wird.

Während bei Nemalion keine ungeschlechtliche Fortpflanzung vorhanden ist, und bei Batrachospermum die ungeschlechtliche Fortpflanzung durch Monosporen besorgt wird, treffen wir bei den meisten Floridech Tetrasporangien an. Ihre Verteilung über die Pflanze kam sehr verschieden sein. In der Regel kommen sie auf gesonderten Individuen 
vor; untersucht man aber eine große Anzahl von Geschlechtspflanzen, so findet man nach Bornet stets einige wenige, welche neben Geschlechtsorganen Tetrasporen bilden.

Monosporen sind auf die Gruppe der Nemalionales beschränkt, sie kommen außer bei der Chantransia-Form von Batrachospermum auch bei den echten Meeres-Chantransien vor. Der ganze Inhalt des Monosporangiums, welches aus einer Scheitelzelle eines kurzen Zweiges gebildet wurde, schlüpft als nackte Energide heraus.

Nun hat SIRodot nachgewiesen, daß unter gewissen Umständen Monosporen nicht auf dem Chantransia-Stadium von Batrachospermum, sondern auf dem eigentlichen Batrachospermum-Stadium vorkommen, und zwar in der Nähe der Antheridien, ja er hat sogar Zwischenstadien

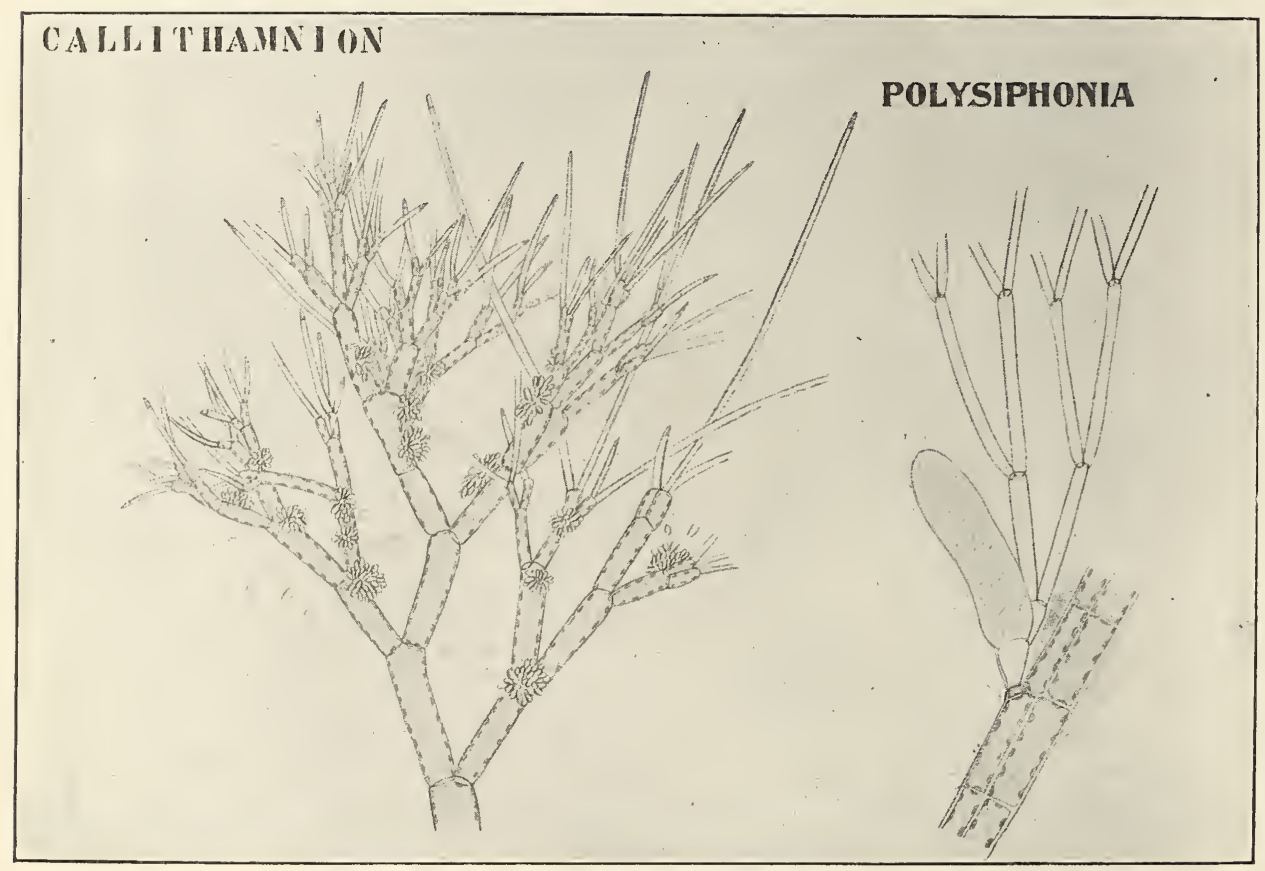

Fig. 215. Antheridienstände von Callithamnion und Polysiphonia (nach Thuret).

zwischen Antheridien und Monosporen gefunden. Dies verführt uns zu der Annahme, daß die Ahnen der Nemalionales sich mittels beweglicher Zoosporen fortpflanzten, daß diese sich in Zoosporen und Gameten differenzierten, daß dann letztere sich in Eier und Spermatozoen differenzierten und daß schließlich auch die Zoosporen und Spermatozoen unbeweglich wurden, wodurch Aplanosporen, Monosporen und Spermatien entstanden ${ }^{1}$ ).

Die Tetrasporangien sind ebenfalls angeschwollene Endzellen von Zellreihen. Der Inhalt teilt sich in 4 nackte, amöboid bewegliche Tetrasporen, welche ausschlüpfen. Sie besitzen wenigstens bei Polysiphonia den Wert von Diplosporangien.

1) Falls dies richtig und falls in den Tetrasporangien immer eine Reduktionsteilung stattfindet, trifft die auf S. 311 vermutungsweise ausgesprochene Homologie zwischen Monosporen und Tetrasporen nicht zu. 
Ihre Verteilung über die Pflanze gleicht der der Antheridien. Wo reichlich verzweigte einreihige.Zellfäden vorkommen, wie bei Callithamnion, sind sie meistens ziemlich regelmäßig über den Thallus verteilt, sowohl über die peripheren wie über die mehr zentral gelegenen Zweige. Sobald aber festere Gewebe auftreten oder die Fäden zu festeren Komplexen vereinigt sind, entstehen die Tetrasporangien in der Rindenschicht, z. B. bei Polyides. Bei den Corallinene begegnen wir den Tetrasporangien in Konzeptakeln; überdies liegen die Tetrasporen hier nicht kreuzweise, sondern in einer einzigen Reihe (Fig. 216,3).

Bei vielen anderen Florideen ist die Tetrasporenbildung auf bestimmte metamorphosierte Zweige, welche den Namen Stichidien führen, beschränkt. Ein Beispiel davon liefert uns Chondria (vergl. Fig. 216).

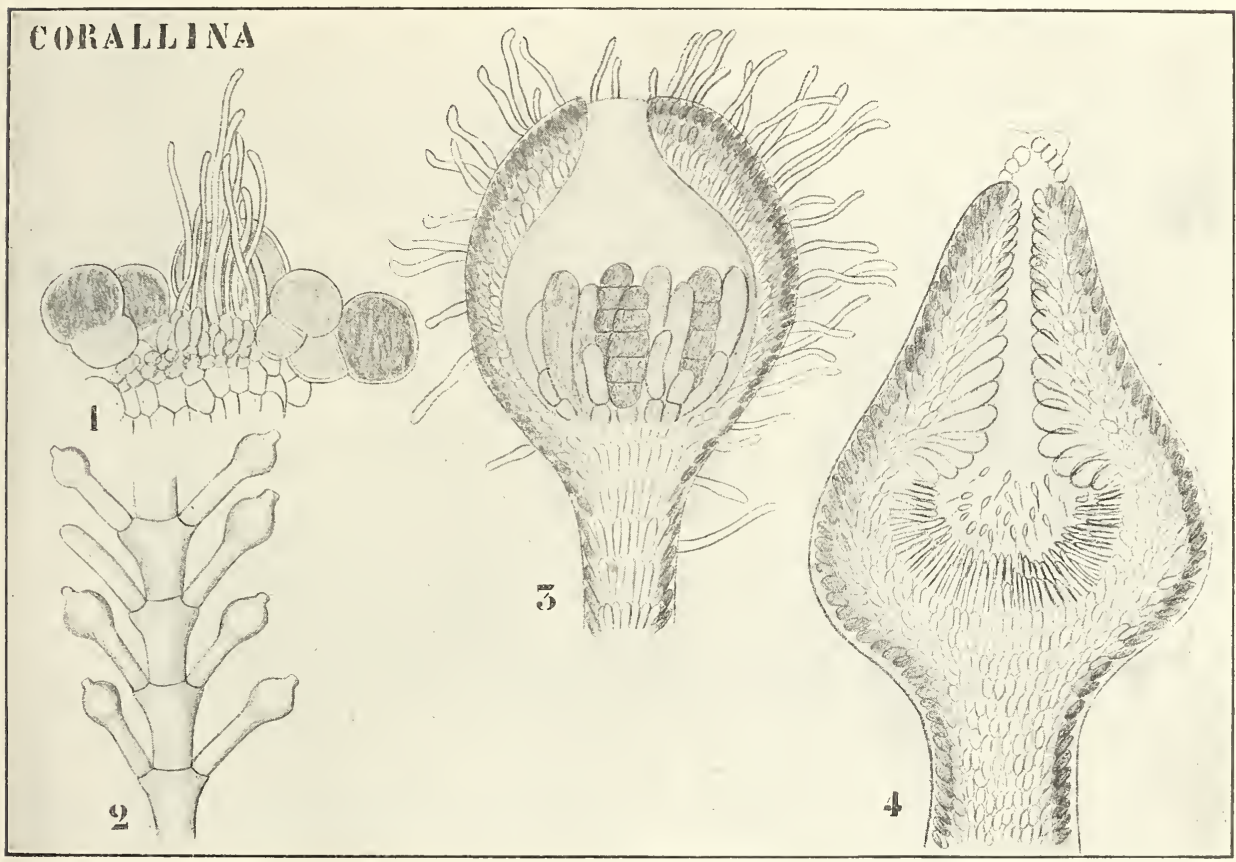

Fig. 216. Corallina (nach THuRET). 1 Inhalt eines weiblichen Konzeptakels. 2 Zweig mit Konzeptakeln von außen betrachtet. 3 Konzeptakel mit Tetrasporangien. 4 Männliches Konzeptakel.

Außer Tetrasporen treten bei gewissen Florideen Brutknospen auf, darüber konsultiere man Oltmanns.

Wie gesagt, stimmen die Antheridien mit den Tetrasporangien in Art der Verteilung über den Thallus überein, wie ein Vergleich der Figuren 212 mit 215 und 213 mit 214 zeigt. Bei Callithammion über den ganzen Thallus zerstrent, sind sie bei massiveren Formen auf die Rinde beschränkt. Bei Corallina treten sie ebenfalls genan so wie die Tetrasporangien in Konzeptakeln auf (Fig. 216), während sie bei Chondria und anderen etwa wie die Tetrasporen auf Stichidia gebildet werden. welche hier aber nicht so genannt werden; man redet von Antheridienständen.

Hiermit könnte ich meine Besprechung der Floridcen schließen. ich möchte Ihnen aber in Verbindung mit der später zu besprechenden Ab- 
stammung gewisser höherer Pilze von den Florideen noch den Beweis liefern, daß Florideen farblos werden können, und zwar so gründlich, daß die Chromatophoren vollständig verloren gehen. Dies wurde 1894 durch Kuckucks Entdeckung von Choreocolax albus bewiesen.

Bei Helgoland traten auf der Floridee Rhodomela subfusca kleine weiße oder bräunliche halbkugelige Polster auf, welche von einem parasitischen Choreocolax verursacht wurden. Es stellte sich heraus, daß die bräunliche Farbe gewisser Exemplare durch die zufällige Anwesenheit von Diatomeen oder Ectocarpaceen verursacht wurde, daß aber der Chloreocolax selber rein weiß war. Die gefundenen Pflänzchen waren schon erwachsen und trugen reichlich gleichfalls farblose Tetrasporen.

Chromatophoren fehlen vollständig, sind auch nicht in der Form von Leukoplasten vorhanden.

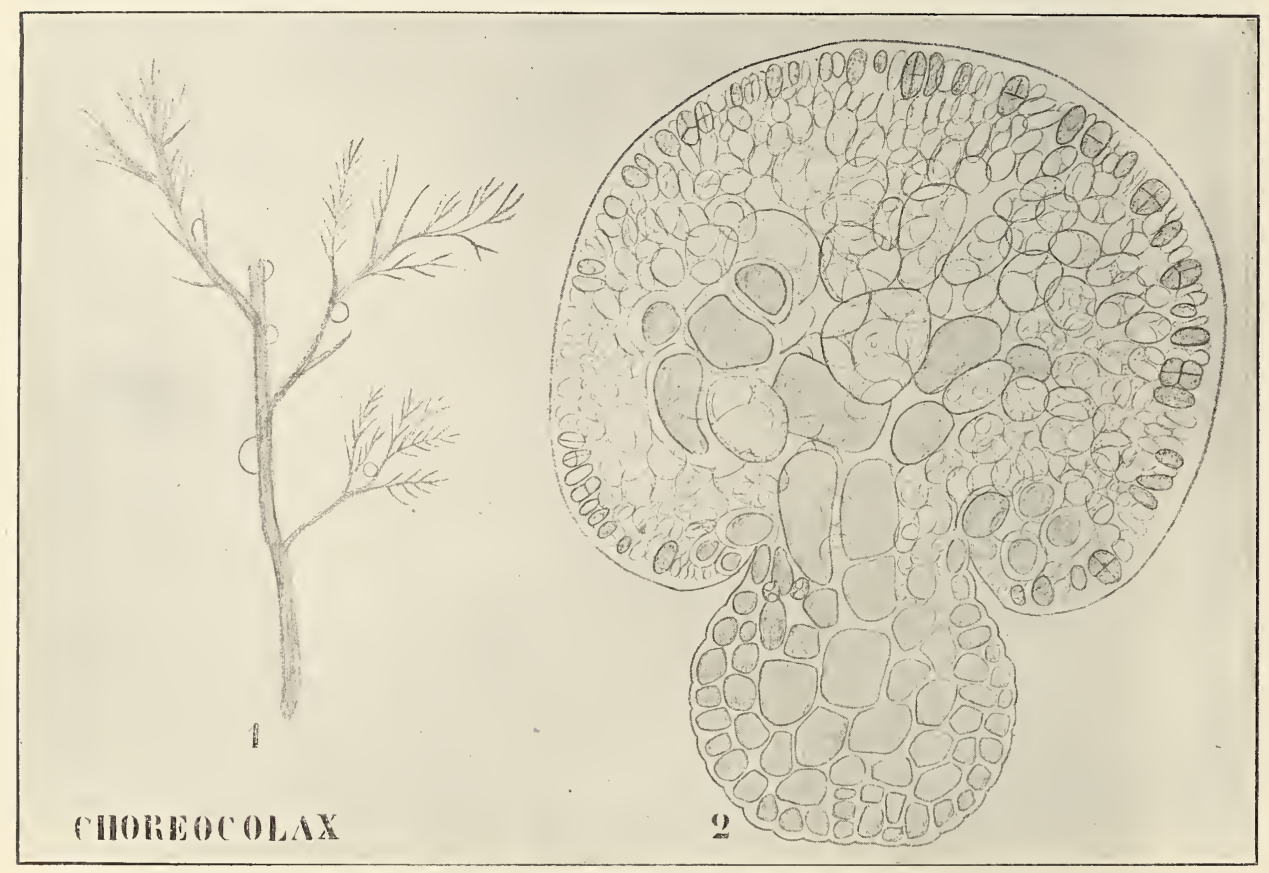

Fig. 217. Choreocolax albus KuCKuck (nach Kuckuck). Links: die weißen Polster des Choreocolax auf der Floridee Rhodomela. Rechts: Querschnitt durch ein solches Polster, die Tetrasporen zeigend.

Wir haben hier also mit einer echten parasitischen Floridee zu tun, welche, da sie keine Chromatophoren besitzt, keine Alge, sondern ein Pilz ist. Sie verursacht auf der Wirtspflanze eine Art von Galle, eine Zellwucherung, welche soweit gehen kann, daß Zellen des Wirtes in den Körper des Parasiten vordringen können (die grauen Zellen im Gewebe des Parasiten auf der Fig. 217). Leider ist die geschlechtliche Fortpflanzung dieses Florideen-Pilzes unbekannt.

Wir müssen uns jetzt einer ganz anderen Gruppe von Organismen, einer auf viel niedrigerer Stufe stehenden zuwenden, der der Schizophyten. 


\section{Vierzehnte Vorlesung.}

\section{Die Schizophyten.}

Die Gruppe der Schirophyten, zu welcher die niedrigsten Organismen, welche wir überhaupt kennen, gehören, ist durch zwei negative Merkmale charakterisiert: das Fehlen einer geschlechtlichen Fortpflanzung und echter Kerne.

Die Gruppe besteht aus gefärbten oder farblosen, monoenergiden, einzelligen oder homocellulären Organismen. Sie kann in 3 Gruppen eingeteilt werden :

1) Schizophyceen.

2) Bakterien.

3) Myxobakterien.

Von diesen Gruppen ist zweifellos die erste die höchst entwickelte, da sie autotroph ist, d. h. ihre eigene Nahrung bereiten kann, während die beiden anderen Gruppen mit wenigen Ausnahmen parasitisch oder saprophytisch leben, und erstere somit stets blaugrün gefärbt ist, während die anderen Gruppen farblos oder von einem Farbstoff tingiert sind, der mit Photosynthese nichts zu tun hat.

Da man früher meinte, daß ausschließlich gefärbte Organismen im stande wären, ihre eigene Nahrung zu bereiten, mußte man wohl annehmen, daß die Schirophyceen die phylogenetisch ältere Gruppe darstellten und daß die beiden anderen oder, richtiger gesagt, daß die Bakterien -- denn Myxobalkterien waren damals noch unbekannt - von den Schirophyceen abstammten, und da sie einfacher als diese sind, wurden sie für reduzierte Nachkommen derselben gehalten.

Jetzt weiß man aber, daß es auch Bakterien gibt, welche im stande sind, ihre eigene Nahrung zu bereiten, und damit fällt eines der wichtigsten Argumente für die Ahnennatur der Schirophyceen fort.

Ueberdies sind, wie wir alsbald sehen werden, die Merkmale beider Gruppen keineswegs solcher Art, daß man zur Amnahme einer sehr engen Verwandtschaft gezwungen wird. Nan kann im Gegenteil über diese nicht viel mehr aussagen, als wir schon bemerkten, nämlich das Fehlen geschlechtlicher Fortpflanzung und echter Kerne in beiden Gruppelı.

Ich glaube deswegen, daß wir bei unserer jetzigen Kemntnis der Gruppe am besten tun, von einer phylogenetischen Betrachtung abzusehen. Da fangen wir also am besten mit den 


\section{Bakterien}

an. Selbstverständlich ist es mir unmöglich, diese Gruppe auch nur einigermaßen eingehend zu behandeln. Die wichtige Rolle, welche diese Lebewesen sowohl im günstigen wie im ungünstigen Sinne in der Natur spielen, ihre aufbauende Rolle beim Sammeln von Stickstoff, ihre abbauende als Krankheits- und Fäulniserreger, hat eine so große Literatur entstehen lassen, daß die Lehre von den Bakterien zu einer gesonderten Wissenschaft geworden ist, welche wohl an jeder Universität, auch an der unserigen, gesondert gelehrt wird. Dennoch darf in diesen Stunden diese Gruppe nicht übersprungen werden und ich werde versuchen, eine ganz kurze Uebersicht über diese höchst interessante Gruppe zu geben. Als Lektüre kann ich Ihnen Fischers Vorlesungen über Bakterien, Jena 1903, und für die Methoden die letzte Auflage von AвBots Principles of Bacteriology, angelegentlich empfehlen. Diesen beiden Werken bin ich hauptsächlich im nachstehenden gefolgt.

Die große Wichtigkeit dieser Gruppe berechtigt wohl zur kurzen Behandlung der Geschichte unserer Kenntnisse.

Im Jahre 1675 entdeckte LEEUWENHOEK mittels von ihm selbst geschliffener Linsen Bakterien in Wasser, in tierischen Exkrementen etc. und bildete 1683 solche aus der Mundhöhle ab.

Selbstverständlich führte diese Entdeckung alsbald zu Spekulationen, die Erklärung der Krankheitsursachen bezweckend.

Die Hypothese, welche 1762 vom venetianischen Arzte Marcus Antonius Plenciz aufgestellt wurde, hat sich als auffallend richtig herausgestellt. Er behauptete, daß die Infektionskrankheiten nur von lebenden Organismen verursacht werden können, und versuchte auf dieser Basis die verschieden lange Inkubationsdauer der verschiedenen Krankheiten zu erklären. Er meint weiter, daß das lebende Kontagium im stande sein muß, sich im Körper des Kranken zu vermehren und spricht von einer möglichen Verbreitung durch die Luft. Er nimmt einen speziellen Mikroorganismus als Ursache einer jeden Krankheit an, indem er sagt, daß ebenso wie ein Roggenkorn nur Roggen, ein Weizenkorn nur Weizen, so auch ein bestimmter Organismus nur eine bestimmte Krankheit erzeugen könne.

In allen faulenden Substanzen fand er Bakterien und so sehr war er vom Zusammenhang beider Erscheinungen überzeugt, daß er das Gesetz aufstellte: Ohne Mikroorganismen keine Fäulnis und ohne Vermehrung der Mikroorganismen keine Fortdauer des Fäulnisprozesses.

Wohl selten ist eine so richtige Theorie auf so wenigen Tatsachen aufgebaut worden.

Aber Plencizs Auffassungen wurden keineswegs von seinen Zeitgenossen geteilt, und sogar noch 1820 sagt der Arzt OzANam, daß er keine Zeit mit der Widerlegung solcher wahnsinnigen Hypothesen vergeuden wolle.

Erst zwischen 1840 und 1850 wurde durch die PAsteurschen Versuche mehr Klarheit gebracht über Fäulnis in Bier, über das Sauerwerden des Weines und durch den von Pollender und Darain geführten Nachweis der Existenz von stäbchenförmigen Organismen im Blute an Milzbrand gestorbener Tiere. Henle war der erste, welcher durch logische Gründe die Infektionstheorie verteidigte.

Ueber den Urspı'ung der Mikroorganismen war man so ziemlich einig: sie sollten durch Generatio aequivoca entstehen. 
Im Jahre 1769 zeigte aber SPallanzini bereits, daß in Infusionen pflanzlicher Substanzen, welche man in hermetisch geschlossenen Flaschen aufbervahrte, Bakterien nicht auftraten, falls man nur vorher die Flasche mitsamt ihrem Inhalt einige Zeit in kochendes Wasser gestellt hatte.

Als Treviranus dagegen bemerkte, daß die Generatio aequivoca in solchen Flaschen nicht stattfinden könne, weil die vorhergegangene hohe Temperatur den Inhalt verändert habe, und daß also in solchen Flaschen Bakterien überhaupt nicht leben könnten, wies NEEDHAM das Irrige dieser Neinung nach, indem er in die gekochte Flasche einen kleinen Riß machte und zeigte, daß dann Bakterien im Inhalt erschienen.

Aehnliche Versuche wurden 1836 von ScHulze ausgeführt. Er wies nach, daß man ruhig Luft zu den ausgekochten Infusionen zutreten lassen konnte, wenn man diese Luft nur vorher von lebenden Mikroorganismen befreit hatte, indem man sie zwang, stark saure oder alkalische Lösungen zu passieren. 1837 erhielt ScHWANn ein mit diesem übereinstimmendes Resultat, indem er die Luft glühendheiße Röhren passieren ließ, während SchröDER und Dusch 1854 durch Einsetzen eimes Wattepfropfens in den Hals der Flasche die Luft sozusagen filtrierten, ein Prinzip, welches noch heute angewendet wird.

1860 zeigte Hofmann und 1861 Chevreuil und Pasteur, daß man auch den Kolbenhals zu einer feinen Röhre ausziehen kann und, diese U-förmig umbiegend, die Bakterien ausschließen kann, wenn man nur das eine Bein dieses U-förmigen Stückes mit einer Flüssigkeit füllt. Das geschieht am leichtesten durch ein einfaches Erhitzen des Kolbens bis der Inhalt kocht, der Dampf kondensiert dann im U-Stücke zu einem Wassertropfen, der die Röhre genügend abschließt, um den Eintritt von Mikroorganismen zu verhindern.

Bei allen beschriebenen Versuchen wurden aber eigentümliche Unregelmäßigkeiten bemerkt. Gewisse Substanzen mußten viel länger gekocht werden als andere, bevor Sterilität eintrat und sogar bei Befolgung aller denkbaren Vorsichtsmaßregeln fand bisweilen Infektion statt.

Schon 1762 vermutete Bonnet, daß der Grund vielleicht in der Anwesenheit besonders resistenter Bakterien oder Bakterieneier liegen könnte.

Mehr als 100 Jahre später versuchte Ferdinand Cohn, ob vielleicht ein experimenteller Grund für diese bloße Vermutung gefunden werden könnte. Nach mühsamer Arbeit zeigte er mit Gewißheit, daß gewisse stäbchenförmige Bakterien das Vermögen besitzen, in ein Ruheoder Sporenstadium zu treten und daß sie während dieses Stadiums viel resistenter sind als während des vegetativen Lebens. Mit der Entdeckung dieser Bakteriensporen gab Corn der Theorie der Generatio aequivoca den Gnadenstoß.

Damit war also der letzte Beweis für den allgemeinen Satz: Omme vivum e vivo erbracht.

Auf medizinischem Gebiete wurde der erste wichtige Schritt von RINDFLEISCH getan. 1866 wies er nach, daß im Myocardium und im allgemeinen in den Muskeln infolge Wundfiebers gestorbener Patienten kleine stecknadelkopfförmige Bakterien vorhanden sind.

Aehnliche Beobachtungen wurden von späteren Untersuchern gemacht, und v. Recklinghausen und KleBs stellten sehr richtige Theorien auf.

Diese Theorien wurden aber keinesweg's allgemein acceptiert. Dazu beruhten sie noch auf zu wenig Tatsachen. Nur das konstante Tor- 
kommen von Bakterien bei den betreffenden Kranken sprach für die Meinung, daß diese auch die Ursache der Krankheit wären.

Man versuchte aber nicht, die Bakterien zu isolieren oder gesunde Individuen mit Bakterien von Kranken zu infizieren.

Ein so berühmter Mediziner wie Billzoth war der Meinung, daß die Bakterien normale Bestandteile der tierischen Gewebe seien, und nahm sogar Versuche vor, welche dies - wie wir jetzt wissen durch Mangel an Schutzmaßregeln gegen Infektion - zu beweisen schienen.

Pasteur, Burdon-Sanderson und Klebs wiesen alsbald das Unhaltbare der Billnothschen Meinung durch Versuche nach. Aber erst im Jahre 1881 wurde die Basis der modernen Bakteriologie von RoBERT KocH gelegt und wohl selten war es einem Untersucher vergönnt, auf den von ihm gebahnten Wegen einen so lebhaften Verkehr zu sehen, wie Robert Koch auf den Heerstraßen der Bakteriologie.

Das Fundamentale der KocHschen Untersuchungen bestand in dem Verfahren des Isolierens der Bakterienarten mittels fester Nahrungsböden, sowie das Hervorrufen der betreffenden Krankheit durch Impfung mit solchen Reinkulturen.

Da unsere gegenwärtigen Methoden nur Modifikationen der KocHschen Methode sind, mag hier beschrieben werden, wie man Bakterien fängt.

Eine recht einfache Weise ist folgende: $500 \mathrm{~g}$ fein zerhacktes fettfreies Fleisch werden während 24 Stunden an kühler Stelle in 11 Wasser ausgezogen. Die Flüssigkeit wird dann durch ein grobes Tuch filtriert und ausgepreßt, bis man 1 l Flüssigkeit erhalten hat. Dazu fügt man $10 \mathrm{~g}$ (1 Proz. also) trockenes Pepton und $5 \mathrm{~g}$ (0,5 Proz.) Kochsalz. Dann wird 10-12 g fein geschnittene Gelatine zugefügt, bis zur Lösung derselben erwärmt und mit $\mathrm{KOH}$ neutralisiert; eine geringe Alkalität schadet nicht. Die Flüssigkeit wird dann in einem emaillierten Gefäße so lange gekocht, bis alle Gelatine vollständig gelöst ist, und dann durch ein angefeuchtetes Faltenfilter filtriert.

Ist alles gut gegangen, so ist die Flüssigkeit vollkommen klar, ist dies nicht der Fall, so gießt man sie in die Pfanne zurück, läßt bis auf $60-70^{\circ} \mathrm{C}$ abkühlen und fügt dann das Weiß zweier Eier hinzu, welches man vorher mit $50 \mathrm{ccm}$ Wasser zu einem Schaum zerschlagen hat. Darauf kocht man so lange, bis alles Eiweiß geronnen ist und filtriert von neuem. Die jetzt durchlaufende Gelatinelösung ist vollkommen klar und bildet ein ausgezeichnetes Kulturmedium für Bakterien, sie ist aber noch nicht steril. Die Flasche, in welcher sich nun die Gelatine befindet, wird mittels eines Wattepfropfens geschlossen, 15 Minuten lang in einen Dampfsterilisator gestellt und dieses Sterilisieren an den zwei folgenden Tagen wiederholt. Man nennt dies fraktioniertes Sterilisieren. Das Prinzip, dem man dabei folgt, ist folgendes: die erste Sterilisierung tötet die vegetativen Bakterien, aber nicht die Sporen, diese keimen während der nächsten 24 Stunden und werden von der zweiten Sterilisation getötet, eventuelle Nachkeimer von der dritten.

Petri-Schälchen (siehe Fig. 218), welche vorher im Sterilisator sterilisiert sind, werden nun mit der sterilisierten Gelatinelösung beschickt und nach Auflegung des Deckels abgekühlt, wodurch die Gelatine fest wird.

Von diesen Petri-Schälchen nehmen wir nun z. B. 6 Stück und stellen sie im Laboratorium in einer Reihe auf den Tisch; dem ersten, dritten und fünften werden die Deckel abgenommen, so daß drei bedeckte 
und drei unbedeckte Schälchen vorhanden sind. Nachdem man sie so einige Stunden hat stehen lassen, legt man die Deckel wieder auf, stellt sämtliche Schälchen ins Dunkle und untersucht sie nach Verlauf ron 48 Stunden. Die bedeckt gebliebenen Schälchen sehen nun aus wie Fig. 218, 2, diejenigen, deren Deckel einige Zeit abgenommen war, wie Fig. 218, 3 und 4. Die Flecken auf den beiden letzteren sind Kolonien von Bakterien, welche sich aus in der Luft befindlichen und auf die Platte gefallenen Keimen entwickelt haben.

Jede Kolonie ist aus einem einzigen Bakterium oder einer Bakterienkolonie entstanden. welche auf die Gelatine fielen. Da ein solches

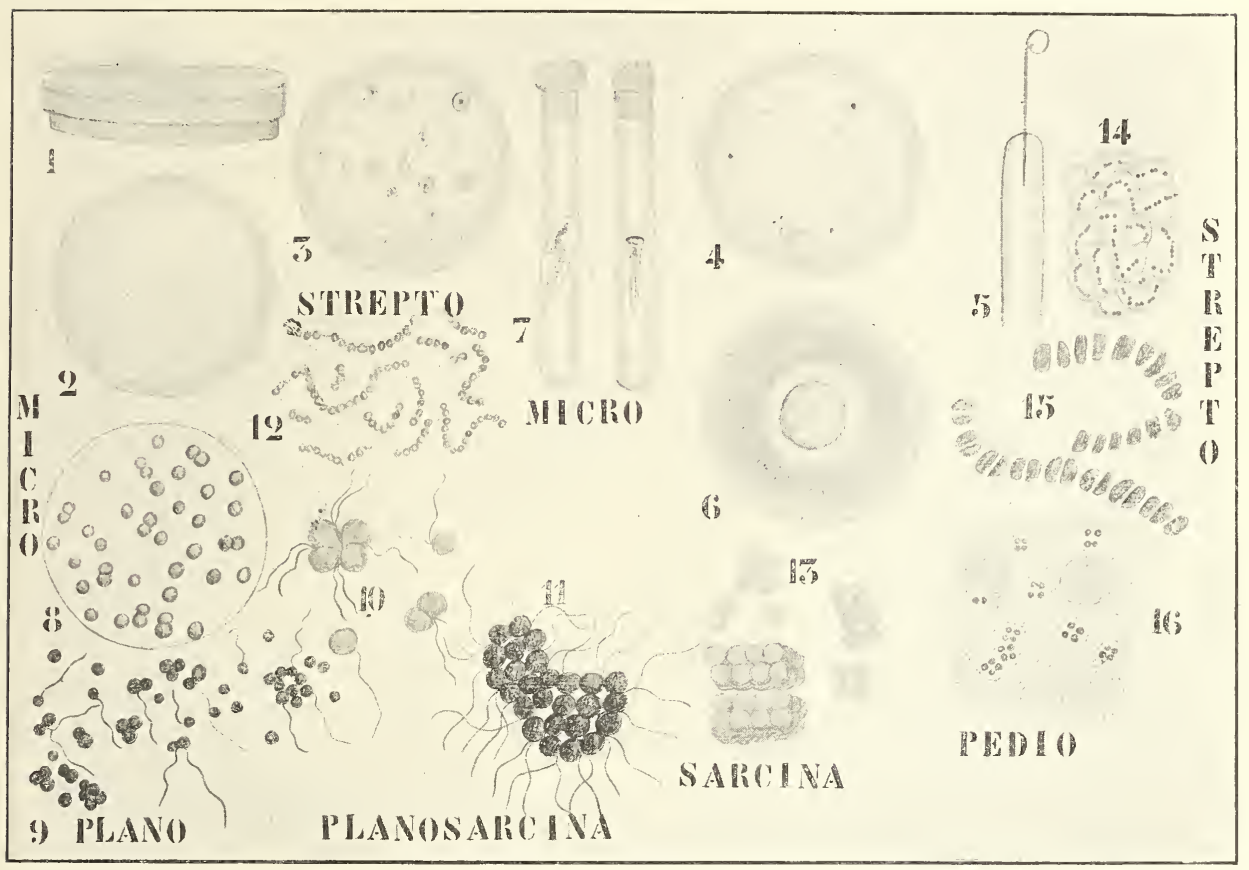

Fig. 218. 1 und 2 PETRI-Schälchen von der Seite und von oben betrachtet. 3 Kolonien aus Keimen, welche aus der Luft gefallen sind. 4 Idem. 5 Impfnadel mit Oese. 6 Eine Kultur von Milchsäurebakterien in mit feiner Kreide vermischter Gelatine; um die zentrale Kolonie herum ist eine durchsichtige Zone, dort wo die Kreide von der Säure gelöst wurde. 7 Micrococcus prodigiosus, links eine Schmier-, rechts eine Stichkultur auf Gelatine. Die Bakterie verflüssigt die Gelatine und hat sich, weil sie aërob ist, an der Oberfläche besser entwickelt wie im Innern. 8 Micrococcus phosphoreus (nach MoLISCH). 9 Planococeus citreus (Menge) Migula (nach Migula). 10 Planosarcina mobilis (Manrea) Migula (nach Migula). 11 Pl. viola cea (Wixogradski) Migula (nach Migula). 12 Streptococeus erysi pelatos Fehleisen (Migula) (nach Migula). 13 Sareina lutea (nach A. Fischer). 14 Streptococens (Leuconostoc) mesenterioides (v. Tieghem) Migula (nach A. Fischer). 15 Streptococeus pyogenes. Zwei Ketten mit sich teilenden und deshalb quer-ellipsoidischen oder halbkugeligen Gliedern (nach A. Fischer). 16 Pediococeus tetragenus (GAfFK)) Miguld. Gewebesaft, gefärbt nach MiguLA.

Bakterium resp. eine Spore nur einige wenige Mikromillimeter Durchmesser hat, und die Kolonien mit unbewaffnetem Auge leicht sichtbar sind, ersieht man daraus, wie schnell sich diese Mikroorganismen relmehren können. Die hier entwickelten Bakterien fielen aus der Luft, 
wo sie also vorhanden sind, aber nicht nur dort, sondern wohl überall sind Bakterien vorhanden, nur ganz geschlossene Räume wie die Bauchund Brusthöhle gesunder Tiere sind steril.

Um nun aus einer Rohkultur, wie die hier erhaltene, Reinkulturen einer einzigen Art zu bekommen, geht man in folgender Weise vor. Man hat vorher Reagensröhrchen mit steriler Gelatinelösung präpariert und einige in aufrechter, andere in schrägliegender Lage erstarren lassen.

Mittels einer Platinnadel, welche man vorher einen Augenblick in eine Bunsensche Gasflamme hält, nimmt man nun von einer Kolonie ein wenig fort und streicht dies auf die Oberfläche der schieferstarrten Gelatine; dadurch erhält man eine sogenannte Strichkultur.

Der Platindraht wird sofort wieder ausgeglüht und von einer anderen Kolonie geimpft, wobei man diesmal die aufrecht erstarrten Röhrchen nimmt und den Draht eine Strecke in die Gelatine hineinsticht; eine solche Kultur nennt man eine Stichkultur.

Dies wird einige Male wiederholt, bis man Reinkulturen verschiedener Bakterien hat.

Wenn man nun nach einigen Tagen das PETRI-Schälchen mit der Rohkultur betrachtet, so findet man, daß der Inhalt ganz, flüssig geworden ist. Es muß also Bakterien geben, welche die Eigenschaft besitzen, Gelatine bei Zimmertemperatur zu verflüssigen. Um zu erfahren, ob alle oder nur gewisse Arten dies können, konsultieren wir unsere Reinkulturen. Da sehen wir, daß einige die Gelatine verflüssigt haben, andere nicht, so daß wir bei dẹn Bakterien 2 Gruppen unterscheiden können, die, welche Gelatine verflüssigen und die, welche sie nicht verflüssigen können.

Den Verflüssigungsvorgang kann man am besten an Stichkulturen verfolgen; man sieht da, daß die Gelatine gleichmäßig um den Stich herum gelöst wird, und wir wissen jetzt, daß dies durch ein aus der Kolonie in die Gelatine diffundierendes Ferment geschieht. Das Diffundieren von Substanzen aus Bakterienkolonien kann man recht hübsch in folgender Weise an Milchsäurebakterien demonstrieren. Man fügt der flüssigen Gelatine fein zerteilte Kreide zu und läßt sie dann erstarren; der Nährboden ist dann weiß und undurchsichtig.

Impft man nun in die Mitte eines mit solchem Nährboden beschickten PETRI-Schälchens Milchsäurebakterien, so bilden diese dort eine Kolonie, welche alsbald von einem hellen Hof (Fig. 218, 6) umgeben wird, da die hinausdiffundierende Milchsäure die Kreide löst.

Betrachten wir nun noch einmal die Stichkultur von B. prodigiosus, so sehen wir, daß die Verflüssigung der Gelatine in viel ausgiebigerem Maße um den oberen als um den unteren Teil des Stiches stattgefunden hat, so daß die Flüssigkeitskolumne nicht die Form eines Cylinders, sondern die eines auf die Spitze gestellten Kegels hat.

Diese Erscheinung kommt zu stande, weil B. prodigiosus sich viel besser an der Oberfläche als in der Tiefe der Gelatine entwickelt, was darin seinen Grund hat, daß an der Oberfläche mehr Sauerstoff als im Innern vorhanden ist.

Wir sehen also, daß es Bakterien gibt, welche zu ihrer Entwickelung Sauerstoff bedürfen, und diese nennt man aërob, andere dagegen brauchen nicht nur keinen Sauerstoff, sondern können sich sogar bei Anwesenheit von solchem nicht entwickeln, man nennt sie anaërob. Diese beiden Extreme kann man die obligaten Aëroben und obligaten Anaëroben nennen. Dazwischen liegen dann die fakultativ aëroben und die fakul- 
tativ anaëroben Formen, so genamnt, weil die ersteren, g’ewöhnlich anaërob, auch aërob, die letzteren, gewöhnlich aërob, auch anaërob leben können, doch im fakultativen Zustand sich schwächer vermehren.

Um anaërobe Bakterien zu kultivieren, muß man also in irgend einer Weise den Sauerstoff entfernen. Das geschieht recht einfach so:

Man stellt das Reagenzröhrchen mit der Kultur in ein größeres Glasrohr, dessen Boden mit $1 \mathrm{~g}$ Pyrogallussäure und $10 \mathrm{ccm} 1 / 10$ Normal $\mathrm{KOH}$ bedeckt ist. Das große Rohr wird fest mit einem Gummipfropfen verschlossen. Da der Sauerstoff alsbald durch die Pyrogallussäure absorbiert wird, befindet sich nun die Kultur" in einer sauerstofffreien Atmosphäre, in welcher sich die Anaëroben vorzüglich entwickeln.

Zur näheren Untersuchung der reinkultivierten Bakterien wird ein wenig von der Kultur auf die Spitze der Platinnadel genommen und in einen Tropfen sterilisierter Bouillon auf ein sorgfältig gereinigtes, steriles Deckgläschen gebracht. Vorher hat man eine feuchte Kammer in folgender Weise hergerichtet. Aus dicker Pappe schneidet man Stückchen, welche genau die Größe eines Objektträgers besitzen, macht in die Mitte eines jeden mittels eines Korkbohrers ein Loch von etwas geringerer Dimension, als der des Deckgläschens, kocht diese perforierten Pappstücke aus, trocknet sie oberflächlich ab, und legt je eins auf einen Objektträger.

Das Deckgläschen wird nun mit dem Bouillontropfen nach unten auf das Loch gelegt. Der Bouillontropfen befindet sich nun in einem dampfgesättigten Raum und ist daher gegen Austrocknen geschützt. Eine solche Kultur nennt man eine Kultur im Hängetropfen. Sie eignet sich besonders zur Beobachtung gewisser Lebenserscheinungen, z. B. der Teilung.

Falls unsere Kultur aus der gewöhnlichen Heubakterie, Bactridium subtilis, besteht, werden wir kurze, stark lichtbrechende, farblose, unbewegliche Stäbchen sehen (Fig. 219, 4 in der Mitte), an welchen weiter nichts Besonderes wahrzunehmen ist. Zunächst interessiert uns nun zu erfahren, ob diese kleinsten Wesen eine Zellwand besitzen oder nicht. Das läßt sich mittels Plasmolyse feststellen, allerdings gerade bei unserem B. subtilis nicht, da dieses vollkommen permeabel ist, wir wählen dazu also z. B. Choleravibrionen. In einer 0,75-proz. Salpeterlösung sieht man diese Organismen scheinbar in Stücke auseinander fallen (Fig. 219, 12 links), was daher rührt, daß sich das Plasma in den Ecken zusammenzieht (Fig. 219, 12 rechts) und die leere Membran in der Mitte unsichtbar ist, außer bei sehr starker Vergrößerung. Letztere zeigt aber sofort den wahren Sachverhalt (Fig. 219, 12 rechts) und die Anwesenheit einer deutlichen Membran. Wir haben also schon ein Entwickelungsstadium einer Bakterie kennen gelernt; ein einzelliges mit Membran bekleidetes unbewegliches kurzes Stäbchen.

Wie vermehrt sich nun ein solches Wesen? Um dies zu erfahren, stellen wir das Mikroskop sorgfältig auf ein bestimmtes Individum ein, und behalten dies sorgfältig im Auge. Sehr lange brauchen wir nicht zu warten, denn es teilt sich $B$. subtilis jede halbe Stunde, das Choleravibrion sogar alle 20 Minuten, so daß dieses in $2+$ Stmmden 1600 Trillionen Nachkommen bilden könnte, was ungefähr 2000 Zentnern Trockensubstanz entsprechen würde, so daß zur ungestörten Termehrung eines einzelnen Choleravibrions bereits ein Riesenexperiment nötig wäre.

So schnell geschieht nun die Vermehrung nie, weshalb nicht, mag hier zunächst erörtert werden. Erstens weil wohl nie die dazu nötige 
Nahrung vorhanden ist, und zweitens, weil der Kampf ums Dasein verschiedene Individuen zu Grunde gehen läßt, oder wenigstens ihre Vermehrung verhindert. Diese Gründe liegen auf der Hand, es gibt deren aber noch zwei, welche wohl des Erwägens wert sind.

Erstens kann eine Bakterienzelle sich zwar sehr lange vermehren, aber wahrscheinlich doch nicht bis ins Unendliche, ohne Unterbrechung durch einen Ruhezustand, und zweitens wirken die Stoffwechselprodukte der Bakterien auch auf sie selber schädlich ein, so wird z. B. das Wachstum der Essigbakterien alsbald von der gebildeten Essigsäure gehemmt.

Betrachten wir unsere Kultur jetzt wieder, so sehen wir darin eine auffällige Veränderung, mehrere Individuen sind beweglich geworden, und wir stellen uns die Frage, wie diese Bewegung stattfindet, aber auch

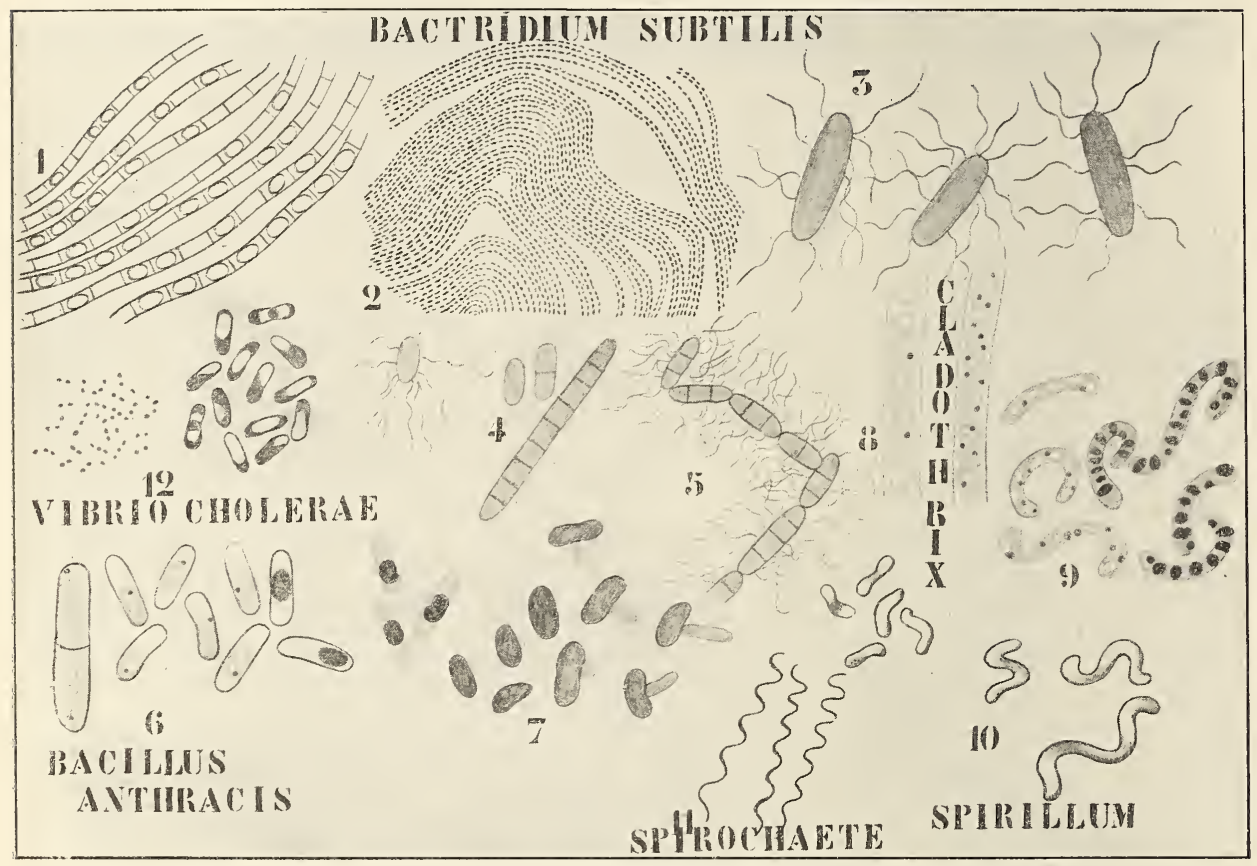

Fig. 219. 1 Bactridium subtilis (Emrenb.) A. Fischer. Sporenbildende Fäden (nach Miguta). 2 Teil einer durch B. subtilis gebildeten Haut (nach Migula). 3 Schwärmende Stäbchen nach der LöFfLERschen Geißelfärbung (nach MIGULA). 4 (Nach A. Fischer.) Links peritriches Kurzstäbchen, in der Mitte unbewegliche Stäbchen, rechts unbewegliche Kette. 5 (Nach FiscHER.) Bewegliche Kette. 6 Bacillus anthracis, Sporenentwickelung (nach FISCHER.) Links die Zellen noch unverändert mit je einem Chromatinkorn, in der Mitte Sporenbildung, rechts Sporenkeimung. $8 \mathrm{Cladothrix-Zellen} \mathrm{mit}$ vakuolisiertem Plasma und Chromatinkörnern (nach FISCHER). 9 Spirillen, links Individuen mit Chromatinkörnern, rechts mit farbstofferfüllten Vakuolen (nach FischeR). $10 \mathrm{Spirillum}$. $11 \mathrm{spirochaete.}$

die sorgfältigste Beobachtung genügt nicht, um Bewegungsorgane zu entdecken.

Wir wollen also versuchen, was sich durch Fixierung und Färbung erreichen läßt. Dazu werden mittels der Platinnadel einige Bakterien der Kultur entnommen und auf ein Deckglas aufgestrichen. Wenn sie gut getrocknet sind, wird das Deckglas mäßig schnell ein paarmal durch 
die Bunsenflamme gezogen, wodurch die Bakterien fixiert werden. Danach werden sie auf eine ziemlich komplizierte Weise ${ }^{1}$ ) nach LöFFLER gefärbt. Tielfach gelingt aber auch schon folgende einfachere Modifikation dieser Methode recht gut.

Man macht eine Mischung von:

5-proz. Gerbsäure in Wasser

$10 \mathrm{ccm}$

kaltgesättigter Ferrosulfatlösung

5

gesättigter wässeriger oder alkoholischer Fuchsinlösung 1 "

Einige Tropfen dieser Mischung werden auf das Deckgläschen, auf welchem die Bakterien aufgeklebt sind, gebracht, und das Deckglas so lange über die Flamme gehalten, bis die Lösung zu dampfen anfängt; kochen darf sie nicht. Darauf wird die Beize zunächst mit Wasser und dann mit Alkohol fortgespült und die Bakterien in einer gesättigten Anilinwasser-Fuchsinlösung gefärbt.

Unser B. subtilis zeigt nun eine Anzahl von Cilien, welche um den ganzen Körper herum inseriert sind (Fig. 219, 3); es ist, wie man das nennt, peritrich. Die Beweglichkeit ist also dem Vorhandensein von Cilien zu danken, und das ist bei fast allen beweglichen Bakterien der Fall und bildet einen Gegensatz zu den beweglichen Schirophyceen, welche der Cilien entbehren.

Die LöFfuERsche Methode hat uns also das Vorkommen von Cilien verraten, sie lehrt uns aber nichts über die Struktur der Bakterienenergide; dafür ist die Färbung viel zu intensiv, es wird zu viel Farbstoff auf dem Körper der Bakterie niedergeschlagen. Wir müssen also einen anderen Weg einschlagen.

Trotzdem dagegen viel gesündigt wird, ist es wohl selbstverständlich, daß in erster Linie eine bessere Fixierungsweise als das Hitzeverfahren verwendet werden muß.

Am einfachsten geschieht dies mittels Jodalkohol. Ein Tropfen dieser Flüssigkeit wird auf einem Deckgläschen unter Bakterien gemischt, und das Ganze bei Zimmertemperatur eingetrocknet, darauf so lange in Wasser und Alkohol abgespült, bis das Fixiermittel vollständig verschwunden ist und dann mit Hämatoxylin oder irgend einem Anilinfarbstoff tingiert.

Es stellt sich nun heraus, daß die Zelle normales, stark vakuolisiertes Plasma enthält (Fig. 219, 8), während sogenannte Chromatinkörner vorhanden sind, für welche man jedoch mit Farbstoff gefüllte Vakuolen nicht halten darf (Fig. 219, 9). Ob diese Chromatinkörner Analoga von Zellkernen sind, muß dahingestellt bleiben, die Fischersche Beobachtung, daß sie Nukleinreaktionen geben, würde, falls sie sich bestätigt, dafür sprechen. Die Erfahrung an Hefezellen, wo so lange metachromatische Körnchen für Kerne gehalten wurden (man vergleiche das darüber bei den Hefen Gesagte), mahnt aber zur größten Torsicht.

Wie wenig man noch über die eigentliche Natur der Bakterien weiß, geht daraus hervor, daß auch wohl der Meinung gehuldigt wird, es sei der ganze Bakterienkörper das Homologon eines Zellkernes der höheren Lebewesen. Es versucht z. B. RuzickA (1904) diese Auffassung mittels Färbungsmethoden und Mikrochemie zu beweisen. Dabei basiert seine Meinumg hauptsächlich auf dem Umstand, daß sogar nach 50 Tagen das sogenannte Plasma nicht durch kümstlichen Magensaft gelöst wird.

1) vgl. Aввот, p. 140.

Lotsy, Botanische Stammesgeschichte. I. 
Bei Färbung mit Narcein + Fuchsin + Methylgrün wurde die gleiche Färbung wie bei Leukocytenkernen erzielt und ein feines, vom Fuchsin rot gefärbtes Netzwerk in dem übrigens grün gefärbten Bakterienkörper angetroffen. Auf die Färbung mit Methylgrün wird hoher Wert gelegt, da sie als eine spezifische Kernfärbung gilt.

Trotzdem möchte ich der Auffassung Ruzickas nicht beipflichten, da ein Kern mit Cilien, welcher in seinem Innern eine Spore bildet, in der ganzen lebenden Welt einzig dastehen würde.

Die einfachste Auffassung scheint mir diese: die Bakterie ist eine Zelle, in welcher entweder der Kern noch nicht differenziert ist und die Nukleine als Chromatinkörner im Körper zerstreut vorkommen, oder aber der Kern überhaupt noch nicht nachgewiesen ist, und die angeblichen Chromatinkörner metachromatische Körperchen sind.

Ist ersteres richtig, sind die Chromatinkörner in der Zelle verteilte Nukleine, welche sich nur zu bestimmten Zeiten zu größeren Klümpchen ansammeln, so hätten wir bei den Bakterien mit einer primitiven Zellstruktur zu tun, bei welcher das Chromatin noch über die ganze Energide verteilt ist, erst bei höheren Lebewesen träte dann durch Beschränkung dieses Chromatins auf ein einziges Organ, auf den Zellkern, Arbeitsteilung ein. Das sind aber bloße Spekulationen, nur das scheint mir sicher zu sein, daß der Körper der Bakterien als eine Zelle, nicht als ein Kern zu betrachten ist.

Während wir uns mit solchen Ueberlegungen beschäftigten, haben in unserem Hängetropfen bedeutende Veränderungen stattgefunden.

Neben den einzelligen Bakterien, von welchen wir ausgingen, haben sich lange unverzweigte Fäden entwickelt, welche sich einfach dadurch gebildet haben, daß die Teilprodukte sich nicht getrennt haben, sondern miteinander in Verbindung geblieben sind. Da diese Fäden also nur Kolonien gleichwertiger Bakterienzellen sind, braucht es uns nicht zu wundern, daß auch bei ihnen die zwei gleichen Phasen auftreten, wie bei den Einzelzellen, nämlich die der Beweglichkeit und die der Unbeweglichkeit. Die LöFFlensche Methode zeigt auch hier das Vorhandensein von Cilien. Es läßt sich nun bei unserer Bakterie noch ein anderes Stadium beobachten, welches meistens nach Erschöpfung der Kulturflüssigkeit auftritt. In den langen Fäden entstehen schwarze Punkte, so daß anscheinend die Kontinuität der Fäden aufgehoben ist. Untersuchung mit stärkerer Vergrößerung zeigt uns, daß in jeder Zelle eine mit derber Membran umgebene Spore entstanden ist (Fig. 219, 1), eine sogenannte Endospore.

Bei B. anthracis, der Milzbrandbakterie, läßt sich die Sporenbildung leicht beobachten. Sie fängt mit einer Kontraktion des Plasmas an (Fig. 219, 6), so daß die Spore anfänglich nur kontrahiertes, wasserarmes Plasma darstellt. Das Chromatinkorn oder die Chromatinkörner, werden dabei natürlich in die junge Spore eingeschlossen und die Sporenanlage wird durch Wasserverlust immer stärker lichtbrechend.

Dieser anfänglich also nackte Plasmaballen umgibt sich nun mit einer derben Membran, womit die Sporenbildung beendet ist. Die Spore ist nun noch-von der leeren Zellhaut, welche nun besonders leicht sichtbar ist, umgeben, diese zerbröckelt aber alsbald und die Spore wird frei.

Die Sporen von B. subtilis sind außerordentlich, ja fast unglaublich widerstandsfähig. Mittels hoher Temperaturen in trockenem Raume sind sie fast gar nicht zu töten, sogar um sie durch Kochen zu vernichten braucht man mehr wie eine Stunde. 
Die Sporen können direkt nach ihrer Reife keimen, aber auch in trockenem Zustande, z. B. in Staub, jahrelang keimfähig bleiben.

In reinem Wasser keimen die Sporen nicht, dazu ist vielmehr ein von organischer Nahrung ausgehender Reiz nötig und eine je nach der Art verschiedene Temperatur.

Das erste Keimungszeichen ist ein langsames Anschwellen der Spore, wodurch diese mehr und mehr Glanz verliert. Bei unserem B. subtilis dauert diese Periode 1-3 Stunden. Dann reißt die Sporenhaut in der Mitte auf, der Inhalt tritt, von einer Membran umgeben, heraus und wächst alsbald zu einer Bakterie aus, an deren Basis die leere Sporenhaut noch lange sichtbar bleibt (Fig. 219, 8). Bei B. subtilis steht also das junge Stäbchen senkrecht zur Achse der Sporenhaut.

Hübsche Doppelfärbung kann man bei $B$. subtilis in folgender Weise erzielen. Aus einer Kultur, welche sowohl noch in die Zelle eingeschlossene, wie freie und keimende Sporen hat, wird ein wenig in ziemlich starke Chromsäure gebracht, um die Undurchlässigkeit der Sporenmembran aufzuheben. Nach Entfernung der Chromsäure durch Auswaschen färbt man alles mit Fuchsin intensiv rot und entfärbt dann so lange mit schwachem $\mathrm{HCl}$, bis nur noch die Sporen und Sporenmembranen rot gefärbt sind, die Bakterien und die leeren Zellen sind dann vollkommen farblos, sie werden nun mit Methylenblau gefärbt. Das Resultat gibt hübsch rote Sporen und blaue Bakterien und Zellwände.

Wir haben jetzt an B. subtilis die sehr einfache Entwickelungsgeschichte einer Bakterie kennen gelernt: Aus der Spore entsteht hier durch seitliche Keimung ein Stäbchen, welches durch Cilienbildung beweglich wird, sich in dem Zustande teilen, ja sogar lange fadenförmige, unverzweigte, ebenfalls bewegliche Kolonien bilden kann, oder aber unbeweglich bleibt und durch Teilung unverzweigte, unbewegliche Fäden bildet. In den Zellen entstehen später durch Plasmakontraktion und Membranbildung sehr resistente Sporen, womit der Cyclus geschlossen ist.

In Bezug auf die feinere Struktur besteht unsere Bakterie im vegetativen Zustande aus einer festen Membran, welche vakuolisiertes Plasma umschließt, das nach Fischer Nukleine, aber nicht in der Form eines Nucleus enthält.

Damit haben wir also eine der Bakterienformen, die Stäbchenbakterien, kennen gelernt. Außer diesen gibt es noch eine Anzahl anderer Formen, von welchen ich-Ihnen zunächst die kugelförmigen vorstellen möchte; da sie uns Gelegenheit bieten, einiges über das Unterscheiden der Arten zu sagen, ein Punkt, der, bevor wir zur Systematik der Bakterien übergehen, erörtert werden muß.

Die Vertreter der Gruppe der kugelförmigen Bakterien oder Kokken bestehen aus äußerst kleinen Kugeln. Diese Gruppe bildet nicht nur die kleinsten Bakterien, sondern die kleinsten Lebewesen überhaupt.

Der größte Coccus hat einen Durchmesser von $2 \mu$, der kleinste gesehene Staphylococcus, eine der häufigsten Eiterbakterien, einen solchen von $0,8 \mu$, das Volum einer solchen Kugel beträgt demnach 1/1 700000 $000 \mathrm{cmm}$. Mehr als eine Milliarde von Individuen hat also reichlich Raum in einem Wassertröpfchen, das $1 \mathrm{cmm}$ groß ist. Dennoch sind das nicht die kleinsten Lebewesen, welche überhaupt existieren, denn wir wissen. daß es solche giebt, welche wir gar nicht sehen kömmen. so z. B. die Organismen, welche die Lungenseuche der Rinder verusachen.

Bei den Kokken sind keine Sporen bekannt; schon dadurch fehlt 
eines der wichtigsten Unterscheidungsmerkmale zwischen den Arten. Die Form von allen Kokken ist die gleiche, es bleibt also nur ein morphologisches Differenzierungsmerkmal übrig: die Größe. Wie steht es nun aber mit den Kokken, welche keine Größendifferenz besitzen, also gleich groß sind. Gehören sie sämtlich zu einer Art?

Offenbar nicht, denn während der eine Coccus ein recht schädlicher, krankheitserregender Organismus ist, ist ein anderer, der gar keine äußerlich wahrnehmbare Differenzen aufweist, vollkommen unschädlich, und da "es nicht möglich ist, den unschädlichen zum krankheitserregenden umzubilden, müssen wir wohl annehmen, daß wir hier mit Arten zu tun haben, Arten aber, welche infolge der einfachen Form dieser Organismen nicht morphologisch, sondern nur physiologisch, nicht der Form nach, sondern der Lebensäußerungen nach zu unterscheiden sind.

Diese morphologische Identität und physiologische Differenz ist keineswegs auf die Kokken beschränkt, sondern kommt auch bei den Stäbchenbakterien vor.

Als Beispiele seien hier Bactridium coli und B. typhi, die gewöhnlichen Colon- und Typhusbakterien, erwähnt!

Beide sind peritrich begeißelt, beide sind stäbchenförmig und ungefähr gleich groß.

$$
\begin{aligned}
& \text { B. typhi } 1-4 \mu \text { lang und } 0,6-0,8 \mu \text { breit } \\
& \text { B. coli } 1-3 \mu \text { " } " 0,4-0,6 \mu ",
\end{aligned}
$$

B. coli ist also etwas kürzer und schlanker, aber die Differenz ist so gering, daß sie zur Unterscheidung nicht genügt. Keines von beiden bildet Sporen oder verflüssigt die Gelatine. Morphologisch sind sie also nicht zu unterscheiden, physiologisch aber wohl.

Erstens verursacht $B$. typhi den bekannten Typhus, B. coli nicht, da aber nur Menschen an Typhus leiden und Infektionsexperimente also ausgeschlossen sind, ist diese Differentialdiagnose natürlich nicht möglich und man mußte versuchen, andere physiologische Unterscheidungsweisen $\mathrm{zu}$ finden. Das ist gelungen: $B$. coli vergärt Zucker zu Milchsäure, Bernsteinsäure, Aethylalkohol und $\mathrm{CO}_{2}$. Kultiviert man es also in Fleischwasser + 2 Proz. Glukose, so beobachtet man reichliche Gasbildung, in Milch bildet es Säure durch Vergärung des Milchzuckers und koaguliert sie also, während $B$. typhi, welches keinen Zucker vergärt, weder das eine noch das andere zu tun vermag.

Also schon durch Kultur in Nilch lassen sich beide Arten unterscheiden: B. coli koaguliert, B. typhi nicht. In der Praxis aber muß man noch einige Kontrollversuche in anderen Medien machen, für unseren Zweck genügte es aber, Sie mit dem Prinzip bekannt zu machen.

Bevor wir uns aber dem System zuwenden, ist es nötig, noch einiges über die Morphologie unserer Organismen zu sagen.

Bis jetzt lernten wir nur gerade Stäbchen und Kugeln kennen, außer diesen gibt es nun noch gebogene Stäbchen, welche man mit den Namen Vibrio, Spirillum und Spirochaete bezeichnet.

Bei den Vibrionen ist die Krümmung schwach und beträgt höchstens $1 / 4$ einer Schraubenwindung. Eine ganze Schraubenwindung kann sie bei Spirillum betragen, während eine enggewundene Korkenzieherform Spirochate eigen ist.

Alle diese Genera sind einzellig (nur von Spirochaete ist dies noch nicht ganz sicher) und gehören also der Gruppe der Haplobakterien an. 
Früher meinte man, daß ein Coccus sich zu einem Tibrio und weiter via Spirillum zu einer Spirochaete entwickeln könnte, daß also die Bakterien recht polymorphe Arten wären. Wir wissen jetzt, daß dies nicht der Fall ist und daß diese Auffassung durch verunreinigte Kulturen verursacht wurde.

Den Haplobakterien gegenüber stehen die Trichobakterien, welche normaliter aus langen Fäden bestehen, deren bakterienähnliche Zellen nur dann aus dem Verbande heraustreten, wenn solches zur Bildung beweglicher Fortpflanzungszellen nötig ist.

Die unverzweigten Trichobakterien werden Leptothrix, die scheinbar verzweigten Formen Cladothrix genannt. Scheinbar verzweigte, sagten wir, da die Zweige aus einer Anzahl von Zellen hervorgehen, welche, an den höher gelegenen vorbeiwachsend, seitlich aus dem Faden herausbiegen und so die Zweige bilden, während echte Verzweigung durch seitliche Ausstülpung einer einzigen Zelle, welche dadurch zur Zweiginitiale wird, verursacht wird.

Sich auf diese und ähnliche Gesichtspunkte stützend, hat ALFRED Fischer folgendes System der Bakterien aufgestellt, welches meiner Auffassung nach große Vorteile bietet.

\section{Erste Ordnung: Haplobacterinae.}

Einzellig, kugelig, cylindrisch oder schraubenförmig; einzeln lebend oder zu homocellulären Fäden verbunden.

\section{Erste Familie: Coccaceae.}

Einzellig, kugelig.

Erste Unterfamilie: Allococcea e.

Ohne bestimmte Teilungsrichtung; Teilung willkürlich, in allen drei Richtungen der Raumes abwechselnd; ohne bestimmte Kolonienform: kurze Ketten, Häufchen, in Paaren oder einzeln.

1) Unbeweglich Micrococсus. Hierzu die meisten

Kokken, z. B. Microc. phosphoreus

2) beweglich . Planococeus, z. B. Pl. citreus.

Zweite Unterfamilie: Ho mococceae.

Die aufeinanderfolgenden Teilungen typisch für die Genera.
A. Teilung in allen
(1) Das höchste
Entwicke-
drei Richtungen
lungsstadium
des Raumes
ein Paketchen Sarcina, z. B. S. lutea
2) Wie vorige, aber beweg-
lich... Planosareina, Z. B. Pl. agilis
13. Teilung in zwei
3) Höchstes Ent-
Richtungen
wickelungs-
stadium ein
T'äfelchen. Pedioeocens. z. B. Pe.tetragems
C. Teilung in einer (4) Es entstehen
Richtumg
Kettell .
Streptococeus, z. B. S.leuconostoc. 


\section{Zweite Familie: Bacteriaceae.}

Zelle ein gerades Stäbchen. Teilung stets senkrecht zur Längsachse, höchstes Entwickelungsstadium unverzweigte Fäden.

Erste Unterfamilie: B acillea e.

Die sporenbildenden Zellen verändern ihre Form nicht, sind also meistens cylindrisch.

1) Unbeweglich . . . . Bacillus, z. B. B. diphtheriae

2) beweglich monotrich, d. h. eine Cilie an dem Pole . Bactrinium, z. B. B. pyocyaneus

3) beweglich lophotrich, d. h. mehr wie eine Cilie an dem Pole . . . . Bactrillum, z. B. B. fluorescens

4) beweglich peritrich, d. h. Cilien um den ganzen Körper herum . . . . Bactridium, z. B. B. subt., B. radicicola.

Zweite Unterfamilie: Clostridieae.

Die sporenbildenden Stäbchen spindelförmig.

1) Unbeweglich . . . . Paracloster, z. B. P. butyricus

2) beweglich, peritrich . . Clostridium, z. B. C. Pasteurianum.

Dritte Unterfamilie: Plectridieae.

Die sporenbildenden Stäbchen trommelschlägerförmig.

1) Unbeweglich . . . Paraplectrum, z. B. P. foetidum

2) beweglich, peritrich . . Plectridium, z. B. P.tetanus.

\section{Dritte Familie: Spirillaceae.}

Zelle gekrümmt, beweglich.

1) Schwache, kommaähnliche Krümmung monotrich . . . . .

2) stärker gekrümmt, lophotrich . .

3) korkzieherartig gewunden, Cilien unbekannt

Tibrio, z. B. V. cholerae asiaticae Spirillum, z. B. Sp. undula

Spirochaete, z. B. Sp. Obermaieri.

\section{Zweite Ordnung: Trichobacterinae.}

Organismus ein unverzweigter Zellfaden, aus welchem sich Zellen oder mehrzellige Stücke als Schwärmer oder als Hormogonien loslösen können.

A. Fäden unbeweglich, straff in einer Scheide eingeschlossen.

a) Unverzweigt.

1) Chlamydothrix. Nicht angewachsen; Schwärmer cylindrisch, z. B. Chl. ochracea (Eisenbakterie).

2) Thiothrix. Angewachsen, schwefelhaltig; Schwärmer cylindrisch.

3) Crenothrix. Angewachsen, kein Schwefel, kugelige Aplanosporen.

ß) Pseudoverzweigung.

4) Cladothrix. Verzweigt, pseudodichotom; Schwärmer cylindrisch.

B) Fäden hin- und herschlagend und langsam kriechend, ohne Scheide.

5) Beggiatoa. Mit Schwefel. 
Ich will nun, recht kurz, ron jeder dieser Gruppen ein oder zwei Beispiele mit Ihnen behandeln.

Fangen wir mit

\section{Micrococcus phosphoreus CoHs 1878}

an. Es ist dies ein unbeweglicher runder oder fast runder Organismus, welcher von einigen auch wohl als ein kurzer Bacillus betrachtet wird. Er verursacht das Leuchten des Fleisches. Folgendes ist Mouischs Verhandlung (1903) entliehen.

Der erste, der leuchtendes Fleisch beschrieb, war der berühmte Paduaner Anatom Fabricius ab Aquapendale. Ostern 1592 leuchteten Stücke Lammfleisch, welche auf dem Markt zu Padua gekauft waren, worüber FAbricius a. a. in seinem Werke: "de oculo vitus organo" folgendes berichtet:

Das Licht muß sich ungefähr $1 \frac{1}{2}$ Tage nach dem Schlachten eingestellt und wenigstens 4 Tage angehalten haben, ein damit in Berührung stehendes Stück Bockfleisch leuchtete gleichfalls, das Licht zeigte sich auf dem muskulösen Fleisch und auf dem Fette, der Glanz war silberweiß, man konnte damit Finger und jeden anderen Körper leuchtend machen, indem sich eine klebrige Feuchtigkeit ausschied.

J. F. Heller (1853) zeigte zuerst, daß die Ursache aller Wahrscheinlichkeit nach ein Mikroorganismus und zwar eine Sarcina war.

In einem Briefe an PENn beschreibt CoHn 1878 diesen Organismus wie folgt:

Micrococcus phosphoreus CoHN 1878: Weit verbreitete glasige Schleimüberzüge bildend. Zellen groß, kugelig. Veranlaßt, daß gekochte Fische und andere Nahrungsmittel (Fleisch, Krebse), die davon überzogen sind. mit weißlichem Lichte leuchten.

Später wurden noch einige Organismen als die Ursache des Leuchtens beschrieben, aber sogar im Jahre 1903, als MoLisch seine Untersuchung publizierte, hatte man noch keine moderne Beschreibung des Organismus, ja man wußte noch nicht, ob das Leuchten von Fisch und Fleisch vom selben oder von verschiedenen Organismen verursacht wurde. Bis zu Molischs Untersuchung meinte man, daß das Leuchten des Fleisches ein äußerst seltenes Ereignis wäre, und MoLISCH konnte zunächst, vornehmlich durch den Argwohn der Fleischer, kein leuchtendes Fleisch erhalten, bis er auf den Gedanken kam, das in seinem eigenen Haushalt verwendete Fleisch zu untersuchen. Alsbald stellte es sich heraus, daß die Anwesenheit von Salz die Leuchtbakterienentwickelung begünstigte, und er konnte nachweisen, daß von Fleischproben, die bei verschiedenen Prager Fleischern gekauft waren und in einer kühlen Kammer aufbewahrt wurden, nach ungefähr 2 Tagen folgende hohe Prozentzahlen leuchteten:

$\begin{array}{clcc}\text { von Rindfleisch } & 52 & \text { Proz. } \\ " \text { Kalbfleisch } & 50 & " \\ " \text { Leber } & 39 & "\end{array}$

Am leichtesten verschafft man sich die Leuchtbakterien in folgender Weise: Gewöhnliches ungekochtes Fleisch von der Größe einer Kinderfaust läßt man eine Viertelstunde in einer 3-proz. Kochsalzlösung verweilen, wodurch Blut etc. auszieht, legt es dam in frische Kochsalzlösung in solcher Weise ein, daß ein 'Teil des Stückes aus der' Lösung 
herausragt. Nit Hilfe dieser Salzwassermethode konnte nachgewiesen werden, daß 89 Proz. des gekauften Rindfleisches und 65,5 Proz. des Pferdefleisches leuchteten. Das Fleisch leuchtet nach 1-4 Tagen, im Mittel nach 2 Tagen.

Die höhere Prozentzahl bei der Salzwassermethode rührt daher, daß

1) die Leuchtbakterie halophil ist und also in Salzlösung besser wächst ;

2) die Salzlösung viele andere Bakterien in der Entwickelung hemmt und der Leuchtbakterie also einen Vorsprung im Kampf ums Dasein gibt.

Daß nach höchstens 6 Tagen das Leuchten aufhört, hat seinen Grund in der Ueberwucherung der Leuchtbakterien durch Fäulnisorganismen. Das Leuchten findet nicht über der ganzen Oberfläche des Fleisches gleichmäßig statt, sondern das Fleisch ist sozusagen mit leuchtenden Sternchen besät.

Der Micrococcus phosphoreus ist aërob, verflüssigt Gelatine, bildet Gas in Salz-Peptongelatine, der 1 Proz. Trauben- oder Rohrzucker zugesetzt ist. Sporen werden nicht gebildet. Auf dem Deckglase eingetrocknete Bakterien konnten nach 2 Monaten nicht mehr zur Entwickelung gebracht werden.

Auf Fischen und im Meerwasser gibt es andere Leuchtbakterien. Eine praktische Verwendung fanden die Leuchtbakterien in den von Dubors und Molisch konstruierten Lampen, welche sogar bis 3 Wochen lang Licht geben. In Minen können diese die Davysche Lampe mit gutem Erfolge ersetzen, jede Gefahr von seiten schlagender Wetter, insoweit sie durch Entzündung an einer Flamme entstehen, ist dabei ausgeschlossen. Das Licht wirkt sowohl auf die photographische Platte wie auf grüne Pflanzen ein, so daß die Kolonien bei eigenem Lichte photographiert werden können und heliotropische Krümmungen bei Phanerogamen dadurch verursacht werden können. Da das Leuchten nur in Gegenwart von Sauerstoff stattfindet, kann es auch als ein Reagens auf Photosynthese gebraucht werden. Man tut dies nach BeiJerinck (1901) in folgender Weise:

Lebende Kleeblätter werden mit Aqua dest. zerrieben, das Filtrat, welches unter anderem auch Chloroplasten enthält, wird mit einer Kultur von Leuchtbakterien in Fischbouillon in Meereswasser gemischt. Man läßt das Ganze eine Weile stehen, bis die Kultur durch den Verbrauch des vorhandenen Sauerstoffes dunkel geworden ist. Bringt man nun die Masse eine Minute in volles Sonnenlicht und darauf ins Dunkle, so sieht man die Bakterien leuchten, durch den infolge der vom Sonnenlicht verursachten Photosynthese der Chloroplasten ausgeschiedenen Sauerstoff. Das Reagens ist so subtil, daß es, um Leuchten zu verursachen, sogar genügt, ein einzelnes Streichholz in unmittelbarer Nähe einer solchen dunkel gestellten Kultur zu verbrennen.

Als Beispiel eines beweglichen Coccus wählen wir

\section{Planococcus citreus,}

welchen wir aus Erbseninfus isolieren. Er bildet auf mancherlei Substrat gelbe Kolonien und bewegt sich mittels langer Cilien.

Viel mehr ist von ihm nicht bekannt. Wir gehen also zur Besprechung: der zweiten Unterfamilie der Coccaceen, zu der der 


\section{Homococceae}

iiber, welche dadurch charakterisiert ist, daß sie Kolonien bestimmter Form bildet, indem die Teilungen in verschiedenen Raumrichtungen und in bestimmter Reihenfolge stattfinden.

Den höchsten Entwickelungszustand erreicht dabei das Genus

\section{Sarcina,}

welches durch Teilung in drei Raumrichtungen quadratischen Paketchen das Dasein gibt. Einige dieser, z. B. S. lutea Schroeter, bilden Pigment. Sie ist neben der orangefarbigen $S$. aurantiaca und der roten S. rosea eine der häufigsten Wasserbakterien. Die unbeweglichen Indi-

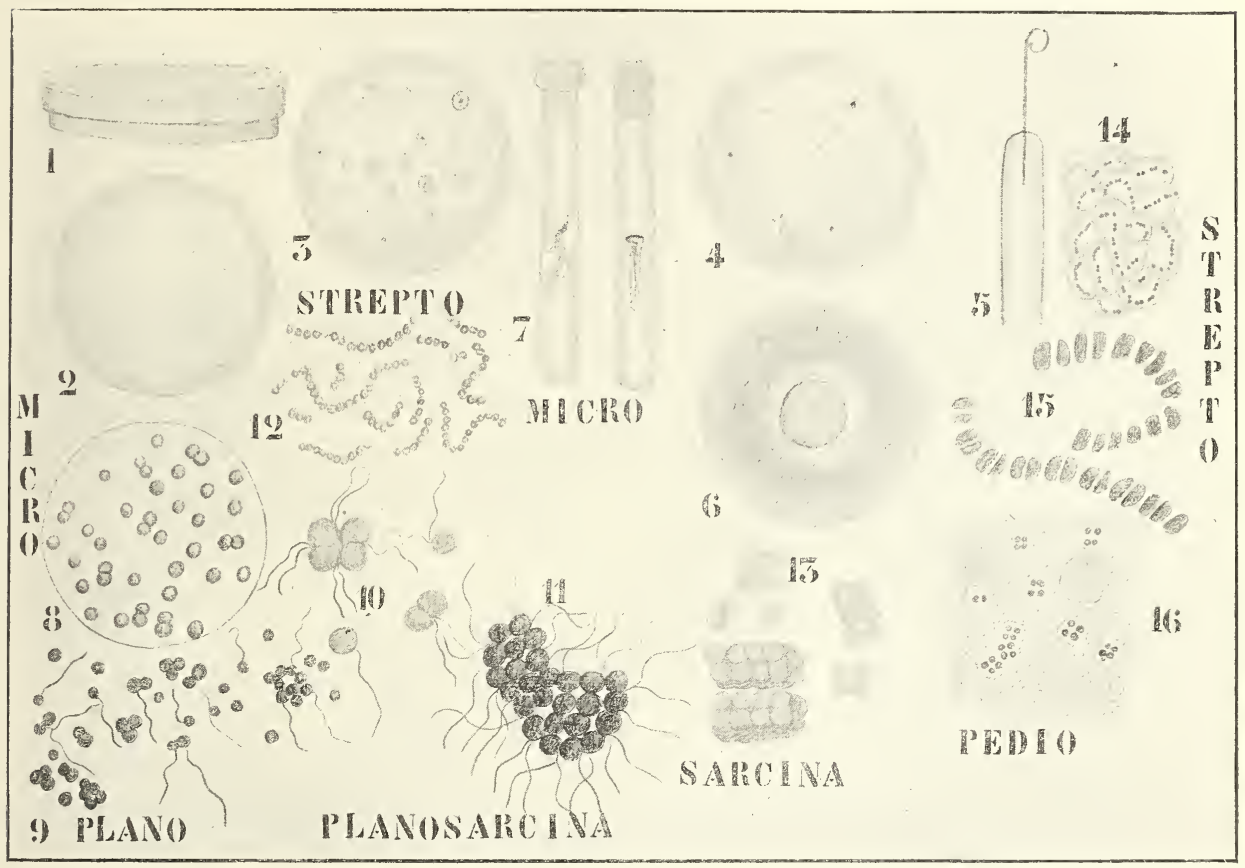

Fig. 220. 9 Planococeus citreus. 10 Planosarcina lutea. 11 Planosarcina violacea. $12 \mathrm{Streptococcus} \mathrm{spec.} 15$ Selbige in rascher Teilung. $13 \mathrm{Sar}-$ cina. 14 Streptococeus mesenterioides. 16 Pediococeustetragenus. (Alle nach MigulA.)

viduen sind rund, haben ungefähr $4 \mu$ im Durchmesser und teilen sich zunächst kreuzweise in zwei aufeinander senkrechten Ebenen, wodurch 4-zählige Täfelchen entstehen, dann in einer Ebene senkrecht zu den beiden ersteren, wodurch Körper gebildet werden. Sie ist chromopar. der Farbstoff aber nicht in Wasser löslich, so daß nu der Schleim der Kolonie gefärbt ist, sie verflüssigt die Gelatine nicht.

\section{Planosaleina}

kamn einfach als eine bewegliche Sarcina charakterisiert werden. Die Teilung findet auch hier in drei Richtungen des Rammes statt, aber nur selten wird die vollkommene Paketform angetroffen, da die Zellen sich 
frühzeitig loslösen. Paketchen erhält man nach Migula meistens nur in zuckerhaltigen Flüssigkeiten. Die Zellen sind durch 1-2 Cilien beweglich und die Tafelform schwimmt wie ein Gonium-Täfelchen herum. Es sind Wasserbakterien. $\mathrm{Pl}$. mobilis bildet orangegelbe Kolonien, $\mathrm{Pl}$. violacea hat violett gefärbten Zellinhalt und enthält Schwefel. Es ist die Thiocystis violacea von Winogradsky. Sie bildet dicke Schleimhüllen, aus welchen sie während des Schwärmstadiums herausschlüpft.

\section{Pediococcus tetragenus}

ist bis auf eine die niedrigste Form. Es ist eine Eiterbakterie, welche meistens bei Tieren, nur selten bei Menschen, angetroffen wird, bei letzteren in Zahnfleischgeschwülsten. Sie bildet Täfelchen von 4 Individuen, welche von einer Schleimhülle, einer sogenannten Kapsel, umgeben sind.

Die niedrigsten Formen dieser Gruppe gehören zum Genus

\section{Streptococeus.}

Sie können sich nur in einer Richtung teilen, es entstehen also Fäden, welche, da die Individuen kugelig sind, die Form von Perlschnüren haben, man redet deswegen von Ketten. Wenn sie sich sehr schnell teilen, findet man nicht die typische Perlschnurform, da die Zellen durch die Teilungswand an einer Seite, ja bei sehr schneller Vermehrung sogar an zwei Seiten abgeflacht sind. Die Streptokokken sind meistens sehr gefährliche pathogene Bakterien, deren verschiedene Arten Erysipel, Eiterung, Puerperalfieber, Neunaugen und ähnliche gefährliche Krankheiten verursachen. Bei allgemeiner Infektion entstehen die gefährlichen Septicämien und Pyämien. Wie alle Parasiten wachsen sie schwer in Kulturen und gehen darin bald zu Grunde. Sie sind fakultativ anaërob und ihr Temperaturoptimum liegt bei $37^{\circ} \mathrm{C}$.

Bei diesen Organismen kommen sogenannte Arthrosporen vor, das sind Zellen mit verdickter Wand, welche größer sind als die vegetativen Zellen und das Licht stärker brechen. Sie spielen dieselbe Rolle wie die Endosporen bei B. subtilis, sind aber viel weniger resistent.

Eine öfters als besonderes Genus, als Leuconostoc, beschriebene Art ist Streptococcus mesenterioides, ein zwar nicht pathogener, aber unter Umständen auch recht lästiger Organismus. In der Melasse der Zuckerfabriken verursacht er nämlich die sogenannte Dextrangärung, deren Endprodukt er aus dem Zucker bildet und als große Schleimhüllen ausscheidet. Das Dextran ist ein Kohlehydrat aus der Cellulosegruppe. Durch die enorme Menge des so gebildeten Schleimes wird die Melasse in einen Schleimklumpen verwandelt, was zumal früher, als man die Ursache nicht kannte, zu großen Kalamitäten in Zuckerfabriken Veranlassung gab.

Jetzt ist das nicht mehr so schlimm, da die Arbeitsweise verändert ist und weil man eine Streptococcus mesenterioides-Infektion leicht durch Desinfektion loswerden kann.

Gehen wir jetzt zur Behandlung der Familie der

\section{Bacteriaceen}

über, von welcher wir zunächst

\section{Bacillus diphtheriae,}

die Ursache der Diphtheriekrankheit, besprechen wollen. Wie Sie wohl wissen werden, entsteht bei Diphtheritis in der Mundhöhle hinten am 
Gaumen eine sogenannte diphtheritische Nembran. Die äußeren Schichten derselben bestehen fast ausschließlich aus Diptheriebacillen.

Da der Diphtheriebacillus ein ausgeprägter Parasit ist, läßt er sich schlecht auf den gewöhnlichen Nährböden kultivieren; ein sehr gutes Substrat liefert Blutserum mit Zuckerbouillon.

Aber sogar auf diesem Medium entstehen alsbald sogenannte Involutionsformen. d. h. Mißbildungen, welche bei sehr vielen Bakterien auftreten, wenn sie in ungünstige Lebensverhältnisse gelangen. Sie können mehr oder weniger fadenförmig sein und wurden deshalb irrtümlicherweise für ein höheres Entwickelungsstadium unseres Organismus gehalten.

Der normale Diphtheriebacillus ist leicht durch seine abweichende Form zu erkenmen, er ist nämlich meistens an einem Ende angeschwollen

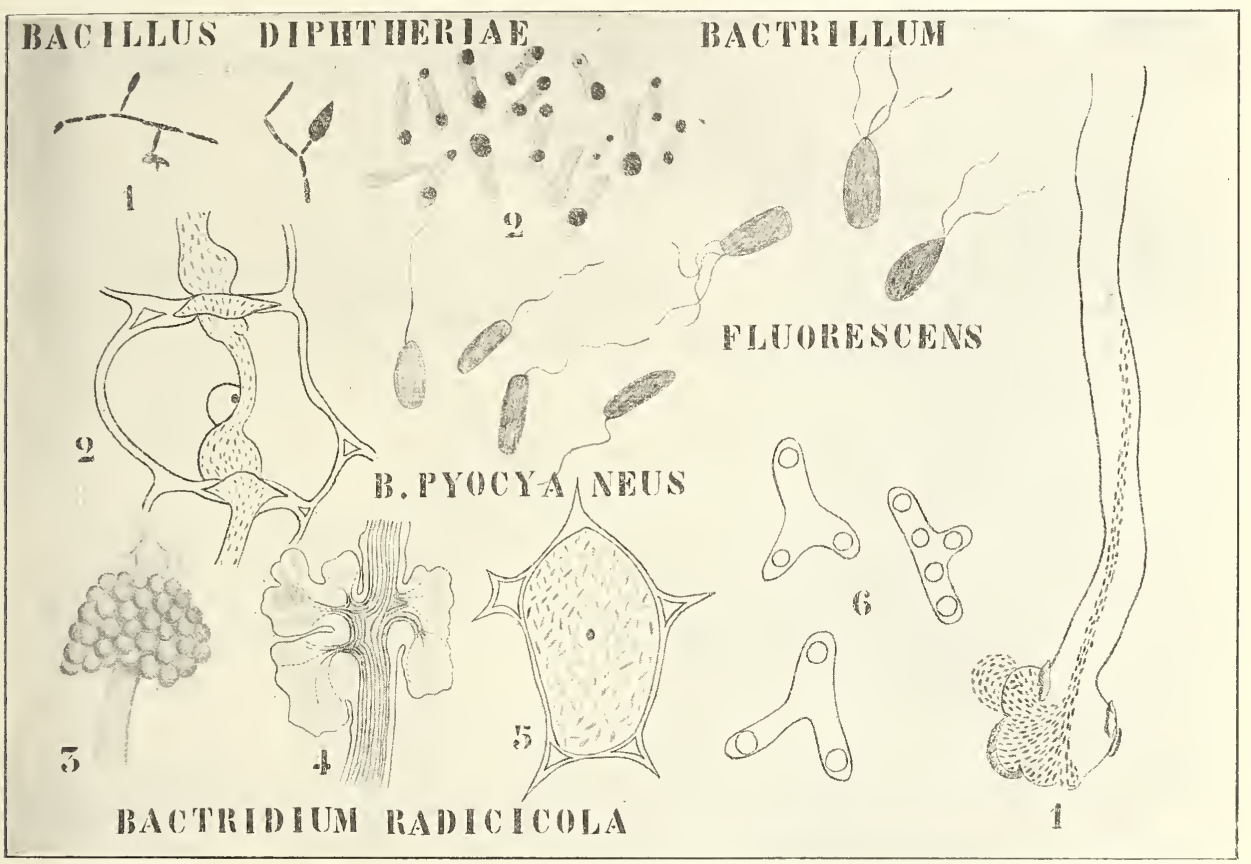

Fig. 221. I. Bacillus diphtheriae. 1 Involutionsformen. 2 Sporenähnliche Chromatinkörner. - II. Bactrillum fluorescens. Lophotriche Zellen. - III. Bacterium pyocyaneus. Monotriche Zellen. - IV. Bactridium radicicola. 1 Eintritt einer Zuogloea in ein Wurzelhaar der Lupine. 2 Durchwachsen der Zellmembranen von der Zoogloea. 3 Bakterienknöllehen. 4 Ein solches im Längsschnitt. 5 Zelle aus demselben mit den Bakterien erfüllt. 6 Bakterioiden. (Nach FIscher, Prazmowskr, Frank und BEIJERINCK.)

(Fig. 221, I 2). Die Chromatinkörner sind besonders deutlich und können so groß sein, daß man meint, Sporen zu sehen (Fig. 221, I 2). Sporen sind jedoch noch nicht bekannt, so daß die systematische Stellung unseres Organismus noch unsicher ist, ihrer Unberreglichkeit wegen stellt man sie am besten zum Genus Bacillus.

Der fürchterliche Verlauf der Diphtheritis wird durch ein von den Bakterien gebildetes Gift, vom sogenannten Diphtherietoxin, verursacht. Dieses Toxin wird auch außerhalb des menschlichen Körpers. z. B. in 
Bouillonkulturen gebildet, kann aber daraus bis jetzt noch nicht rein gewonnen werden.

Um es überhaupt zu gewinnen, werden die Bacillen in reiner Fleischwasserpeptonbouillon ohne irgend eine sonstige Beimischung kultiviert und auf einer Temperatur von $37^{\circ} \mathrm{C}$ gehalten. Nach 2-3 Wochen erreichen diese Kulturen ihre maximale Giftigkeit. Die Kultur wird nun durch einen die Bakterien zurückhaltenden Filter, durch eine sogenannte Chamberland-Kerze filtriert; das Filtrat ist das Bouillongift, selbstverständlich eine Mischung von verschiedenen Substanzen, unter welchen sich das eigentliche Toxin befindet.

Selbstverständlich wird ein solches Bouillongift das eine Mal viel giftiger als das andere Mal sein; deswegen hat man versucht, den Giftigkeitsgrad in einer Formel auszudrücken, und man nennt nun normalgiftig eine Bouillon, von welcher $0,01 \mathrm{ccm}$ subkutan eingespritzt ein Meerschweinchen von $250 \mathrm{~g}$ Körpergewicht innerhalb 5 Tagen töten, oder so wie BeHRING schreibt:

$$
1 \mathrm{ccm}=25000 \mathrm{M} \text {, }
$$

d. h. 1 ccm tötet 100 Meerschweinchen von $250 \mathrm{~g}$ Körpergewicht.

Bekanntlich kann nun das Blut der Tiere gegen verschiedene Bakteriengifte Gegengifte bilden, sogenannte Antitoxine, und BeHRING machte von dieser Eigenschaft Gebrauch, um sein segensreiches Diphtherieheils erum herzustellen.

Von einem Bouillongift von bekannter Stärke (selbstverständlich in jedem Einzelfalle zu bestimmen) wird eine gewisse Dosis einem Pferde eingespritzt. Gesetzt, daß diese Dosis für einen bestimmten Fall $1 \mathrm{ccm}$ beträgt, so wird in die Halsader des Pferdes $1 \mathrm{ccm}$ eingespritzt. Das Pferd wird nun fieberig, fühlt sich unbehaglich, aber hat sich nach 1-2 Tagen erholt. Dann wird eine neue Dosis eingespritzt und während man dem Tiere zwischen je 2 Einspritzungen eine Erholungspause erlaubt, spritzt man 10, 25, こ0, schließlich sogar $200 \mathrm{ccm}$ auf einmal ein, letztere Dosis wird so oft wiederholt, bis dem Pferde mehr als $800 \mathrm{ccm}$ Bouillongift eingespritzt sind.

Ein solches Pferd ist nun gegen Diphtheriebacillen immun, und da das Tier selbst direkt als Reaktion auf das eingespritzte Gift das Gegengift gebildet hat, nennt man ein solches Pferd aktiv immunisiert.

Mit dem vom Pferde gebildeten Antitoxin kann man nun andere Tiere und auch Menschen immunisieren, welche dann pas siv immunisiert werden, da sie nicht selbst das Gegengift ausbilden, sondern ihnen dies fix und fertig eingespritzt wird. Aus $10 \mathrm{l}$ Pferdeblut erhält man so $5 \mathrm{l}$ Heilserum.

Von welch großem Gewicht das Heilserum Benrings für die Menschheit ist, mag aus folgender Uebersicht hervorgehen:

$\begin{array}{llccc} & \text { in leichten } & \text { in mittleren } & \text { in toxisch-septischen } \\ \text { Fällen } & \text { Fällen } & \text { Fällen } \\ \text { Vor Verwendung des Heilserums genasen } & 100 \text { Proz. } & 44,6 \text { Proz. } & 0 \text { Proz. } \\ \text { Nach " " " } & 100, " & 80,4, " & 57,4, "\end{array}$

Wir haben hier beim Pferde mit einer Immunisierung infolge Einspritzung eines Bakteriengiftes zu tun. Dazu wurde erst eine kleine Quantität Gift, welche das Pferd vertragen konnte, eingespritzt, und diese Dosis nach und nach erhöht.

Man kann aber auch mit den Bakterien selbst immunisieren und darauf beruhen mancherlei Impfungen. Die praktische Schwierigkeit bei der Sache liegt darin, daß man dann nicht weiß, wie viel Gift man in 
den Körper bringt, während man dies beim Einspritzen von Toxin wohl weiß; demn da die Bakterien sich vermehren, ist die Quantität des von ihwen produzierten Giftes unberechenbar.

Und doch nicht ganz; man kann Bakterien auf verschiedene Weisen, z. B. durch Kultur bei zu hoher Temperatur dermaßen abschwächen, daß sogar ihre Nachkommen noch einige Zeit viel schwächer als die unabgeschwächten Bakterien sind, also in einem gleichen Zeitraum viel weniger Gift produzieren.

Ian impft nun ein Tier, das man immunisieren will, mit solchen abgeschwächten Kulturen oder auch wohl mit weniger virulenten Rassen des betreffenden Krankheitserregers, und nachdem man ihm Zeit gelassen hat, Antitoxin zu bilden, impft man mit mehr virulenten Formen, bis schließlich das Wesen auch gegen die virulenteste Form immun ist.

In beiden Fällen beruht also das Immunisieren auf einem Gewöhnen des Körpers an steig'ende Dosen des Giftes, bei der Toxineinspritzung durch direkte Vermehrung der zuerst gegebenen Giftquantität. Bei der Impfung wird die zuerst in den Körper mit den Bakterien eingeführte Giftquantität indirekt vermehrt durch Impfen mit mehr virulenten Formen, d. h. mit Formen, welche innerhalb einer bestimmten Zeit mehr Gift produzieren.

Wir sahen soeben, daß man die erste Impfung öfters mit weniger virulenten Rassen ausführt. Darauf beruht z. B. unsere Kuhpockenimpfung, ein Verfahren, das, trotzdem wir den Krankheitserreger nicht einmal kennen, gelingt.

Pocken kommen sowohl bei Kühen wie bei Menschen vor; die Form von der Kuh verursacht beim Menschen nur eine Lokalinfektion, aber immunisiert ihn gegen die Menschenform. Es wurde die Kuhpockenimpfung schon im Jahre 1796 von JenneR entdeckt.

Damit ist Ihnen ein Blick in das weite, höchst interessante Gebiet der Immunität gegeben, welches hier nicht betreten werden kann. Gehen wir also zur Besprechung des nächsten Genus über und wählen wir als Beispiel desselben:

\section{Bactrinium pyocyaneus,}

ein Organismus, der in Wasser, Mist und Erde vorkommt und auch die Ursache des blauen Eiters ist. Aus dem Namen geht schon hervor, daß wir hier mit einer Farbstoff produzierenden Bakterie zu tun haben. Dieser Organismus produziert sogar zwei Pigmente, einen grüngelb fluoreszierenden und einen blauen Farbstoff. Demnoch sind die monotrichen Stäbchen farblos, sie scheiden nur ein Pigment aus, sind also chromopar, und da die Pigmente im Wasser löslich sind, tingieren sie den Nährboden.

Der Umstand, daß diese Pigmente auch im Dupkeln in rollkommen normaler Quantität gebildet werden, deutet schon darauf hin, daß sie mit Photosynthese nichts zu tun haben und daß auch diese Bakterien nicht autotroph sind.

Das Bacteriofluorescin, der fluoreszierende Farbstoff dieser sowie aller anderen fluoreszierenden Bakterien, ist in wässeriger Lösung gelb mit blauer Fluoreszenz, wenigstens wenn die Lösung neutral ist. Alkalien verursachen eine prachtvoll grüne Fluoreszenz. Die Substanz ist noch nicht rein gewonnen worden, aber wahrscheinlich eiweißartiger Natur.

Das Pyocyanin ist ein sehr intensiver Farbstoff ron der Formel $\mathrm{C}_{14} \mathrm{H}_{14} \mathrm{~N}_{2} \mathrm{O}$, gehört also in die Gruppe der Anthracenfarbstotfe. Wahr- 
scheinlich bilden die Bakterien nur die Leucoverbindung und diese färbt sich an der Luft blau. Durch Ausschütteln mit Chloroform kann sie aus der wässerigen Lösung vom Bacteriofluorescin getrennt werden, sie kristallisiert in feinen Nadeln aus. Durch freie Säure wird sie rot, durch Alkali blau.

Da nun B. pyocyaners Salpeter zu Ammoniak reduzieren kann, wodurch die Nährlösung alkalisch wird, hat dies auf die Farbe der Kultur Einfluß, da das Alkali das Bacteriofluorescin grün färbt, das Pyocyanin blau. Weiter kann die Bakterie aus Kohlehydraten Säure bilden, welche die Fluoreszenz aufhebt und das Pyocyanin rot färbt. Dazu kommt nun noch, daß verschiedene oxydierende Verbindungen braune Verfärbungen verursachen, so daß es nicht zu verwundern ist, daß man bei der Kultur unseres Organismus statt der erwarteten schön blauen Kulturen öfters mißfarbige erhält. Durch Ueberimpfung auf geeignete Medien kann man aber stets schön blaue Kulturen erzielen.

Von allen Pigmentbakterien gibt es farblose Rassen, Albinos, den weißen Varietäten gefärbter Blumen vergleichbar.

Von

\section{Bactrillum fluorescens}

sei hier nur erwähnt, daß sie nicht monotrich, sondern lophotrich ist, recht häufig im Wasser vorkommt, Gelatine verflüssigt und chromopar Bacteriofluorescin und keinen anderen Farbstoff bildet.

Vom Genus

\section{Bactridium}

haben wir bereits eine Art, B. subtilis, kennen gelernt, wir wollen noch eine zweite,

\section{B. radicicola,}

besprechen. Die Zellen sind peritrich und also beweglich, sie kommen in Ackerboden vor und führen eine sehr interessante Lebensweise. Es ist Ihnen schon bekannt, daß man viele bewegliche Mikroorganismen, auch Bakterien, mittels Kapillarröhrchen fangen kann, in welchen sich irgend eine Substanz befindet, welche den betreffenden Organismus chemotaktisch anzieht. Von dieser Eigenschaft der Organismen machen die Leguminosen Gebrauch; sie scheiden in ihren Wurzelhaaren irgend eine Substanz aus, welche diese Bakterien anzieht. Diese sammeln sich dadurch an der Spitze der Wurzelhaare an, bilden eine Schleimkolonie und diese sogenannte Zoogloea dringt in das Wurzelhaar ein unter Ausscheidung eines Fermentes, welches die Spitze des Wurzelhaares verschleimt (Fig. 221, IV 1). Vom Wurzelhaar aus dringt die Zoogloea weiter in die Zellen der Wurzel vor (Fig. 221, IV 2) und sammelt sich in Zellen, welche in einiger Entfernung von der Epidermis liegen, an. Das rührt daher, daß diese Organismen an der Oberfläche nicht den ihnen am meisten zusagenden Sauerstoffgehalt finden; auf diese Zellen üben sie einen Reiz aus, wodurch diese sich stark vergrößern, so daß Intercellularräume zwischen ihnen gebildet werden.

So entstehen auf dickeren oder dünneren Wurzeln der Papilionaceen die sogenannten Bakterienknöllchen, welche also ein großzelliges, mit Intercellularräumen versehenes Gewebe enthalten, deren Zellen mit Bakterien ausgefüllt sind. 
Die für ihr Wachstum nötigen Kohlehydrate erhalten diese Bakterien von der Leguminose. In dieser Hinsicht sind sie also Parasiten, ihre Stickstoffnahrung können sie aber selbst erwerben, und zwar aus dem freien Stickstoff der Atmosphäre, welche in den Intercellularräumen des Bakteriengewebes zirkuliert.

Wir haben hier also mit einer höchst eigentümlichen und höchst wichtigen Erscheinung zu tun, mit dem Binden freien Stickstoffs. Da bringt also die Bakterie eine Bindung zu stande, welche im Laboratorium nur sehr schwierig und nur bei hoher Temperatur bewirkt werden kann.

Es dürfte Ihnen bekannt sein, daß die höheren Pflanzen dies Vermögen nicht besitzen; die 70 Proz. Stickstoff der Atmosphäre sind für sie eine unzugängliche Stickstoffquelle, sie brauchen anorganische Stickstoffverbindungen: Salpeter und Ammoniak oder organische, aus welchen sie diese Substanzen bilden können.

Während die Papilionacee bis jetzt die eingedrungenen Bakterien unbehelligt gelassen hat, fängt sie nun an, aktiv einzugreifen, und zwar in einer für die Bakterie schädlichen Weise, wie daraus hervorgeht, daß eigentümlich verzweigte Stäbchen, sogenannte Bakteroiden, gebildet werden, Involutionsformen, welche, wie wir sahen, stets auf ungünstige Lebensbedingungen hinweisen.

In der Tat tötet denn auch die Leguminose die Bakterien und verzehrt sie, dadurch die von ihnen bereiteten Stickstoffverbindungen sich aneignend.

Strikt gesprochen ist es also nicht richtig, daß Leguminosen freien Stickstoff assimilieren können; der freie Stickstoff wird durch die Bakterien assimiliert und die Leguminose entnimmt diesen den von ihr getöteten Bakterien. Nicht alle Bakterien werden jedoch getötet, in den von der Leguminose ausgezogenen Knöllchen bleiben stets noch einige lebende Bakterien zurück, welche das Aussaatmaterial für das nächste Jahr bilden.

Wir haben hier also mit einem Fall von reziprokem Parasitismus zu tun, die Bakterie parasitiert auf der Papitionacee in Bezug auf die Kohlehydrate, diese auf den Bakterien in Bezug auf die Stickstoffverbindungen. Ob man dies Symbiose nennen will oder reziproken Parasitismus, ist meines Erachtens unwichtig.

Vom B. radicicola, welches man, nebenbei bemerkt, noch nicht direkt aus dem Boden hat isolieren können, bestehen verschiedene Rassen, den verschiedenen Papilionaceen-Generis angepaßt. So bilden Erbsenkulturen, mit der Erbsenbakterienrasse geimpft, bedeutend mehr Stickstoffverbindungen, als wenn sie mit Bohnenbakterien geimpft werden. Die Rassen passen sich jedoch so schnell den neuen Verhältnissen an, daß Bakterien aus den Knöllchen mit Bohnenbakterien geimpfter Erbsen schon wieder einer Erbse die normale Quantität gebundenen Stickstoffs verschaffen können.

Die Assimilation des freien Stickstoffs wurde von HELlRIEGEL entdeckt und später von vielen Autoren näher untersucht.

Es mag im Anschluß hieran ein noch gänzlich unerklärtes konstantes Vorkommen von Bakterien in den Blättern gevisser tropischer Bäume an der Hand der Mitteilungen Zinmermanss (190:) erwälnnt werden. nicht weil ich bei diesen Organismen eine Stickstoffassimilation erwarte, sondern nur um eventuelle Besucher der Tropen zu experimenteller Behandlung dieser Frage zu veranlassen. 
Auf den Blättern der Pavetta indica fand Zimmermann kleine, runde Knötchen (Fig. 222, 1), welche auf dem Querschnitt die Anwesenheit zahlloser Bakterien in einem großen Intercellularraum zeigten (Fig. 222, 3). Nähere Untersuchung zeigte, daß dieser Intercellularraum stets gerade unterhalb einer Spaltöffnung (Fig. 222, 2) gelegen war und daß die Knötchen sich nur an der Oberseite des Blattes befinden; das rührt daher, daß die jungen Blätter mit ihren Oberseiten aneinander gepreßt liegen und die Bakterien zwischen ihnen durch in die Spaltöffnungen vordringen. Fig. 222, 1 und 2 der Pavetta lanceolata zeigen einen jungen Intercellularraum mit Bakterien gefüllt, in Fig. 222, 1 noch mit der Außenwelt in Verbindung, in Fig. 222, 2 schon davon abgeschlossen. Die Bakterien üben nun offenbar einen Reiz auf das Blatt aus, wodurch

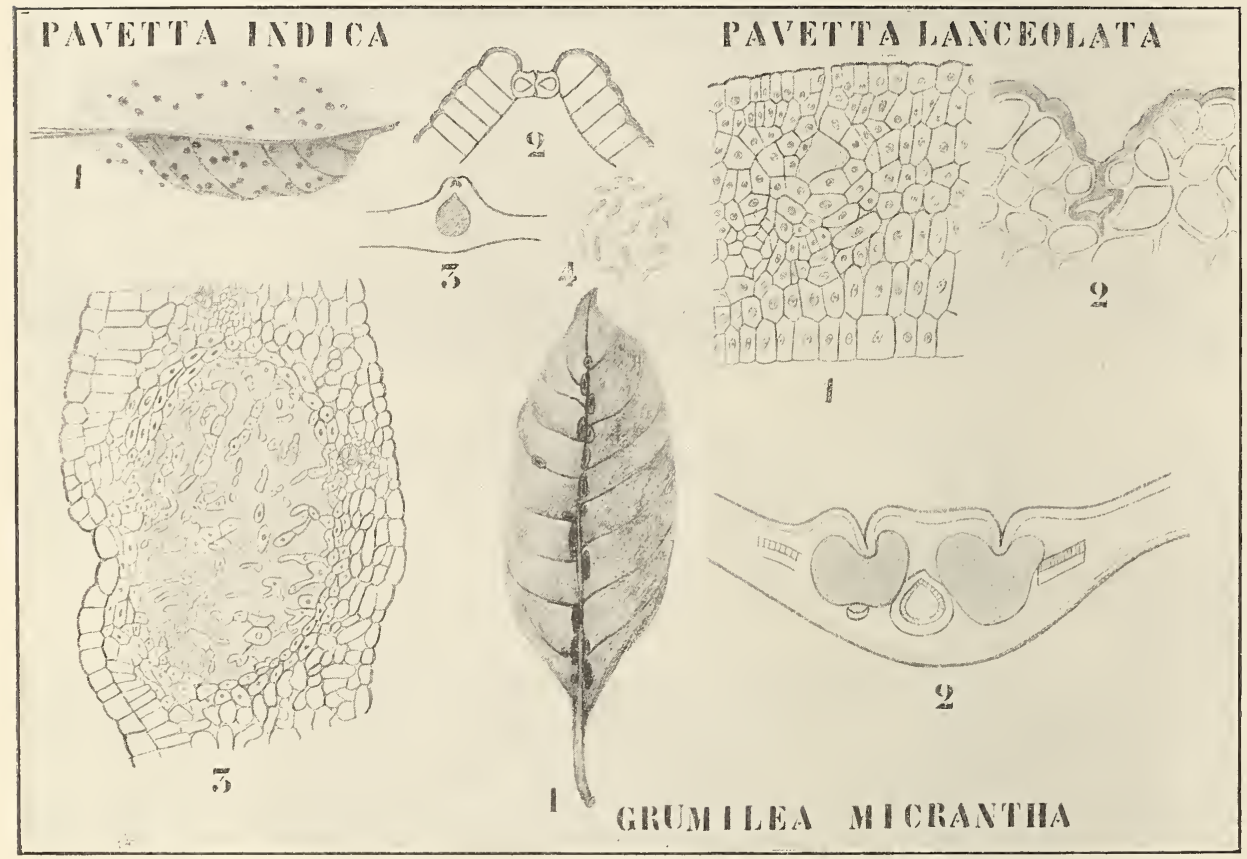

Fig. 222. Bakterienknötchen in Blättern tropischer Bäume (nach ZimmermanN).

der Intercellularraum sich vergrößert und die Knötchen gebildet werden. Das Resultat ist eher günstig als ungünstig zu nennen, denn das Gewebe des Bakterienknötchens ist bei $P$. indica dunkelgrün, auch wenn sie auf vollkommen weißen Stellen panachierter Blätter vorkommen (Fig. 222, 1).

Bei anderen Arten, z. B. bei der von Zimmermann als Grumilea micrantha bezeichneten, kommen die Bakterienknötchen nicht über die ganze Oberfläche des Blattes zerstreut vor, sondern sind auf die Nähe der Nerven speziell des Mittelnerven beschränkt (Fig. 222, 1). so daß auf dem Querschnitt (Fig. 222, 2) die Bakterienzoogloeen hübsch symmetrisch liegen.

Wie gesagt, ist die Funktion dieser Kombination noch gar nicht bekannt, möglicherweise haben wir hier mit einem Falle von reinem Parasitismus der Bakterie auf der höheren Pflanze zu tun. 
Die zweite Unterfamilie der Bacteriaceae, die der

\section{Clostridieae.}

ist durch die Spindelform der sporenbildenden Stäbchen charakterisiert. Zunächst sei von dieser Gruppe

\section{Paracloster butyricus Fischer}

besprochen, dessen Synonym Granulobacillus saccharobutyricus immobilis liquefaciens Schattenfroh und Grassberger eine halbe Diagnose ist, da sie uns sofort sagt, daß wir mit einer unbeweglichen, die Gelatine verflüssigenden Bakterie zu tun haben, welche die Buttersäuregärung verursacht.

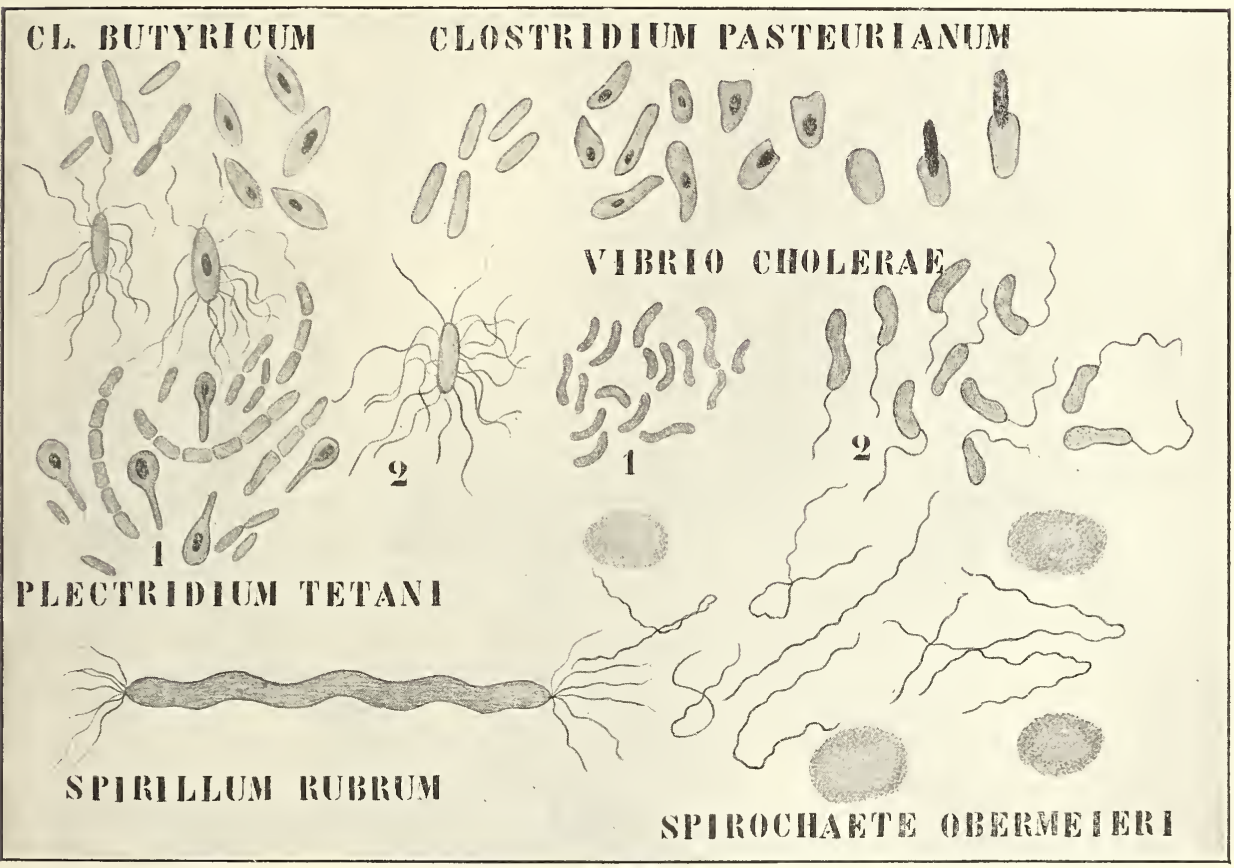

Fig. 223. Verschiedene Bakterien (nach Fischer und MiguLA).

Sie ist eine der häufigsten Buttersäurebakterien und leicht in folgender Weise zu erhalten. Man kocht $5 \mathrm{~g}$ Traubenzucker und $2 \mathrm{~g}$ fein zermahlenes Fibrin in $100 \mathrm{ccm}$ Wasser und infiziert während des Kochens mit ein wenig Gartenerde. Dieses Kochen können nämlich die Sporen des in Gartenerde stets vorhandenen P. butyricus vertragen. Diese Kultur wird nun bei einer Temperatur von $35^{\circ} \mathrm{C}$ gehalten und wir finden nach 24-28 Stunden die Buttersäuregärung in vollem Gange. Viele andere Bakterien verursachen Buttersäuregärung, z. B. Clostridium lutyricum, welches hier oben abgebildet ist, und dessen Genus sich von Paracloster durch seine Beweglichkeit unterscheidet.

Dieser Organismus lebte schon im Karbon, wo er vol van Treghen fossil nachgewiesen wurde. Dieser Nachweis war dadurch möglich, daß unser Pflänzchen an den Wurzeln der Taxodien gewisse charakteristische 
Fäulnisveränderungen hervorbringt, welche genau so bei fossilen Pflanzen gefunden wurden.

Die Fig. 223, I zeigt vegetative und sporenformende Stäbchen, welche, wie gesagt, auffallend verschieden sind.

Betrachten wir jetzt das höchst interessante

\section{Clostridium Pasteurianum Winogradsky,}

dessen Stäbchen beweglich, dessen Cilien aber noch nicht nachgewiesen sind, so daß sie auch auf unserer Figur fehlen. Sehr hübsch ist hier die Spindelform der sporenbildenden Stäbchen im Gegensatz zu der Cylinderform der vegetativen zu sehen.

Unser Organismus ist deswegen so interessant, weil er im Boden ohne Beihilfe von Leguminosen den freien Stickstoff bindet. Er ist 1,5-2 $\mu$ lang, schwach beweglich, wahrscheinlich peritrich und obligat anaërob. Die Endosporen werden nicht durch Zerbröckelung der Zellwand frei, sondern die keimende Spore durchbohrt diese an einem Pole (vergl. Fig. 223). Man kann den Organismus gut in folgender Nährlösung kultivieren :

$$
\begin{aligned}
& 100 \text { Aqua dest. vollkommen } \mathrm{NH}_{3} \text {-frei } \\
& 0,1 \text { Kaliphosphat } \\
& 0,02 \text { Magnesiumphosphat } \\
& \mathrm{NaCl} \\
& \text { Eisensulfat } \\
& \text { Mangansulfat } \\
& 2 \text { Proz. Dextrose } \\
& 4 \mathrm{~g} \text { feiner, gereinigter Kreide }
\end{aligned}
$$

Die einzige organische Energiequelle in dieser Lösung ist Dextrose, ihren Stickstoffbedarf muß die Bakterie mit dem freien Stickstoff der Atmosphäre decken.

Die Menge des gebundenen Stickstoffs ist ungefähr der des vorhandenen Zuckers proportional z. B.

$\begin{array}{ccc}\begin{array}{c}\text { Dextrosegehalt } \\ \text { der Lösung }\end{array} & \text { N in der } & \text { N in der Ernte } \\ 2 & \text { Lösung } & \text { in } \mathrm{mg} \\ 3 & 0 & 2,9 \\ 6 & 0 & 8,1 \\ 6 & 0 & 12,8\end{array}$

Dennoch sind dies nicht einmal die wunderbarsten Bakterien. Wir haben früher gesehen, daß grüne Pflanzen im stande sind, im Lichte organische aus anorganischer Nahrung zu bereiten. Es gibt nun auch Bakterien, z. B. Nitrosomonas und Nitrobacter, fast kokkenförmige Stäbchen, deren systematische Stellung noch unsicher ist, welche das vermögen, ja sogar im Dunkeln aus anorganischer Substanz organische Nahrung bilden können. Den Nachweis dieser autotrophen Bakterien verdanken wir Winogradsky. Sie können aus $\mathrm{CO}_{2}$ Kohlehydrate machen, falls Nitrate oder Ammoniak als Energiequelle vorhanden sind. Es ist hier nicht die Stelle, näher auf diesen höchst interessanten Prozeß einzugehen, ich verweise dazu auf Fischers Vorlesungen über Bakterien, deren Lektüre ich Ihnen überhaupt aufs angelegentlichste empfehle.

Die dritte Unterfamilie der Bacteriaceae, die der

\section{Plectridieae}

ist durch den Besitz trommelstockähnlicher, sporenbildender Stäbchen 
charakterisiert. Es gehören dazu zwei Genera: das unbewegliche Paraplectum und das bewegliche Plectridium.

\section{Paraplectum foetidum}

ist ein anaërobes, gut sporenbildendes Stäbchen, dessen Kulturen stark nach Käse riechen und das bei der Käsereifung eine Rolle spielt. Anscheinend - der Vorgang der Käsereifung ist bei weitem noch nicht anfgeklärt - treten in dem jungen Käse zunächst Milchsäurebakterien auf; diesen folgen Bakterien, welche entweder Milchsäure umsetzen oder sie durch alkalische Exkrete neutralisieren, während dann schließlich die eigentlichen Käsereifer und unter diesen auch unser Paraplectum foetidum auftreten. - Die beweglichen Plectridium-Arten sind peritrich, wir besprechen

\section{Plectridium tetani,}

die Ursache des Wundtetanus oder Starrkrampfs. Es wird in Gartenerde und in Exkrementen verschiedener Tiere angetroffen. Ohne irgend welchen Schaden wird es von Mensch und Tier im Darm aufgenommen und wir alle haben es beim Essen von Salat oder Erdbeeren wohl verschluckt.

Es ist streng anaërob und bildet auf Peptonzuckergelatine, welche es verflüssigt, bei $37^{\circ} \mathrm{C}$ in 1-2 Tagen Sporen.

Gefährlich wird es nur, wenn es in Wunden gelangt, nicht durch das Verursachen einer allgemeinen Infektion - diese bleibt im Gegenteil auf die Wunde beschränkt, sondern durch die Bildung eines fürchterlichen Toxins. Rein ist das Tetanusgift noch nicht gewonnen worden, aber man kennt ein gereinigtes Präparat, von welchem 0,23 mg im stande sind, einen Menschen von $70 \mathrm{~kg}$ Körpergewicht zu töten. Die Stärke dieses Giftes geht daraus hervor, daß zur selben Wirkung 120-130 mg Strychnin nötig sind, so daß das Tetanusgift ungefähr 600 mal stärker ist.

So wie man ein Diphtherieheilserum hergestellt hat, hat man dies auch bei Tetanus getan. Ganz gut gelungen ist es aber noch nicht, am besten ist es, dieses Heilserum sofort nach einer Verwundung, welche Tetanusinfektion befürchten läßt, anzuwenden, sind die Symptome einmal eingetreten, so ist es auch meistens schon zu spät. Von der Familie der

\section{Spirillaceae}

ist das Genus

\section{Vibrio}

durch seine Kommaform, d. h. durch den Umstand, daß seine Stäbchen um 1/4 einer Schraubenwindung gedreht sind, und durch den Besitz einer Polgeißel charakterisiert. Dazu gehört unter anderem der von KocH 1883 auf seiner britisch-indischen Reise entdecke Tibrio cholerae. Im berühmten Streit über die Frage, ob dieser KocHsche Tibrio nun wirklich die Ursache der Cholera war oder nicht, verschluckten PetTexKOFER und EmmerICH absichtlich Kulturen diesel Organismen. wodurch ersterer einen geringen, letzterer aber einen höchst bedenklichen Grad von Cholera bekam.

Kurz nach Kocus Entdeckung meinte man, da damals lieine anderen Vibrionen bekannt waren, daß nichts leichter wäre wie das Erkennen des 
Kommabacillus; jetzt weiß man, daß zahllose, wenigstens für den Menschen unschädliche Vibrionen in Wasser vorkommen und die Unterscheidung ist sehr schwer und kompliziert. Daß die Cholera bei uns keinen festen Fuß fassen kann, liegt daran, daß ihr Optimum viel höher liegt wie unsere Sommertemperatur und daß sie unsere Wintertemperaturen überhaupt nicht vertragen kann. Ursache einer Epidemie ist wohl ausnahmslos infiziertes Trinkwasser.

An Choleravibrionen kann man leicht den entsetzlichen Kampf ums Dasein zeigen, welche in einer künstlichen Bakterienkultur herrscht. Von einer Kultur, welche 12 Stunden nach dem Impfen 23966 Mill. lebende Vibrionen enthielt, überlebten nach 40 Stunden nur 10 Proz.

Das Genus

\section{Spirillum}

unterscheidet sich durch seine stärkere Krümmung und ist nicht monotrich, sondern lophotrich. Bei einzelnen Arten ist Endosporenbildung bekannt. Spirillum rubrum v. Esmarch wächst in Gelatinestichkulturen, so weit wie der Sauerstoff der Atmosphäre eindringt, weiß, tiefer hinein prachtvoll dunkel weinrot.

Das Genus

Spirochaete

entbehrt der Cilien; die korkzieherartig gewundenen Körper sind flexil. Dazu gehört unter anderen die pathogene Spirochaete Obermaieri, welche im Blute des Menschen vorkommt und den Rückfalltyphus verursacht. Jede Kulturmethode war bisher erfolglos. Die Lebensgeschichte ist nur recht unvollständig bekannt. der der

Gehen wir jetzt zur Besprechung der höchsten Bakteriengruppe, zu

\section{Trichobakterien}

über, und wenden wir uns in erster Linie jener Abteilung zu, welche starre unbewegliche, in einer Scheide eingeschlossene Fäden besitzt.

Zur Untergruppe, derjenigen mit unverzweigten Fäden, gehört in erster Linie das Genus

\section{Chlamydothrix,}

von welchem wir Chl. ochracea, welche mit Crenothrix Kuhniana Rabenh. und Cladothrix dichotoma CoHn die Gruppe der sogenannten Eisenbakterien bildet, besprechen wollen.

Von diesen Eisenbakterien ist Chlamydothrix ochracea sicher die wichtigste und nach Winogradsky die Hauptursache der Bildung des Raseneisensteins, der Ferriverbindung $\left[\mathrm{Fe}_{2}(\mathrm{OH})_{6}\right]$.

Auf stillen Wassertümpeln in moorigen Wiesen sieht man öfters eine dünne, fettige, bräunliche Schicht, welche zum größten Teile aus unserer Chlamydothrix besteht.

Am leichtesten verschafft man sich diesen Organismus in folgender Weise. Man übergießt Heu mit Wasser, fügt etwas frisch niedergeschlagenes Eisenoxydhydrat $\mathrm{Fe}_{2}(\mathrm{OH})_{6}$ zu und impft mit Teichschlamm.

Die fadenförmigen Bakterien stecken in einer Schleimscheide, in welcher sie hin und her geschoben werden können (Fig. 224, I, 1), die Schleimscheide bildet also ein Röhrchen, in welchem der Faden liegt. 
Die Zellen können Cilien bilden und davonschwimmen, wobei sie aus der Scheide herauskriechen. In den Scheiden ist Eisenoxydhydrat $\mathrm{Fe}_{2}(\mathrm{OH})_{6}$ angehäuft, wodurch die gelbbraune Farbe verursacht wird.

Nach Wrnogradskys Versuchen sollen auch diese Bakterien autotroph sein. Nach ihm soll nämlich für das Leben dieser Bakterien Eisenoxydul unentbehrlich sein. Dieses Eisenoxydul sollte dann von den lebenden Bakterien zu Eisenoxyd oxydiert werden und die dabei frei werdende Wärme sollte die Energiequelle für die Lebensvorgänge dieser Organismen geben. Das im Wasser vorhandene Eisenoxydul wïrde dann, zu Eisenoxyd oxydiert, in den Schleimscheiden der Bakterien angehäuft werden und durch Akkumulation dieser Scheiden würde der Raseneisenstein gebildet werden.

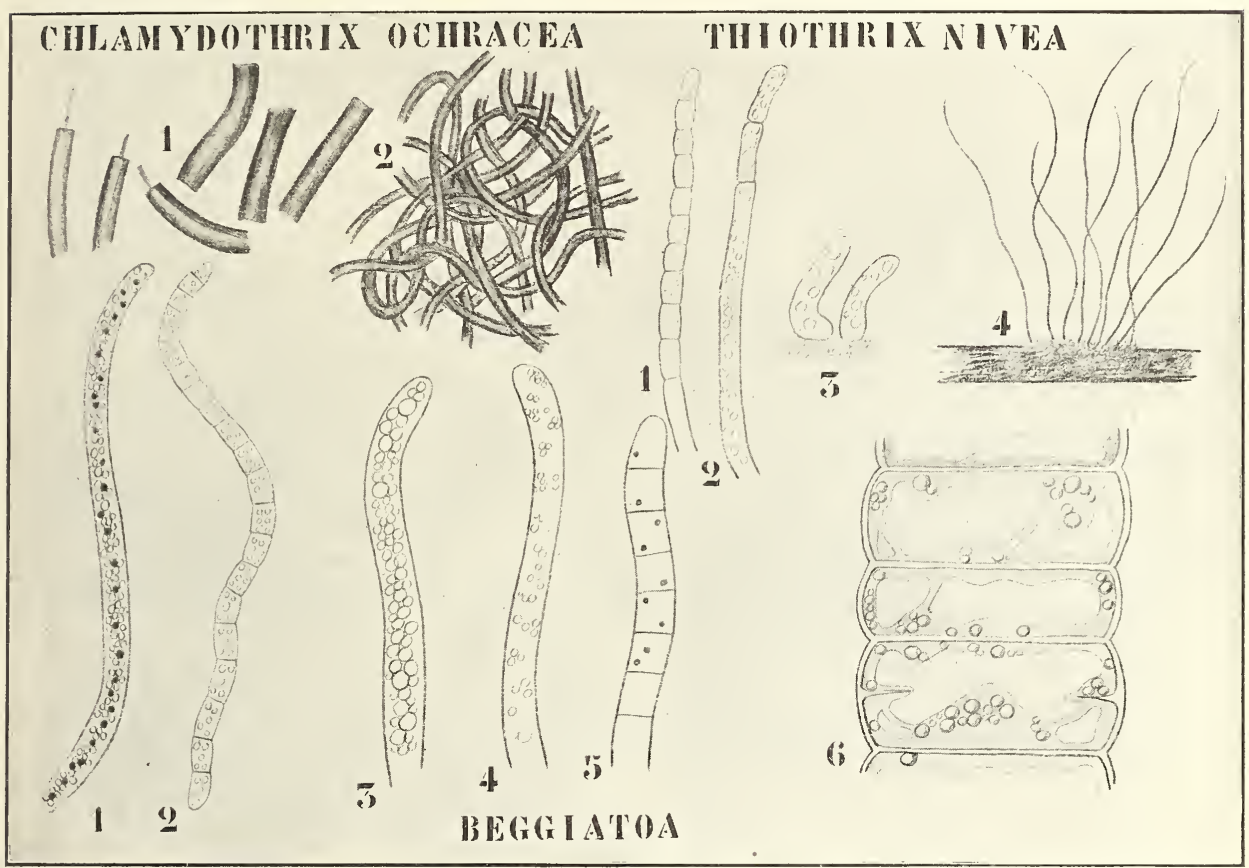

Fig. 224. Eisen. und Schwefelbakterien (nach Molisch, Winogradsky, Fischer und Migula).

Hingegen schließt MoLisch aus seinen Versuchen, daß die Eisenbakterien recht gut ohne Eisen bestehen können und meint, daß der Eisengehalt der Scheiden einfach durch Absorption aus dem umgebenden Wasser erklärt werden muß, ohne daß dabei von einer Tätigkeit seitens der Bakterien die Rede zu sein braucht, da viele gelatinöse Substanzen ein dergleichen akkumulierendes Absorptionsvermögen besitzen. Daß die absorbierten Oxydulverbindungen in Eisenoxyd umgesetzt werden, braucht bei der leichten Oxydierbarkeit dieser Verbindungen keine Verwunderung zu erwecken. Eine Untersuchung von 34 verschiedenen Arten von Raseneisenstein, aus allen Teilen der Telt lierrührend, zeigte, daß nur bei 9 Proz. derselben Eisenbakterien rorlianden waren, so daß Moursch zu dem Schlusse kommt. es werde recht häufig Raseneisenstein ohne Mithilfe von Bakterien gebildet. 
Wer hat nun Recht? Beide sind ausgezeichnete Untersucher, ein Urteil abzugeben ist also schwer, mir persönlich aber scheinen die Auffassungen Molischs die richtigen. Eine Nachuntersuchung ist aber bei diesem Stande der Sache selbstverständlich erwünscht.

Viel besser bekannt ist das Genus

\section{Thiothrix,}

welches mit Beggiatoa, mit dem purpurfarbenen Chromatium okenii, mit Lamprocystis roseopersicina, mit Thiopedia und mit vielen anderen systematisch durchaus nicht nahe verwandten Geschlechtern die physiologische Gruppe der Schwefelbakterien bildet.

Auf faulenden Blättern in Wasser findet man öfters einen schneeweißen Ueberzug, der aus angewachsenen, unverzweigten mit stark lichtbrechenden Tröpfchen gefüllten Fäden besteht. Durch Cilienbildung können die Zellen, welche den Faden zusammensetzen, Schwärmer werden. Neben ihnen findet man öfters die hin- und herschlagenden Fäden von Beggiatoen, deren Zellen gleichfalls mit solchen stark lichtbrechenden Tröpfchen gefüllt sind und in den an einigen Stellen zwischen sie eingesprengten purpurroten Chromatium-Individuen finden sich diese Tröpfchen gleichfalls.

Winogradsky erbrachte den Nachweis, daß diese scheinbaren Tröpfchen in der Tat Schwefelkörnchen sind und daß sie aus den Zellen verschwinden, wenn man diese in reines Wasser bringt.

Das rührt daher, daß der Schwefel für unsere Bakterien eine Reservesubstanz, Atemmaterial, also Energiequelle ist, also die Stelle der Stärke bei den höheren Pflanzen einnimmt. Wie ist dies möglich?

Schwefelbakterien kommen nur vor an Stellen, wo Fäulnisbakterien schon vorhanden sind; bei der Fäulnis entsteht Schwefelwasserstoff und Ammoniak, welches den Schwefelbakterien genügt, falls nur noch ein wenig Ameisensäure oder Propionsäure, ebenfalls gewöhnliche Fäulnisprodukte, als Kohlenstoffquelle geboten werden.

Bekanntlich wird Schwefelwasserstoffwasser an der Luft sehr leicht unter Ausscheidung von Schwefel oxydiert. Die Bakterien scheinen nun die oxydierende Kraft des Luftsauerstoffes entweder rein mechanisch, so wie Watte dies tut, oder aber durch Bildung irgend einer Oxydase $\mathrm{zu}$ aktivieren und gewinnen also mit recht wenig Energieverlust den Schwefel, und damit schon auf ein Grammolekül 12 Kalorien Wärme, welche also schon als Energiequelle für die Lebensprozesse dienen können. Den so angehäuften Schwefel kann nun die Schwefelbakterie $\mathrm{zu} \mathrm{H}_{2} \mathrm{SO}_{4}$ oxydieren, wobei pro Grammolekül 207 Kalorien gewonnen werden.

Tiere und Pflanzen können also die zur Ausübung ihrer Lebensfunktionen nötige Energie in folgender Weise gewinnen:

Tiere direkt aus organischer Nahrung, welche sie anderen Organismen entnehmen durch Oxydation (Atmung).

Grüne Pflanzen bilden zunächst mit der Sonne als Energiequelle aus $\mathrm{CO}_{2}$ und Wasser organische Nahrung und erhalten ihre Energie durch Oxydierung derselben. Sie erhalten also genau so wie die Tiere ihre Energie durch Veratmung organischer Substanz, können aber in Gegensatz zu den Tieren diese selbst bereiten.

Schwefeibakterien gewinnen mit Hilfe des Luftsauerstoffes sehr leicht Schwefel und gewinnen ihre Energie durch Oxydierung, d. h. durch Veratmen dieses Schwefels. 
Von allen Organismen erhalten also die Schwefelbakterien ihr Atmungsmaterial, den Schwefel, am leichtesten, fast ohne jeglichen Energieaufwand, und das ist der Grund, weshalb nach unseren jetzigen Kenntnissen meines Erachtens an Stellen, wo, wie z. B. bei Neapel, unterm Meere Schwefelwasserstoff hervortritt. nach Generatio aequivoca gesuch $\uparrow$ werden muß, das sind Bedingungen, welche wohl am meisten denjenigen entsprechen, welche auf der Erde zur Zeit des Erscheinens der ersten Lebewesen herrschten und da ist eine sich bildender lebender Substanz leicht zugängliche Energiequelle.

Das Genus

\section{Crenothrix}

enthält keinen Schwefel. Es gehören hierzu angewachsene Fadenbakterien, welche im Wasser vorkommen und sich z. B. in Wasserleitungen bisweilen in solchen Quantitäten entwickeln können, daß die Röhren vollständig verstopft werden, und so eine wahre Kalamität entsteht.

Diese Crenothrix besteht im vegetativen Zustande aus unverzweigten, mit einer Scheide versehenen Fäden stäbchenförmiger Zellen. Die Fortpflanzung findet auf zweierlei Weise statt.

Erstens können die Zellindividuen als Aplanosporen ausschlüpfen (Fig. 225, I 8-10), zweitens können sich die Zellen in drei Raumrichtungen teilen, wodurch Mikroaplanosporen entstehen, und dies kann ohne bedeutende Formänderung des Fadens geschehen (Fig. 225, I 12), oder unter keulenförmiger Anschwellung desselben, wodurch das Ganze einem Sporangium gleicht (Fig. 225, I 11). Im letzteren Falle sind die Mikrosporen meistens kleiner wie im ersteren.

Eine Scheinverzweigung kann dadurch zu stande kommen, daß die ausgeschlüpften Mikrosporen am Mutterfaden kleben bleiben und sich dort zu neuen Fäden entwickeln (Fig. 225, I 5, 6, 7).

\section{Cladothrix,}

welche wir jetzt besprechen wollen, ist die einzige verzweigte Form der Thrichobakterien, es ist aber auch hier die Verzweigung nur eine Scheinverzweigung (Fig. 225, II 1).

\section{Cladothrix dichotoma}

ist die bestbekannte Form dieses noch recht unvollständig bekannten, ungefähr 20 Arten zählenden Genus. Sie wächst in verunreinigtem Wasser, wie Gräben u. s. w., und ist durch ihre Pseudoverzweigung charakterisiert. In der Jugend eine unverzweigte Reihe cylinderförmiger Zellen, von dünner Schleimschicht umgeben, wachsen alsbald einige Zellen schief auswärts, wodurch die Scheinverzweigung entsteht (Fig.' 225. II 1,3$)$.

Cladothrix ist jahrelang die Stütze derjenigen gewesen, welche nicht an die Existenz von Genera bei den Bakterien glauben wollen, die im Gegenteil meinen, daß Coccus, Bacillus, Vibrio, Spirillum und Fadenbaliterie nur normaliter einander nachfolgende Entwickelungsstadien ein und desselben Organismus sind.

Im Jahre 1884 schreibt Zopf noch in Schencks Handb. d. Bot., III, 1, p. 15 :

"Nach der von Cons begründeten Theorie ron der Konstanz de1 Spaltpilzformen hat man anzunehmen, daß die oben bezeichneten Formen 
morphologisch volle Selbständigkeit besitzen, d. h. unter den verschiedenen Ernährungsbedingungen nur immer ihresgleichen erzeugen, also zueinander nicht in genetische Beziehungen treten. So vermag z. B. irgend eine Mikrokokkenform nach Сонм nur immer wieder Mikrokokken zu erzeugen, nicht aber Stäbchen oder Schraubenformen, so sollen ferner Spirillenformen nur immer wieder Spirillen, nicht etwa Stäbchen und Kokken bilden u. s. f."

"Diese Theorie hat nur noch historischen Wert. Sie ist in neuester Zeit verdrängt worden durch die von BILLROTH und NäGELI aufgestellte, aber erst neuerdings vom Verfasser näher begründete Lehre vom genetischen Zusammenhang der Spaltpilzformen. Diese Lehre besagt, daß die Spaltpilze (vielleicht mit Ausnahmen) befähigt sind, verschiedene, den

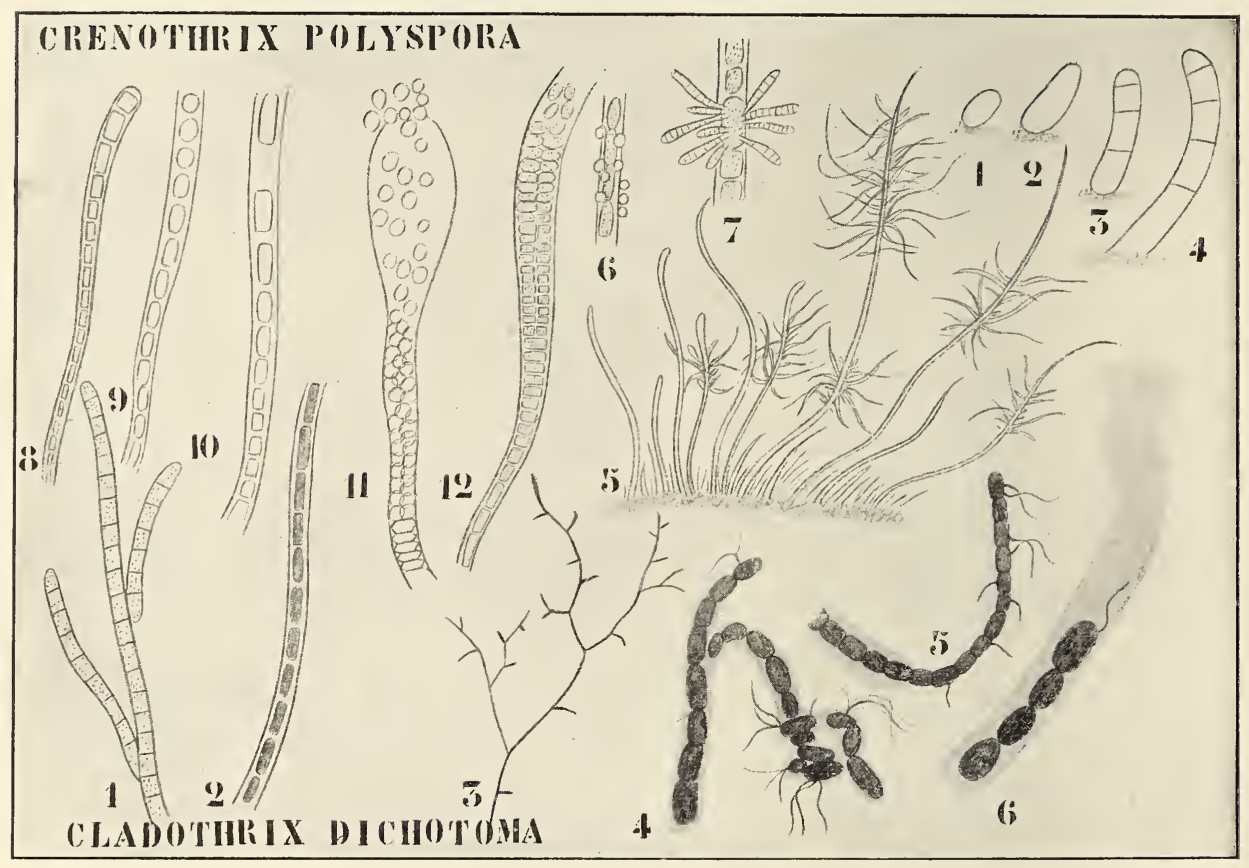

Fig. 225. I. Crenothrix polyspora. - II. Cladothrix dichotoma.

oben charakterisierten Vegetationsformen entsprechende Entwickelungsstadien zu durchlaufen. Nachdem durch Cienkowskis Studien an gewissen Spaltpilzen, sowie durch NeELSEns Untersuchung an dem Pilz der blauen Milch der genetische Zusammenhang von Kokken-, Stäbchen- und Leptothrix-Formen nachgewiesen war, wurde von mir selbst der bestimmte Nachweis geliefert, daß die höchstentwickelten Spaltpilze (Cladothrix, Beggiatoa) nicht bloß jene Entwickelungsformen, sondern auch Schraubenformen in allen Modifikationen (Spirillen, Spirochäten, Vibrionen, Ophidomonaden) bilden."

Wir wissen jetzt, daß im Gegenteil Conss Theorie vollkommen bestätigt worden ist und sich ZopFs Meinung als irrig herausgestellt hat.

Der erste, welcher seine Stimme gegen den Polymorphismus von Cladothrix erhob, war Winogradsky (1888) im ersten Fascikel seiner 
Beiträge zur MLorphologie und Physiologie der Bakterien; seine der Hauptsache nach richtige Schilderung der Entwickelungsgeschichte wurde 1894 von BüsGEN an Reinkulturen bestätigt.

Die beste Weise, um Rohkulturen von Cladothrix zu erhalten, ist folgende. Jan füllt Bechergläser von dem Inhalt eines halben Liters mit einer Lösung von Fleischextrakt in gewöhnlichem Wasser, welche aber so wenig konzentriert ist, daß sie gar nicht oder nur schwach gelblich gefärbt ist. Hinein bringt man einen Rasen Cladothrix, den man in strömendem unreinen Wasser leicht finden kann und läßt ihn 2-3 Tage in der Lösung. Dann wird alles ausgegossen und neue Nährlösung hinzugefügt. An der Wand des Becherglases blieb eine genügend große Zahl von Schwärmsporen zurück, um eine neue Kultur zu erhalten. Reinkulturen kann man durch Herausfischen eines einzelnen CladothrixFadens aus Schmierkulturen auf Gelatine erhalten.

In der Rohkultur gibt es selbstverständlich allerlei andere Bakterienarten, unter anderen stets ein dickes Spirillum, welches z. B. von ZopF für ein Entwickelungsstadium der Cladothrix gehalten wurde.

Die Entwickelung von Cladothrix stellt sich bei genauer Untersuchung als recht einfach heraus. Wir beschrieben schon den erwachsenen pseudoverzweigten Zustand. Jede Zelle eines solchen Fadens kann nun Cilien bilden und fortschwimmen und dann zum neuen Faden auswachsen. Voilà tout.

Dabei wird natürlich die Scheide durchbrochen; sie verschleimt, und da dieses Verschleimen öfters an größeren Strecken des Fadens zugleich, bevor die Schwärmer sich loslösen, stattfindet, und dann größere Fadenstücke (aus zusammenhängenden Schwärmern bestehend) fortschwimmen und sich dabei öfters tordieren, ist es recht begreiflich, daß ZopF solche Stücke für Spirillen hielt, in welcher Meinung er dadurch noch bestärkt werden mußte, daß fast stets mit Cladothrix ein echtes Spirillum zusammen wächst.

Auch hier war wieder Unreinheit der Kultur Ursache der falschen Schlußfolgerung.

Vom einzigen noch zu besprechenden Genus, von

\section{Beggiatoa,}

bleibt nach dem schon bei den Schwefelbakterien Mitgeteilten nicht viel zu sagen übrig. Sie besteht aus langen Fäden ohne Scheide, schlägt hin und her, ja kriecht sogar langsam und fällt behufs Vermehrung in Hormogonien, d. h. cilienlose, flexile, bewegliche Stücke, auseinander. Beggiatoa alba kommt in schwefelhaltigen Brunnen, andere Arten in stinkenden Gräben, wieder andere im Meerwasser vor.

Damit ist die Gruppe der Bakterien wohl genügend besprochen und wir gehen zur Behandlung der Schizophyceen über. 


\section{Fünfzehnte Vorlesung.}

\section{Die Schizophyceen.}

Die Schirophyceen, oder wie man sie meistens nennt, die Cyanophyceen, unterscheiden sich von den Bakterien zunächst durch den Besitz eines meistens blaugrünen, auch wohl roten Farbstoffs, in zweiter Linie durch das Fehlen von Cilien, in dritter Linie durch das Fehlen von Endosporen und in vierter Linie durch die viel kompliziertere Struktur der Energide. Wohl kommen Hormogonien, wie die von Beggiatoa, und Arthrosporen, etwa wie die von Streptococcus vor.

Von diesen Unterschieden sind also zwei positiv, die höhere Organisation der Energide und der Besitz eines meistens blaugrünen Farbstoffs, oder in einem Worte Unterschiede in der Cytologie. Betrachten wir also zunächst die

\section{Cytologie der Cyanophyceen.}

Die Energidenstruktur der Cyanophyceen ist zwar vielfach untersucht worden, zu einem allgemein acceptierten Resultat ist man aber noch nicht gekommen.

Es kann bei dem unsicheren Stand der Frage nicht meine Aufgabe sein, hier im Detail alle Auffassungen zu erörtern; wer sich dafür interessiert, wird die in der Literaturliste erwähnten Arbeiten lesen müssen, auch meine ich, daß es nicht nötig ist, Sie hier mit allen Körnchen und Bläschen bekannt zu machen, welche in der Zelle der Cyanophyceen gefunden sind, sondern ich glaube, meine Besprechungen auf die zwei Hauptteile der Cyanophyceen-Energide beschränken zu können.

Die zwei Hauptteile sind: ein blaugrüner peripherer Teil und ein farbloser zentraler Teil.

\section{Der blaugrüne periphere Teil.}

Zwei Hauptmeinungen herrschen über den morphologischen Wert dieses Teiles. Nach der einen, welche von Alfred Fischer verkündet wird, ist der ganze periphere Teil e in Chromatophor, nach der anderen, der aller sonstigen Untersucher, ist es Cytoplasma. Die Verteidiger der letzteren Auffassung sind jedoch wieder in zwei Gruppen verteilt, einige meinen, daß dieses Cytoplasma zahlreiche, sehr kleine, von Hegrer Cyanoplasten genannte Chromatophoren enthält, nach anderen aber, nach WAGER z. B., ist der Farbstoff in der Form kleiner Körnchen vorhanden, welche man am besten mit den Grana der Chloroplasten der höheren Pflanzen vergleichen kann. 
Sehen wir nun zunächst, welche Gründe Alfred Frscher für die Chromatophorennatur des gefärbten peripheren Teiles der CyanophyceenEnergide beibringt.

Er stützt seine Auffassung zumal auf eine von ihm gefundene Methode zur Isolierung der Chromatophoren. Diese Methode beruht darauf, daß unter bestimmter Anwendung Fluorwasserstoff bei den verschiedensten Organismen die ganze Energide mit Ausnahme der Chromatophoren auflöst.

Zum Beweise dafür bildet er in solcher Weise behandelte Zellen ab. woraus man sieht, daß alles mit Ausnahme der Chromatophoren verschwunden ist, während diese sehr schön erhalten sind.

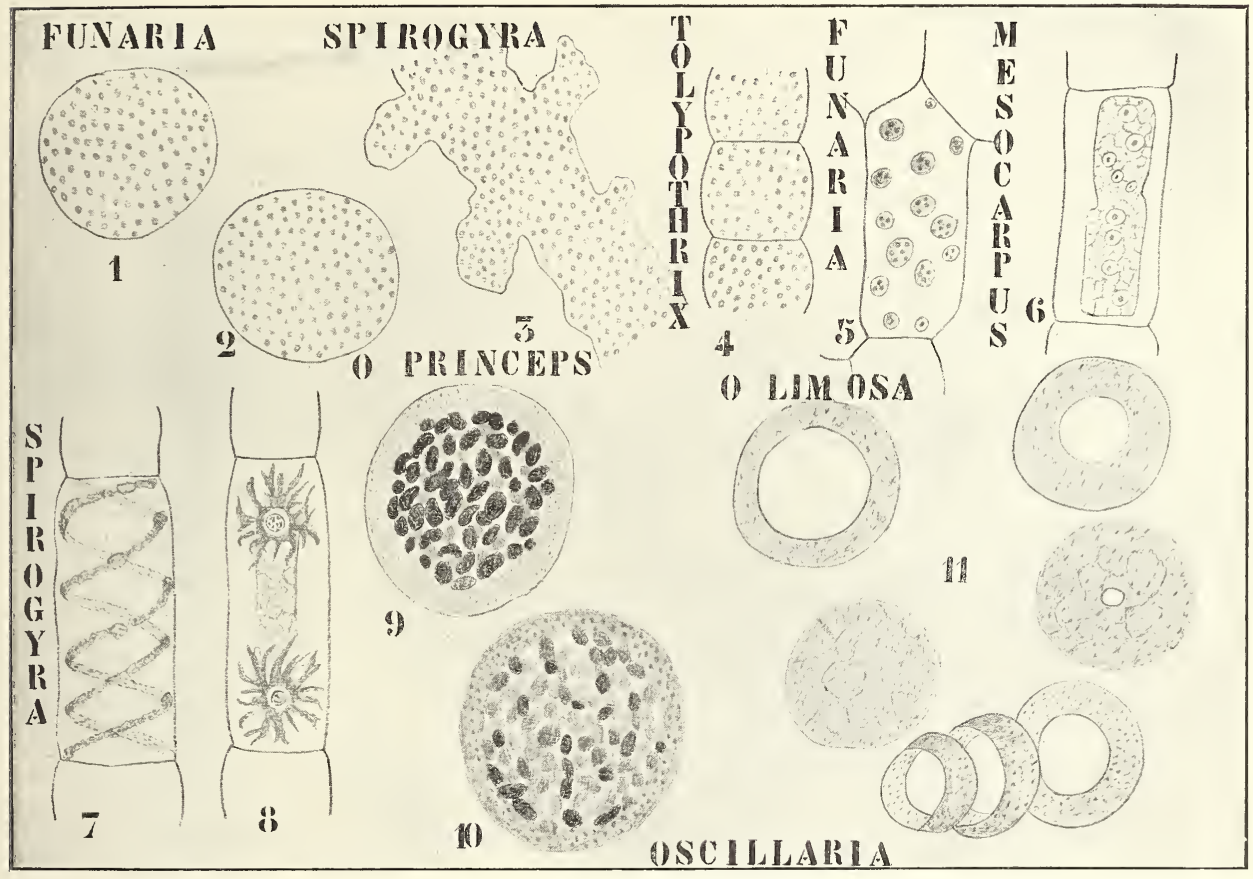
im Text.

Fig. 226. Cytologie der Cyanophye en (nach Alfred Fischer). Erklärung

Auf unserer Fig. 226 z. B. zeigt 5 eine so behandelte Zelle eines Moosblattes, 6 eine solche von Mesocarpus, 7 eine von Spirogyra und 8 eine von Zygnema.

Daß die gefärbten Körnchen der Cyanophyceen volikommen mit den Grana der gewöhnlichen Chloroplasten übereinstimmen, beweist er durch den Vergleich von Salicylaldehydpräparaten verschiedener Chromatophoren mit eben solchen Präparaten von Cyanophyceen. In Fig. 226. 1 und 2 sehen wir solche Präparate von Fumaria-Chloroplasten, 3 stellt ein Stück eines Spiralbandes von Spirogyra dar und 4 ein Fadenstiick von der Cyanophycee Tolypothrix lanata. Wie man sieht. ist die Uebereinstimmung eine vollkommene.

Will man mittels Fluorwasserstoft isolierte Chromatophoren wieder 
gut sichtbar machen und zur Demonstration gebrauchen, so färbt man sie mit "Lichtgrün", was recht naturgetreue Bilder liefert.

Mittels Fluorwasserstoffbehandlung zeigt nun Fischer, daß bei den Cyanophyceen nach Einwirkung dieses Reagens nichts als der periphere Teil der Energide übrig bleibt. Da er nun durch seine Salicylaldehydmethode weiß, daß im peripheren Teil der Farbstoff in Körnchen vorkommt, welche von denen der Grana der Chromatophoren von Funaria, Spirogyra etc. nicht zu unterscheiden sind (man vergl. Fig. 226, 4 mit 1, 2 und 3), schließt er, daß der ganze periphere Teil der CyanophyceenEnergide ein einziges Chromatophor ist.

A priori ist diese Auffassung keineswegs unwahrscheinlich. Im Pflanzenreich treffen wir nämlich im allgemeinen bei den niedrigen Organismen große, bei den höheren kleine Chromatophoren an und da nun die Cyanophyceen gewiß niedrige Organismen sind, ist die Fische Rsche Auffassung a priori wahrscheinlicher, wie die HEGLERsche, welche die kleinen Farbstoffpartikelchen im peripheren Teil als Chromatophoren, als Cyanoplasten auffaßt, Chromatophoren von einer Kleinheit wie sie sonst unbekannt sind.

Es gibt aber noch eine andere Möglichkeit. Wir sahen früher, daß es grüne Organismen gibt, bei welchen man eigentlich nicht von Chromatophoren reden darf, da ein nach Umständen größerer oder geringerer Teil des Plasmas grün gefärbt ist, ohne daß dieser Teil sich nach Ausziehung des Farbstoffs vom übrigen Teil der Energide unterscheiden läßt. Solche Organismen sind z. B. Protosiphon und Hydrodictyon. Einen solchen Fall würden wir hier haben, wenn wir WAGERs Auffassung acceptierten, daß der periphere Teil der Energide aus Cytoplasma mit Far.bstoffgrana besteht.

Die Frage, um welche es sich handelt, ist also diese: Darf man einen nicht in Fluorwasserstoff löslichen Teil des Plasmas eo ipso als ein Chromatophor auffassen oder kann man sich auch vorstellen, daß Plasma mit vielen „Grana“ bei einer eben solchen Behandlung ebenfalls ungelöst bleibt?

Um uns in dieser Frage ein Urteil zu bilden, müssen wir zu finden suchen, worauf die Unlöslichkeit der Chromatophoren in Fluorwasserstoff beruht.

Nach Fischer beruht sie darauf, daß der Farbstoff - das Chlorophyll also bei einem Chloroplasten - bei der bei dieser Methode angewandten Temperatur schmilzt und das Chromatophor mit einer dünnen Schicht bedeckt und es daher in derselben. Weise, wie eine dünne Wachsschicht Glas, gegen die Einwirkung von Fluorwasserstoff schützt.

Falls dies aber richtig ist, und ich bin gerne bereit, dies anzunehmen, kann die Methode unmöglich unterscheiden zwischen einem Chromatophor und zwischen mit Chlorophyllgrana versehenem Plasma. Denn auch im letzteren Falle wird das Chlorophyll schmelzen und es liegt kein Grund vor anzunehmen, daß das schmelzende Chlorophyll hier nicht dem Protoplasma denselben Dienst erweisen würde, wie dort dem Stroma des Chloroplasten.

Genau betrachtet, ist übrigens der ganze Streit nur ein Wortstreit, denn wer kann einen Unterschied zwischen einem Chromatophor und mit Grana versehenem Cytoplasma angeben?

Das ändert aber nichts an der Tatsache, daß Alfred Fischer unsere Kenntnis der Cyanophyceen-Zelle durch seine Flußsäuremethode bedeutend erweitert hat. 
Es seien diese Resultate also zunächst ganz kurz beschrieben.

Die Cyanophyceen-Fäden haben vermutlich in Verbindung mit dem Chitingehalt ihrer Zellwände die Eigenschaft, bei Anwendung der Fluorwasserstoffmethode auseinander zu fallen, wobei dann faktisch nichts wie das Chromatophor übrig bleibt.

Läßt man nun mit der Flußsäure behandelte Fäden auf dem Objektträger eintrocknen, so kleben diese Chromatophoren (resp. Cytoplasmamassen nach WAGER) am Objektträger fest und können nun in Konservierungssubstanzen eingeschlossen werden.

Betrachtet man nun ein solches Präparat von Oscillaria limosa, so sieht man Ringe mit großer zentraler Oeffnung, solche mit kleiner und. mit sehr kleiner Oeffnung, vollkommen solide, flache Scheibchen und

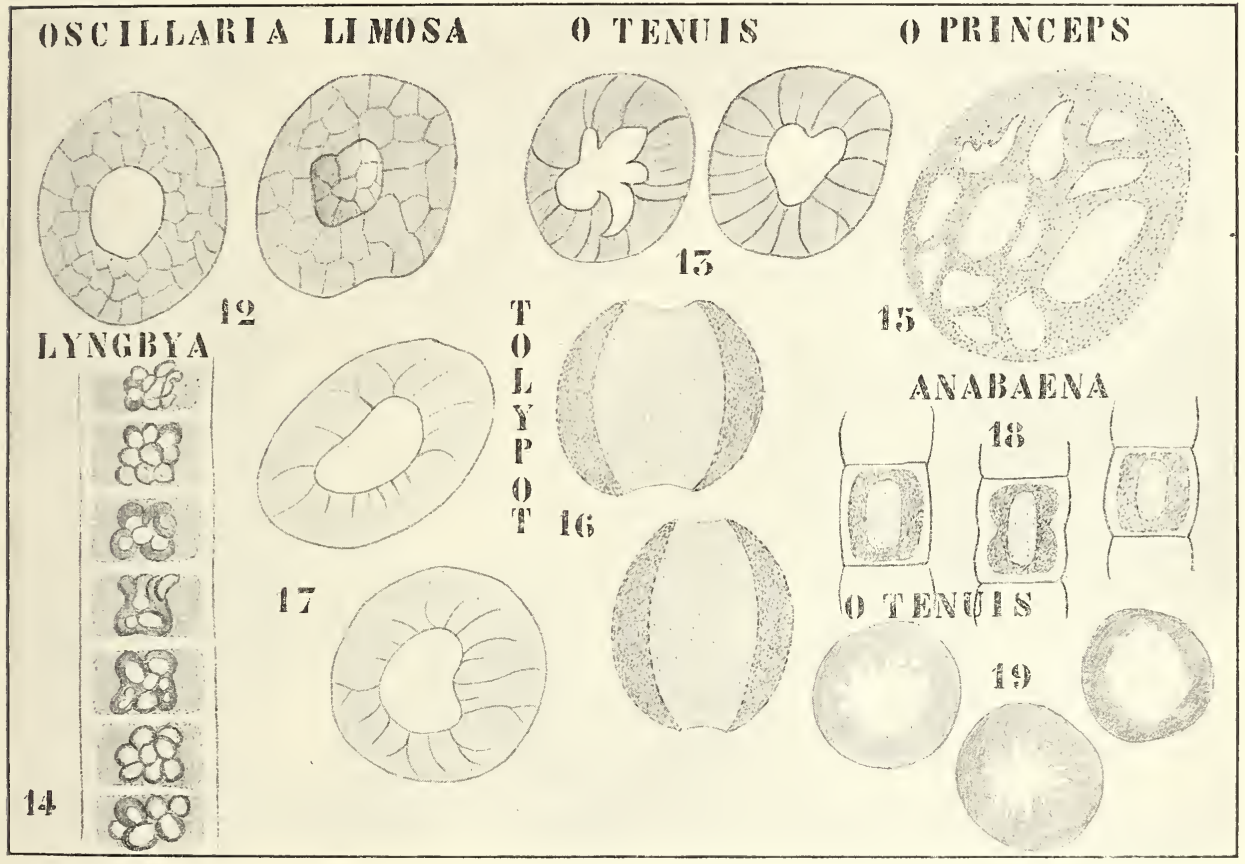

227. Cytologie der Cyanophyceen (nach Fischer).

sehr kurze Cylinderchen mit sehr niedrigem oder sehr breitem aufrechten Rand und flachem Boden (Fig. 227, 11 und 12).

Die Erklärung für diese verschiedenen Bilder findet Fischer in der Form des Chromatophors und in den Veränderungen, welche es während der Teilung der Zelle durchmacht, sowie in der Wirkung der Eintrocknung bei der verwendeten Methode.

Im Ruhezustand der Zelle hat dieses Cytoplasma die Form eines Hohlcylinders, also etwa die Form eines Bambusgliedes mit den beiden angrenzenden Knoten.

Bei der Zellteilung wird dieser allseitig geschlossene Crlinder in der Mitte durchgeschnitten, und es biegen sich die Ränder wieder aufeinander zu, um die allseitig geschlossene (ylinderform wieder herzustellen. Findet die Zellteilung aber, wie das oft rorkommt, sehr schnell 
statt. so haben die Ränder keine Zeit sich umzubiegen und es entstehen dann eine größere oder geringere Zahl von losen Ringen. Das erklärt nun in der Tat alle beobachteten Stadien. Die schmalen Ringe mit weiter Oeffnung sind durch schnelle Zellteilung gebildet, Ringe mit enger bis sehr enger Oeffnung sind durch das Umbiegen der Ränder entstanden. Die soliden Scheibchen sind die Ober- und Unterfläche des allseitig geschlossenen Cylinders von außen betrachtet, während Figuren, wie die von Fig. 227, 12 rechts, solche Stücke von innen betrachtet darstellen.

Bei gewissen Formen wie z. B. bei Oscillaria princeps (Fig. 227, 15) sind die Endflächen netzartig durchbrochen, wodurch sie an das Chromatophor von Cladophora erinnern. Die allseitig geschlossene Cylinderform des Chromatophors kann man sehr schön bei Anabaena sehen (Fig. 227, 18 und Fig. 228, 24).

Die innere Form des Chromatophors hängt nun natürlich von der Form des zentralen Teiles der Energide, des sogenannten Zentralkörpers, ab. Wo dieser wie z. B. bei O. tenuis (Fig. 227, 13 und 19) mehr oder weniger sternförmig ist, ist das Chromatophor sozusagen ein Abguß davon.

Die äußere Form des Chromatophors hängt von der Form der Zelle ab; ist diese mehr oder weniger rund, so erhält auch das Chromatophor eine entsprechende Rundung, wie z. B. bei gewissen Tolypothrix-Arten (Fig. 227, 16).

Nun hat das Chromatophor nicht bei allen Cyanophyceen die Form eines allseitig geschlossenen Cylinders; bei Lyngbya z. B. (Fig. 227, 14) ist der Cylinder an beiden Seiten offen. Bei vielen Anabaena- und Nostoc-Arten hat es die Form einer Hohlkugel.

Daß man bei Oscillarien viel mehr Teilstïcke von Chromatophoren wie intakte sieht, rührt daher, daß bei normal wachsenden Individuen regelmäßig 75 Proz. aller Zellen in Teilung begriffen sind.

Auf die feinere, nach der Meinung einiger netzförmige, nach der Auffassung anderer fibrilläre Struktur des Chromatophors gehe ich hier nicht ein, doch muß noch einiges über das

\section{Produkt der Photosynthese}

gesagt werden. Dieses besteht offenbar aus Glykogen, welches sich denn auch im Chromatophor nachweisen läßt.

HEGLER wies nach, daß das Glykogen aus dunkel gestellten Fäden verschwindet, wenn auch z. B. bei Oscillaria limosa bei einer Temperatur von $10-14^{0} \mathrm{C}$ bisweilen erst nach 4 Wochen. Läßt man dann das Licht wieder zutreten, so ist innerhalb 48 Stunden stets wieder eine reichliche Quantität vorhanden.

Die gebräuchliche Glykogenreaktion ist eine Rotbraunfärbung mittels Jodjodkalium. Aus Fig. 226, 10 ersehen wir das hier leider schwarze Resultat dieser Behandlung.

Nach Hegler kommt das Glykogen nur im peripheren Teil der Zelle vor, im Fischerschen Chromatophor also, und fehlt im Zentralkörper.

Diese Heglersche Meinung wird von Zacharias und KoHL geteilt, während MassarT hingegen gerade den Zentralkörper besonders glykogenreich nennt und OLIVE es überhaupt nicht nachweisen konnte. Конц bemerkt, daß man das Glykogen nie in einigermaßen beträchtlicher Ansammlung hat nachweisen können, so daß die Glykogenvakuolen 
so klein sein müssen, daß man sie sogar mit den stärksten Systemen nicht sehen kann.

Zur näheren Lokalisation war es nun sehr erwünscht, ein weniger diffus färbendes Reagens auf Glykogen wie das Jodjodkali zu finden und es gelang Fischer in der Tat, eine bessere Methode auszudenken.

Fischers Methode zum Nachweise des Glykogens. Glykogen wird durch Gerbsäure und Alkohol niedergeschlagen, der Niederschlag ist leicht in Wasser löslich, aber wird durch Behandlung mit Kaliumbichromat in Wasser fast unlöslich.

Auf diesen Eigenschaften des Glykogens beruht nun Frschers Methode :

Am Fundort selber werden die Cyanophyceen-Fäden in Alkohol konserviert, wodurch das Glykogen präzipitiert wird, aber wasserlöslich bleibt. Darauf schließt man sie in üblicher Weise in Paraffin ein, macht Mikrotomschnitte und klebt diese, selbstverständlich unter Vermeidung von Wasserzusatz, auf. Nach Entfernung des Paraffins mittels Xylol werden die Schnitte während 10 Minuten in 10-proz. wässeriger Tanninlösung gelassen. Das überflüssige Tannin wird nicht mit $\mathrm{H}_{2} \mathrm{O}$, sondern mit 1-proz. Kaliumbichromatlösung abgespült: Hernach werden die Schnitte 5-10 Minuten in 10-proz. Kaliumbichromat gebracht.

Jetzt ist das Glykogen in Wasser unlöslich geworden und man kann die Schnitte also mit Wasser abspülen und mit irgend einem wässerigen Anilinfarbstoff färben, wozu man jeden basischen, aber keinen sauren Farbstoff verwenden kann. Am besten sind Methylenblau in reinem $\mathrm{H}_{2} \mathrm{O}$ gelöst, Safranin oder Gentianaviolett in den bekannten Anilinwasserlösungen.

Zur Färbung braucht man ungefähr 10 Minuten. Zum Vergleich der alten und der neuen Methode können Fig. 226, 9 und 10 dienen. Fig. 226, 10 ist in alter Weise mit Jodjodkali behandelt, Fig. 226, 9 mit Frschers Methode. Trotz des Fehlens der Farbe in der Reproduktion ist das viel schärfere Bild, welches man mit Fischers Methode erhält, auffallend. Nach Fischer geht hieraus hervor, daß der Zentralkörper hauptsächlich das Glykogen enthält, während der periphere Teil fast ganz glykogenfrei ist.

Bei anderen Cyanophyceen oder unter anderen Umständen befindet sich das Glykogen nur im peripheren Teile, nicht im zentralen. So z. B. bei O. tenuis (Fig. 227, 19).

Die Schwierigkeit der Interpretierung der Resultate ist bei beiden Methoden nicht gering.

Jodjodkali färbt sowohl Glykogen wie Eiweißsubstanzen. Die Anilinfarbstoffe färben sowohl Chromatine wie, wenigstens nach Fischer, Glykogen ${ }^{1}$ ).

Wie muß nun zwischen beiden unterschieden werden? Denn der große Streit zwischen Frscher und den übrigen Forschern der Cyanophyceen dreht sich um die Frage, ob der Zentralkörper der Cyanophyceen ein Kern oder aber mit Glykogenreservesubstanz gefülltes Cytoplasma ist.

Nun würde ein unbefangener Beobachter sagen, daß die Entscheidung, falls wenigstens Frschers Prämissen richtig sind, nicht

1) In Leberzellen aber nach der anch hier verwendeten Tamninbeizung um das Glykogen nicht das Chromatin im Kern. 
schwer ist, denn nach FIScher ist das von Alkohol präzipitierte Glykogen noch sehr leicht in Wasser löslich.

Was wäre also anscheinend einfacher wie folgendes Experiment? Mikrotomschnitte desselben Fadens werden in zwei Gruppen A und B geteilt. Die Schnitte A werden nach Entfernung des Paraffins längere Zeit in Wasser ausgezogen, die Schnitte B gar nicht mit Wasser in Berührung gebracht. Jetzt werden A und B in gleicher Weise gefärbt. Ist die Substanz im Zentralkörper nun Glykogen, so müssen die Schnitte A im Zentralkörper keine roten Würstchen zeigen, die Schnitte B müssen welche zeigen. Dieses Experiment suchte ich bei FIscher verg'ebens.

Es würde allerdings nur bei Formen wie O. limosa Aufschluß geben, da bei den meisten Cyanophyceen das Glykogen nach Fischers Auffassung nicht als solches im Zentralkörper angehäuft wird, sondern erst zu Anabänin umgeändert wird.

Fischer nimmt übereinstimmend mit anderen Forschern an, daß das erste sichtbare Produkt der Photosynthese Glykogen ist und zeigt, daß im Einklang mit dieser Auffassung das eine Mal viel, das andere Mal wenig oder gar kein Glykogen vorhanden ist.

Bei Oscillaria limosa kommen, wie wir sahen, im Zentralkörper ovale Körner vor, bei vielen anderen Cyanophyceen, so z. B. bei Oscillaria anguina (Fig. 228, 21, 22) treten im Zentralkörper sich mit Anilinfarbstoffen stark tingierende Körper auf, von der Form von Chromosomen, welche denn auch von vielen Forschern für solche gehalten werden.

Nach Fischer sind dies aber keine Chromosomen, ja sogar keine nukleinartigen Substanzen, sondern Kohlehydrat-Kondensationen, die aus dem wasserunlöslichen Anabänin bestehen.

Summa Summarum bekommen wir also folgende Auffassungen: A. Fischer

1) Die Cyanophyceen-Energide besteht aus:

a) einer dünnen hypothetischen Hautschicht an der Außenseite,

b) einem großen Chromatophor,

c) einem aus Cytoplasma und Reservesubstanz bestehenden Zentralkörper.

2) Im Chromatophor wird als erstes sichtbares Produkt der Photosynthese Glykogen gebildet. Dieses wird als solches nach dem Zentralkörper transportiert und dort

a) als solches aufbewahrt (O. limosa),

b) in wasserunlösliches Anabänin umgesetzt, das öfters in der Form pseudomitotischer Knäuel aufbewahrt wird.

H. WAGER

1) Die Cyanophyceen-Zelle besteht aus:

a) einer peripherischen, blaugrün gefärbten Cytoplasmaschicht,

b) einem zentralen Kern ohne Wand, der sich direkt mit Anklängen an Mitose teilt.

O. Zacharias nimmt an:

1) einen farblosen Zentralkörper,

2) ein diesen umgebendes peripheres Plasma.

Die Chromosomen Wagers u. a. hält er für "Vorsprünge“, „Leisten" etc., also für Ausstülpungen des Zentralkörpers. 
Nach Zacharias können vielleicht im Zentralkörper Nukleine vorkommen, nach Macallum kommt im Zentralkörper stets eine chromatinähnliche Substanz vor, welche aber „never appears to enter any condition ressembling in the remotest degree, that of mitosis".

Am meisten interessiert uns nun die Frage: sind die kernähnlichen Teilungsfiguren im Zentralkörper in der Tat wirkliche, sei es auch stark modifizierte Mitosen, wie WAGER will, oder sind es „Kohlehydratmitosen", wie Fischer sie sarkastisch nennt, oder nur Ausstülpungen des Zentralkörpers, wie Zacharias meint.

Fangen wir mit den Argumenten an, welche WAGER für die Kernnatur des Zentralkörpers anführt.

Schon vor Jahren, zuerst auf dem Glasgow-, später auf dem Southport-Meeting der British Association, hatte ich das Glück, die schönen WAGERschen Präparate zu sehen und im vorvergangenen Jahre konnte ich in Cambridge der Diskussion zwischen WAGER und Zacharias beiwohnen.

Ich erhielt damals den Eindruck, daß es keinen Grund gäbe, an WAGERs Resultaten zu zweifeln, eine Ueberzeugung, welche später durch das Erscheinen des KoHLschen Werkes noch verstärkt wurde.

Daß die chromosomenähnlichen Figuren in hohem Grade Kernteilungsfiguren gleichen, ist über jeden Zweifel erhaben, daß wir etwas dergleichen erwarten müssen, ebenfalls, aber das berechtigt noch nicht zu der Folgerung, daß es nun auch in der Tat Chromosomen seien. Dazu ist ein sorgfältiges Abwägen der WAGERschen Argumente gegen die Fischerschen nötig, machen wir das also.

WAGER findet im Zentralkörper ein Netzwerk, welches er für achromatische Substanz hält und die fraglichen Chromosomen. Diese färben sich mit fast allen Kernfarbstoffen, widerstehen der Einwirkung künstlichen Magensaftes und geben eine deutliche, bisweilen sogar eine starke Reaktion auf Phosphor und maskiertes Eisen mit Macallums Methode. Deswegen muß man sie nach WAGER als eine chromatinähnliche Substanz betrachten.

WAGER schließt denn auch:

„Out of some twelve main characters chemical and morphological, which are found attaching to the nuclei of higher plants, we have seven and possibly nine, occurring in the nuclei of Cyanophyceae.

These are (1) the presence of a nuclear network; (2) its reaction towards nuclear stains; (3) its behaviour towards digestive fluid; (4) the presence of phosphorus; (5) the presence of masked iron; (6) the amitotic division, which resembles in some respects the division in Euglena; and (7) the presence of chromatin granules on a linin framework. It differs from the nucleus of higher plants in the absence of a true mitosis with spindle fibres and in the absence of a nuclear membrane and nucleolus; but under certain conditions the deeply-stained substance of the central body is found condensed into a deeply-stained granule suspended by delicate fibres in the centre of the cell, and in young cells the central body is often limited towards the cytoplasm by a vacuolar membrane, so that the presence under certain conditions of a body resembling a nucleolus and at least a rudimentary nuclear membrane, is not excluded.

If it is not a nucleus, than it can only be (1) a specialised portion of the cytoplasm, (2) a body of the nature of a pyrenoid. or (3) a special organ of the cell of which we know not the function." 
Letzteres ist, wie wir sahen, die Auffassung Fischers. Bei der Wertschätzung seiner Argumente werden wir sehen, daß sie sehr wichtig sind. Es ist mir nicht möglich, Ihnen hier sämtliche Argumente aus Fischers sehr sorgfältiger Untersuchung mitzuteilen, dafür sei auf das Original verwiesen, aber was ich Ihnen mitteilen werde, ist schon von solcher Wichtigkeit, daß meines Erachtens vieles nötig sein wird, um sie mit guten Gründen zu widerlegen.

Nehmen wir als Beispiel

\section{Anabaena.}

Dieses Genus zeigt ebenso schöne "Mitosen" wie z. B. die in Fig. 228, 22 abgebildete Oscillaria anguina, aber Fischer erhielt eine

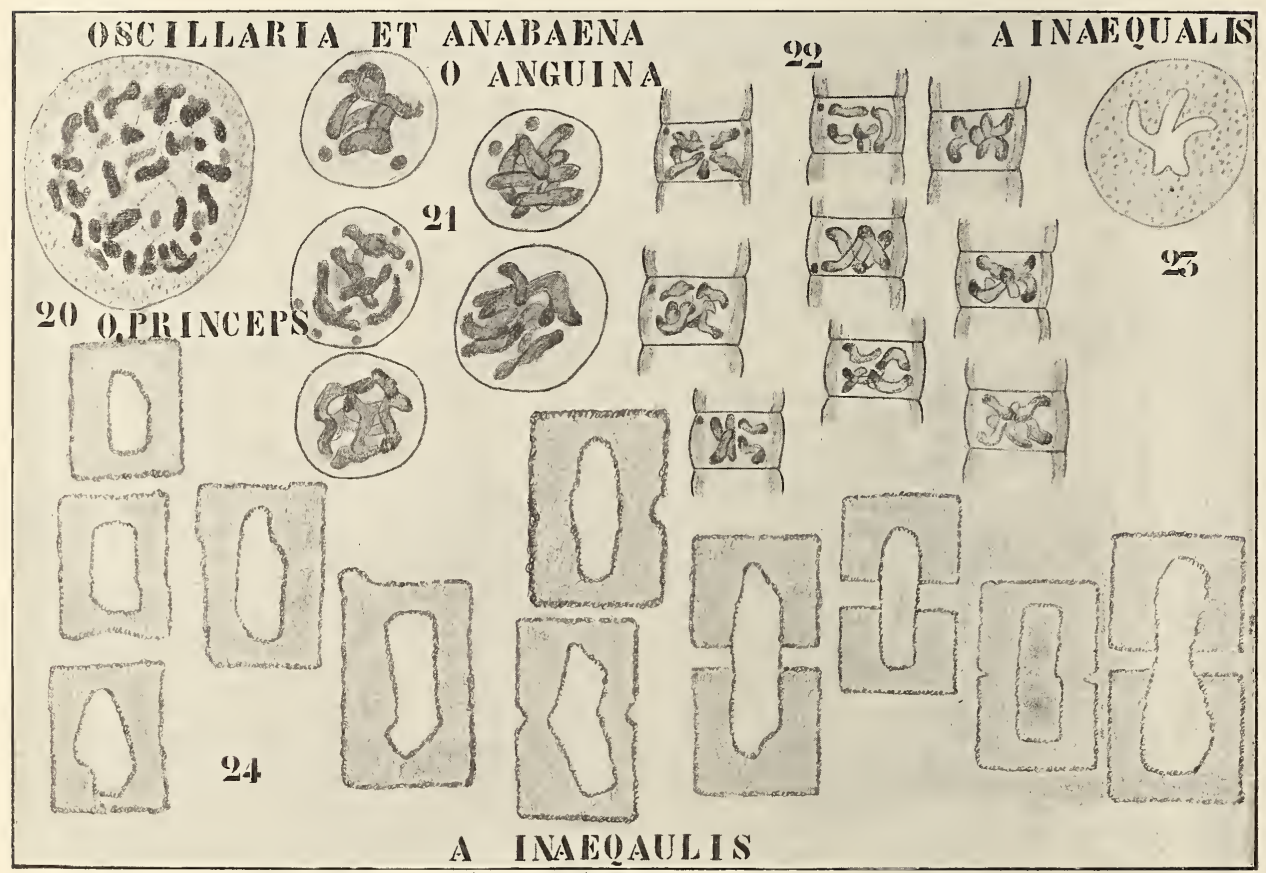

Fig. 228. Cyanophyceen-Cytologie (nach Fischer).

Warnung, diesen Würstchen Chromosomennatur zuzusprechen, als er seine Fäden mit JJK färbte. Die Nitosen färbten sich dabei nicht, sondern blieben, wie der Vikrotomschnitt Fig. 228, 23 zeigt, vollständig farblos. Das spricht in hohem Grade gegen die Chromosomennatur dieser Gebilde, da Chromosomen sich wohl mit JJK färben.

Eine andere Methode zur Unterscheidung zwischen Chromosomen und sonstigen Substanzen beruht auf ihrem besonderen Verhalten in künstlichem Magensaft.

Es stellte sich nun heraus, daß an lebenden, Mitosen enthaltenden Fäden die Mitosen, in Pepsin gebracht, unverändert blieben, dagegen in Pankreatin vollständig verschwinden; das würde also für die Eiweißnatur der betreffenden Gebilde sprechen, falls nicht ein Kontrollversuch lehrte, daß lebende Fäden auch in reinem Wasser die Mitosen ver- 
schwinden lassen, falls man die Kultur nur bei $40^{\circ} \mathrm{C}$ im Thermostaten dunkel stellt.

Diese Autolyse der lebenden Anabaenen konnte unter den soeben genannten Bedingungen ausnahmslos erhalten werden, sogar unter Hinzufïgung gewisser Antiseptica, um einen möglichen Einfluß von Bakteliell zu eliminieren.

Dagegen verschwanden die Mitosen nicht bei toten Fäden, auch nicht in Pankreatin.

Daraus kann man also nur schließen, daß es nicht das Pankreatin ist, welches die Lösung der Mitosen bei lebenden Fäden in Pankreatinlösung verursacht, sondern daß diese durch ein von der Anabaena ausgeschiedenes Ferment geschieht, durch ein Ferment, daß wohl in einer Pankreatinlösung, nicht aber in einer Pepsinlösung arbeitet, vermutlich wegen des $\mathrm{HCl}-\mathrm{Gehaltes}$ der letzteren.

Daraus schließt Fischer, daß die Pseudomitosen nicht aus Eiweiß bestehen, folglich keine Chromosomen sein können, sondern wahrscheinlich aus einem spezifischen Kohlehydrat, aus Anabänin, bestehen, welches von einem bestimmten Enzym, der Anabänase, gelöst werden kann.

Zur näheren Begründung dieser Auffassung läßt er aus AnabaenaFäden das Anabänin durch Autolyse verschwinden; färbt darauf mit verdünntem Delafieldschen Hämatoxylin und zeigt, daß sich dann der Zentralkern nicht färbt (Fig. 228, 24).

Mir scheint, daß sich - die Richtigkeit der Beobachtungen vorausgesetzt - recht wenig gegen FiscHers Schlußfolgerung sagen läßt, nur ist zu bedauern, daß FISCHER nicht Mikrotomschnitte autolysierter Fäden gefärbt hat, denn die in Fig. 228, 24 abgebildeten Zellen wurden in toto tingiert. Erst nachdem Mikrotomschnitte das gleiche Resultat werden ergeben haben, kann man meiner Anschaumg nach mit Sicherheit sagen, daß die Pseudomitosen durch Autolyse verschwunden sind, denn erst dann ist mit Gewißheit der Farbstoff bis zum Zentralkörper durchgedrungen, was bei Färbungen in toto immer zweifelhaft bleibt!

Nachdem nun Fischer schon das Unwahrscheinliche der Auffassung, daß der Zentralkörper ein Kern sei, betont hat, lenkt er unsere Aufmerksamkeit auf den Umstand hin, daß die größte und also die am leichtesten zu untersuchende Oscillaria, die O. princeps, nie mitotische Figuren zeigt, was also ebenfalls gegen die Kernnatur des Zentralkörpers spricht.

Am wahrscheinlichsten scheint es ihm, daß wie bei den Bakterien auch hier das Chromatin noch im Plasma, d. h. hier also seiner Auffassung nach im Zentralkörper zerstreut vorkommt, wodurch der chemische Nachweis von Nukleinen im Zentralkörper durch Fischer, Zacharias, KонL u. a. erklärt sein würde.

Wir haben früher gesehen, daß nach Fischers Meinung das Glykogen im Chromatophor photosynthetisch hergestellt wird, daß dies bei Formen mit einem großen Zentralkörper, wie Oscillaria princeps, als solches, bei Formen mit kleinem Zentralkörper aber erst kondensiert und dann als Anabänin aufbewahrt wird, welches Anabänin dann die Form von Pseudomitosen annehmen kann. Der Umstand, daß er - allerding's nur in einzelnen Fällen - das Anabänin wieder in Glykogen umsetzen konnte, spricht selbstverständlich für seine Auffassung.

Wenn wir also die Fischerschen Auffassungen acceptieren, ist die Energidenstruktur bei Cyanophyceen und Bakterien mogefähr die gleiche. was bei der offenbaren Verwandtschaft beider angenehm berührt. 
Bei den Bakterien würden wir dann mit einer normalen Zelle zu tun haben, aber ohne eigentlichem Kern, die Nukleine wären noch im Plasma verteilt und bildeten nur zeitweise etwas größere Akkumulationen : die Chromatinkörner, welche z. B. bei der Diphtheriebakterie sehr bedeutende Größe erreichen können.

Bei den Cyanophyceen würden wir die gleiche Zellstruktur haben, nur unter Hinzufügung eines Chromatophors, ihrer autotrophen Lebensweise entsprechend, und unter Aufbewahrung von Reservesubstanzen im Zentrum der Zelle.

Daß auch Bakterien Reservesubstanzen aufbewahren können, haben wir am Schwefel der Thiobakterien gesehen.

Wie angenehm uns nun auch diese Uebereinstimmung berührt und wie sehr man geneigt sein könnte, darin eine nähere Stütze für Fischers Auffassung zu sehen, so darf man doch nicht vergessen, daß auch BüTsCHLI trotz ganz anderen Auffassungen eine übereinstimmende Struktur bei Bakterien und Cyanophyceen erhält.

Nach ihm nämlich gibt es auch bei den Bakterien, d. h. bei den höheren Formen derselben, einen Zentralkörper und eine Hautschicht. Diesen Zentralkörper betrachtet er als eine Art von Kern, in welchem das Chromatin nur in der Form von Körnern vorhanden ist. Bei den niedrigeren Bakterien würde diese Hautschicht fehlen und das Ganze also nur aus einem Kern bestehen.

Wir haben schon früher auf das Unwahrscheinliche letzterer Meinung hingewiesen, weil wir dann mit einem sporenbildenden Kern zu tun haben würden.

Viel wahrscheinlicher ist, den Zentralkörper der Bakterien nur als etwas dichteres Plasma zu betrachten, was sich der Fischerschen Auffassung nähert.

Im augenblicklichen Stande der Frage scheint also die Fischersche Auffassung - die Richtigkeit seiner Beobachtungen vorausgesetzt die wahrscheinlichere. Also: sowohl bei Bakterien wie bei Cyanophyceen haben wir mit primitiven Organismen zu tun, bei welchen die Nukleine in der Form sehr kleiner Chromatinkörner im Plasma verteilt sind.

Der Unterschied zwischen beiden liegt im Vorkommen eines Chromatophors, resp. einer grün gefärbten Cytoplasmazone bei den Cyanophyceen und dem Fehlen derselben bei den Bakterien.

So würde dann das Nuklein ursprünglich nicht auf einen Kern beschränkt sein, sondern Nucleus und Plasma, wie BüTscHLI annimmt, das Resultat einer Arbeitsteilung im ursprünglich mit zerstreuten Chromatinkörnern versehenen Plasma sein.

Ueber diese Auffassungen sagt Wilson:

"The nucleus, as Carnoy has well said is like a house built to contain the chromatic elements, and its achromatic elements (linin etc.) were originally a part of the general cell-substance. Moreover as Carnoy points out, the house periodically goes to pieces in the process of mitotic division, the chromatin afterwards building for itself a new dwelling. ${ }^{6}$
1) $\mathrm{Daß}$ sie sich nicht färben mit JJK oder mit $\mathrm{J}+\mathrm{H}_{2} \mathrm{SO}_{4}$,
2) daß sie sich nicht färben mit Karminlösungen und daß sie sich in anderen Farbstoffen nur schwach färben,
3) daß sie in Pepsin und Trypsin nicht verdaut werden, also :

Gegen die Auffassung der Pseudomitosen als Chromosomen spricht 
4) daß im autolytischen Produkt mit Eiweiß präcipitierenden Reagentien kein Präcipitat erzielt werden kann, können.

5) daß die Pseudomitosen künstlich in Glykogen umgesetzt werden

Solange nicht gezeigt wird, daß Fischers Beobachtungen unrichtig sind. darf man meines Erachtens die Pseudomitosen nicht als Chromosomen betrachten. Vielleicht sind sie mit den metachromatischen Körpern in Hefezellen, welche ebenfalls neben Glykogen vorkommen, identisch.

Die Frage nach dem Kern der Cyanophyceen ist demnach meines Erachtens bis jetzt gänzlich unentschieden; denkt man an die Schwierigkeiten des Kernnachweises bei den Hefen, so wäre es nicht einmal unmöglich, daß die Cyanophyceen und Bakterien einen echten Kern enthielten, welcher bis jetzt der Untersuchung entgangen ist.

Ich glaube, daß ohne nähere Untersuchungen eine endgültige Entscheidung über die Natur des Zentralkörpers nicht getroffen werden kann, bekenne mich aber gerne als zu der Fischerschen Auffassung hinneigend, daß die Pseudomitosén trotz ihrer großen Aehnlichkeit mit. Chromosomen keine solchen sind.

Wir haben schon früher beiläufig die Teilung der CyanophyceenZelle erwähnt, betrachten wir jetzt diesen Vorgang einmal etwas genauer.

Recht auffallend ist der Umstand, daß sich die Cyanophyceen-Zellen fast stets in Teilung befinden, und zwar in solchem Maße, daß 75 bis 90 Proz. der Zellen Teilungsstadien aufweisen und eine sich teilende Zelle, schon lange bevor diese Teilung beendet ist, schon wieder dabei ist, verschiedene neue Zellwände zu bilden.

Diese Zellwände werden in der Form von Ringen angelegt, und diese durchschneiden zunächst das Chromatophor und dann den Zentralkörper; von einer aktiven Teilung des Zentralkörpers kann also nicht die Rede sein.

Auffallend ist die Tatsache, daß die Teilung offenbar in jedem Moment unterbrochen werden kann, um später von neuem am Punkte, wo sie unterbrochen wurde, anzufangen. Das spricht auch entschieden gegen die Kernnatur des Zentralkörpers.

Nachdem wir also die Energidenstruktur, soweit es bei unseren mangelhaften Kenntnissen eben ging, besprochen haben, können wir zur Morphologie und Systematik unserer Gruppe schreiten.

Die Gruppe der Cyanophyceen besteht aus Organismen, welche zum Teil frei, zum Teil in Symbiose mit anderen Gewächsen leben.

Die frei lebenden Formen kommen über die ganze Erde verbreitet, sowohl in Süß- wie in Salzwasser, in großen Gewässern wie auf feuchter Erde, an Felsen und Bäumen vor.

In Symbiose bilden viele Cyanophyceen das photosynthetische Element vieler Flechten, z. B. der Collemaceae; auch bilden sie das autotrophe Element gewisser Vertreter der seltenen Gruppe der Basidiolichenes.

Während in den Flechten die Cyanophyceen mit Pilzen symbiotisch leben, leben sie in anderen Fällen mit Vertretern ganz anderer Gruppen zusammen; so z. B. mit Anthoceros unter den Lebermoosen, mit A:olla unter den Pteridophyten, mit Cycas unter den Cycadeen und mit Gummera unter den Phanerogamen.

Einige Cyanophyceen leben in heißen Quellen, wo sie bisweilen unglaubliche 'Temperaturen vertragen kömmen, gewisse Oscillatorien, z. B. in gewissen Fällen bis $85^{0}$ C, wobei aber zu berïlksichtigen ist, daß 
nicht alle Angaben Vertrauen verdienen, da Fehler durch die großen Temperaturunterschiede zwischen zwei benachbarten Punkten in heißen Quellen leicht gemacht werden können. Gewisse Arten inkrustieren sich mit kohlensaurem Kalk, wenn sie in kalkhaltigen Kohlensäurebrunnen wachsen. Da sie bei der Photosynthese die Kohlensäure dem Wasser entziehen, wird der Kalk zwischen den schleimigen Membranen dieser Arten niedergeschlagen. In dieser Weise können, durch Absterben der älteren Algenschichten und fortwährendes Wachstum der jüngeren, enorme Kalkschichten gebildet werden, wie z. B. die Marmorterrassen in den Mammouthsprings vom Yellowstone-Park.

Nicht nur Kalkniederschläge können so entstehen, auch Kieselschichten können so gebildet werden. DE VRIES gibt folgende populäre Beschreibung eines heißen Geysyrs im Yellowstone-Park:

"Trotz der großen Hitze ist die ganze Wand lebendig. Sie besteht aus mikroskopisch kleinen Algen, welche sich mit in dem Wasser gelösten Substanzen ernähren und die Kieselsäure festlegen. Diese Algen sind gallertartig und schlagen auch die Kieselsäure als Gallerte nieder, aber sie werden alsbald so hart, daß man die weiche Oberfläche kaum fühlen oder sehen kann: diese bildet nur eine dünne Schicht über die steinharte, dennoch lebende Masse. Die Wassertemperatur erreicht nahe am Rande fast den Siedepunkt. In einigen Brunnen nahm ich Temperaturen von $86-90^{\circ} \mathrm{C}$ war, während der Bulbus des Thermometers den lebenden Algen angedrückt war."

Bei gewissen Arten leben die Individuen einzeln, bei anderen sind sie zu meistens schleimigen Kolonien von mehr oder weniger bestimmter Form vereint.

Unsere Kenntnisse der Gruppe sind noch sehr mangelhaft, in den letzten Jahren aber zumal von BRAND (1903) sehr vermehrt worden; versuchen wir also an der Hand seiner Arbeit eine Einsicht in die Morphologie dieser Gewächse zu gewinnen.

Bei den Cyanophyceen gibt es eine Anzahl verschiedener Zellenarten, welche entweder eine größere Widerstandsfähigkeit besitzen wie die vegetativen Zellen, oder in irgend einer Weise in Verbindung mit der Fortpflanzung dieser Organismen stehen und welche früher mit dem Kollektivwort: Sporen angedeutet wurden.

Wir unterscheiden jetzt:

1) Dauerzellen

2) Grenzzellen

3) Gonidien.

Betrachten wir zunächst die

D a uerzellen.

Man nannte allgemein Dauerzellen gewöhnliche vegetative Zellen, welche durch Bildung einer dicken Membran und Anhäufung von Reservesubstanzen im stande sind, eine Ruhezeit durchzumachen und erst kurz vor der Keimung in ihrem Innern eine neue Membran bilden und noch eine während der Keimung entstehen lassen.

Diese Dauerzellen wurden von AL. Braun Sporen, von v. Tieghem Cysten, von Wille ruhende Akineten, von Sauvageau bei Nostoc Etat coccoide genannt.

Die hier abgebildeten Dauerzellen von Entophysalis (Chroococcaceae), von Nostoc, Anabaena, Cylindrospermum, Microchaete (sämtlich Nostoc- 
caceae) und ron Hapalosiphon (Stigonemataceae) geben eine Vorstellung dieser Art von "Sporen“.

Man meinte also allgemein und auch Brand ist solcher Meinung, daß kurz vor der Keimung der Dauerzellen innerhalb der ursprünglichen Zellwand eine neue Membran um das Plasma herum gebildet würde, so daß, wenn auch spät, doch schließlich eine Endospore gebildet würde.

In letzter Zeit ist Fritsch, wie mir scheint aus guten Gründen, dieser Auffassung entgegengetreten. Seiner Meinung nach wird höchst wahrscheinlich gar keine neue Zellwand gebildet, sollte dies aber dennoch der Fall sein, so ist nicht die innere Schicht der reifen Sporen die jüngste, sondern gerade die äußere.

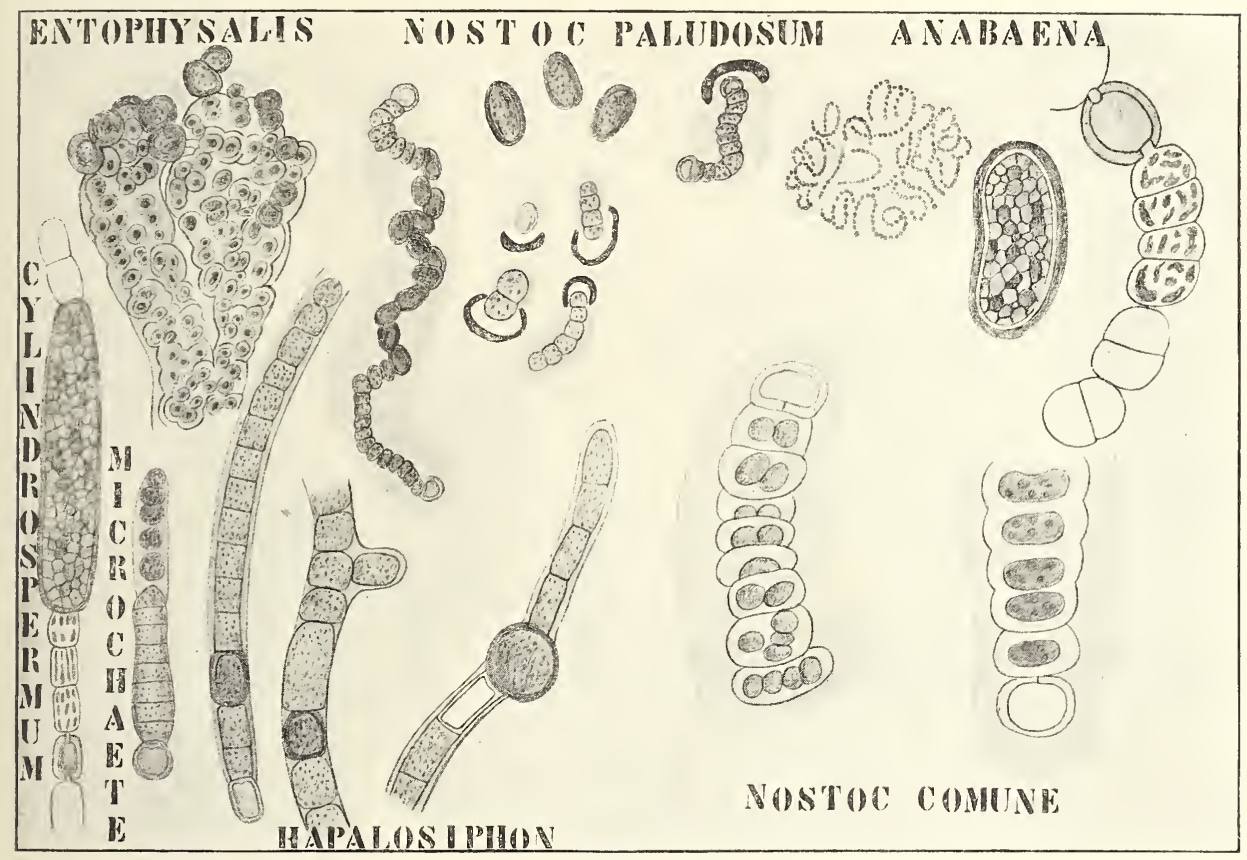

Fig. 229. Dauerzellen verschiedener Cyanophyceen (nach ENgLeR u. Prante und BRAND).

Zum Begriff dieser Auffassung ist es nötig, zunächst den Bau einer Anabaena in vegetativem Zustande kennen zu lernen.

Anabaena ist eine Alge, welche in einer dicken Schleimhülle dünngallertartiger Konsistenz eingeschlossen ist. Von einer Zellwand ist bei jungen Individuen recht wenig zu sehen (Fig. 230, 1), nur die Querwände sind deutlich sichtbar. Dennoch lassen sich auch die Längswände sichtbar machen. Sowohl diese letzteren wie die Querwände sind, wie Brand schon mittels Plasmolyseversuchen nachwies, sehr elastisch, viel elastischer wie die Zellwände der grünen Algen z. B., und Fritsch hält sie denn auch für wenig mehr wie für verdichtetes Plasma. Diese elastische Zellwand schließt also, soweit wir wahrnehmen kömmen, direkt an die umgebende Schleimhülle an, und läßt sich am besten mit der 
Gomontschen Methode sichtbar machen durch Behandlung mit 33-proz. Chromsäure, welches stark oxydierende Reagens innerhalb einer Stunde das Plasma fast gänzlich löst und nur die Zellwand zurück läßt.

Die elastische Natur der Querwände, die erlaubt, daß diese bisweilen stark ausgezogen und entsprechend schmäler werden können (Fig. 230, 3), hat vermutlich Anlaß gegeben zu der Meinung von Borzi, NADson u. a., daß die Zellen der Cyanophyceen in der Weise der Florideen, mittels breiter Plasmastränge, miteinander kommunizierten.

Dieser Irrtum wurde um so leichter begangen, als die Querwände sich bei Behandlung der Fäden mit verschiedenen Reagentien, z. B. mit Methylenblau kontrahieren, wodurch sie ebenfalls viel schmäler werden (Fig. 230, 5).

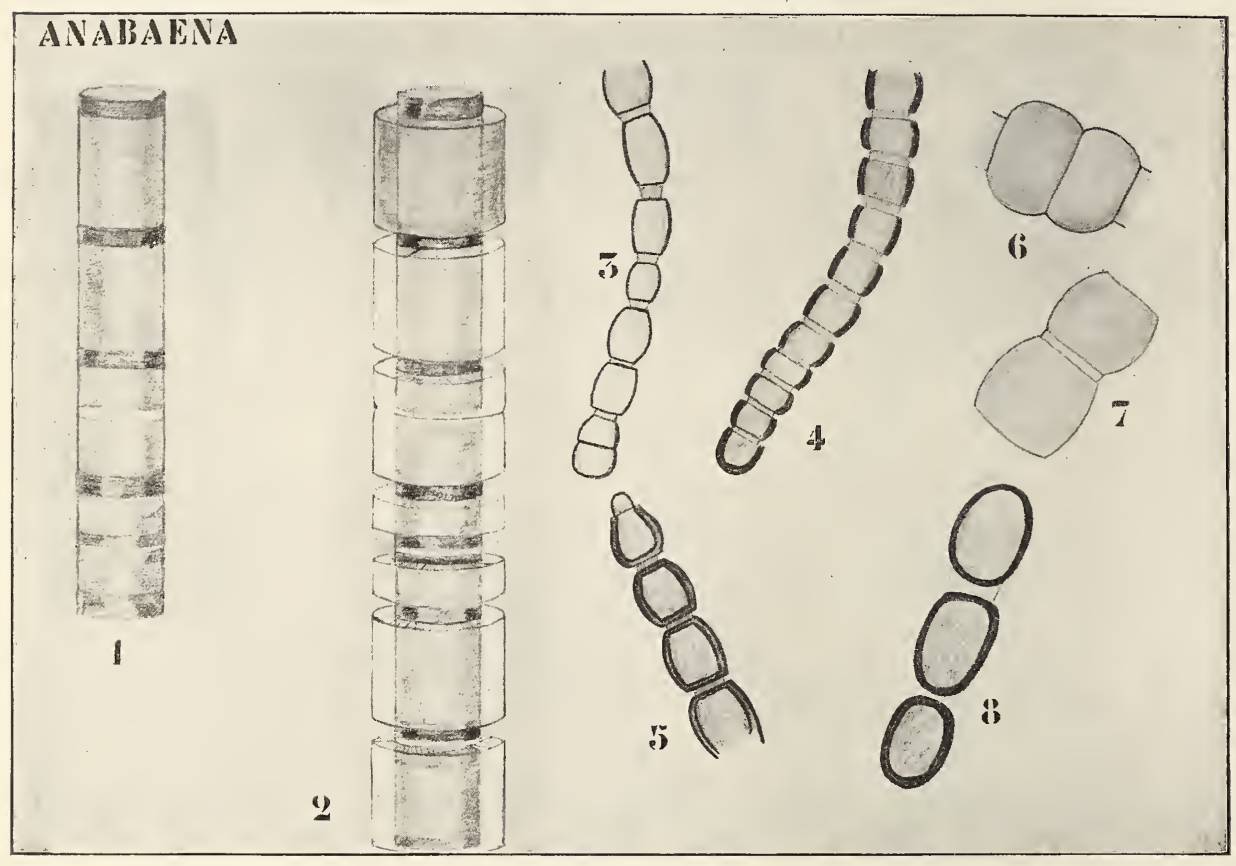

Fig. 230. Sporenbildung bei A n a baen a (nach FrITSCH). 1-2 Schematische Figuren, nach seiner Darstellung konstruiert.

Es ist diese Aufklärung nicht ohne Wichtigkeit, da damit eins der Argumente fortfällt, die Florideen via Bangiaceen von den Cyanophyceen abzuleiten.

Wir haben schon gesehen, daß die Zellen der Cyanophyceen sich teilen, indem sie einen Ringwall bilden, der zum Diaphragma wird und sich schließlich spaltet, wodurch er den neuen, natürlich hart aneinander liegenden Querwänden das Dasein gibt. In der dritten Zelle der Fig. 230, 1 ist dieses Diaphragma in jungem Zustande angegeben, in der unteren Zelle sind die jungen Querwände, zur Illustration des Spaltungsvorganges, in geringer Entfernung voneinander gezeichnet worden.

Untersucht man nun einen Faden, der alsbald Sporen bilden wird, so trifft ein ganz anderes Bild unser Auge (Fig. 230, 2), zwischen der 
Schleimhülle und dem Faden ist eine neue Schicht eingeschoben: eine Scheide, welche aber nicht den ganzen Faden gleichmäßig überzieht, sondern an der Grenze zwischen je 2 Zellen unterbrochen ist, so daß jede Zelle für sich in einer zylindrischen, beiderseits offnen Schleimscheide steckt (Fig. 230, 2). Die Scheiden befinden sich nur um die lebenden Teile der Zelle herum, die Querwände sind scheidenlos.

Aus Behandlung mit 38-proz. Chromsäure geht hervor, daß diese Scheiden viel leichter löslich sind wie die Zellwände, so daß sie vermutlich nur als ein spezialisierter Teil der gemeinsamen Schleimhülle zu betrachten sind.

Falls dies richtig ist, und das scheint in der Tat der Fall zu sein, zeigt auch der von BRAND beschriebene, alsbald zu besprechende Nostoc nicht einen so abweichenden Fall, wie man auf den ersten Blick geneigt wäre, anzunehmen.

Wahrscheinlich ist diese unterbrochene Scheide schon bei erwachsenen vegetativen Anabaena-Fäden vorhanden, und die Sporenbildung beruht nur auf einer gesteigerten Scheidenbildung, ohne daß etwas Neues gebildet wird.

Will man aber in solchen bescheideten Fäden junge sporogene Fäden sehen, so folgt aus Fritschs Beobachtungen wenigstens, daß bei der Sporenbildung nicht eine neue Wand innerhalb der Dauerzelle, sondern im Gegenteil um die Zelle herum gebildet wird.

Nennen wir nun, der leichteren Andeutung wegen, diese bescheideten Fäden sporogene Fäden, so sehen wir, daß solche junge, sporogene Fäden noch teilungsfähig sind. Die Teilung geschieht in ähnlicher Weise wie bei den jungen vegetativen Fäden, nämlich durch Bildung einer zunächst ringförmigen Querwand; aber hier entsteht auch in der Scheide eine ringförmige Einschnürung (Fig. 230, 2, dritte Zelle von oben, Fig. 230, 6, 7), so daß auch die Scheiden geteilt werden. Die Scheidenteilstücke werden nun durch die sich streckenden Querwände auseinander getrieben, und, da die Querwände später aus der Scheide hervorragen, müssen die Scheidenteilstücke sich kontrahieren (Fig. 230, 2, vierte Zelle von oben).

Wenn ein solcher Faden nun zur Sporenbildung schreitet, strecken sich zunächst die Querwände und quellen dabei in solchem Grade, daß sie ohne Reagentien unsichtbar werden, die zylinderförmige Scheide wächst nun nach beiden Seiten aus, biegt sich an den Enden, indem sie durch die verschleimende Querwand hindurchwächst, um (Fig. 230,3-5), und es entstehen so Dauerzellen (Fig. 230, 8), deren jede also ganz in einer zu einer Hohlkugel umgebildeten Scheide eingeschlossen ist.

Jede Dauerzelle besitzt also zwei vollständige Integumente: die Zellwand und die aus der Scheide entstandene äußere Schicht oder das Exosporium.

Das ist nun offenbar die Weise, in welcher in der Regel Dauerzellen gebildet werden; die Meinung, es entstehe die innere Schicht zuletzt, beruht wohl auf dem Umstand, daß die eigentliche Zellwand in den vegetativen Fäden sehr schwer zu sehen ist und er'st in der Dauerzelle gut sichtbar wird.

Meistens sind die Dauerzellen größer wie die vegetativen und in der Regel ist ihre Membran verdickt, stets sind sie gelb oder braun gefärbt.

Es gibt aber Ausnahmen: so sind die Dauerzellen von Wicrochacte tenera nicht größer wie vegetative Zellen, und die Ruhezellen von 
Nostoc commune besitzen nur eine dünne Membran, werden dagegen von einer speziellen Schleimhülle umgeben.

Falls Fritschs Auffassung richtig ist, weicht Nostoc commune also nur wenig vom normalen Verhältnis ab; stellt man sich die Schleimscheide von Anabaena etwas schleimiger und dadurch etwas mehr gequollen vor, so haben wir den Fall von Nostoc commune.

\section{Grenzzellen oder Heterocysten}

gibt es in den Familien der Nostoccaceen, Scytonemataceen, Stigonemataceen und Rivulariaceen. Sie bilden sich nicht, wie die Dauerzellen, zu bestimmten Zeiten, sondern sind stets vorhanden. Je nachdem sie am Ende eines Fadens (Rivularia), oder auch in der Mitte eines solchen

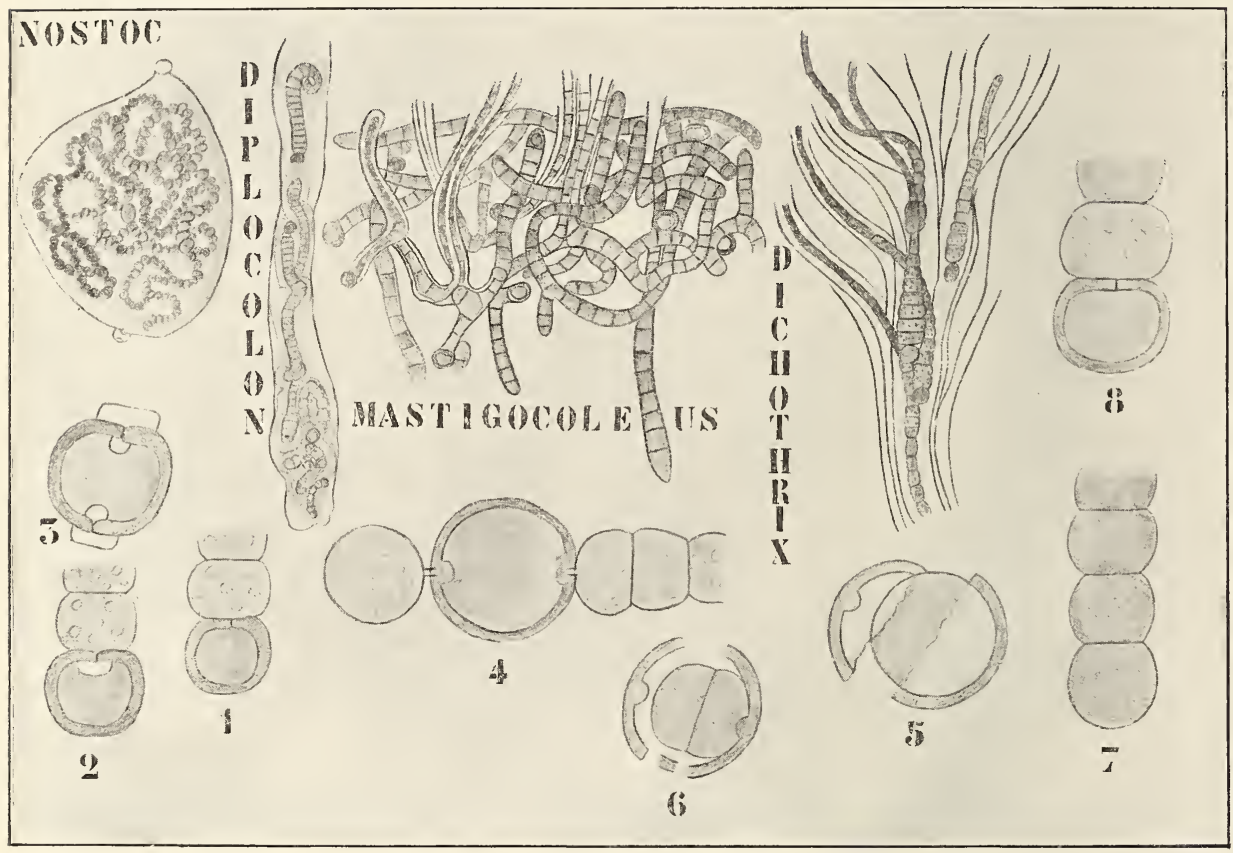
Brand).

Fig. 231. Grenzzellen bei den Cyanophyceen (nach Evgler u. Prantl und

vorkommen (Anabaena), spricht, oder lieber gesagt, sprach man von basalen und interstitialen Zellen.

Auch in diesem Punkte zeigen uns die verschiedenen Meinungen der Cyanophyceen-Forscher, daß noch gar manches zu untersuchen ist. Nach Borzi sind die Grenzzellen wassergefüllte, leere Zellwände.

Hieronymus, Hegler u. A. halten sie für Reservestoffe enthaltende Organe.

Brand sah aus ihrem Inhalt neue Pflänzchen entstehen. In diesem Falle verhielten sie sich also als Fortpflanzungsorgane, als Sporangien, oder, wie er es nennt, als Gonidangien; BraND meint jedoch, daß dies nicht ihre normale Funktion sei, daß im Gegen- 
teil die Grenzzellen reservestoffhaltige Organe sind, welche nur ausnahmsweise selber keimen.

Gegen Borgis Auffassung führt er an, daß er bei Tolypothrix Teilung von Grenzzellen gesehen hat, was offenbar unmöglich wäre, wenn die Grenzzelle eine leere Zelle wäre.

Koнl glaubt zwar nicht, daß die Grenzzellen, wie Borzi will, nur Wasser enthalten, beschreibt aber eine starke Degeneration ihres Inhalts, welche es seines Erachtens unmöglich machte, daß sie, wie Brand will, keimen können.

Auch hält er sie nicht für reservestoffhaltige Organe im gewöhnlichen Sinne des Wortes, da sie ihren Inhalt nur zur eigenen Vergrößerung und zur Verdickung ihrer Membran verwenden sollen. Da die Heterocysten bei den mit einer Scheide versehenen Cyanophyceen mit dieser Scheide verwachsen, meint Kонц, daß sie Stützpunkte für die ausschlüpfenden Hormogonien darstellen, sowie bei der Verzweigung der betreffenden Cyanophycee als solche dienen könmen, da die Zellen sonst nur lose in den Scheiden liegen.

Alle Autoren sind darin einig, daß die Heterocysten aus gewöhnlichen Zellen entstehen. Die meisten nehmen dabei an, daß die Poren, wodurch sie mit benachbarten Zellen in Verbindung stehen, durch Cyanophycinkörnchen verstopft werden, daß sich dann die Zelle vergrößert, der Inhalt verschleimt und die Wand sich verdickt.

Diese Auffassung basiert auf der Meinung, daß die Zellen der Cyanophyceen mittels breiter Plasmastränge miteinander in Verbindung. stehen; ist dies nun, wie Fritsch meint, nicht richtig, sind die vermeintlichen Plasmaverbindungen nur kontrahierte Querwände, so ist es nicht klar, wozu solche verschließende Cyanophycinkörner dienen sollten.

Brand sagt aber, daß die Poren erst entstehen, wenn sich eine Zelle zur Heterocyste umbilden will und erblickt darin gerade das erste Zeichen einer solchen Umbildung; falls dies richtig ist, ist die Rolle der Cyanophycinkörner leicht einzusehen.

Die Sache würde sich dann etwa so verhalten: Der junge Heterocyst bildet zunächṡt offene Kommunikationen mit den benachbarten Zellen, wodurch er Substanz von diesen erhalten kann, darauf schließt er diese Kommunikationen wieder ab und verwendet die erhaltenen Substanzen in erster Linie zum eigenen Wachstum und zur Verdickung seiner Membran (Fig. 231, 1-4).

Meiner Ansicht nach sind die Heterocysten zu reservesubstanzhaltigen Organen verwandelte Sporangien. Ist dies richtig, dann ist leicht einzusehen, daß die Bildung der Kommunikationsöffnungen die Ernährung der Fortpflanzungszellen förderte.

$\mathrm{Zu}$ dieser Auffassung gelange ich durch Brands Beobachtung keimender Heterocysten; eine Beobachtung, welche zwar noch nicht ron anderen Seiten bestätigt wurde, aber an deren Richtigkeit wohl nicht gezweifelt werden kann. Schon Pringsherm hatte nachgewiesen, daß die Grenzzellen nicht so hochgradig degenerierte Zellen sein kömnen als viele meinen, da er Grenzzellen von Rivularia wieder ergrünen sah.

In seinem Artikel über Grenzzellen teilt Brand (1901) folgendes darüber mit.

Keimung von Grenzzellen sieht man bei Nostoc commme nur dann. wenn die Thalli stark eingetrocknet sind und dam befeuchtet werden. In solchen Thalli findet man neben leeren geschrumpften Heterocysten 
auch eine Anzahl normaler. Bei Regenwetter springt die Membran, wie schon Bornet und Flahault sahen, öfters entzwei, und der homogene Inhalt tritt als elastisches Plasmaklümpchen heraus (Fig. 231, 5). Der Inhalt teilt sich alsbald, öfters sogar bevor die Membran abgeworfen ist (Fig. 231, 6) und es bilden sich daraus kleinzellige zunächst fast graue Fäden (Fig. 231, 7), welche aber grüner und grüner werden, bis sie schließlich das Aeußere normaler Nostoc-Fäden erhalten (Fig. 231, 8).

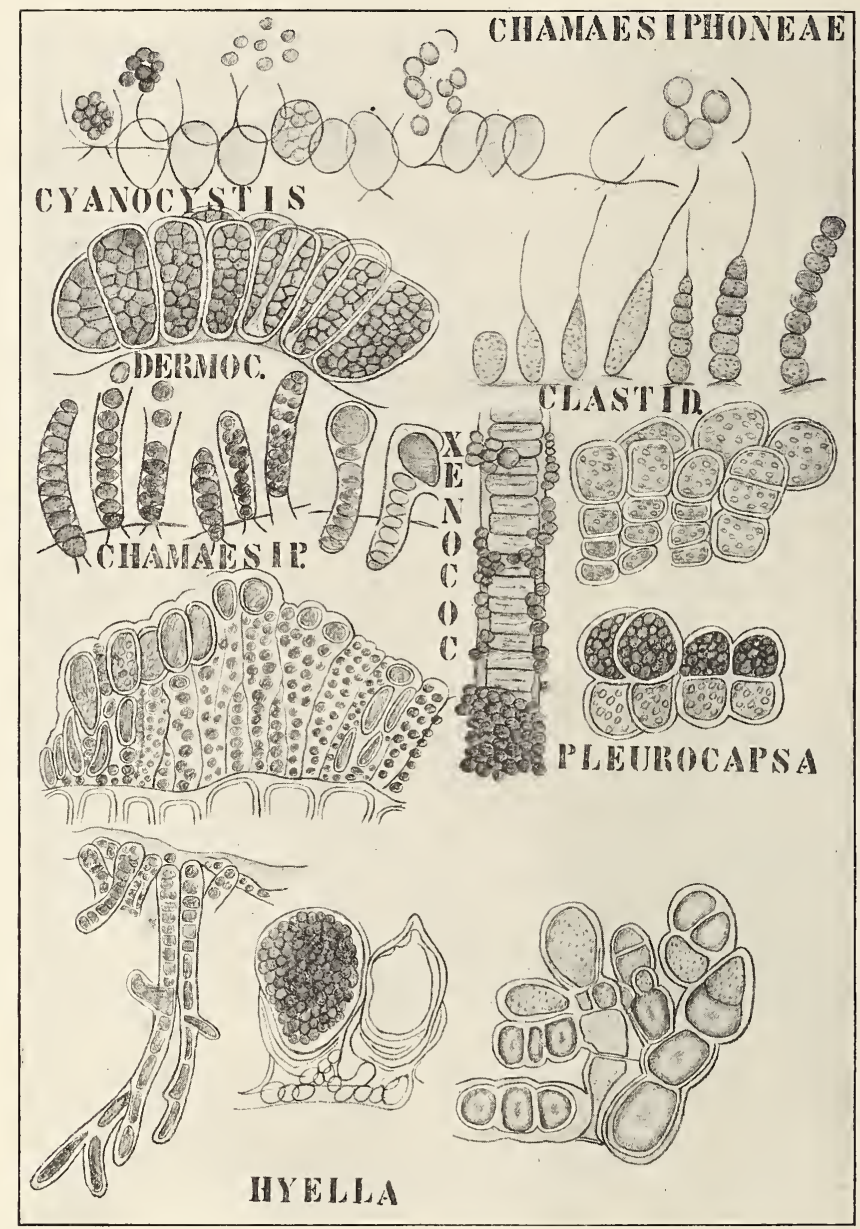

Fig. 232. Chamaesiphone en (nach Engler und Prantu).

Sind die Heterocysten in der Tat ursprünglich Sporangien gewesen, so sind sie denjenigen Organen homolog, welche die CyanophyceenKenner

$$
\text { Gonidangien }
$$

nennen, die ich aber lieber mit dem Namen Sporangien bezeichnen möchte. 
Normaliter kommen sie nur bei einer Cyanophyceen-Familie ror, bei den Chamaesiphoneen.

Darunter befinden sich einzellige Organismen, wie Cyanocystis und Dermocarpa, welche sich nie vegetativ teilen, sonderen deren Inhalt ganz in sogenannte Gonidien auseinanderfällt. Das Organ, in welchem diese entstehen, eine umgewandelte vegetative Zelle, ist also offenbar ein Sporangium, die Gonidien Akinetosporen.

Bringt man damit Goebels Beobachtung in Verbindung, daß bei Merismopoedia Zoosporen gebildet werden, so liegt es auf der Hand, die Gonidien als modifizierte Zoosporangien zu betrachten.

Bei den hölieren Chamaesiphoneen gibt es wohl Zellteilung und die Gonidien werden nicht in jeder Tlialluszelle, sondern in bestimmten Gonidangien gebildet (vergl. Fig. 232 Hyclla).

Ich bin also geneigt, folgenden Entwickelung'sgang nicht für unwalırscheinlich zu halten:

1) Vegetative Zellen werden zu Zoosporangien.

2) Gleichfalls, die Zoosporenbildung wird aber nicht mehr beendet, Cilien nicht mehr gebildet, der Inhalt fällt also in Akinetosporen auseinander.

Merismopoedia

3) Die Reduktion geht weiter, der Zoosporangiuminhalt keimt entweder als Ganzes oder aber es hat das Zoosporangium das Vermögen zur Weiterentwickelung ganz eingebüßt und ist zum bloßen Reservestoffbehälter geworden: die Heterocysten oder Grenzzellen

Chamaesiphoneae

Konkavzellen

kommen bei vielen Cyanophyceen vor; nach Kонц sind es Zellen, welche einem Verschleimungsprozeß erliegen, wodurch sie schließlich ein homogenes glasähnliches Aeußere bekommen. Die Form dieser konkaven Zellen: plankonvex, bikonvex oder konvex-konvex, ist die Folge eines von den benachbarten Zellen ausgeübten Druckes.

Diese Konkavzellen erlauben das Auseinanderfallen der Fäden in Hormogonien und tragen daher öfters den Namen Spaltkörper, scheinen auch Verschleimungszentren zur Erweichung der Scheide zu sein, wodurch das Ausschlïpfen der Hormogonien, sowie der Austritt der Verzweigungen ermöglicht wird, denn wenn diese angelegt werden, findet man stets Konkavzellen, während Grenzzellen dabei zwar ebenfalls gebildet werden, aber öfters erst nachdem der Seitenzweig schon beträchtlich gewachsen ist.

Nach Brand würden die Konkavzellen überhaupt keine Zellen sein, sondern nur Intercellularsubstanz, eine Meinung, welche mir nicht genügend bewiesen vorkommt.

Nekriden, Spaltkörper, „anneaux blanes", "Konkavzellen" sind wohl sämtlich Ausdrücke für den gleichen Zustand, nämlich Degenerationszustände normaler vegetativer Zellen.

Beim Auseinanderfallen eines Fadens in Hormogonien bleibt so eine stark lichtbrechende Konkavzelle öfters am Ende eines Hormogoniums kleben, so daß die sich aus dem Hormogonium entwickelnden Fäden dann eine Kapuze, eben diese Konkavzelle, tragen (vergl. Fig. 233 Oscillaria auf S. 383). 
Wir haben schon öfters das Wort

\section{Hormogonien}

für sich bewegende Fadenstücke von Cyanophyceen verwendet. Es sind diese Hormogonien die wirksamsten Fortpflanzungsorgane in der ganzen Gruppe der Cyanophyceen mit Ausnahme der der Chamaesiphoneen.

Wir wissen, daß viele erwachsene Cyanophyceen, z. B. Oscillarien, sich bewegen können. Diese Bewegung kann nur dann stattfinden, wenn die Oscillaria teilweise an irgend einer festen Substanz ankleben kann oder in einem genügend Widerstand bietenden Medium, z. B. sich in Gelatine befindet. Letzteres wurde von CorResss (1897) nachgewiesen. Die Bewegung kommt dadurch zu stande, daß die Oscillarien eine dünne Schleimschicht ausscheiden und nun aus dieser Schleimröhre herauskriechen, wobei das hervortretende Ende immer wieder Schleim ausscheidet, bald aber auch aus diesen wieder herauskriecht. Dabei drehen sie sich um ihre Achse und dadurch kommt, wenn der Faden nur an einem Ende verklebt ist, eine rotierende Bewegung zu stande.

Das ist nun recht schön, aber CoRrens bemerkt mit Recht, daß dadurch die eigentliche Bewegung keineswegs erklärt ist, denn man weiß nicht, wie die Oscillaria aus der Schleimhülle herauskriecht.

Zur Erklärung der Bewegungen der Oscillarien sind 4 verschiedene Hypothesen aufgestellt worden: 1) Bewegung mittels Cilien, 2) mittels einer peripherischen extracellulären Plasmaschicht, 3) durch Wasser- oder Schleimausstoßung, 4) mittels Kontraktionen. Die erstere ist recht unwahrscheinlich, die letztere die wahrscheinlichere, trotzdem nicht alle Bewegungsweisen dadurch erklärt werden, die große Elastizität der Zellmembranen würde eine solche Kontraktion sicher erlauben.

Sicher ist also nur, daß die Oscillarien sich bewegen und dabei um ihre Längsachse sich drehen.

Was nun die Hormogonien anbelangt, so bewegen sich diese immer, auch wenn die zugehörige erwachsene Cyanophycee dies nicht tut.

Der Hauptunterschied zwischen der Bewegung der Hormogonien und jener der erwachsenen beweglichen Cyanophyceen scheint darin zu liegen, daß erstere auch schwimmen können, d. h. sich bewegen ohne Kontakt mit einem festen Substrat, letztere nicht.

Für erstere genügt also die Reibung gegen das Wasser, für letztere nicht, was darin seinen Grund haben mag, daß die Bewegungskraft der ersteren größer ist wie die der letzteren. Möglicherweise bewegen sich also auch die schwimmenden Hormogonien durch Herauskriechen aus einer Schleimscheide. Für weitere kompliziertere Bewegungen muß ich auf Brands (1903) Studie verweisen.

Nachdem wir uns also einigermaßen über die Cytologie und die Morphologie der Cyanophyceen orientiert haben, müssen wir uns der Systematik dieser Organismen zuwenden.

Daß wir bei unserer recht mangelhaften Kenntnis dieser Organismen keineswegs im stande sind, ein phylogenetisches System aufzustellen, braucht wohl nicht betont zu werden, sogar muß z. B. die jetzt nicht beantwortungsfähige Frage gestellt werden, ob die Familie der Chamaesiphoneae überhaupt wohl zu den Cyanophyceen gehört.

Dennoch können vielleicht wohl einige Verwandtschaftspunkte erwähnt werden. Sehr interessant scheinen mir in dieser Hinsicht Fritschs Beobachtungen über den vegetativen Aufbau vieler Cyanophyceen, welche in Verbindung mit gewissen Eigentümlichkeiten bei der Zellteilung, sowie 
mit unserer Auffassung ïber die Natur der Grenzzellen wohl zu einer Anordnung führen können, welche wenig'stens mögliche Verwandtschaftslinien diagrammatisch, mehr nicht, andeutet.

Als niedrigste Gruppe ist gewiß die Familie der Chroococcaceen zu betrachten, zu welcher unter anderen die Genera Aphanocapsa, Aphanothece, Synechococcus, Gloeocapsa, Gloeothece und Merismopoedia gehören. Im allgemeinen können sie sich ausschließlich durch Teilung vermehren,

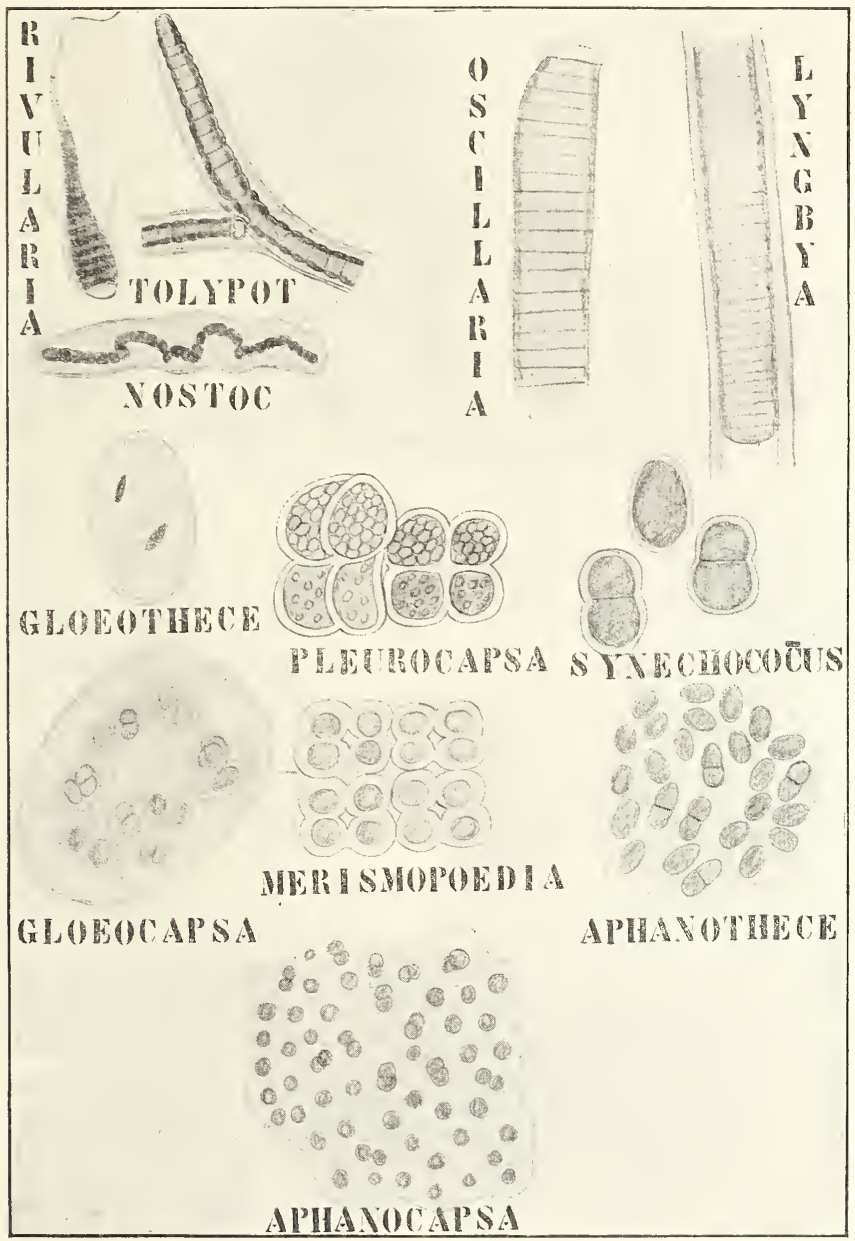

Fig. 233. Cyanophyceen nach möglichen Verwandtschaftslinien angeordnet.

Merismopoedia ist dagegen nach GoEBEL im stande. Schwärmsporen zu bilden. Falls dies richtig - es wurde nur einmal beobachtet - würde sich an diese Form die Gruppe der Chamaesiphoneen, z. B. Pleurocapsa, leicht anschließen lassen durch Umbildung der Schwärmsporen in Akinetosporen.

Aus diesen niedrigen Formen müssen die höheren entstanden seim, und dabei lassen sich zwei Entwickelungsreihen auffinden, deren eine 
in Rivularic und Tolypothrix, deren andere in Oscillaria und Lyngbya endet. In der Rivularia-Reihe besitzt jede Zelle ihre eigene Scheide, wie vorher bei Anabaena beschrieben, in der Oscillaria-Reihe ist nur eine allen Zellen gemeinsame Scheide vorhanden.

Wo die Familie der Stigonemataceen mit echter Verzweigung statt der für Cyanophyceen üblichen Scheinverzweigung unterzubringen ist, ist noch unklar, vielleicht hängt sie mit Formen wie Tolypothrix zusammen.

Wir würden uns also folgenden Entwickelungsgang denken können. Bei Aphanocapsa eine Teilung in allen Richtungen des Raumes, bei Gloeocapsa diese auf drei senkrecht zueinander stehende Richtungen beschränkt. Von Gloeocapsa kọnnte durch Beschränkung der Teilung auf eine Richtung des Raumes eine Form wie Gloeothece abgeleitet werden, wobei jede Zelle ihre eigene Scheide behält. Durch das Dünnflüssigwerden der äußeren Zellwandschicht könnte nun Schleim entstehen, wie wir dies z. B. bei Nosioc und Rivularia um die Zellen herum wahrnehmen, und durch schnell aufeinander folgende Teilungen in einer Richtung würden die Scheiden der einzelnen Zellen nicht mehr vervollständigt, sondern zu offenen Cylindern reduziert werden.

In gleicher Weise wie Gloeothece kann man sich Aphanothece und Synechococcus entstanden denken, bei Synechococcus werden sogar unter Umständen kurze Fäden gebildet. Auch hier wird die äußere Schleimschicht stets dünner, der Schleim von Oscillaria entzieht sich fast stets der Beobachtung, aber die Scheide, welche bei Nostoc z. B. an den Querwänden unterbrochen wird, bildet bei Oscillaria und bei Lyngbya - bei letzterer ist sie ihrer Derbheit wegen leicht zu sehen - eine die Zellen eng umschließende ununterbrochene Schicht.

Die hier skizzierte Entwickelung stimmt ziemlich gut mit der üblichen Einteilung der Cyanophyceen in Familien überein.

Aphanocapsa, Merismopoedia, Aphanothece, Synechoccocus und Gloeothece gehören sämtlich zu den

Pleurocapsa ist eine . . . . . . . . .

Nostoc gehört zu den

Rivularia zu den

Tolypothrix zu den

Lyngbya und Oscillaria zu den .

Chroococcaceen

Chamaesiphonee

Nostoccaceae

Rivulariaceen

Scytonemataceen

Es bleibt also nur noch die Familie der Stigonemataceae, welche, wie bemerkt, durch ihre echte Verzweigung abweicht, übrig, sie steht wohl mit den Scytonemataceen in Relation.

Wir bemerkten anfangs, daß viele Cyanophyceen mit Pilzen zusammen Flechten bilden, diese werden wir erst später bei den Lichenen, wenn nötig, behandeln.

Als letzte Gruppe der Schirophyten bleibt die der Myxobakterien übrig, zu deren Besprechung wir jetzt übergehen wollen. 


\section{Sechzehnte Vorlesung.}

\section{Die Myxobakterien.}

Die Myxobakterien sind erst seit kurzem bekannt, ja ihre Existenz wurde sogar überhaupt noch vor kurzem bezweifelt. Zwar waren schon seit lange hierhergehörige Organismen bekannt, aber ihre SchinophytenNatur wurde nicht erkannt.

Eine von diesen Formen, Chondromyces, wird nicht selten auf alten Rindenstücken, Moosen, Flechten u. dergl., als rote, plasmodiumähnliche Bildungen von der Größe eines Stecknadelkopfes angetroffen.

In der Weise der Myxomyceten, d. h. also ohne Bildung von Hyphen oder ähnlichen Organen werden daraus Aspergillus-ähnliche Fruchtkörper gebildet (vergl. die Figuren von Chondromyces catenulatus und pediculatus auf S. 389), welche einfache oder verzweigte Sterigmaähnliche Zweige tragen.

Dieser Organismus wurde 1857 von Berkeley als ein Hyphomycet, unter dem Namen Chondromyces crocatus B. et C., beschrieben.

1892 erkennt ThaхтеR die Schinophyten-Natur dieses Organismus und gründet auf ihn und einige verwandte Formen die Gruppe der Myxobaliterien.

Inzwischen hatte ZukaL (1896) diesen Organismus, ohne von BerkeLEys oder Thaxters Untersuchungen zu wissen, als Myxomycet, als Myxobotrys variabilis ZukaL beschrieben.

Von drei Untersuchern also, welche jeder für sich diesen Organismus entdeckten, stellt ihn einer zu den Hyphomyceten, einer zu den Myxobakterien und einer zu den Myxomyceten. Gruppe.

Nicht viel besser erging es dem ältesten bekannten Mitgliede dieser

Polyangium vitellinum Link wurde 1795 von Link in seinen Dissertationes botanicae als Gastromycete beschrieben, 1851 von Bonordon in seinem Handbuch der allgemeinen Mykologie für Insekteneier erklärt.

1892 erkennt Thaxter ihn als Myxobalkterie und nennt ihn Myxobakter, welcher Name also durch Polyanginm zu ersetzen ist. ZUKaL und LipPeRT dagegen hielten ihn für einen Myxomyceten. Diese oder eine verwandte Art wird von Schröter auf S. 170 des 3. Bandes der Kryptogamenflora von Schlesien als Cystobaliter beschrieben und zu den Bakterien gestellt, so daß SCHRöTer zuerst die Myxobaliterien als Schi:opluyten erkannt hat; Thaxters Arbeit von 1902 legt aber den Grundstein für unsere Kenntnisse, und ihm gebührt ansschließlich die Ehre, die Gruppe der Myxobaliterien als solche erkannt zu haben. 
Wir sahen schon, daß Zukal 1896, ohne Thaxters Untersuchungen zu kemnen, eine Myxobakterie als Myxomycet beschrieb. 1897 hat ZuraL ThнхтеRs Werk kennen gelernt, meint aber noch an der Myxomycetennatur dieses Organismus festhalten $\mathrm{zu}$ müssen, sagt aber, daß er mit Reinkulturen beschäftigt ist und erst später ein definitives Urteil wird abgeben können. Im gleichen Jahre, gibt er unumwunden $\mathrm{zu}$, daß THAхтеR recht hatte, und daß man hier mit einer Myxobakterie zu tun hat.

Das gleiche Jahr sieht eine Publikation Thaxtens (1897) über Myxobakterien erscheinen, in welcher eine Anzahl neuer Formen beschrieben werden.

Trotzdem genügt sogar der. reichlich verdiente Ruf, den ThaxteR als Mykologe genießt, nicht, um jegliches Mißtrauen der Botaniker zu überwinden. In Migulas System der Bakterien werden sie bloß in der Einleitung erwähnt, im systematischen Teil fehlen sie; die, Pflanzenfamilien" nennen sie nicht und auch WETTsteIN erwähnt sie nur gelegentlich in seinem Handbuche der systematischen Botanik (Bd. I, S. 70).

Seit THaxters zweiter Verhandlung ist wenig über unsere Gruppe erschienen. Miss A. L. Suгтн beschreibt 1903 einen neuen Repräsentanten der Gruppe unter dem Namen Myxococcus pyriformis $\mathrm{n}$. spec. und im Mai des gleichen Jahres erschien eine Abhandlung von der Hand E. Zederbaurs (1903), in welcher die Myxobalterien als nicht existierend geschildert werden, und in der behauptet wird, die so genannte Gruppe von Organisman seien symbiotisch lebende Bakterien und Hyphomyceten, für welche der Namen Spaltpilzflechten ausgedacht wird. Aus einem vom Autor an Thaxter geschickten Präparat geht aber hervor, daß ZEDERBAUR keine einzige echte Myxobalterie untersucht hat; es entpuppte sich z. B. Material, welches er als Chondromyces glomeratus betrachtete, als Coryne sarcodes (JAC.) TuL = Tremella sarcodes Fries, wie aus der dritten Verhandlung THAxтеRs (1904) über die Myxobakterien hervorgeht. Das wurde übrigens auch in einer im gleichen Jahre, wohl ungefähr gleichzeitig ${ }^{1}$ ), erschienenen Arbeit BAUns (1904) vermutet, denn er sagt: "Ich bin überzeugt, ZEDERBAUR hat überhaupt nie ein richtiges Myxobakterium gesehen, sonst hätte er eine derartig verkehrte Ansicht ganz unmöglich vertreten können."

$\mathrm{Zu}$ den niedrigsten Repräsentanten der Gruppe der Myxobalterien gehört das Genus

\section{Myxococeus,}

und da gerade eine der Arten dieses Genus: Myxococccus ruber Baur, durch die Freundlichkeit des Autors, in den "Pilzkulturen" der Association internationale des Botanistes vertreten und so einem jeden zugänglich ist, fangen wir unsere Betrachtungen mit dieser Art, an der Hand von Baurs Untersuchungen an.

Myxococcus ist ein sporenbildendes Genus, während die beiden anderen bekannten Genera: Polyangium und Chondromyces keine Sporen bilden.

Myxococcus ruber ist auch in Europa nicht selten. Wie die meisten Myxobakterien ist er ein Mistbewohner, kommt aber ebensowenig wie diese auf frischem Mist vor, trotzdem sich solcher sehr gut als Kulturmedium verwenden läßt. Die Myxobakterien sind demnach nicht schon

1) Denn weder der eine noch der andere erwähnt diese Arbeit seines Kollegen. 
im Darmkanal der Herbivoren vorhanden, sondern fallen aus der Luft auf den Mist derselben.

Will man sich also Myxobaliterien verschaffen, so muß man Mist sammeln, der wenigstens \& Tage im Freien gelegen hat. Bringt man solchen Mist in eine feuchte Kammer, so kann man ziemlich sicher sein, 8-1t Tagen nach dem Abblühen der Mucorineen irgend eine Myxobaliterie zu erhalten, am sichersten gelingt dies, wenn man die Mistkultur vom Anfang an bei einer Temperatur von $30-35^{\circ} \mathrm{C}$ dunkel hält. Dann entwickeln sich Mucor, Pilobolus und viele andere Fungi nicht, während gerade das Optimum für die Entwickelung der Myxobaliterien bei dieser Temperatur liegt.

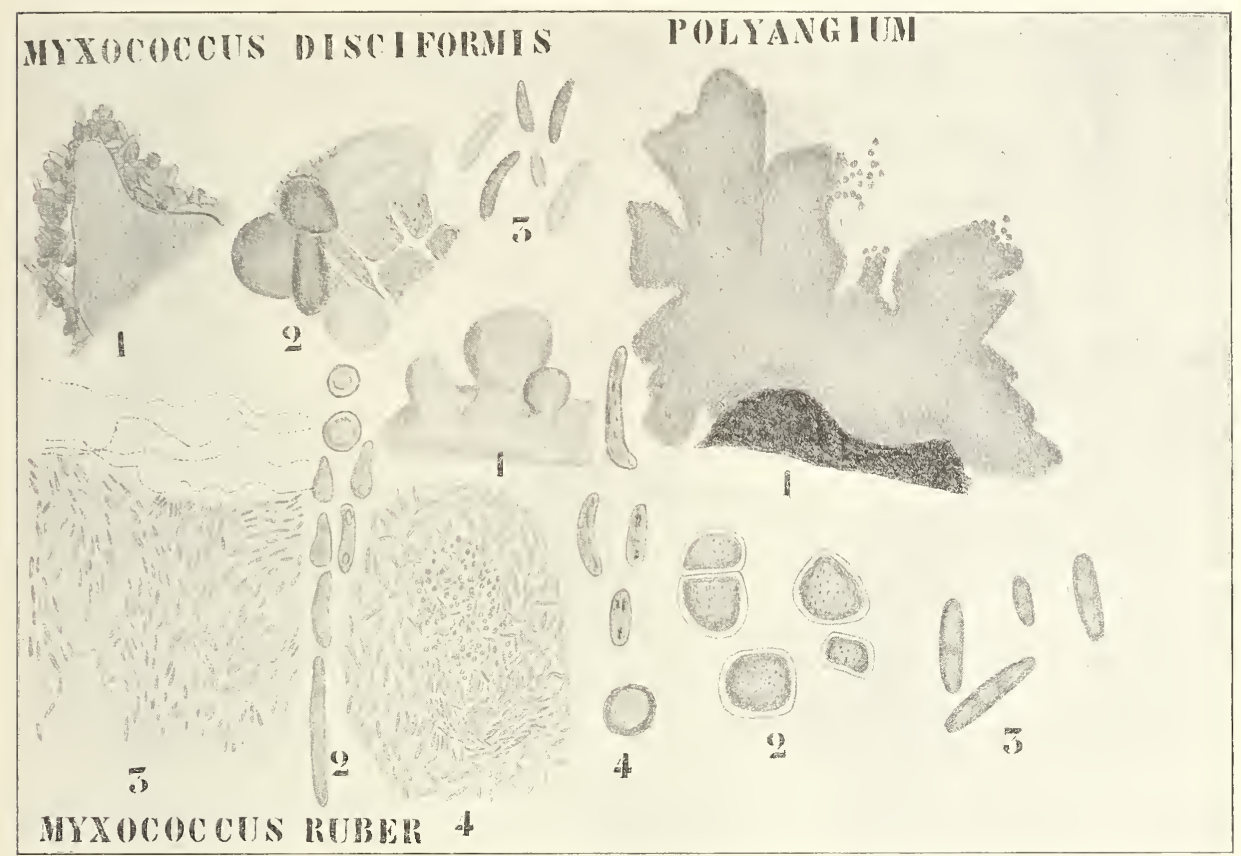

Fig. 234. I. My x o coceus d is ciformis (nach THAxter). 1 Cysten auf einem Blatte. 2 Ein Teil derselben stärker vergrößert. 3 Einzelne Individuen. - II. Poly a ngi um (nach THaxter). 1 Fruchtkörper aus vielen Cysten bestehend. 2 Fünf solcher Cysten vergrößert. 3 Einzelindividuen. - III. Myxococeus ruber (nach BAUR). 1 Fruchtkörper. $2 \mathrm{Zu}$ vegetativen Stäbchen keimende Sporen. 3 Rand einer vegetativen Kolonie. 4 Sporenbildung (links: in der Kolonie; rechts: ein Stäbchen, sich zur Spore verkürzend).

Hat man so einige Fruchtkörper erhalten, so kann man die Myxobalterie leicht auf Mistagar (Mistdekokt + 2 Proz. Agar) weiter kultivieren, indem man sie auf Agarplatten ausschmiert. Dabei darf man nicht, wie sonst vielfach üblich, den mit den Sporen des Organismus beschickten flüssigen Agar in Platten ausgießen, sondern muß erst die Agarplatte erstarren lassen und diese dann impfen. Allseitig von Agar umgebene Myxobakterien-Sporen keimen nämlich nur recht selten. Außer auf İist, Mistwasser und Mistagar kann man unsere Pflänzchen anch auf Mistgelatine kultivieren, welche aber in 1-2 Tagen vom Organismus verflüssigt wird. 
Die Kultur, von welcher BAUR ausging, war spontan auf Filtrierpapier, auf welchem eine alte Mistkultur gelegen hatte, entstanden. Das ganze Papier war mit kleinen, leuchtend roten halbkugeligen oder stumpf konischen Klümpchen von $1 / 4-1 / 2 \mathrm{~mm}$ Durchmesser übersät. Das sind die hier recht einfach gebauten Fruchtkörperchen, welche hier, 1-3 mm voneinander entfernt, üppig sich entwickelten.

Bringt man nun einige Sporen in einen Hängetropfen von Mistdekokt, so kann man die ganze Entwickelung verfolgen. Die Sporen strecken sich (Fig. 234, III 2 von oben nach unten), ohne ihre Membran abzuwerfen - also ganz anders wie bei Bakterien - zu langen Stäbchen, welche recht flexibel sind, sogar in solchem Grade, daß sie sich bisweilen ringförmig biegen. Sie bewegen sich kriechend, etwa in der Weise einer Oscillaria, drehen "sich dabei aber nicht wie diese um ihre Längsachse, Cilien konnten auch mit den besten Färbungsmethoden und optischen Systemen nicht nachgewiesen werden.

Bei einer verwandten Art, bei Myxococcus rubescens bleibt nach Thaxter nach der Keimung doch eine Sporenmembran zurück.

Plasmolysieren kann man die Stäbchen nicht, dennoch ist wohl sicher eine Zellwand vorhanden. Die Stäbchen vermehren sich ausschließlich mittels Querteilung, wozu etwas mehr wie eine halbe Stunde nötig ist. Dann scheint eine Pause einzutreten, so daß in BAURs Kulturen sich die Stäbchen etwa jede 5 Stunden einmal teilen.

Die Stäbchen scheiden Schleim in großen Mengen aus, und diese Schleimbildung scheint sie zusammenzuhalten, da sie offenbar es nicht wagen, die Schleimmasse zu verlassen; ihr Zusammenbleiben beruht also wohl auf Phobotaxie, daher ist denn auch der Rand eines Schwarms so ziemlich gerade, was nicht leicht zu erklären wäre, wenn irgend eine leicht wasserlösliche Substanz die Ursache ihres Zusammenbleibens wäre, aber sehr leicht zu erklären ist, falls ein quellender Schleim die Ursache ist. Nach 3-4 Tagen fängt in Hängetropfenkulturen die Sporenbildung und zwar an irgend einem Punkte der Peripherie des Tropfens an; offenbar infolge eines langsamen Eintrocknens; in der Tat konnte nachgewiesen werden, daß Eintrocknen eine der Ursachen der Sporenbildung ist; aber nicht die einzige, denn auch Flüssigkeitskulturen bilden Sporen, welche öfters einen bedeutenden Bodensatz in der Kulturflasche darstellen. In diesem Falle ist wohl irgend ein abgeschiedenes Stoffwechselprodukt Ursache der Sporenbildung. . Dafür spricht auch der Umstand, daß sporenbildende Stäbchen offenbar irgend eine Substanz ausscheiden, welche andere Stäbchen zur Sporenbildung reizt.

Das ist gerade die Ursache der Bildung von Fruchtkörpern; wo nur einige Stäbchen Sporen bilden, üben sie eine anziehende Kraft auf andere Stäbchen aus, so daß diese sich in großer Anzahl um erstere ansammeln und sofort selber Sporen bilden (Fig. 231, III 4 links). So entstehen größere und größere Sporenmassen, welche schon nach einem halben Tage mit unbewaffnetem Auge sichtbar sind. Unter sich hängen die Sporen durch eine zähe Schleimmasse zusammen, welche durch Eintrocknen an der Peripherie so zähe wird, daß man die roten Kugeln oder Säulchen als Ganzes mit der Nadel abheben kann.

Die rote Farbe der Sporenkörper wird nicht vom Schleime, sondern von den Sporen selber verursacht. Die vegetativen Stäbchen sind leicht fleischrot. Bei starker Vergrößerung erblickt man aber weder an einer Spore noch an einem vegetativen Stäbchen irgendwelche Farbe, nur 
bei schwacher Vergrößerung und Anhäufung von Individuen kann man die Farbe erkennen.

Bei Myxococcus kann also durch Verkürzung und Abrundung (Fig. 234, III 4 rechts) jedes Stäbchen zur Spore und durch Streckung die Spore wieder ein Stäbchen werden.

Bei den beiden anderen Genera der Myxobalterien, bei Polyangium und bei Chondromyces, ist dies nicht der Fall. Da entstehen Ruhezustände, indem eine größere Zahl von Stäbchen zusammen encystiert wird. Auch bei Myxococcus werden solche Stäbchen gefunden, aber dann gehen doch die Stäbchen, sei es vor, sei es nach der Cystenbildung, zur Sporenbildung über, wie z. B. bei Myxococcus disciformis THaxter.

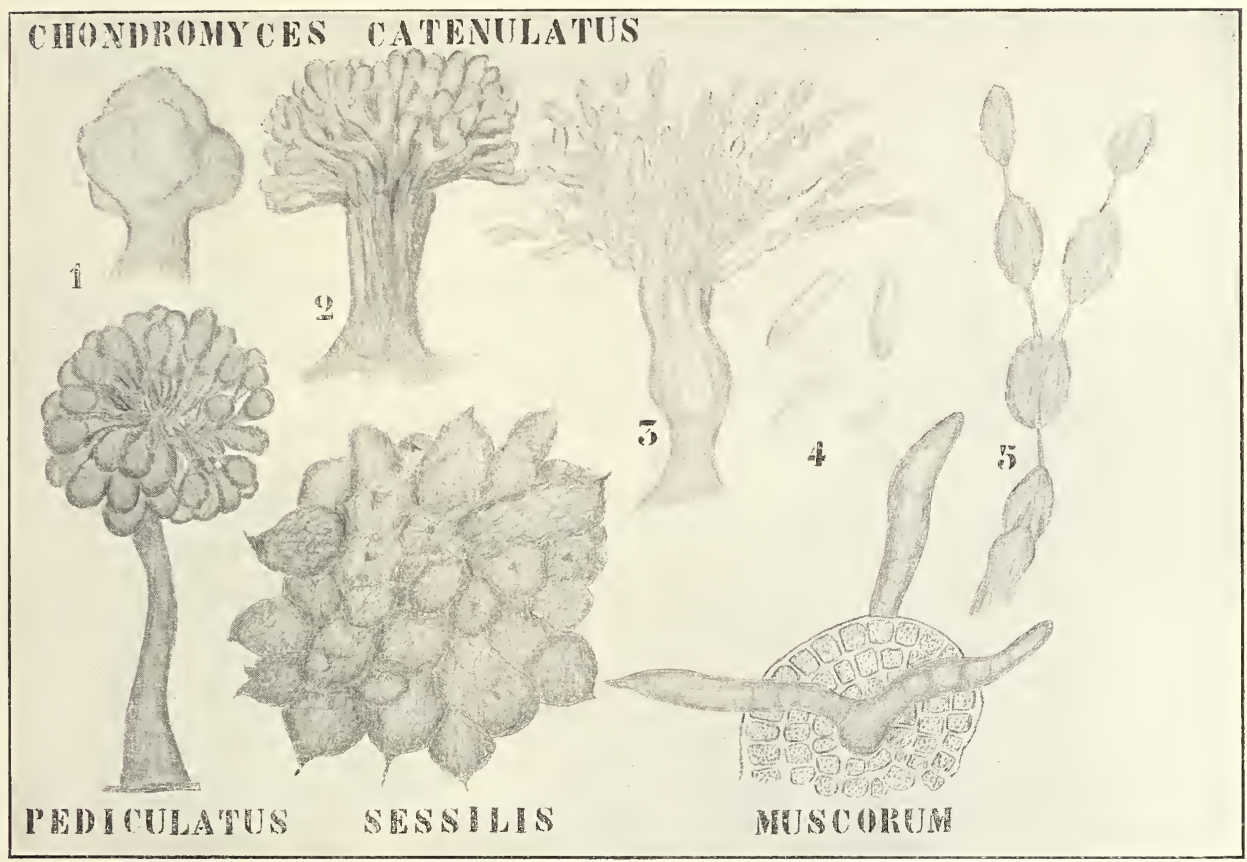

Fig. 235. Cysten-Fruchtkörper verschiedener mit Namen bezeichneter Chondromyces-Arten (nach THAXTER).

In anderen Fällen kann infolge irgend eines Reizes der ganze Schwarm zu einer großen Cyste, z. B. bei Chondromyces muscorum (Fig. 235, rechts unten), oder zu einer großen Anzahl kleiner Cysten, z. B. bei Polyangium sorediatum (Fig. 234, II 1) verwandelt werden; in den meisten Fällen aber bleibt ein Teil des Schwarmes steril und es werden gestielte Fruchtkörper gebildet.

Sehr kurz ist der Stiel und breit und groß sind die Cysten bei Chondromyces sessilis THAXTER. Bei den meisten Formen entstehen lange in vielen Fällen verzweigte Cystophoren, welche num ihre Spitzen, wie von einem Impuls getrieben, simultan zur Cyste umbilden. So entstehen Formen wie die von Chondromyces pediculatus

Der höchst entwickelte Fall kommt bei Chondromyces catenulatus vor.

Fig. 235, 1 stellt den aufstrebenden aber noch sterilen Schwarm dar. 
Auch im Stadium der Fig. 235, 2 ist der Fruchtkörper noch steril, dann fängt der Reiz zur Cystenbildung zu wirken an, meistens unten anfangend wird an den Zweigen eine Cyste gebildet, dann hört der Reiz auf, nach einer Weile wird eine zweite Cyste gebildet und so weiter, bis perlschnurartige Cystenreihen (Fig. 235, 3, 5) entstanden sind.

Wie wir sehen, weichen die Myxobaliterien, in Bezug auf die Art und Weise ihrer Sporenbildung, bedeutend von den Bakterien ab und erinnern, oberflächlich betrachtet, in hohem Grade an den Myxomyceten. In der Tat sind aber die Differenzen so groß, daß viele Autoren nicht geneigt sind, irgend welche Verwandtschaft anzunehmen. Auch ich verspüre dazu gar keine Lust trotz folgender Aeußerung Thaxters.

„It may be further remarked that the writer feels somewhat more inclined than formerly to entertain the suggestion previously made, that these organisms may possibly represent transitional conditions, between the higher bacteria and the lower Mycetozoa, having been partly influenced in this opinion by an examination of Dr. OLIVES preparations of Diplophrys and the Sophoreae, which seem to indicate, that there may not be so wide a difference in cell structure between these groups as has been assumed."

Daß ich, trotzdem ich keine Verwandtschaft zwischen Myxomyceten und Myxobakterien, außer vielleicht zwischen Labyrinthula und den letzteren sehe, die Myxomyceten doch hier anschließe, geschieht, weil ich sie gerade so gut hier wie irgendwo anders behandeln kann, denn ich kann nicht umhin, zu vermuten, daß die Myxomyceten eigentlich gar keine Pflanzen sondern Tiere sind.

Solange aber die Zoologen mit konstanter Bosheit die Tiernatur dieser Lebewesen negieren, müssen wir Botaniker sie wohl behandeln. 


\section{Siebzehnte Vorlesung.}

\section{Myxomyceten.}

Wir können diese große Gruppe amöbenartiger Organismen in zwei Abteilungen spalten, in die

\section{Sorophoreae Zopf und die}

Myxogasteres SCHROETER.

In beiden Gruppen kommen bewegliche, amöboide Stadien vor, welche in einem bestimmten Momente ihres Daseins zu sogenannten Plasmodien zusammentreten. Solche Amöbenansammlungen können aus Millionen von Individuen bestehen, wie z. B. die sogenannte Lohblüte, welche mehrere Quadratmeter mit ihrem Plasmodium bedecken kann.

In diesen Plasmodien nun bleiben bei der Gruppe der Sorophoreen die einzelnen Amöben leicht kenntlich, sie fusionieren nicht, sondern legen sich nur aneinander, aus diesem Grunde redet man von Agregatplasmodien; bei den Myxogasteren hingegen fusionieren sie zu einer großen vielkernigen Masse, zu einem Coenobium, in welchem man ebensowenig die Grenze der einzelnen Amöben unterscheiden kann, wie im Plasmaschlauche einer Vaucheria die Grenze der Energiden; solche Plasmodien heißen Fu si on s p la s m od i en. Wir unterscheiden demnach :

\section{Myxomycetes}

a) mit Aggregatplasmodien . . . . . . Sorophoreae

b) mit Fusionsplasmodien . . . . . . . Myxogasteres

Um Ihnen den Unterschied zwischen beiden klar zu machen, scheint es mir am besten, zunächst von beiden Gruppen einen ziemlich hoch entwickelten Vertreter zu beschreiben, und erst hernach jede Gruppe für sich zu besprechen.

Als Vertreter der Sorophoreen wähle ich die Acrasieen-Art

\section{Polysphondylium violaceum,}

deren Artname von den violetten Sporen herrührt. Verfolgen wir also die Entwickelung von der Spore ausgehend. In gewöhnlichem Wasser läßt sich eine solche Spore nicht zur Entwickelung bringen, dazu ist ein von geeigneter Nahrung ausgehender Reiz nötig, z. B. einer Mistlösung, denn unser Wesen ist ein südeuropäischer Mistbewohner.

Auf geeignetem Substrat wird die Nembran gesprengt und es schlüpft eine nackte Amöbe heraus, welche feste Nahrung aufnehmend über das Substrat zu kriechen anfängt. 
Diese Amöben können sich durch Teilung vermehren. Damit ist das vegetative Leben des Organismus beendet.

Gehen sie zur Fruktifikation über, so sammelt sich eine große Anzahl solcher Amöben zu einem Aggregatplasmodium an, in welchem also die Grenzen der Einzelamöben gut wahrzunehmen sind. Das ist aber kein vegetativer Zustand, sondern die erste Phase des fruktifikativen.

Alsbald sehen wir nun, wie sich mehr und mehr Amöben von den Ausläufern des Aggregatplasmodium nach dem Zentrum hin bewegen, so daß dort eine Ansammlung entsteht, welche sich mehr und mehr vom Substrat erhebt und so einen cylindrischen, mehr oder weniger gebogenen Körper bildet, der aus sich polygonal abflachenden Amöben besteht.

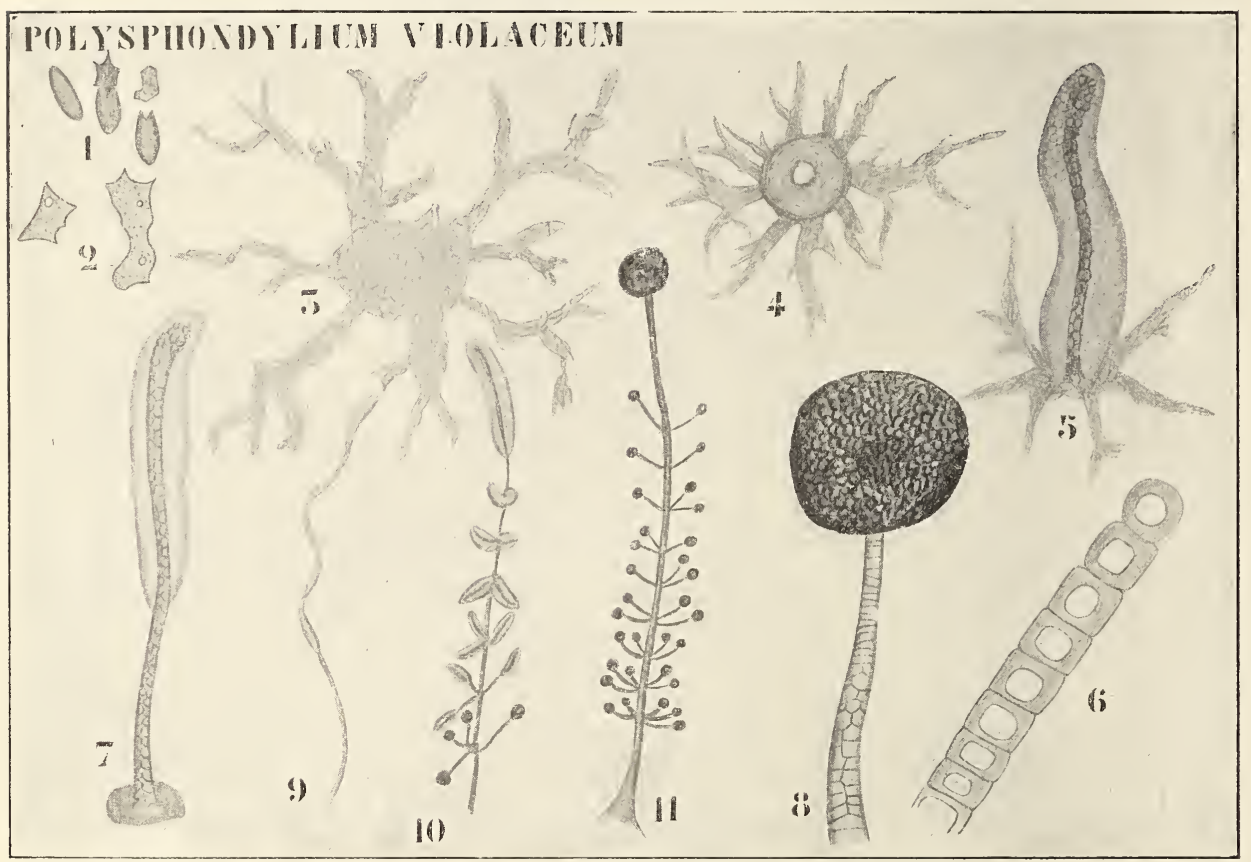

Fig. 236. Polysphondylium violaceum (nach Brefeld). 1 Spore und aus derselben ausschlüpfende Amöbe. 2 Amöben, rechts in Teilung begriffen. 3 Aggregatplasmodium. 4 Anfang der Fruchtkörperentwickelung. 5 Aelteres Stadium, Ausbildung eines zentralen Stranges steril bleibender Amöben. 6 Der Zentralstrang stärker vergrößert. 7 Das fertile Plasmodium kriecht an den sterilen Strang herauf, wodurch der Fruchtkörper gestielt wird. 8 Die Amöben, an der Spitze des Stieles angehäuft, haben sich zu Sporen umgebildet. 9-11 Bildung verzweigter Fruchtkörper.

Alsbald tritt nun in diesem jungen Fruchtkörper eine Differenzierung auf. Zentral gelegene Amöben nehmen viel Wasser auf, wodurch eine Vakuole stark anschwillt, so daß das Plasma gegen die Hautschicht angedrückt wird. Stark vergrößert sehen solche Amöben dann wie Fig. 236. 6 aus.

Durch Wasseraufnahme werden sie stets größer und scheiden schließlich eine Cellulosemembran aus, wodurch eine axile Zellenreihe entsteht, welche durch Verwachsung der Wände recht fest wird.

Dieser Strang wächst dadurch in die Länge, daß am oberen Ende 
des Fruchtkörpers neue Amöben wasserreich werden und sich an den Strang anschließen. In demselben Maße als sich der Strang verlängert kriechen die übrig'en Amöben an ihm empor, so daß schließlich der Fruchtkörper gestielt ist, und alle Amöben zu einer kugeligen Masse an der Spitze des Stieles vereint sind.

Jede dieser Amöben umgibt sich nun mit einer Membran und wird zur Spore; der ganze Fruchtkörper sieht dann wie ein gestieltes Mucorsporangium aus.

Das ist die einfachste Fruktifikationsform; außer dieser gibt es verzweigte Fruchtkörper, welche an Mucorineen mit Makro- und Mikrosporangien erinnern. Dennoch ist die Bildungsweise dieser verzweigten Fruchtkörper ebenfalls recht einfach.

Sie entstehen, wenn die Amöbenmasse nicht als Ganzes an den Stiel heraufsteigt, sondern wenn jedesmal ein Teil zurückbleibt, so daß am Stiele Anhäufungen entstehen (Fig. 236, 9), welche dann alsbald durch nackte Stielstücke voneinander getrennt werden.

Jede dieser Anhäufungen wächst nun vom Stiele hinweg, in der gleichen Weise, wie sich das ganze Plasmodium ursprünglich über den IIist erhob, und in jeder dieser Anhäufungen entsteht ein axiler Strang wasseranziehender Amöben, an welchem die übrigen heraufkriechen, bis sie an der Spitze angelangt sind, wo sie sich zu Sporen umbilden (Fig. 236, 10).

So entstehen also verzweigte Fruchtstände (Fig. 236, 11), welche man so wie die unverzweigten Sorophoren nennt, da die Sporen in Sori gebildet werden.

Als Vertreter der Myxogasteres wähle ich

\section{Badhamia utricularis.}

Wir werden bei dieser wichtige Unterschiede zwischen ihr und Polysphondylium kennen lernen, sowohl in Bezug auf das Keimungsprodukt der Spore wie auf die Bildung des Plasmodiums und die Fruktifikation.

Gehen wir auch hier von der Spore aus. Die Wand wird in der üblichen Weise gesprengt; es tritt aber keine einfache Amöbe heraus. sondern ein mit einer Polcilie versehener Schwärmer. Dieser kann schwimmen, aber sich auch amöboid bewegen, er kann Pseudopodien bilden, mittels welcher Nahrung, meistens in der Form von Bakterien, aufgenommen wird.

So leben diese Myxomonaden (Fig. 237, 1-6), wie man sie auf diesem Stadium nennt, kürzere oder längere Zeit selbständig, während welcher Zeit sie sich üppig durch Teilung vermehren. Die Teilungsprodukte sind wieder Myxomonaden. Darauf verlieren sie die Cilie und werden zur Myxamöbe, welche nun natürlich nicht mehr schwimmen kann, sondern nur kriecht. Auch sie vermehrt sich durch Teilung; ihre Teilungsprodukte sind wieder Myxamöben.

Nach einiger Zeit treten mehrere Myxamöben zu einem kleinen Fusionsplasmodium zusammen; dieses Fusionsplasmodium kriecht über das Substrat, begegnet einem anderen, mit dem es verschmilzt, dieser Vorgang wiederholt sich verschiedene Male, bis große Fusionsplasmodien (Fig. 237, 7) gebildet sind.

Im Gegensatz zu den Aggregatplasmodien der Sorophoreen bilden diese Fusionsplasmodien nicht den Anfang des fruktifikativen Zustandes. sondern gerade den Höhepunkt des vegetativen Lebens der Myxogastere. Auf ihrem Wege umkriechen sie allerlei Körper, nehmen diese in das Plasmodium auf und stoßen sie später wieder aus. Tielleicht gebrauchen 
sie die nahrungshaltigen zur Ernährung, ihre Hauptnahrung scheint aber nicht in festen, sondern in flüssigen Substanzen zu bestehen.

Sie reagieren auf Reize, als wären sie eine physiologische Einheit, wachsen z. B. auf Nahrung und Wasser zu, kriechen an fließendes Wasser herauf u. s. w. Für weitere Auskunft darüber sei auf den interessanten Artikel Stahls (1884) verwiesen.

Bei unserer Badhamia schreitet das Plasmodium nach einiger Zeit zur Sporangienbildung. Dabei entsteht an gewissen Stellen des Plasmodiums Zunahme (Fig. 237, 8), in Uebereinstimmung damit an anderen Stellen Abnahme der Amöbenzahl. So entstehen Schleimballen und Schleimfäden. Bald scheiden sowohl die Ballen wie die Fäden an ihrer Oberfläche eine celluloseähnliche Membran, sowie Kalkkristalle aus, wo-

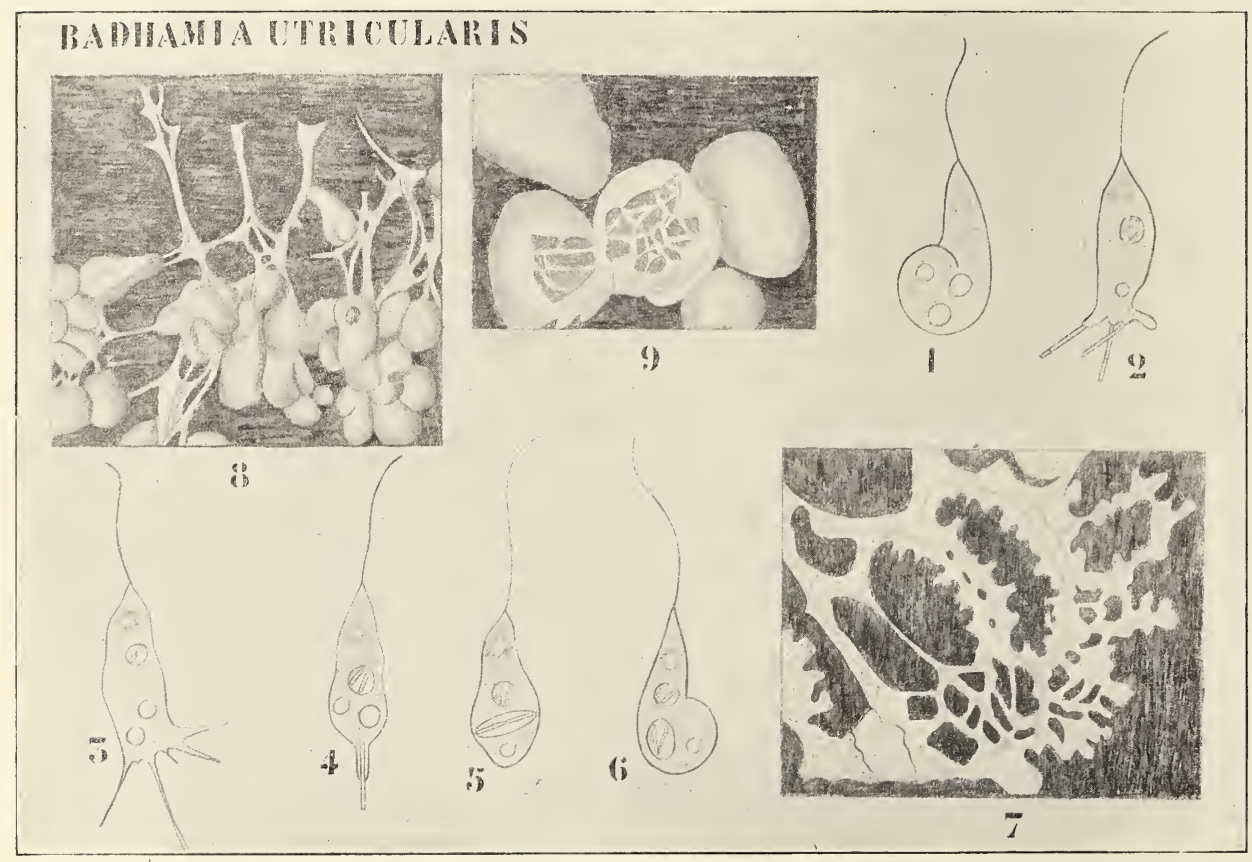

Fig. 237. Badhamia utricularis (nach Fry).

durch spröde,' an Traubenstände entfernt erinnernde Fruktifikationen entstehen, es sind dann die Trauben die Sporangien, die Traubenstiele die Sporangienstiele.

Innerhalb des Sporangiums findet Kernteilung statt, wodurch also die Zahl der Energiden vermehrt wird, dann werden in später zu beschreibender Weise einkernige Plasmastücke gebildet, deren jedes eine stachelige dunkelviolette Membran bildet, wodurch das Sporangium mit Sporen gefüllt wird.

Aber nicht ganz, denn in ebenfalls später zu beschreibender Weise entstehen im Sporangium celluloseartige Stränge, welche zusammen ein Netzwerk, das sogenannte Capillitium, bilden, welches bei dem Ausstreuen der Sporen Dienste erweist.

Nachdem ich Ihnen also von den beiden Gruppen der Myxomyceten 
je ein Beispiel rorgeführt habe, gehen wir zu einer systematischen Betrachtung der ganzen Gruppe ïber und fangen dabei mit der Gruppe der

\section{Sorophoreen ZopF}

an. Diese wird nach der neuesten Monographie von OLIve (1902) in die Gruppen der Acrasieen und der Labyrinthuleae eingeteilt.

Beide Gruppen zeigen wichtige Unterschiede; ein Beispiel der Acrasieen haben wir bereits an Polysphondylium kennen gelernt, als Vertreter der Labyrinthuleae sei hier

\section{Labyrinthula}

behandelt.

Wir haben hier wieder mit einem ganz anderen Plasmodium zu tun, mit einem sogenannten Netzplasmodium, welches mit dem Fusionsplasmodium der Myxogasteres darin übereinstimmt, daß es das wichtigste vegetative Stadium im Leben der betreffenden Organismen bildet; nicht wie das Aggregatplasmodium der Acrasieen das erste Stadium des fruktifikativen Zustandes darstellt, das aber mit den Acrasieen darin übereinstimmt, daß wir auch hier mit einem Aggregatplasmodium zu tun haben. Aber auch von den Acrasieen weichen die Labyrinthuleen bedeutend ab, indem hier die Einheiten nicht amöboid bewegliche Plasmaklümpchen, sondern solche mehr starrer Natur sind, in welcher Hinsicht sie an die Myxobakterien erinnern.

Die Labyrinthula-Art, welche ich hauptsächlich mit Ihnen besprechen möchte, ist eine Art, welche nur Cienkowski gesehen hat; außer ihm ist ZopF der einzige, welcher je eine Labyrinthula sah. Offenbar haben wir also mit seltenen Organismen zu tun.

\section{Labyrinthula vitellina Crenk.}

wurde 1867 von Cinnkowski im Schwarzen Meere bei Odessa entdeckt und beschrieben.

An Pfählen im Hafen von Odessa, welche mit grünen Algen bedeckt waren, wurden diese Organismen als orangegelbe Flecken von der Größe eines Stecknadelkopfes angetroffen (Fig. 238, 1).

Bringt man ein wenig von einem solchen Fleck auf einen Objektträger mit Meerwasser, so entwickeln sich plasmodiumähnliche Gebilde, sogenannte Netzplasmodien (Fig. 238, 2), welche in den Fällen, in welchen die Maschen nicht geschlossen sind, das Aeußere von Bäumchen erhalten können (Fig. 238, 3). An den dünnen Strängen entlang, welche das Netz oder die Bäumchen bilden, bewegen sich die spindelförmigen Individuen langsam in verschiedenen Richtungen.

Die Maschen oder Bäumchen entspringen einer dichten Anhäufung von Individuen, der sogenannten Zentralmasse.

Die Zentralmasse (Fig. 238, 4) besteht aus kleinen Kugeln. Das Ganze wird von einer schleimigen Substanz zusammengehalten, welche an der Peripherie eine Art Rinde bildet. Kleinere Aggregate von Individuen werden an den Maschenecken angetroffen (Fig. 238, 2), diese werden aber nicht von einer solchen Schleimmasse zusammengehalten.

Aus der Zentralmasse, sowie aus den kleineren Aggregaten entspringen, nach allen Richtungen ausstrahlend, sehr dünne, nur selten dickere Fäden, welche anastomosieren und in welchen oder an welchen entlang die spindelförmigen Zellen sich bewegen. 
Welche Verbindung existiert nun zwischen den Spindelzellen und zwischen den Kugelzellen der Zentralmasse?

Das ist sehr einfach: Kugelzellen strecken sich in die Länge, bis sie spindelförmig werden (auch dieses erinnert an die Myxobaliterien) und kriechen an den soeben beschriebenen Schleimsträngen aus der Zentralmasse heraus; so kann sogar schließlich die ganze Zentralmasse verschwinden und das ganze Aggregat ein zierliches Netzplasmodium

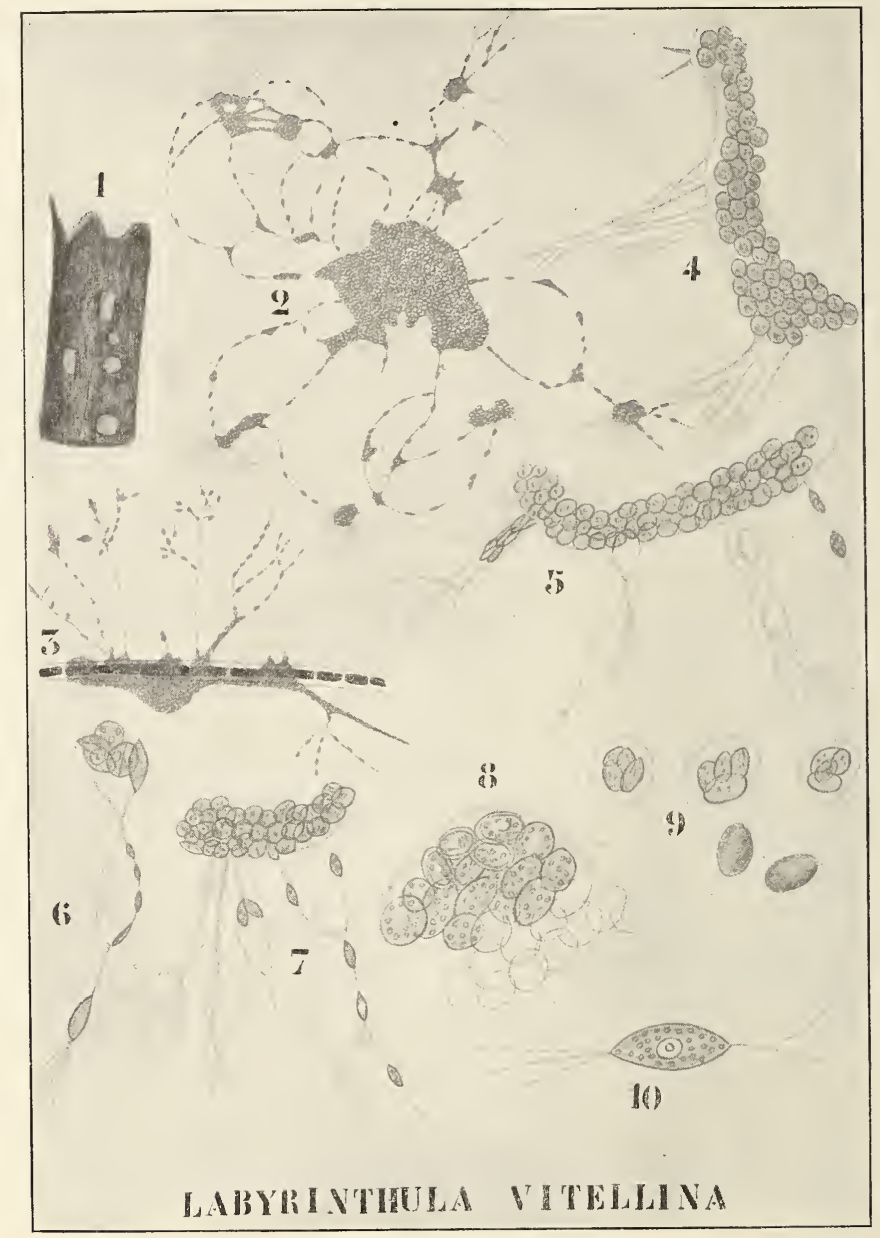

Fig. 238. Labyrinthula vitellina (nach Cienkowski). Figurenerklärung im Text.

werden. Oefters kann man Teilung der Zellen der Zentralmasse beobachten.

Die normale Form der Spindelzellen ist in Fig. 238, 10 abgebildet, zwischen diesen und den Kugelzellen bestehen selbstverständlich allerlei Uebergänge. In der Mitte jeder Spindelzelle ist der Kern leicht zu sehen (wichtiger und meines Erachtens durchschlagender Unterschied gegenüber den Myxobakterien!). Auch die Spindelzellen können sich 
teilen, die orange Farbe derselben, welche durch $\mathrm{H}_{2} \mathrm{SO}_{4}$ in Blau umschlägt, rïhrt wohl von Carotin her.

Beim Kriechen an den Fäden entlang wollen die Spindelzellen offenbar die Peripherie des Wassertropfens erreichen und zeigen große Elastizität, welche zumal sichtbar wiıd, wenn sie sich krümmen, um an den Ecken der Naschen vorbeizukommen, eine eigentlich amöboide Beweg'ung' zeig'en sie aber nie.

TIas ist nun eigentlich das Netzwerk? Wir sahen, daß es öfters in der Form dicker Stränge aus der Zentralmasse entspringt (Fig. 238, 4, 5), welche sich aber schon sehr bald in ganz feine Stränge auflösen können (Fig. 238, 5). Diese Sträng'e sind verhältnismäßig starr, können nicht eingezogen werden, aber bestehen doch auch nicht aus ganz fester Substanz, wie daraus hervorgeht, daß an den Ecken der Maschen öfters Verdickungen angetroffen werden (Fig. 238, ซ), welche abwechselnd dick und dümn werden können.

Wahrscheinlich bestehen die dicken Fäden aus verwebten dünneren, ob diese dünnen Fäden solide Fäden sind, an welchen die Spindelzellen sich entlang bewegen, oder dümne Röhren, in welchen sie lin und her gleiten, komnte CiEnkowskr nicht entscheiden.

Die Frage, welche noch zu beantworten ist, ist diese: Bilden die spindelförmigen Zellen das Strangsystem oder kann es nur von der schleimigen Rindensubstanz der Zentralmasse gebildet werden?

Die Antwort lautet, daß isolierte Spindelzellen im stande sind, ihr eigenes Netzwerk zu bilden.

Jede isolierte Spindelzelle bildet während des Kriechens ihre eigenen Fäden, welche mit denen von anderen Individuen anastomosierend zur Bildung eines Netzwerkes Veranlassung geben; das Netzwerk muß also als eine von den verschiedenen Individuen gebildete Schleimmasse betrachtet werden; wenigstens scheint mir diese Auffassung wahrscheinlicher als die von ZopF und Ourve, welche das Netzwerk für miteinander verschmolzene Pseudopodien halten.

In der Zentralmasse kömnen sich unter ungünstigen Bedingungen die Energiden durch Ausscheidung einer Membran encystieren (Fig. 238, 8). Bei der Keimung teilt sich dann der Inhalt in 4 Teilstücke (Fig. 238, 9), und es wächst wahrscheinlich ein jedes dieser 4 Stücke zu einer Spindelzelle (Fig. 238, 10) aus.

Nachdem wir nun von beiden Gruppen der Sorophoreen einen Vertreter haben kennen gelernt, nämlich Polysphondylium von den Acrasieen, und Labyrinthula von den Labyrinthuleen, wollen wir noch einige weitere Acrasieen-Arten betrachten, um zu sehen, ob wir dadurch vielleicht auf die Spur einer Verwandtschaft zwischen den Myxomyceten und irgend einer anderen Gruppe kommen können.

Das geht nun verhältnismäßig leicht: die niedrigsten Acrasieae zeigen nämlich deutliche Verwandtschaft mit Amöben.

Man weiß, daß eine Amöbe eine einzelne lebende, durch Pseudopodien bewegliche nackte Energide ist, welche sich unter ungüunstigen Lebensbedingungen encystieren kann.

Das niedrigste Genus der Acrasicae,

\section{Sappinia,}

ist nun in der Tat recht wenig mehr als eine solche Amöbe. Sie wurde auf Mist sowohl in Frankreich wie in Nordamerika angetroffen. In vegetativem Zustande ist dieser Organismus eine einfache Amöbe, welche 
selbständig unter Aufnahme fester Nahrung lebt. Unter ungünstigen Lebensbedingungen treten Ruhezustände auf, und zwar gestielte oder ungestielte, welche sich mit einer dünneren oder dickeren Nembran umgeben können.

DANGEARD (1897), welcher diese Organismen zuerst beschrieb, nennt die ungestielten Ruhezustände (Fig. 239, 9) Sporen, die gestielten dünnwandigen (Fig. 239, 6, 7) „Amibes pédicellées", und die gestielten dickwandigen (Fig. 239,8) „Kystes pédicellées“. Zu dieser Unterscheidung, welche nur zu leicht zu falschen Auffassungen Veranlassung gibt, besteht in der Tat kein Grund, es sind eben alles Cysten. Aus solch einer Cyste schlüpft später eine Amöbe heraus. Wie man sieht, ist Sappinia eigentlich nichts als eine Amöbe. Der Grund, weshalb man sie als

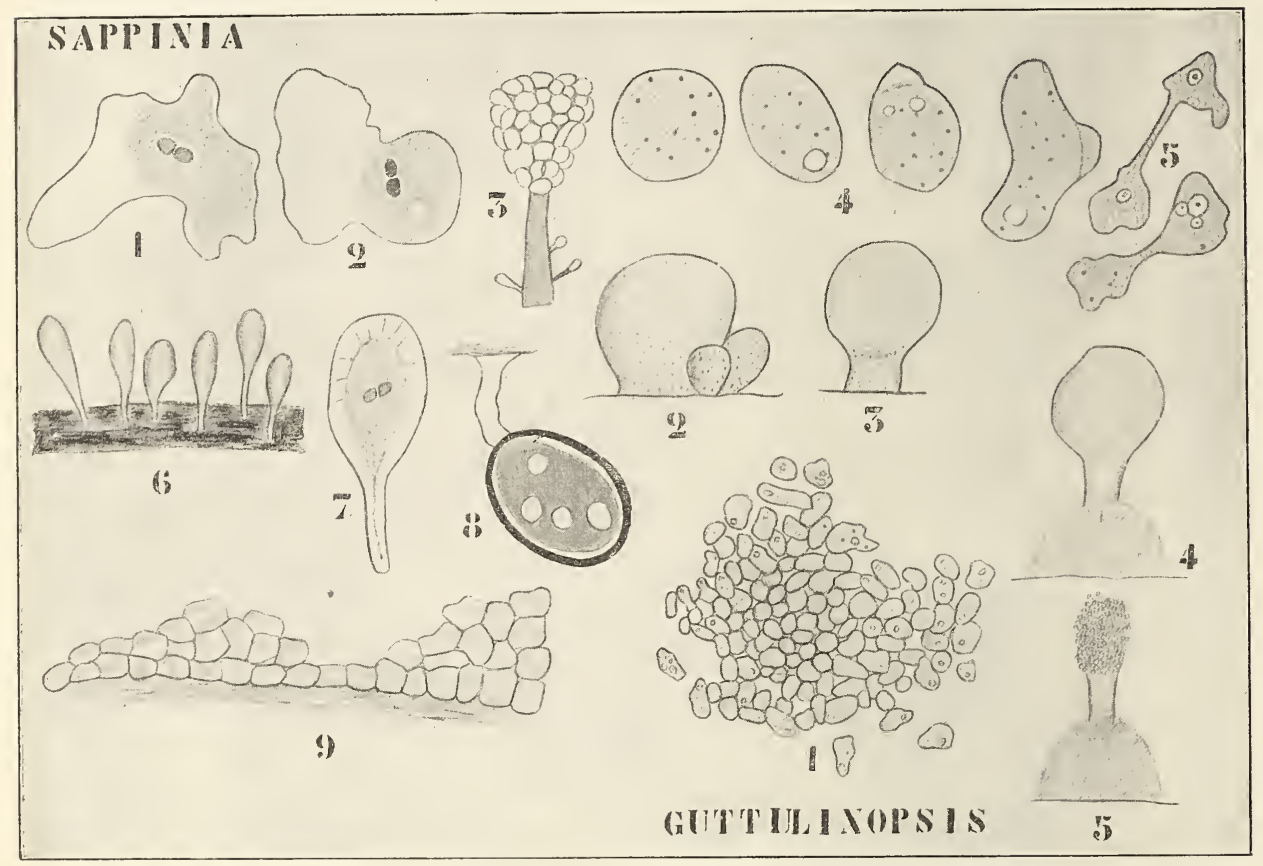

Fig. 239. Sappinia und Guttulinopsis (nach DANGEARD und OLIVE). I. Sap pinia. 1, 2 Vegetative Amöben. 3 Mehrere am Ende eines Strohhalmes encystiert. 4 Aus der Cyste ausgetretene Amöben. 5 Teilungsstadien. 6, 7, 8, 9 Verschiedene Cystenformen. - II. Guttulinopsis. 1 Vegetative Individuen, anfangend, ein Aggregatplasmodium zu bilden. 2-5 Fruchtkörper.

eine niedrige Acrasieae betrachtet, liegt in dem Umstand, daß öfters eine Anzahl von Amöben sich dicht nebeneinander, z. B. an der Spitze eines Strohhalmes (Fig. 239, 3) encystiert und dies uns einen Fingerzeig gibt, in welcher Weise Amöben zu Aggregatplasmodien zusammengetreten sein können.

Ich für meine Person bin überzeugt, daß dies wirklich stattgefunden hat, daß die Myxomyceten im allgemeinen als Amöbengenossenschaften betrachtet werden müssen, in welchen Arbeitsteilung und dadurch Differenzierung stattgefunden hat, für Pflanzen halte ich sie nicht.

Zwischen einer Sappinia und einer hoch entwickelten Acrasieae wie 
Polysphondytium mit seinen hübschen gestielten Fruchtkörpern besteht noch ein großer Unterschied, aber schon bei einem Organismus, welcher nur wenig höher als eine Sappinia steht, bei

\section{Guttulinopsis (OLIVE 1901),}

finden wir Eigenschaften, welche einen Uebergang bilden. Die Amöben von G. vulgaris OLIve, welche sich durch Teilung vermehren, treten zu Aggregatplasmodien (Fig. 239, II 1) zusammen, welche sich über das Substrat erheben (Fig. 239, II 2, 3) und entweder sitzende (2) oder gestielte (3) Fruchtkörper bilden, in welchen sich die Individuen leicht encystieren, ohne jedoch ausgesprochene Sporen zu bilden.

Hier verhalten sich also die Individuen aus dem Stiel und aus dem ïbrigen Teile des Fruchtkörpers vollkommen gleich, aber schon bei G. clavata Olive (Fig. 239, II 4, 5) tritt eine Differenzierung bei den sonst ähnlichen Fruchtkörpern ein, indem die Amöben, welche den Stiel bilden, etwas anders als die übrigen geformt sind und bestehen bleiben, nachdem die übrigen encystierten Individuen schon abgefallen sind (Fig. 239, II 5). Von Guttulinopsis clavata lassen sich also die Dictyosteliaceae, zu welchen als höchster Vertreter das besprochene Polysphondylium violaceum gehört, leicht ableiten. Durch weitere Differenzierung in sterile und fertile Amöben ist ein typischer Stiel entstanden, und durch Bildung einer festen Membran sind die fertilen Amöben zu echten Sporen geworden, im Gegensatz zu den Pseudosporen von Guttulinopsis.

Werfen wir nun auf die Acrasieen einen Rückblick, so sehen wir, daß wir hier mit einer Gruppe zu tun haben, welche zweifellos von Amöben herzuleiten ist. Einzeln lebende Amöben haben, irgend einen Reiz beantwortend, sich zu Aggregatplasmodien vereint; zunächst war jedes Individum eines solchen fruktifikativen Zustandës, denn das sind ja die Aggregatplasmodien, fertil ( $G$. vulgaris), alsbald aber trat eine Differenzierung in fertile und sterile Individuen auf ( $G$. clavata), bis bei den Dictyosteliacecie die bis dahin nur leicht encystierten Individuen durch Ausbildung einer festen Membran zu echten Sporen wurden, und mehr ausgesprochene Differenzierung zur Ausbildung gestielter und verzweigter Fruchtstände wie die von Polysphondylium führte.

Wir haben also meiner Ansicht nach jeglichen Grund, anzunehmen, daß die Acrasieae von Amöben herzuleiten sind.

Aus der Gruppe der Myxogasteres, d. h. aus jener Gruppe, bei welcher aus den Sporen begeißelte Amöben, Myxomonaden entstehen, und bei welcher im Fusionsplasmodium die Einzelindividuen nicht mehr zu unterscheiden sind, möchte ich noch eine sehr einfache Art, die parasitische

\section{Plasmodiophora brassicae}

mit Ihnen besprechen. Sie wird öfters als Typus der besonderen Gruppe der Phytomyxineen betrachtet, meines Erachtens läßt sie sich ganz gut als Myxogastere betrachten. Sämtliche Formen, welche man zu der Gruppe der Phytomyxineen vereint hat (Phytomyxa, Tetramyxa und Sorosphaera), sind Parasiten, und da ist es also nicht leicht zu sagen, ob diese Phytomyxineen primitive Myxogasteres oder reduzierte sind.

Jedenfalls ist Plasmodiophora jetzt, zumal dank den Untersuchungen, Nawaschins (1899) eine der am besten bekannten Myxomyceten und das ist denn auch der Grund, weshalb ich sie hier besprechen möchte. 
Woronin zeigte, daß aus den Sporen der Plasmodiophora (Fig. 240, 1) Myxomonaden entstehen (Fig. 240, 2), welche sich nicht durch Teilung vermehren, sondern in die Wurzeln von Kohlpflanzen und Verwandten eindringen, in deren Zellen sie sich unter Einziehung der Cilie in eine Myxamöbe verwandeln (Fig. 240, 3).

In den kranken Zellen kann man an nach Flemming konserviertem Material die jungen Amöben leicht beobachten, da nur diese, nicht aber das Plasma der Kohlpflanzenzellen Fett enthalten und also nur die jungen Amöben schwarz gefärbt sind (Fig. 240, 4).

Bei der bekannten Dreifärbung: Safranin-Gentianaviolett-Orange werden die Kerne rot, die Stärkekörner blau tingiert und nun stellt es sich heraus, daß die Amöben je·einen Kern besitzen, aber nie Stärke ent-

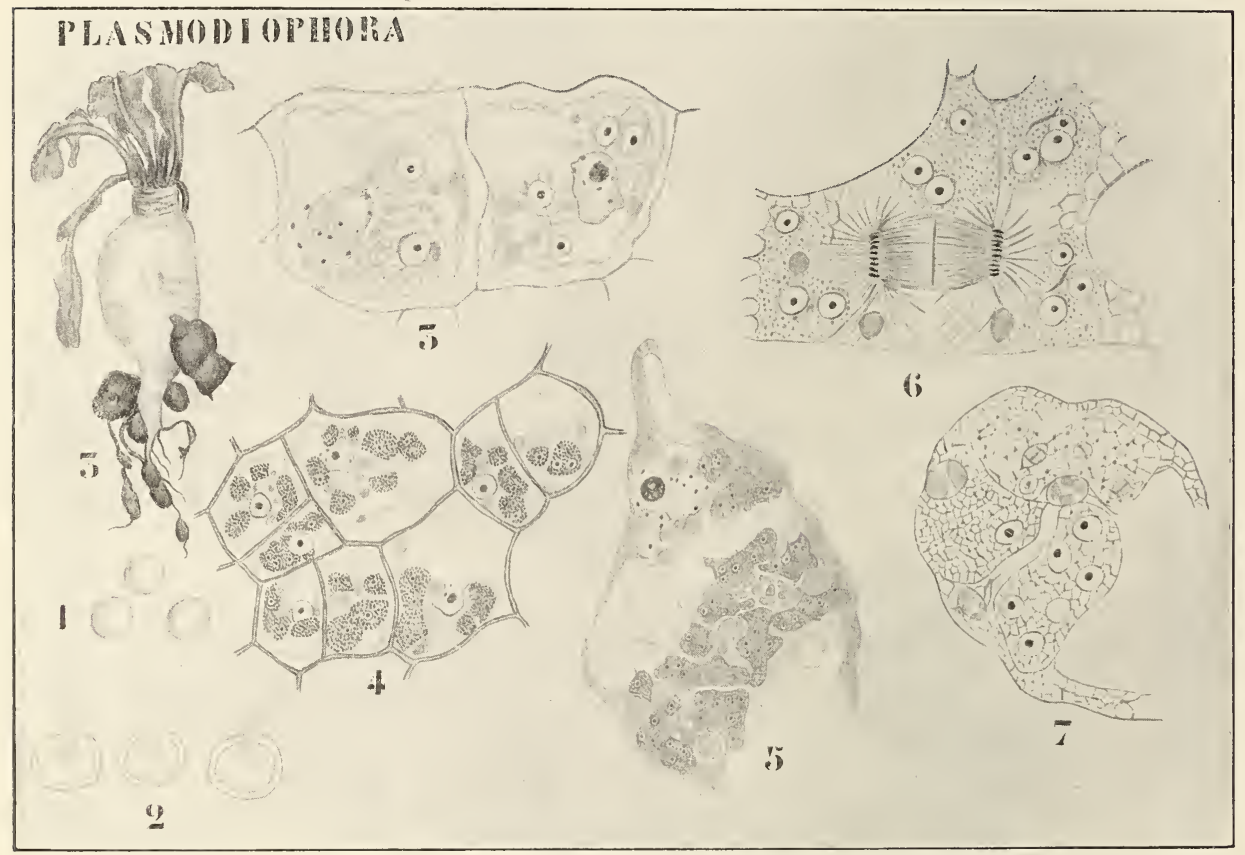

Fig. 240. Plasmodiophora brassicae (nach Woronin und Nawaschin). 1 Sporen. 2 Idem keimend. 3 (links) Hernienkranke Brassica Rapa-Pflanze. 3 (rechts) Zeilen einer Kohlpflanze mit cingedrungenen Amöben, in der linken Zelle befindet sich eine, in der rechten zwei Amöben. 4 Zellen mit jungen ein- bis zweikernigen Amöben. 5 Zellen mit vielkernigen Amöben. 6 Eine Amöben-infizierte Zelle zu Anfang der 'T'eilung, der Zellkern in der Telephase. 7 Amöben die Schaumstruktur ihrer Protoplasten zeigend, es finden sich hier 3 Amöben, von welchen die obere gerade ihre Kcrne teilt.

halten. Sie sind also offenbar nicht im stande, feste Nahrung aufzunehmen, sondern leben wohl von in der Wirtszelle vorhandenen gelösten Nahrungssubstanzen.

Diese jungen Amöben vermehren alsbald ihre Kernzahl, so sind sie z. B. in Fig. 240, 3 zweikernig, in Fig. 240, 5 schon mehrkernig.

Die jungen Amöben liegen in den Vakuolen der Brassicazellen und schaden diesen im ersten Stadium ihres vegetativen Lebens nicht, im Gegenteil reizen sie jene zu erhöhter Teilung (Fig. 240, 6), wodurch die 
großen Geschwïlste (Fig. 240, 3) entstehen, welche man Kohlhernien neunt.

Inzwischen haben sich die Amöben durch Teilung' und zwar vermutlich durch Abschnürung von Ausstülpungen vermehrt und so gelangen in jede von einer infizierten Zelle gebildete Tochterzelle eine oder mehrere Amöben (Fig. 240, 6), welche diese Zelle wieder zu erhöhter Teilung reizen, wodurch stets größere Geschwülste entstehen.

Diese schnell aufeinanderfolgenden Teilungen erinnern an Krebsgeschwülste und es ist in der Tat nicht unmöglich, daß eine Amöbe die Ursache des Carcinoms ist.

In jeder Zelle vermehrt sich nun fortwährend die Zahl der Amöben (Fig. 240, 4, 5), ohne daß diese zu Plasmodien verschmelzen. Zwar ist

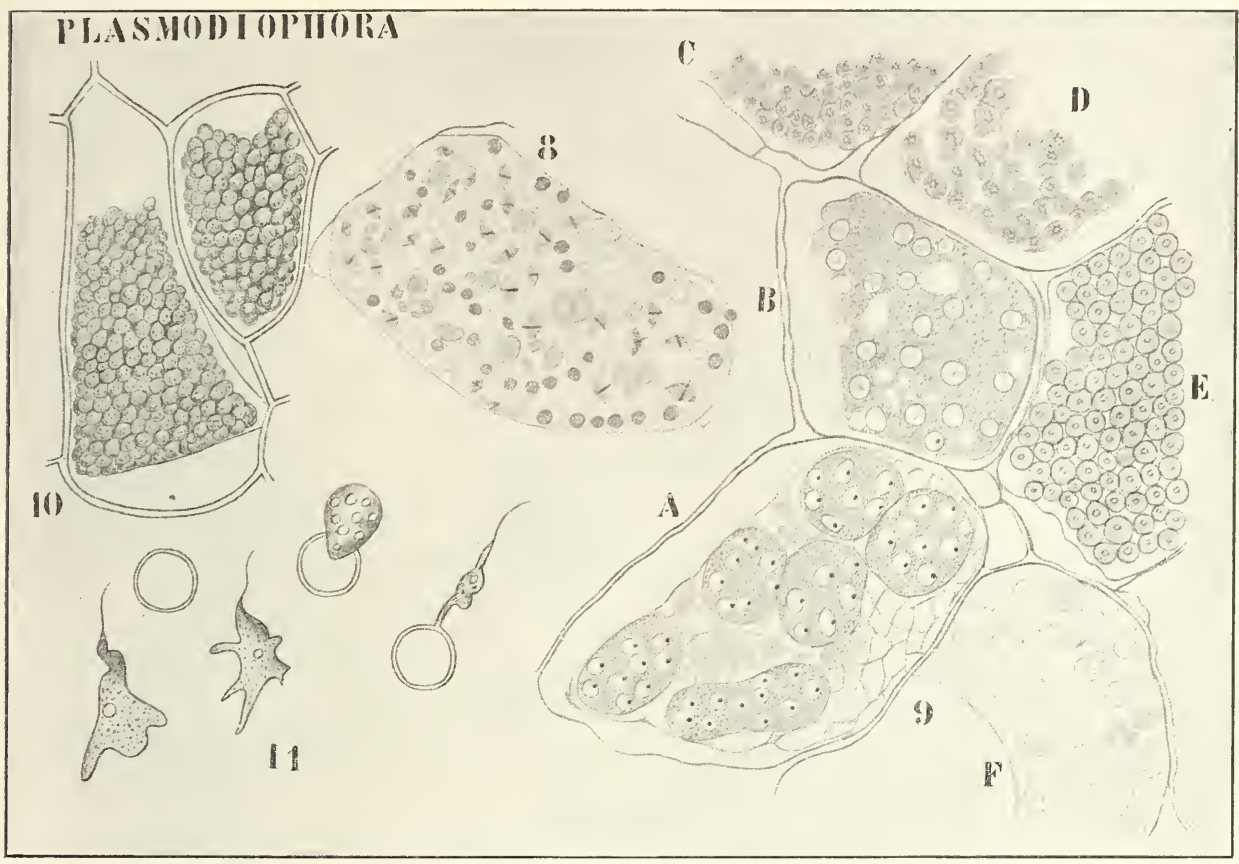
im Text.

Fig. 241. Plasmodiophora (nach Woronis und NAwASChIN). Figurenerklärung

es bisweilen schwer, die Grenzen zwischen den dicht angehäuften Amöben zu sehen, der Umstand aber, daß sich die Kerne einer Amöbe stets simultan teilen, macht es leicht zu sehen, daß wir hier noch mit individuellen Amöben zu tun haben. So z. B. in (Fig. 240, 7), wo drei Amöben vorhanden sind, von welchen gerade eine ihre Kerne teilt. durch welchen man sie leicht von den anderen unterscheiden kann.

Bis jetzt blieben die Amöben getrennt und die Zellen, in welche sie eindrangen, empfanden von ihrer Anwesenheit kaum einen Nachteil. im Gegenteil, solche Zellen enthalten mehr Plasma, als normale Zellen.

Jetzt ändert aber sich die Sache, die Amöben schreiten zur Plasmodiumbildung und fangen an, die Brassicaenergiden aufzufressen, schließlich werden die Zellen der Knollen mit den Sporen des Parasiten 
ausgefüllt (Fig. 241, 10), das Ganze verfault und so gelangen die Sporen ins Freie. Sie können nun wieder Schwärmer bilden (Fig. 241, 11) und neue Pflanzen infizieren.

Verfolgen wir das Entstehen dieser fruktifikativen Phase etwas näher. In Fig. 241, 9 A sehen wir eine biskuitförmige Amöbe, welche offenbar aus der Verschmelzung zweier entstanden ist, so fusionieren schließlich alle Amöben zu einem Fusionsplasmodium (Fig. 241, 8), welches alsbald die ganze Wirtszelle ausfüllt und seine Kerne durch Karyokinese stark vermehrt.

Diese Kernteilung weicht von der Karyokinese in den nicht fusionierten Amöben ab, aber die Objekte sind so klein, daß an eine Zählung der Chromosomen nicht gedacht werden konnte. Man vergleiche darüber des näheren die Angaben NawÁschins, aus welchen folgendes besonders hervorgehoben werden mag.

„In manchen Fällen konnte ich in der Tat (in diesen Plasmodien) keine Spur von differenzierten Kernen nachweisen; die Chromatinsubstanz derselben schien sich über die ganze Masse des Plasmodiums gleichmäßig zu verteilen, als ob es sich dabei um wirkliche Auflösung der Kerne und Vermischung ihrer Bestandteile handelte."

Da bei der Kleinheit der Objekte und der fibrillären Struktur des Amöbenplasmas während dieser Vorgänge aber einzelne Phasen der vermutlichen Auflösung der Kerne nicht festzustellen waren, muß die Frage vorläufig dahingestellt bleiben, wie NAWASCHIN selber bemerkt, ob diese Auflösung wirklich stattfindet oder ob nur die Kerne sich durch außerordentliche Buntheit des Gesamtbildes der Beobachtung entziehen.

In Fig. 241, $9 \mathrm{~B}$ und $\mathrm{F}$ sehen wir die vielkernigen Plasmodien in den Brassicazellen, jetzt fängt, wie bereits bemerkt, lebhafte Kernteilung an (Fig. 241, 8), wonach jede der potentiellen Energiden wieder selbständig wird, sich mehr und mehr abrundet (Fig. 241, 9 C D E) und, indem sie sich mit einer Membran umgibt, zur Spore wird.

Vergleichen wir nun Plasmodiophora mit den Acrasieen, so sehen wir, daß sie auf höherer Entwickelungsstufe wie diese steht:

1) durch den Besitz von Myxomonaden,

2) durch die Vermehrung der Energidenzahl vor der Sporenbildung, auf niedrigerer Entwickelungsstufe aber, da keine Differenzierung in sterile und fertile Amöben stattfindet.

Mit den höheren Myxogasteres, z. B. mit Badhamia verglichen, steht sie niedriger wie diese:

1) weil die Amöben erst sehr spät ein Fusionsplasmodium bilden, nämlich hart vor der Sporenbildung, also am gleichen Punkte, wo die Acrasieae ihre Aggregatplasmodien bilden,

2) weil keine Sporangienwand zum Schutz ihrer Sporen und ebensowenig ein Capillitium entsteht.

Plasmodiophora würde also einen hübschen Uebergang von den Acrasieen zu den Myxogasteres bilden, mit den Acrasieen hat sie noch die späte Bildung eines Plasmodiums sozusagen als Einleitung zu der Sporenbildung gemein sowie die nackte Fruktifikation, mit den Myxogasteres das Zerfließen des Plasmodiums zu einem echten Fusionsplasmodium, die Vermehrung der Energidenzahl vor der Sporenbildung und die Bildung von Myxomonaden, während ihr aber das eigentliche vegetative Plasmodium, sowie die Sporangienwand fehlt.

Aber gerade diese beiden Hauptpunkte sind meines Erachtens die Folgen ihrer parasitischen Lebensweise. Das späte Fusionieren der 
Amöben macht möglich, daß jede derselben ein Nahrungsabsorptionszentrum in einer Vakuole der Wirtsenergide bilden kann, und der vermutlich zur Ausbildung einer Sporangienwand nötige Reiz: Austrocknung, besteht nicht mehr, da aus dem Ausbleiben der Sporangienwandbildung' kein Nachteil entstand, da ihre Funktion: Schutz, von der Zellwand der Wirtszelle erfüllt ward.

Trotzdem also Plasmodiophora etwa die Mitte zwischen den Acrasiece und den nicht-parasitischen Myxogasteres hält, kann ich in ihr doch nur eine durch die parasitische Lebensweise reduzierte Myxogaster erblicken.

Betrachten wir jetzt die Gruppe der

\section{Myxogasteres}

etwas näher. Sie kann in 2 Hauptgruppen geteilt werden, nämlich in Myxogasteres

1) ohne eigentliche Fruchtkörper, und mit sehr später Plasmodiumbildung . . . .

2) Mit ausgesprochenen Fruchtkörpern; die Fusionsplasmodien bilden den Höhepunkt des vegetativen Lebens. . . . . Eumyxogasteres

Die Gruppe der Phytomyxinecie haben wir bereits an der Hand des bestbekannten Vertreters, Plasmodiophora, kennen gelernt, die Gruppe der

\section{Eumyxogasteres}

kann wieder in 2 Untergruppen geteilt werden:

in eine, bei welcher die Sporen an der

Außenseite von Fruchtkörpern gebildet

werden, den

Phytomyxineae

und eine, bei welcher sie im Innern von

Sporangien gebildet werden, den . . Endosporeen

In die Gruppe der

\section{Exosporeen}

gehört nur eine Familie, die der

\section{Ceratiomyxeae}

mit einem einzelnen Genus: Ceratiomyxa, welches nur 2 Arten umfaßt.

Die Ceratiomyxa bilden Sporen, welche nicht wie die der anderen Myxogasteres direkt eine Myxomonade, sondern, wie die der Acrasieen, eine Myxamöbe bilden. Diese Amöben verhalten sich aber in ganz anderer Weise wie die Myxamöben der Acrasieae, sie teilen sich nämlich 3mal, wodurch 8 Myxomonaden gebildet werden, welche später in der üblichen Weise durch Einziehung der Cilie zu Myxamöben werden.

Diese Myxamöben kriechen nun in faulende Baumstämme. Holzbretter oder dergleichen hinein; dort vereinigen sich zahlreiche Individuen zu einem Fusionsplasmodium, welches vorläufig in faulendem Holze bleibt. Erst nach starken Regengiussen tritt das Plasmodium zur Bildung von Fruchtkörpern an die Oberfläche des Holzes und erhebt sich nun alsbald vom Substrat, wobei es säulchen- oder platten- 
förmige, bei C. mucida auch geweihähnliche Fruchtkörper bildet (vergl. die Abbildungen von Ceratiomyxa, Fig. 242). Das ganze Plasmodium ist von einer Hautschicht umgeben, welche an der Luft erstarrt, so daß jedes Säulchen nun aus einem starren Hohlzylinder besteht, in welchem sich das eigentliche Plasmodium befindet. Dieses letztere kriecht nun an der Innenseite des Zylinders herauf; ist es in der Nähe der Spitze angelangt, so individualisieren sich die Energiden, indem sie sich etwas kontrahieren. Diesen Energiden kommt das Vermögen zu, die Hautschicht weich zu machen, wodurch diese alsbald knopfförmig hervorragt, ja sogar zur Bildung einer gestielten Hohlkugel Veranlassung gibt. Die Energide kriecht nun in diese Hohlkugel hinein, wonach letztere durch eine Querwand vom Stielchen getrennt wird und als Konidie oder Exospore abfällt (vergl. Abbildung von Ceratiomyxa, Fig. 242).

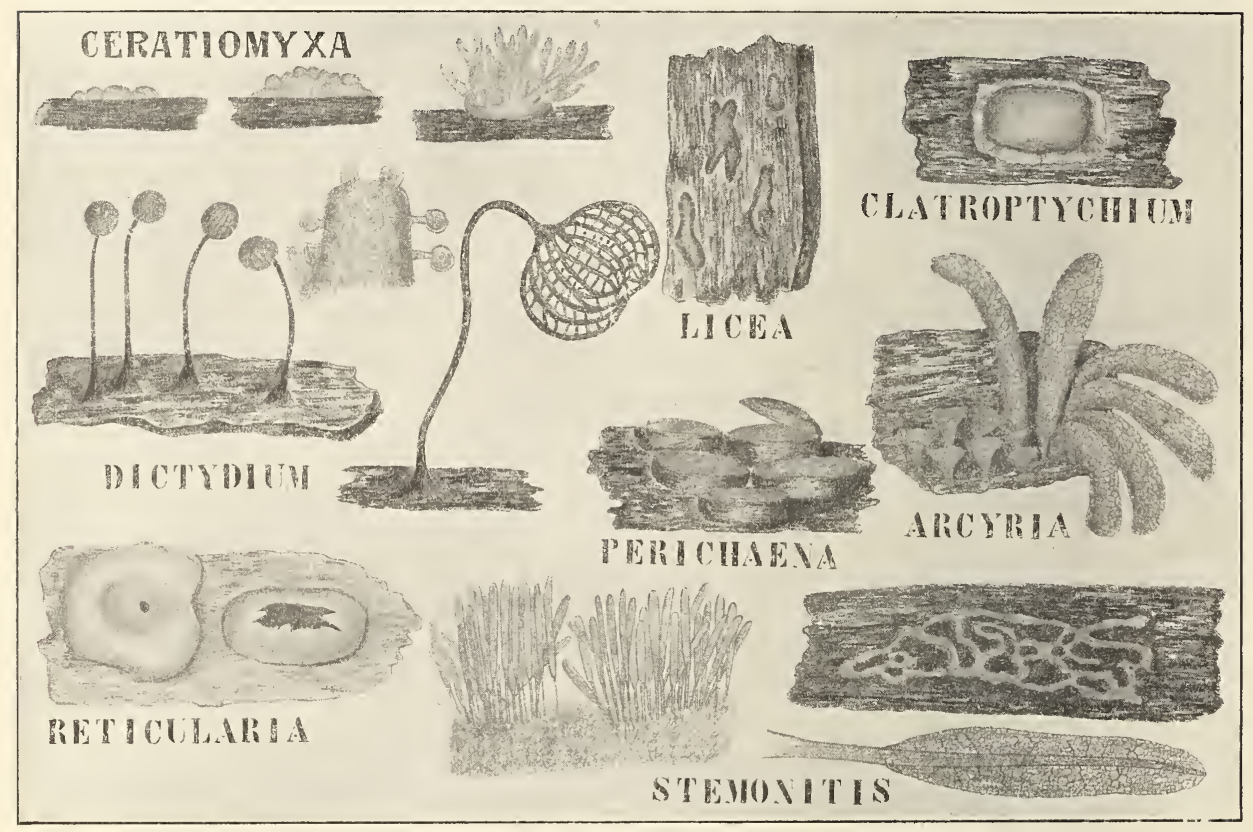

Fig. 242. Habitusbilder von Fruchtkörpern verschiedener mit Namen bezeichneter Myхоmyceten-Genera (nach Engter und PrantL).

\section{Endosporeae.}

Bei dieser Gruppe, bei welcher die Sporen innerhalb sogenannter Sporocysten oder Sporangien gebildet werden, können wir eine Anzahl von Familien unterscheiden. In Badhamia haben wir bereits einen Vertreter kennen gelernt.

Zunächst kann sie wieder in 2 Untergruppen geteilt werden, nämlich :

in eine, bei welcher entweder gar kein sporenzerstreuendes System vorhanden ist, oder bei welcher die Sporenzerstreuung mittels Oeffnungen in der Sporangienwand stattfindet, den Peritricheen 
und in eine, bei welcher ein inneres sporenzerstrenendes System, ein echtes Capillitium angetroffen wird, den ......... Endotricheen

Bevor wir diese Gruppen aber etwas näher betrachten, ist es nötig, die verschiedenen Fruchtkörper der Endosporeen kennen zu lernen. Die höchste Fruchtform, die der Sporocysten, haben wir bereits bei Badhamia kennen gelernt, außer Sporocysten gibt es aber bei den Endosporeen zwei weitere Arten von Fruchtkörpern: die Plasmodiocarpien und die A thalien.

Plasmodiocarpien sind Fruchtkörper, welche der Form nach nur wenig vom Plasmodium abweichen, man könnte sagen, es seien zu Fruchtkörperı erstarrte Plasmodien. Der einzige Formunterschied zwischen beiden ist eigentlich dieser, daß die Plasmodiocarpien durch

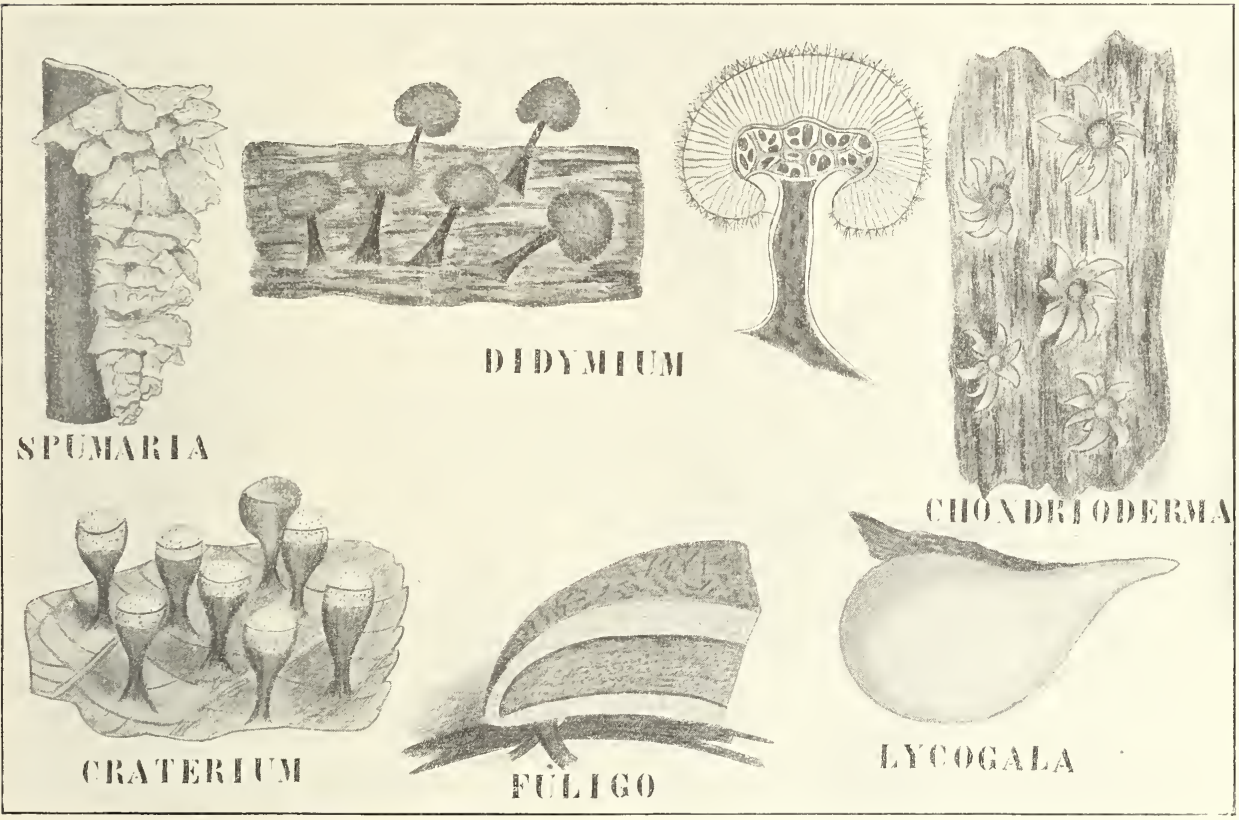

Fig. 243. Fruchtformen verschiedener mit Namen bezeichneter Myx myeeten Genera (nach ENGLER und PraNtL).

Einziehung der feineren Ausstrahlungen etwas einfacher geworden sind, mehr wurmartig, ja sogar durch die stattfindende Kontraktion in Stücke zerfallen können; sie brauchen keineswegs die einzige Fruchtform der betreffenden Art zu sein, neben ihnen können Sporangien vorkommen. Auf der Fig. 242 sind Plasmodiocarpien gezeichnet von Licea und Hemiarcyric; letztere ist nicht mit Namen bezeichnet; es ist die Figur, welche unter Arcyria steht.

Das Aethalium ist die seltenste Fruktifikationsform, es wird ausschließlich bei den Endosporeen angetroffen und dort nur bei eimzelnen zu sehr verschiedenen Gruppen gehörigen Arten. Nach Zopf gibt es unter den 200 bekannten nur 13, welche dethalien bilden kömnen.

Die Aethalien (Fig. 242, Clatroptychim, Reticnlaria, Fig. 2 43 , 
Spumaria, Fuligo) repräsentieren die höchsten Fruchtformen der Myxomyceten, es sind Sporangiensori, in welchen jedes Sporangium seine Individualität mehr oder weniger verliert, wodurch eine ziemlich geschlossene Einheit zu stande kommt. Es ist aber zu beachten, daß nicht alle Aethalien die Sporangiennatur deutlich zeigen, so betrachtet man das größte Aethalium, das von Fuligo, vielleicht besser als eine Sammlung von Plasmodiocarpien. Ueberhaupt ist die Grenze zwischen den verschiedenen Fruchtformen nicht immer leicht zu ziehen. Einige Aethalien sind nackt, $d$. h. bestehen ausschließlich aus mehr oder weniger veränderten Sporangien oder Plasmodiocarpien, andere hingegen, wie die von Fuligo, sind berindet, indem die äußere Schicht des Fruchtkörpers steril bleibt und die Sporenbildung sich auf das Innere beschränkt.

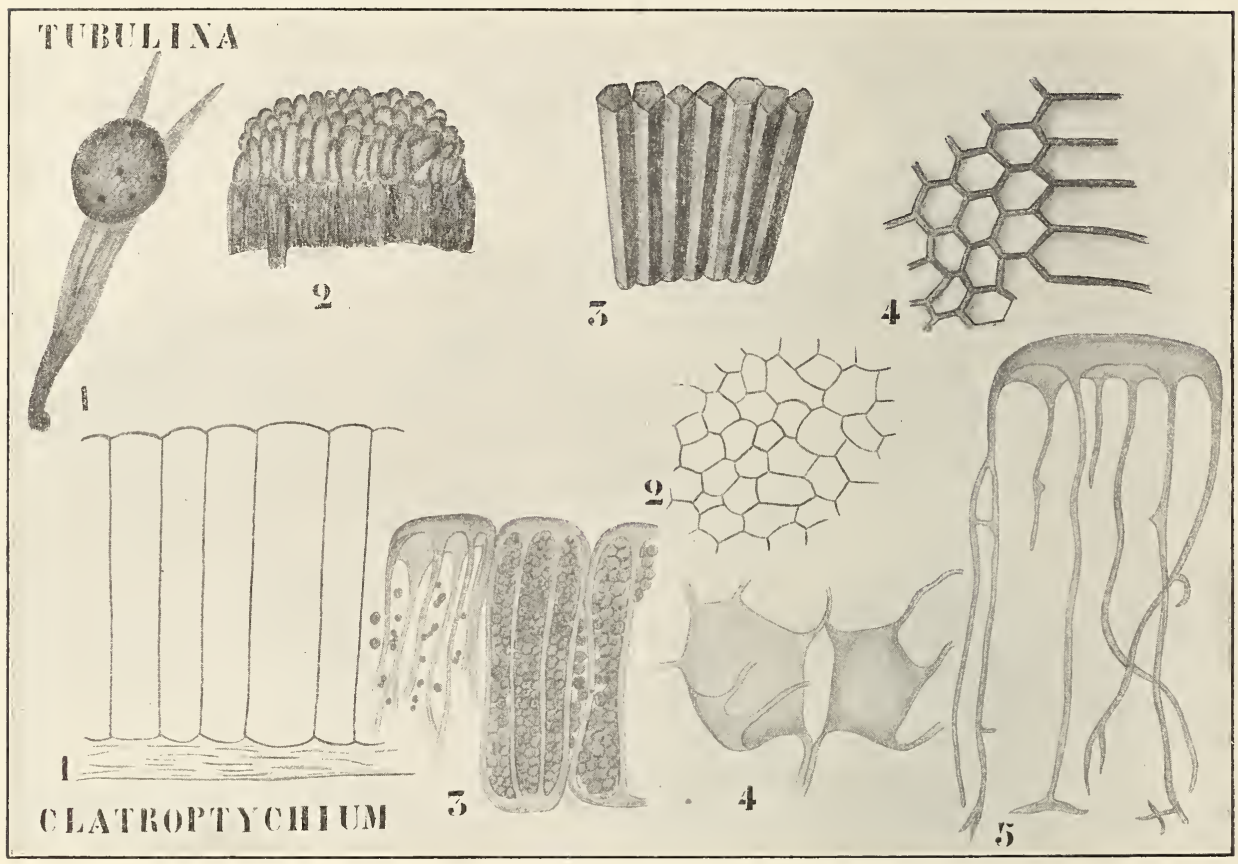

Fig. 244. Aethalien von Tubulina und Clatroptychium (nach ZopF).

Betrachten wir nun einmal die verschiedenen Typen von Aethalien, welche wir bei den Endotricheen antreffen.

Als Beispiel eines Aethaliums, bei welchem der Ursprung aus Sporangien besonders klar liegt, wählen wir Tubulina cylindrica BulL, eine Form, welche auch in unserem Lande, z. B. in Limburg, vorkommt.

Das Aethalium wird auf Tannennadeln oder faulendem Holze gebildet und hat die Form und die Farbe einer Erdbeere (Fig. 244, I 1). Es besteht aus zahllosen, nebeneinander stehenden Sporangien (Fig. 244, I 2,3), welche nicht die Spur eines Capillitiums besitzen und demnach noch auf recht niedriger Entwickelungsstufe stehen. Durch den Druck, welchen die Sporangien aufeinander ausüben, werden die zentral gelegenen polygonal; schließlich öffnen sie sich ziemlich regelmäßig an der Spitze und die Sporen können heraustreten. 
Bei Tubulina ist es also recht klar, daß das Aethalium ein Sporangiensorus darstellt.

Bei Clatroptychium haben wir im Prinzip denselben Fall (Fig. 244, II 1), dort wird aber in jedem Sporangium ein Capillitium gebildet, indem verdickte Stränge der Sporangiumwand, welche mit dem Deckel verbunden sind, bestehen bleiben, wenn der Rest derselben bereits zerstreut ist (Fig. 244, II 3, 4, 5).

Bei Spumaria sind die Sporangien verzweigt und über den größten Teil ihrer Länge miteinander verklebt, sie stehen sehr dicht zusammen und bilden ein stark gelapptes Aethalium, welches, da die Spitzen der Sporangien frei bleiben und über die verklebte Masse hervorragen, ein schwammiges oder korallenähnliches Aussehen hat.

Bei Fuligo ist das Aethalium, wie schon bemerkt, von einer Rinde umgeben. Es besteht aus zahllosen verwebten, ursprünglich hellgelben Röhren, aus welchen sich das Plasma zurückzieht, so daß nur der zentrale Teil fertil wird. Kalkblasen und Capillitiumfäden werden in später zu beschreibender Weise gebildet, für den Moment genügt es, gezeigt zu haben, daß das Aethalium von Fuligo nicht sporangialer Natur, sondern von einem Plasmodiocarp herzuleiten ist.

Auch bei Lycogala treffen wir ein berindetes Aethalium an. In diesem werden die Sporangien entweder gar nicht mehr angelegt oder obliterieren doch frühzeitig; die ganze Zentralmasse bildet sich in Sporen und Capillitiumfäden um.

Nachdem wir also gesehen haben, daß es bei den Endosporeen drei Arten von Fruchtkörpern: Plasmodiocarpien, Sporangien und Aethalien, gibt, können wir diese Gruppe näher betrachten. Wir sahen bereits, daß sie sich in die zwei Gruppen der Peritricheen und der Endotricheen zerlegen läßt; fangen wir mit der Besprechung der

\section{Peritricheen}

an. Dazu gehören drei verschiedene Familien:

1) die der Liceaceae, deren Fruktifikation in der Form von Sporangien, Plasmodiocarpien oder Aethalien stattfindet und bei welcher nicht die Spur eines Capillitiums angetroffen wird. Von der hierher gehörigen Licea flexuosa, welche auf Nadelholzstümpfen in Mitteleuropa vorkommt, sind hier die Plasmodiocarpien abgebildet; daneben bildet sie noch halbkugelige Einzelsporangien. Da die kastanienbraune Sporenmasse durch die dünne Wand hindurchschimmert, sind hier die Plasmodiocarpien braun gefärbt.

Tubulina cylindrica mit ihren erdbeerfarbigen und -förmigen Aethalien, welche ebenfalls hierher gehört, haben wir bereits besprochen. Sie kommt in Mitteleuropa, Nordamerika, Ceylon und Australien vor;

2) die der Clatroptychiaceen, eine Familie, welche nur Aethalien bildet, deren Form wir bereits bei Clatroptychium kennen gelernt haben. Das hier vorhandene Capillitium wird, wie wir sahen, von der Sporangienwand gebildet, wir haben hier also mit einer echten Peritrichee zu tun. Clatroptychium kommt in Europa, Algerien, Nordamerika und Australien auf faulendem Holze vor, und besitzt einen festen Hypothallus (Plasmodiumrest), auf welchem die Aethalien gebildet werden;

3) die der Cribrariaceae, eine viel größere Familie als die beiden anderen. Ihre Vertreter bilden ausschließlich Sporangien und besitzen ein schön entwickeltes Sporenzerstreumgssystem. Als Beispiel sei hier 
das in Fig. 242 auf S. 404 abgebildete Dictydium cernu um behandelt. Die Plasmodien dieser Organismen leben in allen Weltteilen ${ }^{1}$ ) in faulendem Holze und treten zur Bildung der Sporangien als blutrote Tropfen heraus. Alsbald bilden diese auf einem Hypothallus die schwarzgestielten, purpurbraunen Sporangien. Der ganze Inhalt bildet sich zu Sporen um, die Sporangienwand wird aber gitterartig durchbrochen und da der Stiel recht elastisch ist und die Sporangien nicken, stellt das Ganze, wenn es durch den Wind, durch fallende Regentropfen oder andere Erschütterungen bewegt wird, einen schönen Sporenzerstreuungsapparat dar.

Die Gruppe der

\section{Endotricheen}

kann ebenfalls in zwei Untergruppen zerlegt werden:

in die, bei welcher keine Kalkmassen oder nur wenige kleine Körnchen in der Sporangienwand vorkommen, in die . . . . . . . . . . . . . . und in die, bei welcher regelmäßig in verschiedenen

Teilen des Fruchtkörpers Kalkausscheidungen angetroffen werden, in die

Acalcareen

Betrachten wir zunächst die

\section{Acalcareen,}

so sehen wir, daß diese wieder in zwei Abteilungen geteilt werden können :

in die, bei welcher das Capillitium aus Röhren besteht, in die : . . . . . . . . .

und in eine, bei welcher das Capillitium aus soliden

Strängen oder Platten besteht, in die . . . . Stereonemeen.

Bei beiden Gruppen besteht das Capillitium aus einer celluloseähnlichen Substanz.

\section{Coelonemeae.}

Bei dieser Gruppe besteht also das Capillitium aus Röhren. Eine zentrale Säule fehlt. Die Sporenmasse ist stets lebhaft gefärbt: weiß, gelb oder rot, nie ist sie schwarzviolett.

$\mathrm{Zu}$ dieser Gruppe gehört nur eine Familie, die der

\section{Trichiaceen,}

von welcher ich die Genera: Perichaena, Arcyria und Hemiarcyria (vergl. Fig. 245) besprechen will. Unter diesen befinden sich Vertreter der beiden Capillitiumtypen, die bei den Coelonemeen angetroffen werden. Es ist dies der Netztypus, bei welchem die Capillitiumröhrchen zu einem Netze verbunden sind, und der Elaterentypus, bei welchem die Röhren frei zwischen der Sporenmasse liegen. In letzterem Falle sind sie meistens an beiden Seiten zugespitzt und die Wand der Röhre ist durch spiralförmige Verdickungen verstärkt.

1) In Afrika noch nicht nachgewiesen. 
Bei Areyria treffen wir den echten Netztypus, bei Hemiarcyria den Elaterentypus und bei Perichaena einen Zwischentypus an (vergl. Fig. 245), indem bei letzterer öfters mehr oder weniger verzweigte, der Sporangienwand angeheftete Röhreu vorkommen. Zum gleichen Typus gehören auch die mehr oder weniger verzweigten Capillitiumbäumchen, welche bei Lycogala aus der Wand entspringen (vergl. Fig. 245) und welche, indem die Zweige öfters miteinander anastomosieren, sich noch mehr dem Netztypus näheru.

Betrachten wir jetzt diese Genera etwas näher.

\section{Perichaena}

bildet insoweit eine Ausnahme in der Gruppe, als das Peridium, die Fruchtkörperwand, Kalkkörnchen besitzt. So wie bei allen Trichiaceen

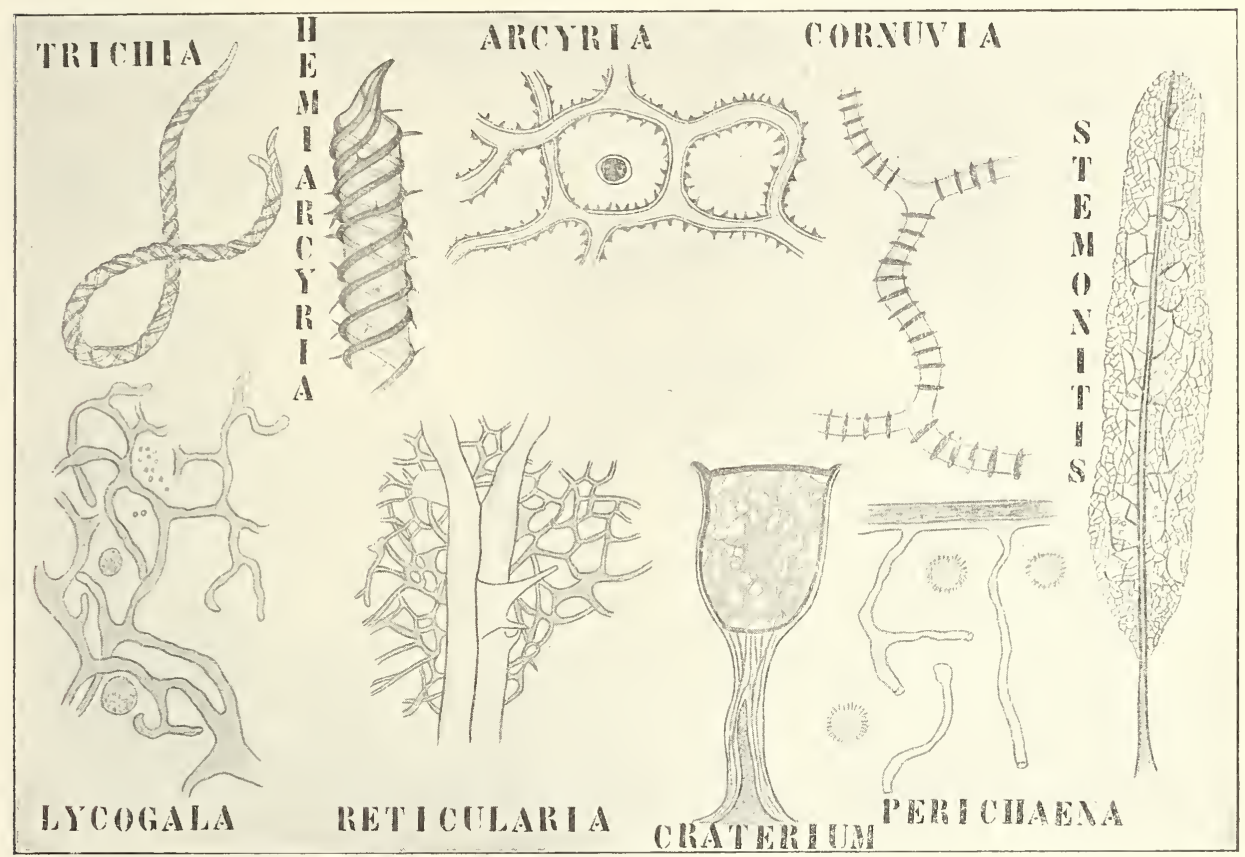

Fig. 245. Capillitiumtypen von mit Namen bezeichneten Genera der Coelonemeen und Stereoneme en (nach Zopf und Engler u. Prantu).

lebt das Plasmodium in faulendem Holze und tritt nur behufs Bildung der Fruchtkörper aus demselben heraus. Die abgebildete Perichaena corticalis bildet unter oder auf der Rinde von Quercus, Populus, Tilia etc. kleine, kaum $1 \mathrm{~mm}$ große, halbkugelige Sporangien, welche sich mittels eines Ringspaltes öffnen, so daß die Spitze deckelförmig abgehoben wird. Das Peridium besteht bei dieser Art aus einer einzelnen Schicht.

\section{Arcyria nutans.}

Bei dieser, sowie bei den anderen Arteu dieses Genus treffen wir kugelige Sporangien an, welche aber in Gegensatz zu denen von Perichaena gestielt sind. Da drinnen findet sich das stark zusammengepreßte große Capillitium, welches, an der Basis der Sporangienwand angeheftet. 
sich plötzlich zu einem etwa $1 \mathrm{~cm}$ langen Netzchen streckt, sobald der Deckel des Sporangiums mittels eines Ringrisses abgeworfen ist. In reifem Zustande sitzt also das Capillitium, welches sich alsbald umbiegt, auf einem gestielten Becherchen, dem Rest des Peridiums, und bildet so einen ausgezeichneten Sporenzerstreuungsapparat. Da es nur lose befestigt ist, wird es öfters in toto vom Winde mitgeführt.

Eine ganz andere Sporenzerstreuungsweise üben nach ZopF (l. c. p. 49) Trichia und Hemiarcyria ${ }^{1}$ ) aus, nämlich mittels Elateren. Wir sahen schon früher, daß Hemiarcyria neben Sporangien Plasmodiocarpien bildet, zwischen den Sporen liegen nun nach ZopF die Elateren, und diese werfen wohl infolge hygroskopischer Krümmungen die Sporen heraus. Hemiarcyria ist über - die ganze Welt verbreitet und wird besonders oft in hohlen Weidenstämmen angetroffen.

Als letztes Beispiel sei Lycogala genannt; wir sahen schon, daß sie berindete Aethalien bildet, innerhalb welcher keine Spur von Sporangienwänden zu sehen ist. Das Aethalium von Lycogala flavo-fusca ist 3 bis $4 \mathrm{~cm}$ groß, birnförmig, mit dicker pergamentartiger Rinde versehen, und umschließt eine tonfarbige Sporenmasse.

Das reich verzweigte Capillitium, welches einen Uebergang zum Netztypus bildet, ist recht dick. Die Rinde ist dreischichtig, die innere und äußere blasig, die mittlere homogen.

Die zweite Untergruppe der Endotricheae, die der

\section{Stereonemeae,}

besitzt, wie gesagt, Capillitien, welche statt aus Röhren aus Strängen oder Platten gebildet sind; auch ist meistens ein stark entwickeltes Säulchen vorhanden; die Sporen sind meist schwarzviolett, bisweilen auch braun.

Sie kann wieder in zwei Gruppen, nach der Struktur des Capillitiums, eingeteilt werden.

Bei der einen Gruppe, welche nur die Familie der Reticulariaceen umfaßt, besteht das Capillitium an der Basis aus soliden Strängen oder Platten, welche sich höher hinauf verteilen und stets dünner werden; bei der anderen Gruppe dagegen besteht das Capillitium aus feinen, einer Säule entspringenden Fäden, welche eine Art Netzwerk bilden. Diese Gruppe umfaßt die beiden Familien der Stemonitaceen und der Brefeldiaceen, von welchen die erstere Sporangien, die zweite Aethalien bildet.

Von den Reticulariaceen sei hier Reticularia Lycoperdon behandelt, welche in Europa nicht selten schon Anfang des Sommers fruktifiziert. Die Plasmodien leben in faulendem Holze oder auch wohl in der Rinde lebender Stämme und treten bei der Fruchtbildung zu weißen oder hellgelben Schleimmassen zusammen; über dem Substrat wird nun ein silberfarbiger Hypothallus gebildet, auf welchem $2-4 \mathrm{~cm}$ breite, bis zu $2 \mathrm{~cm}$ hohe Aethalien entstehen, welche von einer dicken bleifarbigen, papierartigen Rinde umgeben sind. Wenn diese bei der Reife unregelmäßig aufreißt, wird die braune Sporenmasse sichtbar. Das Capillitium besteht aus einer größeren Zahl flockiger Massen, welche alle an der Basis des Aethaliums befestigt sind. Unten aus einem dicken stammartigen Strang bestehend, bildet es höher hinauf Platten und endet in Fäden, welche, anastomosierend, ein Netzwerk bilden.

1) Nach Schroeter kommt bei Hemiarcyria ein netzförmiges Capillitium vor (1. c. p. 24). 
Bei den Stemonitaceen gibt uns Stemonitis die beste Einsicht. Stemonitis bildet ihre Sporangien stets in größeren Gruppen gesellig zusammen. Die Stemonitis-Arten kommen auf faulenden, öfter mit Moos überzogenen Baumstümpfen vor, wo die rotviolette Farbe der Sporangien einen überaus hübschen Effekt verursacht. Die Sporangien sind gestielt, und in der Mitte des Sporangiums verläuft eine sterile pfriemenförmige Masse, das sogenannte Säulchen. Sowohl von dieser Säule, wie von der Sporangientwand gehen zahllose feine Capillitiumfasern aus, welche durch Anastomose und Verflechtung ein vollkommenes Netzwerk bilden. Die ganze Wand des Sporangiums zerstäubt schließlich, und so bildet das Capillitium einen Sporenzerstreungsapparat, welcher in mancher Hinsicht an den von Arcyria erinnert, trotzdem er in ganz anderer Weise gebildet wurde. Bei den Brefeldiaceen, zu welchen Brefeldia und Rostafinstica gehören, werden große Aethalien gebildet.

Die letzte Gruppe der Endotricheen wird von den

\section{Calcareen}

gebildet. Die Gruppe verdankt ihren Namen dem hohen Kalkgehalt der verschiedenen Teile ihrer Fruchtkörper. Während bei den Spumariaceen und Didymiaceen das Capillitium entweder keine Kalkausscheidungen enthält, oder aber diese in Kristallform vorhanden sind, besitzt die andere Gruppe, die der Physariaceen, stets Kalk im Capillitium, und zwar immer in der Form amorpher Körnchen.

Die Spumariaceen sind weiter charakterisiert durch den Besitz langgestreckter, bei Spumaria sogar verzweigter Säulchen (Fig. 246, II 1), während bei den Didymiaceen dieses Säulchen entweder fehlt, oder, falls es vorhanden ist, nicht langgestreckt, sondern halbkugelig oder scheibenförmig ist (vergl. Fig. 243, Didymium, auf S. 405).

Zu den Spumariaceen gehören zwei Genera: Diachaea und Spumaria. Diachaea gleicht im Bau einer Stemonitis, aber weder der Stiel noch das Säulchen sind verkalkt. Die Aethalien von Spumaria lernten wir schon kennen, die verzweigten Säulchen reichen nicht bis zu den Spitzen der Sporangiumverzweigungen, das Peridium ist verkalkt, das Capillitium nicht. Die unreifen Aethalien erinnern an Cicadenschaum, sie überziehen lebende Pflanzen, Zweige, Blätter, Grashalme u. a. und kriechen an diesen hinauf. Schließlich kann das Aethalium bis zu $10 \mathrm{~cm}$ lang werden und zerstäubt zu einer aschgrauen Masse.

Bei den Didymiaceen werden sowohl Plasmodiocarpien wie Sporangien angetroffen. unter anderem auch bei dem auf S. 405 abgebildeten Didymium farinaceum. Diese Art besitzt ein weißes, in Holz lebendes Plasmodium, welches ein ungefähr $1 \mathrm{~mm}$ großes Sporangium bildet, durch dessen dünne Wand die dunkelviolette Sporenmasse hindurchschimmert. Im champignonförmigen Sporangium findet sich ein flaches breites Säulchen, welches auf dem Längsschnitt an die Columella der Mucorineen erinnert. Von dort aus strahlen nicht oder wenigstens nur wenig verzweigte Capillitiumfäden nach der Sporangienwand hinaus, sie enthalten bisweilen einzelne Kalkkristalle, aber die Hauptkalkmasse findet sich in der Sporangienwand, welche mit zahlreichen Kristallen bedeckt ist.

Bei Chondrioderma radiatum (Fig. 243), welche auf Rinde, Moosen etc. in Europa vorkommt, haben wir mit einer Art zu tun, deren Sporangienwand in der Weise gewisser Gasteromyceten sternförmig aufreißt, wodurch die vom Capillitium umschlossene Sporenmasse wie eine Kugel 
frei im aufgerissenen Sporangium liegt. Daß dies ohne Zerreißen des Capillitiums geschehen kann, hat seinen Grund in dem Umstand, daß die Sporenmasse schon frühzeitig durch eine Luftschicht vom Peridium getrennt ist. Das Capillitium entspringt einem stark gewölbten Säulchen.

Bei der Gruppe der Physarieen treffen wir sowohl Sporangien wie Aethalien und Plasmodiocarpien an. Bei Craterium, von welchem Genus auf S. 405 die Art leucocephalum abgebildet ist, kommen aber bloß Sporangien vor. Die Wand dieser Sporangien besteht aus zwei Schichten, einer inneren und einer äußeren. Die äußere ist papierähnlich und springt mittels eines Ringrisses deckelartig auf, die innere ist dünn, an dieser ist das netzförmige Capillitium angeheftet. Die Knoten des Netzwerkes werden von Kalkblasen gebildet, während ein in der Mitte ge-

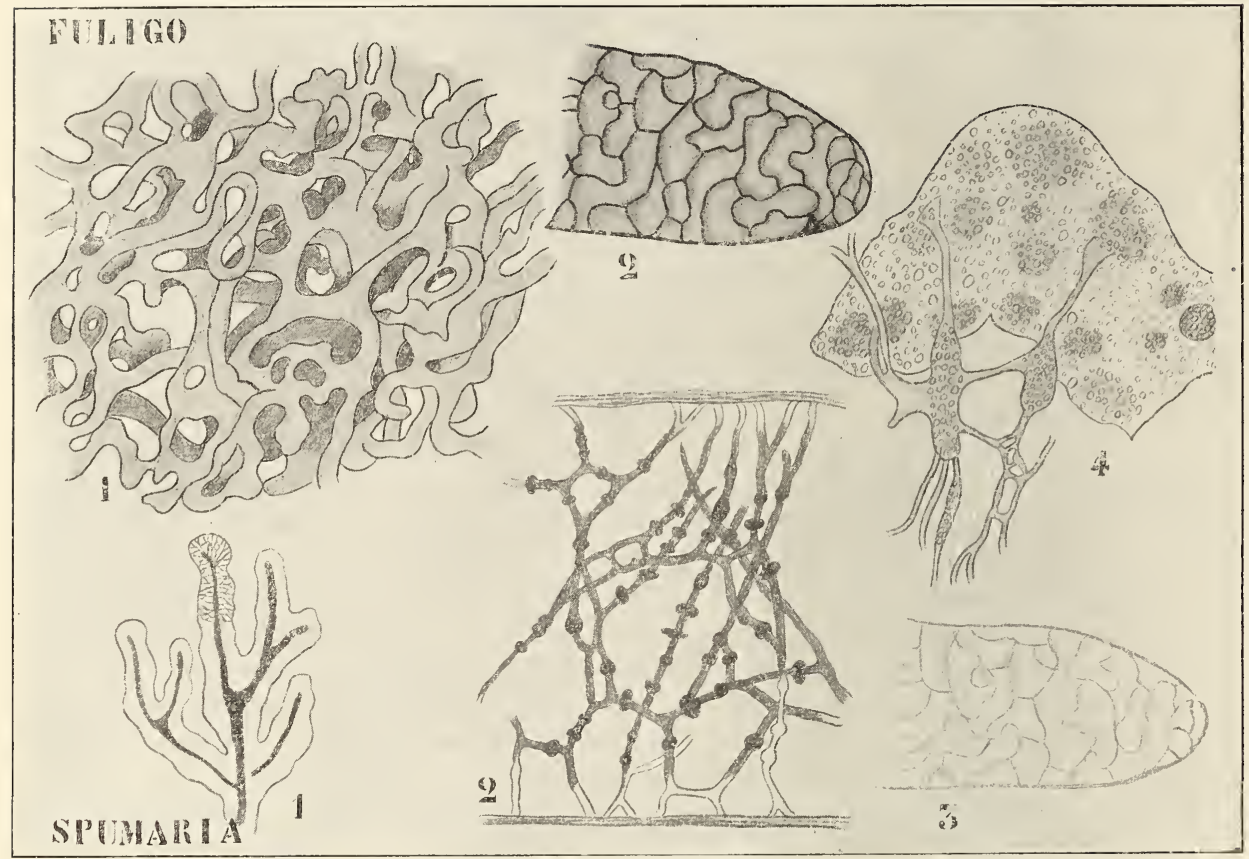

Fig. 246. Calcareae (nach DE BARY und ZOPF). I. Fuligo. 1 Junges Aethalium, 2 älteres, 3 nachdem der Farbstoff auf die Peripherie der Stränge lokalisiert ist. 4 Teil der Rinde, die Kalkblasen zeigend. - II. Spumaria. 1 Verzweigtes Sporangium. 2 Teil des Capillitiums stärker vergrößert.

legener Knoten besonders entwickelt ist und unter dem Namen Zentralknoten als Columella fungiert. Die C. leucocephala ist in Europa nicht selten. behandelt.

Das zu dieser Gruppe gehörige Genus Badhamia haben wir schon

Von der letzten hierher gehörigen Art, von Fuligo varians, haben wir schon die berindeten Aethalien kennen gelernt. Das Capillitium ist netzförmig und umschließt viele unregelmäßige Kalkblasen (Fig. 246, I 4).

Das Plasmodium von Fuligo varians, das größte aller Myxomyceten, ist hellgelb gefärbt und bildet die sogenannte Lohblüte. In Europa, 
Amerika und Australien häufig, ist sie keineswegs auf Lohe beschränkt, ich sah sie u. a. auf Baumstümpfen im Göttinger Wald.

Unsere Keuntnis der feineren Struktur des Myxomyceten-Plasmodiums und der Crtologie der Fruktifikation derselben ist in den letzten Jahren durch die Untersuchungen Harpers (1900) sehr vermehrt worden. Wir wollen also noch einiges darüber sagen und damit einige Mitteilungen über die Bildung der Sporangiumwand und der Capillitiumwand der Myxomyceten verbinden.

Man meinte früher, daß die Sporangiumwand, die Wand der Plasmodiocarpien der Myxomyceten etc. aus erstarrtem Plasma bestehe und daß z. B. die Elateren der Trichiaceen umgebildete Zellen, umgebildete Amöben seien.

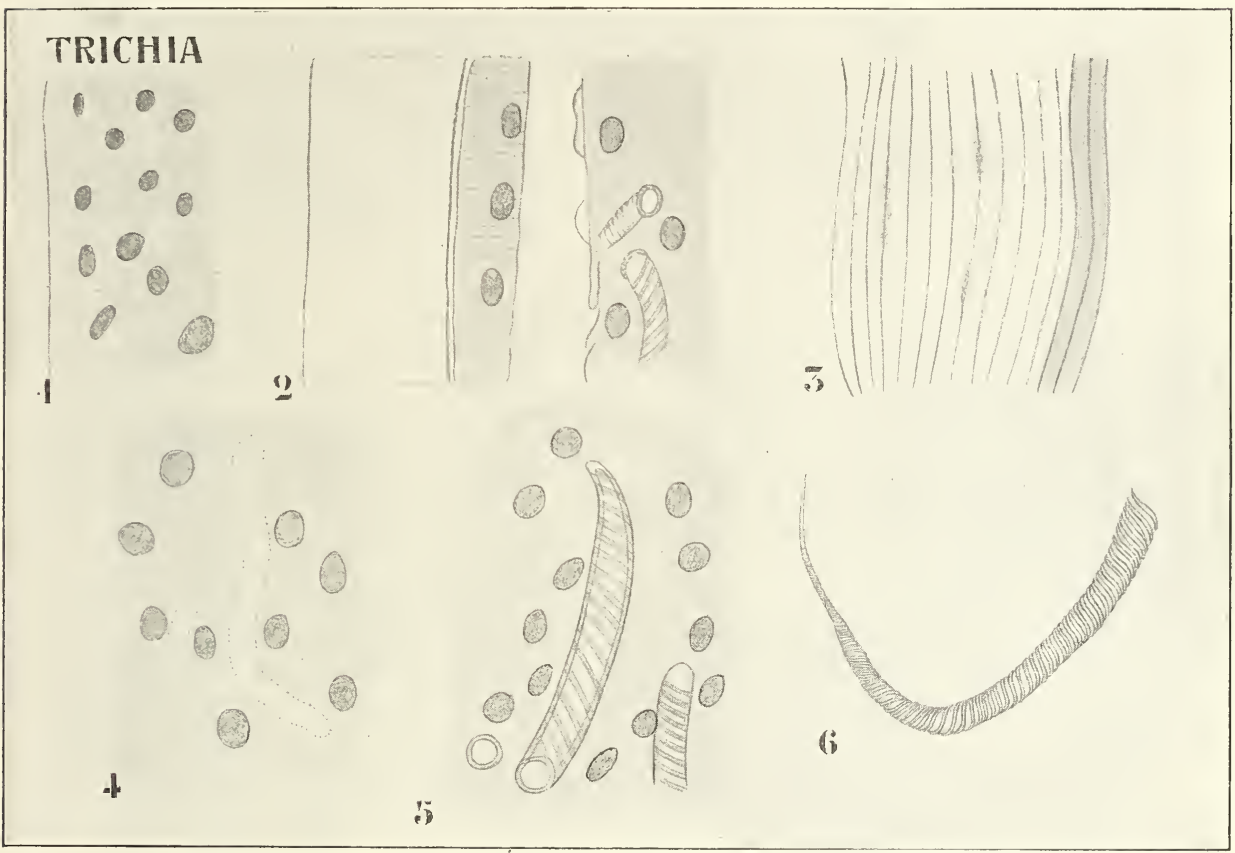

Fig. 247. Wandbildung und Elaterenbildung bei Trichi a fallax (nach STRASBDRGER). 1 Cytoplasma und Hautschicht. 2 Die zum Teil in Wandsubstanz umgesetzte Hautschicht, vom Cytoplasma abgehoben. 3 Längsschnitt durch die geschichtete Sporangienwand. 4 Vakuole, um welche herum eine Capillitiumröhre gebildet wird. 5 Aelteres Stadium. 6 Ausgebildete Capillitiumröhre.

Strasburger (1884) zeigte zuerst, daß dies nicht der Fall ist. Die Wand der Sporangien und der Capillitiumröhren besteht aus einer celluloseartigen Substanz, welche in vollkommen normaler Weise von der Hautschicht des Plasmas ausgeschieden wird, wobei anscheinend diese Hautschicht, welche während dieses Vorganges dünmer und dümmer wird, zu der celluloseartigen Wand umgebildet wird, etwa in der Weise, wie das Pyrenoid von Hydrodictyon in Stärke umgesetzt wird.

Sowohl bei der Bildung der Sporangienwand wie der Capillitiumfasern wirkt also das Plasmodium wieder als ein Ganzes. ebenso wie das Cönobium eines Phycomyceten. 
Die Capillitiumröhren werden um Vakuolen herum, welche die Form dieser Fäden besitzen, gebildet. Auch hier bildet sich die Hautschicht des Plasmas zu einer celluloseähnlichen Substanz um. Im Innern der Capillitiumröhre ist also nie Plasma gewesen, und in Verbindung damit sind denn auch die verstärkenden Spiralen, Rippen, Stacheln u. s. w. (Fig. 245) der Außenseite aufgesetzt. Diese Entstehung der Capillitiumröhren wurde 1884 von STRASBURGER beschrieben; 1900 teilt HarPer mit, daß die Stereonemata, die soliden Capillitiumfasern, von Stemonitis und Lycogala in gleicher Weise gebildet werden. Daraus muß man also wohl schließen, daß es zwischen Cölonemata und Stereonemata nur einen graduellen, nicht einen prinzipiellen Unterschied gibt, und daß ein hohler Faden entsteht, wenn die Vakuole weit, ein solider, wenn sie sehr eng ist.

Die einzigen detaillierten Mitteilungen, welche wir über die Sporenbildung kennen, sind die von Harper bei Fuligo und Nawaschin bei Plasmodiophora. Nawaschins Arbeit war HarPer offenbar noch nicht bekannt, als er die seinige publizierte.

Bei Plasmodiophora isolieren sich, nachdem sie sich, wie aus der lebhaften Kernteilung gefolgert werden muß, bedeutend vermehrt haben, die Energiden durch Kontraktion, runden sich ab und werden zu Sporen. In den Lehrbüchern wird diese Weise der Sporenbildung als gültig für alle Myxomyceten angegeben.

HARPER zeigt aber, daß bei dem Aethalium von Fuligo die Sporen in einer Weise gebildet werden, welche weit mehr an den Vorgang bei Synchytrium und Pilobolus erinnert, und scheint zu meinen, daß es sich herausstellen wird, daß diese Weise bei den Myxomyceten allgemein befolgt wird, was recht gut möglich ist, denn es gelang Nawaschrn offenbar nicht, genau zu beobachten, was am Anfang des sporogenen Stadiums geschieht, wie aus dem oben mitgeteilten Satz über das "Auflösen" der Kerne hervorgeht; andererseits ist es natürlich auch recht gut möglich, daß es bei den Myxomyceten zwei Typen von Sporenbildung gibt, welche man dann den Plasmodiophora- und den Fuligo-Typus würde nennen können. Weitere Untersuchungen werden dies entscheiden müssen. werden.

Sehen wir also, wie bei Fuligo Aethalium und Sporen gebildet

Wir sahen schon früher, daß sich das Fuligo-Plasmodium, wenn es zur Bildung des Aethaliums schreitet, aus der Tiefe des Substrates an dessen Oberfläche begibt und dort ein Reticulum bildet (Fig. 246, 1) welches vom ursprünglichen nur durch größere Dichte abweicht.

Dieses Reticulum kontrahiert sich nun, so daß die Interstitien zwischen den einzelnen Plasmodiumsträngen sehr eug werden, die Stränge also zu einem Knäuel zusammengedrängt werden (Fig. 246, 2). Sämtliche feste Substanzen, welche vom Plasmodium aufgenommen waren, werden während dieses Vorganges herausgepreßt und kommen an die Oberfläche zu liegen; große Quantitäten Wasser mit den gelösten Salzen werden ebenfalls herausgepreßt und das Salz kristallisiert infolge der Verdunstung des Wassers aus. Auch der gelbe Farbstoff zieht heraus, so daß das Reticulum alsbald farblos wird (Fig. 246, 3). Da diese Ausscheidung nicht nur an der Oberfläche des ganzen Aethaliums, sondern auch an der der einzelnen Stränge stattfindet, entsteht so ein System gelbgefärbter, aus Exkreten gebildeter Röhren, in welche nun das farblose Plasmodium eingeschlossen ist. Innerhalb dieser Exkretröhren wird nun noch eine celluloseartige Membran vom Protoplasten gebildet, so daß das Plasmodium in eine vielfach gewundene und verschlungene Celluloseröhre 
eingeschlossen ist. Das Plasmodium zieht sich nun gegen das Zentrum des Aethaliums zusammen, wodurch die peripher gelegenen Teile der Röhre kollabieren und mit den schon fiüher an der Oberfläche ausgeschiedenen Exkreten die noch dünne Rinde bilden.

Die ersten Teilungen, welche zur Sporenbildung führen, finden uun so wie bei Pilobolus ohne jegliche Rücksicht auf die Nuclei statt. Von der Oberfläche der Plasmamasse ausgehend, treten Spalten auf (Fig. 248, 1), welche das Plasma in vielkernige Stücke zerlegen (Fig. 248, 2). Zunächst teilen die Kerne sich nicht, alsbald aber setzt die Kernteilung ein (Fig. 248, 3), aber auch jetzt nehmen die Spalten auf diese noch keine Rïcksicht (Fig. 248, 3), sie fahren fort, die Plasmamasse in vielkernige, nach und nach kleiner werdende Stücke zu zerlegen. Dann

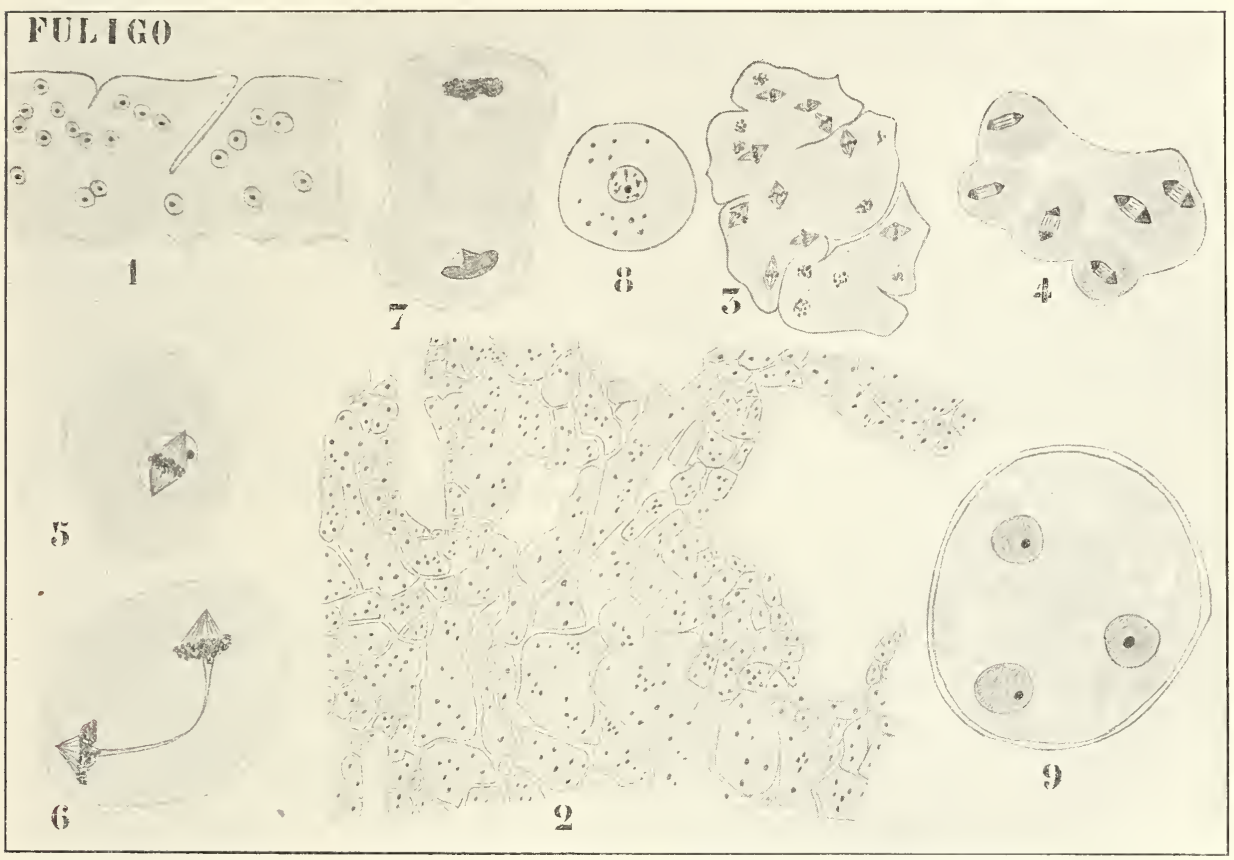

Fig. 248. Sporenbildung bei Fuligo (nach HARPER). Figurenerklärung im Text.

kommt ein Stadium, auf welchem die Nuclei Einfluß ausüben; um jeden sich teilenden Nucleus herum zieht sich das Plasma zusammen (Fig. 248, 4), wodurch in einiger Entfernung der Nuclei hyaline Zonen entstehen, in welchen nun die nächstfolgenden Spalten entstehen, so daß einkernig'e Stücke (Fig. 248, 5) gebildet werden. Da aber der Kern dieser einkernigen Stücke sich in Teilung befindet, werden die Stücke fast sofort wieder zweikernig (Fig. 248, 6), da sich aber das Plasma nun auch teilt (Fig. 248, 7), entstehen dennoch einkernige Sporen.

Da alle Myxomyceten sich in jedem Momente ihres Daseins beim Eintritt ungünstiger Lebensbedingungen einkapseln können, entstehen bisweilen Scheinsporen durch Encystierung von Plasmastückichen, bevor die Spaltungen beendet sind. Solche Stücke sind immer durch ihre Vielkernigkeit (Fig. 248, 9) von echten Sporen zu unterscheiden. 
Die Uebereinstimmung mit der Sporenbildung in anderen großen Sporangien ist auffallend; HARPER sagt darüber:

If we compare the method of sporeformation in Fuligo with that which I have described elsewhere for Synchytrium, Pilobolus and Sporodinia, it will be seen that the processes in all these forms are identical in their main features, while differing in a number of important details. In the four cases the cleavage is progressive from the surface inward, larger segments being first formed, which are later cut up into uninucleated cells, except in Synchytrium taraxaci and Sporodinia, in which the multinucleated segments function directly as spores.

In the earlier stages of cleavage in Pilobolus and Fuligo the furrows pierce through perfectly undifferentiated and quite homogenous protoplasm, while in the later stages the differentiation of hyaline areas, wedge-shaped in transverse section and cutting through the masses to be divided, predetermine the planes of the cleavage furrows. Such hyaline areas were not observed in Synchytrium or Sporodinia. In Synchytrium and Sporodinia nuclear divisions precede cleavage. In Pilobolus nuclear divisions occur during the later stages of cleavage, and in Fuligo nuclear divisions and cleavage proceed simultaneously throughout.

Fuligo is the only one of the five forms in which the uninucleated stages formed by the completion of the cleavage process, and which I have called, protospores, become the functional spores directly without further growth or nuclear division. In this respect perhaps the cleavage of Fuligo represents a more simple primitive type than that of either of the others."

Er sieht in dieser Uebereinstimmung zwischen Phycomyceten und Myxomyceten keine phylogenetische Verbindung, sondern sagt, meines Erachtens mit Recht:

,The occurence of such similar types of cleavage of the multinucleated mass as are found in the aethalium of Fuligo and the sporangia of the Phycomycetes must be regarded as another example of parallel development in structures not phylogenetically connected. The explanation of the similarity in these forms of cleavage is to be sought in the fundamental physiological properties of protoplasm and not in hereditary transmission to the different branches of genetically related forms."

Nachdem wir also eine Uebersicht über die Myxomyceten erhalten haben, bleibt die Frage zu erörtern, ob die Myxogasteres von den Acrasieae abzuleiten sind oder ob beide Gruppen als divergierende Reihen von gemeinsamen Ahnen ausgehend zu betrachten sind.

Dazu ist es in erster Linie nötig, den Nachdruck auf den Umstand zu legen, daß eigentlich das einzige Stadium in der Entwickelungsgeschichte dieser Organismen, welches strikt vergleichbar ist, das selbständige Amöbenstadium, die sogenannte Myxamöbe ist, denn die Plasmodienstadien beider Gruppen haben nur eine ganz oberflächliche Aehnlichkeit, sind in der Tat sehr verschieden.

Während doch bei den Acrasieen das Plasmodium aus einer Ansammlung von Amöben besteht, welche im Begriff sind, sich einzukapseln, also den Anfang der Sporulation darstellt, bildet das Myxogasteren-Plasmodium im Gegenteil das Hauptstadium des vegetativen Daseins dieser Organismen. Es ist auch nicht durch einfache Aggregation von Individuen, sondern durch Fusion derselben entstanden, es wird ein Coenobium gebildet, in welchem die Grenzen der Einzelindividuen unkenntlich werden, und welches sich allerlei Reizen gegenüber wie eine physiolo- 
gische Einheit verhält. Ueberdies gibt es - wie die Kernteilungen zeigen - während des Plasmodiumstadiums Energidenvermehrung; welche sich öfters noch vor der Sporenbildung, z. B. bei Fulligo, wiederholt, was bei den Acrasieen im Plasmodiumstadium nie stattfindet.

Während der Stiel einer Stemmonitis äußerlich einige Aehnlichkeit mit einem solchen von Polysphondylium hat, sind diese morphologisch völlig verschieden; der Stiel von Stemmonitis ist wie das Capillitium nur eine leere Celluloseröhre, derjenige von Polysphondylium besteht aus membranumhüllten Amöben.

Aus diesen großen Verschiedenheiten folgt wohl ohne weiteres, daß wir keine direkte Verwandtschaft zwischen Sorophoreen und Myxogasteres annehmen können. Dazu kommt nun noch, daß die Myxogasteres begeißelte Myxomonaden besitzen, welche den Sorophoreen fehlen. Das macht es, wie DE BARY schon bemerkt, wahrscheinlich, daß die Myxogasteres von Flagellaten herzuleiten sind.

Wir können also kaum mehr sagen, als daß es zwischen Sorophoreae und Myxogasteres eine gewisse Verwandtschaft gibt, wahrscheinlich aber nur eine sehr entfernte.

Die Gruppe der Myxomyceten ist wohl, wenigstens biphyletisch, zum Teil von Amöben (Sorophoreae), zum Teil von Flagellaten (Myxogasteres) herzuleiten.

Es bleibt nun von den farblosen Thallophyten noch eine große Gruppe zu besprechen, nämlich die Gruppe, welche die höheren Pilze umfaßt, die Gruppe der Eumycetes, ihr seien die folgenden Vorlesungen gewidmet. 


\section{Achtzehnte Vorlesung.}

\section{Eum yc etes.}

Diese große Pilzgruppe wird meistens in zwei große Abteilungen zerlegt, in Ascomyceten und Basidiomyceten. Von diesen beiden stehen die Basidiomycetert scharf gegenüber der schon besprochenen Grủppe der Phycomyceten, da ihre Zellen in der x-Generation einen, in der $2 \mathrm{x}$-Generation 2 Nuclei besitzen, während es unter den Ascomyceten sowohl mono- wie polyenergide Formen gibt.

Ascomyceten und Basidiomyceten unterscheiden sich weiter dadurch, daß bei ersterer Gruppe die Sporen der höchsten Sporenform in angeschwollenen, sporangienähnlichen Hyphen, in sogenannten Asci eingeschlossen bleiben, während sie bei letzterer im ausgebildeten Zustande am Ende feiner Stielchen, am Ende sogenannter Sterigmen stehen.

Betrachten wir zunächst die Gruppe der Ascomyceten.

\section{Die Ascomyceten.}

Um in diese, in Bezug auf ihre systematische Verwandtschaft sehr schwierige Gruppe eine gute Einsicht zu erhalten, ist es nötig, eine historische Uebersicht über die Entwickelung unserer Kenntnisse von derselben zu geben.

Diese fing init den höheren Ascomyceten, wie Periza, an, so daß der jetzige Begriff Ascomyceten eine größere Gruppe umfaßt, als anfänglich mit diesem Namen angedeutet wurde, als z. B. von DE BARY darunter verstanden wurde.

Noch im Jahre 1884 schreibt DE BARY in seiner Morphologie:

„Sieht man ab von den am Schlusse als zweifelhafte Ascomyceten ${ }^{1}$ ) zu betrachtenden Formen, so sind die Asci der Ascomyceten Sporenfrüchte im Sinne des $\S 33$ oder Teile von solchen, im letzteren Falle oft zu mehreren bis sehr vielen zu Hymenien zusammengesetzt."

Unter einer Sporenfrucht nun versteht DE BARY ,einen aus einem Archicarp erwachsenden, wesentlich der Sporenbildung dienenden Körper"; unter Achicarp versteht er eine „sexuell oder durch Kopulation befruchtete Zelle" und sagt: „es sei das Wort Archicarpium, Fruchtanfang, gewählt mit Rücksicht auf die anschauliche Tatsache, daß daraus sehr oft die gewöhnliche Frucht, der Fruktifikation genannte Körper, als nächstes Entwickelungsprodukt hervorgeht. Bei den Farnen und Moosen

1) Laboulbenia, Exoascus, Saccharomyces. 
ist dieses Archicarpium die Eizelle im Archeogonium, bei den eibildenden Algen, wie z. B. Taucheria, .... Coleochaete, ebenfalls eine, hier in dem Oogonium entstandene Eizelle; bei den isogamen Algen endlich, z. B. Zygnemeen, Desmidieen, Botrydium, jede in normalen Fällen mit einer gleichnamigen kopulierende ,Gametenzelle.".

Wir würden jetzt statt von Archicarp von einer Zygote, resp. von einem Zygogametangium sprechen.

Ueber die aus dieser Zygote resp. dem Zygogametangium gebildeten Sporenfrüchte sagt DE BARY, daß es recht klar ist, daß eine Moosfrucht eine Sporenfrucht ist, aber daß ebenso gut die reifen Eizellen von Coleochaete, Oedogoniaceen, Desmidieen etc., „welche sich in eine Mehrzahl oder in 4 oder nur 2 als Sporen weiter entwickelte Tochterzellen teilen"... einfache Sporenfrüchte sind.

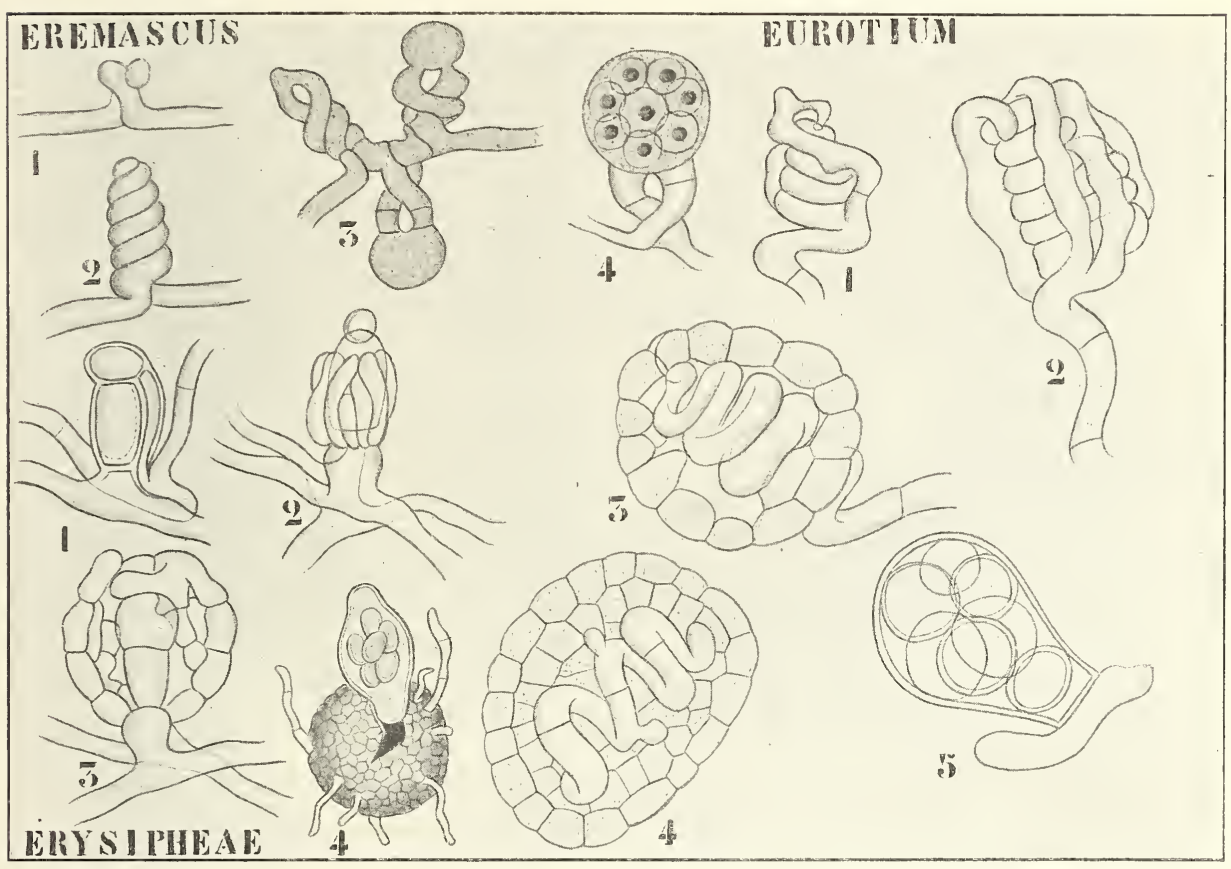

Fig. 249. Fruchtentwickelung mit Namen bezeichneter As comyceten (nach EIDAM und DE BARY). Figurenerklärung im Text.

Nach DE BARY ist also ein Ascus entweder eine ganze Sporenfrucht oder ein Teil einer solchen.

Im ersteren Falle also ein Zygogametangium mit den darin eingeschlossenen Zygoten. Als Beispiel dafür nennt DE BARY Eremascus albus, einen Pilz, der nur einmal von Eidam auf verdorbenem Malzextrakt gefunden und von ihm kultiviert wurde. Später hat man ihn nicht wieder auffinden können.

Bei diesem Pilze, dessen Mycel aus regelmäßig septierten Hyphen besteht, bilden bei der Fortpflanzung zwei benachbarte Zellen hart an der Zwischenwand je eine seitliche Ausstülpung' (Fig. 249, I 1),

Diese Ausstülpungen winden sich schraubenförmig umeinander 
(Fig. 249, I 2) und kopulieren schließlich an den Spitzen, nachdem sie sich mittels einer Querwand vom Mycelium getrennt haben. Die Kopulationsstelle schwillt nun stark an, das Plasma aus beiden Ausstülpungen tritt in die so gebildete Blase ein, diese trennt sich mittels Querwänden von den jetzt leeren Ausstülpungen (Fig. 249, I 3) und die Blase wird zum "Ascus", welcher aus seinem Inhalt 8 Sporen bildet (Fig. 249, 4).

Hier ist also die Zygogametangiumnatur des "Ascus" klar wie Glas.

Bei den Erysipheen wird die Sache durch Ausbildung einer sterilen Schutzhülle um den Ascus herum kompliziert.

Das Archicarp entwickelt sich hier als ein Seitenzweig an einer Hyphe; eine benachbarte Hyphe bildet einen Antheridiumzweig, welcher alsbald seine Spitze mittels einer Querwand als Antheridium abtrennt. Dieses Antheridium schmiegt sich an die Spitze des Archicarps an (Fig. 249, III 1). Nach DE BARY findet hier die Befruchtung etwa wie bei den Phanerogamen ${ }^{1}$ ) durch geschlossene Wände hindurch statt. Nachdem das Archicarp befruchtet ist, entwickeln die Tragfäden sowohl des Archicarps wie des Antheridiums sterile Fäden, welche am befruchteten Archicarp hinaufwachsen (Fig. 249, III 2), sich dort zu einer pseudoparenchymatischen Hülle verweben, und so die Fruchthülle bilden (Fig. 249, III 3, 4). Dann teilt sich das Archicarp in 2 Zellen, von welchen die obere ${ }^{2}$ ) Ascus, die untere Stielzelle wird (Fig. 249, III 3). Hier haben wir also eine Teilung des befruchteten Archicarps in eine sterile und eine fertile Zelle.

Bei Eremascus ist also der Ascus die ganze Sporenfrucht, bei Podosphaera, der oben besprochenen Erysipheae, nur ein Teil der Sporenfrucht.

Während aber bei Porlosphaera die Sporenfrucht doch noch fast ganz vom Ascus gebildet wird, zeigt Eurotium uns klar, daß der Ascus auch nur ein kleiner Teil einer Sporenfrucht sein kann.

Bei diesem Genus entsteht das Archicarp als ein spiralig gewundener Faden, an welchem ein Antheridiumzweig hinaufwächst (Fig. 249, II 1). So bald letzterer mit der Spitze des gewundenen Archicarps in Berührung kommt, werden die trennenden Wände an jener Stelle gelöst, wodurch eine offene Kommunikation zwischen dem Archicarp (Oogon) und dem Antheridium entsteht. Dann fängt das Archicarp stark zu wachsen an, und teilt sich mittels Querwänden in eine Anzahl Zellen (Fig. 249, II 4). Inzwischen ist in ähnlicher Weise wie bei Podosphaera eine Fruchthülle aus sterilen Hyphen gebildet (Fig. 249, II 2, 3, 4), wodurch das Ascogon - wie man das befruchtete Archicarp (Oogon) hier nennt - ganz eingehüllt wird. Durch das Wachstum der jungen Frucht wird nun das Ascogon gestreckt, wodurch die Windungen weiter voneinander entfernt werden (Fig. 249, II 4). An einem bestimmten Moment bildet nun jede Ascogonzelle eine Ausstülpung (Fig. 249, II 4), welche zu einem langen Faden, der sogenannten a s c o g en en Hy phe auswächst. Diese Hyphen schieben sich zwischen die Zellen der Fruchthülle ein, verdrängen und zerstören alle jene Zellen mit Ausnahme der äußeren Schicht, verzweigen sich recht stark und bilden ihre Zweiglein letzter Ordnung zu Asci um. Die ascogenen Hyphen zerfallen alsbald, so daß, wenn die Sporen reif sind, innerhalb der Fruchthülle (Perithecium) nur noch

1) Man meinte damals, daß die Befruchtung bei den Phanerogamen mittels „Diffusion“ stattfände.

2) Nach der damaligen Meinung. 
isolierte Asci, mit Fragmenten der ascogenen Fäden vermischt, vorhanden sind. Schließlich zerbröckeln auch noch die Ascuswände, so daß innerhalb des reifen Peritheciums schließlich nur noch reife Sporen vorhanden sind.

Wir haben also hier mit einem Fall zu tun, wo das Oogon nach der Befruchtung keimt, Hyphen bildet, welche Asci bilden. Der Fall wäre also der keimenden Zygote von Nemalion, welche an sporogenen Fäden Carposporangien bildet, vergleichbar.

Der Ascus ist also hier nicht wie bei Eremascus ein Zygogametangium, ist nicht länger die ganze Sporenfrucht, sondern nur ein Teil derselben.

Während bei Eurotium die ungewohnte spiralige Form des Oogons leicht Veranlassung geben kann, DE BARYs Interpretierung für etwas

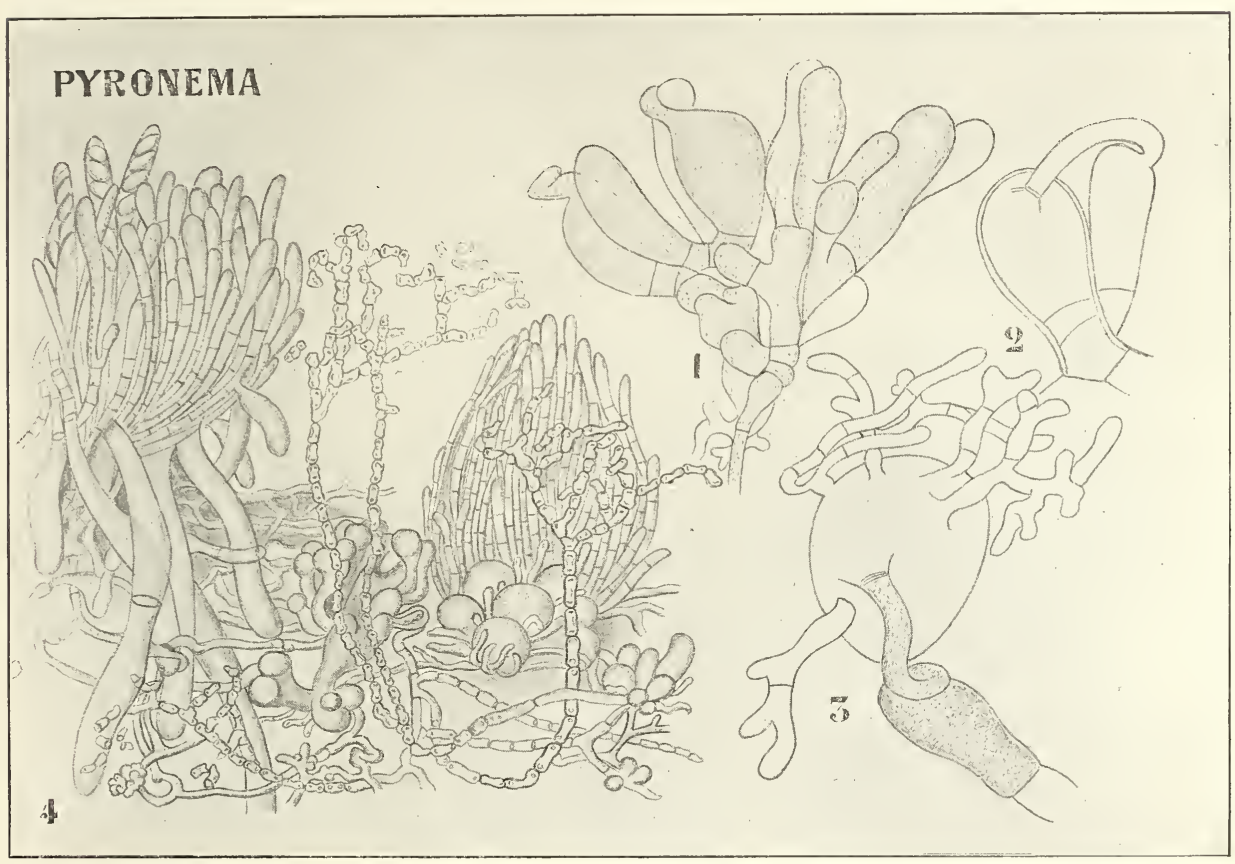

Fig. 250. Pyronema confluens (nach Kinlmann und Tulasne). 1 Oogonien und Antheridien. 2 Kopulation. 3 Bildung der ascogenen Hyphen. 4 Mehrere Fruchtkörper, in verschiedenen Entwickelungsphasen; die kettenförmigen Konidienreihen, welche hier nach TULASNE gezeichnet sind, gehören nicht zur Pyronema.

gewagt zu halten, gibt es Fälle, in welchen die ascogene Hyphen bildenden Oogonien so typische Oogonform besitzen, daß jeder Zweifel an der Natur derselben ausgeschlossen erscheint. Das ist z. B. der Fall bei Pyronema confluens.

Pyronema confluens ist ein Ascomycet, welcher besonders gerne sich auf Brandstellen in Wäldern oder grasigen Triften entwickelt. So waren im trockenen Sommer 1904 das Gras und die Sträucher. welche den Eisenbahndamm zwischen Wolfheezen und Arnheim bedecken, wiederholt vom Feuer der Lokomotiven angezündet, und an den Brandstellen waren am ganzen Wege entlang die roten Flecke der jungen Frucht- 
körper der Periza confluens zu sehen. Dieser Pilz breitet nämlich sein Mycel über große Flächen aus; fängt die Fruktifikation an, so entstehen zunächst reich verzweigte, krause, schief aufwärts wachsende Zweiggrüppchen.

Einzelne derselben, meistens zwei, schwellen bedeutend an, verzweigen sich gabelartig, wachsen senkrecht aufwärts und sistieren alsbald ihr Längenwachstum. Die Gabelzweige bilden dann zusammen eine Art Rosette. Einige derselben bilden ihre Endzellen zu Archicarpien (Oogonien), andere zu Antheridien um.

Das Archicarp oder Oogon ist dick, geschwollen, das Antheridium viel dünner.

Alsbald bildet nun jedes Oogon an seiner Spitze einen Kopulationsschlauch, die sogenannte Trichogyne, welche auf das Antheridium zuwächst, dessen Spitze umschlingt (Fig. 250, 1) und nun mit dem Antheridium, nach Auflösung der Trennungswände, kopuliert (Fig. 250, 2).

Es mag auf den ersten Blick befremdlich scheinen, daß hier das Oogon aktiv auftritt und nicht das Antheridium; der Fall steht aber keineswegs einzig da, ich brauche nur an die Bildung der Kopulationspapille bei Allnigo zu erinnern.

Nach der Kopulation schwillt das Archicarp (Oogon) stark an und bildet eine größere Zahl ascogener Hyphen (Fig. 250, 3).

Inzwischen ist eine aus sterilen Hyphen gebildete Hülle um die Archicarpien herum gewachsen, eine Hülle, welche den größten Teil der Archicarpien umgibt und die Form einer Scheibe besitzt. An der Oberfläche dieser Scheibe entwickeln sich aus den sterilen Hyphen zahlreiche aufrechte, gerade Fäden, die sogenannten Paraphysen.

Diese Paraphysen sind also alle in einer Ebene, an der Oberfläche der parenchymatischen Scheibe, im Hypothecium eingepflanzt und laufen parallel zueinander. Die ascogenen Hyphen, welche nun noch in der scheibenförmigen Hülle, die um die Oogonien gebildet wurde, verborgen sind, wachsen herauf, bis sie das Hypothecium erreicht haben, wonach ihre Spitzen zu Asci anschwellen, welche zwischen den Paraphysen heraufwachsen und zusammen das Hymenium bilden.

Stets sind mehrere Oogonien mit ihren ascogenen Hyphen zu einem Fruchtkörper vereint.

Es stehen hier also Asci und Paraphysen ohne jegliche Umhüllung auf einer flachen Scheibe. Meistens ist dies nicht der Fall; bei der großen Gruppe der Discomyceten hat die Scheibe einen aufrechtstehenden Rand, ist also schüsselförmig. Die Frucht wird dann ein Apothecium genannt, der Rand der Scheibe das Excipulum (Abb. siehe bei Sclerotinia Fig. 253, 4, S. 427).

Solche Apothecien sind meistens in der Jugend geschlossen und werden erst später infolge lateralen Wachstums geöffnet ${ }^{1}$ ), so z. B. bei Ascobolus, bei welchem übrigens wieder ein anderer Ascusbildungsmodus vorkommt.

Die hier ursprünglich geschlossene, später sich öffnende Hülle wird so wie bei Erysiphe durch Verflechtung steriler Hyphen gebildet.

Das Archicarp entsteht als relativ dicker, gebogener Seitenzweig. eines Mycelfadens. Es besteht aus einer Anzahl dicker, ungefähr isodiametrischer Zellen, an welche sich dünne Seitenzweige einer von DE BARY als Antheridium betrachteten Hyphe anschmiegen (vergl. Fig. 251 Ascobolus).

1) Besonders leicht zu demonstrieren an den großen Apothecien von Bulgaria inquinans. 
Nachdem die Hülle gebildet ist, werden alle Ascogonzellen mit Ausnahme der dritten oder vierten ron der Spitze plasmaarm; diese dagegen wird sehr plasmareich und treibt 12 oder mehr ascogene Fäden, an deren Enden die Asci entstehen, welche nun zwischen den Paraphrsen hinaufwachsen (vergl. Fig. 251).

Bei allen bis jetzt betrachteten Formen entsteht also der Ascus stets infolge einer Kopulation zwischen in Antheridien und Oogonien differenzierten Gametangien.

Bei der jetzt zu besprechenden Gruppe ist zwar die Entstehung der Asci ebenfalls die Folge eines Sexualaktes, aber dieser kommt nicht durch Gametangienkopulation zu stande, sondern findet zwischen Trichogrmen und Spermatien wie bei den Florideen statt.

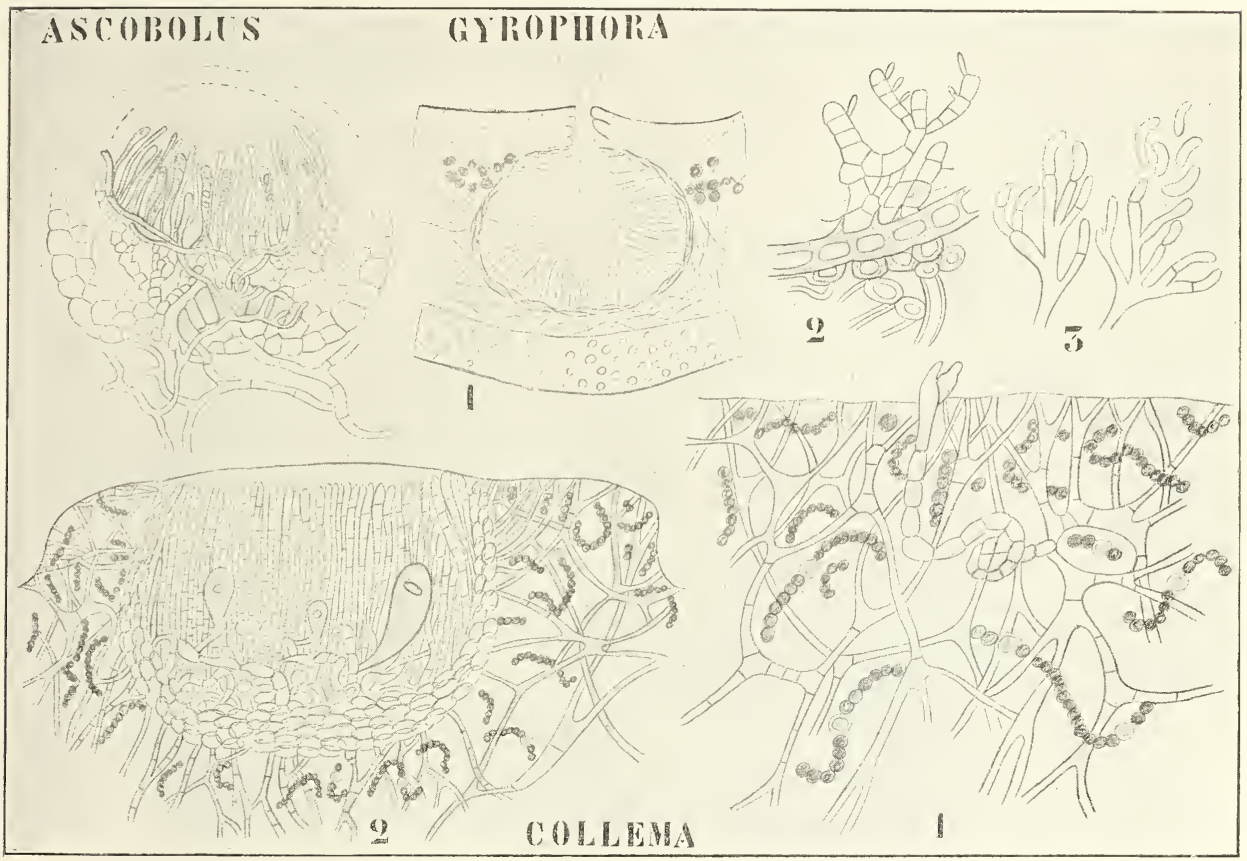

Fig. 251. Fruchtkörperentwickelung verschiedener mit Namen bezeichneter Ascomyceten (nach SACHS, STAHL und DE BARY).

Der erste, der uns über diesen Vorgang gut unterrichtete, war Stahl, der ihn bei Collemaceen nachwies. Bekanntlich ist Collema ein Symbiont, aus der Vereinigung eines Nostoc und eines Ascomyceten hervorgegangen, eine Flechte, bei welcher die Alge mehr Einfluß auf die Form des Ganzen ausübt als meistens der Fall ist. In der gelatinösen Masse der Nostoc-Kolonie bilden die Hyphen des Pilzes ein weitmaschiges Myceliumgeflecht (Fig. 251, III 1). An bestimmten Stellen des Thallus bilden diese Mycelfäden ein dichteres Gewebe, welches eine krugförmige Höhlung umschließt. Es sind dies die sogenannten Spermogonien. An der Innenseite der Spermogonien werden von verzweigten Hyphen in der Weise von Konidien die Spermatien abgeschnürt. Terschiedene Stadien sind oben für eine andere Flechte, für Gyrophora. in Fig. 251, II 1, 2, 3 abgebildet. Die Wand dieser Spermatien ist schleimig: 
und es füllt sich das Spermogonium alsbald mit einem Brei, aus diesen schleimigen Spermatien bestehend, an. Wird der Thallus nun vom Regen befeuchtet, so quillt der Schleim und die Spermatien werden durch die Spermogonienöffnung herausgetrieben und breiten sich mit dem abfließenden Regenwasser über die Oberfläche des Thallus aus.

Dieser ist inzwischen mit zu ihrem Empfang bereiten Organen versehen worden. Es haben sich nämlich als Seitenzweige normaler Hyphen an verschiedenen Stellen des Thallus spiralig gewundene Hyphen gebildet, welche senkrecht hinaufwachsen (Fig. 251, III 1), alsbald die Oberflächenschicht des Thallus durchbohren und als Trichogynen fungieren. Mit der Spitze einer solchen Trichogyne kopuliert ein Spermatium; es entsteht eine offene Kommunikation zwischen beiden und infolgedessen fängt der gewundene Teil des weiblichen Fadens an, ascogene Hyphen zu bilden, an deren Spitzen die Asci entstehen. Aus den sterilen Fäden wurde inzwischen eine Hülle und Paraphysen gebildet, so daß ein vollständiges Apothecium entsteht (Fig. 251, III 2).

Während bei den bis jetzt behandelten Ascomyceten, wie wir sahen, eine sicher nachgewiesene Kopulation der Bildung der Asci vorangeht, werden wir nun mit einer Reihe von Formen bekannt werden, bei welchen die Kopulation stets zweifelhafter wird und welche mit Formen endet, bei denen jede Kopulation ausgeschlossen ist.

Mit anderen Worten, wir werden sehen, wie die Geschlechts organ e verschwinden, womit noch nicht gesagt sein soll, daß nun auch eo ipso die Sexualität aufhört. Wir sahen doch schon früher, daß das Essentielle der geschlechtlichen Fortpflanzung nicht in der Vereinigung zweier Geschlechts organe, sondern in der Vereinigung zweier Kerne liegt. Es wäre also recht gut denkbar, daß die Geschlechtsorgane verschwänden, die Vereinigung der Kerne aber noch stattfände.

Das erste Zeichen eines Verschwindens der Geschlechtsfunktion finden wir bei einer Form, welche durch den Besitz von Trichogynen und Spermatien mit Collema übereinstimmt, trotzdem sie zu einer ganz anderen Familie gehört, nämlich bei der Hypocreacee: Polystigma rubrum (PERS.) DC.

Polystigma rubrum ist die Ursache einer gefürchteten Pflaumenkrankheit. Auf den Blättern der Prunus-Bäume treten im Sommer, Juli bis August, blutrote Flecken auf, welche vom Stroma des Pilzes gebildet werden (Fig. 252, I 1).

An der Unterseite dieses Stromas entstehen die Spermogonien, an der Oberseite die Perithecien. In den jungen Perithecien fällt eine dicke gewundene Hyphe auf (Fig. 252, I 2), welche so wie bei Collema in einer über die Oberfläche des Stromas hervorragenden Trichogyne endet und durch eine Spaltöffnung des Blattes nach außen tritt. An der Spitze dieser Trichogyne hat man öfters Spermatien kleben sehen, Kopulation wurde aber nie beobachtet. Nach verhältnismäßig langer Zeit sterben die Trichogynen ab und das Ascogon vergrößert seine Zellen, während die Peritheciumanlage überhaupt an Größe zunimmt. Dann tritt ein Ruhestadium ein, welches den ganzen Winter anhält. Auf den abgefallenen Blättern bildet im Frühjahr jede Ascogonzelle ascogene Hyphen, welche in üblicher Weise Asci bilden. Hier liegt also Parthenogenese vor.

Bei Xylaria polymorpha haben wir, soweit bekannt, eine noch stärkere Reduktion zu verzeichnen.

Hier besteht, wie DE BARY nachwies, das keulenförmige junge 
Stroma aus einem weißen Markteil, der von einer dicken, kohligen, schwarzen Rindenschicht überzogen ist. Diese Rindenschicht ist wieder von einem konidienbildenden Hymenium bedeckt (Fig. 252, II 1). Konidien sind überhaupt als Nebenfruchtform bei den Ascomyceten weit verbreitet.

Die Perithecienprimordien zeigen sich zuerst als kleine kugelige Körper, welche dicht unter der schwarzen Rinde im Mark liegen; sie sind im Stroma leicht zu sehen, weil sie luftfrei und demnach durchsichtig sind. Sie bestehen aus einem dichten Gevebe dünner Hyphen,

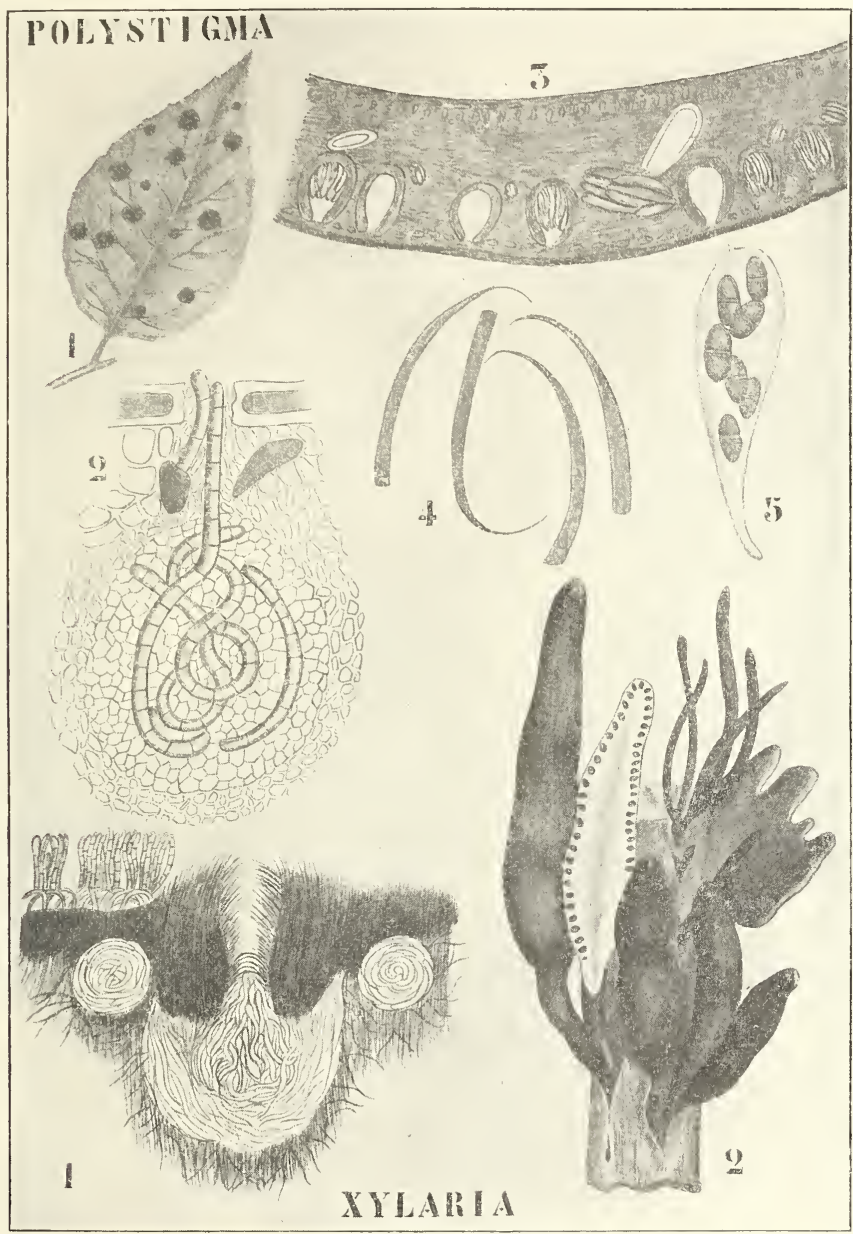

Fig. 252. Fruchtkörperentwickelung bei A scomyceten (nach ENGLER und PRANTL). I. Polystigma rubrum. 1 Prunus-Blatt mit Stromata des Pilzes. 2 Weibliche Hyphe, in eine Trichogyne endend. 3 Querschnitt eines Stromas, welches an der Oberseite die kleinen Spermogonien, an der Unterseite Perithecien zeigt. 4 Spermatien. 5 Ascus. - II. X ylaria polymorphum. 1 Querschnitt eines Stromas, welches an der Oberfläche Konidien produziert, im Inneren Perithecien anlegt. 2 Habitusbild, die variable Form der Stromata zeigend, das halbierte Stroma zeigt die in einer Schicht unter der Oberfläche liegenden Perithecien.

welche viel zarter wie die des Markes sind und also neu in diesem gebildet sein müssen. Auf etwas älteren Stadien liegt im Zentrum dieser Primordien ein unregelmäßiger dickzelliger Hyphenknäuel (Fig. 252. II 1). 
Die kugeligen Primordien werden größer, aus ihrer Außenseite wächst ein konisches Büschel gerader Hyphen auf die Rinde zu, hebt diese zunächst auf und zerreißt sie schließlich (Fig. 252, II 1 in der Mitte).

So ist das Primordium eiförmig geworden; der innere Teil wird später die Basis des Perithecium, der äußere Teil der Hals, mittels dessen jenes nach außen mündet. Die peripheren Elemente werden schwarz, so daß die äußere Hälfte des Halses alsbald mit der Rinde des Stromas eine ununterbrochene schwarze Schicht bildet.

Das Perithecium wird nun im Inneren mit einer Paraphysenschicht bekleidet, zwischen welcher alsbald die ascogenen Hyphen und Asci erscheinen.

Zweifellos erinnert der dicke Hyphenknäuel, welcher im jungen Primordium liegt, die sogenannte Woroninsche Hyphe, stark an ein Ascogon wie das von Polystigma, aber ohne die Trichogyne. Es ist aber noch nicht gelungen, einen Zusammenhang der ascogenen Hyphen mit dieser Woroninschen Hyphe nachzuweisen, geschweige denn eine Befruchtung zu beobachten.

Hier ist also die Existenz von funktionierenden Geschlechtsorganen schon sehr zweifelhaft; es scheint, daß die Woroninsche Hyphe, ohne jegliche Funktion ausgeübt zu haben, zu Grunde geht, und daß die Asci aus benachbarten Hyphen gebildet werden.

DE BARY vergleicht dies mit der Apogamie der Farne, bei welchen die Archegonien ihre Funktion verloren haben und die Farnpflanze direkt auf dem Prothallium gebildet wird.

Bei anderen Ascomyceten ist die Existenz von Geschlechtsorganen überhaupt recht zweifelhaft, so z. B. bei Nectria, bei welcher zu DE Barys Zeiten weder Archicarpien noch Spermatien, noch Gametangien beobachtet waren, sondern bei welcher sich die Asci anscheinend aus Hyphen, welche von den vegetativen nicht zu unterscheiden sind, entwickeln. Dennoch ist hier nach Untersuchungen Hartigs die Existenz eines Archicarps nicht ganz ausgeschlossen.

In zahlreichen Fällen sind aber gar keine Geschlechtsorgane gefunden worden, so daß DE BARY, ganz abgesehen von der Frage, ob die Ascomyceten mono- oder polyphyletischen Ursprungs sind, zum Resultat kommt, daß die Ascomyceten eine Gruppe bilden, deren niedrigere Vertreter zweifellos Sexualität besitzen, diese aber mehr und mehr verlieren, so daß manche höhere Formen apogam sind.

Als Beispiele von Formen, bei welchen keine Spur von Geschlechtsorganen gefunden wurde, mögen Sclerotinia sclerotiorum und Claviceps purpurea genannt werden.

Bei Sclerotinia bildet das Mycel, welches sich aus den Ascosporen entwickelt hat, unter bestimmten Bedingungen sogenannte Sclerotien, das sind zu festen Körpern verflochtene Hyphen, welche, da in denselben zahlreiche Querwände auftreten, auf dem Querschnitt ein parenchymatisches Aussehen zeigen; so entsteht ein sogenanntes Pseudoparenchym oder besser nach Lindau ein Plectenchym. Die peripheren Teile werden als Rinde differenziert (Fig. 253, I 1). Diese Sclerotien keimen, wenn genügende Feuchtigkeit vorhanden ist, d. h. sie bilden die für unseren Pilz charakteristischen Fruchtbecherchen, langgestielte Apothecien (Fig. 253, I 3).

In diesen Bechern werden die Asci, in üblicher Weise zu einem Hymenium vereint, angetroffen (Fig. 253, I 4), und man kann Asci und Paraphysen nicht auf gemeinsame Stammfäden zurückführen, sondern 
ascogene und sterile Hyphen verlaufen nebeneinander im Becher; wo man den Ursprung der ascogenen Hyphen zu suchen hat, bleibt unklar. Es erlaubt uns aber die Entwickelungsgeschichte des Bechers, wenigstens einig'es über den Ursprung dieser ascogenen Hyphen zu vermuten.

Auf dem Querschnitt eines feuchtgehaltenen Sclerotiums sieht man, noch bevor äußerlich auch nur eine Spur von Fruchtkörpern zu sehen ist, gewisse Neubildungen auftreten, welche DE BARY mit dem Namen Primordien bezeichnete. Diese erscheinen in großer Zahl dicht unter der schwarzen Sclerotiumrinde und zeigen sich unserem Auge als durchsichtige runde Körperchen von 70-100 $\mu$ Querschnitt (Fig. 253, I 1). Sie bestehen aus einem verwirrten Knäuel sehr dünner Hyphenzweige mit

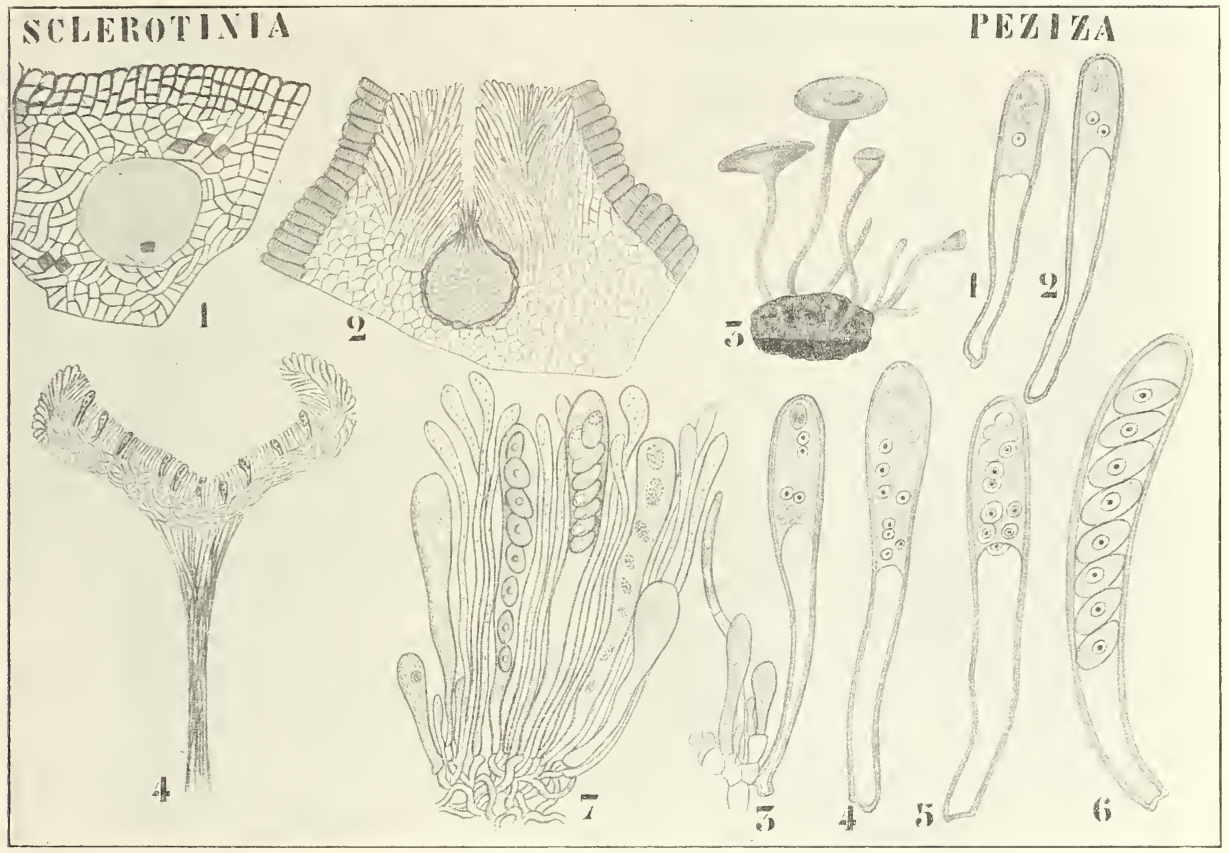

Fig. 253. Fruchtkörper- und sporenentwickelung bei As com y ceten (nach DE BARY). I. Selerotinia sclerotiorum. 1, 2 Anlagen der Fruchtbecher im Sclerotium. 3 Keimung des Sclerotiums. 4 Schematischer Längsschnitt durch einen Becher. - II. Peziza. 1 Einkerniger Ascus. 2 Zweikerniger Ascus. 3 Vierkerniger Ascus. 4 Achtkerniger Ascus. 5 Anfang der Sporenbildung. 6 Ausgebildete Sporen. 7 Querschnitt eines Teiles des Hymeniums.

gelatinöser Membran. Diese bilden sich als Seitenzweig'e normaler Hyphen des Sclerotiums. Der Hyphenbündel, aus welchem nun ein Fruchtbecher entsteht, bricht immer oberhalb eines solchen Primordiums durch die Rinde (Fig. 253, II 2) und es ist sehr wahrscheinlich, daß die ascogenen Hyphen aus dem Primordium entstehen, die Umhüllnngshyphen aus den Sclerotienhyphen. Die Zahl der Primordien ist viel größer als die Zahl der gebildeten Fruchtbecher; viele gehen offenbar zu Grunde, ohne zur Entwickelung zu kommen.

Falls DE Barys Vermutung, daß die ascogenen Hyphen aus dem 
Primordium entstehen, richtig ist, sind zwei Fälle möglich, entweder ist das Primordium ein Ascogon, in welchem Falle Parthenogenese vorläge, oder aber es besteht aus dort gebildeten ascogenen Hyphen in welchem Falle wir mit Apogamie zu tun hätten; der Umstand, daß so viele Primordien, ohne sich zu entwickeln, zu Grunde gehen, deutet wohl am meisten auf Parthenogenese.

Liegt hier also wenigstens noch die Möglichkeit des Vorhandenseins eines Ascogons vor, bei Claviceps purpurea, dem bekannten Mutterkornpilz, auf dessen Lebensgeschichte wir später zurückkommen, scheint dies ausgeschlossen zu sein.

Auch hier keimt das Sclerotium zu Fruchtkörpern (Fig. 254, 4), diese Fruchtkörper sind aber nicht wie bei Sclerotinia Apothecien, sondern

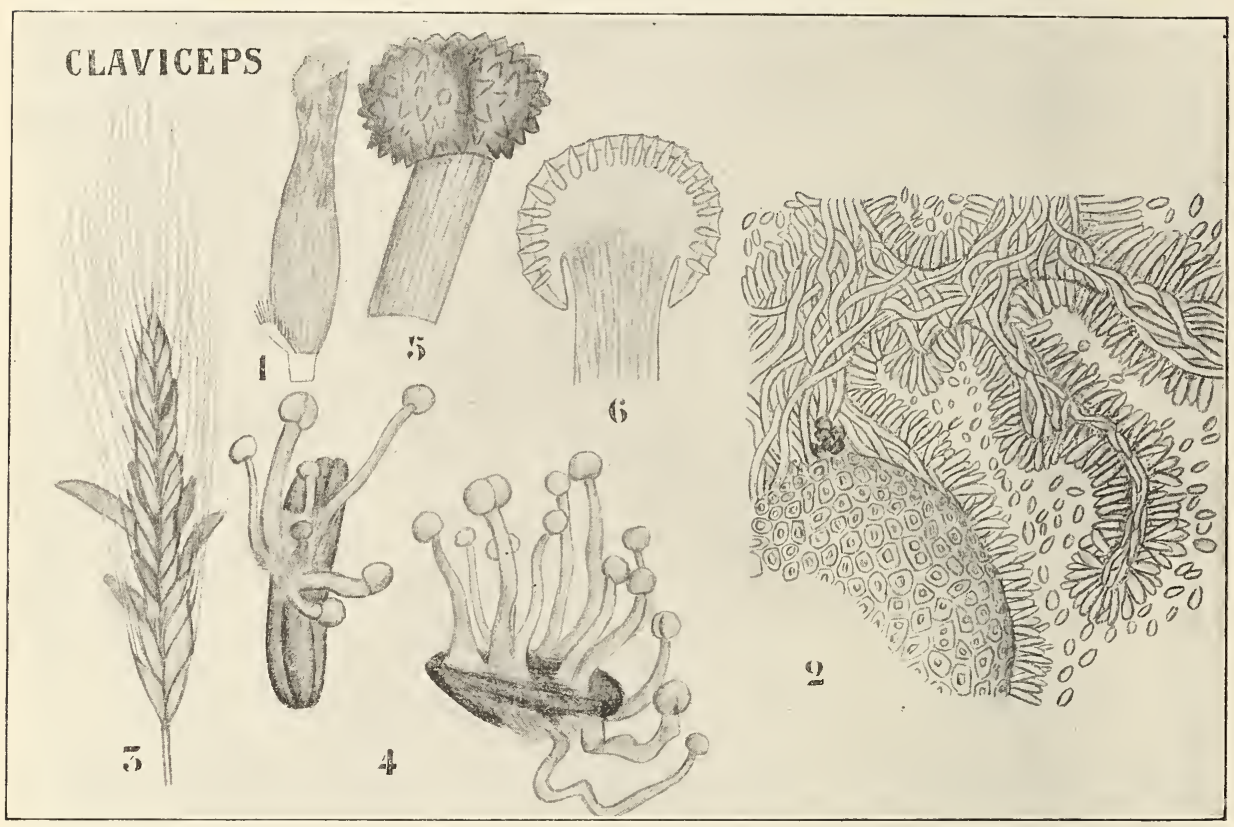

Fig. 254. Claviceps purpurea (nach ENGLer und PrANTL). 1 Fruchtknoten des Roggens vom Pilze befallen. 2 Phaceliastadium. 3 Sclerotien einer Roggenähre. 4 Keimendes Sclerotium. 5 Spitze eines Fruchtkörpers, vergrößert. 6 Längsschnitt durch ein Capitulum, die Perithecien zeigend.

einem jungen Champignon nicht unähnliche Bildungen, sogenannte Capitula, die aus sterilen Hyphen bestehen.

Erst spät bilden sich die Perithecien, welche in nicht genau bekannter Weise als Höhlungen im Capitulum entstehen (Fig. 254, 6) und welche mit Paraphysen und Asci bekleidet werden, ohne daß auch nur die Spur eines Ascogons bemerkt werden kann.

Falls nun DE BARYS Auffassung über Sclerotinia richtig ist, besteht dort der Becher aus einer $2 x$-Generation, den ascogenen Hyphen, welche von einer $x$-Generation, den sterilen Hyphen, umhüllt ist.

Wahrscheinlich ist bei Claviceps das Capitulum eine x-Generation, welche erst verhältnismäßig spät die ascogenen Hyphen der 2 x-Generation apogam bildet. 
Zwar wäre a priori die Möglichkeit nicht ausgeschlossen, daß das ganze Capitulum eine apogam entstandene $2 x$-Generation wäre, in welchem Falle das Capitulum dem Hute eines Fliegenschwamms z. B. homolog: wäre, aber der Umstand, daß sich in den Perithecien Paraphysen befinden, macht dies meines Erachtens nicht wahrscheinlich, da ich diese für Organe der $x$-Generation halte. Hoffentlich werden Untersuchungen die Sache bald entscheiden.

TTie dem auch sei, sicher ist bei Claviceps kein Ascogon mehr vorhanden und es ist also DE Barys Meinung, daß bei den höheren Ascomyceten Geschlechtsverlust stattgefunden hat, sicher richtig.

Bei den bis jetzt behandelten Formen, alle Vertreter der echten Ascomcyeten, ist das typische Organ der höchsten Fruchtform der Ascus, und überall ist der Ascus in derselben Weise gebaut.

Betrachten wir also, bevor wir uns mit anderen Auffassungen über die Natur der Ascomyceten beschäftigen, dieses Organ im Lichte von DE BARYs Zeit. Man meinte damals, daß der junge Ascus genau so wie irgend ein Hyphenzweig entstände oder der Endzelle einer Hyphe entspräche. In den meisten Fällen schwellen diese Zweiginitialen oder* Endzellen keulenförmig an, nur selten werden sie kugelig. In bei weitem den meisten Fällen werden im Ascus 8 Sporen simultan gebildet.

Bei Perina confluens und anderen ist der junge Ascus mit einem feinkörnig’en Plasma, welches nur wenige Vakuolen enthält, gefüllt, und zeigt in der Mitte einen Kern. Beim weiteren Wachstum accumuliert sich das Plasma an der Mitte des Schlauches, indem unten im Ascus sich eine große Vakuole bildet (Fig. 253, II 1). Jetzt fängt die Teilung des Kernes an, so daß man bald 2, dann 4 und schließlich 8 Kerne sieht (Fig. 25̌3, II 2-4). Jeder dieser Kerne umgibt sich mit einer Plasmamasse (Fig. 253, II 5, 6) und mit einer Membran, und bildet so eine Spore. Dabei bleibt ein Teil des Plasmas, das sogenannte Epiplasma, unverbraucht; es enthält, wie ERrera nachwies, viel Glykogen. Für den Ascus ist die Sporenzahl 8 typisch, Abweichungen kommen vor, meistens durch frühzeitiges Zugrundegehen einzelner Kerne, bisweilen auch durch das Auftreten einer größeren Zahl von Kernen.

Wie man sieht bildeten zu Zeiten DE Barys die Ascomyceten eine charakteristische Gruppe und es schien DE BARYs Auffassung über die Sexualitätsverhältnisse recht gut begründet. Wie gesagt, meinte DE BARY, daß es unter den Ascomyceten zweifellos sexuelle Formen gäbe, daß aber die Sexualität am Erlöschen sei und bei den höheren schon durch Apogamie (zwischen Parthenogenese und Apogamie wurde nicht unterschieden) ersetzt wäre.

Dennoch ließen sich alsbald Stimmen gegen DE BARY hören und der erste, welcher DE BARys Meinung entgegen trat, war v. TiEghem, der überhaupt von keiner Sexualität bei den Ascomyceten hören wollte.

Von Formen ohne deutliches Archicarp ausgehend, hebt v. TiEghem hervor, daß die Differenzierung in ascogene Hyphen und Umhüllungshyphen bei den verschiedenen Ascomyceten an verschieden alten Entwickelungsstadien stattfindet und meint, daß die Archicarpien, welche DE BARY bei vielen Formen gesehen hat, nur frühzeitig differenzierte ascogene Hyphen seien, während DE BARYs Antheridien nur sterile Hüllhyphen sein sollen.

Mit Recht bemerkt DE BARy, daß es doch nicht angeht zu verkennen, daß das konstante Vorkommen eines Antheridiums bei Podosphaera und die Erscheinungen bei Pyronema und Eremascus seine 
Meinung sehr stützen, daß das Verhalten dieser Formen laut gegen v. Tieghem redet.

v. Tieghem sucht gar keine Homologien für die ascogenen Hyphen, wodurch er seine Aufgabe leichter wie die von DE BARY an sich gestellte macht, aber fühlt doch wohl, daß Antheridienzweige wie die von Podosphaera, Trichogyne wie die von Collema einiger Erklärung bedürfen.

Nach ihm soll nun das „Antheridium“ in solchen Fällen das Ascogon stützen, während die Trichogyne als Atmungsorgan dienen muß. Darauf antwortet DE BARY mit Recht, daß man diesen Punkt nicht zu diskutieren braucht „bevor einigermaßen wahrscheinlich gemacht wird, daß die Ascogone ohne jene Stütze umzufallen in Gefahr sind, und das betreffende Organ bei Collema mittels eines eigenen Apparates nach Luft schnappen muß und nicht ohne solchen ebensogut $\mathrm{zu}$ respirieren vermag wie die inneren Thalluselemente, neben welchen es steht."

BREFELD schwankt in diesem Moment der Geschichte zwischen de Bary und von v. Tieghem hin und her.

In der Botanischen Zeitung, 1876. S. 56 sagt er, daß er DE BARYs Beobachtungen vollkommen richtig befunden hat. „Aber diese Tatsachen, nach der einen Seite geeignet, eine Sexualität aus ihnen abzuleiten, lassen noch eine andere und zwar meiner jetzigen Auffassung nach noch bessere Deutung zu", wonach er in wenigen Worten eine Meinung verkündet, welche mit v. Tiegheus Auffassung übereinstimmt, dann sagt er: „Alle zahlreichen Versuche, die ich bis jetzt gemacht, entscheiden gegen die Sexualität der Ascomyceten zu Gunsten der zweiten Deutung. Ich will über diese kurzen Andeutungen hier nicht hinausgehen, da eine ausführliche Darlegung meiner Versuche mehr Raum in Anspruch nehmen würde als die ganze Mitteilung."

Das nächste Jahr (Bot. Ztg., 1877, S. 371) ist BREFELD aber viel weiter auf DE BARYs Seite gekommen; dort sagt er: "Und auch bei den Ascomyceten und Aecidiomyceten liegen die Verhältnisse wohl nicht anders. Einer Reihe von Fällen, die für die geschlechtliche Erzeugung der Ascusfrucht sprechen, stehen andere entgegen, die nichts mehr von den Vorgängen besitzen, welche dort zur Annahme der Sexualität führten. Diese Reihe analoger Fälle ..... führen in ihrer Gesamtheit zu der naheliegenden Deutung, daß die Dauersporen und Ascusfrüchte etc. als die analogen Bildungen der bei den niederen Pilzen geschlechtlich erzeugten Früchte, auch hier wohl auf geschlechtlichen Ursprung zurückzuführen sind, daß aber die Sexualität bei den höheren Pilzen im Eingehen begriffen, vielleicht bei den einzelnen Klassen bereits erloschen und verloren gegangen ist."

„Diese Deutung vereinigt die mancherlei sich jetzt entgegenstehenden Auffassungen über die Sexualität der höheren Pilze natürlich und friedlich."

Zwar schlägt BREFELD weiterhin in diesem Artikel eine andere Deutung wie die DE BARYsche vor, welche im Original nachzusehen ist, aber der Hauptsache nach steht er nun doch auf dem DE BARYschen Standpunkt, daß die Ascusfrüchte wenigstens ursprünglich geschlechtlich gebildet sind.

In der Tat ist denn auch diese Auffassung so natürlich, daß sie wohl ohne weiteren Streit einstimmig acceptiert sein würde, falls man nicht den ursprünglichen Begriff „Ascomyceten" bedeutend ausgedehnt und dadurch verwässert hätte. 
Eine wie bedentende Ausdehnung der Begriff Ascomyceten erfahren hat, mag aus einem Vergleich zwischen den in Engler und Prantl dazu gerechneten Gruppen und den von de BARY darunter verstandenen hervorgehen. Im Jahre 1894, also gerade 10 Jahre nach der Behandlung: der Gruppe durch DE BARY in seiner vergleichenden Morphologie der Pilze, rechnet Schroeter in Engler und Prantl zu den Ascomyceten:

1) Hemiascineae mit den Familien Ascoideaceae, Protomycetaceae, Monascaceae,

2) Protascineae mit den Familien Saccharomycetaceae, Endomycetaceae,

3) Protodiscinea mit den Familien Exoascaceae, Ascocorticiaceae.

4) Helvellineae,

5) $P$ rivineae,

6) Phacidiineae,

7) Hysteriineae,

8) Tuberineae,

9) Plectascineae,

10) Pyrenomycetineae,

während LINDAU in unmittelbarer Verbindung damit die Laboulbeniaceae behandelt.

Von diesen Formen betrachtet nun DE BARY die Exoascaceae, die den ihm bekannten Teil von Schroeters dritter Gruppe bilden, die Saccharomycetes, zu Schroeters zweiter Gruppe gehörend, und die Laboulbeniaceae als zweifelhafte Ascomyceten; während er das Geschlecht Protomyces zu Schroeters erster Gruppe gehörig in direkte Verbindung mit den Ustilagineae bringt. Auf S. 198 seiner vergleichenden Morphologie sagt er darüber: „In dem Protomyces macrosporus scheint demnach ein in jeder Hinsicht nächster Verwandter der Ustilagineen vorzuliegen." Von der Schroeterschen Familie der Endomycetaceen betrachtet er Endomyces als einen zweifelhaften Ascomyceten, Eremascus aber als einen typischen (S. 202), wobei er bemerkt (S. 251): Eremascus könnte nach der Beschreibung Eidams fast zu den Mucorineen, speziell Piptocephalideen gestellt werden", andererseits fehlt ihm nichts von den wesentlichen Entwickelungseigenschaften eines Ascomyceten.

Sehen wir nun von Eremascıs ab, so können wir ruhig sagen, daß DE BARys Auffassung über die Sexualität der Ascomyceten auf der Betrachtung von Schroeters Gruppen 4 bis und inklusive 10 beruhte, und daß er also als Ascomyceten betrachtete eine Gruppe von Pilzen, welche durch den Besitz eines speziellen sporenbildenden Organs, des Ascus, natürlich genannt werden dürfte.

Ganz anders wurde die Gruppe der Ascomyceten als Hemiascineae, Protascineae, Protodiscineae und Laboulbeniaceae in sie aufgenommen. Dadurch wurden Formen an die eigentlichen Ascomyceten angereiht, welchen zwar der Umstand der endogenen Sporenbildung gemeinsam war, aber deren sogenannte Asci doch in manchen Fällen recht wenig Uebereinstimmung mit den Asci der eigentlichen Ascomyceten hatten. Vergleicht man z. B. die "Asci“ von Ascoidea oder Protomyces mit denen eines echten Ascomyceten, z. B. von Perira. so sieht man sofort, welche heterogene Sachen in der jetzigen Gruppe der Ascomyceten zusammengeworfen wurden.

Will man im allgemeinen sich eine Neinumg darüber bilden. ob irgend eine.Person in irgend einem bestimmten Falle eine gute Einsicht 
in eine Sache gehabt hat, so muß man den gleichen Gegenstand betrachten wie er, das heißt also bei Pflanzen eine Gruppe betrachten, so wie er diese auffaßte und nicht so, wie man sie später gemacht hat.

Darum scheint es mir geboten, zur Wertschätzung von DE BARYs Auffassungen nur die echten Ascomyceten $\mathrm{zu}$ betrachten und zunächst die später in der Diskussion eingeführten Gruppen der Hemiasci, Protoasci, Protodosci und Laboulbeniaceen außer acht zu lassen. also :

In der Gruppe der typischen Ascomyceten unterscheidet DE BARY

1) Kopulation zwischen Oogonien und Antheridien (z. B. Podosphaera).

2) Kopulation zwischen Trichogynen und Spermatien (z. B. Collema).

3) Apogamie (Geschlechtsverlust) (z. B. Xylaria).

Sehen wir nun, welche Gründe gegen diese Auffassung angeführt worden sind, aber bevor wir dies mit Aussicht auf Erfolg tun können, müssen wir erst noch einige andere Fruktifikationsformen der Ascomyceten kennen lernen.

Wir haben nämlich bis jetzt deren nur einen kennen gelernt: den Ascus, welcher ja auch die Hauptfruktifikation der Ascomyceten bildet. Außer dieser gibt es aber noch andere, die sogenannten Nebenfruktifikationen, und diese sind in Verbindung mit dem, was gegen DE BARYs Auffassung angeführt wurde, von großer Wichtigkeit.

Lernen wir sie also zunächst an der Hand von DE BARY kennen.

1) Den einfachsten Entwickelungsgang finden wir bei denjenigen Formen, bei welchen uns die Ascospore einen wieder Ascosporen bildenden Thallus liefert, ohne daß außer den eventuell dazu nötigen Geschlechtsorganen irgend eine sonstige Fruktifikation gebildet wird. Beispiele davon sind: Pyronema, Ascobolus, Collema.

2) Bei anderen Gruppen aber findet ein di- bis pleomorpher Entwickelungsverlauf statt. Bei diesen besteht insoweit Uebereinstimmung mit der ersteren Gruppe, als auch hier schließlich Asci entstehen, aber erst, nachdem sehr verschiedene Konidienformen gebildet sind.

Diese Konidienfruktifikationen können öfters während vieler Generationen ausschließlich auftreten, so daß Tausende und abermals Tausende Konidiengenerationen gebildet werden, bevor auch nur ein einziger Ascus sich zeigt, z. B. bei dem gewöhnlichen Penicillium.

Aus der Ascospore entsteht dann ein konidienproduzierender Thallus, welcher bis ins Unendliche aus seinen Konidien wieder konidienproduzierende Thalli entstehen läßt, bis endlich einmal ein solcher Thallus Asci bildet, in dieser Hinsicht also stark erinnernd an viele Mucorineen, welche nur selten Zygosporen bilden.

Die Konidien, welche meistens ascogen, nur selten interkalar gebildet werden, können in recht verschiedener Weise entstehen:

1) auf solitären Hyphen resp. an sprossenden Zellen;

2) an der Oberfläche komplizierter Fruchtkörper, z. B. bei Claviceps, Xylaria;

3) in eigentümlichen Hüllen: Pykniden, in welchem Falle sie den Namen Pyknokonidien, Pyknosporen oder Stylosporen tragen.

Gewisse Arten, z. B. Erysiphe, bilden nur eine Art von Konidien, andere, wie z. B. Pleospora, Nectria, mehrere.

Wir werden weitere Beispiele in Hülle und Fülle bei der Behandlung der verschiedenen Ascomyceten-Familien kennen lernen, augenblicklich 
interessiert uns, mit Rücksicht auf die gegen DE BARY angeführten Meimumg'en, hauptsächlich die Gruppe der Pykniden.

TVir haben früher bei Collema schon Spermogonien kemnen gelernt, solche Spermogonien kommen num bei recht vielen Ascomyceten vor, speziell bei Pyrenomyceten (man vergl. z. B. die Abbildungen von Valsa in Fig. 309, S. 524).

Diese Spermogonien nun gleichen so sehr den Pykniden und die Spermatien dermaßen den Pyknosporen oder Stylosporen, daß es meistens untunlich ist, die einen von den anderen zu unterscheiden.

Der Hauptunterschied zwischen beiden besteht darin, daß die Spermatien nicht zu neuen Mycelien auskeimen, die Pyknosporen dagegen wohl, und das ist selbstverständlich, wenn man erstere als männliche Geschlechtszellen, letztere als Konidien betrachtet.

Es wird Thnen nun wohl klar sein, daß die Unmöglichkeit, morphologisch zwischen Spermatien und Pyknokonidien zu unterscheiden, eine sehr geeignete Waffe darbot zur Bestreitung der von STAHL verteidigten Befruchtungsweise der Collemaceen.

Diese Waffe wurde denn auch von BREFELD ergriffen; er meint, daß die an der Trichogyne von Collema gefundenen Körper, welche Sтмнц als Spermatien deutet, nur zufälligerweise an derselben klebende Konidien seien, und betrachtet denn auch die Spermogonien als Pyknokonidien.

Falls dies alles wäre, was Brefeld zur Stütze seiner Meinung beibringen könnte, so würde dem gegenüber die Tatsache, daß STAнL Kopulation zwischen Spermatien und Trichogynen wahrgenommen hätte. die Wagschale gewiß zu seinem Vorteile senken. Aber es gibt mehr. Einer von BREFELDs ausgezeichneten Schülern und einer seiner getreuesten Anhänger, Alfred Möller, zeigte (1888), daß die StTaHLschen Collema-Spermatien, wemn auch schwer, doch zur Keimung zu bringen sind. Damit meint MöLler bewiesen zu haben, daß diese Organe keine Spermatien, sondern Konidien sind, wobei er aber den Umstand übersieht, daß das Auskeimen einer männlichen Geschlechtszelle unter sehr bestimmten Bedingungen noch nichts weiter besagt, als daß auch Parthenogenese im männlichen Geschlecht vorkommen kann, wie z. B. schon lange bei Ectocarpus bekannt war.

Zweifellos aber sind die MöLlenschen Versuche und die späteren Untersuchungen BREFELDS über den gleichen Gegenstand an anderen Formen recht wichtig und sprechen gewiß nicht zum Vorteile der STAHLschen Auffassungen.

Dagegen sind, soweit ,circumstantial evidence" ins Gewicht fällt, von BAUR Beobachtungen gemacht worden, welche STAнLs Auffassung dermaßen stützen, daß meines Erachtens die MöLLERsche Interpretierung der Keimung der Spermatien sehr an Wahrscheinlichkeit verliert.

BAur bemerkte nämlich, daß es bei Collema crispum zwei Arten von Thalli gibt, die eine mit zahllosen Apothecien bedeckt, die andere entweder anscheinend ganz steril oder doch nu wenige Apothecien tragend.

Querschnitte lehrten nun, daß die anscheinend sterilen Thalli in großer Zahl (öfters \pm 1000 pro Thallus) junge Carpogone mit Trichogynen trugen, daß diese aber mit wenigen Ausnahmen, ohne Asci gebildet zu haben, abstarben.

Dagegen gelangt auf den mit Apothecien bedeckten Thalli fast jedes Carpogon zur Bildung eines Apotheciums. 
Nun zeigte nähere Forschung, daß die apothecienreichen Thalli entweder Spermogonien besaßen oder in unmittelbarer Berührung mit spermogonientragenden Thalli standen, während die Thalli, deren Apothecien abstarben, keine Spermogonien besaßen.

Daraus ist meines Erachtens nur ein Schluß zu ziehen, nämlich dieser, daß für die Bildung der Apothecien Spermatien nötig sind, und dies in Verbindung mit der auch von BAUR beobachteten Kopulation zwischen Spermatium und Trichogyne läßt wohl auf die Richtigkeit der Stahlschen Auffassung schließen.

Dazu kommt nun noch, daß BAUR nachweisen konnte, daß nach der Befruchtung die in der Trichogyne vorhandenen Querwände durchbrochen waren, und er niimmt an, daß der Spermatimmnucleus durch diese

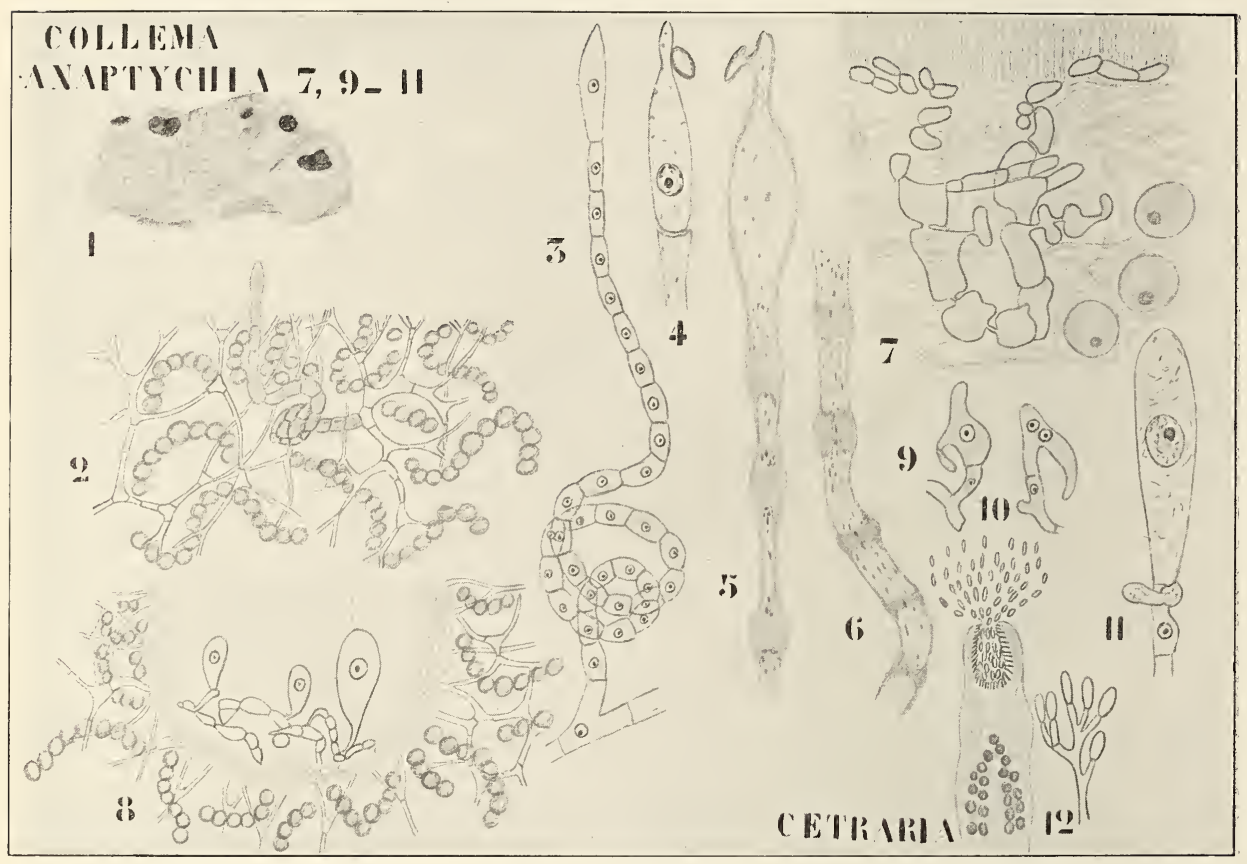

Fig. 255. Collema, Anaptychia und Cetraria (nach STAHL und BAUR). 1 Habitusbild einer Collema mit Apothecien. 2 Ascogon und Trichogyne. 3 Stärker vergrößert. 4 Trichogyne mit Spermatium. 5 Kopulation, Schwellung der Wände der Trichogynenzellen. 6 Durchbohrung derselben. 7-10 Ascusbildung. 11 Die beiden Kerne im Ascus verschmolzen. 12 Pyknide und Spermatien.

Oeffnungen hindurch gewandert ist. Trotzdem dies nicht gesehen wurde, noch weniger eine Kopulation von Spermakern und einem weiblichen Kern nachgewiesen wurde, wird wohl jeder, der ohne Vorurteil ist, der Meinung sein, daß BauRs Untersuchungen neue, wichtige Tatsachen zur Unterstützung der STAHLschen Meinung geliefert haben.

BREFELD cum suis fassen also die Spermatien der Collemaceen, von Polystigma etc., als Konidien (Pyknokonidien, Stylosporen) auf; auch das Ascomyceten-Antheridium findet seit lange sogar in seiner ausgeprägtesten Ausbildung in ihren Augen keine Gnade. Die Antheridien der Ascomyceten sollen nichts wie sterile Hyphen sein, die Fälle beobachteter 
Kopulation nur regetative Schnallenbildungen, wie diese so häufig bei höheren Ascomyceten angetroffen werden.

Ganz abgesehen von der Frage, ob die Schnallenbildungen in allen Fällen von so geringer Bedeutung sind, wie BrEFELD c. s. wollen, gehört meiner Ansicht nach zur Verkennung solcher klaren Oogonien und Antheridien, wie die von Pyronema z. B., eine gehörige Dosis von Voreingenommenheit.

In direkter Verbindung mit seinem Leugnen der Sexualität steht der Versuch Brefelds, welchen er schon seit Jahren unternimmt, zu beweisen, daß der Ascus nicht mit einem Gametangium, sondern mit einem Sporangium homolog ist. Das glaube ich auch, aber falsch ist die Auffassung, als ob dadurch feststände, daß der Bildung des Ascus kein Sexualakt vorangehen kann.

Die Ansicht, daß es nur eine Alternative gibt, daß der Ascus nur ein Gametangium oder eine, wie BrEFELD will, dem Sporangium der Phycomyceten homologe Bildung sein muß, ist überhaupt verkehrt.

Eine Frage, ob z. B. das Farnsporangium das Homologon des Isokonten-Zoosporangiums ist, ist überhaupt nicht ohne weiteres zulässig, da das eine auf der $2 \mathrm{x}$-, das andere auf der $\mathrm{x}$-Generation gebildet wird.

Die Antwort muß lauten, daß ein Farnsporangium eben etwas ganz anderes ist, ein Etwas, das überhaupt nicht entstehen konnte, bevor die $2 \mathrm{x}$-Generation da war.

Meiner Auffassung nach gibt es also für die morphologische Natur des Ascus a priori drei Möglichkeiten:

1) Der Ascus ist einem Gametangium homolog,

2) " " " $"$ Zoosporangium homolog,

3) " " " $"$ Farnsporangium homolog.

Um nun in dergleichen Fällen das Wort Farnsporangium durch ein allgemeineres Wort ersetzen zu können, schlage ich vor, die von einer $x$-Generation gebildeten Sporangien Haplosporangien, die von einer $2 x$-Generation gebildeten Diplosporangien zu nennen, so daß wir die Frage näher treten wollen, ob der Ascus einem Gametangium, einem Haplosporangium oder einem Diplosporangium homolog ist.

Im ersteren Falle ist weiter a priori die Möglichkeit vorhanden, daß Asci parthenogenetisch entstehen, ein Fall, der also der Bildung der "Azygosporen" der Mucorineen homolog wäre, im dritten Falle ist Apogamie möglich.

Diese dritte Möglichkeit der Homologie zwischen Ascus und Diplosporangium nun wird von der BREFELDschen Schule einfach ignoriert. Sie fragen nur, gibt es bei den Ascomyceten Sexualität oder nicht, wenn nicht, so ist der Ascus das Homologon des Phycomyceten-Sporangiums, und dieser Schluß ist, da es gewiß eine dritte Möglichkeit gibt, unlogisch.

Konnten wir bis jetzt unsere Erörterungen auf die Ascomyceten in der DE BARYschen Fassung dieser Gruppe beschränken, so wird das von jetztan unmöglich, denn gerade die ersten Gruppen des Schroeterschen Systems sind für BREFELDs Theorie von größter Wichtigkeit, da BREFELD in den von den Vertretern dieser Gruppen produzierten Asci die gesuchten Zwischenstadien zwischen Sporangien und Asci gefunden zu haben meint.

Eine vorzügliche Uebersicht der BREFELDschen Auffassungen wurde von seinem Assistenten v. Tavel gegeben, an der Hand derselben werde ich versuchen, hier seine Auffassungen zu schildern. 
Brefeld meint, daß die höheren Pilze, nämlich die Ascomyceten und Basidiomyceten, den Phycomyceten scharf entgegengestellt seien, indem sie aus vielzelligen Hyphen bestehen und einer Sexualität völlig entbehren.

In Bezug auf erstere Voraussetzung führt das Wort ,vielzelli g“6 leicht zu falschen Auffassungen, denn sobald man den fundamentalen Begriff Energide einführt, sieht män schon, daß die scharfe Grenze hinwegfällt, denn auch unter. den Ascomyceten gibt es viele polyenergide Formen. Uebrigens bringt v. TAvel selber Basidiobolus, eine vielzellige, monoenergide Form zu den Phycomyceten, damit zeigend, daß auch auf jener Seite die Grenze nicht scharf ist. Der zweite Punkt, die Sexualität, ist eben unter Diskussion.

Die Ascomyceten und Basidiomyceten werden von BREFELD unter dem Namen Mycomyceten zusammengefaßt und die Gruppen der Hemiasci und der Hemibasidien müssen unter dem Namen Mesomyceten Dienst tun, um die Phycomyceten mit den Mycomyceten zu verbinden und zwar durch Vermittelung der Phycomyceten-Gruppe der Zygomyceten.

Von den Fortpflanzungsorganen der Zygomyceten sagt v. TAves: „Die hier vorkommenden ungeschlechtlichen Fruchtformen sind auch die der höheren Pilze. Andere Fortpflanzungsorgane, als die schon besprochenen, kommen bei diesen nicht mehr hinzu, wohl aber prägen sich die genannten immer eigenartiger aus. Dadurch, daß die Fruchtformen der Zygomyceten sich samt und sonders auf das Sporangium in nicht mißzuverstehender Weise zurückführen lassen, bieten diese Pilze den Schlüssel für das Verständnis der Morphologie der höheren."

Wir haben gesehen, wie bei den Phycomyceten Sporangien und Konidien vorkommen, von welchen die letzteren, ich erinnere nur an die Peronospora-Konidien, welche je nach Umständen vegetativ keimen oder Zoosporen bilden, von Sporangien abgeleitet werden können.

Von Sporangien produzierenden Formen leitet nun BREFELD die Ascomyceten ab, von Konidien produzierenden die Basidiomyceten: der Ascus ist demnach ein Sporangium, die Basidie ein Konidiophor und zwar hat in beiden Fällen das gleiche Prinzip gearbeitet, der Uebergang eines Organs, welches eine unbestimmte Sporenzahl bildet, in ein solches, welches Sporen in bestimmter Zahl produziert.

Während im Sporangium der Phycomceten die Sporenzahl unbestimmt ist, ist die typische Sporenzahl im Ascus 8, während die Zahl der Konidien, welche z. B. von einem Peronospora-Konidiophor produziert wird, unbestimmt ist, ist die Zahl für die Basidie der Basidiomyceten typisch 4.

Ueberdies soll Größe und Form der Asci und der Basidien konstanter als die der Sporangien und Konidiophoren sein.

Beschränken wir uns nun zunächst auf BREFELDs AscomycetenReihe und sehen wir, wie er den Ascus vom Sporangium ableitet. Dies geschieht mittels der Gruppe der Hemiasci, welche im "Ascus" eine noch unbestimmte Sporenzahl bilden soll.

$\mathrm{Zu}$ der Gruppe der Hemiasci gehören nach BREFeld die Ascoideen, die Protomyceten und die Theloboleen, von welchen erstere an die exosporangialen, d. h. nackte Sporangien bildenden Zygomyceten, letztere an die carposporangialen, d. h. berindete Sporangien bildenden Zygomyceten anchließen sollen.

Ascoidea ist ein Pilz, der im Wundsaft von Buchen vorkommt und Sporangien bildet, welche in einer leicht quellenden Substanz einge- 
bettet sind, wie die Sporen des Mucor-Sporangiums. Dieser Schleim preßt durch WTasseraufnahme die Sporen heraus, wobei sich das Sporangium an der Spitze öffnet.

Diese Substanz wird ebenso wie die von Mucor von v. Taves als Epiplasma betrachtet ${ }^{1}$ ). Der einzige Grund, weshalb dieses Sporangium als ein Uebergang zum Ascus betrachtet wird, scheint die Meinung zu sein, daß die Sporen in Form und Größe konstanter sind wie z. B. Mucor-Sporen und in der Form denen von Endomyces sehr gleichen.

Von den Protomyceten wählt v. Tavel Protomyces macrosporus als Beispiel. Dieser Organismus lebt parasitisch auf Cichoraceen, auf welchen Pflanzen er in ähnlicher Weise wie dies $P$. macrosporus auf der Umbellifere Aegapodium tut, Schwielen verursacht. In diesen Schwielen

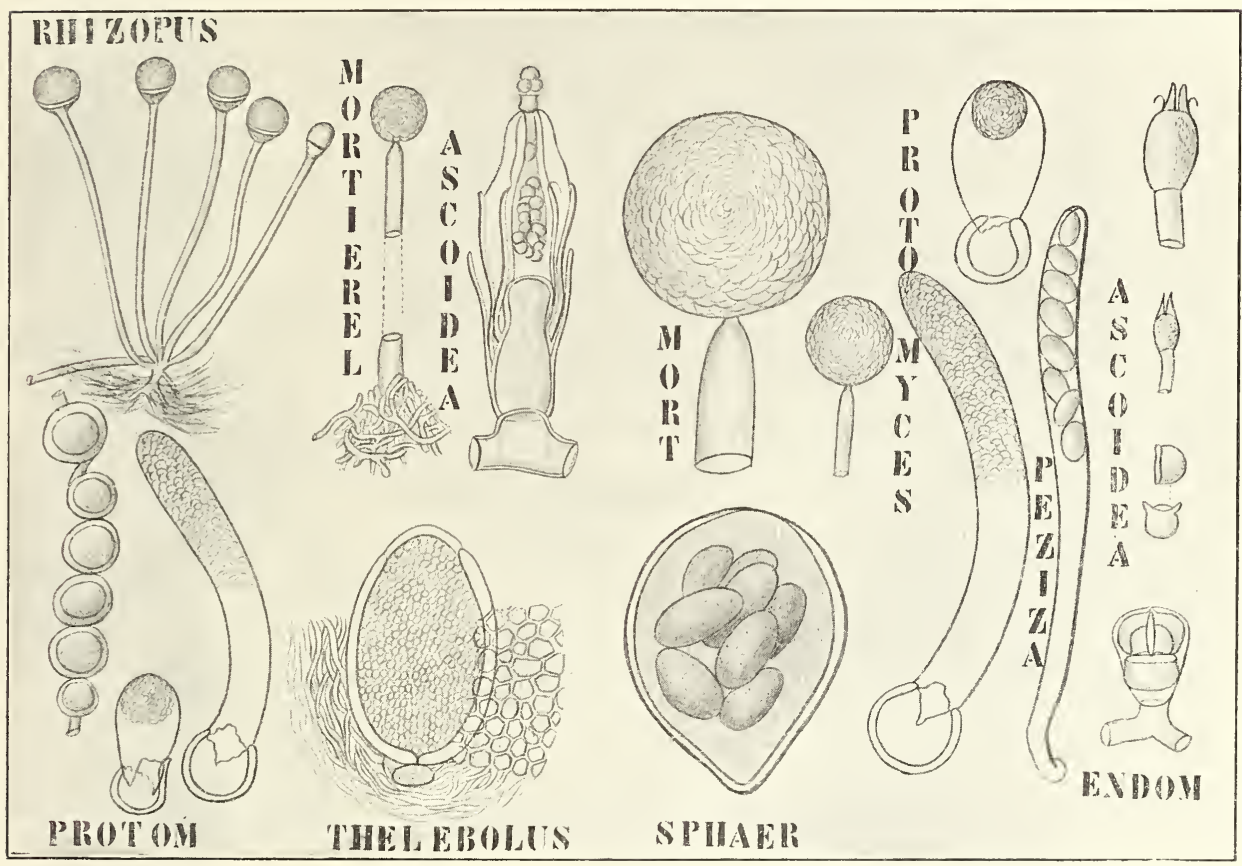

Fig. 256. Fortpflanzungsorgane verschiedener $\mathrm{Phycomy}$ ce ten und Hemiasci nach v. TAVEL angeordnet zur Demonstration des Uebergangs zwischen Sporangien und Ascus. I. Die Theloboleen-Reihe: 1 Rhizopus, Sporangien mit Ernährungshyphen an der Basis. 2 Mortierella, die Basis des einzelnen Sporangiums berindet. 3 Thelobolus, das Sporangium durch Verkürzung des Stieles in die basale Rinde versenkt. $4 \mathrm{Sph}$ a erothe ca, ein echter As com y cet, Ascus aus der Umhüllung der Ascusfrucht isoliert. - II. A s co idea links (neben Mortierella), ein "Ascus“ ganz rechts. Oben zwei Asci weniger vergrößert, unten zwei Ascussporen, darunter Endomyees zur Demonstration der Aehnlichkeit der Ascussporen derselben mit denen von Ascoidea. - III. Protomrees, links auf der Figur eine Reihe von Chlamydosporen, daneben zwei derselben keimend, rechts ein Protomyces-Ascus mit einem Ascus von Peziza verglichen. In der Mitte der Figur oberhalb von Sphaerotheca zwei Mortierella-Sporangien, die variable Grölie dieser Organe zeigend.

finden sich intercelluläre Hyphen, deren Zellen zu dickwandigen, kugeligen Ruhezuständen anschwellen. Diese Ruhezustände fallen nach der

1) v.'TAVEL 1. e. p. 51. 
BREF ELDschen Nomenklatur unter den Begriff „Chlamydosporen“, worunter er im allgemeinen Gemmae versteht, welche nicht vegetativ, sondern fruktifikativ keimen, d. h. nicht ein Mycel, sondern sofort Fruktifikationsorgane, in casu Sporangien bilden.

Die Sporangien, welche aus der Keimung der Chlamydosporen entstehen, sind, wie ein Blick auf die Figur zeigt, in Verbindung mit der wechselnden Größe der Chlamydosporen sehr verschieden groß und besitzen sehr verschiedene Sporenzahl, weshalb es ganz unklar ist, inwieweit sie einen Uebergang zwischen Sporangien und Asci bilden können.

Jetzt die Theleboleen. Es gibt einen mistbewohnenden Organismus, welcher auf kurzen Stielchen ein großes, sowohl in Bezug auf die eigene Größe, wie auf die Größe der Sporenzahl variabeles Sporangium bildet, das durch eine Hyphenrinde geschützt wird. Weshalb dieses nach BreFELD so variabele Organ als ein Uebergang zwischen Sporangium und Ascus betrachtet werden soll, ist unklar ${ }^{1}$ ).

Auch ist die Ableitung des Thelebohıs von den Phycomyceten recht problematisch, wie aus folgendem hervorgeht. Wir sahen früher, daß die kurzen Hyphen unten an den Sporangiophoren von Rhiropus den kurzen Hyphen, welche die Basis des Sporangienträgers von Mortierella umhüllen, homolog sind, Mortierella ließe sich also von einer Form wie Rhiropus ableiten; um nun Thelebolus an Mortierella anschließen zu können, nimmt Brefeld an, daß die Zelle, welche das Sporangium von Thelebolus trägt, die, nebenbei bemerkt, anscheinend öfters fehlt, als ein verkürzter Sporangienträger einer Mortierella zu betrachten ist, so kann man allerdings erstere von letzteren ableiten, zwingend wird man das aber kaum nennen können.

Worauf beruht nun der vermeintliche Anschluß der Hemiasci an die Ascomyceten?

Auch bei letzteren unterscheidet BREFELD zwischen Exoasci und Carpoasci; bei ersteren entstehen die Asci direkt frei auf dem Mycel, bei den zweiten in bestimmten Fruchtkörpern, welche eine aus sterilen Hyphen bestehende Hülle um den Ascus oder die Asci bilden.

Zur Gruppe der Exoasci gehören 2 Untergruppen, die der Endomyceten und die der Taphrineen.

Von den Endomyceten schließt nach Brefeld das Genus Endomyces am engsten an die Hemiasci an. Es bildet z. B. eine gewisse Endomyces decipiens Asci mit 4 Sporen, und da diese Sporen die gleiche Form wie die von Ascoidea haben, muß dieser Umstand als Hauptargument für einen genetischen Zusammenhang beider Genera dienen.

In der Ascomyceten-Gruppe der Taphrineen bildet Taphrina Johansonii auf dem Gynaecium von Populus tremula zwischen Cuticula und Epidermis ein Mycel, welches Asci mit 4 kugeligen Sporen bildet, welche noch im Ascus zu "Hefekonidien" keimen können. Das tun die Sporen von Protomyces, nachdem sie aus dem Sporangium ausgeschlüpft sind und das scheint der Grund zu sein, weshalb Taphrina an die Hemiasci angeschlossen wird, ein anderer ist wenigstens nicht recht klar.

In der Gruppe der Carpoasci wird Sphaerotheca mit Thelebolus und der Ascus mit dem „Sporangium" von Thelebolus verglichen. Da wir jetzt wissen, daß Thelebolus ein echter Ascomycet, sein Sporangium also ein Ascus ist, hat dies für BrEFELDS Theorie keinen Wert.

1) Vor kurzem hat er sich als echter, 8-sporiger Ascus entpuppt, die vermeintlichen Ascussporen sind von den Ascussporen gebildete Konidien. Siehe weiter unten unter Thelebolcae. 
Wie wir sehen, ist die Argumentation recht schwach: Ein Ascus wird betrachtet als ein Sporangium bestimmter Größe und Sporenzahl, ein Sporangium als ein Organ variabeler Größe und Sporenzahl.

Falls man nun die Hemiasci zur Termittelung zwischen Sporangium und Ascus gebrauchen will, sollte man nachweisen, daß die "Sporangien" oder ".Asci“" dieser Gruppe in dieser Hinsicht zwischen echten Sporangien und Asci stehen, also konstanter in Größe und Sporenzahl wie die echten Sporangien, weniger konstant wie die echten Asci sind, aber sowohl die Sporangien der Ascoideen, der Protomyceten, wie die der Theleboleen sind nach BREFELD sehr variabel, sowohl in Größe, wie in Sporenzahl, während von den Ascoideen weiter nur mitgeteilt wird, daß die Größe und Form der Sporen recht beständig ist.

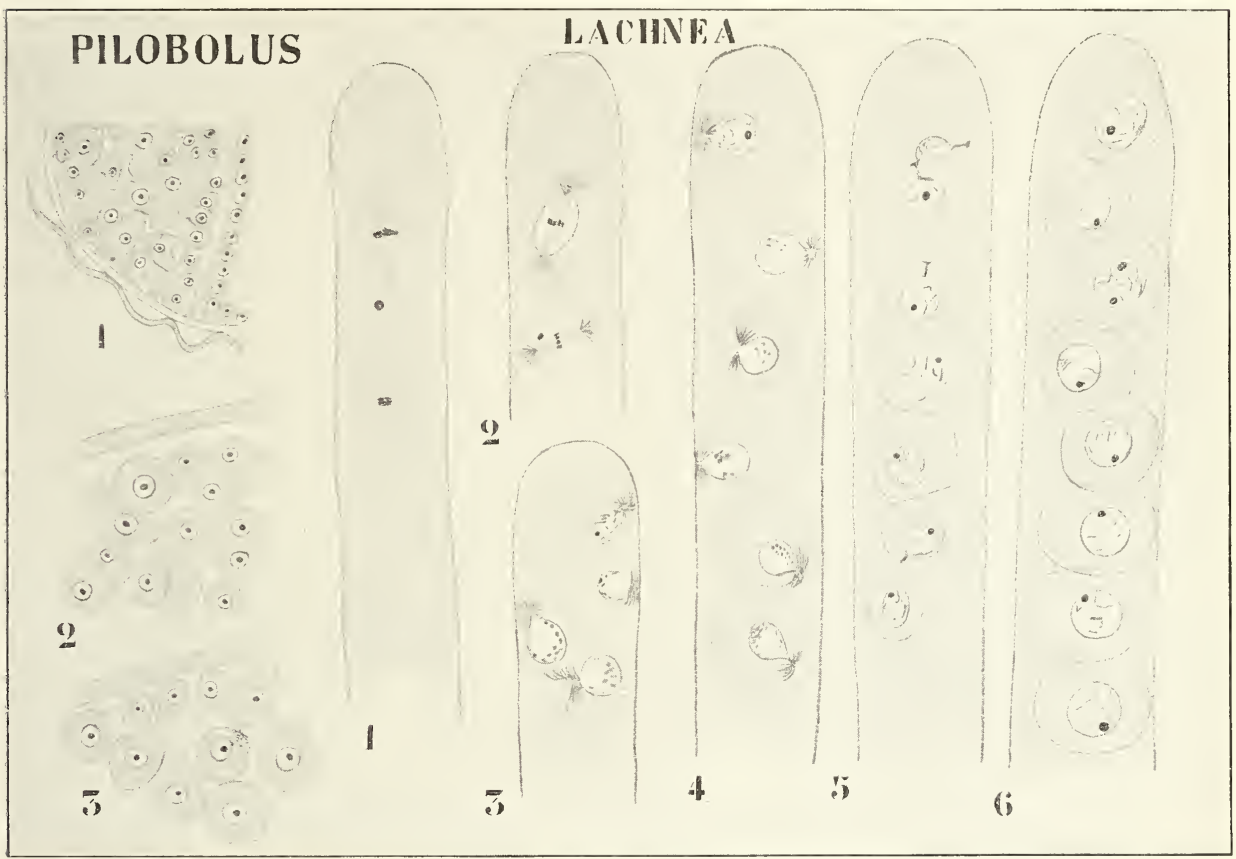

Fig. 257. Sporenbildung beim Phycomyceten Pilobolus und beim Ascomyceten Lachnea (nach HARPER).

Nach Brefelds eigener Definition eines Sporangiums besitzen demnach die Sporenschläuche der Hemiasci ausschließlich Sporangieneigenschaften und gar keine solchen eines Ascus, weshalb ein nicht voreingenommener Botaniker gar keinen Grund hat, sie als Zwischenformen zwischen Sporangien und Asci zu betrachten.

Untersuchungen HarPers (1895-99) lehrten übrigens, daß die Sporenbildung in Sporangien und Asci in ganz anderer Weise vor sich geht, was sicher nicht für die von BREFELD befürwortete Homologie beider Organe spricht.

Es stellte sich nämlich heraus, daß in den Sporangien der Plyycomyceten der protoplasmatische Inhalt mittels Spalten, welche auf die Kerne keinerlei Bezug nehmen, in Sporen zerlegt wird, olme daß dabei 
ein unverwandter Plasmarest übrig bleibt. Die Kerne spielen dabei also keine aktive Rolle.

Dagegen wird bei der Bildung der Ascosporen um jeden Nucleus herum mittels Kinoplasmastrahlen eine Plasmamasse, welche später durch Membranbildung zur Spore wird, ausgeschnitten, wobei vom Gesamtplasma ein bedeutender, allerdings kernfreier Rest übrig bleibt (Fig. 257, 4), das bekannte Epiplasma, welches in keiner Hinsicht mit dem Schleim zwischen den Mucorineen-Sporen zu vergleichen ist.

Ueberdies entstehen die 8 Ascussporen aus der Teilung eines einzigen Nucleus (Fig. 257, 1-4), während bei den Phycomyceten das Sporangium vom Anfang an vielkernig ist.

Dagegen würde man nun noch einwenden können, daß bei niedrigen Pilzen, z. B. bei Synchytrium, Sporangien bekannt sind, welche zunächst einkermig sind und erst später vielkernig werden, aber noch abgesehen von phylogenetischen Gründen ist wohl zu beachten, daß erstens auch bei Synchytrium nach der Bildung der Sporen kein Epiplasma zurückbleibt, zweitens, daß der Ascuskern, aus welchem die Ascussporenkerne entstehen, in ganz anderer Weise entsteht, wie der Sporangiumkern eines Synchytrium.

Während doch bei Synchytrium vom Anfang an der Sporangienkern als solcher vorhanden ist, entsteht der Ascuskern infolge der Fusion zweier Kerne.

Diese wichtige Tatsache wurde bereits vor oben erwähnten Untersuchungen Harpers 1894 von DaNGeard entdeckt. In einer Mitteilung an die französische Akademie erzählt Dangeard, daß er bei Periza vesiculosa beobachtet hat, daß die Asci durch Kopulation zweier einkerniger Gametangien entstehen, ungefähr wie der „Ascus" bei Eremascus. Die beiden Nuclei verschmelzen und dieser Zygotennucleus teilt sich und bildet die Nuclei der Ascussporen.

Alsbald aber konnte er nachweisen, daß er sich geirrt hatte, daß die Asci nicht durch Kopulation zweier Gametangien entstehen, aber daß eine eigentümliche Hakenbildung an den ascogenen Hyphen diese Kopulation vortäuschte, und da nun in der Tat die Asci infolge dieser Hakenbildung entstehen, war die erste Interpretierung ein recht begreiflicher Irrtum.

In einem Artikel in "Le Botaniste" desselben Jahres gibt er die richtige Darstellung der Verhältnisse bei der Ascusbildung von Peziza vesiculosa.

Es stellt sich heraus, daß die Enden der ascogenen Hyphen, welche die Asci bilden werden, anfangen, sich hakenförmig zu krümmen (Fig. 258, II 2). Auf diesem Stadium teilt sich der Nucleus (Fig. 258, II 2), so daß alsbald 2 Kerne vorhanden sind, dann sieht man einen zweiten Nucleus sich teilen (Fig. 258, II 3), so daß nun bald in dem Stiel des Hakens 4 Kerne vorhanden sind. DANGEARD läßt es unentschieden, ob diese 4 Kerne von der Teilung eines oder zweier Kerne herrühren. Die Spitze des Hakens biegt sich nun ganz um und der umgebogene Teil schwillt an, um später den Ascus zu bilden. Dieser junge Ascus scheidet sich nun mittels Querwänden von beiden Beinen des Hakens ab, und zwar so, daß in den jungen Ascus zwei von den 4 Kernen zu liegen kommen (Fig. 258, II 4), einer in die Hakenspitze und einer in den Hakenstiel.

Die beiden Nuclei im Ascus verschmelzen nun zum Ascusnucleus, der später durch Teilung die 8 Nuclei der Ascosporen bilden wird. 
DANGEARD zeigte nun, daß, wie verschieden auch die Zahl der Kerne in den Zellen der vegetativen Hyphen der verschiedenen Ascomyceten-Genera ist, immer 2 Nuclei zu einem Ascusnucleus verschmelzen. Dennoch ist die Zahl der Kerne in den Zellen der vegetativen Hyphen ziemlich verschieden, wie aus folgendem hervorgehen mag: Erysiphe 1, Ascolichenen 1, Exoascus deformans 2, Acetabula calyx? 10-20, Periza, Helvella, Morchella 2-6, Penicillium glaucum ebenfalls 2-6, Aspergillus glaucus 3-20 und mehr.

Daß in der Tat immer 2 Nuclei zusammen den Ascusnucleus bilden, zeigte er an so verschiedenen Typen wie Exoascus deformans, Pezina vesiculosa, Helvella Ephippinu, Borrera ciliaris, Acetabula calyx, Endocarpon miniatum und Aspergillus glaucus, bei letzterer nicht ganz sicher; einige dieser Fälle sind unten abgebildet.

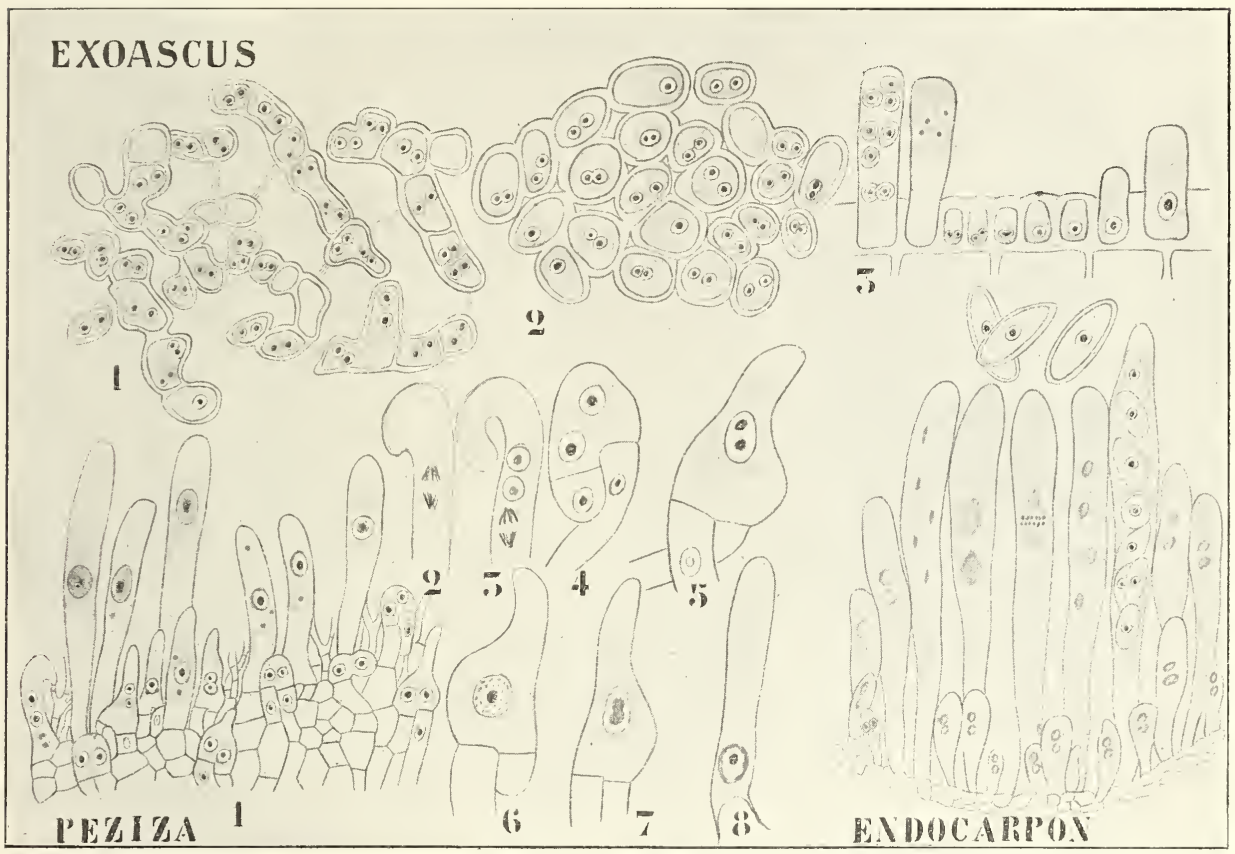

Fig. 258. Bildung des Ascus bei verschiedenen mit Namen bezeichneten Ascomyceten (nach Dangeard). I. bei Exoascus, II. bei Peziza, III. bei Endocarpon.

Auf diese Resultate und auf die von DANGEARD daraus gezogenen Schlüsse kommen wir später zurück, sie wurden hier nur erörtert, um einen weiteren Beweis für die cytologischen Unterschiede zwischen den Asci und den Sporangien der Phycomyceten zu bringen.

Wir haben schon früher betont, daß uns BREFELDs Auffassung der Sporenschläuche der Hemiasci als Zwischending zwischen Sporangien und Asci nicht einleuchtet, und wir haben nicht umhin gekonnt, seine Argumente als schwache zu bezeichnen.

Es wäre aber offenbar möglich, daß spätere Untersuchungen über die Hemiasci Brefelds Meinungen mehr annehmbar gemacht hätten. sehen wir also ob dies der Fall ist, und stellen wir uns zu gleicher Zeit 
die Frage, ob die Hemiasci überhaupt als Vorläufer der Ascomyceten betrachtet werden dürfen.

Wir fangen also mit Brefelds Gruppe der

\section{Ascoideae}

an, indem wir die Genera Ascoidea und Dipodascus besprechen.

\section{Ascoidea.}

Ascoidea rubescens BREF. bildet im Wundsaft von Buchen rötliche, ziemlich dichte, unregelmäßige Mycelflocken, welche später zu einer schmutzigen Masse verschleimen.

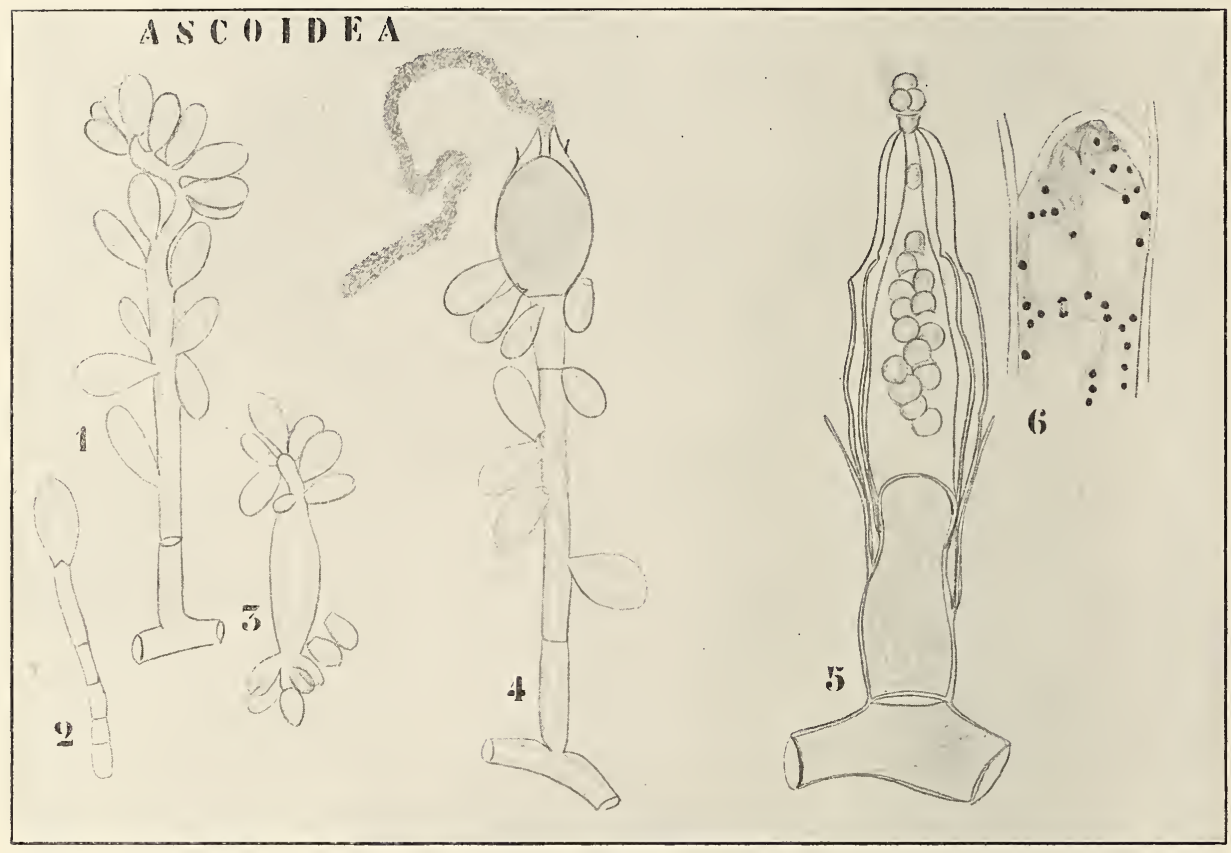

Fig. 259. Ascoidea rubescens (nach BREFELD). 1 Konidienträger. 2 Vegetativ keimende Konidie. 3 Konidie, wieder konidienbildend. 4 Sporangium, die Sporenmasse entlassend. 5 Sporangien stärker vergrößert. 6 (nach PoPTA) die vielen Kerne im jungen Sporangium zeigend.

Die Hyphen sind recht dick und bilden zunächst apikale, alsbald aber durch seitliches Auswachsen des Konidienträgers lateral werdende Konidien.

Diese keimen entweder direkt zu einem neuen Mycel oder bilden unter ungünstigen Bedingungen von neuem Konidien.

Nach einiger Zeit werden sehr große Sporangien gebildet, welche eine große Menge in eine feinkörnige Masse eingebettete Sporen bilden.

Diese feinkörnige Masse wird nun alsbald mit den darin enthaltenen Sporen wurmförmig hinausgepreßt (Fig. 259, 4).

Was ist nun diese feinkörnige Masse? Ist es Epiplasma oder etwas anderes? Wir wissen es nicht; zwar hat Frl. Popta (1899) die Sache 
untersucht, zu einem bestimmten Resultat kam sie aber nicht. Democh hat sie einen für unsere Auffassung von Ascoidea sehr wichtigen Punkt feststellen können, daß nämlich der sogenannte Ascus von Ascoider von Anfang an vielkernig ist, mit einem wirklichen Ascus also nichts zu tun hat. Daraus darf man wohl folgern, daß auch die vegetativen Zellen unseres Pilzes polyenergid sind, und so haben wir also mit einem sporangienbildenden Siphonomyceten zu tun, dessen nähere Verwandtschaft aber vorläufig noch nicht festgestellt werden kann, von welcher man aber ruhig behaupten kann, daß sie mit Ascomyceten nichts zu tun hat; und da sie mit diesen auch nicht einen einzigen Punkt gemeinsam hat, schwerlich als Uebergang zu den Ascomyceten betrachtet werden kann.

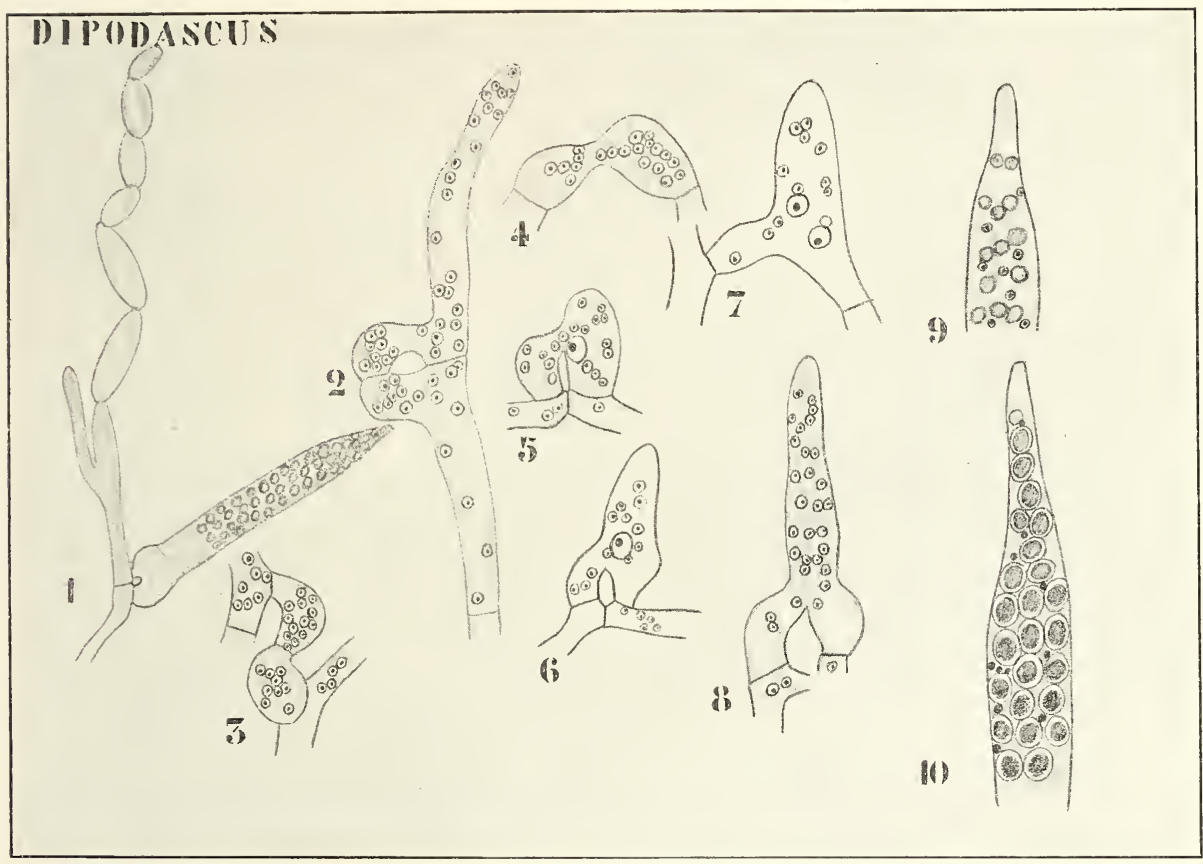

Fig. 260. Dipodascus albidus (nach JUEL). 1 Eine Hyphe, welche Konidien und einen „Ascus“ produziert hat. 2 Junge „Ascusanlage“; benachbarte Zellen des gleichen Fadens kopulieren. 3 Id. Zellen zweier benachbarter Fäden kopulieren. 4 Kopulation. 5, 6 Auftreten des vermutlichen Zygotennucleus. 7 Erste Teilung desselben. 8-10 Sporenbildung.

\section{Dipodascus.}

Dipodascus albidus LAgERHEIM (1892) wurde von LAGERHEIM im Wundsaft abgeschnittener Puya-Stengel (Bromelincerie) bei Quito entdeckt und später von JuEL im Birkenwundsaft in Schweden wiedergefunden.

Der Pilz bildet an der Spitze verzweigter, septierter Hyphen Konidien und öfters an Seitenzweigen derselben Hyphen die langen zugespitzten ,Asci", deren Basis mehr oder weniger deutlich zweischenkelig' ist (Fig. 260, 1, 8).

Eine cytologische Untersuchung lehrte JUEL nun zunächst. daß die Zellen des Dipodascus polyenergid sind. Zur Fortpflanzung bilden zwei benachbarte Zelien derselben (Fig. 260, 2), nder verschiedener (Fig. 260. 3) Hyphen seitliche Ausstülpungen, welche sich aneinander legen und 
durch Auflösung der trennenden Membranstücke kopulieren (Fig. 260, 4). Wir haben hier also mit einer Kopulation von Gametangien zu tun. Im jungen Zygogametangium (Fig. 260, 4) sind noch sämtliche Kerne gleich groß, alsbald aber tritt darin eine Veränderung auf, indem ein Kern sich durch seine auffallende Größe stark von den anderen abhebt (Fig. 260, 5). Trotzdem der Vorgang selber nicht beobachtet wurde, ist dieser Kern wohl als das Resultat der Verschmelzung zweier Kerne zu betrachten, deren jeder aus einem der kopulierenden Gametangien herstammte, wir dürfen ihn also wohl als Zygotenkern betrachten. Fig. 260, 7 darf wohl als das Resultat der Teilung dieses Zygotenkernes aufgefaßt werden.

Weitere Teilungen desselben heben aber offenbar die Größendifferenz auf, so daß auf. etwas späterem Stadium (Fig. 260, 8) die Kerne im Zygogametangium wieder gleich groß sind. Später aber zeigt sich, daß zwischen diesen Kernen dennoch Unterschiede bestehen müssen, denn während einige nach kürzerer oder längerer Zeit zu Grunde gehen, umgeben sich andere mit einer Plasmamasse (Fig. 260, 9) und schließlich mit einer Membran (Fig. 260, 10): sie werden zu Sporen.

Da liegt es also auf der Hand, anzunehmen, daß die sporenbildenden Kerne durch Teilung aus dem Zygotenkern entstanden sind, die degenerierenden Kerne die nichtkopulierten Kerne des Zygogametangiums darstellen.

Die Vorgänge bei Dipodascus erinnern also in hohem Grade an die bei den Albugo-Arten, wird doch in beiden Fällen durch Auswahl eines einzigen weiblichen Kernes unter vielen vorhandenen der Inhalt des Gametangiums zum Ei gemacht. Bei Albugo teilt sich nach stattgefundener Befruchtung der Zygotenkern in eine Anzahl Schwärmsporen bildende Kerne, hier bilden die Teilungsprodukte des Zygotenkernes unbewegliche Sporen statt Schwärmsporen, das ist ja eigentlich der einzige Unterschied zwischen beiden.

Vergleichen wir nun Ascoidea und Dipodascus, so sehen wir, daß zwischen den Organen, welche man bei diesen Genera ,Asci“" nennt, recht große und scheinbar fundamentale Differenzen bestehen. Bei Ascoidea entstehen die „Asci" nämlich ungeschlechtlich, bei Dipodascus geschlechtlich, so daß man den "Ascus" von Ascoidea als Sporangium, den von Dipodascus als Gametangium bezeichnen muß. Ob dies aber richtig ist, muß dahingestellt bleiben; der Umstand, daß Frl. Popta bei Ascoidec eine periplasmatische Substanz — wenn auch nicht ganz zweifellos - wie solche bei Albugo und Dipodascus vorhanden ist, nachwies, legt die Frage nahe, ob Ascoidea nicht eine parthenogenetische Form ist, ob nicht ihr Sporangium in der Tat ein sich parthenogenetisch entwickelndes Gametangium ist.

Wir sehen also, daß Ascoidea mit Ascomyceten nichts gemeinsam hat, und daß bei Dipodascus, den man vielleicht im gewissen Sinne als Uebergang von Albugo zu den Ascomyceten betrachten könnte, der "Ascus" sicher kein Sporangium, sondern ein Zygogametangium ist. Die Ascoidecae können also der Brefeldschen Auffassung der Homologie von Ascus und Sporangium keine Stütze gewähren.

Sehen wir, inwieweit die nächste Familie, die der

\section{Protomyceten}

Brefelds Anschauungen stützt. In Bihang till Svenska Akad. Handlingar, Bd. 27. Afd. III beschreibt Juel einen Pilz unter dem Namen Taphridium 
algeriense. welcher in Algerien in Ferula-Blättern lebt. Er bildet dort Fäden, welche zwischen den Blattzellen verlaufen. Es sind die Zellen dieser Hyphen polyenergid. Zwischen der Epidermis und den Palisadenparenchym rerlauten etwas dickere Hyphen, deren Zellen ebenfalls polyenergid sind; es sind dies die fertilen Hyphen. Nicht alle, aber doch viele Zellen dieser fertilen Hyphen bilden durch einfache Anschwellung die sogenannten Asci (Fig. 261, 1). Inzwischen scheint aber eine Kernvermehrung stattgefunden zu haben, denn der junge Ascus (Fig. 261, 2) enthält viel melır Kerne als die Zelle, aus welcher er hervorging. Dann folgt ein Stadium der Kernvergrößerung (Fig. 261, 3), vermutlich von Karyokinese gefolgt, wenigstens wurde ein solches Stadium (Fig. 261, 4) beim verwandten Taplnidium umbelliferarum beobachtet. Bis jetzt waren

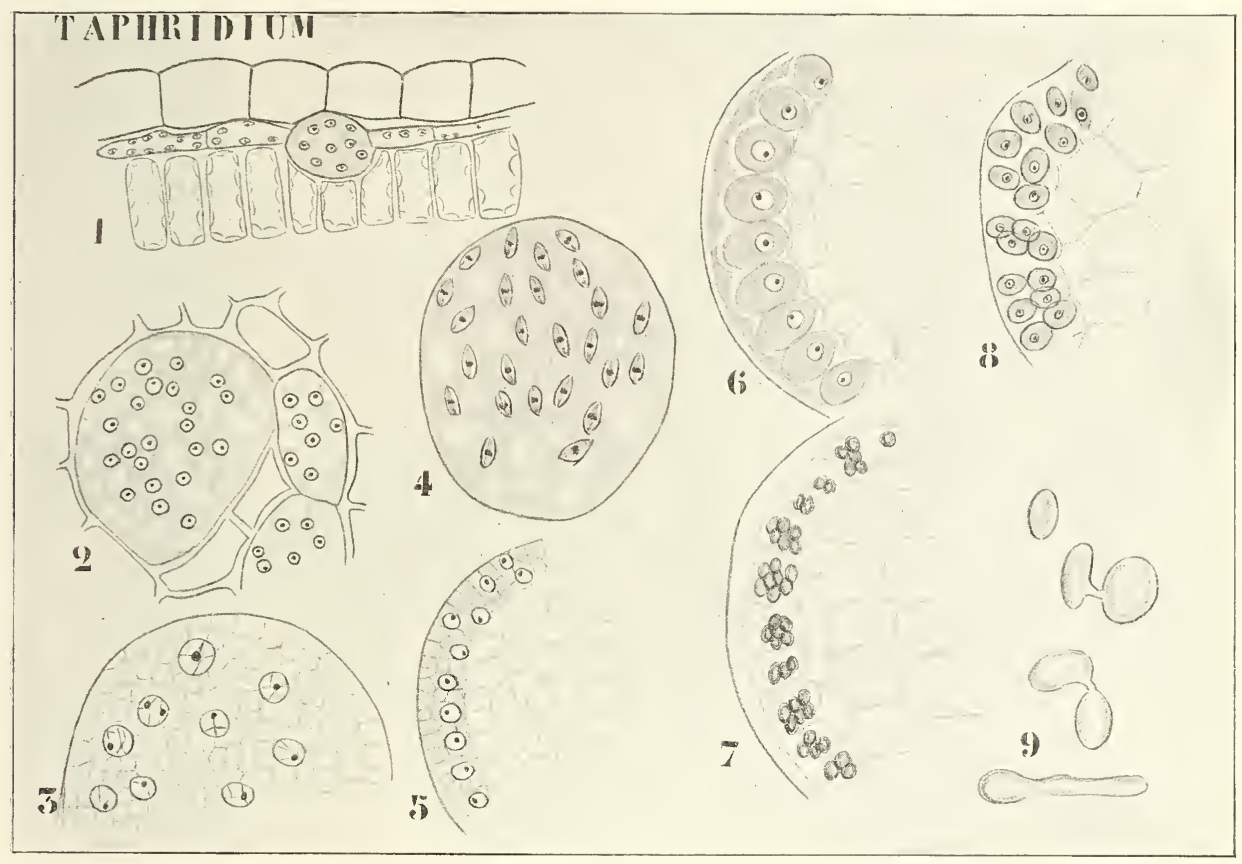

Fig. 261. Taphridium algeriense JUEL (nach JUEL). 1 „Ascusbildung“. 2 Junger „Ascus“ mit vielen Kernen. 3 Die Kerne haben sich v̉ergrößert. 4 Taphridium um belliferarum, Kernteilung im „Ascus“. 5 Bildung einer zentralen kernfreien Plasmamasse im Ascus. 6 Entstehung der Sporenmutterzellen. 7, 8 Bildung der Sporen aus den Sporenmutterzellen. 9 Fusionierung und Keimung der Sporen.

die Kerne regelmäßig über den ganzen Inhalt des „Ascus" verteilt, jetzt aber begeben sich alle an die Peripherie, wodurch eine große zentrale Plasmapartie kernfrei wird (Fig. 261, 5). An der Peripherie angelangt. umgibt sich jeder Kern mit einer Plasmamasse (Fig. 261, 6), welche Plasmamassen sich später in Sporen teilen (Fig. ¿261, 7, 8) und also als Sporenmutterzellen betrachtet werden dürfen; die zentrale Plasmamasse bleibt als Rest zurück. Die einkernigen Sporen fusionieren zusammen: was dabei mit den Kernen geschieht, wissen wir nicht, rermutlich verschmelzen sie nicht.

Es wird Thnen klar geworden sein, daß der ,.Ascus" ron Taphridium 
recht wenig mit dem von Ascoidea oder Dipodascus gemein hat. Bei Dipodascus ein „Ascus“, der zweifellos ein Zygogametangium ist; bei Ascoidea ein Sporangium oder parthenogenetisch sich entwickelndes Gametangium; bei Taphridium ein Organ, in welchem Sporenmutterzellen gebildet werden.

Diese Bildung von Sporenmutterzellen erinnert in hohem Grade an Synchytrium, der Umstand aber, daß die Sporenmutterzellen bildende Zelle bei Synchytrium anfangs einkernig, bei Taphridium vielkernig ist, macht eine enge Verwandtschaft zwischen beiden nicht wahrscheinlich. Mehr Uebereinstimmung besteht zwischen dem Ascus von Taphridium und dem Sporangium von Pilobolus, indem die Sporenmutterzellen des ersteren in mancher Hinsicht mit den Protosporen von Pilobolus übereinstimmen. Ihre Entstehung ist aber sehr verschieden: bei Pilobolus ein restfreies Aufspalten des Plasma, bis selbiges in Protosporen zerlegt ist, ohne daß dabei die Nuclei aktiv wirksam sind, hier ein sehr beträchtlicher Plasmarest und eine Bildung der Sporenmutterzellen infolge von Plasmaakkumulation um jeden Nucleus herum. Die Bildung der kernfreien zentralen Plasmamasse erinnert sehr an das Verhalten der Kerne im Oogon der Albuginaceen.

Sie sehen, wie unmöglich es ist, durch Vergleich mit Ascoidea oder Dipodascus den "Ascus" von Taphridium zu „erklären", wir können nur sagen, daß auch dieser Pilz mit Ascomyceten nichts gemeinsam hat. Auch das andere Protomyceten-Genus

\section{Protomyees}

wirft kein Licht auf die Entstehung der Ascomyceten; bei ihm aber läßt sich der sogenannte Ascus verhältnismäßig leicht deuten.

\section{Protomyces macrosporus}

lebt in verschiedenen Umbelliferen-Arten, besonders gern in Aegopodium podograria, wo es Schwielen auf den Blattstielen verursacht. In den vermutlich polyenergiden Hyphen schwellen gewisse Zellen stark an und bilden eine derbe Membran; sie enthalten viele Kerne. Ich bin geneigt, diese "Asci“ als Chlamydosporen zu betrachten. Nachdem die Chlamydospore gebildet ist, macht sie zunächst eine längere Ruheperiode durch und keimt erst, nachdem der Teil der Wirtspflanze, in welchem sie sich befindet, verfault ist. Dann tritt das Endosporium heraus und das Plasma sammelt sich in demselben in einer peripheren Wandschicht an (P. bellidis, Fig. 262, 1). Bei P. bellidis fand Frl. Popta, daß sich dieses Plasma in "Sporen" (Fig. 262, II 2) aufspaltet, da aber in ihren Zeichnungen (vergl. Fig. 262. II 2 mit 3) diese Spaltungsprodukte viel größer als die Sporen sind, vermute ich, daß sie vielmehr als Sporenmutterzellen, wie wir diese bei Taphridium antrafen, zu betrachten sind. Falls dies richtig, hätte Frl. Popta dieses Stadium in der Sporenbildung übersehen.

Bei $P$. macrosporus beschreibt sie die jungen Sporen als in drei Schichten angeordnet ( $P$. macrosporus, Cytologie Fig. 262, 3). Ihre hier reproduzierte Figur zeigt diese Sporen in Gruppen zusammenliegend, so daß die Interpretierung auf der Hand liegt, daß eine jede solche Gruppe aus einer Sporenmutterzelle, welche hier also ebenfalls übersehen wäre, entstanden sei.

Falls diese Vermutung richtig, ließe sich Protomyces ganz mit Taphridium vergleichen, wir hätten in beiden Fällen mit Chlamydo- 
sporen zu tun und es bestände zwischen beiden Genera und Synchytrium manche Uebereinstimmung, wenn auch, wie gesagt, die polyenergide Natur der Protomyceten und die monoenergide des Synchytrium eine enge Verwandtschaft nicht wahrscheinlich machen.

Betrachten wir nun noch einmal alle diese Formen, bei welchen Brefeld Zwischenstadien zwischen dem Sporangium der Siphonomyceten und dem Ascus der Ascomyceten zu sehen glaubt, so finden wir, daß dieser primitive Ascus bei Ascoidea ein Sporangium oder parthenogenetisches Gametangium, bei Dipodascus ein Zygogametangium und bei Taphridium und Protomyces eine Chlamydospore ist, während keines dieser Genera mit den Ascomyceten verwandt ist.

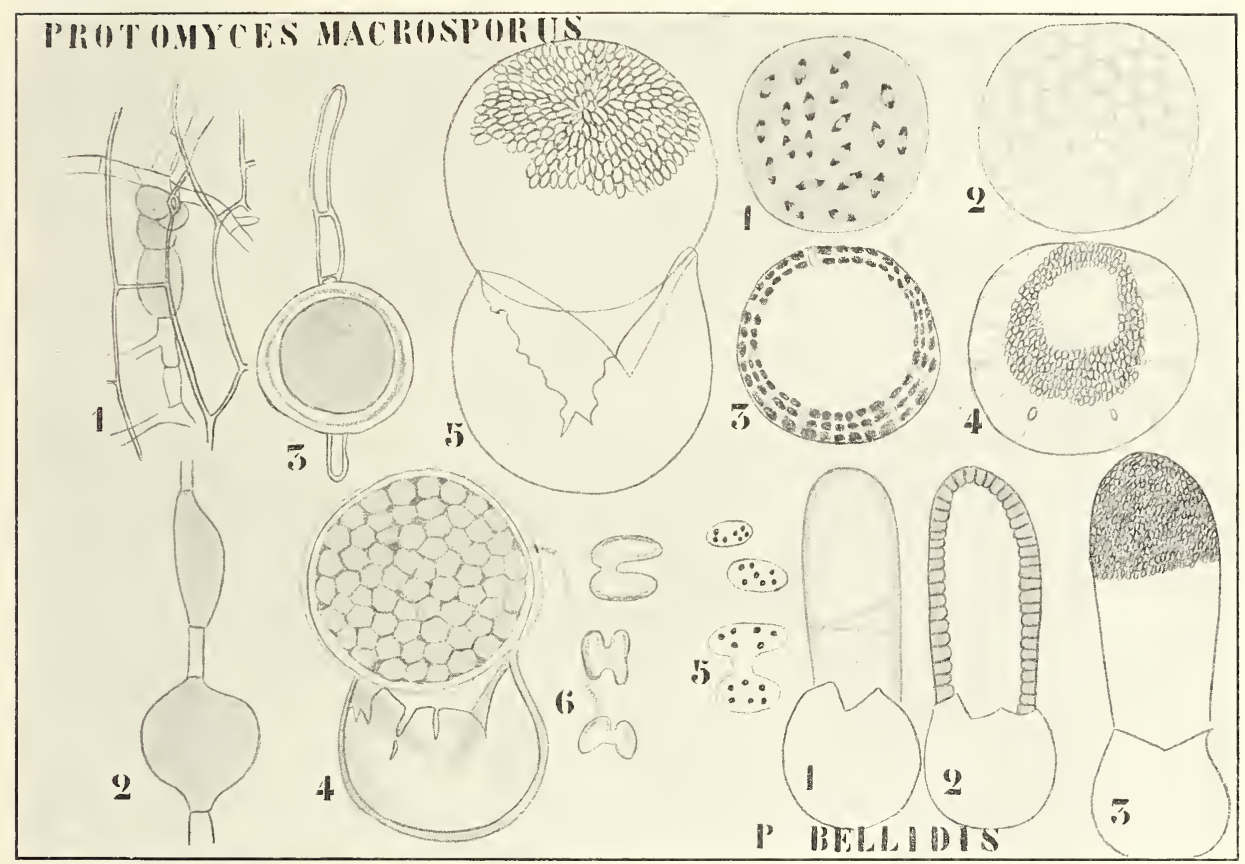

Fig. 262. I. Protom yees macrosporus (nach DE Bary und Frl. Popta). a) Morphologie. 1 Hyphen mit angeschwollenen Zellen im Gewebe der Wirtspllanze. 2 Junge „Chlamydosporen“. 3 Erwachsene Chlamydospore. 4 Der Inhalt hat sich geteilt und tritt, vom Endospor umgeben, heraus. 5 Die Sporen sind gebildet. b) Cytologie. 1 Kernteilung in der Chlamydospore. 2 Spaltung des Plasmas. 3 Querschnitt von 2. 4 Die Sporen sind gebildet. 5, 6 Vielkernige Sporen, fusionierend. - II. Protomyces bellidis (nach Frl. PopTA). 1 Wandständiges Plasma in dem Keimschlauch der Chlamydospore. 2 Selbiges in Sporenmutterzellen zerlegt. 3 Die Sporen sind gebildet.

Gehen wir jetzt zur Besprechung der letzten Familie der Hemiasci, zu der der

\section{Theleboleae}

über, und wählen wir als erstes Beispiel WENTs

\section{Monascus purpureus,}

einen Pilz, über welchen recht viel geschrieben wurde und welcher durch die Kleinheit seiner Kerne und die Anwesenheit einer recht eigentüm- 
lichen Ernährungszelle zu vielerlei Interpretierungen geführt hat. Der Pilz wurde von Went (1895), Uyeda (1902), Barker (1903), Ikeno (1903), Kuyper (1904) und Olive (1905) studiert.

Auf Java wird in der Küche der Eingeborenen ein dunkelroter Farbstoff verwendet, der unter dem Namen Angkak aus China importiert wird. Gewöhnlich kauft man ihn auf dem Markt in der Form eines dunkelroten Pulvers, in welchem man bisweilen ganze, ebenfalls dunkelrote Reiskörner findet. Dem verschiedenen Dr. Vorderman, Inspektor des Medizinischen Dienstes auf Java, gelang es, nachzuweisen, daß die rote Farbe durch einen auf dem Reis wachsenden Pilz verursacht wurde und daß das rote Pulver nur zerstoßener pilzinfizierter Reis war. Es gelang ihm weiter, folgendes über die Bereitung dieses Reises in China

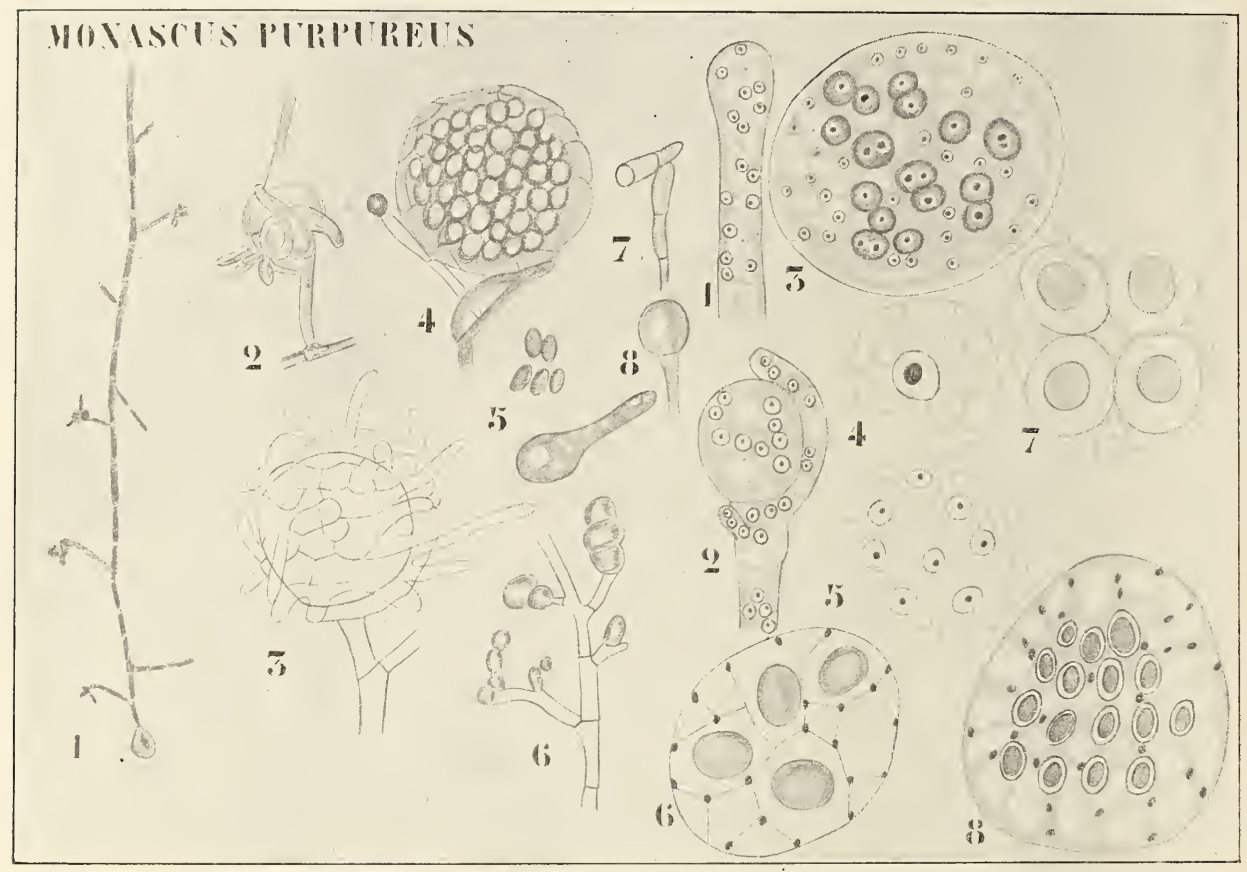

Fig. 263. Monascus purpureus WENT. A. Morphologie (nach WeNt). 1 Pilz mit Fruktifikationsorganen. 2 Junge Ascusfrucht. 3 Aeltere, von außen betrachtet. 4 Reife Ascusfrucht, in optischem Querschnitt. 5 Ascussporen, darunter eine keimend. 6, 7, 8 Konidienund Oidienformen. B. Cytologie (nach IKENO). Erklärung siehe unter Plectascineae, wo dieser Pilz hingehört und besprochen wird.

herauszufinden. Er wird dort in einigen Dörfern der Provinz Quouantoung zugerichtet, und trotzdem man versucht hat, die Zubereitung. geheim zu halten, ist diese bekannt geworden. Man breitet gut gekochten Reis auf großen flachen Schalen aus und sät darauf nach genügender Abkühlung das Angkak-Pulver. Der Reis wird nun etwa 6 Tage an eine kühle dunkle Stelle, vorzugsweise in eine Felsenhöhle, gestellt, wo er rot wird. Die einzige weitere Zubereitung besteht im Trocknen und Pulverisieren der roten Masse.

Went hat darauf eine nähere Untersuchung des Pilzes vorgenommen und seine Morphologie beschrieben. 
Aus Wents Untersuchungen geht zunächst hervor, daß alle Teile des Pilzes rot oder farblos sein kömmen, oder aber, daß der Pilz teilweise rot und teilweise gefärbt auftreten kann. Das scheint von äußeren Bedingungen abzuhängen, zumal von der An- oder Abwesenheit von Sauerstoff. Eigentümlich ist, daß die rote Farbe an das Plasma gebunden und der Zellsaft farblos ist.

Der Pilz pflanzt sich mittels Konidien, Chlamydosporen und Oidien fort, die Hauptfruktifikation besteht aber aus einem vielsporigen großen "Ascus", welcher von einer Hülle steriler Hyphen umgeben ist (Fig. 263, 3, 4 Morphologie).

Die cytologische Untersuchung zeigt die polyenergide Natur der vegetativen Zellen. Nach Went, Ireno, Uyeda und Kuyper wird der Ascus durch Anschwellung einer subterminalen Zelle, an welche sich eine antheridiumähnliche Zelle anschmiegt (Fig. 263, 2 Cytologie), gebildet. Später wird dieser "Ascus" von sterilen, aus darunter gelegenen Zellen entstehenden Fäden umhüllt.

In diesem "Ascus" wurden von verschiedenen Untersuchern Kernverschmelzungen beobachtet, welche der Sporenbildung vorangehen sollten. Dagegen meinte BARKer, daß aus der angeschwollenen Zelle ascogene Fäden hervorgehen, welche erst die wirklichen Asci bilden, hält also den "Ascus" von WENT und seinen Anhängern gar nicht für einen Ascus, sondern für ein Ascogon. Diese Differenz veranlaßte Ineno zu der Meinung, daß Barkers Pilz kein Monascus war. Olive sah die ascogenen Hyphen BARkers und bestätigt also den Kernpunkt seiner Angaben, weicht aber insoweit von ihm ab, als er den Ascus von WENT = Ascogon von BARker nicht für ein Ascogon, sondern für eine Ernährungszelle hält; das eigentliche Ascogon soll nicht diese angeschwollene subterminale, sondern die terminale Zelle sein.

Die Untersuchungen BARKers und OLIves bringen, falls sie richtig sind, den Monascus in die Nähe der Aspergillaceen, und da meiner Meinung nach ihre Auffassung die wahrscheinlichste ist, werde ich sie dort behandeln.

Höchst wahrscheinlich ist also Monascus ein echter Ascomycet mit ascogenen Hyphen und Asci und also für BrefELDs Theorie wertlos; ganz sicher ist dies der Fall mit

\section{Thelebolus,}

der, wie vor kurzem von RAmLow (1906) nachgewiesen wurde, ein echter Ascomycet ist und mit den Hemiasci nichts zu tun hat. Um dies zu begründen, genügt es an dieser Stelle wohl, auf die Beobachtung Ravuows hinzuweisen, daß

1) im Ascus Verschmelzung zweier Kerne stattfindet,

2) zunächst daraus 8 Kerne entstehen,

3) diese Kerne erst durch nachträgliche Teilung im Ascus die Bildung der vielen diesen später ausfüllenden Sporen veranlassen. welche wohl als Konidien zu betrachten sind.

Weiteres über diesen so lange verkannten Pilz wird später bei den Ascoboleen mitgeteilt werden.

Ich glaube, daß aus dem Vorhergehenden wohl zur Genüge hervorgeht, daß Brefeldos Gruppe der Hemiasci ein mixtum compositum sehr heterogener Formen ist und daß BREFELDs Homologisierung von Ascus und Sporangium unrichtig ist; die neueren cytologischen Untersuchumgen 
haben, meiner Meinung nach, die Unhaltbarkeit von Brefelds Auffassungen über die Ascomyceten endgültig bewiesen.

Sehen wir nun, wie es den DE BARYschen Auffassungen gegangen ist. Haben die neueren Untersuchungen auch seine Meinung als unhaltbar gekennzeichnet oder im Gegenteil neue Beweise dafür beigebracht? Resumieren wir nochmals ganz kurz seine Auffassung über die Ascomyceten, so läßt sich diese in zwei Sätze zusammenfassen:

1) Bei den Ascomyceten wird entweder das ganze Archicarp oder ein Teil desselben zum Ascus.

2) Bei den Ascomyceten geht die bei einigen Formen vorhandene Sexualität nach und nach verloren und wird von Apogamie ersetzt.

Vorgreifend können wir sagen, daß die neueren Untersuchungen beide DE BARYschen Sätze der Hauptsache nach glänzend bestätigt haben.

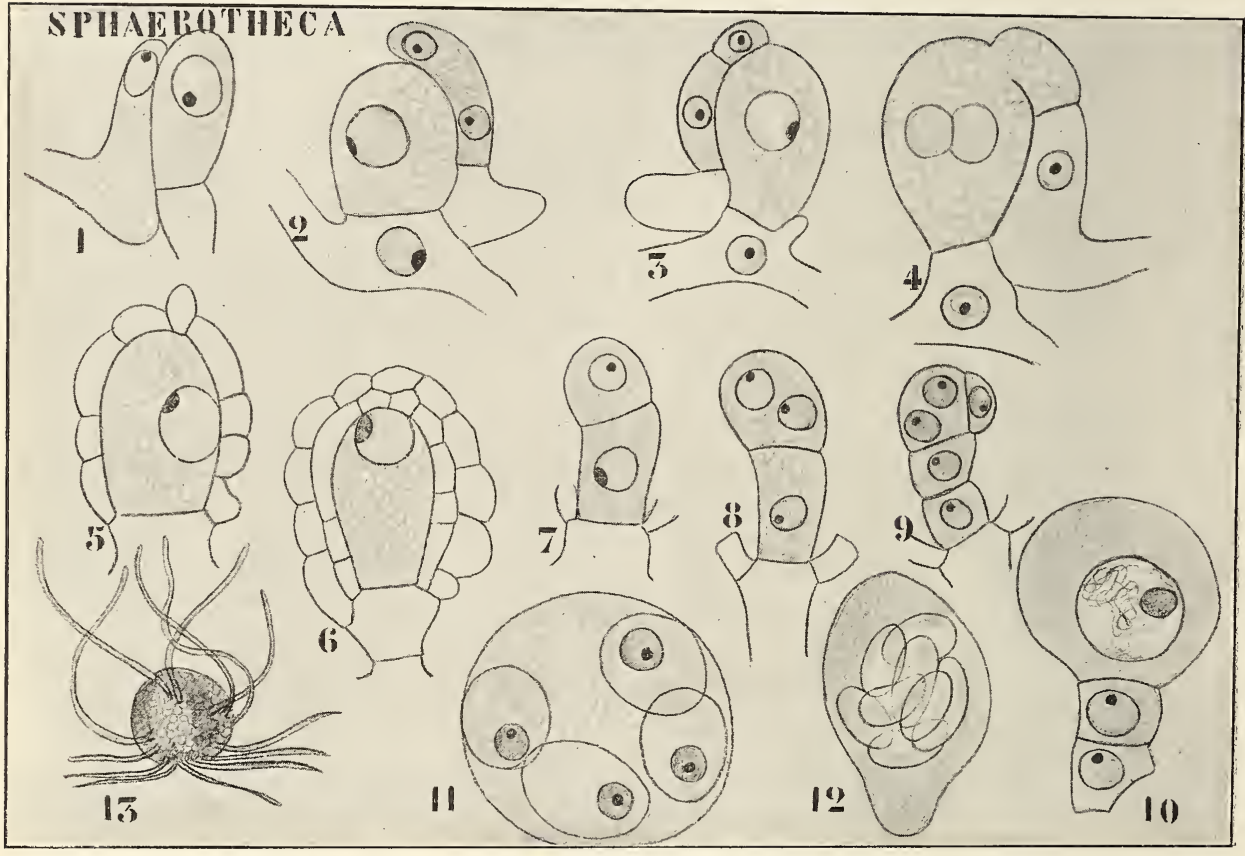

Fig. 264. Sphaerotheca (nach HARPER). 1 Oogon und Antheridiumzweig an. einander geschmiegt. 2 Der Kern im Antheridiumzweig hat sich als Vorbereitung zur Bildung des Antheridiums und der Stielzelle geteilt. 3 Antheridium und Stielzelle gebildet. 4 Antheridium und Oogon kopuliert, der Antheridiumkern in das Oogon übergetreten und dem Eikern angedrückt. 5, 6 Der Zygotenkern in dem inzwischen von sterilen Hyphen umhüllten Oogon. 7 Oogon in eine sich weiter entwickelnde apikale Zelle und eine sich nicht weiter entwickelnde Stielzelle geteilt. 8 Der Kern der apikalen Zelle hat sich geteilt. 9 Die apikale Zelle hat sich zu einem kurzen Zellfaden, von welchem eine Zelle zweikernig ist, entwickelt; diese zweikernige Zelle wird nach Verschmelzung der Kerne unter Vergrößerung zum Ascus. 10 Junger Ascus. 11, 12 Aeltere Stadien. 13 Ascusfrucht mit Appendices.

Fangen wir also mit einem einfachen Falle an, mit dem Falle, wo. nach DE BARY das ganze Archicarp zum Ascus wird, mit

\section{Sphaerotheca.}

Sphaerotheca kommt z. B. auf Hopfenblättern vor. Von solchen Humulus-Blättern, auf welchen der Pilz vorkam, bettete HarPer (1895), 
kleine Stückchen in Paraffin ein, nachdem er sie im FLEmmingschen Gemisch fixiert hatte, zerlegte sie durch senkrecht zur Blattoberfläche geführte Mikrotomschnitte in Serien und färbte diese mit dem bekannten Flemmingschen Dreifarbengemisch.

Die Zellen der Hyphen sind in der Regel einkernig (DANGEARD, Bot., 5. Série), die Hyphen laufen dicht nebeneinander her und so können an verschiedenen Hyphen gebildete Antheridienzweige und Oogonien dennoch sehr nahe zusammenliegen.

Sowohl das Oogon wie der Antheridiumzweig entstehen als Ausstülpungen vegetativer Mycelzellen. Beide trennen sich mittels einer Querwand von der Mutterzelle ab; beide sind einkernig.

Das Oogon vergrößert sich num, ohne seinen Kern zu teilen, der Antheridiumzweig aber teilt sich in zwei monoenergide Zellen, von welchen die obere kürzere zum Antheridium, die untere längere zur Stielzelle wird.

Das Antheridium tritt nun durch eine Kopulationsöffnung mit dem Oogon in Verbindung und läßt seinen Nucleus in dasselbe übertreten, wo dieser sich mit dem Oogonnucleus zum Zygotenkern verbindet.

Zu gleicher Zeit entstehen aus der Tragzelle des Oogons die sterilen Umhüllungshyphen, welche später die für die Systematik dieser Ascomyceten-Gruppe wichtigen Anhängsel oder Appendices (Fig. 264, 13) bilden, welche uns hier aber nicht weiter interessieren.

Das befruchtete Oogon teilt sich nun in eine Stielzelle und eine apikale Zelle, jede mit einem Nucleus versehen (Fig. 264, 7). Die Stielzelle entwickelt sich nicht weiter, der Kern der apikalen Zelle teilt sich sofort (Fig. 264, 8). Aus dieser apikalen Zelle entsteht in noch nicht in den feineren Details festgestellter Weise ein sehr kurzer Zellfaden, dessen Zellen mit Ausnahme einer einzigen einkernig sind. Diese eine Zelle ist zweikernig (Fig. 264, 9), sie schwillt an und wird zum Ascus, indem die beiden Nuclei zum Ascuskern verschmelzen.

Es ist sehr erwünscht, daß die Weise, in welcher dieser Zellfaden gebildet wird, bald genau festgestellt wird, und daß zumal die Zahl der Zellen, aus welchen er besteht, eruiert wird. Nach HARPER besteht er aus 5 bis 6 Zellen, nach DANGEARD aus einer wechselnden Zahl, nach Blackman und Fraser aus wenigstens 4, also wie die hier abgebildete Fig. 264, 9. Ist nun vielleicht letztere Zahl normal und sind höhere Zahlen vielleicht die Folge einer Teilung der Stielzelle? Falls dies richtig wäre, würden, da die 4 Zellen 5 Nuclei enthalten, deren 4 aus dem Kern der apikalen Zelle entstanden sein, und es entstammte die untere (resp. im Falle, daß mehr wie 4 Zellen vorhanden sind, die unteren) der Stielzelle.

Wie sind nun die hier bei den Kernen beobachteten Vorgänge zu deuten? Die beiden nachfolgenden Kernverschmelzungen könnten zur Auffassung führen, daß der Ascusnucleus ein 4x-Nucleus sei, eine Auffassung, welche in der Tat seit kurzem von HARPER vertreten wird und welche wir später bei Phyllactinia besprechen werden. Es gibt aber gewiß auch eine andere Möglichkeit, welche ich hier, um die Aufmerksamkeit von Ascomyceten-Forschern darauf zu lenken, auseinandersetzen möchte, wobei ich hervorheben möchte, daß ich selber darin nichts als eine Hypothese sehe, welche je nach dem Ausgang daraufhin gerichteter Untersuchungen zu verwerfen oder zu acceptieren ist.

Der Zygotenkern (Fig. 264, 6) ist selbstverständlich ein $2 x-\mathrm{Kerm.}$ Die Zygote teilt sich nun in eine zweizellige 2x-Generation (Fig. 264. 7). 
Aus irgend einem Grunde aber tritt alsbald wieder eine Trennung zwischen den vor kurzem erst vereinigten elterlichen ${ }^{1}$ ) Kernen auf, was daraus hervorgeht, daß in einer Zelle zwei Kerne nebeneinander liegen (Fig. 264, 8), welche dieser Hypothese gemäß durch eine Trennungsteilung entstanden sind. Trotzdem gehören beide Zellen der Fig. 264, 8 der $2 \mathrm{x}$-Generation an, denn es ist für das Wesen einer $2 \mathrm{x}$-Generation indifferent, ob deren Zellen je einen $2 x$-Kern oder zwei x-Kerne enthalten; das sehen wir z. B. bei Cyclops, wo längere Zeit in den Zellen der 2x-Generation die elterlichen Kerne nebeneinander liegen und sich jeder für sich, wenn auch simultan, teilen. Das Kernpaar einer solchen zweikernigen Zelle nennt MaIre ein Synkarion. Meiner Hypothese gemäß bestände also die 2x-Generation auf dem Stadium der Fig. 264, 8 aus einer normalen $2 x-Z$-Zlle und einer Synkarionzelle. Das Eigentümliche wäre demnach nicht, daß die 2x-Generation eine Synkarionzelle enthält, sondern der Umstand, daß ein Synkarion aufträte, nachdem schon der Zustand eines 2x-Nucleus existiert hat. Bei Cyclops entsteht erst der Synkarionzustand und schließlich dann der $2 \mathrm{x}$-Zustand, der dann bestehen bleibt. Bei den Ascomyceten dagegen wäre dieser Hypothese gemäß zunächst das Verschmelzen der beiden elterlichen Kerne die Regel, alsbald gefolgt von einer Synkarionbildung, um schließlich im Ascus doch wieder mit dem Verschmelzen zu enden. Das Synkarion von Sphaerotheca teilt sich nun noch einmal, wodurch also 4 Kerne entstehen. Diese Teilung führt aber nicht zur Bildung einer zweiten Synkarionzelle, da sofort nach der Kernteilung, bevor sich noch die Zelle geteilt hat, von jedem der beiden aus je einem Kern des Synkarions entstandenen Tochterkerne einer durch die Bildung einer Scheidewand endgültig geborgen wird (Fig. 264, 9). Dadurch bleiben also in der subterminalen Zelle von Fig. 264, 9 zwei Kerne liegen, ein $\delta$ und eine $q$, und dieses erklärt meines Erachtens, weshalb hier stets eine subterminale Zelle zum Ascus wird. Würde doch die Scheidewand an einer anderen Stelle gebildet, z. B. zwischen den beiden Kernen der subterminalen Zelle, so enthielte die so gebildete terminale Zelle, welche dann die Synkarionzelle sein würde, zwei gleichwertige Kerne, z. B. zwei weibliche Kerne, während jetzt die Synkarionzelle immer einen weiblichen und einen männlichen Kern enthält, welche zum Ascuskern verschmelzen.

Falls diese Auffassung richtig ist, muß also in Fig. 264, 9 der untere Kern ein 2x-Kern sein, der nächstfolgende sagen wir ein männlicher ${ }^{2}$ ) Kern, der nächste wieder ein männlicher und die beiden übrigen weibliche Kerne.

Der untere Kern wäre demnach ein $2 x$-Kern, die übrigen $x$-Kerne, wodurch sich die Hypothese bei den Kernteilungen revidieren ließe.

Ist unsere Hypothese richtig, so muß auch unter Umständen die obere Zelle von Fig. 264, 8 direkt zum Ascus werden können.

Untersuchungen von Maire und Guilliermond an anderen Ascomyceten haben gelehrt, daß die erste Teilung des Ascusnucleus eine Reduktionsteilung ist, und es liegt kein Grund vor, anzunehmen, daß dies bei Sphaerotheca nicht der Fall sein sollte.

Bei Sphaerotheca und, wie wir alsbald sehen werden, auch bei anderen Ascomyceten, verschmelzen also Einucleus und Spermnucleus miteinander; die keimende Zygote bildet eine $2 \mathrm{x}$-Generation, welche

1) Der Oogonnucleus und der Antheridiumnucleus als „Eltern“ betrachtet.

2) Kann selbstverständlich auch ein weiblicher Kern sein, dann wäre der nächste wieder ein weiblicher und die beiden übrigen männliche Kerne. 
meiner Hypothese nach zum Teil aus Zellen mit $2 x-K e r n e n$, zum Teil aus solchen mit Synkarions besteht. Diese Synkarionzellen teilen sich in solcher TTeise, daß schließlich stets eine Zelle gebildet wird, in welcher neben einem männlichen Kern ein weiblicher liegt und diese Zelle wird zum Ascus, während die beiden Kerne miteinander verschmelzen. Der' Ascus wird aber sofort zum Gonotokonten, denn schon die erste Teilung des Ascusnucleus ist eine Trennungsteilung.

Bei Sphaerotheca gibt es also, falls dies richtig, zwei Trennungsteilungen, eine sehr kurz nach stattgefundener Befruchtung (man könnte sagen, der schon anscheinend gelungene Versuch zur Bildung einer normalen 2x-Generation schlägt dennoch fehl und wird aufgegeben zu Gunsten einer 2x-Generation mit Synkarions) und eine wenn das zum Ascusnucleus verschmolzene Synkarionpaar, die Sporenbildung einleitet.

Trotzdem diese Komplikation durch das Auftreten von Synkarions in der 2x-Generation verursacht wird, entsteht also bei Sphcierotheca nach der Befruchtuug eine $2 \mathrm{x}$-Generation, welche als Gonotokonten fungierende Asci bildet.

Halten wir dies fest: daß unserer Hypothese gemäß bei den Ascomyceten auch noch, nachdem schon echte $2 x$-Kerne aufgetreten sind, Synkarions erscheinen können, so ist das Verständnis der Gruppe nicht schwierig, und es braucht die doppelte Kernverschmelzung einmal im Oogon und einmal im Ascus keine Schwierigkeit zu machen. Sie würde meines Erachtens nur beweisen, daß es prinzipiell gleichgültig ist, ob die elterlichen Kerne bei der Bildung einer $2 \mathrm{x}$-Generation miteinander verschmelzen oder nebeneinander in den Zellen derselben vorhanden sind; in beiden Fällen bleiben die elterlichen Chromosomen selbständig nebeneinander bestehen.

Ob nun diese Hypothese sich als richtig herausstellen wird oder ob die Harpersche Auffassung; daß die doppelte Verschmelzung zur Bildung eines $4 \mathrm{x}$-Nucleus (von zwei Reduktionsteilungen gefolgt) im Ascus führt, bestätigt werden wird, ist eigentlich nebensächlich, in beiden Fällen entwickelt sich bei Sphaerotheca eine kleine $2 \mathrm{x}$-Generation ${ }^{1}$ ), und es sind die von diesen gebildeten Asci Gonotokonten, wir haben also bei Sphaerotheca und ähnlichen Ascomyceten mit einem obligaten Generationswechsel, wie solcher bei den Farnen vorliegt, zu tun, die Asci sind demnach weder Gametangien noch Haplosporangien, sondern Diplosporangien homolog.

Wie wir sehen, wurde DE BARYs Meinung, daß bei Sphaerotheca Befruchtung stattfindet, glänzend bestätigt. Zwar wurde dies später von Dangeard (Le Botaniste, 5. Serie) in Frage gestellt und behauptet, es ginge der Antheridiumkern zu Grunde, ohne daß offene Kommunikation zwischen Antheridium und Oogon stattgefunden habe, aber es beruht diese Auffassung wohl auf schlechter Fixierung resp. Abnormalitäten des Materials. Durch Beobachtungen von Blackman und Fraser (1905) sind Harpers Resultate völlig bestätigt, so daß wohl zweifellos, n’en déplaise BrEFELD, bei diesem echten Ascomyceten echte Befruchtung. stattfindet.

Wie steht es nun mit DE Barys zweitem Beispiel, mit Pyronema?

Auch hier hat HARPER Befruchtung nachgewiesen und auch hier hat Dangeard diese bestritten. Der Grund dieser Differenz liegt wohl. wie Blackman und Fraser (1906) kürzlich bemerkten, in dem Um-

1) Es wird nicht, wie DE BARY meinte, das Archicarp (Oogon) sofort zum Ascus, aber auch das ist nebensächlich. 
stande, daß DANGEard mit einer Form mit degeneriertem Antheridium arbeitete. Van Tieghem hatte schon 1884 in einem von Blackman und Fraser wieder aufgefundenen Artikel nachgewiesen, daß $P$. confluens sehr empfindlich gegen Kultur ist. In seinen Kulturen beobachtete er Formen, in welchen das Antheridium fehlte, das Oogon sich trotzdem entwickelte, und allerlei Zwischenformen vorhanden waren. Es hat nun DANGEARD wohl mit einer Form gearbeitet, bei welcher zwar das Antheridium noch vorhanden war, aber seine Funktion verloren hatte. Wie sich trotzdem das Oogon entwickeln konnte, werden wir bei der Besprechung von Humaria sehen.

Jedenfalls ist an der Richtigkeit der HaRPERschen Resultate wohl nicht zu zweifeln.

Wir haben schon früher die äußere Morphologie dieses Pilzes behandelt und können uns jetzt also auf die Darstellung der Cytologie beschränken.

Die Hyphen (Fig. 265, 1) sind polyenergid und auch das Oogon und das Antheridium sind vom Anfang an vielkernig (Fig. 265, 2). Das beste Fixierungsmittel ist Merkels Flüssigkeit ${ }^{1}$ ). Flemmings und alle osmiumsäurehaltigen Fixierflüssigkeiten lieferten für die Geschlechtsorgane ganz untaugliche Präparate infolge der Anwesenheit einer nicht näher bestimmten Reservesubstanz. Auf dem Oogon entsteht alsbald die Trichogyne in der Gestalt einer Papille, welche sich dann in offener Kommunikation mit dem Oogon befindet (Fig. 265, 3). Die Trichogyne wird sehr bald, und lange bevor ihre Spitze mit dem Antheridium kopuliert hat, durch eine Querwand vom Oogon getrennt (Fig. 265, 4). Von jetzt an nehmen die Kerne sowohl im Oogon wie im Antheridium beträchtlich an Größe zu, die in der Trichogyne aber nicht. Diese Trichogynennuclei bleiben klein bis zum Anfang ihrer endgültigen Degeneration, kurz vor welcher sie zur Größe der Sexualnuclei anschwellen, dabei aber sehr durchsichtig werden. Die Spitze der Trichogyne kopuliert nun, während ihre Nuclei degenerieren, mit dem Antheridium, und es entsteht zwischen beiden eine offene Kommunikation. Meistens sind die Nuclei der Trichogyne schon degeneriert, wenn die Fusion zu stande kommt (Fig. 265, 5), bisweilen aber wird der Vorgang verzögert und die Trichogyne enthält noch verhältnismäßig gesunde Nuclei im Momente der Kopulation. Die Antheridiumnuclei fangen nun, sobald offene Kommunikation hergestellt ist, an, in die Trichogyne überzutreten (Fig. 265, 5), und dies wird so lange fortgesetzt, bis so viele Antheridiumnuclei in der Trichogyne liegen, daß deren Durchmesser dadurch sogar vergrößert wird (Fig. 265, 6).

Inzwischen sind im Oogon große Veränderungen aufgetreten; die Nuclei sind nach dem Zentrum hin gezogen und arrangieren sich dort in den typischen Fällen zu einer Hohlkugel. Das Cytoplasma um diese Kerne herum ist stark verändert, die Substanz, welche in früheren Stadien eine starke Färbung des Oogonplasmas verursachte, ist verschwunden; das Plasma ist nun sehr durchsichtig und zeigt infolge der Bildung vieler Vakuolen Wabenstruktur, wodurch die Kerne jetzt viel schärfer differenziert werden können als früher.

Nachdem dieses Stadium erreicht worden ist, bricht die Wand zwischen Oogon und Trichogyne durch, und die Antheridiumnuclei, welche, wie wir sahen, vorläufig in der Trichogyne geborgen waren,

1) 100 Volumteile 1-proz. Chromsäure, 100 Volumteile 1-proz. $\mathrm{PtCl}_{4}$ und 600 Volumteile $\mathrm{H}_{2} \mathrm{O}$. 
treten nun in das Oogon ein (Fig. 265, 8), in der Trichogyne nur einige degenerierte Trichogynennuclei zurücklassend. Die Antheridiumnuclei begeben sich sofort nach den Oogonkernen hin und vermischen sich mit diesen zu einer zentralen Masse (Fig. 265, 8). Die Zahl der Antheridiumkerne ist ungefähr der der Oogonnuclei gleich, aber wie wir alsbald sehen werden, ist Grund vorhanden, anzunehmen, daß diese Zahlen nicht vollkommen gleich sind.

Nachdem die Antheridiennuclei in das Oogon eingetreten sind, wird die Trichogyne wieder durch eine Querwand vom Oogon getrennt, während dagegen der Porus zwischen Antheridium und Oogon bestehen bleibt.

Wir sahen schon, daß $\delta$ - und -Nuclei sich zu einer zentralen Masse vermischen; sie gleichen während dieses Stadiums einander so sehr, daß

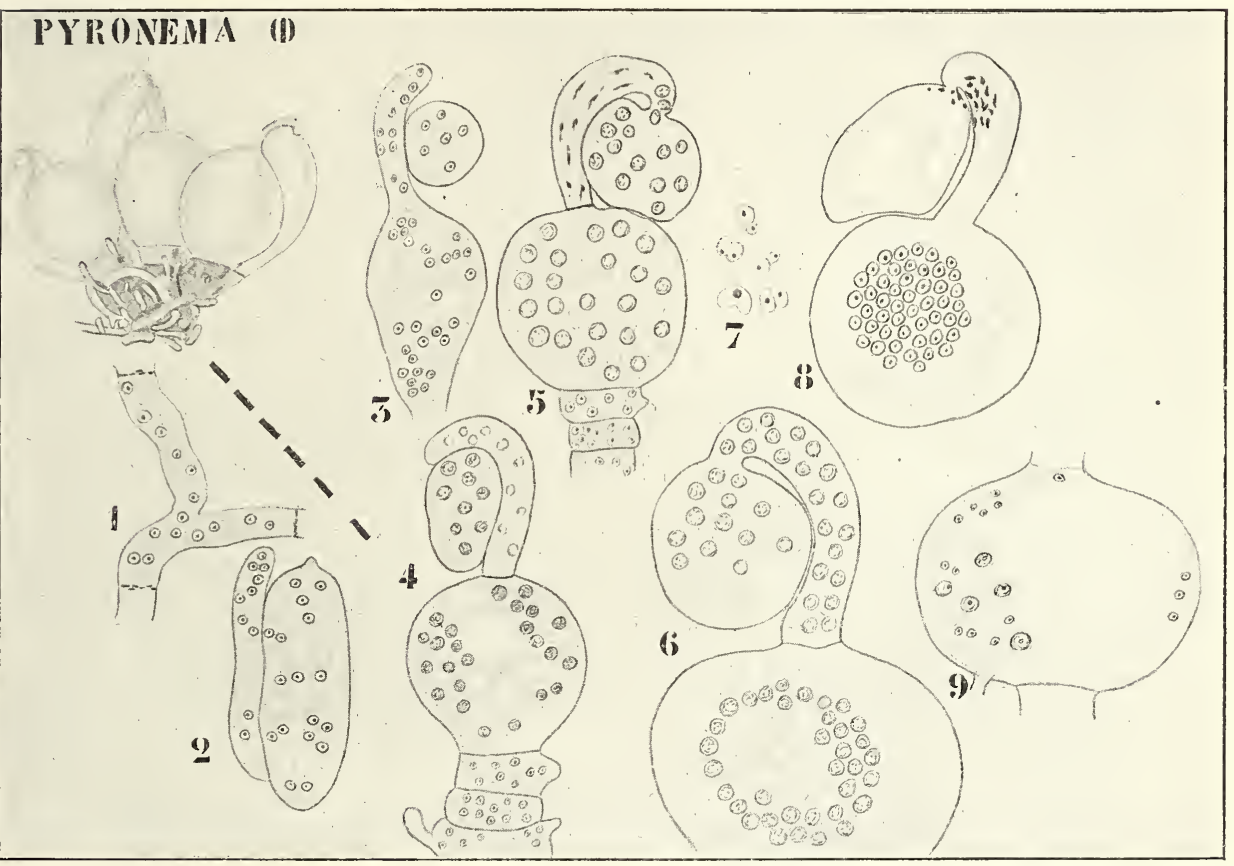

Fig. 265. Pyronema confluens (nach HARPER). Oben links Habitusbild von Oogonien und Antheridien; die Trichogynen auf die Antheridien zuwachsend. 1 Eine poly. energide Mycelzelle. 2 Junges Oogon und Antheridium; das Oogon (rechts) bildet eben eine Papille, welche zur Trichogyne werden wird. 3 Trichogyne und Oogon in offener Verbindung. 4 Trichogyne vom Oogon durch eine Querwand getrennt. 5 Offene Verbindung zwischen dem Antheridium und der Trichogyne; in letzterer sind die Nuclei degeneriert; die ersten Antheridiumkerne treten in die Trichogyne ein. 6 Die meisten Antheridiumkerne sind bereits in die Trichogyne übergetreten, letztere ist jedoch noch durch eine Querwand vom Oogon getrennt; im Oogon liegen die Kerne zu einer Hohlkugel angeordnet. 7 Kopulation von Antheridien- und Oogonkernen. 8 Die Querwand zwischen Oogon und Trichogyne zerstört; Antheridium- und Oogonkerne zu Zygotenkernen verbunden. 9 Zygotenkerme nebst überzähligen Kernen.

es unmöglich ist, zu sagen, ob ein bestimmter Nucleus männlich oder weiblich ist. Alsbald verschmelzen sie aber zu Paaren (Fig. 265, 7), so daß nun im Oogon zahlreiche Zygotenkerne vorhanden sind (Fig. 265, 8). Trotz der Unmöglichkeit, einen weiblichen Nucleus von einem männ- 
lichen zu unterscheiden, ist wohl kein Zweifel daran, daß die Paarung zwischen je einem $\delta$ - und einem q-Nucleus stattfindet. Wenn mehr Nuclei des einen wie des anderen Geschlechts vorhanden sind, findet man neben den Zygotennuclei die überzähligen Nuclei, welche durch ihre geringere Größe leicht von diesen zu unterscheiden sind.

Alsbald fängt nun das Oogon Ausstülpungen zu bilden an, welche anfangs keine Kerne enthalten, in die jedoch alsbald Zygotenkerne eintreten (Fig. 266, 10), nachdem sie ihre Stellung im Zentrum des Oogons aufgegeben haben und sich wieder über das ganze Oogon verbreitet haben (Fig. 266, 11). Diese Ausstülpungen sind die ascogenen Hyphen und jede derselben erhält also eine Anzahl von Zygotenkernen; alsbald sind sämtliche Zygotenkerne in die ascogenen Hyphen eingetreten, das

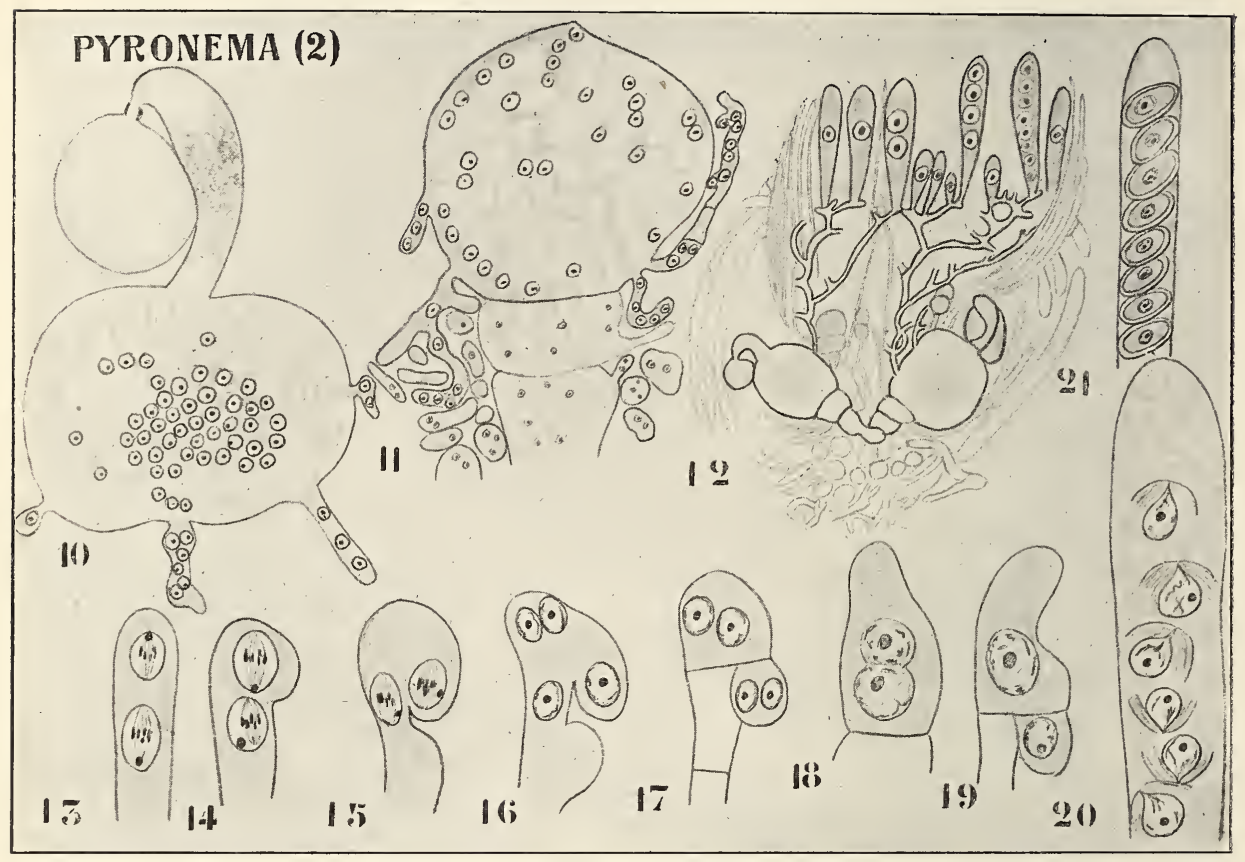

Fig. 266. Pyronema confluens (nach HARPER). Fortsetzung. 10 Erste Anlage der ascogenen Hyphen. 11 Aelteres Stadium. 12 Die ascogenen Hyphen sind zwischen den Umhüllungshyphen hinaufgewachsen und haben Asci gebildet. 13-21 Ascushildung.

Oogon ist also leer. Die ascogenen Hyphen schlängeln sich nun zwischen den inzwischen gebildeten sterilen Hyphen hinauf und werden durch Querwände in eine Anzahl von Abschnitten zerlegt (Fig. 266, 11). Ascogene Hyphen können stets leicht von den Umhüllungshyphen unterschieden werden, da ihre Kerne 2- bis 3mal größer als die der letzteren sind. Die Asci entstehen sowohl an den Spitzen wie seitlich an den ascogenen Hyphen.

An der Spitze einer Hyphe, welche einen Ascus bilden soll, fand Harper stets zwei Kerne, welche sich simultan teilen (Fig. 266, 13), wodurch also 4 Nuclei entstehen. Inzwischen hat sich die Spitze der Hyphe gekrümmt (Fig. 266, 14, 15) und die Kernspindeln sind nun so 
orientiert, daß nach beendeter Kernteilung im krummen Teil des Hakens zwei Kerne dicht nebeneinander liegen, ein Nucleus liegt in der Spitze und einer im Stiel des Hakens. Die zwei nebeneinander liegenden Kerne sind also keine Schwesterkerne, sondern jeder die Hälfte von einem der Kerne in Fig. 266, 13. Jetzt wird eine Querwand gebildet, wodurch dieses krumme Stück mit den beiden darin vorhandenen Kernen abgetrennt wird (Fig. 266, 17), und diese subterminale Zelle wird nach stattgefundener Verschmelzung der Kerne (Fig. 266, 18, 19) zum Ascus, welcher nun alsbald die Sporen bildet (Fig. 266, 20, 21).

Am wahrscheinlichsten scheint mir nun, daß die beiden Kerne der Fig. 266, 13 durch eine Trennungsteilung aus einem Zygotenkern entstanden sind, $\mathrm{x}$-Kerne sind, was mit den Wahrnehmungen DaNGEards

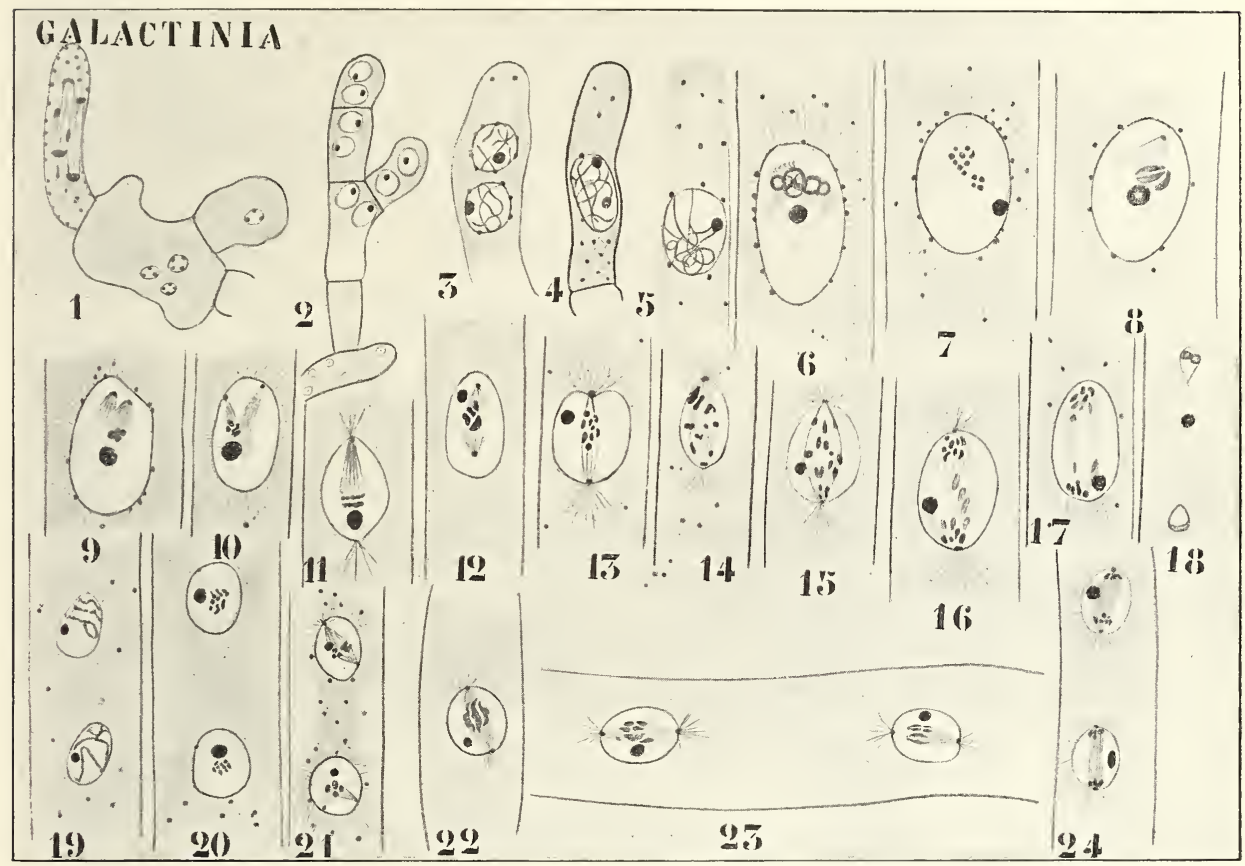

Fig. 267. Galactinia succosa (nach MAIRE). 1 In der Ausstülpung der ascogenen Hyphe findet sich ein Synkarion. 2 Synkarionhyphe, durch die Teilung dieses Synkarions entstanden. 3-5 Bildung des Ascuskernes. 6 Kern im Synapsisstadium. 7 - 24 Kernteilungen im Ascus.

und Harpers übereinstimmt, daß sie dieselbe Chromosomenzahl haben wie die Kerne im Ascus, welche die Sporen bilden. Falls die Auffassung. HARPERs richtig wäre, daß im Ascus zwei $2 x$-Kerne miteinander verschmelzen, ist nicht einzusehen, weshalb bei der Bildung des Ascus so genau darauf geachtet wird, daß nie zwei Schwesterkerne miteinander kopulieren; wir müssen also meiner Meinung nach wohl annehmen, daß auch hier, nachdem schon $2 x$-Kerne gebildet sind, wieder Synkarions gebildet werden.

Ich halte also vorläufig die Teilung, wodurch die beiden Kerne der Fig. 266, 13 entstanden, für eine 'Trennungsteilung', die, welche zu' Bildung der 4 Kerne der Fig. 266, 16 führte, für eine Aequationsteilung. 
Falls dies richtig ist, würde es von Vorteil sein, wenn das Synkarion nicht nur eine Teilung, sondern eine Anzahl solcher durchmachte, denn da dies meiner Auffassung nach alle gleichwertige Teilungen sein würden, würde in dieser Weise jeder Zygotenkern nicht wie bei Pyronema nur zur Bildung eines Ascus Veranlassung geben, sondern zu mehreren Asci führen können.

Solche sich wiederholt teilende Synkarions sind nun von MaIre bei Galactinia succosa Sacc. $\left.{ }^{1}\right)$ gefunden worden.

Unglücklicherweise ist bei diesem Pilze nichts über die Entstehung der ascogenen Hyphen bekannt; sie sind so wie diejenigen von Pyronema vielkernig und an ihnen entstehen kurze Ausstülpungen, in welchen sich je ein Synkarion befindet (Fig. 267, 1). Dieses Synkarion teilt sich weiter und so entsteht eine Hyphe, welche aus Zellen mit je einem Synkarion besteht (Fig. 267, 2).

Diese Hyphe verzweigt sich und jede Zweigspitze kann durch Verschmelzung der beiden Kerne zu einem Ascus werden. MaIRE wies nach, daß die erste Teilung des Ascusnucleus heterotypisch verläuft, also eine Trennungsteilung ist. Daraus folgt also, daß die beiden Kerne im

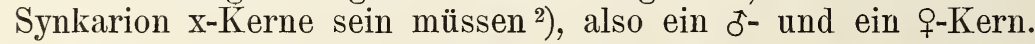

Ist dies richtig, dann müssen also die Kerne der ascogenen Hyphen die doppelte Chromosomenzahl eines jeden Kernes der Synkarionhyphe haben, wenn wenigstens die ascogenen Hyphen hier so wie bei Pyronema entstehen und also Zygotenkerne enthalten.

Es ist aber auch eine andere Möglichkeit denkbar, nämlich die, daß die beiden Kerne des ersten Synkarions nicht aus einer Trennungsteilung e in es Kernes der ascogenen Hyphe entstanden sind, sondern daß deren zwei zusammen das Synkarion bildeten; in diesem Falle wäre es wahrscheinlich 2), daß die "ascogenen Hyphen" hier gewöhnliche vegetative Hyphen wären, der x-Generation angehörig, daß wir also hier mit einem Fall von Apogamie zu tun hätten.

Wir sahen schon früher, daß bei Sphaerotheca aus dem Oogon ein, bei Erysiphe dagegen mehrere Asci gebildet werden; beides sind monoenergide Formen. Dagegen sind Pyronema und andere polyenergid. In Verbindung damit wird bei den Erysipheen im Oogon nur eine Zygote gebildet, bei Pyronema und Verwandten mehrere. In beiden Reihen äußert sich aber das Bestreben, eine Kopulation möglichst auszunützen, d. h. pro Zygote mehr als einen Ascus zu bilden, wie aus folgender Uebersicht hervorgeht:

$$
\begin{aligned}
& \text { Monoenergide }\left\{\begin{array}{l}
\text { Sphaerotheca (HARPER): } \\
1 \text { Zygote, } 1 \text { Ascus, also pro Zygote } 1 \text { Ascus; Summe der Asci } 1 \\
\text { Erysiphe: } \\
1 \text { Zygote, x Asci, also pro Zygote x Asci ; Summe der Asci } \mathrm{x}
\end{array}\right. \\
& \text { Polyenergide }\left\{\begin{array}{l}
\text { Pyronema (HARPER), Pustularia (GuIlliermond): } \\
\text { n Zygoten, n Asci, also pro Zygote } 1 \text { Ascus; Summe der Asci } \mathrm{n} \\
\text { Galactinia (MAIRE), Acetabula (M. G.): } \\
\mathrm{x}^{3} \text { ) Zygoten, xn Asci, also pro Zygote n Asci; Summe der Asci nx. }
\end{array}\right.
\end{aligned}
$$

1) Synonyme sind: Plicaria succosa (Berk.) ReHm (RABENH., Krypt.-Flora, p. 1016); Peziza succosa (Brit. fung., No. 156, Tab. X, Fig. 5); Aleura succosa GILl (Discom. franç., p. 45, c. ic.); Peziza marsupium PERS. (Syn. fung., I, p. 640); Aleuria marsupium QUÉL. (Enchir. fung., p. 373).

2) Wenigstens wenn nicht HARPER recht hat, daß ein $4 x-N u c l e u s$ im Ascus gebildet wird.

3) Das erste Synkarionpaar als "Zygote“ betrachtet. 
Spharrotheca unter den Monoenergiden und Pyronema und Pustularia unter den Polyenergiden bilden also pro Zygote nur einen Ascus, in striktestem Sinne gehören sie also zu DE BARYs Gruppe der Formen, bei welchen das ganze Archicarp (Zygote) zum Ascus wird.

Erysiphe unter den Monoenergiden, Galactinia und. Acetabula unter den Polyenergiden dagegen bilden mehrere Asci pro Zygote; für sie gilt also DE BARYs Ausspruch, daß der Ascus auch nur ein Teil des Archicarps (Zygote) sein kann.

In mancher Hinsicht stimmt ein von Claussen (1905) beschriebene1 Ascomycet mit Pyronema überein. Dieser Pilz wurde von Claussen als Boudiera hyperborea Karst. bestimmt, von Hennigs, dem Material zugeschickt wurde, aber in der Hedwigia, Bd. 42, S.181/182, als eine neue Boudiera-Art beschrieben. Gegen diese Bestimmung ist Cavara (Causeries mycologiques, Annales mycologici, Aug. 1905, p. 363) aufgetreten. Aus Claussens Figuren schließt er, daß der untersuchte Pilz keine Boudiera, sondern eine Ascodesmis, und zwar Ascodesmis nigricans v. Tieghem ist. Falls dies richtig ist, gehört der Pilz zu den Pyronemaceen und seine große Uebereinstimmung mit Pyronema ist also verständlich. Wäre er eine Boudiera-Art, so gehörte er zu den Ascoboleen und würde dann sehr abweichen.

Wahrscheinlich ist also Cavaras Auffassung richtig und der als Boudiera beschriebene Pilz in der Tat eine Ascodesmis, welchen Namen ich hier weiter verwenden werde.

Ascodesmis (= Boudiera Claussen) wurde dann auf Kaninchenmist gefunden und sowohl auf sterilisiertem Kaninchenmist wie auf einem mit Agar erstarrtem Dekokt desselben in Reinkultur weiter gezüchtet. Auf beiden Substraten bildet sie reichlich Ascusfrüchte. CLaussen machte dieselbe Erfahrung wie Harper bei Pyronema, daß nämlich Oogonien und Antheridien, in Flemming fixiert, untauglich sind, dagegen in MERKEL gute Resultate geben. Beim Einbetten in Paraffin sind Temperaturen oberhalb $55^{0} \mathrm{C}$ zu vermeiden. Auch hier gab das Fuemmingsche Dreifarbengemisch die besten Resultate.

Auf Agar-Mistdekokt bilden sich bereits nach 4 Tagen bei $25^{\circ} \mathrm{C}$ zahlreiche Fruchtkörper (Fig. 268, 1). Die Geschlechtsorgane tragenden Zweige entstehen als Seitenzweige an den vegetativen Hyphen und erhalten alsbald durch Gabelung der Spitze die Gestalt eines kurzgestielten T (Fig. 268, 2). Jedes Ende des Querbalkens gabelt sich noch ein oder nehrere Male, aber in einer Ebene, welche dem Substrat parallel verläuft, so daß eine Figur, wie in Fig. 268, 3 abgebildet ist, resultiert.

Dieses Organ nennt Claussen den Schraubenträger; ich ziehe es vor, es mit dem Namen Gynophor zu bezeichnen. Die Form des Gynophors ist selbstverständlich je nach dem Grade, in welchem Gabelung stattgefunden hat, ziemlich verschieden. Nachdem das Gynophor mittels einer Wand vom Stiel getrennt worden ist, wachsen aus der Nähe ein oder mehrere Seitenzweige, Androphoren, auf das Gynophor zu (Fig. 268, 4). Diese Androphoren entstehen nun entweder an denselben Hyphen, welche die Gynophoren tragen, oder an benachbarten Hyphen und sind bereits als kleine Höcker sichtbar, wenn das Gynophor noch recht jung ist (Fig. 268, 2, 3).

Diese Androphoren verzweigen sich nun so ziemlich in derselben Weise wie die Gynophoren (man vergleiche z. B. Fig. 268, 7 rechts mit 3), 
sind aber vielfach viel weniger verzweigt als die Gynophoren (z. B. Fig. 269, 10).

Sowohl die Androphoren wie die Gynophoren bilden nun Gabelzweige, deren Gabeln aber nicht gerade bleiben, sondern sich spiralig krümmen, und nun wächst. ein Gabelzweig eines Androphors zwischen die Gabeln eines Gynophors hindurch (Fig. 269, 12), wobei sich die Gabeln gegenseitig umwinden. In Fig. 269, 12 ist der Vorgang für ein Gabelzweigpaar abgebildet; Fig. 268, 5-8, Fig. 269, 9-11 zeigen, welche komplizierten Figuren in dieser Weise gebildet werden können.

Sowohl die Spiralen der Androphoren wie die der Gynophoren werden nun mittels Querwänden von ihren Trägern abgeschnitten; die so abgetrennten Spitzen werden bei den Androphoren direkt zu An-

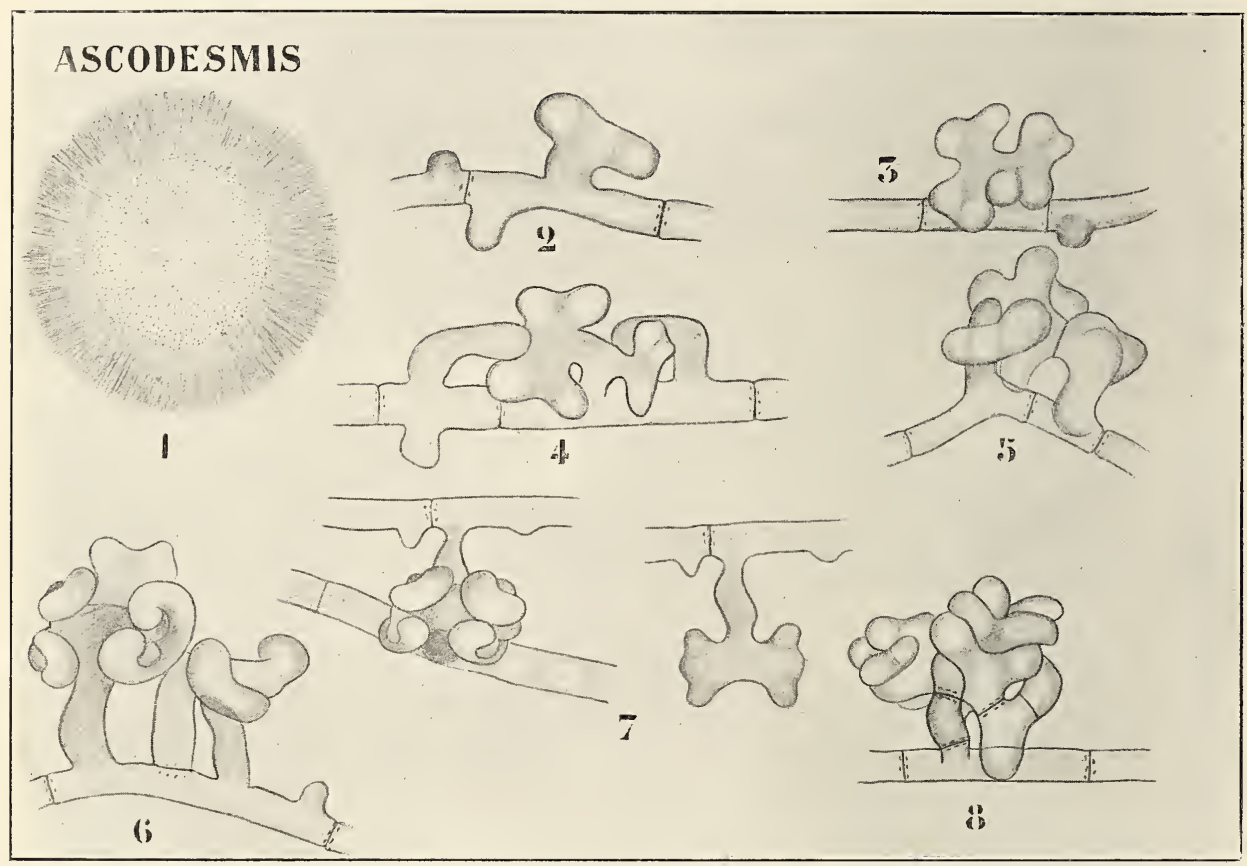

Fig. 268. Ascodesmis (nach Cladsser). 1 Kultur mit Fruchtkörpern. 2 Anlage des Gynophors. 3 Weitere Ausbildung des Gynophors. 4 Die schon in 2 und 3 angelegten Androphoren wachsen auf das Gynophor zu. 5, 6, 7, 8 Die Gynophoren umwachsen von den Androphoren, in 7 rechts ein isoliertes Androphor.

theridien, bei den Gynophoren teilen sie sich aber noch durch eine Querwand in eine kurze Trichogyne und in ein langes Oogon [Fig. 269, 11, Fig. 270, 15 $\left.\left.{ }^{1}\right)\right]$.

Alsbald sieht man nun, daß Trichogyne und Antheridium durch eine kreisförmige Oeffnung, welche in den trennenden Membranen gebildet wird, miteinander in Verbindung treten (Fig. 269, 13). Es gelingt verhältnismäßig leicht, diese Oeffnung zu beobachten, Claussen sah sie mehr wie 1000mal am lebenden Objekt und konnte sogar das Ueberströmen von Teilchen aus dem Antheridium in die Trichogyne beobachten.

1) Die Trichogyne ist hier schematisch dunkel gefärbt. 
Viel schwieriger ist es, die Oeffnung zu beobachten, die in der Wand, welche die Trichogrne vom Oogonium trennt, entsteht, da diese ganz wie bei Pyronema ephemer ist, da auch hier sofort nach stattgefundener Befruchtung an derselben Stelle eine neue Membran gebildet wird.

Nach der Befruchtung verschrumpfen Trichogyne und Antheridium (Fig. 271, 21). Aus dem Oogon entstehen so wie bei Pyronema durch Ausstülpung die ascogenen Hyphen (Fig. 271, 21). Inzwischen sind aus dem Gynophor unterhalb der Oogonien sterile Umhüllungshyphen emporgewachsen (Fig. 270, 16-18), welche alsbald die Geschlechtsorgane ungeben. Zwischen diesen Umhüllungshyphen entwickeln sich dann die Asci; diese Umhüllungshyphen stimmen auch darin mit den gleichnamigen

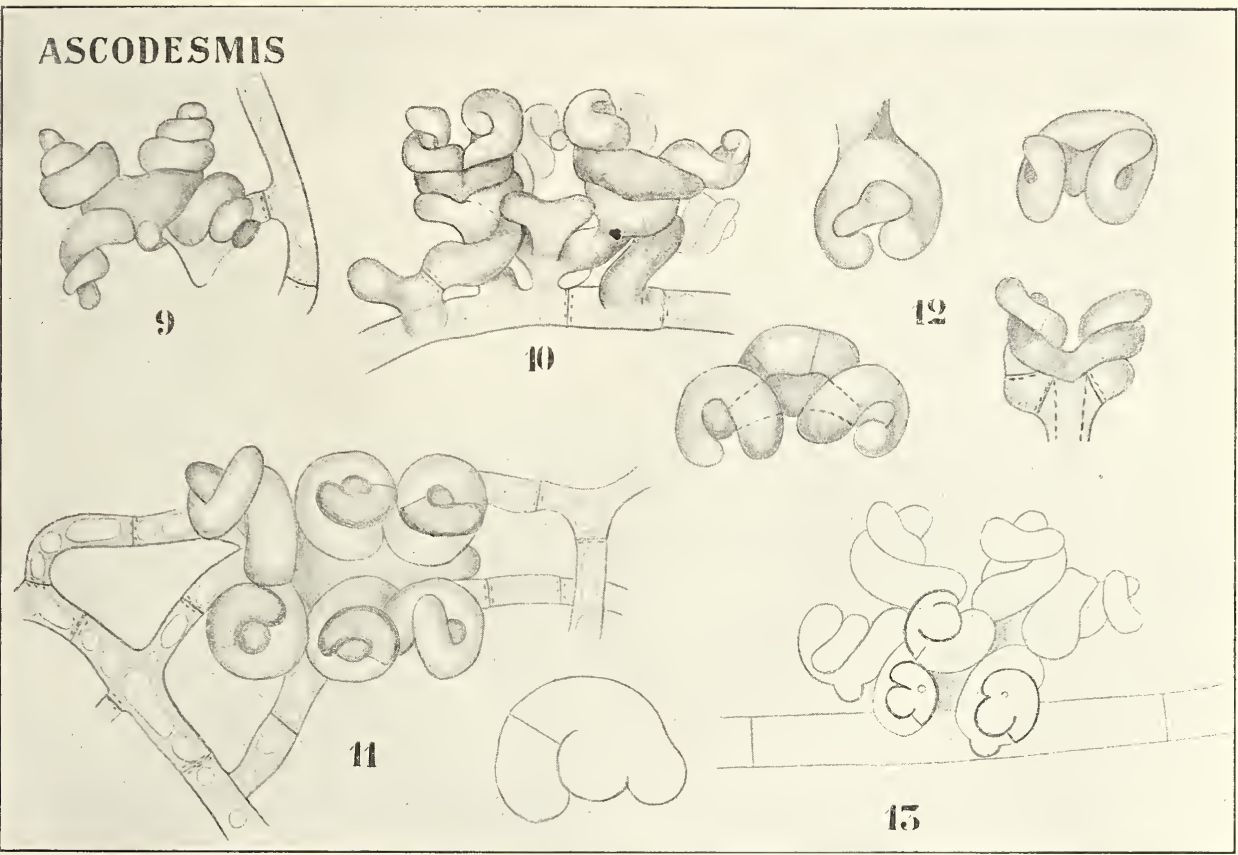

Fig. 269. Ascodesmis (nach Cladussen). 9, 10 Durcheinander geschlängelte Gynound Androphoren. 12 Durcheinandersehlingen einer Gynophorgabel und einer Androphorgabel. 11 Die Trichogynen sind gebildet. 13 Querschnitte, die offene Kommunikation zwischen Trichogyne und Antheridium zeigend.

Organen von Pyronema überein, daß sich einige derselben dem Substrat zuwenden und die Frucht stützen, und auch hier sind, wie bei Pyronema. im "Apothecium" mehrere Geschlechtsorgane vorhanden. Die Stützhyphen dienen hier offenbar der Aufnahme von Nahrungssubstanzen. und die inneren Umhüllungshyphen, die Paraphysen, enthalten Reservesubstanzen, welche, je nachdem die Asci heranreifen, verschwinden, und also offenbar von diesen verbraucht werden.

Die ascogenen Hyphen entstehen vermutlich in der 4- oder 5-Zahl als seitliche Ausstülpungen des Oogons. Aus der ascogenen Hyphe entsteht auf dem Wege der Hakenbildung (Fig. 271, 22-24) ein Ascus aus der subterminalen Zelle. 
Betrachten wir jetzt einmal die Cytologie. So wie bei Pyronema sind auch hier die Zellen polyenergid (Fig. 271, II 1). Auch die jungen Gynophoren und Androphoren sind vielkernig und das gleiche gilt für die Spiralgabeln (Fig. 271, II 2 A), nachdem sie von ihren Trägern durch eine Querwand getrennt sind. In der Oogonmutterzelle liegen dann 7-8 Kerne, im Antheridium dagegen immer ein Paar weniger. Das kommt daher, daß von der Oogonmutterzelle noch die Trichogyne abgeschnitten wird, und also die Zahl der Kerne in der Oogonmutterzelle um ein Paar größer ist als die im Oogon. Schließlich enthalten sowohl das Oogon wie das Antheridium meist 5 Kerne.

In der Trichogyne degenerieren die Kerne nun alsbald, und da die o-Kerne aus dem Antheridium in das Oogon eintreten, sind sowohl die

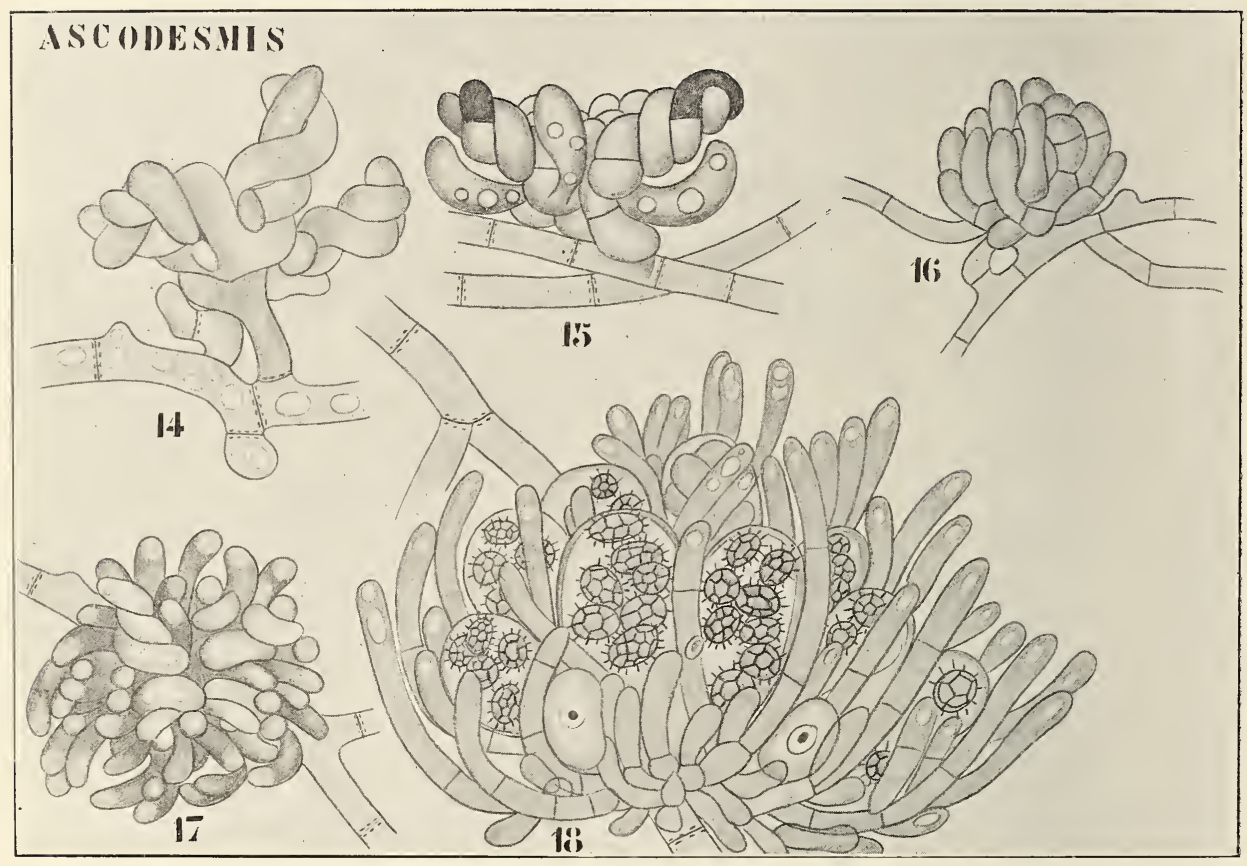

Fig. 270. Ascodesmis (nach Crausser). 14 Antheridien und Oogonien sind verschlungen. 15 Bildung der ersten Umhüllungshyphen. 16 Junge Frucht, von der Seite betrachtet. 17 Von oben. 18 Frucht mit reifen Asci.

Trichogynen wie die Antherien bald kernlos (Fig. 271, II 4), während hingegen die $\delta$ - und q-Paare dicht aneinander gedrückt im Oogon liegen, wie Fig. 271, II 4, in welcher jedoch nur die bei hoher Einstellung sichtbaren Kernpaare eingezeichnet sind, angibt. Diese verschmelzen nun alsbald zu den Zygotenkernen, von welchen Fig. 271, II 5 oben drei, unten vier Stück zeigt.

Dann sprossen aus dem Oogon die ascogenen Hyphen hervor, und zwar wahrscheinlich so viele, als Zygotenkerne vorhanden sind; zwar hat Chaussen nie mehr als 3 ascogene Hyphen zählen können, das mag aber, wie er sagt, seinen Grund in der Schwierigkeit der Präparation haben. 
Jede ascogene Hyphe bildet schließlich auf dem Wege der Hakenbildung eine zweikernige und zwei einkernige Zellen (vergl. Fig. 272), die erstere wird nach Verschmelzung dieser Kerne zum Ascus. Es entstammen also die 4 Kerne der kurzen ascogenen Hyphe wohl sicher einem einzigen Zygotenkern.

Zwischen Ascodesmis und Pyronema besteht also nur ein Unterschied in der Form des Oogons und in der Zahl der darin vorhandenen Kerne, im übrigen ist alles genau dasselbe.

Ascodesmis und Pyronema sind also sehr nahe verwandte Formen und auch Ascodesmis gehört zu denjenigen Formen, welche pro Zygote nur einen Ascus bilden.

Es lehrt uns nun Ascodesmis weiter, daß bei den Ascomyceten in der

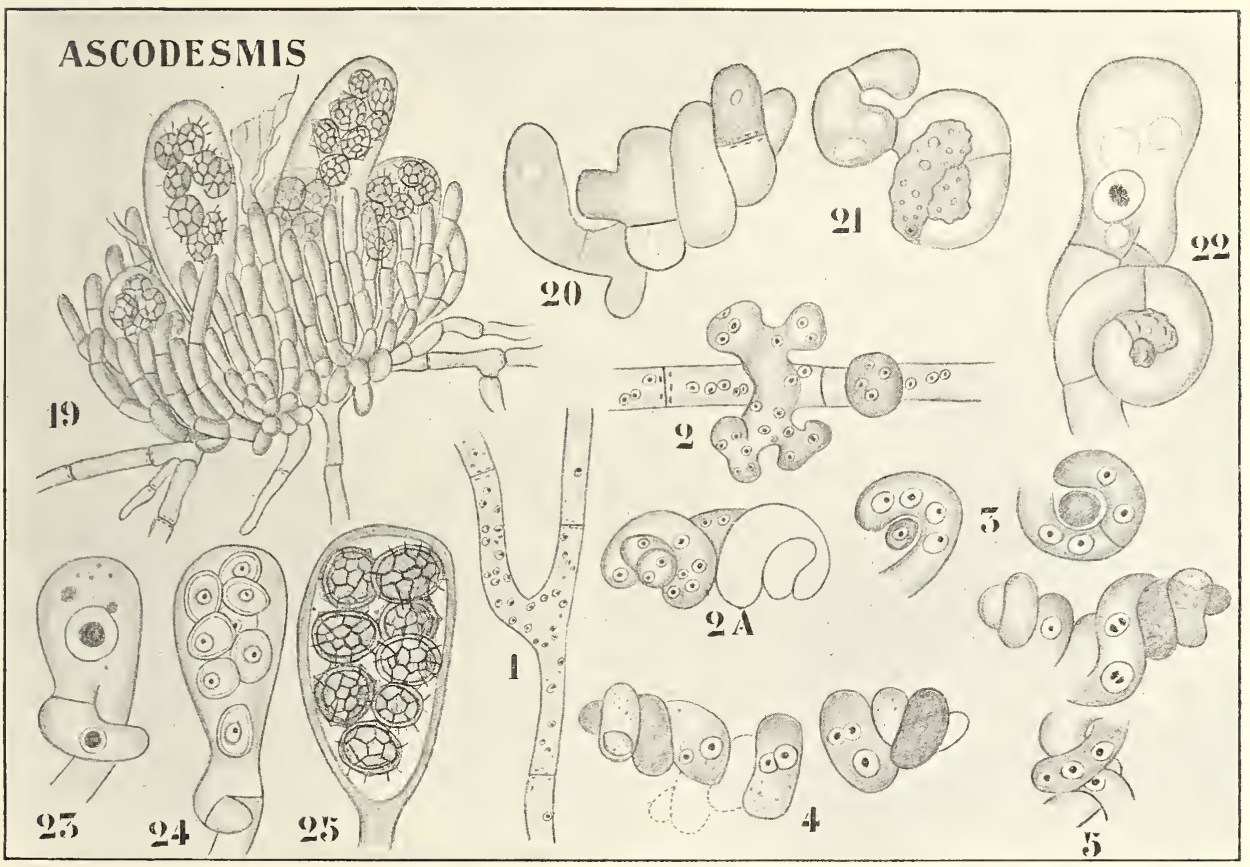

Fig. 271. Ascodesmis (nach Claussen). 19 Asci mit reifen Sporen. 20 Bildung von ascogenen Hyphen und Stützhyphen. 21 Bildung ascogener Hyphen. 22-24 Entstehung des Ascus mittels Hakenbildung. 25 Reifer Ascus. - II. Cytologie. 1 Polyenergide Hyphen. 2 Polyenergides Gynophor und Androphor. 2 A Vielkernige Spiralgabeln. 3 Gynophorgabel: links vor, rechts nach Bildung der Trichogyne. 4 б- und O-Kerne in den Oogonen, Trichogynen kernlos. 5 Oogone mit Zygotenkernen.

Tat spiralförmige Oogonien vorkommen, und das zeigt wieder, daß die Gegner DE BARYs Unrecht hatten, dem Oogon von Eurotium seine Spiralform vorzuwerfen.

Da, wie wir sahen, sowohl bei Pyronema wie bei Boudiera höchst wahrscheinlich jede Zygote nur einem Ascus das Dasein gibt, liegt es auf der Hand, zu vermuten, daß die Vielzelligkeit des befruchteten Eurotium-Oogons dadurch verursacht wird, daß jede Zrgote durch Querwände von den anderen getrennt wird, jede also in eine eigene Zelle zu liegen kommt. 
Macht also die Bildung eines mehrzelligen Ascogons, wie das des Eurotium, aus einem einzelligen keine Schwierigkeit, so ist es doch anders mit den anscheinend $\mathrm{v}$ on A n fang a m mehrzelligen weiblichen Organen, wie die von Ascobolus, welche TULASNe "scolecits" nannte.

Leider ist über die Cytologie von Ascobolus in dieser Hinsicht nichts Näheres bekannt geworden, so daß es nicht einmal feststeht, ob der Scolecit hier wirklich von Anfang an mehrzellig war. Erneute Untersuchung ist nötig, bevor wir versuchen können, einen Ascobolus an ein Eurotium anzuschließen.

Gewiß ist aber auch, daß von Ascobolus nichts bekannt geworden ist, was gegen DE BARYs Auffassung von dieser Form spricht.

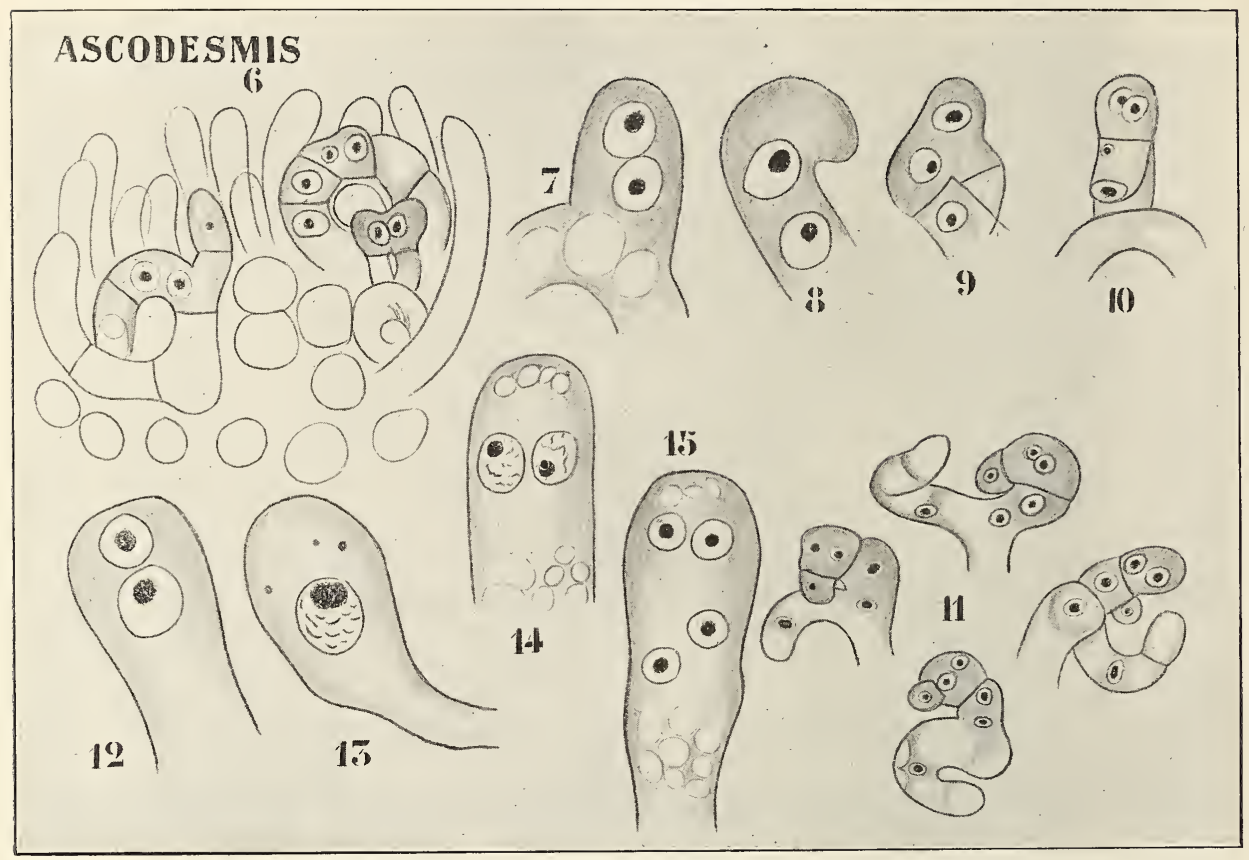

Fig. 272. Ascodesmis. Ascusbildung (nacb Claussen).

Wie wir also sehen, ist DE BARys Meinung über die Sexualität derjenigen Ascomyceten, bei welchen Antheridien und Oogonien vorkommen, durch die modernen Untersuchungsmethoden glänzend bestätigt.

Sehen wir jetzt, wie es mit derjenigen Gruppe steht, bei welcher eine Trichogyne mit einem Spermatium kopuliert.

Wir sahen schon früher, daß BAurs Beobachtung, daß bei Collema Apothecien nicht gebildet werden, wenn Spermatien in der Nähe fehlen, sehr für die Sexualität dieser Organismen spricht, aber genauere cytologische Daten liegen noch nicht vor. Ich kann also auf das schon früher darüber Gesagte verweisen, nur sei noch hinzugefügt, daß der Umstand, daß auch bei den Collemaceen der Ascus auf dem Wege der Hakenbildung entsteht, zur Vorsicht mahnt, wenn man die Collemaceen ebenso wie andere Ascomyceten von anderen Ahnen ableiten will. 
In Bezug auf die Sexualität der Ascomyceten sprechen also die neuen Untersuchungen sämtlich für DE BARrs Meinung. Wie steht es nun mit den Formen mit Sexualitätsverlust? Bisher ist von diesen nur eine einzige genau cytologisch untersucht worden, und es hat sich auch hier DE BArys Meinung, daß es Formen gibt, welche die Sexualität verloren haben, bestätigt.

Diese genau untersuchte Form ist Humaria granulata, welcher Blackman und Fraser einen Artikel in den Proc. of the Royal Society von 1906 widmen.

Humaria granulata QuÉL (= Peziza granulata BuLL) ist ein häufiger Discomycet von gelber, Orange- oder rötlicher Farbe, $5 \mathrm{~mm}$ im Durch-

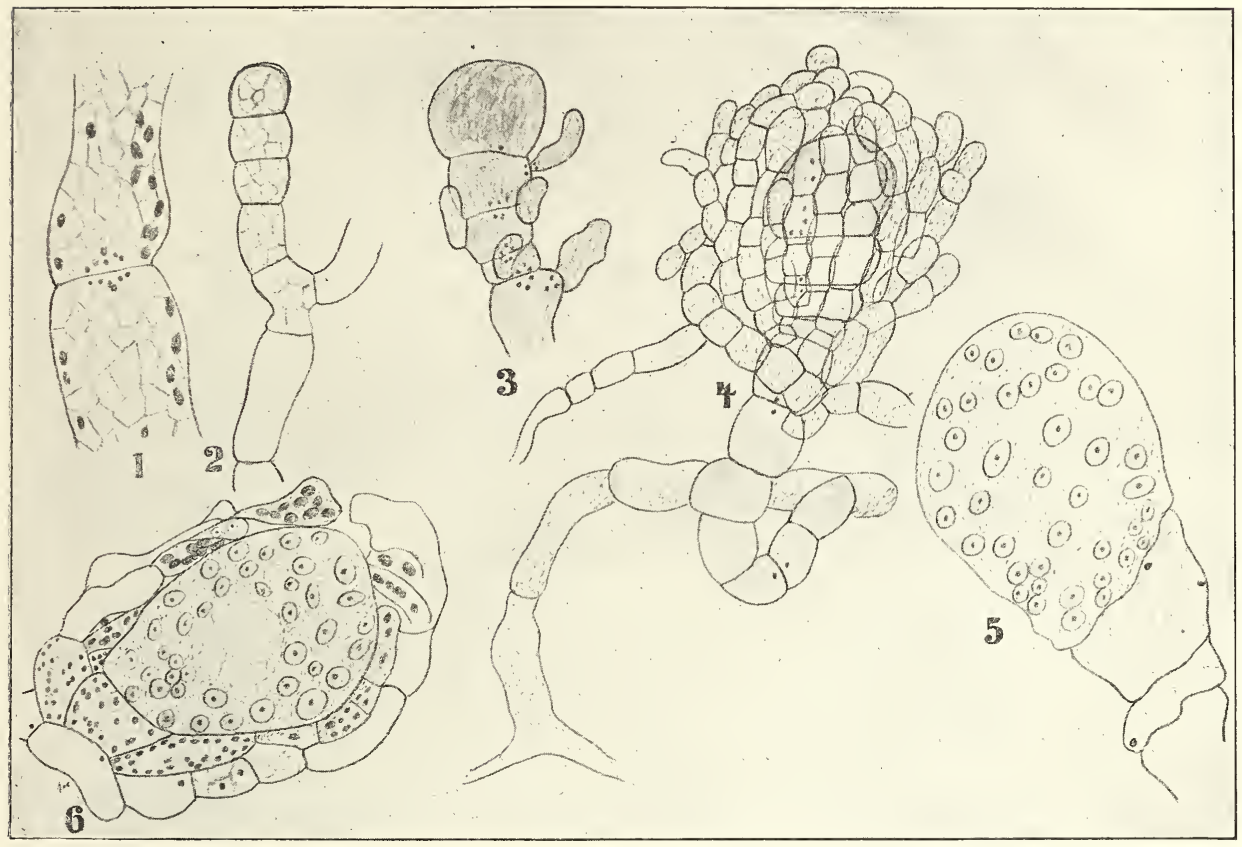

Fig. 273. Humaria granulata (nach BLACKMAN und Fraser). 1 Vegetative Zellen, die Kerne und sich stark färbende Körperchen auf der Querwand zeigend. 2 Junger fertiler Zweig, dessen terminale Zelle zum Oogon werden wird. 3 Oogonzweig, der Umhüllungshyphen zu bilden anfängt. 4 Das Oogon und einige darunter gelegene Zellen sind ganz eingehüllt. 5 Schnitt durch ein junges Oogon, die vielen Kerne zeigend. 6 Idem, durch ein bereits berindetes Oogon.

messer, welcher auf Mist verschiedener Tiere, besonders gern auf Kuhmist wächst, und zwar besonders üppig im Herbst und Winter. Offenbar müssen die Sporen zur Keimung den Darmkanal eines Tieres passieren, denn sogar nach Einwirkung von künstlichem Magensaft konnte keine Keimung erzielt werden, so daß künstliche Kulturen nicht erhalten wurden.

Die jüngsten Stadien der Apothecien konnten sogar mit der Lupe nicht gesehen werden, sie wurden erhalten durch Querschnitte der Oberflächenschicht einer Kuhflade, auf welcher junge Apothecien gerade sichtbar wurden. Die Zellen des vegetativen Mycels sind polyenergid, die Kerme sind schwer zu differenzieren. 
Die Oogonien entstehen, wie Woronin schon 1866 nachwies, durch Anschwellung der terminalen Zelle eines kurzen Seitenzweiges einer gewöhnlichen vegetativen Hyphe (Fig. 273, 2). Er konnte weiter nachweisen, daß das Oogon und ein Teil des Zweiges, welcher es trägt, von sterilen Hyphen umhüllt wird (Fig. 273, 4, 5), und meinte, daß eine von diesen Umhüllungshyphen ein Antheridium wäre, welches von den sterilen Hyphen morphologisch nicht zu unterscheiden sei.

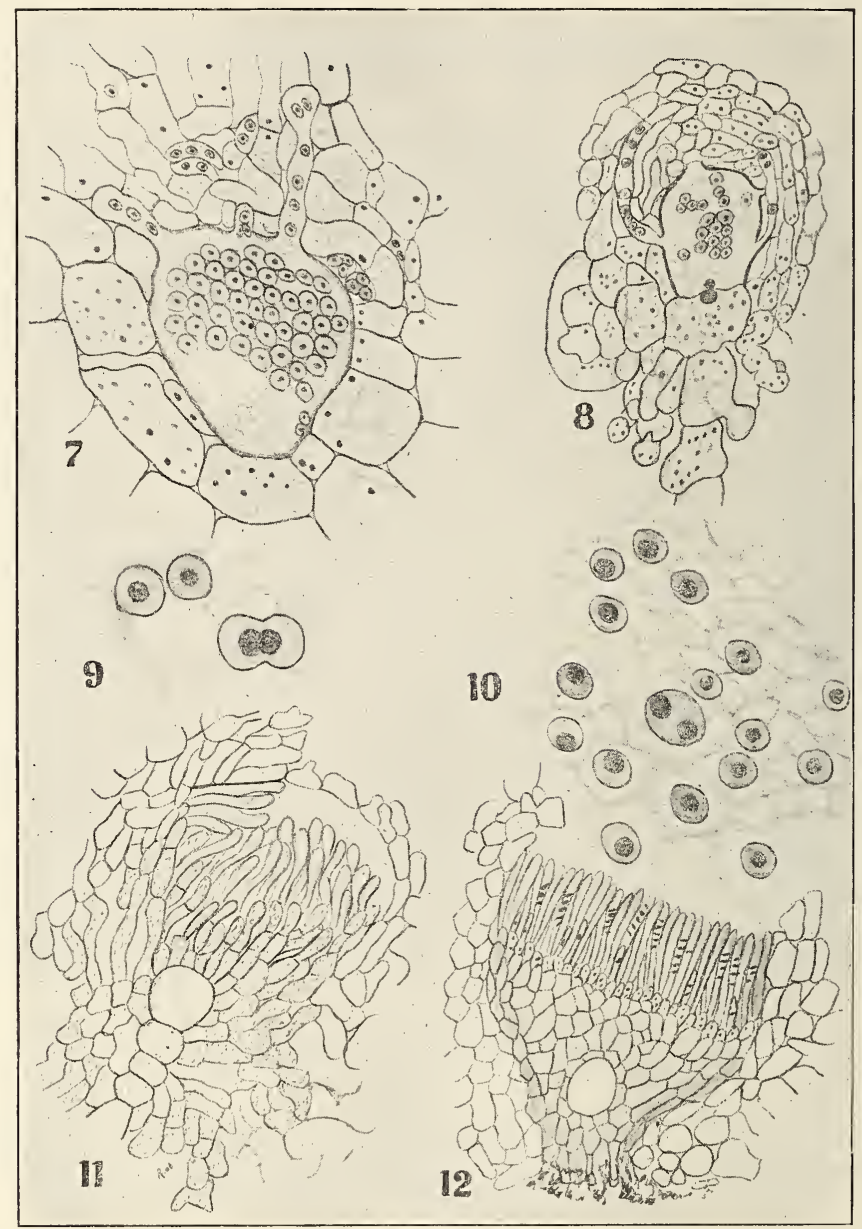

Fig. 274. Humaria granulata (nach Blackman). 7, 8 Bildung ascogener Hyphen. 9, 10 Verschmelzung zweier weiblichen Oogonkerne zur Bildung eines $2 x$-Kernes. 11 Schnitt durch ein junges Apothecium, der Paraphysenkeil durchbricht die Hülle. 12 Die Hülle vollständig durchbrochen, die Asci gebildet. Die Höhlung unten ist der Rest des Oogons.

Mit Ausnahme der Vermutung über die Anwesenheit einesji'Antheridiums konnten Blackman und Fraser Woronins Resultate bestätigen, ein Antheridium gibt es aber bestimmt nicht, die Umhüllungshyphen sind sämtlich steril. Das Oogon ist von Anfang an vielkernig, die Zahl der Kerne nimmt aber beim Heranwachsen noch sehr bedeutend zu. 
Trenn das Oogon von einer mehrschichtigen sterilen Hülle umgeben ist, fängt die Entwickelung der ascogenen Hyphen, welche so wie bei Pyronema aus dem Oogon hervorwachsen, an (Fig. 274, 7). Diese wachsen durch die Umhüllungshyphen hinauf (Fig. 274, 8), und Kerne sowie Cytoplasma aus dem Oogon treten in sie hinein.

Da nun kein Antheridium vorhanden ist, scheint diese Entwickelung auf den ersten Blick eine rein parthenogenetische; dennoch ist dies nicht ganz richtig und man tut wohl besser, hier von einer Form von Apogamie zu reden, denn Blackman und Fraser konnten nachweisen, daß im Oogon paarweise Verschmelzung der Kerne stattfindet (Fig. 274, 9, 10), so daß auch hier die Kerne in den ascogenen Hyphen $2 \mathrm{x}$-Kerne sind, 2x-Kerne, welche jedoch durch Verschmelzung zweier weiblichen x-Kerne entstanden sind.

Die Asci werden auf dem Wege der Hakenbildung aus der zweikernigen subterminalen Zelle gebildet, genau so wie bei Pyronema.

Wir sehen also, wie bei den Ascomyceten Verlust der Sexualität stattfinden kann, und wohl zweifellos werden auch DE BARYs Auffassungen über die apogamen Formen bestätigt werden. Ich persönlich halte es aber für wahrscheinlich, daß es sich herausstellen wird, daß dennoch auch bei den apogamen Formen in den ascogenen Hyphen ent-

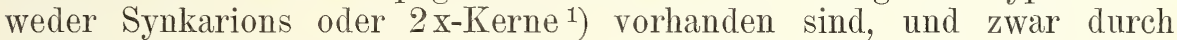
seitliche Kopulation in der Weise der Uredineen (BLAckmas) oder der apogamen Farne (Fraser).

Summa summarum also haben die neuesten Untersuchungen DE BARYs Auffassung über die Sexualität der Ascomyceten glänzend bestätigt und neuen Grund zur Bewunderung seiner genialen Einsicht gegeben.

Der Ascus ist also kein Sporangium und kein Gametangium ${ }^{2}$ ), sondern ein Diplosporangium.

Unter Diplosporangium verstehe ich, wie gesagt, die von der $2 \mathrm{x}$ Generation gebildeten sporenenthaltenden Organe, welche, da sie am Ende der 2x-Generation entstehen, als Gonotokont fungieren. Asci und Farnsporangien sind demnach Diplosporangien; bei beiden ist die erste Teilung des Nucleus eine Trennungsteilung, und der Ascus ist nur darin von den Diplosporangien der Farne verschieden, daß bei ihm eine Teilung mehr wie bei den Farnen bei der Bildung der Sporen stattfindet. Das rührt nach HARPER daher, daß im Ascus eine doppelte Reduktion eines 4x-Kernes stattfindet, möglicherweise aber ist die dritte Teilung nur eine einfache Aequationsteilung. Da im Ascus nur eine Sporenmutterzelle vorhanden ist, während im Farndiplosporangium deren viele gefunden werden, wäre eine weitere Aequationsteilung in den Asci recht wichtig, da dadurch die doch im Vergleich zu den Farnen geringe Sporenzahl wenigstens einmal vergrößert wird.

Die Brefeldsche Lehre, welche in den Asci nur Haplosporangien sieht, beruht auf geschickter, aber falscher Homologisierung der (Haplo-) Sporangien der Phycomyceten und der Asci der Ascomyceten. Dabei wurden die Hemiasci als Zwischenformen angesprochen, eine Rolle, welche sie, wie wir sahen, nicht im stande sind auszufüllen.

DANGEARDs Auffassung, daß im Ascus Befruchtung stattfindet, ist buchstäblich nicht zu leugnen, denn, wenigstens meiner Meinung nach,

1) Dies wurde geschrieben vor der Veröffentlichung der Arbeit ron BLACKMAN und Fraser und ist jetzt für Humaria erwiesen.

2) Wenn man wenigstens meiner Meinung ist, dißB weder Dipodascus noch Eremascus zu den.Ascomyceten gehören. 
findet hier Verschmelzung zweier elterlicher Kerne statt, aber dann muß man auch zugeben, daß bei Cyclops Befruchtung stattfindet, wenn die elterlichen Kerne, gesondert in den Zellen der Keimblätter dieser Organismen vorhanden, sich $\mathrm{zu} 2 \mathrm{x}$-Kernen vereinen, und das ließe sich doch nur verteidigen, wenn man die Augen für alle Homologien schließt. DANGEARDS Fehler liegt darin, daß er die eigentliche Befruchtung im Oogon, so wie sie von Harper und Claussen nachgewiesen wurde, bestreitet, was, wie mir scheint, verursacht wird durch das rein menschliche Verlangen, seine Theorie der Ascusbefruchtung zu retten und scheinbar gestützt wurde durch abnormes Pyronema-Material etc.

Sehen wir nun - uns dabei noch stets an DE BARYs ursprüngliche Umgrenzung der Gruppe haltend - von welchen Formen die Ascomyceten abgeleitet werden können, so scheint mir das für polyenergide Formen, wie Pyronema und Ascodesmis, nicht schwer.

Sowohl die Vielkernigkeit wie das Vorhandensein kopulierender Oogonien und Antheridien zeigt uns den Weg, offenbar müssen wir sie an die Phycomyceten anschließen und man wird wohl ihre Ahnen in der Nähe von Albugo Bliti suchen müssen. Sowohl bei Pyronema wie bei Albugo Bliti verschmelzen im Oogon eine Anzahl Eikerne mit einer Anzahl Spermakerne, und in beiden Fällen wächst das Produkt, die Cönozygote, nicht direkt zu einer neuen Pflanze aus.

Bei Albugo Bliti nämlich werden im Oogon nach der Befruchtung eine Anzahl von Zoosporen gebildet - wohl wenigstens zwei ${ }^{1}$ ), vielleicht mehr, aus einem Zygotenkern - bei Pyronema entstehen pro Zygotenkern 8 Ascosporen.

Diese Zoosporen von Albugo Bliti sind also den Ascosporen von Pyronema homolog.

Der einzige Unterschied zwischen Albugo und Pyronema liegt also darin, daß bei Pyronema das Oogon Keimschläuche (die ascogenen Hyphen) bildet, in welche die Zygotenkerne eintreten. Dadurch können wir sehen (sehr deutlich zumal bei Ascodesmis), daß jeder Zygotenkern sich unabhängig zu Ascosporen weiter entwickelt, was innerhalb eines bestimmten Organs, des Ascus, geschieht.

Das ist alles die Folge des Unabhängigwerdens der Keimung von der Anwesenheit flüssigen Wassers. "Ein gleiches "Isoliertwerden" der Zygotenkerne und eine Bildung spezieller Oogone zur Aufnahme ihrer Keimungsprodukte ist bei den Schwärmsporen bildenden Albugo-Arten nicht nötig.

Wir können also sagen, daß sowohl bei Albugo Bliti wie bei Pyronema eine Cönozygote gebildet wird, daß aber die „Einzelzygoten“ jede für sich keimen, bei ersterer eine noch unbekannte Zahl von Schwärmsporen, bei letzterer 8 unbewegliche Ascosporen bildend.

Auch der Umstand, daß bei Albugo das Oogon die Kopulation durch Bildung einer Kopulationspapille beginnt, spricht für den Anschluß von Pyronema an Albugo-ähnliche Eltern. Sehr leicht kann man sich die Kopulationspapille von Albugo zu der Trichogyne von Pyronema oder Ascodesmis verlängert denken, und der Umstand, daß bei letzteren die Trichogyne vom Oogon mittels einer Querwand getrennt wird, läßt sich sehr gut als eine Anpassung auffassen, durch welche die Konzentrationsdifferenz zwischen dem Zellsaft des Oogons und des Antheridiums ausgeglichen wird. Meines Erachtens liegt also kein Grund vor, die

1) Wenigstens eine Reduktionsteilung wäre nötig. 
Trichogyne von Pyronema mit der Trichogyne der Florideen zu homologisieren.

Während es also keine Schwierigkeiten gibt, welche der Ableitung der polyenergiden Ascomyceten, wie Pyronema, von den Phycomyceten im Wege stehen, sind diese Schwierigkeiten, sobald wir die Ableitung der monoenergiden Formen mit Kopulation von Oogonien und Antheridien, wie z. B. Podosphaera, ins Auge fassen, nicht gering.

Vielleicht darf man sie - die gelegentliche Vielkernigkeit ihrer Zellen würde dafür sprechen - als Nachkommen polyenergider Organismen betrachten, in deren Zellen so viele Querwände auftraten, daß schließlich einkernige Abschnitte gebildet wurden, vielleicht auch muß man sie mit einer Form wie Basidiobolus zu verbinden suchen, eine Form, deren „Einreihung" selber aber schon recht schwierig ist. Dennoch weichen diese monoenergiden Formen nicht so sehr ab, daß sie zur Auffassung zwingen, es sei die Gruppe der Ascomyceten polyphyletischen Ursprungs.

Wohl aber scheint es nötig, einen polyphyletischen Ursprung anzunehmen, wenn man Formen wie Collema in den Kreis seiner Betrachtung hineinzieht.

Der Umstand, daß hier Spermatien vorkommen, schließt wohl jede Möglichkeit, sie an Phycomyceten anzuschließen, aus, worauf auch die überwiegende Monoenergie ihrer Zellen nicht gerade hindeutet.

Da die einzige sonstige Pflanzengruppe, bei welcher Trichogynen und Spermatien vorkommen, die der Florideen ist, und da, wie wir sahen, in Choreocolax albus ein "Algenpilz" vorliegt, liegt es auf der Hand, die Florideen als die Ahnen dieser Ascomyceten-Abteilung zu betrachten.

Wie einleuchtend dies nun auch sein möge, es bleibt doch noch eine Schwierigkeit bei der Annahme eines polyphyletischen oder wenigstens biphyletischen Ursprungs der Ascomyceten bestehen, nämlich diese, daß sowohl bei der Gruppe, welche man von Phycomyceten ableiten möchte, z. B. Pyronema, sowie bei der, welche man von Florideen herleiten möchte, z. B. Collema, die Asci genau in derselben Weise durch Hakenbildung entstehen.

Alles zusammen betrachtend, sind unsere Auffassungen über die Ascomyceten noch die von DE BARY, wir haben nur hier und dort etwas mehr Material zur Stützung seiner Meinung beigebracht, aber viel weiter, wie er war, sind wir auch heute noch nicht, und viel mehr Formen, wie zu seiner Zeit entwickelungsgeschichtlich bekannt waren, sind auch heute nicht bekannt.

Daß es unter diesen Umständen nicht möglich ist, eine phylogenetische Behandlung der Ascomyceten zu versuchen, ist klar; ich werde mich denn auch damit begnügen müssen, Sie mit einigen Formen echter Ascomyceten bekannt zu machen, d. h. solcher Ascomyceten, bei welchen der Ascus in typischer Weise gebildet wird. Die Laboulbeniaceae und Saccharomyceten, von welchen erstere aber auch wohl zweifellos Ascomyceten sind, wie die vor kurzem nachgewiesene Verschmelzung zweier Kerne im Ascus zeigt, behandeln wir erst später.

Machen wir also die Bekanntschaft dieser echten Ascomyceten.

Wir sahen schon, daß an eine natürliche Einteilung dieser oroßen Gruppe nicht gedacht werden kann, bevor die Entwickelungsgeschichte von viel mehr Formen wie die, die wir jetzt kennen, bekannt sein wird. 
Das enthebt uns aber meines Erachtens nicht der Verpflichtung, diejenigen Formen, deren Entwickelungsgeschichte bekannt oder vermutet werden kann, provisorisch zu Gruppen zu vereinen, welche möglichst natürlich sind.

Aus der üblichen Einteilung der Ascomyceten sind nun meines Erachtens die

$$
\begin{aligned}
& \text { Erysiphalen, } \\
& \text { Plectascineen und } \\
& \text { Pyrenomyceten }
\end{aligned}
$$

Gruppen, welche, teilweise unter Einschränkung ihrer Grenzen, zu natürlichen gemacht werden können. Die Vertreter der ersteren Gruppe bilden ihre Fortpflanzungsorgane nach dem Sphaerotheca-Plan, die der zweiten nach dem Eurotium-Plan und die der dritten zeigten wohl ursprünglich Spermatienkopulation, bei ihnen ist aber die Kopulation verloren gegangen, vermutlich gefolgt durch Bildung einer $2 \mathrm{x}$-Generation, etwa in der Weise der Uredineen, letztere Vermutung ist aber rein hypothetisch. Wir werden später übrigens sehen, daß gerade aus den Pyrenomyceten, wie man jetzt diese Gruppe faßt, noch viele Formen ausgewiesen werden müssen, bevor obiges auf sie paßt. Fangen wir also unsere Betrachtungen der Ascomyceten mit der Gruppe der Erysiphales an. 


\section{Neunzehnte Vorlesung.}

\section{Erysiphales.}

Die Familie der Erysipheen ist gekennzeichnet durch den Besitz eines weißen Mycels, welches verschiedene Pflanzenteile, zumal Blätter, mit einem spinngewebeartigen Ueberzug bedeckt. Dieses Mycel sendet Haustorien in die betreffenden Pflanzenteile, meistens nur in die Epidermiszellen.

Im Sommer treten Konidien als Fruktifikation auf, sie werden in solchen Mengen gebildet, daß die befallenen Pflanzenteile wie mit Mehl bestreut sind, weshalb man denn auch die Erysipheen "Mehltau" nennt. Durch diese zahllosen Konidien verbreiten sich die "Erysipheen sehr schnell. Da diese Fruktifikation früher für einen besonderen Pilz gehalten wurde, welchen man Oidium nannte, redet man noch vielfach von einer Oidienfruktifikation der Erysipheen (Fig. 275, 1). Es sind gerade diese „Oidienfruktifikationen“, welche durch die schnelle Verbreitung des betreffenden Pilzes gewisse gefürchtete Pflanzenkrankheiten verursachen, wie z. B. die von Oidium (Erysiphe) Tuckeri verursachte Traubenkrankheit. Diese Oidienkrankheiten werden am besten durch Schwefeln bekämpft. Gegen den Herbst wird dann die Ascusfruktifikation gebildet (bei Oidium Tuckeri u. a. noch nicht bekannt), welche aus runden, nicht mittels einer vorgebildeten Oeffnung, sondern durch unregelmäßige Zerreißung oder Zerbröckelung sich öffnenden Fruchtkörperchen, welche einen (Podosphaera, Sphaerotheca) oder mehrere Asci enthalten, besteht.

Diese Fruchtkörper oder Perithecien besitzen eigentümliche Anhängsel, sogenannte Appendices, welche dem Ganzen öfters ein recht zierliches Aussehen verleihen. Nach der Form dieser Appendices werden die Erysipheen in Genera zerlegt. So werden z. B. Formen mit geraden, pfriemenförmigen, an der Basis angeschwollenen Appendices ins Genus Phyllactinia gebracht, von welchem Genus hier Phyllactinia suffulta. (Rebent) Sacc. genannt werden mag. Dieser Pilz bildet sein MIycel auf beiden Seiten von sehr verschiedenen Baumblättern; meistens aber ist es an der Unterseite der Blätter am üppigsten entwickelt. Auf Corylus, Fraximus, Fagus, Alnus, Betula, Quercus, Hippophaë etc. Kann man es antreffen.

Die Perithecien sind in der Jugend gelb, werden dann braun und schließlich schwarz. Zugleich mit den Appendices entwickeln sich auf der Spitze des Peritheciums stark verzweigte, kurze Hyphen, Pinselhyphen genannt, welche Schleim abscheiden. Der Schleimtropfen enthält 
nahe der Oberfläche Bläschen, wodurch das Vorkommen eines Zellnetzes vorgetäuscht wird, die Schleimmasse ist farblos, so daß die Perithecien wie mit Tautröpfchen bedeckt aussehen.

Im Perithecium sind mehrere Asci vorhanden, welche goldgelbe Sporen enthalten, auch die inneren Schichten des Peritheciums, bisweilen fälschlich Paraphysen genannt, sind goldgelb gefärbt.

Außer diesen Perithecien beschreibt Tulasne sogenannte Pykniden, welche zahlreiche Stylosporen bilden sollen (Fig. 275,5), der Form nach aber von den Perithecien nicht verschieden sein sollen. Es sind dies wahrscheinlich gewöhnliche Perithecien, welche irgend einen Parasiten enthielten.

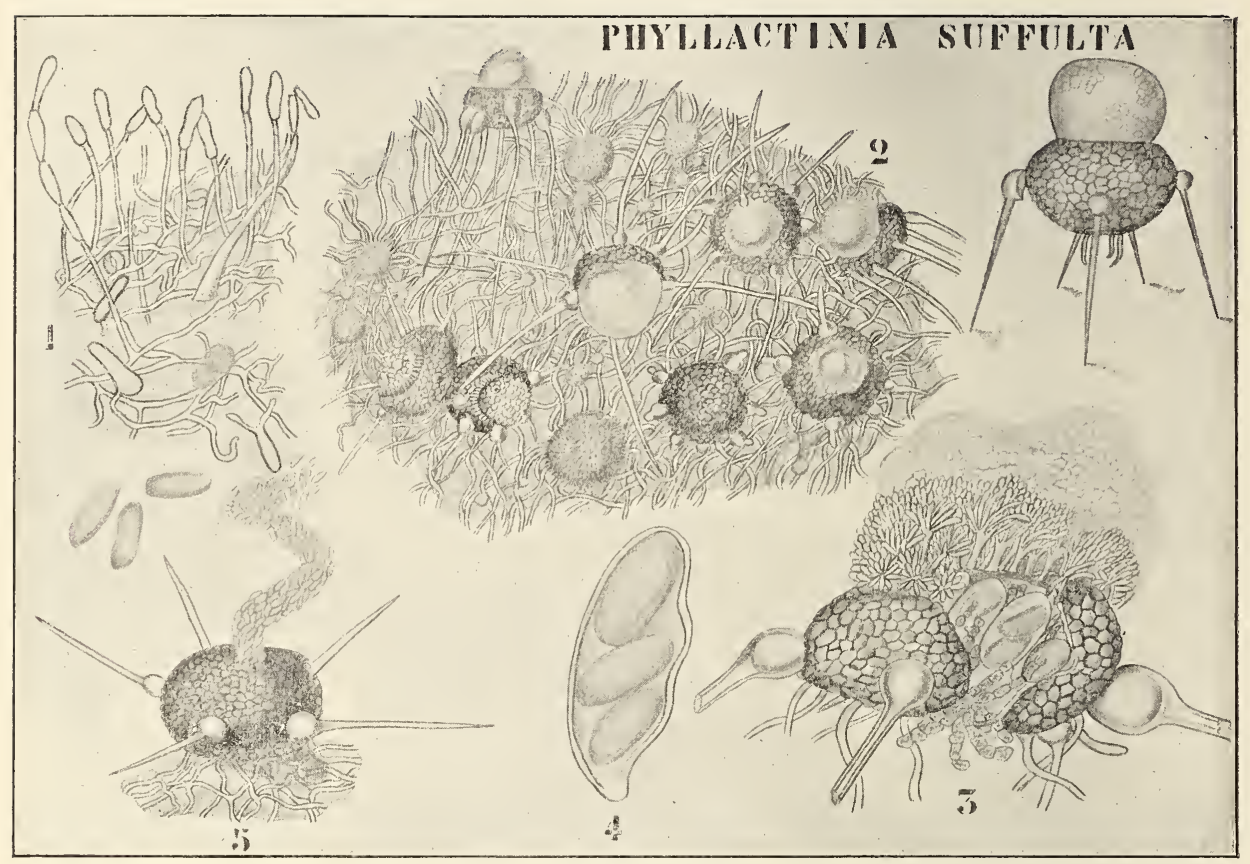

Fig. 275. Phyllactinia suffulta (Rebent) Sacc. (nach Tulasne und Neger). 1 Konidienfruktifikation. 2 Perithecien, links mit ausgebreiteten Appendices, rechts mit heruntergebogenen. 3 Perithecium, halb zerdrückt, die Asci, die Pinselhyphen und die von diesen ausgeschiedene Schleimmasse zeigend. 4 Ascus. 5 Ein wohl von einem Parasiten infiziertes Perithecium, von TULASNe für eine Pyknide gehalten.

In den Ascis entwickeln sich meistens nur 2 Sporen, der abgebildete 3-sporige Ascus ist schon eine Ausnahme. Die geringe Zahl der Sporen wird durch frühzeitiges Zugrundegehen der übrigen verursacht. Die Ascussporen keimen zu neuen Mycelien, welche zunächst während längerer Zeit an aufrechten unverzweigten Konidienträgern Konidien bilden (Fig. 275, 1), die zu neuen konidienbildenden Mycelien auswachsen, ein Vorgang, der sich während des ganzen Sommers wiederholt. Erst im Herbst wird die Konidienbildung eingestellt und diese Fruktifikation von den Perithecien abgelöst.

Die Formen mit hakenähnlich gebogenen Apperrdices werden zum Genus Uncimula gebracht, von welchem Genus U. salicis auf Salix- und 
Populus-Arten eine der häufigsten ist. Trotzdem Tulasne sagt, daß die Asci 4-5 Sporen besitzen, bildet er selber einen solchen mit 8 Sporen ab; die Fig. 276 macht eine weitere Beschreibung wohl überflüssig.

Die Arten des Genus Erysibe oder Erysiphe haben fadenförmige Appendices, welche kaum von normalen vegetativen Hyphen zu unterscheiden sind (Fig. 276,1). E. commmis kommt auf sehr verschiedenen Pflanzen vor, sehr häufig auf Ramunculaceae, Papilionaceae, Dipsacaceae, Valerianaceae, Circaea, Polygonum aviculare etc. Sie bildet 6-8 farblose Sporen pro Ascus und $4-8$ Asci pro Perithecium. Auch hier werden außer Perithecien Konidien gebildet.

Nachdem wir also einen Eindruck von der Familie der Erysipheen

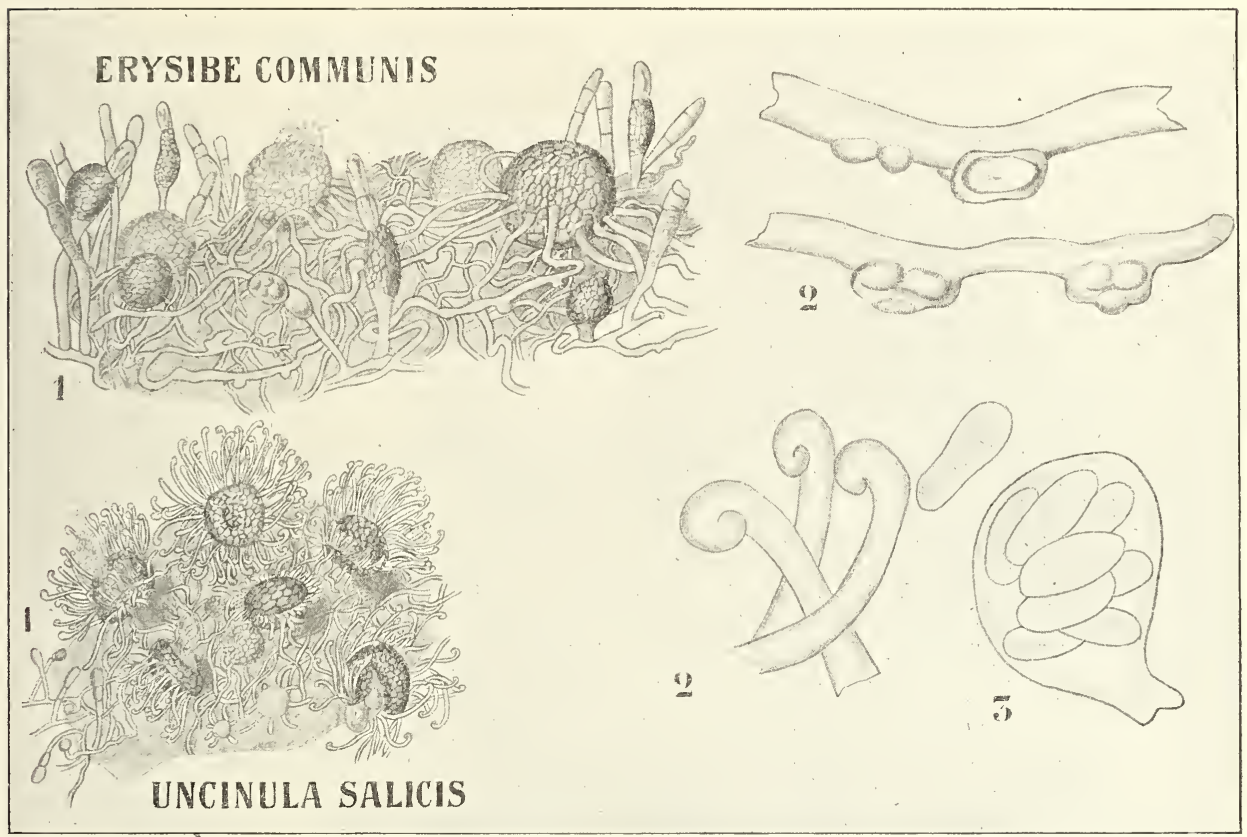

Fig. 276. I. Erysibe communis (nach Tulasne). 1 Fruktifikation. 2 Hyphen mit Appressorien. - II. Uncinula salicis (nach Tulasne). 1 Fruktifikation. 2 Appendices. 3 Ascus.

bekommen haben, wollen wir die verschiedenen erwähnten Organe einmal etwas näher kennen lernen; fangen wir dazu mit den

\section{IIIaustorien}

an, welche zumal durch Grant Smith (1900) und NEGER (1902) näher bekannt geworden sind.

Wir können bei den Erysipheen zwei Fälle unterscheiden: einen, bei welchem Appressorien (Fig. 276, I 2) vorkommen, und einen, bei welchem dies nicht der Fall ist. Appressorien sind Verbreiterungen oder Ausstülpungen von Hyphen, wodurch sich diese an der Stelle, wo das Haustorium gebildet wird, besser am Substrat befestigen.

In beiden Fällen aber werden Haustorien gebildet und diese Haustorienentwickelung findet genau in derselben Weise statt, ob Appres- 
sorien vorhanden sind oder nicht. Sehen wir einmal, wie sie bei Erysiphe communis gebildet werden.

Das erste Zeichen, daß ein Haustorium gebildet werden wird, ist nicht an der Pilzhyphe, sondern an der dieser gegenüberliegenden Wandstelle der Epidermiszelle des Wirtes zu sehen; diese fängt da nämlich an anzuschwellen (Fig. 277, 1, 2). Dies wird wohl durch ein von der Erysiphe-Hyphe ausgeschiedenes Enzym verursacht. In die so gebildete Anschwellung, welche die Zellwand örtlich erweicht, dringt nun alsbald eine sehr feine Ausstülpung des Mycelfadens, das junge Haustorium, ein (Fig. 277, 3). Dieses junge Haustorium läßt den Cellulosepfropf noch stärker anschwellen, wodurch es tief in das Plasma der Epidermiszelle vordringt (Fig. 277, 4), ohne jedoch die Hautschicht des Protoplasten

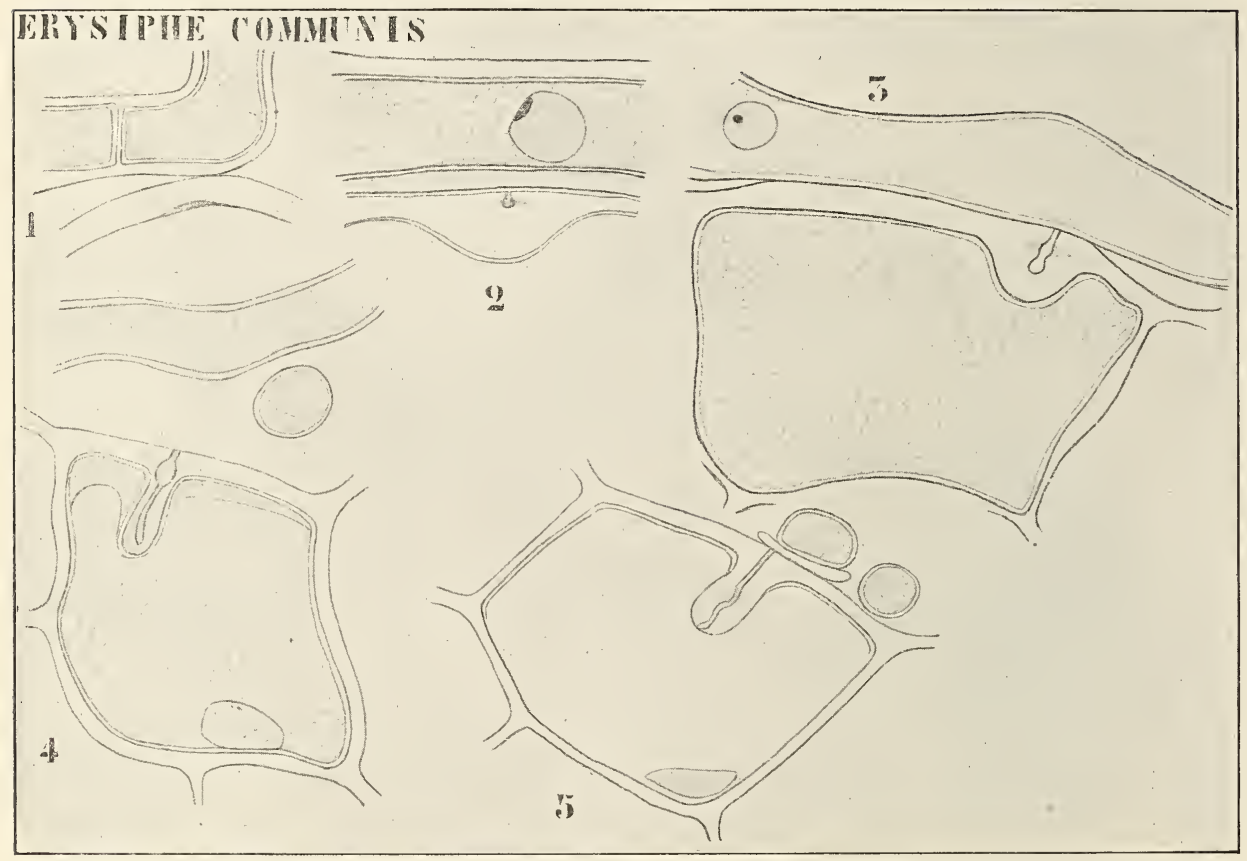

Fig. 277. Haustorienentwickelung bei Erysiphe communis (nach Grant Smith). 1 Erstes Zeichen der Anschwellung der Wand der Epidermiszelle. 2 Nächstes Stadium. 3 Eindringen des jungen Haustoriums. 4, 5 Weiteres Vordringen desselben in der angeschwollenen Wandstelle.

zu durchbohren, diese wird nur eingestülpt. Zu gleicher Zeit übt das junge Haustorium einen lösenden Einfluß auf den Cellulosepfropf aus, wodurch dieser meistens nur granulös wird, bisweilen aber ganz gelöst werden kann (Fig. 278, 8).

Von jetzt an gibt es zwei Möglichkeiten. Es kann das junge Haustorium ohne weiteres den Cellulosepfropf durchbohren und, nachdem es in die Zelle vorgedrungen ist, anschwellen (Fig. 278, 6, 8), in welchem Falle der Cellulosepfropf wie eine Manschette den Haustorienstiel umgibt, oder aber der Cellulosepfropf reißt von seiner Anheftungsstelle ab und wird vom Haustorium in die Zelle hineingeschoben, in welchem Falle größere oder geringere Reste desselben sich am angeschwollenen 
Ende des Haustoriums, öfters in der Form einer Kappe, vorfinden (Fig. 278, 9, 10). Besonders hübsch sind diese Einzelheiten bei E. cichoracecum (vergl. Fig. 279), die öfters mehrere Haustorien in eine Zelle hineinsendet, wahrzunehmen; jede der drei hier abgebildeten Haustorien ist von Resten des Cellulosepfropfes umgeben.

Während in diesen Fällen die Haustorieil recht einfach gebaut sind, kommen bei anderen Arten, z. B. bei Erysiphe graminis, schön gelappte Haustorien vor, welche natürlich durch ihre größere Oberfläche besser zur Aufnahme von Nahrung geeignet sind wie die einfacheren Haustorien der vorigell Arten.

Es ist nun gewiß auffallend, daß die Erysipheen genügend Nahrung erhalten können, ohne weiter als bis in die Epidermis der Wirtspflanze

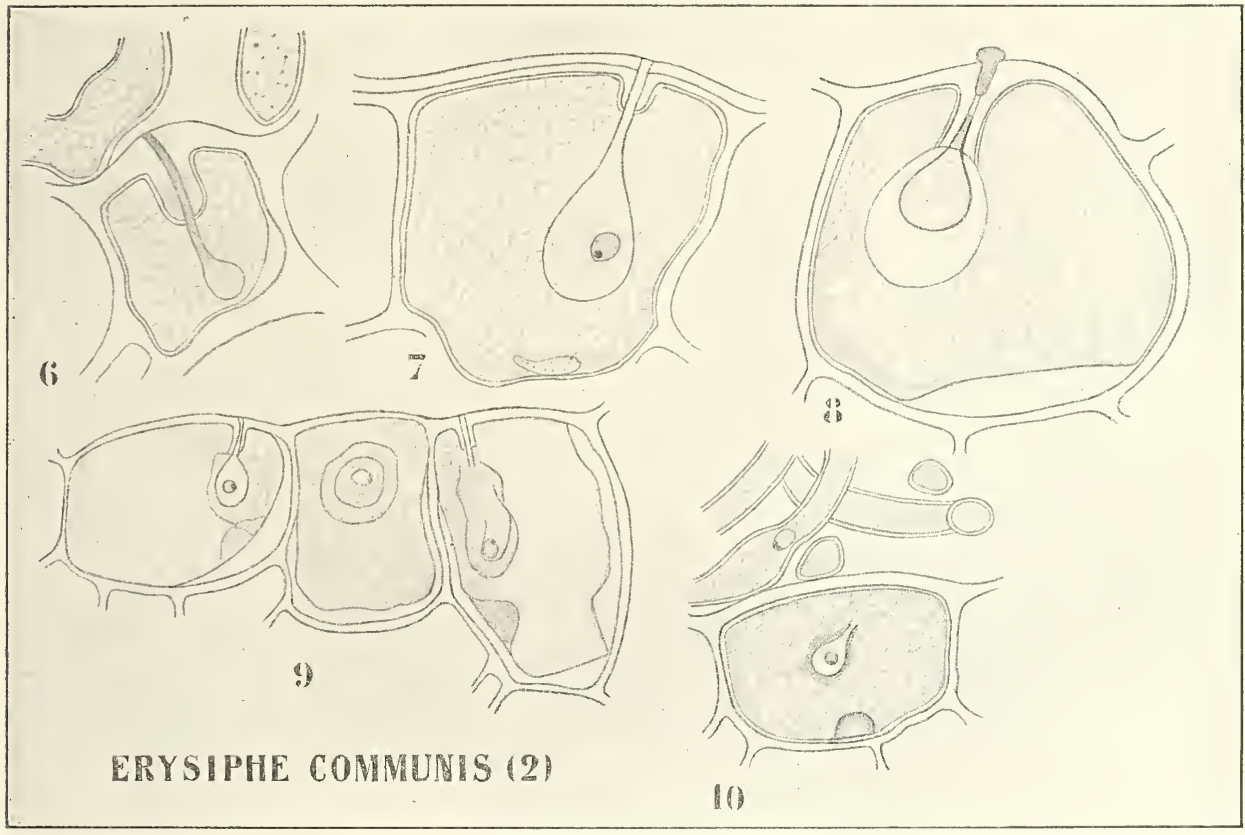

Fig. 278. Haustorienbildung bei Erysiphe communis (nach Grant Smith). Figurenerklärung im Text.

einzudringen. Das rührt daher, daß der Pilz in jenen Fällen die Epidermiszellen nicht tötet, im Gegenteil, wie NEGER nachwies, kann z. B. Sphaerotheca sie zu bedeutender Hypertrophie reizen (vergl. Fig. 280).

In den meisten Fällen aber, wo das Eindringen der Haustorien dieses Resultat nicht hervorruft, genügt auch dem Pilz das Eindring'en in die Epidermis nicht, und er weiß auch noch die darunter gelegenen Palisadenzellen zu erreichen. So z. B. Uncimula salicis, eine Form, welche auch Appressorien (Fig. 279, 2) bildet. Hier dringen die jungen Haustorien ebenfalls in die Epidermiszellen ein, und zwar mehrere in eine Zelle, aber nur wenige der eingedrungenen Haustorien schwellen dort zu gut ausgebildeten Saugorganen an, die meisten setzen ihren Weg fort, durchbohren in der Gestalt feiner Fäden auch noch die untere Zellwand und schwellen erst in den darunter gelegenen Zellen zu guten 
Saugorganen an (Fig. 279, 1). Da die für die Epidermiszellen vorhandenen Haustorien dann öfters den Stiel der Palisadenzellenhaustorien verdecken, scheint es öfters, als ob die Haustorien in den Epidermiszellen die Stielchen der Palisadenzellenhaustorien gebildet haben (Fig. 279, 1,3). Bessere Schnitte (Fig. 279, 2) zeigen aber den richtigen Sachverhalt.

Während die meisten Erysipheen die Epidermis durchbohren, tut dies, wie Palla (1899) zuerst beobachtete, Phyllactinia nicht.

Dieses Genus tritt durch die Spaltöffnungen in das Blatt hinein (vergl. Fig. 280, II 1) und sendet Haustorien in die Mesophyllzellen (Fig. 280, II 2) oder in die in unmittelbarer Nähe der Gefäßbündel gelegenen Zellen (Fig. 280, II 3); letzterer Fall ist der häufigere.

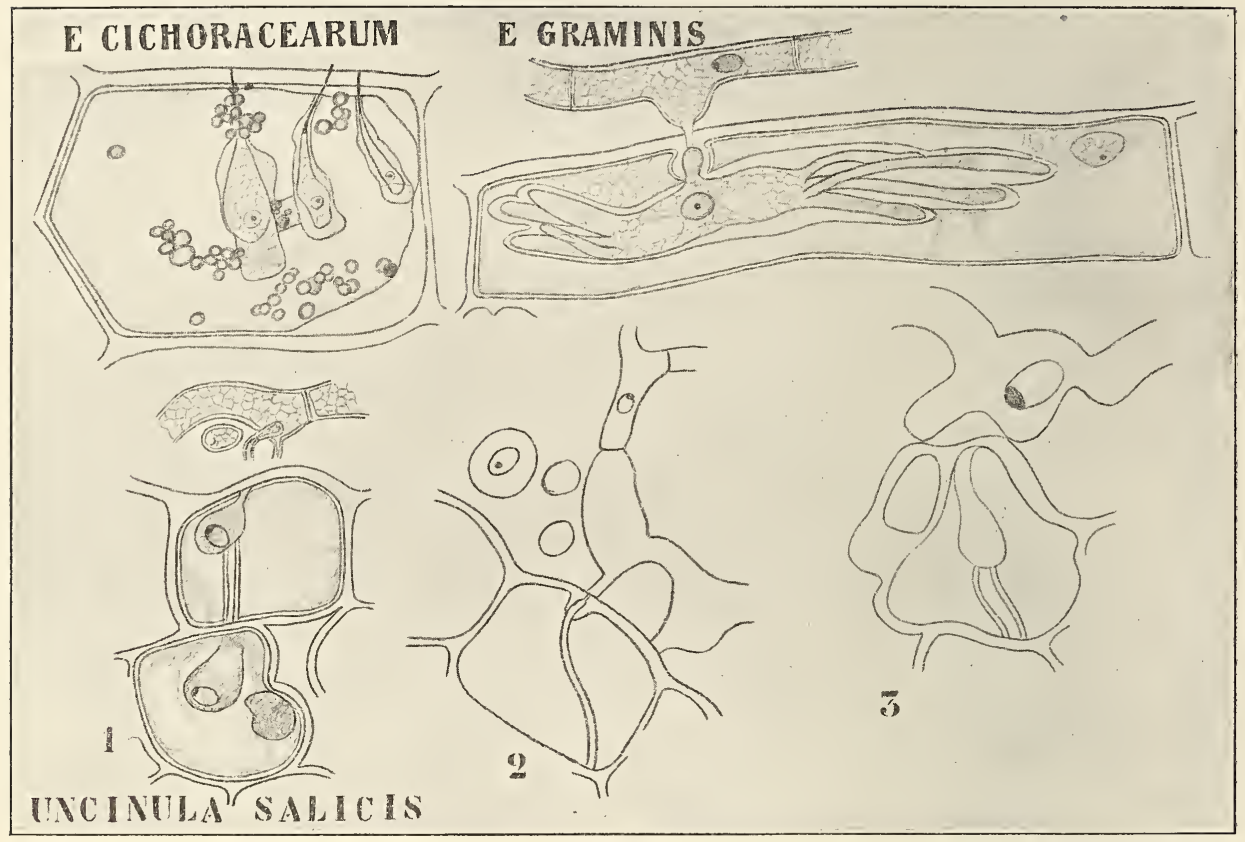

Fig. 279. Verschiedene Haustorienformen bei mit Namen bezeichneten Erysipheen (nach GRANT Sмith). Figurenerklärung im 'T'ext.

Es zeigt dies, daß der Pilz im stande ist, diejenigen Stellen aufzusuchen, wo die meiste Nahrung vorhanden ist, es ist dies wohl einer der vielen Fälle von Chemotaxis, deren Existenz bei Pilzhyphen sehr schön von Mryoshi (1894) nachgewiesen wurde.

Es ist bekannt, daß viele parasitische Pilze so wie unsere Phyllactinia in die Spaltöffnungen der Wirtspflanzen eindringen. Mryoshi untersuchte nun, ob er auch nichtparasitische Pilze, gewöhnliche Saprophyten, wie z. B. Mucor und Penicillium, dazu veranlassen könnte, in Spaltöffnungen einzudringen. Dazu verwendete er Blätter verschiedener Pflanzen, wusch diese in reinem Wasser aus und besäte sie darauf mit Sporen des zu untersuchenden Pilzes. Es zeigte sich nun, daß die Keimschläuche quer über die Stomata hinüber wuchsen; wurde aber das Blatt vorher mit einer Nährlösung, z. B. mit Rohrzucker, imprägniert, 
so wuchsen die Pilzfäden öfters in recht instruktiver Weise auf die Spaltöffnung'en zu und traten in diese ein (vergl. Fig. 280). Es zeigte sich also, daß Pilzhyphen gerade so gut wie Schwärmsporen von ihrem Weg abgelenkt werden können.

Auch in anderer Weise kann man dies nachweisen, nämlich dadurch, daß man perforierte Zelloidinhäutchen auf eine mit einer geeigneten Nährlösung imprägnierte Gelatineschicht legt. Auch hier wachsen die Keimschläuche der auf das Celloidinhäutchen gesäten Pilzsporen durch die perforierten Stellen in die Gelatineschicht hinein. Ist dagegen keine Nahrung unter dem Celloidinhäutchen vorhanden, so wachsen sie quer über die Perforationen hinweg.

Es lag nun auf der Hand, zu untersuchen, ob man annehmen dürfe,

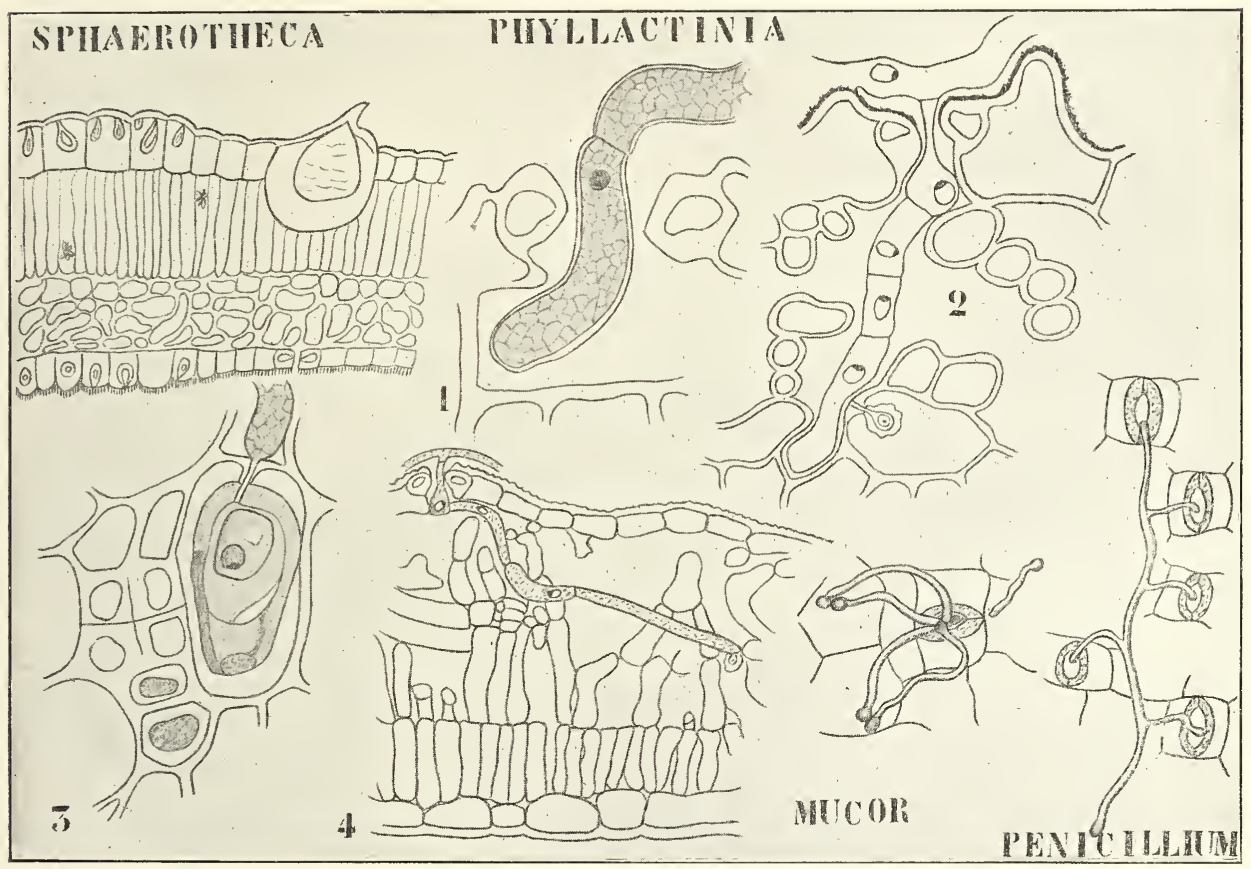

Fig. 280. I. Sphaerotheca (nach NEGER). Eine von einem eingedrungenen Haustorium hypertrophierte Epidermiszelle. - II. Phyllactinia (nach GraNt SMITH). 1 Eine durch eine Spaltöffnung eingedrungene Hyphe. 2 Die Iryphe entsendet Haustorien in das Gewebe des Blattes. 3 Haustorien, stärker vergrößert. 4 Verlauf der Hyphe im Blattgewebe. - III. Mucor und Penicillium (nach MryoshI), in zuckerimprägnierten Spaltöffnungen mit ihren Keimschläuchen eindringend.

daß auch das Durchbohren der Zellwände, was ja bei vielen parasitischen Pilzen vorkommt, auf Chemotaxis beruht, und Mryoshi untersuchte dies dadurch, daß er intakte künstliche Cellulosehäutchen oder Epidermisstückchen der Zwiebel ohne Spaltöffnungen auf einen Nährboden legte, der aus 3 Proz. Gelatine und 2 Proz. Rohrzucker bestand. Sät man auf solchen Cellulosehäutchen Penicillium aus, so wächst dieser Saprophyt quer durch das Häutchen hindurch, legt man dagegen das Häutchen auf eine indifferente, keine Nahrung enthaltende Substanz, so geschieht dies nicht. Es muß also wohl etwas Nahrung durch das Häutchen diosmieren 
und so den Pilz zum Eindringen reizen, und man darf wohl mit einem hohen Grade von Wahrscheinlichkeit annehmen, daß auch das Durchbohren der Zellwände durch parasitische Pilze in der Natur auf dem gleichen Prinzip beruht.

Wir haben früher gesehen, daß bei den Erysipheen zweierlei Arten von Fruktifikation vorkommen: Konidienträger und Perithecien, deren erstere Konidien, letztere Ascosporen bilden. Konidien werden im Sommer, Ascussporen im Herbst gebildet, letztere erlauben also dem Pilz zu überwintern.

Mit Recht sagt NEger, daß eine der wichtigsten Fragen in der Lebensgeschichte der Erysipheen die ist, von welchem Faktor die Bildung von Conidiosporen und Perithecien abhängt, und wie der Pilz überwintert, wenn letztere aus irgend einer Ursache nicht gebildet werden.

Auf letztere Frage kommen wir später zurück, eine sichere Antwort läßt sich noch nicht geben, und auch die erstere kann noch nicht mit Sicherheit beantwortet werden, da bis jetzt alle Versuche, die Erysipheen auf Nährböden zu kultivieren, erfolglos geblieben sind. Darum braucht man noch nicht anzunehmen, daß Erysiphe unter allen Umständen ein obligater Parasit ist. Bis vor wenigen Jahren meinte man, dies mit Sicherheit von Peronospora behaupten zu können, bis es Racrborski in Buitenzorg gelang, sehr schöne Kulturen dieses Pilzes zu erhalten.

Trotz dieses Uebels, welches einer sicheren Entscheidung der Fragen im Wege steht, gelang es NEGER, durch künstliche Infektion lebender Pflanzen dennoch eine Einsicht in gewisse Faktoren zu erhalten, welche auf Konidien- oder Perithecienbildung einwirken.

Er sah unter anderem, daß in der Regel keine Perithecien gebildet werden, wenn vorhergegangene sehr reichliche Konidienbildung den Wirt stark geschwächt hat, daß diese dagegen wohl entstehen, wenn die Konidienbildung spärlich gewesen ist oder wenigstens dem Wirt nur wenig geschadet hat.

Die Konidienbildung selber nun wird durch die Anwesenheit junger, frischer, turgescenter Pflanzenteile gefördert, Perithecien entstehen zumal wenn alte Blätter infiziert werden, in welchen durch nicht $\mathrm{zu}$ starke vorangegangene Konidienproduktion die vorhandene Nahrung noch nicht erschöpft ist.

Wir haben gesehen, daß viele Erysipheen-Perithecien schöne Appendices besitzen, und es liegt auf der Hand, anzunehmen, daß diese bei der Verbreitung der Perithecien irgend eine Rolle spielen, denn bei vielen Erysipheen lösen sich die Perithecien früher oder später vom Substrat.

NEGER untersuchte diese Sache sehr genau und konnte nachweisen, daß es unter den Erysipheen Formen gibt, deren Perithecien am Substrat befestigt bleiben, andere, welche sie loszumachen verstehen. Die Perithecien der Erysipheen reifen im Herbst, öffnen sich aber erst im nächsten Frühjahr, und sind also sowohl zur Aufbewahrung wie zur Verbreitung der Ascosporen besonders geeignet. Sehen wir also an der Hand der NEGERschen Untersuchungen, wie dies geschieht.

Neger fand, daß die Perithecien der meisten, wenn nicht aller Arten von Sphaerotheca und Erysiphe am Substrat befestigt bleiben, daß dagegen die der meisten Uncimula-Arten und aller Arten der Genera Microsphaera, Podosphaera und Phyllactinia sich vom Substrat loszumachen verstehen. 
Worauf beruht nun dieser Unterschied im biologischen Verhalten? Man meinte, daß der anatomische Ban der Perithecien bei allen Erysipheen so ziemlich der gleiche sei, und hatte bis zu NEGERs Arbeit viel zu wenig auf feinere Differenzen geachtet. So bildet z. B. Tulasne Sphaerotheca-Perithecien ab mit Wandzellen, welche weit mehr denen einer Erysiphe als denen einer wirklichen Sphaerotheca gleichen. Am besten sieht man die Unterschiede, wenn man die Perithecien leise mit $\mathrm{KOH}$ erwärmt, dann sieht man z. B., daß sich die Größe einer Wandzelle und die Länge des Querschnittes bei Sphacrotheca verhält wie 1 : 5, bei Uncinula wie $1: 18$, es sind also die Wandzellen von Sphaerotheca verhältnismäßig viel größer, auch sind sie unregelmäßiger.

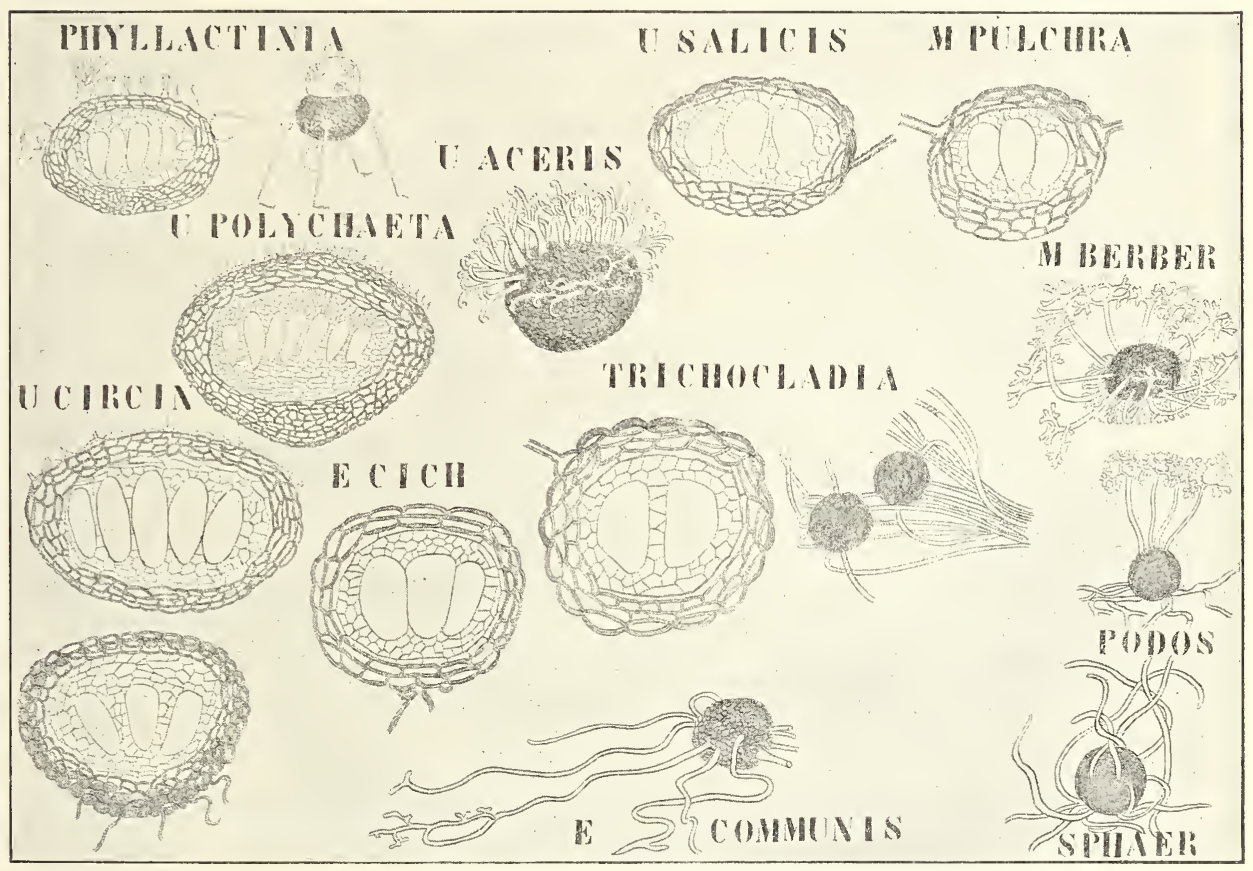

Fig. 281. Querschnitte von Perithecien verschiedener mit Namen bezeichneter Erysipheen (nach NeGER). $U=$ Uncinula. M Berber = Microsphaeraberberidis. $\mathrm{U}$ circin $=$ Uncinula circinalis. $\mathrm{E}=$ Erysiphe. E eich $=$ Erysiphecichoracearum. Podos $=$ Podosphaera. Sphaer $=$ Sphaerotheca.

Ueber den Bau der nicht abfallenden Perithecien (Sphaerotheca, Erysiphe, Uncinula circinata?) ist nichts besonderes zu bemerken; beim Eintrocknen findet die Volumverringerung gleichmäßig statt, so daß auch das trockene Perithecium kugelig ist.

Bei anderen Formen aber findet Formveränderung beim Eintrocknen resp. Aufschwellen der Perithecien statt. Am besten kann man diese beobachten, wenn man die lufttrocknen Perithecien direkt in Paraffin einschließt, sie dann schneidet und das Paraffin mittels Xylol und dieses mittels Aether entfernt. Solche Querschuitte zeigen dann die Form des Peritheciums im trockenen Zustande, läßt man nun zu einem solchen Schnitt Wasser oder wenn nötig verdümnte KOH zutreten, so erhält man die Form des frischen Peritheciums. Die meisten Perithecien zeigen 
nun einen Unterschied im anatomischen Bau der Ober- und der Unterseite, sind also dorsiventral gebaut (vergl. Fig. 281).

Auf Grund des Aufbaues der Perithecien verschiedener ErysipheArten kommt Neger zu dem Resultat, daß DE BARys Subgenus Trichocladium zum Genusrang zu erheben ist, und zwischen Erysiphe und Microsphaera gestellt werden soll. Zu diesem Genus Trichocladia gehört z. B. Magnus' Microsphaera Caraganae (Ber. D. Bot. Ges., XVII, p. 180).

Die Diagnosen dieser 3 Genera werden dann:

Erysiphe. Anhängsel einfach oder verzweigt mit dem Mycel verflochten. Zellen der Perithecienwand ringsum gleichförmig; keine (oder nur eine undeutliche) Differenzierung in Ober- oder Unterseite. Perithecien nicht spontan abfallend.

Trichocladia. Anhängsel wie bei Erysiphe, aber nie mit dem Mycel verflochten. Peritheciumwand differenziert in eine aus englumigen dickwandigen Zellen gebildete Oberseite und eine aus weitlumigen dünnwandigen Zellen bestehende Unterseite. Perithecien bei der Reife spontan abfallend.

Microsphaera. Anhängsel starr, gerade, 2-7mal dicho- oder trichotom verzweigt, nie mit dem Iycel verflochten. Perithecien wie bei Trichocladia; Differenzierung der Peritheciumwand in Ober- und Unterseite noch deutlicher als bei voriger Gattung; Fruchtkörper bei der Reife spontan abfallend.

Wir sehen also, daß die Perithecien bei Erysiphe ${ }^{1}$ ) radiär, bei Trichocladia und Microsphaera dorsiventral gebaut sind, und es sind eben die beiden letzteren, deren Perithecien spontan abfallen. In der Tat ist dies die Folge ihres dorsiventralen Baues, denn es sind bei diesen Genera die Zellen an der Unterseite des Peritheciums dünnwandiger und weitlumiger wie die an der Oberseite (vergl. Fig. 281), infolgedessen wird beim Eintrocknen die Unterseite eingedrückt, und die Mycelfäden, mittels welcher es am Substrat befestigt war, zerreißen. Auf ähnlichen Vorgängen beruht die Loslösung fast aller dazu fähigen ErysipheenPerithecien.

Phyllactinia aber folgt dabei einem anderen Weg: bei Trockenheit drehen sich nämlich die Anhängsel mittels der angeschwollenen Basis gelenkartig nach unten (vergl. Fig. 275), wodurch das Perithecium wie auf Stelzen emporgehoben, und die Befestigungshyphen zerrissen werden. Dieser hübsche Vorgang läßt sich leicht demonstrieren, wenn man Blätter mit diesem Pilze in den Exsiccator stellt; es läßt sich dann zugleich durch Auflegen von Deckgläschen zeigen, daß die entwickelte Kraft ziemlich bedeutend ist: 4 Perithecien heben leicht ein ziemlich dickes Deckglas auf.

Während also bei Phyllactinia die Appendices zur Loslösung des Peritheciums vom Substrat verwendet werden, ist dies bei den anderen Erysipheen nicht der Fall, sie dienen dort vielmehr zur Anheftung an neue Wirtspflanzen oder spielen in anderer Weise bei der Verbreitung eine Rolle.

Sehen wir also zunächst, wie die Perithecien der Erysipheen verbreitet werden. Bei vielen Arten, welche ihre Perithecien nicht selb-

1) Nur Erysiphe graminis zeigt einige Dorsiventralität, wodurch die Perithecien an der Oberseite beim Eintrocknen eingedrückt werden. 
ständig ablösen, werden diese in Verbindung mit größeren Mycelflocken vom Regen verbreitet.

Läßt man z. B. auf ein mit Perithecien bedecktes Blatt von Heracleum spondylium Wasser tropfen, so lösen sich nach kurzer Zeit größere oder kleinere Mycelflocken mit den daran befestigten Perithecien ab und werden weggespült. Da nun alle Erysiphe-Mycelien beim Naßwerden mehr oder weniger verschleimen, haften diese Flocken nach dem Eintrocknen fest am Substrat, welchem sie vom Regenwasser zugeführt wurden.

Bei Trichocladia Astragali, einer Art, welche ihre Perithecien spontan losmacht, vereinigen sich meistens 30-40 Perithecien mittels ihrer Appendices zu größeren Komplexen, welche vom leisesten Windhauch mitgeführt werden. Um dies zu ermöglichen, ist aber die Mitwirkung eines anderen Pilzes nötig. Der Fall liegt so: Die Appendices dieser Perithecien sind sämtlich nach einer Seite gerichtet und verlaufen einander parallel; so gelangen die Appendices mehrever Perithecien (vergl. Fig. 281) in unmittelbare Nähe voneinander und bilden Bündelchen, die aus parallelen Fäden bestehen. Diese Bündelchen werden nun von einem Pilze, und zwar fast immer von Monitia candida, umwachsen und sozusagen zusammengenäht. Wir haben hier also mit einem Fall zu tun, wo ein Pilz dem anderen bei seiner Verbreitung hilft; wie gesagt, ist dies fast immer Monilia candida, welche immer mit Erysiphe zusammen vorkommt, nur in einem Falle wurde die Verbindung der Appendices von Cephalothecium roseum besorgt.

Bei Uncinula salicis spielen die Appendices eine bedeutende Rolle in der Verbreitung des Pilzes. Die Perithecien stehen hier nämlich so dicht gedrängt, daß sie sich fast berühren. Erst wenn sie ihre definitive Größe erreicht haben, entstehen die Appendices, welche nun so sehr zwischen einander wachsen, daß man sie am besten mit ineinander gedrückten Haarbürsten vergleichen kann. So werden die sich spontan ablösenden Perithecien, in Flocken zusammenhängend, vom Winde verbreitet.

Bei den zur Gruppe Eunncinula gehörigen Uncinula-Arten, z. B. bei $U$. aceris, fallen die Perithecien isoliert ab, dennoch spielen die Appendices dieser Art eine wichtige Rolle, nicht bei der Verbreitung des Pilzes, sondern bei dessen Anheftung an neuem Substrat. Da diese Appendices nämlich bei der Befruchtung klebrig werden und diese Klebrigkeit beim Eintrocknen zu einer harten Masse erstarrt, sind sie ein ausgezeichnetes Befestigungsmittel.

Das beste Befestigungsmittel besitzt aber Phyllactinia in ihrem von den Pinselhyphen auf dem Scheitel der Perithecien gebildeten Schleimtropfen. Die Zellhaut, welche nach Tulasse diesen Schleim bedecken soll, besteht nicht, sondern wird vorgetäuscht durch in der schleimigen Masse vorhandene Luftbläschen, infolgedessen besteht denn auch diese "Zellhaut" meistens nur aus isolierten Fetzen. Dieser Schleim ist stark hygroskopisch und trocknet später zu einer festen Masse ein, dadurch ein ausgezeichnetes Befestigungsorgan bildend.

Versuchen wir nun, an der Hand des Gelernten eine Uebersicht über die Phylogenie der Erysipheen zu erhalten, so bemerken wir zunächst. daß es unter den Erysipheen zwei Gruppen gibt, deren Zusammenhang noch recht unklar ist, nämlich die der Monoasci und die der Polyasci.

$\mathrm{Zu}$ den Monoasci gehören nur 2 Genera: Sphaerotheca und Podosphaera, von welchen erstere einfache Appendices und radiäre Perithecien 
besitzt, letztere verzweigte Appendices und dorsiventrale Perithecien. Sphaerotheca stimmt biologisch in Bezug auf die Verbreitung der Perithecien mit Erysiphe, Podosphaera mit Microsphaera überein.

$\mathrm{Zu}$ den Polyasci gehören mehrere Genera, welche sich nach NEGER wie folgt anordnen lassen. In der Uebersicht bedeutet P.: Perithecien; Anh.: Anhängsel oder Appendices.

\section{Phyllactinia}

P. wie bei Uncinula circinata; zweierlei Anh.: stelzenartige und Pinselzellen.

Uncinula circinata Wie Euuncinula, aber P. umgekehrt dorsiventral.

|

Wie Erysiphe, aber P. an der Unterseite starr.

\section{Euuncinula}

Anh. spiralig eingerollt. $P$. dorsiventral, aber anders gebaut als bei Microsphaeroidea.

\section{Uncinula}

(Microsphaeroidea)

Anh. spiralig eingerollt.

P. dorsiventral wie bei Microsphaera.
Microsphaera Anh. dichotom verzweigt.
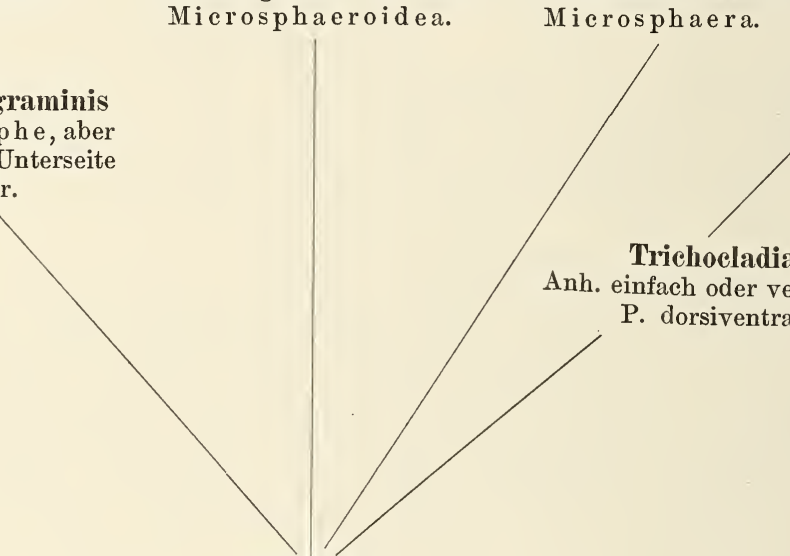

Trichocladia

nh. einfach oder verzweigt.

P. dorsiventral.

Erysiphe

Anh. in der Regel einfach.

P. nicht dorsiventral.

Ein bis jetzt nicht erörterter Punkt und dennoch ein Punkt größter Wichtigkeit ist die Frage nach der Abgrenzung der verschiedenen Arten innerhalb der Genera. Die Erysipheen fallen sofort durch ihre polyphage Natur auf. Formen, welche morphologisch nicht voneinander zu unterscheiden sind, welche man also zu einer Art vereinigen muß, kommen auf Pflanzen der verschiedensten Familien vor, und so zeigen z. B. die Arten des Genus Erysiphe ein für Parasiten sehr ungewöhnliches Vermögen, die verschiedensten Pflanzen zu infizieren.

Wir haben aber früher gesehen, daß morphologisch ununterscheidbare Bakterienarten sich physiologisch dennoch als gute Arten dokumentieren und wir haben weiter gesehen, daß es neben morphologischen auch physiologische Arten gibt.

Die Frage drängt sich uns also auf, ob es vielleicht auch bei den Erysipheen physiologische Arten gibt, und man muß diese Frage nach NeGERs und Salmons Untersuchungen bejahen. Ich will aber auf diese höchst interessanten Ausführungen hier nicht näher eingehen, sondern die Besprechung solcher Fälle lieber bis zur Behandlung der Uredineen aufschieben. 
Wohl aber will ich darauf hinweisen, daß öfters die Keimung der Konidien noch unerwartete Hilfsmittel bietet, um, wenn auch geringe, morphologische Artdifferenzen zu beobachten; für weitere interessante Details darüber muß ich auf NEGER verweisen; es sei nur erwähnt, daß es Verschiedenheiten gibt in der relativen Länge der Keimschläuche, in Bezug auf die der Spore, in der An- oder Abwesenheit von Appressorien, im Verhalten gegen das Licht, ob nämlich heliotropisch oder nicht, Verschiedenheiten, welche NEGER dazu brachten, anzunehmen, daß E. cichoracearum keine einheitliche Art ist, was er später durch Infektionsversuche beweisen konnte.

Es bleibt nun noch die Frage zu beantworten, wie Erysiphe-Arten, welche keine Perithecien produzieren, überwintern. Man findet auf zahllosen Pflanzen Konidien und nichts als Konidien und dennoch werden solche Pflanzen jedes Jahr von neuem infiziert.

Bei perennierenden Pflanzen ist das nun kein Wunder, da z. B. Tubeuf nachwies, daß bei Senecio cordatus das Mycel auf dem Rhizom überwintern kann. Wie steht es aber bei einjährigen Arten?

NEGER meint nun - wiewohl er dies nicht direkt beweisen kann daß es in folgender Weise geschieht.

Nach ihm passen sich die Konidiengenerationen der Erysiphes-Arten sehr schnell in solchem Grade an eine bestimmte Pflanzenart an, daß sie keine andere Art mehr infizieren können; falls sie nun keine Perithecien bilden können, verschwindet dieser Pilz am Ende des Jahres auf immer.

Auf anderen Pflanzen aber sind inzwischen von der Kollektivart, zu welcher vorgenannte an eine Pflanzenart angepaßte Konidiengeneration gehört, Perithecien gebildet, und da die Ascosporen nach NEGERs Meinung viel polyphager wie die Konidien sind, infizieren diese wieder die erste Pflanzenart. Das Mycel bildet Konidien und diese Konidien passen sich wieder sofort der Pflanzenart, auf welcher sie sich befinden, an.

Falls dies richtig ist, können also die Ascussporen der Erysipheen mehrere Pflanzenarten infizieren, die Konidien nur eine oder einige wenige.

Das klingt in der Tat recht plausibel, seitdem hat aber SalmoN (1903) nachgewiesen, daß die NEGERsche Vermutung nicht zutrifft, daß die Ascosporen in ihrem Infektionsvermögen ebenso gut auf bestimmte Pflanzenarten beschränkt sind wie die Konidien, trotzdem die Sammelart auf sehr vielen Pflanzenarten vorkommen kann, so z. B. Erysiphe Polygoni DC. auf 400 Arten, zu 160 verschiedenen Generis gehörig.

Salmon arbeitete mit Ascosporen von Erysiphe graminis, welche auf Hordeum vulgare kultiviert worden war, und infizierte damit verschiedene Gramineen mit folgenden Resultaten:

I m p f m a terial

Ascosporen, auf Hordeum vulgare entstanden do.

do.

do.

do.

do.

do.

do.

do.

do.

Name der infizierte $\mathrm{n}$
Pflanze
Avena sativa
Triticum vulgare
Secale cereale
Hordeum vulgare
,,$\quad$ maritimum
,$\quad$ secalinum
,,$\quad$ jubatum
,$\quad$ bullosum
,$\quad$ zeocriton
,$\quad$ trifurcatum

Resultat der Infektion

0

0

0

$+$

0

0

0

$+$

Wir haben also bei den Erysipheen echte biologische Arten, welche ihre Einheitlichkeit dadurch zeigen, daß sowohl ihre Konidien wie ihre 
Ascosporen nur einige wenige Arten infizieren können, während die Sammelart auf den verschiedensten Arten vorkommt.

In dem hier untersuchten Falle kann die biologische Art auf Hordeum vulgare also z. B. keinen Hafer, Weizen oder Roggen infizieren, ja sogar von 7 Hordeum-Arten nur 3 infizieren.

Damit ist aber keineswegs gesagt, daß sie nicht auf einem Umweg mit Hilfe sogenannter Ueberbrückungsarten (bridging species), noch andere Arten infizieren kann. Es wäre z. B. möglich, daß die Ascosporen der Form auf Hordeum vulgare, wiewohl nicht im stande, direkt Weizen $\mathrm{zu}$ infizieren, irgend eine andere Graminee infizieren könnten, und daß die auf dieser Graminee entstandenen Konidien im stande wären, auf Weizen überzugehen.

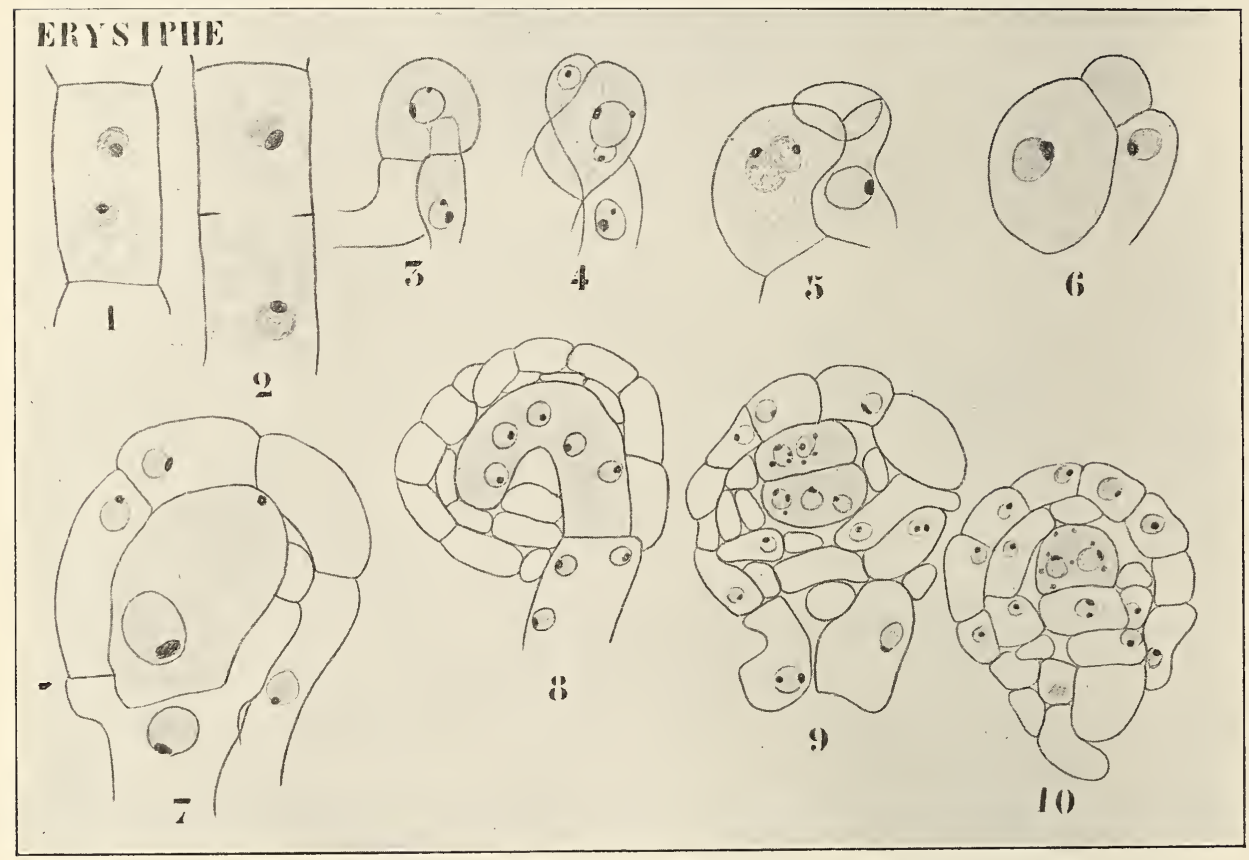

Fig. 282. Erysiphe (nach HARPER). 1 Zweikernige Zelle des Konidienträgers. 2 Bildung einer Querwand in derselben durch Ringbildung, unabhängig von der Kernteilung, vielleicht auf einen Ursprung von polyenergiden Ahnen hinweisend. 3-6 Kopulation. 7 Das Oogon mit dem Zygotenkern, von sterilen Hüllschläuchen berindet. 8 Das Oogon zu einem vielkernigen Schlauch ausgewachsen. 9, 10 Querwände sind im Schlauch gebildet worden.

Die Existenz solcher Ueberbrückungsarten konnte Salmon bei Bromus nachweisen. Die auf Bromus hordaceus, interruptus oder commutatus entstandenen Konidien vermögen nicht direkt Bromus sterilis zu infizieren, wohl aber können sie Bromus tectorum infizieren, und nun ist das Oidium, welches in der Natur auf $B$. tectorum sich findet, im stande, $B$. sterilis zu infizieren, so daß $B$. tectorum vermutlich eine Brücke ist, welche von B. commutatus, hordaceus und interruptus zu $B$. sterilis führt. Wir werden später bei den Uredineen Gelegenheit haben, auf dergleichen Fragen zurückzukommen. 
Wir haben nun früher die Befruchtung bei einem Genus, welches nur einen Ascus pro Perithecium bildet, verfolgt; sehen wir jetzt noch einmal, wie diese bei denjenigen Genera vor sich geht, welche mehrere Asci in den Perithecien bilden. Wir wählen dazu die von Harper (1896 und 1905) untersuchten Genera Erysiphe und Phyllactinia.

Bei Erysiphe entstehen das Oogon und das Antheridium so ziemlich in derselben Weise wie bei Sphaerotheca, nur ist die Untersuchung schwieriger, da das Oogon etwas spiralig gewunden ist. Auch hier enthalten Antheridium und Oogon je einen Kern, welche zusammen den Zygotenkern bilden.

Nach der Befruchtung teilt sich der Zygotenkern, und das Oogon wächst zu einem kurzen, gebogenen Schlauch (Fig. 282, 8) aus, ohne

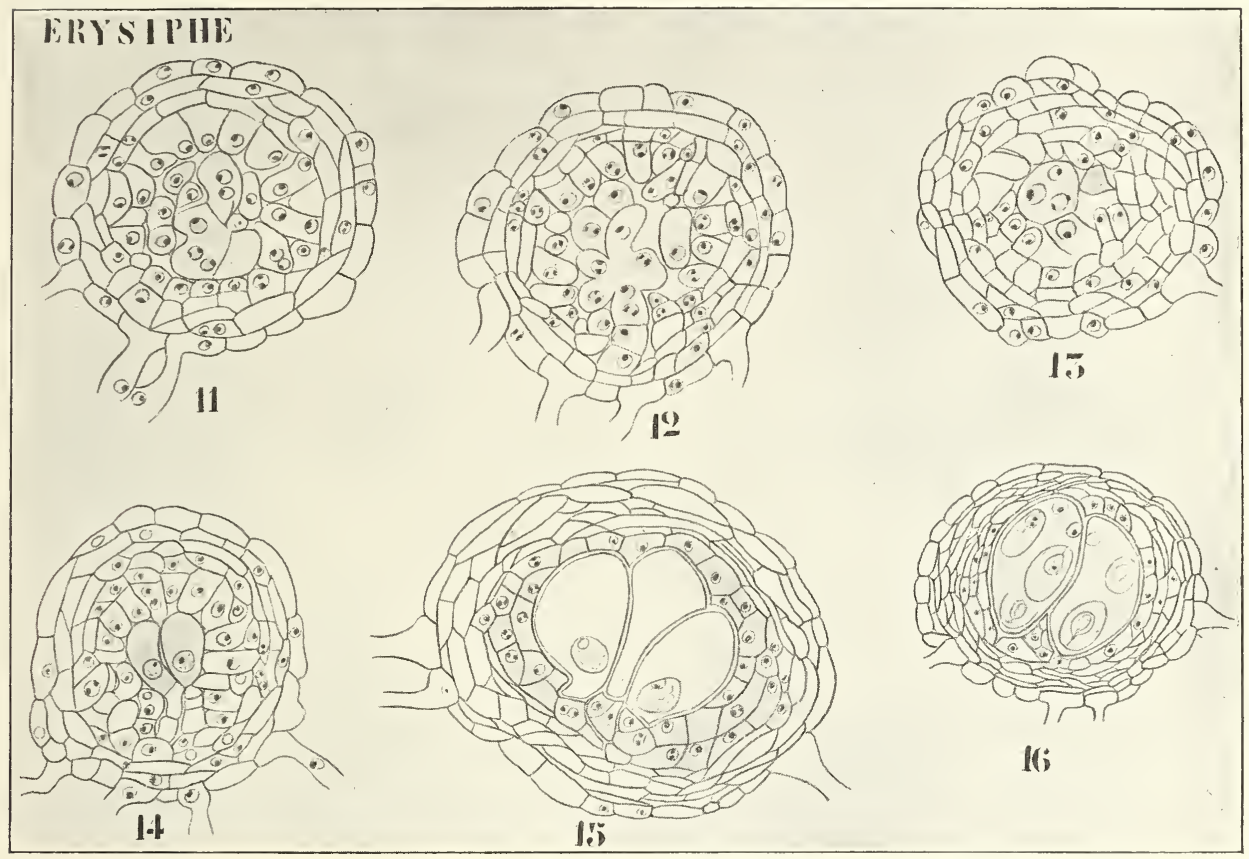

Fig. 283. Erysiphe (nach HARPER). 11-13 Bildung der ascogenen Hyphen. 14-16 Bildung der Asci und der Ascosporen.

daß Querwände auftreten. So entsteht ein vielkerniger, $\check{-}-8$ Kerne enthaltender Oogonschlauch. Dann entstehen Querwände, wodurch einige einkernige Zellen abgeschnitten werden, und einige mit 2 oder mehr Kernen. Ob nur diese oder ob auch die einkernigen Zellen im stande sind, ascogene Hyphen zu bilden, steht noch nicht fest, am wahrscheinlichsten ist es wohl, daß hier eine $2 \mathrm{x}$-Generation gebildet wird, die in allen Zellen fertil ist.

Aus diesen $2 x$-Zellen (resp. aus der $2 x$-Zelle) sprossen nun die ascogenen Hyphen hervor, welche sehr schnell wachsen und alsbald einen Knäuel bilden (Fig. 283, 11--13). Sie teilen sich später in 2-3 Zellen verschiedener Größe, von welchen sich aber im ganzen nur 4-8 Asci bilden. Auch hier sind die Zellen, welche sich zu Asci entwickeln. stets 
zweikernig. Trotzdem die Cytologie noch nicht vollständig bekannt ist, dürfen wir wohl annehmen, daß wir hier einen Fall haben, der dem von Sphaerotheca analog ist, aber dadurch auf einer höheren Entwickelungsstufe steht, daß eine vielkernige $2 \mathrm{x}$-Generation gebildet wird. Das führt zur wesentlichen Verbesserung, daß nicht wie bei Sphaerotheca pro Zygote nur ein Ascus, sondern 4-8 gebildet werden; der Geschlechtsakt wird also besser ausgenutzt. Bei Phyllactinia werden Oogon und Antheridium wie bei Erysiphe angelegt (Fig. 284, 1-3).

Auch die Befruchtung findet in der üblichen Weise statt (Fig. 284, $3,4)$. Nach der Befruchtung wird der Konjugationsporus verschlossen und das Antheridium degeneriert, ein Vorgang, der sich zuerst durch eine Schwellung seiner Membran (Fig. 284, 4) kenntlich macht und der

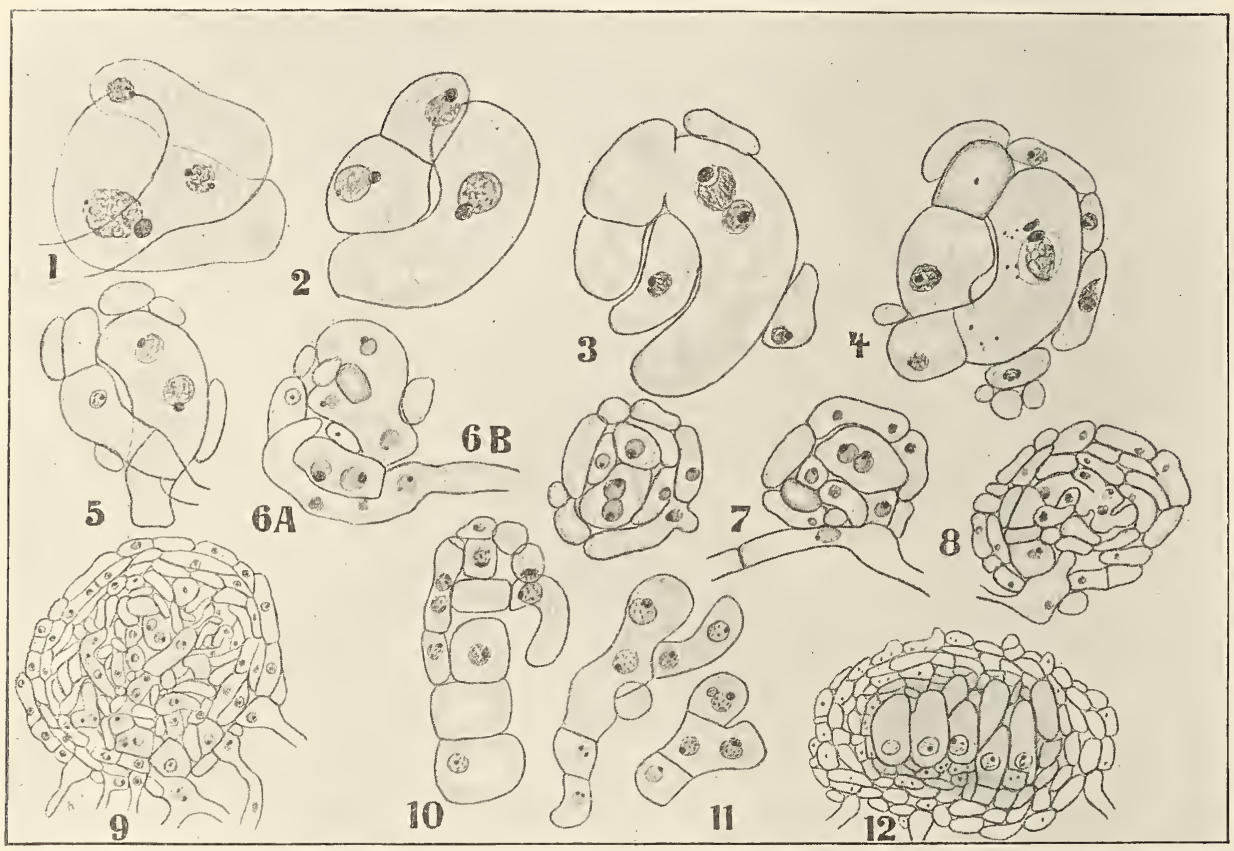

Fig. 284. Phyllactinia (nach HARPER). 1 Männliche und weibliche Zweige, die Gametangien noch nicht durch Querwände abgetrennt, aber der Nucleus im Antheridiumzweig bereits geteilt. 2 Das Antheridium ist von der Stielzelle abgetrennt und liegt der Oogonspitze angedrückt. 3 Offene Kommunikation zwischen Antheridium und Oogon hergestellt, Spermnucleus in das Oogon eingetreten. 4 Der Zygotennucleus gebildet, die Antheridiumwand fängt an aufzuschwellen. 5 Der Zygotennucleus geteilt. $6 \mathrm{~A}, 6 \mathrm{~B}$ Junge Frucht, in zwei Schnitte zerlegt. $6 \mathrm{~B}$ zeigt eine einkernige Zelle, vom vielkernigen, ausgewachsenen Oogon abgeschnitten. 7 Dreizelliges Ascogon, die subterminale Zelle binukleär. 8 Fünfzelliges Ascogon, die subterminale Zelle ascogene Hyphen bildend. 9 Aelteres Stadium, einen Teil des Ascogons und Schnitte durch die vielkernigen ascogenen Hyphen zeigend. 10 Ascogonzellen und vielkernige ascogene Hyphen. 11 Anfang der Ascusbildung. 12 Die Asci gebildet.

bei Anwendung der Flemmingschen Dreifärbungsmethode besonders auffällt, da die verschleimende Membran eine auffallende Affinität für das dabei verwendete Orange hat. Es wird jetzt um das Oogon herum die übliche sterile Hülle gebildet, auch die Stielzelle des Antheridiums bildet solche Umhüllungshyphen. Das auswachsende Oogon, welches 
wir ron jetzt an Ascogon nennen wollen, erhält alsbald eine unregelmäßig gerundete Gestalt, der Kern teilt sich, so daß wir zunächst ein zweikerniges Ascogon erhalten (Fig. 284, 5). Nachdem sich die Kerne weiter geteilt haben, werden Querwände gebildet, wodurch eine 3-5-zellige Zellreihe entsteht (Fig. 284, 6-7), von diesen Zellen enthält die subterminale immer mehr als einen Kern. Dann werden die ascogenen Hyphen gebildet, von welchen es auch hier nicht entschieden werden konnte, ob alle aus der subterminalen Zelle entstehen oder auch aus den anderen Zellen. Die Bildung dieser und der ascogenen Hyphen ist normal, auch hier enthalten die Zellen, welche zum Ascus werden, 2 Kerne. Das Ganze geschieht genau so wie bei Erysiphe, eine Hakenbildung scheint hier bei der Anlage der Asci jedoch nicht stattzufinden.

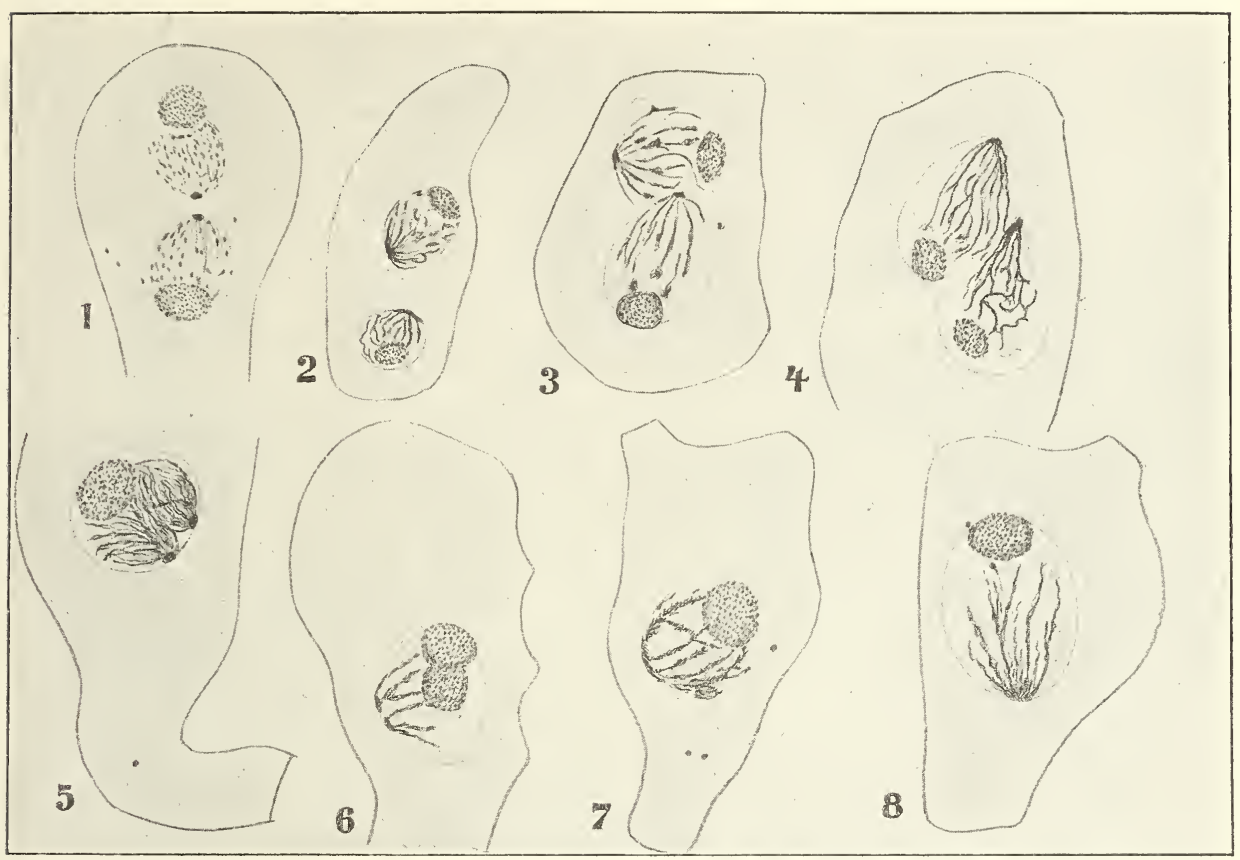

Fig. 285. Die Fusion der Nuclei im Ascus von Phyllactinia (nach HARPER). 1 Junger Ascus mit 2 Kernen, die Centrosomen einander zugewendet, die Nukleolen voneinander abgewendet. 2 Etwas älteres Stadium, die Chromosomen deutlicher. 3 Gerade bevor die Fusion stattfindet. 4 Anfang der Verschmelzung, die Chromatinsysteme zu langen Kegeln ausgezogen. 5 Verschmolzen, Centrosome und Chromatinsysteme aber uoch getrennt, Nukleolen bereits verschmolzen. 6 Stadium gerade vor Vereinigung der Centrosomen, in diesem Falle waren die Nucleoli noch nicht verschmolzen. 7 Die Centrosomen liegen aneinandergepreßt, die Chromatinsysteme verschmelzen. 8 Verschmelzung beendet, sowohl die Chromatinsysteme wie die Centrosomen vereinigt.

Aus Analogie mit den Discomyceten darf man aber wohl annehmen, daß auch hier die beiden Nuclei des jungen Ascus keine Schwesterkerne sind.

Sehen wir jetzt einmal, was weiter im jungen Ascus geschieht. Zunächst fällt bei den Kernen von Phyllactinia die polare Struktur auf, welche dadurch verursacht wird, daß das Chromatin an deren Centrosom (von HARPER "central body" genannt) befestigt ist (vergl. die Abbildungen auf Fig. 285). Ueberall bei Phyliactinia, sowohl im regetativen 
Mycel als in den Ascis, finden wir diese eigentümliche Relation zwischen dem Centrosom und dem Chromatin, und da diese sowohl während der Fusion im Ascus, wie während der Karyokinese sowie im Ruhestadium der Kerne bestehen bleibt, ist damit erwiesen, daß das Centrosom bei Phyllactinia ein permanentes Organ ist.

Es zeigt sich nun, wie Fig. 285 beweist, daß bei der Kernfusion im Ascus zunächst die Chromatinsysteme sowie die Centrosomen unabhängig bleiben, schließlich aber doch sich vereinigen. Der Fusionsnucleus ist sehr groß, nämlich $10 \mu$ im Durchmesser gegenüber den $2 \mu$ der Kerne in den vegetativen Hyphen, was durch die größeren Dimensionen des Ascus aber proportionell etwa auf dasselbe herauskommt, so daß wir hier ein Beispiel haben von der zumal von R. Hertwig, Gerassimoff und Boveri betonten Regel, daß der Nucleus in einer

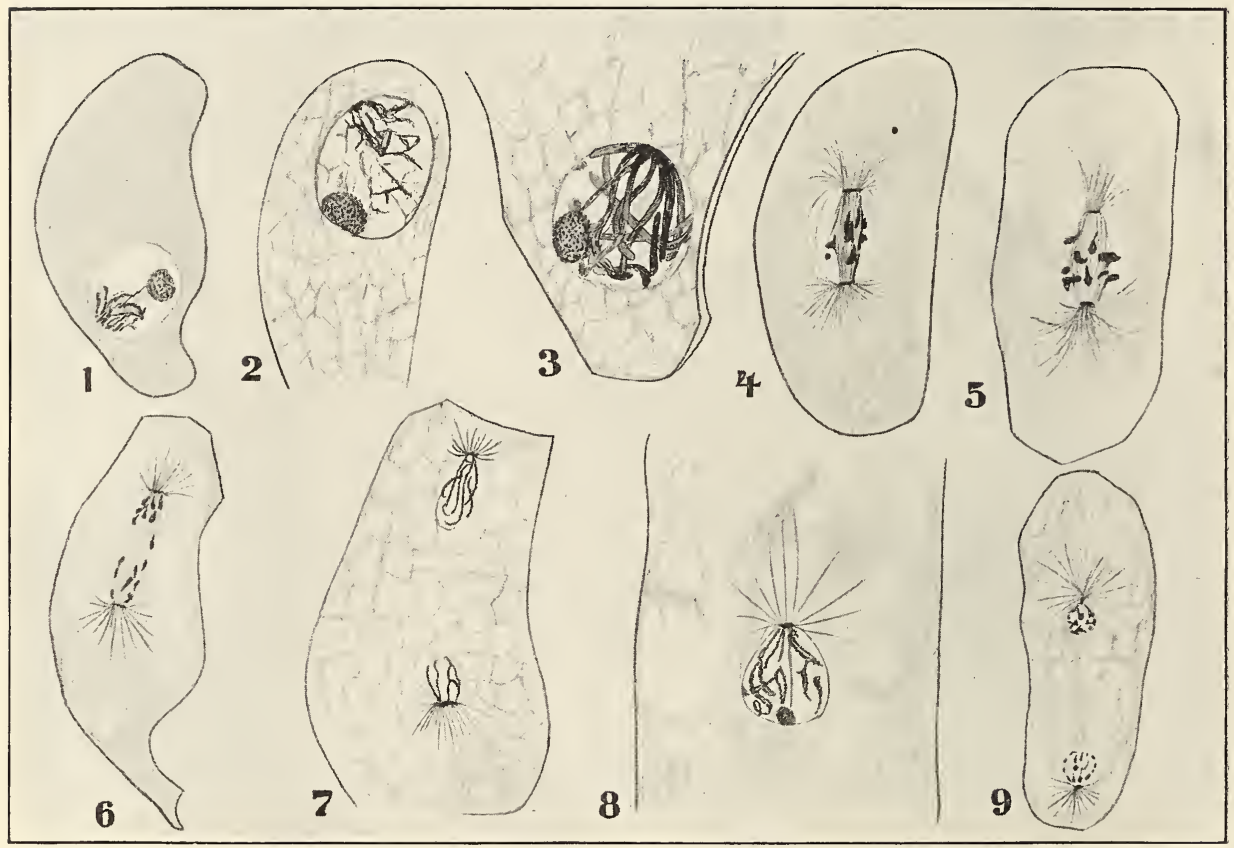

Fig. 286. Phyllactinia (nach HARPER). Synapsisstadium und die erste Teilung des Ascuskernes. 1 Frühes Synapsisstadium. 2 Synapsis, die Enden der Chromatinfasern aus der kontrahierten Masse hervorragend. 3 Spiremstadium. 4 Der Ascusnucleus in Teilung, A equatorialstadium 8 Chromosomen. 5 Junges Metaphasestadium. 6 Telephase. 7 Rekonstruierung der Tochternuclei. 8 Späteres Stadium. 9 Die Tochternuclei gebildet.

bestimmten Größenrelation zu der Quantität des von ihm beeinflußten Cytoplasmas steht.

Die Fusion findet statt gerade bevor die Pinselzellen an der Oberseite der Perithecien hervorsprossen. HARPER zählt, daß 8 oder 9 Chromatinfäden in jedem Nucleus mit dem Centrosom verbunden sind, es läßt sich dies am besten auf einem Stadium wie Fig. 286, 4 feststellen, ganz sicher ist es aber nicht, der Fusionsnucleus würde demnach 16 Chromosomen enthalten.

Bald nachdem der Fusionsnucleus gebildet ist, tritt er in das 
Synapsisstadium ein, d. h. in das Stadium, in welchem vermutlich die Verbindung der Chromosomen zu bivalenten Chromosomen stattfindet, was auch hier durch die außergewöhnliche Dicke des nächstfolgenden Spirems wahrscheinlich ist. Bei der nachfolgenden Kernteilung zeigt es sich, daß jeder Tochterkern 8 Chromosomen erhält, Fig. 286 illustriert dies wohl zur Genüge. Wahrscheinlich werden hier einfach die 16 Chromosomen, welche der Fusionsnucleus erhielt, über die Tochterkerne verteilt, wir haben es hier also mit einer Trennungsteilung zu tun; Fig. 286, 6 zeigt sehr klar, daß 16 Chromosomen auf der Spindel vorhanden sind, von denen 8 nach jedem Tochternucleus gehen.

Die so gebildeten Tochterkerne erreichen nie die Größe des Mutterkernes, aus welchem sie entstanden sind, sie haben nur die halbe Größe desselben und teilen sich meistens sofort wieder.

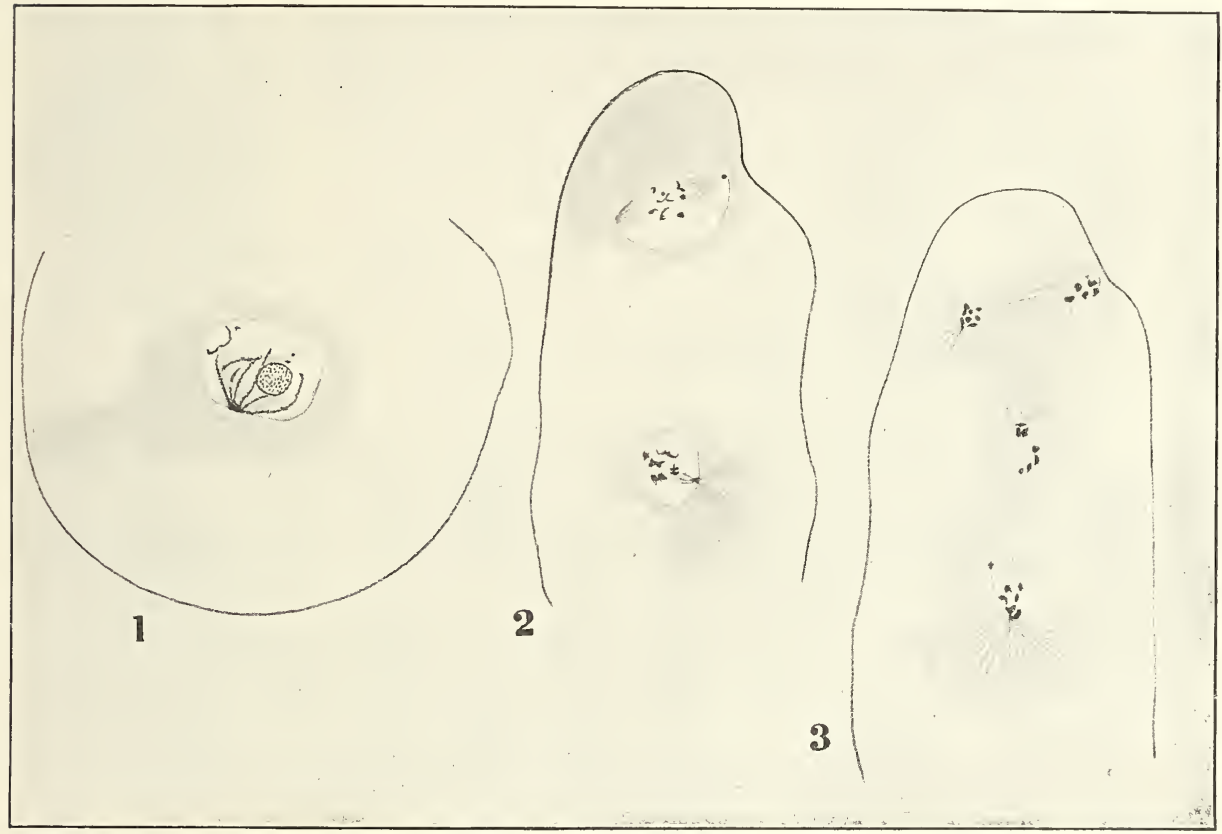

Fig. 287. Phyllactinia (nach HARPER). Die zweite Teilung im Ascus. 1 Der Nucleus im Spirem (Querschnitt des Ascus). 2 Zwei Nuclei im Aequatorialplattenstadium, 8 Chromosomen. 3 Telephasestadium, 8 Chromosomen an jeder Seite der Spindel.

Diese Teilung ist offenbar eine Aequationsteilung, da jeder Tochterkern wieder 8 Chromosomen erhält.

Die Sporen werden dann in normaler Weise, wie schon früher beschrieben, durch Archeplasmastrahlen herausgeschnitten, nur daß hier statt 8 Sporen, wie bei Ascomyceten üblich, durch frühzeitige Degeneration der überzähligen Kerne nur 2 gebildet werden.

Aus Harpers Untersuchungen folgt nun zunächst, daß der ununterbrochene Zusammenhang der Chromosomen mit dem Centrosom eines jeden Nucleus eine neue Stütze für die Permanenz oder Individualität dieser Gebilde bringt. 
Wie wir sehen, lassen sich HARPers Befunde ganz gut mit meiner Vermutung vereinigen, daß zwischen der Bildung des Zygotennucleus und der des Ascusnucleus noch eine Trennungsteilung liegt, Harper meint dagegen, daß die Chromosomen der Kerne, welche sich im Ascus zum Fusionsnucleus vereinen, schon bivalent sind, daß also der Ascusnucleus ein $4 \mathrm{x}$-Nucleus ist, und erblickt in der Bildung dieses $4 \mathrm{x}$-Nucleus ein Mittel, um diesen genügend groß zu machen, um die enorme Plasmamasse des Ascus zu regieren; durch 2 Teilungen kehrt dann seiner Meinung nach der x-Zustand zurück. Für die nähere Auseinandersetzung dieser Anschauung muß ich auf HARPERs Arbeit verweisen, nähere Untersuchungen, in welchen die Schicksale der Nuclei ununterbrochen durch den ganzen Entwickelungsgang eines Ascomyceten in Bezug auf

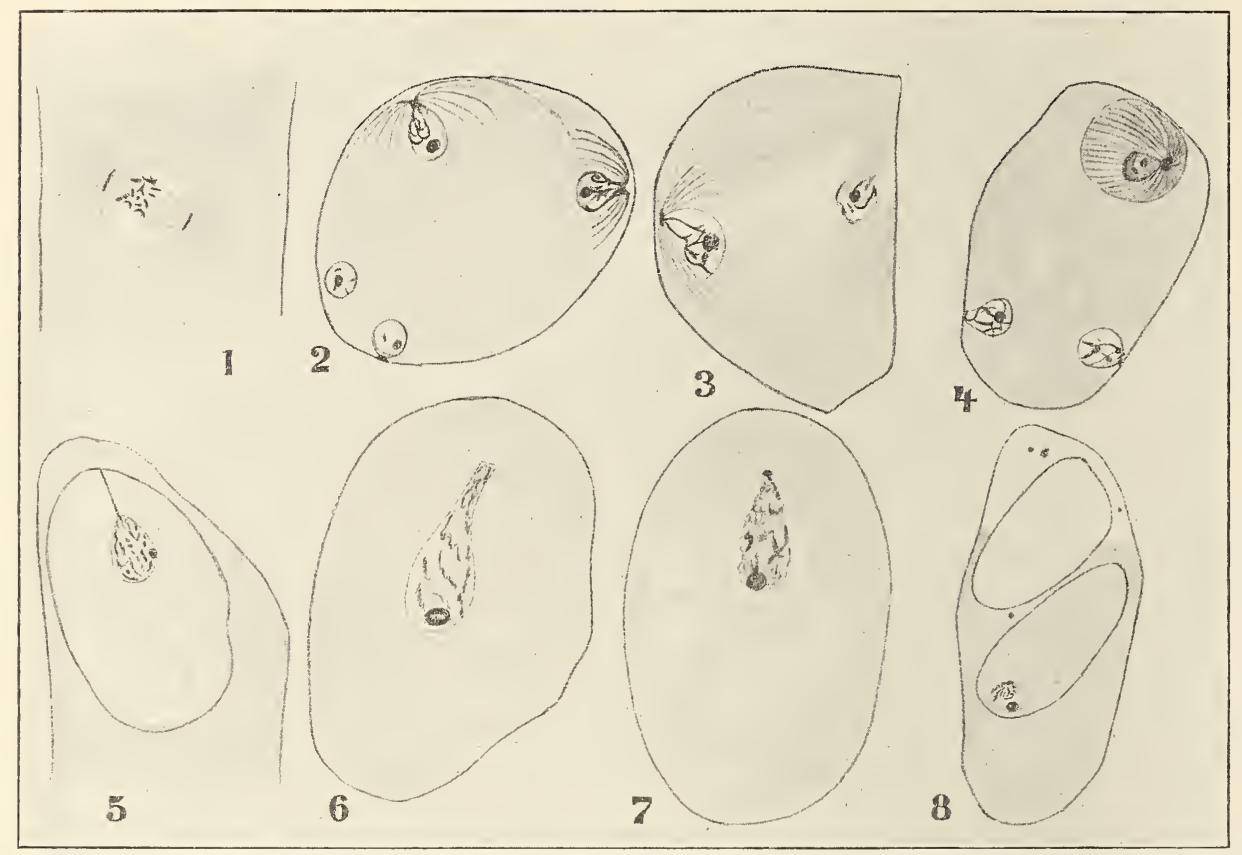

Fig. 288. Phyllactinia (nach HARPER). Die dritte Teilung und die Sporenbildung. 1 Die dritte Teilung im Aequatorialplattenstadium, 8 Chromosomen nach jeder Seite. 2 E ry siphe cichoracearum, die Archeplasmastrahlen biegen sich um, behufs Ausschneidung des Sporenplasmas. 3 Weiteres Stadium. 4 E. com munis, die Archeplasmastrahlen schief von vorne gesehen. 5 E. cichoracearum, die Plasmamembran vollständig, der Schnabel des Nucleus diesem noch angeheftet, Archeplasmastrahlen völlig verschwunden. 6 Der Kernschnabel wird eingezogen.. 7 Späteres Stadium in diesem Vorgang. 8 Ascus mit zwei Sporen, der Nucleus im Ruhestadium.

ihre Chromosomenzahl verfolgt werden, werden die Entscheidung bringen müssen.

Es bleibt nun die schon einmal berührte Frage zu erörtern übrig, ob die Erysipheen eigentliche monoenergide oder polyenergide Organismen sind. Ich möchte meinen, daß sie am Ende einer polyenergiden Entwickelungsreihe stehen, etwa in der Weise, wie gewisse Cladophoren, daß sie also polyenergide sind, in welchen so viele Querwände entstanden, daß die Zellen einkernig wurden. $\mathrm{Zu}$ dieser Auffassung führt mich 
Harpers Mitteilung, daß hier die Querwände ohne direkte Relation zur Kernteilung entstehen, wie z. B. sehr schön in den Konidienträgern von Sphaerotheca zu sehen ist, auch der Umstand, daß bei Erysiphe das Oogon zunächst zu einem schlauchförmigen vielkernigen Ascogon auswächst, dürfte als ein Fingerzeig in dieser Richtung aufgefaßt werden können.

Treten wir jetzt der Frage näher, welche Ascomyceten wir an Erysipheen anschließen können, so meine ich, daß dafür in erster Linie die Plectascineae $^{1}$ ) in Betracht kommen. Gehen wir also zu deren Besprechung ïber.

1) Die Perisporiaceen (Fumago etc.) mit ihren Pykniden und die Microthyriaceae sind in ihrer Entwickelung noch viel zu wenig bekannt, um hier Berücksichtigung zu finden. 


\section{Zwanzigste Vorlesung.}

\section{Die Plectascineae.}

Von diesen stimmt das tropische Genus Meliola äußerlich am meisten mit den Erysipheen überein. Auch hier haben wir mit einem äußerlich an Blättern vorkommenden Mycel zu tun, welches aber im Gegensatz zu dem der Erysipheen nicht weiß, sondern dunkelbraun gefärbt ist. So wie bei den Erysipheen sind Appendices vorhanden, das Perithecium ist aber kohlig; Konidien sind als Nebenfruktifikation vorhanden. Im Gegensatz zu den Erysipheen sind hier die Ascussporen gekammert. Trotzdem diese Meliolas in Bezug auf ihre Entwickelungsgeschichte noch terra incognita sind, liegt es auf der Hand, zu vermuten, daß sie mit den Erysipheen nahe verwandt sind.

Daß von den übrigen Plectascineen keine so sehr einer Erysipheae gleicht wie Meliola, liegt wohl in erster Linie daran, daß keine derselben in so hohem Grade mit Erysiphe in der Lebensweise übereinstimmt.

An eine phylogenetische Ableitung der verschiedenen Familien der Plectascineen ist bei unserer jetzigen fragmentarischen Kenntnis nicht zu denken, aber wir können doch wohl einige anscheinend natürliche Gruppen hervorheben und einige Verwandtschaft zwischen ihnen nachweisen. Als niedrigste Familie muß zweifellos die der

\section{Gymnoasceae}

betrachtet werden, eine Familie, deren Vertreter noch so primitive Fruchtkörper besitzen, daß diese öfters nicht einmal ganz geschlossen sind. Innerhalb dieser Fruchtkörper finden sich zahllose unregelmäßig angeordnete 8-sporige Asci. Die Ascussporen sind einzellig, neben dieser Fruktifikation gibt es Konidienbildung. Die Familie ist in der letzten Zeit von Miss Dale (1903) näher untersucht worden, ihr verdanken wir das wesentlichste der folgenden Angaben.

Gymnoascus Reesii Baranetzky ist ein mistbewohnender Pilz, der zahlreiche Asci innerhalb einer losen, netzartig durchbrochenen Hülle steriler Hyphen bildet. Er ist in Fig. 294 abgebildet.

Von den Ascussporen eines zufällig auf Mist gefundenen Exemplars ausgehend, erhielt Miss DaLE Reinkulturen. Die Beschreibung der von Miss Dale kultivierten Form stimmt insoweit nicht mit der von Fischer oder mit der Abbildung von BREFELD überein, als die Spitzen der Umhüllungshyphen bei Miss DaLEs Exemplaren nicht scharf, sondern stumpf waren. 
Der Keimschlauch septiert sich bald, das Mycelium verzweigt sich, ind etwa 2 Monate nach der Aussaat sind wieder Ascusfrüchte gebildet worden.

Das vegetative Mycelium entwickelt sich je nach der Kulturweise verschieden. Wenn es an der Oberfläche eines trockenen Mediums wächst, bildet es ein kleines Luftmycel, das weich flocculent und rein weiß ist. Darauf erscheimen dann alsbald die Fruchtkörperchen als zunächst weiße, dann gelbe und schließlich steimrote Körperchen.

Hat dagegen das Kulturmedium eine nasse Oberfläche, oder ist es in die Gelatine eingesunken, so verkleben diese Hyphen zu Bündeln, welche als aufrechte Sprossen heraufwachsen. Die Hyphen am Ende dieser Sprosse trennen sich alsbald und wachsen nun zu einem ebenso weißen und flocculenten Mycel aus, wie es auf trockenen Medien direkt gebildet wird. Das Vermögen, diese Sprosse zu bilden, erlaubt also unserem Pilze, sein Mycel oberhalb der Flüssigkeit zu entwickeln. Konidien wurden nie beobachtet.

Der Bildung der Asci geht eine Befruchtung voran. In allen beobachteten Fällen entstanden die männlichen und weiblichen Geschlechtsorgane auf derselben Hyphe, und zwar an benachbarten Zellen in der Nähe der sie trennenden Wand.

Diese zwei Ausstülpungen wachsen senkrecht auf der Hyphe in die Höhe und winden sich ein- oder zweimal umeinander (Fig. 289, 1, 2). Ihre Spitzen schwellen nun stark an und trennen sich mittels einer Querwand vom Tragzweig ab. Die so gebildeten Gametangien schmiegen sich fest aneinander, die Trennungswände werden gelöst und der Inhalt beider mischt sich. Meistens besteht zwischen den beiden Gametangien kein Größenunterschied, bisweilen aber wohl. In letzterem Falle ist das männliche Gametangium fast gerade und das weibliche windet sich in enger Spirale um selbiges herum (Fig. 289, 5, 6).

Nachdem die Kopulation stattgefunden hat, zeigt das Verhalten der Gametangien, welches von beiden das weibliche, welches das männliche war. Das weibliche bildet nämlich einen Fortsatz (Fig. 289, 7), welcher um das männliche herumwächst.

Dieser Fortsatz wird durch das Auswachsen des Oogons zum Ascogon verursacht. Sind das $\delta$ und das + Gametangium etwa gleich groß, d. h. liegen ibre Spitzen etwa in derselben Ebene, so windet sich das junge Ascogon lose um beide Gametangien herum, ist aber das ơ größer, so daß seine Spitze hoch über der Kopulationsstelle liegt, so windet sich das Ascogon dicht um das ơ Gametangium herum.

Nachdem eine bedeutende Windung gebildet ist, wird das Ascogon septiert und also vielzellig (Fig. 289,8). Weitaus die meisten dieser Zellen, nicht nur eine oder zwei, bilden kurze, sich stark verzweigende ascogene Hyphen, welche an ihren Enden die Asci bilden. Später werden um die Ascibündel herum noch sterile Hyphen, Paraphysen (Fig. 289, 12) gebildet, während schließlich das Ganze von der schon angelegten (Fig. 289, 10, 11) oben erwähnten sterilen Hülle eingeschlossen wird.

Die Nuclei verhalten sich, soweit bekannt, folgendermaßen:

Die jungen Gametangien sind einkernig (Fig. 289, 13), im Moment der Kopulation aber vielkernig (Fig. 289, 15). Diese Kerne müssen also durch Teilung des Gametangiumkernes entstanden sein, wir haben also, falls dies richtig ist, im Gymnoascus mit einem monoenergiden Pilz zu tun, der Gametangien mit vielen potentiellen Gameten bildet, welche Gametangien kopulieren. 
Der Inhalt der beiden Gametangien verschmilzt und „doubtless a nuclear fusion now takes place, but this has not been determined with certainty".

Diese vermutlichen Zygotennuclei gelangen später in die ascogenen Hyphen, denn die kopulierenden Gametangien entleeren sich völlig; Miss Dale meint, daß diese Zygotennuclei sich teilen, da die Zahl der pro Kopulation gebildeten Asci so groß ist. Die Entwickelung der Asci ist aber noch recht unvollständig bekannt, die Frage, ob dabei eine Kernfusion stattfindet, noch kaum diskutierbar.

Bei Gymnoascus setosus, welcher auf einem alten Bienennest gefunden wurde, lieferten die ausgesäten Ascussporen nur konidienbildende Mycelien, wie die in Fig. 290, 1 abgebildeten. Ascusfrüchte konnten nicht erzielt werden.

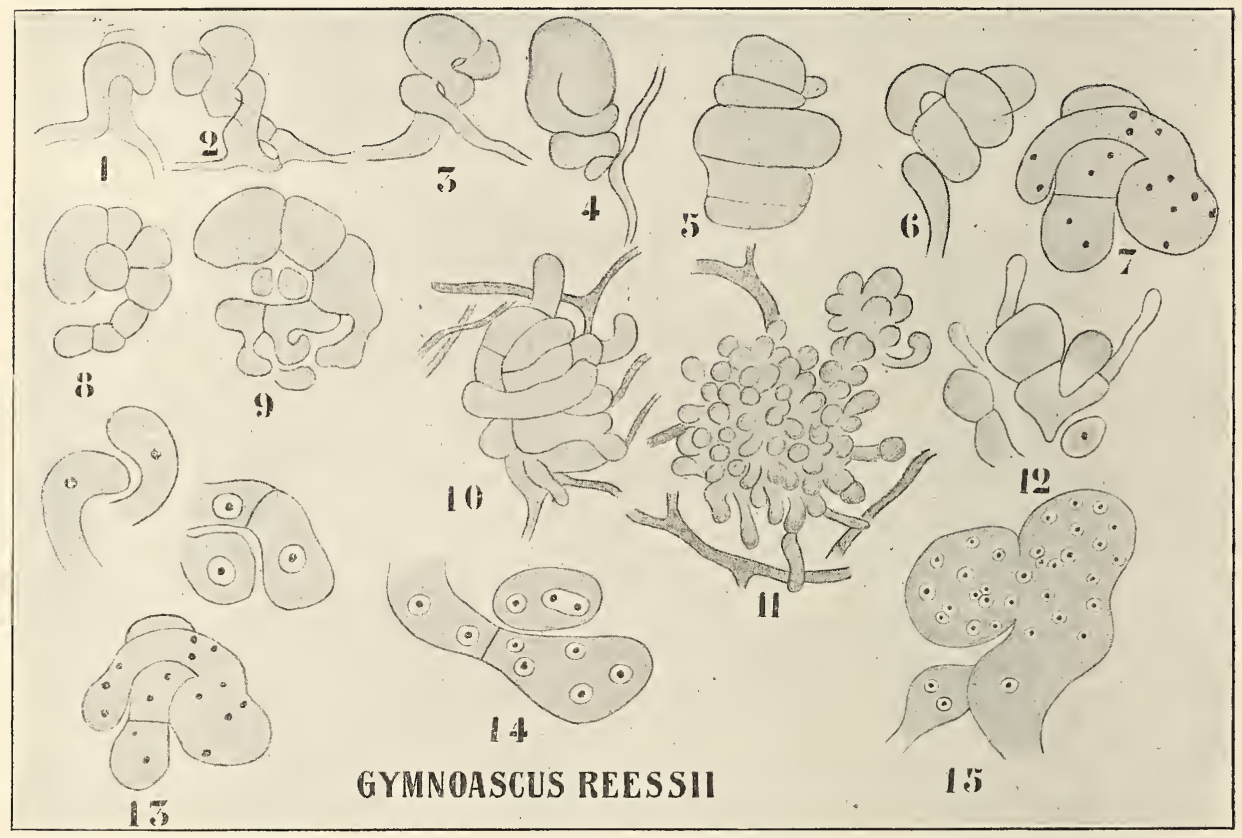

Fig. 289. Gymnoascus Reesii (nach Miss DALE). 1-6 Bildung und Kopulation der Gametangien. 7 Das weibliche Gametangium hat einen Fortsatz gebildet, der sich um das männliche herumwindet. 8 Septierung des Fortsatzes. 9 Hervorsprossen der ascogenen Hyphen aus demselben. 10 Die ascogenen Hyphen von außen betrachtet. 11 Junge Asci. 12 Stärker vergrößert, die Paraphysen zeigend. 13 Oben links : die einkernigen Geschlechtszweige, rechts: die einkernigen Gametangien; unten: ein Stadium wie 7. 14 Mehrkernige Gametangien. 15 Kopulation mehrkerniger Gametangien.

Bei Gymnoascus candidus, auf totem Grase gefunden, lieferten die Aussaaten wieder schöne Ascusfrüchte. Der ganze Pilz, inkl. Sporen, ist farblos; wenige Wochen nach der Aussaat erscheinen wieder Ascusfrüchte, die ersten Geschlechtsorgane wurden 3 Wochen nach der Aussaat bemerkt.

Auch hier umschlängeln sich die Geschlechtszweige, sie werden meistens an verschiedenen Hyphen gebildet.

Der männliche Geschlechtszweig ist keulenförmig angeschwollen, 
der fadenförmige weibliche spiralig um denselben herumgewunden (Fig. 290, 2). Der đo Geschlechtszweig wird dementsprechend zuerst gebildet, der $q$ später. Von beiden wird die Spitze mittels einer Querwand abgeschnitten und so zum Gametangium, welche Gametangien miteinander kopulieren. Wo die Querwand im Oogon liegt, wird von Miss DaLE nicht gesagt, vermutlich aber unten, denn die ganze Spirale wurde später septiert und die meisten der so gebildeten Zellen bilden ascogene Hyphen. Ganz klar ist die Geschichte aber noch nicht, im jungen ơ Gametangium ist nur ein Kern vorhanden (Fig. 290, 3), würde nun dieses lange Oogon auch nur einen Kern enthalten?

Sowohl hier wie bei $G$. Reesii vermisse ich eine Angabe der Kernzahl in den vegetativen Hyphen. Auch bei G. candidus ist die Ent-

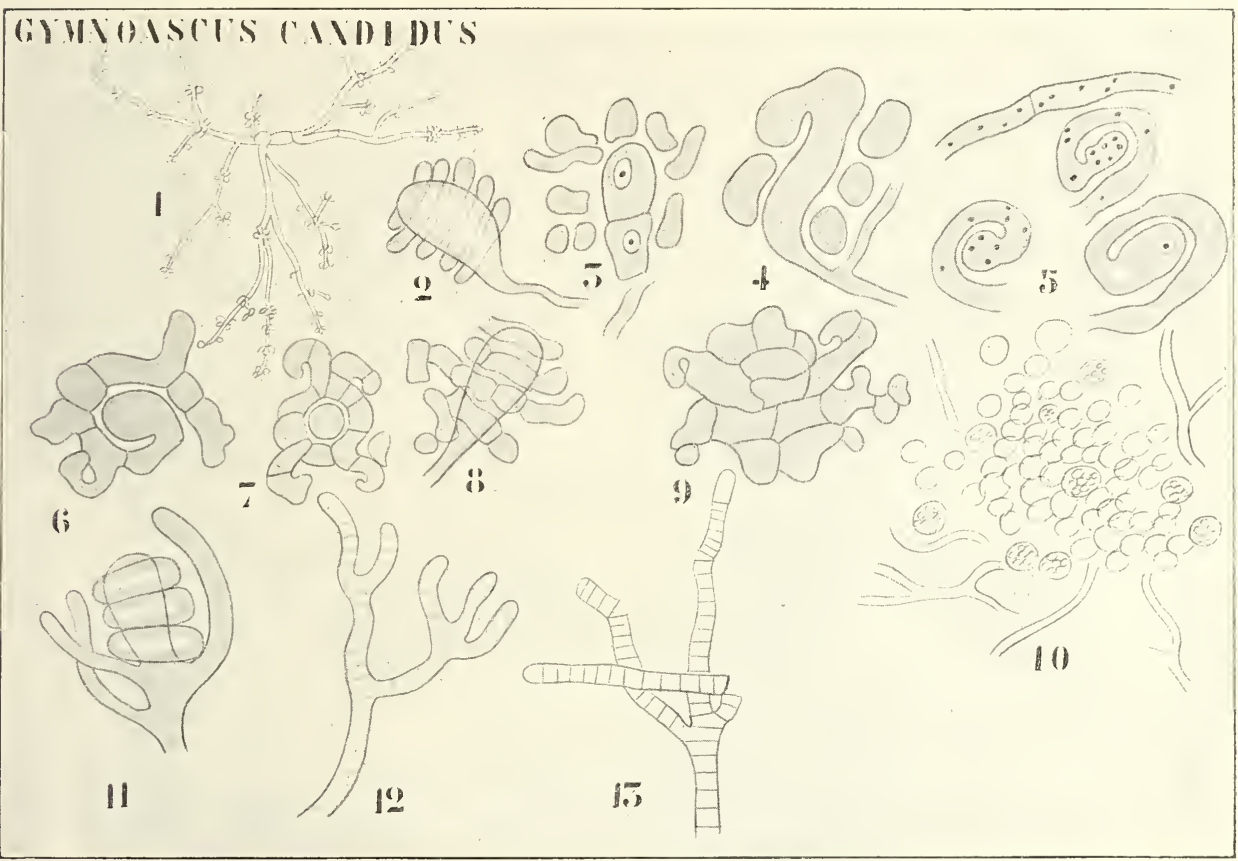

Fig. 290. Gymnoascus (nach Miss DALE). I. G. setosus. 1 Konidienproduzierendes Mycel. - II. G. candidus. 2 Antheridiumzweig vom Oogonzweig umwachsen. 3 Längsschnitt, das einkernige Antheridium zeigend. 4 Auswachsen des Ascogons. 5 Idem. 6 Das Ascogon in Zellen zerlegt. 7-9 Bildung der ascogenen Hyphen. 10 Reife Asci. 11 Stadium wie 2. 12, 13 Oidienbildung.

wickelung der Asci noch sehr ungenügend untersucht. Miss DALE scheint zu meinen, daß hier keine Kernfusion im jungen Ascus stattfindet. Außer Asci bildet unser Pilz noch Oidia. Summa summarum ist also unsere Kenntnis der Gymnoasci noch recht mangelhaft.

Direkt an Gymnoascus, und zwar an G. candidus, schließt offenbar Ctenomyces serratus EIDAM an, soweit dies sich nämlich nach den noch unvollständigeren Angaben über diesen Pilz beurteilen läßt.

Ctenomyces serratus wurde von EIDAM in Schlesien auf faulenden Vogelfedern angetroffen. Die Asci werden hier offenbar in derselben Weise wie bei $G$. candidus gebildet, nur entstehen hier das ơ und das $q$ 
Geschlechtsorgan an benachbarten Zellen der gleichen Hyphe (Fig. 291, 5). Auch dieser Pilz bildet Konidien (Fig. 291, 4). Als Ruhestadien finden sich aus dicken Hyphen bestehende sclerotienartige Körper, welche sich mittels spezieller hakenförmiger Zellen (Fig. 291,3) an den Federn befestigen.

Werfen wir nun einen Rückblick auf die Gymnoasceen, so sehen wir, daß wir aller Wahrscheinlichkeit nach hier mit Formen, die im vollen Besitz der Sexualität sind, zu tun haben. Falls Miß Dales Untersuchungen richtig sind, ist ein Umstand sehr eigentümlich, nämlich das anfängliche Einkernigsein der Gametangien.

Vielleicht ist hier die beste Stelle zur Behandlung eines anderen niedrigeren Ascomyceten, dessen Verwandtschaft noch nicht klar ist: Monascus purpureus WENT.

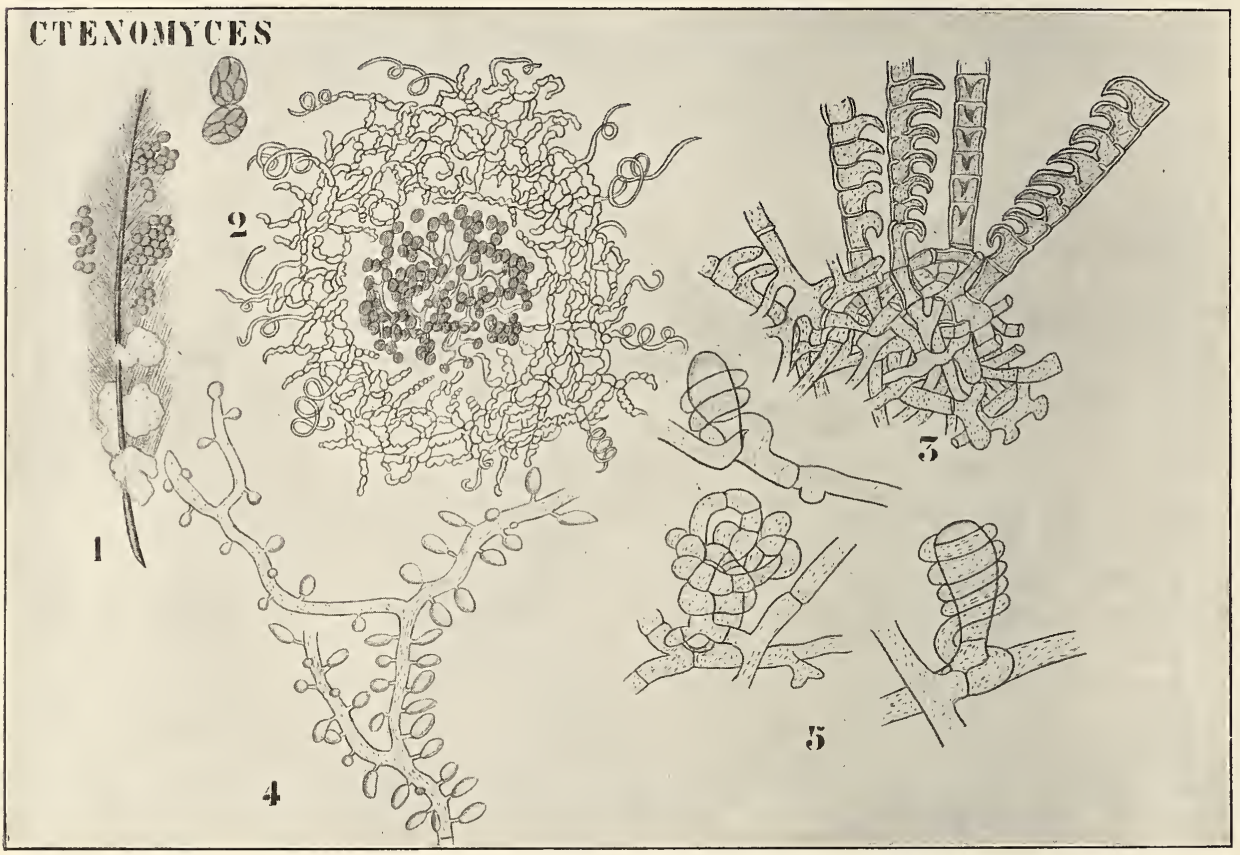

Fig. 291. Ctenomyces serratus (nach FidAM). 1 Feder mit Konidien und Perithecien des Pilzes bedeckt. 2 Perithecium. 3 Haken an den Sklerotien. 4 Konidienbildung. 5 Geschlechtsorgane.

Ueber die Entwickelungsgeschichte dieses Pilzes besteht zwischen den verschiedenen Forschern noch gar keine Uebereinstimmung, ja man kann wohl sagen, daß selten so verschiedene Interpretierungen beobachteter Tatsachen gegeben sind, ein Umstand, der durch die Schwierigkeit des Objektes erklärt wird. Machen wir uns also in möglichster Kürze mit den verschiedenen Meinungen über diesen Unglückspilz bekannt.

Der Streit zwischen den verschiedenen Forschern geht um die Entstehung der Sporen, welche schließlich die große, von einer Hyphenhülle umgebene und von allen Beobachtern wahrgenommene Zelle (Fig. 292, 4) ausfüllen. 
Was ist diese Zelle? Wie entstehen die Sporen? Das sind die Fragen. Man ist nun so ziemlich darüber einig, daß jene Zelle subterminal entstanden ist. Nach WENT (1895) ist sie ein Sporangium, kopuliert also nicht, und wird später von sterilen Hyphen umhüllt. Das bringt ihn dazu, in Uebereinstimmung mit BREFELDs Meinung, daß die Asci abgeleitete Sporangien seien, den Pilz in die Gruppe der Hemiasci zu stellen, und zwar, da der „Hemiascus" umhüllt ist, in die Untergruppe der Carpohemiasci, zusammen mit Thelebolus ${ }^{1}$ ). Schon vor WEnt waren von Van Tieghem (1884) zwei Monascus-Arten aufgestellt und zu den Ascomyceten gebracht worden, während Harz (1890) ohne Kenntnis von Van Tieghems Arbeit einen offenbaren Monascus als Phycomyces heterosporus beschreibt und mit ein paar noch wenig bekannten anderen Genera in einer neuen Ordnung der Lepto-oomyceten unterbringt, wobei er

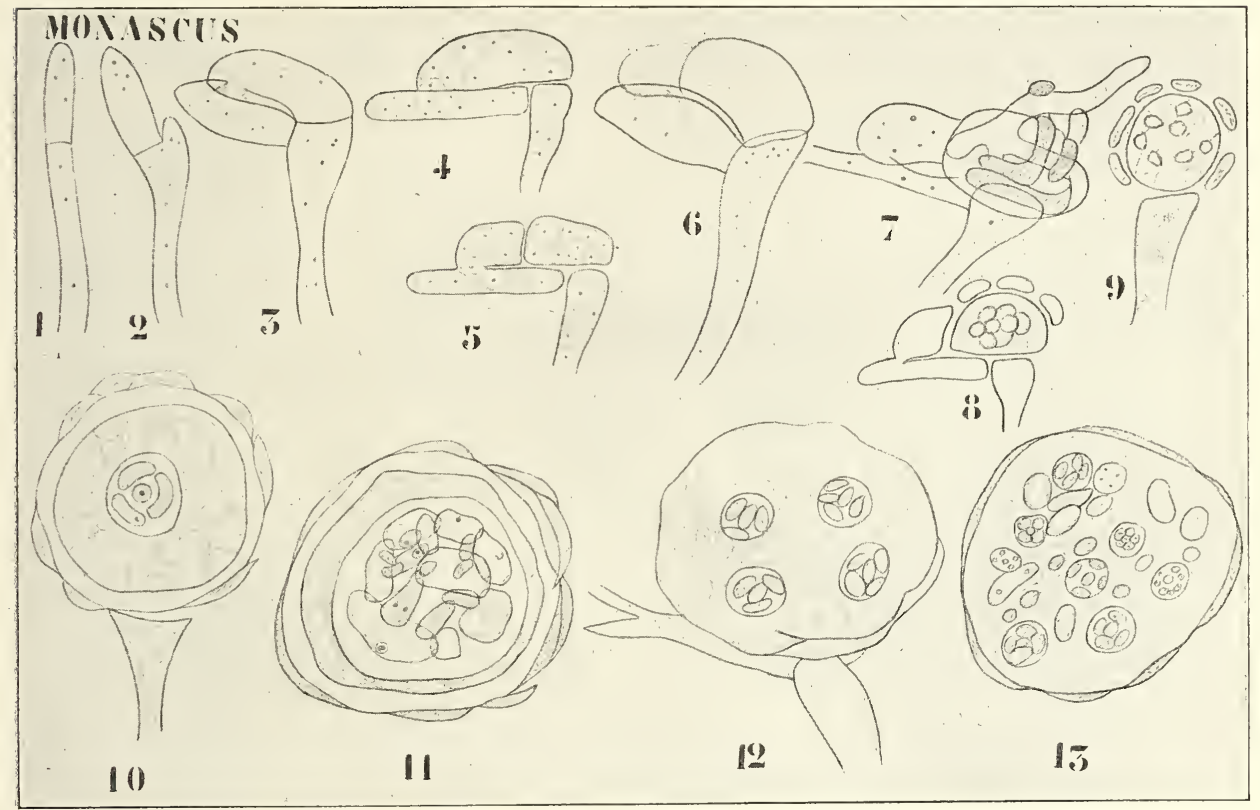

Fig. 292. M on ascus (nach BARKER). 1, 2 Bildung der Gametangien. 3 Die Gametangien kopulieren. 4, 5 Kopulation. 5 Das Oogon hat sich in eine terminale und in eine subterminale Zelle geteilt. 6, 7 Die subterminale Zelle entwickelt sich weiter und wird von sterilen Hyphen umhüllt. 8, 9 Schnitt durch die umhüllte subterminale Zelle. 10 Idem, man sieht oben auf eine kleine Einstülpung der subterminalen Zelle, in welcher sich ascogene Hyphen befinden. 11 Idem, älteres Stadium, die Einstülpung sehr vergrößert. 12, 13 Die Asci. sind gebildet.

die große Zelle als ein sich parthenogenetisch entwickelndes Gametangium betrachtet.

Van Treghem, Went und Harz stimmen also darin überein, daß die sporenenthaltende Zelle ohne Geschlechtsakt entstehe, daß sie entweder ein Sporangium oder ein parthenogenetisch sich entwickelndes Gametangium sei.

Gegen diese Auffassung erklärte sich BARKER (1903). Er weist

1) Wie wir jetzt wissen, ist Thelebolus ein echter Ascomycet. 
nach, daß diese sporenhaltige Zelle ein viel komplizierteres Ding ist, als man bis damals meinte, und daß die Bildung der Sporen von einer Kopulation eingeleitet wird.

Nach seiner Auffassung entsteht diese Zelle, so wie Went schon nachwies, durch Anschwellung einer subterminalen Hyphenzelle (Fig. 292, 5).

Bevor aber diese subterminale Zelle entsteht, hat schon die terminale Zelle mit einem seitlich gebildeten Antheridium kopuliert (Fig. 292, 3). Erst nach dieser Kopulation teilt sich die terminale Zelle in eine vielleicht einer Trichogyne vergleichbare apikale Zelle und in unsere subterminale Zelle (Fig. 292, 5). Die trichogyneähnliche Zelle ${ }^{1}$ ), sowie das Antheridium gehen später zu Grunde, es entwickelt sich nur die subterminale Zelle, welche also als Ascogon zu betrachten ist. Dieses Ascogon enthält nach der Meinung BARKERs eine Anzahl Zygotenkerne ${ }^{2}$ ), wiewohl er die Verschmelzung der Antheridien- und Oogonkerne nicht beobachten konnte; es ist also dem befruchteten Oogon von Pyronema vergleichbar. Es wird alsbald von einer Menge steriler Hyphen eingehüllt.

Inzwischen bildet das Ascogon (befruchtete Oogon) eine oder mehrere Ausstülpungen, die ascogenen Hyphen, welche sich der Außenseite desselben anschmiegen, bis sie eine inzwischen im Ascogon entstandene Einstülpung erreicht haben, in welche sie sich wie in ein Nest hineinlegen (Fig. 292, 10). Diese Einstülpung wird größer und größer, das Oogon also mehr und mehr einem stark eingedrückten Gummiball vergleichbar, dessen Ränder aber aufeinander zuwachsen, so daß die ascogenen Hyphen in eine Höhlung zu liegen kommen, welche nur durch eine kleine Oeffnung mit der Außenwelt kommuniziert. Es scheint also auf einem Schnitt, als lägen die ascogenen Hyphen in der großen Zelle, daß sie in der Tat nur in einer Einstülpung derselben liegen, geht aber daraus hervor, daß die sie umgebende Wand doppelt ist (Fig. 292, 11). Die ascogenen Hyphen verzweigen sich, bilden Asci, drücken das Oogon bis zur Unkenntlichkeit zusammen, die Wände der Asci sowie die der ascogenen Hyphen zerbröckeln und so liegen schließlich innerhalb der sterilen Hülle nur lose Sporen, wodurch das Torhandensein eines Sporangiums vorgetäuscht wird.

Die Bildung der ascogenen Hyphen erinnert also an Pyronema, das Zerbröckeln der ascogenen Hyphen und Asci an die Aspergillaceae. Auf jeden Fall ist nach BARKers Interpretierung Monascus ein echter Ascomycet.

Das wird nun von Ikeno bestritten. Ueber die Befruchtung läßt sich Ikeno nicht aus, ist aber offenbar geneigt, an eine Befruchtung zu glauben. Auf jeden Fall enthält die große Zelle schließlich eine Anzahl von gleich großen Kernen, ob dies Zygotenkerne sind oder nicht, läßt. IKenO dahingestellt.

In diesem "Oogon" fängt nun nach Ikeno die Sporenbildung in folgender Weise an: Es sammelt sich Plasma um einige der Kerne an, so daß Cytoplasmaballen, wie Ikeno sie nennt, entstehen (Fig. 293, II 3), während eine solche Bildung um andere Kerne herum nicht stattfindet. Diese Cytoplasmaballen sollen Sporenmutterzellen sein. In jeder Sporenmutterzelle teilt sich dann nach Ikeno der Kern wiederholt (Fig. 293, II 4, 5), da aber viele Kerne zu Grunde gehen, bildet jede

1) Wird also nach BARKER erst nach der Kopulation vom Oogon gebildet.

2) Monascus ist polyenergid. 
Sporenmutterzelle schließlich doch nur 6 - 8 Sporen. Schließlich desorganisieren die Sporenmutterzellen und das „Oogon" wird mit losen Sporen ausgefüllt (Fig. 293, II 8).

Der Streit zwischen Barker und Ineno geht also um die Interpretierung der dunklen Ballen in Fig. 293, II 3. Nach Ireno sind dies Cytoplasmaballen, welche im Inneren des Oogons liegen, nach BARKER dagegen junge Asci, am Ende ascogener Hyphen gelegen, welche in einer Einstülpung (Invagination) des Oogons liegen. Sie liegen also nur scheinbar im Inneren des Oogons, in Wirklichkeit außerhalb desselben, dieser Schein wird durch die Durchsichtigkeit des Oogons verursacht.

Daß bei so großen Meinungsverschiedenheiten die Autoren zu einander diametral entgegengesetzten Resultaten kommen, ist kein Wunder.

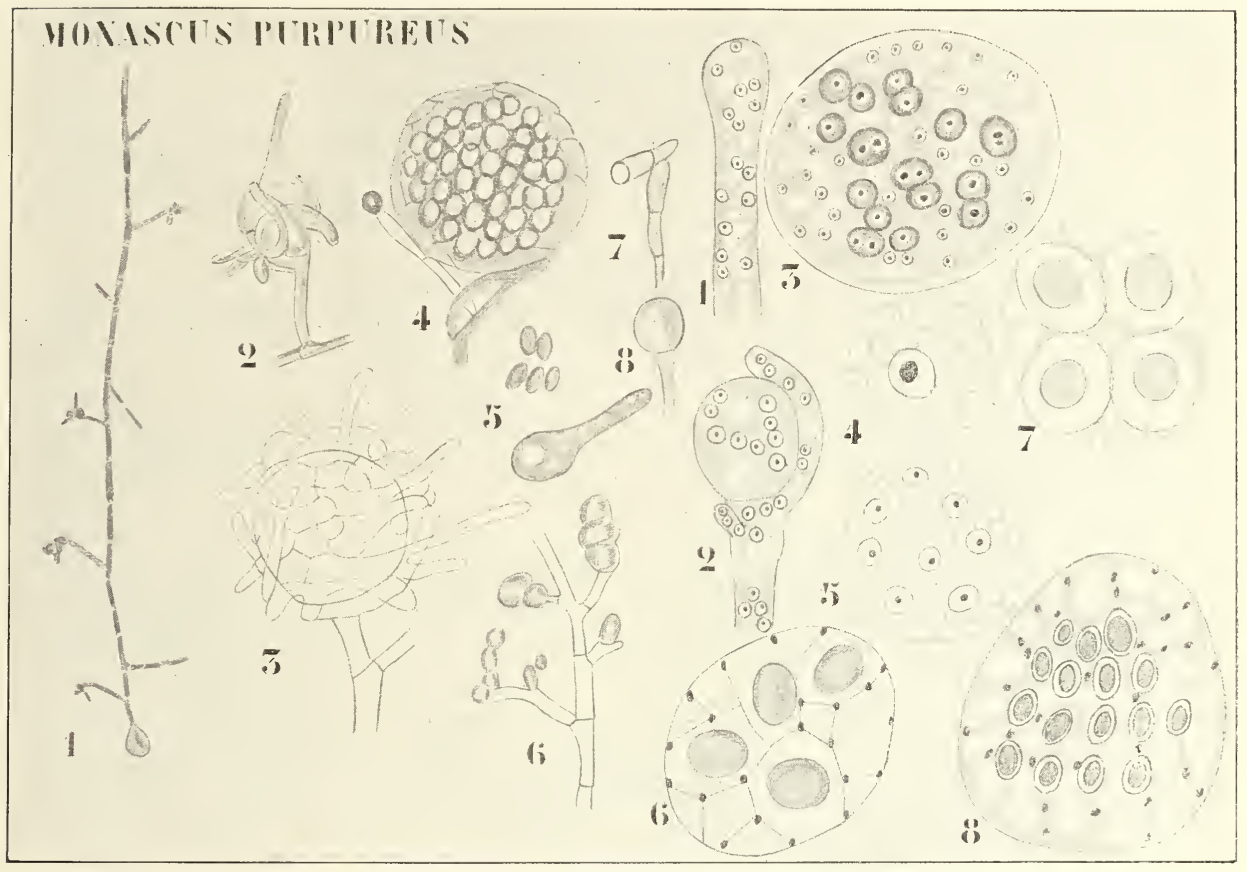

Fig. 293. Mon as cus (wiederholt von S. 448). I. Morphologie (nach WENT). Figurenerklärung siehe S. 448. - II. Cytologie (nach IKwNO). 1 Stück des vielkernigen vegetativen Mycels. 2 Oogon und Antheridium in Kontakt. 3 Bildung von Cytoplasmaballen im Oogon. 4 Einkernige Sporenmutterzelle. 5 Idem mit 8 Kernen (IkENo bildet noch ein älteres Stadium mit 18 Kernchen ab). 6 Wabenbildung in der Sporenmutterzelle. 7 Bildung der Sporen in einer solchen Wabe. 8 Ein fast reifes "Oogon" mit Sporen und degenerierten Kernen.

An diesem Punkte der Geschichte versucht Dangeard die Gemüter zu beruhigen; er erklärt den Monascus, mit welchem BARKer arbeitete, für eine andere Art, wie der von Went und Ikeno untersuchte, und nennt ihn M. Barkeri.

Die Richtigkeit der spezifischen Differenz wird von Kuyper, der beide Arten untersuchte, anerkannt, aber auch bei $M$. Barkieri kann er keine ascogenen Hyphen finden, wohl aber Asci, welche, wie wir sehen werden, offenbar IK ENos Sporenmutterzellen sind.

Folgendes sei seinen Untersuchungen entnommen, wobei wir mit 
M. purpureus anfangen. Eine offene Kommunikation zwischen Oogon und Antheridium hat er nicht nachweisen können. Uebrigens stinmen seine Resultate in Bezug auf die Bildung freier Zellen, sowie die Bildung der Sporen in denselben so ziemlich mit denen von IKeno überein, nur meint er, daß in Ix Enos Sporenmutterzellen oder Cytoplasmaballen eine Kernverschmelzung stattfindet, indem diese erst zweikernig, später einkernig sind.

Bei $M$. Barkeri konnte Kuyper ebensowenig eine offene Kommunikation zwischen Oogon und Antheridium beobachten. Auch hier findet nach ihm freie Zellbildung wie bei $M$. purpureus statt und auch hier verschmelzen die ursprünglich in der Zweizahl in den Protoplasmaballen vorhandenen Kerne zu einem einzigen. Es bilden sich nach Kuyper in jedem Protoplasmaballen 8 Sporen, diese Plasmaballen nennt e1 aber Asci!

Dem gegenüber steht nun wieder BARKERs erneute Untersuchung, in welche er sowohl $M$. Barkeri wie $M$. purpureus hineinzog und nach welcher er bei seiner Meinung beharrt. Auch bei M. purpureus konnte er (Proofsheet of Rep. distrib. at the Meeting of Sect. K. Brit. Ass., Cambridge 1904) ascogene Hyphen in einer Einstülpung des Oogons nachweisen.

Wie soll man nun diese Differenzen erklären? Sie wurden zweifellos durch die Schwierigkeit des Objektes auch in Bezug auf eine gute Fixierung verursacht, und zumal durch die schwere Färbbarkeit der Kerne, welche es öfters unmöglich macht, zu entscheiden, ob ein bestimmtes Partikelchen ein Kern ist oder nicht. Ich bin überzeugt, daß manches "Chromatinkörnchen" von KuyPer die Kritik nicht bestehen kann.

KuyPers Zeichnungen haben den großen Vorteil, daß sie nicht flattiert sind; seine Präparate, welche ich gesehen habe, waren weder besser noch schlechter. Nun schienen mir nach der Lektüre der KuyPerschen Abhandlung die zwischen den Autoren bestehenden Widersprüche leicht miteinander in Einklang zu bringen unter der Annahme, daß die "freien Zellen", die "nackten Asci“ von KUyPER, eine Wand haben und nicht im Inneren des "Oogons", sondern in einer Einstülpung desselben liegen. Dann würden Kuypers Resultate den Barkerschen nicht nur nicht widersprechen, sondern diese sogar ergänzen.

Kuyper hätte dann junge Asci für freie Zellen angesehen und die Verschmelzung der beiden Kerne im Ascus beobachtet; die Plasmabälle der Fig. 293, 33 von Ireno sind denn einfach junge Asci, welche in der Einstülpung des Oogons liegen, die Kerne um diese herum liegen wirklich im „Oogon“; die Durchsichtigkeit des Präparates führte zur Täuschung, daß beide im Inneren des Oogons liegen.

Diese Auffassung schien mir die wahrscheinlichste und sie findet in einem neuen Artikel Olives (1905) wohl in der Hauptsache ihre Bestätigung.

Höchst wahrscheinlich arbeitete auch OLIVE mit demselben Materiale wie KuyPER, beides stammte wenigstens von Java, das eine war von Went, das andere von FaIrohild mitgebracht.

OLIVE sagt nun als Resultat seiner Untersuchung, es sei nicht daran zu zweifeln, daß die in der auch von ihm beobachteten Einstülpung des "Oogons" liegenden Dinge ascogene Hyphen seien, aber er hält das "Oogon" nicht für ein Oogon. 
Seine Auffassung ist diese: Wir erinnern uns, daß das „Oogon" eine subterminale Zelle ist, und daß die terminale Zelle, öfters bevor das „Oogon" gebildet ist, mit dem Antheridium kopuliert.

Diese terminale Zelle, die Trichogyne BARKers, hält nun Orive für das Oogon, die große Zelle, welche man bis jetzt als Oogon (resp. als Sporangium) betrachtete, für eine Ernährungszelle.

Nach ihm biegt sich das, also terminale, Oogon nach der Befruchtung um und schmiegt sich der Ernährungszelle an, welche es mehr und mehr eindrückt, in der IVeise, in welcher man einen Kautschukball, der nicht ganz luftdicht ist, eindrücken kann, und bildet nun in dieser von ihm gemachten Einstülpung die ascogenen Hyphen.

Die große Zelle, die Ernährungszelle, dient also dazu, das befruchtete Oogon zu ernähren, wird also selber ausgesogen und kollabiert infolgedessen.

Diese Auffassung scheint nun in der Tat die wahrscheinlichste, und ich glaube, daß BARker und Olive bewiesen haben, daß Monascus ein echter Ascomycet ist.

Gehen wir jetzt zur Betrachtung der Familie der

\section{Aspergillaceae}

über und wählen wir als erstes Beispiel

\section{Aspergillus herbariorum WiGGERS}

= Eurotium herbariorum LINK = Eurotium aspergillus glaucus DE BARY.

Dieser Pilz, der, wie sein Name andeutet, öfters in Herbaria, aber auch auf vielerlei anderen organischen faulenden Substanzen vorkommt, bildet an der Oberfläche der beschimmelten Teile sein loses, zunächst weißes, dann gelbes oder gelbrotes Mycel.

Die gewöhnlichste Fortpflanzungsweise dieses Pilzes ist die Bildung graugrüner Konidien, welche in Köpfchen zusammenstehen. Der Konidienträger, der aufrecht steht (Fig. 294, II 1), ist nämlich an seiner Spitze kugelig angeschwollen und trägt auf dieser Anschwellung eine Anzahl dichtgedrängt stehender kurzer Hyphenzweige, welche die Konidien abschnüren. Diese sogenannten Sterigmen schnüren fortwährend an ihrer Spitze neue Konidien ab, diese schieben die älteren Konidien, welche reihenförmig zusammenkleben, stets weiter hinauf. Von jeder Konidienreihe ist also die äußere Konidie die älteste, die innere die jüngste.

Diese Konidienform unseres Pilzes trug nun früher den Namen Aspergillus glaucus. Die Perithecien werden auf demselben Mycel wie die Konidien gebildet, sind aber in Vergleich zu diesen selten; sie sind schwefelgelb gefärbt. Die Asci enthalten 8 farblose linsenförmige Sporen.

Ueber die Befruchtungsweise ist in jüngster Zeit nichts Neues bekannt geworden. Wir wissen, daß Aspergillus polyenergid ist, daß ein stark gewundenes Oogon vorhanden ist, daß an diesem ein Antheridium hinaufklettert, welches mit der Spitze desselben kopuliert, und daß, nachdem das Oogon in eine Anzahl von Zellen zerlegt ist, um das Ganze eine Hülle steriler Hyphen gebildet wird. Dann werden die Windungen des Oogons gelockert und jede Zelle desselben bildet ascogene Hyphen. welche die sterile Hülle mit Ausnahme der äußeren Schicht verdrängen und verzehren und schließlich das ganze Perithecium ausfüllen. Ja am Ende zerbröckeln sogar die ascogenen Hyphen und die Wände des Ascus, so daß das reife Perithecium nur Sporen und Trümmer enthält und also 
dem Perithecium von Monascus recht ähnlich ist. Für nähere Angaben über Morphologie, Physiologie und Systematik dieses interessanten Genus vergleiche man Wenmer, Monographie der Pilzgattung Aspergillus, Mémoires de la Société de Physique et d'Histoire générale de Genève, T. XXXIII, 2me Partie, No. 4, eine Arbeit, welche mir leider unzugänglich geblieben ist.

Bei gewissen Arten des Genus Aspergillus, z. B. bei A. nidulans (Eidam) Fischer, kommen Fruchtkörper vor, welche, bevor sie Asci bilden, zunächst meistens eine kurze Ruheperiode durchmachen. Diese Ruheperiode kann unter Umständen so sehr übertrieben werden, daß schließlich gar keine Asci mehr gebildet werden und der Fruchtkörper also zu einem Sclerotium reduziert worden ist. Dies ist z. B. bei

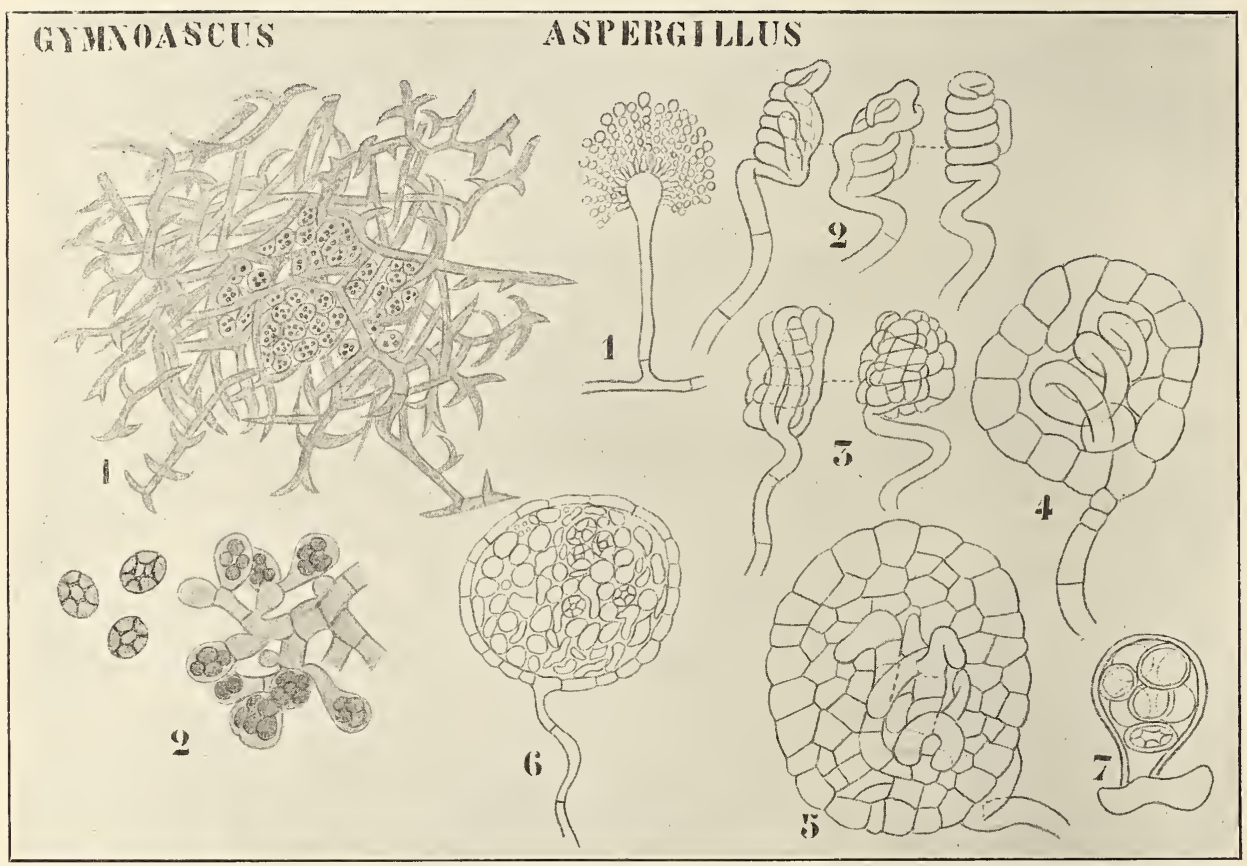

Fig. 294. I. Gymnoascus Reesii (nach Baranetzky). 1 Habitusbild der Ascusfrucht. 2 Asci. - II. Aspergillus (nach DE BARY). 1 Konidienträger. 2 Oogone, mit Antheridien kopulierend. 3 Umhüllung durch sterile Hyphen. 4 Lockerung des befruchteten Oogons, Anfang des Mehrschichtigwerdens der Hülle. 5 Bildung ascogener Hyphen. 6 Bildung der Asci. 7 Ascus, noch an der ascogenen Hyphe befestigt.

A. flavus Link, der schwarze Sclerotien bildet, der Fall. Dagegen sah BREFELD die weißen oder rosafarbenen Sclerotien des A. niger v. TIEghem schließlich doch Asci bilden.

Ein sclerotiumähnlicher Fruchtzustand, d. h. ein Fruchtkörper, der erst sehr spät Asci bildet, kommt nun sehr häufig bei einem anderen Genus, nämlich bei

\section{Penicillium}

vor, einem Genus, das man allgemein als mit Aspergillus nahe verwandt betrachtet, welches aber noch viel genauer untersucht werden muß, 
bevor sich dies mit Sicherheit behaupten läßt. Das gleiche gilt übrigens von den Aspergillus-Arten mit sclerotienartigen Fruchtkörpern, und bei unserem Aspergillus herbariomum, denn wie ähnlich auch die Konidien der zu Aspergillus gebrachten Arten sind, darf man doch nicht vergessen, daß gerade die Konidien ein sehr schlechtes Maß für Verwandtschaft bilden, da die Konidien sehr entfernt verwandter Pilze bisweilen rührende Aehnlichkeiten aufweisen können.

Ist aber die Entwickelung der Penicillium-Sclerotien, wie sie hier unten nach BREFELDs Untersuchungen angegeben wird, richtig, so ist Penicillium gewiß mit Aspergillus nahe verwandt und man kann, einen ähnlichen Entwickelungsgang für die sclerotienbildenden AspergillusArten voraussetzend, diese als Uebergangsformen zwischen Aspergillus herbariorum und Penicillium betrachten. Verfolgen wir also die Entwickelung'sgeschichte ron

\section{Penicillium glaucum Link,}

des am meisten verbreiteten und häufigsten Schimmelpilzes in der ganzen Welt.

In der Regel sieht man von diesem Pilze nur die Konidienträger (Fig. 295, 2), welche sich von denen von Aspergillus dadurch unterscheiden, daß der Konidienträger an seiner Spitze nicht kugelig anschwillt, sondern sich in eine Anzahl pinselförmig vereinter Zweige spaltet, welche an ihren Enden einige Konidienreihen abschnürende Sterigmen tragen.

Die Ascusfrüchte, welche durch ihre Ruheperiode an Sclerotien erinnern, werden nur selten gebildet, und zwar nur bei Abwesenheit von Sauerstoff. Von dieser Eigenschaft machte BREFELD Gebrauch, um diesen Fruchtzustand willkürlich zu erhalten. Dazu nahm er ungesäuertes Brot, zerlegte dies in Schnitte und besäte diese mit Penicillium-Sporen, hielt die Schnitte mäßig feucht und wartete das Erscheinen eines kräftigen Mycels, welches nach 6 bis 7 Tagen gebildet ist, ab.

Noch bevor dieses zur Konidienbildung schreitet, werden die Brotscheiben aufeinander gelegt und so fest wie möglich zwischen zwei Glasplatten gepreßt; dann wird der um die Scheiben herum zwischen den Glasplatten übrig bleibende Raum noch mit Papier ausgefüllt, so daß das Ganze möglichst vollkommen von der Luft abgeschlossen ist. Nach ungefähr 14 Tagen ist das Brot voll Sclerotien.

Die Sclerotienbildung fängt an mit dem Entstehen eines Paares spiralig umeinander gewundener Hyphen, welche vermuten lassen, daß wir hier mit einem Oogon und einem Antheridium zu tun haben (Fig. 295, 3-5), was aber noch nicht feststeht. Einer dieser Spiralfäden, vermutlich das Oogon, bildet nun eine Anzahl ascogener Hyphen, während der ganze Sexualapparat von einer Hülle steriler Hyphen ungeben wird (Fig. 295, 6). So entsteht ein dichter Hyphenknäuel, das junge Sclerotium. Bei der Weiterentwickelung entsteht daraus ein großer $(0,16-0,87 \mathrm{~mm}$ im Querschnitt) pseudoparenchymatischer Körper (Fig. 295, 8), der aus einer gelblichen mehrschichtigen Rinde und einem farblosen Mark besteht.

In diesem Mark verlaufen die ascogenen Hyphen, aber das Markgewebe selbst gehört zum sterilen Sclerotiumgewebe. Die ascogenen Hyphenknäuel sind leicht vom Markparenchym zu unterscheiden (Fig. 295, 8).

Ist dieses Stadium eingetreten, so setzt eine Ruheperiode ein, welche 6 bis 7 Wochen anhält. Man erkennt das Ende der Ruheperiode daran, 
daß die ascogenen Hyphen sich mittels Querwänden in Zellen zerlegen und diese zur Ascusbildung schreiten. Nach den Abbildungen zu urteilen, geschieht dies auf dem Wege der Hakenbildung.

Diese Asci verzehren nun das ganze Mark und schließlich befinden sich innerhalb der Rinde nur Sporen und Ueberbleibsel von Ascuswänden, ascogenen Hyphen und sterilen Zellen. Da die Sporen den ganzen so gebildeten Raum nicht ausfüllen, bleibt eine beträchtliche Höhlung übrig.

Aus den Ascussporen entstehen, wenn sie in der gewöhnlichen Weise unter Luftzutritt ausgesät werden, wieder konidienbildende Mycelien.

Wie wir sahen, gibt es unter den Aspergillus-Arten solche, bei welchen die Fruchtkörper eine Ruheperiode durchmachen, und solche,

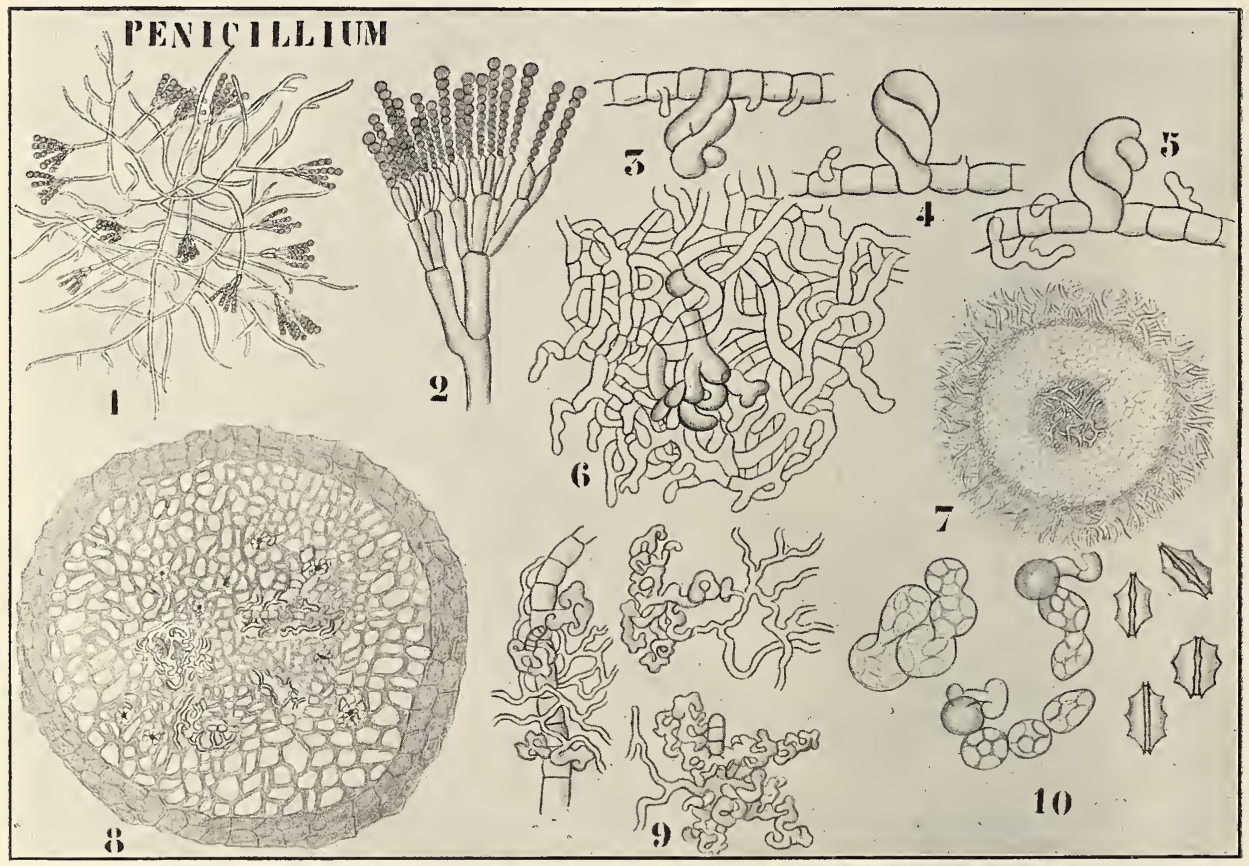

Fig. 295. Penicillium glaucum (nach Brefeld). 1 Mycel mit Konidien. 2 Konidienträger. 3, 4, 5 Geschlechtsorgane. 6 Bildung des Selerotiums und Anlage der ascogenen Hyphen. 7 Differenzierung im Sclerotium. 8 Bildung der Ascusnester. 9 Bildung der Asci, offenbar auf dem Wege der Hakenbildung. 10 Asci und isolierte Sporen.

bei welchen dies nicht der Fall ist; bei Penicillium machen alle bisher daraufhin untersuchten Arten eine Ruheperiode durch mit Ausnahme des von Van Tieghem auf Samen von Bertholletia excelsa gefundenen Penicillium aureum.

Wie schon der Name andeutet, schließt sich das Genus

\section{Penicilliopsis}

an Penicillium an. $\mathrm{Zu}$ diesem Genus gehört nur eine Art:

Penicilliopsis clavariaeformis Solus,

von Solms (1887) im Winter 1883/84 im botanischen Garten zu Buiten- 
zorg auf abgefallenen Früchten von Diospyros macrophylla BL. entdeckt. Nach jedem Regentage erschienen auf solchen Früchten zahllose Konidienträger. welche bei trockenem Wetter wieder verschwanden.

Die Früchte unserer Diospyros haben die Größe eines Apfels, sind grün und werden erst infolge von Fäulnis braun. Die Rinde ist holzig, 2-3 mm dick, und das von derselben umschlossene Fruchtfleisch saftigschleimig. In diesem Fruchtfleisch liegen 10 länglich-bohnenförmige Samen, - die derbe Testa dieser Samen ist braunrot.

Das Mycel der Penicilliopsis ernährt sich hauptsächlich vom Endosperm, welches es zerstört. Die Fruchtkörper des Pilzes haben die Form spitzer, etwa $1 \mathrm{~cm}$ langer Clavaria-ähnlicher, verzweigter oder unverzweigter Sprossen (Fig. 296, I 1).

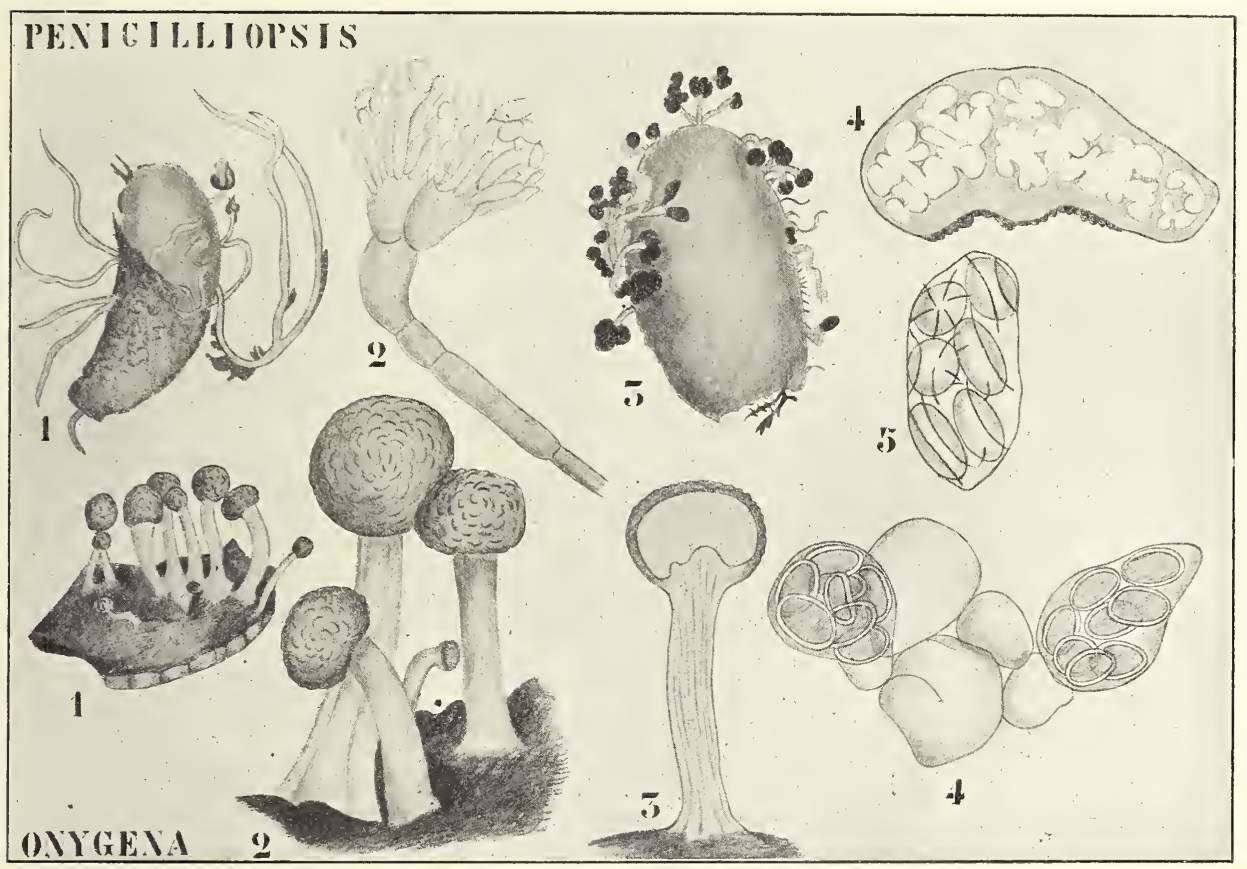

Fig. 296. I. Penicilliopsis clavaria eformis (nach Solms-LadBacH). 1 Dios py ros-Samen, aus welchen die Konidienstromata herausgetreten sind. 2 Konidienträger. 3 Knöllchenbildung (Sporocarpien). 4 Längsschnitt eines Knöllchens, die fertilen Partien zeigend. 5 Ascus. - II. On y gen a equina (nach Tulasne und Fischer). 1 Sporocarpien auf einem Stück Horn. 2 Solche stärker vergrößert. 3 Längsschnitt. 4 Asci.

Diese treten aus dem Samen heraus und in die Höhlung, welche in der Frucht infolge der Fäulnis des Fruchtfleisches entstanden ist, hinein, und schließlich durch Spalten oder Löcher in der Fruchtrinde ins Freie.

Hinausgetreten sind sie schön schwefelgelb und durch unzählige Konidien mehlig bestäubt. An der Unterseite der Früchte, an der Seite, welche auf dem Boden lag, findet man öfters zahlreiche kurze Stromata auf den Samen, Stromata, welche also in der Frucht eingeschlossen blieben; keine konidienbildenden, sondern an deren Oberfläche kleine braune Knöllchen (Fig. 296, I 3) entstanden, welche, nachdem die Stromata abgestorben sind, lose im Innern der Diospyros-Frucht liegen. 
Diese Knöllchen, welche sich also offenbar gerne bei Luftabschluß bilden, sind Ascusfruchtkörper, sogenannte Sporocarpien, welche denen von Penicillium gleichen, aber keine Ruheperiode durchmachen. Sie entstehen bisweilen auch an der Basis von Stromata, deren Spitzen die Außenluft erreicht und Konidien gebildet haben (Fig. 296, 1).

Die Sporen keimen an der Oberfläche der Diospyros-Früchte, das Mycelium wächst auf die Samen zu, dringt in das Endosperm vor und löst die Membranen derselben. Die an den Clavaria-ähnlichen Stromata gebildeten Konidienträger (Fig. 296, I 2) halten etwa die Mitte zwischen denen von Aspergillus und denen von Penicillium.

Die Stromata, welche ausschließlich Sporocarpien bilden, sind ebenfalls vom Clavarien-Habitus, und haben denselben Bau wie die, welche Konidien bilden. Die Sporocarpien entstehen als seitliche Anschwellungen derselben, besitzen eine Rindenschicht und ein lockereres Mark. Ihr Wachstum stimmt vollkommen mit dem der jungen Fruchtkörper von Elaphomyces, wie dieser von DE BARY beschrieben wurde, überein.

Von jetzt an tritt aber ein Unterschied gegen Elaphomyces ${ }^{1}$ ) auf. Während bei diesem der ganze zentrale Teil des Fruchtkörpers schließlich fertil wird, tritt hier im Sporocarp eine Differenzierung in sterile und fertile Partien ein, wodurch das Knöllchen gekammert wird (Fig. 296, I 4).

In den sterilen Teilen wird durch Vergrößerung der Elemente das Gewebe fest und pseudoparenchymatisch, in den fertilen bleibt es locker.

Schließlich aber wird auch das Gewebe in den fertilen Teilen fester und die Interstitien verschwinden, nicht durch Vergrößerung der Elemente, sondern dadurch, daß die an den Hyphen dieser fertilen Partien gebildeten, kurzen, vielzelligen, torulösen, ascogenen Hyphen die Interstitien ausfüllen.

Die Spitze einer jeden ascogenen Hyphe wird zum Ascus, die Asci werden so ziemlich simultan im ganzen Knöllchen gebildet, Details sind aber bis jetzt nicht bekannt.

Wie bei den Aspergillaceen die Regel ist, zerbröckeln die Ascuswände und die ascogenen Hyphen, und schließlich sind die Kammern mit Sporen und Debris gefüllt.

Wir sehen also, daß Penicilliopsis große Uebereinstimmung mit Penicillium zeigt, die Konidienträger sind recht ähnlich und die Sporocarpien sind hauptsächlich dadurch verschieden, daß sie bei Penicillium eine Ruheperiode durchmachen, bei Penicilliopsis nicht, und daß bei Penicilliopsis eine ausgeprägtere Differenzierung in sterile und fertile Partien stattfindet. Letzteres ist nun auch bei

\section{Onygena}

der Fall, einem Pilz, der öfters an Penicilliopsis angeschlossen wird. Von diesem Genus ist in letzter Zeit O. equina genauer von Marshall WARD untersucht, O. corvina war schon früher von Solms geprüft worden.

Onygena corvina findet sich unter anderem auf faulenden Vogelfedern und wurde von Solms 1879 aus dem Göttinger Walde erhalten. Die Sporocarpien wurden von DE BARY einer Eule verfüttert, da sie behufs Keimung, im Magensaft dieses Tieres gewesen sein müssen, und das zurückgegebene Gewölle war alsbald mit den Fruchtkörpern der Onygena

1) Siehe S. 509 . 
besetzt. Konidien wurden nicht angetroffen, die Sporocarpien werden in der Einzahl terminal auf langen Stielen gebildet und sind in reifem Zustande einkammerig. SoLms konnte nun aber nachweisen, daß sie in der Jugend so wie die von Penicilliopsis vielkammerig sind, aber daß die sterilen Platten hier nicht wie dort permanent sind, sondern alsbald zerstört werden.

So ist also eigentlich der einzige Unterschied gegen Penicilliopsis, daß die Fruchtkörper nicht an einer willkürlichen Stelle der Stromata gebildet werden, sondern terminal entstehen, daß die Konidien fehlen oder eventuell nur noch unbekannt sind, und daß die sterilen Partien im Sporocarp zu Grunde gehen, so daß dieses schließlich einkammerig ist.

Man sieht, daß es viele Gründe gab, um Onygena an Penicilliopsis anzuschließen; die neuen Untersuchungen WARDs zeigen aber, daß es

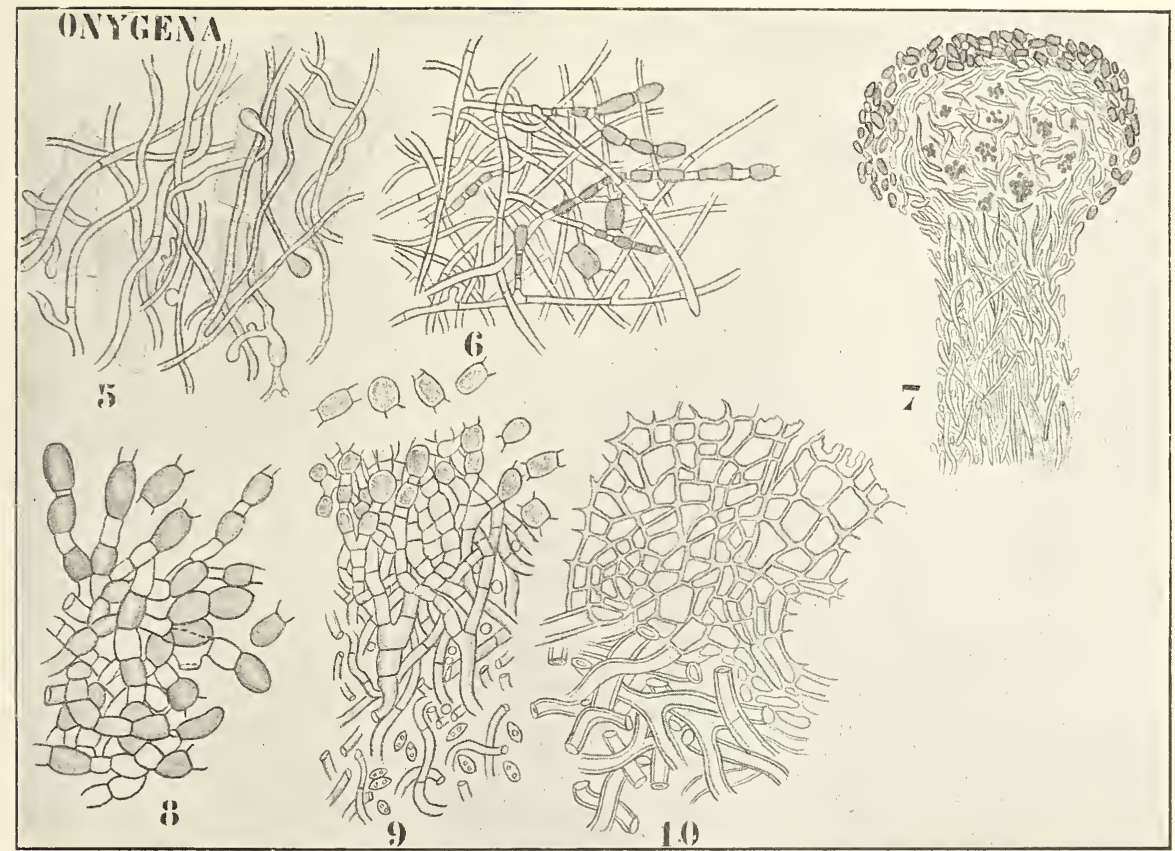

Fig. 297. Onygena equina (nach Marshall Ward). 5 Mycel in der Hornsubstanz. 6 Chlamydosporenbildung an demselben. 7 Junges Sporocarp, von Chlamydosporen bedeckt. 8 Chlamydosporen, stärker vergrößert. 9, 10 Rindenbildung unter Abwerfung der Chlamydosporen.

auch bedeutende Unterschiede gibt und daß unserem Organismus eine etwas isolierte, vielleicht primitive Stelle zukommt.

WARD untersuchte Onygena equina, eine Art, welche auf faulenden Schaf- und Rinderhörnern vorkommt, und fand unter anderem, daß kïnstlicher Magensaft die Sporenkeimung befördert; für dergleichen Beobachtungen muß ich aber auf WaRDs (1899) Artikel verweisell, uns interessieren hier mehr die morphologischen Resultate seiner Untersuchung. Der Pilz fängt damit an, im Horn ein Mycel zu bilden (Fig. 297. 5). infolgedessen dieses weich und käsig wird. Nach einiger Zeit wachsen Zweige nach der Oberfläche und können dort direkt durch Terdickung 
der Wand der Hyphenzellen Chlamydosporen bilden, wie WARD an künstlichen Kulturen nachwies (Fig. 297, 6).

In der Regel geschieht dies aber nicht. Meistens wächst eine größere Zahl von Fäden senkrecht hinauf und verwebt sich zu einem keulenförmigen Stroma (Fig. 297, 7). Die Hyphen verlaufen darin mehr oder weniger springbrunnenartig und bilden zunächst an der Oberfläche der Spitze des Stromas Chlamydosporen (Fig. 297, 7). Hat dies einige Zeit stattgefunden, so vergrößern sich die peripher gelegenen Hyphenzellen, welche sich inzwischen schon zu einer festeren Rindenschicht zusammengefügt hatten, mehr und mehr, wobei sie die Chlamydosporen abwerfen und eine parenchymatische Rinde bilden, auf deren Oberfläche die Narben der Anheftungsstellen der Chlamydosporen sichtbar sind (Fig. 297, 9, 10).

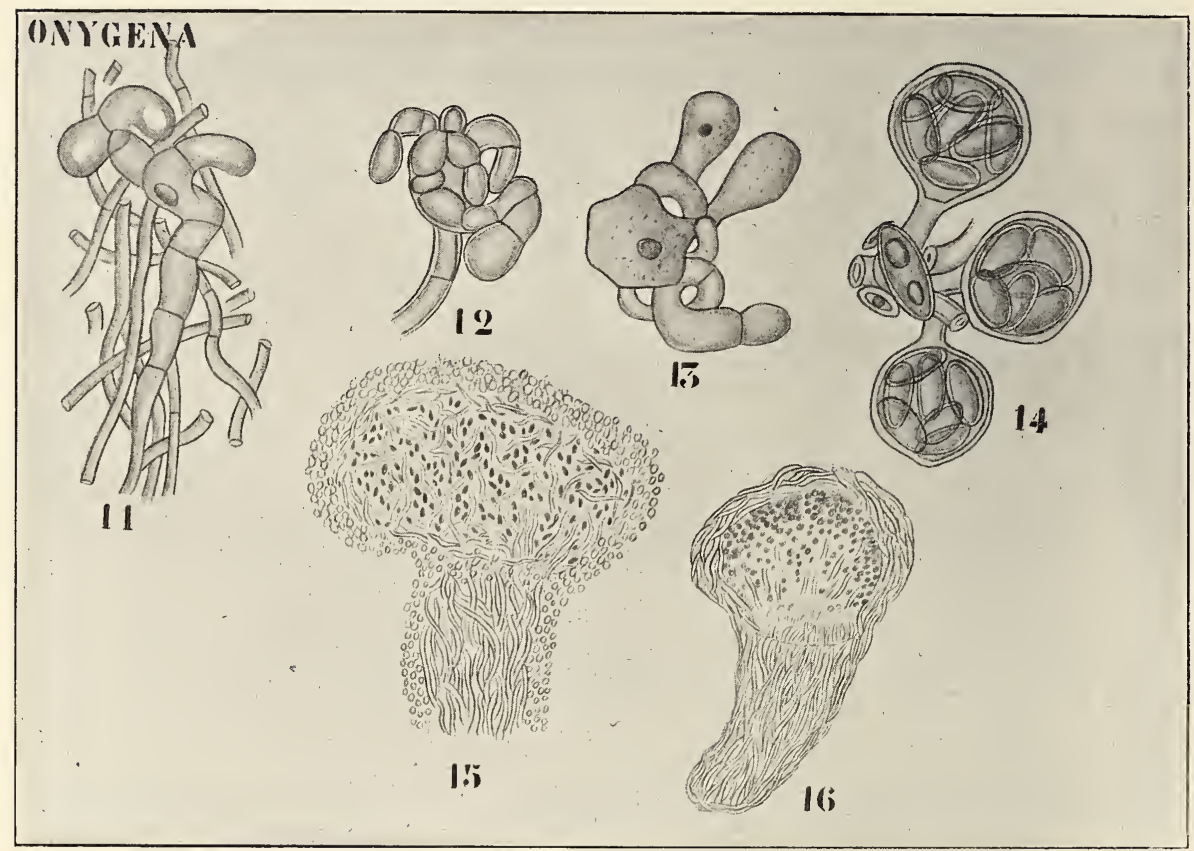

Fig. 298. Onygena equina (nach Marshall Ward). 11-14 Verschiedene Stadien der Ascusbildung. 15 Junges, noch vielkammeriges, 16 älteres einkammeriges Sporocarp.

Inzwischen sind weiter im Inneren als seitliche Sprossen der Stromahyphen die ascogenen Hyphen entstanden. Diese sind öfters schon sichtbar, wenn das Stroma noch Chlamydosporen bildet und wenn infolgedessen das Köpfchen noch bepudert ist (Fig. 297, 7). Details über die Ascusbildung sind noch nicht bekannt, aber die in Fig. 298 reproduzierten Abbildungen Marshall Wards machen es wohl wahrscheinlich, daß dies hier auf dem Wege der Hackenbildung geschieht.

Die sich entwickelnden ascogenen Hyphen werden zahlreicher und größer und so entstehen zahlreiche größere Knäuel, welche die vegetativen Hyphen beiseite schieben, was durch das Wachstum der Köpfchen erleichtert wird. 
So kommt also auch hier ein vielkammeriger Fruchtkörper (Fig. 298, 15) zu stande, schließlich aber werden die sterilen Partien zerstört, das Sporocarp wird einkammerig (Fig. 298, 16; Fig. 296, 4) und ist schließlich mit Sporenpulver und Debris erfüllt.

WARD weist mit Recht darauf hin, daß hier eine äußerliche Uebereinstimmung, sozusagen eine Parallelbildung zu Pilacre unter den niedrigen Basidiomyceten besteht, ganz klar ist die Stellung unseres Organismus sicher noch nicht.

Kehren wir jetzt zu Penicilliopsis zurück. Solms bemerkte schon, daß das Sporocarp von Penicilliopsis in mancher Hinsicht an eine kleine Trüffel erinnert, und meint, daß in der Tat ein Teil der 'Trüffel, die Gruppe der Terferiaceen, von einer Form wie Penicilliopsis abgeleitet werden kann, damit eine Meinung begründend, welche BREFELD, wenn er auf die Verwandtschaft der Penicilliaceen und Tuberaceen hinwies, schon ausgesprochen hatte.

Die andere Gruppe der Tuberaceen (Tuber, Balsamia) zeigt nach Solms, wie auch DE BARY meinte, Verwandtschaft mit den Discomyceten.

In Uebereinstimmung mit dieser Auffassung bringt denn auch Fischer in seiner Bearbeitung dieser Gruppen die Trüffel der Elaphomycetaceen und der Terferiaceen zu den Plectascineae.

Die Trüffelpilze bilden also eine polyphyletische Gruppe, deren Vertreter nur durch Anpassung an eine ähnliche Lebensweise ein gemeinsames Aeußere erhalten haben.

Wir leiten also mit Fischer und Buchuulz von den Penicillieae die Elaphomycetineen und Terferiaceen, von den Helvellineae die Eutuberineae und von den Perizinaceae die Balsamieen ab.

Die Gruppe der

\section{Elaphomycetineen}

läßt sich in zwei Familien zerlegen, deren eine, die der Terferiaceen, keine differenzierte Peridie (Rinde) besitzt, deren andere, die der Elaphomycetaceen, sich des Besitzes einer derben Peridie erfreut. Es wird genügen, hier von jeder Familie einen Vertreter zu behandeln und ich wähle dazu von letzterer Gruppe den

\section{Elaphomyces cervinus (Pers.) Schroeter.}

Elaphomyces cervinus lebt parasitisch auf den Wurzeln verschiedener Bäume oder mit denselben in Symbiose, die sogenannte Mycorrhiza bildend, und ist in Deutschland recht häufig.

Ihre Fruchtkörper, welche unter Tannen, Fichten, Eichen und. Buchen gefunden werden, bilden sich hart an den Wurzeln, sind also unterirdisch. Sie wachsen nicht sehr tief, so daß ihre Gegenwart bisweilen durch die auf ihnen parasitierenden, oberhalb des Bodens hervorragenden Fruchtkörper von Cordyceps ophioglossoides verraten wird.

Die Fruchtkörper sind regelmäßig, kugelig oder abgeflacht und variieren von der Größe einer Haselnuß bis zu der eines Hühnereies. Die Fruchtkörper sind von einer gelben oder gelbbraunen Hülle verflochtener Hyphen und Wurzeln umgeben (Fig. 299, I 1), welche leicht entfernt werden kann.

Darinnen befindet sich der hellgelbe oder gelbbraune, mit kegelförmigen Wärzchen dicht besetzte Fruchtkörper. 
Auf dem Durchschnitt sieht man sofort die $2-4 \mathrm{~mm}$ dicke Rinde oder Peridie, innerhalb welcher die pulverförmige Sporenmasse liegt. Auf einem jüngeren.Stadium (Fig. 299, I 2) sieht man aber, daß das. Innere in sterile und fertile Partien geschieden ist, die ersteren sind plattenförmig.

Die Sporen (Fig. 299, I 3) sind zunächst violett, später schwarz. Sie sind kugelig und besitzen zwei Membranen, deren äußere farblos ist und durch radiäre dunkelgefärbte Stäbchen mit der inneren verbunden ist. Zwischen beiden Membranen findet sich aber außer diesen Stäbchen noch eine farblose Zwischensubstanz.

Sind die Sporen reif, so zerbröckelt die äußere Membran, der periphere Teil der Zwischensubstanz verschwindet, so daß die Enden der

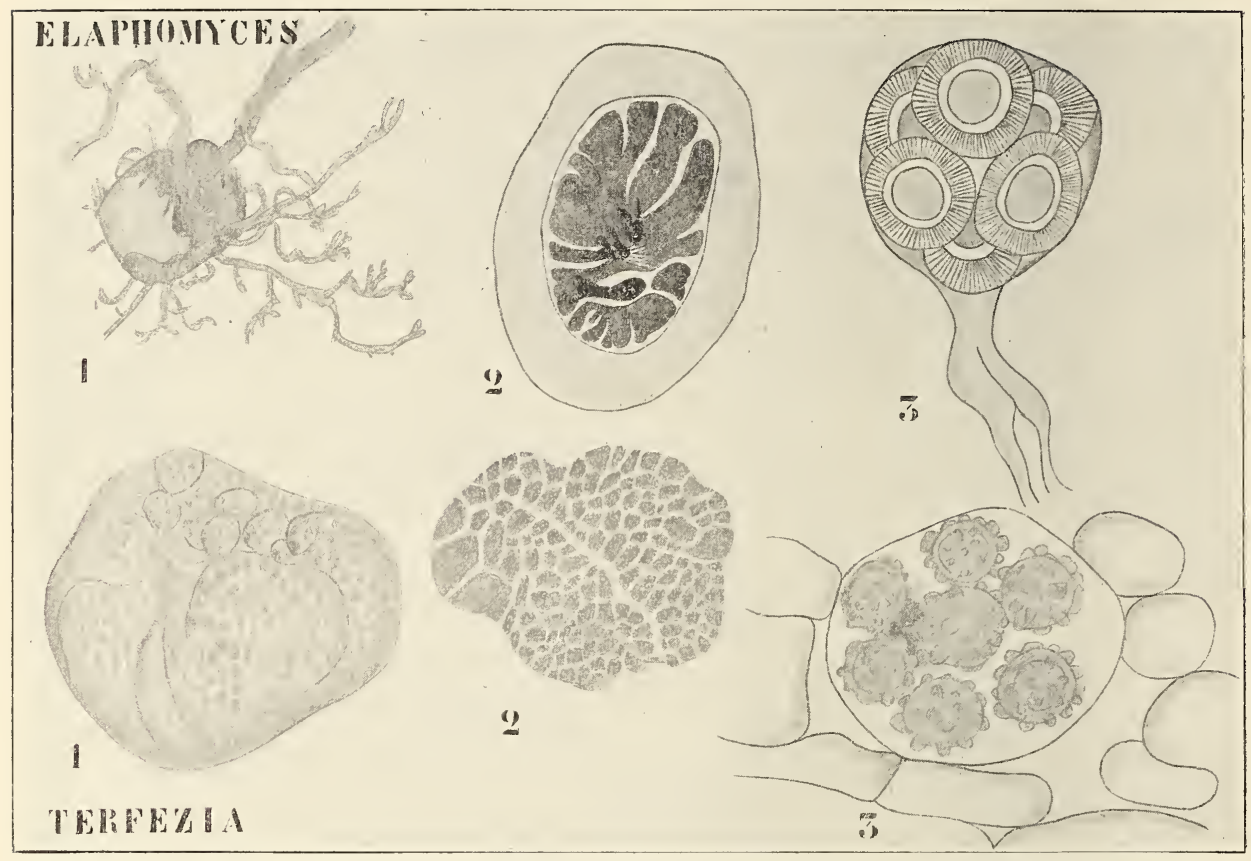

Fig. 299. I. Elaphomyces e ervinus (nach Rees, Fisch und Fischer). 1 Fruchtkörper, in der äußeren Hülle eingeschlossen. 2 Nach Entfernung derselben durchgeschnitten, die dicke Peridie und die Differenzierung des Inncren in fertile und sterile Partien zeigend. 3 Ascus. - II. Terfezia Leon is (nach Tulasse und Fischer). 1 Fruchtkörper, von außen betrachtet. 2 Querschnitt, die Abwesenheit einer Peridie zeigend. 3 Ascus.

Stäbchen hervorragen und die Oberfläche der Spore rauh machen. Inzwischen ist die Spore ganz schwarz und undurchsichtig geworden.

Von der zweiten Familie, der der

\section{Terfeziaceae,}

möchte ich

Terfezia Leonis TuL.

als Beispiel wählen. Es ist dies eine südliche Art, welche um das 
Mittelmeer herum gefunden wird. Die Fruchtkörper variieren in der Größe zwischen einer Nuß und einer Orange.

Unser Pilz ist direkt von Elaphomyces durch das fast völlige Fehlen einer Peridie zu unterscheiden und dadurch, daß überall größere oder kleinere Partien des Gewebes in unregelmäßiger Weise fertil werden. Da nun die asciführenden Partien ockergelb bis braungelb werden, die sterilen aber weiß bleiben, bekommt das Ganze auf dem Durchschnitt ein marmoriertes Aussehen (Fig. 299, II 2), welches sogar, da die Rinde sehr dünn ist, am unverletzten Fruchtkörper (Fig. 299, II 1) wahrgenommen werden kann. Die gelben Sporen besitzen einzelne konische Warzen. Da wir die Elaphomycetineen und Terferiaceen an Penicilliopsis angeschlossen haben, sei hier erwähnt, daß sie auch in der Bildung der eigentümlichen Sporenmembran in mancher Hinsicht mit Penicilliopsis übereinstimmen; für Details darüber sei auf die Solmsche PenicilliopsisArbeit verwiesen.

Gehen wir jetzt zur Behandlung der dritten großen AscomycetenGruppe, zu der der Pyrenomyceten, über. 


\section{Einundzwanzigste Vorlesung.}

\section{Die Pyrenomyceten.}

Von dieser Gruppe sind zunächst die Perisporiales, deren wichtigste Familie, die der Erysipheae, wir schon besprachen, auszuschließen, weiter alle anderen Formen, bei welchen Gametangienkopulation nachgewiesen wurde.

In dieser Weise soll eine Gruppe übrig bleiben, bei welcher wenigstens ursprünglich die Befruchtung mittels Trichogynen und Spermatien stattfand. Das ist nun allerdings ein bis jetzt unanwendbares Kriterium. aber mir scheint das vielfache Vorkommen von Spermatien, sowie der in mancher Hinsicht einheitliche Charakter der Gruppe darauf hinzuweisen, daß eine Zunahme unserer Kenntnisse uns schließlich erlauben wird, einen solchen Kern herauszuschälen, auf welchen ich dann den Begriff „Pyrenomyceten" beschränken möchte. Daß die jetzige Gruppe der Pyrenomyceten noch sehr gestützt werden muß, bevor wir diesen Kern rein werden erhalten haben, wird aus der jetzt vorzunehmenden $\mathrm{Be}$ handlung dieser Gruppe hervorgehen. Ihren Namen verdankt die Gruppe dem Umstand, daß sich die Fruchtkörper mittels einer differenzierten Mündung, mittels eines sogenannten Ostiolums, öffnen.

Nach dem LrNDauschen Beispiele wollen wir die Gruppe vorläufig nach der Struktur des Gehäuses in drei Untergruppen zerlegen, und zwar in die der

Hypocreales mit weichem Gehäuse;

Dothideales ohne Gehäuse, aber mit einem Stroma, das die Fruchtkörper einschließt;

Sphaeriales mit deutlichem, lederartigem, hartem oder kohligem Gehäuse, das entweder in ein Stroma eingeschlossen ist oder nicht.

Fangen wir unsere Betrachtungen mit der Gruppe der

\section{Hypocreales}

an. Diese enthält nur eine, noch recht wenig einheitliche Familie, die der

\section{Hypocreaceae,}

von welchen ich als erstes Beispiel

\section{Melanospora parasitica TuL.}

mit Ihnen behandeln will, um zu zeigen, daß die Gruppe noch keineswegs natürlich ist und sicher bei näherer Untersuchung noch sehr eingeschränkt werden muß. 
Dieser Organismus (Fig. 300, II 1) bildet auf Maikäfern eigentümliche langmündige, schwarze Perithecien, welche einem weißen Stroma entspringen. KinLmans (1883) hat ihre Entwickelung näher untersucht, und findet, daß sich dabei zwei Hyphen spiralig umwinden (Fig. 300, II 2), so daß hier vermutlich keine Befruchtung mittels Spermatien. sondern Gametangienkopulation stattfindet. Der Pilz erheischt auch in anderer Hinsicht eine Bearbeitung. TuLAsNe meint nämlich, daß Botrytis bassiana, ein Parasit, der auf Schmetterlingspuppen vorkommt und zumal die Seidenwürmerkultur gefährdet, die zu dieser Art gehörige Konidienform ist. Kinlmann meint dagegen, daß der Pilz nicht direkt auf dem Maikäfer parasitiert, sondern auf einem der diesen tötenden Insektenpilze, wie Botrytis bassiana, Isaria farinosa, Cordyceps militaris etc.

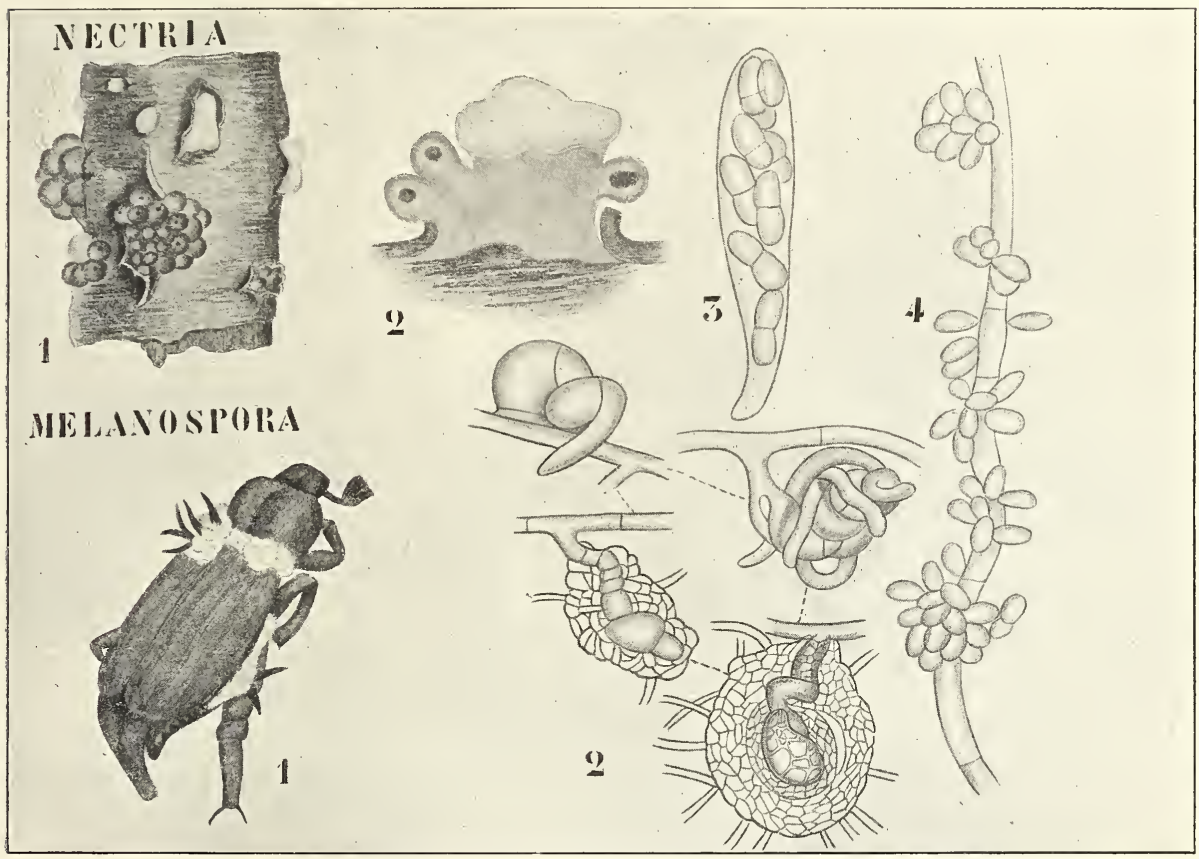

Fig. 300. I. Nectria cinnabarina (nach HARTIG). 1 Habitusbild. 2 Stroma durchschnitten, oben Konidien, seitlich Perithecien tragend. 3 Ascus. 4 Konidien. II. Melanospora parasitica TuL. (nach Kinlmans). 1 Maikäfer mit den schwarzen Perithecien auf dem weißen Stroma eines insektentötenden anderen Pilzes. 2 Verschiedene Stadien der Gametangienkopulation.

\section{Als zweiten Vertreter dieser Familie wähle ich}

Nectria cinnabarina (Tode) F'r.

Es ist dies ein sehr häufiger Pilz (Fig. 300, I 1), der auf fast allen Baumarten vorkommt, wenn diese vom Frost getötet sind, in der Regel also saprophytisch lebt, unter Umständen auch parasitisch auftritt, wozu ihm jedoch irgend eine Wunde Gelegenheit bieten muß. Aber auch damn kann er die lebende Rinde oder das Cambium nicht direkt infizieren. sondern entwickelt sich zunächst im Holze, tötet also den Zweig von innen nach außen. 
Bisweilen erst ein Jahr nach stattgefundener Infektion treten die ersten konidienproduzierenden Stromata durch Risse in der Rinde hervor, sie sind hellrötlich gefärbt. Später verschwinden die Konidien und es entstehen an denselben Stromata (Fig. 300, I 2) die dunkelroten, etwas rauhen Perithecien. Die Asci sind 8-sporig, die Sporen 2-zellig.

Als drittes Beispiel mag das schon früher erwähnte

Polystigma rubrum (Pers.) DC.

gelten. Es bildet rote, fleischige Flecken (Fig. 301, I 1) auf Blättern von Pflaumen und Prunus spinosus. Es sind dies die Stromata, welche

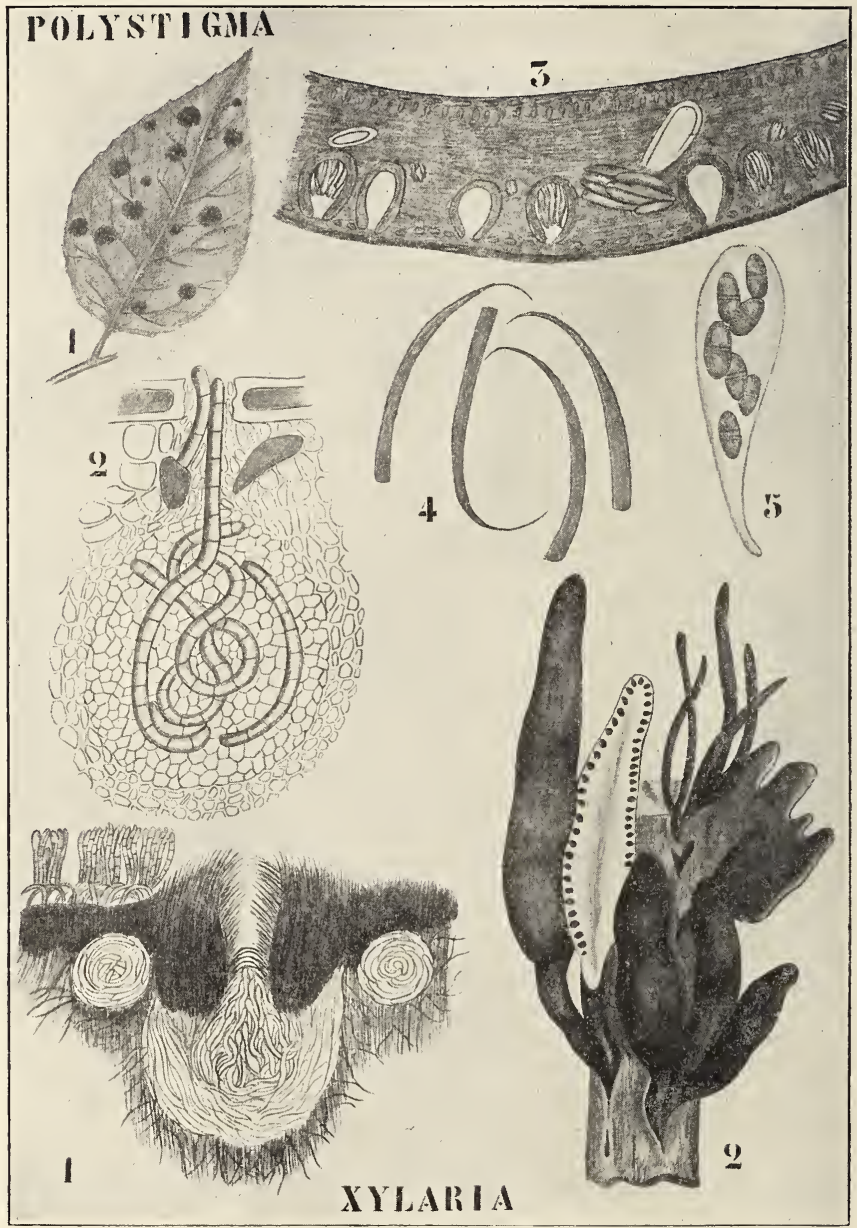

Fig. 301. I. Polystigma rubrum (wiederholt). 1 Pflaumenblatt mit den vom Pilze verursachten Flecken. 2 Ascogone und Trichogynen, durch die Spaltöfnungen hervorragend. 3 Querschnitt durch ein Stroma. 4 Spermatien. 5 Ascus. - II. X yla ri a (gehört nicht hierher).

an der Unterseite Spermogonien, an der Oberseite Trichogynen bilden. Kopulation findet augenscheinlich nicht mehr statt, zwar kann man Spermatien an den Trichogynen kleben sehen, aber zu einer Vereinigung 
kommt es nicht. Im Herbst fallen die Blätter ab und es bilden sich Perithecien, welche sich selbstverständlich an der Oberseite des Stromas entwickeln.

Sät man die Ascosporen auf junge Pflaumenblätter aus, so sind schon nach 3 Wochen neue Spermogonien gebildet. Nebenfruchtformen sind bis heute nicht bekannt geworden.

Eine andere Hypocracee ist

Hуроcrea rufa (Pers.) Fries, ein in Europa und Nordamerika im Herbst auf den Zweigen vieler Bäume und Sträucher, z. B. auf Rubus-Arten, vielfach vorkommender Pilz.

Die Stromata (Fig. 302, 1) wachsen gesellig, haben 3-10 und mehr

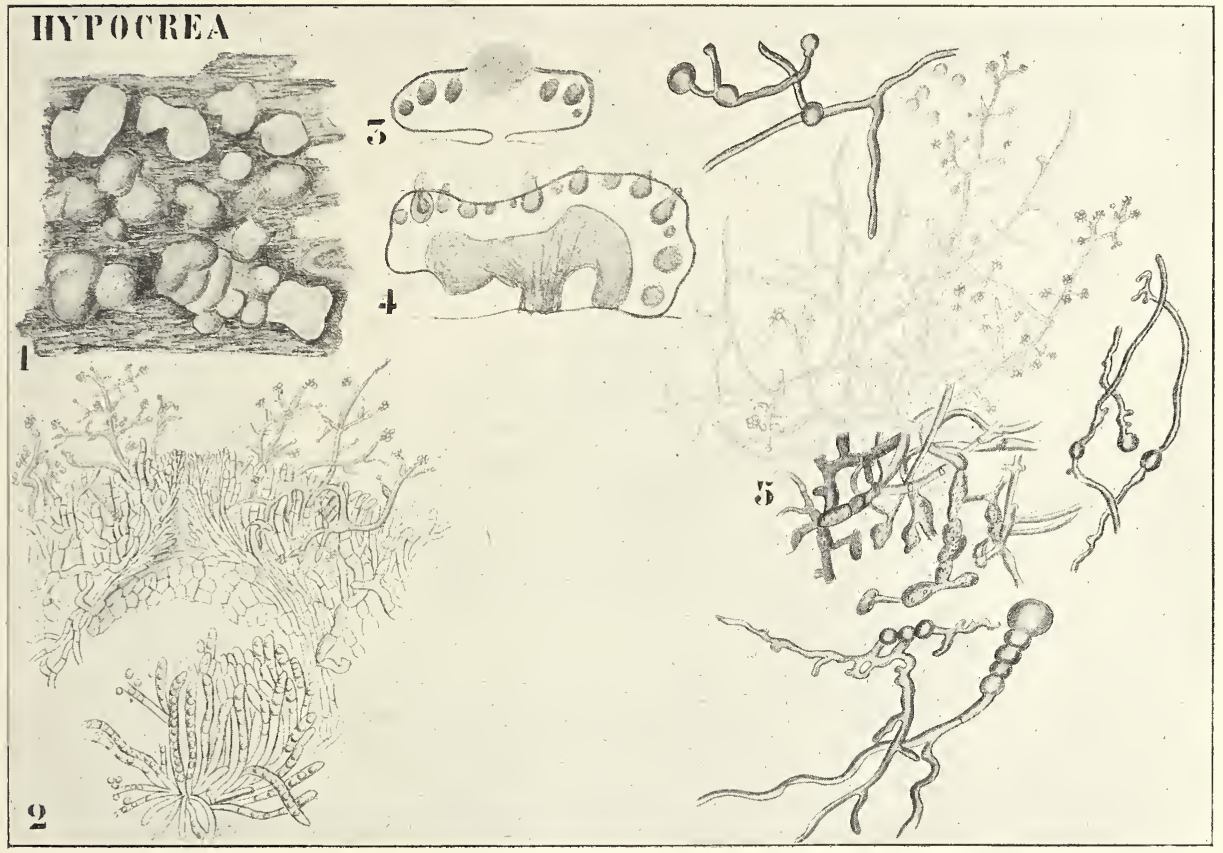

Fig. 302. H y pocrea rufa (Pers.) Fries (nach Tulasse). 1 Stromata, die hellen Konidien, die dunkleren Perithecien produzierend. 2 Längssehnitt durch ein Perithecium, an der Oberseite des Stromas noch einige Konidien. 3 Schnitt durch ein Stroma am Ende der Konidienproduktion, die Perithecien schon angelegt. 4 Schnitt durch ein Stroma nach dem Abblühen der Konidien, reife Perithecienhälse ragen schon hervor. 5 Konidien und Chlamydosporen.

Millimeter im Durchmesser, sind mehr oder weniger kugelig oder polsterförmig, weich-fleischig, öfters zusammenfließend und, wie der Längsschnitt (Fig. 302, 3, 4) zeigt, gestielt. In der Jugend produzieren sie Konidien und sind dann Penicillium-artig grün; später bilden sie die tief eingesunkenen Perithecien, deren Hälse nur wenig über die Oberfläche hervorragen (Fig. 302, 4); sie verändern dann ihre Farbe, werden zunächst blaß-fleischfarbig, dann rot, schließlich rotbraun. Oefter's passiert es, daß die Perithecien schon reif sind (Fig. 302, 2), wemn noch einige wenige Konidien produziert werden. 
Die Asci sind 8-sporig, die Sporen bestehen aus zwei fast kugeligen Zellen, welche sich alsbald loslösen, so daß scheinbar 16 Sporen vorhanden sind.

Die blaugrüne Jugendform wurde früher als gesonderte Art, als Trichoderma viride PERs. beschrieben. Eine andere vielfach vorkommende Hypocreacee ist

Epichloe typhina (Pers.) Tul.,

ein Pilz, der sein Stroma vielfach an den Blattscheiden (Fig. 303, I 1) oder um die Stengel von Holcus und Dactylis herum bildet, so daß das Ganze einer kleinen Typha nicht unähnlich sieht. In der Jugend weiß und flockig, bildet es eiförmige, farblose Konidien von etwa 5 " Länge.

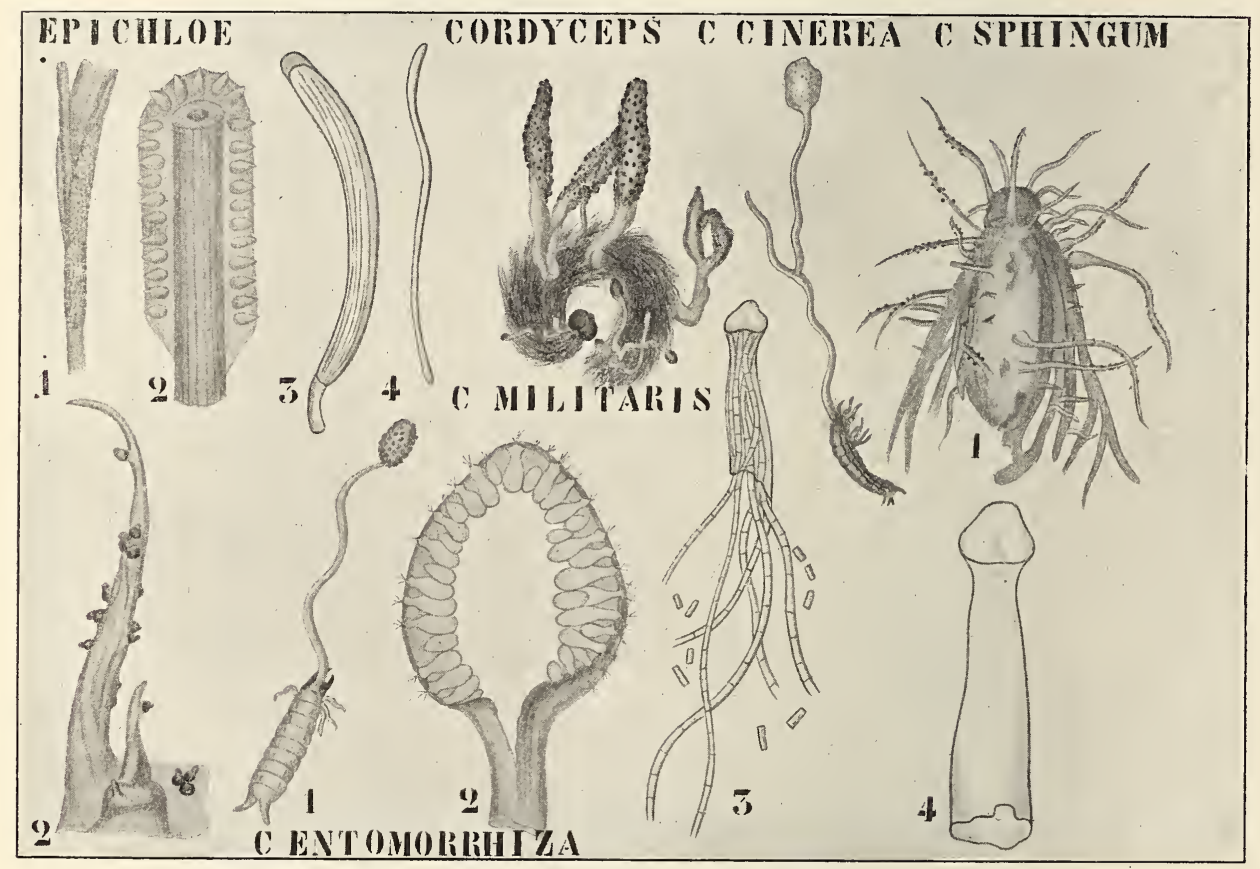

Fig. 303. I. Ep i chlo e typhin a (nach Engler u. PrantL). 1 Blattscheide eines Grases vom Stroma bedeckt. 2 Solches im Längsschnitt. 3 Ascus. 4 Ascusspore. - II. Cord y ce ps Arten (nach Tulasne). - II a. Cordyceps militaris auf einer Raupe. - II b. C. cinerea auf einer Insektenlarve. - II c. C. sphingum. 1 Auf einem Schmetterling. 2 Perithecientragendes Stroma, vergrößert. - IId. C. entomorrhiza. 1 Auf einer Insektenlarve. 2 Längsschnitt des Köpfchens, die Perithecien zeigend. 3 Ascus mit zerfallenden Ascussporen. 4 Leerer Ascus.

Später wird das Stroma goldgelb, schwach-fleischig und bildet die tief eingesunkenen, dicht gedrängten Perithecien. Die Asci enthalten $8 \mathrm{sehr}$ an die von Claviceps erinnernde Sporen.

Ebenfalls zu den Hypocreaceen gehören die verschiedenen Arten des Genus

\section{Cordyceps.}

Diese Pilze sind ausnahmslos Parasiten, die meisten wachsen auf Insekten, einige auf unterirdischen Pilzen, z. B. auf Elaphomyces. 
Es sind dies öfters schön gefärbte Pilze auffallender Form, wie aus den Abbildungen in Fig. 303 hervorgeht. Das Stroma, welches aus dem Insektenkörper hervorbricht, ist öfters keulenförmig, auch wohl geweihförmig; stets im unteren Teile steril, trägt es im oberen die Perithecien, welche bei den keulenförmigen Stromata meistens eingesunken sind (Fig. 303, II d 2), bei den geweihartigen dagegen mehr hervorragen (Fig. 303, II c 2). Die Asci enthalten 8 fadenförmige vielzellige Sporen, welche bald in die einzelnen Zellen auseinander fallen. Die Pilze finden sich auch wohl in unseren Breiten, zeigen aber ihre Hauptentwickelung in wärmeren Gegenden.

An einer auch in Europa nicht seltenen Cordyceps-Art, an

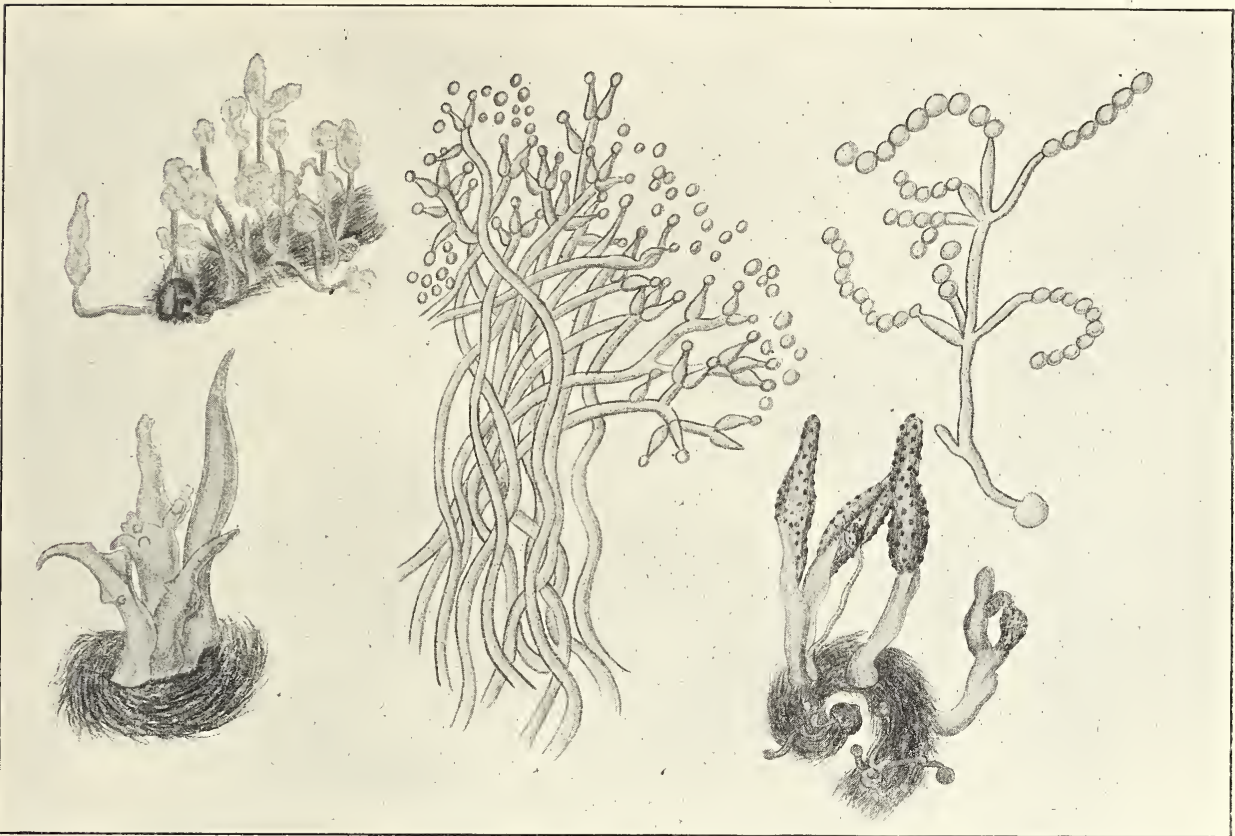

Fig. 304. Cordyceps militaris L. (nach Tulasne und ZoPf). Oben links: Isaria-Zustand; in der Mitte: stärker vergrößert; rechts: Konidienträger aus einer Ascusspore erhalten. Unten links: junge Perithecienstromata; rechts: die Perithecien gebildet.

\section{Cordyceps militaris L.,}

sei der Entwickelungsgang geschildert. Der Pilz tötet Raupen und Puppen und wird im Herbst vielfach in Wäldern angetroffen. Die Stromata können $6 \mathrm{~cm}$ lang werden und sind orange- bis purpurfarbig, keulenförmig. Die normalen fadenförmigen Ascussporen fallen in die einzelnen Zellen auseinander, Zellchen, welche kaum $3 \mu$ lang sind.

Diese können lebende Raupen infizieren. Sie keimen auf der Haut dieser Tiere, bilden einen Keimschlauch, welcher den Chitinpanzer durchbohrt und seine Verzweigungen zwischen der Muskulatur und dem Fettkörper ausbreitet. In diesem Fettkörper angelangt, hört das Längenwachstum auf und sie fallen in Konidien auseinander. Diese Konidien geraten ins Blut und bilden wieder Konidien, welche zwar in großer Zahl von den Phagocyten gefressen werden, aber schließlich doch siegen. 
Das Tier wird nun sehr krank, schlaff und weich und stirbt. Dann keimen die Konidien, die gebildeten Mycelien mumifizieren die Raupe und auf den so gebildeten Sclerotien kann die Perithecienfruktifikation entstehen.

Es kann aber auch eine andere Fruktifikation entstehen; es können reichlich verzweigte Konidienstromata gebildet werden (Fig. 304 oben links), welche $1-2 \mathrm{~cm}$ hoch werden und als Isaria farinosa beschrieben sind. Wohl sicher ist dies nur eine Konidienform unserer Cordyceps, denn wenn es auch noch nicht gelungen ist, aus diesen Konidien die Peritheciumform zu kultivieren, so gelang es wohl durch Aussäen der Ascussporen auf Wasser oder Nährlösung die Konidienform zu erhalten (Fig. 304 oben rechts).

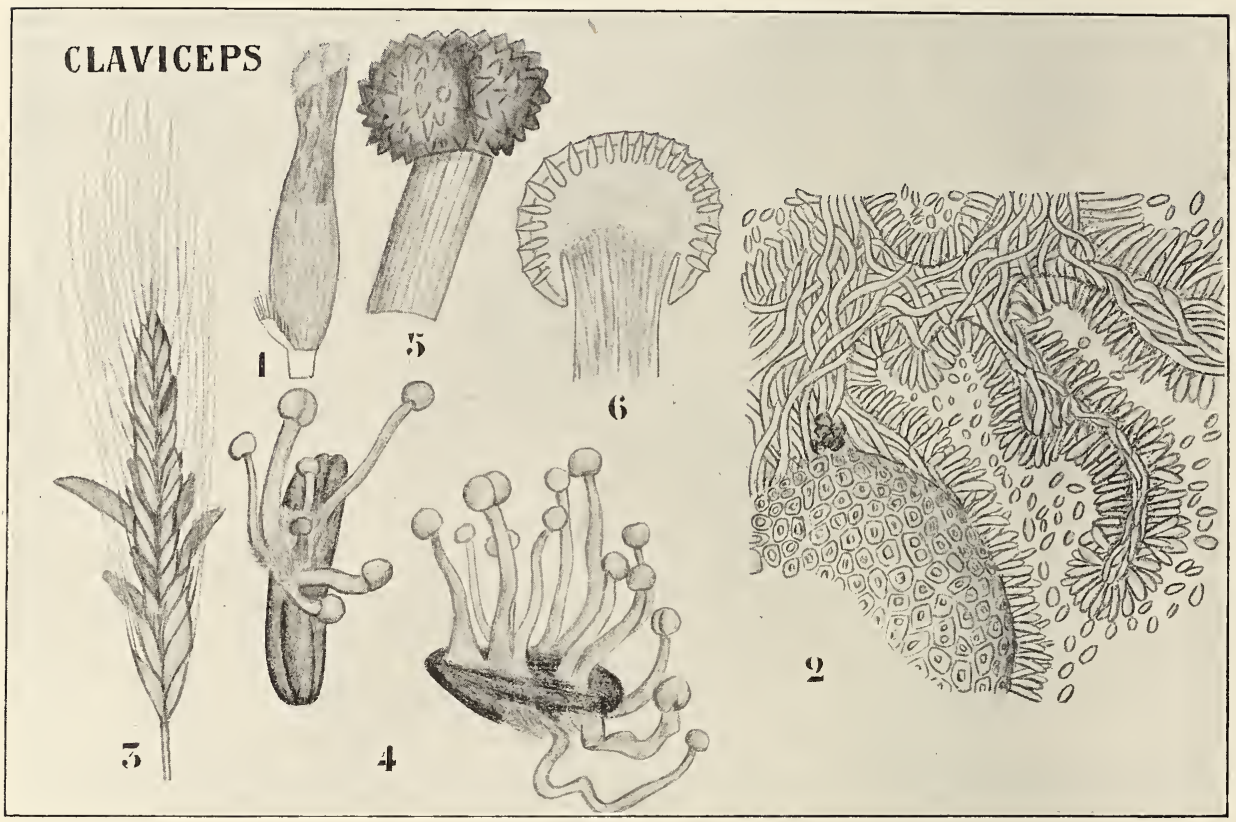

Fig. 305. Claviceps purpurea (Fr.) Tul. (nach Lindau und Tulasne). 1 Fruchtknoten mit dem Sphacelia-Zustande. 2 Querschnitt durch denselben, die Konidien zeigend. 3 Sclerotien in der Aehre. 4 Keimende Sclerotien. 5 Köpfehen der Ascusfruktifikation, stärker vergrößert. 6 Längsschnitt desselben, die Perithecien zeigend.

Sät man die Konidien auf Raupen aus, so dringen sie nicht wie die Ascussporen quer durch die Chitinhaut hindurch, sondern wachsen durch die Stigmata in die Tracheen hinein, durchbohren deren Wand und gelangen so ins Innere des Körpers. Durch Konidienbildung und das Auswachsen dieser nach dem Tode des Insektes wird das Tier mumifiziert und es bilden sich neue Isarien. Perithecien konnte DE BARY auf diesem Wege nicht erhalten.

Als letztes Beispiel einer Hypocreaceae sei

Claviceps purpurea TuL.

behandelt. Wenn die Sporen dieses Pilzes auf eine Roggenblüte fallen, infizieren sie das Ovarium und bilden ihr Mycel in dessen Wand. Die 
Folge zeigt sich bald durch das Runzeligwerden des Fruchtknotens. Diese Runzeln sind vom Mycel durchwachsen, es bricht nun bald hervor und bildet dann die Konidien aus, mit welchen folglich der Fruchtknoten bedeckt ist.

Diese Form war früher unter dem Namen Sphacelia segetum LEv. bekannt. Sie scheidet eine gelbliche oder bräunliche zuckerhaltige Flüssigkeit aus: den sogenannten Honigtau des Roggens, welche, die Konidien mitführend, heruntertropft. In dieser Weise, wohl mehr noch aber durch Insekten, welche durch diese zuckerhaltige Flüssigkeit herangelockt werden, werden neue Blüten infiziert.

Bis jetzt blieb der Pilz auf die Fruchtwand beschränkt, nun aber dringt er, unten anfangend, in die Eizelle vor, bildet dort ein dichtes

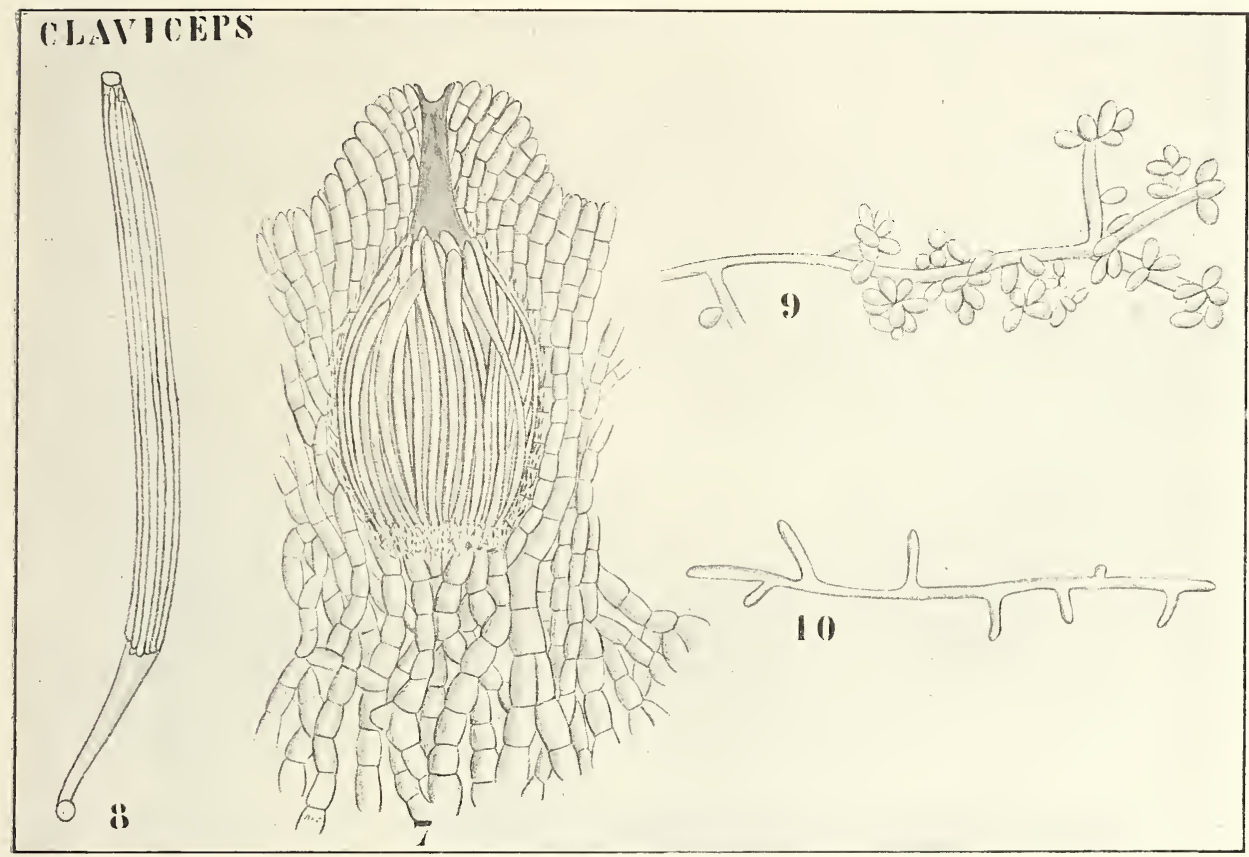

Fig. 306. Claviceps purpurea (nach BREfeLd). 7 Perithecium-Längsschnitt. 8 Ascus mit reifen Sporen. 9, 10 Keimende Ascussporen.

Gewebe und hat alsbald die ganze Frucht in ein Sclerotium verwandelt, welches noch Reste der Roggenfrucht in der Form einer Kappe auf seiner Spitze trägt. Dieses Sclerotium wächst bedeutend in die Länge, so daß es alsbald in der Form des bekannten blauschwarzen Mutterkornes über die Spelzen hervorragt (Fig. 305, 3).

Diese Sclerotien fallen auf den Boden und bilden im Herbst die gestielten, mehr oder wenigen kugeligen Fruchtkörper, welche zahllose Perithecien und in diesen die 8-sporigen Asci bilden.

Die Ascussporen infizieren wieder Roggenblüten, bilden dort zunächst die Sphacelia-Form, dann die Sclerotien u. s.w.

Sowohl Konidien wie Ascussporen bilden in zuckerhaltigem Wasser Keimschläuche, welche bald zur Konidienbildung schreiten. Die Sclerotien 
enthalten ein Alkaloid, welches in der Medizin verwendet wird, sie sind unter dem Namen Secale cornutum in den Apotheken erhältlich. Roggenbrot, welches viel Mutterkorn enthält, kann die sogenannte Kriebelkrankheit verursachen.

Die zweite Gruppe der Pyrenomyceten ist die der

\section{Dothideales,}

welche von LINDAU im Anschluß an die Hypocreales behandelt werden, weil sie mit Claviceps, Cordyceps etc. darin übereinstimmen, daß die Perithecien nicht durch ein eigenes Gehäuse vom Stroma getrennt sind. Die Gruppe ist aber offenbar keine natürliche, wie das übrigens noch keine einzige Pyrenomyceten-Gruppe sein dürfte. Die meisten Mykologen schließen lieber die Sphaeriales an die Hypocreales an, und ich werde auch dieser Gewohnheit folgen und die Dothideales erst später behandeln.

Die

\section{Sphaeriales,}

welche durch ihr lederartiges oder kohlenartig brüchiges Gehäuse charakterisiert sind und deren Perithecien frei auf dem Substrat stehen oder in einem Stroma eingesenkt sind, bilden eine sehr große Gruppe. Schon mehr als 6000 Arten sind bekannt. Daß ich mich also auf die Besprechung einzelner typischer Beispiele beschränken muß, ist selbstverständlich.

Die Gruppe läßt sich in eine Anzahl von Familien zerlegen, deren nähere Verwandtschaft aber noch sehr unklar ist. Fangen wir mit der Familie der

\section{Chaetomiaceae}

an. Diese ist durch den Besitz von Fruchtkörpern, welche frei einem oberflächlich wachsenden Mycel aufsitzen, charakterisiert. Das kleine Gehäuse ist dünn und zerbrechlich. Unsere Pilzchen leben saprophytisch auf faulenden Pflanzenteilen, Nist und Papier. Die Früchte ähneln denen der Perisporiaceen, zumal dann, wenn, wie das vorkommt, das Ostiolum fehlt.

Als Beispiel wähle ich einen Repräsentanten des Genus

\section{Chaetomium Kze.}

Chaetomium globosum Kze. ist ein Pilz, der auf faulenden Pflanzenteilen in Europa und Amerika gesellig wächst und sitzende runde Fruchtkörperchen bildet, welche lange, dünne, wellige Haare tragen. Bei anderen Arten ist die Haarform anders, so sind sie z. B. bei der hier ebenfalls abgebildeten $C$. spirale ZopF spiralig. Bei unserer Form ist ein Ostiolum vorhanden, beim Subgenus Chaetomidium aber fehlt dieses. Die Perithecien des. C. globosum sind $300 \mu$ lang, bis $250 \mu$ dick, die Asci keulenförmig, 8-sporig, die Sporen olivengrün, citronenförmig.

Von der Entwickelungsgeschichte ist nur wenig bekannt, der Anfang der Fruchtbildung scheint eine spiralig gewundene Hyphe zu sein; als Nebenfruktifikation kommen Konidien vor, welche man aber nicht zum Keimen hat veranlassen können. Daß die Stellung dieser Organismen im System noch recht unklar ist, braucht kaum erwähnt zu werden. 
Eine andere Familie der Sphaeriales ist die der

\section{Sordariaceae,}

von welcher

Sordaria fimiseda CES. et DE NoT.

erwähnt werden darf. Vom Genus Sordaria sind schon mehr als 100 Arten bekannt. Das Genus ist durch die eigentümlichen flaschenförmigen Perithecien charakterisiert, deren Hals dem Lichte zuwächst, durch die Abwesenheit eines Stromas und durch die scheinbar einzelligen Ascussporen.

Die Perithecien unserer Art (Fig. 307, II 1) wachsen jedes für sich oder in kleinen Gruppen auf Kuh- oder Pferdemist. Sie sind eiförmig,

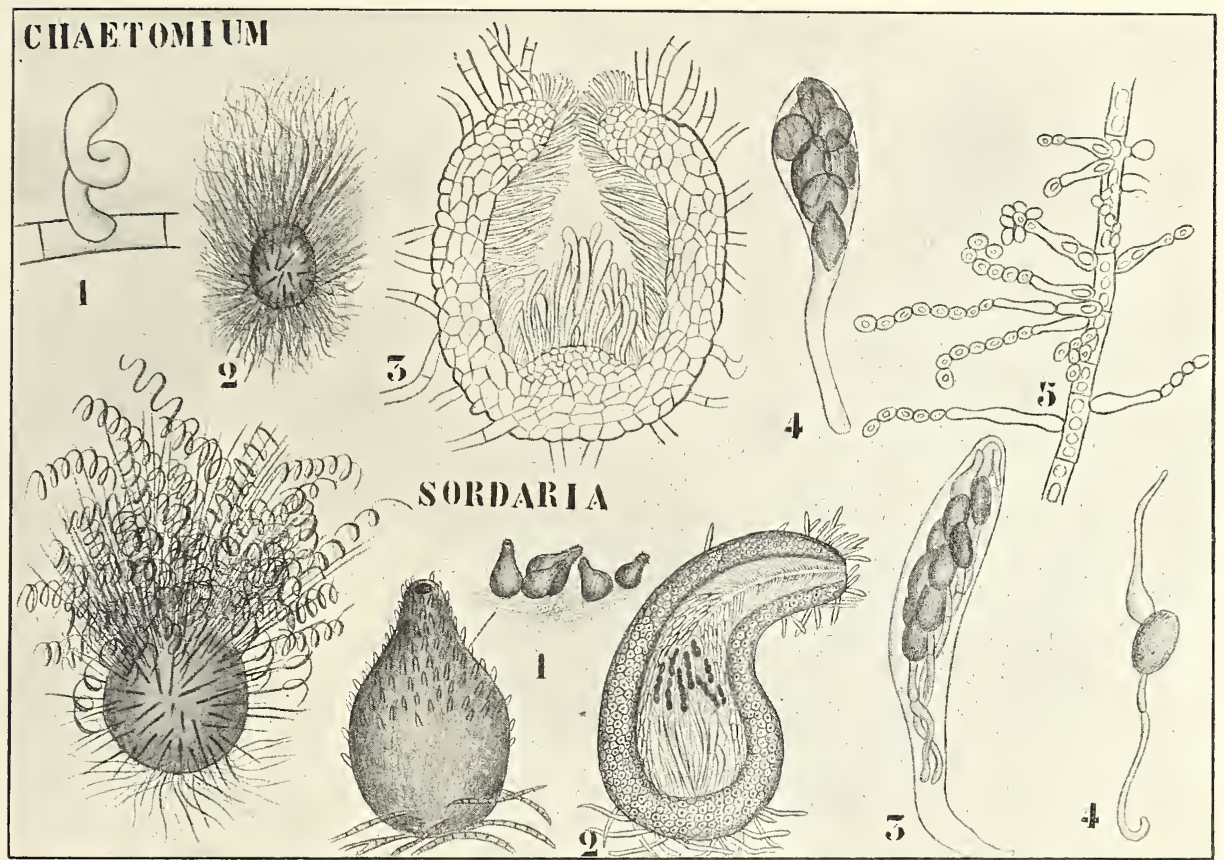

Fig. 307. I. Chatomium. A. C. g]obosum Kunze. 1 Sehr junge Fruchtanlage (nach OLtmanNs). 2 Erwachsener Fruchtkörper (nach ZOPF). 3 Selbiger im Längsschnitt. 4 Ascus. 5 Konidienträger. B. C. spirale ZoPF (nach ZoPF). - IJ. Sordaria fi mi s eda (nach WoroniN). 1 Fruchtkörper. 2 Längsschnitt eines solchen. 3 Ascus. 4 Spore mit Anhängseln.

schwarzbraun, mit kurzen Härchen bedeckt und haben einen verlängerten Hals. Die Sporen liegen im Ascus meistens in zwei Reihen und sind rot- bis schwarzbraun, sie besitzen zwei Schleimanhängsel, mittels welcher sie am Substrat festkleben. Die Entwickelungsgeschichte (Woronin in de Bary et Woronin, Beitr. zur Morph. u. Phys. der Pilze, III. Reihe) lehrt, daß die beiden Anhängsel den Sporen nicht homolog sind.

In erster Linie bemerken wir, daß das obere Anhängsel keine Querwand zeigt, das untere dagegen wohl (Fig. 307, II 4). Tom unteren Annhängsel besitzt nun bloß das Stück 7:wischen der Spore und der 
Querwand eine Membran, das obere Anhängsel und das untere Stück des unteren dagegen nicht.

Der Grund dafür liegt in dem Umstande, daß die junge Spore sich in zwei Zellen teilt, von diesen wird die obere die eigentliche Spore, die untere das die Membran besitzende Stück des unteren Anhängsels. Das obere Anhängsel und das untere Stück des unteren sind nur Schleimmassen.

Die dritte Familie ist die der

\section{Sphaeriaceae.}

Aus der Unterfamilie der Ceratostomaceae wollen wir hier

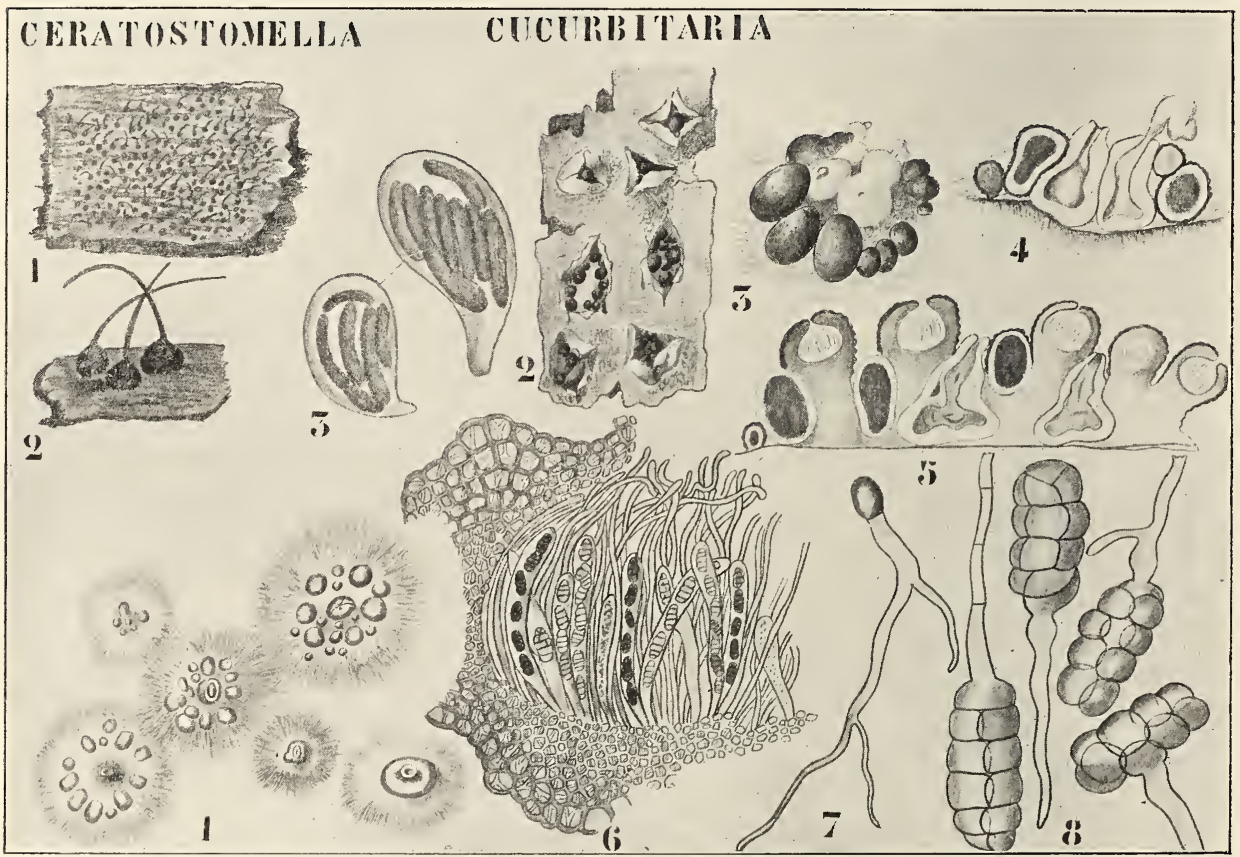

Fig. 308. I. Ceratostomella pirifera (Tr.) Winter (nach LindaU und Winter). 1 Habitusbild. 2 Fruchtkörper, stärker vergrößert. 3 Asci. - II. Cu curbit ari a Laburni (nach TUlasNe). 1 Mycelflecke, unten rechts Bildung eines Spermogoniums. 2 Habitusbild des reifen Pilzes. 3 Pykniden, in einem Kranz um die weißen Spermogonien stehend. 4 Bildung der Perithecien. 5 Aeltere Stadien. 6 Längsschnitt durch ein reifes Perithecium. 7 Keimende Spermatie? 8 Pyknokonidien.

Ceratostomella pilifera (Tr.) Wint.

besprechen. Die ganze Unterfamilie ist durch den Besitz sehr langer, fast fadenförmiger Perithecienhälse charakterisiert (Fig. 308, I 1, 2). Diese Perithecien kommen auf abgestorbenem Tannenholz öfters so zahlreich vor, daß junge tote Tannenstämme von unten bis oben damit bedeckt sind. Die Perithecien sind schwarz, sehr klein, kahl und glatt. Trotzdem der Pilz recht häufig ist, hat doch erst WinTer die Asci und Ascosporen (Fig. 308, I 3) gesehen und auch dieser nur ein einziges 
Mal. Die Asci verschleimen sehr bald. Die Keimung der Sporen ist noch unbekannt.

Als Vertreter der Familie der

\section{Cucurbitariaceen}

mag Cucurbitaria Laburni hier einen Platz finden.

Dieser Pilz wird auf Zweigen von Cytisus Laburni gefunden; er entwickelt sich in der Rinde nahe den äußeren Schichten und bildet dort zunächst weiße runde Mycelmassen (Fig. 308, II 1), die alsbald im Zentrum die hellgefärbten vermutlichen Spermogonien bilden (Fig. 308, II 1 rechts unten). Diese Stadien sind zu erhalten durch Abschälen der äußeren Rindenschicht. Die weißen Spermogonien (?) bilden alsbald einzellige Spermatien (?), welche aber keimen können (Fig. 308, II 7). Um diese zentralen Spermogonien herum entstehen nun alsbald runde Körperchen (Fig. 308, II 1 links oben), von welchen man noch nicht sagen kann, ob sie zu Pykniden oder zu Perithecien auswachsen werden. Zunächst entwickeln sich die Pykniden (Fig. 308, II 3), welche sich von den Spermogonien durch ihre schwarze Farbe und durch ihren Inhalt, welcher aus vielzelligen Konidien (Fig. 308, II 8) besteht, unterscheiden. Nun fängt die Perithecienentwickelung an. Diese sind gestielt (Fig. 308, II, 5), zerdrücken die Spermogonien und Pykniden, heben die äußeren Schichten der Rinde empor und zerreißen sie (Fig. 308, II 2). Sie sitzen dicht gedrängt, sind schwarz, 2-15 mm im Querschnitt groß und besitzen ein kleines papillenartig hervorragendes Ostiolum.

Innerhalb des Peritheciums, welches eine ziemlich dicke und derbe Wand besitzt (Fig. 308, II 6), befinden sich 8-sporige Asci und Paraphysen.

Die Pyknidenform war früher unter dem Namen Diplodia cytisi Auersw. bekannt. Ganz sicher ist es aber nicht, daß diese zum Entwickelungsgang von Cucurbitaria gehören, doch ist dies für die Spermogonien (?) festgestellt, welche BREFELD durch Aussaat der Ascussporen erhielt.

Eine andere Familie der Sphaeriales - viele Familien können hier nicht genannt werden - ist die der

\section{Valsaceae.}

Von dieser Familie enthält das Genus Valsa allein über 400 Arten. von diesen ist

\section{Valsa ceratophora TuL.}

häufig; ihre Früchte finden sich auf trockenen Zweigen von Quercus, Rosa, Rubus und Castanea. Der Pilz entwickelt sich im Herbst. Fig. 309, 1 gibt ein Habitusbild des Pilzes. Man sieht, wie die Perithecien, die Rinde durchbrechend, mit ihren langen schwarzen Hälsen weit hervorragen. Bei den jungen Perithecien sind die Hälse noch kurz, so daß auf einem Zweigstückchen, wie das abgebildete, lange und kurze Perithecien nebeneinander vorkommen. Ganz unten ist ein Grüppchen Perithecien schräg durchgeschnitten. Von einem Stroma ist nichts zu sehen, das Mrcel wächst in der Rinde und schreitet, ohne ein eigentliches Stroma gebildet zu haben, zur Peritheciumbildung. 
Wie der Längsschnitt (Fig. 309, 2) zeigt, heben die Peritheciengruppen während ihrer Entwickelung die Rinde auf und lassen schließlich die langen Hälse hervorbrechen. Die Asci (Fig. 309, 3) enthalten 8 einzellige Sporen. Außer Perithecien bildet Valsa Spermogonien(?), aus welchen, wie Fig. 309, 4 zeigt, in der gewöhnlichen Weise die Spermatien (?) als eine schleimige Masse hervortreten. Der Hals des vermutlichen Spermogoniums ist nur kurz und ragt nur wenig über die Rinde hervor. Der Längsschnitt zeigt, daß das Spermogonium vielkammerig ist. Präpariert man ein solches Spermogon frei, so präsentiert es sich als ein gelappter Sack mit zentraler Mundöffnung (Fig. 309, 5). Bilden sich mehrere Spermogonien nebeneinander, so flachen sie sich gegeneinander $a b$, wodurch die Mündungen lateral an denselben $\mathrm{zu}$ stehen kommen (Fig. 309, 6).

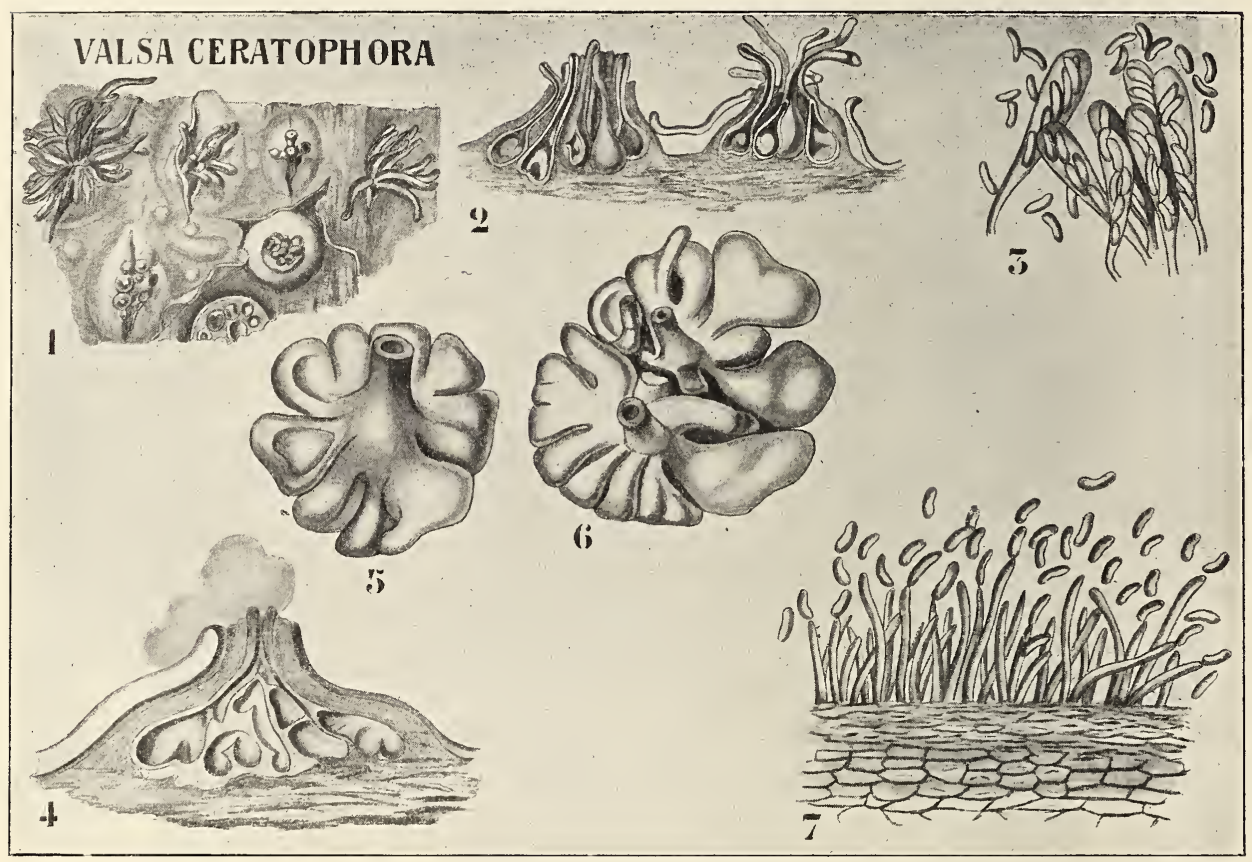

Fig. 309. Valsa ceratophora (nach Tulasne). 1 Habitusbild, die Perithecienhälse weit hervorragend. 2 Längsschnitt durch die Fruchtkörper. 3 Asci. 4 Spermogonien, die Spermatien entlassend. 5 Ein einzelnes Spermogonium. 6 Drei Spermogonien. 7 Spermatien.

In den Spermogonien werden die Spermatien in normaler Weise abgeschnürt (Fig. 309, 7).

Während bei den Valsaceen die Spermatien also in taschenförmigen Spermogonien entwickelt werden, sind die Spermogonien (?) der

\section{Melanconiaceen}

mehr flach, schüsselförmig. Wir wollen von dieser Familie 2 Genera, Melanconis und Calosphaeria, behandeln und fangen mit 


\section{Melanconis}

an, einem Genus mit ausgesprochenem flach-scheibenförmigen Stroma, von welchem wir hier

Melanconis stilbostoma Tur.

besprechen wollen. Das Pflänzchen findet sich auf trockenen Zweigen von Betula alba. Da die Hälse der Perithecien nur eben über das Rindenperiderm hervorragen und der Pilz übrigens fast vollkommen vom Periderm bedeckt bleibt, entdeckt man ihn nur, weil letzteres halbkugelige Erhöhungen von 2-3 mm im Querschnitt zeigt, unter welchen der Pilz verborgen ist. Um diesen zu studieren, ist es also nötig, das Periderm zu entfernen, wie es in Fig. 310, I 1 geschehen ist.

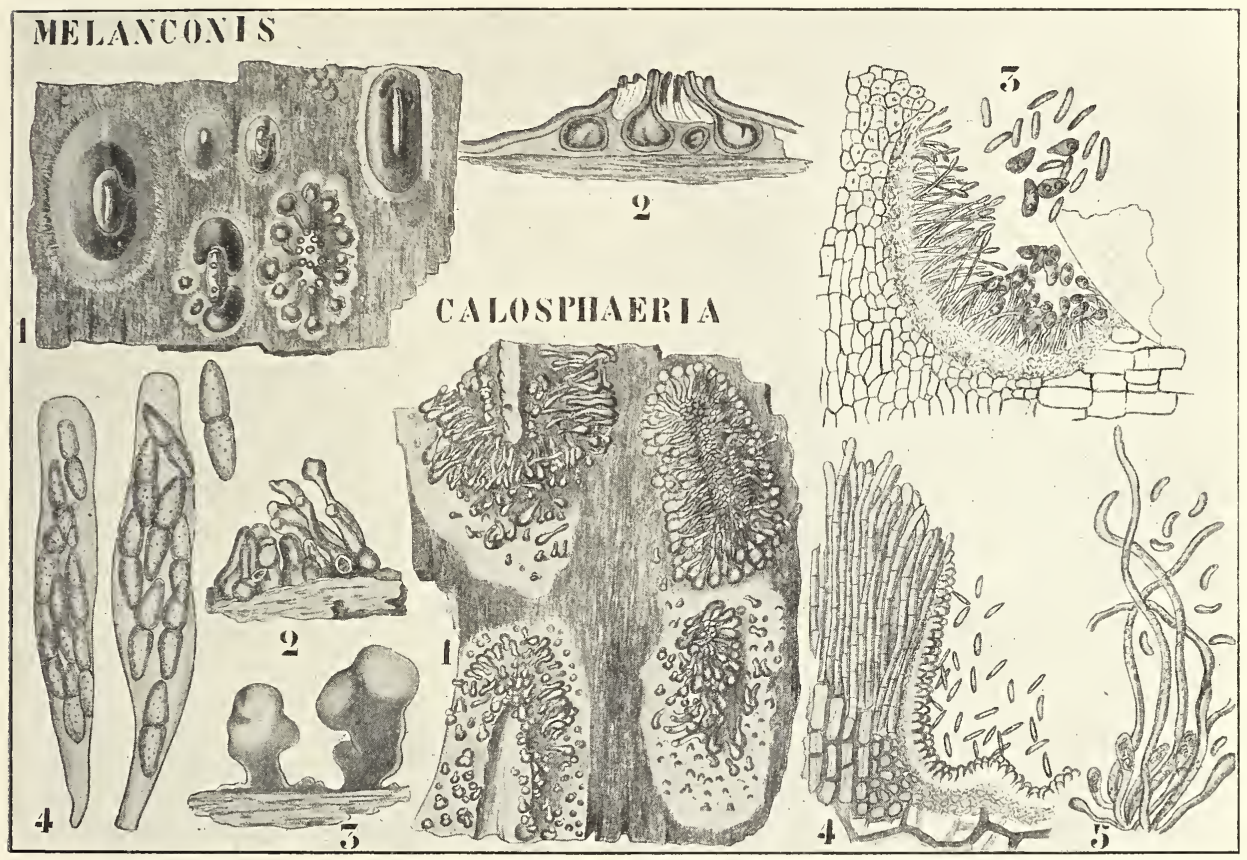

Fig. 310. I. Melanconis stilbostoma (nach Tulasne). 1 Perithecienstromata. 2 Ein solches durchschnitten. 3 Spermogonien(?)stroma. 4 Asci. - II. Calosphaeria princeps (nach Tulasne). 1 Perithecien. 2 Freistehende Perithecien. 3 Unregelmäßig geformte Spermogonien (?). 4 Spermatien(?). 5 Asci und Paraphysen.

Die jungen Stromata zeigen sich dann unserem Auge wie breitkegelförmige Erhöhungen mit gefranzten Rändern. Die Perithecien entstehen darauf kranzförmig (Fig. 310, I 1) und bilden lange Hälse, welche nach dem Zentrum hin gerichtet sind, sich an ihren Enden hinaufkrümmen und eben über die Rinde hervorragen. Sie sind sehr klein. schwarz gefärbt und bleiben beim Abziehen des Periderms öfters an diesem kleben.

Die Asci enthalten 8 zweizellige Sporen. Die Spermogonienstromata (?) zeigen dieselbe Form wie die Perithecienstromata und bilden Fortpflanzungszellchen (Fig. 310, I 3), von welchen es fraglich ist, ob sie 
Konidien oder Spermatien sind. Nach Tulasne gibt es daneben noch sogenannte Mikrokonidienstromata, welche vielleicht die richtigen Spermatienstromata sind. Wie wir sehen, ist ohne Kultur keine Sicherheit zu erhalten.

Verwandt mit den Melanconiaceen ist die Familie der

\section{Diatrypeen,}

bei welcher nur in dem vermutlichen Spermogonienzustand ein Stroma vorkommt. Als Beispiel wähle ich

\section{Calosphaeria princeps TuL.}

Trotzdem die Perithecien hier in Prinzip denselben Bau und dieselbe Anordnung wie die von Melanconis zeigen, fehlt ein eigentliches Stroma. In der Regel treten auch hier, zumal auf den jungen Zweigen des Pflaumen- oder Kirschbaumes, welcher den Pilz trägt, nur die Hälse der Perithecien eben über der Rinde hervor.

Auf älteren Zweigen aber ist die Rinde öfters ganz abgefallen und die Perithecien treten dann ganz zu Tage (Fig. 310, II 2). Oefters stehen die Perithecien recht gedrängt (Fig. 310, II 1 rechts oben) und können unter Umständen ganze Stämme von oben bis unten bedecken.

Zwischen den Perithecien entstehen die spermatienbildenden Stromata als konische Erhöhungen (z. B. Fig. 310, II 2 in der Mitte, Fig. 310, II 3 im Längsschnitt), die aber, wie letztere Abbildung zeigt, recht unregelmäßige Form besitzen können. Sie sind vollkommen solid, im oberen Teil steril und bilden die vermutlichen Spermatien an ihrer Außenseite (Fig. 310, II 4). Die Asci stehen zwischen langen Paraphysen (Fig. 310, II 5). Die Ascussporen (Fig. 310, II 5) sind mehr oder weniger wurstförmig gebogen.

Ob das, was wir hier Spermatien nannten, wirklich Spermatien sind, ist vorläufig nicht zu entscheiden.

Eine andere Familie der Sphaeriales ist die der

\section{Xylariaceae.}

Wir kriegen hier mit Formen mit viel größeren Stromata zu tun; einige, wie z. B. die schon besprochene Xylaria polymorpha, erreichen eine Länge von mehr wie $1 \mathrm{dm}$. In den Stromata, welche meistens eine schwarze kohlige Außenschicht zeigen, sind die Perithecien eingesenkt. Dieselben Stromata produzieren an ihrer Außenseite in der Jugend Konidien.

Zur Erleichterung der Uebersicht kann man die Xylariaceen in zwei Gruppen einteilen, nämlich in die

Hypoxyleae, bei welchen das ganze Stroma fertil ist, und in die

Xylarieae, bei welchen der untere Teil des Stromas steril bleibt.

Die Grenze zwischen beiden ist aber keineswegs scharf. Als Beispiel der

\section{Hypoxyleae,}

einer Subfamilie, welche zumal in den Tropen entwickelt ist, wähle ich

Hypoxylon coccineum BuLL。,

eine kosmopolitische Art, welche vorwiegend auf Fagus-Holz vorkommt. 
Die Stromata sind zunächst steinrot, später dunkelbraunrot, innen schwarz, und verschmelzen öfters zu ziemlich großen Kuchen (Fig. 311, 1). Die Perithecien sind fast ganz in Stroma eingesenkt (Fig. 311, 3), nur die Hälse ragen etwas hervor und haben sich gegenseitig polygonal abgeflacht, wodurch das Ganze etwas warzig wird und eine entfernte Aehnlichkeit mit einer Erdbeere erhält. Zwischen den Asci stehen Paraphysen.

Konidien werden an der Oberfläche junger Stromata gebildet (Fig. 311, 3 rechts), der Konidienüberzug ist anfänglich kupfergrün, wird dann gelb und schließlich bräunlich. Auf sehr feucht liegenden abgefallenen Zweigen kann die Konidienfruktifikation übermäßig stark werden und zu einer Degeneration des Stromas führen (Fig. 311, 2), welches dann außer stande

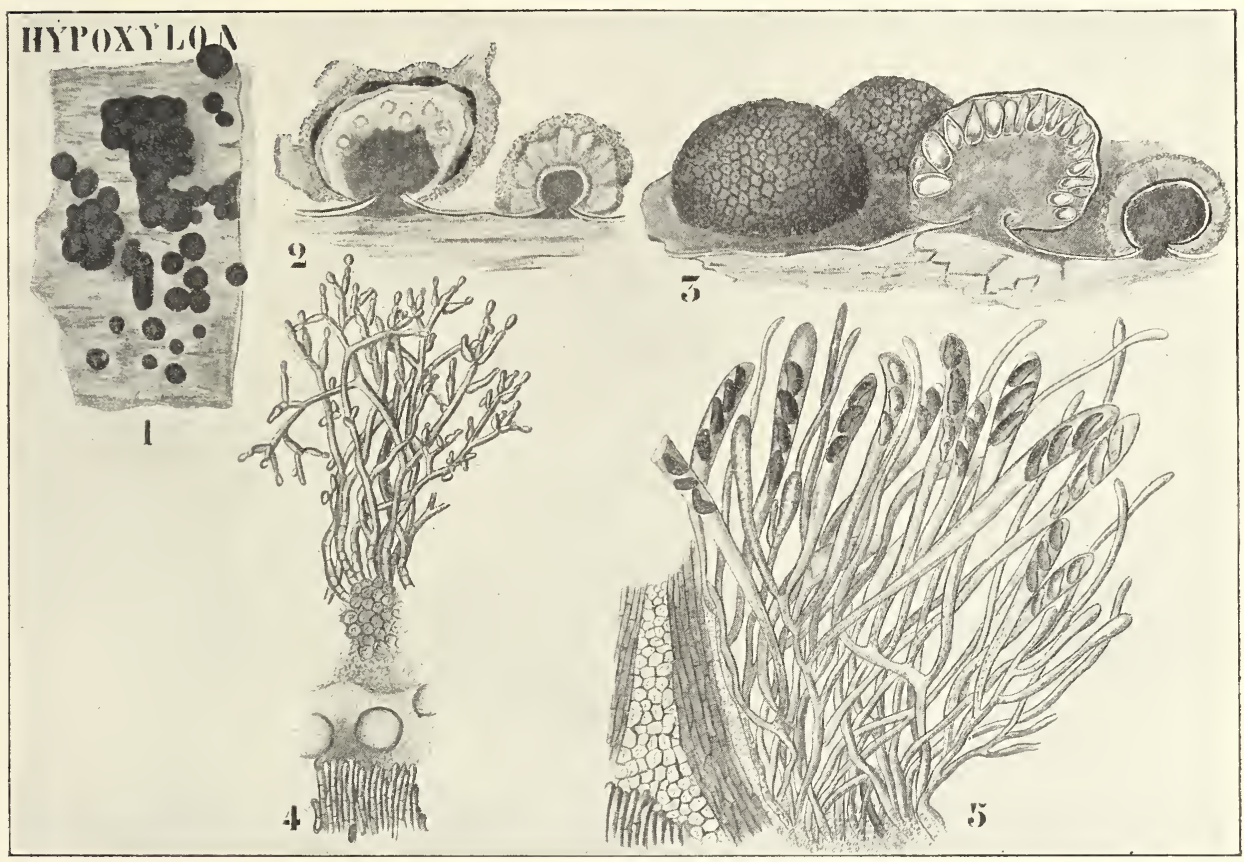

Fig. 311. Hypoxylon coceineum Bull. (nach Tulasne). 1 Stromata, Habitusbild. 2 Uebermäßig konidienproduzierende Stromata. 3 Normale Stromata, die drei links Perithecien bildend, das rechte Konidien produzierend. 4 Konidien. 5 Asci.

ist, später Perithecien zu bilden. Die Konidienträger werden danu länger und unregelmäßiger (Fig. 311, 2 links) und fahlgelb. Diese übermäßig konidienproduzierenden Stromata waren früher unter verschiedenen Namen, wie Isaria umbrina Pers., Institiale acariforme Fries, Anthina flavovirens Fries, Isaria hypoxyli KaLchBR., bekannt.

Als Vertreter der

\section{Xylarieae}

mögen 2 Arten des Genus

\section{Tylaria}

besprochen werden. Wir können in diesem Genus unterscheiden zwischen 
Arten mit gestieltem Stroma, bei welchen der Stiel steril, der Rest aber ganz fertil ist (unter anderen Xyloglossa), und Arten mit gestieltem Stroma, bei welchen nicht nur der Stiel, sondern auch noch die Spitze des Stromas steril ist (unter anderen Xylodactyla).

$\mathrm{Zu}$ der Untergruppe Xyloglossa gehört

\section{Xylaria polymorpha,}

ein Pilz, der in Europa häufig ist. Die Entwickelung der Stromata, der ascogenen Hyphen und Asci, der Konidien, haben wir schon früher kennen gelernt, so daß es jetzt genügen dürfte, auf die Abbildung (Fig. 301, II, p. 514) aufmerksam zu machen, welche die Vielförmigkeit der Stromata deutlich zeigt.

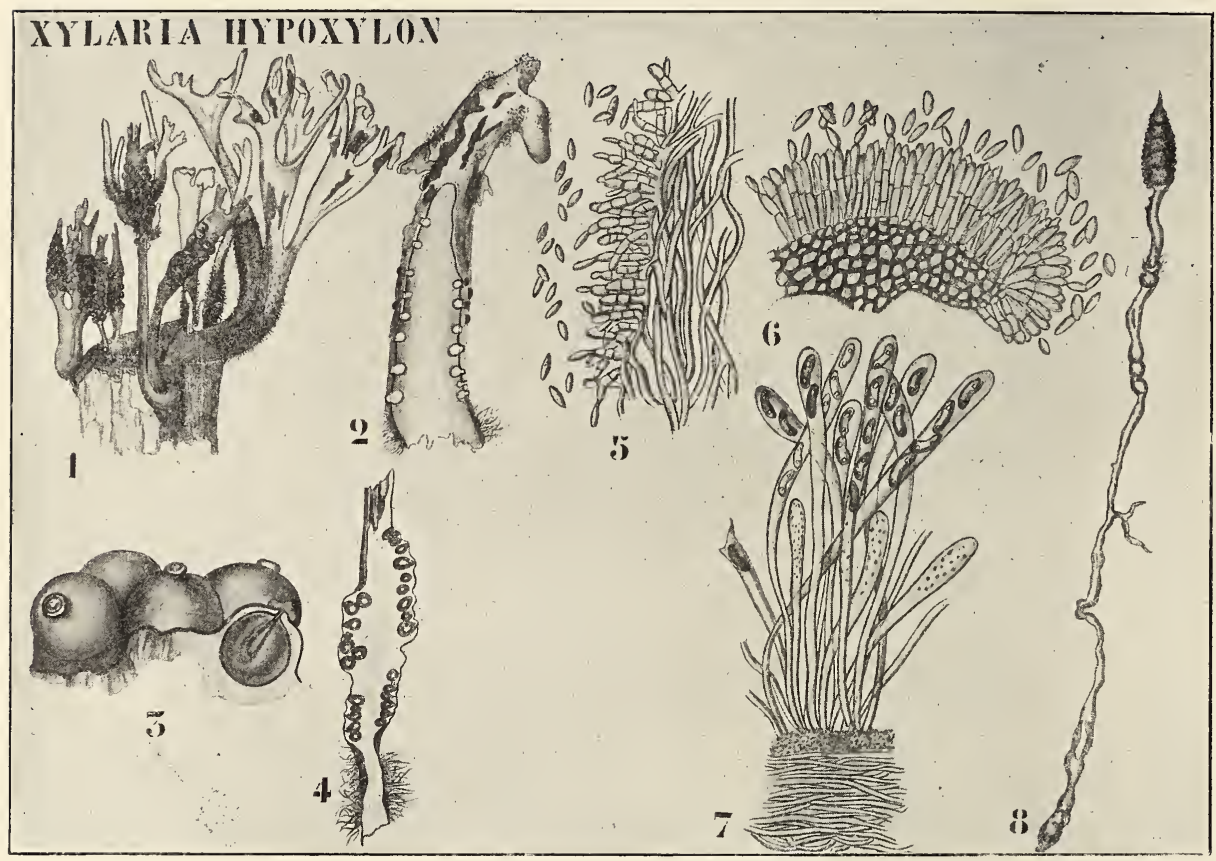

Fig. 312. Xylaria hypoxylon (nach Tulasne). 1 Stromata, oben Konidien, in der Mitte Perithecien produzierend. 2 Längsschnitt eines perithecientragenden Stromas; an der Spitze lösen sich die Konidien in Fetzen ab. 3 Perithecien. 4 Längsschnitt eines Stromas mit Perithecien. 5, 6 Konidienbildung. 7 Asci mit Sporen. 8 Abnormes Stroma.

Viel häufiger wie diese $X$. polymorpha ist die zur Untergruppe Xylodactyla gehörige

\section{Xylaria hypoxylon.}

Ein jeder kennt die geweihartig verzweigten Stromata dieses Pilzes wenigstens im Konidienzustand.

Diese weißgelben, nach der Basis zu schwarz werdenden Geweihe kommen auf allerlei totem Holze vor. Eigentlich ist das ganze Geweih schwarz, die weiße Farbe der apikalen Teile rührt nur von den darauf gebildeten Konidien her. Die Stromata sind 3-8 $\mathrm{cm}$ lang und später in der Mitte an der Stelle, wo die Perithecien gebildet werden, ange- 
schwollen (Fig. 312, 1, 3). Der Perithecienzustand ist im Vergleich zu dem Konidienzustand aber selten. Das Mycel dieses Pilzes bildet rhizomorphaähnliche Stränge und phosphoresziert im Dunkeln, auch das Holz, auf welchem das Mycel wächst, kann leuchten. Wenn die Perithecien gebildet werden, lösen sich die Konidien in Lappen ab (Fig. 312, 2). Zu dieser Art bringt Tulasse auch sehr eigentümliche keulenförmige Stromata (Fig. 312, 8), welche er auf einer Wiese fand und die ein unterirdisches Rhizom von der Dicke einer Gänsefeder und von fast einem Fuß Länge besaßen. Ob diese aber in der Tat hierher gehören, ist fraglich.

Von der großen Gruppe der Pyrenomyceten bleibt nun nur noch die Gruppe der

\section{Dothideales}

zu besprechen übrig. Es sind dies Pilze, deren Mycel in lebenden Pflanzen parasitiert, die aber ihre Früchte erst ausbilden, nachdem sie den Tod des betreffenden Pflanzenteiles verursacht haben. In allen Fällen bilden die Hyphen ein Stroma, welches außen schwarz, im Inneren meistens weiß ist, und vielfach sich im Gewebe des Wirtes befindet. Die Wand der Perithecien ist von der Stromasubstanz nicht zu unterscheiden, oder besser gesagt, sie fehlt, die Perithecien sind demnach nur Höhlen in der Stromasubstanz, Höhlen, in welchen die Asci sich bilden. Die ganze Entwickelung dieser Organismen ist aber noch unbekannt. Für gewisse Arten werden Spermogonien angegeben. Es sei hier nur ein Vertreter:

\section{Phyllachora graminis,}

erwähnt, welche glänzende schwarze Streifen auf Blättern von Gräsern und Carices bildet. In diesen Stromata befinden sich die Perithecien, welche etwas einer eigenen Wand Aehnliches besitzen. Die Asci enthalten 8 Sporen.

Wir haben also bis jetzt die

$$
\begin{aligned}
& \text { Erysiphales, } \\
& \text { Plectascineae und } \\
& \text { Pyrenomyceten }
\end{aligned}
$$

als mehr oder weniger natürliche Gruppen aus den Ascomyceten herausgehoben, wobei wir aber auch schon gesehen haben, wie viel noch an der Natürlichkeit, zumal dieser letzteren Gruppe, fehlt. Wir haben aber der Hoffnung Ausdruck gegeben, daß die Gruppe der Pyrenomyceten nach Ausweisung verschiedener, jetzt noch dazu gerechneter Formen eine natürliche Gruppe sein wird, bei welcher ursprünglich eine Befruchtung mittels Trichogynen und Spermatien stattfand, deren Vertreter aber jetzt apogam geworden sind.

Sehen wir also zunächst einmal, bei welchen anderen AscomycetenGruppen eine Befruchtung mittels Trichogynen und Spermatien stattfindet, um zu sehen, ob eine ähnliche Befruchtungsweise auf eine ziemlich nahe Verwandtschaft hindeutet.

Wir können dann sofort mit einer offenbar sehr natürlichen Gruppe, mit der der

\section{Laboulbeniales}

anfangen. Die Laboulbeniales sind kleine Pilze, welche als Parasiten auf Insekten leben. Die Geschichte dieser Gruppe ist recht eigentümlich. 
Bis vor kurzem meinte man, daß diese Gruppe eine östliche war und nicht weiter westlich als Wien vorkam, wobei man sie noch dazu für eine recht kleine Gruppe hielt.

Nicht wenig Aufsehen erregte daher eine Publikation Thaxters, in der eine große Anzahl, vorwiegend amerikanischer, aber auch z. B. afrikanischer und asiatischer Arten beschrieben wurden. Seitdem erhielt ich auch Laboulbeniaceen aus Holland (Dr. DE MEYERE) und Java (Herr E. JACOBSON) zugeschickt, und es wird mehr und mehr deutlich, daß wir mit einer ziemlich großen kosmopolitischen Gruppe $\mathrm{zu}$ tun haben. Die Laboulbeniales leben parasitisch auf Insekten, und zwar vorwiegend auf Käfern, die im oder in der Nähe des Wassers leben. Im Jahre 1895 gab Thaxter seine Monographie der Ordnung heraus, welcher folgendes entnommen ist.

Die zu den Laboulbeniales gehörigen Pilze sind sehr klein und schwer aufzufinden, da sie in hohem Grade den braunen oder gelben Stacheln oder Haaren gleichen, welche auf Insektenkörpern so häufig sind.

Meistens stehen sie allein oder in Paaren; es gibt aber auch Arten, die an bestimmten Stellen des Insektenkörpers in großer Menge vorkommen, so daß sie einen pelzähnlichen Ueberzug bilden.

Trotzdem die Laboulbeniales zweifellos Parasiten sind, sind sie den Insekten nicht gefährlich und töten diese nicht, im Gegenteil, der Tod des betreffenden Insektes tötet sie. Mit wenigen Ausnahmen bilden sie denn auch keine Haustorien, welche in den Körper des Insektes eindringen, sondern sind damit zufrieden, sich dem Chitinpanzer anzuheften, höchstens darin ein kleines Loch zu machen, ja man kann sagen, daß diese Pilze kaum ein vegetatives Mycel bilden, sondern sich auf die Bildung von Fruchtkörpern beschränken.

Am besten machen wir uns mit dem Aufbau dieser Organismen bekannt, wenn wir die Entwickelung einer Art des Genus

\section{Stigmatomyces}

verfolgen. Die Spore ist zweizellig, und zwar ist die eine Zelle kleiner wie die andere. In jeder Zelle findet sich ein Nucleus (Fig. 313. 1). Die Sporen sind stets von einer Schleimmasse umgeben; sie werden von einem Insekt auf ein anderes durch Berührung übertragen, bei Wasserinsekten wahrscheinlich nur während des Coitus, bei Insekten, welche öfters in größerer Menge an feuchten Stellen zusammenkriechen, auch ohne dies.

Nachdem die Spore mittels ihrer klebrigen Hülle an einem Insekt. befestigt ist, fängt sie direkt zu keimen an. Das erste Keimungszeichen ist gewöhnlich die Erscheinung eines schwarzen Punktes an der Basis der Spore, des sogenannten Fußes (Fig. 313, 2), welcher in der Tat ein kleines, von erhärtetem Schleim umhülltes Zellchen darstellt und so eine feste, aber mehr oder weniger elastische Verbindung mit dem Insekt bewirkt. Die Aufnahme der Nahrung findet bei Stigmatomyces offenbar durch einfache Osmose statt.

Nun fängt die obere Zelle sich zu verlängern an und wird alsbald durch zwei schiefe Querwände in drei Zellen zerlegt (Fig. 313, 3). So entsteht eine Zellreihe, welche mit dem Namen Appendix bezeichnet wird; dieser Appendix bildet später die Spermatien.

Nun teilt sich auch die Stielzelle mittels einer schiefen Wand in zwei Zellen (Fig. 313, 5), deren obere (b) die Tragzelle des Appendix wird. Die untere Zelle teilt sich darauf durch eine Querwand in eine 
Basalzelle und eine Subbasalzelle, welche letztere sich in Fig. 313, 6 schon wieder in eine obere $\left(a^{\prime}\right)$ und eine untere $\left(a^{2}\right)$ Zelle geteilt hat. Die Zelle $a^{\prime}$ wird das weibliche Geschlechtsorgan mit der Trichogyne bilden.

Wir haben also gesehen, daß sich männliche und weibliche Geschlechtsorgane auf demselben Individuum bilden, sehen wir nun, wie jedes sich entwickelt.

Fangen wir dabei mit der Initiale des weiblichen Geschlechtsorgans, unserer Zelle $a^{\prime}$. an. Diese wächst nun zunächst nach oben auswärts aus (Fig. 313, 7) und teilt sich dann mittels einer Querwand in die Zellen $d$ und $c$ (Fig. 313, 8).

Diese Zelle $d$ nennt man die Primordialzelle des weiblichen Geschlechtsorgans, denn dieses wird ausschließlich aus ihr gebildet, die

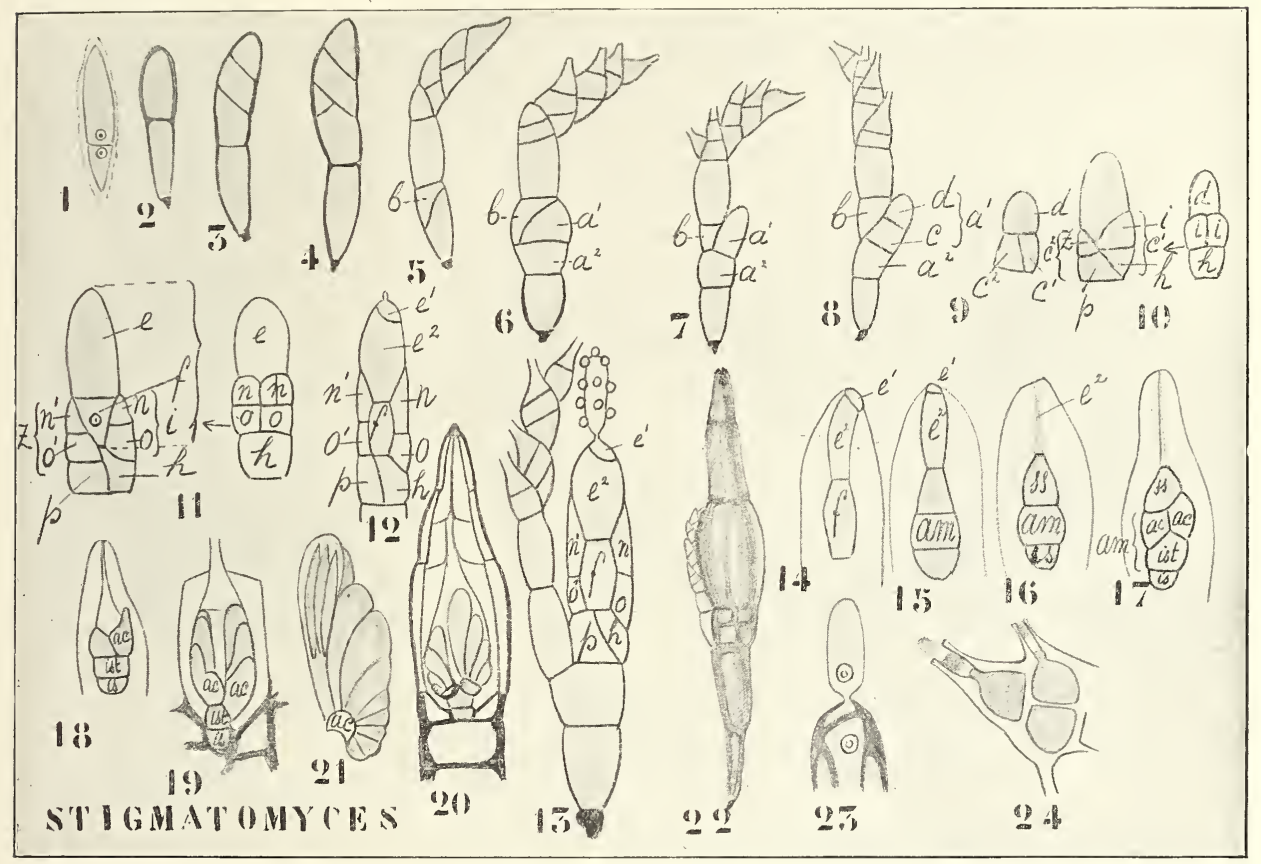

Fig. 313. Stigmatomyces-Entwickelung (nach THAxteR). Figurenerklärung im Text.

untere Zelle $c$ nennt man die Primordialzelle des Peritheciums, weil letzteres aus ihr entsteht.

Es entwickelt sich zunächst dieses Peritheciumprimordium, indem es sich durch eine schiefe Längswand in die Zellen $c^{\dagger}$ und $c^{2}$ teilt (Fig. 313, 9). Die Zelle $c^{2}$ wächst nun hinauf und wird durch eine Querwand (Fig. 313 . 10 links) in eine obere Zelle $\%$ und eine untere $p$ zerlegt. Die Zelle $c^{\prime}$ teilt sich genau so in die Zellen $i$ und $h$ (Fig. 313, 10 links), aber wenn man nun das Objekt um $90^{\circ}$ dreht (Fig. 313, 10 rechts), sieht man, daß die obere Zelle $i$ noch durch eine Längswand in zwei Zellen zerlegt ist.

Sowohl die Zelle $\approx$ wie die Zellen $i i$ wachsen nun nach oben aus, wobei sie die Zelle $d$, das Primordium des weiblichen Geschlechtsorgans, einhüllen. Weitere Teilungen in diesen Peritheciumzellen führen zur 
Bildung eines ordentlichen Ringwalles um die untere Hälfte der Zelle $d$ (Fig. 313, 11).

Die Zelle $d$ teilt sich nun durch eine Querwand in eine untere Zelle $f$, welche das Oogon wird, welches Oogon also ganz vom Peritheciumringwall umschlossen ist (Fig. 313, 11), und eine obere Zelle $e$. Von der oberen Zelle $e$ wird nun durch eine Querwand eine ganz kleine Spitzenzelle $\left(e^{\prime}\right)$ abgetrennt (Fig. 313, 12), welche sofort zu einer Trichogyne (Fig. 313, 13) auswächst.

Die Trichogyne ist also hier vom Oogon durch 2 Querwände getrennt.

Die Antheridien entstehen aus den Segmenten des Appendix. Jede Appendixzelle teilt sich zunächst mittels einer Querwand in eine Antheridiumzelle und eine Stielzelle (Fig. 313, 5). Die Antheridiumzelle teilt sich nun mittels einer zweiten Querwand (Fig. 313, 6-8) in eine Bauchzelle und eine Halszelle. Diese Querwand ist aber unvollständig, da sie in der Mitte ein Loch hat.

In der Bauchzelle werden die nackten unbeweglichen Spermatien gebildet, welche durch den Hals heraustreten und, wenn sie eine Trichogyne gefunden haben, sich in größerer Zahl an diese anheften (Fig. 313, 13).

Die Spermatien schnüren sich nacheinander vom Inhalt der Bauchzelle ab (Fig. 313, 24), und zwar sehr langsam, jede braucht nicht weniger als 2 oder 3 Stunden.

Die eigentliche Befruchtung ist noch nicht bekannt, vermutlich entstehen Löcher in den Wänden zwischen Trichogyne und Oogonium und ein Spermakern verbindet sich mit einem Eikern. Nach stattgefundener Befruchtung fällt die Trichogyne mit Ausnahme der Basis ab (Fig. 313, 14) und der Peritheciumringwall wächst hinauf, bis er die Zelle $e^{2}$, also die Zelle zwischen der Trichogyne und dem Oogon, ganz umhüllt hat (Fig. 313, 14 auf dem Längsschnitt, Fig. 313, 22 von außen betrachtet).

Dann degeneriert auch die Zelle $e^{2}$ und die Weiterentwickelung des vermutlich befruchteten Oogons fängt an. Es bildet sich aus demselben eine dreizellige $2 \mathrm{x}$-Generation ${ }^{1}$ ), von welcher nur die mittlere Zelle $(\mathrm{am})$ fertil ist; die beiden anderen (is und ss) sind steril und gehen alsbald zu Grunde.

Die fertile Zelle teilt sich nun in eine untere Zelle (ist), welche ebenfalls steril bleibt, und eine obere, welche sich durch Längswände in vier teilt, von denen zwei ( $a c, a c$ in Fig. 313, 17) sichtbar sind. Diese Zellen sind die ascogenen Hyphen (resp. Zellen) und bilden als laterale Sprossen die Asci (Fig. 313, 21).

In allerletzter Zeit ist von FAULL nachgewiesen worden, daß auch hier im Ascus eine Fusion von zwei Kernen stattfindet. Da ich aber den betreffenden Artikel noch nicht gesehen habe, kann ich nichts weiteres darüber mitteilen.

Infolge der Bildung der Asci nimmt der Inhalt des Peritheciums sehr zu, wodurch natürlich nach allen Richtungen ein Druck ausgeübt wird. Die Zellen ss, ist und sogar öfters is werden zerstört oder zusammengedrückt. Die reifen Asci lösen sich von den ascogenen Zellen $a b$ und ihre Wand wird, sobald die Sporen reif sind, absorbirt, so daß die Sporen frei in die Höhle des Peritheciums zu liegen kommen. Da diese Sporenmasse fortwährend vermehrt wird, wird sie schließlich durch den Hals des Peritheciums hinausgedrückt.

Wir haben gesehen, daß bei Stigmatomyces die Spermatien im

1) Meiner Ansicht nach. 
Inneren des Antheridiums, also endogen entstehen; das ist der Fall bei allen Laboulbeniales, ausgenommen bei Zodiomyces und Ceratomyces, bei welchen sie exogen entstehen.

Bei Zodiomyces werden sie an den Spitzen spezieller kurzer Zweiglein (Fig. 324, 5) in der Weise von Konidien abgeschnürt und fallen ab; sie besitzen eine Zellwand. Auch bei Ceratomyces werden sie in ähnlicher, wenn auch etwas anderer Weise gebildet.

Wir sahen, daß bei Stigmatomyces die Antheridien in einer Reihe stehen, bei anderen ist die Anordnung weniger regelmäßig und bei einem Genus, Amorphomyces, kommt nur ein einziges Antheridium vor, ein Fall, der sich auch bei einigen Arten von anderen Genera, z. B. bei Laboulbenia texana, zeigt.

Alle bis jetzt besprochenen Antheridien besitzen ihre eigene Ausführöffnung und können darum einfache Antheridien genannt werden. Thnen gegenüber steht die Gruppe mit vereinigten Antheridien, bei welchen eine Anzahl von Antheridien eine gemeinsame Ausführöffnung haben.

Von den 29 bekannten Laboulbenialen-Genera besitzt ungefähr ein Drittel diesen Antheridientypus, und da es bei Dimeromyces am größten und deutlichsten ist, mag dieser als Beispiel dienen. In diesem Genus sind die Pflanzen diözisch, und zwar sind die männlichen ebenso gut wie die weiblichen entwickelt. Das Antheridium (Fig. 315, 6) besitzt eine Stielzelle und vier basale Zellen zwischen dieser und den eigentlichen Antheridiumzellen. Es gibt 6 Antheridiumzellen, welche in zwei Reihen liegen und in eine gemeinsame Ausführröhre ihre Spermatien entleeren. Die Bildung derselben findet genau so wie bei den einfachen endogenen Antheridien statt.

Alle Zellen der Laboulbeniales stehen mittels ziemlich dicker Plasmaarme miteinander in Verbindung, wie zumal bei Behandlung mit $\mathrm{KOH}$ deutlich wird (vergl. Laboulbenia elongata Fig. 321, 7). Die Zellen sind monoenergid.

Thaxter teilt die Laboulbeniales nach den Merkmalen der männlichen Geschlechtsorgane wie folgt ein.

\section{Laboulbeniales.}

Gruppe I. Endogenae.

Die Spermatien entstehen endogen.

\section{Ordnung. Peyritschielleae.}

Antheridien zusammengesetzt.

A. Diözische Genera: Dimorphomyces, Dimeromyces.

B. Monözische Genera: Cantharomyces, Haplomyces, Eucantharomyces, Camptomyces, Enarthromyces, Peyritschiella, Dichomyces, Hydraeomyces, Chitonomyces.

\section{Ordnung. Laboulbeniaceae.}

Antheridien einfach.

A. Diözisches Genus: Amorphomyces.

B. Monözische Genera: Helmintophana, Stigmatomyces, Idiomyces, Corethromyces, Rhadinomyces, Rhi $20-$ myces, Labovibenia, Teratomyees, Diplomyces, Rhachomyces, Chactomyces, Sphaleromyces, Compsomyces, Moschomyces. 
Spermatien entstehen exogen.

\section{Gruppe II. Exogenae.}

3. Ordnung. Zodiomyceteae.

Typisch aquatisch.

Genera: Ceratomyces, Zodiomyces.

Die gesperrten Genera werden wir ganz kurz behandeln. Fangen wir mit den beiden diözischen Genera der

\section{Peyritschielleae}

an, und zwar zunächst mit

\section{Dimorphomyces.}

Die männlichen Individuen der zu diesem Genus gehörigen Arten bestehen aus vier übereinander gestellten Zellen, von welchen die beiden

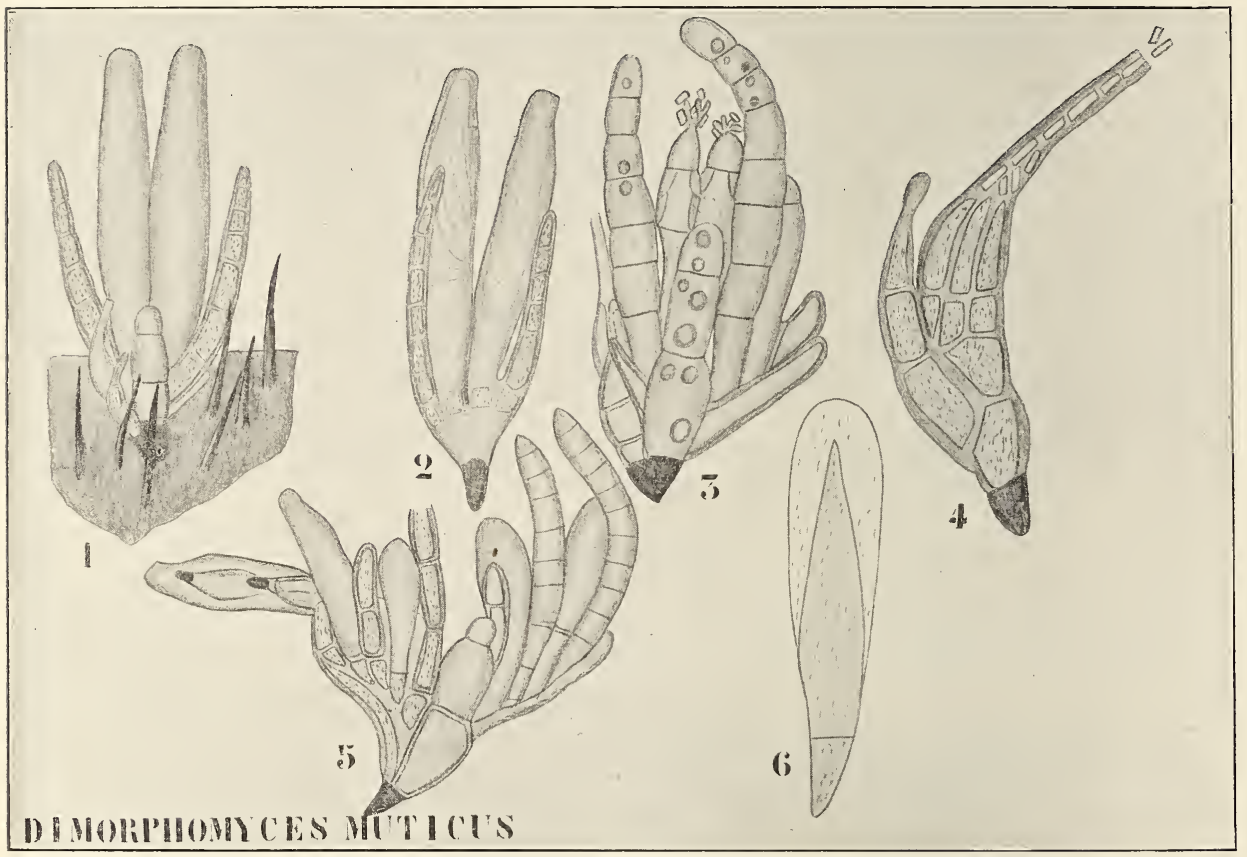

Fig. 314. Dimorphomyces muticus (nach THAXter). 1 Zwei Individuen auf der Haut einer Staphylidine, das $\delta$ vorn, das $q$ hinten. 2 Weibliches Individuum mit zwei Perithecien. 3 Weibliches Individuum mit Spermatien an den Trichogynen. 4 Männliches Individuum mit einem Antheridium. 5 Sporen, innerhalb des Peritheciums keimend.

oberen steril sind und die subbasalen ein zusammengesetztes Antheridium bilden.

Auch beim vierzelligen weiblichen Individuum sind die beiden oberen Zellen und die basale Zelle steril; es bildet die subbasale zwei oder mehr Perithecien und mit diesen alternierende Appendices. An jeder Seite des Körpers entstehen also ein oder mehrere Perithecien und ein 
oder mehrere Appendices, welche wie Flügel am Körper des Pflänzchens stehen.

Die Entwickelung fängt stets mit der Bildung eines Peritheciums und eines Appendix an jeder Seite der Mediane an (Fig. 314, 2) und öfters verharren die Pflänzchen zeitlebens auf diesem Entwickelungsstadium. Die Trichogyne (Fig. 314, 3) ist verzweigt; die Appendices sind einfache einreihige Zellfäden. Es wird nur eine ascogene Zelle gebildet, welche aber eine Anzahl von Asci produziert.

Die Sporen sind normal. So wie bei fast allen Laboulbeniaceae werden 4 Sporen pro Ascus gebildet (nur die Genera, Moschomyces und Compsomyces bilden $S$ Sporen), diese liegen in Paaren, eines etwas höher wie das andere, sie werden so gepaart ejaculiert. Das ist für die diözischen Arten von größter Wichtigkeit, denn aus der einen Spore eines solchen Paares entsteht eine $\delta$, aus der anderen eine $q$ Pflanze ${ }^{1}$ ), welche also nebeneinander auf den Insektenkörper gepflanzt werden.

Bei den monözischen Arten sind die Sporen ebenfalls gepaart, es entsteht dort aber aus jeder Spore ein hermaphrodites Pfiänzchen, nur bei Laboulbenia inflata ist eine der beiden Sporen eines Paares reduziert und bildet auch ein reduziertes Pflänzchen. Inwieweit dies Licht auf die Entstehung der diöcischen Formen werfen kann, muß dahingestellt bleiben.

Der Umstand, daß bei allen diözischen Arten von Laboulbeniaceen ऽ und + Pflanzen nebeneinander vorkommen, spricht sehr sicher für die Notwendigkeit einer Befruchtung. Da FAuLL nun auch eine Kernverschmelzung im Ascus beobachtete, würde man auch hier nach HARPERs Auffassung über die doppelte Reduktion im Ascus 8 Sporen erwarten, statt, wie in der Tat der Fall war, nur 4. Wie schon früher gesagt, müssen neue Untersuchungen entscheiden.

Von den beiden bekannten Arten dieses Genus ist hier Dimorphomyces muticus abgebildet. Beide Arten werden in Massachusetts und Maine auf einer Staphylinidee, auf Falagria dissecta Fr. gefunden, bisweilen beide Arten auf einem Exemplar. Unter Umständen können die Sporen noch innerhalb des Peritheciums (Fig. 314, 5 links) keimen und zu fast vollkommenen Pflänzchen auswachsen.

\section{Dimeromyces}

ist in gewisser Hinsicht eines der interessantesten Laboulbeniaceen-Genera es zeigen hier nämlich die ơ Individuen eine höhere Entwickelung wié bei jeder anderen diözischen Art; statt nur ein Antheridium zu bilden, wie bei Dimorphomyces, bildet hier das đ̃ Pflänzchen deren mehrere.

Sowohl die $\sigma^{\pi}$ wie die $q$ Pflänzchen bestehen aus einer Zellreihe. Die $q$ Individuen bilden lateral eine Reihe steriler Appendices und Perithecien (Fig. 315, 4); die $\delta$ sind den weiblichen gleich, nur stehen an den Stellen der Perithecien Antheridien.

Bis jetzt ist nur noch eine Art, Dimeromyces TH., bekannt und diese wurde nur einmal auf einem Exemplar der Carabidee: Pachyteles luteus Hope aus Liberia angetroffen.

Von den monözischen Genera wollen wir zunächst einen Repräsentanten aus jener Gruppe behandeln, bei welchem die Antheridien auf freien Appendices stehen, d. h. auf Appendices, welche nicht mit dem Recep-

1) Cytologische Untersuchungen wären hier sehr erwünscht; sie könnten vielleicht Licht werfen auf die Ursache der Geschlechtsbestimmung. 
taculum (das sind die Zellen, welche die Geschlechtsorgane tragen) verwachsen sind, nämlich

\section{Haplomyces.}

Das Receptaculum, d. h. also die Zellen, welche die Geschlechtsorgane tragen, besteht aus 2 kleinen Zellen, deren eine das Perithecium, deren andere das Antheridium trägt (Fig. 316, 1).

Das Perithecium ist groß, zugespitzt und im Besitze einer langen Stielzelle, welche die 3 Basalzellen (Fig. 316, 3) des Peritheciums trägt.

Das Antheridium besitzt eine Stielzelle und ist gekammert, so daß es an die plurilokulären Gametangien der Phaeophyceen erinnert. Wo die Spermatozoen heraustreten, ist noch nicht bekannt, sicher nicht aus

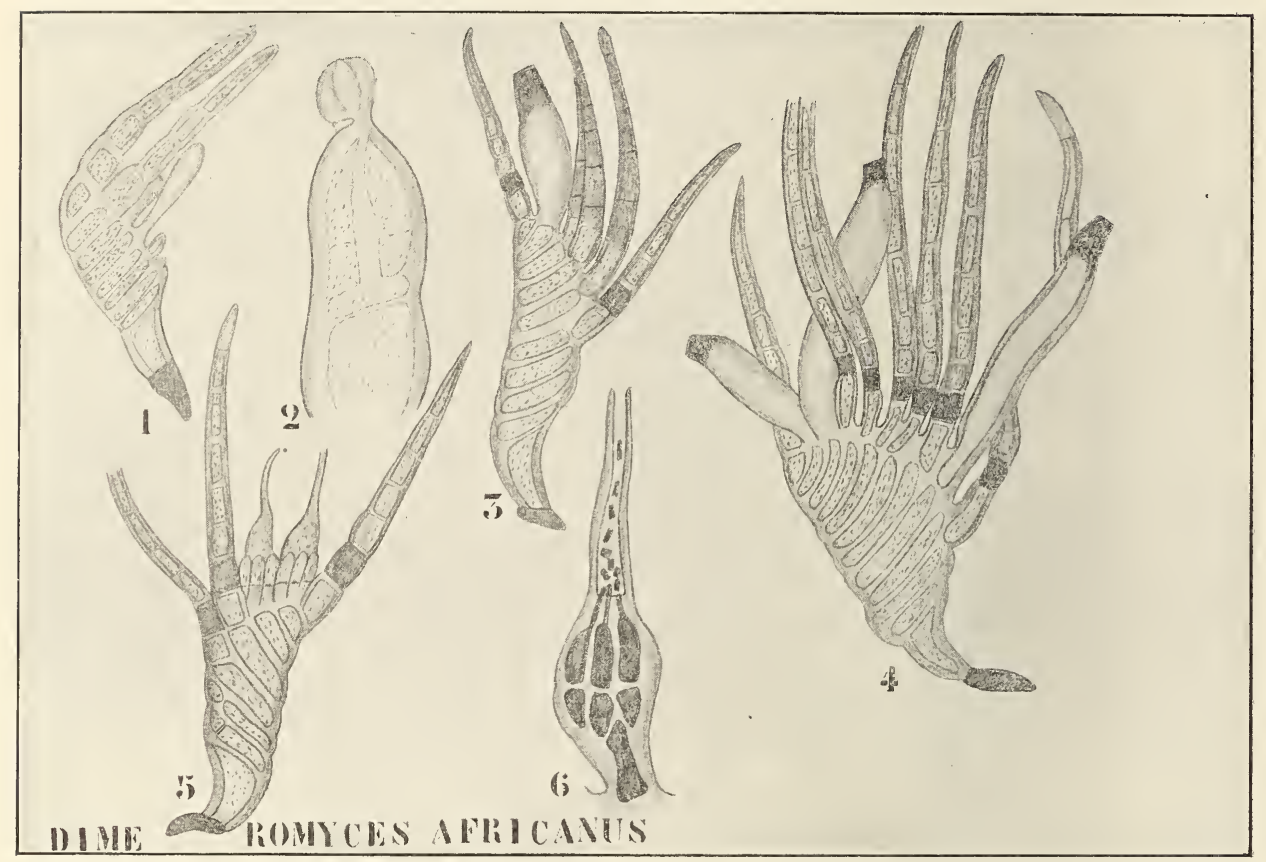

Fig. 315. Dimeromyces africanus TH. (nach THAxter). 1 junges weibliches Individuum. 2 Trichogyne. 3, 4 erwachsene 9 Individuen. 5 ơ Individuum. 6 Zusammengesetztes Antheridium.

dem terminalen, dornähnlichen Fortsatz (Fig. 316, 5), welche vielleicht den Rest der oberen Zelle der Spore repräsentiert, eher durch eine laterale Ausstülpung (Fig. 316, 3, rechts oben am Antheridium). Ob das Antheridium ausschließlich aus fertilen oder aus fertilen und sterilen Zellen besteht, ist ebenfalls unbekannt. Mit einer Oelimmersion meinte Thaxter im Innern des Antheridiums eine zentrale Höhle zu entdecken, welche mit Spermatien gefüllt war und sich bis an die laterale Ausstülpung ausdehnte; wahrscheinlich münden die Antheridiumzellen darauf aus.

Das Perithecium enthält nicht weniger wie 8 ascogene Zellen, welche symmetrisch in 4 Paare angeordnet sind. Die drei bekannten Arten sind 
sämtlich auf Arten des Staphyliniden-Genus Bledius gefunden worden, und zwar in Kalifornien, Virginia und T'exas.

Von der zweiten Gruppe der monözischen Genera, von der Gruppe, bei welcher die Perithecien freistehen und welche scharf zugespitzte, direkt auf dem Receptaculum sitzende ungestielte Antheridien besitzt, sei hier zunächst

\section{Enarthromyces}

besprochen. Es sind dies bernstein- oder strohfarbige Organismen, bei denen das Receptaculum aus 10-20 in einer Reihe stehenden Zellen besteht (vergl. Fig. 317, I). Die beiden unteren Zellen dieses Receptaculums sind stets steril, die dritte trägt immer ein Perithecium; die siebente

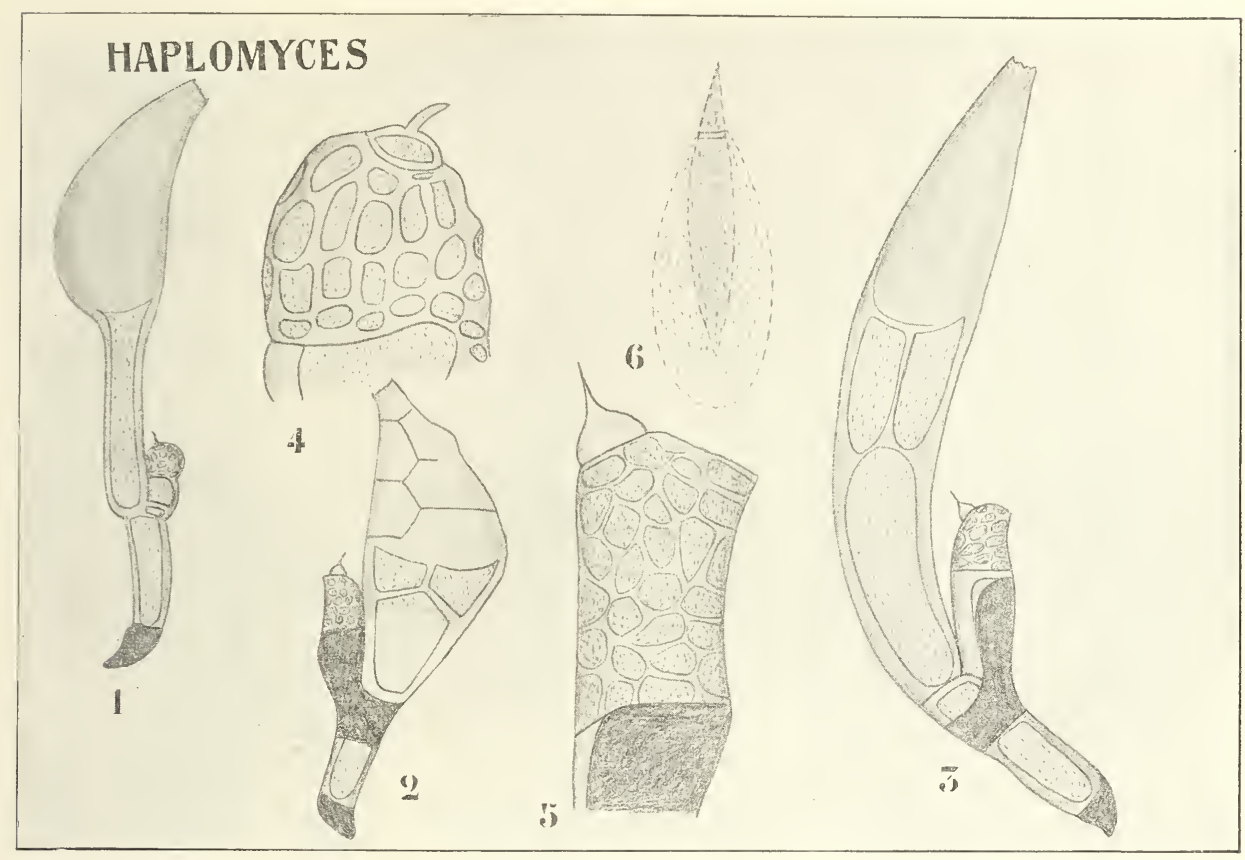

Fig. 316. Haplom yces (nach Thaxter). 1 Pflänzchen mit einem Perithecium und einem Antheridium. 2, 3 id., zwei der drei Basalzellen des Peritheciums zeigend. 4, 5 Antheridien. 6 Spore.

(bisweilen auch die sechste) Zelle trägt ein sitzendes Antheridium (auf unserer Figur zwischen den beiden oberen Perithecien), die Zellen, die direkt ober- und unterhalb der antheridientragenden Zelle gelegen sind, können Perithecien oder Antheridien tragen oder steril bleiben. Die Gesamtzahl der Antheridien beträgt selten mehr wie 3.

Die 5 oder 6 terminalen Zellen des Receptaculums tragen septierte, einfache, laterale, sterile Appendices. Eine Anzahl angelegter Perithecien degeneriert gewöhnlich, vermutlich infolge eines Ausbleibens der Befruchtung.

Die Pflanze wuchs auf einer Carabidee: Pherosophus spec., aus der Booloo-Valley, banks of the Beeas River, N. IV. India. 
Zur gleichen Gruppe gehört

\section{Dichomyces princeps Thaxter.}

Es ist dies ein hübsches, hyalines, hellbraunes Pflänzchen, welches bilateral symmetrisch und abgeflacht dorsiventral ist. Die Seite, aut welcher die Antheridien stehen, nennt Thaxter die Vorderseite; von dieser Seite sieht man das hier abgebildete Exemplar (Fig. 317, II). Oberhalb der beiden Stielzellen sehen wir in der Mediane eine Reihe von 3 Zellen, deren jede zu einem Segment gehört. Das untere Segment ist steril, das nächste, dessen laterale Zellen schief aufwärts wachsen, trägt an der Vorderseite zwei symmetrisch gestellte, zusammengesetzte Antheridien und einige sterile Appendices, das obere zwei ebenfalls symmetrisch gestellte Perithecien und einige sterile Appendices.

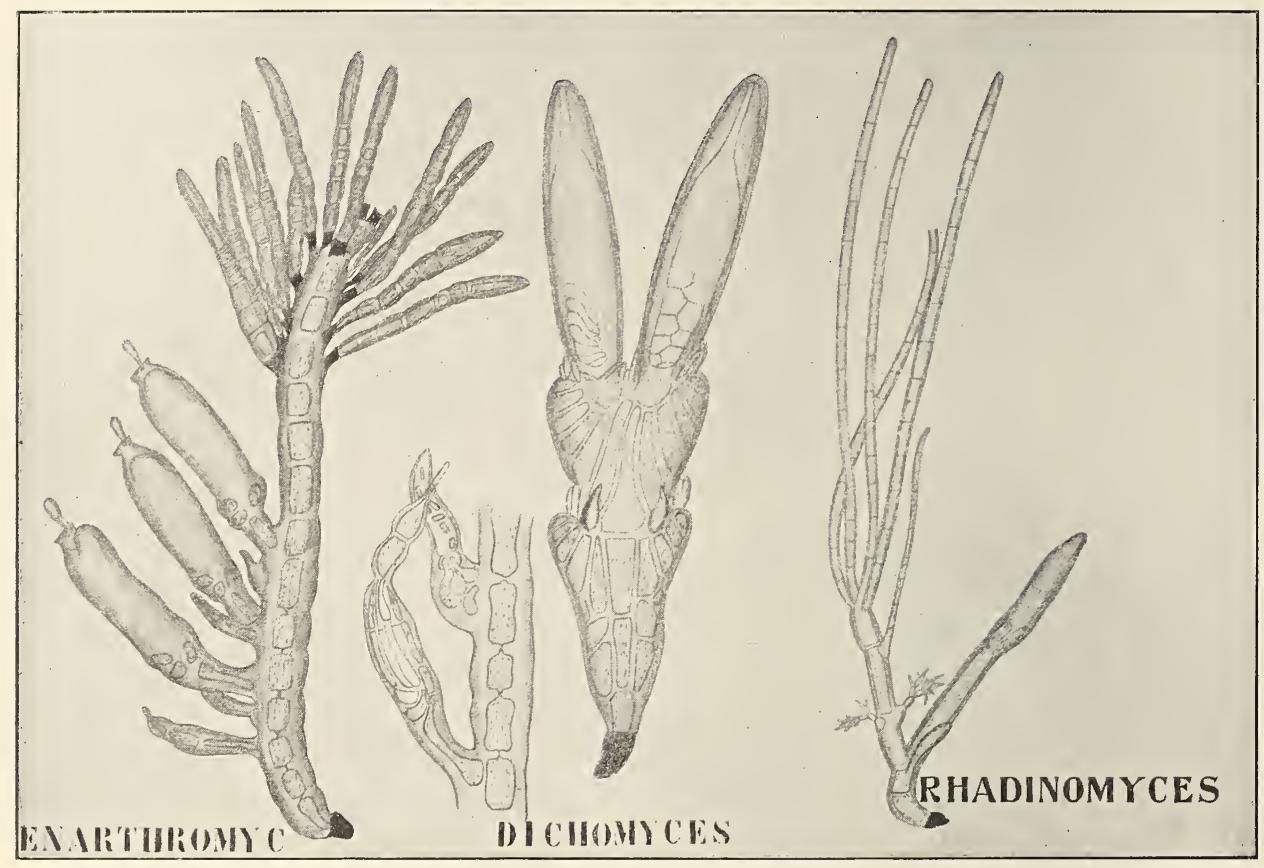

Fig. 317. Verschiedene Laboulbeniace en (nach ThaxTER). I. Enarthromyces, links Habitus, rechts Stück eines Exemplares, die Struktur des Antheridiums zeigend. II. Dichomyces princeps, von der Vorderseite. - III. Rhadinomyces.

Das Pflänzchen wird auf der Staphylinide Philonthus sordidus GRAv. in Massachusetts angetroffen und ist, da der Parasit in größerer Individuenzahl auf der Bauchseite des Insektes vorkommt und durch seine helle Farbe sich scharf vom schwarzen Insekt abhebt, leicht zu entdecken.

Die bis jetzt behandelten Peyritschielleae-Arten leben auf Landinsekten. Es bleiben nun noch zwei Genera übrig, welche auf Wasserinsekten leben und welche keine freien, sondern teilweise mit dem Receptaculum verwachsene Perithecien besitzen. Als Beispiel wählen wir 


\section{Chitonomyees.}

Das Receptaculum besteht aus einem basalen und aus einem terminalen Teile; ersterer besteht aus 2 nebeneinander gestellten Zellen und 3 oder 4 oberen kleineren Zellen, welche die Basis des Perithecium bilden, letzterer aus 4 neben dem Perithecium gelegenen Zellen, von welchen die terminale stets frei ist und einen einzigen Appendix trägt. Die subterminale Zelle trägt das meistens kleine Antheridium.

Das Perithecium ist über eine größere oder kleinere Distanz (Fig. 318, 4-6) mit dem terminalen Teile des Receptaculums verwachsen.

Die hier abgebildete Art ist in Amerika und Europa auf dem $D y$ tiscideen-Genus Laccophilus gefunden worden und zwar stets auf dem Außenrand des linken Elytrons, etwas unterhalb der Mitte, wo sie in

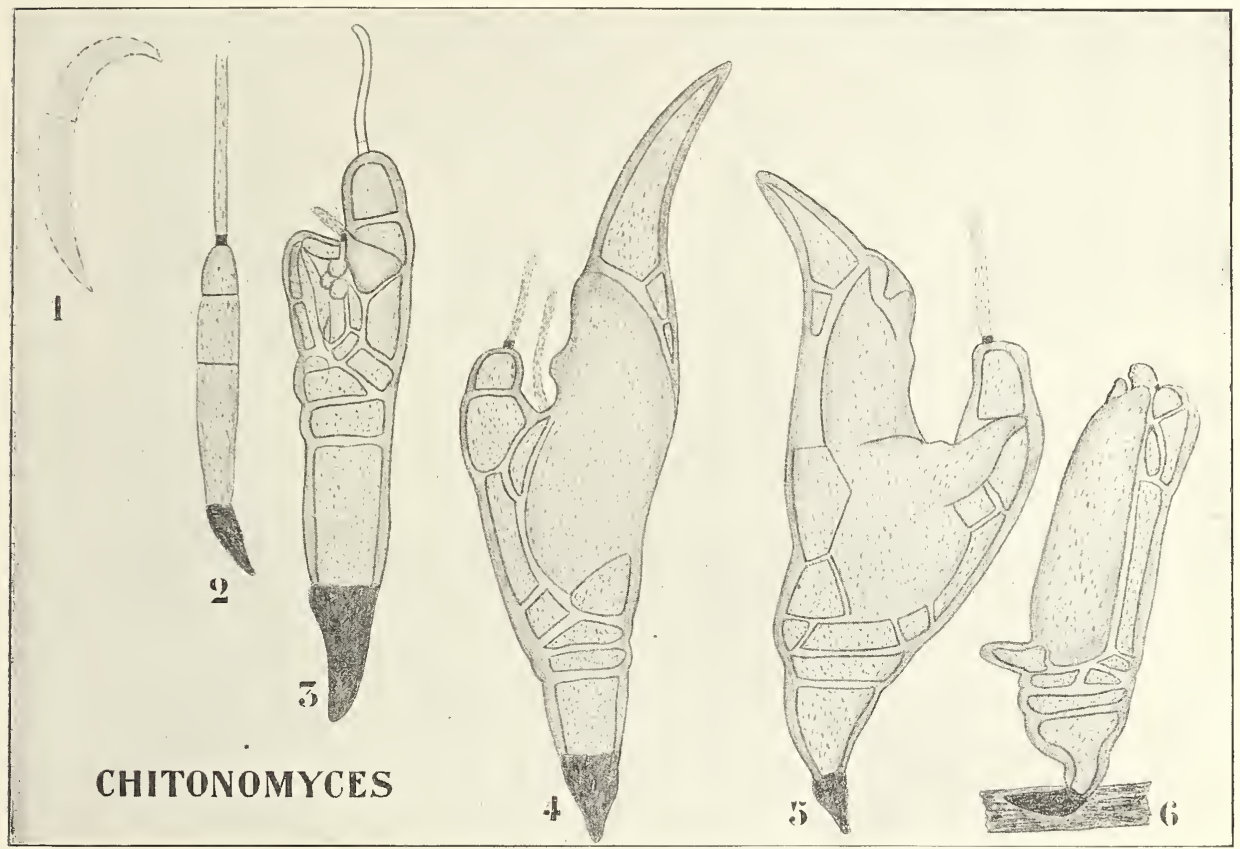

Fig. 318. Chitonomyces paradoxus [Peyritsch] TH. (nach Thaxter). 1 Spore. 2 Junges Pflänzchen. 3 Exemplar mit jungem Perithecium und Antheridium. 4-6 Erwachsene Individuen mit mehr oder weniger angewachsenen Perithecien.

Gruppen von 2-6 Exemplaren vorkommt und durch ihre Größe leicht $\mathrm{zu}$ sehen ist. C. spinigerus ist viel seltener auf dem gleichen Wirt in Connecticut.

Damit sei die Besprechung der ersten Ordnung beendet, und wir können uns der Familie mit einfachen Antheridien zuwenden, der der

\section{Laboulbeniaceae,}

von welcher wir zunächst das diözische Genus 


\section{Amorphomyees}

behandeln wollen (Fig. 319). Das Receptaculum besteht bei den männlichen Individuen aus zwei nebeneinander gelegenen Zellen, von welchen die obere, terminale, ein einzelnes einfaches Antheridium trägt, bei den weiblichen Individuen aus einer einzigen Zelle, welche die 4 (?) Basalzellen des Peritheciums trägt. Die Trichogyne ist kurz und hat radiär ausgebreitete Verzweigungen. Die Sporen sind einzellig; im Perithecium ist nur eine ascogene Zelle vorhanden, welche jedoch zwei Reihen von Asci bildet. Es ist das einzige Genus mit einem apikalen Antheridium. Die abgebildete Art wird in Massachusetts und Maine auf der Staphylinide Falagria dissecta Er. gefunden.

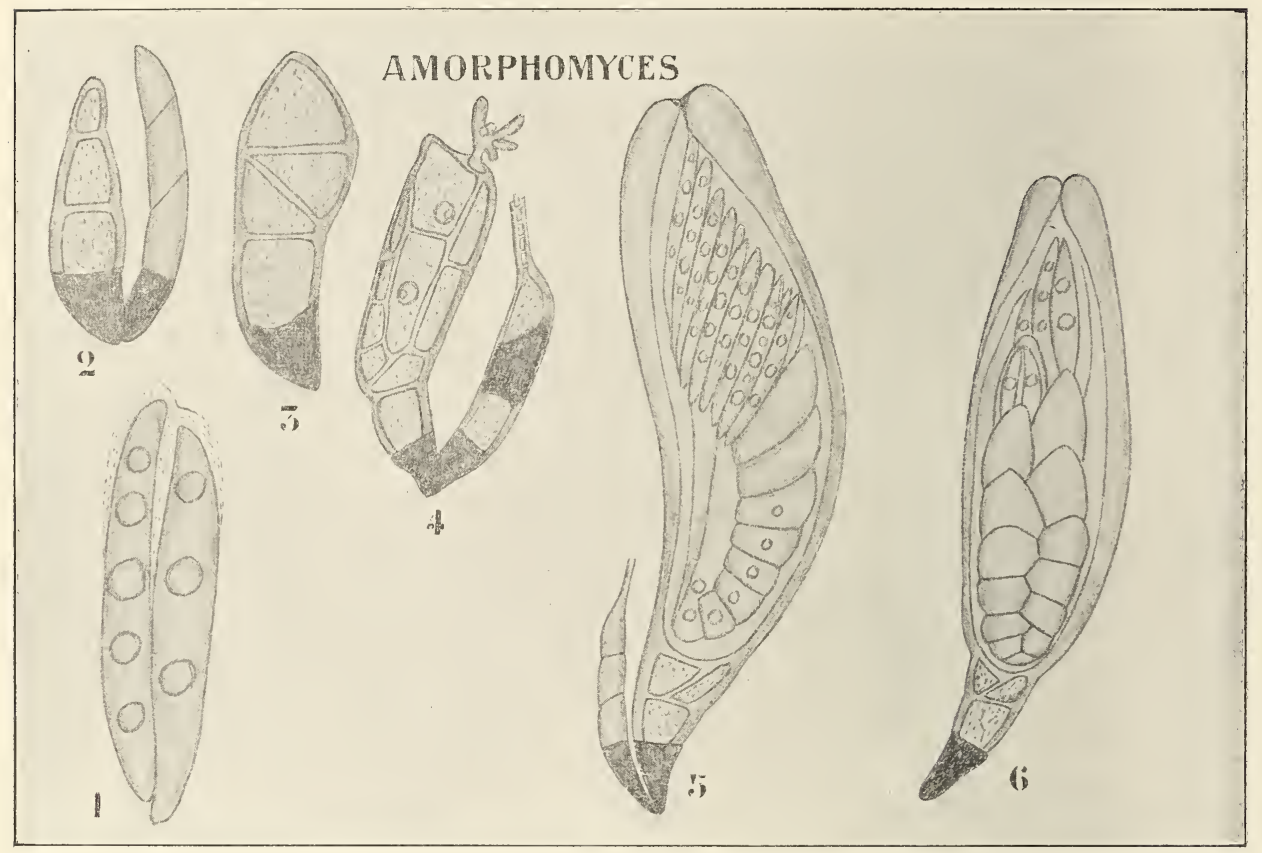

Fig. 319. A morphomyces Falagriae (nach ThAxter). 1 Sporenpaar. 2 Daraus entstandenes Pflänzchenpaar. 3 Weiterentwickelung des weiblichen Individuums. 4 Erwachsenes Paar, links das + mit der Trichogyne, rechts das $\delta$ mit dem terminalen Antheridium. 5 Ein Paar, von dem das reife $q$ Asci enthält, von der Seite, 6 id. von der Rückseite gesehen.

Von den monözischen Genera mit reihenförmig auf Appendices inserierten Antheridien haben wir vom Genus

\section{Stigmatomyees}

schon Stigmatomyces Baeri Pexritsch, welche in Wien auf der Hausfliege, Musca domestica, ziemlich häufig ist, besprochen. Das ganze Genus ist durch den Besitz eines einzelnen antheridientragenden Appendix charakterisiert, aber es ist dies keineswegs typisch für die Gruppe, zu welcher das Genus gehört. Sowohl Idiomyces, wie Corethromyces z. B. besitzen mehrere antheridientragende Appendices, während Rhadinomyces (s. Fig. 317) zwar nur einen antheridientragenden Appendix besitzt, welcher 
aber ron dem von Stigmatomyces recht verschieden ist, indem er terminal sterile Zweige trägt und die Antheridien an Seitenzweigen nahe seiner Basis produziert.

Ton der zweiten Gruppe der Laboulbeniaceae, mit nicht reihenförmig. auf Appendices inserierten Antheridien, sei hier in erster Linie

\section{Rhizomyces}

behandelt (s. Fig. 322). Das Receptaculum besteht aus 2 Zellen, von denen die untere rhizoidenähnliche Ausläufer besitzt, welche in den

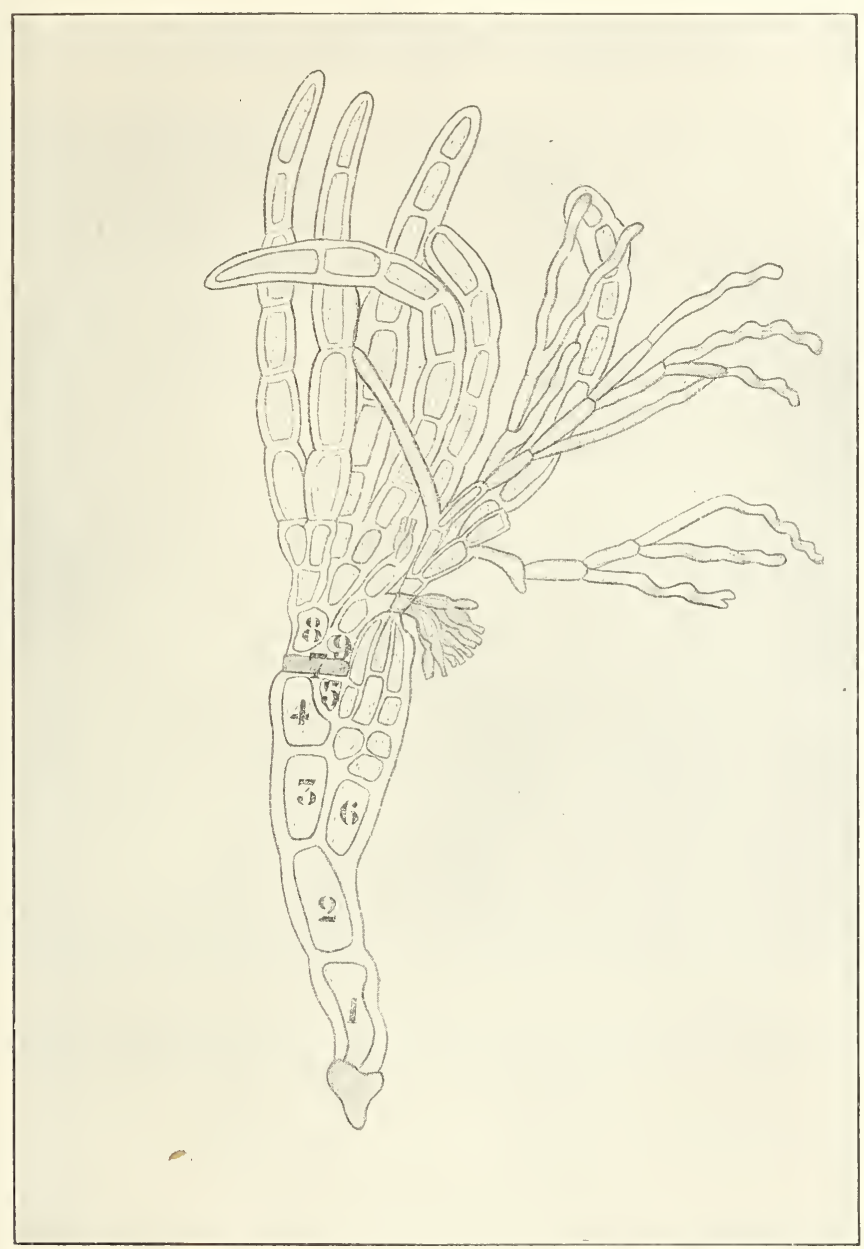

Fig. 320. Laboulbenia elongata (nach THAxten). Figurenerklärung im Text.

Körper des Insektes eindringen. Die obere Zelle trägt das besonders lang gestielte Perithecium und den Appendix.

Die Hauptachse des Appendix ist eigentlich ein Sympodium, jede Zelle ist die Basis eines Zweiges, welcher apikal einen Antheridiumzweig trug; in erwachsenem Zustande aber sind die Antheridiumzweige bei- 
seite gedrängt; die Zahl der Antheridien wechselt. Die einzige Art, Rhizomyces ctenophorus TH., wird in Liberia und bei Sansibar auf der Diptere Diopsis thoraciaca Westw. gefunden.

Zur gleichen Gruppe gehört das Genus

\section{Laboulbenia,}

ein sehr großes Genus. Als Typus möge z. B. Laboulbenia elongata gelten.

Das eigentliche Receptaculum besteht aus zwei übereinander gestellten Zellen (Fig. 320, 1 und 2). Aus der Zelle 2 entspringen zwei Zellenreihen, deren eine aus den Zellen 3, 4 und 5 besteht, während die andere nur aus der Zelle 6 besteht. Die erstere Zellenreihe trägt die

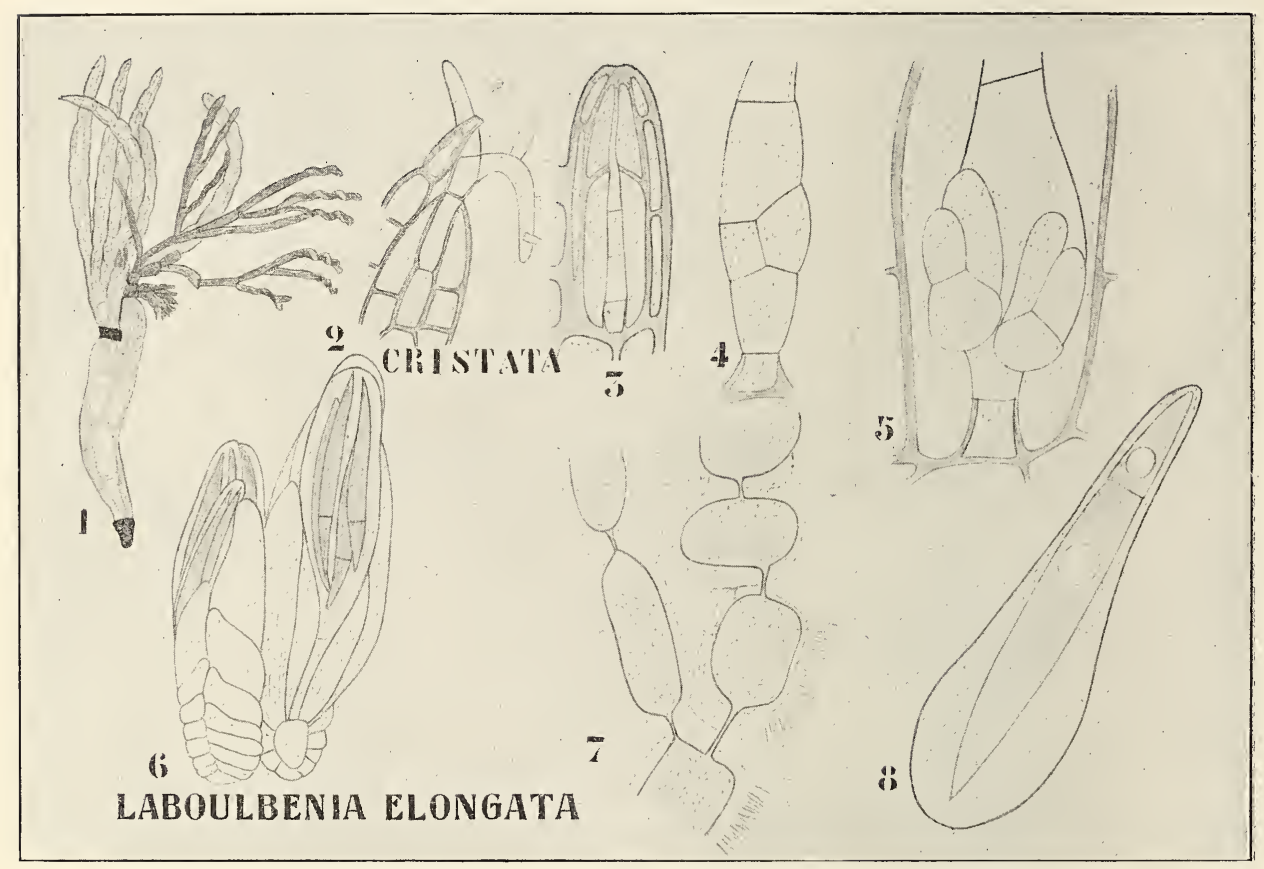

Fig. 321. I. Laboulbenia elongata (nach Thaxter). 3-6 Entwickelung der Asci. 7 Ein Exemplar, mit Kalilauge behandelt, um die Plasmaverbindungen zu zeigen. 8 Spore. - II. 2 L. cristata (nach THAXTER). Trichogyne mit angeklebten Spermatien.

Appendices und die Antheridien, die andere trägt das $q$ Geschlechtsorgan.

Die Appendices werden von einer schwarz gefärbten Zelle 7 getragen. Der Appendixbündel besteht typisch aus 2 basalen Zellen, von welchen die eine (8) einen Bündel steriler, die andere einen fertiler Appendices trägt, letztere bildet die Antheridien ziemlich nahe der Basis.

Die Trichogyne ist sehr stark verzweigt und es sind die Zweige spiralig gewunden, das Ganze bildet, wie Sie aus der Figur ersehen, ein ganz stattliches Organ. Die L. elongata ist auf verschiedenen Insekten in allen Weltteilen, außer Australien, angetroffen. Sie variiert beträchtlich, je nach dem Wirt und der Körperstelle, an welcher sie sich angeheftet hat. 
Auch hier wird nach der Befruchtung eine dreizellige (vermutliche) $2 x$-Generation gebildet, welche aus einer fertilen und zwei sterilen Zellen besteht; auch hier gelien die sterilen zu Grunde und die Asci bilden sich aus der fertilen, etwa wie bei Stigmatomyces.

Die Trichogyne braucht keineswegs ein so stattliches Organ wie bei L. elongata zu sein, bei C. cristata (Fig. 321, 2) sind die Zweige viel kürzer und nicht spiralig gewunden.

Die Arten des Genus Laboulbenia sind sehr verschieden, aber alle können, wie untenstehende Auswahl verschiedener Typen zeigt, auf das Prinzip der $L$. elongata zurückgeführt werden. Die am meisten abweichende dieser Formen ist wohl L. kunkeli, deren Perithecium anscheinend weit über die Anheftungsstelle der Appendices inseriert ist,

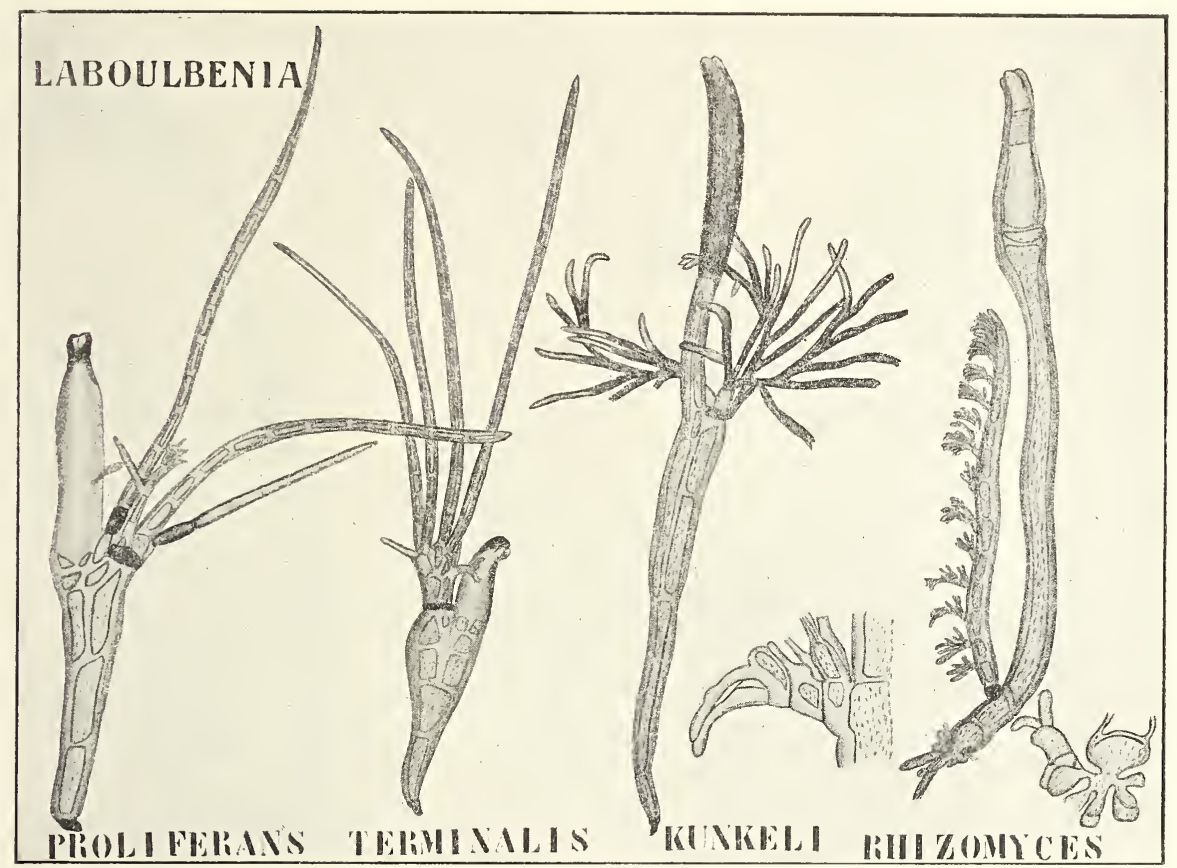

Fig. 322. I. Verschiedene mit Namen bezeichnete Typen des Genus Laboulbenia. II. Rhizomyces ctenophorus TH. (sämtlich nach TAXTER).

das ist jedoch nur scheinbar und nur der außerordentlichen Verlängerung. der basalen Zellen des Peritheciums zu verdanken.

Zu der gleichen Gruppe gehört weiter:

\section{Teratomyces.}

Bei dieser besteht das Receptaculum aus einer Reihe ron drei übereinander gelegenen Zellen, welche durch ein mehr oder weniger becherförmiges Stück gekrönt sind, das durch vertikale und schiefe Septen in eine Reihe zahlreicher, kleiner, peripher gelegener Zellen geteilt ist, die zahlreiche, die Insertionsstelle des Peritheciums ganz einhüllende Appendices bilden. Es sind 1-5, je mit einer langen Stielzelle rersehene Perithecien vorhanden. Die Antheridien stehen an den unteren Seg- 
menten der Appendices. Die hier (Fig. 323, I) abgebildete T. mirificus TH. wurde in Amerika auf Arten des Staphyliden-Genus Acylophorus angetroffen.

Weiter gehört zu dieser Gruppe:

\section{Rhachomyces.}

Hier besteht das Receptaculum aus einer einzigen basalen Zelle, aus welcher ein öfters recht langer Körper entspringt, der aus zwei Zellreihen besteht, deren eine nahe der Spitze lateral das Perithecium trägt, deren andere. aus kleineren Zellen bestehend, zahlreiche bürstenförmige Anhängsel bildet. In reifem Zustande ist das Perithecium scheinbar terminal. Betrachtet man den Organismus von der Rückenseite, so ist von den Anhängsel tragenden Zellen nichts zu sehen; diese sieht man

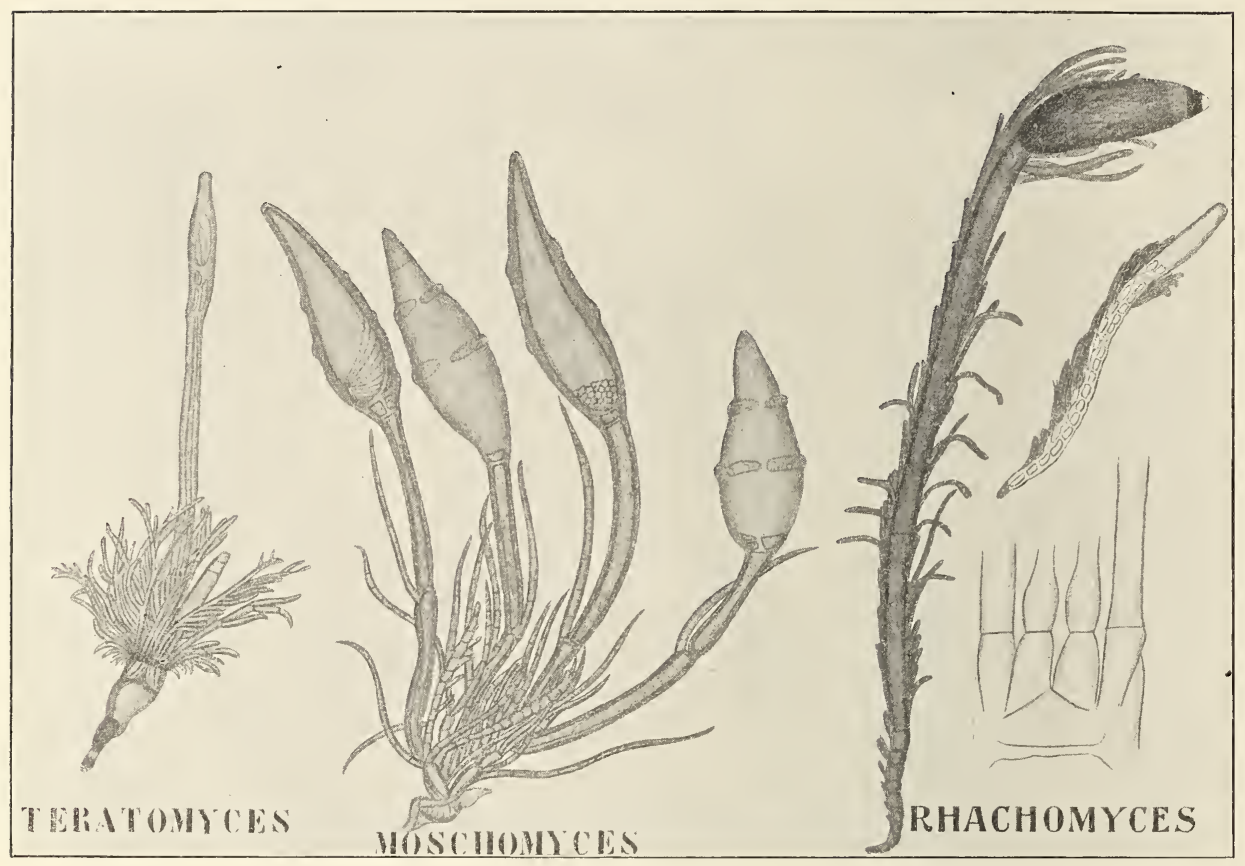

Fig. 323. I. Teratomyces mirificus TH. - II. Moschomyces insignis TH. III. Rhachomyces longissimus TH. (Sämtlich nach THAxTER.)

erst, wenn man ihn von der Seite betrachtet (Fig. 323 III, rechts oben). Die tiefschwarze Farbe gewisser Arten macht öfters die Grenzen zwischen den einzelnen Zellen unkenntlich. Die Antheridien stehen auf kurzen Zweiglein zwischen den Anhängseln in Paaren (Fig. 323 III, rechts unten) und werden durch die Anhängsel dem Auge ganz entzogen.

Der hier abgebildete $R$. longissimus kommt in Guatemali, $R$. hypogaeus in Oesterreich auf Carabideen vor.

Als letzter Repräsentant der Laboulbeniaceen möge das Genus

\section{Moschomyces}

besprochen werden. - Hier haben wir wieder mit einer Form zu tun, welche in den Wirt hineindringt. Die einzige Art, $\boldsymbol{M}$. insignis Тн., 
kommt in Massachusetts auf der Staphylinide Sunius prolixus ER. vor, und zwar ausschließlich auf den weicheren Teilen unter den Elytren oder zwischen den Segmenten und sendet ihre saugerähnliche Basis in den Körper hinein. Dieser Sauger besteht aus einer parenchymatischen Scheibe, welche an ihrer Oberseite eine Anzahl freistehender Zellen bildet, die an ihren distalen Enden gestielte Perithecien und Appenaices bilden (Fig. 323, II). Die Antheridien stehen auf kurzen Seitenzweigen der Appendices.

Möglicherweise aber ist jede freie Zelle das Receptaculum eines Individuums und der Sauger ein Verschmelzungsprodukt verschiedener kleiner Sauger. Diese Auffassung wird gestützt durch den Umstand, daß hier die ejaculierten Sporen meistens zusammenkleben und also in Gruppen auf das Insekt gelangen.

Damit haben wir die endogenen Laboulbeniales abgehandelt und wir wenden uns jetzt der Gruppe der

\section{Exogenen}

zu, welche die beiden Genera Ceratomyces und Zodiomyces umfaßt, von. welchen wir die letzteren besprechen wollen.

\section{Zodiomyees}

ist zweifellos die Laboulbeniaceae mit der höchsten vegetativen Entwickelung; es besteht hier der Körper aus einem ziemlich massiven, umgekehrt kegelförmigen Gebilde, welches mittels einer einzigen basalen Zelle auf dem Wirt befestigt ist, aber von seitlichen parenchymatischen Auswüchsen gestützt wird (Fig. 324, 3). Die einzige bekannte Art, Z. vorticellarius TH., ist recht variabel, aber stets wird am oberen Ende eine Scheibe mit aufrechtem Rand, eine Art Schüssel, gebildet. Auf dem Boden dieses Schüsselchens entstehen zahllose sterile Appendices, welche zahlreiche gestielte, mit Appendiculae versehene Perithecien und Antheridienzweiglein tragen.

Verfolgen wir einmal die Entwickelung. Das basale Segment der reifen Spore ist viel kürzer wie das terminale; die junge Pflanze fängt nun ihre Entwickelung damit an, daß sie in beiden Segmenten zahlreiche Querwände auftreten läßt (Fig. 324, 1), das distale Ende bildet nur sterile Anhängsel, wird also zum primären Appendix. Im unteren Teile entstehen aber alsbald Längswände, welche zur Verbreiterung des Körpers führen; in der Tat entsteht denn auch der Körper des Pilzes nur aus diesem Teile, und der primäre Appendix wird beiseite geschoben und abgeworfen (Fig. 324, 2).

Die Spermatien werden in der Weise von Konidien abgeschnürt (Fig. 324, 5), die Zweiglein, welche sie abschnüren, entstehen zwischen den Perithecien auf dem Boden des terminalen Schüsselchens.

Die Perithecien entstehen als Ausstülpungen der Zellen ebenfalls auf dem Boden dieses Schüsselchens. Eine solche Zelle wächst hierauf und wird in ein dreizelliges Fädchen zerlegt (Fig. 324, 6), dessen terminale Zelle etwas anschwillt; aus dieser terminalen Zelle wird das Perithecium gebildet (Fig. 324, 7-9). Die dabei entstandene lange Trichogyne (Fig. 324, 9) biegt sich nach unten, bis sie ein Spermatium erreicht, fischt dies sozusagen auf und krümmt sich, sobald sie eines erhascht hat, hinauf (Fig. 324, 10).

Nach der Befruchtung wird wieder die dreizellige vermutliche $2 x-$ Generation gebildet, von welcher nur die mittlere Zelle fertil wird und anscheinend nur eine einzige ascogene Zelle bildet. 
Die Perithecienwand bildet eigentümliche hornähnliche Appendices (Fig. 324, 4). Die einzige bekannte Art, Z. vorticellarius TH., wurde an verschiedenen Orten in Nordamerika auf der Hydrophylide Hydrocombus gefunden.

Zweifellos bilden die Laboulbeniales eine natürliche Gruppe; insoweit Sexualität bestehen kann, ohne daß man eine Kopulation zwischen Spermakern und Eikern gesehen hat, sind sie sexuell und zweifellos zeigen sie in mancher Hinsicht Uebereinstimmung mit Florideen, auch sind sie wohl sicher Ascomyceten.

Da aber dennoch eine detaillierte cytologische Untersuchung von größter Wichtigkeit wäre und da sicher auch noch in Westeuropa zahlreiche Arten, seien es neue, seien es schon aus Amerika bekannte, der

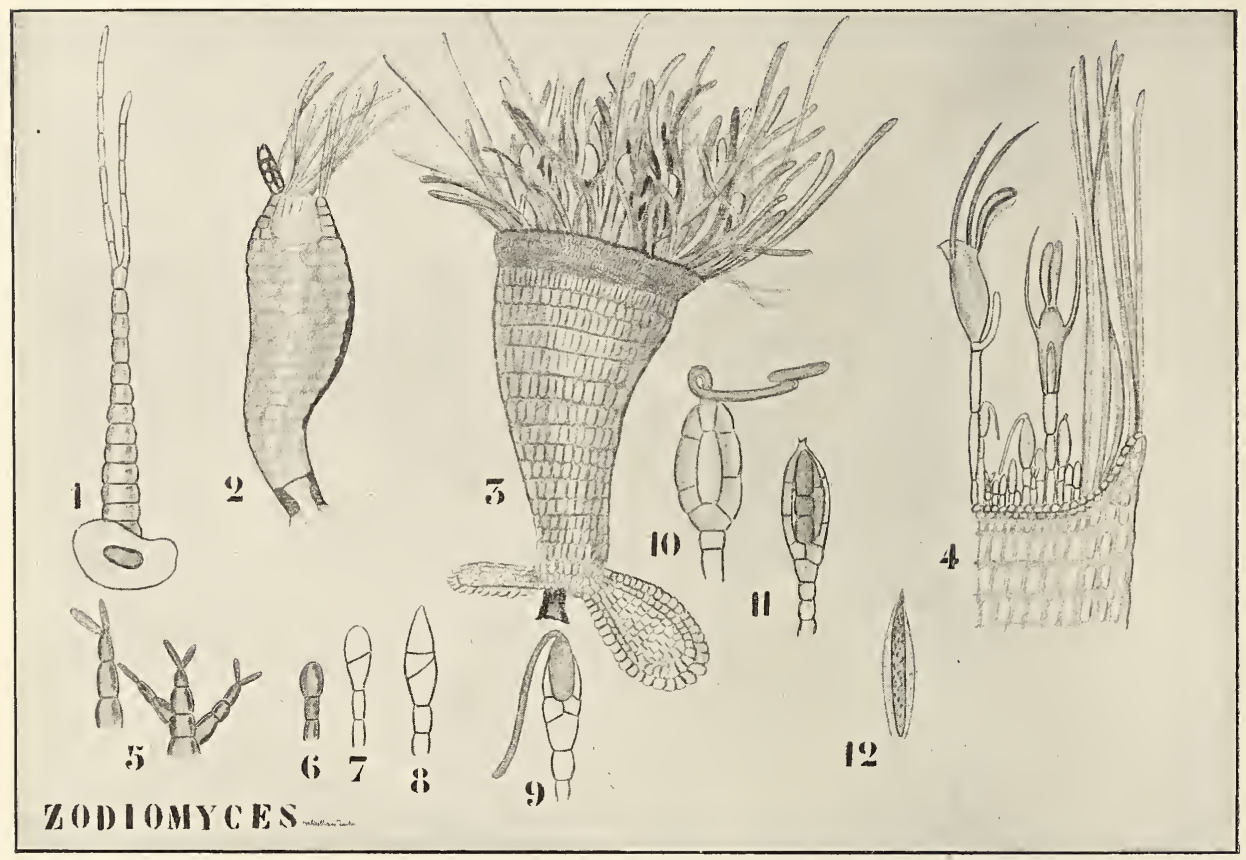

Fig. 324. Zodiomyces vorticellarius TH. (nach THaxter). 1 Junge Pflanze mit primärem Appendix. 2 A elteres Stadium, der primäre Appendix beiseite geschoben (oben links) und schon größtenteils abgefallen. 3 Erwachsenes Stadium. 4 Längsschnitt des Randes eines solchen, die eigentümlich gehörnten Perithecien, und unten auch junge trichogynentragende Oogone und Antheridien zeigend. 5 Antheridien. 6-9 Entwickelung des Oogons. 10 Befruchtung mittels eines heraufgefischten Spermatiums. 11 Bildung der vermutlichen $2 \mathrm{x}$-Generation. 12 Spore.

Entdeckung harren, mag hier wohl einiges über die beste Sammlungsund Konservierungsweise gesagt werden.

Unter den Käfern sind die Carabideae am reichsten an Laboulbeniales-Arten, zumal vom Genus Laboulbenia, die Staphyliden an Genera, während Wasserkäfer mit Ausnahme der Gyridae, welche durch ihr Leben an der Oberfläche des Wassers die Parasiten an die Luft bringen, nur die Genera Zodiomyces, Ceratomyces, Hydraeomyces und Chitonomyces beherbergen. Sechs Genera wurden auf Diptern angetroffen, eine Art auf Termiten und eine auf Spinnen. 
Die meisten Insekten, welche Laboulbeniales beherbergen, leben an feuchten Orten, an den Rändern von Teichen, Bächen, Gräben u. s. w. Man erhält öfters schöne Exemplare, wenn man Algen, Gras u. s. w. an feuchten Stellen anhäuft und diese Haufen von Zeit zu Zeit auf ein weißes Tuch aussschüttelt.

Man kann auch Laboulbeniales durch das Zusammenbringen von infizierten Insekten mit nichtinfizierten züchten, wobei für genügende Feuchtigkeit Sorge getragen werden muß, um eine Wasserkondensation auf den Körper der Tiere zu verursachen, da ohne diese eine Befruchtung der Trichogynen nicht möglich ist. Es ist aber nicht leicht, die guten Bedingungen zu schaffen, so daß man sich keinen zu großen Hoffnungen hingeben darf. Hat man eine Anzahl von Insekten gesammelt, welche nach der Weise ihres Vorkommens u. s. w. infiziert sein können, so findet man auf $5-50$ Proz. derselben Parasiten.

Um diese nun zu sammeln, muß man das Insekt töten und an eine Nadel stecken (eine Nähnadel No. 12, in einem Streichholze befestigt, ist dazu recht bequem) und dann sorgfältig mit der Lupe unter dem Präpariermikroskop erst über einem weißen, dann über einem schwarzen Untergi und absuchen. Die Lupe muß 8-10mal vergrößern, und man muß Sorge tragen, daß die Oberfläche des Insektes rollkommen rein und trocken bleibt. Jeder Teil des Insektes muß dabei sorgfältig berücksichtigt werden.

Die gefundenen Parasiten werden dann mit einer Nähnadel No. 12, deren Spitze auf einem Wetzsteine zu einem etwas schrägen Meißel abgeschliffen ist, abgekratzt und in einen kleinen Wassertropfen auf den Objektträger gebracht. Hier werden sie mit einer Schweinsborste arrangiert und das überflüssige Wasser mittels Fließpapier entfernt. Man läßt die Flüssigkeit einen Augenblick eintrocknen, wodurch die Pflänzchen festkleben, setzt schnell Alkohol zu, legt, nachdem man, um einem Zerquetschtwerden vorzubeugen, neben die Organismen einen Glassplitter gelegt hat, ein Deckglas auf und ersetzt den Alkohol durch Wasser. Dieses tötet die Organismen, wenn man schnell arbeitet, nicht. Darauf wird Glycerin, in welchem ein wenig Eosin und eine Spur $\mathrm{NaCl}$ gelöst ist, vom Rande des Deckglases aus langsam zugelassen.

Als Herbariummaterial bewahrt man die Insekten auf Watte in Pillenschachteln auf.

Wir haben also eine Befruchtung durch Spermatien und Trichogynen bei Pyrenomyceten und Laboulbeniaceen kennen gelernt und wollen jetzt noch eine andere Gruppe, bei welcher dies ebenfalls stattfindet, betrachten, nämlich die Pilze der Ascolichenen.

Wir haben früher schon gesehen, daß bei Collema, trotzdem die Verschmelzung von Ei- und Spermakern noch nicht gesehen ist, wohl sicher Befruchtung angenommen werden darf. Die Zahl der Lichenen, bei welchen die Entwickelung des Apotheciums untersucht wurde, ist noch recht klein. BAUR (1901) stellte die in dieser Hinsicht untersuchten Fälle zusammen und fand, daß typische Carpogone mit über die Oberfläche des Thallus hervorragenden Trichogynen gefunden waren bei:

\author{
Anaptychia (von LINDAU), \\ Physcia (von Lindau, Darbi- \\ SHIRE und MäULE), \\ Parmelia (von Lindau), \\ Ramalina (von LINDAU), \\ Placodium (von LINDAU),
}

Lecanora (von LINDAU),

Pertusaria (von LINDAU),

Gyrophora (von LindaU),

Pyjemula (von BAur),

Collema (von STAHL und BorzI), 


\section{Synechoblastus (von STAHL und Borzi),}

Seitdem sind hinzugekommen:
Physma (von Borzi) und
Lepidocollema (von ZuKAL).

Endocarpon (von BAUR) und

Cladonia (von BAUr),

während BAur (1904) die Fälle von Parmelia, Anaptychia und Lecanora befestigte; auch fügt er noch hinzu, daß auch bei folgenden Genera typische Carpogone gefunden wurden:
Pyrenopsis (von Forsell),
Sticta (von Borzi),
Caloplaca (von Borzi).

Noch nicht ganz sicher ist die Sache bei:
Usnea (WAINio)
Xanthorina (LINDAU)
Lecidella (LINDAU)
Sphaerophoropsis (WaInIO)
Coccocarpia (WaINio) und
Pseudopyrenula (WaInio).

Ascogone, aber ohne Trichogynen sind gefunden bei:

Peltigera
Peltidea
Nephroma
Solorina (von BAUR), Spermatien fehlen,

während KrabBe behauptet, daß die ascogenen Hyphen direkt aus den vegetativen entstehen bei:
Sphyridium
Phlyctis
Phialopsis und
Cladonia,

welche Meinung von Neubner für Calicium geteilt wird. Da Neubners Technik aber sehr unvollkommen war und KRaBBes Meinung über Collema sich als unrichtig herausgestellt hat, ist es fraglich, ob ein solcher Fall überhaupt wohl bei den Lichenen vorkommt.

Faßt man nun alles zusammen, so haben wir bei den Lichenen wohl ursprünglich eine Befruchtung mittels Trichogynen und Spermatien, welche aber schon bei den Peltigeraceen durch Parthenogenese und vielleicht bei anderen durch Apogamie ersetzt worden ist.

Es ist aber, wie schon betont, erst ein kleiner Teil der Lichenen untersucht worden. Ganze Gruppen, wie die Lecideae, Sphaerophoreae und Graphideae, sind noch unbekannt. Jedenfalls haben wir nun schon Trichogynen gesehen bei:

$$
\begin{aligned}
& \text { Pyrenomyceten, } \\
& \text { Laboulbeniales, } \\
& \text { Discomyceten (Ascolichenen). }
\end{aligned}
$$

Dagegen lernten wir andere Discomyceten: Ascobolus und Pyronema kennen, bei welchen die Befruchtung nicht mittels Spermatien, sondern mittels Gametangienkopulation stattfand, und auch unter den Pyrenomyceten gibt es gewiß noch Formen, bei welchen Kopulation von Gametangien stattfindet. Die Fruchtform, Perithecium oder Apothecium, ist also kein Maß für Verwandtschaft, keine gute Basis zur Einteilung, eine solche kann nur durch die Befruchtung in Verbindung mit der Cytologie geliefert werden; da ist aber erst noch vieles zu untersuchen.

Offenbar gehört aber ein großer Teil der Lichenen zu den Formen, bei welchen Befruchtung mittels Trichogyne und Spermatien stattfindet, und es liegt also auf der Hand, diese Gruppe hier zu behandeln. 


\section{Zweiundzwanzigste Vorlesung.}

\section{Die Lichenen.}

Wir wissen, daß die Lichenen früher für einheitliche Organismen gehalten wurden und daß Schwendener der erste war, der zeigte, daß wir hier mit einer Symbiose zwischen Pilzen aus verschiedenen Gruppen, meistens doch Ascomyceten ${ }^{1}$ ), nur einigen wenigen Basidiomyceten, und Algen aus verschiedenen Gruppen zu tun haben.

In Engler und Prante gibt Fünfstǘck eine historische Uebersicht über die Entwickelung unserer Kenntnisse dieser Gruppe, welcher folgendes entnommen werden mag.

Bis 1868 meinte man, daß die Lichenen selbständige Organismen seien und man betrachtete die Algen als Gonidien, wie sie von WALLвотн genannt wurden, d. h. als ungeschlechtliche Fortpflanzungszellen; sowohl aus ihnen wie aus den Sporen kann sich unter günstigen Umständen eine ganze Lichene bilden.

Sogar als später bekannt wurde, daß die Gonidien keine Fortpflanzungszellen waren, hielt man sie noch keineswegs für Algen, sondern für chlorophyllhaltige Anschwellungen der Lichenen-Hyphen.

Noch im Jahre 1865 schloß sich sogar DE BARy dieser Meinung für die heteromeren Lichenen $^{2}$ ) an, aber von den homöomeren ${ }^{3}$ ) sagt er:

„Entweder sind die in Rede stehenden Lichenen die vollkommen entwickelten, fruktifizierenden Zustände von Gewächsen, deren unvollständig entwickelte Formen als Nostoccaceen, Chroococcaceen bisher unter den Algen standen oder die Nostoccaceen und Chroococcaceen sind typische Algen; sie nehmen die Formen der Collemen, Epheben etc. an, dadurch, daß gewisse parasitische Ascomyceten in sie eindringen, ihr Mycelium in dem fortwachsenden Thallus ausbreiten und an dessen phycochromhaltigen Zellen öfters befestigen."

Kurz darauf entdeckte Baranetzky, daß die Gonidien beider Lichenen-Gruppen im stande sind, selbständig außerhalb des Flechtenkörpers zu leben, und fand, daß die Gonidien von Physcia, Evernia, Cladonia Zoosporen bilden können. Daraus schloß er, daß wenigstens die Algengenera Cystococcus, Polycoccus und Nostoc keine Algen wären, sondern freilebende Lichenen-Gonidien.

Erst Schwendener zeigte, daß das Umgekehrte der Fall ist, daß die Lichenen-Gonidien Algen sind. Auch er aber hielt den Pilz für

1) Zu ScHWENDENERs Zeit waren nur Ascolichenen bekannt.

2) Lichenen mit den Algen in einer besonderen Thallusschicht.

3) Lichenen, bei welchen die Algen glcichmäßig über den Thallus verteilt sind. 
einen Parasiten, erst Reinke bestand auf der Symbiose zwischen beiden Komponenten.

Schwendener konnte schon nachweisen, daß unter den Schizophyceen: die Sirosiphoneae, Rivularieae, Scytonemeae, Nostoccaceae und Chroococcaceae, und unter den Chlorophyceen: Confervaceae, Chroolepideae und Palmellaceae in Lichenen-Thalli vorkommen.

Schwendeners Schlußfolgerungen wurden von Bornet bestätigt. Nun fehlte nur noch die Synthese einer Flechte aus ihren beiden Komponenten, was im Jahre 1871 von ReEs für den sterilen Thallus von Collema gelang, während Bonnier (1886) sogar fruktifizierende Lichenen aus ihren Komponenten erzog.

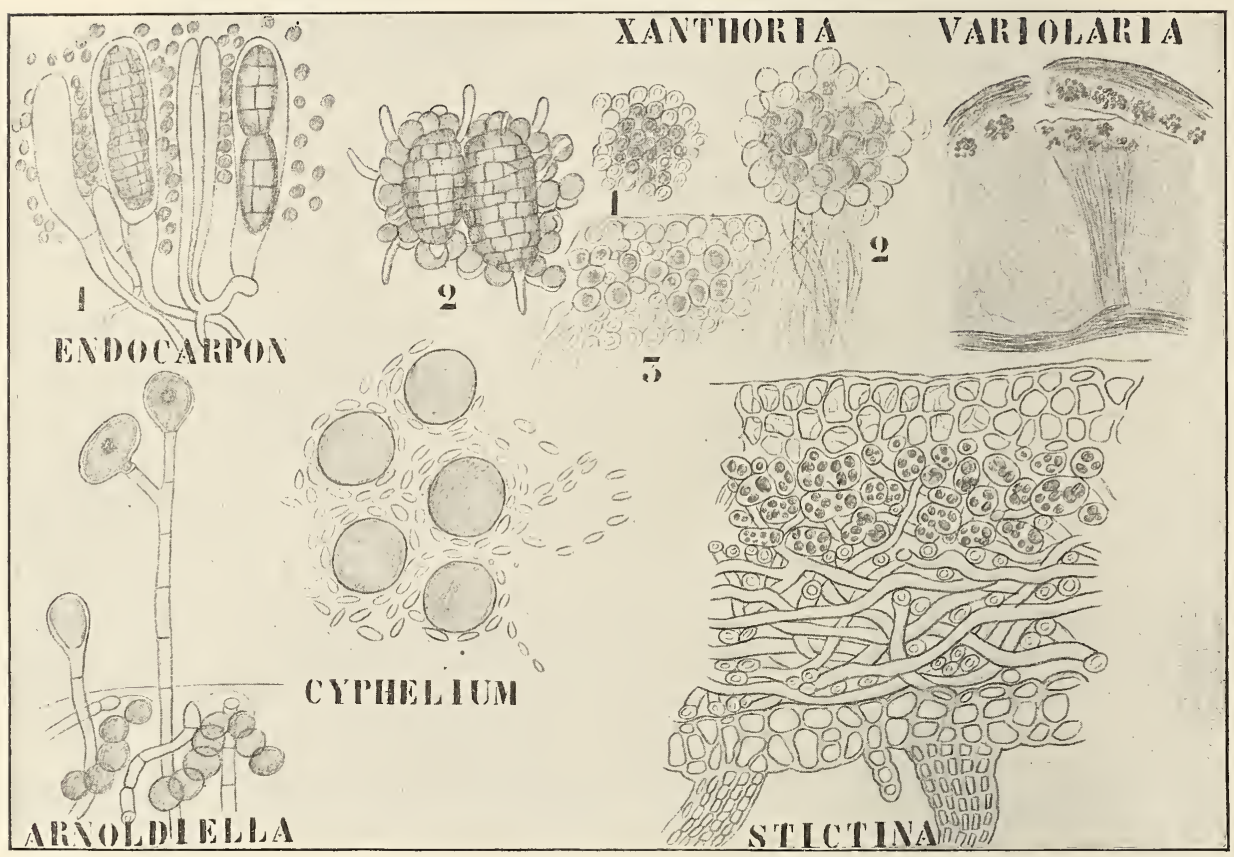

Fig. 325. Verschiedene Fortpflanzungsweisen der Lichenen. I. Endocarpon pusillum (nach STAHL). 1 Teil des Hymeniums mit Hymenialgonidien zwischen den Asci. 2 Ejaculierte Sporen, deren Keimschläuche Hymenialgonidien umsponnen haben. II. Soredien von Xanthoria parietina (nach Schwendener). 1 Soredium mit pseudoparenchymatischer Pilzhülle. 2 Haftfasern bildend. 3 Junger Thallus, aus einem Soredium entstanden. - III. Variolaria globulifera TURN. Soral (nach DARBISHIRE). IV. Arnoldiella minitula (nach BonNeT), die nahezu reifen Konidien zeigend. V. Cyphelium (nach Nedbner). Oidienbildung im Thallus. - VI. Stictina fuliginosa. Thallusschnitt (nach SACHS), als Beispiel einer heteromeren Flechte.

Einen vollkommen fruktifizierenden Lichenen-Pilz ohne Alge zu kultivieren, ist bisher noch nicht gelungen, am weitesten kam Mö́LLER bei Calicium, dessen Pilz er gesondert kultivieren konnte und welchen er bis zur Pyknidenbildung brachte.

Nur bei Cora, einem Basidiolichen, ist der Pilz - eine Thelephora freilebend bekannt.

Beschränken wir uns auf die Ascolichenen, so sehen wir, daß verschiedene Algen und verschiedene Pilze zusammen Lichenen gebildet 
haben; daß diese Gruppe also ein Nixtum compositum und keine natürliche Gruppe ist, braucht kaum betont zu werden.

Bei vielen Lichenen müssen die Sporen jedesmal wieder neue Algen finden, bevor sie eine Flechte bilden können, bei anderen ist die Sache aber besser eingerichtet, indem Algenzellen im Hymenium vorkommen und mit den Sporen gleichzeitig ejaculiert werden. Das ist also ein Umstand, der die Verbreitung dieser Lichenen sehr befördert, ein bekanntes Beispiel davon liefert Endocarpon pusillum (vergl. Fig. 325, I).

Außer dieser Einrichtung zum Zusammenhalten der beiden Komponenten besitzen die Lichenen noch eine Anzahl von Einrichtungen, welche dasselbe bezwecken. Am einfachsten geschieht dies bei Formen wie Cladonia, Parmelia, Sticta u. s. w., bei welchen abgebrochene Thallusfragmente zu neuen Thalli auswachsen können. Ein viel besseres Mittel aber besitzen die soredienbildenden Lichenen, das sind jene, welche einzelnen von Hyphen umsponnenen Algenzellen erlauben, sich vom Thallus abzulösen und zu neuen Thalli auszuwachsen. Gewöhnlich geht die Bildung solcher hyphenumsponnener Algengruppen, der sogenannten Soredien, unter lebhafter Teilung der Algen vor sich, wobei die jungen Algenzellen stets sofort umsponnen werden. Die Rinde wird schließlich zerrissen und die Soredien kommen frei. Sie werden an x-beliebigen Teilen der Thallusoberfläche gebildet. In anderen Fällen aber werden die Soredien in bestimmten, scharf vom übrigen Teil des Thallus getrennten Geweben gebildet. Solche Bildungsstellen (Fig. 325, III) nennt REINkE Sorale; sie sind z. B. bei Roccella und Variolaria nachgewiesen. So wie die Apothecien werden sie tief im Markgewebe angelegt, und DARBISHIRE betrachtet sie denn auch als umgebildete Apothecien, welche Meinung BitTer aber nicht teilen kann.

Während die meisten freilebenden Ascomyceten Nebenfruktifikationen besitzen, sind diese bei den Lichenen-Pilzen sehr selten. Nur bei Arnoldiella minutula und bei Placodium decipiens konnte Borne'T Konidien nachweisen. während bei den Calicieen Oidienbildung, d. h. ein Auseinanderfallen der Thallushyphen in kleine Zellchen nachgewiesen wurde, ob diese aber in der Tat keimen können, weiß man noch nicht.

Aus dem vorangehenden geht zur Genüge hervor, daß an eine wirklich natürliche Behandlung der Lichenen nicht gedacht werden kann. Kennte man die Verwandtschaft der Pilzarten, welche mit Algen Lichenen gebildet haben, so würde man diese im Anschluß an ihre nächsten Verwandten unter den übrigen Pilzen behandeln müssen und die Lichenen als Gruppe fallen lassen. Da dies aber unmöglich ist, folge ich v. WETTsTEINs Einteilung der Lichenen, welche mir am geeignetsten scheint.

Bevor wir dazu übergehen, ist es aber nötig darauf hinzuweisen, daß man bei den Lichenen von einem homöomeren Thallus spricht, wenn die Algen über den ganzen Thallus verbreitet vorkommen, von einem heteromeren, wenn sie auf bestimmten Schichten desselben beschränkt sind. Homöomer ist auf unseren Zeichnungen z. B. Collema (Fig. 251, S. 423 und Fig. 255, S. 434), heteromer Z. B. Stictina (Fig. 325, VI) und Gyrophora.

Wir können nun die Ascolichenen zunächst in zwei große Gruppen einteilen.

I. Das Perithecium bleibt lange geschlossen und öffinet sich schließlich mittels eines Ostiolum

II. Die Fruktifikation ist ein Apothecium 
Betrachten wir zunächst die

\section{Pyrenolichenes.}

Als erste Familie haben wir da die

\section{Verrucariaceae}

von welcher wir das Genus

\section{Verrucaria}

als Beispiel wählen. Die Arten dieses Genus bilden Krusten auf kalkhaltigem Gestein; die Kruste ist öfters durch Risse polygonal gefeldert. Der Thallus ist heteromer. Unter den Verrucaria gibt es viele Arten, welche im stande sind, den Stein zu lösen, wodurch der Thallus endo-

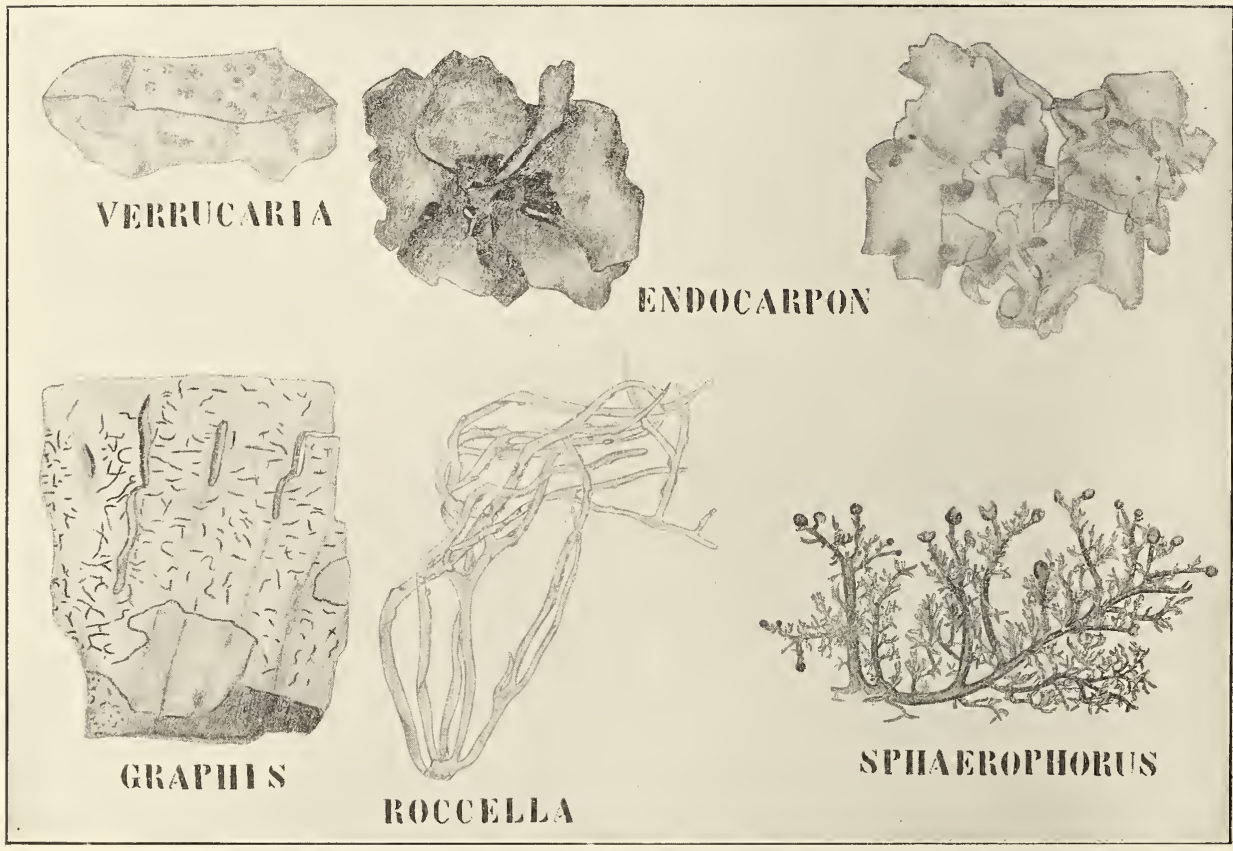

Fig. 326. Verschiedene mit Namen bczeichnete. Pyrenolichenen-Genera aus den Familien der Verrucariaceen und Endopyreniaceen, und Discolichenen-Genera aus den Familien der Graphideen und Con i ocarpaceen. Mit Ausnahme der Figur von Sphaerophorus, welche v. WeTtstein entliehen ist, Original.

lithisch wird, man hat die Hyphen bis zu einer Tiefe von mehr als $1 \mathrm{~cm}$ im Gestein nachweisen können; die Früchte der endolithischen Arten sitzen in Löchern der Steine; sie besitzen wie die aller Verrucaria ein horniges Gehäuse, und sind mehr oder weniger kugelig.

Während die Früchte bei gewissen Arten auf dem Thallus sitzen, bei anderen diesem mehr oder weniger eingesenkt sind, sind die Spermogonien immer im Thallus eingesenkt. Die Spermatien sind nadelförmig, bisweilen bogenförmig gekrümmt. MEzGER (1903) konnte bei C. calciseda wohl Spermatien, aber keine Trichogynen finden; wohl aber 
bei der nahe verwandten Familie der Pyrenulaceen. Es sind mehr wie 100 Terrucaria-Arten aus allen Weltteilen bekannt, der Algenkomponent ist Pleurococcus oder Palmella. Die abgebildete Art (Fig. 326) ist Verrucaria Hochstetteri.

Während wir hier mit einer krustenförmigen Flechte zu tun hatten, gibt es andere Pyrenolichenen mit blattähnlichem Thallus, so z. B. das zur Familie der

\section{Endopyreniaceae}

gehörige Genus

\section{Endocarpon}

Endocarpon miniatum (L.) AcH. (Fig. 326 u. 327) ist eine Flechte, welche auf senkrechten von Wasser überrieselten Felsen vorkommt;

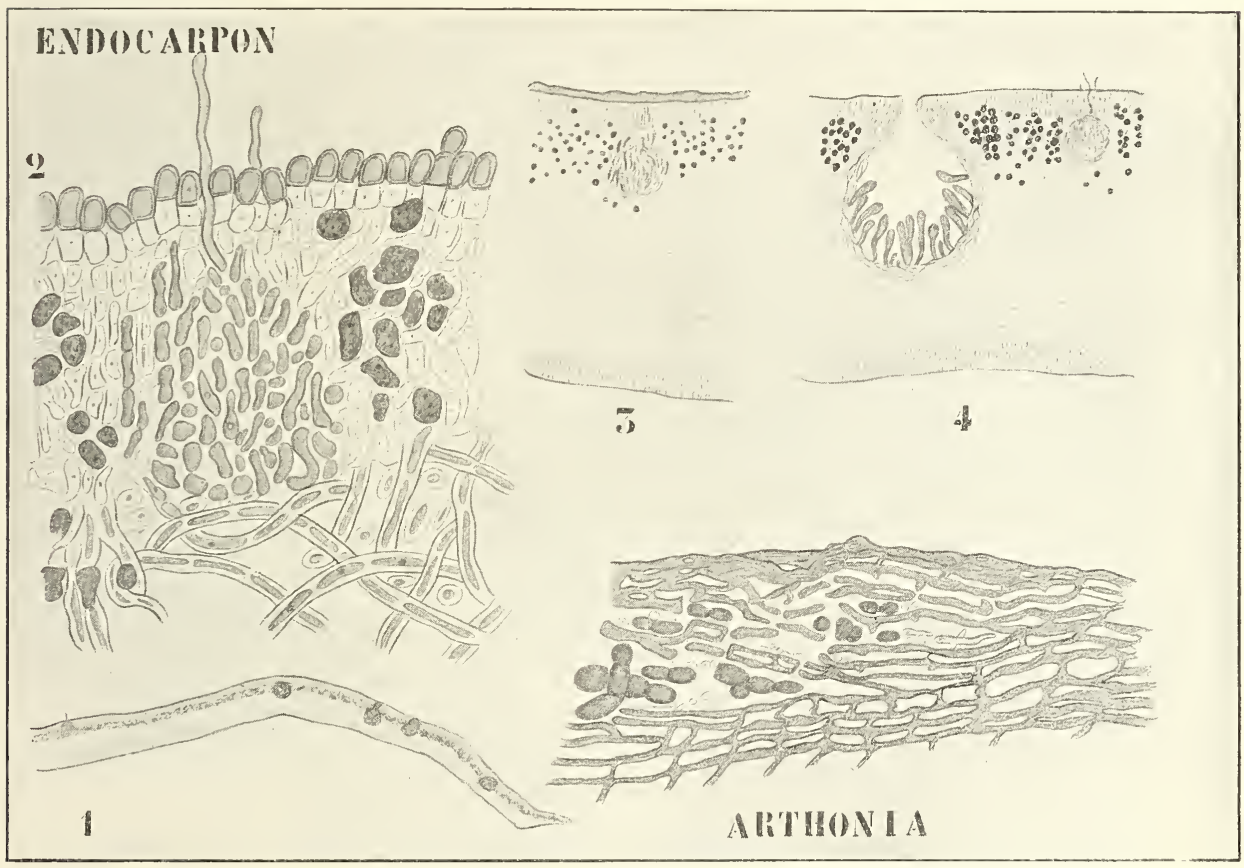

Fig. 327. I. Endocarpon. Peritheciumentwickelung (nach BAUR). 1 Schnitt durch den Thallus, Perithecienanlagen zeigend. 2 Ascogone mit Trichogynen. 3-4 Weitere Ausbildung des Peritheciums. - II. Arthonia. Thallus in die Rinde eingedrungen.

infolgedessen findet man die Thalli im Winter, z. B. im Annatal bei Eisenach, ganz im Eise eingeschlossen. Der Thallus (vergl. Fig. 326) ist blattartig, mehr oder weniger rund, braun-grau lederig und mit einem zentralen Nabel am Fels befestigt.

Die Entwickelung der Perithecien wurde von Baur untersucht, ihm ist folgendes entnommen. Der Thallus ist beiderseitig berindet, die Rinde wird aus unter sich parallel verlaufenden, senkrecht auf die Oberfläche zuwachsenden Hyphen gebildet. Da die Zellen dieser Hyphen sehr kurz sind und ohne Zwischenräume aneinauderschließen, ist die Rinde parenchymatisch (Fig. 327, I 2). Das Mark besteht aus einem 
lockeren Geflecht langzelliger Hyphen. Dicht unter der oberen Rinde, zum Teil sogar in den inneren Schichten derselben, liegen die Algen in Gruppen. Aeltere Thalli sind besät mit kleinen, schwarzen Punkten, den Oeffnungen der ganz eingesenkten Perithecien.

Junge Thalli von $1 / 2-1 \mathrm{~cm}$ Durchmesser tragen meistens keine Perithecien, sondern an ihrem Rande die ersten ebenfalls eingesunkenen Spermogonien. Junge Perithecienprimordien findet man meistens erst auf etwas älteren Thalli, etwas mehr dem Zentrum genähert als die Spermogonien. Meistens liegen 3-8 Carpogone nebeneinander. Die Ascogone liegen in einem dichten Knäuel in der Algenschicht, die Trichogynen durchbohren die Rinde und ragen über dieselbe hervor. So wie die vegetativen Zellen sind die Zellen des Carpogons monoenergid.

Auch auf den alten Thalli findet man reichlich Perithecien in allen Entwickelungsstadien. Die Entwickelung der Carpogone scheint nicht an eine bestimmte Jahreszeit gebunden $\mathrm{zu}$ sein, BAUR fand wenigstens keinen Unterschied zwischen im April und im Juli gesammeltem Material.

Bei Endocarpon scheinen so ziemlich alle Carpogone sich zu Perithecien zu entwickeln. Auch hier verschwindet zunächst die Trichogyne, dann fängt ein lebhaftes Wachstum der die Ascogone umgebenden Hyphen an, sie wachsen über das Ascogon hinaus so ziemlich senkrecht nach oben, wobei sie etwas konvergieren. Auf der Basis des so gebildeten Peritheciumprimordiums liegen die ascogenen Hyphen. Oefters fängt die Ascusbildung schon an, bevor das Perithecium sich an der Spitze durch auseinanderweichende Hyphen geöffnet hat. Die Perithecien bilden jahrelang Sporen, wobei sie nach und nach etwas an Größe zunehmen.

Endocarpon wächst interkalar, es befindet sich eine Zone besonders intensiven Wachstums um den Nabel herum, so daß hier nur sehr junge Carpogone gefunden werden können.

Schreiten wir jetzt zur Betrachtung der Gruppe der

\section{Discolichenes.}

Es kann diese in drei verschiedene Untergruppen zerlegt werden, nämlich in:

A. eine Gruppe mit langgestreckten, asymmetrischen Apothecien, wie bei den Hysterialen und Phacidialen

B. eine Gruppe mit meistens kugeligen sich später öffnenden Apothecien und Paraphysen, welche sich zu einem Capillitium-ähnlichen Geflecht, wie es bei Hysterographium ${ }^{1}$ ) vorkommt, vereinen

C. eine Gruppe mit scheibenförmigen Apothecien, wie bei den Perizaceen

Graphidineae

Fangen wir mit den

\section{Graphidineae}

an. Als Beispiel der krustenförmigen Vertreter dieser Gruppe möge

\section{Graphis scripta I.}

dienen, so genannt, weil sie die Rinde zumal von Buchen mit ihren langen Perithecien wie mit Schriftzügen bedeckt (Fig. 326). Ueber die Entwicke-

1) Abbildung siehe später. 
lungsgeschichte der Geschlechtsorgane ist noch nichts bekannt, in Bezug auf die Entwickelung des Thallus ist es interessant zu erwähnen, daß der Pilzsymbiont hier zunächst saprophytisch in den Rindenschichten lebt, aber erst fruktifizieren kann, wemn er Algenzellen gefunden hat.

Zu den strauchförmigen Vertretern der Familie gehört das Genus Roccella (Fig. 326), eine aufrecht wachsende Flechte, welche mittels einer Basalscheibe am Substrat befestigt ist und so wie Graphis, Chroolepus als Algensymbiont besitzt. Die Verzweigungen des Thallus sind abgeflacht cylindrisch, die Rinde besteht aus transversal verlaufenden Hyphen, die Markhyphen verlaufen der Längsachse des Thallus mehr oder weniger parallel. Die Soredien werden in Soralen gebildet. Die Apothecien von $R$. tinctoria weichen vom gewöhnlichen Typus der Graphideen ab, weil sie viel runder wie gewöhnlich sind, aber DARBishine (1897) fand eine

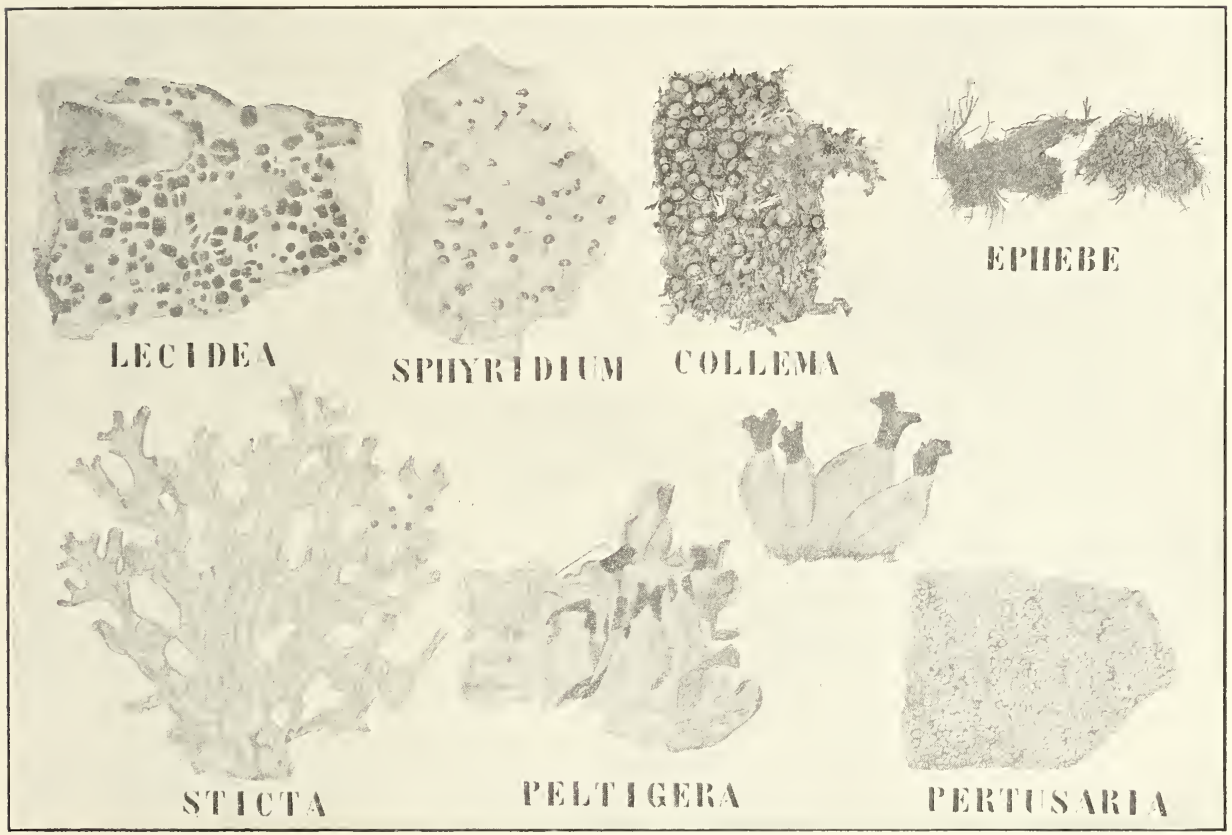

Fig. 328. Verschiedene mit Namen bezeichnete Discolichenen-Genera (Original).

Roccella mit typischen Graphideen-Apothecien. Die Spermogonien sind ganz im Thallus eingesenkt.

Die 23 bekannteren Arten wachsen in wärmeren und gemäßigten Gegenden meistens auf Felsen, und mit besonderer Vorliebe an der Meeresküste, so in Europa z. B. R. tinctoria DC. am Nittelmeer. Verschiedene Roccella-Arten liefern Farbstoffe, unter welchen die Orseille und das Lackmus wohl die bekanntesten sind.

Auch in der Gruppe der Coniocarpincae gibt es Krusten- und Strauchflechten. Zu ersteren gehört das Genus Calicium, von welchem NEuBNER behauptet, es entständen die ascogenen Hyphen direkt aus den vegetativen, eine Angabe, welche von BAur angezweifelt wird. NEuBNers diesbezüglicher Artikel ist mir unzugänglich geblieben. 
Zur zweiten Gruppe gehört das Genus

\section{Sphaerophorus,}

welches in gebirgigen Gegenden auf dem Boden, unten an Felsen oder Baumstümpfen nicht selten ist, z. B. am Inselsberg in Thüringen. Der stark verzweigte, korallenähnliche Thallus bildet große runde Apothecien, welche sehr lange geschlossen bleiben (Fig. 326).

Zur letzten Gruppe, zu der der Discocarpineae, gehört u. a. die Familie der

\section{Lecidiaceae,}

deren Vertreter Krustenflechten sind, welche Pleurococcus als Algensymbiont haben. Die Apothecien sitzen auf dem Thallus, besitzen aber keinen Rand, wodurch Lecidea stets leicht von Lecanora unterschieden wird. Die Spermogonien sind im Thallus eingesenkt. Die ursprünglich runden Apothecien werden, so wie bei der hier (Fig. 328) abgebildeten L. confluens, öfters durch gegenseitigen Druck polygonal. Die Scheibe des Apotheciums ist bei den verschiedenen Arten hell bis schwarz gefärbt, nackt oder bereift.

Es gibt fast 500 Arten, welche zumal in gemäßigten und kalten Gegenden vorkommen. Unsere $L$. confluens kommt auf primären Gesteinen im Gebirge vor. Interessant ist der Umstand, daß viele Lecidien wohl in großer Zahl Apothecien, aber in diesen nie Sporen ausbilden.

Während die Apothecien der Lecidiaceae sitzen, sind dagegen die der

\section{Baeomycetaceae}

gestielt. Baeomyces roseus und Sphyridium byssoides L. = Baeomyces byssoides (L.) ScHwer. sind hübsche kleine Flechten (Fig. 328), welche einen krusten- oder schuppenförmigen Thallus auf dem Boden bilden, dort öfters größere Flächen einnehmen und zumal kurz nach Regen durch ihre fleischfarbigen bis braunroten gestielten Apothecien sehr auffallen und dann eher Pilzchen wie Lichenen gleichen. Sie finden sich öfters auf Wegen im Gebirge. Die Spermogonien sind im Thallus eingesenkt. Die hier genannten Arten haben Pleurococcus als Algensymbiont, aber Baeomyces paeminosus KRPH. hat eine Cyanophycee als solchen; sie wurde auf der Insel Viti auf Baumrinde gefunden.

Nach KrabBE entstehen bei Baeomyces die ascogenen Hyphen direkt aus den vegetativen Hyphen, was aber nähere Bestätigung erheischt.

Daß Zahlbruckner in Engler und Prantl Baeomyces mit den Cladonien zu einer Gruppe vereint, hat wohl seinen Grund in KrabBes Homologisierung der Podetien von Cladonia mit den Apothecien der übrigen Flechten, eine Meinung, welche sich als irrig herausgestellt hat.

Eine andere Familie der Discocarpineae ist die der

\section{Collemaceae,}

eine Lichenen-Familie, welche eine gewisse Quantität Kalk zu brauchen scheint und deshalb in unserem Lande selten ist. Im kalkhaltigen Limburg ist sie aber ziemlich häufig. Während bei den übrigen Lichenen die Alge fast gar keine formbestimmende Rolle spielt, dominiert diese gerade bei den Collemaceen und Ephebaceen. 
Collemaceen werden auf allerlei Substrat, auf dem Boden, auf Moosen, auf Bäumen, sowie auf Felsen angetroffen. Nach Regen leicht zu sehen, trocknen sie bei Dürre zu fast unkenntlichen, fast schwarzen, zerbrechlichen Krusten ein. Sie können öfter's in enormer Zahl Apothecien produzieren, wie z. B. die hier (Fig. 328) abgebildete Collema multifidum.

Die Entwickelung ihrer Apothecien lernten wir schon kennen, es genügt also, zu erwähnen, daß diese bei den verwandten Generis: Leptogium, Synechoblastus, Physma und Lepidocollema in ähnlicher Weise stattfindet. Der Algensymbiont ist Nostoc oder Rivularia.

Bei der Familie der

\section{Ephebaceen}

dominiert gleichfalls der Algensymbiont, welcher hier von Stigonema geliefert wird. Sie bilden schwarze, haarähnliche Massen (Fig. 328) unter überhängenden, zeitweilig feuchten Kalkfelsen, sie schwellen nie, wie die Collemaceen, schleimig auf.

Zur Familie der

\section{Stictaceen}

g’ehören die größten bekannten Lichenen. Trotzdem können sie, wie alle Flechten, recht gut das Eintrocknen vertragen. ScHRöDER (1886) trocknete Sticta pulmonacea 4, 7, ja sogar 17 Wochen über $\mathrm{H}_{2} \mathrm{SO}_{4}$ und fand sie nach Befeuchtung vollkommen lebend, der Wassergehalt betrug resp. 4,88, 4,81 und 4,87 Proz. Der blattähnliche, nach Regen lebhaft grüne, trocken gelbbraune Thallus von Sticta pulmonacea (Fig. 328), welcher eine entfernte A ehnlichkeit mit einer Lunge hat, entwickelt sich auf alten Buchenstämmen in Thüringen zu Thalli von einem halben Meter Durchschnitt. Fruktifikation scheint örtlich zu sein; während sie bei Göttingen sehr selten auftrat, fand ich sie öfters in Thüringen mit schönen Früchten bedeckt. Die verhältnismäßig recht kleinen Apothecien sind braunrot und deutlich berandet. Der Algensymbiont ist eine Cyanophycee. BorzI fand bei diesem Genus typische Carpogone.

An die Stictaceen schließt sich die Familie der

\section{Peltigeraceen}

an. Unter diesen ist Peltigera (Fig. 328) das bekannteste Genus. Die öfters mehr wie handgroßen, blattähnlichen, schwarzgrünen Thallome mit ihrer öfters hellweißen Unterseite und vom Rande abstehenden, vielfach stark eingerollten Apothecien sind einem jeden bekannt.

Den Peltigeren fehlen die Spermatien; es sind aber Ascogone, denen von Collema ähnlich, vorhanden, welche jedoch nie spiralig eingerollt, sondern unregelmäßig hin- und hergebogen sind. Die Ascogone sind, wie Fig. 329, 1 zeigt, durch ihre bedeutende Dicke leicht kenntlich, sie liegen unter der Rinde. Die Ascogone gehen, wenn sie die ascogenen Hyphen gebildet haben, zu Grunde, und alsbald ist nur noch ihre geelbliche, zusammengeschrumpfte Membran übrig, schließlich ist auch diese nicht mehr aufzufinden. Die ascogenen Hyphen wachsen sehr schnell und bilden alsbald ein sehr dichtes Gewebe, an welchem als Aussackungen die Asci entstehen. Im Detail ist dies aber - die FünFstückschen Untersuchungen sind von 1884 - noch nicht näher bekannt. 
Die innere Schicht des oberhalb der Ascogone gelegenen Rindenstückes fängt nun an Paraphysen zu bilden, diese heben die oberen Rindenschichten an jener Stelle auf, da aber die Paraphysenschicht rascher in die Breite wächst wie die äußeren Rindenschichten, entsteht eine Spannung, wodurch die Paraphysenschicht konvex nach innen gekrümmt wird (Fig. 329, 2), und so kommt in der Rinde eine Höhlung zu stande, in welche anfangs noch Fäden beider Rindenschichten hineinwachsen (Fig. 329, 3). Die aufgehobene Rinde stirbt allmählich ab, zerreißt schließlich und so wird das ursprünglich angiocarpe Apothecium gymnocarp.

Da bei Peltigera die Rinde bis zur Bildung der Asci über dem Apothecium geschlossen bleibt, würde jede Möglichkeit zur Befruchtung ausgeschlossen sein, sogar wenn Spermatien vorhanden wären.

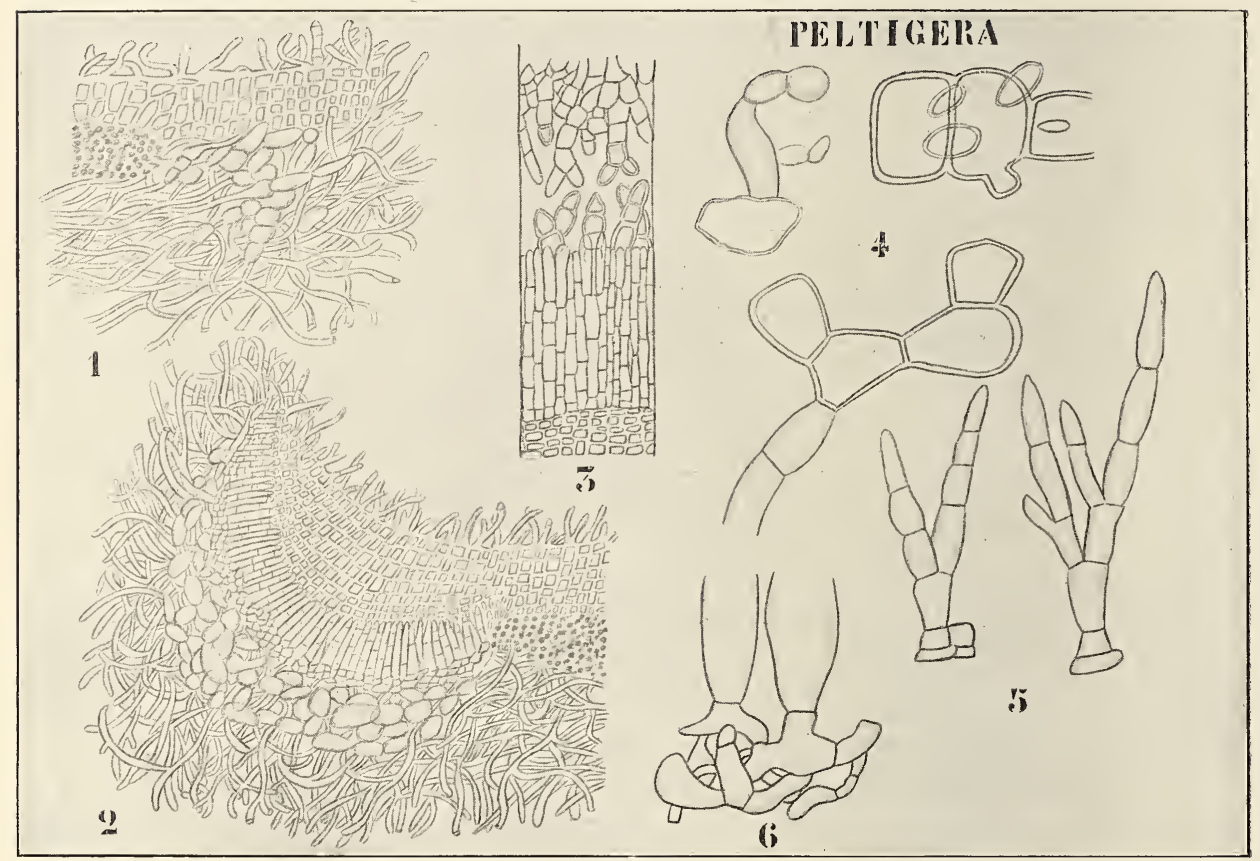

Fig. 329. Peltigera mal a ce a (nach Fünfstück). 1 Schnitt durch eine ganz junge Fruchtanlage, die ascogene und die apotheciale Rindenschicht zeigend. 2 Schnitt durch eine bereits zur Paraphysenbildung vorgeschrittene Frucht; die Ascogone schon in Sprossung begriffen. 3 Abhebung des oberen Teiles der Rindenschicht infolge des Auswachsens der inneren Schichten zu Parenchym. 4 Anlagen der ascogenen Hyphen. 5 Verzweigte Paraphysen. 6 Ascogene Hyphen mit zwei Asci, letztere durchgeschnitten.

Die gleiche Entwickelungsweise konstatierte Fünfstück bei Peltidea. Der einzige Unterschied ist dieser, daß bei Peltigera die Ascogone an dem äußeren Rand des Thallus gebildet werden, wo dieser noch keine Algenzellen besitzt (Fig. 329, 2), also seitlich von der Algenschicht, während sie bei Peltidea stets direkt unter der Algenschicht, also in einiger, wenn auch geringer Entfernung vom Thallusrand gebildet werden.

BAUR untersuchte diese Vorgänge nochmals bei Peltigera canina und konnte Fünfstücks Resultate in jeder Hinsicht bestätigen; er dehnte überdies seine Untersuchungen auf Solorina saccata (L.) AcH. aus, eine 
Peltigeracce, welche in den Voralpen häufig ist und sich von Peltigera hauptsächlich dadurch unterscheidet, daß die Apothecien in der Mediane der Thalluslappen liegen und schüsselförmig eingesenkt sind.

Die Entwickelung der Apothecien findet genau so wie bei Peltigera und Peltidea statt, es liegen hier aber die Ascogone in der Algenschicht (Fig. 330, 5). Sie sind weniger typisch, als bei Peltigera und Peltidea, gelangen aber viel besser zur Entwickelung.

Während bei Peltigera recht viel Apothecienprimordia entstehen und nur sehr wenige zu Apothecien werden, reussiert dagegen bei Solorina jedes angelegte Primordium.

Während bei den bis jetzt behandelten Peltigeraceen keine Spermatien vorkommen, wies FüNFstǘck nach, daß Nephroma AcH. noch Sper-

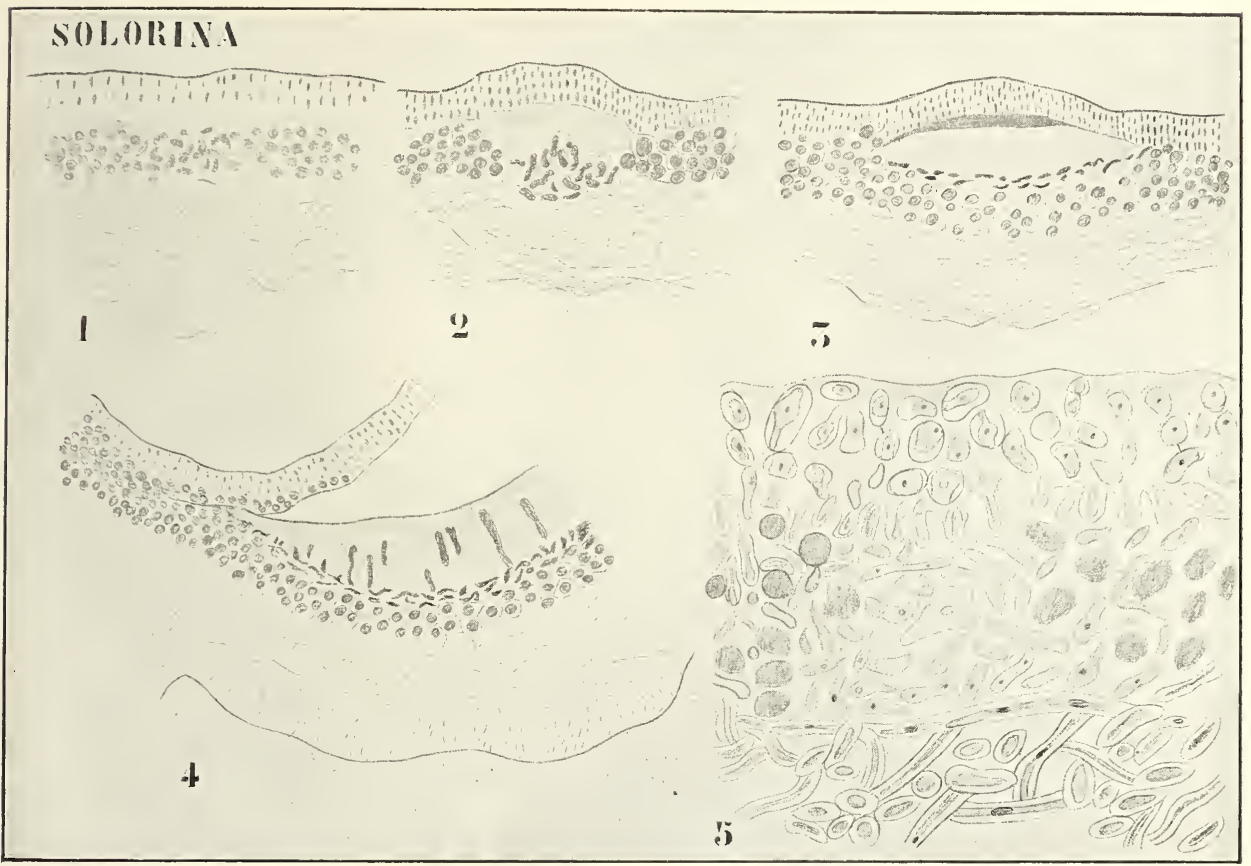

Fig. 330. Solorina saccat a." Entwickelung des Apotheciums (nach BAUR). 1 Querschnitt des vegetativen Thallus. 2-4 Verschiedene Entwickelungsstadien der Apothecien. 5 Die Ascogone in der Algenschicht.

mogonien bildet, welche aber keine ordentliche Spermatien mehr produzieren, und daß auch bei Nephroma die Trichogyne fehlt.

Wir haben also bei den Peltigeraceen eine zunehmende Reduktion der Sexualität, von welcher nur die letzten Reste noch verfolgt werden können, nämlich
1. Nephroma:
Trichogyne fehlt, Spermatien vorhanden, aber rudimentär.

2. Peltigera, Peltidea: Trichogynen und Spermatien fehlen, es werden aber viel mehr Apothecien angelegt als ausgebildet.

3. Solorina : Trichogynen und Spermatien fehlen, alle angelegte Apothecien kommen zur Entwickelung. 
Verlassen wir jetzt die Peltigeraceae und wenden wir uns den

\section{Pertusariaceen}

zu. Das häufigste Genus ist Pertusaria, einige Arten derselben sind Rinden-, andere Steinbewohner. Es sind Lichenen mit meistens grauen krustenförmigen Thalli, welche in fruktifizierendem Zustand so dicht mit runden Apothecien bedeckt sind, daß diese durch gegenseitigen Druck polygonal werden. Die Oeffnung des Apotheciums ist in der Regel klein, oder, wie man das nennt, die Apothecien sind punktförmig. Lindau konstatierte die Anwesenheit einer Trichogyne (Festschr. f. SchwenDENER, mir unzugänglich), BAUR gibt dann in seinem „Flora“-Artikel eine

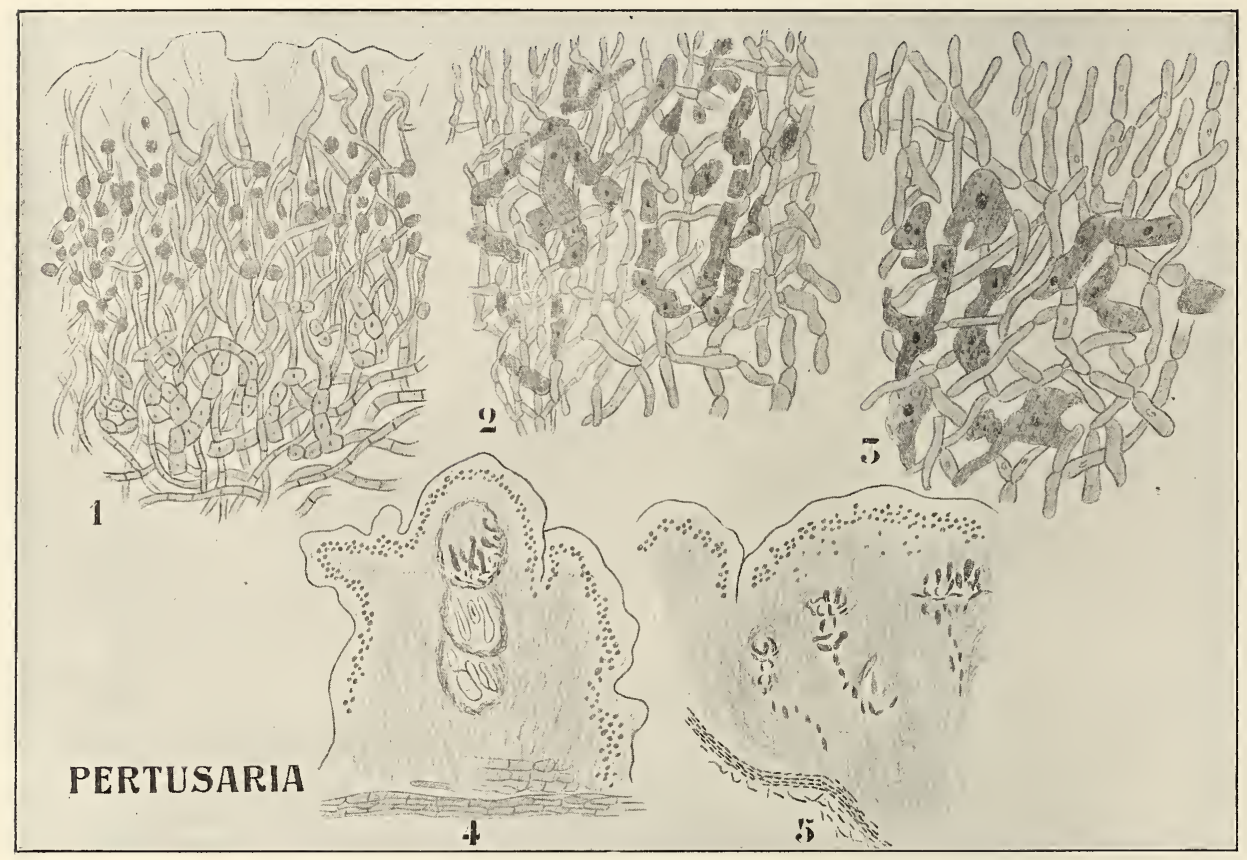

Fig. 331. Pertusaria communis (uach BAUR). 1 Ascogone. 2-3 Entwickelung der ascogenen Hyphen und Anfang der Ascusanlage. 4-5 Bildung von sekundären Apothecien.

nähere Beschreibung der Apothecienentwickelung und bestätigt dabei KrabBes Mitteilungen über die Entstehungsweise der sekundären Apothecien. Aus seiner Untersuchung sei folgendes mitgeteilt. Er untersuchte die rindenbewohnende Pertusaria commınis. Die ersten Spuren der Apothecien findet man ausschließlich in den Randteilen des Thallus, sie liegen als Hyphenknäuel dicht unter der Algenschicht. Auf etwas älteren Stadien unterscheidet man darin leicht die Ascogone von den Umhüllungshyphen. Die Ascogone (Fig. 331, 1) sind vielzellig, aber monoenergid. Trichogynen sind vorhanden, aber die „Blüte“ scheint nur kurz zu dauern. Anscheinend kommen alle Ascogonen zur Entwickelung. Aus den Ascogonen entstehen die ascogenen Hyphen, an welchen, nach 
den BAurschen Abbildungen (Fig. 331, 3) zu urteilen, die Asci auf dem Tege der Hakenbildung entstehen.

Der Pertusaria-Thallus wächst bedeutend in die Dicke und zwar hauptsächlich durch Verdickung der Algenschicht. Durchbrechen nun die Apothecien die obenliegenden Schichten nicht sofort, so geraten die ursprünglich dicht unter der Algenschicht liegenden Apothecien zu tief in den Thallus hinein und müssen degenerieren.

Nun wissen aber die ascogenen Hyphen sich öfters zu retten. Inn einfachsten Falle wachsen sie im Gehäuse des Apotheciums aufwärts, während sie unten absterben, und breiten sich über das Apothecium zu einem nenen Hypothecium aus. Dieser Vorgang kann sich wiederholen, woraus eine Anzahl ïbereinander gelegener Apothecien resultiert

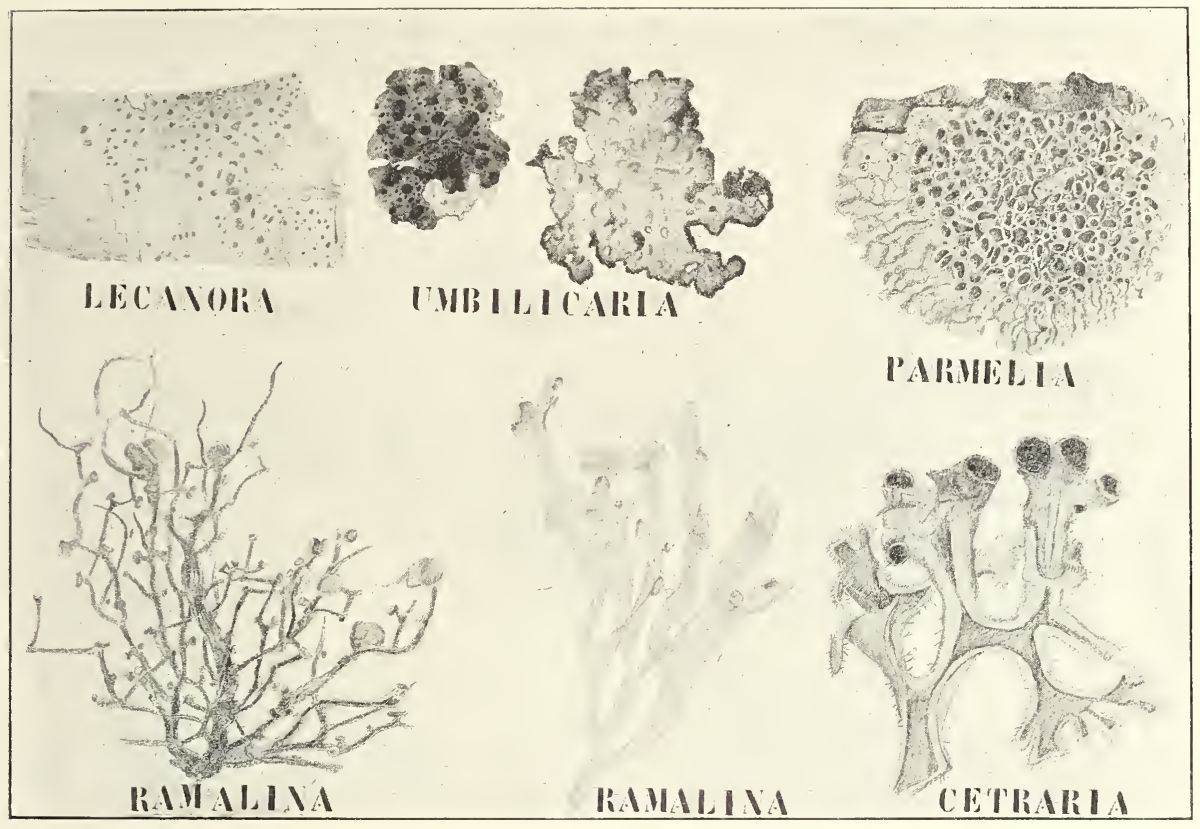

Fig. 332. Verschiedene mit Namen bezeichnete Disco my ceten-Genera (Original).

(Fig. 331, 4). In anderen Fällen wachsen die ascogenen Hyphen der degenerierenden Apothecien aber mehr seitlich aus, und so entstehen die sekundären Apothecien KrabBes (Fig. 331, 5).

Wenden wir uns jetzt der Gruppe der Lecanoraceae zu, einer Gruppe, welche ebenfalls Krustenflechten enthält, welche aber von den Pertusarieae durch die weitgeöffneten Apothecien abweichen.

Die hier (Fig. 332) abgebildete Lecanora subfusca ${ }^{1}$ ) mit ihrem granen Thallus und braunen Apothecien ist eine sehr häufige Rindenflechte. Die Apothecien sind von einem ringförmigen Thallusrande umgeben, welcher Algenzellen enthält. LINDAU zeigte zuerst das Torhandensein von Trichogynen; die Sache wurde darauf von BAUR näher untersucht; ilhm ist folgendes entliehen. Der junge Thallus wächst zunächst einige Zeit steril. 
dann entwickelt er Spermogonien in großer Zahl und zu gleicher Zeit oder etwas später zahlreiche Ascogone. Diese entwickeln sich zu Apothecien und dies wiederholt sich einige Male, so daß unsere Flechte mehrere Blütenperioden hat, zwischen welchen jedoch die Apothecienbildung nicht ganz erlöscht, indem am Thallusrande immerfort einige Spermogonien und Ascogone gebildet werden.

Die Carpogone liegen in Gruppen von 5-10 zusammen, sogar die jüngsten Stadien sehen ziemlich alt aus, da die Paraphysen sich hier besonders früh entwickeln. Die Ascogone liegen auf dem Boden und im Zentrum des Primordiums auf verschiedenen Höhen und enden in Trichogynen, welche nur wenig über den Thallus hervorragen. Die Ascogonzellen sind einkernig. Durch interkalares Wachstum breitet sich das

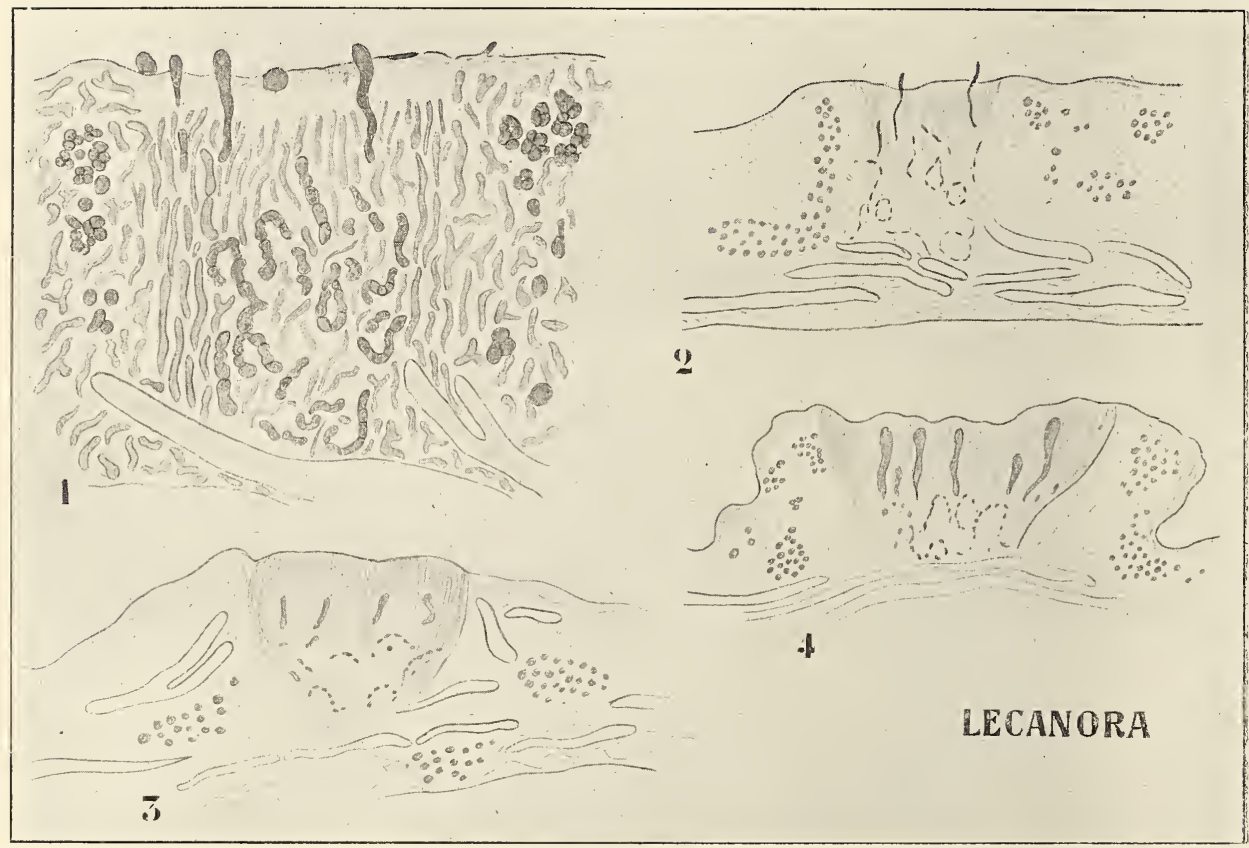

Fig. 333. Lecanora (nach BAUR). 1 Ascogone und Trichogynen. 2 Apotheciumanlage auf etwas älterem Stadium, aber weniger stark vergrößert. 3, 4 Aeltere Stadien.

junge Apothecium seitlich aus und durch lebhaftes Wachstum der benachbarten Thallusteile wird das Apothecium etwas aufgehoben und der Margo thallinus (der Thallusring um die Apothecien herum) gebildet. Das Wachstum der Apothecien ist ein sehr langsames, zwischen Fig. 333, 3 und 4 kann die Zeitdifferenz eines Jahres liegen.

Während die Lecanoraceae Krustenflechten sind, finden wir bei den

\section{Gyrophoraceen,}

wielidie (Fig. 332) abgebildete Umbilicaria pustulata zeigt, schöne blattähnliche mit einem Nabel am Fals befestigte Thalli. Sowohl Gyrophora wie Umbilicaria sind bei Eisenach nicht selten; während erstere einen vollkommen glatten Thallus hat, besitzt Umbilicaria pustulata nicht nur hohle Pusteln, sondern auch eigentümliche schwarze Fransen am Rande 
ihrer Thallomen. Diese korallenähnlich verzweigten Fransen sind nach BitTER ein recht gutes Mittel zur Verbreitung dieser Lichenen, und vermutlich den Soredien analog. Oefters stehen sie um Löcher im Thallus herum, so daß Massart meinte, daß sie infolge von Verwundungen entständen. Nach BitTer ist dies nicht der Fall, sondern die Löcher entstehen erst nachdem die Fransen gebildet sind.

LINDAU entdeckte bei Gyrophora zuerst die Trichogynen, hielt diese aber nicht für die Spitze eines Geschlechtsorganes, sondern hielt sie für Organe, die bestimmt wären, die Rinde zu durchbohren. Deshalb bezeichnet er die Trichogyne mit dem Namen Terebrator.

BAUR hat die Sache nachuntersucht und folgendes gefunden. Die Ascogone (Fig. 334, 1) sind aufgerollt, die Windungen aber deutlich

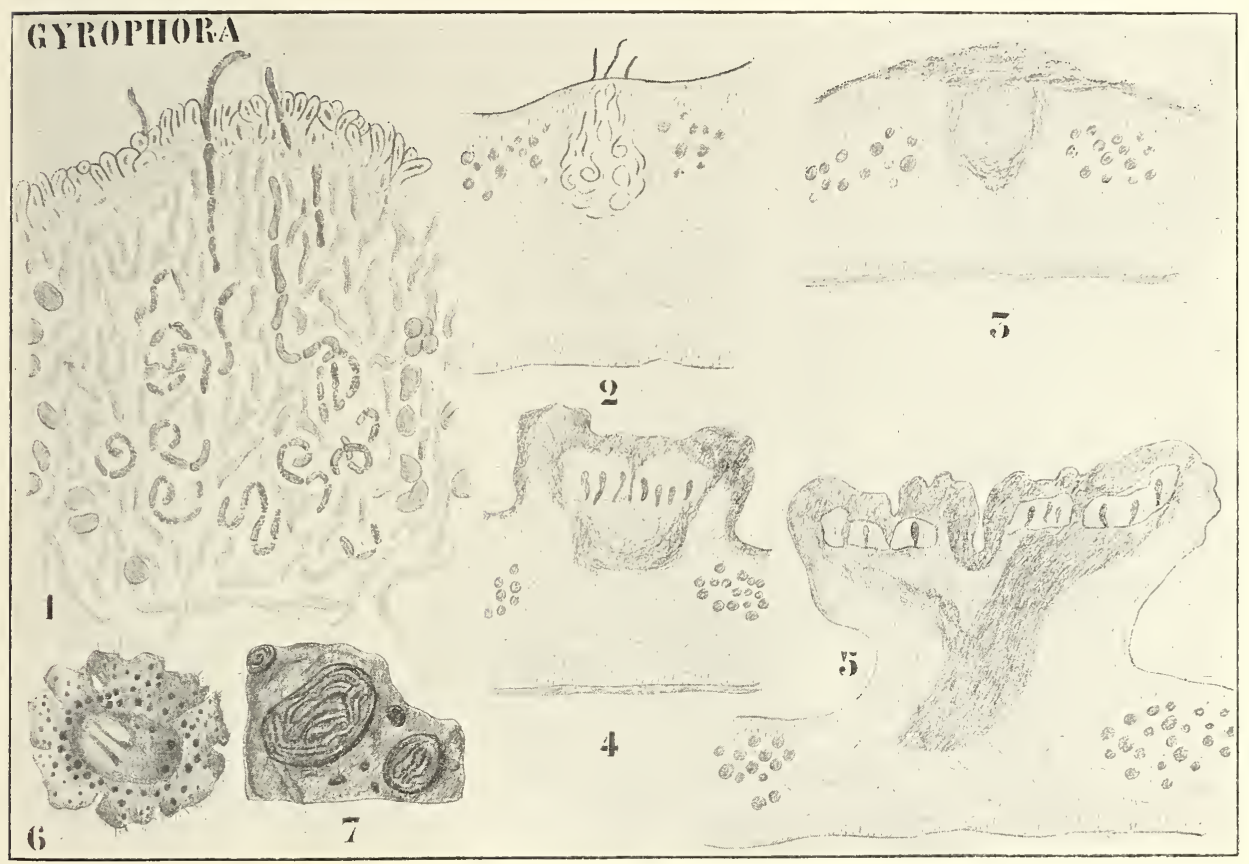

Fig. 334. Gyrophora. Apothecienentwickelung (nach BAUR). 1 Ascogone mit Trichogynen. 2 Etwas älteres Stadium. 3 Bildung des Hymeniums. 4, 5 Teilweises Absterben des Hymeniums, wodurch auf der Oberfläche, wie 7 zeigt, konzentrische sterile Zonen entstehen. 6 Habitusbild des Pilzes (nach v. WeTtstern).

getrennt, im Mai fand er reichlich alle Entwickelungsstadien. Wie wir sahen, meint Lindau nun, daß die Trichogynen die Rinde durchbohren und daß die ersten Paraphysen erst später entstehen. Nach BAUrs Meinung aber hat LINDAU die ersten Paraphysen für Trichogrnen gehalten und es durchbohren nicht die Trichogynen, sondern diese Paraphysen - wie bei den anderen Flechten - die Rinde. Nach ihm gibt es keineswegs so viele Trichogynen wie LINDAU angibt, sonder'l nur 15-20 pro Apothecium. Sie ragen über die Thallusoberfläche hervor'.

Das alte Apothecium von Gyrophora zeigt eine Anzahl mehr oder weniger konzentrische Ringwälle (Fig. 334, 7). Nu die Ringwälle tragen ein Hymenium, die Einsenkungen sind steril. Diesè eigentümliche 
Struktur entsteht durch ein zonenartiges Absterben des ursprünglich scheibenförmigen Hymeniums (Fig. 334, 4, 5).

So kämen wir dann zu einer der häufigsten Lichenen-Familien, zu der der

\section{Parmeliaceae,}

deren Vertreter Blatt- oder Strauchflechten mit meistens stark zerschlitzten Thalli sind. Die Thallusform ist bei den verschiedenen Repräsentanten dieser Familie recht verschieden, wie aus den in Fig 335 abgebildeten Parmelia obscura, Ramalina calicans und fraxinia, Cetraria islandica, Usnea longissima und Bryopogon jubatum hervorgeht.

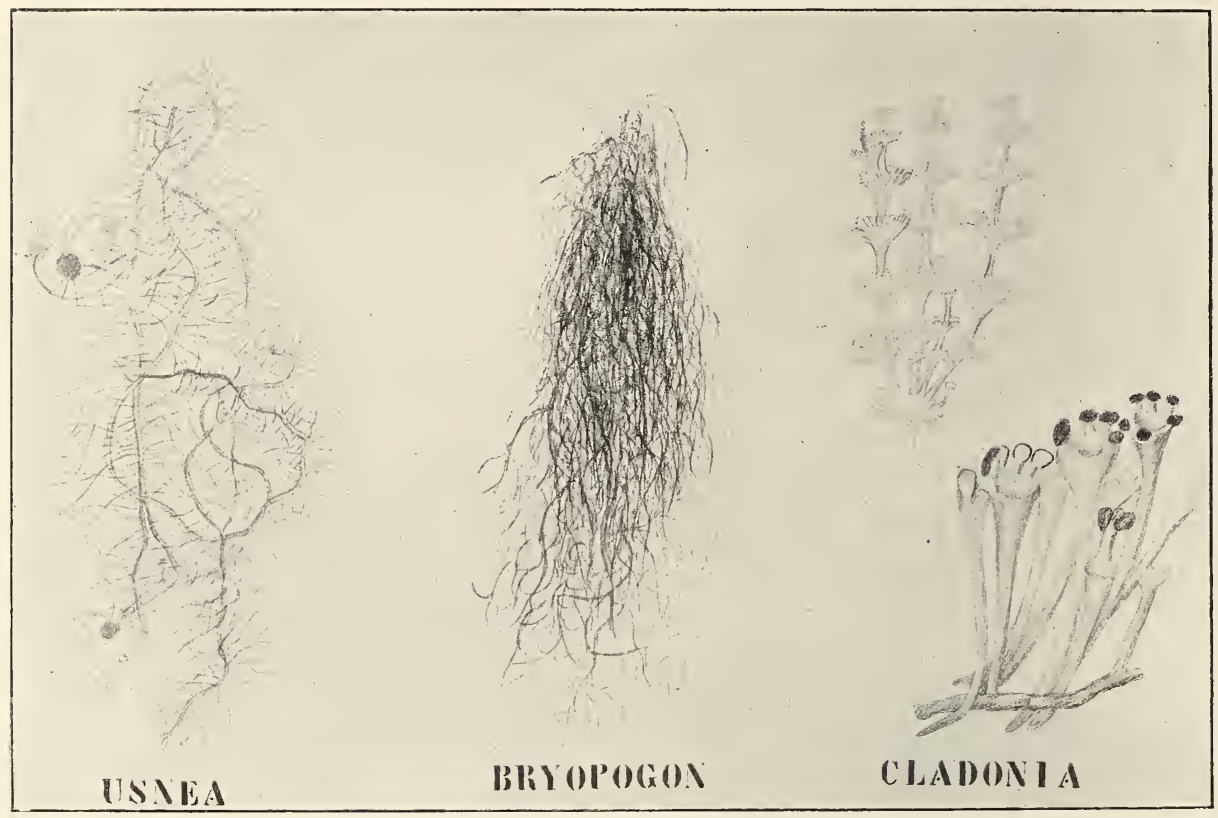

Fig. 335. Verschiedene mit Namen bezeichnete Lichenen-Genera; von den Cladonien sind nur die Podetien abgebildet (Original).

Aus dieser Gruppe ist manches über die Entwickelung der Apothecien bekannt. Fangen wir mit

\section{Parmelia}

an. Jeder kennt die dunkelgrüne baumbewohnende Parmelia acetabulum mit ihren riesigen braunen Apothecien. BAUR hat diese zuletzt untersucht und zwar mit folgendem Resultat.

Parmelia acetabulum bildet, wenigtens im feuchten Kieler Klima. das ganze Jahr Ascogone, nur im Frühjahr und Herbst treten sie etwas reichlicher als sonst auf. Die Ascogone unterscheiden sich von denen aller anderen Lichenen dadurch, daß sie nicht direkt im Thallusgewebe liegen, sondern in Gruppen von 3-6 von einem rindenartigen Plectenchym ${ }^{1}$ ) umgeben sind. Schon bei sehr schwacher Vergrößerung (Fig. 336, 1) kann man diese 50-70 $\mu$ breiten Ascogongruppen in den jungen Thallus-

1) Darunter versteht man ein Hyphengeflecht von parenchymatischem Aeußeren. 
teilen als lokale Verdickungen des Rindengewebes liegen sehen, welche bis in die Algenschicht vordringen. Sie liegen in den jungen Thallusteilen in sehr großer Zahl; öfters trifft ein Schnitt durch einen etwa $1 \mathrm{~cm}$ breiten Lappen bis zu 10 Carpogongruppen; bei kräftigen Thallomen findet man im ILittel 20--30 Carpogongruppen auf einem jungen Lappen von etwa 1 qcm.

Ein Thallus von 10 qcm trägt im Herbst bis zu 500 Carpogongruppen. Das ist sehr viel im Tergleich zu der Zahl der sich entwickelnden Apothecien, welche höchstens 30, meistens aber viel weniger beträgt. Dennoch ragen nicht nur die Trichogynen über die Thallusoberfläche hinaus, sonder'n es finden sich zwischen denselben überall Spermogonien. Wahrscheinlich liegt der Grund darin, daß die sich ent-

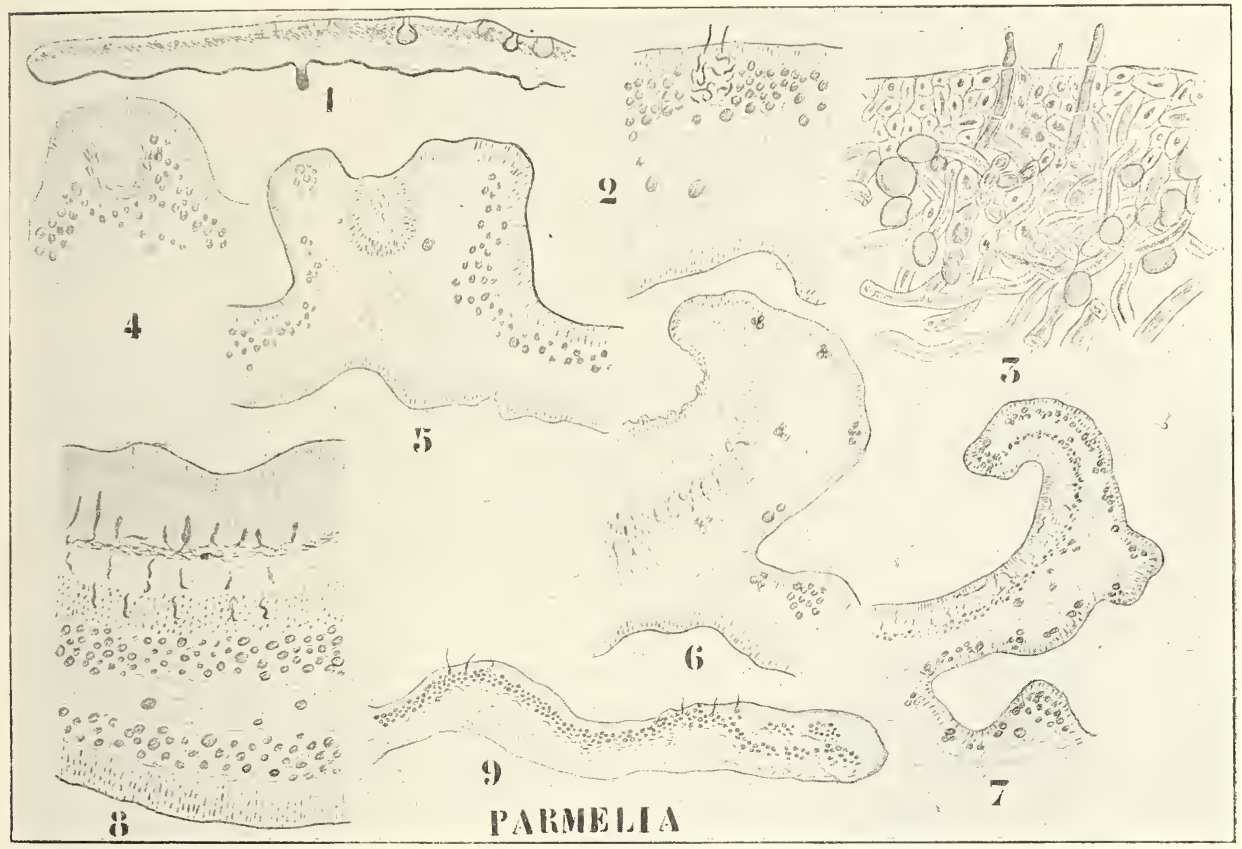

Fig. 336. Parmelia acetabulum (nach BAUR). 1 Thallusquersehnitt mit Apothecienprimordien. 2 Ein Primordium stärker vergrößert, die Trichogynen weit hervorragend. 3 Ascogone und Trichogynen. 4, 5, 6 Differenzierung der ascogenen Hyphen. 7 Die ascogenen Hyphen wachsen in die Rinde hinein. 8 Erwachsenes Apothecium. Erklärung dieser Figur im Text. 9 Trichogynen auf einem Thalluslappen.

wickelnden Apothecien dem Thallusgewebe so viel Nahrung entziehen. daß trotz stattgefundener Befruchtung viele junge Apothecien zu Grunde gehen, möglicherweise aber auch findet keine Befruchtung mehr statt. und nur noch wenige Ascogone haben die Fähigkeit erlangt, sich parthenogenetisch zu entwickeln.

Bei denjenigen Apothecienanlagen, welche sich weiter entwickeln, verschwinden zunächst die Trichogynen und das Primordium rergrößert sich einigermaßen, zu gleicher Zeit fängt ein lebhaftes Wachstum der benachbarten 'Thallusteile an, woran die über' der' Anlage geleg'enen Rindenteile lebhaft teilnehmen. Auf einem etwas älteren Stadium hat 
sich das Primordium über das Niveau des Thallus erhoben; nun sieht man zuerst in demselben eine Differenzierung in eine periphere dunkle Zone (Fig. 336, 4, 5), in welcher vorwiegend die ascogenen Hyphen wuchern, und in eine zentrale Zone englumiger, plasmaarmer, zum Teil wohl toter Hyphen.

Wahrscheinlich nehmen mehrere Ascogone an der Bildung der ascogenen Hyphenschicht teil.

Noch lange ist kein Hymenium sichtbar, es wird dies erst später in sehr eigentümlicher Weise in den oberen Schichten der apothecialen Rinde gebildet. Die ascogenen Hyphen wachsen nämlich (Fig. 336, 7) auf die Rinde zu, dringen in diese ein und breiten sich in den äußeren Schichten derselben zu einem Hymenium aus. Zu gleicher Zeit entstehen aus den Hyphen der Rindenschicht die ersten Paraphysen.

Dadurch erhält das erwachsene Apothecium einen sehr eigenartigen Aufbau (Fig. 336, 8). Der untere Teil desselben besteht aus einer über der Algenschicht gelegenen dunklen Zone, aus dichten Massen ascogener Hyphen bestehend; darüber liegt der größere Teil der ursprünglich apothecialen Rindenschicht, welche durch senkrecht nach der Oberfläche verlaufende ascogene Hyphenzweige durchwachsen wird; darauf folgt eine zweite Schicht ascogener Hyphen und direkt darüber die Asci und Paraphysen. Diesen „Parmelia-Typus" zeigen auch die Apothecien von Usnea.

In der anderen Gruppe von Parmelia, also bei den Arten, welche zur Untergruppe „Hypogymnium" gehören, ist die Fortpflanzung mittels Ascoporen im Verschwinden begriffen; sie wird durch Soredienbildung ersetzt. Während bei dieser Untergruppe nur noch selten Apothecien gebildet werden, sind dagegen Spermogonien noch zahlreich vorhanden. Die Degeneration der Geschlechtsorgane scheint hier also mit den weiblichen anzufangen.

\section{Ramalina}

ist eine strauchförmige Parmeliacee, welche überall an Bäumen vorkommt. Die großen offenen Apothecien entwickeln sich lateral am Thallus. LindaU konnte die Anwesenheit von Trichogynen nachweisen. Ein anderes Genus dieser Familie, welches öfters auf den ersten Blick mit einer Ramalina verwechselt werden kann, ist Evernia. Dieses Geschlecht ist deswegen besonders interessant, weil es ZOPF (1905) gelang, hier, hauptsächlich mittelst chemischer Merkmale, eine Anzahl gut begrenzter „Arten“ zu unterscheiden.

(m) Er konnte nämlich nachweisen, daß unter der Kollektivart Evernia furfuracea wenigstens 6 Arten verborgen waren, welche er

$\begin{array}{cl}\text { Pseudevernia furfuracea (L.) ZoPF, } \\ \text { ceratea (AcH.) ZoPF, } \\ \text { olivetorina ZoPF, } \\ , & \text { ericetorum (Fr.) ZopF, } \\ , & \text { isidiophora ZoPF, } \\ , & \text { soralifera (BITTER) ZopF }\end{array}$

nennt. Einige von diesen waren schon von BitTe R als Varietäten unterschieden und abgegildet, und sehr schöne Abbildungen findet. man in ZopFs Artikel in den Beiheften zum Bot. Centralbl., Teil XIV, 1903. Diese Pseudeverniae sind mit Parmelia verwandt, was schon von Fries aus morphologischen Gründen behauptet und nun von Zopf aus chemischen bestätigt wird. 
Bei den Pseudevernien kommen, etwa wie bei Umbiticaria, Isidien vor, welche die Rolle von Soredien erfüllen. Da sie bei mehreren Arten vorkommen, darf man darin kein Artmerkmal sehen wollen.

Kommen sie in so großer Zahl vor, daß der Thallus dadurch einer Raspel ähnlich wird, so nennt man die Thalli scobicin ${ }^{1}$. Unter obengenannten Arten unterscheiden sich Ps. furfuracea und olivetorina hauptsächlich dadurch, daß erstere keine, die zweite wohl Olivetorsäure bildet. Ich wähle diese beiden Arten zur näheren Besprechung, weil ein ausgezeichneter Lichenen-Kenner, EuEnkin, gegen Zopfs Meinung opponiert hat, was letzterem Gelegenheit bot, zu zeigen, daß doch in der 'Tat das Berücksichtigen chemischer Merkmale neben morphologischen seine Berechtigung hat.

Es hatte nämlich ZopF bei seinen Untersuchungen gefunden, daß Pseudevernia olivetorina nur sehr selten Isidien bildet, und daß anscheinend nie typisch scobicine Formen, wie die der Ps. furfuracea, vorkommen. ELENKin fand nun eine Flechte, welche durch ihre scobicinen Thalli mit E. furfuracea übereinstimmte, aber Olivetorsäure bildete, und schloß daraus, daß E. furfuracea im stande ist, Olivetorsäure zu bilden, und Zopfs Meinung, daß furfuracea und olivetorina sich durch Fehlen oder Vorhandensein von Olivetorsäure unterscheiden ließen, falsch sei. Das ist nun aber selbstverständlich eine Prämisse, welche falsch oder richtig sein kann, denn es gibt auch noch die Möglichkeit, daß olivetorina unter Umständen Isidien bilden kann.

Nun konnte ZopF durch Untersuchungen in den Alpen nachweisen, daß E. olivetorina in der Tat unter selten vorkommenden Bedingungen scobicine Thalli bilden kann, nämlich wenn durch irgend einen Zufall sich ein solcher Thallus in andauernder Feuchtigkeit befindet; dagegen kann $E$. furfuracea unter allen Umständen scobicine Thalli bilden.

Es stellte sich nun weiter heraus, das Ps. olivetorina fast ausschließlich Coniferen bewohnt (Pinus silvestris, cembra, montana; Picea excelsa; Larix decidua). ZoPF fand nie ein Exemplar auf Laubholz; weiter ist olivetorina eine Hochgebirgsform, welche in Bayern und der Schweiz von $1200 \mathrm{~m}$ bis zur Baumgrenze häufig ist. Dagegen bewohnt P. furfuracea außer Coniferen (Pinus silvestris, Picea excelsa) mit Vorliebe Laubholz (Acer, Tilia, Ulmus, Sorbus, Betula, Fraxinus etc.) und fehlt vollständig zwischen 900 und $1900 \mathrm{~m}$ Höhe, also gerade dort, wo Ps. olivetorina häufig ist.

Ps. olivetorina und Ps. furfuracea sind also in Bezug auf ihre vertikale Verbreitung sehr verschieden; EuEnkins Form ist nun eine $E$. olivetorina und keine $E$. furfuracea, wie zum Ueberfluß daraus hervorgeht, daß sie keine Furfuracinsäure enthält, was furfuracea wohl tut. Damit ist also wohl die Berechtigung der Berücksichtigung chemischer Merkmale beim Aufstellen der Flechtenarten erwiesen.

$\mathrm{Zu}$ einem anderen Parmeliaceen-Geschlecht gehört das auf unseren Heiden häufige isländische Moós, Cetraria islandica, eine Flechte mit dunkelbraunen Thalli und großen Apothecien, welche im hohen Norden gegessen wird. Wieder eine ganz andere Thallusform besitzt das Genus Usnea, das Bartmoos, nämlich cylindrische, haarähnliche Thallome, welche schöne gefranste Apothecien tragen, von der Struktur des ParmeliaTypus. Bei der gewöhnlichen Usnea barbata wird öfters eine nichthängende, aufrechte Varietät $\beta$. florida beschrieben, welche aber nicht

1) Von scobicina, die Raspel. 
als solche betrachtet werden darf, da beiderlei Sprosse sich bisweilen am gleichen Individuum finden. Recht haarartig ist der Thallus von Bryopogon jubatum, einer Art, welche im Gebirge nicht selten ist, aber nur sehr selten fruktifiziert.

Aus der Gruppe der

\section{Physciaceae,}

welche hier wohl am besten angeschlossen wird, ist von der Apothecienentwickelung manches bekannt. Die Arten besitzen blattähnliche, gelappte Thalli und sind wohl überall auf Bäumen zu finden.

Darbishire (1900) gab uns eine schöne Untersuchung über Physcia pulverulenta, welcher folgendes entnommen ist.

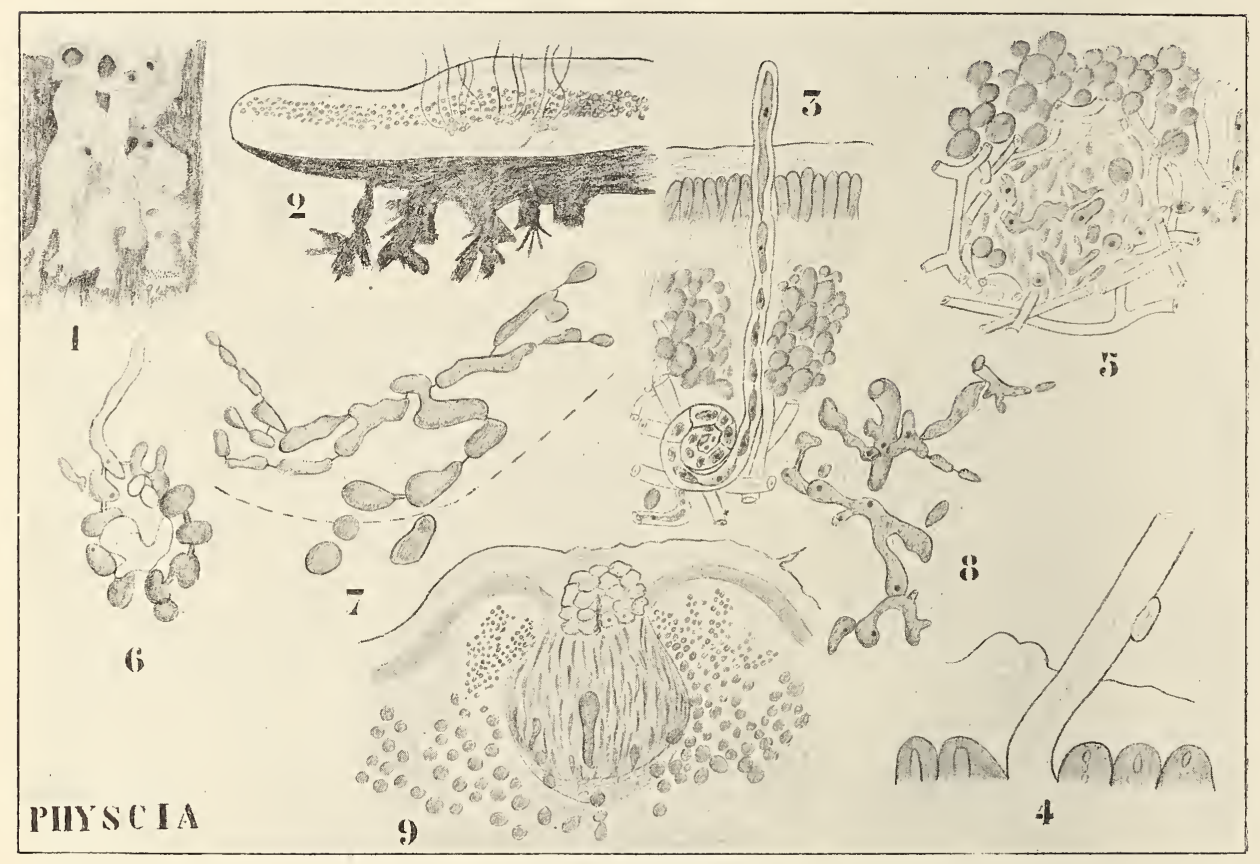

Fig. 337. Physcia pulverulenta (nach Darbishire). 1 Rand eines Thalluslappens, die Punkte auf dem rechten Lappen sind Trichogynen. 2 Querschnitt durch einen Thalluslappen, die langen Trichogynen zeigend. 3 Ascogon und Trichogyne stärker vergrößert. 4 Spermatium an die Trichogyne angeklebt. 5-8 Entwickelung der ascogenen Hyphen. 9 Junges Apothecium.

Hier werden die Apothecien dicht am Rande junger Thalluslappen angelegt, es können sich auf einem ganz kleinen Läppchen 700 bis 1200 Ascogone mit langen, über den Thallus hervortretenden Trichogynen vorfinden, an welchen bisweilen Spermatien kleben. Spermogonien finden sich öfters auf dem gleichen Thallus; trotzdem kommen nur wenige Apothecienanlagen zur Ausbildung. Die Zellen des Ascogons wachsen zu ascogenen Hyphen aus, welche die Asci bilden. Die Paraphysen werden schon früh angelegt; das Apothecium ist zunächst angiocarp. dann gymnocarp. 
Bei der verwandten Anaptychia ciliaris konnte BAUR eine ähnliche Entwickelung nachweisen; der Sporophyt, wie sich BAUR ausdrückt, die $2 x-G e n e r a t i o n$, wie wir sagen würden, ist hier ausgeprägt ${ }^{1}$ ), es zeigte sich hier wieder selı deutlich die Richtigkeit des ScHwENDENERschen Satzes, daß die Paraphysen aus den Hyphen der x-Generation entstehen; ITAHLBergs Meinung, daß sie mit denen der $2 x$-Generation in Verbindung stehen, stellte sich als unrichtig heraus.

So sind wir denn zu der letzten Gruppe der Ascolichenen, zu den

\section{Cladoniaceen}

gelangt, über welche mehr wie über irgend eine andere Lichenen-Gruppe .geschrieben worden ist. Jeder kennt wohl diese Becherflechten. Der

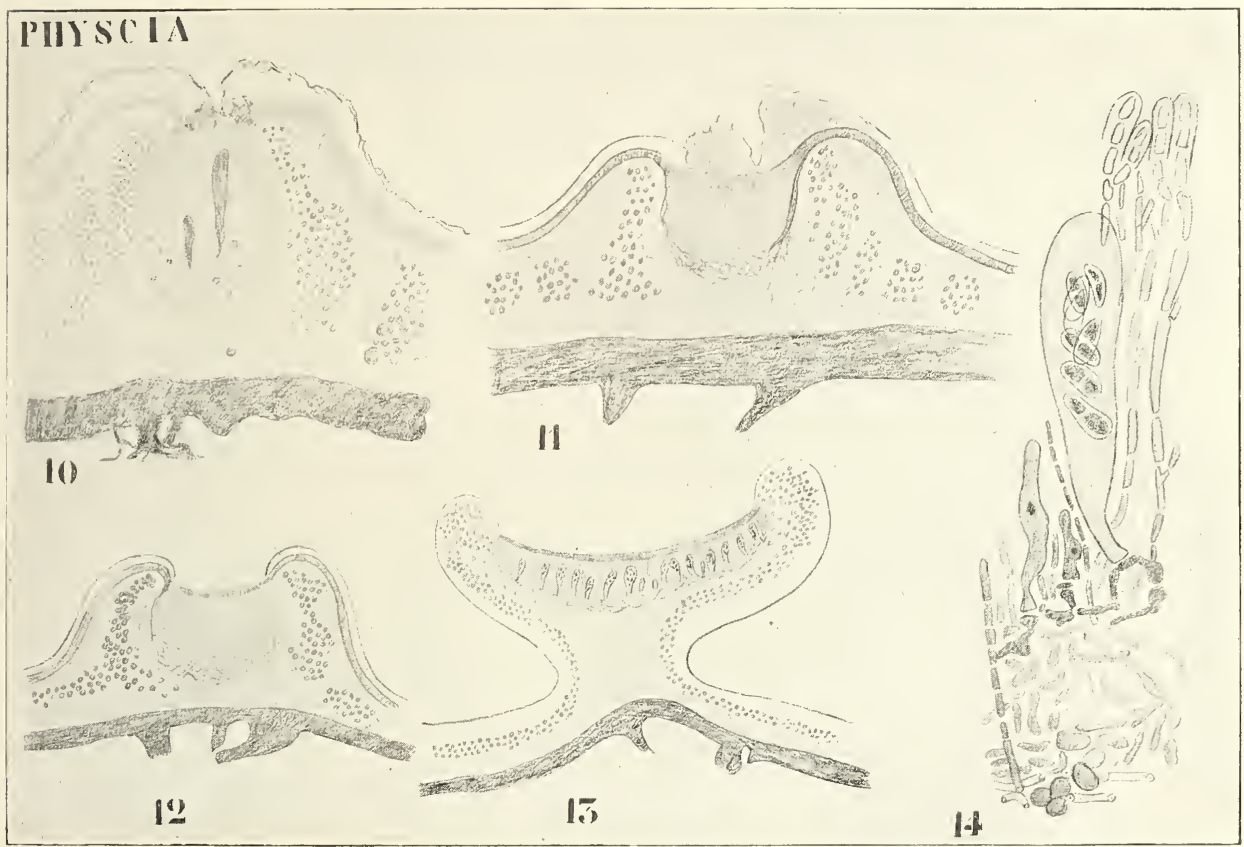

Fig. 338. Physcia pulverulenta (nach DARBishire). 10-13 Das anfangs angiocarpe Apothecium öffnet sich und wird gymnocarp. 14 Ascogene Hyphen, Asci und Paraphysen.

Thallus ist blattartig oder schuppig dem Boden angedrückt, aber verschwindet alsbald; von ihm erheben sich aufrechte trichterförmige oder röhrige verzweigte oder unverzweigte Sprosse, die sogenannten Podetien, welche die Spermogonien und Apothecien tragen und noch lange leben können, nachdem die Thalli schon verschwunden sind. Es gehört hierzu unter anderen das Renntiermoos, Cl. rangiferina, eine der Charakterpflanzen der arktischen Tundren, die aber auch auf unseren Heiden recht häufig ist. Bei dieser Art geht der primäre blattähnliche Thallus besonders schnell zu Grunde und nur die stark verzweigten Podetien

1) Abbildung von Collema siehe Fig. 251, S. 423. 
bleiben übrig. Einfache Podetien besitzt die $C l$. degenerans, mäßig verzweigte die ebenfalls abgebildete $C l$. verticillata.

KraBbE kam nach einer sehr sorgfältigen Untersuchung zur Auffassung, daß das ganze Pothecium das Homologon eines gestielten Apotheciums resp. Spermogoniums war. In diesem "Fruchtkörper", wie er das Podetium bezeichnet, entwickeln sich nach ihm die ascogenen Hyphen einfach als seitliche Sprossen gewöhnlicher "Fruchthyphen". Nach Krabbes Untersuchungen entstehen die ascogenen Hyphen bei den verschiedenen Arten $\mathrm{zu}$ sehr verschiedenen Zeiten, bei einigen sind sie schon kenntlich, wenn das Podetium nur noch ein kleines Wärzchen von kaum $1 / 2 \mathrm{~mm}$ Höhe darstellt; bei anderen, z. B. Cl. rangiferina, sind sie erst in den letzten Verzweigungen der Podetien zu beobachten.

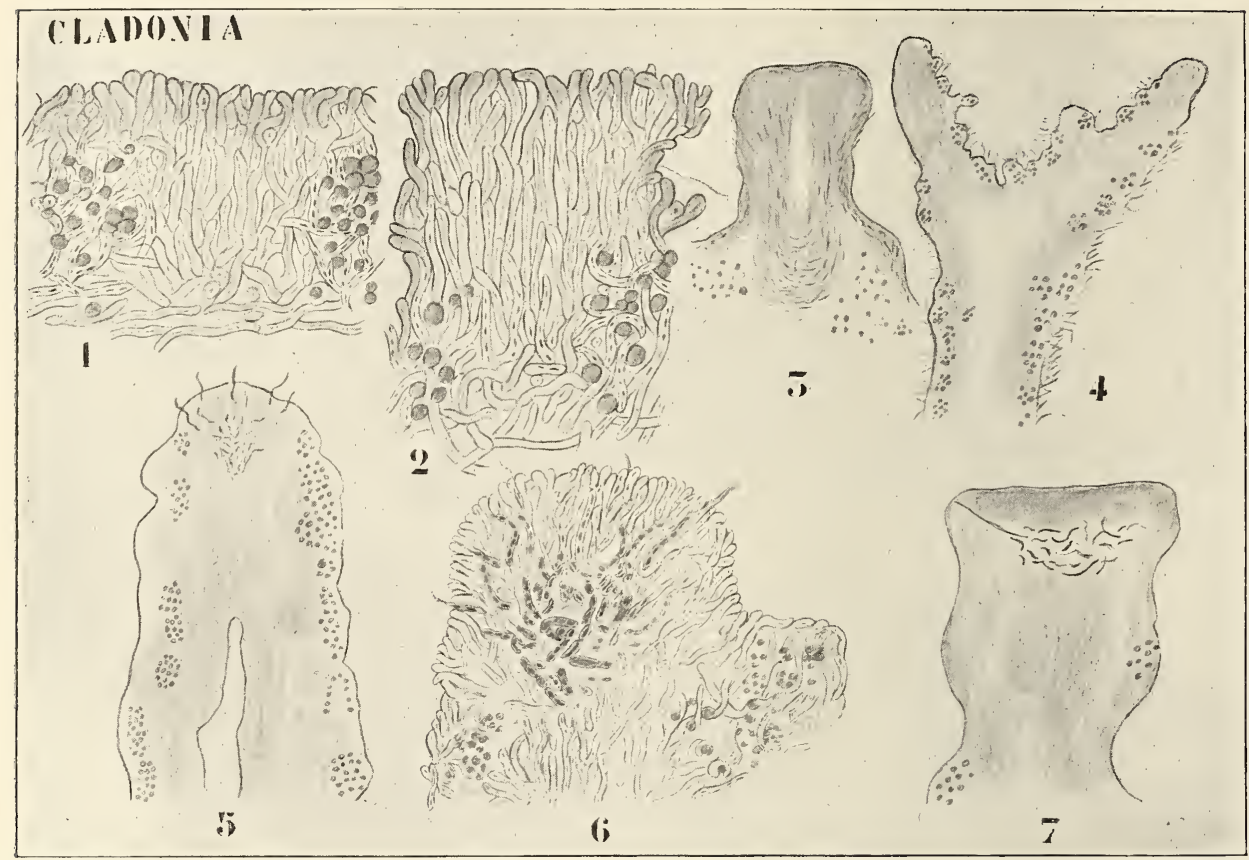

Fig. 339. Cladonia pyxidata (nach BAUR). 1 Sehr junge Podetiumanlage. 2 Etwas älteres Stadium. 3 Erste Bildung der Höhlung im Podetium. 4 Aelteres Stadium, weitere Ausbildung der Hülle, das Podetium, welches in 3 noch keine Algen führte, hat nun diese durch Umspinnen angeflogener Algenzellen erhalten. 5 Bildung der Ascogone und Trichogynen in der Podetiumspitze. 6 Ascogone und Trichogynen stärker entwickelt. 7 Ausbildung des Apotheciums.

Das Podetium von $C l$. rangiferina, d. h. jener Teil der Pflanze, welcher am meisten auffällt, ist nach KraввE (1883, p. 65) „ein reich verzweigtes Apothecium resp. Spermogonium“. Er basiert seine Meinung darauf, daß das Podetium auf der Grenze von Rinden- und Algenschicht endogen seinen Ursprung nimmt, und daß sich darin alsbald die ascogenen Hyphen durch ihre Blaufärbung mit Jodium nachweisen lassen; der Ursprung ist also derselbe, wie der eines apogam gebildeten Apotheciums.

BAUR, der diese Sachen nachuntersuchte, fängt damit an, zu betonen - was KrabBE offenbar entgangen ist - daß BoRzI schon nachgewiesen hatte, daß auch bei den Cladonien Ascogone vorhanden sind, und zwar 
eben an jenen Stellen, wo später Krabbes Hymenien, besser Apothecien, entstehen.

BAUr untersuchte Cladonia pyxidata und konnte KrabBes Angaben über das endogene Entstehen der Podetien bestätigen, kommt aber zu dem Resultate, daß diese Anlagen ausschließlich aus sterilen Hyphen bestehen. Nun wächst der primäre Thallus von Cladonia immer durch Einschiebung von der Algenschicht entstammenden Hyphen in die Breite; die Podetienbildung ist also nur eine lokale Uebertreibung dieses normalen Wachstumsvorganges. Zwischen den Hyphen dieses jungen Podetiums sind Algen nicht vorhanden. Durch Auseinanderweichen der Podetiumhyphen wird später eine zentrale Höhlung gebildet, und entsteht durch peripheres Wachstum das bekannte Becherchen.

Inzwischen hat sich das Podetium durch Umspinnen aufliegender Algen und Soredien eine Algenschicht geschaffell, in der Weise, wie dies schon von KrabBE berichtet wurde.

Nachdem er eine gewisse Größe erreicht hat, bildet der Becher auf seinem Rande Spermogonien und Ascogone mit Trichogynen und aus diesen entstehen die Apothecien. Es kann Jahre dauern, bis ein fruktifizierendes Podetium gebildet ist.

Das Podetium gehört also dem Thallus der Cladonia an, ist also kein Apothecium; ob es vielleicht dennoch phylogenetisch von einem Apothecium abzuleiten ist, ist eine andere Frage, welche noch nähere Untersuchung verlangt.

So haben wir also gesehen, daß bei Pilzen aus den verschiedensten Ascomyceten-Gruppen, bei Pyrenomyceten, bei Laboulbeniaceen und bei den Pilzen der Ascolichenen Befruchtung mittels Spermogonien und Trichogynen stattfindet. Es sind alle diese Formen vorwiegend monoenergid, wenn auch, z. B. bei Peltigera, wie auch bei Florideen, wohl einzelne polyenergide Zellen vorkommen. Ich halte für alle diese Formen einen Zusammenhang mit den Florideen, wahrscheinlich. Jedenfalls geht hieraus hervor, daß die Form der Frucht nicht als ein Kriterium bei Verwandtschaftsfragen benutzt werden darf, denn trotzdem beide Apothecien bilden, wird wohl niemand eine Form wie Ascodesmis mit polyenergiden Hyphen und kopulierenden Gametangien für einen nahen Verwandten halten von Collema oder Physcia mit Trichogynenbefruchtung: durch Spermatien und monoenergiden Hyphen.

Das einzige, was mich noch stutzig macht, ist, daß bei beiden die Asci in so ähnlicher Weise, nämlich durch Hakenbildung, entstehen.

Trotzdem meine ich, daß wir wenigstens als Arbeitshypothese annehmen dürfen, daß die Ascomyceten, ja sogar die Discomyceten, biphyletisch sind, ein Teil stammt von den vorwiegend monoenergiden Florideen, ein Teil von den typisch polyenergiden Siphonomyceten ab.

Da aber in beiden Gruppen Apogamie aufgetreten ist, und da, wie wir sahen, auch aus polyenergiden Organismen durch Scheidewandbildung. fast monoenergide, vielleicht (Erysipheae?) sogar ganz monoenergide entstehen können, da überdies von zahllosen Formen die Entwickelung noch gar nicht oder äußerst dürftig bekannt ist, wiederhole ich, daß an eine phylogenetische Behandlung der Gruppe nicht gedacht werden kann.

Ziemlich sicher sind jetzt weitaus die meisten Discomyceten apogam. Gehen wir jetzt zur Behandlung derjenigen Discomyceten über, welche nicht mit Algen Flechten gebildet haben, und sehen wir, ob wir noch etwas über ihre Abstammung erörtern können. 


\section{Dreiundzwanzigste Vorlesung.}

\section{Die Discomyceten.}

Die erste Gruppe ist die der

\section{Pezizineae,}

welche durch den Besitz anfangs geschlossener (angiocarper), später sich öffnender (gymnocarper) Apothecien charakterisiert ist. Es ist eine der. größten Gruppen, welche mehr als 3000 Arten umfaßt, von welchen wir nur wenige Familien berücksichtigen können.

Hierher gehört zunächst die Familie der

\section{Pyronemaceae,}

von welcher wir schon die Genera Ascodesmis und Pyronema, sowie Humaria behandelten. Wir wissen also, daß wir hier mit typisch polyenergiden Organismen zu tun haben, und bei beiden ersteren mit echter Befruchtung mittels kopulierender Gametangien, also mit Formen, welche von den Siphonomyceten abzuleiten sind.

An die Pyronemaceen schließt man gewöhnlich die Familie der

\section{Pezizaceae}

an. So wie bei allen Discomyceten sind hier die Apothecien erst geschlossen, angiocarp, und werden erst später durch laterales Wachstum geöffnet und dadurch gymnocarp. Ein jeder kennt wohl Vertreter des häufigsten Genus dieser Familie:

\section{Peziza,}

welche öfters hübsch gefärbte Schüsselchen zwischen Moos, auf dem Boden, oder auf alten Baumstümpfen bilden.

Wir haben früher gesehen, daß bei einer der Subgenera dieses Genus, bei Periza (Galactinia) succosa, die Asci an Synkarionhyphen gebildet werden. Diese Synkarionhyphen entstehen als Ausstülpungen dicker polyenergider Hyphen (der ascogenen Hyphen), und auch die vegetativen Hyphen sind polyenergid. Unglücklicherweise ist nun über die Entwickelung nichts weiter bekannt, als daß die beiden Kerne eines Synkarions den Ascuskern bilden und daß später eine Reduktionsteilung im Ascus stattfindet. 
ITir wissen also nur, daß der Kern des Ascus höchst wahrscheinlich ein $2 \mathrm{x}$-Kern ${ }^{1}$ ) ist, und daß also jeder der Kerne eines Synkarionpaares ein $x$-Kern ist.

Die Möglichkeiten sind demnach diese:

A. Die ,ascogenen Hyphen" sind wie bei Pyronema aus einem befruchteten Oogon oder, wie bei Humaria, aus einem Oogon, das durch Verschmelzung von weiblichen Kernen $2 x$-Kerne enthielt, entstanden; sie enthalten dann Zygotenkerne, d. h. 2x-Kerne. Das erste Synkarion ist demnach die Folge einer in einem Zygotenkern stattgefundenen Trennungsteilung.

B. Die „ascogenen Hyphen" sind parthenogenetisch aus einem Oogon entstanden, sie enthalten also nur $x$-Kerne. Von diesen tritt ein Pa ar in das Primordium der Synkarionhyphe ein, es findet dann keine Trennungsteilung statt, sondern nur Aufschub der Verschmelzung bis zur Bildung des Ascusnucleus.

C. Die ,ascogenen Hyphen" sind apogam aus vegetativen Hyphen entstanden und enthalten schon Synkarions, von welchen eines in das Primordium der Synkarionhyphe eintritt.

D. Die „ascogenen Hyphen“ sind bloße vegetative Hyphen, ein P a ar ihrer Kerne bildet das erste Synkarion der Synkarionhyphe.

Vermutlich tritt Fall A nicht auf, und wir haben mit einem der sub B, C oder D erwähnten Fälle zu tun, alșo ist Pe乞iヶa apogam oder parthenogenetisch; mir scheint es am wahrscheinlichsten, daß sie sich als apogam herausstellen wird. Wir müssen aber ruhig nähere Untersuchungen abwarten, bevor wir etwas über die Verwandtschaft aussagen können, wundern täte es mich nicht, wenn es sich herausstellen würde, daß die polyenergiden Penizaceae apogame Pyronemaceae sind.

Hieran schließt Lindau die Gruppe der

\section{Ascoboleae,}

welche mit den Perireae das Aufspringen der Asci mittels eines Deckels gemein hat ${ }^{2}$ ) und sich von ihnen unter anderem unterscheidet durch das Hervorragen der Asci über die Fruchtscheibe (vergl. Fig. 343 von Boudiera). Es sind fast ausschließlich kleine Mistbewohner, mit bisweilen schön violett gefärbten Ascussporen (Ascobolus spec.).

$\mathrm{Zu}$ dieser Gruppe der Ascoboleen wird nun in letzter Zeit von RavLow als vermutlich primitivste Form der viel besprochene

\section{Thelebolus stercoreus Tode}

gebracht. Dieser Pilz wurde 1790 von ToDE zuerst beschrieben; erst 1886 wurde er von ZuKaL näher untersucht und dann durch BREFELDs Hypothesen berühmt; er ergänzte die Zukatschen Untersuchungen zumal dadurch, daß er die Sporen zum Keimen brachte, die Entwickelung des Mycels und die Anlage der Frucht beobachtete und so den geschlossenen Entwickelungsgang allerdings nur in Bezug auf die äußere Morphologie feststellte. Die Frage nach der Zahl, Beschaffenheit und das Terhalten der Kerne im vegetativen wie im fruktifizierenden Teil des Pilzes, sowie nach der Bildung der Sporen blieb offen, bis RAnLow (1906) seine

1) Nach HARPER möglicherweise ein $4 x$-Kern; falls dies richtig, sind die hier gezogenen Schlüsse selbstverständlich unrichtig.

2) Wenigstens in den meisten Fällen. 
Untersuchungen veröffentlichte, in welchen er auch die Entstehung des Fruchtkörpers eingehender als BREFELD beschrieb. Seiner Darstellung sei folgendes entnommen. Thelebolus stercoreus ToDE wächst nicht selten in Gemeinschaft von Rhyparobius- und Ascobolus-Arten auf ziemlich frischer Losung von Hirschen, Rehen, Hasen und Kaninchen. Man findet ihn fast zu jeder Jahreszeit. Seine gelblichen Fruchtkörper stehen oft herdenweise zusammen und sind zur Zeit der Reife an dem deutlich heraustretenden, glänzenden, weißlichen Ascus sehr leicht zu erkennen. Es macht daher keine Schwierigkeit, auf feucht gehaltenem Mist das nötige Material zu beschaffen. RamLow kultivierte die Art in Reinkultur auf sterilem Mist und Mistagar, Stücke von letzteren Kulturen wurden in Paraffin eingebettet, Gelatinekulturen machen Schwierigkeit beim

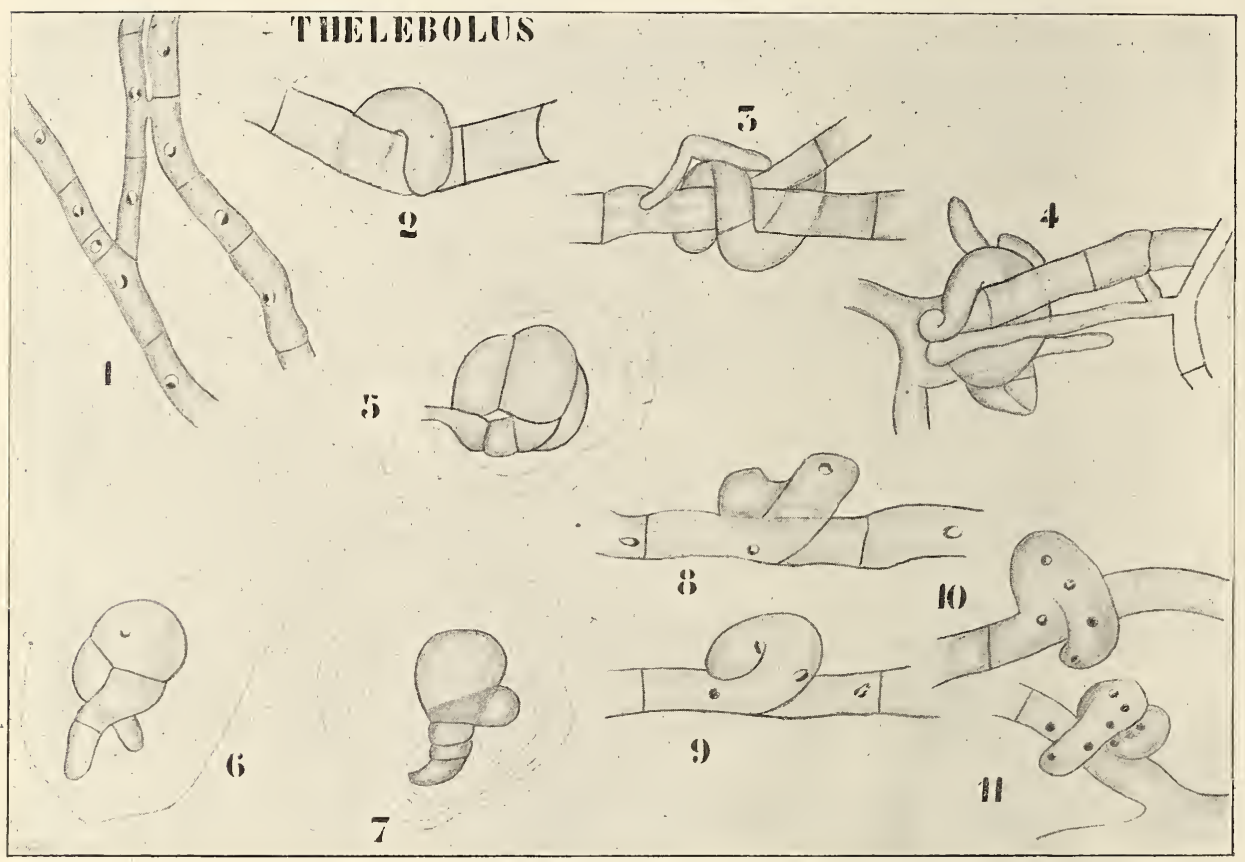

Fig. 340. Thelebolus stercoreus Tode (nach Ramlow). 1 Monoenergides Mycel. 2 Junges Ascogon. 3 Ascogon mit den jüngsten Hüllhyphen. 4 Weiter eingehüllt. 5 Eingehülltes Ascogon, die Hülle nur angedeutet, der junge Ascus schon angeschwollen. 6 Id., im Ascus ein Kern. 7 Id. 8 Einkerniges Ascogon. 9 Id. mit 2 Kernen. 10 Ascogon mit 4 Kernen. 11 Ascogon mit 8 Kernen, noch ohne Querwände und Hüllhyphen.

Schneiden. Fixiert wurde am besten in schwacher Flemming und Merkel, welche nur 2 bis 3 Minuten einwirkte. Gefärbt wurde mit Flemmings Dreifarbengemisch, hauptsächlich aber mit Heidenharns Eisenhämatoxylin.

Die ersten Fruchtanlagen erschienen etwa 8-14 Tage nach der Aussaat der Sporen; die Entwickelung des Mycels wird durch Licht gehemmt, die Bildung von Fruchtkörpern dagegen dadurch gefördert, so daß man am besten die Kulturen erst dunkel, dann hell stellt.

Die ersten Anlagen, die Ascogone, sind mehr oder weniger regelmäßig gewundene Schrauben (Fig. 340, 2), deren Durchmesser anfangs 
dem der Traghyphe mindestens gleich ist, sehr bald aber ihn in mittleren Zellen (Fig: 340, 5) nicht unerheblich übertrifft. Diese Schrauben wachsen bald nach oben, meistens jedoch nach unten, Querwände sind noch nicht vorhanden. Dann werden Hüllhyphen gebildet (Fig. 340, 3, 4), ein Antheridium fehlt aber vollständig, von einer normalen Befruchtung kaun also keine Rede sein. Schließlich treten Querwände auf (Fig. 340, 5) und eine Zelle schwillt besonders stark an, auch die beiden neben ihr liegenden Zellen, von Ramlow Nebenzellen genannt, nehmen noch bedeutend an Größe zu. Die am meisten anwachsende Zelle ist der junge Ascus (Fig. 340, 6, 7), der einkernig ist. Die Stielzelle, welche Brefeld zu sehen glaubt, ist das Ascogon. Die Nebenzellen stehen mittels Tüpfeln mit dem Ascus in Verbindung und führen die zur Entwickelung dieser Riesenzelle nötigen Substanzen herbei.

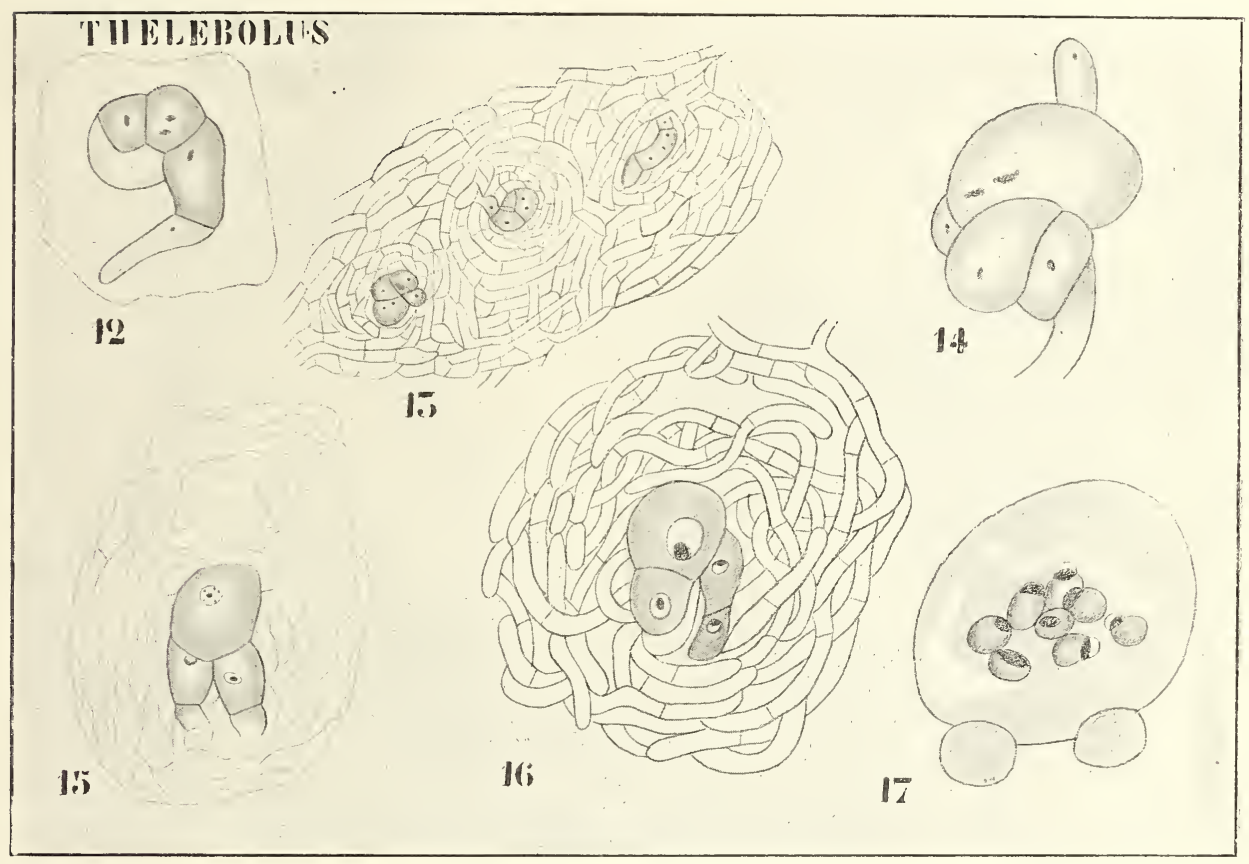

Fig. 341. Thelebolus stercoreus (nach Ramlow). 12 Das Ascogon in einige einkernige und eine zweikernige Zelle zerlegt. 13 Schnitt durch 3 stromatisch verwachsene junge Fruchtkörper. Die Ascuszellen mit je 2 Kernen. 14 Ascus mit 2 Kernen, nur die Nucleoli sichtbar. 15 Ascus mit Fusionskern. 16 Ascuskern vergrößert. 17 8.kerniger Ascus.

Wie steht es nun mit der Cytologie? Die vegetativen Zellen sind monoenergid, enthalten also je einen Kern; auch das junge Ascogon ist einkernig, dieser Kern teilt sich, bis im querwandfreien Ascogon 8 Kerne liegen (Fig. 340, 8-11). Dann tritt Querwandbildung auf, und zwar in solcher Weise, daß in jede Zelle ein Kern zu liegen kommt, mit Ausnahme der größten, welche 2 Kerne erhält.

Diese Zelle wird zum Ascus, die beiden Kerne verschmelzen zum Ascuskern, und aus diesem gehen durch wiederholte Teilung 2, 4, \&. 16. 32,64 , bis wahrscheinlich 1024 Kerne hervor. 
Zur Zeit der Sporenbildung sind die Kerne im Ascus ziemlich gleichmäßig verteilt, es gelang RAMLOw nicht, die wesentlichen Einzelheiten der Sporenbildung genau festzustellen, insbesondere kann er über die Beteiligung des Kernes bei diesem Vorgang nichts Positives mitteilen. Daran ist die Kleinheit der Kerne, welche überhaupt die Untersuchung sehr erschwerte, schuld. Sicher aber findet keine Zerklüftung des Plasmas

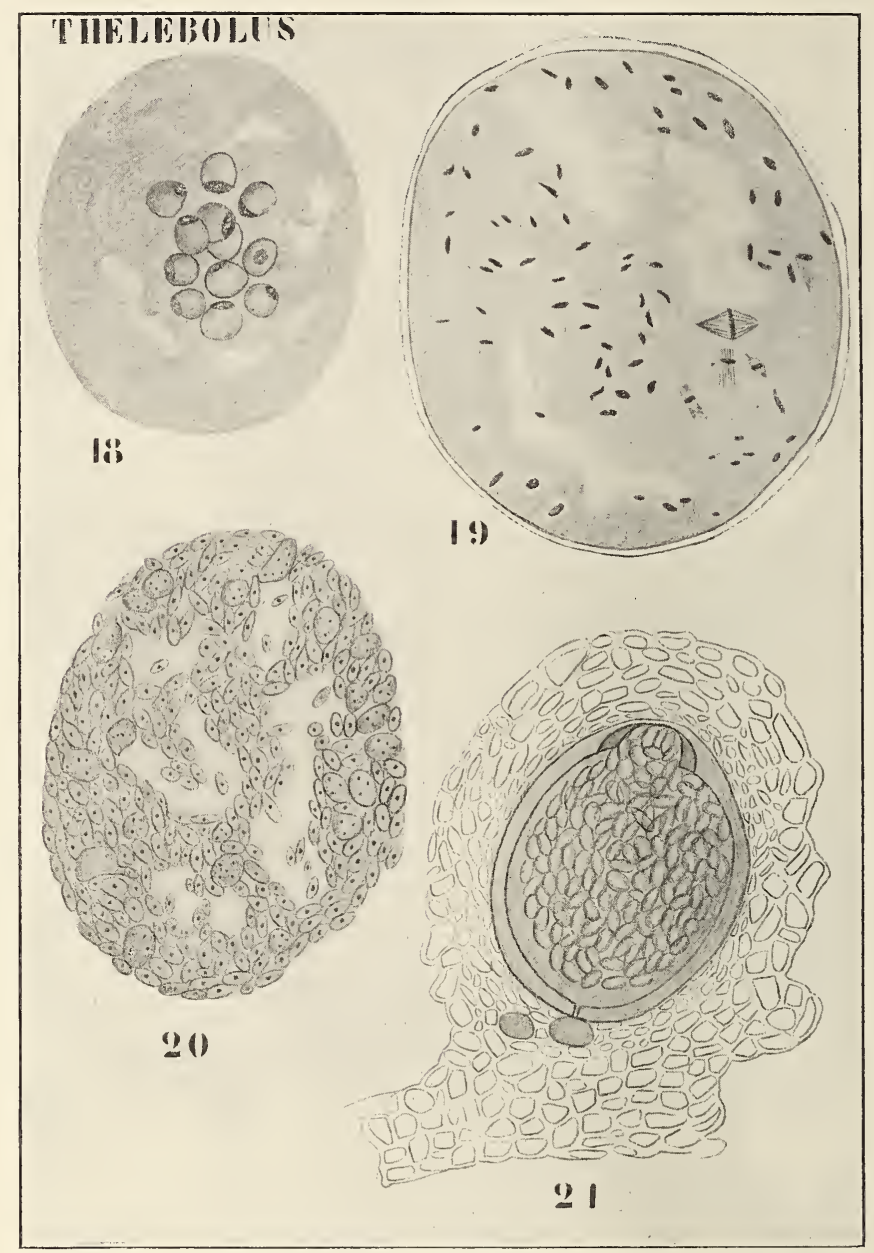

Fig. 342. Thelebolus stercoreus (nach Ramlow). 18 Schnitt durch einen mehrkernigen Ascus. 19 Schnitt durch einen vielkernigen Ascus mit den Kernen in Karyokinese. 20 Sporenbildung, neben fertiggestellten Sporen größere mehrkernige Plasmaballen. 21 Schnitt durch einen reifen Fruchtkörper, der Ascus in Verbindung mit dem Ascogon.

wie im Sporangium der Phycomyceten statt, und sicher bleibt zwischen den Sporen ein deutlicher Rest von Epiplasma zurück. Daraus darf man wohl folgern, daß die Sporen durch freie Zellbildung entstehen, welche Annahme durch die Beobachtung noch wahrscheinlicher gemacht wird, daß die Kerne zuerst seitlich und erst später zentral in den Sporen liegen. Die ganze Sporenmasse wird schließlich, nachdem der durch 
Tasseraufnahme auschwellende Ascus die Hïlle durchbrochen hat, noch in eine Plasma- resp. Schleimhaut eingehüllt mit großer Kraft mindestens $3 \mathrm{~cm}$ ausgeschleudert, wobei der Ascus an der Spitze zerreißt.

Wie lassen sich num diese Sachen erklären? Wie Ramlow mit Recht bemerkt. ist Thelebolus sicher ein Ascomycet, und mir scheint, daß wir hier mit einem Fall zu tun haben, bei welchem die Ascuskerne Konidien im Ascus bilden, z. B. Exoascus analog, nur kommt es hier nicht zur Bildung von Ascussporen, sondern die 8 Kerne derselben teilen sich sofort weiter.

Was nun die Stelle betrifft, welche Thelebolus im System einnehmen muß, schließt Ramlow sich der Schröter-ReHmschen Ansicht an, daß sie zu der Gruppe der Ascoboleen gehört. Reнu sagt darüber: „Unzweifelhaft ist Thelebolus in unmittelbarer Nähe von Rhyparobius zu bringen als einfachste, nur einen Schlauch enthaltende Gattung." RAmLow fügt hinzu: "Man kann annehmen, daß Thelebolus zu Rhyparobius in gleichem Verhältnis steht wie Sphaerotheca zu Erysiphe. Um diese Frage endgültig zu entscheiden, sind jedoch erst Untersuchungen über die Entwickelungsgeschichte anderer Ascobolaceen, besonders über die von Rhyparobius und Ascobolus, notwendig, durch die nachgewiesen werden muß, ob Thelebolus, Rhyparobius und Ascobolus eine, wie es scheint, aufsteigende Reihe bilden, in deren Entwickelung dasselbe Prinzip zur Erscheinung kommt."

Thelebolus ist also zweifellos, wie RAmLOW sich ausdrückt, apogam, richtiger wäre vielleicht, hier von Parthenogenese zu reden. RAvLow ist noch mit Untersuchungen über Rhyparobius und Ascobolus beschäftigt und sagt über diese Genera: „so weit ich aus meinen noch nicht abgeschlossenen Beobachtungen schließen darf, sind auch diese apogam".

Bei Rhyparobius sah aber BARKER (Proofsheet of Report distributed at the Meeting of Sect. K. Brit. Ass., Cambridge 1904) ein Antheridium. Er sagt darüber:

„Both the antheridial branch and the ascogonium are uninucleate when first formed, but subsequent nuclear division occurs in each organ near the time of fusion. The fusion takes place at the point of contact of these structures, this usually being at or near their apices. Probably a nucleus passes from the former to the latter at this period and shortly afterwards walls are formed in both so that the resulting cells are uninucleate with the exception of the subterminal cell of the ascogonium which is sometimes found to contain two nuclei close together. Investing liyphae then develop and encircle the ascogonium which enlarges considerably and for a short period consists of a row of several uninucleate cells."

Später sollen jedoch diese Ascogonzellen 2 oder 4 Kerne enthalten. jede Zelle des Ascogons bildet ascogene Hyphen, aus deren subterminalen binukleären Zellen die Asci hervorgehen.

Rhyparobius und Thelebolus haben also gemeinsam, daß das Ascogon zunächst einkernig ist und keine Querwände aufweist; die nähere Untersuchung RAmLows ist abzuwarten, bevor wir versuchen könuen, beide Formen näher miteinander zu vergleichen.

Ascobolus scheint nun von diesen beiden Formen den Beschreibung'en nach durch den Besitz eines vielzelligen Ascogons abzuweichen; da aber die jüngsten Stadien unbekannt sind, scheint es mir sehr wahrscheinlich. daß auch hier das Ascogon anfänglich einzellig ist. Die jüngste Untersuchung dieses Genus rührt voll HARPER (1896) her. 
Die Ascogonzellen sind einkernig, die Querwände aber durchlöchert. wodurch die Zellen miteinander in Verbindung stehen. Durch Teilung der Kerne entsteht in jeder Zelle eine Anzahl von kleinen Kernen. Eine der Ascogonzellen, ungefähr die vierte von oben, ist größer als die übrigen und bildet die ascogenen Hyphen. Alle Kerne der übrigen Ascogonzellen begeben sich nun in diese große, ascogene Hyphen bildende Zelle, und mit ihnen auch das Plasma; von dort treten sie in die ascogenen Hyphen ein, so daß schließlich das ganze Ascogon leer ist und unkenntlich wird.

Die also vielkernigen ascogenen Hyphen werden mittels Querwänden septiert, die dem Ascogon benachbarten Zellen sind leer und degenerieren, die weiter davon entfernten bilden die Asci, die Art und Weise ist noch nicht genau bekannt ${ }^{1}$ ). Die Kerne im Ascogon sìnd viel größer als die der vegetativen Hyphen und vergrößern sich noch während ihres Eintrittes in die ascogenen Hyphen.

Das vermeintliche Antheridium dürfte kein Antheridium sein, und Ascobolus könnte also apogam sein, vielleicht mit Kernverschmelzungen. etwa wie bei Humaria. Da aber Ramlow auch diese Form untersucht. hat es keinen Zweck, uns über Möglichkeiten auszulassen. Wahrscheinlich wird es sich wohl herausstellen, daß auch hier das Ascogon anfangs einzellig ist.

Wir haben also bei den hier behandelten Formen mit monoenergiden Lebewesen zu tun, welche wohl mit den Perizaceae nicht nahe verwandt sind. und von welchen sich vorläufig gar nicht sagen läßt, wo sie hingehören. wissen wir doch nicht einmal, ob sie von Formen mit Gametangienkopulation oder mit einer Befruchtung mittels Trichogynen und Spermatien herrühren, ersteres dürfte allerdings das wahrscheinlichere sein, in welchem Falle ich sie, wie früher die Erysipheae, für monoenergid gewordene Polyenergide halten möchte.

Ob aber die Ascoboleae, so wie sie z. B. von Lindau gefaßt werden, eine natürliche Gruppe bilden, ob alle z. B. monoenergid sind, muß dahin gestellt bleiben, bis weitere Untersuchungen Licht bringen werden.

Für viel näher mit den Pezizaceen verwandt halte ich die

\section{Helotieae,}

zu welchen u. a. das Genus Sclerotinia gehört, das, wie wir früher schon sahen, höchst wahrscheinlich apogam ist. Ob es, so wie die Periraceae, polyenergid ist, ist bis jetzt nicht bekannt. Als Beispiel dieser Gruppe wähle ich

\section{Sclerotinia Vaccinii Woronin.}

Von Ende Mai bis Mitte Juni findet man in Walde neben normalen Vaccinium vitis idaea-Pflänzchen öfters in nicht geringer Zahl einjährige erkrankte Triebe. Der Stengel dieser kranken Pflänzchen wird über eine gewisse Distanz schlaff, schrumpft und trocknet ein. Ursprünglich grün, wird er erst hell gelbbraun und schließlich dunkelbraun, ja sogar schwarz; meistens biegt er sich dann um. Die an den kranken Stellen des Stengels vorhandenen Blätter vertrocknen ebenfalls und werden braun. ja bisweilen schwarz, meistens ist nur ein Teil des Blattes braun und

1) Zwischen Harpers Fig. 2 und Fig. 3 Taf. XXVII d. Ber. d. D. Bot. Ges. liegen. wohl noch andere Stadien. 
die Spitze bleibt grün. Auf diesen vertrockneten Zweigen und auf den Mittelnerven oder dem Blattstiel des vertrocknenden Blattes tritt alsbald ein schneeweißer, höchstens gelblicher, aus den Konidien unseres Pilzes cebildeter Schimmelüberzug auf.

Diese Konidien werden in Reihen abgeschnürt (Fig. 243, 9) und lösen sich voneinander mittels eigentümlicher Zwischenstücke, Disjunktoren genannt, welche dadurch entstehen, daß die Membran zwischen den ursprünglich sich berührenden Konidien in zwei Lamellen gespaltet wird, und daß jede dieser zur Bildung eines konischen Membranstückes Veranlassung gibt.

Diese Konidien nun besitzen einen ausgesprochenen Mandelgeruch, welcher zumal bemerkt wird, wenn man die Pflänzchen einige Zeit in

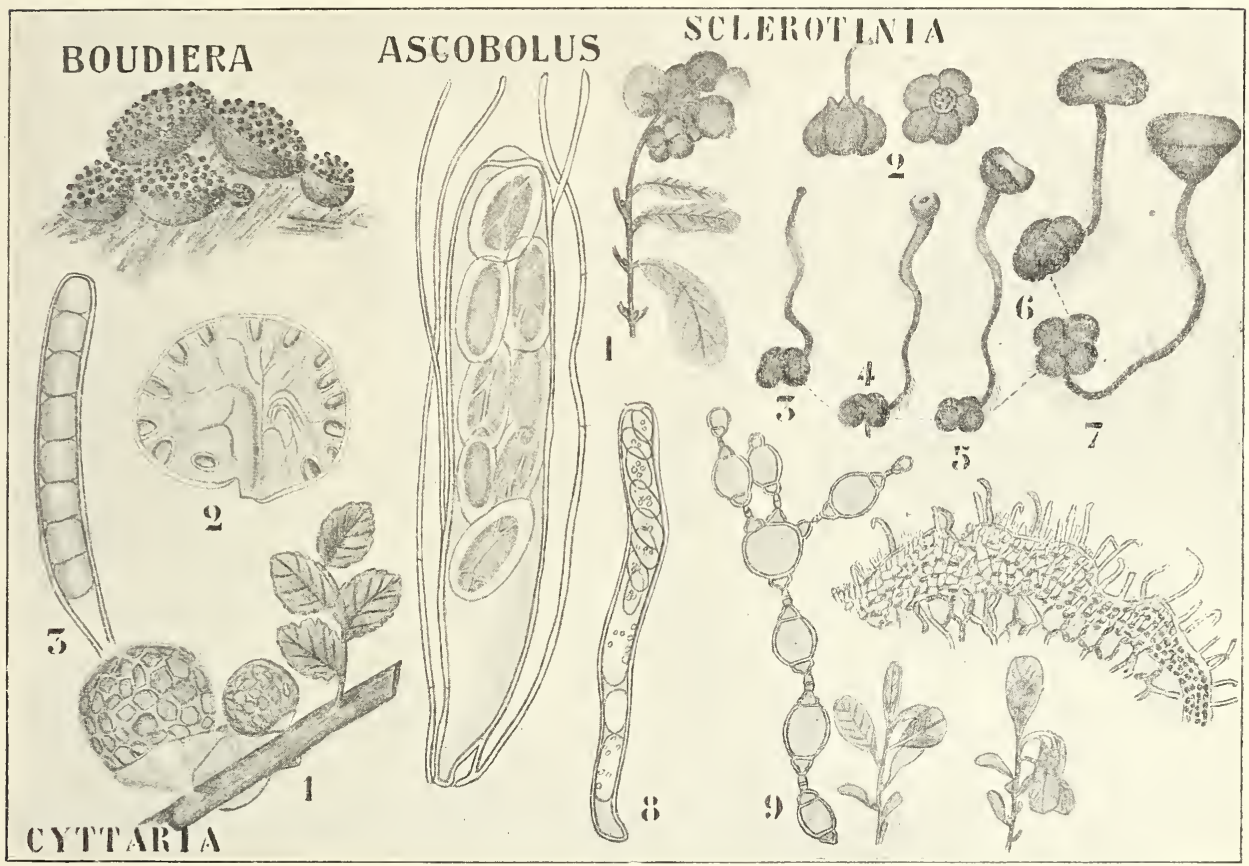

Fig. 343. I. Ascoboleae. - II. Helotieae. - III. Cyttariaceae.-- Ia. Bou diera areolata Cooke et PHILl. (nach PHILlips). Fruchtkörper mit hervorragenden Asci. - Ib. Ascobolus immersus. Ascus (nach LINDAU). - II. Sclerotiniavaccinii (nach Woronis). 1 Infizierte Früchte. 2 Id. vergrößert. $3-7$ Keimende Sclerotien. 8 Ascus. 9 Konidien. Rechts davon: oben Querschnitt eines infizierten Zweiges, unten in. fizierte Zweigspitzen. - III. 1 Cyttaria Gunnii BerK. (nach LINDAU). 2 C. Harioti E. Fischer. Längsschnitt nach E. Fischer. 3 Derselbe, Ascus.

der Botanisierbüchse mitgetragen hat. Durch diesen Mandelduft werden Insekten angelockt, welche sie bei ihrem nachfolgenden Besuch in den Vaccinium-Blüten auf den Stempel bringen. In dem zuckerhaltigen Narbensaft keimen sie zu kräftigen Mycelien aus; in reinem Wasser gelingt dies nicht, dort bilden sie sofort wieder Konidien; setzt man dem Wasser etwas Zucker zu, so bilden sie kurze Mycelien, welche aber alsbald wieder Konidien bilden, in Pflaumendekokt aber erhält man ein kräftiges Mycel. Ein solches entwickelt sich num in der Natur im Frucht- 
knoten des Vaccinium, wodurch der Fruchtknoten mumifiziert wird, und die Beeren statt rot braun werden.

Die mumifizierten Früchte, die Sclerotien also, überwintern und keimen im Frühjahr etwa in derselben Weise wie die Claviceps-Sclerotien, nur mit dem Unterschied natürlich, daß hier die bekannten langgestielten braunen Peziza-ähnlichen Früchte entstehen.

Während hier, wie bei den Ascomyceten üblich, Konidien und Asci auf dem gleichen Substrat, in casu auf der gleichen Pflanzenart gebildet werden, finden wir bei Sclerotinia Ledi die Sclerotien in den Früchten von Ledum palustre, die Konidien aber auf Vaccinium uliginosum.

Wir haben es hier also mit einem Fall von Wirtswechsel zu tun, und zwar mit dem einzigen unter den Ascomyceten; bei den Uredineen werden wir sie später in Hülle und Fülle antreffen.

Eine sehr eigentümliche, von Lindau hier angereihte Familie ist die der

\section{Cyttariaceae.}

Ueber ihre Entwickelung ist leider noch so wenig bekaunt, daß WeTtSTEIn sehr gut recht haben kann, wenn er meint, sie werde besser an die Helvellaceen angeschlossen.

Die Stromata dieser Pilze (Fig. 343) sind knollenförmig und es ist ein auffallender Umstand, daß sowohl die Arten, welche in Tasmanien, sowie diejenigen, welche in Feuerland vorkommen, Parasiten auf Arten des Genus Fagus sind.

Ueber dieses Genus sagt Darwin in seiner Beagle-Reise (p. 224):

„There is one vegetable production deserving notice from its importance as an article of food to the Fuegians. It is a globular, brightyellow fungus which grows in vast numbers on the beechtrees. When young it is elastic and turgid, with a smooth surface; but when mature it shrinks, becomes tougher and has its entire surface deeply pitted or honey-combed. I found a second species on another species of beech in Chile and Dr. Hooker informs me, that just lately a third species has been discovered on a third species of beech in Van Diemen's Land. How singular is this relationship between parasitical fungi on the trees on which they grow, in distant parts of the world. In Tierra del Fuego the fungus in its tough and mature state is collected in large quantities by the women and children and is eaten uncooked. It has a mucilaginous slightly sweet taste, with a faint smell like that of a mushroom. With the exception of a few berries, chiefly of dwarf arbutus, the natives eat no vegetable food beside this fungus."

Die Apothecien sind im Stroma eingesenkt. Nach Fischer entwickeln sie sich unter der Oberfläche und brechen erst später hervor. Auf dem Stiel des Stromas sind spermogonienähnliche Dinge gefunden worden; ob diese aber zum Pilz gehören oder nicht, ist unsicher.

Die zweite Untergruppe der Discomyceten ist die der

\section{Phacidiales.}

Die Vertreter dieser Gruppe, welche saprophytisch oder parasitisch wachsen, besitzen septierte Hyphen. Oefters bilden sie ein Stroma, es kommen aber auch vielfach die Früchte direkt auf dem Mycel vor. Die öfters langgestreckten Früchte sind zunächst geschlossen und öffnen sich 
später durch Spalten oder Risse, indem die darüberliegenden Schichten zerrissen oder lappenähnlich zurückgeschlagen werden, wodurch das $\mathrm{Hy}$ menium mehr oder weniger frei zu liegen kommt. Die Fruchthülle ist tleischig oder lederig.

Als Beispiele mögen hier ein paar europäische Arten behandelt werden.

Naemacyclus niveus (Pfrs.) Sacc.

bildet kleine, lange, gelbe Fruchtkörperchen auf Coniferen-Nadeln und tötet diese. Die Sporen sind lang und hyalin; die verzweigten Paraphysen bilden eine Art Capillitium (Fig. 344, I 3) über sie, wie die von Sphaerophorus unter den Lichenen. Nebenfruktifikationen sind noch nicht mit Sicherheit bekannt.

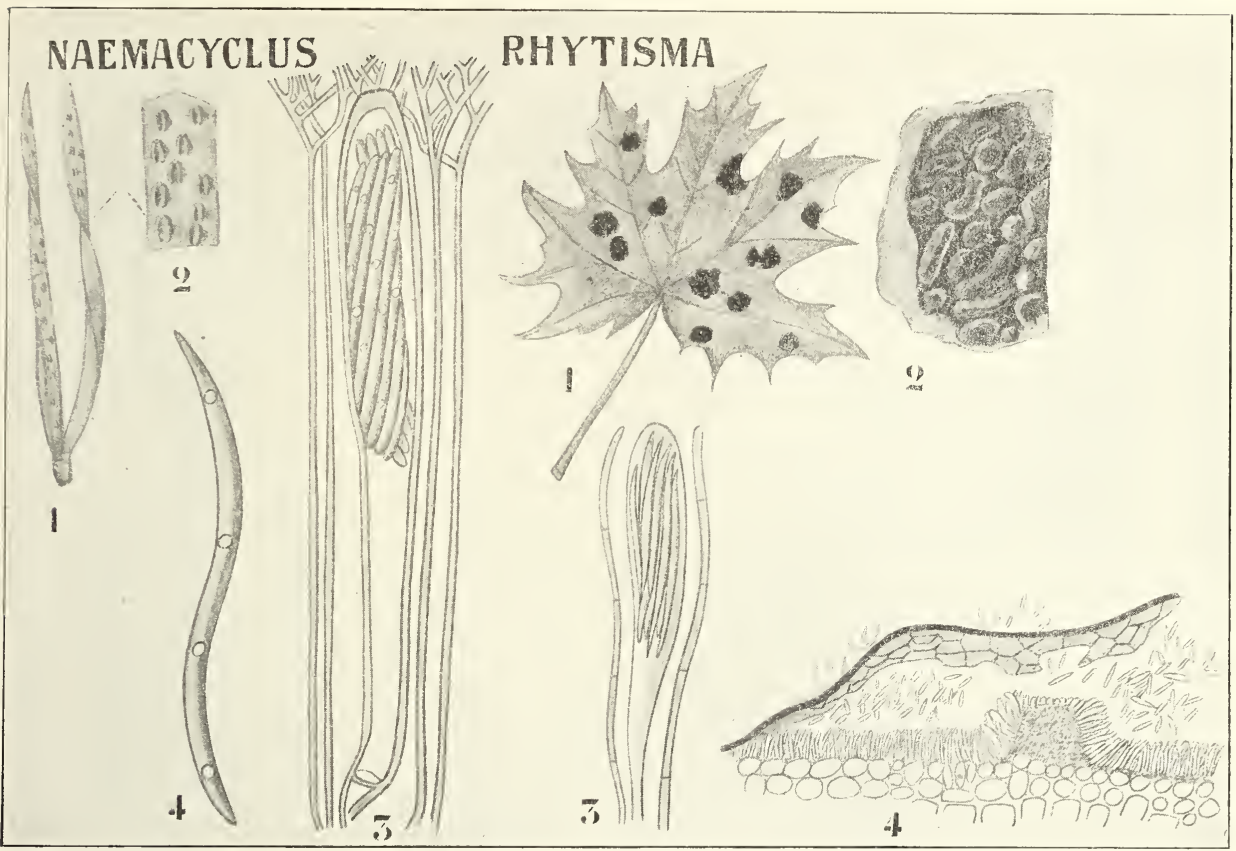

Fig. 344. Phacidiales. I. Na emacyclus niveus [Pers.] SACC. (nach ReHu). 1 Kiefernadeln mit dem Pilz, nat. Größe. 2 Einige Fruchtkörper, etwas vergrößert. 3 Ascus und Paraphysen. 4 Ascusspore. - II. Rhy tis ma a cerina [PERs.] Fr. 1 Habitusbild der Stromata. 2 Ascusfrüchte auf einem Stroma, vergrößert. 3 Ascus und Paraphysen. 4 Stïck eines Konidienlagers (nach LINDAU und TULASNE).

Die bestbekannte Art dieser Gruppe ist sicher

\section{Rhytisma acerina,}

welche durch die Bildung von kohlschwarzen Stromata die Acer-Blätter im Herbst mit schwarzen Flecken überdeckt.

Die Stromata fangen mit der Bildung von Konidien (Fig. 344. II 4) an; erst nachdem die Blätter abgefallen sind und der Winter vorbei ist. entstehen die mehr oder weniger länglichen Apothecien, welche sich mittels einer Längsspalte öffnen (Fig. 344, II 2); die Paraphysen sind unverzweigt. 
Direkt an diese Gruppe kann die dritte Untergruppe der Discomyceten, die der

\section{Hysteriales,}

angeschlossen werden. Auch sie besitzen ein septiertes Mycel; die Apothecien unterscheiden sich von den Phacidiales zumal durch ein besser differenziertes Gehäuse, das in der Weise von Rhytisma mittels einer Längsspalte aufspringt. Eine der schönsten der zu dieser Gruppe gehörigen Arten ist die amerikanische

\section{Parmularia styracis LÉvelLL,}

welche auf den Blättern von Styrax parvifolia in Brasilien angetroffen wird. Die pechschwarzen Stromata sind hier sauber rund, scheiben-

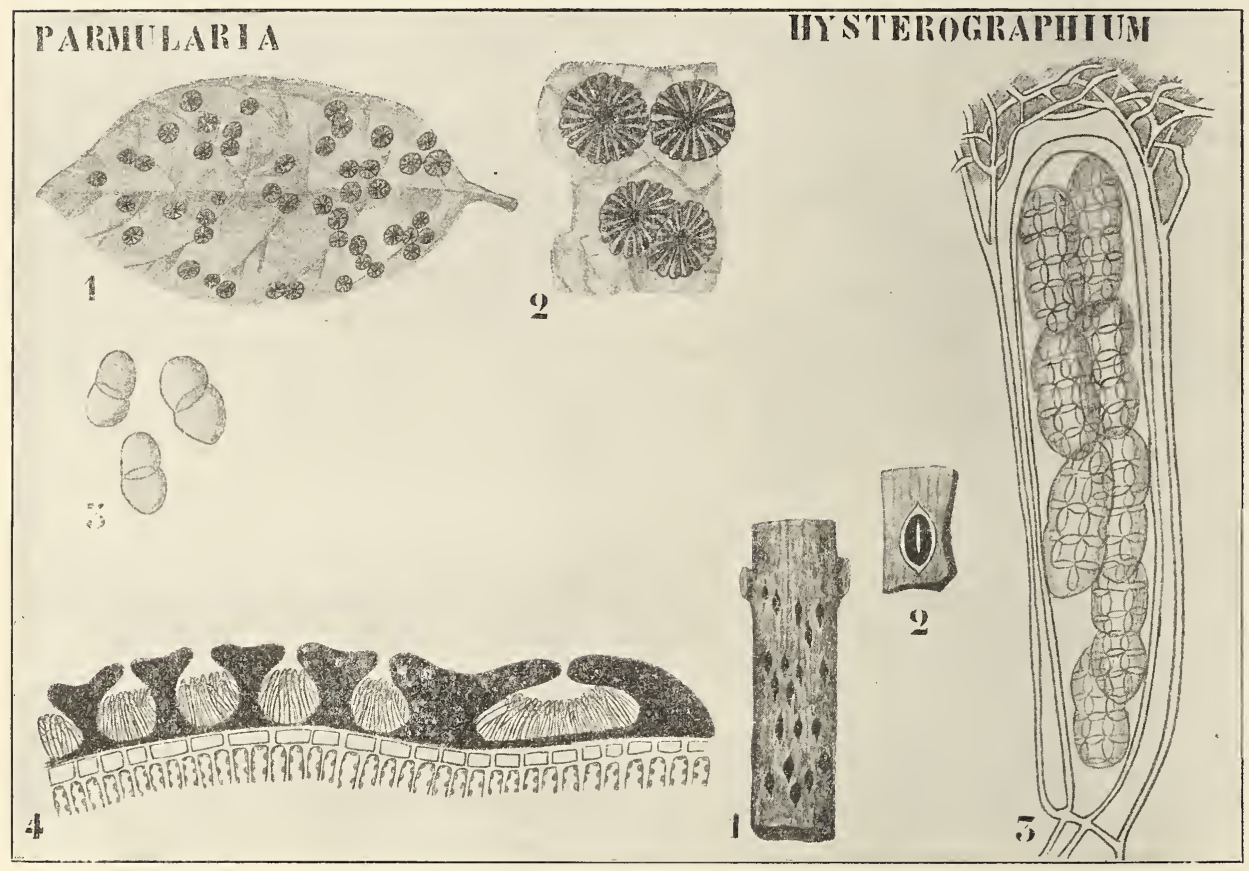

Fig. 345. Hysteriales. I. Parmularia styracis LÉvEILL. (nach LINDAU). 1 Habitus. 2 Stromata mit Früchten, vergrößert. 3 Sporen. 4 Querschnitt durch ein fruktifizierendes Stroma. - II. Hysterographium fraxini (PERs.) DE Not. 1 Habitus. 2 Ein Fruchtkörper vergrößert. 3 Ascus und Paraphysen (nach REHм).

förmig und sitzen der Oberseite des Blattes auf. Das Zentrum eines jeden Stromas ist steril, von ihm aus strahlen strichförmige Apothecien radiär nach der Peripherie; sie stehen dicht gedrängt (Fig. 345, I 2) und öffnen sich mittels einer Längsspalte. Die Sporen sind zweizellig. braun, die Paraphysen nicht verzweigt.

Hingegen bildet Hysterographium mit seinen verzweigten Paraphysen ein Gegenstück zu Naemacychus; auch hier bilden die Verzweigungen der Paraphysen eine Art Capillitium. Die schwarzen, ziemlich breiten. zugespitzt elliptischen, sich mittelst einer Längsspalte öffnenden Fruchtkörperchen von Hysterographium fraxini (PERS.) DE Not. kommen auf 
Zweigen sehr verschiedener Bäume vor. Die vielzelligen Sporen sind zunächst hyalin, dann braun.

Was num die Terwandtschaft von Hysterialen und Phacidialen und den Pevivaceen betrifft, so ist sie vorläufig noch sehr zweifelhaft; der Umstand, daß die sogenannten Konidien von Rhytisma an die als Spermatien gedeuteten Organe der Melanconiacene erimnern, wirft die Frage auf. ob nicht eher eine Verwandtschaft in jener Richtung zu suchen ist.

An die Discomyceten, und zwar speziell an die Peririneen, muß man nach Fischers Meinung, wie schon früher bemerkt, die Trüffel der Familie der

\section{Balsamiaceae}

anschließen, während die echten Trüffel, die Entuberaceen, dagegen an die Helvellaceen angeschlossen werden.

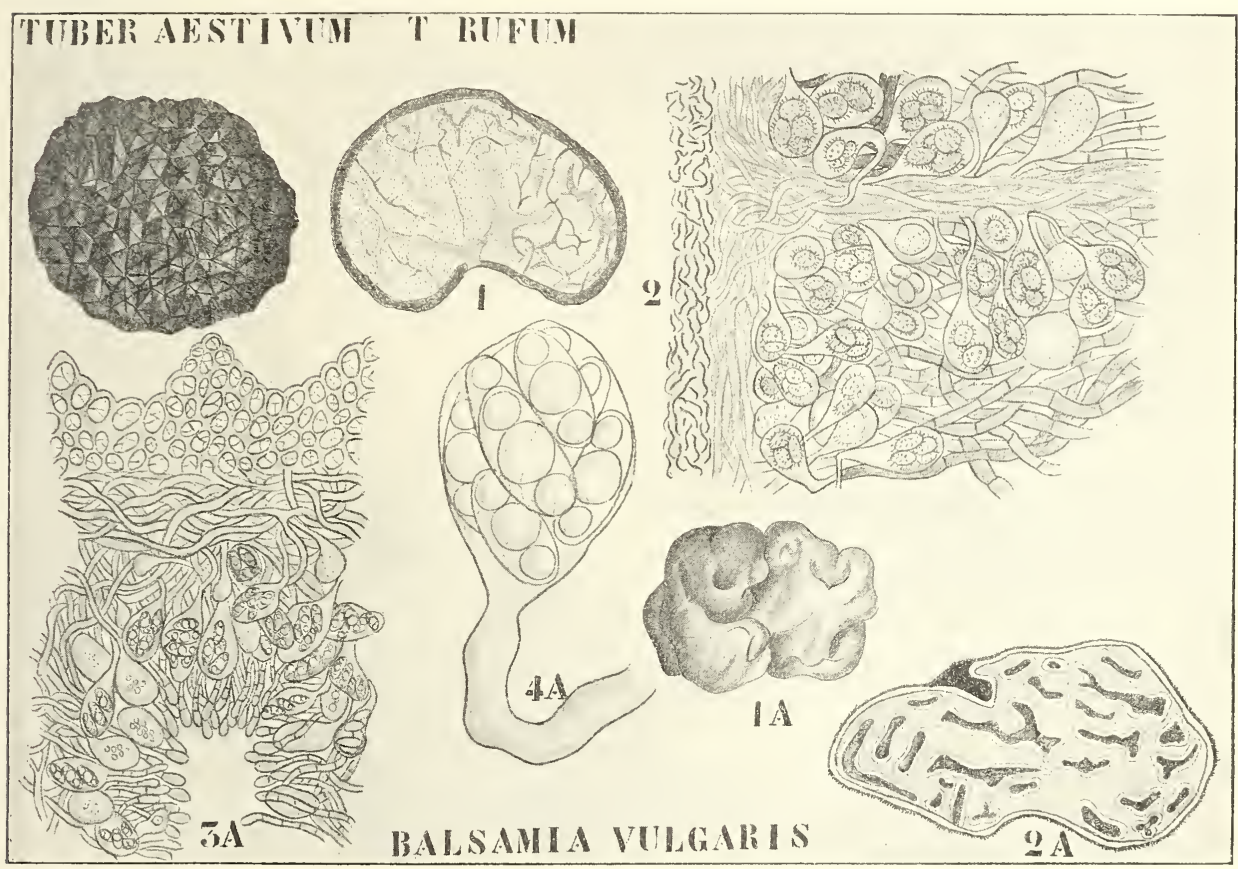

Fig. 346. I Tuber (Erklärung unter Eutuberaceae). - II. B alsamia vulgaris (nach TulasNe). $1 \mathrm{~A}$ Habitusbild. $2 \mathrm{~A}$ Durchschnitt durch den Fruchtkörper. $3 \mathrm{~A}$ Ein Stück der Oberfläche und einer Kammer mit dem Hymenium. 4 A Ascus mit reifen Sporen.

Balsamia vulgaris ist eine in Deutschland, Frankreich, Italien, in der Humusschicht von alten Buchenwäldern, ja sogar im Rasen in Parken, z. B. im Auepark bei Kassel, vorkommende Trüffel. Die Fruchtkörper sind knollenförmig, fleischig, öfters mit Falten und Runzeln versehen, von der Größe einer Nuß und größer. Die Oberfläche ist fein papillös oder fast glatt und rostfarbig.

Das Ganze ist von einer ziemlich dicken Rinde, von einem Peridium. umgeben, dessen Außenschicht aus Pseudoparenchym (Fig. 346, 4A) und dessen Inmenschicht aus festverflochtenen Hyphen besteht. 
Im Innern des Fruchtkörpers sind zahlreiche labyrinthähnliche Gänge. welche mit einem Hymenium bekleidet sind, letzteres besteht aus ziemlich regelmäßig stehenden Paraphysen und ziemlich unregelmäßig arrangierten Asci (Fig. 346, 3). Es gibt 8 Sporen pro Ascus.

Wir haben hier also mit einem vollkommen geschlossenen angiocarp bleibenden Fruchtkörper zu tun; das ist der Grund, weshalb Fischer die Balsamiaceae an die Perixineae anschließt, denn die Fruchtkörper letzterer sind wenigstens in der Jugend angiocarp und unter ihnen gibt es manche, welche sehr lang angiocarp bleiben, z. B. Hydnocystis, ein Genus, welches bleibend geschlossene Fruchtkörper bildet und sich von Balsamia eigentlich nur dadurch, daß der Fruchtkörper nur eine große zentrale Höhle besitzt, unterscheidet. Stellt man sich also Fig 346, 1 A von Balsamia glatt und hohl vor, so hat man eine Hydnocystis. Hydnocystis wird dann auch von einigen zu den Balsamiaceen, von anderen zu den Periraceen gebracht, und ist wohl am besten als eine Uebergangsform zwischen beiden zu betrachten. Man braucht sich nur zu denken, daß das Hymenium, welches die Höhle im Fruchtkörper von Hydnocystis bekleidet, durch von der Wand des Fruchtkörpers ausgehende Wucherungen verdrängt wird, und daß die Höhle bis auf einige wenige, die Ausbildung eines Hymenium erlaubende Spalten von diesen Wucherungen ausgefüllt wird, um die vielkammerige Balsamia zu erhalten.

Es bleibt aber eine nähere Untersuchung der Entwickelungsgeschichte dieser Formen in hohem Grade erwünscht.

Da die übrigen Trüffelarten von den Helvellineae abgeleitet werden, sei diese Gruppe zunächst besprochen. 


\section{Vierundzwanzigste Vorlesung.}

\section{Die Helvellineae.}

Bis vor kurzem meinte man, daß die Vertreter derselben sich von den Discomyceten dadurch unterscheiden, daß ihre Hymenia sich von Anfang an auf der Oberfläche des Fruchtkörpers befinden, also gymnocarp seien. In der letzten Zeit hat es sich aber herausgestellt, daß dies nicht ganz richtig ist; die allerdings nur noch von wenigen Arten, und erst in letzter Zeit bekannt gewordenen jüngsten Entwickelungsstadien zeigen nämlich, daß es Formen gibt, welche anfänglich, wenn auch in geringem Grade, angiocarp sind. Das gleiche gilt aber für gewisse Formen der Tuberaceen, welche man früher gleichfalls für ganz gymnocarp hielt, so daß hieraus keine Schwierigkeiten für den Anschluß beider Gruppen entstanden sind. Nur ist die Grenze zwischen Discomyceten und Helvellineae dadurch weniger scharf geworden.

Es hat sich nun weiter herausgestellt, daß die Helvellineae vollkommen apogam geworden sind und daß die Helvellineae von Pezizeae abzuleiten sind, also der Endpunkt der von den Siphonomyceten abzuleitenden Ascomyceten-Reihe sind.

Die Helvellineae können in 3, übrigens nicht scharf voneinander getrennte Gruppen verteilt werden:

I. Mit gestieltem Fruchtkörper und keulenförmigem oder knopfförmigem fertilen Teile . . . . .

II. Nit gestieltem Fruchtkörper and mehr oder weniger hutförmigem Teile . . . . . . . . . . Helvellaceae

III. Mit ungestieltem Fruchtkörper . . . . . . Rhirinaceae.

Fangen wir mit den

\section{Geoglossaceae}

an, von welchen in Bezug auf die Entwickelungsgeschichte das Genus

\section{Mitrula}

am besten bekannt ist. Die Mitrula-Arten gehören zu den wenigen höheren Pilzen, welche ganz unter Wasser leben, es kommt eine Art, M. phalloides (BALL) SAcC., auch in unserem Lande, Z. B. in der "Renkumsche beek" und bei Oosterbeek vor. Der Pilz ist saprophytisch auf toten Blättern, und besteht aus einem 2-3 cm langen, 2-3 mm breiten weißen Stiel und einem orangefarbenen fertilen keulenförmigen Teile 
(Fig. 347, II 7). Dieses Köpfchen ist schleimig und trägt an seiner Oberfläche das Hymenium. Die Asci besitzen 8 lange spindelförmige farblose Sporen. Der Pilz macht seine ganze Entwickelung unter Wasser durch, er wurde von Diтtrich genau untersucht. Es ergab sich, daß die ascogenen Hyphen schon gebildet werden, wenn der Fruchtkörper nur noch ein äußerst kleiner undifferenzierter eiförmiger Körper ist (Fig. 347, II 1). Oefters vegetiert das Mycel unseres Pilzes zwischen zwei aneinanderklebenden Blättern und das obere Blatt wird vom sich streckenden Fruchtkörper durchbrochen (Fig. 347, II 6). Die Reste des durchbrochenen Blattes werden alsbald vom Wasser mitgeführt, so daß der Pilz dann nur noch einem Blatte aufsitzt. Die Zellen des vegetativen Mycels sind zweikernig.

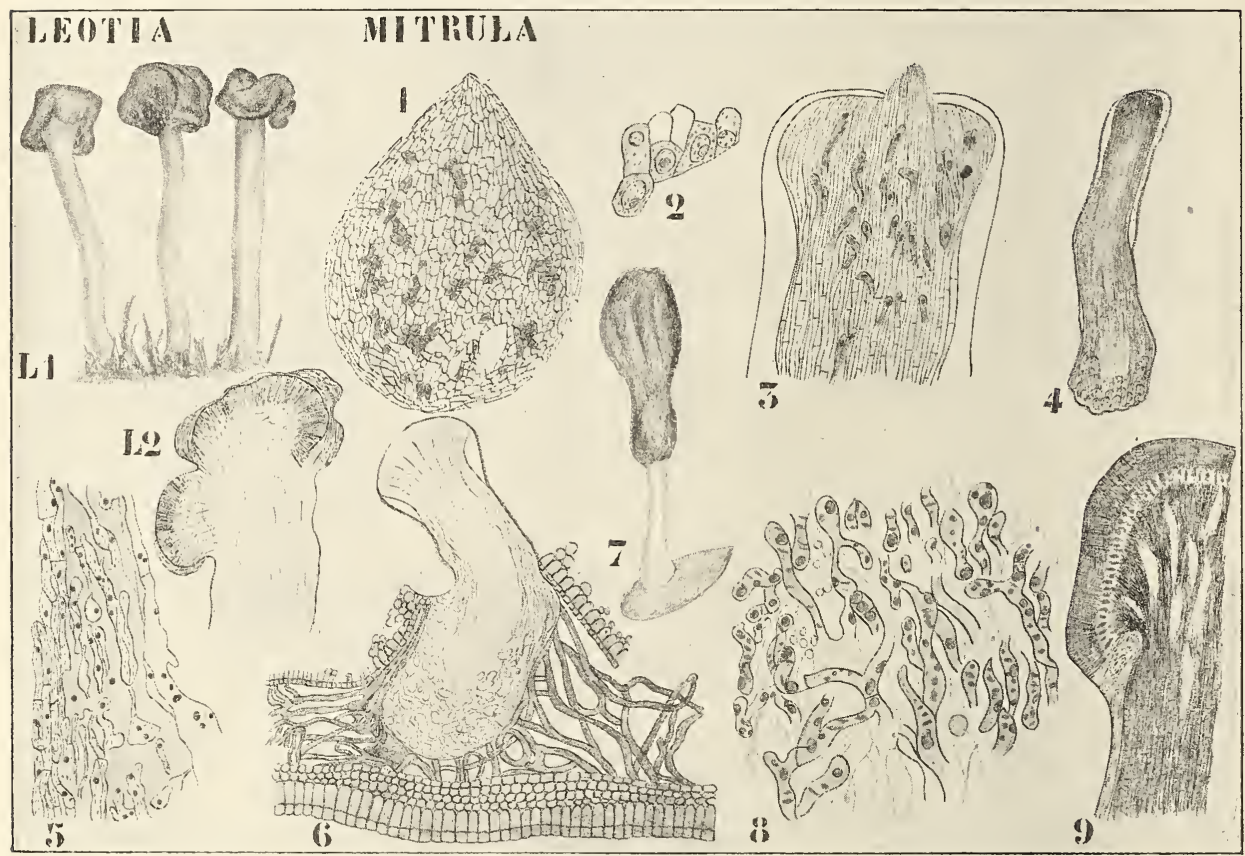

Fig. 347. Geogloss aceae. I. Leotia gelatinosa HrLL. L1 Habitusbild (nach ScHRöTER). L2 Längsschnitt durch einen jungen Fruchtkörper (nach DiTTRICH). - II. M i trula phalloides (nach DiтTRich mit Ausnahme von Fig. 7, nach der Natur). 1 Längsschnitt eines sehr jungen Fruchtkörpers, die ascogenen Hyphen dunkel. 2 Junge ascogene Hyphen. 3 Längsschnitt durch den oberen Teil eines älteren Fruchtkörpers, die ascogenen Hyphen deutlich sichtbar; ein Paraphysenschopf durchbricht die Hülle. 4 Längsschnitt durch einen jungen Fruchtkörper, die Schleimhülle zeigend. 5 Der Verschleimungsvorgang. 6 Ein sich streckender Fruchtkörper ein Blatt durchbrechend. 7 Habitusbild des Pilzes. 8 Ascogene Hyphen. 9 Längsschnitt durch ein älteres Köpfchen, die Schleimhülle nur noch um den Stiel herum vorhanden.

Das Fruchtkörperprimordium entsteht durch Verwebungen von Seitenzweigen des vegetativen Mycels. Die ascogenen Hyphen lassen sich durch ihre größere Affinität zu Farbstoffen schon sehr früh erkennen (Fig. 347, II 1), sie besitzen sehr große Kerne (Fig. 347, II 2) Der junge Fruchtkörper wird von einer dünnen Rinde langgestreckter Elemente umgeben, während der mehr zentrale Teil zumal an der Basis aus Pseudoparenchym besteht. 
Bei der Streckung des Fruchtkörpers, die verursacht wird durch die Terlängerung der Zellen im basalen Teile, werden die ascogenen Hyphen in den oberen Teil des Fruchtkörpers gebracht; die über diesen liegenden Hyphen strecken und verzweigen sich und werden zu Paraphysen.

Die Spitze des Fruchtkörpers wird nun etwas verbreitert (Fig. 347, II 3) und da die äußeren 6-8 Hyphenschichten verschleimen, ist die jumge Frucht ganz in eine Schleimschicht eingehüllt. Bei diesem Verschleimungsprozeß (Fig. 347. II 5) bleiben die Kerne am längsten bewahrt, so daß man auf einem späteren Stadium in der Schleimschicht, nachdem alle Zellstrukturen schon verschwunden sind, noch lange Kerne unterscheiden kann.

Später degenerieren die zentral geleg'enen Hyphen im Stiel, wodurch dieser hohl wird.

Die oberen Zellen des Fruchtkörpers sind die hart unter der Schleimkappe gelegenen Paraphysen; durch das Wachstum dieser entsteht ein Druck, der die Schleimhülle zerreißt, und zwar in der Mitte, wo dann die Paraphysen zopfähnlich hervorragen (Fig. 347, II 3). Alsbald breiten sie sich durch Nachwuchs weiter nach unten gelegener Hyphen, welche sich zwischen sie einschieben und ebenfalls zu Paraphysen werden, seitlich aus. wodurch der Fruchtkörper an der Spitze gewölbt scheibenförmig wird (Fig. 347, II 6).

Die ascogenen Hyphen haben sich inzwischen stark verzweigt (Fig. 347, II 8) und breiten sich in einiger Entfernung von der Spitze zu einem kappenförmigen Hymenium aus (Fig. 347, II 9); da die sterilen Hyphen nicht gleich stark wachsen, entstehen Spalten (Fig. 347, II 9); die sterilen Hyphen werden übrigens alsbald durch das viel Nahrung verlangende Hymenium resorbiert und im erwachsenen Köpfchen finden wir daher eine Höhle mit einem Balkensystem von Hyphenresten.

Auch hier sind also ascogene Hyphen und Paraphysen voneinander getrennt.

Das Hymenium von Mitrula entsteht also nicht gymnocarp, sondern angiocarp, und es ließe sich Mitrula in gewisser Hinsicht mit einem Ascobolus vergleichen, bei welchem sich der unter den ascogenen Hyphen geleg'ene Teil zu einem Stiel gestreckt hätte.

Ein anderes Genus der Geoglossaceae ist Leotia, von welchem hier

\section{Leotia gelatinosa HiLL.}

besprochen werden mag. Es ist dies ein eigentümlicher, fleischiger, schleimiger Pilz, der zumal durch die grünliche Farbe des Hutes auffällt. Der Stiel ist gelb, hohl und 2-4 cm lang (Fig. 347, L 1). Ich fand ihn u. a. auf nackter Erde in Südlimburg.

Auch von Leotia gelatinosa konnte DiтTRICH durch einen glücklichen Zufall die Entwickelungsgeschichte untersuchen, er fand nämlich den Pilz auf Tannennadeln, wodurch die kleinen, sonst unterirdischen Fruchtanfänge gesammelt werden konnten. Die Entwickelung findet in allen wesentlichen Punkten wie bei Mitrula statt, die verschleimende Schicht ist aber dicker. Ein Vergleich der Fig. 347, 9 (Mitmla) und L 2 (Leotia) zeigt nicht nur die große Uebereinstimmung, sondern auch den Umstand, daß die Schleimhülle bei Leotia länger bestehen bleibt wie bei Mitrula.

Bei Leotia ist die Verschleimung keineswegs auf die äußere Hyphenschicht beschränkt; der ganze innere Teil des Fruchtkörpers zeig't schon früh Verschleimungserscheinungen, so daß auf Querschnitten sich die Hyphenkonturen nur undentlich um die zahlreichen Kerne abzeichnen. 
Auch Leotia ist demnach nicht rein gymnocarp. Ein dritter zu dieser Gruppe gehöriger Pilz ist das ebenfalls einheimische

\section{Geoglossum hirsutum Pers.}

Die schwarzen, eigentümlich zungenförmig-keulenartigen Fruchtkörper (Fig. 348, I 1) fand ich z. B. auf grasigen Wegrändern in Südlimburg. Der fertile Teil geht allmählich in den Stiel über. Die Sporen sind durch Querwände vielzellig, schwärzlich. Die Fruchtkörper sind 3-7 cm hoch, der Stiel ist cylindrisch und rauhhaarig, der fertile Teil weichhaarig. Nach LrNDAU soll es in Sümpfen vorkommen, ich fand es aber, wie gesagt, auf mäßig feuchten grasigen Wegrändern.

Die zweite Familie der Helvellineae ist die der

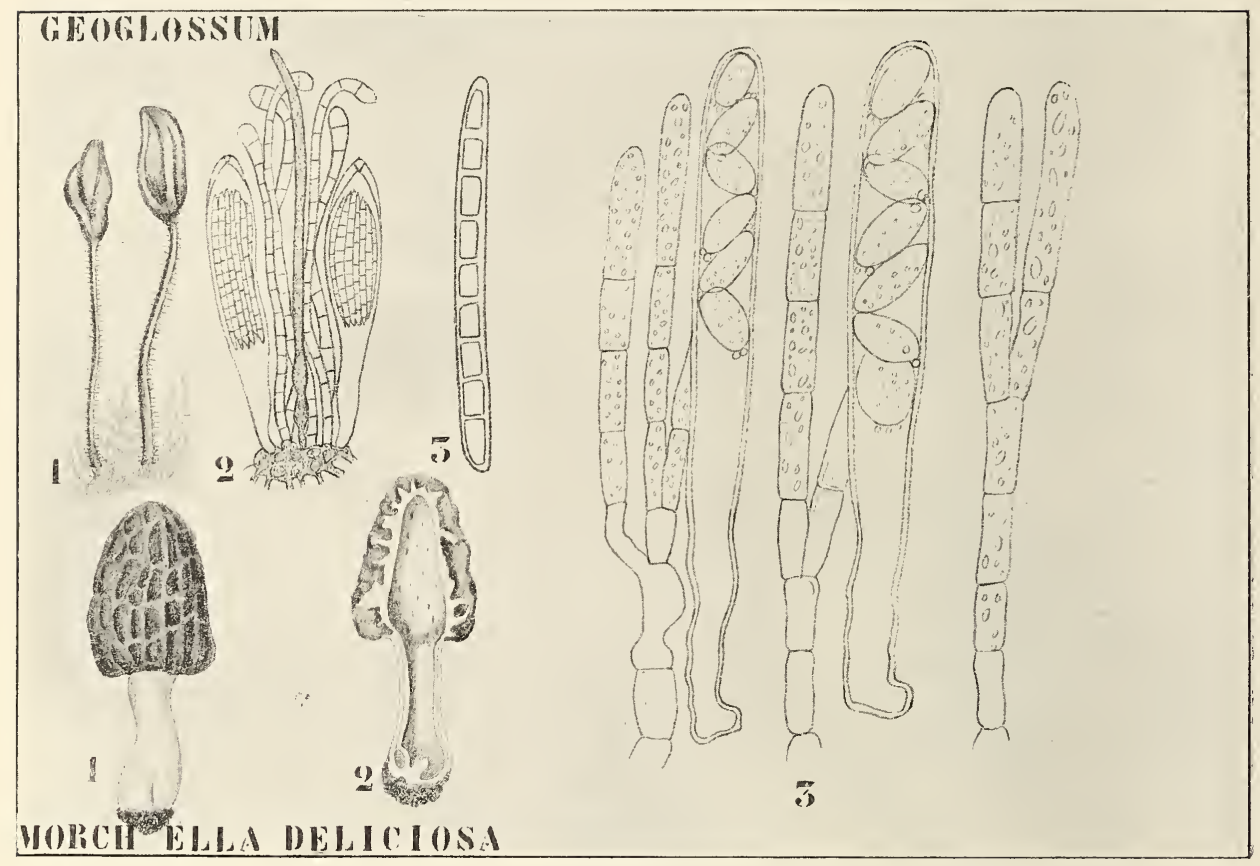

Fig. 348. I. Geog]ossum hirsutum (nach SCHRöter). 1 Habitus. 2 Asci mit Paraphysen. 3 Spore. - II. Morchella deliciosa (nach Bresadola). 1 Habitus. 2 Längsschnitt. 3 Asci und Paraphysen.

\section{Helvellaceae.}

Der fertile Teil ist hier mehr hutförmig entwickelt als bei den vorigen Familien, trotzdem die Grenze nicht scharf ist.

Der Stiel ist dick und hohl, ebenso der Hut. Zumal bei Formen, bei welchen der Hut nur in der Vitte mit dem Stiel verbunden ist und also glockenförmig herunterhängt, ist die Hutform ausgeprägt.

Der Hut ist an seiner Außenseite mit einem Hymenium überzogen, die Paraphysen sind öfters verzweigt. Die zahlreichen Falten und Gruben, Wülste und Erhabenheiten, welche auf dem Hute vieler Helvellaceen entstehen, sind die Folge eines übermäßig starken Wachstums des Hymenium. 
Die jüngsten Entwickelungsstadien sind noch nicht bekannt.

Betrachten wir jetzt die letzte Gruppe der Helvellinere, die der

\section{Rhizinaceae,}

aus welcher wir die Genera Rhinina und Sphaerosoma besprechen wollen.

\section{Rhizina inflata (SCHÄFfer) SACC.}

ist ein Pilz, der auf Brandstellen in Wäldern in Europa bisweilen in großer Menge vorkommt.

Man hält ihn für einen Parasiten, der in sandigen Gegenden eine gefährliche Wurzelkrankheit der Tannen verursacht. Die Fruchtscheibe

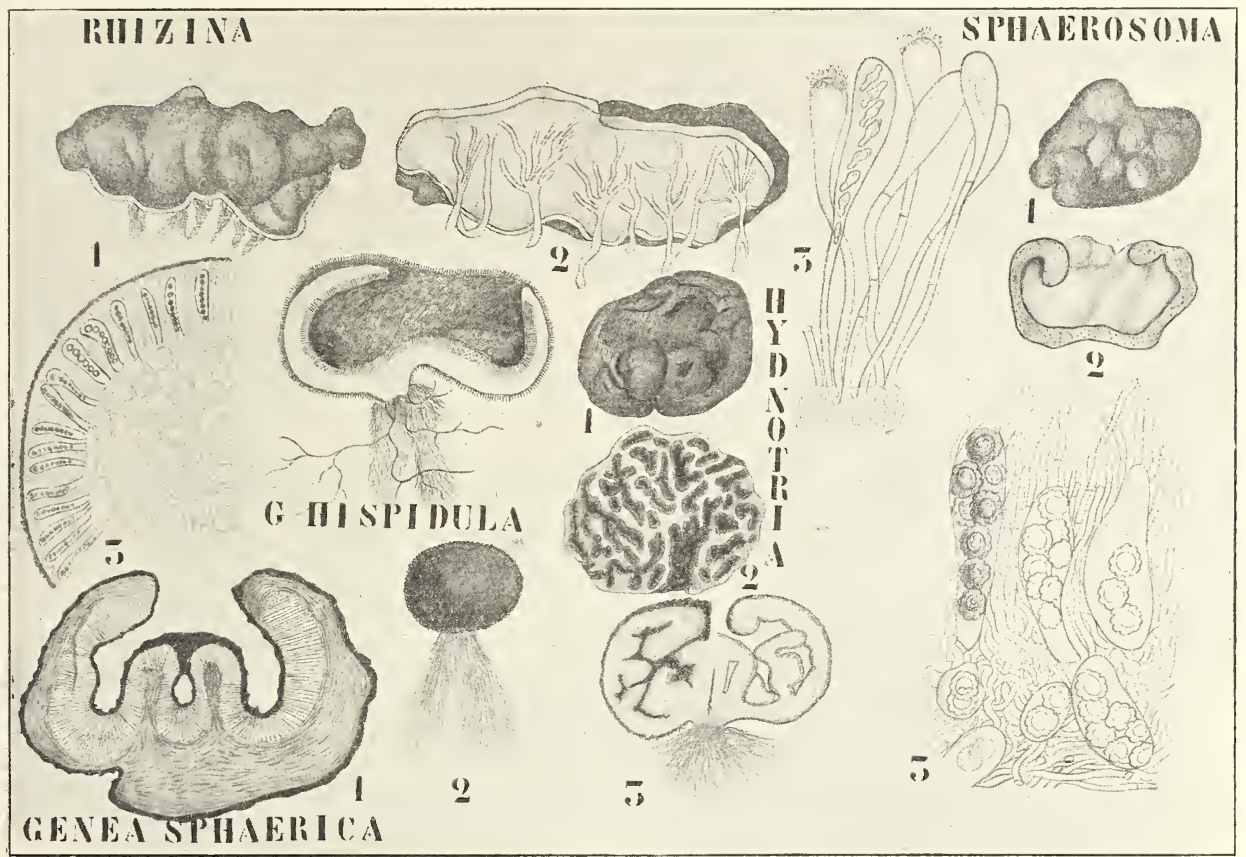

Fig. 349. Rhizinaceae und Eutuberaceae. I. Rhizina inflata (ScḦ̈FFER) SACC. (nach Schröter). 1 Fruchtkörper, von oben betrachtet. 2 Id., von unten. 3 Asci und Paraphysen. - II. Sphaerosoma fuscescens KLotzsch (nach Tulasne). 1 Fruchtkörper. 2 Längs durchschnittener Fruchtkörper. 3 (die Abbildung unter Rhizina) Hymenium. - III. Genea hispidula BERK. (nach Tulasne). - IV. Genea sphaerica. 1 Längsschnitt des jungen Fruchtkörpers. 2 Habitus. 3 Aelteres Stadium. - V. Hydnotria Tulasnei (nach Tulasne und Fischer). 1 Habitus. 2 Schnitt durch den Fruchtkörper. 3 (in der rechten unteren Ecke) Hymeniumschnitt.

(Fig. 349, I 1) ist mit Rhizoiden am Substrat befestigt, zunächst vollkommen flach und rund, später gewölbt, aufgedunsen und wellig gebogen. Vermutlich findet also auch hier wie bei den Helvellaceen ein übermäßiges Wachstum des Hymenium statt. Au der Unterseite ist der Pilz gelbweiß, am Rande weiß und in der Mitte, wo die Asci stehen, kastanienbraun bis schwarz. Ob er, wie man meint, vom Anfang an grmmocarp ist, bleibt abzuwarten. 
Das Genus

\section{Sphaerosoma}

erinnert durch die runde Form seiner Fruchtkörper (Fig. 349, II 1) und durch seine, wenn auch nicht unterirdische, so doch im Humus der Wälder versteckte Lebensweise stark an Trüffeln. Die Knöllchen von $S$. fuscescens, welche in Mitteleuropa angetroffen werden, sind $1-3 \mathrm{~cm}$ breit, braunviolett, später dunkelbraun und warzig. Sie unterscheiden sich bei genauerer Untersuchung sofort von Trüffeln dadurch, daß sie an ihrer ganzen Außenseite (Fig. 349, II 3) von einem Hymenium bedeckt sind.

Fassen wir nun alles zusammen, so glaube ich, daß man Dittrichs Veinung, daß die Helvellaceae als vollständig apogam gewordene Peri«ineae mit starkem Flächenwachstum des Hymenium zu betrachten sind, wenigstens vorläufig acceptieren muß.

Wo es sich nun herausgestellt hat, daß die Helvellaceae keineswegs ganz gymnocarp sind, und wo es sich, wie wir bald sehen werden, gezeigt hat, daß es auch Eutuberaceae gibt, deren Hymenien nicht gymnocarp entstehen, wo also die Grenze zwischen Helvellineae und Discomyceten nicht so scharf ist, wie man bis jetzt meinte, fragt es sich, ob man die Eutuberaceae wohl so scharf von den Balsaminaceae trennen darf als hier geschehen ist, und ob nicht beide Gruppen aus einer Zwischenform zwischen Discomyceten und Helvellineen gemeinsam entsprungen sind. Die Frage ist aber nicht übermäßig wichtig, sicher besteht Verwandtschaft zwischen Periraceen und Helvellineae einerseits und Tuberaceen andererseits.

Sehen wir jetzt an der Hand von Fischers und Buchholtzs Untersuchungen, was über die Abstammung der Eutuberaceen bekannt ist. 


\section{Fünfundzwanzigste Vorlesung.}

\section{Die Eutuberaceae.}

Die Abstammung der Vertreter dieser Gruppe wird jetzt von BucHHOLTz (1905) in dieser Weise dargestellt:

$$
\underset{\substack{\text { Gyrocratera } \\
1 \\
\text { Hydnotria }}}{\rightarrow} \text { Stephensia } \rightarrow\left\{\begin{array} { l } 
{ \text { Eupachyphloeus } } \\
{ 1 } \\
{ \text { Cryptica } }
\end{array} \rightarrow \left\{\begin{array}{l}
\text { Aschion } \\
\text { Eutuber }
\end{array}\right.\right.
$$

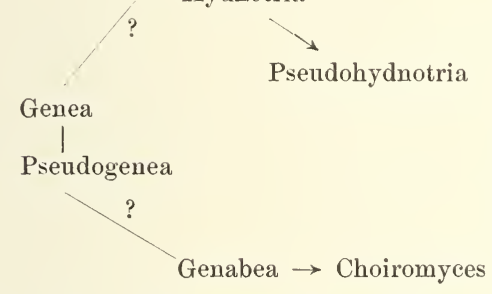

Vou den hier angegebenen Genera stellt man gewöhnlich Genabea und Choiromyces noch zu den Terferiaceae; der Umstand aber, daß sie im Gegensatz zu diesen ein Hymenium besitzen, spricht wohl für die Ansicht Buchroltzs, es muß aber die Entwickelungsgeschichte lehren, inwieweit sie berechtigt ist.

Was nun die echten Eutuberaceen anbelangt, so geht, wie man sieht, Buchнoltz, wenn auch mit einem Fragezeichen, von Genea aus. Das tut auch Fischer, und da nun offenbar Buchioltz und Fischer in allen wesentlichen Punkten übereinstimmen und die feineren Unterschiede von einem, der, wie ich, kein Russisch versteht, aus der russisch geschriebenen Arbeit Buchнoltzs nicht gewürdigt werden können, werde ich mich weiter an Fischers Darstellung. (1896) halten.

Er geht dann, wie gesagt, ebenfalls von Genea aus; schließt daran Pachyphloeus an und betrachtet Stephensia und Aschion als eine dieser parallele Reihe, während er Eutuber an Hydnotria anschließt. Wir bekommen so die drei folgenden Parallelreihen:

$$
\text { Eutuberaceae }\left\{\begin{array}{l}
\text { Genea } \longrightarrow \text { Stephensia } \longrightarrow \text { Pachyphloeus } \\
\text { Hydnotria } \longrightarrow \text { Aschion }
\end{array}\right.
$$

Lernen wir also zunächst diese Genera in Bezug auf die hier in Betracht kommenden Merkmale kennen. Dazu müssen wir uns zunächst einigermaßen mit der Nomenklatur vertraut machen. 
In den einfachsten Fällen, so bei Genea hispidula (Fig. 349, III), ist der Fruchtkörper eine Hohlkugel mit apikaler Oeffnung. In bei weitem den meisten Fällen aber befindet sich im Fruchtkörper ein System von Gängen, welche entweder nach einem Punkte an der Spitze, z. B. Genea sphaerica (Fig. 349, IV 1) und Pachyphloeus (Fig. 349, II 2), oder nach einem Punkte an der Basis, z. B. Stephensia, Aschion (Fig. 350, I), konvergieren und hier ausmünden, oder an zahlreichen Punkten der Oberfläche mit der Außenwelt in Verbindung stehen (Hydnotria, Eutuber).

Die Gänge sind entweder hohl (Hydnotria) oder mit einem Hyphengeflecht ausgefüllt (Pachyphloeus, Stephensia, Aschion, Eutuber), in letzterem Falle nennt man sie Venae externae. Die Trennungswände zwischen diesen Gängen resp. zwischen den Venae externae nennt man Venae internae oder Tramadern, sie sind von einem Hymenium bekleidet.

In unserer Fig. 346, I 2 von T. rufum sind also die dunklen (in Wirklichkeit orange) Fäden die Tramae oder Venae externae, die hellen grauen die Venae internae.

Betrachten wir nun die einfachste

\section{Genea.}

nämlich Genea hispidula, eine Art, welche uṇter Tannen in Deutschland, Frankreich und England gefunden wird, so sehen wir, daß diese (Fig. 349, III) die Form einer zusammengedrückten Hohlkugel besitzt, welche an der Spitze eine ziemlich große Oeffnung hat und an der Innenseite von einem Hymenium bekleidet ist. Sie läßt sich leicht an die Helvellinee Rhisina inflata anschließen unter der Annahme, daß diese ihre Ränder aufwärts gekrümmt hat. Dies scheint mir einfacher, als sie, wie Fischer tut, an Sphaerosoma mit ihrem die Außenseite bekleidenden Hymenium anzuschließen. Sphaerosoma läßt sich als eine nach unten, Genea als eine nach oben umgebogene Rhinina betrachten.

Dagegen läßt sich Hydnotria, wie Frscher angibt, leicht von Sphaerosoma ableiten. Hydnotria Tulasnei (Fig. 349, V) ist nämlich eine knollenförmige Trüffel, welche gleichfalls in Nadelwäldern in Deutschland vorkommt und ein System von Gängen enthält, welche in grubenähnliche Vertiefungen der Oberfläche ausmünden.

Wir haben schon gesehen, daß die Außenseite von Sphaerosoma gleichfalls, wenn auch viel weniger tiefe, Gruben aufweist; nehmen wir nun an, daß die Gruben tiefer geworden sind und sich zu Gängen umgebildet haben, und daß nun die Ausbildung eines Hymenium auf diese Gänge beschränkt ist, so erhalten wir eine Hydnotria. Ich brauche kaum zu betonen, daß daraus keineswegs folgt, daß nun in der Tat Hydnotria in dieser Weise gebildet ist, aber unwahrscheinlich ist es wenigstens nicht.

Von Genea hispidula läßt sich nun leicht Genea sphaerica (Fig. 349, IV) ableiten unter der Annahme einer Oberflächenvergrößerung des Hymenium, wodurch dieses in nach innen vordringende Falten gelegt wurde, und wir werden bald sehen, daß sich von Genea und Hydnotria die anderen Eutuberaceen ohne viel Schwierigkeiten ableiten lassen.

Um dies zu zeigen, war es in erster Linie nötig, zu beweisen, daß die Venae externae einer Tuber-Art in der Tat entwickelungsgeschichtlich aus Gruben der Außenseite entstehen.

Das Genus Tuber besteht nun aus den beiden Untergenera Aschion und Eutuber, und für beide konnte BuchнoLTz den verlangten Nachweis bringen. 
Er fing seine Untersuchungen mit

Tuber (Aschion) excavatum Vittadini

an; seinem Artikel in den Ber. d. D. Bot. Ges. 1897 sei folgendes entliehen.

Tuber excavatum ist in Deutschland in der Humusschicht von Buchen- und Eichenwäldern häufig; die Trüffel ist fast kugelig oder unregelmäßig knollenförmig, mit öfters starken Falten, und erreicht mehr als Walnußgröße, sie ist erst ockergelb, wird später rotbraun und schließlich dunkelbraun.

An der Unterseite findet sich eine tiefe, spaltenförmige Grube, welche öfters mit einem wolligen Filz bekleidet ist. Das Fruchtfleisch ist in

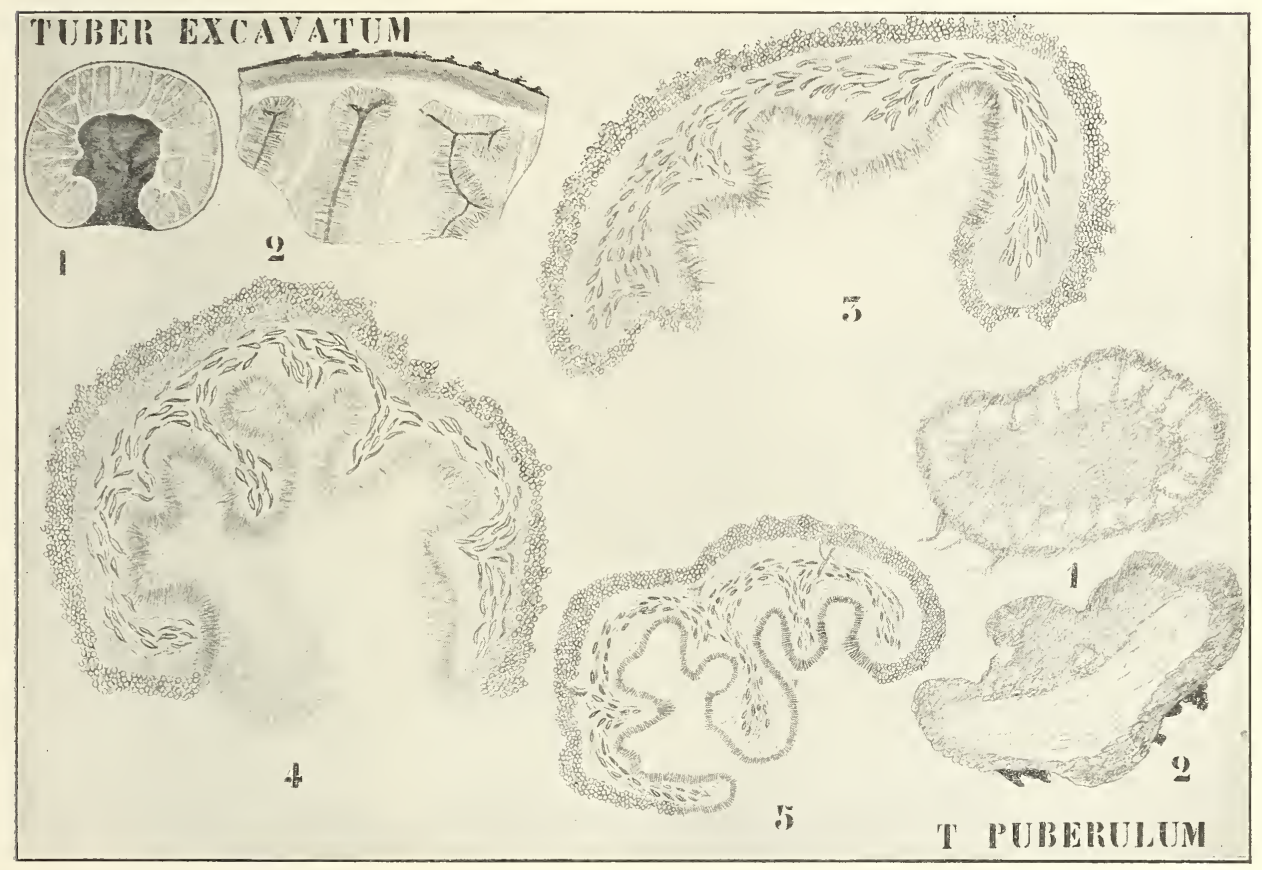

Fig. 350, I. Tuber (Aschion) excavatum VitTadinI (nach BuchHoitz). 1 Fruchtkörper, längs durchschnitten. 2 Längsschnitt. $3 \mathrm{Sehr}$ junges Stadium. 4, 5 Aeltere Stadien. - II. Tuber (Eutuber) puberulum (nach BuchнolTz). 1 Jüngstes Stadium. 2 Etwas älteres Stadium.

reifem Zustand zähe, in trockenen Fruchtkörpern hornig, braun. Aus der Rinde entspringen Tramaadern, welche radial nach der basalen Grube verlaufen (Fig. 350, I 1) und aus äußerst dicht verflochtenen Hyphen bestehen; sie sind von dem Hymenium bekleidet (Fig. 350, I 2). Die Venae externae sind gelbweiß und münden an zahlreichen Punkten der basalen Grube aus (Fig. 350, I 1), nach der Peripherie des Fruchtkörpers hin endigen sie blind.

Als nun BuchHoLtz seine Untersuchungen anfing, war schon bekannt, daß in jungen Exemplaren von etwa $2 \mathrm{~mm}$ Durchmesser die basale Grube sehr groß ist, so daß der ganze Fruchtkörper eine Hohlkugel mit ziemlich dicker Wand bildet (Fig. 350, I 1). Das jüngste 
Stadium, welches Buchнoltz erhielt, hatte $1,5 \mathrm{~mm}$ im Querschnitt, die basale Grube war enorm entwickelt (Fig. 350, I 3), und an der Innenseite des Fruchtkörpers waren schwache Falten vorhanden. An der Außenseite befindet sich eine Rinde, an diese schließt sich an der Innenseite des Fruchtkörpers die die Falten bekleidende Paraphysenschicht an (Fig. 350, I 3). In dieser sind gewisse Elemente länger wie die anderen und ragen über die Paraphysen hervor (Fig. 350, I 3), wodurch die Paraphysenschicht ein haariges Aeußere bekommt. Die von der Paraphysenschicht bekleideten Falten sind die Tramae oder Venae internae, die über die Paraphysen hervorragenden Elemente wachsen zu langen Hyphen, welche durch Verflechtung die Venae externae bilden, aus; später werden zwischen den Paraphysen die Asci gebildet.

Durch Wachstum der Tramae (Fig. 350, I 4, 5) wird die basale Grube je länger desto kleiner, es prägen sich die Gänge mehr und mehr aus, und da letztere sich sehr unregelmäßig schlängeln, scheint es auf einem Schnitt bisweilen, als gäbe es isolierte Höhlungen in den Fruchtkörpern. Die Venae externae-Hyphen wachsen öfters bis in die basale Grube hinein.

Wir haben hier also mit einer gymnocarpen Entstehung des Hymenium zu tun; so wie bei den Helvellineae entstehen hier die Falten durch ein übermäßiges Wachstum des Hymenium. Da das Hymenium sich bei Helvella z. B. an der Außenseite des Fruchtkörpers befindet, entstehen dort Falten an der Außenseite, da es bei Aschion an der Innenseite des Fruchtkörpers vorhanden ist, füllen die Falten die Höhle mehr und mehr aus.

Thuber (Aschion) rufum (Fig. 346, II 1) hat wohl eine ähnliche Entwickelungsgeschichte; die Venae internae sind orange gefärbt, das Hymenium ist schwarz punktiert, die Venae externae grau, sie münden, wie die Abbildung zeigt, in eine Oeffnung an der Basis.

Wie steht es nun bei

\section{Eutuber.}

Dort münden, wie wir sahen, die Venae externae an verschiedenen Stellen der Außenseite.

In den reifen Fruchtkörpern sieht man die Gleba (Hymenium + Paraphysen) mit kleinen, reifen, braunen Sporen besät, von denen 2-3 pro Ascus gebildet werden. Die Tramae oder Venae internae sind auf diesem Stadium nicht mehr kenntlich, die Venae externae als helle Adern bequem zu sehen. Einige reichen bis an die Peripherie, andere sind durchschnitten und zeigen sich unserem Auge als isolierte helle sporenfreie Flecke. Auch das Peridium enthält selbstverständlich keine Sporen und ist in eine äußere dunklere und dichtere Außenschicht und in eine lockerere und hellere Innenschicht differenziert.

Die jüngsten Stadien lehren, daß dieser Tuber höchst wahrscheinlich ein Mycorhiza-Bilder ist. Das jüngste Stadium (Fig. 350, II 1) zeigt ein $0,36 \times 0,54 \mu$ dickes Knöllchen, an welchem die periphere Schicht bedeutend lockerer ist als der zentrale Teil. Auf einem folgenden Stadium (Fig. 350, II 2) sehen wir, wie an der Oberseite Gruben entstehen, die Gänge, welche sich tiefer und tiefer in den Fruchtkörper hineingraben (Fig. 351, I 3,4). Schließlich verwandeln sich die äußeren Schichten in Rindenelemente (Fig. 351, I 5), es füllen sich die Gänge mit Hyphenelementen, den Veniae externae, und der ganze übrige Teil 
des Fruchtkörpers geht zur Fruktifikation über (Fig. 351, I 6), so daß man kaum von Venae internae reden kann.

Auch hier besteht also eine gymnocarpe Entwickelung, die Ausfuhröffnungen der Venae externae an der Außenseite des Fruchtkörpers sind nur die Enden der nach imnen vorgedrungenen Spalten.

Bisweilen findet die Entstehung des Hymenium aber nicht gymnocarp statt, dann ist das ganze Fruchtprimordium (Fig. 351, I 7) von einer schützenden Hyphenschicht umgeben, ohne daß dadurch irgend eine Veränderung in der Entwickelung hervorgebracht wird, woraus man also ersieht, daß man keinen zu großen Wert auf Angiocarpie oder Gymnocarpie legen darf.

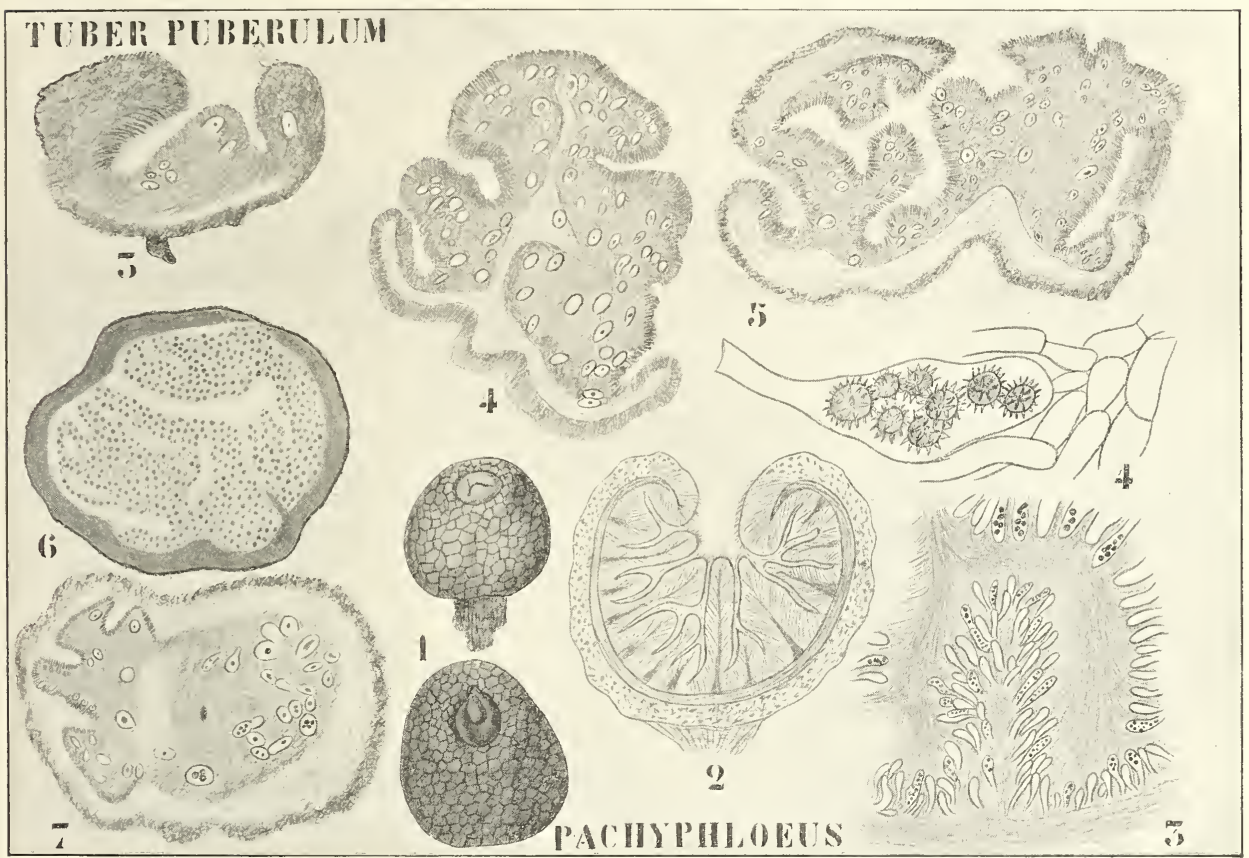

Fig. 351. I. Tuber puberulum (nach BuchноLтz). 3 Weiteres Vordringen der Gruben. 4, 5 Anfang der Rindenbildung. 6 Rinde geschlossen, der ganze Fruchtkörper mit Ausnahme von Rinde und Venae externae fruktifizierend. 7 Junges angiocarpes Stadium. - II. Pachyphloeus melanoxanthus (BERT.) Tul., (1 nach Tulasne, die übrigen nach Fischer). 1 Habitus. 2 Längsschnitt, schematisch. 3 Partie in der Nähe der Fruchtkörperperipherie, unten ein Stück des unter der Rinde liegenden Geflechts. 4 Ascus.

Nachdem wir also gesehen haben, daß die soliden Fruchtkörper des Genus Tuber nicht prinzipiell von den hohlen von Genea und Hydnotria verschieden sind, wollen wir ganz kurz resumieren, wie sich FIscher die Phylogenie vorstellt.

An die schon besprochene Genea hispidula läßt sich Genea sphaerica anschließen (Fig. 349, IV 1-3). Es ist dies eine mehr oder weniger kugelige Trüffel, welche einen Durchmesser von etwa $1 \mathrm{~cm}$ erreicht, mit schwarzer warziger Rinde und öfters mit sehr flachen, nach Spitze und Basis konvergierenden Falten. Der Fruchtkörper hat an der Basis ein großes Mycelbündel, ist hohl und hat eine kleine apikale 
Mündung. An der Innenseite ist er stark gefaltet, die Falten konvergieren nach der Mündung zu. Diese Venae internae sind mit einem Hymenium, aus palisadenartig gestellten Asci und Paraphysen bestehend, bekleidet. Die Paraphysen sind septiert und schließen oberhalb der Asci zu einer pseudoparenchymatischen Rinde, von derselben Struktur wie die Außenrinde des Fruchtkörpers, zusammen. Das Hymenium ist also trotz seines gymnocarpen Ursprungs schließlich vollkommen zwischen Rindenschichten eingeschlossen. Die Trüffel wurde im Bois de Boulogne und in Hessen-Nassau in der Humusschicht unter Buchen und Eichen gefunden.

Von dieser Genea kann nun leicht Pachyphloeus (Eupachyphloeus) melanoxanthus (Fig. 351, II 1,4) abgeleitet werden. Auch hier haben wir nach der Spitze zu konvergierende Gänge, welche aber von einem Hyphengeflecht ausgefüllt sind, also Venae externae heißen.

Die Rinde ist schwarz mit rötlichem Ton, die Früchte haben wie die von Genea eine apikale Oeffnung, die Venae internae entstehen vermutlich genau so wie bei Genea, den einzigen Unterschied bilden die ausgefüllten Gänge mit den Venae externae bei Pachyphloeus.

Die Genera Stephensia und Aschion, von welchem letzteren wir die Arten excavatum und rufum behandelten, unterscheiden sich von Genea und Pachyphloeus hauptsächlich dadurch, daß die Oeffnung nicht an der Unter-, sondern an der Oberseite des Fruchtkörpers liegt. Ihre Entwickelung verläuft also der von Genea-Pachyphloeus parallel. Sowohl bei Stephensia wie bei Aschion sind Venae externae vorhanden. Stephensia haben wir nicht besprochen, es war kaum nötig, da man, wenn man eine Genea sphaerica umdreht und sich die Gänge mit Venae externae ausgefüllt denkt, eine Stephensia hat.

Eutuber läßt sich leicht von Hydnotria ableiten, bei beiden entstehen die Gänge durch Spalten, welche von außen nach innen in den soliden Fruchtkörper vordringen.

Trotzdem also noch manches der näheren Aufklärung bedarf, glaube ich, daß in der Tat Fischers Auffassung, daß man die Tuberaceae von den Helvellineae herleiten soll, recht plausibel ist.

Von den Ascomyceten in der häufigsten Fassung dieser Gruppe bleiben nun noch zwei Gruppen einfacher, und deswegen öfter als primitiver betrachteter Organismen zu besprechen übrig, die Exoascineae und die Saccharomyceten. Von ersteren fragt es sich, ob wir mit primitiven oder mit reduzierten Formen zu tun haben, von letzteren, ob sie überhaupt wohl Ascomyceten sind. Fangen wir mit der Besprechung der ersten Gruppe an. 


\section{Sechsundzwanzigste Vorlesung:}

\section{Die Exoascineae.}

$\mathrm{Zu}$ dieser Gruppe werden in der Regel zwei Familien: die Exoascaceae aus parasitischen, und die Ascocorticiaceae, aus saprophytischen Pilzen bestehend, gebracht.

\section{Exoascaceae.}

Die Vertreter dieser Familie sind sämtlich Parasiten und kommen auf den verschiedensten Pflanzenfamilien vor. Sie bilden ihre Asci entweder direkt am Ende gewöhnlicher vegetativer Hyphen, welche bis an die Oberfläche des infizierten Teiles vordringen, oder sie bilden erst unter der Cuticula ein einschichtiges Lager von Hymenialzellen, deren jede einen Ascus bildet. Paraphysen sind nicht vorhanden.

Die Vertreter der ersteren Gruppe stellt das Genus Magnusiella, die der zweiten werden in der Regel in zwei Genera, Taphrina und Exoascus, zerlegt. Man bringt dann die Formen mit normalen Ascussporen zum Genus Exoascus, die, bei welchen die Ascussporen schon im Ascus Konidien bilden, wodurch der Ascus vielsporig wird, zum Genus Taphrina.

In seiner Monographie der Exoascaceae verwendet aber SADEBECK diese Namen Exoascus und Taphrina in einer anderen Bedeutung, indem er Exoascus diejenigen Formen nennt, deren vegetatives Mycelium in älteren Stengelteilen oder in Knospen überwintert, Taphrina dagegen die einjährigen, vor dem Winter zu Grunde gehenden Arten.

So erhalten wir also z. B. zwei Genera Exoascus, nämlich Exoascus Fuckel und Exoascus SAdeBeck, welche sich nicht decken, was um so mehr zur Verwirrung Anlaß geben muß, da eine Anzahl Arten von Exoascus Fuckel bei Sadebeck Taphrina heißen.

Giesenhagen meint nun, daß die Trennung in Exoascus und Taphrina unnatürlich, unpraktisch und unnötig ist und unterscheidet demnach nur:

Magnusiella mit den Asci direkt auf den vegetativen Hyphen,

Taphrina mit den Asci auf einer subcuticularen Hymeniumschicht.

Der bekannte Exoascus Prumi Fuckel wird dann z. B. Taphrina Pruni Tul.

Von Dangeard, Sadebeck und Ixeno wurde nachgewiesen, daß auch bei. Taphrina der Ascuskern das Verschmelzungsprodukt zweier 
Kerne ist; während aber SADEBECK angibt, daß der Sporenbildung eine echte Karyokinese wie bei den übrigen Ascomyceten vorangeht, versucht IKENO in der Flora 1903 nachzuweisen, daß hier der Kern zu einem Chromatinklümpchen degeneriert, welches durch Sprossung Chromatinmassen für die Sporen absondert.

Ich kann nicht umhin, der Vermutung Ausdruck zu geben, daß IkEnos Resultate auf ungenügend konserviertem Material beruhen; diese ganz abweichende Bildungsweise sollte meiner Ansicht nach durch bessere Dokumente gestützt sein, bevor man sie acceptieren kann. Man würde sich nicht zu wundern brauchen, wenn es sich später herausstellte, daß die lange zwischen Einsammeln und Untersuchung verlaufene Zeit Iк ENo irre geführt hätte. In seinem Artikel in der Flora von 1901 sagt IKENo auf S. 228, daß er sein Material April 1899 gesammelt und erst September 1900 untersucht habe und auch das Material seiner 2. Publikation war vielleicht schon ziemlich alt (Flora 1903, S. 2 „... im Frühjahr des letzten Jahres sammelte ich ..."

Nun sagt nämlich DiтTRICH in seiner Helvellineen-Arbeit:

„Für solches Material, welches nicht sogleich verarbeitet werden kann, ist die längere Aufbewahrung in starkem Alkohol entschieden zu widerraten, weil dadurch eine gute Färbung zumal der einzelnen Kern. bestandteile unmöglich wird. Das reichhaltige Material von Erysipheen, welches ich in dieser Weise konserviert hatte, war, als es nach 2 Monaten untersucht werden sollte, völlig unbrauchbar geworden .... Ich habe infolgedessen später die fixierten und gehärteten Objekte immer gleich bis in den Paraffinblock eingeführt ..."

Unter diesen Umständen scheint mir, wo SADEBECK echte Karyokinese angibt, Ikeno aber eine höchst abweichende Kerndegeneration, die Wahrscheinlichkeit groß zu sein, daß SADEBEcK recht hat.

Summa summarum wissen wir von den Exoascaceen nur, daß eine echte Befruchtung nicht stattfindet, und daß die Hyphen ohne weiteres Asci produzieren. Ob wir hier vielleicht mit Formen zu tun haben, bei denen die $\mathrm{x}$-Generation fehlt, die $2 \mathrm{x}$-Generation unabhängig geworden ist, oder ob das Mycel der x-Generation angehört und doch vielleicht irgendwo Uebertritt von Kernen stattfindet, kann nur durch erneute Untersuchung entschieden werden.

Die Cytologie ist also noch recht unvollständig bekannt, wenden wir uns jetzt der Morphologie zu.

Die Exoascaceae fallen im allgemeinen dadurch auf, daß sie Hypertrophien auf den Wirtspflanzen verursachen. Sie bilden Gallen, z. B. auf Farnblättern, verursachen Wucherungen auf Alnus-Fruchtschuppen, hypertrophieren Carpellen bei Populus und Prunus und veranlassen manche Bäume, übermäßig Knospen zu bilden, wodurch Hexenbesen entstehen.

Ein paar bekannte Fälle sind hier abgebildet. Taphrina Pruni verursacht die sogenannte Taschenkrankheit der Pflaumenbäume.

Das Mycel überwintert in den Fruchtzweigen; von dort aus dringt es in die Carpellen ein, verursacht deren Grünbleiben und verhindert die Bildung des Steines. Da die jungen Pflaumen stark wachsen, infolge der Nichtausbildung des Steines hohl sind und grün bleiben, erinnern sie einigermaßen an Schoten, was zu dem Märchen Veranlassung gab, daß sie gebildet wurden, wenn Pflaumenblüten von Bohnenpollen befruchtet wurden.

Das Hymenium wird unter der Cuticula gebildet, nur die Asci treten 
hervor und bilden einen weißen Ueberzug auf den infizierten Pflaumen. Bei der Aussaat können die Sporen hefeartig sprossen (Fig. 352, 2), hier findet also außerhalb des Ascus statt, was bei vielen anderen TaphrinaArten innerhalb desselben geschieht, so z. B. bei T. Johansoni, welche Hypertrophien der Populus-Carpellen verursacht und diese mit einem goldgelben Hymenium überzieht. Taphrina alnitorqu bildet die bekannten

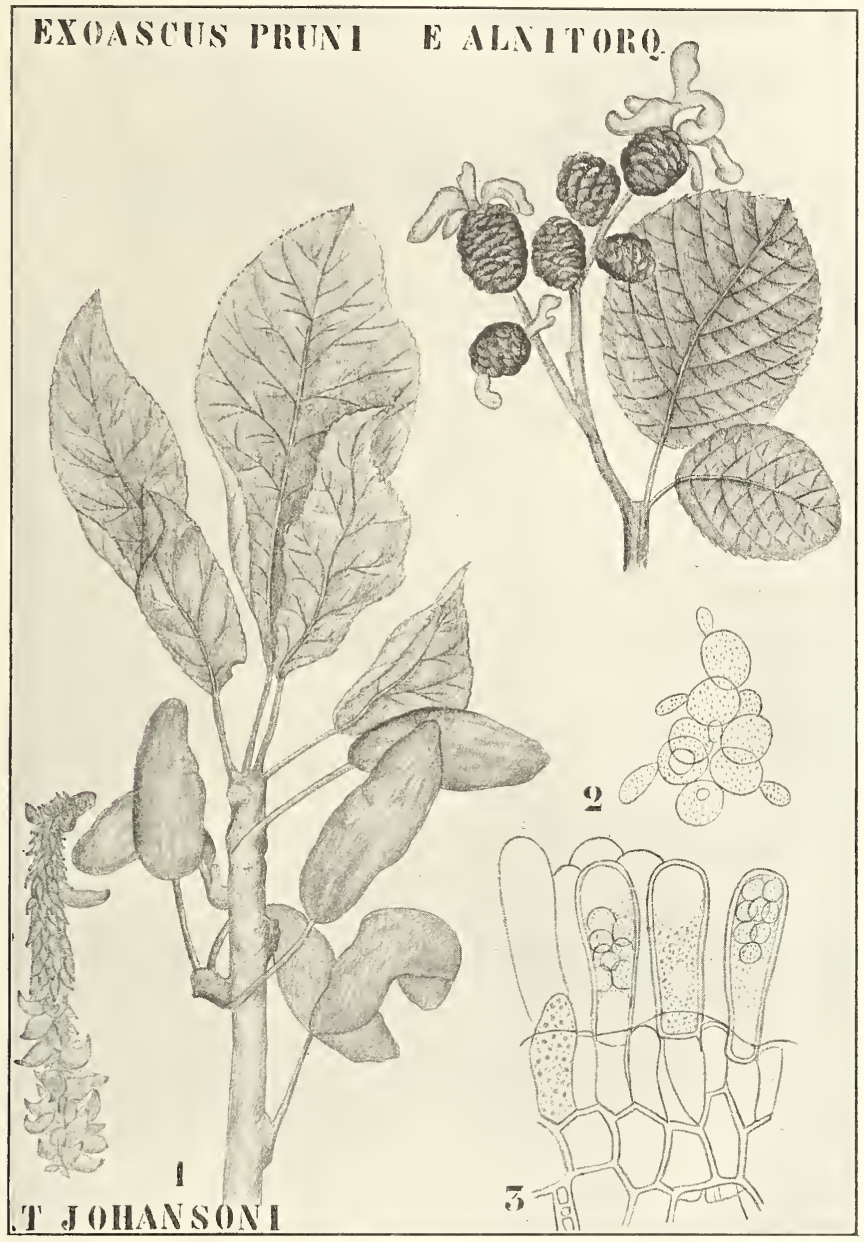

Fig. 352. Links unten: Taphrina Johansoni auf Populus (nach einem von Herrn ScHIPPER in Groningen gesammelten Exemplar. Rechts oben: Taphrina Alnitorquus Tulasne = Excoascus alnitorquus (TuL.) J. KüHN = Exoascus amentorum SAdEB. auf Alnus (nach Schröter). In der Mitte: Taphrina Pruni TulasNe = Exoascus Pruni Fuckel (nach Schröter und dE BARY). 1 Habitus. 2 Sprossende Ascussporen. 3 Junge Asci.

Wucherungen an Alnus-Früchten, meistens durch Hypertrophie der Schuppen, selten durch eine solche der Carpelle verursacht. Diese Art findet sich z. B. in der Umgegend Leidens zwischen Wassenaar und dem Deyl. 
Von der Familie der

\section{Ascocorticieae}

ist nur ein Genus Ascocorticium mit ein oder zwei Arten bekannt. Auf der Rinde abgestorbener Kieferstümpfe fand BREFELD 1891 das A. albidum, einen saprophytisch lebenden Pilz, der auf einem häutigen, flachen, aus dünnen verflochtenen Hyphen gebildeten Lager ein Hymenium bildet, das aus 8-sporigen Asci ohne Paraphysen besteht. Da von der Entwickelungsgeschichte nichts Näheres bekannt ist, läßt sich über die Stellung dieses Pilzes im System nichts aussagen.

Wenden wir uns jetzt der Gruppe der Saccharomyceten zu. 


\section{Siebenundzwanzigste Vorlesung.}

\section{Die Saccharomyceten.}

Lange bevor er diese Organismen kannte, hat der Mensch ihre Eigenschaften vielfach verwendet. So beruht die Bierbrauerei auf der Eigenschaft derselben, aus dem in keimender Gerste, im Malz entstandenen Zucker Alkohol und Kohlensäure zu bilden; bei der Brotbäckerei findet Hefe Verwendung zum Lockern des Brotteiges, was durch die bei der Gärung des auch dort vorhandenen Zuckers gebildete Kohlensäure besorgt wird. Auch bei der Weingärung spielen die Hefezellen durch Vergärung des Zuckers eine große Rolle.

Da es nun keineswegs indifferent ist, welche Hefearten man verwendet, da z. B. auch das Aroma von Wein und Bier von der verwendeten Art beeinflußt wird, arbeitet man mehr und mehr mit Reinkulturen, und die Hefeindustrie hat eine hohe Blüte gewonnen. Das bekannteste Produkt derselben ist die Preßhefe, welche in den Brotbäckereien benutzt wird. Manche Hefen bilden Farbstoffe, so z. B. die vielfach als Verunreinigung von Bakterienkulturen auftretende Rosahefe.

Selbstverständlich können wir hier nicht auf die physiologische Seite der Gärungsprobleme - über welche eine große Spezialliteratur besteht - eingehen, sondern wir müssen uns auf die Systematik beschränken.

Betrachtet man eine gewöhnliche Hefezelle, z. B. Bierhefe, Saccharomyces cerevisiae, ungefärbt unter dem Mikroskop, so sieht man eine ellipsoidische Zelle (Fig. 353, I 1) mit ziemlich viel Plasma und zahlreichen größeren und kleineren Vakuolen. Diese Zellen vermehren sich mittels Sprossung; dabei entstehen an einer oder mehreren Stellen der Wand Aussackungen (Fig. 3533, I 2), welche zu Hefezellen auswachsen und sich mittels einer Querwand von der Mutterzelle trennen. Sie können bisweilen ziemlich lange an der Mutterzelle sitzen bleiben und wieder aussprossen, wodurch Kolonien entstehen (Fig. 353, I 3). In der Regel aber fallen sie bald ab, so daß wir hier mit einem Fall ungeschlechtlicher Vermehrung zu tun haben. Unter bestimmten Umständen können gewisse Arten, z. B. S. ellipsoideus (vergl. Fig. 353, II), zu mycelienartigen Fäden werden.

Unter anderen Bedingungen bildet Saccharomyces im Inneren seiner Zelle Sporen, sogenannte Endosporen (Fig. 353, I 4).

Während bei den meisten Saccharomyces-Arten keine geschlechtliche Fortpflanzung vorkommt, ist eine solche doch in zwei Fällen bekannt, nämlich bei den Generis Zygosaccharomyces und Schirosaccharomyces, von 
welchem letzteren aber Hansen meint, daß es nicht zu den Saccharomyceten gehört.

Bevor wir näher auf die Systematik dieser Organismen eingehen, müssen wir einiges von deren Cytologie wissen. Ueber eine der elementarsten Fragen, welche jedoch hier sehr schwer zu lösen war, nämlich über die An- oder Abwesenheit eines Kernes, ist sehr viel geschrieben worden, das eine Mal wurde die Anwesenheit bejaht, das andere Mal verneint.

Die ausgedehntesten Untersuchungen wurden von GUILLIERMond (1902) publiziert. Seinen Untersuchungen sei folgendes entnommen.

Er fängt an, auf den Umstand hinzuweisen, daß es bei Kernuntersuchungen in dieser Gruppe unbedingt nötig ist, junge und kräftige Individuen zu wählen, bei welchen das Plasma noch dicht und homogen ist. Später entstehen große Vakuolen, welche das Plasma an die Wand drücken, wodurch der Kern zwischen die Vakuole und die Wand gepreßt wird und sich zusammenzieht, was den Nachweis sehr erschwert.

Es kommt noch hinzu, daß sowohl das Plasma wie die Vakuole alsbald Nahrungssubstanzen enthalten, welche sich vielfach intensiver färben als die Kerne und zu falscher Interpretierung Veranlassung geben. Weiter muß dafür gesorgt werden, daß die Zellen in einem günstigen Medium leben, damit verfrühte Degeneration vermieden wird. Die besten Resultate erhielt Guilliermond an Kulturen in Pasteurscher oder Mayerscher Nährlösung. Stets wurden Reinkulturen in ErLENMEYERschen Flaschen verwendet.

Hansen hatte früher nachgewiesen, daß man viele SaccharomycesArten zur Sporenbildung bringen kann durch Kultur auf Gipsblöckchen, Guilliermond rät aber von dieser Methode ab, wenn es sich um cytologische Fragen handelt, da bei dieser Kulturweise öfters eine partielle, sehr hinderliche Degeneration des Plasmas stattfindet. Die Methode ist also nur zu verwenden, wenn keine andere zum Ziele führt; sie ist übrigens nur verwendbar, wenn die Zellen vorher in einem sehr nahrungsreichen Medium gelebt haben.

Am besten verschafft man sich Sporen nach der Methode ReEss: Kultur auf Scheibchen von Mohrrüben (Daucus), welche in 2 bis 3 Tagen Sporen liefert; das gleiche Medium eignet sich sehr gut zum Studium der Keimungserscheinungen.

Zum Sammeln, Fixieren und Färben des Materials hat Guilliermond eine für viele Fälle recht geeignete ingeniöse Methode ausgedacht. $\mathrm{Er}$ säte nämlich mit den Saccharomyces gleichzeitig Pilzsporen aus, z. B. Penicillium glancum, das daraus entstandene Mycel schadet der Hefe nicht, und nimmt man nun später eine Mycelflocke heraus, so sind darin zahlreiche Hefezellen verwirrt, welche man nun leicht fixieren und färben kann. Hat man genügend Material, so daß der Verlust einer Anzahl von Zellen während der Präparation nicht in Betracht kommt, so kann man selbstverständlich auch direkt fixieren und färben.

Die einfachste Fixierflüssigkeit ist konzentrierte wässerige Pikrinsäurelösung; sie wird sorgfältig mit 70-proz. Alkohol ausgewaschen. Meistens ist es unnötig, Schnitte zu machen; wo es zur Kontrolle erwünscht war, benutzte Guilliermond Wagers Methode.

Dabei werden die fixierten und gefärbten Zellen in eine kleine Flasche mit schwachem Alkohol gebracht, welcher allmählich durch stets stärkeren Alkohol, von Xylol und Paraffin ersetzt wird, ohne je die Hefezellen herauszunehmen, welche also auf dem Boden des Fläschchens ver- 
bleiben; schließlich wird letzteres, nachdem das Paraffin erstarrt ist, zerschlagen und das Paraffinblöckchen mit dem Mikrotom zerschnittten.

Die Färbung ist sehr schwierig, da sich das Plasma sehr stark tingiert und da die in großer Zahl vorhandenen Granula den Farbstoff begieriger festhalten als der Kern. Diese sich so intensiv färbenden Körperchen nennt GuILLIERMOND metachromatische Körperchen. Unter diesen Umständen war es nötig, verschiedene Färbungsmethoden zu rerwenden, und es stellte sich heraus, daß WAGERs Färbungsmethode wenig günstig war, da sie nicht den Kern von den metachromatischen Körperchen differenziert.

Die besten Resultate erhielt Guiluiermond mit Methylenblau für die metachromatischen Körperchen und Hämatoxylin für den Kern.

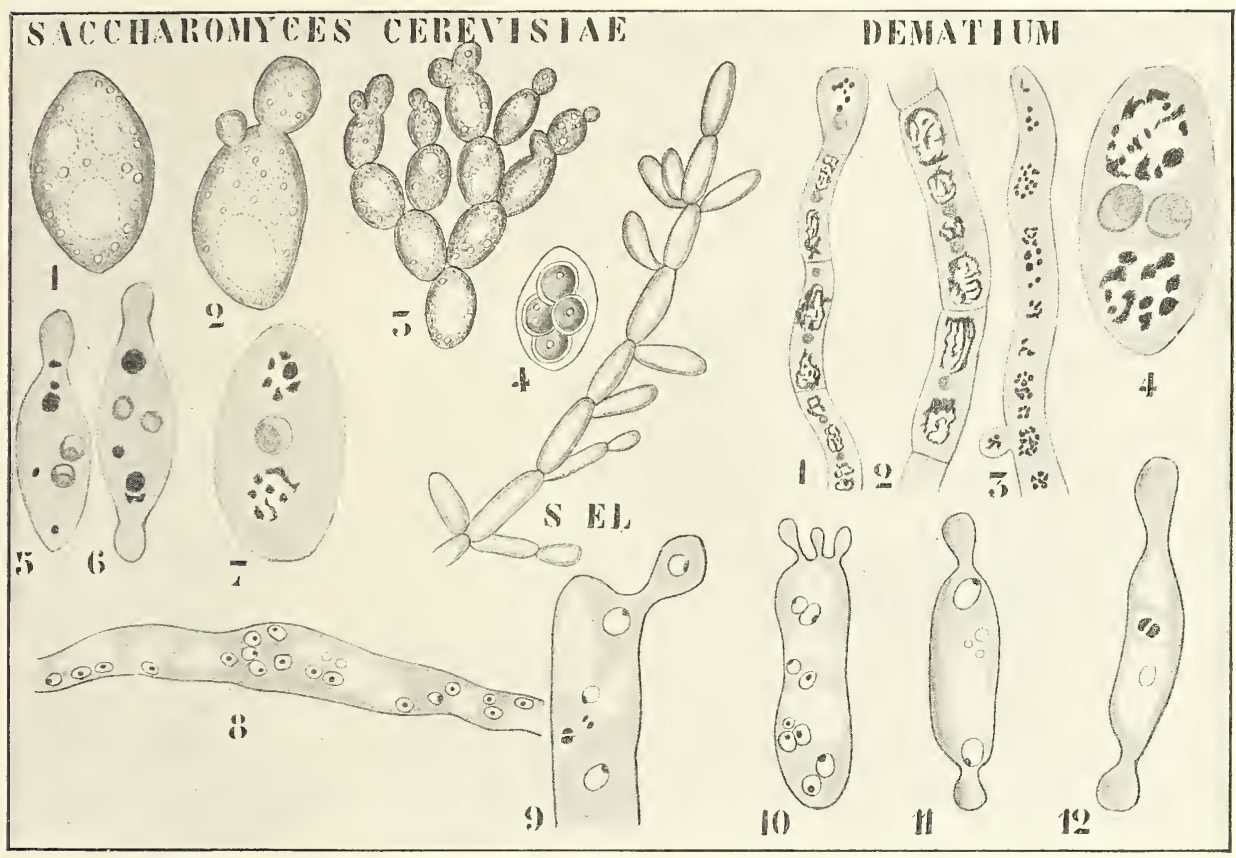

Fig. 353. I. Saccharomyces cerevisiae (nach WeTtSTein). 1 Vegetative Zelle, ungefärbt. 2 Idem, sprossend. 3 Idem, Sproßkolonie. 4 Idem, Sporen. - II. S a c charomyces ellipsoideus, Mycelform. - III. Dematium (nach GuILLIERMond). 1, 2 Mit Hämalum gefärbte Präparate, die runden Körperchen (in Wirklichkeit blau) sind die Kerne, die karyokinesenähnlichen Figuren (in Wirklichkeit rot) sind metachromatische Körperchen. 3 Mit Methylenblau gefärbte Zellen, von den Kernen ist nichts zu sehen, die gefärbten Körperchen (in Wirklichkeit rot) sind metachromatische Körperchen. 4-6 Mit Hämalum gefärbte Konidien von Dematium, die zwei einander benachbarten runden Körperchen (in Wirklichkeit blau) sind die Kerne, die anderen (in Wirklichkeit rot) die metachromatischen Körperchen. 7 Hefezelle genau so behandelt, das zentrale kugelige Körperehen (in Wirklichkeit blau) ist der Kern, die übrigen (in Wirklichkeit rot) die metachromatischen Körperchen. 8-12 D e mat iu mzellen mit HEIDENHAINs Eisenhämatoxylin gefärbt, nur die Kerne färben sich.

Methylenblau in 1-proz. wässeriger Lösung färbt das Plasma hellblau, die metachromatischen Körperchen intensiv blau bis rot; der Kern wird höchstens etwas dunkler blau als das Plasma gefärbt.

Hämatoxylin verwendet man am bequemsten in der Form von Hämalum. Färbung 10 Minuten bis höchstens 1/2 Stunde, einige Augen- 
blicke Auswaschen mit Aq. dest. Resultat: Plasma hellblau, Kern dunkelblau, metachromatische Körperchen dunkelrot.

Wie leicht man metachromatische Körperchen für Kerne halten kann, mag aus den Abbildungen in Fig. 353, III von Myceliumzellen und Konidien einer Dematium-Art hervorgehen, welche GuILLIERMond zum Vergleich heranzog. In Fig. 353, III 3, mit Methylenblau gefärbt, ist keine Spur von Kernen zu sehen, in Fig. 353, III 1, 2, mit Hämalum gefärbt, sind sie deutlich sichtbar, es fallen aber die metachromatischen Körperchen viel mehr auf und werden ihres karyokinesenähnlichen Arrangements wegen leicht für sich teilende Kerne gehalten. Es liegen die metachromatischen Körperchen in Vakuolen.

Der Kern läßt sich also bei Dematium mit Hämalum wohl sichtbar machen, aber nicht differenzieren. Das gelingt erst mit Eisenhämatoxylin nach Heidenhain, wie Fig. 353, III 8-12 zeigt, der scheinbare Nucleolus ist keiner, sondern das Chromatin, wie aus der fast amitotischen Kernteilung (Fig. 353, III 12 oben) hervorgeht.

Die metachromatischen Körperchen verschwinden fast vollständig, wenn man die Dematium-Fäden in Aq. dest. hineinlegt; an ihrer Stelle bilden sich dann Oeltröpfchen, jedoch nicht, wenigstens nicht direkt, auf Kosten der metachromatischen Körperchen. Auf die Natur dieser metachromatischen Körperchen kommen wir später zurück, sie enthalten keine Nucleine und haben also mit einem Kern nichts zu tun. Die WAGERsche, in der Bezeichnung dieser metachromatischen Körperchen als nukleäre Granula verkörperte Interpretierung ist also unrichtig. Es sind diese M.K. ${ }^{1}$ ) wohl dieselben Dinge, welche BABES bei Bakterien schon mit diesem Namen belegte und welche BüTschli rote Körner nannte.

Aus dem Vergleich der Fig. 355, III 4-6, welche DematiumKonidien, und Fig. 355, III 7, welche eine Hefezelle bei gleicher Behandlungsweise darstellt, folgt wohl die große Uebereinstimmung in der Struktur der Energiden bei beiden Genera.

Wir haben also gesehen, daß eine Hefezelle einen Nucleus und daneben M.K. enthält, außerdem enthält sie, wie wir alsbald sehen werden, noch Glykogen. Wir haben schon erwähnt, daß sich die Hefezellen durch Sprossung vermehren; auch die Spore keimt mittels einer solchen Sprossung. Doch gibt es auch eine Ausnahme, nämlich Saccharomyces Ludwigii, dessen Spore (Fig. 355, II 1) mittels eines kurzen Mycels keimt.

Hansen (1904) gibt nun, von diesen Eigenschaften Gebrauch machend, folgendes an.

\section{System der Saccharomyceten.}

\section{A. Echte Saccharomyceten.}

Gruppe I. Die Zellen bilden in zuckerhaltigen Flüssigkeiten sofort eine Ansammlung auf dem Boden (Bodensatzhefe) und erst später ein Häutchen an der Oberfläche der Flüssigkeit (Kahmhaut), welches schleimig ist und keine Luft enthält. Sporen glatt, rund-oval, mit einer oder zwei Sporenhäuten. Keimung mittels Sprossung oder mittels eines Promycels. Alle oder fast alle verursachen Alkoholgärung.

I. Saccharomyces Meyen. Sporen mit einer Sporenhaut, Keimung durch Sprossung. Außer Sproßzellen bis-

1) Abkürzung für metachromatische Körperchen, welche auch weiterhin verwendet wird. 
weilen auch septierte Mycelbildung. Hierher bei weitem die meisten Arten.

II. Zygosaccharomyces BARKER. Wie vorige, aber kopulierend.

III. Saccharomycodes E. Chr. Hansen. Wie I, aber Keimung mittels eines Promycels. Sproßt mit unvollkommener Abschnürung. Mycel mit deutlichen Querwänden. Hierher S. Ludwigii und eine 1896 von BEHRENS beschriebene unbenannte Art.

IV. Saccharomycopsis Schiönning. Wie I, aber Spore mit doppelter Sporenhaut. Hierher S. guttulatus und S. capsularis ScH.

Gruppe II. Die Zellen bilden in zuckerhaltigen Flüssigkeiten sofort eine lufthaltige und daher trockene und matte Kahmhaut. Sporen halbkugelig, eckig, hut- oder citronenförmig; in beiden letzteren Fällen mit ausspringender Leiste; übrigens glatt, mit nur einer Sporenhaut; Keimung mittels Sprossung.

V. Pichia Hansen. Spore halbkugelig oder auch wohl unregelmäßig eckig. Keine Gärung. Starke Mycelbildung. Hierher P. (Sacch.) membranifaciens u. a.

VI. Willia Hansen. Spore hut- oder citronenförmig mit Leiste. Meistens kräftige Esterbildner, einige ohne Gärung. Hierher W. (Sacch.) anomala, W. (Sacch.) saturnus etc.

\section{B. Zweifelhafte Saccharomyceten.}

Monospora Metschnikoff und Nematospora Peglion.

Nach Hansen ist Schizosaccharomyces ganz auszuschließen, sie zeigt nach ihm Verwandtschaft zu den Schiromyceten und zu Oidium.

Betrachten wir jetzt einige dieser Arten etwas näher.

\section{Saccharomyces cerevisiae I}

wurde von Hansen in den Brauereien von Edinburgh isoliert. Die Zellen sind dick, rund oder oval, sehr selten verlängert. Sie bilden $1-4$ Sporen von 3,5 bis $9 \mu$ Durchmesser. Die Kahmhautzellen sind nur wenig verlängert.

In frischem Zustande sieht man die M.K. als stark lichtbrechende Körnchen, welche Brownsche Molekularbewegung zeigen; bisweilen kann man sogar den Kern sehen.

Mit Jodjodkalium behandelt, wird das Plasma gelb, bisweilen sieht man in der Zelle dunkelbraune Flecke, welche die Anwesenheit von Glykogen verraten. Außer M.K. können also die Hefezellen Glykogen enthalten, wie aus der graugefärbten (in Wirklichkeit braunroten) Vakuole der Fig. 354, II 11, 12 hervorgeht.

Mit Methylenblau kann man die M.K. rot färben, das Plasma blau (Fig. 354, I 1), der Kern wird dabei aber nicht sichtbar. Nit Hämalum kann man beide sichtbar machen (Fig. 354, I 2) und mit Eisenhämatoxylin kann man nach geeigneter Entfärbung Präparate erhalten, bei welchen nur der Kern gefärbt und gut differenziert ist (Fig. 354, I 3).

Betrachten wir also - die Struktur dieser Hefe während ihrer Entwickelung in Mayerscher Nährlösung:

Während der ersten Gärungsstunden ist das Plasma mehr oder weniger homogen; im Innern der Zelle sieht man eine oder mehrere 
ganz kleine Vakuolen, welche M.K. enthalten; sie sind erst nur in kleiner Zahl vorhanden, nehmen aber während der Gärung an Anzahl zu; bisweilen kann sogar die ganze Zelle von ihnen erfüllt werden. Zwischen den sie enthaltenden Vakuolen bleiben dann nur dünne Plasmalamellen übrig und das Ganze hat dann die Schaumstruktur von Bütschli. In der Regel sind aber die Vakuolen viel kleiner und nehmen nur einen Teil der Zelle ein. Wenn 2 oder 3 solcher Vakuolen, welche je einen Kranz von M.K. enthalten, dicht neben dem Kern liegen (Fig. 354, 7, 13, 16), und dies ist ihre normale Stellung, so scheint es, als wären diese M.K. ein Chromatinnetz und der wirkliche Kern ein Nucleolus; und so haben in der Tat Eisenschitz, Roncali und WAgER dergleichen Bilder interpretiert. Später verschmelzen die Vakuolen miteinander zu

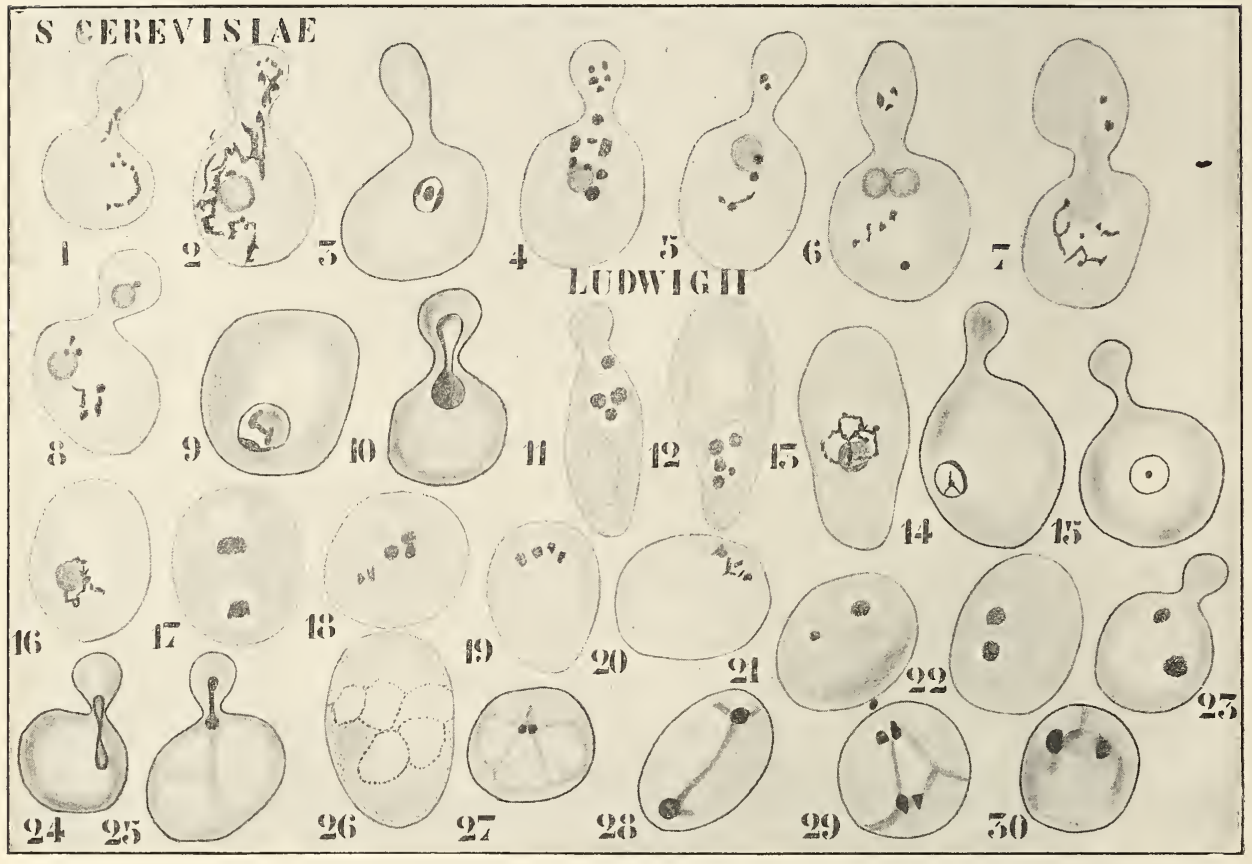

Fig. 354. Hefearten nach GuILliermond. I. S a ceharom yees cerevisiae. 1 Mit Methylenblau, 2 mit Hämalum, 3 mit Eisenhämatoxylin gefärbt. $4-8$ Sprossung; Färbung mit Hämalum. 9 Eine große Vakuole vorhanden, Färbung mit Eisenhämatoxylin. 10 Sprossende Zelle, mił Eisenhämatoxylin gefärbt. - II. S a c charo m y coi des L u dwigii. 11, 12 Zellen, mit Jodjodkali gefärbt, in jeder enthält eine Vakuole Glykogen, die andere M.K. 13 Färbung mit Hämalum. 14, 15 Färbung mit Eisenhämatoxylin, 16 mit Hämalum. 17-20 Abnahme der M.K, Zunahme des Glykogens. 21-23 Verschwinden der Glykogenvakuole. 24-25 Sprossung, Färbung mit Eisenhämatoxylin. 26 Lösung der M.K., in Wirklichkeit ist das Plasma blau gefärbt, die Vakuolen rosa und die Stäbchen an der Peripherie der Vakuole dunkelrot. 27-30 Kernteilung. Weitere Erklärung im Text.

einer zentralen Vakuole und der Kern wird beiseite geschoben (Fig. 354, 14); er kann sogar, en face betrachtet, scheinbar in der Vakuole liegen (Fig. 354, 15).

Oefters findet man die M.K. in den Vakuolen mehr oder weniger sternförmig angeordnet (Fig. 354, 13), was bewirkte, das diejenigen, welche sie für Teile des Kernes hielten, zu falschen Anschauungen 
kamen: so meinte Moeller, daß der Hefekern amöboid beweglich wäre, und Bousv, daß der Kern während der Gärung Chromatin in das Plasma hinübertreten ließe, um so eine intensivere Verbindung zwischen Kern und Plasma herzustellen.

Ungefähr 48 Stunden nach dem Anfang der Gärung wird das Glykogen, von welchem bis dahin nur geringe Mengen im Plasma vorhanden waren, reichlich; die kleinen glykogenhaltigen Vakuolen verschmelzen zu einer großen, und dieses Glykogenreservoir füllt dann fast die ganze Zelle (Fig. 354, 19).

Zu gleicher Zeit verschwinden die M.K.-haltigen Vakuolen und die M.K. werden so wie der Kern gegen die Wand der Zelle gedrückt (Fig. 35̃4, 20). Es gibt demnach zwei Vakuolenarten: M.K.-haltige und glykogenhaltige (Fig. 354, 11, 12).

Wenn die Gärung zu Ende geht, fängt das Glykogen zu verschwinden an, das Plasma begibt sich wieder in das Zentrum der Zelle und drückt die Glykogenvakuole an die Wand, wo sie erst in der Form eines Meniscus vorhanden ist und schließlich ganz verschwindet (Fig. 354, 21, 22, 23). Inzwischen sind die M.K. wieder mehr zentral gelagert und haben sich mit Vakuolen umgeben. Schließlich verschmelzen diese zu einer zentralen Vakuole (Fig. 354, 23), in welcher die M.K. liegen, aber in geringerer Zahl als früher. Auf letzterem Stadium (Fig. 354, 23) können die Zellen längere Zeit verharren, meistens zeigen sie aber alsbald Degenerationserscheinungen. Nach und nach zieht sich nämlich das Plasma zu Klümpchen zusammen, die M.K. degenerieren zu Oel. Schließlich sind in der Zelle nur noch wenig Plasma und viele große Oeltröpfchen vorhanden.

Das sind aber nur pathogene Erscheinungen, mit der Gärung haben diese nichts zu tun, denn genau dasselbe geschieht, wenn die Zellen keine Gärung verursachen.

Sehen wir jetzt einmal, wie die Sprossung stattfindet. In die Aussackung der Zellwand, welche zur Sprossung führt, dringt sofort ein Ausläufer der Vakuole mit einigen M.K. vor und schnürt sich darauf von der großen Vakuole ab (Fig. 355, 4, 5). Meistens hat der Kern sich dann noch nicht geteilt. Die Kernteilung ist also, wie überall, von der Vakuolenteilung unabhängig, wenn auch beide bisweilen zusammenfallen können. Auch übt der Kern offenbar keinen Einfluß auf die Stelle, an welcher sich ein Sproß bilden wird, aus (vergl. Fig. 355, 11 mit 3). Oefters ändert der Kern seinen Platz nicht; liegt er am anderen Ende der Zelle, so verlängert er sich, bis seine Spitze in die Knospe hineinragt, wodurch ein Halter entsteht (Fig. 355, 24), welcher alsbald in der Mitte durchbricht, und so der Knospe ihren Kern liefert. Hat der Kern in der Nähe der Knospe gelegen, so ist der Halter kurz (Fig. 355, 10). Der Kern kann sich aber ebensogut in der Mitte der Zelle teilen (Fig. 355, 6); es begibt sich dann einer der Tochterkerne in die Knospe.

So liegen also die cytologischen Verhältnisse bei den Saccharomyceten nach Gurlumermonds Meinung, und die schönen Abbildungen, sowie das offenbar sehr saubere Arbeiten schließen wohl jeden Zweifel an deren Richtigkeit aus. Für eine Kritik der älteren Meinungen sei auf GuILlermonds Arbeit verwiesen.

Vielleicht kann auch Gumluenmonds Arbeit, in Verbindung mit der von Fischer über Cyanophycecn, Licht werfen auf die Kernfiage bei letzterer Gruppe. Es scheint mir nämlich gar nicht unwahrscheinlich, 
daß die M.K. analoge Bildungen mit dem Anabänin von Fischer sind, und, falls dies richtig, ist die Frage berechtigt, ob man vielleicht bei den Cyanophyceen bis jetzt den Kern nicht noch ganz übersehen hat.

So wie gewisse Autoren die Vakuolen mit M.K. der Hefezellen für den Kern angesehen haben, so könnte es sich herausstellen, daß der Zentralkörper der Cyanophyceen eine Vakuole mit Anabäninen sei, und daß der Kern noch im umgebenden Plasma gesucht werden muß.

Auch darin stimmen die M.K. und das Anabänin überein, daß beides Reservesubstanzen sind; das geht aus dem Verhalten der M.K. bei der Sporenbildung hervor.

Um dies zu studieren, macht G. Kulturen auf Daucus-Schnittchen. Die Struktur der Zellen ist genau dieselbe wie bei den Kulturen in

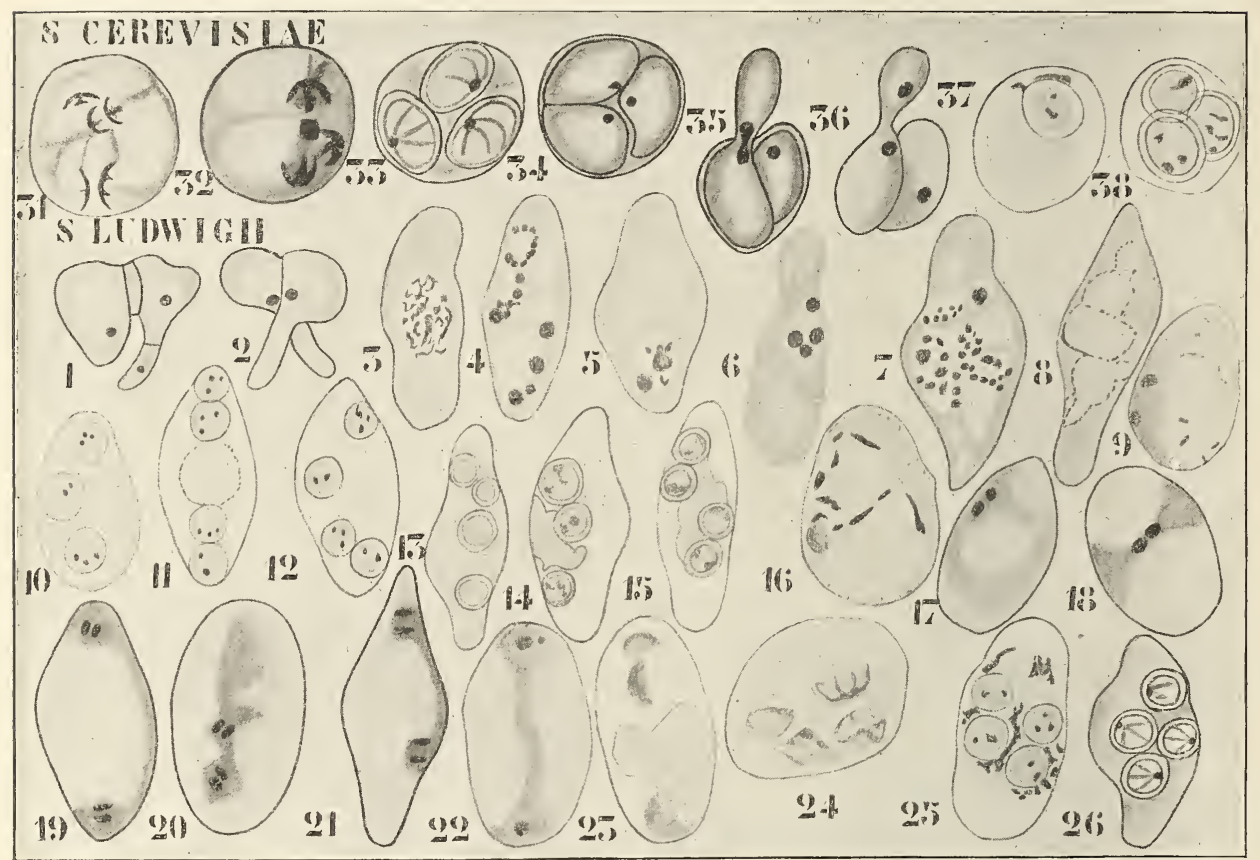

Fig. 355. Cytologie der Saccharomyceten. I. Saccharomyces cerevisiae. 31, 32 Beginnende Sporenbildung. 34 Sporen gebildet. 35-36 Sporenkeimung. 37 Spore in der Zelle, in welcher Glykogen in der Vakuole und ein paar M.K. noch vorhanden sind, in der Spore ebenfalls M.K. 38 Sporen mit M.K. - II. Sacchar omycodes Ludwigii. 1-2 Sporenkeimung. 3 Kleine M.K. in der Zelle. 4 Größere M.K. 5 Auftreten der Glykogenvakuole. 6 Vakuole mit M.K. und Vakuole mit Glykogen. 7-12 Sporenbildung. 7 M.K. noch vorhanden. 8-9 Lösung der M.K. 10 Die Zelle mit gelösten M.K. gefüllt. 11 Die Sporen haben die M.K.-Lösung fast ganz, 12 ganz verbraucht. 13-15 Verbrauch des Glykogens durch die Sporen. 16-21 Kernteilung. 22-26 Sporenbildung. In den Fig. 22-24 ist die Vakuole mit M.K.-Lösung gefüllt, in Fig. 25 daneben M.K., in Fig. 26 ist die Hefezelle leer.

Mayerscher Nährlösung; wir finden eine Vakuole mit M.K., und zwar in größerer Zahl als bei den Flüssigkeitskulturen. Später tritt ebenfalls eine Glykogenvakuole auf, welche alsbald die ganze Zelle ausfüldt. Gegen den dritten oder vierten Tag nimmt diese an Größe ab, und die Vakuole erscheint mit M.K. wieder an einer der Seiten der Zelle, Glykogen und 
M.K. sind nun in größerer Menge vorhanden und die Bedingung zur Sporenbildung scheint so geschaffen.

Jetzt teilt sich sowohl die Glykogenvakuole wie die Vakuole mit II.K. in eine Anzahl kleinere. Schließlich wird das Plasma schaumig. durch die große Zahl von Vakuolen, und da die Vakuolen mit M.K. meistens im Zentrum der Zelle liegen, ähnelt dieses Zentrum einem Zentralkörper. Der Kern liegt immer diesen Vakuolen mit M.K. angepreßt und kann dadurch ganz dem Auge entzogen werden.

Während bis jetzt die M.K. die Vakuolen in der Form von größeren oder kleineren Körnchen fast ganz ausfüllten, nimmt von jetzt an sowohl ihre Zahl, wie ihre Größe ab. Man sieht sie nur noch als kleine Pünktchen (Fig. 35̌, 26) an der Peripherie der Vakuole liegen, während der übrige Inhalt derselben sich diffus rosa färbt. Mit anderen Worten, die M.K. werden gelöst. Wenn dieses Stadium eingetreten ist, fängt die Kernteilung an. Dazu hat letzterer sich erst mit einem Plasmamantel umgeben und teilt sich dann halb amitotisch, wie bei S. Ludwigii näher besprochen werden wird.

Um die Kerne herum bilden sich nun die Sporen aus, die Zerschneidung des Plasmas fängt an einer Seite an, so daß das Sporenprimordium hutförmig ist (Fig. 355, 31).

Vermutlich bilden sich also die Sporen in derselben Weise wie im Ascus der echten Ascomyceten, nämlich dadurch, daß das nötige Plasma von den Kinoplasmastrahlen ausgeschnitten wird. Das Epiplasma desorganisiert und wird offenbar von den heranwachsenden Sporen als Nahrung verbraucht; schließlich liegen die Sporen in einem Zellsaft, in welchem Glykogen und M.K. gelöst sind und noch einige ungelöste M.K. sich vorfinden können.

Beim Heranwachsen absorbieren die Sporen das Glykogen und akkumulieren eine gewisse Quantität desselben in ihren Vakuolen, auch treten in ihnen Vakuolen mit M.K. auf, deren Zahl nach und nach zunimmt.

Schließlich füllen die 4 Sporen den Ascus ganz aus, und es bleibt keine Spur von Epiplasma oder M.K. zurück.

Man sieht, daß G. keine Spur einer Kernfusion im sogenannten "Ascus" der Saccharomyceten gesehen hat. Wohl war das Vorkommen einer solchen früher von JANssens und LeBLANC behauptet worden, aber weder WAGER noch G. konnten dies bestätigen.

Bei Saccharomyces cerevisiae ist der Ascus also kein Diplosporangium, kein Homologon des Ascus der Ascomyceten, es gibt hier keine $2 \mathrm{x}$ Generation.

Wir werden später versuchen, zu bestimmen, was denn der "Ascus" hier wohl ist, müssen aber, bevor wir dies. diskutieren können, erst die Sporenbildung bei anderen Arten kennen lernen.

Bleibt zu betrachten: die Keimung. Im Momente der Keimung sind die Sporen durch Druck gegen die Wand der Hefezelle unregelmäßig eckig oder rundlich geworden. Eine Anzahl der Sporen kann degenerieren, der Rest keimt durch Bildung einer Knospe (Fig. 355, 35, 36), der meistens andere folgen, genau so, wie bei der Sprossung der vegetativen Zelle. Während der Keimung wird das Glykogen verbraucht, die M.K. bleiben aber bestehen und treten zum Teil, wie bei der regetativen Sprossung, in die jungen Zellen ein.

Bei S. cererisiae bilden also die M.K. eine Reservesubstanz, welche speziell bei der Sporenbildung verbraucht wird. Nikrochemisch kounte 
G. nachweisen, daß sie keine Nucleine sind; auch geben sie keine Proteinreaktion. Bei Kultur in Aq. dest. verschwinden sie innerhalb 48 Stunden, ihre wahre Natur bleibt vorläufig unbekannt.

Die übrigen Arten des Genus Saccharomyces verhalten sich im allgemeinen wie S. cerevisiae. Scharf steht diesem Genus das Geschlecht

\section{Zygosaccharomyees}

dadurch gegenüber, daß der Sporenbildung eine Kopulation vorangeht. Diese von BARKER entdeckte Form war GUILLIERMOND noch nicht bekannt. Sie wurde von BARKer (1901) auf Ingwer gefunden. Es ist eine gewöhnliche Sproßhefe, deren Zellen aber in Paaren mittels zweier Ausstülpungen etwa wie Spirogyra kopulieren. In jeder Ausstülpung liegt ein sich intensiv färbender Körper, der vermutlich ein Kern ist; diese beiden verschmelzen; später teilt sich der Fusionskern; jede Hälfte tritt in die kopulierenden Zellen zurück und teilt sich in eine Anzahl Sporenkerne. Im Jahre 1902 publizierte Barker einen langen illustrierten Aufsatz in dem Journal of the Federated Institute of Brewing, welchen ich nur im Auszug kenne. Er zeigt darin, daß eine übereinstimmende Kopulation stattfindet bei Schirosaccharomyces octosporus Beijerinck und bei S. Pombe, und da nun Guillliermond die Kopulation bei diesen beiden Arten sorgfältig beschreibt und mir BARKERS Artikel, wie gesagt, unzugänglich ist, scheint es mir besser, die Frage der Kopulation bei den Saccharomyceten bis zur Besprechung jener Formen aufzuschieben. Schreiten wir also zur Besprechung eines anderen Genus, von welchem ich die Art

\section{Saccharomycodes Ludwigii Hansfin}

wähle. Ludwig entdeckte diese Form im Wundsaft von Eichen und anderen Bäumen, sie wurde aber von ihm für einen Hefezustand von Oidium Magnusii gehalten. Hansen machte Reinkulturen und zeigte, daß hier eine echte Hefe vorliegt.

Die Form der Zellen ist sehr variabel, elliptisch verlängerte, flaschenund zitronenförmige Zellen kommen nebeneinander vor. Sie bilden leicht Sporen, sogar in der Kahmhaut; gewöhnlich 2-4 Sporen pro Zelle, bisweilen $6-8$, typisch ist die Vierzahl; ihr Durchmesser beträgt 3-4 $\mu$.

Es sind zwei Varietäten bekannt, eine sporogene und eine asporogene; letztere bildet sogar unter den günstigsten Bedingungen keine Sporen.

Die Keimung ist sehr eigentümlich, und darauf beruht die Abtrennung dieser Art zu einem besonderen Genus. Während nämlich beim Genus Saccharomyces die Spore wie eine vegetative Zelle sproßt, keimt S. Ludwigii mittelst eịnes einzelnen kurzen Keimschlauches, der, nachdem er eine gewisse Länge erreicht hat, eine Querwand bildet, wodurch eine terminale Zelle abgetrennt wird (Fig. 355, II 1, 2). Diese Zelle teilt sich nun mittelst einer Anzahl von Querwänden; die so gebildeten Zellen isolieren sich und erst diese vermehren sich durch Sprossung. BARKER sieht darin einen Uebergang zum Genus Schizosaccharomyces, Hansen meint dagegen, daß hier nur Bildnng eines Promycels stattfindet und will Schinosaccharomyces, der nie sproßt, aus der Hefengruppe ausweisen.

Nach Hansen entsteht nun das Promycelium bei unserer Art aus Sporen, welche in Paaren mittelst Kopulationsschläuchen kopuliert haben, so daß eine offene Kommunikation zwischen beiden stattfindet. Ob dabei 
Kernverschmelzung stattfindet, ist nicht bekannt; jedenfalls erblickt Hanser darin keinen Sexualakt, sondern, da nur eine der beiden kopulierten Sporen ein Promycelium bildet, nur ein Mittel, um diesem mehr Nahrung zuzuführen und ihm zu erlauben, Zellen zu bilden. Für diese Auffassung spricht auch der Umstand, daß nur junge Sporen kopulieren, ältere dagegen auch ohne dies zu keimen vermögen (Fig. 355, II 2). Selbstverständlich wollte G. gerne die Cytologie dieses Vorganges untersuchen, aber die Sporen seiner S. Ludwigii keimten alle ohne Kopulation, so daß er schon an Hansens Beobachtungen zu zweifeln anfing, als ihm dieser Kulturen schickte, welche die Kopulation sehr schön zeigten; leider zu spät, um die Cytologie noch für die hier besprochene Arbeit zu untersuchen.

Während des vegetativen Stadiums verhalten sich die Zellen wie die von S. cerevisice, zunächst sind die M.K. als feine Körnchen vorhanden (Fig. 355, II 3), später bilden sie größere Akkumulationen (Fig. 355, II 4), dann treten Glykogenvakuolen auf (Fig. 355, II 5), und man kann schön sehen, daß M.K. und Glykogen in verschiedenen Vakuolen vorkommen. Dann werden bei der Sporenbildung die M.K. gelöst; schließlich verschwindet auch das Glykogen mehr und mehr, und nur die Sporen bleiben übrig. Die hier abgebildeten Stadien (Fig. 355, II 3-12) machen das wohl ohne weiteres klar. Genau derselbe Vorgang also wie bei S. cerevisiae. Was uns hier interessiert, ist der Umstand, daß die Kernteilung hier deutlicher ist als in allen anderen beobachteten Fällen. Kurz vor der Sporenbildung sieht man den Kern neben einer großen Vakuole liegen (Fig. 355, II 16), in welcher entweder gar keine oder nur wenige M.K. liegen; sie ist aber von gelösten M.K. ganz rosa gefärbt.

Alsbald teilt sich der Kern (Fig. 355, II 17, 18) und die Tochterkerne begeben sich in der Regel nach den Polen der Zelle, wo sie sich von neuem teilen (Fig. 355, II 19), dies kann aber auch geschehen, wenn sie noch in unmittelbarer Nähe liegen (Fig. 355, II 20). Trotzdem auch hier die Präparate keineswegs vorzüglich sind, zeigt doch wohl z. B. ein Stadium, wie das der Fig. 355, II 21, daß hier Karyokinese stattfindet.

Normalerweise sind die Pole, in welchen die Tochterkerne liegen, mittels einer Plasmabrücke verbunden (Fig. 355, II 22). Um jeden Nucleus herum wird nun offenbar Plasma herausgeschnitten (Fig. 355, II 23, 24), dieses umgibt sich mit einer Membran, und es sind die Sporen, meistens 4 (Fig. 355, II 25, 26), gebildet. Trotzdem die Kerne zu klein sind, um die Details zu verfolgen, erinnert dies alles sehr an die Sporenbildung im Ascus.

Die Zahl der Sporen ist konstanter wie bei Saccharomyces cerevisiat, aber auch hier ist die Zahl variabel.

Das Genus Saccharomycopsis unterscheidet sich von Saccharomyces nur durch den Besitz von 2 Sporenmembranen.

Von der zweiten Gruppe von Hansen sei hier zumächst

\section{Pichia membranifaciens HANSEN}

erwähnt. Sie wurde von Hansen im schleimigen Exsudat von UlmusWurzeln entdeckt. Diese Hefe bildet auf Bierwürze eine Kahmhant und 2 Sporen pro Zelle. Während Hansen die Sporen als halbkugelig, eckig, hut- oder zitronenförmig beschreibt, nennt Gulluiermond sie 
„sphériques ou ovales", bildet aber neben vollkommen runden fast viereckige Sporen ab. Die ebenfalls hierher gehörige

\section{Willia anomala HANseN}

wurde von Hansen in unreiner Hefe einer bayerischen Brauerei gefunden. Die Zellen sind klein, oval, bisweilen länglich. Die Sporen haben die Form eines Hutes, d. h. die einer Halbkugel, welche unten einen breiten Rand besitzt. In jeder Zelle werden 2-4 Sporen gebildet. Sie haben einen Durchmesser von $2-3 \mu$, und erinnern in ihrer Form an die von Ascoidea oder an die von Endomyces decipiens.

Nach Hansen gehören die Schizosaccharomyces-Arten nicht zu den Saccharomyceten. GUILliermond rechnt sie wohl dazu und Barker meint, daß sie durch Saccharomycodes Ludwigii und Saccharomyces verbunden sind.

Diese Auffassung scheint mir richtig; auch meine ich, daß die Genera Zygosaccharomyces und Schirosaccharomyces Licht werfen auf die Weise, in welcher die Saccharomyceten aus Ascomyceten entstanden sein können.

Lernen wir also zunächst das Genus

\section{Schizosaccharomyces}

kennen. Der erste Repräsentant wurde von Lindner entdeckt. Die Gruppe lebt in warmen Ländern, Afrika, der Türkei, Kleinasien etc. und unterscheidet sich von anderen Hefegenera dadurch, daß sie sich nicht durch Sprossung, sondern durch Streckung und Querteilung der Zellen vermehrt.

Es sind 3 oder 4 A1ten bekannt; das hängt davon ab, ob man Schir. asporus mit EIJKMAN als Art oder mit BEIJERINCK als eine Schi\%. pombe betrachtet. Die 3 übrigen Arten bilden wohl Sporen und interessieren uns zumal, weil der Bildung derselben eine Kopulation vorangeht.

Es sind: Schinosaccharomyces Pombe LIndner, octosporus BEIJRINCK, mellacei JöRGENSEN.

Letztere Art ist noch wenig bekannt; sie wurde bei der Rumbereitung auf Jamaica angetroffen; auch sie unterscheidet sich nur wenig von $S$. Pombe und ist nach BEIJERINCK nur eine Varietät derselben.

Am besten bekannt ist

\section{Schizosaccharomyces octosporus.}

Er wurde von BeIJERINck auf Korinthen aus Griechenland, Kleinasien und der Türkei, sowie auf aus Smyrna importierten Feigen entdeckt.

Die Zellen sind kugelig, sie strecken sich vor der Vermehrung und teilen sich quer (Fig. 356, 1). Bisweilen bleiben die Tochterzellen ziemlich lange zusammen, so daß mycelähnliche Fäden gebildet werden. BEIJERINCK fand 8 Sporen in den verlängerten Zellen und schließt aus dieser konstanten Zahl, daß wir hier mit einem typischen Ascus zu tun haben, und also die Saccharomyceten hierdurch definitiv mit den Ascomyceten in Verbindung gebracht werden, eine meines Erachtens etwas sehr optimistische Folgerung.

Glykogen wird bei unserem Organismus nicht gefunden und M.K. sind in nur geringer Quantität vorhanden; der Nucleus läßt sich nur sehr schwer sichtbar machen. 
Man kann den ganzen Entwickelungsgang dieses Pilzes in einem Hängetropfen von Rosinendekokt +8 Proz. Gelatine verfolgen.

Meistens zerreißt die Ascusmembran (Fig. 356, 1), bevor die Sporen zu keimen anfangen. Diese schwellen an, ihre Membran wird dünner und dünner und sie strecken sich zu Zellen normaler Länge. Diese teilen sich mittels einer Querwand (Fig. 356, 2), trennen sich aber nicht direkt, und können sogar durch weitere Teilung ein kurzes Fädchen bilden. Läuft die zweite Wand der ersten parallel, so liegen 3 Zellen hintereinander, steht sie senkrecht auf der ersteren, so entstehen 4 kreuzweise angeordnete Zellen (Fig. 356, 3). Nach wenigen Tagen fängt die Sporenbildung an; die Zellen lösen sich erst voneinander, runden sich $a b$ und kopulieren in Paaren (Fig. 356, 4); nach 3 oder 4 Tagen sind alle Paare zu länglichen Asci verschmolzen (Fig. 356, 6).

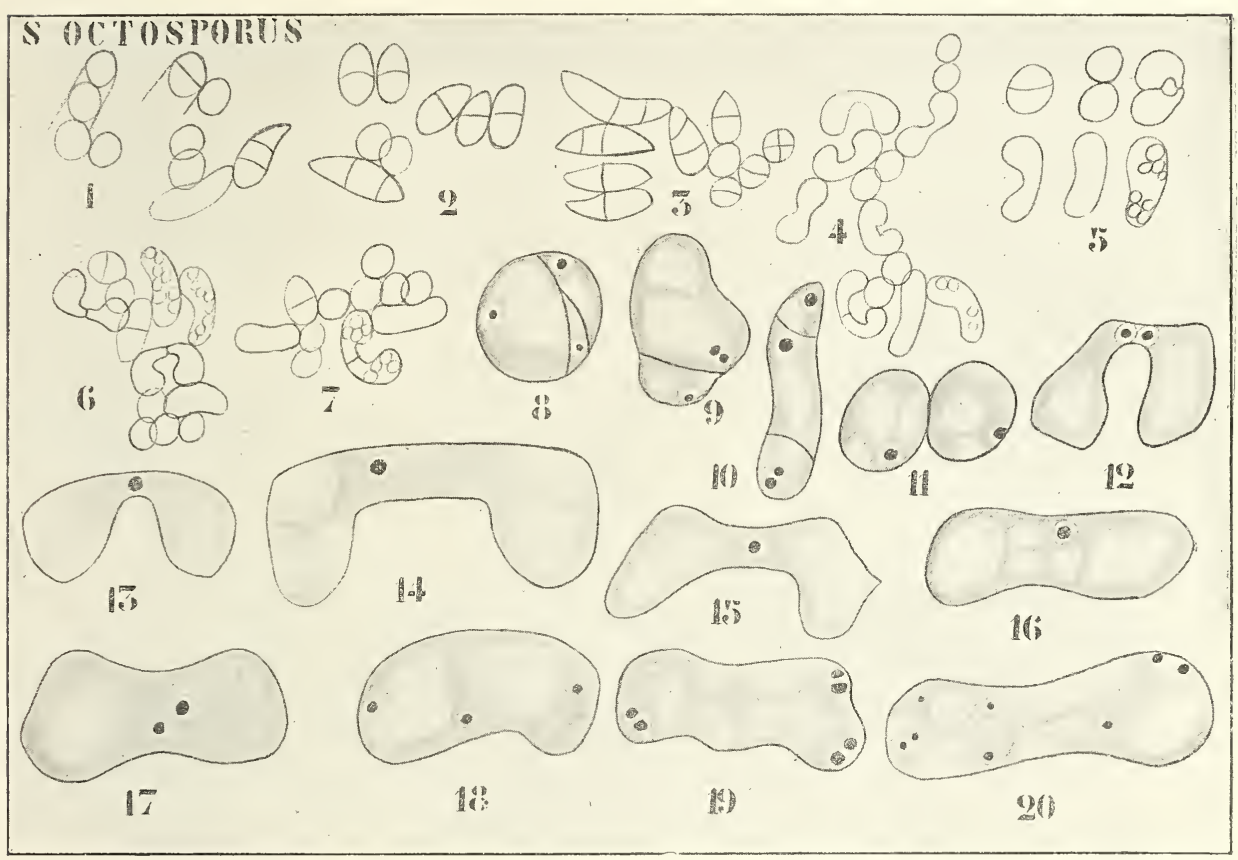

Fig. 356. Schizosaccharomyces octosporus (nach Gullutermond). 1 Die Sporen entschlüpfen aus dem Ascus und keimen. 2, 3 Vermehrung. 4 Kopulation. 5 Gleichfalls. 6 Sporenbildung. 7 Parthenogenetische Sporenbildung. 8-11 Teilung. 12 Erstes Stadium der Kopulation, die Kerne im Kopulationskanal. 13-16 Die Kerne verschmolzen. 17-20 Kernteilung im Ascus.

Oefters kopulieren Schwesterzellen. Dies wurde zuerst von SchiöNNING beobachtet, der dabei einfache Lösung der Querwand beobachtete. In der Regel aber verläuft der Vorgang wie Fig. 356, 5 zeigt, die Zellen bilden seitliche Ausstülpungen, diese fusionieren an den Spitzen, der Kopulationskanal streckt sich, wird weiter, und es ist eine längliche Zelle gebildet, in welcher 8 Sporen in 2 Gruppen ron je $t$ liegen. Der ganze Vorgang kann unterm Nikroskop verfolgt werden, die Einzelfiguren der Fig. 356,5 sind um resp. 8, 10, 1, 2, 5 und 6 Uhr desselben Tages gezeichnet. 
Bei Sch. octosporus können also zwei x-beliebige Zellen kopulieren, ob sie Schwesterzellen sind oder nicht.

In gewissen Fällen finden wir Parthenogenese, die Querwand der kopulierenden Zellen wird nicht gelöst, in jeder entstehen nun 4 Sporen (Fig. 356, 7). Was wissen wir nun von der Cytologie? Dieses: Die Kerne der beiden kopulierenden Zellen verschmelzen, der Fusionskern teilt sich, und jeder der Tochterkerne teilt sich zweimal, so daß jeder 4, beide zusammen 8 Sporen bilden. Fig. 356, 12-20 und Fig. 357, I 23 machen dies ohne weiteres klar.

\section{Schizosaccharomyces Pombe LINDNER}

wurde von Lindner 1890 entdeckt. Er ist viel kleiner wie die vorige Art und kann ziemlich lange Mycelfäden (Fig. 357, II 1) bilden. Auch ent-

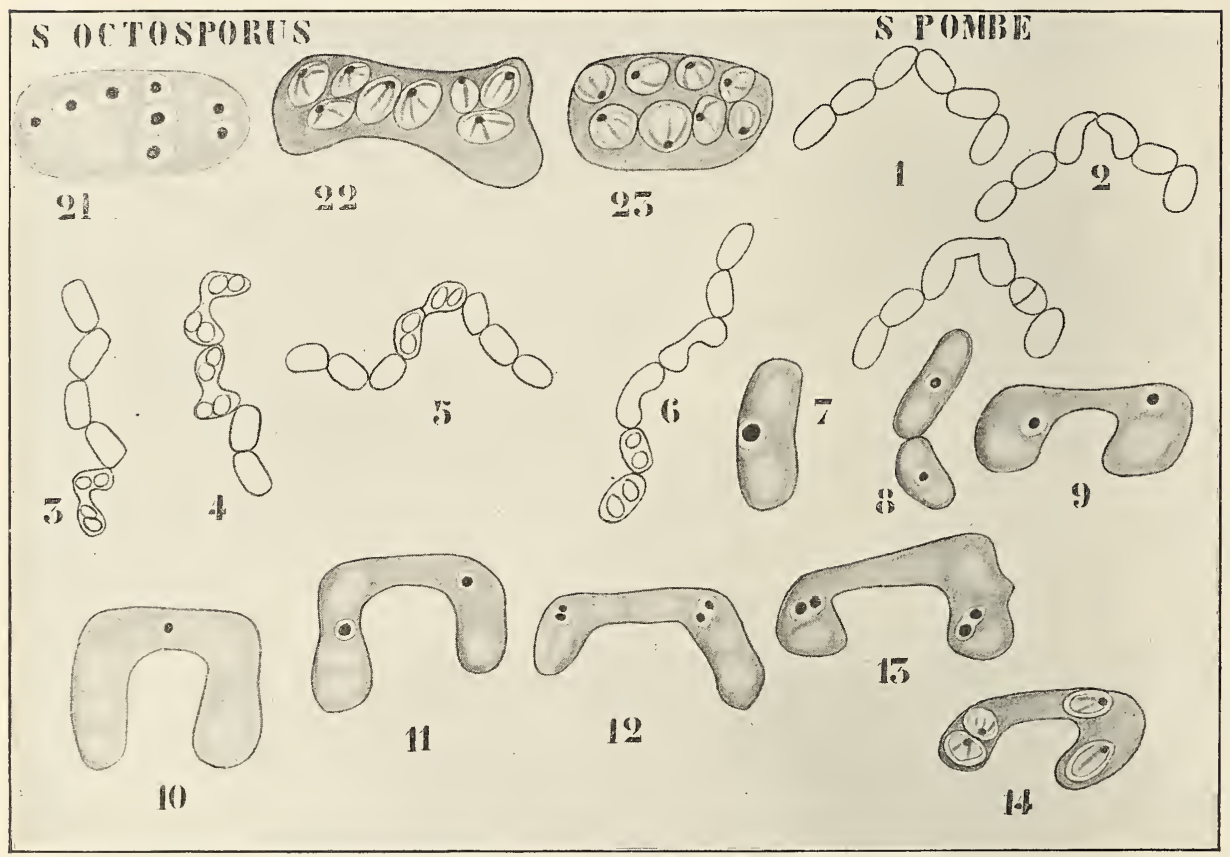

Fig. 357. I. Schizosaccharomyces octosporus (nach GuILliermond). 21-23 Sporenbildung. - II. S ch. Pombe (nach GuIllitermond). 1 Vegetativer Faden. 2-6 Kopulation. 5 Ein Fall von Parthenogenese. 7-14 Cytologie der Kopulation und Sporenbildung.

hält er kein Glykogen. Asci erhält man am besten in kleinen Kolonien auf Dancus-Schnittchen. Auch hier entsteht der Ascus durch Kopulation (Fig. 357, II 2-6). Die Kopulation verläuft im wesentlichen genau wie bei S. octosporus (Fig. 357, 8-14), es werden aber nur 4 (2×2) Sporen statt $8(2 \times 4)$ pro Ascus gebildet.

Obenstehende Figuren machen alles weitere wohl klar. Bei S. mellacei geht die Sache wie bei S. Pombe.

Wie sollen wir nun diese Vorgänge erklären? Möglicherweise so: Bei den Ascomyceten bestand ursprünglich, so wie jetzt noch bei einigen Arten, eine geschlechtliche Fortpflanzung. Gewisse Formen sind partheno- 
genetisch geworden, andere apogam und wieder andere, was man apogam-parthenogenetisch nennen könnte.

Bei den parthenogenetischen Formen entwickelt sich das Ei (resp. die Coenogamete) ohne Befruchtung, z. B. bei Polystigma rubrum; bei den apogamen Formen bilden 2 Kerne aus Hyphen der $x$-Generation ein Synkarion oder einen $2 x$-Nucleus, das ist gleichgültig.

Die Saccharomyceten sind nun vielleicht stark reduzierte Ascomyceten, welche bei Schirosaccharomyces noch apogam, eine $2 \mathrm{x}$-Generation, den Fusionskern bilden, worauf sofort eine Reduktionsteilung folgt. Die anderen Saccharomyceten haben sogar ihre Apogamie verloren, sind apogam-parthenogenetisch geworden.

Die Zelle der Saccharomyceten gehörte dann der x-Generation an, daher ist es indifferent, ob sie 1, 2, 4 oder mehr Sporen pro Zelle bei den apogam-parthenogenetischen Arten bildet; sobald aber Kopulation stattfindet, muß sie doppelt soviel Sporen bilden wie sonst.

Der Ascus von Zygosaccharomyces wäre also ein Diplosporangium, der von Saccharomyces ein Haplosporangium, welches aber phylogenetisch als reduziertes Diplosporangium betrachtet werden könnte.

So ließen sich die Saccharomyceten mit den Ascomyceten in Verbindung bringen; man kann aber nicht behaupten, daß diese Erklärung ungezwungen wäre, deshalb ist es noch recht gut möglich, daß es sich herausstellen wird, daß die Saccharomyceten mit den Ascomyceten nichts zu tun haben.

So sind wir dann am Ende unserer Besprechung der Ascomyceten angelangt, es bleibt nun noch eine große Gruppe höherer Pilze zu betrachten übrig, die der Basidiomyceten. 


\section{Achtundzwanzigste Vorlesung.}

\section{Die Gruppe der Basidiomyceten.}

Die echten Basidiomyceten, z. B. der Champignon, sind charakterisiert durch den Besitz von Zellen, welche an 4 Fortsätzen, sogenannten Sterigmen, 4 Sporen bilden, welche Basidio-Sporen genannt werden.

BREFELD will diese Basidiosporen, und man ist ihm darin ziemlich allgemein gefolgt, von Konidien ableiten. Nach seiner Ansicht sind sowohl die Ascomyceten wie die Basidiomyceten Descendenten von Phycomyceten und zwar zwei von diesen aus parallel verlaufende Entwickelungsreihen.

Bei den Ascomyceten entwickelte sich das Sporangium weiter und wurde zum Ascus; bei den Basidiomyceten entwickelten sich die Konidienträger, indem sie sowohl in Bezug auf die Form wie auf die Zahl der von ihnen produzierten Konidien konstant wurden und sich so in das Basidium, das ist die Zelle, welche die Basidiosporen bildet, verwandelten.

Nach Brefeld ist also der "Hutpilz" eine Konidien produzierende $\mathrm{x}$-Generation, ist die Basidie das Homologon eines Konidienträgers, und in letzter Instanz auch des Ascus, welch letzterer als modifiziertes Sporangium auf einer niedrigeren Entwickelungsstufe wie die Basidie steht, denn Konidien sind abgeleitete Sporangien; nach ihm ist also, wie wir schon sahen, der Ascus ein Haplosporangium.

Von allem diesem trifft nun meines Erachtens nur eins zu, nämlich die Homologie von Ascus und Basidie, aber da wir schon sahen, daß der Ascus ein Diplosporangium ist, muß auch die Basidie ein solches sein. Wir werden sehen, daß dies richtig ist und daß überdies ein Hutpilz eine $2 \mathrm{x}$-Generation darstellt.

Bevor ich die Gründe, auf welchen diese Anschauung beruht, auseinandersetze, scheint es mir am besten, Sie zunächst mit BrEFELDs Anschauungen bekannt zu machen, und dann an diesen an der Hand der neueren cytologischen Untersuchungen Kritik zu üben.

Ich halte mich dabei an die interessanten, wenn auch meiner Ansicht nach gänzlich unzutreffenden Betrachtungen von v. TAVEL.

v. Tavel teilt dann die aus den Phycomyceten hervorgegangene Konidienreihe wie folgt ein :

\section{Hemibasidieae.}

1) Ustilagineae, 2) Tilletieae. 
II. Basidiomyceten.
A. Protobasidiomyceten:
1) Urectineae, 4) Tremellineas;
3) Pilacreae,
B. Autobasidiomyceten:
1) Dacryomyceten, 2) Hymenomyceten, 3) Gastero- myceten, 4) Phalloideae.

Betrachten wir nun einige dieser Gruppen, welche jede für sich noch unserer jetzigen Einteilung so ziemlich entsprechen, wenn wir auch ein anderes Band zwischen ihnen sehen, etwas näher. Fangen wir dazu mit den

\section{Hemibasidieae}

an. Diese Gruppe ist charakterisiert durch den Besitz von Chlamydosporen, welche fruktifikativ, d. h. hier unter direkter Bildung eines Konidienträgers, keimen. Sie nehmen also in BREFELDs Konidienreihe dieselbe Stelle ein, welche Protomyces z. B. in der Sporangienreihe okkupiert, bei letzterer jedoch keimen die Chlamydosporen ebenfalls fruktifikativ, dort aber unter Bildung eines Sporangiums.

Die

\section{Ustilagineae}

sind allgemein unter dem Namen „Brandpilze“ bekannt infolge des verbrannten Aeußeren der Organe, in welchen sie ihre Chlamydosporen bilden. Oefters geschieht dies in den Fruchtknoten, welche durch die sich entwickelnden Sporen violett bis schwarz werden und bisweilen außerordentlich anschwellen. Die Fig. 358 illustriert dies.

Es liegt nun auf der Hand, anzunehmen, daß bei denjenigen Formen, welche ihre Chlamydosporen in den Fruchtanfängen bilden, die Blüten direkt infiziert werden. Das ist nun in der Tat öfters der Fall (vergl. Hecke [1905] und BREFELD und FALK [1905]); aber es kommt diese Infektion auch noch in anderer Weise zu stande, nämlich durch Infektion der jungen Pflanze, lange bevor sie blüht. Man meinte nun früher, daß nur die jungen Keimlinge infiziert werden könnten, daß dagegen die erwachsenen Pflanzen gegen die Infektion immun seien. Das gilt aber nur noch für die vegetativen Teile, da HECKE, BrEFELD und FALK nachgewiesen haben, daß Blüteninfektion stattfinden kann. Diese geschieht in der Weise, daß die jungen Fruchtknoten mit ihren Narben von dem durch die Luft verstäubten Infektionskeime direkt befallen werden, daß der Brand sich aber in demselben Jahre nicht mehr entwickelt, sondern das gebildete Mycel in dem Embryo des Samens überwintert. Das konnte HEcke durch Infektion blühender Gerste mit Brandsporen zeigen, nach welcher er die Mycelnester im Embryo meistens in der Nähe des Vegetationskegels, am reichlichsten, oft ausschließlich, im Scutellum antraf.

Im Keimling, der aus einem solchen infizierten Embryo hervorgeht, entwickelt sich dann der Pilz in derselben Weise weiter, wie unten bei der Infektion der jungen Pflanzen beschrieben ist.

Wir haben schon gesehen, daß die Chlamydosporen der Ustilagineen unter Bildung eines Konidienträgers keimen. Diese Chlamydosporen gelangen nun beim Brand unserer Getreidearten entweder in die Blüten anderer Individuen, welche sie dann, wie oben erwähnt, infizieren können, meistens aber mit der Saat in den Boden. 
Nehmen wir als Beispiel die von BREFELD sorgfältig untersuchte

\section{Ustilago segetum Bull.}

oder U. carbo, welche den Flugbrand des Hafers verursacht. In gedüngtem Boden keimen die Chlamydosporen mittels eines Promycels (Fig. 359, I 1), welches aus ziemlich langen Zellen besteht, die seitlich - die Endzelle auch apikal - Konidien produzieren.

Diese Konidien vermehren sich mittels Sprossung in der Weise wie Hefezellen (Fig. 359, I 2) bis ins Unendliche. Wenn aber das Erdkrümchen, auf welchem sie sproßten, erschöpft ist, d. h. ihm alle Nahrung entzogen ist, wachsen sie zu Keimschläuchen aus (Fig. 359, I 4) und diese sind es, welche junge Haferpflanzen infizieren können.

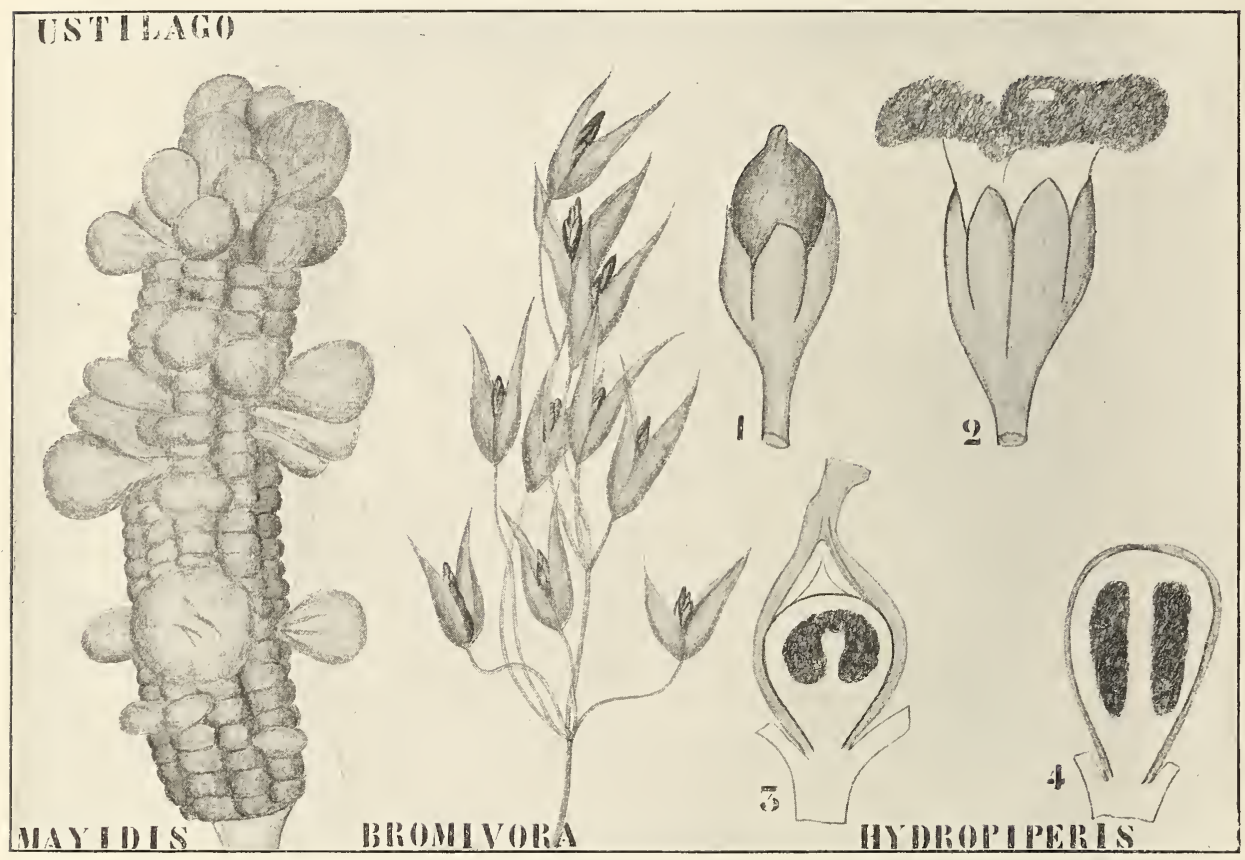

Fig. 358. Verschiedene Ustilago-Arten. I. Ustilago maydis (DC.) TuL. (nach DieTEL). - II. Us tilago bromivora (nach DieTEL). - III. Ustilago H ydropiperides (Schum.) Schröt., in der Blüte von Polygonum Hydropiper (nach DE BARY). 1 Reifer Fruchtkörper des Pilzes, aus der Blüte hervorragend. 2 Aufgesprungener Fruchtkörper, der weiße Fleck oben ist die Spitze der Columella. 3 Längsschnitt durch einen gaṇz jungen Fruchtkörper. 4 Durch einen älteren.

Mittels Kulturen konnte Brefeld nachweisen, daß die hefeartige Sprossung, von welcher oben die Rede war, nicht ohne Schaden bis ins Unendliche fortgesetzt werden kann. Hat sie in nahrungsreichen Kulturen etwa 10 Monate angehalten, so verlieren die Konidien das Vermögen, sogar wenn die Nährlösung nicht erschöpft ist, Keimschläuche zu bilden, womit sie also auch ihr Infektionsvermögen eingebüßt haben.

Sie können nun weiter die Haferpflanze nur dann infizieren, wenn sie in eben keimenden Körnern wie jungen Pflänzchen auf der Grenze des Wurzelknotens eindringen können. Sie durchbohren dort zunächst 
die Epidermis und wachsen damn durch die tieferen Schichten hindurch, bis sie den Vegetationspunkt erreicht haben. Kann der Parasit den Tegetationspunkt nicht erreichen, was z. B. der Fall ist, wenn das Haferpflänzchen zu schnell wächst, so mißlingt die Infektion.

In dem Tegetationspunkt nu bleiben die Hyphen unseres Pilzes latent; infizierte Pflanzen sind von gesunden nicht zu unterscheiden, der Pilz schadet seinem Wirt vorläufig nicht. Er wartet hier ruhig ab, bis die Blüten angelegt werden, dann erwacht er, dringt in die Fruchtknoten vor und bildet dort Chlamydosporen, welche einfach durch Anschwellung von Myceliumzellen entstehen, nachdem sich die Hyphen hier stark verzweigt haben. Dabei verschleimen die Zellwände und die Sporen entstehen durch Bildung einer neuen Membran innerhalb der alten Zelle

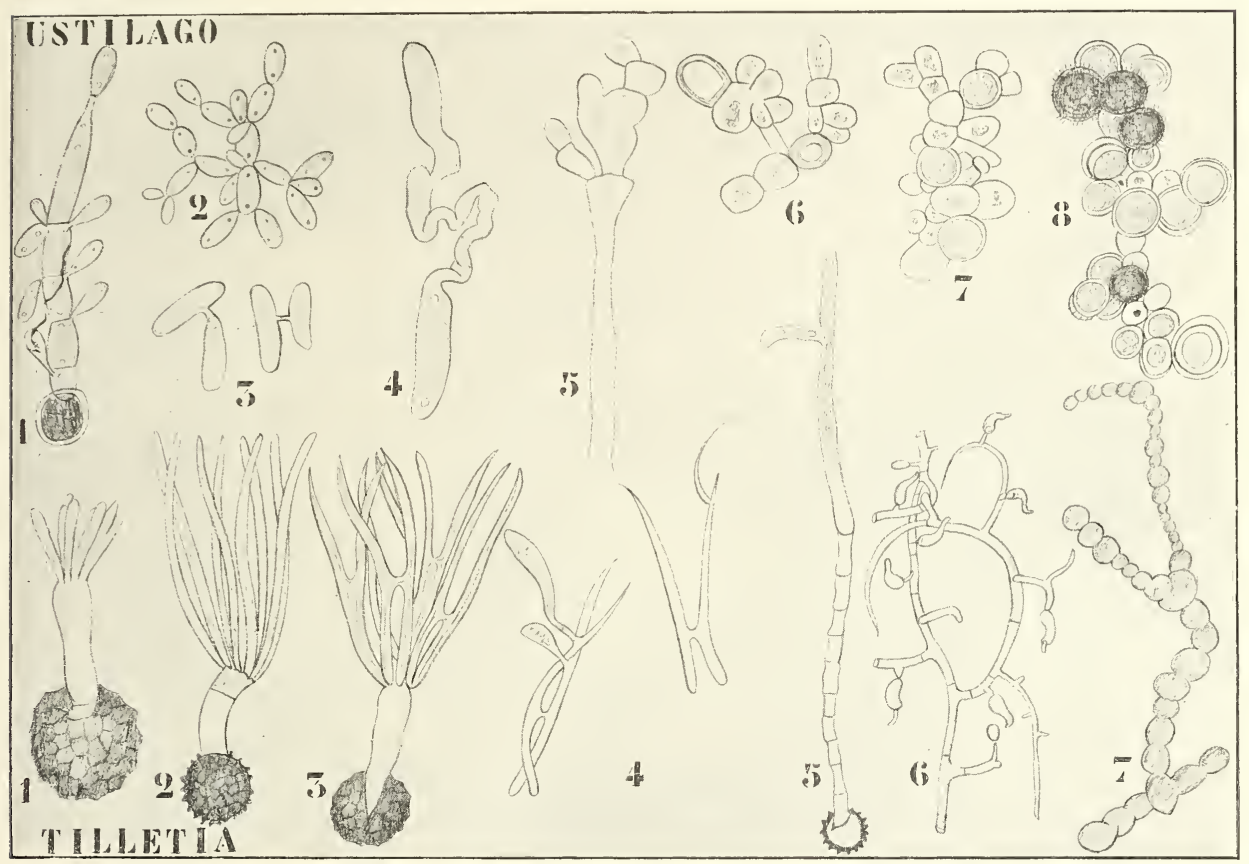

Fig. 359. I. Ustilago segetum (nach BREFELd und DANGEARD). 1 Fruktifikative Keimung der Chlamydosporen. 2 Hefenartig sprossende Konidien. 3 Kopulierende Konidien. 4 Vegetativ keimende Konidie. 5-8 Chlamydosporenbildung. - II. Tilletia caries (nach DE BARY, BREFELD und DANGEARD). 1, 2 Keimungsstadien der Chlamydosporen. 3 Kopu. lation der Konidien. 4 Links: Bildung von Sekundärkonidien, rechts: Bildung eines Keimschlauches. 5 Eine zu tief vergrabene Chlamydospore bildet mehrere leere Zellen, um über den Boden hervortreten zu können. 6 Konidienbildung an einem Mycel in Nährlösung. 7 Chlamydosporenbildung in Nährlösung.

(Fig. 359, I 5-8), mutatis mutandis also ebenso, wie sich die Chlamydosporen in den Sporangienträgern der Mucor-Arten bilden.

Das Mycel wird dabei ganz verbraucht, so daß schließlich die Chlamydosporen als eine schwarze Staubmasse in der Blüte liegen und vom Winde verbreitet werden; daher der Name Staubbrand.

Was wissen wir nun von der Cytologie dieser Organismen? Bis jetzt recht wenig. 
Schmitz fand im Mycel von Ustilago longissima viele Kerne; bei der Sporenbildung wird es in einkernige Zellen zerlegt, deren jede eine Chlamydospore bildet. Zum gleichen Resultate gelangte Fisch.

In den Konidien, welche sich hefeartig vermehren, fand Moeller nur einen Kern pro Zelle, und auch DANGEARD kommt zu dem gleichen Resultate. Dagegen fand Istvanffi bei einer Anzahl von UstilagineenKonidien 3 Kerne pro Spore, einen in der Mitte und einen an jedem Pole, während bei $U$. antherarum nach ihm die Kernteilung der Sprossung vorangeht, so daß man Konidien mit einer größeren Zahl von Kernen finden kann.

In den Mycelzellen, welche die Chlamydosporen bilden, fand DANGEARD 2 Kerne, welche später miteinander verschmelzen, so daß die Chlamydospore nur einen Kern besitzt. Darin erblickt er einen Sexualakt und hält deswegen die Chlamydosporen für Zygoten. Die Zellen des Promycels sind, wie er meint, wieder einkernig. Beim verwandten Genus Tilletia (Fig. 359), wo die Sporidien meistens fusionieren, besitzt jede Konidie einen Kern und diese verschmelzen nach DaNGEARD nicht.

Wie wir sehen, widersprechen sich manche cytologische Angaben.

So findet z. B. Moeller pro Konidie 1 Kern, Istvanffi 3, davon einen in der Mitte und je einen an jedem Pole; kurz vor der Keimung aber viele.

MaIRE zeigte nun zunächst, daß MoELler recht hatte und daß die beiden polaren Kerne Istvanffis keine Kerne, sondern metachromatische Körperchen sind. Das wurde von GuILliERmond bestätigt, der weiter nachwies, daß auch die vielkernigen Konidien von IsTvANFFI in der Tat einkernig sind und daß auch hier der Irrtum von der Anwesenheit metachromatischer Körperchen verursacht wurde.

Es bleibt die Frage, inwieweit die Verschmelzung der Kerne in den Chlamydosporen richtig ist. MaIRE versuchte darüber Sicherheit zu erlangen, konnte aber wegen den großen mit der Färbung verknüpften Schwierigkeiten zu keinen bestimmten Resultaten gelangen. Sicher darf man auch hier, sowie bei den vielkernigen Hyphenzellen von ScHмiтz, an einen durch die Anwesenheit von metachromatischen Körperchen verursachten Irrtum denken.

Wahrscheinlich scheint es mir demnach, daß die Ustilagineae rein monoenergide Organismen sind ohne eine Spur einer geschlechtlichen Fortpflanzung.

Sehen wir nun, welche Basidiomyceten-Eigenschaften sie besitzen, so muß die Antwort lauten: keine einzige, und ebensowenig wie ich in den Hemiasci Uebergangsformen von den Phycomyceten zu den Ascomyceten erblicken kann, kann ich solche in den Hemibasidien zwischen jenen und den Basidiomyceten sehen.

Betrachten wir zunächst noch einige andere Ustilagineen. Während bei der soeben besprochenen $U$. segetum die in den Fruchtknoten eingedrungenen Hyphen ganz zur Bildung von Chlamydosporen verbraucht wurden und man also bei diesem Pilz nicht von einem Fruchtkörper reden kann, gibt es andere Arten, bei denen eine Differenzierung in sterile und fertile Hyphen stattfindet und bei welchen man also mit einigem Recht von einem Fruchtkörper reden kann. Das ist z. B. der Fall bei

\section{Ustilago Hydropiperides,}

welchen Unterschied DE BARY für wichtig genug hielt, um ihm als Typus eines neuen Genus den Namen Sphacelotheca Hydropiperides zu geben. 
Der Fruchtkörper wird hier im Eichen von Polygonum hydropiper gebildet. Das Eichen ist orthotrop, die Myceliumfäien dringen durch den Blütenstiel und durch den Blütenboden bis in den Fruchtknoten ein und erreichen das Eichen durch den Foeniculus. Sie mumifizieren die Samenknospe nun ganz; nur die Spitzen der Integumente bleiben frei und wie eine Art Calyptra auf der Hyphenmasse sitzen (Fig. 358, III 3). Diese Hyphenmasse besteht aus gelatinösen Fäden, nimmt an Volumen zu und es wird das Ganze eiförmig. Alsbald differenzieren sich darin nun ein oder zwei Sporenmassen (Fig. 358, III 3, 4), während die peripheren Pilzhyphen eine Art Wand bilden. Von unten findet stets Zuwachs und Differenzierung in die verschiedenen Gewebeformen statt, wodurch der Fruchtkörper cylindrisch wird; schließlich zerreißt er an der Spitze und streut die Sporen aus.

In diesem Falle wird nur die Samenknospe der Blüte infiziert, die Staubfäden bleiben intakt; wir können also sagen, daß wir hier einen Pilz vor uns haben, der die Blume kastriert in Bezug auf die weiblichen Geschlechtsorgane.

Dagegen gibt es andere Ustilago, welche die männlichen Organe kastrieren, die Staubfäden vernichten, und die doch - wie paradox dies auch klingt - das Vermögen besitzen, Staubfäden in Blüten entstehen zu lassen, welche solche normalerweise nicht besitzen, die sie dann sofort wieder vernichten.

Das ist der Fall bei

\section{Ustilago violacea.}

Dieser Pilz lebt in den Blumen von Melandryum album Garcke $=$ Lychnis vespertina SIвтн (1794) und in denen von Melandryum rubrum GARCKE = Lychnis diurna SIBTH (1794), welche Arten früher nur als Varietäten von Lychnis dioica L. betrachtet wurden.

Es ist Ihnen bekannt, daß diese Pflanzen ơ und $q$ Blüten produzieren; werden nun ơ Blüten infiziert, so wächst der Schimmel in die Staubfäden hinein und reift seine Chlamydosporen in den Antheren, kastriert diese also; infiziert er aber $q$ Blüten, so verursacht er in diesen zuerst die Entstehung der Organe, in welchen er seine Chlamydosporen bilden kann, d. h. er veranlaßt sie zur Staubfädenbildung, verwandelt also eine $\$$ Blüte in eine hermaphrodite, um diese aber sofort durch Kastration der Staubfäden wieder $q$ zu machen. Dies ist um so merkwürdiger, als kein anderer Reiz bekannt ist, der aus einer $q$ Blüte eine hermaphrodite bilden kann.

VuIllemin meinte, daß dies nicht richtig wäre. In den q Blüten von Melandryum befinden sich nämlich mit der Lupe kaum sichtbare Staubfädenrudimente, und nun meinte Vuillemis, daß der Pilz nur die Hypertrophie eines solchen Höckerchens veranlaßte, daß diese Rudimente aber nicht im stande wären, ein Archespor zu bilden, also nicht als Staubfäden betrachtet werden dürften. Magnin und Strasburger (1900) wiesen jedoch nach, daß dies wohl der Fall ist, daß der Pilz erst diese Rudimente zum Auswachsen zu echten Staubfäden mit einem Archespor reizt, und erst dann virulent wird und sie vernichtet.

Die Anwesenheit des Pilzes wirkt hier, trotzdem er den Fruchtknoten nicht infiziert, schädlich auf diesen eiu; wohl können Eichen g'ebildet werden, ein Embryosack entwickelt sich aber nicht.

Daß man trotzdem von infizierten Pflanzen Samen gewimnen kann. rührt daher, daß die Wirkung des Pilzes sich auf die infizierten Blïten 
beschränkt und die nicht infizierten derselben Pflanze normale Samen liefern.

Wir haben also in Ustilago violacea ein Mittel, um einen morphogenen Reiz auf die + Blüten von Melandryum auszuüben, wodurch Staubfäden gebildet werden, und bis jetzt ist sie das einzige Mittel dazu.

Alle Ustilago, welche wir bis jetzt besprochen haben, bilden ihre Chlamydosporen in Blüten; das ist aber keineswegs immer der Fall. Ustilago bistortarum bildet z. B. ihre Chlamydosporen in Gallen, welche sie auf den Blättern von Polygonum bistortum verursacht, und Ustilago Treubii bildet ihre Chlamydosporen in Stengelteilen von Polygonum sinense, einer Pflanze, welche auf Java, woher dieser Pilz stammt, häufig ist.

5

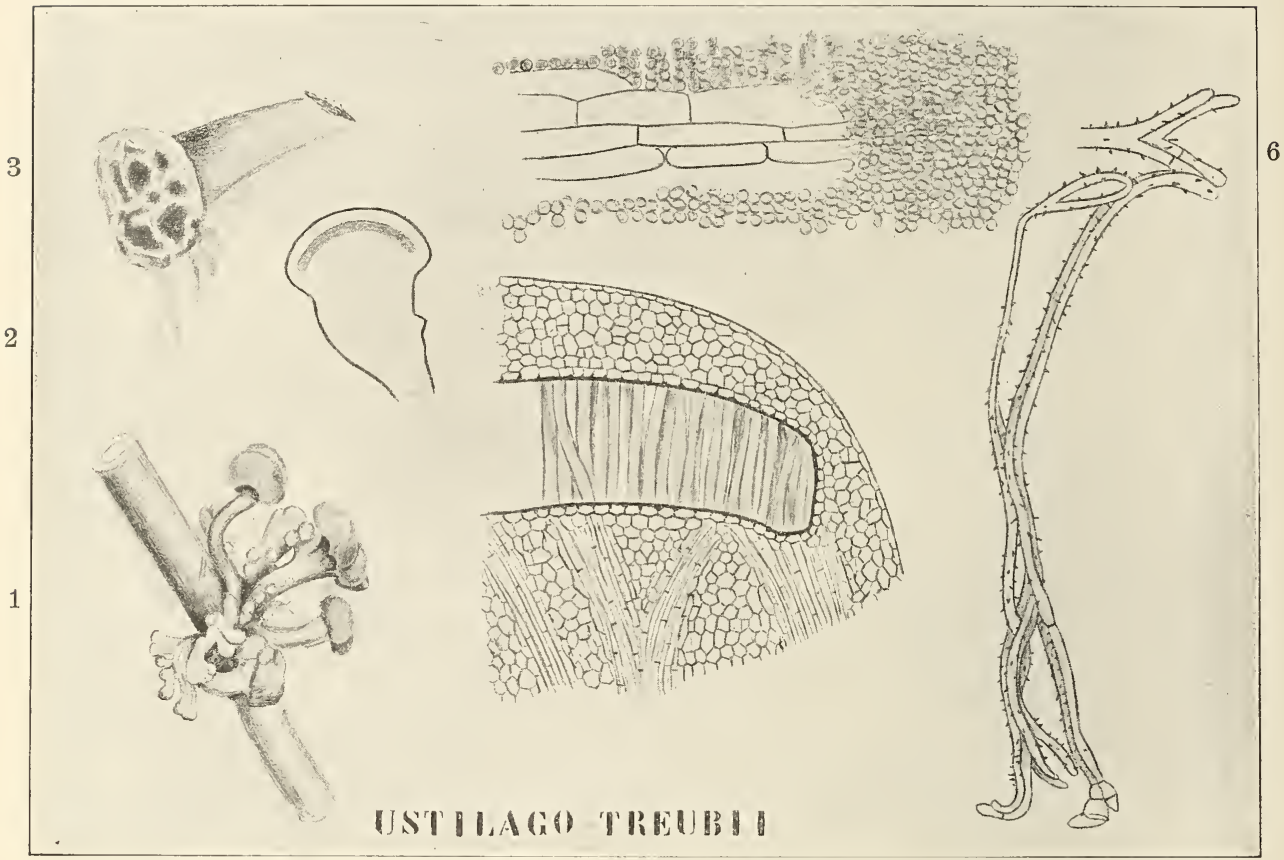

4

Fig. 360. Ustilago Treubii (nach Solms). 1 Polygonumstamm mit den Fruchtgallen von Ustilago Treubii. 2 Längsschnitt einer Fruchtgalle, das Sporenlager zeigend. 3 Reife eröffnete Fruchtgalle des Pilzes mit heraushängenden Capillitiumflocken. 4 Längsschnitt des Sporenlagers einer reifen Fruchtgalle nach Auspinselung der Sporen. 5 Stück eines einzelnen von seiner Sporenhülle umgebenen Capillitiumstranges aus der reifen Fruchtgalle. 6 Fadengeflecht des Capillitiums.

Er bildet große hutpilzähnliche, von den reifenden Sporen violett gefärbte Gallen auf den Stengeln des Wirtes (Fig. 360, 1). Schneidet man eine solche Galle der Länge nach durch, so findet man das Sporenlager des Pilzes nahe der Spitze und der Oberfläche parallel (Fig. 360, 2). Die dünne Gewebeschicht oberhalb der Sporenschicht zerreißt später unregelmäßig (Fig. 360,3) und erlaubt so den Sporen das Austreten, wobei offenbar ein jetzt sich zeigendes capillitiumähnliches Fadengeflecht Dienste erweist. 
Gerade dieses Capillitium ist nun die interessanteste Bildung im Leben dieses Pilzes, da es nicht vom Pilze, sondern vom Wirt gebildet wird.

Während die Galle außer den darin verlaufenden Gefäßbündeln aus Parenchym besteht, ist die Schicht, wo sich die Sporen bilden, sehr eigentümlich ausgebildet. Sie besteht nämlich aus einer Anzahl untereinander paralleler Säulen (Fig. 360, 4). Nähere Betrachtung lehrt, daß jede Säule aus einer oder mehreren Reihen langgestreckter cylindrischer Zellen besteht, und daß jeder Strang von einer dicken Schicht violetter Sporen umgeben ist. Solange die Galle geschlossen ist, sind diese fest mit den Säulen verklebt, sie lösen sich erst ab, wenn sich die Galle geöffnet hat, und die Säulchen hängen dann als Capillitiumfäden heraus.

Hier bildet also der Wirt das Capillitium für den Parasiten, fördert also die Verbreitung desselben und schadet sich selbst.

Dies mag Ihnen eine genügende Einsicht in die Gruppe der Ustilagineen gegeben haben, wenden wir uns also der zweiten Gruppe der Hemibasidii, der der

\section{Tilletiaceae}

zu. Sie unterscheidet sich von der Gruppe der Ustilagineae durch das Produkt der Keimung der Chlamydosporen. Während bei den Ustilagineen ein vielzelliges Promycel gebildet wurde, welches lateral die Konidien, auch wohl Sporidien genannt, abschnürte, ist dieses Promycel bei den Tilletiaceen einzellig und bildet seine Konidien terminal (Fig. 359, II 1). Zwar kann der Keimschlauch septiert werden, wenn die Konidien z. B. tief unter Wasser keimen (Fig. 359, II 5), aber damit wird er noch nicht wirklich vielzellig, denn nur die terminale Zelle enthält eine Energide, die übrigen sind leer; sie entstehen dadurch, daß das vorwärts kriechende Plasma stets hinter sich eine Querwand bildet.

Die Konidien können unter Fusion mit einer anderen oder ohne solche keimen, und dann entweder Keimschläuche oder Konidien bilden (Fig. 359, II 4). Die Keimung geschieht hier meistens, nachdem die Konidien abgefallen sind, die Fusionierung öfter, bevor dies geschah, wodurch die Konidien in H-förmigen Paaren an der Spitze des Promycels stehen (Fig. 359, II 3). In solchen Paaren fallen sie dann auch ab (Fig. 359, III 4).

Die sekundären Konidien keimen ebenfalls mit einem kurzen Keimschlauch. Dies alles gilt für die Keimung in Wasser. Läßt man aber die Konidien in guter Nährlösung kéimen, so bildet sich ein kräftiges septiertes Mycel (Fig. 359, II 6), welches an kurzen Seitenzweiglein Konidien bildet.

Cytologisch wurde die Sache von DANGEARD untersucht, aber da diese Untersuchungen zu einer Zeit gemacht wurden, als man noch nicht zwischen Kernen und metachromatischen Körperchen unterschied, genügt es wohl, hier mitzuteilen, daß man sie in Le Botaniste, 3. Série, finden kann. Nachuntersuchung wäre gewiß erwünscht.

Vermutlich sind auch die Tilletieae monoenergide Formen ohne eine Spur einer Sexualität; möglicherweise aber sind sie polyenergid. Machen wir zunächst einmal die nähere Bekanntschaft einiger Tilletieae.

Tilletia caries

oder T. tritici, an welcher wir schon die Keimung der Chlamydosporen kennen lernten, verursacht den so gefürchteten Stinkbrand oder Stein- 
brand des Weizens. Aeußerlich ist den kranken Pflanzen nichts anzusehen, die Früchte sind scheinbar gut und kräftig geraten, aber die Spelzen umschließen nur eine schwarzbraune, leicht zerstäubende und nach Heringen riechende Brandsporenmasse. Meistens sind alle Früchte einer Aehre infiziert. Die olivenbraunen, kugeligen Sporen zeigen netzförmige, anastomosierende Leisten; sie keimen bei genügender Feuchtigkeit in wenigen Tagen, aber können sogar 81/2 Jahre trockenes Aufbewahren vertragen.

Am kurzen, dicken Promycel entstehen 4-12 in einem Kranz um die Spitze gestellte, fadenförmige Sporidien, in welche der Inhalt des Promycels hineintritt. Diese Sporidien können, wie wir schon bemerkten, bei der Keimung sekundäre Sporidien bilden. Beide entwickeln sich in

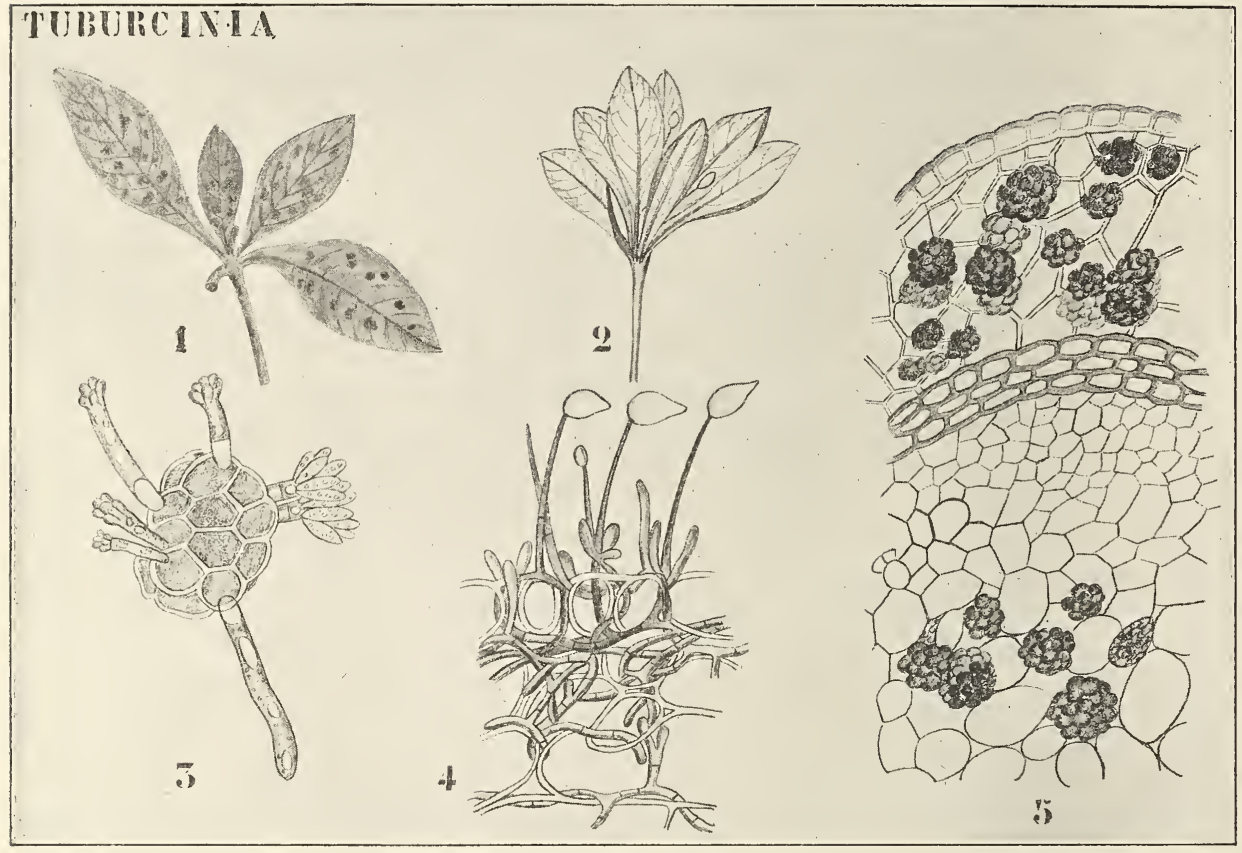

Fig. 361. Tubureinia trientalis (Berk. et Br.) Woron. (nach Woronis). 1 Chlamydosporenlager auf den Blättern. 2 Konidienlager auf der Unterseite junger Blätter. 3 Keimender Sporenballen. 4 Konidien. 5 Chlamydosporenballen.

gleicher Weise; sie keimen mit einem Schlauche, der in derselben Weise in die jungen Keimpflänzchen von Weizen eindringt, wie dies Ustilago in Haferpflänzchen tut. Auch die weitere Entwickelung verläuft ebenso.

Während man aber von Ustilago nur in der Wirtspflanze Chlamydosporen erhalten kann, gelang es BREFELD, an Tilletia auch in künstlichen Kulturen Chlamydosporen zu erzielen. Auf bestimmten Nährböden hören die aus den Konidien gebildeten Hyphen nach einiger Zeit zu wachsen auf, und verdicken sich torulös. Darauf bilden sich Querwände, welche sich spalten, wodurch die Zellen sich isolieren und nach Bildung der Membranskulptur zu Chlamydosporen werden (Fig. 35̃9, II 7).

Während nun Tilletia auf ihrem Wirt nur Chlamydosporen, nie Konidien bildet, gibt es andere Genera, bei welchen sowohl die Chlamydo- 
sporen wie die Konidien auf dem Wirt gebildet werden. Während also bei Tilletia das Chlamydosporenmycel parasitisch, das Konidienmycel (resp. Promycel) saprophytisch lebt, sind bei anderen Genera beide Parasiten, so z. B. bei der von Woronin beschriebenen

\section{Tuburcinia trientalis,}

welche sich weiterhin noch von Ustilago dadurch unterscheidet, daß die Chlamydosporen in Ballen gebildet werden.

Die Chlamydosporen entstehen in den Blättern von Trientalis europaea und bilden an der Oberseite derselben graue Flecke (Fig. 361, 1).

Sie entstehen aus dicht geknäulten Mycelfäden, so daß sie in Ballen zusammen liegen (Fig. 361, 5). Diese Ballen sind dunkelbraun, anfangs .

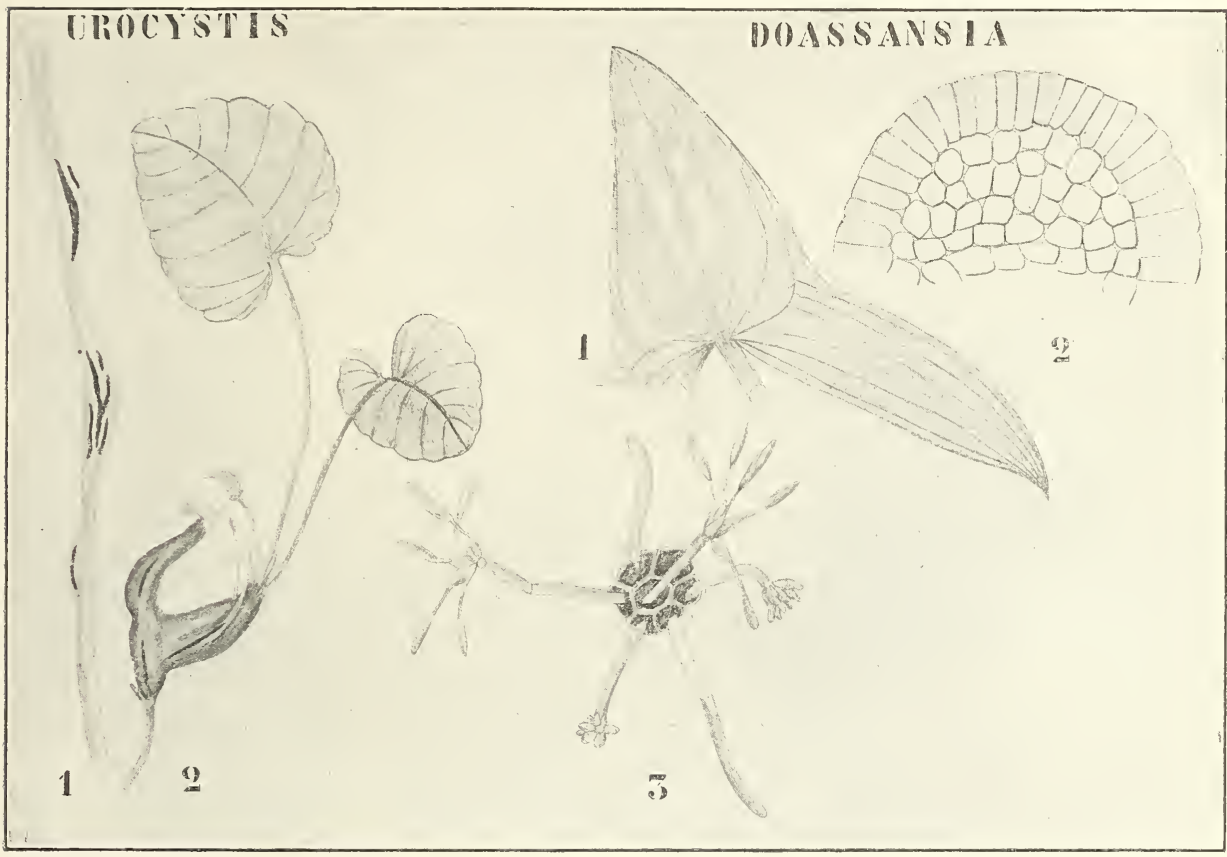

Fig. 362. I. Urocystis violae (Sow.) F. v. WaldH. (nach Dretel u. Brefeld). 1, 2 Habitusbilder des Pilzes an Viola odorata. 3 Keimender Chlamydosporenballen. - II. Doassansia (nach DieTEL). 1 D. sagittariae, die vom Pilze verursachten Flecken auf einem Sagittaria-Blatte zeigend. 2 D. alismatis, Teil eines Schnittes durch einen Chlamydosporenballen.

von einer sterilen Hyphenschicht eingehüllt, welche jedoch bald zerstört wird. Die Chlamydosporen gelangen als solche ins Freie, jede Spore keimt aber für sich, und bildet in der Weise von Tilletia ihre Sporidien (Fig. 361, 3), welche in Paaren fusionieren und sekundäre, ja sogar tertiäre Sporidien bilden können.

An der Unterseite des Blattes entstehen zahllose Konidienträger (Fig. 361, 4), welche aus den Spaltöffnungen hervorragen und eiförmige Mycelkonidien bilden. Sie entstehen im Frühjahr an der Unterseite blasser, klein bleibender Blätter in solcher Zahl, daß sie einen weißen Pilzüberzug bilden (Fig. 361, 2). 
Diese Konidien infizieren neue Pflanzen, auf welchen sie kleine, Chlamydosporen bildende Mycelien verursachen. Als man ihre Zugehörigkeit zu den Chlamydosporen noch nicht kannte, wurden sie als Ascomyces Trientalis BERK. beschrieben. Von dieser Tuburcinia unterscheidet sich

\section{Urocystis violae}

eigentlich nur durch das Fehlen der Mycelkonidien und dadurch, daß die Außenschicht der Chlamydosporen bildenden Hyphenknäuel steril bleibt, wodurch eine permanente Hülle um die Chlamydosporenballen herum gebildet wird (Fig. 361, 3).

Sie verursacht lange grünbleibende Anschwellungen an Blattstielen, Blattnerven und Ausläufern von Viola, welche sich mittels Längsrissen öffnen und die dunkel braunroten Sporen austreten lassen. Auch hier können sekundäre, tertiäre, ja quaternäre Sporidien gebildet werden.

Doassansia, welche auf Alisma und Sagittaria gelbe, später braune Flecken bildet, besitzt ebenfalls Chlamydosporenballen. Die sterilen Hüllzellen sind hier meistens radiär gestellt (Fig. 362, II 2) und dunkler gefärbt wie die Sporen, sie dienen dazu, den Sporenballen auf dem Wasser schwimmen zu lassen. Auch hier keimen die Sporen mit fusionierenden Konidien, welche sich in Nährlösung hefeartig vermehren können und zwar in solchem Grade, daß sie dicke Kahmhäute bilden.

Werfen wir nun einen Rückblick auf BREFELDS Gruppe der Hemibasidii, so sehen wir, daß kein Grund vorliegt, diese als mit den Basidiomyceten verwandte Organismen zu betrachten. Weshalb BREFELD dies wohl tat, werden wir bei der Behandlung der echten Basidiomyceten sehen.

Auch hier sah DE BARY meines Erachtens die Sachen besser ein, er weist darauf hin, daß bei Protomyces die Sporen, welche im Sporangium entstehen, fusionieren und meint, daß sowohl Protomyces wie die Ustilagineae und Tilletieae Verwandtschaftsbeziehungen zu den Chytridiaceen zeigen, aus welchen man sich die Protomyceten als sporangientragende, die Hemibasidii als konidientragende Reihe hervorgegangen denken kann.

Nach oben zu haben die Hemibasidii nach DE Barys Meinung keinen Anschluß; sie stellen das Ende einer von den Chytridiaceen ausgehenden Entwickelungsreihe dar. Man meine aber nicht, daß DE BARY diesen Anschluß für bewiesen hielt, er gibt ihn nur als eine Möglichkeit; weiter sind wir auch jetzt nicht.

Schreiten wir jetzt zur Besprechung der

\section{Basidiomyceten ${ }^{1}$,}

und betrachten wir zunächst Brefelds Gruppe der

\section{Protobasidiomyceten,}

zu welchen er die Familien der Uredineae, Auricularieae, Pilacreae und Tremellineae bringt.

Betrachten wir zunächst die erste Familie, die der Uredineae.

1) Ich ziehe vor, statt diesem Namen die Bezeichnung Teleutosporineae zu verwenden und den Begriff Basidiomyceten zu beschränken auf die Protobasidiomyceten nach Ausschluß der Uredineen und auf die Autobasidiomycelen, man vergl. S. 665. 


\section{Neunundzwanzigste Vorlesung.}

\section{Die Uredineae.}

Die Uredineae oder Rostpilze sind monoenergide Pilze, welche parasitisch auf Phanerogamen leben, durch die orangegelbe Farbe ihrer Hyphen und Sporen auffallen, und auf den ersten Blick eine verwirrend große Zahl von Fortpflanzungszellen produzieren.

$\mathrm{Zu}$ einer kompletten Uredinee gehören nämlich nicht weniger wie 5 verschiedene Arten von Fortpflanzungszellen, nämlich:

1) Aecidiosporen, in Aecidien gebildet,

2) Spermatien, in Spermogonien gebildet,

3) Uredosporen, in Uredolagern gebildet,

4) Teleutosporen, zwischen den Uredosporen oder in gesonderten Teleutosporenlagern gebildet,

5) Sporidien, auf dem Keimschlauch der Teleutospore gebildet.

Da man früher die Zusammengehörigkeit dieser Sporenformen nicht kannte, hat man dieselben Pilze das eine Mal Aecidium, das andere Mal Uredo genannt etc.; jetzt benennt man sie meistens nach den Wintersporen, welche die einfachsten Merkmale aufweisen.

Die am meisten auffallenden Fortpflanzungsorgane sind:

die Aecidien, kleine Becherchen, in welchen die Aecidiosporen in großer Zahl gebildet werden;

die Spermogonien gleichen, abgesehen von der orange Farbe, denen der Pyrenomyceten;

die Uredosporen sind einzellige Sporen, welche auf einfachen Konidienträgern abgeschnürt werden; ihre Wand ist dünn; die Teleutosporen werden ganz wie die Uredosporen gebildet, sind aber mehrzellig und besitzen eine dicke Wand;

die Sporidien entstehen in der 4-Zahl an dem septierten Keimschlauch der Teleutospore, welchen man Promycel nennt; ihre Wand ist sehr dünn.

Die Verbindung zwischen diesen verschiedenen Fortpflanzungsorganen ist folgende:

Aecidien und Spermogonien werden auf dem gleichen Mycel gebildet; die Aecidiosporen liefern nach der Aussaat ein Hycel, welches Uredosporen produziert. Diese Uredosporen setzen den Pilz in den Stand, sich während der günstigen Jahreszeit stark zu vermehren; sie erfüllen, trotzdem sie diesen, wie wir sehen werden, nicht homolog sind, die Rolle der Konidien der Erysipheen. Nachdem so während des 
Sommers eine große Zahl Uredosporen produzierende Mycelien entstanden sind, bilden sich im Herbst zwischen den Uredosporen auf denselben Mycelien die Teleutosporen.

Mittels dieser Teleutosporen überwintert der Pilz; diese keimen im Frühjahr, bilden an ihrem Promycel die Sporidien und diese keimen zu einem Mycel, das wieder Aecidien und Spermogonien bildet.

Es ist nun durch die Untersuchungen von Sappin-Trouffy, DanGEard, Raciborski und Blackman festgestellt worden, daß wir hier mit einem echten Generationswechsel zu tun haben, daß bei den Uredineen zwischen einer $\mathrm{x}$ - und einer $2 \mathrm{x}$-Generation unterschieden werden muß. Und zwar produziert die $x$-Generation Aecidien und Spermogonien, die $2 \mathrm{x}$-Generation Uredo- und Teleutosporen: letztere beiden Organe sind also nicht den Konidien der Erysipheen homolog, denn sie werden auf der $2 x$-Generation gebildet; es erfüllen aber die Uredosporen die gleiche Rolle, man könnte sie also Diplokonidien nennen; die Teleutosporen sind, wie wir alsbald sehen werden, den Basidien homolog und fungieren als Gonotokonten.

Das Eigentümliche beider Generationen liegt darin, daß die $2 \mathrm{x}-\mathrm{Ge}-$ neration in ihren Zellen nicht $2 x$-Kerne, sondern zwei $x$-Kerne aufzuweisen hat. Die $\mathrm{x}$-Generation enthält pro Zelle einen, die 2x-Generation zwei x-Kerne. Die Konstatierung dieser höchst wichtigen Tatsache, der Basis unserer jetzigen Anschauungen, verdanken wir SAPPIN-Trouffy.

Nun ist bei den Uredineen die Sache dadurch für das Verständnis kompliziert, daß Apogamie, und zwar bisweilen eine sehr weitgehende Apogamie, eingetreten ist.

Ich glaube Ihnen die Sache am besten klar machen zu können, wenn ich annehme, die ursprüngliche verloren gegangene Form zu kennen, und von dieser hypothetischen Urform ausgehe.

Ich stelle mir also vor, daß die Uredineen, als sie noch die ursprüngliche geschlechtliche Fortpflanzung besaßen, in den Aecidienbecherchen eine Anzahl Oogonien hatten, deren jedes in eine Trichogyne endete.

An der Spitze jeder Trichogyne heftete sich ein Spermatium an; das Oogon wurde befruchtet und teilte sich in eine Anzahl sich bald lösender Zellen, in die Aecidiosporen.

Diese keimten zu der 2x-Generation, welche die Uredo- und Teleutosporen produzierte.

Dieser Zustand ist jetzt verschwunden, die Trichogynen sind degeneriert und die Spermatien außer Dienst gestellt. Da mußte natürlich die 2x-Generation in anderer Weise gebildet werden und zwar apogam.

Sehen wir also, wie dies geschieht. Die am wenigsten reduzierten Formen sind die, bei welchen zwei benachbarte Oogonien miteinander kopulieren. Da verschmelzen also statt einer 9 mit einer ô Gamete zwei weibliche miteinander, also im Prinzip derselbe Fall, den BLackman und Fraser bei dem Ascomyceten Humaria konstatierten.

Es wurde diese Bildungsweise der $2 \mathrm{x}$-Generation von ChristMan bei Phragmidium speciosum konstatiert. Es ist dies eine nordamerikanische Art, welche auf Rosa nitida und humilis vorkommt.

Das Genus Phragmidium unterscheidet sich von den höchsten Uredineen dadurch, daß die Aecidiosporen nicht in Becherchen gebildet werden, sondern daß das Becherchen von einem Kranz von Paraphysen ${ }^{1}$ ) umgeben ist. Solche einfache Aecidien nennt man Caeoma.

1) Auch die Uredosporen sind von solchen Pharaphysen umgeben. 
Diese Caeoma werden als eine Mrycelanhäufnng unter der Epidermis angelegt (Fig. 363. 6), alsbald wachsen num Zellen dieser Anlage aufwärts (Fig. 363, 7) und schneiden an ihrer Spitze eine kleine Zelle ab (Fig. 36t, 8), welche ich für die rudimentäre Trichogyne halte, die untere Zelle ist das Oogonium.

Die Trichogynen degenerieren alsbald (Fig. 364, 9) und die Oogonien kopulieren in Paaren (Fig. 364, 10, 11). Die Kerne verschmelzen nicht, sondern lagern sich dicht an den Kopulationskanal (Fig. 364, 11) und teilen sich simultan karyokinetisch (Fig. 364, 12).

Darauf verlängert sich die Spitze des Zygo-Oogoniums und in diese Verlängerung begibt sich ein Tochterkern von jedem Oogonnucleus, während die beiden anderen Tochterkerne in ihr Oogon zurücktreten,

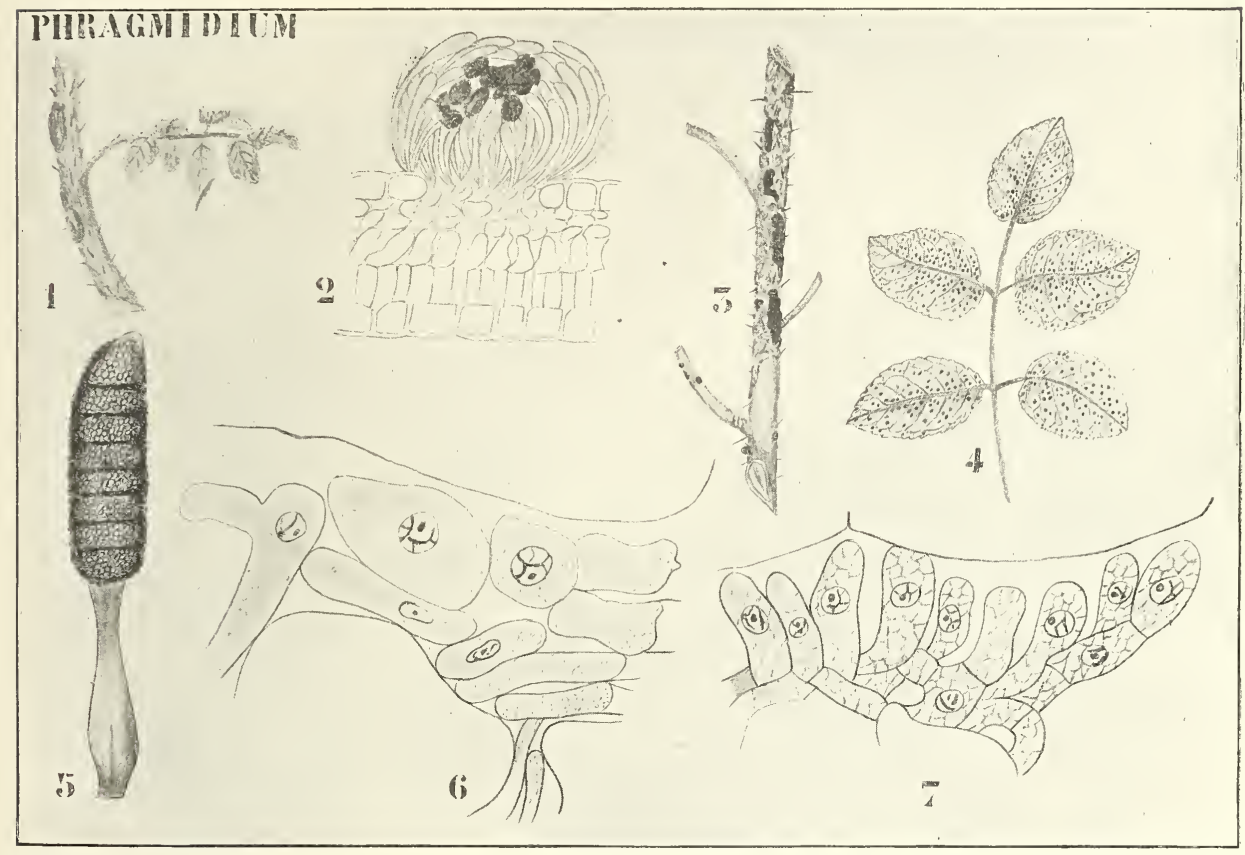

Fig. 363. Phragmidium. 1 Phragmidium Rosae Alpinae (DC.), Caeoma am Stengel von Rosa alpina (nach Dietel). 2 Schnitt durch ein Rosenblatt mit einem Uredolager von Phragmidium subcorticium (Schrnk.) Wint. (nach DieTEL). 3 Phragmidium speciosum Fr., Teleutosporenlager am Stengel von Rosa nitida (nach DieteL). 4 Phragmidium subcorticium (Schrnk.) Wint., Teleutosporenlager auf Ros a centifolia (nach Dietel). 5 Teleutospore von Ph ragmidium Rubi Idaei (Pers.) Wixt. 6 Jüngste Anlage eines Caeoma (nach CHristman). 7 Die Zellen der Caeomoanlage wachsen aufwärts (nach CHRISTMAN).

(Fig. 364, 13). Darauf wird der obere Teil des Zygo-Oogons mittels einer Querwand abgeschnitten (Fig. 364, 14); die abgeschnittene Zelle. die erste Aecidiosporenmutterzelle, enthält also 2 Kerne. Sie teilt sich alsbald in die Aecidiospore und in eine rudimentäre Zelle, die sogenannte interkalare Zelle (Fig. 364, 15).

Das Zygo-Oogonium wiederholt den soeben beschriebenen Vorgang: und so bildet jedes kopulierte Oogonimpar eine Reihe von Aecidiosporen und interkalaren Zellen. 
Wir haben hier also mit einem Fall von weiblicher Befruchtung zu tun, da zwei Oogonien zusammen kopulieren. Da das Oogon auf der $\mathrm{x}$-Generation gebildet wird, besteht kein fundamenteller Unterschied zwischen dem Oogonkern und einem Kern der vegetativen Mycelzellen. Man könnte sich also a priori noch zwei Weisen vorstellen, in welchen das gleiche Resultat erreicht werden könnte, nämlich durch Kopulation eines Oogons mit einer vegetativen Zelle und durch Kopulation zweier vegetativer Zellen.

Beide Fälle sind in der Tat realisiert; ersterer wurde von Blackman bei einer anderen Art des gleichen Genus, und zwar bei Phragmidium violaceum beschrieben, die erste Untersuchung, welche uns überhaupt über die Apogamie der Uredineen belehrte, denn Christmans Arbeit

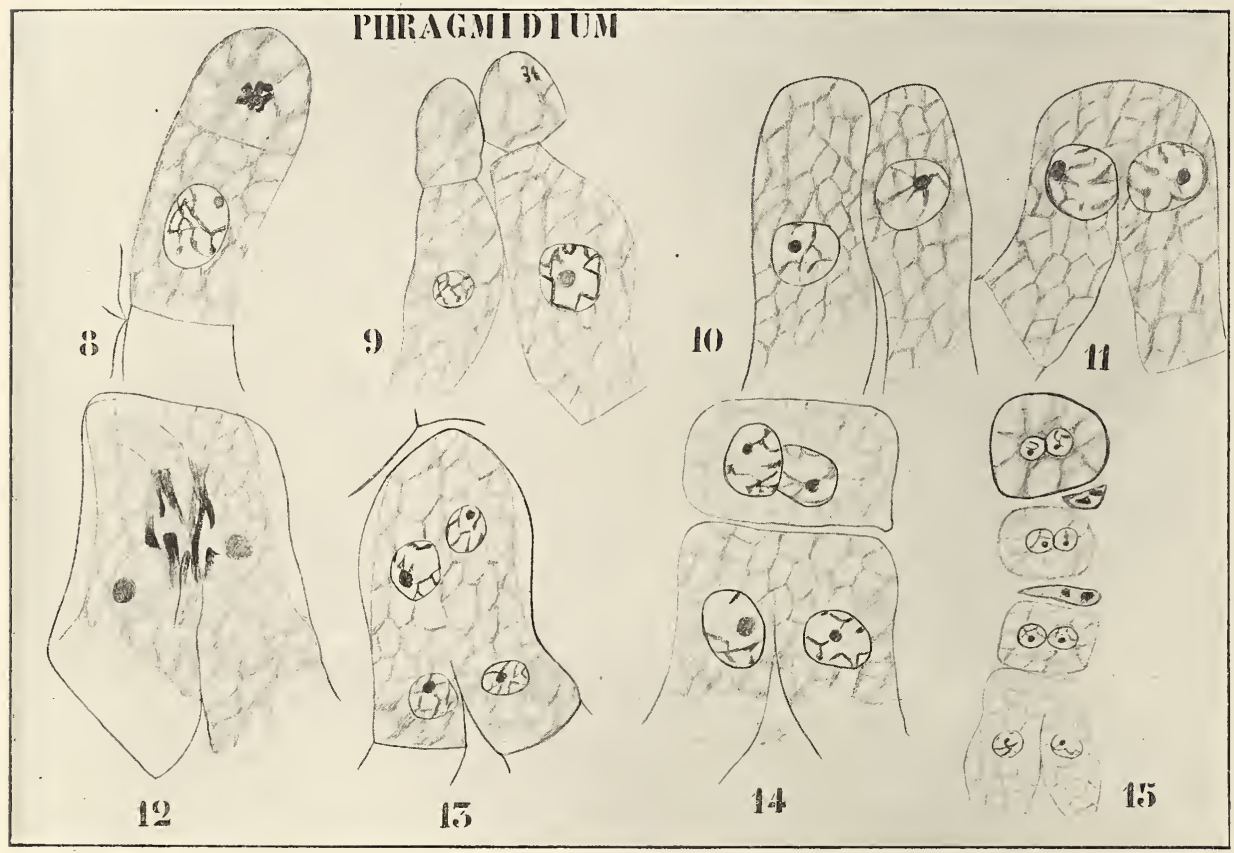

Fig. 364. Phragmidium speciosum (nach Christman). 8 Bildung von 'l'richogyne und Oogon. 9 Degeneration der Trichogynen. 10 Anfang der Kopulation. 11 Kopulation; die Kerne liegen dem Kopulationskanal gegenüber. 12 Simultane Teilung der Oogonkerne. 13 Die Tochterkerne in die Verlängerung des Zygo-Oogoniums eingetreten. 14 Die Spitze des Zygo-Oogoniums abgeschnitten und dadurch zur Aecidiosporenmutterzelle geworden. 15 Bildung von Aecidiosporen und interkalaren Zellen.

erschien erst ein Jahr später. Blackman gebührt die Ehre, zuerst die ganze Entwickelung einer Uredinee cytologisch verfolgt zu haben.

Sehen wir also, wie diese verläuft.

Gehen wir dabei aus von den Sporidien, welche an dem Keimschlauch (Promycel) der Teleutosporen gebildet werden. Diese keimen $\mathrm{zu}$ einem monoenergiden Mycelium (Fig. 365, 4), welches alsbald Caeoma und Spermogonien bildet (Fig. 365, 5, 6).

Die Spermatien werden in den Spermogonien (Fig. 365, 5) an den Spitzen der spermatienbildenden Hyphen abgeschnürt, welche, dicht gedrängt stehend, ein Hymenium bilden. Die Wand der Spermogonien wird bei Phragmidium von Paraphysen gebildet. 
Es zeigt sich, daß die Spermatien einen besonders großen und dichten Kern besitzen und nur sehr wenig Cytoplasma aufzuweisen haben, keine Reservesubstanz enthalten und eine nur sehr dünne Zellwand haben, alle Merkmale von o Zellen und nicht von Konidien, für welche sie von BrEFELD c. s. gehalten werden. Es sind zweifellos männliche Zellen, welche ihre Funktion verloren haben.

Das Caeoma wird bei Phr. violaceum, sowie bei Phr. speciosum unter der Epidermis gebildet (Fig. 366, 6). Die auch hier gerade hinaufwachsenden Hyphenzellen schneiden zunächst eine kleine sterile 7elle von der Spitze ab. Es ist dies die rudimentäre Trichogyne; der übrig' bleibende Teil ist das Oogon. Auch hier tritt in das Oogon ein Kern ein, aber nicht, wie bei Phr. speciosum, ein Kern eines anderen Oogons,

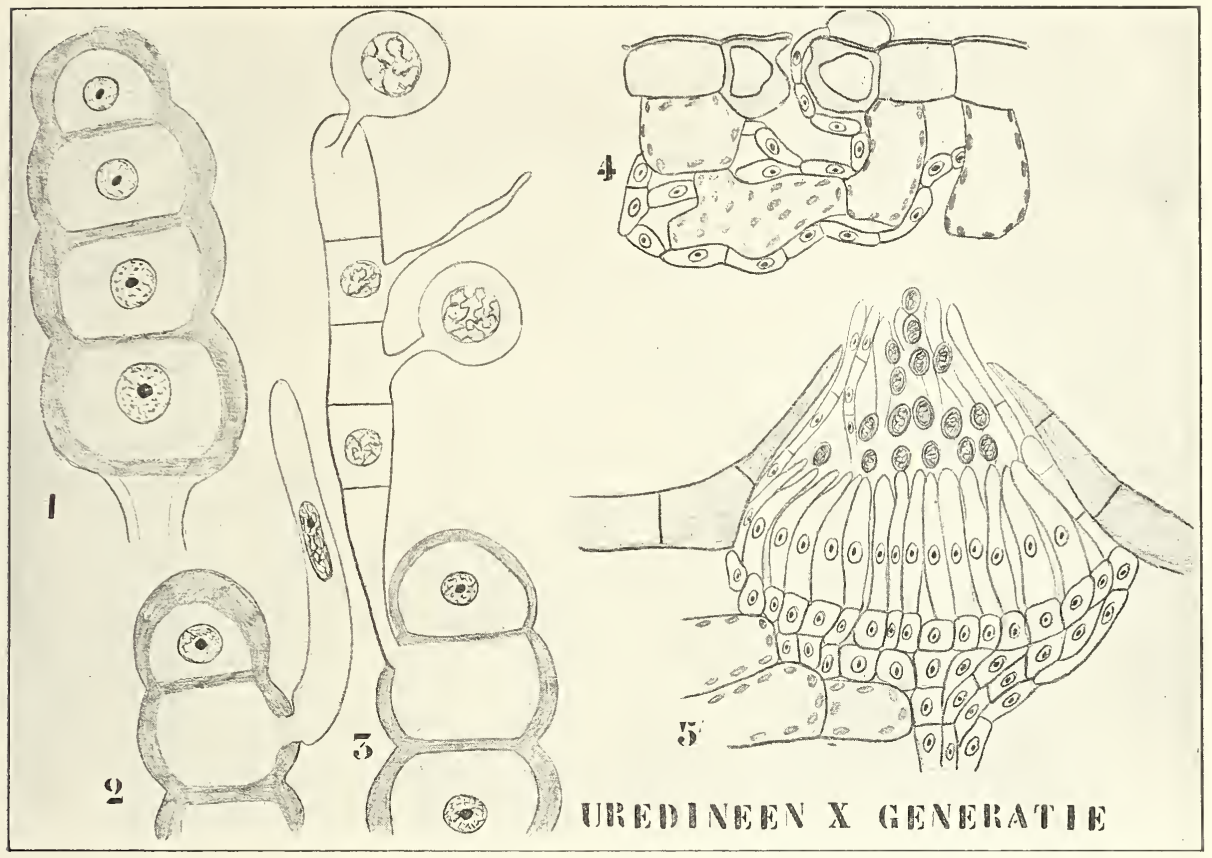

Fig. 365. Phragmidium violaceum. Entwickelung der x-Generation (nach BlackMAN), schematisiert. 1 Reife Teleutospore. 2 Anfang der Bildung eines Promyceliums, der Kern der Teleutosporenzelle ist in den Keimschlauch getreten. 3 Promycelium mit 2 Sporidien. 4 Keimende Sporidie und Bildung des uninukleären Mycels. 5 Spermogonium.

sondern ein Kern aus einer darunter gelegenen vegetativen Zelle (Fig. 366, 6, unten). Das ist ein großer Vorteil, denn während bei Phr. speciosum jedesmal ein Paar Oogonien zur Bildung einer Reihe von Aecidiosporen nötig ist, kann hier jedes Oogon eine solche Reihe bilden, bei gleicher Oogonzahl ist also die Aecidiosporenproduktion verdoppelt.

Die abgefallenen Aecidiosporen keimen nun zu einem Mycel, das 2 Kerne pro Zelle enthält (Fig. 366, 7), welches ebenfalls binukleäre Uredosporen (Fig. 366, 8) bildet. Mittels dieser kann sich die 2x-Generation bis ins Unendliche vermehren, ohne, wie dies z. B. ein Farn tum muß, auf die $x$-Generation zurückzugreifen, so daß in einem Sommer zahllose $2 x$-Generationen sich bilden können. 
Diese Uredosporen oder Diplokonidien sind also eine Neubildung. Im Herbst entstehen auf demselben Mycel, welches die Uredosporen hervorbrachte, die Teleutosporen. Es sind diese im Gegensatz zu den Uredosporen mehrzellig. Auch sie enthalten pro Zelle 2 Kerne, welche aber alsbald miteinander verschmelzen und zusammen einen $2 \mathrm{x}$-Kern bilden. Wir haben also bei den Uredineen mit einer lang aufgeschobenen Verschmelzung der elterlichen Kerne in der $2 \mathrm{x}$-Generation $\mathrm{zu}$ tun, also mit einem Fall, der dem von Cyclops analog, aber weiter durchgeführt ist.

Bei der Keimung bildet jede Teleutosporenzelle, welche als Spore $\mathrm{zu}$ betrachten ist, denn was wir Teleutospore nennen, ist eigentlich eine Reihe von solchen, ein Promycel, in welches der $2 x$-Kern hineintritt (Fig. 365, 2).

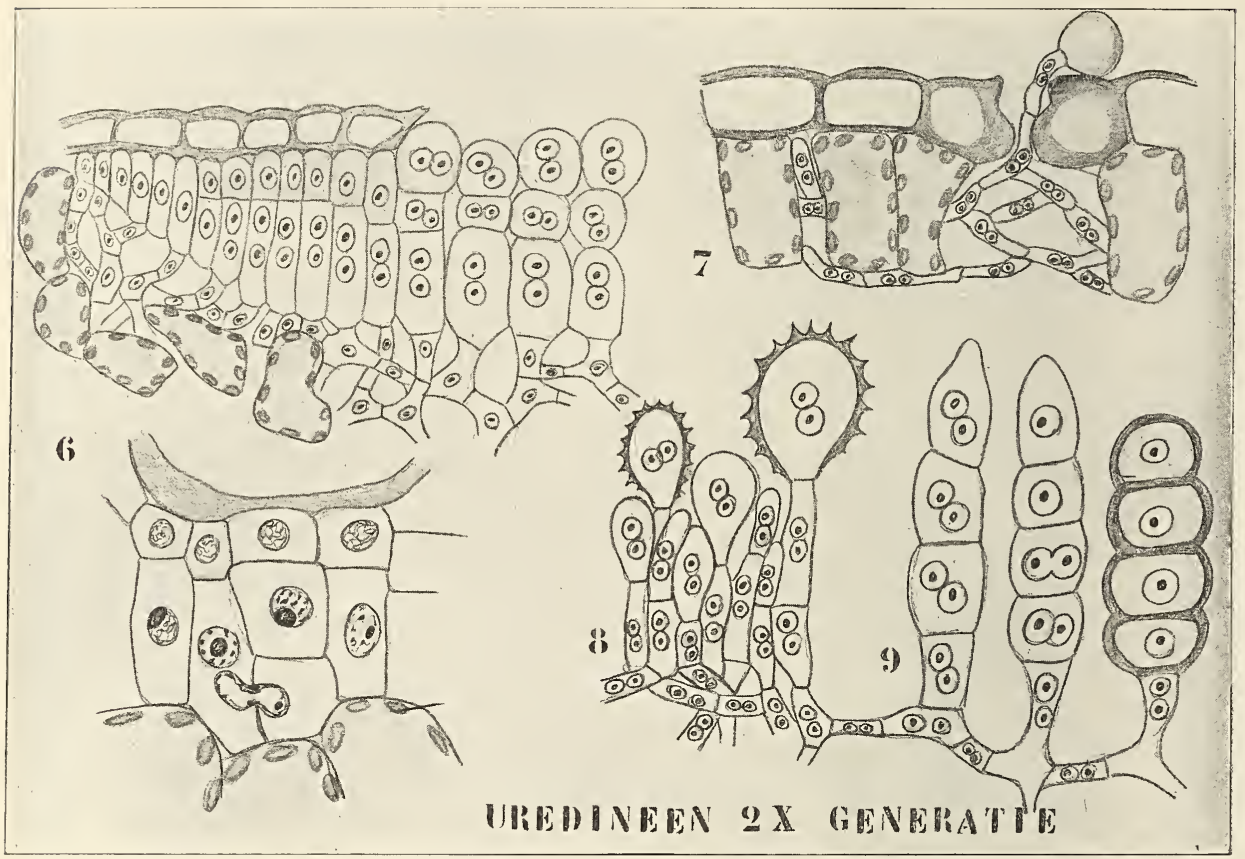

Fig. 366. Phragmidium violaceum. Entwickelung der $2 \mathrm{x}$-Generation (schematisiert nach BLACKMAN). 6 Peripherer Teil eines jungen Caeoma. In der oberen Figur sind einige der fertilen Zellen bereits binukleär; in der unteren sieht man, wie die fertilen Zellen durch seitliche Kopulation binukleär werden. 7 Keimung einer Aecidiospore. 8 Uredosporen. 9 Junge (noch binukleäre) und alte uninukleäre Teleutosporen.

Hier teilt er sich, wodurch 4 Zellen im Promycel entstehen (Fig. 365, 3), und dabei muß eine Reduktionsteilung stattfinden, welche aber durch die große Zahl der Chromosomen noch nicht konstatiert werden konnte.

Jede dieser Promycelzellen bildet eine Sporidie, welche also die erste Zelle der x-Generation ist, und diese keimen zu Spermogonien und aecidienproduzierenden $\mathrm{x}$-Generationen, womit der Zyklus vollendet ist.

Während wir nun bei den Caeoma von Phragmidium mit einer sehr einfachen Struktur der weiblichen Fortpflanzungsorgane zu tun haben, nämlich mit einem von Paraphysen umgebenen Sorus von Oogonien (die Paraphysen können sogar fehlen), ist die Struktur der Becher- 
aecidien viel komplizierter und verdiente also eine nähere Untersuchung, welche von BlackMaN und Miss Fraser (1906) unternommen wurde.

Bei Phragmidium werden die Oogonien, wie wir sahen, direkt unter der Epidermis gebildet, das echte Aecidium entsteht verhältnismäßig tief im Gewebe des Wirtes. Blackman und Fraser untersuchten die Entwickelung bei Uromyces Poae Rabenh. und bei Puccinia Poarum Niels. Uromyces Poae unterscheidet sich von Phragmidium in erster Linie dadurch, daß $x$ - und $2 x-G e n e r a t i o n$ nicht auf demselben, sondern auf verschiedenen Wirten vorkommen. Die Pflanze zeigt also einen mit dem Generationswechsel verknüpften Wirtswechsel.

Diejenigen Uredineen, deren $\mathrm{x}$ - und $2 \mathrm{x}$-Generationen auf der gleichen Pflanzenart vorkommen, nennt man autöcisch, diejenigen, bei welchen sie sich auf verschiedenen Pflanzenarten entwickeln, heteröcisch. Uromyces Pocie ist also eine heteröcische Art, deren $\mathrm{x}$-Generation auf Ficaria ranunculoides und deren 2x-Generation auf Poa vorkommt; also die Aecidien und Spermogonien auf Ficaria, die Uredos und Teleutos auf Poa.

Die interessante Erscheinung der Heteröcie wurde von DE BARY für den Getreiderost, dessen Aecidium auf Berberis vorkommt, entdeckt.

Das x-Mycelium der Uromyces Poae wird also in den Blattstielen von Ficaria angetroffen. Die Hyphen besitzen einen Kern pro Zelle. Die Spermogonien erscheinen zuerst auf der Oberseite des Blattes; sie sind typisch flaschenförmig und schnüren Spermatien mit großen Kernen und reduziertem Cytoplasma ab. Sie sind funktionslos. Die erste Andeutung des jungen Aecidiums besteht aus einer Masse verwebter Hyphen, welche direkt unter der Epidermis an der Unterseite der Blattlamina liegen oder, wenn sie in dem Blattstiel entstehen, in tiefer gelegenen Schichten.

Diese Hyphenmasse nimmt an Größe zu und differenziert sich in zwei deutlich verschiedene Teile, von welchen der untere aus einer Masse dichtgedrängter, kurzer, uninukleärer Zellen mit dichtem Inhalt, der obere aus großen, unregelmäßigen, fast leeren Hyphen besteht (Fig. 367, 1).

Diese obere IIasse scheint, wenigstens teilweise, von der unteren gebildet zu sein, wie daraus hervorgeht, daß man sehen kann, wie sich Zellen des unteren Teiles vergrößern und ihren Inhalt verlieren.

Bei der weiteren Entwickelung werden die Zellen der unteren Masse etwas größer und hier und dort sieht man binukleäre Zellen auftreten (Fig. 367, 2). Immer mehr Zellen werden binukleär und arrangieren sich zu einer Schicht an der Basis des jungen Aecidiums, wonach jede derselben eine Reihe Aecidiosporen und interkalare Zellen bildet (Fig. 367, 3). Diese Zellen sind vermutlich Oogonia; ob sie noch eine rudimentäre Trichogyne bilden, konnte nicht festgestellt werden; die in sie eingedrungenen Kerne rühren von vegetativen Zellen her. Die Wand des Aecidium, der Becher, besteht einfach aus reduzierten Aecidiosporenmutterzellen, was daraus hervorgeht, daß die Zellen desselben binukleär sind (Fig. 367, 3), und daß keine intrakalaren Zellen zwischen ihnen gebildet werden. Sie umschließen in der Jugend das ganz Aecidium; später zerreißt der Becher an der Spitze.

BlackmaN scheint überzeugt zu sein, daß es hier Oogonien sind, welche durch Kopulation mit einer vegetativen Zelle binukleär werden. Ich bin dessen nicht so gewiß. Vielleicht hat hier schon eine weitere Reduktion stattgefunden und es kopulieren nur zwei vegetative Zellen miteinander, die tiefgelegene binukleäre Zelle rechts in Fig. 367, 2 läßt dies vermuten. Auf jeden Fall aber sind solche vou BLAckuan nach- 
gewiesen worden und zwar bei Puccinia Poarum, einer ebenfalls heteröcischen Art, welche ihre Aecidien auf Tussilago farfara bildet.

Die Entwickelung des Aecidium findet hier so ziemlich in derselben Weise wie bei Uromyces Poae statt, aber man sieht schon ein Hinüberkriechen von Kernen, bevor irgend eine Differenzierung im Primordium stattgefunden hat, und solche vegetativ binukleär gewordenen Zellen

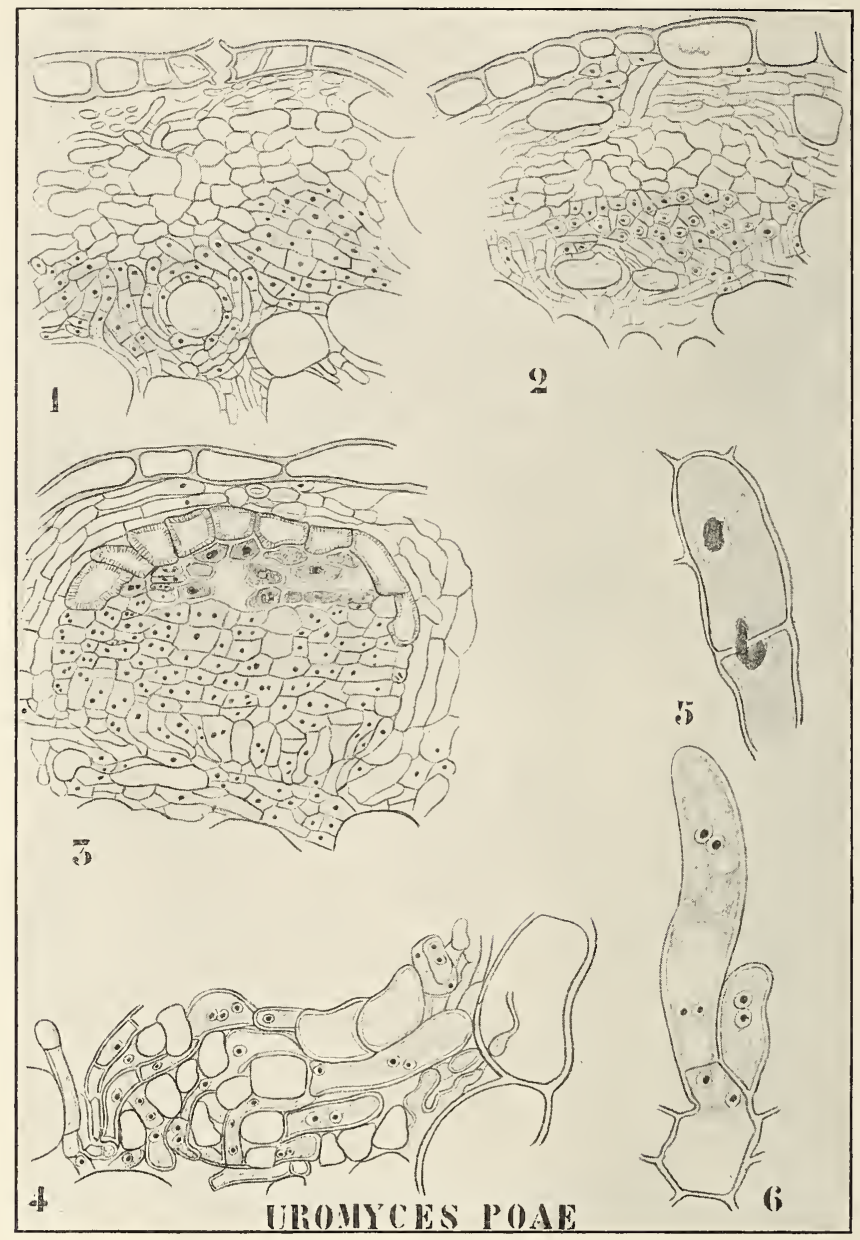

Fig. 367. Urom yces Poae (nach Blackman und Fraser). 1 Aecidienprimordium in untere uninukleäre Zellen mit dichtem Plasma und obere fast leere Zellen differenziert. 2 Einige wenige Zellen des unteren Teiles binukleär. 3 Die unteren Zellen sämtlich binukleär, die mittleren bilden Aecidiosporen und interkalare Zellen, die peripheren den aus umgebildeten Aecidiosporenmutterzellen bestehenden Becher.

können ebenfalls Aecidiosporen bilden. Daneben kommt aber auch Ueberkriechen von Kernen in rudimentäre Oogonien vor, so daß im Aecidium von Puccinia Poarum die Aecidiosporen zum Teil von Oogonien, in welche ein vegetativer Nucleus eingetreten ist, gebildet werden, zum Teil von vegetativen Zellen, in welche der Nucleus einer anderen vegetativen Zelle hineingewandert ist. 
Letzteres zeigt wohl zum Ueberfluß, daß die Kerne der vegetativen Zellen und der Oogonien und Spermatien binukleär sind. Es wäre recht g’ut möglich, daß vegetative Bastarde in ähnlicher Weise gebildet würden.

Tir haben also gesehen, daß bei den Uredineen ein echter Generationswechsel, ein obligater Wechsel zwischen $2 \mathrm{x}$ - und $\mathrm{x}$-Generation vorliegt. Es sind aber bei gewissen Uredineen eigentümliche Abkürzungen bekannt, z. B. ein gänzliches Wegfallen des Aecidiums, welche die Frage nahe legen, wie bei ihnen denn die $2 x$-Generation gebildet wird.

Sehen wir also zunächst, welche Abkürzungen vorkommen. Die verschiedenen Arten der Abkürzung werden nach ScHröter recht einfach dadurch angegeben, daß man dem Gattungsnamen bestimmte Silben vorsetzt, bezüglich anhängt. So erhält man z. B. für das Genus Puccinia folgende Tabelle, in welcher I Aecidio-, II Uredo- und III Teleutosporen heißt.

I, II, III • . • . • . • . . . . . . . Eupuccinia

Spermogonien II, III . . . . . . . . . . Brachypuccinia

I, III (einzelne Uredosporen können vorkommen) • Pucciniopsis

II, III . . . . . . . . . . . . . . . . Hemipuccinia

III (erst nach dem Winter keimend) . . . . Micropuccinia

III (sofort keimend) . . . . . . . . . Leptopuccinia.

Es ist wohl besser, die beiden letzteren unter dem Namen Leptopuccinia zusammenzufassen "und den Mikro-Namen also nicht zu benutzen. Selbstverständlich können in diesen Gruppen verschiedene Modifikationen vorkommen oder nicht. In der Eu-Gruppe gibt es keine Modifikationen, so daß folgendes Schema für diese allgemeine Gültigkeit hat.

\section{Eu-Gruppe.}
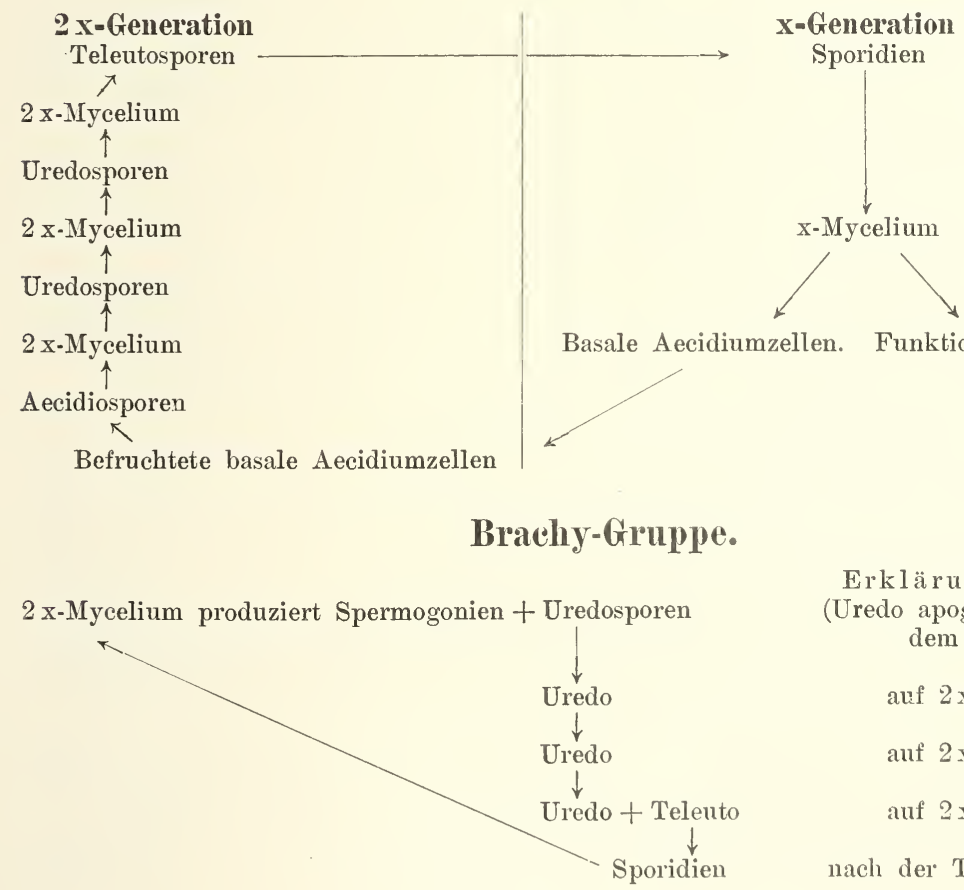

Basale Aecidiumzellen. Funktionslose Spermatien $\nwarrow$

Befruchtete basale Aecidiumzellen

\section{Brachy-Gruppe.}

$2 \mathrm{x}-$ Mycelium produziert Spermogonien + Uredosporen
Erklärungsversuch:

(Uredo apogam gebildet auf dem $x$-Mycel)

auf $2 x-M y c e l i u m$

auf $2 \mathrm{x}$-Mycelium

auf $2 \mathrm{x}$-Mycelium

nach der Trennungsteilung 


\section{-0psis-Gruppe.}

Erster Fall (Beispiel Uromyces Ervi).

$\mathrm{x}$-Mycel mit Spermogonien + Aecidien

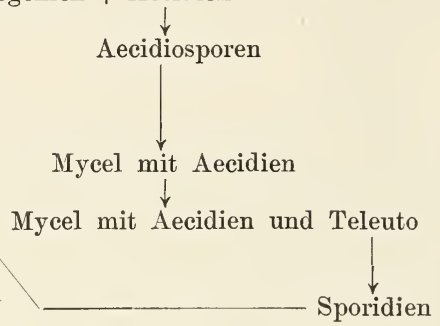

Erklärungsversuch: $\mathrm{x}-$ Mycelium

(vermutlich parthenogenetisch, also $x$-Sporen, während sonst die Aecidiospore eine $2 \mathrm{x}$-Spore ist)

$$
\mathrm{x} \text {-Mycel }
$$

x-Mycel, auf welchem die Teleuto apogam gebildet werden

$\mathrm{x}$

\section{Zweiter Fall (Beispiel Gymnosporangium).}

$\mathrm{x}$-Mycel mit Spermogonien + Aecidien

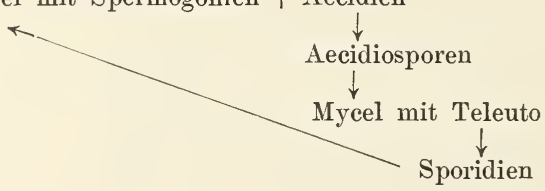

Erklärungsversuch: $\mathrm{x}$-Mycel

$2 \mathrm{x}$

$2 \mathrm{x}-\mathrm{Mycel}$

$\mathrm{x}$

Dritter Fall (Beispiel Puccinia graminella [Speg., Diet. et Holw.]).

$\mathrm{x}$-Mycel mit Spermogonien und Aecidien

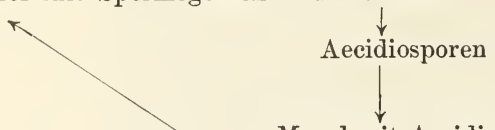

Mycel mit Aecidien und Teleuto

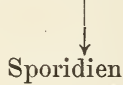

\section{Hemi-Gruppe.}

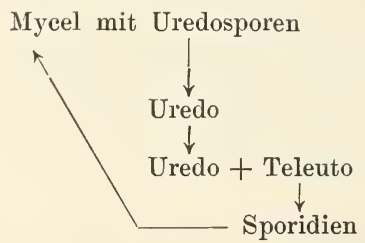

Erklärungsversuch: $\mathrm{x}$-Mycel

(vermutlich parthenogenetisch, also $x$-Sporen)

$\mathrm{x}$-Mycel, auf welchem apogam Teleuto entsteht

$\mathrm{x}$

Erklärungsversuch : $\mathrm{x}$-Mycel, auf welchem Uredosporen apogam gebildet wurden

auf $2 \mathrm{x}-\mathrm{Mycel}$

auf $2 \mathrm{x}-$ Mycel

$\mathbf{x}$

\section{Miero- und Lepto-Gruppe.}

Mycel mit Teleuto

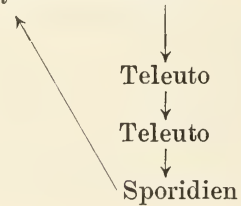

Erklärungsversuch:

(Teleuto apogam entstanden auf $\mathrm{x}-\mathrm{Mycel}$ )

auf $2 x-$ Mycel

auf $2 x-$ Mycel 
Außer diesen kennen wir noch ein ganz abweichendes UredineenGenus, bei welchem die Aecidiosporen mittels eines Promycels keimen und Sporidien bilden, nämlich Endophyllum. Wir bekommen also:

\section{Endophyllum-Gruppe.}

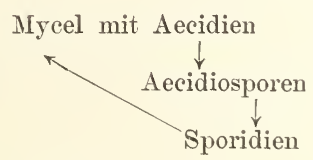

Erklärungsversuch: $\mathrm{x}-\mathrm{Mycel}$

$2 \mathrm{x}-$ Sporen

$\mathrm{x}$

Bei diesen Erklärungsversuchen ist nichts Unwahrscheinliches vermutet. Die angenommenen Möglichkeiten sind folgende:

1) Uredosporen können apogam auf einem x-Mycel gebildet werden.

2) Die basalen Zellen eines Aecidiums, die Oogonien, können parthenogenetisch Aecidiosporen bilden, welche statt der üblichen zwei Kerne nur einen besitzen.

3) Teleutosporen können apogam auf einem x-Mycel gebildet werden.

4) Aecidiumsporen können mittels eines Promycels keimen und Sporidien bilden.

Ueber die vierte Möglichkeit brauchen wir keine Worte zu verlieren, denn man sieht sie bei Endophyllum realisiert, auch braucht man in dem Falle nichts Wunderbares zu erblicken, da sowohl Aecidiosporen wie Teleutosporen $2 \mathrm{x}$-Zellen sind, und also eine übereinstimmende Keimungsweise nicht zu wundern braucht. wissen?

Die Frage ist also nur, was wir über die Möglichkeiten 1, 2 und 3

Nun hat Sappin-Trouffy schon nachgewiesen, daß bei Leptopuccinia Malvacearum die Teleutosporen auf einem X-Mycel, statt wie üblich, auf einem $2 x-M y c e l$ gebildet werden, so daß dieses schon für die apogame Bildung bei der Lepto-Gruppe spricht. Der Nachweis wurde dann in der Tat von BLAckMAN erbracht, der zeigte, daß hier die Teleutosporen von binukleären Zellen, welche auf dem uninukleären Mycel entstehen, gebildet werden. Trotzdem er den Uebertritt der Kerne nicht sah, sind diese binukleären Zellen wohl sicher durch Kopulation zweier vegetativer Zellen des x-Mycels gebildet, und dürfen also wir die apogame Bildung von Teleutosporen auf x-Mycelien als bewiesen erachten.

In der oben mit der Lepto-Gruppe vereinigten Micro-Gruppe kommen aber auch Fälle vor, wo die Teleutosporen nicht auf einem x-, sondern auf einem 2x-Mycel vorkommen, die einfachste Supposition würde da sein, daß bei der Bildung der Sporidien keine Reduktionsteilung stattfand (Analogie mit Taraxacum) und also die Sporidien einen $2 x$-Nucleus enthielten, welcher sich später bei der Bildung des Mycels in zwei x-Nuclei zerlegte. Möglich ist es aber ebensogut, daß ein rudimentäres x-Mycel besteht, welches durch Fusion vegetativer Zellen einem sich entwickelnden 2x-Mycel das Dasein gibt.

Diese Voraussetzung ist vielleicht mit Rücksicht auf das bei Autobasidiomyceten Bekannte die wahrscheinlichere. Nähere Untersuchung. muß da entscheiden.

Daß Uredosporen apogam auf x-Mycelien entstehen können, wurde gleichfalls von Buackman gezeigt, und zwar bei Uromyces Ficariae. Trotzdem Sappin-Trouffy angab, daß hier daß Mycel, welches die 
Uredo- und Teleutosporen bildet, binukleär ist, konnte Blackman nachweisen, daß dies nur bei den Hyphen, welche in direkter Verbindung mit dem Teleutolager (in welchen bisweilen einzelne Uredosporen vorkommen) stehen, der Fall ist, und der Rest des Mycels uninukleär ist.

Noch nicht bekannt sind uninukleäre, also parthenogenetische Aecidiosporen; das ist also die einzige Voraussetzung ohne morphologische Basis.

Da wir nun im allgemeinen mit der Bedeutung der verschiedenen Sporenformen bei den Uredineen vertraut geworden sind, ist es Zeit, verschiedene Formen kennen $\mathrm{zu}$ lernen und wir fangen unsere diesbezüglichen Betrachtungen mit

\section{Puccinia graminis Pers.}

an. Folgendes ist KLebahns höchst interessantem Werke „Die wirtswechselnden Rostpilze", Berlin 1904, entliehen.

Puccinia graminis ist eine Uredineae, welche den sogenannten Getreiderost verursacht. Schon seit lange hatte man bemerkt, daß Berberitzen in der Nähe von Getreidefeldern die Aehrenbildung verhindern, und schon 1720 war ein englischer Bauer so sehr von der Schädlichkeit der Berberitzen überzeugt, daß er des Nachts heißes Wasser auf die Wurzeln einer seinem Nachbar gehörenden Berberitze ausgoß.

Am 13. Januar 1755 wurde in Massachusetts ein Gesetz angenommen, welches verordnete, daß alle Berberitzensträucher im Lande ausgerottet werden sollten. Dennoch hatte man damals keine blasse Ahnung vom wirklichen Bande zwischen der Berberitze nnd dem Getreiderost, sondern meinte nur, daß die Berberitze schädlich wäre für das Getreide. 1805 wurde ein ähnliches Gesetz in Lippe und 1815 in Bremen erlassen.

Ziemlich allgemein wurde aber an der Schädlichkeit der Berberitze in wissenschaftlichen Kreisen gezweifelt; Duhameu (1754) und Sowerby (1790) sind sehr skeptisch. Aber sogar Marshalle, welcher 1784 experimentell die Schädlichkeit einer Berberitze in einem Getreidefelde nachwies, hatte noch keine Ahnung von der eigentlichen Ursache. TreVIRANUS (1803) spricht von einer „dynamischen Einwirkung, welche jeder lebende Organismus auf die übrige Natur äußert", mehr verbreitet war aber die Neinung, daß das Pollen der Berberitze das Getreide schädigte.

1804 oder etwas früher fand WILDEnow auf Getreide in der Nähe von Berberis-Sträuchern Uredo linearis und auf der Berberitze Aecidium berberidis und sagt:

„Ich schloß sogleich, daß der Same dieses kleinen Gewächses den Uredo linearis hervorbringen mußte, was so augenscheinlich war, daß mir kein Zweifel übrig bleiben konnte." Er beschloß also, Aussaatversuche zu machen im Botanischen Garten zu Berlin, was aber nicht möglich war, da der Roggen schon spontan rostig wurde. Bei Aussaat der Aecidiensporen auf verschiedene andere Pflanzenarten erhielt er auf einem so beschickten Blatte von Populus balsamifera zufälligerweise Uredo populina und schließt nun unrichtigerweise, daß diese aus den ausgesäten Sporen entstanden sei und daß es also nur von den Qualitäten der Epidermis abhänge, ob sich der Pilz unserem Auge wie ein Aecidium berberidis, ein Uredo linearis oder ein Uredo populina zeigt.

$\mathrm{Zu}$ gleicher Zeit, aber unabhängig von WiLdenow gelangt BanKS zur gleichen Auffassung, so daß man ruhig sagen kann, daß BANKs und Wildenow zuerst eine richtige Meinung über die Schädlichkeit der 
Berberitze für das Getreide verkündet haben. Auch in anderen Ländern ist man ungefähr gleichzeitig auf denselben Gedanken gekommen.

Die erste experimentelle Roggeninfektion durch Berberitzenaecidien wurde aber erst 1816 von ScнӧLER, einem dänischen Schulmeister und Kirchenvorsänger gemacht. Er strich über taubedeckte Roggenhalme mit aecidientragenden Berberitzenblättern hin, befestigte die Halme an einem Stabe und wies nach, daß nur die so behandelten Halme nach 5 Tagen ${ }^{1}$ ) Rost zeigten, während alle anderen Halme des Feldes rostfrei waren. Dennoch gelang es ScHöLER nicht, mit seiner Meinung durchzudringen, da eine im Jahre 1832 ernannte Regierungskommission - aus 22 Kirchspielvorstehern bestehend! — zu seinen Ungunsten entschied.

Ebenfalls gut reussierte Infektionsversuche machte, ohne von ScHöLERs Versuchen zu wissen, der deutsche Landwirt v. Bönnighausen im Jahre 1818; er wies weiter nach, daß der Rost auch von Halm auf Halm übergehen kann, ohne Vermittelung der Berberitze, entdeckte also die Vermehrung mittels Uredosporen. Auch diese Versuche fanden wenig Beachtung und sogar 1853 spricht sich DE BARY noch gegen die Schädlichkeit der Berberitze aus.

So stand die Sache zur Zeit, als DE BARY 1865 seine sorgfältigen Versuche publizierte.

Er bekam den ganzen Entwickelungsgang des Pilzes heraus, der seinen Untersuchungèn gemäß folgenden Verlauf hat.

Gehen wir von einem jungen Mycel, welches in den Intercellularräumen eines Berberitzenblattes verläuft, aus, so sehen wir, wie die jungen Aecidien als Hyphenknäuel sich in den Intercellularräumen bilden. DE BARY entdeckte die basalen Zellen, welche die Aecidiosporen bilden, und konstatiert, daß die Wand des Aecidiums, der Becher, in ähnlicher Weise entsteht, mit der Abweichung, daß zwischen den Aecidiosporen interkalare Zellen gebildet werden, welche im Becher fehlen. Das junge Aecidium durchbricht die darüberliegenden Zellschichten, reißt auf und die Aecidiensporen werden frei (Fig. 368, II 1).

Auch entdeckte DE BARY die Spermogonien (Fig. 368, II 1) und die von ihnen abgeschnürten Spermatien, homologisiert diese mit Ascomyceten-Spermatien und weist nach, daß sie früher als die Aecidien gebildet werden.

Er konnte feststellen, daß die Aecidiosporen nicht im stande sind, eine Berberitzenpflanze zu infizieren, sondern in Roggenpflanzen durch die Spaltöffnungen eindringen können und diese so infizieren. Das hier gebildete Mycel bildet dann die roten Rostflecken, welche aus den am Ende aufrechter Hyphenzweige abgeschnürten Uredosporen (Fig. 368, II 4) bestehen. Er wies weiter nach, daß man mit diesen Uredosporen neue Roggenpflanzen infizieren kann und daß diese dann wieder Rostflecken tragen, an welchen Uredosporen gebildet werden. Später, Anfang des Herbstes, werden zwischen den Uredosporen so lange Teleutosporen gebildet, bis die Rostflecken ganz braunschwarz geworden sind (Fig. 368, II 5, 6). Diese überwintern und keimen im nächsten Frühjahr mittels eines Promycels, welches Sporidien bildet. Diese infizieren die Berberitzenpflanze, und das so entstandene Mycel bildet wieder Spermogonien und Aecidien.

Damit schien die Geschichte der Puccinia graminis erledigt. Als-

1) Besonders früh. 


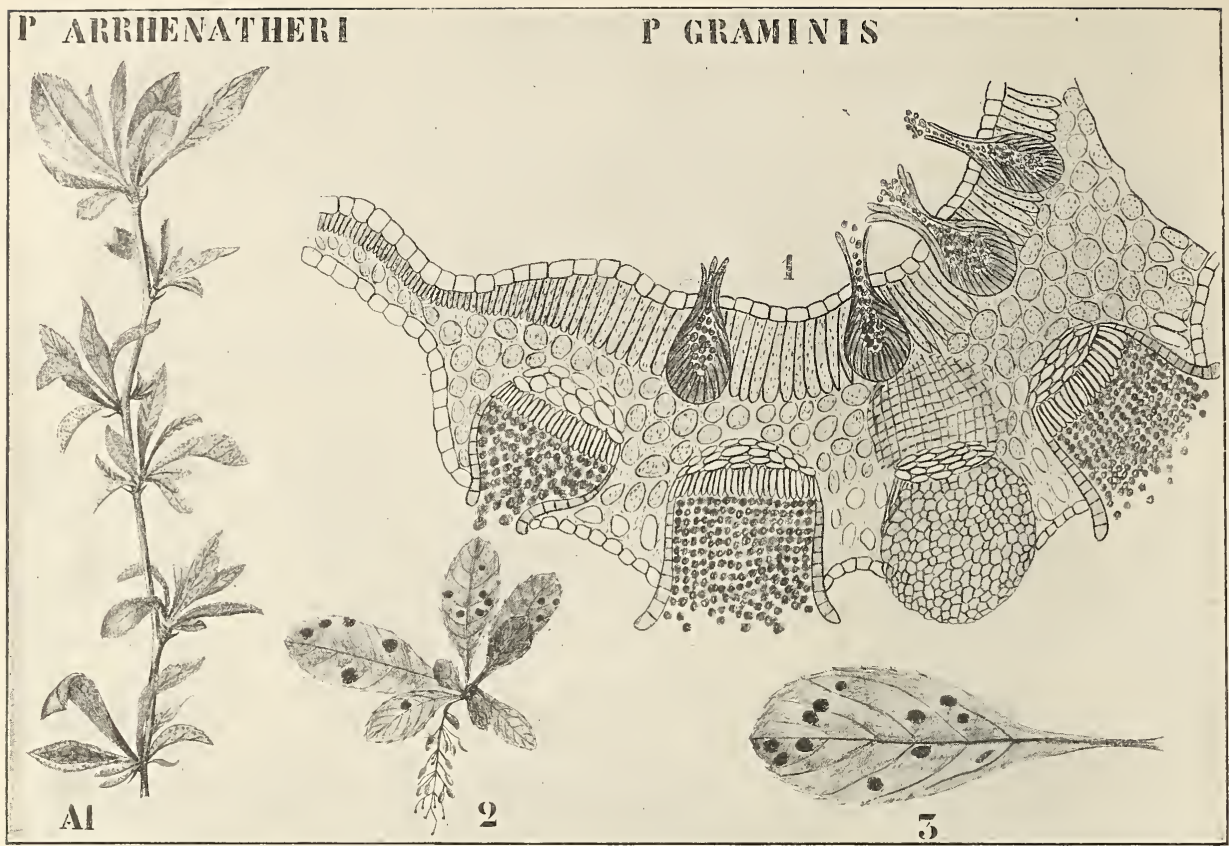

Fig. 368. I. Puccinia Arrhen atheri (nach Eriksson). A1 Infizierte Berberitzenzweige, alle Sprosse mit Ausnahme des terminalen an der Blattunterseite mit dichtgedrängt stehenden Aecidien bedeckt. - II. P. graminis. 1 Querschnitt eines Berberis-Blattes mit Oogonien und Antheridien (nach DE BARY). 2, 3 Berberitzenblätter mit den n i ch t gedrängt stehenden Oogonien (nach der Natur).

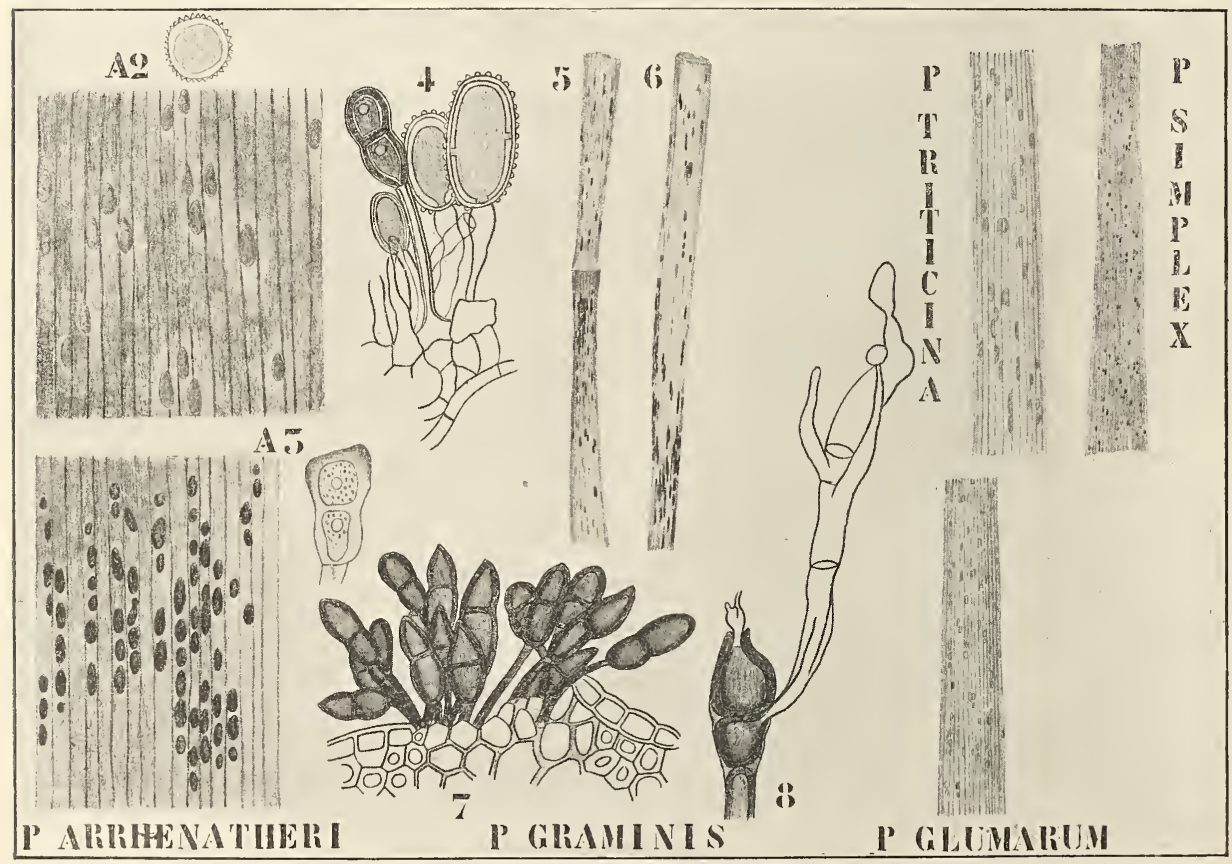

Fig. 369. I. Puccinia Arrhenatheri (nach Eriksson). A2 Uredo auf Arrhenatherum, oben eine Uredospore. A 3 Teleuto auf Arrhenatherum, rechts eine Teleutospore. - II. Puccinia gramin is. 4 Uredosporen (nach DE BARY), 5, 6 Teleutolager (nach der Natur). 7 Teleutosporen (nach DF. BARY). 8 Teleutosporen keimend (nach DE BARY). - III. P.triticina auf Triticum (nach der Natur). - IV. P. simplex auf Gerste (nach der Natur). - V. P. glumarum auf Weizen (nach der Natur). 
bald aber zeigten sich verschiedene Schwierigkeiten. Man bemerkte nämlich. daß Rost regelmäßig vorkam in großen Entferuungen von Berberitzen, und die einfachste Erklärung dafür war wohl diese, daß die Uredosporen überwintern konnten, oder daß die von den Telentosporen produzierten Sporidien doch im stande waren, Roggen zu infizieren.

Es ist nun aber bewiesen, daß Sporidien dieses Vermögen nicht besitzen, und bis vor kurzem meinte man aus zahllosen Versuchen schließen zu dürfen, daß auch Uredosporen nicht überwintern können.

Aber mehr und mehr Beobachtungen zeigen (Christman 1905, Mac Alpine 1891 etc.), daß sogar in strengen Wintern Uredosporen am Leben bleiben können, sogar wenn die Temperatur 3 Monate lang unter $0^{0} \mathrm{C}$ sinkt.

Damit ist also erklärt wie Rost in berberitzenfreien Gegenden vorkommen kann; es hatte übrigens KLEBAHN schon nachgewiesen, daß man die Entfernung, in welcher eine Berberitze Infektion verursachen kann, nicht unterschätzen darf. Auch TuBEuF hatte schon gesagt: „Die Entfernungen der Infektionsgefahr ... werden nicht nur von ERIKsson, sondern allgemein bedeutend unterschätzt".

KLebahn weist auf die Tatsache hin, daß Staub aus Afrika bis nach Hamburg geweht wurde (1901), und es müssen also die weit leichteren Schimmelsporen über eine wenigstens eben so große Entfernung verbreitet werden können. Nun war es in erster Linie nötig, nachzuweisen, daß die Luft in der Tat Rostsporen enthält.

Dazu hing KLEBAHN unter kleinen Blechdächern zirkelrunde Scheiben auf, von etwa $12 \mathrm{~cm}$ im Durchschnitt, auf welchen feine Verbandwatte ausgebreitet wurde. Von diesen wurden unter anderen No. 1 und 2 in der Nähe Hamburgs, No. 3 in Thüringen aufgehängt; es fanden sich zahlreiche Uredineen-Sporen, nämlich:

No. 14600 Sporen unter welchen 2700 vom Aeußeren der P.graminis No. $28400 \quad$, $\quad$ " $\quad 3840$

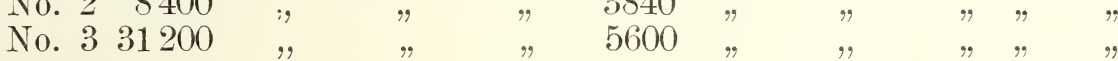

Aecidiosporen wurden nur wenige angetroffen, Teleutosporen nur sehr wenige.

Zahllose Uredosporen sind also in in der Luft vorhanden und fallen in großer Zahl auf eine sogar recht kleine Scheibe.

Damit läßt sich viel Räitselhaftes im Entstehen von Rostepidemieen erklären, und es wird äußerst sorgfältige Isolierung zur Pflicht, wenn man zeigen will, daß auf andere Weise, als durch Uredo- oder andere Sporen, Rost entstehen kann.

Letzteres versucht ERIKsson seit Jahren; er hat nämlich eine Mycoplasmatheorie aufgestellt, nach welcher es einen noch unbekannten Zustand im Leben der Uredineen geben soll, nämlich einen amöboiden Zustand, welchen man vielleicht am besten mit dem amöboiden Zustand der Schwärmsporen des Olpidium vergleichen kann. wintern.

In diesem amöboiden Zustande soll dann der Pilz im Samen über-

Er stützt sich dabei zumal auf Versuche in dichten Glaskästen. welche aber zum Teil so wenig dicht waren, daß sogar Blattläuse eindringen konnten. Wiederholung mit von Eriksson persönlich geernteten Samen, welche nach ihm rostige Pflanzen hervorbringen mußten, lieferte KLebahn nur dann rostige Pflanzen, wenn er sie im Freien 
keimen ließ, und dann noch von einer anderen Rostart befallene, als nach ERIKssons Meinnng im Samen vorhanden sein sollte.

Lange gab ErIKsson keine Abbildungen seines Mycoplasmas, als dies in 1901-1902 geschah, wurde Marshall Ward betroffen über die Aehnlichkeit dieser Bilder mit den Haustorien der Uredineen.

Folgendes ist WARDS Artikel: Recent Researches on the Parasitism of Fungi, Ann. of Bot., Jan. 1905, entliehen, einem Aufsatz, dessen Lektüre ich sehr empfehlen kann. An einer anderen Puccina-Art, für $P$. dispar, wies WARD (1903) nach, daß die Abbildungen, welche ErIKsSON für sein Mycoplasma gab, seine sogenannten „Corpuscules spéciaux (Ann. d. Sc. nat. 1902, T. XV, Pl. 3) nur Haustorien des Rostpilzes sind. Dies wurde später von EriKsson zugegeben, deswegen aber die Mycoplasmatheorie noch nicht aufgegeben. Eine cytologische Untersuchung, die gemeinsam mit TISCHLER unternommen wurde, hatte ihn nämlich eigentümliche Plasmamassen in den Zellen des Gramineen-Blattes kennen gelernt, die zugleich mit einer Vergrößerung und Degeneration der Kerne auftraten, welche nach ihm von dem Mycoplasma verursacht wurden.

Ich hatte vor 2 Jahren Gelegenheit, in Cambridge ErIKssons Zeichnungen zu sehen und kann nur sagen, daß sie mich nicht überzeugt haben.

Es fand nun ERIKsson in gewissen Hyphenzellen des Pilzes eine große Anzahl von Kernen - während die Uredineen sonst monoenergid sind - und auch Klebahn (Ber. D. Bot. Ges. 1904) bildet solche Hyphen ab. Auf S. 258 bildet er eine Hyphe ab mit einem großen und zahlreichen kleinen Kernen. Der große Kern könnte nach KLEBAHN ein Kern der Wirtspflanze sein und dann würde man also hier an eine Mischung des Rostplasma und des Plasma der Wirtspflanze im Sinne ERIKsSONs denken können.

Mir ist, in Verbindung mit Guilliermonds Befunden an Saccharomyces und anderen Pilzen, die Frage gekommen, ob nicht dieser große Kern der eigentliche Pilzhyphenkern sein könnte, und die anderen Kerne metachromatische Körperchen. Vielleicht ist dieser Gedanke der Prüfung wert.

Alles zusammengenommen, scheint es mir, daß ErIKssons Mycoplasmatheorie auf einem Irrtum beruht.

Dagegen sind andere Untersuchungen Erikssons auf dem Gebiete der Rostpilzfrage von größter Wichtigkeit; wenden wir uns also lieber diesen zu.

ErIKsson zeigte, daß Puccina graminis in eine Anzahl Formen zerlegt werden muß, welche zwar keine morphologische, aber sehr ausgeprägte physiologische Differenzen aufweisen, so daß $P$. graminis aus mehreren physiologischen Arten besteht.

Diese haben alle die Berberitze als Aecidienwirt, aber verschiedene Uredowirte. Er zeigte weiter, daß diese Formen ebenfalls in ihren Aecidien in entsprechender Weise differenziert sind, trotzdem alle auf der Berberitze vorkommen und morphologisch nicht unterschieden werden können.

So fand er folgende physiologische Arten in der Puccinia graminis verborgen :

1) Puccinia graminis Secalis

2) " $" \quad$ Tritici

3) " " Avenae

4) " $"$ Airae

5) $" \quad$ Agrostis

6) " $"$ Poae. 
Jede dieser physiologischen Arten kann nur einen bestimmten beschränkten Artenkreis infizieren. Uredosporen von P.graminis agrostidis können z. B. Secale, Hordeum und Avena nicht infizieren, ebensowenig kömnen die von $P$. graminis secalis Agrostis infizieren.

Aus seinen Versuchen ging hervor, daß:

die Form Secalis: folgende Arten als Wirte benutzen kann: Secale cereale L., Hordeum vulgare L., H. jubatum L., H. murinum L., H. comosum J. U. C. PresL., Agropyrum repens Beauv., A. caninum R. et ScH.. A. desertorum FiscH., Elymus arenarins L., E. sibiricus L., Bromus secatimus L.

die Form Tritici: Triticum vulgare L., Hordeum vulgare L., Secale cereale L., Avena sativa L. Sie ist also nach ERIKssons Meinung nicht scharf fixiert.

die Form Avenae: Avena sativa L., A. sterilis L., A. brevis Roth, Arrhenatherum elatius MERL en KocH, Dactylis glomerata L., Alopecums pratensis L., Millium effusum L., Lamarclica aurea MicH., Trisetum distichophyllum Beauv., Koeleria setacea DC., Bromus arvensis L., B. brachystachyus HoRNung, B. madritensi L., Festuca Myum EнRн., F. ovina L., F. sciuroides Roth., Phalaris canariensis L., Phleum asperum VILL., Brina maxima L.

die Form Airae: Aira caespitosa L., A. bothnica.

die Form Agrostis: Agrostis canina L., A. alba L.

die Form Poae: Poa compressa L., P. pratensis L.

Diese Spezialisierung gilt, wie schon bemerkt, nicht nur für die Uredosporen, sondern auch für die Aecidiosporen, z. B.:

Uredosporen von Secale cereale infizierten Hordeum und Secale, dagegen nicht Triticum und Avena,

aus Teleutos poren von $S$. cereale gezogene Aecidien infizierten Hordeum und Secale, dagegen nicht Triticum und Avena.

Unnötig ist es zu sagen, daß zahllose sorgfältige Untersuchungen nötig waren, um diese Resultate zu erhalten und zweifellos sind ERIKssons Verdienste um die Spezialisierungsfrage sehr große.

Wenn wir resumieren, haben wir also gesehen, daß sowohl auf der Berberitze, wie auf verschiedenen Getreidearten verschiedene physiologische Arten von $P$. graminis vorkommen.

Damit ist aber die Zahl der Rostarten, welche überhaupt auf diesen Pflanzen vorkommt, keineswegs erschöpft. Auf der Berberitze wurde außer dem Aecidium von $P$. graminis noch ein anderes Aecidium gefunden, welches unseren Getreidearten nichts schadet, und auf Getreide sind noch eine ganze Anzahl anderer Puccinia-Arten gefunden worden. welche ihr Aecidium nicht auf der Berberitze, sondern auf anderen Pflanzen entwickeln. Fangen wir mit der Art, die ebenfalls ihr Aecidium auf Berberis bildet, mit

\section{Puccinia Arrhenatheri KLEB.}

an. Auch hier wurde die Lebensgeschichte von Errksson (1904) aufgeklärt.

Der gewöhnliche Berberitzenrost, das Aecidium von Pucimia graminis s. l., verursacht isolierte Flecke auf Blättern und Fruchtknoten 
(Fig. 368, 2, 3). In der Regel sind nur einzelne Blätter einer Rosette infiziert. Nun beschrieb Berkeley in Hookers Flora antarctica von 1847 eine neue Art von Becherrost, welche schon auf den ersten Blick von Aecidium Berberidis dadurch verschieden ist, daß die Becherchen dicht gedrängt auf der Unterseite der Blätter stehen. Diese neue Art wurde Aecidium Magellanicum genannt, da sie auf Berberis-Zweigen an der Magellanstraße gefunden wurde.

Magnus (1876) entdeckte diesen Pilz in lebendem Zustande in den Jahren 1874-75 auf der Pfaueninsel bei Potsdam und konnte nachweisen, daß er schon viel früher in Europa gesammelt worden war, aber für Aec. Berberidis ${ }^{1}$ ) gehalten worden war. Später ist er an verschiedenen Stellen gefunden worden. Er erscheint auffallend früh, bei Berlin schon Mitte April, bei Stockholm in der ersten Hälfte des Mai.

In den kranken Rosetten sind stets alle Blätter krank, ja an ganzen Zweigen können alle Rosetten erkrankt sein.

Der Pilz kann mittels seines in den Stamm eindringenden Mycels perennieren.

Schon Magnus hatte bemerkt, daß die Keimschläuche der Aecidiosporen nicht in das Blatt von Triticum repens eindringen und daß auf der Pfaueninsel bei Potsdam trotz reichlichen Vorkommens des Pilzes die dort angebauten Getreide, Hafer, Roggen und Gerste, nicht besonders rostig waren.

Nun war schon seit einiger Zeit eine Puccinia auf Arrhenaterum elatius (syn. Avena elatior) bekannt und Eriksson konnte nachweisen, daß diese P. Arrhenateri zum Aecidium magellanicum gehört (Fig. 369, A 2, A 3).

Nach Eriksson können die Aecidiosporen auf der Berberitze selber wieder zu äcidienproduzierenden Mycelien auskeimen; seine Versuche sind aber kaum beweisend. Auch soll nach ihm das Mycel bis in das Cambium und in die Zellen desselben vordringen, aber Magnus zeigte, daß, was ErIKsson hier für Pilzhyphen hielt, höchstwahrscheinlich nur kontrahierte Plasmaschläuche der Cambiumzellen sind. In der Tat ist das der Eindruck, welchen Erikssons Zeichnung von diesen „Hyphen“ macht.

Wir sahen also, daß auf der Berberitze außer den physiologischen Arten von P. graminis auch die P. Arrhenatheri vorkommt; auf den Getreidearten kommen nun noch viel mehr Arten vor.

Aus den Untersuchungen von DE BARY war schon bekannt, daß ein Pilz, der unter den Namen: Puccinia striaeformis Westend, P. straminis Fuck. und $P$. Rubigo vera (DC.) Wrnt. bekannt war, seine Aecidien auf Anchusa officinalis L. und A. arvensis Marsh. v. Bie B (syn. Lycopsis arvensis L.) bildet, welches Aecidium als Aecidium asperifolii PeRs. bekannt war.

Eriksson wies nach, daß unter dieser Puccinia Rubigo vera zwei Arten versteckt waren, nämlich :

P. dispersa Erikss. (Fig. 370, II 1, 2) = „Braunrost", mit Uredo und Teleuto ausschließlich auf Secale cereale und S. montanum und dem Aecidium auf Anchusa resp. Lycopsis, und

1) Ich fand ihn unter diesem Namen im Herbarium Persoon in Leiden, aber mit der Bemerkung Persooss, daß er von P. Berberidis abweicht. Leider fehlt eine Fundortsangabe. 
P. glumarum (Sсhmidt) Erikss. et Henn. (Fig. 369, V) = "Gelbrost", mit einer Anzahl physiologischer Arten, welche nach ihren Hauptwirten genannt sind, nämlich

$$
\begin{aligned}
& \text { P. glumarum Tritici, } \\
& " \quad " \text { Hordei, } \\
& \text { " " Elymi, } \\
& \text { und deren" Aecidium noch unbekannt ist. }
\end{aligned}
$$

Nun ist die Sache etwas verwirt geworden, da ErIKsson die echte $P$. dispersa ERIKss. zunächst nicht von einer Art unterschied, welche er P. dispersa Erikss. et Hens. nannte und welche auf einer Anzahl Getreidearten vorkommt.

$P$. dispersa Erikss. und P. dispersa Erikss. et Henn. sind demnach nicht synonym. Daß aber in der Tat $P$. dispersa EnIKss. eine eigene Art ist, konnte Klebahn bestätigen.

Puccinia dispersa Erikss. et Hens. besteht aus einer Anzahl von Arten, nämlich aus:

1) P. Symphyti-Bromorum F. MüLL. = P. bromina ERIKss. Nit dieser Art nahm Marshall Ward seine interessanten Versuche vor;

2) P. triticina ERIKss., deren Aecidium noch unbekannt ist;

3) P. agropylina Erikss.;

4) P. holcina ERIKss.;

5) P. Triseti Erikss.,

und dann bleibt noch ein näher zu untersuchender Rest übrig:

Puccinia triticina ErIKss. (Fig. 369, III) kommt fast ausschließlich auf Triticum vor; das Aecidium ist noch nicht bekannt.

P. simplex (Körn.) EriKss. et Henn. (Fig. 369, IV), Syn.: P. straminis var. simplex KöRNICKE 1865 , Uromyces Hordei NiElseN 1875 ; P. anomala Rostrup 1876, der "Zwergrost", ist auf Gerste beschränkt, das zugehörige Aecidium noch unbekannt. P. coronata CoRdA (Fig. 370, I 1,2 ) ist von KLEBAHN in zwei Arten zerlegt worden. Für die eine behält er den Namen $P$. coronata bei. Sie bildet ihre Aecidien auf Rhamms Frangula L. (Frangula alnus). Sie besteht wieder aus einer Anzahl physiologischer Arten, welche nach ihren hauptsächlichen PucciniaWirten genannt werden:

P. coronata Calamagrostis ERIKss.;

P. coronata Phalaridis Kleb. (?), nach Klebahn wahrscheinlich von voriger nicht verschieden;

P. coronata Holci KLeB.;

$" \quad " \quad$ Agrostis ERIKss.;

Die von $P$. coronata abgetrennte Art nennt KLEBAhn:

P. coronifera KLeb. (Fig. 370, III 1, 2). Sie bildet ihr tecidium auf Rhamnus cathartica L. Sie besteht alis folgenden physiologischen Arten:
P. coronifera Avenae ERIKss.,
$" \quad " \quad$ Lolii ERIKSs.,
" " $" \quad$ Festucae Erikss., 


$$
\begin{array}{ccc}
\text { P. coronifera } & \text { Holci KuEB., } \\
" & " & \text { Alopecuri ERIKss., } \\
" & " & \text { Glyceriae ERIKss. }
\end{array}
$$

Es kommen also auf unseren Getreidearten vor:

A ecidium auf:

der Schwarzrost, P. graminis Pers. . . . Berberis vulgaris L.

der Roggenbraunrost, P. dispersa Erikss. - Anchusa und Lycopsis

der Weizenbraunrost, $P$. triticina ErIkss. . unbekannt

der Zwergrost, P. simplex (Körn.) Erikss. et

HENN.

der Gelbrost, P. glumarum Schmidt . . unbekannt

der Kronenrost, P. coronata Conda . . . . Rhamnus Frangula L.

der Haferkronenrost, P. coronifera KLEB. - Rhamnus cathartica L.

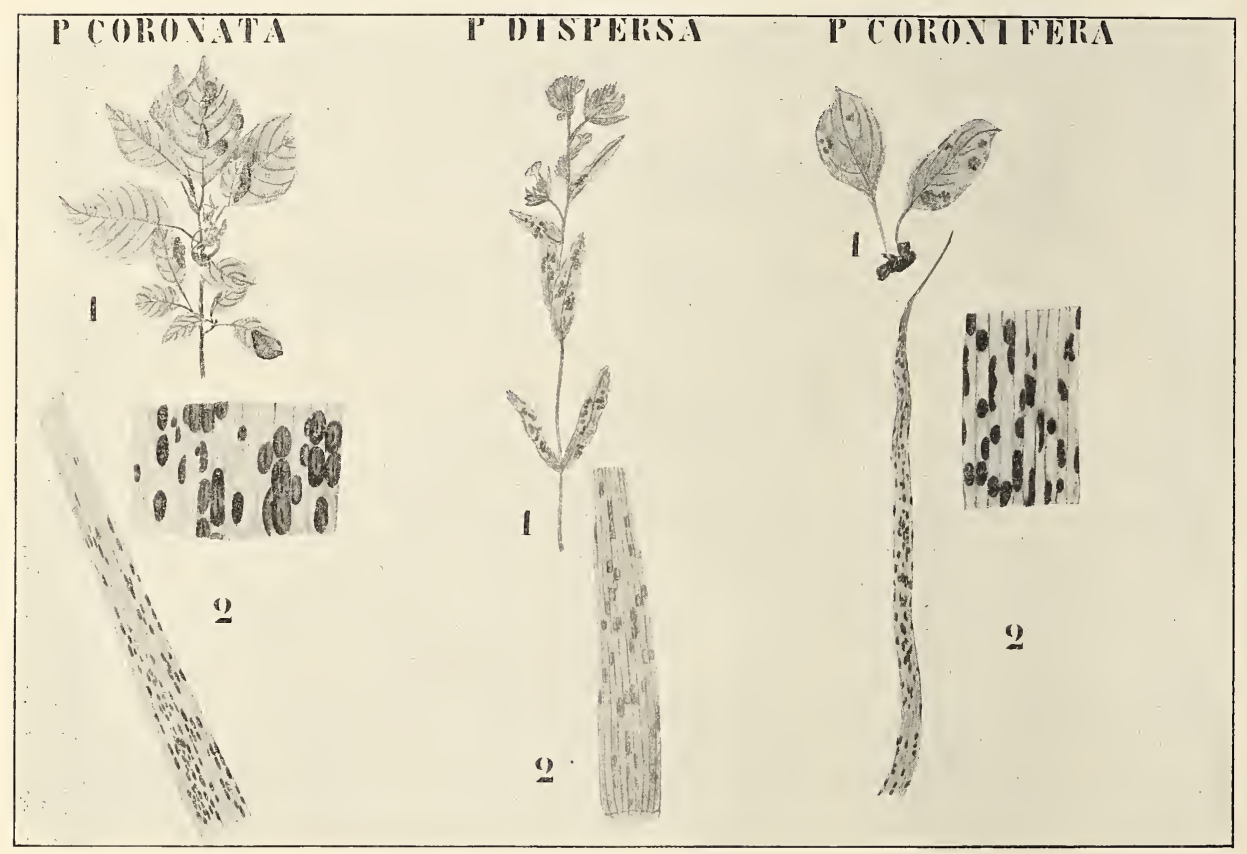

Fig. 370. I. Puccinia coronata. 1 Aecidien auf Rhamnus Frangula L. 2 Teleuto auf Calamagrustis. - II. P. dispersa. 1 Aecidien auf Lycopsis arvensis L. '2 Teleuto auf Secale cereale L. - III. P. coronifera. 1 Aecidien auf Rhamnus cathartica L. 2 Teleuto auf Avena sativa.

Unter den nicht auf unseren Getreidearten vorkommenden Rostarten ist P. Symphyti-Bromorum F. MÜLL. durch die Untersuchungen Marshall WARDS besonders interessant geworden. Wir kommen darauf bei der Besprechung der Rostarten im allgemeinen zurück.

Betrachten wir erst noch einige wichtige Formen.

Wir können die Uredineen nach ihren Teleutosporenmerkmalen in folgende Familien einteilen, eine Einteilung, die aber selbstverständlich eine vorläufige ist: 
I. Keine Teleutosporen . . . . . . . . . . . Endophyllaceae

II. Teleutosporen ungestielt. . . . . . . . . . Melampsoraceae

III. Teleutosporen gestielt . . . . . . . . Pucciniaceae.

Von der Familie der

\section{Endophyllaceae}

ist bis jetzt nur das Genus

\section{Endophyllım}

einigermaßen vollständig bekannt. Endophyllum Sempervivi bildet seine Aecidien auf den Blättern von Sempervivum-Arten (Fig. 371, E 1). Der Pilz überwintert mittels seines Mycels in den Blättern des Wirtes, welche sich dadurch verlängern und einen aufrechten Stand annehmen. Die

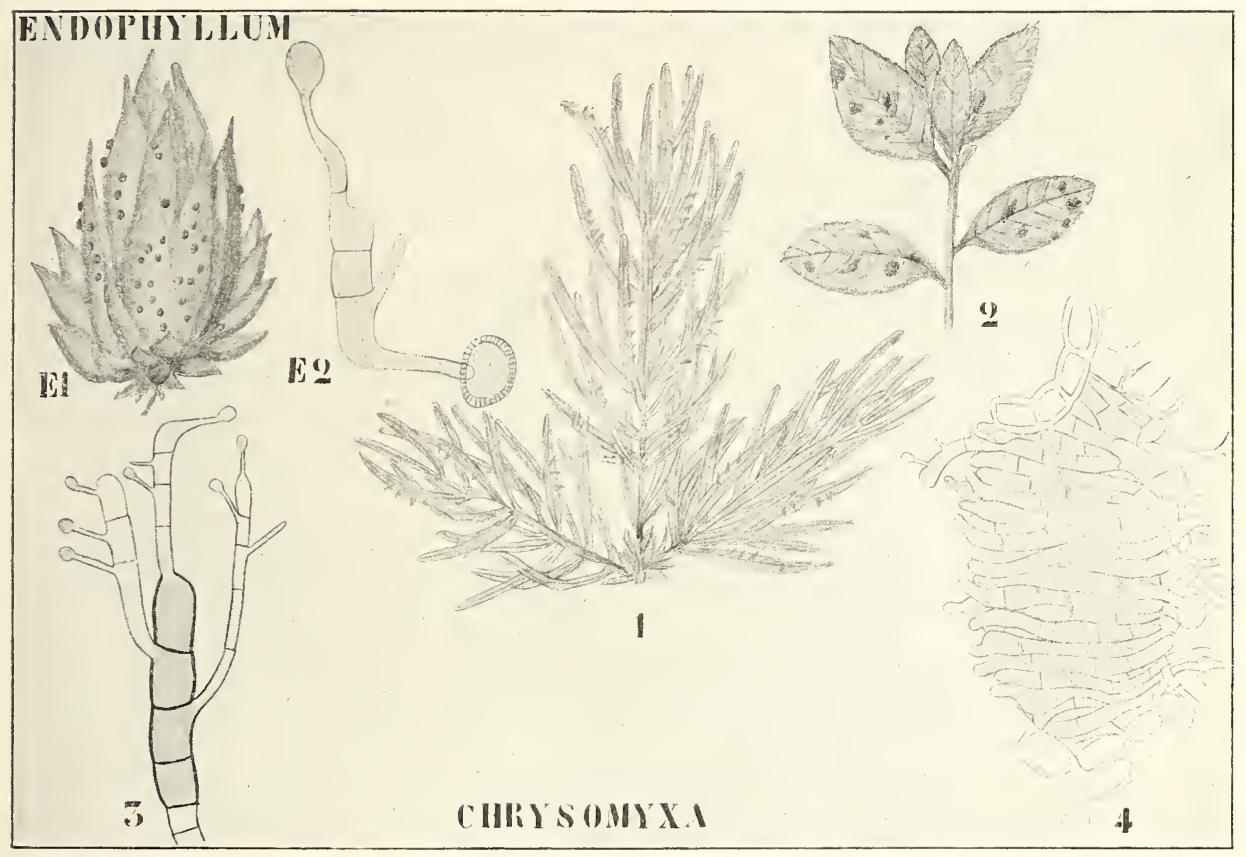

Fig. 371. I. Endophyllum Sempervivi (ALB. et Schw.) DE BARY). E1 Habitusbild (nach Kerner). E2 Keimende Aecidiospore (nach DE BARY). - II. Chrysomyxa Rhododendri (DC.) DE BARY. 1 Aecidium auf Picea excelsa (nach V. WETTSTEIN). 2 Teleuto auf Rhododendron hirsutum (nach v. WETTSTEIN). 3 Keimende Teleutospore. 4 Schnitt durch ein Teleutosporenlager mit in situ keimenden Teleutosporen (beide nach DE BARY).

Aecidiosporen keimen mittels eines sporidienbildenden Promycels (Fig. 371, E 2), während die Sporidien wieder auf Sempervivum keimen. Wir haben hier also mit einer autöcischen Art zu tun, deren $2 \mathrm{x}$-Generation auf ein Minimum, nämlich auf die Aecidiosporen reduziert ist; sei es denn, daß es sich herausstellen würde, daß hier die Aecidiosporen sich parthenogenetisch entwickelten und also nur einen Kern enthalten, was nicht wahrscheinlich ist. 
Bei der zweiten Familie, bei den

\section{Melampsoraceae,}

haben wir mit ungestielten 1-4-zelligen Teleutosporen zu tun.

Wir können sie in folgender Weise einteilen:

I. Teleutosporen in Reihen gebildet. . . . Chrysomyxeae Chrysomyxa Cronartium

II. Teleutosporen nicht in Reihen gebildet:

a) Sporen mit einem Promycel keimend . . Melampsoreae

a) Teleutosporen einzellig

$\beta$ ) Teleutosporen aus 4 nebeneinander stehenden Zellen bestehend

b) Sporen, die sich bei der Keimung in 4 Zellen teilen, kein Promycel

$\{$ Melampsora

Melampsorella

Calyptospora

Coleosporieae

Fangen wir mit den

\section{Chrysomyxeae}

an, und wählen wir als Beispiel

Chrysomyxa Rhododendri (DC.) DE BARY.

Seit längerer Zeit war auf Fichten (Picea excelsa Lk.) ein Aecidium bekannt, das den Namen Aecidium abietinum AlB. et ScHw. trug; DE BARY bemerkte, daß dieses Aecidium in den Alpen sehr häufig an solchen Stellen war, wo Alpenrosen (Rhododendron) vorkommen, und er konnte die Lebensgeschichte ausarbeiten.

Im Sommer kommt unser Pilz auf den Alpenrosen vor. Schon im Herbst werden dort die Teleutosporen angelegt; sie reifen sofort nach der Schneeschmelze und bilden zu jener Jahreszeit braunrote Flecke an der Unterseite der Blätter (Fig. 371, II 2).

Die bei der Keimung der Sporidien gebildeten Keimschläuche dringen in die jungen, dann eben ausschlagenden Fichtennadeln ein und bilden auf denselben die hellgelben Flecken des Aecidium abietinum (Fig. 371, II, 1). Die kranken Nadeln fallen ab, die Aecidiosporen bilden in den Rhododendron-Blättern ein Mycel, welches während des Sommers Uredosporen bildet und gegen den Herbst Teleutosporen anlegt, die erst nächstes Frühjahr reifen und dann sofort keimen.

Sind keine Fichten vorhanden, so bleibt der Pilz mittels seiner Uredosporen auf dem Rhododendron bestehen. Während er in Gegenden, wo Fichten sind, wenige oder sogar gar keine Uredosporen bildet, macht er solche in großer Zahl an oberhalb der Baumgrenze gelegenen Fundorten. DE BARY schreibt dies klimatischen Umständen zu; möglicherweise führt auch eine lange Uredosporenbildung $\mathrm{zu}$ einem schließlich ausschließlichen Auftreten derselben.

Die Chrysomyxa auf Rhododendron kann sich also auch hoch im Gebirge behaupten, wo keine Fichten mehr sind; umgekehrt stellte es sich aber heraus, daß in der Ebene, wo keine Alpenrosen sind, ein dem Aecidium abietinum vollkommen ähnliches Aecidium auf Fichten vorkam.

DE BARY konnte nun nachweisen, daß die zugehörige Uredoform auf Ledum palustre lebte. 
Das hat also den Anschein physiologischer Arten und war der erste bekannte Fall eines solchen Verhaltens, aber es konnte DE BARY dennoch kleine morphologische Verschiedenheiten zwischen den Aecidien finden, so daß wir hier mit einer Art zu tun haben, die auf der Grenze des Physiologischen und des Morphologischen steht.

Als zweites Beispiel einer Chrysomyxee, d. h. also einer Melampsoracee, bei welcher die Teleutosporen in Reihen gebildet werden, sei hier

\section{Cronartium}

besprochen. Auf verschiedenen Tannenarten kommen Aecidien vor, welche in mancher Hinsicht unter sich gleich sind und als Peridermium Pini oder nahe verwandte Arten beschrieben wurden.

Sorgfältige Untersuchungen von Cornu, KLeBahn und Fischer haben aber gelehrt, daß darunter eine Anzahl verschiedener Arten versteckt sind, welche teils dem Genus Cronartium, teils dem Genus Coleosporium angehören. Die zum Genus Cronartium gehörigen mögen hier sehr kurz besprochen werden.

\section{Cronartium asclepiadeum (WILLD.) Fr.}

Auf Pinus silvestris kommt ein sogenannter Blasenrost vor: Peridermium Pini (Wrllo.) f. corticola ex p. (Fig. 372, I 1). Diese Aecidien werden von einem in Holz und Rinde perennierenden Nycel gebildet, welches alljährlich im Frühjahr neue Aecidien bildet.

Dadurch wird die Rinde rauh, was zu der Benennung Kiefernräude für diese Krankheit geführt hat. Die orangegelben, großen Aecidien können nur an jungen Zweigen mit noch dünner Borke hervortreten; junge Pflanzen werden von der Krankheit bald getötet.

Connu zeigte, daß die Uredoform auf Vincetoxicum officinale MoEncH. als Cronartium asclepiadeum lebt. Dies wurde von KLEBAHN bestätigt. Während nun, wie wir sahen, im allgemeinen die Rostarten sehr spezialisiert sind, stellte es sich heraus, daß Cronartium asclepiadeum hingegen stark pleophag ist; sie kommt auf 4 verschiedenen Arten aus 4 verschiedenen Familien vor, nämlich auf Vinceioxicum (Asclepiadeae), Paeonia (Ramunculaceae), Nemesia (Scrophularineae) und Verbena (Verbenaceae).

Wir sahen bereits, daß KLEBAHn Cornus Resultate bestätigte, aber keineswegs sofort. Im Gegenteil gelang es ihm längere Zeit nicht, mit der in Deutschland häufigsten Form des Peridermium Pini ein Asclepias zu infizieren, und solches gelang ihm erst, nachdem er mit in Frankreich und bei Greiz gesammeltem Material arbeitete.

Später stellte es sich heraus, daß die in Deutschland häufigste Form des Peridermium Pini, trotzdem sie kaum von voriger zu unterscheiden ist, wahrscheinlich dennoch zu einem anderen Cronartium gehört, welches aber trotz vieler Infektionsversuche auf den verschiedensten Pflanzen von KLEBAHN noch nicht gefunden werden konnte.

Als Gegenstück zu diesem Peridermium, dessen Cronartium noch unbekannt ist, haben wir in Cronartium gentianeum Tнüм. auf Gentiana. asclepiadea ein Beispiel eines Cronartium, dessen zugehöriges Peridermin noch fehlt.

Damit ist aber die Geschichte der Peridermia noch keinesweg's erschöpft. Peridermium giganteum (Marr) Tub. auf Pims-Arten in Japan gehört nach SHIRAI zu dem dort auf verschiedenen Eichenarten rorkommenden Cronartium Quercum (Cooke) Mryabe, und das 


\section{Peridermium Strobi KLeB.}

gehört zu Cronartium ribicola. Die Aecidienform (Fig. 372, II 1, 2) ähnelt in mancher Hinsicht der des Cronartium asclepiadeum, aber es gibt doch, zumal bei mikroskopischer Untersuchung, deutliche Verschiedenheiten.

In unserem Lande hat sich der Pilz in den letzten 20 Jahren so sehr verbreitet, daß ich bezweifle, ob noch eine gesunde Pinus Strobus in den Niederlanden existiert. Das Mycel perenniert viele Jahre lang in der Zweigrinde, wächst jedes Jahr etwas weiter auf den Stamm zu und produziert seine Aecidien. Nachdem diese leer sind, stirbt die infizierte Rinde in der Regel ab und hat ein zerfressenes Aeußere; die

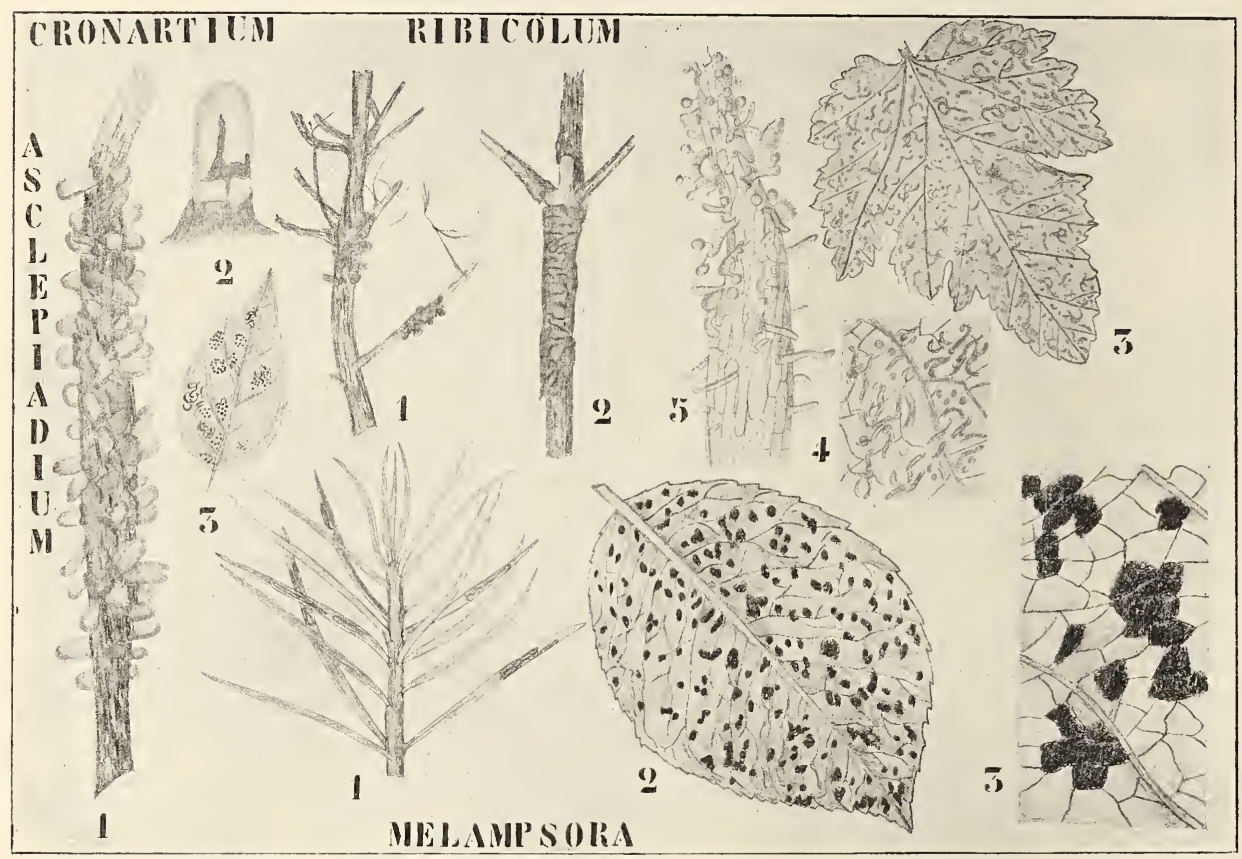

Fig. 372. I. Cronartium asclepiadeum (nach DIETEL). 1 Ein Kiefernzweig mit zahlreichen Aecidien. 2 Ein einzelnes Aecidium vergrößert. 3 Das Teleutosporenlager auf Vincetoxicum (Original). - II. Cronartium ribicolum DieTr. 1, 2 Aecidienlager nach Tubeur. 3 Teleutosporenlager auf Ribes nigrum. 4 Ein Teil desselben vergrößert (beide nach DieTEL). 5 Spitzenteil eines Teleutosporenlagers mit keimenden Teleutosporen und einigen anhaftenden Uredosporen (nach TULAsNe). - III. Melampsora LariciCaprearum KLeb. 1 Aecidium auf Larix (nach Hartig). 2, 3 Teleuto auf Salix Caprea (nach DieteL).

Aecidien des nächsten Jahres treten an der Peripherie dieses zerfressenen Teiles auf. Die Spermogonien zeigen sich meistens an jungen Zweigen im Juli und August, die Spermatien liegen in einer süßlichen Flüssigkeit und werden von Insekten verbreitet. Die Uredo- und Teleutosporen werden auf Ribes-Arten gefunden, und zwar meistens auf $R$.nigrum und aureum, aber auch auf anderen Arten, nur R. Grossularia ist sehr wenig empfindlich. Für nähere Details sei auf KLEBAHN verwiesen. Das Cronartium bildet spitze Uredo- und Teleutosporensori auf den Blättern dieser Ribes-Arten (Fig. 372, II 3-5). 
Wenden wir uns jetzt der zweiten Untergruppe der Melampsoraceae zu, derjenigen der Melampsoreae, und zwar zunächst denen, deren Teleutosporen mit einem Promycel keimen. Als erstes Beispiel sei

\section{Melampsoral}

gewählt. Auf Larix sind nicht weniger wie 5 Arten einfach gebauter Aecidien (Caeoma) bekannt, welche zu verschiedenen Melampsora-Arten gehören (Fig. 372, III 1). Die zugehörigen Uredo und Teleuto kommen auf Populus und Salix vor. Daraus darf man aber keinesweg's schließen. daß die auf diesen Pflanzen vorkommenden Melampsora sämtlich ihre Aecidien auf Larix bilden; im Gegenteil: von den 5 Melampsora-Arten, welche auf Populus vorkommen, hat nur eine ihr Aecidium auf Larix, die anderen auf Mercurialis, Chelidonium, Corydalis und Pinus.

Als Beispiel mag

Melampsora Larici-Caprearum KцEв.,

nach KLEBAHns Untersuchungen eine der häufigsten Uredineen um Hamburg, gewählt werden.

Schon im Sommer werden die Uredo auf Salix: Caprea, zunächst als einzelne große, später als zahllose kleinere, bisweilen die ganze Unterseite der Blätter bedeckende Flecken gefunden.

Wenn gegen den Herbst die Teleutosporen gebildet werden, scheint sich der Pilz noch bedeutend auszubreiten. Diese bilden sich unter der Cuticula an der Oberseite der Blätter, infolgedessen diese zunächst gelbe, später braunrote bis dunkelbraune Flecke erhält (Fig. 372, III 2, 3). Auf den auf dem Boden liegenden Salix-Blättern keimen die Teleutosporen schon früh im Jahre. Mit den so erhaltenen Sporidien konnte nun KLebahn Larix decidua infizieren, und mit den auf diesen gebildeten Aecidiosporen wieder Salix Capraea, so daß der Lebenszyklus unseres Pilzes damit vollständig bekannt ist.

Vom verwandten Genus Melampsorella, welches vielfach als ein Subgenus von Melampsora betrachtet wird, kennen wir

Melampsorella Caryophyllacearum (DC.) Schroet.

zumal durch Fischers Untersuchungen als die Ursache des Aecidium elatinum, welches schöne Hexenbesen auf Abies pectinata LAn. et DC. bildet.

Im Gebirge sieht man öfters diese Hexenbesen; sehr schön sah ich sie im vergangenen Jahre in den Wäldern am Wege von Altaussee (Salzkammergut) nach dem Salzbergwerk. Sie werden dadurch verursacht, daß das in den Zweigen perennierende Mycel einen besonders starken Wachstumsreiz ausübt. Hat nun die Infektion an einer Stelle, wo keine Knospen vorhanden sind, stattgefunden, so entsteht nach HARTig ${ }^{1}$ ) durch das abnorm starke Cambiumwachstum eine Anschwellung, welche zu riesigen Beulen gesteigert werden kann. Infolge dieser Hypertrophie entstehen Risse in der Rinde, und öfter dringen in die so entstandenen Wunden Sporen anderer Parasiten ein, so z. B. von Polyporus Hartigii und Agaricus adiposus.

Hat die Infektion aber an einer Stelle, wo schlafende Augen vorhanden sind, stattgefunden, so treiben diese aus und bilden aufwärtswachsende Zweige (Fig. 373, 2), welche infolge der Anwesenheit des Pilzmycels eine fieischige Rinde und kurze Nadeln bekommen; es entsteht der sogenannte Hexenbesen. Die Nadeln sind blaßgrün mud tragen im August die Aecidien.

1) Heck (Der Weißtannenkrebs, 1894) widerspricht dem, nach ihm ist an ciner solchen Stelle vorher ein Hexeubesen gewesen. 
Ende August streuen diese ihre Sporen aus und die Nadeln fallen ab. Jedes Jahr wächst das Mycel in die neuen Knospen, welche der Hexenbesen treibt, hinein, und verursacht ihre Entwickelung, so daß sozusagen eine Symbiose zwischen der Uredinee und den betreffenden Zweigen entsteht, die als Hexenbesen auf der Fichte parasitieren.

Nach und nach dringt das Nycel auch in den Zweig ein, und so entsteht an diesem 'eine Beule, genau so wie bei den Infektionen an Stellen, wo keine Knospen vorhanden waren. Solche Hexenbesen können sehr alt, bisweilen über 20 Jahre, und demnach sehr groß werden, ja sogar nach ihrem Absterben kann die Beule noch an Größe zunehmen.

Selbstverständlich hat man wiederholt versucht, die Uredo- und Teleutoform dieses Pilzes aufzufinden. Schließlich gelang es Ed. Fischer,

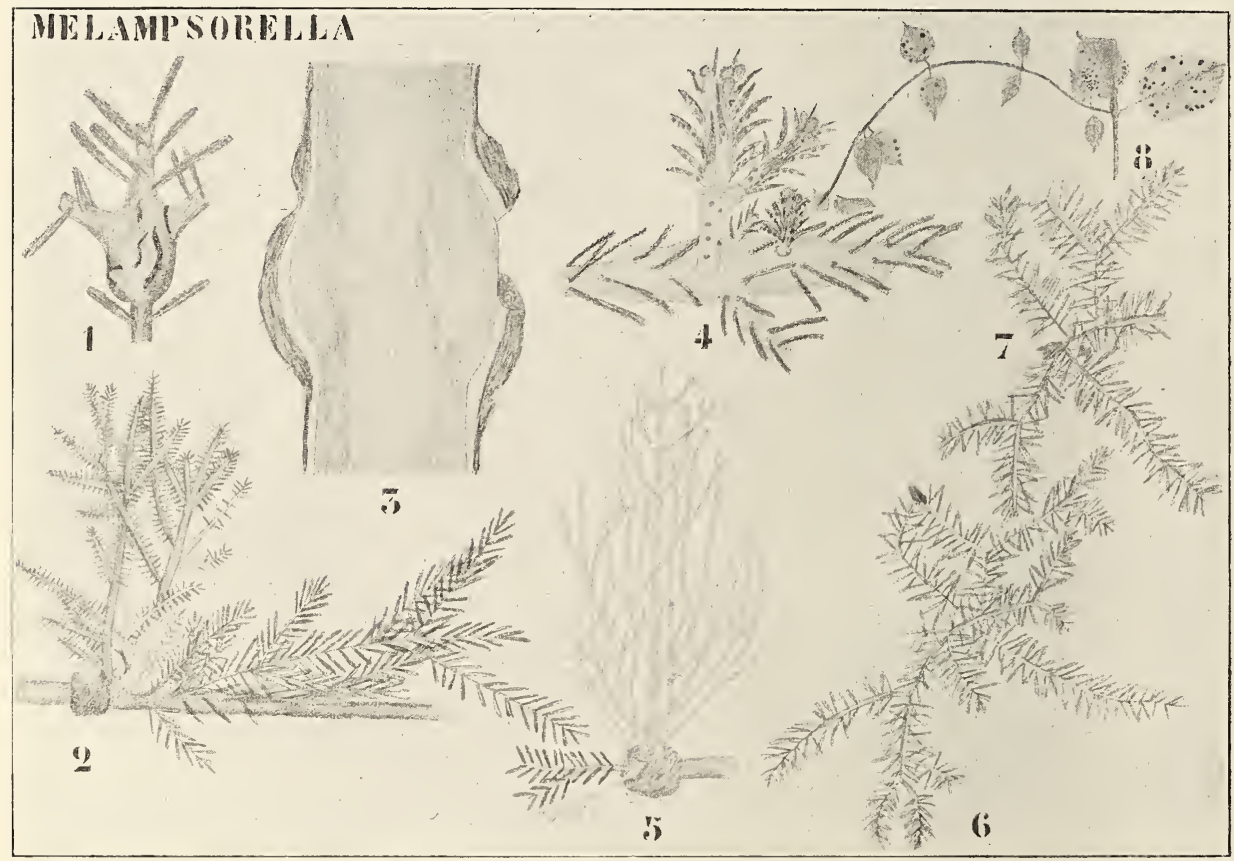

Fig. 373. Melampsorella Caryophyllaccarum. 1 Resultat einer Fichteninfektion an einer Stelle, wo keine schlafenden Augen vorhanden waren (nach HARTIG). 2 Junger Hexenbesen (nach v. Wettstein). 3 Längsschnitt durch eine Anschwellung wie die in 1 (nach HARtig). 4 Hexenbesen, die fleischige Rinde, sowie die Accidien auf den Nadeln zeigend (nach HaRTiG). 5 Hexenbesen im Winter (nach HARTIG). 6, 7 Zweige der Fichte, mit den Sporen der Melampsorella besät, und die typisch fleischige Rinde der Hexenbesen entwiekelnd (nach Fischen). 8 Teleutosporen auf Stellaria media (nach der Natur).

zu zeigen, daß die Melampsorella auf Stellaria nemorum L. die lange gesuchte war. Eine Anzahl verwandter Arten kann die Uredo- und Teleutosporen tragen, z. B. Stellaria media, S. Holostea, S. graminea, Arenaria serpyllifolia, Cerastium triviale, Malachium aquaticum, Moehringia trinervia etc. Die Frage nach einer eventuellen Spezialisierung steht noch offen: Diese Melampsorella nun kommt auch an Stellen vor, wo Fichten fehlen, sie kann dies tun, weil ihr Mycel perenniert und Uredosporen produziert. 
Zu den mittels eines Promycels keimenden Melampsoreae gehört weiter das Genus Calyptospora, welches sich aber von Melampsora und Melampsorella dadurch unterscheidet, daß die Teleutosporen aus 4 nebeneinander stehenden Zellen bestehen.

Als Beispiel mag

\section{Calyptospora Goeppertiana J. KÜHN}

= Pucciniastrum Goeppertianum (J. Küнn) KLев. dienen.

Von Hartig wurde durch Aussaatversuche in beiden Richtungen bewiesen, daß zu der auf T'accinium Vitis Idaea parasitierenden Teleuto-

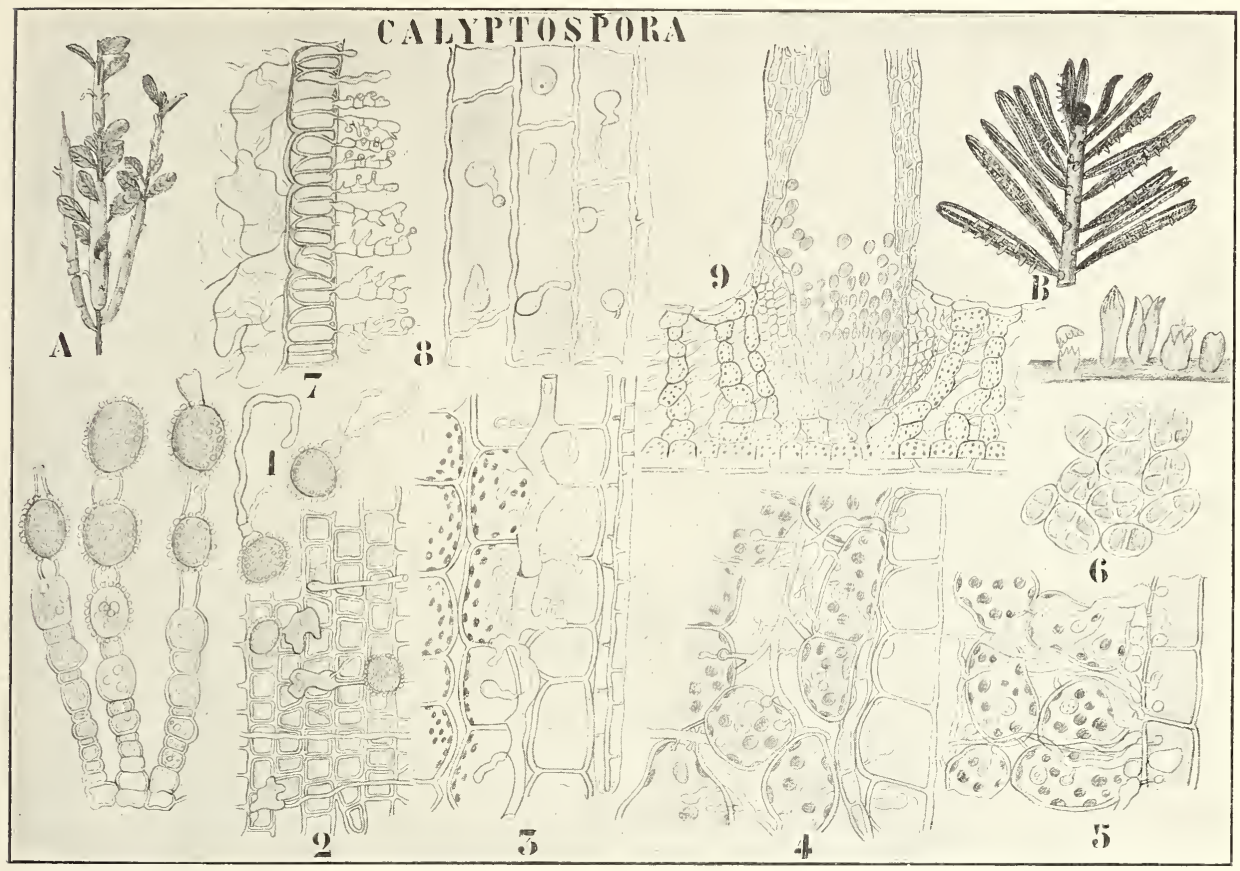

Fig. 374. Calyptospora Goeppertiana (nach HARTiG). A. Die Teleutos auf Vaccinium Vitis Idaea. B. Das Aecidium auf A bies peetinata LAM. 2 links: Reihen von Aecidiosporen, rechts: solche auf Vaceinium Vitis Id a ea keimend. 3, 4 Das Myeel in Vaccinium Vitis Idaea. 5 Anfang der Teleutosporenbilduug in der Epidermis von Vaceinium Vitis Idaca. 6 Quersehnitt durch die Epidermiszellen, die Vierergruppen der Teleutosporen zeigend (nach DIETEL). 7 Die Epidermis mit größtenteils schon keimenden Teleutosporen gefüllt. 8 Die Sporidien, auf Abies peetinata keimend. 9 Längssehnitt durch ein Aecidium.

form als Aecidienform das Aecidium colnmmare ALB. et ScHw. auf Abies pectinata LAm. et DC. gehört.

Die Aecidiosporen keimen auf Vacciminm Titis Idaea, dringen durch die Spaltöffnungen der Rinde in die jungen Sprosse ein und bilden dort ein Mycel, welches sich in der Rinde breit macht; äuberlich sichtbare Veränderungen entstehen dadurch aber noch nicht. Erst im nächsten Jahre, wenn sich die neuen Sprosse bilden, verursacht das in diese eintretende Mycel eine Vergrößerung der Rindenzellen und dadurch ein Anschwellen dieser Zweige bis zur Dicke einer Gämsefeder (Fig. 37t, A). Dieses schwammartige Gewebe ist zunächst weiß oder hübsch rosa, wird 
aber später braun bis schwarzbraun. Der obere Teil des Sprosses schwillt nicht an, so daß dort der Stengel seine normale Struktur behält, trotzdem das Mycel auch schon dort vorhanden ist, ja, in die Knospe vordringend, diese zum vorzeitigen Austreiben reizt. So können 2-3 Etagen von Anschwellungen übereinander entstehen, da das Mycel auch wieder in die Knospen der vorzeitig ausgetriebenen Sprosse eintritt und auch diese zum Austreiben bringen kann. Da nun überdies das Längenwachstum der Pflanze gesteigert wird, ragen die infizierten Exemplare weit über die gesunden hervor und erreichen nicht selten eine Höhe von $30 \mathrm{~cm}$.

Das Mycel verläuft intercellular, sendet aber Haustorien in die Zellen hinein, wächst dann auf die Peripherie zu und bildet unter der Epidermis eine Schicht von Hyphen, welche Ausstülpungen in die Epidermiszellen hineinsendet. Es sind diese zum Teil Haustorien, zum Teil aber Teleutosporenmutterzellen. Von letzteren dringen 4-8, meistens 6 , in jede Epidermiszelle hinein, vergrößern sich dort und occupieren die Zelle alsbald ganz.

Mittels gekreuzter Wände teilt sich jede in 4 Teleutosporen, welche also nebeneinander liegen (Fig. 374, 6).

Im Mai des nächsten Jahres keimt jede derselben zu einem Promycel aus, wobei die Sporen aber in dem Vaccinium sitzen bleiben; die Sporidien keimen auf den Fichtennadeln, an deren Unterseite sie 2 Reihen von Aecidien bilden, welche eine sehr lange Peridie besitzen. Die Aecidiosporen keimen, wie beschrieben, auf der Rinde von Vaccinium Vitis Idaea.

Von den Melampsoraceae bleibt nun nur noch diejenige Gruppe zu besprechen übrig, deren Teleutosporen nicht mittelst eines Promycels keimen, nämlich die

\section{Coleosporieae:}

Dazu gehören zwei Genera, Ochropsora (Fig. 375, I) und Coleosporium (Fig. 375, II). Von Ochropsore ist nur eine Art,

\section{Ochropsora Sorbi,}

bekannt, welche auf Sorbus aucuparia und anderen Sorbus-Arten, sowie auf Spirce aruncus vorkommt. Die Uredolager sind sehr klein, zu unregelmäßigen Gruppen vereint und von Paraphysen umgeben. Die Teleutosporenlager bilden unregelmäßige blaßgelbe Krusten an der Unterseite der Blätter. Auch hier keimen die Teleutosporen auf dem Wirte (Fig. 375, I 1), teilen sich dabei aber in 4 übereinander gelegene Zellen, deren jede eine Sporidie bildet.

Mit Sicherheit ist das zugehörige Aecidium noch nicht bekannt, höchstwahrscheinlich aber sind TRAnzschels vorläufige Versuchsresultate richtig und das Aecidium leucospermum DC. auf Anemone nemorosa L. gehört in den Entwickelungsgang dieses Pilzes.

Das andere Melampsoreen-Genus mit in ähnlicher Weise keimenden Teleutosporen ist

von welchem hier

\section{Coleosporium,}

\section{Coleosporium Senecionis}

besprochen werden mag.

R. WolfF (Bot. Ztg. 1874) zeigte zuerst, daß zu diesem Coleosporium als Aecidienform das Peridermium Pini f. acicola gehört. Spätere 
Versuche haben dies bewiesen. Die Aeciedienform sieht man im April und Mai öfters in großer Zahl auf den ein- und zweijährigen Nadeln jüngerer Fichten. Die Aecidien sind einige Millimeter groß, rotgelb: zwischen ihnen kann man die braungefärbten Spermogonien als schwarze Fleckchen sehen. Die Teleutosporen, die auf Senecio gebildet werden. teilen sich bei der Keimung in 4 übereinander gelegene Zellen, deren jede eine Sporidie bildet.

Wir haben also 3 Genera kennen gelernt, bei welchen die Teleutosporen auf der Stelle, wo sie gebildet werden, keimen, nämlich:

1) Calyptospora,

2) Ochropsora,

3) Coleosporium.

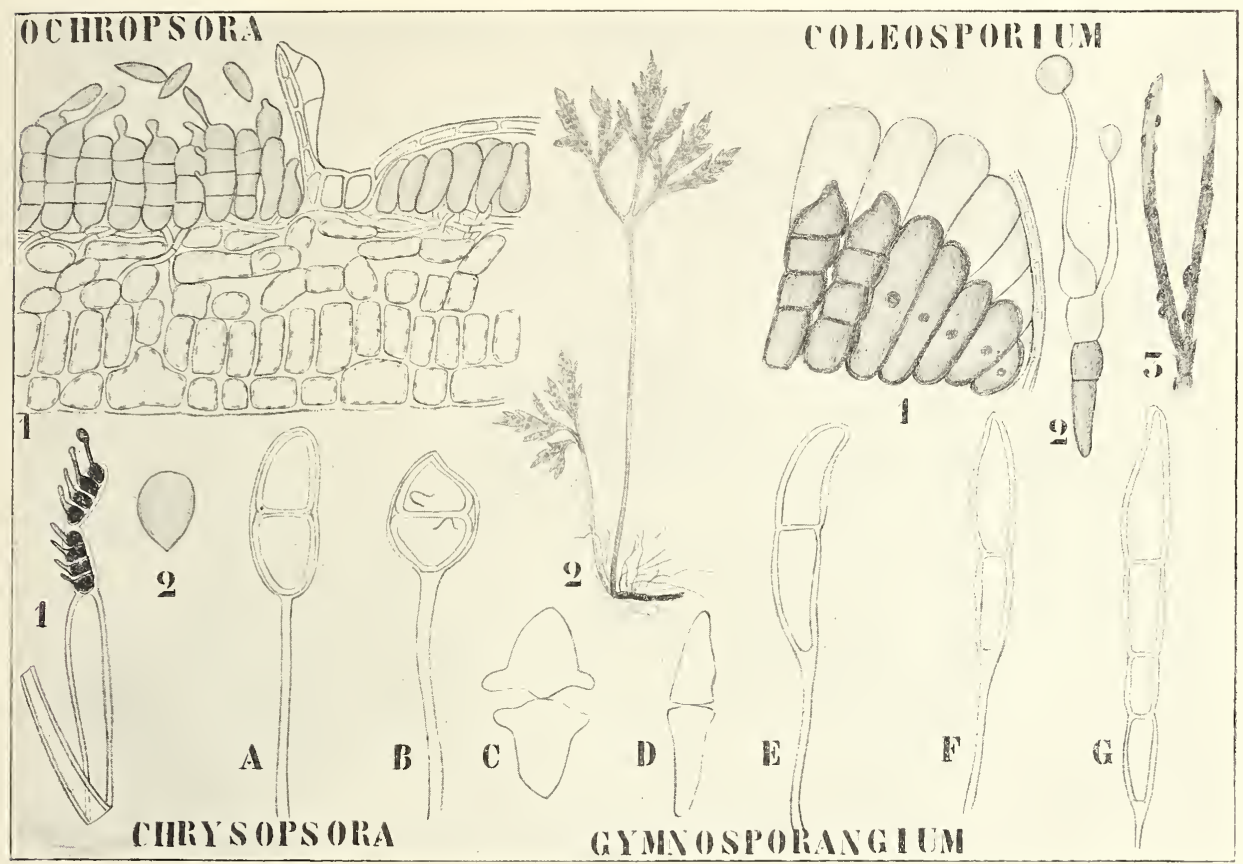

Fig. 375. I. Ochropsora Sorbi (Oud.) Diet. 1 Telentosporenlager auf Sorbus a u cuparia, links mit keimenden, rechts mit ungekeimten Teleutosporen. 2 Das wahrscheinlich hierzu gehörige A ecidium leucospermum auf Anemone nemorosa (Original). - II. Coleosporium. 1 C. Euphrasiae (Schum.). Schnitt durch den Randteil des Teleutosporenlagers (nach DIETEL). 2 C. Senecionis, keimende Teleutospore mir Sporidien an zwei Sterigmen (nach Plowrigrt). 3 Das hierzu gehörige Peridermium Pini f. acicola (nach Wettstein). - III. Chrysopsora Gynoxidis Lagerh. 1 Sporidienbildende Teleutospore. 2 Sporidie (beide nach DIETEL). - IV. Telentosporenformen verschiedener Gymnosporangium-Arten (nach Dietel). A Von G. tremelloides A. BR. B, C Von G. juniperinum (L.) Wint,, eine dick- und eine dünnwandige. letztere in Keimung begriffen und deren änßere Membranschicht durch Quellung gelöst. D u. E Dünnund dickwandige von G. clavaria eforme (JACQ.) ReEs. F u. G Eine :- und eine 4-zellige von G. Ellisii (Berk.) FARL. (nach Dietel).

Die Ursache dieser Erscheinung ist wohl diese, daß sie, unter der Cuticula gebildet, dort genügend Feuchtigkeit finden, um zu keimen.

Die Teleutosporen von Calyptospora keimen normal mit einem Promycel, die von Ochrospora und Coleosporium ohne ein solches, oder wohl 
besser mit einem inneren Promycel, denn auch hier teilt sich die Teleutospore in 4 Zellen, bildet also ebensogut 4 Sporidien, wie die von Calyptospora, und man hat zweifellos recht, die 4 Teilzellen als ein im Innern der Teleutospore gebildetes Promycel aufzufassen.

Schreiten wir jetzt zur Besprechung der letzten Gruppe der Uredineen, zu derjenigen der

\section{Pucciniaceae ${ }^{1}$.}

Wir können diese wie folgt einteilen:

A. Kein auswendiges Promycel, die Teleutospore keimt wie bei Ochropsora . . .

B. Teleutosporen keimen mit einem normalen Promycel.

a) Tremelloide Formen, die Teleutosporen in einer geléeartigen Masse auf Cupressineae . . . . . . . . . .

b) Nichttremelloid, Teleuto nicht auf Coniferen.

1) Teleutosporen ein- oder mehrzellig, am Ende einfacher Hyphen, nicht in Köpfchen.

a) Teleutospore einzellig

ß) Teleutospore zweizellig (bisweilen mit einzelligen gemischt, sehr selten drei- oder mehrzellig).

Chrysopsora

) Teleutospore drei- oder mehrzellig, auf Rosaceen . . . . . . .

2) Teleutosporen in Köpfchen am Ende von Hyphenbündeln . . . . Raven elia

Von diesen Gruppen haben wir Phragmidium schon ganz kennen gelernt, von Uromyces kennen wir die Cytologie und von Puccinia die Cytologie des ganzen Genus, sowie die Morphologie der Getreideroste; das dürfte genügen, so daß wir für diese auf das schon Gesagte verweisen. Betrachten wir also die ïbrigen Formen.

Vom Genus

\section{Chrysopsora}

ist nur eine Art bekannt, nämlich

\section{Chrysopsora Gynoxidis LAGERH.,}

welche von LAgerhem in Ecuador auf der Composite Gynoxis laurifolia angetroffen wurde. Die Form ist noch recht unvollständig bekannt; sie bildet auf der Oberseite der Blätter kleine Spermogoniumgrüppchen, auf der Unterseite zweizellige langgestielte mennigrote Teleutosporen in ringförmigen Polstern. Bei der Keimung teilt sich jede dieser zwei Zellen in vier übereinander gelegene (Fig. 375, III 1), deren jede eine Sporidie bildet. Wir haben hier also offenbar mit einem inneren Promycel zu tun, mit einem Fall, wo die Teleutospore zweifellos zum Gonotokonten geworden ist.

1) Selbstverständlich ist die Gruppe der Pucciniaceae ebenso wie die der Melampsoraceae in der hier gegebenen Fassung künstlich, so bringt z. B. DiETEL jetzt Chrysopsora zu den Coleosporiaceae. Die hier gegebene ältere Darstellung DiETELs wurde aber der bequemen Uebersichtlichkeit wegen beibehalten. 
Betrachten wir jetzt einmal eine tremelloide Form, z. B.

\section{Gymnosporangium Sabinae.}

Die Teleutosporen kommen in gallertartigen, an Themella erinnernden. rotbramen Lagern auf den Zweigen von Jumiperus Sabina vor. Diese Lager können eine Länge von etwa $1 \mathrm{~cm}$ erreichen (Fig. 376, 1). Seit lange ist das zugehörige Aecidium bekannt, welches als Roestelia cancellata (Fig. 376, 2, 3) auf Birnenblättern lebt.

Dort bildet der Pilz orangegelbe öfters geschwollene Flecken, auf welchen die gelblich-weißen Aecidien eingepflanzt sind. Das Becherchen ist hier an der Spitze geschlossen, zugespitzt und öffnet sich mittelst Längsspalten. Diese Längspalten sind von kurzen Querbändern unter-

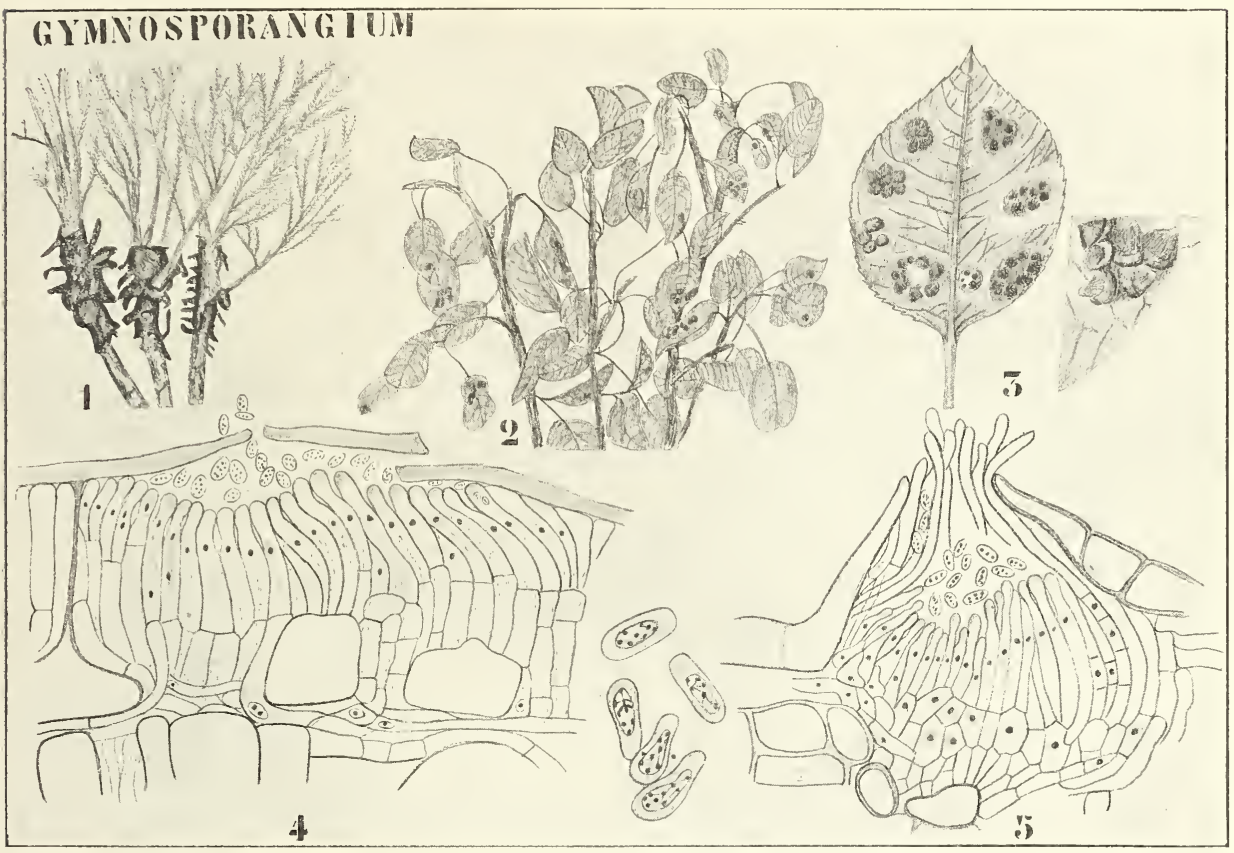

Fig. 376. I. Gymnosporangium Sabinae (nach Tubeuf und Warming). 1 Teleutosporenlager auf Juniperus Sabina. 2, 3 Aecidien auf Pirus communis. II. G. clavaria eforme (nach BLackmar). 4, 5 Spermogonien, Spermatien abschnürend.

brochen, wodurch der ganze Becher gitterartig durchlöchert ist und so die Sporen ausstreut. Diese keimen auf Jumiperus Sabina und bilden dort die Teleutosporenlager.

Bei einer verwandten Form, bei Gymmosporangium clarariaeforme. hat Blackman die Cytologie untersucht. Diese bildet die Rocstelia lacerata (Sow.) MÉrat auf Blättern von Crataegus oxyacanther und monogyna. Die Teleutosporen kommen auf Juniperms communis vor, wo sie sich alljährlich aus einem perennierenden Mycel auf den Zweigen entwickeln. Die Sporidien bilden auf den Blättern von Cratoggus ein mninukleäres Mycel, welches Spermogonien entwickelt, an welchen die Sper'matien in normaler Weise abgeschnürt werden (Fig. 376, 4, 5). Sie besitzen einen großen Kern und rudimentäres Cytoplasma, die Merkmale männlicher Geschlechts- 
zellen also, sind aber funktionslos geworden. Die Aecidien werden tief in den Hypertrophien des Crataegus-Blattes angelegt, nachdem die meisten Spermogonien verschwunden sind. Die jüngsten Stadien wurden nicht beobachtet, so daß es bis jetzt noch unbekannt ist, wie die Aecidiosporen zweikernig werden. Sie keimen auf Jumiperus zu einem binukleären Mycel.

Die Teleutosporen werden auf gleichfalls binukleären Tragzellen gebildet. Jede von diesen bildet 3-4 Ausstülpungen, welche zu gestielten 2-zelligen Teleutosporen werden. Jede dieser Ausstülpungen besitzt 2 Kerne; diese teilen sich, und so entstehen zwei binukleäre Zellen, deren Kerne alsbald zu 2x-Nuclei verschmelzen. Jede Zelle keimt normaliter mit einem Promycel, welches 4 Sporidien bildet.

Von der Gruppe mit nicht-tremelloiden Teleutolagern sei hier nur Hemileic vastatrix als Ursache der Kaffeeblattkrankheit genannt. Bis

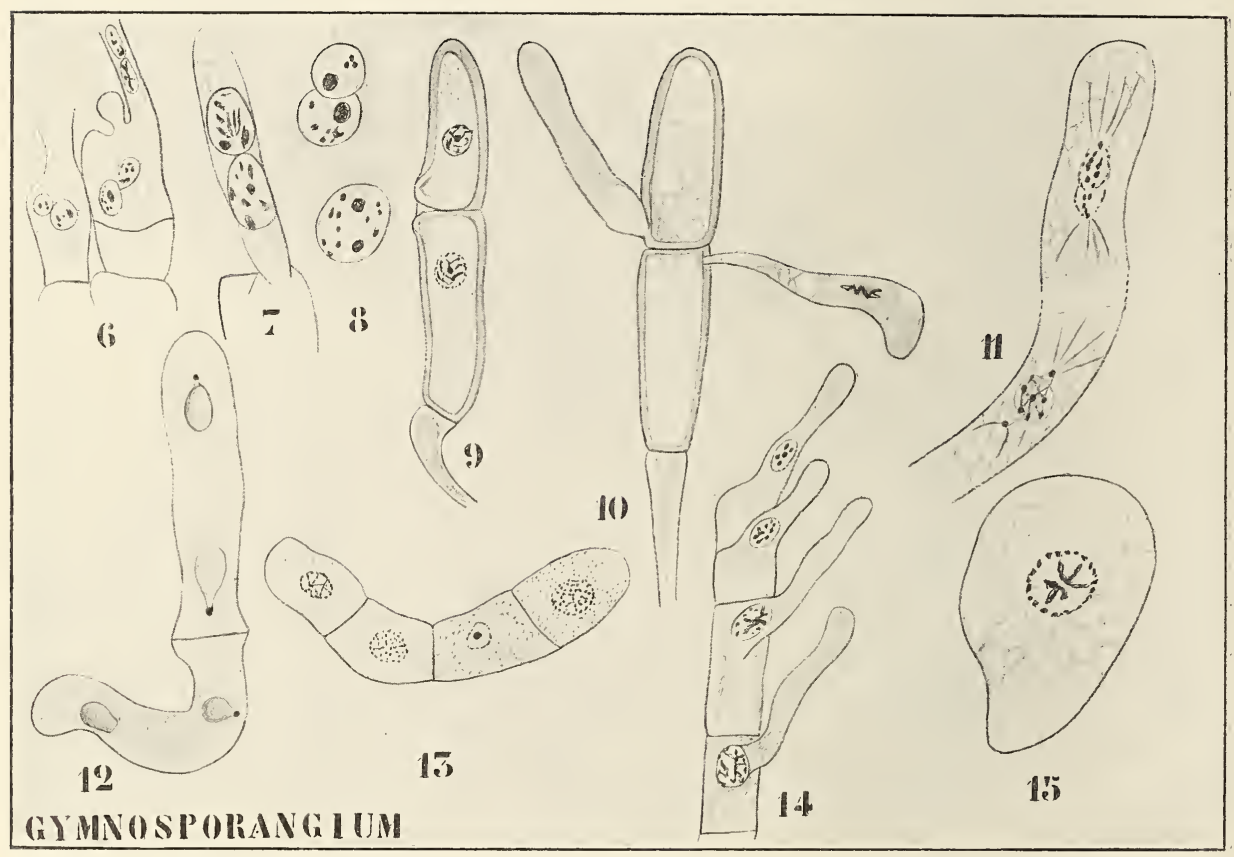

Fig. 377. Gymnosporangium clavariaeforme (nach Blackman). 6 Zweikernige Tragzellen der Teleutosporen. 7 Junge zweikernige Teleutospore. 8 Verschmelzung der Kerne in den Zellen der Teleutospore. 9 Teleutospore mit $2 x$-Kernen im ersten Anfang der Sprossung. 10 Keimende Teleutospore, in dem einen Keimschlauch ist der sich teilende Kern sichtbar. 11-13 Teilungen im Promycel. 14 Sporidienbildung. 15 Sporidie.

jetzt kennen wir von diesem Pilze nur Uredo- und Teleutosporen auf Kaffeeblättern; er bietet, wissenschaftlich gesprochen, nichts Besonderes.

Zum Genus

\section{Uromyces}

gehören nicht weniger wie 250 Arten. So wie bei Puccinia findet man darunter sowohl heteröcische wie autöcische Formen; Eu-, -opsis, Brachyund Lepto-Formen sind bekannt.

Hier sei eine der häufigsten Arten, nämlich

Uromyces Pisi (Pers.) Wint.

kurz besprochen. Die Uredo- und Teleutosporen werden auf den Blättern 
vou Pisum satimum und anderen Papilionaceen gebildet. Die Sporidien infizieren Euphorbia cyparissias, deren Habitus sie auffallend verändern. indem die Blätter rund und fleischig werden, und die Stengel unverzweigt bleiben und nicht zur Blütenbildung kommen können (vergl. Fig. 378).

Das Mrcelium perenniert im IVurzelstock.

Ton

\section{Puccinia}

haben wir die Getreideroste als die interessantesten Formen bereits besprochen. ITir haben auch schon g'esehen, daß durch Hinwegfallen verschiedener Sporenformen der Entwickelungsgang bedeutend verkürzt werden kann, so daß es wohl genügt, noch darauf himzuweisen, daß es auch autöcische Arten gibt, wie z. B. Puccinia Helianthi ScHw. auf unseren Somnenblumen. Sie hat sich in Europa von Rußland aus, wo

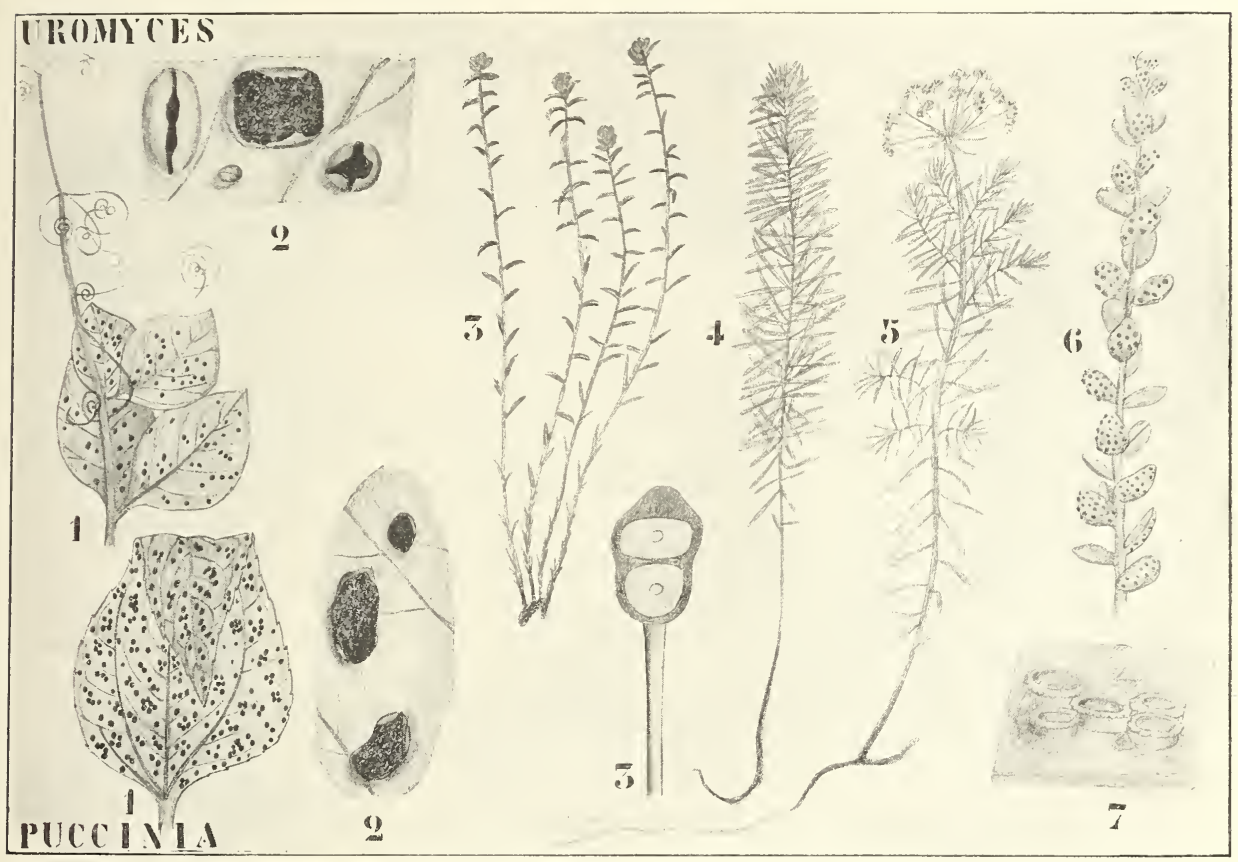

Fig. 378. I. Uromyees Pisi. 1 Habitus des Teleuto auf Pisum sativum L. (nach Dietel). 2 Teleutosporenlager vergrößert. 3 Aecidientragende Pflanze von Euphor. bia cyparissias. 4, 5 Normale Pflanzen, erstere vor, letztere während der Blüte (Original). 6 Aecidientragender $Z$ weig (nach UIETEI). 7 Aecidien vergrößert (nach DIETEL). - II. Puceinia Helianthi ScHw. (nach Dretel). 1 Habitus der Teleutosporenlager auf H elianthus annus. 2 Teleutosporenlager vergrößert. 3 Teleutospore.

örtlich die Kultur infolge dieser Krankheit unmöglich geworden ist, seit 20 Jahren verbreitet. Die Aecidien stehen auf großen dichtgedrängten Flecken, die kastanienbraunen Uredo- und die schwarzbraunen Teleutolager bilden speziell an der Unterseite der Blätter kleine Flecken.

Eine interessante Puccinia ist weiter P. graminella (Speg.) Dret. und Holw. auf Stipa in Südamerika und Kalifornien; nicht nur dadurch. daß sie die einzige l'uccimia ist, welche auf einer Cramince Aecidien bildet, sondern zumal dadurch, daß das x-Mycel neben Aecidien Teleutosporeu bildet, welche letzteren wohl apogam auf dem x-Mrcel entstehen. 
Da wir das Genus Phragmidium schon besprochen haben, können wir jetzt noch einen Blick auf das eigentümliche Genus Ravenelia werfen, um dann noch einiges über Uredineen im allgemeinen zu sagen, bevor wir zur Besprechung der übrigen Protobasidiomyceten Brefelds schreiten.

Das Genus Ravenelia kommt auf Leguminosen und Euphorbiaceen wärmerer Länder zwischen $40^{\circ} \mathrm{S}$. und N. Breite vor. Die Aecidien, Spermogonien und Uredosporen bieten nichts Besonderes, interessant sind aber die Teleutosporenköpfchen, welche am Ende von zu Bündelchen verklebten Hyphen gebildet werden und an ihrer Basis einen Kranz angeschwollener steriler Zellen, sogenannter Cystiden, tragen. Die hier nach Dietes ab-
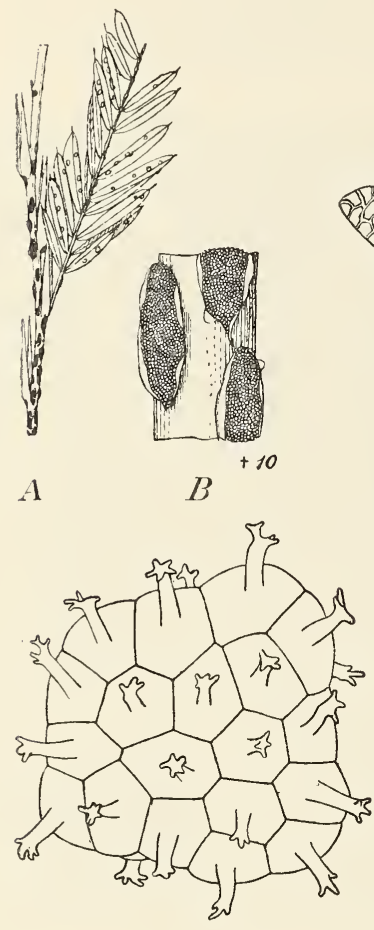

$D$

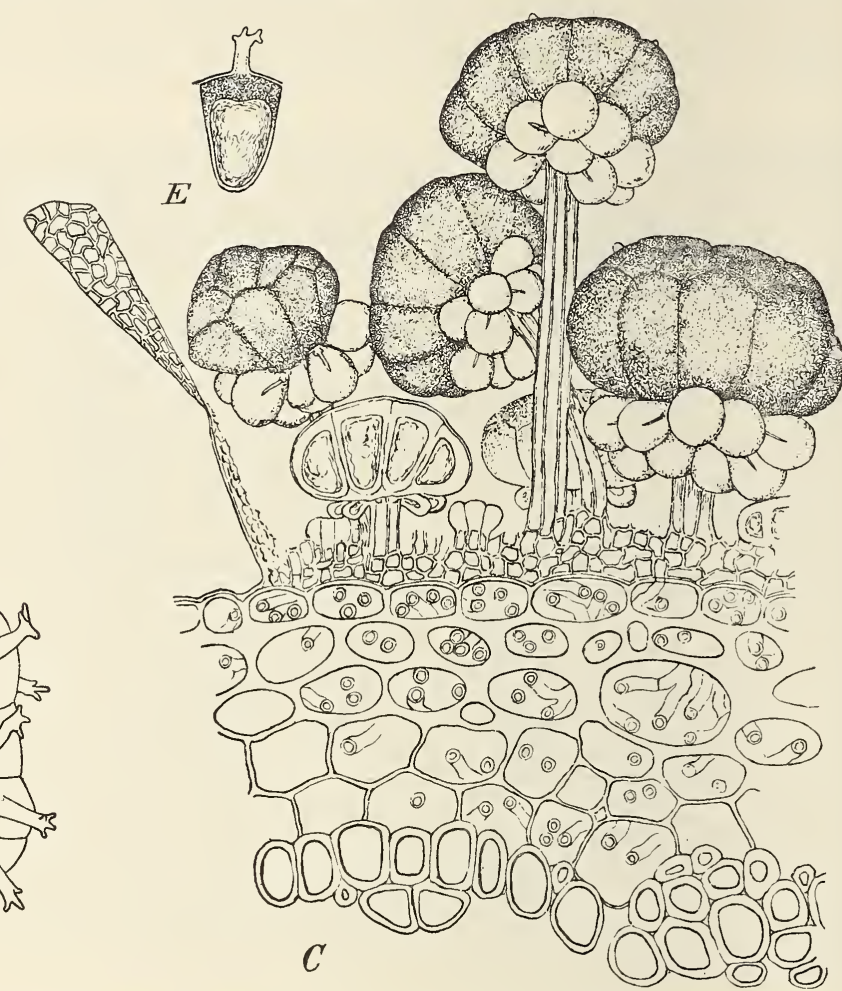

Fig. 379. Ravenelia (nach Dieter). $A-C$ Ravenelia cassiicola AtKins. $A$ Ein von dem Pilze befallenes Zweigstück von Cassia nictitans mit Teleutosporenlagern am Stengel und Uredolagern auf den Blättern. Nat. Gr. $B$ Ein Stück des Stengels vergr. Die Teleutosporenköpfchen sind schon bei schwacher Vergrößerung einzeln sichtbar. $C$ Schnitt durch den Randteil eines stengelständigen Teleutosporenlagers. Die Cuticula ist abgesprengt nnd erscheint durch anhaftende Hyphenreste gefeldert. Das Mycel ist in den Rindenzellen sichtbar. Das Sporenlager zeigt reife und jugendliche Köpfchen in verschiedenen Entwickelungsstadien, eines der letzteren im Durchschnitt, Nach einem Präparate in Milchsäure 350/1. D Ein Köpfchen von Ravenelia appendiculata LAGERH. et DiET. von oben gesehen 400/1. $E$ Eine isolierte Einzelspore derselben in der Seitenansicht $400 / 1$.

gebildete $R$. cassiicola Atкins. bildet auf den Blättern von Cassia nictitans zimmtfarbene Uredolager mit blaßbraunen kurzstacheligen Uredosporen. Die Teleutosporen werden mit Vorliebe auf den Stengelteilen gebildet, wo sie schwarze Wulste bilden. Die Köpfchen bestehen aus einer Anzahl einzelliger dicht gedrängter Teleutosporen von dunkel- 
bramner Farbe. Cysten und Stiel sind hellbrann. Sie wird in Alabama und Mississippi gefunden.

Beror wir nun die Uredineen verlassen, wollen wir an der Hand KLEBAHNS noch einige

\section{Allgemeine Betrachtungen}

austellen. Eine der interessantesten Erscheinungen, welche wir bei den Uredineen haben kennen lernen, ist die des Wirtswechsels. Auch im Tierreich wird ähnliches gefunden, ich brauche dazu nur an die Distomum-Arten zu erinnern, welche meistens sogar in drei verschiedenen TTirten leben. Die Larven der Distomen leben z. B. in Schnecken und werden dort Sporocysten oder Redien, diese bilden Cercarien, welche in ein anderes Wassertier eindringen, in eine andere Schnecke, in ein Insekt, in einen Krebs, Wurm oder Fisch; dort werden sie zu eingekapselten Distomen. Wird nun ihr Wirt von einem Säugetier, z. B. von einem trinkenden Schafe, zufälligerweise verschluckt, so bildet sich in demselben das geschlechtsreife Distomum, dessen Eier wieder die Larven, von welchen wir ausgingen, liefern.

Einer der interessantesten und kompliziertesten Fälle im Tierreiche ist der Virtswechsel bei gewissen Läusen, welche die sogenannten Ananasgallen auf Coniferen bilden. Cholodkowsky (Bot. Centralbl. 1900, p. 265) zerlegt die bekannte Chermes Abietis, welche die Ananasgallen auf Fichtensprossen bildet, in 2 Arten.

Die eine, neue Art, Ch. Abietis, lebt ausschließlich auf der Fichte und interessiert uns hier weiter nicht; die andere, Ch. viridis, hat einen sehr komplizierten Entwickelungsgang aufzuweisen, wie aus folgendem Schema hervorgeht.

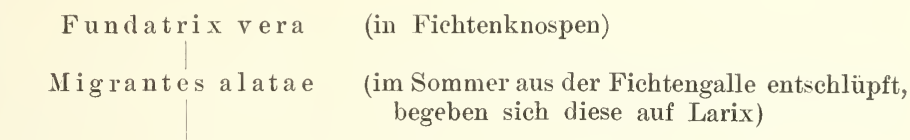

Fundatrices spuriae (saugen an den Larix-Nadeln und überwintern auf der Rinde)

$\begin{aligned} & \text { Chermes } \\ & \text { viridis: }\end{aligned}$
Sexuparae $\begin{array}{r}\text { saugen an den } \\ \text { Larix-Nadeln, } \\ \text { knicken diese und } \\ \text { fliegen schließlich } \\ \text { von der Larix } \\ \text { nach der Fichte) }\end{array}$
Fundatrices verae (auf der
Fichte)

Exsules

Chermes
strobilobius

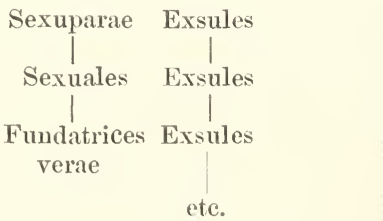


Das will sagen. daß die aus den befruchteten Eiern entstandene Generation der Fundatrices verae in den Endknospen der Fichtenzweige lebt, dort überwintert, im Frühjahr parthenogenetisch Eier legt und stirbt.

In die von ihrem Stich gebildeten Gallen, kriechen die aus ihren Eiern ausgebrochenen Läuse ein, saugen dort, verpuppen sich und schwärmen im Sommer als geflügelte Insekten (Migrantes alatae) aus, begeben sich nach einer Larix und legen dort parthenogenetisch Eier.

Im Herbst entstehen daraus Larven, welche an den Nadeln saugen, auf der Rinde überwintern, und im Frühjahr als Fundatrices spuriae parthenogenetisch Eier legen. Die aus diesen Eiern entstandenen Lärvchen saugen an den Larix-Nadeln, knicken diese und werden geflügelt (Sexuparae), wonach sie auf die Fichte fliegen und dort parthenogenetisch Eier legen, aus welchen ungeflügelte Männchen und Weibchen (Sexuales) kriechen, aus deren befruchteten Eiern sich wieder Fundatrices verae entwickeln.

Damit ist der Entwickelungsgang des Chermes viridis beendet.

Chermes strobilobius macht einen ähnlichen Lebenslauf durch, welcher aber dadurch kompliziert ist, daß aus den Eiern der Fundatrices spmiae neben den auf die Fichte zurückkehrenden geflügelten Sexuparae auch ungeflügelte Exsules entstehen, welche auf der Larix bleiben und sich dort durch zahlreiche Generationen parthenogenetisch fortpflanzen, dabei aber stets auf die Fichte zurückkehrende Sexuparae abspalten.

Diese Exsules innern also, und das ist der uns zumal interessierende Punkt, in hohem Grade an die Uredosporen der Uredineen.

Falls die Exsules aufhörten, Sexuales abzuspalten, würde man einen Fall erhalten, dem derjenigen Uredineen, welche sich ausschließlich durch ihre Uredos zu behaupten wissen, analog.

Ein solcher Fall scheint sich nun in der Tat ausgebildet zu haben, wenigstens kann der ausschließlich auf Larix lebende Chermes viridianus als eine solche selbständig gewordene Exsules-Generation betrachtet werden.

Wir sehen also, daß der Wirtswechsel eine sowohl im Tier- wie im Pflanzenreiche vorkommende Erscheinung ist. Auffallend ist nun der Umstand, daß sie nicht nur vorkommt, wo beide Wirte habituell nebeneinander leben, sondern daß öfters verschiedenen Pflanzenformationen angehörige Pflanzenarten als Wirte dienen.

Die Gelegenheit zur Entstehung des Wirtswechsels ist in letzterem Falle nur dann geboten, wenn die verschiedenen Formationen sich irgendwo berühren, wie z. B. die Fichten und Alpenrosen im Hochgebirge, oder wenn die Rostsporen sich auf große Entfernungen verbreiten können. Vermutlich ist letztere, wie wir sahen, den Rostsporen allgemein zukommende Eigenschaft, die wichtigste bei der Entstehung der Heteröcie gewesen, und das Vermögen der heteröcischen Formen sich beim Mangel des einen Wirtes durch die Uredosporen zu behaupten, ist eine für die Erhaltung dieser Formen sehr wichtige Eigenschaft. Ueber die Weise aber, in welcher die Heteröcie entstanden ist, existieren noch mancherlei Meinungen, welche man bei KLEBAHN resumiert findet, ohne daß bis jetzt ein feststehendes Resultat erhalten wurde.

Mehr wissen wir über einen anderen sehr interessanten Punkt, nämlich über die Immunisationsfrage.

Es ist eine bekannte Tatsache, daß gewisse Arten gegen gewisse Krankheiten immun sind, welche andere Arten befallen, und daß dies 
sogar der Fall sein kann bei Infektionskrankheiten, die anscheinend vom gleichen Organismus verursacht sind. Daß man auch hier noch lange nicht einig ist, wird Thnen klar sein, wenn ich Sie daran erinnere, daß nach Kосн die Rindertuberkulose Menschen nicht gefährdet, nach anderen im Gegenteil eine Quelle fortwährender Gefahr für den Menschen bildet. Nach KocH gibt es also unter den Tuberkelbacillen zwei physiologische Arten. deren eine auf Rinder, deren andere auf Menschen spezialisiert ist.

Wir sahen schon, daß ERIKsson solche Spezialisierungen bei unseren Getreiderosten für Puccinia nachwies, die genauesten Untersuchungen über diesen Gegenstand verdanken wir aber Marshall Ward.

Bei dem Bromus-Rost zeigte er, daß es in der Tat solche physiologische Rassen (den Ausdruck physiologische Art will er nicht verwenden) gibt, welche bisweilen sehr fein spezialisiert sind, mittels Ueberbrückungsarten ${ }^{1}$ ) aber auch immune Arten gefährden können. Nachdem dies festgestellt war, war die interessanteste Fråge nun diese: Weshalb ist die eine Art immun und die andere nicht? Nan hatte gemeint, daß die Ursache in der Blattstruktur, in den Behaarungen, in der Dicke der Cuticula etc. liegen könnte, aber Marshall Ward zeigte durch eine lange Reihe sorgfältigster Untersuchungen das Unhaltbare dieser Meinung.

Massee versuchte nachzuweisen, daß die Infektion auf positiver Chemotaxis beruht und daß also eine Pflanze immun ist, wenn ihr diejenigen chemischen Substanzen abgehen, welche die Keimschläuche der Pilzsporen zum Eintritt reizen.

Miss Gibson wies aber in Wards Laboratorium nach, daß die Keimschläuche der Uredineen-Sporen in eine Anzahl von Pflanzen durch die Stromata eintreten können, auch wenn sie keine eigentliche Infektion verursachen können.

Das ganze Problem der Infektion beruht also auf sehr komplizierten Interrelationen zwischen dem Pilz und der Phanerogame, welche aber alle in diesen Satz zusammengefaßt werden können: Infektion und Resistenz hängen ab von dem Vermögen des Protoplasmas, die Resistenz der Zellen des Wirtes mittels Enzymen oder Toxinen zu überwinden und von dem Vermögen der Zellen des Wirtes, Substanzen auszuscheiden. welche solche Enzyme oder Toxine unschädlich machen oder den Pilz chemotaktisch abschrecken.

Es kann aber auch der Angriff von seiten des Pilzes ein zu starker sein. Für die Existenz der Uredineen ist es nötig, daß die Zellen des Wirtes am Leben bleiben, scheidet nun der Pilz so schädliche Substanzen aus, daß die Zellen um den Infektionspunkt herum getötet werden, so begeht er Selbstmord.

Es existieren also offenbar sehr feine Interrelationen, so zeigten z. B. WARD und Evans, daß man schon angefangene Infektion aufhalten kann durch Eingriffe in die Ernährung des Wirtes, z. B. durch Vorenthalten des nötigen $\mathrm{CO}_{2}$ oder der nötigen Salze oder auch durch Abkühlen der Wurzeln.

Infektion kann also nur dann stattfinden, wenn der Pilz gerade die Resistenz der Pflanze überwinden kann, aber nicht schädlich genug wirkt, um die Gewebe zu töten oder sogar nur krank zu machen; in gewissem Sinne muß die Urcdinee also in Symbiose zu ihrem Wirt treten. Daß unter diesen Umständen Spezialisiermo eingetreten ist. scheint

1) Siehe unter Erysipheen. 
weniger wunderbar als es schien, bevor man die feinen Interrelationen kannte.

Höchst auffallend und interessant ist nun der vor kurzem von BIFFEN nachgewiesene Umstand, daß Immunität und Susceptibilität bei gewissen Getreiderosten mendeln, d. h. daß wenn man eine immune Varietät mit einer susceptiblen kreuzt, in der zweiten Generation Spaltung auftritt. wodurch beide Varietäten wieder rein zum Vorschein kommen.

Auf der Hybrid-Conference, die in August dieses Jahres in London abgehalten wurde, teilte BIFFEN mit, daß er Michigan Bronce-Weizen mit einer anderen bei BrFFen erhältlichen, gegen Rost immunen Weizenart kreuzte. Die Michigan Bronce ist in England dem Roste so susceptibel, daß BIFFen von ihr in längerer Zeit nur 6 Samen, welche noch dazu nicht keimfähig waren, erhielt.

Der Hybride zwischen dieser Michigan Bronce und der Brffenschen immunen Art war nun gerade so rostig wie die Michigan Bronce, setzte aber Samen an.

Aus diesem Samen gingen Pflanzen auf, deren Gesamtanblick ebenfalls sehr rostig war, bei welchen aber Zählungen nachwiesen, daß unter 1609 rostigen Pflanzen 523 absolut rostfreie Pflanzen sich fanden, so daß Spaltung in Mendelschem Sinne in Bezug auf die "Rostigkeit" stattgefunden hat.

Wir können auf diese Sachen hier nicht weiter eingehen, möchten nur darauf hinweisen, daß hiermit die Möglichkeit zur erfolgreichen Bekämpfung des Gelbrostes (um diesen handelt es sich hier) gegeben ist, welcher in Deutschland allein jährlich für etwa 400 Millionen Mark Schaden verursacht.

Resumieren wir jetzt, was wir von der Phylogenie der Uredineen vermuten können, so scheint es mir am wahrscheinlichsten, daß sie von Florideen-ähnlichen Ahmen abstammen, deren Trichogynen von Spermatien befruchtet wurden. Jetzt aber ist, wie wir sahen, Apogamie eingetreten, welche zu sehr bedeutenden Reduktionen bei gewissen Arten geführt hat.

Wir haben gesehen, daß bei den Uredineen der normale Entwickelungsgang: Aecidiosporen, Uredosporen. Teleutosporen und Sporidien umfaßt. Wir haben weiter gesehen, daß die Aecidiosporen jetzt apogam gebildet werden, aber daß wahrscheinlich ursprünglich die in den Aecidien vorhandenen Oogonien von Spermatien befruchtet wurden.

Wir erhielten also bei den vollständigen Uredineen: x-Generation mit Aecidien und Spermogonien. Aus den Aecidiosporen bildet sich die $2 x$-Generation mit Uredosporen und Teleutosporen, welche letztere mittels eines Promycels keimen, das 4 Sporidien bildet, welche wieder das $\mathrm{x}-\mathrm{Mycel}$ entstehen lassen.

Eine Abkürzung dieses Entwickelungsganges sahen wir bei der Ochropsora Sorbi. Bei dieser bilden die Teleutosporen nicht mehr ein Promycel, sondern teilen sich in 4 Zellen, und jede der Teilzellen bildet eine Sporidie; es wird also die Teleutospore durch Bildung eines inneren Promycels direkt Gonotokont.

Wir haben nun weiter gesehen, daß bei den Uredineen sich die 2x-Generation von der der meisten sonstigen Gewächse dadurch unterscheidet, daß pro Zelle nicht ein $2 x-K e r n$, sondern zwei $x-K e r n e$ vorkommen, welche sich erst im allerletzten Moment kurz vor der Reduktionsteilung in der Teleutospore $\mathrm{zu}$ einem $2 \mathrm{x}$-Kern vereinigen.

Aus dem Gesagten geht direkt hervor, daß die Teleutospore kein 
Homologon einer Konidie, im Brefendschen Sinme, sein kann, sondern vielmehr dem Ascus homolog ist.

In der Tat sind meiner Meinung nach die Uredineen und die monoenergiden Ascomyceten gemeinsamer Abstammung, und zwar beide aus den Florideen hervorgegangen.

Wir haben nun weiter gesehen, daß bei vielen Uredineen die Aecidien wegoefallen sind und daß auch die Uredosporen fortfallen können.

In solchen Fällen bekommen wir eine x-Generation, welche stellenweise kleine $2 x$-Thalli apogam bildet, welche $2 \mathrm{x}$-Hyphen die Teleutosporen bilden.

Falls solches bei Ochropsora geschähe, würden wir dort ein x-Mycel erhalten, darauf eine rudimentäre 2x-Generation, welche Teleutosporen trägt, die, da sie auf der Stelle keimen, alsbald je 4 Sporidien bilden, wobei sich die Teleutospore in 4 Zellen teilt.

Falls nun die x-Generation klein bliebe, das $2 x-M y c e l$ sich aber mehr ausbildete, würden wir dort schon einen von BREfelds übrigen Protobasidiomyceten, z. B. eine Auricularia, haben, und bliebe die Teilung in der Teleutospore aus, so wäre die Teleutospore zur echten Basidie geworden: die Sporidie zur Basidiospore.

Falls dies nun richtig ist, muß es sich herausstellen, daß das Mycel eines echten Basidiomyceten wenigstens in gewissen Fällen eine x-Generation ist, daß der Körper derselben eine $2 \mathrm{x}$-Generation mit 2 Kernen pro Zelle ist - und daß in der Basidie die so lange aufgeschobene Vereinigung dieser beiden Kerne stattfindet.

Das trifft, wie wir alsbald sehen werden, und wie MaIrE nachwies, in der Tat zu.

Statt Brefelds Einteilung möchte ich also die höheren Pilze wie folgt einteilen :

\section{Eumycetes.}

A. Die Sporen der Hauptfruktifikation werden in Schläuchen gebildet .

B. Die Sporen der Hauptfruktifikation werden nicht in Schläuchen gebilde

1) es überwiegt die $x$-Generation .

Ascomycetes

Teleutosporineae

Uredineae

Basidiomyceten

Protobasidiomyceten ${ }^{1}$ )

$\alpha$ ) das die Sporen bildende Organ mehrzellig

$\beta)$ das die Sporen bildende Organ einzellig

Autobasidiomyceten.

Betrachten wir also die Gruppe der Basidiomyceten in diesem Sinne etwas näher.

1) d. h. die Brefeldsche Gruppe dieses Namens nach Ausschluß der Uredineae. 


\section{Dreissigste Vorlesung.}

\section{Die Basidiomyceten.}

Nachdem eine Anzahl von Untersuchern, wie Strasburger, Wager, Juel, Dangeard, um wenigstens einige zu nennen, mehr oder weniger wichtige Tatsachen in der Cytologie der Basidiomyceten ans Licht gebracht hatten und so der Weg zu besseren Auffassungen gebahnt war, ohne daß jedoch das Ziel erreicht worden war, brachte eine vorläufige Mitteilung Réné Marres die jetzt wohl allgemein akzeptierte Anschaumingsweise.

MaIre wies nach, daß die Zellen der Hymenomyceten von der Bildung des Fruchtkörpers an bis zur Basidie zweikernig sind, daß sie konjugierte Mitosen, d. h. Synkarions aufweisen, denen der Uredincen vergleichbar, daß nicht - wie WAGER meinte - mehr wie zwei Kerne in der Basidie verschmelzen, sondern nur zwei; er studierte das aus der Basidiospore eines Coprinus entstandene Mycel und fand, daß in diesem die Zellen einkernig sind. Auch zeigte er (Bull. Soc. Myc. de France, 1902, und Soc. Biol., 13 avril 1905, p. 726-728), daß in der Basidie eine Reduktionsteilung stattfindet.

So war also von MAIRE eine vollkommene Homologie zwischen dem Entwickelungsgang gewisser Uredineen und Basidiomyceten konstatiert, in der Weise, wie wir sie oben als möglich angaben. Wir kommen darauf später zurück, wollen aber erst noch die Morphologie der zu den Basidiomyceten gebrachten Formengruppen kurz besprechen.

Wir haben schon gesehen, daß BREFELD die Basidiomyceten in Protobasidiomyceten mit mehrzelligen Basidien, und in Autobasidiomyceten mit einzelligen Basidien einteilte.

$\mathrm{Zu}$ den Protobasidiomyceten gehören seinem System nach die Uredineen, Auricularieae, Pilacreae und Tremellineae, zu den Autobasidiomyceten die Dacryomyceten, Hymenomyceten, Gasteromyceten und Phalloideae.

Wir haben früher schon gesehen, daß man die Uredineen besser herausschält und als einen Vorläufer der eigentlichen Protobasidiomyceten betrachtet.

Die Einteilung von BREFELD ist ziemlich allgemein akzeptiert worden, 1893 aber publizierte v. Tieghem im Journal de Botanique einen Artikel, in welchem er gegen diese Anschauungen Front macht.

Bevor wir aber auf diese und andere den Brefeldschen Meinungen nicht entsprechende Anschauungen eingehen, müssen wir die Hauptformen, um welche sich die Diskussion dreht, kennen lernen. 
Fangen wir also mit den

\section{Auricularineen}

an und wählen wir als Beispiel das Genus

\section{Auricularia.}

von welchem Sappin-Trouffy Auricularia Auricula Judae L., JuEL und MaIre Auricularia mesenterica Dicks. untersuchten. Abgesehen von einigen Details in der Karyokinese kommen alle zum gleichen Resultat, so daß wir hier nur die Untersuchungen von SApprn-Trouffy resumieren.

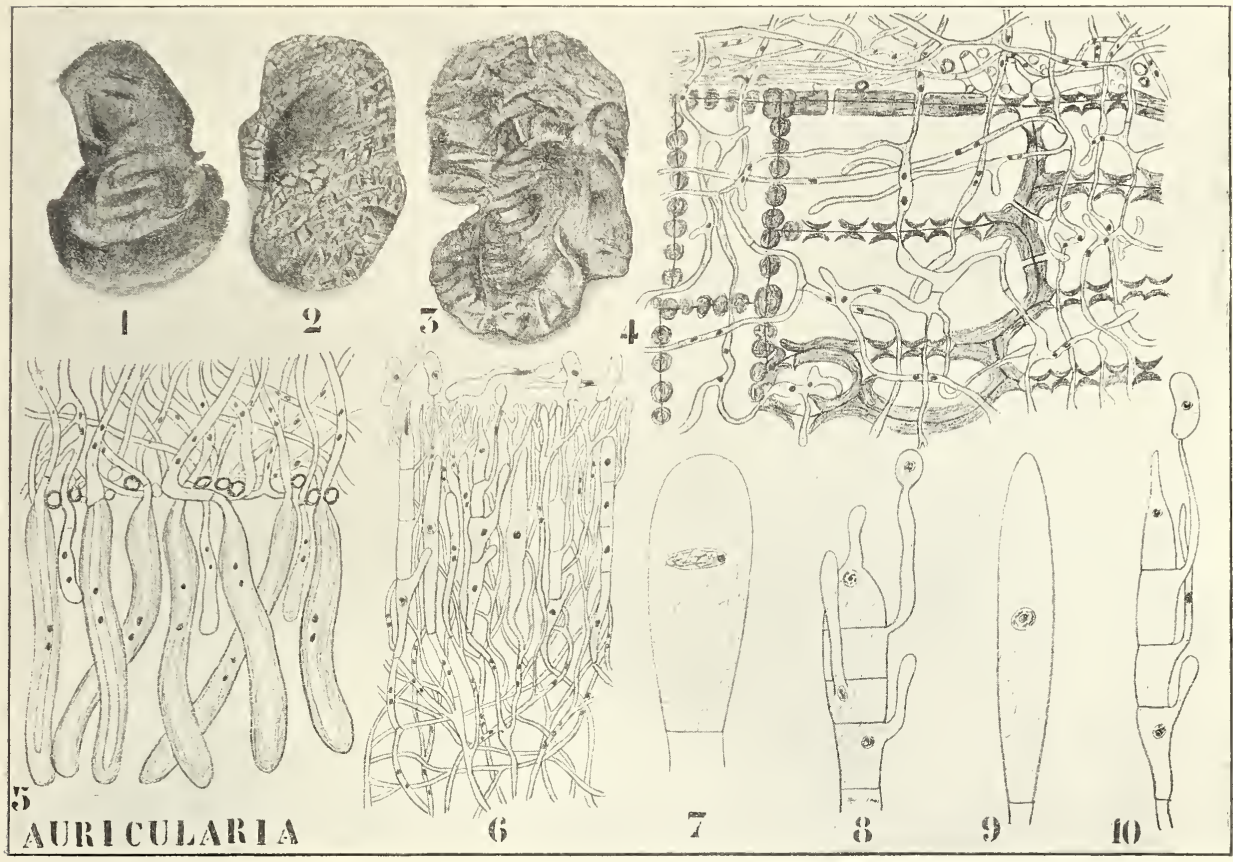

Fig. 380. Auricularia A uriculae Judae. 1-3 Habitusbilder nach MöLLER. 4 Das binukleäre Mycel in der Pinde des Wirtes. 5 Das binukleäre Mycel mit den ebenfalls binukleären dickwandigen Haaren. 6 Das binukleäre Mycel, die einkernigen Sporen bildend. $7-10$ Basidien (nach SAPPIN-TroufFY).

Das Judasohr lebt mit Vorliebe auf Sambucus-Stämmen. Es besteht aus einer faltigen, gelatinösen Masse, welche ohrenförmig. gebogen ist und mittelst eines Stielchens dem Substrate angeheftet ist. Die konvexe Unterseite ist steril, die konkave Oberseite trägt das Hymenium.

Der Pilz wird das ganze Jahr hindurch an denselben Stellen angetroffen, trocknet während der trockenen Periode zu einer hornartigen, dünnen Schicht ein, nimmt aber an feuchten Tagen sofort wieder die Ohrform und die gelatinöse Beschaffenheit an.

Der Körper besteht aus verzweigten Fïden. welche aus binukleäreu 
Zellen zusammengesetzt sind. Dieses Mycel dringt in die noch lebende Sambucus-Rinde, durch die Tüpfel der Zellwände bis ins Innere der Zellen (Fig. 380, 4) ein. Im Ohre bilden die Hyphen in der gelatinösen Substanz ein weitmaschiges Netzwerk und an der Unterseite des Ohres lange, unverzweigte dickwandige Haare (Fig. 380, 5), welche der Oberfläche ein sammetartiges Aeußere verleihen; an der Oberseite treten sie zu einem Hymenium zusammen.

Die Basidien (Fig. 380, 7,9) sind cylindrisch oder keulenförmig. zwischen ihnen finden sich sterile Fäden.

Jede junge Basidie besitzt zwei Kerne, welche aber alsbald miteinander verschmelzen. Darauf vergrößert sich der Fusionskern bedeutend und es teilt sich die Basidie zunächst durch eine Querwand in zwei Zellen, deren jede sich noch einmal teilt, so daß das Ganze vierzellig:

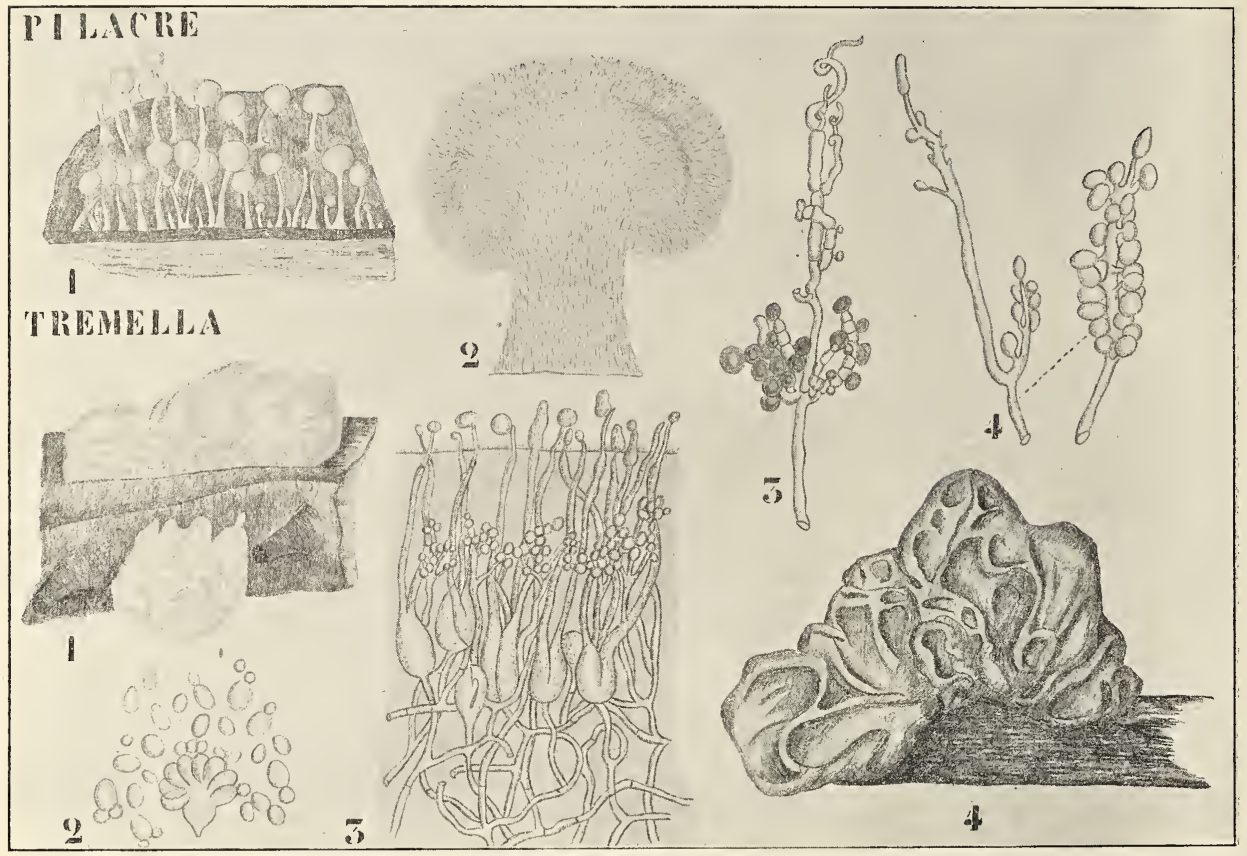

Fig. 381. T. Pila ere Petersi i Bert. et CukT (nach Brefeld). 1 Habitus. 2 Fruchtkörper im Längsschnitte, die äußere helle Zone ist die Peridie, die dunkle die Basidienzone. 3 Basidienbildender Faden, im oberen Ende in die Peridie übergehend. 4 Konidiophoren mit Konidien. - II. Tremella. 1 Tr. lutescens Pers., Habitus nach Brefeld. 2 Sproßkonidien derselben. 3 Schnitt durch das Hymenium. 4 Tr. mesenterica, Habitus.

wird. Jede dieser Zellen bildet darauf am Ende einer Ausstülpung. eines Sterigmas, eine Spore.

Die junge Basidie ist hier also offenbar der Teleutospore von Ochropsora homolog, die vierzellige Basidie das Resultat der Keimung mittels eines inneren Promycels, die Basidiosporen also den Sporidien der Uredineen homolog.

Nach Istvanffi keimen die Basidiosporen zu einem Mycel, welches uninukleäre Konidien produziert. 
Betrachten wir jetzt die Familie der

\section{Pilacreae,}

so begegnen wir in

\section{Pilacere}

einem Genus, welches in mancher Hinsicht den Auricularieen gleicht, sich von diesen jedoch dadurch unterscheidet, daß die Basidien von einer peridienartigen Hülle umgeben sind.

P. Petersii Bert. et Curt wurde von Brefeld sorgfältig untersucht. Es ist ein kleines Pilzchen, welches, nicht häufig, gesellig wachsend auf der Rinde alter Fagus- und Carpims-Stämme vorkommt. Die zunächst weißen (Fig. 381, 1), später bräunlichen Köpfchen stehen auf zierlichen bis $4 \mathrm{~cm}$ langen Stielchen.

Die Stielchen bestehen aus parallelen, in der Längsrichtung des Stielchens verlaufenden Fäden, welche sich im Köpfchen garbenartig ausbreiten und in einer bestimmten Entfernung von der Stielchenspitze die Basidien bilden, ohne jedoch ihr Wachstum einzustellen, im Gegenteil, sich noch weiter verlängern und so eine schützende Hülle, die Peridie, über die Basidien bilden. Diese Peridie zerbröckelt, wenn die Basidiosporen reif sind, so daß diese dann verbreitet werden können.

Die Basidien sind vierzellig und tragen auf sehr kurzen Sterigmen die 4 Basidiosporen. Auch hier sind die Basidien zunächst einzellig und werden erst bei der Keimung durch Bildung von Querwänden vierzellig.

Trotzdem über die Cytologie noch nichts bekannt ist, darf man wohl annehmen, daß auch hier eine Kernverschmelzung in der jungen Basidie stattfindet und die Basidie also in der Tat eine gekeimte Teleutospore ist.

Zu den

\section{Tremellineae}

geliört u. a. das Genus

\section{Tremella.}

Die gelben, gallertartigen, an die tremelloiden Gymnosporangien erinnernden Fruchtkörper der Tremella lutescens PERS. finden sich auf Baumzweigen fast über die ganze Erde verbreitet.

Bei dieser Tr. lutescens ist die Oberfläche des Stromas anfänglich mit einem Hymenium reichlich verzweigter Konidienträger bedeckt. In diesem Zustande sind die Fruchtkörper lebhaft orangegelb. Nun fangen sie zu wachsen an; neue breitere Wülste entstehen zwischen den früheren und diese fangen alsbald, zunächst noch mit Konidiosporen gemischte, Basidien zu bilden an (Fig. 381, II 3), später lassen sie aber nur Basidien entstehen. Die Basidien sind mittelst gekreuzter Längswände in vier Zellen geteilt, und jede der Teilzellen bildet am Ende eines langen Sterigmas, welches über die Schleimschicht hervorragt, eine Basidiospore.

Basidien und Konidien können am gleichen Mrcelfaden gebildet werden, so wie bei gewissen Uredincen die Telento- und die Uredosporen.

Die keimende Basidiospore bildet durch hefenartige Sprossung Konidien. Bei vielen Tremellen fehlen die Konidien und die Stromata bilden nur Basidien. 
Dangeard (1895) fand, daß die Thalluszellen von Tremella mesenterica binukleär sind, auch die Konidien besitzen zwei Kerne, sind also Diplokonidien, und den Uredosporen homolog.

Die jungen Basidien sind anfänglich ebenfalls binukleär, deren Kerne verschmelzen aber alsbald. Bei der Keimung der Basidien, bei der Bildung der Basidiosporen also, werden gekreuzte Wände gebildet, und es tritt in jedes Sterigma ein einzelner Kern ein, welcher sich zur Basidiospore (Sporidie) begibt, die demnach einkernig ist.

Damit haben wir einige Beispiele von Protobasidiomyceten kennen gelernt, betrachten wir nun noch einen Autobasidiomyceten.

\section{Dacryomyces delinquescens BuLL.}

ist, wie Tremella, gallertartig. Er ist im Winter häufig auf totem

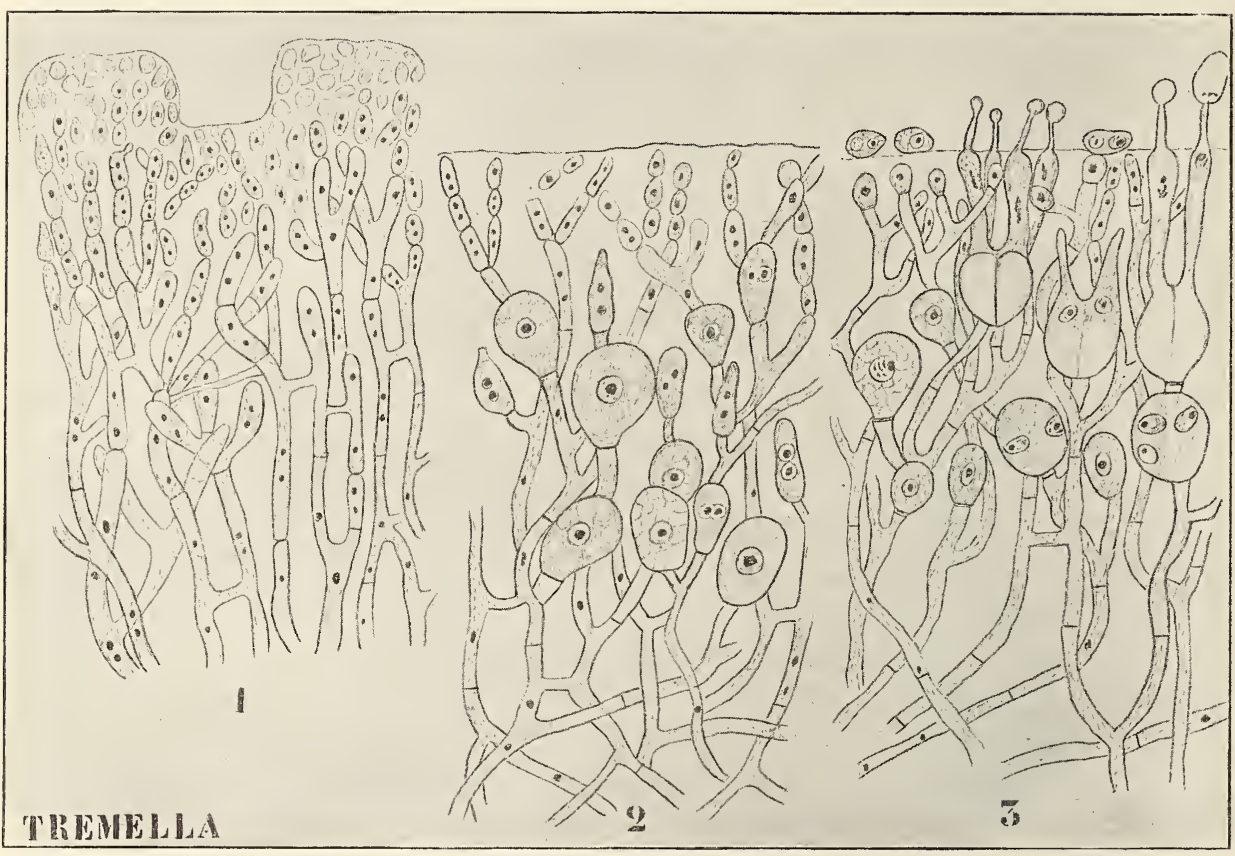

Fig. 382. Treme11a mesenterica (nach Dangeand). 1 Binukleäres Mycel mit binukleären Konidien. 2 Junge zweikernige und ältere einkernige Basidien. 3 Basidien keimend, oben einzelne binukleäre Konidien.

Holze, sowohl auf alten Baumstümpfen, wie auf Brettern, Holzhecken etc. anzutreffen.

Es gibt von dieser Art zwei Formen, deren eine orangefarbene Oidien produziert, und deren andere bernsteingelbe Basidien bildet.

Das Stroma der Konidienform besteht aus farblosen, dünnen Filamenten, von denen die unteren tief in das Holz eindringen. Sie sind aus binukleären Zellen zusammengestellt.

Dazwischen verlaufen dickere Filamente, welche von einem Lipochrom orange gefärbt sind, und an der Peripherie des Thallus in zweikernige Oidien auseinanderfallen; sie keimen zu einem binukleären Mycel, sind also wieder den Uredosporen der Uredineen vergleichbar. 
Die basidienbildenden Individuen, welche zumal von IstranfFr, JUEL und MAIRE untersucht wurden, besitzen in den jungen Basidien zwei Kerne, welche alsbald fusionieren. Das ist also vollkommen normal; statt 4 Sterigmen bildet die Basidie von Dacryomyces aber nur zwei solche. In Uebereinstimmung damit sollte sich nach DANGEARD der Fusionskern nur einmal teilen, aber IstvanfFy, JuEL und MaIRE wiesen nach, daß dies nicht richtig ist, und auch hier in der Basidie eine zweimalige Teilung des Fusionskernes in 4 Kerne stattfindet, von welchen aber nur zwei in die beiden Sterigmen eintreten, während die beiden übrigen in der Basidie liegen bleiben.

Die beiden Kerne, welche in der Basidie bleiben, treten, nachdem die ersten Sporen abgefallen sind, in die Sterigmen ein und werden zu einer zweiten Produktion von Basidiosporen benutzt. Statt also simultan 4 Basidiosporen an 4 Sterigmen zu bilden, bildet hier die Basidie zweimal zwei Basidiosporen an 2 Sterigmen.

Diese Sporen keimen alsbald zu einem kurzen Fädchen, das aus uninukleären Zellen besteht, deren jede entweder zu einem Mycelium auswächst, oder Konidien produziert.

Bei den übrigen Autobasidiomyceten verläuft die Entwickelung der Basidie wie bei Dacryomyces, nur mit dem Unterschied, daß die Sporen simultan an 4 Sterigmen gebildet werden.

Nachdem wir also in großen Zügen die Haupttypen der Basidienformen kennen gelernt haben, sind wir in der Lage, die verschiedenen Theorien über die Phylogenie der Basidie mit Verständnis zu diskutieren.

Lange hat man sich um die Frage der Sexualität bei den Basidiomyceten gestritten. Im Jahre 1729 nimmt Micheli bei den Basidiomyceten die Anwesenheit apetaler monostemoner Blüten an. Später sucht Karsten nach der Befruchtung auf dem Mycelium und findet 1867 auf jungen Mycelien von Ag. campester und A. vaginatus ein „Gebilde. welches er für eine Eizelle hält". „Es besteht in einer ovalen Zelle, welche auf einem dümmen Stiele steht. An sie legt sich an und verwächst mit ihr ein benachbarter Zellfaden (Antheridium), welcher in der Nähe gleichfalls aus dem Mycelium hervorwächst." Nach Karstens Meinung entsteht nun der Körper eines Hutpilzes aus dieser befruchteten Eizelle.

Nachfolger Karstens wie Reess (1875), v. Tieghem (1876), KirchNER (1875), DE SEYNes (1875) und EIDAM (1875) nehmen an, daß eine Befruchtung mittels Spermatien stattfindet, und halten die Konidien. welche auf den aus den Basidiosporen hervorgegangenen Mycelien gebildet werden, für diese Spermatien.

Hingegen meinten Sicard (1874) und Worthington G. Smith (1875), daß die Spermatozoiden im Innern von Antheridien entstehen. und sprachen die Cystiden als solche an.

Im gleichen Jahre (1875) noch zeigt aber van TIEghem, daß die vermeintlichen Spermatien Konidien sind, und zahllose sorgfältige Kulturen, zumal von BREFELD, führen mehr und mehr zu der Meinung. daß den Basidiomyceten jede Spur einer Sexualität abgeht.

In Bezug auf die Abstammung der Basidiomyceten weist DE BARY schon 1867 auf die Homologie von Basidie und Teleutospore hin.

Sich auf einen vorangehenden Artikel in der Bot. Ztg. 1867 bezielıend, sagt er auf S. 77 :

„Ich möchte nur hervorheben, daß ein Gegensatz zwischen Basidien und Teleutosporen gar nicht besteht... Jede Tredineen-Teleutospore kann nach ihren sogenannten Kimungserscheinungen eine Basidie g'e- 
nannt werden; manche, z. B. die von Coleosporium, in des Wortes strengster Bedeutung. Was man bei manchen Tremellinen, zumal Hirneola Auricula Judae, Basidien nennt und $\mathrm{zu}$ nennen allen Grund hat. entspricht der Form und Entwickelung nach genau den Teleutosporen von Coleosporium ...."

In seiner Morphologie der Pilze sagt DE BARY über die Verwandtschaftsbeziehungen der Basidiomyceten auf S. 363:

„Die Vergleichung ergibt nun eine unzweifelhaft nächste Verwandtschaft zwischen den Tremellinen und den tremelloiden Uredineen. In der Tat besteht zwischen diesen beiden Gruppen ein wesentlicher Unterschied überhaupt nicht, weder in dem Entwickelungsgang noch dem Bau der Fruchtkörper.... Uredineen, wie Leptochrysomyxa abietis, sind

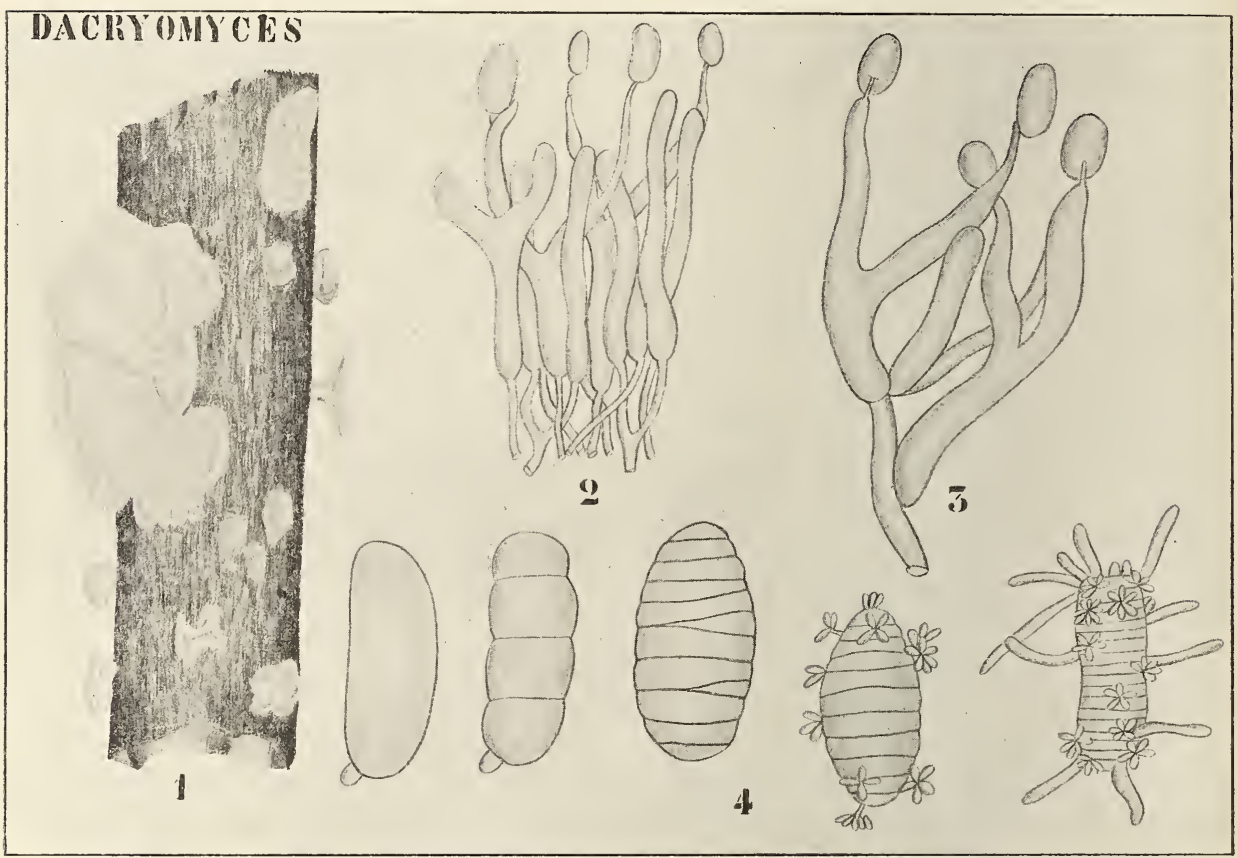

Fig. 383. Dacryomyces chrysocomus (nach Brefeld). 1 Habitus. 2 Teil des Hymeniums. 3 Basidien. 4 Keimung der Basidiosporen.

einfach Tremellinen und müßten im System unter diesen stehen, wenn nicht ihre Aecidien bildenden Verwandten bekannt wären. Dasselbe kann ohne Uebertreibung von den Leptopuccinien gesagt werden, denn die in Vergleich zu ziehenden Teleutosporen dieser sind Basidien von Tremellinen nicht unähnlicher als viele der letzteren untereinander."

"Nach den in früheren Paragraphen gegebenen Darstellungen sind die Teleutosporen, für manche Fälle vielleicht erst die aus ihnen erwachsenen Promycelien der tremelloiden Uredineen, den Basidien der Tremellinen nicht nur sehr ähnlich, sondern streng homolog. Dasselbe Verhältnis besteht zwischen den Sporidien einerseits, den Basidien andererseits." 
Lch glaube nicht, daß wir wesentliches hier zufügen können, DE Barys geniale Einsicht hat glänzend bestanden.

Weiter fragt DE BARY, ob man nun annehmen soll, daß die Aecidien bildenden Uredineen aus Tremellineen entstanden sind, und also das Aecidium eine Neubildung ist, oder aber ob die Tremellineen und Basidiomyceten das Aecidium verloren haben, also regressiv entstanden sind. Letzteres hält er für das wahrscheinlichere.

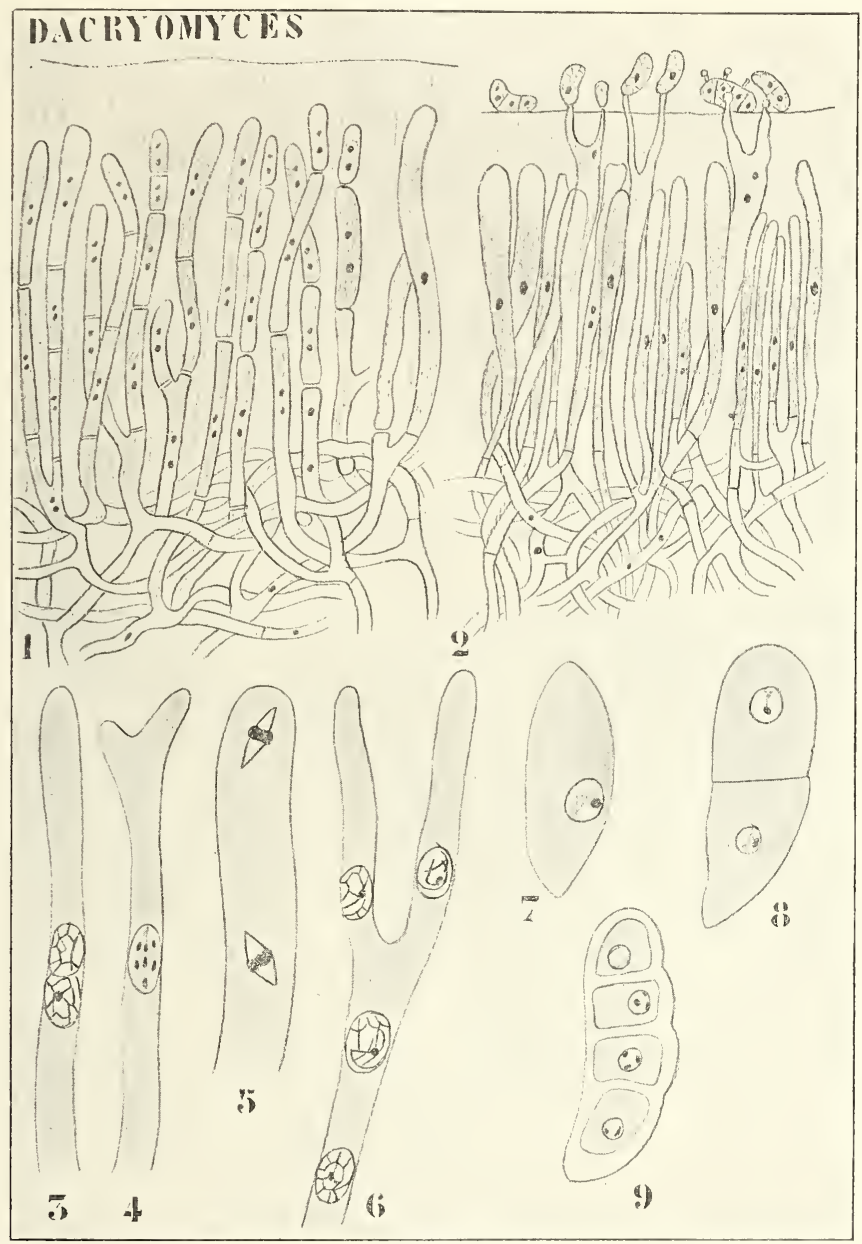

Fig. 384. Dacryomyces delinquescens (nach Dangeard und Maire). 1 Bildung von binukleären Oidien am binukleären Mycel. 2 Basidien, zum Teil zweikernig, zum Teil einkernig, einige gekeimt, die uninukleären aber alsbald keimende Basidiosporen bildend. 3 Die Kerne in der Basidie beim Anfang der Fusion. 4 Die erste Teilung des Fusionskernes. 5 Die zweite Kernteilung in der Basidie. 6 Die vier Kerne in der Basidie, zwei derselben in die Sterigmen eingetreten. 7 Die einkernige Basidiospore. 8, 9 Keimung derselben.

Da er die Uredineen von Ascomyceten ableitet, betrachtet er in letzter Instanz die Basidiomyceten als „anf regressivem Wege entstandene Abkömmlinge derjenigen Angehörigen der Ascomyceten-Reihe, auf welche die Beobachtung direkt hinweist". 
In gewisser Hinsicht ist dies richtig, in anderer aber nicht, denn eine Tremella steht insoweit höher wie ein Pyronema, z. B. als die Tremella eine 2x-Generation, Pyronema eine $\mathrm{x}$-Generation ist.

Basidiomyceten und Ascomyceten verhalten sich in dieser Hinsicht wie Farne und Moose, bei den Basidiomyceten und den Farnen dominiert die 2x-Generation, bei den Ascomyceten und Moosen die x-Generation.

BREFELD huldigt, wie wir schon sahen, anderen Auffassungen. Von der großen Aehnlichkeit zwischen Basidien und äußerlich den Basidien ähnlichen Konidiophoren gewisser Basidiomyceten getroffen, homologisiert er beide und letztere mit den Konidiophoren niedriger Pilze, so daß er zu einer Homologie zwischen den Basidien und den Konidiophoren niedriger Pilze gelangt.

Die cytologischen Resultate der letzten Jahre machen es ein leichtes, an einem Beispiel die Unhaltbarkeit der BrEFELDschen Auffassung zu zeigen.

Bei Pilacre homologisiert er die Basidien und die Konidiophoren. die Basidiosporen und die Konidien. Die Basidiosporen enthalten aber nur einen Kern, die Konidien zweifellos (nachgewiesen wurde dies bei der verwandten Auricularia) zwei Kerne.

Hier wird also eine Zelle der $\mathrm{x}$-Generation mit einer solchen der. $2 \mathrm{x}$-Generation homologisiert, und ebensowenig darf man die Konidiophoren von Pilacre mit denen der konidienproduzierenden Mucorineen. homologisieren, denn erstere gehören der 2x-, die letzteren der x-Generation an.

Die Basidie ist also nicht - wie Brefeld will -- ein in Bezug auf die Zahl der produzierten Sporen konstant gewordenes Konidiophor. sondern etwas Neues, was überhaupt erst entstehen konnte, nachdem eine $2 \mathrm{x}$-Generation entstanden war, ein Gonotokont.

Wohl sind Ascus und Basidie homolog, aber nicht, weil sie, wie BrEFELD will, Sporangien und Konidiophoren sind, sondern weil sie als Diplosporangien und Diplokonidiophoren homologe Organe sind.

Ascus, Basidie, Teleutospore sind also in letzter Instanz Diplosporangien, sind Organe, welche nicht entstehen konnten, bevor eine

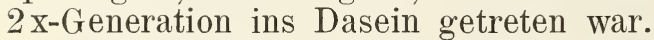

Mit Brefeld beginnt also die Periode des Leugnens der Sexualität bei den Basidiomyceten.

Im Jahre 1893 greift aber die Cytologie ein, es entdecken DANGEARD und Sappin-Trouffy (1893-1895) die Kernfusion in Teleutospore und Basidie, welche sie als Befruchtung deuten, 1895 findet DANGEARD die Kernfusion im Ascus und dehnt seine Befruchtungstheorie auf diese Gruppe aus.

WAGER $(1892,1894)$ meinte, daß mehr wie zwei Kerne in der Basidie fusionieren, aber MaIre (1900) und Ruhland (1901) zeigten die Richtigkeit der DangEARDschen Beobachtung.

MaIRE ist der erste, welcher eine gute Erklärung gibt und welcher die beiden Kerne der binukleären Zellen als einem 2 x-Kern gleichwertig betrachtet. Nach ihm ist ein $2 x-$ Kern nichts als ein Synkarion, bei welchem beide Kerne in einer Membran eingeschlossen sind. Daher schlägt er vor, die Sporophyten Synkaryophyten zu nennen. Hier entwickelt MaIre sehr kurz so ziemlich die gleiche Theorie über die xund 2x-Generation, welche ich später publizierte, so daß, wenn darin etwas Gutes steckt, die Priorität zweifellos ihm gebührt. Unnötig ist es, zu sagen, daß mir seine diesbezügliche Veröffentlichung damals un- 
bekannt war: wir sind übrigens auf recht verschiedenem Wege zum gleichen Resultat gelangt, was die Wahrscheinlichkeit der Richtigkeit nuı erhöhen kann.

Wir haben also bei den Basidiomyceten eine $\mathrm{x}$ - und eine 2x-Generation, zur ersteren gehört das aus der Basidiospore entstandene Mycel, zur zweiten z. B. der Hut eines Hutpilzes.

Die 2x-Generation entsteht wohl in ähnlicher Weise wie bei den Lepto-Uredineen, auf der x-Generation apogam, durch Hinüberschlüpfen eines Kernes aus irgend einer Hyphenzelle in eine andere. Wo dieses genau geschieht, weiß ich nicht, Miss NicHous hat darüber etwas publiziert (The nature and origin of the binucleated cells in certain Basidiomycetes. Trans. Wisc. Acad., Sc. XV, 1905), ihren Artikel habe ich mir bis jetzt nicht verschaffen können. Darüber sagt HARPER:

.There seems no doubt in view of Miss NicHoLs's results, that in certain Basidiomycetes the origin of the binucleated cells is not found in any such definite structures or at any such fixed point in the life cycle as in the rusts", womit er wohl nur Uredineen mit Aecidien meint. Wahrscheinlich hat also Miss Nichols etwas Aehnliches gefunden, wie BrackMAN bei den Leptopuccinien.

Die Cytologie hat also die lang ersehnte Lösung der Sexualitätsfrage für die Basidiomyceten erbracht, unde ebenfalls gezeigt, daß BREFELDS Homologisierung von Basidie und Konidiophore nicht richtig ist. Damit wird also seine Gruppe der Hemibasidien wertlos, seine Einteilung der Basidiomyceten in Proto- und Autobasidiomyceten wird aber keineswegs beeinträchtigt.

van Tieghem (1893) will aber auch diese Einteilung nicht gelten lassen. Er hält die Weise, in welcher die Sporen an der Basidie angeheftet sind, ob lateral oder apikal, für überaus wichtig und teilt danach die Basidiomyceten in Pleurosporeae und in Acrosporeae ein. Infolgedessen werden Tilletieae und Agaricaceae zu der Gruppe der Acrosporeae vereinigt, die Ustilagineae zu den Pleurosporeae gebracht.

Es ist gewiß auffallend, daß das Resultat der Durchführung dieses Prinzips, die Vereinigung so heterogener Typen, wie Tilletia und Agaricus, Herrn v. Tieghem nicht an der Richtigkeit des Prinzips zweifeln macht, das gleiche gilt für seine Einteilung der Phanerogamen, wo die konsequente Durchführung des dort acceptierten Ovularprinzips zu nicht weniger überraschenden Resultaten führt.

In seiner Auffassung steht denn auch vaN TiEGHEM so ziemlich allein und schon im gleichen Jahre wandte sich VuILLEMIN (1895) gegen die vaN TiEghemsche Auffassung und verteidigte das gute Recht der BrEFELDschen Gruppe der Protobasidiomyceten, schließt aber die Ustilagineae, wie wir oben taten, von den Basidiomyceten aus. Auch homologisiert er nicht die Basidie mit den Konidiophoren, sondern mit dem Ascus. Er will die Basidie direkt vom Ascus ableiten, und betrachtet die Basidie als einen Ascus, dessen Sporenenergiden in Ausstülpungen der Ascuswand hineinkriechen, sich dann mittels einer Querwand abtrennen, und so besser an Transport durch den Wind angepaßt sind.

Wörtlich sagt er: „Une baside est un asque, dont chaque cellule-fille, avant de passer à l'état de spore, fait saillie au dehors et se transforme en une sorte de conidie, pour mieux s'adapter au transport sur le rent."

So wie bei den niederen Pilzen die Konidie sich aus einem Sporangium entwickelt hat, so entstand also nach Tuthlemis die Basidie aus dem Ascus. 
Die cloisonnierten Basidien, die Protobasidien sind nach ihm Asci, in welchen die Sporen nicht zur Entwickelung kamen, sondern bei welchen sofort nach der Kernteilung Querwände auftraten. Nach ihm haben wir also hier mit einer accelerierten Entwickelung des Ascus zu tun, herbeigeführt durch eine verfrühte Keimung, welche durch den hohen Feuchtigkeitsgrad des gallertigen Stromas herbeigeführt wurde.

So werden die Tremellineae von niederen Ascomyceten, etwa von Ascocorticium abgeleitet. Von den Tremellineen leitet dann VuiluEmin die Pucciniaceae via Auricularieen ab. Das Aecidium würde demnach eine Neubildung sein; meines Erachtens ist DE BARYs Auffassung, nach welcher Tremellineen aus Uredineen durch Verlust des Aecidiums entstanden sind, sicher richtiger, denn das Tremellineen-Stroma ist wie das Teleutosporenlager der Gymnosporangien eine 2x-Generation, während bei Ableitung der Tremellineen von den niedrigen Ascomyceten eine x-Generation mit einer $2 \mathrm{x}$-Generation homologisiert wird und sich bei $\mathrm{Ab}$ leitung der Pucciniaceae von den Tremellineen die sonderbare Erscheinung des Entstehens einer $\mathrm{x}$-Generation (Aecidium) zeigen würde, nachdem die zugehörige $2 \mathrm{x}$-Generation schon bestand.

Der erste, welcher versuchte, an der Hand der Cytologie die Phylogenie der Basidiomyceten zu begründen, war JuEL.

Von der Erfahrung ausgehend, daß wir bei den Protobasidiomyceten zwei Typen von Basidien kennen, nämlich quergeteilte und längsgeteilte, fragte er sich, ob bei den Autobasidiomyceten die Richtung der Kernspindel in der Basidie uns vielleicht auf die Spur ihrer Abstammung bringen könnte.

In der Tat fand er bei gewissen Basidiomyceten z. B. bei Dacryomyces (Fig. 384), die Kernspindel parallel der Längsachse, also wie bei den quergeteilten Auricularia-Basidien, bei anderen die Kernspindel quer zur Längsachse, also wie bei den längsgeteilten Tremellineen-Basidien.

Formen, bei denen die Kernspindel der Längsachse der Basidie parallel verläuft, nennt JUEL Stichobasidien solche, bei denen sie senkrecht zur Längsachse steht, Chiastobasidien.

So kommt er zu folgender Phylogenie der Basidiomyceten:

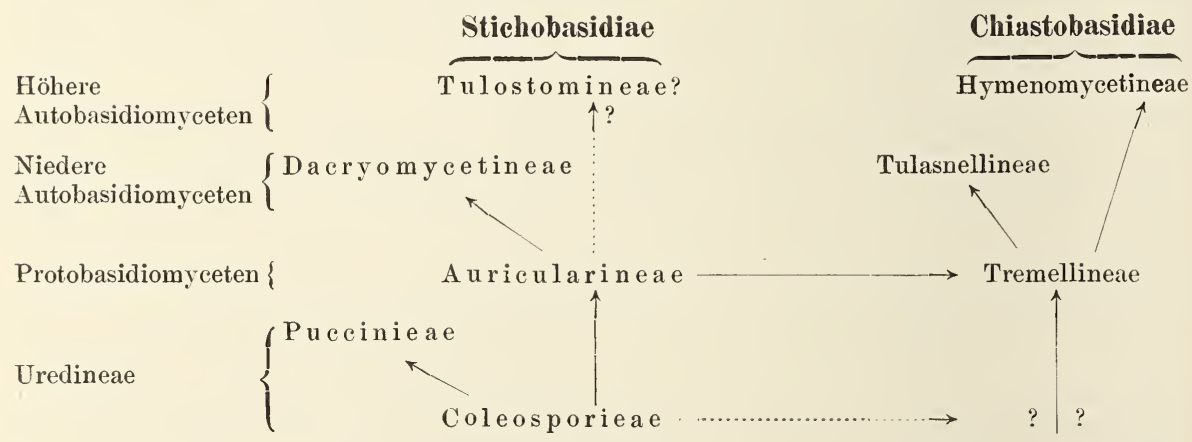

Der einzige Gasteromycet in diesem Schema ist Tulostoma, von welchem Genus van Treghem die Kernspindel beschreibt, aber nicht abbildet. $\mathrm{Zu}$ jener Zeit fehlte es an anderen Angaben über die Kernteilung bei den Gasteromyceten. JuEL vermutet aber, daß sich die Mehrzahl als chiastobasidial herausstellen wird und also neben die $H y$ menomyceten gestellt werden muß, eine Meinung, welche sich schon für 
gewisse Genera, z. B. für Hydnangium, nach r. Bamвекеs Untersuchungen als richtig herausgestellt hat.

Tulostoma sollte noch untersucht werden, die Aufgabe ist aber nicht leicht, da dazu sehr junge Individuen nötig sind. Nur Schroeter und van Tieghem haben die Basidien gesehen, weder Maire noch PatouilLARD konnten sich geeignetes Material verschaffen.

JUEL betrachtet die Coleosporieae als die Stammformen der Puccincae, da er meint. daß die Teleutospore von Coleosporium die ursprüngliche Keimungsweise der "Basidie" zeigt und die Promycelbildung der Pucciniaceen als eine durch die Anpassung an den Winter verursachte Modifikation betrachtet. Nach seiner Ansicht ist nämlich die Teleutospore von Puccinia eine encystierte Basidie und das Promycel eine durch die Dicke der Sporenwand gebotene Keimungsweise; das ist sehr wohl möglich, wir sahen aber, daß es auch Pucciniacerve (Chrysopsora) gibt, teren Teleutosporen wie die von Coleosporium keimen.

Ich glaube nun wohl, daß man mit einem großen Grade von Wahrscheinlichkeit sagen kann, daß die Basidiomyceten aus Uredineen-artigen Ahnen durch Verlust der Geschlechtsorgane und damit gepaarter apogamer Bildung der 2x-Generation hervorgegangen sind. Die Uredireen zeigen in letzter Instanz verwandtschaftliche Beziehungen zu den Florideen und ich stelle mir vor, daß die Florideen etwa in folgender Weise zur Entstehung höherer Pilzgruppen Veranlassung gegeben haben.

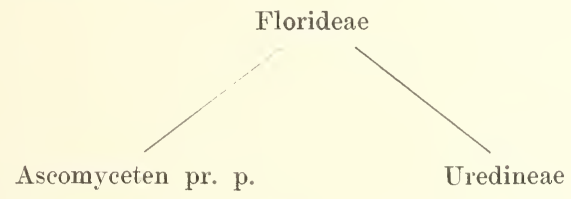

Basidiomyceten

Daß die Uredineen aus Ascomyceten hervorgegangen sein sollten, scheint mir, wie oben auseinander gesetzt, in Anbetracht der Aecidien in hohem Grade unwahrscheinlich. Diese Ableitung würde nur für die Uredineen ohne Aecidien überhaupt möglich sein, und man würde dann zum Resultat kommen, daß gewisse Uredineen mit abgekürztem Entwickelungsgang von solchen mit komplettem Lebenszyklus abstammten, andere dagegen aus apogamen Ascomyceten hervorgegangen wären, eine Auffassung, welche mir nicht sehr überzeugend vorkommt.

JuELs Einteilung der Basidiomyceten in Stichobasidiineae und Chiastobasidiineae beruht wohl auf einem richtigen Prinzip, aber JuEL selber legte den Nachdruck auf den Umstand, daß man noch viel zu wenig Formen kennt, um bestimmen zu können, wie die Grenze zwischen Stichobasidiineae und Chiastobasidiineae verläuft.

In der Tat ist denn auch aus MaIres Untersuchmoen hervorgegangen, daß nicht, wie JUEL meinte, alle Hymenomyceten chiastobasidial sind und daß man also die Hymenomyceten nicht direkt ron Tremellineen ableiten darf.

Im Gegenteil scheinen die chiastobasidialen Protobasidiomyeten nur wenigen Autobasidiomyceten, nämlich nur den Tulasnellaceen und den Trilleminiaceen das Dasein gegeben zu haben.

Dagegen fand MAIRE in den Cantharellaceen eine intermediäre Gruppe, welche einerseits an die stichobasidialen Protobasidiomyepten 
sich anschließt, andererseits zu den chiastobasidialen Hymenomyceter führt, so daß offenbar die stichobasidiale Reihe einen chiastobasidialen Seitenzweig hervorgebracht hat, aus welchem die höheren Autobasidiomyceten hervorgegangen sind.

MaIRE läßt es nun unentschieden, von welchen Formen die stichobasidialen Protobasidiomyceten abzuleiten sind, nimmt aber an, daß diese stichobasidiale Reihe dem kurzen chiastobasidialen Seitenzweig der Tremellineae-Tulasnelliaceae-Vuilleminiaceae und den stichobasidialen Ecchynaceen das Dasein gegeben hat, aus welchen letzteren vielleicht die Tulostomaceen hervorgegangen sind.

Weiter hat sie zur Entstehung der stichobasidialen Autobasiodiomyceten (Dacryomyceten) geführt und hat dann wieder via Clavariaceen einen chiastobasidialen Zweig gebildet, aus welchem die höheren Autobasidiomyceten hervorgegangen sind.

So kommt MaIre zum folgenden, wie er selber sagt, provisorischen Stammbaum, welcher aber meines Erachtens der beste der bis jetzt vorgeschlagenen ist:

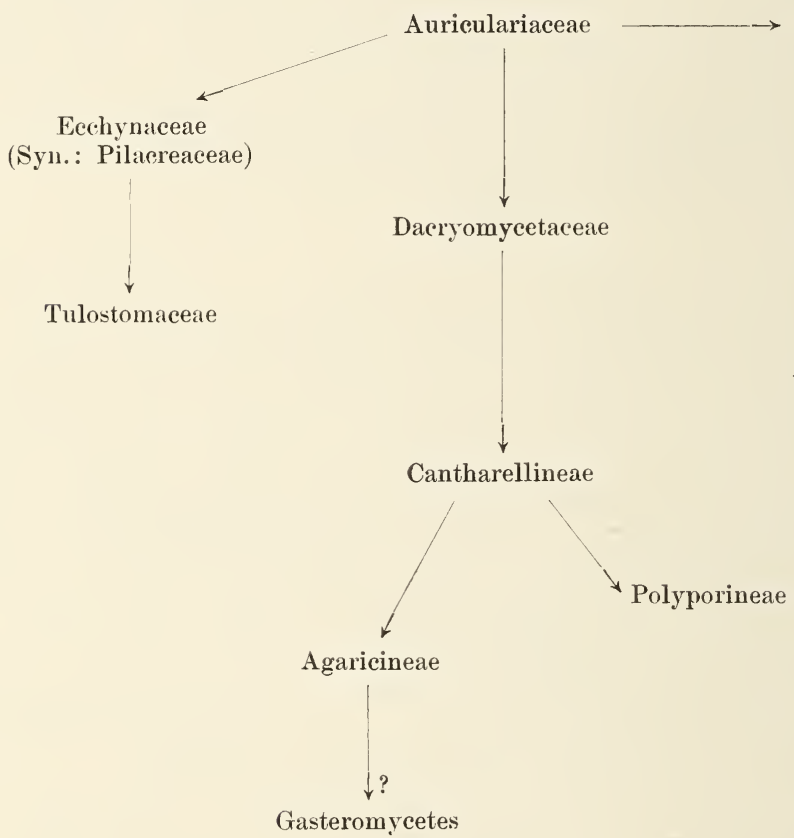

Von den Auriculariaceen haben wir schon einen Repräsentanten kennen gelernt, und Pilacre von den Ecchynaceen kann als eine angiocarpe Auriculariacee betrachtet werden.

Davon aber direkt, wie BREFELD will, die Gasteromyceten abzuleiten, stößt auf die Schwierigkeit, daß letztere chiastobasidial und überhaupt zu hoch entwickelt sind, um einen so frühen Anschluß an die stichobasidiale Reihe zu rechtfertigen. Zugegeben muß aber werden, daß der Anschluß der Gasteromyceten noch recht problematisch ist.

Betrachten wir nun die chiastobasidiale Reihe, so begegnen wir zunächst den Tremellaceen, von welcher Gruppe wir ebenfalls schon einen Vertreter kennen lernten, es bleibt also nur noch $\mathrm{zu}$ erörtern, mit 
welchem Rechte Marre die Tulasnellacene und Vuilleminacene von den Tremellineen ableitet. Betrachten wir dazu zunächst die Familie der

\section{Tulasnellaceae,}

eine Familie, welche von JukL (Bih. till K. Sv. Vet. Akad. Handl., Bd. 23, Afd. III. No. 12, p. 21) aufgestellt und in folgender Weise definiert wurde:

Gymnocarpe Basidiomyceten mit kugeligen, stets einzelligen Basidien ohne Sterigmen. Sporen nicht abfallend, sondern an der Basidie keimend, und Sporidien bildend.

Dazu gehören zwei Genera: Thasnella Schroeter und Muciportls JUEL.

\section{Tulasnella.}

Im Jahre 1872 wurde dieser Pilz von den Gebrüdern Tulasne entdeckt und abgebildet, aber irrtümlich für Corticium incarnatum TR. gehalten. Später beschrieb ScHRoeter eine andere Art mit dem gleichen Basidienbau, welche er mit der Tulasneschen Art zum Genus Tulasnella vereinte und in einem Anhang zu den Tremellineen stellte.

Einige Monate später entdeckte Patouillard auch eine neue Tulasnella: da er aber ScHRoETERs Arbeit nicht kannte, schlägt er für die Tulasnesche Art und seine eigene das neue Genus Prototremella vor, welches er zu den „Hymenomycetes hétérobasidiées" (Protobasidiomyceten) stellt.

Im Jahre 1899 erschien in Brefelds Untersuchungen die von Johan OLsen verfaßte Beschreibung des neuen Genus Pachysterigma mit 4 Arten, welches el zu der Familie der Tomentelleen, d. h. zu den niedrigsten Autobasidiomyceten, stellt. Auch dieses Genus ist mit Tulasnella identisch.

Machen wir jetzt an der Hand der Boudierschen Beschreibung von Tulasnella calospora (Boud.) JuEL (Journ. de Bot., T. X, p. 85) mit diesem Pilzgenus Bekanntschaft.

Der Pilz (Fig. 385, I 1) wurde von HÉtier unter Straßenkehricht der Stadt St. Denis bei Paris auf einem faulenden Stückchen Leinwand entdeckt, auf welchem er einen weißen Ueberzug bildete, der bei eintretendem feuchten Wetter aschfarbig wurde, ja sogar einen blaugrünen Schimmer erhalten konnte.

Am Ende der Basidie (Fig. 385, I 2) entstehen 4 ungestielte Sporen (Fig. 385, I 3), welche nicht abfallen, sondern auf der Stelle keimen (Fig. 385, I 4) und je eine Sporidie bilden (Fig. 385, I 5). Diese Sporidien (Fig. 385, I 6) fallen ab und können sogar Sekundärsporidien bilden (Fig. 385, I 7), keimen meistens aber sofort zu einem neuen Mycel aus.

Die ungewohnte Form der Sporen und die Abwesenleit eines Sterigmas bewirkten, daß Boudier sie so wie seine Volgänger als Sterigmen betrachtete, was schon JoHAN OLsEN dazu gebracht hatte, dieses Genus Pachysterigma zu nennen. Die Sporidien hielt er für die Basidiosporen und betrachtete nun die 4 von ihm als Sterigmen gedeuteten Basidiosporen als das Aequivalent der 4 Tellen der TremellaBasidie, welche nach ihm gespreizt waren. Damit befand er sich in Einklang mit Patounllard (Journ. de Bot., T. II, p. 267) und bringt denn auch seinen Pilz wie dieser zum Genus Prototremella. 
Erst durch JueLs Untersuchungen an

\section{Mucipor'us}

stellte es sich heraus, daß die Tulasnellaceae Autobasidiomyceten sind, und es entstand die richtige, oben vertretene Auffassung der TulasnellaBasidie.

\section{Muciporus deliquescens JuEL}

wurde Mitte April 1896 auf einem abgeworfenen Baststücke einer alten Populus tremula bei Upsala von Juel entdeckt. Er bildete an der Oberfläche des Holzes einen ziemlich unscheinbaren dünnen und schleimigen Ueberzug.

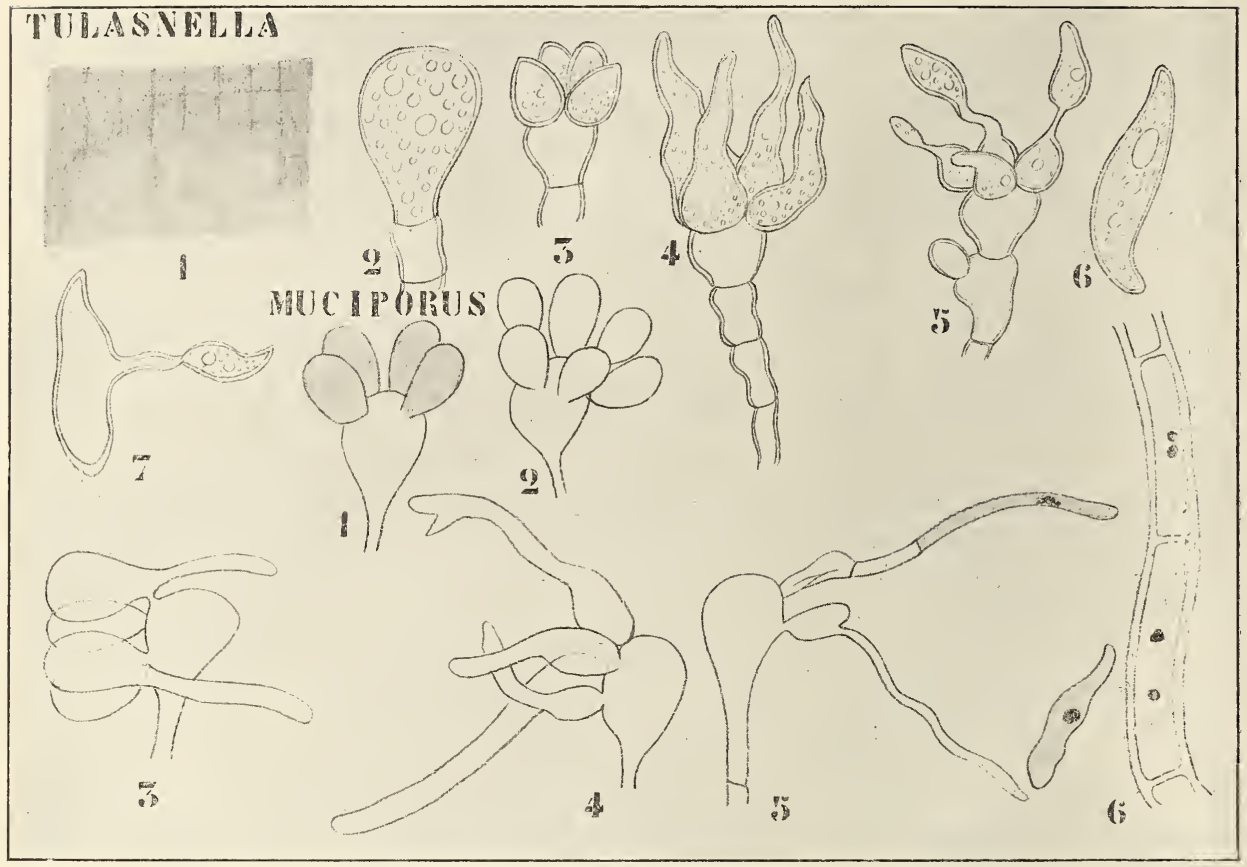

Fig. 385. I. Tulasnella ealospora (Boud.) Juel (nach Boudier). 1 Habitus. 2 Basidie. 3 Basidie mit Sporen. 4 Die Sporen keimend. 5 Die Sporen bilden Sporidien. 6 Abgefallene Sporidie. 7 Eine solche eine Sekundärsporidie bildend. - II. M u ciporus deliquescens Juel (nach JuEL). 1 Viersporige Basidie. 2 Sechssporige Basidie. 3 Die Sporen keimend. 4 Gleichfalls. 5 Sporidienbildung. 6 Das binukleäre Mycel.

An bestimmten Stellen war dieser Ueberzug kräftiger entwickelt und mit deutlichen Gruben versehen, so daß diese Teile einer resupinaten Polyporee ähnlich sahen.

Die schleimige Masse bestand aus einer reichlichen Basidienfruktifikation, die Basidiosporen besaßen keine Sterigmen (Fig. 385, II 1).

In der Basidie sind 4 Kerne vorhanden, diese schlüpfen mit dem Plasma in die 4 Sporen über. Vereinzelt wurden Basidien mit 6 Sporen angetroffen. Bisweilen stehen die Sporen lateral; vermutlich standen solche Basidien schief im Hymenium, so daß die sporenbildende Seite nach oben gekehrt war. 
Die Sporen keimen in der Regel, während sie noch an der Basidie befestigt sind, nur selten fallen sie ab. Die Keimung tritt sofort auf, wenn der Pilz feucht gehalten wird; wahrscheinlich führt der Pilz überhaupt ein sehr ephemeres Dasein.

In typischen Fällen bildet die Basidie einen Keimschlauch an der Spitze und bildet am Ende desselben eine Sporidie oder Konidie. Diese ist einzellig und monoenergid und teilt sich alsbald in zwei ebenfalls monoenergide Zellen.

Dennoch ist das Mycel binukleär, wie das zu stande kommt, weiß man noch nicht.

Bei einer anderen Art, bei

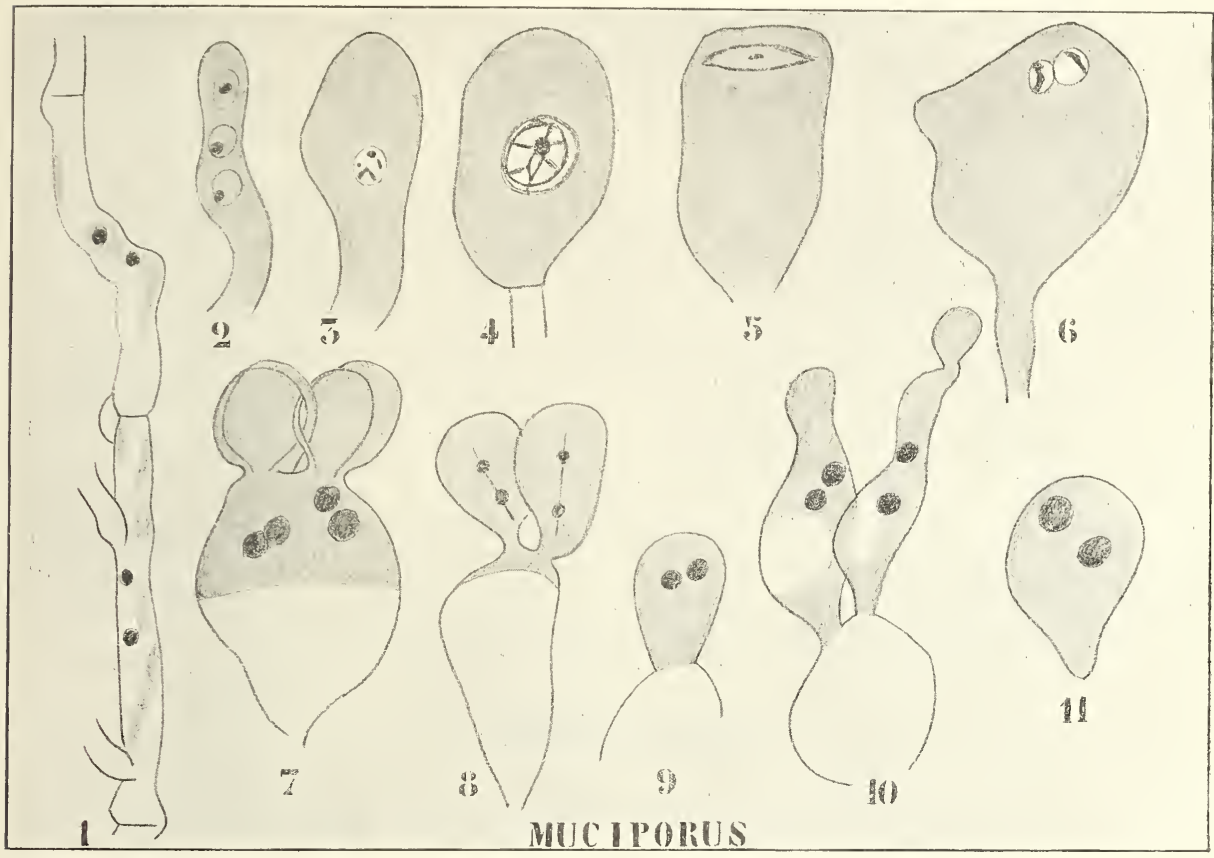

Fig. 386. Muciporus corticola (Fr.) JueL (nach JueL). 1 Das binukleäre Mycel. 2 Junge Basidienanlage. 3 Der aus der Verschmelzung der beiden Kerne hervorgegangene Fusionskern. 4 Der Fusionskern hat sich vergrößert. 5 Erste Teilung. 6 Zweikerniges, 7 vierkerniges Stadium. 8 Die ursprünglich einkernigen Sporen sind zweikernig geworden. 9 Idem. 10 Die Sporen keimend. 11 Zweikernige Sporidie.

Muciporus corticola (FR.) JuEL,

konnte JuEL die Cytologie besser studieren. Es kommt diese in zwei Formen vor, die eine besteht bloß aus einer Basidienschicht und wird die forma thelephora genannt, die andere gleicht einem Polyporus; ihre Poren sind vom sehr vergänglichen Hymenium überzogen. Letztere Form wurde früher für einen echten Polyporus gehalten und erhielt den Namen Polyporus corticola Fr.

Auch hier enthält die junge Basidie zwei Kerne, welche alsbald fusionieren. Der Fusionskern schwebt im Zentrum der Basidie (Fig. 386, 4). begibt sich aber alsbald nach der Spitze und teilt sich dort. Die Kernspindel steht dabei transversal (Fig. 386, 5). Bald hernach findet noch 
eine zweite Teilung statt, bei welcher die Kernspindel wieder transversal steht. In jede Spore begibt sich ein Kern, welcher sich alsbald teilt, wodurch die Sporen zweikernig werden, ein Vorgang, der wohl als verfrühte Keimung zu deuten ist. Am Ende des Keimschlauches wird eine Konidie gebildet, und diese kann, nachdem sie abgefallen ist, sekundäre Konidien bilden. Auch die Konidien scheinen hier zweikernig zu sein (Fig. 386, 11).

Ob dies die zwei Kerne der verfrüht gekeimten Basidiospore sind, oder ob nur ein Kern in die Konidie eintritt, der sich dort aber alsbald teilt, ist nicht bekannt. Zwar sagt MaIre (l. c. p. 79): „Dès que la spore est formée, son noyau se divise, puis elle germe en produisant un promycelium terminée par un conidie où passe un des nouyaux-fils", da er aber keine eigenen Untersuchungen über diesen Punkt angestellt hat, kann dies wohl nur eine Vermutung sein.

Wo ist nun die Verwandtschaft dieser Tulasnellacee zu suchen? Die Kugelform der Basidien erinnert stark an die der Tremellineen, auch die alsbald nach der Keimung eintretende Konidienbildung haben sie mit Tremellineen gemein. Dies ist überhaupt ein bei Protomyceten sehr häufiges Vorkommnis, bei Autobasidiomyceten dagegen eine große Seltenheit, welche nur bei Exobasidium und bei einer Radula-Art bekannt ist; offenbar müssen also die Thlasnellaceen als Autobasidiomyceten betrachtet werden, mit Verwandtschaftsbeziehungen zu den Protobasidiomyceten.

Da die Kernteilung chiastobasidial stattfindet, können sie nicht an die Dacryomyceten angeschlossen werden, und es ist also wohl am besten, sie an die Tremellineen anzuschließen, wozu die schleimige Konsistenz des Lagers der niederen Formen wie von selbst führt, und wogegen die Polyporus-Form der höheren Formen nicht spricht, da sogar bei einer echten Tremellinee aus Brasilien die Polyporus-Form von MöLler beschrieben wurde.

An diese Tulasnellaceen schließt nun MaIre die

\section{Vuilleminiaceen}

an.

\section{Vuilleminia commedens (Nees) R. MaIre}

wurde von NEEs für ein Corticium gehalten und Corticium commedens NeEs genannt.

In Lothringen ist sie im Herbst und Winter auf toten Eichenzweigen, welche sie entrindet, häufig. Sie zeigt sich dem Auge als eine wachsartige gelatinöse Schicht mit wenig scharf begrenzter Kontur, von einer Dicke von $1 / 10$ bis $2 / 10 \mathrm{~mm}$.

Die dünnen Mycelfäden, welche im Gewebe des Eichenzweiges verlaufen, bestehen aus binukleären Zellen. Sie verweben sich zu der wachsartigen Schicht, indem ihre Membranen mehr oder weniger verschleimen. Im Fall sich diese Schicht etwas tief in der Rinde bildet, gibt sie zur Decortication Veranlassung.

Die Basidien werden tief in dieser Schicht angelegt, es sind einfach binukleäre Endzellen normaler Hyphen.

Ihre Form ist cylindrisch, sie vergrößern sich, die Kerne fusionieren, und es wächst die junge Basidie sehr in die Länge, bis sie die äußeren Rindenschichten erreicht hat. Hier schwillt die Spitze an, wodurch sie einer der Tremellineen-Basidien ähnlich sieht. Diese Basidie bildet nun 
eine Terlängerung. welche die Oberfläche der gelatinösen Schicht zu erreichen sucht und sich dort verbreitert. In diese Anschwellung tritt der Kern ein. Dort teilt er sich in solcher Weise, daß die Kernspindel transversal steht, was sich, so wie bei den Thlasnellaceen, wiederholt, wodurch 4 Tochterkerne entstehen.

Nun werden 4 große Sterigmata gebildet, deren jedes eine Spore bildet, in welche ein Kern hineintritt. Die Spore enthält also einen Kern. welcher sich alsbald teilt; dabei können normale Querwände auftreten (Fig. 387, 8), aber auch ausbleiben (Fig. 387, 9).

Mit den Vuilleminiaceen hat nach der Meinung Marres die ursprüngliche Chiastobasidien-Reihe ihren Endpunkt erreicht.

Ton der stichobasidialen Reihe haben wir schon in Pilacre einen

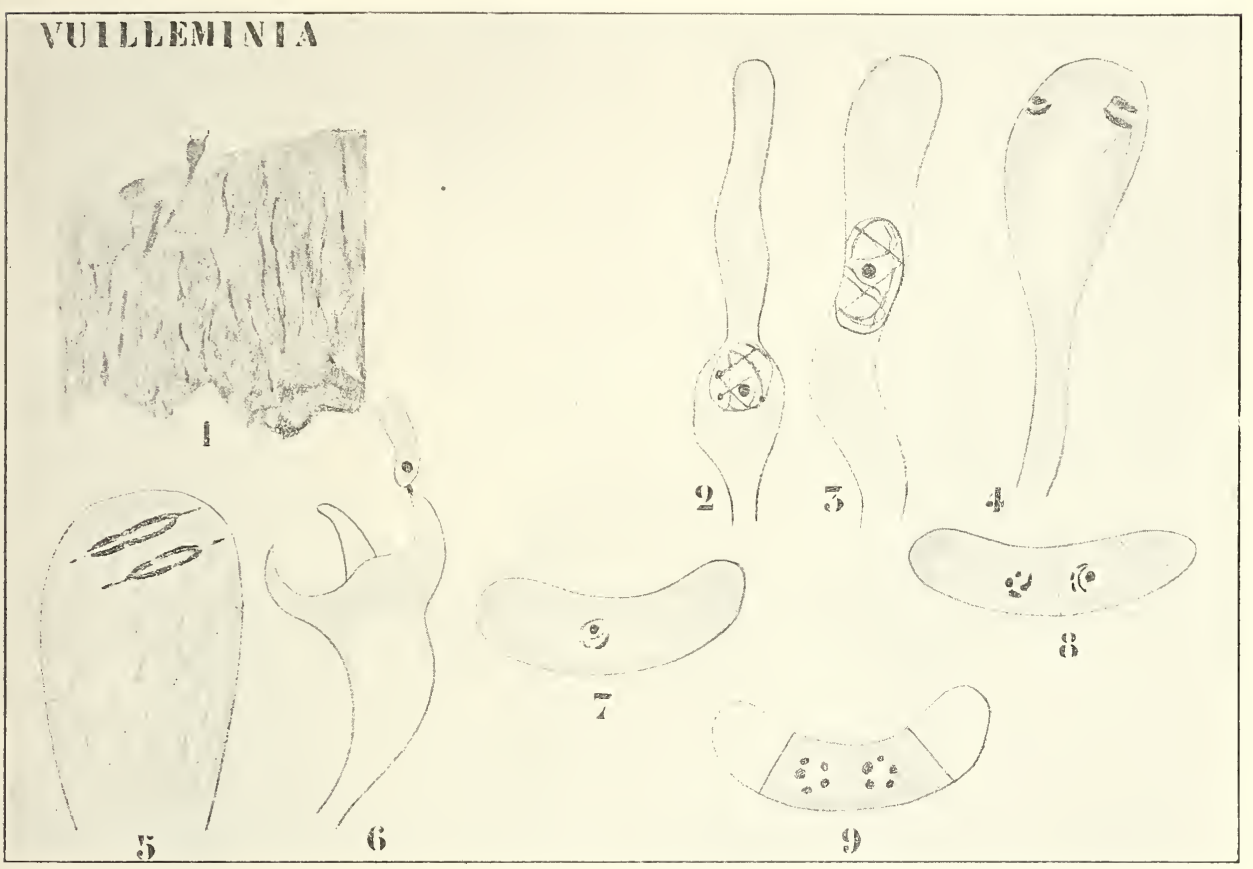

Fig. 387. Vuilleminia commedens (NeEs) R. MaIre (nach MaIre). 1 Querschnitt, eine Basidie zeigend. 2-6 Basidienentwickelung. 7 Abgefallene Spore. 8-9 Sporenkeimung.

Repräsentanten der Ecchynaceen kennen gelernt. Wir sahen, daß diese von den Auricularieen dadurch verschieden ist, daß die Basidien nicht an der Oberfläche liegen, sondern von einer Art lockerer Peridie bedeckt sind. Da nun nach van TIEGHEM unter den Gasteromyceten das Genus Tulostoma stichobasidial ist, schließt MAIRE vorläufig die Tulostomaceen hier an, nähere Untersuchung tut aber sehr not.

Die Tulostomaceen besitzen, soweit bekannt, lateral inserierte Sporen; wir werden diese Gruppe, deren Anschluß an die Ecchynaceen noch sehr problematisch ist, später in Verbindung mit den Gasteromyceten behandeln.

Gehen wir also zur Betrachtung des Hauptstammes der Basidiomyceten, wie sich MaIrE diesen vorstellt, über. 
Den Anschluß der Dacryomyceten an die Auricularineen haben wir schon behandelt; an diese Dacryomyceten schließt nun MaIrE die

\section{Clavariaceen,}

welche er mit einer Anzahl anderer Familien zur großen Gruppe der Cantharellineae vereinigt, an. $\mathrm{Zu}$ diesen

\section{Cantharellineen}

gehören die Peniophoraceae, Clavariaceae, Phylacteriaceae (Thelephoraceae), Cantharellaceae, Hydnaceae und Exobasidieae.

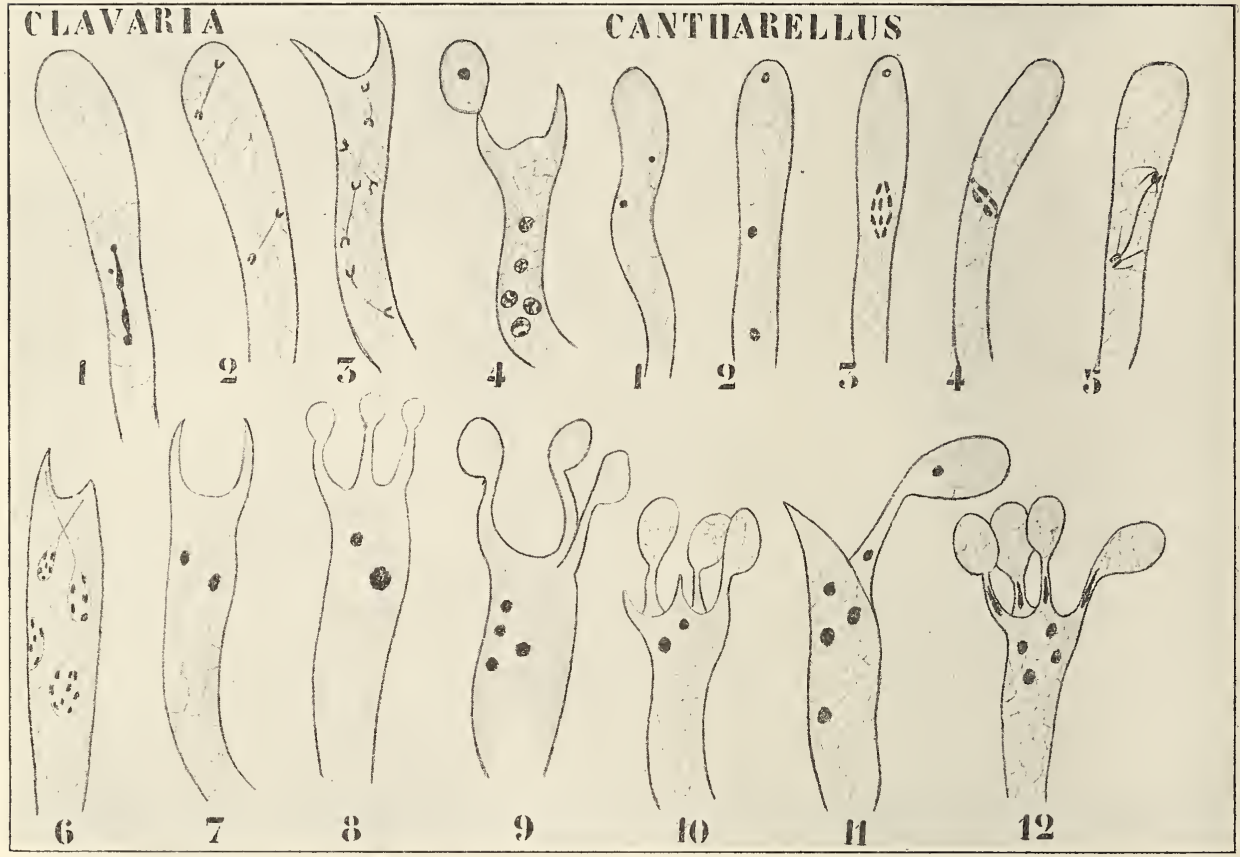

Fig. 388. Cytologie der Cantharellineae (nach MAIRE). I. Clavaria rugosa Bull. 1-4 Entwickelung der Basidie. - II. Cantharellus cinereus. 1-12 Entwickelung der Basidie.

Die große Gruppe der Cantharellineae umfaßt alle jene Autobasidiomyceten, welche Basidien von inferieurem Typus besitzen, die durch längs- oder schiefgestellte Kernspindeln an die der Auriculariaceen und Dacryomycetaceen erinnern, und bei welchen die Sporenzahl pro Basidie noch ziemlich variabel ist.

Jener Basidientypus ist am besten bei den Cantharellaceen und Clavariaceen studiert worden. Von einer jeden dieser Gruppen wählen wir hier ein Beispiel.

Die Cytologie von

Clavaria rugosa BuLl.

ist nach Marre folgende. In den vegetativen Hyphen des Fruchtkörpers 
sind die Zellen binukleär. Die Oberfläche der Carpophoren ist mit senkrecht zur Oberfläche gestellten Basidien bedeckt. In den jungen Basidien sind zwei Kerne vorhanden, welche sehr früh miteinander verschmelzen.

Die Basidie (Fig. 388, 1-4) ist fadenförmig, der Kern liegt in der Mitte. Er teilt sich, ohne seinen Platz zu ändern; dieser Teilung folgt bald eine zweite, bisweilen auch eine dritte. Während aller dieser Teilungen stehen die Spindeln longitudinal oder mehr oder weniger schief.

Die Zahl der Sterigmata ist variabel, sie werden nicht simultan. sondern successive gebildet, nämlich so, daß mehrere „Sporenernten" an jeder Basidie stattfinden.

Tom Genus Cantharellus wählen wir

\section{Cantharellus cinereus.}

Auch bei diesem sind die Carpophorzellen binukleär; es werden die terminalen Hyphenzellen des Hutes zu Basidien. Da sich hier die Basidien nicht simultan, sondern successive entwickeln, ist Cantharellus cinereus ein der cytologischen Untersuchung recht günstiges Objekt, da ein Schnitt öfters alle gewünschten Stadien liefert. Die beiden Kerne der jungen Basidie verschmelzen erst verhältnismäßig spät. Die Spindel der ersten Kernteilung (Fig. 388, II 3-5) steht schief und bleibt weit von der Spitze der Basidie entfernt. Auch hier sind die Basidien sehr polymorph; bei denen, welche 4 Sterigmata bilden (Fig. 388, 8-12), folgt die zweite Kernteilung der ersten alsbald, während welcher die Spindel ebenfalls schief steht.

Nachdem die 4 Kerne gebildet sind, entstehen die ersten schwachen Andeutungen der Sterigmata. Ein Kinoplasmafädchen wird sichtbar, welches die Kerne mit den Sterigmatd verbindet (Fig. 388, 6), und es werden die Kerne von dieser fibrillären Masse offenbar etwas ausgezogen, dann auf die Sterigmata zugezogen und so veranlaßt, in die Sporen einzutreten, wobei sie sich, um die dünnen Sterigmata zu passieren, sehr in die Länge strecken müssen (Fig. 388, II 12).

Allerlei Abweichungen kommen aber vor. Bisweilen teilt sich der Basidienkern nur einmal, woraus also wohl gefolgert werden darf, daß die erste Teilung die Reduktionsteilung ist, bisweilen aber auch dreimal; 2, 3, 4, 5, 6, 7, ja 8 Sterigmata können gebildet werden und zwar öfters ohne jegliche Beziehung auf die Kernzahl, so daß Sporen zu Grunde gehen, weil sie keinen Kern erhalten.

Dieser Polymorphismus der Basidien scheint für die Cantharellaceen typisch zu sein, und ist einer der Gründe, weshalb sie MaIRE für verhältnismäßig niedere Formen hält. Die Richtung der Kernspindeln zeigt gewiß Verwandtschaft zu stichobasidialen Typen und es scheint daher der Anschluß an die Dacryomycetaceen der natürlichste. An die Cantharellinerıe schließt nun Marre die Polyporineen und die Agaricineen an. Die Polyporineen besitzen Basidien mit apikalen und transversal gestellten Kernspindeln. Fistulina bildet außer Basidien binukleäre Konidien, welche also offenbar mit den Uredosporen der Uredineen vergleichbar sind. Die Polyporineen stehen offenbar mit den Cantharellineen mittels der Cyphellaceen in Verbindung, so daß die Cantharellaceen mit ihren schiefen Kernspindeln offenbar den Uebergang von den stichobasidialen zu den chiastobasidialen Typen bilden.

Auch die Agaricineen besitzen apikale und transversale Kernspindelu, nur bei den allerniedrigsten Formen stehen die Spindeln mehr oder weniger schief. Ihr Anschluß an die Cantharellineen liegt also auf der 
Hand. Es haben sich also offenbar die noch in mancher Hinsicht stichobasidialen Cantharellineae in zwei chiastobasidiale Zweige, in die Polyporineen und in die Agaricineen gespalten. An letztere schließt dann MaIre mit allen Reserven die Gasteromyceten an.

Selbstverständlich ist die Phylogenie der Basidiomyceten noch sehr ${ }^{*}$ problematisch, aber wir sehen, daß auch hier die Cytologie die Fragen zu beleuchten anfängt.

Wir wollen also jetzt, nachdem das System in seinen großen Zügen klar geworden ist, die Hauptformen kennen lernen.

MaIre teilt nun ${ }^{1}$ ) die Autobasidiomyceten wie folgt ein:

\section{Autobasidiomyceten.}

I. Heterobasidieae: Die Basidiosporen bilden öfters Sporidien oder Konidien: Dacryomycetes, Tulesnellaceae.

II. Homobasidieae: Die Basidiosporen keimen mittels eines Mycels.

A. Protohymeniales: Vuilleminiaceae.

B. Euhymeniales: Alle übrigen Autobasidiomycetes.

Die Dacryomyceten, Tulesnellaceae und Vuilleminiaceae haben wir schon kennen gelernt und brauchen also nur noch die

\section{Euhymeniales}

zu berücksichtigen. Sie werden von MaIRE nach der Struktur ihrer Basidien wie folgt eingeteilt:

\section{Euhymeniales.}

A. Formen mit wenig entwickeltem Basidientypus (Kernspindel longitudinal
oder schief, Zahl der Toch- Cantharellineae terkerne, der Sporen und der Sterigmata variabel)

Gymnocarp

B. Formen mit hochentwickel- | Polyporineae tem Basidientypus (Kernspindel quer und apikal, Zahl der Tochterkerne, Agaricineae Hemiangiocarp Sterigmata und Sporen mit wenigen Ausnahmen konstant)

Gasteromycetes Angiocarp

Betrachten wir also zunächst MaIres Gruppe der

\section{Cantharellineae.}

Sie umfaßt alle Autobasidiomyceten vom Basidientypus, welchen wir bei Clavaria und Cantharellus haben kennen lernen und kann wie folgt eingeteilt werden. (Für den genetischen Zusammenhang siehe das Schema auf S. 694.)

A. Normale, saphrophytische Formen mit normalem

Hymenium :

1) Für die Verbindung zwischen den Gruppen sehe man S. 678. 
a) Resupinat oder aufgerichtet mit sitzendem Hute und unilateralem glattem Hymenium, Crstiden vorhanden . . . . . . .

b) Baumförmig;, amphigenes Hymenium, Cystiden fehlen . . . . . . . . .

Periophoraceae

Aus mehr oder weniger verzweigten Blättern oder Lamellen bestehend, Hymenium mehr oder weniger warzig

Clavariaceae

The lep horaceae (Syn.: Phylacteriaceae)

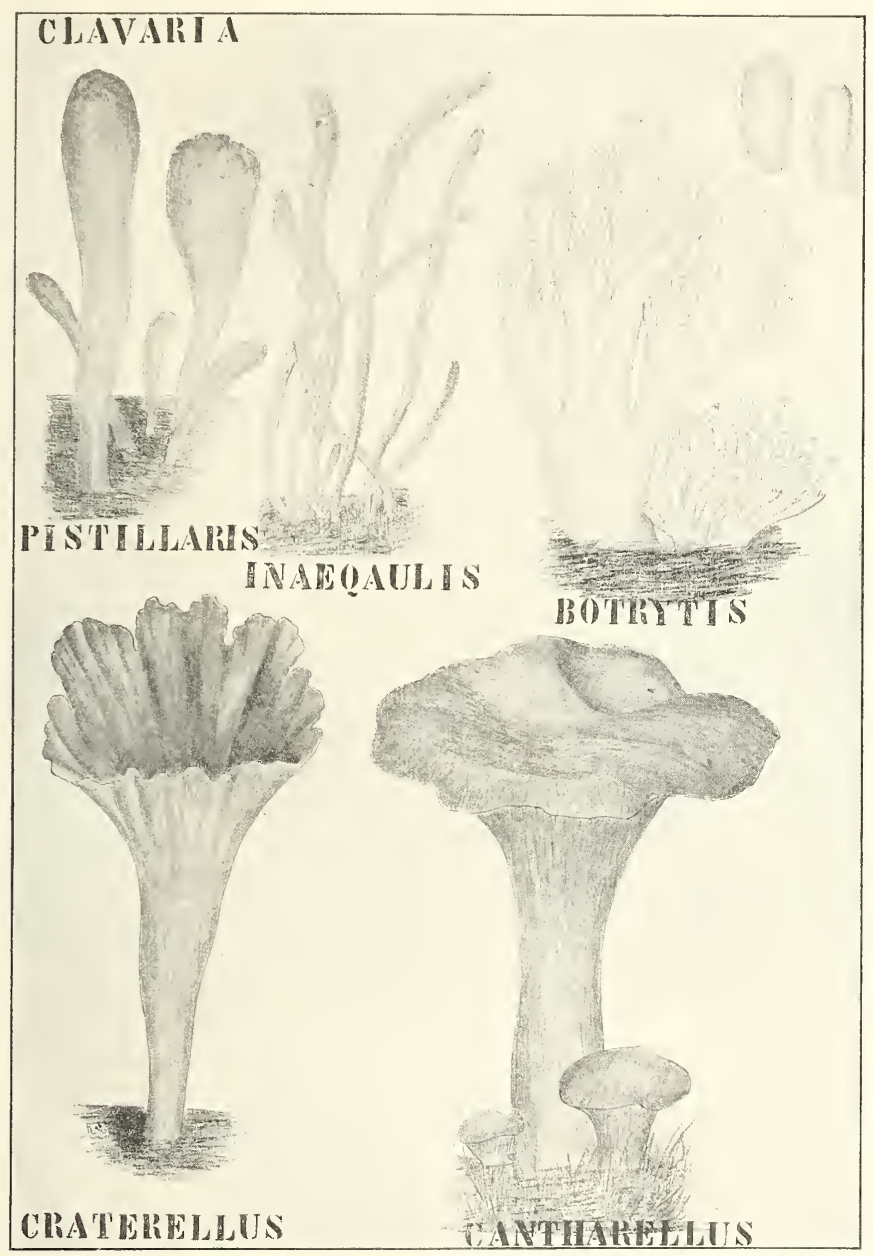

Fig. 389. $1 \mathrm{Clavaria}$ pistularis L. $2 \mathrm{Cl}$. inaequal is MüLL. $3 \mathrm{Cl}$. Botrytis Pers. 4 Craterellus lutescens Pers. (Fr.) $5 \mathrm{Chantharellus} \mathrm{cibarius} \mathrm{Fr.} \mathrm{(Alles}$ nach Henkings.)

d) Hut gut differenziert, von einem Stiel getragen, Hymenium unilateral, mehr oder weniger faltig........ Cantharellaceae

e) Wie d), das Hymenium, aber stachelig . Hydnaceae 
B. Parasitische Formen mit unterbrochenem $\mathrm{Hy}$ menium

Betrachten wir zunächst die Familie der

\section{Clavariaceae.}

Wir sahen schon, daß diese in Anbetracht der Struktur ihrer Basidien an die Dacryomyceten angeschlossen werden müssen. Es gehören zu dieser Familie verschiedene Genera, von welchem Clavaria das wichtigste ist. Es wird dieses in 3 Sektionen, wie folgt eingeteilt.

1. Holocoryne. Carpophoren unverzweigt, einzeln. Hierher z. B. C. pistillaris L. mit fleischigen $8-20 \mathrm{~cm}$ langen, gefüllten, gelben, später grauen oder rotbraunen Fruchtkörpern (Fig. 389, 1).

2. Syncoryne. Mit ungeteilten Fruchtkörpern, büschelig vereint. Hierher z. B. C. inaequalis MüLL. mit gelben, öfters schwach zusammengedrückten Fruchtkörpern (Fig. $389,2)$.

3. Ramaria. Mit verzweigten Fruchtkörpern. Hierher z. B. die weiße Cl. Botrytis Pers. (Fig. 389, 3).

An die Clavariaceen schließen sich direkt die Cantharellaceae, deren Basidienstruktur wir ebenfalls schon kennen lernten an. Diese

\section{Cantharellaceae}

umfassen Formen mit mehr oder weniger röhrenförmigen fleischigen Carpophoren und besitzen ein fast glattes Hymenium bei den niedrigen Formen, während es bei den höheren gefaltet ist und öfters den Lamellen einer Agaricinee gleicht. Die Familie enthält die Genera Craterellus und Cantharellus.

Das Genus

\section{Craterellus}

ist durch seine meistens trompetenförmigen Fruchtkörper mit glattem Hymenium charakterisiert. Craterellus lutescens (Pers.) Fries (Fig. 389, 4) besitzt einen fleischig-häutigen, trompetenförmigen, hohlen Fruchtkörper, mit dünnem, öfters welligem Rande, oben rauchgrau, flockig geschuppt, fast glatt. Der Stiel ist glatt, gelb, das Hymenium gelb mit weit voneinander entfernten flachen Rippen, später mit verzweigten Runzeln. Der Pilz findet sich in Nadelholzwäldern auf dem Boden.

Der verwandte $C$. cornucopioides $\mathrm{L}$. wurde von MAIRE untersucht, wobei es sich herausstellte, daß die Basidien sich wie die des Cantharellus cinereus entwickeln.

Das Genus

\section{Cantharellus}

umfaßt die Formen mit mehr faltigen Hymenien, die den Lamellenhymenien der Agaricineen ähnlich sind. Die bekannteste Art dieses Genus, Cantharellus aurantiacus, gehört aber nicht hierher, da MaIRE nachweisen konnte, daß sie eine echte Agaricinee ist, welche den Namen Clitocybe aurantiaca MaIRE tragen soli.

MaIre untersuchte Cantharellus cinereus tubaeformis und cibarius, welche alle den gleichen Basidientypus besitzen. 
C. cibarius ist einer der besten Speisepilze, der als Pfifferling, Eierschwamm, Gelbhänel bekannt ist. Der Hut ist fleischig, fest, kahl, eidottergelb oder gelb, innen weiß oder gelblich und bis $8 \mathrm{~cm}$ breit. Der Stiel ist gefüllt und fest, nach unten verdünnt, die Hymeniumfalten oder Lamellen vielfach dichotom verzweigt, dick, aderförmig. Er wird auf dem Boden in sandigen Gegenden, sowohl in Nadel- wie in Laubwäldern angetroffen und ist außer Europa in Nordamerika und Brasilien bekannt.

Von den Cantharellaceen stammen wohl die

\section{Peniophoraceen}

ab. Zu dieser Familie gehört das Genus Peniophora und höchst wahrscheinlich auch Stereum. Die Familie ist durch das Hymenium, welches

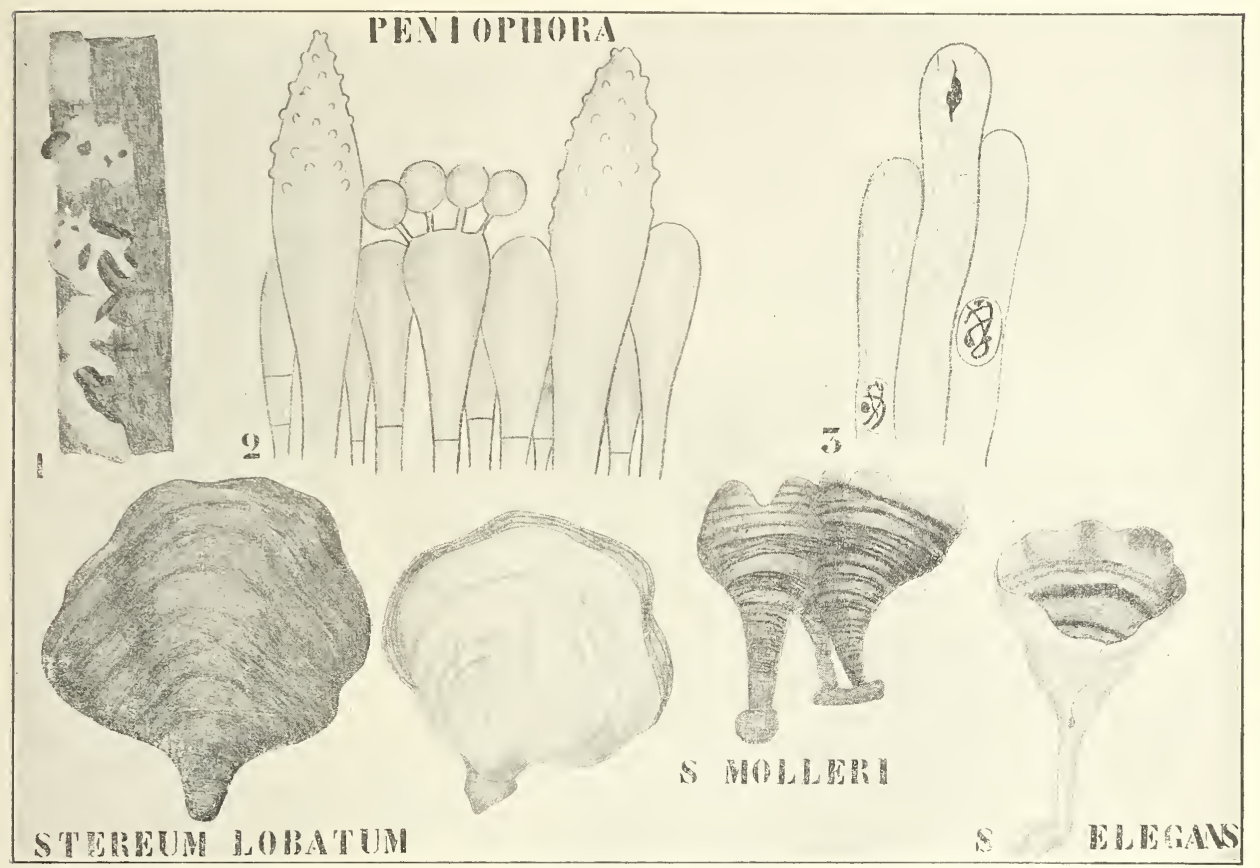

Fig. 390. I. Peniophora quercina (Pers.) Cooke (nach Hennings). 1 Habitus. 2 Basidien und Cystiden. 3 Kernteilung (nach MAIRE). - II. Stereum lobatum Fr. Links: von oben; rechts: von unten gesehen, das Hymenium zeigend (nach HENNINGs). III. Stereum Mölle ri BREs. et P. HENn. (nach HENnings). - IV. Stereum elegans MEY. (nach HenNings).

auf einem sitzenden oder resupinaten Hute getragen wird, und Cystiden besitzt (Fig. 390, I 2), charakterisiert. Die Zugehörigkeit von Stereum ist wahrscheinlich, aber nicht sicher, solange die Cytologie der Basidien noch unbekannt ist.

Das Genus

\section{Peniophor:a}

besteht aus resupinaten ${ }^{1}$ ) Formen, der Rand des Fruchtkörper's ist öfters

1) Resupinat = umgekehrt, weil das Hymenium dip Oberseite bekleidet. 
umgebogen. Die Cystiden sind im Hymenium eingesunken, ragen aber mit den Spitzen noch hervor. Die Basidien sind keulenförmig und tragen an 4 Sterigmen 4 Sporen. Peniophora quercina (Fig. 390, I 1-3) bildet Corticium-artige Fruchtkörper auf der Rinde verschiedener Laubhölzer, speziell von Eichen, Linden und Buchen, aber auch auf Syringa, Lonicera, Rhammus etc. und ist z. B. bei Lisse in der Umgebung Leidens häufig. Die Fruchtkörper liegen flach auf dem Substrat, sind knorpeligwachsartig, fleischfarben, in trockenem Zustande mit umgebogenem Rande; unten schwärzlich, kahl. Die Sporen sind farblos.

MaIRE konnte nachweisen, daß die Hyphenzellen ursprünglich binukleär sind, später aber öfters multinucleär werden, vielleicht weil die Querwände nicht gebildet werden, vielleicht auch durch Amitoșe.

Die Fäden, welche das Hymenium bilden, sind aber stets so wie die jungen Basidien binukleär; auch die jungen Cystiden; die Nuclei der letzteren degenerieren aber bald, und die alten Cystiden enthalten anscheinend nur noch eine wässerige Flüssigkeit. Die Kerne in den Basidien fusionieren zum Basidiennucleus, der nun bald ins Synapsisstadium eintritt. Darauf verlängert sich die Basidie (Fig. 390, I 3), erhebt sich über das Hymenium und gleicht dann in hohem Grade einer Basidie von Cantharellus oder Craterellus. Der Kern tritt in die Spitze und teilt sich dort longitudinal. Die folgende schiefe Teilung führt zu der Bildung von 4 Kernen, deren jeder in eine Spore eintritt.

\section{Stereum.}

Die Stereum-Arten besitzen lederartige oder holzige perenne Fruchtkörper, welche aus verschiedenen Schichten, nämlich aus einer Außenschicht, einer Mittenschicht und einer Hymeniumschicht bestehen. Es gibt resupinate und hutförmige Arten darunter, ja sogar gestielte. Die Basidien bilden 4 farblose Sporen. Die meisten Stereum-Arten wachsen auf Holz, nur wenige am Boden, sie werden in allen W'eltteilen angetroffen.

Es sind ungefähr 240 Arten bekannt, welche in 4 Sektionen zerlegt werden :

1. Resupinata. Fruchtkörper krustig, von unbestimmter Gestalt, kein deutlicher Hut. Hierher z. B. Stereum alneım FrIES, an faulenden Almus-Stämmen.

2. Apus. Fruchtkörper halbiert, hutförmig. Hierher Stereum lobatum Fr. (Fig. 390, II), von Java, Ostindien, Südamerika, Australien und Afrika.

3. Pleиториs. Hut spatel-fächerförmig, mit mehr oder weniger entwickeltem Stiel, z. B. St. Mölleri (Fig. 390, III), aus Brasilien.

4. Mesopus. Hut zentral gestielt, meist trichterförmig, z. B. Stereum elegans MEY. (Fig. 390, IV), aus Amerika, Australien und Afrika.

An die Peniophoraceen schließt MaIne als durch Parasitismus reduzierte Formen die

\section{Exobasidiaceae}

an. So wie bei Peniophora teilt sich hier der Kern in der Basidie longitudinal (Fig. 391). 
Ton Exobasidium sind eine Reihe von Species beschrieben worden, deren Artberechtigung aber zweifelhaft ist.

Exobasidium Taccinii Woronin bildet die bekannten Anschwellungen (Fig. 391, I 1) an Stämmen und Blättern von Vaccinium-Arten, die Basidien werden unter der Cuticula gebildet, brechen hervor und bilden 3, 4 oder 5 Sterigmata mit ebenso vielen Sporen. Das Mycel verläuft intercellular, die Sporen teilen sich, wenn sie noch kaum gebildet sind, fallen ab und bilden dann durch hefeartige Sprossung Konidien.

An die Cantharellaceae müssen wir weiter die Familie der

\section{Thelephoraceae}

oder Phylacteriaceae anschließen. Sie ist durch ihr glattes oder granulöses Hymenium und ihre blattartigen, ungeteilten oder geteilten Carpo-

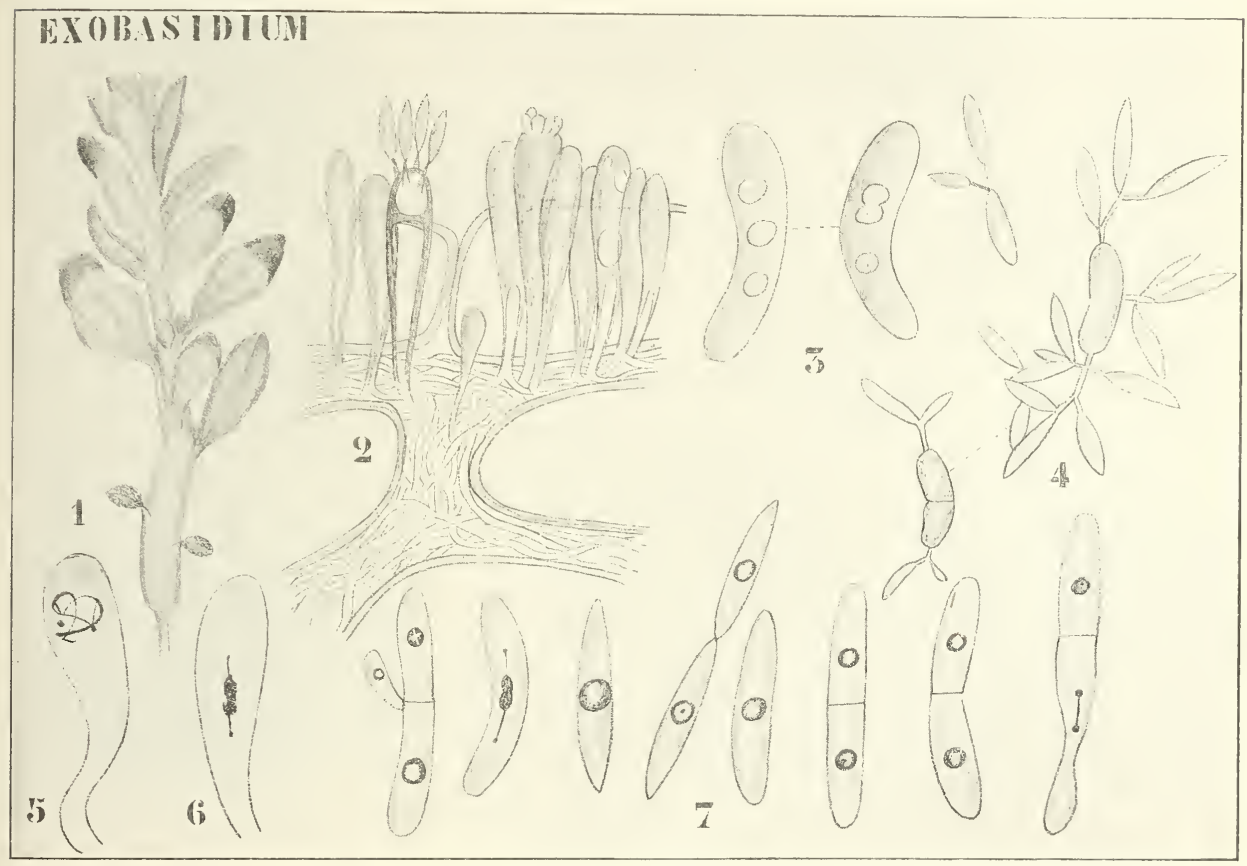

Fig. 391. I. Exobasidium Vaceinii Woronte (nach Hennings und Woronis). 1 Habitus. 2 Hymenium. 3 Sporen. 4 Keimende Sporen. - II. Exobasidium Andromedae (nach MAIRE). 5 Basidienkern in Synapsis. 6 Erste Kernteilung. 7 Hefeartige Knospung der Sporen.

phoren, sowie durch die Abwesenheit von Cystiden charakterisiert. Thre niedrigeren Formen schließen sich an Hydnum an. Bis jetzt ist nur ein Genus

\section{Theleophor:a,}

Syn.: Phylacteria, bekannt.

Das Genus wird in 4 Sektionen geteilt, nämlich:

1. Hypochniopsis Schröter, mit einem flachen, dem Substrat anliegenden Fruchtkörper. Hierher Th. discolor ZoLL. auf Holz und Blättern in Java. 
2. Euthelephora, mit ungestielten, aber sich in verschiedener Weise vom Substrat erhebenden Fruchtkörpern. Hierher z. B. Th. terrestris (Fig. 392, II $1-3$ ) mit dachziegelähnlichen, flachen, weich-ledrigen, später harten, braunen Fruchtkörpern, welche in Nadelholzwäldern und auf Heiden in Europa und Nordamerika häufig ist.

3. Merisma, mit gestielten, vielfach verzweigten Fruchtkörpern. Hierher z. B. Th. palmata (Fig. 392, III) mit lederigen, zähen, aufrechten, stark verzweigten, $4-7 \mathrm{~cm}$ hohen Fruchtkörpern. Die Zweige sind flach, handförmig zerteilt und an der Spitze weiß gefranst. Sie ist in Nadelholzwäldern häufig.

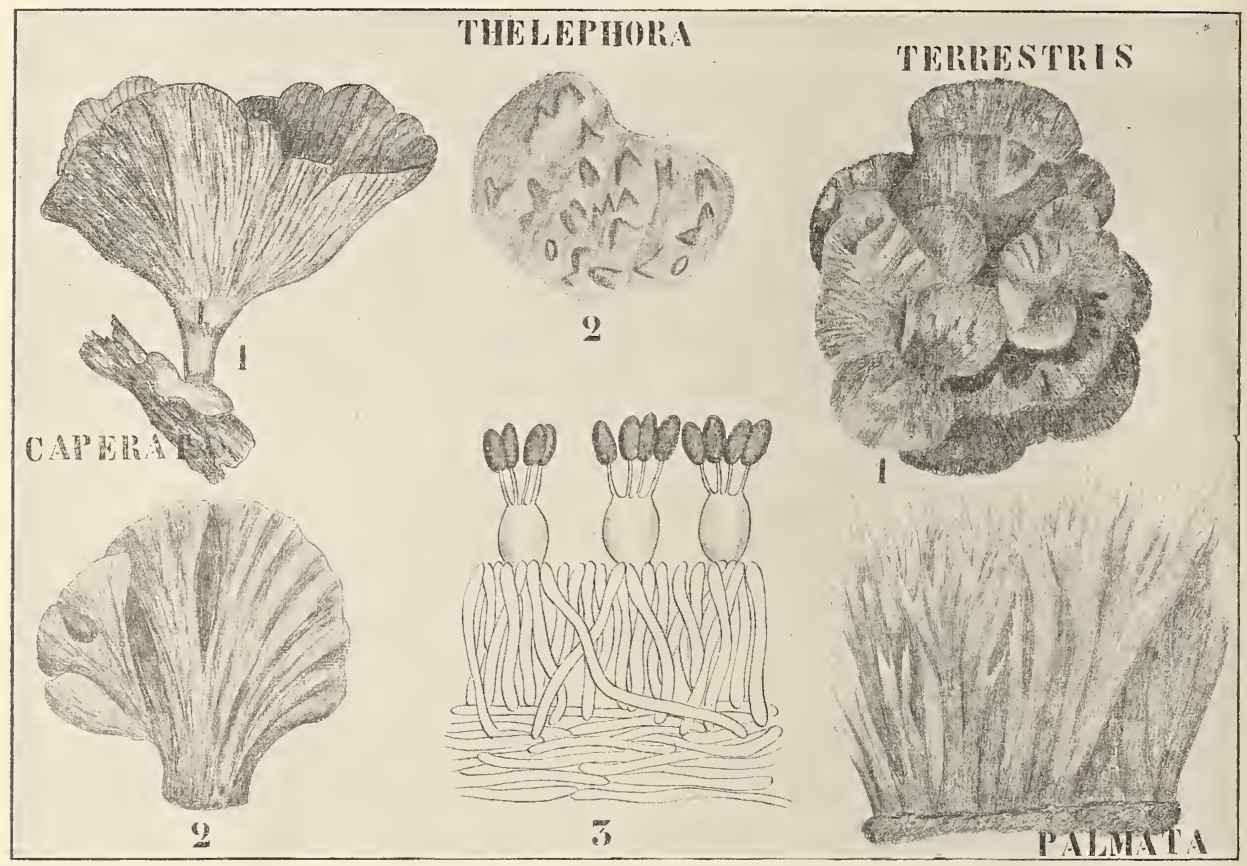

Fig. 392. Thelephora (nach Hennings). I. Th. caperata B. et Mont. 1 Habitus. 2 Hymenium. - II. Th. terrestris EнRH. 1 Habitus. 2 Hymenium. 3 Basidien. III. Th. palmata (Scop.) FrIEs, Habitus.

4. Scyophilus, mit gestielten, trichterförmigen Fruchtkörpern. Hierher Th. caperata (Fig. 392, I 1, 2). Der Hut ist zentral gestielt, trichterförmig, bis zu $20 \mathrm{~cm}$ breit, an der Oberseite mit runzeligen Falten, in der Mitte zottig, am Rande dünn, gekerbt, braun. Eine in den Tropen auf Baumstämmen häufige Forn.

Von diesen wurde Thelephora palmata von MaIre untersucht. Die Hyphen laufen im Fruchtkörper parallel und bestehen aus binukleären Zellen; sie verzweigen sich und biegen sich an der Unterseite senkrecht aufwärts, indem sie die subhymeniale und hymeniale Schicht bilden.

Die subhymenialen Hyphen bestehen aus binukleären kurzen Zellen, deren Kerne sich mittels konjugierter Mitose teilen. Gewisse subhymeniale Zellen werden zu Basidien, andere machen eine Reihe kon- 
jugierter Mitosen durch, ohne daß Querwände gebildet werden, wodurch multinukleäre sterile Zellen entstehen, denen von Hydnum repandum. analog. Wieder andere subhymeniale Zellen verzweigen sich und dringen zwischen die Basidien ein, wodurch das Hymenium in gewissem Grade disloziert wird. Die Hymeniumelemente sind übrigens locker, in welcher Hinsicht sie ebenfalls an Hydnum erinnern.

Die jungen Basidien besitzen zwei Kerne, welche alsbald verschmelzen, der Kern teilt sich in der Mitte der Basidie, die Spindel steht schief. So wie bei Cantharellus, bei Hydnum repandum, bei Peniophora und bei Clavaria hat hier die Basidie die Form einer gewöhnlichen Hyphe und ist weder in Bezug auf die Form noch in Bezug auf die Zảhl der Kernteilungen vollkommen differenziert.

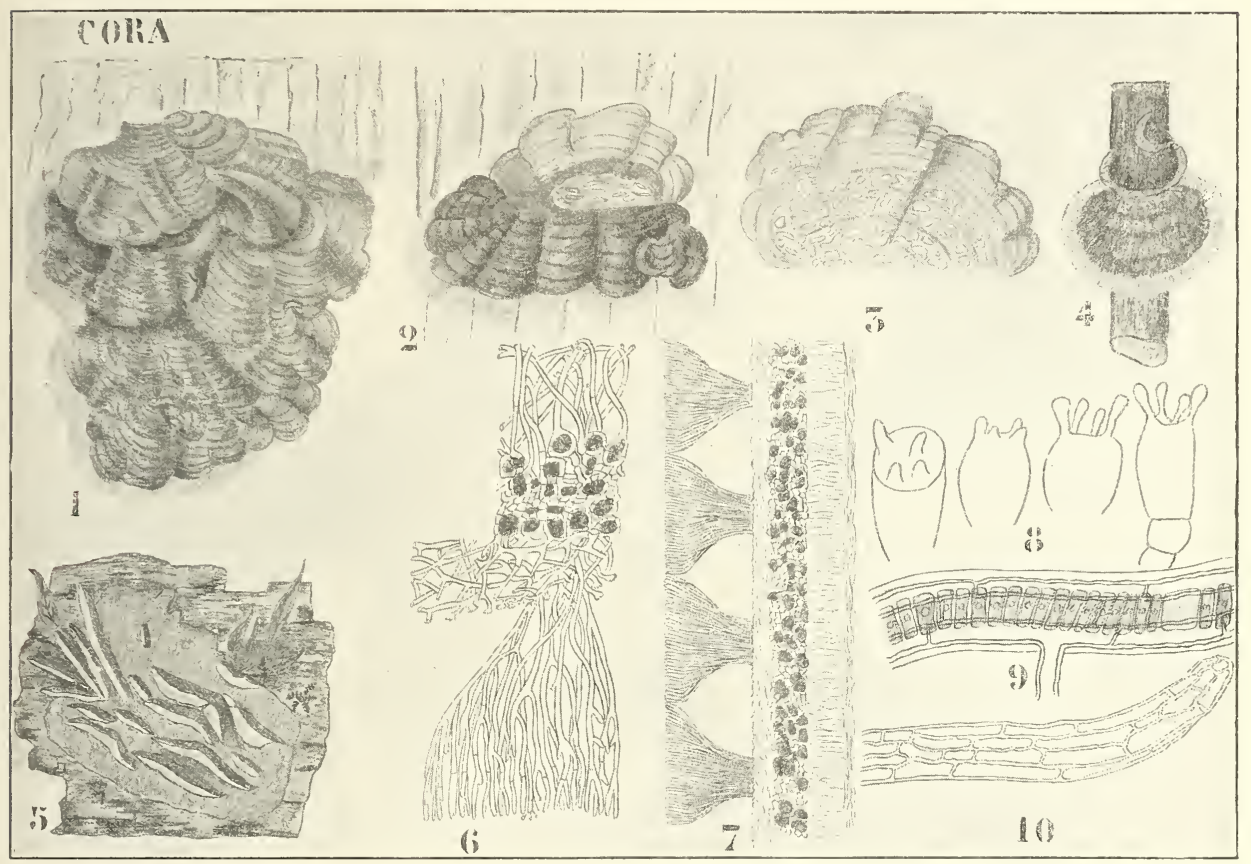

Fig. 393. Cora pavonia (nach JoHow). 1 Cora-Form. 2 Gleichfalls, mit aufgeschlagenem Oberlappen. 3 Die Unterseite, das Hymenium zeigend. 4 Die DietyonemaForm. 5 Die Laudatea-Form. 6 Ein Teil des Hymeniums, stark vergrößert, unten die Basidien zeigend. 7 Schnitt durch einen größeren Teil des Hymeniums. 8 Junge Basidien. 9 Scytonema-Faden von einer Hülle von Pilzhyphen umgeben. 10 Die Hülle von oben betrachtet.

Das Genus Thelephora ist wieder besonders interessant, weil eine seiner Arten mit einer Alge eine Flechte, also eine Basidiolichene bildet. Schon lange war das Lichenengenus Cora bekannt, bevor jemand vermutete, daß es von den übrigen Lichenen durch die Anwesenheit ron Basidien verschieden war. Daß dies dennoch der Fall, wurde von MATTIROLO (1881) infolge einer Untersuchung vou Herbariummaterial entdeckt, welches ihn schließlich veranlaßte, die Gruppe der Hymenolichenen aufzustellen.

Das Genus wurde aber erst durch foHows (188t) Untersuchungen 
an Ort und Stelle in Südamerika gut bekannt, der nachwies, daß der Algenkomponent eine Scytonema ist. Von Bornet wurden später die Genera Rhipidonema, Dictyonema und Laudatea als Hymenolichenen erkannt, Genera, welche man vor ihrer Untersuchung für Algen gehalten hatte, von diesen wurden ebenfalls Laudatea und Dictyonema von JoHow näher untersucht. Er bestätigte und erweiterte MatTinolos Resultate und kommt zu dem Schlußresultat, daß die Gruppe der Hymenolichenen die Genera Cora, Rhipidonema, Dictyonema und Laudatea umfaßt. Mit Ausnahme von Rhipidonema sind alle in Fig. 393 abgebildet.

Möller (1893) konnte aber an Ort und Stelle in Brasilien nachweisen, daß diese Genera nur verschiedene Formen von einer und derselben Thelephora-Art sind, wenn diese mit Scytonema zusammen eine Flechte bildet. Sehr interessant ist es, daß hier die frei lebende Thelephora aufgefunden wurde, sie ist weiß, lebt auf der Erde, und gab Gelegenheit, alle Uebergänge zwischen ihr und den verschiedenen Formen der Flechte nachzuweisen. Dominiert die Thelephora, so haben wir die typische Cora-Form, halten Thelephora und die Alge ungefäh1 das Gleichgewicht, so erhält man die Dictyonema-Form, dominiert die Scytonema, so resultiert die Laudatea-Form. Die Abbildungen in Fig. 393 machen das wohl klar.

Ob Rhipidonema nicht mit Dictyonema identisch ist, muß vorläufig dahingestellt werden, von mir in Java gesammelte Exemplare gleichen der Dictyonema sehr.

Von den Thelephoraceen leitet MaIre die Familie der Hydnaceen ab.

Die Gruppe der Cantharellineae kann also durch folgendes, von MaIRE entliehenes Schema dargestellt werden:

(Dacryomyectes)
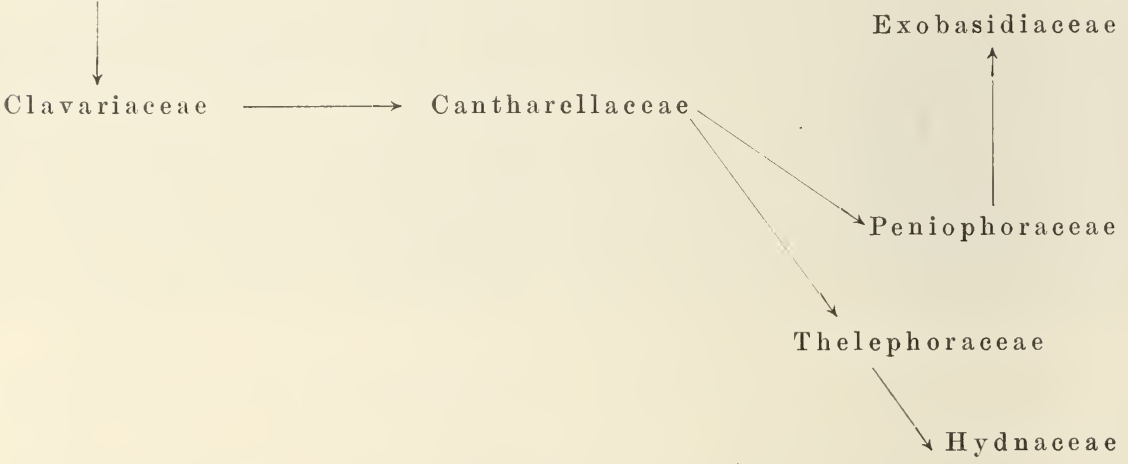

Zur Familie der

\section{Hydnaceae}

gehören mit Sicherheit nach Marres Untersuchungen nur Hydnum repandam und rufescens. Das Genus Hydnum ist von den Cantharellineen durch das Hymenium verschieden. Dieses bekleidet nämlich nicht Falten, sondern Nadeln.

Ob der hier abgebildete Phaedon eine echte Hydnacee ist, ist fraglich, dieses Genus, sowie Calodon, Mycoleptodon etc. können recht gut zu den Polyporaceen gehören, während Odontium vielleicht an Corticium 
anzuschließen ist. Sowohl das Genus Hydmm, wie die Hydnaceen im allgemeinen verlangen also dringend nähere cytologische Untersuchung, um zu entscheiden, welche von ihmen in der Tat zu den Hydnaceen gehören. und welche zu anderen Gruppen gebracht werden müssen. Einige Arten sind hier abgebildet, die Figur von $H$. basiasperatum gibt ein gutes Bild der typischen Hymeniumstacheln.

Die zweite Gruppe der Euhymeniales von MaIre ist die der

\section{Polyporineae.}

Diese Gruppe ist polymorph; sie ist durch den Besitz eines gymnocarpen Carpophors charakterisiert, dessen typisch basidienführendes Hy-

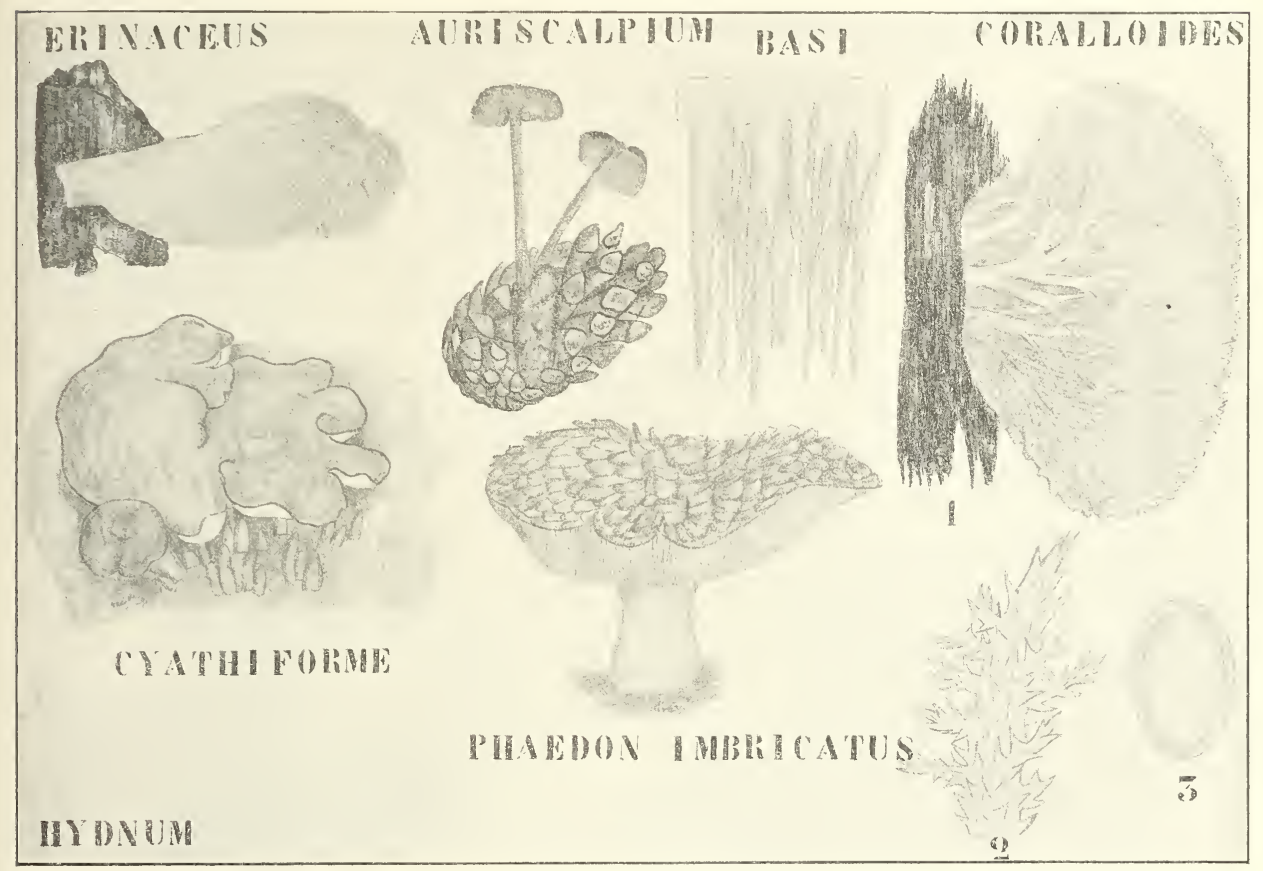

Fig. 394. Hydnaceae. I. Hydnum Erinaceus BuLL. - II. H. auriscal piam L. - III. Hymenium von H. basiasperatum P. HenN. - IV. H. coralloides Scop. 1 Habitus. 2 Zweigstück schwach vergrößert. 3 Spore. - V. H. cyathiforme SchaefF. - VI. Phaedon imbricatus (L.) Schröt. (Alles nach Hennings.)

menium in Poren oder auf Nadeln gestellt, glatt (Corticium), ja sogar, z. B. bei Hypochnus, ununterbrochen sein kann. Wie verschieden nun auch diese Hymeniumtypen sind, so konnte doch Patourllard (1900) nachweisen, daß sie alle durch Uebergänge miteinander verbunden sind. werden :

Die Polyporineae können in die drei folgenden Familien zerlegt

1. Hymenium glatt, warzig oder faltig

2. Hymenium in Poren, Lamellen oder Nadeln

3. Hymenium im Inmern gesonderter Röhren
Cyphellaceae Polyporaceate Fistulinacear 


\section{Cyphellaceae.}

Die Familie der Cyphellaceae, eine durch ihre Heterogenität gewiß erst provisorische Gruppierung, verbindet Cantharellaceae mit den Polyporaceen, so daß sich die Entstehung der Polyporineae aus den Cantharellaceen in folgender Weise vorstellen läßt:

Cantharellaceae

Cyphellaceae

$\searrow$ Polyporaceae $\longrightarrow$ Fistulinaceae

Andererseits aber sind die zu den Cyphellaceen gehörigen Meruliaceae vielleicht wieder als weiter reduzierte Polyporaceae zu betrachten, und die ebenfalls zu den Cyphellaceae gehörigen Sparassidae zeigen wieder Verwandtschaft zu den Thelephoraceae. Folgendes Schema mag also die Verwandtschaftsmöglichkeiten etwas mehr detailliert angeben.

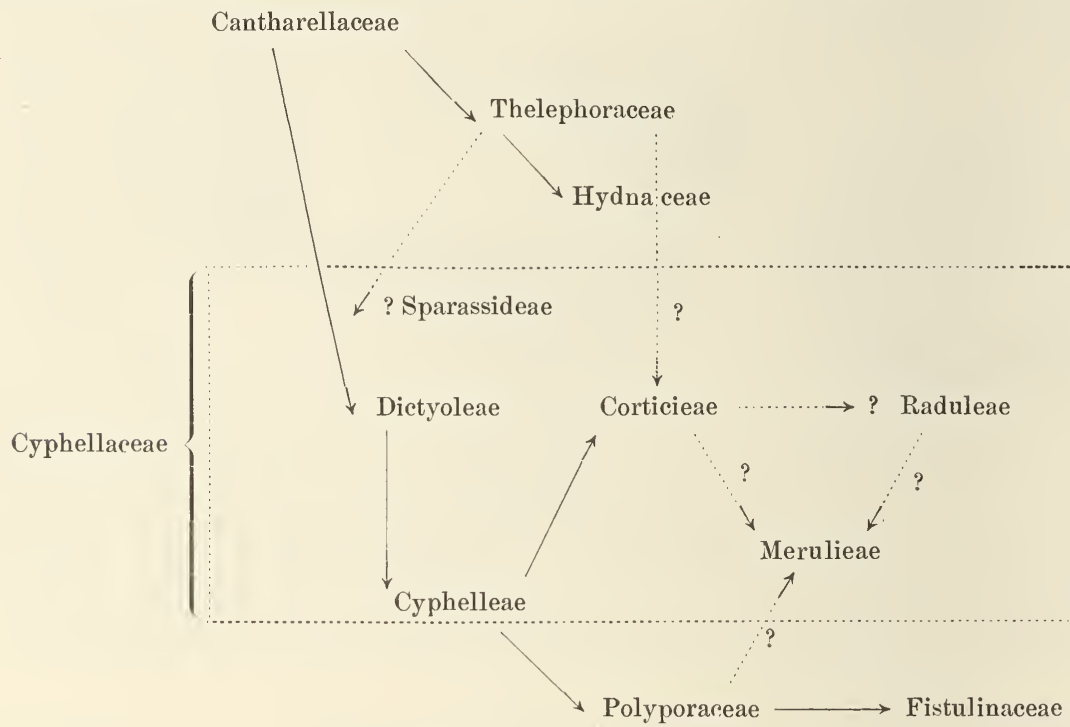

Die vielen Fragezeichen zeigen wohl zur Genüge, wie problematisch noch die Abstammung der verschiedenen Gruppen der Familie der $C_{y}$ phellaceae ist; viel mehr läßt sich noch nicht sagen, als daß sie den Uebergang zwischen den Cantharellaceen und den Polyporaceae bilden.

Die Familie der Cyphellaceae teilen wir nach MaIre wie folgt ein:

I. Clavaria-Typus, aber mit abgeflachten Zweigen.

Sparassis........... . Sparassideae

II. Periza-Typus.

Cyphella, Solenia, Auriculariopsis . . Cyphelleae

III. Einem Cantharellus gleichend.

Dictyolus, Arrhenia? . . . . . . Dictyoleae

IV. Resupinat, mit glattem oder unterbrochenem $\mathrm{Hy}-$ menium.

Corticium, Hypochnus....... Corticieae 
T. Resupinat, mit warzigem Hymenium.

Grandinia, Radulum........ Raduleae

VI. Resupinat oder halb aufgerichtet, Hymenium faltig; alveoliert etc.

Leucosporae: Plicatura, Merulius, Phlebial

Chromosporae: Gyrophana........ Merulieae

\section{Sparassideae.}

Hierher gehört nur das Genus Sparassis, welches man, bis MaIre es untersuchte, in der Regel zu den Clavariaceen stellte. Davon ist es aber durch die Basidienstruktur sehr verschieden und zeigt auf der

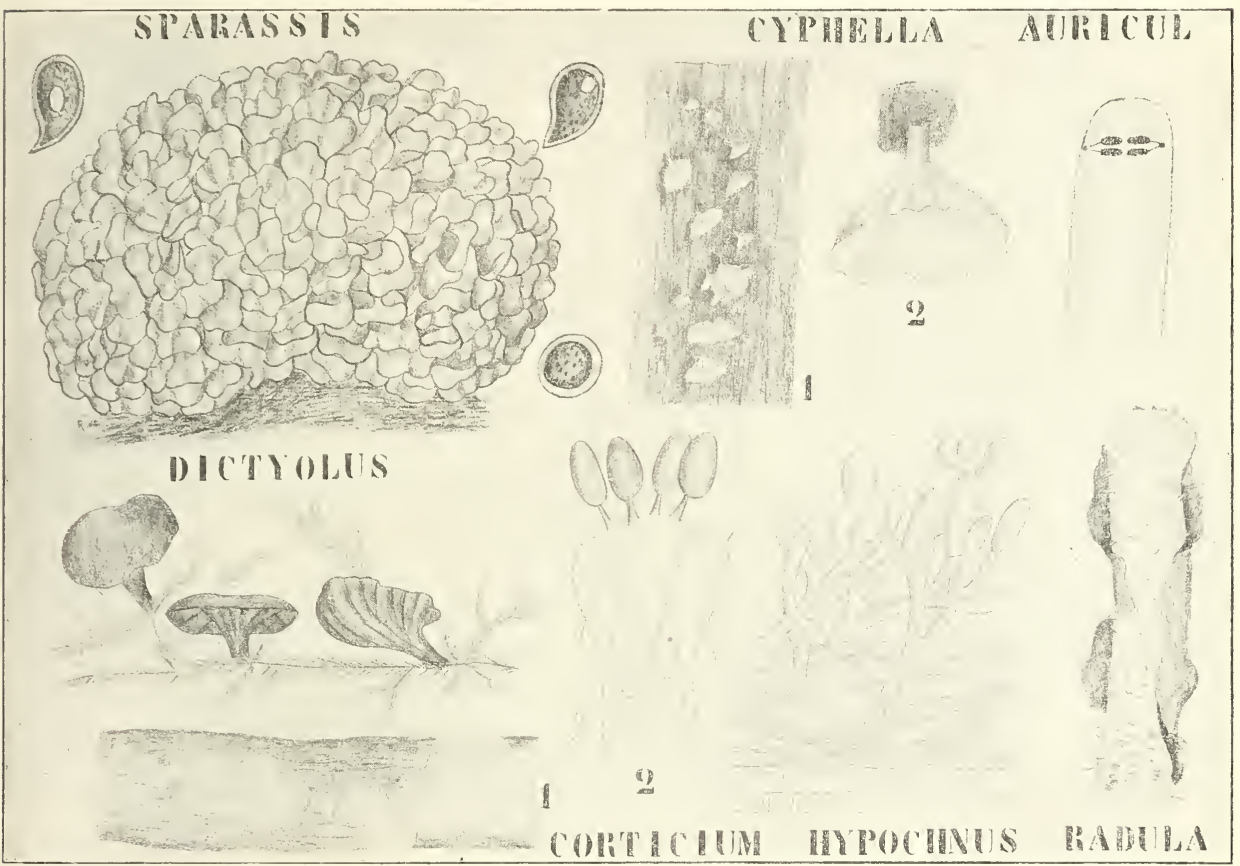

Fig. 395. Cy phellacea e. Erster Teil. I. S parass is r a mosa (SchaefF.) Schröt. II. 1 Cyphella Urbani Henn. 2 C. musa e JUNGH. - III. A uriculariopsis a mple. Erste Teilung des Basidienkernes. - IV. Dictyolus bryophilus Pers. - V. Corticium coeruleum (Schrad.) Fr. 1 Habitus. 2 Basidien. - VI. Hy pochnus Solani PrILL. et Delac. Habitus. - VII. Radulum hydnoideum (Pers.) Schröt. (III nach MaIre, VI, VII nach BREFELD, die übrigen nach HeNNINGS).

anderen Seite deutliche Beziehungen zu den Thelephoraceen, so daß es als eine der Uebergangsformen zwischen den Canthaifllineae und den Polyporineen betrachtet werden muß.

Von Sparassis sind 4 Arten bekannt, welche in Europa und Nordamerika auf dem Boden und an Baumstimpfen rorkommen. Die bekannteste Art ist Sparassis crispa Wulf [S. ramosa (Schieff.) Schröt.], ein ausgezeichneter Speisepilz, der unter dem Namen Ziegenbart. Judenbart oder. Feisterling in Deutschland auf den Märkten verkauft wird. 
Das Carpophor hat die Form eines Kohles und mißt 5-20, ja sogar bis $40 \mathrm{~cm}$ im Durchmesser. Die Fig. 395, I gibt wohl besser als jede Beschreibung ein Bild dieses Pilzes, es mag noch hinzugefügt werden, daß er weißgelb, später bräunlich ist und in Nadelwäldern gefunden wird.

In den langen Zellen der Hyphen haben sich die Nuclei durch Amitose in zahlreiche Fragmente geteilt. Fragmente, welche keine reine Kernstruktur aufweisen. Zwischen diesen dicken Hyphen gibt es dünnere plasmareiche, sowie Milchsafthyphen.

Die dünneren plasmareichen Hyphen und andere, welche sich an der Oberfläche der flachen Zweige entwickeln, bilden das Hymenium. Die jungen Basidien sind binukleär, ihre Kerne verschmelzen, und der Fusionskern teilt sich apikal und transversal. Nach der zweiten Teilung verlängert sich die Basidie, bildet 4 Sterigmata und 4 Sporen, in deren jede ein Kern eintritt.

\section{Cyphelleae.}

Diese Gruppe besteht aus pezizoiden Formen (Fig. 395, II) mit einem faltigen Hymenium. Sie ist mit den Dictyoleae durch Dictyolus retirugus etc. und mit den Corticieae durch Aleurodiscus verwandt. Die wichtigsten Genera sind: Cyphella, Solenia, Aleurodiscus, Cytidia und Auriculariopsis, von welchen Cyphella und Auriculariopsis cytologisch bekannt sind. Das Genus Cyphella besteht aus nicht weniger als 138 Arten, welche in allen Weltteilen vorkommen, davon 20 in Deutschland. Die in Fig. 395, II 1 abgebildete $C$. Urbani P. Henn. ist weiß, seidig behaart, mit aderförmigem Hymenium und wurde auf faulenden Canna-Blättern in den Warmhäusern des botanischen Gartens in Berlin gefunden. An Cyphella villosa PERs. konnte MaIre nachweisen, daß die Mitosen in den Basidien apikal und transversal stattfinden.

Auriculariopsis ist ein neues Genus, von MaIre auf Cyphella ampla LEv. basiert, eine Art, welche einer Auricularia so sehr gleicht, daß sie auch schon als Auricularia Leveillei beschrieben worden ist. Die Mitosen in den Basidien finden auch hier apikal und transversal statt.

\section{Dictycleae.}

Diese kleine Gruppe steht den Cantharellaceen am nächsten, weicht aber durch den Besitz von Basidien eines höheren Typus (transversale und apikale Mitosen, Konstanz der Zahl der Sterigmata) ab. Sie nähern sich auch Corticium, Hypochnus und Cyphella. Der Typus ist Dictyolus, vielleicht gehört auch Arrhenia hierher.

Die Dictyolus-Arten besitzen ein muschelförmiges Carpophor mit gefaltetem Hymenium. D. bryophilus Pers. kommt auf Moosen in Europa vor (Fig. 395, IV).

\section{Corticieae.}

Es sind dies degradierte Formen, welche aus einer einfachen Kruste mit zusammenhängendem glatten Hymenium oder nur aus einem flocculösen, wattigen Mycel bestehen, welches seine terminalen Zellen zu Basidien umbildet. Zum ersteren Typus gehört Corticium (Fig. 395, V), zum letzteren Hypochnus (Fig. 395, VI).

Die Abbildungen von Corticium coeruleum und Hypochmus Solani 
(Fig. 395, V. TT) demonstrieren diese 'Typen wohl zur Genüge; ersteres, das durch die schön blauen Fruchtkörper auffällt, ist kosmopolit, letzterer. stammit aus Ecuador.

An der einen Seite sind die Corticiene mit den Cyphelleae verwandt, an der anderen Seite aber gelangt man mittels kaum merkbarer Uebergänge zu den Raduleae und Merulieae und zu den Thelephoreae. Vermutlich enthält also die Gruppe der Corticieae degenerierte Formen verschiedenen Ursprung's.

Corticium, Cryptochaete und Hypochnus wurden von MaIre studiert; bei Corticium und Hypochmus und vermutlich auch bei Cryptochaete finden die Mitosen in der Basidie transversal und apikal statt.

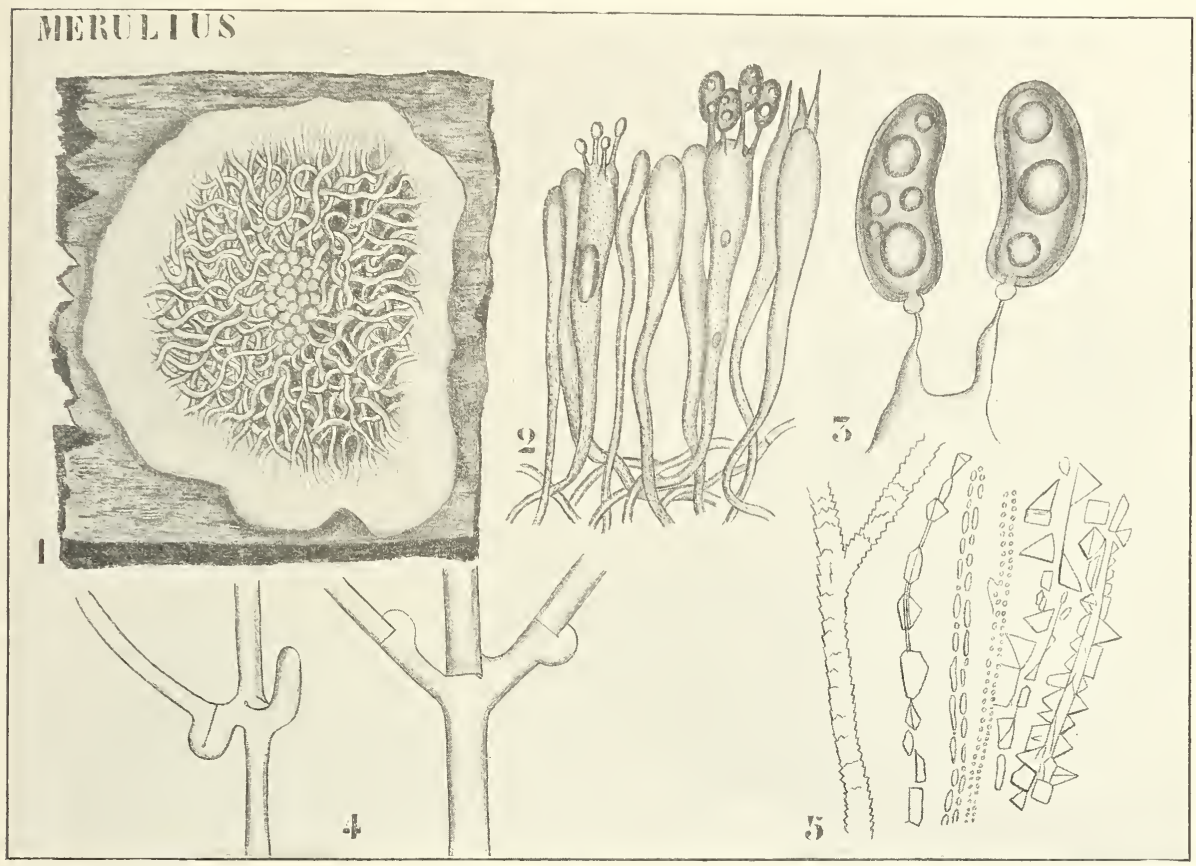

Fig. 396. Cyphelleae. Zweiter Teil. Gyrophana lacrymans (Wulf) Matre. 1 Habitus. 2 Stück des Hymeniums. 3 Sporen an den Sterigmen. 4 Schnallenbildungen. 5 Mycelfadenstücke mit oxalsaurem Kalk besetzt. (1 nach Hexrings, das übrige nach HaRtig.)

\section{Raduleae.}

Diese Gruppe ist, wie oben bemerkt, mit den Corticieae mittels kaum merkbarer Uebergänge verbunden, an der anderen Seite berührt sie Irpex, welches Genus, wie wir jetzt wissen, als ein aus schlecht entwickelten Polyporaceae zusammengesetztes betrachtet werden muß.

Radulum laetum (Corticium hydnoiden PERs.) und $R$. molare wurden von MaIre untersucht. Auch hier sind die Mitosen in den Basidien apikal und transversal.

Radulum laetum oder hydnoiderm (Fig. 395, TII) entrindet Baumzweige und bildet seine fleischroten bis orangefarbigen. bestachelten Fruchtkörper auf dem Holzteile des r/wreiges. Es ist ganz mit dem Hymenium bedeckt und etwas fleischig. Früher hat man es als eine 
Varietät der Vuilleminia commedens beschrieben, von welcher es aber sofort durch die bauchig angeschwollenen Cystiden zu unterscheiden ist.

\section{Merulieae.}

Diese Familie berührt auf der einen Seite die Corticieae, auf der anderen die Raduleae und schließlich auch die Polyporaceae.

Sie umfaßt die Genera Merulius, Gyrophana, Plicatura etc.

Die in Fig. 396 abgebildete Gyrophora lacrymans (Wulf) MaIre ist besser unter dem Namen Merilius lacrymans (Wulf) Schum. bekannt und verdankt ihren neuen Genusnamen dem Umstande, daß sie braune Sporen besitzt, weil MaIre das Genus Merulius auf Arten mit farblosen Sporen beschränkt. Unsere Gyrophana lacrymans ist der bekannte Hausschwamm, welcher Bretter und Balken verfaulen läßt, auf diesen aber prachtvolle weiße Mycelien bildet, die goldgelbe Flüssigkeitstropfen ausscheiden.

Später wird der Fruchtkörper lederartig und kann sogar dachziegelartig gestellte Hüte bilden. Das Hymenium ist ockergelb, weiß am Rande, dickfilzig, anfangs faltig, welche Falten später anastomosieren und Maschen bilden, ja sogar an den Ecken stachelig werden können und mit dem Hymenium bekleidet sind. Infolge der Sporenfarbe werden sie braun. Am Mycel ist Schnallenbildung häufig, während oxalsaurer Kalk unter Umständen in sehr großen Quantitäten ausgeschieden wird.

Wir kommen jetzt zu der zweiten Gruppe der Polyporineae, zu der der

\section{Polyporaceae.}

Diese Familie ist durch den Besitz eines Hymeniums charakterisiert, welches in Poren, selten auf Lamellen oder Stacheln gebildet wird. Sie umfaßt eine ganze Reihe von Genera.

Von diesen sind nur einige von MaIre untersucht worden, und zwar Lenzites, Trametes, Coriolus und Polyporus. Näheres Studium tut sehr not, da man aus Bequemlichkeit alle Formen mit dem Hymenium in Poren in diese Gruppe zu stellen pflegt, sogar wenn der Fruchtkörper, wie z. B. bei Boletus, hemiangiocarp ist.

Augenblicklich ist also eine Uebersicht über die Gruppe unmöglich, und ich werde mich deswegen auf die Besprechung einiger weniger Formen beschränken, welche aller Wahrscheinlichkeit nach hierher gehören.

Eine der eigentümlichsten Arten, welche durch die Unregelmäßigkeit der Poren und durch die Weichheit der Fruchtkörper den Uebergang: zu den Merulieae bildet, ist Mycodendron paradoxum von Madagascar, welches auf faulendem Holze vorkommt. Es bildet einen braunen zugespitzten Stiel von 6-9 $\mathrm{cm}$ Höhe und $3-4 \mathrm{~mm}$ Dicke, an welchem sich 4-6 oben horizontal zueinander gestellte Hüte befinden von fast gallertiger Konsistenz. Das Hymenium bekleidet die unregelmäßigen Poren an der Unterseite dieser Hüte und enthält Cystiden.

Viel deutlichere Poren hat das Genus Poria aufzuweisen, von welchem Poria Radula Pers. in Fig. 397, II abgebildet ist. Bei dieser Art findet sich das Hymenium an der Oberseite, es handelt sich also um eine resupinate Form, welche weiße, krustenförmige Fruchtkörper auf faulendem Holze bildet und in sterilem Zustande stark an Merulius erinnert. Auch 
diese Poria kommt vielfach in Häusern vor, wo sie ähnlichen Schaden wie Merulius anrichtet.

Erst beim Genus Fomes kriegen wir mit der für die echten Polyporaceen so typischen Holzigkeit der Fruchtkörper zu tun. Auch bilden sich hier durch die Langlebigkeit der Fruchtkörper verschiedene Porenschichten aus, wie das ebenfalls bei den langlebigen Polypori der Fall ist.

Fomes annosus (Trametes radiciperda HART.) bildet in hohlen Baumstämmen, an WTurzeln etc. seine Fruchtkörper und ist ein gefürchteter Feind der Fichtenkulturen. Nach Brefeld bildet der Pilz als Nebenfruktifikation die in Fig. 397, III 3 abgebildeten Konidiophoren. Vom Genus Fomes unterscheiden sich die Genera Polyporns und Polystictus durch die Struktur ihrer Fruchtkörper.

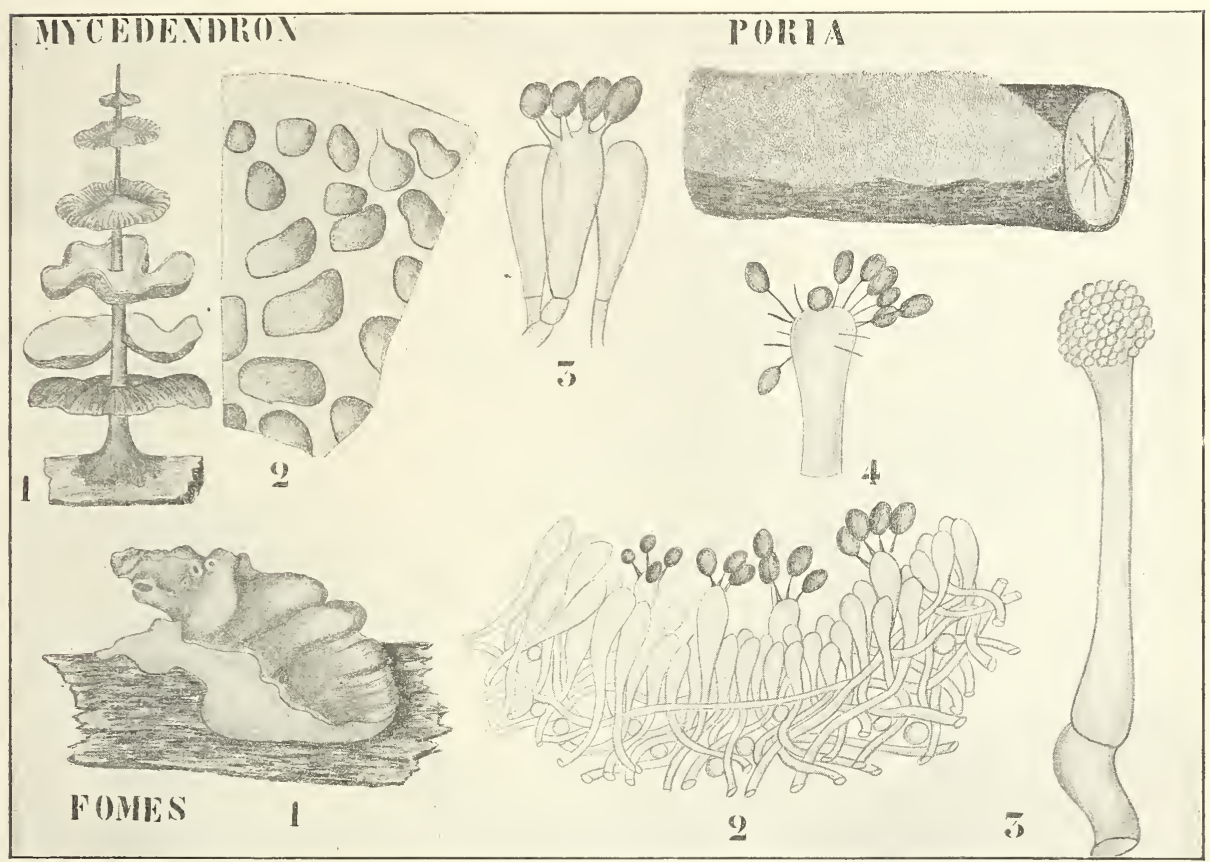

Fig. 397. Poly poraceae. Erster Teil. T. Mycedendron paradoxum Massee (nach Massee). 1 Habitus. 2 Stück des Hymeniums. 3 Basidien. - II. Poria Radula Pers. Habitus (nach Hennings). - III. Fomes annosus Fr. 1 Habitus. 2 Stück des Hymeniums. 3 Konidiophore. 4 Ein Teil des Konidienträgers, stärker vergrößert. (Nach HenNings und BREFELD.)

Während bei Fomes der Fruchtkörper von Anfang an holzig ist, ist dies bei den holzigen Polyporus-Arten nicht der Fall, diese werden erst später holzig und sind anfangs fleischig, dagegen sind die Fruchtkörper von Polystictus nie holzig, sondern häutig, lederig oder wergartig.

Alle 4 Genera: Poria, Fomes, Polyporns und Polystictus, haben dies gemeinsam, daß die Substanz, welche sich zwischen den rom Hymenium bekleideten Röhren befindet, von der des Hutes verschieden ist. Damit stehen sie in Gegensatz zu Trametes, bei welchem diese Zwischensubstanz die gleiche Struktur wie die des Hutes anfweist.

Das Genus Polyporus ist sehr groß, mehr als 500 Arten sind be- 
kannt, von denen etwa 70 in Deutschland gefunden wurden. Die meisten wachsen auf Baumstämmen, einige am Boden. Die Konsistenz der Hüte ist bei den verschiedenen Arten sehr verschieden: holzige, korkartige, schwammige, fleischige Hüte kommen vor, die Oberseite kann glatt oder schuppig sein, die Form dachziegelartig, halb-hutförmig, verzweigt, gelappt, gestielt und ungestielt sein etc. etc.

Der hier abgebildete Polyporus betulinus ist zunächst saftig-fleischig und wird später korkartig, gehört also zu einer Gruppe, welche man die Suberosi nennt. Er ist in Europa an Birkenstämmen häufig, die Fruchtkörper sind meistens hufförmig, besitzen einen stumpfen Rand und weisen keine Zonen auf. Zunächst weiß, werden sie von einer leicht abtrennbaren braunen Hautschicht bedeckt. Die Poren sind kurz, klein und

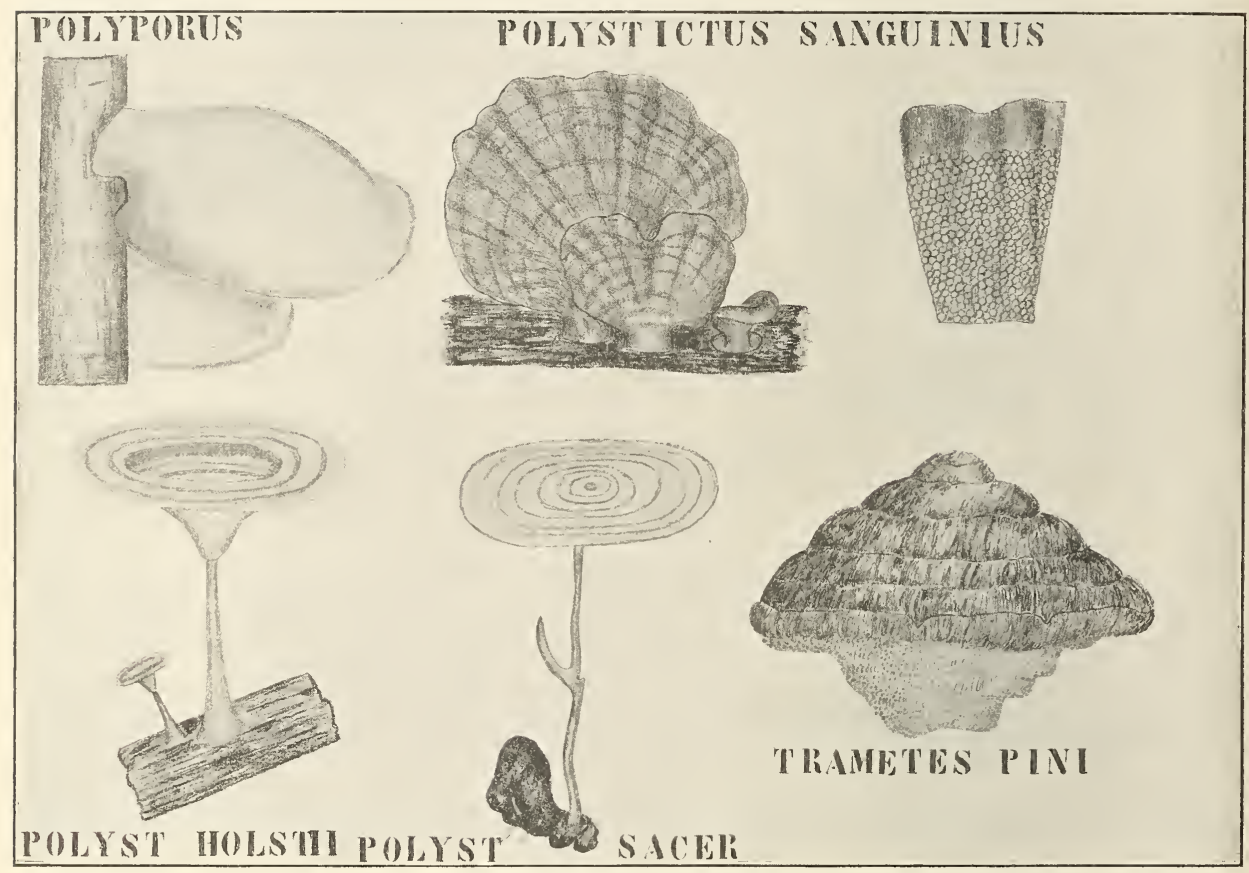

Fig. 398. Polyporaceae. Zweiter Teil. I. Polyporus betulinus (Bull.) Fr. II. Polystictus sanguineus (L.) Fr. 1 Habitus. 2 Hymenium. - III. Polystictus Holstii P. Henr. - IV. Polystictus sacer Fr. - V. Trametes odoratus (WULf) Fr. (Alles nach Hennings.)

weiß, das korkige weiße Fleisch wird technisch zu Kohlenstiften verarbeitet.

Vom Genus Polyporus wurde der fleischige $P$. acanthoides Bulu., welcher unter anderem auf alten Buchen vorkommt, von MaIRe untersucht. In den jungen Fruchtkörpern sind die Zellen binukleär, später werden sie multinukleär. Die Mitosen in den Basidien sind transversal und apikal.

Bei Polystictus sind die Röhren nicht geschichtet, sie entwickeln sich meistens centripetal vom Rande aus und sind anfänglich oberflächlich, punktförmig, im übrigen wie die von Polyporus. Auch Polystictus 
ist ein sehr großes Genus, welches sich mittels seiner etwa 450 Arten über die ganze TVelt verbreitet hat. Der hier abgebildete hübsch rote P. sanguimens ist in allen tropischen Ländern häufig; der Hut ist lederig, dünn. mehr oder weniger gestielt, muschelförmig, glatt, außen und innen mennigrot, fast glänzend und $2-12 \mathrm{~cm}$ breit.

Einen trichterförmigen gestielten Hut besitzt Polystictus Holstii P. Henn. aus Ostafrika, der Hut ist von fast papierartiger Konsistenz, hellbraun und mit dunkelbraunen Zonen versehen. Verwandte Arten, z. B. $P$. sacer Fr. aus dem malayischen Archipel, bilden große Sclerotien.

Das Genus Trametes ist, wie schon bemerkt, durch die Uebereinstimmung in der Struktur der Zwischensubstanz mit der des Hutes charakterisiert, was einen Gegensatz zu den übrigen Genera liefert, aber

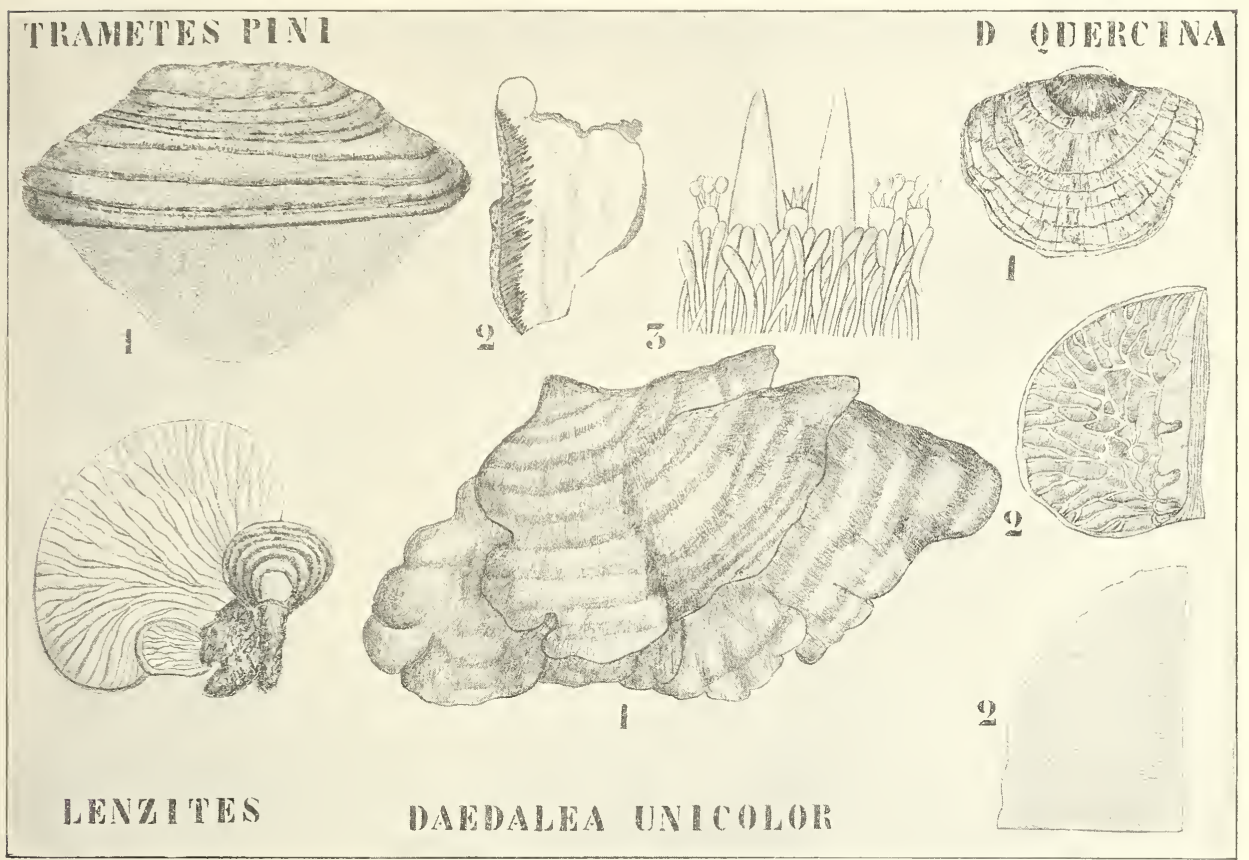

Fig. 399. Polyporaceae. Dritter Teil. I. Trametes pini (Brot) Fr. 1 Habitus. 2 Schnitt durch den Fruchtkörper. 3 Stück des Hymeniums mit Cystiden und Basidien. - II. Lenzites betulina (L.) Fr. - III. Daedalea unicolor (BuLL.) Fr. 1 Habitus. 2 Hymenium. - IV. Daedalea quercina (L.) Pers. 1 Habitus. 2 Hymenium (alles nach HENNINGs).

dieser Gegensatz ist so wenig scharf, daß Hennings in EngLer und Prantl sagt, Schröter habe das Genus Trametes vielleicht mit Recht mit Polyporus vereint.

Trametes suaveolens Fr. wurde von MaIRE cytologisch untersucht. Sehr leicht ist es hier, die Fusion der beiden Kerne in der Basidie zu beobachten. Von dem kaum von Trametes verschiedenen Genus Coriolus untersuchte MaIRe Coriolus versicolor L., bei welchem er apikale und transversale Mitose in den Basidien konstatieren konnte.

Vom Genus Trametes sind hier abgebildet T\% odoratus (ITULF) Fr. mit $5-8 \mathrm{~cm}$ breitem Hute, welcher auf alten Fichtenstämmen und an 
Minenholz vorkommt und einen fenchelartigen Duft besitzt, sowie Tr. pini, welcher konsolenartige Hüte von sehr fester korkig-holziger Substanz und 8-16 $\mathrm{cm}$ Breite bildet und den Fichten schädlich ist, bei welchen er Kernfäule und Rindenschälung verursacht.

Von den Polyporaceen bleiben nun noch die Genera Daedalea und Lenzites zu besprechen übrig. Bei ihnen befindet sich das Hymenium nicht in Röhren, sondern in langgestreckten Gängen, welche bei Daedalea labyrinthartig, bei Lenrites lamellenartig entwickelt sind. Bei Lenzites flaccida konnte MaIre nachweisen, daß die Mitosen in den Basidien transversal und apikal sind.

Vom Genus Daedalea bilden wir hier D. quercina (L.) Pers. ab. Der Fruchtkörper ist halb-hutförmig. korkig-holzig; es perenniert, ist hell ockerfarbig und kommt auf lebenden Holzstämmen, mit Vorliebe auf Eichen, in Europa recht häufig vor. Die Hymeniumgänge sind anfangs lang oder porenförmig, später labyrinthartig gewunden, anastomosierend, ja werden sogar lamellenartig.

Die ebenfalls abgebildete Daedalea unicolor (BuLu.) Fr. hat gleichfalls halb-hutförmige Fruchtkörper, welche öfters in Etagen übereinander gestellt sind. Der Hut ist lederartig, dünn, grau oder hell-ockerfarbig und scharf berandet. Die Gänge sind sehr eng, labyrinthartig gewunden, später fast zahnartig. zerschlitzt, grau oder graubraun. Die Art ist an Laubstämmen in Europa gemein.

Beim Genus Lenrites bekleidet das Hymenium die Lamellen; es ist eng mit den höheren Daedaleen verwandt, ja Lenzites ist sogar von Daedalea nicht scharf zu trennen. Die abgebildete Lensites betulina bildet korkig-lederige, fächer- oder nierenförmige, sitzende Fruchtkörper mit schmutzig-weißen Lamellen. Sie kommt hauptsächlich an Birkenstämmen in Europa vor.

Als letzte Familie der Polyporineae ist die der

\section{Fistulinaceae}

$\mathrm{zu}$ besprechen. Sie ist durch das in gesonderte Röhren eingeschlossene Hymenium gut charakterisiert (Fig. 400, 2).

Fistulina Hepatica (Fig. 400, 1-4) ist ein fleischiger Pilz, dessen Fruchtkörper außen braunrot, innen blutrot und mit einem roten Saft gefüllt ist, so daß der Pilz beim Durchschneiden blutet. Die Form ist mehr oder weniger die einer Zunge oder eines Spatels, während durch Verschmälerung der Basis eine Art Stiel gebildet wird; es sind die Fruchtkörper 10-30 $\mathrm{cm}$ breit und etwa $6 \mathrm{~cm}$ dick, klebrig und büschelig behaart. Die Röhren an der Unterseite entstehen als punktförmige Erhöhungen, welche hohl werden und sich bei der Reife an der Spitze öffnen.

Die Röhren sind gesondert, etwa $1 \mathrm{~cm}$ lang, zunächst blaß, später rotbraun, die Sporen glatt, hellbraun. An der Oberfläche des Fruchtkörpers bilden sich unter Umständen Chlamydosporen, welche einzeln am Ende verzweigter Hyphen abgeschnürt werden und ockergelb sind. Im Haarlemerhout, unweit Leiden, gibt es schöne Exemplare. Der junge Pilz ist eßbar und hat roh einen säuerlichen Geschmack, er kommt in Deutschland unter dem Namen Leber- oder Zungenpilz auf den Markt.

Damit ist die Gruppe der Polyporinecue wohl genügend besprochen.

Es bleiben nun noch die Agaricineae und die Gasteromyceten $\mathrm{zu}$ besprechen. Erstere leitet MaIre ebenfalls von den Cantharellaceen ab und zwar in folgender Weise: 


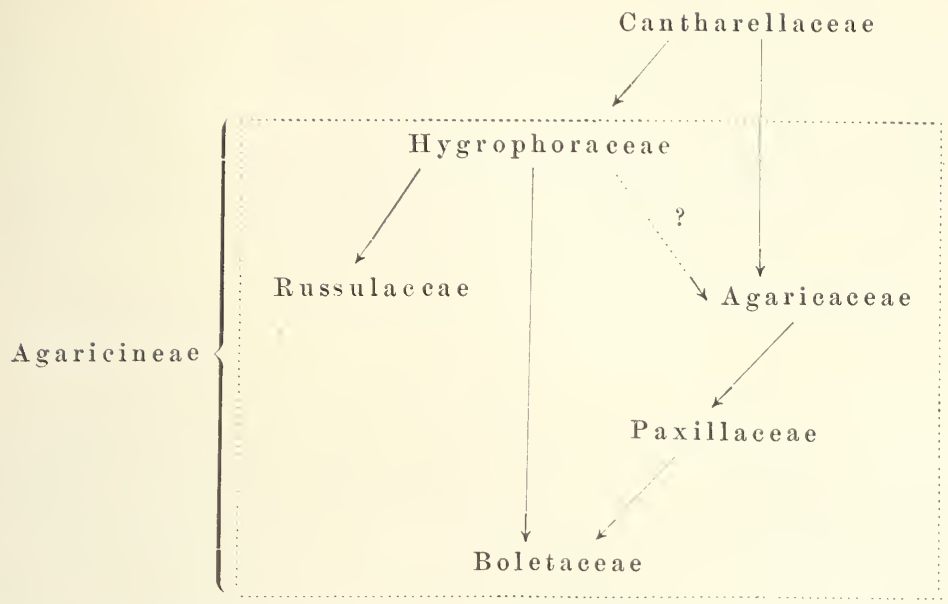

Daraus geht also hervor, daß seiner Meinung nach die Boletaceae zum Teile von den Agaricaceae, und zwar durch Vermittelung der Paxillaceae, zum Teile von den Hygrophoraceae, und zwar durch Vermittelung von Gomphidius abstammen.

Vielleicht sind auch die Agaricaceae biphyletisch, sie stehen durch Clitorybe aurantiaca mit den Cantharellaceen, durch Mycena aber mit den Hygrophoraceen in Verbindung.

Die Hygrophoraceae stehen wieder durch Camarophyllus mit dèn Cantharellareen und durch Russula nigricans-ähnliche Typen mit den Russulaceen in Verbindung.

Die große Gruppe der Agaricineae nun besteht aus hemiangiocarpen Pilzen, d. h. aus solchen, bei denen der Fruchtkörper in der Jugend mehr oder weniger in einer Hyphenhülle eingeschlossen ist, welche den Namen Velum universale oder Volva trägt.

Wenn sich nun bei der späteren Entwickelung der Stiel des betreffenden Hutpilzes streckt, wird die Volva zerrissen. Dies kann so geschehen (Fig. 400, II 2), daß ein Teil nach Art der Vaginula der Moose unten am Stiel bestehen bleibt (Annulus inferus oder Vagina), und der Rest in Flocken oder Lappen auf der Hutoberfläche zurückbleibt, oder es wird ein Schleier (Velum partiale) zwischen dem Stiel und dem Hutrande gebildet, und wenn dieser durch die Streckung des Stieles zerrissen wird, bleibt entweder (Fig. 400, II 3) ein Ring hoch am Stiel bestehen (Annulus superus), oder aber der Schleier macht sich ganz vom Stiel los und hängt vom Rande des Hutes herunter (Fig. 400, II 4), er bildet dann eine sogenannte Cortina.

Bei gewissen Gruppen, z. B. bei den Hygrophoraceen, ist die Hemiangiocarpie wenig ausgesprochen; ein Schleier wird nicht gebildet, so daß diese Formen sich an die Cantharellaceen anschließen. Andere Repräsentanten mit bleibender Volva bilden den Uebergang zu den Gasteromyceten.

Man kann nun mit MaIRe die große Gruppe der Agaricineen in folgender Weise einteilen:

\section{Agaricineac.}

I. Formen mit nicht vom Hute treunbaren Lamellen:

a) Lamellen dick, wachsartig, Sporen glatt, Basidien öfters unregelmäßig .

Hygrophoraceae

Lotsy, Butauische sammesgeschicite. I. 
b) Lamellen dünn oder dick, Sporen stachelig, Trama (Lamellengewebe) aus sphärischen, blasigen Zellen bestehend, welche mit normalen Hyphen und Milchsafthyphen gemischt sind . . . . . .

c) Lamellen dünn, Tramagewebe auslangen Elementen bestehend, Sporen öfters glatt, Basidien regelmäßig

II. Formen mit vom Hute trennbaren Lamellen oder Russulaceae

\section{Agaricaceae}

Röhren :

a) mit Lamellen

b) mit Röhren .

Paxillaceae

Boletaceae

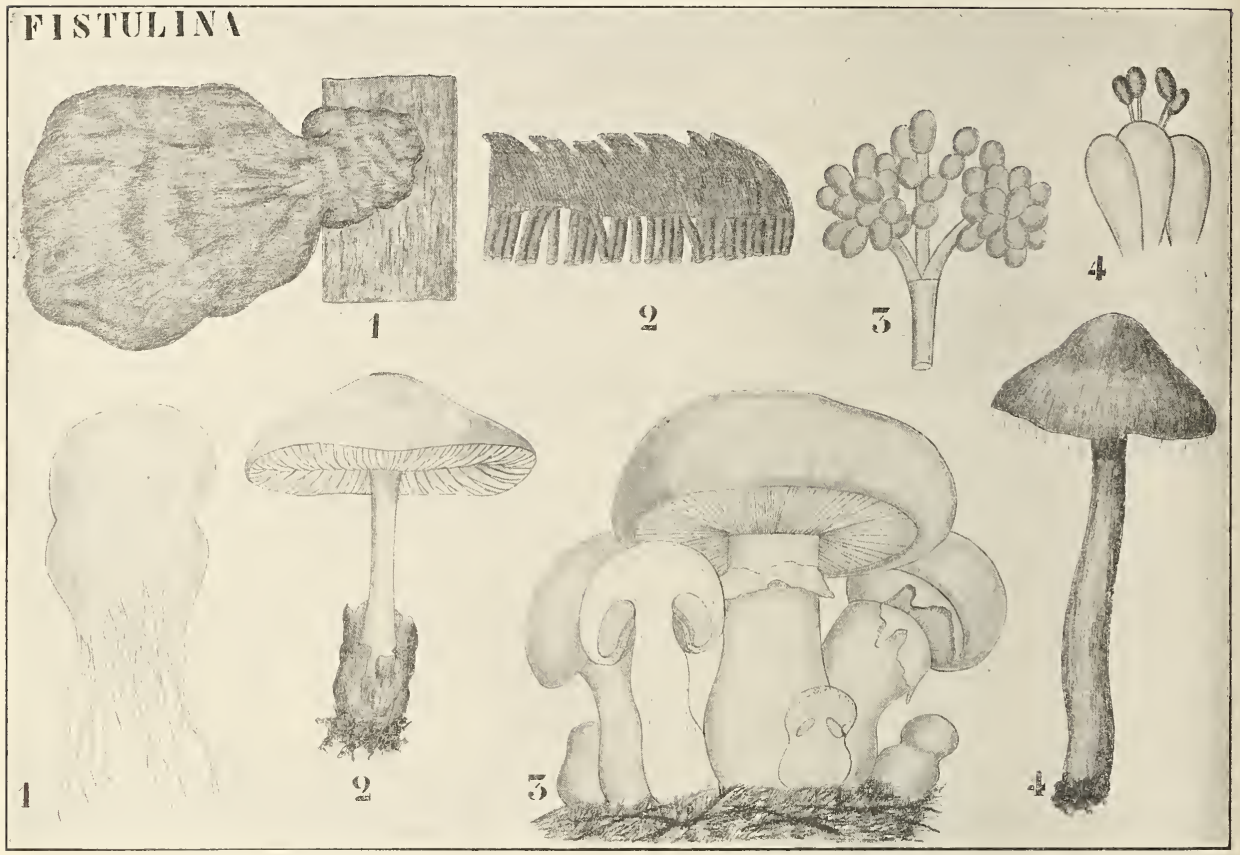

Fig. 400. I. Rest der Poly porineae. 1-4 Fistulina hepatica (ScHAEFF.) Fr. (nach Hennings und Brefeld). 1 Habitus. 2 Schnitt durch das Hymenium. 3 Chlamydosporen. 4 Basidien. - II. Verschiedene Schleierbildungen bei den A garicineen. 1 Das Velum universale oder die Volva einer ganz jungen Psaliota. 2 Der Annulus inferus oder die Vagina um die Stielbasis herum, und die Volvareste auf dem Hute bei Volvoria. 3 Die Bildung des Ringes oder Annulus superus bei Psaliota. 4 Die Schleierreste am Hutrande (Cortine) bei Cortinarius.

Als niedrigste Gruppe ist die der

\section{Hygrophoraceae}

zu betrachten. Sie ist durch dicke, wachsartige, weit auseinander stehende, abwechselnd lange und kurze Lamellen charakterisiert. Die Sporen sind weiß, das Tramagewebe wenig oder gar nicht differenziert, die Basidien öfters unregelmäßig mit apikalen und transversalen Mitosen.

Sie umfaßt eine Anzahl von Genera, unter denen Camorophyllus, Hygrocybe, Godfrinia, Hygrophorus, Nyctalis und Gomphidius die wichtigsten sind; von diesen weicht Gomphidius vom Typus der Gruppe durch den Besitz gefärbter Sporen ab. 
Die Genera Camorophyllus, Hygrocybe und Hygrophorus sind so nahe verwandt, daß sie vielfach nur als Subgenera von Hygrophorus betrachtet werden.

Hygrophorus (Fig. 401, I) erinnert in seinem Habitus sehr an Cantharellus, mit welchem Genus er in der Tat nahe verwandt ist. Von Schleier oder Annulus ist keine Spur vorhanden. Der Hut ist oben klebrig, und die abwechselnd langen und kurzen Lamellen gehen unmerklich in den Stiel über. Der in Fig. 401, I abgebildete Hygrophorus ficoides (Bull.) Schröt. gehört zum Subgenus Camarophyllus. Der Hut ist zunächst gewölbt, dann flach, kreisförmig, gelbbraun, 3-11 cm breit. Der Stiel ist voll, glatt und kahl, 3-12 cm lang, die Lamellen weißlich.

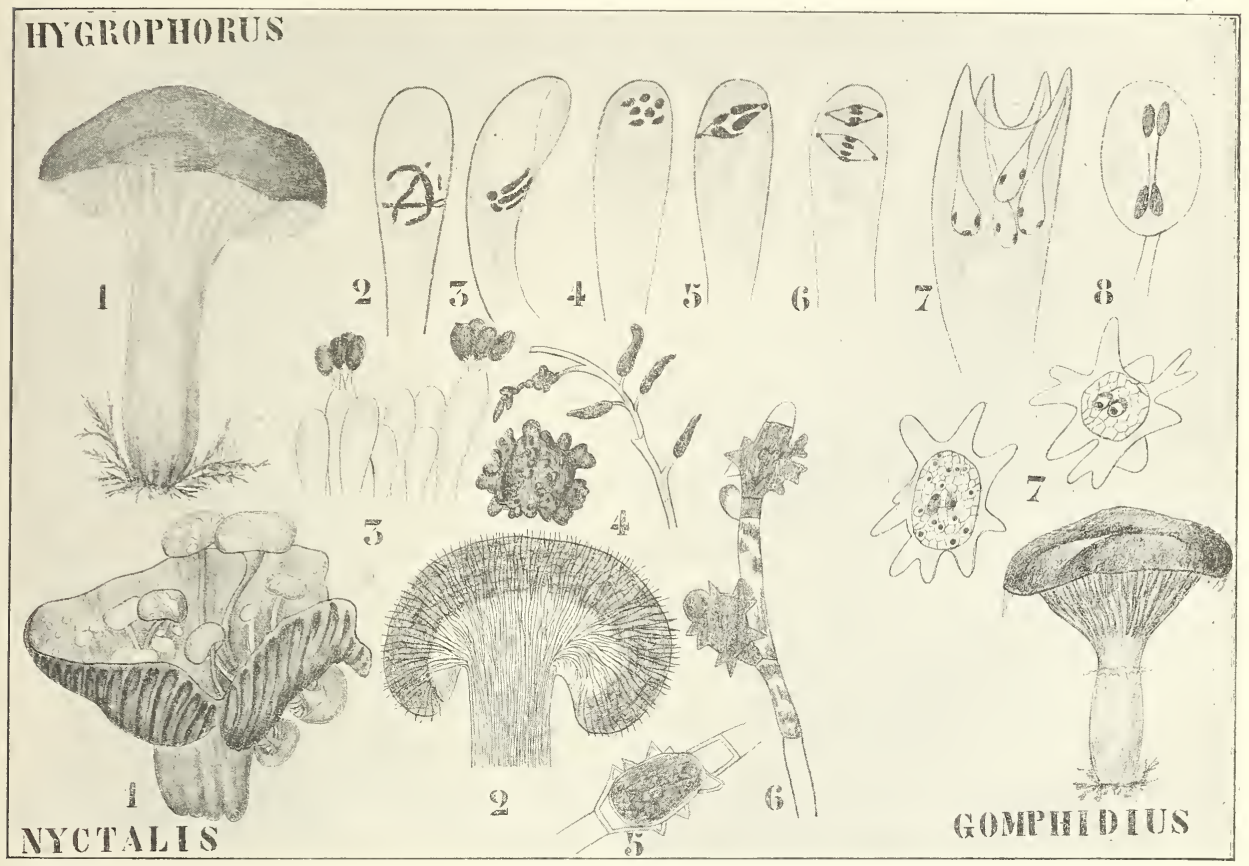

Fig. 401. Hygrophoraceae. I. Hygrophorus ficoides (BUlL.) Schröt. (nach Hennings). - II. 2-8 Kernteilungen in der Basidie von Hygrophorus agathosmus Fr. (nach MaIre). - III. Nyctalis as terophora Fr. 1 Exemplare auf einer Russula schmarotzend (nach HenNiNGs). 2 Längsschnitt durch den Hut, die dunklen Chlamydosporen zeigend. 3 Basidien. 4-6 Chlamydosporen (2, 3, 5, 6 nach DE BARY, 4 nach BREFELD). 7 Die zweikernigen Chlamydosporen (nach MAIRE). - IV. Gomphidius vis cidus (L.) Fr. (nach Hennings).

Der Pilz ist auf Wiesen in Europa häufig und gehört zu den Speisepilzen.

Hygrophorus agathosmus Fr. (Fig. 401, II 2-8) wurde von MaIRE cytologisch untersucht. In den Basidien verschmelzen die Kerne frühzeitig, und der Fusionskern tritt alsbald in die Synapsis ein (Fig. 401, II 2). Er liegt dann auf etwa ${ }^{2 / 3}$ der Höhe in der Basidie. Während er noch im Synapsisstadium ist (Fig. 401, II 3), erscheint in der Spitze der Basidie ein Kinoplasma, welches den Kern heranzieht (Fig. t(1), II 4). Die Mitosen (Fig. 401, II 5, 6) finden also apikal und transversal statt. 
Nach der zweiten Teilung werden die Sterigmata ausgestülpt, in welche die Kerne, offenbar durch Kinoplasma (Fig. 401, II 7) hineingezogen werden. In der Spore unternimmt der Kern alsbald wieder eine Teilung (Fig. 401, II 8), welche wohl als eine verfrühte Keimung gedeutet werden muß, eine Verfrühung, welche sogar so weit gehen kann, daß die Teilung schon innerhalb der Basidie stattfindet, wodurch diese dann 8-kernig wird.

Das Genus

\section{Nyctalis}

ist durch zwei Umstände interessant, erstens, weil es auf anderen Hutpilzen parasitiert, und zweitens, weil an der Oberseite des Hutes zahllose Chlamydosporen gebildet werden. Ueber diese Chlamydosporen ist vieles geschrieben worden; während Krombholz, de Bary, Vuillemin und De Seynes sie für Chlamydosporen von Nyctalis hielten, meinte Tulasne darin nur Parasiten sehen zu dürfen. DE BARY wies ihre Zugehörigkeit zu Nyctalis zweifellos nach, ja konstatierte sogar, daß sie die hauptsächlichste Fruktifikation dieses Pilzes bilden. An der Oberfläche des Hutes bildet sich nämlich eine dicke Chlamydosporenschicht (Fig. 401, II 2); infolgedessen bleiben die Lamellen rudimentär, und nur an sehr kräftigen Exemplaren kommt es zu einer Produktion von Basidien. Das ist der Fall, wie er bei $N$. asterophora Fr. vorliegt; bei $N$. paradoxa Fr. werden die Chlamydosporen im Gewebe der stark angeschwollenen Lamellen gebildet; die übrigen Teile des Hutes enthalten keine, aber auch hier gelangen nur selten Basidien zur Entwickelung. BREFELD hat die Richtigkeit der DE BARYschen Untersuchungsresultate an Reinkulturen bestätigt gefunden.

Nyctalis asterophora Fr., die Fig. 401, III abgebildete Art, ist hutförmig, anfangs mit einer weißflockigen Oberhaut bedeckt, welche später, wenn die Chlamydosporen erscheinen, verschwindet. Die Chlamydosporen selber sind ockergelb-braun, der Pilz kommt in Europa und Nordamerika auf faulenden Russula- und Lactarius-Arten vor ${ }^{1}$ ).

DANGEard und IstvanfFy waren uneinig über die Zahl der Kerne in den Chlamydosporen, nach ersterem waren 2, nach letzterem nur ein Kern vorhanden. MaIre fand Dangeards Angabe richtig, was übrigens bei einer Zelle der $2 \mathrm{x}$-Generation zu erwarten war.

Höher als diese beiden Arten steht das Genus Gomphidius (Fig. 401, IV), welches von Hygrophorus durch den Besitz eines Annulus superior, sowie durch die Form seiner Sporen und Cystiden abweicht, sich dadurch aber Paxillus nähert. Der Ring ist natürlich der Rest des Schleiers, der hier spinngewebeartig und schleimig ist. Die Lamelien sind dick, herablaufend, weich, mit fast schleimiger Zwischensubstanz, und mit großen cylindrischen Cystiden bedeckt. Der in Fig. 401 abgebildete G. viscidus (L.) Fr. hat einen klebrigen, braunroten Hut, die Lamellen sind zunächst purpurbraun, später dunkelbraun; es ist ein in Nadelwäldern häufiger Pilz.

Die zweite Familie der Agaricineen ist die der

\section{Russulaceae.}

Diese sehr natürliche Familie ist durch ihre sehr eigentümlichen, dem bloßen Auge körnig erscheinenden Tramae leicht kenntlich. Mikroskopisch sieht man, daß sie aus einer Menge von mit gewöhnlichen

1) In den Niederlanden z. B. unweit Weert. 
Hyphen und Milchsafthyphen gemischten Sphärocysten besteht; die Sporen sind stachelig, die ziemlich dicken Lamellen sind etwas herablaufend.

Die Russulaceae umfassen zwei weißsporige Genera: Lactarius und Russula und ein chromospores: Russulina.

Das Genus Lactarius Fr. (Lactaria PERs.) unterscheidet sich von Russula direkt dadurch, daß beim Durchbrechen des Hutes ein weißer oder gefärbter Milchsaft austritt. Nach SAccardo gibt es etwa 130 Arten, alle aus der gemäßigten Zone.

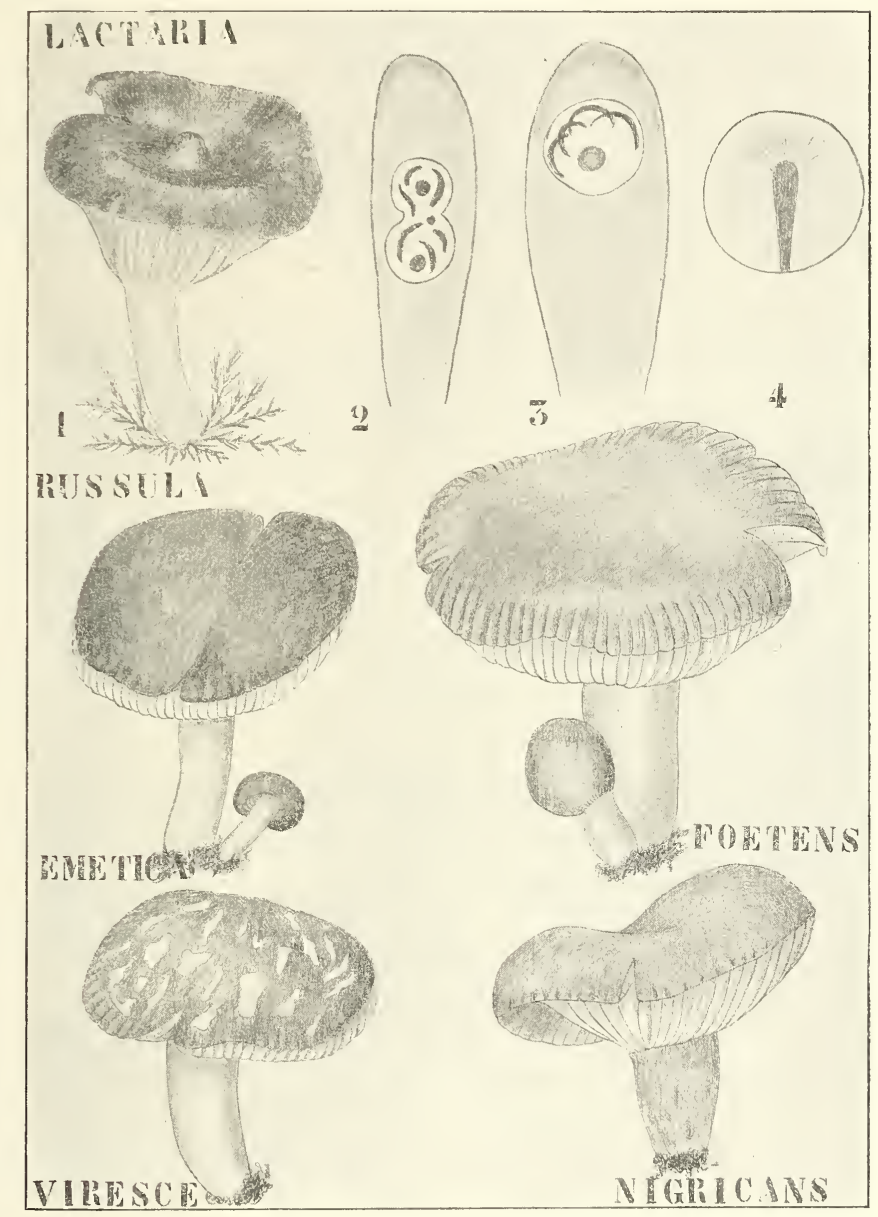

Fig. 402. Russulaceae. I. Lactaria rufa (Scop.) Schröt. (nach Hennixgs). - II. Cytologie von Laetarius delieiosus. 2 Kernfusion in der jungen Basidie. 3 Der Fusionskern in der Prophase. 4 Die Spore in dem Augenblicke, in dem der Kern hineintritt (nach MaIRe). - III, Russula emetica (SchiefF.) Fr. - IV. R. foetens I'ens. - V. R. virescens (SchatfF.) Fr. - VI. R. nigrieans (But...) Fr.

Die in Fig. 492, I abgebildete Lactarin rufa (Sсог.) Sснвӧт. hat einen buckeligen, fleischigen, später trichterförmigen, trockenen Hut ron braunroter Farbe, er ist glänzend und 5-11 cm breit. Der volle rötliche Stiel ist 5-10 cm lang, die Lamellen ockergelb oder rötlich. die 
Milch scharf, weiß, von brenzlichem Geschmack. Der Pilz ist überall in Nadelwäldern häufig. Trotzdem man ihn in Deutschland nach Hennings überall für giftig hält, wird er in Ostpreußen und Rußland in Essig eingelegt und dann gegessen. Der Pilz hat viele chromogene Substanzen in den Milchhyphen sowie im Hymenium, so daß er bei der Konservierung mittels Flemming pechschwarz wird. Während Weiss meinte, daß diese Milchsafthyphen durch Verschmelzung plurinukleärer Zellen entstehen, zeigten Istvanffy und Johan-Olsen, daß diese Hyphen aus einigen speziellen Zellen gebildet werden, welche lateral an normalen Hyphen entstehen, und welche nur durch Wachsen und Verzweigung zu Milchsafthyphen werden; erst später entstehen in diesen langen Röhren einige Querwände. Die normalen Hyphen bestehen aus binukleären Zellen. Die Mitosen in den Basidien sind transversal und apikal. Die Sphärocysten, welche auf dem Querschnitt in Gruppen von je 5 rosettenartig vereinten Zellen liegen, sind normale, stark vergrößerte Hyphenzellen. Auch sie enthalten ursprünglich je 2 Kerne.

\section{Russula.}

Die Arten des Genus Russula besitzen ebensowenig wie die von Lactarius einen Schleier. Die Sporen sind weiß, stachelig. Etwa 100 Arten sind bekannt. Nach der Konsistenz des Hutes wird also das Genus in folgende Sektionen zerlegt.

1. Fragiles.

2. Heterophyllae.

3. Rigidae.

4. Furcatae.

5. Compactae.
Hut mehr oder weniger fleischig, steif, am Rande dünn, sehr zerbrechlich. Lamellen meistens gleich lang. Hierher z. B. R. emetica (Fig. 402, III). Hut fleischig, fest, am Rande dünn. Lamellen von verschiedener Länge. Hierher z. B. R. foetens (Fig. 402, IV).

Hut stets trocken, steif. Hierher z. B. R. virescens (Fig. 402, V).

Hut fleischig, gewölbt, später ausgebreitet. Lamellen gegabelt. Hierher z. B. R. bifida (BulL.) ScHRÖT.

Hut bis am Rande fleischig. Lamellen verschieden lang. Hierher z. B. R. nigricans (Fig. 402, VI).

Von den in Fig. 402 abgebildeten Arten sei noch folgendes erwähnt: Russula emetica (Schaeff.) Fries hat einen Hut von 5-10 cm Durchmesser, der im feuchten Zustande etwas klebrig, im trockenen glänzend ist. Die Farbe ist meistens blutrot, öfters verblassend, der Stiel 6-8 cm lang, im Inneren schwammig, außen weiß oder rosa, glatt. Die Lamellen sind weiß. In Wäldern in Europa, Nordamerika, Asien und Australien: Der deutsche Name ist Speiteufel oder roter Täubling, er gilt als giftig.

Russula foetens PERs. hat einen 8-15 cm breiten, klebrigen, gelbbraunen Hut, einen weißen Stiel und zunächst weiße, später graubraune Lamellen. Diese Lamellen scheiden in der Jugend Wasser aus. In Europa, vielfach unter Birken.

Russula virescens (Schatff.) Fries hat einen 8-12 cm breiten, spangrünen Hut mit flockig zerreißender Oberhaut. Die Lamellen und der Stiel sind weiß; der Pilz ist eßbar und kommt in Europa und Nordamerika in Buchen- und Birkenwäldern vor. 
Russula nigricans (Buld.) Fries hat einen $12 \mathrm{~cm}$ breiten, olivengrünen, später schwärzlichen, in der Jugend klebrigen Hut. Auch der Stiel ist olivengrün, die Lamellen aber weiß. Schließlich wird der ganze Pilz pechschwarz.

Histologie und Cytologie sind dieselben wie bei Lactarizus, nur fehlen die Milchsafthyphen. Das Genus Russulina ist von Russula nur durch die gefärbten Sporen verschieden.

Die dritte Familie der Agaricineae ist die der

\section{Agaricaceae.}

Diese enorm große Familie ist sehr formenreich, alle Vertreter sind aber durch den Besitz dünner Lamellen, mit fast immer regelmäßigen Basidien und glatten, gefärbten oder ungefärbten Sporen charakterisiert. MLARE teilt die Agaricaceae wie folgt ein:

\section{Agaricaceac.}

Sporen
ohne
Keim-
porus $\quad \begin{aligned} & \text { Lamellen herablaufend, frei oder adnat, kein } \\ & \text { Ring, kein Schleier, weiße Sporen } \\ & \text { Lamellen adnat, öfter sinuat, ein ephemerer } \\ & \text { Schleier vorhanden, weiße oder farbige } \\ & \text { Sporen }\end{aligned}$

\section{Clitocybeae.}

Diese Gruppe umfaßt eine Anzahl ziemlich verschiedener Formen, von denen die niedrigsten sich an die Cantharellaceen und an die Hygrophoraceen anschließen.

Laccaria erinnert durch ihre dicken und wachsartigen Lamellen an die Hygrophori, durch ihre stacheligen Sporen an die Russulaceen, während Clitocybe einem Cantharellus sehr ähnlich sieht.

Die wichtigsten Genera sind: Clitocybe, Laccaria, Omphalia, Armillariella, Pleurotus, Crepidotus, Panus, Lentimus, Favolus, Androsaccus, Crinipellis, Heliomyces, Collybia, Mucidula, Mycena, Marasmius etc.

Von diesen können nur einige wenige hier kurz besprochen werden.

\section{Clitocybe aurantiaca (Wulf) STUder}

war bis vor kurzem unter dem Namen Cantharellus aurantiacus WULF bekannt. Ihre große Aehnlichkeit mit Cantharellus cibarius L. führte dazu, und sie wurde dafür gehalten, bis STUDER 1900 aus histologischen Gründen ihre Zugehörigkeit zu Clitocybe nachwies. Eine genaue makroskopische Untersuchung lehrt übrigens schon, daß unsere Pflanze echte Lamellen besitzt, während die Cantharelli höchstens lamellenähnliche Falten aufweisen können. Die von Marre untersuchte Cytologie hat die Berechtigung dieser Schlußfolgerung klar dargestellt, indem die Mitosen in den Basidien nicht wie bei den Cantharellaceen schief, sondern wie bei 
den Agaricaceen transversal und apikal stattfinden. Die Farbe unseres Pilzes ist orange, und nur bei genauer Untersuchung läßt sich Clitocybe von Cantharellus unterscheiden.

Armillariella oder Armillaria mellea (VAHL) ist durch ihre wurzelähnlichen Sclerotien, welche früher als ein gesondertes Genus unter dem Namen Rhiromorpha beschrieben sind, allgemein bekannt. Diese schwarzbraunen Sclerotien (Fig. 403, A 1) leben zum Teil parasitisch auf Laubund Nadelhölzern, und zwar zwischen Holz und Rinde, sehr häufig z. B. auf Weiden um Leiden herum, zum Teil saphrophytisch in faulendem Holze und Humus, zumal auf letzterem bilden sich dann später die Fruchtkörper (Fig. 403, A 2). Der Hut ist 4-18 cm breit, honiggelb,

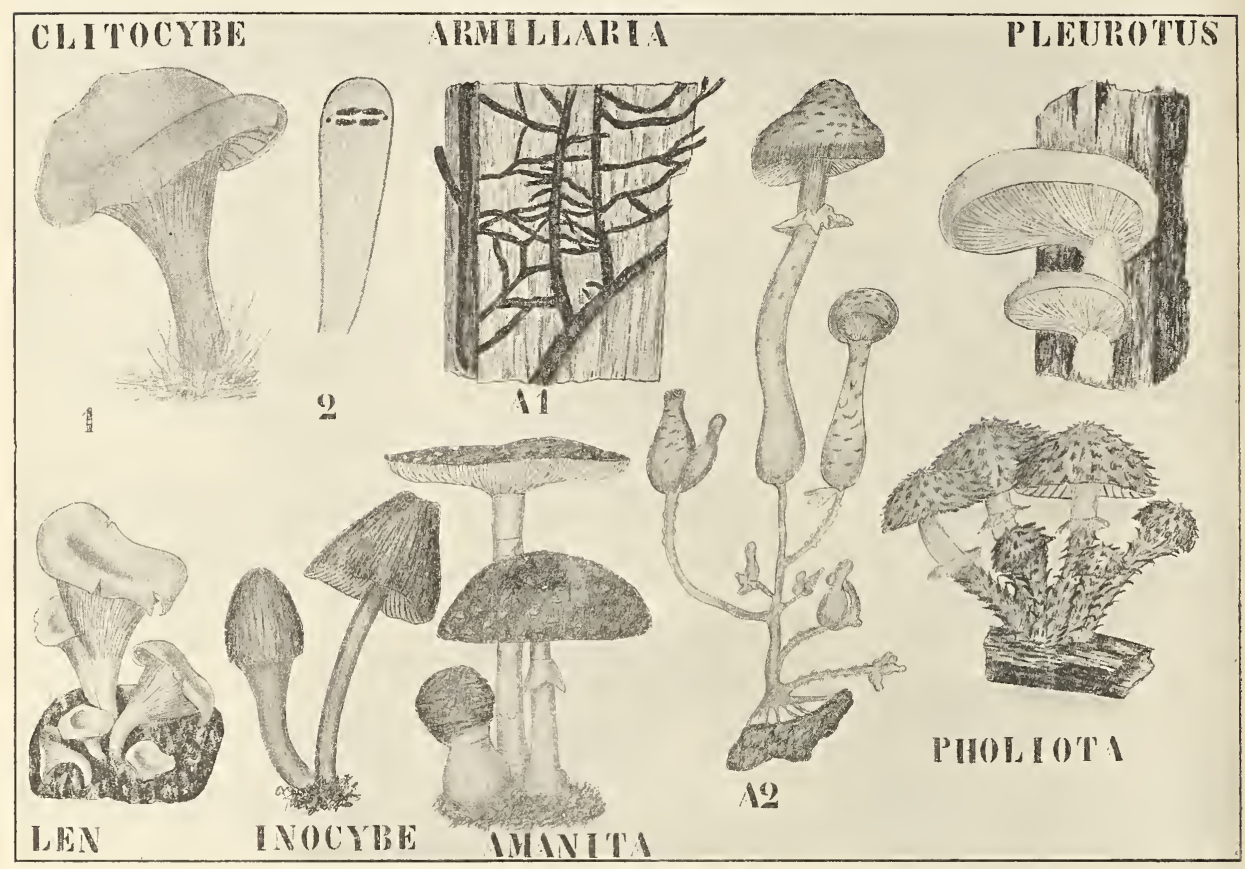

Fig. 403. Clitocybeae (I-V), Tricholomeae (V), A maniteae (VI) und Pholioteae (VII). I. Clitocy be a rantiaca (Wulf) Studer. 1 Habitus (nach Hennings). 2 Kernteilung in der Basidie (nach MaIRE). - II. A rmillaria mellea (VAHL). A 1 Der Rhizomorpha-Zustand (nach WARming). A 2 Entwickelung des Pilzes. - IIJ. Pleurotus nidulans (nach Hennings). - IV. Lentinus Tuber regium Fr. (nach Hennings). - V. Inocybe fastigiata (Schaeff.) Sacc. (nach Hennings). - VI. Amanita muscaria (nach Strasburger). - VII. Pholiota squarrosa (Müll.) Karst.

mit gelbbraunen Schuppen, der Stiel hell-fleischfarbig, Lamellen, Ringund Schleier sind weiß.

Das Genus Pleurotus ist durch die Anwesenheit eines exzentrischen Stieles oder durch die gänzliche Stiellosigkeit charakterisiert. Pleurotus nidulans (Fig. 403, III) kommt an abgestorbenen Baumstämmen vor, im ganzen gibt es nicht weniger als 250 Arten.

Vom Genus Lentinus sind gegen 340 Arten bekannt. Eine der eigentümlichsten ist der hier abgebildete Lentinus Tuber regium (Fig. 403, IV) von Amboina, welcher von Rumphius beschrieben wurde, und bei 
welchem die weißen Fruchtkörper fast schwarzen kopforoßen Sclerotien entspringen.

Die zweite Untergruppe der Agaricaceae wird von den

\section{Tricholomeae}

gebildet. Sie enthält die Genera: Tricholoma, Melanoleuca, Cortinellus, Armillaria, Cortinellus, Cortinarius, Hebeloma, Inocybe etc.

Mittels Melanolenca steht sie mit Collybia der Clitocybeae in Verbindung und mittels Cortinarius largus, dessen Lamellen vom Hute abtrennbar sind, mit Paxillus.

Das Genus Inocybe umfaßt 180 Arten. Der Hutrand und der Stiel sind in der Jugend meistens mittels eines spinngevebeartigen Schleiers verbunden. Der Stiel hat keinen Ring. Die Lamellen sind angeheftet oder frei, an der Schneide öfters im Besitze von Cystiden. Die hier abgebildete Inocybe fastigiata (SchaefF.) Sacc. (Fig. 403, V) hat einen fleischigen, dünnen, gelbbraunen, glockenförmigen Hut mit gelben Lamellen; sie wird an Wegrändern in Wäldern in Europa gefunden. Der Stiel ist blaßbraun.

Die dritte Untergruppe der Agaricaceae ist die der

\section{Goniosporeae.}

Sie umfaßt alle Agaricaceae mit rosafarbigen, eckigen Sporen. Die wichtigsten Genera sind: Entoloma, Leptonia, Nolanea, Eccilia, Clitopilus etc.

Sie ist mit den Tricholomeae durch die Entolomae, mit den Clitocybeen durch alle übrigen ihrer Genera verwandt. Höchst wahrscheinlich ist diese Gruppe eine künstliche, die durch Konvergenz aberranter Typen der Clitocybeen und Tricholomeen gebildet wird.

Clitopilus orcella BuLl., eine mit Clitocybe eng verwandte Form, ist die einzige Art, welche cytologisch untersucht worden ist, sie weist allerlei Abweichungen auf. So entstehen bisweilen statt 4 Kernen deren 8 in den Basidien, von denen jede Spore dann 2 Stück enthält, welche sich weiter teilen, so daß die reifen Sporen 4, 6, ja 8 Kerne besitzen können.

Die vierte Untergruppe der Agaricaceae wird von den

\section{Amaniteae}

gebildet. Der Hut läßt bei den Vertretern derselben leicht vom Stiel los, und fast alle besitzen einen Schleier oder Ring. Die wichtigsten Genera sind: Locellina, Volvaria, Ammlaria, Pluteus, Lepiota, Amanita und Amanitopsis.

Die bekannteste Art ist der feuerrote Fliegenpilz, Amanita muscaria (Fig. 403, 8), welcher äußerst giftig ist. Beim verwandten A. pantherina DC. werden in der Basidie in normaler Weise 4 Kerne gebildet, deren je einer in eine der vier Sporen eintritt, dort aber sich durch verfrühte Keimung bald teilt, so daß die reifen Sporen binukleär sind.

Die fünfte Untergruppe der Agaricaceae besteht aus den

\section{Pholioteae,}

einer Uebergangsgruppe zu den Coprincae, welche sämtliche ochrospore Formen umfaßt. Dazu gehören hauptsächlich die Genera Pholiota. 
Flammula, Naucoria, Galera und Tubaria, während auch Rozites hier wohl am besten untergebracht wird.

Pholiota ist wieder ein ganz großes Genus mit mehr als 120 Arten, welche zum Teil auf dem Boden, zum Teil auf Holz wachsen. Der Hut ist mehr oder weniger dickfleischig, in der Jugend mit dem Stiel mittels eines häutigen Schleiers verbunden, von welchem schließlich ein abstehender Ring übrig bleibt. Die Sporen sind braun.

Die hier abgebildete Pholiota squarrosa (MülL.) Karst (Fig. 403, 9) hat einen blaßgelben, $6-10 \mathrm{~cm}$ breiten, mit dunkleren Schuppen bedeckten Hut. Sie findet sich an Baumstümpfen in Europa. Das interessanteste Genus dieser Gruppe ist aber

\section{Rozites}

weil es eine Art $R$. gogylophora A. MöLL., enthält, welche von Ameisen als Gemüse kultiviert wird.

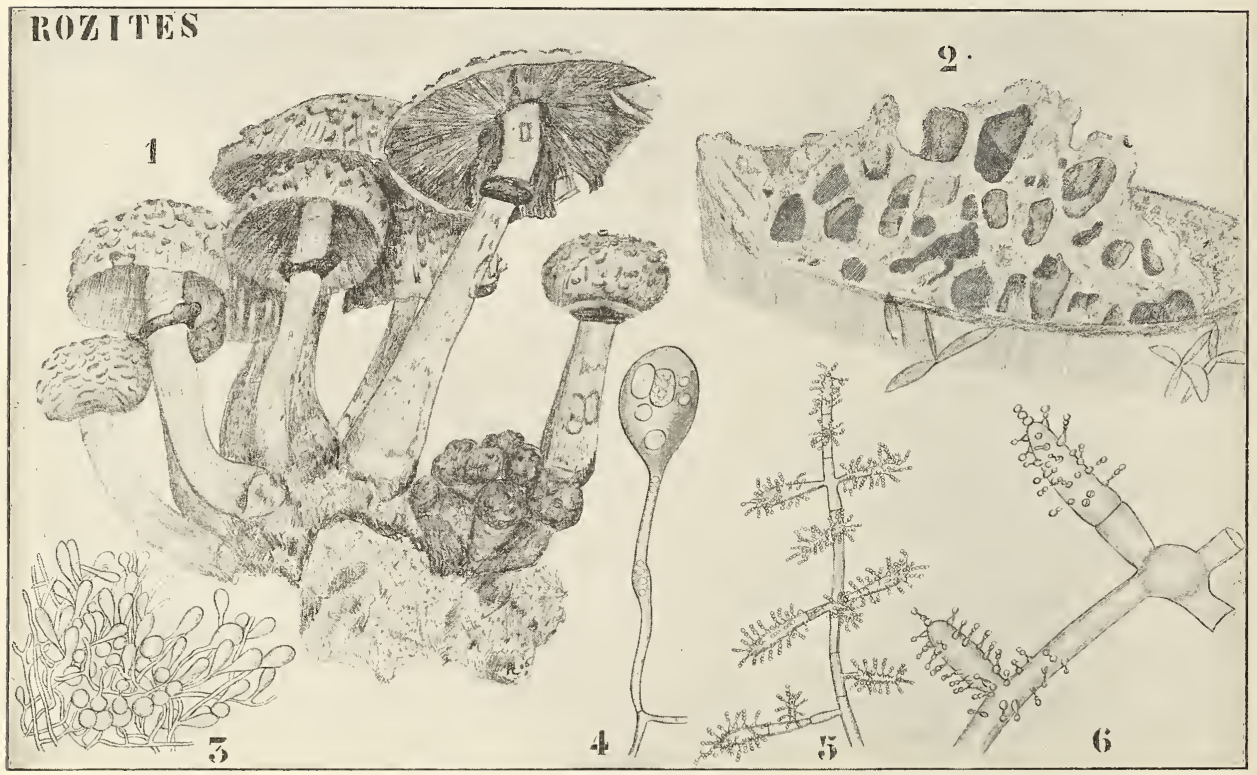

Fig. 404. Rozites gongylophora A. MöLL. 1 Hauptfruktifikation wie sie nur sich ausbilden kann, wenn die Ameisen die Kultur verlassen haben. 2 Ein von den Ameisen in der Gefangenschaft aus zerkauten Blattstückchen gebildetes Pilzbeet, ein sogenannter Pilzgarten. 3, 4 Die Kulturform des Myceliums, welche den Ameisen als Nahrung dient. 5, 6 Nebenfruktifikationen.

Es ist Ihnen wohl bekannt, daß in Südamerika verschiedene Ameisenarten leben, welche die eigentümliche Gewohnheit haben, Stücke aus Baumblättern herauszuschneiden und diese nach ihren Nestern zu bringen, wo sie diese zerkauen und bei ihrem Nestbau benutzen. Nach dieser Eigenschaft werden diese Tierchen Blattschneiderameisen genannt.

Der bekannte englische naturwissenschaftliche Reisende BELT kam als erster auf den Gedanken, daß diese Blattstückchen den Ameisen als Kulturmaterial für Speisepilze dienten.

Der Beweis wurde aber erst von MöLler erbracht, daß die Ameisen in ihren Nestern aus diesen zerkauten Blattstückchen einen ordentlich 
rentilierten Haufen aufschichten, welcher der Kultur des betreffenden Pilzes dient, und deswegen von MöLler Pilzgarten genannt wird. Man darf hier, wie Möller fand, mit Recht von Pilzgärten reden, denn mit der größten Sorge wird der Garten von den Ameisen unkrautrein gehalten, werden die rom Mycelium ausgesogenen Blattkrïmchen entfernt und durch neue ersetzt etc.

Man meine nun nicht, daß Zweck der Kultur das Erhalten der hier abgebildeten, hübsch rosenroten Hutpilze ist; im Gegenteil, so lange der Garten nicht von den Ameisen verlassen ist, kommen diese Fruchtkörper nie zur Entwickelung, da die Ameisen die Mycelien fortwährend zuschneiden und die höhere Fruchtform also erst erscheinen kann, nachdem das Nest verlassen worden ist.

Die Ameisen wollen nur das Mycelium der eigentümlichen blumenkohlähnlichen Seitenzweige desselben wegen erhalten (Fig. 404, 3), welche einen hohen Eiweißgehalt haben und die Nahrung der Ameisen bilden. Außer diesen treten verschiedene Konidienformen (Fig. 404, 5, 6) als Nebenfruktifikationen auf. Wie FarrchrLD nachwies, kultivieren die Termiten auf Java einen ähnlichen Pilz auf von ihnen zerkautem Holze, meines Wissens sind diese Untersuchungen noch nicht publiziert, ich hatte aber Gelegenheit, die Pilzkulturen dieser Termiten auf Java zu beobachten, als FAIRchilD mit deren Untersuchung beschäftigt war.

Die letzte Gruppe der Agaricaceae ist die der

\section{Coprineae}

welche alle Genera umfaßt, deren Vertreter konstant Sporen mit Keimporen besitzen. Die Sporen sind meistens schwarz oder violett. Bei den am höchsten stehenden Formen, wie z. B. bei Coprinus, findet die Entwickelung außerordentlich schnell statt.

Zahlreiche Genera gehören hierher, die wichtigsten sind: Chitonia, Psalliota, Stropharia, Psathyra, Psathyrella, Coprimus, Bolbitus, Lencocoprinus, unter welchen Psalliota und Coprinus die bekanntesten sein dürften.

Psalliota campestris (L.) FR. ist der allgemein beliebte Champignon. Der Hut ist dickfleischig, anfangs kugelförmig, später flach gewölbt, $6-15 \mathrm{~cm}$ breit, mit in der Jugend eingebogenem Rand, weiß oder bräunlich, seidenhaari,g, flockig oder kleinschuppig. Das Fleisch ist weiß, bei Verwundung rosa anlaufend, der Stiel 6-18 cm lang, $1-2 \mathrm{~cm}$ dick, voll, weiß und trägt in der Mitte einen dicken, häutigen, weißen Ring. Die Lammellen stehen dicht gedrängt, sind hinten abgerundet und frei, anfangs rosenrot, später schwarzbraun. Das Sporenpulver ist schwarzbraun. Im wilden Zustande trifft man ihn meistens in Wiesen an, die Speisechampignons sind aber fast ausnahmslos kultiviert aus der sogenannten Champignonbrut, d. h. aus dem Mycel.

Marre wies nach, daß die Zellen des Fruchtkörpers zunächst binukleär sind, später durch Amitose und Zerbröckelung der Kerne undeutlich multinukleär werden. Die Teilungen in den Basidien sind normal apikal und transversal, es werden aber nur 2 Sterigmata, selten 3, gebildet. In jede Spore treten 2 Kerne ein, welche sich teilen, so daß die reife Spore 4 Kerne enthält. Bisweilen bleibt die zweite Teilung in der Basidie aus, in welchem Falle jede Spore nur einen Kern enthält. welcher sich dort ein oder mehrere Male teilt.

Diese Unregelmäßigkeit ist Psalliotu cumpestris eigen. nicht aber 
den verwandten Arten, weshalb, wie MaIrE bemerkt, dies möglicherweise nur eine Kulturabnormität ist, und die Untersuchung wilder Champignous erwünscht wäre!

Die Coprimus-Arten sind durch schnelles Wachstum und durch das Verschleimen des Hutes gekennzeichnet. Infolge letzterer Eigenschaft trieft die Sporenmasse wie schwarze Tinte hinunter.

Coprinus stercorarius (Fig. 405) entwickelt sich auf Mist in wenigen Stunden, als Nebenfruktifikation besitzt er, wie BREFELD nachwies. Konidien (Fig. 405).

Diese Art ist nur wenige Zentimeter hoch, andere, wie z. B. C. sterquilinus und $C$. porcellanus erreichen bedeutende Größe, sind aber so wie C. stercorarius äußerst kurzlebig.

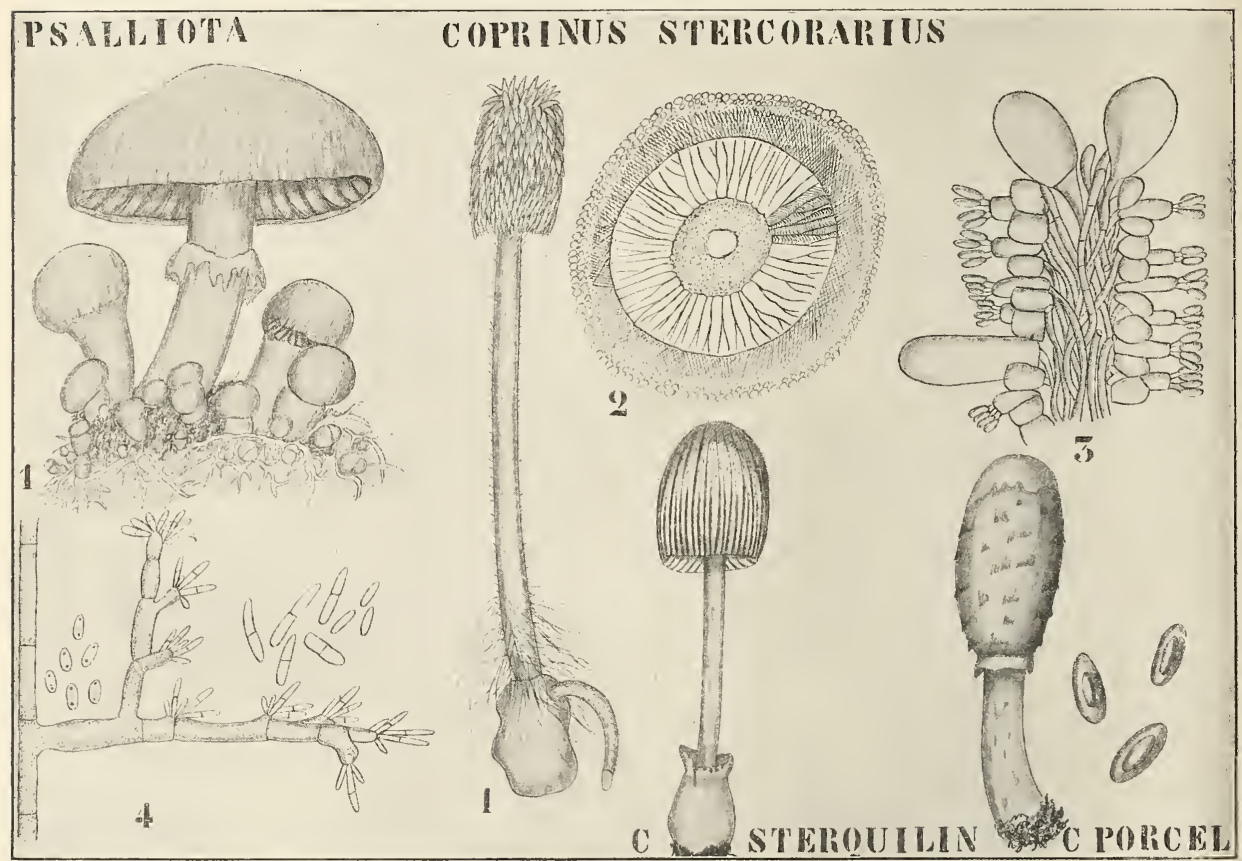

Fig. 405. Coprineae. I. Psalliota campestris (L.) Fr. (nach Hennings). II. Coprinus stercorarius Fr. (uach Brefeld). 1 Habitus. 2 Hut, von unten gesehen. 3 Querschnitt durch eine Lamelle. 4 Konidien. - III C. sterquilinus Fr. (nach Massee). - IV. C. porcellanus (Schaef.) Schröt. (nach Hennings).

An Coprinus radiatus Bolt. konnte MAIre nachweisen, daß die Zellen des Mycels uninukleär, die des Carpophoren, schon wenn dieser erst 1/10 mm Durchmesser hat, binukleär sind. Wie dies zu stande kam, konnte er aber nicht genau verfolgen, vermutlich wohl in ähnlicher Weise wie bei den Lepto-Formen der Uredineen.

Von der großen Gruppe der Agaricineae bleiben nur noch zwei Familien, die Paxillaceae und die Boletacene, zu besprechen übrig. Die Familie der

\section{Paxillaceae}

ist nur klein. Sie hält die Mitte zwischen den Agaricaceen und den 
Boletaceen. mit ersteren ist sie durch den Besitz von Lamellen sowie durch den Habitus verwandt, mit letzteren durch die Trennbarkeit der Lamellen rom Hute, sowie durch die Histologie.

In Bezug auf die Sporen und Cystiden zeigt sie Anklänge an das Genus Gomphidins der Hygrophoracene. Sie umschließt nur die Genera Paxillus und Phylloporus, welche überdies noch von manchem für synonym gehalten werden.

Paxillus Pelletieri (Fig. 406, II) steht Boletus am nächsten. Bei ihm, sowie bei einigen anderen Arten bilden die aderförmig verbundenen Lamellen öfters röhrenartige Höhlungen, die fast wie die Röhren eines Boletus gebaut sind. Der Hut ist kastanienbraun, die Lamellen gelb,

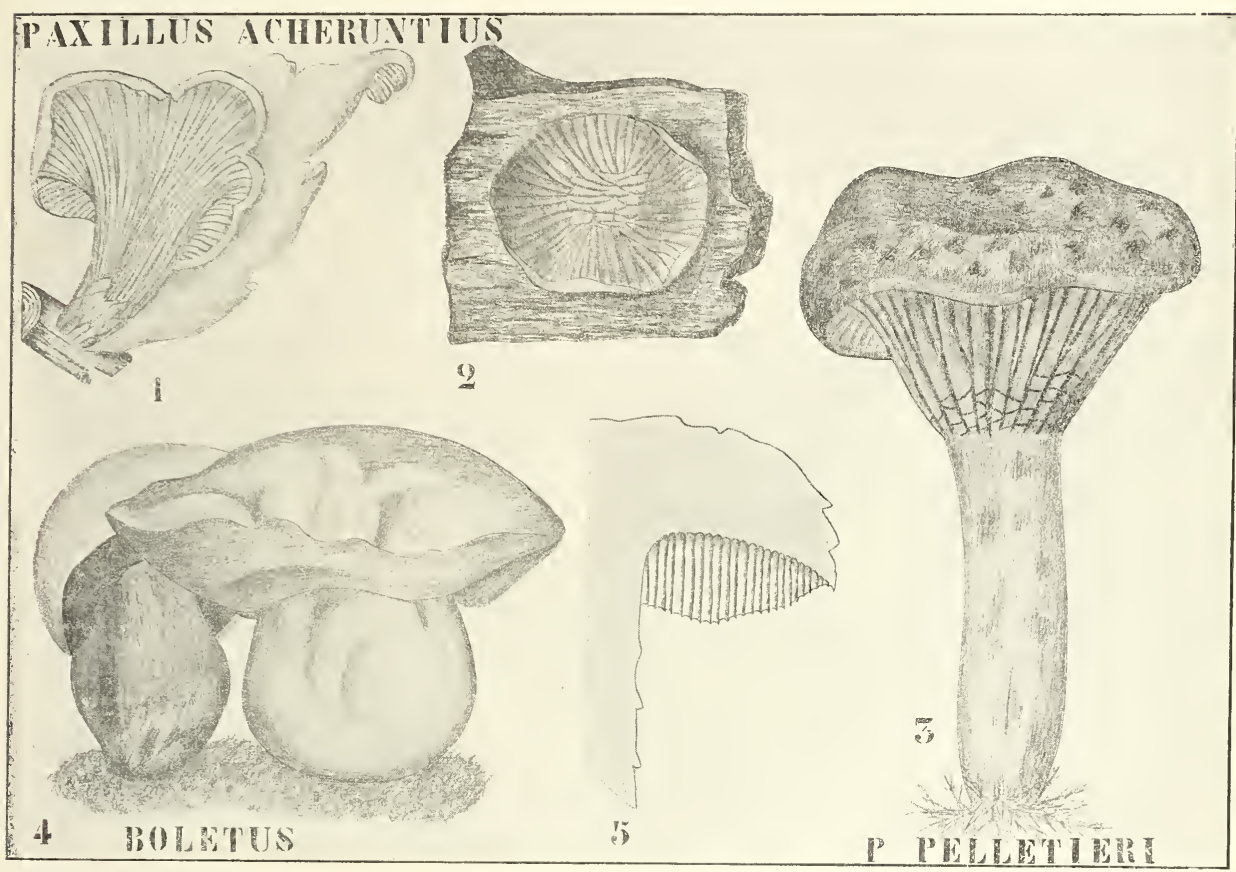

Fig. 406. Paxillaceae und Boletaceae (nach Hennings und Strasburger). I. Paxillus acheruntius (Humb.) ScHröt. 1 var.pannoides Fr. 2 var acheruntius Humb. - II. Paxillus Pelletieri LÉv. - III. Boletus Satanas. 4 Habitus. 5 Längsschnitt, die Röhren zeigend.

der Stiel rotbraun und die Boletus-artigen Poren finden sich an der Grenze zwischen Lamellen und Stiel. Die Cystiden enthalten einen gelben Saft.

Bei der hier ebenfalls abgebildeten $P$. acheruntius sind die Hüte im Lichte Cantharellus-artig (Fig. 406, I 1), im Dunkeln resupinat (Fig. 406, I 2).

Die letzte Familie der Agaricineae ist die der

\section{Boletaceae.}

Sie ist durch den Besitz von Röhren, nach Art der Polyporeen, an der Unterseite des Hutes charakterisiert, Röhren, welche leicht vom Hute abgetrennt werden können. 
Die wichtigsten Genera sind: Krombholziu, Boletus, Cricunopus, Strobilomyces, Gyrodon, Tylopilus und Suillus.

Das Genus Boletus enthält neben eßbaren Arten auch sehr giftige, wie Z. B. B. Satanas, welcher beim Durchschneiden sofort blauschwarz wird. Der bis $20 \mathrm{~cm}$ breite Hut ist gelbbraun, der Stiel braun bis purpurrot, die Röhren orange.

Von der Gruppe der Basidiomyceten bleiben nun noch die

\section{Gasteromyceten}

zu besprechen. Ihr Anschluß an die übrigen Basidiomyceten-Gruppen, sowie die Verwandtschaftsbeziehungen ihrer Vertreter unter sich sind noch recht unklar, viel mehr muß noch sowohl von ihrer Entwickelungsgeschichte wie von ihrer Cytologie bekannt sein, bevor sich etwas mit Sicherheit aussagen läßt. MAIRE sagt darüber:

„Quant aux Gastromycètes, leur origine est encore bien obscure; l'analogie des figures de division de certains Bolets avec celles des Lycoperdon et des Scleroderma nous a fait penser à chercher dans les Bolétacées l'origine de certains Gastromycètes, mais ce n'est qu'avec les plus grandes reserves que nous suggérerons cette hypothèse."

Ich halte mich bei der Besprechung dieser Gruppe an den besten Kenner derselben, an Ed. Fischer.

Die Gasteromyceten sind von den übrigen Autobasidiomyceten dadurch verschieden, daß bei ihnen die Hymenien sich im Innern des Fruchtkörpers befinden, und nicht frei an der Oberfläche liegen.

Diese Gruppe der Gasteromyceten wurde nun meistens in 4 Unterabteilungen geteilt: die Phalloideen, Lycoperdaceen, Nidulariaceen und. Hymenogastraceen.

Die Phalloideen waren dadurch charakterisiert, daß die Hymenien in einer besonderen Gewebeschicht (Gleba) gebildet werden, welche bei der Reife von dem sich streckenden Stiele aus einer Volva herausgehoben wird, während bei den übrigen Gruppen die Hymenien im Inneren der Fruchtkörper verbleiben. Unter letzteren zerfällt die Gleba der Lycoperdaceen bei der Reife pulverig und ist meist von einem Capillitium durchsetzt, während bei den Nidulariaceen die wenig zahlreichen Glebakammern sich bei der Reife als kleine harte Körperchen (Peridiolen) voneinander isolieren. Die Hymenogastraceen umfaßten die einfachsten Formen, bei denen die Gleba meist bis zur Reife eine mehr oder weniger fleischige Beschaffenheit beibehält. Eine wichtige Aenderung wurde darin von ScHRöTER vorgenommen durch die Ausscheidung der Plectobasidii aus den Lycoperdineae, indem er sie, da ihre Basidien nicht in regelmäßigen Hymenien stehen, sondern regellos über das Innere des Fruchtkörpers verteilt sind, allen anderen Gasteromyceten gegenüberstellt.

So erhält man dann folgende Einteilung:

\section{Gasteromycetes.}

A. Basidien nicht zu Hymenien vereint, sondern im Fruchtkörperinneren regellos verteilt oder knäuelartige Gruppen. bildend . .

B. Basidien zu Hymenien vereint, welche sich in einer besonderen Gewebeschicht, der Gleba, befinden

Plectobasidiineae

Gasteromycetineae 
I. Die Gleba im Inneren sich nicht streckender Fruchtkörper.

1. Hymeniumkammern ${ }^{1}$ ) bei der Reife in Zusammenhang bleibend.

a) Fruchtkörper bei der Reife fleischig bleibend, Capillitium fehlt .

ß) Fruchtkörper bei der Reife mit pulveriger Sporenmasse und Capillitium erfüllt .

2. Hymeniumkammern bei der Reife sich voneinander trennend.

Hymenogastraceae

Lycoperdaceae

Nidulariaceae

II. Die Gleba wird vom sich streckenden Stiele des Fruchtkörpers emporgehoben, wobei die Volva zerreißt . . . Phallaceae.

Die Plectobasidii und die Gasteromycetineae, erstere mit regellos im Fruchtkörpergeflecht eingebetteten Basidien, letztere mit hohlen Kammern und palisadenartig gestellten Basidien, also mit eigentlichen Hymenien, sind als parallele Reihen zu betrachten, die im gleichen Verhältnis zueinander stehen wie bei den Ascomyceten die Plectascineen zu den Tuberineen. Zwar existieren eine Anzahl Formen, deren Stellung zu der einen oder anderen dieser beiden Hauptgruppen etwas fraglich ist (so die Podaxaceen), oder die von der einen zur anderen himneigen (Melanogaster), aber es lassen sich doch die Formen der einen nicht von denen der anderen oder von Mittelformen ableiten, Plectobasidii und Gasteromycetineae sind eben Parallelreihen.

Betrachten wir also zunächst die

\section{Plectobasidiineae.}

Das Mycelium der Plectobasidiineae ist flockig oder strangförmig; gewisse Formen bilden mit Wurzeln höherer Pflanzen Mykorrhizen, so z. B. Pisolithus crassipes mit Kiefernwurzeln. Die Fruchtkörper sind unterirdisch oder epigäisch, die Basidien liegen reg'ellos im Fruchtinneren verteilt. Bei der Reife zerfällt das basidienhaltige Gewebe meist zu einer pulverigen Masse mit oder ohne Capillitium.

Eine gewöhnlich hierher gestellte Gruppe, die der Podaxaceae, ist noch so wenig untersucht, daß man nicht sagen kann, ob sie hierher oder zu den Gasteromycetiineae gehört. Wer sich für sie interessiert, kann näheres in EngLER und Prantu nachsehen, sie kann hier, bis genauere Untersuchungen den Bau ihres basidienhaltigen Gewebes und dessen Entwickelung klargelegt haben, unbesprochen bleiben.

Die Hauptreihe der Plectobasidii wird durch Formen, welche man als Sclerodermataceen und Calostomataceen zusammenfassen kann, gebildet, an welche sich als Seitenlinie die Pisolithaceen anschließen, eine Gruppe, welche den Nidulariaceen unter den Gasteromycetiineae vergleichbar ist, indem auch hier die Fruchtschicht in "Peridiolen" auseinanderfällt.

Die Stellung der vielfach hierher gebrachten Tulostomaceen und Sphaerobolaceen ist noch sehr zweifelhaft; wir kommen darauf später zurück.

Als Resultat unserer vorläufigen Uebersicht finden wir also, daß die Einordnung der Podaxaceae, Tulostomaceae und Sphaerobolaceac an dieser

1) Unter Hymeniumkammern versteht man Höhlungen in der Glebas welche rom Hymenium bekleidet sind. 
Stelle von recht zweifelhafter Gültigkeit ist, und daß sich die typischen Plectobasidiineae etwa in folgender Weise anordnen lassen:

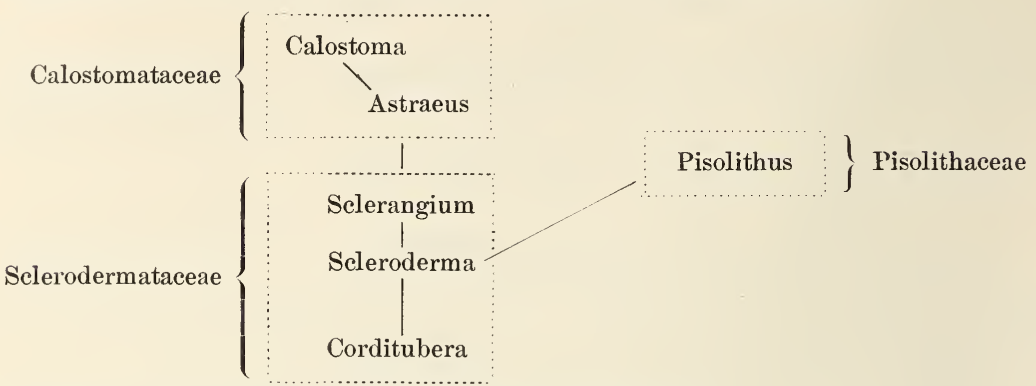

Lernen wir nun die Formen einmal kennen.

Die

\section{Sclerodermataceae}

umfassen Formen mit unterirdischen oder epigäischen, ungestielten oder kaum gestielten Fruchtkörpern und meist einfacher, bei der Reife un-

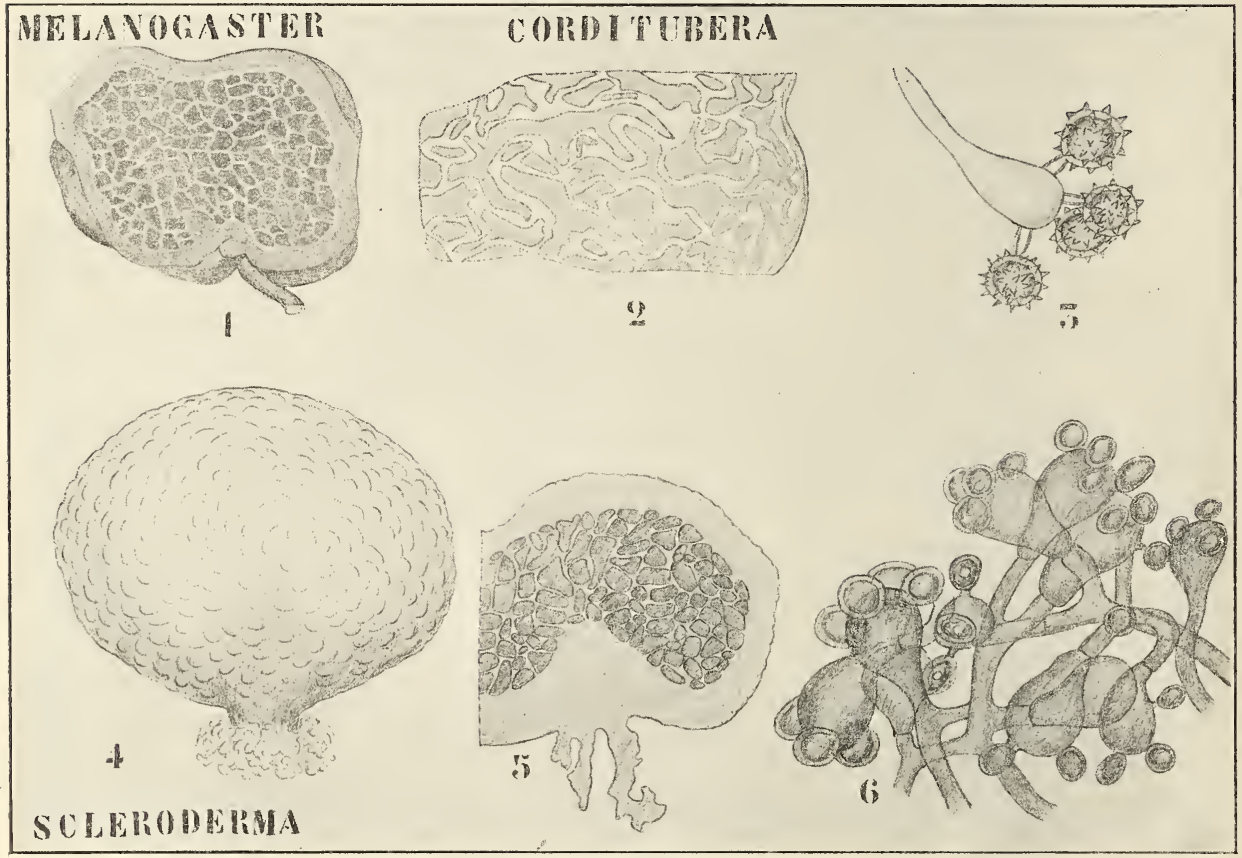

Fig. 407. Sclerodermataceae. T. Melanogaster variegatus (VitT.) TuL. Habitus (nach Tulasne). - II. Corditubera Staudtii Henn. 1 Stück aus dem Fruchtkörperinneren und Peridie. 2 Basidien. - III. Scleroderma verrucosum BuLL. Habitus (nach Fischer). - IV. Scle roderma vulgare Honnemann. 1 Längsschnitt durch einen nicht ganz reifen Fruchtkörper. 2 Basidien (nach TulasNe).

regelmäßig aufreißender Peridie, die Gleba (d.h. das Gewebe, in welchem sich die Basidien befinden) enthält scharf abgegrenzte rundliche oder unregelmäßige basidienführende Partien, welche durch sterile Adern ge- 
trennt werden und in welchen die Basidien ganz regellos liegen. Das Capillitium ist, wenn überhaupt vorhanden, rudimentär.

Tom einfachsten Genus, von

\section{Corditubera,}

ist eine Art, C. Staudtii Hennings, aus Kamerun bekannt (Fig. 407, II). Der Fruchtkörper ist herzförmig, $5 \mathrm{~cm}$ lang, 2-21/2 $\mathrm{cm}$ breit, anfangs hell, später blutrot gefärbt, das Innere rötlich. Die ganze Gliederung des Fruchtkörpers ist hier noch eine relativ einfache. Unter der von einer dünnen Rinde bedeckten Oberfläche finden wir, sagt FIscHER, eine Schicht von sterilem Hyphengeflecht, die kaum den Namen einer Peridie verdient, da sie nach innen nicht scharf abgegrenzt ist und die direkte Fortsetzung der sterilen Adern bildet, welche die basidienführenden Nester voneinander trennen. Aehnlich verhält sich Melanogaster (Fig: 407, I), nur sieht man hier die basidienführenden Hyphen mehr oder weniger deutlich in der Richtung von den sterilen Adern gegen das Innere der basidienführenden Geflechtspartien verlaufen, wodurch ein Anklang an ein Hymenium zu stande kommt.

Als nächst höhere Stufe reiht sich dann

\section{Scleroderma}

an. welches im Vergleich zu Corditubera eine schärfer differenzierte, wohlausgebildete, derbe, lederige oder brüchige Peridie besitzt. Zu diesem Genus gehören etwa 25 Arten. Das hier abgebildete Scleroderma vermcosum (Fig. 407, III) hat einen etwas gestielten Fruchtkörper mit einer fast holzigen bräunlichen Peridie, der oben mit breiten, dicken, gefelderten Schuppen besetzt ist und am Scheitel mit weiter Oeffnung aufbricht, wodurch er zuletzt becherförmig wird. Die Sporenmasse ist graubraun; der Pilz kommt in Europa und Afrika vor. Das im Längsschnitt abgebildete Scl. vulgare HornEMANn (Fig. 407, IV) hat eine weitere Verbreitung, indem es schon in allen Weltteilen mit Ausnahme Asiens aufgefunden wurde. Der Fruchtkörper ist sitzend, knollenförmig, meist $3-6 \mathrm{~cm}$ breit im Durchmesser, mit korkiger, 2-3 $\mathrm{mm}$ dicker Peridie, welche außen fast glatt oder warzig gefeldert, meistens unter Bildung von Rissen aufspringt. Die Gleba ist anfangs weiß, später schiefergrau, dann schwarz; die Sporen kugelig mit warzig-stacheliger Membran.

Ist hier bei Scleroderma also die Peridie schon weiter ausgebildet als bei Corditubera, so übertrifft Sclerangium ein Scleroderma wenigstens um ebenso viel wie dieses Corditubera, indem die Peridie in zwei Schichten, in eine zarte, brüchige innere und eine fleischige oder zähe äußere differenziert ist, von denen letztere bei der Reife sternförmig-lappig aufreißt; so bildet Sclerangium den Uebergang zu Astraeus und verbindet so die Sclerodermatacecie mit den

\section{Calostomataceae.}

Die Familie ist durch die mehrschichtige Peridie, sowie durch den Besitz eines wohlausgebildeten netzförmigen Capillitiums, welches mit der innersten Peridienschicht in direkter Verbindung steht, charakterisiert.

Die Familie besteht aus 2 Genera, aus Calostoma und Astracus. 
Das Genus

\section{Astraeus}

wurde von Morgan aufgestellt, für die bis damals Geaster hygrometricus genannte Art, die aber von Geaster hauptsächlich durch das Fehlen von mit Hymenium bekleideten Kammern und durch den Bau der äußeren Peridie abweicht.

Die Peridie ist doppelt, das Exoperidium besteht aus mehreren Schichten, nämlich aus einer äußeren, von dünnen, regellos verflochtenen Hyphen. aus einer mittleren, von korkiger Konsistenz, von ebenfalls regellos verflochtenen Hyphen und aus einer innersten hornigen, von vorwiegend radial angeordneten Hyphen gebildet. Letztere nennt man die Kollenchymschicht. Das Endoperidium ist dünn, häutig oder papierartig.

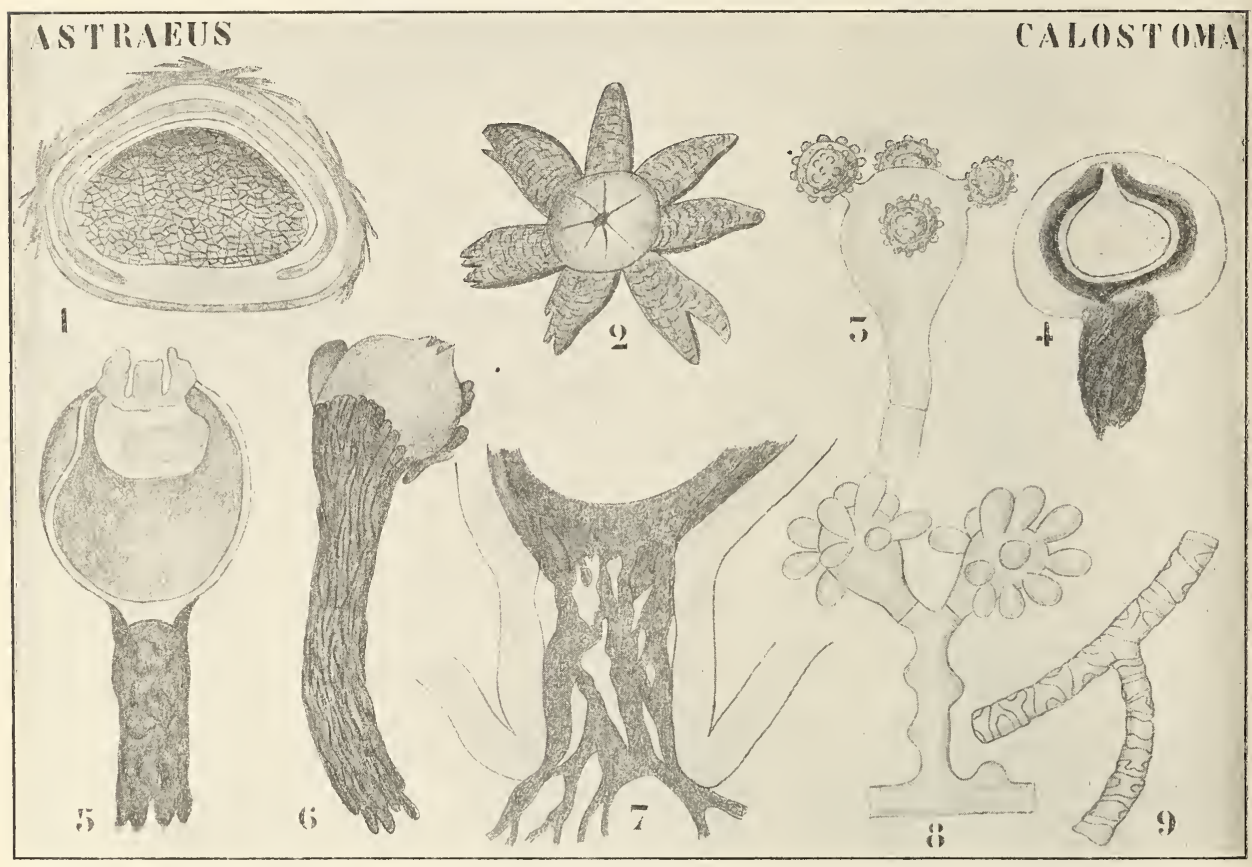

Fig. 408. Calostomataceae. I. Astraeus stellatus (Scop.) Morgan (nach DE BARY, Fischer und TulasNE). 1 Längsschnitt durch einen jüngeren Fruchtkörper. 2 Offener Fruchtkörper. 3 Basidie. - II. Calostom a 1 u tescens (SCHW.) MAss. 4 Längsschnitt durch einen jüngeren Fruchtkörper. 5 Idem durch einen reifen Fruchtkörper. 6 Habitus des Fruchtkörpers in reifem Zustande mit langem Fuß; die äußerste Peridiumschicht ist verschwunden. III. C. cinn abarinum (DEsv.) MASs. 7 Schematische Darstellung des Ansatzes des Fußes. 8 Basidien. 9 Capillitium (nach Burnap und FIscher).

Bei der Reife reißt die äußere Peridie sternförmig auf und es tritt der anfänglich unterirdische, ringsum vom Mycel bekleidete Fruchtkörper über die Erde. Bis jetzt ist nur eine Art, der hier abgebildete Astraeus stellatus (ScOpoli) Morgan, bekaunt. Weitere Untersuchungen werden ergeben müssen, ob vielleicht noch mehr von den bis jetzt zu Geaster gestellten Arten hierher gehören. 


\section{Calostoma}

Der Fruchtkörper von Calostoma (Fig. 408) unterscheidet sich bei der Reife sofor't ron dem eines Astraeus durch den Besitz eines stielartigen Fußes.

Der junge Fruchtkörper ist rundlich und besitzt eine mehrschichtige Peridie. Die äußere, dickste Schicht ist weich und weiß und zerreißt bei der Fruchtreife unregelmäßig; sie ist von der folgenden Schicht durch eine Lage von meist rotgefärbtem Geflecht getrennt. Die folgende hohlkugelige Schicht ist knorpelig, gelb, braun oder grünlich gefärbt und am Scheitel mit einer vorgebildeten, oft rotumsäumten, sternförmigen Mündung versehen. Tom Scheitel derselben hängt bei der Reife die innerste Peridienschicht als ein dünnwandiger Sack frei herunter (Fig. 408, 5), im unreifen Fruchtkörper ist sie von der Knorpelschicht mittels einer später verschwindenden Schicht getrennt. Aus der Basis der knorpeligen Schicht wächst während des Heranreifens des Fruchtkörpers ein stielartiger oder wurzelartiger Fuß herunter, der meist aus zahlreichen, unregelmäßig verbogenen, knorpeligen Strängen besteht und die äußere Schicht durchbricht (Fig. 408, 7). 'Die Gleba ist ungekammert, durch schwache, sterile Geflechtstränge in undeutliche Partien gesondert. Die Basidien sind recht unregelmäßig, die Zahl der Sporen von 5-12 wechselnd. Die in Fig. 408 abgebildete $C$. lutescens (ScHweinitz) Mass stammt aus Nordund Südamerika; unter den 12 bekannten Arten gibt es keine europäischen.

Als ein Seitenzweig der Sclerodermataceae, der sich an Scleroderma anschließt. darf die monotypische Familie der

\section{Pisolithaceen}

betrachtet werden mit dem etwa 18 Arten enthaltenden Genus Pisolithus, welches sich von den Sclerodermataceen dadurch unterscheidet, daß die Gleba in Peridiolen auseinanderfällt.

\section{Pisolithus arenarius AıB. et Schw.}

ist ein Pilz, der auf sandigem Boden in Europa, Australien und Neuseeland vorkommt, ebenso wie $P$. crassipes (D́C.) ScHröter. Der Fruchtkörper hat ganz das Aeußere eines Scleroderma und ist davon auch nur dadurch verschieden, daß sich beim Heranreifen des Fruchtkörpers infolge von Spaltung und Desorganisation der sterilen Adern die einzelnen basidien- resp. sporenführenden Partien als Peridiolen voneinander trennen. Nach Fischer dürften bei den Gattungen Scoleciocarpus BERKElEy (aus Südafrika und Chile), Favillea Fr. (aus Neu-Holland), Polygaster Fr. (aus Ostasien), Aruchnion Schweinitz (aus Amerika und Australien) und Ciliocrrpus Corda (unterirdisch auf Orchideenknollen in Böhmen) ähnliche Verhältnisse vorliegen, sie sind aber sämtlich noch zu ungenügend bekannt. Sollte sich Fischers Vermutung als richtig herausstellen, so wären sie mit Pisolithus in die Familie der Pisolithaceen zu stellen. Fig. $409 \mathrm{mag}$ das über Pisolithus Gesagte illustrieren.

Es bleiben also von den Plectobasidiinene nur noch die beiden Gruppen der Tulostomaceen und der Sphaeroboleen, deren Zugehörigkeit hier zweifelhaft ist, zu besprechen.

Die

\section{Tulostomataceen ${ }^{1}$ ).}

Die Tulostomataceen sind, wie schon früher erörtert, charakterisiert durch die eigentümliche laterale Insertion der Sporen an den Basidien,

1) In seinen „Tylostomeae“, Cincinnati, Febr. 1906, fügt C. G. Lıovo noch die Genera 
wie dies die Fig. 410, う von Tulostoma mammosum zeigt. Ursprünglich unterirdisch, werden sie durch Streckung einer basalen Gewebspartie alsbald über den Boden emporgehoben. Es sind 6 Genera: Tulostoma, Queletin, Battarrea und Sphaericeps bekannt, von welchen letzterer jedoch mit Battarrea zu vereinigen sein dürfte, so daß ich nur die 3 ersteren mit Ihnen besprechen will, wobei bemerkt werden muß, daß die Zugehörigkeit der Genera Queletia und Buttarea zweifelhaft bleibt, solange ihr Glebabau nicht genauer bekannt ist.

W Werfen wir jedoch einen Blick auf untenstehende Figuren, so sehen wir, daß bei allen die Gleba von der inneren Peridie umgeben emporgehoben wird, was gewiß für eine Verwandtschaft spricht.

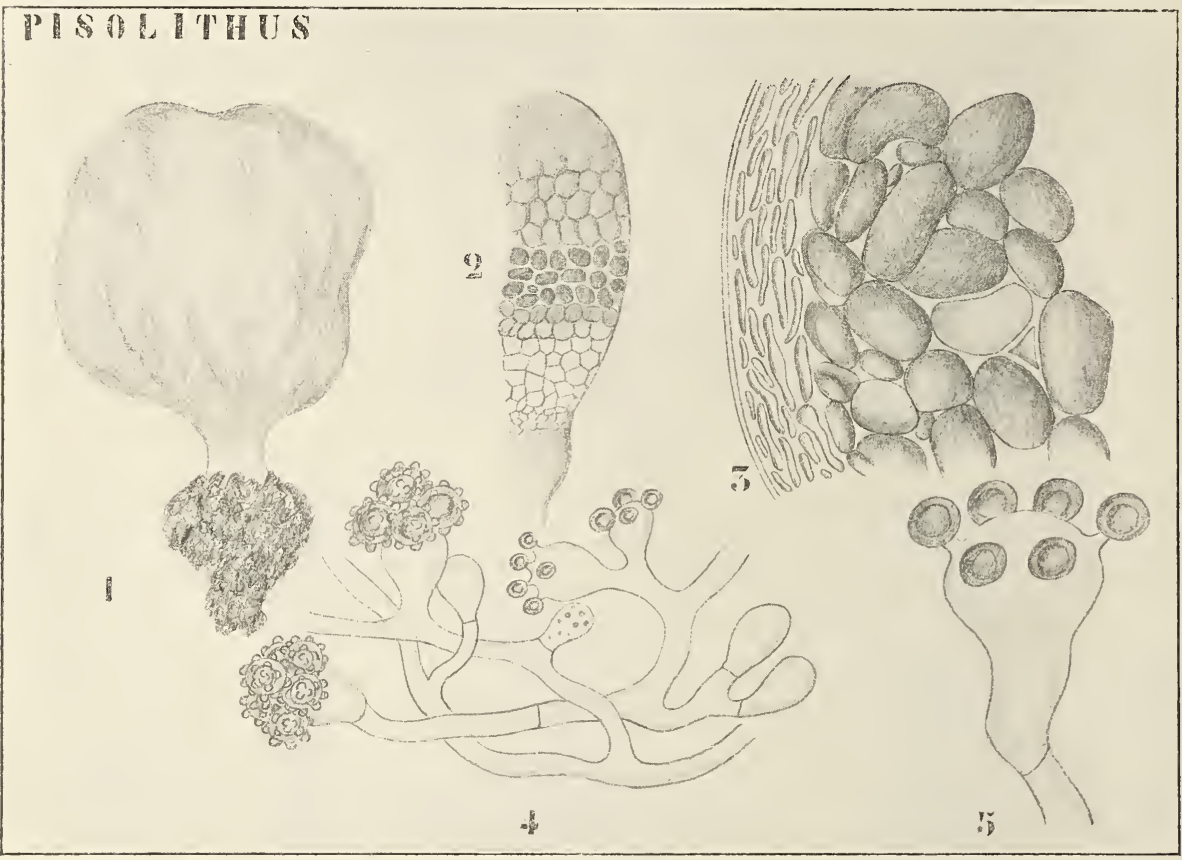

Fig. 409. Pisolithaceae. Pisolithus (nach Fischer, Vittadini und Tulasne). I. P. a renarius ALB. et SCHw. 1 Habitus. 2 Stück aus einem Längsschnitt, die Peridiolen zeigend. - II. P. erassipes (DC.) Schröt. 3 Stück eines Schnittes, die Struktur der Peridie und die Peridiolen zeigend. 4, 5 Basidien.

Die Figuren machen die hier vorliegenden Verhältnisse wohl so klar, daß nur weniges hinzugefügt zu werden braucht.

\section{Tulostoma Persoon}

bildet seine anfänglich unterirdischen Fruchtkörper aus einer sclerotiumartigen Anschwellung des Mycels. Die Peridie besteht aus einer rindenartigen, später zerfallenden Außenschicht und einer häutigen mehr oder weniger derben Innenschicht, letztere wird bei der Reife vom sich streckenden Stiele emporgehoben und öffnet sich durch einen scheitel-

Schizostoma, auf Tulostoma laceratum basiert, und Chlamydopus sowie Dictyocephalos hinzu. Letztere gehören, wie der Autor selber zugibt, höchstwahrscheinlich gar nicht hierher. Ihre Basidienstruktur ist nach PATOUILLARD eine ganz andere. 
ständigen Porus. Die Basidien liegen gleichmäßig in der Gleba zerstreut und tragen die Sporen lateral. Capillitiumfasern sind reichlich vorhanden.

Ton den etwa 40 bekannten Arten ist Tulostoma mammosum (MICHELI) PERs. mit seinem 2-3 (selten bis 10) $\mathrm{cm}$ langen Stiele in den Dünen um Leiden herum häufig. Da aber die Basidien nur in sehr jungen Fruchtanlagen noch existieren, später ganz zerstört werden, ist es noch nicht gelungen, die sehr erwünschte Cytologie dieser Gebilde festzustellen.

\section{Queletia Fr.}

unterscheidet sich von Tulostoma dadurch, daß die innere Peridie sich nicht mit einem scheitelständigen Porus öffnet, sondern unregelmäßig

\section{TULOSTOMA}

BAT'TARIIA

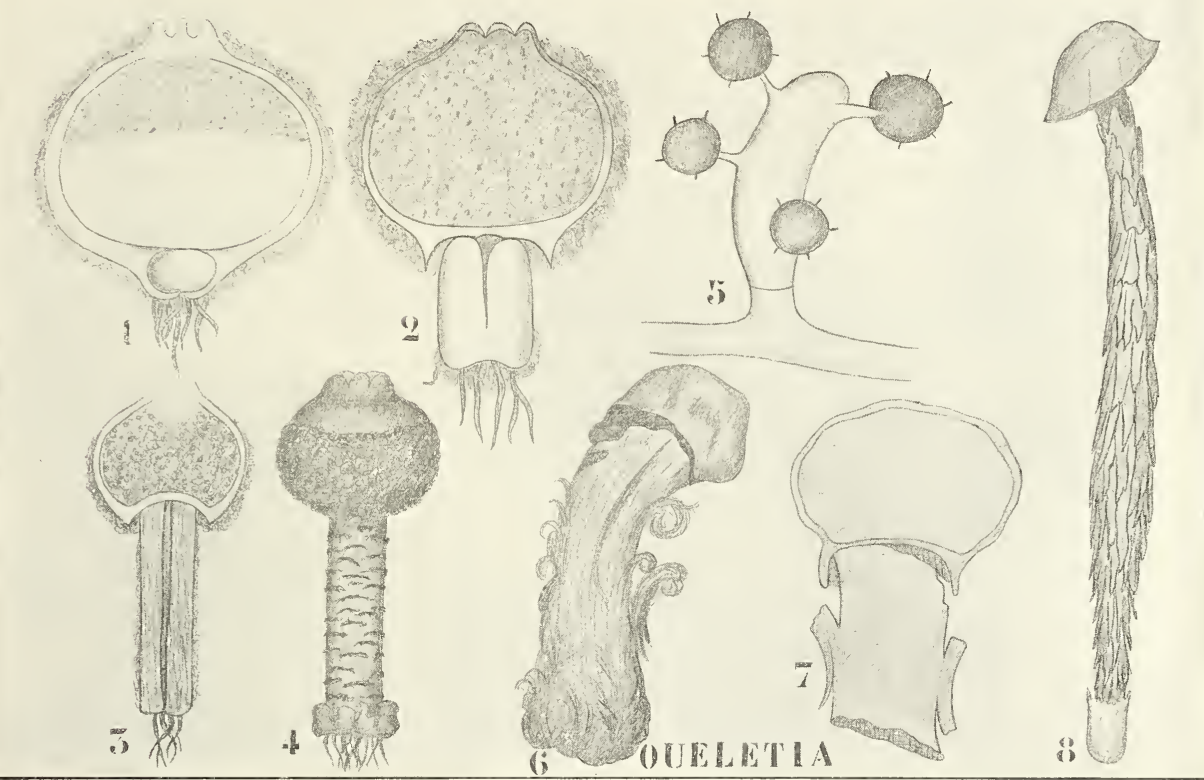

Fig. 410. Tulostomataceae. I. Tulostoma mammosum (Micheli) Pers. (nach VITTADINI und SCHRÖTER). 1 Fruchtkörper im Längsschnitt vor der Stielstreckung. 2 Während der Stielstreckung. 3 Nach der Stielstreckung. 4 Habitus des reifen Fruchtkörpers. 5 Basidien. - II. Queletia mirabilis Fr. (nach FrIEs). 6 Habitus. 7 Längsschnitt der Peridie und des oberen Teiles des Stieles. - III. Battarrea Tepperiana LUDW. 8 Reifer Fruchtkörper nach der Stielstreckung, auch hat sich die obere Hälfte von der inneren Peridie bereits abgelöst, und nur noch die untere ist übrig geblieben (nach r. TAVEI).

zerfällt. Auch hier ist der Fruchtkörper anfangs unterirdisch und die Peridie wird vom sich streckenden Stiel emporgehoben. Die Peridie ist einfach, häutig und am Grunde mit einem ringförmigen Torsprunge rersehen.

Die einzige, unvollständig bekannte Art, ?. mirabilis Fries (Fig. 410. II, wurde in Frankreich gefunden.

\section{Battarrea Pers.}

besitzt ebenfalls ursprünglich unterirdische, knollenförmige Fruchtkörper. deren innere Peridie vom sich streckenden Stiele emporgehoben wird. 
Dabei zerreißt die äußere Peridie, deren untere Hälfte wie eine Vagina um die Stielbasis stehen bleibt, während ihr oberer Teil noch einige Zeit in Form von Fetzen an der inneren Peridie hängen bleibt. Zuletzt löst sich die obere Hälfte der inneren Peridie durch einen horizontalen Riß längs des Randes ab, und die untere Hälfte derselben bleibt nach Ausstreuung der Sporenmasse als hutförmige Haut am Ende des Stieles zurück. Auf diesem Stadium befand sich das in Fig. 410, 8 reproduzierte Exemplar von B. Tepperiana LUDw., als es abgebildet wurde. Die Art stammt aus Australien.

Die letzte zweifelhafte Plectobasidiineen-Familie ist die der

\section{Sphaerobolaceae.}

Die Familie ist durch den Besitz oberirdischer Fruchtkörper mit mehrschichtiger Peridie und einen eigentümlichen Glebabau charak-

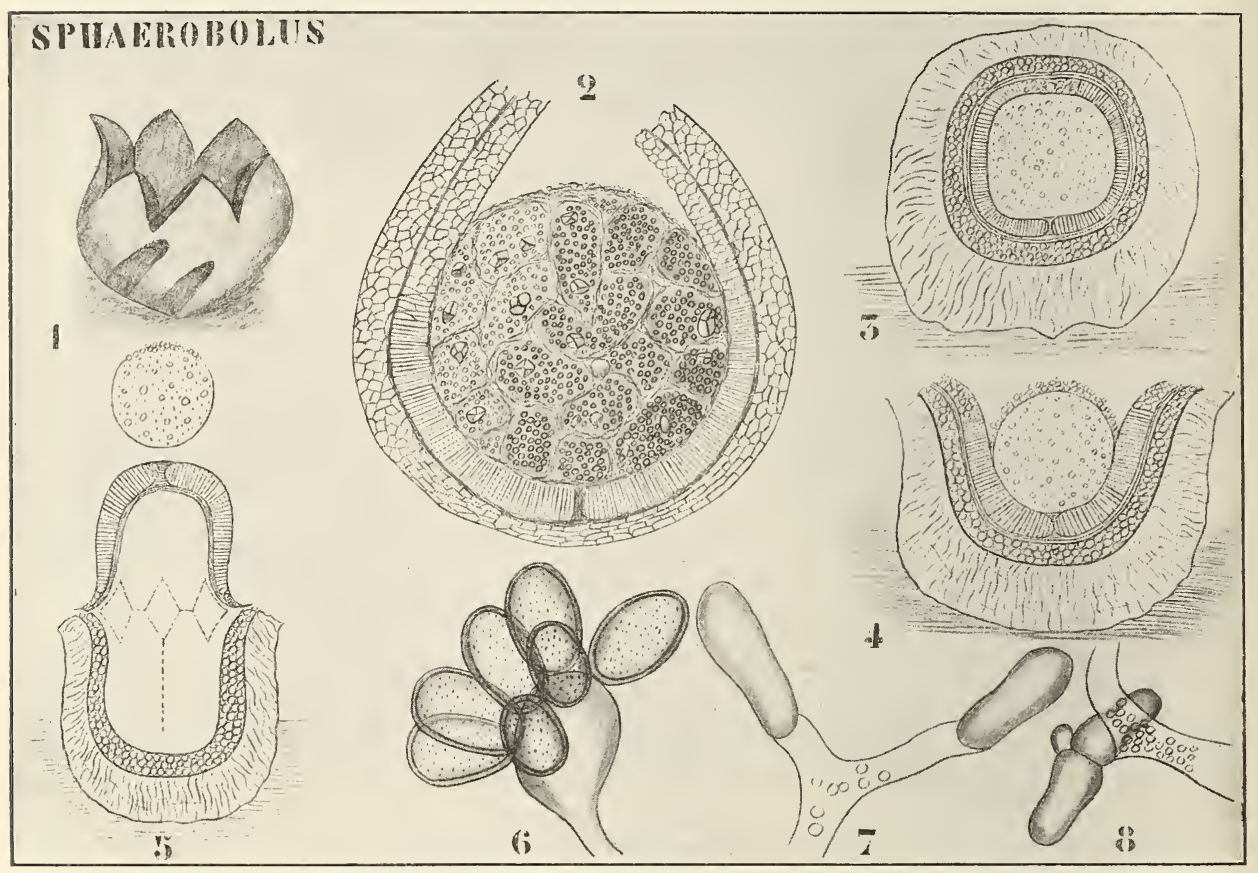

Fig. 411. Sphaeroboleae. Sphaerobolus Carpobolus L. 1 Sich öffnender Fruchtkörper. 2 Längsschnitt durch einen Fruchtkörper, der im Begriff steht, sich zu öffnen; die äußere gallertige Peridienschicht nicht gezeichnet. $3-5$ Schematische Längsschnittbilder zur Erläuterung des Vorganges beim Oeffnen des Fruchtkörpers und dem Herausschleudern der Gleba. 6 Basidie. 7, 8 Gemmenbildung.

terisiert, es besteht nämlich die äußere Schicht der Gleba aus palisadenförmig radial gestellten, turgescenten Zellen, dem sogenannten Receptaculum. Bei der Reife wird die Gleba schleimig und als Ganzes hinausgeworfen.

$\mathrm{Zu}$ der Familie gehört nur ein Genus,

Sphaerobolus Tode

mit 5 Arten, von denen aber nur 


\section{S. carpobolus L.}

genauer bekannt ist. Der Fruchtkörper (Fig. 411, 1) ist in der Jugend kugelig, mißt $1^{1} /_{2}-2 \mathrm{~mm}$, ist außen weiß, an der Innenseite der sternförmigen Lappen sowie im oberen Teile der Gleba orangegelb. Das Pilzchen ist in der Nähe von Lisse, bei Leiden, auf faulendem Holze nicht selten.

Die Peridie besteht aus einer äußeren dicken Gallertschicht, einer mittleren Pseudoparenchymschicht und einer inneren Faserschicht. Die Gleba besteht aus dem schon erwähnten Receptaculum und dem basidienführenden Gewebe. Neben Basidien enthält die Gleba noch Gemmen, welche direkt zu neuen Mycelien auswachsen können.

Bei der Reife wird die Gleba schleimig und läßt sich leicht vom Receptaculum trennen; Peridie und Receptaculum reißen am Scheitel sternförmig auf, wodurch die kugelige Gleba oben frei wird. Darauf trennt sich die innere Faserschicht der Peridie von der Pseudoparenchymschicht und wird mit dem Receptaculum, mit welchem sie fest verbunden bleibt, gewaltsam und rasch nach außen umgestülpt (Fig. 411, 5), wobei die Gleba fortgeschossen wird. Die Gleba keimt als Ganzes, wohl hauptsächlich durch die in ihr vorhandenen Gemmen.

Das Receptaculum ist wohl dem Receptaculum der Phalloideen vergleichbar; auch erinnert das Schleimigwerden der Gleba an diese Gruppe, so daß man vielleicht Sphaerobolus als eine bei den Plectobasidiineae vorhandene Parallelreihe zu den Phalloideae, unter den Gasteromycetineae betrachten darf.

Daß in beiden Gruppen mehrere solche Parallelreihen vorkommen, werden wir alsbald sehen.

\section{Gasteromycetineae.}

Unter diesen, sagt Fischer, werden wir auf den ersten Blick als sehr natürliche Gruppen festhalten die Nidulariaceen, die Lycoperdaceen und Phalloideen, welch letztere aber ihrerseits in zwei völlig getrennte Reihen, die Clathraceen und Phallaceen zerlegt werden müssen.

Prüfen wir diese Gruppen auf ihren Anschluß nach unten, so werden wir überall auf Formen treffen, die man bisher als Hymenogastraceen vereinigte. Daraus geht hervor, daß die letzteren nicht eine eimheitliche Gruppe darstellen, sondern vielmehr die Ausgangspunkte mehrerer Reihen in sich vereinigen.

Diese Reihen sind nun nach Fischer:

1) die Reihe der Secotiaceen-Phallaceen;

2) die Reihe der Hysterangiaceen-Clathraceen;

3) die Reihe der Hymenogastraceen s. str.-Lycoperdaceen;

4) als Seitenlinie der letzteren die Nidulariaceen.

Da haben wir nun die schönsten Parallelreihen zu den Formen, welche wir bei den Plectobasidii haben kennen gelernt, indem die $H_{y-}$ menogastraceen s. str.-Lycoperdaceen, den Sclerodermataceen-Calostomataceen und die Nidulariceen mit ihren Peridiolen den Pisolithaceen parallel verlaufen.

Die beiden ersten Reihen haben wenigstens bei den Plectobasidineae eine Andeutung in den Tulostomataceen und Sphacrobolaceen.

Der Parallelismus wird vou Fischer in folgender Treise recht hübsch dem Gedanken eingeprägt. 


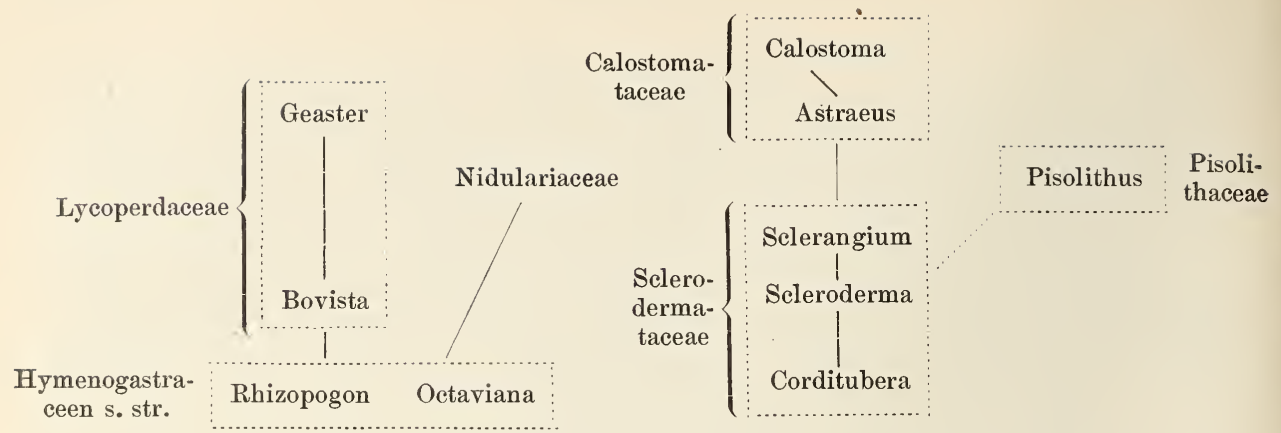

Für die ganze Gruppe der Gasteromycetineae bekommen wir also folgende Anordnung:

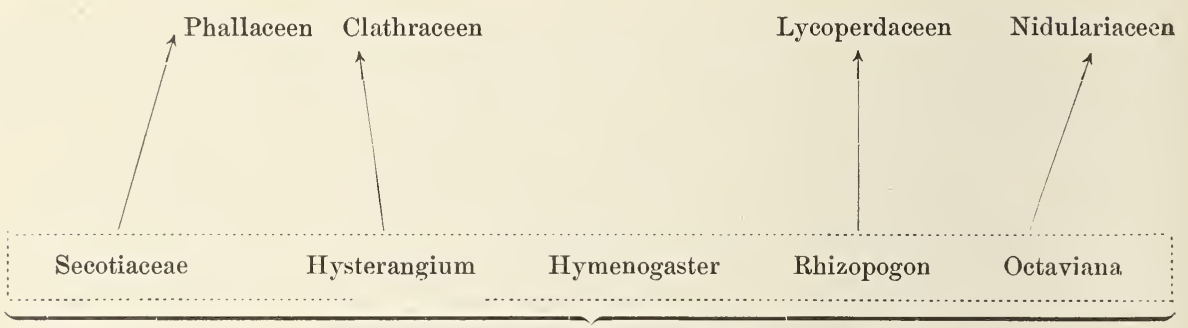

Die frühere Gruppe der Hymenogastrineae

Betrachten wir also zunächst die

\section{Lycoperdaceen-R eihe.}

Deren Ursprung liegt nach Fischer bei

\section{Rhizopogon Fries ${ }^{1}$ ).}

Diese Gattung besteht aus unterirdischen trüffelähnlichen Arten. Die Fruchtkörper sind knollenförmig, mit häutigen oder fast lederartigen Peridien, welche schwer oder gar nicht von der Gleba zu trennen sind. Die Gleba ist selbstverständlich gekammert; die Kammern sind klein, unregelmäßig und sehr dicht stehend, mit dem Hymenium ausgekleidet; die Basidien tragen 2-8 glatte Sporen.

Die Entstehung der Gleba erfolgt in der Weise, daß im Innern der jungen Fruchtkörperanlage eine Differenzierung in dichtere und lockerere Partien stattfindet. Die dichteren Partien werden zu unregelmäßigen Knäueln, deren Oberfläche mit einem Hymenium bekleidet wird (Fig. 412, 3). Diese Knäuel bilden dann Wülste, anastomosieren untereinander und bilden so schließlich die Kammerwände.

Von diesem Pilz leitet nun Fischer die Lycoperdaceen ab, was sehr leicht möglich ist, da die Lycoperdaceen sich wesentlich nur durch die höhere Differenzierung der Peridie und die Ausbildung eines Capillitiums von Rhinopogon unterscheiden.

Unter den Lycoperdaceen gibt es nun eine Anzahl von Genera mit einschichtiger, unregelmäßig bei der Reife zerfallender, äußerer Peridie,

1) Die Art rubescens ist in den Niederlanden in Nadelwäldern unweit Weert häufig。 
nämlich Lycoperdon, Globaria, Catastoma, Bovistella, Borista und Mycenastrum, und ein Genus, bei welchem die äußere Peridie zweischichtig ist und bei der Reife sternförmig aufreißt, nämlich Geaster.

Es seien hier Lycoperdon und Bovista der ersteren Reihe und Geaster kurz besprochen.

Das Genus

\section{Lycoperdon}

umfaßt nach Fischers Schätzung etwa 100 Arten. Die Fruchtkörper sind über der Erde, rundlich, nach unten in einen stielförmigen Teil zusammengezogen. Die Peridie ist in Endo- und Exoperidium differenziert, letzteres ist einschichtig, anfang's fleischig, zerbröckelt aber bei der Reife.

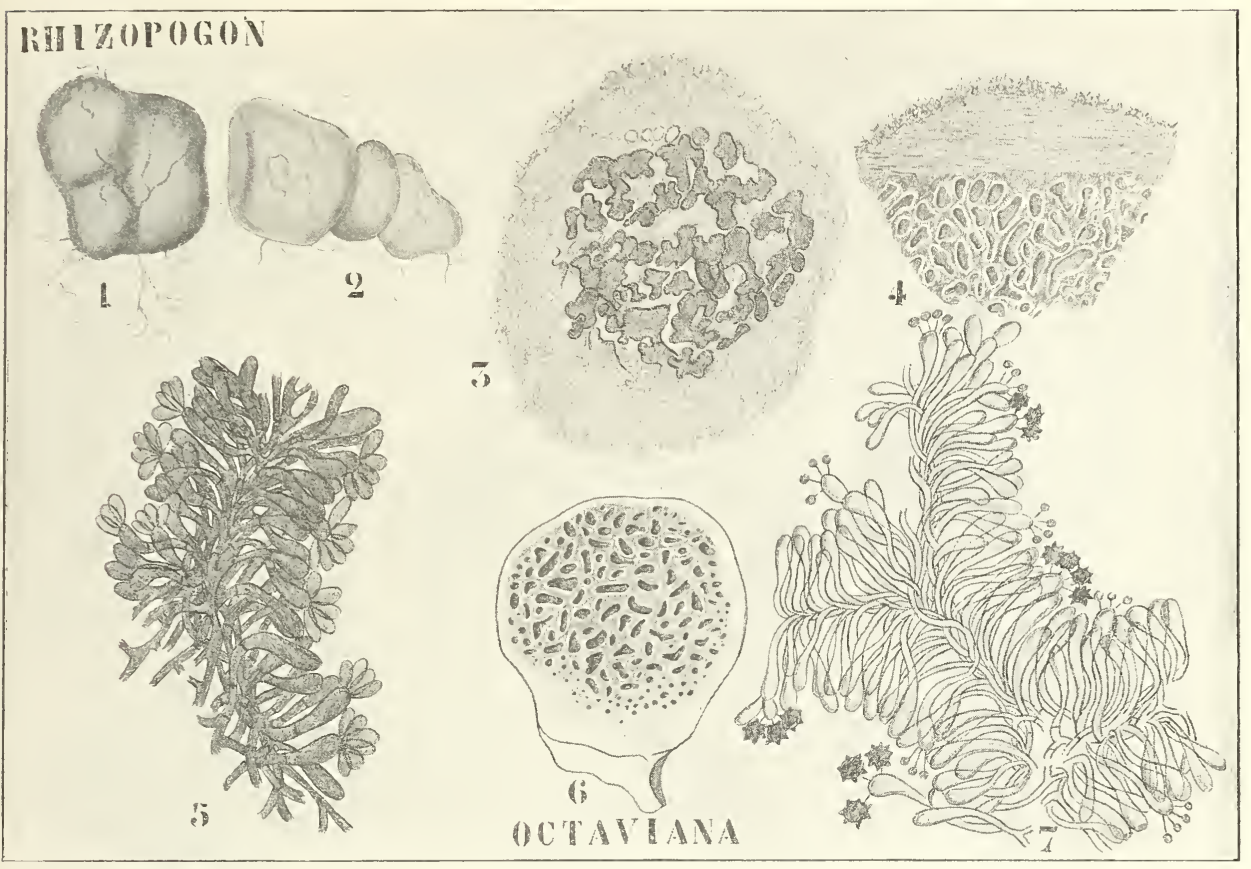

Fig. 412. I. Rhizopogon. 1, 2 Habitus. 3 Medianer Längsschnitt durch einen jungen Fruchtkörper. 4 Stück aus der Peripherie eines reifen Fruchtkörpers. 5 Hymenium. (1, 2, 4, 5 von Rh. luteolus Fr. [nach Tulasne], 3 von Rh. rubescens Tul. [nach Rehsteiner]). - II. Octaviana asterosperma VitTad. 6 Längsschnitt durch den Fruchtkörper. 7 Hymenium (nach Tulasne).

Die Gleba besitzt zahlreiche kleine Kammern, welche im oberen Teil mit Hymenien bekleidet, also fertil, im unteren aber steril sind (Fig. 413, 2), so daß die Gleba in dem hier abgebildeten Fall in einen fertilen, kugeligen und einen sterilen, den stielbildenden Teil, differenziert ist. Ein Capillitium ist vorhanden und steht mit der inneren Peridie in Verbindung.

Der hier abgebildete $I$. gemmatum BAтscH hat einen birnförmig gestielten Fruchtkörper, die äußere Peridie ist anfangs weiß, mit mehr oder weniger regelmäßig gestellten Warzen oder Stacheln, die sterile Glebapartie ragt etwas, kurz-collumellartig, in die fertile hervor; der Pilz ist über ganz Europa, sowie über einen großen 'Teil der außereuropäischen Welt verbreitet. Die Bildung der Glebakammern beginnt 
in der zentralen Partie der Fruchtkörperanlage durch Entstehung von Lücken im anfänglich homogenen Geflecht. Von da schreitet die Ausbildung der Gleba zentrifugal fort, bei Lycoperdon dauert die Bildung der Kammern längere Zeit an, weil da im oberen Teil des Fruchtkörpers eine kappenförmige Bildungszone nach innen successive neue Glebateile abgibt (Fig. 413, 3).

\section{Bovista}

ist in mancher Hinsicht einfacher gebaut als Lycoperdon, zwar ist die Peridienstruktur beider Gattungen durchaus ähnlich, aber Bovista hat keine Differenzierung der Gleba in einen sterilen und einen fertilen Teil aufzuweisen. sondern ist ganz fertil; dagegen ist das Capillitium besser ausgebildet.

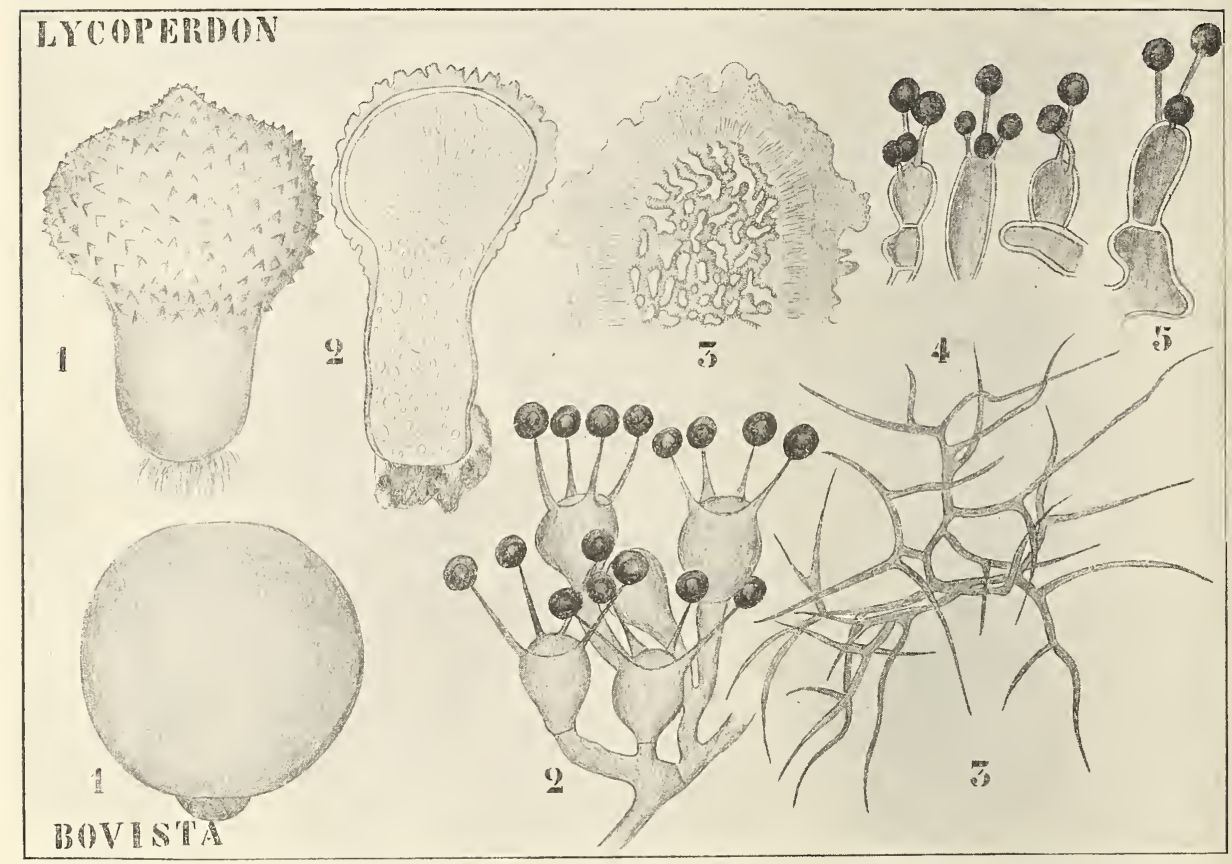

Fig. 413. Ly coperdaceae. I. Ly coperdon gem mat um BATsch (nach FischeR und ReHsteINeR). 1 Habitus. 2 Längsschnitt, die Differenzierung der Gleba in einen fertilen, oberen, kugeligen und einen sterilen, stielförmigen Teil zeigend. 3 Längsschnitt durch einen jungen Fruchtkörper, die kappenförmige Bildungszone zeigend. 4, 5 Basidien. - II. B o vis ta njgrescens Pers. (nach Fischer und Tulasne). 1 Habitus. 2 Basidien. 3 Capillitium.

Die hier abgebildete $B$. nigrescens Pers. ist in Europa, Asien und Nordamerika häufig.

Bovista steht also etwa in einer Höhe mit Scleroderma unter den Plectobasidiineae, während hingegen

\section{Geaster}

auf derselben Entwickelungsstufe wie Astraeus unter den Plectobasidii steht, welcher, wie wir schon sahen, denn auch früher für einen Geaster gehalten wurde. 
Man leitet das Genus wohl am besten von Lycoperdon ab, da auch hier die Gleba in einen fertilen und einen sterilen Teil differenziert ist, von welchen letzterer als Columella viel weiter in den fertilen Teil hineimragt (Fig. 414, I 1) als bei Lycoperdon. Sowohl der fertile, wie der sterile Teil sind auch hier wie bei Lycoperdon gekammert, aber später wird die Columella ungekammert. Auffallend ist die öfters deutlich radiale regelmäßig'e Anordnung der Kammern bei diesen Pilzen.

Die Peridie besteht auch hier aus einer Endo- und Exoperidie, letztere ist aber überdies noch in eine inmere pseudoparenchymatische und eine äußere Faserschicht differenziert. Die äußere Peridie reißt schließlich an der Spitze, die pseudoparenchymatische Schicht löst sich von der inneren Peridie los und spaltet sich dabei in sternförmige Lappen, welche durch Zerreißen der pseudoparenchymatischen Schicht

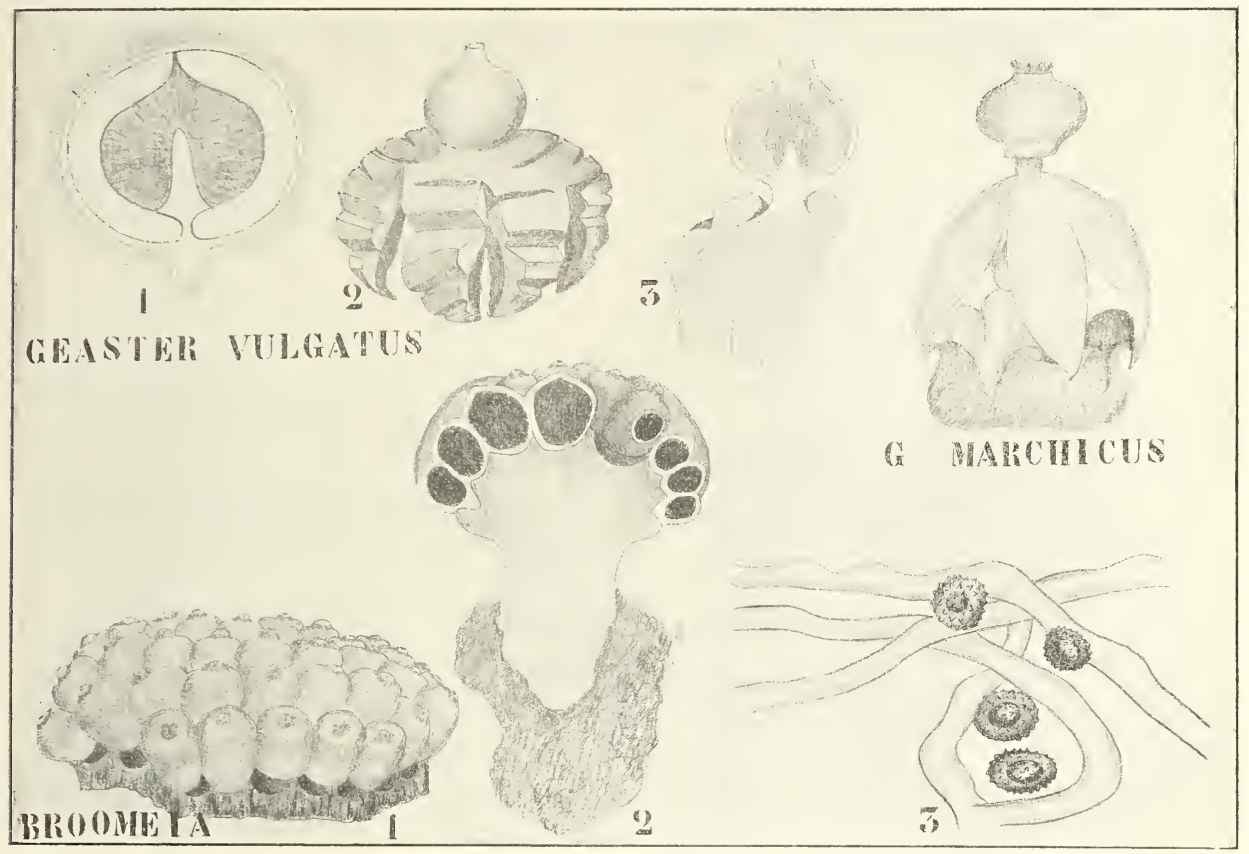

Fig. 414. I. Geaster vulgatus ViтT. 1 Junger Fruchtkörper im Längsschnitt. Außen die Faserschicht, dann die breite weiße Pseudoparenchymschicht, der die sehr dünne Endoperidie folgt, welche die in einen fertilen Kammerteil und eine Columella differenzierte Gleba umschließt. 2 Der Fruchtkörper nach dem Zurückschlagen ảer Exoperidiumlappen; die kugelige Endoperidie liegt in der Mitte; die Pseudoparenchymschicht der Exoperidie gekammert. 3 Längsschnitt, die Anheftung der Endoperidie zeigend. - II. Geaster m a rehicus Hennings. Geöffnetes Exemplar, die myceliale Hülle im Boden als becherförmigen Untersatz zurücklassend. - III. Broomeia congregat a BERK. et CuRT. 1 Stück eines Stromas mit Fruchtkörpern. 2 Längsschnitt durch ein gestieltes Stroma. 3 Capillitium und Sporen.

gekerbt aussehen können (Fig. 414, 2). Das ist z. B. der Fall bei dem hier abgebildeten Geaster vulgatus VıтT.; wie man sieht, steht die innere Peridie mit einem Stielchen mit der äußeren in Verbindung, daher wird sie nicht wie bei Sphaerobolus weggeschossen.

Die Fruchtkörper sind in der Jugend meistens !nuterirdisch; sind sie dabei, wie bei dem abgebildeten G. marchicus Hénvings, in einer 
Myceliumhülle eingeschlossen, so bleibt diese, nachdem sich die Exoperidiumlappen zurückgeschlagen haben, als becherförmiger Untersatz im Boden zurück (Fig. 414, II).

Ein höchst eigentümliches Genus, dessen Hierhergehörigkeit aber noch zweifelhaft ist, ist Broomeia, welches sich von allen anderen Genera dadurch unterscheidet, daß die Fruchtkörper nicht einzeln stehen, sondern einem gestielten oder ungestielten Stroma von korkiger Beschaffenheit èingesenkt sind. Solange aber der Bau der Gleba nicht bekannt ist, läßt sich über die Stellung nichts Sicheres aussagen; es sind zwei Arten aus Afrika und Amerika bekannt, die abgebildete (Fig. 414, III) kommt in Südafrika und in Nordamerika vor.

So wie die Pisolithaceen mit ihren Peridiolen unter den Plectobasidiieae als ein Seitenzweig der Sclerodermataceen zu betrachten sind, so sind hier die Nidulariaceen als ein Seitenzweig der Lycoperdaceen zu betrachten, ein Seitenzweig, der sich jedoch schon sehr früh gebildet hat und von Fischer von Octaviana abgeleitet wird.

\section{Octaviana}

unterscheidet sich von Rhizopogon durch die isodiametrische Form der Glebakammern und durch den Bau ihrer Kammerwände, der es möglich macht, daß diese sich leicht in zwei Lamellen spalten lassen. Uebrigens entstehen auch hier die Kammern so wie bei Rhizopogon durch lokales Auseinanderweichen des Hyphengeflechtes. Die hier abgebildete Octaviana asterosperma VITTAD. zeigt in Fig. 412, 7 diese leichte Spaltbarkeit der Kammerwände sehr deutlich, und man hat sich dieses Spalten nur stattgefunden zu denken, um den Fruchtkörper mit Peridiolen zu füllen. Unsere Art kommt in Mitteleuropa und England vor.

Diese Annäherung an eine Peridiolenbildung veranlaßt Fischer, den Anschluß der Nidulariaceen hier zu versuchen.

\section{Nidulariaceae.}

Trotzdem die Nidulariaceen im fertigen Zustande von allen übrigen Gasteromyceten stark abweichen, zeigen sie nämlich insoweit die nächsten Beziehungen zu Rhisopogon, Octaviana und den Lycoperdaceen, als die Kammern ebenfalls durch lokales Auseinanderweichen des Hyphengeflechtes entstehen.

Die Fruchtkörper der Nidulariaceen sind in der Jugend cylindrisch, kreiselförmig oder kugelig. Die Peridie ist einfach oder zwei- bis mehrschichtig und öffnet sich bei der Reife becherartig (Fig. 415, I 1).

Betrachtet man einen offenen Becher, z. B. von dem hierher gehörigen Genus Crucibulum, so sieht man auf dem Boden desselben eine Anzahl harter runder Gebilde liegen, welche, wie der Längsschnitt (Fig. 415, I 2) zeigt, durch Mycelstränge mit der Wand des Bechers in Verbindung stehen. Macht man einen Schnitt durch diese sehr harten Gebilde, so sieht man, daß sie hohl und von einem Hymenium bekleidet sind.

Es sind nämlich diese harten Gebilde die Peridiolen, und Crucibulum läßt sich mit einer Octaviana vergleichen, bei welcher die Kammern in geringer Zahl angelegt werden und sich loslösen. Wie kommt es nun, daß diese Peridiolen so lose im Becher herumliegen? Anfangs war der ganze Becher mit einem gleichmäßigen Hyphengeflecht erfüllt, in welchem jedoch bald durch Anseinanderweichen der Hyphen Höhlungen, die Kammern, entstanden. Die Hyphen, welche diese Kammern un- 
mittelbar umgaben, verflochten sich darauf äußerst dicht und verdickten ihre Wände, so daß jede Glebakammer von einer derben, knorpeligen Schicht umschlossen, zur Peridiole wurde (Fig. 415, I 3). Diese Peridiolen liegen also noch immer mitten in der Hyphemmasse, welche den Fruchtkörper erfüllt. Jetzt fängt eine allgemeine Verschleimung dieser Hyphenmasse an mit Ausnahme von strangförmigen Partien zwischen den Peridiolen und der Wand des Fruchtkörpers; die entstandene Gallerte zerfließt zuletzt und rerschwindet, so daß dann die Peridiolen als kleine linsenförmige Körperchen, mit je einem dünnen Strange an der Wand angeheftet, im hohlen Fruchtbecherchen liegen.

Bei einem anderen Genus werden vom inneren Hyphengeflechte keine strangförmigen Hyphenmassen vou der Verschleimung ausgeschlossen,

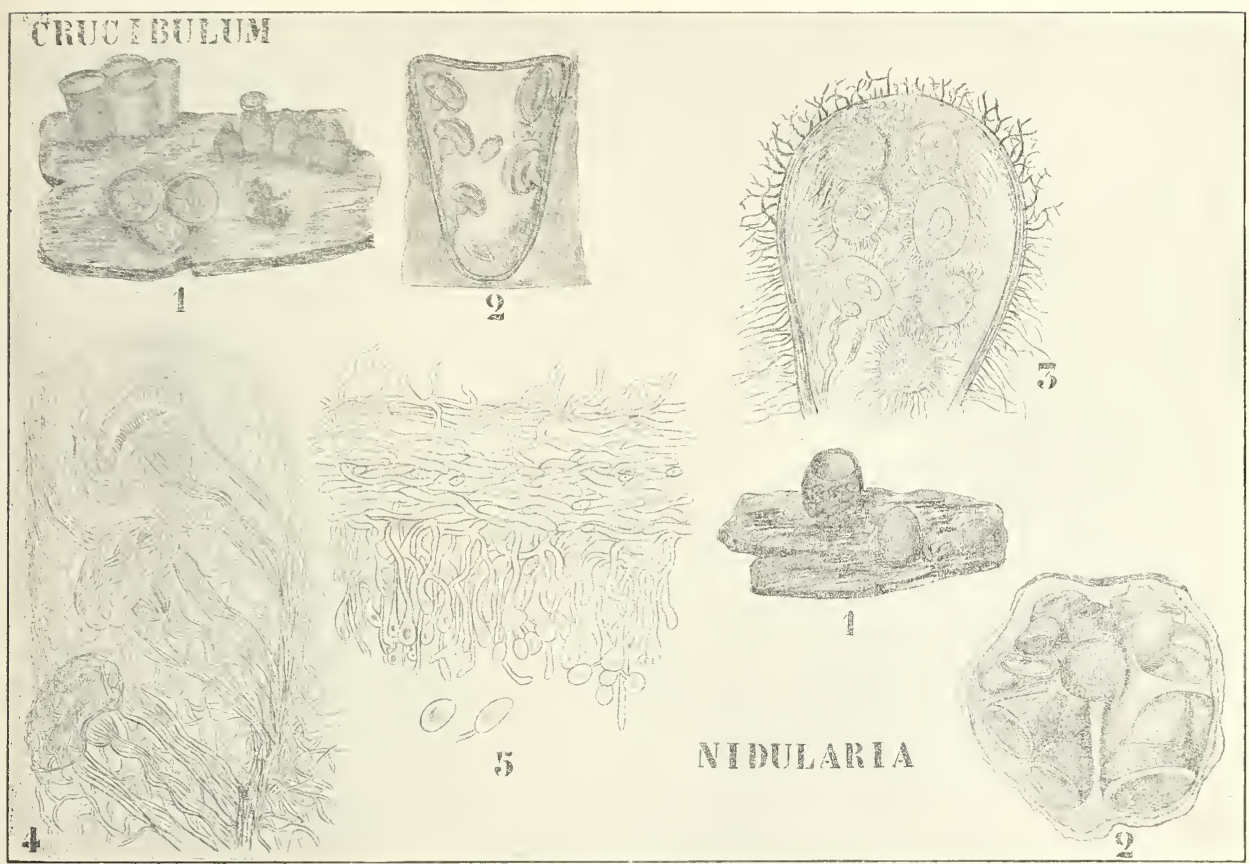

Fig. 415. Nidulariaceae. I. Crucibulum vulgare Tut. (1 nach Fiscrer, die übrigen nach SACHS). 1 Habitus junger und reifer Fruchtkörper. 2 Längsschnitt durch einen reifen Fruchtkörper, die Peridiolen mit den Nabelsträngen zeigend. 3 Die jungen Peridiolen noch im Hyphengeflecht eingeschlossen. 4 Ebenfalls, aber älteres Stadium, die Gallertbildung anfangend. 5 Stück eines Teiles einer Peridiolenwand mit Hymenium. II. Nidularia a ustralis TuL. 1 Habitus. 2 Längsschnitt durch den Fruchtkörper, die Peridiolen frei in der Höhlung liegend (nach Fischer).

so daß dort die Peridiolen schließlich ganz frei in den Fruchtbechern liegen. Das ist nämlich bei Nidularia der Fall.

Unter der früher aufgestellten Gruppe der Hymenogastrincae gibt es nun noch ein Genus, von welchem man frither wohl die Phallaceen hat ableiten wollen, welches aber besser als ein nach oben isoliertes betrachtet wird. Es ist dies

\section{IIymenogaster,}

bei welchem, wenigstens bei der hierauf näher untersuchteu Art (H.decorus), 
die Glebakammern nicht durch einfaches Auseinanderweichen des Hyphengeflechtes entstehen, sondern bei welcher die Wände derselben, die Tramaplatten, als nach unten gerichtete Wulste und Falten oben in der jungen Fruchtanlage gebildet werden (Fig. 416, II 4); diese vom Hymenium bekleideten Tramaplatten verlängern sich, bilden Anastomosen und so entstehen die Glebakammern (Fig. 416, II 5, 6).

H. decorus TUL., dessen Entwickelung hier nach REHsterner abgebildet ist, hat eine weißliche gelbfleckige Peridie und eine schwarzviolette Gleba. Er lebt unterirdisch und kommt in Mitteleuropa und England vor. $\mathrm{Ob}$ alle Hymenogaster-Arten die gleiche Entwickelung der Glebakammern aufzuweisen haben, ist fraglich und bedarf näherer Untersuchung. Der Umstand, daß diese Entwickelungsweise der Tramaplatten

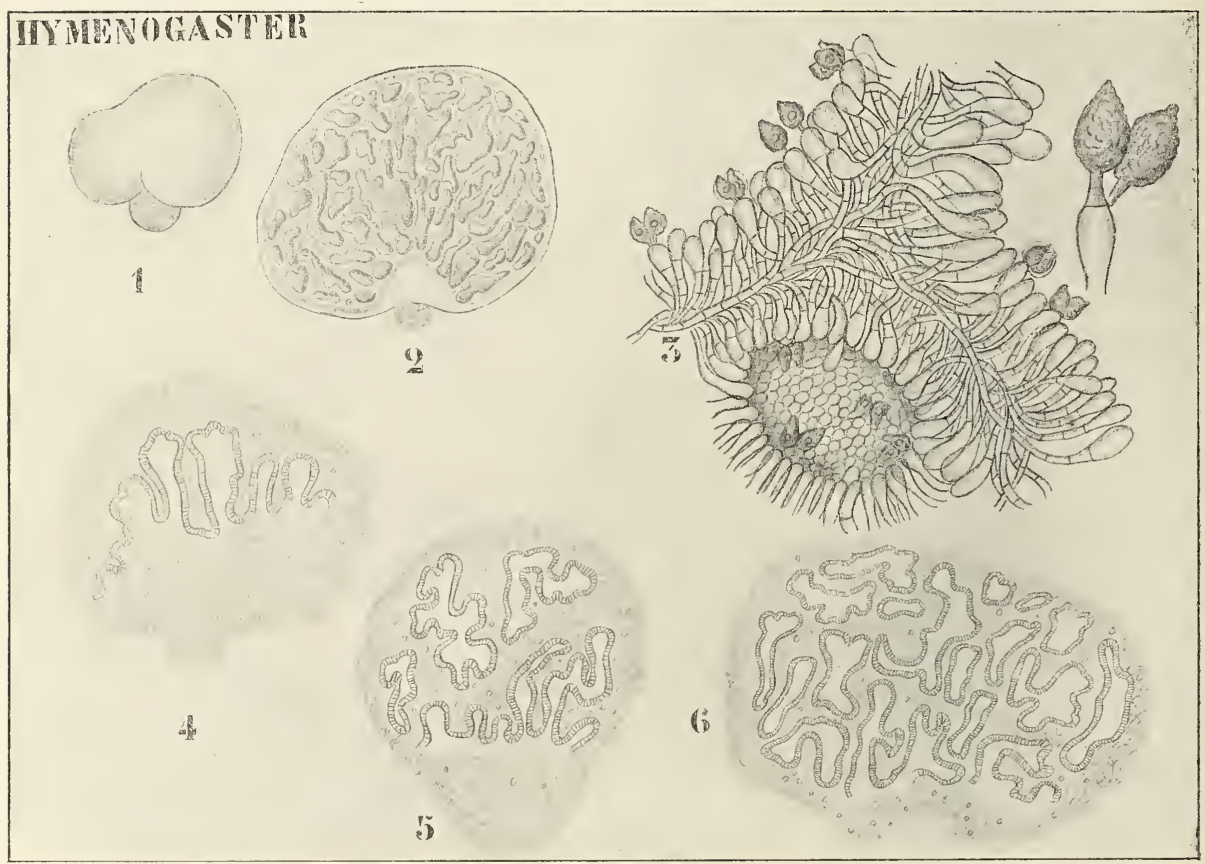

Fig. 416. Hymenogaster (nach Tulasne und Rehsteiner). I. H. ten e r Berk. 1 Habitus. 2 Längsschnitt. 3 Stück aus der Gleba, das Hymenium zeigend. - II. Entwickelung von H. decorus Tul. 4 Erste Anlage der Tramaplatten. 5, 6 Bildung der Glebakammern.

an ähnliche Vorgänge bei Phalloideen erinnert, hat dazu geführt, eine Verwandtschaft zwischen Hymenogaster und diesen zu konstruieren, welche wohl kaum richtig ist.

Es bleiben also noch die Clathraceen- und die Phallaceer-Reihe zu besprechen.

\section{Die Clathraceen-Reihe.}

Die Glieder dieser Reihe sind dadurch charakterisiert, daß bei ihnen die Tramaplatten als peripherische Vorwölbungen der Oberfläche einer axilen Geflechtspartie entstehen und in radialer Richtung zentrifugal weiter wachsen. 
Als Ursprungsform ist wohl

\section{Hysterangium}

zu betrachten. Es gibt davon 10 Arten, von welchen Hysterangium clathroides Vittadini von Rehsteiner näher untersucht wurde. Es ist dies ein unterirdisch wachsender haselnußgroßer Pilz von der Form einer Trüffel, der mit einem starken verzweigten Nycelstrange im Boden befestigt ist und eine häutige, glatte, zunächst weiße, dann bräunliche Peridie besitzt. Die reife Gleba ist bräunlich-grün bis olivenfarbig mit bläulich durchscheinenden Tramaplatten.

Die Peridie ist dümn und leicht von der Gleba zu trennen. Letztere ist mehr oder weniger zäh-elastisch und besitzt Tramaplatten ver-

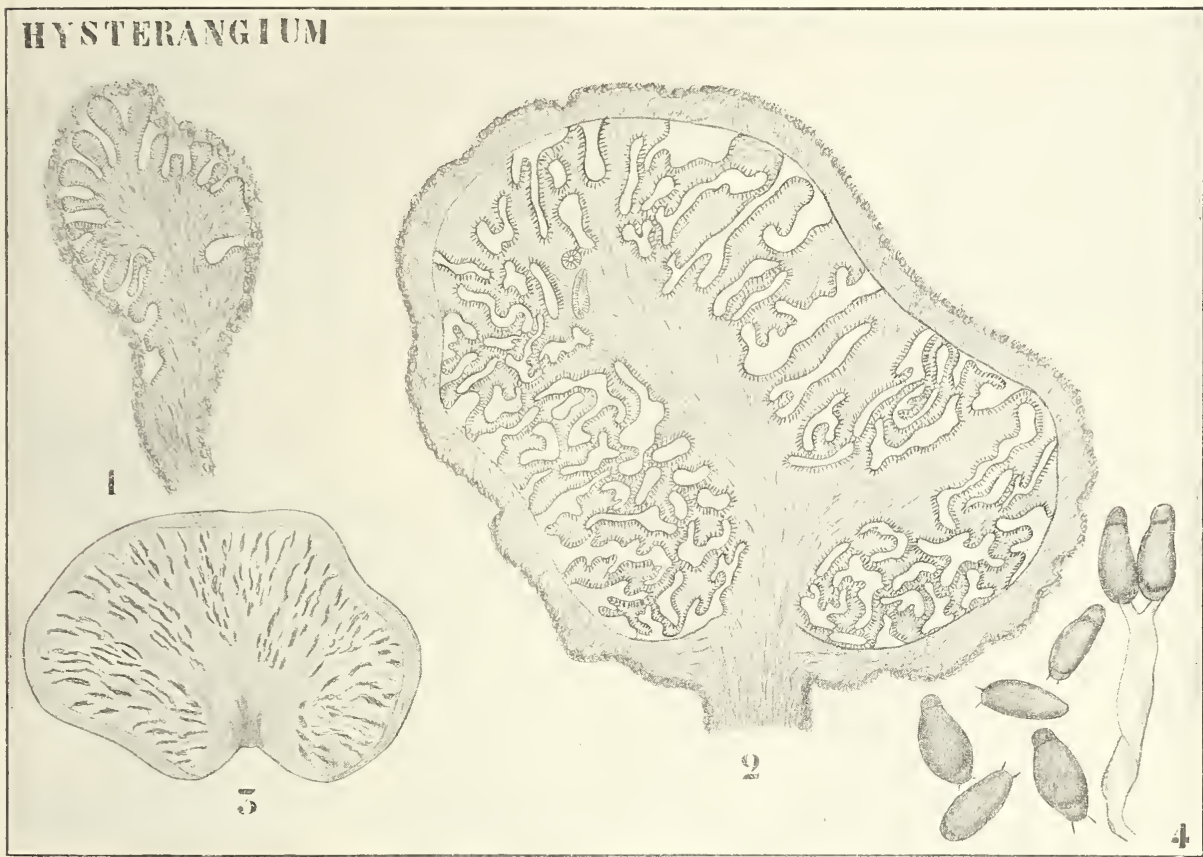

Fig. 417. Hysterangium elathroides VitT. (nach Fischer, Rehsteiner und TulasNe). 1 Längsschnitt durch einen sehr jungen Fruchtkörper, die Anlage der Tramaplatten an der Peripherie des Zentralstranges zeigend. 2 Aelteres Stadium, die Tramaplatten sind zentrifugal weiter gewachsen und haben durch Anastomosierung die Glebakammern gebildet. 3 Reifer Zustand. 4 Basidie und Basidiosporen.

schiedener Dicke, welche mehr oder weniger deutlich an einem axilen, oft verzweigten Strange, der sich an der Basis des Fruchtkörpers befindet, entspringen. Die Glebakammern sind labyrinthartig, vorwiegend radial verlängert und münden an der Peripherie direkt unter der Peridie.

Der axile Strang, von dem oben die Rede war, ist nun derjenige Teil, welcher zuerst gebildet wird, so daß der junge Fruchtlörper sozusagen nur aus einem mit einer Peridie überzogenen axilen Strange besteht. An der Peripherie dieses Stranges werden dam die Tramaplatten als mit Hymeniun überzogene Wulste angelegt (Fig. 417, 1). Diese Tramaplatten wachsen radial weiter, bilden Falten, welche zur Bildung 
der Glebakammern führen und erreichen eine solche Länge (Fig. 417, 2, 3), daß im reifen Fruchtkörper der axile Strang wirklich axil verläuft.

An Hysterangium kann man

\section{Phallogaster}

anschließen, bei dessen Vertretern anfangs der Fruchtkörper ebenfalls wie bei Hysterangium nur aus einem von einer Peridie überzogenen axilen Strang besteht. An der Peripherie treten dann bald lappige Vorsprünge auf, welche nicht wie bei Hymenogaster direkt zu Tramaplatten werden, sondern sich an ihrem peripheren Ende erweitern und so auf dem Querschnitt (Fig. 418, 1) die Form von T-Stücken erhalten. Die Querbalken dieser T-Stücke stoßen seitlich fast zusammen, so daß sie

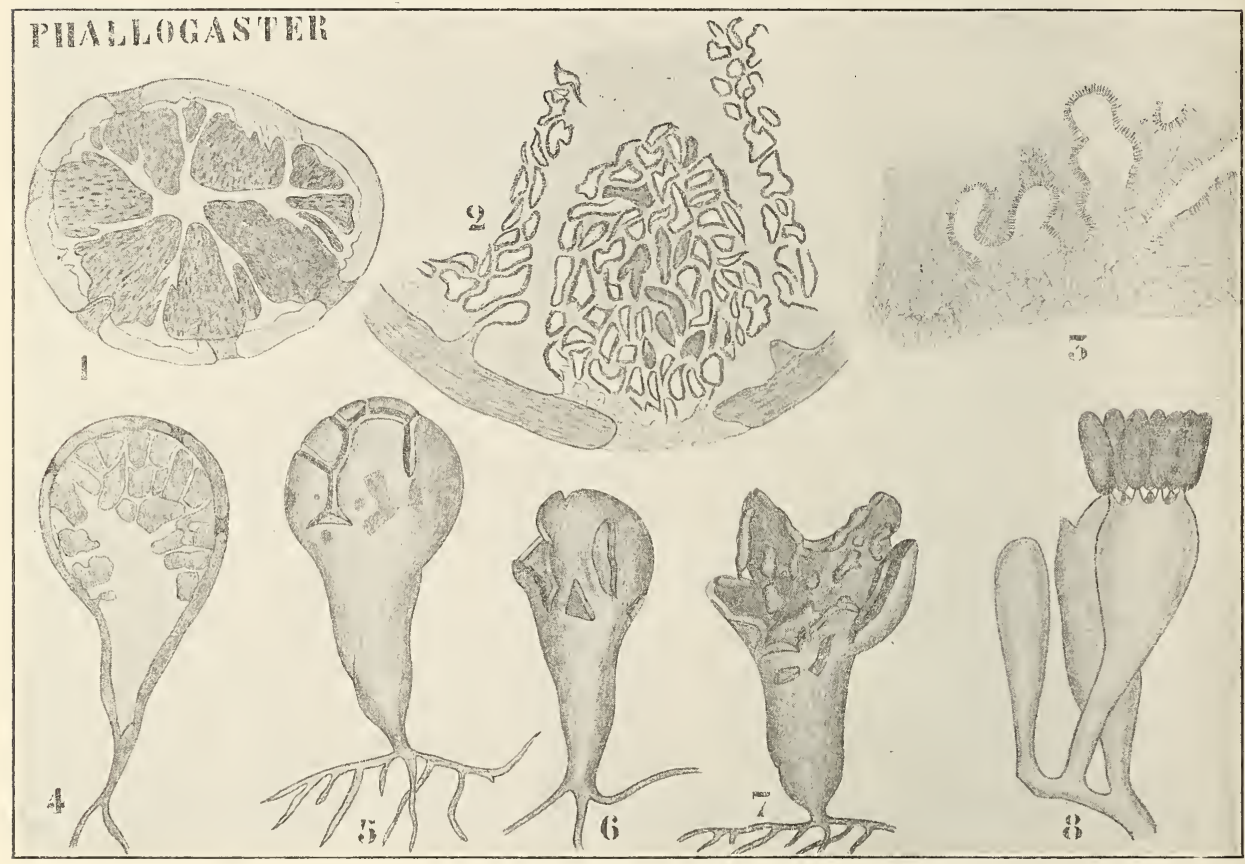

Fig. 418. Phallogaster saceatus Morgax. 1 Schnitt durch einen jungen Fruchtkörper, die Volvagallerte, die Gallertplatten und die Glebastücke zeigend, jedes Glcbastück stößt in der Mitte an die Peridie an, da dort die Volvagallerte unterbrochen ist. 2 Ein Stück der Peripherie stärker vergiößert, das Anstoßen eines Glebastückes an die Peridie zeigend. 3 Idem, noch stärker vergrößert. 4 Längsschnitt durch den Fruchtkörper, den Zentralstrang und dessen Zweige, welche durch Verbreiterung die Volvagallerte bilden, zeigend. 5 Außenansicht vor dem Oeffnen. 6, 7 Oeffnung. 8 Basidie. (1-3 nach FIscher, das übrige nach THAXTER.)

eine nur wenig unterbrochene Schicht direkt unter der Peridie bilden; da die T-Stücke später verschleimen, nennt man diese Schicht die Volvagallerte. Seitlich an den T-Stücken entstehen die Tramaplatten, welche durch Anastomosen etc. die Glebakammern liefern. So wird also in dem Fruchtkörper eine hohle Gallertmasse gebildet, welche im Innern durch Gallertlamellen gekammert und an der Peripherie gitterartig durchbrochen ist; jede diese Kammern ist mit Glebagewebe gefüllt und in den peripheren Kammern stößt das Glebagewebe in der Mitte einer jeden 
Kammer, wo die Tolvagallerte gitterartig durchbrochen ist, an die Peridie, münden also die Glebagäng'e aus. An den Stellen, wo die Gleba direkt an die Peridie anstößt, stirbt diese letztere frühzeitig ab und wird dadurch ebenfalls gitterartig durchbrochen, so daß sie ein Bild der Durchbrechung der Volvagallerte gibt. Später zerreißt die Peridie an der Spitze und das Ganze öffnet sich, und da der Fruchtkörper birnförmig ist, sieht es dann wie ein Becher mit zerschlitztem Rand aus. Die Figuren geben wohl besser wie jede Beschreibung die Verhältnisse wieder.

In erwachsenem Zustand besteht also die einzige nordamerikanische Art dieses Genus, $P$. saccatus Morgan, aus einem oberirdischen birnförmig'en Fruchtkörper mit kräftiger Peridie, in welchem jedoch unregelmäßig gestaltete Stellen frühzeitig absterben, wodurch er schließlich gitterartig durchbrochen wird. Die Gleba ist von radialen Platten von Gallertgefiecht durchsetzt, welche von einem aus der Basis des Fruchtkörpers sich erhebenden Geflechtsstrange abgehen und sich nach außen in die Volvagallerte fortsetzen, welche jedoch an den Stellen, an welchen die Gleba direkt an die Peridie stößt, unregelmäßig durchbrochen ist, während diese letztere an den von der Gleba berührten Stellen abstirbt, so daß auch sie gitterartig durchbrochen wird (Fig. 418, 5, 6). Schließlich, beim klappenartigen Aufreißen der Peridie, trennen sich die einzelnen Portionen der Gleba, da die Gallerte inzwischen zerflossen ist, und zerfließen schließlich selber.

An diesen Phallogaster kann man nun direkt die

\section{Clathraceae}

anschließen (Fig. 419, II und Fig. 420).

Bei den Clathraceen entstehen die Fruchtkörper an den.Mycelsträngen in Gestalt von eiförmigen Körpern, welche hier in der Tat meistens „Eier“ genannt werden und bei den größeren Arten mehrere Zentimeter Höhe und Durchmesser erreichen können.

In diesem Eizustande bestehen sie aus einer sogenannten Volva, einer Hülle, welche aus einer dünnen Rinde und einer mächtigen Gallertschicht besteht. Letztere ist aber an den Stellen, wo die Aeste des inneren Teiles des Eies an sie grenzen, von dünnen Platten eines nicht gallertartigen Geflechts quer durchsetzt, welche den wenigen Hyphenfasern entsprechen, die bei Phallogaster an den Stellen liegen, wo die Volvagallerte durchbrochen ist. Der innere Teil des Fruchtkörpers besteht hauptsächlich aus der Gleba und einem für die Clathraceen und Phallaceen charakteristischen Gebilde, dem sogenannten Receptaculum.

Die Gleba ist bei den Clathraccen so ziemlich wie bei Phallogaster gebaut, das Receptaculum liegt zwischen Gleba und Volva und besteht aus isodiametrischen oder röhrig verlängerten, von gallertigem Geflecht ausgefüllten Kammern mit pseudoparenchymatischen Wänden. Kurz vor der Reife des Fruchtkörpers sind diese Kammern zusammengedrückt, ihre Wände gefaltet, bei der Reife srecken sich aber diese Wände gerade, wodurch das Receptaculum sich streckt, die Volva zerreißt und als stattlicher zierlicher Körper hervortritt.

Auch bei den Phallaceen kommt ein solches Receptaculum vor, es liegt dort aber axil und bildet nach der Streckumg den Stiel des Phallus.

In den typischen Fällen ist also das Receptaculum, wie Fig: 419 zeigt, bei den Phallaceen, hier von Dictyophora repräsentiert, stielförmig; 
bei den Clathraceen netzförmig (Clathrus), aber auch bei den Clathraceen kommen Annäherungen an die Phallaceen vor, indem das Receptaculum (Asaroe) in seinem unteren Teile stielförmig sein kann. Bei der abgebildeten Dictyophora sind der Hut und der Schleier Komplikationen, welche uns zunächst nicht interessieren, sie sind accessorische Bildungen des Receptaculums.

Sehen wir uns nun einen bestimmten Fall näher an.

\section{Clathrus cancellatus Tounnef.}

ist ein ziemlich großer Pilz mit blutrotem gitterartig durchbrochenen Receptaculum, welchen ich 1888 im Garten der Villa Thuret bei Antibes in einem Bambusagärtchen sammelte. Außer im Nittelmeergebiete wurde

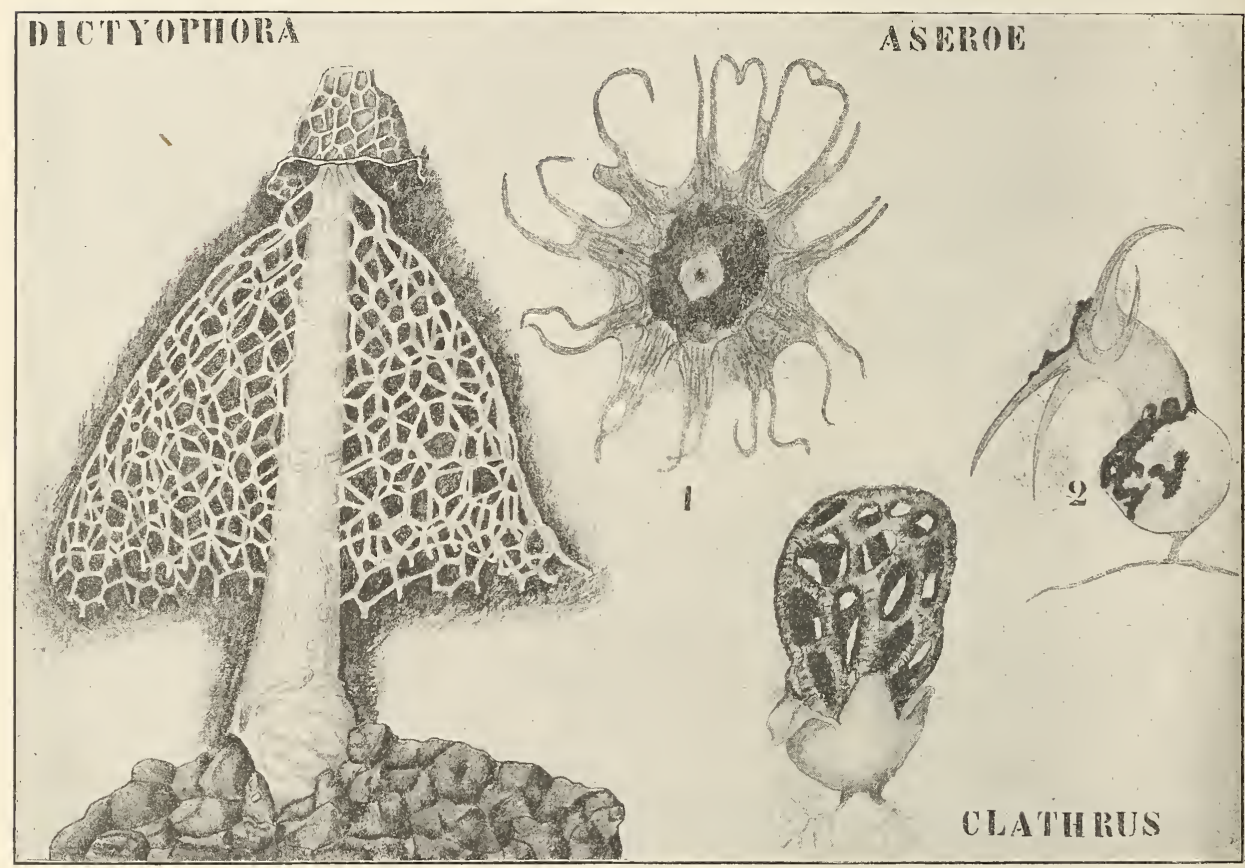

Fig. 419. Verschiedene Receptaculumformen bei Phallaceen und Clathraceen. - I. Phallaceen. 1 Dictyo phora phalloid ea DiETr. (nach A. Möller). - II. Clathraceen. Clathrus cancellatus (nach FAYOD). Asaroe rubra. 1 von oben, 2 von der Seite gesehen (nach einer Skizze vom Verf. in Java gemacht).

der Pilz in Südengland, Holland und Nordamerika gefunden. Bei der Reife bedeckt die Sporenmasse entweder die ganze Innenseite der Gitteräste oder hängt als zusammenklebende Masse vom Scheitel derselben herunter.

Die Entwickelung wurde von A. Fischer studiert. Da zeigte sich in den jüngsten Stadien eine große Uebereinstimmung mit Hysterangium clathroides, indem auch hier der Pilz aus einem von einer Peridie (Volva) überzogenen Zentralstrang besteht. Die von diesem gebildeten Vorsprünge oder Zweige wachsen zentrifugal, verschleimen in ihrem peripheren, sich verbreiternden Teile und bilden so die Volvagallerte, 
während der mehr zentrale Teil durch Ausstülpungen die Tramaplatten und so die Wände der Glebakammern bildet.

Das Receptaculumgewebe entsteht in den Gängen zwischen den Zweigen des Zentralstrauges, also in jungen Glebakammern, welche, so wie die Gänge von Tuber von den Venae externae, von einem Hyphengeflecht ausgefüllt werden. Es besteht auch das Receptaculum der Phalloideen nach Fischer aus Glebakammern, welche von einem pseudoparenchymatisch werdenden Paraphysengeflecht ausgefüllt werden; bei den Clathraceen stehen diese Paraphysenbildungen mit der Fruchtkörperoberfläche in Verbindung, bei den Phallaceen nicht.

Wie wir sehen, vermittelt also Phallogaster sehr hübsch den Uebergang zwischen Hysterangium und den Clathraceen.

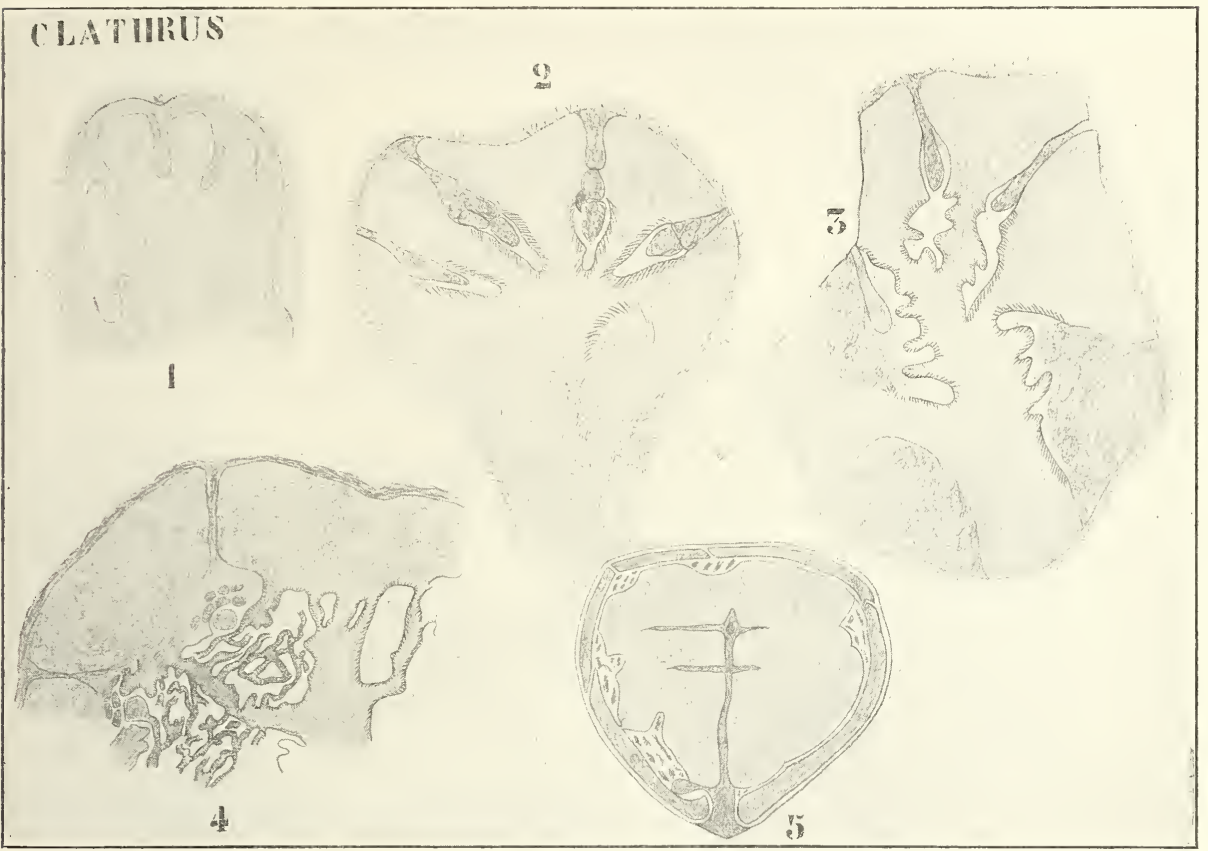

Fig. 420. Clathrus cancellatus. 1 Längsschnitt durch einen sehr jungen Fruchtkörper, die Bildung der Zweige, deren periphere Teile später die Volvagallerte bilden, zeigend. 2 Späteres Stadium; zwischen den Platten hat sich das Receptaculum gebildet. 3 Bildung von lateralen Ausstülpungen, welche die Kammerwände darstellen, so wie bei Hysterangium. 4 Aelteres Stadium, Bildung der Volvagallerte etwa wie bei Phyllogaster (Querschnitt).

5 Längsschnitt durch ein fast reifes Ei. Die hellen Dreiecke gehören zu dem Receptaculum.

Es bleibt also noch die letzte Reihe, die der Phallaceen, zu besprechen übrig.

\section{Die Phallaceen-Reihe.}

Der Anschluß dieser Reihe nach unten wurde von REHsteInER in Hymenogaster gesucht, eine Auffassung, die manches für sich hatte, aber jetzt wohl besser zu Gunsten der Ammahme eines Auschlusses an die Secotiaceen verlassen werden muß. Trotzdem die drt noch recht wenig bekannt ist, scheint mir der Anschluß am leichtesten an 


\section{Secotium olbium TuL.}

möglich zu sein. Es ist dies ein Pilzchen mit sehr kleinen, etwa $1-2 \mathrm{~cm}$ hohen Fruchtkörperchen, das in Südfrankreich oberirdisch wächst. Die kugelige, feinschuppige bis kleiige, weiße bis bräunliche Peridie wird von einem glatten cylindrischen Stiele getragen.

Macht man einen Längsschnitt durch ein junges Exemplar, so sieht man, daß der Stiel als axile Columella bis zum Scheitel des Fruchtkörpers reicht (Fig. 421, 2, 3). Um diese Columella herum befindet sich ein mit Tramaplatten gefüllter Hohlraum, welche Platten teils von der Peridie, teils vom oberen Teil der Columella ausgehen. So wird der obere Teil der Peridie also zu einem die Tramaplatten, d. h. also die Gleba tragenden Hute, der sich sogar beim verwandten Genus Elasmomyces nach Art der Agaricaceen ausbreiten kann. Die von den verschlungenen Tramaplatten gebildeten Glebakammern sind von einem Hymenium bekleidet.

Vergleicht man nun unter den

\section{Phallaceen}

das Genus

\section{Mutinus}

mit diesem Secotium olbium, so sieht man auf einem Stadium wie Fig. 421, 8 große Uebereinstimmung, indem auch hier der obere Teil der Peridie hutartig die Lamellen trägt, und ein columellaartiges Gebilde im Zentrum des Fruchtkörpers vorhanden ist.

Letzteres Gebilde ist aber viel komplizierter als die einfache Columella von Secotium; gehen wir also der Entwickelung von Mutinus an der Hand von Fischers Untersuchungen nach und verschaffen wir uns damit eine Einsicht in den Bau der Phallaceen.

Machen wir einen Längsschnitt durch eine ganz junge Fruchtanlage von Mutinus caninus, so sehen wir die Mitte von einem an seinem Ende kopfförmig verbreiteten axilen Strang eingenommen (Fig. 421, II 5). Oberhalb dieses knopfförmigen Stückes verschleimt eine glockenförmige Hülle, welche die Volvagallerte bilden wird (Fig. 421, II 6). Der Raum zwischen dieser Volvaschicht und dem axilen Strange wird vom ursprünglichen Hyphengeflecht eingenommen und ist der Sitz aller weiteren Differenzierungen. Auf ihn wollen wir also weiter unsere Aufmerksamkeit beschränken; es sind daher auch in den folgenden Figuren die Volvagallerte und die außerhalb dieser gelegene Schicht nicht gezeichnet worden. Die Schicht, welche direkt an die Volvagallerte grenzt, wird zum Hute und bildet die nach innen $\mathrm{zu}$ wachsenden Tramaplatten (Fig. 421, II 7, 8), welche also die kammerige Gleba bilden; der Hut ist oben offen, da sich der Zentralstrang dort bis an die Volvagallerte fortsetzt.

Um den axilen Strang herum entwickeln sich die nach innen offenen Kammern des sich später streckenden Stieles, also des Receptaculums. Das Gewebe zwischen dem Receptaculum und der Gleba ertährt keine weiteren Veränderungen. Bei der Reife zerfließt das Gewebe des Zentralstranges, wodurch der Stiel hohl wird, auch verschleimen alle außerhalb der Gleba gelegenen Schichten, so daß schließlich bei der Streckung des Stieles die Außenseite der Gleba frei zu Tage liegt, und die Sporenmasse durch die jetzt auch die Gleba ergreifende Verschleimung alsbald am Stiele heruntertropft. 
Von Mutims unterscheidet sich nun

\section{Phallus}

durch den Umstand, daß die Sporenmasse des reifen Exemplars, wie bei Mutims, nicht dem Ende des Stieles anscheinend direkt aufsitzt, sondern auf einem beweglichen Hütchen sich befindet. Die Erklärung ist recht einfach; wie wir sahen, sitzt auch bei Mutinus die Sporenmasse nicht direkt dem Stiele auf, sondern einem undifferenzierten Hyphengeflechte. Bei Phallus tritt aber in diesem Hyphengeflechte wohl eine Differenzierung auf, indem unmittelbar an der Innenseite der Gleba ein glockenförmiger Hut differenziert wird, der durch Verschleimung. des Hyphengeflechtes, welches sich zwischen ihm und dem Stiele befindet (Fig. 422, 2), alsbald frei herunterhängt.

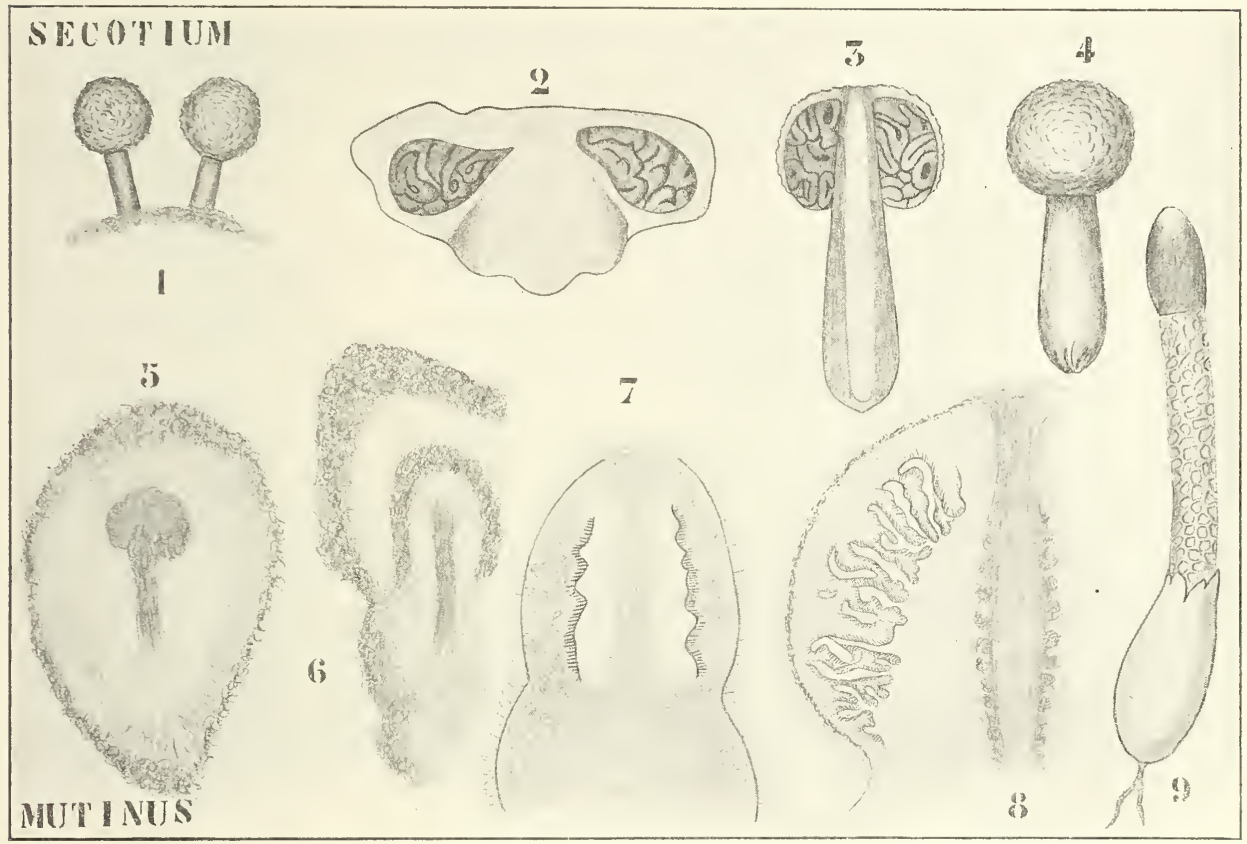

Fig. 421. I. Secotium olbiu m Tul. (nach Tulasne). 1, 4 Habitus. 2 Längsschnitt durch einen jungen, 3 durch einen alten Fruchtkörper. - II. M utinus caninus (HuDs.) FR. 5 Sehr junger Fruchtkörper mit eben differenziertem axilen Strang. 6 Ausbildung der Volvagallerte. 7 Aelteres Stadium, nach Entfernung der Volvagallerte, die Ausbildung des Hutes und den Anfang der Tramaplatten zeigend. 8 Weitere Ausbildung der Tramaplatten und Anlage der nach innen offenen Kammern der Stielwand. 9 Habitus.

Uebrigens ist die Entwickelung von Phallus in allen wesentlichen Punkten der von Mutimus gleich, so daß es wohl genügt, auf Fig. 422 und deren Erklärung hinzuweisen.

th Das Indusium von Dictyophora ist eine weitere Differenzierung in dem Hyphengeflechte zwischen dem Hute und dem Stiele, man liömnte sagen, das Indusium sei eim zweiter Hut.

Für näheres über die Phallaccen sei auf die schönen Arbeiten Fischers verwiesen; es sei nur noch bemerkt, daß die Phallacecn. durch Vermittlung von gewissen Secotiaceen mit lainellenartigen Tramaplatten. 
Anklänge an Hymenomyceten zeigen, welche jedoch noch wohl zu vag sind, um nähere Spekulationen zu erlauben.

Daß die Gasteromyceten manche Parallelbildungen zu Tuberaceen aufweisen, ist schon hie und da erwähnt worden, besonders sei in dieser Hinsicht auf Fischers Artikel in der D. Bot. Ges. verwiesen; der Parallelismus ist um so auffallender, als die Fruchtkörper der Tuberaceen, mit Ausnahme der ascogenen Hyphen, der x-Generation, die der Gasteromyceten der $2 \mathrm{x}$-Generation angehören.

Daß solche Parallelbildungen den Phylogenetiker nicht gerade freudig. stimmen, braucht kaum betont zu werden.

Um den Zusammenhang zwischen den verschiedenen Gasteromyceten-

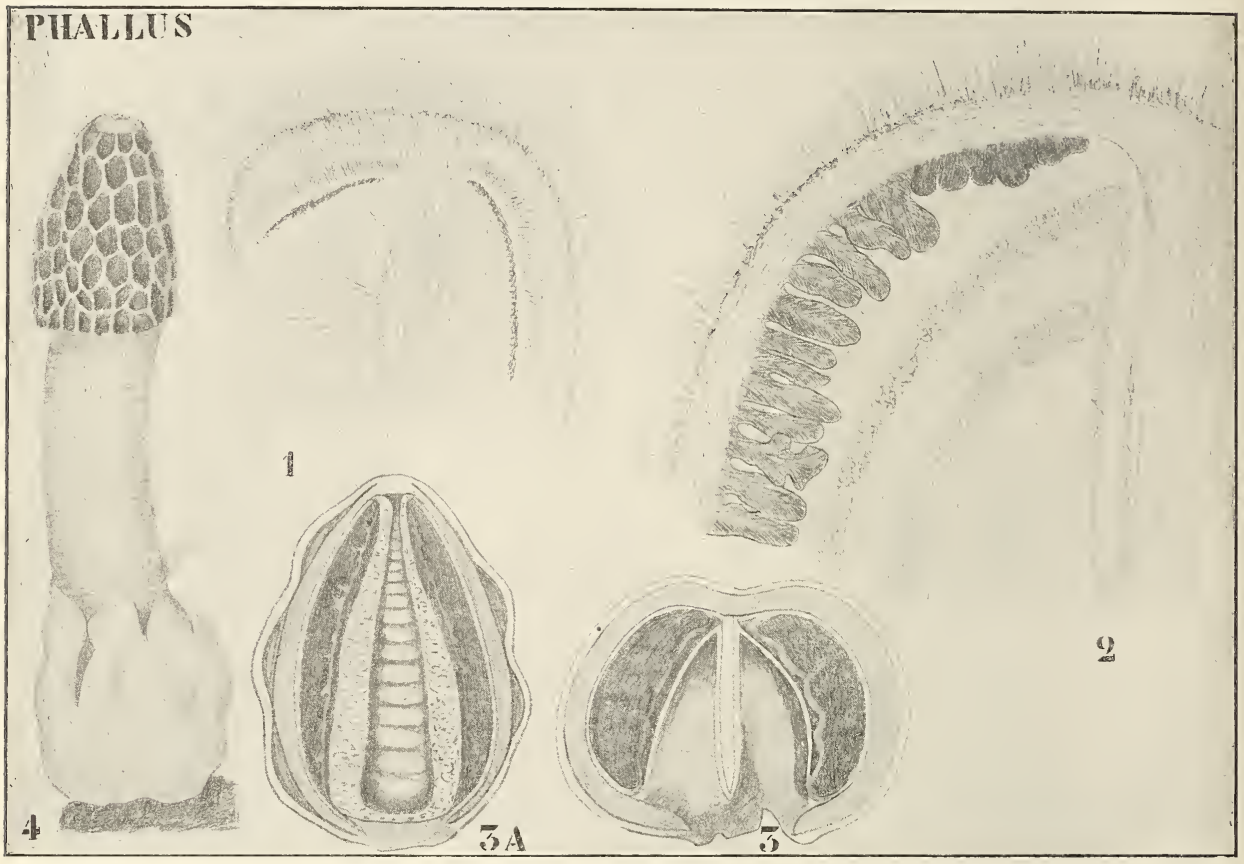

Fig. 422. Phallus impudicus. 1 Sehr junger Fruchtkörper, die erste Anlage der Gleba zeigend. 2 Aelteres Stadium, Anfang der Stielbildung. $3 \mathrm{Ei}$, im Längsschnitt die Anlage des Hutes zeigend. 4 Exemplar nach der Streckung. $3 \mathrm{~A}$ Ein Ei von Phallus tenuis kurz vor der Streckung des Stieles.

Gruppen so deutlich wie möglich hervortreten zu lassen, haben wir die Darstellung nicht durch die Behandlung der kleinen Gruppe der

\section{Gasterolichenen}

unterbrochen, welche sonst wohl am besten bei der Besprechung der Lycoperdaceen-Reihe stattgefunden hätte.

Sie besteht aus nur zwei Genera: Emericella und Trichocoma.

Emericella variecolor BERK. wurde von M. J. BERKELEY nach Exemplaren, die von seinem Sohne in dessen Garten zu Bowenpilly bei Secunderabad gesammelt waren, beschrieben. 
Das Pflänzchen wächst gesellig (Fig. 423, 1) und gleicht einem kleinen Gasteromyceten, ist aber grün. In seiner Struktur nähert es sich einem Lycoperdon.

Das Capillitium ist hellgelb, die Sporen purpurbraun, kugelig und im Besitze eines Kranzes von Dornen. Die Peridie öff̈net sich durch Zerbröckelung des oberen Teiles, wie bei Lycoperdon coelatum. Die Alge gleicht Palmella botryoides Grév., unterscheidet sich aber von derselben durch die grünen Fäden, welche die einzelnen Zellen vereinen. MASSEE sagt über diese sonderbare Struktur:

„From the chlorophyllose portion of the cell a green eseptate filament passes through the cell-wall, where it is joined at some distance

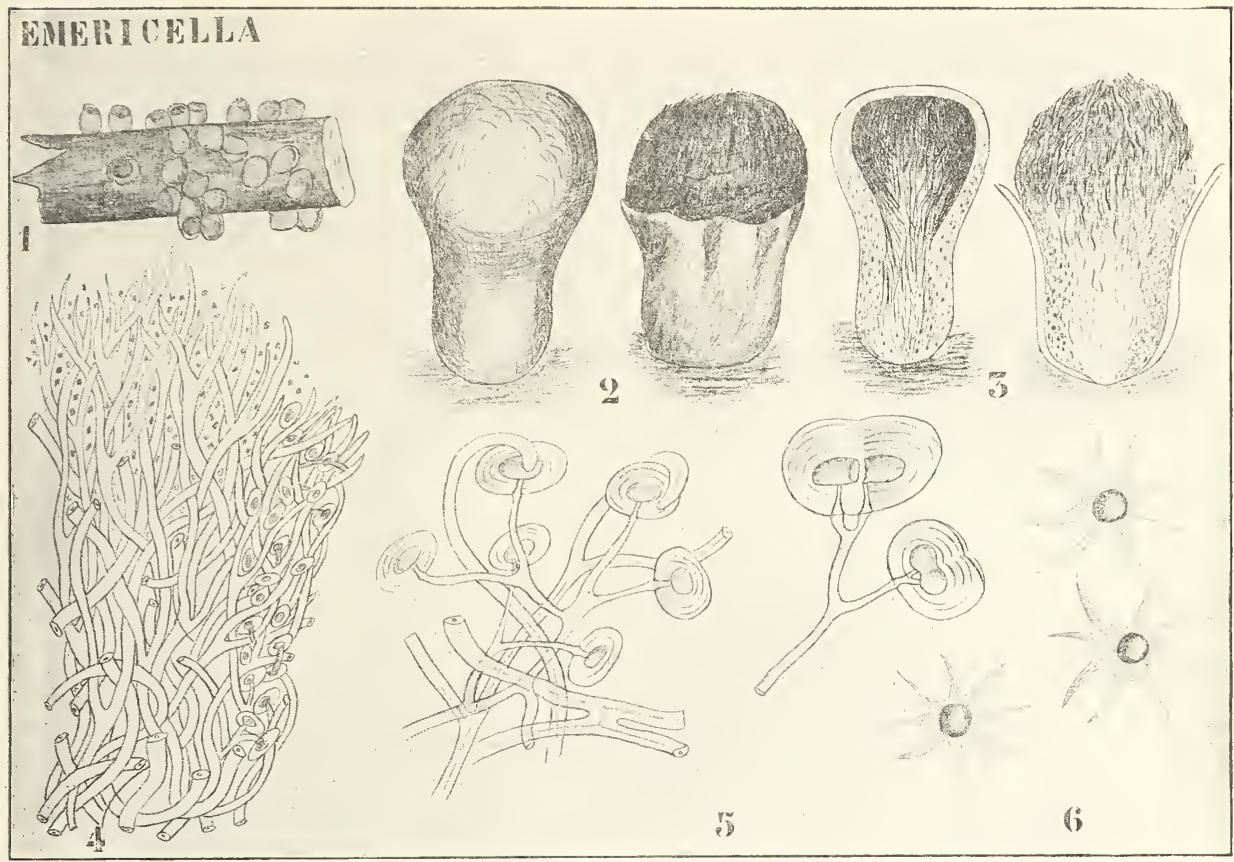

Fig. 423. Emericella variecolor Berk. (nach Massee). 1 Habitus. 2 Ungeöffneter und geöffneter Fruchtkörper. 3 Längsschnitte derselben. 4 Längsschnitte durch einen Teil des Fruchtkörpers, die Algen, das Capilïitium und die Sporen zeigend. 5 Die Algen von den Pilzhyphen umsponnen. 6 Sporen.

to a similar thread from another cell, the two forming a common stem, on which several pairs of cells are supported on similar lateral bifurcating threads. These pairs of cells originate from the fission of a single cell, each half of the parent cell giving origin to a green filament, the bifurcation of which is at first included in the cell-wall."

Die Alge findet sich in den Intercellularräumen im lockeren, peripherischen, basalen Teile des Pilzes, von wo sie in die Peridie vordringt, und dem Ganzen einen grünen Ton verleiht.

Das andere Genus ist Trichocoma, von welchem bis zu MAssees Bearbeitung der Gruppe nur die Art Trichocoma paradoxa Jungh. bekannt war, die von JUNGHUHN in Java entdeckt worden war.

Auch sie wächst gesellig und erreicht eine Größe von $1.8-4 \mathrm{~cm}$. 
Der sterile basale Teil ist napfförmig (Fig. 424, I 3), vom Rande desselben wachsen die Hyphen aufwärts und bilden ein lockeres membranöses Peridium. Das Capillitium gleicht, nachdem die Peridie zerstört ist, einem Pinsel. Die Sporen sind braun-purpurn, grobwarzig. Die ganz gewöhnlichen Algenzellen, nach Massee zu Botryococcus Käтz. gehörig, bilden eine Schicht an der Basis des Capillitiums. Die Pflanze wurde von Massee im Herbarium zu Kew aus Sikkim, East Nepaul den Nilghiris und Ceylon vorgefunden. Zu gleicher Zeit beschreibt er die nur wenig abweichende, hier ebenfalls abgebildete neue Art: Trichocoma laevispora aus Nord-Carolina.

Gasterolichenen sind also bis jetzt aus Britisch-Indien, Java und Nordamerika bekannt geworden.

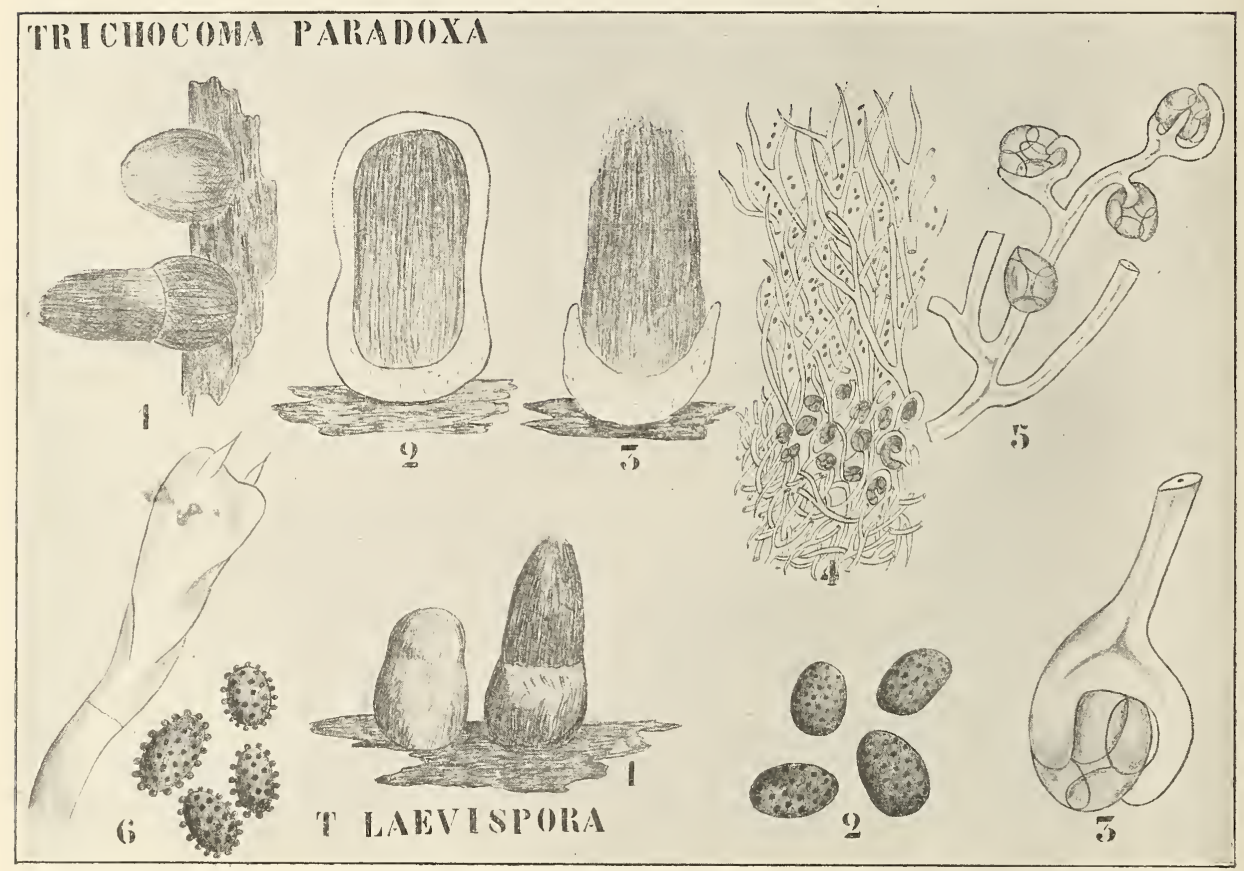

Fig. 424. I. Trichocoma paradoxa JUNGH. 1 Habitus eines ungeöffneten und eines geöffneten Exemplares. 2 Längsschnitt durch einen ungeöffneten, 3 durch einen geöffneten Teil. 4 Schnitt, die Algenschicht, das Capillitium und die Sporen zeigend. 5 Algen von den Pilzhyphen umsponnen. 6 Basidie und Sporen. - II. Trichocoma laevispora MasseE. 1 Habitus. 2 Sporen. 3 Hyphenumsponnene Algen.

Von der Gruppe der Pilze bleibt nun noch eine zu erwähnen, welche den Namen

\section{Fungi imperfecti}

trägt. Ich glaube, es genügt, hier abzudrucken, was Lindau bei seiner Bearbeitung dieser Gruppe für Engler und Prantl über ihre systematische Berechtigung sagt:

"Unter dem Namen Fungi imperfecti faßte Fuckel alle diejenigen Formen zusammen, die seiner Ansicht nach keine vollendeten, d. h. 
höheren Fruchtformen (Schläuche, Basidien) bilden. Daß viele Nebenfruchtformen zu Ascomyceten gehören, war bereits vor ihm bekannt. Der Ausdruck Deuteromyceten von SACCARDo ist ebensowenig glücklich wie der ron Fuckel. - Daraus, daß viele Arten der Fungi imperfecti als Nebenfruchtformen von Ascomyceten erkannt sind, geht schon hervor, daß die Gruppe keine geschlossene systematische Einheit darstellt. Es ist ein buntes Gemisch von allerlei heterogenen Formen, mit denen man sonst nichts anzufangen weiß und aus denen man unter Hervorziehung eines gemeinsamen Merkmals größere Gruppen nach Art der Familien gebildet hat. Wie mit diesen größeren systematischen Einheiten, so ist es auch mit den kleineren, den Gattungen. Auch diese sind künstlich, schließen durchaus nicht immer verwandte Formen ein und sind deshalb mit den phylogenetischen Einheiten, die man sonst Gattungen nennt, nicht zu vergleichen."

Das enthebt uns also wohl der Verpflichtung, sie zu behandeln.

Es bleibt uns nun noch eine Pflanzengruppe zu besprechen, eine Gruppe, welche man meistens zu den Algen stellt, deren systematische Stellung aber höchst zweifelhaft ist und welche, um dieser Meinung Ausdruck zu geben, hier behandelt werden mag, die Gruppe der

\section{Charophyten.}

Am Boden von Teichen, Tümpeln, Gräben findet man öfters ziemlich straffe grüne Pflänzchen, welche aus einem mehr oder weniger verzweigten Hauptstamm, der mehrere Wirtel pfriemenförmiger unverzweigter Seitenzweige trägt, bestehen. Die wirtelige Anordnung der Seitenzweige ist so regelmäßig, daß man diesen Gewächsen den Namen Armleuchtergewächse gegeben hat.

Die Seitenzweige nennt man „Blätter“, ihre Insertionsstelle Knoten und das Stück zwischen je zwei Knoten ein Internodium.

Je nach Länge und Dicke, Zahl und Regelmäßigkeit der verschiedenen Teile ist natürlich der Habitus verschieden; besser als jede lange Beschreibung mag Fig. 425 dies klarmachen.

Gräbt man eine solche Chara aus dem Schlamm aus, so findet man, daß sie mittels farbloser Rhizoide darin befestigt ist.

Abgesehen von Kernfragmentierung in übermäßig langen Zellen sind die Zellen der Characeen streng monoenergid. Daß die Zellen aber übermäßig lang werden können, geht daraus hervor, daß die Internodien, falls sie nicht nachträglich von den Knoten aus berindet werden, je aus einer einzigen Zelle bestehen.

Die Blätter tragen bei genauer Betrachtung wieder Seitenorgane, und zwar sehr kurze, die sogenannten Blättchen, und die Fortpflanzung'sorgane. Diese sind zweierlei Art, männliche und weibliche, und beide ziemlich kompliziert gebaut. Die weiblichen nennt man Eiknospen, die männlichen Antheridien. Beide sind in reifem Zustande meistens rot oder hochgelb und verleihen der fruktifizierenden Pflanze einen wirklich reizenden Anblick.

Die Eiknospe (Fig. 430,4) ist am einfachsten geebant und besteht aus einem Oogon, welches, von schlauchförmigen Zellen eingehüllt, berindet ist. Diese schlauchförmigen Zellen lassen an der Spitze eine Oeffnung frei, wodurch die Spermatozoen in das Oogon vordringen und mit dem dieses Oogon ganz ausfüllenden Ei rerschmelzen kömmen. 
Das kugelige Antheridium (Fig. 429, 7) besitzt eine aus 9 Zellen gebildete Wand, die untere ist klein und sitzt dem Stielchen auf, die 8 anderen sind groß, schildförmig, rot gefärbt und tragen den Namen Schilder.

Der Mitte eines jeden dieser Schilder aufgesetzt findet sich im Inneren des Antheridiums eine kleinere, auf das Zentrum des Ganzen hin gerichtete Zelle, der sogenannte Schildgriff oder das Manubrium. Jedes Manubrium trägt an seiner Spitze eine (selten mehrere) rundliche Zelle, das Köpfchen. Von dieser entspringen ungefähr 6 sekundäre Köpfchen, deren jedes 4 lange peitschenförmige, je aus 100 bis 225 Zellen bestehende Zellreihen trägt (Fig. 429, 6). Diese Zellen sind die Spermatiden, denn in jeder derselben bildet sich ein „Spermatozoid“, was also

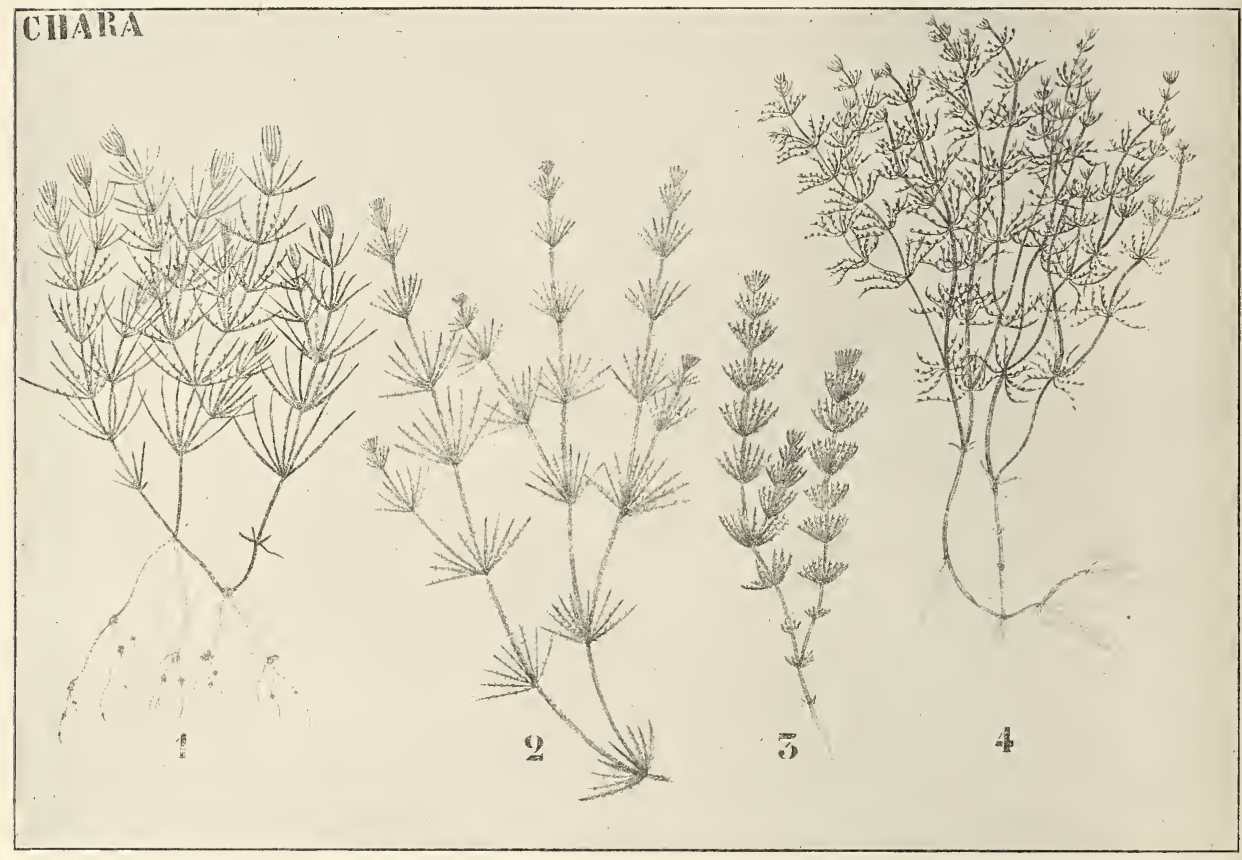

Fig. 425. Verschiedene Chara-Species (nach MiguLA). $1 \mathrm{Ch}$. fragifera. $2 \mathrm{Ch}$. baltica. $3 \mathrm{Ch}$. intermedia f. decipiens. $4 \mathrm{Ch}$. foetida.

für das ganze „Antheridium“ etwa 38000 Spermatozoiden ausmacht. Diese sind spiralig gewunden, tragen je 2 Cilien und gleichen den Spermatozoen gewisser Archegoniaten.

Bei der Keimung bildet die Zygote nicht sofort eine neue CharaPflanze, sondern zunächst einen Vorkeim. Das erste Resultat der Keimung ist die Teilung der Zygote durch eine Querwand in eine vordere kleinere, besonders plasmareiche Zelle (von DE BARY die erste Knotenzelle genannt) und eine größere reservesubstanzreiche Zelle, die Basalzelle. Die Basalzelle entwickelt sich nicht weiter, sondern fungiert nur als Nahrungsreservoir für die junge Pflanze. Die kleine Zelle zerfällt durch eine in Bezug auf die Achse der Oospore longitudinal gerichtete Wand in eine untere Wurzelzelle (Fig. 410, 1 W) und eine obere Vorkeim- 
zelle (TK). Die Wurzelzelle verlängert sich zu einem Wurzelharare, oder kann sich auch noch teilen und so mehr als ein Wurzelhaar bilden, diese dringen in den Schlamm ein und verankern so den Keim (Fig. 426, 2).

Die Vorkeimzelle ergrünt und wächst gerade aufwärts, dabei teilt sie sich durch Querwände, bildet sich also in eine aus anscheinend gleichwertigen Zellen bestehende Zellreihe um (Fig. 426, 2). Die Einzelzellen verhalten sich aber sehr verschieden: Die unterste derselben streckt sich und wird zur unteren Vorkeimzelle (UVK), einige obere Zellen strecken sich ebenfalls, teilen sich aber nicht oder doch nur wenige Male weiter und werden zu den oberen Vorkeimzellen (OVK). Diese Reihe von oberen Vorkeimzellen ist nun von der unteren Vorkeimzelle nur durch eine einzige scheibenförmige Zelle getrennt, aber diese Zelle ist eben die wichtigste.

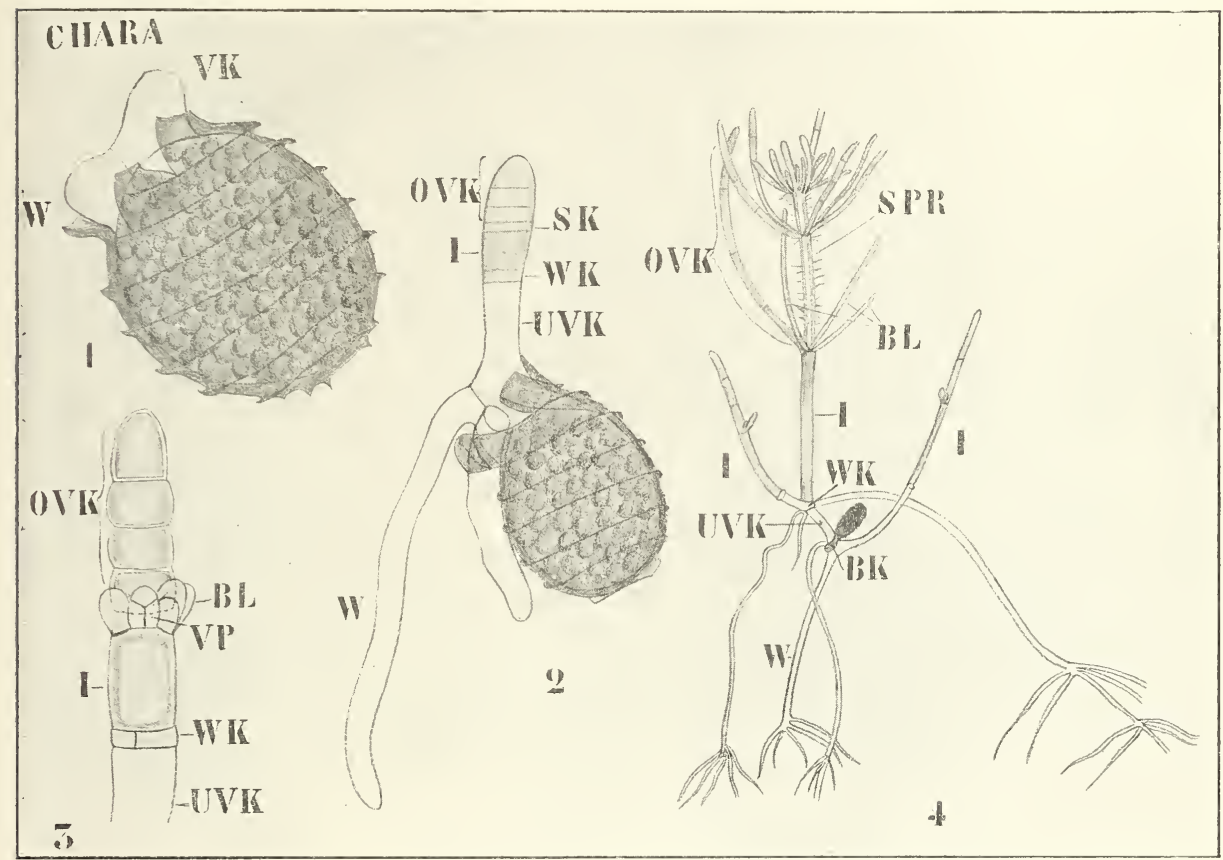

Fig. 426. Keimung von $\mathrm{Chara}$ (nach DE BARY und PRingsheIM). Figurenerklärung im Text. In 4 bedeutet SPR den Charasproß aus SK von 2 entstanden. BL die Blätter dieses Sprosses. 3 zeigt die erste Entwickelung von SK zu dem Charasproß, VP dessen Vegetationspunkt, BL dessen Blätter.

Sie teilt sich in 3 Zellen, in eine scheibenförmige untere Wurzelknotenzelle (WK), in ein mittleres, sich alsbald außerordentlich in die Länge streckendes Internodium (I) und in eine obere scheibenförmige Sproßknotenzelle (SK).

Die Turzelknotenzelle bildet, nachdem sie mehrere Teilung'en durchgemacht hat, Rhizoiden, welche dem Vorkeim wohl Nahrung zuführen. die Sproßknotenzelle aber bildet die Char $a$-Pflanze, welche also als eine Knospe am Vorkeim entsteht.

Die Verhältnisse werden vielfach, wie auch in der hier abgebildeten Fig. 426, 4, dadurch kompliziert, daß accessorische Torkeime ${ }^{1}$ ) sowohl am

1) die beiden lateralen Sprosse der Fig. 426, 4, welehe mit I bezeichnet sind. 
Wurzelknoten des Vorkeimes wie an der Wurzelzelle, welche bei der Keimung der Oospore entsteht, gebildet werden können, welche sich wie die soeben beschriebenen Vorkeime weiter entwickeln.

Die Cytologie hat gelehrt, daß weder bei der Bildung der Eizelle noch bei der der Spermatozoen eine Reduktionsteilung eintritt. Die Chara-Pflanze ist also eine $\mathrm{x}$-Generation, und da sie einen Vorkeim hat, hat man manchmal versucht, sie mit den Moosen in Verbindung zu bringen, aber dies ist offenbar nicht gut möglich, weil die $2 x$-Generation auf die Zygote beschränkt ist. Aber auch mit den Algen läßt sie sich kaum in Verbindung bringen, denn wo findet man bei ihnen solche "Antheridien" und so gestaltete Spermatozoen.

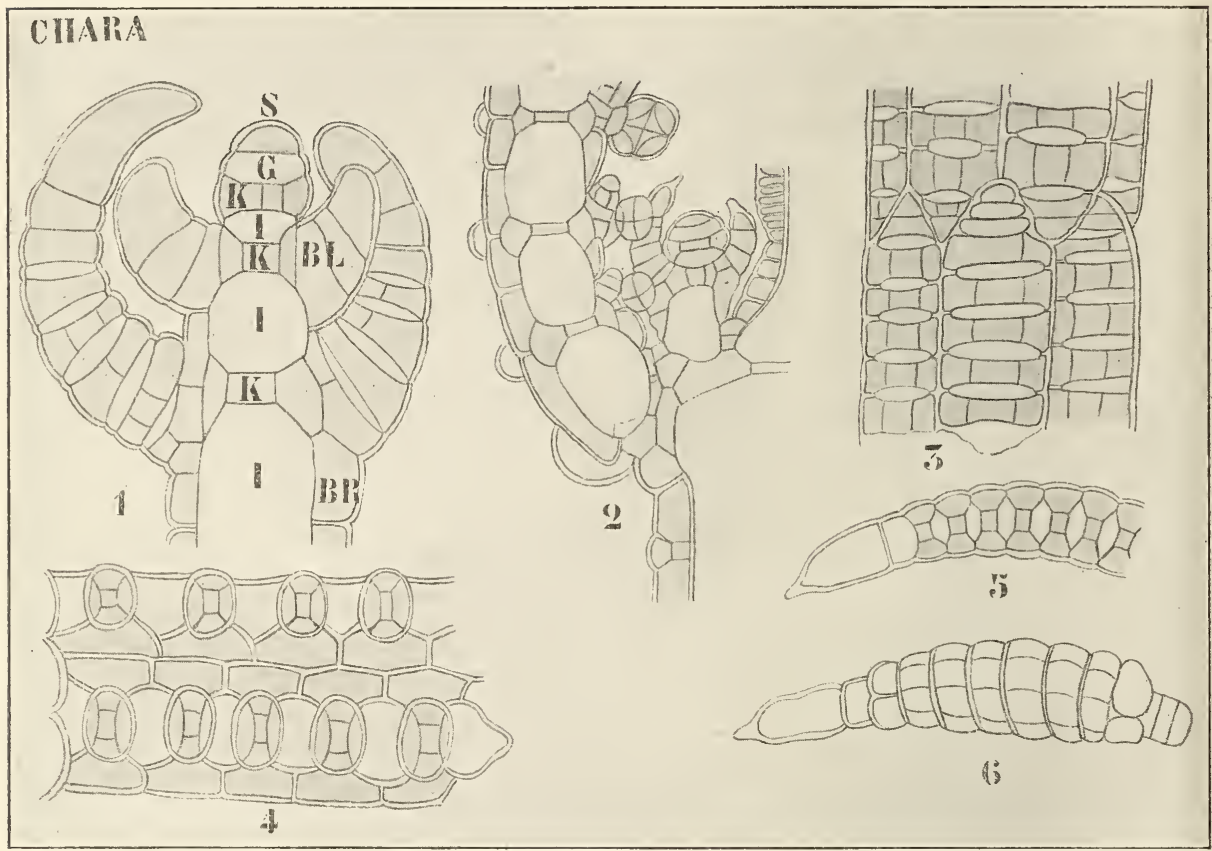

Fig. 427. Chara fragilis (nach SACHs). 1 Längsschnitt der Stammspitze. Ganz oben liegt die Scheitelzelle (S), welche nach unten ein Segment, die sogenannte Gliederzelle (G), abgeschnitten hat. Diese Gliederzelle teilt sich nun in zwei Zellen, eine Knotenzelle (K) und eine Internodienzelle (I), von denen erstere sich weiter teilt, während die andere sich nur streckt. Die zwei nächsten Etagen zeigen also, was aus einer Gliederzelle hervorgeht. Die dann folgenden nächsten Etagen zeigen, wie sich die Internodienzelle schon etwas gestreckt, und wie die Knotenzelle Blätter (BL) gebildet hat, während die beiden unteren Etagen schon besser entwickelte Blätter zeigen, die Internodienzelle an ihnen schon sehr bedeutend gestreckt ist, und man sieht, wie von den Blättern ausgehend Zellen (BR) hinunterwachsen, welche die Internodienzelle berinden. 2 Ein Blatt mit den Anlagen der Geschlechtsorgane, in seiner Achsel einen Seitensproß tragend; man sieht, daß die Blätter genau denselben Aufbau wie der Hauptsproß haben. 3 Die Berindung eines Internodiums in der Mitte; die Stelle, wo die vom oberen Blattwirtel herstammenden Rindenstücke die vom unteren gebildeten treffen. 4 Aeltere Rindenstücke mit rudimentären Blättchen. 5 Junges Blatt, im Längsschnitt. 6 Idem, von der Seite betrachtet.

Letzterer Umstand veranlaßt Oltmanns, einer Vereinigung der Charen mit den Algen zu widerstreben. Er sagt aber: „Freilich, das ist nur etwas Negatives, Positives vermag ich nicht zu bieten und ... 
kann ich nur noch betonen, daß mir ein zu enger Anschluß der Charen an die Moose auch nicht einleuchten will. Sie stehen für mich zunächst völlig einsam da."

Auch für mich. Da wir nun im großen und ganzen über die Lebensgeschichte der Charen orientiert sind, und das Wenige, was sich überhaupt über deren systematische Stellung sagen läßt, gesagt haben, bleibt nur noch die Entwickelung dieser Pflanzen, sowohl ihrer vegetativen Teile wie ihrer Sexualorgane, zu besprechen übrig.

\section{Die Entwickelung der vegetativen Teile.}

Als Beispiel seien hier Chara fragitis DEsv. und die sehr nahe mit ihr verwandte Ch. delicanila var. bulbifera, welche in der Entwickelung fast vollständig übereinstimmen, gewählt.

Die Characeen wachsen mittels einer Scheitelzelle, d. h. also, daß die terminale Zelle eines jeden Sprosses den betreffenden Sproß aufbaut.

Die Abbildungen in Fig. 427 geben eine Uebersicht von der Weise, in welcher dies geschieht. Es sei einmal an Ch. delicatula f. bulbifera an der Hand der Untersuchungen Kuczewskis gezeigt, wie genau man den ganzen Aufbau der Pflanze Zelle für Zelle verfolgen kann, was ïbrigens Giesenhagen für Nitella und einige unberindete Charen schon gezeigt hatte.

Entwickelung des Hauptsprosses (man vergl. Fig. 427 und 428).

Das Wachstum des Hauptsprosses ist wie bei allen Characeen unbegrenzt. Die Scheitelzelle S teilt sich durch eine Querwand in eine neue Scheitelzelle $s$ und eine Gliederzelle $g$, was sich also folgendermaßen ausdrücken läßt:

$$
\mathrm{S}=\mathrm{s}+\mathrm{g} \text {. }
$$

Die neue Scheitelzelle s wächst nun wieder zu ihrer ursprünglichen Größe S heran, noch bevor sie diese aber erreicht hat, teilt die Gliederzelle sich durch eine nach oben gewölbte Querwand in eine obere Knotenzelle $\mathrm{k}$ und eine untere bikonkave Internodialzelle i, was sich also so ausdrücken läßt:

$$
\mathrm{g}=\mathrm{k}+\mathrm{i} \text {. }
$$

Da dies so weitergeht, kann man also das Wachstum des aus einer Chara-Scheitelzelle hervorgehenden Sprosses in folgende Formel fassen:

$$
\mathrm{S}=\left[\mathrm{s}+\left(\mathrm{k}_{\mathrm{n}}+\mathrm{i}_{\mathrm{n}}\right)+\left(\mathrm{k}_{\mathrm{n}-1}+\mathrm{i}_{\mathrm{n}-1}\right)+\ldots\left(\mathrm{k}_{1}+\mathrm{i}_{1}\right)+(\mathrm{k}+\mathrm{i})\right],
$$

eine Formel, welche ohne Ausnahme für den Aufbau aller CharaceenSprosse gilt.

Die Internodialzellen erfahren nun, wie schon aus Fig. 427 ersichtlich, keine weiteren Teilungen, wohl aber die scheibenförmigen Knotenzellen.

In der Knotenzelle (Fig. 428) tritt zunächst eine Längswand auf, welche sie in eine linke (hl) und rechte Hälfte (hr) zerlegt. Dann werden rechts und links von derselben Segmente abgegliedert. Die erste dieser Randzellen $u_{1}$ wird rechts von der primären Längswand angelegt, die zweite $\mathrm{u}_{2}$ links u. s. w. (Fig. 428, 1-ñ).

Wir können also für die Teilungen der Knnotenzelle mit GIEsENHAGEN folgende Formel anwenden:

$\mathrm{k}=\mathrm{hr}+\mathrm{hl}=\left(\mathrm{cr}+\mathrm{u}_{1}+\mathrm{u}_{3}+\mathrm{u}_{5}+\mathrm{u}_{7}\right)+\left(\mathrm{cl}+\mathrm{u}_{2}+\mathrm{u}_{4}+\mathrm{u}_{6}+\mathrm{u}_{8}\right)$.

So entstehen also bei Chara delicatula in der Regel in jedem Kinoten 8 Randzellen und 2 zentrale Zellen. Die beiden Zentralzellen sind die 
niedrigsten des Knotens und nehmen an der weiteren Entwickelung des Sprosses geringen Anteil, indem sie nicht mehr teilungsfähig sind.

Aus den Randzellen gehen die Blätter, welche, wie wir schon sahen, im wesentlichen den gleichen Bau wie der Hauptsproß zeigen, hervor, indem sich die Randzellen halbkugelig vorwölben und sich nach der Formel

$$
\mathrm{u}=\mathrm{s}^{1}+\mathrm{g}^{1}
$$

in eine Blattscheitelzelle $\mathrm{s}^{1}$ und eine Gliederzelle $\mathrm{g}^{1}$ teilen (Fig. 428, 6, 7), und indem $\mathrm{s}^{1}$ die Entwickelung fortsetzt, als wäre sie eine Stammscheitelzelle, nur daß ihre Teilungsfähigkeit bald erlischt und sie sich zu der Blattspitzenzelle streckt (Fig. 428, т). Die Blätter wären also besser mit dem Namen Kurztriebe zu bezeichnen.

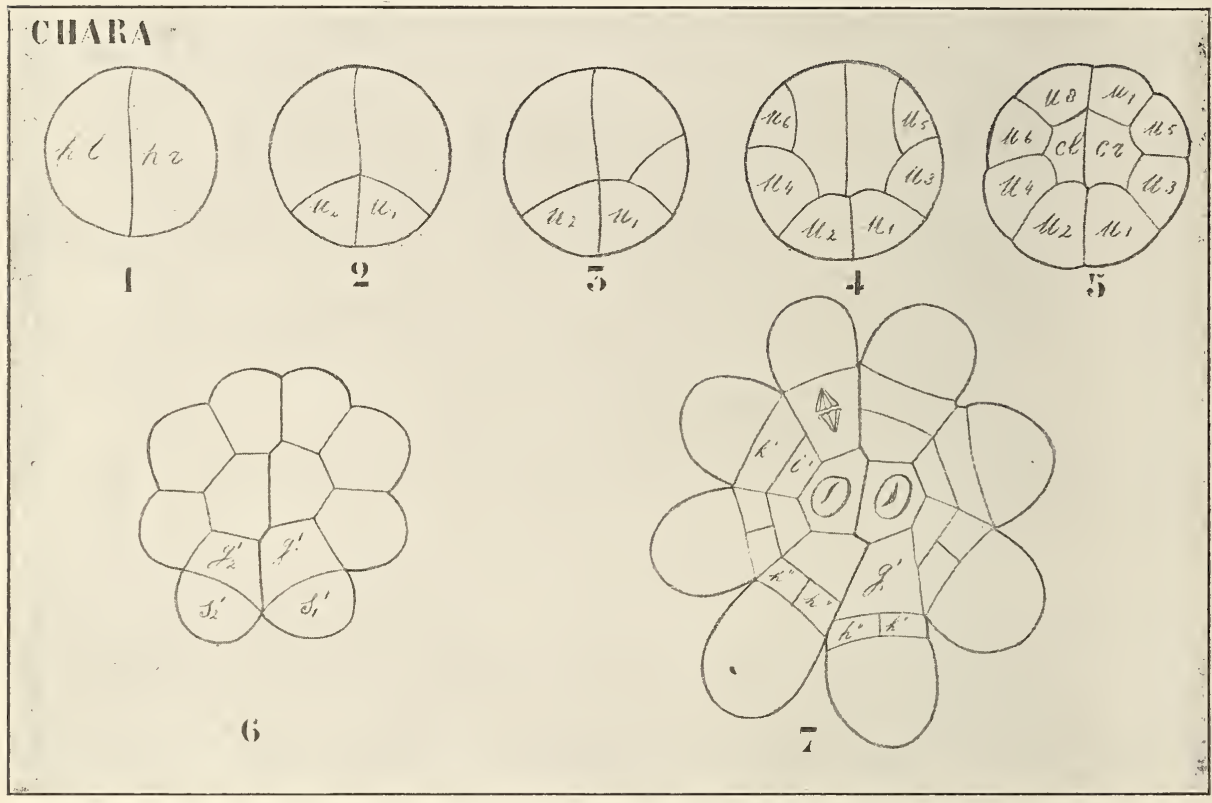

Fig. 428. Schema der Entwickelung der Knotenzelle bei Chara delicatula f. b ulbifera (nach Kuczewski). 1-5 Bildung der Segmente oder Blatturzellen. 6 Teilung der Blatturzellen in eine Scheitelzelle $s^{1}$ und eine Gliederzelle $g^{1}$. 7 Weitere Teilung der Gliederzelle in eine Knotenzelle $\mathrm{k}^{1}$ und eine Internodialzelle $\mathrm{i}^{1}$. In den beiden unteren Blättern hat sich die Knotenzelle schon wieder in eine linke und eine rechte Hälfte, $\mathbf{h}^{\mathbf{l}}$ und $\mathrm{h}^{\prime \prime}$, geteilt.

In dieser Weise läßt sich nun die ganze Chara-Pflanze in Formeln bringen, wer sich dafür interessiert, lese die Arbeiten GiEsenHaGens und Kuczewskis, welche als Nuster genauer Beobachtung bezeichnet werden dürfen.

Ich möchte aber, da Chara vom phylogenetischen Standpunkte bis jetzt nicht wichtig ist, wissen wir doch gar nicht, wo sie hingehört, ihr nicht zu viel Raum widmen und nur noch ganz kurz die Entwickelung der Sexualorgane besprechen.

Sehen wir zunächst, wie sich bei Nitella, einem anderen zu den Characeen gehörigen Genus, die 
Antheridien

entwickeln. Die Antheridien stehen hier, von einigen Blättchen umgeben, terminal an den Blättern (Fig. 429, 7) und sind in der Tat umgebildete Scheitelzellen, sie sitzen also einem Knoten auf, jedoch nicht ganz unvermittelt, denn bevor sie sich zum Antheridium umbildeten, hat die Blattscheitelzelle noch ein oder zwei scheibenförmige Zellen abgeschnitten, welche jetzt als Basalzellen das junge Antheridium tragen (Fig. 429, 1, 2). Das von diesen Basalzellen getragene kugelige Antheridiumprimordium wird zunächst durch eine Querwand in eine obere und eine untere Zelle, weiter durch gekreuzte Längswände in 4 obere und 4 untere Oktanten zerlegt (Fig. 429, 2, 3).

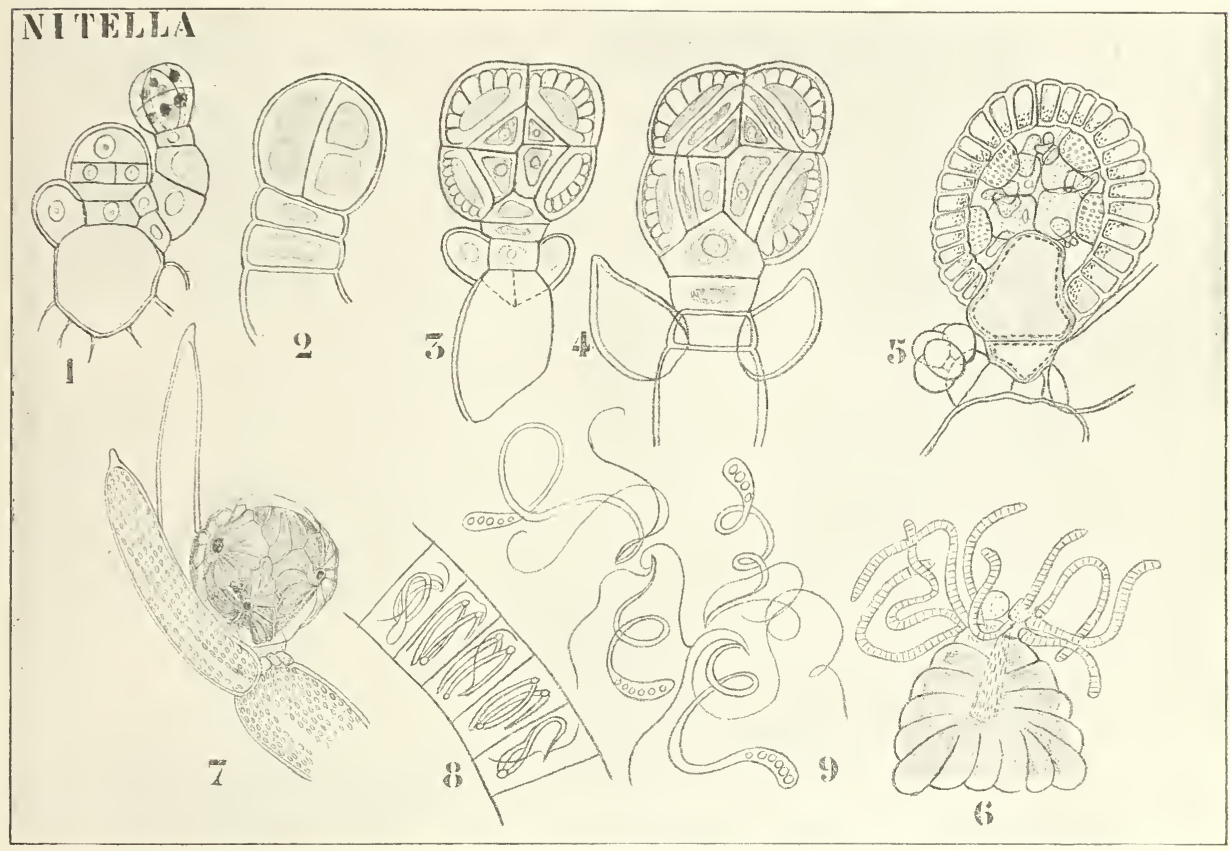

Fig. 429. Nitella flexilis. Antheridienentwickelung (nach SACHs). 1, 2 Das Antheridium in Oktanten geteilt. 3 Jede Oktantenzelle in eine innere und eine äußere Zelle zerlegt. 4 Jede Oktantenzelle in eine periphere, mittlere und zentrale zerlegt. 5 Durch Flächenwachstum der peripheren Zellen ein Hohlraum gebildet, die periphere Zelle zum Schild, die mittlere zum Manubrium, die zentrale zum Köpfchen geworden. 6 Ein Oktant des reifen Antheridiums, das Schild, das Manubrium und die spermatozoenbildenden Zellenreihen zeigend. 7 Reifes Antheridium. 8 Spermatozoen in ihren Mutterzellen. 9 Freie Spermatozoen.

Jeder dieser Oktanten zerfällt nun durch eine der Oberfläche parallele Wand in eine innere und eine äußere Zelle (Fig. 429, 3), die innere wird nochmals in gleicher Weise geteilt, so daß jeder Olitant nun aus 3 Zellen, einer zentralen, einer mittleren und einer peripheren besteht (Fig. 429, 4). Die peripheren Kellen zeigen starkes Flächenwachstum und werden zu den Schildern, die mittleren Zellen zu den Manubrien und die zentralen zu deu Köptchen. Durch das Flächenwachstum der Schilder ist im Antheridium ein Hohluam entstanden. in 
welchem sich die als seitliche Ausstülpungen an den Köpfchen entstehenden, Spermatozoen bildenden Zellfäden ausbreiten. Inzwischen hat sich die basale Zelle zwischen die 4 unteren Oktantenzellen eingedrängt (Fig. 429, 3, 4), so daß die Wand des Antheridiums aus 9 Zellen besteht.

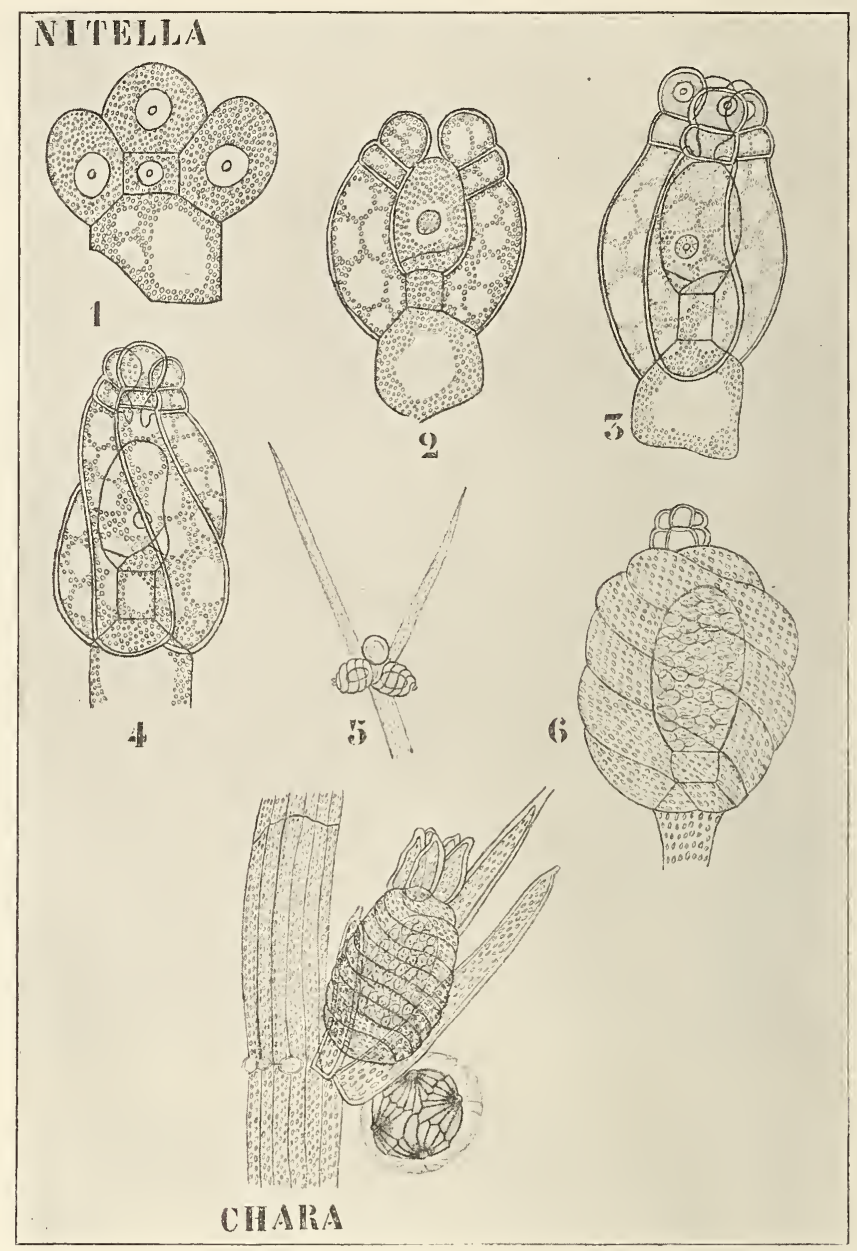

Fig. 430. 1-6 Entwickelung des Oogoniums von Nitella (nach SACHS). Unten eine Figur von Chara, zum Vergleiche des Krönchens.

\section{Oogonien.}

Bei monöcischen Nitella-Arten entstehen die Oogonien aus dem Knoten, der die Antheridien trägt (Fig. 430, 5), also an der Stelle, wo sonst Blättchen sich bilden würden.

Die Randzelle wölbt sich dazu vor und teilt sich durch zwei Querwände in eine obere, eine mittlere und eine untere (Fig. 430, 1). Die obere ist eine Scheitelzelle, die mittlere eine Knotenzelle, die untere eine Internodiumzelle, das Ganze also eine Knospe. 
Die Scheitelzelle wird das Oogon, die Knotenzelle bildet 5 Randzellen, welche zu den Hüllschläuchen auswachsen, und die Internodialzelle wird zum Stielchen. Bei Nitella bilden die Hüllschläuche je 2 kleine Zellen an der Spitze, bei Chara nur eine, diese Spitzen bilden zusammen das Krönchen, welches also bei Chara aus einer, bei Nitella aus zwei Etagen besteht.

Die Scheitelzelle wird aber nicht sofort zum Oogonium, sondern scheidet erst 3 Wendezellen ab (Fig. 430, 2-4), welche sehr verschieden gedeutet worden sind. Nach Goebel sind sie den ersten Teilungen im Antheridium homolog, während im Antheridium sämtliche Quadranten fertil sind, wäre hier nur einer fertil. Nach GoEtz sollen sie die Reste der Wand eines einstigen Archegoniums sein, und die Characeen wären eine Art reduzierte Moose. Vorläufig ist wohl die Bedeutung der Wendezellen ebenso unklar, wie die systematische Stellung der Characeen überhaupt; ob sie als erste Andeutung der Bildung eines Archegons gelten dürfen, wird bei den Archegoniaten besprochen werden.

Trotz der flüchtigen Behandlung glaube ich das für unsere Zwecke nötigste über die Characeen mitgeteilt zu haben, vielleicht kommen wir später noch auf die Cytologie der Spermatozoenbildung, wenn wir diese bei den Archegoniaten behandeln, zurück. 


\section{Literatur.}

Für die Algen findet man die Literatur bis 1904 in OLtmanns, Morphologie und Biologie der Algen, Jena, G. Fischer, 1904-1905.

\section{Erste Vorlesung.}

Blackman, F. F., 1900. The primitive Algae and the Flagellata. Annals of Botany, 14, Dec.

- and Tansley, 1902. A revision of the classification of the green Algae. The New Phytologist, p. 21 seq.

Dangeard, 1898. Mémoire sur les Chlamydomonadinées. Le Botaniste, 6. Série, p. 66-290.

Dill, 1895. Die Gattung Chlamydomonas und ihre nächsten Verwandten. Pringsheims Jahrb. f. wiss. Bot., 28, p. 323-35\%.

Francé, R., 1894. Die Polytomeen, eine morphologisch-entwickelungsgeschichtliche Studie. Pringsh. Jahrb., 26, p. 295.

Goroschankin, 1891, 1892. Beiträge zur Kenntnis der Morphologie und Systematik der Chlamydomonaden. Bull. de la Soc. Imp. de Moscou.

Klebs, G., 1891. Ueber die Bildung der Fortpflanzungszellen bei Hydrodictyon utriculatum Roth. Bot. Ztg., Sp. 789, 805, 821, 837, 853.

- 1896. Bedingungen der Fortpflanzung bei Algen und Pilzen, Jena.

Meyer, Arth., 1883. Ueber Kristalloide der Trophoplasten und über die Chromoplasten der Angiospermen. Bot. Ztg., 41, p. 489, 505, 525.

v. Sachs, J., 1892. Energiden und Zellen (Physiologische Notizen, II). Flora, p. 57-63.

Schimper, F. A. W., 1883. Ueber die Entwickelung der Chlorophyllkörner und Farbkörper. Bot. Ztg., 41, p. 105, 121, 13\%, 153, 809 (Erwiderung).

- 1885. Untersuchungen über die Chlorophyllkörper und die ihnen homologen Gebilde. Pringsh. Jahrb. f. wiss. Bot., 16, p. 1-246.

Schmitz, 1884. Beiträge zur Kenntnis der Chromatophoren. Pringsh. Jahrb. f. wiss. Bot., 15, p. $1-1 \%$.

Spencer, H., 1i64. The Principles of Biology, London.

Timberlake, H. G., 1901. Starch formation in Hydrodictyon utriculatum. Annals of Botany, 15, p. 619-635.

\section{Zweite Vorlesung. Volvocales.}

Goebel, K., 1882. Grundzüge der systematischen und speziellen Pflanzenmorphologie (Eudorina, p. 43). Leipzig, Engelmann.

Klein, L., 1889. Morphologische und biologische Studien über die Gattung Volvox. Pringsh. Jahrb., 20, p. 133.

- 1889. Neue Beiträge zur Kenntnis der Gattung Volvox. Ber. d. D. bot. Gés., \%, p. 42.

Oltmanns, F., 1904-1.905. Morphologie und Biologie der Algen, Jena, Gustav Fischer.

Overton, 1889. Beitrag zur Kenntnis der Gattung Volvox. Bot. Centralbl., 39, p. 65.

\section{Dritte Vorlesung. Siphonales.}

Askenasy, 1888. Ueber die Entwickelung von Pediastrum. Ber. d. D. bot. Ges., 6, p. 124 (mit Taf. VI).

de Bary und Strasburger, 187\%. Acetabularia mediterranea. Bot. Ztg., 35.

Berthold, G., 1882. Beiträge zur Morphologie und Biologie der Meeresalgen. Jahrb. f. wiss. Bot., 13, p. 569.

Borge, 1894. Ueber die Rhizoidenbildung bei einigen fadenförmigen Chlorophyceen. Inaug.Diss Basel.

Brand, 1899. Cladophora-Studien. Bot. Centralbl., p. 213.

Davis, B. M., 1904. Oogenesis in Vaucheria. Bot. Gazette, 38, p. 81. 
Ernst, A., 1903. Siphoneenstudien. I. Dichotomosiphon tuberosus (A. Br.) Ernst. Beih. z. Bot. Centralbl., 13, p. 115 (mit Taf. TI-X).

- 1904. Siphoneenstudien. II. Beiträge zur Kenntnis der Codiaceen. Beih.z. Bot. Centralbl., 16, p. 199 (mit Taf. VII-IX).

- 190\%. Siphoneenstudien. III. Zur Morphologie und Physiologie der Fortpflanzungszellen der Gattung Taucheria DC. Beih. z. Bot. Centralbl., 16, p. 36\%.

Fairchild, D. G., 1894. Ein Beitrag zur Kenntnis der Kernteilung bei Valonia. Ber. d. D. Bot. Ges., 12, p. 335 .

Goetz, H., 1897. Zur Systematik der Gattung Vaucheria, speziell der Arten der Umgebung Basels. Flora, $\mathbf{S 3}$, p. 88 .

Herbst, C., 1896. Ueber die Regeneration von Antennen-ähnlichen Organen an Stelle von Augen. I. Arch. f. Entw.-Hech., 2, p. 544 .

Janse, J. M., 1890. Die Bewegungen des Protoplasma von Caulerpa prolifera. Pringsh. Jahrb., 21, p. 263.

Klebahn, H., 1899. Die Befruchtung der Sphaeroplaea annulina Ag. Festschrift für Schwendener, Berlin, p. 81 .

Klebs, G., 1890. Ueber die Vermehrung von Hydrodictyon utriculatum. Flora, p. 351.

- 1890. Nachtrag. Biol. Centralbl., 9, p. 753.

- 1891. Ueber die Bildung der Fortpflanzungszellen bei Hydrodictyon utriculatum Roth. Bot. Ztg.

Klemm, P., 1893. Ueber Caulerpa prolifera, ein Beitrag zur Erforschung der Form- und Richtkräfte in Planzen. Flora, \%, p. 460.

- 1894. Ueber die Regenerationsvorgänge bei den Siphoneen. Ein Beitrag zur Erkenntnis der Mechanik der Protoplasmabewegungen. Flora, $8 \mathcal{8}$, p. $29 \mathrm{ff}$.

Kuckuck, P., 1903. Zur Fortpflanzung von Valonia Gin. (Vorl. Mitt.) Ber. d. D. bot. Ges., 20, p. $355-35 \%$.

Lagerheim, G. de, 1893. Rhodochytrium nov. gen., eine Uebergangsform von den Protococcaceen zu den Chytridiaceen. Bot. Ztg., p. 43-51.

Loeb, J., 1891-1892. Untersuchungen zur physiologischen Morphologie der Tiere. I und II. Würzburg.

Meyer, A., 1891. Notiz über die Zusammensetzung des Zellsaftes von Valonia utricularis. Ber. d. D. bot. Ges., 9, p. $7 \%$.

Noul, F., 1888. Ueber den Einfluß der Lage auf die morphologische Ausbildung einiger Siphoneen. Arb. a. d. bot. Inst. in Würzburg, 3, p. 466.

- 1890. Experimentelle Untersuchungen über das Wachstum der Zellmembran. Abh. d. Senckenb. Naturf. Ges., 15, p. 101.

- 1900. Ueber die Umkehrungsversuche mit Bryopsis nebst Bemerkungen ïber ihren zelligen Aufbau (Energiden). Ber. d. D. bot. Ges., 18, p. 444.

Oltmanns, F., 1895. Ueber die Entwickelung der Sexualorgane bei Vaucheria. Flora, 80 , p. 388.

Pfeffer, 1890. Zur Kenntnis der Plasmahaut und der Vakuolen nebst Bemerkungen über den Aggregatzustand des Protoplasmas und über osmotische Vorgänge. Abh. d. math.phys. Kl. d. Sächs. Gesellsch. d. Wiss., 16, p. 185-345.

Reinke, J., 1899. Ueber Caulerpa. Wiss. Meeresunters., herausg. v. d. Komm. z. Unters. d. deutschen Meere etc., Abt. Kiel, N. F. 5, p. 1.

Solms-Laubach, H., 1893. Ueber die Algengenera Cymopolia, Neomeris und Bornetella. Ann. d. Jard. Bot. Buitenzorg, 11, p. 6\%.

Stahl, E., 1897. Ueber die Ruhezustände der Vaucheria geminata. Bot. Ztg., 3\%, p. 129.

Timberlake, H. G., 1901. Starch-formation in Hydrodictyon utriculatum. Ann. of Botany, 15, p. 619.

- 1902. Development and structure of the swarm-spores of Hydrodictyon. Trans. Wisc. Acad. of Sc., 13, p. 486-522, Pls. XXIX-XXX.

de Vries, H., 1885. Plasmolytische Studien ïber die Wand der Vakuolen. Jahrb. f. wiss. Bot., 16, p. 465 .

Weber-v. Bosse, A., 1890. Etudes sur les Algues de l'Archipel Malasien. I. Tirentepohlia spongophila n. sp. et Struvea delicatula Kütz. (Cladophora? anastomosans Harv.). Ann. d. Jard. Bot. de Buitenzorg, 8, 1890, p. 79.

- 1898. Monographie des Caulerpes. Ann. d. Jard. Bot. de Buitenzorg, 15, p. 243 $-396$.

Went, F. A. H. C., 1888. Die Vermehrung der normalen Vaknolen durch Teilung. Pringsh. Jahrb. 19, p. 295-353.

- - 1890. Die Entwickelung der Vakuolen in den Fortpflanzungszellen der Algen. Pringsh. Jahrb., 21.

Winkler, H., 1900. Ueber Polarität, Regeneration und Heteromorphose bei Bryopsis. Jahrb. f. wiss. Bot., 25, p. 449.

Woronin, M., 1862. Recherches sur les Algues marines Acetabularia et Espera. Ann. Se. nat. Bot., 4. Série, 16, p. 200. 


\section{Vierte Vorlesung. Archimyretes und Siphonomycetes.}

Berlese, 1898. Ueber die Befruchtung und Entwickelung der Oosphäre bei den Peronosporeen. Jahrb. f. wiss. Bot., 31, p. 159.

Blakeslee, 1904. Sexual reproduction in the Mucorineae. Proc. Am. Acad., 40, p. 200 $-319,4 \mathrm{Pl}$.

- 1906. Zygospore-germinations in the Mucorineae. Annales Mycologici, p. 1-28.

Braun, A., 1855. Ueber Psendolpidium unter dem Namen: Chytridium saprolegniae. In: Ueber Chytridium. Abhdlg. der Berliner Akad.

Brefeld, O., 1873. Untersuchungen über die Entwickelung der Empusa muscae und E. radicans. Abh. d. naturf. Gesellsch. zu Halle, 12, p. 1-50.

- 1872, 1881. Botanische Untersuchungen über Schimmelpilze. 1, 1872; IV, 1881.

Cornu, M., 1871. Monoblepharis. Bull. de la Soc. bot., 28, p. 59.

- 1872. Ueber Pseudolpidium unter dem Namen Olpidiopsis. In: Monographie des Saprolegniacées. Ann. d. Sc. nat., 5. Série, 15.

- 1872. Monographie des Saprolegniées. Ann. d. Sc. nat. Bot., 5. Série, 15, p. 82.

Cunningham, D. D., 1878. On the occurence of conidial fructification in the Mucorineae. Transact. of the Linn. Soc. of London, 2. Ser. Bot., 1.

Dangeard, 1893. Recherches histologiques sur les champignons (für Synchytrium). Le Botaniste, 2, p. 61-150.

-- 1906. La fécondation nucléaire chez les Mucorinées. C. R. Ac. d. Sc., 142, 12 mars, p. $645-646$.

Davis, M., 1900. The fertilization of Albugo candida. Bot. Gaz., 29, p. 29\%.

- 1903. Oogenesis in Saprolegnia. Bot. Gaz., 35.

Falck, R., 1902. Die Bedingungen und die Bedeutung der Zygotenbildung bei Sporodinia grandis. Cohns Beitr. z. Biol. d. Pflanzen, 8, H. 2, p. 213.

Fischer, A., 1880. Ueber die Stachelkugeln in Saprolegnia-Schläuchen. Bot. Ztg., p. 689, 705,721 .

- 1884. Untersuchungen über die Parasiten der Saprolegnieen. Pringsh. Jahrb., 14, p. 286 (mit Taf. $X I I I-X V$ ).

- 1892. Phycomycetes. Rabenhorst, Kryptogamenflora. Die Pilze. IV. Abteilung.

Gruber, E., 1901. Ueber das Verhalten der Zellkerne in den Zygosporen von Sporodinia grandis. Ber. d. D. bot. Ges., 19, p. 51.

Harper, 1899. Celldivision in Sporangia and Asci (für Synchytrium). Ann. of Botany, $13, p .467$.

Humphrey, 1892. The Saprolegniaceae of the U. S. Am. Philos. Soc., Nov. 18.

Klebs, G., 1898. Zur Physiologie der Fortpflanzung einiger Pilze. Pringsh. Jahrb. f. wiss. Bot., 32, p. 1 .

- 1899. Zur Physiologie der Fortpflanzung einiger Pilze. II. Saprolegnia mixta de Bary. Jahrb. f. wiss. Bot., 33, p. 513.

- 1902. Ueber Sporodinia grandis. Bot. Ztg., No. 12/13, Sp. 17\%.

Lagerheim, G., 1900. Untersuchungen über Monoblepharideen. Bih. till K. Svenska Vet. Akad. Handlingar, 25, Afd. III, No. 8.

Loewenthal, W., 1904. Weitere Untersuchungen an Chytridiaceen. Arch. f. Protistenkunde, 5.

Miyake, K., 1901. The fertilization of Pythium de Baryanum. Ann. of Bot., 15, p. 65s.

Nägeli, C., 1846. Pseudolpidium in Jahrb. f. u'iss. Bot., 1, H. 3, p. 29.

Nowakowski, 1876. Polyphagus Englenae. Colns Beitr. z. Biol. d. Pflanzen, 2.

Olive, E. W., 1906. Cytological Studies on the Enthomophtoreae. I. The Morphology and Development of Empusa. Bot. Gaz., 41, p. 192 (2 Plates). II. Nuclear and Celldivision of Empusa. Ibid., p. 229.

Pringsheim, 1858. Beitrag zur Morphologie und Systematik der Algen. II. Die Saprolegnieen. Jahrb. f. wiss. Bot., 1.

- 1860. Nachträge zur Morphologie der Saprolegnieen. Jahrb. f. wiss. Bot.

Reinsch, 1878. Beobachtungen über einige newe Saprolegniaceen. Pringsh. Jahrb. f. wiss. Bot., 11, p. 293.

Rosen, F., 1893. Beiträge zur Kenntnis der Pflanzenzellen. II. Studien über die Kerne und die Membranbildung bei Myxımyceten und Pilzen (für Synchytrium). Cohns Beitr. z. Biol. d. Pflanzen. 6, p. 237266.

Ruhland, W., 1904. Studien über die Befruchtıng der Albugo Lepigoni und einiger Peronosporeen. Pringsh. Juhrb., 39, p. 135.

Stevens, F. L., 1899. The compound oosphere of Albugo Bliti. Bot Gaz., 28, p. 149.

- 1901. Gametogenesis and Fertilization in Albugo. Bot. Gaz., 32, p. $7 \%$.

- and A. C., 1903. Mitoses of the primary nuclens in Synchytrium decipiens. Bot. Gaz., 35.

v. Tavel, 1892. Vergleichende Morphologie der Pilze. Jena, Gustav Fischer.

Thaxter, R., 1888. The Entomophthorene of the United States. Mem. Boston Soc. Nat. Hist., 4, p. 133-201, Pl. XIV-XXI. 
Thaxter, R., 1895. New or pecnliar aquatic Fungi. I. Monoblepharis. Bot. Gaz., 20, p. $433-440$.

Trow, A. H., 1901. Observations on the Biology and Cytology of Pythinm ultimum nov. sp. Ann. of Bot., 15, $p$. $26 \%$.

- 1904. On Fertilisation in the Saprolegnieae. Ann. of Bot., p. 541.

Vuillemin, P., 1900. Développement des azygospores d'Entomophthora. C. R. Acad. Sc. Paris, $130, p .522524$.

Wager, H., 1889. On the nuclei of Peronospora parasitica and on their behaviour during the formation of the oospore. Ann. of Bot., 4, p. $12 \%$.

- 1896. On the structure and reproduction of Cystopus candidus. Ann. of. Bot., 10, p. 295.

Woronin, M., 1868. Entwichelungsgeschichte von Synchytrium Mercurialis. Bot. Ztg., p. 88.

- 1902. Beitrag zur Kenntnis der Monoblepharideen. Mémoires de l'Acad. Imp. d. Sc. de St. Petersbourg, \& Série, 16, No. 4 .

Zalewsky, A., 1883. Ueber Sporenabschnürung und Sporenabfallen bei den Pilzen. Flora, $6 \boldsymbol{6}$. (Ref. im Bot. Centralbl., 15, p. 129.)

Zopf, W., 1884. Zur Kenntnis der Phycomyceten. I. Zur Morphologie und Biologie der Ancylisteae und Chytridiaceae. Nova Acta Acad. Leop. Carol., $4 \%$.

\section{Fünfte Vorlesung. Multicelluläre monoenergide Isokonten.}

Allen, 1905. Die Keimung der Zygote bei Coleochaete. Ber. d. D. bot. Ges., p. 285.

Beijerinck, $\boldsymbol{M}$. W., 1890. Kulturversuche mit Zoochlorellen, Lichenengonidien und anderen niederen Algen. Bot. Ztg., p. 725.

Chmielevsky, 1890. Beiträge zur Morphologie und Physiologie des geschlechtlichen Prozesses bei den niederen Pfanzen, Charkow. (Russisch.)

Cienkouski, L., 1876. Zur Morphologie der Ulotricheen. Bull. de l'Acad. d. Sc. de St. Petersbourg, 22, p. 550 .

Chodat et Malinesco, O., 1893. Sur le polymorphisme du Scenedesmus acutus. Bull. de l'Herb. Boiss., 1, p. 184.

Eidam, E., 1886. Basidiobolus, eine neue Gattung der Entomophthoraceen. Cohns Beitr. z. Biol. d. Pflanzen, 4, H. 2.

Fairchild, D., 189\%. Ueber Kernteilung und Befruchtung bei Basidiobolus ranarum Eid. Jahrb. f. wiss. Bot., 30.

Karsten, 1891. Untersuchungen über die Familie der Chroolepideen. Ann. d. Jard. Bot. de Buitenzorg, 10, p. 1.

Klebs, G., 1896. Die Bedingungen der Fortpflanzung bei Algen und Pilzen, Jena, Gustav Fischer.

Palla, E., 1894. Ueber ein neues Organ der Conjugatenzelle. Ber. d. D. bot. Ges., 12, p. 153 .

Raciborski, M., 1896. Ueber den Einfuß äußerer Bedingungen auf die Wachstumsweise des Basidiobolus ranarum. Flora, Heft 2; auch Ber. d. Akad. d. Wiss. zu Krakau, 1899, Fasc., 142.

Schmidle, W., 1894. Aus der Chlorophyceenflora der Torfstiche zu Tirnheim. Flora, p. 42.

Senn, G., 1899. Ueber einige kolonienbildende einzellige Algen. Bot. Ztg., 4\%, p. 40.

Wille, N., 188\%. Ueber die Schwärmzellen und deren Kopulation bei Trentepohlia Murt. Pringsh. Jahrb., 18, p. 426.

Woycicki, Z., 1904. Einige neue Beiträge zur Entwickelungsgeschichte von Basidiobolus ranarum Eidam. Flora, $p .8 \%$.

\section{Sechste Vorlesung. Stephanokonten.}

Kraskovits, G., 1905. Ein Beitrag zur Kenntnis der Zellteilung bei Oedogoniam. Sitzber. d. k. Akad. d. Wiss. in Wien, math.-naturw. Kl., 11\&, Heft 3 u. 4, März und April, Abt. 1, p. 23\%, wo man die ältere Literatur über Oedogoninm findet.

Oltmanns, Morphologie und Biologie der Algen fïr Derbesia.

\section{Siebente Vorlesung. Heterokonten.}

Bohlin, K., 189\%. Zur Morphologie und Biologie einzelliger Algen. Ofiersigt uf Kgl. Sienska Vet. Akad. Förhandlingar, No. 9.

- 1897. Studier öfver nagra slagten af Alggruppen Confervales Borzi. Meddelanden från Stockholms Högskola. Bihang till K. Svenska Vet. Lkad. Handlingar, 23, 4fid. III, No. 3.

Gay, F., 1891. Recherches sur le développement et la classification. de quelques alques vertes. Thèse de Paris.

Klebs, G., 1896. Die Bedingungen der Fortptlanzung bei llgen und. Pilzcn. Jena.

Luther, A., 1899. Ueber Chlorosaccns, eine newe Gattming der sïßuasicralgen. Bihung till K. Svenska Akad. Handl., 21, Afd. III, To. 18. 


\section{Achte Vorlesung. Desmidiaceae.}

de Bary, A., 1858. Untersuchungen ïber die Familie der Conjugaten, Leipzig.

Hauptfleisch, P., 1888. Zellmembran und Hüllgallerte der Desmidiaceen. Diss. Greifswald. Klebahn, H., 1888. Keimung von Closterium und Cosmarium. Pringsh. Jahrb., 22, p. 415. - 1888. Ueber die Zygosporen einiger Conjugaten. Ber. d. D. bot. Ges., 6, p. 160.

Klebs, G., 1886. Bewegung und Schleimbildung der Desmidiaceen. Biol. Centralbl. 1885/86, 5, p. 353.

Lütkemüller, J., 1902. Die Zellmembran der Desmidiaceen. Cohns Beitr. z. Biol. d. Pflanzen, $8, p .347$.

Palla, E., 1894. Ueber ein neues Organ der Conjugatenzelle. Ber. d. D. bot. Ges. 12, p. 153.

Schroeder, B., 1902. Untersuchungen über die Gallertbildungen der Algen. Verh. $d$. nat.-med. Vereins zu Heidelberg, N. $F^{*}$., \%, p. 139.

\section{Neunte Vorlesung. Die Phaeophytenreihe.}

Klebs, G., 1892. Flagellatenstudien. Jahrb. f. wiss. Zool., 55, p. 265.

Lohman, H., 1902. Die Coccolithophoridae, eine Monographie der Coccolithen bildenden Flagellaten. Arch. f. Protistenkunde, 1, p. 89.

Rostafinski, J., 1882. Hydrurus et ses affinités. Ann. d. Sc. nat. Bot., 6. Sér., $14, p .1$. Senn, G. Flagellaten in Engler und Prantl, Natürl. Pflanzenfam., 1, Abt. 1a.

Woronin, 1880. Chromophyton Rosanoffi. Bot. Ztg.

\section{Zehnte Vorlesung. Die Peridinales.}

Schütt, $\boldsymbol{F}$. Peridineen in Engler und Prantl, Natürl. Pflanzenfam., 1, Abt. $1 b$. - Die Peridineen der Planktonexpédition, I. Teil. Ergebnisse, 4.

Zederbauer, E., 1904. Geschlechtliche und ungeschlechtliche Fortpflanzung von Ceratium hirundinella. Ber. d. D. bot. Ges., 22, p. 1.

\section{Elfte Vorlesung. Die Diatomeen.}

Flögel, J. H. L., 1884. Researches on the structure of the cell-wals of Diatoms. Journ. R. micr. Soc., Ser. II, 4, p. 505, 611, 655, 851.

Karsten, 1904. Die sogenannten Mikrosporen der Planktondiatomeen und ihre weitere Entwickelung, beobachtet an Corethron Valdiviae n. sp. Ber. d. D. bot. Ges., 24. Dez., p. 544 .

Lauterborn, 1896. Untersuchungen über Bau, Kernteilung und Bewegung der Diatomeen, Leipzig, Engelmann.

Mïller, O. Aufsätze in Ber. d. D. bot. Ges., von 1885 an.

Pfitzer, E., 18\%1. Untersuchungen über Bau und Entwickelung derj Bacillariaceen. Hamb. bot. Abh., Heft 2.

\section{Zwölfte Vorlesung. Phaeophyceae.}

Berthold, G., 1881. Die geschlechtliche Fortpflanzung der eigentlichen Phaeosporeen. Mitt. a. d. zool. Station zu Neapel, 2, 1881.

Bitter, G., 1899. Zur Anatomie und Physiologie von Padina Pavonia. Ber. d. D. bot. Ges., 1\%, p. 255.

Bornet, Ed., 1891. Note sur quelques Ectocarpus. Bull. de la Soc. bot. de France, 38.

Bower, 1880. On the development of the conceptacle in the Fucaceae. Quart. Journ. of microsc. Science.

Falkenberg, G., 18\%6. Die Befruchtung und der Generationswechsel von Cutleria. Mitt. a. d. zool. Station zu Neapel, 1.

Farmer, J. B. and Williams, J. Ll., 1898. Contributions to our knowledge of the Fucaceae, their life-history and cytology. Phil. Trans., 190, p. 623-645.

Hauck. Meeresalgen in Rabenh. Kryptogamenflora.

Kjelmann, F. R., Fucoideae in Engler u. Prantl, Natürl. Pflanzenfam., 1, 2.

- 1883. The Algae of the Arctic sea. Kgl. Svensk. Vet. Akad. Handlingar, 20, No. 5.

Kuckuck, 1899. Die Gattung Myriotrichia in Beitr. z. Kenntn. d. Meeresalgen, Biol. Anst. auf Helgoland.

- Ueber den Generationswechsel von Cutleria multifida Grev. Wiss. Meeresunt., Abt. Helgoland, N. F. 3.

- Bemerkungen zur marinen Algenvegetation von Helgoland. I u. II. Wiss. Meeresunters., Abt. Helgoland, N. F. 1 u. 2 .

- Beiträge zur Kenntnis der Meeresalgen. Wiss. Mceresunters., Abt. Helgoland, N. F. $2 u_{\bullet} 3$. Kützing, 1860-1861. Tabulae Phycologicae, 10-11, Nordhausen.

Mottier, D. M., 1900. Nuclear and cell division of Dictyota dichotoma. Ann. of Botany, 14, p. $163-193$. 
Murray. G., 1883. Notes on the morphology of the Fucaceae. Murrays Phycological Memoirs, Pt. 2, p. 29.

Oltmanns, F., 1889. Beiträge zur Kenntnis der Fucaceen. Bibliotheca botanica, Heft 14.

- 1904. Morphologie und Biologie der Algen, Jena.

Reinke, J., Ueber die Entwickelung von Phyllutes, Scytosiphon und Asperococcus. Pringsh. Jahrb., 11, p. 262.

- 1889-1892. Atlas deutscher Meeresalgen, Kiel.

- 1878. Entwickelungsgeschichtliche Untersuchungen über die Dictyotaceen des Golfes von Neapel. Nova Acta Leopold., 50.

- 18\%6, Ueber das Wachstum und die Fortpflanzung von Zanardinia collaris Cronan. Monatsber. d. Akad. Berlin, p. 565.

- 1878. Entwickelungsgeschichtliche Untersuchungen über die Cutleriaceen. Nova Acta Leop. p. 59.

Sauvageau, C., 1896. Observations relatives à la sexualité des Phéosporées. Journ. de Bot., 10, p. $35 \%$.

- 1896. Sur le Strepsithalia, nouveau genre des Phéosporées. Journ. de Bot., 10.

- 1898. Sur quelques Myrionémacées. Ann. d. Sc. nat., Bot., 8. Sér., 5.

- 1899. Les Cutleriacées et leur alternance de générations. Ann. d. Sc. nat., Bot., 8. Sér., $10, p .265$.

Simons, E., 1906. A morphological study of Sargassum filipendula. Contrib. from the Hull Bot. Lab., Bot. Gaz., 41, p. 161.

Strasburger, E., 189\%. Kernteilung und Befruchtung bei Fucus. Pringsh. Jahrb., 30, p. 351 .

Thuret et Bornet, 1878. Etudes phycologiques.

\section{Dreizehnte Vorlesung. Rhodophyceae.}

Berthold, G., 1882. Bangiaceen des Golfes von Neapel. Fauna und Flora des Golfes von Neapel, $\mathcal{S}$.

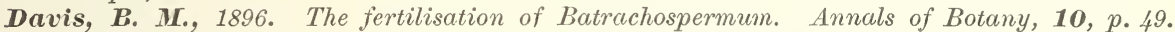

Falkenberg, P., 1901. Die Rhodomelaceen des Golfes von Neapel und der angrenzenden Meeresabschnitte. Fauna und Flora des Golfes, 26. Monographie, Berlin.

Hassencamp, A., 1902. Ueber die Entwickelung der Cystocarpien bei einigen Florideen. Bot. Ztg., $60, p .65$.

Kuckuck, P., 1894. Choreocolax albus n. sp., ein echter Schmarotzer unter den Fllorideen. Sitzber. d. Kgl. preußischen Akademie d. Wissensch. zu Berlin, 26. Juli, 38, p. 983 bis $98 \% .1$ Taf.

Oltmanns, F., Zur Entwickelungsgeschichte der Florideae. Bot. Ztg., 56, p. 99.

- 1904. Algen. Jena.

Osterhout, M. J. V., 1900. Befruchtung bei Batrachospermum. Flora, 8\%, p. 109.

Schmidle, W., 1899. Einiges über die Befmuchtung, Keimung und Haarinsertion von Batrachospermum. Bot. Ztg., 5\%, p. 125.

Sirodot, L., 1884. Les Batrachospermes, Paris.

Thuret et Bornet, 18\%8. Etudes phycologiques.

Yamanouchi, S., 1906. The life history of Polysiphonia violacea. Bot. Gazette, 41, June, p. 425.

Wille, N., 1894. Ueber die Befruchtung von Nemalion multifidum (Web. et Mohr). Ber. d. D. bot. Ges., 12, p. 59.

Wolfe, J. J., 1904. Cytological studies on Nemalion. Ann. of Bot., 18, p. 60\%.

Vierzehnte Vorlesung. Die Schizophyten (Bakterien).

Abbot, 1894. Principles of Bacteriology. Philadelphia.

de Bary, 1884. Vergl. Morphologie und Biologie der Pilze, Mycetozoen und Batiterien, Leipzig, p. 496, 506.

Behring, 1892. Die Blutserumtherapie. I. Die praktischen Ziele und die Immunisierungsmethode zum Zwecke der Gewinnung von Heilserum; II. Das Tetanusheilserum, und seine Anwendung auf tetanuskranke Menschen.

- und Wernicke, 1892. Ueber Immunisierung und Heilung von Versuchstieren bei der Diphtherie. Zeitschr. f. Hygiene, 12.

Beijerinck, $\boldsymbol{M}$. W., 1893. Les organismes anaérobiennes obligatoires ont-ils besoin d'oxygène libre. Archives Néerlandaises, 2, Série 2.

- 1888. Die Bakterien der Papillionaceenknöllchen. Bot. Ztg.

- 1891. Over ophooping van atmospherische stickstof in culturen van Bacillus radicicola. Acad. v. Wetensch., Amsterdam.

- 1901. Photobacteria as a reaction in the investigation of the chlorophyllinution. I. Acad. $v$. Wetensch, Amsterdam, session of June $26, p .45$.

Brefeld, O., Untersuchungen über Schimmelpilze. IV. (Bacillus subtilis.) 
Büsgen, M., 1894. Kulturversuche mit Cladothrix dichotoma. Ber. d. D. bot. Ges., p. 147 Cohn, $\boldsymbol{H} .$, 1876. Untersuchungen über Bakterien. IV. Beitr. z. Biologie der Pfanzen, 2. (Erste eingehende Beschreibung der Bakteriensporen.)

- 1876. System. in Untersuchungen über Bakterien. Cohns Beitr. z. Biol. d. Pfanzen, 2.

Engelmann, 1881. Neue Methode zur Untersuchung der Sauerstoffausscheidung pflanzlicher und tierischer Organismen. Bot. Ztg.

- 1882. Ueber Sauerstoffausscheidungen von Pflanzenzellen im Mikrospektrum. Bot. Ztg.

Fischer, A., 1891. Die Plasmolyse der Bakterien. Sitzber. d. Kgl. Sächs. Ges. d. Wiss., mathem. $K l$.

- 1900. Die Empfindlichkeit der Bakterienzellen. Zeitschr. f. Hygiene, 35.

- 1903. Vorlesungen über Bakterien, 2. Aufl., Jena, Fischer, worin die wichtigste Bakterienliteratur bis 1903 nachzuschlagen ist.

- 189\%. Untersuchungen über den Bau der Cyanophyceen und Bakterien, Jena.

Giltay et Aberson, 1892. Recherches sur un mode de dénitrification. Arch. Néerlandaises d. Sc. nat., 25.

Heller, J. F., 1893. Ueber das Leuchten im Pfanzen- und Tierreich. Arch. f. physiol. u. pathol. Chemie u. Mikroskopie mit bes. Rücksicht auf mediz. Diagnostik u. Therapie. N. H. $1853 / 54, p .13 \%$.

Hellriegel und Wilfarth, 1888. Untersuchungen über die Stickstoffnahrung der Gramineen und Leguminosen. Beilageheft zu der Zeitschr. d. Vereins f. d. Rübenzuckerindustrie d. D. R.

Hinze, 1901, 1902. Ueber Iden Bau der Zellen von Beggiatoa mirabilis. Ber. d. D. bot. Ges., 19 (1901), und ausfïhrlich in: Wiss. Meeresunters., herausg. v. d. Kommission zur Unters. d. dcutschen Meere, $\boldsymbol{\sigma}$ (1902).

Hüppe, Methoden der Balterienforschnng. 5. Aufl. (Erste Anwendung von Agar für Bakterienkulturen von Frau Hesse.)

Koch, R., 18\%6, Kreisphysikus in Wollstein. Die Aetiologie der Milzbrandkrankheit, begründet auf die Entwickelungsgeschichte des Bacillus anthracis. Cohns Beitr. z. Biol.d. Pfanzen, 2.

- 1881. Zur Untersuchung von pathogenen Organismen. Mitt. a. d. k. Gesundheitsamte, 1. (Einfiihrung der Gelatine als Kulturmedium.)

- 1884. Ueber die Cholerabaltcrien. Deutsche med. Wochenschr.

v. Leuvenhoek, A., 1683. Arcana naturae detecta.

Löffler, 188\%. Vorlesungen über die geschichtlichc Entwickelung der Lehre von den Bakterien, I. Teil bis zum Jahre 1878, Leipzig.

Migula, 1897-1900. System der Bakterien. 2 Bde.

Molisch, H., 1892. Die Pfanze in ihren Bcziehungen zum Eisen, Jena, p. 60.

- 1903. Ueber das Leuchten des Fleisches, insbesondere toter Schlachttiere. Bot. Ztg., 61, p. 1 .

Nobbe und Hiltner, 1896. Ueber die Anpassungsfähigkeit der Knöllchenbakterien ungleichen Ursprungs an verschiedene Leguminosengattungen. Landwirtschaftliche Versuchsstationen, $\mathbf{4 \%}$.

Omeliansky, 1899. Ueber die Isolierung der Nitrifikationsmikroben aus dem Erdboden. Bakteriologisches Centralbl., 2. Abt., 5.

Pasteur, L., 1862. Mémoires sur les corpusculcs qui existent dans l'atmosphère. Examen de la doctrine des générations spontanées. Annales de Chimie et Physique, 3. Série, 64.

- 1876. Études sur la bière, Paris.

Prazmowski, 1880. Untersuchungen über die Entwickelungsgeschichte und Fermentwirkung einiger Bakterienarten.

- 1888. Ueber die Wurzelknöllchen der Leguminosen. Bot. Ztg.

Ruzicka, 1904. Weitere Ĺntersuchnngen über den Bau und die biologische Natur der Bakterien. Arch. f. Hygiene, 51, p. 281-318.

van Tieghem, P., 1880. Sur le ferment butyrique à l'époque de la houille. C. R. Paris, séance du 29 dèc. 1879.

Winogradsky, 188\%. Ueber Schwefelbakterien. Bot. Ztg.

- 1888. Ueber Eisenbakterien. Bot. Ztg.

- 1889-1891. Recherches sur lcs organismes de la nitrification. 1.-5. mémoire. Annales de l'Institut Pastenr, 4 et 5.

- 1892. Contributions à la morphologie des organismes de la nitrification. Archives de Sciences biol., publié par l'Inst. impér. de Méd. expérim. St. Petersbourg, 1.

- 1893. Sur l'assimilation de l'azote gazenx de l'atmosphère par les microbes. Compt. rendus, Paris 1893, p. 1385, 1894, p. 353.

- 1896. Zur Mikrobiologie des Nitrifikationsprozesses. Bakteriol. Centralbl., 2. Abt., 2.

- und Omeliansky, 1890. Ueber den Einfluß der organischen Substanzen auf die Arbeit der nitrifizierenden Organismen. Bakteriol. Centralbl., 2. Abt., 5.

Zimmermann, A., 1902. Ueber Bakterienknoten in den Blättern einiger Rubiaceen. Pringsh. Jahrb. f. wiss. Bot., 36. 
Zopf, 18s2. Zur Morphologie der Spaltplze, Leipzig.

- Bakterien, in Schenks Handb. d. Botanik, 3, 1, p. 15.

\section{Fünfzehnte Vorlesung. Schizophyceen.}

de Bary, A., 1863. Beitrag zur Kenntnis der Nostoccaceen. Flora.

i. Beck, G. v. Mannagetta, 1898. Die Sporen von Microchaeta tenera und deren Keimung. Oester. bot. Zeitschr.

Bornet et Flahault, 1886-188s. Revision des Nostoccacées hetérocystées. Ann. de Sc. nat., Sér. YII, 3, $\mathbf{7}, \mathbf{5}, \mathbf{\%}$.

Borzi, A., 1878. Nachträge zur Biologie und Morphologie der Nostoccaceen. Flora, $\boldsymbol{6 1 .}$

- 18\%8-1882. Nota alla morfologia e biologia delle Alghe ficochromacee. Nuovo Giorn. bot. ital.. 10, 11, 11.

- 1886. Le communicazioni intercellulari della Nostochince. Malpighia, 1, p. 74.

Brand, F., 1900. Der Formenkreis von Gloeocapsa alpina Näg. Bot. Centralbl., 83.

- 1901. Bemerkungen über Grenzzellen und über spontan rote Inhaltskörper der Cyanophyceen. Ber. d. D. bot. Ges., 19.

- 1903. Morphologisch-physiologische Betrachtungen ïber Cyanophyceen. Beih. z. Bot. Centraibl., 15, H. 1.

- 1903. Ueber das osmotische Verhalten der Cyanophyceenzelle. Ber. d. D. bot. Ges., 21, p. 302.

Braun, Al., 1851. Betrachtungen iiber die Erscheinung der Verjüngung in der Natur, Leipzig.

Bütschli, O., 1890. Ueber den Bau der Bakterien und verwandter Organismen, Leipzig.

- 1896. Weitere Ausfïhrungen ïber den Bau der Cyanophyceen und Bakterien, Leipzig.

- Notiz ïber Teilungszustände des Zentralkörpers bei einer Nostoccacee. Verh. d. naturh.med. Vereins Heidelberg, N. F. G, p. 63--68.

- 1902. Bemerkungen ïber Cyanophyceen und Bacteriaceen. Arch. f. Protistenkunde, H. 1.

Cavara, F., 1902. Resistenza fisiologica del Microcoleus chtonoplastes Thur. etc. Nuovo Giorn. bot. it., 9.

Chodat, R., 1894. Contenu cellulaire des Cyanophycées. Arch. d. Sc. phys. et mat. Genève, Sér. 3, 32.

- et Malinesco, 1893. La structure cellulaire des Cyanophycées. Lab. de Bot. de l'Université de Genève, Sér. 1, Fasc. V, p. 62-63.

Cohn, F., 186\%. Beiträge zur Physiologie der Phycochromaceen und Florideen. Arch. $f$. mikrosk. Anat. von M. Schultze, 3.

Correns, C., 189\%. Ueber die Membran und die Bewegung der Oscillarien. Ber. d. D. bot. Ges., 15.

Dangeard, P., 1892. Le noyau d'une Cyanophycée. Le Botaniste, 3. Série, p. 28.

- 1899. L'autophagie sexuelle. Le Botaniste, 6. Série.

Deinega, V., 1891. Der gegenwärtige Zustand unserer Kenntnisse ïber den Zellinhalt der Phycochromaceen. Bull. de la Soc. des Natur. de Moscou.

Dujardin, F., 1838. Thèse sur le Nostoc.

Ernst, P., 1889. Ueber Kern- und Sporenbildung bei Bakterien. Heidelberger Habilitationsschrift. Ztschr. f. Hygiene, 5.

Fischer, A., 1891. Diskussion über Bütschlis Nucleus der Oscillatorien. Sitzber. d. $K$. Sächs. Gesellsch. d. Wiss., math.-phys. Kl., März.

- 189\%. Untersuchungen ïber den Bau der Cyanophyceen und Bakterien, Jena.

- 1899. Fixierung, Färbung und Bau des Protoplasmas, Jena.

- 1901. Ueber Protoplasmastruktur. Arch.f. Entwickelungsmech., 13.

- 1905. Die Zelle der Cyanophyceen. Bot. Ztg., H. $4 / 5$.

Fresenius, 1845. Ueber den Bau und das Leben der Oscillarien. Museum Senckenbergianum. Abh. a. d. Geb. d. Naturgesch., 3.

Fritsch, F. E., 1904. Studies on Cyanophyceae. I. Some points in the structure of an Anabaena. New Phytologist, 3, No. 4.

-- 1905. Studies on Cyanophycede. II. Structure of the investment and spore-development in some Cyanophyceae. Beih. z. Bot. Centralbl., 18.

Goebel, K., 1882. Grundzüge der Systematik und speziellen Pfanzenmorphologie, Leipsig, p. 24 (Schwärmzellen bei Merismopoedia erwähnt).

Gomont, M., 1888. Recherches sur les enveloppes cellulaires des Nosioceacées. Bull. de la Soc. bot. de France, 35.

- 1892. Monographie des Oscillariées. Amm. de Sc. nat., Série \%, 15 et $\mathbf{1 6}$.

Hansgirg, A., 1885. Ein Beitrag zur Kenntnis von der Terbreitung der Chromatophoren und Zellkerne bei den Phytochromaccen. Ber. d. D. bot. (res., 3. 1). 14.

- 1890. Ueber neue Sü̈bwasser-und Meeresulgen sitzber. A. K. Böhm. Ges. I. IIiss.. 1.

- 1892. Prodromus der Algcnflora von Böhmen, T. II, Prag.

Hariot, P., 1892. Sur une algue qui vit dans les racines des Cycadés. C. R., 11.j. 
Hegler, R., 1901. Untersuchungen über die Organisation der Phycochromaceen-Zelle. Jahrb. f. wiss. Bot., 26, p. 229-353.

Hieronymus, G., 1892. Die Organisation der Phycochromaceen-Zelle. Cohns Beitr. z. Biol. d. Pflanzen, 5, p. 461.

- 1893. Ueber die Organisation der Phycochromaceen-Zelle. Bot. Ztg., p. 73.

Itzigsohn, H., 1875. Ueber Gloeocapsa. Gesellsch. naturf. Freunde in Berlin.

Kirchner, O., 1900. Schizophyceae. In Engler und Prantl, Natürl. Pflanzenfam., 1, 1a.

Klebahn, 1895. Gasvakuolen, ein Bestandteil der wasserblütebildenden Phycochromaceen. Flora.

Klebs, G., 1886-1888. Ueber die Organisation der Gallerte bei einigen Algen und Flagellaten. Unters. aus dem bot. Institut Tübingen, 2.

Kohl, F. G., 1903. Ueber die Organisation und Physiologie der Cyanophyceen-Zelle und die mitotische Teilung ihres Kernes, Jena.

- 1905. Zur Frage nach der Organisation der Cyanophyceen-Zelle und nach der mitotischen Teilung ihres Kernes. Beih. z. Bot. Centralbl., 18, p. 1-8.

Kolkwitz, R., 1896. Ueber die Krümmungen bei den Oscillariaceen. Ber. d. D. bot. Ges., 14.

- 189\%. Ueber die Krümmungen und den Membranbau bei einigen Spaltalgen. Ber. d. D. bot. Ges., 15.

Kützing, 1843. Phycologia generalis.

Lawson, A. A., 1903. On the relationship of the nuclear membrane to the Protoplast. Bot. Gaz., 35, p. 305-31\%.

Macallum, A. B., 1899. On the cytology of non nucleated organisms. Transact. Canadian Institute, $\boldsymbol{6}$, Toronto.

Macchiati, L., 1890. Sulla Lyngbya Borziana etc. Nuovo Giorn. bot. ital., 22.

- 1893. Sulla formazione delle spore nelle Oscillariacee. Atti del Congresso bot. internazion. di Genova.

Marx, F. A., 1892. Untersuchungen über die Zellen der Oscillarien. Erlanger Diss.

Massart, J., 1901. Sur le protoplasme des Schizophytes. Mém. couronnées et publiées par l'Acad. Roy. de Belgique, 61. Auch in: Recueil de l'Institut botan. Bruxelles, 5.

Meyer, A., 1883. Das Chlorophyllkorn.

- 1904. Orientierende Untersuchungen über die Verbreitung etc. des Volutins. Bot. Ztg.

Molisch, H., 1903. Die sogenannten Gasvakuolen und das Schweben gewisser Phycochromaceen. Bot. Ztg.

- 1905. Das Phycocyan, ein kristallisierbarer Eiweißkörper. Bot. Ztg.

Nadson, G., 1895. Ueber den Bau des Cyanophyceen-Protoplasts.

Nägeli, C., 1849. Gattungen einzelliger Algen, Zürich.

- 1858. Die Stärkekörner. Pfanzenphysiol. Unters. von Nägeli und Kramer, H. 2, Zürich.

Nasse, O., 1885. Ueber Verbindungen des Glykogens. Arch. $f$. d. ges. Physiologie, 37.

Olive, E. W., 1905. Mitotic division of the nuclei of the Cyanophyceae. Beih. z. Bot. Centralbl., 18, p. $9-38$.

Palla, E., 1893. Beitrag zur Kenntnis des Baues des Cyanophyceen-Protoplastes. Jahrb. f. wiss. Bot., 25.

Pringsheim, N., 1855. Ueber die Befruchtung und Keimung der Algen. Monatsber. d. K. Akad. d. Wiss. zu Berlin.

Reinhardt, 1885. Algologische Untersuchungen, Odessa.

Sachs, J., 1855. Zur Entwickelungsgeschichte von Collema bulbosum. Bot. Ztg., 13.

Sauvageau, C., 189\%. Sur l'état coccoide d'un Nostoc. C. R., 115.

Schimper, A. F. W., 1885. Untersuchungen über die Chlorophyllkörper und ihnen homologe Gebilde. Jahrb. f. wiss. Bot., 16.

Schmidle, W., 1896. Zur Entwickelung von Sphaerozyga oscillarioides. Ber. d. D. bot. Ges., 15.

Schmitz, 1879. Untersuchungen über den Zellkern der Thallophyten. Sitzber. d. Niederrhein. Ges., Bonn.

- 1880. Untersuchungen ïber die Struktur des Protoplasmas und der Zellkerne der Pfanzenzellen. Ibid.

- 1882. Die Chromatophoren der Algen, Bonn.

- 1883. Die Schizophyten oder Spaltpflanzen. Leopoldina, 19, No. 11-14.

Schröder, B., 1902. Untersuchungen über Gallertbildungen der Algen. Verh. d. naturhist.mediz. Vereins zu Heidelberg, N. F. $\%$

Schwarz, Fr., 188\%. Die morphologische und chemische Zusammensetzung des Protoplasmas. Beitr. z. Biol. d. Pflanzen, 5.

Schwendener, S., 1894. Zur Wachstumsgeschichte der Rivularien. Sitzber. d. K. Preuß. Akad. d. Wissensch., 2.

Scott, D. H., 1888. On nuclei in Oscillaria and Tolypothrix. Journ. of the Linn. Soc. Botany, 24. 
stockmeyer, S., 1894. Ueber spaltalgen. Ber. d. D. bot. Ges., 12, p. 102-104.

Strasburger, E., 1882. Teber den Teilungsvorgang der Zellkerne und das Verhältnis der Kernteilung zur Zellteilung, Bonn.

Thuret, G., 1844. Note sur le mode de réproduction du Nostoc verrucosum. Ann. Sc. nat., Sér. 3, Bot., 2.

- 185\%. Observation sur la réproduction de quelques Nostochinées. Mém. de la Soc. Impér. de Sc. nat. Cherbourg, 5.

- 18\%5. Essai de classification des Nostochinées. Ann. Sc. nat., Sér. 6. Bot., 1.

Vaucher, 1803. Histoire des conferves d'eau douce, Genève.

Wager, H., 1903. The cell-structure of the Cyanophyceae. Preliminary Paper. Proc. Royal Soc., $\because 2$, p. 401-408.

Wille, N., 1883. Ueber die Zellkerne und die Poren der Wände bei den Phycochromaceen. Ber. d. D. bot. Ges., 1, p. 243.

- 188\%. Algologische Mitteilungen. Jahrb. f. wiss. Bot., 18.

Wilson, E. B., 1900. The cell, New York, Mc. Millan.

Zacharias, E., 18s\%. Beiträge zur Kenntnis des Zellkernes und der Sexualzellen. Bot. Ztg., p. 300 .

- 1890. Ueber die Zellen der Cyanophyceen. Bot. Ztg., p. 1.

- 1892. Idem. Bot. Ztg., No. 38.

- 1893. Ueber die chemische Beschaffenheit von Cytoplasma und Zellkern. Ber. d. D. bot. Ges., 11.

- 1900. Ueber die Cyanophyceen. Abh. a. d.. Gebiete d. Naturw., Hamburg.

- 1901. Besprecheng der Arbeit Heglers. Bot. Ztg., p. 321.

- 1904. Ueber die Cyanophyceen. Jahrb. d. Hamburger wiss. Anstalten, 21.

Zimmermann, A., 1896. Die Morphologie und Physiologie des pflanzlichen Zellkernes, Jena.

Zukal, H., 1892. Ueber dem Zellinhalt der Schizophyten. Ber. d. D. bot. Ges., 10.

- 1894. Zur Frage nach den Zellinhalt der Cyanophyceen. Ber. d. D. bot. Ges., p. 49.

- 1894. Beitrag zur Kenntnis der Cyanophyceen. Oesterr. Bot. Ztg., p. 284.

- 1894. Neue Beobachtungen ïber einige Cyanophyceen. Ber. d. D. bot. Ges., p. 256.

\section{Sechzehnte Vorlesung. Die Myxobakterien.}

Baur, E., 1904. Myxobakterienstudien. Arch. f. Protistenkunde, 5, p. 92-121.

Berkeley, 185\%. Introduction to Cryptogamic Botany, London (p. 313: Chondromyces crocatus als Hyphomycet, Chondromyces aurantiacus als Stigmatella, zitiert nach Baur).

Link, 1795. Dissertationes botanicae ( $p$. 42: Polyangium vitellinum als Gasteromycet, zitiert nach Baur).

Schröter. Kryptogamenflora von Schlesien, 3 (p. 170: Cystobacter = Polyangium bezw. Chondromyces, zitiert nach Baur).

Smith, A. L., 1901. Myxobacteria. Journ. of Botany, p. 69.

Thaxter, R., 1892. On the Myxobacteriaceae, a new order of Schizomycetes. Bot. Gaz., 17, p. 389.

- 189\%. Further observations on the Myxobacteriaceae. Bot. Gaz., 23, p. 395.

- 1904. Notes on the Myxobacteriaceae. Bot. Gaz., 3\%, p. 405.

Zederbauer, E., 1903. Myxobacteriaceae, eine Symbiose zuischen Pilzen und Bakterien. Sitzber. d. K. Akad. d. Wiss. in Wien, math.-nat. Klasse, 22. Mai.

Zaskal, H., 1896. Myxobotrys variabilis als Repräsentant einer neuen Myxomyceten-Gattung. Ber. d. D. bot. Ges., 14, p. 340 .

- 189\%. Notiz zu meiner Mitteilung über Myxobotrys variabilis Zukal im 9. Hefte des Jahrganges 1896. Ber. d. D. bot. Ges., 15, p. 1\%.

- 189\%. Ueber die Myxobalterien. Ber. d. D. bot. Ges., 15, p. 542.

\section{Siebzehnte Vorlesung. Myxomyceten.}

de Bary, A., 1858. Ueber die Myxomycetes. Bot. Ztg.

- 1859. Die Mycetozoen, ein Beitrag zur Kenntnis der niedrigsten Tiere. Ztschr. $f$. wiss. Zool.

- 1864. Die Mycetozoen, ein Beitrag zur Kenntnis der niedersten Organismen, Leipzig, Engelmann.

Berlese, 1888. Myxomyceteae in Saccardo, Sylloge Fungorum, \%, P. 1, Patavii.

Brefeld, O., 1869. Dictyostelium mucoroides. Abh. d. Senchenberg. Gescllsch. Frankifurt.

- 1884. Untersuchungen aus dem Gesamtgebiete der Mykologie, B, Leipzig.

Cienkousky, 1863. Zur Entwickelungsgeschichte der Myxomyceten; das Plasmodium. Pringsh. Jahrb., 3.

- 186\%. Ueber den Bau und die Entwickelung der Labyrinthuleen. Arch. i. mikr. Anat., $3, p .274$.

- 1873. Ueber einige protoplasmatische Organismen. Terh. A. Thus. Naturt.- Ters. zu Kusan.

Dangeard; 189\%. Contribution à l'étude des Acrasiées. Le Bot., 5. Séric, 1896-1897, p. 2. 
Literatur.

Famintzin, A. und Woronin, M., 18\%3. Ueber zwei neue Formen von Schleimpilzen: Ceratium hydnoides und Ceratium poroides. Mém. de l'Acad. de St. Fetersbourg.

Goebel, K., 1884. T'etramyxa parasitica. H'lora.

Harper, 1900. Cell and nuclear division in Fuligo varians. Bot. Gaz., p. $21 \%$.

Jahn, E., 1899. Der Stand unserer Kenntnisse über die Schleimpilze. Nat. Rundschau.

- 1901. Myxomycetenstudien. 1. Dictydium umbilicatnm Schrader. Ber. d. D. bot. Ges., 19, p. $9 \%$.

- 1902. Myxomycetenstudien. 2. Arten aus Blumenau. Ber. d. D. bot. Ges., 20, p. 268.

- 1904. Myxomycetenstudien. 3. Kernteilung und Geißelbildung bei den Schwärmern von Stemonitis flaccida Lister. Ber. d. D. bot. Ges., 22, p. 84.

- 1905. Myxomycetenstudien. 4. Die Keimung der Sporen. Ber. d. D. bot. Ges., 23, p. 489.

Lippert, Chr., 1896. Ein Beitrag zur Biologie der Myxomyceten. Verh. d. k. k. zool.bot. Ges. zu Wien, p. 235.

Lister, A., 1893. On the division of nuclei in the Mycetozoa. Linn. Soc. Journ., 29, p. 529.

- 1894. A monograph of the Mycetozoa, London.

- 1901. On the cultivation of Mycetozoa from spores. Journ. of Botany.

Mac Bride, Th. H., 1899. The North American slime Moulds, New York and London.

Massee, G., A monograph of Myxogasteres, London.

Nawaschin, S., 1899. Beobachtungen über den feineren Bau und Umwandlungen von Plasmodiophora Brassicae Woronin im Laufe ihres intracellulären Lebens. Flora, p. $404-42 \%$.

olive, W., 1902. Preliminary enumeration of the Sorophoreae. Proc. of the American Academy of Arts and Sciences, 28, p. 333-344.

Plenge, H., 1899. Ueber die Verbindungen zwischen Geißel und Kern bei den Schwärmerzellen der Mycetozoen etc. Verh. d. naturh.-mediz. Vereins zu Heidelberg, N. F., $\boldsymbol{6}$, Heft 3.

Rosen, F., Beiträge zur Kenntnis der Pfanzenzellen. II. Studien über die Kerne und die Membranbuldung bei Myxomyceten und Pilzen. Beitr. z. Biol. d. Pfanzen, 6, p. 245.

Rostafinski, J. T., 18\%3. Versuch eines Systems der Mycetozoen. Diss. Straßburg. - 1875-1876. Sluzowce (Mycetozoa), Paryz.

Schröter, J., 189\%. Myxomycetes in Engler und Prantl, Natürl. Pflanzenfam. 1 1. Abt.

Stahl, E., 1884. Zur Biologie der Plasmodien. Bot. Ztg.

Stolc, A., 1900. Beobachtungen und Versuche über die Verdauung und Bildung der Kohlenhydrate bei einem amöbenartigen Organismus, Pelomyxa palustris Greeff. Zeitschr. $f$. wiss. Zoologie, 68, p. 625 .

Strasburger, E., 1884. Zur Entwickelungsgeschichte der Sporangien von Trichia fallax. Bot. Ztg., p. 306, 321.

van Tieghem, P., 1899. Sur quelques Myxomycètes à plasmode aggrégé. Bull. de la Soc. bot. de France, $18 \% 9$.

Woronin, M., 1878. Plasmodiophora brassicae. Pringsh. Jahrb. f. wiss. Bot., 11.

Zopf, 1885. Die Pilatiere oder Schleimpilze in Schenks Handb. d. Botanik.

\section{Achtzehnte Vorlesung. Die Ascomyceten.}

Barker, B. T. P., 1903. The morphology and development of the ascocarp in Monascus. Annals of Botany, 18, p. 16\%.

de Bary, A., 1863. Ueber die Fruchtentwickelung der Ascomyceten, Leipzig.

- 18\%0. Eurotium, Erysiphe, Cincinnobolus, nebst Bemerkungen über die Geschlechtsorgane der Ascomyceten in Beitr. z. Morphol. u. Physiol. d. Pilze, III, Frankfurt, u. Beitr. IV, p. $111 \mathrm{f}$.

- 1884. Vergleichende Morphologie und Biologie der Pilze, Mycetozoen und Bakterien, Leipzig, Engelmann.

Baur, E., 1901. Die Anlage und Entwickelung einiger Flechtenapothecien. Flora, 88 , p. 319.

Blackman and Fraser, 1906. On the sexuality and development of the ascocarp of Humaria granulata Quél. Proc. Roy. Soc., Ser. B, z7, No. B 518.

Borzi, A., 18\%8. Stndii sulla sessualita degli Ascomicete. N. Giorn. botan. ital., 10, p. 43.

Brefeld, O., Botanische Untersuchungen über Schimmelpilze, II (Penicillium), IV.

- 18\%6. Die Entwickelungsgeschichte der Basidıomyceten. Bot. Ztg., Sp. 56, Notiz 23 (über Sexualität der Ascomyceten).

- 18\%\%. Bot. Ztg., Sp. 371.

Cavara, 1905. Causeries mycologiques. Annales mycologici, Aug., p. 363 (Boudiera, von Claussen untersucht, ist eine Ascodermis).

Claussen, P., 1905. Zur Entwickelungsgeschichte der Ascomyceten, Boudiera. Bot. Ztg., $63, p .1$. 
Dangeard, P. A., 1892. Recherches sur la reproduction sexuelle des Champignons. Le Botaniste, 3. Série.

- 1844-1895. La reproduction sexuelle les Ascomycètes. Le Botaniste, 4. Série, p. 21-58.

- 1894-1895. La Truffe, recherches sur son développement, sa structure, sa reproduction sexuelle. Ibid. p. $63-8 \%$.

- 1896-1897. La reproduction sexuelle dans le Sphaerotheca castagnei. Ibid., 5. Série, p. $27-31$.

- 1896-189\%. Second mémoire sur la reproduction sexuelle des Ascomycètes. Ibid., 5. Série, p. $245-284$.

- 1898. Théorie de la sexualité. Ibid., 6. Série, p. 268-290.

- 1900. La reproduction sexuelle des Champignons. Etude critique. Ibid., 7. Série, p. 88-180.

- 1900. Programme d'un essai sur la reproduction sexuelle. Ibid., \%. Série, p. 263-268.

- 1900. La reproduction sexuelle des Champignons supérieurs comparée à celle de l'Actinosphaerium. Ibnd. p. 273-278.

- 1904-1906. Recherches sur le développement du Périthèce chez les Ascomycètes. Ibid., 9. Série, p. 60, 159.

- 1903. Sur le nouveau genre Protascus. Ibid., 9. Série, p. 23.

- 1903. La sexualité dans le genre Monascus. Ibid., 9. Série, p. 28.

- 1903. Sur le Pyronema confuens. Ibid., 9. Série, p. 31.

- 1903. Sur le genre Protascris. Ibid., 9. Série, p. з3.

- 1903. Nouvelles considérations sur la reproduction sexuelle des Champignons supérieurs. Ibid. p. 25.

Eidam, Beiträge zur Kenntnis der Gymnoasceen. Cohns Beitr. z. Biol. d. Pflanzen, 3, p. 271 .

- Zur Kenntnis der Entwickelung der Ascomyceten. Ibid. p. 37\%.

- 187\%. Ueber Pykniden. Bot. Ztg., Sp. 60.

Errera, L., 1882. L'épiplasme des Ascomycètes et la glycogène des végétaux, Bruxelles, Thèse.

Fisch, C., 1882. Zur Entwickelungsgeschichte der Ascomyceten. Bot. Ztg.

Fuisting, 1867-1868. Zur Entwickelungsgeschichte der Pyrenomyceten. Bot. Ztg.

Gjurasin, 1893. Uebcr die Kernteilung in den Schläuchen von Peziza vesiculosa Bull. Ber. d. D. bot. Ges., p. 113.

Guilliermond, 1903. Contribution d̀ étude de l'épiplasme des Ascomycètes. Ann. Mycol., 1.

- 1903. Nouvelles recherches sur l'épiplasme des Ascomycètes. C. R., Paris, 30. nov.

- 1904. Contribution à l'étude de la formation des asques et de l'épiplasme des Ascomycètes. Rev. gén. de Bot., 16.

- 1904. Recherches sur la karyokinèse chez les Ascomycètes. Ibid. 16.

- 1904. Remarques sur la cytologie des Ascomycètes. C. R. Soc. Biol., 23 juillet.

- 1905. Sur le nombre des Chromosomes chez les Ascomycètes. Ibid. 58, 11 fevr.

- 1905. Remarques sur la karyokinèse des Ascomycètes. Ann. Mycol., p. 343.

Harper, R., 1895. Beiträge zur Kenntnis der Kernteilung und Sporenbildung im Ascus. Ber. d. D. bot. Ges., p. 6\%.

- 1896. Die Entwickelung des Peritheciums bei Sphaerotheca castagnei. Ibid. p. 473.

- 1896. Ueber das Verhalten der Kerne bei der Fruchtentwickelung einiger Ascomyccten. Jahrb. f. wiss. Bot., 29, p. 655.

- 189\%. Kernteilung und freie Zellbildung im Ascus. Pringsh. Jahrb. f. wiss. Bot., 30, p. 249.

- 1899. Cell division in sporangia and asci. Ann. of Bot., s, p. $46 \%$.

- 1900. Sexual reproduction in Pyronema confluens. Ann. of Bot., 11, p. 321.

- 1905. Sexual reproduction and the organization of the nucleus in certain Mildews. Public. Carnegie Instit., No. 3\%.

Hartig, R., Untersuchungen a. d. Forstbot. Institut zu München, I (Rosellinia, Nectria).

Hennings, P., Einrge deutsche Dung bewohnende Ascomyceten. Hedwigia, 4:, p. 181. (Beschreibung der Bouciera Claussenii nov. spec., welche nach Cavara eine Ascodesmis ist.)

Ikeno, 1903. Die Sporenbildung der Taphrina-Arten. Flora, 9:, p. 1.

-- 1903. Ueber die Sporenbildung und systematische Stcllung non Monascus purpureus Went und Monascus Barkeri Dang.

Jancewski, E., 1871. Morphologie des Ascobolus furfuracens. Bot. Ztg., 29, p. $25 \%$.

Juel, H. O., 1902. Ueber Zellinhalt, Befruchtung und Sporenbildurg bei Dipodascus. Flora, 91, p. $4 \%$.

- 1901-1902. Taphridium Lagerh. et Juel, eine neue Gattung der Protomyectaceen. Bihang till Kgl. Svensk. Vet. Akad. Ilandl., 2z, Afl. III.

Kihlmann, O., 1883. Zur Entwickelungsgeschichte der Ascomyceten (Pyronema, Melanospora). Acta Soc. Sc. Fennicae, 13.

Kuyper, H. P., 1905. Die Perithecien-Entwickelung von Monascus purpureus Went und Monascus Barkeri Dangeard, sovie die systematrsche stellung dieser Pilze. Alnmales 
Mycologici, 3, p. 1. Auch erschienen in Versl. und Mededeclingen der K. Acad. van Wetensch. Amsterdam, in Recueil des Traveaux botaniqués Néerlandaises und als Inaug.Diss. Utrecht.

Lagerheim, 1899. Dipodascus, eine neue geschlechtliche Hemiascee. Jahrb. f. wiss. Bot., 24. Lindau, P., 189\%. Ascomycetes in Engler u. Prantl, 1, Abt. 1.

Maire, R., 1903. Recherches cytologiques sur le Galactinia succosa. C. R., Paris, 9. nov. - 1903. La formation des asques chez les Pezizes et l'évolution nucléaire des Ascomycètes. C. R. Soc. Biol., 14. Nov.

- 1904. Remarques sur la cytologie de quelques Ascomycètes. C. R. Soc. Biol., 16 janvier.

- 1904. Sur les divisions nuclêaires dans l'asque de la Morille et de quelques autres Ascomycètes. Ibid. 21. Mai.

- 1905. Recherches cytologiques sur quelques Ascomycètes. Annales Mycologici, 3, April, p. 123.

Möller, A., 1888. Ueber die sogenannten Spermatien der Ascomyceten. Bot. Ztg., p. 421 ff. - 1900. Phycomyceten und Ascomyceten in Schimpers Bot. Mitt. a. d. Tropen, Heft 9.

Olive, E. W., 1905. The morphology of Monascus purpureus Went. Bot. Gaz., 39, No. 1, p. 56 .

Popta, C., 1899. Beiträge zur Kenntnis der Hemiasci. Flora, 86.

Ramlow, G., 1906. Zur Entwickelungsgeschichte von Thelebolus stercoreus Tode. Bot. Ztg., Heft 5.

Schröter, J., 1894. Heminascineae in Engler u. Prantl, 1. Abt., 1.

Stahl, E., 187\%. Beiträge zur Entwickelungsgeschichte der Flechten, I, Leipzig.

v. Tavel, F., 1892. Vergleichende Morphologie der Pilze, Jena.

van Tieghem, Ph., 1884. Culture et développement du Pyronema confluens. Bull. de la Soc. Bot. de France, 31, p. 35.

Tulasne, 1851. Fungi hypogaei, Paris.

- Selecta fungorum carpologia, 1-3, Paris.

Uyeda, 1902. Ueber den Benekoji-Pilz aus Formosa. The Bot. Magazine Tokyo, 15, No. 178 u. 179.

Went, F. A. F. C., 1895. Le Champignon de l'Ang-Quac, une nouvelle Thélébolèe. Ann. de Sc. nat., Bot. Sér. 8, 1.

Wilhelm, K., 187\%. Beiträge zur Kenntnis der Pilzgattung Aspergillus. Diss. Berlin.

Woronin, Entwickelungsgeschichte des Ascobolus pulcherrimus und einiger Pezizen. Beitr. zur Morph. u. Physiol. d. Pilze, 2.

- Sphaeria Lemaneae, Sordaria etc. Ibid. 3.

\section{Neunzehnte Vorlesung. Erysiphales.}

de Bary, A., 1871. Eurotium, Erysiphe, Cincinnobolus. Abh. d. Senkenbergschen Naturf. Ges., \%.

- 1863. Recherches sur quelqnes Champignons parusites. Ann. Sc. nat., Bot., Sér. 4, 20.

Blackman and Fraser, 1905. Fertilization in Sphaerotheca. Ann. of Bot., \%6, p. 56\%.

Büsgen, M., 1893. Ueber einige Eigenschaften der Keimlinge parasitischer Pilze. Bot. Ztg., 51.

Harper, R. A., 1896. Die Entwickelung des Peritheciums bei Sphaerotheca castagnei. Ber. d. D. bot. Ges., p. 4\%3.

- 1896. Ueber das Verhalten der Kerne bei der Fruchtentwickelung einiger Ascomyceten. Jahrb. f. wiss. Bot., 29, p. 655.

- 1906. Sexual reproduction and the organization of the nucleus in certain Mildews. Publ. Carnegie Institut, Washington, 3\%, Sept.

Maive, $\boldsymbol{R} ., 1905$. Remarques sur quelques Erysiphacées. Bull. Soc. Sc. Nancy, Sér. 3, 6, p. $31-37, \mathrm{Pl}$. II.

Miyoshi, M., 1894. Ueber Chemotropismus der Pilze. Bot. Ztg., Heft 1, und Pringsh. Jahrb. f. wiss. Bot., 30.

Neger, 1901. Beiträge zur Biologie der Erysipheen, I. Flora, $8 \boldsymbol{8}$.

- 1902. Beiträge zur Biologie der Erzsipheen, II. Flora, 90, p. 221.

Palla, 1899. Ueber die Gattung Phyllactinia. Ber. d. D. bot. Ges., 1\%.

Salmon, 1900. A monograph of the Erysiphaceae. Mem. Torrey Bot. Club, 9.

- 1900. The Strawberry mildew (Sphaerotheca Humili). Journ. R. Hortic. Soc., 25.

- 1902. Supplementary notes on the Erysipheae. Bull. Torr. Bot. Club, 29, p. $12-18$.

- 1903. Infection-powers of Ascospores of Erysiphaceae. Journ. of Bot., p. 159, 165.

- 1904. Cultural experiments with "Biologic Forms" of the Erysiphaceae. Phil. Trans., 19\%, p. 107-122.

- 1904. On Erysiphe graminis DC. and its adaptive parasitism with the genus Bromus. Annal. Mycol., 11, p. 261, 262.

- 1905. On endophytic adaptation shown by Erysiphe graminis DC. under cultural conditions, Phil. Trans., 198, p. $8 \%$. 
Salmon, 1905. On the variation shown by the conidial stage of Phyllactinia corylea (Pers.) Karst., I. Ann. Mycolog., 3, p. 493.

- 1905. Further cultural experiments with „Biologic Forms" of the Erysipheae. Ann. of Bot.. 19, p. 125 .

- 1906. On Oidiopsis taurica (Lér.), an endophytic member of the Erysiphaceae. Ann. of Bot., :0, p. $18 \%$.

Smith, Grant, 1900. The haustoria of the Erysiphaceae. Bot. Gaz., 29, p. 153.

Tulasne, 1861. Selecta fungorum carpologia, 1, Paris.

Wolff, R., 18\%.j. Beitrag zur Kenntnis der Schmarotzerpilze (Erysiphe graminis und E. communis).

\section{Zwanzigste Vorlesung. Pletascineae.}

Für Monascus siehe die Literatur der achtzehnten Vorlesung.

Baranetzky, 1872. Entwickelungsgeschichte des Gymnoascus Reessii. Bot. Ztg., No. 10.

de Bary A., 18\%0. Eurotium, Erysiphe, Cincinnobolus, nebst Bemerkungen über die Geschlechtsorgane der Ascomyceten. Beitr. z. Morphol. u. Physiol. der Pilze, 3. Reihe, Frankfurt.

- 1884. Vergleichende Morphologie und Biologie der Pilze, Leipzig, p. 200, 376.

Brefeld, O., 1874. Botanische Untersuchungen über Schimmelpilze. H. 2: Die Entvickelungsgeschichte von Penicillium, Leipzig.

- 18.91. Untersuchnngen aus dem Gesamtgebiete der Mykologie. H. 10: Ascomyceten, II, p. $158-160$.

Dale, E. (Miss), 1903. Observations on the Gymnoasceae. Ann. of Bot., 1\%, p. $5 \% 1$.

Eidam, E., 1880. Beitrag zur Kenntnis der Gymnoasceen. Cohns.Beitr. z. Biol. d. Pflanzen, 3.

Fischer, Ed., 1896. Plectascineae, in Engler und Prantl, Natürl. Pflanzenfam., 1, Abt. 1.

Harz, C. O., 1890. Physomyces heterosporus nov. sp. Bot. Centralbl., 41, p. 378.

Reess, M. und Fisch, C., 188\%. Untersuchungen ïber Bau und Lebensweise der Hirschtrüffel, Elaphomyces. Bibliotheca botanica, H. \%.

Schröter, 1893. Gymnoasci, Aspergillacei, Onygenacei, Elaphomycetacei. Kryptogamenflora von Schlesien, 3, Pilze.

Solms-Laubach, H., Graf zu, 1886. Penicilliopsis clavariaeformis, ein neuer javanischer Ascomycet. Ann. du Jardin Botan. de Buitenzorg, $\boldsymbol{G}$.

Tulasne, L. R. et C., 1841. Observations sur le genre Elaphomyces et description de quelques espèces nouvelles. Ann. de Sc. nat., Bot., 2. Sér., 6.

- 1844. Note sur l'organisation et le mode de fructification des Onygena. 1bid., Bot., 3. Sér., 1.

Ward, H. Marshall, 1899. Onygena equina Willd. a horn destroying Fungus. Philos. Transact. of the Roy. Soc. London, Series B, 191, p. 269-289.

Winter, 188\%. Gymnoasceen und Perisporiaceen. Rabenhorst, Kryptogamenflora, 1.

\section{Einundzwanzigste Vorlesung. Pyrenomyceten und Laboulbeniales.}

de Bary, A., 18\%0. Eurotium, Erysiphe, Cincinnobolus, nebst Bemerkungen über die Geschlechtsorgane der Ascomyceten. Beiträge zur Morphologie und Physiologie der Pilze, 3, Frankfurt.

- 1884. Zweifelhafte Ascomyceten. Vergl. Morph. u. Biol. der Pilze, Leipzig.

Bauke, 187\%. Beiträge zur Kenntnis der Pykniden. Nova Acta Acad. Carol., 38, 1876, und Bot. Ztg., 187\%, p. 313.

Berlese, A. N., 1889. Rivista delle Laboulbeniacee e descrizione d'ma nuovo specie di questa famiglia. Malpighia, 3, p. 44.

Brefeld, O. Untersuchungen aus dem Gesamtgebiete der Mykologie, H. 10.

Fisch, C., 1882. Beiträge zur Entwickelungsgeschichte einiger Ascomyceten. Bot. Ztg., p. $851,875,899$.

Frank, 1883. Ueber einige neue und weniger bekannte Pfanzenkrankheiten. Landw. Jahrb., 12, p. 511.

Hartig, R., 1900. Lehrbuch der Pfanzenkrankheiten, 3. Aufl., Berlin.

Kihlmann, O., 1883. Zur Entwickelungsgeschichte der Ascomyceten (Pyronema, Melanospora). Acta Soc. Sc. Fennicae, 13.

Kühn, 1863. Ueber Claviceps. Mitt. d. landw. Instituts in Halle, 1.

Lindau, G., 189\%. Pyrenomycetineae. Engler und Pranil, 1, 1bt. 1.

Oltmanns, 188\%. Entwickelung der Perithecien von Chretomium. Bot. Ztg.

Peyritsch, J., 1871. Ueber einige Pilze aus der Familie der Laboulbenien. Sitzber. d. K. Akad. d. Wissensch., 64, p. 441.

- 1873. Beiträge zur Kenntnis der Laboulbenien. Ibid., (is, 1). $22 \%$.

- 1875. Ueber Vorkommen und Biologie von Laboulbenien. Ibid., :2, p. 62. 
Thaxter, R., 1890. On some North American species of Laboulbeniaceae. Proc. Amer. Acad. of Arts and Sciences, 24, p. 1.

- 1891. Supplementary Note. Ibid., 24, p. 261.

- 1892. Further additions. Ibid., 27, p. 29.

- 1893. New species of Laboulbeniaceae from various localities. Ibid., 28, p. 156.

- 1893. New genera and species of Laboulbeniaceae with a synopsis of the known species. Ibid., 29.

- 1894. Notes on Laboulbeniaceae with descriptions of new species. Ibid., 30, p. $46 \%$.

- 1895. Monograph of the Laboulbeniaceae. Mem. Am. Acad. of Arts and Sc., 12, p. 18\%. van Tieghem, Ph., 1875. Développement du fruit du Chaetomium. C. R., déc. 1875.

Tulasne. Selecta fungorum carpologia, 1-3, Paris.

Winter. Die deutschen Sordarien. Abh. d. naturf. Ges. Halle, 13.

Zopf, 1881. Zur Entwickelungsgeschichte der Ascomyceten. Chaetomium. Nova Acta Acad. Leop. Carol., 33.

\section{Zweiundzwanzigste Vorlesung. Lichenen.}

Baranetzky, J., 1869. Beitrag zur Kenntnis des selbständigen Lebcns der Flechtengonidien. Pringsh. Jahrb. f. wiss. Bot., \%, p. 11.

de Bary, A., 1884. Vergleichende Morphologie und Physiologie der Pilze.

Baur, E., 1898. Zur Frage nach der sexualität der Collemaceen. Ber. d. D. bot. Ges.

- 1901. Ueber Anlage und Entwickelung einiger Flechtenapothecien. Hlora, 88.

- 1904. Untersuchungen ïber die Entwickelungsgeschichte der Flechtenapothecien. Bot. Ztg., H. 2, März.

Bitter, G., 1901. Ueber die Variabilität einiger Laubflechten etc. Pringsh. Jahrb., 36.

- 1901. Zur Morphologie und Systematik von Parmelia, Untergattung Hypogymnia. Hedwigia, $\mathbf{4 0 .}$

Bonnier, G., 1889. Recherches sur la synthèse des Lichens. Ann. de Sc. nat., Bot., 7. Sér., 9, p. 1.

Bornet, E., 1873. Recherches sur les gonidies des Lichens. Ann. de Sc. nat., Bot., 5. Sér., $17, p .45$.

Borzi, 1870. Studia sulla sessualità degli ascomiceti. Nuovo Giorn. bot. ital., 10.

Darbishire, O. V., 1897-1898. Ueber die Flechtentribus der Roccellei. Ber. d. D. bot. Ges.

- 1900. Ueber die Apotheciumentwickelung der Flechte Physcia pulverulenta (Schrb.) Nyl. Pringsh. Jahrb., $3 \mathbf{4}$.

Elenkin, 1905. Zur Frage des Polymorphismus von Evernia purpuracea (L.) Mann als selbstïndige Art. Bull. du Jard. Imp. Bot. de St. Pétersbourg, 5, p. 9-22. Russisch mit deutschem Resumé.

Famintzin, A. und Baranetzky, J., 1867-1868. Zur Entwickelungsgeschichte der Gonidien und Zoosporenbildung der Lichenen. Bot. Ztg., 186\%, p. 189; 1868, p. 169.

Forsell, K. B. J., 1885. Beiträge zur Kenntnis der Anatomie und systematik der Gloeolichenen, Stockholm.

Fuisting, W., 1868. Zur Entwickelungsgeschichte der Lichenen. Bot. Ztg., p. 641.

Fünfstück, M., 1884. Beiträge zur Entwickelungsgeschichte der Lichenen. Jahrb. $d . K$. Bot. Gartens u. Museums zu Berlin.

- 1898. Lichenes, in Engler und Prantl, Natürl. Pflanzenfam.

- 1902. Der gegenwärtige Stand der Flechtenkunde, nebst Ausblicken auf deren voraussichtliche Weiterentwickelung. Ref. Gcneralvers. d. D. bot. Ges., Ber. 1902.

Krabbe, 1882. Entwickelung, Sprossung und Teilung einıer Flechtenapothecien. Bot. Ztg.

- 1884. Morphologie und Entwickelungsgeschichte der Cladonien. Ber. d. D. bot. Ges., 1.

- 1891. Entwickelungsyeschichte und Morphologie der polymorphen Flechtengattung Cladonia, Leipzig.

v. Krempelhuber, A., 1867-1872. Geschichte und Literatur der Lichenologie bis 1865 resp. $18 \% 0,3$ Bde., München.

Lindau, G., 1888. Ueber Anlage und Entwickelung einiger Flechtenapothecien. Flora.

- 1899. Beiträge zur Kenntris der Gattung Gyrophora. F'estschrift für Schwendener, Berlin.

Mezger, 1903. Uebcr Verrucaria. Fünfstück Beitr. z. wiss. Bot., 5, p. $108-144$.

Möller, 188\%. Ueber die Kultur flechterbildender Ascomvceten ohne Algen, Münster.

Neubner, 1893. Untersuchungen über den Thallus und die Fruchtanfänge der Calicien, Plauen $i . V$.

Reess, M., 18\%1. Ueber die Entstehung der Flechte Collema glaucescens. Monatsber. d. K. preuß. Akad. d. Wiss., Berlin, Oktnber.

Reinke, J., 1873. Morphologische Abhandlungen, Leipzig.

- 1894-1896. Abhandlungen über Flechten. Pringsh. Jahrb., 26, 28, 29.

Schwendener, S., 1860. Untersuchungen über den Flechtenthallus. Nägelis Beitr. z. wiss. Bot., H. 2-4, Leipzig. 
Schuendener, S., 1864. U'eber die Apothecia primitus aperta und die Entwickelungsgeschichte der Apothecien im allgemeinen. Flora.

- 1869. Die Algentypen der Flechtengonidien, Basel.

Stahl, E., 187\%. Beiträge zur Entwickelungsgeschichte der Flechten, Leipzig.

Treub, M., 18\%3. Onderzoekingen over de natuur der Lichenen, Leiden.

Wainio, 189\%. Monographia Cladoniarum universalis. Acta Societ. pro fauna et flora fennica, 20 .

v. Wettstein, R., 1901. Handbuch der Systematik, Wien.

Zahlbruckner. Lichenes, in Engler und Prantl, Natïrl. Pfanzenfamilien.

Zopf, W., 1903. Vergleichende Untersuchungen über Flechten in Bezug auf ihre Stoffwechselprodukte. Beih. z. Bot. Centralbl., 14, p. 95.

- 1905. Biologische und morphologische Beobachtungen an Flechten. Ber. d. D. bot. Ges., p. $49 \%$.

\section{Dreiundzwanzigste Vorlesung. Discomyceten.}

Barker, B. T. P., 1904. Further observations on the ascocarp of Ryparobius. Leaflet Brit. Assoc. Meeting.

de Bary, A., 1866. Ueber einige Sclerotinien und Sclerotienkrankheiten. Bot. Ztg.

Brefeld, O., 1891. Untersuchungen aus dem Gesamtgebiete der Mykologie. Ascomycetes, H. $9,10$.

- 1901. Ueber die geschlechtlichen und ungeschlechtlichen Fruchtformen bei den kopulierenden Pilzen. Jahresber. d. schles. Gesellsch. f. vaterländische Kultur.

Darvin, Ch., ed. 1890. A naturalist's voyage. Journ. of Researches during the voyage of H. M. S. Beagle round the world, New Edition, Murray, p. 225 (Cyttaria).

Fischer, Ed., 1896. Tuberineae, in Engler und Prantl, Natürl. Pflanzenfam., 1, Abt. 1.

Harper, 1896. Ueber das Verhalten der Kerne bei der Fruchtentwickelung einiger Ascomyceten. Jahrb. f. wiss. Bot., 29, p. 655.

Heimerl, 1889. Niederösterreichische Ascoboleen. 15. Jahresber. d. k. k. Oberrealschule Wien.

Jancewski, 18\%1. Morphologie des Ascobolus furfuraceus. Bot. Ztg.

Lindau, 1894-1896. Pezizineae, Phacidiineae, Hysteriineae, in Engler und Prantl, Natürl. Pflanzenfam., 1, Abt. 1.

Ramlow, G., 1906. Zur Entwickelungsgeschichte von Thelebolus stercoreus Tode. Bot. Ztg., $H .5$.

v. Wettstein, $\boldsymbol{R} .$, 1901. Handbuch der Botanik, Wien.

Woronin, M., 1888. Ueber die Sclerotienkrankheit der Vaccinieen-Beeren. Mém. de l'Acad. Imp. des Sciences de St. Petersbourg, \%. Série, 36, No. 6.

\section{Vierundzwanzigste Vorlesung. Helvellineae.}

Dittrich, G., 1892. Zur Entwickelungsgeschichte der Helvellineen. Cohns Beitr. z. Biol. d. Pflanzen, p. $1 \%$.

Schroeter, J., 1894. Helvellineae, in Engler und Prantl, Natürl. Pflanzenfam., 1, Abt. 1.

Fünfundzwanzigste Vorlesung. Eutuberaceae.

Buchholtz, F., 189\%. Zur Entwickelungsgeschichte der Tuberaceen. Ber. d. D. bot. Ges., 15.

- 1901. Pseudogenea Vallisumbrosae nov. gen. et spec. Hedrvigia, 40.

- 1902. Beiträge zur Morphologie und Systematik der Hypogaeen, Moskau und St. Petersburg. (Russisch mit deutschem Resumé.)

- 1903. Zur Morphologie und Systematit der Fungi hypogei. Ann. Mycol., 1.

Fischer, Ed., 1896. Tuberineae et Plectascineae, in Engler und Prantl, Natiirl. Pjanzenfam.

-- 1896. Ueber den Parallelismus der Tuberaceen und Gasteromyceten. Ber. d. D. bot. Ges., 14.

- 189\%. Tuberaceae und Hemiasceae, in Rabenhorst, Kryptogamenflora, 1, Abt. I.

- 1900. Bemerkungen ïber dic Tuberaceengattungen Gyrocratera und Hydnotria. Hedwigia, 39.

Mattirolo, O., 1900. Gïi Ipogei di Sardegna e di Sicilia. Alalpighic, 1t.

- 1900. Elenco dei Fungi hypogei raccolti nelle foreste di Tallombroso. Mid., 1.

Tulasne, 1862. Fungi hypogei. Ed. 2.

Vittadini, 1831. Monographia Tuberacearum, Mediolani.

\section{Sechsundzwanzigste Vorlesung. Exoaseinear.}

Giesenhagen, K., 1901. Taphrina, Exoascus, Magnusiella. Bot. Ztg., H. \%, wo die voillständige Literatur angegcben ist.

Lotsy, Botanische Stammesgeschichte. I. 
Siebenundzwanzigste Vorlesung. Die Saccharomyceten.

Barker, 1901. Proc. Royal Soc., 58, p. 345-348.

- 1902. On spore-formation among the Saccharomycetes. Journ. of the Federated Institute of Brewing, 8, No. 1, 26 pp., 50 fig.

Guilliermond, 1902. Recherches cytologiques sur les levures et quelques formes Levures. Thèse, Paris, A. Storch \& Co.

Hansen, 1904. (Für System.) Centralbl. f. Bakt. u. Parasitenk., Abt. II, 12, p. 520.

\section{Achtundzwanzigste Vorlesung. Basidiomycetes, Hemibasidii.}

de Bary, A., 1853. Untersuchungen über Brandpilze und die durch sie verursachten Krankheiten der Pflanzen, Berlin.

- 1884. Vergleichende Morphologie und Physiologie der Pilze, Leipzig.

Brefeld, O., 1883. Botanische Untersuchungen über Hefepilze. H. 5: Die Brandpilze, Leipzig.

- 1888. Neue Untersuchungen über die Brandpilze. Nachr. a. d. Klub der Landwirte zu Berlin.

- 1895. Untersuchungen aus dem Gesamtgebiete der Mykologie. H. 11 u. 12: Die Brandpilze, II u. III, Münster.

- 1903. Ueber Blüteninfektion durch Flugbrand. Nachr. a. d. Klub der Landwirte zu Berlin, No. 466.

- und Falck, R., 1905. Die Blüteninfektion bei den Brandpilzen und die natürliche Verbreitung der Brandkrankheiten. In: Brefeld, Untersuchungen aus dem Gesamtgebiete der Mykologie, H. 13 (mit 2 Lichtdrucktafeln).

Dangeard, P. A., 1892. Sur la reproduction sexuelle des Champignons. Chapitre II. Recherches histologiques sur la famille des Ustilaginées. Le Botaniste, 3. Série, p. 240.

- 1893. La reproduction sexuelle des Ustilaginées. C. R., 9 oct.

Dietel, $\boldsymbol{P} .$, 1900. Hemibasidii (Ustilagineae und Tilletieae), in Engler und Prantl, Natürl. Pflanzenfam., 1, 1. Abt. ***.

Fisch, 1885. Ueber das Verhalten der Zellkerne in fusionierenden Pilzzellen. Tagebl. der 58. Versamml. deutscher Naturforscher u. Aerzte.

Hecke, L., 1905. Zur Theorie der Blüteninfektion des Getreides durch Flugbrand. Ber. d. D. bot. Ges., 23, p. 248.

de Istvanffi, G., 1895. Ueber die Rolle der Zellkerne bei der Entwickelung der Pilze. Ber. d. D. bot. Ges.

Maire, R., 1898. Note sur le développement saprophytique et la structure cytologique des sporidies-levures chez l'Ustilago maydis. Bull. Soc. Mycol.

- 1902. Recherches cytologiques et taxonomiques sur les Basidiomycètes. Annexé au Bull. de la S'oc. Mycol. de France, Fasc. 4.

Schmitz, 1879. Untersuchungen über die Zellkerne der Thallophyten. Verh. des naturhist. Vereins der preuß. Rheinlande $u$. Westjalens, $p .346$.

Solms-Laubach, Graf zu, H., 1886. Ustilago Treubii, Solms. Ann. du Jardin Botan. de Buitenzorg, $\boldsymbol{G}$.

Strasburger, E., 1900. Versuche mit diöcischen Pfanzen (Ustilago antherarum, p. 692). Biol. Centralbl., 20, No. 20-24.

v. Tavel, F., 1892. Vergleichende Morphologie der Pilze, Jena.

Tulasne, $\boldsymbol{L}$. $\boldsymbol{R}$. et $\boldsymbol{C}$., 184\%. Mémoire sur les Ustilaginées comparées aux Urédinées. Ann. des Sc. nat., Paris, 3. Série, \%.

- - 1848. Second mémoire sur les Urédinées et Ustilaginées. Ibid., 4. Série, 2.

Vuillemin, $\boldsymbol{P} .$, 1891. Sur les effets du parasitisme de l'Ustilago antherarum. $C . R$. Acad. Sc.

Woronin, M., 1882. Beiträge zur Kenntnis der Ustilagineen, in de Bary und Woronin, Beiträge zur Morphologie und Physiologie der Pilze, 5. Reihe.

\section{Neunundzwanzigste Vorlesung. Die Uredineae.}

Vollständige Literatur über wirtswechselnde Rostpilze bis 1904 bei KLEBAHN, Die wirtswechselnden Rostpilze, Berlin 1904.

Arthur, J. C., 1904. The aecidium as a device to restore vigor to the fungus. Proc. Soc. Promotion agric. Science, 23. annual meeting.

Banks, J., 1805. A short Account of the Cause of the Disease in Corn, called by the Farmers the Blight, the Mildew and the Rust. Annals of Agricult., London, 43, p. 521.

de Bary, A., 1853. Untersuchungen ïber die Brandpilze und die durch sie verursachten Krankheiten der Pflanzen etc., Berlin.

- 1865. Neue Untersuchungen über die Uredineen, insbesondere die Entwickelung der Puccinia graminis, und den Zusammenhang derselben mit Aecidium Berberidis. Monatsber. der K. Akad. der Wiss., Berlin, p. 25. 
de Bary. A., 1866. Teue Untersuchnngen über Uredineen. Ibid., p. 211.

- 186\%. Teber den Krebs und die Hexenbesen der Weißtanne (Abies pectinata DC.). Bot. Zig., p. $25 \%$.

- 18\%5. Notiz ïber Cronartium Ribicola. Ibid., p. 119.

- 1884. Vergleichende Morphologie und Biologie der Pilze etc., Leipzig.

Blackman, I. H., 1904. On the fertilization, alternation of generations, and general cytology of the Uredineae. Ann. of Bot., 18, p. 323.

- and Fraser, 1906. Further studies on the scxuality of the Uredineae. Ann. of Bot., 20, $p .36$.

v. Bönnighausen, C., 1818. Ueber die schädliche Wirkung des Sauerdorns. Mögliner Annalen der Landwirtsch., 4, p. 280.

Brefeld, O., 1877-1881. Botanische Untersuchungen über Schimmelpilze, H. $3,4$.

- 1888-1895. Untersuchungen aus dem Gesamtgebiete der Mykologie, \%, 8, 9, 11.

Cholodkousky, N., 1900. Teber den Lebenscyklus der Chermes-Arten und die damit verbundenen allgemeinen Fragen. Biol. Centralbl., 20, p. 265.

Christman, A. H., 1905. Sexual reproduction of the Rusts. Bot. Gaz., 39, p. $26 \%$.

Dangeard, P. A. et Sappin-Trouffy, P., 1893. Recherches histologiques sur les Urédinées. C. R., 116. p. 211 .

- 1893. Cne pseudofécondation chez les Urédinées. C. R., 116, p. 267; Le Botaniste, 3. Série, p. 123.

- - 1894-1895. Réponse à une note de MM. G. Poirault et Raciborski sur la karyokinèse chez les Urédinées. Le Botaniste, 4. Série, p. 196.

Dietel, P., 1894. Die Gattung Ravenelia. Hedvigia.

- 1894. Ochropsora, eine neue Uredineengattung. Ber. d. D. bot. Ges.

- 1895. Ueber Rostpilze mit viederholter Aecidienbildung. Flora.

- 1897 (?). Uredinales, in Engler und Prantl, Natürl. Pflanzenfam., 1, 1. Abt. **, 1900.

Eriksson, J., 1894. Ueber die Spezialisierung des Parasitismus bei den Getreiderostpilzen. Ber. d. D. bot. Ges., 12, p. 292.

- 1896. Neue Untersuchungen über die Spezialisierung, Verbreitung und Herkunft des Schwarzrostes (Puccinia graminis Pers.). Jahrb. f. wiss. Bot., 29, p. 499.

- 189\%. Der heutige Stand der Getreiderostfrage. Ber. d. D. bot. Ges., 15, p. 183.

- 1898. Studien über den Hexenbesenrost der Berberitze (Puccinia Arrhenatheri Kleb.). Cohns Beitr. z. Biol. d. Pflanzen, 8, p. 1.

- 1901. Fortgesetzte Studien ïber die Hexenbesenbildung bei der gewöhnlichen Berberitze. Ibid., p. 111.

- 1901-1902. Sur l'origine et la propagation de la rouille des céréales pour la sémence. Ann. de Sc. nat., 8. Série, 14, p. 1-24; 15, p. 1-160.

- 1903. Sur l'appareil végétatif de la rouille jaune des céréales. C. R., p. 5\%8.

- 1903. The researches of Professor H. Marshall Ward on the Brown-Rust on the Bromus and the IIycoplasm hypothesis. Ark. f. Botanik, Stockholm, p. 139.

- 1904. Ueber das vegetative Leben der Getreiderostpilze, I. Kgl: Sv. Vet. Akad. Handl., 3\%, No. 6 .

- 1904. Ueber das vegetative Leben der Getreiderostpilze, II-III. Kgl. Sv. Vet. Akad. Handl., 38, No. 3.

- 1904. Nouvelles recherches sur l'appareil végétatif de certaines Urédinées. C. R., p.85.

- 1905. On the vegetative life of some Uredineae. Ann. of Botany, 93, p. 55.

- und Henning, E., 1894. Die Hauptresultate einer neuen Untersuchung ïber die Getreideroste. Ztschr. f. Pflanzenkrankheiten, 4, p. 66 u. 140.

- - 1896. Die Getreideroste, ihre Geschichte und Natur, sowie Maßregeln gegen dieselben. Stockholm.

Fischer, E., 1901. Der Wirtwechsel des Aecidium elatinum. Schweiz. Ztschr. f. Forstwesen.

- 1901. Die Uredo- und Teleutosporengeneration von Aecidium elatinum. Ber. d. D. bot. Ges., 19, p. $89 \%$.

- 1902. Aecidium elatinum Alb. et Schw., der Urheber des Weißtannen-Hexenbesens, und seine Uredo- und Teleutosporenform. Ztschr.f. Pflanzenkrankh., 11, p. 321; 12, p. 198.

Freeman, E., 1902. Experiments on the Brown Rust of Bromes (Puccinia dispersa). Ann. of Botany, 16, p. $48 \%$.

Hartig, R., 1880. Calyptospora Goeppertiana Kühn und Aecidium columnare A. u. S. Allgem. Forst- u. Jagdzeitung, p. 289.

- 1881. Ueber Aecidium columnare A. u. S. snd Calyptospora Goeppertiana Kühn. Flora, p. 45.

- 1882, 1889. Lehrbuch der Baumkrankheiten, 1. u. 2. Auflage.

Heck, $\boldsymbol{R} ., 1894$. Der Weißtannenkrebs, Berlin.

Klebahn, H., 1888. Weitere Beobactitungen über die Blasenroste der Kiefern. Ber. $d$. D. bot. Ges.

- 1904. Die wirtswechselnden Rostpilze. Versuch eincr Gesamtdarstellung ihrer biologischen Verhältnisse, $3 \%+447$ pp., Berlin. 
Lagerheim, G., 1891. Puccinia, Chrysopsora, Alveolaria und Trichopsora, vier neue Uredineengattungen mit tremelloider Entwickelung. Ber. d. D. bot. Ges.

Léveillé, J. H., 1826. Observations sur deux Champignons de la famille des Urédinées. Mém. Soc. Linn. de Paris, 4, p. 202.

Magnus, P., 189\%. Ueber das Aecidium Magellanicum Berk. Ber. d. D. bot. Ges., 15, p. 148.

- 189\%. Ein auf Berberis auftretendes Aecidium der Magellanstr. Ibid., p. 270.

- 1899. Beitrag zur Kenntnis der Melampsorella Caryophyllacearum (DC.) Schroet. Ber. d. D. bot. Ges., 1\%, p. 337 .

Maire, R., 1902. Recherches cytologiques et taxonomiques sur les Basidiomycètes. Annexé au Bull. de la. Soc. Mycologique de France, Fasc. 4.

Massee, G., 1888. On the presence of sexual organs in Aecidium. Ann. of Botany, 2, p. 4\%.

Neumann, $\boldsymbol{R} .$, 1894. Ueber die Entwickelungsgeschichte der Aecidien und Spermogonien der Uredineen. Hedwigia, 33, p. 346.

Poirault, G., 1895. Les phénomènes de karyokinèse dans les Urédinées. C. R., Paris, p. 178.

- et Raciborski, M., 1895. Sur les noyaux des Urédinées. Journ. de Bot., 9, p. 318 u. 381.

Richavds, H. M., 1896. On some points in the development of the Aecidia. Proc. Amer. Acad. Sc., 31, p. 255-270, Pl. 1.

Sappin-Trouffy, P., 1893. La pseudo-fécondation chez les Urédinées et les phénomènes qui s'y rattachent. C. R., 116, p. 1304.

- 1896/9\%. Recherches histologiques sur la famille des Urédinées. Le Botaniste, 5, p. $59-244$.

Schroeter, J., 1874. Melampsorella, eine neue Uredineengattung. Hedwigia, 13, p. 81.

- 1875. Beobachtungen üher die Zusammengehörigkeit von Aecidium Euphorbiae Pers. und Uromyces Pisi (Str.). Hedwigia, 14, p. 98.

- 1893. Zur Entwickelungsgeschichte der Uredineen. Schles. Ges. f. vaterländ. Kultur, 71. Jahresber., Bot. Sekt., p. 31.

Shirai, M., 1899. On the genetic connection between Peridermium giganteum (Mayr) Tub. and Cronartium quercuum (Cke.) Miyabe. Bot. Mag., 13, p. 74.

Tranzschel, W., 1893. Kulturversuche mit Caeoma interstitiale Schlechtd. Hedwigia, p. $25 \%$.

v. Tubeuf, C., 1891. Ueber seine Infektionsversuche mit Gymnosporangiumarten. Bot. Centralbl., 46, p. 19.

- 1900. Die Ueberwinterung und Verbreitung des Gitterrosts der Birnbäume. D. landw. Presse, p. 216.

- 1891. Generations- und Wirtswechsel unserer einheimischen Gymnosporangiumarten und die hierbei auftretenden Fornveränderungen. Centralbl. $f$. Bakt., 9, p. 89, 167.

Tulasne, L. R. et Ch., 184\%. Mémoire sur les Ustilaginées comparées aux Urédinées. Ann. Sc. nat., 3. Série, \%, p. 12.

- 1854. Second mémoire sur les Urédinées et les Ustilaginées. Ann. Sc. nat., 4. Série, 2.

Vuillemin, $\boldsymbol{P}$., Sur la fécondation des Puccininées. C. R., 116, p. 1464.

Ward, H. Marshall, 1888-1889. Illustrations of the structure and life-history of Puccinia graminis. Ann. of Botany, 2, p. 21\%, Pl. 11, 12.

- 1901. The Bromes and their Rust fungus (Puccinia dispersa). Ann. of Bot., 15, p. 560.

- 1902. On the question of "Predisposition" and "Immunity" in plants. Proc. Cambridge Philos. Soc., 11, p. $30 \%$.

- 1902. Experiments on the effect of mineral starvation on the parasitism of the UredineFungus, Puccinia dispersa, on species of Bromus. Proc. Roy. Soc., \%1, p. 138.

- 1902. On pure cultures of a Uredine, Puccinia dispersa (Erikss.). Ibid., p. 451.

- 1902. On the relations between host and parasite in the Bromes and their Brown Rust, Puccinia dispersa (Erikss.). Ann. of Botany, 16, p. 233.

- 1903. Further observations on the Brown Rust of the Bromes, Puccinia dispersa (Erikss.) and its adaptive parasitism. Annales Mycologici, 1, p. 132.

- 1903. On the histology of Uredo dispersa (Erikss.) and the Mycoplasm hypothesis. Proc. Roy. Soc., 71, p. 353 and Philosophical Transactions Roy. Soc. London, Ser. B, 196, p. $29-46$.

- 1905. Recent researches on the parasitism of Fungi. Ann. of Bot., \%3, p. 1.

Warming, E., 1901. Lehrbuch der Systematik, Berlin.

v. Wettstein, $\boldsymbol{R} .$, 1901. Handbuch der systematischen Botanik, Wien.

Wolff, R., 18\%4. Zugehörigkeit des Peridermium Pini. Lév. zu Coleosporium Compositarum Lév. form. senecionis. Bot. Ztg., p. 184.

Woronin, M., 1872. Untersuchungen über die Entwickelung des Rostpilzes (Puccinia Helianthi), welcher die Krankheit der Sonnenblume verursacht. Bot. Ztg., p. 67\%.

Dreißigste Vorlesung. Basidiomyceten.

Erster Teil bis zu den Gasteromyceten.

van Bambeke, C., 1903. Sur l'évolution nucléaire et la sporulation chez Hydnangium carneum W'allr. Mémoires de l’Acad. Royale de Sc., Bruxelles, 54. 
de Bamy, 1., 1859. Zur Kenntnis einiger Agaricineen. Bot. Ztg. (Ueber Nyctalis. Sp. 385.) - 1884. Vergleichende Morphologie und Physiologie der Pilae, Jena.

Boudier, 1896. Note sur une nouvelle espèce de Prototremella Pat. Journ. de Botanique, $10, p .85$.

Brefeld, O., 1876. Die Entwickelungsgeschichte der Basidiomyceten. Bot. Ztg.

- 18ss. Untersuchungen aus dem Gesamtgebiete der Mykologie, Heft $\boldsymbol{\%}$, Protobasidiomycetes.

- 1889. Untersuchungen aus dem Gesamtgebiete der Mykologie, Heft 8 , Hymenomyceten. Es sei hier anch auf die Literatur der Gruppe verwiesen.

Dangeard, P.. 1893. Recherches sur la reproduction sexuelle des Champignons. Le Bot.

- 1894. La reproduction sexuelle des Basidiomycètes. Ibid.

- 1895. Mémoire sur la reproduction sexuelle des Basidiomycètes. Ibid.

- 1.900. La reproduction sexuelle des Champignons. Ibid.

Eidam, 1875. Zur Kenntnis der Befruchtung bei den Agaricusarten. Bot. Ztg., p. 649.

Hennings, P., 189\%. Dacryomycetineae, in Engler und Prantl, Natïrl. Pflanzenfam., 1, 1. Abt. ***, p. 96.

- 189\%. Exobasidiineae, in Engler u. Prantl, Natürl. Pflanzenfam., 1, 1. Abt. ***, p. 108.

- 189\%. Hymenomycetineae, in Engler u. Prantl, Natïrl. Pflanzenfam., 1, 1. Abt. **, p. 105.

de Istvanffi, G., 1895. Ueber die Rolle der Zellkerne bei der Entwickelung der Pilze. Ber. d. D. bot. Ges.

Sohow, F., 1884. Die Gruppe der Hymenolichenen. Ein Beitrag zur Kenntnis basidiosporer Flechten. Pringsh. Jahrb.. 15, p. 361.

Juel, 189\%. Muciporus und die Familie der Tulasnellaceen. Bihang till Kgl. Svensk. Vet. Ak. Handlingar, 23.

-- 189s. Die Kernteilungen in den Basidien und die Phylogenie der Basidiomyceten. Pringsh. Jahrb.

- 1898. Ein bisher verkannter Basidiomycet. Bihang till Kgl. Svensk. Vet. Ak. Handlingar, 24.

Karsten, 186\%. Zur Befruchtung der Pilze, in Karsten, Botanische Untersuchungen, I.

Kirchner, 1875. Beobachtungen der Geschlechtsorgane der Gattung Coprinus. Berichte über die Tütigkeit der hot. Sekt. d. Schles. Ges.

Lindau, G., 189\%. Auriculariales, in Engler u. Prantl, Natürl. Pflanzenfam., 1, Abt. ***, p. 82 .

- 189\%. Tremellineae. Ibid., p. 88.

Maire, R., 1900. Sur la cytologie des Hymenomycètes. C. R., Paris, 9 juillet.

- 1900. Sur la cytologie des Gasteromycètes. C. R., Paris, 24 déc.

- 1901. Les variations de la baside et la phylogenèse des Autobasidiomycètes. Bull. de la Soc. des Sciences, Nancy.

- 1901. Nouvelles recherches sur la cytologie des Hyménomycètes. C. R., Paris, 1 avrit.

- 1902, De l'utilisation des données cytologiques dans la taxonomie des Basidiomycètes. Bull. de la Soc. Bot. de France, session extraord. en Corse, I.

- 1902. Recherches cytologiques et taxonomiques sur les Basidiomycètes, Annexé au. Bull. de la Soc. Mycol. de France, Fasc. 4.

Mattirolo, O., 1881. Contribuzioni allo studio del genere Cora Fries. Nuov. Giorn. bot. ital., 13, No. 4. p. 245-26\%, 2 Tav.

Micheli. 1729. Nova plantarum Genera, Fllorentiae.

Möller, A., 1893. Ueber eine Telephoree, welche die Hymenolichenen Cora, Dictyonema und Laudatea bildet. Flora, p. 254.

- 1893. Die Pilzgärten einiger südamerikanischer Ameisen. Schimpers Bot. Mitt. aus den Tropen, Heft $\boldsymbol{6}$, Jena.

- 1895. Brasilische Pilablumen. Schimpers Bot. Mitt. aus den Tropen, Heft ;, Jena.

- 1895. Protobasidiomyceten. Schimpers Bot. Mitt. aus den Tropen, Heft $\boldsymbol{S}$, Jena.

Nichols (Miss), 1905. The nature and origin of the binucleated cells in certain Basidiomycetes. Transact. Wisc. Ac. Sc., 15.

Olsen, J., 1888. Ueber Pachysterigma, in Brefeld, Unters. a. d. Gesamtgeb. d. Mrykologie, Heft

Patouillard, N., 1888. Prototremella, nouveau genre d'Hyménomycètes hétérobasidiés. Journ. de Bot., p. $26 \%$.

Reess, 1875. Ueber den Befruchtungsvorgang bei den Basidiomyeeten. Progr. z. Eintritt in die philos. Fakultät, Erlangen.

Ruhland, W., 1901. Zur Kenntnis der intracellulären Karyogamic bei den Basidionyceten. Bot. Ztg.

Sappin-Trouffy, 1893. Recherches histologiques sur les Urédinćes. (. R., Paris, so janv.

- 1893. La pseudofécondation chez les Urédinées et les phénomènes qui s’y rattachent, C. R. Ac., juin.

- 1896. Sur la signification de la fécondation chez les Urédimécs. (Y. R., Paris, 10 férr. 
Sappin-Trouffy, 1896. Recherches mycologiques. Le Bolaniste.

- 1896. Recherches histologiques sur la famille des Urédinées. Ibid.

Schroeter, J., 188\%. Ueber die Entwickelung und die systematische Stellung von Tulostoma Pers. Cohns Beitr. z. Biologie der Pflanzen, 2, p. 65.

de Seynes, 1875. Note sur l'organe femelle de Lepiota cepaestipes. Bull. Soc. bot. France, p. 99.

Smith Worthington, G., 1875. Reproduction in Coprinus radiatus. Grevillea 4, p. 53, Pl. $54-61$.

Strasburger, 1894. The periodic reduction of the number of chromosomes in the lifehistory of living organisms. Annals of Botany, $\boldsymbol{8}$.

van Tieghem, Ph., 18\%5. Sur la fécondation des Basidiomycètes. C. R., Paris.

- 1875. Sur le développement du fruit des Coprins et la prétendue sexualité des Basidiomycètes. C. R., Paris.

- 1876. Nouvelles observations sur le développement du fruit et sur la prétendue sexualité des Basidiomycètes et Ascomycètes. Bull. Soc. bot. France, p. 99.

- 1893. Sur la classification des Basidiomycètes. Journ. de Bot., 7.

Vuillemin, P., 1893. Remarques sur les affinités des Basidiomycètes. Ibid., \%.

Wager, The sexuatity of the Fungi. Annals of Botany, 13.

Woronin, 186\%. Exobasidium Vaccinii. Verh. Naturf. Ges. zu Freiburg, 4, mit 3 Tafeln.

\section{Dreissigste Vorlesung. Basidiomyceten.}

\section{Zweiter Teil. Gasteromyceten.}

van Bambeke, C., 1903. Sur l'évolution nucléaire et la sporulation chez Hydnangium carneum Wallr. Mémoires de l'Acad. Royale de Sc., Bruxelles, 54.

Brefeld, O., 18\%\%. Botanische Untersuchungen über Schimmelpilze, Heft 3, p. 176-180. (Ueber Nidulariaceae.)

Burnap, E., 189\%. Notes on the genus Calostoma. Bot. Gaz., 23.

Burt, E. A., 1896. The development of Mutinus caninus (Huds.) Fr. Ann. of Botany, 10, p. 343-372.

Corda, 1842-1854. Icones fungorum, $\mathbf{5}, \boldsymbol{6}$.

Eidam, E., 18\%6. Die Keimung der Sporen und die Entstehung der Fruchtkörper bei den Nidularieen. Cohns Beitr. z. Biol. d. Pflanzcn. 2, p. 221-245.

Fischer, E., 1884. Zur Entwickelungsgeschichte der Gasteromyceten. Bot. Ztg. (Sphaerobolus).

- 1886. Zur Entwickelungsgeschichte der Fruchtkörper einiger Phalloideen. Ann. d. Jard. Bot. de Buitenzorg, 6 .

- 1886. Versuch einer systematischen Uebersicht über die bisher bekannten Phalloideen. Jahrb. d. bot. Gartens und des bot. Museums zu Berlin, 4.

- 1890. Untersuchungen zur vergleichenden Entwickelungsgeschichte der Phalloideen. Denkschr. d. Schweiz. naturf. Ges., 32, I.

- 1893. Neue Untersuchungen zur vergleichenden Entwickelungsgeschichte und Systematik der Phalloideen. Ibid., 33, I.

- 1895. Die Entwickelung der Fruchtkörper von Mutinus caninus (Huds.). Ber. d. D. bot. Ges., 13, p. 128-13\%.

- 1896. Ueber den Parallelismus der Tuberaceen und Gasteromyceten. Ber. d. D. bot. Ges., 14.

- 1898-1899. Phallineae, Hymenogastrineae, Lycoperdineae, Nidulariaceae und Plectobasidiineae, in Engler u. Prantl, Natürl. Pflanzenfam., 1, Abt. 1\%*.

- 1900. Untersuchungen zur vergleichenden Entwickelungsgeschichte und Systematik der Phalloideen. Denkschr. d. Schweiz. naturf. Ges., 36, II, mit einem Anhang: Verwandtschaftsverhältnisse der Gasteromyceten.

Hennings, P., 1895. Fungi camerunenses, I. Englers Bot. Jahrb., 22.

Hesse, R., 1891. Die Hypogaeen Deutschlands, 1, Die Hymenogastreen, Halle a./S.

- 18\%6. Mikroskopische Unterscheidungsmerkmale der typischen Lycoperdaceengenera. Pringsh. Jahrb., 10, p. 383.

- 1876. Keimung der Sporen von Cyathus striatus Willd., einer Gasteromycetenspecies. Pringsh. Jahrb., 10, p. 199-203.

Maire, R., 1900. Sur la cytologie des Gasteromycètes. C. R., Paris, 24 déc.

Massee, G., 188\%. A monograph of the genus Lycoperdon. Journ. of the Royal Micro. scopical Society.

- 188\%. Revision of Polysaccum. Grevillea, 16.

- 1888. A monograph of the genus Calostoma. Ann. of Botany, 2.

Möller, A., 1895. Brasilianische Pilzblumen. Schimpers Botan. Mitt. aus den Tropen, Heft \%. Hierin auch Protubera.

Montagne, 1846-1849. Ueber Secotium, in Exploration scientifique de l'Algérie. Sciences naturelles, Botanique Acotyledones. 
Patouillard, $\boldsymbol{N} .$, Is98. Quelques Champignons de Java. Bull. de la Soc. mycol. de France, 14, p. 182.

Penzig, O., 1899. Ueber javanische Phalloideen. Ann. du Jardin Bot. de Buitenzorg, 2. Série, 1, p. $133-173$.

Rabinowitsch, L., 1894. Beiträge zur Entwvickelungsgeschichte der Fruchtkörper einiger Gasteromyceten. Flora.

Rehsteiner, 1892. Beiträge zur Entwickelungsgeschichte der Fruchtkörper einiger Gasteromyceten. Bot. Ztg.

Sachs. J., 1855. Morphologie des Crucibulum vulgare Tulasne. Bot. Ztg., p. 843-845, $849-861$.

Schröter, J., 188\%. Ueber die Entwickelung und die systematische Stellung von Tulostoma Pers. Cohns Beitr. z. Biol. d. Pflanzen, 2, p. 65.

Thaxter, R., 1893. Note on Phallogaster saccatus. Bot. Gazette, 18, p. 11\%.

Thilasne, L. R. et Ch., 1842. Sur les genres Polysaccum et Geaster. Ann. de Sc. nat., Série 2, 1S, p. 129.

- 1844. Recherches sur l'organisation et le mode de fructification des Champignons de la tribu des Nidulariées, suivies d'un essai monographique. Ann. de Sc., Botanique, 3. Série, 1, p. 41-10\%.

- 1845. Description d'une espèce nouvelle du genre Secotium Kze., appartenant à la flore française. Ann. d. Sc. nat., 4, Série 3, Botanique, p. 169.

- 1851. Fungi hypogaei, Histoire et monographie des Champignons hypogés, Paris. 


\section{Namenregister.}

Die fetten Ziffern deuten die Stellen an, wo die betreffende Gruppe, Genus, Spezies, Organ oder Eigentümlichkeit ausführlich besprochen ist. Ein * bedeutet Abbildung.

Absidia 139.

A.

Acalcareae 408.

Acetabula calyx Sacc. 441, 459.

Acetabularia 56, 90, 93, $95 \mathrm{ff}$.

- crenulata Lamour. 95 .

- mediterranea Lamx. 96*.

Acetabulariaceae 90, 95 ff.

Achlya 162, 163*, $164^{*}, 165$.

- de Baryana Humphrey 166, 167, 168.

- polyandra Hildebr. 163*, 167.

— racemosa Hildebr. 163*, 166.

Achnantes 253*.

Acrasieae 391, 395, 402, 403, 416, 417.

Acrosiphonia vernalis Ag. 106.

Acrosporeae v. Tiegh. 675 .

Aecidium 627.

- abietinum A. et S. 648 .

- berberidis Gmel. 638, 644.

- columnare A. et S. 653.

- elatinum A. et S. 651 .

- leucospermum DC. $655^{*}$.

- magellanicum Berk. 644 ; in Herb. Persoon unterschieden 644 .

Agaricaceae 705, 706, 711.

- leucosporeae 711.

- ochrosporeae 711.

- rhodosporeae 711 .

Agaricineae 675, 678, 685, 686, 704, 705, $706^{*}$.

Agaricus 130.

- campester L. 671.

- vaginatus Bull. 671.

Aglaozonia 280.

Akinetosporeae $257,287$.

Akonten 5, 6, 7, 194.

Albuginaceae 151.

Albugo 146, 151, 160, 161, 162, 444, 446.

- Bliti (Biv.) O. Kuntze 153*, 154* ff., 156, $160,162,468$.

- candida (Pers.) Kuntze 151, 152*, 155, $157^{*}, 160,162$.

- Lepigoni (de Bary) Kuntze 158.

- Tragopogonis (Pers.) S. F. Gray 156*, $157^{*}, 158,160,162$.

Aleuria marsupium Quél. 458.

- succosa Gill. 458.
Aleurodiscus 698.

Allococceae 341.

Amanita 713.

- muscaria (L.) Pers. 712*, 713.

- pantherina DC. 713.

Amaniteae 711, 712*, 713.

Amanitopsis 713 .

Amöben 397, 399.

Amorphomyces 533, 540*.

- Falagriae Th. $540^{*}$.

Anabaena $365^{*}, 366,370,374,375^{*}, 376^{*}$, $378,384$.

- inaequalis $370^{*}$.

Anadyomene 56.

- flabellata Lamour. 102*, 103.

Anaptychia $434^{*}, 547,548$.

- ciliaris (L.) Körbr. 569.

Androsaccus 711.

Annularia 713.

Antelminellia 243*.

Anthina flavovirens Fr. 527.

Anthoceros 373.

Aphanocapsa 383*, 384.

Aphanothece $383^{*}, 384$.

Aplanes $164^{*}, 165$.

- Braunii De Bary 164.

Apodachlya pyrifera Zopf 170 *

Arachnion Schw. 723.

Archegoniaten 5, 6, 746, 753.

Archimycetes 110, 111.

Arcyria 404*, 408, 409*, 411.

- nutans (Bull.) Rost 409.

Arınillaria 713.

- mellea Vahl 712*.

Armillariella 711, 712.

Arnoldiella minutula Born. 550*, 551 .

Arrhenia 698.

Arthronia 553*.

Aschion 591, 592, 593, 596.

Ascoboleae 573.

Ascobolus 143*, 144, 422, 423*, 432, 548, 573, 577, ว87.

- immersus (Pers.) 579*.

Ascocorticiaceae 431, 597, 600.

Ascocorticium 676.

- albidum Bref. 600 .

Ascocyclus 258, 259, 263. 
Ascocyclus secundus Reinke '263*.

Ascodesmis 571, 572.

- nigricans $\nabla$. Tieghem 459, 460*, 461*, $462 *, 463^{*}, 464 *, 468$.

Ascoidea 431, 436, 437*, $\mathbf{4 2 .}$

- rubescens Bref. 442*, 444, 446.

Ascoideaceae 431, 436, 439.

Ascoideae 442.

Ascolichenes 441, 549, 571.

Ascomyces Trientalis Berk. 626.

Ascomycetes 121, 143*, 418, 571, 616, 665, $673,674,676$.

Ascophyllum 296, 299, 301, 302* .

Aseroe rubra La Bill 738.

Aspergillaceae 498, 501.

Aspergillus 502*, 503.

- flavus Link 502.

- glaucus Link 441, 501.

- herbariorum Wiggers 501, 533.

- nidulans (Eidam) Fischer 50\%。

- niger v. Tieghem 502.

Asperococceae 258, 264, 26 อ̆.

Asperococcus 258, 267.

- bullosus Lamx. 268, 269*.

- scaber Kuckuck 267, 268*.

Astraeus 720, 721, 722*, 728, 730.

- stellatus (Scop.) Morgan 722*.

Auricularia 667, 676.

- Auricula Judae L. 667*, 672.

- Leveillei Quél. 698.

- mesenterica Dicks. 667.

Auricularieae 617, 626, 666, 667, 678, 683, 684.

Auricularineae 676.

Auriculariopsis 696, 698.

- ampla (Lév.) Maire 697*.

Autobasidiomyceten $617,665,666,670,676$, $677,678,682,684,686,718$.

Bacilleae 342.

\section{B.}

Bacillus 359 .

- anthracis Koch et Cohn 336*, 338.

- diphtheriae Löffler 342, 346, 347*.

Bacteriaceae 342, 346.

Bactridium 342, 350 .

- coli Fischer 340.

- radicicola Fischer 342, 347*, 350 .

- subtilis (Ehrenb.) A. Fisch. 335, 337, $339,342,350$.

- typhi Fischer 340.

Bactrillum 342.

- fluorescens Fischer 342, 347*, 350.

Bactrinium 342.

- pyocyaneus Fischer 342, 347*, 349.

Badhamia 402, 404, 405, 412.

- utricularis (Bull.) Berk. 393, 394*.

Baeomyces byssoides (L) Schw. 556 .

-- paeminosus Krph. 556.

- roseus Pers. 556.

Baeomycetaceae 556.

Bakterien 3, 7, 329, อి30, 371, 372, 390.

Balsamina 509.

- vulgaris Vittadini 583*.

Balsamiae 509, 583, 590 .

Bangiaceae 307, 312, 376.
Basidioboleae 200.

Basidiobolus 200, 436.

- ranarum Eidam 200*.

Basidiolichenen 373, 500, 693.

Basidiomyceten 216, 418, 436, $\mathbf{6 1 6}, \mathbf{6 2 6}, 665$, 666, 675 .

Batrachospermum 311, 314*, 315, 325.

Battarea 724, 725.

- Tepperiana Ludw. 725*, 726 .

Beggiatoa 342, 357*, 358, $\mathbf{3 6 1}$.

- alba (Vauch.) Trevisan 361.

Binuclearia 216.

Blaualgen $=$ Cyanophyceae.

Bolbitius 715, 718.

Boletaceae 705, 706, 717*.

Boletus 130, 700, 718.

- Satanas Lenz 717, 718.

Bornetella 56, 90, 94*, 97.

Bornetelleae 90, 94, 95.

Borrera ciliaris Ach. 441.

Botrydiaceae 53, $21 \%$.

Botrydium 49.

- granulatum (L.) Grev. 53, 54.

Botryococcus Kätz. 744.

Botrytes bassiana Bals. 513.

Boudiera 573.

- arceolata Cooke et Phill. 579*.

- hyperborea Karst. 459.

Bovista 728, 729, 730.

- nigrescens Pers. 730*.

Bovistella 729.

Brachypuccinia 635.

Brefeldia 411.

Brefeldiaceae 410, 411.

Broomeia 732.

- congregata Berk. et Curt. 731*.

Bryophyten 749, 753.

Bryopogon jubatum L. 564*, 567.

Bryopsideae 56, 78.

Bryopsis $56 \mathrm{ff} ., 57^{*}, 77$.

Bulgaria inquinans (Pers.) Fr. 422.

C.

Calcareen 408, 411, 412*.

Calicieen 551 .

Calicium 548, 550, 555 .

Callithamnion corymbosum C. Ag. 323, 327.

Calodon 694.

Caloplaca 548.

Calosphaeria 524 .

- princeps Tul. 525*, 526.

Calostoma 720, 721, 722*. 723, 728.

- cinnabarinum (Desv.) Mass. 722*.

- lutescens (Schw.) Mass. 722*, 723.

Calostomataceae 719, 720, 721, 728.

Calyptospora 648, $653,655$.

- Goeppertiana J. Kühn 653*.

Camarophyllus 705, 706, 707.

Camptomyces 533.

Cantharellaceae 677, 684, 686, 6Ss, 694. $696,705,711$.

Cantharellineae 684, (686.

Cantharellus 6SS.

- aurantiacus Wulf. 6S8, 711.

- cibarins Fr. 687*, 68s, 689. 
Cantharellus cibarius L. 711.

- cinereus Pers. 684*, 685, 688.

- tubaeformis Fr. 688.

Cantharomyces 533.

Carpoasci 438.

Carpohemiasci 497.

Castagnea 258, 272.

- virescens Carm. 273*.

Catastoma 729.

Caulerpa 56, 57, 71, 78, 109.

- alternifolia J. Ag. 73.

- Ashmeadi Harv. 72*, 73, 74, 77.

- cactoides J. Ag. 72*, 73, 74 .

- cupressoides J. A. 72*, 73.

- fastigiata Mont. $72 *, 73,76$.

- Harveyi v. Müll. 72*, 73, 75*.

- hypnoides J. Ag. 72*, 73, 74, 75*.

- Lycopodium Harv. 75.

- macrodisca Reinke 72*, 73, 74.

- papillosa J. Ag. 72*, 73, 74 .

- pinnata Grév. 75 *.

- plumaris J. Ag. 75*.

- prolifera Lamx. $72^{*}, 73,75^{*}, 76$.

- racemosa J. Ag. 74.

- verticillata J. Ag. 72*, 73, 75*, 76 .

Caulerpaceae 56, 71.

Cephaleuros 190.

- laevis Karst. 190*.

- mycoidea (Cunn.) Karst. 190*.

Cephalothecium roseum Corda 481.

Ceramiales 321.

Ceramieen 325 .

Ceratiomyxa 403.

- mucida (Pers.) Schröt. 404*.

Ceratiomyxeae 403.

Ceratium 236, 239*, 240*.

- hirundinella (O. F. M.) 239.

- macroceras Stein 234, 235*.

- tripos Nitzsch. 234, 235*.

Ceratomyces 533, 534, 545, 546 .

Ceratostomaceae 522.

Ceratostomella pilifera (Tr.) Wint. 522*.

Cetraria $434^{*}, 561^{*}$.

- islandica L. 561*, 564, 567.

Chaetangiaceae 316.

Chaetoceras 256.

Chaetocladiaceae 134, 145.

Chaetocladium 145, 146.

- Brefeldii van Tieghem et Le Monnier $145^{*}$.

Chaetomiaceae 520.

Chaetomidium 520.

Chaetomium Kze. 520, 521*.

- globosum Kze. 520, 521*.

- spirale Zopf 520, $521^{*}$.

Chaetomorpha 56, 103, 104*.

Chaetomyces 533.

Chaetophoraceae 186, 259, 263, 269.

Chamaesiphon $380 *$.

Chamaesiphoneae $380 *$, 381, 382, 383, 384 .

Chantransia $315,316,326$.

- secundata Lyngb. 323.

Chara $746^{*}, 747^{*}, 753$.

- baltica (Fries) Wahlstedt $746^{*}$.

- delicatula A. Br. var. bulbifera 749, $750^{*}$.
Chara foetida A. Br. $746^{*}$.

- fragifera Dur. 746*.

- fragilis Desv. 749.

- intermedia A. Br. f. decipiens $746 *$.

Characeae 216.

Charophyten 5, 6, 745.

Chermes Abietis Kalt (Läuse) 661 .

- strobilobius Kalt 661, 662.

- viridis Rats 661,662 .

Chiastobasidiineae Juel 676, 683.

Chitonia 715.

Chitonomyces 533, 539*, 546.

- paradoxus (Peyritsch) Th. 539*.

- spinigerus Th. 539.

Chlamydomonas 7,9 ff., $13,17,18,19,31$, $171,172,203$.

- Braunii Gor. 11*, 14, 15*.

- Ehrenbergii Stein 11*.

- longistigma Dill 14, $15^{*}$.

- Steinii Dill 15, 15*.

Chlamydomucor racemosus (Fres.) Bref. 137*.

Chlamydopus 724 (Note).

Chlamydothrix 342, 356 .

- ochracea Winogr. 342, 356, 357*.

Chloramoeba 212.

- heteromorpha Bohl. 213*.

Chlorangium 172 ff., 177.

- stentorinum (Ehrb.) Stein 172, 173*.

Chlorella vulgaris Beyer. 175, 176*, 177.

Chlorochytrium 32 ff., 35, 37, 38, 39, 174.

- inclusum Kjellm. 33.

- Knyanum Kirchn. 32*, 33, 35.

- Lemnae Cohn 32*, 33.

Chlorodesmus 229, 230.

Chloromonaden 5, 6, 212.

Chlorophyceae 550 .

Chlorosaccus 212, 213.

- fluidus Luth. 213*.

Chlorotheciaceae 212.

Choanephora 144.

- infundibulifera (Currey) Sacc. 144*.

Choanephoraceae 134, 144.

Choiromyces 591.

Chondria $324^{*}, 325^{*}, 327$.

Chondrioderma 405*'.

- difforme (Pers.) Rostaf. 70.

- radiatum (L.) Rostaf. 405*, 411.

Chondromyces $385,386,389$.

- catenulatus Th. 385, 389*.

- crocatus B. et C. 385.

- glomeratus Zed. 386.

- muscorum Th. 389*.

- pediculatus Th. 385, 389*.

- sessilis Thaxter $389^{*}$.

Chorda 258, 278, 286.

- filum L. 278, 279*.

Chordeae 258.

Choreocolax albus Kuckuck 328, 469.

Choristocarpeen 287.

Chromatium okenii (Cohn) Schröt. 358.

Chromophyton Rosanoffi Wor. 226.

Chromulina 226.

- mucicola Wor. 227.

- Rosanoffi (Wor.) Bütschli 226*.

Chromulinaceae 225. 
Chroococcaceae 374, 383, 381, 549, 550.

Chroolepideen 189, 190*, 550 .

Chroolepus 159, 555 .

- umbrina Küitz. 190*.

Chrysamoeba :2.5.

Chrysomonaden 6, 7, 2.25.

Chrysomyxa 648.

- Rhododendri (DC.) De Bary 647*, 6t8.

Chrysomyreae 6t5.

Chrysopsora $6 \mathbf{5} 6$.

- Gynoxidis Lagerh. 655*, 656.

Chrysosphaerella 229.

Chylocladia $321^{*}, 322^{*}, 325$.

- kaliformis Hassenk. 323.

Chytridiaceae $6: 6$.

Ciliocarpus Corda 7\%3.

Cladonia 548, 549, 551, 556, 564.

- degenerans Fke. 570.

- pyxidata (L.) Fr. 571.

- rangiferina (L.) Hoffm. 569.

- verticillata Hoffm. 570.

Cladoniaceae $\mathbf{5 6 9}$.

Cladophora 45, 56, 101, 104*, 104, 109.

- glomerata Hansg. 106*.

- hamosa Kütz. 106*.

- profunda 59.

Cladophoraceae 56, 103.

Cladothrix $336^{*}, 341,342$, 3099.

- dichotoma Cohn 356, 359.

Clastidium 380*.

Clathraceae 727, 728, 734, 737, 738*, 739*.

Clathrus cancellatus Tournef. 738*, 739*.

Clatroptychiaceae 407.

Clatroptychium 404*,405, 406*, 407.

Clavaria Botrytis Pers. 687*.

- inaequalis Müll. 687*.

- pistularis L. $687^{*}, 688^{*}$.

- rugosa Bull. 684\%.

Claviariaceae 678, 68t, 686, 687, 694, 697.

Claviceps purpurea Tul. 426, 428*, 436, 518*, 519*.

Clitocybe 711, 712*.

- aurantiaca Maire 688.

- aurantiaca (Wulf.) Studer 705, 711.

Clitocybeae 711, 712*, 713.

Clitopilus 713.

- orcella Bull. 713.

Closterium 55, 217, 218*, 219, ¿20*, 221, $222^{*}$.

- lineatum Ehrbg. 222*, 224.

- lunula Ehrbg. $222 *$ 223.

- parvulum Nägeli $222 *, 223$.

- rostratum Ehrb. 222*, 224.

Clostridiaceae $\mathbf{3 5 3}$.

Clostridieae 34\%.

Clostridium 342.

- butyricum Fisch. 353*.

- pasteurianum Winogr. 342, 353*, 354.

Coccaceae 341

Coccocarpia 548.

Coccolithophoren 229.

Cocconeis 248, 253*.

Coccus $339,341,359$.

Codiaceae 56, 61, 78, 88 .

Codium 56, 62, 63* 69, 77, 78, 105, 109. tomentosum (Huds.) Stackh 64*.
Coelastrum reticulatum (Dangeard) Senn 178, 179*.

Coelonomeae 408.

Coleochaetaceae 186, 189, 191.

Coleochaete 191*, 308, 419.

- pulvinata Br. 191*, 192*.

- scutata Bréb. 191*, 193, 263, 270, 271.

Coleosporieae 648, 654, 676, 677.

Coleosporium 649, 654, 655, 672 .

- Euphrasiae Schum. 655*.

- Senecionis (Pers.) Fr. 654, 655*.

Collema 423*, 432, 433, 434*, 547, 551 , $555^{*}, 571$.

- crispum Rbh. 433.

- multifidum Scop. 555*, 557.

Collemaceae 373, 5 อ.6.

Collybia 711., 713.

Compsomyces 533, 535.

Conferva 185, 215, 216, 2:20.

- bombycina (Ag.) Wille 215*.

- minor Klebs 215*.

Confervaceae 558.

Confervales 21\%, 213.

Conjugaten 194.

Conocarpaceae 552*

Conocarpineae 554, 555.

Coprineae 711, 713, 715.

Coprinus 715, 716 .

- porcellanus (Schaeff.) Schröt. $716^{*}$.

- radiatus Bolt. 716 .

- stercorarius Fr. 716*.

- sterquilinus Fr. 716*.

Cora 693*, 694.

- pavonia Fr. 693*.

Corallina 327.

Corallineae 327.

Corditubera 720, 721, 728 .

- Staudtii Henn. 720*, 721.

Cordyceps $\mathbf{5 1 6}$.

- cinerea (Tul.) Sacc. 516*.

- entomorrhiza (Dicks.) Fr. 516*

- militaris (I.) Link 513, 516*, 517*.

- ophioglossoides (Ehrh.) Link 509.

- sphingum (Tul.) Sacc. 516*.

Corethromyces 533, 540 .

Corethron Valdiviae Karst. 255*.

Coriolus 700, 703.

— versicolor L. 703.

Cornuvia 409*.

Corticieae 696, 698, 699.

Corticium 694, 695, 696, 698, 699.

- coeruleum (Schrad.) Fr. 697*, 698.

- commedens Nees. 682.

- hydnoideum Pers. 699.

- incarnatum Fr. 679.

Cortinarius $706^{*}, 713$.

- largus (Busch) Fr. 713.

Cortinellus 713.

Coryne sarcodes (Jac.) Tul. 386.

Cosmarium 217, 218*, 219, 220*, 221.

Craterellus 688.

- cornucopioides L. $6 \mathrm{SS}$.

- lutescens (Pers.) Fr. 687*, 688.

Craterium 405*, 409*, 41\%.

- leucocephalum (Pers.) Rostaf. 405*, 412.

Craterospermum 199. 
Crenothrix 342, 3 วэ9.

- Kuhniana Rbh. 356.

Crepidotus 711 .

Cribrariaceae 407.

Cricunopus 718 .

Crinipellis 711 .

Cronartium asclepiadeum (Willd.) Fr. 649, $650^{*}$.

- gentianeum Thüm. 649.

- quercuum (Cooke) Miyabe 649.

- rubicolum Dietr. 650*.

Crucibulum 732.

- vulgare Tul. 733*.

Cryptica 591.

Cryptochaete 699.

Cryptomeniales 317, 321.

Cryptomonaden 6,7 .

Cryptomonadinen 306.

Ctenomyces serratus Eidam 495.

Cucurbitaria Laburni (Pers.) Ces. et de Not. $522^{*}, 523$.

Cucurbitariaceae 523.

Cutleria 280, 281*, 282*, 283*, 284*.

- multifida (Smith) Grév. 280.

Cutleriaceae 257, 280.

Cyanocystis $380^{*}, 381$.

Cyanophyceae 7, 362, 556, 557 .

Cyclonexis 230*, '231.

Cyclosporeae 257, 287.

Cylindrocapsa 185.

- involuta Remsch. 185, 186*.

Cylindrocystis 195*, 196.

- Brebissonii Menegh. 121, 195*.

Cylindrospermum 374, 375*.

Cymopolia 56, 90, 92*, 93, 95.

Cyphelium 550*.

Cyphella 696, 698.

- ampla Lév. 698.

- musae Jungh. 697*.

- Urbani Henn. 697*, 698.

- villosa Pers. 698.

Cyphellaceae 685, 695, 696, 697*, 699*.

Cyphelleae 696, 698, 699.

Cystobakter 385.

Cystococeus 549.

- humicola Beijer. 174*, 175, 177.

Cystopus 151.

Cystoseira 271, 294.

Cytidia 698.

Cyttaria Gunnii Berk. 579*.

- Harioti E. Fisch. 579*.

Cyttariaceae 580.

\section{D.}

Dacryomyces chrysocomus 672*.

- delinquescens Bull. 670, 673*, 676.

Dacryomyceten $617,666,678,686$.

Dacryomycetineae 676, 682, 684, 685, 694 .

Dactylococcus $177^{*}$.

Daedalea 704.

- quercina (L.) Pers. 703*, 704.

- unicolor (Bull.) Fr. 704.

Dasya elegans (Mart.) Ag. 320, 321, 323.

Dasycladaceae 90,94 .

Dasycladeae 90 ff., 95 .
Dasycladus 56, 90.

- claviformis (Roth) Ag. 91*.

Debarya $197^{*}, 198$.

Delamarea 258, 279.

Dematium 603*.

Derbesia 203.

- Lamourouxii Sol. 204*.

- marina Kjellm. 204*.

Derbesiaceae 203.

Dermocarpa 380*, 381.

Dermonema 316*, 325 .

- dichotoma Grév. 316*.

Desmarestia 258, 26**.

- aculeata L. $264^{*}$

Desmarestieae 258, 264.

Desmidiaceae 194, 216, 217, 218*, 220*, 419.

Deuteromycetes 745 .

Diachea 411.

Diatomeae 7, 194, 217, 231, 232, 238, 241. 242.

- angewachsene 242, 247.

- Centricae 245.

- Pennatae 245.

- Plankton 242.

- Schlamm 242, 245.

Diatrypeae 526.

Dichomyces 533, 538*.

- princeps Th. 538*.

Dichotomosiphon 56, 78, 81, 88 .

- tuberosus (A. Br.) Ernst 88, 89*.

Dichothrix 378*.

Dictydium $404^{*}$.

- cernuum (Pers.) Schrad. 408.

Dictyocephalus 7:24 (Note).

Dictyoleae 696, 698.

Dictyolus 696, 698.

- bryophilus Pers. 697*, 698.

Dictyonema 693*, 694.

Dictyophora 737, 7:38*.

- phalloidea Dietr. 738*.

Dictyosiphon 258.

Dictyosiphoneae 258, 277.

Dictyosteliaceae 399.

Dictyota 288, 291, 304.

- dichotoma Huds. 292*, 293*, 294*.

Dictyotaceae 287, 288, 309.

Dictyuchus 164*, 165.

Didymiaceae 411 .

Didymium $405^{*}$.

- farinaceum Schrad. $405^{*}, 411$.

Dimeromyces Th. 533, 535, $536 *$.

- africanus Th. 536*.

Dimorphomyces 533, 534*.

- muticus Th. 534*, 535 .

Dinobryon 225, 230*.

Dinophysen 235, 236*, 238, 241.

Dinophysis $238^{*}$.

- aggregata Weber v. Bosse 239.

Diphtheriebakterie 372.

Diplocolon $378^{*}$.

Diplodia cytisi Awd. 523.

Diplomyces 533.

Diplophrys 390.

Dipodascus 442, 443.

- albidus Lagerh. 443*, 446.

Discocarpineae 554. 
Discolichenes 551, 552*, อコ்4.

Discomyceten $422,571,572,590$.

Doassansia 6:6.

- alismatis (Nees) Cornu 625*.

- sagittariae (West) Fisch. 625*.

Dothideales 512, 520, 5\%9.

Draparnaldia $186 \mathrm{ff} ., 187$ *

Dudresnaya 317*, 318*.

-- purpurifera J. Ag. 318*, 319*.

Durvillea 301.

\section{E.}

Ecchynaceae 678, 683.

Eccilia 713.

Ectocarpaceae 257, 287.

Ectocarpeae $\mathbf{2 5 9}$.

Ectocarpus 258, 259*, 433.

- irregularis Kck. 259*, ‘60, 274.

- lucifugus Kck. 260, 261*.

- ovatus Kck. 259*.

- Reinboldii Reinke 261*.

- sanderianus Kck. 259*, 260.

- secundus Kck. 262, 263*, 285.

- siliculosus (Dillw.) Lingb. 259, 260, 261*.

Elachistea $258,271$.

- pulvinata Kütz. $272 *$.

Elachisteae 258, 271.

Elaphomyces 506.

- cervinus (Pers.) Schw. 509, 510*, 516.

Elaphomycetaceae 509.

Elaphomycetineae 509.

Elasmomyces 740.

Emericella 742.

_. variecolor Berk. 742, 743*.

Empusa americana Th. 150.

- aphidis Hoffm. 149, 150.

- culicis Braun 150*, 151.

- muscae Cohn 146, 147*, 150, 151.

- sciarae Olive $147,149,150 *$.

- sepulchralis Thaxter $147^{*}, 148,149 *$.

Enarthromyces 533, 537, 538*.

Endocarpon 548, 552*, 5อ̉3.

- miniatum (L.) Ach. 552*, 553*.

- pusillum Fr. 550*, 551 .

Endomyces 431, 436, 437*, 438.

- decipiens (Tul.) Reess 438.

Endomycetaceae 431, 438.

Endophyllaceae 647 .

Endophyllum 647.

- Sempervivi (A. et S.) de Bary 647*.

Endopyreniaceae 552*, อ็ 53.

Endosphaera 3**, 35, 38, 41, 53, 110, 117.

- biennis Klebs 34 .

Endosphaeraceae 31 ff., 32, 53, 54, 110, 174.

Endosporeen 403, 404, 405 .

Endotricheen 405, 406, 408.

Enteromorpha 179, 295.

Entoloma 713.

Entomophthora 150.

- gloeospora Vuill. 151.

Entomophthoreae 132, 146.

Entophysalis $374,375^{*}$.

Ephebaceae 556.

Ephebe 55๊ 5 *

Epichloë typhina (Pers.) Tul. 516*.

Eremascus 419*, 421, 429, 431, 440.
Eremascus albus Eidam 419.

Erysibe s. Erysiphe.

Erysiphales 470, 471, 529, 571.

- Monoasci 481.

- Polyasci 481.

Erysiphe $419^{*}, 422,432,441,458,459, \mathbf{4 7 3}$, $474^{*}, 475^{*}, 476^{*}, 478,480,482,484^{*}, 485^{*}$.

- cichoracearum DC. $475,476^{*}, 479^{*}, 483$.

- communis Wallr. 473*, 474*, 475*, 479*, 483

- graminis DC. $475,476^{*}, 480,482$.

- Polygoni DC. 483.

Euastropsis Lagerheim 39.

Euastrum 217, 218*, 219, 220*.

Eucantharornyces 533.

Eudesmeae 258, 272.

Eudorina 20 ff., 25, 26.

- elegans Ehrenb. 21*.

Euglena 119.

Englenoidina 5, 6 .

Euhymeniales 686.

Eumycetes $4 \mathbf{1 8 .}$

Eumyxogasteres 403.

Eupachyphloeus 591.

Euperidineae 235.

Eupodiscus 243*.

- argus Müll. 244.

Eupuccinia 635.

Eurotium 419*, 420, 463.

- aspergillus glaucus de Bary 501.

- herbariorum Link 501.

Eutuber 591, 592, 594, 596.

Eutuberaceae $\mathbf{5 9 1 .}$.

Eutuberineae 509.

Euuncinula 481, 482.

Evernia 549, 566 .

- furfuracea L. 566.

Exoascaceae 431, 597.

Exoascineae 596, 597.

Exoascus Fuckel 418, 438, 577, 597.

- Sadeb. 597.

- alnitorquus (Tul.) J. Kühn 599*.

- amentorum Sadeb. 599*.

- deformans (Berk.) Fuckel 441*.

- Pruni Fuck. 597.

Exobasidieae 684, 686, 690, 694

Exobasidium 682, 690, 691.

-_ Andromedae Woron. 691*.

- Vaccinii Woron 691*.

Exosporeae 403.

Exuviella 238*.

- marina Cienk. 240*.

F.

Farne $=$ Filices.

Favillea Fr. 723.

Favolus 711.

Filices 26, 48 .

Fistulina hepatica (Schaeff.) Fr. 704, 706*.

Fistulinaceae 695, 696, 704.

Flagellaten 2, 5, 6, 8, 10, 203, 225, 231.

- blaugrüne $306^{\circ}$

- rote 306.

Flammula 714.

Flechten cf. Lichenes. 
Florideen 6, 7, 238, 307, 309, 376, 469, $571,677$.

Fomes 700, 701.

- annosus Fr. 701*.

Fucaceen 231, 288, 294.

Fucus 7, 271, 295 ff., 295*, 297*, 298*, 302*, $303^{*}, 304^{*}$.

- platycarpus Th. 295*, 296.

- serratus L. 296.

- vesiculosus L. 296, 298.

Fuligo 405*, 407, 414, 417.

- varians Sommerf. $412^{*}$.

Funaria 363*.

Fungi 2, 6, 7, 17, 39.

- imperfecti 744 .

G.

Galactinia succosa Sacc. 457*, 458, 459.

Galaxaura 325.

- marginata Link $316^{*}$.

Galera 714.

Gasterolichenes $\mathbf{7 4 2}$.

Gasteromycetes 617, 666, 676, 678, 683, 688, 704, 705, 718.

Gasteromycetineae 718, 727.

Geaster 728, 729, 730.

- hygrometricus Pers. 722.

- marchicus Henn. 731*.

- vulgatus Vitt. 731*.

Gefäßkryptogamen = Pteridophyten.

Genabea 591.

Genea 591, 592, 595, 596.

- hispidula Berk. 589*, 592, 595 .

- sphaerica Tul. 589*, 592, 595.

Geoglossaceae 585, 587.

Geoglossum hirsutum Pers. 588*.

Gigartinales 322.

Globaria 729.

Gloencapsa 383*, 384.

Gloeothece 383*, 384.

Godfrinia 706 .

Gomphidius 705, 706, 708, 717.

- viscidus (L.) Fr. 707*.

Gonapodya 123.

Gongrosira 80.

Goniodoma 233, 235.

- acuminatum Ehrenb. 234*.

Goniosporeae 711, 713.

Gonium 19, 20, 230, 231.

- pectorale Müll. 18*, 19.

- sociale Warm. 18*, 19.

Grandinia 697.

Granulobacillus saccharobutyricus immobilis liquefaciens Schattenfroh und Grassberger 353.

Graphideae 548, 552*.

Graphidineae 554.

Graphis 552*, 554 .

- scripta L. 552*,

Grünalgen 5, 16.

Guttulinopsis Olive 398*, 399.

- clavata Olive 399.

- vulgaris Olive 399.

Gymnoasceae 492.

Gymnoascus candidus Eidam 494, 495*.
Gymnoascus Reesii Bar. 492, 494*, 502*.

- setosus Eidam 494, 495*.

Gymnodiniaceae 232*, 233.

Gymnodinium rhomboides Schütt 232*.

- spirale Bergh. 232*.

Gymnosporangium 636, 656, 676.

- clavariaeforme (Jacq.) Rees 655*, 657*.

- Ellisii (Berk.) Farl. 655*.

- juniperinum (L.) Wint. 655*.

- Sabinae (Dicks.) Wint. 657*.

- tremelloides A. Br. 655*.

Gyrocratera 591.

Gyrodon 718 .

Gyrophana 697, 699, 700.

-- lacrymans (Wulf) Maire 699*, 700.

Gyrophora 423*, 547, 551, 562, 563*.

Gyrophoraceae 562.

H.

Halicoryne 56, 90, 94*, 95.

Hapalosiphon $375^{*}$.

Haplobacterineae 340, 341.

Haplomyces 533, 536, 537*.

Hebeloma 713.

Heliomyces 711.

Helminthora 310*, 312.

Helotieae 578.

Helotium 121.

Helminthophana 533.

Helvella 441.

- Ephippium Lév. 441.

Helvellaceae 580, 585, 588.

Helvellineae 431, 509, 585.

Hemiarcyria 404*, 405, 408, 409*, 410.

Hemiascineae 431, 436.

Hemibasidieae 436, 616, 617, 675.

Hemileia 656.

- vastatrix Berk. 658.

Hemipuccinia 635.

Heterobasidieae Maire 686.

Heterocapsa $240^{*}$.

Heterokonten 5, 6, 211, 212 \}(Entstehung), 215.

Himanthalia 271, 294, 295, 301, 302*, 305.

- lorea (L.) Lingb. 305*.

Hirneola $=$ Auricularia.

Holochytridiaceae 121.

Holocoryne 688.

Homobasidieae Maire 686.

Homococceae 341, 345.

Humaria 572, 573, 578.

- granulata Quel. 465*, 466*.

Hydnaceae $684,686, \mathbf{6 9 4}, 695^{*}, 696$.

Hydnangium 677.

Hydnocystis 584 .

Hydnotria 591, 592, 595, 596.

- Tulasnei Berk. et Br. 589*, 592.

Hydnum 691, 694, 695.

- auriscalpium L. 695*.

- basiasperatum P. Henn. 695*.

- coralloides Scop. 695*.

- cyathiforme Schaeff. 695*.

- Erinaceus Bull. 695*.

- repandum L. 693, 694.

- rufescens Pers. 694. 
Hydraeomyces 533, 546.

Hydrodictyaceae 31, 35, 37, 39, 53, 54, 174.

Hydrodictyon $\mathrm{S}, 39,40, \mathbf{4 1}, 42^{*}, 44^{*}, 53$, $66,70,104,108,364$.

Hrdrurus $227 \mathrm{ff} ., 22 \mathrm{~S}^{*}$.

Hyella $380^{*}, 381$.

Hygrocy be 706, 707.

Hygrophoraceae 705, 706, 711, 717.

Hygrophorus 706, 707*, 708.

- agathosmus Fr. 707 *

- ficoides (Bull.) Schröt. 707*.

Hymenogaster 728, 733.

- decorus Tul. 734*.

- tener Berk. 734*.

Hymenogastraceae 718, 719.

Hymenogastrineae 727, 728, 733.

Hymenolichenen 693.

Hymenomonadaceae 225, 229.

Hymenomonas 229.

Hymenomyceten 617, 666, 742.

Hymenomycètes hétérobasidiées 679.

Hymenomycetineae 676, 677, 678.

Hyphochytridiaceae $\mathbf{1 2 1}$.

Hyphochytrium 110.

- infestans Zopf 121, 122*.

Hyphomycetes 386.

Hypochnus 695, 696, 695, 699.

— Solani Prill. et Delac. 697*, 698.

Hypocrea rufa (Pers.) Fr. 515*.

Hypocreaceae 512.

Hypocreales $\mathbf{5 1 2 .}$

Hypogymnium 566.

Hypoxyleae ‘) 26.

Hypoxylon coccineum Bull. 526, 527*.

Hysterangiaceae 727 .

Hysterangium 728, 735*, 736, 739.

— clathroides Vitt. 735*, 738.

Hysteriales 554, 58?.

Hysteriineae 431.

Hysterographium 554.

- fraxini (Pers.) de Not. 582*.

\section{I.}

Idiomyces 533, 540 .

Inocybe 713.

- fastigiata (Schaeff.) Sacc. 712*, 713.

Institiale acariforme Fr. 527.

Irpex 699.

Isaria farinosa (Dicks.) Fr. 513, 518.

- hypoxyli Kalchbr. 527.

- umbrina Pers. 527.

Isokonten 5, 6, 7, 78, 194, 203, 231, 237.

- multicelluläre, monoenergide $172 \mathrm{ff}$.

Krombholzia 718.

K.

L.

Laboulbenia 418, 533, 541*, 542*, 543*.

- cristata Th. $542^{*}$.

- elongata Th. 533, 541*, 542.

- inflata Th. 535.

- Kunkeli Th. 543*.

- proliferans Th. $543^{*}$.
Laboulbenia terminalis Th. 543*.

- texana Th. 533.

Laboulbeniaceae 431, 469, 533, 5399, 571.

Laboulbeniales 529-548.

- endogenae 533.

- exogenae 534, 545.

Labyrinthula $390,395$.

- vitellina Cienk. 395, 396*.

Labyrinthuleae 395.

Laccaria 711.

Lachnea 439.

Lactaria Pers. 709.

- rufa (Scop.) Schröt. 709*.

Lactarius Fr. 709.

- deliciosus (L.) Schröt. 709*.

Lagenidium 110, 201.

- Rabenhorstii Zopf 117, 118\%.

Laminaria 285, 286*, 287*, 298.

- Cloustoni Edm. 285, 286*.

-- Digitata-Gruppe 285.

- Saccharina L. 286*, 287*.

- - Trruppe 285.

Laminariaceae 257, 285.

Lamprocystis roseopersicina Winogr. 358.

Laudatea $693^{*}, 694$.

Lecanora 547, 548, 556, 561*.

- subfusca L. $\beta$ distans $561 *, 562 *$.

Lecanoraceae 561.

Lecidea 555*, 556 .

- confluens Fr. 556.

Lecideaceae 556.

Lecideae 548.

Lecidella 548.

Lentinus 711, 712.

- Tuber regium Fr. $712^{*}$.

Lenzites 700,704 .

- betulina (L.) Fr. 703*, 704.

- flaccida (Bull.) Fr. 704.

Leotia gelatinosa Hill. 586*, 587.

Lepidocollema 548, 557.

Lepinta 713.

Leptochrysomyxa abietis (Wall.) Unger 672.

Leptogium 557.

Leptomitaceae 170.

Leptomitus $170^{*}$.

Leptonia 713.

Lepto-oomyceten 497.

Leptopuccinia 635.

- Malvacearum Mont. 637.

Leptothrix 341.

Leucocoprinus 715 .

Leuconostoc 346.

Licea $404^{*}, 405$.

- flexuosa Pers. 407.

Liceaceae 407.

Lichenes 174, 373, 423, 549.

- heteromere 549 .

- homoiomere $549^{*}$.

Licmophora 248, 249*.

Locellina 713.

Lycogala 405*, 407, 409*, 410, 414.

- flavo-fusca (Ehrenb.) Schröt. $\$ 10$.

Lycoperdaceae 718, 719, 727, 725, 732.

Lycoperdineae 718.

Lycoperdon 729.

- coelatum Bull. 743. 
Lycoperdon gemmatum Batsch. 729, 730*. Lyngbya $365^{*}, 366,383^{*}, 384$.

\section{M.}

Macrocystis 285.

Magnusiella 597.

Marasmius 711.

Mastigocoleus $378^{*}$.

Melampsora 648, 651 .

- Larici-Caprearum Kleb. 651.

Melampsoraceae 647, 648.

Melampsoreae 648, 651.

Melampsorella 648, 651.

- Caryophyllacearum (DC.) Schröt. 651, $652 *$

Melanconiaceae 524, 583.

Melanconis $524,525$.

-- stilbostoma Tul. 525*.

Melanogaster 719,721 .

- variegatus (Vitt.) Tul. 720*.

Melanoleuca 713.

Melanospora parasitica 'Tul. 512, 513*.

Meliola 492.

Melosira 254*.

Merismopoedia 381, 383*, 384.

Merolpidiaceae 114.

Meruliaceae 696, 699, 700.

Merulieae chromosporae 697.

- leucosporae 697.

Merulius 697, 700.

- lacrymans (Wulf) Schum. 700.

Mesocarpus 363*.

Mesomyceten 436.

Mesotaeniaceae 194, 195, 199, 216, 224.

Mesotaenium 194, 195*, 196.

- Braunii De Bary 195*.

- chlamydosporum De Bary 195*.

Microchaete 374, 375*.

- tenera Thuret 377.

Micrococcus 341.

- phosphoreus Cohn 333*, 341, 343.

- prodigiosus Fisch. 333*, 334.

Micropuccinia 63\%.

Microsphaera 478, 480.

- Berberidis (DC.) Lév. 479*.

- Caraganae Magn. 480.

-. pulchra Cooke et Peck. 479*.

Microsphaeroidea 482.

Microthyriaceae 491.

Mitrula 585.

- phalloides (Ball.) Sacc. 585, 586*.

Monascaceae 431.

Monascus Barkeri Dang. 499, 500.

- purpureus Went. $447,448^{*}, 496-501$, 497*, 499*.

Monilia 39.

- candida Bon. 481.

Monoblepharideae 122.

Monoblepharis $110,122,125^{*}, 126^{*}, 127^{*}$.

- brachyandra Th. $126,127$.

- $-\beta$ longicollis 129.

- insignis Thaxter 123*.

- macrandra (Lagerh.) Woronin 129*.

- polymorpha Cornu 122, 126, 127, 128*, 129.

_ _ - var. macrandra Lagerh. 129.
Monoblepharis sphaerica Cornu 122, 128*, 129.

Monolpidiaceae 111.

Monospora Metschn. 605.

Monostroma 180, 181*.

- fuscum Th. 181*.

Morchella 441.

- deliciosa Bres. 588*.

Mortierella Rostafinskii Bref. 142*, 145, $437^{*}$.

Mortierellaceae 134, 142.

Moschomyces 533, 535, 544.

- insignis Th. 544*.

Mougeotia 59, 196*, 197*, 198.

Mucidula 711.

Muciporus Juel 678.

- corticola (Fr.) Juel 681*.

- deliquescens Juel 680*.

Mucor 134*, 136, 138, 140, 145, 476.

- alternans v. Tiegh. 135*, 136.

- heterogamus Vuill. 139.

- Mucedo L. $135^{*}, 136,137,139$.

- spinosus v. Tiegh. 1:35*, 136.

Mucoraceae 134.

Mucorineae 117, 132, 134.

Multicelluläre, monoenergide Isokonten $172 \mathrm{ff}$.

Mutinus $\mathbf{7 4 0}$.

- caninus (Huds.) Fr. 741*.

Mycena 705, 711 .

Mycenastrum 729.

Mycochytridiaceae 111, 117.

Mycodendron paradoxum Massee 700, 701*.

Mycoleptodon 694.

Mycomycetes 436.

Myrioblepharis 110, 124, 164.

- paradoxa Th. 124, 125*.

Myrionema 258, 270.

- vulgare Thur. 270.

Myrionemeae 258, 269.

Myriotricha 258, 265, 268, 275.

- protasperococcus Berthold 266, 267*,275.

- repens (Hauck) Karst. 265, 266*, 280.

Myxobakter 385 .

Myxobakterien 7, 329, 385, 395, 396.

Myxobotrys variabilis Zukal 385.

Myxochytridiaceae 111.

Myxococcus $386,389$.

- disciformis Thaxter $387^{*}, 389$.

- pyriformis Smith 386.

- ruber Baur 386, 387*.

- rubescens Baur 388.

Myxogasteres Schroeter 391, 393, 399, 402, $403,416$.

Myxomyceten 2, 6, 7, 390, 391.

\section{N.}

Naemacyclus niveus (Pers.) Sacc. 581*.

Naucoria 714.

Navicula ostrearia Molisch 248.

Nectria $426,432$.

- cinnabarina (Tode) Fr. 513*.

Nemalion 311, 312, 315, 324, 325.

- multifidum Ag. 311*, 312, 313*.

Nemalionales 321, 325, 326. 
Nematospora Peglion 605.

Neomeris 56, 90, $91 \mathrm{ff}, 9^{*} *, 95$.

Nephronia Ach. $5 \pm 8$.

Nidularia australis Tul. 733*.

Nidulariaceae 718, 719, 727, 728, 73:2.

Nitella $751,752,753$.

— flexilis $\mathrm{Ag}$. 751*, 752*.

Nitrobacter 354 .

Nitromonas 3.

Nitrosomonas 354 .

Nolanea 713 .

Nostoc 366, 374, 378, 383*, 384, 549, 557.

- commune Vaucher 375*, 378, 379.

- paludosum Küitz. 375*.

Nostoccaceae $374,375,378,381,384,549$, 550.

Nyctalis 706, 708.

- asterophora Fr. $707^{*}$.

- paradoxa Fr. 70S.

\section{0.}

Ochromonadaceae $225,230^{*}$.

Ochromonas 230*, 231.

- mutabilis Klebs. 230 .

Ochropsora 65t, 655, 668.

- Sorbi (Oud.) Diet. 654, 655*.

Octaviana 728, 732 .

- asterosperma Vitt. 729*, 732.

Odontium 694.

Oedogoniaceae 203, 204, 419 .

Oedogonium $204 \mathrm{ff}$., 207*, 208*, 209*, 210*, 221.

- Boscii Brab. 210*.

- Braunii Kütz. "210*.

- ciliatum (Hass.) Pringsh. 210*.

- crispum Wittr. 207*.

_-. diplandrum Jur. 210*.

— gemelliparum Pringsh. 207*.

- tumidulum Kütz. 207*

- Vaucherii A. Br. 207*.

Oidium 471, 605.

- Magnusii 610.

- Tuckeri Berk. 471.

Olpidiopsis 110 .

- Schenkiana Cornu 113*.

Omphalia 711 .

Onygena 506.

- corvina A. et S. 506.

— equina (Willd.) Pers. 505*, 506, 507*, 508.

Oomycetes $86, \mathbf{1 3 0}, \mathbf{1 5 1 .}$

Ophiocytium 214*, 215, 216.

Ornithoceras 235, '236*', 237.

Oscillaria $381,382,383^{*}, 384$.

- anguina $368,370^{*}$.

- limosa Ag. 363*, 365*, 368.

- princeps Vaucher 363*, 365*, 366, 370*, 371.

- tenuis Ag. 365*, 366.

Oscillariaceae 384.

\section{P.}

Pachyphloeus 591, 592, 596.

- melanoxanthus (Bert.) Tul. 595*, 596.

Pachysterigma Olsen 679.
Padina 255*, 289*, 290*, 291*, 304.

Palmella 14, 180, 553.

- botryoides Grév. 743.

Palmellaceae 550.

Pandorina 27, 230.

Panus 711.

Paracloster 342.

- butyricus Fisch. 342, 353.

Paraplectrum 342.

- foetidum Fisch. 342, 3̋55.

Parmelia 547, 548, 551, 561*, 564.

- acetabulum (Neck.) Dub. 564, 565*.

- obscura Fr. 561*, 564.

Parmeliaceae 564.

Parmularia styracis Lév. 582*.

Paxillaceae 705, 706, 716, 717*.

Paxillus 708, 713, 717.

- acheruntius (Humb.) Schröt. 717.

_ - var. pannoides Fr. 717*.

- - var. acheruntius Humb. 717*.

- Pelletieri Lév. 717*.

Pediastrum 39, 41, 53, 174.

- Boryanum (Turp.) Menegh. $40^{*}$.

Pediococcus 341.

- tetragenus (Gaffky) Migula 333*, 341, $3 \pm 6$.

Peltidea 548, 557.

Peltigera 548, 555*, 557, 571 .

- canina (L.) Schaer 558.

Peltigeraceae 557 .

Pelvetia 301, 302*, 303.

Penicilliopsis 5̌04, 507, 509.

- clavariaeformis Solms 504, 505*.

Penicillium 432, 476, 502 ff., 506.

- aureum v. Tiegh. 504.

- glaucum Link 441, 503, 504*.

Peniophoraceae 684, 687, 685, 689, 694.

Peniophora quercina (Pers.) Cooke 689*, 690.

Penium 217, 218*, 221.

Perichaena 404*, 408, 409*.

- corticalis Batsch 409.

Peridermium giganteum (Mayr) Tul. $6 \pm 9$.

- Pini Willd. 649.

_ - f. acicola $654,655^{*}$.

- - f. corticola 649, 650*.

- Strobi Kleb. 650.

Peridinaceae $232,233$.

Peridinales '231, 292 ff.

Peridineen 7.

Peridinium 238*.

- divergens Ehrenb. 237.

- ovatum Klebs 237.

Perisporiaceae 491.

Perisporiales 512.

Peritricheen 404, 407.

Peronospora 146, 158, 161, 162, 478.

- Alsinearum Caspary $158^{\circ}$

- densa Rbh. 158*, 159.

- Lactucae Unger 155*, 15\%.

- leptosperma De Bary 15.

- nivea Unger 158*.

- parasitica (Pers.) Tul. 150*, 1(6), 162.

- Raddii De Bary 158\%, 159.

Peronosporaceae 151.

Peronosporcae 151. 
Pertusaria 547, 555*.

- communis D.C. b60*.

Pertusariaceae 560.

Peyritschiella 533.

Peyritschielleae 533, 534.

Peziza 418, 427*, 431, 441*, 572, 573.

- confluens cf. Pyronema.

- granulata Bull. 465.

- marsupium Pers. 458.

- (Galactinia) succosa Berk. 458, 572.

- vesiculosa Bull. 440, 441.

Pezizaceae 121, 554.

Pezizineae 431, 509, 572.

Phacidiales 554, 580 .

Phacidiineae 431.

Phaedon imbricatus (L.) Schröt. 694, 695*.

Phaeococcus 231.

Phaeophyceae 6, 7, 83, 256, 257.

Phaeophyten $225 \mathrm{ff}$.

Phaeosporeae $2 \check{7}$.

Phaeothamnion 231.

Phalacroma mitra Schütt. 235, 236*, 239.

Phallaceae 719, 727, 728, 733, 734, 737, 738*, 739.

Phallogaster 736, 739.

- saccatus Morg. 736*.

Phalloideae 617, 666, 718, 727.

Phallus 741.

- impudicus L. 742*.

- tenuis Fischer 742*.

Phialopsis 548.

Phlebia 697.

Phlyctis 548.

Pholiota 713, 714.

- squarrosa (Müll.) Karst. 712*, 714.

Pholioteae 711, 712*, 713.

Phragmidium 656.

- Rosae alpinae D.C. 629*.

- Rubi Idaei (Pers.) Wint. 629*.

- speciosum Fr. 628, 629*, 630*, 631.

- subcorticium (Schrnk.) Wint. 629*.

- violaceum (Schulz) Wint. 630, 631*, $632 *$.

Phycomyces 138, 139.

- heterosporus Harz. 497.

- nitens Kuntze 138.

Phycomyceten 418, 435, 436, 468, 469, 616.

Phyllachora graminis (Pers.) Fuck. 529.

Phyllacteriaceae 684, 687, 691.

Phyllactinia 451, 477*, 478, 479*, 480, 481, 482, 485, 486*, 487*, 488*, 489*, 490*.

- suffulta (Rebenth.) Sacc. 471, 472*, $476,477^{*}$

Phyllitis 258, 276.

- caespitosa Thur. 278*.

Phyllobium 35, 38, 39, 53.

- dimorphum Klebs 36.

Physariaceae 411, 412.

Physcia 547, 549.

- parietina L. $174^{*}, 175$.

- pulverulenta Schrb. 568*, 569*, 571.

Physciaceae 568.

Physma 548, 557.

Phytomyxa 399.

Phytomyxineae 399, 403.
Pichia Hans. 605.

- (Sacch.) membranifaciens Hans. 605, 611.

Pilacre 509.

- Petersii Bert. et Curt. 668*, 669.

Pilacreae 617, 626, 666, 669, 678.

Pilayella 258.

Pilobolus 132*, 133, 147, 414.

- cristallinus Bref. 135*, 136, 137.

Pilze $=$ Fungi.

Pinnularia 245, 248*.

- viridis Nitzsch. 245*.

Piptocephalidaceae 134, 145.

Piptocephalis 145, 146.

- Freseniana de Bary 145*.

Pirella circinans Bainier 135*.

Pisolithaceae 719, 720, 723, 724*, 727, 728, 732.

Pisolithus 720, 728.

- arenarius A. et S. 793, 724*.

- crassipes (D.C.) Schröter 719.

Placodium 547.

- decipiens 551.

Planococcus citreus (Menge) Migula 333*; $341,344$.

Planosarcina $341,345$.

- agilis Migula 341.

- mobilis (Munrea) Migula 333*, 346.

- violacea (Winogr.) Migula 333*.

Plasmodiophora 401*, 414.

- brassicae Woronin 399, 400*.

Platoma $310^{*}$.

Plectascineae 431, 470, 492, 529, 719.

Plectobasidiineae $718, \mathbf{7 1 9}, 727,730,732$.

Plectridieae 342, 354.

Plectridium 342, 354.

- Tetani Fisch. 342, 353*, 355.

Plcospora 432.

Pleurocapsa 380*, 383*, 384.

Pleurococcaceae 173, 175, 194.

Pleurococcus 553, 556.

Pleurosporeae v. Tiegh. 675.

Pleurotaenium 217, $218^{*}$.

Pleurotus 711, 712.

- nidulans Fr. 712*.

Plicaria succosa (Berk.) Rehm 458.

Plicatura 697, 700 .

Pluteus 713.

Podaxaceae 719.

Podosphaera 143*, 144, 420, 429, 132, 478, $479^{*}, 481$.

Polyangium $386,387^{*}, 389$.

- sorediatum Th. 389.

- vitellinum Link 385.

Polyblepharideae 5, 6, 8 .

Polycoceus 549.

Polyedrium 41.

Polygaster Fr. 723.

Polyides $324 * 327$.

- rotundus Gmel. 106.

Polyphagus 110.

- Euglenae Now. 119, 120*.

Polyporaceae 694, 695, 696, 699, 700.

Polyporineae 678, 685, 686, 695.

Polyporus 700, 701, 702.

- acanthoides Bull. 702. 
Polyporus betulinus (Bull.) Fr. 702.

- corticoli Fr. 702.

- Sectio Suberosi 702 .

Polysiphonia 18s, 32t, 326.

- violacea Roth 310.

Polysphondylium 391, 399, 417.

-- violaceun Bref. 391, 392*, 399.

Polystictus 701, 702, 703.

- Holstii P. Henn. 702*.

- sacer Fr. 702*, 703.

- sanguineus (L.) Fr. 702*, 703.

Polystigma rubrum (Pers.) D.C. 424, 425*, $434,514^{*}, 615$.

Polytoma 17, 110.

- Urella Francé 17.

Poria Radula Pers. 700, 701*.

Porphyra 295, 307, 312.

- laciniata Liqhtf. 308*, 309*.

- leucosticta Thur. 307, 308*, 309.

Pringsheimia scutata Reinke 1SS, 189*.

Prorocentrae 232, 240*.

Prorocentrium micans Ehrb. :40*.

Protascineae 431.

Protobasidiomyceten $617, \mathbf{6 2 6}, 665,666$, $675,676,677,678,679,682$.

Protococcaceae 173, 174 ff., 194.

Protodiscineae 431.

Protohymeniales 686 .

Protomastigina $3 \mathrm{ff} ., 5,6,7,225$.

Protomyces 431, 437*, $\mathbf{4 1 6}, 626$.

— bellidis $446,447^{*}$.

- macrosporus Unger 431, 436, 446, 447*

Protomycetaceae 431, 436, 439, 444.

Protosiphon 56, 364.

- botryoides (Kütz) Klebs 53 ff., 54*.

Protosiphoneae 31, 58, 56 .

Protrotremella 679.

Psalliota $706^{*}, 715$.

- campestris (L.) Fr. 715, 716*.

Psatinyra 715.

Psathyrella 715.

Pseudevernia cereatea (Ach.) Zopf 566.

- ericetorum (Fr.) Zopf 566.

- furfuracea (L.) Zopf 566.

-_ isidiophora Zopf 566.

- olivetorina Zopf 566, 567.

- soralifera (Bitter) Zopf 566.

Pseudocodium 56, 62, 63*.

Pseudogenea 591.

Pseudohydnotria 591.

Pseudolpidium 38, 110, 113.

- Saprolegniae (A. Br.) Fisch. 111, 112*.

Pseudopyrenula 548.

Pteridophyten 27.

Puccinia 656, 659.

- agropyrina Erikss. 645.

- anomala Rostrup 645.

-- Arrhenatheri (Kleb.) Erikss. 640*, 643.

- bromina Erikss. 645.

- coronata Corda $645,646^{*}$.

- - Agropyri Erikss. 645.

- - Agrostis Erikss. 645.

- - Calamagrostis Erikss. 645.

- - Holci Kleb. 645.

- - Phalaridis Kleb. 645.

- coronifera Kleb. $645,646^{*}$.
Puccinia coronifera Alopecuri Erikss. 646.

- - Avenae Erikss. 645.

- - Festucae Erikss. 645.

- - Glyceriae Erikss. 645.

- - Holci Kleb. 646.

- - Lolii Erikss. 645.

- dispar 642.

- dispersa Erikss. et Henn. 644, 645, 646*.

- glumarum (Schmidt) Erikss. et Henn. $640^{*}, 645,646$.

- - Agropyri Erikss. 645

- Elymi Erikss. 645.

- - Hordei Erikss. 645.

- - Tritici Erikss. 645.

- graminella (Speg.) Diet. et Holw. 636, 659 .

- graminis Pers. 638, 640*, 646.

- - Agrostis Erikss. 642, 643.

- - Airae Erikss. et Henn. 642, 643.

- - Avenae Erikss. et Henn. 642, 643.

- - Poae Erikss. et Henn. 642, 643.

- - Secalis Erikss. et Henn. 642, 643.

- - Tritici Erikss. et Henn. 642, 643.

- Helianthi Schn. 659*.

- holcina Erikss. 645.

- Poarum Niels. 633.

- Rubigo vera (D.C.) W. 644.

- simplex (Körn.) Erikss. et Henn. 640*, 645,646 .

-- straminis Fuck. 644.

- - var. simplex Körn. 645.

- striaeformis Westend. 644.

- Symphyti-Bromorum F. Müll. 645, 646.

- Triseti Erikss. 645.

- triticina Erikss. 640*, 645, 646.

Pucciniaceae 647, 656, 676.

Pucciniastrum Goeppertianum (J. Kühn) Kleb. 653.

Puccinieae 676, 677.

Pucciniopsis 635.

Punctaria 258, 274.

- latifolia Grév. 274*.

- plantaginea (Roth) Grév. 275.

Punctarieae 258, 274.

Pustularia 458, 459 .

Pyramidomonas 5, 7, S ff., 9*, 10, 19, 203.

- tetrarhynchus $9^{*}$.

Pyrenolichenes 551, 552*.

Pyrenomycetes 126, 529, 571.

Pyrenomycetineae 431, 470, 512.

Pyrenopsis 548.

Pyrenula 547.

Pyrenulaceae 553.

Pyronema 548, 572, 573.

- confluens (Pers.) Carus. 421*, 429, 432, $453 \mathrm{ff} ., 455^{*}, 458,459,463,468$.

Pyronemaceae 572, 573.

Pyrophacus 2 $40^{*}$.

Pythiaceae 151, 160.

Pythiopsis $16 t^{*}$.

Pythium 110, 121, 160

- de Baryanum Hesse 160, 161, 162.

Queletia 724, 70-

Q.

- mirabilis Fr. $725^{*}$. 


\section{R.}

Rachomyces 533, $5 \mathbf{4 4}$.

- hypogaeus Th. 544 .

- longissimus Th. $544^{*}$.

Radiofilum 182.

Radula 682.

Raduleae 696, 697, 699, 700.

Radulum 697.

- hydnoideum (Pers.) Schröt. 697**, 699.

- laetum Fr. 699.

- molare Fr. 699.

Ralfsia 258, 270, 271*, 282.

Ramalina 547, 561*, 566*.

- calicaris (L.) Ach. 561*, 564 .

- fraxinea (L.) Fr. 561*, 564.

Ramaria 688

Ravenelia 656, 660*.

- appendiculata Lagerh. et Dietr. 660*.

- cassiicola Atkins. 660*.

Renntiermoos 569 .

Reticularia $404^{*}, 405,409^{*}$.

- Lycoperdon Bull. 410.

Reticulariaceae 410.

Rhabdonema 243*.

— adriaticum Kütz. 254*.

- arcuatum (Lyngb.) Kütz. 254*.

Rhadinomyces 533, 538*, 540.

Rhipidium 170*.

- interruptum Cornu 170*.

Rhipidonema 694.

Rhizidium 110, 120.

- bulligerum Zopf 119*.

Rhizina inflata (Schaeff.) Sacc. 589*.

Rhizinaceae 585, 589.

Rhizomorpha 712.

Rhizonyces $533,5+1,543 *$.

- ctenophorus Th. 542, 543*.

Rhizopogon Fr. 728, 729*, 732.

- luteolus Fr. 729*.

- rubescens Tul. 728, 729*.

Rhizopus 134*, 135, 138, 437*, 438.

Rhizosolenia 249.

Rhodochytrium 38.

- spilanthidis Lagerh. 38*.

Rhodomela suffusca (Woodward) Ag. 328.

Rhodomonas baltica Karsten 306.

Rhodomyneales 323.

Rhodophyceae $306, \mathbf{3 0 7}$.

Rhodopalodia gibba O. Müller 251, 252*.

Rhyparobius 577.

Rhytisma acerina (Pers.) Fr. 581*.

Rivularia 378, 379, 383*, 384 .

Rivulariaceae $378,384,550,557$.

Roccella $551,552^{*}, 555$.

- tinctoria D.C. 555 .

Roestelia cancellata (Jacq.) Rebent. 657.

- lacerata (Sow.) Merat. 657.

Rostafinskia 411 .

Rozites 714.

- gongylophora A. Möll. 714*.

Russula 709, 710.

— bifida (Bull.) Schröt. 710.

- emetica (Schaeff.) Fr. 709*, 710.

- foetens Pers. 709*, 710.

- nigricans (Bull.) Fr. 705, 709*, 710, 711.

- virescens (Schaeff.) Fr. 709*, 110.
Russulaceae 705, 706, 708.

Russulae compactae 710 .

- fragiles 710 .

- furcatae 710 .

- Heterophyllae 710.

- rigidae 710 .

Russulina 709, 711.

S.

Saccharomyces Meyen 418,'604.

- cerevisiae Meyen 601, 603*, 605, 606*, $608^{*}$.

- ellipsoideus Reess 601, 603*.

Saccharomycetaceae 431, 469.

Saccharomycetes 138, 596, 601 .

Saccharomycodes E. C. Hansen 605.

- Ludwigii Hansen 605, 606*, 608*, 610, 612 .

Saccharomycopsis Schiönning 605, 611.

- capsularis sich. 60ว.

- guttulatus sch. 605 .

Sappinia 397, 398*.

Saprolegnia 111, 112, 164*, 165*, 168.

- ferax (Gruikhuisen) Thuret 167.

- mixta de Bary 167*, 168, 169.

- monilifera de Bary 167.

- siliquaeformis Reinsch 122.

Saprolegniaceae 162.

Saprolegnieae 122, 127, 151.

Sarcina $341,343, \mathbf{3}+5$.

- aurantiaca Flügge 345 .

- lutea Schröter $333^{*}, 341,345$.

- rosea 345 .

Sarcophycus 301, 302*.

Sargassum 294, 299, 300*, 301*.

- filipendula Ag. 301.

Scenedesmus 176, 177.

- acutus Meyen 177*.

- caudatus Corda 17.*.

Schizomyceten 605 .

Schizophyceen 7, 306, 329, 362, 550 .

Schizophyten $6,7,329$.

Schizosaccharomyces 601, 605, 611, 612, 615.

- asporus Hansen 612 .

- mellacei Jörgensen 612, 614.

- octosporus Beijerinck 610,612,613*,614*.

- Pombe Lindner 610, 612, 614.

Schizostoma 724 Note.

Sclerangium 720, 721, 728.

Scleroderma 718, 720, 721, 728, 730.

— verrucosum Bull. 720*, 721 .

- vulgare Hornemann $720^{*}$.

Sclerodermataceae $719,720^{*}, 723,728,732$.

Sclerotinia 42\%, 578.

- Ledi Nawasch. 580.

- sclerotiorum Lib. 426, 427*.

- Vaccini Woron. 578, 579*.

Scoleciocarpus Berk. 723.

Scytonema 694.

Scytonemaceae 378, 384, 550.

Scytosiphon 258, 279.

- adriaticus 265.

- lomentarius (Lyngb.) Ag. 275, 277*.

- pygmaeus Reinke 277*.

Scytosiphoneae 258, 275, 277. 
Secale cornutum Bald. 520.

Secotiaceae $727,728,739,741$.

Secotium olbium Tul. 740, 741*.

Siphonales 16, 17, 30, 31 ff., 37, 5̈3, 108, $110,194$.

Siphoneen 31, 55, 56 .

Siphonocladaceae 56, 100, 103.

Siphonocladeae 31, 55, 56, 90, 9S.

Siphonocladus 56, 101, 103.

— pusillus (Kütz) Hauck 101*.

Siphonomycetes 111, 121, 130, 571, 572.

Siphonophyceen 121, 122.

Sirogonium 198.

Sirosiphoneae 550 .

Solenia 696, 698.

Solorina 548.

- saccata (L.) Ach. อ̌s, 559*.

Sordaria fimicola Ces, et de -Not. 521*.

Sordariaceae $\mathbf{5} \mathbf{2 1}$.

Sorophoreae Zopf 390, 391, 39é, 417.

Sorosphaera 399.

Sparassideae 696, 697.

Sparassis 696.

- crispa Wulf 697.

- ramosa (Schaeff.) śchröt. 697*.

Spermaphyta $\bar{j}, 6$.

Sphacelariaceae $257,285,287$.

Sphacelia segetum Lév. 519.

Sphacelotheca Hydropiperidis De Bary 620 .

Sphaeriaceae $\mathbf{5 2 2}$.

Sphaeriales 512, 520 .

Sphaericeps 724 .

Sphaerobolaceae 719, 723, 726, 727.

Sphaerobolus Tode 726, 727.

- carpobolus L. 726*, 727 .

Sphaerophoreae 548 .

Sphaerophorus $552 *, 556$.

Sphaerophoropsis 548.

Sphaeroplaea 56, 107*, 109.

- annulina (Roth) Ag. 108.

- Braunii Kleb. 107*, 108.

- crassisepta Kleb. 107*, 108.

Sphaeroplaeaceae 56, 107.

Sphaerosira Volvox Ehrenb. 23 (Svnon.)

Sphaerosoma fuscescens Klotzsch 589*, 590, 592.

Sphaerotheca $437^{*}, 438,450^{*}, 458,459,477^{*}$, $478,479 *, 481$.

Sphaleromyces 533 .

Sphyridium 548, 555*.

- byssoides L. 556*, 557.

Spirillaceae 342, 355.

Spirillum 333*, 340, 342, 356, 359, 361.

- rubrum v. Esmarch 353, 356.

- undula Ehrenb. 342.

Spirochaete $336^{*}, 340,342$, 356.

- Obermeieri Cohn 342, 353*, 356.

Spirogyra 15, 27, 59, 113, 117, 119, 196**, 197*, 198, 199, 363*.

- crassa Kütz. 198.

- inflata Kütz. 198.

Spirotaenia 196.

Spondylomorum 18.

- quaternarium Ehrenb. 18*, 19*.

Spongocladia 103 .

-- vaucheriaeformis Aresch. 103.
Sporochytriaceae 118.

Sporodinia grandis Link 130, 131*, 133*, $138,139^{*}$.

Spumaria 405*, 407, 411, 412*.

Spumariaceae 411.

Staphylococcus 339.

Stemmonitaceae 410 .

Stemmonitis $404^{*}, 409^{*}, \mathbf{4 1 1}, 414,417$.

Stephanokonten 5, 6, 203, 212 .

Stephanosphaera $19 \mathrm{ff} ., 27$.

- pluvialis Cohn 19, 20*.

Stereonema 408, 410.

Stephensia 591, 592, 596.

Stereum 689, 690.

- Sectio Apus 690.

- - Mesopus 690.

- Pleuropus 690.

- Resupinata 690.

- alneum Fr. 690.

- elegans Mey. 689, 690.

- lobatum Fr. 689*, 690.

- Mölleri Bres. et P. Henn. $689^{*}, 690$.

Stichobasidiineae Juel 676.

Sticta 548, 551, 555*.

— pulmonacea Ach. 557.

Stictaceae 557.

Stictina 550*, 551 .

- fuliginosa (Dicks.) Nyl. 550*.

Stictyosiphon '258, 275.

- tortilosus Reinke 276*.

Stigeoclonium 188.

Stigmatomyces 530, 533, 540*.

- Baeri Peyr. 540.

Stigonema 557.

Stigonemataceae 375, 378, 384.

Strepsithalia 258, $\mathbf{2 6 9}, 270$.

- Liagorae Sauvageau $270^{*}$.

Streptococcus 341, $\mathbf{3 4 6 .}$

- erysipelatus (Fehleisen) Migula 333*.

- leuconostoc Fischer 341.

- (Leuconostoc) mesenterioides (v. Tieghem) Migula $333^{*}, 346$.

- pyogenes Rosenbach $333^{*}$.

Strobilomyces 718.

Stropharia 715 .

Struvea 56, 101*, 102.

- delicatula $102 *, 103$.

Suillus 718 .

Surirella 249, 253*.

- calcarata Pfitzer 250*, 251*.

Synchytriaceae 38 .

Synchytrium 38, 110, 132, 414, 440, 446, 147.

- decipiens Farlon 116, 133.

- Mercurialis Fehl. 114, 115*.

- Taraxaci de Bary u. Woronin 117, 132, 133.

Syncoryne 688.

Synechoblastus 548, 557.

Synechococcus 383*, 334.

Synedra 229, 230.

- affinis Küitz. $25 t^{*}$.

Synura 229, 230 .

T.

Taphridium algeriense Juel 445 .

- umbelliferarum Juel $445^{*}$. 
Taphrina 597.

— alnitorquus Tul. 599*.

- Johanseni Sadeb. 438, 599*.

- Pruni Tul. 597.

Taphrineen 438.

Teleutosporineae 626,665 .

Teratomyces $533, \mathbf{5 4 3}$.

- mirificus Th. $544^{*}$.

Terfezia Leonis Tul. 510*.

Terfeziaceae 509, 510, 591.

Tetmemorus 219, 220*.

Tetramyxa 399.

Tetraspora 179, 180*.

- lubrica (Roth) Ag. 179.

Thamnidiaceae 134, 140, 146.

Thamnidium elegans Link $140,141^{*}, 145$.

Theleboleae 436, 437*, 438, 439, 447.

Thelebolus 437*, 438, 449, 497, 577 (System. Stelle).

- stercoreus Tode 573, 574*, 575*, 576*.

Thelephora 550, 691, 692*.

- Sectio Euthelephora 692.

- - Hypochniopsis Schröter 691.

-- - Merisma 692.

- - Scyophilus 692.

- caperata B. et Mont. 692.

- discolor Zoll 691.

- palmata (Scop.) Fr. 692.

- terrestris Ehrh. 692*.

Telephoraceae 684, 687, 691, 694, 696, 699.

Thiobakterien 372 .

Thiocystis violacea Winogr. 346.

Thiopedia 358.

Thiothrix 342, 3ə̌s.

- nivea Winograd. 357*.

Tilletia caries Tul. $619^{*}, 6 \mathbf{6 3}$.

- tritici (Bjerk.) Wint. 623.

Tilletieae 616, 623, 626, 675 .

Tilopterideae 287.

Tolypothrix $363^{*}, 365^{*}, 366,379,383^{*}, 384$.

Tomentelleae 679 .

Trametes $700,703$.

- odoratus (Wulf) Fr. 702*, 703.

- pini (Brot.) Fr. 703*, 704.

- radiciperda Hart. 700 .

- suaveolens Fr. 703.

Tremella 669, 674.

- lutescens Pers. 668*, 669.

- mesenterica (Schaeff.) Retz. 668*, 670*

- sarcodes Fr. 386.

Tremellineae 617, 626, 666, 669, 673, 676 677, 678, 682 .

Trentepohlia 190.

- Bleischii Karst. 190*.

Triceratium 243*.

- favus Ehrenb. 244*.

Trichia 409*, 410 .

- fallax Pers. 413.

Trichiaceae 408.

Trichobakterien 341, 342, 356 .

Trichocladia $479^{*}, 480, \mathbf{4 8 1}, 482$.

- Astragali Harz 481.

Trichocoma 742, 74:3.

- laevispora Massee 744*

- paradoxa Jungh. 743, 744*.

Trichoderma viride Pers. 516.
Tricholoma 713.

Tricholomeae 711, 712*, 713.

Triploporella 56, 90, $9 \mathbf{4}^{*}$.

Triploporelleae 90, 94 .

Tubaria 714.

Tuber 509.

- (Aschion) excavatum Vitt. 593*.

- (Eutuber) puberulum Berk. et Br. 593*, $595^{*}$.

- rufum Pico 592, 594.

Tuberaceae 509, 742.

Tuberineae 431, 719 .

Tubulina $406^{*}, 407$.

- cylindrica Bull. 406, 407.

Tuburcinia trientalis (Berk. et Br.) Wor. $624^{*}, 625$.

Tulasnella Schroeter 678.

- calospora (Boud.) Juel 679, 680*.

Tulasnellaceae $677,678,679-682,686$.

Tulasnellineae 676 .

Tulostoma 676, 677, 683, 724 .

- laceratum Fr. 724 (Note).

- mammosum (Micheli) Pers. 725*.

Tulostomaceae 719, 723, 727.

Tulostomineae 676,678 .

Tylopilus 718.

\section{U.}

Udotea 56, 61 ff., 64 .

- Desfontainei (Lamx.) Dcne 61, 62*, 63*.

- minima Ernst 61, 62*.

Ulothrichales 16, 17, 31, 173, 194.

Ulothrix 182, 184, 263, 295.

- zonata (Web. et Mohr) Kütz. 182, 183*.

Ulva 181.

- lactuca Wulf 182*.

Ulvaceae 173,274 .

Ulvales 173, 194.

Umbilicaria $561^{*}, 562$.

- pustulata (L.) Hoffm. 561*, 562.

Uncinula $472,478$.

- Aceris (DC.) Sacc. 479*.

- circinata Cook. et Peck. 479*, 482.

- polychaeta Berk. et Curt. 479 .

- salicis (DC.) Wint. 472, 473*, 475, 476*, $479^{*}, 481$.

Uredineen $49^{*}, 50 *, 617,626, \mathbf{6 2 7}, 665,666$, $672,676$.

Uredo 627.

- linearis Pers. 638, 644.

- populina Mart. 638 .

Urocystis violae (Sow.) F. v. Waldh. 625*, 626.

Uromyces 656, 658 .

- Ervi (Wallr.) Plowr. 636.

- Ficariae (Schum.) Diet. 637.

- Hordei Nielsen 645.

—.Pisi (Pers.) Wint. 6ā8, 659*.

- Poae Rabenh. 633, 634*.

Urospora $104^{*}$.

Usnea 548

- barbata L. 567.

- - L. $\beta$ florida 567.

- longissima L. 564*.

Ustilagineae 431, 616, 617, 626, 675.

Ustilago antherarum Fr. 620. 
Ustilago bistortarum (DC.) Schroet. 622 .

- bromivora Fisch. r. Waldh. 618*.

- Carbo DC. 618.

- Hydropiperidis (Schum.) Schröt. 618*, 620.

- longissima Sorr. 620.

- Maydis (DC.) Tul. 618*.

- segetum Bull. 618, 619*.

- Treubii Solms 622*.

- violacea (Pers.) Tul. 621.

\section{V.}

Valonia 56, 98, 101.

- ovalis (Lyngb.) Ag. 100.

- utricularis (Roth) Ag. 100*.

- rentricosa Ag. 100.

Taloniaceae 56,98.

Valsa 433.

- ceratophora Tul. 528, 524*.

Valsaceae $\mathbf{0 2 0 3}$.

Variolaria 551.

- globulifera Turn. 550*.

Vaucheria 56, 57, 59, 61, 78, 79, 109, 124, 155,419 .

- aversa Hass. 80, 86.

- de Baryana Woron. 80.

- geminata (Vauch.) DC. 79, 82.

- - racemosa Walz. 86*.

- ornithocephala Ag. 81.

- piloboloides Thur. 81, 83*.

- polysperma Hass. 81.

- racemosa (Vauch.) DC. 82.

- sessilis (Vaucher) DC. 82*, 86.

- terrestris Lyngb. 80, 88.

- tuberosa A. Br. = Dichotomosiphon tuberosus Ernst.

- uncinata Kütz. 81, 82.

Vaucheriaceae 55, 56, 78 .

Verrucaria 552*.

- calciseda DC. 552.

- Hochstetteri Fr. 552*, 553.

Verrucariaceae 552*.

Verticillatae $55,90 \mathrm{ff}$.

Vibrio $340,342,355$, 359.

- cholerae Koch 335, 353*.

- - asiaticae Koch 342.
Volvaria $706^{*}, 713$.

Volvocineae 16, 17, 18 ff., 31, 108, 110, 194, 229.

Volvox 22 ff., 108, 230.

- aureus Ehrenb. 23 Synonym.

- globator Ehrenb. 23, 24*, '25, 26.

- minor Stein 23*, 24*, 25, 26, 27.

Vuilleminia commedens (Nees) Maire 682, $683^{*}, 700$.

Vuilleminiaceae 677, 678, 679, 682, 686.

\section{W.}

Willia Hansen 605.

- (Sacch.) anomala Hansen, 605, 612.

- - saturnus Hansen 605

Wysotzkia 229.

- biciliata (Wys.) Lemm. 229.

$\mathbf{X}$.

Xanthidium 219, 220*.

Xanthoria 548.

-- parietina (L.) Fr. 550*.

Xenococcus $380^{*}$.

Xylaria 432, 527.

- hypoxylon (L.) Grév. 528*.

- polymorpha (Pers.) Grév. 424, 425*, 528.

Xylariaceae $\mathbf{5 2 6}$

Xylarieae 526, 527.

X ylodactyla 528.

Xyloglossa 528.

\section{Z.}

Zodiomyces 533, 534, 545, 546*.

- vorticellarius Th. 545, 546*.

Zodiomycetaceae 534 .

Zygnema 193*.

Zygnemaceae 194, 195, 216, 419

Zygomycetes 130, 151.

- conidiophorae 132, 134, 144.

- sporangiophorae 132, 134.

Zygorhizidium Willei Loew. 1:20.

Zygosaccharomyces Barker 601, 605, 610, 612,615 . 


\section{Sachregister.}

A.

Achromatische Figur 29*.

Aecidien 50*, 627, 635, 673, 676, 677; Getreiderost 639; Gymnosporangium 657; Phragmidium 632*, 633; Puccinia 634, 659 ; Uromyces $633,634^{*}, 635-637,659 *$. Aecidienwirte 642, 644, 645, 646, 651 (Melampsora).

Aecidiosporen als 2x-Generation bei Endophyllum 647.

- Ausstreuung bei Gymnosporangium 657.

- binukleäre 631, 632*, 633, 634*.

- Keimung: Calyptospora 653*; Endophyllum 647.

- Mutterzelle: Phragmidium 629, 630*; Uromyces 633, 634*.

- und Aecidiosporenbildung 50, 627, 628, 635, 636 ; Phragmidium 629, 630*, 631, 632*; Uromyces $634^{*}$.

- vermutlich parthenogenetische 636,637, 638.

Aequationsteilung 29, 48; Coleochaete 193; Phyllactinia 489; Pyronema 457; Ulothrix 184.

Aequatorialstadium der Ascuskernteilung $488^{*}$.

Aërobe Bakterien 334, 344.

- - (fakultativ) 334 .

- - (obligat) 334 .

Aethalien 404*, 405*, 406*, 407, 410, 411, $412 *, 414$.

- berindete 406, 407, 410, 412*.

- Bildung 406, 410, 414 .

- nackte 406.

Agaralbumin in Kulturen 169.

Aggregatplasmodium 391, 392, 395, 398*, $399,402$.

Aglaozoniastadium bei Cutleriaceae $\mathbf{2 8 0}$, $281 *, 282 \mathrm{ff} ., 283^{*}$

Akineten bei Chlorangium 172, 173*; Cladophora 106; Ulothrix 184*, 185, 186 .

- Keimung: Ulothrix 185.

- (ruhende) bei Cyanophyceae 185.

Akinetosporen bei Cyanophyceae 381, 383.

Algenkomponent der Ascolichenen 549, 550, 553, 556; Basidiolichenen 694; Gasterolichenen $743^{*}, 744^{*}$.

Algenkulturen 175, 176.
Alkoholgärung 604.

ALLEN über Coleochaete 193, 308.

AltmanN über Granulae in der Zelle 67.

Ameisenpilze 714.

Ameisensäure bei der Fäulnis 358 .

Amibes pédicellées 398 .

Amitose 715 ; Peniophora 690; Sparassis 698. Ammoniak, Entstehen bei der Fäulnis 358. Ammoniumsulfat, Einfluß in Kulturen 201. Amöben der Myxomyceten 391, 392, 398*, $400^{*}$.

- - als Ursache des Carcinoms 401.

- - Differenzierung 402.

- - mehrkernige $400^{*}$.

- - Teilung 392*, 398*, 399, 401.

Amöboide Bewegung cf. Bewegung.

Anabänase 371.

Anabänin 368, 371, 608.

Anaërobe Bakterien 334, 346, 354, 355.

- - fakultativ 334, 346.

- - obligat 334, 354.

Anastomosen bei Florideae 324 .

Androphoren bei Ascodesmis 459, 460*, 461*.

Androspore bei Oedogonium 210*.

Angiocarpie: Euhymeniales 686; Eutuber 595*; Helvellinaceae 585, 587; Lichenes $558,568,569^{*}, 572,584$.

Angkak (Farbstoff) 448.

Anneaux blancs der Cyanophyceae 381 .

Annulus inferus, Agaricineae 705, 706*.

- superus, Agaricineae 706*, 708.

Anpassung bei Caulerpa 76 .

Antheridien und Antheridienbildung bei: Ascomyceten allgemein 420,421, 422, 429, Ascobolus 578, Ascodesmis 460, Aspergillus 501, Ctenomyces 496, Erysiphe 485, Gymnoascus 49:3, 494*, 495*, Monascus 497*, 498, Penicillium 503, $504^{*}$, Phyllactinia 486*, Pyronema 421*, 422, 454, 455*, Rhyparobius 577, Sphaerotheca 450*, 451; Charophyten 745, 746, 751*; Chroolepidaceae 191*, 192*; Dictyotaceae 289, 290, 291*-293*; Fucaceae 301*, 303, 304*; Laboulbeniaceae Amorphomyces $540 *$, Chitonomyces 539*, Dichomyces 538, Dimeromyces 533, 535, Enarthromyces 537, Haplomyces 536, 537*, Laboulbenia 
$5+1^{*}, 542$, Rhachomyces 544, Stigmatomyces 531*, 532, Teratomyces 544, Zodiomrees 545, 546*; Leptomitaceae 170*; Oedogoniaceae 209, 210*; Olpidiopsis 114; Oomycetes Albugo $10^{*}$, 154, 155, Peronospora 158*, 159*, Pythium 161*, 162; Rhodophyceae 30ั5, 312, 315, 326*; Saprolegniacene 164 ; Spharroplea 108 ; T'aucheriaceae Dichotomosiphon 89*, Vaucheria 8:, $83,87^{*} ;$ Zygomycetes Monoblepharis $123,126^{*}, 127^{*}, 128^{*}, 129,130$, Mucorineae 139 .

Antheridien und Antheridienbildung ef. auch Cytologie.

Antheridien, Anordnung bei den Dictyotaceae 29.2, Fucaceae 301*, 304*, Laboulbeniaceae 533, ว40, 541, Monoblepharis 128*, 129, Rhodophyceae 313*, 314*, $318^{*}, 325^{*}, 327$.

- Ascomyceten, Auffassung Brefelds (als sterile Hyphen) 434; van Tieghems 430.

- Ausfuhrötfnung, Laboulbeniales 533 , 536, ว37*.

- (einfache) der Laboulbeniales 533.

- (epigyne) bei Monoblepharis 128*, 129

- gekammerte bei Haplomyces 536, 537*.

- hypogyne bei Monoblepharis 128*, 129.

- Kerne cf. Cytologie.

- Köpfchen bei Rhodophyceae $313^{*}, 314^{*}$ $318 *$.

- Mutterzelle als Androspore bei Oedogonium 211.

- Oeffnung, Monoblepharis 128*.

- Primordium bei Charophyten 751*.

- Schilder, Charophyten 746, 751*.

- Sorus bei Dictyotaceae 292.

- Stände bei Fucaceae 301*, 304*, Rhodophyceae $325^{*}, 327$.

- Stielzelle 292, 450*, 451.

- Uebergänge zu den Monosporen bei Rhodophyceae 326.

- (zusammengesetzte) bei den Laboulbeniales 533, 534*, 536*.

Anthracenfarbstoffe 349 .

Antiklinen: Eudorina 21*, Myriotricha 266, $267^{*}$, Scytosiphoneae 275.

Antitoxine $348,349$.

Anziehung (gegenseitige) der Gameten 22. - - der Geschlechtsorgane 293, 296.

Apikalporus der Peridineae 233, 234, 237.

Aplanosporen bei: Bakterien 342, 359; Conferva 215*, 216; Phaeophyceae 257, 263 ; Scenedesmus 177*; Ulothrix 185; Vaucheria 80, \$1, 82, 83.

- Keimung bei Conferva '215*, '216*.

Apogame Teleutosporen 636, 637, 659.

Apogames Entstehen der ' $2 \mathrm{x}$-Generation $675,677$.

Apogamie 571; Ascobolus 578, Ascomyceten im allgemeinen $426,428,435,450,573$; Cymopolia 93; Gralactinia 458; Helvellinaceae 585, 590; Humaria 467; Lichenes 548; Pyrenomyceten 5229; Schizosaceharomyceten 615 ; Sclerotinia 578; Thele- bolus 577; Uredineae 628, 630, 635, $636,664$.

Apogam-parthenogenetisch: Saccharomyces 615 .

Apothecien: Ascomyceten 422, 424, Hysteriales 582, Phacidiales 581, Sclerotinia $426,427^{*}$, cf. auch Fruchtkörper; Lichenes 547, Baeomycetaceae 556, Cladonia 570*, 571, Collemaceae 434, 557, Discolichenes 547, 551, 554, Graphideae 555, Gyrophora 563*, Lecanora 562*, Lecidiaceae 556, Parmelia 564, 565*, 566, Peltigeraceae 557, 558*, 559 Pertusaria 560*, Physciaceae 568*, Solorina 559*, Sphaerophorus 556, Stictaceae 557.

- angiocarpe 558, 568, 569*, 572, 584.

- Aufspringen: Hysteriales 582, Phacidiales 581 .

- gymnocarpe 558, 568, 569*, 572.

- Oeffnung 422.

- Parmelia-Typus 566.

- punktförmige 560.

- sekundäre bei Pertusaria 560*, 561.

- weitgeöffnete 561 .

Appendices bei : Erysiphe 471, 472*, 473* 480, 481; Laboulbeniales 530, 531*, 534, 535, 537, 538, 539, 540, 541*, 542, 543, 545, 546*; Meliola 492; Sphaerotheca (an der Ascusfrucht) 450*, 451.

- ifreie) bei Haplomyces 535.

- Funktion bei der Ânheftung $481 \mathrm{ff}$., bei der Loslösung $480 \mathrm{ff}$., bei der Verbreitung 481.

- verzweigte 482.

Appendiculae bei Zodiomyces 545 .

Appressorien bei Erysiphe $473^{*}$.

Apposition (Bildung von Celluloseschichten durch) bei Caulerpa 76, Chlorochytrium 33.

Arbeitsteilung 4; Castagnea 274; Volvocineae 30 .

- zwischen den einzelnen Zellen eines Individuums bei Draparnaldia 187, Volvocineae 30.

Archicarpium 418, 420, 422, 426, 429 (Auffassung von van Tieghem).

Archiplasmastrahlen 489.

Armleuchtergewächse 745 .

ARTARI über: Dactylococcus 177*, Hydrodictyon $42^{*}, 44^{*}$.

Artbegriff bei Bakterien 340.

Arten (Autöcische) bei Uredineae 647.

- (biologischel cf. physiologische

- (immune) bei Uredineae 663.

- (morphologische) bei Bakterien 340, Erysiphales 482.

- (physiologische) bei Bakterien 310 , Erysiphales 482, 483, Uredineae (64:, $649,663$.

- (Ueberbrückungs-) bei Erysiphales 484, Uredineac 663.

-- Unterschejden mittelst chemischer Merkmale bei Evernia 566, 567.

Arthrosporen bei Bakterien 346, Cyanophyceas 362. 
Ascogene Hyphen, Allg. 420, 429, Ascoboleae 577, 578, Ascodesmis 461, 462, 463* Aspergillus 501, 502*, Baeomyces 556, Cladonia 570, Claviceps 428, Collema 424, Endocarpon 554, Erysiphe 485*, Eurotium 420, Galactinia 458, Gymnoascus 493, 494*, 495*, Helvellineae 586*, 587, Humaria $466^{*}, 467$, Laboulbeniales 532, Lichenes 548, Monascus 449, 497*, 498, 500, 501, Onygena 508, Parmelia 565, 566, Peltigera 557, 558*, Penicilliopsis 506, Penicillium 503, Pertusaria 560*. Peziza 572, Phyllactinia 486*, 487, Physcia 568*, 569*, Polystigma 424, Pyronema 421*, 42i, 423, 456*, Sclerotinia 427 , Xylaria 426.

- - apogame Bildung 426, 428.

- - Entwicklungsmöglichkeiten bei Discomyceten 573.

- - parthenogenetische Bildung 424, 428.

- Z Zerbröckelung bei : Aspergillaceae 498, 501, Monascus 498, Onygena 509, Penicilliopsis 506.

- Zelle bei den Laboulbeniaceae: 532, 535, 536, 540, 545 ('Zodiomyces).

Ascogon, ef. auch Oogon, Allgemeines 428; bei: Aspergillus 501, Cladonia 570*, 571, Endocarpon 553*, 554, Eurotium 420, Gymnoascus 493, 494*, 495*, Gyrophora 563*, Lecanora 562*, Lichenes 434, 548, Monascus 449, 498, Parmelia 564, 566, Peltidea 558, 559*, Peltigera 557, 558*, Pertusaria 560*, Phyllactinia 487, Physcia 568*, Pyronema 423, Rhyparobius 577, Thelebolus $574^{*}, 575$.

- mehrzelliges, Ascobolus 464, 577, 578, Eurotium 463, 464.

- spiralförmiges $463,464$.

Ascoidea als Siphonomycet 443.

Ascomycetes, Einteilung 431; Entwicklungsgang 432; Homologien 468 f., Sexualität cf. Sexualität.

Ascus und Ascusbildung, Allgemeines 143, $174^{*}, 418,420$ ff., $\mathbf{4 2 9}, 431,434^{*}, 438$, 440, 441*, 571, 615, Acetabula 441, Ascobolus 422, 423, Ascodesmis 461, 463*, 464*, Aspergillus 441, 502*, Borrera 441, Claviceps 428, Collema 424, Ctenomyces 495, Dipodascus 443*, 444, Endocarpon $441^{*}, 554$, Eremascus 420, Erysiphe 420, $441,485^{*}$, Eurotium 420, 4*1, Eutuberaceae 594, 596, Exoasceae 441*, 597, 599*, Gymnoascus 494, 495, Helvellineae 441, 588*, Humaria 457, Laboulbeniales $531^{*}, 532,540^{*}, 542^{*}, 543$, Lichenes, Allgemeines $434^{*}, 441,550^{*}$, Monascus 448*, 449, Nectria 426, Onygena 508*, Peltigera 557, 558*, Penicilliopsis 506, Penicillium 441, 504*, Pertusaria 560, Peziza 427*, 441*, 572, Phacidiales 581*, Phyllactinia 486*, 487, Physcia 569*', Podosphaera 420, Polystigma 424, Pyronema 421, 422, 456* ff., Rhyparobius 577, Sclerotinia 426, 429, Sphaerotheca
450*, 451, Thelebolus 449, 574*, 575, Xylaria $425,426$.

Ascus und Ascusbildung durch Apogamie $426,432$.

- - durch Gametangienkopulation 423, 432,464 .

- - durch Kopulation bei Saccharomyceten : Allgemeines 609, 615, Saccharomyces $605, \mathbf{6 0 9}, 610$, Saccharomycodes 610 , 611, Schizosaccharomyces $610,611,612$, $613^{*}, 614$, Zygosaccharomyces 610 .

- - durch Kopulation zwischen Trichogyne und Spermatien 423, 424, 432, 464 .

- - durch zweifelhafte Kopulation 424, 426.

- - ohne Kopulation 424, 426.

Ascus als Gonotokont 453, 467.

- Aufspringen mittelst Deckel 573.

- Homologien 435, vergl. Ascus und Basidie etc.

- Nucleus bei Sphaerotheca ein $4 x-N u$ cleus 451.

- - Entstehung 440, 441*.

- - Fusion ef. Nuklei-Fusion.

- - Teilung 488*.

- Parthenogenetische Bildung 435.

- (sogenannter) bei : Ascoidea 442, Dipodascus $443^{*}$, Protomyceten 446, Taphridium $445^{*}, 446$.

- (vielsporiger) 597, 599 (Exoascaceae).

- Zahl pro Zygote 45s, 486.

Ascus und Basidie 616, 674, 675.

- - Diplosporangien 435, 451-453, 467, (Saccharomyces) 609, 615.

- Farnsporangium 467.

- - Gametangium 435, 444, 467 (Note).

- - Haplosporangium 435, $436 \mathrm{ff}$. - $\mathbf{4 1}$, $437^{*}, 444,446,447,449,467$.

- - Protobasidien 676.

- - Sporangien der Siphonomyceten 143.

- - Sporenfrucht 144, 420, 421.

- - Teleutospore 665 .

Ascusbildung apogame 426, 450.

- aus einem Teil des Archicarps 420, 450, 459 .

- das ganze Archicarp wird zum Ascus $419,450,459$.

- (Hakenbildung bei der) 469, 560, 571, Ascodesmis 461, Humaria 467, Onygena 508*, Penicillium 504*, Pyronema $440,457$.

Ascusfrucht und Zygosporenfrucht 144.

Ascussporen, Allgemeines 439*, 440; Balsamia 583*, Calosphaeria 526, Ceratostomella 522*, Claviceps 519*, Cordyceps 516*, Epichloe 516*, Erysiphe 473, 485, Gymnoascus 492, Hysteriales 582*, 583, Laboulbeniales 530, 537, 539*, 542*, 546*, Monascus 496-500, Peziza 427*', 429, Phacidiales 581*, Phyllactinia 472*, 489, Pichia 611, Saccharomyces 602, $608 *, 609$, Saccharomycodes 611, Sclerotinia 426, 429, Sordaria 521*, Taphrina 598. Thelebolus 449, 575*, 576*, 577, Uncinula $473^{*}$, Valsa 524 , Willia 612.

- Ausschleuderung bei Thelebolus 577. 
Ascussporen, Fusion, Protomyces 446*, Taphridium $445^{*}$.

- (gekammerte) Meliola 492.

- (gepaarte) Laboulbeniaceae 535, 540*.

- Homologie mit den Zoosporen von Albugo: Pyronema $46 \mathrm{~S}$.

- Infektionsrermögen, Erysiphe 483, 484.

- Keimung: Claviceps 51S, 519*, Cordyceps 517*, Erysiphales 472, Laboulbeniales $530,531^{*}, 534^{*}, 535$, saccharomrces 608*, 609, Saccharomrcodes 608*, 610 , Schizosaccharomyces $613^{*}$, Taphrina $599^{*}$.

- Mutterzelle bei Protomyces 446, 447*, Taphridium 445*.

- (scheinbar einzellige): Sordaria 521, 522.

- Verbreitung 478, 577.

- (vielsporige) bei Exoasceae 597, 599.

- (vielzellige) bei Helvellinaceae 588*.

- Zahl pro Ascus: Allgemeines 436, 535, 615; Errsiphe (6-8) 473; Laboulbeniales (4) 315, Phyllactinia (2) 472*; Saccharomyceten (4) 609, Schizosaccharomrces (8) 612, 614, (4) 614; Uncinula $\left(4-5,8\right.$ ?) $473^{*}$.

- Zerfall bei Cordyceps 516*, 517.

- (zweizellige) bei Hypocrea 516, Melanconis 525*, Nectria 5̃14, Parmularia 582*.

Askenasy über: Pediastrum 40*, 41.

Asparagin als Reagens 70 .

Assimilationszellen bei Laminaria 286.

Assimilation des freien Stickstoffs 351.

Assimilatoren bei: Bryopsis 56-60, 57*; Castagnea 273, 274; Caulerpa 7.2, 74, 75*, 76; Chorda 279; Derbesia 203: Dictyosiphoneae 278; Elachistea 272; Myrionema 270; Nemalion 312, 315; Ralfsia 271.

Astzellen bei Valonia 100.

Atmung 358.

Augenfleck = Stigma.

Autöcische Arten bei Uredineae 647.

Autöcische Rostpilze 633.

Autolyse bei Anabaena 371.

Autotrophe Organismen 39; Bakterien 329, $354,357,372$.

Auxiliarmutterzelle der Ceramiales 322.

Auxiliarzellen bei: Ceramiales 3*1*, 322*, 323, 325; Dudresnaya 317, 318*', 319*', 320.

Auxosporenbildung der Diatomeae $2 \varrho 1 \mathrm{ff}$., $252^{*}, 253 *$.

Azygosporen (Zygomyceten) 151, 435.

- (Kernverschmelzung bei den) $1 \grave{1 .}$

\section{B.}

BABES über metachromatische Körper 604.

BAINIER über: Pirella 135*, Thamnidium $141^{*}$.

Bakterien aërobe 334, 344.

- anaërobe 334,355 .

- angewachsene 342 .

- autotrophe 354.

- bewegliche 353, 354, 355.

- in Blättern 351, 352*.
Bakterien chromopare 345, 349, 350 .

- (Eisen) 356, 357*.

- (Eiter) 339, 346.

- Faden 359.

- Farbstoff produzierende 349.

- Fäulnis 358.

- Formen 339, Zusammenhang 360.

- gekrümmte 340,342 .

- Gelatine verflüssigende 334, 344, 345, $353,355$.

- Isolierung 332.

- Ketten 341, 342, 346.

- Knöllchen 347*, 350.

- Knötchen 352*.

- kommaförmige 355 .

- kugelförmige 339 .

- Kulturen 332, 335, 353, 361.

- (Leucht-) 343.

- lophotriche $342,347^{*}, 350,356$.

- (Milchsäure) 355 .

- monotriche $342,347^{*}, 349$, 356.

- obligat anaërobe 354 .

- Paketchen 341, 345, bewegliche 341.

- pathogene $346^{\circ}, 353^{*}, 355,356$.

- peritriche $336^{*}, 340,342,350$.

- pigmentbildende 345, 349, id. farblose Rassen 350.

- Schwefel enthaltende 342, 346, 357*, 358.

- stäbchenförmige 339, 340, 342.

- System 341.

- Täfelchen 341, 346; bewegliche 346.

- Temperaturoptimum 346.

- unbewegliche 342 , 343, 345, 347, 353, 355,357 .

- verzweigte 341, 342.

- Wachstumshemmung durch die Stoffwechselprodukte 336 .

- (Wurzel) 347*, 350.

Bakteriofluorescin 349, 350 .

Bakterioiden $347^{*}$, 351.

Bakteriologie, Historische Uebersicht $330 \mathrm{ff}$.

VAN BAMBEKE über Hydnangium 677.

BANKs über Getreiderost 638.

BARANETzKY über Gymnoascus $502 \%$, Lichenes 549 .

BARKER über Monascus 448, 449, 497*501 ; Rhyparobius 577, Zygosaccharonyces 610 .

Basalblase bei Acetabularia 97.

Basalkragen der Mucoraceae 135*, 136.

Basalscheibe der Phaeophyceae: Asperococcus '268*, Cutleria 280, Dictyota 288, Ectocarpeae 258, 259, Fucus 298, Laminaria 285, Myrionema 270.

Basalzelle bei Charophyten $746,747^{*}$, Rhodophyceae 322 , Ulothrix 182.

Basidien und Basidienbildung: Allgemeines 666, Agaricaceac 705, 706, 707\%, 708, 711, Auricularia $667^{*}, 668$, Calostomaceae 726*, 723, Cantharellaceae 65t*, 655, Clathraceae $735^{*}, 736^{*}$, Cora 693*, Craterellus 668, C'yphellaceae 697*, 698, 699, Daeryomyces $671,672^{*}, 673^{*}$, Ecchynaceae 683, Exobasidium 691, Fistulinaceae 706*, Gasteromycetineae 719, Lycoperdaceae $728,730^{*}$, Yeniophoraceae $689^{*}, 690$, 
Pilacre 668*, 669, Pisolithaceae $724^{*}$, Plectobasidii 718, 719, Polyporaceae 685, 701*,703*, Sclerodermataceae 720*, Sphaerobolaceae $726^{*}, 727$, Thelephora 692, Tremella 669, 670*, Trichocoma 744*, Tulasnellaceae $679,680^{*}, 681^{*}$, Tulostomaceae 723, 724 (Note), 725*, Vuilleminia $682,683^{*}$.

Basidien (Chiasto) 676, 677, 678, 682, 685. - cloisonnierte 676 .

- einzellige 666.

- (als) Gonotokont 674.

- konstante Sporenzahl 686.

- mehrzellige 666.

- Phylogenie 671, 672, 676.

- Richtung der Kernspindel 673*, 676, $681,68 \%, 683,684,685,686,690,698$, $699,702,703,704,706,707^{*}, 710,711$, $712^{*}, 715$.

- Sticho cf. Stichobasidien.

- und Ascus 616, 674, 675.

- und Diplosporangium 616.

- und Konidienträger 436, 616, 674.

- und Teleutospore 628, 665, 668, 669, 671, $672,677$.

- unvollkommen differenzierte 683.

- variable Sporenzahl: Cantharellus 685, Clavaria 685, Exobasidium 684, 686.

- verfrühte Keimung bei Hygrophorus 708 .

Basidiomycetes, Einteilung 616, 617.

Basidiosporen: Allgemeines 616, 671, Ableitung 616, Agaricineae 705, 706, 711, Auricularia 667*, 668, Broomeia 731*, Calostoma 723, Clathraceae 735*, Dacryomycetes 671, 673*, Exobasidium 691*, Hygrophorus 707*, 708, Peniophoraceae 690, Pilacre 669, Psalliota 715, Rhizopogon 728, Russulaceae 709, 710, Sparassis 698 , Tremella $669,670^{*}$, Tulasnellaceae 681*, 682, Vuilleminia 683*.

- Anheftung an der Basidie 675, 683, 723.

- Freikommen bei Pilacre 669.

- Insertion bei Tulostoma 723 .

- Keimporus 711, 715.

- Keimung: Allgemeines 675, Auricularia 668, Autobasidiomyceten 686, Dacryomyces $671,672^{*}, 673^{*}$, Exobasidium 691*, Tremella 669, Vuilleminia $683^{*}$.

- Keimung (verfrühte) : Amanita 713, Hygrophorus 707*, 708, Tulasnellaceae 679 , $680^{*}, 681,682$.

- mehrkernige bei Chtopilus 713.

- und Konidien 674, 675 .

- und Sporidien cf. Sporidie.

- wechselnde Zahl bei Calostoma 723, Rhizopogon 728 .

Bastarde $=\mathrm{Hy}$ briden .

Bauchzelle der Antheridien bei Laboulbeniaceae 532 .

BAUR über: Anaptychia 569, Apothecienentwicklung im allgem. 547, 548, Calicium 555, Cladonia 570*, 571, Collema 433, 434*, 464, Endocarpon 553*, Gyrophora 563*, Lecanora 561, 562*, Мyхobakterien 386, 387*, 388, Parmelia 564,
Peltigera 558, Pertusaria 560*, Solorina $559 *$.

Beeinflussung (gegenseitige) der Zellen 41. Becherflechten 569 .

Befestigung am Substrat mittelst Basalscheibe cf. Basalscheibe.

_ _ _ - Haftscheiben cf. Haftscheibe.

- _ - - Haustorien ef. Haustorien.

- - - Rhizoiden ef. Rhizoiden.

Befruchtung cf. Gameten- und Gametangienkopulation, Geschlechtsfunktion und Sexualität.

- bei Ascomyceten 420, 422, Aspergillus 501, Erysiphe 485, Gymnoascus 493, 495, Phyllactinia 486*, Pyronema 453 ff., Sphaerotheca 451 ; Laboulbeniales 532 , 546*; Uredineae 630, Phragmidium speciosum 628, 629, 630*, $\mathrm{P}$. violaceum 631, 632*, Puccinia 634, Uromyces 633.

- mittelst Spermatien und Trichogyne bei : Ascolichenes 547, 548, 571; Laboulbeniales 522, 546*, Pyronema 512, 514, 529.

- und Parthenogenesis 166*, 167.

BeHRING über Diphtherieserum 348.

BENECKE über Zygnemaceae 196.

BERGEN über Diatomeae 254.

BERKELEY über: Gasterolichenes 742, 743, Myxobakterien 385.

BerLese über Peronospora 160.

Berlinerblau 76.

BERTHOLD über: Bryopsis 57, 58; Cladophora 105; Codium 63*; Craterospermum 199; Derbesia 204; Dudresnaya $317^{*}$; Endocarpeae 261, 262*; Hydrurus 228*; Porphyra 307, 308*, 309.

Beweglichkeit (Verlust der) 10, 16.

Bewegung (amöboide) bei A kontae(Gameten) 194; Batrachospermum ('Tetrasporen) 326; Chloramoeba 212; Chrysomonaden 225, 226, 227; Conferva (Zoosporen) 216; Draparnaldia (Gameten) 188; Hymenomonaden 229, 230; Monoblepharis (Spermatozoiden) 124, (Zygote) 127; Myxomycetes 391, 393; Nemalion (Carpospore) 312 ; Ochromonaden 231; Porphyra (Carpospore) 308, (Sporen) 307; Protomastigina 5; Pseudolpidium 112*; Ulothrix (Zoosporen) 185; Vaucheria (Schwärmer) 80

- (Aufhören der) 26.

- der: Bakterien 336, 337, 341, 342 ; Bakterienfäden 342; Chrysomonaden 226, 228; Cyanophyceae 382, Desmidiaceae 220; Diatomeae 247, 248*; Myxobakterien 388; Oscillarien 382.

- der Gameten cf. Gameten.

- der Individuen 33, 35.

- der Hormogonien 382.

- der Zoosporen cf. Zoosporen.

- mittelst Cilien 8, 25 cf. auch Cilien.

- molekuläre 219.

BeIJERINCK über Bakterien 347*, Chlorella $176^{*}$, Cystococcus $174^{*}, 175$, Leuchtbakterien 344, Scenedesmus 177*, Schizosaccharomyces 612 . 
Biaiometamorphose ef. auch Lebensbedingungen (Einfluß der), Licht, Temperatur ete.

- bei Basidiobolus 201, 202, Batrachospermum 316, Bryopsis 5̌', 59, Ceratien '236, scenedesmus 177,178 .

BIFFEx über Uredineae 664.

Billnoth über Bakterien 332, 360.

BITTER ïber Evernia 566, Padina 288, Soredien 551, Umbilicaria 563.

BLACKMAx über Algensystem i6, 55, 56, 90, Grmnosporangium 657*, Humaria $465^{*}, 466^{*}$, Prronema 453 , Sphaerotheca 451, 453, Uredineae 49*, 50*, 628, 630, 631*, 632*, 633, 6334*, 637.

BLAKEsLEE über Befruchtung bei Mucor 138.

Blättchen der Charophyten 745.

Blätter der Charophyten 745, 748*, 750*.

Blattflechten 562, 5̄6\%, 569.

Blattscheitelzelle, Charophrten 750*.

Blattschneiderameisen 714 .

Blattspitzenzelle, Charophyten 750*.

Blatturzellen, Charophyten $750^{*}$.

Bledius als Laboulbeniaceae-IVirt 537.

Bodensatzhefe 604 .

BoHLIN über Heterokontern 212, 213*, 214*.

BoNNET über Bakterieninfektion 331.

BONNIER über Lichenes 550 .

VON BÖNNINGSHAUSEN über Getreiderost 639.

BoNoRDEN über Polyangium 385.

BOODLE über Siphonocladus 101*

BoRGE über Rhizoidbildung bei Algen 59.

BoRNET über Asperococcus 269*, Ectocarpus 263*, Elachistea 272, Hymenolichenes 694, Lichenes 550, 551, Punctaria 275, Rhodophyceae 311, 326, Schizophyceae 380 .

BorzI über Apothecien-Entwicklung 547, 548, 557, 570, Cyanophyceae 376, 378, 379, Vaucheria 79.

Boudier über Tulasnella 679, 680*.

Bourn über Saccharomyces 607 .

BoverI über Kern als Träger der elterlichen Eigenschaften 13, Kern und Cytoplasma 488.

Bower über Fucus 298, ‘299, 300.

Brachy-Gruppe bei Uredineae 6:35, Uromyces 6058 .

BRAND über Cyanophyceae 374, 375, 377 , 379, 381, 382, Rhizoidbildung bei Cladophora 59.

Brandpilze 617.

Braun, A. über Cyanophyceae 374, Dichotomosiphon 88, Pediastrum 40, Pseudolpidium 111, Sphaeroplea 107.

vaN BREemen über Mikrosporen bei Diatomeae 255.

BREFELD über Ascomyceten-Sexualität 430 -442, 453, 467; Basidiomyceten 616, Einteilung 666, Befruchtung und Auffassung 671, 1;74; Chaetocladium 145*, 146; Claviceps 519*; Coprinus 716*; Cucurbitaria 523; Dacryomyces 672* Empusa 147*; Fomes 701*; Gasteromyceten-Abstammung 678; Hemiasci
442-449,443*; Hemibasidien 617; Konidienbildung im allgem. 111; Mortierellaceae 142, 144; Mucoraceae 134, 135, $137^{*}$; Nyctalis $707^{*}$; Penicillium 503, 504*; Pilacre668*, 669; Polysphondylium 392 ; Protobasidien 665; Thamnidiaceae 141*; Thelebolus 573, 575; Tremella 668*; Tuberaceae, Phylogenie 509; Uroeystis 625*; Ustilago 618, 619*.

BRESADOLA über Morchella 588*.

Brutknöllchen bei Dichotomosiphon 89*.

Brutknospen der Rhodophyceae $3: 27$.

BuchноLтz, Eutuberaceae 590, 591, 592 , 593*, 595*; Phylogenie der 'Trüffelpilze 509.

BURDON-SANDERSON uber Bakterien 332. BÜSGEN über Cladothrix 361 .

BüTsCHLI über rote Körner bei Bakterien 604, Schizophyceae-Cytologie 372, Volvox 25 .

Buttersäuregärung 353.

C.

Caeoma bei Phragmidium 628, 629*, 630, $631,632 *$

Capillitium bei: Broomeia 731*, Calostomaceae 721, 72:2*, Gasterolichenes 743*, 744*, Hysteriales 582, Lichenes 554, Lycoperdaceae 718, 719, 728, 729, 730*, Myxomyceten 394, 402, 405, 406, 407, -412*, 413*, 414, Phacidiales 581*, Plectobasidiineae 719, Sclerodermataceae 721, Tulostomaceae 725, Ustilago Treubii $622 * 623$.

- Bau bei Myxonyceten 408, 410.

- Bäumchen bei Myxom. 409.

- Bildung bei Myxom. 413*, 414.

- Elaterentypus $408^{*}, 409 *$.

- Netztypus 408, 409*, 410, 411, 412.

- plattenförmiges $408,410$.

- röhrenförmiges $408,409^{*}$.

- stangenförmiges 408, 410.

Capitulum von Claviceps 428*.

Carabideae als Wirte von Laboulbeniales $535,537,544,546$.

Carcinom 401.

Carotine 36, 39, 55, 189, 397.

- Reaktion 36.

Carpogon bei: Florideae $315 \mathrm{ff}$., 320*; Lichenes 547, 548, Endocarpon 554, Lecanora 562, Parmelia 565, Sticta 557. -Aeste der Florideae 320*, 321*, 322.

Carpophor bei Cantharellus 655, Clavaria 685, Dictyolus 698, Sparassis 697*, 698, Thelephoraceae 691 .

Carposporangiale Zygomrceten 436 .

Carposporen bei: Bangiaceae :30), 309 Ceramiales 321--324, Dudresnava $318^{*}$, 319, 320*, Floridcen 312, 313े, 31**, 315 .

- amöboide Bewegung bei Nemalion 312, Porphyra 305 .

- Austritt 308*, 313

- Keimung bei Bangiaceae 3us, Florideen $\mathbf{3 1}$ ). 
Cavara über Ascodesmis 459, Entomophthora 150 .

Cellulose 2, 8, 33, 77, 225, 408, 413.

- -artige Substanz bei Caulerpa 77.

- Balken bei Bryopsis 57, Caulerpa 71, 73, 75, 76, Codium 77.

- Membran bei Chlamydomonas 10, 14, 15; Hydrodictyon 46; Myxomyceten 392, 394; Peridinales 232, 240; Valonia 99 ; Vaucheria 80.

- Pfropf beim Eindringen der Haustorien der Erysiphales 474, 475*, 476*.

- Ring bei der Wandbildung bei : Cladophora 105, Desmidiaceae 221, Oedogonium 205, Zygnemaceae 197.

Central body Harpers bei Phyllactinia 487.

Centrosom bei Diatomeae 249, 250, Phyllactinia $487^{*}, 488,489$.

- und Chromatin, Relation bei Phyllactinia 488.

Chamberlandkerze 348.

Champignonbrut 715.

Chantransia-Stadium 326.

Chemotaktisches Durchbohren der 'Zellwände durch parasitische Pilze 477.

- Eindringen der Keimschläuche nicht parasitischer Pilze 476, 477.

Chemotaxis 198, 319, 350, 476, 477*.

- Rolle bei der Infektion 663.

Chevreuil über Bakterien 331 .

Chiastobasidien $\mathbf{6 7 6}, 677,678,682,685$.

Chitin in der Membran bei Chromulina 227, Cyanophyceae 365.

Chlamydosporen bei Chlamydomucor $137^{*}$, 138, Fistulina 704, 706*, Hypocrea 515*'. Monascus 449, Nyctalis $707^{*}, 708$, Onygena 507*, 508, Prolomyces 437*, 438, 446, 447*, Taphridium 447, Tilletia $619^{*}, 624$ (durch Kultur), 'Tuburcinia $624^{*}, 625$, Ustilago 619*, 622.

- Ballen bei Doassansia $625^{*}, 626$, Tuburcinia $624^{*}, 625$, Urocystis $625^{*}$.

- Bildungsstelle, Ustilagineae 622,

624 (Tilletia).

- Bildungszeit Ustilago 619.

- Keimung bei Chlamydomucor 137, 135*, Tilletia 619*, 623, Tuburcinia 624*, Urocystis 625*.

-_ - (fruktifikativ) bei Ustilago 617, 619*.

- Kernzahl 708.

- Mycelium bei Tilletia 625, Tuburcinia $624^{*}, 625$.

Chlorammonium, Einfluß in Kulturen 201. Chlornatrium Einfluß in Kulturen 201.

Chlorophyll 2, 39.

- Körner = Chloroplasten.

- Verlust 17, 39, 178, 212.

Chloroplasten $3,27,58,64,175, \mathbf{1 7 6}, 363$; bei Chroolepideae 189; Codiaceae 61; Sphaeroplea 108; Vaucheria 87.

- in den männlichen Fortpflanzungsorganen bei Coleochaete 192, Oedogonium 209, 210, Vaucheria 87.

- Lichtempfindlichkeit 58.

- Lokalisierung bei Sphaeroplea 108.

Chmielevsky uiber Spirogyra 27, 199, 200.
Сноnat über Pleomorphismus bei Algen 178, Tetraspora $180^{*}$.

Christman über Phragmidium 628, 629*, $630^{*}$, Uredineae 641.

Chromatin 28, 312, 367, 369, 371, 487, 604 (Hefe).

- Faden 51.

- Körner 336*, 337, 347*; 372, 500 (Monascus).

- - Nukleinreaktion 337.

- und Centrosom (Relation bei Phyllactinia) $488,489$.

- Verteilung bei Bakterien 338, Мyxomycetes 402 .

Chromatophoren 7, 8, 27, 66, 67, 69.

- bandförmige 172, 182, 183*, 187, 218.

- Bau bei Cyanophyceae 363 ff., Hydrodictyon 42, Nemalion $311^{*}, 312$, Protosiphon 53, Sphaeroplea 107*.

- braune bei Diatomeae 248, 250, 251, Peridinales 232, Phaeophyten 238, 241, 260, 261, 265, 273, 283, 284, 292, 297.

- Cyanophyceae 362, 363ff., 366 (Form), $371,372,373$.

- diatomeenbraune. 248.

-- Entstehung 27.

- farblose 312 .

- (Fehlen der) bei Polytoma 17.

- gelappte 208, 307.

- gelbbraune bei Chrysomonaden 225, 228, $229,230,231$

- gelbe bei Codium 64, Cutleria 284, Diatomeen 248, Peridinales 238.

- gelbgrüne bei Heterokonten 212, 213,216.

- goldgelbe bei Phaeophyceae 225.

- grüne bei Bryopsis 56, 57; Chlamydomonas 7, 8, 10; Chlorangium 172; Cladophoraceae 104, 105, 107*; Codiaceae 61, 64; Coleochaete 193; Cystococcus 175; Desmidiaceae 218, 224; Draparnaldia 187; Hydrodictyon 42*, 43*, 44, 45; Mesotaenium 194; Monostroma 181*; Oedogonium 208, 210; Peridinales 238; Pleurococcaceae 176, 178; Protosiphon 53; Pyramidomonas 8; Sphaeroplea 108; Ulothrix 182, 183*, 184 ; Valonia 98; Vaucheria 79; Volvocineae 23, 24, 26; Zygnemaceae 196*, 197,199 .

- in den männlichen Fortpflanzungszellen: Allgemein 27; bei : Codium 64; Cutleria 284; Dictyota 292; Fucus 297; Oedogonium 210; Volvox 26.

- Isolierungsmethoden 363.

- kugelförmige bei Coelastrum 178, Volvox 23.

- Nemalion 311*, 312.

- netzförmige der Cladophoraceae 104, $105,107 *$.

- Peridineen, Anordnung 238*.

- plattenförmige bei Diatomeae 248, Mesotaenium 194, Ophiocytium 216, Porphyra 307, Prorocentreae 241, Zygnemaceae 197.

- Reduktion bei Closterien 224; künstlich bei Diatomeen 249 . 
Chromatophoren, Regeneration (künstliche) bei Diatomeen 249 .

-- rote bei : Nemalion $311^{*}$, Peridinales 238, Rhodomonas 306, Rhodophyceae 307, \$1:.

- scheibenförmige bei : Codiaceae 61, Valonia $9 S$.

- spiralige bei Zygnemaceae 197.

- sternförmige bei Mesotaeniaceae 194, 197.

- Teilung 8, 27, 193, 199, 260, 280, 311*, 373.

- Vererbung 27.

- Verhalten bei der Befruchtung 199.

- Zygnemaceae $196^{*}, 197$.

Chromogene Substanzen bei Russula 710. Chromoplastenfarben 5 .

Chromosomen 2s, 29*, $51 \mathrm{ff}$, 193; bei : Cyanophyceae 368, 369, 370, 371, 372; Dictyota 292, 293; Myxomyceten 402; Nemalion 312; Rhodophyceae 310, 312, 314.

- Beibehalten der Individualität bei der Kernverschmelzung 51.

- Bivalenz 52.

- elterliche 453 .

- feinerer Aufbau 30*.

- Konstanz der Zahl 29, 48.

- Längsspaltung $29^{*}, 52$.

- Trennung väterlicher und mütterlicher 53.

- Univalenz 5\%.

- Verhalten gegen künstlichen Magensaft $369,370$.

- Zahl bei: Nemalion 312; Phyllactinia 488, Rhodophyceae 310, 312, 314.

- Zahl, Reduktion ef. Reduktionsteilung.

CHURCH über Neomeris 92.

Cienkowsky über Bakterien 360, Chlorangium $173^{*}$, Cylindrocapsa $185,186^{*}$, Labyrinthula 395, 396*, 397, Ulothrix $184^{*}$.

Cilien bei einciligen Organismen: Bakterien $342,344,345^{*}$, 355, Chromulina 225, $226^{*}$.

- bei: 7 Gameten 22, 26; Bryopsis 57; Charophyten 746, 751*; Codium 64; Choleochaete 192; Cutleria 284*; Cylindrocapsa 185 ; Dictyota 292; Ectocarpus 263; Fucus 304*; Monoblepharideae 124, 127*, 128; Oedogonium 210*; Phaeosporeae 261; Phyllobium 36; Sphaeroplea 108; Vaucheria 83, 87.

- bei : O Gameten 36, 57, 64; Cutleria $284^{*}$; Phaeosporeae 261, 263.

- bei: Isogameten 14, 20; Chlorochytrium 33̈; Chroolepideae 190*; Diatomeen 255; Draparnaldia 188; Ectocarpus 261*; Elachistea 272; Endosphaeraceae 35,38 ; Hydrodictyaceae 40*, 41, 46*; Monostroma 181; Phyllitis 277, 278*; Rhodochytrium 39; Siphonales 55, 91, 97, 104, 107; Sporochytriaceae 120; Ulothrix 184.

- bei mehrciligen Organismen: Bakterien $336^{*}, 337,338,342,350,353^{*}, 354,355$,
356; Chlamydomonas (4) 7; Pyramidomonas 14,9 .

Cilien bei Schwärmsporen bei: Chlamydomonas 8; Chromulina 227; Cladothrix 361; Hydrurus 228; Radiofilum 182; Siphonales 55; Stephanokonten 203; Volvocineae 20.

- bei Zoosporen bei: Chlorangium 173; Chlorella 176 (Fehlen); Chroolepideae 190*; Cladophora 104, 106; Coleochaetaceae 192; Conferva 215*, 216; Cutleriaceae $281 *$, 283; Derbesia 204; Draparnaldia 187*, 188; Endosphaeraceae 37; Hydrodictyaceae 40, 45, 46; Hyphochytriaceae 12:*; Lagenidium 117; Monoblepharideae 124, 125\%, 127; Monostroma 181; Oedogonium 209; Olpidiopsis 113; Phaeosporeae 257, 260, 269*, 272*; Pringsheimia 189; Protococcaceae 175; Pseudolpidium 111; Pythiaceae 161; Saproleginaceae 163, $164^{*}$; Sporochytriaceae $119^{*}, 121$; Synchytrium 115; Ulothrix 183*; Valonia 100; Vaucheriaceae 78, 81.

- bei zweiciligen Organismen: Chlamydomonas $7,8,11^{*}, 14,15^{*}$, Chloramoeba 212; Chlorangium 172; Hymenomonaden 229*, 230; Ochromonaden 230*; Peridinales 232*, 233, 241; Planosarcina $345^{*}$; Polytoma 16*; Protomastigina 5; Tetraspora 180; Wysotzkia '229, 230*.

- Bewegung 8, 25, 233.

- Bildung 180, 182, 185, 210.

- Cyanophyceae 382.

- Einziehen vor der Befruchtung 284*.

- Insertion bei: Bakterien 337, Chrysomonaden 231; Cutleriaceae 283; Ectocarpeae 260; Endusphaeraceae 38; Peridinales 232; Pseudolpidium 38; Saprolegniaceae 165; Vaucheriaceae 78, 83; Zygorhizidium 121

- Kranz bei Oedogonium 203, 204, 209.

- Myxomyceten 393, 403.

- Regeneration bei der Fortpflanzung 9, $10,20,22$.

- Spalte bei Peridinales 233, 237.

- Verhalten bei der Kopulation 10, 14, $22,36,284 *$.

- Verlust 10, 14, 33, 46, 111, 188, 194, 403 (Myxomycetes).

Claussen über Boudiera (Ascodesmis) $459-464$ (460* $\left.461^{*}, 462^{*}, 463^{*}, 464^{*}\right)$.

Coenobien bei Endosphaeraceae $34^{*}$, 35, 37, 110; Hydrodictyaceae $40^{*}, 41,46,53$; Myxomycetes 391, 416; Volrocineae 16.

- Stadium bei Synchytrium 116, 117.

Coenocentrum bei Oomyceten 153*, 155, $156^{*}, 159^{*}, 160,168$.

Coenocyte $=$ Polyenergide

Coenogamete 155, 156* $160,16 \%$.

Coenozoospore 155 .

Coenozygote 155, 468 (Ascomyceten).

CoHn F. über Bakterien 331, 343, 359.

Collema, scheinbare Thallusdifferenzierung 433. 
Colonbakterie 340 .

Cölonemata 414.

Columella bei : Geaster 731, Lycoperdon 729, Mucorineae 134, 135*, 136, 137, $140,141^{*}, 142,145,299$, Mutinus 740 , $741^{*}$, Secotium 740 .

- Bildungsweise und Form 136, 141*.

Copulae der Diatomeae 243.

Coraform von Cora 693*, 694 .

CORNu über Cronartium 649, Leptomitaceae 170*, Monoblepharis 122,123 , Pseudolpidium 111.

Corona inferior bei Acetabularia $96^{*}, 97$.

- superior bei Acetabularia 95, 96*, 97, 98. Corpuscules spéciaux von Eriksson 64:.

CorRens über Cyanophyceae 382.

Cortina der Agaricineae 705, 706*.

Cramer über Dasycladaceae $92^{*}, 94^{*}$.

Cunningham über Choanephora 144*, 145.

Cuticula bei Caulerpa 76, Ralfsia '271, Zygnemaceae 196.

Cuticularröhre der Zygnemaceae 196.

Cyanophyceenzelle, Auffassungen 368.

Cyanophycein 379.

Cyanoplasten 362, 364.

Cyclops als Beispiel des Verhaltens der elterlichen Kerne 50.

- als Substrat 172.

Cysten bei : Chromulina 227 : Cyanophyceae 374; Dasycladaceae 92, 93, 94*, 95, 96*, 97; Myxobakterien 387*, 389*, 390; Myxomyceten 397, 398*; Protosiphon $54^{*}, 55$; Vaucheria 79*, 80.

Fruchtkörper, Myxobakterien 38?**.

gedeckelte $93,95,96^{*}, 97$.

Keimung 79*, 80, 96, 97, 397, 398.

- polyenergide 96.

Cystide bei: Cantharellineae 687, Empusa 649, Gomphidium 708, Inocybe 713, Paxillariaceae 717, Peniophoraceae 689*, 690, Polyporaceae 700, 7()3*, Raduleae 700, Ravenelia 660, Thelephoraceae (Fehlen) 691.

- Auffassung als Spermatozoiden bei Basidiomyceten 691.

Cystocarp 315.

Cystophoren der Myxobakterien 389.

Cytoplasma bei Cyanophyceae 362, 364, 36.5, 367, 372, Erysiphales 488, Мухоmyceten 413 .

- Ballen bei Monascus 499*.

Cytologie bei: Ascomyceten Allgem. 439*, 140, 441*, 450*, Ascodesmis 462, 463*, 464*, Ascoidea 442*, Dipodascus 443, Wrysiphe 484*, 485*, Gymnoascus 493, 494*, Humaria 465, 466*, 467, Monascus 448*, 449, 498, 499*, Phyllactinia $486^{*}-490^{*}$, Protomyces $447^{*}$, Pyronema $454^{*}, 455^{*}, 456^{*}$, Sphaerotheca $450 *$, Taphridium 445*, Thelebolus 575-578; Bakterien 338, 339; Basidiobolus 201; Basidiomyceten Allgem. 666, 674, 675, Agaricineae 706, 707* Cantharellineae $684^{*}, 685$, Clitocybe 711 , Clitopilus 713, Coprinus 716, Cyphella 698, Dacryomyces 671, Lactarius 709*, Muci- porus 681*, Polyporaceae 702-704, Psalliota 71วj; Charophyten 748; Coleochaete 192, 193; Cyanophyceae 362 ff., 363*, 365*, 368, 370, peripherer Teil 362, 365, zentraler Teil 366, 368, 370 , 371; Desmidiaceae 223*; Diatomeae 250*, 25.*; Exoascinecie 598; Gasteromyceten 718 , Tulostomaceae 7.25; Monoblepharideae 127; Myxomyceten 402, 413*, 414, 415; Oomyceten Albugo 153*, 154*, 156*, 157*, Peronosporal59*, 160, Pythium 161*, 162, Saprolegnia 165*, 167*, 168*; Phaeophyceae Dictyota 292, 293, 294*, Fucus 297*; Rhodophyceae 31\%, 313*, 314, 319*, 320*, 322, 323; Saccharomycetes $602 \mathrm{ff} ., 606^{*}, 60^{-}, 608^{*}$, Saccharomycodes 611, Schizosaccharomyces 612*, 613*, 614*; Stephanokonten Derbesia 204, Oedogonium 211; Synchytriaceae 116*; Uredineae Gymnosporangium 657, 658*, Phragmidium 629, 630*; Ustilagineae Tilletia 623, Ustilago 620 ; Vaucheriaceae $84^{*}, 85^{*}, 86^{*}, 87^{*}$; Zygnemaceue 199; Zygomyceten $\mathrm{Pi}$ lobolus $132 *$, sporodinia $133^{*}$.

\section{D.}

DALE (Miss) über Gymnoascus 492-496 $\left(494^{*}, 495^{*}\right)$.

DANGEARD über Ascuskernfusion 440,441*, 467, Basidiomyceten Cytologie 666, 674, Dacryomyces 671, 673, Gametenkopulation 12, Monascus 499, Nyctalis 708, Pyronema 453, 457, Sappinia 398, sphaerotheca 451, 453, Sporodinia 131, Synchytrium 116, Taphrina 597, Tilletia 623, Tremella 670*, Uredineae 628, Ustilago $619 *, 620$.

DARAIN über Bakterien 330.

DARBISHIRE über Lichenes 547, 550*, 551 (Soredien), 555, 568.

DARWIN über Cyttaria 580, Pangenesis 68, $69,71$.

Dauer-Aplanosporen bei Conferva 215*.

Dauergametangien bei Rhodochytrium $38^{*}$, 39.

Dauersporen bei: Draparnaldia 187, Empusa $150^{*}, 151$, Synchytrium $114,115^{*}$, 117 , 132, cf. auch Dauerzellen und Cysten.

Dauerzellen bei : Ceratium 239*, 240, Chromulina 227, Cyanophyceae $374,375^{*}$, 376*, Dinobryon $230^{*}$, Draparnaldia 187*', 188, Hydrurus 228*, Peridineae $239 *$.

- Keimung 375.

Dauerzustände bei: Chlorochytrium 33, Mortierella 143, cf. auch Encystierungs-, Ruhe- und Ueberwinterungszustände.

DAvis über Albugo 153, 155, 157, Batrachospermum 315, Saprolegnia 165*, $167^{*}$, Vaucheria 86*, 87.

DE BARY über Acetabularia 96, Achlya 163*, Albugo 152*, Ascomyceten Neben- 
iruktifikationen 432, Asc. Sexualität $415-4: 6$ ( $\left.419 *, 423^{*}\right), 4 \div 6-431$ (427*), 450-46t, 467,469, Aspergillus 502 , Basidiomyeeten Phrlogenie 671, 672, Chara 747 , Chrrsomiva 648 , Cordyceps 515, Desmidiaceae 218*, 222*, Exoascaceae 599*, Hemibasidien 626, Lichenes j49, Mesotaeniaceae 195*, Myxomycetes 412*, 417, Nyctalis 707*, 708, Oedogonium 205, Onrgena 506, Peronospora 15.\%, Protomyces $447 *$, Tuberaceae Phrlogenie 509, Uredineae 639, 644, Ustilago 618*, 619*, Zygnemaceae 197*. Deckel der Peridineen 233, 234.

Degenerationserscheinungen, Saccharonycetes 607 .

Degeneration der Kerne cf. Nuklei.

DE SEYNes über Basidiomyceten 671, 708.

DE VRIEs über Pangenentheorie 68, Takuolen und Tonoplasten 65--70.

Dextrangärung 346.

Dextrose in Nährlösung 354.

Diaphragmenbildung bei Chorda 27s.

Diatomeenerde 242.

Dichotome Verzreigung bei: Dichotomosiphon 88, 89*, Dictyota 291, 293*, Fucus 298, Himanthalia 306, Laminaria 285 , Udotea 61.

Dichotomie (Pseudo) bei Bakterien 342, Vaucheria 79.

Dickenwachstum bei Fucus 298, Laminaria 236 , sicytosiphon 275 .

Dictyonema-Form bei Cora 693*, 694.

Dretel über Coleosporium 655*, Doassansia 625*, Gymnosporangium 655*, Phragmidium 629*, Ravenelia 660*, Urocystis 625*, Urompces 659\%, Ustilago $618^{*}$.

Differentialdiagnose 340.

Differenzierung innerhalb der Energide 56.

DILL über Gametenkopulation 10 .

Dimorphismus bei Dacryomyces 670 .

Diöcie 22, 209, 291, 307, bei Laboulbeniales 533, 534, 540.

Diöcische Formen, Entstehung bei Laboul. beniales 535 .

Diopsis thoracica Westw. als LaboulbenialesWirt 542.

Diphtherieheilserum 348.

Diphtherietoxin 347.

Diphtheritis 346.

Diphtheritische Membran 347.

Diplokonidien, Tremella 670*, Uredineae 628,632 .

- und Uredosporen 670.

Diplokonidiophoren 674.

Diplosporangien 326 (Polysiphonia), 435, $\mathbf{4 6 7}$ (Ascomyceten), 609, 615 (Iichenes), 674.

- als Gonotokont 467 (Ascomycetes).

- und Ascus 435, 451-453, 467.

- und Basidien 616.

DIPPEL über Caulerpa 75, Oedogonium 205.

Disjunktoren bei Sclerotinia 579.

Ditrsich über Helvellinaceae 586*, 587. Lotsy, Botanische Stammesgeschichte. I.
Drxon über Codium 77.

DODEL über Ulothrix 184.

Dominieren von Eigenschaften 12.

Doppelfärbung bei Bakterien 339 .

Doppelspore bei Desmidiaceae 223 .

DoRIs über Albugo 157*.

Dorsiventralität bei Caulerpa 74, Dichomyces 538, Erysiphales Perithecien 480 .

Dubourg über Mucor 135*

DUHAMEL über Getreiderost 638.

Dusch über sterilisierung 331.

Dyadenstadium 5:.

Drtiscideae als Laboulbeniaceae-Wirte 539.

\section{E.}

EIDAM über Basidiobolus 200, Basidiomyceten Befruchtung 671, id. Ascom. $419 *$.

Eier 14, 48, bei : Coleochaete 192, 193, Cutleria ‘84, Cylindrocapsa 185, 186*, Dictyota 291*, '292, 293, Fucus 296, 301, $302^{*}, 303$, Himanthalia 305*, Monoblepharideae $123 *, 124$, Oomycetes 154 , 155. 157, 160, 162, 166, 167*, 168, Padina 290, Sphaeroplea 107*, 108, Vaucheria $82^{*}, 83,89$, Volvocineae $21 *, 24$, $25,26$.

- deg'enerierte 302*.

- einkernige, Entwicklung aus der Coenogamete, Oomycetes $155,157,160, \mathbf{1 6 2}$.

- Freiwerden 29:2, 302*, 303.

- Nuklei 27, 85, 159*, 312.

- parthenogenetische $2 \%, 292$.

- Struktur 26.

- vielkernige 107, 108.

Eigenschaften (Aktivierung latenter) 12.

- Dominieren 12.

- Träger 13, 28.

- Vermischung elterlicher 11, 13.

Eiknospen, Charophyten 745.

Einfluß der Lebensbedingungen ef. Lebensbedingungen und auch Ernährung, Eintrocknen, Licht und Temperatur.

Einkapselung = Encystierung.

Einteilung der Eumyceten 665, Laboulbeniales 533, cf. auch Phylogenie und Stammbaum.

Eintrocknen, Resistenz 55.

- Ursache der Sporenbildung bei Mrxobakterien 388.

Eintrocknungsvermögen der Lichenen 557. EISENSCHITz über Saccharomyceten 606.

Eisenbakterien $342,356,357^{*}$.

Eiterbakterien 339,346 .

Eiter, blauer 349.

Eiweißstoffe 3, 349, 367, 370, 371.

Eizelle 13, 22, 27.

Elateren $410,+1: 3^{*}$.

EIENKIN über Psendevernia 567.

Emmericu ïber Ursache der Cholera 355.

Enıfängnisfleck $89^{*}$, 108 .

Empfindlichkeit des Plasmas ( Trolvox) 25. Encystierung bei: Chloramocba 212, $213^{*}$, Chromulina 226*, Mrxobakterien 359, Myxomyceten 415, Protosiphon 54, Pyra-

51 
midomonas $9 *$, Sapinia 397, 398, Saprolegnia 164, 165, Vaucheria 80.

Endknoten der Raphe bei Diatomeen 245*, $246,247^{*}$.

Endochiton bei Fucus-Oogonien 302, 303.

Endoperidium bei: Calostomaceae 7'22, Geaster 731*, Lycoperdon 729 .

Endophyllum-Gruppe der Uredineae 637.

Endosmose 147, 247.

Endospore bei: Bakterien 338, 346, 354 , 356, Cyanophyceae 375, Saccharom yceten $601,603^{*}$

Endosporium bei: Endosphaeraceae 32, 34, Hydrodictyaceae 40, 41, 47, Protomyces 446, Synchytrium 115.

Endplatten der Peridineae 234.

Energide $4 \mathrm{ff}$., 16.

-- Arbeitsteilung 4.

- Koloniebildung 4.

- nackte 111, Chloramoeba 212, Chromulina 225, Dictyotaceae 289, '292, Hymenomonaden 229 , Merolpidiaceae 114, 115, Monoblepharideae 1'24, Monolpidiaceae 11\%, 113, Ochromonaden 230, 231, Peridinales 232, Rhodophyceae 308, 312, 315, 326, Sappinia 397.

- Struktur bei Bakterien 337, 339, Cyanophyceae 362-372, Myxomycetes 402, Peridinales 237, 238*, Saccharomyces $603 *, 604,606$.

- Teilung 4, 31, Chlorangium 172, 173*, Coelastrum 178, Cystococcus 175, Hydrurus 228, Myxomyceten 394, 402, 417, Peridineae 238, Porphyra 307, 308.

- und Zelle cf. 'Lelle.

Energiequellen bei Pflanzen und Tieren 358.

Entstehung höherer Pflanzen 173, 194.

Entwicklungsformeln der Charophyten 749, 750.

- -gang der Ascomycetes 432, Charophyten $747^{*}, 748^{*}, 749,750$, Laboulbeniales $530,531 *, 546^{*}$. Uredineae 664 .

- optimum, Bakterien 346, Myxobakterien 387.

Enzyme 154, 178, 334, 350.

- bei Cyanophyceae 371, Erysiphe 474.

- zellwandlösende 154 .

Eosin als Reagens 65, 197.

Epidermisbildung (scheinbare) Bornetella 95, Neomeris 92, Valonia 99, 100*.

Epiplasma 436, $\mathbf{4 0}, 442,576,609$.

Epitheca der Diatomeae 245, 250.

ErIKsson: Uredineae 633, 640*, 641, 642, $643,644$.

Ernährung 2, 3, 17, 188.

- höherer Pflanzen 351.

- des Wirtes, Einfluß auf die UredineenInfektion 663.

- Einfluß auf die Fortpflanzung 43, 44, 47, 169, 177, 183, 184.

- - auf die Form der Konidienträger (Choanephora) 144.

- - auf die Gametangien 169.

- - auf die Gemmenkeimung 138.

- _ auf die Keimung der Chlamydospore 138.
Ernährung, Einfluß auf die Sporangienbildung (Thamnidium) 140 .

- _ auf die Zoosporen 169.

- - auf die Zygotenbildung 201.

Ernährungsweise, tierische, bei Chrvsomonaden 225, 229, Wysotzkia 230, 231.

Erneuerungssprosse bei Acetabularia 96, 97.

ERNst über Codiaceae 61, 62*, Dichotomosiphon $78,88,89 *$, Vaucheria 81, $83^{*}$.

ERRERA über Glykogen im Ascus 429.

Esterbildung bei Willia 605 .

Etat coccoide der Cyanophyceae 374.

Eu-Gruppe der Uredineae 635, Uromyces 658.

Eumycetes und Phyconoycetes 436.

EvANs über Infektion durch Uredineen 663.

Excipulum der Ascomyceten 422.

Exochiton der Fucus-Oogonien 302*, 303.

Exoperidium der Calostomaceae 72:, Geaster 731*, Lycoperdon 729.

Exosmose 247.

Exosporangiale 'Lygomyceten 436.

Exospore der Myxomyceten 404.

Exosporium Albugo 152, Cyanophyceae, Dauerzelle 377, Mucorineae 139, sporodinia 130, Synchytrium 115.

- Auswüchse 139.

Exsules (Chermes) 661, 662.

EIJKMANN über Schizosaccharomyces 612 .

\section{F.}

FAbricius al AQUAPENDale, Leuchtendes Fleisch 343.

Facettenrinde bei Bornetella 95.

Fadenbildung bei Bakterien 338 .

Fadenzerbrechung bei Mougeotia 196.

FAIRCHILD über Ameisenpilze 715, Basidiobolus 200, 201, Valonia 98.

Falagria dissecta Er. als Wirt von Laboulbeniales 535, 540 .

FALCK über Sporangienbildung bei Mucorineae 140.

FALK über Ustilaginaceae 617.

FAlKenberg über Cutleria 281*, Dasya $320 *$.

FAMINTZJN über Valonia 100*.

Farbeverlust 80.

Farbstoffe blaue, Diatomeen 248.

- blaugrüne 306,362 .

- braune 108, 114, 127, 128, 129, 193.

- braungelbe 108, 259.

- gelbrote 189, 362, 388 (Myxobakt.).

- goldgelbe in Perithecien 472.

- Lichenes 555 .

- orange $22,26,36$.

- rotbraune 88.

- rote $10,19,20,22,26,39,55,97,108$, 211, 306, 315, 449 .

- bei Bakterien 345, 346, 349.

- bei Hefen 601.

Farbstoffgrana der Cyanophyceae 364.

Färbungsmethoden 367 , bei Saccharomyces $603 *, 604$ 
FARMER über Fucaceae 297, 301, 302*, $304^{*}, 305$.

Farnsporangium und Diplosporangium 467 .

FAULL über Laboulbeniales 532, 535.

Fäulnisbakterien $35 \mathrm{~S}$.

Feisterling 697.

Ferment ef. Enzrme.

Fettbildung bei Monoblepharis 127.

Feuchte Kammer für Kulturen 335.

Fibrin in Kulturen 169, 353.

Frsch über Elaphomyces 510*, Ustilago 620.

Fischer über Bakterien 336*, 339, 341 (System), 347*, 353*, 354, 357*, Balsaminaceae 553, 584, Cronartium 649, Cyanophyceae 362 , 363-371, 367*, 370* (Cytologie), Crttaria 580, Elaphomyces 510*, Eutuberaceae 589*, 590, 591, 595*, Gasteromycetes 718, 720*, 721, 724*, $727,728,730^{*}, 732,735^{*}, 736^{*}, 738$, (Clathrus), 740 (Mutinus), 741 (Phallaceae), Leptomitaceae 171, Melampsorella 651, Monolpidiaceae 111, 112*, Onygena 505 .

Fixierungsmittel bei Ascomyceten (Nerkel) 454 , 459, Bakterien (auf dem Deckglase) 336, 337, Saccharomyceten 602.

FlahaUlt über Heterocysten 380.

Flechten, Algenkomponent cf. Algen.

- Farbstoffe ef. Farbstoffe.

- photosynthetisches Element 373.

- Pilzkomponent freilebend bekannt bei Cora 694.

FLöGEL, über Diatomeen 246.

Florideen pilz (Choreocolax) 328.

Flügelbildung bei Diatomeae 245̄, Peridineae 235

Fluorwasserstoff als Reagens 363, 364.

ForSELL über Apothecienentwicklung 548.

Fortpflanzung, Begriff 1.

- geschlechtliche cf. B efruchtung und Gameten und Gametangienkopulation und Sexualität.

- - Ursache $12 \mathrm{ff}$.

- ungeschlechtliche durch Akineten cf. Akineten.

- - durch Aplanosporen ef. Aplanosporen.

- - durch Arthrosporen cf. Arthrosporen.

- - durch Brutknöllchen ef. Brutknöllchen.

- - durch Chlamydosporen cf. Chlamydosporen.

- - durch Endosporen cf. Endosporen.

- - durch Fransen an den Thallomen bei Umbilicariaceae 562, 563.

- - durch Fragmentierung cf. Fragmentierung.

- - durch Gemmen ef. Gemmen.

- - durch Hormogonien ef. Hormogonien.

— - durch Hypnosporen ef. Hypnosporen.

- - durch Knospung ef. Knospung.

- - durch Konidien cf. Konidien.

- - durch Oidien cf. Oidien.

- - durch Pyknokonidien ef. Pyknokonidien.
Fortpflanzung, ungeschlechtliche durch Schwärmer cf. Schwärmer.

- - durch Soredien ef. Soredien.

- - durch Sprossung ef. Sprossung.

- - durch Streckung und Querteilung der Zellen bei Schizosaccharomyces 612 , $613^{*}$.

- - durch Teilung ef. Teilung.

- - durch Tetrasporen cf. Tetrasporen.

- - durch Zoosporen ef. Zoosporen.

- - Einfluß auf die Vererbung 76.

Fortpflanzungsorgane geschlechtliche ef. Antheridien und Oogonies.

- Verschleimung der Membran 83.

Fortpflanzungsweisen der Lichenen 550*, 551 , der Uredineen (Zusammenhang) 62 $\overline{7}$ '.

Fortpflanzungszellen (geschlechtliche) ef. Gameten.

Fossilien, Bakterien 353, Triploporelleae 94.

Fragmentierung als Fortpflanzungsweise bei Caulerpa 74.

FRANK über Bakterien $347^{*}$.

Fransen an den Thallomen bei Umbilicariaceaè 562, 563.

Fraser über Uredineae 633, 634*.

- und Blackmann über Humaria 465 ff. (465*, 466*), Pyronema 453, Sphaerotheca 451,453 .

Freeman über Chlorochytrium 33.

FRIEs über Pseudevernia 566.

Fritsch über Cyanophyceae 375, 376, 377, 382.

Fruchtbecher bei Sclerotinia 427.

Fruchthüllebildung bei Ascomyceten 420, 422, 424, Ascodesmis 461, 462, Aspergillus 501, 502*, Erysiphe 484*, Gymnoascus 493, 494*, Humaria 496, Monascus 449, 497*, 498, Peniciliium 503, 504*, Phyllactinia 486*, Pyronema 456*, Sphaerotheca $450^{*}, 451^{*}$, Thelebolus $574 *, 575$.

Fruchtkörper bei: Ascomyceten Ascodesmis 461, 462*, Aspergillus 562, Balsamia 583*, Claviceps 428*, Collema 424, 425*, Ctenomyces $496^{*}$, Cyttaria 580, Erremascus 41\%*, Erysiphe 471, 472*, $478,484^{*}, 485$, Eurotium 420, Eutuberaceae $593^{*}, 594,595^{*}, 596$, Gymnoascus 492, 494*, Helvellinaceae 585, 586*, 587, 588, 589, Hysteriales 582*, Melanospora 513*, Monascus 498, Nectria 426, Onygena 508*, 509, Penicilliopsis 505*, 506, 509, Penicillium 503, Phacidiales 580, 581*, Phyllactinia $486^{*}$, Podosphaeria 419*, 420, Polystigma 424, Pyronema $421^{*}, 456^{*}$, Sclerotinia $427^{*}, 580$, Thelebolus 575*, Xylaria 425*; Basidiomycetes Agaricineae 705, 706, 707*, 708 (Gomphidius), 709* (Russulacea), 710, 712, 713, 714* (Rozites), 715, 716* (Coprinus), Boletaceae $717^{*}$, Fistulinaccae 704, 706*, Paxillaceae $717^{*}$, Polsporaceae $700,701^{*}, 702,703^{*}, 704$; Gasteromyceten Broomcia 731*, 73., Calostomaccae 722*, 723, Clathraceac 737, 739*, Gasterolichenes $743^{*}, 744^{*}$. Hysterangium $735^{*}$, 
Lycoperdaceae 728, 729*, 731*, Mutinus 740, 741*, Nidulariaceae 732, 733*, Phallogaster 736*, Phallus 742, Pisolithaceae 723, 724*, Plectobasidiineae 719, Sclerodermataceae 720*,721, Secotium 740, $741^{*}$, Sphaerobolaceae $726^{*}$, Tulostomaceae 724, 725*; Myxobakterien 385, $387^{*}, 388,389 *$; Myxomyceten 342*, 393, 394* 398*, 399, 403, 404*, 405*', 409 ; Ustilago $618^{*}, 620,621$.

Fruchtkörper cf. auch Apothecien und Perithecien.

- angiokarpe, Euhymeniales 686, Eutuber $595^{*}$, Helvellinaceae 585, 587, Lichenes $558,568,569^{*}, 572,584$.

- Bau bei Balsamia 583, Basidiomyceten im allgem. 672, Erysiphales 479*, 480, Eutuberaceae 589*, 592, 593*, 595*, 596, Helvellinaceae 586*, 588, 589*, 590, Hydnocystis 584, Pilacre 668*, 669, Stereum 690, Thelephora 692.

- Differenzierung in sterile und fertile Partien bei Ascomyceten 505*, 506, 507, 509, 511, Corditubera 721, Melanogaster 721 , Pisolithaceae 723, 724*, Scleroderma 721 .

- Form bei: Cantharellaceae 687*, 688, Clavariaceae 687*, 688, Cyphellaceae 696, 697*, Gyrophana 699*, 700, Hydnaceae 695*, Peniophora 690, Stereum 690, Thelephoraceae 691, 692.

- gestielte Myxomyceten 409, 411.

- gymnokarpe bei Euhymeniales 686, Eutuberaceae 594, 595, 596, Helvellinaceae 587-589, Polyporineae 695.

- Hemiangiokarpe 686, 700, 705.

- Loslösung bei Erysiphe 480 .

- Oeffnungsweise 471, 59:2, 596 (Eutuberaceae), 726* (Sphaerobolus).

- Ur:ache des spontanen Abfallens bei Erysiphe 480.

- Wand bei Myxomyceten 402, 403, 407, 409.

Fry über Badhamia 394*.

FÜNFSTÜCK über Apothecien-Entwicklung 548, Peltigeraceae 557, 558*

Fundatrices spuriae (Chermes) 661, 662.

- verae (Chermes) 661, 662.

Fungi imperfecti vielfach als Nebenfruktifikationen von Ascomyceten 745 .

- polyphyletischer Ursprung 7, 17.

- parasitische 109.

- saprophytische 109.

Furfuracinsäure 567.

Fusion der Sporen bei Protomyces 446*, Taphridium $445^{*}$.

- des Oogoniums mit den Auxiliarzellen bei Rhodophyceae 324 .

Fusionsnucleus cf. Nucleus.

Fusionsplasmodium 391，393，395，402, 403.

Fusionszelle der Rhodophyceae 319, 320, 324.

Fuß bei Laboulbeniales 530, 531*.

Fußzelle der Rhodophyceae 319, 322*, 324.
G.

Gallenbildung durch Algen 35, 38, 328.

- durch Pilze 114, 115*, 116, 446, 598, $599 *, 622 *$ (Ustilago).

Gallerthülle $=$ Schleimhülle

Gallertstielchen 172, 173*.

Gametangien und Gametangienkopulation ef. auch Antheridien und Ooogomien; Allgemeines 32, 130, 10̈, 194, Ascom. $419,548,571$, bei Akontae 194; Ascomycetes: Ascobolus 423, Aspergillus 501, Dipodascus 444, Eremascus 419*, 420, Erysiphe 420, 485, Gymnoascus 493-496 (mehrkernige 494*), Melanospora 513*, Monascus 497*, 498, Phyllactinia 486, Podosphaera 420, Pyronema $421^{*}, 422,455,572$, Sphaerotheca 450* , 451; Asperococceae 266, 26?, 268; Cladophoraceae 104, 108; Chroolepideae $190^{*}$; Cutleriaceae 280, 283*, 284*; Dasycladaceae $90,91^{*}, 92-98,94^{*}, 96^{*}$; Desmarestieae 264*; Ectocarpeae 260, $262^{*}, 263^{*}$; Elachisteae 272*; Endosphaeraceae 32-39, 34*, 36*, 38*; Eudesmeae 273*; Fucaceae 301; Hydrodictyaceae 41,42*, 46; Myrionemeae 269, '270*, 271*; Oomyceten 152*, 154 ff., 159, 161, 169 (Saprolegnia), 170; Punctarieae' $274^{*}, 275$; Scytosiphoneae 275, 276, 277*, 278*; Siphonales 55; Siphoneae 57*, 63, 64*, 69; Vaucheriaceae 78, 83 ff.; Zygomycetes (gleichgestaltete Gam.) 130, 131*, 139*, 140, 142, 144*, 148, 149*.

Gametangien, Anordnung bei den Verticillaten 91, 95, 97.

- Differenzierung 63, 139, 263.

- Keimung 93.

- Kopulation als Entwicklungshemmung 131.

- Makro- 63, 64, 263*, 264.

- Mikro- 64*, 263*, 264*.

- Oeffnungsweise $36,38^{*}, 39$.

- plurilokulare 301.

- 'Träger 140.

- und Ascus 435, 444, 467 (Note).

- Verwachsung 95, 96. 97.

Gameten und Gametenkopulation, Hetero bei: Bangiaceae 307, 308*, 310; Chlamydomonas 14, 15*; Coleochaete 191*, 19.2*, 193; Cutleria 282, 284*; Cylindrocapsa 186; Dictyotaceae 290, 291, 292, 293; Ectocarpeae 261*, 263*; Endosphaeraceae $36^{*}$; Florideae $312,313^{*}, 314^{*}$, $316^{*}, 318^{*}, 319^{*}, 320^{*}, 322$; Fucaceae 296, 297*, 301*, 302*, 304*, 305; Monoblepharideae $124,126^{*}, 127^{*}, 128^{*}, 129^{*}$; Ocdogonium 210*, 211; Olpidiopsis 113*, 114; Oomycetes 151, Achlya 164, Albugo 152*, 156, 157*, Peronospora 159*, Pythium 161*, Saprolegnia 166, 167; Siphonales 57*, 64*; Sphaeroplea $107^{*}, 108$; Vaucheriaceae $78,82^{*}, 83$, 88, 89*; Volvocineae 21*, $22,24^{*}$, 26: Zygnemaceae 198; Zygorhizidium 121. 
Gameten und Gametenkopulation, Iso: 10, 27, 198; Akontae 195*, 197*, 198, 200* 201; Albugo 154, 155; Chroolepideae 190*; Chlamydomonas 10, 11*, 15*; Cladophoraceà 10t, 107; Chromulina 173; Dasycladaceae 91*, 93, 96*, 97; Desmidiaceae 222, '223; Diatomeae 251, 252*. 253*, 255*; Endosphaeraceae 32*, 33, 34*, 35, 38*, 39; Hydrodictyaceae $40^{*}, 41,42^{*}, 46,48$; Isokonten Allg. 15; Lagenidinm 117, 118*; Monostroma 181; Peridinales 239, 240*; Phyllitis 276; Polyphagus 120*; Polytoma 16*; Pringsheimia 189; Protosiphon 54*, 55; Punctaria 275; Tetraspora 180*; Ulothrix 183, 184*; Ulva 181; Volvocineae 20*; Zygomycetes 130, 131*, 138, 139*, $148,149^{*}$.

- Iso, von verschiedenen Individuen herrührend 91, 93, 97 (Dasycladaceae). Gameten, Anheftung bei Ectocarpeae 260, $26 \ddot{3}$.

- Austreten aus den Gametangien 261, 276.

- Bewegung 10, 22, 40 .

- Bildung, Verhalten der Vakuolen, Codium 69.

- cilienlose 124, 198.

- Differenzierung 326.

- gegenseitige Anziehung 22.

- Kopulation im allgemeinen 10, $12 \mathrm{ff}$. $27,48,183,184$.

-. membranlose 15.

- Nuklei 50, 154* (Kopulation).

- Ursache der Kopulation 12 ff.

- ungetrennt bleibende 130.

Gametophyt 2S0, 282.

Gärung, alkoholische 138, 504.

- Buttersäure 353.

- Dextran 354.

- Milchsäure 340.

- Saccharomyces 606, 607

GAY über Conferva 215*, Ulothrix 184*.

GAYoN über Mucor 135*.

Geißelfärbung, Bakterien 336.

Geißelspalte, Peridineae 233, 2:37.

Gelatine verflüssigende Bakterien 334, 344.

Gemmen bei Chlamydomucor 137*, 138; Entomophthora 146, 149*; Monoblepharis 126*; Mortierella 142*; Saprolegnia 168, 169; Sphaerobolaceae 726*, 727.

- Keimung 146, 147**149*, 150*.

_- fruktifikativ 137*, 138, 438 (Ascomyceten).

- - vegetativ 137*, 138.

- Vermehrung durch Sprossung 138.

- Zusammenbleiben 150.

Generatio aequivoca 359.

x-Generation 48 ff., 314; Begriff 49; bei Anaptychia 569; Ascomyceten 418, 428, 435 ; Basidiomyceten 616, 665, 674, 675, 676; Charophyten 748; Cutleriaceae 280, 282; Desmidiaceae 224; Diatomeae 252, 253, 256; Dictyotaceae 290, 291; Exoascus 598; Fucus 304, 305, 309,
310, 314, 317; Peziza 575; Tuberaceae 742 ; Uredineae 628, 631*, 633, 635, 636. $\mathrm{x}$-Generation $\mathrm{cf}$. auch $\mathrm{Nuklei}$, einkerniges Stadium.

- Entwickelungsmöglichkeiten 194.

2x-Generation 48 ff., 173, 193, 194, 293, 314, 324; Begriff 49; Anaptychia 569; Ascomycetes 418, 428, 435, Erysiphe 485, Galactinia 458, Humaria 466, 467, Laboulbeniales 532, 543, 545, 546*, Peziza 573, Pyronema 457, Sphaerotheca 451 -453; Basidiomyceten 616, 665, 674, 675, 676; Charophyten 748; Coleochaete 193; Conferva 216; Cutleriaceae 280; Diatomeae 252, 253; Dictyotaceae 290, 291, 293; Endophyllum 647; Exoascaceae 598; Fucus 304; Gasteromycetes 742; Nyctalis 708; Rhodophyceae 308, $309,310,314,316,317,321$, 324 ff.; Saccharomycetes 609,615 ; Saprolegnia 168; Uredineae 628, 631, 632*, 633, 635, 636.

- cf. auch N u klei, zweikerniges Stadium.

- Dauer des zweikernigen Stadiums $50 \mathrm{ff}$. - einkerniges Stadium 51.

- Entwicklung bei Rhodophyceae 325.

- freilebendes Stadium 310, 320.

- Größe 309, 316.

- Parasit auf x-Generation 310, 314, 317, $319,320,325$.

- Verschmelzung der Kerne 50 ff.; cf. auch Nuklei, Fusion.

Generationswechsel 37, 48, 49, 51, 88, 114, 192, 289; Uredineae 628, 633, 635.

- Bedeutung 201.

- obligater bei Ascomyceten 453 .

Geotropismus 59.

Gerassmofe über Kern und Cytoplasma 488.

Gerbsäure als Glykogenreagens 367.

Geschlechter, Verteilung 27.

Geschlechtsbestimmung bei Laboulbeniales 535.

Geschlechtsfunktion, Verschwinden bei Ascomyceten $424 \mathrm{ff} ., 465$, cf. auch sexualität.

Geschlechtsorgane, Verschwinden bei Ascomyceten $424 \mathrm{ff}$.

Geschlechtspflanzen (Rhodophyceen) 326.

- als x-Generation 310.

Gewebebildung cf. auch Thallusaufbau ; Asperococceae 267*, 268, Chorda 279*, Codiaceae 61, 62, Cutleriaceae 284\%, Desmarestieae 264*, Dictrotaceae 289, 291, Elachistene 272*, Eudesmeae 273, Laminariaceae $286,287 *$, Mrrionemeae 269, Scytosiphoneae 275, 276*, 27.*, $278^{*}$.

Gewebedifferenzierung 61, 25\%

Gibson (Miss) über Tredineen-Infektion 663.

Gresenhagex über Charophyten 749 , 750, Exoascaceae 597.

Giftigkeitsorad, Formel 345.

Gipsblöckchen (Fporenbildung der Hefen auf) $60^{\circ}$. 
Gipskriställchen der Desmidiaceae 219.

Gleba, Allgemeines 718, 719; Calostomaceae 723 ; Clathraceae 737; Eutuberaceae 594, Hymenogaster 734; Hysterangium 735; Lycoperdaceae 728, 729, 730*; Phallaceae 740; Phallogaster $736^{*}$, 737, Sclerodermataceae 720, 721; Secotium 740; Sphaerobolaceae 726, 727; Tulostomaceae 724 .

Gleba (Auswerfen der) bei Sphaerobolaceae $726^{*}, 727$.

- Differenzierung, Geaster 731, Lycoperdon $729,730 *$.

- Kammer 718, 728; Clathraceae 739*; Geaster 731; Hymenogaster 734*; Hysterangium 735*; Lycoperdon 729, 730; Nidulariaceae 732; Octaviana 732; Phallogaster $736,737$.

- Keimung als Ganzes bei Sphaerobolus 727.

Gliederzelle der Charophyten 748*, 749.

Glukose, Einfluß in Kulturen 201, 202.

Glykogen Ascomyceten 429, Saccharomyceten $604,605,606^{*}, 607,608^{*}, 609$, Schizophyceae 366, 368, 371, 373.

- Lokalisierung 366.

- lose Hefen 612, 614.

- Reaktion 366, 367.

- Vakuole (Saccharom.) 606*, 607.

- Verbrauch (Saccharom.) bei der Sporenbildung 609, 611, Sporenkeimung 609, Sprossung 607.

Glyzerine, Einfluß in Kulturen 202.

GoEBEI, über Eudorina 21*,22, Merismopoedia 381, 383, Wendezellen der Charophyten 753 .

GOETZ über Vaucheria 79, 81, Wendezellen der Charophyten 753.

Gonen 49, 50, 52, 55 .

- Rudimentärbleiben 55 .

Gongrosira-Zustand bei Vaucheria 80.

Gonidangien der Cranophyceae 378, 350, 381.

Gonidien der Cyanophyceae 374, 381, Lichenen 549.

- als modifizierte 'Zoosporangien 381.

Gonimoblasten bei Batrachospermum 315.

Gonotokont 4S-52; Desmidiaceae 224, Diatomeae 256.

- Ascus bei Sphaerotheca 453, $\mathbf{4 6 7}$.

- Basidie 674.

- Definition 4S.

- Diplosporangium 467.

- Entstehung der $2 x$-Generation 51.

- Teleutospore 628, 656, 664.

- Tetraspore, Dictyota 293; Florideae $310,311$.

- Zentralzelle oder Produkte, Florideen 314,320 .

- Zygote Cylindrocystis 195; Desmidiaceae 2\%4; Diatomeae 256; Florideae 309; Oedogonium 211; Protosiphon 55, Sphaeroplea 108.

GoROsCHANKIN über Chlamydomonas 9*, $10,11^{*}, 15^{*}$, Eudorina 22.

GraM über Mikrosporen bei Diatomeae $249,254$.
Grant Smith über Haustorien bei Erysiphe $473,474^{*}, 475^{*}, 476^{*}, 477^{*}$.

Granulae (Altmannsche) 67, 71 .

- (Nukleäre) bei Hefe 604 .

- (Wolfe'sche) bei Rhodophyceae 312.

Grenzzellen der Cyanophyceae 374, 378* ff.

Gruber über Derbesia 204*, Padina '288*, Spirogyra 198, Sporodinia 130, 131*, Udotea $63 *$.

GUIGNARD über Fucus 304*.

GUILLIERMOND über Ascomyceten 452, Cytologie der Saccharomycetes $602 \mathrm{ff}$., 603*, 606*, 608*, 613*, 614*, Ustilago 6:0.

Gürtel bei: Desmidiaceae 221, 222, Diatomeae 242, Peridineae 233, 235, 240.

Gürtelpanzer der Peridineae 233.

Gymnokarpie bei: Euhymeniales 686, Eutuberaceae 594, 595, 596, Helvellinaceae 587, 588, 589, Polyporineae 695.

Gynophor bei Ascodesmis 459, 460*, 461*. Gy ridae als Wirte von Laboulbeniaceae $546^{\circ}$.

\section{H.}

Haarbildung bei: Asperococceae 265, Auricularia 667*, 668, Chaetophoreae 187, 188, Chorda 279, Codium 63, Coleochaete 191, Cutleria 281*, 283, Cylindrocapsa 186, Dasycladaceae 91, 93, Dictyotaceae 289, 292*, Ectocarpeae 259, 263*, 264, Elachistea 271, Eudesmeae 273, Fucaceae 298 ff., Myrionemeae 270, Perithecien (Chaetomium) 320, (Sordaria) 521*, Punctarieae 274*, Scytosiphoneae 275.

Haarbüschel '̌74*, 275, 281, 283, 292, 299.

Haare, gefärbte 271.

Haargrübchen, Fucus 298*, 299, Sargassum 299, 300*, 301*.

Haar (Scheiden-) 191.

Hafter bei Struvea 101*, 103.

Haftscheibe (cf. auch Basalscheibe) 285; Fucaceae 288, 298.

Hakenbildung bei der Ascusbildung cf. Ascusbildung.

- an Sclerotien von Ctenomyces 496*.

Hakensporangium der Chroolepideae 190.

Halichondria als Symbiont mit Struvea 103.

Halszelle der Antheridien der Laboulbeniales 532.

Hämoglobin in Kulturen 169.

Hängetropfenkultur 335 .

HANSEN über Saccharomyceten 601, (System) 604, Saccharomycodes 610 .

Haplosporangium 435, 436, 437, 615 (Saccharomyces).

- und Ascus cf. Ascus.

HARPER über: Ascobolus 577, Ascosporenbildung 439*, Erysiphe 484*, 485*, Мyхоmyceten 413, 414, 415*, Phyllactinia 486*, 487*, 488*, 489*, 490*, Pilobolus 132*, Pyronema 453, 455*, 456*, 457*, Sphaerotheca 450 ff., Sporodinia 133*, Synchytrium $116^{*}$. 
Hartig ïber: Calvptospora 653*, Grrophana 699*, Hexenbesen 651, 652*, Nectria $4^{\circ} 6,513^{*}$.

Harz über Monascus 497 .

Hasserk AMP über Chylocladia 321*, 322*, 3ำ.

HAUCK über Himanthalia $305^{*}$.

HAUPTFLEISCH übel Schleimbildung bei Desmidiaceae 2:0*.

Haustorien bei: Albugo 152*, Calyptospora 654, Empusa 146, Erysiphe 471, 473 ff., 474*, Peronospora 158, Phyllactinia 476, $477^{*}$, Piptocephalis 145*, Uncinula 475, $476^{*}, 478$, Uredineae 642 .

Hautbildung; Bakterien 336*.

- (Kahm-) cf. Kahmhaut.

Hautschicht, Allgemeines 65, 67, 71, Bakterien 37\%, Hrdrodictyon 41,42*,43*, 15, Myxomycetes 39.2, 404, 413*, Pyramidomonas 8, Ulothrix 183.

HECKE über Ustilagineae 617 .

Hefe, Färbung 603*, 604.

- Fixierung 602.

Hefekonidien bei Taphrina 438 .

Hefekultur 602.

Hefesprossung cf. Sprossung.

Hefe, Verwendung 691.

Hefezelle, Bau 601, 603*.

Hegler über Cyanophyceae 362, 364, 366, 378.

HeINRICHER über Sphaeroplea 107*.

Heliotropismus 344.

Hellek, J. F. über leuchtende Bakterien 343.

HellRIEger, über Assimilation des freien Stickstoffes $35 ̃ 1$.

Hemiangiokarpie 686, 700, 705.

Hemiasci (Deutung der BREFELDschen Gruppe der) $443,444,446,447,449,467$.

Hemiascus 497.

Hemibasidien, Auffassung 617, 620, 626.

Hemi-Gruppe der Uredineae 636.

HeNLE über Bakterieninfektion 330 .

HrNNings über: Agaricineae 707*, 709*, 710, 712*, Boudiera 459, Gyrophana 699*, Peniophoraceae 689*, Polyporaceae 701*' $702^{*}$

Herbst über Metamorphose bei Tieren 59 .

Hermaphrodite Blüten, Bildung durch Pilzreize 621,622 .

Hermaphroditismus 64, 129*, 296.

Hernienkrankheit 400.

Hertwig, R. über Kern und Cytoplasma 488.

Heteröcie 633, 662 cf. auch Wirtswechsel.

Heterocysten der Cyanophyceae 378*; Auffassung 378, 379; Keimung 378*, 379.

Heterogameten ef. Gameten.

Heterogamie 198, 257.

- (Entstehung der) 153.

Heteromerer Thallus bei Lichenen 550*, 551,552 .

Heteromorphose bei Bryopsis 60, Tieren 59.

Heterotypische Kernteilung 193.

HétreR über Tulasnella 679.

Hexenbesen 598, 651 (Melampsorella), 652*
Hieronymus äber Grenzzellen der Cranophyceae 378, Stephanosphaera 20*.

HINGsT, J. über Laminariaschwärmer 287 , Taucheria 81.

Hinterhorn der Peridineae '234.

HrRN über Oedogonium 205, 209*, ‘10*.

HOFFMANN über sterilisierung 331 .

Hofmerster über Oedogonium, Zellteilung 205.

Homocelluläre Organismen 117, 121.

Homologien der Ascomyceten cf. Ascus und Ascomyceten.

Homöomerer Thallus bei Lichenen 551.

Homöotypische Kernteilung 193.

Honigtau des Roggens 519.

Hormogonien der Bakterien 342; Cranophyceae 361, 362, 379, 380, 382 (Bewegung).

Hörner der Peridineae 234, 235*, 236.

Howe über Acetabularia 98.

Hummer, Heteromorphose 59.

Humphrey über Achlya 163.

Hunger als Ursache der geschlechtlichen Fortpflanzung $1 \% \mathrm{ff}$.

Hybriden 12, 13, 27, 129 (Monoblepharis), 296 (Fucaceae), 635, 664 (Uredineae).

- Mendeln bei Uredineae 664 .

- vegetative 635.

Hydra viridis $175,176^{*}$.

Hydrocombus als Wirt bei Laboulbeniales 546.

Hygroskopizität 136, 140, 147, 410.

Hygroskopische Krümmungen 410.

Hymenialgonidien 550*.

Hymenialzellen (ascusbildende) bei Exoascaceae $\overline{0} 97$.

Hymenium und Hymeniumbildung bei Albugo 151, Ascomycetes (Allg.) 42\%, 426, Auricularia 667, 668, Balsamia (Verteilung) 583*, 584, Boletaceae 717*, Cantharellaceae 689, Cantharellineae 586, 687, Clavariaceae 688, Cora 693*, Cyphellaceae 696, 697*, 699*, 700, Dacryomvces 672, Eutuberaceae $589^{*}, 591$. 592, 593*, 595*, 596, Exobasidium 671*, Fistulinaceae 704, 706*, Gasteromycetes 718, 719, Gyrophora 563*, 561*, Helvellinaceae 585, 586, 587, 589*, 590, Hrdnocystis 584, Hrdnum 694, 695*, Hymenogaster 734*, Ḧrsterangium 735*, Lycoperdaceae 728, 729*, 730*, '731, Nidulariaceae 732, 733*, Paxillaceae 717, Polyporaceae 695, 700, 701*, 702*, 703*, 704*, Sclerodermataceae 721, Secotium 740, Thelephoraceae 691, 692*, Tremella 669 .

- Kammer der Gasteromycetel 719.

Hrpertrophie, hervorgerufen durch ( $\mathrm{C}^{\mathrm{a}}$ Iyptospora 653, 65 4 , Erysiphe 475, 476*, Exoascaceae 598, 599*, Plasmodiophora $400^{*}$, Sphaerotheca $477^{*}$, Srnchrtrium 114, 116 , Urocrst is 626 , ['stiligincate $617,\left(118^{*}\right.$.

Hyphen ascogene of. Iscogene Hyphen.

- (Hiill-) der Ascomrecten bei: Ascodesmis $4\left(61,46^{*} *\right.$, Erviphe $4 t^{*}$, Grmno- 
ascus 493, 494*, Humaria 466, Monascus 449, 497*, 498, Phyllactinia 486*, Pyronema 456*, Sphaerotheca $450 *$, 451*, Thelebolus 574*, 575 .

Hyphen (Milchsaft-) bei Agaricineae 706, 709, 710, Russula 710, Sparassis 698.

- monoenergide 571, 574* (Thelebolus).

- (Pinsel-) 471, 472*, 481, 482.

- polyenergide 571, 572 (Discomyceten), 642 (Puccinia).

- septierte der Hysteriales 582, Phacidiales 680.

- (Stütz-) bei Ascodesmis 461.

- (Synkarion-) bei Galactinia 457*, 458; 573.

- Woroninsche 426.

Hypnocystenbildung bei Ulothrix 184*, 185. Hypnosporen $184^{*}, 185$.

Hypothallus der Myxomyceten 407, 408, 410.

Hypotheca der Diatomeae 245, 250.

Hypothecium der Ascomyceten 422.

\section{I.}

Ikeno über Monascus 448*, 449, 498, 499*, 500, Taphrina 597.

Immunisationsfrage bei Bakterien 663 , Uredineae 662 .

Immunisierung, aktive 348 .

- positive 348 .

Immunität 348, 349.

Impfung 348.

Individuen (Loslösen der) bei Mougeotia 196.

- ungeschlechtliche bei Porphyra 307, Volvocineae 19, 25, 27.

Indusium bei Dictyophora 741 .

Infektion bei physiologischen Arten 483, 484 .

- durch Claviceps 519, Getreiderost 639, Ustilagineae 617, 618, 621, 624 (Tilletia), 626 (Tuburcinia).

- in großer Entfernung 641.

Infektionskrankheiten, Ursache 330.

Infektionskreis der Uredineae 643, 644.

Infektion und Resistenz 663.

Initialzelle der Haargrübchen der Fucaceae $299,300^{*}$.

Inkrustierung mit Kalk ef. Kalkinkrustierung.

Intercellulare Pangenesis 67, 6 S.

Interkalare 'Zelle bei Phragmidium 629, 630*, Uromyces 634*.

Interkalarstreifen der Peridineae 236, 237*.

Internodien bei Caulerpa 76, Charophyten $745,747 *, 748$, Phaeophyceae 258, '264, 266.

Internodienzelle der Charophyten 748*, 749, 750 *.

Involutionsformen der Bakterien 347*, 351.

Isariazustand bei Cordiceps 517*, 518 .

Isidien bei Pseudevernia 567.

Isogame Befruchtung 185, 186.

Isogameten cf. Gameten.

- Kopulation cf. Gametenkopulation.

Isoganie 191, 198, 257.

Isokonten 110, Entstehungsmöglichkeiten 15.
IsTVANFFI über Auricularia 668, Dacryomyces 671, Nyctalis 708, Russulaceae 710 , Ustilago $6: 0$.

\section{J.}

JANSE über Caulerpa 75*, 77.

JANssEns über Kernfusion der Saccharomyceten 609.

JENNER über Kuhpockenimpfung 349.

Jodalkohol als Fixierungsmittel bei Bakterien 337.

JoHow über Cora 693*, 694 .

Judenbart 697.

JUEL über Auricularia 667, Basidiomyceten Cytologie 666, Phylogenie 676, 677, Dacryomyces 671, Dipodascus 443*, 'Taphridium 445*, Tulasnellaceae 679, $680^{*}, 681^{*}$.

Jugendstadien der Rhodophyceae 311, 314*. JURYANI über Oedogonium 210*.

\section{K.}

Kaffeeblattkrankheit 658

Kahmhaut Doassansia 626, Saccharomycetes 604,605 .

Kalisalpeterlösung als Reagens 65 .

Kalkabscheidung bei Myxomyceten 394, 408, 409, 411.

Kalkblasen der Myxomyceten 407, 412*.

Kalkinkrustierung bei Codiaceae 61 , Cyanophyceae 374, Dasycladaceae 90, 92, 93, $94 *, 95,97$.

Kalkoxalat bei Gyrophana 699*, 700 .

- Nadeln bei Mucor 136, Thamnidium 140.

Kampf ums Dasein 12.

Kappe bei Oedogonium 205, 206; Bildung 205, 206 ff., 207*, 208*.

Kappenzelle 205, 207*, 208*.

KARSTEN: über Basidiomyceten 6:1, Chroolepideae 190*, Diatomeae 248. 251, $253 *, 254.255 *$.

Karyoiden bei '/ygnemaceae 197.

- Funktion 197.

Karyokinese 45, 51, 52, 85, 87, 98, 207, 402, 576* (Thelebolus), 598 (Ascussporenbildung), 6:29 (Phragmidium).

Käsereifung 355 .

Keimpflänzchen bei Cutleria 281*, 282*, $283^{*}$; Ectocarpaceae 265, 266, 268, 272*, $273^{*}, 274^{*}, 275,277^{*}, 278^{*}, 279^{*}$; Laminaria 285; Phaeophyceae 288, 292*, $297 * 305 *$.

Keimporus der Basidiosporen 711, 715 .

Kern $=$ Nucleus.

- Faden 28, 51, 52, 293.

- (Klein-) der Diatomeae 251, 252, 255.

- Membran, Auflösung 29.

- Pol 29.

Kernsäckchen 197, 249, 250.

Kiefernräude 649.

Kieselgur 241.

Kieselmembran bei Diatomeae 242, .256, Hydrurus, Dauerzellen 228.

Kieselschichtenbildung bei Cyanophyceae 374. 
Kimlarax: : ̈̈her Melanospora 513*, Pyronema $421 *$.

KrrchNer über Basidiomyeeten 6:1, Volrox $24 *, 27$.

KJellataxy über Acrosiphonia 106*, Castagnea 274, Derbesia 204, Ectocarpaceae $25 \%$.

KLLEBAHN : ïber Closterium 55, 223*, 224; Diatomeae (Auxosporen) 251, 252*; Oedogonium 210*; Sphaeroplea 107*, 108; Uredineae $638 \mathrm{ff} ., 661-664$.

KLeBs über Bakterien 331, 332, Chlamydomonas 13, Conferva 215*, Desmidiaceae $220^{*}$, Draparnaldia $187^{*}, 188$, Endosphaeraceae $32^{*}, 33,34^{*}, 35,36^{*}, \mathrm{Hy-}$ drodictyon $8,42^{*}, 43,44,47$, Hydrurus $228^{*}$, Óchromonaden 230*, Protosiphon 53, $4 *$, Saprolegnia 168, 170, Sporodinia 139, 140, Ulothrix 183*, 184, Vakuolenbildung 70 , Vaucheria 82,88 .

KIJEIN über Volvox 23*, 24, 28.

Kleinkern der Diatomeae 251, 255.

KLEMM über Regeneration bei Caulerpa 7t, Valonia 99.

Knöllchenbildung bei Penicilliopsis 505*, 506.

Knospenbildung bei Protosiphon 54*.

Knotenbildung bei Caulerpa 76, Charophyten $745,748^{*}, 749$, Phaeophyceae 2.58, 261, 266.

- Zelle der Charophyten 748\%, 749, 750*.

- - (erste) De Bary 746, 747*.

KNy über Mucoraceae 134*.

Koagulation von Milch durch Bakterien 340.

KocH über Bakterien 332, 355.

KoHL über Cranophyceae 366, 369, 371, $379,381$.

Kohlehydrate, Einfluß auf die Zygotenbildung 140 .

Kohlhernien 401.

Kollenchymschicht der Calostomaceae 722.

Kolonien und Koloniebildung 4, 5, 15, 30; Bakterien 338, 341，345，350, Chlorangium 172, 173*, Chrysosphaerella 229*, Cyanophyceae 374, Diatomeae 248, '249*, Hydrodictyon $40 *$, Hydrurus '28, 230*' Mesotaenium 194, Myxobakterien 387, Ochromonaden 230*, 231, Peridineae 239, Scenedesmus 177, 178, Volvocineae 16, $18^{*}, 19,21-25,24^{*}, 30$.

- Ausschlüpfen der Tochterkolonien 19, $22,26$.

- bewegliche bei Chrysosphaerella 229*, Ochromonaden 230, 231, Volvox $23 \mathrm{ff}$.

- (Eigenschaften der verschiedenen) 25.

- verzweigte 231.

Konidien und Konidienbildung bei: Ascoidea 442, Aspergillus 501, 502*, Basidiobolus 200*, Coprinus 716*, Dematium 603*, 604, Dichotomosiphon 81, 89, Dipodascus 443, Erysiphe 471, 472*, 473, Exobasidium 691, Fistulina 685, Lichenes 550*, 551, Monascus 449, Muciporus 68' (bei der Keimung der Basidien), Myxomyceten 404, Oomyceten 151, 152, 158*, Penicilliopsis 505*, Penicillium 503, 504*,
Pilacre 668*, Rhytisma 581*, Rozites $714^{*}, 715$, Sclerotinia 579*, Thelebolus 577, Tilletia $619,623,624$, Tremella $670^{*}$, Tuburcinia $624^{*}, 625$. Zygomyceten 131 , $134,141,145^{*}, 146,148,149^{*}, 150 *, 151$. Konidien als Nebenfruktifikation bei Ascomyceten 425*, 432, Aspergillus 501, Ctenomyces 496*, Gymnoascus 492, 494, 495*, Meliola 492, Monascus $448^{*}, 449$; Basidiomyceten 671.

- als reduzierte Zoosporangien 81, \$9, 131, 132.

- Anordnung bei Mucorineae 134.

- Ascomyceten, Auffassung Brefelds 434.

-n Ausschleuderung 147, 148.

- Basidiomyceten, Auffassung als Spermatien 671.

- bildendes Stroma 527*, 528*.

- Bildungsweisen bei Ascomyceten 432.

- Bildung, Bedingungen bei Erysiphe 478.

- Generation der Ascomyceten 432, Chaetomium 520, 521*, Claviceps 518*, $519^{*}$, Cordyceps 517*, 518, Cucurbitaria 522*, 523, Erysiphe (Anpassung an bestimmte Arten) 483, Hypocrea 515*, Hypoxylon 527*, Melanospora 513, Nectria 513, Xylaria 526, 528*.

- Keimung 158*, 159, 442* (Ascoidea), 483, 579 (Sclerotinia).

- - fruktifikative 147*, 148, 442* (Ascoidea).

- - vegetative $145^{*}, 146,147^{*}, 152^{*}, 442 *$ (Ascoidea), 619* (Ustilagineae).

- Ketten 145, 146, 152.

- - und Sporangien 146.

- Kopulation bei Doassansia 621, Tilletia $619^{*}, 623$, Ustilago $619^{*}$

- multinukleäre $150^{*}, 151,152$.

- Mycelium bei Tilletia 625, Tuburcinia $624^{*}, 625$.

- Träger bei Aspergillus 501, 502*, Basidiobolus 200, Fomes 701*, Oomyceten 152, 158*, Penicilliopsis 505*, 506, Penicillium 503, 504*, Pilacre 668*, Rhytisma 581*, Tremella 669, Zygomyceten $144^{*}, 145 *$, $146,147^{*}, 148,150,151$.

- Träger und Basidien 436, 616, 67t.

- - verzweigte $148,149^{*}, 150^{*}$.

- und Basidiosporen 674, 675.

- und Sporangien 190.

- und Sporangiolen 141, 146, 147.

- und Zoosporangium 159.

- Verbreitung bei Sclerotinia 579.

Konidiophor $=$ Konidienträger.

Konkavzellen bei Cranophryeae 381 .

Kontagium vivum 330.

Kontaktreiz 58, 59, 74, 79.

Kontraktionen als Bewegungsursache der Cyanophyceae 38\%.

Konzeptakel der Fucaceae $295^{*}, 299,300^{*}$, $301^{*}, 303^{*}, 305$.

- (Tetrasporangium) Rhodophyc. 32-

Köptehen an Manubrium der Charophyten $746,751^{*}$.

Kopulation (rergl. anch Gameten und Gatmetangienkopulation) $10,11,1: 2,14,105$ : 
Ascomyceten 420, 421* (Pyronema), 422, 423 (Collema), 424, 434*, Aspergillus 501, 502*; Basidiobolus 200; Desmidiaceae $222 *$ ff, ; Diatomeae $251 \mathrm{ff}$., 252*: Endosphaeraceae 33, 35*; Lagenidium 117, 118*; Monoblepharis 127; Mucorineae 138; Oomyceten 153*; Peridineen 239, 240*; Saccharomyceten 605 , 610, 615, Saccharomycodes 610, 611, Schizosaccharomyces 613*, 614*, Zygosaccharomyces 605, 610; Volvocineae 20*, 26; Zygnemaceae 27, 197* ff.

Kopulation, Ascomyceten $=$ vegetative Schnallenbildung Brefeld 435 .

- knieförmige 198.

- seitliche 199.

-- zwischen benachbarten Zellen des gleichen Fadens 443* (Dipodascus).

- zwischen Konidien cf. Konidienkopulation.

- zwischen Oogonien und Antheridien bei Ascomyceten 450*, 452 .

- zwischen Oogonien und einer vegetativen Zelle bei Phragmidium 630, 631, 632*, Puccinia 634, Uromyces 633.

- zwischen Oogonien (zwei) bei Uredineen $628,629,630^{*}$.

- zwischen Sichwestergameten 33, 254.

- zwischen Trichogyne und Antheridium bei : Ascodesmis 460, 461*, Pyronema $422,454,455^{*}$.

- zwischen Trichogyne und Spermatien $424,432,464$.

- zwischen zwei Individuen bei Akontae 194, 195*, 197 ff., Desmidiaceae 223, 224, Diatomeae $25^{\circ}$ ff., Empusa 148, 149*, Lagenidium 118*, Mucor 138, Polyphagus 120*, 121, 'Zygnemaceae 197* ff.

- zwischen zwei vegetativen Zellen 630 , Leptopuccinia 637, Puccinia 634, Uromyces 633, 634*.

- zwischen zwei weiblichen Kernen bei Humaria $466^{*}, 467$.

- zwischen zwei Zweigen eines Individuums bei Lagenidium 118, Zygnemaceae $197 \mathrm{ff}$.

Kopulationskanal 195, 198, 223, 224.

Kopulationspapille 154 .

Körner (rote) von BÜTsCHLI 604.

Körnerplasma 41, 42*, 64, 65, 67.

KRABBE über Apothecienentwickelung §48, Baeomyces 556, Cladonia 570, 571, Pertusaria 560, 561, Podetien 556.

Kraskovits über Oedogonium 205, 206, $207 *, 208 *$

Krebsgeschwülste 401.

Kriebelkrankheit 520 .

KrombHoLz über Nyctalis 708.

Krönchen der Charophyten-Oogonien 753. Krustenflechten 561 .

KUCKUCK über: Asperococceae 265, 266*, $267^{*}, 268^{*}$, Choreocolax 328*, Cutleriaceae 281*, 282*, 283*, Derbesia 204*, Ectocarpaceae 257, Ectocarpeae 259*, 260, 261*, Laminaria 287*, Myrionemaceae 271*, Valonia 100.

KuCZEWski über Chara 749, 750*.
Kugelzellen bei Myxomyceten 396.

Kuhpockenimpfung 349.

Kulturen von Algen 175, 176, Bakterien 332, 335, 353, 361, Myxobakterien 387.

- Rein- cf. Reinkultur.

Kurztriebe bei Bryopsis 56, Chara 750, Draparnaldia 187, Phaeophyceae 264, Rhodophyceae $312,315$.

KüTzrNG über Castagnea '273*.

KuYPER über Monascus 448, 449, 499.

Kystes pédicellées bei Sappinia 398 .

\section{I.}

Laboulbeniales. Einteilung 533, Konservierung 546, Sammlung §46, 547.

Laccophilus als Laboulbenialen-Wirt 539.

Lackmus 555.

LAGERHEIM über: Dipodascus 443, Monoblepharideae $125,126^{*}, 127^{*}, 1: \overline{8}, 129$, Rhodochytrium 38*, 39.

Lamellengewebe Cier Agaricineae 706.

Lampe (Bakterien) von Dubois und Molisch 344 .

Landbewohnen (Aenderungen durch das) 111, 131, 189, 191.

Längenwachstum 183.

- unbegrenztes 56.

Längsfurche der Peridineae 232*, 233.

Längsteilung als Fortpflanzungsweise bei Chlamydomonas 10 , Pyramidomonas 8 .

Langtriebe, Bryopsis 56, Draparnaldia 187*, Phaeophyceae 264.

Laubwechsel der Laminarien '285, 286*.

Laudatea-Form bei Cora 693*.

LAUTERBORN über Diatomeae '245*, 246 , $249,250^{*}, 251^{*}$.

Lebensbedingungen, Einfluß (cf. auch Licht, Luftfeuchtigkeit, Schwerkraft, Wärme etc.) im allgemeinen auf: Basidiobolus 201, Batrachospermum 315, Chloramoeba 212, Chlorochytrium 33, Cutleria 281, Hydrodictyon 43, Protosiphon 55, Volvocineae 9,23 .

- - Aenderungen beim Uebergang vom Wasser- zum Landleben 111, 131, 189, 191.

- - auf die Behaarung der Chaetophoraceae 188.

- -- auf die Chromatophoren der Diatomeae 249.

- - auf die Cystenbildung der Myxobakterien 397 .

- - auf die Farbe bei Monascus 449.

- - auf den Formenreichtum bei Caulerpa 76.

- - auf die Fortpflanzung 13, bei: Chlamydomonas 137, 138, Choanephora 145, Endosphaera 37, Hydrodictyon 47, Myxobakterien 388, Padina 289, Protosiphon 55, Saprolegniaceae 168, 169, Sporodinia 131, 139, Ulothrix 184, Vaucheria 80, 88.

- - auf die Fortpflanzungsorgane - Ausbildung bei Sporodinia 139, 140, Vaucheria 88 . 
Lebensbedingungen, Einfluß a uf die Gestalt bei Bryopsis 58, 59 .

- - auf die Konidienbildung bei Penivilliopsis 505 .

- - auf die Mrceliumbildung von Grmnoascus 493 .

- - auf die Perithecienbildung 503.

- - auf die Polarität bei Bryopsis 60.

- $\overline{59}$ auf die Regeneration bei Bryopsis $59,62$.

- - auf die Sporenkeimung bei Onrgena $50 \%$.

- - auf die Teilung bei Protosiphon 54.

- - auf die Thallusbildung (Ausbildung scobeciner Thalli) 567.

- - auf die Zoosporenbildung bei Vaucheria 8:.

- - auf die Zygotenbildung bei Draparnaldia 188 , Sporodinia 140.

- (ungünstige), Einfluß 138, 397.

- - - auf die Bakterienform 34i, 351

- _ - auf die Gametangienbildung '260.

Lebewesen, Begriff 1.

- erste 2, 5 .

Leblanc über Kernfusion bei Saccharomyceten 609 .

LEEUWENHOEK über Bakterien 330.

Lepto-Gruppe bei Uredineen 636, Uromrces $6 \overline{8} 8$.

Leuchtbakterien 343 .

Leuchtendes Fleisch 343.

Leucin in Kulturen $10^{\circ} 9$.

Leukoplasten $27,66,176,238$.

Leukosin 225, 226.

Lichenen, Algenkomponent cf. Algenk.

- Farbstoffe cf. Farbstoffe.

- historische Uebersicht j49.

- Kultur der Komponenten 550.

- photosynthetisches Element 373.

- Pilzkomponent freilebend bekannt bei Cora 694.

- Reinkultur der Algen 175.

- Srnthese 550.

Licht, Einfluß im allgemeinen 54, 58, 82.

- - auf Batrachospermum 315.

- - auf die Fortpflanzung 47, 55.

- - auf die Fruchtkörperbildung bei Thelebolus 574.

- - auf die Glykogenbildung 366.

- - auf die Hutausbildung bei Paxillus 717 .

- Einfluß auf die Mycelbildung bei Thelebolus 574 .

- Einfluß auf die Organbildung 58, 60.

- Einfluß auf die Protonemabildung 315.

Lichtempfindlichkeit 55, 58, 183, 188.

Lichtintensität, Einfluß auf die Polarität 59.

LINDAU über Apothecienentwicklung 547, 548, Ascoboleae 573, 578, Ceratostomella $522^{*}$, Claviceps 518*, Cyttariaceae 580, Dothideales 520, Gyrophora 563, Lecanoraceae 561, Parmularia 582*, Pertusaria 560, Plectenchym 426, Pyrenomyceten Einteilung 512, Rhytisma 581*.

LINDNER über Schizosaccharomyces 612 .

LrNא über Myxobakterien 385.
Lipochrom bei Dacryomjces 670 .

LIPPERT über Myxobakterien 385 .

Lloyd C. G. über Tylostoma 723 (Note). LOEB über Heteromorphose bei Tieren 59, Träger der Eigenschaften 13.

Loewenthal über Synchytrium 116, Zygorhizidium 120.

LÖFFLER über Cilienfärbung bei Bakterien 337.

Lohblüte 391, 412.

LOHMANN über Coccolithophoren 229.

Lophotriche Bakterien 342, 347*, 350 .

Loslösen der Individuen bei Mougeotia 196.

LUDWIG über Saccharomycodes 610 .

Luftfeuchtigkeit (Einfluß der) auf die Bildung der Fortpflanzungsorgane 140.

- und Sporenausstreuung 136, 140.

LUTHER über Chlorosaccus $213^{*}$.

LÜTKEMÜLLER über Desmidiaceae 219, 220*, $221 *, 222$.

\section{M.}

MACALLUM über Cyanophyceae 369 .

MAC Alpine über Uredineae 641.

Magnus über Puccinia 644, Ustilago violacea 621 .

MaIRE R. über Agaricineae 707*, 708, Ascomyceten (Reduktionsteilung) 452, Auricularia 667, Basidiomyceten 665, 678, 686 (Eint.), 704, 705 (Cytologie), Clavaria 684, Cantharellus 685, 688, Clitocybe 711, Coprinus 716, Corticium 699, Craterellus 688, Cyphella 698, Dacryomyces $671,673^{*}, 674$, Galactinia $457^{*}, 458$, Gasteromycetes 718, Peniophoraceae 689*, 690, Polyporaceae 700, 702, 703, 704, Psalliota 715, Raduleae 699, Synkarionbildung 51, 452, Thelephora 692, Tulostoma 677, Ustilago 620.

Makrogameten bei Chlamydomonas 14, Codium 64*, Ectocarpus 263*, 284, Phyllobium $36^{*}, 37$.

Makrogametangien bei Codium 63, 64, Ectocarpus 263*, 284*.

Makrosporen bei Ectocarpus 263.

Makrozoospore bei Ulothrix 183*, Bildung und Keimung 183*.

Männliche Individuen 14.

Mantelzellen bei Myriotricha 267.

Manubrium bei Charophyten $746,751^{*}$.

Margothallinus bei Lecanora 562.

Markbildung bei Ectocarpaceae 275 .

Marshall Ward über Mycoplasmatheorie 642, Onygena 506, 507*, 508, Uredineae 663.

Marshalle über Getreiderost 638.

MAssart über Glykogen bei Cyanophyceae 366 , Umbilicaria 563.

MAsSEe über Gasterolichenen 743*, Mreedodendron $701^{*}$, Uredineen Infektion 663.

MatTirolo über Cora 693.

Mäule über Apothecien-lintwicklung $54 i$.

Mehltau 471.

Membran $=$ Kellwand.

- diphtheritische 347 . 
Merkmal cf. Eigenschaft.

Mesochiton der Fucus-Oogonien 302*, 303.

Metachromatische Körper bei Bakterien 337.

- - bei Saccharomyceten 373, 603*, 604, Saccharomyces $605,606^{*}, 608^{*}, 609$, Saccharomycodes 611, Schizosaccharomyces 612 .

- - bei Uredineae fragliches Vorhandensein 642

- - bei Ustilagineae 620.

- - Anordnung 606*, 607.

- Deutung 608, 609, 610.

- Verhalten bei der sporenbildung $608^{*}, 609,611$.

Metaphase-Stadium der Ascuskernteilung $488^{* k}$.

Meyer über Pyrenoide 8.

- A. über Valonia-Zellsaft 98.

- H. über Chrysomonaden 225.

MeZger über Verrucaria 552.

Micheli über Basidiomyceten 671.

Micro-Gruppe der Uredineae 636.

Migrantes alatae 661, 662 (Chermes).

Migula über Bakterien 336*, 35̃3*, 357*, Myxobakterien 386.

Mikroaplanosporen bei Bakterien 359.

Mikrogametangien $64^{*}, 263^{*}, 284^{*}$.

Mikrogameten bei Chlamydomonas 14, Codium $64^{*}$, Cutleria 284*, Ectocarpus $263^{*}$, Phyllobium 36, 37.

Mikrokonidienstromata bei Melanconium $5 \cdot 26$.

Mikrosporen bei Diatomeae 249, 253, 25̄5, Ectocarpus 263.

Mikrozoosporen bei Draparnaldia 187*, 188, Ulothrix $183^{*}$.

- Keimung 183*.

- Kopulation 187*, 188.

Milchkoagulation durch Bakterien 340 .

Milchsafthyphen bei Agaricineae 706, 709, 710, Sparassis 698.

- Entstehung bei Russula 710.

Milchsäurebakterien 355.

Milzbrandbakterien 338.

Mißbildungen durch Parasiten verursacht, cf. Gallen und Hypertrophien.

Mitose 369, 370, 371.

- konjugierte ef. Synkarion.

Mittelknoten in der Raphe der Diatomeae 246.

Mittellamelle zwischen den einzelnen Individuen von Volvox 24.

Mryake über Pythium 161*.

Miyoshi über Chemotaxis bei parasitischen Pilzen 476, 477*.

VoN MoHL über Oedogonium-Zellteilung 205.

Molekularbewegung (BRownsche) 605 .

Molisch über blaue Diatomee 248, leuchtende Organismen 343, Trichobakterien $357^{*}$.

MöLler über Calicium 550, Collema 433, Cora 694, Rozites 714, Saccharomycetes 607, Ustilago 620.

Monadenstadium 52.
Monascus, systematische Stellung 497.

- verschiedene Auffassungen 497, 498, 501.

Monoecie 23, 57, 64, 185, 209, 210, 289, 296, 307, 531, 533 (Laboulbeniales).

Monoenergide Organismen 5, 9, 33, 40*, 225, 259, 328, 418, 458 (Ascom.), 469 (id.), 490 (id.), 493 (id.), 554 (Lichenes), 620 (Ustilagineae), 623 (Tilletia), 627 (Uredineae).

- multicelluläre 171, 197, 200, 203, 215.

Monosporangium 326.

Monosporen der Rhodophyceae 311, 314*, 315, 323*, 325, 326.

- Uebergänge zu den Antheridien 326.

Monotriche Bakterien 342, 347*, 349.

Morphogenie 41.

Morphologie der Agaricineae 705, 706*.

Morren über Kopulation bei Closterium 222.

Mortierella und die Ascomyceten 143.

Motrier über Tetrasporen bei Dictyota 293.

Mucorineae, hermaphrodite 138.

- heterothallische 138.

- homothallische 138.

- Verteilung der Geschlechter 138.

Muller, O. über Diatomeae 244*, 245*, $246,247,248^{*}$.

MurRAy über Fucaceae 302*, Mikrosporen bei Diatomeae 254, Struvea 101.

Musca domestica als Laboulbenialeswirt 540.

Mutterindividuen 10.

- Verhalten bei der Gebärung 22, 26.

$\mathrm{x}$-Mycelium, Puccinia 659.

Mycelium der Hyphochytridiaceae 121, Sporochytriaceae 118, 119*, 120*.

Myceliumartige Fäden bei Hefen $601,603^{*}$.

Mycelium, Bildung (septiertes Myc.) Hefen $705,612,614^{*}$.

- binukleäres 50*.

- Differenzierung bei Mucoraceae 134*, 135 .

- einkerniges der Uredineae 50, cf. auch Nucleus (eirkerniges Stadium).

- (Ernährungs-) Mucorineae 134, 140, 142, Rhizopus 135.

- (Fortpflanzungs-) bei Mucoraceae 135, $136,140$.

- homocelluläres bei Basidiobolus 200, Hyphochytrium 121.

- Hülle bei Geaster $731^{*}, 732$

-- (Luft-) der Mucorineae 135.

- perennierendes 641, bei Cronartium 649, 650, Melampsorella 651, 652, Ustilagineae 617.

Mycoplasma, Theorie 641.

Mycorrhizen 509, 594, 719 (Plectobasidiineae).

Myxamöbe 393, 400*, 403, 416.

Myxobakterien, Kulturmethoden 387.

Myxomonaden 393, 399, 400, 402, 403.

- begeißelte 417 .

Myxomyceten, Bewegung 391, 393, 396.

- Vakuolenbildung im Plasmodium 70 
x.

Nabson über Cranophyceae 376.

N.̈Gel über Dasicladus 91*, Desmidiaceae 218*, Polymorphismus bei Bakterien 360, Pseudolpidium 111.

Nährboden 169, 175; Bakterien 332, 335, $347,353,355$.

Nïhrlösung - Kulturen: Bakterien 354 , Hrdrodictron 47. Tilletia $619^{k}$, Valonia $99^{\circ}$.

- Einfluß 201, 202.

Nährsalze, tufnahme 57.

Nährstoffe, Transport 90.

Nahrung, Aufnahme durch Osmose 530, cf. auch Osmose.

- - fester 398 .

- organische 358 .

Nahrungspartikelchen bei Rhodophyceae 312.

NaWaschin über Mrxomyceten 401*, 402 414, Plasmodiophora 399, 400*, 401*.

Nebenfruktifikationen bei Agaricineae $707^{*}$, 70S. Ascomrceten 425, 432, Coprinus $716^{*}$, Lichenes 550*, 551, Monascus 449 Incorineae 137, 138, 142, Pilacre 668*, Polyporaceae 701,704 , Rozites $714^{*}$, 715.

Nebenzellen, Thelebolus 575.

NeEdHaM über Bakterien 331.

Neelsex über Polymorphismus bei Bakterien 360 .

NEGER über Einteilung der Erysiphales 482, Haustorien Errsiphe 473, Konidienund Perithecienbildung 478, Perithecien der Errsiphales 478ft., 479*, Phrllactinia $472^{*}$, physiologische Arten der Errsiphales $482,483$.

Nekriden der Cyanophyceae 381.

Neizplasmodium 395, 396.

NEUBNER über Apothecienentwickelung $548,550^{*}, 555$.

NrCHols über Basidiomyceten 675 .

Noctilucca 175.

NoLL über Bryopsis 57, 58, 59, Caulerpa 76, 77, Valonia-Kultur 99.

NoRDHAUSEN über Cladophora 106*.

Normal giftige Bouillon 348.

Nowakowsky über Polyphagus 119, $120^{*}$.

Nucleolus 28, 312.

Nucleus $3 \mathrm{ff} ., 27,28 \mathrm{ff} ., 48 \mathrm{ff} ., 66 \mathrm{ff}$, cf. auch Cytologie.

- bei: Albugo 153 ff., Ascomyceten, Auffassung des Ascusnucleus 440, 441*, 487, Bakterien 337, 338,372, Chlamydomonas $7 *, 10$, Coelastrum 178, Cyanophyceae 367, 369, 370* 371, 607, 608, Desmidiaceae 2.23*, 224, Diatomeae $250^{*}$, 251, '252*, 255*, Dictyota $311^{*}, 312,319^{*}$, $320^{*}$, Hydrodictyon 42, 43*, 44, Myxomyceten 396, 400, 402, Oedogonium 2\%, Phyllactinia 487, Saccharomy ceten 603*, 604, Sphaerotheca (Auffassung H ARPERs und Lotsys) 451, 45\%, Ulothrix 184, Vaucheriaceae 78, Volvocineae $24^{*}, 25$, 26, Zygnemaceae 197.
$\mathrm{x}-\mathrm{Nucleus} 319,573$ (Discomycetes), 664 (Uredineae).

$2 \mathrm{x}$-Nucleus 51, 319, 322, 573 (Discomycetes), 658* (Gymnosporangium), 664 (Ũ redineae), 674 (Basidiomyceten).

4 x-Nucleus: Galactinia 458, Phyllactinia 490, Pyronema 457, Sphaerotheca (HARPER) $451^{k}$

Nucleus, Anordnung in den (Jogonien von Prronema 454, 456.

- Degeneration in der Cystide von Peniophora 690.

- - im Ei nach der Befruchtung: Albugo $156,157^{*}$, Oomyceten im allgemeinen $\mathbf{1 6 2}$.

- - bei der Eibildung bei Fucaceae 301, 305*, Nemalion $311^{*}, 312$, 313, Saprolegnia 168.

_ - bei der Gametenbildung der Diatomeae 253.

- bei der Siporenbildung von Taphrina 598.

- - in der Trichogyne der Ascomyceten 454, 45̄5, 462, 463*, Nemalion 313.

- - bei der Verschleimung der Hyphenhülle der Helvellineae 587.

- - im Zygogametangium von Dipodascus 444 .

- - bei der Zygotenkeimung der Desmidiaceae $2: 3 *, 244$

- einkerniges Stadium bei Auricularia $667^{*}, 668$, Basidiomyceten im allgemeinen 666, Coprinus 716, Dacryomyces 671, 673*, Muciporus 681*.

- Fehlen echter Nuklei bei Schizophyten 328.

- Form 26.

- Fragmentierung bei Charophyten 745. Sparassis 698.

- Fusion der Nuclei 13, 48, 50, 51, 449, bei: Ascomyceten im Ascus 487*, 488, Discomyceten 572, 573. 575*, 577, 578, Gymnoascus 494, 495̃, Laboulbeniaceae 532, 535, Monascus 500, Phyllactinia 488*, 489*, 490, Saccharomvceten 609, schizosaccharomyces 613,614 , Taphrina 597, Zygosaccharomyces 610; Azygosporen von Empusa 151; Basidien 665̃, 674, Auricularia 668, Cantharellineae 685, Dacryomyces 671, 673*, Hrgrophorus $707^{*}$, Lactarius $709^{*}$, Mucijorus $681^{*}$, Peniophora 690, Pilacre 669, Sparassis 698, Telephora 693, Trametes 703 , Tremella 670, Vuilleminia 682; Chlamydosporen Ustilago 620; Teleutospore 664, Grmnosporangium 65S. Zygnemaceae 199, 201.

- Größe in den ascogenen Hyphen 456.

- Größerelation zum Eytoplasina 488.

- Kopulation bei Ascomrceten: Ascodesmis $46^{\circ}$, Humaria (zwei reibl.) $466^{*}$, Prronemal 45t. $\$ 55 \%$, sphaterotheca 451.

- reduzierter 25:.

- ruluender 28.

- Synkarion $452,45 \%$, 5 s.

- 'leilung (für Basidiomyceten of. Basidie, Richtung (ler Kernspindel) bei: Nlbugo 
153*, im Ascus 488*, 489*, bei Desmidiaceae 223*, 224, Diatomeae '250*, 251, Dictyota 293, 294*, Florideen $311^{*}, 312$, 319*, Hydrodictyon 44, Myxomyceten 400*, Oedogonium 207, Saccharomyceten 606*, 608*, 611, Ulothrix 18t, Volvocineae $24^{*}, 25,28$ ff., 29*, '/ygnemaceae 197.

Nucleus, Teilung allgemein 8, $28 \mathrm{ff} ., 48 \mathrm{ff}$., 184.

- - heterotypische 193.

- - homöotypische 193.

- - simultane $154^{*}, 156,157^{*}, 160,161$.

- Stellung der Wände 297.

- Tinktion 28.

- Träger der Eigenschaften 13, 28, 68.

__ _ _ experimenteller Beweis $13 \mathrm{ff}$.

- Trennung elterlicher Nuclei $50 \mathrm{ff}$.

- Uebertritt aus der Zygote in die Auxiliarzellen der Rhodophyceae $321^{*}$.

- und Plasma 68.

- Vergrößerung: Dipodascus 443*, 444, Taphridium 445 .

- Verhalten bei der Sprossung der Saccharomyceten $606^{*}, 607$.

- Vermehrung durch Fragmentierung cf. Fragmentierung.

_ _ durch Teilung ef. Teilung.

- Verteilung der Nuclei bei Taphridium $445^{*}$.

- Zahl bei Ustilago 620.

- - in den Zellen der vegetativen Hyphen der Ascomyceten 441.

- Zeitpunkt der Verschmelzurg 128, 632 (Uredineae).

- Zerbiöckelung bei Psalliota 715 .

- Zusammenbleiben elterlicher Nuclei $50 \mathrm{ff}$.

- Zusammenkunft elterlicher Nuclei $50 \mathrm{ff}$.

- zweikerniges Stadium bei: Ascomyceten Sphaerotheca 452 ; Basidiomyceten 666, Auricularia 667*, 668, Cantharellineae 685, Coprinus 716, Dacryomyces $670,671,673 \%$, Muciporus 681*, Peniophora 690, Polyporus 702, Psalliota 715, Sparassis 698, Thelephora 692, 693, Tremella 670*, Vuilleminia 68.2.

- Zygotennucleus bei Dipodascus $443^{*}, 444$

Nukleine 4, 8; bei Bakterien 338, 339 Cyanophyceae 369, 371, 372.

- Verteilung 372

Nukleinereaktion der Chromatinkörner 337.

\section{0.}

Oberschale der Peridineae 233, 235.

Oeffnungspapille 154.

Oel $35,36,37,84,88,213,218$.

Oelbildung 80, 83, 124, 178, 186, 189, 212. - bei Hefen 604, 607.

- in der 'Zygote 225, 248.

Oel, fettes 245, 248.

Oidien bei Chlamydomucor 137, 138, Dacryomyces $670,673^{*}$, Gymnoascus $495^{*}$. Lichenes 550*, 551, Monascus 448*, 449,

- Fruktifikation 471.
Oidien, Keimung bei Dacryomyces 670 .

- und Uredospore cf." Uredospore.

OLrve über Cyanophyceae-Glykogen 366 , Empusa 148, 149, 150*, 151, Monascus 448, 449, 500, Myxogasteres 395, 397.

Olivetorsäure 567.

OLsEN, Јон. über Russulaceae 710, Tulasnellaceae 679 .

OLtmanns über Akontae 194, Bryopsiảeae 57, Castagnea 274, Chaetomium 521* Chaetophoreae $187^{*}, 188$, Chroolepideae 190, 192*, 193, Cladophoraceae 106*, Codiaceae 63*, 64, Dasyclarlaceae 90, $91^{*}, 92 *, 98$, Desmarestieae 264*, Desmidiaceae '217, 223, Diatomeae 251, Dictyosiphoneae 277*, Dictyotaceae 290 , Ectocarpaceae 261, 262, Fucaceae 294, 296, 297, $298,299,301,302^{*}, 305^{*}, \mathrm{He}-$ terokonten $212,215^{*}, 216$, Laminariaceae 285, 286*, 287, Peridinales 233, 234, Phaeosporeae 257, Rhodophyceae 309, $311^{*}, 320^{*}, 321,323^{*}, 325,327$, Scytosiphoneae $277^{*}$, Siphonocladaceae 102*, Sphacelariaceae '285, Stephanokonten 203, 204*, 210, 211, Ulotrichales 185, Valonia 100*, Vaucheriaceae 80, $82 *$, $84^{*}, 85^{*}, 86,87^{*}, 88$, Volvocineae 27.

Oogamie 78, 122, 189, 204, 209, 257.

Oogame Befruchtung 185, 186.

Oogonien und Oogonienbildung bei : Ascomyceten 420, 421, Ascodesmis 460, Aspergillus 501, Ctenomyces 496, Erysiphe 484*, Gymnoascus 493, 494*, 495*, Humaria $465^{*}, 466$, Laboulbeniales $531^{*}$, 532, 540*, 546* ('Lodiomyces), Monascus 497*, 498, 501, Penicillium 503, 504*, Phyllactinia 486*, Pyronema 421*, 42\%, 454 ，455*, Sphaerotheca 450*, 451; Bangiaceae 308, 309*; Charophyten 745, Nitella 75'2*, 753; Coleochretaceae 191*, 192*; Cylindrocapsa 186*; Dictyotaceae 289, 290, 291*, 293*; Florideae $311^{*}, 312,313^{*}, 314^{*}, 315$ $316^{*}, 318^{*}, 321^{*}$; Fucaceae $301^{*}, 302^{*}$, 304, 305*, 306; Monoblepharideae $123^{*}, 124,126^{*}, 127^{*}, 128^{*}, 130 ;$ Мonolpidiaceae 114; Oedogoninm 209, 210*; Oomyceten 162, Albugo 151, $152^{*}, 153^{*}, 154^{*}$, Leptomitaceae 170*, Peronospora 158*, 159*, 160, Pythium $161^{*}$, Saprolegnia 163*, 164*, 167*; Phragmidium 630*, 631; Sphaeroplea 108; Vaucheriaceae 82*, 83, $86^{*}, 89^{*}$; Zygomycetes 139 .

Oogonien, aktives Auftreten bei der Befruchtung 422 .

- Anordnung der Kerne 153*.

- Ausschlüpfen $30^{\circ}$.

- Cytologie cf. Cytologie.

- Hals 83, 124

- Kern 311* ef. Cytologie.

- Kopulation bei Phragmidium 628, 629, $630^{*}$.

- Oeffnung \$5, 89, 124, 126*, 210*, 302

- Rinde bei Charophyten 745, 753.

- Sorus 291, 293. 
Oogonien, spiralförmige bei Ascompceten $460,463$.

_- Stielzelle cf. Stielzelle.

- Teilung in eine terminale und subterminale Zelle bei Monascus 497*, Phyllactinia 457 .

- Terminale 128.

- Wand 302*, Wandstruktur 128.

- Umhüllung bei den Rhodophyceae 316 .

Oosporen $129,16 \%$.

- Keimung 167.

Opsis-Gruppe der Uredineae 636, Lromyces 658.

Optimum der Entwickelung 356.

- der Temperatur bei Bakterien 346.

Orseille 555.

Osmotischer Druck 207.

- Ursache des Ausschlüpfens der Fortpflanzungszellen S1.

Ostiolum bei Cucurbitaria 515, Lichenen 551, Prrenomyceten 512, Sphaeriales 520 .

Overton über Volvox 24*, ZygnemaceaeKopulation 199.

Orocentrum im Oogonium von Saprolegnia $167^{*}, 165$

Oxydase 358 .

OzANAM über Mikroorganismen 330.

\section{P.}

Pachyteles luteus Hope als Wirt von Laboulbeniaceae 535 .

Palissadenschläche bei Codiaceae $63^{*}, 64^{*}$.

Palla über Desmidiaceae 218, Phyllactinia 476, Zygnemaceae 196*, 197.

Palmellastadium bei Basidiobolus 202, Chĩamydomonas $11^{*}, \mathbf{1 4}$, Tetraspora 180 , Ulotrichales $184^{*}, 185,186^{*}$.

Pangenen 67, 68.

Pangenesis, intercellulare 67.

Panzermembran bei Peridineae 233, 235, 236.

- Ring bei Diatomeae '243.

- Schuppen bei Diatomeae 243.

Parallelreihen 231, der Gasteromyceten 719, 727, Gasteromycetineae 727, 728, 742.

Paraphysen bei Ascomyceten 422, 423, 424, 426, 428, 461, Calosphaeria 526, Clathraceae 739, Cucurbitaria 523, Elachistea 272, Eutuberaceae 593*, 594, 596, Gyrophora 563, Helvellinaceae 586*, 587, 588*, 589*, Humaria 466*, Hypoxylon 527*, Hysteriales 582, Laminaria 286, Lecanora 562, Ochropsora 654, Parmelia 566, Peltigera 558*, Phacidiales 581*, Phaeophyceae 257, Phalloideae 739, Phragmidium 628, 630, Physcia. 568, $569 *$.

- aus den Hyphen der $\mathrm{x}$-Generation bei Lichenen 569.

Parasitismus: Bakterien 351, 352, Cephaleuros 190, Cladophora 106, Elaphomyces 509, Endosphaeraceae 32, 35, 38, 39, Merolpidiaceae 111, 112*, 113, Monolpidiaceae $111,112 *, 113$, Mycochytridia- ceae 117, 118*, Oomyceten 151, 152*, 15S, 160, 161*, Plasmodiophora 399, 400, Rhodophyceae 328 , Sporochytriaceae $119^{*}, 120,121,7 y$ gomycetes 130,134 , $145^{*}, 146$.

Parasitismus auf Tieren 146, 147*, 148, 149.

- Eindringen in die Nährpflanze bei : Auricularia 668, Claviceps 518, Cordyceps 517, 518, Endosphaeraceae 32, 35, 37, 39, Erysiphe 474*, 475*, 476*, Laboulbeniales 530, 531, 544, ว45, Merolpidiaceae 115, Monolpidiaceae 112*, 113, Mycochytridiaceae 117, 118*, Oomyceten 151, 152*, 160, 161*, Phyllactinia 477*, Plasmodiophora 400, Sporochytriaceae $119 *, 120,121$, Uncinula $476^{*}$, Uredineae 639, 644, 648, 653, Zygomycetes 145 .

- Deformieren der $\mathrm{W}$ irtspflanze 114, 151, $152 *, 621$ (Ustilago), ef. hermaphrodite Blüten, Hypertrophien, (Pilz) Gallen.

- Folgen des 402.

- obligater 478.

- reziproker 351 .

Parthenogenesis 13, bei Ascoidea 444, 446, Ascomyceten 424, 428, 435, 615, Codium 64, Cutleriaceae 284, Diatomeae 254, '256, Dictyotaceae 290, 292, Discomyceten 573, Draparnaldia 188, 284, Endophyllum 647, Hydrodictyon 47, Lichenes (Allgem.) 548, Monoblepharis 129; oomyceten Albugo 151, Saprolegniaceae 162, 164, 166; Parmelia 565, Protosiphon 54*, 55, Schizosaccharomyces 613*, 614*, Sporodinia 139, Thelebolus 577, Ulotrichales 184, 186, Volvocineae 25.

- bei Tieren: Chermes 662 .

- im männl. Geschlecht 433.

Parthenogenesis und Befruchtung $166^{*}, 167$.

Parthenogonidien der Volvocıneae 23*, 25 , 26, 27.

Parthenosporen bei Cutleria 284, Draparnaldia 188, Hydrodictyon 47, 48, Monoblepharis 129 , Oomyceten 163, 183*, 184, Protosiphon 54*, 55 .

- Keimung 163*, 183*, 184.

- - fruktifikativ 163 \%

- vegetativ $163^{*}$.

Patouillard über Polyporineae 695, Tulasnella 679, Tulostoma 677, 724 (Note). Pepton (Einfluß in Kulturen) 201, 202.

Peptonzuckergelatine 355.

Peridien der Ascomyceten Balsamia 583, Eutuberaceae 594; Basidiomyceten Pilacre 668, 669, 683; Gasterolichenen 743, 744; Gasteromyceten Clathrus 738, Hymenogaster 734, Hrsterangium 735, Lycoperdaceae 725, 729, 730, MLutinus 740, Nidulariaceae 732, Phallogaster $737^{*}$, Sclerodermataceae $720^{*}, 721$. Secotium 740; My.xomyceten 4(79, 410 . $411,412$.

- Aufreißen, Geaster 731.

- (Endo-) ef. Endoperidium. 
Peridien (Exo-) ef. Exoperidium.

- gitterartige Durchbrechung bei Phallogaster $737^{*}$.

- mehrschichtige bei Calostomaceae 721, $72: *$, Geaster 7.29, Sclerodermataceae 721, Sphaerobolus 726, 727, Tulostomaceae $724,7 \cdot 25 *, 7 \cdot 26$.

- Oeffnungsweise bei Calostomaceae 723, Nidulariaceae 732, Phallogaster 736*, Scleroderma 721, Sphaerobolaceae 727, Tulostoma 724, 725*, 726.

Peridiolen bei Nidulariaceae 718, 727, 732, $733^{*}$, Octaviana 732, Pisolithaceae 719, $7: 23,724 *$.

Perikline 275

Periplasma 152, 153* 154, 155, 160.

- Kerne 154, 155.

Perithecien der Ascomyceten 420, 424, $425^{*}, 428^{*}$, Aspergillus 501, Calosphaeria 525*, 526 , Ceratostomella $522^{*}$, Chaetomium 520, 521*, Claviceps 518*, 519, Cordyceps 517*, Cucurbitaria 522*, 523, Hypocrea 515, Melanconis 525*, Polystigma 515, Sordaria 521*, Valsa 523, $524^{*}$, X ylaria 528*, 529; Laboulbeniales Chitonomyces 539*, Dimorphomyces 534, Haplomyces 536, 537*, Stigmatomyces 531*, Zodiomyces 545, 546*; Lichenes 551, 553, Endocarpon 553*; Rhodophycecie 316.

Perithecien, Bau bei Ceratostomella 522*, Chaetomium 521*, Claviceps 519*, Cucurbitaria 522*, Elaphomyces 506, 510* Hypocrea 515*, Onygena 505*, $507^{*}$, Penicilliopsis 505*, 506, Penicillium 503, $504^{*}$, Sordaria 521*, Valsa 524*.

- Basalzellen 531, 536, 537*.

- Bedingungen der P.-Bildung 503.

- dorsiventrale bei Erysiphe 480, 482 .

- freie der Laboulbeniales 534, 537*, 538*, $539^{*}, 540^{*}, 541,543,544^{*}, \overline{0} 45,546^{*}$.

- freistehende 520, 521*.

- Gehäuse 520.

- Hals (fadenförmiger), Calosphaeria 526, Ceratostomella 522*, Melanconis 525, Valsa 523, 524*.

- (mit dem Receptaculum verwachsene) Laboulbeniales 538, 539*.

- Oeffnungsweise, Pyronema 512.

- Primordien, Sclerotinia 427*, 428, Xylaria $4 \cdot 25^{*}$.

- radiäre 480,481

- Verbreitung, Erysiphe 480, 481.

- - mit Hilfe anderer Pilze 481.

Peritriche Bakterien :336*, 337, 350, 354, 355.

Perizonium der Diatomeae 252.

PETRI-Schälchen 332.

PeTtenkofer über Vibrio cholerae 355.

PFefFer über Vakuolenbildung 70, 71.

Pflanze, Begriff 1.

- Entstehung höherer Pflanzen 173.

- farblose 3.

- Unterschied gegenüber Tieren 1 ff.

Phaceliastadium bei Claviceps 428 .

Pherosophus als Laboulbeniaceae-Wirt 537.
Philonthus sordidus Grav, als La oulbeniaceae-Wirt 538.

Phobotaxie 388.

Phosphoreszenz vom Mycelium 529.

Photosynthese 3, 7, 8, 17, 27, 56, 63, 92, $93,187,197,225,229,238,248,265$ $27 \cdot 2,315,358.366,368,371,374$.

- Leuchtbakterien als Reagens 344.

- Organe 63, 93, 187, 265, 272, 315 .

- Produkte 8, G'lykogen 366, 368, 371, Leukosin 225, Oel 238, 248, Stärke 56, 197.

Phylogenie der Ascomyceten 436, 438, 571; Discomyceten 572, 578, 583, 589, Erysipheae 481, Eutuberaceae 509, 591, 592, 595,596 , Helvellinaceae 585, 590, Saccharomyceten 612,615 ; Ascomyceten monoenergide 469 , polyenergide 468 ; der Basidie 671, 672-675, 676; Basidiomyceten $616,671-675, \mathbf{6 7 6}, 677$, $678,683,685,700,704,705$, Agaricaceae $705,711,713,717$, Cantharellaceae 685, 694, Cyphellaceae 696, 698, 699, 700, Polyporineae 696, Tulasnellaceae 682; Caulerpaceae 7.2 ; Charophyten 748, 749, 753'; Cyanophyceae $382 \mathrm{ff}$., 38t; Desmidiaceae 217; Diatomeae 241; Eumycetes BREFELD 436; Fungi im Allg. 111; Gasteromyceten 678, 683, 686, 718, 719, 724, 727, 728, 732, $733,734,739$, Plectobasidiineae 720 ; Hemibasidien 626; Myxomycetes 402, 416; Phacophyten 231, Dictyotaceae 294, Phaeophyceae 287; Rhodophyceae 306, 307; Schizophycene 306, 329; Siphonomyceten 12.2; Uredineue $664,665,672,673$.

- cf. auch Sta m mbaum.

Pigmentbildende Bakterien 345, 349.

Pilzgärten 714*, 715.

Pilzkulturen der Association Internationale des Botanistes 386 .

Pilze, unterirdische 509.

Pinselhyphen 471, 472*, 481, 482.

Planarien, Heteromorphose 59.

Plankton 19, 125, 242.

Plasma 3 ff., 14, 16, 44, 65, 67, 68 .

- alveoläres 123 .

- Ballen (mehrkernige) bei Thelebolus 576 .

- Bewerung bei Diatomeae 247.

- extracellulares bei Peridineae '237, 28\%

- grün gefärbtes 364 .

- Hautschicht cf. Hautschicht.

- Kontinuität 312 .

- Regeneration bei Valonia 99.

- Stränge bei Cyanophyceae 376, 379.

- Strömungen 219.

- Struktur 4, 123; Myxomyceten 400*.

- vakuolisiertes $336^{*}, 337$.

- Verbindungen bei Laboulbeniales 533 , 542*, Rhodophyceae 312, 314, Volvocineae $18^{*}, 19,24,25,230$.

- - der Fortpflanzungszellen 25.

- wandständiges 41, 56, 218.

- Zusammenstellung 99.

Plasmodesmen 24. 
Plasmodien 391.

- (Aggregat) 391, 392, 395, 398*, 399.

- Bildung 401*, $402, \mathbf{4 1 3}$; Zeitpunkt 402, 403.

(Fusions) 391.

-. (Netz) 395, 396.

Plasmodiocarpien $404^{*}, 405^{*}, 407,410,411$, $412,413$.

Plasmolrse 65, 335.

Platten bei Peridineen-Panzern 233, 234, $236,237$.

- Befestigung 237*.

Plectenchym bei Parmelia 564, Sclerotinia 426.

Plencez (Marcus Antonius) ïber Mikroorganismen 330.

Pleomorphismus bei Scenedesmus 178.

Pleophagie bei Cronartium 649.

Pleura der Diatomeae 242 .

Plowright über Coleosporium 655*.

Podetien bei Cladonia 556, 569, 570*, 571 (Deutung).

Pol, antapikaler, Peridineae 233.

- apikaler, Peridineae 233.

Polarität (morphologische) bei Bryopsis 58 , 60, Oedogonium 205 , Volvocineae $22,25$.

- erbliche 61 .

- Umkehrung 58, 59.

Polcilie der Myxomyceten 393.

Polgeißel der Bakterien 355.

Polspalte bei Diatomeae 245*, 246, 247*.

Pollender über Mikroorganismen 330.

Polsterbildung 191, ‘269, 270, 271.

Polyeder bei Hydrodictyon 42, 47, 48, Pediastrum $40^{*}, 41$.

Polyenergide 16, 418, 490, 498, Ascoidea 443, Ascomyceten 436, 458, 468, Aspergillus 501, Bryopsis 15, 58, Codiaceae 61, Diatomeae 249, Dipodascus 443, Empusa 149, Endosphaeraceae 37, Humaria 465, Hydrodictyaceae 40, 42, 45 , Hyphochytridiaceae 121, Monascus 498, Monoblepharideae 123, 126, Mycochytridiaceae 117, Rhodophyceae 3ن3, Saprolegniaceae 163, 164, siphonales 53, 55, Vaucheriaceae 79, Zygomyceten 130.

- Entstehung 202,

- - künstlich bei Basidiobolus 202.

- Hyphen, Ascodesmis 262, '263*, Galactinia 457, 458, Humaria 465, Monascus 449, Protomyces 446, 447, Pyronema 454, Taphridium 445.

- monocellulare bei Akontae 215, Empusa 149, Isokonten 171, Siphonocladeae 98, Stephanokonten 203.

- multicellulare bei Cladophoraceae 104, 105, Siphonocladeae 98.

- Sporen bei Protomyces 447.

- Wandbildung cf. Wandbildung.

Polymorphismus, Bakterien 341, 360, Cantharellaceae 685 (Basidie), Cora 693*, 694, Muciporus 682, Rhodophyceae $314^{*}$, 315, Scenedesmus 178, Tremellineae 682.

Polyphyletischer Ursprung 7, 17, der monoenergiden Ascomyceten 469.

Lotsy, Botanische Stammesgeschichte. I.
Popta über Ascoidea $442^{*}$, 144, über Protomyces $446,447^{*}$.

Polyporusform bei Muciporus 681, 682, Tremellineae $68^{\circ}$.

Poren bei Cyanophyceae 379, Peridineae 237.

- in der Kellwand bei Rhodophyceae 312.

- Kanäle 219, Diatomeae '244.

- Knoten Desmidiaceae 219

- Mantel Desmidiaceae 219.

- Nelken Desmidiaceae 219

- Verteilung Desmidiaceae 219.

Postäquatorialplatten der Peridineae 234.

Prääquatorialplatten der Peridineae 233, 234.

Prazmonowsky über Bakterien 347*.

Preßhefe 601.

Primordialzelle der Oogonien bei Laboulbeniales $531 \%$.

- der Perithecien bei Laboulbeniales 531*.

Primordium der Perithecien bei Sclerótinia $427^{*}, 428$, Xylaria 425*.

Pringsherm über Chara 747, Coleochaete 191, Cyanophyceae 379, Oedogonium 205, 207*, 209*, 210*, Pseudolpidium 111, Vaucheria 88.

Promycelium bei Endophyllum 647, Gymnosporangium 658*, Melampsoraceae 648, 651, 653, 655, 656, Phragmidium 630, 631*, 632, Pucciniaceae 656, Saccharomycetes 604, 605, 610, Tilletia 623, Uredineae $49^{*}, 627$, Ustilago 618 .

- der Aecidiosporen 637.

- Inneres bei Auricularia 668, Chrysospora 656.

- Nucleus 50 .

Propionsäure 358 .

Proteidkristalloiden 8 .

Proterogynie 23.

Prothallien (Filices) 49.

Protobasidien 676 .

- und Asci 676.

Protoplasma cf. Plasma.

Protosporen bei Pilobolus 446.

- multinukleäre (Sporodinia) 133*.

- uninukleäre (Sporodinia) 133.

Pseudocilien bei Tetraspora 179, 180*.

Pseudodichotomie bei Bakterien 342.

Pseudomitose der Cyanophyceae 370, 371 372.

Pseudoparenchymbildung bei Balsamia 583, Helvellineae 585, Phaeophrceen 25S, 269, 270, 271, 283, Sclerotinia 426.

Pseudopodien der Protoplasten 24.

Pseudosporen bei Mrxomyceten 399.

Pusulen bei Peridineae 237, 241 .

- Sack 237, 238*.

- (Sammel-) 237, 238*

Pykniden 432, Cucurbitaria 522^, 523, Phyllactinia $472^{*}$.

Pyknokonidien 132, 433, 434, 522*, 523.

Pyknosporen 432.

- Keimung 433.

Pyocyanin 349

Pyrenoide 8, t2 ff., 312 , bei Bryopsis 56 , Chlam vdomonas $7 *$, Cladophoracea 104. 105, Codiaceae 61, Coelastrum 1is, Crstococeus 175, Diatomeac 251. Endo-

$5 \div$ 
sphaeraceae 33, Hydrodictyon 42*, 43*, 44*, Oedogonium 208, Polytoma 17, Protosiphon 53, Pyramidomonas \&, 10, Rhodophyceae 307, 312, Sphaeroplea $107^{*}, 108$, Vaucheriaceae 79, Volvocineae 23, 24*, 26, Zynemaceae 197.

Pyrenoide, Auflösung 8, 45.

Pyrenoidenstärke 8, 45.

Pyrenoidenteilung 8.

Pyrogallussäure in Bakterienkulturen 335.

\section{Q.}

Quadrantenteilung 21, 22*, 266, 267*, 275, 279.

Querfurche bei Peridineae 232*, 233, 235.

Querwandbildung bei Oedogonium 207, $209 *$.

\section{R.}

RACIBORSKI über Basidiobolus 200, 201, Peronospora 478, Uredineae 628.

RALFs über Closterium (Kopulation) 222.

RAMLOW über Thelebolus 449, 573, 574*, $575^{*}, 576^{*}, 577$.

Randwachstum bei Cutleria 282, Dictyota 288, Ralfsia 271.

Randzellen bei Charophyten 748*, 749, Pediastrum 40, Valonia 99, 100.

Raphe der Diatomeae 245*, 246, 247*.

Raseneisenstein 356, 357.

Rassen bei Bakterien 350, 351.

- (physiologische) bei Uredineae 663.

Receptaculum bei: Gasteromyceten Clathraceae 737, 738*, 739*, Phallaceae 737, 738*, 740, Sphaerobolaceae 726, 727; Laboulbeniaceae Amorphomyces 540, Chitonomyces 539, Enarthronyces 537, Haplomyces 536, Laboulbeniaceae 542, Moschomyces 545, Rachomyces 544, Rhizomyces 541, Teratomyces 543.

voN ReCKLinghaUsen 331.

Reduktion der Chromosomen cf. Reduktionsteilung.

Reduktionsteilung 48, 49, 51, 52, bei Basidiomyceten 666, Cantharellineae 685, Charophyten 748, Coleochaete 193, Diatomeae 184, Dictyotacea 293 , Florideae $310,314,315,324$, Fucaceae 304, Galactinia 458, Peziza 572, 573, Phyllactinia 489, Saprolegniaceae 168, Schizosaccharomyces 615 , Sphaerotheca 452 , 453, Ulothrix 184, Uredineae 632, 637.

ReESS über Basidiomyceten 671, Elaphomyces 510*, Saccharomyceten 602 .

Regeneration bei Bryopsis $57 \mathrm{ff}$, 60, Codiaceae 62*, Peridineae 239, Vaucheria 80; tierische 59 .

- der Chromatophoren (künstliche) bei Diatomeae 249.

- der Protoplasten bei Valonia 99.

REHм über Naemacyclus 581*, Thelebolus 577.

ReHSTEINer über Gasteromyceten 730*, $734^{*}, 735^{*}, 739$.
Reinke über Ascocyclus 263*, Castagnea $273^{*}, 274$, Caulerpa $72^{*}, 73,75^{*}, 76$, 77, Chorda 279*, Desmarestia 264, Dictyotaceae $288^{*}, 289^{*}, 290^{*}, 291^{*}$, Lichenes 550, 551, Pringsheimia 189*, Tetraspora $180^{*}$, Scytosiphoneae 276*, $277^{*}$.

Reinkulturen, Anfertigen von 168, 175, 334. ReINsch über Cylindrocapsa 185, Monoblepharis 122 .

Reize (chemische) als Ursache der Cystenbildung bei Myxobakterien 388, 390.

- - bei der Sporenkeinung der Myxomyceten 391.

- - bei der Zoosporangienbildung bei Empusa 170.

- Kontakt 59, 79, 103.

- (morphogene) 621, 622.

- zur Ausbildung der Sporangienwand der Myxomyceten 403.

Reizleitung 25.

Reservesubstanz 17 (Stärke), 28 (im Nucleolus) 106, 185 (in den Akineten von Ulothrix), 358 (Schwefel), 372, 374, 379 (in den Heterocysten), 461, 608 (Anabänin, metachromatische Körper), 609 (Glykogen).

Reservesubstanzbehälter 379, 381 .

Resistenz gegen Eintrocknen bei Lichenen 557.

Resupinater Hut 688, 689.

Reticulum der Myxomyceten 414.

Rhizoiden bei: Bryopsis 56, 58, 59, Caulerpaceae 73, 75, Charophyten 745, 747, Cladophoraceae 104*, 105, Codiaceae 61, Cutleria 282, 283, Dasycladaceae 90, 97, Draparnaldia 187, Empusa 150, Fucaceae 297, Monostroma 181, Oedogonium 204, 205, 208, Porphyra 307, Protosiphon 54, Rhizina 589, Rhodochvtrium 38*, 39, Siphonocladaceae 101, 102, 103, Ulothrix 183, Ulva 181, 182*, Valonia 99 100, Vaucheriaceae 79, Zvgnemaceae 199.

- Bildung durch Kontakt bei Bryopsis 59, Struvea 103, Vaucheria 79.

- Entstehungsort bei Ulva 181, 182*.

Rhizom bei Caulerpa 72, 74, Cladophoracea $€ 105$, 106* (Keimung 105, 106*), Derbesia 203, Xylaria 529.

Rhizomorphabildung bei Armillaria 712*, Xylaria 529.

Rhodophyceae, Batrachospermum-Stadium $3.4^{*}$.

- Chantransia-Stadium $314^{*}, \mathbf{3 1 5}$.

Rindenbildung 62; Elaphomycetaceae 509, 510*, Eutuberaceae 594, 595*, 596, Onygena 507*, 508 (Perithecien), Phaeophyceae $258,264,265,268,275,276$, 277, 278, 279*, 284, 289, 291.

- um die Oogonien 192.

- bei Ascomyceten-Fruchtkörpern 425, 465* (Humaria), 466.

Rindensubstanz der Myxomyceten 396, 397.

RiNdFleisch über Bakterien 331.

Ring der Agaricineae 705, 706*, 715.

Ringbildung bei Oedogonium 206, 207*, 209*. 
RoxcALI über Saccharomyces 606 .

Rosahefe 601.

Rosex ïber Srnchrtrium 116.

Rosenvinge ïber Chaetomorpha 104*, Cladophora 106*, Monostroma 181*.

Rost (Berberitzen) 638, 639 ff., zweite Form $6+1$.

- (Braun-) 64t.

- (Gelb-) 645, 646.

- (Getreide-) 633, 638 (hist. Uebersicht), 639 (Entwickelung).

- Sporen in der Luft 641.

- (Kronen-) 646.

- (Roggenbraun-) $6 \pm 6$.

- (Schwarz-) 646.

- (Weizenbraun-) 646.

- (Zwerg-) 645, 646.

Rostafinsky über Hydrurus 228*, Protosiphon 53, 54*.

Rostpilze, antöcische 633, 658, 659.

- heteröcische 633, 658, 659 (cf. auch Wirtswechsel und Heteröcie).

Rotation der Fucus-Eier 296, 304*.

Ruhezelle 36, 37.

Ruheperiode der Gronotokonten 52.

Ruhezustand im allgemeinen bei: Aspergillus (Perithecien) 502, (Sklerotien) 502, Bakterien 336, Chlamydomonas 10, 14, Chlorosaccus 213, Chrysamoeba 221, Coelastrum 178, 179*, Ctenomyces (Sklerotien) 496*, Cranophyceae 374, Dasycladaceae 93, Diatomeae 256, Endosphaeraceae 33, 36, Hydrodictyon 47, Myxobakterien 380, Myxomyceten 398, Penicillium (Perithecien)503, (Sklerotien) 503, 504*, Peridineen 240, Protosiphon 55, Ulothrix 185, Vaucheria 81, 83, 88.

RUHLand über Albugo (Cytologie) 153, 158, Basidiomyceten (Cytologie) 674, Peronospora 160 .

RuzickA über Bakterien 337.

\section{S.}

Saccharomyceten, Auffassung als Entwickelungsstadien von Mucorineae 138.

- Einteilung 604.

- Entwickelung 605, 606*, 608*, 609, Saccharomycodes 611 , Schizosaccharomyces $613^{*}$.

SACHS über Ascomyceten 423*, Begriff Energide 4, Charophyten 748*, 749, 751*, 752*, Piptocephalis 145*, Vaucheria 82*.

SADEBECK über Exoascaceae 597, Taphrina $597,598$.

Salamander (Regeneration) 59.

SALMON über physiologische Arten bei Erysiphe 482, 483, 484.

Salpeterwert von lösungen 98 .

SAPPIN-TRoufFy über Auricularia 667* Cytologie Basidiomyceten 674, Tredineae $628,637$.

Saprophytismus 134, 162, 178, 248.

Sauerstoffmangel als Ursache der Peritheciumbildung bei Penicillium 50:3.

Säulchen bei Cutleria 280, 281*, 282, 284.
Säule (zentrale) bei Mrxomyceten 408,410 , $411,412$.

SAUVAGEAU über Cutleria 280, 281*, 282*, Dauerzellen bei Nostoc 374, Ectocarpus $263^{*}$. Strepsithalia 270*.

Schalenaufbau der Diatomeae 243*, 244*, 246, Peridineae $233 \mathrm{ff} ., 234^{*}, 235^{*}, \mathbf{2 3 6}$.

Schattenform von Batrachospermum 315.

Scheibenform als reduzierte Polsterform $191,270$.

Scheide bei Bakterien 342, Cyanophyceae 377, 384, Oedogonium 205, 206.

Scheidenzelle bei Oedogonium 205, 208*.

Scheinverzweigung ef. Verzweigung und Dichotomie.

Scheitelzelle bei Cladophora 104, Charophyten 749, Cyclosporeae 288*, 289*, 291, 293*, 299, 305̃, Hydrurus 228, Monoblepharis 123, Phaeosporeae 257, 258, 260, 265, 275, 277, 285, Rhodophyceae 310*, 312, Siphonocladus 101, Struvea 103.

Schildgriff der Charophyten 746, 751*.

Schilling über Dauerzellen bei Ceratium 239*.

SCHIMPER über Chromatophorenentstehung 27, 43, Pyrenoid 8.

ŚcHIÖNNING über Schizosaccharomyceten 613.

Schizomerisstadium bei Ulothrix $18 t^{*}, 185$.

Schleier der Agaricaceae 705, 710, Amanitaceae 713, Pholioteae 714, Tricholomeae 713.

Schleim und Schleimbildung bei Bakterien 346, 350, 356, 359, 361, Ceratostomella (Asci) 523, Chlamydomonas 11, 14, Chlorangium 172, Chrysomonaden 226*, 227, 228, Coelastrum 178, 179*, Cranophyceae $374,375,378,379,381,382$, 384, Cylindrocapsa 185, Desmidiaceae 219, 220*, 223, Diatomeae 248*, 252, 253*, Dictyotaceae 292, Draparnaldia 187, Endosphaeraceae 32, 35, Ervsiphe $471,472 *$, 481, Fucaceae 302, 303, Heterokonten 212, 215, Hrdrodictraceae $40,41,46,47$, Laboulbeniales 530. Laminariaceae 286, Mrxobakterien 388, Myxomyceten 397, Nidulariaceae (Peridiolenbildung) 733*, Oedogonium 206, 210*, 211, Peridinales 232, Radiofilum 182, Sphaeroboleae 726,727 , Tetraspora 179, 180, Ulothrix 184*, 185, Vaucheria $80,83,88,89$, Volvocineae $19,20,21 *$ $22,23,24,26$, Zy gnemaceae $19 \%$.

- Anhängsel bei den Fporen ron Sordiria $521 *$.

- Ausstoßung :35.2.

- Bildung bei den Fortpflanzungsorganen 83. 89 .

- Fortsätze 180 .

- Haut bei Thelebolus 5.:

- Hülle bei Bakterien 36. Chlamviomonas 14, Chrysomonaden 2.2-, 2.25

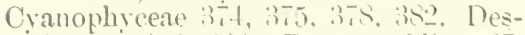

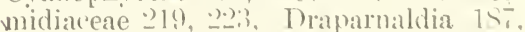

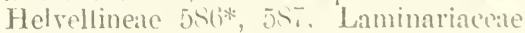
j.) 
286, Peridinales 232, Radiofilum 182 , Volvocineae $19,20,21 *, 22$, Zygnemaceae 194, 196, 197.

Schleim, Kanal bei Desmidiaceae 219, 220*, Diatomeae 253*.

- Kolonie 212, 215*, Bakterien 350.

- Papille bei Oedogonium 210*, 211.

- Reagens 219.

- Scheide der Bakterien 356, 359, 361, Cyanophyceae 377, 384.

-- Schicht bei Clathraceae 737, 738, Coelastrum 178, 179*, Diatomeae 248, 252, Phallaceae 740, Radiofilum 182, Tremella 669, Zygnemaceae 197.

Schloßpanzer der Peridineae 233.

Schloßplatte der Peridineae 234.

SCHMIDLE über Batrachospermum 314*, Radiofilum 182.

Schmidt über Oedogonium 209*.

Schmrtz über Castagnea 274, Chromatophorenentstehung 27, Dermonema 316*, Dudresnava 320, Pyrenoid 8, Siphonocladus 101*, Ustilago 620, Valonia 100\%.

Schnabel der Oogonien von Vaucheria 83. Schnallenbildung bei Givrophana 699*, 700.

SCHÖLER über Infektion der BerberitzenAecidien 639.

Schraubenträger bei Ascodesmis 459, 460*, $461^{*}$.

SCHRöDER üher Bakterien 331, Desmidiaceae 220, Eintrocknen von Flechten 557.

SCHRÖTER über Ascomyceten (Einteilung) 431, Exoascaceae 599*, Gasteromyceten 718, 725*, Myxobakterien 385, Myxomyceten 410 (Note), Rhizina 589*, Trametes 703 , Tulasnella 679 , Tulostomaceae $677,725^{*}$.

Schulze über Bakterien 331.

SснÜтT über Diatomeae 243*, Peridineae $232^{*} 234^{*}, 235^{*}, 236^{*}, 237^{*}, 238^{*}, 239^{*}$ $240^{*}$.

Schutzhülle (sterile) der Fruchtkörper, cf. Fruchthülle.

ScHWANN über Bakterien 331.

Schwärmer bei Bakterien 342, Castagnea 273, Chaetophoreae 189*, Chlamydomonas $7^{*}, 8$, Chlorangium 173*, Chrysomonaden 225, 226* 227, 228*, Coleochaete 191*, Elachistea 272*, Hydrodictyaceae $41,42^{*}, 47,48$, Laminariaceae 287, Monoblepharideae 111, 112*, 113, Myxomyceten 393, 402, Phyllitis 278*, Pleurococcaceae 176, Protococcaceae 175, Protosiphon 54*, 55, Punctaria 275, Sporochytriaceae 119, 120, Vaucheriaceae 79, 80, Volvocineae 20, 27.

- amöboide Bewegung, Vaucheria 79*, 80.

- Ausschlüpfen 226*,227.

- Isokonten 175.

- Keimung 79*, 80, 112, 272, 273*, 287.

Schwärmspore bei Chlamydomonas 8 , Cladophora 106, 107, Ectocarpaceae 260, Heterokonten 212,213*,215*, Peridinales 239, 240*, Sphaeroplea 108, Stephanokonten 203, Ulotrichales 182, Valonia $100^{*}$.
Schwärmspore, Ausschlüpfen 107, 119*, 120 . Schwebevorrichtung bei Diatomeae 248, Peridineae 236.

Schwefel als Reservesubstanz 358.

- in Bakterien 342, 346, 355\%, 3อ̄8.

Schwefelwasserstoff 358 .

Schwellkörper bei Oedogonium 206, 207*.

SCHWENDENER über Lichenen 549, 550*.

Schwerkraft 219.

- Einfluß auf die Organbildung 58, 60.

— - auf die Polarität 59.

- - auf die Verzweigung 58, 59.

Schwimmblase bei Fucus 298.

Scobiciner Thallus bei Evernia 567.

Scolecit bei Ascobolus 464.

Scytonemaform bei Cora 693*, 694 .

SENN über Chrysomonaden 225, Coelastrum 178, 179*, Ochromonaden 230*, Scenedesmus 177*.

Septicämien bei Bakterieninfektion 346 .

Serum, Diphtherie 348.

- Tetanus 355.

Sexuales (Chermes) 661, 662.

Sexualität der Ascomyceten 424-442, 452, 453, 464, Gymnoascus 496, Laboulbeniales 546 ; Basidiomyceten $671-675$, 677.

- Abnahme bei Ascomyceten 424 ff., 465, 467 (Lichenes), 548, 558 (Peltigera), 559, 566 (Parmelia), 615; Uredineae 628.

- Verlust bei Basidiomyceten 677, Gymnosporangium 657, 658, Uredineae 664.

Sexuparae (Chermes) 661, 662.

SICARD über Basidiomyceten, Befruchtung 671.

Sicherheitslampe (Bakterien) 344.

SimoNs über Konzeptakelentwicklung bei Sargassum 299, 300*, 301*.

Sirodot über Batrachospermum $314^{*}, 315$, $316,326$.

Sklerotien bei Armillaria 712*, Aspergillus 502, Claviceps 428*, 518*, 519 , Cordyceps 518, Ctenomyces 496* (Hakenbildung), Lentinus 713, Penicillium 502, 503 , 504*, Polystictus 703, sclerotinia 426, 427*, 580, Tulostoma 724 .

- Keimung Claviceps 427, 428*, 518*, 519, Sclerotinia 579*, 580.

Syith, A. L. über Diatomeae 243*, 249*, Myxobakterien 386.

- W. G. über Basidiomyceten, Befruchtung 671.

SOLIER über Derbesia $204^{*}$.

Solms-LAUBACH über Dasycladaceae 92*, 93, 94*, 97, Onygena 506, 507, Penicilliopsis 504, $505^{*}$, Phylogenie der Trïffelpilze 509, 511, Ustilago Treubii $622 *$.

Sorale 550*, 551, 555 .

Soredien (Lichenes) 563, 566.

- Auffassung 551.

- Bildung 550*, 551, 555 .

- Bildungsstellen (bestimmte) 551, 555.

Sorophoren 293.

Sorus (Sporangien) 267, 275, 276.

SOWERBY über Getreiderost 638.

Spallanzini über Bakterien 331 
Epaltkörper der Cyanophỵceae 381.

Spaltpilz ef. Bakterie.

Spaltpilzflechten 386.

SPExcen, Herbert über Begriff der Lebewesen 1.

Spermakern 107, 108, 15**, 159*, 161*, 292, $29 \%$.

Spermatangien bei Nemalion 312.

Spermatiden 52, der Charophyten 746, 751* 752 .

Spermatien bei: Ascomyceten 423*, 424, 4.25*, 43:3, Calosphaeria 525*, 526, Cucurbitaria 523, Melanconis 526, Valsa 524*; Lichenes 548, Nephroma 559, Physcia $565^{*}$, Verrucaria 552; Rhodophycecte $305,312,313,314$; Uredineae 627, 628, 635, Cronartium 650, Gymnnsporangium 657*, Puccinia 639, Phragmidium 631, Uromrees 633.

- bei Laboulbeniales 531*, 532, 534*, $542 *$.

- bei Laboulbeniales, endogene: Stigmatomyces 531*, 532, Zodiomyces 545, 546*.

- bei Laboulbeniales, exogene: 533, 546*.

- Befruchtung ef. Ascus und Ascusbildung, Kopulation.

- Basidiomyceten (Theorie) 671.

- Bildung 308\%, 312.

- Keimung 433, Cucurbitaria 522*, 523.

- Kern 30 S.

- lose Lichenen 557.

- Mutterzelle $311^{*}, 312$.

- rudimentäre bei Nephroma 559 .

- Verbreitung bei Cronartium 650.

Spermatozoiden 13, 14, 27, 48, 52*, 130; bei Batrachospermum 315, Charophyten $7 \pm 5,746,751 *$, Coleochaete 192, 193, Cutleria 284*, Cylindrocapsa 185, 186*, Dictrotaceae 290, 292, 293, Fucaceae $296,302 *, 304 *$, Oedogonium 209, 210* Ionoblepharideae 124, 127*, 128*, 129, 130, Sphaeroplea 107*, 108, Vaucheriaceae $82 *, 83,88,89$, Volvocineae 20, 21*, $22,23^{*}, 24,26,27$.

- Ausschlüpfen 108, 123*, 126*, 127*, 210.

- Bewegung 124, Dictyota 292.

- - amöboide, Monoblepharis 124.

- Bildung 22, 52*, 123*, 124, 126*, 130 $304 *$.

- - bei den Tieren 52*.

- Bündel 21*, 22, 23*, 24*, 26.

- Eindringen in das Ei 26, 107*, 108, 124, $127^{*}, 128^{*}, 129,302 *, 304^{*}$

- - in die weiblichen Individuen 22, 26.

- farblose 192.

- grüne 192.

- Mutterzelle 185, 186*.

- - Ausschlüpfen bei Oedogonium 210*

- unbewegliche bei Batrachospermum 315.

Spermogonien 423, 424, 425\%, 433; bei $\boldsymbol{A s}$ comyceten Cucurbitaria 522*, 523, Cyttaria 580, Dothideales 529, Polystigma 514*, Valsa 524*; Lichenes Baeomyces 556, Cladonia 569, 570, 571, Endocarpon 554, Graphideae 555, Lecanora 502, Lecidiaceae 556, Nephroma 5.59, Parmelia 565, 566, Physcia 568, Verrucaria 552;
Uredineat 49*, 627, 630, Chrysopsora 656, Grmnosporangium 657*, Phragmidium 631*, Puccinia 631, Uromyces 633.

Spermogonien, Stroma bei Calosphaeria 525*, 526, Melanconis 525*.

Spezialisierung der einzelnen Energiden 5. Sphaceliazustand von Claviceps 518*, 519. Sphärocysten 709, 710.

Spindelzelle bei Myxomyceten 396, 397.

Spiremstadium der Ascuskernteilung 488*, 489.

Spitzenwachstum bei Caulerpa 74, 75, Vaucheria 79.

Sporangien cf. auch Zoosporangium 132.

- bei Ascoidea 442\%, Cyanophyceae 380, 381, Ectocarpus 260, Monolpidiaceae 112*, 113*, 114, Myxomy ceten 403, 404, 405, 407, 408, 411, 412. Pediastrum 40, Vaucheria 81, 83*, 'Zygomyceten 132*', $133^{*}, 134,136,137^{*}, 138,140,141^{*}, 142$, $143,144^{*}, 145^{*}$.

- Ausschleuderung 137.

- (berindete) der Zygomvceten 136, 137*.

- Bildung 394*.

- - künstliche 145 .

- - Verlust 145 .

- Deutung 132.

- Differenzierung 134, 140.

- der x-Generation 435.

- der 2x-Generation 435.

- Haupt 134.

- Haut äußere cf. Exospor.

_- - innere cf. Endospor.

- Inkrustierung bei Pilobolus 136.

- nackte bei Zygomyceten 136 .

- Oeffnung bei Myxomyceten to9, 410 , 411,412 .

- polyenergide $132 *$.

- plurilokulare bei Asperococceae 265, 266, 267, 268, Cutleriaceae 280, 284, Ectocarpeae 260, 262, Elachisteae 27.2*, Eudesmeae 273*, Myrionemeae 270*, 271*, Punctarieae 274*. 275, Sertosiphoneae $275,276^{*}, 277^{*}, 278^{*}$

- Entstehung 266, 267*, 268.

- Sorus bei Myxomyceten 406 .

- ..- (plurilokulare) 267, 275.

- Sporenbildung $132^{*}, 133^{*}, 136$.

- Träger 136, 13\%*, 135, 140, 141*, 142, 143 .

- Trennung vom übrigen Teil der Zelle 133.

- unilokulare bei Asperococceae 265, 267, 268, Chorda 279*, Cutleriaceae 280, 281*, 283, Desmarestieae 264*, 265, Ectocarpeae 259, 260, Elachisteae $272 *$, Eudesmeae $273^{*}$, Laminariaceae $286,25 \%$, Myrionemeae 269, 270*, 271\%, Punctarireae $27 t^{*}$.

- - Entstehung 267, 206, 274, 279.

- vegetatives Auskeimen \$1, \$.ं*.

- verzweigte bei Mromyceten $40 \%, 412 *$

- Wand 136, Mrxomyceten $402,403,40 \%$ $409,+12,+13 *$

Sporangiolen der Thamnidiaceae 14()$, 1+1^{*}$, 145 .

- und Konidien 1\$1, 1.16. 
Sporen ef. auch Ascussporen, Basidiosporen Endosporen, Pyknosporen, Schwärmsporen und Zoosporen.

- und Sporenbildung bei: Bakterien 336*, 338, 353*, Cyanophyceae 374, 375*, 376*' 377, Dipodascus $443^{*}, 444$, Eumycetes 665, Gasterolichenen 743*, Myxobakterien $386,387^{*}, 388,390$, Myxomyceten 391, 394, 398, 399, 402, 403, 404, 408, 414, 415*, Pilobolus 439*, Protomyces 446, 447*, Naccharomyceten Allg. 615, Schizosaccharomyces $613^{*}, 614^{*}$, Taphridium $445^{*}$.

- Ausstreuung 136, 137, 140.

- Austreten aus den Sporangiolen 141*.

- Bau bei Saccharomyceten 604, 605, 611.

- bildende Zellen der Bakterien 342.

- Bildung endogene 431, cf. auch Endosporen.

Sporenfrucht 418, 419 (Ascomyceten), cf. auch Fruchtkörper.

- und Podosphaera 148.

Sporenhaut 155 .

- Keimung bei Bakterien 336*, 338, Empusa 146, Myxobakterien 387*, 388, Myxomyceten 392*, 393, 400*, 'Thamnidieae 141*.

- 2-kernige bei Pilobolus 133.

- Massa, Aufsitzen auf dem Stiel bei Phalloideae 741, 742*.

- Membran bei Elaphomyces 510*, Myxobakterien 388, Terfezia 511.

- Mutterzelle 48, 49, bei Monascus 499*.

- Resistenz bei Bakterien 338.

- vielkernige bei Protomyces 447*.

- Wand, Verschleimung 136.

- Zerstreuung bei Myxomyceten 404, 405 407, 408, 410, 411.

Sporidien bei Calyptospora 653, Chrysopsora $655^{*}, 656$, Coleosporium 655, Endophyllum 647, Gymnosporangium 658*, Tilletia 624, Tuburcinia 626, Tulasnellaceae 679, 680*, 681*, Uredineae im Allg. 49*, 50, 627, Urocystis 626 .

- Keimung 49*, 50, Calyptospora 653.

- mit '2x-Nucleus 637.

- sekundäre $679,680^{*}$.

- und Basidiospore 665, 668, 670, 672.

Sporocarpien bei Onygena 505*, 507, 508*, Penicilliopsis 505k, 506, 509.

Sporocysten der Myxomyceten 404, 405.

Sporogene Fäden der Rhodophyceae $313^{*}$, $314,315,316^{*}, 318^{*}, 319,320,321,322$, 325.

- Chromosomen, Reduktion 314.

_ - Fusion mit den Auxiliarzellen 318, 319*. Sporogene Zelle der Rhodophyceae 322. Sporophyt 280, 282.

Spreitenbildung bei Struvea 101*, 103. Sproßknotenzelle der Charophyten $747^{*}$.

Sprossung (hefeähnliche) bei Doassansia 626, Empusa 146, 147*, Exobasidium (Basidiosporen) 691*, Mucorineae 138, Saccharomyces 601, 603*, 604, 605, 606*, 607, Taphrina 599*, Tremella 669, Ustilago $618,619 *, 620$.
Stäbchen bei Bakterien 353*, 354, Desmidiaceae 219, Myxobakterien 387*, 388. - sporenbildende bei Bakterien 353*, 354,

- vegetative bei Bakterien 354.

STAHL über Apotheeienentwickelung 547, 550*, Collema 423*, 433, 434*, Mухо gasteres 394, Vaucheria 79*, 80.

Stammbaum 5, der Basidiomyceten 678, Cantharellineae 694, Cyphellaceae 696, Ectocarpaceae 258, Gasteromyceten 728, Isokonten 17, des Pflanzenreichs 6, der Siphonales 31, 56 .

Staphyliniden als Laboulbeniaceae-Wirte $535,537,538,540,544,545,546$.

Stärke $3,8,17,35,37,44,56,79,88,181$, $197,208,238,400,413$.

- Ablagerung $44 *$.

- Bildung aus anorganischer Nahrung 66.

- - aus organischer Nahrung 17, 66.

- Lösung 44, 45.

- Pyrenoiden cf. Pyrenoidenstärke.

STEIN über Peridineae 234*, 235*.

Steinbrand 623 .

StTEINMANN über Triploporella $94^{*}$.

Stentor $175 *$.

Stereonemata 414.

Sterigmen bei: Basidiomyceten 418, 616 , Auricularia 668, Autobasidiomyceten im allgemeinen 671, Cantharellineae 685, Dacryomyces (Zweizahl) 671, Gyrophana 699*, Hygrophorus 707*, 708, Pilacre 669, Psalliota 715, Sparassis 698, Tremella 639, Tulasnella (Fehlen) 679, 680, Vuilleminia 683.

- bei Chaetocladium 145*.

- successive Bildung bei Cantharellus 685, Clavaria 685.

Sterilisieren, fraktioniertes 332.

STEVENs über Albugo 153*, 154*, 155, $156^{*}, 157^{*}$, Synchytrium 116.

Stichidien bei Chondra 324*, 327.

Stichkultur 334.

Stichobasidien 676, 677, 678, 685 .

Stickstoff, Assimilation. Bakterien 351. - _ des freien $\mathbf{3} \mathbf{5 6}$.

Stielbildung bei Myxomyceten 392, 399, Phallaceac 737, $742^{*}$, Tulostomaceae 723, 725*.

Stielzelle der Antheridien cf. Antheridien.

- der Ascomyceten 420.

- der Carposporen bei Rhodophyceae 313, $320,324$.

- der Oogonien 290, 291, 301, 302, Sphaerotheca $450^{*}, 451$.

Stigma bei Chlamydomonas 7, 8, 10, Chlorangium 172, Chromulina 192, Cutleria 283, Dasycladaceae 91, Draparnaldia 187, 188, Ectocarpeae 260, Fucaceae 304, Ochromonaden 230, Protosiphon 55, Ulothrix 183, Volvocineae 22, 23, $24 *, 26$.

Stinkbrand 623 .

STrAsBURger über Acetabularia 96*, Basidiomyceten, Cytologie 666, Caulerpa 75*, Cladophora 105*, Fucus 297, 304, 305, Myxomyceten 413*, 414, Oedo- 
gonium 205, 207*, Ustilago violacea 621 , Vaucheria $83^{*}$.

Strauchflechten 56t, 566.

Streckung und Querteilung der Zellen als Fortpflanzungsweise bei Schizosaccharomyces $612,613^{*}$.

Stroma, Aufbau bei Ascomyceten 424, 425*.

- Bildungen bei Ascomvceten 505*, 513*, $51 \pm, 515^{*}, 516^{*}, 517,525 *, 526,527,52 S^{*}$, 529.

- Differenzierung in sterile und fertile Teile 526, 528.

Struktur, spezifische 76 .

STUDER über Clitocybe aurantiacus 711.

Stützhrphen bei Ascodesmis 461 .

Stylosporen 432, 434, Phyllactinia 472.

Substanz, Eigenschaften der lebendigen 99.

Sunius prolixus Er. als LaboulbeniaceaeWirt 545.

Suspensoren bei Chaetocladium 145.

Symbiose bei Cyanophyceae 373, 386.

- bei Uredineae 663.

- von Algen und Tieren 102*, 103 (Strurea), 175 (Chlorella).

- von Pilzen und Algen, Lichenes 423, 549

- von Pilzen und Phanerogamen 509.

Svmmetrie 218.

- bilaterale 245.

- radiäre 245 .

Srnapsisstadium der Ascuskernteilung 488*, 489.

Synkarion cf. auch Nuclei, zweikerniges Stadium.

- bei: Ascomyceten Galactinia 457*,458, Humaria 467 (und Note), Peziza 572, 573, Pyronema 457, Sphaerotheca 452; Basidiomyceten 666, 674, 692 (Thelephora).

- Hyphe 457*, 458, 573

- wiederholte Teilung 458.

Synkarionzelle (Kerne der) 452, 453.

Synkariophyten 674.

Syntonin in Kulturen 169.

Systematik als Stammesgeschichte 5.

\section{T.}

TANsIEY über Algensystem 16, 55, 56, Stellung der Dasycladaceae 90.

Taschenkrankheit der Pflaume 598, 599*. voN TAVEL über Sexualität der Ascomyceten $435 \mathrm{ff}$., über Zoosporen und $\mathrm{Ko}$ nidien 146.

Teilung als Fortpflanzungsweise, cf. auch Kolonie und Koloniebildung und Längsteilung.

- bei : Bakterien 335, 341, 342, 345, 346, Chlamydomonas 4, 8, 10, Chlorangium 172, Chrysomonaden 226*, 228, Coelastrum 178, Desmidiaceae 222, Diatomeae 249, 250*, 251*, Heterokonten 212, 213, Myxobakterien 388, Myxomyceten $392,396,401,403$, Ochromonaden 231. Peridineae 239*, 241, Pleurococcaceae 176*, Protococcaceae 175, Scenedesmus 177, Tetraspora 180, Volvocineae 21.

- Aequations- 29.
Teilung bei Entstehung der Fortpflanzungszellen 33, 34, 39, 40, 45 .

- bei Koloniebildung ef. Koloniebildung.

- des Nucleus cf. Nucleus.

- der Zellen cf. Zellteilung.

- heterotypische 304.

- (Längs-) 213 cf. Längsteilung.

- (Quer-) 194, 195*, 197, ef. auch Streckung und Querteilung.

- Richtung bei Bakterien 341, 342, 345, 436.

Telephase - Stadium der Ascuskernteilung 488*.

Teleutosporen $49^{*}, 50, \mathbf{6 2 7}, 635$, bei Calyptospora $653 *, 654$, Coleosporium $655^{*}$, Gymnosporangium 655*, 657, 658, Ochropsora 655*, Phragmidium 62.*', 631*, 632, 635, 636, Puccinia 640*, 659, Ravenelia 660, Uromyces 659*.

- apogame 636, Leptopuccinia 637, 659.

- binucleäre $632 \%$.

- Einteilung der Uredineae nach den T. $647,648,656$

- einzellige $648,656$.

- gestielte 647 .

- Keimung bei Calyptospora 654, 656, Chrysomyxa 647*, 648, Chrysopsora $655^{*}$, Coleosporieae $648,654,655^{*}$, Melampsoreae 648, 651, Ochropsora 655*, Puccinia $640 * 656$.

- Köpfchen 656, 660* (Ravenelia).

- Lager 627, Phragmidium 629*.

- mehrzellige 632,656 .

- Reihen 648, 649.

- ungestielte 647, 648, 650.

- und Ascus 665 .

- und Basidie 628, 665 .

- und Konidie 665.

- uninucleäre 632*.

- vierzellige $648,653^{*}$.

- zweizellige $655^{*}, 656,659 *$.

Temperatur, Einfluß auf die Fortpflanzung 47,55

- Optimum 346.

Terebrator bei Umbilicaria 563 .

Termite 546.

Tetradenstadium 52.

Tetrasporangien bei Dictyotaceae 288*, 289, 290*, 241, 292*, Rhodophrceae 310, 324, $325,326$.

- Anordnung 326, 32\%.

- Kern 293.

Tetrasporen bei Cyclosporeae 257, 287, Dictyotaceae 289, 290, 291, 292*, 293; Rhodophyceae Florideae: Ceramiales $323^{*}, 326,327,328$, Nemalionales 309, 310, 311, Porphrra 309.

- als Gonotokont cf. Gonotokont.

- amöboide Bewegung bei Batrachospermum 326.

- Crtologie, Dictyota $293,294^{*}$.

- Keimung $290 *, 292$.

- Mutterzelle 310, 320.

- Pflanze bei Crclosporeae 292*, 293*, 294, Rhodophyceae 309, 310, 320, 326.

Thallomen 61 .

Thallus ef. auch stroma 55. 
Thallus, Aufbau bei Lichenen 423*, 434*, 550*, 551, 567, Collema 423*, 43́4*, Endocarpon 553*, Graphideae 555, Gyrophora 563*, Lecanora 562*, Parmelia 565*, 566, Peltigera 558*, Physcia 568*, Solorina 539*, Stictina 550*; Phaeophyten : Cutleria 281*, 284*, Dictyota 291, 292*, '293*, Ectocarpaceae 267, 268*, $270^{*}, 271^{*}, 272^{*}, 274^{*}, 275,276 *, 277^{*}$ ', 278*, 279*, Fucus 298, Himanthalia 305, Laminaria 286, 287*, Padina 288*; Rhodophycecie 307, 310*, 312, 321*, $322 *$, 323, 328*.

- Bildung bei Lichenen 550*, 555 .

- Differenzierung bei Collema 433.

- endolitischer 552 .

- Formen der Lichenen 561, 562, 564, 566, 567, 568, 569 .

- heteromerer 550*, 551 .

- homöomerer $423^{*}, 434^{*}, 551$.

- scobiciner, Evernia 567.

Thaxter über Empusa 147, 148, 149*, Laboulbeniales $530-547$ (531*, 534*, 536*, $537^{*}, 538 *, 539 *, 540 *, 541 *, 542 *, 543 *$, $544 *, 546 *$, Monoblepharideae 123*, 124, 125*, Myxobakterien 385, 386, 387*, 388, 389*, Phallogaster 736*.

Thelebolus gehört zu den Hemiasci 449 .

THURET über Asperococcus 269*, Castagnea $273^{*}$, Ceramiales $323^{*}, 324^{*}$, Chaetomorpha 104*, Cladophora 105*, Codium 64*, Cutleria 284*, Dictyota 292*, 293*, Dudresnaya 318*, Elachistea 272*, Fucaceae 295*, 296, 302*, 304*, 305*, Laminaria 286, Punctaria 274*,275, Scytosiphoneae 278*, Ulva 182*.

VAN TIEGHEM über Basidiomyceten 666, 671, Dauerzellen der Cyanophyceae 374, fossile Bakterien 353, Monascus 497, Pyronema 454, Sexualität der Ascomyceten 429, Tulostoma 675, 676, 677.

Tier und Pflanze 2.

Timberlake über Hydrodictyon (Chromatophor) 42, 44, 45, Pyrenoid 8.

Tischler, Mycoplasmatheorie 642.

ToDE über Thelebolus 573.

Tonoplast $65 \mathrm{ff}$.

Toxin, Diphtherie- 347.

- - Gewinnung 348

- Tetanus- 355 .

Tragzelle der Rhodophyceae 322.

Trama der Russulaceae 706.

Tramaadern der Eutuberaceae 592, 593.

Tramaplatten bei Clathraceae 734, 735*, 736, 739, Hymenogaster 734*, Mutinus $740,741^{*}$, secotium 740 .

Transpiration als Ursache der Sporangienbildung 140 .

TRANZSCHEL über Monoblepharis 128, Ochropsora $6 \overline{5} 4$.

Traubenzucker in Kulturen 353.

Trennungsteilung cf. Reduktionsteilung.

Treviranus über Bakterien 331, Getreiderost 638 .

Trichogyne bei: Ascomyceten Ascodesmis 460. 461*, Monascus 498, Polystigma 424, 425*, 514*, Pyronema 422*, 454,
455*; Laboulbeniacene 531*, 532, 535̃, 536*, 540, 542, 543, 545; Lichenes Cladonia 570*, 571, Collema 424, 430, 433, 434*, Endocarpon 553*, 554, Gyrophora 563*, Lecanora 561, 562*, Parmelia 565*, Pertusaria 560, 561, Physcia 568*; Rhodophycecte 311*, '312, 313, 314, $318 *$; Uredineae 628, 629, 630*, 631 . Trichogyne, Ascomyceten als Atmungsorgan, VAN Tieghem 430.

- homolog mit der Kopulationspapille bei Albugo 468 .

- Degeneration bei Ascomyceten 629, 630*.

Trichothallisches Wachstum bei Ectocarpus 260.

Trichterkörper der Diatomeae 245*, 24l, $247 *$.

Trow über Pythium 161, Saprolegnia 164, $166,167,168$.

voN TUBEUF über Erysipheen 403, Gymnosporangium $657 *$.

Tubularia mesembryanthemum (Regeneration) 59 .

Tulasne über Calosphaeria $525 *$, Claviceps 518*, Cordyceps 516*, 517*, Cucurbitaria 522*, Erysiphales 472*, 473*, 481, Eutuberaceae 589*, 595*. Hymenogaster $734^{*}, 735^{*}$, Hypocrea 515 , Hypoxylon 527*, Melanconis 525*, Melanospora 513, Nyctalis 708, Onygena 505*, Pisolithaceae 724*, Pyronema 421*, Rhytisma 581*, Sclerodermataceae 720*, Secotium 741*, Sphaerosoma 589, Tulasnella 679 , Valsa $524^{*}$, Xylaria $528 *, 529$.

Tüpfeln (Verbindungs-) bei Ascobolus 578 , Thelebolus 575 .

Turgor 77, 97, 98, 99, 196.

- beim Herauswerfen der Gleba bei den Sphaerobolaceae 726 .

Typhusbakterie 340 .

U.

Ueberbrückungs-Arten bei physiologischen Arten 484.

Ueberwinterndes Mycelium bei Cronartium 649,650 , Ustilago 61\%.

Ueberwinterungsblase bei Acetabularia 96, 97.

Ueberwinterungsorgane 201.

Ueberwinterungszustände cf. auch Dauerzustände.

- bei Acetabularia 96, Albugo 157, Chrysomyxa 648, Cladophora 105, 106, Coleochaete 193, Cronartium 649, 650, Cutleria 280, Desmarestia 265, Endophyllum 647, Erysipheae 483, Exoascaceae 597, 598, Melampsorella 65̃1, Peronospora 160, Pythium 162, Uredineae 641.

- einjähriger, nicht perithecienbildender Erysipheae 483.

- Perithecien 478.

- Sklerotien 580 cf. auch Sklerotien.

Umbildungen durch Parasiten hervorgerufen cf. auch Hypertrophien und Gallen: Ustilago 621.

Umhüllungshyphen cf. auch Fruchthülle und ' Zygosporenfrucht 420 . 
Umhïllungshyphen bei Ascodesmis 461, 402, Aspergillus 501, Erysiphe 484*, Grmnoascus $493,494^{*}$, Humaria 466 , Monascus 429, $497 *, 498$, Mortierella 142*, Phyllactinia 486*, Pyronema 456*, sphaerotheca $450^{*}, 451^{*}$.

Ungeschlechtliche Individuen 19, 25, 27, 307.

Unicelluläre polyenergide Individuen 16.

Unterschale der Peridineae 233, 235.

Uredineae, Entwicklung 627, 630 ff., 635 - $63 \%$.

- - Abkürzungen 635-637.

- - Möglichkeiten 635-637.

Uredolager 627, 629*.

Uredosporen 50, 627, 631, 635, Phragmidium 631, Puccinia 659, Ravenelia 660.

- apogame 635, 636, 637.

- binukleäre 631, 632.

- Ueberwinterung 641.

- und Diplokonidien 670.

- und Oidien von Dacryomyces 670.

Uredowirt 642 .

Ustilagineae, Infektion 617, 618, 621, Tilletia 624, Tuburcinia 626 .

UYEDA über Monascus 448, 449.

\section{Y.}

Vagina der Agaricineae 705, 706*.

Vakuole 28, 6t ff., 69, 87, bei Codiaceae 69, Desmidiaceae 218, Heterokonten 212, Hydrodictyon 41, 44, Monoblepharideae 125, Myxomyceten 392, 413, 414, Peridineae 237, Pleurococcaceae 175, Protosiphon 53, Pyronema 454, Saccharomyces $602,606^{*}, 607,609$.

- farbstofferfüllte bei Bakterien 336*, 337.

- (Glykogen-) bei Saccharomyces 606*, 607.

- Inhalt 98.

- wasseranziehende Kraft 98.

- kontraktile bei Chlamydomonas 7*, 8 10, Chlorangium 172, Chrysomonaden 225, Draparnaldia 187, Heterokonten 212, 213, Hydrodictyon 45, Ochromonaden 230, Peridineae 237, Volvocineae $23,24^{*}, 26$.

- mit metachromatischen Körperchen bel Saccharomyces 607, 608*, 609.

- (Nahrungs-) 225, 230*, 231.

- pathologische 66, 70 .

- Teilung 66, 69.

- Verhalten bei der Sprossung der Saccharomyceten $606^{*}, 607$.

- Verschmelzung 66,87, Saccharomyceten 606.

- Wand 41, 42*, 43*, 65, 69, 71.

- zentrale bei Ácetabularia 97, Bryopsideae 56, Codiaceae 69, Desmidiaceae 218, Protosiphon 53, 55, Saccharomyces 606, Saprolegnia 165*, 168, Valonia 98, Vaucheriaceae 78, 84.

Valonia-Kultur 99.

Valva bei Diatomeae 242.

VAN REES über Ursache der Gametenkopulation 12 .

Vegetationspunkt bei Caulerpaceae $75^{*}$, 76, 77.

- Schutz 76.
Velum partiale der Agaricineae 705.

- universale der Agaricineae 705.

Venae externae bei Eutuberaceae 592, 593*, $594,596$.

- - Entstehung aus Gruben der Außenseite $592,594,595 *$.

- internae der Eutuberaceae 592, 594, 595, 596.

Verankerungsschläuche bei Codium $63 *$.

Verbreitung der Laboulbeniales 530 .

Vererbung 28.

Verflüissigung der Gelatine durch Bakterien 334.

Verkieselung 242, 256, cf. auch Kiesel.

Vermehrung cf. Fortpflanzung.

Vervollkommnung 5.

Verwandtschaft 5.

Verwundung, Einfluß der 77, 79.

Verzweigung bei: Acetabularia 97, 100, Andyomene 103, Caulerpa 74, 77, Charophyten $745,746^{*}, 748^{*}, 749$, Cladophora-104, Cyanophyceae 379, 384, Hydrurus 228*, Phaeophyceae 262*, $264^{*}, 265,268,269,273^{*}, 275,283$, 291, Siphonocladus 101, Struvea 101*, 103, Vaucheria 79.

- dichotome cf. Dichotomie.

- scheinbare bei Bakterien 341, 359, cf. Pseudođrchotomie.

- wirtelige $90,91$.

Vielkernige Zelle cf. Polyenergide.

Vierteilung bei der Bildung der Geschlechts energiden 304.

Virulenz 349.

VITTAdINI über Pisolithaceae 724*, Tulostomaceae $725 \%$.

Volva der Agaricineae 705, 706*, Clathraceae 737, 738, Phalloideae 718, 719.

Volvagallerte bei Clathrus 738, 739*, Mutinus $740,741 *$, Phallogaster $736^{*}, 737$.

Vorderhorn der Peridineae 234.

VORDERMAN über Monascus 448.

Vorkeime der Charophyten 746, 747*.

- _ - accessorische 747*.

Vorkeimzelle obere der Charophyten 746 , $747 *$.

- untere der Charophyten 747*.

VUILLEMN über Einteilung Basidiomyceten 675, Entomophthora 151, Nyctalis 708, Ustilago violacea 621 .

IV.

Wachstum begrenztes 75 .

- der Phaeophyceae 260, 265.

- (Dicken-) cf. Dickenwachstum.

- interkalares bei Caulerpaceae 75, 7 , Cutleriaceae 283, Desmidiacea 2.21, Draparnaldia 187, Ectocarpaceae $25 \%$ $259 *, 260,265,273,275,277$, Endocarpón 551, Laminariaceae $25 \%, 285$, Oedogonium $205,207 * 208$.

- mittelst Scheitelzelle cf. Scheitelzelle.

- (Spitzen-) cf. Spitzenwachstum.

- trichothallisches bei Ectocarpus ?60.

- unbegrenztes beim (Caulerpa-Rhizom it.

WAGER ïber Albugo 153, 15, , 15\%, Basidiomyceten Cytologie (ibit, (i). Cra- 
nophyceae $362,364,365,369$, Peronospora $159^{*}, 160$, Saccharomyces $606,609$.

WAGERsche Färbungsmethode für Hefen 603.

W AINIO über Apothecien - Entwicklung 548.

WALLROTH über Lichenen 549.

WALZ über Vaucheria 81.

Wandbildung bei Polyenergiden 571, bei Ascobolus 578, Brvopsis 57, Codiaceae 63, Dasycladaceae 90, 97, 98, Entomophthoraceae 146, 149, Mucoraceae 135, 136, 138, Peronospora 158*, Protosiphon 54, Siphonocladeae 101, 102, Thelebolus 578, Valonia 99, Vaucheria 79, 81, 83, 87.

Wandstruktur bei Desmidiaceae 219, 220*, cf. auch Zellwandstruktur.

WARD, Uredineae-Infektion 663.

WARMING über Gymnosporangium 657*, Hydrodictyon $42 *$.

Wasser als Bedingung für die Kopulation ausgetretener Gameten 131.

WEBER VAN Bosse über Bornetella 95, Caulerpaceae 71, 74, Chlorella 175, Struvea 102*, 103.

WEHMER über Aspergillus 502.

Weibliche Individuen 14, 27.

WEIss über Russulaceae 710 .

Wendezellen der Oogonien bei Charophyten 753.

WENT über Carotine 39, Codium 64, Monascus 448*, 449, 497, Vakuolen und Tonoplasten 66,69 .

von WetTstern über Acetabularia 96*, Batrachospermum 314*, Cyttariaceae 580, Myxobakterien 386.

WILDENOW über Getreiderost 638 .

WILL über Chlamydomonas $15^{*}$.

WILLE über Chroolepideae 190*, Dauerzellen der Cyanophyceae 374, Diatomeae 243*, Eudorina 22, Nemalion $313^{*}, 314$, Stellung der Caulerpaceae und Codiaceae 78 .

WILLIAMS über Dictyota 292, 293*, 294*, Fucaceae 296, 297, 301, 304.

WILson über Cyanophyceae 372.

WINKLER über Regeneration bei Bryopsis $58,59,60$.

WINogradsky über Bakterien 354, 356 , $357^{*}, 358,360$.

WINTER über Ceratostomella 542*.

Wirtspflanze, Deformation durch Parasiten 474, Erysiphe cf. auch Gallen und Hypertrophien.

Wirtswechsel bei Sclerotinia 580 .

- bei Uredineae 633, 661, 662 (Entstehung).

- im Tierreich 661, Chermes 661, Distomum 661.

WIтTRосK über Zygnemaceae-Kopulation $197 *$.

WoLfE über Nemalion $311^{*}, 312,313^{*}, 314$.

WolfF, R. über Coleosporium 654.

Woronin über Acetabularia 96*, Botrydium (Protosiphon) 53, 54*, Chromulina 226*, Humaria 466, Monoblepharideae 123, 124, 128*, 129*, Myxomyceten 400*, 401* (Plasmodiophora), Phyllobium 35,
Sordaria 521*, Synchytrium 114, 115*, Tuburcinia $624 *$.

Woroninsche Hyphe 426.

WоусICHI über Basidiobolus 200, 201.

Wright über Bryopsis 57.

Wundsaft, Bestandteile 442; 443, 610.

Wurzelbakterien, Eindringen 347*, 350.

Wurzelhaare cf. Rhizoiden.

Wurzelknotenzelle bei Charophyten $747^{*}$.

Wurzeln bei Caulerpa cf. Rhizoiden.

Wurzelzelle der Charophyten 746, 747*, 748 .

X.

Xanthophyll 212.

$\mathrm{x}$-Generation und 2x-Generation cf. Generation.

$\mathrm{x}$-Nucleus und 2x-Nucleus cf. Nucleus.

$\mathbf{Y}$.

YAMANOUCHI über Reduktionsteilung bei Polysiphonia 310.

\section{Z.}

ZACHARIAS über Cyanophyceae 366, 369, 371.

4-Zahl der Basidie 436.

8-Zahl der Ascosporen 436.

Zahl der Chromosomen cf. Chromosenzahl.

- der Chromosomen, Reduktion cf. Reduktionsteilung.

- der Sporen im Ascus cf. Ascussporenzahl.

'ZAHLBRUCHNER über Baeomyces 556 .

ZALEWSKI über Albugo 152.

Zederbauer über Myxobakterien 386, Peridineae 239, 240*.

Zelle 10.

- (ascogene) cf. Ascogene Zelle.

- (Basal-) Charophyten 746, 747*.

- (binucleäre) $50^{*}$.

- (Blattscheitel-) Charophyten 750*.

- (Blattspitzen-) Charophyten 750*.

- (Blattur-) Charophyten 750*.

- (erste Knoten-) De Bary bei Charophyten $746,747^{*}$.

- (generative) der Pollenkörner 27.

- (Glieder-) der Charophyten 748*, 749.

- (Internodial-) der Charophyten 748*, 749, $750^{*}$.

- (Knoten-) der Charophyten 748*, 749, $750 *$.

- (multinucleäre) sterile bei Hydnum 693, Thelephora 693.

- (nackte) 32 cf. auch Energiden nackte.

- (obere Vorkeim-) der Charophyten 746, $747^{*}$.

- (Rand-) der Charophyten 748*, 749.

- (Scheitel-) cf. Scheitelzelle.

- (sporogene) der Rhodophyceae 322.

- (Sproßknoten-) der Charophyten $747^{*}$.

- (uninucleäre) 50.

- (untere Vorkeim-) der Charophyten 747*.

- vielkernige ef. Polyenergide.

- (Wende-) der Charophyten 753.

- (Wurzel-) der Charophyten 746, 747*,748.

- (Wurzelknoten-) der Charophyten 746, $747^{*}, 748$.

- (Zentral-) der Charophyten 749. 
'Zellen, Bildung (freie) bei Thelebolus 576 .

- Büschel 16.

- Fäden 16, 173, 181, 1 S6.

- Fusion bei Rhodophyceae 324, 325.

- Kern = Nucleus.

- Körper 16.

- Platten 16, 173, 181, Phaeophyceae 288.

- Scheiber 1S6.

- und Energiden (Allgemeines) 4, 5, 13, $27 \mathrm{ff} ., 35,42 \mathrm{ff} ., 47 \mathrm{ff} ., 58 \mathrm{ff} ., 65 \mathrm{ff}$.

- Verbindurgen bei Rhodophyceen 312, cf. auch Plasmaverbindungen.

Zellhautring 205.

Zellsaft $6 \pm, 66,98$.

Zellstoffring 205.

Zellstruktur 197 (Zygnema) cf. Energidenstruktur.

Zellteilung $51 \mathrm{ff}$, bei Cladophora $105^{*}$, Codium 105*, 197, Confervales 213, 215*, Cyanophyceae 365, 373, Desmidiaceae $221 \mathrm{ff}$., Oedogoniaceae 205 ff., 207*, 208*, Peridineae 235 ff., 239*, Protosiphon 54.

- in der Ontogenie 25, 31.

- neomeristische 66, 71.

- panmeristische 66, 71 .

Zellwand 7, 9, 10, 11, 22, 111 ; Bakterien 335, Caulerpa 76, Confervales 212, 213*, 214, 215*, Cyanophyceae 375, 376, Endosphaeraceae 32.

- (Abwerfen der) 10, 14.

Zellwand, Auflösung bei der Kopulation bei Ascomyceten 420, 422.

_ - cf. auch Wandbildung bei Polyenergiden und Cystenbildung.

- Bildung bei Bakterien(sporen) 338, Chlorella 176 , Cladophora 105*, Chrysomonaden 225, 227, Cyanophyceae 373, 376. Diatomeae 252, Ectocarpeae 260, Endosphaeriaceae 34, 39, Fucaceae 297, Heterokonten 213, Hydrodictyaceae 40, 41, 46, 47, Merolpidiaceae 116, Monolpidiaceae 112, 113, 114, Myxomyceten 393, 398, 402, Ochromonaden 231, Oedogonium 210*, Peridineae 238, 240, Peronospora 159, Protosiphon 55, Rhodophyceae (Spermatien) 308, Saprolegniaceae 163, Sphaeroplea 107*, 108, Ulothrix 183, Volvocineae 27.

- Durchlöcherung bei Peridineae 237*.

- Fehlen der 5, 7, 8, 15.

- Kalkinkrustierung cf. Kalk.

- Kieselinkrustierung cf. Kiesel.

- Kragen 225, 231.

- partielle Lösung 14.

- Schichtung 35, 76.

- Skulptur 10.

- Struktur bei Confervales 212, 213*, 214*, 215, Diatomeae 243, 244*, Ochromonaden 231, Peridineae 236, 237*, 240.

- Verdickung bei Fortpflanzungszellen bei: Chlamydomonas 10, Chlorangium 172, Cylindrocapsa 186, Dasycladus 90, Diatomeae 245, Endosphaeraceae 32, 33, 35. 39, Monoblepharideae 127, Peridineae 237, Tetraspora 180, Ulothrix 185, Vaucheria 83.

- - durch Apposition 33.
Zellwand, Verdickung, örtliche bei Dichotomosiphon $88,89^{*}$, Udotea 61 .

- - rungförmige bei Oedogonium 205.

- vegetativer 'Zellên bei Cyanophyceae 374, cf. auch Cystenbildung.

- Verdünnung bei Rhodophyceae 312.

- Verschleimung bei Chrysomonaden 206, Draparnaldia 187, Endosphaeraceae 32, 35, Hydrodictyaceae 40, 41, 46, 47, Oedogoniaceae 226*, 227, Ulothrix 184*, 185 , Ustilago 619, Vaucheriaceae 80,88 , Volvocineae 19, 24

- Zerbröckelung 88, 354.

Zentralknoten der Mrxomyceten 412.

- Körper der Bakterien 372, Cyanophyceae 366, 367, 369, 371, 373.

- Säule cf. Säule.

- Strang bei Myxomyceten 392*.

- Zelle der Charophyten 749, Rhodophyceae $319,322^{*}, 324$.

- - der Rhodoph. als Gonotokont 320.

ZIMMERMANN über Bakterien in Blättern $351,352 *$.

Zoochlorellen $175,176^{*}$.

Zoogloeastadium bei Bakterien $347^{*}, 350$.

Zoosporangium und 'Zoosporangienbildung bei Asperococceae 267, 268, 269: Chaetophoreae 187, Chroolepideae 190*, Cladophoraceae 104, 106*, Coleochaetaceae 192*, Cutleriaceae '280, Cyanophyceae 381, Derbesiaceae 204*, Ectocarpaceae 260, Endosphaeraceae 33, 34*, 35, 36*, 37, Hydrodictyaceae $42 *, 46$. Laminariaceae 257 , Leptomitaceae $170^{*}$, Merolpidiaceae $110,111,115,116^{*}, 132,133$, Monoblepharideae $123^{*}, 124,125^{*}, 127$, 128*, 129*, 130, Mucorineae 131, 132, Mycochytridiaceae 117, 118*, Oedogonium 209*, Saprolegniaceae 161*, 163, 165, 167, 169, 170, siphonales 55, Sporochytriaceae 119,120,121, Ulotrichales 185.

- Anordnung der Zoosporen 130.

- Entstehung 81.

- gekammertes 165 .

- Keimung 131, 161*.

- Oeffnung 121.

- Umbildung beim Anfang des Landbewohnens 132 .

- Umbildung zu Konidien 111.

- Wand (Verschleimung) 117.

Zoosporen und 'Loosporenbildung bei Albugo 146, 151, 152*, 153, Asperococceae 265, 269*, Chaetophoreae 18\%*, 18S, 1S9*, Chorda 279, Chroolepideae 190*, Coleochaetaceae 192 , Cutleriaceae $2 \$ 1^{*}, 2 \Omega 3$, Cranophyceae 381, 383, 1)erbesia 204, Ectocarpeae 260, 263, Endosphaeraceae $32,34,35,36^{*}, 37,38$, Heterokonten $215^{*}, 216$, Hrdrodictraceae $4\left(0,41,42^{*}\right.$ $45,46,47,45$, Hrphochrtrium 122*, Merolpidiaceae $115^{*}, 116^{*}$, Momollepharideae $124,125^{*}, 12\left(6^{*}, 12 \%, 120 *\right.$, Monolpidiaceac $113^{*}$, Nycochrtridiaceae $11 \%$, 118, Oedogonium $20 \% * 200 *$, Peronosporacea 160 , Phacophrceac 25. . Protococcacea 1\%, Protosiphon 5.), Punctaria 27, Pythiaceae 161, saprolexniaceae 
$163,164,165^{*}, 166,168,170$, Sphaeroplea $107^{*}, 108$, Siphonocladeae 100, 101, 103, 104*, Sporochytriaceae 120*, 121*, Vaucheriaceae 78, 80, 81, 88.

Zoosporen, Bewegung 46.

- _ amöboide Conferva 216, Ulothrix 185.

- biplanetische $163^{*}, 164,165$.

- Keimung bei Asperococceae 265, 269*, Chorda 279, Cutleria 283, Draparnaldia 188, Ectocarpeae 260, Endosphaeraceae $36^{*}$, Monoblepharideae 126*, 129*, 130, 131, Monolpidiaceae 113*, Oedogonium 209*, Siphonocladeae 100, 101.

- monoplanetische 164.

- vielcilige 78 ff., 124,125 .

- zusammengesetzte 78, 81 .

ZopF über Chaetomium 521*, Cordyceps 517*, Evernia 566, Hyphochytrium 121, $122^{*}$, Labyrinthula 395, 397, Lagenidium 117, 118*, Leptomitaceae 170*, Mucor 135*, Myxomyceten 405, 406*, 409*, 410*, 412*, Olpidiopsis 113*, Polymorphismus Cladothrix 359, Rhizidium 119*.

ZUKAL über Apothecien - Entwicklung 548, Myxobakterien 385, 386, Thelebolus 573.

Zungenzelle der Haargrübchen bei Fucus 299, 300*.

Zwergmännchen, Oedogonium 209, 210.

- Ausschlüpfen der Spermatozoen 210.

- Bildung 210.

- mehrzellige 210.

Zwischenband bei Peridineae 233.

- Hörner der Peridineae 234.

Zwischensubstanz in den Mucoraceae-Sporangien 136.

Zygogametangien der Ascomyceten 419, 420, 421, Dipodascus 444, 446, Pyroneina $455^{*}$, Sphaerotheca $450^{*}, 451$; Zygomyceten 130, 131, 139, 141, 144*.

- Anordnung der Kerne 130, 131*.

- Wand 130, 131*.

Zygomyceten carposporangiale 436 .

- exosporangiale 436.

Zygo-Oogonium bei Phragmidium 629, 630*.

Zygosporen der Entomophthoraceae 148, 149*, Oomyceten (Albugo) 152*, 155, 156,157 , Mucorineae 138, 139*, 141, $142^{*}, 143,145^{*}$.

- Bildung 152*.

- Formen bei Mucorineae 139.

- Frucht 142*, 144.

- Keimung der Umhüllungshyphen $142 *, 143$.

- -- und Ascusfrucht 144.

- Keimung 152*.

- Verlust der Keimkraft 143.

- Wand 156.

Zygote und Zygotenbildung 10, 26 ff., 47 ff., 131, 193, 199, Akontae 195*, 198, 199 Ascomyceten 419, ('Kahl der Asci pro Z.) 458, 463, Basidiobolus 201, Bryopsideae
$57^{*}$, Charophyten $747^{*}$, Chaetophoraceae 187*, 188, Chlamydomonas 10, 11*, 12, 15, Cladophoraceae 104, 107, Codiaceae 64, Coleochaete 191*, 19.*, 193, Cutleriaceae 280, 281* Cylindrocapsa 186*, Dasycladaceae $91,96^{*}, 97$, Desmidiaceae 223*, 224, Diatomeae 252 ff., 255, 256, Dictyotaceae 293, 294, Ectocarpeae 262, Endosphaeraceae $32^{*}, 33,34^{*}, 36^{*}, 37$, 38*, 39, Fucaceae 297*, Hydrodictyaceae $41,42 *, 47,48,49$, Monoblepharideae $123^{*}, 124,127^{*}, 128$, Monolpidiaceae 114, Monostroma 181, Mycochytridiaceae 117, 118*, Oedogonium 210*, 211; oomy cetes : Albugo 152, 153, 154, 157, Peronosporeae 160, Pythiaceae 162, Saprolegniaceae 163; Peridineae 239, 240*, Protosiphon 54*, 55, Rhodophyceae 308, 313*, 314, 324 ff., Sphaeropleaceae 107*' 108, Sporochytriaceae 121, Tetraspora 180, Ulothrix 184, Vaucheriaceae 83, 85, 88, 89*, Volvocineae 20*, 22, 23*, 26, 27.

Zygoten als Gonotokont 108, 195, 211, 224 , 256, 308, 309 .

- amöboide Bewegung 124, 127 (Monoblepharis).

- Ausschlüpfen aus den Oogonien 127, 128*.

- Bildungsbedingungen 201.

- Bildung in den Zygogametangien 131.

- (Cöno-) 468.

- Einkapselung 127*, 128*.

- (Einzel-) 468

- Frucht 193.

- Hülle bei Closterium 224.

- Keimung bei Akontae 195*, 199, Basidiobolus 201, Bryopsideae 57*, Chaetophoraceae 188, Charophyten 746, 747*, 748, Chlamydomonas $10,11^{*}$, Cladophoraceae 104, 107*, Codiaceae 64, Coleochaetaceae 191, 192*, 193, Cutleria 280, 281*, Dasycladaceae 91, 96*, 97, Desmidiaceae 223*, 224, Endosphaeraceae $32^{*}, 33,34^{*}, 36^{*}, 38^{*}, 39$, Fucaceae 297*, Hydrodictyaceae $42 *, 47$, Monoblepharideae 127*, Monolpidiaceae 114, Monostroma 181, Oedogonium 211, Oomyceten $153,157,160,163$, Rhodophyceae 308, 313*, 314, 324 ff., Sphaeropleaceae 108, Tetraspora 180, Ulothrix 184, Vaucheriaceae 83, 89, Volvocineae 20, 22, $24^{*}, 27$.

-- Kern 13, 28, 48, 51, 156, 199.

- Membran 10, 11*, 15, 27, 33, 39.

- Oeffnung 199.

- Schwärmer 33, 35, 42*, 210*, 211, cf. auch Schwärmer.

- Wandbildung 85, 195, 198, 201.

- Wandverdickung 127, 152, 211.

- Wandverschleimung 11.

- Zusammengesetzte 130 . 


$$
\begin{aligned}
& \text { in } \\
& \text { (1) } \\
& -7 \\
& \text { 1) }
\end{aligned}
$$

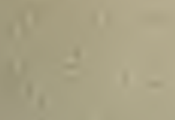

$$
\begin{aligned}
& x^{2}+x^{2} \\
& x+y= \\
& \text { in } \\
& \text { if } \\
& \text { 1) }
\end{aligned}
$$

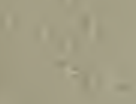

$$
\begin{aligned}
& +\frac{1}{1-x}
\end{aligned}
$$

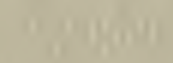

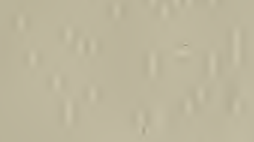

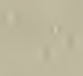

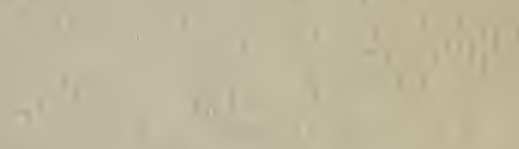

$$
\begin{aligned}
& \text { 1. }
\end{aligned}
$$

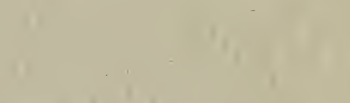

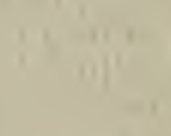

$$
\begin{aligned}
& 1-1
\end{aligned}
$$

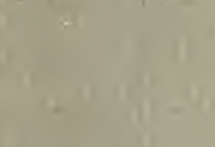

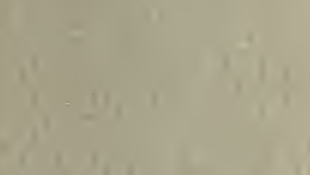

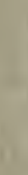

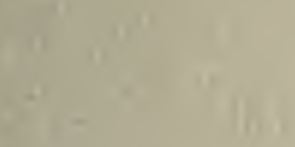

$$
\begin{aligned}
& \text { 1. } \\
& \text { 1) } 10=0 \\
& 10
\end{aligned}
$$

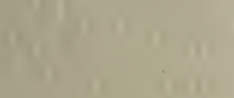





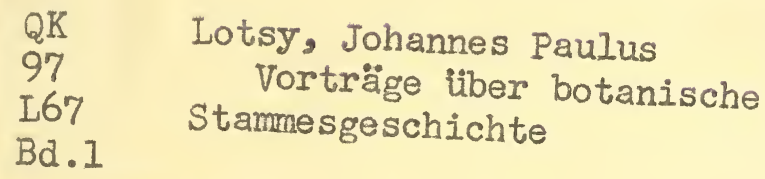

QK

97

L67 $\mathrm{Bd} .1$

Lotsy, Johannes Paulus

Vorträge liber botanische Stammesgeschichte

P\&A Sci.

PLEASE DO NOT REMOVE CARDS OR SLIPS FROM THIS POCKET 
